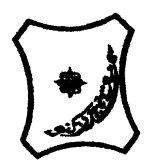

Bayero Journal of Pure and Applied Sciences, 13(2): 1 - 12

Received: November, 2020

Accepted: December, 2020

ISSN $2006-6996$

\title{
BIODEGRADATION POTENTIAL OF IMMOBILIZED BACTERIA IN THE TREATMENT OF TANNERY INDUSTRIAL EFFLUENTS FROM INDUSTRIAL ESTATES IN KANO STATE, NIGERIA
}

\author{
Abdullateef, B., ${ }^{1 *}$ Shuaibu, T. G., ${ }^{1}$ Babagana, K., ${ }^{1}$ Suleman, H. B. ${ }^{2}$ and Dauda, B. ${ }^{3}$ \\ ${ }^{1}$ Department of Pure and Applied Chemistry, Faculty of Science, University of Maiduguri, Borno State, \\ Nigeria \\ ${ }^{2}$ Department of Microbiology, Faculty of Science, University of Maiduguri, Borno State, Nigeria \\ ${ }^{3}$ Department of Chemical Engineering, Faculty of Engineering, University of Maiduguri, Borno State, \\ Nigeria \\ *Corresponding author: babslega@gmail.com; abelega2007@yahoo.com; +2348061309753
}

\section{ABSTRACT}

Industrial Effluents Samples from Gashash Tanneries (TAN1) in Bompai Industrial estate, Larabee Tannery Industry (TAN2) in Sharada Industrial estate and Z Tannery Industries (TAN3) in Challawa Industrial estate, Kano State, Nigeria were collected over a period of six months (August 2017 to January 2018) for assessing the biodegradation potentials of bacteria in the treatment of organic pollutants within the effluents. Bacteria were isolated from the effluents and immobilized on agar-agar. Different masses (5 g, $10 \mathrm{gr}, 15$ $\mathrm{g}, 20 \mathrm{~g}$, and $25 \mathrm{~g}$ ) of the bacteria were used in the treatment of $250 \mathrm{ml}$ of the effluents for ten days in a shaker incubator (Gallenkamp-OC-4364-L) at the temperature $30{ }^{\circ} \mathrm{C}$ and speed of $60 \mathrm{rpm}$. Pre-treatment analysis of the effluents for Temperature, pH, Biochemical Oxygen Demand (BOD), Chemical Oxygen Demand (COD), Suspended Solid (SS) and Total Dissolved Solids (TDS) gives the following results; temperature $\left({ }^{\circ} \mathrm{C}\right.$ )

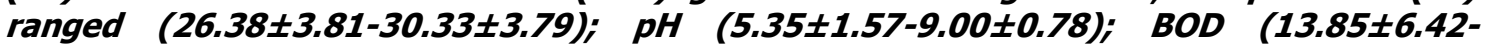
$38.75 \pm 16.20) ;$ COD (1406 $\pm 208-3532 \pm 1373) ;$ SS (208 $\pm 235-780 \pm 739)$ and TDS (266 $\pm 253-5276 \pm 2971)$. No statistical differences ( $p \leq 0.05)$ was observed for all the results among the different industries. The bacterial isolates were identified as Neisseria spp, Bacillus cereus, and Staphylococcus aureus, in TAN1, TAN2, and TAN3, respectively. After treatment of the effluent with the different masses of the isolated bacteria, the mean level of BOD was found to range as (0.55 $\pm 0.36-6.92 \pm 5.49) ; C O D$ (ND-3134 \pm 1595$)$;

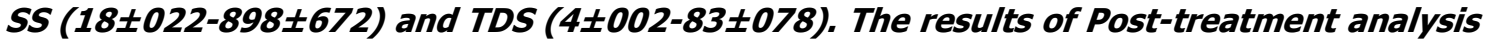
showed that there is overall decrease in the levels of the parameters determined when compared with that of the pre-treatment. The overall percentage reduction of the immobilised bacteria in the treatment of the respective effluents was in the order TAN2 (72\%)>TAN1 (70\%)>TAN3 (62\%). Hence, the immobilized bacteria are having higher biodegradation potential for the treatment of the tannery effluents.

Keywords: Biodegradation, bacteria, effluent, immobilization, tannery.

\section{INTRODUCTION}

Tannery industrial wastewater is a serious consequence of the pollution point of view for streams, freshwater, and land used for agriculture. The lack of awareness in the modern industrial practice has resulted in the discharge of tannery effluents which exhibit very high value of chromium ( $\mathrm{Cr}$ ), Sulfide, and chloride, Total Dissolved Solid (TDS), Total Suspended Solid (TSS), Biochemical Oxygen Demand (BOD) and Chemical Oxygen Demand (COD) in the water stream or land (Mohammed et al., 2001). Tanning is the process, which One ton of skin generally leads to the production of 20 to $80 \mathrm{~m}^{3}$ of turbid and foul-smelling converts the protein of the rawhide or skin into a stable material, which will not putrefy and is suitable for a wide variety of end applications (Elsheikh, 2009). The highly polluting chromium is the most commonly used tanning material producing leather that is more flexible and pliable than vegetable-tanned leather and does not discolor or lose shape in water as drastically as vegetable-tan (Elsheikh, 2009). Tannery effluent is among the most hazardous industrial pollutants due to its huge organic and inorganic load, which is highly toxic to human life and the environment (Kongjao et al., 2008). wastewater including chromium (100-400 mg/l), sulfide $(200-800 \mathrm{mg} / \mathrm{l})$, high levels of fat and 
BAJOPAS Volume 13 Number 2, December, 2020 other solid wastes, and notable pathogen contamination as well as pesticides added for skin conservation during transport (Elsheikh, 2009). There are more than 6000 tanneries in Nigeria with an annual processing capacity of 700,000 tons of hides and skins (Omoleke, 2004; Singh et al., 2008). It was reported that the total amount of waste produced per animal slaughtered is approximately $35 \%$ of its weight (World Bank, 1995). Also, for every $1000 \mathrm{~kg}$ of carcass weight, a slaughtered beef produces 5.5 $\mathrm{kg}$ of manure (excluding rumen contents or stockyard manure) and $100 \mathrm{~kg}$ of paunch manure (undigested food) (Verheijen et al., 1996). Tanneries generate wastewater in the range of 30-35 $\mathrm{L} \mathrm{kg}^{-1}$ skin/hide processed with variable $\mathrm{pH}$, Biological Oxygen Demand (BOD), Chemical Oxygen Demand (COD), high concentrations of suspended solids (SS), and tannins as well as chromium (Zahoor and Abdul, 2009).

Being heterogeneous and composed of a wide variety of compounds, it is very difficult to select a unique direct method for estimating the biodegradability of organic contents and biokinetic parameters for a wastewater sample (Rajor, 2004). For this purpose, some indirect estimation such as determination of biochemical oxygen demand (BOD) and chemical oxygen demand (COD) are applied as common laboratory investigations [9]. During retanning procedures, synthetic tannins (Syntan), oils and resins are added to form softer leather at varying doses (Munz et al., 2009). One of the refractory groups of chemicals in tannery effluents derives mainly from tannins (Ramasami et al., 2004). Syntans are characterized by complex chemical structures, because they are composed of an extended set of chemicals such as phenol-, naphthalene-, formaldehyde- and melamine-based syntans, and acrylic resins (Beem, 1994). Organic pollutants (proteic and lipidic components) are originated from skins (it is calculated that the raw skin has $30 \%$ loss of organic material during the working cycle) or they are introduced during processes (Hugo Springer, 1994).

Many conventional processes such as oxidation, chemical and biological processes were carried out to treat tanneries wastewater (Ebtesam et al, 2013). Biological processes have received more attention because of their costeffectiveness, lower sludge production and environmental friendliness (Noorjahan, 2014). Naturally occurring micro-organisms degrade the hazardous organic wastes including xenobiotic compounds, such as pesticides, polycyclic aromatic hydrocarbons (PAHs) and polychlorinated biphenyls (PCBs) in due course of time (Ranen and Sharadinadra, 2009). Bioremediation is based on the idea that all organisms remove substances from the environment to carry outgrowth and metabolism (Bouwer and Zehnder, 1993). Bacteria, protista and fungi are found to be very good at degrading complex molecules and incorporating the breakdown products into their metabolism (Bouwer and Zehnder, 1993). The resultant metabolic wastes that they produce are generally safe and somehow recycled into other organisms (Ranen and Sharadinadra, 2009). An acclimatized indigenous population of microorganisms capable of degradation of the compounds of interest must exist at the site for a successful bioremediation mode (Ranen and Sharadinadra, 2009). It has been observed that for a successful bioremediation mode, an acclimatized indigenous population of microorganisms capable of degradation of the compounds of interest must exist at the site under investigation (Ranen and Sharadinadra, 2009). Even though there are numerous physical and chemical methods employed in the disposal of wastes the advantage in using bacterium is that they play a key role in the reduction of COD, BOD, total protein, total tannin and total phenol (Saravanan and Saravanan, 1998)

Baba et al. (2020) studied the bioremediation potential of immobilized corynebacterium kutsceri in the Treatment of tannery industrial effluent from Challawa Industrial Estate, Kano State, Nigeria. The aim of the work is to study the reduction in the level of the contaminants through the process of bioremediation using the isolated bacteria. Immobilized bacteria can withstand various temperatures, $\mathrm{pH}$ and substrate concentrations; consequently, increasing the efficiency and the lifespan of the bacteria. Immobilized bacteria are widely applied in the treatment of wastewater and can be separated and recovered after the treatment with the same efficiency (Baba et al., 2020).

\section{MATERIALS AND METHODS \\ Study Area}

This study was carried out in Bompai, Sharada and Challawa industrial estates in Kano, Figure 1. Kano lies on Latitude $11^{\circ} 30^{\prime} \mathrm{N}$ and $8^{\circ} 30^{\prime} \mathrm{E}$ and Longitude $11^{\circ} 5^{\prime} \mathrm{N}$ and $8^{\circ} 5^{\prime} \mathrm{E}$ in Northern Nigeria. It is one of the developed industrial cities in Nigeria. Tannery activities are the dominating industries and this could be one of the reasons for her high population density (Dan'Azumi and Bichi, 2010). Many researchers have studied biodegradation of tannery effluent using microorganisms. However, limited literature is available on the biodegradation of tannery effluent in Kano industrial estates using 
BAJOPAS Volume 13 Number 2, December, 2020 immobilized bacterial cells. This research work focuses on the potential of the use of the indigenous immobilized bacterial isolates in the treatment of tannery effluents in the industrial estates.

\section{Sample Collection}

Effluents were collected from the Tannery Industries from Bompai, Challawa and Sharada Industrial Estates, Kano, Nigeria. The effluents were collected over a period of six months (August 2017 to January 2018). Samples collected in a sterile 4-liter plastic container with a unique identification number were preserved using an ice-box that was transported to the Microbiology Laboratory, Department of Microbiology, Bayero University of Kano for analysis

\section{Sample Preparation and Sample Analysis}

Immediately after the collection of the effluent, $\mathrm{pH}$, TSS, TDS, COD, BOD levels were determined before treatment (Pre-treatment determination) and ten days after treatment (Post-treatment determination) as described in
APHA (1989) standard methods. $\mathrm{pH}$ was determined using Ecotests $\mathrm{pH}$ meter and TDS was determined using AQUALYTIC TDS Salinometer. BOD was determined as described by the standard method (APHA, 1992). COD and SS were determined using DR/2010 HACH portable data logging spectrophotometer (DWAF, 1992)

\section{Identification and Biochemical} Characterization of the Bacterial Isolates

The bacteria were isolated from the effluents using Serial Dilution according to the method described by APHA (1989). The biochemical tests such as oxidase, catalase, coagulase, indole (from $1 \%$ tryptone broth), citrate (Simmons citrate agar), methyl red/VogesProskauer (MR/VP), nitrate reduction, Starch Hydrolysis, Glucose, Maltose, and Lactose tests were carried out on the bacterial isolates to identify the bacteria through the bacteria biochemical characteristics according to Ajao et al. (2011).

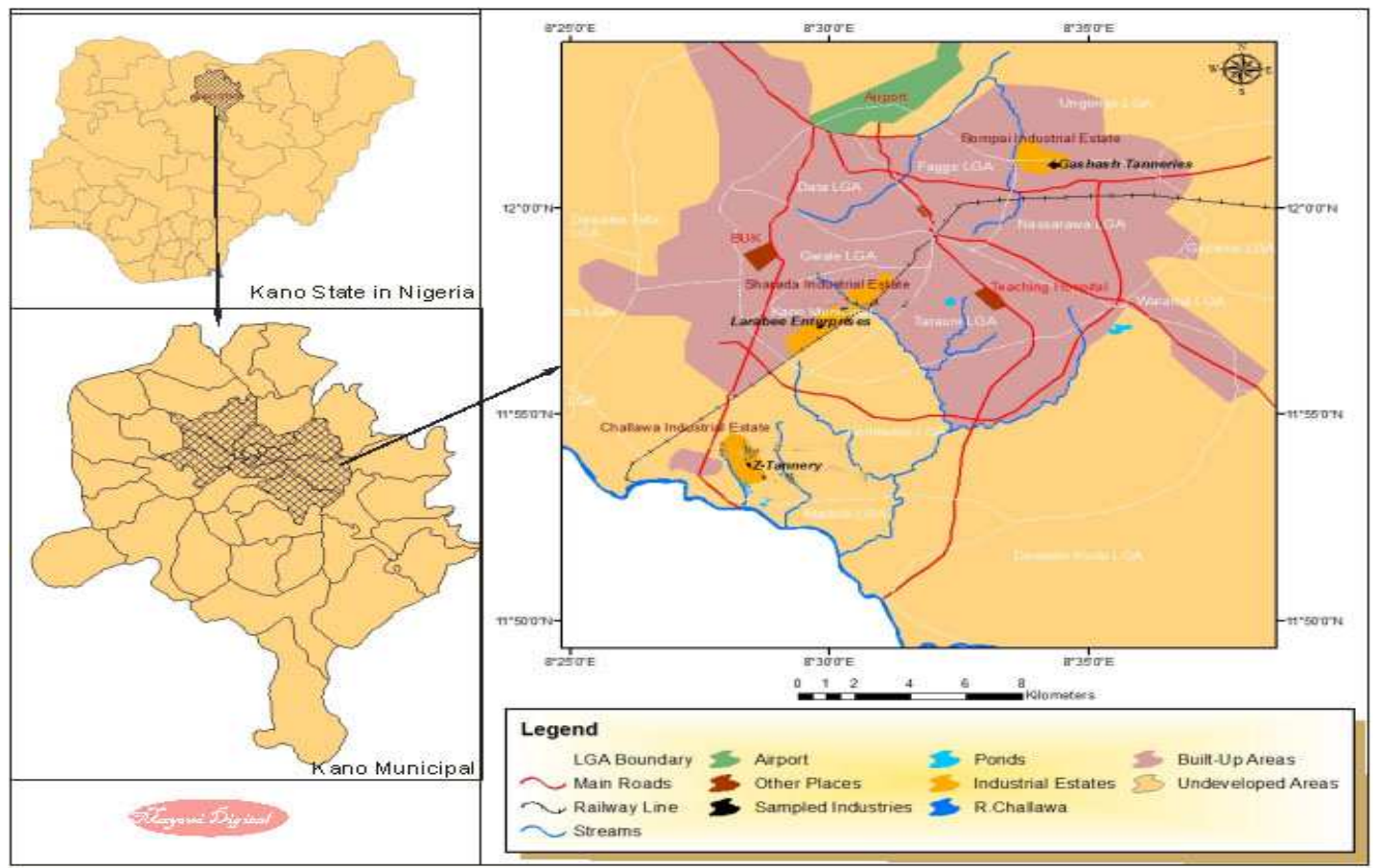

Fig. 1 Map showing the study areas

Source: Mayomi Digital Productions, GIS Laboratory, Department of Geography, UNIMAID (2017)

\section{Determination of Growth Rate of the Bacteria in Effluent Sample}

The bacteria growth rates were determined by transferring $2 \mathrm{~mL}$ of the bacterial isolates from the tannery effluent in broth medium into 100 $\mathrm{mL}$ sterile effluents in conical flasks and kept in an incubator (Giffrin cool) for 10 days. Control was also set up by incubating another $100 \mathrm{~mL}$ each of the sterile effluents without the bacteria. The optical density of the content was determined at the wavelength of $600 \mathrm{~nm}$ on a daily interval and recorded. 
BAJOPAS Volume 13 Number 2, December, 2020 Immobilization of Bacteria

Agar solution and inoculi were prepared separately. Fifty milliliters $(50 \mathrm{~mL})$ of nutrient broth each of the inoculi was prepared in a McCartney bottle and incubated for 24 hours. A solution of agar-agar was prepared by dissolving $10 \mathrm{~g}$ of the powder in distilled water and made up to $500 \mathrm{~mL}$ mark in an Erlenmeyer flask and was sterilized in an autoclave (280A) for 15 minutes and allowed to cool to $40-45^{\circ} \mathrm{C}$ (Ajao et al., 2011). Four milliliters ( $4 \mathrm{~mL})$ of the bacterial isolates in the nutrient broth was mixed with 36 $\mathrm{ml}$ of the prepared agar-agar media in petri-dish plates and then allowed to solidify. This was kept in the refrigerator for bioremediation.

\section{Bioremediation (Treatment) of the Effluents}

The solidified agar block (immobilized bacteria) was cut into cubes using a sterile knife; $0.1 \mathrm{~mL}$ phosphate buffer ( $\mathrm{pH} \mathrm{7.0)}$ was added and kept in the refrigerator for 1 hour for curing. The phosphate buffer was decanted after 1 hour and the cubes were washed with sterile distilled water 3-4 times before it was used (Ajao et al., 2011). Two liters (2 L) of the effluent was supplemented with the minimum basal medium in $\mathrm{g} / \mathrm{L}: \mathrm{NaCl}(0.8), \mathrm{MgSO}_{4} .7 \mathrm{H}_{2} \mathrm{O}(0.001), \mathrm{KH}_{2} \mathrm{PO}_{4}$ (2), $\mathrm{NaNO}_{3}$ (2), $\quad \mathrm{CaCl}_{2} .2 \mathrm{H}_{2} \mathrm{O} \quad(0.5)$ and $\mathrm{NaHPO}_{4} .12 \mathrm{H}_{2} \mathrm{O}(2)$ and sterilized in an autoclave at $121^{\circ} \mathrm{C}$ for 15 minutes (Margesin and Schinner, 2001). Two hundred and fifty milliliters $(250 \mathrm{~mL})$ of the effluents were transferred into different $250 \mathrm{ml}$ conical flasks. The content was covered with a cotton-wool ramped with foil paper to avoid contamination. Five grams $(5 \mathrm{~g})$ of the immobilized bacteria were quickly transferred into each of the effluents in the conical flasks in an inoculating chamber. The same procedures were carried out for the $10 \mathrm{~g}, 15 \mathrm{~g}, 20 \mathrm{~g}$ and 25 $\mathrm{g}$ of the immobilized bacteria in separate $250 \mathrm{~mL}$ effluents in conical flasks and agitated for ten days in a shaker incubator (Gallenkamp-OC4364-L) at a temperature $30^{\circ} \mathrm{C}$ and speed of 60 rpm. The treated effluent samples were taken on the tenth day and analyzed for the parameters $\mathrm{pH}$, SS, TDS, COD, and BOD, (Posttreatment determination) for the different grams of bacteria to evaluate and compare the biodegradation potential. (Baba et al., 2020).

\section{Statistical Analysis}

The data were represented as Mean \pm Standard deviation and analyzed statistically using oneway Analysis of Variance (ANOVA) and Tukey's HSD as Post Hoc Tests with the aid of SPSS 16.0. The correlation coefficient was also used to measure the strength of the relationship between the different masses of the bacteria and the parameters. All $\mathrm{p} \leq 0.05$ were considered as statistically significant.

\section{RESULTS AND DISCUSSION Physico-chemical parameters in the Industrial Effluents before the Biodegradation.}

Results of the Physico-chemical parameters in the industrial effluents before the Biodegradation is shown in table 1 . The mean temperatures $\left({ }^{\circ} \mathrm{C}\right)$ observed in TAN1, TAN2, and TAN3 samples were $28.07 \pm 0.65 ; 27.77 \pm 0.64$ and $26.38 \pm 3.81$ respectively. The order of the mean temperature of the samples from the three industries can be arranged as TAN1 > TAN2>TAN3. The temperature observed at TAN1, TAN2, and TAN3 samples were found below the WHO $\left(35^{\circ} \mathrm{C}\right)$ and NESREA $\left(40^{\circ} \mathrm{C}\right)$ limits. The low values of temperature might be due to the processes used at the time of sampling. High temperature brings down the solubility of gases in water that ultimately expresses as high BOD and COD. Statistical analysis shows that there is no significant difference $(p<0.05)$ between the mean values of temperature among the industries. This might be due to similar tannery activities involved in the tannery industries at the time of sampling. The average values of temperature observed in this present study are less than those observed by Akan et al. (2007), Akan et al. (2009) and Baba et al. (2020).

The mean level of $\mathrm{pH}$ observed in TAN1, TAN2 and TAN3, samples were $7.77 \pm 2.93$; $8.35 \pm 0.28$ and $7.52 \pm 0.76$ respectively. The order of the mean $\mathrm{pH}$ of the samples from the three industries can be arranged as TAN2> TAN1 $>$ TAN3. The $\mathrm{pH}$ of the samples falls within the WHO (7.0-8.5) and NESREA (6-9) standard limits. Statistical analysis shows that there is no significant difference $(p<0.05)$ between the mean values of $\mathrm{pH}$ among the industries. This might be due to similar tannery activities involved in the tannery industries at the time of sampling. Maheshwari et al. (2017) reported that the level of $\mathrm{pH}$ in the effluents from the tannery industry in Vaniyambadi, India was 6.5 which was lower than that observed in the present study. The $\mathrm{pH}$ in the effluents from the tannery industries in Kano and Kaduna were reported to be 7.64 and 6.89, respectively (Akan et al., 2007; Mohammed et al., 2017). The average values of $\mathrm{pH}$ observed in this present study are less than those observed by Mohammed et al. (2017) and Baba et al. (2020). The mean level of SS $(\mathrm{mg} / \mathrm{l})$ observed in TAN1, TAN2, and TAN3 samples were 374 \pm 124 ; $358 \pm 335$ and $780 \pm 739$ respectively. The order of the mean SS in the samples from the three industries can be arranged as TAN3 > TAN1 $>$ TAN2. 
The SS observed in the samples were far above the recommended standard limits of regulating bodies WHO $(30 \mathrm{mg} / \mathrm{l})$ and NESREA $(10 \mathrm{mg} / \mathrm{l})$. Statistical analysis shows that there is no significant difference $(p<0.05)$ between the mean values of SS among the industries. This might be due to similar tannery activities involved in the tannery industries at the time of sampling. The average values of SS observed in this present study are less than that observed $(3700 \pm 122 \mathrm{mg} / \mathrm{l})$ by Akan et al. (2009) for tanneries in Kano. Also, the average values of SS observed in this present study are less than that observed by Mohammed et al. (2017) and Baba et al. (2020) with the exception in TAN3.

The mean level of TDS (mg/l) observed in TAN1, TAN2, and TAN3 samples were $3941 \pm 3703$; $3300 \pm 1714$ and $2653 \pm 1240$ respectively. The order of the mean TDS in the samples from the three industries can be arranged as TAN1>TAN2>TAN3. The TDS observed in the samples were far above the recommended standard limits of WHO $(250 \mathrm{mg} / \mathrm{l})$ and NESREA $(500 \mathrm{mg} / \mathrm{l})$. Statistical analysis shows that there is no significant difference $(p<0.05)$ between the mean values of TDS among the industries. This might be due to similar tannery activities involved in the tannery industries at the time of sampling. TDS in the effluents from the tannery industries in Kano, Nigeria was reported to be $1281 \mathrm{mg} / \mathrm{l}$ (Akan et al., 2007). The average values of SS observed in this present study are less than those observed by Mohammed et al. (2017) and Baba et al. 2020)

The mean level of COD (mg/l) observed in TAN1, TAN2 and TAN3 samples seasons were $2372 \pm 938 ; \quad 1406 \pm 208$ and $3532 \pm 1373$ respectively. The order of the mean COD of the samples from the three industries can be arranged as TAN3>TAN1> TAN2. The COD observed in TAN1, TAN2 and TAN3 samples were far above the recommended standard limits of regulating bodies $\mathrm{WHO}(40 \mathrm{mg} / \mathrm{l})$ and NESREA (40 mg/l). Statistical analysis shows that there is no significant difference $(p<0.05)$ in COD among the industries. This might be due to similar tannery activities involved in the tannery industries as at the time of sampling. The Chemical Oxygen demand (COD) is the amount of oxygen, in $\mathrm{mg} / \mathrm{L}$, required for the degradation of the compound of wastewater to occur. In comparison, the average values of COD observed in this present study were higher than that observed by Mohammed et al. (2017) but lower than that observed by Baba et al. (2020).

The mean levels of BOD $(\mathrm{mg} / \mathrm{l})$ observed in TAN1, TAN2 and TAN3 samples were $13.85 \pm 6.42 ; \quad 19.46 \pm 0.50$ and $17.13 \pm 3.14$ respectively. The order of the mean BOD in the samples from the three industries can be arranged as TAN2>TAN3>TAN1. The BOD observed in TAN1, TAN2 and TAN3 samples were found below the recommended limits of NESREA (200 mg/l) but above WHO (10 mg/l). Statistical analysis shows that there is no significant difference $(p<0.05)$ between the mean values of BOD among the industries. This might be due to similar tannery activities involved in the tannery industries at the time of sampling. The low level of BOD recorded in this study is an indication of the low level of biodegradable organic solids in the effluent. The average values of BOD observed in this present study were lower than those observed by Mohammed et al. (2017) and Baba et al. (2020).

Table 1: Mean Values \pm S.D of Physico-chemical parameters of effluents from the Tannery Industries before Treatment.

\begin{tabular}{llllllll}
\hline Parameter & Tannery 1 & Tannery 2 & Tannery 3 & $\mathrm{a}$ & $\mathrm{b}$ & $\mathrm{c}$ & $\mathrm{d}$ \\
\cline { 2 - 7 } Temperature $\left({ }^{\circ} \mathrm{C}\right)$ & $28.07 \mathrm{a} \pm 0.65$ & $27.77 \mathrm{a} \pm 0.64$ & $26.38 \mathrm{a} \pm 3.81$ & & $29.50 \pm 4.68$ & 35 & 40 \\
pH & $7.77 \mathrm{a} \pm 2.93$ & $8.35 \mathrm{a} \pm 0.28$ & $7.52 \mathrm{a} \pm 0.76$ & 6.89 & $5.35 \pm 1.57$ & $7.0-8.5$ & $6.0-9.0$ \\
$\mathrm{COD}(\mathrm{mg} / \mathrm{l})$ & $2372 \mathrm{a} \pm 938$ & $1406 \mathrm{a} \pm 208$ & $3532 \mathrm{a} \pm 1373$ & 2.2 & $3106 \pm 2753$ & 40 & 40 \\
$\mathrm{BOD}(\mathrm{mg} / \mathrm{l})$ & $13.85 \mathrm{a} \pm 6.42$ & $19.46 \mathrm{a} \pm 0.50$ & $17.13 \mathrm{a} \pm 3.14$ & 1032 & $26.17 \pm 9.49$ & 10 & 200 \\
$\mathrm{SS}(\mathrm{mg} / \mathrm{l})$ & $374 \mathrm{a} \pm 124$ & $358 \mathrm{a} \pm 335$ & $780 \mathrm{a} \pm 739$ & 501 & $562 \pm 482$ & 30 & 10 \\
TDS $(\mathrm{mg} / \mathrm{l})$ & $3941 \mathrm{a} \pm 3703$ & $3300 \mathrm{a} \pm 1714$ & $2653 \mathrm{a} \pm 1240$ & 532.7 & $444 \pm 507$ & 250 & 500 \\
\hline
\end{tabular}

The values given in the table above are means of 6 replicate values, $\mathrm{n}=6$ ( 1 sample was taken monthly for 6 months). Within the rows, means with different alphabets are statistically different $(p<0.05)$. WHO: World Health Organisation. NESREA: National Environmental Standard and Regulatory Enforcement Agency. a = Mohammed et al.(2017), b = Baba et al. (2020), c = WHO (2006), $d=$ NESSRA (2009) 
BAJOPAS Volume 13 Number 2, December, 2020

Identification, Biochemical Characterization and growth rates of the Bacterial Isolates

Results of identification and biochemical characterization of the bacterial isolates were shown in table 2. After 24 hours of incubation, the nutrient agar media plates were checked for bacterial growth. The results showed the presence of different strains in the samples. The TAN1 bacteria isolate was found to be gramnegative cocci while TAN3 was gram-positive cocci. TAN2 bacteria isolate was found to be gram-positive, rod-shaped. TAN1, TAN2, and TAN3 bacteria isolates recorded positive results for spore former.

The results of the biochemical tests indicated that all the bacteria were positive for catalase, oxidase, citrate, maltose, glucose, lactose (negative in TAN1), mannitol (negative in TAN2), starch hydrolysis and coagulase (negative in TAN2) tests. The bacteria showed negative results for nitrate reduction, $M R$ (positive in TAN2), VP (positive in TAN1), Indole (positive in TAN2) tests. Base on the morphological and biochemical test results, TAN1, TAN2, and TAN3 bacteria isolates were identified to be Nesseria spp, Bacillus cereus, and Staphylococcus aureus respectively.

The growth rate of the TAN1, TAN2 and TAN3 Isolates were shown in figure 2. Generally, the optical density increase with the increase in time (day) and decrease as time goes on. The highest optical density was shown by bacillus cereus in TAN2 while the lowest was shown by Staphylococcus aureus in TAN3.

The initial growth phase of TAN1 Isolate bacteria occurred within 2-day of incubation as the growth rate increases up to the 6th-day incubation when the maximum growth was observed. Beyond the 6th day, the growth of the bacteria declined (which might be due to a shortage of nutrients in the effluents) until it reached its death phase (which might be due to the unavailability of nutrients in the effluents).

A similar trend of growth was also observed for TAN2 Isolate as the initial growth phase also occurred within 2-day of incubation but maximum growth rate observed on the 4th day of incubation. The stationary stage occurred between the 4th day and the 8th day. Beyond the 8th day, the growth of the bacteria declined (which might be due to a shortage of nutrients in the effluents) until it reached its death phase (which might be due to the unavailability of nutrients in the effluents).

The initial growth phase of TAN3 bacterial Isolate occurred within the 3-day incubation as the growth rate increases up to the 6th-day incubation when the maximum growth was observed. Beyond the 6th day, the growth of the bacteria declined (which might be due to a shortage of nutrients in the effluents) until it reached its death phase (which might be due to the unavailability of nutrients in the effluents).

Table 2: Morphological and Biochemical characteristics of bacterial isolates

\begin{tabular}{lllll} 
Bacterial Isolates & & TAN1 & TAN2 & TAN3 \\
\hline $\begin{array}{lllll}\text { Morphological } \\
\text { characteristics }\end{array}$ & Shape & Cocci & Rod & Cocci \\
& Spore & & & \\
& former & + & + & + \\
Gram & & & \\
Biochemical characteristics & reaction & - & + & + \\
& Citrate & + & + & + \\
& Catalase & + & + & + \\
& Coagulase & + & - & + \\
Starch & + & + & + \\
& Glucose & + & + & + \\
Oxidase & + & + & + \\
& Indo & - & + & - \\
Lactose & - & + & + \\
Manitol & + & - & + \\
Maltose & + & + & + \\
MR & - & + & - \\
VP & + & - & - \\
& Nitrate & - & - & - \\
Reduction & - Neisseria & Bacillus & Staphylococcus \\
& Bacterial & cereus & aureus \\
& name & spp & cas
\end{tabular}

+ = Positive; - = Negative; MR=Methyl Red; VP= Voges-Proskauer 


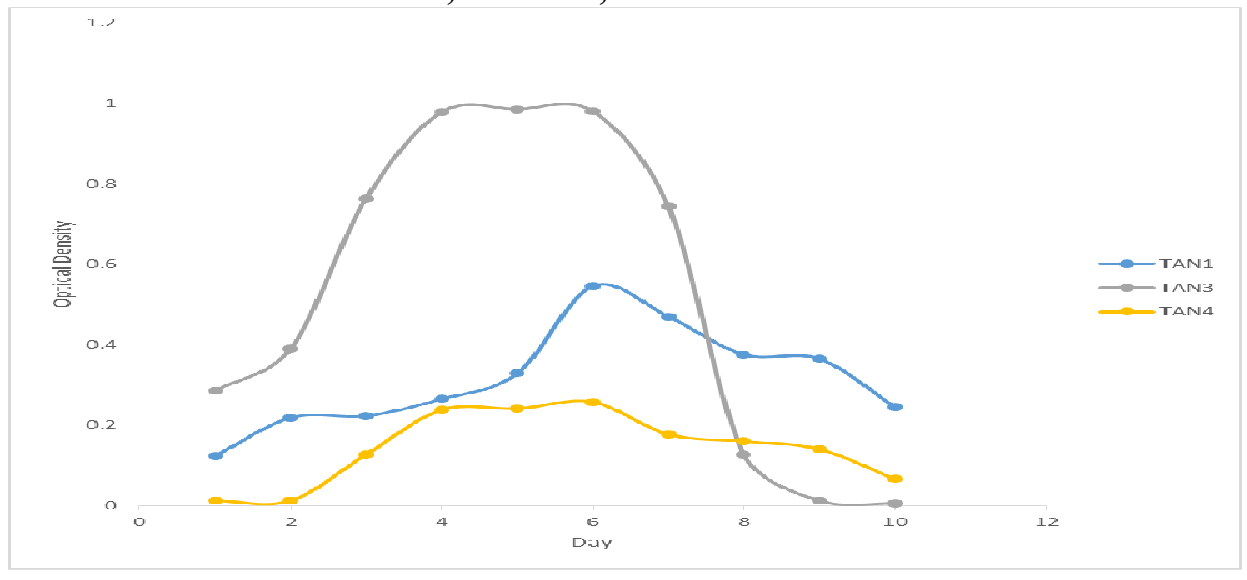

Fig. 2 Growth rates of the isolates in the effluents from the Tannery Industries

\section{Physico-chemical Parameters in the Industrial Effluents after the biodegradation.}

Table 3 shows the mean results of the physicochemical parameter before and after bioremediation using the different masses $(5 \mathrm{~g}$, $10 \mathrm{~g}, 15 \mathrm{~g}, 20 \mathrm{~g}$, and $25 \mathrm{~g}$ ) of the respective immobilized bacteria. Also, Table 4 shows the mean results of correlation coefficient ( $r$ ) between different masses of bacteria and physicochemical parameters.

The mean values $(\mathrm{mg} / \mathrm{l})$ of the SS after the bioremediation varies between $243 \pm 45$ and $898 \pm 672$. The mean concentration $(\mathrm{mg} / \mathrm{l})$ of SS remediated by the different masses $(5 \mathrm{~g}, 10 \mathrm{~g}$, $15 \mathrm{~g}, 20 \mathrm{~g}$, and $25 \mathrm{~g}$ ) of the bacteria varies. The SS in the samples fluctuates up and down after the bioremediation process when compared with the SS of the raw samples before the bioremediation. The increase in the levels of the SS might be due to the aggregation of the TDS which are large enough to result into SS. The increase in the levels of the SS might be also due to the influence of the nutrients which was added into the effluents in order to make the microorganisms more active and viable for fast degradation of organic contaminants in the effluent. The relative potential or efficiency of the different masses of the bacteria in remediating SS in TAN1 samples was in the order $25 \mathrm{~g}>20 \mathrm{~g}>15 \mathrm{~g}>10 \mathrm{~g}>5 \mathrm{~g}$. For TAN2 and TAN3 samples, the order was $25 \mathrm{~g}>20 \mathrm{~g}>15$ $\mathrm{g}>10 \mathrm{~g}>5 \mathrm{~g}$. These might be due to the variations in the surface areas of the different masses of the immobilized bacteria. Statistical analysis shows that there is no significant difference $(p<0.05)$ between the mean values of SS among the masses in the respective industries. Positive and significant correlations exist between the masses of bacteria and Suspended Solid (SS). This showed that there is general increase in the levels of the SS as the masses of the immobilized bacteria increases. TAN3 (90\%) and TAN1 (80\%) showed a very high correlation with the masses of the bacteria while TAN2 (61\%) showed a very low correlation.

The mean values $(\mathrm{mg} / \mathrm{l})$ of the TDS after the bioremediation varies between $46 \pm 11$ and $83 \pm 78$. The mean concentration $(\mathrm{mg} / \mathrm{l})$ of TDS remediated by the different masses $(5 \mathrm{~g}, 10 \mathrm{~g}$, $15 \mathrm{~g}, 20 \mathrm{~g}$, and $25 \mathrm{~g}$ ) of the bacteria varies. There is a reduction in all the TDS of all the samples after the bioremediation process compared with the TDS of the raw samples before the bioremediation. The relative potential or efficiency of the different masses of the bacteria in remediating TDS in TAN1 and TAN3 samples was in the order $5 \mathrm{~g}>10 \mathrm{~g}>15 \mathrm{~g}>20$ $\mathrm{g}>25 \mathrm{~g}$. For TAN2 samples, the order was 20 $g>10 \quad g>25 \quad g>15 \quad g>5 \quad g$. Statistical analysis shows that there is no significant difference $(p<0.05)$ between the mean values of TDS among the masses in the respective industries. These might be due to the variations in the surface areas of the different masses of the immobilized bacteria. Positive and significant correlations exist between the masses of bacteria and TDS with the exception in TAN2 (negative and insignificant correlation). The positive correlations showed that there is general increase in the levels of the TDS as the masses of the immobilized bacteria increases. TAN1 $(96 \%)$ showed a very high correlation with the masses of the bacteria while TAN2 (47\%) showed a very low correlation.

The mean values $(\mathrm{mg} / \mathrm{l})$ of the BOD after the bioremediation varies between $1.56 \pm 0.20 \mathrm{mg} / \mathrm{l}$ and $6.92 \pm 5.49 \mathrm{mg} / \mathrm{l}$. The mean concentration $(\mathrm{mg} / \mathrm{l})$ of BOD remediated by the different masses $(5 \mathrm{~g}, 10 \mathrm{~g}, 15 \mathrm{~g}, 20 \mathrm{~g}$, and $25 \mathrm{~g}$ ) of the bacteria varies. There is a reduction in all the BOD of all the samples after the bioremediation process compared with the $\mathrm{BOD}$ of the raw 
BAJOPAS Volume 13 Number 2, December, 2020 samples before the bioremediation. The relative potential or efficiency of the different masses of the bacteria in remediating BOD in TAN1, TAN2 and TAN3 samples were in the order $25 \mathrm{~g}>20$ $\mathrm{g}>15 \mathrm{~g}>10 \mathrm{~g}>5 \mathrm{~g}, 25 \mathrm{~g}>15 \mathrm{~g}>5 \mathrm{~g}>10 \mathrm{~g}>20 \mathrm{~g}$ and $20 \mathrm{~g}>10 \mathrm{~g}>25 \mathrm{~g}>15 \mathrm{~g}>5 \mathrm{~g}$ respectively. Statistical analysis shows that there is significant difference $(p<0.05)$ between the mean values of BOD among the masses in the respective industries. These might be due to the variations in the surface areas of the different masses of the immobilized bacteria. Negative and significant correlations exist between the masses of bacteria and BOD. This showed that there is general decrease in the levels of the BOD as the masses of the immobilized bacteria increases. TAN1 (94\%) showed a very high correlation with the masses of the bacteria while TAN2 (4\%) showed a very low correlation.

The mean values $(\mathrm{mg} / \mathrm{l})$ of the COD after the bioremediation varies between $250 \pm 154$ and $3134 \pm 1595$. The mean concentration $(\mathrm{mg} / \mathrm{l})$ of COD remediated by the different masses $(5 \mathrm{~g}$, $10 \mathrm{~g}, 15 \mathrm{~g} 20 \mathrm{~g}$, and $25 \mathrm{~g}$ ) of the bacteria varies. There is a reduction in all the COD of all the samples after the bioremediation process compared with the COD of the raw samples before the bioremediation. The relative potential or efficiency of the different masses of the bacteria in remediating COD in TAN1, TAN2 and TAN3 samples were in the order $25 \mathrm{~g}>20 \mathrm{~g}>15$ $\mathrm{g}>5 \mathrm{~g}>10 \mathrm{~g}, 25 \mathrm{~g}>20 \mathrm{~g}>15 \mathrm{~g}>10 \mathrm{~g}>5 \mathrm{~g}$ and 10 g>5 g>25 g>15 g>20 g respectively. Statistical analysis shows that there were significant difference $(p<0.05)$ between the mean values of COD among the masses in the respective industries except for effluents treated with $25 \mathrm{~g}$. These might be due to the variations in the surface areas of the different masses of the immobilized bacteria. Negative and insignificant correlations exist between the masses of bacteria and COD with the exception in TAN3 (positive and significant correlation). The negative correlations showed that there is general decrease in the levels of the COD as the masses of the immobilized bacteria increases. TAN2 (100\%) showed a very high correlation with the masses of the bacteria while TAN3 (36\%) showed a very low correlation.

Generally, there was an overall decrease in the concentration of these physicochemical parameters after the bioremediation using the different masses of the bacterial isolates. These might be due to the variations in the surface areas of the different masses of the immobilized bacteria. This is in line with the work of Jimoh et al. (2018) and Baba et al. (2020).

Table 3: Mean Values $(\mathrm{mg} / \mathrm{l}) \pm$ S.D of Physicochemical parameters in effluents from the Tannery Industries before and after Treatment of the effluents $(250 \mathrm{ml})$ with the different masses $(5 \mathrm{~g}, 10 \mathrm{~g}$, $15 \mathrm{~g}, 20 \mathrm{~g}$, and $25 \mathrm{~g}$ ) of the bacteria.

\begin{tabular}{llllllll}
\hline $\mathrm{P}$ & IND & Before & \multicolumn{5}{c}{ After } \\
\cline { 4 - 7 } & & & $5 \mathrm{~g}$ & $10 \mathrm{~g}$ & $15 \mathrm{~g}$ & $20 \mathrm{~g}$ & $25 \mathrm{~g}$ \\
\hline \multirow{2}{*}{ COD } & TAN1 & $2372 \pm 938$ & $1708 \mathrm{a} \pm 861$ & $2045 \mathrm{a} \pm 1205$ & $845 \mathrm{a} \pm 369$ & $300 \mathrm{a} \pm 167$ & $250 \mathrm{a} \pm 154$ \\
& TAN2 & $1406 \pm 208$ & $1195 \mathrm{a} \pm 208$ & $1125 \mathrm{a} \pm 384$ & $1055 \mathrm{a} \pm 317$ & $956 \mathrm{a} \pm 310$ & $870 \mathrm{ab} \pm 240$ \\
& TAN3 & $3532 \pm 1373$ & $2374 \mathrm{a} \pm 1344$ & $1976 \mathrm{a} \pm 1405$ & $2757 \mathrm{a} \pm 1266$ & $3134 \mathrm{a} \pm 1595$ & $2614 \mathrm{~b} \pm 1105$ \\
BOD & TAN1 & $13.85 \pm 6.42$ & $6.92 \mathrm{a} \pm 5.49$ & $6.42 \mathrm{a} \pm 5.07$ & $5.72 \mathrm{a} \pm 5.35$ & $4.62 \mathrm{a} \pm 4.37$ & $2.82 \mathrm{ab} \pm 1.26$ \\
& TAN2 & $19.46 \pm 0.50$ & $1.75 \mathrm{~b} \pm 0.22$ & $1.73 \mathrm{~b} \pm 0.18$ & $1.58 \mathrm{a} \pm 0.16$ & $1.91 \mathrm{a} \pm 0.22$ & $1.56 \mathrm{~b} \pm 0.20$ \\
& TAN3 & $17.13 \pm 3.14$ & $4.24 \mathrm{ab} \pm 0.77$ & $3.29 \mathrm{ab} \pm 0.37$ & $4.11 \mathrm{a} \pm 0.07$ & $3.23 \mathrm{a} \pm 0.91$ & $3.33 \mathrm{a} \pm 1.28$ \\
SS & TAN1 & $374 \pm 124$ & $243 \mathrm{a} \pm 45$ & $471 \mathrm{a} \pm 226$ & $475 \mathrm{a} \pm 182$ & $492 \mathrm{a} \pm 128$ & $611 \mathrm{a} \pm 217$ \\
& TAN2 & $358 \pm 335$ & $460 \mathrm{a} \pm 400$ & $543 \mathrm{a} \pm 414$ & $544 \mathrm{a} \pm 402$ & $551 \mathrm{a} \pm 414$ & $554 \mathrm{a} \pm 405$ \\
& TAN3 & $780 \pm 739$ & $586 \mathrm{a} \pm 594$ & $758 \mathrm{a} \pm 656$ & $787 \mathrm{a} \pm 676$ & $861 \mathrm{a} \pm 635$ & $898 \mathrm{a} \pm 672$ \\
TDS & TAN1 & $3941 \pm 3703$ & $51 \mathrm{a} \pm 10$ & $53 \mathrm{a} \pm 10$ & $55 \mathrm{a} \pm 15$ & $61 \mathrm{a} \pm 20$ & $63 \mathrm{a} \pm 26$ \\
& TAN2 & $3300 \pm 1714$ & $83 \mathrm{a} \pm 78$ & $47 \mathrm{a} \pm 20$ & $48 \mathrm{a} \pm 22$ & $47 \mathrm{a} \pm 17$ & $48 \mathrm{a} \pm 17$ \\
& TAN3 & $2653 \pm 1240$ & $46 \mathrm{a} \pm 11$ & $55 \mathrm{a} \pm 24$ & $55 \mathrm{a} \pm 25$ & $58 \mathrm{a} \pm 23$ & $61 \mathrm{a} \pm 28$ \\
\hline
\end{tabular}

Replicate $=6$ (months)

Within the rows, for the same parameter, means with different alphabets are statistically different $(p<0.05)$.

$\mathrm{P}=$ parameter, IND = Industries 
BAJOPAS Volume 13 Number 2, December, 2020

Table 4: Correlation coefficient $(r)$ between different masses of the bacteria and the physicochemical parameters.

\begin{tabular}{llll}
\hline Industries & Parameter & Correlation coefficient $(r)$ & $\begin{array}{l}\text { Percent dependence (rxrx100) } \\
(\%)\end{array}$ \\
\hline TAN1 & COD & -0.9 & 82 \\
& BOD & -0.97 & 94 \\
& SS & $0.90^{*}$ & 80 \\
TAN2 & TDS & $0.98^{*}$ & 96 \\
& COD & -1 & 100 \\
& BOD & -0.21 & 4 \\
& SS & $0.78^{*}$ & 61 \\
& TDS & -0.69 & 47 \\
& COD & $0.60^{*}$ & 36 \\
& BOD & -0.6 & 37 \\
& SS & $0.95^{*}$ & 90 \\
& TDS & $0.94^{*}$ & 89 \\
\hline
\end{tabular}

The correlation coefficient $(r)$ with * is statistically significant $(p<0.05)$.

Percentage reduction of the Parameters

Table 5 shows the percentage reduction of Parameters in industrial samples before and after the treatment of the effluents $(250 \mathrm{ml})$ with the different masses $(5 \mathrm{~g}, 10 \mathrm{~g}, 15 \mathrm{~g}, 20 \mathrm{~g}$, and $25 \mathrm{~g}$ ) of the Immobilized Bacteria.

In TAN1 samples, the percentage reduction (\%) of COD ranged (14-89); BOD (50-80); SS (-32$35)$ and TDS (98-99). In TAN2 samples, the percentage decrease $(\%)$ of COD ranged (15$38) ;$ BOD (90-92); SS [-28-(-55)] and TDS (9798). In TAN3 samples, the percentage decrease (\%) of COD ranged (11-44); BOD (76-81); SS (15-25) and TDS (98). The percentage increase in the levels COD, BOD and TDS might be due to the increase in the surface area of the different masses of the immobilized bacteria. However, the percentage decrease in the levels of the SS might be due to the aggregation of the TDS which are large enough to result into SS. The percentage decrease in the levels of the SS might be also due to the influence of the nutrients which was added into the effluents in order to make the microorganisms more active and viable for fast degradation of organic contaminants in the effluent. This is in line with the work of Jimoh et al. (2018) in which the concentration of the SS increase after the bioremediation of effluents.

Sreemoyee and Priti (2013) assessed and reduced several Physico-chemical parameters of dairy wastewater using Niesseria $s p$. and concluded that the species are well known to degrade organic compounds. This is in agreement with the current study in which the immobilized Niesseria $s p$ degrade the organic contaminants as indicated by the BOD, COD and TDS.

Jimoh et al. (2018) observed that TSS of the effluents was increased after treatment with immobilized bacteria and concluded that it might be due to the biostimulation method adopted for the research.

The optimum $\mathrm{pH}$ Biosorption of Chromium by Bacillus spp and Staphylococcus spp. from tannery effluent was investigated by Mythili and Karthikeyan (2011). The maximum adsorption of Chromium $(86.4 \mathrm{mg} / \mathrm{L})$ was showed by Bacillus spp and Staphylococcus spp showed $70.6 \mathrm{mg} / \mathrm{L}$ at an initial concentration of $100 \mathrm{mg} / \mathrm{L}$. In the present study, immobilised Bacillus spp and Staphylococcus spp. from the tannery industrial effluents reduced the levels of the organic pollutants with high potential as indicated by the percentage reduction of BOD, COD and TDS.

Enzymes often can work in multiple environments especially if they are immobilized. This makes the microorganisms' enzymes even more resistant to harsh environments and enables the enzymes to be recovered and recycled after they are no longer needed (Gianfreda and Rao 2004). Ramesh and Singh (1993) reported that the immobilized bacteria having more efficiency to remove the suspended particles than free cells. Using the immobilized cell is preferable due to its capability for using several times with the same efficiency, which makes it more economical. Similar work was done by Sikander et al. (2007) showing the higher reduction with permeabilized cells of Ochrobactrum intermedium strain SDCr-5. 
BAJOPAS Volume 13 Number 2, December, 2020

The results revealed the isolation and identification of isolates with the potential for the reduction of $\mathrm{Cr}$ (VI) to $\mathrm{Cr}$ (III). Results indicated that immobilized $B$. cereus could be efficiently used for the reduction of $\mathrm{Cr}$ (VI).

Table 5: Percentage reduction of the tested Parameters from the tannery industrial samples of the Immobilized Bacteria.

\begin{tabular}{lllllll}
\hline \multirow{2}{*}{ Industries } & & \multicolumn{5}{c}{ Percentage Reduction $(\%)$} \\
\cline { 3 - 7 } & & $5 \mathrm{~g}$ & $10 \mathrm{~g}$ & $15 \mathrm{~g}$ & $20 \mathrm{~g}$ & $25 \mathrm{~g}$ \\
\hline TAN1 & COD & 28 & 14 & 64 & 87 & 89 \\
& BOD & 50 & 54 & 59 & 67 & 80 \\
& SS & 35 & -26 & -27 & -32 & -63 \\
& TDS & 99 & 99 & 99 & 98 & 98 \\
TAN2 & COD & 15 & 20 & 25 & 32 & 38 \\
& BOD & 91 & 91 & 92 & 90 & 92 \\
& SS & -28 & -52 & -52 & -54 & -55 \\
& TDS & 97 & 99 & 99 & 99 & 99 \\
& COD & 33 & 44 & 22 & 11 & 26 \\
& BOD & 75 & 81 & 76 & 81 & 81 \\
& SS & 25 & 3 & -1 & -10 & -15 \\
& TDS & 98 & 98 & 98 & 98 & 98 \\
\hline
\end{tabular}

Percentage Reduction $=(B-A) / B \times 100 \%$

$A=$ Concentration of the parameter after treatment

$\mathrm{B}=$ Concentration of the parameter before treatment

$+=$ percentage decrease

- = percentage increase

In general, immobilization makes the enzyme more resistant to temperature, $\mathrm{pH}$, and substrate concentration swings giving it a longer lifetime and higher productivity per active unit (Gianfreda and Rao, 2004; FuIlbrook, 1996; Russell et al, 2003; Kandelbauer et al., 2004). Immobilized cells have been used and studied extensively for the production of useful chemicals (Ohtake and Silver, 1994), the treatment of wastewaters (Chen et al., 2003; Wang et al., 2010). Although many workers described microbial degradation of tannery effluent, limited literature is available on the bioremediation of tannery effluent using immobilized bacterial cells in the Kano Industrial Estates.

\section{CONCLUSION}

The samples contained variable levels of the physicochemical parameters. The results of the Analysis of variance revealed that, no statistical difference $(p<0.05)$ was observed for the temperature, $\mathrm{pH}, \mathrm{SS}, \mathrm{TDS}, \mathrm{BOD}$ and $\mathrm{COD}$ among the three tannery industries before the treatment. The levels of some of the parameters
(SS, TDS and COD) observed in the samples were found above the recommended limits of WHO and NESREA, which called for the treatment of the effluents before discharge into the environment. Base on the morphological and biochemical test results, TAN1, TAN2, and TAN3 bacterial isolates were identified to be Neisseria spp, Bacillus cereus, and Staphylococcus aureus respectively. The results of Post-treatment analysis showed that there is overall decrease in the levels of the parameters determined when compared with that of the pre-treatment. The overall percentage reduction of the immobilised bacteria in the treatment of the respective effluents was in the order TAN2 (72\%)>TAN1 $(70 \%)>$ TAN3 $(62 \%)$. Hence, the immobilized bacteria are having higher biodegradation potential for the treatment of the tannery effluents.

\section{Acknowledgments}

The authors wish to acknowledge the University of Maiduguri for the financial support. The authors are grateful to the Kano State Ministry of Environment for their support in obtaining the effluent samples. 


\section{REFERENCES}

Ajao, A. T., Adebayo, G. B., and Yakubu, S. E. (2011). Bioremediation of textile industrial effluent using mixed culture of Pseudomonas aeruginosa and Bacillus subtilis immobilized on agar-agar in a bioreactor. J. Microbiol. Biotech. Res, 1(3), 50-56.

Akan, J. C., Moses, E. A., Ogugbuaja, V. O., and Abah, J. (2007). Assessment of tannery industrial effluents from Kano metropolis, Kano State, Nigeria. Journal of Applied Sciences, 7(19), 2788-2793.

Akan, J. C., Ogugbuaja, V. O., Abdulrahman, F. I., and Ayodele, J. T. (2009). Pollutant levels in effluent samples from tanneries and textiles of Kano industrial areas, Nigeria. Global journal of pure and applied sciences, 15(3-4).

APHA (1989). Standard methods for Examination of Will bete and Will betewater.15 $5^{\text {th }}$ edition. Brydpass Springfield Will behington DC. pp. 164-176

APHA (1992). Standard Methods for the Examination of Water and Wastewater. Health, 69, 1116-9.

Baba, A., Garba, S. T., and Bello, H. S. (2020). Bioremediation Potential of Immobilized corynebacterium kutsceri in the Treatment of Tannery Industrial Effluent from Challawa Industrial Estate, Kano State, Nigeria. Journal of the Turkish Chemical Society Section A: Chemistry, $7(2), 335-350$.

Beem, E. I. V. (1994). reduction of solvent VOC emission. J. Oil Col. Chem. Ass, 77, 158.

Bouwer, E. J., and Zehnder, A. J. (1993). Bioremediation of organic compoundsputting microbial metabolism to work. Trends in biotechnology, 11(8), 360367.

Chen, K. C., Wu, J. Y., Liou, D. J., and Hwang, S. C. J. (2003). Decolorization of the textile dyes by newly isolated bacterial strains. Journal of Biotechnology, 101(1), 57-68.

Dan'Azumi, S., and Bichi, M. H. (2010). INDUSTRIAL POLLUTION AND HEAVY METALS PROFILE OF CHALLAWA RIVER IN KANO, NIGERIA. Journal of Applied Sciences in Environmental Sanitation, $5(1)$.

DWAF. (1992). Analytical Methods Manual, TR 151. Department of Water Affairs and Forestry, Pretoria.

El-Bestawy, E. (2013). Biological treatment of leather-tanning industrial wastewater using free living bacteria.
Elsheikh, M. A. S. (2009). Tannery wastewater pre-treatment. Water Science and Technology, 60(2), 433-440.

FuIlbrook, P. D. (1996). "Kinetics." Industrial enzymology: The application of enzymes in Industry. 2nd Ed. T. Godfrey and J Reichelt. eds.. Nature. New York.

Gianfreda, L., and Rao, M. A. (2004). Potential of extra cellular enzymes in remediation of polluted soils: a review. Enzyme and microbial technology, 35(4), 339354.

Hugo Springer. (1994). John Arthur Wilson Memorial Lecture "Treatment of Industrial Wastes of the Leather Industry - is it still a Major Problem". JALCA, 89, 153-185

Jimoh, A. A., Ganiyu, B. A., Baba, D., and Baba, A. (2018) Bioremediation Process of Effluent from Detergent and Food Industries in Jos, Nigeria: Kinetics and Thermodynamics. International Journal of Engineering Science Invention (IJESI), 762-73

Kandelbauer, A., Maute, O., Kessler, R. W., Erlacher, A., and Gübitz, G. M. (2004). Study of dye decolorization in an immobilized laccase enzyme-reactor using online spectroscopy. Biotechnology and bioengineering, 87(4), 552-563.

Kongjao, S., Damronglerd, S., and Hunsom, M. (2008). Simultaneous removal of organic and inorganic Pollutants in tannery wastewater using electrocoagulation technique. Korean Journal of chemical engineering, 25(4), 703.

Maheshwari, U. M., Aruna, S., Gomathi, M., and AbdulJaffar, A. H. (2017). Bioremediation by Free and Immobilized Bacteria Isolated from Tannery Effluent. International Journal of Research in Applied, Natural and Social Sciences. 5(7), 75-90

Margesin, R., and Schinner, F. (2001). Bioremediation (natural attenuation and biostimulation) of diesel-oilcontaminated soil in an alpine glacier skiing area. Applied and environmental microbiology, 677), 3127-3133.

Mohammed, A., Sekar, P., and George, J. (2011). Efficacy of microbes in bioremediation of tannery effluent. Inter. J. Curr. Res, 3(4), 324-326.

Mohammed, S. S. D., Orukotan, A. A., and Abdullahi, H. (2017). Physicochemical and Bacteriological Assessment of Tannery Effluent from Samaru-Zaria, 
BAJOPAS Volume 13 Number 2, December, 2020 Kaduna State, Nigeria. Journal of Applied

Sciences and Environmental Management, 21(4), 734-740.

Munz, G., De Angelis, D., Gori, R., Mori, G., Casarci, M., and Lubello, C. (2009). The role of tannins in conventional and membrane treatment of tannery wastewater. Journal of hazardous materials, 164(2-3), 733-739

Mythili, K., and Karthikeyan, B. (2011). Bioremediation of $\mathrm{Cr}$ (VI) from tannery effluent using Bacillus spp and Staphylococcus spp. International Multidisciplinary Research Journal, 1(6).

NESREA (2009). National Environmental Standards for Effluent Limitations and Regulation. 1233-1236

Noorjahan, C. M. (2014). Physicochemical characteristics, identification of bacteria and biodegradation of industrial effluent. Journal of bioremediation and Biodegradation, 5(3).

Ohtake, H. I., and Silver, A. O. (1994). Bacterial reduction of toxic chromate. Biological degradation and bioremediation of toxic chemicals, 403-415.

Omoleke, I. I. (2004). Management of environmental pollution in Ibadan, an African city: the challenges of health hazard facing government and the people. Journal of Human Ecology, 15(4), 265-275.

Rajor, A., Reddy, A.S., and Singh, B. (2004). Determination of BOD kinetic Parameters and evaluation of alternate methods, M.Sc. Thesis, Department of biotechnology \& environmental Science, Thapar Institute of Engineering and Technology, Patiala

Ramasami, T., Rajamani, S., and Rao, J. R. (1994, March). Pollution control in leather industry: Emerging technological options. In International symposium on surface and colloidal science and its relevance to soil pollution, madras.

Ramesh, J. V. S., and Singh, S. P. (1993). Yearly variation in certain physicochemical parameters of pond at eastern Doon Valley. Uttar Pradesh J. Zoo, 12 (1), 7577.

Ranen, S., and Sharadinadra, C. (2009). Biotechnology applications to environmental remediation in resource exploitation. Current science, 97, 6-25
Russell, A. J., Berberich, J. A., Drevon, G. F., and Koepsel, R. R. (2003). Biomaterials for mediation of

chemical and biological warfare agents. Annual review of biomedical engineering, 5(1), 1-27.

Saravanan, P., and Saravanan, A. (1999). Decolourization of tannery effluent by Flavobacterium sp. EK 1. Indian Journal of Environmental Protection, 19, 19-24.

Sikander, S., and Shahida, H. (2007). Reduction of toxic hexavalent chromium by Ochrobactrum intermedium strain SDCr5 stimulated by heavy metals. Bioresource Technol, 98, 340-344.

Singh, N., Sharma, B. K., and Bohra, P. C. (2000). Impact assessment of industrial effluent of arid soils by using satellite imageries. Journal of the Indian Society of Remote Sensing, 28(2-3), 79.

Sreemoyee, C., and Priti, P. (2013). Assessment of physico-chemical parameters of dairy waste water and isolation and characterization of bacterial strains in terms of cod reduction. Int J Sci, 2(3), 395-400.

Verheijen, L. A. H. M., Wiersema, D., Pol, L. H., and De Wit, J. (1996). Management of wastes from animal product processing. Livestock and environment, Finding a balance. International Agriculture Center, Wageningen, The Netherlands.

Wang, F., Yao, J., Si, Y., Chen, H., Russel, M., Chen, K., and Bramanti, E. (2010). Short-time effect of heavy metals upon microbial community activity. Journal of Hazardous Materials, 173(13), 510-516.

WHO (World Health Organization). (2006). Air quality guidelines: global update 2005: particulate matter, ozone, nitrogen dioxide, and sulfur dioxide. World Health Organization.

World Bank. (1995). Nigeria's strategic options for redressing industrial pollution. World Bank, industry and energy division. 1st edition, West Central Africa Department; Annexes: 1995; pp 60-62.

Zahoor, A., and Abdul, R. (2009). Enumeration of Coliforms. Journal of Environmental Sciences. 21, 814-820 


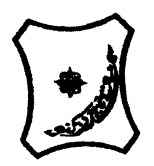

Bayero Journal of Pure and Applied Sciences, 13(2): 1 - 12

Received: November, 2020

Accepted: December, 2020

ISSN $2006-6996$

\title{
BIODEGRADATION POTENTIAL OF IMMOBILIZED BACTERIA IN THE TREATMENT OF TANNERY INDUSTRIAL EFFLUENTS FROM INDUSTRIAL ESTATES IN KANO STATE, NIGERIA
}

\author{
Abdullateef, B., ${ }^{1 *}$ Shuaibu, T. G., ${ }^{1}$ Babagana, K., ${ }^{1}$ Suleman, H. B. ${ }^{2}$ and Dauda, B. ${ }^{3}$ \\ ${ }^{1}$ Department of Pure and Applied Chemistry, Faculty of Science, University of Maiduguri, Borno State, \\ Nigeria \\ ${ }^{2}$ Department of Microbiology, Faculty of Science, University of Maiduguri, Borno State, Nigeria \\ ${ }^{3}$ Department of Chemical Engineering, Faculty of Engineering, University of Maiduguri, Borno State, \\ Nigeria \\ *Corresponding author: babslega@gmail.com; abelega2007@yahoo.com; +2348061309753
}

\section{ABSTRACT}

Industrial Effluents Samples from Gashash Tanneries (TAN1) in Bompai Industrial estate, Larabee Tannery Industry (TAN2) in Sharada Industrial estate and Z Tannery Industries (TAN3) in Challawa Industrial estate, Kano State, Nigeria were collected over a period of six months (August 2017 to January 2018) for assessing the biodegradation potentials of bacteria in the treatment of organic pollutants within the effluents. Bacteria were isolated from the effluents and immobilized on agar-agar. Different masses (5 g, $10 \mathrm{gr}, 15$ $\mathrm{g}, 20 \mathrm{~g}$, and $25 \mathrm{~g}$ ) of the bacteria were used in the treatment of $250 \mathrm{ml}$ of the effluents for ten days in a shaker incubator (Gallenkamp-OC-4364-L) at the temperature $30{ }^{\circ} \mathrm{C}$ and speed of $60 \mathrm{rpm}$. Pre-treatment analysis of the effluents for Temperature, pH, Biochemical Oxygen Demand (BOD), Chemical Oxygen Demand (COD), Suspended Solid (SS) and Total Dissolved Solids (TDS) gives the following results; temperature $\left({ }^{\circ} \mathrm{C}\right.$ )

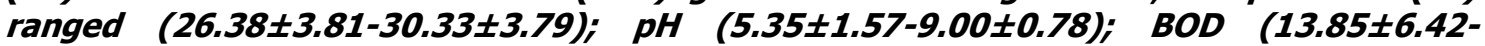
$38.75 \pm 16.20) ;$ COD (1406 $\pm 208-3532 \pm 1373) ;$ SS (208 $\pm 235-780 \pm 739)$ and TDS (266 $\pm 253-5276 \pm 2971)$. No statistical differences ( $p \leq 0.05)$ was observed for all the results among the different industries. The bacterial isolates were identified as Neisseria spp, Bacillus cereus, and Staphylococcus aureus, in TAN1, TAN2, and TAN3, respectively. After treatment of the effluent with the different masses of the isolated bacteria, the mean level of BOD was found to range as (0.55 $\pm 0.36-6.92 \pm 5.49) ; C O D$ (ND-3134 \pm 1595$)$;

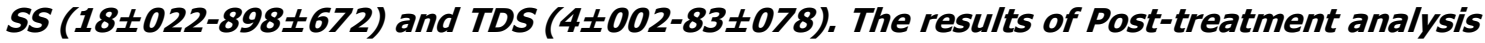
showed that there is overall decrease in the levels of the parameters determined when compared with that of the pre-treatment. The overall percentage reduction of the immobilised bacteria in the treatment of the respective effluents was in the order TAN2 (72\%)>TAN1 (70\%)>TAN3 (62\%). Hence, the immobilized bacteria are having higher biodegradation potential for the treatment of the tannery effluents.

Keywords: Biodegradation, bacteria, effluent, immobilization, tannery.

\section{INTRODUCTION}

Tannery industrial wastewater is a serious consequence of the pollution point of view for streams, freshwater, and land used for agriculture. The lack of awareness in the modern industrial practice has resulted in the discharge of tannery effluents which exhibit very high value of chromium ( $\mathrm{Cr}$ ), Sulfide, and chloride, Total Dissolved Solid (TDS), Total Suspended Solid (TSS), Biochemical Oxygen Demand (BOD) and Chemical Oxygen Demand (COD) in the water stream or land (Mohammed et al., 2001). Tanning is the process, which One ton of skin generally leads to the production of 20 to $80 \mathrm{~m}^{3}$ of turbid and foul-smelling converts the protein of the rawhide or skin into a stable material, which will not putrefy and is suitable for a wide variety of end applications (Elsheikh, 2009). The highly polluting chromium is the most commonly used tanning material producing leather that is more flexible and pliable than vegetable-tanned leather and does not discolor or lose shape in water as drastically as vegetable-tan (Elsheikh, 2009). Tannery effluent is among the most hazardous industrial pollutants due to its huge organic and inorganic load, which is highly toxic to human life and the environment (Kongjao et al., 2008). wastewater including chromium (100-400 mg/l), sulfide $(200-800 \mathrm{mg} / \mathrm{l})$, high levels of fat and 
BAJOPAS Volume 13 Number 2, December, 2020 other solid wastes, and notable pathogen contamination as well as pesticides added for skin conservation during transport (Elsheikh, 2009). There are more than 6000 tanneries in Nigeria with an annual processing capacity of 700,000 tons of hides and skins (Omoleke, 2004; Singh et al., 2008). It was reported that the total amount of waste produced per animal slaughtered is approximately $35 \%$ of its weight (World Bank, 1995). Also, for every $1000 \mathrm{~kg}$ of carcass weight, a slaughtered beef produces 5.5 $\mathrm{kg}$ of manure (excluding rumen contents or stockyard manure) and $100 \mathrm{~kg}$ of paunch manure (undigested food) (Verheijen et al., 1996). Tanneries generate wastewater in the range of 30-35 $\mathrm{L} \mathrm{kg}^{-1}$ skin/hide processed with variable $\mathrm{pH}$, Biological Oxygen Demand (BOD), Chemical Oxygen Demand (COD), high concentrations of suspended solids (SS), and tannins as well as chromium (Zahoor and Abdul, 2009).

Being heterogeneous and composed of a wide variety of compounds, it is very difficult to select a unique direct method for estimating the biodegradability of organic contents and biokinetic parameters for a wastewater sample (Rajor, 2004). For this purpose, some indirect estimation such as determination of biochemical oxygen demand (BOD) and chemical oxygen demand (COD) are applied as common laboratory investigations [9]. During retanning procedures, synthetic tannins (Syntan), oils and resins are added to form softer leather at varying doses (Munz et al., 2009). One of the refractory groups of chemicals in tannery effluents derives mainly from tannins (Ramasami et al., 2004). Syntans are characterized by complex chemical structures, because they are composed of an extended set of chemicals such as phenol-, naphthalene-, formaldehyde- and melamine-based syntans, and acrylic resins (Beem, 1994). Organic pollutants (proteic and lipidic components) are originated from skins (it is calculated that the raw skin has $30 \%$ loss of organic material during the working cycle) or they are introduced during processes (Hugo Springer, 1994).

Many conventional processes such as oxidation, chemical and biological processes were carried out to treat tanneries wastewater (Ebtesam et al, 2013). Biological processes have received more attention because of their costeffectiveness, lower sludge production and environmental friendliness (Noorjahan, 2014). Naturally occurring micro-organisms degrade the hazardous organic wastes including xenobiotic compounds, such as pesticides, polycyclic aromatic hydrocarbons (PAHs) and polychlorinated biphenyls (PCBs) in due course of time (Ranen and Sharadinadra, 2009). Bioremediation is based on the idea that all organisms remove substances from the environment to carry outgrowth and metabolism (Bouwer and Zehnder, 1993). Bacteria, protista and fungi are found to be very good at degrading complex molecules and incorporating the breakdown products into their metabolism (Bouwer and Zehnder, 1993). The resultant metabolic wastes that they produce are generally safe and somehow recycled into other organisms (Ranen and Sharadinadra, 2009). An acclimatized indigenous population of microorganisms capable of degradation of the compounds of interest must exist at the site for a successful bioremediation mode (Ranen and Sharadinadra, 2009). It has been observed that for a successful bioremediation mode, an acclimatized indigenous population of microorganisms capable of degradation of the compounds of interest must exist at the site under investigation (Ranen and Sharadinadra, 2009). Even though there are numerous physical and chemical methods employed in the disposal of wastes the advantage in using bacterium is that they play a key role in the reduction of COD, BOD, total protein, total tannin and total phenol (Saravanan and Saravanan, 1998)

Baba et al. (2020) studied the bioremediation potential of immobilized corynebacterium kutsceri in the Treatment of tannery industrial effluent from Challawa Industrial Estate, Kano State, Nigeria. The aim of the work is to study the reduction in the level of the contaminants through the process of bioremediation using the isolated bacteria. Immobilized bacteria can withstand various temperatures, $\mathrm{pH}$ and substrate concentrations; consequently, increasing the efficiency and the lifespan of the bacteria. Immobilized bacteria are widely applied in the treatment of wastewater and can be separated and recovered after the treatment with the same efficiency (Baba et al., 2020).

\section{MATERIALS AND METHODS \\ Study Area}

This study was carried out in Bompai, Sharada and Challawa industrial estates in Kano, Figure 1. Kano lies on Latitude $11^{\circ} 30^{\prime} \mathrm{N}$ and $8^{\circ} 30^{\prime} \mathrm{E}$ and Longitude $11^{\circ} 5^{\prime} \mathrm{N}$ and $8^{\circ} 5^{\prime} \mathrm{E}$ in Northern Nigeria. It is one of the developed industrial cities in Nigeria. Tannery activities are the dominating industries and this could be one of the reasons for her high population density (Dan'Azumi and Bichi, 2010). Many researchers have studied biodegradation of tannery effluent using microorganisms. However, limited literature is available on the biodegradation of tannery effluent in Kano industrial estates using 
BAJOPAS Volume 13 Number 2, December, 2020 immobilized bacterial cells. This research work focuses on the potential of the use of the indigenous immobilized bacterial isolates in the treatment of tannery effluents in the industrial estates.

\section{Sample Collection}

Effluents were collected from the Tannery Industries from Bompai, Challawa and Sharada Industrial Estates, Kano, Nigeria. The effluents were collected over a period of six months (August 2017 to January 2018). Samples collected in a sterile 4-liter plastic container with a unique identification number were preserved using an ice-box that was transported to the Microbiology Laboratory, Department of Microbiology, Bayero University of Kano for analysis

\section{Sample Preparation and Sample Analysis}

Immediately after the collection of the effluent, $\mathrm{pH}$, TSS, TDS, COD, BOD levels were determined before treatment (Pre-treatment determination) and ten days after treatment (Post-treatment determination) as described in
APHA (1989) standard methods. $\mathrm{pH}$ was determined using Ecotests $\mathrm{pH}$ meter and TDS was determined using AQUALYTIC TDS Salinometer. BOD was determined as described by the standard method (APHA, 1992). COD and SS were determined using DR/2010 HACH portable data logging spectrophotometer (DWAF, 1992)

\section{Identification and Biochemical} Characterization of the Bacterial Isolates

The bacteria were isolated from the effluents using Serial Dilution according to the method described by APHA (1989). The biochemical tests such as oxidase, catalase, coagulase, indole (from $1 \%$ tryptone broth), citrate (Simmons citrate agar), methyl red/VogesProskauer (MR/VP), nitrate reduction, Starch Hydrolysis, Glucose, Maltose, and Lactose tests were carried out on the bacterial isolates to identify the bacteria through the bacteria biochemical characteristics according to Ajao et al. (2011).

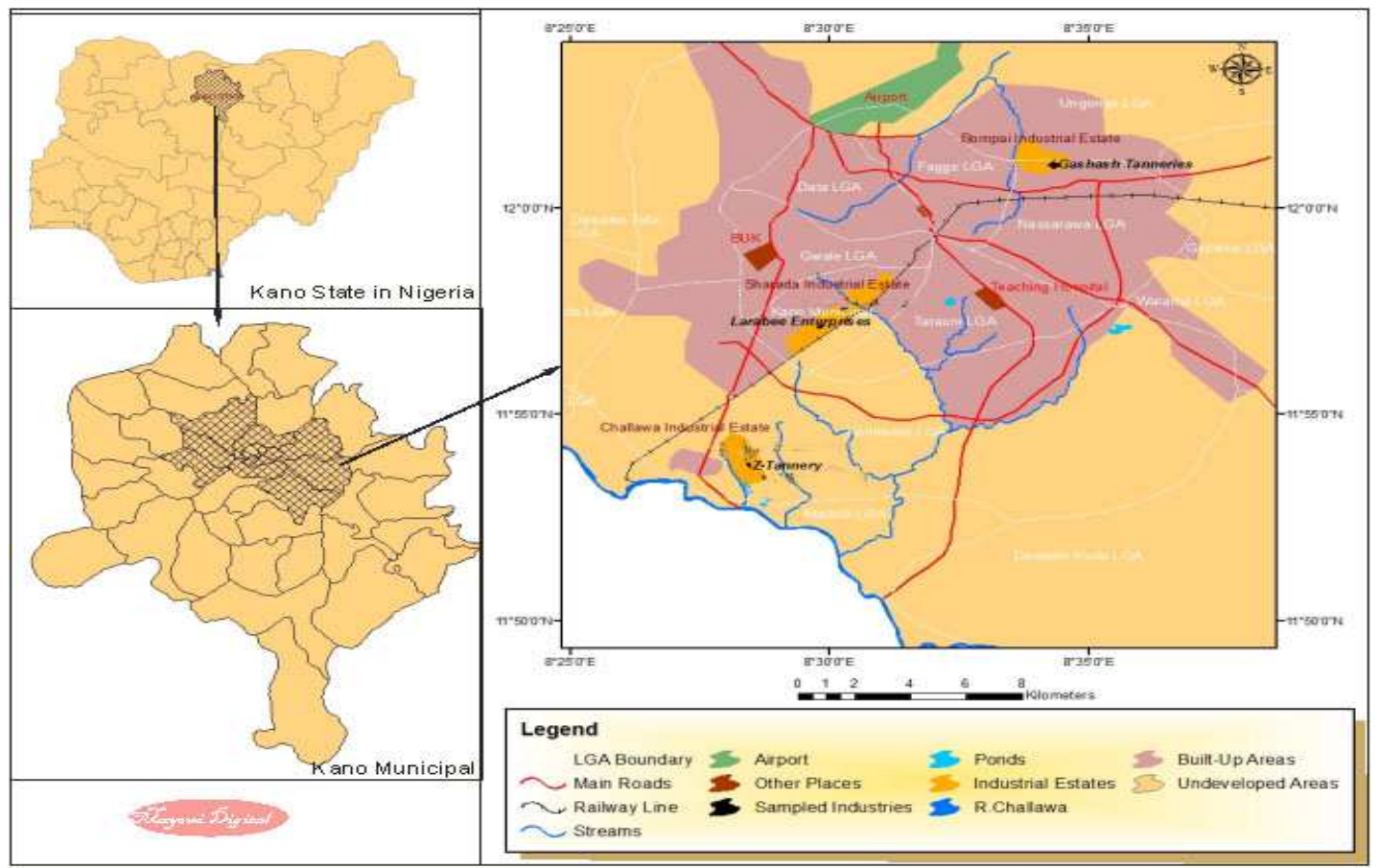

Fig. 1 Map showing the study areas

Source: Mayomi Digital Productions, GIS Laboratory, Department of Geography, UNIMAID (2017)

\section{Determination of Growth Rate of the Bacteria in Effluent Sample}

The bacteria growth rates were determined by transferring $2 \mathrm{~mL}$ of the bacterial isolates from the tannery effluent in broth medium into 100 $\mathrm{mL}$ sterile effluents in conical flasks and kept in an incubator (Giffrin cool) for 10 days. Control was also set up by incubating another $100 \mathrm{~mL}$ each of the sterile effluents without the bacteria. The optical density of the content was determined at the wavelength of $600 \mathrm{~nm}$ on a daily interval and recorded. 
BAJOPAS Volume 13 Number 2, December, 2020 Immobilization of Bacteria

Agar solution and inoculi were prepared separately. Fifty milliliters $(50 \mathrm{~mL})$ of nutrient broth each of the inoculi was prepared in a McCartney bottle and incubated for 24 hours. A solution of agar-agar was prepared by dissolving $10 \mathrm{~g}$ of the powder in distilled water and made up to $500 \mathrm{~mL}$ mark in an Erlenmeyer flask and was sterilized in an autoclave (280A) for 15 minutes and allowed to cool to $40-45^{\circ} \mathrm{C}$ (Ajao et al., 2011). Four milliliters ( $4 \mathrm{~mL})$ of the bacterial isolates in the nutrient broth was mixed with 36 $\mathrm{ml}$ of the prepared agar-agar media in petri-dish plates and then allowed to solidify. This was kept in the refrigerator for bioremediation.

\section{Bioremediation (Treatment) of the Effluents}

The solidified agar block (immobilized bacteria) was cut into cubes using a sterile knife; $0.1 \mathrm{~mL}$ phosphate buffer ( $\mathrm{pH} \mathrm{7.0)}$ was added and kept in the refrigerator for 1 hour for curing. The phosphate buffer was decanted after 1 hour and the cubes were washed with sterile distilled water 3-4 times before it was used (Ajao et al., 2011). Two liters (2 L) of the effluent was supplemented with the minimum basal medium in $\mathrm{g} / \mathrm{L}: \mathrm{NaCl}(0.8), \mathrm{MgSO}_{4} .7 \mathrm{H}_{2} \mathrm{O}(0.001), \mathrm{KH}_{2} \mathrm{PO}_{4}$ (2), $\mathrm{NaNO}_{3}$ (2), $\quad \mathrm{CaCl}_{2} .2 \mathrm{H}_{2} \mathrm{O} \quad(0.5)$ and $\mathrm{NaHPO}_{4} .12 \mathrm{H}_{2} \mathrm{O}(2)$ and sterilized in an autoclave at $121^{\circ} \mathrm{C}$ for 15 minutes (Margesin and Schinner, 2001). Two hundred and fifty milliliters $(250 \mathrm{~mL})$ of the effluents were transferred into different $250 \mathrm{ml}$ conical flasks. The content was covered with a cotton-wool ramped with foil paper to avoid contamination. Five grams $(5 \mathrm{~g})$ of the immobilized bacteria were quickly transferred into each of the effluents in the conical flasks in an inoculating chamber. The same procedures were carried out for the $10 \mathrm{~g}, 15 \mathrm{~g}, 20 \mathrm{~g}$ and 25 $\mathrm{g}$ of the immobilized bacteria in separate $250 \mathrm{~mL}$ effluents in conical flasks and agitated for ten days in a shaker incubator (Gallenkamp-OC4364-L) at a temperature $30^{\circ} \mathrm{C}$ and speed of 60 rpm. The treated effluent samples were taken on the tenth day and analyzed for the parameters $\mathrm{pH}$, SS, TDS, COD, and BOD, (Posttreatment determination) for the different grams of bacteria to evaluate and compare the biodegradation potential. (Baba et al., 2020).

\section{Statistical Analysis}

The data were represented as Mean \pm Standard deviation and analyzed statistically using oneway Analysis of Variance (ANOVA) and Tukey's HSD as Post Hoc Tests with the aid of SPSS 16.0. The correlation coefficient was also used to measure the strength of the relationship between the different masses of the bacteria and the parameters. All $\mathrm{p} \leq 0.05$ were considered as statistically significant.

\section{RESULTS AND DISCUSSION Physico-chemical parameters in the Industrial Effluents before the Biodegradation.}

Results of the Physico-chemical parameters in the industrial effluents before the Biodegradation is shown in table 1 . The mean temperatures $\left({ }^{\circ} \mathrm{C}\right)$ observed in TAN1, TAN2, and TAN3 samples were $28.07 \pm 0.65 ; 27.77 \pm 0.64$ and $26.38 \pm 3.81$ respectively. The order of the mean temperature of the samples from the three industries can be arranged as TAN1 > TAN2>TAN3. The temperature observed at TAN1, TAN2, and TAN3 samples were found below the WHO $\left(35^{\circ} \mathrm{C}\right)$ and NESREA $\left(40^{\circ} \mathrm{C}\right)$ limits. The low values of temperature might be due to the processes used at the time of sampling. High temperature brings down the solubility of gases in water that ultimately expresses as high BOD and COD. Statistical analysis shows that there is no significant difference $(p<0.05)$ between the mean values of temperature among the industries. This might be due to similar tannery activities involved in the tannery industries at the time of sampling. The average values of temperature observed in this present study are less than those observed by Akan et al. (2007), Akan et al. (2009) and Baba et al. (2020).

The mean level of $\mathrm{pH}$ observed in TAN1, TAN2 and TAN3, samples were $7.77 \pm 2.93$; $8.35 \pm 0.28$ and $7.52 \pm 0.76$ respectively. The order of the mean $\mathrm{pH}$ of the samples from the three industries can be arranged as TAN2> TAN1 $>$ TAN3. The $\mathrm{pH}$ of the samples falls within the WHO (7.0-8.5) and NESREA (6-9) standard limits. Statistical analysis shows that there is no significant difference $(p<0.05)$ between the mean values of $\mathrm{pH}$ among the industries. This might be due to similar tannery activities involved in the tannery industries at the time of sampling. Maheshwari et al. (2017) reported that the level of $\mathrm{pH}$ in the effluents from the tannery industry in Vaniyambadi, India was 6.5 which was lower than that observed in the present study. The $\mathrm{pH}$ in the effluents from the tannery industries in Kano and Kaduna were reported to be 7.64 and 6.89, respectively (Akan et al., 2007; Mohammed et al., 2017). The average values of $\mathrm{pH}$ observed in this present study are less than those observed by Mohammed et al. (2017) and Baba et al. (2020). The mean level of SS $(\mathrm{mg} / \mathrm{l})$ observed in TAN1, TAN2, and TAN3 samples were 374 \pm 124 ; $358 \pm 335$ and $780 \pm 739$ respectively. The order of the mean SS in the samples from the three industries can be arranged as TAN3 > TAN1 $>$ TAN2. 
The SS observed in the samples were far above the recommended standard limits of regulating bodies WHO $(30 \mathrm{mg} / \mathrm{l})$ and NESREA $(10 \mathrm{mg} / \mathrm{l})$. Statistical analysis shows that there is no significant difference $(p<0.05)$ between the mean values of SS among the industries. This might be due to similar tannery activities involved in the tannery industries at the time of sampling. The average values of SS observed in this present study are less than that observed $(3700 \pm 122 \mathrm{mg} / \mathrm{l})$ by Akan et al. (2009) for tanneries in Kano. Also, the average values of SS observed in this present study are less than that observed by Mohammed et al. (2017) and Baba et al. (2020) with the exception in TAN3.

The mean level of TDS (mg/l) observed in TAN1, TAN2, and TAN3 samples were $3941 \pm 3703$; $3300 \pm 1714$ and $2653 \pm 1240$ respectively. The order of the mean TDS in the samples from the three industries can be arranged as TAN1>TAN2>TAN3. The TDS observed in the samples were far above the recommended standard limits of WHO $(250 \mathrm{mg} / \mathrm{l})$ and NESREA $(500 \mathrm{mg} / \mathrm{l})$. Statistical analysis shows that there is no significant difference $(p<0.05)$ between the mean values of TDS among the industries. This might be due to similar tannery activities involved in the tannery industries at the time of sampling. TDS in the effluents from the tannery industries in Kano, Nigeria was reported to be $1281 \mathrm{mg} / \mathrm{l}$ (Akan et al., 2007). The average values of SS observed in this present study are less than those observed by Mohammed et al. (2017) and Baba et al. 2020)

The mean level of COD (mg/l) observed in TAN1, TAN2 and TAN3 samples seasons were $2372 \pm 938 ; \quad 1406 \pm 208$ and $3532 \pm 1373$ respectively. The order of the mean COD of the samples from the three industries can be arranged as TAN3>TAN1> TAN2. The COD observed in TAN1, TAN2 and TAN3 samples were far above the recommended standard limits of regulating bodies $\mathrm{WHO}(40 \mathrm{mg} / \mathrm{l})$ and NESREA (40 mg/l). Statistical analysis shows that there is no significant difference $(p<0.05)$ in COD among the industries. This might be due to similar tannery activities involved in the tannery industries as at the time of sampling. The Chemical Oxygen demand (COD) is the amount of oxygen, in $\mathrm{mg} / \mathrm{L}$, required for the degradation of the compound of wastewater to occur. In comparison, the average values of COD observed in this present study were higher than that observed by Mohammed et al. (2017) but lower than that observed by Baba et al. (2020).

The mean levels of BOD $(\mathrm{mg} / \mathrm{l})$ observed in TAN1, TAN2 and TAN3 samples were $13.85 \pm 6.42 ; \quad 19.46 \pm 0.50$ and $17.13 \pm 3.14$ respectively. The order of the mean BOD in the samples from the three industries can be arranged as TAN2>TAN3>TAN1. The BOD observed in TAN1, TAN2 and TAN3 samples were found below the recommended limits of NESREA (200 mg/l) but above WHO (10 mg/l). Statistical analysis shows that there is no significant difference $(p<0.05)$ between the mean values of BOD among the industries. This might be due to similar tannery activities involved in the tannery industries at the time of sampling. The low level of BOD recorded in this study is an indication of the low level of biodegradable organic solids in the effluent. The average values of BOD observed in this present study were lower than those observed by Mohammed et al. (2017) and Baba et al. (2020).

Table 1: Mean Values \pm S.D of Physico-chemical parameters of effluents from the Tannery Industries before Treatment.

\begin{tabular}{llllllll}
\hline Parameter & Tannery 1 & Tannery 2 & Tannery 3 & $\mathrm{a}$ & $\mathrm{b}$ & $\mathrm{c}$ & $\mathrm{d}$ \\
\cline { 2 - 7 } Temperature $\left({ }^{\circ} \mathrm{C}\right)$ & $28.07 \mathrm{a} \pm 0.65$ & $27.77 \mathrm{a} \pm 0.64$ & $26.38 \mathrm{a} \pm 3.81$ & & $29.50 \pm 4.68$ & 35 & 40 \\
pH & $7.77 \mathrm{a} \pm 2.93$ & $8.35 \mathrm{a} \pm 0.28$ & $7.52 \mathrm{a} \pm 0.76$ & 6.89 & $5.35 \pm 1.57$ & $7.0-8.5$ & $6.0-9.0$ \\
$\mathrm{COD}(\mathrm{mg} / \mathrm{l})$ & $2372 \mathrm{a} \pm 938$ & $1406 \mathrm{a} \pm 208$ & $3532 \mathrm{a} \pm 1373$ & 2.2 & $3106 \pm 2753$ & 40 & 40 \\
$\mathrm{BOD}(\mathrm{mg} / \mathrm{l})$ & $13.85 \mathrm{a} \pm 6.42$ & $19.46 \mathrm{a} \pm 0.50$ & $17.13 \mathrm{a} \pm 3.14$ & 1032 & $26.17 \pm 9.49$ & 10 & 200 \\
$\mathrm{SS}(\mathrm{mg} / \mathrm{l})$ & $374 \mathrm{a} \pm 124$ & $358 \mathrm{a} \pm 335$ & $780 \mathrm{a} \pm 739$ & 501 & $562 \pm 482$ & 30 & 10 \\
TDS $(\mathrm{mg} / \mathrm{l})$ & $3941 \mathrm{a} \pm 3703$ & $3300 \mathrm{a} \pm 1714$ & $2653 \mathrm{a} \pm 1240$ & 532.7 & $444 \pm 507$ & 250 & 500 \\
\hline
\end{tabular}

The values given in the table above are means of 6 replicate values, $\mathrm{n}=6$ ( 1 sample was taken monthly for 6 months). Within the rows, means with different alphabets are statistically different $(p<0.05)$. WHO: World Health Organisation. NESREA: National Environmental Standard and Regulatory Enforcement Agency. a = Mohammed et al.(2017), b = Baba et al. (2020), c = WHO (2006), $d=$ NESSRA (2009) 
BAJOPAS Volume 13 Number 2, December, 2020

Identification, Biochemical Characterization and growth rates of the Bacterial Isolates

Results of identification and biochemical characterization of the bacterial isolates were shown in table 2. After 24 hours of incubation, the nutrient agar media plates were checked for bacterial growth. The results showed the presence of different strains in the samples. The TAN1 bacteria isolate was found to be gramnegative cocci while TAN3 was gram-positive cocci. TAN2 bacteria isolate was found to be gram-positive, rod-shaped. TAN1, TAN2, and TAN3 bacteria isolates recorded positive results for spore former.

The results of the biochemical tests indicated that all the bacteria were positive for catalase, oxidase, citrate, maltose, glucose, lactose (negative in TAN1), mannitol (negative in TAN2), starch hydrolysis and coagulase (negative in TAN2) tests. The bacteria showed negative results for nitrate reduction, $M R$ (positive in TAN2), VP (positive in TAN1), Indole (positive in TAN2) tests. Base on the morphological and biochemical test results, TAN1, TAN2, and TAN3 bacteria isolates were identified to be Nesseria spp, Bacillus cereus, and Staphylococcus aureus respectively.

The growth rate of the TAN1, TAN2 and TAN3 Isolates were shown in figure 2. Generally, the optical density increase with the increase in time (day) and decrease as time goes on. The highest optical density was shown by bacillus cereus in TAN2 while the lowest was shown by Staphylococcus aureus in TAN3.

The initial growth phase of TAN1 Isolate bacteria occurred within 2-day of incubation as the growth rate increases up to the 6th-day incubation when the maximum growth was observed. Beyond the 6th day, the growth of the bacteria declined (which might be due to a shortage of nutrients in the effluents) until it reached its death phase (which might be due to the unavailability of nutrients in the effluents).

A similar trend of growth was also observed for TAN2 Isolate as the initial growth phase also occurred within 2-day of incubation but maximum growth rate observed on the 4th day of incubation. The stationary stage occurred between the 4th day and the 8th day. Beyond the 8th day, the growth of the bacteria declined (which might be due to a shortage of nutrients in the effluents) until it reached its death phase (which might be due to the unavailability of nutrients in the effluents).

The initial growth phase of TAN3 bacterial Isolate occurred within the 3-day incubation as the growth rate increases up to the 6th-day incubation when the maximum growth was observed. Beyond the 6th day, the growth of the bacteria declined (which might be due to a shortage of nutrients in the effluents) until it reached its death phase (which might be due to the unavailability of nutrients in the effluents).

Table 2: Morphological and Biochemical characteristics of bacterial isolates

\begin{tabular}{lllll} 
Bacterial Isolates & & TAN1 & TAN2 & TAN3 \\
\hline $\begin{array}{lllll}\text { Morphological } \\
\text { characteristics }\end{array}$ & Shape & Cocci & Rod & Cocci \\
& Spore & & & \\
& former & + & + & + \\
Gram & & & \\
Biochemical characteristics & reaction & - & + & + \\
& Citrate & + & + & + \\
& Catalase & + & + & + \\
& Coagulase & + & - & + \\
Starch & + & + & + \\
& Glucose & + & + & + \\
Oxidase & + & + & + \\
& Indo & - & + & - \\
Lactose & - & + & + \\
Manitol & + & - & + \\
Maltose & + & + & + \\
MR & - & + & - \\
VP & + & - & - \\
& Nitrate & - & - & - \\
Reduction & - Neisseria & Bacillus & Staphylococcus \\
& Bacterial & cereus & aureus \\
& name & spp & cas
\end{tabular}

+ = Positive; - = Negative; MR=Methyl Red; VP= Voges-Proskauer 


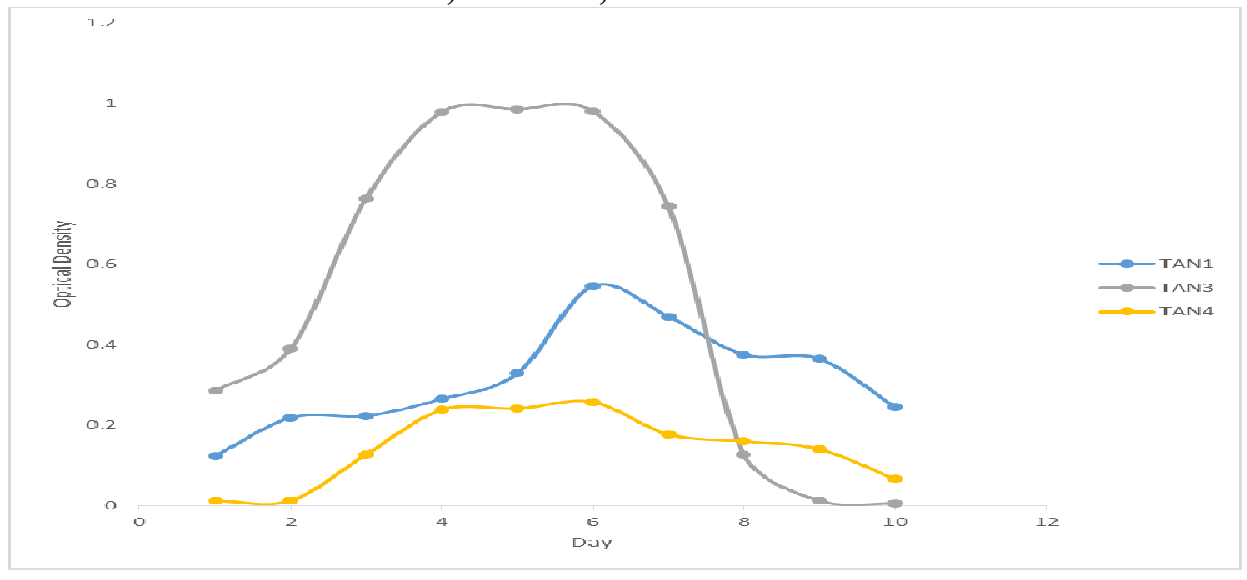

Fig. 2 Growth rates of the isolates in the effluents from the Tannery Industries

\section{Physico-chemical Parameters in the Industrial Effluents after the biodegradation.}

Table 3 shows the mean results of the physicochemical parameter before and after bioremediation using the different masses $(5 \mathrm{~g}$, $10 \mathrm{~g}, 15 \mathrm{~g}, 20 \mathrm{~g}$, and $25 \mathrm{~g}$ ) of the respective immobilized bacteria. Also, Table 4 shows the mean results of correlation coefficient ( $r$ ) between different masses of bacteria and physicochemical parameters.

The mean values $(\mathrm{mg} / \mathrm{l})$ of the SS after the bioremediation varies between $243 \pm 45$ and $898 \pm 672$. The mean concentration $(\mathrm{mg} / \mathrm{l})$ of SS remediated by the different masses $(5 \mathrm{~g}, 10 \mathrm{~g}$, $15 \mathrm{~g}, 20 \mathrm{~g}$, and $25 \mathrm{~g}$ ) of the bacteria varies. The SS in the samples fluctuates up and down after the bioremediation process when compared with the SS of the raw samples before the bioremediation. The increase in the levels of the SS might be due to the aggregation of the TDS which are large enough to result into SS. The increase in the levels of the SS might be also due to the influence of the nutrients which was added into the effluents in order to make the microorganisms more active and viable for fast degradation of organic contaminants in the effluent. The relative potential or efficiency of the different masses of the bacteria in remediating SS in TAN1 samples was in the order $25 \mathrm{~g}>20 \mathrm{~g}>15 \mathrm{~g}>10 \mathrm{~g}>5 \mathrm{~g}$. For TAN2 and TAN3 samples, the order was $25 \mathrm{~g}>20 \mathrm{~g}>15$ $\mathrm{g}>10 \mathrm{~g}>5 \mathrm{~g}$. These might be due to the variations in the surface areas of the different masses of the immobilized bacteria. Statistical analysis shows that there is no significant difference $(p<0.05)$ between the mean values of SS among the masses in the respective industries. Positive and significant correlations exist between the masses of bacteria and Suspended Solid (SS). This showed that there is general increase in the levels of the SS as the masses of the immobilized bacteria increases. TAN3 (90\%) and TAN1 (80\%) showed a very high correlation with the masses of the bacteria while TAN2 (61\%) showed a very low correlation.

The mean values $(\mathrm{mg} / \mathrm{l})$ of the TDS after the bioremediation varies between $46 \pm 11$ and $83 \pm 78$. The mean concentration $(\mathrm{mg} / \mathrm{l})$ of TDS remediated by the different masses $(5 \mathrm{~g}, 10 \mathrm{~g}$, $15 \mathrm{~g}, 20 \mathrm{~g}$, and $25 \mathrm{~g}$ ) of the bacteria varies. There is a reduction in all the TDS of all the samples after the bioremediation process compared with the TDS of the raw samples before the bioremediation. The relative potential or efficiency of the different masses of the bacteria in remediating TDS in TAN1 and TAN3 samples was in the order $5 \mathrm{~g}>10 \mathrm{~g}>15 \mathrm{~g}>20$ $\mathrm{g}>25 \mathrm{~g}$. For TAN2 samples, the order was 20 $g>10 \quad g>25 \quad g>15 \quad g>5 \quad g$. Statistical analysis shows that there is no significant difference $(p<0.05)$ between the mean values of TDS among the masses in the respective industries. These might be due to the variations in the surface areas of the different masses of the immobilized bacteria. Positive and significant correlations exist between the masses of bacteria and TDS with the exception in TAN2 (negative and insignificant correlation). The positive correlations showed that there is general increase in the levels of the TDS as the masses of the immobilized bacteria increases. TAN1 $(96 \%)$ showed a very high correlation with the masses of the bacteria while TAN2 (47\%) showed a very low correlation.

The mean values $(\mathrm{mg} / \mathrm{l})$ of the BOD after the bioremediation varies between $1.56 \pm 0.20 \mathrm{mg} / \mathrm{l}$ and $6.92 \pm 5.49 \mathrm{mg} / \mathrm{l}$. The mean concentration $(\mathrm{mg} / \mathrm{l})$ of BOD remediated by the different masses $(5 \mathrm{~g}, 10 \mathrm{~g}, 15 \mathrm{~g}, 20 \mathrm{~g}$, and $25 \mathrm{~g}$ ) of the bacteria varies. There is a reduction in all the BOD of all the samples after the bioremediation process compared with the $\mathrm{BOD}$ of the raw 
BAJOPAS Volume 13 Number 2, December, 2020 samples before the bioremediation. The relative potential or efficiency of the different masses of the bacteria in remediating BOD in TAN1, TAN2 and TAN3 samples were in the order $25 \mathrm{~g}>20$ $\mathrm{g}>15 \mathrm{~g}>10 \mathrm{~g}>5 \mathrm{~g}, 25 \mathrm{~g}>15 \mathrm{~g}>5 \mathrm{~g}>10 \mathrm{~g}>20 \mathrm{~g}$ and $20 \mathrm{~g}>10 \mathrm{~g}>25 \mathrm{~g}>15 \mathrm{~g}>5 \mathrm{~g}$ respectively. Statistical analysis shows that there is significant difference $(p<0.05)$ between the mean values of BOD among the masses in the respective industries. These might be due to the variations in the surface areas of the different masses of the immobilized bacteria. Negative and significant correlations exist between the masses of bacteria and BOD. This showed that there is general decrease in the levels of the BOD as the masses of the immobilized bacteria increases. TAN1 (94\%) showed a very high correlation with the masses of the bacteria while TAN2 (4\%) showed a very low correlation.

The mean values $(\mathrm{mg} / \mathrm{l})$ of the COD after the bioremediation varies between $250 \pm 154$ and $3134 \pm 1595$. The mean concentration $(\mathrm{mg} / \mathrm{l})$ of COD remediated by the different masses $(5 \mathrm{~g}$, $10 \mathrm{~g}, 15 \mathrm{~g} 20 \mathrm{~g}$, and $25 \mathrm{~g}$ ) of the bacteria varies. There is a reduction in all the COD of all the samples after the bioremediation process compared with the COD of the raw samples before the bioremediation. The relative potential or efficiency of the different masses of the bacteria in remediating COD in TAN1, TAN2 and TAN3 samples were in the order $25 \mathrm{~g}>20 \mathrm{~g}>15$ $\mathrm{g}>5 \mathrm{~g}>10 \mathrm{~g}, 25 \mathrm{~g}>20 \mathrm{~g}>15 \mathrm{~g}>10 \mathrm{~g}>5 \mathrm{~g}$ and 10 g>5 g>25 g>15 g>20 g respectively. Statistical analysis shows that there were significant difference $(p<0.05)$ between the mean values of COD among the masses in the respective industries except for effluents treated with $25 \mathrm{~g}$. These might be due to the variations in the surface areas of the different masses of the immobilized bacteria. Negative and insignificant correlations exist between the masses of bacteria and COD with the exception in TAN3 (positive and significant correlation). The negative correlations showed that there is general decrease in the levels of the COD as the masses of the immobilized bacteria increases. TAN2 (100\%) showed a very high correlation with the masses of the bacteria while TAN3 (36\%) showed a very low correlation.

Generally, there was an overall decrease in the concentration of these physicochemical parameters after the bioremediation using the different masses of the bacterial isolates. These might be due to the variations in the surface areas of the different masses of the immobilized bacteria. This is in line with the work of Jimoh et al. (2018) and Baba et al. (2020).

Table 3: Mean Values $(\mathrm{mg} / \mathrm{l}) \pm$ S.D of Physicochemical parameters in effluents from the Tannery Industries before and after Treatment of the effluents $(250 \mathrm{ml})$ with the different masses $(5 \mathrm{~g}, 10 \mathrm{~g}$, $15 \mathrm{~g}, 20 \mathrm{~g}$, and $25 \mathrm{~g}$ ) of the bacteria.

\begin{tabular}{llllllll}
\hline $\mathrm{P}$ & IND & Before & \multicolumn{5}{c}{ After } \\
\cline { 4 - 7 } & & & $5 \mathrm{~g}$ & $10 \mathrm{~g}$ & $15 \mathrm{~g}$ & $20 \mathrm{~g}$ & $25 \mathrm{~g}$ \\
\hline \multirow{2}{*}{ COD } & TAN1 & $2372 \pm 938$ & $1708 \mathrm{a} \pm 861$ & $2045 \mathrm{a} \pm 1205$ & $845 \mathrm{a} \pm 369$ & $300 \mathrm{a} \pm 167$ & $250 \mathrm{a} \pm 154$ \\
& TAN2 & $1406 \pm 208$ & $1195 \mathrm{a} \pm 208$ & $1125 \mathrm{a} \pm 384$ & $1055 \mathrm{a} \pm 317$ & $956 \mathrm{a} \pm 310$ & $870 \mathrm{ab} \pm 240$ \\
& TAN3 & $3532 \pm 1373$ & $2374 \mathrm{a} \pm 1344$ & $1976 \mathrm{a} \pm 1405$ & $2757 \mathrm{a} \pm 1266$ & $3134 \mathrm{a} \pm 1595$ & $2614 \mathrm{~b} \pm 1105$ \\
BOD & TAN1 & $13.85 \pm 6.42$ & $6.92 \mathrm{a} \pm 5.49$ & $6.42 \mathrm{a} \pm 5.07$ & $5.72 \mathrm{a} \pm 5.35$ & $4.62 \mathrm{a} \pm 4.37$ & $2.82 \mathrm{ab} \pm 1.26$ \\
& TAN2 & $19.46 \pm 0.50$ & $1.75 \mathrm{~b} \pm 0.22$ & $1.73 \mathrm{~b} \pm 0.18$ & $1.58 \mathrm{a} \pm 0.16$ & $1.91 \mathrm{a} \pm 0.22$ & $1.56 \mathrm{~b} \pm 0.20$ \\
& TAN3 & $17.13 \pm 3.14$ & $4.24 \mathrm{ab} \pm 0.77$ & $3.29 \mathrm{ab} \pm 0.37$ & $4.11 \mathrm{a} \pm 0.07$ & $3.23 \mathrm{a} \pm 0.91$ & $3.33 \mathrm{a} \pm 1.28$ \\
SS & TAN1 & $374 \pm 124$ & $243 \mathrm{a} \pm 45$ & $471 \mathrm{a} \pm 226$ & $475 \mathrm{a} \pm 182$ & $492 \mathrm{a} \pm 128$ & $611 \mathrm{a} \pm 217$ \\
& TAN2 & $358 \pm 335$ & $460 \mathrm{a} \pm 400$ & $543 \mathrm{a} \pm 414$ & $544 \mathrm{a} \pm 402$ & $551 \mathrm{a} \pm 414$ & $554 \mathrm{a} \pm 405$ \\
& TAN3 & $780 \pm 739$ & $586 \mathrm{a} \pm 594$ & $758 \mathrm{a} \pm 656$ & $787 \mathrm{a} \pm 676$ & $861 \mathrm{a} \pm 635$ & $898 \mathrm{a} \pm 672$ \\
TDS & TAN1 & $3941 \pm 3703$ & $51 \mathrm{a} \pm 10$ & $53 \mathrm{a} \pm 10$ & $55 \mathrm{a} \pm 15$ & $61 \mathrm{a} \pm 20$ & $63 \mathrm{a} \pm 26$ \\
& TAN2 & $3300 \pm 1714$ & $83 \mathrm{a} \pm 78$ & $47 \mathrm{a} \pm 20$ & $48 \mathrm{a} \pm 22$ & $47 \mathrm{a} \pm 17$ & $48 \mathrm{a} \pm 17$ \\
& TAN3 & $2653 \pm 1240$ & $46 \mathrm{a} \pm 11$ & $55 \mathrm{a} \pm 24$ & $55 \mathrm{a} \pm 25$ & $58 \mathrm{a} \pm 23$ & $61 \mathrm{a} \pm 28$ \\
\hline
\end{tabular}

Replicate $=6$ (months)

Within the rows, for the same parameter, means with different alphabets are statistically different $(p<0.05)$.

$\mathrm{P}=$ parameter, IND = Industries 
BAJOPAS Volume 13 Number 2, December, 2020

Table 4: Correlation coefficient $(r)$ between different masses of the bacteria and the physicochemical parameters.

\begin{tabular}{llll}
\hline Industries & Parameter & Correlation coefficient $(r)$ & $\begin{array}{l}\text { Percent dependence (rxrx100) } \\
(\%)\end{array}$ \\
\hline TAN1 & COD & -0.9 & 82 \\
& BOD & -0.97 & 94 \\
& SS & $0.90^{*}$ & 80 \\
TAN2 & TDS & $0.98^{*}$ & 96 \\
& COD & -1 & 100 \\
& BOD & -0.21 & 4 \\
& SS & $0.78^{*}$ & 61 \\
& TDS & -0.69 & 47 \\
& COD & $0.60^{*}$ & 36 \\
& BOD & -0.6 & 37 \\
& SS & $0.95^{*}$ & 90 \\
& TDS & $0.94^{*}$ & 89 \\
\hline
\end{tabular}

The correlation coefficient $(r)$ with * is statistically significant $(p<0.05)$.

Percentage reduction of the Parameters

Table 5 shows the percentage reduction of Parameters in industrial samples before and after the treatment of the effluents $(250 \mathrm{ml})$ with the different masses $(5 \mathrm{~g}, 10 \mathrm{~g}, 15 \mathrm{~g}, 20 \mathrm{~g}$, and $25 \mathrm{~g}$ ) of the Immobilized Bacteria.

In TAN1 samples, the percentage reduction (\%) of COD ranged (14-89); BOD (50-80); SS (-32$35)$ and TDS (98-99). In TAN2 samples, the percentage decrease $(\%)$ of COD ranged (15$38) ;$ BOD (90-92); SS [-28-(-55)] and TDS (9798). In TAN3 samples, the percentage decrease (\%) of COD ranged (11-44); BOD (76-81); SS (15-25) and TDS (98). The percentage increase in the levels COD, BOD and TDS might be due to the increase in the surface area of the different masses of the immobilized bacteria. However, the percentage decrease in the levels of the SS might be due to the aggregation of the TDS which are large enough to result into SS. The percentage decrease in the levels of the SS might be also due to the influence of the nutrients which was added into the effluents in order to make the microorganisms more active and viable for fast degradation of organic contaminants in the effluent. This is in line with the work of Jimoh et al. (2018) in which the concentration of the SS increase after the bioremediation of effluents.

Sreemoyee and Priti (2013) assessed and reduced several Physico-chemical parameters of dairy wastewater using Niesseria $s p$. and concluded that the species are well known to degrade organic compounds. This is in agreement with the current study in which the immobilized Niesseria $s p$ degrade the organic contaminants as indicated by the BOD, COD and TDS.

Jimoh et al. (2018) observed that TSS of the effluents was increased after treatment with immobilized bacteria and concluded that it might be due to the biostimulation method adopted for the research.

The optimum $\mathrm{pH}$ Biosorption of Chromium by Bacillus spp and Staphylococcus spp. from tannery effluent was investigated by Mythili and Karthikeyan (2011). The maximum adsorption of Chromium $(86.4 \mathrm{mg} / \mathrm{L})$ was showed by Bacillus spp and Staphylococcus spp showed $70.6 \mathrm{mg} / \mathrm{L}$ at an initial concentration of $100 \mathrm{mg} / \mathrm{L}$. In the present study, immobilised Bacillus spp and Staphylococcus spp. from the tannery industrial effluents reduced the levels of the organic pollutants with high potential as indicated by the percentage reduction of BOD, COD and TDS.

Enzymes often can work in multiple environments especially if they are immobilized. This makes the microorganisms' enzymes even more resistant to harsh environments and enables the enzymes to be recovered and recycled after they are no longer needed (Gianfreda and Rao 2004). Ramesh and Singh (1993) reported that the immobilized bacteria having more efficiency to remove the suspended particles than free cells. Using the immobilized cell is preferable due to its capability for using several times with the same efficiency, which makes it more economical. Similar work was done by Sikander et al. (2007) showing the higher reduction with permeabilized cells of Ochrobactrum intermedium strain SDCr-5. 
BAJOPAS Volume 13 Number 2, December, 2020

The results revealed the isolation and identification of isolates with the potential for the reduction of $\mathrm{Cr}$ (VI) to $\mathrm{Cr}$ (III). Results indicated that immobilized $B$. cereus could be efficiently used for the reduction of $\mathrm{Cr}$ (VI).

Table 5: Percentage reduction of the tested Parameters from the tannery industrial samples of the Immobilized Bacteria.

\begin{tabular}{lllllll}
\hline \multirow{2}{*}{ Industries } & & \multicolumn{5}{c}{ Percentage Reduction $(\%)$} \\
\cline { 3 - 7 } & & $5 \mathrm{~g}$ & $10 \mathrm{~g}$ & $15 \mathrm{~g}$ & $20 \mathrm{~g}$ & $25 \mathrm{~g}$ \\
\hline TAN1 & COD & 28 & 14 & 64 & 87 & 89 \\
& BOD & 50 & 54 & 59 & 67 & 80 \\
& SS & 35 & -26 & -27 & -32 & -63 \\
& TDS & 99 & 99 & 99 & 98 & 98 \\
TAN2 & COD & 15 & 20 & 25 & 32 & 38 \\
& BOD & 91 & 91 & 92 & 90 & 92 \\
& SS & -28 & -52 & -52 & -54 & -55 \\
& TDS & 97 & 99 & 99 & 99 & 99 \\
& COD & 33 & 44 & 22 & 11 & 26 \\
& BOD & 75 & 81 & 76 & 81 & 81 \\
& SS & 25 & 3 & -1 & -10 & -15 \\
& TDS & 98 & 98 & 98 & 98 & 98 \\
\hline
\end{tabular}

Percentage Reduction $=(B-A) / B \times 100 \%$

$A=$ Concentration of the parameter after treatment

$\mathrm{B}=$ Concentration of the parameter before treatment

$+=$ percentage decrease

- = percentage increase

In general, immobilization makes the enzyme more resistant to temperature, $\mathrm{pH}$, and substrate concentration swings giving it a longer lifetime and higher productivity per active unit (Gianfreda and Rao, 2004; FuIlbrook, 1996; Russell et al, 2003; Kandelbauer et al., 2004). Immobilized cells have been used and studied extensively for the production of useful chemicals (Ohtake and Silver, 1994), the treatment of wastewaters (Chen et al., 2003; Wang et al., 2010). Although many workers described microbial degradation of tannery effluent, limited literature is available on the bioremediation of tannery effluent using immobilized bacterial cells in the Kano Industrial Estates.

\section{CONCLUSION}

The samples contained variable levels of the physicochemical parameters. The results of the Analysis of variance revealed that, no statistical difference $(p<0.05)$ was observed for the temperature, $\mathrm{pH}, \mathrm{SS}, \mathrm{TDS}, \mathrm{BOD}$ and $\mathrm{COD}$ among the three tannery industries before the treatment. The levels of some of the parameters
(SS, TDS and COD) observed in the samples were found above the recommended limits of WHO and NESREA, which called for the treatment of the effluents before discharge into the environment. Base on the morphological and biochemical test results, TAN1, TAN2, and TAN3 bacterial isolates were identified to be Neisseria spp, Bacillus cereus, and Staphylococcus aureus respectively. The results of Post-treatment analysis showed that there is overall decrease in the levels of the parameters determined when compared with that of the pre-treatment. The overall percentage reduction of the immobilised bacteria in the treatment of the respective effluents was in the order TAN2 (72\%)>TAN1 $(70 \%)>$ TAN3 $(62 \%)$. Hence, the immobilized bacteria are having higher biodegradation potential for the treatment of the tannery effluents.

\section{Acknowledgments}

The authors wish to acknowledge the University of Maiduguri for the financial support. The authors are grateful to the Kano State Ministry of Environment for their support in obtaining the effluent samples. 


\section{REFERENCES}

Ajao, A. T., Adebayo, G. B., and Yakubu, S. E. (2011). Bioremediation of textile industrial effluent using mixed culture of Pseudomonas aeruginosa and Bacillus subtilis immobilized on agar-agar in a bioreactor. J. Microbiol. Biotech. Res, 1(3), 50-56.

Akan, J. C., Moses, E. A., Ogugbuaja, V. O., and Abah, J. (2007). Assessment of tannery industrial effluents from Kano metropolis, Kano State, Nigeria. Journal of Applied Sciences, 7(19), 2788-2793.

Akan, J. C., Ogugbuaja, V. O., Abdulrahman, F. I., and Ayodele, J. T. (2009). Pollutant levels in effluent samples from tanneries and textiles of Kano industrial areas, Nigeria. Global journal of pure and applied sciences, 15(3-4).

APHA (1989). Standard methods for Examination of Will bete and Will betewater.15 $5^{\text {th }}$ edition. Brydpass Springfield Will behington DC. pp. 164-176

APHA (1992). Standard Methods for the Examination of Water and Wastewater. Health, 69, 1116-9.

Baba, A., Garba, S. T., and Bello, H. S. (2020). Bioremediation Potential of Immobilized corynebacterium kutsceri in the Treatment of Tannery Industrial Effluent from Challawa Industrial Estate, Kano State, Nigeria. Journal of the Turkish Chemical Society Section A: Chemistry, $7(2), 335-350$.

Beem, E. I. V. (1994). reduction of solvent VOC emission. J. Oil Col. Chem. Ass, 77, 158.

Bouwer, E. J., and Zehnder, A. J. (1993). Bioremediation of organic compoundsputting microbial metabolism to work. Trends in biotechnology, 11(8), 360367.

Chen, K. C., Wu, J. Y., Liou, D. J., and Hwang, S. C. J. (2003). Decolorization of the textile dyes by newly isolated bacterial strains. Journal of Biotechnology, 101(1), 57-68.

Dan'Azumi, S., and Bichi, M. H. (2010). INDUSTRIAL POLLUTION AND HEAVY METALS PROFILE OF CHALLAWA RIVER IN KANO, NIGERIA. Journal of Applied Sciences in Environmental Sanitation, $5(1)$.

DWAF. (1992). Analytical Methods Manual, TR 151. Department of Water Affairs and Forestry, Pretoria.

El-Bestawy, E. (2013). Biological treatment of leather-tanning industrial wastewater using free living bacteria.
Elsheikh, M. A. S. (2009). Tannery wastewater pre-treatment. Water Science and Technology, 60(2), 433-440.

FuIlbrook, P. D. (1996). "Kinetics." Industrial enzymology: The application of enzymes in Industry. 2nd Ed. T. Godfrey and J Reichelt. eds.. Nature. New York.

Gianfreda, L., and Rao, M. A. (2004). Potential of extra cellular enzymes in remediation of polluted soils: a review. Enzyme and microbial technology, 35(4), 339354.

Hugo Springer. (1994). John Arthur Wilson Memorial Lecture "Treatment of Industrial Wastes of the Leather Industry - is it still a Major Problem". JALCA, 89, 153-185

Jimoh, A. A., Ganiyu, B. A., Baba, D., and Baba, A. (2018) Bioremediation Process of Effluent from Detergent and Food Industries in Jos, Nigeria: Kinetics and Thermodynamics. International Journal of Engineering Science Invention (IJESI), 762-73

Kandelbauer, A., Maute, O., Kessler, R. W., Erlacher, A., and Gübitz, G. M. (2004). Study of dye decolorization in an immobilized laccase enzyme-reactor using online spectroscopy. Biotechnology and bioengineering, 87(4), 552-563.

Kongjao, S., Damronglerd, S., and Hunsom, M. (2008). Simultaneous removal of organic and inorganic Pollutants in tannery wastewater using electrocoagulation technique. Korean Journal of chemical engineering, 25(4), 703.

Maheshwari, U. M., Aruna, S., Gomathi, M., and AbdulJaffar, A. H. (2017). Bioremediation by Free and Immobilized Bacteria Isolated from Tannery Effluent. International Journal of Research in Applied, Natural and Social Sciences. 5(7), 75-90

Margesin, R., and Schinner, F. (2001). Bioremediation (natural attenuation and biostimulation) of diesel-oilcontaminated soil in an alpine glacier skiing area. Applied and environmental microbiology, 677), 3127-3133.

Mohammed, A., Sekar, P., and George, J. (2011). Efficacy of microbes in bioremediation of tannery effluent. Inter. J. Curr. Res, 3(4), 324-326.

Mohammed, S. S. D., Orukotan, A. A., and Abdullahi, H. (2017). Physicochemical and Bacteriological Assessment of Tannery Effluent from Samaru-Zaria, 
BAJOPAS Volume 13 Number 2, December, 2020 Kaduna State, Nigeria. Journal of Applied

Sciences and Environmental Management, 21(4), 734-740.

Munz, G., De Angelis, D., Gori, R., Mori, G., Casarci, M., and Lubello, C. (2009). The role of tannins in conventional and membrane treatment of tannery wastewater. Journal of hazardous materials, 164(2-3), 733-739

Mythili, K., and Karthikeyan, B. (2011). Bioremediation of $\mathrm{Cr}$ (VI) from tannery effluent using Bacillus spp and Staphylococcus spp. International Multidisciplinary Research Journal, 1(6).

NESREA (2009). National Environmental Standards for Effluent Limitations and Regulation. 1233-1236

Noorjahan, C. M. (2014). Physicochemical characteristics, identification of bacteria and biodegradation of industrial effluent. Journal of bioremediation and Biodegradation, 5(3).

Ohtake, H. I., and Silver, A. O. (1994). Bacterial reduction of toxic chromate. Biological degradation and bioremediation of toxic chemicals, 403-415.

Omoleke, I. I. (2004). Management of environmental pollution in Ibadan, an African city: the challenges of health hazard facing government and the people. Journal of Human Ecology, 15(4), 265-275.

Rajor, A., Reddy, A.S., and Singh, B. (2004). Determination of BOD kinetic Parameters and evaluation of alternate methods, M.Sc. Thesis, Department of biotechnology \& environmental Science, Thapar Institute of Engineering and Technology, Patiala

Ramasami, T., Rajamani, S., and Rao, J. R. (1994, March). Pollution control in leather industry: Emerging technological options. In International symposium on surface and colloidal science and its relevance to soil pollution, madras.

Ramesh, J. V. S., and Singh, S. P. (1993). Yearly variation in certain physicochemical parameters of pond at eastern Doon Valley. Uttar Pradesh J. Zoo, 12 (1), 7577.

Ranen, S., and Sharadinadra, C. (2009). Biotechnology applications to environmental remediation in resource exploitation. Current science, 97, 6-25
Russell, A. J., Berberich, J. A., Drevon, G. F., and Koepsel, R. R. (2003). Biomaterials for mediation of

chemical and biological warfare agents. Annual review of biomedical engineering, 5(1), 1-27.

Saravanan, P., and Saravanan, A. (1999). Decolourization of tannery effluent by Flavobacterium sp. EK 1. Indian Journal of Environmental Protection, 19, 19-24.

Sikander, S., and Shahida, H. (2007). Reduction of toxic hexavalent chromium by Ochrobactrum intermedium strain SDCr5 stimulated by heavy metals. Bioresource Technol, 98, 340-344.

Singh, N., Sharma, B. K., and Bohra, P. C. (2000). Impact assessment of industrial effluent of arid soils by using satellite imageries. Journal of the Indian Society of Remote Sensing, 28(2-3), 79.

Sreemoyee, C., and Priti, P. (2013). Assessment of physico-chemical parameters of dairy waste water and isolation and characterization of bacterial strains in terms of cod reduction. Int J Sci, 2(3), 395-400.

Verheijen, L. A. H. M., Wiersema, D., Pol, L. H., and De Wit, J. (1996). Management of wastes from animal product processing. Livestock and environment, Finding a balance. International Agriculture Center, Wageningen, The Netherlands.

Wang, F., Yao, J., Si, Y., Chen, H., Russel, M., Chen, K., and Bramanti, E. (2010). Short-time effect of heavy metals upon microbial community activity. Journal of Hazardous Materials, 173(13), 510-516.

WHO (World Health Organization). (2006). Air quality guidelines: global update 2005: particulate matter, ozone, nitrogen dioxide, and sulfur dioxide. World Health Organization.

World Bank. (1995). Nigeria's strategic options for redressing industrial pollution. World Bank, industry and energy division. 1st edition, West Central Africa Department; Annexes: 1995; pp 60-62.

Zahoor, A., and Abdul, R. (2009). Enumeration of Coliforms. Journal of Environmental Sciences. 21, 814-820 


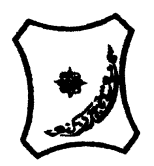

Bayero Journal of Pure and Applied Sciences, 13(2): 1 - 12

Received: November, 2020

Accepted: December, 2020

ISSN $2006-6996$

\title{
BIODEGRADATION POTENTIAL OF IMMOBILIZED BACTERIA IN THE TREATMENT OF TANNERY INDUSTRIAL EFFLUENTS FROM INDUSTRIAL ESTATES IN KANO STATE, NIGERIA
}

\author{
Abdullateef, B., ${ }^{1 *}$ Shuaibu, T. G., ${ }^{1}$ Babagana, K., ${ }^{1}$ Suleman, H. B. ${ }^{2}$ and Dauda, B. ${ }^{3}$ \\ ${ }^{1}$ Department of Pure and Applied Chemistry, Faculty of Science, University of Maiduguri, Borno State, \\ Nigeria \\ ${ }^{2}$ Department of Microbiology, Faculty of Science, University of Maiduguri, Borno State, Nigeria \\ ${ }^{3}$ Department of Chemical Engineering, Faculty of Engineering, University of Maiduguri, Borno State, \\ Nigeria \\ *Corresponding author: babslega@gmail.com; abelega2007@yahoo.com; +2348061309753
}

\section{ABSTRACT}

Industrial Effluents Samples from Gashash Tanneries (TAN1) in Bompai Industrial estate, Larabee Tannery Industry (TAN2) in Sharada Industrial estate and Z Tannery Industries (TAN3) in Challawa Industrial estate, Kano State, Nigeria were collected over a period of six months (August 2017 to January 2018) for assessing the biodegradation potentials of bacteria in the treatment of organic pollutants within the effluents. Bacteria were isolated from the effluents and immobilized on agar-agar. Different masses (5 g, $10 \mathrm{gr}, 15$ $\mathrm{g}, 20 \mathrm{~g}$, and $25 \mathrm{~g}$ ) of the bacteria were used in the treatment of $250 \mathrm{ml}$ of the effluents for ten days in a shaker incubator (Gallenkamp-OC-4364-L) at the temperature $30{ }^{\circ} \mathrm{C}$ and speed of $60 \mathrm{rpm}$. Pre-treatment analysis of the effluents for Temperature, pH, Biochemical Oxygen Demand (BOD), Chemical Oxygen Demand (COD), Suspended Solid (SS) and Total Dissolved Solids (TDS) gives the following results; temperature $\left({ }^{\circ} \mathrm{C}\right.$ )

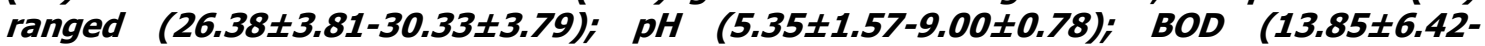
$38.75 \pm 16.20) ;$ COD (1406 $\pm 208-3532 \pm 1373) ;$ SS (208 $\pm 235-780 \pm 739)$ and TDS (266 $\pm 253-5276 \pm 2971)$. No statistical differences ( $p \leq 0.05)$ was observed for all the results among the different industries. The bacterial isolates were identified as Neisseria spp, Bacillus cereus, and Staphylococcus aureus, in TAN1, TAN2, and TAN3, respectively. After treatment of the effluent with the different masses of the isolated bacteria, the mean level of BOD was found to range as (0.55 $\pm 0.36-6.92 \pm 5.49) ; C O D$ (ND-3134 \pm 1595$)$;

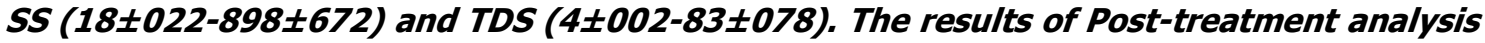
showed that there is overall decrease in the levels of the parameters determined when compared with that of the pre-treatment. The overall percentage reduction of the immobilised bacteria in the treatment of the respective effluents was in the order TAN2 (72\%)>TAN1 (70\%)>TAN3 (62\%). Hence, the immobilized bacteria are having higher biodegradation potential for the treatment of the tannery effluents.

Keywords: Biodegradation, bacteria, effluent, immobilization, tannery.

\section{INTRODUCTION}

Tannery industrial wastewater is a serious consequence of the pollution point of view for streams, freshwater, and land used for agriculture. The lack of awareness in the modern industrial practice has resulted in the discharge of tannery effluents which exhibit very high value of chromium ( $\mathrm{Cr}$ ), Sulfide, and chloride, Total Dissolved Solid (TDS), Total Suspended Solid (TSS), Biochemical Oxygen Demand (BOD) and Chemical Oxygen Demand (COD) in the water stream or land (Mohammed et al., 2001). Tanning is the process, which One ton of skin generally leads to the production of 20 to $80 \mathrm{~m}^{3}$ of turbid and foul-smelling converts the protein of the rawhide or skin into a stable material, which will not putrefy and is suitable for a wide variety of end applications (Elsheikh, 2009). The highly polluting chromium is the most commonly used tanning material producing leather that is more flexible and pliable than vegetable-tanned leather and does not discolor or lose shape in water as drastically as vegetable-tan (Elsheikh, 2009). Tannery effluent is among the most hazardous industrial pollutants due to its huge organic and inorganic load, which is highly toxic to human life and the environment (Kongjao et al., 2008). wastewater including chromium (100-400 mg/l), sulfide $(200-800 \mathrm{mg} / \mathrm{l})$, high levels of fat and 
BAJOPAS Volume 13 Number 2, December, 2020 other solid wastes, and notable pathogen contamination as well as pesticides added for skin conservation during transport (Elsheikh, 2009). There are more than 6000 tanneries in Nigeria with an annual processing capacity of 700,000 tons of hides and skins (Omoleke, 2004; Singh et al., 2008). It was reported that the total amount of waste produced per animal slaughtered is approximately $35 \%$ of its weight (World Bank, 1995). Also, for every $1000 \mathrm{~kg}$ of carcass weight, a slaughtered beef produces 5.5 $\mathrm{kg}$ of manure (excluding rumen contents or stockyard manure) and $100 \mathrm{~kg}$ of paunch manure (undigested food) (Verheijen et al., 1996). Tanneries generate wastewater in the range of 30-35 $\mathrm{L} \mathrm{kg}^{-1}$ skin/hide processed with variable $\mathrm{pH}$, Biological Oxygen Demand (BOD), Chemical Oxygen Demand (COD), high concentrations of suspended solids (SS), and tannins as well as chromium (Zahoor and Abdul, 2009).

Being heterogeneous and composed of a wide variety of compounds, it is very difficult to select a unique direct method for estimating the biodegradability of organic contents and biokinetic parameters for a wastewater sample (Rajor, 2004). For this purpose, some indirect estimation such as determination of biochemical oxygen demand (BOD) and chemical oxygen demand (COD) are applied as common laboratory investigations [9]. During retanning procedures, synthetic tannins (Syntan), oils and resins are added to form softer leather at varying doses (Munz et al., 2009). One of the refractory groups of chemicals in tannery effluents derives mainly from tannins (Ramasami et al., 2004). Syntans are characterized by complex chemical structures, because they are composed of an extended set of chemicals such as phenol-, naphthalene-, formaldehyde- and melamine-based syntans, and acrylic resins (Beem, 1994). Organic pollutants (proteic and lipidic components) are originated from skins (it is calculated that the raw skin has $30 \%$ loss of organic material during the working cycle) or they are introduced during processes (Hugo Springer, 1994).

Many conventional processes such as oxidation, chemical and biological processes were carried out to treat tanneries wastewater (Ebtesam et al, 2013). Biological processes have received more attention because of their costeffectiveness, lower sludge production and environmental friendliness (Noorjahan, 2014). Naturally occurring micro-organisms degrade the hazardous organic wastes including xenobiotic compounds, such as pesticides, polycyclic aromatic hydrocarbons (PAHs) and polychlorinated biphenyls (PCBs) in due course of time (Ranen and Sharadinadra, 2009). Bioremediation is based on the idea that all organisms remove substances from the environment to carry outgrowth and metabolism (Bouwer and Zehnder, 1993). Bacteria, protista and fungi are found to be very good at degrading complex molecules and incorporating the breakdown products into their metabolism (Bouwer and Zehnder, 1993). The resultant metabolic wastes that they produce are generally safe and somehow recycled into other organisms (Ranen and Sharadinadra, 2009). An acclimatized indigenous population of microorganisms capable of degradation of the compounds of interest must exist at the site for a successful bioremediation mode (Ranen and Sharadinadra, 2009). It has been observed that for a successful bioremediation mode, an acclimatized indigenous population of microorganisms capable of degradation of the compounds of interest must exist at the site under investigation (Ranen and Sharadinadra, 2009). Even though there are numerous physical and chemical methods employed in the disposal of wastes the advantage in using bacterium is that they play a key role in the reduction of COD, BOD, total protein, total tannin and total phenol (Saravanan and Saravanan, 1998)

Baba et al. (2020) studied the bioremediation potential of immobilized corynebacterium kutsceri in the Treatment of tannery industrial effluent from Challawa Industrial Estate, Kano State, Nigeria. The aim of the work is to study the reduction in the level of the contaminants through the process of bioremediation using the isolated bacteria. Immobilized bacteria can withstand various temperatures, $\mathrm{pH}$ and substrate concentrations; consequently, increasing the efficiency and the lifespan of the bacteria. Immobilized bacteria are widely applied in the treatment of wastewater and can be separated and recovered after the treatment with the same efficiency (Baba et al., 2020).

\section{MATERIALS AND METHODS \\ Study Area}

This study was carried out in Bompai, Sharada and Challawa industrial estates in Kano, Figure 1. Kano lies on Latitude $11^{\circ} 30^{\prime} \mathrm{N}$ and $8^{\circ} 30^{\prime} \mathrm{E}$ and Longitude $11^{\circ} 5^{\prime} \mathrm{N}$ and $8^{\circ} 5^{\prime} \mathrm{E}$ in Northern Nigeria. It is one of the developed industrial cities in Nigeria. Tannery activities are the dominating industries and this could be one of the reasons for her high population density (Dan'Azumi and Bichi, 2010). Many researchers have studied biodegradation of tannery effluent using microorganisms. However, limited literature is available on the biodegradation of tannery effluent in Kano industrial estates using 
BAJOPAS Volume 13 Number 2, December, 2020 immobilized bacterial cells. This research work focuses on the potential of the use of the indigenous immobilized bacterial isolates in the treatment of tannery effluents in the industrial estates.

\section{Sample Collection}

Effluents were collected from the Tannery Industries from Bompai, Challawa and Sharada Industrial Estates, Kano, Nigeria. The effluents were collected over a period of six months (August 2017 to January 2018). Samples collected in a sterile 4-liter plastic container with a unique identification number were preserved using an ice-box that was transported to the Microbiology Laboratory, Department of Microbiology, Bayero University of Kano for analysis

\section{Sample Preparation and Sample Analysis}

Immediately after the collection of the effluent, $\mathrm{pH}$, TSS, TDS, COD, BOD levels were determined before treatment (Pre-treatment determination) and ten days after treatment (Post-treatment determination) as described in
APHA (1989) standard methods. $\mathrm{pH}$ was determined using Ecotests $\mathrm{pH}$ meter and TDS was determined using AQUALYTIC TDS Salinometer. BOD was determined as described by the standard method (APHA, 1992). COD and SS were determined using DR/2010 HACH portable data logging spectrophotometer (DWAF, 1992)

\section{Identification and Biochemical} Characterization of the Bacterial Isolates

The bacteria were isolated from the effluents using Serial Dilution according to the method described by APHA (1989). The biochemical tests such as oxidase, catalase, coagulase, indole (from $1 \%$ tryptone broth), citrate (Simmons citrate agar), methyl red/VogesProskauer (MR/VP), nitrate reduction, Starch Hydrolysis, Glucose, Maltose, and Lactose tests were carried out on the bacterial isolates to identify the bacteria through the bacteria biochemical characteristics according to Ajao et al. (2011).

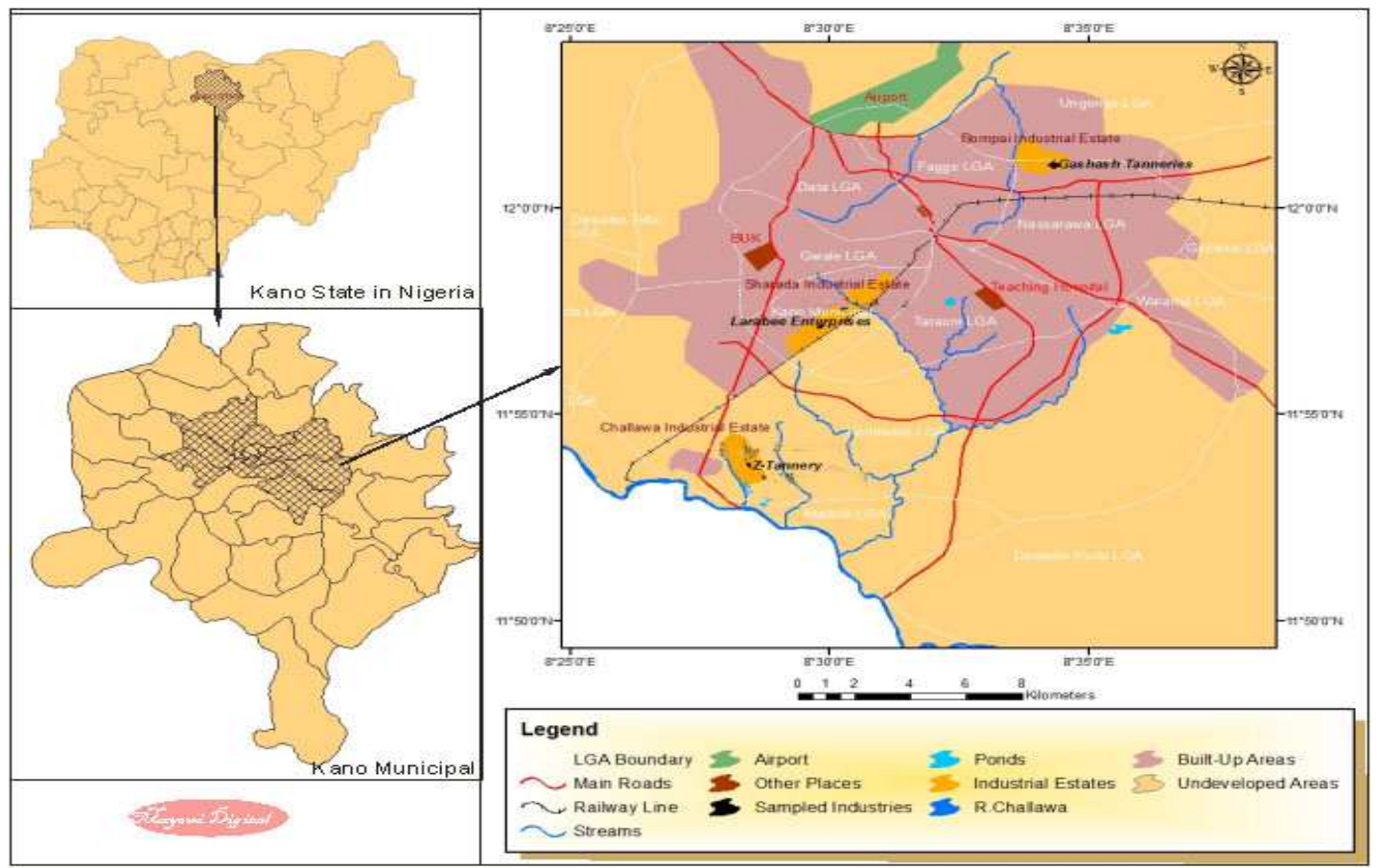

Fig. 1 Map showing the study areas

Source: Mayomi Digital Productions, GIS Laboratory, Department of Geography, UNIMAID (2017)

\section{Determination of Growth Rate of the Bacteria in Effluent Sample}

The bacteria growth rates were determined by transferring $2 \mathrm{~mL}$ of the bacterial isolates from the tannery effluent in broth medium into 100 $\mathrm{mL}$ sterile effluents in conical flasks and kept in an incubator (Giffrin cool) for 10 days. Control was also set up by incubating another $100 \mathrm{~mL}$ each of the sterile effluents without the bacteria. The optical density of the content was determined at the wavelength of $600 \mathrm{~nm}$ on a daily interval and recorded. 
BAJOPAS Volume 13 Number 2, December, 2020 Immobilization of Bacteria

Agar solution and inoculi were prepared separately. Fifty milliliters $(50 \mathrm{~mL})$ of nutrient broth each of the inoculi was prepared in a McCartney bottle and incubated for 24 hours. A solution of agar-agar was prepared by dissolving $10 \mathrm{~g}$ of the powder in distilled water and made up to $500 \mathrm{~mL}$ mark in an Erlenmeyer flask and was sterilized in an autoclave (280A) for 15 minutes and allowed to cool to $40-45^{\circ} \mathrm{C}$ (Ajao et al., 2011). Four milliliters ( $4 \mathrm{~mL})$ of the bacterial isolates in the nutrient broth was mixed with 36 $\mathrm{ml}$ of the prepared agar-agar media in petri-dish plates and then allowed to solidify. This was kept in the refrigerator for bioremediation.

\section{Bioremediation (Treatment) of the Effluents}

The solidified agar block (immobilized bacteria) was cut into cubes using a sterile knife; $0.1 \mathrm{~mL}$ phosphate buffer ( $\mathrm{pH} \mathrm{7.0)}$ was added and kept in the refrigerator for 1 hour for curing. The phosphate buffer was decanted after 1 hour and the cubes were washed with sterile distilled water 3-4 times before it was used (Ajao et al., 2011). Two liters (2 L) of the effluent was supplemented with the minimum basal medium in $\mathrm{g} / \mathrm{L}: \mathrm{NaCl}(0.8), \mathrm{MgSO}_{4} .7 \mathrm{H}_{2} \mathrm{O}(0.001), \mathrm{KH}_{2} \mathrm{PO}_{4}$ (2), $\mathrm{NaNO}_{3}$ (2), $\quad \mathrm{CaCl}_{2} .2 \mathrm{H}_{2} \mathrm{O} \quad(0.5)$ and $\mathrm{NaHPO}_{4} .12 \mathrm{H}_{2} \mathrm{O}(2)$ and sterilized in an autoclave at $121^{\circ} \mathrm{C}$ for 15 minutes (Margesin and Schinner, 2001). Two hundred and fifty milliliters $(250 \mathrm{~mL})$ of the effluents were transferred into different $250 \mathrm{ml}$ conical flasks. The content was covered with a cotton-wool ramped with foil paper to avoid contamination. Five grams $(5 \mathrm{~g})$ of the immobilized bacteria were quickly transferred into each of the effluents in the conical flasks in an inoculating chamber. The same procedures were carried out for the $10 \mathrm{~g}, 15 \mathrm{~g}, 20 \mathrm{~g}$ and 25 $\mathrm{g}$ of the immobilized bacteria in separate $250 \mathrm{~mL}$ effluents in conical flasks and agitated for ten days in a shaker incubator (Gallenkamp-OC4364-L) at a temperature $30^{\circ} \mathrm{C}$ and speed of 60 rpm. The treated effluent samples were taken on the tenth day and analyzed for the parameters $\mathrm{pH}$, SS, TDS, COD, and BOD, (Posttreatment determination) for the different grams of bacteria to evaluate and compare the biodegradation potential. (Baba et al., 2020).

\section{Statistical Analysis}

The data were represented as Mean \pm Standard deviation and analyzed statistically using oneway Analysis of Variance (ANOVA) and Tukey's HSD as Post Hoc Tests with the aid of SPSS 16.0. The correlation coefficient was also used to measure the strength of the relationship between the different masses of the bacteria and the parameters. All $\mathrm{p} \leq 0.05$ were considered as statistically significant.

\section{RESULTS AND DISCUSSION Physico-chemical parameters in the Industrial Effluents before the Biodegradation.}

Results of the Physico-chemical parameters in the industrial effluents before the Biodegradation is shown in table 1 . The mean temperatures $\left({ }^{\circ} \mathrm{C}\right)$ observed in TAN1, TAN2, and TAN3 samples were $28.07 \pm 0.65 ; 27.77 \pm 0.64$ and $26.38 \pm 3.81$ respectively. The order of the mean temperature of the samples from the three industries can be arranged as TAN1 > TAN2>TAN3. The temperature observed at TAN1, TAN2, and TAN3 samples were found below the WHO $\left(35^{\circ} \mathrm{C}\right)$ and NESREA $\left(40^{\circ} \mathrm{C}\right)$ limits. The low values of temperature might be due to the processes used at the time of sampling. High temperature brings down the solubility of gases in water that ultimately expresses as high BOD and COD. Statistical analysis shows that there is no significant difference $(p<0.05)$ between the mean values of temperature among the industries. This might be due to similar tannery activities involved in the tannery industries at the time of sampling. The average values of temperature observed in this present study are less than those observed by Akan et al. (2007), Akan et al. (2009) and Baba et al. (2020).

The mean level of $\mathrm{pH}$ observed in TAN1, TAN2 and TAN3, samples were $7.77 \pm 2.93$; $8.35 \pm 0.28$ and $7.52 \pm 0.76$ respectively. The order of the mean $\mathrm{pH}$ of the samples from the three industries can be arranged as TAN2> TAN1 $>$ TAN3. The $\mathrm{pH}$ of the samples falls within the WHO (7.0-8.5) and NESREA (6-9) standard limits. Statistical analysis shows that there is no significant difference $(p<0.05)$ between the mean values of $\mathrm{pH}$ among the industries. This might be due to similar tannery activities involved in the tannery industries at the time of sampling. Maheshwari et al. (2017) reported that the level of $\mathrm{pH}$ in the effluents from the tannery industry in Vaniyambadi, India was 6.5 which was lower than that observed in the present study. The $\mathrm{pH}$ in the effluents from the tannery industries in Kano and Kaduna were reported to be 7.64 and 6.89, respectively (Akan et al., 2007; Mohammed et al., 2017). The average values of $\mathrm{pH}$ observed in this present study are less than those observed by Mohammed et al. (2017) and Baba et al. (2020). The mean level of SS $(\mathrm{mg} / \mathrm{l})$ observed in TAN1, TAN2, and TAN3 samples were 374 \pm 124 ; $358 \pm 335$ and $780 \pm 739$ respectively. The order of the mean SS in the samples from the three industries can be arranged as TAN3 > TAN1 $>$ TAN2. 
The SS observed in the samples were far above the recommended standard limits of regulating bodies WHO $(30 \mathrm{mg} / \mathrm{l})$ and NESREA $(10 \mathrm{mg} / \mathrm{l})$. Statistical analysis shows that there is no significant difference $(p<0.05)$ between the mean values of SS among the industries. This might be due to similar tannery activities involved in the tannery industries at the time of sampling. The average values of SS observed in this present study are less than that observed $(3700 \pm 122 \mathrm{mg} / \mathrm{l})$ by Akan et al. (2009) for tanneries in Kano. Also, the average values of SS observed in this present study are less than that observed by Mohammed et al. (2017) and Baba et al. (2020) with the exception in TAN3.

The mean level of TDS (mg/l) observed in TAN1, TAN2, and TAN3 samples were $3941 \pm 3703$; $3300 \pm 1714$ and $2653 \pm 1240$ respectively. The order of the mean TDS in the samples from the three industries can be arranged as TAN1>TAN2>TAN3. The TDS observed in the samples were far above the recommended standard limits of WHO $(250 \mathrm{mg} / \mathrm{l})$ and NESREA $(500 \mathrm{mg} / \mathrm{l})$. Statistical analysis shows that there is no significant difference $(p<0.05)$ between the mean values of TDS among the industries. This might be due to similar tannery activities involved in the tannery industries at the time of sampling. TDS in the effluents from the tannery industries in Kano, Nigeria was reported to be $1281 \mathrm{mg} / \mathrm{l}$ (Akan et al., 2007). The average values of SS observed in this present study are less than those observed by Mohammed et al. (2017) and Baba et al. 2020)

The mean level of COD (mg/l) observed in TAN1, TAN2 and TAN3 samples seasons were $2372 \pm 938 ; \quad 1406 \pm 208$ and $3532 \pm 1373$ respectively. The order of the mean COD of the samples from the three industries can be arranged as TAN3>TAN1> TAN2. The COD observed in TAN1, TAN2 and TAN3 samples were far above the recommended standard limits of regulating bodies $\mathrm{WHO}(40 \mathrm{mg} / \mathrm{l})$ and NESREA (40 mg/l). Statistical analysis shows that there is no significant difference $(p<0.05)$ in COD among the industries. This might be due to similar tannery activities involved in the tannery industries as at the time of sampling. The Chemical Oxygen demand (COD) is the amount of oxygen, in $\mathrm{mg} / \mathrm{L}$, required for the degradation of the compound of wastewater to occur. In comparison, the average values of COD observed in this present study were higher than that observed by Mohammed et al. (2017) but lower than that observed by Baba et al. (2020).

The mean levels of BOD $(\mathrm{mg} / \mathrm{l})$ observed in TAN1, TAN2 and TAN3 samples were $13.85 \pm 6.42 ; \quad 19.46 \pm 0.50$ and $17.13 \pm 3.14$ respectively. The order of the mean BOD in the samples from the three industries can be arranged as TAN2>TAN3>TAN1. The BOD observed in TAN1, TAN2 and TAN3 samples were found below the recommended limits of NESREA (200 mg/l) but above WHO (10 mg/l). Statistical analysis shows that there is no significant difference $(p<0.05)$ between the mean values of BOD among the industries. This might be due to similar tannery activities involved in the tannery industries at the time of sampling. The low level of BOD recorded in this study is an indication of the low level of biodegradable organic solids in the effluent. The average values of BOD observed in this present study were lower than those observed by Mohammed et al. (2017) and Baba et al. (2020).

Table 1: Mean Values \pm S.D of Physico-chemical parameters of effluents from the Tannery Industries before Treatment.

\begin{tabular}{llllllll}
\hline Parameter & Tannery 1 & Tannery 2 & Tannery 3 & $\mathrm{a}$ & $\mathrm{b}$ & $\mathrm{c}$ & $\mathrm{d}$ \\
\cline { 2 - 7 } Temperature $\left({ }^{\circ} \mathrm{C}\right)$ & $28.07 \mathrm{a} \pm 0.65$ & $27.77 \mathrm{a} \pm 0.64$ & $26.38 \mathrm{a} \pm 3.81$ & & $29.50 \pm 4.68$ & 35 & 40 \\
pH & $7.77 \mathrm{a} \pm 2.93$ & $8.35 \mathrm{a} \pm 0.28$ & $7.52 \mathrm{a} \pm 0.76$ & 6.89 & $5.35 \pm 1.57$ & $7.0-8.5$ & $6.0-9.0$ \\
$\mathrm{COD}(\mathrm{mg} / \mathrm{l})$ & $2372 \mathrm{a} \pm 938$ & $1406 \mathrm{a} \pm 208$ & $3532 \mathrm{a} \pm 1373$ & 2.2 & $3106 \pm 2753$ & 40 & 40 \\
$\mathrm{BOD}(\mathrm{mg} / \mathrm{l})$ & $13.85 \mathrm{a} \pm 6.42$ & $19.46 \mathrm{a} \pm 0.50$ & $17.13 \mathrm{a} \pm 3.14$ & 1032 & $26.17 \pm 9.49$ & 10 & 200 \\
$\mathrm{SS}(\mathrm{mg} / \mathrm{l})$ & $374 \mathrm{a} \pm 124$ & $358 \mathrm{a} \pm 335$ & $780 \mathrm{a} \pm 739$ & 501 & $562 \pm 482$ & 30 & 10 \\
TDS $(\mathrm{mg} / \mathrm{l})$ & $3941 \mathrm{a} \pm 3703$ & $3300 \mathrm{a} \pm 1714$ & $2653 \mathrm{a} \pm 1240$ & 532.7 & $444 \pm 507$ & 250 & 500 \\
\hline
\end{tabular}

The values given in the table above are means of 6 replicate values, $\mathrm{n}=6$ ( 1 sample was taken monthly for 6 months). Within the rows, means with different alphabets are statistically different $(p<0.05)$. WHO: World Health Organisation. NESREA: National Environmental Standard and Regulatory Enforcement Agency. a = Mohammed et al.(2017), b = Baba et al. (2020), c = WHO (2006), $d=$ NESSRA (2009) 
BAJOPAS Volume 13 Number 2, December, 2020

Identification, Biochemical Characterization and growth rates of the Bacterial Isolates

Results of identification and biochemical characterization of the bacterial isolates were shown in table 2. After 24 hours of incubation, the nutrient agar media plates were checked for bacterial growth. The results showed the presence of different strains in the samples. The TAN1 bacteria isolate was found to be gramnegative cocci while TAN3 was gram-positive cocci. TAN2 bacteria isolate was found to be gram-positive, rod-shaped. TAN1, TAN2, and TAN3 bacteria isolates recorded positive results for spore former.

The results of the biochemical tests indicated that all the bacteria were positive for catalase, oxidase, citrate, maltose, glucose, lactose (negative in TAN1), mannitol (negative in TAN2), starch hydrolysis and coagulase (negative in TAN2) tests. The bacteria showed negative results for nitrate reduction, $M R$ (positive in TAN2), VP (positive in TAN1), Indole (positive in TAN2) tests. Base on the morphological and biochemical test results, TAN1, TAN2, and TAN3 bacteria isolates were identified to be Nesseria spp, Bacillus cereus, and Staphylococcus aureus respectively.

The growth rate of the TAN1, TAN2 and TAN3 Isolates were shown in figure 2. Generally, the optical density increase with the increase in time (day) and decrease as time goes on. The highest optical density was shown by bacillus cereus in TAN2 while the lowest was shown by Staphylococcus aureus in TAN3.

The initial growth phase of TAN1 Isolate bacteria occurred within 2-day of incubation as the growth rate increases up to the 6th-day incubation when the maximum growth was observed. Beyond the 6th day, the growth of the bacteria declined (which might be due to a shortage of nutrients in the effluents) until it reached its death phase (which might be due to the unavailability of nutrients in the effluents).

A similar trend of growth was also observed for TAN2 Isolate as the initial growth phase also occurred within 2-day of incubation but maximum growth rate observed on the 4th day of incubation. The stationary stage occurred between the 4th day and the 8th day. Beyond the 8th day, the growth of the bacteria declined (which might be due to a shortage of nutrients in the effluents) until it reached its death phase (which might be due to the unavailability of nutrients in the effluents).

The initial growth phase of TAN3 bacterial Isolate occurred within the 3-day incubation as the growth rate increases up to the 6th-day incubation when the maximum growth was observed. Beyond the 6th day, the growth of the bacteria declined (which might be due to a shortage of nutrients in the effluents) until it reached its death phase (which might be due to the unavailability of nutrients in the effluents).

Table 2: Morphological and Biochemical characteristics of bacterial isolates

\begin{tabular}{lllll} 
Bacterial Isolates & & TAN1 & TAN2 & TAN3 \\
\hline $\begin{array}{lllll}\text { Morphological } \\
\text { characteristics }\end{array}$ & Shape & Cocci & Rod & Cocci \\
& Spore & & & \\
& former & + & + & + \\
Gram & & & \\
Biochemical characteristics & reaction & - & + & + \\
& Citrate & + & + & + \\
& Catalase & + & + & + \\
& Coagulase & + & - & + \\
Starch & + & + & + \\
& Glucose & + & + & + \\
Oxidase & + & + & + \\
& Indo & - & + & - \\
Lactose & - & + & + \\
Manitol & + & - & + \\
Maltose & + & + & + \\
MR & - & + & - \\
VP & + & - & - \\
& Nitrate & - & - & - \\
Reduction & - Neisseria & Bacillus & Staphylococcus \\
& Bacterial & cereus & aureus \\
& name & spp & cas
\end{tabular}

+ = Positive; - = Negative; MR=Methyl Red; VP= Voges-Proskauer 


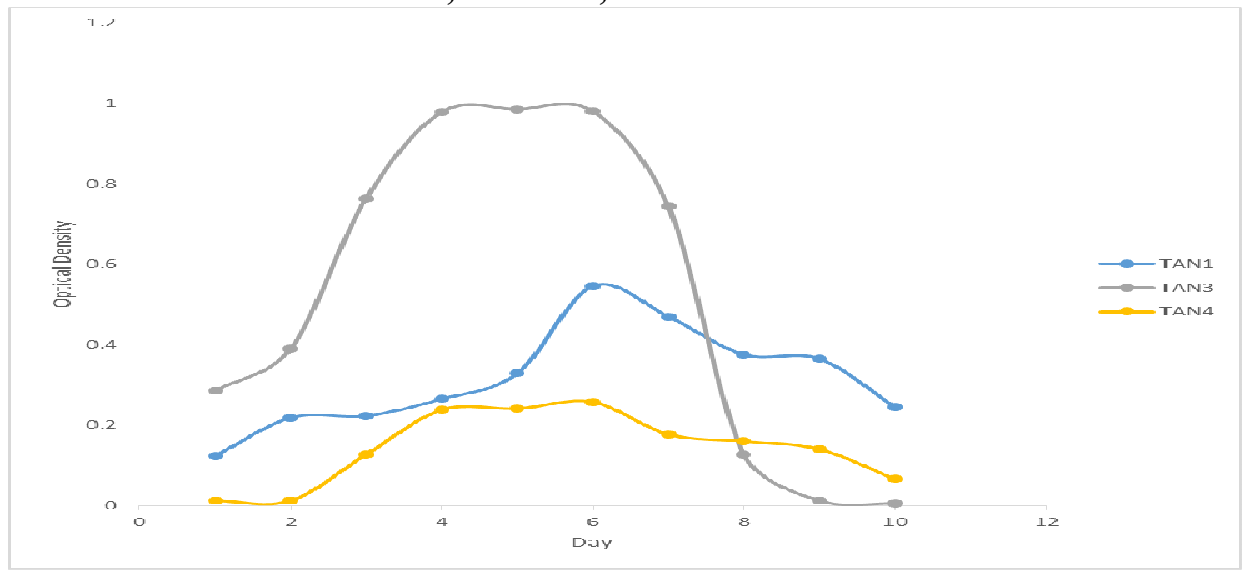

Fig. 2 Growth rates of the isolates in the effluents from the Tannery Industries

\section{Physico-chemical Parameters in the Industrial Effluents after the biodegradation.}

Table 3 shows the mean results of the physicochemical parameter before and after bioremediation using the different masses $(5 \mathrm{~g}$, $10 \mathrm{~g}, 15 \mathrm{~g}, 20 \mathrm{~g}$, and $25 \mathrm{~g}$ ) of the respective immobilized bacteria. Also, Table 4 shows the mean results of correlation coefficient ( $r$ ) between different masses of bacteria and physicochemical parameters.

The mean values $(\mathrm{mg} / \mathrm{l})$ of the SS after the bioremediation varies between $243 \pm 45$ and $898 \pm 672$. The mean concentration $(\mathrm{mg} / \mathrm{l})$ of SS remediated by the different masses $(5 \mathrm{~g}, 10 \mathrm{~g}$, $15 \mathrm{~g}, 20 \mathrm{~g}$, and $25 \mathrm{~g}$ ) of the bacteria varies. The SS in the samples fluctuates up and down after the bioremediation process when compared with the SS of the raw samples before the bioremediation. The increase in the levels of the SS might be due to the aggregation of the TDS which are large enough to result into SS. The increase in the levels of the SS might be also due to the influence of the nutrients which was added into the effluents in order to make the microorganisms more active and viable for fast degradation of organic contaminants in the effluent. The relative potential or efficiency of the different masses of the bacteria in remediating SS in TAN1 samples was in the order $25 \mathrm{~g}>20 \mathrm{~g}>15 \mathrm{~g}>10 \mathrm{~g}>5 \mathrm{~g}$. For TAN2 and TAN3 samples, the order was $25 \mathrm{~g}>20 \mathrm{~g}>15$ $\mathrm{g}>10 \mathrm{~g}>5 \mathrm{~g}$. These might be due to the variations in the surface areas of the different masses of the immobilized bacteria. Statistical analysis shows that there is no significant difference $(p<0.05)$ between the mean values of SS among the masses in the respective industries. Positive and significant correlations exist between the masses of bacteria and Suspended Solid (SS). This showed that there is general increase in the levels of the SS as the masses of the immobilized bacteria increases. TAN3 (90\%) and TAN1 (80\%) showed a very high correlation with the masses of the bacteria while TAN2 (61\%) showed a very low correlation.

The mean values $(\mathrm{mg} / \mathrm{l})$ of the TDS after the bioremediation varies between $46 \pm 11$ and $83 \pm 78$. The mean concentration $(\mathrm{mg} / \mathrm{l})$ of TDS remediated by the different masses $(5 \mathrm{~g}, 10 \mathrm{~g}$, $15 \mathrm{~g}, 20 \mathrm{~g}$, and $25 \mathrm{~g}$ ) of the bacteria varies. There is a reduction in all the TDS of all the samples after the bioremediation process compared with the TDS of the raw samples before the bioremediation. The relative potential or efficiency of the different masses of the bacteria in remediating TDS in TAN1 and TAN3 samples was in the order $5 \mathrm{~g}>10 \mathrm{~g}>15 \mathrm{~g}>20$ $\mathrm{g}>25 \mathrm{~g}$. For TAN2 samples, the order was 20 $g>10 \quad g>25 \quad g>15 \quad g>5 \quad g$. Statistical analysis shows that there is no significant difference $(p<0.05)$ between the mean values of TDS among the masses in the respective industries. These might be due to the variations in the surface areas of the different masses of the immobilized bacteria. Positive and significant correlations exist between the masses of bacteria and TDS with the exception in TAN2 (negative and insignificant correlation). The positive correlations showed that there is general increase in the levels of the TDS as the masses of the immobilized bacteria increases. TAN1 $(96 \%)$ showed a very high correlation with the masses of the bacteria while TAN2 (47\%) showed a very low correlation.

The mean values $(\mathrm{mg} / \mathrm{l})$ of the BOD after the bioremediation varies between $1.56 \pm 0.20 \mathrm{mg} / \mathrm{l}$ and $6.92 \pm 5.49 \mathrm{mg} / \mathrm{l}$. The mean concentration $(\mathrm{mg} / \mathrm{l})$ of BOD remediated by the different masses $(5 \mathrm{~g}, 10 \mathrm{~g}, 15 \mathrm{~g}, 20 \mathrm{~g}$, and $25 \mathrm{~g}$ ) of the bacteria varies. There is a reduction in all the BOD of all the samples after the bioremediation process compared with the $\mathrm{BOD}$ of the raw 
BAJOPAS Volume 13 Number 2, December, 2020 samples before the bioremediation. The relative potential or efficiency of the different masses of the bacteria in remediating BOD in TAN1, TAN2 and TAN3 samples were in the order $25 \mathrm{~g}>20$ $\mathrm{g}>15 \mathrm{~g}>10 \mathrm{~g}>5 \mathrm{~g}, 25 \mathrm{~g}>15 \mathrm{~g}>5 \mathrm{~g}>10 \mathrm{~g}>20 \mathrm{~g}$ and $20 \mathrm{~g}>10 \mathrm{~g}>25 \mathrm{~g}>15 \mathrm{~g}>5 \mathrm{~g}$ respectively. Statistical analysis shows that there is significant difference $(p<0.05)$ between the mean values of BOD among the masses in the respective industries. These might be due to the variations in the surface areas of the different masses of the immobilized bacteria. Negative and significant correlations exist between the masses of bacteria and BOD. This showed that there is general decrease in the levels of the BOD as the masses of the immobilized bacteria increases. TAN1 (94\%) showed a very high correlation with the masses of the bacteria while TAN2 (4\%) showed a very low correlation.

The mean values $(\mathrm{mg} / \mathrm{l})$ of the COD after the bioremediation varies between $250 \pm 154$ and $3134 \pm 1595$. The mean concentration $(\mathrm{mg} / \mathrm{l})$ of COD remediated by the different masses $(5 \mathrm{~g}$, $10 \mathrm{~g}, 15 \mathrm{~g} 20 \mathrm{~g}$, and $25 \mathrm{~g}$ ) of the bacteria varies. There is a reduction in all the COD of all the samples after the bioremediation process compared with the COD of the raw samples before the bioremediation. The relative potential or efficiency of the different masses of the bacteria in remediating COD in TAN1, TAN2 and TAN3 samples were in the order $25 \mathrm{~g}>20 \mathrm{~g}>15$ $\mathrm{g}>5 \mathrm{~g}>10 \mathrm{~g}, 25 \mathrm{~g}>20 \mathrm{~g}>15 \mathrm{~g}>10 \mathrm{~g}>5 \mathrm{~g}$ and 10 g>5 g>25 g>15 g>20 g respectively. Statistical analysis shows that there were significant difference $(p<0.05)$ between the mean values of COD among the masses in the respective industries except for effluents treated with $25 \mathrm{~g}$. These might be due to the variations in the surface areas of the different masses of the immobilized bacteria. Negative and insignificant correlations exist between the masses of bacteria and COD with the exception in TAN3 (positive and significant correlation). The negative correlations showed that there is general decrease in the levels of the COD as the masses of the immobilized bacteria increases. TAN2 (100\%) showed a very high correlation with the masses of the bacteria while TAN3 (36\%) showed a very low correlation.

Generally, there was an overall decrease in the concentration of these physicochemical parameters after the bioremediation using the different masses of the bacterial isolates. These might be due to the variations in the surface areas of the different masses of the immobilized bacteria. This is in line with the work of Jimoh et al. (2018) and Baba et al. (2020).

Table 3: Mean Values $(\mathrm{mg} / \mathrm{l}) \pm$ S.D of Physicochemical parameters in effluents from the Tannery Industries before and after Treatment of the effluents $(250 \mathrm{ml})$ with the different masses $(5 \mathrm{~g}, 10 \mathrm{~g}$, $15 \mathrm{~g}, 20 \mathrm{~g}$, and $25 \mathrm{~g}$ ) of the bacteria.

\begin{tabular}{llllllll}
\hline $\mathrm{P}$ & IND & Before & \multicolumn{5}{c}{ After } \\
\cline { 4 - 7 } & & & $5 \mathrm{~g}$ & $10 \mathrm{~g}$ & $15 \mathrm{~g}$ & $20 \mathrm{~g}$ & $25 \mathrm{~g}$ \\
\hline \multirow{2}{*}{ COD } & TAN1 & $2372 \pm 938$ & $1708 \mathrm{a} \pm 861$ & $2045 \mathrm{a} \pm 1205$ & $845 \mathrm{a} \pm 369$ & $300 \mathrm{a} \pm 167$ & $250 \mathrm{a} \pm 154$ \\
& TAN2 & $1406 \pm 208$ & $1195 \mathrm{a} \pm 208$ & $1125 \mathrm{a} \pm 384$ & $1055 \mathrm{a} \pm 317$ & $956 \mathrm{a} \pm 310$ & $870 \mathrm{ab} \pm 240$ \\
& TAN3 & $3532 \pm 1373$ & $2374 \mathrm{a} \pm 1344$ & $1976 \mathrm{a} \pm 1405$ & $2757 \mathrm{a} \pm 1266$ & $3134 \mathrm{a} \pm 1595$ & $2614 \mathrm{~b} \pm 1105$ \\
BOD & TAN1 & $13.85 \pm 6.42$ & $6.92 \mathrm{a} \pm 5.49$ & $6.42 \mathrm{a} \pm 5.07$ & $5.72 \mathrm{a} \pm 5.35$ & $4.62 \mathrm{a} \pm 4.37$ & $2.82 \mathrm{ab} \pm 1.26$ \\
& TAN2 & $19.46 \pm 0.50$ & $1.75 \mathrm{~b} \pm 0.22$ & $1.73 \mathrm{~b} \pm 0.18$ & $1.58 \mathrm{a} \pm 0.16$ & $1.91 \mathrm{a} \pm 0.22$ & $1.56 \mathrm{~b} \pm 0.20$ \\
& TAN3 & $17.13 \pm 3.14$ & $4.24 \mathrm{ab} \pm 0.77$ & $3.29 \mathrm{ab} \pm 0.37$ & $4.11 \mathrm{a} \pm 0.07$ & $3.23 \mathrm{a} \pm 0.91$ & $3.33 \mathrm{a} \pm 1.28$ \\
SS & TAN1 & $374 \pm 124$ & $243 \mathrm{a} \pm 45$ & $471 \mathrm{a} \pm 226$ & $475 \mathrm{a} \pm 182$ & $492 \mathrm{a} \pm 128$ & $611 \mathrm{a} \pm 217$ \\
& TAN2 & $358 \pm 335$ & $460 \mathrm{a} \pm 400$ & $543 \mathrm{a} \pm 414$ & $544 \mathrm{a} \pm 402$ & $551 \mathrm{a} \pm 414$ & $554 \mathrm{a} \pm 405$ \\
& TAN3 & $780 \pm 739$ & $586 \mathrm{a} \pm 594$ & $758 \mathrm{a} \pm 656$ & $787 \mathrm{a} \pm 676$ & $861 \mathrm{a} \pm 635$ & $898 \mathrm{a} \pm 672$ \\
TDS & TAN1 & $3941 \pm 3703$ & $51 \mathrm{a} \pm 10$ & $53 \mathrm{a} \pm 10$ & $55 \mathrm{a} \pm 15$ & $61 \mathrm{a} \pm 20$ & $63 \mathrm{a} \pm 26$ \\
& TAN2 & $3300 \pm 1714$ & $83 \mathrm{a} \pm 78$ & $47 \mathrm{a} \pm 20$ & $48 \mathrm{a} \pm 22$ & $47 \mathrm{a} \pm 17$ & $48 \mathrm{a} \pm 17$ \\
& TAN3 & $2653 \pm 1240$ & $46 \mathrm{a} \pm 11$ & $55 \mathrm{a} \pm 24$ & $55 \mathrm{a} \pm 25$ & $58 \mathrm{a} \pm 23$ & $61 \mathrm{a} \pm 28$ \\
\hline
\end{tabular}

Replicate $=6$ (months)

Within the rows, for the same parameter, means with different alphabets are statistically different $(p<0.05)$.

$\mathrm{P}=$ parameter, IND = Industries 
BAJOPAS Volume 13 Number 2, December, 2020

Table 4: Correlation coefficient $(r)$ between different masses of the bacteria and the physicochemical parameters.

\begin{tabular}{llll}
\hline Industries & Parameter & Correlation coefficient $(r)$ & $\begin{array}{l}\text { Percent dependence (rxrx100) } \\
(\%)\end{array}$ \\
\hline TAN1 & COD & -0.9 & 82 \\
& BOD & -0.97 & 94 \\
& SS & $0.90^{*}$ & 80 \\
TAN2 & TDS & $0.98^{*}$ & 96 \\
& COD & -1 & 100 \\
& BOD & -0.21 & 4 \\
& SS & $0.78^{*}$ & 61 \\
& TDS & -0.69 & 47 \\
& COD & $0.60^{*}$ & 36 \\
& BOD & -0.6 & 37 \\
& SS & $0.95^{*}$ & 90 \\
& TDS & $0.94^{*}$ & 89 \\
\hline
\end{tabular}

The correlation coefficient $(r)$ with * is statistically significant $(p<0.05)$.

Percentage reduction of the Parameters

Table 5 shows the percentage reduction of Parameters in industrial samples before and after the treatment of the effluents $(250 \mathrm{ml})$ with the different masses $(5 \mathrm{~g}, 10 \mathrm{~g}, 15 \mathrm{~g}, 20 \mathrm{~g}$, and $25 \mathrm{~g}$ ) of the Immobilized Bacteria.

In TAN1 samples, the percentage reduction (\%) of COD ranged (14-89); BOD (50-80); SS (-32$35)$ and TDS (98-99). In TAN2 samples, the percentage decrease $(\%)$ of COD ranged (15$38) ;$ BOD (90-92); SS [-28-(-55)] and TDS (9798). In TAN3 samples, the percentage decrease (\%) of COD ranged (11-44); BOD (76-81); SS (15-25) and TDS (98). The percentage increase in the levels COD, BOD and TDS might be due to the increase in the surface area of the different masses of the immobilized bacteria. However, the percentage decrease in the levels of the SS might be due to the aggregation of the TDS which are large enough to result into SS. The percentage decrease in the levels of the SS might be also due to the influence of the nutrients which was added into the effluents in order to make the microorganisms more active and viable for fast degradation of organic contaminants in the effluent. This is in line with the work of Jimoh et al. (2018) in which the concentration of the SS increase after the bioremediation of effluents.

Sreemoyee and Priti (2013) assessed and reduced several Physico-chemical parameters of dairy wastewater using Niesseria $s p$. and concluded that the species are well known to degrade organic compounds. This is in agreement with the current study in which the immobilized Niesseria $s p$ degrade the organic contaminants as indicated by the BOD, COD and TDS.

Jimoh et al. (2018) observed that TSS of the effluents was increased after treatment with immobilized bacteria and concluded that it might be due to the biostimulation method adopted for the research.

The optimum $\mathrm{pH}$ Biosorption of Chromium by Bacillus spp and Staphylococcus spp. from tannery effluent was investigated by Mythili and Karthikeyan (2011). The maximum adsorption of Chromium $(86.4 \mathrm{mg} / \mathrm{L})$ was showed by Bacillus spp and Staphylococcus spp showed $70.6 \mathrm{mg} / \mathrm{L}$ at an initial concentration of $100 \mathrm{mg} / \mathrm{L}$. In the present study, immobilised Bacillus spp and Staphylococcus spp. from the tannery industrial effluents reduced the levels of the organic pollutants with high potential as indicated by the percentage reduction of BOD, COD and TDS.

Enzymes often can work in multiple environments especially if they are immobilized. This makes the microorganisms' enzymes even more resistant to harsh environments and enables the enzymes to be recovered and recycled after they are no longer needed (Gianfreda and Rao 2004). Ramesh and Singh (1993) reported that the immobilized bacteria having more efficiency to remove the suspended particles than free cells. Using the immobilized cell is preferable due to its capability for using several times with the same efficiency, which makes it more economical. Similar work was done by Sikander et al. (2007) showing the higher reduction with permeabilized cells of Ochrobactrum intermedium strain SDCr-5. 
BAJOPAS Volume 13 Number 2, December, 2020

The results revealed the isolation and identification of isolates with the potential for the reduction of $\mathrm{Cr}$ (VI) to $\mathrm{Cr}$ (III). Results indicated that immobilized $B$. cereus could be efficiently used for the reduction of $\mathrm{Cr}$ (VI).

Table 5: Percentage reduction of the tested Parameters from the tannery industrial samples of the Immobilized Bacteria.

\begin{tabular}{lllllll}
\hline \multirow{2}{*}{ Industries } & & \multicolumn{5}{c}{ Percentage Reduction $(\%)$} \\
\cline { 3 - 7 } & & $5 \mathrm{~g}$ & $10 \mathrm{~g}$ & $15 \mathrm{~g}$ & $20 \mathrm{~g}$ & $25 \mathrm{~g}$ \\
\hline TAN1 & COD & 28 & 14 & 64 & 87 & 89 \\
& BOD & 50 & 54 & 59 & 67 & 80 \\
& SS & 35 & -26 & -27 & -32 & -63 \\
& TDS & 99 & 99 & 99 & 98 & 98 \\
TAN2 & COD & 15 & 20 & 25 & 32 & 38 \\
& BOD & 91 & 91 & 92 & 90 & 92 \\
& SS & -28 & -52 & -52 & -54 & -55 \\
& TDS & 97 & 99 & 99 & 99 & 99 \\
& COD & 33 & 44 & 22 & 11 & 26 \\
& BOD & 75 & 81 & 76 & 81 & 81 \\
& SS & 25 & 3 & -1 & -10 & -15 \\
& TDS & 98 & 98 & 98 & 98 & 98 \\
\hline
\end{tabular}

Percentage Reduction $=(B-A) / B \times 100 \%$

$A=$ Concentration of the parameter after treatment

$\mathrm{B}=$ Concentration of the parameter before treatment

$+=$ percentage decrease

- = percentage increase

In general, immobilization makes the enzyme more resistant to temperature, $\mathrm{pH}$, and substrate concentration swings giving it a longer lifetime and higher productivity per active unit (Gianfreda and Rao, 2004; FuIlbrook, 1996; Russell et al, 2003; Kandelbauer et al., 2004). Immobilized cells have been used and studied extensively for the production of useful chemicals (Ohtake and Silver, 1994), the treatment of wastewaters (Chen et al., 2003; Wang et al., 2010). Although many workers described microbial degradation of tannery effluent, limited literature is available on the bioremediation of tannery effluent using immobilized bacterial cells in the Kano Industrial Estates.

\section{CONCLUSION}

The samples contained variable levels of the physicochemical parameters. The results of the Analysis of variance revealed that, no statistical difference $(p<0.05)$ was observed for the temperature, $\mathrm{pH}, \mathrm{SS}, \mathrm{TDS}, \mathrm{BOD}$ and $\mathrm{COD}$ among the three tannery industries before the treatment. The levels of some of the parameters
(SS, TDS and COD) observed in the samples were found above the recommended limits of WHO and NESREA, which called for the treatment of the effluents before discharge into the environment. Base on the morphological and biochemical test results, TAN1, TAN2, and TAN3 bacterial isolates were identified to be Neisseria spp, Bacillus cereus, and Staphylococcus aureus respectively. The results of Post-treatment analysis showed that there is overall decrease in the levels of the parameters determined when compared with that of the pre-treatment. The overall percentage reduction of the immobilised bacteria in the treatment of the respective effluents was in the order TAN2 (72\%)>TAN1 $(70 \%)>$ TAN3 $(62 \%)$. Hence, the immobilized bacteria are having higher biodegradation potential for the treatment of the tannery effluents.

\section{Acknowledgments}

The authors wish to acknowledge the University of Maiduguri for the financial support. The authors are grateful to the Kano State Ministry of Environment for their support in obtaining the effluent samples. 


\section{REFERENCES}

Ajao, A. T., Adebayo, G. B., and Yakubu, S. E. (2011). Bioremediation of textile industrial effluent using mixed culture of Pseudomonas aeruginosa and Bacillus subtilis immobilized on agar-agar in a bioreactor. J. Microbiol. Biotech. Res, 1(3), 50-56.

Akan, J. C., Moses, E. A., Ogugbuaja, V. O., and Abah, J. (2007). Assessment of tannery industrial effluents from Kano metropolis, Kano State, Nigeria. Journal of Applied Sciences, 7(19), 2788-2793.

Akan, J. C., Ogugbuaja, V. O., Abdulrahman, F. I., and Ayodele, J. T. (2009). Pollutant levels in effluent samples from tanneries and textiles of Kano industrial areas, Nigeria. Global journal of pure and applied sciences, 15(3-4).

APHA (1989). Standard methods for Examination of Will bete and Will betewater.15 $5^{\text {th }}$ edition. Brydpass Springfield Will behington DC. pp. 164-176

APHA (1992). Standard Methods for the Examination of Water and Wastewater. Health, 69, 1116-9.

Baba, A., Garba, S. T., and Bello, H. S. (2020). Bioremediation Potential of Immobilized corynebacterium kutsceri in the Treatment of Tannery Industrial Effluent from Challawa Industrial Estate, Kano State, Nigeria. Journal of the Turkish Chemical Society Section A: Chemistry, $7(2), 335-350$.

Beem, E. I. V. (1994). reduction of solvent VOC emission. J. Oil Col. Chem. Ass, 77, 158.

Bouwer, E. J., and Zehnder, A. J. (1993). Bioremediation of organic compoundsputting microbial metabolism to work. Trends in biotechnology, 11(8), 360367.

Chen, K. C., Wu, J. Y., Liou, D. J., and Hwang, S. C. J. (2003). Decolorization of the textile dyes by newly isolated bacterial strains. Journal of Biotechnology, 101(1), 57-68.

Dan'Azumi, S., and Bichi, M. H. (2010). INDUSTRIAL POLLUTION AND HEAVY METALS PROFILE OF CHALLAWA RIVER IN KANO, NIGERIA. Journal of Applied Sciences in Environmental Sanitation, $5(1)$.

DWAF. (1992). Analytical Methods Manual, TR 151. Department of Water Affairs and Forestry, Pretoria.

El-Bestawy, E. (2013). Biological treatment of leather-tanning industrial wastewater using free living bacteria.
Elsheikh, M. A. S. (2009). Tannery wastewater pre-treatment. Water Science and Technology, 60(2), 433-440.

FuIlbrook, P. D. (1996). "Kinetics." Industrial enzymology: The application of enzymes in Industry. 2nd Ed. T. Godfrey and J Reichelt. eds.. Nature. New York.

Gianfreda, L., and Rao, M. A. (2004). Potential of extra cellular enzymes in remediation of polluted soils: a review. Enzyme and microbial technology, 35(4), 339354.

Hugo Springer. (1994). John Arthur Wilson Memorial Lecture "Treatment of Industrial Wastes of the Leather Industry - is it still a Major Problem". JALCA, 89, 153-185

Jimoh, A. A., Ganiyu, B. A., Baba, D., and Baba, A. (2018) Bioremediation Process of Effluent from Detergent and Food Industries in Jos, Nigeria: Kinetics and Thermodynamics. International Journal of Engineering Science Invention (IJESI), 762-73

Kandelbauer, A., Maute, O., Kessler, R. W., Erlacher, A., and Gübitz, G. M. (2004). Study of dye decolorization in an immobilized laccase enzyme-reactor using online spectroscopy. Biotechnology and bioengineering, 87(4), 552-563.

Kongjao, S., Damronglerd, S., and Hunsom, M. (2008). Simultaneous removal of organic and inorganic Pollutants in tannery wastewater using electrocoagulation technique. Korean Journal of chemical engineering, 25(4), 703.

Maheshwari, U. M., Aruna, S., Gomathi, M., and AbdulJaffar, A. H. (2017). Bioremediation by Free and Immobilized Bacteria Isolated from Tannery Effluent. International Journal of Research in Applied, Natural and Social Sciences. 5(7), 75-90

Margesin, R., and Schinner, F. (2001). Bioremediation (natural attenuation and biostimulation) of diesel-oilcontaminated soil in an alpine glacier skiing area. Applied and environmental microbiology, 677), 3127-3133.

Mohammed, A., Sekar, P., and George, J. (2011). Efficacy of microbes in bioremediation of tannery effluent. Inter. J. Curr. Res, 3(4), 324-326.

Mohammed, S. S. D., Orukotan, A. A., and Abdullahi, H. (2017). Physicochemical and Bacteriological Assessment of Tannery Effluent from Samaru-Zaria, 
BAJOPAS Volume 13 Number 2, December, 2020 Kaduna State, Nigeria. Journal of Applied

Sciences and Environmental Management, 21(4), 734-740.

Munz, G., De Angelis, D., Gori, R., Mori, G., Casarci, M., and Lubello, C. (2009). The role of tannins in conventional and membrane treatment of tannery wastewater. Journal of hazardous materials, 164(2-3), 733-739

Mythili, K., and Karthikeyan, B. (2011). Bioremediation of $\mathrm{Cr}$ (VI) from tannery effluent using Bacillus spp and Staphylococcus spp. International Multidisciplinary Research Journal, 1(6).

NESREA (2009). National Environmental Standards for Effluent Limitations and Regulation. 1233-1236

Noorjahan, C. M. (2014). Physicochemical characteristics, identification of bacteria and biodegradation of industrial effluent. Journal of bioremediation and Biodegradation, 5(3).

Ohtake, H. I., and Silver, A. O. (1994). Bacterial reduction of toxic chromate. Biological degradation and bioremediation of toxic chemicals, 403-415.

Omoleke, I. I. (2004). Management of environmental pollution in Ibadan, an African city: the challenges of health hazard facing government and the people. Journal of Human Ecology, 15(4), 265-275.

Rajor, A., Reddy, A.S., and Singh, B. (2004). Determination of BOD kinetic Parameters and evaluation of alternate methods, M.Sc. Thesis, Department of biotechnology \& environmental Science, Thapar Institute of Engineering and Technology, Patiala

Ramasami, T., Rajamani, S., and Rao, J. R. (1994, March). Pollution control in leather industry: Emerging technological options. In International symposium on surface and colloidal science and its relevance to soil pollution, madras.

Ramesh, J. V. S., and Singh, S. P. (1993). Yearly variation in certain physicochemical parameters of pond at eastern Doon Valley. Uttar Pradesh J. Zoo, 12 (1), 7577.

Ranen, S., and Sharadinadra, C. (2009). Biotechnology applications to environmental remediation in resource exploitation. Current science, 97, 6-25
Russell, A. J., Berberich, J. A., Drevon, G. F., and Koepsel, R. R. (2003). Biomaterials for mediation of

chemical and biological warfare agents. Annual review of biomedical engineering, 5(1), 1-27.

Saravanan, P., and Saravanan, A. (1999). Decolourization of tannery effluent by Flavobacterium sp. EK 1. Indian Journal of Environmental Protection, 19, 19-24.

Sikander, S., and Shahida, H. (2007). Reduction of toxic hexavalent chromium by Ochrobactrum intermedium strain SDCr5 stimulated by heavy metals. Bioresource Technol, 98, 340-344.

Singh, N., Sharma, B. K., and Bohra, P. C. (2000). Impact assessment of industrial effluent of arid soils by using satellite imageries. Journal of the Indian Society of Remote Sensing, 28(2-3), 79.

Sreemoyee, C., and Priti, P. (2013). Assessment of physico-chemical parameters of dairy waste water and isolation and characterization of bacterial strains in terms of cod reduction. Int J Sci, 2(3), 395-400.

Verheijen, L. A. H. M., Wiersema, D., Pol, L. H., and De Wit, J. (1996). Management of wastes from animal product processing. Livestock and environment, Finding a balance. International Agriculture Center, Wageningen, The Netherlands.

Wang, F., Yao, J., Si, Y., Chen, H., Russel, M., Chen, K., and Bramanti, E. (2010). Short-time effect of heavy metals upon microbial community activity. Journal of Hazardous Materials, 173(13), 510-516.

WHO (World Health Organization). (2006). Air quality guidelines: global update 2005: particulate matter, ozone, nitrogen dioxide, and sulfur dioxide. World Health Organization.

World Bank. (1995). Nigeria's strategic options for redressing industrial pollution. World Bank, industry and energy division. 1st edition, West Central Africa Department; Annexes: 1995; pp 60-62.

Zahoor, A., and Abdul, R. (2009). Enumeration of Coliforms. Journal of Environmental Sciences. 21, 814-820 


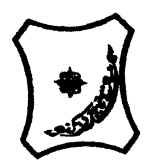

Bayero Journal of Pure and Applied Sciences, 13(2): 1 - 12

Received: November, 2020

Accepted: December, 2020

ISSN $2006-6996$

\title{
BIODEGRADATION POTENTIAL OF IMMOBILIZED BACTERIA IN THE TREATMENT OF TANNERY INDUSTRIAL EFFLUENTS FROM INDUSTRIAL ESTATES IN KANO STATE, NIGERIA
}

\author{
Abdullateef, B., ${ }^{1 *}$ Shuaibu, T. G., ${ }^{1}$ Babagana, K., ${ }^{1}$ Suleman, H. B. ${ }^{2}$ and Dauda, B. ${ }^{3}$ \\ ${ }^{1}$ Department of Pure and Applied Chemistry, Faculty of Science, University of Maiduguri, Borno State, \\ Nigeria \\ ${ }^{2}$ Department of Microbiology, Faculty of Science, University of Maiduguri, Borno State, Nigeria \\ ${ }^{3}$ Department of Chemical Engineering, Faculty of Engineering, University of Maiduguri, Borno State, \\ Nigeria \\ *Corresponding author: babslega@gmail.com; abelega2007@yahoo.com; +2348061309753
}

\section{ABSTRACT}

Industrial Effluents Samples from Gashash Tanneries (TAN1) in Bompai Industrial estate, Larabee Tannery Industry (TAN2) in Sharada Industrial estate and Z Tannery Industries (TAN3) in Challawa Industrial estate, Kano State, Nigeria were collected over a period of six months (August 2017 to January 2018) for assessing the biodegradation potentials of bacteria in the treatment of organic pollutants within the effluents. Bacteria were isolated from the effluents and immobilized on agar-agar. Different masses (5 g, $10 \mathrm{gr}, 15$ $\mathrm{g}, 20 \mathrm{~g}$, and $25 \mathrm{~g}$ ) of the bacteria were used in the treatment of $250 \mathrm{ml}$ of the effluents for ten days in a shaker incubator (Gallenkamp-OC-4364-L) at the temperature $30{ }^{\circ} \mathrm{C}$ and speed of $60 \mathrm{rpm}$. Pre-treatment analysis of the effluents for Temperature, pH, Biochemical Oxygen Demand (BOD), Chemical Oxygen Demand (COD), Suspended Solid (SS) and Total Dissolved Solids (TDS) gives the following results; temperature $\left({ }^{\circ} \mathrm{C}\right.$ )

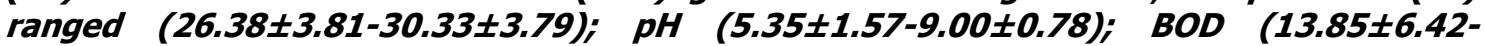
$38.75 \pm 16.20) ;$ COD (1406 $\pm 208-3532 \pm 1373) ;$ SS (208 $\pm 235-780 \pm 739)$ and TDS (266 $\pm 253-5276 \pm 2971)$. No statistical differences ( $p \leq 0.05)$ was observed for all the results among the different industries. The bacterial isolates were identified as Neisseria spp, Bacillus cereus, and Staphylococcus aureus, in TAN1, TAN2, and TAN3, respectively. After treatment of the effluent with the different masses of the isolated bacteria, the mean level of BOD was found to range as (0.55 $\pm 0.36-6.92 \pm 5.49) ; C O D$ (ND-3134 \pm 1595$)$;

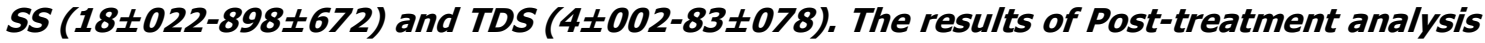
showed that there is overall decrease in the levels of the parameters determined when compared with that of the pre-treatment. The overall percentage reduction of the immobilised bacteria in the treatment of the respective effluents was in the order TAN2 (72\%)>TAN1 (70\%)>TAN3 (62\%). Hence, the immobilized bacteria are having higher biodegradation potential for the treatment of the tannery effluents.

Keywords: Biodegradation, bacteria, effluent, immobilization, tannery.

\section{INTRODUCTION}

Tannery industrial wastewater is a serious consequence of the pollution point of view for streams, freshwater, and land used for agriculture. The lack of awareness in the modern industrial practice has resulted in the discharge of tannery effluents which exhibit very high value of chromium ( $\mathrm{Cr}$ ), Sulfide, and chloride, Total Dissolved Solid (TDS), Total Suspended Solid (TSS), Biochemical Oxygen Demand (BOD) and Chemical Oxygen Demand (COD) in the water stream or land (Mohammed et al., 2001). Tanning is the process, which One ton of skin generally leads to the production of 20 to $80 \mathrm{~m}^{3}$ of turbid and foul-smelling converts the protein of the rawhide or skin into a stable material, which will not putrefy and is suitable for a wide variety of end applications (Elsheikh, 2009). The highly polluting chromium is the most commonly used tanning material producing leather that is more flexible and pliable than vegetable-tanned leather and does not discolor or lose shape in water as drastically as vegetable-tan (Elsheikh, 2009). Tannery effluent is among the most hazardous industrial pollutants due to its huge organic and inorganic load, which is highly toxic to human life and the environment (Kongjao et al., 2008). wastewater including chromium (100-400 mg/l), sulfide $(200-800 \mathrm{mg} / \mathrm{l})$, high levels of fat and 
BAJOPAS Volume 13 Number 2, December, 2020 other solid wastes, and notable pathogen contamination as well as pesticides added for skin conservation during transport (Elsheikh, 2009). There are more than 6000 tanneries in Nigeria with an annual processing capacity of 700,000 tons of hides and skins (Omoleke, 2004; Singh et al., 2008). It was reported that the total amount of waste produced per animal slaughtered is approximately $35 \%$ of its weight (World Bank, 1995). Also, for every $1000 \mathrm{~kg}$ of carcass weight, a slaughtered beef produces 5.5 $\mathrm{kg}$ of manure (excluding rumen contents or stockyard manure) and $100 \mathrm{~kg}$ of paunch manure (undigested food) (Verheijen et al., 1996). Tanneries generate wastewater in the range of 30-35 $\mathrm{L} \mathrm{kg}^{-1}$ skin/hide processed with variable $\mathrm{pH}$, Biological Oxygen Demand (BOD), Chemical Oxygen Demand (COD), high concentrations of suspended solids (SS), and tannins as well as chromium (Zahoor and Abdul, 2009).

Being heterogeneous and composed of a wide variety of compounds, it is very difficult to select a unique direct method for estimating the biodegradability of organic contents and biokinetic parameters for a wastewater sample (Rajor, 2004). For this purpose, some indirect estimation such as determination of biochemical oxygen demand (BOD) and chemical oxygen demand (COD) are applied as common laboratory investigations [9]. During retanning procedures, synthetic tannins (Syntan), oils and resins are added to form softer leather at varying doses (Munz et al., 2009). One of the refractory groups of chemicals in tannery effluents derives mainly from tannins (Ramasami et al., 2004). Syntans are characterized by complex chemical structures, because they are composed of an extended set of chemicals such as phenol-, naphthalene-, formaldehyde- and melamine-based syntans, and acrylic resins (Beem, 1994). Organic pollutants (proteic and lipidic components) are originated from skins (it is calculated that the raw skin has $30 \%$ loss of organic material during the working cycle) or they are introduced during processes (Hugo Springer, 1994).

Many conventional processes such as oxidation, chemical and biological processes were carried out to treat tanneries wastewater (Ebtesam et al, 2013). Biological processes have received more attention because of their costeffectiveness, lower sludge production and environmental friendliness (Noorjahan, 2014). Naturally occurring micro-organisms degrade the hazardous organic wastes including xenobiotic compounds, such as pesticides, polycyclic aromatic hydrocarbons (PAHs) and polychlorinated biphenyls (PCBs) in due course of time (Ranen and Sharadinadra, 2009). Bioremediation is based on the idea that all organisms remove substances from the environment to carry outgrowth and metabolism (Bouwer and Zehnder, 1993). Bacteria, protista and fungi are found to be very good at degrading complex molecules and incorporating the breakdown products into their metabolism (Bouwer and Zehnder, 1993). The resultant metabolic wastes that they produce are generally safe and somehow recycled into other organisms (Ranen and Sharadinadra, 2009). An acclimatized indigenous population of microorganisms capable of degradation of the compounds of interest must exist at the site for a successful bioremediation mode (Ranen and Sharadinadra, 2009). It has been observed that for a successful bioremediation mode, an acclimatized indigenous population of microorganisms capable of degradation of the compounds of interest must exist at the site under investigation (Ranen and Sharadinadra, 2009). Even though there are numerous physical and chemical methods employed in the disposal of wastes the advantage in using bacterium is that they play a key role in the reduction of COD, BOD, total protein, total tannin and total phenol (Saravanan and Saravanan, 1998)

Baba et al. (2020) studied the bioremediation potential of immobilized corynebacterium kutsceri in the Treatment of tannery industrial effluent from Challawa Industrial Estate, Kano State, Nigeria. The aim of the work is to study the reduction in the level of the contaminants through the process of bioremediation using the isolated bacteria. Immobilized bacteria can withstand various temperatures, $\mathrm{pH}$ and substrate concentrations; consequently, increasing the efficiency and the lifespan of the bacteria. Immobilized bacteria are widely applied in the treatment of wastewater and can be separated and recovered after the treatment with the same efficiency (Baba et al., 2020).

\section{MATERIALS AND METHODS \\ Study Area}

This study was carried out in Bompai, Sharada and Challawa industrial estates in Kano, Figure 1. Kano lies on Latitude $11^{\circ} 30^{\prime} \mathrm{N}$ and $8^{\circ} 30^{\prime} \mathrm{E}$ and Longitude $11^{\circ} 5^{\prime} \mathrm{N}$ and $8^{\circ} 5^{\prime} \mathrm{E}$ in Northern Nigeria. It is one of the developed industrial cities in Nigeria. Tannery activities are the dominating industries and this could be one of the reasons for her high population density (Dan'Azumi and Bichi, 2010). Many researchers have studied biodegradation of tannery effluent using microorganisms. However, limited literature is available on the biodegradation of tannery effluent in Kano industrial estates using 
BAJOPAS Volume 13 Number 2, December, 2020 immobilized bacterial cells. This research work focuses on the potential of the use of the indigenous immobilized bacterial isolates in the treatment of tannery effluents in the industrial estates.

\section{Sample Collection}

Effluents were collected from the Tannery Industries from Bompai, Challawa and Sharada Industrial Estates, Kano, Nigeria. The effluents were collected over a period of six months (August 2017 to January 2018). Samples collected in a sterile 4-liter plastic container with a unique identification number were preserved using an ice-box that was transported to the Microbiology Laboratory, Department of Microbiology, Bayero University of Kano for analysis

\section{Sample Preparation and Sample Analysis}

Immediately after the collection of the effluent, $\mathrm{pH}$, TSS, TDS, COD, BOD levels were determined before treatment (Pre-treatment determination) and ten days after treatment (Post-treatment determination) as described in
APHA (1989) standard methods. $\mathrm{pH}$ was determined using Ecotests $\mathrm{pH}$ meter and TDS was determined using AQUALYTIC TDS Salinometer. BOD was determined as described by the standard method (APHA, 1992). COD and SS were determined using DR/2010 HACH portable data logging spectrophotometer (DWAF, 1992)

\section{Identification and Biochemical} Characterization of the Bacterial Isolates

The bacteria were isolated from the effluents using Serial Dilution according to the method described by APHA (1989). The biochemical tests such as oxidase, catalase, coagulase, indole (from $1 \%$ tryptone broth), citrate (Simmons citrate agar), methyl red/VogesProskauer (MR/VP), nitrate reduction, Starch Hydrolysis, Glucose, Maltose, and Lactose tests were carried out on the bacterial isolates to identify the bacteria through the bacteria biochemical characteristics according to Ajao et al. (2011).

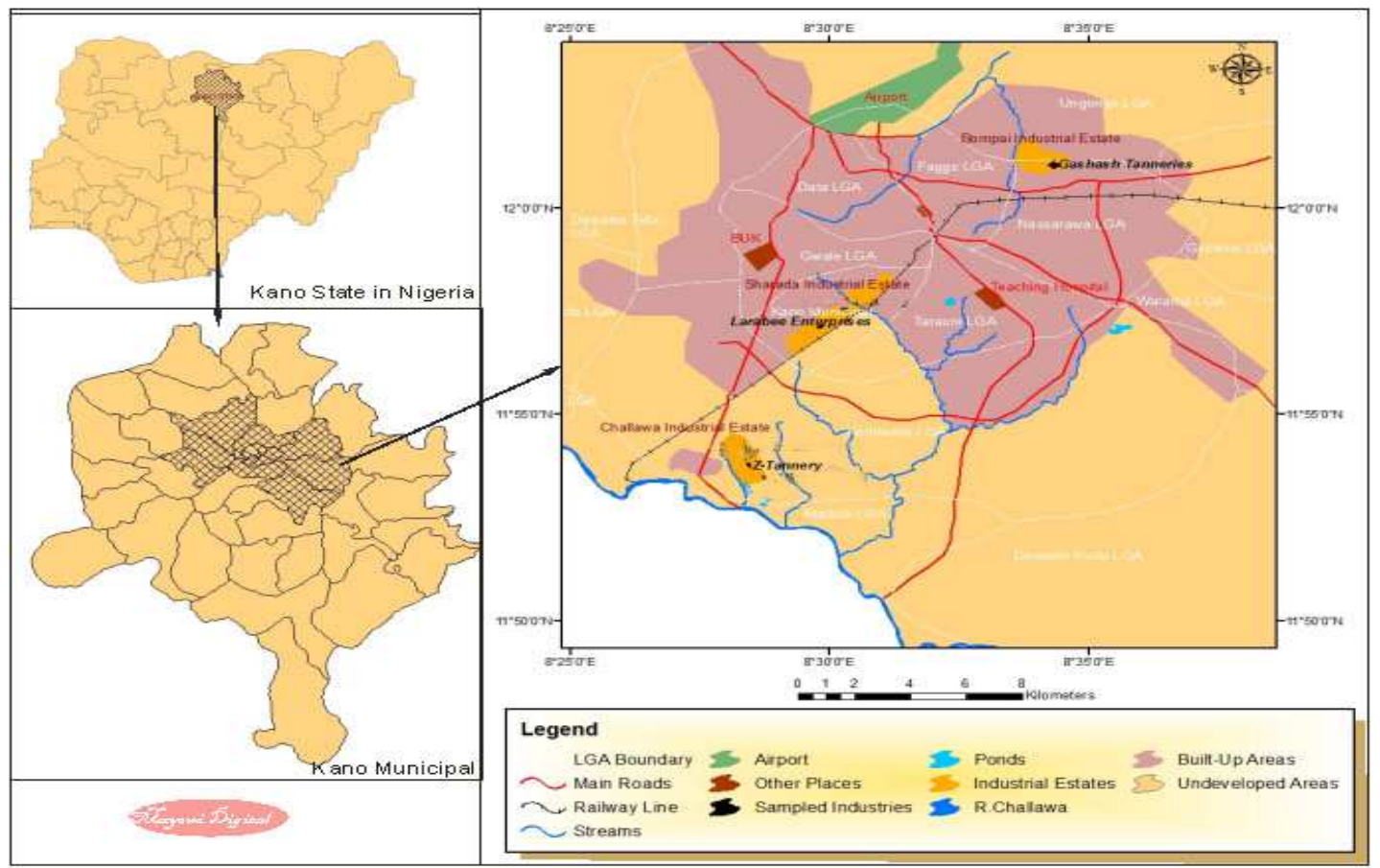

Fig. 1 Map showing the study areas

Source: Mayomi Digital Productions, GIS Laboratory, Department of Geography, UNIMAID (2017)

\section{Determination of Growth Rate of the Bacteria in Effluent Sample}

The bacteria growth rates were determined by transferring $2 \mathrm{~mL}$ of the bacterial isolates from the tannery effluent in broth medium into 100 $\mathrm{mL}$ sterile effluents in conical flasks and kept in an incubator (Giffrin cool) for 10 days. Control was also set up by incubating another $100 \mathrm{~mL}$ each of the sterile effluents without the bacteria. The optical density of the content was determined at the wavelength of $600 \mathrm{~nm}$ on a daily interval and recorded. 
BAJOPAS Volume 13 Number 2, December, 2020 Immobilization of Bacteria

Agar solution and inoculi were prepared separately. Fifty milliliters $(50 \mathrm{~mL})$ of nutrient broth each of the inoculi was prepared in a McCartney bottle and incubated for 24 hours. A solution of agar-agar was prepared by dissolving $10 \mathrm{~g}$ of the powder in distilled water and made up to $500 \mathrm{~mL}$ mark in an Erlenmeyer flask and was sterilized in an autoclave (280A) for 15 minutes and allowed to cool to $40-45^{\circ} \mathrm{C}$ (Ajao et al., 2011). Four milliliters ( $4 \mathrm{~mL})$ of the bacterial isolates in the nutrient broth was mixed with 36 $\mathrm{ml}$ of the prepared agar-agar media in petri-dish plates and then allowed to solidify. This was kept in the refrigerator for bioremediation.

\section{Bioremediation (Treatment) of the Effluents}

The solidified agar block (immobilized bacteria) was cut into cubes using a sterile knife; $0.1 \mathrm{~mL}$ phosphate buffer ( $\mathrm{pH} \mathrm{7.0)}$ was added and kept in the refrigerator for 1 hour for curing. The phosphate buffer was decanted after 1 hour and the cubes were washed with sterile distilled water 3-4 times before it was used (Ajao et al., 2011). Two liters (2 L) of the effluent was supplemented with the minimum basal medium in $\mathrm{g} / \mathrm{L}: \mathrm{NaCl}(0.8), \mathrm{MgSO}_{4} .7 \mathrm{H}_{2} \mathrm{O}(0.001), \mathrm{KH}_{2} \mathrm{PO}_{4}$ (2), $\mathrm{NaNO}_{3}$ (2), $\quad \mathrm{CaCl}_{2} .2 \mathrm{H}_{2} \mathrm{O} \quad(0.5)$ and $\mathrm{NaHPO}_{4} .12 \mathrm{H}_{2} \mathrm{O}(2)$ and sterilized in an autoclave at $121^{\circ} \mathrm{C}$ for 15 minutes (Margesin and Schinner, 2001). Two hundred and fifty milliliters $(250 \mathrm{~mL})$ of the effluents were transferred into different $250 \mathrm{ml}$ conical flasks. The content was covered with a cotton-wool ramped with foil paper to avoid contamination. Five grams $(5 \mathrm{~g})$ of the immobilized bacteria were quickly transferred into each of the effluents in the conical flasks in an inoculating chamber. The same procedures were carried out for the $10 \mathrm{~g}, 15 \mathrm{~g}, 20 \mathrm{~g}$ and 25 $\mathrm{g}$ of the immobilized bacteria in separate $250 \mathrm{~mL}$ effluents in conical flasks and agitated for ten days in a shaker incubator (Gallenkamp-OC4364-L) at a temperature $30^{\circ} \mathrm{C}$ and speed of 60 rpm. The treated effluent samples were taken on the tenth day and analyzed for the parameters $\mathrm{pH}$, SS, TDS, COD, and BOD, (Posttreatment determination) for the different grams of bacteria to evaluate and compare the biodegradation potential. (Baba et al., 2020).

\section{Statistical Analysis}

The data were represented as Mean \pm Standard deviation and analyzed statistically using oneway Analysis of Variance (ANOVA) and Tukey's HSD as Post Hoc Tests with the aid of SPSS 16.0. The correlation coefficient was also used to measure the strength of the relationship between the different masses of the bacteria and the parameters. All $\mathrm{p} \leq 0.05$ were considered as statistically significant.

\section{RESULTS AND DISCUSSION Physico-chemical parameters in the Industrial Effluents before the Biodegradation.}

Results of the Physico-chemical parameters in the industrial effluents before the Biodegradation is shown in table 1 . The mean temperatures $\left({ }^{\circ} \mathrm{C}\right)$ observed in TAN1, TAN2, and TAN3 samples were $28.07 \pm 0.65 ; 27.77 \pm 0.64$ and $26.38 \pm 3.81$ respectively. The order of the mean temperature of the samples from the three industries can be arranged as TAN1 > TAN2>TAN3. The temperature observed at TAN1, TAN2, and TAN3 samples were found below the WHO $\left(35^{\circ} \mathrm{C}\right)$ and NESREA $\left(40^{\circ} \mathrm{C}\right)$ limits. The low values of temperature might be due to the processes used at the time of sampling. High temperature brings down the solubility of gases in water that ultimately expresses as high BOD and COD. Statistical analysis shows that there is no significant difference $(p<0.05)$ between the mean values of temperature among the industries. This might be due to similar tannery activities involved in the tannery industries at the time of sampling. The average values of temperature observed in this present study are less than those observed by Akan et al. (2007), Akan et al. (2009) and Baba et al. (2020).

The mean level of $\mathrm{pH}$ observed in TAN1, TAN2 and TAN3, samples were $7.77 \pm 2.93$; $8.35 \pm 0.28$ and $7.52 \pm 0.76$ respectively. The order of the mean $\mathrm{pH}$ of the samples from the three industries can be arranged as TAN2> TAN1 $>$ TAN3. The $\mathrm{pH}$ of the samples falls within the WHO (7.0-8.5) and NESREA (6-9) standard limits. Statistical analysis shows that there is no significant difference $(p<0.05)$ between the mean values of $\mathrm{pH}$ among the industries. This might be due to similar tannery activities involved in the tannery industries at the time of sampling. Maheshwari et al. (2017) reported that the level of $\mathrm{pH}$ in the effluents from the tannery industry in Vaniyambadi, India was 6.5 which was lower than that observed in the present study. The $\mathrm{pH}$ in the effluents from the tannery industries in Kano and Kaduna were reported to be 7.64 and 6.89, respectively (Akan et al., 2007; Mohammed et al., 2017). The average values of $\mathrm{pH}$ observed in this present study are less than those observed by Mohammed et al. (2017) and Baba et al. (2020). The mean level of SS $(\mathrm{mg} / \mathrm{l})$ observed in TAN1, TAN2, and TAN3 samples were 374 \pm 124 ; $358 \pm 335$ and $780 \pm 739$ respectively. The order of the mean SS in the samples from the three industries can be arranged as TAN3 > TAN1 $>$ TAN2. 
The SS observed in the samples were far above the recommended standard limits of regulating bodies WHO $(30 \mathrm{mg} / \mathrm{l})$ and NESREA $(10 \mathrm{mg} / \mathrm{l})$. Statistical analysis shows that there is no significant difference $(p<0.05)$ between the mean values of SS among the industries. This might be due to similar tannery activities involved in the tannery industries at the time of sampling. The average values of SS observed in this present study are less than that observed $(3700 \pm 122 \mathrm{mg} / \mathrm{l})$ by Akan et al. (2009) for tanneries in Kano. Also, the average values of SS observed in this present study are less than that observed by Mohammed et al. (2017) and Baba et al. (2020) with the exception in TAN3.

The mean level of TDS (mg/l) observed in TAN1, TAN2, and TAN3 samples were $3941 \pm 3703$; $3300 \pm 1714$ and $2653 \pm 1240$ respectively. The order of the mean TDS in the samples from the three industries can be arranged as TAN1>TAN2>TAN3. The TDS observed in the samples were far above the recommended standard limits of WHO $(250 \mathrm{mg} / \mathrm{l})$ and NESREA $(500 \mathrm{mg} / \mathrm{l})$. Statistical analysis shows that there is no significant difference $(p<0.05)$ between the mean values of TDS among the industries. This might be due to similar tannery activities involved in the tannery industries at the time of sampling. TDS in the effluents from the tannery industries in Kano, Nigeria was reported to be $1281 \mathrm{mg} / \mathrm{l}$ (Akan et al., 2007). The average values of SS observed in this present study are less than those observed by Mohammed et al. (2017) and Baba et al. 2020)

The mean level of COD (mg/l) observed in TAN1, TAN2 and TAN3 samples seasons were $2372 \pm 938 ; \quad 1406 \pm 208$ and $3532 \pm 1373$ respectively. The order of the mean COD of the samples from the three industries can be arranged as TAN3>TAN1> TAN2. The COD observed in TAN1, TAN2 and TAN3 samples were far above the recommended standard limits of regulating bodies $\mathrm{WHO}(40 \mathrm{mg} / \mathrm{l})$ and NESREA (40 mg/l). Statistical analysis shows that there is no significant difference $(p<0.05)$ in COD among the industries. This might be due to similar tannery activities involved in the tannery industries as at the time of sampling. The Chemical Oxygen demand (COD) is the amount of oxygen, in $\mathrm{mg} / \mathrm{L}$, required for the degradation of the compound of wastewater to occur. In comparison, the average values of COD observed in this present study were higher than that observed by Mohammed et al. (2017) but lower than that observed by Baba et al. (2020).

The mean levels of BOD $(\mathrm{mg} / \mathrm{l})$ observed in TAN1, TAN2 and TAN3 samples were $13.85 \pm 6.42 ; \quad 19.46 \pm 0.50$ and $17.13 \pm 3.14$ respectively. The order of the mean BOD in the samples from the three industries can be arranged as TAN2>TAN3>TAN1. The BOD observed in TAN1, TAN2 and TAN3 samples were found below the recommended limits of NESREA (200 mg/l) but above WHO (10 mg/l). Statistical analysis shows that there is no significant difference $(p<0.05)$ between the mean values of BOD among the industries. This might be due to similar tannery activities involved in the tannery industries at the time of sampling. The low level of BOD recorded in this study is an indication of the low level of biodegradable organic solids in the effluent. The average values of BOD observed in this present study were lower than those observed by Mohammed et al. (2017) and Baba et al. (2020).

Table 1: Mean Values \pm S.D of Physico-chemical parameters of effluents from the Tannery Industries before Treatment.

\begin{tabular}{llllllll}
\hline Parameter & Tannery 1 & Tannery 2 & Tannery 3 & $\mathrm{a}$ & $\mathrm{b}$ & $\mathrm{c}$ & $\mathrm{d}$ \\
\cline { 2 - 7 } Temperature $\left({ }^{\circ} \mathrm{C}\right)$ & $28.07 \mathrm{a} \pm 0.65$ & $27.77 \mathrm{a} \pm 0.64$ & $26.38 \mathrm{a} \pm 3.81$ & & $29.50 \pm 4.68$ & 35 & 40 \\
pH & $7.77 \mathrm{a} \pm 2.93$ & $8.35 \mathrm{a} \pm 0.28$ & $7.52 \mathrm{a} \pm 0.76$ & 6.89 & $5.35 \pm 1.57$ & $7.0-8.5$ & $6.0-9.0$ \\
$\mathrm{COD}(\mathrm{mg} / \mathrm{l})$ & $2372 \mathrm{a} \pm 938$ & $1406 \mathrm{a} \pm 208$ & $3532 \mathrm{a} \pm 1373$ & 2.2 & $3106 \pm 2753$ & 40 & 40 \\
$\mathrm{BOD}(\mathrm{mg} / \mathrm{l})$ & $13.85 \mathrm{a} \pm 6.42$ & $19.46 \mathrm{a} \pm 0.50$ & $17.13 \mathrm{a} \pm 3.14$ & 1032 & $26.17 \pm 9.49$ & 10 & 200 \\
$\mathrm{SS}(\mathrm{mg} / \mathrm{l})$ & $374 \mathrm{a} \pm 124$ & $358 \mathrm{a} \pm 335$ & $780 \mathrm{a} \pm 739$ & 501 & $562 \pm 482$ & 30 & 10 \\
TDS $(\mathrm{mg} / \mathrm{l})$ & $3941 \mathrm{a} \pm 3703$ & $3300 \mathrm{a} \pm 1714$ & $2653 \mathrm{a} \pm 1240$ & 532.7 & $444 \pm 507$ & 250 & 500 \\
\hline
\end{tabular}

The values given in the table above are means of 6 replicate values, $\mathrm{n}=6$ ( 1 sample was taken monthly for 6 months). Within the rows, means with different alphabets are statistically different $(p<0.05)$. WHO: World Health Organisation. NESREA: National Environmental Standard and Regulatory Enforcement Agency. a = Mohammed et al.(2017), b = Baba et al. (2020), c = WHO (2006), $d=$ NESSRA (2009) 
BAJOPAS Volume 13 Number 2, December, 2020

Identification, Biochemical Characterization and growth rates of the Bacterial Isolates

Results of identification and biochemical characterization of the bacterial isolates were shown in table 2. After 24 hours of incubation, the nutrient agar media plates were checked for bacterial growth. The results showed the presence of different strains in the samples. The TAN1 bacteria isolate was found to be gramnegative cocci while TAN3 was gram-positive cocci. TAN2 bacteria isolate was found to be gram-positive, rod-shaped. TAN1, TAN2, and TAN3 bacteria isolates recorded positive results for spore former.

The results of the biochemical tests indicated that all the bacteria were positive for catalase, oxidase, citrate, maltose, glucose, lactose (negative in TAN1), mannitol (negative in TAN2), starch hydrolysis and coagulase (negative in TAN2) tests. The bacteria showed negative results for nitrate reduction, $M R$ (positive in TAN2), VP (positive in TAN1), Indole (positive in TAN2) tests. Base on the morphological and biochemical test results, TAN1, TAN2, and TAN3 bacteria isolates were identified to be Nesseria spp, Bacillus cereus, and Staphylococcus aureus respectively.

The growth rate of the TAN1, TAN2 and TAN3 Isolates were shown in figure 2. Generally, the optical density increase with the increase in time (day) and decrease as time goes on. The highest optical density was shown by bacillus cereus in TAN2 while the lowest was shown by Staphylococcus aureus in TAN3.

The initial growth phase of TAN1 Isolate bacteria occurred within 2-day of incubation as the growth rate increases up to the 6th-day incubation when the maximum growth was observed. Beyond the 6th day, the growth of the bacteria declined (which might be due to a shortage of nutrients in the effluents) until it reached its death phase (which might be due to the unavailability of nutrients in the effluents).

A similar trend of growth was also observed for TAN2 Isolate as the initial growth phase also occurred within 2-day of incubation but maximum growth rate observed on the 4th day of incubation. The stationary stage occurred between the 4th day and the 8th day. Beyond the 8th day, the growth of the bacteria declined (which might be due to a shortage of nutrients in the effluents) until it reached its death phase (which might be due to the unavailability of nutrients in the effluents).

The initial growth phase of TAN3 bacterial Isolate occurred within the 3-day incubation as the growth rate increases up to the 6th-day incubation when the maximum growth was observed. Beyond the 6th day, the growth of the bacteria declined (which might be due to a shortage of nutrients in the effluents) until it reached its death phase (which might be due to the unavailability of nutrients in the effluents).

Table 2: Morphological and Biochemical characteristics of bacterial isolates

\begin{tabular}{lllll} 
Bacterial Isolates & & TAN1 & TAN2 & TAN3 \\
\hline $\begin{array}{lllll}\text { Morphological } \\
\text { characteristics }\end{array}$ & Shape & Cocci & Rod & Cocci \\
& Spore & & & \\
& former & + & + & + \\
Gram & & & \\
Biochemical characteristics & reaction & - & + & + \\
& Citrate & + & + & + \\
& Catalase & + & + & + \\
& Coagulase & + & - & + \\
Starch & + & + & + \\
& Glucose & + & + & + \\
Oxidase & + & + & + \\
& Indo & - & + & - \\
Lactose & - & + & + \\
Manitol & + & - & + \\
Maltose & + & + & + \\
MR & - & + & - \\
VP & + & - & - \\
& Nitrate & - & - & - \\
Reduction & - Neisseria & Bacillus & Staphylococcus \\
& Bacterial & cereus & aureus \\
& name & spp & cas
\end{tabular}

+ = Positive; - = Negative; MR=Methyl Red; VP= Voges-Proskauer 


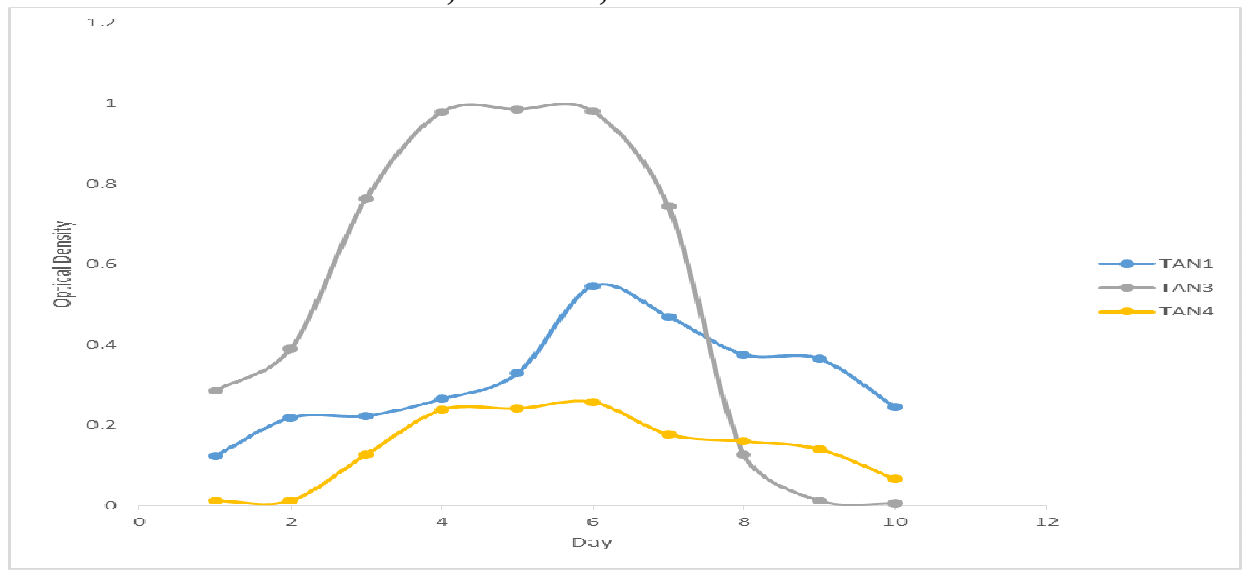

Fig. 2 Growth rates of the isolates in the effluents from the Tannery Industries

\section{Physico-chemical Parameters in the Industrial Effluents after the biodegradation.}

Table 3 shows the mean results of the physicochemical parameter before and after bioremediation using the different masses $(5 \mathrm{~g}$, $10 \mathrm{~g}, 15 \mathrm{~g}, 20 \mathrm{~g}$, and $25 \mathrm{~g}$ ) of the respective immobilized bacteria. Also, Table 4 shows the mean results of correlation coefficient ( $r$ ) between different masses of bacteria and physicochemical parameters.

The mean values $(\mathrm{mg} / \mathrm{l})$ of the SS after the bioremediation varies between $243 \pm 45$ and $898 \pm 672$. The mean concentration $(\mathrm{mg} / \mathrm{l})$ of SS remediated by the different masses $(5 \mathrm{~g}, 10 \mathrm{~g}$, $15 \mathrm{~g}, 20 \mathrm{~g}$, and $25 \mathrm{~g}$ ) of the bacteria varies. The SS in the samples fluctuates up and down after the bioremediation process when compared with the SS of the raw samples before the bioremediation. The increase in the levels of the SS might be due to the aggregation of the TDS which are large enough to result into SS. The increase in the levels of the SS might be also due to the influence of the nutrients which was added into the effluents in order to make the microorganisms more active and viable for fast degradation of organic contaminants in the effluent. The relative potential or efficiency of the different masses of the bacteria in remediating SS in TAN1 samples was in the order $25 \mathrm{~g}>20 \mathrm{~g}>15 \mathrm{~g}>10 \mathrm{~g}>5 \mathrm{~g}$. For TAN2 and TAN3 samples, the order was $25 \mathrm{~g}>20 \mathrm{~g}>15$ $\mathrm{g}>10 \mathrm{~g}>5 \mathrm{~g}$. These might be due to the variations in the surface areas of the different masses of the immobilized bacteria. Statistical analysis shows that there is no significant difference $(p<0.05)$ between the mean values of SS among the masses in the respective industries. Positive and significant correlations exist between the masses of bacteria and Suspended Solid (SS). This showed that there is general increase in the levels of the SS as the masses of the immobilized bacteria increases. TAN3 (90\%) and TAN1 (80\%) showed a very high correlation with the masses of the bacteria while TAN2 (61\%) showed a very low correlation.

The mean values $(\mathrm{mg} / \mathrm{l})$ of the TDS after the bioremediation varies between $46 \pm 11$ and $83 \pm 78$. The mean concentration $(\mathrm{mg} / \mathrm{l})$ of TDS remediated by the different masses $(5 \mathrm{~g}, 10 \mathrm{~g}$, $15 \mathrm{~g}, 20 \mathrm{~g}$, and $25 \mathrm{~g}$ ) of the bacteria varies. There is a reduction in all the TDS of all the samples after the bioremediation process compared with the TDS of the raw samples before the bioremediation. The relative potential or efficiency of the different masses of the bacteria in remediating TDS in TAN1 and TAN3 samples was in the order $5 \mathrm{~g}>10 \mathrm{~g}>15 \mathrm{~g}>20$ $\mathrm{g}>25 \mathrm{~g}$. For TAN2 samples, the order was 20 $g>10 \quad g>25 \quad g>15 \quad g>5 \quad g$. Statistical analysis shows that there is no significant difference $(p<0.05)$ between the mean values of TDS among the masses in the respective industries. These might be due to the variations in the surface areas of the different masses of the immobilized bacteria. Positive and significant correlations exist between the masses of bacteria and TDS with the exception in TAN2 (negative and insignificant correlation). The positive correlations showed that there is general increase in the levels of the TDS as the masses of the immobilized bacteria increases. TAN1 $(96 \%)$ showed a very high correlation with the masses of the bacteria while TAN2 (47\%) showed a very low correlation.

The mean values $(\mathrm{mg} / \mathrm{l})$ of the BOD after the bioremediation varies between $1.56 \pm 0.20 \mathrm{mg} / \mathrm{l}$ and $6.92 \pm 5.49 \mathrm{mg} / \mathrm{l}$. The mean concentration $(\mathrm{mg} / \mathrm{l})$ of BOD remediated by the different masses $(5 \mathrm{~g}, 10 \mathrm{~g}, 15 \mathrm{~g}, 20 \mathrm{~g}$, and $25 \mathrm{~g}$ ) of the bacteria varies. There is a reduction in all the BOD of all the samples after the bioremediation process compared with the $\mathrm{BOD}$ of the raw 
BAJOPAS Volume 13 Number 2, December, 2020 samples before the bioremediation. The relative potential or efficiency of the different masses of the bacteria in remediating BOD in TAN1, TAN2 and TAN3 samples were in the order $25 \mathrm{~g}>20$ $\mathrm{g}>15 \mathrm{~g}>10 \mathrm{~g}>5 \mathrm{~g}, 25 \mathrm{~g}>15 \mathrm{~g}>5 \mathrm{~g}>10 \mathrm{~g}>20 \mathrm{~g}$ and $20 \mathrm{~g}>10 \mathrm{~g}>25 \mathrm{~g}>15 \mathrm{~g}>5 \mathrm{~g}$ respectively. Statistical analysis shows that there is significant difference $(p<0.05)$ between the mean values of BOD among the masses in the respective industries. These might be due to the variations in the surface areas of the different masses of the immobilized bacteria. Negative and significant correlations exist between the masses of bacteria and BOD. This showed that there is general decrease in the levels of the BOD as the masses of the immobilized bacteria increases. TAN1 (94\%) showed a very high correlation with the masses of the bacteria while TAN2 (4\%) showed a very low correlation.

The mean values $(\mathrm{mg} / \mathrm{l})$ of the COD after the bioremediation varies between $250 \pm 154$ and $3134 \pm 1595$. The mean concentration $(\mathrm{mg} / \mathrm{l})$ of COD remediated by the different masses $(5 \mathrm{~g}$, $10 \mathrm{~g}, 15 \mathrm{~g} 20 \mathrm{~g}$, and $25 \mathrm{~g}$ ) of the bacteria varies. There is a reduction in all the COD of all the samples after the bioremediation process compared with the COD of the raw samples before the bioremediation. The relative potential or efficiency of the different masses of the bacteria in remediating COD in TAN1, TAN2 and TAN3 samples were in the order $25 \mathrm{~g}>20 \mathrm{~g}>15$ $\mathrm{g}>5 \mathrm{~g}>10 \mathrm{~g}, 25 \mathrm{~g}>20 \mathrm{~g}>15 \mathrm{~g}>10 \mathrm{~g}>5 \mathrm{~g}$ and 10 g>5 g>25 g>15 g>20 g respectively. Statistical analysis shows that there were significant difference $(p<0.05)$ between the mean values of COD among the masses in the respective industries except for effluents treated with $25 \mathrm{~g}$. These might be due to the variations in the surface areas of the different masses of the immobilized bacteria. Negative and insignificant correlations exist between the masses of bacteria and COD with the exception in TAN3 (positive and significant correlation). The negative correlations showed that there is general decrease in the levels of the COD as the masses of the immobilized bacteria increases. TAN2 (100\%) showed a very high correlation with the masses of the bacteria while TAN3 (36\%) showed a very low correlation.

Generally, there was an overall decrease in the concentration of these physicochemical parameters after the bioremediation using the different masses of the bacterial isolates. These might be due to the variations in the surface areas of the different masses of the immobilized bacteria. This is in line with the work of Jimoh et al. (2018) and Baba et al. (2020).

Table 3: Mean Values $(\mathrm{mg} / \mathrm{l}) \pm$ S.D of Physicochemical parameters in effluents from the Tannery Industries before and after Treatment of the effluents $(250 \mathrm{ml})$ with the different masses $(5 \mathrm{~g}, 10 \mathrm{~g}$, $15 \mathrm{~g}, 20 \mathrm{~g}$, and $25 \mathrm{~g}$ ) of the bacteria.

\begin{tabular}{llllllll}
\hline $\mathrm{P}$ & IND & Before & \multicolumn{5}{c}{ After } \\
\cline { 4 - 7 } & & & $5 \mathrm{~g}$ & $10 \mathrm{~g}$ & $15 \mathrm{~g}$ & $20 \mathrm{~g}$ & $25 \mathrm{~g}$ \\
\hline \multirow{2}{*}{ COD } & TAN1 & $2372 \pm 938$ & $1708 \mathrm{a} \pm 861$ & $2045 \mathrm{a} \pm 1205$ & $845 \mathrm{a} \pm 369$ & $300 \mathrm{a} \pm 167$ & $250 \mathrm{a} \pm 154$ \\
& TAN2 & $1406 \pm 208$ & $1195 \mathrm{a} \pm 208$ & $1125 \mathrm{a} \pm 384$ & $1055 \mathrm{a} \pm 317$ & $956 \mathrm{a} \pm 310$ & $870 \mathrm{ab} \pm 240$ \\
& TAN3 & $3532 \pm 1373$ & $2374 \mathrm{a} \pm 1344$ & $1976 \mathrm{a} \pm 1405$ & $2757 \mathrm{a} \pm 1266$ & $3134 \mathrm{a} \pm 1595$ & $2614 \mathrm{~b} \pm 1105$ \\
BOD & TAN1 & $13.85 \pm 6.42$ & $6.92 \mathrm{a} \pm 5.49$ & $6.42 \mathrm{a} \pm 5.07$ & $5.72 \mathrm{a} \pm 5.35$ & $4.62 \mathrm{a} \pm 4.37$ & $2.82 \mathrm{ab} \pm 1.26$ \\
& TAN2 & $19.46 \pm 0.50$ & $1.75 \mathrm{~b} \pm 0.22$ & $1.73 \mathrm{~b} \pm 0.18$ & $1.58 \mathrm{a} \pm 0.16$ & $1.91 \mathrm{a} \pm 0.22$ & $1.56 \mathrm{~b} \pm 0.20$ \\
& TAN3 & $17.13 \pm 3.14$ & $4.24 \mathrm{ab} \pm 0.77$ & $3.29 \mathrm{ab} \pm 0.37$ & $4.11 \mathrm{a} \pm 0.07$ & $3.23 \mathrm{a} \pm 0.91$ & $3.33 \mathrm{a} \pm 1.28$ \\
SS & TAN1 & $374 \pm 124$ & $243 \mathrm{a} \pm 45$ & $471 \mathrm{a} \pm 226$ & $475 \mathrm{a} \pm 182$ & $492 \mathrm{a} \pm 128$ & $611 \mathrm{a} \pm 217$ \\
& TAN2 & $358 \pm 335$ & $460 \mathrm{a} \pm 400$ & $543 \mathrm{a} \pm 414$ & $544 \mathrm{a} \pm 402$ & $551 \mathrm{a} \pm 414$ & $554 \mathrm{a} \pm 405$ \\
& TAN3 & $780 \pm 739$ & $586 \mathrm{a} \pm 594$ & $758 \mathrm{a} \pm 656$ & $787 \mathrm{a} \pm 676$ & $861 \mathrm{a} \pm 635$ & $898 \mathrm{a} \pm 672$ \\
TDS & TAN1 & $3941 \pm 3703$ & $51 \mathrm{a} \pm 10$ & $53 \mathrm{a} \pm 10$ & $55 \mathrm{a} \pm 15$ & $61 \mathrm{a} \pm 20$ & $63 \mathrm{a} \pm 26$ \\
& TAN2 & $3300 \pm 1714$ & $83 \mathrm{a} \pm 78$ & $47 \mathrm{a} \pm 20$ & $48 \mathrm{a} \pm 22$ & $47 \mathrm{a} \pm 17$ & $48 \mathrm{a} \pm 17$ \\
& TAN3 & $2653 \pm 1240$ & $46 \mathrm{a} \pm 11$ & $55 \mathrm{a} \pm 24$ & $55 \mathrm{a} \pm 25$ & $58 \mathrm{a} \pm 23$ & $61 \mathrm{a} \pm 28$ \\
\hline
\end{tabular}

Replicate $=6$ (months)

Within the rows, for the same parameter, means with different alphabets are statistically different $(p<0.05)$.

$\mathrm{P}=$ parameter, IND = Industries 
BAJOPAS Volume 13 Number 2, December, 2020

Table 4: Correlation coefficient $(r)$ between different masses of the bacteria and the physicochemical parameters.

\begin{tabular}{llll}
\hline Industries & Parameter & Correlation coefficient $(r)$ & $\begin{array}{l}\text { Percent dependence (rxrx100) } \\
(\%)\end{array}$ \\
\hline TAN1 & COD & -0.9 & 82 \\
& BOD & -0.97 & 94 \\
& SS & $0.90^{*}$ & 80 \\
TAN2 & TDS & $0.98^{*}$ & 96 \\
& COD & -1 & 100 \\
& BOD & -0.21 & 4 \\
& SS & $0.78^{*}$ & 61 \\
& TDS & -0.69 & 47 \\
& COD & $0.60^{*}$ & 36 \\
& BOD & -0.6 & 37 \\
& SS & $0.95^{*}$ & 90 \\
& TDS & $0.94^{*}$ & 89 \\
\hline
\end{tabular}

The correlation coefficient $(r)$ with * is statistically significant $(p<0.05)$.

Percentage reduction of the Parameters

Table 5 shows the percentage reduction of Parameters in industrial samples before and after the treatment of the effluents $(250 \mathrm{ml})$ with the different masses $(5 \mathrm{~g}, 10 \mathrm{~g}, 15 \mathrm{~g}, 20 \mathrm{~g}$, and $25 \mathrm{~g}$ ) of the Immobilized Bacteria.

In TAN1 samples, the percentage reduction (\%) of COD ranged (14-89); BOD (50-80); SS (-32$35)$ and TDS (98-99). In TAN2 samples, the percentage decrease $(\%)$ of COD ranged (15$38) ;$ BOD (90-92); SS [-28-(-55)] and TDS (9798). In TAN3 samples, the percentage decrease (\%) of COD ranged (11-44); BOD (76-81); SS (15-25) and TDS (98). The percentage increase in the levels COD, BOD and TDS might be due to the increase in the surface area of the different masses of the immobilized bacteria. However, the percentage decrease in the levels of the SS might be due to the aggregation of the TDS which are large enough to result into SS. The percentage decrease in the levels of the SS might be also due to the influence of the nutrients which was added into the effluents in order to make the microorganisms more active and viable for fast degradation of organic contaminants in the effluent. This is in line with the work of Jimoh et al. (2018) in which the concentration of the SS increase after the bioremediation of effluents.

Sreemoyee and Priti (2013) assessed and reduced several Physico-chemical parameters of dairy wastewater using Niesseria $s p$. and concluded that the species are well known to degrade organic compounds. This is in agreement with the current study in which the immobilized Niesseria $s p$ degrade the organic contaminants as indicated by the BOD, COD and TDS.

Jimoh et al. (2018) observed that TSS of the effluents was increased after treatment with immobilized bacteria and concluded that it might be due to the biostimulation method adopted for the research.

The optimum $\mathrm{pH}$ Biosorption of Chromium by Bacillus spp and Staphylococcus spp. from tannery effluent was investigated by Mythili and Karthikeyan (2011). The maximum adsorption of Chromium $(86.4 \mathrm{mg} / \mathrm{L})$ was showed by Bacillus spp and Staphylococcus spp showed $70.6 \mathrm{mg} / \mathrm{L}$ at an initial concentration of $100 \mathrm{mg} / \mathrm{L}$. In the present study, immobilised Bacillus spp and Staphylococcus spp. from the tannery industrial effluents reduced the levels of the organic pollutants with high potential as indicated by the percentage reduction of BOD, COD and TDS.

Enzymes often can work in multiple environments especially if they are immobilized. This makes the microorganisms' enzymes even more resistant to harsh environments and enables the enzymes to be recovered and recycled after they are no longer needed (Gianfreda and Rao 2004). Ramesh and Singh (1993) reported that the immobilized bacteria having more efficiency to remove the suspended particles than free cells. Using the immobilized cell is preferable due to its capability for using several times with the same efficiency, which makes it more economical. Similar work was done by Sikander et al. (2007) showing the higher reduction with permeabilized cells of Ochrobactrum intermedium strain SDCr-5. 
BAJOPAS Volume 13 Number 2, December, 2020

The results revealed the isolation and identification of isolates with the potential for the reduction of $\mathrm{Cr}$ (VI) to $\mathrm{Cr}$ (III). Results indicated that immobilized $B$. cereus could be efficiently used for the reduction of $\mathrm{Cr}$ (VI).

Table 5: Percentage reduction of the tested Parameters from the tannery industrial samples of the Immobilized Bacteria.

\begin{tabular}{lllllll}
\hline \multirow{2}{*}{ Industries } & & \multicolumn{5}{c}{ Percentage Reduction $(\%)$} \\
\cline { 3 - 7 } & & $5 \mathrm{~g}$ & $10 \mathrm{~g}$ & $15 \mathrm{~g}$ & $20 \mathrm{~g}$ & $25 \mathrm{~g}$ \\
\hline TAN1 & COD & 28 & 14 & 64 & 87 & 89 \\
& BOD & 50 & 54 & 59 & 67 & 80 \\
& SS & 35 & -26 & -27 & -32 & -63 \\
& TDS & 99 & 99 & 99 & 98 & 98 \\
TAN2 & COD & 15 & 20 & 25 & 32 & 38 \\
& BOD & 91 & 91 & 92 & 90 & 92 \\
& SS & -28 & -52 & -52 & -54 & -55 \\
& TDS & 97 & 99 & 99 & 99 & 99 \\
& COD & 33 & 44 & 22 & 11 & 26 \\
& BOD & 75 & 81 & 76 & 81 & 81 \\
& SS & 25 & 3 & -1 & -10 & -15 \\
& TDS & 98 & 98 & 98 & 98 & 98 \\
\hline
\end{tabular}

Percentage Reduction $=(B-A) / B \times 100 \%$

$A=$ Concentration of the parameter after treatment

$\mathrm{B}=$ Concentration of the parameter before treatment

$+=$ percentage decrease

- = percentage increase

In general, immobilization makes the enzyme more resistant to temperature, $\mathrm{pH}$, and substrate concentration swings giving it a longer lifetime and higher productivity per active unit (Gianfreda and Rao, 2004; FuIlbrook, 1996; Russell et al, 2003; Kandelbauer et al., 2004). Immobilized cells have been used and studied extensively for the production of useful chemicals (Ohtake and Silver, 1994), the treatment of wastewaters (Chen et al., 2003; Wang et al., 2010). Although many workers described microbial degradation of tannery effluent, limited literature is available on the bioremediation of tannery effluent using immobilized bacterial cells in the Kano Industrial Estates.

\section{CONCLUSION}

The samples contained variable levels of the physicochemical parameters. The results of the Analysis of variance revealed that, no statistical difference $(p<0.05)$ was observed for the temperature, $\mathrm{pH}, \mathrm{SS}, \mathrm{TDS}, \mathrm{BOD}$ and $\mathrm{COD}$ among the three tannery industries before the treatment. The levels of some of the parameters
(SS, TDS and COD) observed in the samples were found above the recommended limits of WHO and NESREA, which called for the treatment of the effluents before discharge into the environment. Base on the morphological and biochemical test results, TAN1, TAN2, and TAN3 bacterial isolates were identified to be Neisseria spp, Bacillus cereus, and Staphylococcus aureus respectively. The results of Post-treatment analysis showed that there is overall decrease in the levels of the parameters determined when compared with that of the pre-treatment. The overall percentage reduction of the immobilised bacteria in the treatment of the respective effluents was in the order TAN2 (72\%)>TAN1 $(70 \%)>$ TAN3 $(62 \%)$. Hence, the immobilized bacteria are having higher biodegradation potential for the treatment of the tannery effluents.

\section{Acknowledgments}

The authors wish to acknowledge the University of Maiduguri for the financial support. The authors are grateful to the Kano State Ministry of Environment for their support in obtaining the effluent samples. 


\section{REFERENCES}

Ajao, A. T., Adebayo, G. B., and Yakubu, S. E. (2011). Bioremediation of textile industrial effluent using mixed culture of Pseudomonas aeruginosa and Bacillus subtilis immobilized on agar-agar in a bioreactor. J. Microbiol. Biotech. Res, 1(3), 50-56.

Akan, J. C., Moses, E. A., Ogugbuaja, V. O., and Abah, J. (2007). Assessment of tannery industrial effluents from Kano metropolis, Kano State, Nigeria. Journal of Applied Sciences, 7(19), 2788-2793.

Akan, J. C., Ogugbuaja, V. O., Abdulrahman, F. I., and Ayodele, J. T. (2009). Pollutant levels in effluent samples from tanneries and textiles of Kano industrial areas, Nigeria. Global journal of pure and applied sciences, 15(3-4).

APHA (1989). Standard methods for Examination of Will bete and Will betewater.15 $5^{\text {th }}$ edition. Brydpass Springfield Will behington DC. pp. 164-176

APHA (1992). Standard Methods for the Examination of Water and Wastewater. Health, 69, 1116-9.

Baba, A., Garba, S. T., and Bello, H. S. (2020). Bioremediation Potential of Immobilized corynebacterium kutsceri in the Treatment of Tannery Industrial Effluent from Challawa Industrial Estate, Kano State, Nigeria. Journal of the Turkish Chemical Society Section A: Chemistry, $7(2), 335-350$.

Beem, E. I. V. (1994). reduction of solvent VOC emission. J. Oil Col. Chem. Ass, 77, 158.

Bouwer, E. J., and Zehnder, A. J. (1993). Bioremediation of organic compoundsputting microbial metabolism to work. Trends in biotechnology, 11(8), 360367.

Chen, K. C., Wu, J. Y., Liou, D. J., and Hwang, S. C. J. (2003). Decolorization of the textile dyes by newly isolated bacterial strains. Journal of Biotechnology, 101(1), 57-68.

Dan'Azumi, S., and Bichi, M. H. (2010). INDUSTRIAL POLLUTION AND HEAVY METALS PROFILE OF CHALLAWA RIVER IN KANO, NIGERIA. Journal of Applied Sciences in Environmental Sanitation, $5(1)$.

DWAF. (1992). Analytical Methods Manual, TR 151. Department of Water Affairs and Forestry, Pretoria.

El-Bestawy, E. (2013). Biological treatment of leather-tanning industrial wastewater using free living bacteria.
Elsheikh, M. A. S. (2009). Tannery wastewater pre-treatment. Water Science and Technology, 60(2), 433-440.

FuIlbrook, P. D. (1996). "Kinetics." Industrial enzymology: The application of enzymes in Industry. 2nd Ed. T. Godfrey and J Reichelt. eds.. Nature. New York.

Gianfreda, L., and Rao, M. A. (2004). Potential of extra cellular enzymes in remediation of polluted soils: a review. Enzyme and microbial technology, 35(4), 339354.

Hugo Springer. (1994). John Arthur Wilson Memorial Lecture "Treatment of Industrial Wastes of the Leather Industry - is it still a Major Problem". JALCA, 89, 153-185

Jimoh, A. A., Ganiyu, B. A., Baba, D., and Baba, A. (2018) Bioremediation Process of Effluent from Detergent and Food Industries in Jos, Nigeria: Kinetics and Thermodynamics. International Journal of Engineering Science Invention (IJESI), 762-73

Kandelbauer, A., Maute, O., Kessler, R. W., Erlacher, A., and Gübitz, G. M. (2004). Study of dye decolorization in an immobilized laccase enzyme-reactor using online spectroscopy. Biotechnology and bioengineering, 87(4), 552-563.

Kongjao, S., Damronglerd, S., and Hunsom, M. (2008). Simultaneous removal of organic and inorganic Pollutants in tannery wastewater using electrocoagulation technique. Korean Journal of chemical engineering, 25(4), 703.

Maheshwari, U. M., Aruna, S., Gomathi, M., and AbdulJaffar, A. H. (2017). Bioremediation by Free and Immobilized Bacteria Isolated from Tannery Effluent. International Journal of Research in Applied, Natural and Social Sciences. 5(7), 75-90

Margesin, R., and Schinner, F. (2001). Bioremediation (natural attenuation and biostimulation) of diesel-oilcontaminated soil in an alpine glacier skiing area. Applied and environmental microbiology, 677), 3127-3133.

Mohammed, A., Sekar, P., and George, J. (2011). Efficacy of microbes in bioremediation of tannery effluent. Inter. J. Curr. Res, 3(4), 324-326.

Mohammed, S. S. D., Orukotan, A. A., and Abdullahi, H. (2017). Physicochemical and Bacteriological Assessment of Tannery Effluent from Samaru-Zaria, 
BAJOPAS Volume 13 Number 2, December, 2020 Kaduna State, Nigeria. Journal of Applied

Sciences and Environmental Management, 21(4), 734-740.

Munz, G., De Angelis, D., Gori, R., Mori, G., Casarci, M., and Lubello, C. (2009). The role of tannins in conventional and membrane treatment of tannery wastewater. Journal of hazardous materials, 164(2-3), 733-739

Mythili, K., and Karthikeyan, B. (2011). Bioremediation of $\mathrm{Cr}$ (VI) from tannery effluent using Bacillus spp and Staphylococcus spp. International Multidisciplinary Research Journal, 1(6).

NESREA (2009). National Environmental Standards for Effluent Limitations and Regulation. 1233-1236

Noorjahan, C. M. (2014). Physicochemical characteristics, identification of bacteria and biodegradation of industrial effluent. Journal of bioremediation and Biodegradation, 5(3).

Ohtake, H. I., and Silver, A. O. (1994). Bacterial reduction of toxic chromate. Biological degradation and bioremediation of toxic chemicals, 403-415.

Omoleke, I. I. (2004). Management of environmental pollution in Ibadan, an African city: the challenges of health hazard facing government and the people. Journal of Human Ecology, 15(4), 265-275.

Rajor, A., Reddy, A.S., and Singh, B. (2004). Determination of BOD kinetic Parameters and evaluation of alternate methods, M.Sc. Thesis, Department of biotechnology \& environmental Science, Thapar Institute of Engineering and Technology, Patiala

Ramasami, T., Rajamani, S., and Rao, J. R. (1994, March). Pollution control in leather industry: Emerging technological options. In International symposium on surface and colloidal science and its relevance to soil pollution, madras.

Ramesh, J. V. S., and Singh, S. P. (1993). Yearly variation in certain physicochemical parameters of pond at eastern Doon Valley. Uttar Pradesh J. Zoo, 12 (1), 7577.

Ranen, S., and Sharadinadra, C. (2009). Biotechnology applications to environmental remediation in resource exploitation. Current science, 97, 6-25
Russell, A. J., Berberich, J. A., Drevon, G. F., and Koepsel, R. R. (2003). Biomaterials for mediation of

chemical and biological warfare agents. Annual review of biomedical engineering, 5(1), 1-27.

Saravanan, P., and Saravanan, A. (1999). Decolourization of tannery effluent by Flavobacterium sp. EK 1. Indian Journal of Environmental Protection, 19, 19-24.

Sikander, S., and Shahida, H. (2007). Reduction of toxic hexavalent chromium by Ochrobactrum intermedium strain SDCr5 stimulated by heavy metals. Bioresource Technol, 98, 340-344.

Singh, N., Sharma, B. K., and Bohra, P. C. (2000). Impact assessment of industrial effluent of arid soils by using satellite imageries. Journal of the Indian Society of Remote Sensing, 28(2-3), 79.

Sreemoyee, C., and Priti, P. (2013). Assessment of physico-chemical parameters of dairy waste water and isolation and characterization of bacterial strains in terms of cod reduction. Int J Sci, 2(3), 395-400.

Verheijen, L. A. H. M., Wiersema, D., Pol, L. H., and De Wit, J. (1996). Management of wastes from animal product processing. Livestock and environment, Finding a balance. International Agriculture Center, Wageningen, The Netherlands.

Wang, F., Yao, J., Si, Y., Chen, H., Russel, M., Chen, K., and Bramanti, E. (2010). Short-time effect of heavy metals upon microbial community activity. Journal of Hazardous Materials, 173(13), 510-516.

WHO (World Health Organization). (2006). Air quality guidelines: global update 2005: particulate matter, ozone, nitrogen dioxide, and sulfur dioxide. World Health Organization.

World Bank. (1995). Nigeria's strategic options for redressing industrial pollution. World Bank, industry and energy division. 1st edition, West Central Africa Department; Annexes: 1995; pp 60-62.

Zahoor, A., and Abdul, R. (2009). Enumeration of Coliforms. Journal of Environmental Sciences. 21, 814-820 


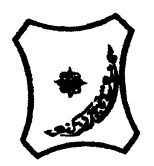

Bayero Journal of Pure and Applied Sciences, 13(2): 1 - 12

Received: November, 2020

Accepted: December, 2020

ISSN $2006-6996$

\title{
BIODEGRADATION POTENTIAL OF IMMOBILIZED BACTERIA IN THE TREATMENT OF TANNERY INDUSTRIAL EFFLUENTS FROM INDUSTRIAL ESTATES IN KANO STATE, NIGERIA
}

\author{
Abdullateef, B., ${ }^{1 *}$ Shuaibu, T. G., ${ }^{1}$ Babagana, K., ${ }^{1}$ Suleman, H. B. ${ }^{2}$ and Dauda, B. ${ }^{3}$ \\ ${ }^{1}$ Department of Pure and Applied Chemistry, Faculty of Science, University of Maiduguri, Borno State, \\ Nigeria \\ ${ }^{2}$ Department of Microbiology, Faculty of Science, University of Maiduguri, Borno State, Nigeria \\ ${ }^{3}$ Department of Chemical Engineering, Faculty of Engineering, University of Maiduguri, Borno State, \\ Nigeria \\ *Corresponding author: babslega@gmail.com; abelega2007@yahoo.com; +2348061309753
}

\section{ABSTRACT}

Industrial Effluents Samples from Gashash Tanneries (TAN1) in Bompai Industrial estate, Larabee Tannery Industry (TAN2) in Sharada Industrial estate and Z Tannery Industries (TAN3) in Challawa Industrial estate, Kano State, Nigeria were collected over a period of six months (August 2017 to January 2018) for assessing the biodegradation potentials of bacteria in the treatment of organic pollutants within the effluents. Bacteria were isolated from the effluents and immobilized on agar-agar. Different masses (5 g, $10 \mathrm{gr}, 15$ $\mathrm{g}, 20 \mathrm{~g}$, and $25 \mathrm{~g}$ ) of the bacteria were used in the treatment of $250 \mathrm{ml}$ of the effluents for ten days in a shaker incubator (Gallenkamp-OC-4364-L) at the temperature $30{ }^{\circ} \mathrm{C}$ and speed of $60 \mathrm{rpm}$. Pre-treatment analysis of the effluents for Temperature, pH, Biochemical Oxygen Demand (BOD), Chemical Oxygen Demand (COD), Suspended Solid (SS) and Total Dissolved Solids (TDS) gives the following results; temperature $\left({ }^{\circ} \mathrm{C}\right.$ )

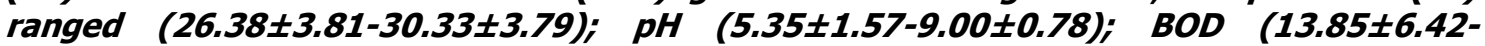
$38.75 \pm 16.20) ;$ COD (1406 $\pm 208-3532 \pm 1373) ;$ SS (208 $\pm 235-780 \pm 739)$ and TDS (266 $\pm 253-5276 \pm 2971)$. No statistical differences ( $p \leq 0.05)$ was observed for all the results among the different industries. The bacterial isolates were identified as Neisseria spp, Bacillus cereus, and Staphylococcus aureus, in TAN1, TAN2, and TAN3, respectively. After treatment of the effluent with the different masses of the isolated bacteria, the mean level of BOD was found to range as (0.55 $\pm 0.36-6.92 \pm 5.49) ; C O D$ (ND-3134 \pm 1595$)$;

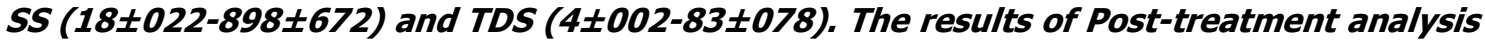
showed that there is overall decrease in the levels of the parameters determined when compared with that of the pre-treatment. The overall percentage reduction of the immobilised bacteria in the treatment of the respective effluents was in the order TAN2 (72\%)>TAN1 (70\%)>TAN3 (62\%). Hence, the immobilized bacteria are having higher biodegradation potential for the treatment of the tannery effluents.

Keywords: Biodegradation, bacteria, effluent, immobilization, tannery.

\section{INTRODUCTION}

Tannery industrial wastewater is a serious consequence of the pollution point of view for streams, freshwater, and land used for agriculture. The lack of awareness in the modern industrial practice has resulted in the discharge of tannery effluents which exhibit very high value of chromium ( $\mathrm{Cr}$ ), Sulfide, and chloride, Total Dissolved Solid (TDS), Total Suspended Solid (TSS), Biochemical Oxygen Demand (BOD) and Chemical Oxygen Demand (COD) in the water stream or land (Mohammed et al., 2001). Tanning is the process, which One ton of skin generally leads to the production of 20 to $80 \mathrm{~m}^{3}$ of turbid and foul-smelling converts the protein of the rawhide or skin into a stable material, which will not putrefy and is suitable for a wide variety of end applications (Elsheikh, 2009). The highly polluting chromium is the most commonly used tanning material producing leather that is more flexible and pliable than vegetable-tanned leather and does not discolor or lose shape in water as drastically as vegetable-tan (Elsheikh, 2009). Tannery effluent is among the most hazardous industrial pollutants due to its huge organic and inorganic load, which is highly toxic to human life and the environment (Kongjao et al., 2008). wastewater including chromium (100-400 mg/l), sulfide $(200-800 \mathrm{mg} / \mathrm{l})$, high levels of fat and 
BAJOPAS Volume 13 Number 2, December, 2020 other solid wastes, and notable pathogen contamination as well as pesticides added for skin conservation during transport (Elsheikh, 2009). There are more than 6000 tanneries in Nigeria with an annual processing capacity of 700,000 tons of hides and skins (Omoleke, 2004; Singh et al., 2008). It was reported that the total amount of waste produced per animal slaughtered is approximately $35 \%$ of its weight (World Bank, 1995). Also, for every $1000 \mathrm{~kg}$ of carcass weight, a slaughtered beef produces 5.5 $\mathrm{kg}$ of manure (excluding rumen contents or stockyard manure) and $100 \mathrm{~kg}$ of paunch manure (undigested food) (Verheijen et al., 1996). Tanneries generate wastewater in the range of 30-35 $\mathrm{L} \mathrm{kg}^{-1}$ skin/hide processed with variable $\mathrm{pH}$, Biological Oxygen Demand (BOD), Chemical Oxygen Demand (COD), high concentrations of suspended solids (SS), and tannins as well as chromium (Zahoor and Abdul, 2009).

Being heterogeneous and composed of a wide variety of compounds, it is very difficult to select a unique direct method for estimating the biodegradability of organic contents and biokinetic parameters for a wastewater sample (Rajor, 2004). For this purpose, some indirect estimation such as determination of biochemical oxygen demand (BOD) and chemical oxygen demand (COD) are applied as common laboratory investigations [9]. During retanning procedures, synthetic tannins (Syntan), oils and resins are added to form softer leather at varying doses (Munz et al., 2009). One of the refractory groups of chemicals in tannery effluents derives mainly from tannins (Ramasami et al., 2004). Syntans are characterized by complex chemical structures, because they are composed of an extended set of chemicals such as phenol-, naphthalene-, formaldehyde- and melamine-based syntans, and acrylic resins (Beem, 1994). Organic pollutants (proteic and lipidic components) are originated from skins (it is calculated that the raw skin has $30 \%$ loss of organic material during the working cycle) or they are introduced during processes (Hugo Springer, 1994).

Many conventional processes such as oxidation, chemical and biological processes were carried out to treat tanneries wastewater (Ebtesam et al, 2013). Biological processes have received more attention because of their costeffectiveness, lower sludge production and environmental friendliness (Noorjahan, 2014). Naturally occurring micro-organisms degrade the hazardous organic wastes including xenobiotic compounds, such as pesticides, polycyclic aromatic hydrocarbons (PAHs) and polychlorinated biphenyls (PCBs) in due course of time (Ranen and Sharadinadra, 2009). Bioremediation is based on the idea that all organisms remove substances from the environment to carry outgrowth and metabolism (Bouwer and Zehnder, 1993). Bacteria, protista and fungi are found to be very good at degrading complex molecules and incorporating the breakdown products into their metabolism (Bouwer and Zehnder, 1993). The resultant metabolic wastes that they produce are generally safe and somehow recycled into other organisms (Ranen and Sharadinadra, 2009). An acclimatized indigenous population of microorganisms capable of degradation of the compounds of interest must exist at the site for a successful bioremediation mode (Ranen and Sharadinadra, 2009). It has been observed that for a successful bioremediation mode, an acclimatized indigenous population of microorganisms capable of degradation of the compounds of interest must exist at the site under investigation (Ranen and Sharadinadra, 2009). Even though there are numerous physical and chemical methods employed in the disposal of wastes the advantage in using bacterium is that they play a key role in the reduction of COD, BOD, total protein, total tannin and total phenol (Saravanan and Saravanan, 1998)

Baba et al. (2020) studied the bioremediation potential of immobilized corynebacterium kutsceri in the Treatment of tannery industrial effluent from Challawa Industrial Estate, Kano State, Nigeria. The aim of the work is to study the reduction in the level of the contaminants through the process of bioremediation using the isolated bacteria. Immobilized bacteria can withstand various temperatures, $\mathrm{pH}$ and substrate concentrations; consequently, increasing the efficiency and the lifespan of the bacteria. Immobilized bacteria are widely applied in the treatment of wastewater and can be separated and recovered after the treatment with the same efficiency (Baba et al., 2020).

\section{MATERIALS AND METHODS \\ Study Area}

This study was carried out in Bompai, Sharada and Challawa industrial estates in Kano, Figure 1. Kano lies on Latitude $11^{\circ} 30^{\prime} \mathrm{N}$ and $8^{\circ} 30^{\prime} \mathrm{E}$ and Longitude $11^{\circ} 5^{\prime} \mathrm{N}$ and $8^{\circ} 5^{\prime} \mathrm{E}$ in Northern Nigeria. It is one of the developed industrial cities in Nigeria. Tannery activities are the dominating industries and this could be one of the reasons for her high population density (Dan'Azumi and Bichi, 2010). Many researchers have studied biodegradation of tannery effluent using microorganisms. However, limited literature is available on the biodegradation of tannery effluent in Kano industrial estates using 
BAJOPAS Volume 13 Number 2, December, 2020 immobilized bacterial cells. This research work focuses on the potential of the use of the indigenous immobilized bacterial isolates in the treatment of tannery effluents in the industrial estates.

\section{Sample Collection}

Effluents were collected from the Tannery Industries from Bompai, Challawa and Sharada Industrial Estates, Kano, Nigeria. The effluents were collected over a period of six months (August 2017 to January 2018). Samples collected in a sterile 4-liter plastic container with a unique identification number were preserved using an ice-box that was transported to the Microbiology Laboratory, Department of Microbiology, Bayero University of Kano for analysis

\section{Sample Preparation and Sample Analysis}

Immediately after the collection of the effluent, $\mathrm{pH}$, TSS, TDS, COD, BOD levels were determined before treatment (Pre-treatment determination) and ten days after treatment (Post-treatment determination) as described in
APHA (1989) standard methods. $\mathrm{pH}$ was determined using Ecotests $\mathrm{pH}$ meter and TDS was determined using AQUALYTIC TDS Salinometer. BOD was determined as described by the standard method (APHA, 1992). COD and SS were determined using DR/2010 HACH portable data logging spectrophotometer (DWAF, 1992)

\section{Identification and Biochemical} Characterization of the Bacterial Isolates

The bacteria were isolated from the effluents using Serial Dilution according to the method described by APHA (1989). The biochemical tests such as oxidase, catalase, coagulase, indole (from $1 \%$ tryptone broth), citrate (Simmons citrate agar), methyl red/VogesProskauer (MR/VP), nitrate reduction, Starch Hydrolysis, Glucose, Maltose, and Lactose tests were carried out on the bacterial isolates to identify the bacteria through the bacteria biochemical characteristics according to Ajao et al. (2011).

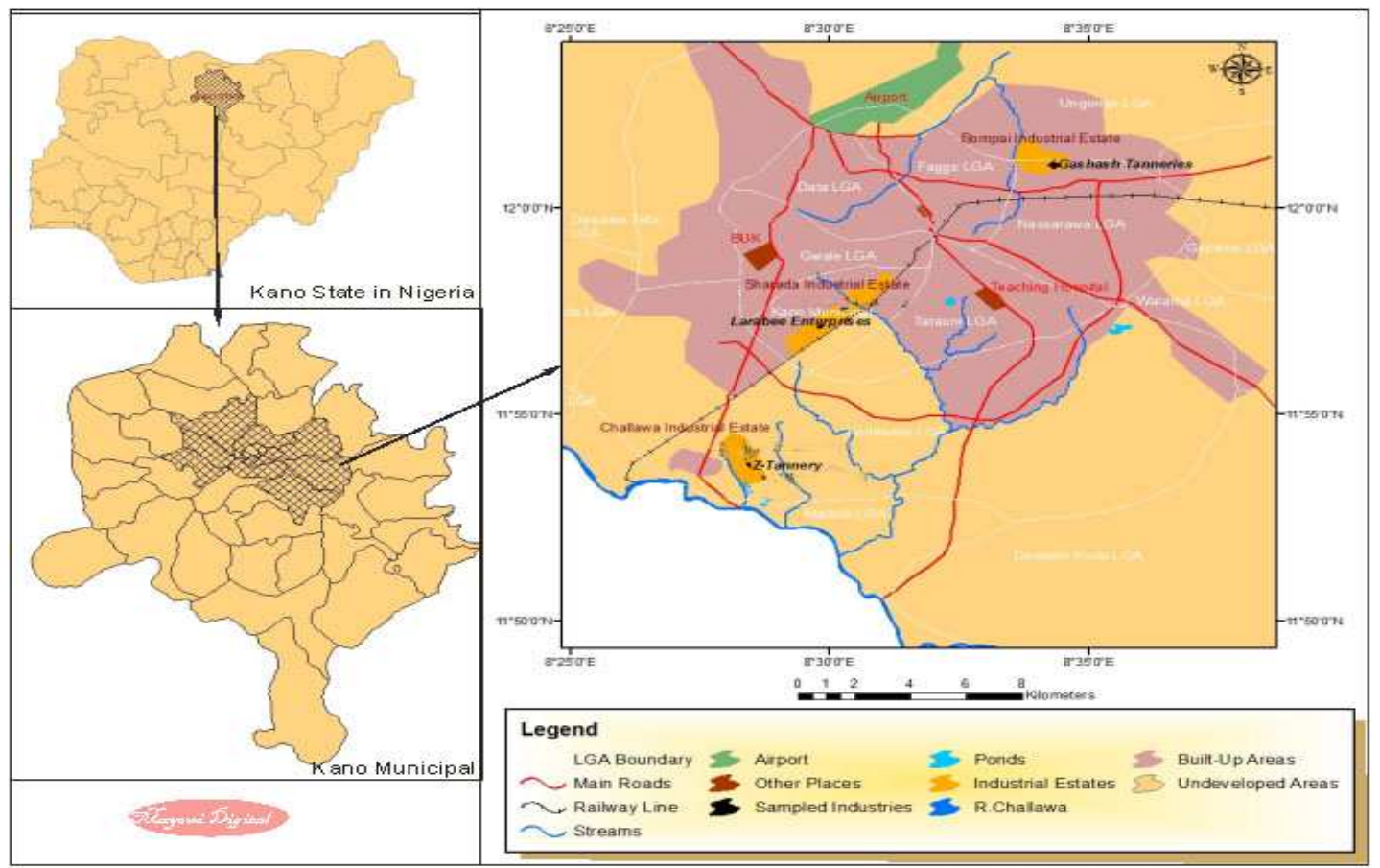

Fig. 1 Map showing the study areas

Source: Mayomi Digital Productions, GIS Laboratory, Department of Geography, UNIMAID (2017)

\section{Determination of Growth Rate of the Bacteria in Effluent Sample}

The bacteria growth rates were determined by transferring $2 \mathrm{~mL}$ of the bacterial isolates from the tannery effluent in broth medium into 100 $\mathrm{mL}$ sterile effluents in conical flasks and kept in an incubator (Giffrin cool) for 10 days. Control was also set up by incubating another $100 \mathrm{~mL}$ each of the sterile effluents without the bacteria. The optical density of the content was determined at the wavelength of $600 \mathrm{~nm}$ on a daily interval and recorded. 
BAJOPAS Volume 13 Number 2, December, 2020 Immobilization of Bacteria

Agar solution and inoculi were prepared separately. Fifty milliliters $(50 \mathrm{~mL})$ of nutrient broth each of the inoculi was prepared in a McCartney bottle and incubated for 24 hours. A solution of agar-agar was prepared by dissolving $10 \mathrm{~g}$ of the powder in distilled water and made up to $500 \mathrm{~mL}$ mark in an Erlenmeyer flask and was sterilized in an autoclave (280A) for 15 minutes and allowed to cool to $40-45^{\circ} \mathrm{C}$ (Ajao et al., 2011). Four milliliters ( $4 \mathrm{~mL})$ of the bacterial isolates in the nutrient broth was mixed with 36 $\mathrm{ml}$ of the prepared agar-agar media in petri-dish plates and then allowed to solidify. This was kept in the refrigerator for bioremediation.

\section{Bioremediation (Treatment) of the Effluents}

The solidified agar block (immobilized bacteria) was cut into cubes using a sterile knife; $0.1 \mathrm{~mL}$ phosphate buffer ( $\mathrm{pH} \mathrm{7.0)}$ was added and kept in the refrigerator for 1 hour for curing. The phosphate buffer was decanted after 1 hour and the cubes were washed with sterile distilled water 3-4 times before it was used (Ajao et al., 2011). Two liters (2 L) of the effluent was supplemented with the minimum basal medium in $\mathrm{g} / \mathrm{L}: \mathrm{NaCl}(0.8), \mathrm{MgSO}_{4} .7 \mathrm{H}_{2} \mathrm{O}(0.001), \mathrm{KH}_{2} \mathrm{PO}_{4}$ (2), $\mathrm{NaNO}_{3}$ (2), $\quad \mathrm{CaCl}_{2} .2 \mathrm{H}_{2} \mathrm{O} \quad(0.5)$ and $\mathrm{NaHPO}_{4} .12 \mathrm{H}_{2} \mathrm{O}(2)$ and sterilized in an autoclave at $121^{\circ} \mathrm{C}$ for 15 minutes (Margesin and Schinner, 2001). Two hundred and fifty milliliters $(250 \mathrm{~mL})$ of the effluents were transferred into different $250 \mathrm{ml}$ conical flasks. The content was covered with a cotton-wool ramped with foil paper to avoid contamination. Five grams $(5 \mathrm{~g})$ of the immobilized bacteria were quickly transferred into each of the effluents in the conical flasks in an inoculating chamber. The same procedures were carried out for the $10 \mathrm{~g}, 15 \mathrm{~g}, 20 \mathrm{~g}$ and 25 $\mathrm{g}$ of the immobilized bacteria in separate $250 \mathrm{~mL}$ effluents in conical flasks and agitated for ten days in a shaker incubator (Gallenkamp-OC4364-L) at a temperature $30^{\circ} \mathrm{C}$ and speed of 60 rpm. The treated effluent samples were taken on the tenth day and analyzed for the parameters $\mathrm{pH}$, SS, TDS, COD, and BOD, (Posttreatment determination) for the different grams of bacteria to evaluate and compare the biodegradation potential. (Baba et al., 2020).

\section{Statistical Analysis}

The data were represented as Mean \pm Standard deviation and analyzed statistically using oneway Analysis of Variance (ANOVA) and Tukey's HSD as Post Hoc Tests with the aid of SPSS 16.0. The correlation coefficient was also used to measure the strength of the relationship between the different masses of the bacteria and the parameters. All $\mathrm{p} \leq 0.05$ were considered as statistically significant.

\section{RESULTS AND DISCUSSION Physico-chemical parameters in the Industrial Effluents before the Biodegradation.}

Results of the Physico-chemical parameters in the industrial effluents before the Biodegradation is shown in table 1 . The mean temperatures $\left({ }^{\circ} \mathrm{C}\right)$ observed in TAN1, TAN2, and TAN3 samples were $28.07 \pm 0.65 ; 27.77 \pm 0.64$ and $26.38 \pm 3.81$ respectively. The order of the mean temperature of the samples from the three industries can be arranged as TAN1 > TAN2>TAN3. The temperature observed at TAN1, TAN2, and TAN3 samples were found below the WHO $\left(35^{\circ} \mathrm{C}\right)$ and NESREA $\left(40^{\circ} \mathrm{C}\right)$ limits. The low values of temperature might be due to the processes used at the time of sampling. High temperature brings down the solubility of gases in water that ultimately expresses as high BOD and COD. Statistical analysis shows that there is no significant difference $(p<0.05)$ between the mean values of temperature among the industries. This might be due to similar tannery activities involved in the tannery industries at the time of sampling. The average values of temperature observed in this present study are less than those observed by Akan et al. (2007), Akan et al. (2009) and Baba et al. (2020).

The mean level of $\mathrm{pH}$ observed in TAN1, TAN2 and TAN3, samples were $7.77 \pm 2.93$; $8.35 \pm 0.28$ and $7.52 \pm 0.76$ respectively. The order of the mean $\mathrm{pH}$ of the samples from the three industries can be arranged as TAN2> TAN1 $>$ TAN3. The $\mathrm{pH}$ of the samples falls within the WHO (7.0-8.5) and NESREA (6-9) standard limits. Statistical analysis shows that there is no significant difference $(p<0.05)$ between the mean values of $\mathrm{pH}$ among the industries. This might be due to similar tannery activities involved in the tannery industries at the time of sampling. Maheshwari et al. (2017) reported that the level of $\mathrm{pH}$ in the effluents from the tannery industry in Vaniyambadi, India was 6.5 which was lower than that observed in the present study. The $\mathrm{pH}$ in the effluents from the tannery industries in Kano and Kaduna were reported to be 7.64 and 6.89, respectively (Akan et al., 2007; Mohammed et al., 2017). The average values of $\mathrm{pH}$ observed in this present study are less than those observed by Mohammed et al. (2017) and Baba et al. (2020). The mean level of SS $(\mathrm{mg} / \mathrm{l})$ observed in TAN1, TAN2, and TAN3 samples were 374 \pm 124 ; $358 \pm 335$ and $780 \pm 739$ respectively. The order of the mean SS in the samples from the three industries can be arranged as TAN3 > TAN1 $>$ TAN2. 
The SS observed in the samples were far above the recommended standard limits of regulating bodies WHO $(30 \mathrm{mg} / \mathrm{l})$ and NESREA $(10 \mathrm{mg} / \mathrm{l})$. Statistical analysis shows that there is no significant difference $(p<0.05)$ between the mean values of SS among the industries. This might be due to similar tannery activities involved in the tannery industries at the time of sampling. The average values of SS observed in this present study are less than that observed $(3700 \pm 122 \mathrm{mg} / \mathrm{l})$ by Akan et al. (2009) for tanneries in Kano. Also, the average values of SS observed in this present study are less than that observed by Mohammed et al. (2017) and Baba et al. (2020) with the exception in TAN3.

The mean level of TDS (mg/l) observed in TAN1, TAN2, and TAN3 samples were $3941 \pm 3703$; $3300 \pm 1714$ and $2653 \pm 1240$ respectively. The order of the mean TDS in the samples from the three industries can be arranged as TAN1>TAN2>TAN3. The TDS observed in the samples were far above the recommended standard limits of WHO $(250 \mathrm{mg} / \mathrm{l})$ and NESREA $(500 \mathrm{mg} / \mathrm{l})$. Statistical analysis shows that there is no significant difference $(p<0.05)$ between the mean values of TDS among the industries. This might be due to similar tannery activities involved in the tannery industries at the time of sampling. TDS in the effluents from the tannery industries in Kano, Nigeria was reported to be $1281 \mathrm{mg} / \mathrm{l}$ (Akan et al., 2007). The average values of SS observed in this present study are less than those observed by Mohammed et al. (2017) and Baba et al. 2020)

The mean level of COD (mg/l) observed in TAN1, TAN2 and TAN3 samples seasons were $2372 \pm 938 ; \quad 1406 \pm 208$ and $3532 \pm 1373$ respectively. The order of the mean COD of the samples from the three industries can be arranged as TAN3>TAN1> TAN2. The COD observed in TAN1, TAN2 and TAN3 samples were far above the recommended standard limits of regulating bodies $\mathrm{WHO}(40 \mathrm{mg} / \mathrm{l})$ and NESREA (40 mg/l). Statistical analysis shows that there is no significant difference $(p<0.05)$ in COD among the industries. This might be due to similar tannery activities involved in the tannery industries as at the time of sampling. The Chemical Oxygen demand (COD) is the amount of oxygen, in $\mathrm{mg} / \mathrm{L}$, required for the degradation of the compound of wastewater to occur. In comparison, the average values of COD observed in this present study were higher than that observed by Mohammed et al. (2017) but lower than that observed by Baba et al. (2020).

The mean levels of BOD $(\mathrm{mg} / \mathrm{l})$ observed in TAN1, TAN2 and TAN3 samples were $13.85 \pm 6.42 ; \quad 19.46 \pm 0.50$ and $17.13 \pm 3.14$ respectively. The order of the mean BOD in the samples from the three industries can be arranged as TAN2>TAN3>TAN1. The BOD observed in TAN1, TAN2 and TAN3 samples were found below the recommended limits of NESREA (200 mg/l) but above WHO (10 mg/l). Statistical analysis shows that there is no significant difference $(p<0.05)$ between the mean values of BOD among the industries. This might be due to similar tannery activities involved in the tannery industries at the time of sampling. The low level of BOD recorded in this study is an indication of the low level of biodegradable organic solids in the effluent. The average values of BOD observed in this present study were lower than those observed by Mohammed et al. (2017) and Baba et al. (2020).

Table 1: Mean Values \pm S.D of Physico-chemical parameters of effluents from the Tannery Industries before Treatment.

\begin{tabular}{llllllll}
\hline Parameter & Tannery 1 & Tannery 2 & Tannery 3 & $\mathrm{a}$ & $\mathrm{b}$ & $\mathrm{c}$ & $\mathrm{d}$ \\
\cline { 2 - 7 } Temperature $\left({ }^{\circ} \mathrm{C}\right)$ & $28.07 \mathrm{a} \pm 0.65$ & $27.77 \mathrm{a} \pm 0.64$ & $26.38 \mathrm{a} \pm 3.81$ & & $29.50 \pm 4.68$ & 35 & 40 \\
pH & $7.77 \mathrm{a} \pm 2.93$ & $8.35 \mathrm{a} \pm 0.28$ & $7.52 \mathrm{a} \pm 0.76$ & 6.89 & $5.35 \pm 1.57$ & $7.0-8.5$ & $6.0-9.0$ \\
$\mathrm{COD}(\mathrm{mg} / \mathrm{l})$ & $2372 \mathrm{a} \pm 938$ & $1406 \mathrm{a} \pm 208$ & $3532 \mathrm{a} \pm 1373$ & 2.2 & $3106 \pm 2753$ & 40 & 40 \\
$\mathrm{BOD}(\mathrm{mg} / \mathrm{l})$ & $13.85 \mathrm{a} \pm 6.42$ & $19.46 \mathrm{a} \pm 0.50$ & $17.13 \mathrm{a} \pm 3.14$ & 1032 & $26.17 \pm 9.49$ & 10 & 200 \\
$\mathrm{SS}(\mathrm{mg} / \mathrm{l})$ & $374 \mathrm{a} \pm 124$ & $358 \mathrm{a} \pm 335$ & $780 \mathrm{a} \pm 739$ & 501 & $562 \pm 482$ & 30 & 10 \\
TDS $(\mathrm{mg} / \mathrm{l})$ & $3941 \mathrm{a} \pm 3703$ & $3300 \mathrm{a} \pm 1714$ & $2653 \mathrm{a} \pm 1240$ & 532.7 & $444 \pm 507$ & 250 & 500 \\
\hline
\end{tabular}

The values given in the table above are means of 6 replicate values, $\mathrm{n}=6$ ( 1 sample was taken monthly for 6 months). Within the rows, means with different alphabets are statistically different $(p<0.05)$. WHO: World Health Organisation. NESREA: National Environmental Standard and Regulatory Enforcement Agency. a = Mohammed et al.(2017), b = Baba et al. (2020), c = WHO (2006), $d=$ NESSRA (2009) 
BAJOPAS Volume 13 Number 2, December, 2020

Identification, Biochemical Characterization and growth rates of the Bacterial Isolates

Results of identification and biochemical characterization of the bacterial isolates were shown in table 2. After 24 hours of incubation, the nutrient agar media plates were checked for bacterial growth. The results showed the presence of different strains in the samples. The TAN1 bacteria isolate was found to be gramnegative cocci while TAN3 was gram-positive cocci. TAN2 bacteria isolate was found to be gram-positive, rod-shaped. TAN1, TAN2, and TAN3 bacteria isolates recorded positive results for spore former.

The results of the biochemical tests indicated that all the bacteria were positive for catalase, oxidase, citrate, maltose, glucose, lactose (negative in TAN1), mannitol (negative in TAN2), starch hydrolysis and coagulase (negative in TAN2) tests. The bacteria showed negative results for nitrate reduction, $M R$ (positive in TAN2), VP (positive in TAN1), Indole (positive in TAN2) tests. Base on the morphological and biochemical test results, TAN1, TAN2, and TAN3 bacteria isolates were identified to be Nesseria spp, Bacillus cereus, and Staphylococcus aureus respectively.

The growth rate of the TAN1, TAN2 and TAN3 Isolates were shown in figure 2. Generally, the optical density increase with the increase in time (day) and decrease as time goes on. The highest optical density was shown by bacillus cereus in TAN2 while the lowest was shown by Staphylococcus aureus in TAN3.

The initial growth phase of TAN1 Isolate bacteria occurred within 2-day of incubation as the growth rate increases up to the 6th-day incubation when the maximum growth was observed. Beyond the 6th day, the growth of the bacteria declined (which might be due to a shortage of nutrients in the effluents) until it reached its death phase (which might be due to the unavailability of nutrients in the effluents).

A similar trend of growth was also observed for TAN2 Isolate as the initial growth phase also occurred within 2-day of incubation but maximum growth rate observed on the 4th day of incubation. The stationary stage occurred between the 4th day and the 8th day. Beyond the 8th day, the growth of the bacteria declined (which might be due to a shortage of nutrients in the effluents) until it reached its death phase (which might be due to the unavailability of nutrients in the effluents).

The initial growth phase of TAN3 bacterial Isolate occurred within the 3-day incubation as the growth rate increases up to the 6th-day incubation when the maximum growth was observed. Beyond the 6th day, the growth of the bacteria declined (which might be due to a shortage of nutrients in the effluents) until it reached its death phase (which might be due to the unavailability of nutrients in the effluents).

Table 2: Morphological and Biochemical characteristics of bacterial isolates

\begin{tabular}{lllll} 
Bacterial Isolates & & TAN1 & TAN2 & TAN3 \\
\hline $\begin{array}{lllll}\text { Morphological } \\
\text { characteristics }\end{array}$ & Shape & Cocci & Rod & Cocci \\
& Spore & & & \\
& former & + & + & + \\
Gram & & & \\
Biochemical characteristics & reaction & - & + & + \\
& Citrate & + & + & + \\
& Catalase & + & + & + \\
& Coagulase & + & - & + \\
Starch & + & + & + \\
& Glucose & + & + & + \\
Oxidase & + & + & + \\
& Indo & - & + & - \\
Lactose & - & + & + \\
Manitol & + & - & + \\
Maltose & + & + & + \\
MR & - & + & - \\
VP & + & - & - \\
& Nitrate & - & - & - \\
Reduction & - Neisseria & Bacillus & Staphylococcus \\
& Bacterial & cereus & aureus \\
& name & spp & cas
\end{tabular}

+ = Positive; - = Negative; MR=Methyl Red; VP= Voges-Proskauer 


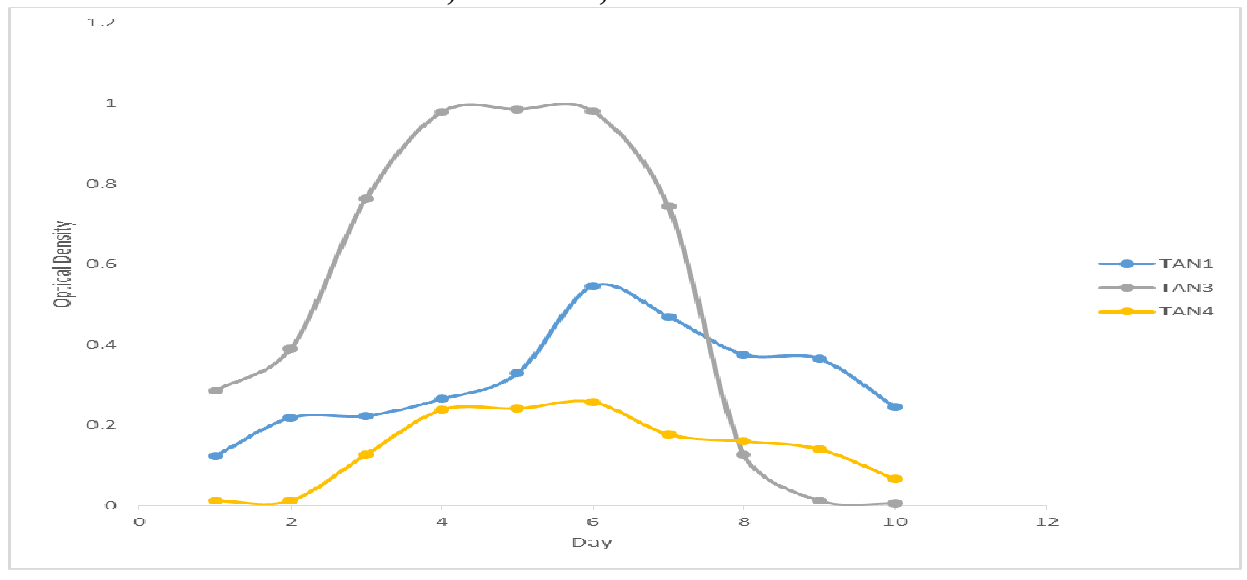

Fig. 2 Growth rates of the isolates in the effluents from the Tannery Industries

\section{Physico-chemical Parameters in the Industrial Effluents after the biodegradation.}

Table 3 shows the mean results of the physicochemical parameter before and after bioremediation using the different masses $(5 \mathrm{~g}$, $10 \mathrm{~g}, 15 \mathrm{~g}, 20 \mathrm{~g}$, and $25 \mathrm{~g}$ ) of the respective immobilized bacteria. Also, Table 4 shows the mean results of correlation coefficient ( $r$ ) between different masses of bacteria and physicochemical parameters.

The mean values $(\mathrm{mg} / \mathrm{l})$ of the SS after the bioremediation varies between $243 \pm 45$ and $898 \pm 672$. The mean concentration $(\mathrm{mg} / \mathrm{l})$ of SS remediated by the different masses $(5 \mathrm{~g}, 10 \mathrm{~g}$, $15 \mathrm{~g}, 20 \mathrm{~g}$, and $25 \mathrm{~g}$ ) of the bacteria varies. The SS in the samples fluctuates up and down after the bioremediation process when compared with the SS of the raw samples before the bioremediation. The increase in the levels of the SS might be due to the aggregation of the TDS which are large enough to result into SS. The increase in the levels of the SS might be also due to the influence of the nutrients which was added into the effluents in order to make the microorganisms more active and viable for fast degradation of organic contaminants in the effluent. The relative potential or efficiency of the different masses of the bacteria in remediating SS in TAN1 samples was in the order $25 \mathrm{~g}>20 \mathrm{~g}>15 \mathrm{~g}>10 \mathrm{~g}>5 \mathrm{~g}$. For TAN2 and TAN3 samples, the order was $25 \mathrm{~g}>20 \mathrm{~g}>15$ $\mathrm{g}>10 \mathrm{~g}>5 \mathrm{~g}$. These might be due to the variations in the surface areas of the different masses of the immobilized bacteria. Statistical analysis shows that there is no significant difference $(p<0.05)$ between the mean values of SS among the masses in the respective industries. Positive and significant correlations exist between the masses of bacteria and Suspended Solid (SS). This showed that there is general increase in the levels of the SS as the masses of the immobilized bacteria increases. TAN3 (90\%) and TAN1 (80\%) showed a very high correlation with the masses of the bacteria while TAN2 (61\%) showed a very low correlation.

The mean values $(\mathrm{mg} / \mathrm{l})$ of the TDS after the bioremediation varies between $46 \pm 11$ and $83 \pm 78$. The mean concentration $(\mathrm{mg} / \mathrm{l})$ of TDS remediated by the different masses $(5 \mathrm{~g}, 10 \mathrm{~g}$, $15 \mathrm{~g}, 20 \mathrm{~g}$, and $25 \mathrm{~g}$ ) of the bacteria varies. There is a reduction in all the TDS of all the samples after the bioremediation process compared with the TDS of the raw samples before the bioremediation. The relative potential or efficiency of the different masses of the bacteria in remediating TDS in TAN1 and TAN3 samples was in the order $5 \mathrm{~g}>10 \mathrm{~g}>15 \mathrm{~g}>20$ $\mathrm{g}>25 \mathrm{~g}$. For TAN2 samples, the order was 20 $g>10 \quad g>25 \quad g>15 \quad g>5 \quad g$. Statistical analysis shows that there is no significant difference $(p<0.05)$ between the mean values of TDS among the masses in the respective industries. These might be due to the variations in the surface areas of the different masses of the immobilized bacteria. Positive and significant correlations exist between the masses of bacteria and TDS with the exception in TAN2 (negative and insignificant correlation). The positive correlations showed that there is general increase in the levels of the TDS as the masses of the immobilized bacteria increases. TAN1 $(96 \%)$ showed a very high correlation with the masses of the bacteria while TAN2 (47\%) showed a very low correlation.

The mean values $(\mathrm{mg} / \mathrm{l})$ of the BOD after the bioremediation varies between $1.56 \pm 0.20 \mathrm{mg} / \mathrm{l}$ and $6.92 \pm 5.49 \mathrm{mg} / \mathrm{l}$. The mean concentration $(\mathrm{mg} / \mathrm{l})$ of BOD remediated by the different masses $(5 \mathrm{~g}, 10 \mathrm{~g}, 15 \mathrm{~g}, 20 \mathrm{~g}$, and $25 \mathrm{~g}$ ) of the bacteria varies. There is a reduction in all the BOD of all the samples after the bioremediation process compared with the $\mathrm{BOD}$ of the raw 
BAJOPAS Volume 13 Number 2, December, 2020 samples before the bioremediation. The relative potential or efficiency of the different masses of the bacteria in remediating BOD in TAN1, TAN2 and TAN3 samples were in the order $25 \mathrm{~g}>20$ $\mathrm{g}>15 \mathrm{~g}>10 \mathrm{~g}>5 \mathrm{~g}, 25 \mathrm{~g}>15 \mathrm{~g}>5 \mathrm{~g}>10 \mathrm{~g}>20 \mathrm{~g}$ and $20 \mathrm{~g}>10 \mathrm{~g}>25 \mathrm{~g}>15 \mathrm{~g}>5 \mathrm{~g}$ respectively. Statistical analysis shows that there is significant difference $(p<0.05)$ between the mean values of BOD among the masses in the respective industries. These might be due to the variations in the surface areas of the different masses of the immobilized bacteria. Negative and significant correlations exist between the masses of bacteria and BOD. This showed that there is general decrease in the levels of the BOD as the masses of the immobilized bacteria increases. TAN1 (94\%) showed a very high correlation with the masses of the bacteria while TAN2 (4\%) showed a very low correlation.

The mean values $(\mathrm{mg} / \mathrm{l})$ of the COD after the bioremediation varies between $250 \pm 154$ and $3134 \pm 1595$. The mean concentration $(\mathrm{mg} / \mathrm{l})$ of COD remediated by the different masses $(5 \mathrm{~g}$, $10 \mathrm{~g}, 15 \mathrm{~g} 20 \mathrm{~g}$, and $25 \mathrm{~g}$ ) of the bacteria varies. There is a reduction in all the COD of all the samples after the bioremediation process compared with the COD of the raw samples before the bioremediation. The relative potential or efficiency of the different masses of the bacteria in remediating COD in TAN1, TAN2 and TAN3 samples were in the order $25 \mathrm{~g}>20 \mathrm{~g}>15$ $\mathrm{g}>5 \mathrm{~g}>10 \mathrm{~g}, 25 \mathrm{~g}>20 \mathrm{~g}>15 \mathrm{~g}>10 \mathrm{~g}>5 \mathrm{~g}$ and 10 g>5 g>25 g>15 g>20 g respectively. Statistical analysis shows that there were significant difference $(p<0.05)$ between the mean values of COD among the masses in the respective industries except for effluents treated with $25 \mathrm{~g}$. These might be due to the variations in the surface areas of the different masses of the immobilized bacteria. Negative and insignificant correlations exist between the masses of bacteria and COD with the exception in TAN3 (positive and significant correlation). The negative correlations showed that there is general decrease in the levels of the COD as the masses of the immobilized bacteria increases. TAN2 (100\%) showed a very high correlation with the masses of the bacteria while TAN3 (36\%) showed a very low correlation.

Generally, there was an overall decrease in the concentration of these physicochemical parameters after the bioremediation using the different masses of the bacterial isolates. These might be due to the variations in the surface areas of the different masses of the immobilized bacteria. This is in line with the work of Jimoh et al. (2018) and Baba et al. (2020).

Table 3: Mean Values $(\mathrm{mg} / \mathrm{l}) \pm$ S.D of Physicochemical parameters in effluents from the Tannery Industries before and after Treatment of the effluents $(250 \mathrm{ml})$ with the different masses $(5 \mathrm{~g}, 10 \mathrm{~g}$, $15 \mathrm{~g}, 20 \mathrm{~g}$, and $25 \mathrm{~g}$ ) of the bacteria.

\begin{tabular}{llllllll}
\hline $\mathrm{P}$ & IND & Before & \multicolumn{5}{c}{ After } \\
\cline { 4 - 7 } & & & $5 \mathrm{~g}$ & $10 \mathrm{~g}$ & $15 \mathrm{~g}$ & $20 \mathrm{~g}$ & $25 \mathrm{~g}$ \\
\hline \multirow{2}{*}{ COD } & TAN1 & $2372 \pm 938$ & $1708 \mathrm{a} \pm 861$ & $2045 \mathrm{a} \pm 1205$ & $845 \mathrm{a} \pm 369$ & $300 \mathrm{a} \pm 167$ & $250 \mathrm{a} \pm 154$ \\
& TAN2 & $1406 \pm 208$ & $1195 \mathrm{a} \pm 208$ & $1125 \mathrm{a} \pm 384$ & $1055 \mathrm{a} \pm 317$ & $956 \mathrm{a} \pm 310$ & $870 \mathrm{ab} \pm 240$ \\
& TAN3 & $3532 \pm 1373$ & $2374 \mathrm{a} \pm 1344$ & $1976 \mathrm{a} \pm 1405$ & $2757 \mathrm{a} \pm 1266$ & $3134 \mathrm{a} \pm 1595$ & $2614 \mathrm{~b} \pm 1105$ \\
BOD & TAN1 & $13.85 \pm 6.42$ & $6.92 \mathrm{a} \pm 5.49$ & $6.42 \mathrm{a} \pm 5.07$ & $5.72 \mathrm{a} \pm 5.35$ & $4.62 \mathrm{a} \pm 4.37$ & $2.82 \mathrm{ab} \pm 1.26$ \\
& TAN2 & $19.46 \pm 0.50$ & $1.75 \mathrm{~b} \pm 0.22$ & $1.73 \mathrm{~b} \pm 0.18$ & $1.58 \mathrm{a} \pm 0.16$ & $1.91 \mathrm{a} \pm 0.22$ & $1.56 \mathrm{~b} \pm 0.20$ \\
& TAN3 & $17.13 \pm 3.14$ & $4.24 \mathrm{ab} \pm 0.77$ & $3.29 \mathrm{ab} \pm 0.37$ & $4.11 \mathrm{a} \pm 0.07$ & $3.23 \mathrm{a} \pm 0.91$ & $3.33 \mathrm{a} \pm 1.28$ \\
SS & TAN1 & $374 \pm 124$ & $243 \mathrm{a} \pm 45$ & $471 \mathrm{a} \pm 226$ & $475 \mathrm{a} \pm 182$ & $492 \mathrm{a} \pm 128$ & $611 \mathrm{a} \pm 217$ \\
& TAN2 & $358 \pm 335$ & $460 \mathrm{a} \pm 400$ & $543 \mathrm{a} \pm 414$ & $544 \mathrm{a} \pm 402$ & $551 \mathrm{a} \pm 414$ & $554 \mathrm{a} \pm 405$ \\
& TAN3 & $780 \pm 739$ & $586 \mathrm{a} \pm 594$ & $758 \mathrm{a} \pm 656$ & $787 \mathrm{a} \pm 676$ & $861 \mathrm{a} \pm 635$ & $898 \mathrm{a} \pm 672$ \\
TDS & TAN1 & $3941 \pm 3703$ & $51 \mathrm{a} \pm 10$ & $53 \mathrm{a} \pm 10$ & $55 \mathrm{a} \pm 15$ & $61 \mathrm{a} \pm 20$ & $63 \mathrm{a} \pm 26$ \\
& TAN2 & $3300 \pm 1714$ & $83 \mathrm{a} \pm 78$ & $47 \mathrm{a} \pm 20$ & $48 \mathrm{a} \pm 22$ & $47 \mathrm{a} \pm 17$ & $48 \mathrm{a} \pm 17$ \\
& TAN3 & $2653 \pm 1240$ & $46 \mathrm{a} \pm 11$ & $55 \mathrm{a} \pm 24$ & $55 \mathrm{a} \pm 25$ & $58 \mathrm{a} \pm 23$ & $61 \mathrm{a} \pm 28$ \\
\hline
\end{tabular}

Replicate $=6$ (months)

Within the rows, for the same parameter, means with different alphabets are statistically different $(p<0.05)$.

$\mathrm{P}=$ parameter, IND = Industries 
BAJOPAS Volume 13 Number 2, December, 2020

Table 4: Correlation coefficient $(r)$ between different masses of the bacteria and the physicochemical parameters.

\begin{tabular}{llll}
\hline Industries & Parameter & Correlation coefficient $(r)$ & $\begin{array}{l}\text { Percent dependence (rxrx100) } \\
(\%)\end{array}$ \\
\hline TAN1 & COD & -0.9 & 82 \\
& BOD & -0.97 & 94 \\
& SS & $0.90^{*}$ & 80 \\
TAN2 & TDS & $0.98^{*}$ & 96 \\
& COD & -1 & 100 \\
& BOD & -0.21 & 4 \\
& SS & $0.78^{*}$ & 61 \\
& TDS & -0.69 & 47 \\
& COD & $0.60^{*}$ & 36 \\
& BOD & -0.6 & 37 \\
& SS & $0.95^{*}$ & 90 \\
& TDS & $0.94^{*}$ & 89 \\
\hline
\end{tabular}

The correlation coefficient $(r)$ with * is statistically significant $(p<0.05)$.

Percentage reduction of the Parameters

Table 5 shows the percentage reduction of Parameters in industrial samples before and after the treatment of the effluents $(250 \mathrm{ml})$ with the different masses $(5 \mathrm{~g}, 10 \mathrm{~g}, 15 \mathrm{~g}, 20 \mathrm{~g}$, and $25 \mathrm{~g}$ ) of the Immobilized Bacteria.

In TAN1 samples, the percentage reduction (\%) of COD ranged (14-89); BOD (50-80); SS (-32$35)$ and TDS (98-99). In TAN2 samples, the percentage decrease $(\%)$ of COD ranged (15$38) ;$ BOD (90-92); SS [-28-(-55)] and TDS (9798). In TAN3 samples, the percentage decrease (\%) of COD ranged (11-44); BOD (76-81); SS (15-25) and TDS (98). The percentage increase in the levels COD, BOD and TDS might be due to the increase in the surface area of the different masses of the immobilized bacteria. However, the percentage decrease in the levels of the SS might be due to the aggregation of the TDS which are large enough to result into SS. The percentage decrease in the levels of the SS might be also due to the influence of the nutrients which was added into the effluents in order to make the microorganisms more active and viable for fast degradation of organic contaminants in the effluent. This is in line with the work of Jimoh et al. (2018) in which the concentration of the SS increase after the bioremediation of effluents.

Sreemoyee and Priti (2013) assessed and reduced several Physico-chemical parameters of dairy wastewater using Niesseria $s p$. and concluded that the species are well known to degrade organic compounds. This is in agreement with the current study in which the immobilized Niesseria $s p$ degrade the organic contaminants as indicated by the BOD, COD and TDS.

Jimoh et al. (2018) observed that TSS of the effluents was increased after treatment with immobilized bacteria and concluded that it might be due to the biostimulation method adopted for the research.

The optimum $\mathrm{pH}$ Biosorption of Chromium by Bacillus spp and Staphylococcus spp. from tannery effluent was investigated by Mythili and Karthikeyan (2011). The maximum adsorption of Chromium $(86.4 \mathrm{mg} / \mathrm{L})$ was showed by Bacillus spp and Staphylococcus spp showed $70.6 \mathrm{mg} / \mathrm{L}$ at an initial concentration of $100 \mathrm{mg} / \mathrm{L}$. In the present study, immobilised Bacillus spp and Staphylococcus spp. from the tannery industrial effluents reduced the levels of the organic pollutants with high potential as indicated by the percentage reduction of BOD, COD and TDS.

Enzymes often can work in multiple environments especially if they are immobilized. This makes the microorganisms' enzymes even more resistant to harsh environments and enables the enzymes to be recovered and recycled after they are no longer needed (Gianfreda and Rao 2004). Ramesh and Singh (1993) reported that the immobilized bacteria having more efficiency to remove the suspended particles than free cells. Using the immobilized cell is preferable due to its capability for using several times with the same efficiency, which makes it more economical. Similar work was done by Sikander et al. (2007) showing the higher reduction with permeabilized cells of Ochrobactrum intermedium strain SDCr-5. 
BAJOPAS Volume 13 Number 2, December, 2020

The results revealed the isolation and identification of isolates with the potential for the reduction of $\mathrm{Cr}$ (VI) to $\mathrm{Cr}$ (III). Results indicated that immobilized $B$. cereus could be efficiently used for the reduction of $\mathrm{Cr}$ (VI).

Table 5: Percentage reduction of the tested Parameters from the tannery industrial samples of the Immobilized Bacteria.

\begin{tabular}{lllllll}
\hline \multirow{2}{*}{ Industries } & & \multicolumn{5}{c}{ Percentage Reduction $(\%)$} \\
\cline { 3 - 7 } & & $5 \mathrm{~g}$ & $10 \mathrm{~g}$ & $15 \mathrm{~g}$ & $20 \mathrm{~g}$ & $25 \mathrm{~g}$ \\
\hline TAN1 & COD & 28 & 14 & 64 & 87 & 89 \\
& BOD & 50 & 54 & 59 & 67 & 80 \\
& SS & 35 & -26 & -27 & -32 & -63 \\
& TDS & 99 & 99 & 99 & 98 & 98 \\
TAN2 & COD & 15 & 20 & 25 & 32 & 38 \\
& BOD & 91 & 91 & 92 & 90 & 92 \\
& SS & -28 & -52 & -52 & -54 & -55 \\
& TDS & 97 & 99 & 99 & 99 & 99 \\
& COD & 33 & 44 & 22 & 11 & 26 \\
& BOD & 75 & 81 & 76 & 81 & 81 \\
& SS & 25 & 3 & -1 & -10 & -15 \\
& TDS & 98 & 98 & 98 & 98 & 98 \\
\hline
\end{tabular}

Percentage Reduction $=(B-A) / B \times 100 \%$

$A=$ Concentration of the parameter after treatment

$\mathrm{B}=$ Concentration of the parameter before treatment

$+=$ percentage decrease

- = percentage increase

In general, immobilization makes the enzyme more resistant to temperature, $\mathrm{pH}$, and substrate concentration swings giving it a longer lifetime and higher productivity per active unit (Gianfreda and Rao, 2004; FuIlbrook, 1996; Russell et al, 2003; Kandelbauer et al., 2004). Immobilized cells have been used and studied extensively for the production of useful chemicals (Ohtake and Silver, 1994), the treatment of wastewaters (Chen et al., 2003; Wang et al., 2010). Although many workers described microbial degradation of tannery effluent, limited literature is available on the bioremediation of tannery effluent using immobilized bacterial cells in the Kano Industrial Estates.

\section{CONCLUSION}

The samples contained variable levels of the physicochemical parameters. The results of the Analysis of variance revealed that, no statistical difference $(p<0.05)$ was observed for the temperature, $\mathrm{pH}, \mathrm{SS}, \mathrm{TDS}, \mathrm{BOD}$ and $\mathrm{COD}$ among the three tannery industries before the treatment. The levels of some of the parameters
(SS, TDS and COD) observed in the samples were found above the recommended limits of WHO and NESREA, which called for the treatment of the effluents before discharge into the environment. Base on the morphological and biochemical test results, TAN1, TAN2, and TAN3 bacterial isolates were identified to be Neisseria spp, Bacillus cereus, and Staphylococcus aureus respectively. The results of Post-treatment analysis showed that there is overall decrease in the levels of the parameters determined when compared with that of the pre-treatment. The overall percentage reduction of the immobilised bacteria in the treatment of the respective effluents was in the order TAN2 (72\%)>TAN1 $(70 \%)>$ TAN3 $(62 \%)$. Hence, the immobilized bacteria are having higher biodegradation potential for the treatment of the tannery effluents.

\section{Acknowledgments}

The authors wish to acknowledge the University of Maiduguri for the financial support. The authors are grateful to the Kano State Ministry of Environment for their support in obtaining the effluent samples. 


\section{REFERENCES}

Ajao, A. T., Adebayo, G. B., and Yakubu, S. E. (2011). Bioremediation of textile industrial effluent using mixed culture of Pseudomonas aeruginosa and Bacillus subtilis immobilized on agar-agar in a bioreactor. J. Microbiol. Biotech. Res, 1(3), 50-56.

Akan, J. C., Moses, E. A., Ogugbuaja, V. O., and Abah, J. (2007). Assessment of tannery industrial effluents from Kano metropolis, Kano State, Nigeria. Journal of Applied Sciences, 7(19), 2788-2793.

Akan, J. C., Ogugbuaja, V. O., Abdulrahman, F. I., and Ayodele, J. T. (2009). Pollutant levels in effluent samples from tanneries and textiles of Kano industrial areas, Nigeria. Global journal of pure and applied sciences, 15(3-4).

APHA (1989). Standard methods for Examination of Will bete and Will betewater.15 $5^{\text {th }}$ edition. Brydpass Springfield Will behington DC. pp. 164-176

APHA (1992). Standard Methods for the Examination of Water and Wastewater. Health, 69, 1116-9.

Baba, A., Garba, S. T., and Bello, H. S. (2020). Bioremediation Potential of Immobilized corynebacterium kutsceri in the Treatment of Tannery Industrial Effluent from Challawa Industrial Estate, Kano State, Nigeria. Journal of the Turkish Chemical Society Section A: Chemistry, $7(2), 335-350$.

Beem, E. I. V. (1994). reduction of solvent VOC emission. J. Oil Col. Chem. Ass, 77, 158.

Bouwer, E. J., and Zehnder, A. J. (1993). Bioremediation of organic compoundsputting microbial metabolism to work. Trends in biotechnology, 11(8), 360367.

Chen, K. C., Wu, J. Y., Liou, D. J., and Hwang, S. C. J. (2003). Decolorization of the textile dyes by newly isolated bacterial strains. Journal of Biotechnology, 101(1), 57-68.

Dan'Azumi, S., and Bichi, M. H. (2010). INDUSTRIAL POLLUTION AND HEAVY METALS PROFILE OF CHALLAWA RIVER IN KANO, NIGERIA. Journal of Applied Sciences in Environmental Sanitation, $5(1)$.

DWAF. (1992). Analytical Methods Manual, TR 151. Department of Water Affairs and Forestry, Pretoria.

El-Bestawy, E. (2013). Biological treatment of leather-tanning industrial wastewater using free living bacteria.
Elsheikh, M. A. S. (2009). Tannery wastewater pre-treatment. Water Science and Technology, 60(2), 433-440.

FuIlbrook, P. D. (1996). "Kinetics." Industrial enzymology: The application of enzymes in Industry. 2nd Ed. T. Godfrey and J Reichelt. eds.. Nature. New York.

Gianfreda, L., and Rao, M. A. (2004). Potential of extra cellular enzymes in remediation of polluted soils: a review. Enzyme and microbial technology, 35(4), 339354.

Hugo Springer. (1994). John Arthur Wilson Memorial Lecture "Treatment of Industrial Wastes of the Leather Industry - is it still a Major Problem". JALCA, 89, 153-185

Jimoh, A. A., Ganiyu, B. A., Baba, D., and Baba, A. (2018) Bioremediation Process of Effluent from Detergent and Food Industries in Jos, Nigeria: Kinetics and Thermodynamics. International Journal of Engineering Science Invention (IJESI), 762-73

Kandelbauer, A., Maute, O., Kessler, R. W., Erlacher, A., and Gübitz, G. M. (2004). Study of dye decolorization in an immobilized laccase enzyme-reactor using online spectroscopy. Biotechnology and bioengineering, 87(4), 552-563.

Kongjao, S., Damronglerd, S., and Hunsom, M. (2008). Simultaneous removal of organic and inorganic Pollutants in tannery wastewater using electrocoagulation technique. Korean Journal of chemical engineering, 25(4), 703.

Maheshwari, U. M., Aruna, S., Gomathi, M., and AbdulJaffar, A. H. (2017). Bioremediation by Free and Immobilized Bacteria Isolated from Tannery Effluent. International Journal of Research in Applied, Natural and Social Sciences. 5(7), 75-90

Margesin, R., and Schinner, F. (2001). Bioremediation (natural attenuation and biostimulation) of diesel-oilcontaminated soil in an alpine glacier skiing area. Applied and environmental microbiology, 677), 3127-3133.

Mohammed, A., Sekar, P., and George, J. (2011). Efficacy of microbes in bioremediation of tannery effluent. Inter. J. Curr. Res, 3(4), 324-326.

Mohammed, S. S. D., Orukotan, A. A., and Abdullahi, H. (2017). Physicochemical and Bacteriological Assessment of Tannery Effluent from Samaru-Zaria, 
BAJOPAS Volume 13 Number 2, December, 2020 Kaduna State, Nigeria. Journal of Applied

Sciences and Environmental Management, 21(4), 734-740.

Munz, G., De Angelis, D., Gori, R., Mori, G., Casarci, M., and Lubello, C. (2009). The role of tannins in conventional and membrane treatment of tannery wastewater. Journal of hazardous materials, 164(2-3), 733-739

Mythili, K., and Karthikeyan, B. (2011). Bioremediation of $\mathrm{Cr}$ (VI) from tannery effluent using Bacillus spp and Staphylococcus spp. International Multidisciplinary Research Journal, 1(6).

NESREA (2009). National Environmental Standards for Effluent Limitations and Regulation. 1233-1236

Noorjahan, C. M. (2014). Physicochemical characteristics, identification of bacteria and biodegradation of industrial effluent. Journal of bioremediation and Biodegradation, 5(3).

Ohtake, H. I., and Silver, A. O. (1994). Bacterial reduction of toxic chromate. Biological degradation and bioremediation of toxic chemicals, 403-415.

Omoleke, I. I. (2004). Management of environmental pollution in Ibadan, an African city: the challenges of health hazard facing government and the people. Journal of Human Ecology, 15(4), 265-275.

Rajor, A., Reddy, A.S., and Singh, B. (2004). Determination of BOD kinetic Parameters and evaluation of alternate methods, M.Sc. Thesis, Department of biotechnology \& environmental Science, Thapar Institute of Engineering and Technology, Patiala

Ramasami, T., Rajamani, S., and Rao, J. R. (1994, March). Pollution control in leather industry: Emerging technological options. In International symposium on surface and colloidal science and its relevance to soil pollution, madras.

Ramesh, J. V. S., and Singh, S. P. (1993). Yearly variation in certain physicochemical parameters of pond at eastern Doon Valley. Uttar Pradesh J. Zoo, 12 (1), 7577.

Ranen, S., and Sharadinadra, C. (2009). Biotechnology applications to environmental remediation in resource exploitation. Current science, 97, 6-25
Russell, A. J., Berberich, J. A., Drevon, G. F., and Koepsel, R. R. (2003). Biomaterials for mediation of

chemical and biological warfare agents. Annual review of biomedical engineering, 5(1), 1-27.

Saravanan, P., and Saravanan, A. (1999). Decolourization of tannery effluent by Flavobacterium sp. EK 1. Indian Journal of Environmental Protection, 19, 19-24.

Sikander, S., and Shahida, H. (2007). Reduction of toxic hexavalent chromium by Ochrobactrum intermedium strain SDCr5 stimulated by heavy metals. Bioresource Technol, 98, 340-344.

Singh, N., Sharma, B. K., and Bohra, P. C. (2000). Impact assessment of industrial effluent of arid soils by using satellite imageries. Journal of the Indian Society of Remote Sensing, 28(2-3), 79.

Sreemoyee, C., and Priti, P. (2013). Assessment of physico-chemical parameters of dairy waste water and isolation and characterization of bacterial strains in terms of cod reduction. Int J Sci, 2(3), 395-400.

Verheijen, L. A. H. M., Wiersema, D., Pol, L. H., and De Wit, J. (1996). Management of wastes from animal product processing. Livestock and environment, Finding a balance. International Agriculture Center, Wageningen, The Netherlands.

Wang, F., Yao, J., Si, Y., Chen, H., Russel, M., Chen, K., and Bramanti, E. (2010). Short-time effect of heavy metals upon microbial community activity. Journal of Hazardous Materials, 173(13), 510-516.

WHO (World Health Organization). (2006). Air quality guidelines: global update 2005: particulate matter, ozone, nitrogen dioxide, and sulfur dioxide. World Health Organization.

World Bank. (1995). Nigeria's strategic options for redressing industrial pollution. World Bank, industry and energy division. 1st edition, West Central Africa Department; Annexes: 1995; pp 60-62.

Zahoor, A., and Abdul, R. (2009). Enumeration of Coliforms. Journal of Environmental Sciences. 21, 814-820 


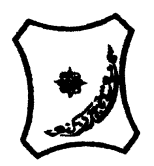

Bayero Journal of Pure and Applied Sciences, 13(2): 1 - 12

Received: November, 2020

Accepted: December, 2020

ISSN $2006-6996$

\title{
BIODEGRADATION POTENTIAL OF IMMOBILIZED BACTERIA IN THE TREATMENT OF TANNERY INDUSTRIAL EFFLUENTS FROM INDUSTRIAL ESTATES IN KANO STATE, NIGERIA
}

\author{
Abdullateef, B., ${ }^{1 *}$ Shuaibu, T. G., ${ }^{1}$ Babagana, K., ${ }^{1}$ Suleman, H. B. ${ }^{2}$ and Dauda, B. ${ }^{3}$ \\ ${ }^{1}$ Department of Pure and Applied Chemistry, Faculty of Science, University of Maiduguri, Borno State, \\ Nigeria \\ ${ }^{2}$ Department of Microbiology, Faculty of Science, University of Maiduguri, Borno State, Nigeria \\ ${ }^{3}$ Department of Chemical Engineering, Faculty of Engineering, University of Maiduguri, Borno State, \\ Nigeria \\ *Corresponding author: babslega@gmail.com; abelega2007@yahoo.com; +2348061309753
}

\section{ABSTRACT}

Industrial Effluents Samples from Gashash Tanneries (TAN1) in Bompai Industrial estate, Larabee Tannery Industry (TAN2) in Sharada Industrial estate and Z Tannery Industries (TAN3) in Challawa Industrial estate, Kano State, Nigeria were collected over a period of six months (August 2017 to January 2018) for assessing the biodegradation potentials of bacteria in the treatment of organic pollutants within the effluents. Bacteria were isolated from the effluents and immobilized on agar-agar. Different masses (5 g, $10 \mathrm{gr}, 15$ $\mathrm{g}, 20 \mathrm{~g}$, and $25 \mathrm{~g}$ ) of the bacteria were used in the treatment of $250 \mathrm{ml}$ of the effluents for ten days in a shaker incubator (Gallenkamp-OC-4364-L) at the temperature $30{ }^{\circ} \mathrm{C}$ and speed of $60 \mathrm{rpm}$. Pre-treatment analysis of the effluents for Temperature, pH, Biochemical Oxygen Demand (BOD), Chemical Oxygen Demand (COD), Suspended Solid (SS) and Total Dissolved Solids (TDS) gives the following results; temperature $\left({ }^{\circ} \mathrm{C}\right.$ )

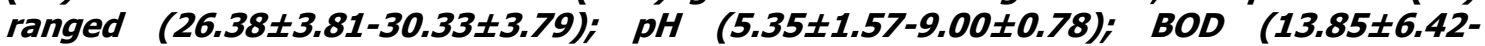
$38.75 \pm 16.20) ;$ COD (1406 $\pm 208-3532 \pm 1373) ;$ SS (208 $\pm 235-780 \pm 739)$ and TDS (266 $\pm 253-5276 \pm 2971)$. No statistical differences ( $p \leq 0.05)$ was observed for all the results among the different industries. The bacterial isolates were identified as Neisseria spp, Bacillus cereus, and Staphylococcus aureus, in TAN1, TAN2, and TAN3, respectively. After treatment of the effluent with the different masses of the isolated bacteria, the mean level of BOD was found to range as (0.55 $\pm 0.36-6.92 \pm 5.49) ; C O D$ (ND-3134 \pm 1595$)$;

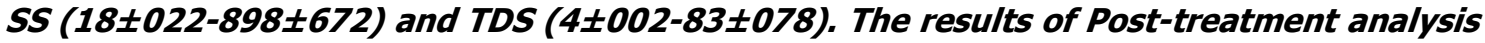
showed that there is overall decrease in the levels of the parameters determined when compared with that of the pre-treatment. The overall percentage reduction of the immobilised bacteria in the treatment of the respective effluents was in the order TAN2 (72\%)>TAN1 (70\%)>TAN3 (62\%). Hence, the immobilized bacteria are having higher biodegradation potential for the treatment of the tannery effluents.

Keywords: Biodegradation, bacteria, effluent, immobilization, tannery.

\section{INTRODUCTION}

Tannery industrial wastewater is a serious consequence of the pollution point of view for streams, freshwater, and land used for agriculture. The lack of awareness in the modern industrial practice has resulted in the discharge of tannery effluents which exhibit very high value of chromium ( $\mathrm{Cr}$ ), Sulfide, and chloride, Total Dissolved Solid (TDS), Total Suspended Solid (TSS), Biochemical Oxygen Demand (BOD) and Chemical Oxygen Demand (COD) in the water stream or land (Mohammed et al., 2001). Tanning is the process, which One ton of skin generally leads to the production of 20 to $80 \mathrm{~m}^{3}$ of turbid and foul-smelling converts the protein of the rawhide or skin into a stable material, which will not putrefy and is suitable for a wide variety of end applications (Elsheikh, 2009). The highly polluting chromium is the most commonly used tanning material producing leather that is more flexible and pliable than vegetable-tanned leather and does not discolor or lose shape in water as drastically as vegetable-tan (Elsheikh, 2009). Tannery effluent is among the most hazardous industrial pollutants due to its huge organic and inorganic load, which is highly toxic to human life and the environment (Kongjao et al., 2008). wastewater including chromium (100-400 mg/l), sulfide $(200-800 \mathrm{mg} / \mathrm{l})$, high levels of fat and 
BAJOPAS Volume 13 Number 2, December, 2020 other solid wastes, and notable pathogen contamination as well as pesticides added for skin conservation during transport (Elsheikh, 2009). There are more than 6000 tanneries in Nigeria with an annual processing capacity of 700,000 tons of hides and skins (Omoleke, 2004; Singh et al., 2008). It was reported that the total amount of waste produced per animal slaughtered is approximately $35 \%$ of its weight (World Bank, 1995). Also, for every $1000 \mathrm{~kg}$ of carcass weight, a slaughtered beef produces 5.5 $\mathrm{kg}$ of manure (excluding rumen contents or stockyard manure) and $100 \mathrm{~kg}$ of paunch manure (undigested food) (Verheijen et al., 1996). Tanneries generate wastewater in the range of 30-35 $\mathrm{L} \mathrm{kg}^{-1}$ skin/hide processed with variable $\mathrm{pH}$, Biological Oxygen Demand (BOD), Chemical Oxygen Demand (COD), high concentrations of suspended solids (SS), and tannins as well as chromium (Zahoor and Abdul, 2009).

Being heterogeneous and composed of a wide variety of compounds, it is very difficult to select a unique direct method for estimating the biodegradability of organic contents and biokinetic parameters for a wastewater sample (Rajor, 2004). For this purpose, some indirect estimation such as determination of biochemical oxygen demand (BOD) and chemical oxygen demand (COD) are applied as common laboratory investigations [9]. During retanning procedures, synthetic tannins (Syntan), oils and resins are added to form softer leather at varying doses (Munz et al., 2009). One of the refractory groups of chemicals in tannery effluents derives mainly from tannins (Ramasami et al., 2004). Syntans are characterized by complex chemical structures, because they are composed of an extended set of chemicals such as phenol-, naphthalene-, formaldehyde- and melamine-based syntans, and acrylic resins (Beem, 1994). Organic pollutants (proteic and lipidic components) are originated from skins (it is calculated that the raw skin has $30 \%$ loss of organic material during the working cycle) or they are introduced during processes (Hugo Springer, 1994).

Many conventional processes such as oxidation, chemical and biological processes were carried out to treat tanneries wastewater (Ebtesam et al, 2013). Biological processes have received more attention because of their costeffectiveness, lower sludge production and environmental friendliness (Noorjahan, 2014). Naturally occurring micro-organisms degrade the hazardous organic wastes including xenobiotic compounds, such as pesticides, polycyclic aromatic hydrocarbons (PAHs) and polychlorinated biphenyls (PCBs) in due course of time (Ranen and Sharadinadra, 2009). Bioremediation is based on the idea that all organisms remove substances from the environment to carry outgrowth and metabolism (Bouwer and Zehnder, 1993). Bacteria, protista and fungi are found to be very good at degrading complex molecules and incorporating the breakdown products into their metabolism (Bouwer and Zehnder, 1993). The resultant metabolic wastes that they produce are generally safe and somehow recycled into other organisms (Ranen and Sharadinadra, 2009). An acclimatized indigenous population of microorganisms capable of degradation of the compounds of interest must exist at the site for a successful bioremediation mode (Ranen and Sharadinadra, 2009). It has been observed that for a successful bioremediation mode, an acclimatized indigenous population of microorganisms capable of degradation of the compounds of interest must exist at the site under investigation (Ranen and Sharadinadra, 2009). Even though there are numerous physical and chemical methods employed in the disposal of wastes the advantage in using bacterium is that they play a key role in the reduction of COD, BOD, total protein, total tannin and total phenol (Saravanan and Saravanan, 1998)

Baba et al. (2020) studied the bioremediation potential of immobilized corynebacterium kutsceri in the Treatment of tannery industrial effluent from Challawa Industrial Estate, Kano State, Nigeria. The aim of the work is to study the reduction in the level of the contaminants through the process of bioremediation using the isolated bacteria. Immobilized bacteria can withstand various temperatures, $\mathrm{pH}$ and substrate concentrations; consequently, increasing the efficiency and the lifespan of the bacteria. Immobilized bacteria are widely applied in the treatment of wastewater and can be separated and recovered after the treatment with the same efficiency (Baba et al., 2020).

\section{MATERIALS AND METHODS \\ Study Area}

This study was carried out in Bompai, Sharada and Challawa industrial estates in Kano, Figure 1. Kano lies on Latitude $11^{\circ} 30^{\prime} \mathrm{N}$ and $8^{\circ} 30^{\prime} \mathrm{E}$ and Longitude $11^{\circ} 5^{\prime} \mathrm{N}$ and $8^{\circ} 5^{\prime} \mathrm{E}$ in Northern Nigeria. It is one of the developed industrial cities in Nigeria. Tannery activities are the dominating industries and this could be one of the reasons for her high population density (Dan'Azumi and Bichi, 2010). Many researchers have studied biodegradation of tannery effluent using microorganisms. However, limited literature is available on the biodegradation of tannery effluent in Kano industrial estates using 
BAJOPAS Volume 13 Number 2, December, 2020 immobilized bacterial cells. This research work focuses on the potential of the use of the indigenous immobilized bacterial isolates in the treatment of tannery effluents in the industrial estates.

\section{Sample Collection}

Effluents were collected from the Tannery Industries from Bompai, Challawa and Sharada Industrial Estates, Kano, Nigeria. The effluents were collected over a period of six months (August 2017 to January 2018). Samples collected in a sterile 4-liter plastic container with a unique identification number were preserved using an ice-box that was transported to the Microbiology Laboratory, Department of Microbiology, Bayero University of Kano for analysis

\section{Sample Preparation and Sample Analysis}

Immediately after the collection of the effluent, $\mathrm{pH}$, TSS, TDS, COD, BOD levels were determined before treatment (Pre-treatment determination) and ten days after treatment (Post-treatment determination) as described in
APHA (1989) standard methods. $\mathrm{pH}$ was determined using Ecotests $\mathrm{pH}$ meter and TDS was determined using AQUALYTIC TDS Salinometer. BOD was determined as described by the standard method (APHA, 1992). COD and SS were determined using DR/2010 HACH portable data logging spectrophotometer (DWAF, 1992)

\section{Identification and Biochemical} Characterization of the Bacterial Isolates

The bacteria were isolated from the effluents using Serial Dilution according to the method described by APHA (1989). The biochemical tests such as oxidase, catalase, coagulase, indole (from $1 \%$ tryptone broth), citrate (Simmons citrate agar), methyl red/VogesProskauer (MR/VP), nitrate reduction, Starch Hydrolysis, Glucose, Maltose, and Lactose tests were carried out on the bacterial isolates to identify the bacteria through the bacteria biochemical characteristics according to Ajao et al. (2011).

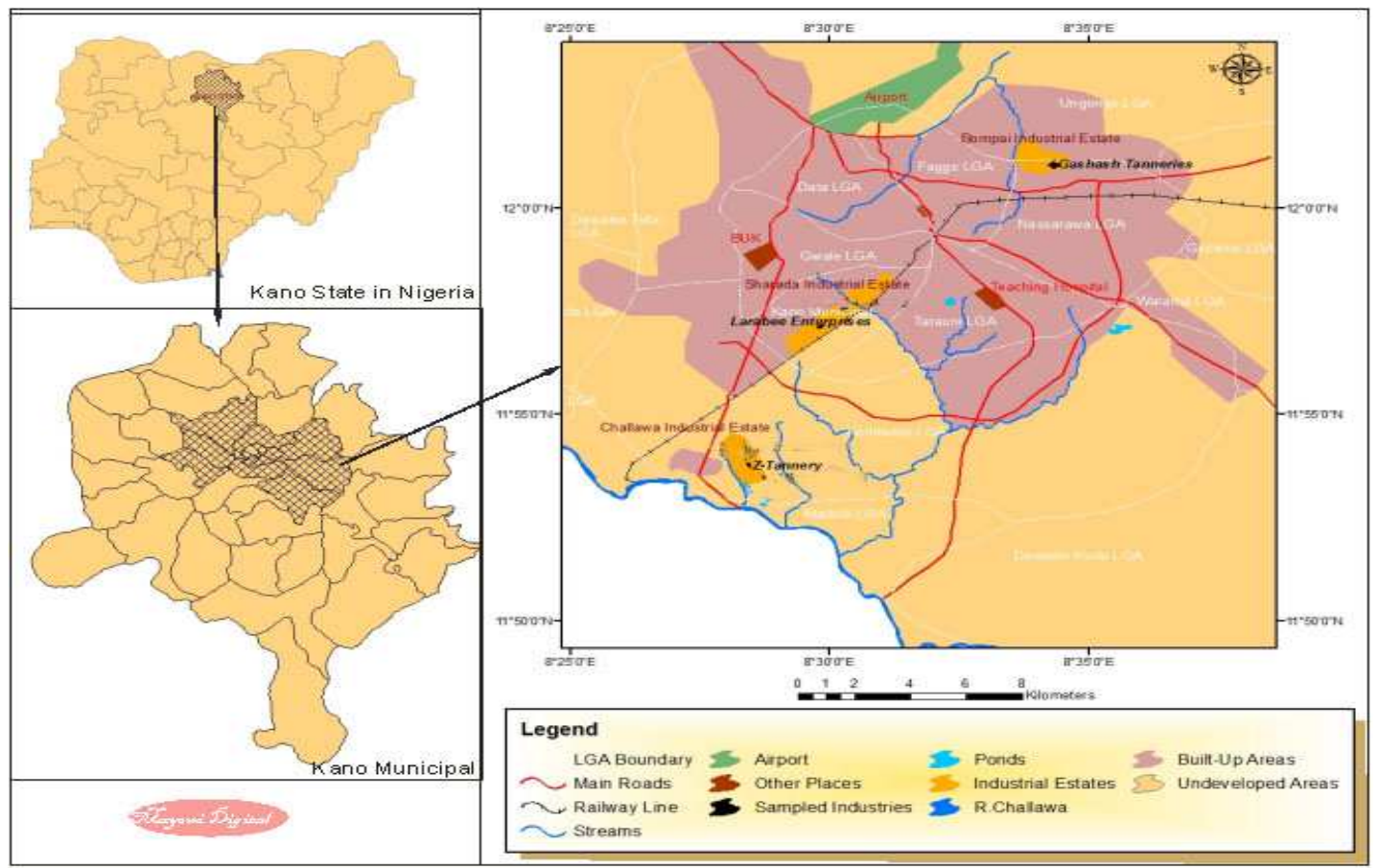

Fig. 1 Map showing the study areas

Source: Mayomi Digital Productions, GIS Laboratory, Department of Geography, UNIMAID (2017)

\section{Determination of Growth Rate of the Bacteria in Effluent Sample}

The bacteria growth rates were determined by transferring $2 \mathrm{~mL}$ of the bacterial isolates from the tannery effluent in broth medium into 100 $\mathrm{mL}$ sterile effluents in conical flasks and kept in an incubator (Giffrin cool) for 10 days. Control was also set up by incubating another $100 \mathrm{~mL}$ each of the sterile effluents without the bacteria. The optical density of the content was determined at the wavelength of $600 \mathrm{~nm}$ on a daily interval and recorded. 
BAJOPAS Volume 13 Number 2, December, 2020 Immobilization of Bacteria

Agar solution and inoculi were prepared separately. Fifty milliliters $(50 \mathrm{~mL})$ of nutrient broth each of the inoculi was prepared in a McCartney bottle and incubated for 24 hours. A solution of agar-agar was prepared by dissolving $10 \mathrm{~g}$ of the powder in distilled water and made up to $500 \mathrm{~mL}$ mark in an Erlenmeyer flask and was sterilized in an autoclave (280A) for 15 minutes and allowed to cool to $40-45^{\circ} \mathrm{C}$ (Ajao et al., 2011). Four milliliters ( $4 \mathrm{~mL})$ of the bacterial isolates in the nutrient broth was mixed with 36 $\mathrm{ml}$ of the prepared agar-agar media in petri-dish plates and then allowed to solidify. This was kept in the refrigerator for bioremediation.

\section{Bioremediation (Treatment) of the Effluents}

The solidified agar block (immobilized bacteria) was cut into cubes using a sterile knife; $0.1 \mathrm{~mL}$ phosphate buffer ( $\mathrm{pH} \mathrm{7.0)}$ was added and kept in the refrigerator for 1 hour for curing. The phosphate buffer was decanted after 1 hour and the cubes were washed with sterile distilled water 3-4 times before it was used (Ajao et al., 2011). Two liters (2 L) of the effluent was supplemented with the minimum basal medium in $\mathrm{g} / \mathrm{L}: \mathrm{NaCl}(0.8), \mathrm{MgSO}_{4} .7 \mathrm{H}_{2} \mathrm{O}(0.001), \mathrm{KH}_{2} \mathrm{PO}_{4}$ (2), $\mathrm{NaNO}_{3}$ (2), $\quad \mathrm{CaCl}_{2} .2 \mathrm{H}_{2} \mathrm{O} \quad(0.5)$ and $\mathrm{NaHPO}_{4} .12 \mathrm{H}_{2} \mathrm{O}(2)$ and sterilized in an autoclave at $121^{\circ} \mathrm{C}$ for 15 minutes (Margesin and Schinner, 2001). Two hundred and fifty milliliters $(250 \mathrm{~mL})$ of the effluents were transferred into different $250 \mathrm{ml}$ conical flasks. The content was covered with a cotton-wool ramped with foil paper to avoid contamination. Five grams $(5 \mathrm{~g})$ of the immobilized bacteria were quickly transferred into each of the effluents in the conical flasks in an inoculating chamber. The same procedures were carried out for the $10 \mathrm{~g}, 15 \mathrm{~g}, 20 \mathrm{~g}$ and 25 $\mathrm{g}$ of the immobilized bacteria in separate $250 \mathrm{~mL}$ effluents in conical flasks and agitated for ten days in a shaker incubator (Gallenkamp-OC4364-L) at a temperature $30^{\circ} \mathrm{C}$ and speed of 60 rpm. The treated effluent samples were taken on the tenth day and analyzed for the parameters $\mathrm{pH}$, SS, TDS, COD, and BOD, (Posttreatment determination) for the different grams of bacteria to evaluate and compare the biodegradation potential. (Baba et al., 2020).

\section{Statistical Analysis}

The data were represented as Mean \pm Standard deviation and analyzed statistically using oneway Analysis of Variance (ANOVA) and Tukey's HSD as Post Hoc Tests with the aid of SPSS 16.0. The correlation coefficient was also used to measure the strength of the relationship between the different masses of the bacteria and the parameters. All $\mathrm{p} \leq 0.05$ were considered as statistically significant.

\section{RESULTS AND DISCUSSION Physico-chemical parameters in the Industrial Effluents before the Biodegradation.}

Results of the Physico-chemical parameters in the industrial effluents before the Biodegradation is shown in table 1 . The mean temperatures $\left({ }^{\circ} \mathrm{C}\right)$ observed in TAN1, TAN2, and TAN3 samples were $28.07 \pm 0.65 ; 27.77 \pm 0.64$ and $26.38 \pm 3.81$ respectively. The order of the mean temperature of the samples from the three industries can be arranged as TAN1 > TAN2>TAN3. The temperature observed at TAN1, TAN2, and TAN3 samples were found below the WHO $\left(35^{\circ} \mathrm{C}\right)$ and NESREA $\left(40^{\circ} \mathrm{C}\right)$ limits. The low values of temperature might be due to the processes used at the time of sampling. High temperature brings down the solubility of gases in water that ultimately expresses as high BOD and COD. Statistical analysis shows that there is no significant difference $(p<0.05)$ between the mean values of temperature among the industries. This might be due to similar tannery activities involved in the tannery industries at the time of sampling. The average values of temperature observed in this present study are less than those observed by Akan et al. (2007), Akan et al. (2009) and Baba et al. (2020).

The mean level of $\mathrm{pH}$ observed in TAN1, TAN2 and TAN3, samples were $7.77 \pm 2.93$; $8.35 \pm 0.28$ and $7.52 \pm 0.76$ respectively. The order of the mean $\mathrm{pH}$ of the samples from the three industries can be arranged as TAN2> TAN1 $>$ TAN3. The $\mathrm{pH}$ of the samples falls within the WHO (7.0-8.5) and NESREA (6-9) standard limits. Statistical analysis shows that there is no significant difference $(p<0.05)$ between the mean values of $\mathrm{pH}$ among the industries. This might be due to similar tannery activities involved in the tannery industries at the time of sampling. Maheshwari et al. (2017) reported that the level of $\mathrm{pH}$ in the effluents from the tannery industry in Vaniyambadi, India was 6.5 which was lower than that observed in the present study. The $\mathrm{pH}$ in the effluents from the tannery industries in Kano and Kaduna were reported to be 7.64 and 6.89, respectively (Akan et al., 2007; Mohammed et al., 2017). The average values of $\mathrm{pH}$ observed in this present study are less than those observed by Mohammed et al. (2017) and Baba et al. (2020). The mean level of SS $(\mathrm{mg} / \mathrm{l})$ observed in TAN1, TAN2, and TAN3 samples were 374 \pm 124 ; $358 \pm 335$ and $780 \pm 739$ respectively. The order of the mean SS in the samples from the three industries can be arranged as TAN3 > TAN1 $>$ TAN2. 
The SS observed in the samples were far above the recommended standard limits of regulating bodies WHO $(30 \mathrm{mg} / \mathrm{l})$ and NESREA $(10 \mathrm{mg} / \mathrm{l})$. Statistical analysis shows that there is no significant difference $(p<0.05)$ between the mean values of SS among the industries. This might be due to similar tannery activities involved in the tannery industries at the time of sampling. The average values of SS observed in this present study are less than that observed $(3700 \pm 122 \mathrm{mg} / \mathrm{l})$ by Akan et al. (2009) for tanneries in Kano. Also, the average values of SS observed in this present study are less than that observed by Mohammed et al. (2017) and Baba et al. (2020) with the exception in TAN3.

The mean level of TDS (mg/l) observed in TAN1, TAN2, and TAN3 samples were $3941 \pm 3703$; $3300 \pm 1714$ and $2653 \pm 1240$ respectively. The order of the mean TDS in the samples from the three industries can be arranged as TAN1>TAN2>TAN3. The TDS observed in the samples were far above the recommended standard limits of WHO $(250 \mathrm{mg} / \mathrm{l})$ and NESREA $(500 \mathrm{mg} / \mathrm{l})$. Statistical analysis shows that there is no significant difference $(p<0.05)$ between the mean values of TDS among the industries. This might be due to similar tannery activities involved in the tannery industries at the time of sampling. TDS in the effluents from the tannery industries in Kano, Nigeria was reported to be $1281 \mathrm{mg} / \mathrm{l}$ (Akan et al., 2007). The average values of SS observed in this present study are less than those observed by Mohammed et al. (2017) and Baba et al. 2020)

The mean level of COD (mg/l) observed in TAN1, TAN2 and TAN3 samples seasons were $2372 \pm 938 ; \quad 1406 \pm 208$ and $3532 \pm 1373$ respectively. The order of the mean COD of the samples from the three industries can be arranged as TAN3>TAN1> TAN2. The COD observed in TAN1, TAN2 and TAN3 samples were far above the recommended standard limits of regulating bodies $\mathrm{WHO}(40 \mathrm{mg} / \mathrm{l})$ and NESREA (40 mg/l). Statistical analysis shows that there is no significant difference $(p<0.05)$ in COD among the industries. This might be due to similar tannery activities involved in the tannery industries as at the time of sampling. The Chemical Oxygen demand (COD) is the amount of oxygen, in $\mathrm{mg} / \mathrm{L}$, required for the degradation of the compound of wastewater to occur. In comparison, the average values of COD observed in this present study were higher than that observed by Mohammed et al. (2017) but lower than that observed by Baba et al. (2020).

The mean levels of BOD $(\mathrm{mg} / \mathrm{l})$ observed in TAN1, TAN2 and TAN3 samples were $13.85 \pm 6.42 ; \quad 19.46 \pm 0.50$ and $17.13 \pm 3.14$ respectively. The order of the mean BOD in the samples from the three industries can be arranged as TAN2>TAN3>TAN1. The BOD observed in TAN1, TAN2 and TAN3 samples were found below the recommended limits of NESREA (200 mg/l) but above WHO (10 mg/l). Statistical analysis shows that there is no significant difference $(p<0.05)$ between the mean values of BOD among the industries. This might be due to similar tannery activities involved in the tannery industries at the time of sampling. The low level of BOD recorded in this study is an indication of the low level of biodegradable organic solids in the effluent. The average values of BOD observed in this present study were lower than those observed by Mohammed et al. (2017) and Baba et al. (2020).

Table 1: Mean Values \pm S.D of Physico-chemical parameters of effluents from the Tannery Industries before Treatment.

\begin{tabular}{llllllll}
\hline Parameter & Tannery 1 & Tannery 2 & Tannery 3 & $\mathrm{a}$ & $\mathrm{b}$ & $\mathrm{c}$ & $\mathrm{d}$ \\
\cline { 2 - 7 } Temperature $\left({ }^{\circ} \mathrm{C}\right)$ & $28.07 \mathrm{a} \pm 0.65$ & $27.77 \mathrm{a} \pm 0.64$ & $26.38 \mathrm{a} \pm 3.81$ & & $29.50 \pm 4.68$ & 35 & 40 \\
pH & $7.77 \mathrm{a} \pm 2.93$ & $8.35 \mathrm{a} \pm 0.28$ & $7.52 \mathrm{a} \pm 0.76$ & 6.89 & $5.35 \pm 1.57$ & $7.0-8.5$ & $6.0-9.0$ \\
$\mathrm{COD}(\mathrm{mg} / \mathrm{l})$ & $2372 \mathrm{a} \pm 938$ & $1406 \mathrm{a} \pm 208$ & $3532 \mathrm{a} \pm 1373$ & 2.2 & $3106 \pm 2753$ & 40 & 40 \\
$\mathrm{BOD}(\mathrm{mg} / \mathrm{l})$ & $13.85 \mathrm{a} \pm 6.42$ & $19.46 \mathrm{a} \pm 0.50$ & $17.13 \mathrm{a} \pm 3.14$ & 1032 & $26.17 \pm 9.49$ & 10 & 200 \\
$\mathrm{SS}(\mathrm{mg} / \mathrm{l})$ & $374 \mathrm{a} \pm 124$ & $358 \mathrm{a} \pm 335$ & $780 \mathrm{a} \pm 739$ & 501 & $562 \pm 482$ & 30 & 10 \\
TDS $(\mathrm{mg} / \mathrm{l})$ & $3941 \mathrm{a} \pm 3703$ & $3300 \mathrm{a} \pm 1714$ & $2653 \mathrm{a} \pm 1240$ & 532.7 & $444 \pm 507$ & 250 & 500 \\
\hline
\end{tabular}

The values given in the table above are means of 6 replicate values, $\mathrm{n}=6$ ( 1 sample was taken monthly for 6 months). Within the rows, means with different alphabets are statistically different $(p<0.05)$. WHO: World Health Organisation. NESREA: National Environmental Standard and Regulatory Enforcement Agency. a = Mohammed et al.(2017), b = Baba et al. (2020), c = WHO (2006), $d=$ NESSRA (2009) 
BAJOPAS Volume 13 Number 2, December, 2020

Identification, Biochemical Characterization and growth rates of the Bacterial Isolates

Results of identification and biochemical characterization of the bacterial isolates were shown in table 2. After 24 hours of incubation, the nutrient agar media plates were checked for bacterial growth. The results showed the presence of different strains in the samples. The TAN1 bacteria isolate was found to be gramnegative cocci while TAN3 was gram-positive cocci. TAN2 bacteria isolate was found to be gram-positive, rod-shaped. TAN1, TAN2, and TAN3 bacteria isolates recorded positive results for spore former.

The results of the biochemical tests indicated that all the bacteria were positive for catalase, oxidase, citrate, maltose, glucose, lactose (negative in TAN1), mannitol (negative in TAN2), starch hydrolysis and coagulase (negative in TAN2) tests. The bacteria showed negative results for nitrate reduction, $M R$ (positive in TAN2), VP (positive in TAN1), Indole (positive in TAN2) tests. Base on the morphological and biochemical test results, TAN1, TAN2, and TAN3 bacteria isolates were identified to be Nesseria spp, Bacillus cereus, and Staphylococcus aureus respectively.

The growth rate of the TAN1, TAN2 and TAN3 Isolates were shown in figure 2. Generally, the optical density increase with the increase in time (day) and decrease as time goes on. The highest optical density was shown by bacillus cereus in TAN2 while the lowest was shown by Staphylococcus aureus in TAN3.

The initial growth phase of TAN1 Isolate bacteria occurred within 2-day of incubation as the growth rate increases up to the 6th-day incubation when the maximum growth was observed. Beyond the 6th day, the growth of the bacteria declined (which might be due to a shortage of nutrients in the effluents) until it reached its death phase (which might be due to the unavailability of nutrients in the effluents).

A similar trend of growth was also observed for TAN2 Isolate as the initial growth phase also occurred within 2-day of incubation but maximum growth rate observed on the 4th day of incubation. The stationary stage occurred between the 4th day and the 8th day. Beyond the 8th day, the growth of the bacteria declined (which might be due to a shortage of nutrients in the effluents) until it reached its death phase (which might be due to the unavailability of nutrients in the effluents).

The initial growth phase of TAN3 bacterial Isolate occurred within the 3-day incubation as the growth rate increases up to the 6th-day incubation when the maximum growth was observed. Beyond the 6th day, the growth of the bacteria declined (which might be due to a shortage of nutrients in the effluents) until it reached its death phase (which might be due to the unavailability of nutrients in the effluents).

Table 2: Morphological and Biochemical characteristics of bacterial isolates

\begin{tabular}{lllll} 
Bacterial Isolates & & TAN1 & TAN2 & TAN3 \\
\hline $\begin{array}{lllll}\text { Morphological } \\
\text { characteristics }\end{array}$ & Shape & Cocci & Rod & Cocci \\
& Spore & & & \\
& former & + & + & + \\
Gram & & & \\
Biochemical characteristics & reaction & - & + & + \\
& Citrate & + & + & + \\
& Catalase & + & + & + \\
& Coagulase & + & - & + \\
Starch & + & + & + \\
& Glucose & + & + & + \\
Oxidase & + & + & + \\
& Indo & - & + & - \\
Lactose & - & + & + \\
Manitol & + & - & + \\
Maltose & + & + & + \\
MR & - & + & - \\
VP & + & - & - \\
& Nitrate & - & - & - \\
Reduction & - Neisseria & Bacillus & Staphylococcus \\
& Bacterial & cereus & aureus \\
& name & spp & cas
\end{tabular}

+ = Positive; - = Negative; MR=Methyl Red; VP= Voges-Proskauer 


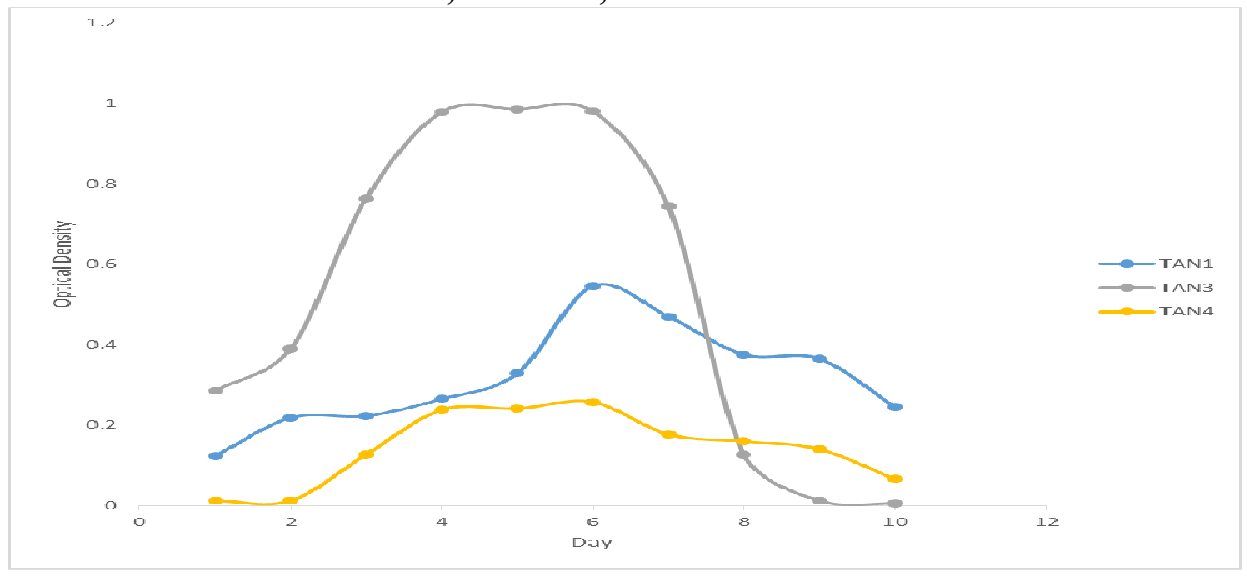

Fig. 2 Growth rates of the isolates in the effluents from the Tannery Industries

\section{Physico-chemical Parameters in the Industrial Effluents after the biodegradation.}

Table 3 shows the mean results of the physicochemical parameter before and after bioremediation using the different masses $(5 \mathrm{~g}$, $10 \mathrm{~g}, 15 \mathrm{~g}, 20 \mathrm{~g}$, and $25 \mathrm{~g}$ ) of the respective immobilized bacteria. Also, Table 4 shows the mean results of correlation coefficient ( $r$ ) between different masses of bacteria and physicochemical parameters.

The mean values $(\mathrm{mg} / \mathrm{l})$ of the SS after the bioremediation varies between $243 \pm 45$ and $898 \pm 672$. The mean concentration $(\mathrm{mg} / \mathrm{l})$ of SS remediated by the different masses $(5 \mathrm{~g}, 10 \mathrm{~g}$, $15 \mathrm{~g}, 20 \mathrm{~g}$, and $25 \mathrm{~g}$ ) of the bacteria varies. The SS in the samples fluctuates up and down after the bioremediation process when compared with the SS of the raw samples before the bioremediation. The increase in the levels of the SS might be due to the aggregation of the TDS which are large enough to result into SS. The increase in the levels of the SS might be also due to the influence of the nutrients which was added into the effluents in order to make the microorganisms more active and viable for fast degradation of organic contaminants in the effluent. The relative potential or efficiency of the different masses of the bacteria in remediating SS in TAN1 samples was in the order $25 \mathrm{~g}>20 \mathrm{~g}>15 \mathrm{~g}>10 \mathrm{~g}>5 \mathrm{~g}$. For TAN2 and TAN3 samples, the order was $25 \mathrm{~g}>20 \mathrm{~g}>15$ $\mathrm{g}>10 \mathrm{~g}>5 \mathrm{~g}$. These might be due to the variations in the surface areas of the different masses of the immobilized bacteria. Statistical analysis shows that there is no significant difference $(p<0.05)$ between the mean values of SS among the masses in the respective industries. Positive and significant correlations exist between the masses of bacteria and Suspended Solid (SS). This showed that there is general increase in the levels of the SS as the masses of the immobilized bacteria increases. TAN3 (90\%) and TAN1 (80\%) showed a very high correlation with the masses of the bacteria while TAN2 (61\%) showed a very low correlation.

The mean values $(\mathrm{mg} / \mathrm{l})$ of the TDS after the bioremediation varies between $46 \pm 11$ and $83 \pm 78$. The mean concentration $(\mathrm{mg} / \mathrm{l})$ of TDS remediated by the different masses $(5 \mathrm{~g}, 10 \mathrm{~g}$, $15 \mathrm{~g}, 20 \mathrm{~g}$, and $25 \mathrm{~g}$ ) of the bacteria varies. There is a reduction in all the TDS of all the samples after the bioremediation process compared with the TDS of the raw samples before the bioremediation. The relative potential or efficiency of the different masses of the bacteria in remediating TDS in TAN1 and TAN3 samples was in the order $5 \mathrm{~g}>10 \mathrm{~g}>15 \mathrm{~g}>20$ $\mathrm{g}>25 \mathrm{~g}$. For TAN2 samples, the order was 20 $g>10 \quad g>25 \quad g>15 \quad g>5 \quad g$. Statistical analysis shows that there is no significant difference $(p<0.05)$ between the mean values of TDS among the masses in the respective industries. These might be due to the variations in the surface areas of the different masses of the immobilized bacteria. Positive and significant correlations exist between the masses of bacteria and TDS with the exception in TAN2 (negative and insignificant correlation). The positive correlations showed that there is general increase in the levels of the TDS as the masses of the immobilized bacteria increases. TAN1 $(96 \%)$ showed a very high correlation with the masses of the bacteria while TAN2 (47\%) showed a very low correlation.

The mean values $(\mathrm{mg} / \mathrm{l})$ of the BOD after the bioremediation varies between $1.56 \pm 0.20 \mathrm{mg} / \mathrm{l}$ and $6.92 \pm 5.49 \mathrm{mg} / \mathrm{l}$. The mean concentration $(\mathrm{mg} / \mathrm{l})$ of BOD remediated by the different masses $(5 \mathrm{~g}, 10 \mathrm{~g}, 15 \mathrm{~g}, 20 \mathrm{~g}$, and $25 \mathrm{~g}$ ) of the bacteria varies. There is a reduction in all the BOD of all the samples after the bioremediation process compared with the $\mathrm{BOD}$ of the raw 
BAJOPAS Volume 13 Number 2, December, 2020 samples before the bioremediation. The relative potential or efficiency of the different masses of the bacteria in remediating BOD in TAN1, TAN2 and TAN3 samples were in the order $25 \mathrm{~g}>20$ $\mathrm{g}>15 \mathrm{~g}>10 \mathrm{~g}>5 \mathrm{~g}, 25 \mathrm{~g}>15 \mathrm{~g}>5 \mathrm{~g}>10 \mathrm{~g}>20 \mathrm{~g}$ and $20 \mathrm{~g}>10 \mathrm{~g}>25 \mathrm{~g}>15 \mathrm{~g}>5 \mathrm{~g}$ respectively. Statistical analysis shows that there is significant difference $(p<0.05)$ between the mean values of BOD among the masses in the respective industries. These might be due to the variations in the surface areas of the different masses of the immobilized bacteria. Negative and significant correlations exist between the masses of bacteria and BOD. This showed that there is general decrease in the levels of the BOD as the masses of the immobilized bacteria increases. TAN1 (94\%) showed a very high correlation with the masses of the bacteria while TAN2 (4\%) showed a very low correlation.

The mean values $(\mathrm{mg} / \mathrm{l})$ of the COD after the bioremediation varies between $250 \pm 154$ and $3134 \pm 1595$. The mean concentration $(\mathrm{mg} / \mathrm{l})$ of COD remediated by the different masses $(5 \mathrm{~g}$, $10 \mathrm{~g}, 15 \mathrm{~g} 20 \mathrm{~g}$, and $25 \mathrm{~g}$ ) of the bacteria varies. There is a reduction in all the COD of all the samples after the bioremediation process compared with the COD of the raw samples before the bioremediation. The relative potential or efficiency of the different masses of the bacteria in remediating COD in TAN1, TAN2 and TAN3 samples were in the order $25 \mathrm{~g}>20 \mathrm{~g}>15$ $\mathrm{g}>5 \mathrm{~g}>10 \mathrm{~g}, 25 \mathrm{~g}>20 \mathrm{~g}>15 \mathrm{~g}>10 \mathrm{~g}>5 \mathrm{~g}$ and 10 g>5 g>25 g>15 g>20 g respectively. Statistical analysis shows that there were significant difference $(p<0.05)$ between the mean values of COD among the masses in the respective industries except for effluents treated with $25 \mathrm{~g}$. These might be due to the variations in the surface areas of the different masses of the immobilized bacteria. Negative and insignificant correlations exist between the masses of bacteria and COD with the exception in TAN3 (positive and significant correlation). The negative correlations showed that there is general decrease in the levels of the COD as the masses of the immobilized bacteria increases. TAN2 (100\%) showed a very high correlation with the masses of the bacteria while TAN3 (36\%) showed a very low correlation.

Generally, there was an overall decrease in the concentration of these physicochemical parameters after the bioremediation using the different masses of the bacterial isolates. These might be due to the variations in the surface areas of the different masses of the immobilized bacteria. This is in line with the work of Jimoh et al. (2018) and Baba et al. (2020).

Table 3: Mean Values $(\mathrm{mg} / \mathrm{l}) \pm$ S.D of Physicochemical parameters in effluents from the Tannery Industries before and after Treatment of the effluents $(250 \mathrm{ml})$ with the different masses $(5 \mathrm{~g}, 10 \mathrm{~g}$, $15 \mathrm{~g}, 20 \mathrm{~g}$, and $25 \mathrm{~g}$ ) of the bacteria.

\begin{tabular}{llllllll}
\hline $\mathrm{P}$ & IND & Before & \multicolumn{5}{c}{ After } \\
\cline { 4 - 7 } & & & $5 \mathrm{~g}$ & $10 \mathrm{~g}$ & $15 \mathrm{~g}$ & $20 \mathrm{~g}$ & $25 \mathrm{~g}$ \\
\hline \multirow{2}{*}{ COD } & TAN1 & $2372 \pm 938$ & $1708 \mathrm{a} \pm 861$ & $2045 \mathrm{a} \pm 1205$ & $845 \mathrm{a} \pm 369$ & $300 \mathrm{a} \pm 167$ & $250 \mathrm{a} \pm 154$ \\
& TAN2 & $1406 \pm 208$ & $1195 \mathrm{a} \pm 208$ & $1125 \mathrm{a} \pm 384$ & $1055 \mathrm{a} \pm 317$ & $956 \mathrm{a} \pm 310$ & $870 \mathrm{ab} \pm 240$ \\
& TAN3 & $3532 \pm 1373$ & $2374 \mathrm{a} \pm 1344$ & $1976 \mathrm{a} \pm 1405$ & $2757 \mathrm{a} \pm 1266$ & $3134 \mathrm{a} \pm 1595$ & $2614 \mathrm{~b} \pm 1105$ \\
BOD & TAN1 & $13.85 \pm 6.42$ & $6.92 \mathrm{a} \pm 5.49$ & $6.42 \mathrm{a} \pm 5.07$ & $5.72 \mathrm{a} \pm 5.35$ & $4.62 \mathrm{a} \pm 4.37$ & $2.82 \mathrm{ab} \pm 1.26$ \\
& TAN2 & $19.46 \pm 0.50$ & $1.75 \mathrm{~b} \pm 0.22$ & $1.73 \mathrm{~b} \pm 0.18$ & $1.58 \mathrm{a} \pm 0.16$ & $1.91 \mathrm{a} \pm 0.22$ & $1.56 \mathrm{~b} \pm 0.20$ \\
& TAN3 & $17.13 \pm 3.14$ & $4.24 \mathrm{ab} \pm 0.77$ & $3.29 \mathrm{ab} \pm 0.37$ & $4.11 \mathrm{a} \pm 0.07$ & $3.23 \mathrm{a} \pm 0.91$ & $3.33 \mathrm{a} \pm 1.28$ \\
SS & TAN1 & $374 \pm 124$ & $243 \mathrm{a} \pm 45$ & $471 \mathrm{a} \pm 226$ & $475 \mathrm{a} \pm 182$ & $492 \mathrm{a} \pm 128$ & $611 \mathrm{a} \pm 217$ \\
& TAN2 & $358 \pm 335$ & $460 \mathrm{a} \pm 400$ & $543 \mathrm{a} \pm 414$ & $544 \mathrm{a} \pm 402$ & $551 \mathrm{a} \pm 414$ & $554 \mathrm{a} \pm 405$ \\
& TAN3 & $780 \pm 739$ & $586 \mathrm{a} \pm 594$ & $758 \mathrm{a} \pm 656$ & $787 \mathrm{a} \pm 676$ & $861 \mathrm{a} \pm 635$ & $898 \mathrm{a} \pm 672$ \\
TDS & TAN1 & $3941 \pm 3703$ & $51 \mathrm{a} \pm 10$ & $53 \mathrm{a} \pm 10$ & $55 \mathrm{a} \pm 15$ & $61 \mathrm{a} \pm 20$ & $63 \mathrm{a} \pm 26$ \\
& TAN2 & $3300 \pm 1714$ & $83 \mathrm{a} \pm 78$ & $47 \mathrm{a} \pm 20$ & $48 \mathrm{a} \pm 22$ & $47 \mathrm{a} \pm 17$ & $48 \mathrm{a} \pm 17$ \\
& TAN3 & $2653 \pm 1240$ & $46 \mathrm{a} \pm 11$ & $55 \mathrm{a} \pm 24$ & $55 \mathrm{a} \pm 25$ & $58 \mathrm{a} \pm 23$ & $61 \mathrm{a} \pm 28$ \\
\hline
\end{tabular}

Replicate $=6$ (months)

Within the rows, for the same parameter, means with different alphabets are statistically different $(p<0.05)$.

$\mathrm{P}=$ parameter, IND = Industries 
BAJOPAS Volume 13 Number 2, December, 2020

Table 4: Correlation coefficient $(r)$ between different masses of the bacteria and the physicochemical parameters.

\begin{tabular}{llll}
\hline Industries & Parameter & Correlation coefficient $(r)$ & $\begin{array}{l}\text { Percent dependence (rxrx100) } \\
(\%)\end{array}$ \\
\hline TAN1 & COD & -0.9 & 82 \\
& BOD & -0.97 & 94 \\
& SS & $0.90^{*}$ & 80 \\
TAN2 & TDS & $0.98^{*}$ & 96 \\
& COD & -1 & 100 \\
& BOD & -0.21 & 4 \\
& SS & $0.78^{*}$ & 61 \\
& TDS & -0.69 & 47 \\
& COD & $0.60^{*}$ & 36 \\
& BOD & -0.6 & 37 \\
& SS & $0.95^{*}$ & 90 \\
& TDS & $0.94^{*}$ & 89 \\
\hline
\end{tabular}

The correlation coefficient $(r)$ with * is statistically significant $(p<0.05)$.

Percentage reduction of the Parameters

Table 5 shows the percentage reduction of Parameters in industrial samples before and after the treatment of the effluents $(250 \mathrm{ml})$ with the different masses $(5 \mathrm{~g}, 10 \mathrm{~g}, 15 \mathrm{~g}, 20 \mathrm{~g}$, and $25 \mathrm{~g}$ ) of the Immobilized Bacteria.

In TAN1 samples, the percentage reduction (\%) of COD ranged (14-89); BOD (50-80); SS (-32$35)$ and TDS (98-99). In TAN2 samples, the percentage decrease $(\%)$ of COD ranged (15$38) ;$ BOD (90-92); SS [-28-(-55)] and TDS (9798). In TAN3 samples, the percentage decrease (\%) of COD ranged (11-44); BOD (76-81); SS (15-25) and TDS (98). The percentage increase in the levels COD, BOD and TDS might be due to the increase in the surface area of the different masses of the immobilized bacteria. However, the percentage decrease in the levels of the SS might be due to the aggregation of the TDS which are large enough to result into SS. The percentage decrease in the levels of the SS might be also due to the influence of the nutrients which was added into the effluents in order to make the microorganisms more active and viable for fast degradation of organic contaminants in the effluent. This is in line with the work of Jimoh et al. (2018) in which the concentration of the SS increase after the bioremediation of effluents.

Sreemoyee and Priti (2013) assessed and reduced several Physico-chemical parameters of dairy wastewater using Niesseria $s p$. and concluded that the species are well known to degrade organic compounds. This is in agreement with the current study in which the immobilized Niesseria $s p$ degrade the organic contaminants as indicated by the BOD, COD and TDS.

Jimoh et al. (2018) observed that TSS of the effluents was increased after treatment with immobilized bacteria and concluded that it might be due to the biostimulation method adopted for the research.

The optimum $\mathrm{pH}$ Biosorption of Chromium by Bacillus spp and Staphylococcus spp. from tannery effluent was investigated by Mythili and Karthikeyan (2011). The maximum adsorption of Chromium $(86.4 \mathrm{mg} / \mathrm{L})$ was showed by Bacillus spp and Staphylococcus spp showed $70.6 \mathrm{mg} / \mathrm{L}$ at an initial concentration of $100 \mathrm{mg} / \mathrm{L}$. In the present study, immobilised Bacillus spp and Staphylococcus spp. from the tannery industrial effluents reduced the levels of the organic pollutants with high potential as indicated by the percentage reduction of BOD, COD and TDS.

Enzymes often can work in multiple environments especially if they are immobilized. This makes the microorganisms' enzymes even more resistant to harsh environments and enables the enzymes to be recovered and recycled after they are no longer needed (Gianfreda and Rao 2004). Ramesh and Singh (1993) reported that the immobilized bacteria having more efficiency to remove the suspended particles than free cells. Using the immobilized cell is preferable due to its capability for using several times with the same efficiency, which makes it more economical. Similar work was done by Sikander et al. (2007) showing the higher reduction with permeabilized cells of Ochrobactrum intermedium strain SDCr-5. 
BAJOPAS Volume 13 Number 2, December, 2020

The results revealed the isolation and identification of isolates with the potential for the reduction of $\mathrm{Cr}$ (VI) to $\mathrm{Cr}$ (III). Results indicated that immobilized $B$. cereus could be efficiently used for the reduction of $\mathrm{Cr}$ (VI).

Table 5: Percentage reduction of the tested Parameters from the tannery industrial samples of the Immobilized Bacteria.

\begin{tabular}{lllllll}
\hline \multirow{2}{*}{ Industries } & & \multicolumn{5}{c}{ Percentage Reduction $(\%)$} \\
\cline { 3 - 7 } & & $5 \mathrm{~g}$ & $10 \mathrm{~g}$ & $15 \mathrm{~g}$ & $20 \mathrm{~g}$ & $25 \mathrm{~g}$ \\
\hline TAN1 & COD & 28 & 14 & 64 & 87 & 89 \\
& BOD & 50 & 54 & 59 & 67 & 80 \\
& SS & 35 & -26 & -27 & -32 & -63 \\
& TDS & 99 & 99 & 99 & 98 & 98 \\
TAN2 & COD & 15 & 20 & 25 & 32 & 38 \\
& BOD & 91 & 91 & 92 & 90 & 92 \\
& SS & -28 & -52 & -52 & -54 & -55 \\
& TDS & 97 & 99 & 99 & 99 & 99 \\
& COD & 33 & 44 & 22 & 11 & 26 \\
& BOD & 75 & 81 & 76 & 81 & 81 \\
& SS & 25 & 3 & -1 & -10 & -15 \\
& TDS & 98 & 98 & 98 & 98 & 98 \\
\hline
\end{tabular}

Percentage Reduction $=(B-A) / B \times 100 \%$

$A=$ Concentration of the parameter after treatment

$\mathrm{B}=$ Concentration of the parameter before treatment

$+=$ percentage decrease

- = percentage increase

In general, immobilization makes the enzyme more resistant to temperature, $\mathrm{pH}$, and substrate concentration swings giving it a longer lifetime and higher productivity per active unit (Gianfreda and Rao, 2004; FuIlbrook, 1996; Russell et al, 2003; Kandelbauer et al., 2004). Immobilized cells have been used and studied extensively for the production of useful chemicals (Ohtake and Silver, 1994), the treatment of wastewaters (Chen et al., 2003; Wang et al., 2010). Although many workers described microbial degradation of tannery effluent, limited literature is available on the bioremediation of tannery effluent using immobilized bacterial cells in the Kano Industrial Estates.

\section{CONCLUSION}

The samples contained variable levels of the physicochemical parameters. The results of the Analysis of variance revealed that, no statistical difference $(p<0.05)$ was observed for the temperature, $\mathrm{pH}, \mathrm{SS}, \mathrm{TDS}, \mathrm{BOD}$ and $\mathrm{COD}$ among the three tannery industries before the treatment. The levels of some of the parameters
(SS, TDS and COD) observed in the samples were found above the recommended limits of WHO and NESREA, which called for the treatment of the effluents before discharge into the environment. Base on the morphological and biochemical test results, TAN1, TAN2, and TAN3 bacterial isolates were identified to be Neisseria spp, Bacillus cereus, and Staphylococcus aureus respectively. The results of Post-treatment analysis showed that there is overall decrease in the levels of the parameters determined when compared with that of the pre-treatment. The overall percentage reduction of the immobilised bacteria in the treatment of the respective effluents was in the order TAN2 (72\%)>TAN1 $(70 \%)>$ TAN3 $(62 \%)$. Hence, the immobilized bacteria are having higher biodegradation potential for the treatment of the tannery effluents.

\section{Acknowledgments}

The authors wish to acknowledge the University of Maiduguri for the financial support. The authors are grateful to the Kano State Ministry of Environment for their support in obtaining the effluent samples. 


\section{REFERENCES}

Ajao, A. T., Adebayo, G. B., and Yakubu, S. E. (2011). Bioremediation of textile industrial effluent using mixed culture of Pseudomonas aeruginosa and Bacillus subtilis immobilized on agar-agar in a bioreactor. J. Microbiol. Biotech. Res, 1(3), 50-56.

Akan, J. C., Moses, E. A., Ogugbuaja, V. O., and Abah, J. (2007). Assessment of tannery industrial effluents from Kano metropolis, Kano State, Nigeria. Journal of Applied Sciences, 7(19), 2788-2793.

Akan, J. C., Ogugbuaja, V. O., Abdulrahman, F. I., and Ayodele, J. T. (2009). Pollutant levels in effluent samples from tanneries and textiles of Kano industrial areas, Nigeria. Global journal of pure and applied sciences, 15(3-4).

APHA (1989). Standard methods for Examination of Will bete and Will betewater.15 $5^{\text {th }}$ edition. Brydpass Springfield Will behington DC. pp. 164-176

APHA (1992). Standard Methods for the Examination of Water and Wastewater. Health, 69, 1116-9.

Baba, A., Garba, S. T., and Bello, H. S. (2020). Bioremediation Potential of Immobilized corynebacterium kutsceri in the Treatment of Tannery Industrial Effluent from Challawa Industrial Estate, Kano State, Nigeria. Journal of the Turkish Chemical Society Section A: Chemistry, $7(2), 335-350$.

Beem, E. I. V. (1994). reduction of solvent VOC emission. J. Oil Col. Chem. Ass, 77, 158.

Bouwer, E. J., and Zehnder, A. J. (1993). Bioremediation of organic compoundsputting microbial metabolism to work. Trends in biotechnology, 11(8), 360367.

Chen, K. C., Wu, J. Y., Liou, D. J., and Hwang, S. C. J. (2003). Decolorization of the textile dyes by newly isolated bacterial strains. Journal of Biotechnology, 101(1), 57-68.

Dan'Azumi, S., and Bichi, M. H. (2010). INDUSTRIAL POLLUTION AND HEAVY METALS PROFILE OF CHALLAWA RIVER IN KANO, NIGERIA. Journal of Applied Sciences in Environmental Sanitation, $5(1)$.

DWAF. (1992). Analytical Methods Manual, TR 151. Department of Water Affairs and Forestry, Pretoria.

El-Bestawy, E. (2013). Biological treatment of leather-tanning industrial wastewater using free living bacteria.
Elsheikh, M. A. S. (2009). Tannery wastewater pre-treatment. Water Science and Technology, 60(2), 433-440.

FuIlbrook, P. D. (1996). "Kinetics." Industrial enzymology: The application of enzymes in Industry. 2nd Ed. T. Godfrey and J Reichelt. eds.. Nature. New York.

Gianfreda, L., and Rao, M. A. (2004). Potential of extra cellular enzymes in remediation of polluted soils: a review. Enzyme and microbial technology, 35(4), 339354.

Hugo Springer. (1994). John Arthur Wilson Memorial Lecture "Treatment of Industrial Wastes of the Leather Industry - is it still a Major Problem". JALCA, 89, 153-185

Jimoh, A. A., Ganiyu, B. A., Baba, D., and Baba, A. (2018) Bioremediation Process of Effluent from Detergent and Food Industries in Jos, Nigeria: Kinetics and Thermodynamics. International Journal of Engineering Science Invention (IJESI), 762-73

Kandelbauer, A., Maute, O., Kessler, R. W., Erlacher, A., and Gübitz, G. M. (2004). Study of dye decolorization in an immobilized laccase enzyme-reactor using online spectroscopy. Biotechnology and bioengineering, 87(4), 552-563.

Kongjao, S., Damronglerd, S., and Hunsom, M. (2008). Simultaneous removal of organic and inorganic Pollutants in tannery wastewater using electrocoagulation technique. Korean Journal of chemical engineering, 25(4), 703.

Maheshwari, U. M., Aruna, S., Gomathi, M., and AbdulJaffar, A. H. (2017). Bioremediation by Free and Immobilized Bacteria Isolated from Tannery Effluent. International Journal of Research in Applied, Natural and Social Sciences. 5(7), 75-90

Margesin, R., and Schinner, F. (2001). Bioremediation (natural attenuation and biostimulation) of diesel-oilcontaminated soil in an alpine glacier skiing area. Applied and environmental microbiology, 677), 3127-3133.

Mohammed, A., Sekar, P., and George, J. (2011). Efficacy of microbes in bioremediation of tannery effluent. Inter. J. Curr. Res, 3(4), 324-326.

Mohammed, S. S. D., Orukotan, A. A., and Abdullahi, H. (2017). Physicochemical and Bacteriological Assessment of Tannery Effluent from Samaru-Zaria, 
BAJOPAS Volume 13 Number 2, December, 2020 Kaduna State, Nigeria. Journal of Applied

Sciences and Environmental Management, 21(4), 734-740.

Munz, G., De Angelis, D., Gori, R., Mori, G., Casarci, M., and Lubello, C. (2009). The role of tannins in conventional and membrane treatment of tannery wastewater. Journal of hazardous materials, 164(2-3), 733-739

Mythili, K., and Karthikeyan, B. (2011). Bioremediation of $\mathrm{Cr}$ (VI) from tannery effluent using Bacillus spp and Staphylococcus spp. International Multidisciplinary Research Journal, 1(6).

NESREA (2009). National Environmental Standards for Effluent Limitations and Regulation. 1233-1236

Noorjahan, C. M. (2014). Physicochemical characteristics, identification of bacteria and biodegradation of industrial effluent. Journal of bioremediation and Biodegradation, 5(3).

Ohtake, H. I., and Silver, A. O. (1994). Bacterial reduction of toxic chromate. Biological degradation and bioremediation of toxic chemicals, 403-415.

Omoleke, I. I. (2004). Management of environmental pollution in Ibadan, an African city: the challenges of health hazard facing government and the people. Journal of Human Ecology, 15(4), 265-275.

Rajor, A., Reddy, A.S., and Singh, B. (2004). Determination of BOD kinetic Parameters and evaluation of alternate methods, M.Sc. Thesis, Department of biotechnology \& environmental Science, Thapar Institute of Engineering and Technology, Patiala

Ramasami, T., Rajamani, S., and Rao, J. R. (1994, March). Pollution control in leather industry: Emerging technological options. In International symposium on surface and colloidal science and its relevance to soil pollution, madras.

Ramesh, J. V. S., and Singh, S. P. (1993). Yearly variation in certain physicochemical parameters of pond at eastern Doon Valley. Uttar Pradesh J. Zoo, 12 (1), 7577.

Ranen, S., and Sharadinadra, C. (2009). Biotechnology applications to environmental remediation in resource exploitation. Current science, 97, 6-25
Russell, A. J., Berberich, J. A., Drevon, G. F., and Koepsel, R. R. (2003). Biomaterials for mediation of

chemical and biological warfare agents. Annual review of biomedical engineering, 5(1), 1-27.

Saravanan, P., and Saravanan, A. (1999). Decolourization of tannery effluent by Flavobacterium sp. EK 1. Indian Journal of Environmental Protection, 19, 19-24.

Sikander, S., and Shahida, H. (2007). Reduction of toxic hexavalent chromium by Ochrobactrum intermedium strain SDCr5 stimulated by heavy metals. Bioresource Technol, 98, 340-344.

Singh, N., Sharma, B. K., and Bohra, P. C. (2000). Impact assessment of industrial effluent of arid soils by using satellite imageries. Journal of the Indian Society of Remote Sensing, 28(2-3), 79.

Sreemoyee, C., and Priti, P. (2013). Assessment of physico-chemical parameters of dairy waste water and isolation and characterization of bacterial strains in terms of cod reduction. Int J Sci, 2(3), 395-400.

Verheijen, L. A. H. M., Wiersema, D., Pol, L. H., and De Wit, J. (1996). Management of wastes from animal product processing. Livestock and environment, Finding a balance. International Agriculture Center, Wageningen, The Netherlands.

Wang, F., Yao, J., Si, Y., Chen, H., Russel, M., Chen, K., and Bramanti, E. (2010). Short-time effect of heavy metals upon microbial community activity. Journal of Hazardous Materials, 173(13), 510-516.

WHO (World Health Organization). (2006). Air quality guidelines: global update 2005: particulate matter, ozone, nitrogen dioxide, and sulfur dioxide. World Health Organization.

World Bank. (1995). Nigeria's strategic options for redressing industrial pollution. World Bank, industry and energy division. 1st edition, West Central Africa Department; Annexes: 1995; pp 60-62.

Zahoor, A., and Abdul, R. (2009). Enumeration of Coliforms. Journal of Environmental Sciences. 21, 814-820 


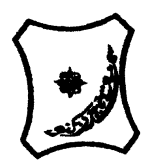

Bayero Journal of Pure and Applied Sciences, 13(2): 1 - 12

Received: November, 2020

Accepted: December, 2020

ISSN $2006-6996$

\title{
BIODEGRADATION POTENTIAL OF IMMOBILIZED BACTERIA IN THE TREATMENT OF TANNERY INDUSTRIAL EFFLUENTS FROM INDUSTRIAL ESTATES IN KANO STATE, NIGERIA
}

\author{
Abdullateef, B., ${ }^{1 *}$ Shuaibu, T. G., ${ }^{1}$ Babagana, K., ${ }^{1}$ Suleman, H. B. ${ }^{2}$ and Dauda, B. ${ }^{3}$ \\ ${ }^{1}$ Department of Pure and Applied Chemistry, Faculty of Science, University of Maiduguri, Borno State, \\ Nigeria \\ ${ }^{2}$ Department of Microbiology, Faculty of Science, University of Maiduguri, Borno State, Nigeria \\ ${ }^{3}$ Department of Chemical Engineering, Faculty of Engineering, University of Maiduguri, Borno State, \\ Nigeria \\ *Corresponding author: babslega@gmail.com; abelega2007@yahoo.com; +2348061309753
}

\section{ABSTRACT}

Industrial Effluents Samples from Gashash Tanneries (TAN1) in Bompai Industrial estate, Larabee Tannery Industry (TAN2) in Sharada Industrial estate and Z Tannery Industries (TAN3) in Challawa Industrial estate, Kano State, Nigeria were collected over a period of six months (August 2017 to January 2018) for assessing the biodegradation potentials of bacteria in the treatment of organic pollutants within the effluents. Bacteria were isolated from the effluents and immobilized on agar-agar. Different masses (5 g, $10 \mathrm{gr}, 15$ $\mathrm{g}, 20 \mathrm{~g}$, and $25 \mathrm{~g}$ ) of the bacteria were used in the treatment of $250 \mathrm{ml}$ of the effluents for ten days in a shaker incubator (Gallenkamp-OC-4364-L) at the temperature $30{ }^{\circ} \mathrm{C}$ and speed of $60 \mathrm{rpm}$. Pre-treatment analysis of the effluents for Temperature, pH, Biochemical Oxygen Demand (BOD), Chemical Oxygen Demand (COD), Suspended Solid (SS) and Total Dissolved Solids (TDS) gives the following results; temperature $\left({ }^{\circ} \mathrm{C}\right.$ )

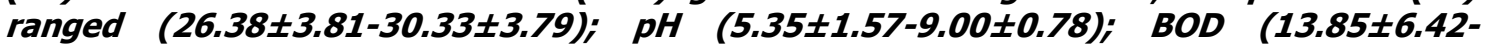
$38.75 \pm 16.20) ;$ COD (1406 $\pm 208-3532 \pm 1373) ;$ SS (208 $\pm 235-780 \pm 739)$ and TDS (266 $\pm 253-5276 \pm 2971)$. No statistical differences ( $p \leq 0.05)$ was observed for all the results among the different industries. The bacterial isolates were identified as Neisseria spp, Bacillus cereus, and Staphylococcus aureus, in TAN1, TAN2, and TAN3, respectively. After treatment of the effluent with the different masses of the isolated bacteria, the mean level of BOD was found to range as (0.55 $\pm 0.36-6.92 \pm 5.49) ; C O D$ (ND-3134 \pm 1595$)$;

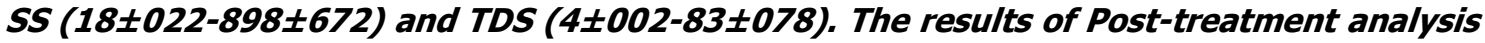
showed that there is overall decrease in the levels of the parameters determined when compared with that of the pre-treatment. The overall percentage reduction of the immobilised bacteria in the treatment of the respective effluents was in the order TAN2 (72\%)>TAN1 (70\%)>TAN3 (62\%). Hence, the immobilized bacteria are having higher biodegradation potential for the treatment of the tannery effluents.

Keywords: Biodegradation, bacteria, effluent, immobilization, tannery.

\section{INTRODUCTION}

Tannery industrial wastewater is a serious consequence of the pollution point of view for streams, freshwater, and land used for agriculture. The lack of awareness in the modern industrial practice has resulted in the discharge of tannery effluents which exhibit very high value of chromium ( $\mathrm{Cr}$ ), Sulfide, and chloride, Total Dissolved Solid (TDS), Total Suspended Solid (TSS), Biochemical Oxygen Demand (BOD) and Chemical Oxygen Demand (COD) in the water stream or land (Mohammed et al., 2001). Tanning is the process, which One ton of skin generally leads to the production of 20 to $80 \mathrm{~m}^{3}$ of turbid and foul-smelling converts the protein of the rawhide or skin into a stable material, which will not putrefy and is suitable for a wide variety of end applications (Elsheikh, 2009). The highly polluting chromium is the most commonly used tanning material producing leather that is more flexible and pliable than vegetable-tanned leather and does not discolor or lose shape in water as drastically as vegetable-tan (Elsheikh, 2009). Tannery effluent is among the most hazardous industrial pollutants due to its huge organic and inorganic load, which is highly toxic to human life and the environment (Kongjao et al., 2008). wastewater including chromium (100-400 mg/l), sulfide $(200-800 \mathrm{mg} / \mathrm{l})$, high levels of fat and 
BAJOPAS Volume 13 Number 2, December, 2020 other solid wastes, and notable pathogen contamination as well as pesticides added for skin conservation during transport (Elsheikh, 2009). There are more than 6000 tanneries in Nigeria with an annual processing capacity of 700,000 tons of hides and skins (Omoleke, 2004; Singh et al., 2008). It was reported that the total amount of waste produced per animal slaughtered is approximately $35 \%$ of its weight (World Bank, 1995). Also, for every $1000 \mathrm{~kg}$ of carcass weight, a slaughtered beef produces 5.5 $\mathrm{kg}$ of manure (excluding rumen contents or stockyard manure) and $100 \mathrm{~kg}$ of paunch manure (undigested food) (Verheijen et al., 1996). Tanneries generate wastewater in the range of 30-35 $\mathrm{L} \mathrm{kg}^{-1}$ skin/hide processed with variable $\mathrm{pH}$, Biological Oxygen Demand (BOD), Chemical Oxygen Demand (COD), high concentrations of suspended solids (SS), and tannins as well as chromium (Zahoor and Abdul, 2009).

Being heterogeneous and composed of a wide variety of compounds, it is very difficult to select a unique direct method for estimating the biodegradability of organic contents and biokinetic parameters for a wastewater sample (Rajor, 2004). For this purpose, some indirect estimation such as determination of biochemical oxygen demand (BOD) and chemical oxygen demand (COD) are applied as common laboratory investigations [9]. During retanning procedures, synthetic tannins (Syntan), oils and resins are added to form softer leather at varying doses (Munz et al., 2009). One of the refractory groups of chemicals in tannery effluents derives mainly from tannins (Ramasami et al., 2004). Syntans are characterized by complex chemical structures, because they are composed of an extended set of chemicals such as phenol-, naphthalene-, formaldehyde- and melamine-based syntans, and acrylic resins (Beem, 1994). Organic pollutants (proteic and lipidic components) are originated from skins (it is calculated that the raw skin has $30 \%$ loss of organic material during the working cycle) or they are introduced during processes (Hugo Springer, 1994).

Many conventional processes such as oxidation, chemical and biological processes were carried out to treat tanneries wastewater (Ebtesam et al, 2013). Biological processes have received more attention because of their costeffectiveness, lower sludge production and environmental friendliness (Noorjahan, 2014). Naturally occurring micro-organisms degrade the hazardous organic wastes including xenobiotic compounds, such as pesticides, polycyclic aromatic hydrocarbons (PAHs) and polychlorinated biphenyls (PCBs) in due course of time (Ranen and Sharadinadra, 2009). Bioremediation is based on the idea that all organisms remove substances from the environment to carry outgrowth and metabolism (Bouwer and Zehnder, 1993). Bacteria, protista and fungi are found to be very good at degrading complex molecules and incorporating the breakdown products into their metabolism (Bouwer and Zehnder, 1993). The resultant metabolic wastes that they produce are generally safe and somehow recycled into other organisms (Ranen and Sharadinadra, 2009). An acclimatized indigenous population of microorganisms capable of degradation of the compounds of interest must exist at the site for a successful bioremediation mode (Ranen and Sharadinadra, 2009). It has been observed that for a successful bioremediation mode, an acclimatized indigenous population of microorganisms capable of degradation of the compounds of interest must exist at the site under investigation (Ranen and Sharadinadra, 2009). Even though there are numerous physical and chemical methods employed in the disposal of wastes the advantage in using bacterium is that they play a key role in the reduction of COD, BOD, total protein, total tannin and total phenol (Saravanan and Saravanan, 1998)

Baba et al. (2020) studied the bioremediation potential of immobilized corynebacterium kutsceri in the Treatment of tannery industrial effluent from Challawa Industrial Estate, Kano State, Nigeria. The aim of the work is to study the reduction in the level of the contaminants through the process of bioremediation using the isolated bacteria. Immobilized bacteria can withstand various temperatures, $\mathrm{pH}$ and substrate concentrations; consequently, increasing the efficiency and the lifespan of the bacteria. Immobilized bacteria are widely applied in the treatment of wastewater and can be separated and recovered after the treatment with the same efficiency (Baba et al., 2020).

\section{MATERIALS AND METHODS \\ Study Area}

This study was carried out in Bompai, Sharada and Challawa industrial estates in Kano, Figure 1. Kano lies on Latitude $11^{\circ} 30^{\prime} \mathrm{N}$ and $8^{\circ} 30^{\prime} \mathrm{E}$ and Longitude $11^{\circ} 5^{\prime} \mathrm{N}$ and $8^{\circ} 5^{\prime} \mathrm{E}$ in Northern Nigeria. It is one of the developed industrial cities in Nigeria. Tannery activities are the dominating industries and this could be one of the reasons for her high population density (Dan'Azumi and Bichi, 2010). Many researchers have studied biodegradation of tannery effluent using microorganisms. However, limited literature is available on the biodegradation of tannery effluent in Kano industrial estates using 
BAJOPAS Volume 13 Number 2, December, 2020 immobilized bacterial cells. This research work focuses on the potential of the use of the indigenous immobilized bacterial isolates in the treatment of tannery effluents in the industrial estates.

\section{Sample Collection}

Effluents were collected from the Tannery Industries from Bompai, Challawa and Sharada Industrial Estates, Kano, Nigeria. The effluents were collected over a period of six months (August 2017 to January 2018). Samples collected in a sterile 4-liter plastic container with a unique identification number were preserved using an ice-box that was transported to the Microbiology Laboratory, Department of Microbiology, Bayero University of Kano for analysis

\section{Sample Preparation and Sample Analysis}

Immediately after the collection of the effluent, $\mathrm{pH}$, TSS, TDS, COD, BOD levels were determined before treatment (Pre-treatment determination) and ten days after treatment (Post-treatment determination) as described in
APHA (1989) standard methods. $\mathrm{pH}$ was determined using Ecotests $\mathrm{pH}$ meter and TDS was determined using AQUALYTIC TDS Salinometer. BOD was determined as described by the standard method (APHA, 1992). COD and SS were determined using DR/2010 HACH portable data logging spectrophotometer (DWAF, 1992)

\section{Identification and Biochemical} Characterization of the Bacterial Isolates

The bacteria were isolated from the effluents using Serial Dilution according to the method described by APHA (1989). The biochemical tests such as oxidase, catalase, coagulase, indole (from $1 \%$ tryptone broth), citrate (Simmons citrate agar), methyl red/VogesProskauer (MR/VP), nitrate reduction, Starch Hydrolysis, Glucose, Maltose, and Lactose tests were carried out on the bacterial isolates to identify the bacteria through the bacteria biochemical characteristics according to Ajao et al. (2011).

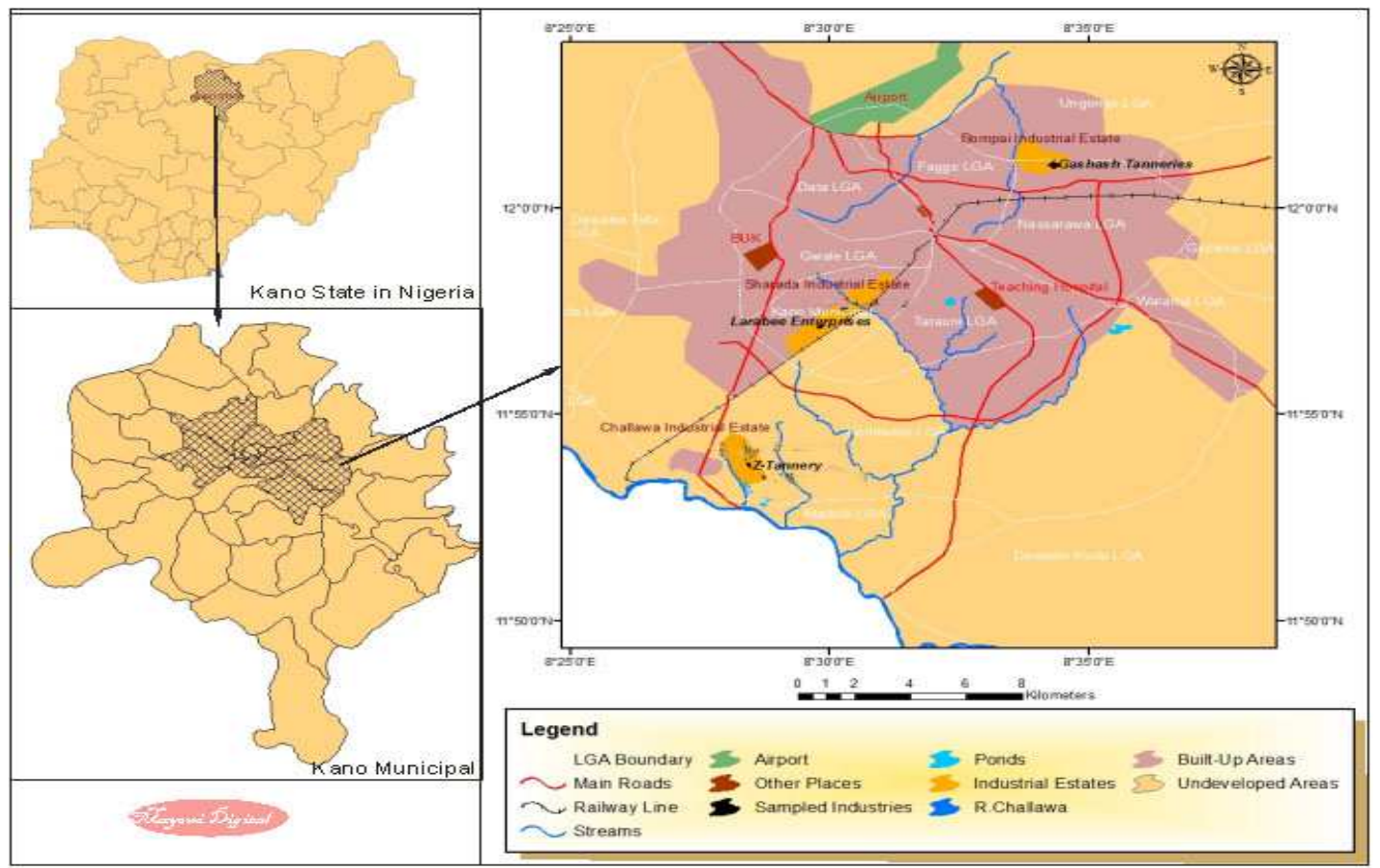

Fig. 1 Map showing the study areas

Source: Mayomi Digital Productions, GIS Laboratory, Department of Geography, UNIMAID (2017)

\section{Determination of Growth Rate of the Bacteria in Effluent Sample}

The bacteria growth rates were determined by transferring $2 \mathrm{~mL}$ of the bacterial isolates from the tannery effluent in broth medium into 100 $\mathrm{mL}$ sterile effluents in conical flasks and kept in an incubator (Giffrin cool) for 10 days. Control was also set up by incubating another $100 \mathrm{~mL}$ each of the sterile effluents without the bacteria. The optical density of the content was determined at the wavelength of $600 \mathrm{~nm}$ on a daily interval and recorded. 
BAJOPAS Volume 13 Number 2, December, 2020 Immobilization of Bacteria

Agar solution and inoculi were prepared separately. Fifty milliliters $(50 \mathrm{~mL})$ of nutrient broth each of the inoculi was prepared in a McCartney bottle and incubated for 24 hours. A solution of agar-agar was prepared by dissolving $10 \mathrm{~g}$ of the powder in distilled water and made up to $500 \mathrm{~mL}$ mark in an Erlenmeyer flask and was sterilized in an autoclave (280A) for 15 minutes and allowed to cool to $40-45^{\circ} \mathrm{C}$ (Ajao et al., 2011). Four milliliters ( $4 \mathrm{~mL})$ of the bacterial isolates in the nutrient broth was mixed with 36 $\mathrm{ml}$ of the prepared agar-agar media in petri-dish plates and then allowed to solidify. This was kept in the refrigerator for bioremediation.

\section{Bioremediation (Treatment) of the Effluents}

The solidified agar block (immobilized bacteria) was cut into cubes using a sterile knife; $0.1 \mathrm{~mL}$ phosphate buffer ( $\mathrm{pH} \mathrm{7.0)}$ was added and kept in the refrigerator for 1 hour for curing. The phosphate buffer was decanted after 1 hour and the cubes were washed with sterile distilled water 3-4 times before it was used (Ajao et al., 2011). Two liters (2 L) of the effluent was supplemented with the minimum basal medium in $\mathrm{g} / \mathrm{L}: \mathrm{NaCl}(0.8), \mathrm{MgSO}_{4} .7 \mathrm{H}_{2} \mathrm{O}(0.001), \mathrm{KH}_{2} \mathrm{PO}_{4}$ (2), $\mathrm{NaNO}_{3}$ (2), $\quad \mathrm{CaCl}_{2} .2 \mathrm{H}_{2} \mathrm{O} \quad(0.5)$ and $\mathrm{NaHPO}_{4} .12 \mathrm{H}_{2} \mathrm{O}(2)$ and sterilized in an autoclave at $121^{\circ} \mathrm{C}$ for 15 minutes (Margesin and Schinner, 2001). Two hundred and fifty milliliters $(250 \mathrm{~mL})$ of the effluents were transferred into different $250 \mathrm{ml}$ conical flasks. The content was covered with a cotton-wool ramped with foil paper to avoid contamination. Five grams $(5 \mathrm{~g})$ of the immobilized bacteria were quickly transferred into each of the effluents in the conical flasks in an inoculating chamber. The same procedures were carried out for the $10 \mathrm{~g}, 15 \mathrm{~g}, 20 \mathrm{~g}$ and 25 $\mathrm{g}$ of the immobilized bacteria in separate $250 \mathrm{~mL}$ effluents in conical flasks and agitated for ten days in a shaker incubator (Gallenkamp-OC4364-L) at a temperature $30^{\circ} \mathrm{C}$ and speed of 60 rpm. The treated effluent samples were taken on the tenth day and analyzed for the parameters $\mathrm{pH}$, SS, TDS, COD, and BOD, (Posttreatment determination) for the different grams of bacteria to evaluate and compare the biodegradation potential. (Baba et al., 2020).

\section{Statistical Analysis}

The data were represented as Mean \pm Standard deviation and analyzed statistically using oneway Analysis of Variance (ANOVA) and Tukey's HSD as Post Hoc Tests with the aid of SPSS 16.0. The correlation coefficient was also used to measure the strength of the relationship between the different masses of the bacteria and the parameters. All $\mathrm{p} \leq 0.05$ were considered as statistically significant.

\section{RESULTS AND DISCUSSION Physico-chemical parameters in the Industrial Effluents before the Biodegradation.}

Results of the Physico-chemical parameters in the industrial effluents before the Biodegradation is shown in table 1 . The mean temperatures $\left({ }^{\circ} \mathrm{C}\right)$ observed in TAN1, TAN2, and TAN3 samples were $28.07 \pm 0.65 ; 27.77 \pm 0.64$ and $26.38 \pm 3.81$ respectively. The order of the mean temperature of the samples from the three industries can be arranged as TAN1 > TAN2>TAN3. The temperature observed at TAN1, TAN2, and TAN3 samples were found below the WHO $\left(35^{\circ} \mathrm{C}\right)$ and NESREA $\left(40^{\circ} \mathrm{C}\right)$ limits. The low values of temperature might be due to the processes used at the time of sampling. High temperature brings down the solubility of gases in water that ultimately expresses as high BOD and COD. Statistical analysis shows that there is no significant difference $(p<0.05)$ between the mean values of temperature among the industries. This might be due to similar tannery activities involved in the tannery industries at the time of sampling. The average values of temperature observed in this present study are less than those observed by Akan et al. (2007), Akan et al. (2009) and Baba et al. (2020).

The mean level of $\mathrm{pH}$ observed in TAN1, TAN2 and TAN3, samples were $7.77 \pm 2.93$; $8.35 \pm 0.28$ and $7.52 \pm 0.76$ respectively. The order of the mean $\mathrm{pH}$ of the samples from the three industries can be arranged as TAN2> TAN1 $>$ TAN3. The $\mathrm{pH}$ of the samples falls within the WHO (7.0-8.5) and NESREA (6-9) standard limits. Statistical analysis shows that there is no significant difference $(p<0.05)$ between the mean values of $\mathrm{pH}$ among the industries. This might be due to similar tannery activities involved in the tannery industries at the time of sampling. Maheshwari et al. (2017) reported that the level of $\mathrm{pH}$ in the effluents from the tannery industry in Vaniyambadi, India was 6.5 which was lower than that observed in the present study. The $\mathrm{pH}$ in the effluents from the tannery industries in Kano and Kaduna were reported to be 7.64 and 6.89, respectively (Akan et al., 2007; Mohammed et al., 2017). The average values of $\mathrm{pH}$ observed in this present study are less than those observed by Mohammed et al. (2017) and Baba et al. (2020). The mean level of SS $(\mathrm{mg} / \mathrm{l})$ observed in TAN1, TAN2, and TAN3 samples were 374 \pm 124 ; $358 \pm 335$ and $780 \pm 739$ respectively. The order of the mean SS in the samples from the three industries can be arranged as TAN3 > TAN1 $>$ TAN2. 
The SS observed in the samples were far above the recommended standard limits of regulating bodies WHO $(30 \mathrm{mg} / \mathrm{l})$ and NESREA $(10 \mathrm{mg} / \mathrm{l})$. Statistical analysis shows that there is no significant difference $(p<0.05)$ between the mean values of SS among the industries. This might be due to similar tannery activities involved in the tannery industries at the time of sampling. The average values of SS observed in this present study are less than that observed $(3700 \pm 122 \mathrm{mg} / \mathrm{l})$ by Akan et al. (2009) for tanneries in Kano. Also, the average values of SS observed in this present study are less than that observed by Mohammed et al. (2017) and Baba et al. (2020) with the exception in TAN3.

The mean level of TDS (mg/l) observed in TAN1, TAN2, and TAN3 samples were $3941 \pm 3703$; $3300 \pm 1714$ and $2653 \pm 1240$ respectively. The order of the mean TDS in the samples from the three industries can be arranged as TAN1>TAN2>TAN3. The TDS observed in the samples were far above the recommended standard limits of WHO $(250 \mathrm{mg} / \mathrm{l})$ and NESREA $(500 \mathrm{mg} / \mathrm{l})$. Statistical analysis shows that there is no significant difference $(p<0.05)$ between the mean values of TDS among the industries. This might be due to similar tannery activities involved in the tannery industries at the time of sampling. TDS in the effluents from the tannery industries in Kano, Nigeria was reported to be $1281 \mathrm{mg} / \mathrm{l}$ (Akan et al., 2007). The average values of SS observed in this present study are less than those observed by Mohammed et al. (2017) and Baba et al. 2020)

The mean level of COD (mg/l) observed in TAN1, TAN2 and TAN3 samples seasons were $2372 \pm 938 ; \quad 1406 \pm 208$ and $3532 \pm 1373$ respectively. The order of the mean COD of the samples from the three industries can be arranged as TAN3>TAN1> TAN2. The COD observed in TAN1, TAN2 and TAN3 samples were far above the recommended standard limits of regulating bodies $\mathrm{WHO}(40 \mathrm{mg} / \mathrm{l})$ and NESREA (40 mg/l). Statistical analysis shows that there is no significant difference $(p<0.05)$ in COD among the industries. This might be due to similar tannery activities involved in the tannery industries as at the time of sampling. The Chemical Oxygen demand (COD) is the amount of oxygen, in $\mathrm{mg} / \mathrm{L}$, required for the degradation of the compound of wastewater to occur. In comparison, the average values of COD observed in this present study were higher than that observed by Mohammed et al. (2017) but lower than that observed by Baba et al. (2020).

The mean levels of BOD $(\mathrm{mg} / \mathrm{l})$ observed in TAN1, TAN2 and TAN3 samples were $13.85 \pm 6.42 ; \quad 19.46 \pm 0.50$ and $17.13 \pm 3.14$ respectively. The order of the mean BOD in the samples from the three industries can be arranged as TAN2>TAN3>TAN1. The BOD observed in TAN1, TAN2 and TAN3 samples were found below the recommended limits of NESREA (200 mg/l) but above WHO (10 mg/l). Statistical analysis shows that there is no significant difference $(p<0.05)$ between the mean values of BOD among the industries. This might be due to similar tannery activities involved in the tannery industries at the time of sampling. The low level of BOD recorded in this study is an indication of the low level of biodegradable organic solids in the effluent. The average values of BOD observed in this present study were lower than those observed by Mohammed et al. (2017) and Baba et al. (2020).

Table 1: Mean Values \pm S.D of Physico-chemical parameters of effluents from the Tannery Industries before Treatment.

\begin{tabular}{llllllll}
\hline Parameter & Tannery 1 & Tannery 2 & Tannery 3 & $\mathrm{a}$ & $\mathrm{b}$ & $\mathrm{c}$ & $\mathrm{d}$ \\
\cline { 2 - 7 } Temperature $\left({ }^{\circ} \mathrm{C}\right)$ & $28.07 \mathrm{a} \pm 0.65$ & $27.77 \mathrm{a} \pm 0.64$ & $26.38 \mathrm{a} \pm 3.81$ & & $29.50 \pm 4.68$ & 35 & 40 \\
pH & $7.77 \mathrm{a} \pm 2.93$ & $8.35 \mathrm{a} \pm 0.28$ & $7.52 \mathrm{a} \pm 0.76$ & 6.89 & $5.35 \pm 1.57$ & $7.0-8.5$ & $6.0-9.0$ \\
$\mathrm{COD}(\mathrm{mg} / \mathrm{l})$ & $2372 \mathrm{a} \pm 938$ & $1406 \mathrm{a} \pm 208$ & $3532 \mathrm{a} \pm 1373$ & 2.2 & $3106 \pm 2753$ & 40 & 40 \\
$\mathrm{BOD}(\mathrm{mg} / \mathrm{l})$ & $13.85 \mathrm{a} \pm 6.42$ & $19.46 \mathrm{a} \pm 0.50$ & $17.13 \mathrm{a} \pm 3.14$ & 1032 & $26.17 \pm 9.49$ & 10 & 200 \\
$\mathrm{SS}(\mathrm{mg} / \mathrm{l})$ & $374 \mathrm{a} \pm 124$ & $358 \mathrm{a} \pm 335$ & $780 \mathrm{a} \pm 739$ & 501 & $562 \pm 482$ & 30 & 10 \\
TDS $(\mathrm{mg} / \mathrm{l})$ & $3941 \mathrm{a} \pm 3703$ & $3300 \mathrm{a} \pm 1714$ & $2653 \mathrm{a} \pm 1240$ & 532.7 & $444 \pm 507$ & 250 & 500 \\
\hline
\end{tabular}

The values given in the table above are means of 6 replicate values, $\mathrm{n}=6$ ( 1 sample was taken monthly for 6 months). Within the rows, means with different alphabets are statistically different $(p<0.05)$. WHO: World Health Organisation. NESREA: National Environmental Standard and Regulatory Enforcement Agency. a = Mohammed et al.(2017), b = Baba et al. (2020), c = WHO (2006), $d=$ NESSRA (2009) 
BAJOPAS Volume 13 Number 2, December, 2020

Identification, Biochemical Characterization and growth rates of the Bacterial Isolates

Results of identification and biochemical characterization of the bacterial isolates were shown in table 2. After 24 hours of incubation, the nutrient agar media plates were checked for bacterial growth. The results showed the presence of different strains in the samples. The TAN1 bacteria isolate was found to be gramnegative cocci while TAN3 was gram-positive cocci. TAN2 bacteria isolate was found to be gram-positive, rod-shaped. TAN1, TAN2, and TAN3 bacteria isolates recorded positive results for spore former.

The results of the biochemical tests indicated that all the bacteria were positive for catalase, oxidase, citrate, maltose, glucose, lactose (negative in TAN1), mannitol (negative in TAN2), starch hydrolysis and coagulase (negative in TAN2) tests. The bacteria showed negative results for nitrate reduction, $M R$ (positive in TAN2), VP (positive in TAN1), Indole (positive in TAN2) tests. Base on the morphological and biochemical test results, TAN1, TAN2, and TAN3 bacteria isolates were identified to be Nesseria spp, Bacillus cereus, and Staphylococcus aureus respectively.

The growth rate of the TAN1, TAN2 and TAN3 Isolates were shown in figure 2. Generally, the optical density increase with the increase in time (day) and decrease as time goes on. The highest optical density was shown by bacillus cereus in TAN2 while the lowest was shown by Staphylococcus aureus in TAN3.

The initial growth phase of TAN1 Isolate bacteria occurred within 2-day of incubation as the growth rate increases up to the 6th-day incubation when the maximum growth was observed. Beyond the 6th day, the growth of the bacteria declined (which might be due to a shortage of nutrients in the effluents) until it reached its death phase (which might be due to the unavailability of nutrients in the effluents).

A similar trend of growth was also observed for TAN2 Isolate as the initial growth phase also occurred within 2-day of incubation but maximum growth rate observed on the 4th day of incubation. The stationary stage occurred between the 4th day and the 8th day. Beyond the 8th day, the growth of the bacteria declined (which might be due to a shortage of nutrients in the effluents) until it reached its death phase (which might be due to the unavailability of nutrients in the effluents).

The initial growth phase of TAN3 bacterial Isolate occurred within the 3-day incubation as the growth rate increases up to the 6th-day incubation when the maximum growth was observed. Beyond the 6th day, the growth of the bacteria declined (which might be due to a shortage of nutrients in the effluents) until it reached its death phase (which might be due to the unavailability of nutrients in the effluents).

Table 2: Morphological and Biochemical characteristics of bacterial isolates

\begin{tabular}{lllll} 
Bacterial Isolates & & TAN1 & TAN2 & TAN3 \\
\hline $\begin{array}{lllll}\text { Morphological } \\
\text { characteristics }\end{array}$ & Shape & Cocci & Rod & Cocci \\
& Spore & & & \\
& former & + & + & + \\
Gram & & & \\
Biochemical characteristics & reaction & - & + & + \\
& Citrate & + & + & + \\
& Catalase & + & + & + \\
& Coagulase & + & - & + \\
Starch & + & + & + \\
& Glucose & + & + & + \\
Oxidase & + & + & + \\
& Indo & - & + & - \\
Lactose & - & + & + \\
Manitol & + & - & + \\
Maltose & + & + & + \\
MR & - & + & - \\
VP & + & - & - \\
& Nitrate & - & - & - \\
Reduction & - Neisseria & Bacillus & Staphylococcus \\
& Bacterial & cereus & aureus \\
& name & spp & cas
\end{tabular}

+ = Positive; - = Negative; MR=Methyl Red; VP= Voges-Proskauer 


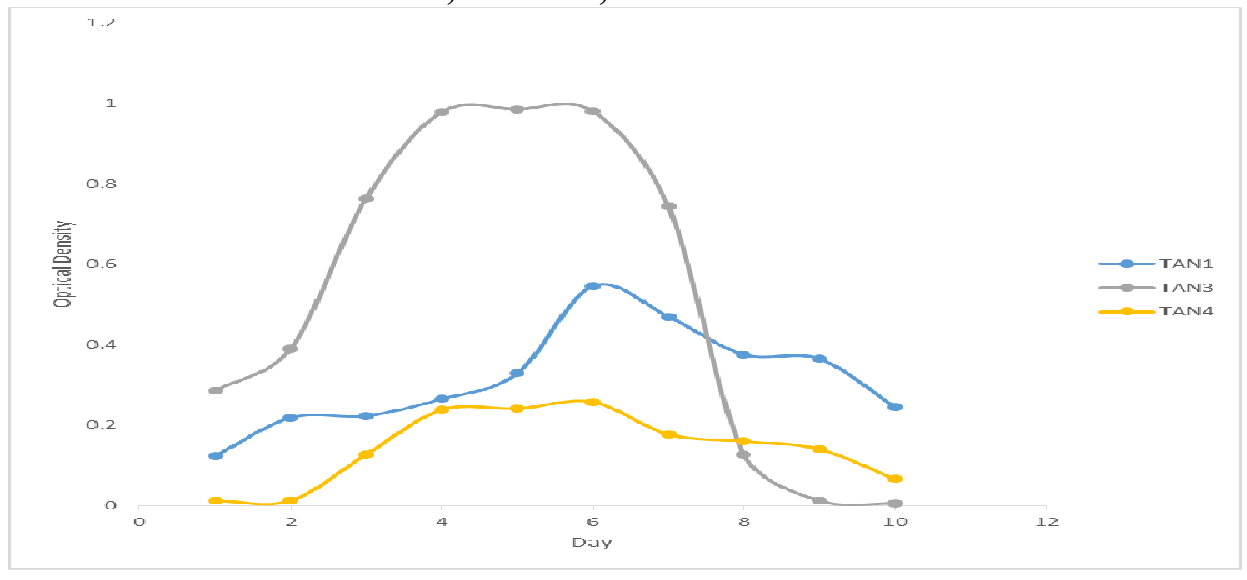

Fig. 2 Growth rates of the isolates in the effluents from the Tannery Industries

\section{Physico-chemical Parameters in the Industrial Effluents after the biodegradation.}

Table 3 shows the mean results of the physicochemical parameter before and after bioremediation using the different masses $(5 \mathrm{~g}$, $10 \mathrm{~g}, 15 \mathrm{~g}, 20 \mathrm{~g}$, and $25 \mathrm{~g}$ ) of the respective immobilized bacteria. Also, Table 4 shows the mean results of correlation coefficient ( $r$ ) between different masses of bacteria and physicochemical parameters.

The mean values $(\mathrm{mg} / \mathrm{l})$ of the SS after the bioremediation varies between $243 \pm 45$ and $898 \pm 672$. The mean concentration $(\mathrm{mg} / \mathrm{l})$ of SS remediated by the different masses $(5 \mathrm{~g}, 10 \mathrm{~g}$, $15 \mathrm{~g}, 20 \mathrm{~g}$, and $25 \mathrm{~g}$ ) of the bacteria varies. The SS in the samples fluctuates up and down after the bioremediation process when compared with the SS of the raw samples before the bioremediation. The increase in the levels of the SS might be due to the aggregation of the TDS which are large enough to result into SS. The increase in the levels of the SS might be also due to the influence of the nutrients which was added into the effluents in order to make the microorganisms more active and viable for fast degradation of organic contaminants in the effluent. The relative potential or efficiency of the different masses of the bacteria in remediating SS in TAN1 samples was in the order $25 \mathrm{~g}>20 \mathrm{~g}>15 \mathrm{~g}>10 \mathrm{~g}>5 \mathrm{~g}$. For TAN2 and TAN3 samples, the order was $25 \mathrm{~g}>20 \mathrm{~g}>15$ $\mathrm{g}>10 \mathrm{~g}>5 \mathrm{~g}$. These might be due to the variations in the surface areas of the different masses of the immobilized bacteria. Statistical analysis shows that there is no significant difference $(p<0.05)$ between the mean values of SS among the masses in the respective industries. Positive and significant correlations exist between the masses of bacteria and Suspended Solid (SS). This showed that there is general increase in the levels of the SS as the masses of the immobilized bacteria increases. TAN3 (90\%) and TAN1 (80\%) showed a very high correlation with the masses of the bacteria while TAN2 (61\%) showed a very low correlation.

The mean values $(\mathrm{mg} / \mathrm{l})$ of the TDS after the bioremediation varies between $46 \pm 11$ and $83 \pm 78$. The mean concentration $(\mathrm{mg} / \mathrm{l})$ of TDS remediated by the different masses $(5 \mathrm{~g}, 10 \mathrm{~g}$, $15 \mathrm{~g}, 20 \mathrm{~g}$, and $25 \mathrm{~g}$ ) of the bacteria varies. There is a reduction in all the TDS of all the samples after the bioremediation process compared with the TDS of the raw samples before the bioremediation. The relative potential or efficiency of the different masses of the bacteria in remediating TDS in TAN1 and TAN3 samples was in the order $5 \mathrm{~g}>10 \mathrm{~g}>15 \mathrm{~g}>20$ $\mathrm{g}>25 \mathrm{~g}$. For TAN2 samples, the order was 20 $g>10 \quad g>25 \quad g>15 \quad g>5 \quad g$. Statistical analysis shows that there is no significant difference $(p<0.05)$ between the mean values of TDS among the masses in the respective industries. These might be due to the variations in the surface areas of the different masses of the immobilized bacteria. Positive and significant correlations exist between the masses of bacteria and TDS with the exception in TAN2 (negative and insignificant correlation). The positive correlations showed that there is general increase in the levels of the TDS as the masses of the immobilized bacteria increases. TAN1 $(96 \%)$ showed a very high correlation with the masses of the bacteria while TAN2 (47\%) showed a very low correlation.

The mean values $(\mathrm{mg} / \mathrm{l})$ of the BOD after the bioremediation varies between $1.56 \pm 0.20 \mathrm{mg} / \mathrm{l}$ and $6.92 \pm 5.49 \mathrm{mg} / \mathrm{l}$. The mean concentration $(\mathrm{mg} / \mathrm{l})$ of BOD remediated by the different masses $(5 \mathrm{~g}, 10 \mathrm{~g}, 15 \mathrm{~g}, 20 \mathrm{~g}$, and $25 \mathrm{~g}$ ) of the bacteria varies. There is a reduction in all the BOD of all the samples after the bioremediation process compared with the $\mathrm{BOD}$ of the raw 
BAJOPAS Volume 13 Number 2, December, 2020 samples before the bioremediation. The relative potential or efficiency of the different masses of the bacteria in remediating BOD in TAN1, TAN2 and TAN3 samples were in the order $25 \mathrm{~g}>20$ $\mathrm{g}>15 \mathrm{~g}>10 \mathrm{~g}>5 \mathrm{~g}, 25 \mathrm{~g}>15 \mathrm{~g}>5 \mathrm{~g}>10 \mathrm{~g}>20 \mathrm{~g}$ and $20 \mathrm{~g}>10 \mathrm{~g}>25 \mathrm{~g}>15 \mathrm{~g}>5 \mathrm{~g}$ respectively. Statistical analysis shows that there is significant difference $(p<0.05)$ between the mean values of BOD among the masses in the respective industries. These might be due to the variations in the surface areas of the different masses of the immobilized bacteria. Negative and significant correlations exist between the masses of bacteria and BOD. This showed that there is general decrease in the levels of the BOD as the masses of the immobilized bacteria increases. TAN1 (94\%) showed a very high correlation with the masses of the bacteria while TAN2 (4\%) showed a very low correlation.

The mean values $(\mathrm{mg} / \mathrm{l})$ of the COD after the bioremediation varies between $250 \pm 154$ and $3134 \pm 1595$. The mean concentration $(\mathrm{mg} / \mathrm{l})$ of COD remediated by the different masses $(5 \mathrm{~g}$, $10 \mathrm{~g}, 15 \mathrm{~g} 20 \mathrm{~g}$, and $25 \mathrm{~g}$ ) of the bacteria varies. There is a reduction in all the COD of all the samples after the bioremediation process compared with the COD of the raw samples before the bioremediation. The relative potential or efficiency of the different masses of the bacteria in remediating COD in TAN1, TAN2 and TAN3 samples were in the order $25 \mathrm{~g}>20 \mathrm{~g}>15$ $\mathrm{g}>5 \mathrm{~g}>10 \mathrm{~g}, 25 \mathrm{~g}>20 \mathrm{~g}>15 \mathrm{~g}>10 \mathrm{~g}>5 \mathrm{~g}$ and 10 g>5 g>25 g>15 g>20 g respectively. Statistical analysis shows that there were significant difference $(p<0.05)$ between the mean values of COD among the masses in the respective industries except for effluents treated with $25 \mathrm{~g}$. These might be due to the variations in the surface areas of the different masses of the immobilized bacteria. Negative and insignificant correlations exist between the masses of bacteria and COD with the exception in TAN3 (positive and significant correlation). The negative correlations showed that there is general decrease in the levels of the COD as the masses of the immobilized bacteria increases. TAN2 (100\%) showed a very high correlation with the masses of the bacteria while TAN3 (36\%) showed a very low correlation.

Generally, there was an overall decrease in the concentration of these physicochemical parameters after the bioremediation using the different masses of the bacterial isolates. These might be due to the variations in the surface areas of the different masses of the immobilized bacteria. This is in line with the work of Jimoh et al. (2018) and Baba et al. (2020).

Table 3: Mean Values $(\mathrm{mg} / \mathrm{l}) \pm$ S.D of Physicochemical parameters in effluents from the Tannery Industries before and after Treatment of the effluents $(250 \mathrm{ml})$ with the different masses $(5 \mathrm{~g}, 10 \mathrm{~g}$, $15 \mathrm{~g}, 20 \mathrm{~g}$, and $25 \mathrm{~g}$ ) of the bacteria.

\begin{tabular}{llllllll}
\hline $\mathrm{P}$ & IND & Before & \multicolumn{5}{c}{ After } \\
\cline { 4 - 7 } & & & $5 \mathrm{~g}$ & $10 \mathrm{~g}$ & $15 \mathrm{~g}$ & $20 \mathrm{~g}$ & $25 \mathrm{~g}$ \\
\hline \multirow{2}{*}{ COD } & TAN1 & $2372 \pm 938$ & $1708 \mathrm{a} \pm 861$ & $2045 \mathrm{a} \pm 1205$ & $845 \mathrm{a} \pm 369$ & $300 \mathrm{a} \pm 167$ & $250 \mathrm{a} \pm 154$ \\
& TAN2 & $1406 \pm 208$ & $1195 \mathrm{a} \pm 208$ & $1125 \mathrm{a} \pm 384$ & $1055 \mathrm{a} \pm 317$ & $956 \mathrm{a} \pm 310$ & $870 \mathrm{ab} \pm 240$ \\
& TAN3 & $3532 \pm 1373$ & $2374 \mathrm{a} \pm 1344$ & $1976 \mathrm{a} \pm 1405$ & $2757 \mathrm{a} \pm 1266$ & $3134 \mathrm{a} \pm 1595$ & $2614 \mathrm{~b} \pm 1105$ \\
BOD & TAN1 & $13.85 \pm 6.42$ & $6.92 \mathrm{a} \pm 5.49$ & $6.42 \mathrm{a} \pm 5.07$ & $5.72 \mathrm{a} \pm 5.35$ & $4.62 \mathrm{a} \pm 4.37$ & $2.82 \mathrm{ab} \pm 1.26$ \\
& TAN2 & $19.46 \pm 0.50$ & $1.75 \mathrm{~b} \pm 0.22$ & $1.73 \mathrm{~b} \pm 0.18$ & $1.58 \mathrm{a} \pm 0.16$ & $1.91 \mathrm{a} \pm 0.22$ & $1.56 \mathrm{~b} \pm 0.20$ \\
& TAN3 & $17.13 \pm 3.14$ & $4.24 \mathrm{ab} \pm 0.77$ & $3.29 \mathrm{ab} \pm 0.37$ & $4.11 \mathrm{a} \pm 0.07$ & $3.23 \mathrm{a} \pm 0.91$ & $3.33 \mathrm{a} \pm 1.28$ \\
SS & TAN1 & $374 \pm 124$ & $243 \mathrm{a} \pm 45$ & $471 \mathrm{a} \pm 226$ & $475 \mathrm{a} \pm 182$ & $492 \mathrm{a} \pm 128$ & $611 \mathrm{a} \pm 217$ \\
& TAN2 & $358 \pm 335$ & $460 \mathrm{a} \pm 400$ & $543 \mathrm{a} \pm 414$ & $544 \mathrm{a} \pm 402$ & $551 \mathrm{a} \pm 414$ & $554 \mathrm{a} \pm 405$ \\
& TAN3 & $780 \pm 739$ & $586 \mathrm{a} \pm 594$ & $758 \mathrm{a} \pm 656$ & $787 \mathrm{a} \pm 676$ & $861 \mathrm{a} \pm 635$ & $898 \mathrm{a} \pm 672$ \\
TDS & TAN1 & $3941 \pm 3703$ & $51 \mathrm{a} \pm 10$ & $53 \mathrm{a} \pm 10$ & $55 \mathrm{a} \pm 15$ & $61 \mathrm{a} \pm 20$ & $63 \mathrm{a} \pm 26$ \\
& TAN2 & $3300 \pm 1714$ & $83 \mathrm{a} \pm 78$ & $47 \mathrm{a} \pm 20$ & $48 \mathrm{a} \pm 22$ & $47 \mathrm{a} \pm 17$ & $48 \mathrm{a} \pm 17$ \\
& TAN3 & $2653 \pm 1240$ & $46 \mathrm{a} \pm 11$ & $55 \mathrm{a} \pm 24$ & $55 \mathrm{a} \pm 25$ & $58 \mathrm{a} \pm 23$ & $61 \mathrm{a} \pm 28$ \\
\hline
\end{tabular}

Replicate $=6$ (months)

Within the rows, for the same parameter, means with different alphabets are statistically different $(p<0.05)$.

$\mathrm{P}=$ parameter, IND = Industries 
BAJOPAS Volume 13 Number 2, December, 2020

Table 4: Correlation coefficient $(r)$ between different masses of the bacteria and the physicochemical parameters.

\begin{tabular}{llll}
\hline Industries & Parameter & Correlation coefficient $(r)$ & $\begin{array}{l}\text { Percent dependence (rxrx100) } \\
(\%)\end{array}$ \\
\hline TAN1 & COD & -0.9 & 82 \\
& BOD & -0.97 & 94 \\
& SS & $0.90^{*}$ & 80 \\
TAN2 & TDS & $0.98^{*}$ & 96 \\
& COD & -1 & 100 \\
& BOD & -0.21 & 4 \\
& SS & $0.78^{*}$ & 61 \\
& TDS & -0.69 & 47 \\
& COD & $0.60^{*}$ & 36 \\
& BOD & -0.6 & 37 \\
& SS & $0.95^{*}$ & 90 \\
& TDS & $0.94^{*}$ & 89 \\
\hline
\end{tabular}

The correlation coefficient $(r)$ with * is statistically significant $(p<0.05)$.

Percentage reduction of the Parameters

Table 5 shows the percentage reduction of Parameters in industrial samples before and after the treatment of the effluents $(250 \mathrm{ml})$ with the different masses $(5 \mathrm{~g}, 10 \mathrm{~g}, 15 \mathrm{~g}, 20 \mathrm{~g}$, and $25 \mathrm{~g}$ ) of the Immobilized Bacteria.

In TAN1 samples, the percentage reduction (\%) of COD ranged (14-89); BOD (50-80); SS (-32$35)$ and TDS (98-99). In TAN2 samples, the percentage decrease $(\%)$ of COD ranged (15$38) ;$ BOD (90-92); SS [-28-(-55)] and TDS (9798). In TAN3 samples, the percentage decrease (\%) of COD ranged (11-44); BOD (76-81); SS (15-25) and TDS (98). The percentage increase in the levels COD, BOD and TDS might be due to the increase in the surface area of the different masses of the immobilized bacteria. However, the percentage decrease in the levels of the SS might be due to the aggregation of the TDS which are large enough to result into SS. The percentage decrease in the levels of the SS might be also due to the influence of the nutrients which was added into the effluents in order to make the microorganisms more active and viable for fast degradation of organic contaminants in the effluent. This is in line with the work of Jimoh et al. (2018) in which the concentration of the SS increase after the bioremediation of effluents.

Sreemoyee and Priti (2013) assessed and reduced several Physico-chemical parameters of dairy wastewater using Niesseria $s p$. and concluded that the species are well known to degrade organic compounds. This is in agreement with the current study in which the immobilized Niesseria $s p$ degrade the organic contaminants as indicated by the BOD, COD and TDS.

Jimoh et al. (2018) observed that TSS of the effluents was increased after treatment with immobilized bacteria and concluded that it might be due to the biostimulation method adopted for the research.

The optimum $\mathrm{pH}$ Biosorption of Chromium by Bacillus spp and Staphylococcus spp. from tannery effluent was investigated by Mythili and Karthikeyan (2011). The maximum adsorption of Chromium $(86.4 \mathrm{mg} / \mathrm{L})$ was showed by Bacillus spp and Staphylococcus spp showed $70.6 \mathrm{mg} / \mathrm{L}$ at an initial concentration of $100 \mathrm{mg} / \mathrm{L}$. In the present study, immobilised Bacillus spp and Staphylococcus spp. from the tannery industrial effluents reduced the levels of the organic pollutants with high potential as indicated by the percentage reduction of BOD, COD and TDS.

Enzymes often can work in multiple environments especially if they are immobilized. This makes the microorganisms' enzymes even more resistant to harsh environments and enables the enzymes to be recovered and recycled after they are no longer needed (Gianfreda and Rao 2004). Ramesh and Singh (1993) reported that the immobilized bacteria having more efficiency to remove the suspended particles than free cells. Using the immobilized cell is preferable due to its capability for using several times with the same efficiency, which makes it more economical. Similar work was done by Sikander et al. (2007) showing the higher reduction with permeabilized cells of Ochrobactrum intermedium strain SDCr-5. 
BAJOPAS Volume 13 Number 2, December, 2020

The results revealed the isolation and identification of isolates with the potential for the reduction of $\mathrm{Cr}$ (VI) to $\mathrm{Cr}$ (III). Results indicated that immobilized $B$. cereus could be efficiently used for the reduction of $\mathrm{Cr}$ (VI).

Table 5: Percentage reduction of the tested Parameters from the tannery industrial samples of the Immobilized Bacteria.

\begin{tabular}{lllllll}
\hline \multirow{2}{*}{ Industries } & & \multicolumn{5}{c}{ Percentage Reduction $(\%)$} \\
\cline { 3 - 7 } & & $5 \mathrm{~g}$ & $10 \mathrm{~g}$ & $15 \mathrm{~g}$ & $20 \mathrm{~g}$ & $25 \mathrm{~g}$ \\
\hline TAN1 & COD & 28 & 14 & 64 & 87 & 89 \\
& BOD & 50 & 54 & 59 & 67 & 80 \\
& SS & 35 & -26 & -27 & -32 & -63 \\
& TDS & 99 & 99 & 99 & 98 & 98 \\
TAN2 & COD & 15 & 20 & 25 & 32 & 38 \\
& BOD & 91 & 91 & 92 & 90 & 92 \\
& SS & -28 & -52 & -52 & -54 & -55 \\
& TDS & 97 & 99 & 99 & 99 & 99 \\
& COD & 33 & 44 & 22 & 11 & 26 \\
& BOD & 75 & 81 & 76 & 81 & 81 \\
& SS & 25 & 3 & -1 & -10 & -15 \\
& TDS & 98 & 98 & 98 & 98 & 98 \\
\hline
\end{tabular}

Percentage Reduction $=(B-A) / B \times 100 \%$

$A=$ Concentration of the parameter after treatment

$\mathrm{B}=$ Concentration of the parameter before treatment

$+=$ percentage decrease

- = percentage increase

In general, immobilization makes the enzyme more resistant to temperature, $\mathrm{pH}$, and substrate concentration swings giving it a longer lifetime and higher productivity per active unit (Gianfreda and Rao, 2004; FuIlbrook, 1996; Russell et al, 2003; Kandelbauer et al., 2004). Immobilized cells have been used and studied extensively for the production of useful chemicals (Ohtake and Silver, 1994), the treatment of wastewaters (Chen et al., 2003; Wang et al., 2010). Although many workers described microbial degradation of tannery effluent, limited literature is available on the bioremediation of tannery effluent using immobilized bacterial cells in the Kano Industrial Estates.

\section{CONCLUSION}

The samples contained variable levels of the physicochemical parameters. The results of the Analysis of variance revealed that, no statistical difference $(p<0.05)$ was observed for the temperature, $\mathrm{pH}, \mathrm{SS}, \mathrm{TDS}, \mathrm{BOD}$ and $\mathrm{COD}$ among the three tannery industries before the treatment. The levels of some of the parameters
(SS, TDS and COD) observed in the samples were found above the recommended limits of WHO and NESREA, which called for the treatment of the effluents before discharge into the environment. Base on the morphological and biochemical test results, TAN1, TAN2, and TAN3 bacterial isolates were identified to be Neisseria spp, Bacillus cereus, and Staphylococcus aureus respectively. The results of Post-treatment analysis showed that there is overall decrease in the levels of the parameters determined when compared with that of the pre-treatment. The overall percentage reduction of the immobilised bacteria in the treatment of the respective effluents was in the order TAN2 (72\%)>TAN1 $(70 \%)>$ TAN3 $(62 \%)$. Hence, the immobilized bacteria are having higher biodegradation potential for the treatment of the tannery effluents.

\section{Acknowledgments}

The authors wish to acknowledge the University of Maiduguri for the financial support. The authors are grateful to the Kano State Ministry of Environment for their support in obtaining the effluent samples. 


\section{REFERENCES}

Ajao, A. T., Adebayo, G. B., and Yakubu, S. E. (2011). Bioremediation of textile industrial effluent using mixed culture of Pseudomonas aeruginosa and Bacillus subtilis immobilized on agar-agar in a bioreactor. J. Microbiol. Biotech. Res, 1(3), 50-56.

Akan, J. C., Moses, E. A., Ogugbuaja, V. O., and Abah, J. (2007). Assessment of tannery industrial effluents from Kano metropolis, Kano State, Nigeria. Journal of Applied Sciences, 7(19), 2788-2793.

Akan, J. C., Ogugbuaja, V. O., Abdulrahman, F. I., and Ayodele, J. T. (2009). Pollutant levels in effluent samples from tanneries and textiles of Kano industrial areas, Nigeria. Global journal of pure and applied sciences, 15(3-4).

APHA (1989). Standard methods for Examination of Will bete and Will betewater.15 $5^{\text {th }}$ edition. Brydpass Springfield Will behington DC. pp. 164-176

APHA (1992). Standard Methods for the Examination of Water and Wastewater. Health, 69, 1116-9.

Baba, A., Garba, S. T., and Bello, H. S. (2020). Bioremediation Potential of Immobilized corynebacterium kutsceri in the Treatment of Tannery Industrial Effluent from Challawa Industrial Estate, Kano State, Nigeria. Journal of the Turkish Chemical Society Section A: Chemistry, $7(2), 335-350$.

Beem, E. I. V. (1994). reduction of solvent VOC emission. J. Oil Col. Chem. Ass, 77, 158.

Bouwer, E. J., and Zehnder, A. J. (1993). Bioremediation of organic compoundsputting microbial metabolism to work. Trends in biotechnology, 11(8), 360367.

Chen, K. C., Wu, J. Y., Liou, D. J., and Hwang, S. C. J. (2003). Decolorization of the textile dyes by newly isolated bacterial strains. Journal of Biotechnology, 101(1), 57-68.

Dan'Azumi, S., and Bichi, M. H. (2010). INDUSTRIAL POLLUTION AND HEAVY METALS PROFILE OF CHALLAWA RIVER IN KANO, NIGERIA. Journal of Applied Sciences in Environmental Sanitation, $5(1)$.

DWAF. (1992). Analytical Methods Manual, TR 151. Department of Water Affairs and Forestry, Pretoria.

El-Bestawy, E. (2013). Biological treatment of leather-tanning industrial wastewater using free living bacteria.
Elsheikh, M. A. S. (2009). Tannery wastewater pre-treatment. Water Science and Technology, 60(2), 433-440.

FuIlbrook, P. D. (1996). "Kinetics." Industrial enzymology: The application of enzymes in Industry. 2nd Ed. T. Godfrey and J Reichelt. eds.. Nature. New York.

Gianfreda, L., and Rao, M. A. (2004). Potential of extra cellular enzymes in remediation of polluted soils: a review. Enzyme and microbial technology, 35(4), 339354.

Hugo Springer. (1994). John Arthur Wilson Memorial Lecture "Treatment of Industrial Wastes of the Leather Industry - is it still a Major Problem". JALCA, 89, 153-185

Jimoh, A. A., Ganiyu, B. A., Baba, D., and Baba, A. (2018) Bioremediation Process of Effluent from Detergent and Food Industries in Jos, Nigeria: Kinetics and Thermodynamics. International Journal of Engineering Science Invention (IJESI), 762-73

Kandelbauer, A., Maute, O., Kessler, R. W., Erlacher, A., and Gübitz, G. M. (2004). Study of dye decolorization in an immobilized laccase enzyme-reactor using online spectroscopy. Biotechnology and bioengineering, 87(4), 552-563.

Kongjao, S., Damronglerd, S., and Hunsom, M. (2008). Simultaneous removal of organic and inorganic Pollutants in tannery wastewater using electrocoagulation technique. Korean Journal of chemical engineering, 25(4), 703.

Maheshwari, U. M., Aruna, S., Gomathi, M., and AbdulJaffar, A. H. (2017). Bioremediation by Free and Immobilized Bacteria Isolated from Tannery Effluent. International Journal of Research in Applied, Natural and Social Sciences. 5(7), 75-90

Margesin, R., and Schinner, F. (2001). Bioremediation (natural attenuation and biostimulation) of diesel-oilcontaminated soil in an alpine glacier skiing area. Applied and environmental microbiology, 677), 3127-3133.

Mohammed, A., Sekar, P., and George, J. (2011). Efficacy of microbes in bioremediation of tannery effluent. Inter. J. Curr. Res, 3(4), 324-326.

Mohammed, S. S. D., Orukotan, A. A., and Abdullahi, H. (2017). Physicochemical and Bacteriological Assessment of Tannery Effluent from Samaru-Zaria, 
BAJOPAS Volume 13 Number 2, December, 2020 Kaduna State, Nigeria. Journal of Applied

Sciences and Environmental Management, 21(4), 734-740.

Munz, G., De Angelis, D., Gori, R., Mori, G., Casarci, M., and Lubello, C. (2009). The role of tannins in conventional and membrane treatment of tannery wastewater. Journal of hazardous materials, 164(2-3), 733-739

Mythili, K., and Karthikeyan, B. (2011). Bioremediation of $\mathrm{Cr}$ (VI) from tannery effluent using Bacillus spp and Staphylococcus spp. International Multidisciplinary Research Journal, 1(6).

NESREA (2009). National Environmental Standards for Effluent Limitations and Regulation. 1233-1236

Noorjahan, C. M. (2014). Physicochemical characteristics, identification of bacteria and biodegradation of industrial effluent. Journal of bioremediation and Biodegradation, 5(3).

Ohtake, H. I., and Silver, A. O. (1994). Bacterial reduction of toxic chromate. Biological degradation and bioremediation of toxic chemicals, 403-415.

Omoleke, I. I. (2004). Management of environmental pollution in Ibadan, an African city: the challenges of health hazard facing government and the people. Journal of Human Ecology, 15(4), 265-275.

Rajor, A., Reddy, A.S., and Singh, B. (2004). Determination of BOD kinetic Parameters and evaluation of alternate methods, M.Sc. Thesis, Department of biotechnology \& environmental Science, Thapar Institute of Engineering and Technology, Patiala

Ramasami, T., Rajamani, S., and Rao, J. R. (1994, March). Pollution control in leather industry: Emerging technological options. In International symposium on surface and colloidal science and its relevance to soil pollution, madras.

Ramesh, J. V. S., and Singh, S. P. (1993). Yearly variation in certain physicochemical parameters of pond at eastern Doon Valley. Uttar Pradesh J. Zoo, 12 (1), 7577.

Ranen, S., and Sharadinadra, C. (2009). Biotechnology applications to environmental remediation in resource exploitation. Current science, 97, 6-25
Russell, A. J., Berberich, J. A., Drevon, G. F., and Koepsel, R. R. (2003). Biomaterials for mediation of

chemical and biological warfare agents. Annual review of biomedical engineering, 5(1), 1-27.

Saravanan, P., and Saravanan, A. (1999). Decolourization of tannery effluent by Flavobacterium sp. EK 1. Indian Journal of Environmental Protection, 19, 19-24.

Sikander, S., and Shahida, H. (2007). Reduction of toxic hexavalent chromium by Ochrobactrum intermedium strain SDCr5 stimulated by heavy metals. Bioresource Technol, 98, 340-344.

Singh, N., Sharma, B. K., and Bohra, P. C. (2000). Impact assessment of industrial effluent of arid soils by using satellite imageries. Journal of the Indian Society of Remote Sensing, 28(2-3), 79.

Sreemoyee, C., and Priti, P. (2013). Assessment of physico-chemical parameters of dairy waste water and isolation and characterization of bacterial strains in terms of cod reduction. Int J Sci, 2(3), 395-400.

Verheijen, L. A. H. M., Wiersema, D., Pol, L. H., and De Wit, J. (1996). Management of wastes from animal product processing. Livestock and environment, Finding a balance. International Agriculture Center, Wageningen, The Netherlands.

Wang, F., Yao, J., Si, Y., Chen, H., Russel, M., Chen, K., and Bramanti, E. (2010). Short-time effect of heavy metals upon microbial community activity. Journal of Hazardous Materials, 173(13), 510-516.

WHO (World Health Organization). (2006). Air quality guidelines: global update 2005: particulate matter, ozone, nitrogen dioxide, and sulfur dioxide. World Health Organization.

World Bank. (1995). Nigeria's strategic options for redressing industrial pollution. World Bank, industry and energy division. 1st edition, West Central Africa Department; Annexes: 1995; pp 60-62.

Zahoor, A., and Abdul, R. (2009). Enumeration of Coliforms. Journal of Environmental Sciences. 21, 814-820 


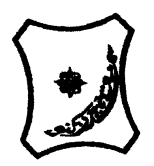

Bayero Journal of Pure and Applied Sciences, 13(2): 1 - 12

Received: November, 2020

Accepted: December, 2020

ISSN $2006-6996$

\title{
BIODEGRADATION POTENTIAL OF IMMOBILIZED BACTERIA IN THE TREATMENT OF TANNERY INDUSTRIAL EFFLUENTS FROM INDUSTRIAL ESTATES IN KANO STATE, NIGERIA
}

\author{
Abdullateef, B., ${ }^{1 *}$ Shuaibu, T. G., ${ }^{1}$ Babagana, K., ${ }^{1}$ Suleman, H. B. ${ }^{2}$ and Dauda, B. ${ }^{3}$ \\ ${ }^{1}$ Department of Pure and Applied Chemistry, Faculty of Science, University of Maiduguri, Borno State, \\ Nigeria \\ ${ }^{2}$ Department of Microbiology, Faculty of Science, University of Maiduguri, Borno State, Nigeria \\ ${ }^{3}$ Department of Chemical Engineering, Faculty of Engineering, University of Maiduguri, Borno State, \\ Nigeria \\ *Corresponding author: babslega@gmail.com; abelega2007@yahoo.com; +2348061309753
}

\section{ABSTRACT}

Industrial Effluents Samples from Gashash Tanneries (TAN1) in Bompai Industrial estate, Larabee Tannery Industry (TAN2) in Sharada Industrial estate and Z Tannery Industries (TAN3) in Challawa Industrial estate, Kano State, Nigeria were collected over a period of six months (August 2017 to January 2018) for assessing the biodegradation potentials of bacteria in the treatment of organic pollutants within the effluents. Bacteria were isolated from the effluents and immobilized on agar-agar. Different masses (5 g, $10 \mathrm{gr}, 15$ $\mathrm{g}, 20 \mathrm{~g}$, and $25 \mathrm{~g}$ ) of the bacteria were used in the treatment of $250 \mathrm{ml}$ of the effluents for ten days in a shaker incubator (Gallenkamp-OC-4364-L) at the temperature $30{ }^{\circ} \mathrm{C}$ and speed of $60 \mathrm{rpm}$. Pre-treatment analysis of the effluents for Temperature, pH, Biochemical Oxygen Demand (BOD), Chemical Oxygen Demand (COD), Suspended Solid (SS) and Total Dissolved Solids (TDS) gives the following results; temperature $\left({ }^{\circ} \mathrm{C}\right.$ )

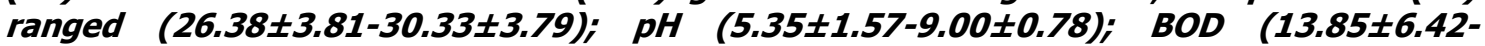
$38.75 \pm 16.20) ;$ COD (1406 $\pm 208-3532 \pm 1373) ;$ SS (208 $\pm 235-780 \pm 739)$ and TDS (266 $\pm 253-5276 \pm 2971)$. No statistical differences ( $p \leq 0.05)$ was observed for all the results among the different industries. The bacterial isolates were identified as Neisseria spp, Bacillus cereus, and Staphylococcus aureus, in TAN1, TAN2, and TAN3, respectively. After treatment of the effluent with the different masses of the isolated bacteria, the mean level of BOD was found to range as (0.55 $\pm 0.36-6.92 \pm 5.49) ; C O D$ (ND-3134 \pm 1595$)$;

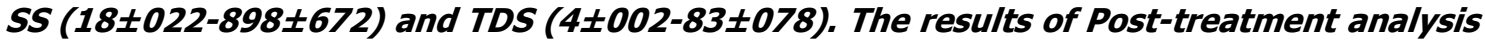
showed that there is overall decrease in the levels of the parameters determined when compared with that of the pre-treatment. The overall percentage reduction of the immobilised bacteria in the treatment of the respective effluents was in the order TAN2 (72\%)>TAN1 (70\%)>TAN3 (62\%). Hence, the immobilized bacteria are having higher biodegradation potential for the treatment of the tannery effluents.

Keywords: Biodegradation, bacteria, effluent, immobilization, tannery.

\section{INTRODUCTION}

Tannery industrial wastewater is a serious consequence of the pollution point of view for streams, freshwater, and land used for agriculture. The lack of awareness in the modern industrial practice has resulted in the discharge of tannery effluents which exhibit very high value of chromium ( $\mathrm{Cr}$ ), Sulfide, and chloride, Total Dissolved Solid (TDS), Total Suspended Solid (TSS), Biochemical Oxygen Demand (BOD) and Chemical Oxygen Demand (COD) in the water stream or land (Mohammed et al., 2001). Tanning is the process, which One ton of skin generally leads to the production of 20 to $80 \mathrm{~m}^{3}$ of turbid and foul-smelling converts the protein of the rawhide or skin into a stable material, which will not putrefy and is suitable for a wide variety of end applications (Elsheikh, 2009). The highly polluting chromium is the most commonly used tanning material producing leather that is more flexible and pliable than vegetable-tanned leather and does not discolor or lose shape in water as drastically as vegetable-tan (Elsheikh, 2009). Tannery effluent is among the most hazardous industrial pollutants due to its huge organic and inorganic load, which is highly toxic to human life and the environment (Kongjao et al., 2008). wastewater including chromium (100-400 mg/l), sulfide $(200-800 \mathrm{mg} / \mathrm{l})$, high levels of fat and 
BAJOPAS Volume 13 Number 2, December, 2020 other solid wastes, and notable pathogen contamination as well as pesticides added for skin conservation during transport (Elsheikh, 2009). There are more than 6000 tanneries in Nigeria with an annual processing capacity of 700,000 tons of hides and skins (Omoleke, 2004; Singh et al., 2008). It was reported that the total amount of waste produced per animal slaughtered is approximately $35 \%$ of its weight (World Bank, 1995). Also, for every $1000 \mathrm{~kg}$ of carcass weight, a slaughtered beef produces 5.5 $\mathrm{kg}$ of manure (excluding rumen contents or stockyard manure) and $100 \mathrm{~kg}$ of paunch manure (undigested food) (Verheijen et al., 1996). Tanneries generate wastewater in the range of 30-35 $\mathrm{L} \mathrm{kg}^{-1}$ skin/hide processed with variable $\mathrm{pH}$, Biological Oxygen Demand (BOD), Chemical Oxygen Demand (COD), high concentrations of suspended solids (SS), and tannins as well as chromium (Zahoor and Abdul, 2009).

Being heterogeneous and composed of a wide variety of compounds, it is very difficult to select a unique direct method for estimating the biodegradability of organic contents and biokinetic parameters for a wastewater sample (Rajor, 2004). For this purpose, some indirect estimation such as determination of biochemical oxygen demand (BOD) and chemical oxygen demand (COD) are applied as common laboratory investigations [9]. During retanning procedures, synthetic tannins (Syntan), oils and resins are added to form softer leather at varying doses (Munz et al., 2009). One of the refractory groups of chemicals in tannery effluents derives mainly from tannins (Ramasami et al., 2004). Syntans are characterized by complex chemical structures, because they are composed of an extended set of chemicals such as phenol-, naphthalene-, formaldehyde- and melamine-based syntans, and acrylic resins (Beem, 1994). Organic pollutants (proteic and lipidic components) are originated from skins (it is calculated that the raw skin has $30 \%$ loss of organic material during the working cycle) or they are introduced during processes (Hugo Springer, 1994).

Many conventional processes such as oxidation, chemical and biological processes were carried out to treat tanneries wastewater (Ebtesam et al, 2013). Biological processes have received more attention because of their costeffectiveness, lower sludge production and environmental friendliness (Noorjahan, 2014). Naturally occurring micro-organisms degrade the hazardous organic wastes including xenobiotic compounds, such as pesticides, polycyclic aromatic hydrocarbons (PAHs) and polychlorinated biphenyls (PCBs) in due course of time (Ranen and Sharadinadra, 2009). Bioremediation is based on the idea that all organisms remove substances from the environment to carry outgrowth and metabolism (Bouwer and Zehnder, 1993). Bacteria, protista and fungi are found to be very good at degrading complex molecules and incorporating the breakdown products into their metabolism (Bouwer and Zehnder, 1993). The resultant metabolic wastes that they produce are generally safe and somehow recycled into other organisms (Ranen and Sharadinadra, 2009). An acclimatized indigenous population of microorganisms capable of degradation of the compounds of interest must exist at the site for a successful bioremediation mode (Ranen and Sharadinadra, 2009). It has been observed that for a successful bioremediation mode, an acclimatized indigenous population of microorganisms capable of degradation of the compounds of interest must exist at the site under investigation (Ranen and Sharadinadra, 2009). Even though there are numerous physical and chemical methods employed in the disposal of wastes the advantage in using bacterium is that they play a key role in the reduction of COD, BOD, total protein, total tannin and total phenol (Saravanan and Saravanan, 1998)

Baba et al. (2020) studied the bioremediation potential of immobilized corynebacterium kutsceri in the Treatment of tannery industrial effluent from Challawa Industrial Estate, Kano State, Nigeria. The aim of the work is to study the reduction in the level of the contaminants through the process of bioremediation using the isolated bacteria. Immobilized bacteria can withstand various temperatures, $\mathrm{pH}$ and substrate concentrations; consequently, increasing the efficiency and the lifespan of the bacteria. Immobilized bacteria are widely applied in the treatment of wastewater and can be separated and recovered after the treatment with the same efficiency (Baba et al., 2020).

\section{MATERIALS AND METHODS \\ Study Area}

This study was carried out in Bompai, Sharada and Challawa industrial estates in Kano, Figure 1. Kano lies on Latitude $11^{\circ} 30^{\prime} \mathrm{N}$ and $8^{\circ} 30^{\prime} \mathrm{E}$ and Longitude $11^{\circ} 5^{\prime} \mathrm{N}$ and $8^{\circ} 5^{\prime} \mathrm{E}$ in Northern Nigeria. It is one of the developed industrial cities in Nigeria. Tannery activities are the dominating industries and this could be one of the reasons for her high population density (Dan'Azumi and Bichi, 2010). Many researchers have studied biodegradation of tannery effluent using microorganisms. However, limited literature is available on the biodegradation of tannery effluent in Kano industrial estates using 
BAJOPAS Volume 13 Number 2, December, 2020 immobilized bacterial cells. This research work focuses on the potential of the use of the indigenous immobilized bacterial isolates in the treatment of tannery effluents in the industrial estates.

\section{Sample Collection}

Effluents were collected from the Tannery Industries from Bompai, Challawa and Sharada Industrial Estates, Kano, Nigeria. The effluents were collected over a period of six months (August 2017 to January 2018). Samples collected in a sterile 4-liter plastic container with a unique identification number were preserved using an ice-box that was transported to the Microbiology Laboratory, Department of Microbiology, Bayero University of Kano for analysis

\section{Sample Preparation and Sample Analysis}

Immediately after the collection of the effluent, $\mathrm{pH}$, TSS, TDS, COD, BOD levels were determined before treatment (Pre-treatment determination) and ten days after treatment (Post-treatment determination) as described in
APHA (1989) standard methods. $\mathrm{pH}$ was determined using Ecotests $\mathrm{pH}$ meter and TDS was determined using AQUALYTIC TDS Salinometer. BOD was determined as described by the standard method (APHA, 1992). COD and SS were determined using DR/2010 HACH portable data logging spectrophotometer (DWAF, 1992)

\section{Identification and Biochemical} Characterization of the Bacterial Isolates

The bacteria were isolated from the effluents using Serial Dilution according to the method described by APHA (1989). The biochemical tests such as oxidase, catalase, coagulase, indole (from $1 \%$ tryptone broth), citrate (Simmons citrate agar), methyl red/VogesProskauer (MR/VP), nitrate reduction, Starch Hydrolysis, Glucose, Maltose, and Lactose tests were carried out on the bacterial isolates to identify the bacteria through the bacteria biochemical characteristics according to Ajao et al. (2011).

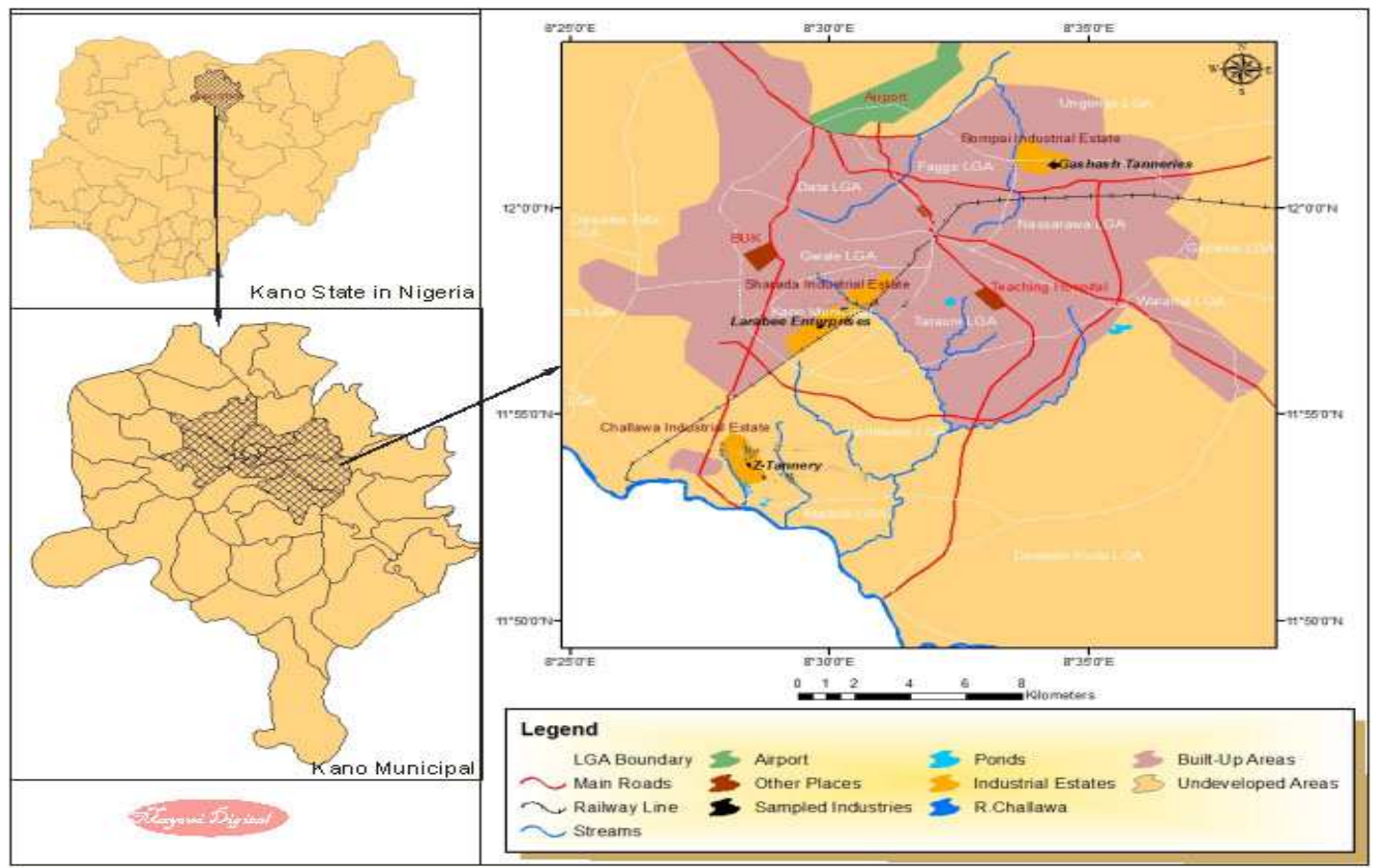

Fig. 1 Map showing the study areas

Source: Mayomi Digital Productions, GIS Laboratory, Department of Geography, UNIMAID (2017)

\section{Determination of Growth Rate of the Bacteria in Effluent Sample}

The bacteria growth rates were determined by transferring $2 \mathrm{~mL}$ of the bacterial isolates from the tannery effluent in broth medium into 100 $\mathrm{mL}$ sterile effluents in conical flasks and kept in an incubator (Giffrin cool) for 10 days. Control was also set up by incubating another $100 \mathrm{~mL}$ each of the sterile effluents without the bacteria. The optical density of the content was determined at the wavelength of $600 \mathrm{~nm}$ on a daily interval and recorded. 
BAJOPAS Volume 13 Number 2, December, 2020 Immobilization of Bacteria

Agar solution and inoculi were prepared separately. Fifty milliliters $(50 \mathrm{~mL})$ of nutrient broth each of the inoculi was prepared in a McCartney bottle and incubated for 24 hours. A solution of agar-agar was prepared by dissolving $10 \mathrm{~g}$ of the powder in distilled water and made up to $500 \mathrm{~mL}$ mark in an Erlenmeyer flask and was sterilized in an autoclave (280A) for 15 minutes and allowed to cool to $40-45^{\circ} \mathrm{C}$ (Ajao et al., 2011). Four milliliters ( $4 \mathrm{~mL})$ of the bacterial isolates in the nutrient broth was mixed with 36 $\mathrm{ml}$ of the prepared agar-agar media in petri-dish plates and then allowed to solidify. This was kept in the refrigerator for bioremediation.

\section{Bioremediation (Treatment) of the Effluents}

The solidified agar block (immobilized bacteria) was cut into cubes using a sterile knife; $0.1 \mathrm{~mL}$ phosphate buffer ( $\mathrm{pH} \mathrm{7.0)}$ was added and kept in the refrigerator for 1 hour for curing. The phosphate buffer was decanted after 1 hour and the cubes were washed with sterile distilled water 3-4 times before it was used (Ajao et al., 2011). Two liters (2 L) of the effluent was supplemented with the minimum basal medium in $\mathrm{g} / \mathrm{L}: \mathrm{NaCl}(0.8), \mathrm{MgSO}_{4} .7 \mathrm{H}_{2} \mathrm{O}(0.001), \mathrm{KH}_{2} \mathrm{PO}_{4}$ (2), $\mathrm{NaNO}_{3}$ (2), $\quad \mathrm{CaCl}_{2} .2 \mathrm{H}_{2} \mathrm{O} \quad(0.5)$ and $\mathrm{NaHPO}_{4} .12 \mathrm{H}_{2} \mathrm{O}(2)$ and sterilized in an autoclave at $121^{\circ} \mathrm{C}$ for 15 minutes (Margesin and Schinner, 2001). Two hundred and fifty milliliters $(250 \mathrm{~mL})$ of the effluents were transferred into different $250 \mathrm{ml}$ conical flasks. The content was covered with a cotton-wool ramped with foil paper to avoid contamination. Five grams $(5 \mathrm{~g})$ of the immobilized bacteria were quickly transferred into each of the effluents in the conical flasks in an inoculating chamber. The same procedures were carried out for the $10 \mathrm{~g}, 15 \mathrm{~g}, 20 \mathrm{~g}$ and 25 $\mathrm{g}$ of the immobilized bacteria in separate $250 \mathrm{~mL}$ effluents in conical flasks and agitated for ten days in a shaker incubator (Gallenkamp-OC4364-L) at a temperature $30^{\circ} \mathrm{C}$ and speed of 60 rpm. The treated effluent samples were taken on the tenth day and analyzed for the parameters $\mathrm{pH}$, SS, TDS, COD, and BOD, (Posttreatment determination) for the different grams of bacteria to evaluate and compare the biodegradation potential. (Baba et al., 2020).

\section{Statistical Analysis}

The data were represented as Mean \pm Standard deviation and analyzed statistically using oneway Analysis of Variance (ANOVA) and Tukey's HSD as Post Hoc Tests with the aid of SPSS 16.0. The correlation coefficient was also used to measure the strength of the relationship between the different masses of the bacteria and the parameters. All $\mathrm{p} \leq 0.05$ were considered as statistically significant.

\section{RESULTS AND DISCUSSION Physico-chemical parameters in the Industrial Effluents before the Biodegradation.}

Results of the Physico-chemical parameters in the industrial effluents before the Biodegradation is shown in table 1 . The mean temperatures $\left({ }^{\circ} \mathrm{C}\right)$ observed in TAN1, TAN2, and TAN3 samples were $28.07 \pm 0.65 ; 27.77 \pm 0.64$ and $26.38 \pm 3.81$ respectively. The order of the mean temperature of the samples from the three industries can be arranged as TAN1 > TAN2>TAN3. The temperature observed at TAN1, TAN2, and TAN3 samples were found below the WHO $\left(35^{\circ} \mathrm{C}\right)$ and NESREA $\left(40^{\circ} \mathrm{C}\right)$ limits. The low values of temperature might be due to the processes used at the time of sampling. High temperature brings down the solubility of gases in water that ultimately expresses as high BOD and COD. Statistical analysis shows that there is no significant difference $(p<0.05)$ between the mean values of temperature among the industries. This might be due to similar tannery activities involved in the tannery industries at the time of sampling. The average values of temperature observed in this present study are less than those observed by Akan et al. (2007), Akan et al. (2009) and Baba et al. (2020).

The mean level of $\mathrm{pH}$ observed in TAN1, TAN2 and TAN3, samples were $7.77 \pm 2.93$; $8.35 \pm 0.28$ and $7.52 \pm 0.76$ respectively. The order of the mean $\mathrm{pH}$ of the samples from the three industries can be arranged as TAN2> TAN1 $>$ TAN3. The $\mathrm{pH}$ of the samples falls within the WHO (7.0-8.5) and NESREA (6-9) standard limits. Statistical analysis shows that there is no significant difference $(p<0.05)$ between the mean values of $\mathrm{pH}$ among the industries. This might be due to similar tannery activities involved in the tannery industries at the time of sampling. Maheshwari et al. (2017) reported that the level of $\mathrm{pH}$ in the effluents from the tannery industry in Vaniyambadi, India was 6.5 which was lower than that observed in the present study. The $\mathrm{pH}$ in the effluents from the tannery industries in Kano and Kaduna were reported to be 7.64 and 6.89, respectively (Akan et al., 2007; Mohammed et al., 2017). The average values of $\mathrm{pH}$ observed in this present study are less than those observed by Mohammed et al. (2017) and Baba et al. (2020). The mean level of SS $(\mathrm{mg} / \mathrm{l})$ observed in TAN1, TAN2, and TAN3 samples were 374 \pm 124 ; $358 \pm 335$ and $780 \pm 739$ respectively. The order of the mean SS in the samples from the three industries can be arranged as TAN3 > TAN1 $>$ TAN2. 
The SS observed in the samples were far above the recommended standard limits of regulating bodies WHO $(30 \mathrm{mg} / \mathrm{l})$ and NESREA $(10 \mathrm{mg} / \mathrm{l})$. Statistical analysis shows that there is no significant difference $(p<0.05)$ between the mean values of SS among the industries. This might be due to similar tannery activities involved in the tannery industries at the time of sampling. The average values of SS observed in this present study are less than that observed $(3700 \pm 122 \mathrm{mg} / \mathrm{l})$ by Akan et al. (2009) for tanneries in Kano. Also, the average values of SS observed in this present study are less than that observed by Mohammed et al. (2017) and Baba et al. (2020) with the exception in TAN3.

The mean level of TDS (mg/l) observed in TAN1, TAN2, and TAN3 samples were $3941 \pm 3703$; $3300 \pm 1714$ and $2653 \pm 1240$ respectively. The order of the mean TDS in the samples from the three industries can be arranged as TAN1>TAN2>TAN3. The TDS observed in the samples were far above the recommended standard limits of WHO $(250 \mathrm{mg} / \mathrm{l})$ and NESREA $(500 \mathrm{mg} / \mathrm{l})$. Statistical analysis shows that there is no significant difference $(p<0.05)$ between the mean values of TDS among the industries. This might be due to similar tannery activities involved in the tannery industries at the time of sampling. TDS in the effluents from the tannery industries in Kano, Nigeria was reported to be $1281 \mathrm{mg} / \mathrm{l}$ (Akan et al., 2007). The average values of SS observed in this present study are less than those observed by Mohammed et al. (2017) and Baba et al. 2020)

The mean level of COD (mg/l) observed in TAN1, TAN2 and TAN3 samples seasons were $2372 \pm 938 ; \quad 1406 \pm 208$ and $3532 \pm 1373$ respectively. The order of the mean COD of the samples from the three industries can be arranged as TAN3>TAN1> TAN2. The COD observed in TAN1, TAN2 and TAN3 samples were far above the recommended standard limits of regulating bodies $\mathrm{WHO}(40 \mathrm{mg} / \mathrm{l})$ and NESREA (40 mg/l). Statistical analysis shows that there is no significant difference $(p<0.05)$ in COD among the industries. This might be due to similar tannery activities involved in the tannery industries as at the time of sampling. The Chemical Oxygen demand (COD) is the amount of oxygen, in $\mathrm{mg} / \mathrm{L}$, required for the degradation of the compound of wastewater to occur. In comparison, the average values of COD observed in this present study were higher than that observed by Mohammed et al. (2017) but lower than that observed by Baba et al. (2020).

The mean levels of BOD $(\mathrm{mg} / \mathrm{l})$ observed in TAN1, TAN2 and TAN3 samples were $13.85 \pm 6.42 ; \quad 19.46 \pm 0.50$ and $17.13 \pm 3.14$ respectively. The order of the mean BOD in the samples from the three industries can be arranged as TAN2>TAN3>TAN1. The BOD observed in TAN1, TAN2 and TAN3 samples were found below the recommended limits of NESREA (200 mg/l) but above WHO (10 mg/l). Statistical analysis shows that there is no significant difference $(p<0.05)$ between the mean values of BOD among the industries. This might be due to similar tannery activities involved in the tannery industries at the time of sampling. The low level of BOD recorded in this study is an indication of the low level of biodegradable organic solids in the effluent. The average values of BOD observed in this present study were lower than those observed by Mohammed et al. (2017) and Baba et al. (2020).

Table 1: Mean Values \pm S.D of Physico-chemical parameters of effluents from the Tannery Industries before Treatment.

\begin{tabular}{llllllll}
\hline Parameter & Tannery 1 & Tannery 2 & Tannery 3 & $\mathrm{a}$ & $\mathrm{b}$ & $\mathrm{c}$ & $\mathrm{d}$ \\
\cline { 2 - 7 } Temperature $\left({ }^{\circ} \mathrm{C}\right)$ & $28.07 \mathrm{a} \pm 0.65$ & $27.77 \mathrm{a} \pm 0.64$ & $26.38 \mathrm{a} \pm 3.81$ & & $29.50 \pm 4.68$ & 35 & 40 \\
pH & $7.77 \mathrm{a} \pm 2.93$ & $8.35 \mathrm{a} \pm 0.28$ & $7.52 \mathrm{a} \pm 0.76$ & 6.89 & $5.35 \pm 1.57$ & $7.0-8.5$ & $6.0-9.0$ \\
$\mathrm{COD}(\mathrm{mg} / \mathrm{l})$ & $2372 \mathrm{a} \pm 938$ & $1406 \mathrm{a} \pm 208$ & $3532 \mathrm{a} \pm 1373$ & 2.2 & $3106 \pm 2753$ & 40 & 40 \\
$\mathrm{BOD}(\mathrm{mg} / \mathrm{l})$ & $13.85 \mathrm{a} \pm 6.42$ & $19.46 \mathrm{a} \pm 0.50$ & $17.13 \mathrm{a} \pm 3.14$ & 1032 & $26.17 \pm 9.49$ & 10 & 200 \\
$\mathrm{SS}(\mathrm{mg} / \mathrm{l})$ & $374 \mathrm{a} \pm 124$ & $358 \mathrm{a} \pm 335$ & $780 \mathrm{a} \pm 739$ & 501 & $562 \pm 482$ & 30 & 10 \\
TDS $(\mathrm{mg} / \mathrm{l})$ & $3941 \mathrm{a} \pm 3703$ & $3300 \mathrm{a} \pm 1714$ & $2653 \mathrm{a} \pm 1240$ & 532.7 & $444 \pm 507$ & 250 & 500 \\
\hline
\end{tabular}

The values given in the table above are means of 6 replicate values, $\mathrm{n}=6$ ( 1 sample was taken monthly for 6 months). Within the rows, means with different alphabets are statistically different $(p<0.05)$. WHO: World Health Organisation. NESREA: National Environmental Standard and Regulatory Enforcement Agency. a = Mohammed et al.(2017), b = Baba et al. (2020), c = WHO (2006), $d=$ NESSRA (2009) 
BAJOPAS Volume 13 Number 2, December, 2020

Identification, Biochemical Characterization and growth rates of the Bacterial Isolates

Results of identification and biochemical characterization of the bacterial isolates were shown in table 2. After 24 hours of incubation, the nutrient agar media plates were checked for bacterial growth. The results showed the presence of different strains in the samples. The TAN1 bacteria isolate was found to be gramnegative cocci while TAN3 was gram-positive cocci. TAN2 bacteria isolate was found to be gram-positive, rod-shaped. TAN1, TAN2, and TAN3 bacteria isolates recorded positive results for spore former.

The results of the biochemical tests indicated that all the bacteria were positive for catalase, oxidase, citrate, maltose, glucose, lactose (negative in TAN1), mannitol (negative in TAN2), starch hydrolysis and coagulase (negative in TAN2) tests. The bacteria showed negative results for nitrate reduction, $M R$ (positive in TAN2), VP (positive in TAN1), Indole (positive in TAN2) tests. Base on the morphological and biochemical test results, TAN1, TAN2, and TAN3 bacteria isolates were identified to be Nesseria spp, Bacillus cereus, and Staphylococcus aureus respectively.

The growth rate of the TAN1, TAN2 and TAN3 Isolates were shown in figure 2. Generally, the optical density increase with the increase in time (day) and decrease as time goes on. The highest optical density was shown by bacillus cereus in TAN2 while the lowest was shown by Staphylococcus aureus in TAN3.

The initial growth phase of TAN1 Isolate bacteria occurred within 2-day of incubation as the growth rate increases up to the 6th-day incubation when the maximum growth was observed. Beyond the 6th day, the growth of the bacteria declined (which might be due to a shortage of nutrients in the effluents) until it reached its death phase (which might be due to the unavailability of nutrients in the effluents).

A similar trend of growth was also observed for TAN2 Isolate as the initial growth phase also occurred within 2-day of incubation but maximum growth rate observed on the 4th day of incubation. The stationary stage occurred between the 4th day and the 8th day. Beyond the 8th day, the growth of the bacteria declined (which might be due to a shortage of nutrients in the effluents) until it reached its death phase (which might be due to the unavailability of nutrients in the effluents).

The initial growth phase of TAN3 bacterial Isolate occurred within the 3-day incubation as the growth rate increases up to the 6th-day incubation when the maximum growth was observed. Beyond the 6th day, the growth of the bacteria declined (which might be due to a shortage of nutrients in the effluents) until it reached its death phase (which might be due to the unavailability of nutrients in the effluents).

Table 2: Morphological and Biochemical characteristics of bacterial isolates

\begin{tabular}{lllll} 
Bacterial Isolates & & TAN1 & TAN2 & TAN3 \\
\hline $\begin{array}{lllll}\text { Morphological } \\
\text { characteristics }\end{array}$ & Shape & Cocci & Rod & Cocci \\
& Spore & & & \\
& former & + & + & + \\
Gram & & & \\
Biochemical characteristics & reaction & - & + & + \\
& Citrate & + & + & + \\
& Catalase & + & + & + \\
& Coagulase & + & - & + \\
Starch & + & + & + \\
& Glucose & + & + & + \\
Oxidase & + & + & + \\
& Indo & - & + & - \\
Lactose & - & + & + \\
Manitol & + & - & + \\
Maltose & + & + & + \\
MR & - & + & - \\
VP & + & - & - \\
& Nitrate & - & - & - \\
Reduction & - Neisseria & Bacillus & Staphylococcus \\
& Bacterial & cereus & aureus \\
& name & spp & cas
\end{tabular}

+ = Positive; - = Negative; MR=Methyl Red; VP= Voges-Proskauer 


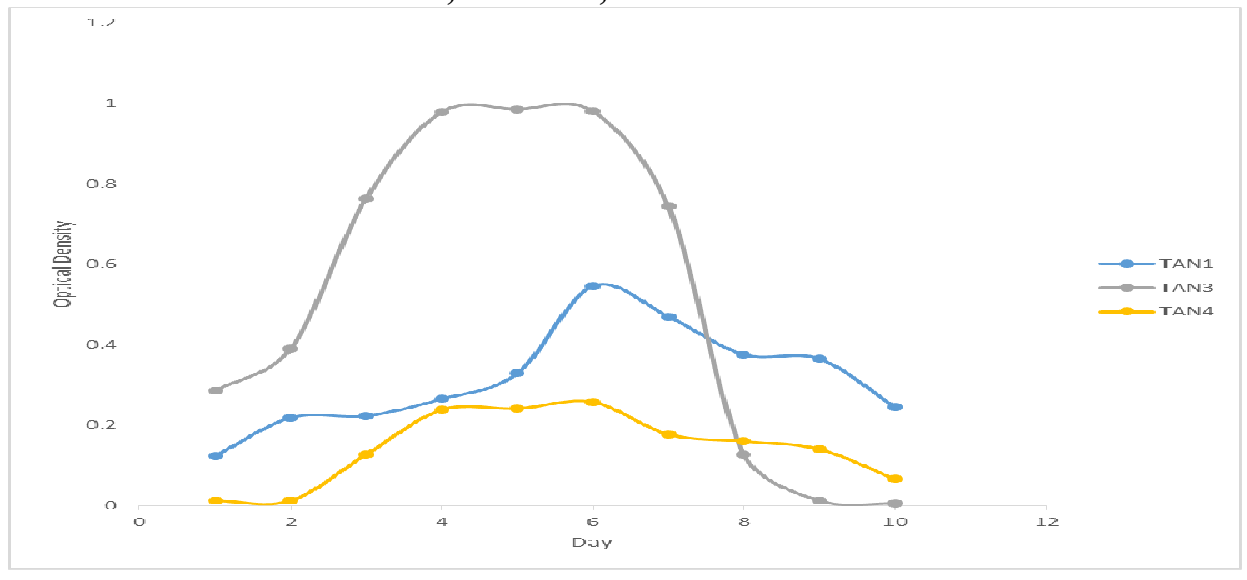

Fig. 2 Growth rates of the isolates in the effluents from the Tannery Industries

\section{Physico-chemical Parameters in the Industrial Effluents after the biodegradation.}

Table 3 shows the mean results of the physicochemical parameter before and after bioremediation using the different masses $(5 \mathrm{~g}$, $10 \mathrm{~g}, 15 \mathrm{~g}, 20 \mathrm{~g}$, and $25 \mathrm{~g}$ ) of the respective immobilized bacteria. Also, Table 4 shows the mean results of correlation coefficient ( $r$ ) between different masses of bacteria and physicochemical parameters.

The mean values $(\mathrm{mg} / \mathrm{l})$ of the SS after the bioremediation varies between $243 \pm 45$ and $898 \pm 672$. The mean concentration $(\mathrm{mg} / \mathrm{l})$ of SS remediated by the different masses $(5 \mathrm{~g}, 10 \mathrm{~g}$, $15 \mathrm{~g}, 20 \mathrm{~g}$, and $25 \mathrm{~g}$ ) of the bacteria varies. The SS in the samples fluctuates up and down after the bioremediation process when compared with the SS of the raw samples before the bioremediation. The increase in the levels of the SS might be due to the aggregation of the TDS which are large enough to result into SS. The increase in the levels of the SS might be also due to the influence of the nutrients which was added into the effluents in order to make the microorganisms more active and viable for fast degradation of organic contaminants in the effluent. The relative potential or efficiency of the different masses of the bacteria in remediating SS in TAN1 samples was in the order $25 \mathrm{~g}>20 \mathrm{~g}>15 \mathrm{~g}>10 \mathrm{~g}>5 \mathrm{~g}$. For TAN2 and TAN3 samples, the order was $25 \mathrm{~g}>20 \mathrm{~g}>15$ $\mathrm{g}>10 \mathrm{~g}>5 \mathrm{~g}$. These might be due to the variations in the surface areas of the different masses of the immobilized bacteria. Statistical analysis shows that there is no significant difference $(p<0.05)$ between the mean values of SS among the masses in the respective industries. Positive and significant correlations exist between the masses of bacteria and Suspended Solid (SS). This showed that there is general increase in the levels of the SS as the masses of the immobilized bacteria increases. TAN3 (90\%) and TAN1 (80\%) showed a very high correlation with the masses of the bacteria while TAN2 (61\%) showed a very low correlation.

The mean values $(\mathrm{mg} / \mathrm{l})$ of the TDS after the bioremediation varies between $46 \pm 11$ and $83 \pm 78$. The mean concentration $(\mathrm{mg} / \mathrm{l})$ of TDS remediated by the different masses $(5 \mathrm{~g}, 10 \mathrm{~g}$, $15 \mathrm{~g}, 20 \mathrm{~g}$, and $25 \mathrm{~g}$ ) of the bacteria varies. There is a reduction in all the TDS of all the samples after the bioremediation process compared with the TDS of the raw samples before the bioremediation. The relative potential or efficiency of the different masses of the bacteria in remediating TDS in TAN1 and TAN3 samples was in the order $5 \mathrm{~g}>10 \mathrm{~g}>15 \mathrm{~g}>20$ $\mathrm{g}>25 \mathrm{~g}$. For TAN2 samples, the order was 20 $g>10 \quad g>25 \quad g>15 \quad g>5 \quad g$. Statistical analysis shows that there is no significant difference $(p<0.05)$ between the mean values of TDS among the masses in the respective industries. These might be due to the variations in the surface areas of the different masses of the immobilized bacteria. Positive and significant correlations exist between the masses of bacteria and TDS with the exception in TAN2 (negative and insignificant correlation). The positive correlations showed that there is general increase in the levels of the TDS as the masses of the immobilized bacteria increases. TAN1 $(96 \%)$ showed a very high correlation with the masses of the bacteria while TAN2 (47\%) showed a very low correlation.

The mean values $(\mathrm{mg} / \mathrm{l})$ of the BOD after the bioremediation varies between $1.56 \pm 0.20 \mathrm{mg} / \mathrm{l}$ and $6.92 \pm 5.49 \mathrm{mg} / \mathrm{l}$. The mean concentration $(\mathrm{mg} / \mathrm{l})$ of BOD remediated by the different masses $(5 \mathrm{~g}, 10 \mathrm{~g}, 15 \mathrm{~g}, 20 \mathrm{~g}$, and $25 \mathrm{~g}$ ) of the bacteria varies. There is a reduction in all the BOD of all the samples after the bioremediation process compared with the $\mathrm{BOD}$ of the raw 
BAJOPAS Volume 13 Number 2, December, 2020 samples before the bioremediation. The relative potential or efficiency of the different masses of the bacteria in remediating BOD in TAN1, TAN2 and TAN3 samples were in the order $25 \mathrm{~g}>20$ $\mathrm{g}>15 \mathrm{~g}>10 \mathrm{~g}>5 \mathrm{~g}, 25 \mathrm{~g}>15 \mathrm{~g}>5 \mathrm{~g}>10 \mathrm{~g}>20 \mathrm{~g}$ and $20 \mathrm{~g}>10 \mathrm{~g}>25 \mathrm{~g}>15 \mathrm{~g}>5 \mathrm{~g}$ respectively. Statistical analysis shows that there is significant difference $(p<0.05)$ between the mean values of BOD among the masses in the respective industries. These might be due to the variations in the surface areas of the different masses of the immobilized bacteria. Negative and significant correlations exist between the masses of bacteria and BOD. This showed that there is general decrease in the levels of the BOD as the masses of the immobilized bacteria increases. TAN1 (94\%) showed a very high correlation with the masses of the bacteria while TAN2 (4\%) showed a very low correlation.

The mean values $(\mathrm{mg} / \mathrm{l})$ of the COD after the bioremediation varies between $250 \pm 154$ and $3134 \pm 1595$. The mean concentration $(\mathrm{mg} / \mathrm{l})$ of COD remediated by the different masses $(5 \mathrm{~g}$, $10 \mathrm{~g}, 15 \mathrm{~g} 20 \mathrm{~g}$, and $25 \mathrm{~g}$ ) of the bacteria varies. There is a reduction in all the COD of all the samples after the bioremediation process compared with the COD of the raw samples before the bioremediation. The relative potential or efficiency of the different masses of the bacteria in remediating COD in TAN1, TAN2 and TAN3 samples were in the order $25 \mathrm{~g}>20 \mathrm{~g}>15$ $\mathrm{g}>5 \mathrm{~g}>10 \mathrm{~g}, 25 \mathrm{~g}>20 \mathrm{~g}>15 \mathrm{~g}>10 \mathrm{~g}>5 \mathrm{~g}$ and 10 g>5 g>25 g>15 g>20 g respectively. Statistical analysis shows that there were significant difference $(p<0.05)$ between the mean values of COD among the masses in the respective industries except for effluents treated with $25 \mathrm{~g}$. These might be due to the variations in the surface areas of the different masses of the immobilized bacteria. Negative and insignificant correlations exist between the masses of bacteria and COD with the exception in TAN3 (positive and significant correlation). The negative correlations showed that there is general decrease in the levels of the COD as the masses of the immobilized bacteria increases. TAN2 (100\%) showed a very high correlation with the masses of the bacteria while TAN3 (36\%) showed a very low correlation.

Generally, there was an overall decrease in the concentration of these physicochemical parameters after the bioremediation using the different masses of the bacterial isolates. These might be due to the variations in the surface areas of the different masses of the immobilized bacteria. This is in line with the work of Jimoh et al. (2018) and Baba et al. (2020).

Table 3: Mean Values $(\mathrm{mg} / \mathrm{l}) \pm$ S.D of Physicochemical parameters in effluents from the Tannery Industries before and after Treatment of the effluents $(250 \mathrm{ml})$ with the different masses $(5 \mathrm{~g}, 10 \mathrm{~g}$, $15 \mathrm{~g}, 20 \mathrm{~g}$, and $25 \mathrm{~g}$ ) of the bacteria.

\begin{tabular}{llllllll}
\hline $\mathrm{P}$ & IND & Before & \multicolumn{5}{c}{ After } \\
\cline { 4 - 7 } & & & $5 \mathrm{~g}$ & $10 \mathrm{~g}$ & $15 \mathrm{~g}$ & $20 \mathrm{~g}$ & $25 \mathrm{~g}$ \\
\hline \multirow{2}{*}{ COD } & TAN1 & $2372 \pm 938$ & $1708 \mathrm{a} \pm 861$ & $2045 \mathrm{a} \pm 1205$ & $845 \mathrm{a} \pm 369$ & $300 \mathrm{a} \pm 167$ & $250 \mathrm{a} \pm 154$ \\
& TAN2 & $1406 \pm 208$ & $1195 \mathrm{a} \pm 208$ & $1125 \mathrm{a} \pm 384$ & $1055 \mathrm{a} \pm 317$ & $956 \mathrm{a} \pm 310$ & $870 \mathrm{ab} \pm 240$ \\
& TAN3 & $3532 \pm 1373$ & $2374 \mathrm{a} \pm 1344$ & $1976 \mathrm{a} \pm 1405$ & $2757 \mathrm{a} \pm 1266$ & $3134 \mathrm{a} \pm 1595$ & $2614 \mathrm{~b} \pm 1105$ \\
BOD & TAN1 & $13.85 \pm 6.42$ & $6.92 \mathrm{a} \pm 5.49$ & $6.42 \mathrm{a} \pm 5.07$ & $5.72 \mathrm{a} \pm 5.35$ & $4.62 \mathrm{a} \pm 4.37$ & $2.82 \mathrm{ab} \pm 1.26$ \\
& TAN2 & $19.46 \pm 0.50$ & $1.75 \mathrm{~b} \pm 0.22$ & $1.73 \mathrm{~b} \pm 0.18$ & $1.58 \mathrm{a} \pm 0.16$ & $1.91 \mathrm{a} \pm 0.22$ & $1.56 \mathrm{~b} \pm 0.20$ \\
& TAN3 & $17.13 \pm 3.14$ & $4.24 \mathrm{ab} \pm 0.77$ & $3.29 \mathrm{ab} \pm 0.37$ & $4.11 \mathrm{a} \pm 0.07$ & $3.23 \mathrm{a} \pm 0.91$ & $3.33 \mathrm{a} \pm 1.28$ \\
SS & TAN1 & $374 \pm 124$ & $243 \mathrm{a} \pm 45$ & $471 \mathrm{a} \pm 226$ & $475 \mathrm{a} \pm 182$ & $492 \mathrm{a} \pm 128$ & $611 \mathrm{a} \pm 217$ \\
& TAN2 & $358 \pm 335$ & $460 \mathrm{a} \pm 400$ & $543 \mathrm{a} \pm 414$ & $544 \mathrm{a} \pm 402$ & $551 \mathrm{a} \pm 414$ & $554 \mathrm{a} \pm 405$ \\
& TAN3 & $780 \pm 739$ & $586 \mathrm{a} \pm 594$ & $758 \mathrm{a} \pm 656$ & $787 \mathrm{a} \pm 676$ & $861 \mathrm{a} \pm 635$ & $898 \mathrm{a} \pm 672$ \\
TDS & TAN1 & $3941 \pm 3703$ & $51 \mathrm{a} \pm 10$ & $53 \mathrm{a} \pm 10$ & $55 \mathrm{a} \pm 15$ & $61 \mathrm{a} \pm 20$ & $63 \mathrm{a} \pm 26$ \\
& TAN2 & $3300 \pm 1714$ & $83 \mathrm{a} \pm 78$ & $47 \mathrm{a} \pm 20$ & $48 \mathrm{a} \pm 22$ & $47 \mathrm{a} \pm 17$ & $48 \mathrm{a} \pm 17$ \\
& TAN3 & $2653 \pm 1240$ & $46 \mathrm{a} \pm 11$ & $55 \mathrm{a} \pm 24$ & $55 \mathrm{a} \pm 25$ & $58 \mathrm{a} \pm 23$ & $61 \mathrm{a} \pm 28$ \\
\hline
\end{tabular}

Replicate $=6$ (months)

Within the rows, for the same parameter, means with different alphabets are statistically different $(p<0.05)$.

$\mathrm{P}=$ parameter, IND = Industries 
BAJOPAS Volume 13 Number 2, December, 2020

Table 4: Correlation coefficient $(r)$ between different masses of the bacteria and the physicochemical parameters.

\begin{tabular}{llll}
\hline Industries & Parameter & Correlation coefficient $(r)$ & $\begin{array}{l}\text { Percent dependence (rxrx100) } \\
(\%)\end{array}$ \\
\hline TAN1 & COD & -0.9 & 82 \\
& BOD & -0.97 & 94 \\
& SS & $0.90^{*}$ & 80 \\
TAN2 & TDS & $0.98^{*}$ & 96 \\
& COD & -1 & 100 \\
& BOD & -0.21 & 4 \\
& SS & $0.78^{*}$ & 61 \\
& TDS & -0.69 & 47 \\
& COD & $0.60^{*}$ & 36 \\
& BOD & -0.6 & 37 \\
& SS & $0.95^{*}$ & 90 \\
& TDS & $0.94^{*}$ & 89 \\
\hline
\end{tabular}

The correlation coefficient $(r)$ with * is statistically significant $(p<0.05)$.

Percentage reduction of the Parameters

Table 5 shows the percentage reduction of Parameters in industrial samples before and after the treatment of the effluents $(250 \mathrm{ml})$ with the different masses $(5 \mathrm{~g}, 10 \mathrm{~g}, 15 \mathrm{~g}, 20 \mathrm{~g}$, and $25 \mathrm{~g}$ ) of the Immobilized Bacteria.

In TAN1 samples, the percentage reduction (\%) of COD ranged (14-89); BOD (50-80); SS (-32$35)$ and TDS (98-99). In TAN2 samples, the percentage decrease $(\%)$ of COD ranged (15$38) ;$ BOD (90-92); SS [-28-(-55)] and TDS (9798). In TAN3 samples, the percentage decrease (\%) of COD ranged (11-44); BOD (76-81); SS (15-25) and TDS (98). The percentage increase in the levels COD, BOD and TDS might be due to the increase in the surface area of the different masses of the immobilized bacteria. However, the percentage decrease in the levels of the SS might be due to the aggregation of the TDS which are large enough to result into SS. The percentage decrease in the levels of the SS might be also due to the influence of the nutrients which was added into the effluents in order to make the microorganisms more active and viable for fast degradation of organic contaminants in the effluent. This is in line with the work of Jimoh et al. (2018) in which the concentration of the SS increase after the bioremediation of effluents.

Sreemoyee and Priti (2013) assessed and reduced several Physico-chemical parameters of dairy wastewater using Niesseria $s p$. and concluded that the species are well known to degrade organic compounds. This is in agreement with the current study in which the immobilized Niesseria $s p$ degrade the organic contaminants as indicated by the BOD, COD and TDS.

Jimoh et al. (2018) observed that TSS of the effluents was increased after treatment with immobilized bacteria and concluded that it might be due to the biostimulation method adopted for the research.

The optimum $\mathrm{pH}$ Biosorption of Chromium by Bacillus spp and Staphylococcus spp. from tannery effluent was investigated by Mythili and Karthikeyan (2011). The maximum adsorption of Chromium $(86.4 \mathrm{mg} / \mathrm{L})$ was showed by Bacillus spp and Staphylococcus spp showed $70.6 \mathrm{mg} / \mathrm{L}$ at an initial concentration of $100 \mathrm{mg} / \mathrm{L}$. In the present study, immobilised Bacillus spp and Staphylococcus spp. from the tannery industrial effluents reduced the levels of the organic pollutants with high potential as indicated by the percentage reduction of BOD, COD and TDS.

Enzymes often can work in multiple environments especially if they are immobilized. This makes the microorganisms' enzymes even more resistant to harsh environments and enables the enzymes to be recovered and recycled after they are no longer needed (Gianfreda and Rao 2004). Ramesh and Singh (1993) reported that the immobilized bacteria having more efficiency to remove the suspended particles than free cells. Using the immobilized cell is preferable due to its capability for using several times with the same efficiency, which makes it more economical. Similar work was done by Sikander et al. (2007) showing the higher reduction with permeabilized cells of Ochrobactrum intermedium strain SDCr-5. 
BAJOPAS Volume 13 Number 2, December, 2020

The results revealed the isolation and identification of isolates with the potential for the reduction of $\mathrm{Cr}$ (VI) to $\mathrm{Cr}$ (III). Results indicated that immobilized $B$. cereus could be efficiently used for the reduction of $\mathrm{Cr}$ (VI).

Table 5: Percentage reduction of the tested Parameters from the tannery industrial samples of the Immobilized Bacteria.

\begin{tabular}{lllllll}
\hline \multirow{2}{*}{ Industries } & & \multicolumn{5}{c}{ Percentage Reduction $(\%)$} \\
\cline { 3 - 7 } & & $5 \mathrm{~g}$ & $10 \mathrm{~g}$ & $15 \mathrm{~g}$ & $20 \mathrm{~g}$ & $25 \mathrm{~g}$ \\
\hline TAN1 & COD & 28 & 14 & 64 & 87 & 89 \\
& BOD & 50 & 54 & 59 & 67 & 80 \\
& SS & 35 & -26 & -27 & -32 & -63 \\
& TDS & 99 & 99 & 99 & 98 & 98 \\
TAN2 & COD & 15 & 20 & 25 & 32 & 38 \\
& BOD & 91 & 91 & 92 & 90 & 92 \\
& SS & -28 & -52 & -52 & -54 & -55 \\
& TDS & 97 & 99 & 99 & 99 & 99 \\
& COD & 33 & 44 & 22 & 11 & 26 \\
& BOD & 75 & 81 & 76 & 81 & 81 \\
& SS & 25 & 3 & -1 & -10 & -15 \\
& TDS & 98 & 98 & 98 & 98 & 98 \\
\hline
\end{tabular}

Percentage Reduction $=(B-A) / B \times 100 \%$

$A=$ Concentration of the parameter after treatment

$\mathrm{B}=$ Concentration of the parameter before treatment

$+=$ percentage decrease

- = percentage increase

In general, immobilization makes the enzyme more resistant to temperature, $\mathrm{pH}$, and substrate concentration swings giving it a longer lifetime and higher productivity per active unit (Gianfreda and Rao, 2004; FuIlbrook, 1996; Russell et al, 2003; Kandelbauer et al., 2004). Immobilized cells have been used and studied extensively for the production of useful chemicals (Ohtake and Silver, 1994), the treatment of wastewaters (Chen et al., 2003; Wang et al., 2010). Although many workers described microbial degradation of tannery effluent, limited literature is available on the bioremediation of tannery effluent using immobilized bacterial cells in the Kano Industrial Estates.

\section{CONCLUSION}

The samples contained variable levels of the physicochemical parameters. The results of the Analysis of variance revealed that, no statistical difference $(p<0.05)$ was observed for the temperature, $\mathrm{pH}, \mathrm{SS}, \mathrm{TDS}, \mathrm{BOD}$ and $\mathrm{COD}$ among the three tannery industries before the treatment. The levels of some of the parameters
(SS, TDS and COD) observed in the samples were found above the recommended limits of WHO and NESREA, which called for the treatment of the effluents before discharge into the environment. Base on the morphological and biochemical test results, TAN1, TAN2, and TAN3 bacterial isolates were identified to be Neisseria spp, Bacillus cereus, and Staphylococcus aureus respectively. The results of Post-treatment analysis showed that there is overall decrease in the levels of the parameters determined when compared with that of the pre-treatment. The overall percentage reduction of the immobilised bacteria in the treatment of the respective effluents was in the order TAN2 (72\%)>TAN1 $(70 \%)>$ TAN3 $(62 \%)$. Hence, the immobilized bacteria are having higher biodegradation potential for the treatment of the tannery effluents.

\section{Acknowledgments}

The authors wish to acknowledge the University of Maiduguri for the financial support. The authors are grateful to the Kano State Ministry of Environment for their support in obtaining the effluent samples. 


\section{REFERENCES}

Ajao, A. T., Adebayo, G. B., and Yakubu, S. E. (2011). Bioremediation of textile industrial effluent using mixed culture of Pseudomonas aeruginosa and Bacillus subtilis immobilized on agar-agar in a bioreactor. J. Microbiol. Biotech. Res, 1(3), 50-56.

Akan, J. C., Moses, E. A., Ogugbuaja, V. O., and Abah, J. (2007). Assessment of tannery industrial effluents from Kano metropolis, Kano State, Nigeria. Journal of Applied Sciences, 7(19), 2788-2793.

Akan, J. C., Ogugbuaja, V. O., Abdulrahman, F. I., and Ayodele, J. T. (2009). Pollutant levels in effluent samples from tanneries and textiles of Kano industrial areas, Nigeria. Global journal of pure and applied sciences, 15(3-4).

APHA (1989). Standard methods for Examination of Will bete and Will betewater.15 $5^{\text {th }}$ edition. Brydpass Springfield Will behington DC. pp. 164-176

APHA (1992). Standard Methods for the Examination of Water and Wastewater. Health, 69, 1116-9.

Baba, A., Garba, S. T., and Bello, H. S. (2020). Bioremediation Potential of Immobilized corynebacterium kutsceri in the Treatment of Tannery Industrial Effluent from Challawa Industrial Estate, Kano State, Nigeria. Journal of the Turkish Chemical Society Section A: Chemistry, $7(2), 335-350$.

Beem, E. I. V. (1994). reduction of solvent VOC emission. J. Oil Col. Chem. Ass, 77, 158.

Bouwer, E. J., and Zehnder, A. J. (1993). Bioremediation of organic compoundsputting microbial metabolism to work. Trends in biotechnology, 11(8), 360367.

Chen, K. C., Wu, J. Y., Liou, D. J., and Hwang, S. C. J. (2003). Decolorization of the textile dyes by newly isolated bacterial strains. Journal of Biotechnology, 101(1), 57-68.

Dan'Azumi, S., and Bichi, M. H. (2010). INDUSTRIAL POLLUTION AND HEAVY METALS PROFILE OF CHALLAWA RIVER IN KANO, NIGERIA. Journal of Applied Sciences in Environmental Sanitation, $5(1)$.

DWAF. (1992). Analytical Methods Manual, TR 151. Department of Water Affairs and Forestry, Pretoria.

El-Bestawy, E. (2013). Biological treatment of leather-tanning industrial wastewater using free living bacteria.
Elsheikh, M. A. S. (2009). Tannery wastewater pre-treatment. Water Science and Technology, 60(2), 433-440.

FuIlbrook, P. D. (1996). "Kinetics." Industrial enzymology: The application of enzymes in Industry. 2nd Ed. T. Godfrey and J Reichelt. eds.. Nature. New York.

Gianfreda, L., and Rao, M. A. (2004). Potential of extra cellular enzymes in remediation of polluted soils: a review. Enzyme and microbial technology, 35(4), 339354.

Hugo Springer. (1994). John Arthur Wilson Memorial Lecture "Treatment of Industrial Wastes of the Leather Industry - is it still a Major Problem". JALCA, 89, 153-185

Jimoh, A. A., Ganiyu, B. A., Baba, D., and Baba, A. (2018) Bioremediation Process of Effluent from Detergent and Food Industries in Jos, Nigeria: Kinetics and Thermodynamics. International Journal of Engineering Science Invention (IJESI), 762-73

Kandelbauer, A., Maute, O., Kessler, R. W., Erlacher, A., and Gübitz, G. M. (2004). Study of dye decolorization in an immobilized laccase enzyme-reactor using online spectroscopy. Biotechnology and bioengineering, 87(4), 552-563.

Kongjao, S., Damronglerd, S., and Hunsom, M. (2008). Simultaneous removal of organic and inorganic Pollutants in tannery wastewater using electrocoagulation technique. Korean Journal of chemical engineering, 25(4), 703.

Maheshwari, U. M., Aruna, S., Gomathi, M., and AbdulJaffar, A. H. (2017). Bioremediation by Free and Immobilized Bacteria Isolated from Tannery Effluent. International Journal of Research in Applied, Natural and Social Sciences. 5(7), 75-90

Margesin, R., and Schinner, F. (2001). Bioremediation (natural attenuation and biostimulation) of diesel-oilcontaminated soil in an alpine glacier skiing area. Applied and environmental microbiology, 677), 3127-3133.

Mohammed, A., Sekar, P., and George, J. (2011). Efficacy of microbes in bioremediation of tannery effluent. Inter. J. Curr. Res, 3(4), 324-326.

Mohammed, S. S. D., Orukotan, A. A., and Abdullahi, H. (2017). Physicochemical and Bacteriological Assessment of Tannery Effluent from Samaru-Zaria, 
BAJOPAS Volume 13 Number 2, December, 2020 Kaduna State, Nigeria. Journal of Applied

Sciences and Environmental Management, 21(4), 734-740.

Munz, G., De Angelis, D., Gori, R., Mori, G., Casarci, M., and Lubello, C. (2009). The role of tannins in conventional and membrane treatment of tannery wastewater. Journal of hazardous materials, 164(2-3), 733-739

Mythili, K., and Karthikeyan, B. (2011). Bioremediation of $\mathrm{Cr}$ (VI) from tannery effluent using Bacillus spp and Staphylococcus spp. International Multidisciplinary Research Journal, 1(6).

NESREA (2009). National Environmental Standards for Effluent Limitations and Regulation. 1233-1236

Noorjahan, C. M. (2014). Physicochemical characteristics, identification of bacteria and biodegradation of industrial effluent. Journal of bioremediation and Biodegradation, 5(3).

Ohtake, H. I., and Silver, A. O. (1994). Bacterial reduction of toxic chromate. Biological degradation and bioremediation of toxic chemicals, 403-415.

Omoleke, I. I. (2004). Management of environmental pollution in Ibadan, an African city: the challenges of health hazard facing government and the people. Journal of Human Ecology, 15(4), 265-275.

Rajor, A., Reddy, A.S., and Singh, B. (2004). Determination of BOD kinetic Parameters and evaluation of alternate methods, M.Sc. Thesis, Department of biotechnology \& environmental Science, Thapar Institute of Engineering and Technology, Patiala

Ramasami, T., Rajamani, S., and Rao, J. R. (1994, March). Pollution control in leather industry: Emerging technological options. In International symposium on surface and colloidal science and its relevance to soil pollution, madras.

Ramesh, J. V. S., and Singh, S. P. (1993). Yearly variation in certain physicochemical parameters of pond at eastern Doon Valley. Uttar Pradesh J. Zoo, 12 (1), 7577.

Ranen, S., and Sharadinadra, C. (2009). Biotechnology applications to environmental remediation in resource exploitation. Current science, 97, 6-25
Russell, A. J., Berberich, J. A., Drevon, G. F., and Koepsel, R. R. (2003). Biomaterials for mediation of

chemical and biological warfare agents. Annual review of biomedical engineering, 5(1), 1-27.

Saravanan, P., and Saravanan, A. (1999). Decolourization of tannery effluent by Flavobacterium sp. EK 1. Indian Journal of Environmental Protection, 19, 19-24.

Sikander, S., and Shahida, H. (2007). Reduction of toxic hexavalent chromium by Ochrobactrum intermedium strain SDCr5 stimulated by heavy metals. Bioresource Technol, 98, 340-344.

Singh, N., Sharma, B. K., and Bohra, P. C. (2000). Impact assessment of industrial effluent of arid soils by using satellite imageries. Journal of the Indian Society of Remote Sensing, 28(2-3), 79.

Sreemoyee, C., and Priti, P. (2013). Assessment of physico-chemical parameters of dairy waste water and isolation and characterization of bacterial strains in terms of cod reduction. Int J Sci, 2(3), 395-400.

Verheijen, L. A. H. M., Wiersema, D., Pol, L. H., and De Wit, J. (1996). Management of wastes from animal product processing. Livestock and environment, Finding a balance. International Agriculture Center, Wageningen, The Netherlands.

Wang, F., Yao, J., Si, Y., Chen, H., Russel, M., Chen, K., and Bramanti, E. (2010). Short-time effect of heavy metals upon microbial community activity. Journal of Hazardous Materials, 173(13), 510-516.

WHO (World Health Organization). (2006). Air quality guidelines: global update 2005: particulate matter, ozone, nitrogen dioxide, and sulfur dioxide. World Health Organization.

World Bank. (1995). Nigeria's strategic options for redressing industrial pollution. World Bank, industry and energy division. 1st edition, West Central Africa Department; Annexes: 1995; pp 60-62.

Zahoor, A., and Abdul, R. (2009). Enumeration of Coliforms. Journal of Environmental Sciences. 21, 814-820 


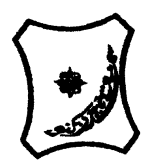

Bayero Journal of Pure and Applied Sciences, 13(2): 1 - 12

Received: November, 2020

Accepted: December, 2020

ISSN $2006-6996$

\title{
BIODEGRADATION POTENTIAL OF IMMOBILIZED BACTERIA IN THE TREATMENT OF TANNERY INDUSTRIAL EFFLUENTS FROM INDUSTRIAL ESTATES IN KANO STATE, NIGERIA
}

\author{
Abdullateef, B., ${ }^{1 *}$ Shuaibu, T. G., ${ }^{1}$ Babagana, K., ${ }^{1}$ Suleman, H. B. ${ }^{2}$ and Dauda, B. ${ }^{3}$ \\ ${ }^{1}$ Department of Pure and Applied Chemistry, Faculty of Science, University of Maiduguri, Borno State, \\ Nigeria \\ ${ }^{2}$ Department of Microbiology, Faculty of Science, University of Maiduguri, Borno State, Nigeria \\ ${ }^{3}$ Department of Chemical Engineering, Faculty of Engineering, University of Maiduguri, Borno State, \\ Nigeria \\ *Corresponding author: babslega@gmail.com; abelega2007@yahoo.com; +2348061309753
}

\section{ABSTRACT}

Industrial Effluents Samples from Gashash Tanneries (TAN1) in Bompai Industrial estate, Larabee Tannery Industry (TAN2) in Sharada Industrial estate and Z Tannery Industries (TAN3) in Challawa Industrial estate, Kano State, Nigeria were collected over a period of six months (August 2017 to January 2018) for assessing the biodegradation potentials of bacteria in the treatment of organic pollutants within the effluents. Bacteria were isolated from the effluents and immobilized on agar-agar. Different masses (5 g, $10 \mathrm{gr}, 15$ $\mathrm{g}, 20 \mathrm{~g}$, and $25 \mathrm{~g}$ ) of the bacteria were used in the treatment of $250 \mathrm{ml}$ of the effluents for ten days in a shaker incubator (Gallenkamp-OC-4364-L) at the temperature $30{ }^{\circ} \mathrm{C}$ and speed of $60 \mathrm{rpm}$. Pre-treatment analysis of the effluents for Temperature, pH, Biochemical Oxygen Demand (BOD), Chemical Oxygen Demand (COD), Suspended Solid (SS) and Total Dissolved Solids (TDS) gives the following results; temperature $\left({ }^{\circ} \mathrm{C}\right.$ )

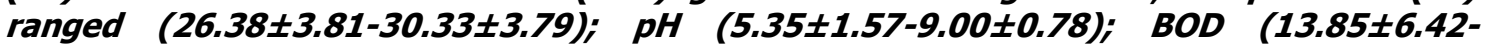
$38.75 \pm 16.20) ;$ COD (1406 $\pm 208-3532 \pm 1373) ;$ SS (208 $\pm 235-780 \pm 739)$ and TDS (266 $\pm 253-5276 \pm 2971)$. No statistical differences ( $p \leq 0.05)$ was observed for all the results among the different industries. The bacterial isolates were identified as Neisseria spp, Bacillus cereus, and Staphylococcus aureus, in TAN1, TAN2, and TAN3, respectively. After treatment of the effluent with the different masses of the isolated bacteria, the mean level of BOD was found to range as (0.55 $\pm 0.36-6.92 \pm 5.49) ; C O D$ (ND-3134 \pm 1595$)$;

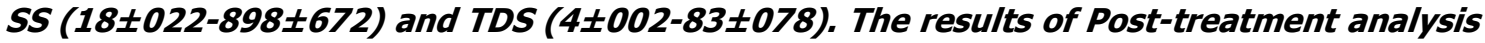
showed that there is overall decrease in the levels of the parameters determined when compared with that of the pre-treatment. The overall percentage reduction of the immobilised bacteria in the treatment of the respective effluents was in the order TAN2 (72\%)>TAN1 (70\%)>TAN3 (62\%). Hence, the immobilized bacteria are having higher biodegradation potential for the treatment of the tannery effluents.

Keywords: Biodegradation, bacteria, effluent, immobilization, tannery.

\section{INTRODUCTION}

Tannery industrial wastewater is a serious consequence of the pollution point of view for streams, freshwater, and land used for agriculture. The lack of awareness in the modern industrial practice has resulted in the discharge of tannery effluents which exhibit very high value of chromium ( $\mathrm{Cr}$ ), Sulfide, and chloride, Total Dissolved Solid (TDS), Total Suspended Solid (TSS), Biochemical Oxygen Demand (BOD) and Chemical Oxygen Demand (COD) in the water stream or land (Mohammed et al., 2001). Tanning is the process, which One ton of skin generally leads to the production of 20 to $80 \mathrm{~m}^{3}$ of turbid and foul-smelling converts the protein of the rawhide or skin into a stable material, which will not putrefy and is suitable for a wide variety of end applications (Elsheikh, 2009). The highly polluting chromium is the most commonly used tanning material producing leather that is more flexible and pliable than vegetable-tanned leather and does not discolor or lose shape in water as drastically as vegetable-tan (Elsheikh, 2009). Tannery effluent is among the most hazardous industrial pollutants due to its huge organic and inorganic load, which is highly toxic to human life and the environment (Kongjao et al., 2008). wastewater including chromium (100-400 mg/l), sulfide $(200-800 \mathrm{mg} / \mathrm{l})$, high levels of fat and 
BAJOPAS Volume 13 Number 2, December, 2020 other solid wastes, and notable pathogen contamination as well as pesticides added for skin conservation during transport (Elsheikh, 2009). There are more than 6000 tanneries in Nigeria with an annual processing capacity of 700,000 tons of hides and skins (Omoleke, 2004; Singh et al., 2008). It was reported that the total amount of waste produced per animal slaughtered is approximately $35 \%$ of its weight (World Bank, 1995). Also, for every $1000 \mathrm{~kg}$ of carcass weight, a slaughtered beef produces 5.5 $\mathrm{kg}$ of manure (excluding rumen contents or stockyard manure) and $100 \mathrm{~kg}$ of paunch manure (undigested food) (Verheijen et al., 1996). Tanneries generate wastewater in the range of 30-35 $\mathrm{L} \mathrm{kg}^{-1}$ skin/hide processed with variable $\mathrm{pH}$, Biological Oxygen Demand (BOD), Chemical Oxygen Demand (COD), high concentrations of suspended solids (SS), and tannins as well as chromium (Zahoor and Abdul, 2009).

Being heterogeneous and composed of a wide variety of compounds, it is very difficult to select a unique direct method for estimating the biodegradability of organic contents and biokinetic parameters for a wastewater sample (Rajor, 2004). For this purpose, some indirect estimation such as determination of biochemical oxygen demand (BOD) and chemical oxygen demand (COD) are applied as common laboratory investigations [9]. During retanning procedures, synthetic tannins (Syntan), oils and resins are added to form softer leather at varying doses (Munz et al., 2009). One of the refractory groups of chemicals in tannery effluents derives mainly from tannins (Ramasami et al., 2004). Syntans are characterized by complex chemical structures, because they are composed of an extended set of chemicals such as phenol-, naphthalene-, formaldehyde- and melamine-based syntans, and acrylic resins (Beem, 1994). Organic pollutants (proteic and lipidic components) are originated from skins (it is calculated that the raw skin has $30 \%$ loss of organic material during the working cycle) or they are introduced during processes (Hugo Springer, 1994).

Many conventional processes such as oxidation, chemical and biological processes were carried out to treat tanneries wastewater (Ebtesam et al, 2013). Biological processes have received more attention because of their costeffectiveness, lower sludge production and environmental friendliness (Noorjahan, 2014). Naturally occurring micro-organisms degrade the hazardous organic wastes including xenobiotic compounds, such as pesticides, polycyclic aromatic hydrocarbons (PAHs) and polychlorinated biphenyls (PCBs) in due course of time (Ranen and Sharadinadra, 2009). Bioremediation is based on the idea that all organisms remove substances from the environment to carry outgrowth and metabolism (Bouwer and Zehnder, 1993). Bacteria, protista and fungi are found to be very good at degrading complex molecules and incorporating the breakdown products into their metabolism (Bouwer and Zehnder, 1993). The resultant metabolic wastes that they produce are generally safe and somehow recycled into other organisms (Ranen and Sharadinadra, 2009). An acclimatized indigenous population of microorganisms capable of degradation of the compounds of interest must exist at the site for a successful bioremediation mode (Ranen and Sharadinadra, 2009). It has been observed that for a successful bioremediation mode, an acclimatized indigenous population of microorganisms capable of degradation of the compounds of interest must exist at the site under investigation (Ranen and Sharadinadra, 2009). Even though there are numerous physical and chemical methods employed in the disposal of wastes the advantage in using bacterium is that they play a key role in the reduction of COD, BOD, total protein, total tannin and total phenol (Saravanan and Saravanan, 1998)

Baba et al. (2020) studied the bioremediation potential of immobilized corynebacterium kutsceri in the Treatment of tannery industrial effluent from Challawa Industrial Estate, Kano State, Nigeria. The aim of the work is to study the reduction in the level of the contaminants through the process of bioremediation using the isolated bacteria. Immobilized bacteria can withstand various temperatures, $\mathrm{pH}$ and substrate concentrations; consequently, increasing the efficiency and the lifespan of the bacteria. Immobilized bacteria are widely applied in the treatment of wastewater and can be separated and recovered after the treatment with the same efficiency (Baba et al., 2020).

\section{MATERIALS AND METHODS \\ Study Area}

This study was carried out in Bompai, Sharada and Challawa industrial estates in Kano, Figure 1. Kano lies on Latitude $11^{\circ} 30^{\prime} \mathrm{N}$ and $8^{\circ} 30^{\prime} \mathrm{E}$ and Longitude $11^{\circ} 5^{\prime} \mathrm{N}$ and $8^{\circ} 5^{\prime} \mathrm{E}$ in Northern Nigeria. It is one of the developed industrial cities in Nigeria. Tannery activities are the dominating industries and this could be one of the reasons for her high population density (Dan'Azumi and Bichi, 2010). Many researchers have studied biodegradation of tannery effluent using microorganisms. However, limited literature is available on the biodegradation of tannery effluent in Kano industrial estates using 
BAJOPAS Volume 13 Number 2, December, 2020 immobilized bacterial cells. This research work focuses on the potential of the use of the indigenous immobilized bacterial isolates in the treatment of tannery effluents in the industrial estates.

\section{Sample Collection}

Effluents were collected from the Tannery Industries from Bompai, Challawa and Sharada Industrial Estates, Kano, Nigeria. The effluents were collected over a period of six months (August 2017 to January 2018). Samples collected in a sterile 4-liter plastic container with a unique identification number were preserved using an ice-box that was transported to the Microbiology Laboratory, Department of Microbiology, Bayero University of Kano for analysis

\section{Sample Preparation and Sample Analysis}

Immediately after the collection of the effluent, $\mathrm{pH}$, TSS, TDS, COD, BOD levels were determined before treatment (Pre-treatment determination) and ten days after treatment (Post-treatment determination) as described in
APHA (1989) standard methods. $\mathrm{pH}$ was determined using Ecotests $\mathrm{pH}$ meter and TDS was determined using AQUALYTIC TDS Salinometer. BOD was determined as described by the standard method (APHA, 1992). COD and SS were determined using DR/2010 HACH portable data logging spectrophotometer (DWAF, 1992)

\section{Identification and Biochemical} Characterization of the Bacterial Isolates

The bacteria were isolated from the effluents using Serial Dilution according to the method described by APHA (1989). The biochemical tests such as oxidase, catalase, coagulase, indole (from $1 \%$ tryptone broth), citrate (Simmons citrate agar), methyl red/VogesProskauer (MR/VP), nitrate reduction, Starch Hydrolysis, Glucose, Maltose, and Lactose tests were carried out on the bacterial isolates to identify the bacteria through the bacteria biochemical characteristics according to Ajao et al. (2011).

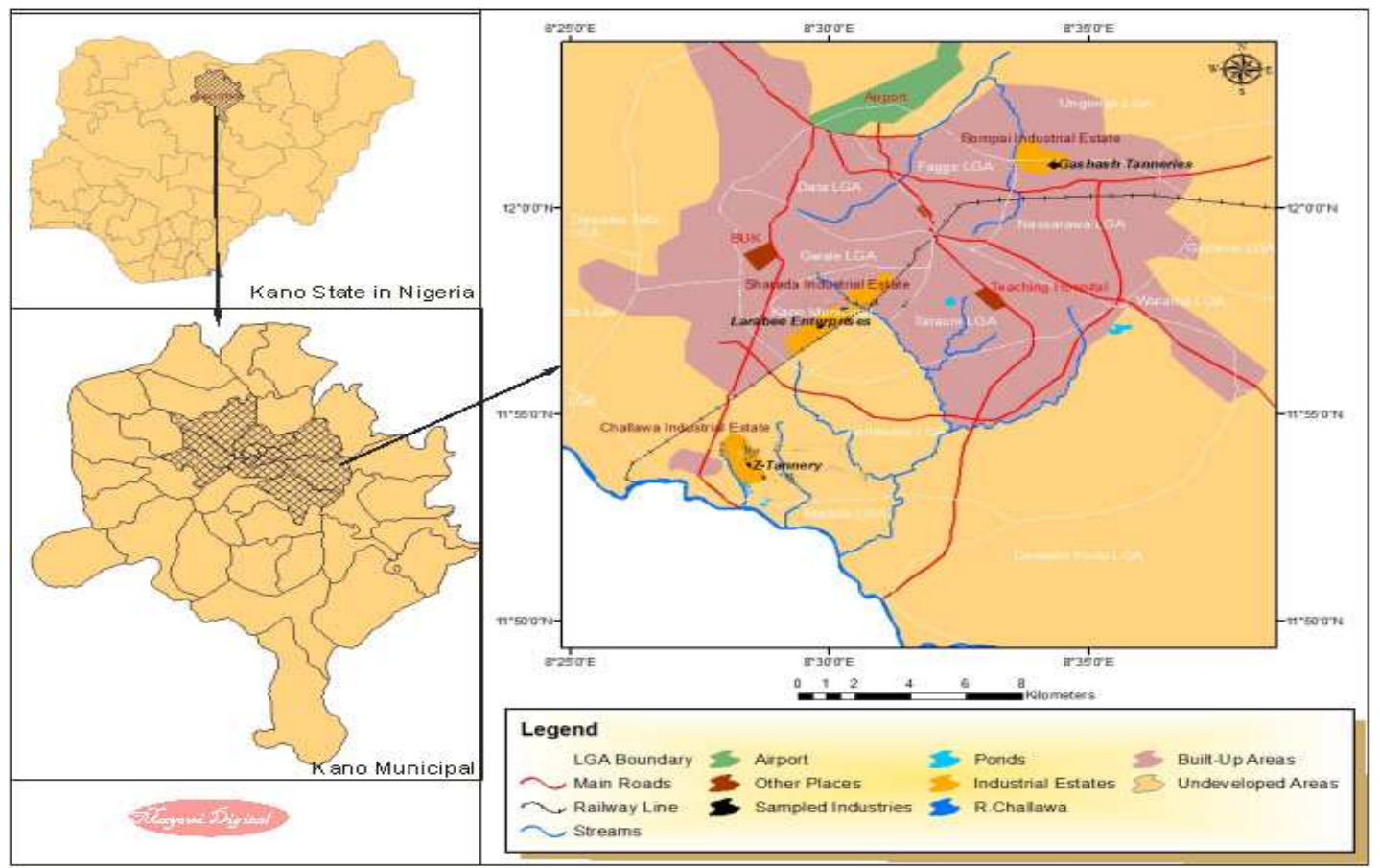

Fig. 1 Map showing the study areas

Source: Mayomi Digital Productions, GIS Laboratory, Department of Geography, UNIMAID (2017)

\section{Determination of Growth Rate of the Bacteria in Effluent Sample}

The bacteria growth rates were determined by transferring $2 \mathrm{~mL}$ of the bacterial isolates from the tannery effluent in broth medium into 100 $\mathrm{mL}$ sterile effluents in conical flasks and kept in an incubator (Giffrin cool) for 10 days. Control was also set up by incubating another $100 \mathrm{~mL}$ each of the sterile effluents without the bacteria. The optical density of the content was determined at the wavelength of $600 \mathrm{~nm}$ on a daily interval and recorded. 
BAJOPAS Volume 13 Number 2, December, 2020 Immobilization of Bacteria

Agar solution and inoculi were prepared separately. Fifty milliliters $(50 \mathrm{~mL})$ of nutrient broth each of the inoculi was prepared in a McCartney bottle and incubated for 24 hours. A solution of agar-agar was prepared by dissolving $10 \mathrm{~g}$ of the powder in distilled water and made up to $500 \mathrm{~mL}$ mark in an Erlenmeyer flask and was sterilized in an autoclave (280A) for 15 minutes and allowed to cool to $40-45^{\circ} \mathrm{C}$ (Ajao et al., 2011). Four milliliters ( $4 \mathrm{~mL})$ of the bacterial isolates in the nutrient broth was mixed with 36 $\mathrm{ml}$ of the prepared agar-agar media in petri-dish plates and then allowed to solidify. This was kept in the refrigerator for bioremediation.

\section{Bioremediation (Treatment) of the Effluents}

The solidified agar block (immobilized bacteria) was cut into cubes using a sterile knife; $0.1 \mathrm{~mL}$ phosphate buffer ( $\mathrm{pH} \mathrm{7.0)}$ was added and kept in the refrigerator for 1 hour for curing. The phosphate buffer was decanted after 1 hour and the cubes were washed with sterile distilled water 3-4 times before it was used (Ajao et al., 2011). Two liters (2 L) of the effluent was supplemented with the minimum basal medium in $\mathrm{g} / \mathrm{L}: \mathrm{NaCl}(0.8), \mathrm{MgSO}_{4} .7 \mathrm{H}_{2} \mathrm{O}(0.001), \mathrm{KH}_{2} \mathrm{PO}_{4}$ (2), $\mathrm{NaNO}_{3}$ (2), $\quad \mathrm{CaCl}_{2} .2 \mathrm{H}_{2} \mathrm{O} \quad(0.5)$ and $\mathrm{NaHPO}_{4} .12 \mathrm{H}_{2} \mathrm{O}(2)$ and sterilized in an autoclave at $121^{\circ} \mathrm{C}$ for 15 minutes (Margesin and Schinner, 2001). Two hundred and fifty milliliters $(250 \mathrm{~mL})$ of the effluents were transferred into different $250 \mathrm{ml}$ conical flasks. The content was covered with a cotton-wool ramped with foil paper to avoid contamination. Five grams $(5 \mathrm{~g})$ of the immobilized bacteria were quickly transferred into each of the effluents in the conical flasks in an inoculating chamber. The same procedures were carried out for the $10 \mathrm{~g}, 15 \mathrm{~g}, 20 \mathrm{~g}$ and 25 $\mathrm{g}$ of the immobilized bacteria in separate $250 \mathrm{~mL}$ effluents in conical flasks and agitated for ten days in a shaker incubator (Gallenkamp-OC4364-L) at a temperature $30^{\circ} \mathrm{C}$ and speed of 60 rpm. The treated effluent samples were taken on the tenth day and analyzed for the parameters $\mathrm{pH}$, SS, TDS, COD, and BOD, (Posttreatment determination) for the different grams of bacteria to evaluate and compare the biodegradation potential. (Baba et al., 2020).

\section{Statistical Analysis}

The data were represented as Mean \pm Standard deviation and analyzed statistically using oneway Analysis of Variance (ANOVA) and Tukey's HSD as Post Hoc Tests with the aid of SPSS 16.0. The correlation coefficient was also used to measure the strength of the relationship between the different masses of the bacteria and the parameters. All $\mathrm{p} \leq 0.05$ were considered as statistically significant.

\section{RESULTS AND DISCUSSION Physico-chemical parameters in the Industrial Effluents before the Biodegradation.}

Results of the Physico-chemical parameters in the industrial effluents before the Biodegradation is shown in table 1 . The mean temperatures $\left({ }^{\circ} \mathrm{C}\right)$ observed in TAN1, TAN2, and TAN3 samples were $28.07 \pm 0.65 ; 27.77 \pm 0.64$ and $26.38 \pm 3.81$ respectively. The order of the mean temperature of the samples from the three industries can be arranged as TAN1 > TAN2>TAN3. The temperature observed at TAN1, TAN2, and TAN3 samples were found below the WHO $\left(35^{\circ} \mathrm{C}\right)$ and NESREA $\left(40^{\circ} \mathrm{C}\right)$ limits. The low values of temperature might be due to the processes used at the time of sampling. High temperature brings down the solubility of gases in water that ultimately expresses as high BOD and COD. Statistical analysis shows that there is no significant difference $(p<0.05)$ between the mean values of temperature among the industries. This might be due to similar tannery activities involved in the tannery industries at the time of sampling. The average values of temperature observed in this present study are less than those observed by Akan et al. (2007), Akan et al. (2009) and Baba et al. (2020).

The mean level of $\mathrm{pH}$ observed in TAN1, TAN2 and TAN3, samples were $7.77 \pm 2.93$; $8.35 \pm 0.28$ and $7.52 \pm 0.76$ respectively. The order of the mean $\mathrm{pH}$ of the samples from the three industries can be arranged as TAN2> TAN1 $>$ TAN3. The $\mathrm{pH}$ of the samples falls within the WHO (7.0-8.5) and NESREA (6-9) standard limits. Statistical analysis shows that there is no significant difference $(p<0.05)$ between the mean values of $\mathrm{pH}$ among the industries. This might be due to similar tannery activities involved in the tannery industries at the time of sampling. Maheshwari et al. (2017) reported that the level of $\mathrm{pH}$ in the effluents from the tannery industry in Vaniyambadi, India was 6.5 which was lower than that observed in the present study. The $\mathrm{pH}$ in the effluents from the tannery industries in Kano and Kaduna were reported to be 7.64 and 6.89, respectively (Akan et al., 2007; Mohammed et al., 2017). The average values of $\mathrm{pH}$ observed in this present study are less than those observed by Mohammed et al. (2017) and Baba et al. (2020). The mean level of SS $(\mathrm{mg} / \mathrm{l})$ observed in TAN1, TAN2, and TAN3 samples were 374 \pm 124 ; $358 \pm 335$ and $780 \pm 739$ respectively. The order of the mean SS in the samples from the three industries can be arranged as TAN3 > TAN1 $>$ TAN2. 
The SS observed in the samples were far above the recommended standard limits of regulating bodies WHO $(30 \mathrm{mg} / \mathrm{l})$ and NESREA $(10 \mathrm{mg} / \mathrm{l})$. Statistical analysis shows that there is no significant difference $(p<0.05)$ between the mean values of SS among the industries. This might be due to similar tannery activities involved in the tannery industries at the time of sampling. The average values of SS observed in this present study are less than that observed $(3700 \pm 122 \mathrm{mg} / \mathrm{l})$ by Akan et al. (2009) for tanneries in Kano. Also, the average values of SS observed in this present study are less than that observed by Mohammed et al. (2017) and Baba et al. (2020) with the exception in TAN3.

The mean level of TDS (mg/l) observed in TAN1, TAN2, and TAN3 samples were $3941 \pm 3703$; $3300 \pm 1714$ and $2653 \pm 1240$ respectively. The order of the mean TDS in the samples from the three industries can be arranged as TAN1>TAN2>TAN3. The TDS observed in the samples were far above the recommended standard limits of WHO $(250 \mathrm{mg} / \mathrm{l})$ and NESREA $(500 \mathrm{mg} / \mathrm{l})$. Statistical analysis shows that there is no significant difference $(p<0.05)$ between the mean values of TDS among the industries. This might be due to similar tannery activities involved in the tannery industries at the time of sampling. TDS in the effluents from the tannery industries in Kano, Nigeria was reported to be $1281 \mathrm{mg} / \mathrm{l}$ (Akan et al., 2007). The average values of SS observed in this present study are less than those observed by Mohammed et al. (2017) and Baba et al. 2020)

The mean level of COD (mg/l) observed in TAN1, TAN2 and TAN3 samples seasons were $2372 \pm 938 ; \quad 1406 \pm 208$ and $3532 \pm 1373$ respectively. The order of the mean COD of the samples from the three industries can be arranged as TAN3>TAN1> TAN2. The COD observed in TAN1, TAN2 and TAN3 samples were far above the recommended standard limits of regulating bodies $\mathrm{WHO}(40 \mathrm{mg} / \mathrm{l})$ and NESREA (40 mg/l). Statistical analysis shows that there is no significant difference $(p<0.05)$ in COD among the industries. This might be due to similar tannery activities involved in the tannery industries as at the time of sampling. The Chemical Oxygen demand (COD) is the amount of oxygen, in $\mathrm{mg} / \mathrm{L}$, required for the degradation of the compound of wastewater to occur. In comparison, the average values of COD observed in this present study were higher than that observed by Mohammed et al. (2017) but lower than that observed by Baba et al. (2020).

The mean levels of BOD $(\mathrm{mg} / \mathrm{l})$ observed in TAN1, TAN2 and TAN3 samples were $13.85 \pm 6.42 ; \quad 19.46 \pm 0.50$ and $17.13 \pm 3.14$ respectively. The order of the mean BOD in the samples from the three industries can be arranged as TAN2>TAN3>TAN1. The BOD observed in TAN1, TAN2 and TAN3 samples were found below the recommended limits of NESREA (200 mg/l) but above WHO (10 mg/l). Statistical analysis shows that there is no significant difference $(p<0.05)$ between the mean values of BOD among the industries. This might be due to similar tannery activities involved in the tannery industries at the time of sampling. The low level of BOD recorded in this study is an indication of the low level of biodegradable organic solids in the effluent. The average values of BOD observed in this present study were lower than those observed by Mohammed et al. (2017) and Baba et al. (2020).

Table 1: Mean Values \pm S.D of Physico-chemical parameters of effluents from the Tannery Industries before Treatment.

\begin{tabular}{llllllll}
\hline Parameter & Tannery 1 & Tannery 2 & Tannery 3 & $\mathrm{a}$ & $\mathrm{b}$ & $\mathrm{c}$ & $\mathrm{d}$ \\
\cline { 2 - 7 } Temperature $\left({ }^{\circ} \mathrm{C}\right)$ & $28.07 \mathrm{a} \pm 0.65$ & $27.77 \mathrm{a} \pm 0.64$ & $26.38 \mathrm{a} \pm 3.81$ & & $29.50 \pm 4.68$ & 35 & 40 \\
pH & $7.77 \mathrm{a} \pm 2.93$ & $8.35 \mathrm{a} \pm 0.28$ & $7.52 \mathrm{a} \pm 0.76$ & 6.89 & $5.35 \pm 1.57$ & $7.0-8.5$ & $6.0-9.0$ \\
$\mathrm{COD}(\mathrm{mg} / \mathrm{l})$ & $2372 \mathrm{a} \pm 938$ & $1406 \mathrm{a} \pm 208$ & $3532 \mathrm{a} \pm 1373$ & 2.2 & $3106 \pm 2753$ & 40 & 40 \\
$\mathrm{BOD}(\mathrm{mg} / \mathrm{l})$ & $13.85 \mathrm{a} \pm 6.42$ & $19.46 \mathrm{a} \pm 0.50$ & $17.13 \mathrm{a} \pm 3.14$ & 1032 & $26.17 \pm 9.49$ & 10 & 200 \\
$\mathrm{SS}(\mathrm{mg} / \mathrm{l})$ & $374 \mathrm{a} \pm 124$ & $358 \mathrm{a} \pm 335$ & $780 \mathrm{a} \pm 739$ & 501 & $562 \pm 482$ & 30 & 10 \\
TDS $(\mathrm{mg} / \mathrm{l})$ & $3941 \mathrm{a} \pm 3703$ & $3300 \mathrm{a} \pm 1714$ & $2653 \mathrm{a} \pm 1240$ & 532.7 & $444 \pm 507$ & 250 & 500 \\
\hline
\end{tabular}

The values given in the table above are means of 6 replicate values, $\mathrm{n}=6$ ( 1 sample was taken monthly for 6 months). Within the rows, means with different alphabets are statistically different $(p<0.05)$. WHO: World Health Organisation. NESREA: National Environmental Standard and Regulatory Enforcement Agency. a = Mohammed et al.(2017), b = Baba et al. (2020), c = WHO (2006), $d=$ NESSRA (2009) 
BAJOPAS Volume 13 Number 2, December, 2020

Identification, Biochemical Characterization and growth rates of the Bacterial Isolates

Results of identification and biochemical characterization of the bacterial isolates were shown in table 2. After 24 hours of incubation, the nutrient agar media plates were checked for bacterial growth. The results showed the presence of different strains in the samples. The TAN1 bacteria isolate was found to be gramnegative cocci while TAN3 was gram-positive cocci. TAN2 bacteria isolate was found to be gram-positive, rod-shaped. TAN1, TAN2, and TAN3 bacteria isolates recorded positive results for spore former.

The results of the biochemical tests indicated that all the bacteria were positive for catalase, oxidase, citrate, maltose, glucose, lactose (negative in TAN1), mannitol (negative in TAN2), starch hydrolysis and coagulase (negative in TAN2) tests. The bacteria showed negative results for nitrate reduction, $M R$ (positive in TAN2), VP (positive in TAN1), Indole (positive in TAN2) tests. Base on the morphological and biochemical test results, TAN1, TAN2, and TAN3 bacteria isolates were identified to be Nesseria spp, Bacillus cereus, and Staphylococcus aureus respectively.

The growth rate of the TAN1, TAN2 and TAN3 Isolates were shown in figure 2. Generally, the optical density increase with the increase in time (day) and decrease as time goes on. The highest optical density was shown by bacillus cereus in TAN2 while the lowest was shown by Staphylococcus aureus in TAN3.

The initial growth phase of TAN1 Isolate bacteria occurred within 2-day of incubation as the growth rate increases up to the 6th-day incubation when the maximum growth was observed. Beyond the 6th day, the growth of the bacteria declined (which might be due to a shortage of nutrients in the effluents) until it reached its death phase (which might be due to the unavailability of nutrients in the effluents).

A similar trend of growth was also observed for TAN2 Isolate as the initial growth phase also occurred within 2-day of incubation but maximum growth rate observed on the 4th day of incubation. The stationary stage occurred between the 4th day and the 8th day. Beyond the 8th day, the growth of the bacteria declined (which might be due to a shortage of nutrients in the effluents) until it reached its death phase (which might be due to the unavailability of nutrients in the effluents).

The initial growth phase of TAN3 bacterial Isolate occurred within the 3-day incubation as the growth rate increases up to the 6th-day incubation when the maximum growth was observed. Beyond the 6th day, the growth of the bacteria declined (which might be due to a shortage of nutrients in the effluents) until it reached its death phase (which might be due to the unavailability of nutrients in the effluents).

Table 2: Morphological and Biochemical characteristics of bacterial isolates

\begin{tabular}{lllll} 
Bacterial Isolates & & TAN1 & TAN2 & TAN3 \\
\hline $\begin{array}{lllll}\text { Morphological } \\
\text { characteristics }\end{array}$ & Shape & Cocci & Rod & Cocci \\
& Spore & & & \\
& former & + & + & + \\
Gram & & & \\
Biochemical characteristics & reaction & - & + & + \\
& Citrate & + & + & + \\
& Catalase & + & + & + \\
& Coagulase & + & - & + \\
Starch & + & + & + \\
& Glucose & + & + & + \\
Oxidase & + & + & + \\
& Indo & - & + & - \\
Lactose & - & + & + \\
Manitol & + & - & + \\
Maltose & + & + & + \\
MR & - & + & - \\
VP & + & - & - \\
& Nitrate & - & - & - \\
Reduction & - Neisseria & Bacillus & Staphylococcus \\
& Bacterial & cereus & aureus \\
& name & spp & cas
\end{tabular}

+ = Positive; - = Negative; MR=Methyl Red; VP= Voges-Proskauer 


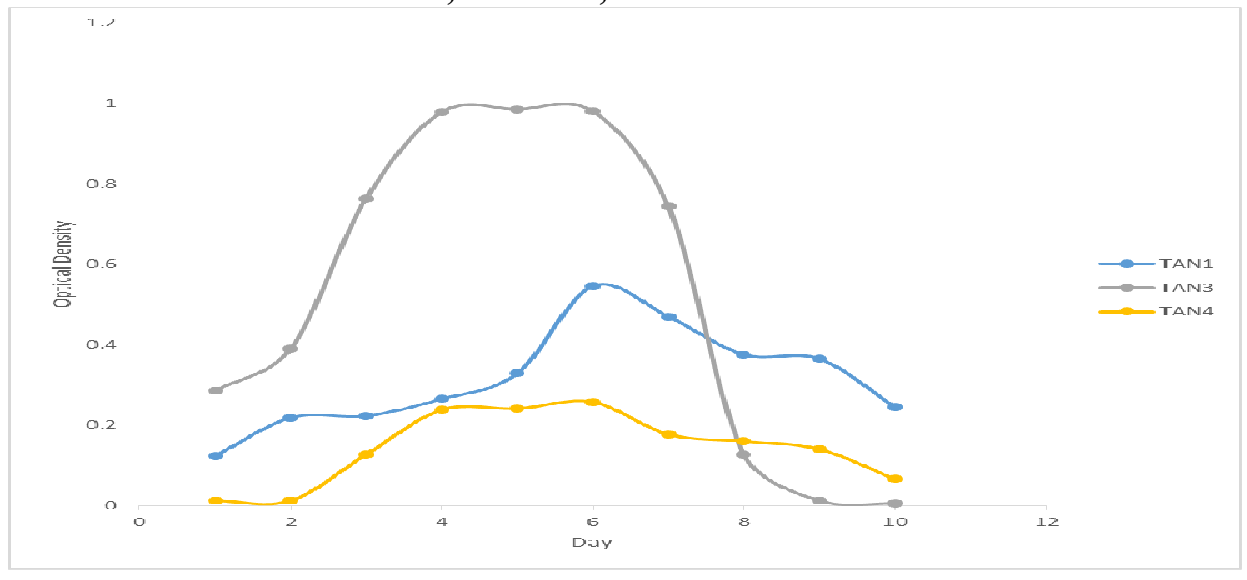

Fig. 2 Growth rates of the isolates in the effluents from the Tannery Industries

\section{Physico-chemical Parameters in the Industrial Effluents after the biodegradation.}

Table 3 shows the mean results of the physicochemical parameter before and after bioremediation using the different masses $(5 \mathrm{~g}$, $10 \mathrm{~g}, 15 \mathrm{~g}, 20 \mathrm{~g}$, and $25 \mathrm{~g}$ ) of the respective immobilized bacteria. Also, Table 4 shows the mean results of correlation coefficient ( $r$ ) between different masses of bacteria and physicochemical parameters.

The mean values $(\mathrm{mg} / \mathrm{l})$ of the SS after the bioremediation varies between $243 \pm 45$ and $898 \pm 672$. The mean concentration $(\mathrm{mg} / \mathrm{l})$ of SS remediated by the different masses $(5 \mathrm{~g}, 10 \mathrm{~g}$, $15 \mathrm{~g}, 20 \mathrm{~g}$, and $25 \mathrm{~g}$ ) of the bacteria varies. The SS in the samples fluctuates up and down after the bioremediation process when compared with the SS of the raw samples before the bioremediation. The increase in the levels of the SS might be due to the aggregation of the TDS which are large enough to result into SS. The increase in the levels of the SS might be also due to the influence of the nutrients which was added into the effluents in order to make the microorganisms more active and viable for fast degradation of organic contaminants in the effluent. The relative potential or efficiency of the different masses of the bacteria in remediating SS in TAN1 samples was in the order $25 \mathrm{~g}>20 \mathrm{~g}>15 \mathrm{~g}>10 \mathrm{~g}>5 \mathrm{~g}$. For TAN2 and TAN3 samples, the order was $25 \mathrm{~g}>20 \mathrm{~g}>15$ $\mathrm{g}>10 \mathrm{~g}>5 \mathrm{~g}$. These might be due to the variations in the surface areas of the different masses of the immobilized bacteria. Statistical analysis shows that there is no significant difference $(p<0.05)$ between the mean values of SS among the masses in the respective industries. Positive and significant correlations exist between the masses of bacteria and Suspended Solid (SS). This showed that there is general increase in the levels of the SS as the masses of the immobilized bacteria increases. TAN3 (90\%) and TAN1 (80\%) showed a very high correlation with the masses of the bacteria while TAN2 (61\%) showed a very low correlation.

The mean values $(\mathrm{mg} / \mathrm{l})$ of the TDS after the bioremediation varies between $46 \pm 11$ and $83 \pm 78$. The mean concentration $(\mathrm{mg} / \mathrm{l})$ of TDS remediated by the different masses $(5 \mathrm{~g}, 10 \mathrm{~g}$, $15 \mathrm{~g}, 20 \mathrm{~g}$, and $25 \mathrm{~g}$ ) of the bacteria varies. There is a reduction in all the TDS of all the samples after the bioremediation process compared with the TDS of the raw samples before the bioremediation. The relative potential or efficiency of the different masses of the bacteria in remediating TDS in TAN1 and TAN3 samples was in the order $5 \mathrm{~g}>10 \mathrm{~g}>15 \mathrm{~g}>20$ $\mathrm{g}>25 \mathrm{~g}$. For TAN2 samples, the order was 20 $g>10 \quad g>25 \quad g>15 \quad g>5 \quad g$. Statistical analysis shows that there is no significant difference $(p<0.05)$ between the mean values of TDS among the masses in the respective industries. These might be due to the variations in the surface areas of the different masses of the immobilized bacteria. Positive and significant correlations exist between the masses of bacteria and TDS with the exception in TAN2 (negative and insignificant correlation). The positive correlations showed that there is general increase in the levels of the TDS as the masses of the immobilized bacteria increases. TAN1 $(96 \%)$ showed a very high correlation with the masses of the bacteria while TAN2 (47\%) showed a very low correlation.

The mean values $(\mathrm{mg} / \mathrm{l})$ of the BOD after the bioremediation varies between $1.56 \pm 0.20 \mathrm{mg} / \mathrm{l}$ and $6.92 \pm 5.49 \mathrm{mg} / \mathrm{l}$. The mean concentration $(\mathrm{mg} / \mathrm{l})$ of BOD remediated by the different masses $(5 \mathrm{~g}, 10 \mathrm{~g}, 15 \mathrm{~g}, 20 \mathrm{~g}$, and $25 \mathrm{~g}$ ) of the bacteria varies. There is a reduction in all the BOD of all the samples after the bioremediation process compared with the $\mathrm{BOD}$ of the raw 
BAJOPAS Volume 13 Number 2, December, 2020 samples before the bioremediation. The relative potential or efficiency of the different masses of the bacteria in remediating BOD in TAN1, TAN2 and TAN3 samples were in the order $25 \mathrm{~g}>20$ $\mathrm{g}>15 \mathrm{~g}>10 \mathrm{~g}>5 \mathrm{~g}, 25 \mathrm{~g}>15 \mathrm{~g}>5 \mathrm{~g}>10 \mathrm{~g}>20 \mathrm{~g}$ and $20 \mathrm{~g}>10 \mathrm{~g}>25 \mathrm{~g}>15 \mathrm{~g}>5 \mathrm{~g}$ respectively. Statistical analysis shows that there is significant difference $(p<0.05)$ between the mean values of BOD among the masses in the respective industries. These might be due to the variations in the surface areas of the different masses of the immobilized bacteria. Negative and significant correlations exist between the masses of bacteria and BOD. This showed that there is general decrease in the levels of the BOD as the masses of the immobilized bacteria increases. TAN1 (94\%) showed a very high correlation with the masses of the bacteria while TAN2 (4\%) showed a very low correlation.

The mean values $(\mathrm{mg} / \mathrm{l})$ of the COD after the bioremediation varies between $250 \pm 154$ and $3134 \pm 1595$. The mean concentration $(\mathrm{mg} / \mathrm{l})$ of COD remediated by the different masses $(5 \mathrm{~g}$, $10 \mathrm{~g}, 15 \mathrm{~g} 20 \mathrm{~g}$, and $25 \mathrm{~g}$ ) of the bacteria varies. There is a reduction in all the COD of all the samples after the bioremediation process compared with the COD of the raw samples before the bioremediation. The relative potential or efficiency of the different masses of the bacteria in remediating COD in TAN1, TAN2 and TAN3 samples were in the order $25 \mathrm{~g}>20 \mathrm{~g}>15$ $\mathrm{g}>5 \mathrm{~g}>10 \mathrm{~g}, 25 \mathrm{~g}>20 \mathrm{~g}>15 \mathrm{~g}>10 \mathrm{~g}>5 \mathrm{~g}$ and 10 g>5 g>25 g>15 g>20 g respectively. Statistical analysis shows that there were significant difference $(p<0.05)$ between the mean values of COD among the masses in the respective industries except for effluents treated with $25 \mathrm{~g}$. These might be due to the variations in the surface areas of the different masses of the immobilized bacteria. Negative and insignificant correlations exist between the masses of bacteria and COD with the exception in TAN3 (positive and significant correlation). The negative correlations showed that there is general decrease in the levels of the COD as the masses of the immobilized bacteria increases. TAN2 (100\%) showed a very high correlation with the masses of the bacteria while TAN3 (36\%) showed a very low correlation.

Generally, there was an overall decrease in the concentration of these physicochemical parameters after the bioremediation using the different masses of the bacterial isolates. These might be due to the variations in the surface areas of the different masses of the immobilized bacteria. This is in line with the work of Jimoh et al. (2018) and Baba et al. (2020).

Table 3: Mean Values $(\mathrm{mg} / \mathrm{l}) \pm$ S.D of Physicochemical parameters in effluents from the Tannery Industries before and after Treatment of the effluents $(250 \mathrm{ml})$ with the different masses $(5 \mathrm{~g}, 10 \mathrm{~g}$, $15 \mathrm{~g}, 20 \mathrm{~g}$, and $25 \mathrm{~g}$ ) of the bacteria.

\begin{tabular}{llllllll}
\hline $\mathrm{P}$ & IND & Before & \multicolumn{5}{c}{ After } \\
\cline { 4 - 7 } & & & $5 \mathrm{~g}$ & $10 \mathrm{~g}$ & $15 \mathrm{~g}$ & $20 \mathrm{~g}$ & $25 \mathrm{~g}$ \\
\hline \multirow{2}{*}{ COD } & TAN1 & $2372 \pm 938$ & $1708 \mathrm{a} \pm 861$ & $2045 \mathrm{a} \pm 1205$ & $845 \mathrm{a} \pm 369$ & $300 \mathrm{a} \pm 167$ & $250 \mathrm{a} \pm 154$ \\
& TAN2 & $1406 \pm 208$ & $1195 \mathrm{a} \pm 208$ & $1125 \mathrm{a} \pm 384$ & $1055 \mathrm{a} \pm 317$ & $956 \mathrm{a} \pm 310$ & $870 \mathrm{ab} \pm 240$ \\
& TAN3 & $3532 \pm 1373$ & $2374 \mathrm{a} \pm 1344$ & $1976 \mathrm{a} \pm 1405$ & $2757 \mathrm{a} \pm 1266$ & $3134 \mathrm{a} \pm 1595$ & $2614 \mathrm{~b} \pm 1105$ \\
BOD & TAN1 & $13.85 \pm 6.42$ & $6.92 \mathrm{a} \pm 5.49$ & $6.42 \mathrm{a} \pm 5.07$ & $5.72 \mathrm{a} \pm 5.35$ & $4.62 \mathrm{a} \pm 4.37$ & $2.82 \mathrm{ab} \pm 1.26$ \\
& TAN2 & $19.46 \pm 0.50$ & $1.75 \mathrm{~b} \pm 0.22$ & $1.73 \mathrm{~b} \pm 0.18$ & $1.58 \mathrm{a} \pm 0.16$ & $1.91 \mathrm{a} \pm 0.22$ & $1.56 \mathrm{~b} \pm 0.20$ \\
& TAN3 & $17.13 \pm 3.14$ & $4.24 \mathrm{ab} \pm 0.77$ & $3.29 \mathrm{ab} \pm 0.37$ & $4.11 \mathrm{a} \pm 0.07$ & $3.23 \mathrm{a} \pm 0.91$ & $3.33 \mathrm{a} \pm 1.28$ \\
SS & TAN1 & $374 \pm 124$ & $243 \mathrm{a} \pm 45$ & $471 \mathrm{a} \pm 226$ & $475 \mathrm{a} \pm 182$ & $492 \mathrm{a} \pm 128$ & $611 \mathrm{a} \pm 217$ \\
& TAN2 & $358 \pm 335$ & $460 \mathrm{a} \pm 400$ & $543 \mathrm{a} \pm 414$ & $544 \mathrm{a} \pm 402$ & $551 \mathrm{a} \pm 414$ & $554 \mathrm{a} \pm 405$ \\
& TAN3 & $780 \pm 739$ & $586 \mathrm{a} \pm 594$ & $758 \mathrm{a} \pm 656$ & $787 \mathrm{a} \pm 676$ & $861 \mathrm{a} \pm 635$ & $898 \mathrm{a} \pm 672$ \\
TDS & TAN1 & $3941 \pm 3703$ & $51 \mathrm{a} \pm 10$ & $53 \mathrm{a} \pm 10$ & $55 \mathrm{a} \pm 15$ & $61 \mathrm{a} \pm 20$ & $63 \mathrm{a} \pm 26$ \\
& TAN2 & $3300 \pm 1714$ & $83 \mathrm{a} \pm 78$ & $47 \mathrm{a} \pm 20$ & $48 \mathrm{a} \pm 22$ & $47 \mathrm{a} \pm 17$ & $48 \mathrm{a} \pm 17$ \\
& TAN3 & $2653 \pm 1240$ & $46 \mathrm{a} \pm 11$ & $55 \mathrm{a} \pm 24$ & $55 \mathrm{a} \pm 25$ & $58 \mathrm{a} \pm 23$ & $61 \mathrm{a} \pm 28$ \\
\hline
\end{tabular}

Replicate $=6$ (months)

Within the rows, for the same parameter, means with different alphabets are statistically different $(p<0.05)$.

$\mathrm{P}=$ parameter, IND = Industries 
BAJOPAS Volume 13 Number 2, December, 2020

Table 4: Correlation coefficient $(r)$ between different masses of the bacteria and the physicochemical parameters.

\begin{tabular}{llll}
\hline Industries & Parameter & Correlation coefficient $(r)$ & $\begin{array}{l}\text { Percent dependence (rxrx100) } \\
(\%)\end{array}$ \\
\hline TAN1 & COD & -0.9 & 82 \\
& BOD & -0.97 & 94 \\
& SS & $0.90^{*}$ & 80 \\
TAN2 & TDS & $0.98^{*}$ & 96 \\
& COD & -1 & 100 \\
& BOD & -0.21 & 4 \\
& SS & $0.78^{*}$ & 61 \\
& TDS & -0.69 & 47 \\
& COD & $0.60^{*}$ & 36 \\
& BOD & -0.6 & 37 \\
& SS & $0.95^{*}$ & 90 \\
& TDS & $0.94^{*}$ & 89 \\
\hline
\end{tabular}

The correlation coefficient $(r)$ with * is statistically significant $(p<0.05)$.

Percentage reduction of the Parameters

Table 5 shows the percentage reduction of Parameters in industrial samples before and after the treatment of the effluents $(250 \mathrm{ml})$ with the different masses $(5 \mathrm{~g}, 10 \mathrm{~g}, 15 \mathrm{~g}, 20 \mathrm{~g}$, and $25 \mathrm{~g}$ ) of the Immobilized Bacteria.

In TAN1 samples, the percentage reduction (\%) of COD ranged (14-89); BOD (50-80); SS (-32$35)$ and TDS (98-99). In TAN2 samples, the percentage decrease $(\%)$ of COD ranged (15$38) ;$ BOD (90-92); SS [-28-(-55)] and TDS (9798). In TAN3 samples, the percentage decrease (\%) of COD ranged (11-44); BOD (76-81); SS (15-25) and TDS (98). The percentage increase in the levels COD, BOD and TDS might be due to the increase in the surface area of the different masses of the immobilized bacteria. However, the percentage decrease in the levels of the SS might be due to the aggregation of the TDS which are large enough to result into SS. The percentage decrease in the levels of the SS might be also due to the influence of the nutrients which was added into the effluents in order to make the microorganisms more active and viable for fast degradation of organic contaminants in the effluent. This is in line with the work of Jimoh et al. (2018) in which the concentration of the SS increase after the bioremediation of effluents.

Sreemoyee and Priti (2013) assessed and reduced several Physico-chemical parameters of dairy wastewater using Niesseria $s p$. and concluded that the species are well known to degrade organic compounds. This is in agreement with the current study in which the immobilized Niesseria $s p$ degrade the organic contaminants as indicated by the BOD, COD and TDS.

Jimoh et al. (2018) observed that TSS of the effluents was increased after treatment with immobilized bacteria and concluded that it might be due to the biostimulation method adopted for the research.

The optimum $\mathrm{pH}$ Biosorption of Chromium by Bacillus spp and Staphylococcus spp. from tannery effluent was investigated by Mythili and Karthikeyan (2011). The maximum adsorption of Chromium $(86.4 \mathrm{mg} / \mathrm{L})$ was showed by Bacillus spp and Staphylococcus spp showed $70.6 \mathrm{mg} / \mathrm{L}$ at an initial concentration of $100 \mathrm{mg} / \mathrm{L}$. In the present study, immobilised Bacillus spp and Staphylococcus spp. from the tannery industrial effluents reduced the levels of the organic pollutants with high potential as indicated by the percentage reduction of BOD, COD and TDS.

Enzymes often can work in multiple environments especially if they are immobilized. This makes the microorganisms' enzymes even more resistant to harsh environments and enables the enzymes to be recovered and recycled after they are no longer needed (Gianfreda and Rao 2004). Ramesh and Singh (1993) reported that the immobilized bacteria having more efficiency to remove the suspended particles than free cells. Using the immobilized cell is preferable due to its capability for using several times with the same efficiency, which makes it more economical. Similar work was done by Sikander et al. (2007) showing the higher reduction with permeabilized cells of Ochrobactrum intermedium strain SDCr-5. 
BAJOPAS Volume 13 Number 2, December, 2020

The results revealed the isolation and identification of isolates with the potential for the reduction of $\mathrm{Cr}$ (VI) to $\mathrm{Cr}$ (III). Results indicated that immobilized $B$. cereus could be efficiently used for the reduction of $\mathrm{Cr}$ (VI).

Table 5: Percentage reduction of the tested Parameters from the tannery industrial samples of the Immobilized Bacteria.

\begin{tabular}{lllllll}
\hline \multirow{2}{*}{ Industries } & & \multicolumn{5}{c}{ Percentage Reduction $(\%)$} \\
\cline { 3 - 7 } & & $5 \mathrm{~g}$ & $10 \mathrm{~g}$ & $15 \mathrm{~g}$ & $20 \mathrm{~g}$ & $25 \mathrm{~g}$ \\
\hline TAN1 & COD & 28 & 14 & 64 & 87 & 89 \\
& BOD & 50 & 54 & 59 & 67 & 80 \\
& SS & 35 & -26 & -27 & -32 & -63 \\
& TDS & 99 & 99 & 99 & 98 & 98 \\
TAN2 & COD & 15 & 20 & 25 & 32 & 38 \\
& BOD & 91 & 91 & 92 & 90 & 92 \\
& SS & -28 & -52 & -52 & -54 & -55 \\
& TDS & 97 & 99 & 99 & 99 & 99 \\
& COD & 33 & 44 & 22 & 11 & 26 \\
& BOD & 75 & 81 & 76 & 81 & 81 \\
& SS & 25 & 3 & -1 & -10 & -15 \\
& TDS & 98 & 98 & 98 & 98 & 98 \\
\hline
\end{tabular}

Percentage Reduction $=(B-A) / B \times 100 \%$

$A=$ Concentration of the parameter after treatment

$\mathrm{B}=$ Concentration of the parameter before treatment

$+=$ percentage decrease

- = percentage increase

In general, immobilization makes the enzyme more resistant to temperature, $\mathrm{pH}$, and substrate concentration swings giving it a longer lifetime and higher productivity per active unit (Gianfreda and Rao, 2004; FuIlbrook, 1996; Russell et al, 2003; Kandelbauer et al., 2004). Immobilized cells have been used and studied extensively for the production of useful chemicals (Ohtake and Silver, 1994), the treatment of wastewaters (Chen et al., 2003; Wang et al., 2010). Although many workers described microbial degradation of tannery effluent, limited literature is available on the bioremediation of tannery effluent using immobilized bacterial cells in the Kano Industrial Estates.

\section{CONCLUSION}

The samples contained variable levels of the physicochemical parameters. The results of the Analysis of variance revealed that, no statistical difference $(p<0.05)$ was observed for the temperature, $\mathrm{pH}, \mathrm{SS}, \mathrm{TDS}, \mathrm{BOD}$ and $\mathrm{COD}$ among the three tannery industries before the treatment. The levels of some of the parameters
(SS, TDS and COD) observed in the samples were found above the recommended limits of WHO and NESREA, which called for the treatment of the effluents before discharge into the environment. Base on the morphological and biochemical test results, TAN1, TAN2, and TAN3 bacterial isolates were identified to be Neisseria spp, Bacillus cereus, and Staphylococcus aureus respectively. The results of Post-treatment analysis showed that there is overall decrease in the levels of the parameters determined when compared with that of the pre-treatment. The overall percentage reduction of the immobilised bacteria in the treatment of the respective effluents was in the order TAN2 (72\%)>TAN1 $(70 \%)>$ TAN3 $(62 \%)$. Hence, the immobilized bacteria are having higher biodegradation potential for the treatment of the tannery effluents.

\section{Acknowledgments}

The authors wish to acknowledge the University of Maiduguri for the financial support. The authors are grateful to the Kano State Ministry of Environment for their support in obtaining the effluent samples. 


\section{REFERENCES}

Ajao, A. T., Adebayo, G. B., and Yakubu, S. E. (2011). Bioremediation of textile industrial effluent using mixed culture of Pseudomonas aeruginosa and Bacillus subtilis immobilized on agar-agar in a bioreactor. J. Microbiol. Biotech. Res, 1(3), 50-56.

Akan, J. C., Moses, E. A., Ogugbuaja, V. O., and Abah, J. (2007). Assessment of tannery industrial effluents from Kano metropolis, Kano State, Nigeria. Journal of Applied Sciences, 7(19), 2788-2793.

Akan, J. C., Ogugbuaja, V. O., Abdulrahman, F. I., and Ayodele, J. T. (2009). Pollutant levels in effluent samples from tanneries and textiles of Kano industrial areas, Nigeria. Global journal of pure and applied sciences, 15(3-4).

APHA (1989). Standard methods for Examination of Will bete and Will betewater.15 $5^{\text {th }}$ edition. Brydpass Springfield Will behington DC. pp. 164-176

APHA (1992). Standard Methods for the Examination of Water and Wastewater. Health, 69, 1116-9.

Baba, A., Garba, S. T., and Bello, H. S. (2020). Bioremediation Potential of Immobilized corynebacterium kutsceri in the Treatment of Tannery Industrial Effluent from Challawa Industrial Estate, Kano State, Nigeria. Journal of the Turkish Chemical Society Section A: Chemistry, $7(2), 335-350$.

Beem, E. I. V. (1994). reduction of solvent VOC emission. J. Oil Col. Chem. Ass, 77, 158.

Bouwer, E. J., and Zehnder, A. J. (1993). Bioremediation of organic compoundsputting microbial metabolism to work. Trends in biotechnology, 11(8), 360367.

Chen, K. C., Wu, J. Y., Liou, D. J., and Hwang, S. C. J. (2003). Decolorization of the textile dyes by newly isolated bacterial strains. Journal of Biotechnology, 101(1), 57-68.

Dan'Azumi, S., and Bichi, M. H. (2010). INDUSTRIAL POLLUTION AND HEAVY METALS PROFILE OF CHALLAWA RIVER IN KANO, NIGERIA. Journal of Applied Sciences in Environmental Sanitation, $5(1)$.

DWAF. (1992). Analytical Methods Manual, TR 151. Department of Water Affairs and Forestry, Pretoria.

El-Bestawy, E. (2013). Biological treatment of leather-tanning industrial wastewater using free living bacteria.
Elsheikh, M. A. S. (2009). Tannery wastewater pre-treatment. Water Science and Technology, 60(2), 433-440.

FuIlbrook, P. D. (1996). "Kinetics." Industrial enzymology: The application of enzymes in Industry. 2nd Ed. T. Godfrey and J Reichelt. eds.. Nature. New York.

Gianfreda, L., and Rao, M. A. (2004). Potential of extra cellular enzymes in remediation of polluted soils: a review. Enzyme and microbial technology, 35(4), 339354.

Hugo Springer. (1994). John Arthur Wilson Memorial Lecture "Treatment of Industrial Wastes of the Leather Industry - is it still a Major Problem". JALCA, 89, 153-185

Jimoh, A. A., Ganiyu, B. A., Baba, D., and Baba, A. (2018) Bioremediation Process of Effluent from Detergent and Food Industries in Jos, Nigeria: Kinetics and Thermodynamics. International Journal of Engineering Science Invention (IJESI), 762-73

Kandelbauer, A., Maute, O., Kessler, R. W., Erlacher, A., and Gübitz, G. M. (2004). Study of dye decolorization in an immobilized laccase enzyme-reactor using online spectroscopy. Biotechnology and bioengineering, 87(4), 552-563.

Kongjao, S., Damronglerd, S., and Hunsom, M. (2008). Simultaneous removal of organic and inorganic Pollutants in tannery wastewater using electrocoagulation technique. Korean Journal of chemical engineering, 25(4), 703.

Maheshwari, U. M., Aruna, S., Gomathi, M., and AbdulJaffar, A. H. (2017). Bioremediation by Free and Immobilized Bacteria Isolated from Tannery Effluent. International Journal of Research in Applied, Natural and Social Sciences. 5(7), 75-90

Margesin, R., and Schinner, F. (2001). Bioremediation (natural attenuation and biostimulation) of diesel-oilcontaminated soil in an alpine glacier skiing area. Applied and environmental microbiology, 677), 3127-3133.

Mohammed, A., Sekar, P., and George, J. (2011). Efficacy of microbes in bioremediation of tannery effluent. Inter. J. Curr. Res, 3(4), 324-326.

Mohammed, S. S. D., Orukotan, A. A., and Abdullahi, H. (2017). Physicochemical and Bacteriological Assessment of Tannery Effluent from Samaru-Zaria, 
BAJOPAS Volume 13 Number 2, December, 2020 Kaduna State, Nigeria. Journal of Applied

Sciences and Environmental Management, 21(4), 734-740.

Munz, G., De Angelis, D., Gori, R., Mori, G., Casarci, M., and Lubello, C. (2009). The role of tannins in conventional and membrane treatment of tannery wastewater. Journal of hazardous materials, 164(2-3), 733-739

Mythili, K., and Karthikeyan, B. (2011). Bioremediation of $\mathrm{Cr}$ (VI) from tannery effluent using Bacillus spp and Staphylococcus spp. International Multidisciplinary Research Journal, 1(6).

NESREA (2009). National Environmental Standards for Effluent Limitations and Regulation. 1233-1236

Noorjahan, C. M. (2014). Physicochemical characteristics, identification of bacteria and biodegradation of industrial effluent. Journal of bioremediation and Biodegradation, 5(3).

Ohtake, H. I., and Silver, A. O. (1994). Bacterial reduction of toxic chromate. Biological degradation and bioremediation of toxic chemicals, 403-415.

Omoleke, I. I. (2004). Management of environmental pollution in Ibadan, an African city: the challenges of health hazard facing government and the people. Journal of Human Ecology, 15(4), 265-275.

Rajor, A., Reddy, A.S., and Singh, B. (2004). Determination of BOD kinetic Parameters and evaluation of alternate methods, M.Sc. Thesis, Department of biotechnology \& environmental Science, Thapar Institute of Engineering and Technology, Patiala

Ramasami, T., Rajamani, S., and Rao, J. R. (1994, March). Pollution control in leather industry: Emerging technological options. In International symposium on surface and colloidal science and its relevance to soil pollution, madras.

Ramesh, J. V. S., and Singh, S. P. (1993). Yearly variation in certain physicochemical parameters of pond at eastern Doon Valley. Uttar Pradesh J. Zoo, 12 (1), 7577.

Ranen, S., and Sharadinadra, C. (2009). Biotechnology applications to environmental remediation in resource exploitation. Current science, 97, 6-25
Russell, A. J., Berberich, J. A., Drevon, G. F., and Koepsel, R. R. (2003). Biomaterials for mediation of

chemical and biological warfare agents. Annual review of biomedical engineering, 5(1), 1-27.

Saravanan, P., and Saravanan, A. (1999). Decolourization of tannery effluent by Flavobacterium sp. EK 1. Indian Journal of Environmental Protection, 19, 19-24.

Sikander, S., and Shahida, H. (2007). Reduction of toxic hexavalent chromium by Ochrobactrum intermedium strain SDCr5 stimulated by heavy metals. Bioresource Technol, 98, 340-344.

Singh, N., Sharma, B. K., and Bohra, P. C. (2000). Impact assessment of industrial effluent of arid soils by using satellite imageries. Journal of the Indian Society of Remote Sensing, 28(2-3), 79.

Sreemoyee, C., and Priti, P. (2013). Assessment of physico-chemical parameters of dairy waste water and isolation and characterization of bacterial strains in terms of cod reduction. Int J Sci, 2(3), 395-400.

Verheijen, L. A. H. M., Wiersema, D., Pol, L. H., and De Wit, J. (1996). Management of wastes from animal product processing. Livestock and environment, Finding a balance. International Agriculture Center, Wageningen, The Netherlands.

Wang, F., Yao, J., Si, Y., Chen, H., Russel, M., Chen, K., and Bramanti, E. (2010). Short-time effect of heavy metals upon microbial community activity. Journal of Hazardous Materials, 173(13), 510-516.

WHO (World Health Organization). (2006). Air quality guidelines: global update 2005: particulate matter, ozone, nitrogen dioxide, and sulfur dioxide. World Health Organization.

World Bank. (1995). Nigeria's strategic options for redressing industrial pollution. World Bank, industry and energy division. 1st edition, West Central Africa Department; Annexes: 1995; pp 60-62.

Zahoor, A., and Abdul, R. (2009). Enumeration of Coliforms. Journal of Environmental Sciences. 21, 814-820 


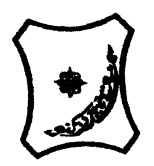

Bayero Journal of Pure and Applied Sciences, 13(2): 1 - 12

Received: November, 2020

Accepted: December, 2020

ISSN $2006-6996$

\title{
BIODEGRADATION POTENTIAL OF IMMOBILIZED BACTERIA IN THE TREATMENT OF TANNERY INDUSTRIAL EFFLUENTS FROM INDUSTRIAL ESTATES IN KANO STATE, NIGERIA
}

\author{
Abdullateef, B., ${ }^{1 *}$ Shuaibu, T. G., ${ }^{1}$ Babagana, K., ${ }^{1}$ Suleman, H. B. ${ }^{2}$ and Dauda, B. ${ }^{3}$ \\ ${ }^{1}$ Department of Pure and Applied Chemistry, Faculty of Science, University of Maiduguri, Borno State, \\ Nigeria \\ ${ }^{2}$ Department of Microbiology, Faculty of Science, University of Maiduguri, Borno State, Nigeria \\ ${ }^{3}$ Department of Chemical Engineering, Faculty of Engineering, University of Maiduguri, Borno State, \\ Nigeria \\ *Corresponding author: babslega@gmail.com; abelega2007@yahoo.com; +2348061309753
}

\section{ABSTRACT}

Industrial Effluents Samples from Gashash Tanneries (TAN1) in Bompai Industrial estate, Larabee Tannery Industry (TAN2) in Sharada Industrial estate and Z Tannery Industries (TAN3) in Challawa Industrial estate, Kano State, Nigeria were collected over a period of six months (August 2017 to January 2018) for assessing the biodegradation potentials of bacteria in the treatment of organic pollutants within the effluents. Bacteria were isolated from the effluents and immobilized on agar-agar. Different masses (5 g, $10 \mathrm{gr}, 15$ $\mathrm{g}, 20 \mathrm{~g}$, and $25 \mathrm{~g}$ ) of the bacteria were used in the treatment of $250 \mathrm{ml}$ of the effluents for ten days in a shaker incubator (Gallenkamp-OC-4364-L) at the temperature $30{ }^{\circ} \mathrm{C}$ and speed of $60 \mathrm{rpm}$. Pre-treatment analysis of the effluents for Temperature, pH, Biochemical Oxygen Demand (BOD), Chemical Oxygen Demand (COD), Suspended Solid (SS) and Total Dissolved Solids (TDS) gives the following results; temperature $\left({ }^{\circ} \mathrm{C}\right.$ )

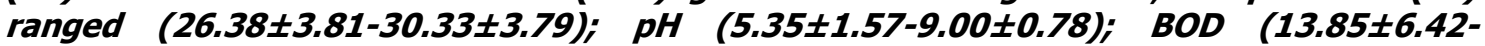
$38.75 \pm 16.20) ;$ COD (1406 $\pm 208-3532 \pm 1373) ;$ SS (208 $\pm 235-780 \pm 739)$ and TDS (266 $\pm 253-5276 \pm 2971)$. No statistical differences ( $p \leq 0.05)$ was observed for all the results among the different industries. The bacterial isolates were identified as Neisseria spp, Bacillus cereus, and Staphylococcus aureus, in TAN1, TAN2, and TAN3, respectively. After treatment of the effluent with the different masses of the isolated bacteria, the mean level of BOD was found to range as (0.55 $\pm 0.36-6.92 \pm 5.49) ; C O D$ (ND-3134 \pm 1595$)$;

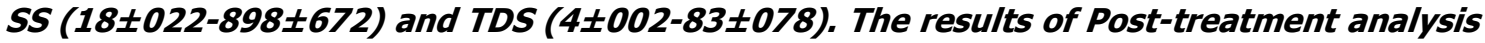
showed that there is overall decrease in the levels of the parameters determined when compared with that of the pre-treatment. The overall percentage reduction of the immobilised bacteria in the treatment of the respective effluents was in the order TAN2 (72\%)>TAN1 (70\%)>TAN3 (62\%). Hence, the immobilized bacteria are having higher biodegradation potential for the treatment of the tannery effluents.

Keywords: Biodegradation, bacteria, effluent, immobilization, tannery.

\section{INTRODUCTION}

Tannery industrial wastewater is a serious consequence of the pollution point of view for streams, freshwater, and land used for agriculture. The lack of awareness in the modern industrial practice has resulted in the discharge of tannery effluents which exhibit very high value of chromium ( $\mathrm{Cr}$ ), Sulfide, and chloride, Total Dissolved Solid (TDS), Total Suspended Solid (TSS), Biochemical Oxygen Demand (BOD) and Chemical Oxygen Demand (COD) in the water stream or land (Mohammed et al., 2001). Tanning is the process, which One ton of skin generally leads to the production of 20 to $80 \mathrm{~m}^{3}$ of turbid and foul-smelling converts the protein of the rawhide or skin into a stable material, which will not putrefy and is suitable for a wide variety of end applications (Elsheikh, 2009). The highly polluting chromium is the most commonly used tanning material producing leather that is more flexible and pliable than vegetable-tanned leather and does not discolor or lose shape in water as drastically as vegetable-tan (Elsheikh, 2009). Tannery effluent is among the most hazardous industrial pollutants due to its huge organic and inorganic load, which is highly toxic to human life and the environment (Kongjao et al., 2008). wastewater including chromium (100-400 mg/l), sulfide $(200-800 \mathrm{mg} / \mathrm{l})$, high levels of fat and 
BAJOPAS Volume 13 Number 2, December, 2020 other solid wastes, and notable pathogen contamination as well as pesticides added for skin conservation during transport (Elsheikh, 2009). There are more than 6000 tanneries in Nigeria with an annual processing capacity of 700,000 tons of hides and skins (Omoleke, 2004; Singh et al., 2008). It was reported that the total amount of waste produced per animal slaughtered is approximately $35 \%$ of its weight (World Bank, 1995). Also, for every $1000 \mathrm{~kg}$ of carcass weight, a slaughtered beef produces 5.5 $\mathrm{kg}$ of manure (excluding rumen contents or stockyard manure) and $100 \mathrm{~kg}$ of paunch manure (undigested food) (Verheijen et al., 1996). Tanneries generate wastewater in the range of 30-35 $\mathrm{L} \mathrm{kg}^{-1}$ skin/hide processed with variable $\mathrm{pH}$, Biological Oxygen Demand (BOD), Chemical Oxygen Demand (COD), high concentrations of suspended solids (SS), and tannins as well as chromium (Zahoor and Abdul, 2009).

Being heterogeneous and composed of a wide variety of compounds, it is very difficult to select a unique direct method for estimating the biodegradability of organic contents and biokinetic parameters for a wastewater sample (Rajor, 2004). For this purpose, some indirect estimation such as determination of biochemical oxygen demand (BOD) and chemical oxygen demand (COD) are applied as common laboratory investigations [9]. During retanning procedures, synthetic tannins (Syntan), oils and resins are added to form softer leather at varying doses (Munz et al., 2009). One of the refractory groups of chemicals in tannery effluents derives mainly from tannins (Ramasami et al., 2004). Syntans are characterized by complex chemical structures, because they are composed of an extended set of chemicals such as phenol-, naphthalene-, formaldehyde- and melamine-based syntans, and acrylic resins (Beem, 1994). Organic pollutants (proteic and lipidic components) are originated from skins (it is calculated that the raw skin has $30 \%$ loss of organic material during the working cycle) or they are introduced during processes (Hugo Springer, 1994).

Many conventional processes such as oxidation, chemical and biological processes were carried out to treat tanneries wastewater (Ebtesam et al, 2013). Biological processes have received more attention because of their costeffectiveness, lower sludge production and environmental friendliness (Noorjahan, 2014). Naturally occurring micro-organisms degrade the hazardous organic wastes including xenobiotic compounds, such as pesticides, polycyclic aromatic hydrocarbons (PAHs) and polychlorinated biphenyls (PCBs) in due course of time (Ranen and Sharadinadra, 2009). Bioremediation is based on the idea that all organisms remove substances from the environment to carry outgrowth and metabolism (Bouwer and Zehnder, 1993). Bacteria, protista and fungi are found to be very good at degrading complex molecules and incorporating the breakdown products into their metabolism (Bouwer and Zehnder, 1993). The resultant metabolic wastes that they produce are generally safe and somehow recycled into other organisms (Ranen and Sharadinadra, 2009). An acclimatized indigenous population of microorganisms capable of degradation of the compounds of interest must exist at the site for a successful bioremediation mode (Ranen and Sharadinadra, 2009). It has been observed that for a successful bioremediation mode, an acclimatized indigenous population of microorganisms capable of degradation of the compounds of interest must exist at the site under investigation (Ranen and Sharadinadra, 2009). Even though there are numerous physical and chemical methods employed in the disposal of wastes the advantage in using bacterium is that they play a key role in the reduction of COD, BOD, total protein, total tannin and total phenol (Saravanan and Saravanan, 1998)

Baba et al. (2020) studied the bioremediation potential of immobilized corynebacterium kutsceri in the Treatment of tannery industrial effluent from Challawa Industrial Estate, Kano State, Nigeria. The aim of the work is to study the reduction in the level of the contaminants through the process of bioremediation using the isolated bacteria. Immobilized bacteria can withstand various temperatures, $\mathrm{pH}$ and substrate concentrations; consequently, increasing the efficiency and the lifespan of the bacteria. Immobilized bacteria are widely applied in the treatment of wastewater and can be separated and recovered after the treatment with the same efficiency (Baba et al., 2020).

\section{MATERIALS AND METHODS \\ Study Area}

This study was carried out in Bompai, Sharada and Challawa industrial estates in Kano, Figure 1. Kano lies on Latitude $11^{\circ} 30^{\prime} \mathrm{N}$ and $8^{\circ} 30^{\prime} \mathrm{E}$ and Longitude $11^{\circ} 5^{\prime} \mathrm{N}$ and $8^{\circ} 5^{\prime} \mathrm{E}$ in Northern Nigeria. It is one of the developed industrial cities in Nigeria. Tannery activities are the dominating industries and this could be one of the reasons for her high population density (Dan'Azumi and Bichi, 2010). Many researchers have studied biodegradation of tannery effluent using microorganisms. However, limited literature is available on the biodegradation of tannery effluent in Kano industrial estates using 
BAJOPAS Volume 13 Number 2, December, 2020 immobilized bacterial cells. This research work focuses on the potential of the use of the indigenous immobilized bacterial isolates in the treatment of tannery effluents in the industrial estates.

\section{Sample Collection}

Effluents were collected from the Tannery Industries from Bompai, Challawa and Sharada Industrial Estates, Kano, Nigeria. The effluents were collected over a period of six months (August 2017 to January 2018). Samples collected in a sterile 4-liter plastic container with a unique identification number were preserved using an ice-box that was transported to the Microbiology Laboratory, Department of Microbiology, Bayero University of Kano for analysis

\section{Sample Preparation and Sample Analysis}

Immediately after the collection of the effluent, $\mathrm{pH}$, TSS, TDS, COD, BOD levels were determined before treatment (Pre-treatment determination) and ten days after treatment (Post-treatment determination) as described in
APHA (1989) standard methods. $\mathrm{pH}$ was determined using Ecotests $\mathrm{pH}$ meter and TDS was determined using AQUALYTIC TDS Salinometer. BOD was determined as described by the standard method (APHA, 1992). COD and SS were determined using DR/2010 HACH portable data logging spectrophotometer (DWAF, 1992)

\section{Identification and Biochemical} Characterization of the Bacterial Isolates

The bacteria were isolated from the effluents using Serial Dilution according to the method described by APHA (1989). The biochemical tests such as oxidase, catalase, coagulase, indole (from $1 \%$ tryptone broth), citrate (Simmons citrate agar), methyl red/VogesProskauer (MR/VP), nitrate reduction, Starch Hydrolysis, Glucose, Maltose, and Lactose tests were carried out on the bacterial isolates to identify the bacteria through the bacteria biochemical characteristics according to Ajao et al. (2011).

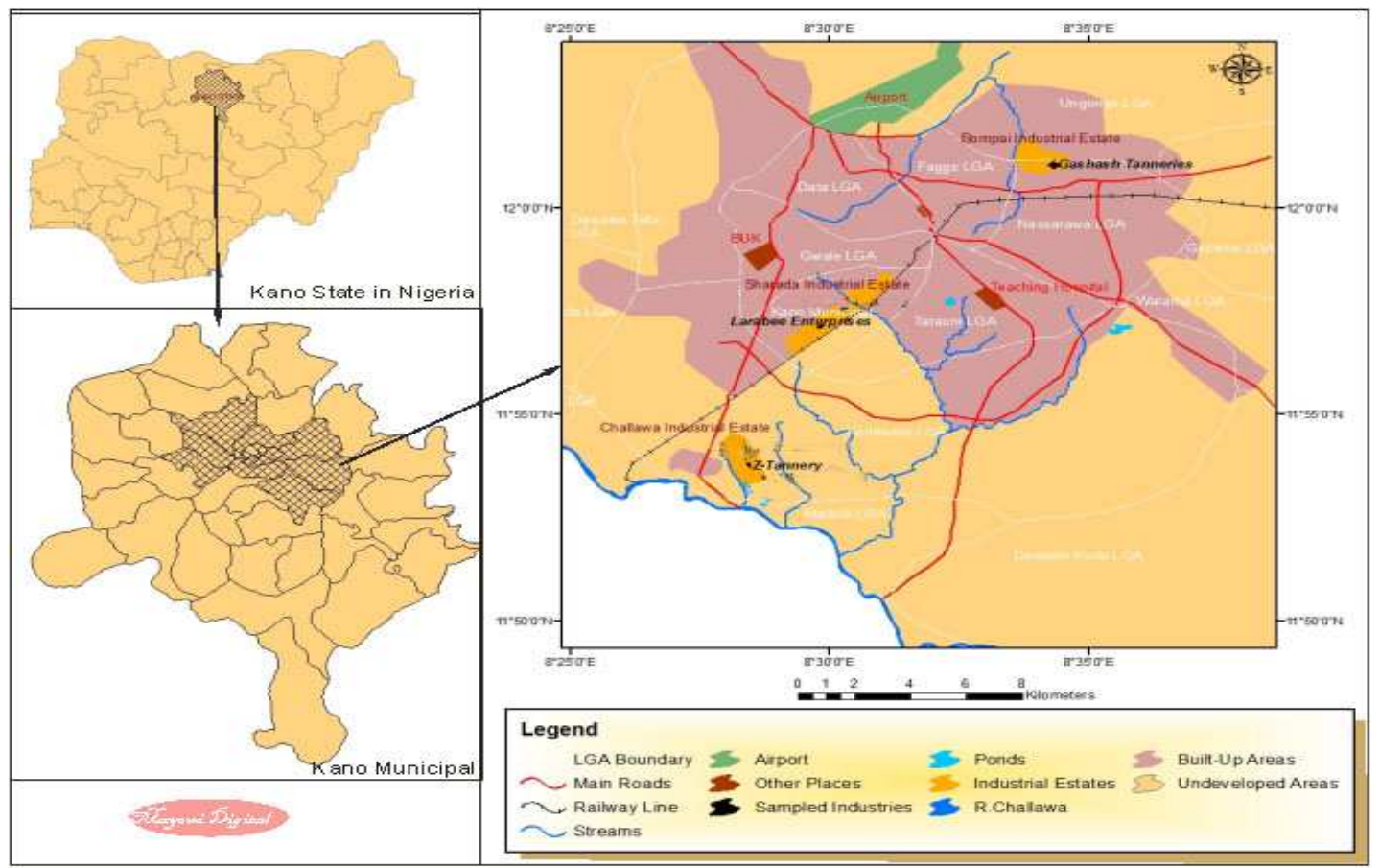

Fig. 1 Map showing the study areas

Source: Mayomi Digital Productions, GIS Laboratory, Department of Geography, UNIMAID (2017)

\section{Determination of Growth Rate of the Bacteria in Effluent Sample}

The bacteria growth rates were determined by transferring $2 \mathrm{~mL}$ of the bacterial isolates from the tannery effluent in broth medium into 100 $\mathrm{mL}$ sterile effluents in conical flasks and kept in an incubator (Giffrin cool) for 10 days. Control was also set up by incubating another $100 \mathrm{~mL}$ each of the sterile effluents without the bacteria. The optical density of the content was determined at the wavelength of $600 \mathrm{~nm}$ on a daily interval and recorded. 
BAJOPAS Volume 13 Number 2, December, 2020 Immobilization of Bacteria

Agar solution and inoculi were prepared separately. Fifty milliliters $(50 \mathrm{~mL})$ of nutrient broth each of the inoculi was prepared in a McCartney bottle and incubated for 24 hours. A solution of agar-agar was prepared by dissolving $10 \mathrm{~g}$ of the powder in distilled water and made up to $500 \mathrm{~mL}$ mark in an Erlenmeyer flask and was sterilized in an autoclave (280A) for 15 minutes and allowed to cool to $40-45^{\circ} \mathrm{C}$ (Ajao et al., 2011). Four milliliters ( $4 \mathrm{~mL})$ of the bacterial isolates in the nutrient broth was mixed with 36 $\mathrm{ml}$ of the prepared agar-agar media in petri-dish plates and then allowed to solidify. This was kept in the refrigerator for bioremediation.

\section{Bioremediation (Treatment) of the Effluents}

The solidified agar block (immobilized bacteria) was cut into cubes using a sterile knife; $0.1 \mathrm{~mL}$ phosphate buffer ( $\mathrm{pH} \mathrm{7.0)}$ was added and kept in the refrigerator for 1 hour for curing. The phosphate buffer was decanted after 1 hour and the cubes were washed with sterile distilled water 3-4 times before it was used (Ajao et al., 2011). Two liters (2 L) of the effluent was supplemented with the minimum basal medium in $\mathrm{g} / \mathrm{L}: \mathrm{NaCl}(0.8), \mathrm{MgSO}_{4} .7 \mathrm{H}_{2} \mathrm{O}(0.001), \mathrm{KH}_{2} \mathrm{PO}_{4}$ (2), $\mathrm{NaNO}_{3}$ (2), $\quad \mathrm{CaCl}_{2} .2 \mathrm{H}_{2} \mathrm{O} \quad(0.5)$ and $\mathrm{NaHPO}_{4} .12 \mathrm{H}_{2} \mathrm{O}(2)$ and sterilized in an autoclave at $121^{\circ} \mathrm{C}$ for 15 minutes (Margesin and Schinner, 2001). Two hundred and fifty milliliters $(250 \mathrm{~mL})$ of the effluents were transferred into different $250 \mathrm{ml}$ conical flasks. The content was covered with a cotton-wool ramped with foil paper to avoid contamination. Five grams $(5 \mathrm{~g})$ of the immobilized bacteria were quickly transferred into each of the effluents in the conical flasks in an inoculating chamber. The same procedures were carried out for the $10 \mathrm{~g}, 15 \mathrm{~g}, 20 \mathrm{~g}$ and 25 $\mathrm{g}$ of the immobilized bacteria in separate $250 \mathrm{~mL}$ effluents in conical flasks and agitated for ten days in a shaker incubator (Gallenkamp-OC4364-L) at a temperature $30^{\circ} \mathrm{C}$ and speed of 60 rpm. The treated effluent samples were taken on the tenth day and analyzed for the parameters $\mathrm{pH}$, SS, TDS, COD, and BOD, (Posttreatment determination) for the different grams of bacteria to evaluate and compare the biodegradation potential. (Baba et al., 2020).

\section{Statistical Analysis}

The data were represented as Mean \pm Standard deviation and analyzed statistically using oneway Analysis of Variance (ANOVA) and Tukey's HSD as Post Hoc Tests with the aid of SPSS 16.0. The correlation coefficient was also used to measure the strength of the relationship between the different masses of the bacteria and the parameters. All $\mathrm{p} \leq 0.05$ were considered as statistically significant.

\section{RESULTS AND DISCUSSION Physico-chemical parameters in the Industrial Effluents before the Biodegradation.}

Results of the Physico-chemical parameters in the industrial effluents before the Biodegradation is shown in table 1 . The mean temperatures $\left({ }^{\circ} \mathrm{C}\right)$ observed in TAN1, TAN2, and TAN3 samples were $28.07 \pm 0.65 ; 27.77 \pm 0.64$ and $26.38 \pm 3.81$ respectively. The order of the mean temperature of the samples from the three industries can be arranged as TAN1 > TAN2>TAN3. The temperature observed at TAN1, TAN2, and TAN3 samples were found below the WHO $\left(35^{\circ} \mathrm{C}\right)$ and NESREA $\left(40^{\circ} \mathrm{C}\right)$ limits. The low values of temperature might be due to the processes used at the time of sampling. High temperature brings down the solubility of gases in water that ultimately expresses as high BOD and COD. Statistical analysis shows that there is no significant difference $(p<0.05)$ between the mean values of temperature among the industries. This might be due to similar tannery activities involved in the tannery industries at the time of sampling. The average values of temperature observed in this present study are less than those observed by Akan et al. (2007), Akan et al. (2009) and Baba et al. (2020).

The mean level of $\mathrm{pH}$ observed in TAN1, TAN2 and TAN3, samples were $7.77 \pm 2.93$; $8.35 \pm 0.28$ and $7.52 \pm 0.76$ respectively. The order of the mean $\mathrm{pH}$ of the samples from the three industries can be arranged as TAN2> TAN1 $>$ TAN3. The $\mathrm{pH}$ of the samples falls within the WHO (7.0-8.5) and NESREA (6-9) standard limits. Statistical analysis shows that there is no significant difference $(p<0.05)$ between the mean values of $\mathrm{pH}$ among the industries. This might be due to similar tannery activities involved in the tannery industries at the time of sampling. Maheshwari et al. (2017) reported that the level of $\mathrm{pH}$ in the effluents from the tannery industry in Vaniyambadi, India was 6.5 which was lower than that observed in the present study. The $\mathrm{pH}$ in the effluents from the tannery industries in Kano and Kaduna were reported to be 7.64 and 6.89, respectively (Akan et al., 2007; Mohammed et al., 2017). The average values of $\mathrm{pH}$ observed in this present study are less than those observed by Mohammed et al. (2017) and Baba et al. (2020). The mean level of SS $(\mathrm{mg} / \mathrm{l})$ observed in TAN1, TAN2, and TAN3 samples were 374 \pm 124 ; $358 \pm 335$ and $780 \pm 739$ respectively. The order of the mean SS in the samples from the three industries can be arranged as TAN3 > TAN1 $>$ TAN2. 
The SS observed in the samples were far above the recommended standard limits of regulating bodies WHO $(30 \mathrm{mg} / \mathrm{l})$ and NESREA $(10 \mathrm{mg} / \mathrm{l})$. Statistical analysis shows that there is no significant difference $(p<0.05)$ between the mean values of SS among the industries. This might be due to similar tannery activities involved in the tannery industries at the time of sampling. The average values of SS observed in this present study are less than that observed $(3700 \pm 122 \mathrm{mg} / \mathrm{l})$ by Akan et al. (2009) for tanneries in Kano. Also, the average values of SS observed in this present study are less than that observed by Mohammed et al. (2017) and Baba et al. (2020) with the exception in TAN3.

The mean level of TDS (mg/l) observed in TAN1, TAN2, and TAN3 samples were $3941 \pm 3703$; $3300 \pm 1714$ and $2653 \pm 1240$ respectively. The order of the mean TDS in the samples from the three industries can be arranged as TAN1>TAN2>TAN3. The TDS observed in the samples were far above the recommended standard limits of WHO $(250 \mathrm{mg} / \mathrm{l})$ and NESREA $(500 \mathrm{mg} / \mathrm{l})$. Statistical analysis shows that there is no significant difference $(p<0.05)$ between the mean values of TDS among the industries. This might be due to similar tannery activities involved in the tannery industries at the time of sampling. TDS in the effluents from the tannery industries in Kano, Nigeria was reported to be $1281 \mathrm{mg} / \mathrm{l}$ (Akan et al., 2007). The average values of SS observed in this present study are less than those observed by Mohammed et al. (2017) and Baba et al. 2020)

The mean level of COD (mg/l) observed in TAN1, TAN2 and TAN3 samples seasons were $2372 \pm 938 ; \quad 1406 \pm 208$ and $3532 \pm 1373$ respectively. The order of the mean COD of the samples from the three industries can be arranged as TAN3>TAN1> TAN2. The COD observed in TAN1, TAN2 and TAN3 samples were far above the recommended standard limits of regulating bodies $\mathrm{WHO}(40 \mathrm{mg} / \mathrm{l})$ and NESREA (40 mg/l). Statistical analysis shows that there is no significant difference $(p<0.05)$ in COD among the industries. This might be due to similar tannery activities involved in the tannery industries as at the time of sampling. The Chemical Oxygen demand (COD) is the amount of oxygen, in $\mathrm{mg} / \mathrm{L}$, required for the degradation of the compound of wastewater to occur. In comparison, the average values of COD observed in this present study were higher than that observed by Mohammed et al. (2017) but lower than that observed by Baba et al. (2020).

The mean levels of BOD $(\mathrm{mg} / \mathrm{l})$ observed in TAN1, TAN2 and TAN3 samples were $13.85 \pm 6.42 ; \quad 19.46 \pm 0.50$ and $17.13 \pm 3.14$ respectively. The order of the mean BOD in the samples from the three industries can be arranged as TAN2>TAN3>TAN1. The BOD observed in TAN1, TAN2 and TAN3 samples were found below the recommended limits of NESREA (200 mg/l) but above WHO (10 mg/l). Statistical analysis shows that there is no significant difference $(p<0.05)$ between the mean values of BOD among the industries. This might be due to similar tannery activities involved in the tannery industries at the time of sampling. The low level of BOD recorded in this study is an indication of the low level of biodegradable organic solids in the effluent. The average values of BOD observed in this present study were lower than those observed by Mohammed et al. (2017) and Baba et al. (2020).

Table 1: Mean Values \pm S.D of Physico-chemical parameters of effluents from the Tannery Industries before Treatment.

\begin{tabular}{llllllll}
\hline Parameter & Tannery 1 & Tannery 2 & Tannery 3 & $\mathrm{a}$ & $\mathrm{b}$ & $\mathrm{c}$ & $\mathrm{d}$ \\
\cline { 2 - 7 } Temperature $\left({ }^{\circ} \mathrm{C}\right)$ & $28.07 \mathrm{a} \pm 0.65$ & $27.77 \mathrm{a} \pm 0.64$ & $26.38 \mathrm{a} \pm 3.81$ & & $29.50 \pm 4.68$ & 35 & 40 \\
pH & $7.77 \mathrm{a} \pm 2.93$ & $8.35 \mathrm{a} \pm 0.28$ & $7.52 \mathrm{a} \pm 0.76$ & 6.89 & $5.35 \pm 1.57$ & $7.0-8.5$ & $6.0-9.0$ \\
$\mathrm{COD}(\mathrm{mg} / \mathrm{l})$ & $2372 \mathrm{a} \pm 938$ & $1406 \mathrm{a} \pm 208$ & $3532 \mathrm{a} \pm 1373$ & 2.2 & $3106 \pm 2753$ & 40 & 40 \\
$\mathrm{BOD}(\mathrm{mg} / \mathrm{l})$ & $13.85 \mathrm{a} \pm 6.42$ & $19.46 \mathrm{a} \pm 0.50$ & $17.13 \mathrm{a} \pm 3.14$ & 1032 & $26.17 \pm 9.49$ & 10 & 200 \\
$\mathrm{SS}(\mathrm{mg} / \mathrm{l})$ & $374 \mathrm{a} \pm 124$ & $358 \mathrm{a} \pm 335$ & $780 \mathrm{a} \pm 739$ & 501 & $562 \pm 482$ & 30 & 10 \\
TDS $(\mathrm{mg} / \mathrm{l})$ & $3941 \mathrm{a} \pm 3703$ & $3300 \mathrm{a} \pm 1714$ & $2653 \mathrm{a} \pm 1240$ & 532.7 & $444 \pm 507$ & 250 & 500 \\
\hline
\end{tabular}

The values given in the table above are means of 6 replicate values, $\mathrm{n}=6$ ( 1 sample was taken monthly for 6 months). Within the rows, means with different alphabets are statistically different $(p<0.05)$. WHO: World Health Organisation. NESREA: National Environmental Standard and Regulatory Enforcement Agency. a = Mohammed et al.(2017), b = Baba et al. (2020), c = WHO (2006), $d=$ NESSRA (2009) 
BAJOPAS Volume 13 Number 2, December, 2020

Identification, Biochemical Characterization and growth rates of the Bacterial Isolates

Results of identification and biochemical characterization of the bacterial isolates were shown in table 2. After 24 hours of incubation, the nutrient agar media plates were checked for bacterial growth. The results showed the presence of different strains in the samples. The TAN1 bacteria isolate was found to be gramnegative cocci while TAN3 was gram-positive cocci. TAN2 bacteria isolate was found to be gram-positive, rod-shaped. TAN1, TAN2, and TAN3 bacteria isolates recorded positive results for spore former.

The results of the biochemical tests indicated that all the bacteria were positive for catalase, oxidase, citrate, maltose, glucose, lactose (negative in TAN1), mannitol (negative in TAN2), starch hydrolysis and coagulase (negative in TAN2) tests. The bacteria showed negative results for nitrate reduction, $M R$ (positive in TAN2), VP (positive in TAN1), Indole (positive in TAN2) tests. Base on the morphological and biochemical test results, TAN1, TAN2, and TAN3 bacteria isolates were identified to be Nesseria spp, Bacillus cereus, and Staphylococcus aureus respectively.

The growth rate of the TAN1, TAN2 and TAN3 Isolates were shown in figure 2. Generally, the optical density increase with the increase in time (day) and decrease as time goes on. The highest optical density was shown by bacillus cereus in TAN2 while the lowest was shown by Staphylococcus aureus in TAN3.

The initial growth phase of TAN1 Isolate bacteria occurred within 2-day of incubation as the growth rate increases up to the 6th-day incubation when the maximum growth was observed. Beyond the 6th day, the growth of the bacteria declined (which might be due to a shortage of nutrients in the effluents) until it reached its death phase (which might be due to the unavailability of nutrients in the effluents).

A similar trend of growth was also observed for TAN2 Isolate as the initial growth phase also occurred within 2-day of incubation but maximum growth rate observed on the 4th day of incubation. The stationary stage occurred between the 4th day and the 8th day. Beyond the 8th day, the growth of the bacteria declined (which might be due to a shortage of nutrients in the effluents) until it reached its death phase (which might be due to the unavailability of nutrients in the effluents).

The initial growth phase of TAN3 bacterial Isolate occurred within the 3-day incubation as the growth rate increases up to the 6th-day incubation when the maximum growth was observed. Beyond the 6th day, the growth of the bacteria declined (which might be due to a shortage of nutrients in the effluents) until it reached its death phase (which might be due to the unavailability of nutrients in the effluents).

Table 2: Morphological and Biochemical characteristics of bacterial isolates

\begin{tabular}{lllll} 
Bacterial Isolates & & TAN1 & TAN2 & TAN3 \\
\hline $\begin{array}{lllll}\text { Morphological } \\
\text { characteristics }\end{array}$ & Shape & Cocci & Rod & Cocci \\
& Spore & & & \\
& former & + & + & + \\
Gram & & & \\
Biochemical characteristics & reaction & - & + & + \\
& Citrate & + & + & + \\
& Catalase & + & + & + \\
& Coagulase & + & - & + \\
Starch & + & + & + \\
& Glucose & + & + & + \\
Oxidase & + & + & + \\
& Indo & - & + & - \\
Lactose & - & + & + \\
Manitol & + & - & + \\
Maltose & + & + & + \\
MR & - & + & - \\
VP & + & - & - \\
& Nitrate & - & - & - \\
Reduction & - Neisseria & Bacillus & Staphylococcus \\
& Bacterial & cereus & aureus \\
& name & spp & cas
\end{tabular}

+ = Positive; - = Negative; MR=Methyl Red; VP= Voges-Proskauer 


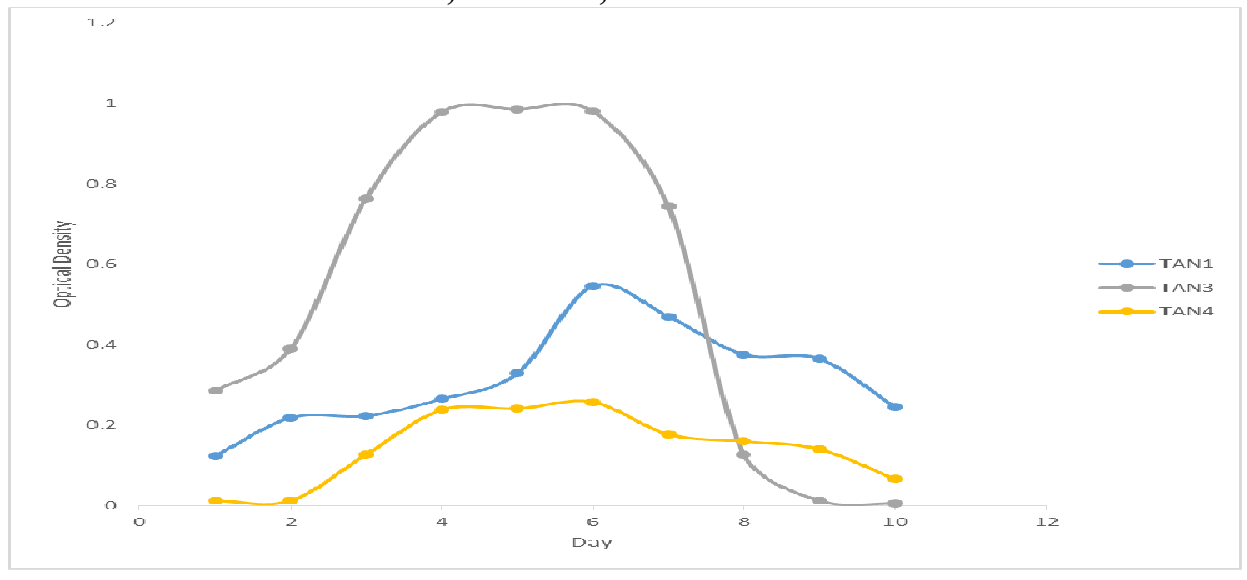

Fig. 2 Growth rates of the isolates in the effluents from the Tannery Industries

\section{Physico-chemical Parameters in the Industrial Effluents after the biodegradation.}

Table 3 shows the mean results of the physicochemical parameter before and after bioremediation using the different masses $(5 \mathrm{~g}$, $10 \mathrm{~g}, 15 \mathrm{~g}, 20 \mathrm{~g}$, and $25 \mathrm{~g}$ ) of the respective immobilized bacteria. Also, Table 4 shows the mean results of correlation coefficient ( $r$ ) between different masses of bacteria and physicochemical parameters.

The mean values $(\mathrm{mg} / \mathrm{l})$ of the SS after the bioremediation varies between $243 \pm 45$ and $898 \pm 672$. The mean concentration $(\mathrm{mg} / \mathrm{l})$ of SS remediated by the different masses $(5 \mathrm{~g}, 10 \mathrm{~g}$, $15 \mathrm{~g}, 20 \mathrm{~g}$, and $25 \mathrm{~g}$ ) of the bacteria varies. The SS in the samples fluctuates up and down after the bioremediation process when compared with the SS of the raw samples before the bioremediation. The increase in the levels of the SS might be due to the aggregation of the TDS which are large enough to result into SS. The increase in the levels of the SS might be also due to the influence of the nutrients which was added into the effluents in order to make the microorganisms more active and viable for fast degradation of organic contaminants in the effluent. The relative potential or efficiency of the different masses of the bacteria in remediating SS in TAN1 samples was in the order $25 \mathrm{~g}>20 \mathrm{~g}>15 \mathrm{~g}>10 \mathrm{~g}>5 \mathrm{~g}$. For TAN2 and TAN3 samples, the order was $25 \mathrm{~g}>20 \mathrm{~g}>15$ $\mathrm{g}>10 \mathrm{~g}>5 \mathrm{~g}$. These might be due to the variations in the surface areas of the different masses of the immobilized bacteria. Statistical analysis shows that there is no significant difference $(p<0.05)$ between the mean values of SS among the masses in the respective industries. Positive and significant correlations exist between the masses of bacteria and Suspended Solid (SS). This showed that there is general increase in the levels of the SS as the masses of the immobilized bacteria increases. TAN3 (90\%) and TAN1 (80\%) showed a very high correlation with the masses of the bacteria while TAN2 (61\%) showed a very low correlation.

The mean values $(\mathrm{mg} / \mathrm{l})$ of the TDS after the bioremediation varies between $46 \pm 11$ and $83 \pm 78$. The mean concentration $(\mathrm{mg} / \mathrm{l})$ of TDS remediated by the different masses $(5 \mathrm{~g}, 10 \mathrm{~g}$, $15 \mathrm{~g}, 20 \mathrm{~g}$, and $25 \mathrm{~g}$ ) of the bacteria varies. There is a reduction in all the TDS of all the samples after the bioremediation process compared with the TDS of the raw samples before the bioremediation. The relative potential or efficiency of the different masses of the bacteria in remediating TDS in TAN1 and TAN3 samples was in the order $5 \mathrm{~g}>10 \mathrm{~g}>15 \mathrm{~g}>20$ $\mathrm{g}>25 \mathrm{~g}$. For TAN2 samples, the order was 20 $g>10 \quad g>25 \quad g>15 \quad g>5 \quad g$. Statistical analysis shows that there is no significant difference $(p<0.05)$ between the mean values of TDS among the masses in the respective industries. These might be due to the variations in the surface areas of the different masses of the immobilized bacteria. Positive and significant correlations exist between the masses of bacteria and TDS with the exception in TAN2 (negative and insignificant correlation). The positive correlations showed that there is general increase in the levels of the TDS as the masses of the immobilized bacteria increases. TAN1 $(96 \%)$ showed a very high correlation with the masses of the bacteria while TAN2 (47\%) showed a very low correlation.

The mean values $(\mathrm{mg} / \mathrm{l})$ of the BOD after the bioremediation varies between $1.56 \pm 0.20 \mathrm{mg} / \mathrm{l}$ and $6.92 \pm 5.49 \mathrm{mg} / \mathrm{l}$. The mean concentration $(\mathrm{mg} / \mathrm{l})$ of BOD remediated by the different masses $(5 \mathrm{~g}, 10 \mathrm{~g}, 15 \mathrm{~g}, 20 \mathrm{~g}$, and $25 \mathrm{~g}$ ) of the bacteria varies. There is a reduction in all the BOD of all the samples after the bioremediation process compared with the $\mathrm{BOD}$ of the raw 
BAJOPAS Volume 13 Number 2, December, 2020 samples before the bioremediation. The relative potential or efficiency of the different masses of the bacteria in remediating BOD in TAN1, TAN2 and TAN3 samples were in the order $25 \mathrm{~g}>20$ $\mathrm{g}>15 \mathrm{~g}>10 \mathrm{~g}>5 \mathrm{~g}, 25 \mathrm{~g}>15 \mathrm{~g}>5 \mathrm{~g}>10 \mathrm{~g}>20 \mathrm{~g}$ and $20 \mathrm{~g}>10 \mathrm{~g}>25 \mathrm{~g}>15 \mathrm{~g}>5 \mathrm{~g}$ respectively. Statistical analysis shows that there is significant difference $(p<0.05)$ between the mean values of BOD among the masses in the respective industries. These might be due to the variations in the surface areas of the different masses of the immobilized bacteria. Negative and significant correlations exist between the masses of bacteria and BOD. This showed that there is general decrease in the levels of the BOD as the masses of the immobilized bacteria increases. TAN1 (94\%) showed a very high correlation with the masses of the bacteria while TAN2 (4\%) showed a very low correlation.

The mean values $(\mathrm{mg} / \mathrm{l})$ of the COD after the bioremediation varies between $250 \pm 154$ and $3134 \pm 1595$. The mean concentration $(\mathrm{mg} / \mathrm{l})$ of COD remediated by the different masses $(5 \mathrm{~g}$, $10 \mathrm{~g}, 15 \mathrm{~g} 20 \mathrm{~g}$, and $25 \mathrm{~g}$ ) of the bacteria varies. There is a reduction in all the COD of all the samples after the bioremediation process compared with the COD of the raw samples before the bioremediation. The relative potential or efficiency of the different masses of the bacteria in remediating COD in TAN1, TAN2 and TAN3 samples were in the order $25 \mathrm{~g}>20 \mathrm{~g}>15$ $\mathrm{g}>5 \mathrm{~g}>10 \mathrm{~g}, 25 \mathrm{~g}>20 \mathrm{~g}>15 \mathrm{~g}>10 \mathrm{~g}>5 \mathrm{~g}$ and 10 g>5 g>25 g>15 g>20 g respectively. Statistical analysis shows that there were significant difference $(p<0.05)$ between the mean values of COD among the masses in the respective industries except for effluents treated with $25 \mathrm{~g}$. These might be due to the variations in the surface areas of the different masses of the immobilized bacteria. Negative and insignificant correlations exist between the masses of bacteria and COD with the exception in TAN3 (positive and significant correlation). The negative correlations showed that there is general decrease in the levels of the COD as the masses of the immobilized bacteria increases. TAN2 (100\%) showed a very high correlation with the masses of the bacteria while TAN3 (36\%) showed a very low correlation.

Generally, there was an overall decrease in the concentration of these physicochemical parameters after the bioremediation using the different masses of the bacterial isolates. These might be due to the variations in the surface areas of the different masses of the immobilized bacteria. This is in line with the work of Jimoh et al. (2018) and Baba et al. (2020).

Table 3: Mean Values $(\mathrm{mg} / \mathrm{l}) \pm$ S.D of Physicochemical parameters in effluents from the Tannery Industries before and after Treatment of the effluents $(250 \mathrm{ml})$ with the different masses $(5 \mathrm{~g}, 10 \mathrm{~g}$, $15 \mathrm{~g}, 20 \mathrm{~g}$, and $25 \mathrm{~g}$ ) of the bacteria.

\begin{tabular}{llllllll}
\hline $\mathrm{P}$ & IND & Before & \multicolumn{5}{c}{ After } \\
\cline { 4 - 7 } & & & $5 \mathrm{~g}$ & $10 \mathrm{~g}$ & $15 \mathrm{~g}$ & $20 \mathrm{~g}$ & $25 \mathrm{~g}$ \\
\hline \multirow{2}{*}{ COD } & TAN1 & $2372 \pm 938$ & $1708 \mathrm{a} \pm 861$ & $2045 \mathrm{a} \pm 1205$ & $845 \mathrm{a} \pm 369$ & $300 \mathrm{a} \pm 167$ & $250 \mathrm{a} \pm 154$ \\
& TAN2 & $1406 \pm 208$ & $1195 \mathrm{a} \pm 208$ & $1125 \mathrm{a} \pm 384$ & $1055 \mathrm{a} \pm 317$ & $956 \mathrm{a} \pm 310$ & $870 \mathrm{ab} \pm 240$ \\
& TAN3 & $3532 \pm 1373$ & $2374 \mathrm{a} \pm 1344$ & $1976 \mathrm{a} \pm 1405$ & $2757 \mathrm{a} \pm 1266$ & $3134 \mathrm{a} \pm 1595$ & $2614 \mathrm{~b} \pm 1105$ \\
BOD & TAN1 & $13.85 \pm 6.42$ & $6.92 \mathrm{a} \pm 5.49$ & $6.42 \mathrm{a} \pm 5.07$ & $5.72 \mathrm{a} \pm 5.35$ & $4.62 \mathrm{a} \pm 4.37$ & $2.82 \mathrm{ab} \pm 1.26$ \\
& TAN2 & $19.46 \pm 0.50$ & $1.75 \mathrm{~b} \pm 0.22$ & $1.73 \mathrm{~b} \pm 0.18$ & $1.58 \mathrm{a} \pm 0.16$ & $1.91 \mathrm{a} \pm 0.22$ & $1.56 \mathrm{~b} \pm 0.20$ \\
& TAN3 & $17.13 \pm 3.14$ & $4.24 \mathrm{ab} \pm 0.77$ & $3.29 \mathrm{ab} \pm 0.37$ & $4.11 \mathrm{a} \pm 0.07$ & $3.23 \mathrm{a} \pm 0.91$ & $3.33 \mathrm{a} \pm 1.28$ \\
SS & TAN1 & $374 \pm 124$ & $243 \mathrm{a} \pm 45$ & $471 \mathrm{a} \pm 226$ & $475 \mathrm{a} \pm 182$ & $492 \mathrm{a} \pm 128$ & $611 \mathrm{a} \pm 217$ \\
& TAN2 & $358 \pm 335$ & $460 \mathrm{a} \pm 400$ & $543 \mathrm{a} \pm 414$ & $544 \mathrm{a} \pm 402$ & $551 \mathrm{a} \pm 414$ & $554 \mathrm{a} \pm 405$ \\
& TAN3 & $780 \pm 739$ & $586 \mathrm{a} \pm 594$ & $758 \mathrm{a} \pm 656$ & $787 \mathrm{a} \pm 676$ & $861 \mathrm{a} \pm 635$ & $898 \mathrm{a} \pm 672$ \\
TDS & TAN1 & $3941 \pm 3703$ & $51 \mathrm{a} \pm 10$ & $53 \mathrm{a} \pm 10$ & $55 \mathrm{a} \pm 15$ & $61 \mathrm{a} \pm 20$ & $63 \mathrm{a} \pm 26$ \\
& TAN2 & $3300 \pm 1714$ & $83 \mathrm{a} \pm 78$ & $47 \mathrm{a} \pm 20$ & $48 \mathrm{a} \pm 22$ & $47 \mathrm{a} \pm 17$ & $48 \mathrm{a} \pm 17$ \\
& TAN3 & $2653 \pm 1240$ & $46 \mathrm{a} \pm 11$ & $55 \mathrm{a} \pm 24$ & $55 \mathrm{a} \pm 25$ & $58 \mathrm{a} \pm 23$ & $61 \mathrm{a} \pm 28$ \\
\hline
\end{tabular}

Replicate $=6$ (months)

Within the rows, for the same parameter, means with different alphabets are statistically different $(p<0.05)$.

$\mathrm{P}=$ parameter, IND = Industries 
BAJOPAS Volume 13 Number 2, December, 2020

Table 4: Correlation coefficient $(r)$ between different masses of the bacteria and the physicochemical parameters.

\begin{tabular}{llll}
\hline Industries & Parameter & Correlation coefficient $(r)$ & $\begin{array}{l}\text { Percent dependence (rxrx100) } \\
(\%)\end{array}$ \\
\hline TAN1 & COD & -0.9 & 82 \\
& BOD & -0.97 & 94 \\
& SS & $0.90^{*}$ & 80 \\
TAN2 & TDS & $0.98^{*}$ & 96 \\
& COD & -1 & 100 \\
& BOD & -0.21 & 4 \\
& SS & $0.78^{*}$ & 61 \\
& TDS & -0.69 & 47 \\
& COD & $0.60^{*}$ & 36 \\
& BOD & -0.6 & 37 \\
& SS & $0.95^{*}$ & 90 \\
& TDS & $0.94^{*}$ & 89 \\
\hline
\end{tabular}

The correlation coefficient $(r)$ with * is statistically significant $(p<0.05)$.

Percentage reduction of the Parameters

Table 5 shows the percentage reduction of Parameters in industrial samples before and after the treatment of the effluents $(250 \mathrm{ml})$ with the different masses $(5 \mathrm{~g}, 10 \mathrm{~g}, 15 \mathrm{~g}, 20 \mathrm{~g}$, and $25 \mathrm{~g}$ ) of the Immobilized Bacteria.

In TAN1 samples, the percentage reduction (\%) of COD ranged (14-89); BOD (50-80); SS (-32$35)$ and TDS (98-99). In TAN2 samples, the percentage decrease $(\%)$ of COD ranged (15$38) ;$ BOD (90-92); SS [-28-(-55)] and TDS (9798). In TAN3 samples, the percentage decrease (\%) of COD ranged (11-44); BOD (76-81); SS (15-25) and TDS (98). The percentage increase in the levels COD, BOD and TDS might be due to the increase in the surface area of the different masses of the immobilized bacteria. However, the percentage decrease in the levels of the SS might be due to the aggregation of the TDS which are large enough to result into SS. The percentage decrease in the levels of the SS might be also due to the influence of the nutrients which was added into the effluents in order to make the microorganisms more active and viable for fast degradation of organic contaminants in the effluent. This is in line with the work of Jimoh et al. (2018) in which the concentration of the SS increase after the bioremediation of effluents.

Sreemoyee and Priti (2013) assessed and reduced several Physico-chemical parameters of dairy wastewater using Niesseria $s p$. and concluded that the species are well known to degrade organic compounds. This is in agreement with the current study in which the immobilized Niesseria $s p$ degrade the organic contaminants as indicated by the BOD, COD and TDS.

Jimoh et al. (2018) observed that TSS of the effluents was increased after treatment with immobilized bacteria and concluded that it might be due to the biostimulation method adopted for the research.

The optimum $\mathrm{pH}$ Biosorption of Chromium by Bacillus spp and Staphylococcus spp. from tannery effluent was investigated by Mythili and Karthikeyan (2011). The maximum adsorption of Chromium $(86.4 \mathrm{mg} / \mathrm{L})$ was showed by Bacillus spp and Staphylococcus spp showed $70.6 \mathrm{mg} / \mathrm{L}$ at an initial concentration of $100 \mathrm{mg} / \mathrm{L}$. In the present study, immobilised Bacillus spp and Staphylococcus spp. from the tannery industrial effluents reduced the levels of the organic pollutants with high potential as indicated by the percentage reduction of BOD, COD and TDS.

Enzymes often can work in multiple environments especially if they are immobilized. This makes the microorganisms' enzymes even more resistant to harsh environments and enables the enzymes to be recovered and recycled after they are no longer needed (Gianfreda and Rao 2004). Ramesh and Singh (1993) reported that the immobilized bacteria having more efficiency to remove the suspended particles than free cells. Using the immobilized cell is preferable due to its capability for using several times with the same efficiency, which makes it more economical. Similar work was done by Sikander et al. (2007) showing the higher reduction with permeabilized cells of Ochrobactrum intermedium strain SDCr-5. 
BAJOPAS Volume 13 Number 2, December, 2020

The results revealed the isolation and identification of isolates with the potential for the reduction of $\mathrm{Cr}$ (VI) to $\mathrm{Cr}$ (III). Results indicated that immobilized $B$. cereus could be efficiently used for the reduction of $\mathrm{Cr}$ (VI).

Table 5: Percentage reduction of the tested Parameters from the tannery industrial samples of the Immobilized Bacteria.

\begin{tabular}{lllllll}
\hline \multirow{2}{*}{ Industries } & & \multicolumn{5}{c}{ Percentage Reduction $(\%)$} \\
\cline { 3 - 7 } & & $5 \mathrm{~g}$ & $10 \mathrm{~g}$ & $15 \mathrm{~g}$ & $20 \mathrm{~g}$ & $25 \mathrm{~g}$ \\
\hline TAN1 & COD & 28 & 14 & 64 & 87 & 89 \\
& BOD & 50 & 54 & 59 & 67 & 80 \\
& SS & 35 & -26 & -27 & -32 & -63 \\
& TDS & 99 & 99 & 99 & 98 & 98 \\
TAN2 & COD & 15 & 20 & 25 & 32 & 38 \\
& BOD & 91 & 91 & 92 & 90 & 92 \\
& SS & -28 & -52 & -52 & -54 & -55 \\
& TDS & 97 & 99 & 99 & 99 & 99 \\
& COD & 33 & 44 & 22 & 11 & 26 \\
& BOD & 75 & 81 & 76 & 81 & 81 \\
& SS & 25 & 3 & -1 & -10 & -15 \\
& TDS & 98 & 98 & 98 & 98 & 98 \\
\hline
\end{tabular}

Percentage Reduction $=(B-A) / B \times 100 \%$

$A=$ Concentration of the parameter after treatment

$\mathrm{B}=$ Concentration of the parameter before treatment

$+=$ percentage decrease

- = percentage increase

In general, immobilization makes the enzyme more resistant to temperature, $\mathrm{pH}$, and substrate concentration swings giving it a longer lifetime and higher productivity per active unit (Gianfreda and Rao, 2004; FuIlbrook, 1996; Russell et al, 2003; Kandelbauer et al., 2004). Immobilized cells have been used and studied extensively for the production of useful chemicals (Ohtake and Silver, 1994), the treatment of wastewaters (Chen et al., 2003; Wang et al., 2010). Although many workers described microbial degradation of tannery effluent, limited literature is available on the bioremediation of tannery effluent using immobilized bacterial cells in the Kano Industrial Estates.

\section{CONCLUSION}

The samples contained variable levels of the physicochemical parameters. The results of the Analysis of variance revealed that, no statistical difference $(p<0.05)$ was observed for the temperature, $\mathrm{pH}, \mathrm{SS}, \mathrm{TDS}, \mathrm{BOD}$ and $\mathrm{COD}$ among the three tannery industries before the treatment. The levels of some of the parameters
(SS, TDS and COD) observed in the samples were found above the recommended limits of WHO and NESREA, which called for the treatment of the effluents before discharge into the environment. Base on the morphological and biochemical test results, TAN1, TAN2, and TAN3 bacterial isolates were identified to be Neisseria spp, Bacillus cereus, and Staphylococcus aureus respectively. The results of Post-treatment analysis showed that there is overall decrease in the levels of the parameters determined when compared with that of the pre-treatment. The overall percentage reduction of the immobilised bacteria in the treatment of the respective effluents was in the order TAN2 (72\%)>TAN1 $(70 \%)>$ TAN3 $(62 \%)$. Hence, the immobilized bacteria are having higher biodegradation potential for the treatment of the tannery effluents.

\section{Acknowledgments}

The authors wish to acknowledge the University of Maiduguri for the financial support. The authors are grateful to the Kano State Ministry of Environment for their support in obtaining the effluent samples. 


\section{REFERENCES}

Ajao, A. T., Adebayo, G. B., and Yakubu, S. E. (2011). Bioremediation of textile industrial effluent using mixed culture of Pseudomonas aeruginosa and Bacillus subtilis immobilized on agar-agar in a bioreactor. J. Microbiol. Biotech. Res, 1(3), 50-56.

Akan, J. C., Moses, E. A., Ogugbuaja, V. O., and Abah, J. (2007). Assessment of tannery industrial effluents from Kano metropolis, Kano State, Nigeria. Journal of Applied Sciences, 7(19), 2788-2793.

Akan, J. C., Ogugbuaja, V. O., Abdulrahman, F. I., and Ayodele, J. T. (2009). Pollutant levels in effluent samples from tanneries and textiles of Kano industrial areas, Nigeria. Global journal of pure and applied sciences, 15(3-4).

APHA (1989). Standard methods for Examination of Will bete and Will betewater.15 $5^{\text {th }}$ edition. Brydpass Springfield Will behington DC. pp. 164-176

APHA (1992). Standard Methods for the Examination of Water and Wastewater. Health, 69, 1116-9.

Baba, A., Garba, S. T., and Bello, H. S. (2020). Bioremediation Potential of Immobilized corynebacterium kutsceri in the Treatment of Tannery Industrial Effluent from Challawa Industrial Estate, Kano State, Nigeria. Journal of the Turkish Chemical Society Section A: Chemistry, $7(2), 335-350$.

Beem, E. I. V. (1994). reduction of solvent VOC emission. J. Oil Col. Chem. Ass, 77, 158.

Bouwer, E. J., and Zehnder, A. J. (1993). Bioremediation of organic compoundsputting microbial metabolism to work. Trends in biotechnology, 11(8), 360367.

Chen, K. C., Wu, J. Y., Liou, D. J., and Hwang, S. C. J. (2003). Decolorization of the textile dyes by newly isolated bacterial strains. Journal of Biotechnology, 101(1), 57-68.

Dan'Azumi, S., and Bichi, M. H. (2010). INDUSTRIAL POLLUTION AND HEAVY METALS PROFILE OF CHALLAWA RIVER IN KANO, NIGERIA. Journal of Applied Sciences in Environmental Sanitation, $5(1)$.

DWAF. (1992). Analytical Methods Manual, TR 151. Department of Water Affairs and Forestry, Pretoria.

El-Bestawy, E. (2013). Biological treatment of leather-tanning industrial wastewater using free living bacteria.
Elsheikh, M. A. S. (2009). Tannery wastewater pre-treatment. Water Science and Technology, 60(2), 433-440.

FuIlbrook, P. D. (1996). "Kinetics." Industrial enzymology: The application of enzymes in Industry. 2nd Ed. T. Godfrey and J Reichelt. eds.. Nature. New York.

Gianfreda, L., and Rao, M. A. (2004). Potential of extra cellular enzymes in remediation of polluted soils: a review. Enzyme and microbial technology, 35(4), 339354.

Hugo Springer. (1994). John Arthur Wilson Memorial Lecture "Treatment of Industrial Wastes of the Leather Industry - is it still a Major Problem". JALCA, 89, 153-185

Jimoh, A. A., Ganiyu, B. A., Baba, D., and Baba, A. (2018) Bioremediation Process of Effluent from Detergent and Food Industries in Jos, Nigeria: Kinetics and Thermodynamics. International Journal of Engineering Science Invention (IJESI), 762-73

Kandelbauer, A., Maute, O., Kessler, R. W., Erlacher, A., and Gübitz, G. M. (2004). Study of dye decolorization in an immobilized laccase enzyme-reactor using online spectroscopy. Biotechnology and bioengineering, 87(4), 552-563.

Kongjao, S., Damronglerd, S., and Hunsom, M. (2008). Simultaneous removal of organic and inorganic Pollutants in tannery wastewater using electrocoagulation technique. Korean Journal of chemical engineering, 25(4), 703.

Maheshwari, U. M., Aruna, S., Gomathi, M., and AbdulJaffar, A. H. (2017). Bioremediation by Free and Immobilized Bacteria Isolated from Tannery Effluent. International Journal of Research in Applied, Natural and Social Sciences. 5(7), 75-90

Margesin, R., and Schinner, F. (2001). Bioremediation (natural attenuation and biostimulation) of diesel-oilcontaminated soil in an alpine glacier skiing area. Applied and environmental microbiology, 677), 3127-3133.

Mohammed, A., Sekar, P., and George, J. (2011). Efficacy of microbes in bioremediation of tannery effluent. Inter. J. Curr. Res, 3(4), 324-326.

Mohammed, S. S. D., Orukotan, A. A., and Abdullahi, H. (2017). Physicochemical and Bacteriological Assessment of Tannery Effluent from Samaru-Zaria, 
BAJOPAS Volume 13 Number 2, December, 2020 Kaduna State, Nigeria. Journal of Applied

Sciences and Environmental Management, 21(4), 734-740.

Munz, G., De Angelis, D., Gori, R., Mori, G., Casarci, M., and Lubello, C. (2009). The role of tannins in conventional and membrane treatment of tannery wastewater. Journal of hazardous materials, 164(2-3), 733-739

Mythili, K., and Karthikeyan, B. (2011). Bioremediation of $\mathrm{Cr}$ (VI) from tannery effluent using Bacillus spp and Staphylococcus spp. International Multidisciplinary Research Journal, 1(6).

NESREA (2009). National Environmental Standards for Effluent Limitations and Regulation. 1233-1236

Noorjahan, C. M. (2014). Physicochemical characteristics, identification of bacteria and biodegradation of industrial effluent. Journal of bioremediation and Biodegradation, 5(3).

Ohtake, H. I., and Silver, A. O. (1994). Bacterial reduction of toxic chromate. Biological degradation and bioremediation of toxic chemicals, 403-415.

Omoleke, I. I. (2004). Management of environmental pollution in Ibadan, an African city: the challenges of health hazard facing government and the people. Journal of Human Ecology, 15(4), 265-275.

Rajor, A., Reddy, A.S., and Singh, B. (2004). Determination of BOD kinetic Parameters and evaluation of alternate methods, M.Sc. Thesis, Department of biotechnology \& environmental Science, Thapar Institute of Engineering and Technology, Patiala

Ramasami, T., Rajamani, S., and Rao, J. R. (1994, March). Pollution control in leather industry: Emerging technological options. In International symposium on surface and colloidal science and its relevance to soil pollution, madras.

Ramesh, J. V. S., and Singh, S. P. (1993). Yearly variation in certain physicochemical parameters of pond at eastern Doon Valley. Uttar Pradesh J. Zoo, 12 (1), 7577.

Ranen, S., and Sharadinadra, C. (2009). Biotechnology applications to environmental remediation in resource exploitation. Current science, 97, 6-25
Russell, A. J., Berberich, J. A., Drevon, G. F., and Koepsel, R. R. (2003). Biomaterials for mediation of

chemical and biological warfare agents. Annual review of biomedical engineering, 5(1), 1-27.

Saravanan, P., and Saravanan, A. (1999). Decolourization of tannery effluent by Flavobacterium sp. EK 1. Indian Journal of Environmental Protection, 19, 19-24.

Sikander, S., and Shahida, H. (2007). Reduction of toxic hexavalent chromium by Ochrobactrum intermedium strain SDCr5 stimulated by heavy metals. Bioresource Technol, 98, 340-344.

Singh, N., Sharma, B. K., and Bohra, P. C. (2000). Impact assessment of industrial effluent of arid soils by using satellite imageries. Journal of the Indian Society of Remote Sensing, 28(2-3), 79.

Sreemoyee, C., and Priti, P. (2013). Assessment of physico-chemical parameters of dairy waste water and isolation and characterization of bacterial strains in terms of cod reduction. Int J Sci, 2(3), 395-400.

Verheijen, L. A. H. M., Wiersema, D., Pol, L. H., and De Wit, J. (1996). Management of wastes from animal product processing. Livestock and environment, Finding a balance. International Agriculture Center, Wageningen, The Netherlands.

Wang, F., Yao, J., Si, Y., Chen, H., Russel, M., Chen, K., and Bramanti, E. (2010). Short-time effect of heavy metals upon microbial community activity. Journal of Hazardous Materials, 173(13), 510-516.

WHO (World Health Organization). (2006). Air quality guidelines: global update 2005: particulate matter, ozone, nitrogen dioxide, and sulfur dioxide. World Health Organization.

World Bank. (1995). Nigeria's strategic options for redressing industrial pollution. World Bank, industry and energy division. 1st edition, West Central Africa Department; Annexes: 1995; pp 60-62.

Zahoor, A., and Abdul, R. (2009). Enumeration of Coliforms. Journal of Environmental Sciences. 21, 814-820 


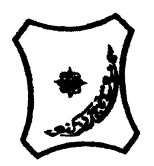

Bayero Journal of Pure and Applied Sciences, 13(2): 1 - 12

Received: November, 2020

Accepted: December, 2020

ISSN $2006-6996$

\title{
BIODEGRADATION POTENTIAL OF IMMOBILIZED BACTERIA IN THE TREATMENT OF TANNERY INDUSTRIAL EFFLUENTS FROM INDUSTRIAL ESTATES IN KANO STATE, NIGERIA
}

\author{
Abdullateef, B., ${ }^{1 *}$ Shuaibu, T. G., ${ }^{1}$ Babagana, K., ${ }^{1}$ Suleman, H. B. ${ }^{2}$ and Dauda, B. ${ }^{3}$ \\ ${ }^{1}$ Department of Pure and Applied Chemistry, Faculty of Science, University of Maiduguri, Borno State, \\ Nigeria \\ ${ }^{2}$ Department of Microbiology, Faculty of Science, University of Maiduguri, Borno State, Nigeria \\ ${ }^{3}$ Department of Chemical Engineering, Faculty of Engineering, University of Maiduguri, Borno State, \\ Nigeria \\ *Corresponding author: babslega@gmail.com; abelega2007@yahoo.com; +2348061309753
}

\section{ABSTRACT}

Industrial Effluents Samples from Gashash Tanneries (TAN1) in Bompai Industrial estate, Larabee Tannery Industry (TAN2) in Sharada Industrial estate and Z Tannery Industries (TAN3) in Challawa Industrial estate, Kano State, Nigeria were collected over a period of six months (August 2017 to January 2018) for assessing the biodegradation potentials of bacteria in the treatment of organic pollutants within the effluents. Bacteria were isolated from the effluents and immobilized on agar-agar. Different masses (5 g, $10 \mathrm{gr}, 15$ $\mathrm{g}, 20 \mathrm{~g}$, and $25 \mathrm{~g}$ ) of the bacteria were used in the treatment of $250 \mathrm{ml}$ of the effluents for ten days in a shaker incubator (Gallenkamp-OC-4364-L) at the temperature $30{ }^{\circ} \mathrm{C}$ and speed of $60 \mathrm{rpm}$. Pre-treatment analysis of the effluents for Temperature, pH, Biochemical Oxygen Demand (BOD), Chemical Oxygen Demand (COD), Suspended Solid (SS) and Total Dissolved Solids (TDS) gives the following results; temperature $\left({ }^{\circ} \mathrm{C}\right.$ )

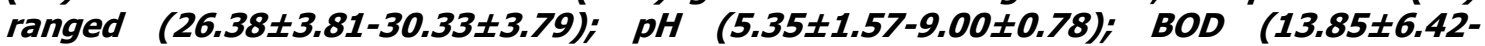
$38.75 \pm 16.20) ;$ COD (1406 $\pm 208-3532 \pm 1373) ;$ SS (208 $\pm 235-780 \pm 739)$ and TDS (266 $\pm 253-5276 \pm 2971)$. No statistical differences ( $p \leq 0.05)$ was observed for all the results among the different industries. The bacterial isolates were identified as Neisseria spp, Bacillus cereus, and Staphylococcus aureus, in TAN1, TAN2, and TAN3, respectively. After treatment of the effluent with the different masses of the isolated bacteria, the mean level of BOD was found to range as (0.55 $\pm 0.36-6.92 \pm 5.49) ; C O D$ (ND-3134 \pm 1595$)$;

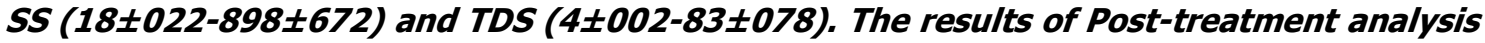
showed that there is overall decrease in the levels of the parameters determined when compared with that of the pre-treatment. The overall percentage reduction of the immobilised bacteria in the treatment of the respective effluents was in the order TAN2 (72\%)>TAN1 (70\%)>TAN3 (62\%). Hence, the immobilized bacteria are having higher biodegradation potential for the treatment of the tannery effluents.

Keywords: Biodegradation, bacteria, effluent, immobilization, tannery.

\section{INTRODUCTION}

Tannery industrial wastewater is a serious consequence of the pollution point of view for streams, freshwater, and land used for agriculture. The lack of awareness in the modern industrial practice has resulted in the discharge of tannery effluents which exhibit very high value of chromium ( $\mathrm{Cr}$ ), Sulfide, and chloride, Total Dissolved Solid (TDS), Total Suspended Solid (TSS), Biochemical Oxygen Demand (BOD) and Chemical Oxygen Demand (COD) in the water stream or land (Mohammed et al., 2001). Tanning is the process, which One ton of skin generally leads to the production of 20 to $80 \mathrm{~m}^{3}$ of turbid and foul-smelling converts the protein of the rawhide or skin into a stable material, which will not putrefy and is suitable for a wide variety of end applications (Elsheikh, 2009). The highly polluting chromium is the most commonly used tanning material producing leather that is more flexible and pliable than vegetable-tanned leather and does not discolor or lose shape in water as drastically as vegetable-tan (Elsheikh, 2009). Tannery effluent is among the most hazardous industrial pollutants due to its huge organic and inorganic load, which is highly toxic to human life and the environment (Kongjao et al., 2008). wastewater including chromium (100-400 mg/l), sulfide $(200-800 \mathrm{mg} / \mathrm{l})$, high levels of fat and 
BAJOPAS Volume 13 Number 2, December, 2020 other solid wastes, and notable pathogen contamination as well as pesticides added for skin conservation during transport (Elsheikh, 2009). There are more than 6000 tanneries in Nigeria with an annual processing capacity of 700,000 tons of hides and skins (Omoleke, 2004; Singh et al., 2008). It was reported that the total amount of waste produced per animal slaughtered is approximately $35 \%$ of its weight (World Bank, 1995). Also, for every $1000 \mathrm{~kg}$ of carcass weight, a slaughtered beef produces 5.5 $\mathrm{kg}$ of manure (excluding rumen contents or stockyard manure) and $100 \mathrm{~kg}$ of paunch manure (undigested food) (Verheijen et al., 1996). Tanneries generate wastewater in the range of 30-35 $\mathrm{L} \mathrm{kg}^{-1}$ skin/hide processed with variable $\mathrm{pH}$, Biological Oxygen Demand (BOD), Chemical Oxygen Demand (COD), high concentrations of suspended solids (SS), and tannins as well as chromium (Zahoor and Abdul, 2009).

Being heterogeneous and composed of a wide variety of compounds, it is very difficult to select a unique direct method for estimating the biodegradability of organic contents and biokinetic parameters for a wastewater sample (Rajor, 2004). For this purpose, some indirect estimation such as determination of biochemical oxygen demand (BOD) and chemical oxygen demand (COD) are applied as common laboratory investigations [9]. During retanning procedures, synthetic tannins (Syntan), oils and resins are added to form softer leather at varying doses (Munz et al., 2009). One of the refractory groups of chemicals in tannery effluents derives mainly from tannins (Ramasami et al., 2004). Syntans are characterized by complex chemical structures, because they are composed of an extended set of chemicals such as phenol-, naphthalene-, formaldehyde- and melamine-based syntans, and acrylic resins (Beem, 1994). Organic pollutants (proteic and lipidic components) are originated from skins (it is calculated that the raw skin has $30 \%$ loss of organic material during the working cycle) or they are introduced during processes (Hugo Springer, 1994).

Many conventional processes such as oxidation, chemical and biological processes were carried out to treat tanneries wastewater (Ebtesam et al, 2013). Biological processes have received more attention because of their costeffectiveness, lower sludge production and environmental friendliness (Noorjahan, 2014). Naturally occurring micro-organisms degrade the hazardous organic wastes including xenobiotic compounds, such as pesticides, polycyclic aromatic hydrocarbons (PAHs) and polychlorinated biphenyls (PCBs) in due course of time (Ranen and Sharadinadra, 2009). Bioremediation is based on the idea that all organisms remove substances from the environment to carry outgrowth and metabolism (Bouwer and Zehnder, 1993). Bacteria, protista and fungi are found to be very good at degrading complex molecules and incorporating the breakdown products into their metabolism (Bouwer and Zehnder, 1993). The resultant metabolic wastes that they produce are generally safe and somehow recycled into other organisms (Ranen and Sharadinadra, 2009). An acclimatized indigenous population of microorganisms capable of degradation of the compounds of interest must exist at the site for a successful bioremediation mode (Ranen and Sharadinadra, 2009). It has been observed that for a successful bioremediation mode, an acclimatized indigenous population of microorganisms capable of degradation of the compounds of interest must exist at the site under investigation (Ranen and Sharadinadra, 2009). Even though there are numerous physical and chemical methods employed in the disposal of wastes the advantage in using bacterium is that they play a key role in the reduction of COD, BOD, total protein, total tannin and total phenol (Saravanan and Saravanan, 1998)

Baba et al. (2020) studied the bioremediation potential of immobilized corynebacterium kutsceri in the Treatment of tannery industrial effluent from Challawa Industrial Estate, Kano State, Nigeria. The aim of the work is to study the reduction in the level of the contaminants through the process of bioremediation using the isolated bacteria. Immobilized bacteria can withstand various temperatures, $\mathrm{pH}$ and substrate concentrations; consequently, increasing the efficiency and the lifespan of the bacteria. Immobilized bacteria are widely applied in the treatment of wastewater and can be separated and recovered after the treatment with the same efficiency (Baba et al., 2020).

\section{MATERIALS AND METHODS \\ Study Area}

This study was carried out in Bompai, Sharada and Challawa industrial estates in Kano, Figure 1. Kano lies on Latitude $11^{\circ} 30^{\prime} \mathrm{N}$ and $8^{\circ} 30^{\prime} \mathrm{E}$ and Longitude $11^{\circ} 5^{\prime} \mathrm{N}$ and $8^{\circ} 5^{\prime} \mathrm{E}$ in Northern Nigeria. It is one of the developed industrial cities in Nigeria. Tannery activities are the dominating industries and this could be one of the reasons for her high population density (Dan'Azumi and Bichi, 2010). Many researchers have studied biodegradation of tannery effluent using microorganisms. However, limited literature is available on the biodegradation of tannery effluent in Kano industrial estates using 
BAJOPAS Volume 13 Number 2, December, 2020 immobilized bacterial cells. This research work focuses on the potential of the use of the indigenous immobilized bacterial isolates in the treatment of tannery effluents in the industrial estates.

\section{Sample Collection}

Effluents were collected from the Tannery Industries from Bompai, Challawa and Sharada Industrial Estates, Kano, Nigeria. The effluents were collected over a period of six months (August 2017 to January 2018). Samples collected in a sterile 4-liter plastic container with a unique identification number were preserved using an ice-box that was transported to the Microbiology Laboratory, Department of Microbiology, Bayero University of Kano for analysis

\section{Sample Preparation and Sample Analysis}

Immediately after the collection of the effluent, $\mathrm{pH}$, TSS, TDS, COD, BOD levels were determined before treatment (Pre-treatment determination) and ten days after treatment (Post-treatment determination) as described in
APHA (1989) standard methods. $\mathrm{pH}$ was determined using Ecotests $\mathrm{pH}$ meter and TDS was determined using AQUALYTIC TDS Salinometer. BOD was determined as described by the standard method (APHA, 1992). COD and SS were determined using DR/2010 HACH portable data logging spectrophotometer (DWAF, 1992)

\section{Identification and Biochemical} Characterization of the Bacterial Isolates

The bacteria were isolated from the effluents using Serial Dilution according to the method described by APHA (1989). The biochemical tests such as oxidase, catalase, coagulase, indole (from $1 \%$ tryptone broth), citrate (Simmons citrate agar), methyl red/VogesProskauer (MR/VP), nitrate reduction, Starch Hydrolysis, Glucose, Maltose, and Lactose tests were carried out on the bacterial isolates to identify the bacteria through the bacteria biochemical characteristics according to Ajao et al. (2011).

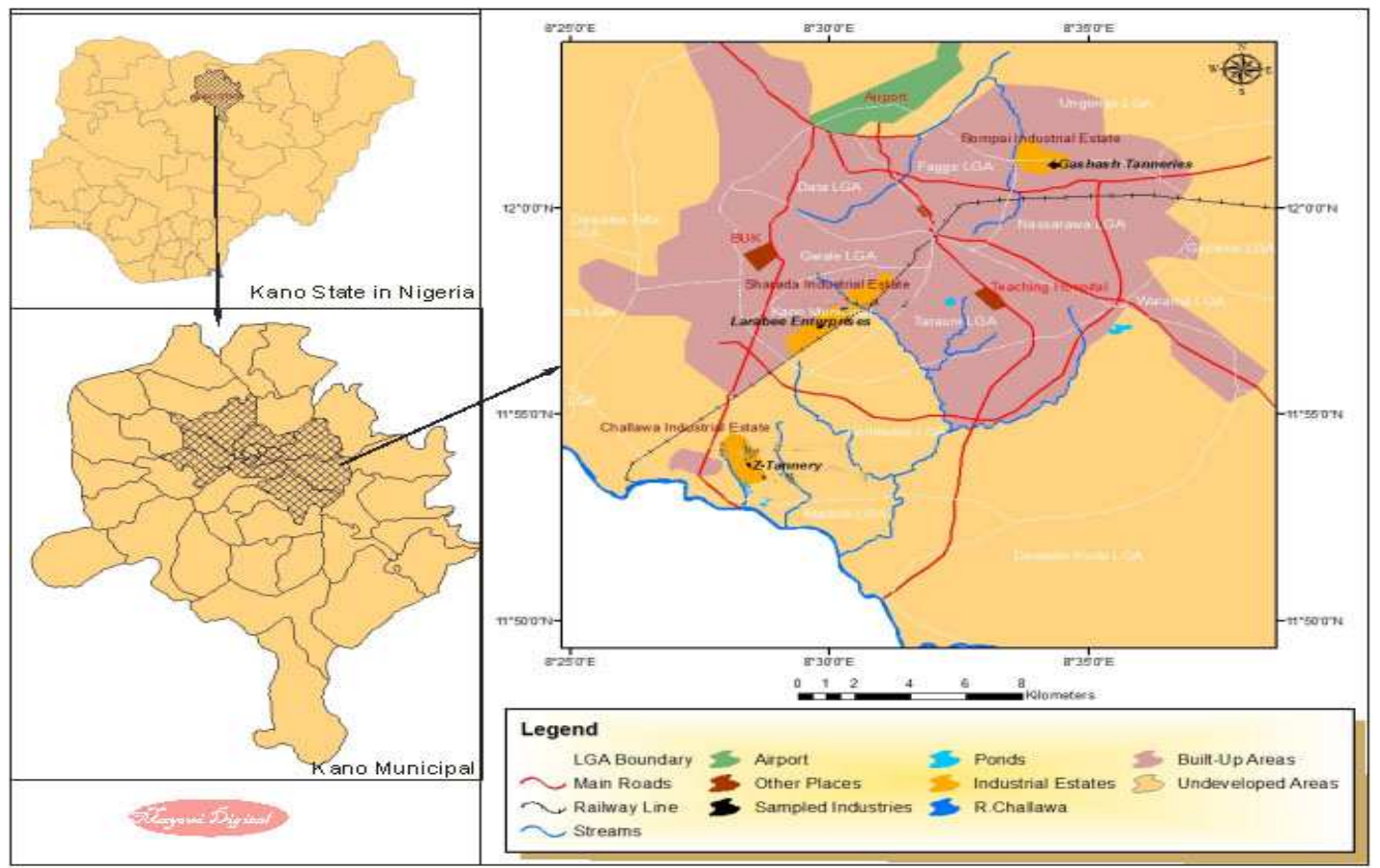

Fig. 1 Map showing the study areas

Source: Mayomi Digital Productions, GIS Laboratory, Department of Geography, UNIMAID (2017)

\section{Determination of Growth Rate of the Bacteria in Effluent Sample}

The bacteria growth rates were determined by transferring $2 \mathrm{~mL}$ of the bacterial isolates from the tannery effluent in broth medium into 100 $\mathrm{mL}$ sterile effluents in conical flasks and kept in an incubator (Giffrin cool) for 10 days. Control was also set up by incubating another $100 \mathrm{~mL}$ each of the sterile effluents without the bacteria. The optical density of the content was determined at the wavelength of $600 \mathrm{~nm}$ on a daily interval and recorded. 
BAJOPAS Volume 13 Number 2, December, 2020 Immobilization of Bacteria

Agar solution and inoculi were prepared separately. Fifty milliliters $(50 \mathrm{~mL})$ of nutrient broth each of the inoculi was prepared in a McCartney bottle and incubated for 24 hours. A solution of agar-agar was prepared by dissolving $10 \mathrm{~g}$ of the powder in distilled water and made up to $500 \mathrm{~mL}$ mark in an Erlenmeyer flask and was sterilized in an autoclave (280A) for 15 minutes and allowed to cool to $40-45^{\circ} \mathrm{C}$ (Ajao et al., 2011). Four milliliters ( $4 \mathrm{~mL})$ of the bacterial isolates in the nutrient broth was mixed with 36 $\mathrm{ml}$ of the prepared agar-agar media in petri-dish plates and then allowed to solidify. This was kept in the refrigerator for bioremediation.

\section{Bioremediation (Treatment) of the Effluents}

The solidified agar block (immobilized bacteria) was cut into cubes using a sterile knife; $0.1 \mathrm{~mL}$ phosphate buffer ( $\mathrm{pH} \mathrm{7.0)}$ was added and kept in the refrigerator for 1 hour for curing. The phosphate buffer was decanted after 1 hour and the cubes were washed with sterile distilled water 3-4 times before it was used (Ajao et al., 2011). Two liters (2 L) of the effluent was supplemented with the minimum basal medium in $\mathrm{g} / \mathrm{L}: \mathrm{NaCl}(0.8), \mathrm{MgSO}_{4} .7 \mathrm{H}_{2} \mathrm{O}(0.001), \mathrm{KH}_{2} \mathrm{PO}_{4}$ (2), $\mathrm{NaNO}_{3}$ (2), $\quad \mathrm{CaCl}_{2} .2 \mathrm{H}_{2} \mathrm{O} \quad(0.5)$ and $\mathrm{NaHPO}_{4} .12 \mathrm{H}_{2} \mathrm{O}(2)$ and sterilized in an autoclave at $121^{\circ} \mathrm{C}$ for 15 minutes (Margesin and Schinner, 2001). Two hundred and fifty milliliters $(250 \mathrm{~mL})$ of the effluents were transferred into different $250 \mathrm{ml}$ conical flasks. The content was covered with a cotton-wool ramped with foil paper to avoid contamination. Five grams $(5 \mathrm{~g})$ of the immobilized bacteria were quickly transferred into each of the effluents in the conical flasks in an inoculating chamber. The same procedures were carried out for the $10 \mathrm{~g}, 15 \mathrm{~g}, 20 \mathrm{~g}$ and 25 $\mathrm{g}$ of the immobilized bacteria in separate $250 \mathrm{~mL}$ effluents in conical flasks and agitated for ten days in a shaker incubator (Gallenkamp-OC4364-L) at a temperature $30^{\circ} \mathrm{C}$ and speed of 60 rpm. The treated effluent samples were taken on the tenth day and analyzed for the parameters $\mathrm{pH}$, SS, TDS, COD, and BOD, (Posttreatment determination) for the different grams of bacteria to evaluate and compare the biodegradation potential. (Baba et al., 2020).

\section{Statistical Analysis}

The data were represented as Mean \pm Standard deviation and analyzed statistically using oneway Analysis of Variance (ANOVA) and Tukey's HSD as Post Hoc Tests with the aid of SPSS 16.0. The correlation coefficient was also used to measure the strength of the relationship between the different masses of the bacteria and the parameters. All $\mathrm{p} \leq 0.05$ were considered as statistically significant.

\section{RESULTS AND DISCUSSION Physico-chemical parameters in the Industrial Effluents before the Biodegradation.}

Results of the Physico-chemical parameters in the industrial effluents before the Biodegradation is shown in table 1 . The mean temperatures $\left({ }^{\circ} \mathrm{C}\right)$ observed in TAN1, TAN2, and TAN3 samples were $28.07 \pm 0.65 ; 27.77 \pm 0.64$ and $26.38 \pm 3.81$ respectively. The order of the mean temperature of the samples from the three industries can be arranged as TAN1 > TAN2>TAN3. The temperature observed at TAN1, TAN2, and TAN3 samples were found below the WHO $\left(35^{\circ} \mathrm{C}\right)$ and NESREA $\left(40^{\circ} \mathrm{C}\right)$ limits. The low values of temperature might be due to the processes used at the time of sampling. High temperature brings down the solubility of gases in water that ultimately expresses as high BOD and COD. Statistical analysis shows that there is no significant difference $(p<0.05)$ between the mean values of temperature among the industries. This might be due to similar tannery activities involved in the tannery industries at the time of sampling. The average values of temperature observed in this present study are less than those observed by Akan et al. (2007), Akan et al. (2009) and Baba et al. (2020).

The mean level of $\mathrm{pH}$ observed in TAN1, TAN2 and TAN3, samples were $7.77 \pm 2.93$; $8.35 \pm 0.28$ and $7.52 \pm 0.76$ respectively. The order of the mean $\mathrm{pH}$ of the samples from the three industries can be arranged as TAN2> TAN1 $>$ TAN3. The $\mathrm{pH}$ of the samples falls within the WHO (7.0-8.5) and NESREA (6-9) standard limits. Statistical analysis shows that there is no significant difference $(p<0.05)$ between the mean values of $\mathrm{pH}$ among the industries. This might be due to similar tannery activities involved in the tannery industries at the time of sampling. Maheshwari et al. (2017) reported that the level of $\mathrm{pH}$ in the effluents from the tannery industry in Vaniyambadi, India was 6.5 which was lower than that observed in the present study. The $\mathrm{pH}$ in the effluents from the tannery industries in Kano and Kaduna were reported to be 7.64 and 6.89, respectively (Akan et al., 2007; Mohammed et al., 2017). The average values of $\mathrm{pH}$ observed in this present study are less than those observed by Mohammed et al. (2017) and Baba et al. (2020). The mean level of SS $(\mathrm{mg} / \mathrm{l})$ observed in TAN1, TAN2, and TAN3 samples were 374 \pm 124 ; $358 \pm 335$ and $780 \pm 739$ respectively. The order of the mean SS in the samples from the three industries can be arranged as TAN3 > TAN1 $>$ TAN2. 
The SS observed in the samples were far above the recommended standard limits of regulating bodies WHO $(30 \mathrm{mg} / \mathrm{l})$ and NESREA $(10 \mathrm{mg} / \mathrm{l})$. Statistical analysis shows that there is no significant difference $(p<0.05)$ between the mean values of SS among the industries. This might be due to similar tannery activities involved in the tannery industries at the time of sampling. The average values of SS observed in this present study are less than that observed $(3700 \pm 122 \mathrm{mg} / \mathrm{l})$ by Akan et al. (2009) for tanneries in Kano. Also, the average values of SS observed in this present study are less than that observed by Mohammed et al. (2017) and Baba et al. (2020) with the exception in TAN3.

The mean level of TDS (mg/l) observed in TAN1, TAN2, and TAN3 samples were $3941 \pm 3703$; $3300 \pm 1714$ and $2653 \pm 1240$ respectively. The order of the mean TDS in the samples from the three industries can be arranged as TAN1>TAN2>TAN3. The TDS observed in the samples were far above the recommended standard limits of WHO $(250 \mathrm{mg} / \mathrm{l})$ and NESREA $(500 \mathrm{mg} / \mathrm{l})$. Statistical analysis shows that there is no significant difference $(p<0.05)$ between the mean values of TDS among the industries. This might be due to similar tannery activities involved in the tannery industries at the time of sampling. TDS in the effluents from the tannery industries in Kano, Nigeria was reported to be $1281 \mathrm{mg} / \mathrm{l}$ (Akan et al., 2007). The average values of SS observed in this present study are less than those observed by Mohammed et al. (2017) and Baba et al. 2020)

The mean level of COD (mg/l) observed in TAN1, TAN2 and TAN3 samples seasons were $2372 \pm 938 ; \quad 1406 \pm 208$ and $3532 \pm 1373$ respectively. The order of the mean COD of the samples from the three industries can be arranged as TAN3>TAN1> TAN2. The COD observed in TAN1, TAN2 and TAN3 samples were far above the recommended standard limits of regulating bodies $\mathrm{WHO}(40 \mathrm{mg} / \mathrm{l})$ and NESREA (40 mg/l). Statistical analysis shows that there is no significant difference $(p<0.05)$ in COD among the industries. This might be due to similar tannery activities involved in the tannery industries as at the time of sampling. The Chemical Oxygen demand (COD) is the amount of oxygen, in $\mathrm{mg} / \mathrm{L}$, required for the degradation of the compound of wastewater to occur. In comparison, the average values of COD observed in this present study were higher than that observed by Mohammed et al. (2017) but lower than that observed by Baba et al. (2020).

The mean levels of BOD $(\mathrm{mg} / \mathrm{l})$ observed in TAN1, TAN2 and TAN3 samples were $13.85 \pm 6.42 ; \quad 19.46 \pm 0.50$ and $17.13 \pm 3.14$ respectively. The order of the mean BOD in the samples from the three industries can be arranged as TAN2>TAN3>TAN1. The BOD observed in TAN1, TAN2 and TAN3 samples were found below the recommended limits of NESREA (200 mg/l) but above WHO (10 mg/l). Statistical analysis shows that there is no significant difference $(p<0.05)$ between the mean values of BOD among the industries. This might be due to similar tannery activities involved in the tannery industries at the time of sampling. The low level of BOD recorded in this study is an indication of the low level of biodegradable organic solids in the effluent. The average values of BOD observed in this present study were lower than those observed by Mohammed et al. (2017) and Baba et al. (2020).

Table 1: Mean Values \pm S.D of Physico-chemical parameters of effluents from the Tannery Industries before Treatment.

\begin{tabular}{llllllll}
\hline Parameter & Tannery 1 & Tannery 2 & Tannery 3 & $\mathrm{a}$ & $\mathrm{b}$ & $\mathrm{c}$ & $\mathrm{d}$ \\
\cline { 2 - 7 } Temperature $\left({ }^{\circ} \mathrm{C}\right)$ & $28.07 \mathrm{a} \pm 0.65$ & $27.77 \mathrm{a} \pm 0.64$ & $26.38 \mathrm{a} \pm 3.81$ & & $29.50 \pm 4.68$ & 35 & 40 \\
pH & $7.77 \mathrm{a} \pm 2.93$ & $8.35 \mathrm{a} \pm 0.28$ & $7.52 \mathrm{a} \pm 0.76$ & 6.89 & $5.35 \pm 1.57$ & $7.0-8.5$ & $6.0-9.0$ \\
$\mathrm{COD}(\mathrm{mg} / \mathrm{l})$ & $2372 \mathrm{a} \pm 938$ & $1406 \mathrm{a} \pm 208$ & $3532 \mathrm{a} \pm 1373$ & 2.2 & $3106 \pm 2753$ & 40 & 40 \\
$\mathrm{BOD}(\mathrm{mg} / \mathrm{l})$ & $13.85 \mathrm{a} \pm 6.42$ & $19.46 \mathrm{a} \pm 0.50$ & $17.13 \mathrm{a} \pm 3.14$ & 1032 & $26.17 \pm 9.49$ & 10 & 200 \\
$\mathrm{SS}(\mathrm{mg} / \mathrm{l})$ & $374 \mathrm{a} \pm 124$ & $358 \mathrm{a} \pm 335$ & $780 \mathrm{a} \pm 739$ & 501 & $562 \pm 482$ & 30 & 10 \\
TDS $(\mathrm{mg} / \mathrm{l})$ & $3941 \mathrm{a} \pm 3703$ & $3300 \mathrm{a} \pm 1714$ & $2653 \mathrm{a} \pm 1240$ & 532.7 & $444 \pm 507$ & 250 & 500 \\
\hline
\end{tabular}

The values given in the table above are means of 6 replicate values, $\mathrm{n}=6$ ( 1 sample was taken monthly for 6 months). Within the rows, means with different alphabets are statistically different $(p<0.05)$. WHO: World Health Organisation. NESREA: National Environmental Standard and Regulatory Enforcement Agency. a = Mohammed et al.(2017), b = Baba et al. (2020), c = WHO (2006), $d=$ NESSRA (2009) 
BAJOPAS Volume 13 Number 2, December, 2020

Identification, Biochemical Characterization and growth rates of the Bacterial Isolates

Results of identification and biochemical characterization of the bacterial isolates were shown in table 2. After 24 hours of incubation, the nutrient agar media plates were checked for bacterial growth. The results showed the presence of different strains in the samples. The TAN1 bacteria isolate was found to be gramnegative cocci while TAN3 was gram-positive cocci. TAN2 bacteria isolate was found to be gram-positive, rod-shaped. TAN1, TAN2, and TAN3 bacteria isolates recorded positive results for spore former.

The results of the biochemical tests indicated that all the bacteria were positive for catalase, oxidase, citrate, maltose, glucose, lactose (negative in TAN1), mannitol (negative in TAN2), starch hydrolysis and coagulase (negative in TAN2) tests. The bacteria showed negative results for nitrate reduction, $M R$ (positive in TAN2), VP (positive in TAN1), Indole (positive in TAN2) tests. Base on the morphological and biochemical test results, TAN1, TAN2, and TAN3 bacteria isolates were identified to be Nesseria spp, Bacillus cereus, and Staphylococcus aureus respectively.

The growth rate of the TAN1, TAN2 and TAN3 Isolates were shown in figure 2. Generally, the optical density increase with the increase in time (day) and decrease as time goes on. The highest optical density was shown by bacillus cereus in TAN2 while the lowest was shown by Staphylococcus aureus in TAN3.

The initial growth phase of TAN1 Isolate bacteria occurred within 2-day of incubation as the growth rate increases up to the 6th-day incubation when the maximum growth was observed. Beyond the 6th day, the growth of the bacteria declined (which might be due to a shortage of nutrients in the effluents) until it reached its death phase (which might be due to the unavailability of nutrients in the effluents).

A similar trend of growth was also observed for TAN2 Isolate as the initial growth phase also occurred within 2-day of incubation but maximum growth rate observed on the 4th day of incubation. The stationary stage occurred between the 4th day and the 8th day. Beyond the 8th day, the growth of the bacteria declined (which might be due to a shortage of nutrients in the effluents) until it reached its death phase (which might be due to the unavailability of nutrients in the effluents).

The initial growth phase of TAN3 bacterial Isolate occurred within the 3-day incubation as the growth rate increases up to the 6th-day incubation when the maximum growth was observed. Beyond the 6th day, the growth of the bacteria declined (which might be due to a shortage of nutrients in the effluents) until it reached its death phase (which might be due to the unavailability of nutrients in the effluents).

Table 2: Morphological and Biochemical characteristics of bacterial isolates

\begin{tabular}{lllll} 
Bacterial Isolates & & TAN1 & TAN2 & TAN3 \\
\hline $\begin{array}{lllll}\text { Morphological } \\
\text { characteristics }\end{array}$ & Shape & Cocci & Rod & Cocci \\
& Spore & & & \\
& former & + & + & + \\
Gram & & & \\
Biochemical characteristics & reaction & - & + & + \\
& Citrate & + & + & + \\
& Catalase & + & + & + \\
& Coagulase & + & - & + \\
Starch & + & + & + \\
& Glucose & + & + & + \\
Oxidase & + & + & + \\
& Indo & - & + & - \\
Lactose & - & + & + \\
Manitol & + & - & + \\
Maltose & + & + & + \\
MR & - & + & - \\
VP & + & - & - \\
& Nitrate & - & - & - \\
Reduction & - Neisseria & Bacillus & Staphylococcus \\
& Bacterial & cereus & aureus \\
& name & spp & cas
\end{tabular}

+ = Positive; - = Negative; MR=Methyl Red; VP= Voges-Proskauer 


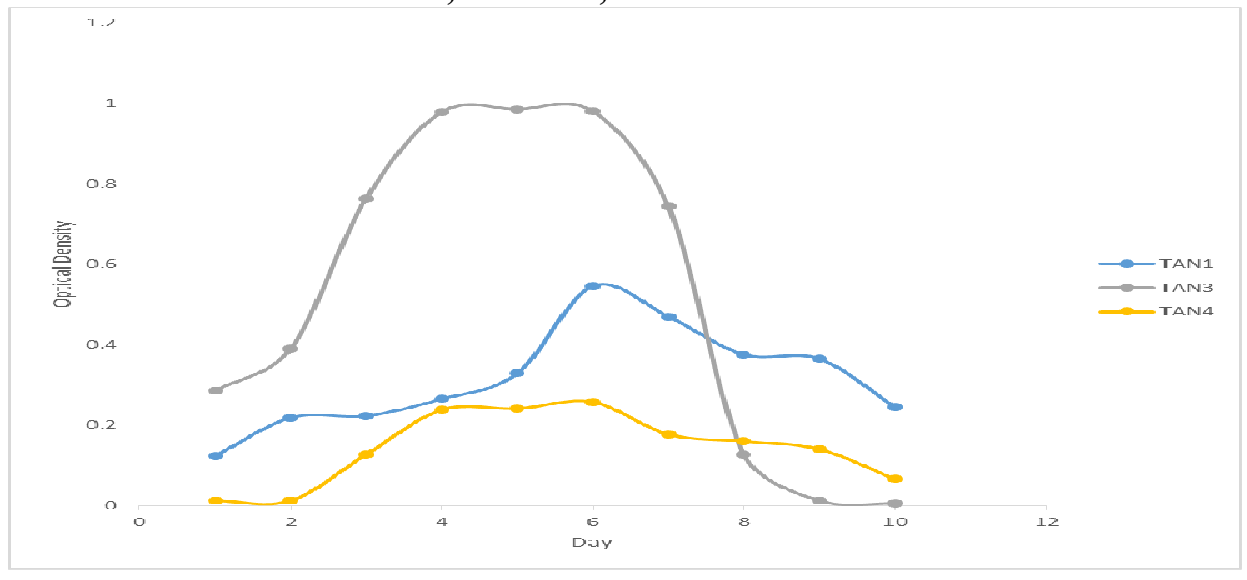

Fig. 2 Growth rates of the isolates in the effluents from the Tannery Industries

\section{Physico-chemical Parameters in the Industrial Effluents after the biodegradation.}

Table 3 shows the mean results of the physicochemical parameter before and after bioremediation using the different masses $(5 \mathrm{~g}$, $10 \mathrm{~g}, 15 \mathrm{~g}, 20 \mathrm{~g}$, and $25 \mathrm{~g}$ ) of the respective immobilized bacteria. Also, Table 4 shows the mean results of correlation coefficient ( $r$ ) between different masses of bacteria and physicochemical parameters.

The mean values $(\mathrm{mg} / \mathrm{l})$ of the SS after the bioremediation varies between $243 \pm 45$ and $898 \pm 672$. The mean concentration $(\mathrm{mg} / \mathrm{l})$ of SS remediated by the different masses $(5 \mathrm{~g}, 10 \mathrm{~g}$, $15 \mathrm{~g}, 20 \mathrm{~g}$, and $25 \mathrm{~g}$ ) of the bacteria varies. The SS in the samples fluctuates up and down after the bioremediation process when compared with the SS of the raw samples before the bioremediation. The increase in the levels of the SS might be due to the aggregation of the TDS which are large enough to result into SS. The increase in the levels of the SS might be also due to the influence of the nutrients which was added into the effluents in order to make the microorganisms more active and viable for fast degradation of organic contaminants in the effluent. The relative potential or efficiency of the different masses of the bacteria in remediating SS in TAN1 samples was in the order $25 \mathrm{~g}>20 \mathrm{~g}>15 \mathrm{~g}>10 \mathrm{~g}>5 \mathrm{~g}$. For TAN2 and TAN3 samples, the order was $25 \mathrm{~g}>20 \mathrm{~g}>15$ $\mathrm{g}>10 \mathrm{~g}>5 \mathrm{~g}$. These might be due to the variations in the surface areas of the different masses of the immobilized bacteria. Statistical analysis shows that there is no significant difference $(p<0.05)$ between the mean values of SS among the masses in the respective industries. Positive and significant correlations exist between the masses of bacteria and Suspended Solid (SS). This showed that there is general increase in the levels of the SS as the masses of the immobilized bacteria increases. TAN3 (90\%) and TAN1 (80\%) showed a very high correlation with the masses of the bacteria while TAN2 (61\%) showed a very low correlation.

The mean values $(\mathrm{mg} / \mathrm{l})$ of the TDS after the bioremediation varies between $46 \pm 11$ and $83 \pm 78$. The mean concentration $(\mathrm{mg} / \mathrm{l})$ of TDS remediated by the different masses $(5 \mathrm{~g}, 10 \mathrm{~g}$, $15 \mathrm{~g}, 20 \mathrm{~g}$, and $25 \mathrm{~g}$ ) of the bacteria varies. There is a reduction in all the TDS of all the samples after the bioremediation process compared with the TDS of the raw samples before the bioremediation. The relative potential or efficiency of the different masses of the bacteria in remediating TDS in TAN1 and TAN3 samples was in the order $5 \mathrm{~g}>10 \mathrm{~g}>15 \mathrm{~g}>20$ $\mathrm{g}>25 \mathrm{~g}$. For TAN2 samples, the order was 20 $g>10 \quad g>25 \quad g>15 \quad g>5 \quad g$. Statistical analysis shows that there is no significant difference $(p<0.05)$ between the mean values of TDS among the masses in the respective industries. These might be due to the variations in the surface areas of the different masses of the immobilized bacteria. Positive and significant correlations exist between the masses of bacteria and TDS with the exception in TAN2 (negative and insignificant correlation). The positive correlations showed that there is general increase in the levels of the TDS as the masses of the immobilized bacteria increases. TAN1 $(96 \%)$ showed a very high correlation with the masses of the bacteria while TAN2 (47\%) showed a very low correlation.

The mean values $(\mathrm{mg} / \mathrm{l})$ of the BOD after the bioremediation varies between $1.56 \pm 0.20 \mathrm{mg} / \mathrm{l}$ and $6.92 \pm 5.49 \mathrm{mg} / \mathrm{l}$. The mean concentration $(\mathrm{mg} / \mathrm{l})$ of BOD remediated by the different masses $(5 \mathrm{~g}, 10 \mathrm{~g}, 15 \mathrm{~g}, 20 \mathrm{~g}$, and $25 \mathrm{~g}$ ) of the bacteria varies. There is a reduction in all the BOD of all the samples after the bioremediation process compared with the $\mathrm{BOD}$ of the raw 
BAJOPAS Volume 13 Number 2, December, 2020 samples before the bioremediation. The relative potential or efficiency of the different masses of the bacteria in remediating BOD in TAN1, TAN2 and TAN3 samples were in the order $25 \mathrm{~g}>20$ $\mathrm{g}>15 \mathrm{~g}>10 \mathrm{~g}>5 \mathrm{~g}, 25 \mathrm{~g}>15 \mathrm{~g}>5 \mathrm{~g}>10 \mathrm{~g}>20 \mathrm{~g}$ and $20 \mathrm{~g}>10 \mathrm{~g}>25 \mathrm{~g}>15 \mathrm{~g}>5 \mathrm{~g}$ respectively. Statistical analysis shows that there is significant difference $(p<0.05)$ between the mean values of BOD among the masses in the respective industries. These might be due to the variations in the surface areas of the different masses of the immobilized bacteria. Negative and significant correlations exist between the masses of bacteria and BOD. This showed that there is general decrease in the levels of the BOD as the masses of the immobilized bacteria increases. TAN1 (94\%) showed a very high correlation with the masses of the bacteria while TAN2 (4\%) showed a very low correlation.

The mean values $(\mathrm{mg} / \mathrm{l})$ of the COD after the bioremediation varies between $250 \pm 154$ and $3134 \pm 1595$. The mean concentration $(\mathrm{mg} / \mathrm{l})$ of COD remediated by the different masses $(5 \mathrm{~g}$, $10 \mathrm{~g}, 15 \mathrm{~g} 20 \mathrm{~g}$, and $25 \mathrm{~g}$ ) of the bacteria varies. There is a reduction in all the COD of all the samples after the bioremediation process compared with the COD of the raw samples before the bioremediation. The relative potential or efficiency of the different masses of the bacteria in remediating COD in TAN1, TAN2 and TAN3 samples were in the order $25 \mathrm{~g}>20 \mathrm{~g}>15$ $\mathrm{g}>5 \mathrm{~g}>10 \mathrm{~g}, 25 \mathrm{~g}>20 \mathrm{~g}>15 \mathrm{~g}>10 \mathrm{~g}>5 \mathrm{~g}$ and 10 g>5 g>25 g>15 g>20 g respectively. Statistical analysis shows that there were significant difference $(p<0.05)$ between the mean values of COD among the masses in the respective industries except for effluents treated with $25 \mathrm{~g}$. These might be due to the variations in the surface areas of the different masses of the immobilized bacteria. Negative and insignificant correlations exist between the masses of bacteria and COD with the exception in TAN3 (positive and significant correlation). The negative correlations showed that there is general decrease in the levels of the COD as the masses of the immobilized bacteria increases. TAN2 (100\%) showed a very high correlation with the masses of the bacteria while TAN3 (36\%) showed a very low correlation.

Generally, there was an overall decrease in the concentration of these physicochemical parameters after the bioremediation using the different masses of the bacterial isolates. These might be due to the variations in the surface areas of the different masses of the immobilized bacteria. This is in line with the work of Jimoh et al. (2018) and Baba et al. (2020).

Table 3: Mean Values $(\mathrm{mg} / \mathrm{l}) \pm$ S.D of Physicochemical parameters in effluents from the Tannery Industries before and after Treatment of the effluents $(250 \mathrm{ml})$ with the different masses $(5 \mathrm{~g}, 10 \mathrm{~g}$, $15 \mathrm{~g}, 20 \mathrm{~g}$, and $25 \mathrm{~g}$ ) of the bacteria.

\begin{tabular}{llllllll}
\hline $\mathrm{P}$ & IND & Before & \multicolumn{5}{c}{ After } \\
\cline { 4 - 7 } & & & $5 \mathrm{~g}$ & $10 \mathrm{~g}$ & $15 \mathrm{~g}$ & $20 \mathrm{~g}$ & $25 \mathrm{~g}$ \\
\hline \multirow{2}{*}{ COD } & TAN1 & $2372 \pm 938$ & $1708 \mathrm{a} \pm 861$ & $2045 \mathrm{a} \pm 1205$ & $845 \mathrm{a} \pm 369$ & $300 \mathrm{a} \pm 167$ & $250 \mathrm{a} \pm 154$ \\
& TAN2 & $1406 \pm 208$ & $1195 \mathrm{a} \pm 208$ & $1125 \mathrm{a} \pm 384$ & $1055 \mathrm{a} \pm 317$ & $956 \mathrm{a} \pm 310$ & $870 \mathrm{ab} \pm 240$ \\
& TAN3 & $3532 \pm 1373$ & $2374 \mathrm{a} \pm 1344$ & $1976 \mathrm{a} \pm 1405$ & $2757 \mathrm{a} \pm 1266$ & $3134 \mathrm{a} \pm 1595$ & $2614 \mathrm{~b} \pm 1105$ \\
BOD & TAN1 & $13.85 \pm 6.42$ & $6.92 \mathrm{a} \pm 5.49$ & $6.42 \mathrm{a} \pm 5.07$ & $5.72 \mathrm{a} \pm 5.35$ & $4.62 \mathrm{a} \pm 4.37$ & $2.82 \mathrm{ab} \pm 1.26$ \\
& TAN2 & $19.46 \pm 0.50$ & $1.75 \mathrm{~b} \pm 0.22$ & $1.73 \mathrm{~b} \pm 0.18$ & $1.58 \mathrm{a} \pm 0.16$ & $1.91 \mathrm{a} \pm 0.22$ & $1.56 \mathrm{~b} \pm 0.20$ \\
& TAN3 & $17.13 \pm 3.14$ & $4.24 \mathrm{ab} \pm 0.77$ & $3.29 \mathrm{ab} \pm 0.37$ & $4.11 \mathrm{a} \pm 0.07$ & $3.23 \mathrm{a} \pm 0.91$ & $3.33 \mathrm{a} \pm 1.28$ \\
SS & TAN1 & $374 \pm 124$ & $243 \mathrm{a} \pm 45$ & $471 \mathrm{a} \pm 226$ & $475 \mathrm{a} \pm 182$ & $492 \mathrm{a} \pm 128$ & $611 \mathrm{a} \pm 217$ \\
& TAN2 & $358 \pm 335$ & $460 \mathrm{a} \pm 400$ & $543 \mathrm{a} \pm 414$ & $544 \mathrm{a} \pm 402$ & $551 \mathrm{a} \pm 414$ & $554 \mathrm{a} \pm 405$ \\
& TAN3 & $780 \pm 739$ & $586 \mathrm{a} \pm 594$ & $758 \mathrm{a} \pm 656$ & $787 \mathrm{a} \pm 676$ & $861 \mathrm{a} \pm 635$ & $898 \mathrm{a} \pm 672$ \\
TDS & TAN1 & $3941 \pm 3703$ & $51 \mathrm{a} \pm 10$ & $53 \mathrm{a} \pm 10$ & $55 \mathrm{a} \pm 15$ & $61 \mathrm{a} \pm 20$ & $63 \mathrm{a} \pm 26$ \\
& TAN2 & $3300 \pm 1714$ & $83 \mathrm{a} \pm 78$ & $47 \mathrm{a} \pm 20$ & $48 \mathrm{a} \pm 22$ & $47 \mathrm{a} \pm 17$ & $48 \mathrm{a} \pm 17$ \\
& TAN3 & $2653 \pm 1240$ & $46 \mathrm{a} \pm 11$ & $55 \mathrm{a} \pm 24$ & $55 \mathrm{a} \pm 25$ & $58 \mathrm{a} \pm 23$ & $61 \mathrm{a} \pm 28$ \\
\hline
\end{tabular}

Replicate $=6$ (months)

Within the rows, for the same parameter, means with different alphabets are statistically different $(p<0.05)$.

$\mathrm{P}=$ parameter, IND = Industries 
BAJOPAS Volume 13 Number 2, December, 2020

Table 4: Correlation coefficient $(r)$ between different masses of the bacteria and the physicochemical parameters.

\begin{tabular}{llll}
\hline Industries & Parameter & Correlation coefficient $(r)$ & $\begin{array}{l}\text { Percent dependence (rxrx100) } \\
(\%)\end{array}$ \\
\hline TAN1 & COD & -0.9 & 82 \\
& BOD & -0.97 & 94 \\
& SS & $0.90^{*}$ & 80 \\
TAN2 & TDS & $0.98^{*}$ & 96 \\
& COD & -1 & 100 \\
& BOD & -0.21 & 4 \\
& SS & $0.78^{*}$ & 61 \\
& TDS & -0.69 & 47 \\
& COD & $0.60^{*}$ & 36 \\
& BOD & -0.6 & 37 \\
& SS & $0.95^{*}$ & 90 \\
& TDS & $0.94^{*}$ & 89 \\
\hline
\end{tabular}

The correlation coefficient $(r)$ with * is statistically significant $(p<0.05)$.

Percentage reduction of the Parameters

Table 5 shows the percentage reduction of Parameters in industrial samples before and after the treatment of the effluents $(250 \mathrm{ml})$ with the different masses $(5 \mathrm{~g}, 10 \mathrm{~g}, 15 \mathrm{~g}, 20 \mathrm{~g}$, and $25 \mathrm{~g}$ ) of the Immobilized Bacteria.

In TAN1 samples, the percentage reduction (\%) of COD ranged (14-89); BOD (50-80); SS (-32$35)$ and TDS (98-99). In TAN2 samples, the percentage decrease $(\%)$ of COD ranged (15$38) ;$ BOD (90-92); SS [-28-(-55)] and TDS (9798). In TAN3 samples, the percentage decrease (\%) of COD ranged (11-44); BOD (76-81); SS (15-25) and TDS (98). The percentage increase in the levels COD, BOD and TDS might be due to the increase in the surface area of the different masses of the immobilized bacteria. However, the percentage decrease in the levels of the SS might be due to the aggregation of the TDS which are large enough to result into SS. The percentage decrease in the levels of the SS might be also due to the influence of the nutrients which was added into the effluents in order to make the microorganisms more active and viable for fast degradation of organic contaminants in the effluent. This is in line with the work of Jimoh et al. (2018) in which the concentration of the SS increase after the bioremediation of effluents.

Sreemoyee and Priti (2013) assessed and reduced several Physico-chemical parameters of dairy wastewater using Niesseria $s p$. and concluded that the species are well known to degrade organic compounds. This is in agreement with the current study in which the immobilized Niesseria $s p$ degrade the organic contaminants as indicated by the BOD, COD and TDS.

Jimoh et al. (2018) observed that TSS of the effluents was increased after treatment with immobilized bacteria and concluded that it might be due to the biostimulation method adopted for the research.

The optimum $\mathrm{pH}$ Biosorption of Chromium by Bacillus spp and Staphylococcus spp. from tannery effluent was investigated by Mythili and Karthikeyan (2011). The maximum adsorption of Chromium $(86.4 \mathrm{mg} / \mathrm{L})$ was showed by Bacillus spp and Staphylococcus spp showed $70.6 \mathrm{mg} / \mathrm{L}$ at an initial concentration of $100 \mathrm{mg} / \mathrm{L}$. In the present study, immobilised Bacillus spp and Staphylococcus spp. from the tannery industrial effluents reduced the levels of the organic pollutants with high potential as indicated by the percentage reduction of BOD, COD and TDS.

Enzymes often can work in multiple environments especially if they are immobilized. This makes the microorganisms' enzymes even more resistant to harsh environments and enables the enzymes to be recovered and recycled after they are no longer needed (Gianfreda and Rao 2004). Ramesh and Singh (1993) reported that the immobilized bacteria having more efficiency to remove the suspended particles than free cells. Using the immobilized cell is preferable due to its capability for using several times with the same efficiency, which makes it more economical. Similar work was done by Sikander et al. (2007) showing the higher reduction with permeabilized cells of Ochrobactrum intermedium strain SDCr-5. 
BAJOPAS Volume 13 Number 2, December, 2020

The results revealed the isolation and identification of isolates with the potential for the reduction of $\mathrm{Cr}$ (VI) to $\mathrm{Cr}$ (III). Results indicated that immobilized $B$. cereus could be efficiently used for the reduction of $\mathrm{Cr}$ (VI).

Table 5: Percentage reduction of the tested Parameters from the tannery industrial samples of the Immobilized Bacteria.

\begin{tabular}{lllllll}
\hline \multirow{2}{*}{ Industries } & & \multicolumn{5}{c}{ Percentage Reduction $(\%)$} \\
\cline { 3 - 7 } & & $5 \mathrm{~g}$ & $10 \mathrm{~g}$ & $15 \mathrm{~g}$ & $20 \mathrm{~g}$ & $25 \mathrm{~g}$ \\
\hline TAN1 & COD & 28 & 14 & 64 & 87 & 89 \\
& BOD & 50 & 54 & 59 & 67 & 80 \\
& SS & 35 & -26 & -27 & -32 & -63 \\
& TDS & 99 & 99 & 99 & 98 & 98 \\
TAN2 & COD & 15 & 20 & 25 & 32 & 38 \\
& BOD & 91 & 91 & 92 & 90 & 92 \\
& SS & -28 & -52 & -52 & -54 & -55 \\
& TDS & 97 & 99 & 99 & 99 & 99 \\
& COD & 33 & 44 & 22 & 11 & 26 \\
& BOD & 75 & 81 & 76 & 81 & 81 \\
& SS & 25 & 3 & -1 & -10 & -15 \\
& TDS & 98 & 98 & 98 & 98 & 98 \\
\hline
\end{tabular}

Percentage Reduction $=(B-A) / B \times 100 \%$

$A=$ Concentration of the parameter after treatment

$\mathrm{B}=$ Concentration of the parameter before treatment

$+=$ percentage decrease

- = percentage increase

In general, immobilization makes the enzyme more resistant to temperature, $\mathrm{pH}$, and substrate concentration swings giving it a longer lifetime and higher productivity per active unit (Gianfreda and Rao, 2004; FuIlbrook, 1996; Russell et al, 2003; Kandelbauer et al., 2004). Immobilized cells have been used and studied extensively for the production of useful chemicals (Ohtake and Silver, 1994), the treatment of wastewaters (Chen et al., 2003; Wang et al., 2010). Although many workers described microbial degradation of tannery effluent, limited literature is available on the bioremediation of tannery effluent using immobilized bacterial cells in the Kano Industrial Estates.

\section{CONCLUSION}

The samples contained variable levels of the physicochemical parameters. The results of the Analysis of variance revealed that, no statistical difference $(p<0.05)$ was observed for the temperature, $\mathrm{pH}, \mathrm{SS}, \mathrm{TDS}, \mathrm{BOD}$ and $\mathrm{COD}$ among the three tannery industries before the treatment. The levels of some of the parameters
(SS, TDS and COD) observed in the samples were found above the recommended limits of WHO and NESREA, which called for the treatment of the effluents before discharge into the environment. Base on the morphological and biochemical test results, TAN1, TAN2, and TAN3 bacterial isolates were identified to be Neisseria spp, Bacillus cereus, and Staphylococcus aureus respectively. The results of Post-treatment analysis showed that there is overall decrease in the levels of the parameters determined when compared with that of the pre-treatment. The overall percentage reduction of the immobilised bacteria in the treatment of the respective effluents was in the order TAN2 (72\%)>TAN1 $(70 \%)>$ TAN3 $(62 \%)$. Hence, the immobilized bacteria are having higher biodegradation potential for the treatment of the tannery effluents.

\section{Acknowledgments}

The authors wish to acknowledge the University of Maiduguri for the financial support. The authors are grateful to the Kano State Ministry of Environment for their support in obtaining the effluent samples. 


\section{REFERENCES}

Ajao, A. T., Adebayo, G. B., and Yakubu, S. E. (2011). Bioremediation of textile industrial effluent using mixed culture of Pseudomonas aeruginosa and Bacillus subtilis immobilized on agar-agar in a bioreactor. J. Microbiol. Biotech. Res, 1(3), 50-56.

Akan, J. C., Moses, E. A., Ogugbuaja, V. O., and Abah, J. (2007). Assessment of tannery industrial effluents from Kano metropolis, Kano State, Nigeria. Journal of Applied Sciences, 7(19), 2788-2793.

Akan, J. C., Ogugbuaja, V. O., Abdulrahman, F. I., and Ayodele, J. T. (2009). Pollutant levels in effluent samples from tanneries and textiles of Kano industrial areas, Nigeria. Global journal of pure and applied sciences, 15(3-4).

APHA (1989). Standard methods for Examination of Will bete and Will betewater.15 $5^{\text {th }}$ edition. Brydpass Springfield Will behington DC. pp. 164-176

APHA (1992). Standard Methods for the Examination of Water and Wastewater. Health, 69, 1116-9.

Baba, A., Garba, S. T., and Bello, H. S. (2020). Bioremediation Potential of Immobilized corynebacterium kutsceri in the Treatment of Tannery Industrial Effluent from Challawa Industrial Estate, Kano State, Nigeria. Journal of the Turkish Chemical Society Section A: Chemistry, $7(2), 335-350$.

Beem, E. I. V. (1994). reduction of solvent VOC emission. J. Oil Col. Chem. Ass, 77, 158.

Bouwer, E. J., and Zehnder, A. J. (1993). Bioremediation of organic compoundsputting microbial metabolism to work. Trends in biotechnology, 11(8), 360367.

Chen, K. C., Wu, J. Y., Liou, D. J., and Hwang, S. C. J. (2003). Decolorization of the textile dyes by newly isolated bacterial strains. Journal of Biotechnology, 101(1), 57-68.

Dan'Azumi, S., and Bichi, M. H. (2010). INDUSTRIAL POLLUTION AND HEAVY METALS PROFILE OF CHALLAWA RIVER IN KANO, NIGERIA. Journal of Applied Sciences in Environmental Sanitation, $5(1)$.

DWAF. (1992). Analytical Methods Manual, TR 151. Department of Water Affairs and Forestry, Pretoria.

El-Bestawy, E. (2013). Biological treatment of leather-tanning industrial wastewater using free living bacteria.
Elsheikh, M. A. S. (2009). Tannery wastewater pre-treatment. Water Science and Technology, 60(2), 433-440.

FuIlbrook, P. D. (1996). "Kinetics." Industrial enzymology: The application of enzymes in Industry. 2nd Ed. T. Godfrey and J Reichelt. eds.. Nature. New York.

Gianfreda, L., and Rao, M. A. (2004). Potential of extra cellular enzymes in remediation of polluted soils: a review. Enzyme and microbial technology, 35(4), 339354.

Hugo Springer. (1994). John Arthur Wilson Memorial Lecture "Treatment of Industrial Wastes of the Leather Industry - is it still a Major Problem". JALCA, 89, 153-185

Jimoh, A. A., Ganiyu, B. A., Baba, D., and Baba, A. (2018) Bioremediation Process of Effluent from Detergent and Food Industries in Jos, Nigeria: Kinetics and Thermodynamics. International Journal of Engineering Science Invention (IJESI), 762-73

Kandelbauer, A., Maute, O., Kessler, R. W., Erlacher, A., and Gübitz, G. M. (2004). Study of dye decolorization in an immobilized laccase enzyme-reactor using online spectroscopy. Biotechnology and bioengineering, 87(4), 552-563.

Kongjao, S., Damronglerd, S., and Hunsom, M. (2008). Simultaneous removal of organic and inorganic Pollutants in tannery wastewater using electrocoagulation technique. Korean Journal of chemical engineering, 25(4), 703.

Maheshwari, U. M., Aruna, S., Gomathi, M., and AbdulJaffar, A. H. (2017). Bioremediation by Free and Immobilized Bacteria Isolated from Tannery Effluent. International Journal of Research in Applied, Natural and Social Sciences. 5(7), 75-90

Margesin, R., and Schinner, F. (2001). Bioremediation (natural attenuation and biostimulation) of diesel-oilcontaminated soil in an alpine glacier skiing area. Applied and environmental microbiology, 677), 3127-3133.

Mohammed, A., Sekar, P., and George, J. (2011). Efficacy of microbes in bioremediation of tannery effluent. Inter. J. Curr. Res, 3(4), 324-326.

Mohammed, S. S. D., Orukotan, A. A., and Abdullahi, H. (2017). Physicochemical and Bacteriological Assessment of Tannery Effluent from Samaru-Zaria, 
BAJOPAS Volume 13 Number 2, December, 2020 Kaduna State, Nigeria. Journal of Applied

Sciences and Environmental Management, 21(4), 734-740.

Munz, G., De Angelis, D., Gori, R., Mori, G., Casarci, M., and Lubello, C. (2009). The role of tannins in conventional and membrane treatment of tannery wastewater. Journal of hazardous materials, 164(2-3), 733-739

Mythili, K., and Karthikeyan, B. (2011). Bioremediation of $\mathrm{Cr}$ (VI) from tannery effluent using Bacillus spp and Staphylococcus spp. International Multidisciplinary Research Journal, 1(6).

NESREA (2009). National Environmental Standards for Effluent Limitations and Regulation. 1233-1236

Noorjahan, C. M. (2014). Physicochemical characteristics, identification of bacteria and biodegradation of industrial effluent. Journal of bioremediation and Biodegradation, 5(3).

Ohtake, H. I., and Silver, A. O. (1994). Bacterial reduction of toxic chromate. Biological degradation and bioremediation of toxic chemicals, 403-415.

Omoleke, I. I. (2004). Management of environmental pollution in Ibadan, an African city: the challenges of health hazard facing government and the people. Journal of Human Ecology, 15(4), 265-275.

Rajor, A., Reddy, A.S., and Singh, B. (2004). Determination of BOD kinetic Parameters and evaluation of alternate methods, M.Sc. Thesis, Department of biotechnology \& environmental Science, Thapar Institute of Engineering and Technology, Patiala

Ramasami, T., Rajamani, S., and Rao, J. R. (1994, March). Pollution control in leather industry: Emerging technological options. In International symposium on surface and colloidal science and its relevance to soil pollution, madras.

Ramesh, J. V. S., and Singh, S. P. (1993). Yearly variation in certain physicochemical parameters of pond at eastern Doon Valley. Uttar Pradesh J. Zoo, 12 (1), 7577.

Ranen, S., and Sharadinadra, C. (2009). Biotechnology applications to environmental remediation in resource exploitation. Current science, 97, 6-25
Russell, A. J., Berberich, J. A., Drevon, G. F., and Koepsel, R. R. (2003). Biomaterials for mediation of

chemical and biological warfare agents. Annual review of biomedical engineering, 5(1), 1-27.

Saravanan, P., and Saravanan, A. (1999). Decolourization of tannery effluent by Flavobacterium sp. EK 1. Indian Journal of Environmental Protection, 19, 19-24.

Sikander, S., and Shahida, H. (2007). Reduction of toxic hexavalent chromium by Ochrobactrum intermedium strain SDCr5 stimulated by heavy metals. Bioresource Technol, 98, 340-344.

Singh, N., Sharma, B. K., and Bohra, P. C. (2000). Impact assessment of industrial effluent of arid soils by using satellite imageries. Journal of the Indian Society of Remote Sensing, 28(2-3), 79.

Sreemoyee, C., and Priti, P. (2013). Assessment of physico-chemical parameters of dairy waste water and isolation and characterization of bacterial strains in terms of cod reduction. Int J Sci, 2(3), 395-400.

Verheijen, L. A. H. M., Wiersema, D., Pol, L. H., and De Wit, J. (1996). Management of wastes from animal product processing. Livestock and environment, Finding a balance. International Agriculture Center, Wageningen, The Netherlands.

Wang, F., Yao, J., Si, Y., Chen, H., Russel, M., Chen, K., and Bramanti, E. (2010). Short-time effect of heavy metals upon microbial community activity. Journal of Hazardous Materials, 173(13), 510-516.

WHO (World Health Organization). (2006). Air quality guidelines: global update 2005: particulate matter, ozone, nitrogen dioxide, and sulfur dioxide. World Health Organization.

World Bank. (1995). Nigeria's strategic options for redressing industrial pollution. World Bank, industry and energy division. 1st edition, West Central Africa Department; Annexes: 1995; pp 60-62.

Zahoor, A., and Abdul, R. (2009). Enumeration of Coliforms. Journal of Environmental Sciences. 21, 814-820 


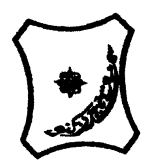

Bayero Journal of Pure and Applied Sciences, 13(2): 1 - 12

Received: November, 2020

Accepted: December, 2020

ISSN $2006-6996$

\title{
BIODEGRADATION POTENTIAL OF IMMOBILIZED BACTERIA IN THE TREATMENT OF TANNERY INDUSTRIAL EFFLUENTS FROM INDUSTRIAL ESTATES IN KANO STATE, NIGERIA
}

\author{
Abdullateef, B., ${ }^{1 *}$ Shuaibu, T. G., ${ }^{1}$ Babagana, K., ${ }^{1}$ Suleman, H. B. ${ }^{2}$ and Dauda, B. ${ }^{3}$ \\ ${ }^{1}$ Department of Pure and Applied Chemistry, Faculty of Science, University of Maiduguri, Borno State, \\ Nigeria \\ ${ }^{2}$ Department of Microbiology, Faculty of Science, University of Maiduguri, Borno State, Nigeria \\ ${ }^{3}$ Department of Chemical Engineering, Faculty of Engineering, University of Maiduguri, Borno State, \\ Nigeria \\ *Corresponding author: babslega@gmail.com; abelega2007@yahoo.com; +2348061309753
}

\section{ABSTRACT}

Industrial Effluents Samples from Gashash Tanneries (TAN1) in Bompai Industrial estate, Larabee Tannery Industry (TAN2) in Sharada Industrial estate and Z Tannery Industries (TAN3) in Challawa Industrial estate, Kano State, Nigeria were collected over a period of six months (August 2017 to January 2018) for assessing the biodegradation potentials of bacteria in the treatment of organic pollutants within the effluents. Bacteria were isolated from the effluents and immobilized on agar-agar. Different masses (5 g, $10 \mathrm{gr}, 15$ $\mathrm{g}, 20 \mathrm{~g}$, and $25 \mathrm{~g}$ ) of the bacteria were used in the treatment of $250 \mathrm{ml}$ of the effluents for ten days in a shaker incubator (Gallenkamp-OC-4364-L) at the temperature $30{ }^{\circ} \mathrm{C}$ and speed of $60 \mathrm{rpm}$. Pre-treatment analysis of the effluents for Temperature, pH, Biochemical Oxygen Demand (BOD), Chemical Oxygen Demand (COD), Suspended Solid (SS) and Total Dissolved Solids (TDS) gives the following results; temperature $\left({ }^{\circ} \mathrm{C}\right.$ )

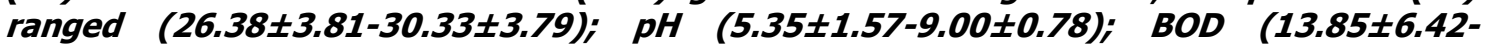
$38.75 \pm 16.20) ;$ COD (1406 $\pm 208-3532 \pm 1373) ;$ SS (208 $\pm 235-780 \pm 739)$ and TDS (266 $\pm 253-5276 \pm 2971)$. No statistical differences ( $p \leq 0.05)$ was observed for all the results among the different industries. The bacterial isolates were identified as Neisseria spp, Bacillus cereus, and Staphylococcus aureus, in TAN1, TAN2, and TAN3, respectively. After treatment of the effluent with the different masses of the isolated bacteria, the mean level of BOD was found to range as (0.55 $\pm 0.36-6.92 \pm 5.49) ; C O D$ (ND-3134 \pm 1595$)$;

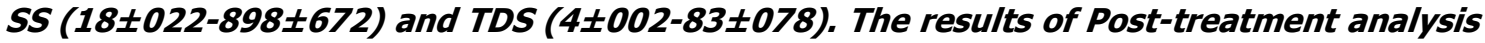
showed that there is overall decrease in the levels of the parameters determined when compared with that of the pre-treatment. The overall percentage reduction of the immobilised bacteria in the treatment of the respective effluents was in the order TAN2 (72\%)>TAN1 (70\%)>TAN3 (62\%). Hence, the immobilized bacteria are having higher biodegradation potential for the treatment of the tannery effluents.

Keywords: Biodegradation, bacteria, effluent, immobilization, tannery.

\section{INTRODUCTION}

Tannery industrial wastewater is a serious consequence of the pollution point of view for streams, freshwater, and land used for agriculture. The lack of awareness in the modern industrial practice has resulted in the discharge of tannery effluents which exhibit very high value of chromium ( $\mathrm{Cr}$ ), Sulfide, and chloride, Total Dissolved Solid (TDS), Total Suspended Solid (TSS), Biochemical Oxygen Demand (BOD) and Chemical Oxygen Demand (COD) in the water stream or land (Mohammed et al., 2001). Tanning is the process, which One ton of skin generally leads to the production of 20 to $80 \mathrm{~m}^{3}$ of turbid and foul-smelling converts the protein of the rawhide or skin into a stable material, which will not putrefy and is suitable for a wide variety of end applications (Elsheikh, 2009). The highly polluting chromium is the most commonly used tanning material producing leather that is more flexible and pliable than vegetable-tanned leather and does not discolor or lose shape in water as drastically as vegetable-tan (Elsheikh, 2009). Tannery effluent is among the most hazardous industrial pollutants due to its huge organic and inorganic load, which is highly toxic to human life and the environment (Kongjao et al., 2008). wastewater including chromium (100-400 mg/l), sulfide $(200-800 \mathrm{mg} / \mathrm{l})$, high levels of fat and 
BAJOPAS Volume 13 Number 2, December, 2020 other solid wastes, and notable pathogen contamination as well as pesticides added for skin conservation during transport (Elsheikh, 2009). There are more than 6000 tanneries in Nigeria with an annual processing capacity of 700,000 tons of hides and skins (Omoleke, 2004; Singh et al., 2008). It was reported that the total amount of waste produced per animal slaughtered is approximately $35 \%$ of its weight (World Bank, 1995). Also, for every $1000 \mathrm{~kg}$ of carcass weight, a slaughtered beef produces 5.5 $\mathrm{kg}$ of manure (excluding rumen contents or stockyard manure) and $100 \mathrm{~kg}$ of paunch manure (undigested food) (Verheijen et al., 1996). Tanneries generate wastewater in the range of 30-35 $\mathrm{L} \mathrm{kg}^{-1}$ skin/hide processed with variable $\mathrm{pH}$, Biological Oxygen Demand (BOD), Chemical Oxygen Demand (COD), high concentrations of suspended solids (SS), and tannins as well as chromium (Zahoor and Abdul, 2009).

Being heterogeneous and composed of a wide variety of compounds, it is very difficult to select a unique direct method for estimating the biodegradability of organic contents and biokinetic parameters for a wastewater sample (Rajor, 2004). For this purpose, some indirect estimation such as determination of biochemical oxygen demand (BOD) and chemical oxygen demand (COD) are applied as common laboratory investigations [9]. During retanning procedures, synthetic tannins (Syntan), oils and resins are added to form softer leather at varying doses (Munz et al., 2009). One of the refractory groups of chemicals in tannery effluents derives mainly from tannins (Ramasami et al., 2004). Syntans are characterized by complex chemical structures, because they are composed of an extended set of chemicals such as phenol-, naphthalene-, formaldehyde- and melamine-based syntans, and acrylic resins (Beem, 1994). Organic pollutants (proteic and lipidic components) are originated from skins (it is calculated that the raw skin has $30 \%$ loss of organic material during the working cycle) or they are introduced during processes (Hugo Springer, 1994).

Many conventional processes such as oxidation, chemical and biological processes were carried out to treat tanneries wastewater (Ebtesam et al, 2013). Biological processes have received more attention because of their costeffectiveness, lower sludge production and environmental friendliness (Noorjahan, 2014). Naturally occurring micro-organisms degrade the hazardous organic wastes including xenobiotic compounds, such as pesticides, polycyclic aromatic hydrocarbons (PAHs) and polychlorinated biphenyls (PCBs) in due course of time (Ranen and Sharadinadra, 2009). Bioremediation is based on the idea that all organisms remove substances from the environment to carry outgrowth and metabolism (Bouwer and Zehnder, 1993). Bacteria, protista and fungi are found to be very good at degrading complex molecules and incorporating the breakdown products into their metabolism (Bouwer and Zehnder, 1993). The resultant metabolic wastes that they produce are generally safe and somehow recycled into other organisms (Ranen and Sharadinadra, 2009). An acclimatized indigenous population of microorganisms capable of degradation of the compounds of interest must exist at the site for a successful bioremediation mode (Ranen and Sharadinadra, 2009). It has been observed that for a successful bioremediation mode, an acclimatized indigenous population of microorganisms capable of degradation of the compounds of interest must exist at the site under investigation (Ranen and Sharadinadra, 2009). Even though there are numerous physical and chemical methods employed in the disposal of wastes the advantage in using bacterium is that they play a key role in the reduction of COD, BOD, total protein, total tannin and total phenol (Saravanan and Saravanan, 1998)

Baba et al. (2020) studied the bioremediation potential of immobilized corynebacterium kutsceri in the Treatment of tannery industrial effluent from Challawa Industrial Estate, Kano State, Nigeria. The aim of the work is to study the reduction in the level of the contaminants through the process of bioremediation using the isolated bacteria. Immobilized bacteria can withstand various temperatures, $\mathrm{pH}$ and substrate concentrations; consequently, increasing the efficiency and the lifespan of the bacteria. Immobilized bacteria are widely applied in the treatment of wastewater and can be separated and recovered after the treatment with the same efficiency (Baba et al., 2020).

\section{MATERIALS AND METHODS \\ Study Area}

This study was carried out in Bompai, Sharada and Challawa industrial estates in Kano, Figure 1. Kano lies on Latitude $11^{\circ} 30^{\prime} \mathrm{N}$ and $8^{\circ} 30^{\prime} \mathrm{E}$ and Longitude $11^{\circ} 5^{\prime} \mathrm{N}$ and $8^{\circ} 5^{\prime} \mathrm{E}$ in Northern Nigeria. It is one of the developed industrial cities in Nigeria. Tannery activities are the dominating industries and this could be one of the reasons for her high population density (Dan'Azumi and Bichi, 2010). Many researchers have studied biodegradation of tannery effluent using microorganisms. However, limited literature is available on the biodegradation of tannery effluent in Kano industrial estates using 
BAJOPAS Volume 13 Number 2, December, 2020 immobilized bacterial cells. This research work focuses on the potential of the use of the indigenous immobilized bacterial isolates in the treatment of tannery effluents in the industrial estates.

\section{Sample Collection}

Effluents were collected from the Tannery Industries from Bompai, Challawa and Sharada Industrial Estates, Kano, Nigeria. The effluents were collected over a period of six months (August 2017 to January 2018). Samples collected in a sterile 4-liter plastic container with a unique identification number were preserved using an ice-box that was transported to the Microbiology Laboratory, Department of Microbiology, Bayero University of Kano for analysis

\section{Sample Preparation and Sample Analysis}

Immediately after the collection of the effluent, $\mathrm{pH}$, TSS, TDS, COD, BOD levels were determined before treatment (Pre-treatment determination) and ten days after treatment (Post-treatment determination) as described in
APHA (1989) standard methods. $\mathrm{pH}$ was determined using Ecotests $\mathrm{pH}$ meter and TDS was determined using AQUALYTIC TDS Salinometer. BOD was determined as described by the standard method (APHA, 1992). COD and SS were determined using DR/2010 HACH portable data logging spectrophotometer (DWAF, 1992)

\section{Identification and Biochemical} Characterization of the Bacterial Isolates

The bacteria were isolated from the effluents using Serial Dilution according to the method described by APHA (1989). The biochemical tests such as oxidase, catalase, coagulase, indole (from $1 \%$ tryptone broth), citrate (Simmons citrate agar), methyl red/VogesProskauer (MR/VP), nitrate reduction, Starch Hydrolysis, Glucose, Maltose, and Lactose tests were carried out on the bacterial isolates to identify the bacteria through the bacteria biochemical characteristics according to Ajao et al. (2011).

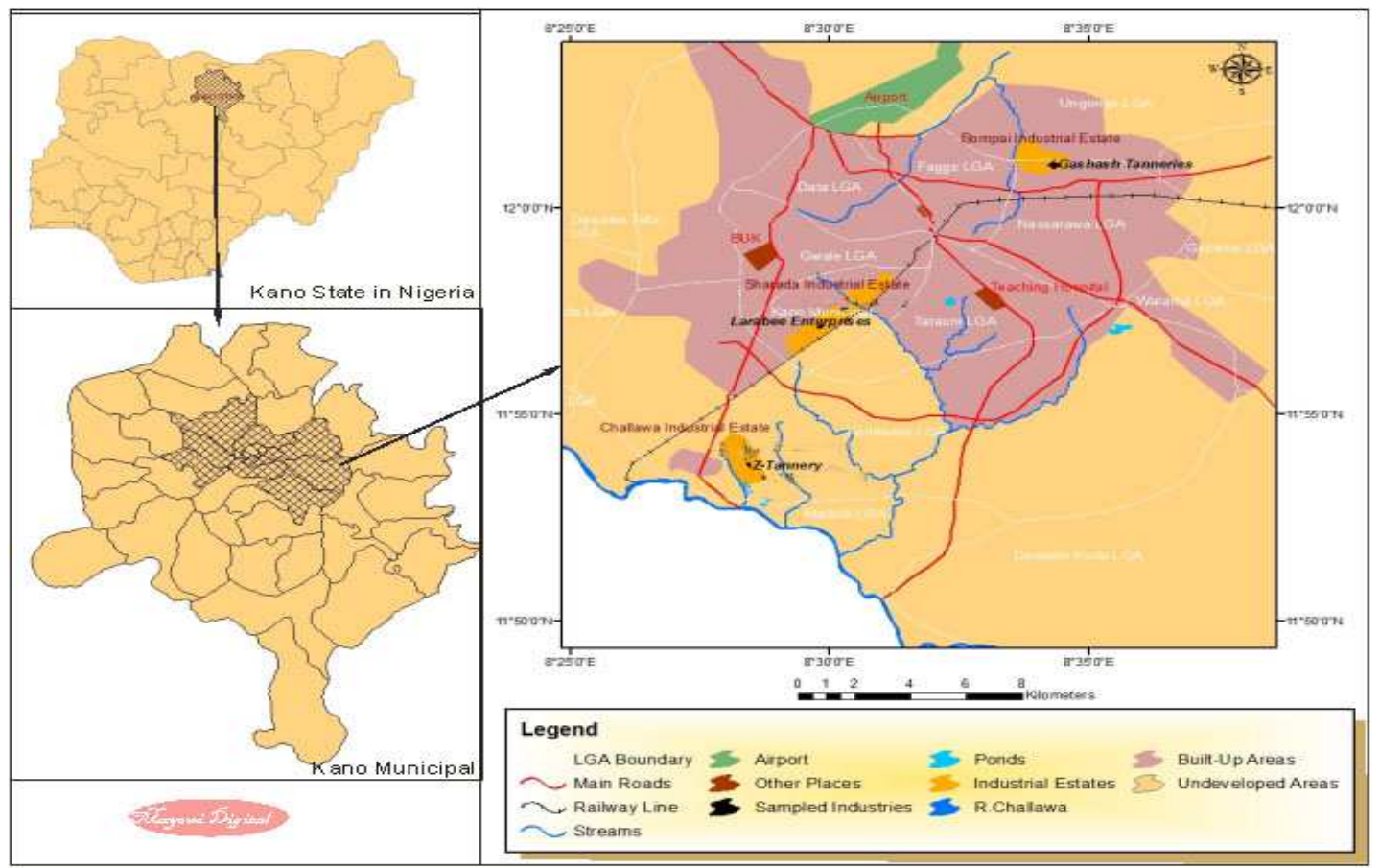

Fig. 1 Map showing the study areas

Source: Mayomi Digital Productions, GIS Laboratory, Department of Geography, UNIMAID (2017)

\section{Determination of Growth Rate of the Bacteria in Effluent Sample}

The bacteria growth rates were determined by transferring $2 \mathrm{~mL}$ of the bacterial isolates from the tannery effluent in broth medium into 100 $\mathrm{mL}$ sterile effluents in conical flasks and kept in an incubator (Giffrin cool) for 10 days. Control was also set up by incubating another $100 \mathrm{~mL}$ each of the sterile effluents without the bacteria. The optical density of the content was determined at the wavelength of $600 \mathrm{~nm}$ on a daily interval and recorded. 
BAJOPAS Volume 13 Number 2, December, 2020 Immobilization of Bacteria

Agar solution and inoculi were prepared separately. Fifty milliliters $(50 \mathrm{~mL})$ of nutrient broth each of the inoculi was prepared in a McCartney bottle and incubated for 24 hours. A solution of agar-agar was prepared by dissolving $10 \mathrm{~g}$ of the powder in distilled water and made up to $500 \mathrm{~mL}$ mark in an Erlenmeyer flask and was sterilized in an autoclave (280A) for 15 minutes and allowed to cool to $40-45^{\circ} \mathrm{C}$ (Ajao et al., 2011). Four milliliters ( $4 \mathrm{~mL})$ of the bacterial isolates in the nutrient broth was mixed with 36 $\mathrm{ml}$ of the prepared agar-agar media in petri-dish plates and then allowed to solidify. This was kept in the refrigerator for bioremediation.

\section{Bioremediation (Treatment) of the Effluents}

The solidified agar block (immobilized bacteria) was cut into cubes using a sterile knife; $0.1 \mathrm{~mL}$ phosphate buffer ( $\mathrm{pH} \mathrm{7.0)}$ was added and kept in the refrigerator for 1 hour for curing. The phosphate buffer was decanted after 1 hour and the cubes were washed with sterile distilled water 3-4 times before it was used (Ajao et al., 2011). Two liters (2 L) of the effluent was supplemented with the minimum basal medium in $\mathrm{g} / \mathrm{L}: \mathrm{NaCl}(0.8), \mathrm{MgSO}_{4} .7 \mathrm{H}_{2} \mathrm{O}(0.001), \mathrm{KH}_{2} \mathrm{PO}_{4}$ (2), $\mathrm{NaNO}_{3}$ (2), $\quad \mathrm{CaCl}_{2} .2 \mathrm{H}_{2} \mathrm{O} \quad(0.5)$ and $\mathrm{NaHPO}_{4} .12 \mathrm{H}_{2} \mathrm{O}(2)$ and sterilized in an autoclave at $121^{\circ} \mathrm{C}$ for 15 minutes (Margesin and Schinner, 2001). Two hundred and fifty milliliters $(250 \mathrm{~mL})$ of the effluents were transferred into different $250 \mathrm{ml}$ conical flasks. The content was covered with a cotton-wool ramped with foil paper to avoid contamination. Five grams $(5 \mathrm{~g})$ of the immobilized bacteria were quickly transferred into each of the effluents in the conical flasks in an inoculating chamber. The same procedures were carried out for the $10 \mathrm{~g}, 15 \mathrm{~g}, 20 \mathrm{~g}$ and 25 $\mathrm{g}$ of the immobilized bacteria in separate $250 \mathrm{~mL}$ effluents in conical flasks and agitated for ten days in a shaker incubator (Gallenkamp-OC4364-L) at a temperature $30^{\circ} \mathrm{C}$ and speed of 60 rpm. The treated effluent samples were taken on the tenth day and analyzed for the parameters $\mathrm{pH}$, SS, TDS, COD, and BOD, (Posttreatment determination) for the different grams of bacteria to evaluate and compare the biodegradation potential. (Baba et al., 2020).

\section{Statistical Analysis}

The data were represented as Mean \pm Standard deviation and analyzed statistically using oneway Analysis of Variance (ANOVA) and Tukey's HSD as Post Hoc Tests with the aid of SPSS 16.0. The correlation coefficient was also used to measure the strength of the relationship between the different masses of the bacteria and the parameters. All $\mathrm{p} \leq 0.05$ were considered as statistically significant.

\section{RESULTS AND DISCUSSION Physico-chemical parameters in the Industrial Effluents before the Biodegradation.}

Results of the Physico-chemical parameters in the industrial effluents before the Biodegradation is shown in table 1 . The mean temperatures $\left({ }^{\circ} \mathrm{C}\right)$ observed in TAN1, TAN2, and TAN3 samples were $28.07 \pm 0.65 ; 27.77 \pm 0.64$ and $26.38 \pm 3.81$ respectively. The order of the mean temperature of the samples from the three industries can be arranged as TAN1 > TAN2>TAN3. The temperature observed at TAN1, TAN2, and TAN3 samples were found below the WHO $\left(35^{\circ} \mathrm{C}\right)$ and NESREA $\left(40^{\circ} \mathrm{C}\right)$ limits. The low values of temperature might be due to the processes used at the time of sampling. High temperature brings down the solubility of gases in water that ultimately expresses as high BOD and COD. Statistical analysis shows that there is no significant difference $(p<0.05)$ between the mean values of temperature among the industries. This might be due to similar tannery activities involved in the tannery industries at the time of sampling. The average values of temperature observed in this present study are less than those observed by Akan et al. (2007), Akan et al. (2009) and Baba et al. (2020).

The mean level of $\mathrm{pH}$ observed in TAN1, TAN2 and TAN3, samples were $7.77 \pm 2.93$; $8.35 \pm 0.28$ and $7.52 \pm 0.76$ respectively. The order of the mean $\mathrm{pH}$ of the samples from the three industries can be arranged as TAN2> TAN1 $>$ TAN3. The $\mathrm{pH}$ of the samples falls within the WHO (7.0-8.5) and NESREA (6-9) standard limits. Statistical analysis shows that there is no significant difference $(p<0.05)$ between the mean values of $\mathrm{pH}$ among the industries. This might be due to similar tannery activities involved in the tannery industries at the time of sampling. Maheshwari et al. (2017) reported that the level of $\mathrm{pH}$ in the effluents from the tannery industry in Vaniyambadi, India was 6.5 which was lower than that observed in the present study. The $\mathrm{pH}$ in the effluents from the tannery industries in Kano and Kaduna were reported to be 7.64 and 6.89, respectively (Akan et al., 2007; Mohammed et al., 2017). The average values of $\mathrm{pH}$ observed in this present study are less than those observed by Mohammed et al. (2017) and Baba et al. (2020). The mean level of SS $(\mathrm{mg} / \mathrm{l})$ observed in TAN1, TAN2, and TAN3 samples were 374 \pm 124 ; $358 \pm 335$ and $780 \pm 739$ respectively. The order of the mean SS in the samples from the three industries can be arranged as TAN3 > TAN1 $>$ TAN2. 
The SS observed in the samples were far above the recommended standard limits of regulating bodies WHO $(30 \mathrm{mg} / \mathrm{l})$ and NESREA $(10 \mathrm{mg} / \mathrm{l})$. Statistical analysis shows that there is no significant difference $(p<0.05)$ between the mean values of SS among the industries. This might be due to similar tannery activities involved in the tannery industries at the time of sampling. The average values of SS observed in this present study are less than that observed $(3700 \pm 122 \mathrm{mg} / \mathrm{l})$ by Akan et al. (2009) for tanneries in Kano. Also, the average values of SS observed in this present study are less than that observed by Mohammed et al. (2017) and Baba et al. (2020) with the exception in TAN3.

The mean level of TDS (mg/l) observed in TAN1, TAN2, and TAN3 samples were $3941 \pm 3703$; $3300 \pm 1714$ and $2653 \pm 1240$ respectively. The order of the mean TDS in the samples from the three industries can be arranged as TAN1>TAN2>TAN3. The TDS observed in the samples were far above the recommended standard limits of WHO $(250 \mathrm{mg} / \mathrm{l})$ and NESREA $(500 \mathrm{mg} / \mathrm{l})$. Statistical analysis shows that there is no significant difference $(p<0.05)$ between the mean values of TDS among the industries. This might be due to similar tannery activities involved in the tannery industries at the time of sampling. TDS in the effluents from the tannery industries in Kano, Nigeria was reported to be $1281 \mathrm{mg} / \mathrm{l}$ (Akan et al., 2007). The average values of SS observed in this present study are less than those observed by Mohammed et al. (2017) and Baba et al. 2020)

The mean level of COD (mg/l) observed in TAN1, TAN2 and TAN3 samples seasons were $2372 \pm 938 ; \quad 1406 \pm 208$ and $3532 \pm 1373$ respectively. The order of the mean COD of the samples from the three industries can be arranged as TAN3>TAN1> TAN2. The COD observed in TAN1, TAN2 and TAN3 samples were far above the recommended standard limits of regulating bodies $\mathrm{WHO}(40 \mathrm{mg} / \mathrm{l})$ and NESREA (40 mg/l). Statistical analysis shows that there is no significant difference $(p<0.05)$ in COD among the industries. This might be due to similar tannery activities involved in the tannery industries as at the time of sampling. The Chemical Oxygen demand (COD) is the amount of oxygen, in $\mathrm{mg} / \mathrm{L}$, required for the degradation of the compound of wastewater to occur. In comparison, the average values of COD observed in this present study were higher than that observed by Mohammed et al. (2017) but lower than that observed by Baba et al. (2020).

The mean levels of BOD $(\mathrm{mg} / \mathrm{l})$ observed in TAN1, TAN2 and TAN3 samples were $13.85 \pm 6.42 ; \quad 19.46 \pm 0.50$ and $17.13 \pm 3.14$ respectively. The order of the mean BOD in the samples from the three industries can be arranged as TAN2>TAN3>TAN1. The BOD observed in TAN1, TAN2 and TAN3 samples were found below the recommended limits of NESREA (200 mg/l) but above WHO (10 mg/l). Statistical analysis shows that there is no significant difference $(p<0.05)$ between the mean values of BOD among the industries. This might be due to similar tannery activities involved in the tannery industries at the time of sampling. The low level of BOD recorded in this study is an indication of the low level of biodegradable organic solids in the effluent. The average values of BOD observed in this present study were lower than those observed by Mohammed et al. (2017) and Baba et al. (2020).

Table 1: Mean Values \pm S.D of Physico-chemical parameters of effluents from the Tannery Industries before Treatment.

\begin{tabular}{llllllll}
\hline Parameter & Tannery 1 & Tannery 2 & Tannery 3 & $\mathrm{a}$ & $\mathrm{b}$ & $\mathrm{c}$ & $\mathrm{d}$ \\
\cline { 2 - 7 } Temperature $\left({ }^{\circ} \mathrm{C}\right)$ & $28.07 \mathrm{a} \pm 0.65$ & $27.77 \mathrm{a} \pm 0.64$ & $26.38 \mathrm{a} \pm 3.81$ & & $29.50 \pm 4.68$ & 35 & 40 \\
pH & $7.77 \mathrm{a} \pm 2.93$ & $8.35 \mathrm{a} \pm 0.28$ & $7.52 \mathrm{a} \pm 0.76$ & 6.89 & $5.35 \pm 1.57$ & $7.0-8.5$ & $6.0-9.0$ \\
$\mathrm{COD}(\mathrm{mg} / \mathrm{l})$ & $2372 \mathrm{a} \pm 938$ & $1406 \mathrm{a} \pm 208$ & $3532 \mathrm{a} \pm 1373$ & 2.2 & $3106 \pm 2753$ & 40 & 40 \\
$\mathrm{BOD}(\mathrm{mg} / \mathrm{l})$ & $13.85 \mathrm{a} \pm 6.42$ & $19.46 \mathrm{a} \pm 0.50$ & $17.13 \mathrm{a} \pm 3.14$ & 1032 & $26.17 \pm 9.49$ & 10 & 200 \\
$\mathrm{SS}(\mathrm{mg} / \mathrm{l})$ & $374 \mathrm{a} \pm 124$ & $358 \mathrm{a} \pm 335$ & $780 \mathrm{a} \pm 739$ & 501 & $562 \pm 482$ & 30 & 10 \\
TDS $(\mathrm{mg} / \mathrm{l})$ & $3941 \mathrm{a} \pm 3703$ & $3300 \mathrm{a} \pm 1714$ & $2653 \mathrm{a} \pm 1240$ & 532.7 & $444 \pm 507$ & 250 & 500 \\
\hline
\end{tabular}

The values given in the table above are means of 6 replicate values, $\mathrm{n}=6$ ( 1 sample was taken monthly for 6 months). Within the rows, means with different alphabets are statistically different $(p<0.05)$. WHO: World Health Organisation. NESREA: National Environmental Standard and Regulatory Enforcement Agency. a = Mohammed et al.(2017), b = Baba et al. (2020), c = WHO (2006), $d=$ NESSRA (2009) 
BAJOPAS Volume 13 Number 2, December, 2020

Identification, Biochemical Characterization and growth rates of the Bacterial Isolates

Results of identification and biochemical characterization of the bacterial isolates were shown in table 2. After 24 hours of incubation, the nutrient agar media plates were checked for bacterial growth. The results showed the presence of different strains in the samples. The TAN1 bacteria isolate was found to be gramnegative cocci while TAN3 was gram-positive cocci. TAN2 bacteria isolate was found to be gram-positive, rod-shaped. TAN1, TAN2, and TAN3 bacteria isolates recorded positive results for spore former.

The results of the biochemical tests indicated that all the bacteria were positive for catalase, oxidase, citrate, maltose, glucose, lactose (negative in TAN1), mannitol (negative in TAN2), starch hydrolysis and coagulase (negative in TAN2) tests. The bacteria showed negative results for nitrate reduction, $M R$ (positive in TAN2), VP (positive in TAN1), Indole (positive in TAN2) tests. Base on the morphological and biochemical test results, TAN1, TAN2, and TAN3 bacteria isolates were identified to be Nesseria spp, Bacillus cereus, and Staphylococcus aureus respectively.

The growth rate of the TAN1, TAN2 and TAN3 Isolates were shown in figure 2. Generally, the optical density increase with the increase in time (day) and decrease as time goes on. The highest optical density was shown by bacillus cereus in TAN2 while the lowest was shown by Staphylococcus aureus in TAN3.

The initial growth phase of TAN1 Isolate bacteria occurred within 2-day of incubation as the growth rate increases up to the 6th-day incubation when the maximum growth was observed. Beyond the 6th day, the growth of the bacteria declined (which might be due to a shortage of nutrients in the effluents) until it reached its death phase (which might be due to the unavailability of nutrients in the effluents).

A similar trend of growth was also observed for TAN2 Isolate as the initial growth phase also occurred within 2-day of incubation but maximum growth rate observed on the 4th day of incubation. The stationary stage occurred between the 4th day and the 8th day. Beyond the 8th day, the growth of the bacteria declined (which might be due to a shortage of nutrients in the effluents) until it reached its death phase (which might be due to the unavailability of nutrients in the effluents).

The initial growth phase of TAN3 bacterial Isolate occurred within the 3-day incubation as the growth rate increases up to the 6th-day incubation when the maximum growth was observed. Beyond the 6th day, the growth of the bacteria declined (which might be due to a shortage of nutrients in the effluents) until it reached its death phase (which might be due to the unavailability of nutrients in the effluents).

Table 2: Morphological and Biochemical characteristics of bacterial isolates

\begin{tabular}{lllll} 
Bacterial Isolates & & TAN1 & TAN2 & TAN3 \\
\hline $\begin{array}{lllll}\text { Morphological } \\
\text { characteristics }\end{array}$ & Shape & Cocci & Rod & Cocci \\
& Spore & & & \\
& former & + & + & + \\
Gram & & & \\
Biochemical characteristics & reaction & - & + & + \\
& Citrate & + & + & + \\
& Catalase & + & + & + \\
& Coagulase & + & - & + \\
Starch & + & + & + \\
& Glucose & + & + & + \\
Oxidase & + & + & + \\
& Indo & - & + & - \\
Lactose & - & + & + \\
Manitol & + & - & + \\
Maltose & + & + & + \\
MR & - & + & - \\
VP & + & - & - \\
& Nitrate & - & - & - \\
Reduction & - Neisseria & Bacillus & Staphylococcus \\
& Bacterial & cereus & aureus \\
& name & spp & cas
\end{tabular}

+ = Positive; - = Negative; MR=Methyl Red; VP= Voges-Proskauer 


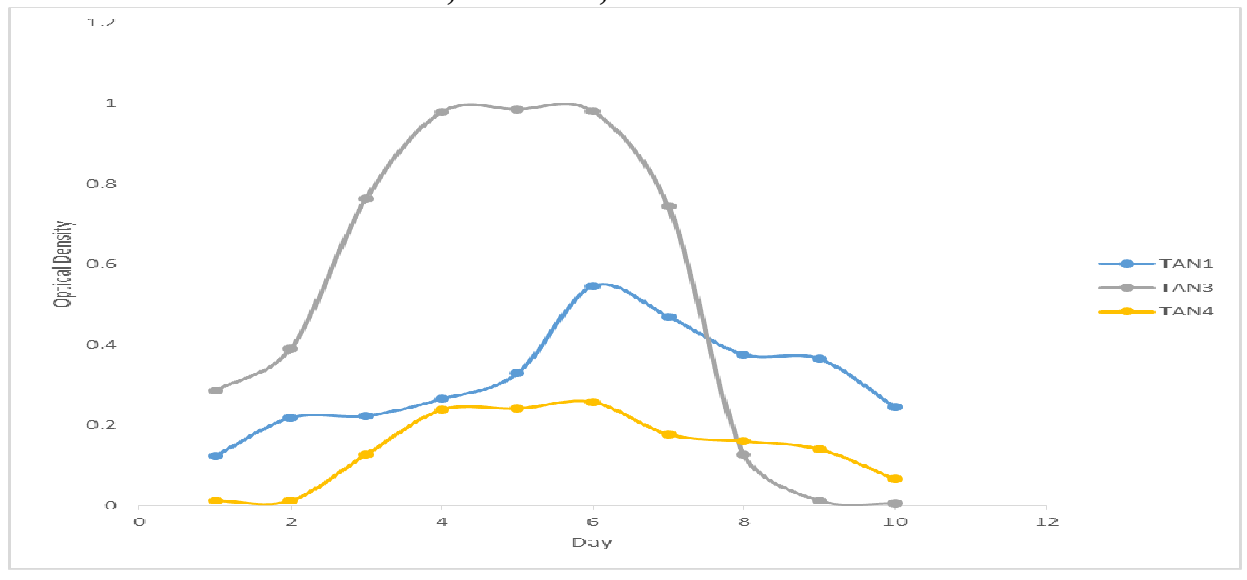

Fig. 2 Growth rates of the isolates in the effluents from the Tannery Industries

\section{Physico-chemical Parameters in the Industrial Effluents after the biodegradation.}

Table 3 shows the mean results of the physicochemical parameter before and after bioremediation using the different masses $(5 \mathrm{~g}$, $10 \mathrm{~g}, 15 \mathrm{~g}, 20 \mathrm{~g}$, and $25 \mathrm{~g}$ ) of the respective immobilized bacteria. Also, Table 4 shows the mean results of correlation coefficient ( $r$ ) between different masses of bacteria and physicochemical parameters.

The mean values $(\mathrm{mg} / \mathrm{l})$ of the SS after the bioremediation varies between $243 \pm 45$ and $898 \pm 672$. The mean concentration $(\mathrm{mg} / \mathrm{l})$ of SS remediated by the different masses $(5 \mathrm{~g}, 10 \mathrm{~g}$, $15 \mathrm{~g}, 20 \mathrm{~g}$, and $25 \mathrm{~g}$ ) of the bacteria varies. The SS in the samples fluctuates up and down after the bioremediation process when compared with the SS of the raw samples before the bioremediation. The increase in the levels of the SS might be due to the aggregation of the TDS which are large enough to result into SS. The increase in the levels of the SS might be also due to the influence of the nutrients which was added into the effluents in order to make the microorganisms more active and viable for fast degradation of organic contaminants in the effluent. The relative potential or efficiency of the different masses of the bacteria in remediating SS in TAN1 samples was in the order $25 \mathrm{~g}>20 \mathrm{~g}>15 \mathrm{~g}>10 \mathrm{~g}>5 \mathrm{~g}$. For TAN2 and TAN3 samples, the order was $25 \mathrm{~g}>20 \mathrm{~g}>15$ $\mathrm{g}>10 \mathrm{~g}>5 \mathrm{~g}$. These might be due to the variations in the surface areas of the different masses of the immobilized bacteria. Statistical analysis shows that there is no significant difference $(p<0.05)$ between the mean values of SS among the masses in the respective industries. Positive and significant correlations exist between the masses of bacteria and Suspended Solid (SS). This showed that there is general increase in the levels of the SS as the masses of the immobilized bacteria increases. TAN3 (90\%) and TAN1 (80\%) showed a very high correlation with the masses of the bacteria while TAN2 (61\%) showed a very low correlation.

The mean values $(\mathrm{mg} / \mathrm{l})$ of the TDS after the bioremediation varies between $46 \pm 11$ and $83 \pm 78$. The mean concentration $(\mathrm{mg} / \mathrm{l})$ of TDS remediated by the different masses $(5 \mathrm{~g}, 10 \mathrm{~g}$, $15 \mathrm{~g}, 20 \mathrm{~g}$, and $25 \mathrm{~g}$ ) of the bacteria varies. There is a reduction in all the TDS of all the samples after the bioremediation process compared with the TDS of the raw samples before the bioremediation. The relative potential or efficiency of the different masses of the bacteria in remediating TDS in TAN1 and TAN3 samples was in the order $5 \mathrm{~g}>10 \mathrm{~g}>15 \mathrm{~g}>20$ $\mathrm{g}>25 \mathrm{~g}$. For TAN2 samples, the order was 20 $g>10 \quad g>25 \quad g>15 \quad g>5 \quad g$. Statistical analysis shows that there is no significant difference $(p<0.05)$ between the mean values of TDS among the masses in the respective industries. These might be due to the variations in the surface areas of the different masses of the immobilized bacteria. Positive and significant correlations exist between the masses of bacteria and TDS with the exception in TAN2 (negative and insignificant correlation). The positive correlations showed that there is general increase in the levels of the TDS as the masses of the immobilized bacteria increases. TAN1 $(96 \%)$ showed a very high correlation with the masses of the bacteria while TAN2 (47\%) showed a very low correlation.

The mean values $(\mathrm{mg} / \mathrm{l})$ of the BOD after the bioremediation varies between $1.56 \pm 0.20 \mathrm{mg} / \mathrm{l}$ and $6.92 \pm 5.49 \mathrm{mg} / \mathrm{l}$. The mean concentration $(\mathrm{mg} / \mathrm{l})$ of BOD remediated by the different masses $(5 \mathrm{~g}, 10 \mathrm{~g}, 15 \mathrm{~g}, 20 \mathrm{~g}$, and $25 \mathrm{~g}$ ) of the bacteria varies. There is a reduction in all the BOD of all the samples after the bioremediation process compared with the $\mathrm{BOD}$ of the raw 
BAJOPAS Volume 13 Number 2, December, 2020 samples before the bioremediation. The relative potential or efficiency of the different masses of the bacteria in remediating BOD in TAN1, TAN2 and TAN3 samples were in the order $25 \mathrm{~g}>20$ $\mathrm{g}>15 \mathrm{~g}>10 \mathrm{~g}>5 \mathrm{~g}, 25 \mathrm{~g}>15 \mathrm{~g}>5 \mathrm{~g}>10 \mathrm{~g}>20 \mathrm{~g}$ and $20 \mathrm{~g}>10 \mathrm{~g}>25 \mathrm{~g}>15 \mathrm{~g}>5 \mathrm{~g}$ respectively. Statistical analysis shows that there is significant difference $(p<0.05)$ between the mean values of BOD among the masses in the respective industries. These might be due to the variations in the surface areas of the different masses of the immobilized bacteria. Negative and significant correlations exist between the masses of bacteria and BOD. This showed that there is general decrease in the levels of the BOD as the masses of the immobilized bacteria increases. TAN1 (94\%) showed a very high correlation with the masses of the bacteria while TAN2 (4\%) showed a very low correlation.

The mean values $(\mathrm{mg} / \mathrm{l})$ of the COD after the bioremediation varies between $250 \pm 154$ and $3134 \pm 1595$. The mean concentration $(\mathrm{mg} / \mathrm{l})$ of COD remediated by the different masses $(5 \mathrm{~g}$, $10 \mathrm{~g}, 15 \mathrm{~g} 20 \mathrm{~g}$, and $25 \mathrm{~g}$ ) of the bacteria varies. There is a reduction in all the COD of all the samples after the bioremediation process compared with the COD of the raw samples before the bioremediation. The relative potential or efficiency of the different masses of the bacteria in remediating COD in TAN1, TAN2 and TAN3 samples were in the order $25 \mathrm{~g}>20 \mathrm{~g}>15$ $\mathrm{g}>5 \mathrm{~g}>10 \mathrm{~g}, 25 \mathrm{~g}>20 \mathrm{~g}>15 \mathrm{~g}>10 \mathrm{~g}>5 \mathrm{~g}$ and 10 g>5 g>25 g>15 g>20 g respectively. Statistical analysis shows that there were significant difference $(p<0.05)$ between the mean values of COD among the masses in the respective industries except for effluents treated with $25 \mathrm{~g}$. These might be due to the variations in the surface areas of the different masses of the immobilized bacteria. Negative and insignificant correlations exist between the masses of bacteria and COD with the exception in TAN3 (positive and significant correlation). The negative correlations showed that there is general decrease in the levels of the COD as the masses of the immobilized bacteria increases. TAN2 (100\%) showed a very high correlation with the masses of the bacteria while TAN3 (36\%) showed a very low correlation.

Generally, there was an overall decrease in the concentration of these physicochemical parameters after the bioremediation using the different masses of the bacterial isolates. These might be due to the variations in the surface areas of the different masses of the immobilized bacteria. This is in line with the work of Jimoh et al. (2018) and Baba et al. (2020).

Table 3: Mean Values $(\mathrm{mg} / \mathrm{l}) \pm$ S.D of Physicochemical parameters in effluents from the Tannery Industries before and after Treatment of the effluents $(250 \mathrm{ml})$ with the different masses $(5 \mathrm{~g}, 10 \mathrm{~g}$, $15 \mathrm{~g}, 20 \mathrm{~g}$, and $25 \mathrm{~g}$ ) of the bacteria.

\begin{tabular}{llllllll}
\hline $\mathrm{P}$ & IND & Before & \multicolumn{5}{c}{ After } \\
\cline { 4 - 7 } & & & $5 \mathrm{~g}$ & $10 \mathrm{~g}$ & $15 \mathrm{~g}$ & $20 \mathrm{~g}$ & $25 \mathrm{~g}$ \\
\hline \multirow{2}{*}{ COD } & TAN1 & $2372 \pm 938$ & $1708 \mathrm{a} \pm 861$ & $2045 \mathrm{a} \pm 1205$ & $845 \mathrm{a} \pm 369$ & $300 \mathrm{a} \pm 167$ & $250 \mathrm{a} \pm 154$ \\
& TAN2 & $1406 \pm 208$ & $1195 \mathrm{a} \pm 208$ & $1125 \mathrm{a} \pm 384$ & $1055 \mathrm{a} \pm 317$ & $956 \mathrm{a} \pm 310$ & $870 \mathrm{ab} \pm 240$ \\
& TAN3 & $3532 \pm 1373$ & $2374 \mathrm{a} \pm 1344$ & $1976 \mathrm{a} \pm 1405$ & $2757 \mathrm{a} \pm 1266$ & $3134 \mathrm{a} \pm 1595$ & $2614 \mathrm{~b} \pm 1105$ \\
BOD & TAN1 & $13.85 \pm 6.42$ & $6.92 \mathrm{a} \pm 5.49$ & $6.42 \mathrm{a} \pm 5.07$ & $5.72 \mathrm{a} \pm 5.35$ & $4.62 \mathrm{a} \pm 4.37$ & $2.82 \mathrm{ab} \pm 1.26$ \\
& TAN2 & $19.46 \pm 0.50$ & $1.75 \mathrm{~b} \pm 0.22$ & $1.73 \mathrm{~b} \pm 0.18$ & $1.58 \mathrm{a} \pm 0.16$ & $1.91 \mathrm{a} \pm 0.22$ & $1.56 \mathrm{~b} \pm 0.20$ \\
& TAN3 & $17.13 \pm 3.14$ & $4.24 \mathrm{ab} \pm 0.77$ & $3.29 \mathrm{ab} \pm 0.37$ & $4.11 \mathrm{a} \pm 0.07$ & $3.23 \mathrm{a} \pm 0.91$ & $3.33 \mathrm{a} \pm 1.28$ \\
SS & TAN1 & $374 \pm 124$ & $243 \mathrm{a} \pm 45$ & $471 \mathrm{a} \pm 226$ & $475 \mathrm{a} \pm 182$ & $492 \mathrm{a} \pm 128$ & $611 \mathrm{a} \pm 217$ \\
& TAN2 & $358 \pm 335$ & $460 \mathrm{a} \pm 400$ & $543 \mathrm{a} \pm 414$ & $544 \mathrm{a} \pm 402$ & $551 \mathrm{a} \pm 414$ & $554 \mathrm{a} \pm 405$ \\
& TAN3 & $780 \pm 739$ & $586 \mathrm{a} \pm 594$ & $758 \mathrm{a} \pm 656$ & $787 \mathrm{a} \pm 676$ & $861 \mathrm{a} \pm 635$ & $898 \mathrm{a} \pm 672$ \\
TDS & TAN1 & $3941 \pm 3703$ & $51 \mathrm{a} \pm 10$ & $53 \mathrm{a} \pm 10$ & $55 \mathrm{a} \pm 15$ & $61 \mathrm{a} \pm 20$ & $63 \mathrm{a} \pm 26$ \\
& TAN2 & $3300 \pm 1714$ & $83 \mathrm{a} \pm 78$ & $47 \mathrm{a} \pm 20$ & $48 \mathrm{a} \pm 22$ & $47 \mathrm{a} \pm 17$ & $48 \mathrm{a} \pm 17$ \\
& TAN3 & $2653 \pm 1240$ & $46 \mathrm{a} \pm 11$ & $55 \mathrm{a} \pm 24$ & $55 \mathrm{a} \pm 25$ & $58 \mathrm{a} \pm 23$ & $61 \mathrm{a} \pm 28$ \\
\hline
\end{tabular}

Replicate $=6$ (months)

Within the rows, for the same parameter, means with different alphabets are statistically different $(p<0.05)$.

$\mathrm{P}=$ parameter, IND = Industries 
BAJOPAS Volume 13 Number 2, December, 2020

Table 4: Correlation coefficient $(r)$ between different masses of the bacteria and the physicochemical parameters.

\begin{tabular}{llll}
\hline Industries & Parameter & Correlation coefficient $(r)$ & $\begin{array}{l}\text { Percent dependence (rxrx100) } \\
(\%)\end{array}$ \\
\hline TAN1 & COD & -0.9 & 82 \\
& BOD & -0.97 & 94 \\
& SS & $0.90^{*}$ & 80 \\
TAN2 & TDS & $0.98^{*}$ & 96 \\
& COD & -1 & 100 \\
& BOD & -0.21 & 4 \\
& SS & $0.78^{*}$ & 61 \\
& TDS & -0.69 & 47 \\
& COD & $0.60^{*}$ & 36 \\
& BOD & -0.6 & 37 \\
& SS & $0.95^{*}$ & 90 \\
& TDS & $0.94^{*}$ & 89 \\
\hline
\end{tabular}

The correlation coefficient $(r)$ with * is statistically significant $(p<0.05)$.

Percentage reduction of the Parameters

Table 5 shows the percentage reduction of Parameters in industrial samples before and after the treatment of the effluents $(250 \mathrm{ml})$ with the different masses $(5 \mathrm{~g}, 10 \mathrm{~g}, 15 \mathrm{~g}, 20 \mathrm{~g}$, and $25 \mathrm{~g}$ ) of the Immobilized Bacteria.

In TAN1 samples, the percentage reduction (\%) of COD ranged (14-89); BOD (50-80); SS (-32$35)$ and TDS (98-99). In TAN2 samples, the percentage decrease $(\%)$ of COD ranged (15$38) ;$ BOD (90-92); SS [-28-(-55)] and TDS (9798). In TAN3 samples, the percentage decrease (\%) of COD ranged (11-44); BOD (76-81); SS (15-25) and TDS (98). The percentage increase in the levels COD, BOD and TDS might be due to the increase in the surface area of the different masses of the immobilized bacteria. However, the percentage decrease in the levels of the SS might be due to the aggregation of the TDS which are large enough to result into SS. The percentage decrease in the levels of the SS might be also due to the influence of the nutrients which was added into the effluents in order to make the microorganisms more active and viable for fast degradation of organic contaminants in the effluent. This is in line with the work of Jimoh et al. (2018) in which the concentration of the SS increase after the bioremediation of effluents.

Sreemoyee and Priti (2013) assessed and reduced several Physico-chemical parameters of dairy wastewater using Niesseria $s p$. and concluded that the species are well known to degrade organic compounds. This is in agreement with the current study in which the immobilized Niesseria $s p$ degrade the organic contaminants as indicated by the BOD, COD and TDS.

Jimoh et al. (2018) observed that TSS of the effluents was increased after treatment with immobilized bacteria and concluded that it might be due to the biostimulation method adopted for the research.

The optimum $\mathrm{pH}$ Biosorption of Chromium by Bacillus spp and Staphylococcus spp. from tannery effluent was investigated by Mythili and Karthikeyan (2011). The maximum adsorption of Chromium $(86.4 \mathrm{mg} / \mathrm{L})$ was showed by Bacillus spp and Staphylococcus spp showed $70.6 \mathrm{mg} / \mathrm{L}$ at an initial concentration of $100 \mathrm{mg} / \mathrm{L}$. In the present study, immobilised Bacillus spp and Staphylococcus spp. from the tannery industrial effluents reduced the levels of the organic pollutants with high potential as indicated by the percentage reduction of BOD, COD and TDS.

Enzymes often can work in multiple environments especially if they are immobilized. This makes the microorganisms' enzymes even more resistant to harsh environments and enables the enzymes to be recovered and recycled after they are no longer needed (Gianfreda and Rao 2004). Ramesh and Singh (1993) reported that the immobilized bacteria having more efficiency to remove the suspended particles than free cells. Using the immobilized cell is preferable due to its capability for using several times with the same efficiency, which makes it more economical. Similar work was done by Sikander et al. (2007) showing the higher reduction with permeabilized cells of Ochrobactrum intermedium strain SDCr-5. 
BAJOPAS Volume 13 Number 2, December, 2020

The results revealed the isolation and identification of isolates with the potential for the reduction of $\mathrm{Cr}$ (VI) to $\mathrm{Cr}$ (III). Results indicated that immobilized $B$. cereus could be efficiently used for the reduction of $\mathrm{Cr}$ (VI).

Table 5: Percentage reduction of the tested Parameters from the tannery industrial samples of the Immobilized Bacteria.

\begin{tabular}{lllllll}
\hline \multirow{2}{*}{ Industries } & & \multicolumn{5}{c}{ Percentage Reduction $(\%)$} \\
\cline { 3 - 7 } & & $5 \mathrm{~g}$ & $10 \mathrm{~g}$ & $15 \mathrm{~g}$ & $20 \mathrm{~g}$ & $25 \mathrm{~g}$ \\
\hline TAN1 & COD & 28 & 14 & 64 & 87 & 89 \\
& BOD & 50 & 54 & 59 & 67 & 80 \\
& SS & 35 & -26 & -27 & -32 & -63 \\
& TDS & 99 & 99 & 99 & 98 & 98 \\
TAN2 & COD & 15 & 20 & 25 & 32 & 38 \\
& BOD & 91 & 91 & 92 & 90 & 92 \\
& SS & -28 & -52 & -52 & -54 & -55 \\
& TDS & 97 & 99 & 99 & 99 & 99 \\
& COD & 33 & 44 & 22 & 11 & 26 \\
& BOD & 75 & 81 & 76 & 81 & 81 \\
& SS & 25 & 3 & -1 & -10 & -15 \\
& TDS & 98 & 98 & 98 & 98 & 98 \\
\hline
\end{tabular}

Percentage Reduction $=(B-A) / B \times 100 \%$

$A=$ Concentration of the parameter after treatment

$\mathrm{B}=$ Concentration of the parameter before treatment

$+=$ percentage decrease

- = percentage increase

In general, immobilization makes the enzyme more resistant to temperature, $\mathrm{pH}$, and substrate concentration swings giving it a longer lifetime and higher productivity per active unit (Gianfreda and Rao, 2004; FuIlbrook, 1996; Russell et al, 2003; Kandelbauer et al., 2004). Immobilized cells have been used and studied extensively for the production of useful chemicals (Ohtake and Silver, 1994), the treatment of wastewaters (Chen et al., 2003; Wang et al., 2010). Although many workers described microbial degradation of tannery effluent, limited literature is available on the bioremediation of tannery effluent using immobilized bacterial cells in the Kano Industrial Estates.

\section{CONCLUSION}

The samples contained variable levels of the physicochemical parameters. The results of the Analysis of variance revealed that, no statistical difference $(p<0.05)$ was observed for the temperature, $\mathrm{pH}, \mathrm{SS}, \mathrm{TDS}, \mathrm{BOD}$ and $\mathrm{COD}$ among the three tannery industries before the treatment. The levels of some of the parameters
(SS, TDS and COD) observed in the samples were found above the recommended limits of WHO and NESREA, which called for the treatment of the effluents before discharge into the environment. Base on the morphological and biochemical test results, TAN1, TAN2, and TAN3 bacterial isolates were identified to be Neisseria spp, Bacillus cereus, and Staphylococcus aureus respectively. The results of Post-treatment analysis showed that there is overall decrease in the levels of the parameters determined when compared with that of the pre-treatment. The overall percentage reduction of the immobilised bacteria in the treatment of the respective effluents was in the order TAN2 (72\%)>TAN1 $(70 \%)>$ TAN3 $(62 \%)$. Hence, the immobilized bacteria are having higher biodegradation potential for the treatment of the tannery effluents.

\section{Acknowledgments}

The authors wish to acknowledge the University of Maiduguri for the financial support. The authors are grateful to the Kano State Ministry of Environment for their support in obtaining the effluent samples. 


\section{REFERENCES}

Ajao, A. T., Adebayo, G. B., and Yakubu, S. E. (2011). Bioremediation of textile industrial effluent using mixed culture of Pseudomonas aeruginosa and Bacillus subtilis immobilized on agar-agar in a bioreactor. J. Microbiol. Biotech. Res, 1(3), 50-56.

Akan, J. C., Moses, E. A., Ogugbuaja, V. O., and Abah, J. (2007). Assessment of tannery industrial effluents from Kano metropolis, Kano State, Nigeria. Journal of Applied Sciences, 7(19), 2788-2793.

Akan, J. C., Ogugbuaja, V. O., Abdulrahman, F. I., and Ayodele, J. T. (2009). Pollutant levels in effluent samples from tanneries and textiles of Kano industrial areas, Nigeria. Global journal of pure and applied sciences, 15(3-4).

APHA (1989). Standard methods for Examination of Will bete and Will betewater.15 $5^{\text {th }}$ edition. Brydpass Springfield Will behington DC. pp. 164-176

APHA (1992). Standard Methods for the Examination of Water and Wastewater. Health, 69, 1116-9.

Baba, A., Garba, S. T., and Bello, H. S. (2020). Bioremediation Potential of Immobilized corynebacterium kutsceri in the Treatment of Tannery Industrial Effluent from Challawa Industrial Estate, Kano State, Nigeria. Journal of the Turkish Chemical Society Section A: Chemistry, $7(2), 335-350$.

Beem, E. I. V. (1994). reduction of solvent VOC emission. J. Oil Col. Chem. Ass, 77, 158.

Bouwer, E. J., and Zehnder, A. J. (1993). Bioremediation of organic compoundsputting microbial metabolism to work. Trends in biotechnology, 11(8), 360367.

Chen, K. C., Wu, J. Y., Liou, D. J., and Hwang, S. C. J. (2003). Decolorization of the textile dyes by newly isolated bacterial strains. Journal of Biotechnology, 101(1), 57-68.

Dan'Azumi, S., and Bichi, M. H. (2010). INDUSTRIAL POLLUTION AND HEAVY METALS PROFILE OF CHALLAWA RIVER IN KANO, NIGERIA. Journal of Applied Sciences in Environmental Sanitation, $5(1)$.

DWAF. (1992). Analytical Methods Manual, TR 151. Department of Water Affairs and Forestry, Pretoria.

El-Bestawy, E. (2013). Biological treatment of leather-tanning industrial wastewater using free living bacteria.
Elsheikh, M. A. S. (2009). Tannery wastewater pre-treatment. Water Science and Technology, 60(2), 433-440.

FuIlbrook, P. D. (1996). "Kinetics." Industrial enzymology: The application of enzymes in Industry. 2nd Ed. T. Godfrey and J Reichelt. eds.. Nature. New York.

Gianfreda, L., and Rao, M. A. (2004). Potential of extra cellular enzymes in remediation of polluted soils: a review. Enzyme and microbial technology, 35(4), 339354.

Hugo Springer. (1994). John Arthur Wilson Memorial Lecture "Treatment of Industrial Wastes of the Leather Industry - is it still a Major Problem". JALCA, 89, 153-185

Jimoh, A. A., Ganiyu, B. A., Baba, D., and Baba, A. (2018) Bioremediation Process of Effluent from Detergent and Food Industries in Jos, Nigeria: Kinetics and Thermodynamics. International Journal of Engineering Science Invention (IJESI), 762-73

Kandelbauer, A., Maute, O., Kessler, R. W., Erlacher, A., and Gübitz, G. M. (2004). Study of dye decolorization in an immobilized laccase enzyme-reactor using online spectroscopy. Biotechnology and bioengineering, 87(4), 552-563.

Kongjao, S., Damronglerd, S., and Hunsom, M. (2008). Simultaneous removal of organic and inorganic Pollutants in tannery wastewater using electrocoagulation technique. Korean Journal of chemical engineering, 25(4), 703.

Maheshwari, U. M., Aruna, S., Gomathi, M., and AbdulJaffar, A. H. (2017). Bioremediation by Free and Immobilized Bacteria Isolated from Tannery Effluent. International Journal of Research in Applied, Natural and Social Sciences. 5(7), 75-90

Margesin, R., and Schinner, F. (2001). Bioremediation (natural attenuation and biostimulation) of diesel-oilcontaminated soil in an alpine glacier skiing area. Applied and environmental microbiology, 677), 3127-3133.

Mohammed, A., Sekar, P., and George, J. (2011). Efficacy of microbes in bioremediation of tannery effluent. Inter. J. Curr. Res, 3(4), 324-326.

Mohammed, S. S. D., Orukotan, A. A., and Abdullahi, H. (2017). Physicochemical and Bacteriological Assessment of Tannery Effluent from Samaru-Zaria, 
BAJOPAS Volume 13 Number 2, December, 2020 Kaduna State, Nigeria. Journal of Applied

Sciences and Environmental Management, 21(4), 734-740.

Munz, G., De Angelis, D., Gori, R., Mori, G., Casarci, M., and Lubello, C. (2009). The role of tannins in conventional and membrane treatment of tannery wastewater. Journal of hazardous materials, 164(2-3), 733-739

Mythili, K., and Karthikeyan, B. (2011). Bioremediation of $\mathrm{Cr}$ (VI) from tannery effluent using Bacillus spp and Staphylococcus spp. International Multidisciplinary Research Journal, 1(6).

NESREA (2009). National Environmental Standards for Effluent Limitations and Regulation. 1233-1236

Noorjahan, C. M. (2014). Physicochemical characteristics, identification of bacteria and biodegradation of industrial effluent. Journal of bioremediation and Biodegradation, 5(3).

Ohtake, H. I., and Silver, A. O. (1994). Bacterial reduction of toxic chromate. Biological degradation and bioremediation of toxic chemicals, 403-415.

Omoleke, I. I. (2004). Management of environmental pollution in Ibadan, an African city: the challenges of health hazard facing government and the people. Journal of Human Ecology, 15(4), 265-275.

Rajor, A., Reddy, A.S., and Singh, B. (2004). Determination of BOD kinetic Parameters and evaluation of alternate methods, M.Sc. Thesis, Department of biotechnology \& environmental Science, Thapar Institute of Engineering and Technology, Patiala

Ramasami, T., Rajamani, S., and Rao, J. R. (1994, March). Pollution control in leather industry: Emerging technological options. In International symposium on surface and colloidal science and its relevance to soil pollution, madras.

Ramesh, J. V. S., and Singh, S. P. (1993). Yearly variation in certain physicochemical parameters of pond at eastern Doon Valley. Uttar Pradesh J. Zoo, 12 (1), 7577.

Ranen, S., and Sharadinadra, C. (2009). Biotechnology applications to environmental remediation in resource exploitation. Current science, 97, 6-25
Russell, A. J., Berberich, J. A., Drevon, G. F., and Koepsel, R. R. (2003). Biomaterials for mediation of

chemical and biological warfare agents. Annual review of biomedical engineering, 5(1), 1-27.

Saravanan, P., and Saravanan, A. (1999). Decolourization of tannery effluent by Flavobacterium sp. EK 1. Indian Journal of Environmental Protection, 19, 19-24.

Sikander, S., and Shahida, H. (2007). Reduction of toxic hexavalent chromium by Ochrobactrum intermedium strain SDCr5 stimulated by heavy metals. Bioresource Technol, 98, 340-344.

Singh, N., Sharma, B. K., and Bohra, P. C. (2000). Impact assessment of industrial effluent of arid soils by using satellite imageries. Journal of the Indian Society of Remote Sensing, 28(2-3), 79.

Sreemoyee, C., and Priti, P. (2013). Assessment of physico-chemical parameters of dairy waste water and isolation and characterization of bacterial strains in terms of cod reduction. Int J Sci, 2(3), 395-400.

Verheijen, L. A. H. M., Wiersema, D., Pol, L. H., and De Wit, J. (1996). Management of wastes from animal product processing. Livestock and environment, Finding a balance. International Agriculture Center, Wageningen, The Netherlands.

Wang, F., Yao, J., Si, Y., Chen, H., Russel, M., Chen, K., and Bramanti, E. (2010). Short-time effect of heavy metals upon microbial community activity. Journal of Hazardous Materials, 173(13), 510-516.

WHO (World Health Organization). (2006). Air quality guidelines: global update 2005: particulate matter, ozone, nitrogen dioxide, and sulfur dioxide. World Health Organization.

World Bank. (1995). Nigeria's strategic options for redressing industrial pollution. World Bank, industry and energy division. 1st edition, West Central Africa Department; Annexes: 1995; pp 60-62.

Zahoor, A., and Abdul, R. (2009). Enumeration of Coliforms. Journal of Environmental Sciences. 21, 814-820 


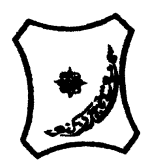

Bayero Journal of Pure and Applied Sciences, 13(2): 1 - 12

Received: November, 2020

Accepted: December, 2020

ISSN $2006-6996$

\title{
BIODEGRADATION POTENTIAL OF IMMOBILIZED BACTERIA IN THE TREATMENT OF TANNERY INDUSTRIAL EFFLUENTS FROM INDUSTRIAL ESTATES IN KANO STATE, NIGERIA
}

\author{
Abdullateef, B., ${ }^{1 *}$ Shuaibu, T. G., ${ }^{1}$ Babagana, K., ${ }^{1}$ Suleman, H. B. ${ }^{2}$ and Dauda, B. ${ }^{3}$ \\ ${ }^{1}$ Department of Pure and Applied Chemistry, Faculty of Science, University of Maiduguri, Borno State, \\ Nigeria \\ ${ }^{2}$ Department of Microbiology, Faculty of Science, University of Maiduguri, Borno State, Nigeria \\ ${ }^{3}$ Department of Chemical Engineering, Faculty of Engineering, University of Maiduguri, Borno State, \\ Nigeria \\ *Corresponding author: babslega@gmail.com; abelega2007@yahoo.com; +2348061309753
}

\section{ABSTRACT}

Industrial Effluents Samples from Gashash Tanneries (TAN1) in Bompai Industrial estate, Larabee Tannery Industry (TAN2) in Sharada Industrial estate and Z Tannery Industries (TAN3) in Challawa Industrial estate, Kano State, Nigeria were collected over a period of six months (August 2017 to January 2018) for assessing the biodegradation potentials of bacteria in the treatment of organic pollutants within the effluents. Bacteria were isolated from the effluents and immobilized on agar-agar. Different masses (5 g, $10 \mathrm{gr}, 15$ $\mathrm{g}, 20 \mathrm{~g}$, and $25 \mathrm{~g}$ ) of the bacteria were used in the treatment of $250 \mathrm{ml}$ of the effluents for ten days in a shaker incubator (Gallenkamp-OC-4364-L) at the temperature $30{ }^{\circ} \mathrm{C}$ and speed of $60 \mathrm{rpm}$. Pre-treatment analysis of the effluents for Temperature, pH, Biochemical Oxygen Demand (BOD), Chemical Oxygen Demand (COD), Suspended Solid (SS) and Total Dissolved Solids (TDS) gives the following results; temperature $\left({ }^{\circ} \mathrm{C}\right.$ )

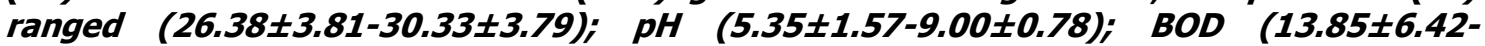
$38.75 \pm 16.20) ;$ COD (1406 $\pm 208-3532 \pm 1373) ;$ SS (208 $\pm 235-780 \pm 739)$ and TDS (266 $\pm 253-5276 \pm 2971)$. No statistical differences ( $p \leq 0.05)$ was observed for all the results among the different industries. The bacterial isolates were identified as Neisseria spp, Bacillus cereus, and Staphylococcus aureus, in TAN1, TAN2, and TAN3, respectively. After treatment of the effluent with the different masses of the isolated bacteria, the mean level of BOD was found to range as (0.55 $\pm 0.36-6.92 \pm 5.49) ; C O D$ (ND-3134 \pm 1595$)$;

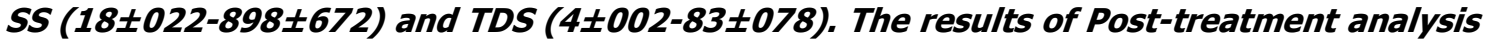
showed that there is overall decrease in the levels of the parameters determined when compared with that of the pre-treatment. The overall percentage reduction of the immobilised bacteria in the treatment of the respective effluents was in the order TAN2 (72\%)>TAN1 (70\%)>TAN3 (62\%). Hence, the immobilized bacteria are having higher biodegradation potential for the treatment of the tannery effluents.

Keywords: Biodegradation, bacteria, effluent, immobilization, tannery.

\section{INTRODUCTION}

Tannery industrial wastewater is a serious consequence of the pollution point of view for streams, freshwater, and land used for agriculture. The lack of awareness in the modern industrial practice has resulted in the discharge of tannery effluents which exhibit very high value of chromium ( $\mathrm{Cr}$ ), Sulfide, and chloride, Total Dissolved Solid (TDS), Total Suspended Solid (TSS), Biochemical Oxygen Demand (BOD) and Chemical Oxygen Demand (COD) in the water stream or land (Mohammed et al., 2001). Tanning is the process, which One ton of skin generally leads to the production of 20 to $80 \mathrm{~m}^{3}$ of turbid and foul-smelling converts the protein of the rawhide or skin into a stable material, which will not putrefy and is suitable for a wide variety of end applications (Elsheikh, 2009). The highly polluting chromium is the most commonly used tanning material producing leather that is more flexible and pliable than vegetable-tanned leather and does not discolor or lose shape in water as drastically as vegetable-tan (Elsheikh, 2009). Tannery effluent is among the most hazardous industrial pollutants due to its huge organic and inorganic load, which is highly toxic to human life and the environment (Kongjao et al., 2008). wastewater including chromium (100-400 mg/l), sulfide $(200-800 \mathrm{mg} / \mathrm{l})$, high levels of fat and 
BAJOPAS Volume 13 Number 2, December, 2020 other solid wastes, and notable pathogen contamination as well as pesticides added for skin conservation during transport (Elsheikh, 2009). There are more than 6000 tanneries in Nigeria with an annual processing capacity of 700,000 tons of hides and skins (Omoleke, 2004; Singh et al., 2008). It was reported that the total amount of waste produced per animal slaughtered is approximately $35 \%$ of its weight (World Bank, 1995). Also, for every $1000 \mathrm{~kg}$ of carcass weight, a slaughtered beef produces 5.5 $\mathrm{kg}$ of manure (excluding rumen contents or stockyard manure) and $100 \mathrm{~kg}$ of paunch manure (undigested food) (Verheijen et al., 1996). Tanneries generate wastewater in the range of 30-35 $\mathrm{L} \mathrm{kg}^{-1}$ skin/hide processed with variable $\mathrm{pH}$, Biological Oxygen Demand (BOD), Chemical Oxygen Demand (COD), high concentrations of suspended solids (SS), and tannins as well as chromium (Zahoor and Abdul, 2009).

Being heterogeneous and composed of a wide variety of compounds, it is very difficult to select a unique direct method for estimating the biodegradability of organic contents and biokinetic parameters for a wastewater sample (Rajor, 2004). For this purpose, some indirect estimation such as determination of biochemical oxygen demand (BOD) and chemical oxygen demand (COD) are applied as common laboratory investigations [9]. During retanning procedures, synthetic tannins (Syntan), oils and resins are added to form softer leather at varying doses (Munz et al., 2009). One of the refractory groups of chemicals in tannery effluents derives mainly from tannins (Ramasami et al., 2004). Syntans are characterized by complex chemical structures, because they are composed of an extended set of chemicals such as phenol-, naphthalene-, formaldehyde- and melamine-based syntans, and acrylic resins (Beem, 1994). Organic pollutants (proteic and lipidic components) are originated from skins (it is calculated that the raw skin has $30 \%$ loss of organic material during the working cycle) or they are introduced during processes (Hugo Springer, 1994).

Many conventional processes such as oxidation, chemical and biological processes were carried out to treat tanneries wastewater (Ebtesam et al, 2013). Biological processes have received more attention because of their costeffectiveness, lower sludge production and environmental friendliness (Noorjahan, 2014). Naturally occurring micro-organisms degrade the hazardous organic wastes including xenobiotic compounds, such as pesticides, polycyclic aromatic hydrocarbons (PAHs) and polychlorinated biphenyls (PCBs) in due course of time (Ranen and Sharadinadra, 2009). Bioremediation is based on the idea that all organisms remove substances from the environment to carry outgrowth and metabolism (Bouwer and Zehnder, 1993). Bacteria, protista and fungi are found to be very good at degrading complex molecules and incorporating the breakdown products into their metabolism (Bouwer and Zehnder, 1993). The resultant metabolic wastes that they produce are generally safe and somehow recycled into other organisms (Ranen and Sharadinadra, 2009). An acclimatized indigenous population of microorganisms capable of degradation of the compounds of interest must exist at the site for a successful bioremediation mode (Ranen and Sharadinadra, 2009). It has been observed that for a successful bioremediation mode, an acclimatized indigenous population of microorganisms capable of degradation of the compounds of interest must exist at the site under investigation (Ranen and Sharadinadra, 2009). Even though there are numerous physical and chemical methods employed in the disposal of wastes the advantage in using bacterium is that they play a key role in the reduction of COD, BOD, total protein, total tannin and total phenol (Saravanan and Saravanan, 1998)

Baba et al. (2020) studied the bioremediation potential of immobilized corynebacterium kutsceri in the Treatment of tannery industrial effluent from Challawa Industrial Estate, Kano State, Nigeria. The aim of the work is to study the reduction in the level of the contaminants through the process of bioremediation using the isolated bacteria. Immobilized bacteria can withstand various temperatures, $\mathrm{pH}$ and substrate concentrations; consequently, increasing the efficiency and the lifespan of the bacteria. Immobilized bacteria are widely applied in the treatment of wastewater and can be separated and recovered after the treatment with the same efficiency (Baba et al., 2020).

\section{MATERIALS AND METHODS \\ Study Area}

This study was carried out in Bompai, Sharada and Challawa industrial estates in Kano, Figure 1. Kano lies on Latitude $11^{\circ} 30^{\prime} \mathrm{N}$ and $8^{\circ} 30^{\prime} \mathrm{E}$ and Longitude $11^{\circ} 5^{\prime} \mathrm{N}$ and $8^{\circ} 5^{\prime} \mathrm{E}$ in Northern Nigeria. It is one of the developed industrial cities in Nigeria. Tannery activities are the dominating industries and this could be one of the reasons for her high population density (Dan'Azumi and Bichi, 2010). Many researchers have studied biodegradation of tannery effluent using microorganisms. However, limited literature is available on the biodegradation of tannery effluent in Kano industrial estates using 
BAJOPAS Volume 13 Number 2, December, 2020 immobilized bacterial cells. This research work focuses on the potential of the use of the indigenous immobilized bacterial isolates in the treatment of tannery effluents in the industrial estates.

\section{Sample Collection}

Effluents were collected from the Tannery Industries from Bompai, Challawa and Sharada Industrial Estates, Kano, Nigeria. The effluents were collected over a period of six months (August 2017 to January 2018). Samples collected in a sterile 4-liter plastic container with a unique identification number were preserved using an ice-box that was transported to the Microbiology Laboratory, Department of Microbiology, Bayero University of Kano for analysis

\section{Sample Preparation and Sample Analysis}

Immediately after the collection of the effluent, $\mathrm{pH}$, TSS, TDS, COD, BOD levels were determined before treatment (Pre-treatment determination) and ten days after treatment (Post-treatment determination) as described in
APHA (1989) standard methods. $\mathrm{pH}$ was determined using Ecotests $\mathrm{pH}$ meter and TDS was determined using AQUALYTIC TDS Salinometer. BOD was determined as described by the standard method (APHA, 1992). COD and SS were determined using DR/2010 HACH portable data logging spectrophotometer (DWAF, 1992)

\section{Identification and Biochemical} Characterization of the Bacterial Isolates

The bacteria were isolated from the effluents using Serial Dilution according to the method described by APHA (1989). The biochemical tests such as oxidase, catalase, coagulase, indole (from $1 \%$ tryptone broth), citrate (Simmons citrate agar), methyl red/VogesProskauer (MR/VP), nitrate reduction, Starch Hydrolysis, Glucose, Maltose, and Lactose tests were carried out on the bacterial isolates to identify the bacteria through the bacteria biochemical characteristics according to Ajao et al. (2011).

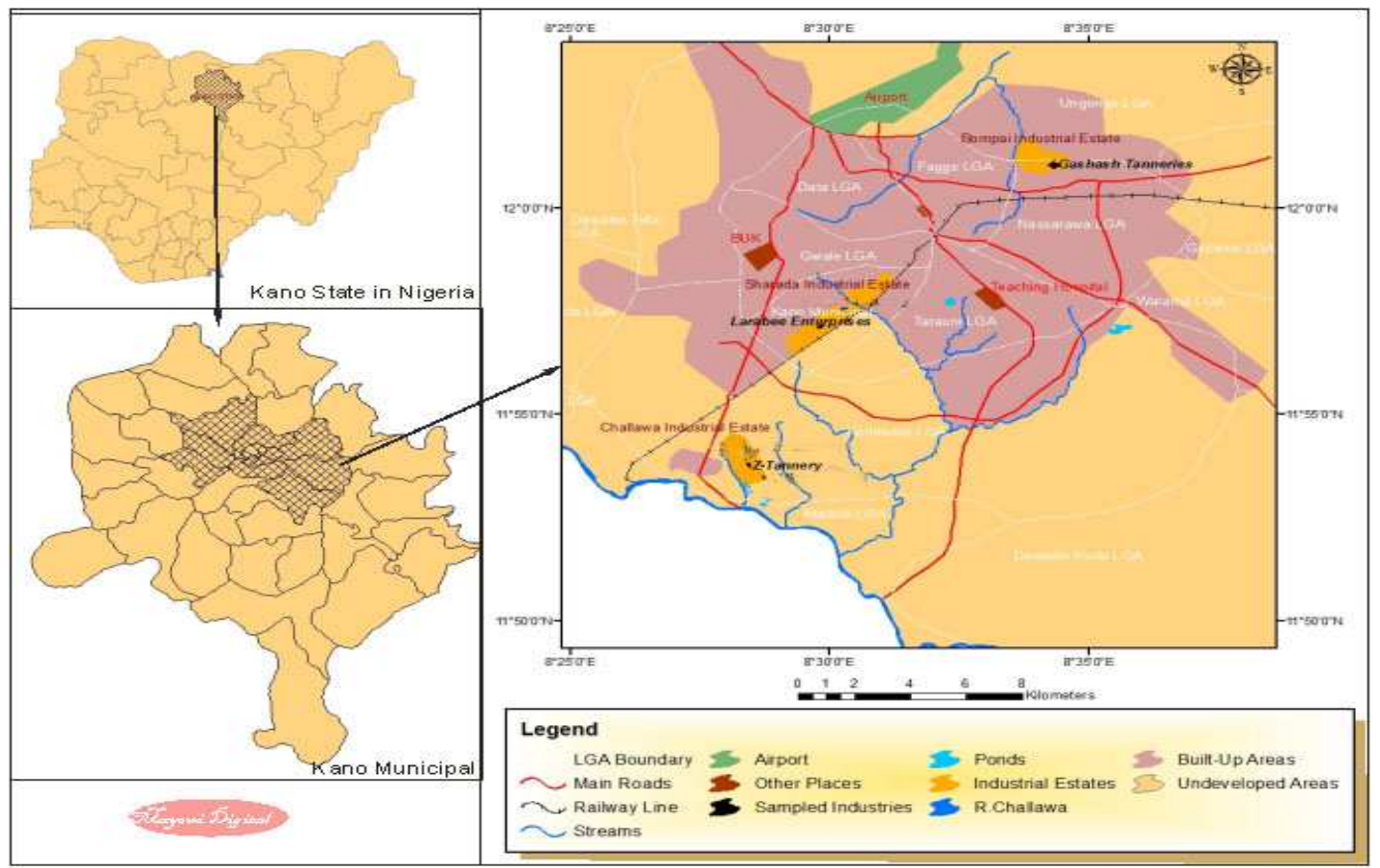

Fig. 1 Map showing the study areas

Source: Mayomi Digital Productions, GIS Laboratory, Department of Geography, UNIMAID (2017)

\section{Determination of Growth Rate of the Bacteria in Effluent Sample}

The bacteria growth rates were determined by transferring $2 \mathrm{~mL}$ of the bacterial isolates from the tannery effluent in broth medium into 100 $\mathrm{mL}$ sterile effluents in conical flasks and kept in an incubator (Giffrin cool) for 10 days. Control was also set up by incubating another $100 \mathrm{~mL}$ each of the sterile effluents without the bacteria. The optical density of the content was determined at the wavelength of $600 \mathrm{~nm}$ on a daily interval and recorded. 
BAJOPAS Volume 13 Number 2, December, 2020 Immobilization of Bacteria

Agar solution and inoculi were prepared separately. Fifty milliliters $(50 \mathrm{~mL})$ of nutrient broth each of the inoculi was prepared in a McCartney bottle and incubated for 24 hours. A solution of agar-agar was prepared by dissolving $10 \mathrm{~g}$ of the powder in distilled water and made up to $500 \mathrm{~mL}$ mark in an Erlenmeyer flask and was sterilized in an autoclave (280A) for 15 minutes and allowed to cool to $40-45^{\circ} \mathrm{C}$ (Ajao et al., 2011). Four milliliters ( $4 \mathrm{~mL})$ of the bacterial isolates in the nutrient broth was mixed with 36 $\mathrm{ml}$ of the prepared agar-agar media in petri-dish plates and then allowed to solidify. This was kept in the refrigerator for bioremediation.

\section{Bioremediation (Treatment) of the Effluents}

The solidified agar block (immobilized bacteria) was cut into cubes using a sterile knife; $0.1 \mathrm{~mL}$ phosphate buffer ( $\mathrm{pH} \mathrm{7.0)}$ was added and kept in the refrigerator for 1 hour for curing. The phosphate buffer was decanted after 1 hour and the cubes were washed with sterile distilled water 3-4 times before it was used (Ajao et al., 2011). Two liters (2 L) of the effluent was supplemented with the minimum basal medium in $\mathrm{g} / \mathrm{L}: \mathrm{NaCl}(0.8), \mathrm{MgSO}_{4} .7 \mathrm{H}_{2} \mathrm{O}(0.001), \mathrm{KH}_{2} \mathrm{PO}_{4}$ (2), $\mathrm{NaNO}_{3}$ (2), $\quad \mathrm{CaCl}_{2} .2 \mathrm{H}_{2} \mathrm{O} \quad(0.5)$ and $\mathrm{NaHPO}_{4} .12 \mathrm{H}_{2} \mathrm{O}(2)$ and sterilized in an autoclave at $121^{\circ} \mathrm{C}$ for 15 minutes (Margesin and Schinner, 2001). Two hundred and fifty milliliters $(250 \mathrm{~mL})$ of the effluents were transferred into different $250 \mathrm{ml}$ conical flasks. The content was covered with a cotton-wool ramped with foil paper to avoid contamination. Five grams $(5 \mathrm{~g})$ of the immobilized bacteria were quickly transferred into each of the effluents in the conical flasks in an inoculating chamber. The same procedures were carried out for the $10 \mathrm{~g}, 15 \mathrm{~g}, 20 \mathrm{~g}$ and 25 $\mathrm{g}$ of the immobilized bacteria in separate $250 \mathrm{~mL}$ effluents in conical flasks and agitated for ten days in a shaker incubator (Gallenkamp-OC4364-L) at a temperature $30^{\circ} \mathrm{C}$ and speed of 60 rpm. The treated effluent samples were taken on the tenth day and analyzed for the parameters $\mathrm{pH}$, SS, TDS, COD, and BOD, (Posttreatment determination) for the different grams of bacteria to evaluate and compare the biodegradation potential. (Baba et al., 2020).

\section{Statistical Analysis}

The data were represented as Mean \pm Standard deviation and analyzed statistically using oneway Analysis of Variance (ANOVA) and Tukey's HSD as Post Hoc Tests with the aid of SPSS 16.0. The correlation coefficient was also used to measure the strength of the relationship between the different masses of the bacteria and the parameters. All $\mathrm{p} \leq 0.05$ were considered as statistically significant.

\section{RESULTS AND DISCUSSION Physico-chemical parameters in the Industrial Effluents before the Biodegradation.}

Results of the Physico-chemical parameters in the industrial effluents before the Biodegradation is shown in table 1 . The mean temperatures $\left({ }^{\circ} \mathrm{C}\right)$ observed in TAN1, TAN2, and TAN3 samples were $28.07 \pm 0.65 ; 27.77 \pm 0.64$ and $26.38 \pm 3.81$ respectively. The order of the mean temperature of the samples from the three industries can be arranged as TAN1 > TAN2>TAN3. The temperature observed at TAN1, TAN2, and TAN3 samples were found below the WHO $\left(35^{\circ} \mathrm{C}\right)$ and NESREA $\left(40^{\circ} \mathrm{C}\right)$ limits. The low values of temperature might be due to the processes used at the time of sampling. High temperature brings down the solubility of gases in water that ultimately expresses as high BOD and COD. Statistical analysis shows that there is no significant difference $(p<0.05)$ between the mean values of temperature among the industries. This might be due to similar tannery activities involved in the tannery industries at the time of sampling. The average values of temperature observed in this present study are less than those observed by Akan et al. (2007), Akan et al. (2009) and Baba et al. (2020).

The mean level of $\mathrm{pH}$ observed in TAN1, TAN2 and TAN3, samples were $7.77 \pm 2.93$; $8.35 \pm 0.28$ and $7.52 \pm 0.76$ respectively. The order of the mean $\mathrm{pH}$ of the samples from the three industries can be arranged as TAN2> TAN1 $>$ TAN3. The $\mathrm{pH}$ of the samples falls within the WHO (7.0-8.5) and NESREA (6-9) standard limits. Statistical analysis shows that there is no significant difference $(p<0.05)$ between the mean values of $\mathrm{pH}$ among the industries. This might be due to similar tannery activities involved in the tannery industries at the time of sampling. Maheshwari et al. (2017) reported that the level of $\mathrm{pH}$ in the effluents from the tannery industry in Vaniyambadi, India was 6.5 which was lower than that observed in the present study. The $\mathrm{pH}$ in the effluents from the tannery industries in Kano and Kaduna were reported to be 7.64 and 6.89, respectively (Akan et al., 2007; Mohammed et al., 2017). The average values of $\mathrm{pH}$ observed in this present study are less than those observed by Mohammed et al. (2017) and Baba et al. (2020). The mean level of SS $(\mathrm{mg} / \mathrm{l})$ observed in TAN1, TAN2, and TAN3 samples were 374 \pm 124 ; $358 \pm 335$ and $780 \pm 739$ respectively. The order of the mean SS in the samples from the three industries can be arranged as TAN3 > TAN1 $>$ TAN2. 
The SS observed in the samples were far above the recommended standard limits of regulating bodies WHO $(30 \mathrm{mg} / \mathrm{l})$ and NESREA $(10 \mathrm{mg} / \mathrm{l})$. Statistical analysis shows that there is no significant difference $(p<0.05)$ between the mean values of SS among the industries. This might be due to similar tannery activities involved in the tannery industries at the time of sampling. The average values of SS observed in this present study are less than that observed $(3700 \pm 122 \mathrm{mg} / \mathrm{l})$ by Akan et al. (2009) for tanneries in Kano. Also, the average values of SS observed in this present study are less than that observed by Mohammed et al. (2017) and Baba et al. (2020) with the exception in TAN3.

The mean level of TDS (mg/l) observed in TAN1, TAN2, and TAN3 samples were $3941 \pm 3703$; $3300 \pm 1714$ and $2653 \pm 1240$ respectively. The order of the mean TDS in the samples from the three industries can be arranged as TAN1>TAN2>TAN3. The TDS observed in the samples were far above the recommended standard limits of WHO $(250 \mathrm{mg} / \mathrm{l})$ and NESREA $(500 \mathrm{mg} / \mathrm{l})$. Statistical analysis shows that there is no significant difference $(p<0.05)$ between the mean values of TDS among the industries. This might be due to similar tannery activities involved in the tannery industries at the time of sampling. TDS in the effluents from the tannery industries in Kano, Nigeria was reported to be $1281 \mathrm{mg} / \mathrm{l}$ (Akan et al., 2007). The average values of SS observed in this present study are less than those observed by Mohammed et al. (2017) and Baba et al. 2020)

The mean level of COD (mg/l) observed in TAN1, TAN2 and TAN3 samples seasons were $2372 \pm 938 ; \quad 1406 \pm 208$ and $3532 \pm 1373$ respectively. The order of the mean COD of the samples from the three industries can be arranged as TAN3>TAN1> TAN2. The COD observed in TAN1, TAN2 and TAN3 samples were far above the recommended standard limits of regulating bodies $\mathrm{WHO}(40 \mathrm{mg} / \mathrm{l})$ and NESREA (40 mg/l). Statistical analysis shows that there is no significant difference $(p<0.05)$ in COD among the industries. This might be due to similar tannery activities involved in the tannery industries as at the time of sampling. The Chemical Oxygen demand (COD) is the amount of oxygen, in $\mathrm{mg} / \mathrm{L}$, required for the degradation of the compound of wastewater to occur. In comparison, the average values of COD observed in this present study were higher than that observed by Mohammed et al. (2017) but lower than that observed by Baba et al. (2020).

The mean levels of BOD $(\mathrm{mg} / \mathrm{l})$ observed in TAN1, TAN2 and TAN3 samples were $13.85 \pm 6.42 ; \quad 19.46 \pm 0.50$ and $17.13 \pm 3.14$ respectively. The order of the mean BOD in the samples from the three industries can be arranged as TAN2>TAN3>TAN1. The BOD observed in TAN1, TAN2 and TAN3 samples were found below the recommended limits of NESREA (200 mg/l) but above WHO (10 mg/l). Statistical analysis shows that there is no significant difference $(p<0.05)$ between the mean values of BOD among the industries. This might be due to similar tannery activities involved in the tannery industries at the time of sampling. The low level of BOD recorded in this study is an indication of the low level of biodegradable organic solids in the effluent. The average values of BOD observed in this present study were lower than those observed by Mohammed et al. (2017) and Baba et al. (2020).

Table 1: Mean Values \pm S.D of Physico-chemical parameters of effluents from the Tannery Industries before Treatment.

\begin{tabular}{llllllll}
\hline Parameter & Tannery 1 & Tannery 2 & Tannery 3 & $\mathrm{a}$ & $\mathrm{b}$ & $\mathrm{c}$ & $\mathrm{d}$ \\
\cline { 2 - 7 } Temperature $\left({ }^{\circ} \mathrm{C}\right)$ & $28.07 \mathrm{a} \pm 0.65$ & $27.77 \mathrm{a} \pm 0.64$ & $26.38 \mathrm{a} \pm 3.81$ & & $29.50 \pm 4.68$ & 35 & 40 \\
pH & $7.77 \mathrm{a} \pm 2.93$ & $8.35 \mathrm{a} \pm 0.28$ & $7.52 \mathrm{a} \pm 0.76$ & 6.89 & $5.35 \pm 1.57$ & $7.0-8.5$ & $6.0-9.0$ \\
$\mathrm{COD}(\mathrm{mg} / \mathrm{l})$ & $2372 \mathrm{a} \pm 938$ & $1406 \mathrm{a} \pm 208$ & $3532 \mathrm{a} \pm 1373$ & 2.2 & $3106 \pm 2753$ & 40 & 40 \\
$\mathrm{BOD}(\mathrm{mg} / \mathrm{l})$ & $13.85 \mathrm{a} \pm 6.42$ & $19.46 \mathrm{a} \pm 0.50$ & $17.13 \mathrm{a} \pm 3.14$ & 1032 & $26.17 \pm 9.49$ & 10 & 200 \\
$\mathrm{SS}(\mathrm{mg} / \mathrm{l})$ & $374 \mathrm{a} \pm 124$ & $358 \mathrm{a} \pm 335$ & $780 \mathrm{a} \pm 739$ & 501 & $562 \pm 482$ & 30 & 10 \\
TDS $(\mathrm{mg} / \mathrm{l})$ & $3941 \mathrm{a} \pm 3703$ & $3300 \mathrm{a} \pm 1714$ & $2653 \mathrm{a} \pm 1240$ & 532.7 & $444 \pm 507$ & 250 & 500 \\
\hline
\end{tabular}

The values given in the table above are means of 6 replicate values, $\mathrm{n}=6$ ( 1 sample was taken monthly for 6 months). Within the rows, means with different alphabets are statistically different $(p<0.05)$. WHO: World Health Organisation. NESREA: National Environmental Standard and Regulatory Enforcement Agency. a = Mohammed et al.(2017), b = Baba et al. (2020), c = WHO (2006), $d=$ NESSRA (2009) 
BAJOPAS Volume 13 Number 2, December, 2020

Identification, Biochemical Characterization and growth rates of the Bacterial Isolates

Results of identification and biochemical characterization of the bacterial isolates were shown in table 2. After 24 hours of incubation, the nutrient agar media plates were checked for bacterial growth. The results showed the presence of different strains in the samples. The TAN1 bacteria isolate was found to be gramnegative cocci while TAN3 was gram-positive cocci. TAN2 bacteria isolate was found to be gram-positive, rod-shaped. TAN1, TAN2, and TAN3 bacteria isolates recorded positive results for spore former.

The results of the biochemical tests indicated that all the bacteria were positive for catalase, oxidase, citrate, maltose, glucose, lactose (negative in TAN1), mannitol (negative in TAN2), starch hydrolysis and coagulase (negative in TAN2) tests. The bacteria showed negative results for nitrate reduction, $M R$ (positive in TAN2), VP (positive in TAN1), Indole (positive in TAN2) tests. Base on the morphological and biochemical test results, TAN1, TAN2, and TAN3 bacteria isolates were identified to be Nesseria spp, Bacillus cereus, and Staphylococcus aureus respectively.

The growth rate of the TAN1, TAN2 and TAN3 Isolates were shown in figure 2. Generally, the optical density increase with the increase in time (day) and decrease as time goes on. The highest optical density was shown by bacillus cereus in TAN2 while the lowest was shown by Staphylococcus aureus in TAN3.

The initial growth phase of TAN1 Isolate bacteria occurred within 2-day of incubation as the growth rate increases up to the 6th-day incubation when the maximum growth was observed. Beyond the 6th day, the growth of the bacteria declined (which might be due to a shortage of nutrients in the effluents) until it reached its death phase (which might be due to the unavailability of nutrients in the effluents).

A similar trend of growth was also observed for TAN2 Isolate as the initial growth phase also occurred within 2-day of incubation but maximum growth rate observed on the 4th day of incubation. The stationary stage occurred between the 4th day and the 8th day. Beyond the 8th day, the growth of the bacteria declined (which might be due to a shortage of nutrients in the effluents) until it reached its death phase (which might be due to the unavailability of nutrients in the effluents).

The initial growth phase of TAN3 bacterial Isolate occurred within the 3-day incubation as the growth rate increases up to the 6th-day incubation when the maximum growth was observed. Beyond the 6th day, the growth of the bacteria declined (which might be due to a shortage of nutrients in the effluents) until it reached its death phase (which might be due to the unavailability of nutrients in the effluents).

Table 2: Morphological and Biochemical characteristics of bacterial isolates

\begin{tabular}{lllll} 
Bacterial Isolates & & TAN1 & TAN2 & TAN3 \\
\hline $\begin{array}{lllll}\text { Morphological } \\
\text { characteristics }\end{array}$ & Shape & Cocci & Rod & Cocci \\
& Spore & & & \\
& former & + & + & + \\
Gram & & & \\
Biochemical characteristics & reaction & - & + & + \\
& Citrate & + & + & + \\
& Catalase & + & + & + \\
& Coagulase & + & - & + \\
Starch & + & + & + \\
& Glucose & + & + & + \\
Oxidase & + & + & + \\
& Indo & - & + & - \\
Lactose & - & + & + \\
Manitol & + & - & + \\
Maltose & + & + & + \\
MR & - & + & - \\
VP & + & - & - \\
& Nitrate & - & - & - \\
Reduction & - Neisseria & Bacillus & Staphylococcus \\
& Bacterial & cereus & aureus \\
& name & spp & cas
\end{tabular}

+ = Positive; - = Negative; MR=Methyl Red; VP= Voges-Proskauer 


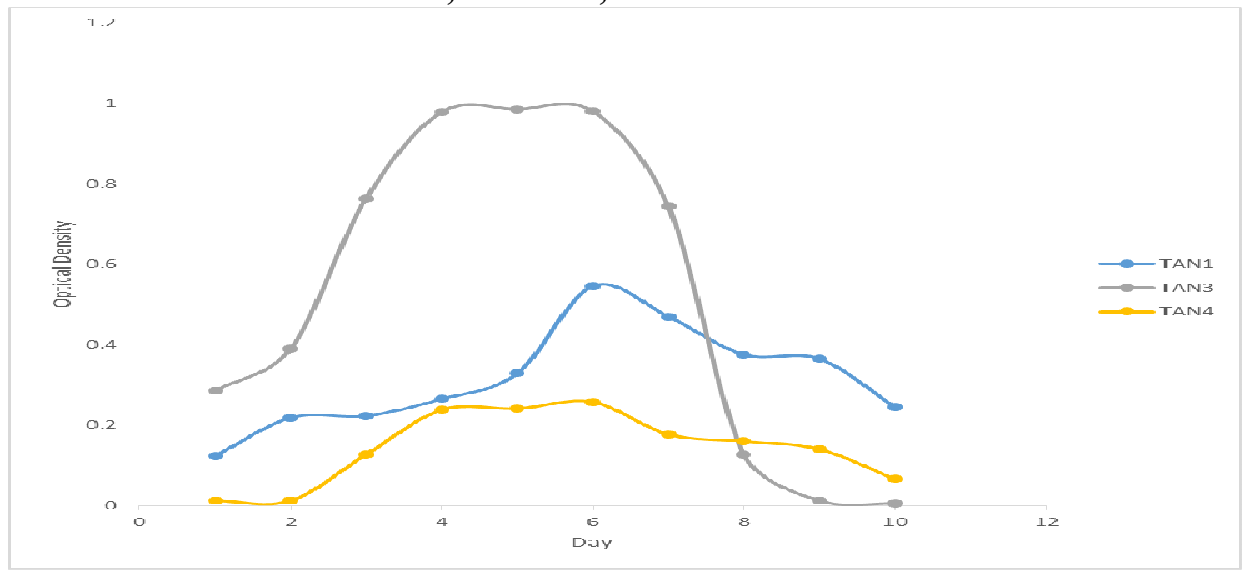

Fig. 2 Growth rates of the isolates in the effluents from the Tannery Industries

\section{Physico-chemical Parameters in the Industrial Effluents after the biodegradation.}

Table 3 shows the mean results of the physicochemical parameter before and after bioremediation using the different masses $(5 \mathrm{~g}$, $10 \mathrm{~g}, 15 \mathrm{~g}, 20 \mathrm{~g}$, and $25 \mathrm{~g}$ ) of the respective immobilized bacteria. Also, Table 4 shows the mean results of correlation coefficient ( $r$ ) between different masses of bacteria and physicochemical parameters.

The mean values $(\mathrm{mg} / \mathrm{l})$ of the SS after the bioremediation varies between $243 \pm 45$ and $898 \pm 672$. The mean concentration $(\mathrm{mg} / \mathrm{l})$ of SS remediated by the different masses $(5 \mathrm{~g}, 10 \mathrm{~g}$, $15 \mathrm{~g}, 20 \mathrm{~g}$, and $25 \mathrm{~g}$ ) of the bacteria varies. The SS in the samples fluctuates up and down after the bioremediation process when compared with the SS of the raw samples before the bioremediation. The increase in the levels of the SS might be due to the aggregation of the TDS which are large enough to result into SS. The increase in the levels of the SS might be also due to the influence of the nutrients which was added into the effluents in order to make the microorganisms more active and viable for fast degradation of organic contaminants in the effluent. The relative potential or efficiency of the different masses of the bacteria in remediating SS in TAN1 samples was in the order $25 \mathrm{~g}>20 \mathrm{~g}>15 \mathrm{~g}>10 \mathrm{~g}>5 \mathrm{~g}$. For TAN2 and TAN3 samples, the order was $25 \mathrm{~g}>20 \mathrm{~g}>15$ $\mathrm{g}>10 \mathrm{~g}>5 \mathrm{~g}$. These might be due to the variations in the surface areas of the different masses of the immobilized bacteria. Statistical analysis shows that there is no significant difference $(p<0.05)$ between the mean values of SS among the masses in the respective industries. Positive and significant correlations exist between the masses of bacteria and Suspended Solid (SS). This showed that there is general increase in the levels of the SS as the masses of the immobilized bacteria increases. TAN3 (90\%) and TAN1 (80\%) showed a very high correlation with the masses of the bacteria while TAN2 (61\%) showed a very low correlation.

The mean values $(\mathrm{mg} / \mathrm{l})$ of the TDS after the bioremediation varies between $46 \pm 11$ and $83 \pm 78$. The mean concentration $(\mathrm{mg} / \mathrm{l})$ of TDS remediated by the different masses $(5 \mathrm{~g}, 10 \mathrm{~g}$, $15 \mathrm{~g}, 20 \mathrm{~g}$, and $25 \mathrm{~g}$ ) of the bacteria varies. There is a reduction in all the TDS of all the samples after the bioremediation process compared with the TDS of the raw samples before the bioremediation. The relative potential or efficiency of the different masses of the bacteria in remediating TDS in TAN1 and TAN3 samples was in the order $5 \mathrm{~g}>10 \mathrm{~g}>15 \mathrm{~g}>20$ $\mathrm{g}>25 \mathrm{~g}$. For TAN2 samples, the order was 20 $g>10 \quad g>25 \quad g>15 \quad g>5 \quad g$. Statistical analysis shows that there is no significant difference $(p<0.05)$ between the mean values of TDS among the masses in the respective industries. These might be due to the variations in the surface areas of the different masses of the immobilized bacteria. Positive and significant correlations exist between the masses of bacteria and TDS with the exception in TAN2 (negative and insignificant correlation). The positive correlations showed that there is general increase in the levels of the TDS as the masses of the immobilized bacteria increases. TAN1 $(96 \%)$ showed a very high correlation with the masses of the bacteria while TAN2 (47\%) showed a very low correlation.

The mean values $(\mathrm{mg} / \mathrm{l})$ of the BOD after the bioremediation varies between $1.56 \pm 0.20 \mathrm{mg} / \mathrm{l}$ and $6.92 \pm 5.49 \mathrm{mg} / \mathrm{l}$. The mean concentration $(\mathrm{mg} / \mathrm{l})$ of BOD remediated by the different masses $(5 \mathrm{~g}, 10 \mathrm{~g}, 15 \mathrm{~g}, 20 \mathrm{~g}$, and $25 \mathrm{~g}$ ) of the bacteria varies. There is a reduction in all the BOD of all the samples after the bioremediation process compared with the $\mathrm{BOD}$ of the raw 
BAJOPAS Volume 13 Number 2, December, 2020 samples before the bioremediation. The relative potential or efficiency of the different masses of the bacteria in remediating BOD in TAN1, TAN2 and TAN3 samples were in the order $25 \mathrm{~g}>20$ $\mathrm{g}>15 \mathrm{~g}>10 \mathrm{~g}>5 \mathrm{~g}, 25 \mathrm{~g}>15 \mathrm{~g}>5 \mathrm{~g}>10 \mathrm{~g}>20 \mathrm{~g}$ and $20 \mathrm{~g}>10 \mathrm{~g}>25 \mathrm{~g}>15 \mathrm{~g}>5 \mathrm{~g}$ respectively. Statistical analysis shows that there is significant difference $(p<0.05)$ between the mean values of BOD among the masses in the respective industries. These might be due to the variations in the surface areas of the different masses of the immobilized bacteria. Negative and significant correlations exist between the masses of bacteria and BOD. This showed that there is general decrease in the levels of the BOD as the masses of the immobilized bacteria increases. TAN1 (94\%) showed a very high correlation with the masses of the bacteria while TAN2 (4\%) showed a very low correlation.

The mean values $(\mathrm{mg} / \mathrm{l})$ of the COD after the bioremediation varies between $250 \pm 154$ and $3134 \pm 1595$. The mean concentration $(\mathrm{mg} / \mathrm{l})$ of COD remediated by the different masses $(5 \mathrm{~g}$, $10 \mathrm{~g}, 15 \mathrm{~g} 20 \mathrm{~g}$, and $25 \mathrm{~g}$ ) of the bacteria varies. There is a reduction in all the COD of all the samples after the bioremediation process compared with the COD of the raw samples before the bioremediation. The relative potential or efficiency of the different masses of the bacteria in remediating COD in TAN1, TAN2 and TAN3 samples were in the order $25 \mathrm{~g}>20 \mathrm{~g}>15$ $\mathrm{g}>5 \mathrm{~g}>10 \mathrm{~g}, 25 \mathrm{~g}>20 \mathrm{~g}>15 \mathrm{~g}>10 \mathrm{~g}>5 \mathrm{~g}$ and 10 g>5 g>25 g>15 g>20 g respectively. Statistical analysis shows that there were significant difference $(p<0.05)$ between the mean values of COD among the masses in the respective industries except for effluents treated with $25 \mathrm{~g}$. These might be due to the variations in the surface areas of the different masses of the immobilized bacteria. Negative and insignificant correlations exist between the masses of bacteria and COD with the exception in TAN3 (positive and significant correlation). The negative correlations showed that there is general decrease in the levels of the COD as the masses of the immobilized bacteria increases. TAN2 (100\%) showed a very high correlation with the masses of the bacteria while TAN3 (36\%) showed a very low correlation.

Generally, there was an overall decrease in the concentration of these physicochemical parameters after the bioremediation using the different masses of the bacterial isolates. These might be due to the variations in the surface areas of the different masses of the immobilized bacteria. This is in line with the work of Jimoh et al. (2018) and Baba et al. (2020).

Table 3: Mean Values $(\mathrm{mg} / \mathrm{l}) \pm$ S.D of Physicochemical parameters in effluents from the Tannery Industries before and after Treatment of the effluents $(250 \mathrm{ml})$ with the different masses $(5 \mathrm{~g}, 10 \mathrm{~g}$, $15 \mathrm{~g}, 20 \mathrm{~g}$, and $25 \mathrm{~g}$ ) of the bacteria.

\begin{tabular}{llllllll}
\hline $\mathrm{P}$ & IND & Before & \multicolumn{5}{c}{ After } \\
\cline { 4 - 7 } & & & $5 \mathrm{~g}$ & $10 \mathrm{~g}$ & $15 \mathrm{~g}$ & $20 \mathrm{~g}$ & $25 \mathrm{~g}$ \\
\hline \multirow{2}{*}{ COD } & TAN1 & $2372 \pm 938$ & $1708 \mathrm{a} \pm 861$ & $2045 \mathrm{a} \pm 1205$ & $845 \mathrm{a} \pm 369$ & $300 \mathrm{a} \pm 167$ & $250 \mathrm{a} \pm 154$ \\
& TAN2 & $1406 \pm 208$ & $1195 \mathrm{a} \pm 208$ & $1125 \mathrm{a} \pm 384$ & $1055 \mathrm{a} \pm 317$ & $956 \mathrm{a} \pm 310$ & $870 \mathrm{ab} \pm 240$ \\
& TAN3 & $3532 \pm 1373$ & $2374 \mathrm{a} \pm 1344$ & $1976 \mathrm{a} \pm 1405$ & $2757 \mathrm{a} \pm 1266$ & $3134 \mathrm{a} \pm 1595$ & $2614 \mathrm{~b} \pm 1105$ \\
BOD & TAN1 & $13.85 \pm 6.42$ & $6.92 \mathrm{a} \pm 5.49$ & $6.42 \mathrm{a} \pm 5.07$ & $5.72 \mathrm{a} \pm 5.35$ & $4.62 \mathrm{a} \pm 4.37$ & $2.82 \mathrm{ab} \pm 1.26$ \\
& TAN2 & $19.46 \pm 0.50$ & $1.75 \mathrm{~b} \pm 0.22$ & $1.73 \mathrm{~b} \pm 0.18$ & $1.58 \mathrm{a} \pm 0.16$ & $1.91 \mathrm{a} \pm 0.22$ & $1.56 \mathrm{~b} \pm 0.20$ \\
& TAN3 & $17.13 \pm 3.14$ & $4.24 \mathrm{ab} \pm 0.77$ & $3.29 \mathrm{ab} \pm 0.37$ & $4.11 \mathrm{a} \pm 0.07$ & $3.23 \mathrm{a} \pm 0.91$ & $3.33 \mathrm{a} \pm 1.28$ \\
SS & TAN1 & $374 \pm 124$ & $243 \mathrm{a} \pm 45$ & $471 \mathrm{a} \pm 226$ & $475 \mathrm{a} \pm 182$ & $492 \mathrm{a} \pm 128$ & $611 \mathrm{a} \pm 217$ \\
& TAN2 & $358 \pm 335$ & $460 \mathrm{a} \pm 400$ & $543 \mathrm{a} \pm 414$ & $544 \mathrm{a} \pm 402$ & $551 \mathrm{a} \pm 414$ & $554 \mathrm{a} \pm 405$ \\
& TAN3 & $780 \pm 739$ & $586 \mathrm{a} \pm 594$ & $758 \mathrm{a} \pm 656$ & $787 \mathrm{a} \pm 676$ & $861 \mathrm{a} \pm 635$ & $898 \mathrm{a} \pm 672$ \\
TDS & TAN1 & $3941 \pm 3703$ & $51 \mathrm{a} \pm 10$ & $53 \mathrm{a} \pm 10$ & $55 \mathrm{a} \pm 15$ & $61 \mathrm{a} \pm 20$ & $63 \mathrm{a} \pm 26$ \\
& TAN2 & $3300 \pm 1714$ & $83 \mathrm{a} \pm 78$ & $47 \mathrm{a} \pm 20$ & $48 \mathrm{a} \pm 22$ & $47 \mathrm{a} \pm 17$ & $48 \mathrm{a} \pm 17$ \\
& TAN3 & $2653 \pm 1240$ & $46 \mathrm{a} \pm 11$ & $55 \mathrm{a} \pm 24$ & $55 \mathrm{a} \pm 25$ & $58 \mathrm{a} \pm 23$ & $61 \mathrm{a} \pm 28$ \\
\hline
\end{tabular}

Replicate $=6$ (months)

Within the rows, for the same parameter, means with different alphabets are statistically different $(p<0.05)$.

$\mathrm{P}=$ parameter, IND = Industries 
BAJOPAS Volume 13 Number 2, December, 2020

Table 4: Correlation coefficient $(r)$ between different masses of the bacteria and the physicochemical parameters.

\begin{tabular}{llll}
\hline Industries & Parameter & Correlation coefficient $(r)$ & $\begin{array}{l}\text { Percent dependence (rxrx100) } \\
(\%)\end{array}$ \\
\hline TAN1 & COD & -0.9 & 82 \\
& BOD & -0.97 & 94 \\
& SS & $0.90^{*}$ & 80 \\
TAN2 & TDS & $0.98^{*}$ & 96 \\
& COD & -1 & 100 \\
& BOD & -0.21 & 4 \\
& SS & $0.78^{*}$ & 61 \\
& TDS & -0.69 & 47 \\
& COD & $0.60^{*}$ & 36 \\
& BOD & -0.6 & 37 \\
& SS & $0.95^{*}$ & 90 \\
& TDS & $0.94^{*}$ & 89 \\
\hline
\end{tabular}

The correlation coefficient $(r)$ with * is statistically significant $(p<0.05)$.

Percentage reduction of the Parameters

Table 5 shows the percentage reduction of Parameters in industrial samples before and after the treatment of the effluents $(250 \mathrm{ml})$ with the different masses $(5 \mathrm{~g}, 10 \mathrm{~g}, 15 \mathrm{~g}, 20 \mathrm{~g}$, and $25 \mathrm{~g}$ ) of the Immobilized Bacteria.

In TAN1 samples, the percentage reduction (\%) of COD ranged (14-89); BOD (50-80); SS (-32$35)$ and TDS (98-99). In TAN2 samples, the percentage decrease $(\%)$ of COD ranged (15$38) ;$ BOD (90-92); SS [-28-(-55)] and TDS (9798). In TAN3 samples, the percentage decrease (\%) of COD ranged (11-44); BOD (76-81); SS (15-25) and TDS (98). The percentage increase in the levels COD, BOD and TDS might be due to the increase in the surface area of the different masses of the immobilized bacteria. However, the percentage decrease in the levels of the SS might be due to the aggregation of the TDS which are large enough to result into SS. The percentage decrease in the levels of the SS might be also due to the influence of the nutrients which was added into the effluents in order to make the microorganisms more active and viable for fast degradation of organic contaminants in the effluent. This is in line with the work of Jimoh et al. (2018) in which the concentration of the SS increase after the bioremediation of effluents.

Sreemoyee and Priti (2013) assessed and reduced several Physico-chemical parameters of dairy wastewater using Niesseria $s p$. and concluded that the species are well known to degrade organic compounds. This is in agreement with the current study in which the immobilized Niesseria $s p$ degrade the organic contaminants as indicated by the BOD, COD and TDS.

Jimoh et al. (2018) observed that TSS of the effluents was increased after treatment with immobilized bacteria and concluded that it might be due to the biostimulation method adopted for the research.

The optimum $\mathrm{pH}$ Biosorption of Chromium by Bacillus spp and Staphylococcus spp. from tannery effluent was investigated by Mythili and Karthikeyan (2011). The maximum adsorption of Chromium $(86.4 \mathrm{mg} / \mathrm{L})$ was showed by Bacillus spp and Staphylococcus spp showed $70.6 \mathrm{mg} / \mathrm{L}$ at an initial concentration of $100 \mathrm{mg} / \mathrm{L}$. In the present study, immobilised Bacillus spp and Staphylococcus spp. from the tannery industrial effluents reduced the levels of the organic pollutants with high potential as indicated by the percentage reduction of BOD, COD and TDS.

Enzymes often can work in multiple environments especially if they are immobilized. This makes the microorganisms' enzymes even more resistant to harsh environments and enables the enzymes to be recovered and recycled after they are no longer needed (Gianfreda and Rao 2004). Ramesh and Singh (1993) reported that the immobilized bacteria having more efficiency to remove the suspended particles than free cells. Using the immobilized cell is preferable due to its capability for using several times with the same efficiency, which makes it more economical. Similar work was done by Sikander et al. (2007) showing the higher reduction with permeabilized cells of Ochrobactrum intermedium strain SDCr-5. 
BAJOPAS Volume 13 Number 2, December, 2020

The results revealed the isolation and identification of isolates with the potential for the reduction of $\mathrm{Cr}$ (VI) to $\mathrm{Cr}$ (III). Results indicated that immobilized $B$. cereus could be efficiently used for the reduction of $\mathrm{Cr}$ (VI).

Table 5: Percentage reduction of the tested Parameters from the tannery industrial samples of the Immobilized Bacteria.

\begin{tabular}{lllllll}
\hline \multirow{2}{*}{ Industries } & & \multicolumn{5}{c}{ Percentage Reduction $(\%)$} \\
\cline { 3 - 7 } & & $5 \mathrm{~g}$ & $10 \mathrm{~g}$ & $15 \mathrm{~g}$ & $20 \mathrm{~g}$ & $25 \mathrm{~g}$ \\
\hline TAN1 & COD & 28 & 14 & 64 & 87 & 89 \\
& BOD & 50 & 54 & 59 & 67 & 80 \\
& SS & 35 & -26 & -27 & -32 & -63 \\
& TDS & 99 & 99 & 99 & 98 & 98 \\
TAN2 & COD & 15 & 20 & 25 & 32 & 38 \\
& BOD & 91 & 91 & 92 & 90 & 92 \\
& SS & -28 & -52 & -52 & -54 & -55 \\
& TDS & 97 & 99 & 99 & 99 & 99 \\
& COD & 33 & 44 & 22 & 11 & 26 \\
& BOD & 75 & 81 & 76 & 81 & 81 \\
& SS & 25 & 3 & -1 & -10 & -15 \\
& TDS & 98 & 98 & 98 & 98 & 98 \\
\hline
\end{tabular}

Percentage Reduction $=(B-A) / B \times 100 \%$

$A=$ Concentration of the parameter after treatment

$\mathrm{B}=$ Concentration of the parameter before treatment

$+=$ percentage decrease

- = percentage increase

In general, immobilization makes the enzyme more resistant to temperature, $\mathrm{pH}$, and substrate concentration swings giving it a longer lifetime and higher productivity per active unit (Gianfreda and Rao, 2004; FuIlbrook, 1996; Russell et al, 2003; Kandelbauer et al., 2004). Immobilized cells have been used and studied extensively for the production of useful chemicals (Ohtake and Silver, 1994), the treatment of wastewaters (Chen et al., 2003; Wang et al., 2010). Although many workers described microbial degradation of tannery effluent, limited literature is available on the bioremediation of tannery effluent using immobilized bacterial cells in the Kano Industrial Estates.

\section{CONCLUSION}

The samples contained variable levels of the physicochemical parameters. The results of the Analysis of variance revealed that, no statistical difference $(p<0.05)$ was observed for the temperature, $\mathrm{pH}, \mathrm{SS}, \mathrm{TDS}, \mathrm{BOD}$ and $\mathrm{COD}$ among the three tannery industries before the treatment. The levels of some of the parameters
(SS, TDS and COD) observed in the samples were found above the recommended limits of WHO and NESREA, which called for the treatment of the effluents before discharge into the environment. Base on the morphological and biochemical test results, TAN1, TAN2, and TAN3 bacterial isolates were identified to be Neisseria spp, Bacillus cereus, and Staphylococcus aureus respectively. The results of Post-treatment analysis showed that there is overall decrease in the levels of the parameters determined when compared with that of the pre-treatment. The overall percentage reduction of the immobilised bacteria in the treatment of the respective effluents was in the order TAN2 (72\%)>TAN1 $(70 \%)>$ TAN3 $(62 \%)$. Hence, the immobilized bacteria are having higher biodegradation potential for the treatment of the tannery effluents.

\section{Acknowledgments}

The authors wish to acknowledge the University of Maiduguri for the financial support. The authors are grateful to the Kano State Ministry of Environment for their support in obtaining the effluent samples. 


\section{REFERENCES}

Ajao, A. T., Adebayo, G. B., and Yakubu, S. E. (2011). Bioremediation of textile industrial effluent using mixed culture of Pseudomonas aeruginosa and Bacillus subtilis immobilized on agar-agar in a bioreactor. J. Microbiol. Biotech. Res, 1(3), 50-56.

Akan, J. C., Moses, E. A., Ogugbuaja, V. O., and Abah, J. (2007). Assessment of tannery industrial effluents from Kano metropolis, Kano State, Nigeria. Journal of Applied Sciences, 7(19), 2788-2793.

Akan, J. C., Ogugbuaja, V. O., Abdulrahman, F. I., and Ayodele, J. T. (2009). Pollutant levels in effluent samples from tanneries and textiles of Kano industrial areas, Nigeria. Global journal of pure and applied sciences, 15(3-4).

APHA (1989). Standard methods for Examination of Will bete and Will betewater.15 $5^{\text {th }}$ edition. Brydpass Springfield Will behington DC. pp. 164-176

APHA (1992). Standard Methods for the Examination of Water and Wastewater. Health, 69, 1116-9.

Baba, A., Garba, S. T., and Bello, H. S. (2020). Bioremediation Potential of Immobilized corynebacterium kutsceri in the Treatment of Tannery Industrial Effluent from Challawa Industrial Estate, Kano State, Nigeria. Journal of the Turkish Chemical Society Section A: Chemistry, $7(2), 335-350$.

Beem, E. I. V. (1994). reduction of solvent VOC emission. J. Oil Col. Chem. Ass, 77, 158.

Bouwer, E. J., and Zehnder, A. J. (1993). Bioremediation of organic compoundsputting microbial metabolism to work. Trends in biotechnology, 11(8), 360367.

Chen, K. C., Wu, J. Y., Liou, D. J., and Hwang, S. C. J. (2003). Decolorization of the textile dyes by newly isolated bacterial strains. Journal of Biotechnology, 101(1), 57-68.

Dan'Azumi, S., and Bichi, M. H. (2010). INDUSTRIAL POLLUTION AND HEAVY METALS PROFILE OF CHALLAWA RIVER IN KANO, NIGERIA. Journal of Applied Sciences in Environmental Sanitation, $5(1)$.

DWAF. (1992). Analytical Methods Manual, TR 151. Department of Water Affairs and Forestry, Pretoria.

El-Bestawy, E. (2013). Biological treatment of leather-tanning industrial wastewater using free living bacteria.
Elsheikh, M. A. S. (2009). Tannery wastewater pre-treatment. Water Science and Technology, 60(2), 433-440.

FuIlbrook, P. D. (1996). "Kinetics." Industrial enzymology: The application of enzymes in Industry. 2nd Ed. T. Godfrey and J Reichelt. eds.. Nature. New York.

Gianfreda, L., and Rao, M. A. (2004). Potential of extra cellular enzymes in remediation of polluted soils: a review. Enzyme and microbial technology, 35(4), 339354.

Hugo Springer. (1994). John Arthur Wilson Memorial Lecture "Treatment of Industrial Wastes of the Leather Industry - is it still a Major Problem". JALCA, 89, 153-185

Jimoh, A. A., Ganiyu, B. A., Baba, D., and Baba, A. (2018) Bioremediation Process of Effluent from Detergent and Food Industries in Jos, Nigeria: Kinetics and Thermodynamics. International Journal of Engineering Science Invention (IJESI), 762-73

Kandelbauer, A., Maute, O., Kessler, R. W., Erlacher, A., and Gübitz, G. M. (2004). Study of dye decolorization in an immobilized laccase enzyme-reactor using online spectroscopy. Biotechnology and bioengineering, 87(4), 552-563.

Kongjao, S., Damronglerd, S., and Hunsom, M. (2008). Simultaneous removal of organic and inorganic Pollutants in tannery wastewater using electrocoagulation technique. Korean Journal of chemical engineering, 25(4), 703.

Maheshwari, U. M., Aruna, S., Gomathi, M., and AbdulJaffar, A. H. (2017). Bioremediation by Free and Immobilized Bacteria Isolated from Tannery Effluent. International Journal of Research in Applied, Natural and Social Sciences. 5(7), 75-90

Margesin, R., and Schinner, F. (2001). Bioremediation (natural attenuation and biostimulation) of diesel-oilcontaminated soil in an alpine glacier skiing area. Applied and environmental microbiology, 677), 3127-3133.

Mohammed, A., Sekar, P., and George, J. (2011). Efficacy of microbes in bioremediation of tannery effluent. Inter. J. Curr. Res, 3(4), 324-326.

Mohammed, S. S. D., Orukotan, A. A., and Abdullahi, H. (2017). Physicochemical and Bacteriological Assessment of Tannery Effluent from Samaru-Zaria, 
BAJOPAS Volume 13 Number 2, December, 2020 Kaduna State, Nigeria. Journal of Applied

Sciences and Environmental Management, 21(4), 734-740.

Munz, G., De Angelis, D., Gori, R., Mori, G., Casarci, M., and Lubello, C. (2009). The role of tannins in conventional and membrane treatment of tannery wastewater. Journal of hazardous materials, 164(2-3), 733-739

Mythili, K., and Karthikeyan, B. (2011). Bioremediation of $\mathrm{Cr}$ (VI) from tannery effluent using Bacillus spp and Staphylococcus spp. International Multidisciplinary Research Journal, 1(6).

NESREA (2009). National Environmental Standards for Effluent Limitations and Regulation. 1233-1236

Noorjahan, C. M. (2014). Physicochemical characteristics, identification of bacteria and biodegradation of industrial effluent. Journal of bioremediation and Biodegradation, 5(3).

Ohtake, H. I., and Silver, A. O. (1994). Bacterial reduction of toxic chromate. Biological degradation and bioremediation of toxic chemicals, 403-415.

Omoleke, I. I. (2004). Management of environmental pollution in Ibadan, an African city: the challenges of health hazard facing government and the people. Journal of Human Ecology, 15(4), 265-275.

Rajor, A., Reddy, A.S., and Singh, B. (2004). Determination of BOD kinetic Parameters and evaluation of alternate methods, M.Sc. Thesis, Department of biotechnology \& environmental Science, Thapar Institute of Engineering and Technology, Patiala

Ramasami, T., Rajamani, S., and Rao, J. R. (1994, March). Pollution control in leather industry: Emerging technological options. In International symposium on surface and colloidal science and its relevance to soil pollution, madras.

Ramesh, J. V. S., and Singh, S. P. (1993). Yearly variation in certain physicochemical parameters of pond at eastern Doon Valley. Uttar Pradesh J. Zoo, 12 (1), 7577.

Ranen, S., and Sharadinadra, C. (2009). Biotechnology applications to environmental remediation in resource exploitation. Current science, 97, 6-25
Russell, A. J., Berberich, J. A., Drevon, G. F., and Koepsel, R. R. (2003). Biomaterials for mediation of

chemical and biological warfare agents. Annual review of biomedical engineering, 5(1), 1-27.

Saravanan, P., and Saravanan, A. (1999). Decolourization of tannery effluent by Flavobacterium sp. EK 1. Indian Journal of Environmental Protection, 19, 19-24.

Sikander, S., and Shahida, H. (2007). Reduction of toxic hexavalent chromium by Ochrobactrum intermedium strain SDCr5 stimulated by heavy metals. Bioresource Technol, 98, 340-344.

Singh, N., Sharma, B. K., and Bohra, P. C. (2000). Impact assessment of industrial effluent of arid soils by using satellite imageries. Journal of the Indian Society of Remote Sensing, 28(2-3), 79.

Sreemoyee, C., and Priti, P. (2013). Assessment of physico-chemical parameters of dairy waste water and isolation and characterization of bacterial strains in terms of cod reduction. Int J Sci, 2(3), 395-400.

Verheijen, L. A. H. M., Wiersema, D., Pol, L. H., and De Wit, J. (1996). Management of wastes from animal product processing. Livestock and environment, Finding a balance. International Agriculture Center, Wageningen, The Netherlands.

Wang, F., Yao, J., Si, Y., Chen, H., Russel, M., Chen, K., and Bramanti, E. (2010). Short-time effect of heavy metals upon microbial community activity. Journal of Hazardous Materials, 173(13), 510-516.

WHO (World Health Organization). (2006). Air quality guidelines: global update 2005: particulate matter, ozone, nitrogen dioxide, and sulfur dioxide. World Health Organization.

World Bank. (1995). Nigeria's strategic options for redressing industrial pollution. World Bank, industry and energy division. 1st edition, West Central Africa Department; Annexes: 1995; pp 60-62.

Zahoor, A., and Abdul, R. (2009). Enumeration of Coliforms. Journal of Environmental Sciences. 21, 814-820 


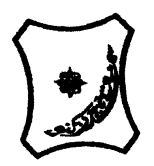

Bayero Journal of Pure and Applied Sciences, 13(2): 1 - 12

Received: November, 2020

Accepted: December, 2020

ISSN $2006-6996$

\title{
BIODEGRADATION POTENTIAL OF IMMOBILIZED BACTERIA IN THE TREATMENT OF TANNERY INDUSTRIAL EFFLUENTS FROM INDUSTRIAL ESTATES IN KANO STATE, NIGERIA
}

\author{
Abdullateef, B., ${ }^{1 *}$ Shuaibu, T. G., ${ }^{1}$ Babagana, K., ${ }^{1}$ Suleman, H. B. ${ }^{2}$ and Dauda, B. ${ }^{3}$ \\ ${ }^{1}$ Department of Pure and Applied Chemistry, Faculty of Science, University of Maiduguri, Borno State, \\ Nigeria \\ ${ }^{2}$ Department of Microbiology, Faculty of Science, University of Maiduguri, Borno State, Nigeria \\ ${ }^{3}$ Department of Chemical Engineering, Faculty of Engineering, University of Maiduguri, Borno State, \\ Nigeria \\ *Corresponding author: babslega@gmail.com; abelega2007@yahoo.com; +2348061309753
}

\section{ABSTRACT}

Industrial Effluents Samples from Gashash Tanneries (TAN1) in Bompai Industrial estate, Larabee Tannery Industry (TAN2) in Sharada Industrial estate and Z Tannery Industries (TAN3) in Challawa Industrial estate, Kano State, Nigeria were collected over a period of six months (August 2017 to January 2018) for assessing the biodegradation potentials of bacteria in the treatment of organic pollutants within the effluents. Bacteria were isolated from the effluents and immobilized on agar-agar. Different masses (5 g, $10 \mathrm{gr}, 15$ $\mathrm{g}, 20 \mathrm{~g}$, and $25 \mathrm{~g}$ ) of the bacteria were used in the treatment of $250 \mathrm{ml}$ of the effluents for ten days in a shaker incubator (Gallenkamp-OC-4364-L) at the temperature $30{ }^{\circ} \mathrm{C}$ and speed of $60 \mathrm{rpm}$. Pre-treatment analysis of the effluents for Temperature, pH, Biochemical Oxygen Demand (BOD), Chemical Oxygen Demand (COD), Suspended Solid (SS) and Total Dissolved Solids (TDS) gives the following results; temperature $\left({ }^{\circ} \mathrm{C}\right.$ )

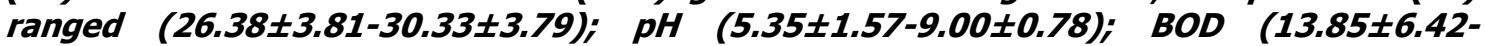
$38.75 \pm 16.20) ;$ COD (1406 $\pm 208-3532 \pm 1373) ;$ SS (208 $\pm 235-780 \pm 739)$ and TDS (266 $\pm 253-5276 \pm 2971)$. No statistical differences ( $p \leq 0.05)$ was observed for all the results among the different industries. The bacterial isolates were identified as Neisseria spp, Bacillus cereus, and Staphylococcus aureus, in TAN1, TAN2, and TAN3, respectively. After treatment of the effluent with the different masses of the isolated bacteria, the mean level of BOD was found to range as (0.55 $\pm 0.36-6.92 \pm 5.49) ; C O D$ (ND-3134 \pm 1595$)$;

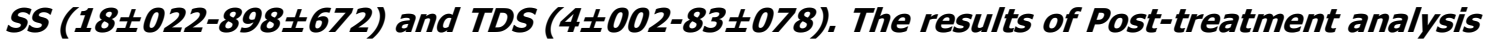
showed that there is overall decrease in the levels of the parameters determined when compared with that of the pre-treatment. The overall percentage reduction of the immobilised bacteria in the treatment of the respective effluents was in the order TAN2 (72\%)>TAN1 (70\%)>TAN3 (62\%). Hence, the immobilized bacteria are having higher biodegradation potential for the treatment of the tannery effluents.

Keywords: Biodegradation, bacteria, effluent, immobilization, tannery.

\section{INTRODUCTION}

Tannery industrial wastewater is a serious consequence of the pollution point of view for streams, freshwater, and land used for agriculture. The lack of awareness in the modern industrial practice has resulted in the discharge of tannery effluents which exhibit very high value of chromium ( $\mathrm{Cr}$ ), Sulfide, and chloride, Total Dissolved Solid (TDS), Total Suspended Solid (TSS), Biochemical Oxygen Demand (BOD) and Chemical Oxygen Demand (COD) in the water stream or land (Mohammed et al., 2001). Tanning is the process, which One ton of skin generally leads to the production of 20 to $80 \mathrm{~m}^{3}$ of turbid and foul-smelling converts the protein of the rawhide or skin into a stable material, which will not putrefy and is suitable for a wide variety of end applications (Elsheikh, 2009). The highly polluting chromium is the most commonly used tanning material producing leather that is more flexible and pliable than vegetable-tanned leather and does not discolor or lose shape in water as drastically as vegetable-tan (Elsheikh, 2009). Tannery effluent is among the most hazardous industrial pollutants due to its huge organic and inorganic load, which is highly toxic to human life and the environment (Kongjao et al., 2008). wastewater including chromium (100-400 mg/l), sulfide $(200-800 \mathrm{mg} / \mathrm{l})$, high levels of fat and 
BAJOPAS Volume 13 Number 2, December, 2020 other solid wastes, and notable pathogen contamination as well as pesticides added for skin conservation during transport (Elsheikh, 2009). There are more than 6000 tanneries in Nigeria with an annual processing capacity of 700,000 tons of hides and skins (Omoleke, 2004; Singh et al., 2008). It was reported that the total amount of waste produced per animal slaughtered is approximately $35 \%$ of its weight (World Bank, 1995). Also, for every $1000 \mathrm{~kg}$ of carcass weight, a slaughtered beef produces 5.5 $\mathrm{kg}$ of manure (excluding rumen contents or stockyard manure) and $100 \mathrm{~kg}$ of paunch manure (undigested food) (Verheijen et al., 1996). Tanneries generate wastewater in the range of 30-35 $\mathrm{L} \mathrm{kg}^{-1}$ skin/hide processed with variable $\mathrm{pH}$, Biological Oxygen Demand (BOD), Chemical Oxygen Demand (COD), high concentrations of suspended solids (SS), and tannins as well as chromium (Zahoor and Abdul, 2009).

Being heterogeneous and composed of a wide variety of compounds, it is very difficult to select a unique direct method for estimating the biodegradability of organic contents and biokinetic parameters for a wastewater sample (Rajor, 2004). For this purpose, some indirect estimation such as determination of biochemical oxygen demand (BOD) and chemical oxygen demand (COD) are applied as common laboratory investigations [9]. During retanning procedures, synthetic tannins (Syntan), oils and resins are added to form softer leather at varying doses (Munz et al., 2009). One of the refractory groups of chemicals in tannery effluents derives mainly from tannins (Ramasami et al., 2004). Syntans are characterized by complex chemical structures, because they are composed of an extended set of chemicals such as phenol-, naphthalene-, formaldehyde- and melamine-based syntans, and acrylic resins (Beem, 1994). Organic pollutants (proteic and lipidic components) are originated from skins (it is calculated that the raw skin has $30 \%$ loss of organic material during the working cycle) or they are introduced during processes (Hugo Springer, 1994).

Many conventional processes such as oxidation, chemical and biological processes were carried out to treat tanneries wastewater (Ebtesam et al, 2013). Biological processes have received more attention because of their costeffectiveness, lower sludge production and environmental friendliness (Noorjahan, 2014). Naturally occurring micro-organisms degrade the hazardous organic wastes including xenobiotic compounds, such as pesticides, polycyclic aromatic hydrocarbons (PAHs) and polychlorinated biphenyls (PCBs) in due course of time (Ranen and Sharadinadra, 2009). Bioremediation is based on the idea that all organisms remove substances from the environment to carry outgrowth and metabolism (Bouwer and Zehnder, 1993). Bacteria, protista and fungi are found to be very good at degrading complex molecules and incorporating the breakdown products into their metabolism (Bouwer and Zehnder, 1993). The resultant metabolic wastes that they produce are generally safe and somehow recycled into other organisms (Ranen and Sharadinadra, 2009). An acclimatized indigenous population of microorganisms capable of degradation of the compounds of interest must exist at the site for a successful bioremediation mode (Ranen and Sharadinadra, 2009). It has been observed that for a successful bioremediation mode, an acclimatized indigenous population of microorganisms capable of degradation of the compounds of interest must exist at the site under investigation (Ranen and Sharadinadra, 2009). Even though there are numerous physical and chemical methods employed in the disposal of wastes the advantage in using bacterium is that they play a key role in the reduction of COD, BOD, total protein, total tannin and total phenol (Saravanan and Saravanan, 1998)

Baba et al. (2020) studied the bioremediation potential of immobilized corynebacterium kutsceri in the Treatment of tannery industrial effluent from Challawa Industrial Estate, Kano State, Nigeria. The aim of the work is to study the reduction in the level of the contaminants through the process of bioremediation using the isolated bacteria. Immobilized bacteria can withstand various temperatures, $\mathrm{pH}$ and substrate concentrations; consequently, increasing the efficiency and the lifespan of the bacteria. Immobilized bacteria are widely applied in the treatment of wastewater and can be separated and recovered after the treatment with the same efficiency (Baba et al., 2020).

\section{MATERIALS AND METHODS \\ Study Area}

This study was carried out in Bompai, Sharada and Challawa industrial estates in Kano, Figure 1. Kano lies on Latitude $11^{\circ} 30^{\prime} \mathrm{N}$ and $8^{\circ} 30^{\prime} \mathrm{E}$ and Longitude $11^{\circ} 5^{\prime} \mathrm{N}$ and $8^{\circ} 5^{\prime} \mathrm{E}$ in Northern Nigeria. It is one of the developed industrial cities in Nigeria. Tannery activities are the dominating industries and this could be one of the reasons for her high population density (Dan'Azumi and Bichi, 2010). Many researchers have studied biodegradation of tannery effluent using microorganisms. However, limited literature is available on the biodegradation of tannery effluent in Kano industrial estates using 
BAJOPAS Volume 13 Number 2, December, 2020 immobilized bacterial cells. This research work focuses on the potential of the use of the indigenous immobilized bacterial isolates in the treatment of tannery effluents in the industrial estates.

\section{Sample Collection}

Effluents were collected from the Tannery Industries from Bompai, Challawa and Sharada Industrial Estates, Kano, Nigeria. The effluents were collected over a period of six months (August 2017 to January 2018). Samples collected in a sterile 4-liter plastic container with a unique identification number were preserved using an ice-box that was transported to the Microbiology Laboratory, Department of Microbiology, Bayero University of Kano for analysis

\section{Sample Preparation and Sample Analysis}

Immediately after the collection of the effluent, $\mathrm{pH}$, TSS, TDS, COD, BOD levels were determined before treatment (Pre-treatment determination) and ten days after treatment (Post-treatment determination) as described in
APHA (1989) standard methods. $\mathrm{pH}$ was determined using Ecotests $\mathrm{pH}$ meter and TDS was determined using AQUALYTIC TDS Salinometer. BOD was determined as described by the standard method (APHA, 1992). COD and SS were determined using DR/2010 HACH portable data logging spectrophotometer (DWAF, 1992)

\section{Identification and Biochemical} Characterization of the Bacterial Isolates

The bacteria were isolated from the effluents using Serial Dilution according to the method described by APHA (1989). The biochemical tests such as oxidase, catalase, coagulase, indole (from $1 \%$ tryptone broth), citrate (Simmons citrate agar), methyl red/VogesProskauer (MR/VP), nitrate reduction, Starch Hydrolysis, Glucose, Maltose, and Lactose tests were carried out on the bacterial isolates to identify the bacteria through the bacteria biochemical characteristics according to Ajao et al. (2011).

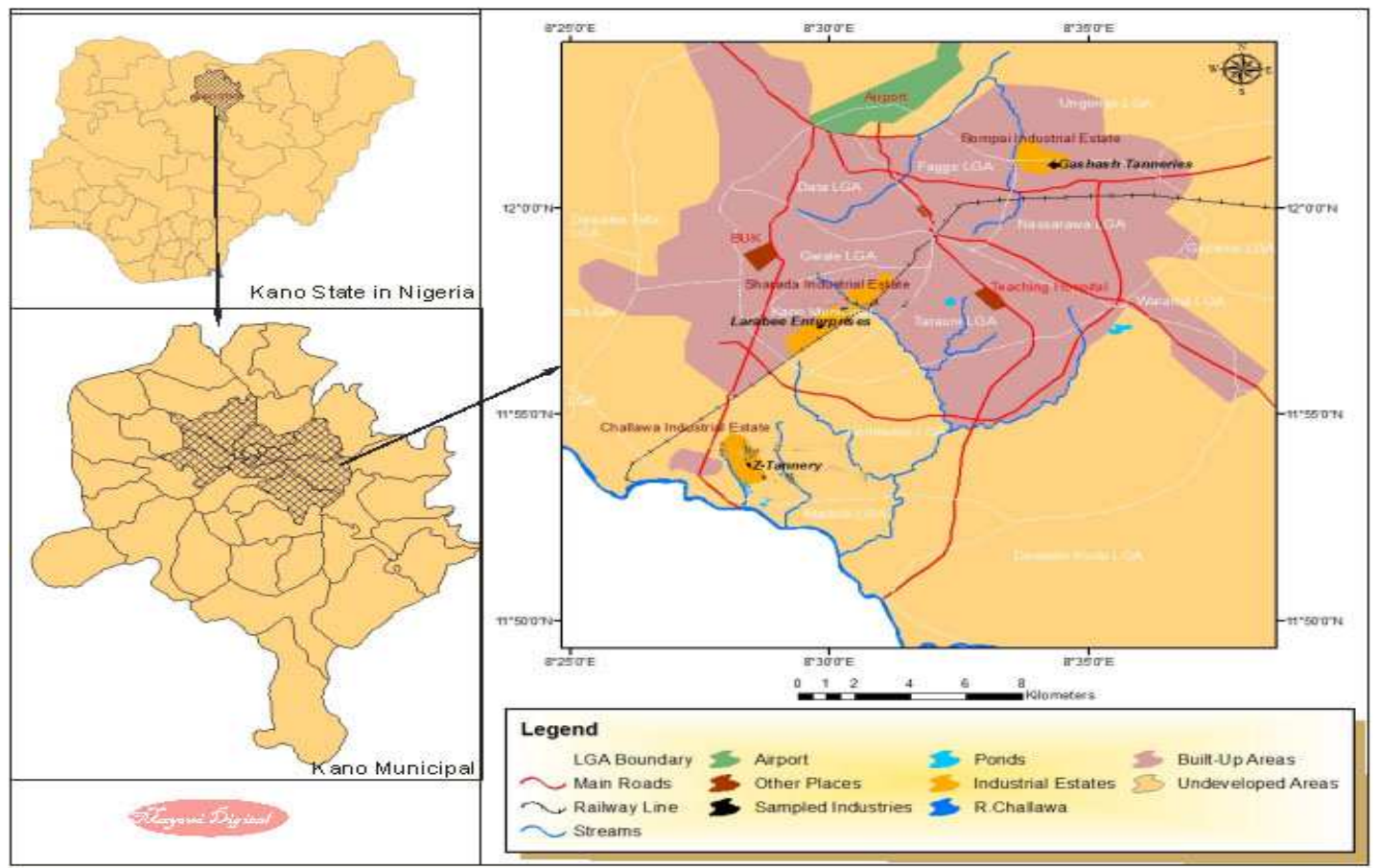

Fig. 1 Map showing the study areas

Source: Mayomi Digital Productions, GIS Laboratory, Department of Geography, UNIMAID (2017)

\section{Determination of Growth Rate of the Bacteria in Effluent Sample}

The bacteria growth rates were determined by transferring $2 \mathrm{~mL}$ of the bacterial isolates from the tannery effluent in broth medium into 100 $\mathrm{mL}$ sterile effluents in conical flasks and kept in an incubator (Giffrin cool) for 10 days. Control was also set up by incubating another $100 \mathrm{~mL}$ each of the sterile effluents without the bacteria. The optical density of the content was determined at the wavelength of $600 \mathrm{~nm}$ on a daily interval and recorded. 
BAJOPAS Volume 13 Number 2, December, 2020 Immobilization of Bacteria

Agar solution and inoculi were prepared separately. Fifty milliliters $(50 \mathrm{~mL})$ of nutrient broth each of the inoculi was prepared in a McCartney bottle and incubated for 24 hours. A solution of agar-agar was prepared by dissolving $10 \mathrm{~g}$ of the powder in distilled water and made up to $500 \mathrm{~mL}$ mark in an Erlenmeyer flask and was sterilized in an autoclave (280A) for 15 minutes and allowed to cool to $40-45^{\circ} \mathrm{C}$ (Ajao et al., 2011). Four milliliters ( $4 \mathrm{~mL})$ of the bacterial isolates in the nutrient broth was mixed with 36 $\mathrm{ml}$ of the prepared agar-agar media in petri-dish plates and then allowed to solidify. This was kept in the refrigerator for bioremediation.

\section{Bioremediation (Treatment) of the Effluents}

The solidified agar block (immobilized bacteria) was cut into cubes using a sterile knife; $0.1 \mathrm{~mL}$ phosphate buffer ( $\mathrm{pH} \mathrm{7.0)}$ was added and kept in the refrigerator for 1 hour for curing. The phosphate buffer was decanted after 1 hour and the cubes were washed with sterile distilled water 3-4 times before it was used (Ajao et al., 2011). Two liters (2 L) of the effluent was supplemented with the minimum basal medium in $\mathrm{g} / \mathrm{L}: \mathrm{NaCl}(0.8), \mathrm{MgSO}_{4} .7 \mathrm{H}_{2} \mathrm{O}(0.001), \mathrm{KH}_{2} \mathrm{PO}_{4}$ (2), $\mathrm{NaNO}_{3}$ (2), $\quad \mathrm{CaCl}_{2} .2 \mathrm{H}_{2} \mathrm{O} \quad(0.5)$ and $\mathrm{NaHPO}_{4} .12 \mathrm{H}_{2} \mathrm{O}(2)$ and sterilized in an autoclave at $121^{\circ} \mathrm{C}$ for 15 minutes (Margesin and Schinner, 2001). Two hundred and fifty milliliters $(250 \mathrm{~mL})$ of the effluents were transferred into different $250 \mathrm{ml}$ conical flasks. The content was covered with a cotton-wool ramped with foil paper to avoid contamination. Five grams $(5 \mathrm{~g})$ of the immobilized bacteria were quickly transferred into each of the effluents in the conical flasks in an inoculating chamber. The same procedures were carried out for the $10 \mathrm{~g}, 15 \mathrm{~g}, 20 \mathrm{~g}$ and 25 $\mathrm{g}$ of the immobilized bacteria in separate $250 \mathrm{~mL}$ effluents in conical flasks and agitated for ten days in a shaker incubator (Gallenkamp-OC4364-L) at a temperature $30^{\circ} \mathrm{C}$ and speed of 60 rpm. The treated effluent samples were taken on the tenth day and analyzed for the parameters $\mathrm{pH}$, SS, TDS, COD, and BOD, (Posttreatment determination) for the different grams of bacteria to evaluate and compare the biodegradation potential. (Baba et al., 2020).

\section{Statistical Analysis}

The data were represented as Mean \pm Standard deviation and analyzed statistically using oneway Analysis of Variance (ANOVA) and Tukey's HSD as Post Hoc Tests with the aid of SPSS 16.0. The correlation coefficient was also used to measure the strength of the relationship between the different masses of the bacteria and the parameters. All $\mathrm{p} \leq 0.05$ were considered as statistically significant.

\section{RESULTS AND DISCUSSION Physico-chemical parameters in the Industrial Effluents before the Biodegradation.}

Results of the Physico-chemical parameters in the industrial effluents before the Biodegradation is shown in table 1 . The mean temperatures $\left({ }^{\circ} \mathrm{C}\right)$ observed in TAN1, TAN2, and TAN3 samples were $28.07 \pm 0.65 ; 27.77 \pm 0.64$ and $26.38 \pm 3.81$ respectively. The order of the mean temperature of the samples from the three industries can be arranged as TAN1 > TAN2>TAN3. The temperature observed at TAN1, TAN2, and TAN3 samples were found below the WHO $\left(35^{\circ} \mathrm{C}\right)$ and NESREA $\left(40^{\circ} \mathrm{C}\right)$ limits. The low values of temperature might be due to the processes used at the time of sampling. High temperature brings down the solubility of gases in water that ultimately expresses as high BOD and COD. Statistical analysis shows that there is no significant difference $(p<0.05)$ between the mean values of temperature among the industries. This might be due to similar tannery activities involved in the tannery industries at the time of sampling. The average values of temperature observed in this present study are less than those observed by Akan et al. (2007), Akan et al. (2009) and Baba et al. (2020).

The mean level of $\mathrm{pH}$ observed in TAN1, TAN2 and TAN3, samples were $7.77 \pm 2.93$; $8.35 \pm 0.28$ and $7.52 \pm 0.76$ respectively. The order of the mean $\mathrm{pH}$ of the samples from the three industries can be arranged as TAN2> TAN1 $>$ TAN3. The $\mathrm{pH}$ of the samples falls within the WHO (7.0-8.5) and NESREA (6-9) standard limits. Statistical analysis shows that there is no significant difference $(p<0.05)$ between the mean values of $\mathrm{pH}$ among the industries. This might be due to similar tannery activities involved in the tannery industries at the time of sampling. Maheshwari et al. (2017) reported that the level of $\mathrm{pH}$ in the effluents from the tannery industry in Vaniyambadi, India was 6.5 which was lower than that observed in the present study. The $\mathrm{pH}$ in the effluents from the tannery industries in Kano and Kaduna were reported to be 7.64 and 6.89, respectively (Akan et al., 2007; Mohammed et al., 2017). The average values of $\mathrm{pH}$ observed in this present study are less than those observed by Mohammed et al. (2017) and Baba et al. (2020). The mean level of SS $(\mathrm{mg} / \mathrm{l})$ observed in TAN1, TAN2, and TAN3 samples were 374 \pm 124 ; $358 \pm 335$ and $780 \pm 739$ respectively. The order of the mean SS in the samples from the three industries can be arranged as TAN3 > TAN1 $>$ TAN2. 
The SS observed in the samples were far above the recommended standard limits of regulating bodies WHO $(30 \mathrm{mg} / \mathrm{l})$ and NESREA $(10 \mathrm{mg} / \mathrm{l})$. Statistical analysis shows that there is no significant difference $(p<0.05)$ between the mean values of SS among the industries. This might be due to similar tannery activities involved in the tannery industries at the time of sampling. The average values of SS observed in this present study are less than that observed $(3700 \pm 122 \mathrm{mg} / \mathrm{l})$ by Akan et al. (2009) for tanneries in Kano. Also, the average values of SS observed in this present study are less than that observed by Mohammed et al. (2017) and Baba et al. (2020) with the exception in TAN3.

The mean level of TDS (mg/l) observed in TAN1, TAN2, and TAN3 samples were $3941 \pm 3703$; $3300 \pm 1714$ and $2653 \pm 1240$ respectively. The order of the mean TDS in the samples from the three industries can be arranged as TAN1>TAN2>TAN3. The TDS observed in the samples were far above the recommended standard limits of WHO $(250 \mathrm{mg} / \mathrm{l})$ and NESREA $(500 \mathrm{mg} / \mathrm{l})$. Statistical analysis shows that there is no significant difference $(p<0.05)$ between the mean values of TDS among the industries. This might be due to similar tannery activities involved in the tannery industries at the time of sampling. TDS in the effluents from the tannery industries in Kano, Nigeria was reported to be $1281 \mathrm{mg} / \mathrm{l}$ (Akan et al., 2007). The average values of SS observed in this present study are less than those observed by Mohammed et al. (2017) and Baba et al. 2020)

The mean level of COD (mg/l) observed in TAN1, TAN2 and TAN3 samples seasons were $2372 \pm 938 ; \quad 1406 \pm 208$ and $3532 \pm 1373$ respectively. The order of the mean COD of the samples from the three industries can be arranged as TAN3>TAN1> TAN2. The COD observed in TAN1, TAN2 and TAN3 samples were far above the recommended standard limits of regulating bodies $\mathrm{WHO}(40 \mathrm{mg} / \mathrm{l})$ and NESREA (40 mg/l). Statistical analysis shows that there is no significant difference $(p<0.05)$ in COD among the industries. This might be due to similar tannery activities involved in the tannery industries as at the time of sampling. The Chemical Oxygen demand (COD) is the amount of oxygen, in $\mathrm{mg} / \mathrm{L}$, required for the degradation of the compound of wastewater to occur. In comparison, the average values of COD observed in this present study were higher than that observed by Mohammed et al. (2017) but lower than that observed by Baba et al. (2020).

The mean levels of BOD $(\mathrm{mg} / \mathrm{l})$ observed in TAN1, TAN2 and TAN3 samples were $13.85 \pm 6.42 ; \quad 19.46 \pm 0.50$ and $17.13 \pm 3.14$ respectively. The order of the mean BOD in the samples from the three industries can be arranged as TAN2>TAN3>TAN1. The BOD observed in TAN1, TAN2 and TAN3 samples were found below the recommended limits of NESREA (200 mg/l) but above WHO (10 mg/l). Statistical analysis shows that there is no significant difference $(p<0.05)$ between the mean values of BOD among the industries. This might be due to similar tannery activities involved in the tannery industries at the time of sampling. The low level of BOD recorded in this study is an indication of the low level of biodegradable organic solids in the effluent. The average values of BOD observed in this present study were lower than those observed by Mohammed et al. (2017) and Baba et al. (2020).

Table 1: Mean Values \pm S.D of Physico-chemical parameters of effluents from the Tannery Industries before Treatment.

\begin{tabular}{llllllll}
\hline Parameter & Tannery 1 & Tannery 2 & Tannery 3 & $\mathrm{a}$ & $\mathrm{b}$ & $\mathrm{c}$ & $\mathrm{d}$ \\
\cline { 2 - 7 } Temperature $\left({ }^{\circ} \mathrm{C}\right)$ & $28.07 \mathrm{a} \pm 0.65$ & $27.77 \mathrm{a} \pm 0.64$ & $26.38 \mathrm{a} \pm 3.81$ & & $29.50 \pm 4.68$ & 35 & 40 \\
pH & $7.77 \mathrm{a} \pm 2.93$ & $8.35 \mathrm{a} \pm 0.28$ & $7.52 \mathrm{a} \pm 0.76$ & 6.89 & $5.35 \pm 1.57$ & $7.0-8.5$ & $6.0-9.0$ \\
$\mathrm{COD}(\mathrm{mg} / \mathrm{l})$ & $2372 \mathrm{a} \pm 938$ & $1406 \mathrm{a} \pm 208$ & $3532 \mathrm{a} \pm 1373$ & 2.2 & $3106 \pm 2753$ & 40 & 40 \\
$\mathrm{BOD}(\mathrm{mg} / \mathrm{l})$ & $13.85 \mathrm{a} \pm 6.42$ & $19.46 \mathrm{a} \pm 0.50$ & $17.13 \mathrm{a} \pm 3.14$ & 1032 & $26.17 \pm 9.49$ & 10 & 200 \\
$\mathrm{SS}(\mathrm{mg} / \mathrm{l})$ & $374 \mathrm{a} \pm 124$ & $358 \mathrm{a} \pm 335$ & $780 \mathrm{a} \pm 739$ & 501 & $562 \pm 482$ & 30 & 10 \\
TDS $(\mathrm{mg} / \mathrm{l})$ & $3941 \mathrm{a} \pm 3703$ & $3300 \mathrm{a} \pm 1714$ & $2653 \mathrm{a} \pm 1240$ & 532.7 & $444 \pm 507$ & 250 & 500 \\
\hline
\end{tabular}

The values given in the table above are means of 6 replicate values, $\mathrm{n}=6$ ( 1 sample was taken monthly for 6 months). Within the rows, means with different alphabets are statistically different $(p<0.05)$. WHO: World Health Organisation. NESREA: National Environmental Standard and Regulatory Enforcement Agency. a = Mohammed et al.(2017), b = Baba et al. (2020), c = WHO (2006), $d=$ NESSRA (2009) 
BAJOPAS Volume 13 Number 2, December, 2020

Identification, Biochemical Characterization and growth rates of the Bacterial Isolates

Results of identification and biochemical characterization of the bacterial isolates were shown in table 2. After 24 hours of incubation, the nutrient agar media plates were checked for bacterial growth. The results showed the presence of different strains in the samples. The TAN1 bacteria isolate was found to be gramnegative cocci while TAN3 was gram-positive cocci. TAN2 bacteria isolate was found to be gram-positive, rod-shaped. TAN1, TAN2, and TAN3 bacteria isolates recorded positive results for spore former.

The results of the biochemical tests indicated that all the bacteria were positive for catalase, oxidase, citrate, maltose, glucose, lactose (negative in TAN1), mannitol (negative in TAN2), starch hydrolysis and coagulase (negative in TAN2) tests. The bacteria showed negative results for nitrate reduction, $M R$ (positive in TAN2), VP (positive in TAN1), Indole (positive in TAN2) tests. Base on the morphological and biochemical test results, TAN1, TAN2, and TAN3 bacteria isolates were identified to be Nesseria spp, Bacillus cereus, and Staphylococcus aureus respectively.

The growth rate of the TAN1, TAN2 and TAN3 Isolates were shown in figure 2. Generally, the optical density increase with the increase in time (day) and decrease as time goes on. The highest optical density was shown by bacillus cereus in TAN2 while the lowest was shown by Staphylococcus aureus in TAN3.

The initial growth phase of TAN1 Isolate bacteria occurred within 2-day of incubation as the growth rate increases up to the 6th-day incubation when the maximum growth was observed. Beyond the 6th day, the growth of the bacteria declined (which might be due to a shortage of nutrients in the effluents) until it reached its death phase (which might be due to the unavailability of nutrients in the effluents).

A similar trend of growth was also observed for TAN2 Isolate as the initial growth phase also occurred within 2-day of incubation but maximum growth rate observed on the 4th day of incubation. The stationary stage occurred between the 4th day and the 8th day. Beyond the 8th day, the growth of the bacteria declined (which might be due to a shortage of nutrients in the effluents) until it reached its death phase (which might be due to the unavailability of nutrients in the effluents).

The initial growth phase of TAN3 bacterial Isolate occurred within the 3-day incubation as the growth rate increases up to the 6th-day incubation when the maximum growth was observed. Beyond the 6th day, the growth of the bacteria declined (which might be due to a shortage of nutrients in the effluents) until it reached its death phase (which might be due to the unavailability of nutrients in the effluents).

Table 2: Morphological and Biochemical characteristics of bacterial isolates

\begin{tabular}{lllll} 
Bacterial Isolates & & TAN1 & TAN2 & TAN3 \\
\hline $\begin{array}{lllll}\text { Morphological } \\
\text { characteristics }\end{array}$ & Shape & Cocci & Rod & Cocci \\
& Spore & & & \\
& former & + & + & + \\
Gram & & & \\
Biochemical characteristics & reaction & - & + & + \\
& Citrate & + & + & + \\
& Catalase & + & + & + \\
& Coagulase & + & - & + \\
Starch & + & + & + \\
& Glucose & + & + & + \\
Oxidase & + & + & + \\
& Indo & - & + & - \\
Lactose & - & + & + \\
Manitol & + & - & + \\
Maltose & + & + & + \\
MR & - & + & - \\
VP & + & - & - \\
& Nitrate & - & - & - \\
Reduction & - Neisseria & Bacillus & Staphylococcus \\
& Bacterial & cereus & aureus \\
& name & spp & cas
\end{tabular}

+ = Positive; - = Negative; MR=Methyl Red; VP= Voges-Proskauer 


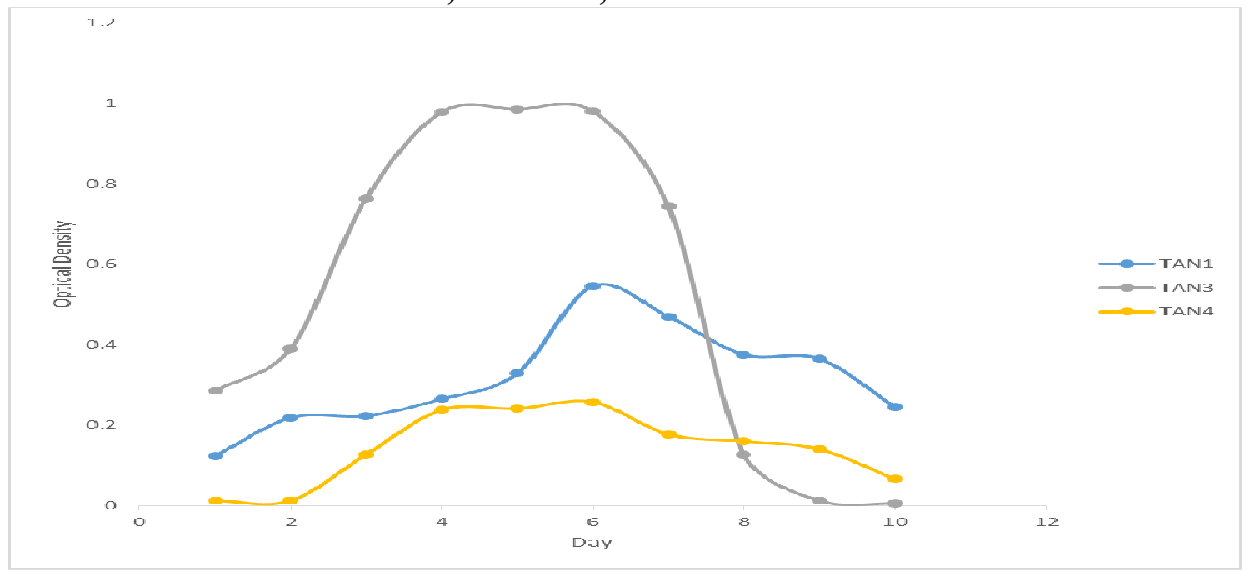

Fig. 2 Growth rates of the isolates in the effluents from the Tannery Industries

\section{Physico-chemical Parameters in the Industrial Effluents after the biodegradation.}

Table 3 shows the mean results of the physicochemical parameter before and after bioremediation using the different masses $(5 \mathrm{~g}$, $10 \mathrm{~g}, 15 \mathrm{~g}, 20 \mathrm{~g}$, and $25 \mathrm{~g}$ ) of the respective immobilized bacteria. Also, Table 4 shows the mean results of correlation coefficient ( $r$ ) between different masses of bacteria and physicochemical parameters.

The mean values $(\mathrm{mg} / \mathrm{l})$ of the SS after the bioremediation varies between $243 \pm 45$ and $898 \pm 672$. The mean concentration $(\mathrm{mg} / \mathrm{l})$ of SS remediated by the different masses $(5 \mathrm{~g}, 10 \mathrm{~g}$, $15 \mathrm{~g}, 20 \mathrm{~g}$, and $25 \mathrm{~g}$ ) of the bacteria varies. The SS in the samples fluctuates up and down after the bioremediation process when compared with the SS of the raw samples before the bioremediation. The increase in the levels of the SS might be due to the aggregation of the TDS which are large enough to result into SS. The increase in the levels of the SS might be also due to the influence of the nutrients which was added into the effluents in order to make the microorganisms more active and viable for fast degradation of organic contaminants in the effluent. The relative potential or efficiency of the different masses of the bacteria in remediating SS in TAN1 samples was in the order $25 \mathrm{~g}>20 \mathrm{~g}>15 \mathrm{~g}>10 \mathrm{~g}>5 \mathrm{~g}$. For TAN2 and TAN3 samples, the order was $25 \mathrm{~g}>20 \mathrm{~g}>15$ $\mathrm{g}>10 \mathrm{~g}>5 \mathrm{~g}$. These might be due to the variations in the surface areas of the different masses of the immobilized bacteria. Statistical analysis shows that there is no significant difference $(p<0.05)$ between the mean values of SS among the masses in the respective industries. Positive and significant correlations exist between the masses of bacteria and Suspended Solid (SS). This showed that there is general increase in the levels of the SS as the masses of the immobilized bacteria increases. TAN3 (90\%) and TAN1 (80\%) showed a very high correlation with the masses of the bacteria while TAN2 (61\%) showed a very low correlation.

The mean values $(\mathrm{mg} / \mathrm{l})$ of the TDS after the bioremediation varies between $46 \pm 11$ and $83 \pm 78$. The mean concentration $(\mathrm{mg} / \mathrm{l})$ of TDS remediated by the different masses $(5 \mathrm{~g}, 10 \mathrm{~g}$, $15 \mathrm{~g}, 20 \mathrm{~g}$, and $25 \mathrm{~g}$ ) of the bacteria varies. There is a reduction in all the TDS of all the samples after the bioremediation process compared with the TDS of the raw samples before the bioremediation. The relative potential or efficiency of the different masses of the bacteria in remediating TDS in TAN1 and TAN3 samples was in the order $5 \mathrm{~g}>10 \mathrm{~g}>15 \mathrm{~g}>20$ $\mathrm{g}>25 \mathrm{~g}$. For TAN2 samples, the order was 20 $g>10 \quad g>25 \quad g>15 \quad g>5 \quad g$. Statistical analysis shows that there is no significant difference $(p<0.05)$ between the mean values of TDS among the masses in the respective industries. These might be due to the variations in the surface areas of the different masses of the immobilized bacteria. Positive and significant correlations exist between the masses of bacteria and TDS with the exception in TAN2 (negative and insignificant correlation). The positive correlations showed that there is general increase in the levels of the TDS as the masses of the immobilized bacteria increases. TAN1 $(96 \%)$ showed a very high correlation with the masses of the bacteria while TAN2 (47\%) showed a very low correlation.

The mean values $(\mathrm{mg} / \mathrm{l})$ of the BOD after the bioremediation varies between $1.56 \pm 0.20 \mathrm{mg} / \mathrm{l}$ and $6.92 \pm 5.49 \mathrm{mg} / \mathrm{l}$. The mean concentration $(\mathrm{mg} / \mathrm{l})$ of BOD remediated by the different masses $(5 \mathrm{~g}, 10 \mathrm{~g}, 15 \mathrm{~g}, 20 \mathrm{~g}$, and $25 \mathrm{~g}$ ) of the bacteria varies. There is a reduction in all the BOD of all the samples after the bioremediation process compared with the $\mathrm{BOD}$ of the raw 
BAJOPAS Volume 13 Number 2, December, 2020 samples before the bioremediation. The relative potential or efficiency of the different masses of the bacteria in remediating BOD in TAN1, TAN2 and TAN3 samples were in the order $25 \mathrm{~g}>20$ $\mathrm{g}>15 \mathrm{~g}>10 \mathrm{~g}>5 \mathrm{~g}, 25 \mathrm{~g}>15 \mathrm{~g}>5 \mathrm{~g}>10 \mathrm{~g}>20 \mathrm{~g}$ and $20 \mathrm{~g}>10 \mathrm{~g}>25 \mathrm{~g}>15 \mathrm{~g}>5 \mathrm{~g}$ respectively. Statistical analysis shows that there is significant difference $(p<0.05)$ between the mean values of BOD among the masses in the respective industries. These might be due to the variations in the surface areas of the different masses of the immobilized bacteria. Negative and significant correlations exist between the masses of bacteria and BOD. This showed that there is general decrease in the levels of the BOD as the masses of the immobilized bacteria increases. TAN1 (94\%) showed a very high correlation with the masses of the bacteria while TAN2 (4\%) showed a very low correlation.

The mean values $(\mathrm{mg} / \mathrm{l})$ of the COD after the bioremediation varies between $250 \pm 154$ and $3134 \pm 1595$. The mean concentration $(\mathrm{mg} / \mathrm{l})$ of COD remediated by the different masses $(5 \mathrm{~g}$, $10 \mathrm{~g}, 15 \mathrm{~g} 20 \mathrm{~g}$, and $25 \mathrm{~g}$ ) of the bacteria varies. There is a reduction in all the COD of all the samples after the bioremediation process compared with the COD of the raw samples before the bioremediation. The relative potential or efficiency of the different masses of the bacteria in remediating COD in TAN1, TAN2 and TAN3 samples were in the order $25 \mathrm{~g}>20 \mathrm{~g}>15$ $\mathrm{g}>5 \mathrm{~g}>10 \mathrm{~g}, 25 \mathrm{~g}>20 \mathrm{~g}>15 \mathrm{~g}>10 \mathrm{~g}>5 \mathrm{~g}$ and 10 g>5 g>25 g>15 g>20 g respectively. Statistical analysis shows that there were significant difference $(p<0.05)$ between the mean values of COD among the masses in the respective industries except for effluents treated with $25 \mathrm{~g}$. These might be due to the variations in the surface areas of the different masses of the immobilized bacteria. Negative and insignificant correlations exist between the masses of bacteria and COD with the exception in TAN3 (positive and significant correlation). The negative correlations showed that there is general decrease in the levels of the COD as the masses of the immobilized bacteria increases. TAN2 (100\%) showed a very high correlation with the masses of the bacteria while TAN3 (36\%) showed a very low correlation.

Generally, there was an overall decrease in the concentration of these physicochemical parameters after the bioremediation using the different masses of the bacterial isolates. These might be due to the variations in the surface areas of the different masses of the immobilized bacteria. This is in line with the work of Jimoh et al. (2018) and Baba et al. (2020).

Table 3: Mean Values $(\mathrm{mg} / \mathrm{l}) \pm$ S.D of Physicochemical parameters in effluents from the Tannery Industries before and after Treatment of the effluents $(250 \mathrm{ml})$ with the different masses $(5 \mathrm{~g}, 10 \mathrm{~g}$, $15 \mathrm{~g}, 20 \mathrm{~g}$, and $25 \mathrm{~g}$ ) of the bacteria.

\begin{tabular}{llllllll}
\hline $\mathrm{P}$ & IND & Before & \multicolumn{5}{c}{ After } \\
\cline { 4 - 7 } & & & $5 \mathrm{~g}$ & $10 \mathrm{~g}$ & $15 \mathrm{~g}$ & $20 \mathrm{~g}$ & $25 \mathrm{~g}$ \\
\hline \multirow{2}{*}{ COD } & TAN1 & $2372 \pm 938$ & $1708 \mathrm{a} \pm 861$ & $2045 \mathrm{a} \pm 1205$ & $845 \mathrm{a} \pm 369$ & $300 \mathrm{a} \pm 167$ & $250 \mathrm{a} \pm 154$ \\
& TAN2 & $1406 \pm 208$ & $1195 \mathrm{a} \pm 208$ & $1125 \mathrm{a} \pm 384$ & $1055 \mathrm{a} \pm 317$ & $956 \mathrm{a} \pm 310$ & $870 \mathrm{ab} \pm 240$ \\
& TAN3 & $3532 \pm 1373$ & $2374 \mathrm{a} \pm 1344$ & $1976 \mathrm{a} \pm 1405$ & $2757 \mathrm{a} \pm 1266$ & $3134 \mathrm{a} \pm 1595$ & $2614 \mathrm{~b} \pm 1105$ \\
BOD & TAN1 & $13.85 \pm 6.42$ & $6.92 \mathrm{a} \pm 5.49$ & $6.42 \mathrm{a} \pm 5.07$ & $5.72 \mathrm{a} \pm 5.35$ & $4.62 \mathrm{a} \pm 4.37$ & $2.82 \mathrm{ab} \pm 1.26$ \\
& TAN2 & $19.46 \pm 0.50$ & $1.75 \mathrm{~b} \pm 0.22$ & $1.73 \mathrm{~b} \pm 0.18$ & $1.58 \mathrm{a} \pm 0.16$ & $1.91 \mathrm{a} \pm 0.22$ & $1.56 \mathrm{~b} \pm 0.20$ \\
& TAN3 & $17.13 \pm 3.14$ & $4.24 \mathrm{ab} \pm 0.77$ & $3.29 \mathrm{ab} \pm 0.37$ & $4.11 \mathrm{a} \pm 0.07$ & $3.23 \mathrm{a} \pm 0.91$ & $3.33 \mathrm{a} \pm 1.28$ \\
SS & TAN1 & $374 \pm 124$ & $243 \mathrm{a} \pm 45$ & $471 \mathrm{a} \pm 226$ & $475 \mathrm{a} \pm 182$ & $492 \mathrm{a} \pm 128$ & $611 \mathrm{a} \pm 217$ \\
& TAN2 & $358 \pm 335$ & $460 \mathrm{a} \pm 400$ & $543 \mathrm{a} \pm 414$ & $544 \mathrm{a} \pm 402$ & $551 \mathrm{a} \pm 414$ & $554 \mathrm{a} \pm 405$ \\
& TAN3 & $780 \pm 739$ & $586 \mathrm{a} \pm 594$ & $758 \mathrm{a} \pm 656$ & $787 \mathrm{a} \pm 676$ & $861 \mathrm{a} \pm 635$ & $898 \mathrm{a} \pm 672$ \\
TDS & TAN1 & $3941 \pm 3703$ & $51 \mathrm{a} \pm 10$ & $53 \mathrm{a} \pm 10$ & $55 \mathrm{a} \pm 15$ & $61 \mathrm{a} \pm 20$ & $63 \mathrm{a} \pm 26$ \\
& TAN2 & $3300 \pm 1714$ & $83 \mathrm{a} \pm 78$ & $47 \mathrm{a} \pm 20$ & $48 \mathrm{a} \pm 22$ & $47 \mathrm{a} \pm 17$ & $48 \mathrm{a} \pm 17$ \\
& TAN3 & $2653 \pm 1240$ & $46 \mathrm{a} \pm 11$ & $55 \mathrm{a} \pm 24$ & $55 \mathrm{a} \pm 25$ & $58 \mathrm{a} \pm 23$ & $61 \mathrm{a} \pm 28$ \\
\hline
\end{tabular}

Replicate $=6$ (months)

Within the rows, for the same parameter, means with different alphabets are statistically different $(p<0.05)$.

$\mathrm{P}=$ parameter, IND = Industries 
BAJOPAS Volume 13 Number 2, December, 2020

Table 4: Correlation coefficient $(r)$ between different masses of the bacteria and the physicochemical parameters.

\begin{tabular}{llll}
\hline Industries & Parameter & Correlation coefficient $(r)$ & $\begin{array}{l}\text { Percent dependence (rxrx100) } \\
(\%)\end{array}$ \\
\hline TAN1 & COD & -0.9 & 82 \\
& BOD & -0.97 & 94 \\
& SS & $0.90^{*}$ & 80 \\
TAN2 & TDS & $0.98^{*}$ & 96 \\
& COD & -1 & 100 \\
& BOD & -0.21 & 4 \\
& SS & $0.78^{*}$ & 61 \\
& TDS & -0.69 & 47 \\
& COD & $0.60^{*}$ & 36 \\
& BOD & -0.6 & 37 \\
& SS & $0.95^{*}$ & 90 \\
& TDS & $0.94^{*}$ & 89 \\
\hline
\end{tabular}

The correlation coefficient $(r)$ with * is statistically significant $(p<0.05)$.

Percentage reduction of the Parameters

Table 5 shows the percentage reduction of Parameters in industrial samples before and after the treatment of the effluents $(250 \mathrm{ml})$ with the different masses $(5 \mathrm{~g}, 10 \mathrm{~g}, 15 \mathrm{~g}, 20 \mathrm{~g}$, and $25 \mathrm{~g}$ ) of the Immobilized Bacteria.

In TAN1 samples, the percentage reduction (\%) of COD ranged (14-89); BOD (50-80); SS (-32$35)$ and TDS (98-99). In TAN2 samples, the percentage decrease $(\%)$ of COD ranged (15$38) ;$ BOD (90-92); SS [-28-(-55)] and TDS (9798). In TAN3 samples, the percentage decrease (\%) of COD ranged (11-44); BOD (76-81); SS (15-25) and TDS (98). The percentage increase in the levels COD, BOD and TDS might be due to the increase in the surface area of the different masses of the immobilized bacteria. However, the percentage decrease in the levels of the SS might be due to the aggregation of the TDS which are large enough to result into SS. The percentage decrease in the levels of the SS might be also due to the influence of the nutrients which was added into the effluents in order to make the microorganisms more active and viable for fast degradation of organic contaminants in the effluent. This is in line with the work of Jimoh et al. (2018) in which the concentration of the SS increase after the bioremediation of effluents.

Sreemoyee and Priti (2013) assessed and reduced several Physico-chemical parameters of dairy wastewater using Niesseria $s p$. and concluded that the species are well known to degrade organic compounds. This is in agreement with the current study in which the immobilized Niesseria $s p$ degrade the organic contaminants as indicated by the BOD, COD and TDS.

Jimoh et al. (2018) observed that TSS of the effluents was increased after treatment with immobilized bacteria and concluded that it might be due to the biostimulation method adopted for the research.

The optimum $\mathrm{pH}$ Biosorption of Chromium by Bacillus spp and Staphylococcus spp. from tannery effluent was investigated by Mythili and Karthikeyan (2011). The maximum adsorption of Chromium $(86.4 \mathrm{mg} / \mathrm{L})$ was showed by Bacillus spp and Staphylococcus spp showed $70.6 \mathrm{mg} / \mathrm{L}$ at an initial concentration of $100 \mathrm{mg} / \mathrm{L}$. In the present study, immobilised Bacillus spp and Staphylococcus spp. from the tannery industrial effluents reduced the levels of the organic pollutants with high potential as indicated by the percentage reduction of BOD, COD and TDS.

Enzymes often can work in multiple environments especially if they are immobilized. This makes the microorganisms' enzymes even more resistant to harsh environments and enables the enzymes to be recovered and recycled after they are no longer needed (Gianfreda and Rao 2004). Ramesh and Singh (1993) reported that the immobilized bacteria having more efficiency to remove the suspended particles than free cells. Using the immobilized cell is preferable due to its capability for using several times with the same efficiency, which makes it more economical. Similar work was done by Sikander et al. (2007) showing the higher reduction with permeabilized cells of Ochrobactrum intermedium strain SDCr-5. 
BAJOPAS Volume 13 Number 2, December, 2020

The results revealed the isolation and identification of isolates with the potential for the reduction of $\mathrm{Cr}$ (VI) to $\mathrm{Cr}$ (III). Results indicated that immobilized $B$. cereus could be efficiently used for the reduction of $\mathrm{Cr}$ (VI).

Table 5: Percentage reduction of the tested Parameters from the tannery industrial samples of the Immobilized Bacteria.

\begin{tabular}{lllllll}
\hline \multirow{2}{*}{ Industries } & & \multicolumn{5}{c}{ Percentage Reduction $(\%)$} \\
\cline { 3 - 7 } & & $5 \mathrm{~g}$ & $10 \mathrm{~g}$ & $15 \mathrm{~g}$ & $20 \mathrm{~g}$ & $25 \mathrm{~g}$ \\
\hline TAN1 & COD & 28 & 14 & 64 & 87 & 89 \\
& BOD & 50 & 54 & 59 & 67 & 80 \\
& SS & 35 & -26 & -27 & -32 & -63 \\
& TDS & 99 & 99 & 99 & 98 & 98 \\
TAN2 & COD & 15 & 20 & 25 & 32 & 38 \\
& BOD & 91 & 91 & 92 & 90 & 92 \\
& SS & -28 & -52 & -52 & -54 & -55 \\
& TDS & 97 & 99 & 99 & 99 & 99 \\
& COD & 33 & 44 & 22 & 11 & 26 \\
& BOD & 75 & 81 & 76 & 81 & 81 \\
& SS & 25 & 3 & -1 & -10 & -15 \\
& TDS & 98 & 98 & 98 & 98 & 98 \\
\hline
\end{tabular}

Percentage Reduction $=(B-A) / B \times 100 \%$

$A=$ Concentration of the parameter after treatment

$\mathrm{B}=$ Concentration of the parameter before treatment

$+=$ percentage decrease

- = percentage increase

In general, immobilization makes the enzyme more resistant to temperature, $\mathrm{pH}$, and substrate concentration swings giving it a longer lifetime and higher productivity per active unit (Gianfreda and Rao, 2004; FuIlbrook, 1996; Russell et al, 2003; Kandelbauer et al., 2004). Immobilized cells have been used and studied extensively for the production of useful chemicals (Ohtake and Silver, 1994), the treatment of wastewaters (Chen et al., 2003; Wang et al., 2010). Although many workers described microbial degradation of tannery effluent, limited literature is available on the bioremediation of tannery effluent using immobilized bacterial cells in the Kano Industrial Estates.

\section{CONCLUSION}

The samples contained variable levels of the physicochemical parameters. The results of the Analysis of variance revealed that, no statistical difference $(p<0.05)$ was observed for the temperature, $\mathrm{pH}, \mathrm{SS}, \mathrm{TDS}, \mathrm{BOD}$ and $\mathrm{COD}$ among the three tannery industries before the treatment. The levels of some of the parameters
(SS, TDS and COD) observed in the samples were found above the recommended limits of WHO and NESREA, which called for the treatment of the effluents before discharge into the environment. Base on the morphological and biochemical test results, TAN1, TAN2, and TAN3 bacterial isolates were identified to be Neisseria spp, Bacillus cereus, and Staphylococcus aureus respectively. The results of Post-treatment analysis showed that there is overall decrease in the levels of the parameters determined when compared with that of the pre-treatment. The overall percentage reduction of the immobilised bacteria in the treatment of the respective effluents was in the order TAN2 (72\%)>TAN1 $(70 \%)>$ TAN3 $(62 \%)$. Hence, the immobilized bacteria are having higher biodegradation potential for the treatment of the tannery effluents.

\section{Acknowledgments}

The authors wish to acknowledge the University of Maiduguri for the financial support. The authors are grateful to the Kano State Ministry of Environment for their support in obtaining the effluent samples. 


\section{REFERENCES}

Ajao, A. T., Adebayo, G. B., and Yakubu, S. E. (2011). Bioremediation of textile industrial effluent using mixed culture of Pseudomonas aeruginosa and Bacillus subtilis immobilized on agar-agar in a bioreactor. J. Microbiol. Biotech. Res, 1(3), 50-56.

Akan, J. C., Moses, E. A., Ogugbuaja, V. O., and Abah, J. (2007). Assessment of tannery industrial effluents from Kano metropolis, Kano State, Nigeria. Journal of Applied Sciences, 7(19), 2788-2793.

Akan, J. C., Ogugbuaja, V. O., Abdulrahman, F. I., and Ayodele, J. T. (2009). Pollutant levels in effluent samples from tanneries and textiles of Kano industrial areas, Nigeria. Global journal of pure and applied sciences, 15(3-4).

APHA (1989). Standard methods for Examination of Will bete and Will betewater.15 $5^{\text {th }}$ edition. Brydpass Springfield Will behington DC. pp. 164-176

APHA (1992). Standard Methods for the Examination of Water and Wastewater. Health, 69, 1116-9.

Baba, A., Garba, S. T., and Bello, H. S. (2020). Bioremediation Potential of Immobilized corynebacterium kutsceri in the Treatment of Tannery Industrial Effluent from Challawa Industrial Estate, Kano State, Nigeria. Journal of the Turkish Chemical Society Section A: Chemistry, $7(2), 335-350$.

Beem, E. I. V. (1994). reduction of solvent VOC emission. J. Oil Col. Chem. Ass, 77, 158.

Bouwer, E. J., and Zehnder, A. J. (1993). Bioremediation of organic compoundsputting microbial metabolism to work. Trends in biotechnology, 11(8), 360367.

Chen, K. C., Wu, J. Y., Liou, D. J., and Hwang, S. C. J. (2003). Decolorization of the textile dyes by newly isolated bacterial strains. Journal of Biotechnology, 101(1), 57-68.

Dan'Azumi, S., and Bichi, M. H. (2010). INDUSTRIAL POLLUTION AND HEAVY METALS PROFILE OF CHALLAWA RIVER IN KANO, NIGERIA. Journal of Applied Sciences in Environmental Sanitation, $5(1)$.

DWAF. (1992). Analytical Methods Manual, TR 151. Department of Water Affairs and Forestry, Pretoria.

El-Bestawy, E. (2013). Biological treatment of leather-tanning industrial wastewater using free living bacteria.
Elsheikh, M. A. S. (2009). Tannery wastewater pre-treatment. Water Science and Technology, 60(2), 433-440.

FuIlbrook, P. D. (1996). "Kinetics." Industrial enzymology: The application of enzymes in Industry. 2nd Ed. T. Godfrey and J Reichelt. eds.. Nature. New York.

Gianfreda, L., and Rao, M. A. (2004). Potential of extra cellular enzymes in remediation of polluted soils: a review. Enzyme and microbial technology, 35(4), 339354.

Hugo Springer. (1994). John Arthur Wilson Memorial Lecture "Treatment of Industrial Wastes of the Leather Industry - is it still a Major Problem". JALCA, 89, 153-185

Jimoh, A. A., Ganiyu, B. A., Baba, D., and Baba, A. (2018) Bioremediation Process of Effluent from Detergent and Food Industries in Jos, Nigeria: Kinetics and Thermodynamics. International Journal of Engineering Science Invention (IJESI), 762-73

Kandelbauer, A., Maute, O., Kessler, R. W., Erlacher, A., and Gübitz, G. M. (2004). Study of dye decolorization in an immobilized laccase enzyme-reactor using online spectroscopy. Biotechnology and bioengineering, 87(4), 552-563.

Kongjao, S., Damronglerd, S., and Hunsom, M. (2008). Simultaneous removal of organic and inorganic Pollutants in tannery wastewater using electrocoagulation technique. Korean Journal of chemical engineering, 25(4), 703.

Maheshwari, U. M., Aruna, S., Gomathi, M., and AbdulJaffar, A. H. (2017). Bioremediation by Free and Immobilized Bacteria Isolated from Tannery Effluent. International Journal of Research in Applied, Natural and Social Sciences. 5(7), 75-90

Margesin, R., and Schinner, F. (2001). Bioremediation (natural attenuation and biostimulation) of diesel-oilcontaminated soil in an alpine glacier skiing area. Applied and environmental microbiology, 677), 3127-3133.

Mohammed, A., Sekar, P., and George, J. (2011). Efficacy of microbes in bioremediation of tannery effluent. Inter. J. Curr. Res, 3(4), 324-326.

Mohammed, S. S. D., Orukotan, A. A., and Abdullahi, H. (2017). Physicochemical and Bacteriological Assessment of Tannery Effluent from Samaru-Zaria, 
BAJOPAS Volume 13 Number 2, December, 2020 Kaduna State, Nigeria. Journal of Applied

Sciences and Environmental Management, 21(4), 734-740.

Munz, G., De Angelis, D., Gori, R., Mori, G., Casarci, M., and Lubello, C. (2009). The role of tannins in conventional and membrane treatment of tannery wastewater. Journal of hazardous materials, 164(2-3), 733-739

Mythili, K., and Karthikeyan, B. (2011). Bioremediation of $\mathrm{Cr}$ (VI) from tannery effluent using Bacillus spp and Staphylococcus spp. International Multidisciplinary Research Journal, 1(6).

NESREA (2009). National Environmental Standards for Effluent Limitations and Regulation. 1233-1236

Noorjahan, C. M. (2014). Physicochemical characteristics, identification of bacteria and biodegradation of industrial effluent. Journal of bioremediation and Biodegradation, 5(3).

Ohtake, H. I., and Silver, A. O. (1994). Bacterial reduction of toxic chromate. Biological degradation and bioremediation of toxic chemicals, 403-415.

Omoleke, I. I. (2004). Management of environmental pollution in Ibadan, an African city: the challenges of health hazard facing government and the people. Journal of Human Ecology, 15(4), 265-275.

Rajor, A., Reddy, A.S., and Singh, B. (2004). Determination of BOD kinetic Parameters and evaluation of alternate methods, M.Sc. Thesis, Department of biotechnology \& environmental Science, Thapar Institute of Engineering and Technology, Patiala

Ramasami, T., Rajamani, S., and Rao, J. R. (1994, March). Pollution control in leather industry: Emerging technological options. In International symposium on surface and colloidal science and its relevance to soil pollution, madras.

Ramesh, J. V. S., and Singh, S. P. (1993). Yearly variation in certain physicochemical parameters of pond at eastern Doon Valley. Uttar Pradesh J. Zoo, 12 (1), 7577.

Ranen, S., and Sharadinadra, C. (2009). Biotechnology applications to environmental remediation in resource exploitation. Current science, 97, 6-25
Russell, A. J., Berberich, J. A., Drevon, G. F., and Koepsel, R. R. (2003). Biomaterials for mediation of

chemical and biological warfare agents. Annual review of biomedical engineering, 5(1), 1-27.

Saravanan, P., and Saravanan, A. (1999). Decolourization of tannery effluent by Flavobacterium sp. EK 1. Indian Journal of Environmental Protection, 19, 19-24.

Sikander, S., and Shahida, H. (2007). Reduction of toxic hexavalent chromium by Ochrobactrum intermedium strain SDCr5 stimulated by heavy metals. Bioresource Technol, 98, 340-344.

Singh, N., Sharma, B. K., and Bohra, P. C. (2000). Impact assessment of industrial effluent of arid soils by using satellite imageries. Journal of the Indian Society of Remote Sensing, 28(2-3), 79.

Sreemoyee, C., and Priti, P. (2013). Assessment of physico-chemical parameters of dairy waste water and isolation and characterization of bacterial strains in terms of cod reduction. Int J Sci, 2(3), 395-400.

Verheijen, L. A. H. M., Wiersema, D., Pol, L. H., and De Wit, J. (1996). Management of wastes from animal product processing. Livestock and environment, Finding a balance. International Agriculture Center, Wageningen, The Netherlands.

Wang, F., Yao, J., Si, Y., Chen, H., Russel, M., Chen, K., and Bramanti, E. (2010). Short-time effect of heavy metals upon microbial community activity. Journal of Hazardous Materials, 173(13), 510-516.

WHO (World Health Organization). (2006). Air quality guidelines: global update 2005: particulate matter, ozone, nitrogen dioxide, and sulfur dioxide. World Health Organization.

World Bank. (1995). Nigeria's strategic options for redressing industrial pollution. World Bank, industry and energy division. 1st edition, West Central Africa Department; Annexes: 1995; pp 60-62.

Zahoor, A., and Abdul, R. (2009). Enumeration of Coliforms. Journal of Environmental Sciences. 21, 814-820 


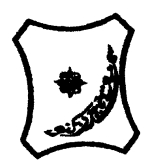

Bayero Journal of Pure and Applied Sciences, 13(2): 1 - 12

Received: November, 2020

Accepted: December, 2020

ISSN $2006-6996$

\title{
BIODEGRADATION POTENTIAL OF IMMOBILIZED BACTERIA IN THE TREATMENT OF TANNERY INDUSTRIAL EFFLUENTS FROM INDUSTRIAL ESTATES IN KANO STATE, NIGERIA
}

\author{
Abdullateef, B., ${ }^{1 *}$ Shuaibu, T. G., ${ }^{1}$ Babagana, K., ${ }^{1}$ Suleman, H. B. ${ }^{2}$ and Dauda, B. ${ }^{3}$ \\ ${ }^{1}$ Department of Pure and Applied Chemistry, Faculty of Science, University of Maiduguri, Borno State, \\ Nigeria \\ ${ }^{2}$ Department of Microbiology, Faculty of Science, University of Maiduguri, Borno State, Nigeria \\ ${ }^{3}$ Department of Chemical Engineering, Faculty of Engineering, University of Maiduguri, Borno State, \\ Nigeria \\ *Corresponding author: babslega@gmail.com; abelega2007@yahoo.com; +2348061309753
}

\section{ABSTRACT}

Industrial Effluents Samples from Gashash Tanneries (TAN1) in Bompai Industrial estate, Larabee Tannery Industry (TAN2) in Sharada Industrial estate and Z Tannery Industries (TAN3) in Challawa Industrial estate, Kano State, Nigeria were collected over a period of six months (August 2017 to January 2018) for assessing the biodegradation potentials of bacteria in the treatment of organic pollutants within the effluents. Bacteria were isolated from the effluents and immobilized on agar-agar. Different masses (5 g, $10 \mathrm{gr}, 15$ $\mathrm{g}, 20 \mathrm{~g}$, and $25 \mathrm{~g}$ ) of the bacteria were used in the treatment of $250 \mathrm{ml}$ of the effluents for ten days in a shaker incubator (Gallenkamp-OC-4364-L) at the temperature $30{ }^{\circ} \mathrm{C}$ and speed of $60 \mathrm{rpm}$. Pre-treatment analysis of the effluents for Temperature, pH, Biochemical Oxygen Demand (BOD), Chemical Oxygen Demand (COD), Suspended Solid (SS) and Total Dissolved Solids (TDS) gives the following results; temperature $\left({ }^{\circ} \mathrm{C}\right.$ )

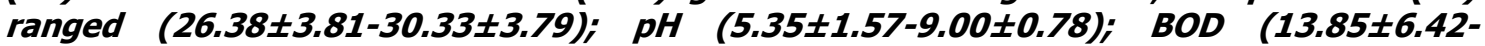
$38.75 \pm 16.20) ;$ COD (1406 $\pm 208-3532 \pm 1373) ;$ SS (208 $\pm 235-780 \pm 739)$ and TDS (266 $\pm 253-5276 \pm 2971)$. No statistical differences ( $p \leq 0.05)$ was observed for all the results among the different industries. The bacterial isolates were identified as Neisseria spp, Bacillus cereus, and Staphylococcus aureus, in TAN1, TAN2, and TAN3, respectively. After treatment of the effluent with the different masses of the isolated bacteria, the mean level of BOD was found to range as (0.55 $\pm 0.36-6.92 \pm 5.49) ; C O D$ (ND-3134 \pm 1595$)$;

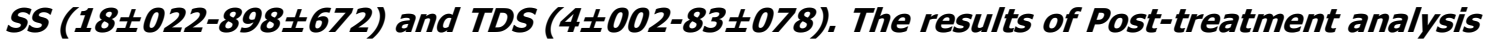
showed that there is overall decrease in the levels of the parameters determined when compared with that of the pre-treatment. The overall percentage reduction of the immobilised bacteria in the treatment of the respective effluents was in the order TAN2 (72\%)>TAN1 (70\%)>TAN3 (62\%). Hence, the immobilized bacteria are having higher biodegradation potential for the treatment of the tannery effluents.

Keywords: Biodegradation, bacteria, effluent, immobilization, tannery.

\section{INTRODUCTION}

Tannery industrial wastewater is a serious consequence of the pollution point of view for streams, freshwater, and land used for agriculture. The lack of awareness in the modern industrial practice has resulted in the discharge of tannery effluents which exhibit very high value of chromium ( $\mathrm{Cr}$ ), Sulfide, and chloride, Total Dissolved Solid (TDS), Total Suspended Solid (TSS), Biochemical Oxygen Demand (BOD) and Chemical Oxygen Demand (COD) in the water stream or land (Mohammed et al., 2001). Tanning is the process, which One ton of skin generally leads to the production of 20 to $80 \mathrm{~m}^{3}$ of turbid and foul-smelling converts the protein of the rawhide or skin into a stable material, which will not putrefy and is suitable for a wide variety of end applications (Elsheikh, 2009). The highly polluting chromium is the most commonly used tanning material producing leather that is more flexible and pliable than vegetable-tanned leather and does not discolor or lose shape in water as drastically as vegetable-tan (Elsheikh, 2009). Tannery effluent is among the most hazardous industrial pollutants due to its huge organic and inorganic load, which is highly toxic to human life and the environment (Kongjao et al., 2008). wastewater including chromium (100-400 mg/l), sulfide $(200-800 \mathrm{mg} / \mathrm{l})$, high levels of fat and 
BAJOPAS Volume 13 Number 2, December, 2020 other solid wastes, and notable pathogen contamination as well as pesticides added for skin conservation during transport (Elsheikh, 2009). There are more than 6000 tanneries in Nigeria with an annual processing capacity of 700,000 tons of hides and skins (Omoleke, 2004; Singh et al., 2008). It was reported that the total amount of waste produced per animal slaughtered is approximately $35 \%$ of its weight (World Bank, 1995). Also, for every $1000 \mathrm{~kg}$ of carcass weight, a slaughtered beef produces 5.5 $\mathrm{kg}$ of manure (excluding rumen contents or stockyard manure) and $100 \mathrm{~kg}$ of paunch manure (undigested food) (Verheijen et al., 1996). Tanneries generate wastewater in the range of 30-35 $\mathrm{L} \mathrm{kg}^{-1}$ skin/hide processed with variable $\mathrm{pH}$, Biological Oxygen Demand (BOD), Chemical Oxygen Demand (COD), high concentrations of suspended solids (SS), and tannins as well as chromium (Zahoor and Abdul, 2009).

Being heterogeneous and composed of a wide variety of compounds, it is very difficult to select a unique direct method for estimating the biodegradability of organic contents and biokinetic parameters for a wastewater sample (Rajor, 2004). For this purpose, some indirect estimation such as determination of biochemical oxygen demand (BOD) and chemical oxygen demand (COD) are applied as common laboratory investigations [9]. During retanning procedures, synthetic tannins (Syntan), oils and resins are added to form softer leather at varying doses (Munz et al., 2009). One of the refractory groups of chemicals in tannery effluents derives mainly from tannins (Ramasami et al., 2004). Syntans are characterized by complex chemical structures, because they are composed of an extended set of chemicals such as phenol-, naphthalene-, formaldehyde- and melamine-based syntans, and acrylic resins (Beem, 1994). Organic pollutants (proteic and lipidic components) are originated from skins (it is calculated that the raw skin has $30 \%$ loss of organic material during the working cycle) or they are introduced during processes (Hugo Springer, 1994).

Many conventional processes such as oxidation, chemical and biological processes were carried out to treat tanneries wastewater (Ebtesam et al, 2013). Biological processes have received more attention because of their costeffectiveness, lower sludge production and environmental friendliness (Noorjahan, 2014). Naturally occurring micro-organisms degrade the hazardous organic wastes including xenobiotic compounds, such as pesticides, polycyclic aromatic hydrocarbons (PAHs) and polychlorinated biphenyls (PCBs) in due course of time (Ranen and Sharadinadra, 2009). Bioremediation is based on the idea that all organisms remove substances from the environment to carry outgrowth and metabolism (Bouwer and Zehnder, 1993). Bacteria, protista and fungi are found to be very good at degrading complex molecules and incorporating the breakdown products into their metabolism (Bouwer and Zehnder, 1993). The resultant metabolic wastes that they produce are generally safe and somehow recycled into other organisms (Ranen and Sharadinadra, 2009). An acclimatized indigenous population of microorganisms capable of degradation of the compounds of interest must exist at the site for a successful bioremediation mode (Ranen and Sharadinadra, 2009). It has been observed that for a successful bioremediation mode, an acclimatized indigenous population of microorganisms capable of degradation of the compounds of interest must exist at the site under investigation (Ranen and Sharadinadra, 2009). Even though there are numerous physical and chemical methods employed in the disposal of wastes the advantage in using bacterium is that they play a key role in the reduction of COD, BOD, total protein, total tannin and total phenol (Saravanan and Saravanan, 1998)

Baba et al. (2020) studied the bioremediation potential of immobilized corynebacterium kutsceri in the Treatment of tannery industrial effluent from Challawa Industrial Estate, Kano State, Nigeria. The aim of the work is to study the reduction in the level of the contaminants through the process of bioremediation using the isolated bacteria. Immobilized bacteria can withstand various temperatures, $\mathrm{pH}$ and substrate concentrations; consequently, increasing the efficiency and the lifespan of the bacteria. Immobilized bacteria are widely applied in the treatment of wastewater and can be separated and recovered after the treatment with the same efficiency (Baba et al., 2020).

\section{MATERIALS AND METHODS \\ Study Area}

This study was carried out in Bompai, Sharada and Challawa industrial estates in Kano, Figure 1. Kano lies on Latitude $11^{\circ} 30^{\prime} \mathrm{N}$ and $8^{\circ} 30^{\prime} \mathrm{E}$ and Longitude $11^{\circ} 5^{\prime} \mathrm{N}$ and $8^{\circ} 5^{\prime} \mathrm{E}$ in Northern Nigeria. It is one of the developed industrial cities in Nigeria. Tannery activities are the dominating industries and this could be one of the reasons for her high population density (Dan'Azumi and Bichi, 2010). Many researchers have studied biodegradation of tannery effluent using microorganisms. However, limited literature is available on the biodegradation of tannery effluent in Kano industrial estates using 
BAJOPAS Volume 13 Number 2, December, 2020 immobilized bacterial cells. This research work focuses on the potential of the use of the indigenous immobilized bacterial isolates in the treatment of tannery effluents in the industrial estates.

\section{Sample Collection}

Effluents were collected from the Tannery Industries from Bompai, Challawa and Sharada Industrial Estates, Kano, Nigeria. The effluents were collected over a period of six months (August 2017 to January 2018). Samples collected in a sterile 4-liter plastic container with a unique identification number were preserved using an ice-box that was transported to the Microbiology Laboratory, Department of Microbiology, Bayero University of Kano for analysis

\section{Sample Preparation and Sample Analysis}

Immediately after the collection of the effluent, $\mathrm{pH}$, TSS, TDS, COD, BOD levels were determined before treatment (Pre-treatment determination) and ten days after treatment (Post-treatment determination) as described in
APHA (1989) standard methods. $\mathrm{pH}$ was determined using Ecotests $\mathrm{pH}$ meter and TDS was determined using AQUALYTIC TDS Salinometer. BOD was determined as described by the standard method (APHA, 1992). COD and SS were determined using DR/2010 HACH portable data logging spectrophotometer (DWAF, 1992)

\section{Identification and Biochemical} Characterization of the Bacterial Isolates

The bacteria were isolated from the effluents using Serial Dilution according to the method described by APHA (1989). The biochemical tests such as oxidase, catalase, coagulase, indole (from $1 \%$ tryptone broth), citrate (Simmons citrate agar), methyl red/VogesProskauer (MR/VP), nitrate reduction, Starch Hydrolysis, Glucose, Maltose, and Lactose tests were carried out on the bacterial isolates to identify the bacteria through the bacteria biochemical characteristics according to Ajao et al. (2011).

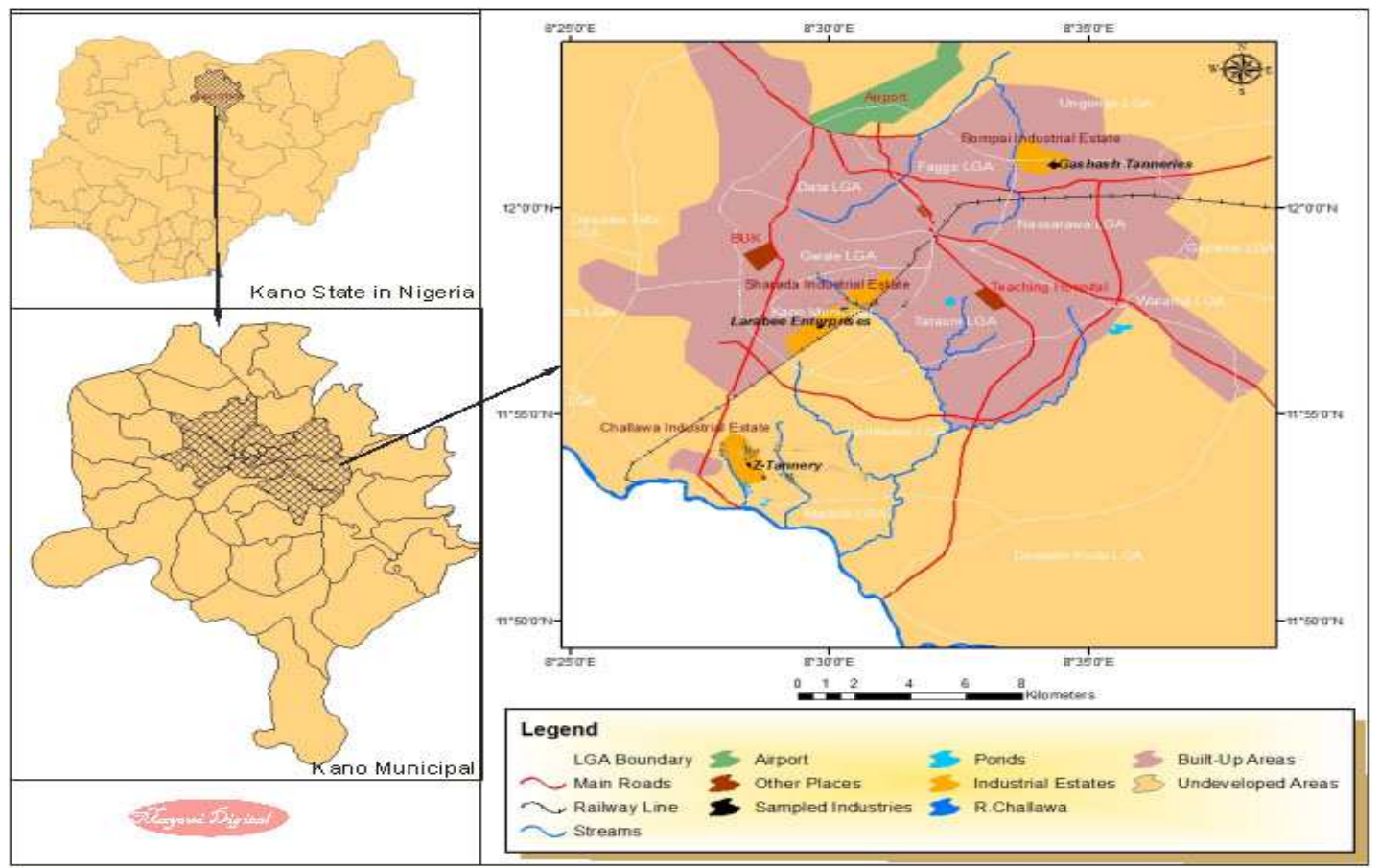

Fig. 1 Map showing the study areas

Source: Mayomi Digital Productions, GIS Laboratory, Department of Geography, UNIMAID (2017)

\section{Determination of Growth Rate of the Bacteria in Effluent Sample}

The bacteria growth rates were determined by transferring $2 \mathrm{~mL}$ of the bacterial isolates from the tannery effluent in broth medium into 100 $\mathrm{mL}$ sterile effluents in conical flasks and kept in an incubator (Giffrin cool) for 10 days. Control was also set up by incubating another $100 \mathrm{~mL}$ each of the sterile effluents without the bacteria. The optical density of the content was determined at the wavelength of $600 \mathrm{~nm}$ on a daily interval and recorded. 
BAJOPAS Volume 13 Number 2, December, 2020 Immobilization of Bacteria

Agar solution and inoculi were prepared separately. Fifty milliliters $(50 \mathrm{~mL})$ of nutrient broth each of the inoculi was prepared in a McCartney bottle and incubated for 24 hours. A solution of agar-agar was prepared by dissolving $10 \mathrm{~g}$ of the powder in distilled water and made up to $500 \mathrm{~mL}$ mark in an Erlenmeyer flask and was sterilized in an autoclave (280A) for 15 minutes and allowed to cool to $40-45^{\circ} \mathrm{C}$ (Ajao et al., 2011). Four milliliters ( $4 \mathrm{~mL})$ of the bacterial isolates in the nutrient broth was mixed with 36 $\mathrm{ml}$ of the prepared agar-agar media in petri-dish plates and then allowed to solidify. This was kept in the refrigerator for bioremediation.

\section{Bioremediation (Treatment) of the Effluents}

The solidified agar block (immobilized bacteria) was cut into cubes using a sterile knife; $0.1 \mathrm{~mL}$ phosphate buffer ( $\mathrm{pH} \mathrm{7.0)}$ was added and kept in the refrigerator for 1 hour for curing. The phosphate buffer was decanted after 1 hour and the cubes were washed with sterile distilled water 3-4 times before it was used (Ajao et al., 2011). Two liters (2 L) of the effluent was supplemented with the minimum basal medium in $\mathrm{g} / \mathrm{L}: \mathrm{NaCl}(0.8), \mathrm{MgSO}_{4} .7 \mathrm{H}_{2} \mathrm{O}(0.001), \mathrm{KH}_{2} \mathrm{PO}_{4}$ (2), $\mathrm{NaNO}_{3}$ (2), $\quad \mathrm{CaCl}_{2} .2 \mathrm{H}_{2} \mathrm{O} \quad(0.5)$ and $\mathrm{NaHPO}_{4} .12 \mathrm{H}_{2} \mathrm{O}(2)$ and sterilized in an autoclave at $121^{\circ} \mathrm{C}$ for 15 minutes (Margesin and Schinner, 2001). Two hundred and fifty milliliters $(250 \mathrm{~mL})$ of the effluents were transferred into different $250 \mathrm{ml}$ conical flasks. The content was covered with a cotton-wool ramped with foil paper to avoid contamination. Five grams $(5 \mathrm{~g})$ of the immobilized bacteria were quickly transferred into each of the effluents in the conical flasks in an inoculating chamber. The same procedures were carried out for the $10 \mathrm{~g}, 15 \mathrm{~g}, 20 \mathrm{~g}$ and 25 $\mathrm{g}$ of the immobilized bacteria in separate $250 \mathrm{~mL}$ effluents in conical flasks and agitated for ten days in a shaker incubator (Gallenkamp-OC4364-L) at a temperature $30^{\circ} \mathrm{C}$ and speed of 60 rpm. The treated effluent samples were taken on the tenth day and analyzed for the parameters $\mathrm{pH}$, SS, TDS, COD, and BOD, (Posttreatment determination) for the different grams of bacteria to evaluate and compare the biodegradation potential. (Baba et al., 2020).

\section{Statistical Analysis}

The data were represented as Mean \pm Standard deviation and analyzed statistically using oneway Analysis of Variance (ANOVA) and Tukey's HSD as Post Hoc Tests with the aid of SPSS 16.0. The correlation coefficient was also used to measure the strength of the relationship between the different masses of the bacteria and the parameters. All $\mathrm{p} \leq 0.05$ were considered as statistically significant.

\section{RESULTS AND DISCUSSION Physico-chemical parameters in the Industrial Effluents before the Biodegradation.}

Results of the Physico-chemical parameters in the industrial effluents before the Biodegradation is shown in table 1 . The mean temperatures $\left({ }^{\circ} \mathrm{C}\right)$ observed in TAN1, TAN2, and TAN3 samples were $28.07 \pm 0.65 ; 27.77 \pm 0.64$ and $26.38 \pm 3.81$ respectively. The order of the mean temperature of the samples from the three industries can be arranged as TAN1 > TAN2>TAN3. The temperature observed at TAN1, TAN2, and TAN3 samples were found below the WHO $\left(35^{\circ} \mathrm{C}\right)$ and NESREA $\left(40^{\circ} \mathrm{C}\right)$ limits. The low values of temperature might be due to the processes used at the time of sampling. High temperature brings down the solubility of gases in water that ultimately expresses as high BOD and COD. Statistical analysis shows that there is no significant difference $(p<0.05)$ between the mean values of temperature among the industries. This might be due to similar tannery activities involved in the tannery industries at the time of sampling. The average values of temperature observed in this present study are less than those observed by Akan et al. (2007), Akan et al. (2009) and Baba et al. (2020).

The mean level of $\mathrm{pH}$ observed in TAN1, TAN2 and TAN3, samples were $7.77 \pm 2.93$; $8.35 \pm 0.28$ and $7.52 \pm 0.76$ respectively. The order of the mean $\mathrm{pH}$ of the samples from the three industries can be arranged as TAN2> TAN1 $>$ TAN3. The $\mathrm{pH}$ of the samples falls within the WHO (7.0-8.5) and NESREA (6-9) standard limits. Statistical analysis shows that there is no significant difference $(p<0.05)$ between the mean values of $\mathrm{pH}$ among the industries. This might be due to similar tannery activities involved in the tannery industries at the time of sampling. Maheshwari et al. (2017) reported that the level of $\mathrm{pH}$ in the effluents from the tannery industry in Vaniyambadi, India was 6.5 which was lower than that observed in the present study. The $\mathrm{pH}$ in the effluents from the tannery industries in Kano and Kaduna were reported to be 7.64 and 6.89, respectively (Akan et al., 2007; Mohammed et al., 2017). The average values of $\mathrm{pH}$ observed in this present study are less than those observed by Mohammed et al. (2017) and Baba et al. (2020). The mean level of SS $(\mathrm{mg} / \mathrm{l})$ observed in TAN1, TAN2, and TAN3 samples were 374 \pm 124 ; $358 \pm 335$ and $780 \pm 739$ respectively. The order of the mean SS in the samples from the three industries can be arranged as TAN3 > TAN1 $>$ TAN2. 
The SS observed in the samples were far above the recommended standard limits of regulating bodies WHO $(30 \mathrm{mg} / \mathrm{l})$ and NESREA $(10 \mathrm{mg} / \mathrm{l})$. Statistical analysis shows that there is no significant difference $(p<0.05)$ between the mean values of SS among the industries. This might be due to similar tannery activities involved in the tannery industries at the time of sampling. The average values of SS observed in this present study are less than that observed $(3700 \pm 122 \mathrm{mg} / \mathrm{l})$ by Akan et al. (2009) for tanneries in Kano. Also, the average values of SS observed in this present study are less than that observed by Mohammed et al. (2017) and Baba et al. (2020) with the exception in TAN3.

The mean level of TDS (mg/l) observed in TAN1, TAN2, and TAN3 samples were $3941 \pm 3703$; $3300 \pm 1714$ and $2653 \pm 1240$ respectively. The order of the mean TDS in the samples from the three industries can be arranged as TAN1>TAN2>TAN3. The TDS observed in the samples were far above the recommended standard limits of WHO $(250 \mathrm{mg} / \mathrm{l})$ and NESREA $(500 \mathrm{mg} / \mathrm{l})$. Statistical analysis shows that there is no significant difference $(p<0.05)$ between the mean values of TDS among the industries. This might be due to similar tannery activities involved in the tannery industries at the time of sampling. TDS in the effluents from the tannery industries in Kano, Nigeria was reported to be $1281 \mathrm{mg} / \mathrm{l}$ (Akan et al., 2007). The average values of SS observed in this present study are less than those observed by Mohammed et al. (2017) and Baba et al. 2020)

The mean level of COD (mg/l) observed in TAN1, TAN2 and TAN3 samples seasons were $2372 \pm 938 ; \quad 1406 \pm 208$ and $3532 \pm 1373$ respectively. The order of the mean COD of the samples from the three industries can be arranged as TAN3>TAN1> TAN2. The COD observed in TAN1, TAN2 and TAN3 samples were far above the recommended standard limits of regulating bodies $\mathrm{WHO}(40 \mathrm{mg} / \mathrm{l})$ and NESREA (40 mg/l). Statistical analysis shows that there is no significant difference $(p<0.05)$ in COD among the industries. This might be due to similar tannery activities involved in the tannery industries as at the time of sampling. The Chemical Oxygen demand (COD) is the amount of oxygen, in $\mathrm{mg} / \mathrm{L}$, required for the degradation of the compound of wastewater to occur. In comparison, the average values of COD observed in this present study were higher than that observed by Mohammed et al. (2017) but lower than that observed by Baba et al. (2020).

The mean levels of BOD $(\mathrm{mg} / \mathrm{l})$ observed in TAN1, TAN2 and TAN3 samples were $13.85 \pm 6.42 ; \quad 19.46 \pm 0.50$ and $17.13 \pm 3.14$ respectively. The order of the mean BOD in the samples from the three industries can be arranged as TAN2>TAN3>TAN1. The BOD observed in TAN1, TAN2 and TAN3 samples were found below the recommended limits of NESREA (200 mg/l) but above WHO (10 mg/l). Statistical analysis shows that there is no significant difference $(p<0.05)$ between the mean values of BOD among the industries. This might be due to similar tannery activities involved in the tannery industries at the time of sampling. The low level of BOD recorded in this study is an indication of the low level of biodegradable organic solids in the effluent. The average values of BOD observed in this present study were lower than those observed by Mohammed et al. (2017) and Baba et al. (2020).

Table 1: Mean Values \pm S.D of Physico-chemical parameters of effluents from the Tannery Industries before Treatment.

\begin{tabular}{llllllll}
\hline Parameter & Tannery 1 & Tannery 2 & Tannery 3 & $\mathrm{a}$ & $\mathrm{b}$ & $\mathrm{c}$ & $\mathrm{d}$ \\
\cline { 2 - 7 } Temperature $\left({ }^{\circ} \mathrm{C}\right)$ & $28.07 \mathrm{a} \pm 0.65$ & $27.77 \mathrm{a} \pm 0.64$ & $26.38 \mathrm{a} \pm 3.81$ & & $29.50 \pm 4.68$ & 35 & 40 \\
pH & $7.77 \mathrm{a} \pm 2.93$ & $8.35 \mathrm{a} \pm 0.28$ & $7.52 \mathrm{a} \pm 0.76$ & 6.89 & $5.35 \pm 1.57$ & $7.0-8.5$ & $6.0-9.0$ \\
$\mathrm{COD}(\mathrm{mg} / \mathrm{l})$ & $2372 \mathrm{a} \pm 938$ & $1406 \mathrm{a} \pm 208$ & $3532 \mathrm{a} \pm 1373$ & 2.2 & $3106 \pm 2753$ & 40 & 40 \\
$\mathrm{BOD}(\mathrm{mg} / \mathrm{l})$ & $13.85 \mathrm{a} \pm 6.42$ & $19.46 \mathrm{a} \pm 0.50$ & $17.13 \mathrm{a} \pm 3.14$ & 1032 & $26.17 \pm 9.49$ & 10 & 200 \\
$\mathrm{SS}(\mathrm{mg} / \mathrm{l})$ & $374 \mathrm{a} \pm 124$ & $358 \mathrm{a} \pm 335$ & $780 \mathrm{a} \pm 739$ & 501 & $562 \pm 482$ & 30 & 10 \\
TDS $(\mathrm{mg} / \mathrm{l})$ & $3941 \mathrm{a} \pm 3703$ & $3300 \mathrm{a} \pm 1714$ & $2653 \mathrm{a} \pm 1240$ & 532.7 & $444 \pm 507$ & 250 & 500 \\
\hline
\end{tabular}

The values given in the table above are means of 6 replicate values, $\mathrm{n}=6$ ( 1 sample was taken monthly for 6 months). Within the rows, means with different alphabets are statistically different $(p<0.05)$. WHO: World Health Organisation. NESREA: National Environmental Standard and Regulatory Enforcement Agency. a = Mohammed et al.(2017), b = Baba et al. (2020), c = WHO (2006), $d=$ NESSRA (2009) 
BAJOPAS Volume 13 Number 2, December, 2020

Identification, Biochemical Characterization and growth rates of the Bacterial Isolates

Results of identification and biochemical characterization of the bacterial isolates were shown in table 2. After 24 hours of incubation, the nutrient agar media plates were checked for bacterial growth. The results showed the presence of different strains in the samples. The TAN1 bacteria isolate was found to be gramnegative cocci while TAN3 was gram-positive cocci. TAN2 bacteria isolate was found to be gram-positive, rod-shaped. TAN1, TAN2, and TAN3 bacteria isolates recorded positive results for spore former.

The results of the biochemical tests indicated that all the bacteria were positive for catalase, oxidase, citrate, maltose, glucose, lactose (negative in TAN1), mannitol (negative in TAN2), starch hydrolysis and coagulase (negative in TAN2) tests. The bacteria showed negative results for nitrate reduction, $M R$ (positive in TAN2), VP (positive in TAN1), Indole (positive in TAN2) tests. Base on the morphological and biochemical test results, TAN1, TAN2, and TAN3 bacteria isolates were identified to be Nesseria spp, Bacillus cereus, and Staphylococcus aureus respectively.

The growth rate of the TAN1, TAN2 and TAN3 Isolates were shown in figure 2. Generally, the optical density increase with the increase in time (day) and decrease as time goes on. The highest optical density was shown by bacillus cereus in TAN2 while the lowest was shown by Staphylococcus aureus in TAN3.

The initial growth phase of TAN1 Isolate bacteria occurred within 2-day of incubation as the growth rate increases up to the 6th-day incubation when the maximum growth was observed. Beyond the 6th day, the growth of the bacteria declined (which might be due to a shortage of nutrients in the effluents) until it reached its death phase (which might be due to the unavailability of nutrients in the effluents).

A similar trend of growth was also observed for TAN2 Isolate as the initial growth phase also occurred within 2-day of incubation but maximum growth rate observed on the 4th day of incubation. The stationary stage occurred between the 4th day and the 8th day. Beyond the 8th day, the growth of the bacteria declined (which might be due to a shortage of nutrients in the effluents) until it reached its death phase (which might be due to the unavailability of nutrients in the effluents).

The initial growth phase of TAN3 bacterial Isolate occurred within the 3-day incubation as the growth rate increases up to the 6th-day incubation when the maximum growth was observed. Beyond the 6th day, the growth of the bacteria declined (which might be due to a shortage of nutrients in the effluents) until it reached its death phase (which might be due to the unavailability of nutrients in the effluents).

Table 2: Morphological and Biochemical characteristics of bacterial isolates

\begin{tabular}{lllll} 
Bacterial Isolates & & TAN1 & TAN2 & TAN3 \\
\hline $\begin{array}{lllll}\text { Morphological } \\
\text { characteristics }\end{array}$ & Shape & Cocci & Rod & Cocci \\
& Spore & & & \\
& former & + & + & + \\
Gram & & & \\
Biochemical characteristics & reaction & - & + & + \\
& Citrate & + & + & + \\
& Catalase & + & + & + \\
& Coagulase & + & - & + \\
Starch & + & + & + \\
& Glucose & + & + & + \\
Oxidase & + & + & + \\
& Indo & - & + & - \\
Lactose & - & + & + \\
Manitol & + & - & + \\
Maltose & + & + & + \\
MR & - & + & - \\
VP & + & - & - \\
& Nitrate & - & - & - \\
Reduction & - Neisseria & Bacillus & Staphylococcus \\
& Bacterial & cereus & aureus \\
& name & spp & cas
\end{tabular}

+ = Positive; - = Negative; MR=Methyl Red; VP= Voges-Proskauer 


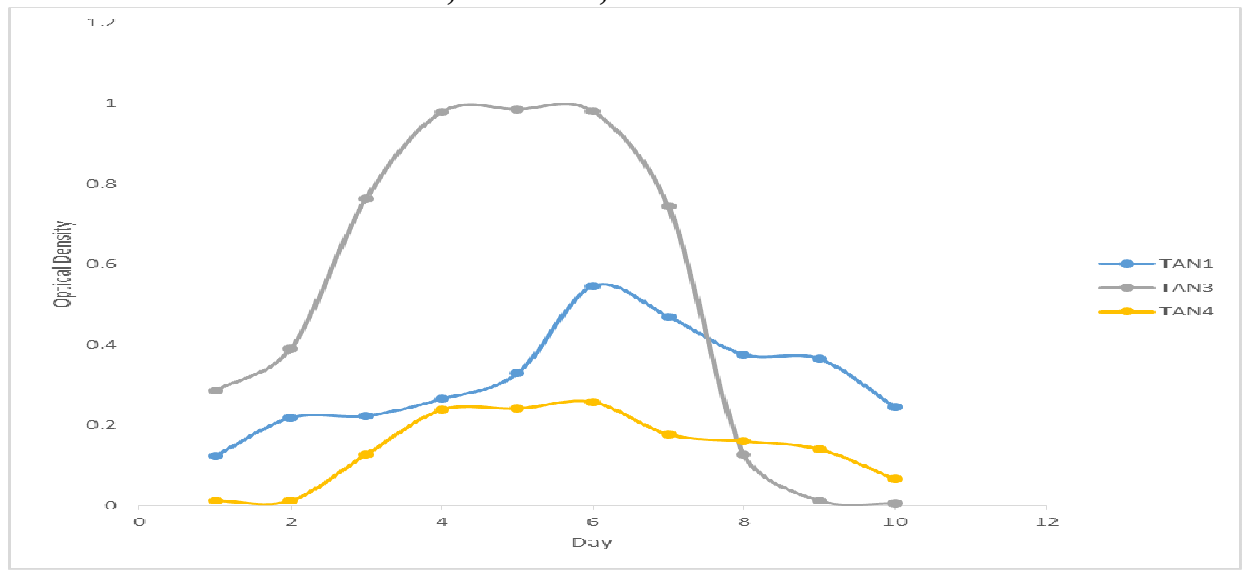

Fig. 2 Growth rates of the isolates in the effluents from the Tannery Industries

\section{Physico-chemical Parameters in the Industrial Effluents after the biodegradation.}

Table 3 shows the mean results of the physicochemical parameter before and after bioremediation using the different masses $(5 \mathrm{~g}$, $10 \mathrm{~g}, 15 \mathrm{~g}, 20 \mathrm{~g}$, and $25 \mathrm{~g}$ ) of the respective immobilized bacteria. Also, Table 4 shows the mean results of correlation coefficient ( $r$ ) between different masses of bacteria and physicochemical parameters.

The mean values $(\mathrm{mg} / \mathrm{l})$ of the SS after the bioremediation varies between $243 \pm 45$ and $898 \pm 672$. The mean concentration $(\mathrm{mg} / \mathrm{l})$ of SS remediated by the different masses $(5 \mathrm{~g}, 10 \mathrm{~g}$, $15 \mathrm{~g}, 20 \mathrm{~g}$, and $25 \mathrm{~g}$ ) of the bacteria varies. The SS in the samples fluctuates up and down after the bioremediation process when compared with the SS of the raw samples before the bioremediation. The increase in the levels of the SS might be due to the aggregation of the TDS which are large enough to result into SS. The increase in the levels of the SS might be also due to the influence of the nutrients which was added into the effluents in order to make the microorganisms more active and viable for fast degradation of organic contaminants in the effluent. The relative potential or efficiency of the different masses of the bacteria in remediating SS in TAN1 samples was in the order $25 \mathrm{~g}>20 \mathrm{~g}>15 \mathrm{~g}>10 \mathrm{~g}>5 \mathrm{~g}$. For TAN2 and TAN3 samples, the order was $25 \mathrm{~g}>20 \mathrm{~g}>15$ $\mathrm{g}>10 \mathrm{~g}>5 \mathrm{~g}$. These might be due to the variations in the surface areas of the different masses of the immobilized bacteria. Statistical analysis shows that there is no significant difference $(p<0.05)$ between the mean values of SS among the masses in the respective industries. Positive and significant correlations exist between the masses of bacteria and Suspended Solid (SS). This showed that there is general increase in the levels of the SS as the masses of the immobilized bacteria increases. TAN3 (90\%) and TAN1 (80\%) showed a very high correlation with the masses of the bacteria while TAN2 (61\%) showed a very low correlation.

The mean values $(\mathrm{mg} / \mathrm{l})$ of the TDS after the bioremediation varies between $46 \pm 11$ and $83 \pm 78$. The mean concentration $(\mathrm{mg} / \mathrm{l})$ of TDS remediated by the different masses $(5 \mathrm{~g}, 10 \mathrm{~g}$, $15 \mathrm{~g}, 20 \mathrm{~g}$, and $25 \mathrm{~g}$ ) of the bacteria varies. There is a reduction in all the TDS of all the samples after the bioremediation process compared with the TDS of the raw samples before the bioremediation. The relative potential or efficiency of the different masses of the bacteria in remediating TDS in TAN1 and TAN3 samples was in the order $5 \mathrm{~g}>10 \mathrm{~g}>15 \mathrm{~g}>20$ $\mathrm{g}>25 \mathrm{~g}$. For TAN2 samples, the order was 20 $g>10 \quad g>25 \quad g>15 \quad g>5 \quad g$. Statistical analysis shows that there is no significant difference $(p<0.05)$ between the mean values of TDS among the masses in the respective industries. These might be due to the variations in the surface areas of the different masses of the immobilized bacteria. Positive and significant correlations exist between the masses of bacteria and TDS with the exception in TAN2 (negative and insignificant correlation). The positive correlations showed that there is general increase in the levels of the TDS as the masses of the immobilized bacteria increases. TAN1 $(96 \%)$ showed a very high correlation with the masses of the bacteria while TAN2 (47\%) showed a very low correlation.

The mean values $(\mathrm{mg} / \mathrm{l})$ of the BOD after the bioremediation varies between $1.56 \pm 0.20 \mathrm{mg} / \mathrm{l}$ and $6.92 \pm 5.49 \mathrm{mg} / \mathrm{l}$. The mean concentration $(\mathrm{mg} / \mathrm{l})$ of BOD remediated by the different masses $(5 \mathrm{~g}, 10 \mathrm{~g}, 15 \mathrm{~g}, 20 \mathrm{~g}$, and $25 \mathrm{~g}$ ) of the bacteria varies. There is a reduction in all the BOD of all the samples after the bioremediation process compared with the $\mathrm{BOD}$ of the raw 
BAJOPAS Volume 13 Number 2, December, 2020 samples before the bioremediation. The relative potential or efficiency of the different masses of the bacteria in remediating BOD in TAN1, TAN2 and TAN3 samples were in the order $25 \mathrm{~g}>20$ $\mathrm{g}>15 \mathrm{~g}>10 \mathrm{~g}>5 \mathrm{~g}, 25 \mathrm{~g}>15 \mathrm{~g}>5 \mathrm{~g}>10 \mathrm{~g}>20 \mathrm{~g}$ and $20 \mathrm{~g}>10 \mathrm{~g}>25 \mathrm{~g}>15 \mathrm{~g}>5 \mathrm{~g}$ respectively. Statistical analysis shows that there is significant difference $(p<0.05)$ between the mean values of BOD among the masses in the respective industries. These might be due to the variations in the surface areas of the different masses of the immobilized bacteria. Negative and significant correlations exist between the masses of bacteria and BOD. This showed that there is general decrease in the levels of the BOD as the masses of the immobilized bacteria increases. TAN1 (94\%) showed a very high correlation with the masses of the bacteria while TAN2 (4\%) showed a very low correlation.

The mean values $(\mathrm{mg} / \mathrm{l})$ of the COD after the bioremediation varies between $250 \pm 154$ and $3134 \pm 1595$. The mean concentration $(\mathrm{mg} / \mathrm{l})$ of COD remediated by the different masses $(5 \mathrm{~g}$, $10 \mathrm{~g}, 15 \mathrm{~g} 20 \mathrm{~g}$, and $25 \mathrm{~g}$ ) of the bacteria varies. There is a reduction in all the COD of all the samples after the bioremediation process compared with the COD of the raw samples before the bioremediation. The relative potential or efficiency of the different masses of the bacteria in remediating COD in TAN1, TAN2 and TAN3 samples were in the order $25 \mathrm{~g}>20 \mathrm{~g}>15$ $\mathrm{g}>5 \mathrm{~g}>10 \mathrm{~g}, 25 \mathrm{~g}>20 \mathrm{~g}>15 \mathrm{~g}>10 \mathrm{~g}>5 \mathrm{~g}$ and 10 g>5 g>25 g>15 g>20 g respectively. Statistical analysis shows that there were significant difference $(p<0.05)$ between the mean values of COD among the masses in the respective industries except for effluents treated with $25 \mathrm{~g}$. These might be due to the variations in the surface areas of the different masses of the immobilized bacteria. Negative and insignificant correlations exist between the masses of bacteria and COD with the exception in TAN3 (positive and significant correlation). The negative correlations showed that there is general decrease in the levels of the COD as the masses of the immobilized bacteria increases. TAN2 (100\%) showed a very high correlation with the masses of the bacteria while TAN3 (36\%) showed a very low correlation.

Generally, there was an overall decrease in the concentration of these physicochemical parameters after the bioremediation using the different masses of the bacterial isolates. These might be due to the variations in the surface areas of the different masses of the immobilized bacteria. This is in line with the work of Jimoh et al. (2018) and Baba et al. (2020).

Table 3: Mean Values $(\mathrm{mg} / \mathrm{l}) \pm$ S.D of Physicochemical parameters in effluents from the Tannery Industries before and after Treatment of the effluents $(250 \mathrm{ml})$ with the different masses $(5 \mathrm{~g}, 10 \mathrm{~g}$, $15 \mathrm{~g}, 20 \mathrm{~g}$, and $25 \mathrm{~g}$ ) of the bacteria.

\begin{tabular}{llllllll}
\hline $\mathrm{P}$ & IND & Before & \multicolumn{5}{c}{ After } \\
\cline { 4 - 7 } & & & $5 \mathrm{~g}$ & $10 \mathrm{~g}$ & $15 \mathrm{~g}$ & $20 \mathrm{~g}$ & $25 \mathrm{~g}$ \\
\hline \multirow{2}{*}{ COD } & TAN1 & $2372 \pm 938$ & $1708 \mathrm{a} \pm 861$ & $2045 \mathrm{a} \pm 1205$ & $845 \mathrm{a} \pm 369$ & $300 \mathrm{a} \pm 167$ & $250 \mathrm{a} \pm 154$ \\
& TAN2 & $1406 \pm 208$ & $1195 \mathrm{a} \pm 208$ & $1125 \mathrm{a} \pm 384$ & $1055 \mathrm{a} \pm 317$ & $956 \mathrm{a} \pm 310$ & $870 \mathrm{ab} \pm 240$ \\
& TAN3 & $3532 \pm 1373$ & $2374 \mathrm{a} \pm 1344$ & $1976 \mathrm{a} \pm 1405$ & $2757 \mathrm{a} \pm 1266$ & $3134 \mathrm{a} \pm 1595$ & $2614 \mathrm{~b} \pm 1105$ \\
BOD & TAN1 & $13.85 \pm 6.42$ & $6.92 \mathrm{a} \pm 5.49$ & $6.42 \mathrm{a} \pm 5.07$ & $5.72 \mathrm{a} \pm 5.35$ & $4.62 \mathrm{a} \pm 4.37$ & $2.82 \mathrm{ab} \pm 1.26$ \\
& TAN2 & $19.46 \pm 0.50$ & $1.75 \mathrm{~b} \pm 0.22$ & $1.73 \mathrm{~b} \pm 0.18$ & $1.58 \mathrm{a} \pm 0.16$ & $1.91 \mathrm{a} \pm 0.22$ & $1.56 \mathrm{~b} \pm 0.20$ \\
& TAN3 & $17.13 \pm 3.14$ & $4.24 \mathrm{ab} \pm 0.77$ & $3.29 \mathrm{ab} \pm 0.37$ & $4.11 \mathrm{a} \pm 0.07$ & $3.23 \mathrm{a} \pm 0.91$ & $3.33 \mathrm{a} \pm 1.28$ \\
SS & TAN1 & $374 \pm 124$ & $243 \mathrm{a} \pm 45$ & $471 \mathrm{a} \pm 226$ & $475 \mathrm{a} \pm 182$ & $492 \mathrm{a} \pm 128$ & $611 \mathrm{a} \pm 217$ \\
& TAN2 & $358 \pm 335$ & $460 \mathrm{a} \pm 400$ & $543 \mathrm{a} \pm 414$ & $544 \mathrm{a} \pm 402$ & $551 \mathrm{a} \pm 414$ & $554 \mathrm{a} \pm 405$ \\
& TAN3 & $780 \pm 739$ & $586 \mathrm{a} \pm 594$ & $758 \mathrm{a} \pm 656$ & $787 \mathrm{a} \pm 676$ & $861 \mathrm{a} \pm 635$ & $898 \mathrm{a} \pm 672$ \\
TDS & TAN1 & $3941 \pm 3703$ & $51 \mathrm{a} \pm 10$ & $53 \mathrm{a} \pm 10$ & $55 \mathrm{a} \pm 15$ & $61 \mathrm{a} \pm 20$ & $63 \mathrm{a} \pm 26$ \\
& TAN2 & $3300 \pm 1714$ & $83 \mathrm{a} \pm 78$ & $47 \mathrm{a} \pm 20$ & $48 \mathrm{a} \pm 22$ & $47 \mathrm{a} \pm 17$ & $48 \mathrm{a} \pm 17$ \\
& TAN3 & $2653 \pm 1240$ & $46 \mathrm{a} \pm 11$ & $55 \mathrm{a} \pm 24$ & $55 \mathrm{a} \pm 25$ & $58 \mathrm{a} \pm 23$ & $61 \mathrm{a} \pm 28$ \\
\hline
\end{tabular}

Replicate $=6$ (months)

Within the rows, for the same parameter, means with different alphabets are statistically different $(p<0.05)$.

$\mathrm{P}=$ parameter, IND = Industries 
BAJOPAS Volume 13 Number 2, December, 2020

Table 4: Correlation coefficient $(r)$ between different masses of the bacteria and the physicochemical parameters.

\begin{tabular}{llll}
\hline Industries & Parameter & Correlation coefficient $(r)$ & $\begin{array}{l}\text { Percent dependence (rxrx100) } \\
(\%)\end{array}$ \\
\hline TAN1 & COD & -0.9 & 82 \\
& BOD & -0.97 & 94 \\
& SS & $0.90^{*}$ & 80 \\
TAN2 & TDS & $0.98^{*}$ & 96 \\
& COD & -1 & 100 \\
& BOD & -0.21 & 4 \\
& SS & $0.78^{*}$ & 61 \\
& TDS & -0.69 & 47 \\
& COD & $0.60^{*}$ & 36 \\
& BOD & -0.6 & 37 \\
& SS & $0.95^{*}$ & 90 \\
& TDS & $0.94^{*}$ & 89 \\
\hline
\end{tabular}

The correlation coefficient $(r)$ with * is statistically significant $(p<0.05)$.

Percentage reduction of the Parameters

Table 5 shows the percentage reduction of Parameters in industrial samples before and after the treatment of the effluents $(250 \mathrm{ml})$ with the different masses $(5 \mathrm{~g}, 10 \mathrm{~g}, 15 \mathrm{~g}, 20 \mathrm{~g}$, and $25 \mathrm{~g}$ ) of the Immobilized Bacteria.

In TAN1 samples, the percentage reduction (\%) of COD ranged (14-89); BOD (50-80); SS (-32$35)$ and TDS (98-99). In TAN2 samples, the percentage decrease $(\%)$ of COD ranged (15$38) ;$ BOD (90-92); SS [-28-(-55)] and TDS (9798). In TAN3 samples, the percentage decrease (\%) of COD ranged (11-44); BOD (76-81); SS (15-25) and TDS (98). The percentage increase in the levels COD, BOD and TDS might be due to the increase in the surface area of the different masses of the immobilized bacteria. However, the percentage decrease in the levels of the SS might be due to the aggregation of the TDS which are large enough to result into SS. The percentage decrease in the levels of the SS might be also due to the influence of the nutrients which was added into the effluents in order to make the microorganisms more active and viable for fast degradation of organic contaminants in the effluent. This is in line with the work of Jimoh et al. (2018) in which the concentration of the SS increase after the bioremediation of effluents.

Sreemoyee and Priti (2013) assessed and reduced several Physico-chemical parameters of dairy wastewater using Niesseria $s p$. and concluded that the species are well known to degrade organic compounds. This is in agreement with the current study in which the immobilized Niesseria $s p$ degrade the organic contaminants as indicated by the BOD, COD and TDS.

Jimoh et al. (2018) observed that TSS of the effluents was increased after treatment with immobilized bacteria and concluded that it might be due to the biostimulation method adopted for the research.

The optimum $\mathrm{pH}$ Biosorption of Chromium by Bacillus spp and Staphylococcus spp. from tannery effluent was investigated by Mythili and Karthikeyan (2011). The maximum adsorption of Chromium $(86.4 \mathrm{mg} / \mathrm{L})$ was showed by Bacillus spp and Staphylococcus spp showed $70.6 \mathrm{mg} / \mathrm{L}$ at an initial concentration of $100 \mathrm{mg} / \mathrm{L}$. In the present study, immobilised Bacillus spp and Staphylococcus spp. from the tannery industrial effluents reduced the levels of the organic pollutants with high potential as indicated by the percentage reduction of BOD, COD and TDS.

Enzymes often can work in multiple environments especially if they are immobilized. This makes the microorganisms' enzymes even more resistant to harsh environments and enables the enzymes to be recovered and recycled after they are no longer needed (Gianfreda and Rao 2004). Ramesh and Singh (1993) reported that the immobilized bacteria having more efficiency to remove the suspended particles than free cells. Using the immobilized cell is preferable due to its capability for using several times with the same efficiency, which makes it more economical. Similar work was done by Sikander et al. (2007) showing the higher reduction with permeabilized cells of Ochrobactrum intermedium strain SDCr-5. 
BAJOPAS Volume 13 Number 2, December, 2020

The results revealed the isolation and identification of isolates with the potential for the reduction of $\mathrm{Cr}$ (VI) to $\mathrm{Cr}$ (III). Results indicated that immobilized $B$. cereus could be efficiently used for the reduction of $\mathrm{Cr}$ (VI).

Table 5: Percentage reduction of the tested Parameters from the tannery industrial samples of the Immobilized Bacteria.

\begin{tabular}{lllllll}
\hline \multirow{2}{*}{ Industries } & & \multicolumn{5}{c}{ Percentage Reduction $(\%)$} \\
\cline { 3 - 7 } & & $5 \mathrm{~g}$ & $10 \mathrm{~g}$ & $15 \mathrm{~g}$ & $20 \mathrm{~g}$ & $25 \mathrm{~g}$ \\
\hline TAN1 & COD & 28 & 14 & 64 & 87 & 89 \\
& BOD & 50 & 54 & 59 & 67 & 80 \\
& SS & 35 & -26 & -27 & -32 & -63 \\
& TDS & 99 & 99 & 99 & 98 & 98 \\
TAN2 & COD & 15 & 20 & 25 & 32 & 38 \\
& BOD & 91 & 91 & 92 & 90 & 92 \\
& SS & -28 & -52 & -52 & -54 & -55 \\
& TDS & 97 & 99 & 99 & 99 & 99 \\
& COD & 33 & 44 & 22 & 11 & 26 \\
& BOD & 75 & 81 & 76 & 81 & 81 \\
& SS & 25 & 3 & -1 & -10 & -15 \\
& TDS & 98 & 98 & 98 & 98 & 98 \\
\hline
\end{tabular}

Percentage Reduction $=(B-A) / B \times 100 \%$

$A=$ Concentration of the parameter after treatment

$\mathrm{B}=$ Concentration of the parameter before treatment

$+=$ percentage decrease

- = percentage increase

In general, immobilization makes the enzyme more resistant to temperature, $\mathrm{pH}$, and substrate concentration swings giving it a longer lifetime and higher productivity per active unit (Gianfreda and Rao, 2004; FuIlbrook, 1996; Russell et al, 2003; Kandelbauer et al., 2004). Immobilized cells have been used and studied extensively for the production of useful chemicals (Ohtake and Silver, 1994), the treatment of wastewaters (Chen et al., 2003; Wang et al., 2010). Although many workers described microbial degradation of tannery effluent, limited literature is available on the bioremediation of tannery effluent using immobilized bacterial cells in the Kano Industrial Estates.

\section{CONCLUSION}

The samples contained variable levels of the physicochemical parameters. The results of the Analysis of variance revealed that, no statistical difference $(p<0.05)$ was observed for the temperature, $\mathrm{pH}, \mathrm{SS}, \mathrm{TDS}, \mathrm{BOD}$ and $\mathrm{COD}$ among the three tannery industries before the treatment. The levels of some of the parameters
(SS, TDS and COD) observed in the samples were found above the recommended limits of WHO and NESREA, which called for the treatment of the effluents before discharge into the environment. Base on the morphological and biochemical test results, TAN1, TAN2, and TAN3 bacterial isolates were identified to be Neisseria spp, Bacillus cereus, and Staphylococcus aureus respectively. The results of Post-treatment analysis showed that there is overall decrease in the levels of the parameters determined when compared with that of the pre-treatment. The overall percentage reduction of the immobilised bacteria in the treatment of the respective effluents was in the order TAN2 (72\%)>TAN1 $(70 \%)>$ TAN3 $(62 \%)$. Hence, the immobilized bacteria are having higher biodegradation potential for the treatment of the tannery effluents.

\section{Acknowledgments}

The authors wish to acknowledge the University of Maiduguri for the financial support. The authors are grateful to the Kano State Ministry of Environment for their support in obtaining the effluent samples. 


\section{REFERENCES}

Ajao, A. T., Adebayo, G. B., and Yakubu, S. E. (2011). Bioremediation of textile industrial effluent using mixed culture of Pseudomonas aeruginosa and Bacillus subtilis immobilized on agar-agar in a bioreactor. J. Microbiol. Biotech. Res, 1(3), 50-56.

Akan, J. C., Moses, E. A., Ogugbuaja, V. O., and Abah, J. (2007). Assessment of tannery industrial effluents from Kano metropolis, Kano State, Nigeria. Journal of Applied Sciences, 7(19), 2788-2793.

Akan, J. C., Ogugbuaja, V. O., Abdulrahman, F. I., and Ayodele, J. T. (2009). Pollutant levels in effluent samples from tanneries and textiles of Kano industrial areas, Nigeria. Global journal of pure and applied sciences, 15(3-4).

APHA (1989). Standard methods for Examination of Will bete and Will betewater.15 $5^{\text {th }}$ edition. Brydpass Springfield Will behington DC. pp. 164-176

APHA (1992). Standard Methods for the Examination of Water and Wastewater. Health, 69, 1116-9.

Baba, A., Garba, S. T., and Bello, H. S. (2020). Bioremediation Potential of Immobilized corynebacterium kutsceri in the Treatment of Tannery Industrial Effluent from Challawa Industrial Estate, Kano State, Nigeria. Journal of the Turkish Chemical Society Section A: Chemistry, $7(2), 335-350$.

Beem, E. I. V. (1994). reduction of solvent VOC emission. J. Oil Col. Chem. Ass, 77, 158.

Bouwer, E. J., and Zehnder, A. J. (1993). Bioremediation of organic compoundsputting microbial metabolism to work. Trends in biotechnology, 11(8), 360367.

Chen, K. C., Wu, J. Y., Liou, D. J., and Hwang, S. C. J. (2003). Decolorization of the textile dyes by newly isolated bacterial strains. Journal of Biotechnology, 101(1), 57-68.

Dan'Azumi, S., and Bichi, M. H. (2010). INDUSTRIAL POLLUTION AND HEAVY METALS PROFILE OF CHALLAWA RIVER IN KANO, NIGERIA. Journal of Applied Sciences in Environmental Sanitation, $5(1)$.

DWAF. (1992). Analytical Methods Manual, TR 151. Department of Water Affairs and Forestry, Pretoria.

El-Bestawy, E. (2013). Biological treatment of leather-tanning industrial wastewater using free living bacteria.
Elsheikh, M. A. S. (2009). Tannery wastewater pre-treatment. Water Science and Technology, 60(2), 433-440.

FuIlbrook, P. D. (1996). "Kinetics." Industrial enzymology: The application of enzymes in Industry. 2nd Ed. T. Godfrey and J Reichelt. eds.. Nature. New York.

Gianfreda, L., and Rao, M. A. (2004). Potential of extra cellular enzymes in remediation of polluted soils: a review. Enzyme and microbial technology, 35(4), 339354.

Hugo Springer. (1994). John Arthur Wilson Memorial Lecture "Treatment of Industrial Wastes of the Leather Industry - is it still a Major Problem". JALCA, 89, 153-185

Jimoh, A. A., Ganiyu, B. A., Baba, D., and Baba, A. (2018) Bioremediation Process of Effluent from Detergent and Food Industries in Jos, Nigeria: Kinetics and Thermodynamics. International Journal of Engineering Science Invention (IJESI), 762-73

Kandelbauer, A., Maute, O., Kessler, R. W., Erlacher, A., and Gübitz, G. M. (2004). Study of dye decolorization in an immobilized laccase enzyme-reactor using online spectroscopy. Biotechnology and bioengineering, 87(4), 552-563.

Kongjao, S., Damronglerd, S., and Hunsom, M. (2008). Simultaneous removal of organic and inorganic Pollutants in tannery wastewater using electrocoagulation technique. Korean Journal of chemical engineering, 25(4), 703.

Maheshwari, U. M., Aruna, S., Gomathi, M., and AbdulJaffar, A. H. (2017). Bioremediation by Free and Immobilized Bacteria Isolated from Tannery Effluent. International Journal of Research in Applied, Natural and Social Sciences. 5(7), 75-90

Margesin, R., and Schinner, F. (2001). Bioremediation (natural attenuation and biostimulation) of diesel-oilcontaminated soil in an alpine glacier skiing area. Applied and environmental microbiology, 677), 3127-3133.

Mohammed, A., Sekar, P., and George, J. (2011). Efficacy of microbes in bioremediation of tannery effluent. Inter. J. Curr. Res, 3(4), 324-326.

Mohammed, S. S. D., Orukotan, A. A., and Abdullahi, H. (2017). Physicochemical and Bacteriological Assessment of Tannery Effluent from Samaru-Zaria, 
BAJOPAS Volume 13 Number 2, December, 2020 Kaduna State, Nigeria. Journal of Applied

Sciences and Environmental Management, 21(4), 734-740.

Munz, G., De Angelis, D., Gori, R., Mori, G., Casarci, M., and Lubello, C. (2009). The role of tannins in conventional and membrane treatment of tannery wastewater. Journal of hazardous materials, 164(2-3), 733-739

Mythili, K., and Karthikeyan, B. (2011). Bioremediation of $\mathrm{Cr}$ (VI) from tannery effluent using Bacillus spp and Staphylococcus spp. International Multidisciplinary Research Journal, 1(6).

NESREA (2009). National Environmental Standards for Effluent Limitations and Regulation. 1233-1236

Noorjahan, C. M. (2014). Physicochemical characteristics, identification of bacteria and biodegradation of industrial effluent. Journal of bioremediation and Biodegradation, 5(3).

Ohtake, H. I., and Silver, A. O. (1994). Bacterial reduction of toxic chromate. Biological degradation and bioremediation of toxic chemicals, 403-415.

Omoleke, I. I. (2004). Management of environmental pollution in Ibadan, an African city: the challenges of health hazard facing government and the people. Journal of Human Ecology, 15(4), 265-275.

Rajor, A., Reddy, A.S., and Singh, B. (2004). Determination of BOD kinetic Parameters and evaluation of alternate methods, M.Sc. Thesis, Department of biotechnology \& environmental Science, Thapar Institute of Engineering and Technology, Patiala

Ramasami, T., Rajamani, S., and Rao, J. R. (1994, March). Pollution control in leather industry: Emerging technological options. In International symposium on surface and colloidal science and its relevance to soil pollution, madras.

Ramesh, J. V. S., and Singh, S. P. (1993). Yearly variation in certain physicochemical parameters of pond at eastern Doon Valley. Uttar Pradesh J. Zoo, 12 (1), 7577.

Ranen, S., and Sharadinadra, C. (2009). Biotechnology applications to environmental remediation in resource exploitation. Current science, 97, 6-25
Russell, A. J., Berberich, J. A., Drevon, G. F., and Koepsel, R. R. (2003). Biomaterials for mediation of

chemical and biological warfare agents. Annual review of biomedical engineering, 5(1), 1-27.

Saravanan, P., and Saravanan, A. (1999). Decolourization of tannery effluent by Flavobacterium sp. EK 1. Indian Journal of Environmental Protection, 19, 19-24.

Sikander, S., and Shahida, H. (2007). Reduction of toxic hexavalent chromium by Ochrobactrum intermedium strain SDCr5 stimulated by heavy metals. Bioresource Technol, 98, 340-344.

Singh, N., Sharma, B. K., and Bohra, P. C. (2000). Impact assessment of industrial effluent of arid soils by using satellite imageries. Journal of the Indian Society of Remote Sensing, 28(2-3), 79.

Sreemoyee, C., and Priti, P. (2013). Assessment of physico-chemical parameters of dairy waste water and isolation and characterization of bacterial strains in terms of cod reduction. Int J Sci, 2(3), 395-400.

Verheijen, L. A. H. M., Wiersema, D., Pol, L. H., and De Wit, J. (1996). Management of wastes from animal product processing. Livestock and environment, Finding a balance. International Agriculture Center, Wageningen, The Netherlands.

Wang, F., Yao, J., Si, Y., Chen, H., Russel, M., Chen, K., and Bramanti, E. (2010). Short-time effect of heavy metals upon microbial community activity. Journal of Hazardous Materials, 173(13), 510-516.

WHO (World Health Organization). (2006). Air quality guidelines: global update 2005: particulate matter, ozone, nitrogen dioxide, and sulfur dioxide. World Health Organization.

World Bank. (1995). Nigeria's strategic options for redressing industrial pollution. World Bank, industry and energy division. 1st edition, West Central Africa Department; Annexes: 1995; pp 60-62.

Zahoor, A., and Abdul, R. (2009). Enumeration of Coliforms. Journal of Environmental Sciences. 21, 814-820 


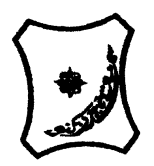

Bayero Journal of Pure and Applied Sciences, 13(2): 1 - 12

Received: November, 2020

Accepted: December, 2020

ISSN $2006-6996$

\title{
BIODEGRADATION POTENTIAL OF IMMOBILIZED BACTERIA IN THE TREATMENT OF TANNERY INDUSTRIAL EFFLUENTS FROM INDUSTRIAL ESTATES IN KANO STATE, NIGERIA
}

\author{
Abdullateef, B., ${ }^{1 *}$ Shuaibu, T. G., ${ }^{1}$ Babagana, K., ${ }^{1}$ Suleman, H. B. ${ }^{2}$ and Dauda, B. ${ }^{3}$ \\ ${ }^{1}$ Department of Pure and Applied Chemistry, Faculty of Science, University of Maiduguri, Borno State, \\ Nigeria \\ ${ }^{2}$ Department of Microbiology, Faculty of Science, University of Maiduguri, Borno State, Nigeria \\ ${ }^{3}$ Department of Chemical Engineering, Faculty of Engineering, University of Maiduguri, Borno State, \\ Nigeria \\ *Corresponding author: babslega@gmail.com; abelega2007@yahoo.com; +2348061309753
}

\section{ABSTRACT}

Industrial Effluents Samples from Gashash Tanneries (TAN1) in Bompai Industrial estate, Larabee Tannery Industry (TAN2) in Sharada Industrial estate and Z Tannery Industries (TAN3) in Challawa Industrial estate, Kano State, Nigeria were collected over a period of six months (August 2017 to January 2018) for assessing the biodegradation potentials of bacteria in the treatment of organic pollutants within the effluents. Bacteria were isolated from the effluents and immobilized on agar-agar. Different masses (5 g, $10 \mathrm{gr}, 15$ $\mathrm{g}, 20 \mathrm{~g}$, and $25 \mathrm{~g}$ ) of the bacteria were used in the treatment of $250 \mathrm{ml}$ of the effluents for ten days in a shaker incubator (Gallenkamp-OC-4364-L) at the temperature $30{ }^{\circ} \mathrm{C}$ and speed of $60 \mathrm{rpm}$. Pre-treatment analysis of the effluents for Temperature, pH, Biochemical Oxygen Demand (BOD), Chemical Oxygen Demand (COD), Suspended Solid (SS) and Total Dissolved Solids (TDS) gives the following results; temperature $\left({ }^{\circ} \mathrm{C}\right.$ )

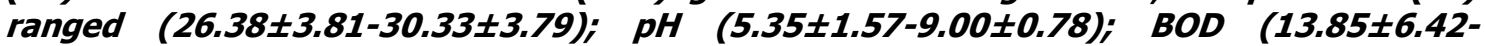
$38.75 \pm 16.20) ;$ COD (1406 $\pm 208-3532 \pm 1373) ;$ SS (208 $\pm 235-780 \pm 739)$ and TDS (266 $\pm 253-5276 \pm 2971)$. No statistical differences ( $p \leq 0.05)$ was observed for all the results among the different industries. The bacterial isolates were identified as Neisseria spp, Bacillus cereus, and Staphylococcus aureus, in TAN1, TAN2, and TAN3, respectively. After treatment of the effluent with the different masses of the isolated bacteria, the mean level of BOD was found to range as (0.55 $\pm 0.36-6.92 \pm 5.49) ; C O D$ (ND-3134 \pm 1595$)$;

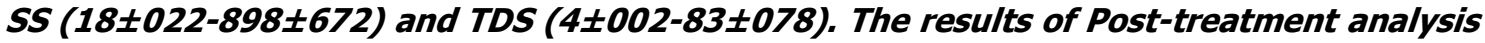
showed that there is overall decrease in the levels of the parameters determined when compared with that of the pre-treatment. The overall percentage reduction of the immobilised bacteria in the treatment of the respective effluents was in the order TAN2 (72\%)>TAN1 (70\%)>TAN3 (62\%). Hence, the immobilized bacteria are having higher biodegradation potential for the treatment of the tannery effluents.

Keywords: Biodegradation, bacteria, effluent, immobilization, tannery.

\section{INTRODUCTION}

Tannery industrial wastewater is a serious consequence of the pollution point of view for streams, freshwater, and land used for agriculture. The lack of awareness in the modern industrial practice has resulted in the discharge of tannery effluents which exhibit very high value of chromium ( $\mathrm{Cr}$ ), Sulfide, and chloride, Total Dissolved Solid (TDS), Total Suspended Solid (TSS), Biochemical Oxygen Demand (BOD) and Chemical Oxygen Demand (COD) in the water stream or land (Mohammed et al., 2001). Tanning is the process, which One ton of skin generally leads to the production of 20 to $80 \mathrm{~m}^{3}$ of turbid and foul-smelling converts the protein of the rawhide or skin into a stable material, which will not putrefy and is suitable for a wide variety of end applications (Elsheikh, 2009). The highly polluting chromium is the most commonly used tanning material producing leather that is more flexible and pliable than vegetable-tanned leather and does not discolor or lose shape in water as drastically as vegetable-tan (Elsheikh, 2009). Tannery effluent is among the most hazardous industrial pollutants due to its huge organic and inorganic load, which is highly toxic to human life and the environment (Kongjao et al., 2008). wastewater including chromium (100-400 mg/l), sulfide $(200-800 \mathrm{mg} / \mathrm{l})$, high levels of fat and 
BAJOPAS Volume 13 Number 2, December, 2020 other solid wastes, and notable pathogen contamination as well as pesticides added for skin conservation during transport (Elsheikh, 2009). There are more than 6000 tanneries in Nigeria with an annual processing capacity of 700,000 tons of hides and skins (Omoleke, 2004; Singh et al., 2008). It was reported that the total amount of waste produced per animal slaughtered is approximately $35 \%$ of its weight (World Bank, 1995). Also, for every $1000 \mathrm{~kg}$ of carcass weight, a slaughtered beef produces 5.5 $\mathrm{kg}$ of manure (excluding rumen contents or stockyard manure) and $100 \mathrm{~kg}$ of paunch manure (undigested food) (Verheijen et al., 1996). Tanneries generate wastewater in the range of 30-35 $\mathrm{L} \mathrm{kg}^{-1}$ skin/hide processed with variable $\mathrm{pH}$, Biological Oxygen Demand (BOD), Chemical Oxygen Demand (COD), high concentrations of suspended solids (SS), and tannins as well as chromium (Zahoor and Abdul, 2009).

Being heterogeneous and composed of a wide variety of compounds, it is very difficult to select a unique direct method for estimating the biodegradability of organic contents and biokinetic parameters for a wastewater sample (Rajor, 2004). For this purpose, some indirect estimation such as determination of biochemical oxygen demand (BOD) and chemical oxygen demand (COD) are applied as common laboratory investigations [9]. During retanning procedures, synthetic tannins (Syntan), oils and resins are added to form softer leather at varying doses (Munz et al., 2009). One of the refractory groups of chemicals in tannery effluents derives mainly from tannins (Ramasami et al., 2004). Syntans are characterized by complex chemical structures, because they are composed of an extended set of chemicals such as phenol-, naphthalene-, formaldehyde- and melamine-based syntans, and acrylic resins (Beem, 1994). Organic pollutants (proteic and lipidic components) are originated from skins (it is calculated that the raw skin has $30 \%$ loss of organic material during the working cycle) or they are introduced during processes (Hugo Springer, 1994).

Many conventional processes such as oxidation, chemical and biological processes were carried out to treat tanneries wastewater (Ebtesam et al, 2013). Biological processes have received more attention because of their costeffectiveness, lower sludge production and environmental friendliness (Noorjahan, 2014). Naturally occurring micro-organisms degrade the hazardous organic wastes including xenobiotic compounds, such as pesticides, polycyclic aromatic hydrocarbons (PAHs) and polychlorinated biphenyls (PCBs) in due course of time (Ranen and Sharadinadra, 2009). Bioremediation is based on the idea that all organisms remove substances from the environment to carry outgrowth and metabolism (Bouwer and Zehnder, 1993). Bacteria, protista and fungi are found to be very good at degrading complex molecules and incorporating the breakdown products into their metabolism (Bouwer and Zehnder, 1993). The resultant metabolic wastes that they produce are generally safe and somehow recycled into other organisms (Ranen and Sharadinadra, 2009). An acclimatized indigenous population of microorganisms capable of degradation of the compounds of interest must exist at the site for a successful bioremediation mode (Ranen and Sharadinadra, 2009). It has been observed that for a successful bioremediation mode, an acclimatized indigenous population of microorganisms capable of degradation of the compounds of interest must exist at the site under investigation (Ranen and Sharadinadra, 2009). Even though there are numerous physical and chemical methods employed in the disposal of wastes the advantage in using bacterium is that they play a key role in the reduction of COD, BOD, total protein, total tannin and total phenol (Saravanan and Saravanan, 1998)

Baba et al. (2020) studied the bioremediation potential of immobilized corynebacterium kutsceri in the Treatment of tannery industrial effluent from Challawa Industrial Estate, Kano State, Nigeria. The aim of the work is to study the reduction in the level of the contaminants through the process of bioremediation using the isolated bacteria. Immobilized bacteria can withstand various temperatures, $\mathrm{pH}$ and substrate concentrations; consequently, increasing the efficiency and the lifespan of the bacteria. Immobilized bacteria are widely applied in the treatment of wastewater and can be separated and recovered after the treatment with the same efficiency (Baba et al., 2020).

\section{MATERIALS AND METHODS \\ Study Area}

This study was carried out in Bompai, Sharada and Challawa industrial estates in Kano, Figure 1. Kano lies on Latitude $11^{\circ} 30^{\prime} \mathrm{N}$ and $8^{\circ} 30^{\prime} \mathrm{E}$ and Longitude $11^{\circ} 5^{\prime} \mathrm{N}$ and $8^{\circ} 5^{\prime} \mathrm{E}$ in Northern Nigeria. It is one of the developed industrial cities in Nigeria. Tannery activities are the dominating industries and this could be one of the reasons for her high population density (Dan'Azumi and Bichi, 2010). Many researchers have studied biodegradation of tannery effluent using microorganisms. However, limited literature is available on the biodegradation of tannery effluent in Kano industrial estates using 
BAJOPAS Volume 13 Number 2, December, 2020 immobilized bacterial cells. This research work focuses on the potential of the use of the indigenous immobilized bacterial isolates in the treatment of tannery effluents in the industrial estates.

\section{Sample Collection}

Effluents were collected from the Tannery Industries from Bompai, Challawa and Sharada Industrial Estates, Kano, Nigeria. The effluents were collected over a period of six months (August 2017 to January 2018). Samples collected in a sterile 4-liter plastic container with a unique identification number were preserved using an ice-box that was transported to the Microbiology Laboratory, Department of Microbiology, Bayero University of Kano for analysis

\section{Sample Preparation and Sample Analysis}

Immediately after the collection of the effluent, $\mathrm{pH}$, TSS, TDS, COD, BOD levels were determined before treatment (Pre-treatment determination) and ten days after treatment (Post-treatment determination) as described in
APHA (1989) standard methods. $\mathrm{pH}$ was determined using Ecotests $\mathrm{pH}$ meter and TDS was determined using AQUALYTIC TDS Salinometer. BOD was determined as described by the standard method (APHA, 1992). COD and SS were determined using DR/2010 HACH portable data logging spectrophotometer (DWAF, 1992)

\section{Identification and Biochemical} Characterization of the Bacterial Isolates

The bacteria were isolated from the effluents using Serial Dilution according to the method described by APHA (1989). The biochemical tests such as oxidase, catalase, coagulase, indole (from $1 \%$ tryptone broth), citrate (Simmons citrate agar), methyl red/VogesProskauer (MR/VP), nitrate reduction, Starch Hydrolysis, Glucose, Maltose, and Lactose tests were carried out on the bacterial isolates to identify the bacteria through the bacteria biochemical characteristics according to Ajao et al. (2011).

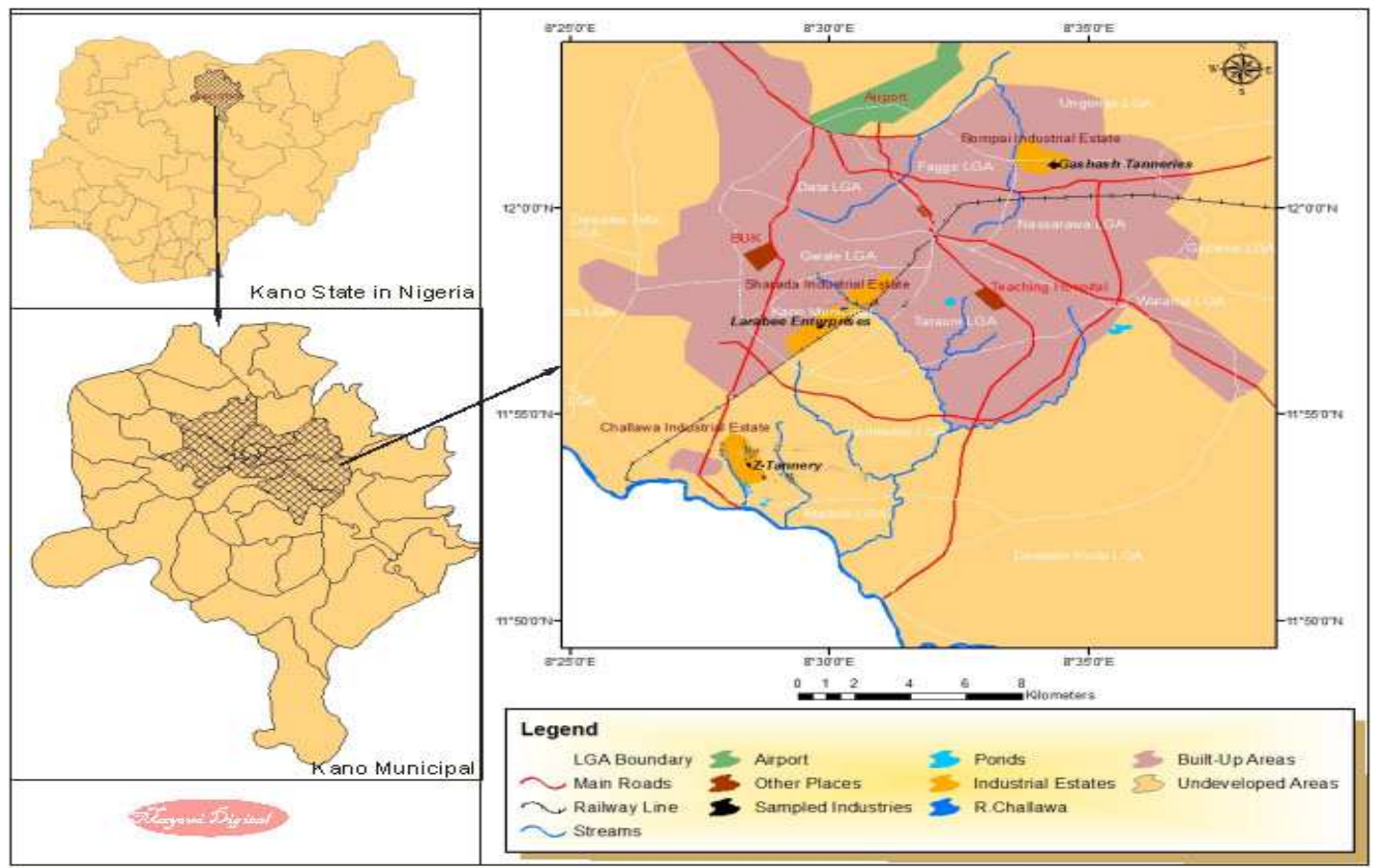

Fig. 1 Map showing the study areas

Source: Mayomi Digital Productions, GIS Laboratory, Department of Geography, UNIMAID (2017)

\section{Determination of Growth Rate of the Bacteria in Effluent Sample}

The bacteria growth rates were determined by transferring $2 \mathrm{~mL}$ of the bacterial isolates from the tannery effluent in broth medium into 100 $\mathrm{mL}$ sterile effluents in conical flasks and kept in an incubator (Giffrin cool) for 10 days. Control was also set up by incubating another $100 \mathrm{~mL}$ each of the sterile effluents without the bacteria. The optical density of the content was determined at the wavelength of $600 \mathrm{~nm}$ on a daily interval and recorded. 
BAJOPAS Volume 13 Number 2, December, 2020 Immobilization of Bacteria

Agar solution and inoculi were prepared separately. Fifty milliliters $(50 \mathrm{~mL})$ of nutrient broth each of the inoculi was prepared in a McCartney bottle and incubated for 24 hours. A solution of agar-agar was prepared by dissolving $10 \mathrm{~g}$ of the powder in distilled water and made up to $500 \mathrm{~mL}$ mark in an Erlenmeyer flask and was sterilized in an autoclave (280A) for 15 minutes and allowed to cool to $40-45^{\circ} \mathrm{C}$ (Ajao et al., 2011). Four milliliters ( $4 \mathrm{~mL})$ of the bacterial isolates in the nutrient broth was mixed with 36 $\mathrm{ml}$ of the prepared agar-agar media in petri-dish plates and then allowed to solidify. This was kept in the refrigerator for bioremediation.

\section{Bioremediation (Treatment) of the Effluents}

The solidified agar block (immobilized bacteria) was cut into cubes using a sterile knife; $0.1 \mathrm{~mL}$ phosphate buffer ( $\mathrm{pH} \mathrm{7.0)}$ was added and kept in the refrigerator for 1 hour for curing. The phosphate buffer was decanted after 1 hour and the cubes were washed with sterile distilled water 3-4 times before it was used (Ajao et al., 2011). Two liters (2 L) of the effluent was supplemented with the minimum basal medium in $\mathrm{g} / \mathrm{L}: \mathrm{NaCl}(0.8), \mathrm{MgSO}_{4} .7 \mathrm{H}_{2} \mathrm{O}(0.001), \mathrm{KH}_{2} \mathrm{PO}_{4}$ (2), $\mathrm{NaNO}_{3}$ (2), $\quad \mathrm{CaCl}_{2} .2 \mathrm{H}_{2} \mathrm{O} \quad(0.5)$ and $\mathrm{NaHPO}_{4} .12 \mathrm{H}_{2} \mathrm{O}(2)$ and sterilized in an autoclave at $121^{\circ} \mathrm{C}$ for 15 minutes (Margesin and Schinner, 2001). Two hundred and fifty milliliters $(250 \mathrm{~mL})$ of the effluents were transferred into different $250 \mathrm{ml}$ conical flasks. The content was covered with a cotton-wool ramped with foil paper to avoid contamination. Five grams $(5 \mathrm{~g})$ of the immobilized bacteria were quickly transferred into each of the effluents in the conical flasks in an inoculating chamber. The same procedures were carried out for the $10 \mathrm{~g}, 15 \mathrm{~g}, 20 \mathrm{~g}$ and 25 $\mathrm{g}$ of the immobilized bacteria in separate $250 \mathrm{~mL}$ effluents in conical flasks and agitated for ten days in a shaker incubator (Gallenkamp-OC4364-L) at a temperature $30^{\circ} \mathrm{C}$ and speed of 60 rpm. The treated effluent samples were taken on the tenth day and analyzed for the parameters $\mathrm{pH}$, SS, TDS, COD, and BOD, (Posttreatment determination) for the different grams of bacteria to evaluate and compare the biodegradation potential. (Baba et al., 2020).

\section{Statistical Analysis}

The data were represented as Mean \pm Standard deviation and analyzed statistically using oneway Analysis of Variance (ANOVA) and Tukey's HSD as Post Hoc Tests with the aid of SPSS 16.0. The correlation coefficient was also used to measure the strength of the relationship between the different masses of the bacteria and the parameters. All $\mathrm{p} \leq 0.05$ were considered as statistically significant.

\section{RESULTS AND DISCUSSION Physico-chemical parameters in the Industrial Effluents before the Biodegradation.}

Results of the Physico-chemical parameters in the industrial effluents before the Biodegradation is shown in table 1 . The mean temperatures $\left({ }^{\circ} \mathrm{C}\right)$ observed in TAN1, TAN2, and TAN3 samples were $28.07 \pm 0.65 ; 27.77 \pm 0.64$ and $26.38 \pm 3.81$ respectively. The order of the mean temperature of the samples from the three industries can be arranged as TAN1 > TAN2>TAN3. The temperature observed at TAN1, TAN2, and TAN3 samples were found below the WHO $\left(35^{\circ} \mathrm{C}\right)$ and NESREA $\left(40^{\circ} \mathrm{C}\right)$ limits. The low values of temperature might be due to the processes used at the time of sampling. High temperature brings down the solubility of gases in water that ultimately expresses as high BOD and COD. Statistical analysis shows that there is no significant difference $(p<0.05)$ between the mean values of temperature among the industries. This might be due to similar tannery activities involved in the tannery industries at the time of sampling. The average values of temperature observed in this present study are less than those observed by Akan et al. (2007), Akan et al. (2009) and Baba et al. (2020).

The mean level of $\mathrm{pH}$ observed in TAN1, TAN2 and TAN3, samples were $7.77 \pm 2.93$; $8.35 \pm 0.28$ and $7.52 \pm 0.76$ respectively. The order of the mean $\mathrm{pH}$ of the samples from the three industries can be arranged as TAN2> TAN1 $>$ TAN3. The $\mathrm{pH}$ of the samples falls within the WHO (7.0-8.5) and NESREA (6-9) standard limits. Statistical analysis shows that there is no significant difference $(p<0.05)$ between the mean values of $\mathrm{pH}$ among the industries. This might be due to similar tannery activities involved in the tannery industries at the time of sampling. Maheshwari et al. (2017) reported that the level of $\mathrm{pH}$ in the effluents from the tannery industry in Vaniyambadi, India was 6.5 which was lower than that observed in the present study. The $\mathrm{pH}$ in the effluents from the tannery industries in Kano and Kaduna were reported to be 7.64 and 6.89, respectively (Akan et al., 2007; Mohammed et al., 2017). The average values of $\mathrm{pH}$ observed in this present study are less than those observed by Mohammed et al. (2017) and Baba et al. (2020). The mean level of SS $(\mathrm{mg} / \mathrm{l})$ observed in TAN1, TAN2, and TAN3 samples were 374 \pm 124 ; $358 \pm 335$ and $780 \pm 739$ respectively. The order of the mean SS in the samples from the three industries can be arranged as TAN3 > TAN1 $>$ TAN2. 
The SS observed in the samples were far above the recommended standard limits of regulating bodies WHO $(30 \mathrm{mg} / \mathrm{l})$ and NESREA $(10 \mathrm{mg} / \mathrm{l})$. Statistical analysis shows that there is no significant difference $(p<0.05)$ between the mean values of SS among the industries. This might be due to similar tannery activities involved in the tannery industries at the time of sampling. The average values of SS observed in this present study are less than that observed $(3700 \pm 122 \mathrm{mg} / \mathrm{l})$ by Akan et al. (2009) for tanneries in Kano. Also, the average values of SS observed in this present study are less than that observed by Mohammed et al. (2017) and Baba et al. (2020) with the exception in TAN3.

The mean level of TDS (mg/l) observed in TAN1, TAN2, and TAN3 samples were $3941 \pm 3703$; $3300 \pm 1714$ and $2653 \pm 1240$ respectively. The order of the mean TDS in the samples from the three industries can be arranged as TAN1>TAN2>TAN3. The TDS observed in the samples were far above the recommended standard limits of WHO $(250 \mathrm{mg} / \mathrm{l})$ and NESREA $(500 \mathrm{mg} / \mathrm{l})$. Statistical analysis shows that there is no significant difference $(p<0.05)$ between the mean values of TDS among the industries. This might be due to similar tannery activities involved in the tannery industries at the time of sampling. TDS in the effluents from the tannery industries in Kano, Nigeria was reported to be $1281 \mathrm{mg} / \mathrm{l}$ (Akan et al., 2007). The average values of SS observed in this present study are less than those observed by Mohammed et al. (2017) and Baba et al. 2020)

The mean level of COD (mg/l) observed in TAN1, TAN2 and TAN3 samples seasons were $2372 \pm 938 ; \quad 1406 \pm 208$ and $3532 \pm 1373$ respectively. The order of the mean COD of the samples from the three industries can be arranged as TAN3>TAN1> TAN2. The COD observed in TAN1, TAN2 and TAN3 samples were far above the recommended standard limits of regulating bodies $\mathrm{WHO}(40 \mathrm{mg} / \mathrm{l})$ and NESREA (40 mg/l). Statistical analysis shows that there is no significant difference $(p<0.05)$ in COD among the industries. This might be due to similar tannery activities involved in the tannery industries as at the time of sampling. The Chemical Oxygen demand (COD) is the amount of oxygen, in $\mathrm{mg} / \mathrm{L}$, required for the degradation of the compound of wastewater to occur. In comparison, the average values of COD observed in this present study were higher than that observed by Mohammed et al. (2017) but lower than that observed by Baba et al. (2020).

The mean levels of BOD $(\mathrm{mg} / \mathrm{l})$ observed in TAN1, TAN2 and TAN3 samples were $13.85 \pm 6.42 ; \quad 19.46 \pm 0.50$ and $17.13 \pm 3.14$ respectively. The order of the mean BOD in the samples from the three industries can be arranged as TAN2>TAN3>TAN1. The BOD observed in TAN1, TAN2 and TAN3 samples were found below the recommended limits of NESREA (200 mg/l) but above WHO (10 mg/l). Statistical analysis shows that there is no significant difference $(p<0.05)$ between the mean values of BOD among the industries. This might be due to similar tannery activities involved in the tannery industries at the time of sampling. The low level of BOD recorded in this study is an indication of the low level of biodegradable organic solids in the effluent. The average values of BOD observed in this present study were lower than those observed by Mohammed et al. (2017) and Baba et al. (2020).

Table 1: Mean Values \pm S.D of Physico-chemical parameters of effluents from the Tannery Industries before Treatment.

\begin{tabular}{llllllll}
\hline Parameter & Tannery 1 & Tannery 2 & Tannery 3 & $\mathrm{a}$ & $\mathrm{b}$ & $\mathrm{c}$ & $\mathrm{d}$ \\
\cline { 2 - 7 } Temperature $\left({ }^{\circ} \mathrm{C}\right)$ & $28.07 \mathrm{a} \pm 0.65$ & $27.77 \mathrm{a} \pm 0.64$ & $26.38 \mathrm{a} \pm 3.81$ & & $29.50 \pm 4.68$ & 35 & 40 \\
pH & $7.77 \mathrm{a} \pm 2.93$ & $8.35 \mathrm{a} \pm 0.28$ & $7.52 \mathrm{a} \pm 0.76$ & 6.89 & $5.35 \pm 1.57$ & $7.0-8.5$ & $6.0-9.0$ \\
$\mathrm{COD}(\mathrm{mg} / \mathrm{l})$ & $2372 \mathrm{a} \pm 938$ & $1406 \mathrm{a} \pm 208$ & $3532 \mathrm{a} \pm 1373$ & 2.2 & $3106 \pm 2753$ & 40 & 40 \\
$\mathrm{BOD}(\mathrm{mg} / \mathrm{l})$ & $13.85 \mathrm{a} \pm 6.42$ & $19.46 \mathrm{a} \pm 0.50$ & $17.13 \mathrm{a} \pm 3.14$ & 1032 & $26.17 \pm 9.49$ & 10 & 200 \\
$\mathrm{SS}(\mathrm{mg} / \mathrm{l})$ & $374 \mathrm{a} \pm 124$ & $358 \mathrm{a} \pm 335$ & $780 \mathrm{a} \pm 739$ & 501 & $562 \pm 482$ & 30 & 10 \\
TDS $(\mathrm{mg} / \mathrm{l})$ & $3941 \mathrm{a} \pm 3703$ & $3300 \mathrm{a} \pm 1714$ & $2653 \mathrm{a} \pm 1240$ & 532.7 & $444 \pm 507$ & 250 & 500 \\
\hline
\end{tabular}

The values given in the table above are means of 6 replicate values, $\mathrm{n}=6$ ( 1 sample was taken monthly for 6 months). Within the rows, means with different alphabets are statistically different $(p<0.05)$. WHO: World Health Organisation. NESREA: National Environmental Standard and Regulatory Enforcement Agency. a = Mohammed et al.(2017), b = Baba et al. (2020), c = WHO (2006), $d=$ NESSRA (2009) 
BAJOPAS Volume 13 Number 2, December, 2020

Identification, Biochemical Characterization and growth rates of the Bacterial Isolates

Results of identification and biochemical characterization of the bacterial isolates were shown in table 2. After 24 hours of incubation, the nutrient agar media plates were checked for bacterial growth. The results showed the presence of different strains in the samples. The TAN1 bacteria isolate was found to be gramnegative cocci while TAN3 was gram-positive cocci. TAN2 bacteria isolate was found to be gram-positive, rod-shaped. TAN1, TAN2, and TAN3 bacteria isolates recorded positive results for spore former.

The results of the biochemical tests indicated that all the bacteria were positive for catalase, oxidase, citrate, maltose, glucose, lactose (negative in TAN1), mannitol (negative in TAN2), starch hydrolysis and coagulase (negative in TAN2) tests. The bacteria showed negative results for nitrate reduction, $M R$ (positive in TAN2), VP (positive in TAN1), Indole (positive in TAN2) tests. Base on the morphological and biochemical test results, TAN1, TAN2, and TAN3 bacteria isolates were identified to be Nesseria spp, Bacillus cereus, and Staphylococcus aureus respectively.

The growth rate of the TAN1, TAN2 and TAN3 Isolates were shown in figure 2. Generally, the optical density increase with the increase in time (day) and decrease as time goes on. The highest optical density was shown by bacillus cereus in TAN2 while the lowest was shown by Staphylococcus aureus in TAN3.

The initial growth phase of TAN1 Isolate bacteria occurred within 2-day of incubation as the growth rate increases up to the 6th-day incubation when the maximum growth was observed. Beyond the 6th day, the growth of the bacteria declined (which might be due to a shortage of nutrients in the effluents) until it reached its death phase (which might be due to the unavailability of nutrients in the effluents).

A similar trend of growth was also observed for TAN2 Isolate as the initial growth phase also occurred within 2-day of incubation but maximum growth rate observed on the 4th day of incubation. The stationary stage occurred between the 4th day and the 8th day. Beyond the 8th day, the growth of the bacteria declined (which might be due to a shortage of nutrients in the effluents) until it reached its death phase (which might be due to the unavailability of nutrients in the effluents).

The initial growth phase of TAN3 bacterial Isolate occurred within the 3-day incubation as the growth rate increases up to the 6th-day incubation when the maximum growth was observed. Beyond the 6th day, the growth of the bacteria declined (which might be due to a shortage of nutrients in the effluents) until it reached its death phase (which might be due to the unavailability of nutrients in the effluents).

Table 2: Morphological and Biochemical characteristics of bacterial isolates

\begin{tabular}{lllll} 
Bacterial Isolates & & TAN1 & TAN2 & TAN3 \\
\hline $\begin{array}{lllll}\text { Morphological } \\
\text { characteristics }\end{array}$ & Shape & Cocci & Rod & Cocci \\
& Spore & & & \\
& former & + & + & + \\
Gram & & & \\
Biochemical characteristics & reaction & - & + & + \\
& Citrate & + & + & + \\
& Catalase & + & + & + \\
& Coagulase & + & - & + \\
Starch & + & + & + \\
& Glucose & + & + & + \\
Oxidase & + & + & + \\
& Indo & - & + & - \\
Lactose & - & + & + \\
Manitol & + & - & + \\
Maltose & + & + & + \\
MR & - & + & - \\
VP & + & - & - \\
& Nitrate & - & - & - \\
Reduction & - Neisseria & Bacillus & Staphylococcus \\
& Bacterial & cereus & aureus \\
& name & spp & cas
\end{tabular}

+ = Positive; - = Negative; MR=Methyl Red; VP= Voges-Proskauer 


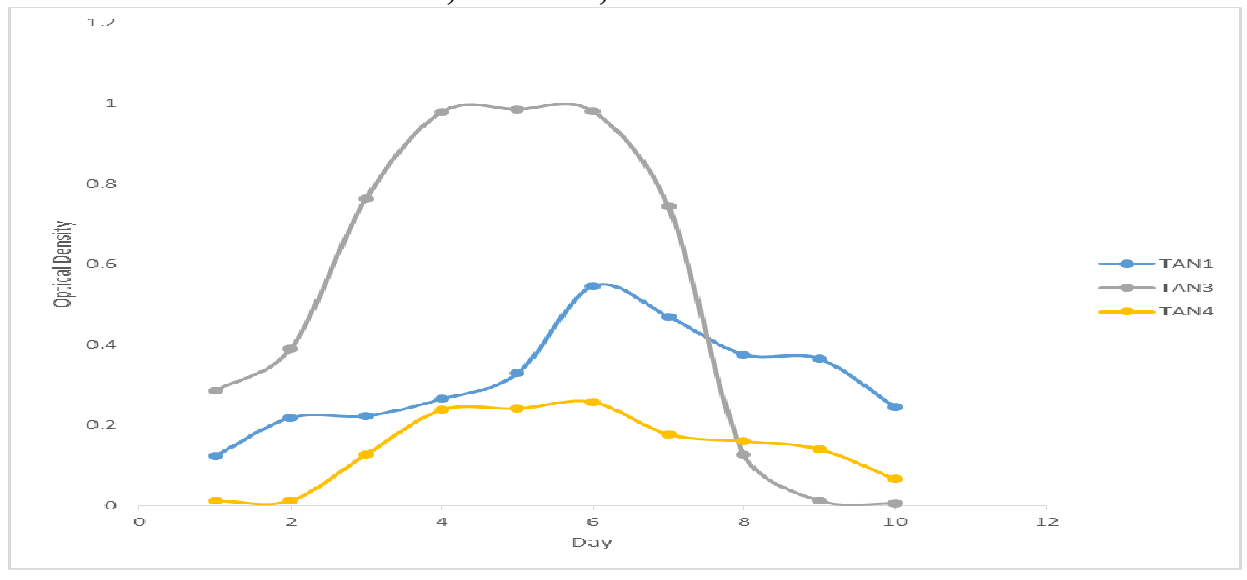

Fig. 2 Growth rates of the isolates in the effluents from the Tannery Industries

\section{Physico-chemical Parameters in the Industrial Effluents after the biodegradation.}

Table 3 shows the mean results of the physicochemical parameter before and after bioremediation using the different masses $(5 \mathrm{~g}$, $10 \mathrm{~g}, 15 \mathrm{~g}, 20 \mathrm{~g}$, and $25 \mathrm{~g}$ ) of the respective immobilized bacteria. Also, Table 4 shows the mean results of correlation coefficient ( $r$ ) between different masses of bacteria and physicochemical parameters.

The mean values $(\mathrm{mg} / \mathrm{l})$ of the SS after the bioremediation varies between $243 \pm 45$ and $898 \pm 672$. The mean concentration $(\mathrm{mg} / \mathrm{l})$ of SS remediated by the different masses $(5 \mathrm{~g}, 10 \mathrm{~g}$, $15 \mathrm{~g}, 20 \mathrm{~g}$, and $25 \mathrm{~g}$ ) of the bacteria varies. The SS in the samples fluctuates up and down after the bioremediation process when compared with the SS of the raw samples before the bioremediation. The increase in the levels of the SS might be due to the aggregation of the TDS which are large enough to result into SS. The increase in the levels of the SS might be also due to the influence of the nutrients which was added into the effluents in order to make the microorganisms more active and viable for fast degradation of organic contaminants in the effluent. The relative potential or efficiency of the different masses of the bacteria in remediating SS in TAN1 samples was in the order $25 \mathrm{~g}>20 \mathrm{~g}>15 \mathrm{~g}>10 \mathrm{~g}>5 \mathrm{~g}$. For TAN2 and TAN3 samples, the order was $25 \mathrm{~g}>20 \mathrm{~g}>15$ $\mathrm{g}>10 \mathrm{~g}>5 \mathrm{~g}$. These might be due to the variations in the surface areas of the different masses of the immobilized bacteria. Statistical analysis shows that there is no significant difference $(p<0.05)$ between the mean values of SS among the masses in the respective industries. Positive and significant correlations exist between the masses of bacteria and Suspended Solid (SS). This showed that there is general increase in the levels of the SS as the masses of the immobilized bacteria increases. TAN3 (90\%) and TAN1 (80\%) showed a very high correlation with the masses of the bacteria while TAN2 (61\%) showed a very low correlation.

The mean values $(\mathrm{mg} / \mathrm{l})$ of the TDS after the bioremediation varies between $46 \pm 11$ and $83 \pm 78$. The mean concentration $(\mathrm{mg} / \mathrm{l})$ of TDS remediated by the different masses $(5 \mathrm{~g}, 10 \mathrm{~g}$, $15 \mathrm{~g}, 20 \mathrm{~g}$, and $25 \mathrm{~g}$ ) of the bacteria varies. There is a reduction in all the TDS of all the samples after the bioremediation process compared with the TDS of the raw samples before the bioremediation. The relative potential or efficiency of the different masses of the bacteria in remediating TDS in TAN1 and TAN3 samples was in the order $5 \mathrm{~g}>10 \mathrm{~g}>15 \mathrm{~g}>20$ $\mathrm{g}>25 \mathrm{~g}$. For TAN2 samples, the order was 20 $g>10 \quad g>25 \quad g>15 \quad g>5 \quad g$. Statistical analysis shows that there is no significant difference $(p<0.05)$ between the mean values of TDS among the masses in the respective industries. These might be due to the variations in the surface areas of the different masses of the immobilized bacteria. Positive and significant correlations exist between the masses of bacteria and TDS with the exception in TAN2 (negative and insignificant correlation). The positive correlations showed that there is general increase in the levels of the TDS as the masses of the immobilized bacteria increases. TAN1 $(96 \%)$ showed a very high correlation with the masses of the bacteria while TAN2 (47\%) showed a very low correlation.

The mean values $(\mathrm{mg} / \mathrm{l})$ of the BOD after the bioremediation varies between $1.56 \pm 0.20 \mathrm{mg} / \mathrm{l}$ and $6.92 \pm 5.49 \mathrm{mg} / \mathrm{l}$. The mean concentration $(\mathrm{mg} / \mathrm{l})$ of BOD remediated by the different masses $(5 \mathrm{~g}, 10 \mathrm{~g}, 15 \mathrm{~g}, 20 \mathrm{~g}$, and $25 \mathrm{~g}$ ) of the bacteria varies. There is a reduction in all the BOD of all the samples after the bioremediation process compared with the $\mathrm{BOD}$ of the raw 
BAJOPAS Volume 13 Number 2, December, 2020 samples before the bioremediation. The relative potential or efficiency of the different masses of the bacteria in remediating BOD in TAN1, TAN2 and TAN3 samples were in the order $25 \mathrm{~g}>20$ $\mathrm{g}>15 \mathrm{~g}>10 \mathrm{~g}>5 \mathrm{~g}, 25 \mathrm{~g}>15 \mathrm{~g}>5 \mathrm{~g}>10 \mathrm{~g}>20 \mathrm{~g}$ and $20 \mathrm{~g}>10 \mathrm{~g}>25 \mathrm{~g}>15 \mathrm{~g}>5 \mathrm{~g}$ respectively. Statistical analysis shows that there is significant difference $(p<0.05)$ between the mean values of BOD among the masses in the respective industries. These might be due to the variations in the surface areas of the different masses of the immobilized bacteria. Negative and significant correlations exist between the masses of bacteria and BOD. This showed that there is general decrease in the levels of the BOD as the masses of the immobilized bacteria increases. TAN1 (94\%) showed a very high correlation with the masses of the bacteria while TAN2 (4\%) showed a very low correlation.

The mean values $(\mathrm{mg} / \mathrm{l})$ of the COD after the bioremediation varies between $250 \pm 154$ and $3134 \pm 1595$. The mean concentration $(\mathrm{mg} / \mathrm{l})$ of COD remediated by the different masses $(5 \mathrm{~g}$, $10 \mathrm{~g}, 15 \mathrm{~g} 20 \mathrm{~g}$, and $25 \mathrm{~g}$ ) of the bacteria varies. There is a reduction in all the COD of all the samples after the bioremediation process compared with the COD of the raw samples before the bioremediation. The relative potential or efficiency of the different masses of the bacteria in remediating COD in TAN1, TAN2 and TAN3 samples were in the order $25 \mathrm{~g}>20 \mathrm{~g}>15$ $\mathrm{g}>5 \mathrm{~g}>10 \mathrm{~g}, 25 \mathrm{~g}>20 \mathrm{~g}>15 \mathrm{~g}>10 \mathrm{~g}>5 \mathrm{~g}$ and 10 g>5 g>25 g>15 g>20 g respectively. Statistical analysis shows that there were significant difference $(p<0.05)$ between the mean values of COD among the masses in the respective industries except for effluents treated with $25 \mathrm{~g}$. These might be due to the variations in the surface areas of the different masses of the immobilized bacteria. Negative and insignificant correlations exist between the masses of bacteria and COD with the exception in TAN3 (positive and significant correlation). The negative correlations showed that there is general decrease in the levels of the COD as the masses of the immobilized bacteria increases. TAN2 (100\%) showed a very high correlation with the masses of the bacteria while TAN3 (36\%) showed a very low correlation.

Generally, there was an overall decrease in the concentration of these physicochemical parameters after the bioremediation using the different masses of the bacterial isolates. These might be due to the variations in the surface areas of the different masses of the immobilized bacteria. This is in line with the work of Jimoh et al. (2018) and Baba et al. (2020).

Table 3: Mean Values $(\mathrm{mg} / \mathrm{l}) \pm$ S.D of Physicochemical parameters in effluents from the Tannery Industries before and after Treatment of the effluents $(250 \mathrm{ml})$ with the different masses $(5 \mathrm{~g}, 10 \mathrm{~g}$, $15 \mathrm{~g}, 20 \mathrm{~g}$, and $25 \mathrm{~g}$ ) of the bacteria.

\begin{tabular}{llllllll}
\hline $\mathrm{P}$ & IND & Before & \multicolumn{5}{c}{ After } \\
\cline { 4 - 7 } & & & $5 \mathrm{~g}$ & $10 \mathrm{~g}$ & $15 \mathrm{~g}$ & $20 \mathrm{~g}$ & $25 \mathrm{~g}$ \\
\hline \multirow{2}{*}{ COD } & TAN1 & $2372 \pm 938$ & $1708 \mathrm{a} \pm 861$ & $2045 \mathrm{a} \pm 1205$ & $845 \mathrm{a} \pm 369$ & $300 \mathrm{a} \pm 167$ & $250 \mathrm{a} \pm 154$ \\
& TAN2 & $1406 \pm 208$ & $1195 \mathrm{a} \pm 208$ & $1125 \mathrm{a} \pm 384$ & $1055 \mathrm{a} \pm 317$ & $956 \mathrm{a} \pm 310$ & $870 \mathrm{ab} \pm 240$ \\
& TAN3 & $3532 \pm 1373$ & $2374 \mathrm{a} \pm 1344$ & $1976 \mathrm{a} \pm 1405$ & $2757 \mathrm{a} \pm 1266$ & $3134 \mathrm{a} \pm 1595$ & $2614 \mathrm{~b} \pm 1105$ \\
BOD & TAN1 & $13.85 \pm 6.42$ & $6.92 \mathrm{a} \pm 5.49$ & $6.42 \mathrm{a} \pm 5.07$ & $5.72 \mathrm{a} \pm 5.35$ & $4.62 \mathrm{a} \pm 4.37$ & $2.82 \mathrm{ab} \pm 1.26$ \\
& TAN2 & $19.46 \pm 0.50$ & $1.75 \mathrm{~b} \pm 0.22$ & $1.73 \mathrm{~b} \pm 0.18$ & $1.58 \mathrm{a} \pm 0.16$ & $1.91 \mathrm{a} \pm 0.22$ & $1.56 \mathrm{~b} \pm 0.20$ \\
& TAN3 & $17.13 \pm 3.14$ & $4.24 \mathrm{ab} \pm 0.77$ & $3.29 \mathrm{ab} \pm 0.37$ & $4.11 \mathrm{a} \pm 0.07$ & $3.23 \mathrm{a} \pm 0.91$ & $3.33 \mathrm{a} \pm 1.28$ \\
SS & TAN1 & $374 \pm 124$ & $243 \mathrm{a} \pm 45$ & $471 \mathrm{a} \pm 226$ & $475 \mathrm{a} \pm 182$ & $492 \mathrm{a} \pm 128$ & $611 \mathrm{a} \pm 217$ \\
& TAN2 & $358 \pm 335$ & $460 \mathrm{a} \pm 400$ & $543 \mathrm{a} \pm 414$ & $544 \mathrm{a} \pm 402$ & $551 \mathrm{a} \pm 414$ & $554 \mathrm{a} \pm 405$ \\
& TAN3 & $780 \pm 739$ & $586 \mathrm{a} \pm 594$ & $758 \mathrm{a} \pm 656$ & $787 \mathrm{a} \pm 676$ & $861 \mathrm{a} \pm 635$ & $898 \mathrm{a} \pm 672$ \\
TDS & TAN1 & $3941 \pm 3703$ & $51 \mathrm{a} \pm 10$ & $53 \mathrm{a} \pm 10$ & $55 \mathrm{a} \pm 15$ & $61 \mathrm{a} \pm 20$ & $63 \mathrm{a} \pm 26$ \\
& TAN2 & $3300 \pm 1714$ & $83 \mathrm{a} \pm 78$ & $47 \mathrm{a} \pm 20$ & $48 \mathrm{a} \pm 22$ & $47 \mathrm{a} \pm 17$ & $48 \mathrm{a} \pm 17$ \\
& TAN3 & $2653 \pm 1240$ & $46 \mathrm{a} \pm 11$ & $55 \mathrm{a} \pm 24$ & $55 \mathrm{a} \pm 25$ & $58 \mathrm{a} \pm 23$ & $61 \mathrm{a} \pm 28$ \\
\hline
\end{tabular}

Replicate $=6$ (months)

Within the rows, for the same parameter, means with different alphabets are statistically different $(p<0.05)$.

$\mathrm{P}=$ parameter, IND = Industries 
BAJOPAS Volume 13 Number 2, December, 2020

Table 4: Correlation coefficient $(r)$ between different masses of the bacteria and the physicochemical parameters.

\begin{tabular}{llll}
\hline Industries & Parameter & Correlation coefficient $(r)$ & $\begin{array}{l}\text { Percent dependence (rxrx100) } \\
(\%)\end{array}$ \\
\hline TAN1 & COD & -0.9 & 82 \\
& BOD & -0.97 & 94 \\
& SS & $0.90^{*}$ & 80 \\
TAN2 & TDS & $0.98^{*}$ & 96 \\
& COD & -1 & 100 \\
& BOD & -0.21 & 4 \\
& SS & $0.78^{*}$ & 61 \\
& TDS & -0.69 & 47 \\
& COD & $0.60^{*}$ & 36 \\
& BOD & -0.6 & 37 \\
& SS & $0.95^{*}$ & 90 \\
& TDS & $0.94^{*}$ & 89 \\
\hline
\end{tabular}

The correlation coefficient $(r)$ with * is statistically significant $(p<0.05)$.

Percentage reduction of the Parameters

Table 5 shows the percentage reduction of Parameters in industrial samples before and after the treatment of the effluents $(250 \mathrm{ml})$ with the different masses $(5 \mathrm{~g}, 10 \mathrm{~g}, 15 \mathrm{~g}, 20 \mathrm{~g}$, and $25 \mathrm{~g}$ ) of the Immobilized Bacteria.

In TAN1 samples, the percentage reduction (\%) of COD ranged (14-89); BOD (50-80); SS (-32$35)$ and TDS (98-99). In TAN2 samples, the percentage decrease $(\%)$ of COD ranged (15$38) ;$ BOD (90-92); SS [-28-(-55)] and TDS (9798). In TAN3 samples, the percentage decrease (\%) of COD ranged (11-44); BOD (76-81); SS (15-25) and TDS (98). The percentage increase in the levels COD, BOD and TDS might be due to the increase in the surface area of the different masses of the immobilized bacteria. However, the percentage decrease in the levels of the SS might be due to the aggregation of the TDS which are large enough to result into SS. The percentage decrease in the levels of the SS might be also due to the influence of the nutrients which was added into the effluents in order to make the microorganisms more active and viable for fast degradation of organic contaminants in the effluent. This is in line with the work of Jimoh et al. (2018) in which the concentration of the SS increase after the bioremediation of effluents.

Sreemoyee and Priti (2013) assessed and reduced several Physico-chemical parameters of dairy wastewater using Niesseria $s p$. and concluded that the species are well known to degrade organic compounds. This is in agreement with the current study in which the immobilized Niesseria $s p$ degrade the organic contaminants as indicated by the BOD, COD and TDS.

Jimoh et al. (2018) observed that TSS of the effluents was increased after treatment with immobilized bacteria and concluded that it might be due to the biostimulation method adopted for the research.

The optimum $\mathrm{pH}$ Biosorption of Chromium by Bacillus spp and Staphylococcus spp. from tannery effluent was investigated by Mythili and Karthikeyan (2011). The maximum adsorption of Chromium $(86.4 \mathrm{mg} / \mathrm{L})$ was showed by Bacillus spp and Staphylococcus spp showed $70.6 \mathrm{mg} / \mathrm{L}$ at an initial concentration of $100 \mathrm{mg} / \mathrm{L}$. In the present study, immobilised Bacillus spp and Staphylococcus spp. from the tannery industrial effluents reduced the levels of the organic pollutants with high potential as indicated by the percentage reduction of BOD, COD and TDS.

Enzymes often can work in multiple environments especially if they are immobilized. This makes the microorganisms' enzymes even more resistant to harsh environments and enables the enzymes to be recovered and recycled after they are no longer needed (Gianfreda and Rao 2004). Ramesh and Singh (1993) reported that the immobilized bacteria having more efficiency to remove the suspended particles than free cells. Using the immobilized cell is preferable due to its capability for using several times with the same efficiency, which makes it more economical. Similar work was done by Sikander et al. (2007) showing the higher reduction with permeabilized cells of Ochrobactrum intermedium strain SDCr-5. 
BAJOPAS Volume 13 Number 2, December, 2020

The results revealed the isolation and identification of isolates with the potential for the reduction of $\mathrm{Cr}$ (VI) to $\mathrm{Cr}$ (III). Results indicated that immobilized $B$. cereus could be efficiently used for the reduction of $\mathrm{Cr}$ (VI).

Table 5: Percentage reduction of the tested Parameters from the tannery industrial samples of the Immobilized Bacteria.

\begin{tabular}{lllllll}
\hline \multirow{2}{*}{ Industries } & & \multicolumn{5}{c}{ Percentage Reduction $(\%)$} \\
\cline { 3 - 7 } & & $5 \mathrm{~g}$ & $10 \mathrm{~g}$ & $15 \mathrm{~g}$ & $20 \mathrm{~g}$ & $25 \mathrm{~g}$ \\
\hline TAN1 & COD & 28 & 14 & 64 & 87 & 89 \\
& BOD & 50 & 54 & 59 & 67 & 80 \\
& SS & 35 & -26 & -27 & -32 & -63 \\
& TDS & 99 & 99 & 99 & 98 & 98 \\
TAN2 & COD & 15 & 20 & 25 & 32 & 38 \\
& BOD & 91 & 91 & 92 & 90 & 92 \\
& SS & -28 & -52 & -52 & -54 & -55 \\
& TDS & 97 & 99 & 99 & 99 & 99 \\
& COD & 33 & 44 & 22 & 11 & 26 \\
& BOD & 75 & 81 & 76 & 81 & 81 \\
& SS & 25 & 3 & -1 & -10 & -15 \\
& TDS & 98 & 98 & 98 & 98 & 98 \\
\hline
\end{tabular}

Percentage Reduction $=(B-A) / B \times 100 \%$

$A=$ Concentration of the parameter after treatment

$\mathrm{B}=$ Concentration of the parameter before treatment

$+=$ percentage decrease

- = percentage increase

In general, immobilization makes the enzyme more resistant to temperature, $\mathrm{pH}$, and substrate concentration swings giving it a longer lifetime and higher productivity per active unit (Gianfreda and Rao, 2004; FuIlbrook, 1996; Russell et al, 2003; Kandelbauer et al., 2004). Immobilized cells have been used and studied extensively for the production of useful chemicals (Ohtake and Silver, 1994), the treatment of wastewaters (Chen et al., 2003; Wang et al., 2010). Although many workers described microbial degradation of tannery effluent, limited literature is available on the bioremediation of tannery effluent using immobilized bacterial cells in the Kano Industrial Estates.

\section{CONCLUSION}

The samples contained variable levels of the physicochemical parameters. The results of the Analysis of variance revealed that, no statistical difference $(p<0.05)$ was observed for the temperature, $\mathrm{pH}, \mathrm{SS}, \mathrm{TDS}, \mathrm{BOD}$ and $\mathrm{COD}$ among the three tannery industries before the treatment. The levels of some of the parameters
(SS, TDS and COD) observed in the samples were found above the recommended limits of WHO and NESREA, which called for the treatment of the effluents before discharge into the environment. Base on the morphological and biochemical test results, TAN1, TAN2, and TAN3 bacterial isolates were identified to be Neisseria spp, Bacillus cereus, and Staphylococcus aureus respectively. The results of Post-treatment analysis showed that there is overall decrease in the levels of the parameters determined when compared with that of the pre-treatment. The overall percentage reduction of the immobilised bacteria in the treatment of the respective effluents was in the order TAN2 (72\%)>TAN1 $(70 \%)>$ TAN3 $(62 \%)$. Hence, the immobilized bacteria are having higher biodegradation potential for the treatment of the tannery effluents.

\section{Acknowledgments}

The authors wish to acknowledge the University of Maiduguri for the financial support. The authors are grateful to the Kano State Ministry of Environment for their support in obtaining the effluent samples. 


\section{REFERENCES}

Ajao, A. T., Adebayo, G. B., and Yakubu, S. E. (2011). Bioremediation of textile industrial effluent using mixed culture of Pseudomonas aeruginosa and Bacillus subtilis immobilized on agar-agar in a bioreactor. J. Microbiol. Biotech. Res, 1(3), 50-56.

Akan, J. C., Moses, E. A., Ogugbuaja, V. O., and Abah, J. (2007). Assessment of tannery industrial effluents from Kano metropolis, Kano State, Nigeria. Journal of Applied Sciences, 7(19), 2788-2793.

Akan, J. C., Ogugbuaja, V. O., Abdulrahman, F. I., and Ayodele, J. T. (2009). Pollutant levels in effluent samples from tanneries and textiles of Kano industrial areas, Nigeria. Global journal of pure and applied sciences, 15(3-4).

APHA (1989). Standard methods for Examination of Will bete and Will betewater.15 $5^{\text {th }}$ edition. Brydpass Springfield Will behington DC. pp. 164-176

APHA (1992). Standard Methods for the Examination of Water and Wastewater. Health, 69, 1116-9.

Baba, A., Garba, S. T., and Bello, H. S. (2020). Bioremediation Potential of Immobilized corynebacterium kutsceri in the Treatment of Tannery Industrial Effluent from Challawa Industrial Estate, Kano State, Nigeria. Journal of the Turkish Chemical Society Section A: Chemistry, $7(2), 335-350$.

Beem, E. I. V. (1994). reduction of solvent VOC emission. J. Oil Col. Chem. Ass, 77, 158.

Bouwer, E. J., and Zehnder, A. J. (1993). Bioremediation of organic compoundsputting microbial metabolism to work. Trends in biotechnology, 11(8), 360367.

Chen, K. C., Wu, J. Y., Liou, D. J., and Hwang, S. C. J. (2003). Decolorization of the textile dyes by newly isolated bacterial strains. Journal of Biotechnology, 101(1), 57-68.

Dan'Azumi, S., and Bichi, M. H. (2010). INDUSTRIAL POLLUTION AND HEAVY METALS PROFILE OF CHALLAWA RIVER IN KANO, NIGERIA. Journal of Applied Sciences in Environmental Sanitation, $5(1)$.

DWAF. (1992). Analytical Methods Manual, TR 151. Department of Water Affairs and Forestry, Pretoria.

El-Bestawy, E. (2013). Biological treatment of leather-tanning industrial wastewater using free living bacteria.
Elsheikh, M. A. S. (2009). Tannery wastewater pre-treatment. Water Science and Technology, 60(2), 433-440.

FuIlbrook, P. D. (1996). "Kinetics." Industrial enzymology: The application of enzymes in Industry. 2nd Ed. T. Godfrey and J Reichelt. eds.. Nature. New York.

Gianfreda, L., and Rao, M. A. (2004). Potential of extra cellular enzymes in remediation of polluted soils: a review. Enzyme and microbial technology, 35(4), 339354.

Hugo Springer. (1994). John Arthur Wilson Memorial Lecture "Treatment of Industrial Wastes of the Leather Industry - is it still a Major Problem". JALCA, 89, 153-185

Jimoh, A. A., Ganiyu, B. A., Baba, D., and Baba, A. (2018) Bioremediation Process of Effluent from Detergent and Food Industries in Jos, Nigeria: Kinetics and Thermodynamics. International Journal of Engineering Science Invention (IJESI), 762-73

Kandelbauer, A., Maute, O., Kessler, R. W., Erlacher, A., and Gübitz, G. M. (2004). Study of dye decolorization in an immobilized laccase enzyme-reactor using online spectroscopy. Biotechnology and bioengineering, 87(4), 552-563.

Kongjao, S., Damronglerd, S., and Hunsom, M. (2008). Simultaneous removal of organic and inorganic Pollutants in tannery wastewater using electrocoagulation technique. Korean Journal of chemical engineering, 25(4), 703.

Maheshwari, U. M., Aruna, S., Gomathi, M., and AbdulJaffar, A. H. (2017). Bioremediation by Free and Immobilized Bacteria Isolated from Tannery Effluent. International Journal of Research in Applied, Natural and Social Sciences. 5(7), 75-90

Margesin, R., and Schinner, F. (2001). Bioremediation (natural attenuation and biostimulation) of diesel-oilcontaminated soil in an alpine glacier skiing area. Applied and environmental microbiology, 677), 3127-3133.

Mohammed, A., Sekar, P., and George, J. (2011). Efficacy of microbes in bioremediation of tannery effluent. Inter. J. Curr. Res, 3(4), 324-326.

Mohammed, S. S. D., Orukotan, A. A., and Abdullahi, H. (2017). Physicochemical and Bacteriological Assessment of Tannery Effluent from Samaru-Zaria, 
BAJOPAS Volume 13 Number 2, December, 2020 Kaduna State, Nigeria. Journal of Applied

Sciences and Environmental Management, 21(4), 734-740.

Munz, G., De Angelis, D., Gori, R., Mori, G., Casarci, M., and Lubello, C. (2009). The role of tannins in conventional and membrane treatment of tannery wastewater. Journal of hazardous materials, 164(2-3), 733-739

Mythili, K., and Karthikeyan, B. (2011). Bioremediation of $\mathrm{Cr}$ (VI) from tannery effluent using Bacillus spp and Staphylococcus spp. International Multidisciplinary Research Journal, 1(6).

NESREA (2009). National Environmental Standards for Effluent Limitations and Regulation. 1233-1236

Noorjahan, C. M. (2014). Physicochemical characteristics, identification of bacteria and biodegradation of industrial effluent. Journal of bioremediation and Biodegradation, 5(3).

Ohtake, H. I., and Silver, A. O. (1994). Bacterial reduction of toxic chromate. Biological degradation and bioremediation of toxic chemicals, 403-415.

Omoleke, I. I. (2004). Management of environmental pollution in Ibadan, an African city: the challenges of health hazard facing government and the people. Journal of Human Ecology, 15(4), 265-275.

Rajor, A., Reddy, A.S., and Singh, B. (2004). Determination of BOD kinetic Parameters and evaluation of alternate methods, M.Sc. Thesis, Department of biotechnology \& environmental Science, Thapar Institute of Engineering and Technology, Patiala

Ramasami, T., Rajamani, S., and Rao, J. R. (1994, March). Pollution control in leather industry: Emerging technological options. In International symposium on surface and colloidal science and its relevance to soil pollution, madras.

Ramesh, J. V. S., and Singh, S. P. (1993). Yearly variation in certain physicochemical parameters of pond at eastern Doon Valley. Uttar Pradesh J. Zoo, 12 (1), 7577.

Ranen, S., and Sharadinadra, C. (2009). Biotechnology applications to environmental remediation in resource exploitation. Current science, 97, 6-25
Russell, A. J., Berberich, J. A., Drevon, G. F., and Koepsel, R. R. (2003). Biomaterials for mediation of

chemical and biological warfare agents. Annual review of biomedical engineering, 5(1), 1-27.

Saravanan, P., and Saravanan, A. (1999). Decolourization of tannery effluent by Flavobacterium sp. EK 1. Indian Journal of Environmental Protection, 19, 19-24.

Sikander, S., and Shahida, H. (2007). Reduction of toxic hexavalent chromium by Ochrobactrum intermedium strain SDCr5 stimulated by heavy metals. Bioresource Technol, 98, 340-344.

Singh, N., Sharma, B. K., and Bohra, P. C. (2000). Impact assessment of industrial effluent of arid soils by using satellite imageries. Journal of the Indian Society of Remote Sensing, 28(2-3), 79.

Sreemoyee, C., and Priti, P. (2013). Assessment of physico-chemical parameters of dairy waste water and isolation and characterization of bacterial strains in terms of cod reduction. Int J Sci, 2(3), 395-400.

Verheijen, L. A. H. M., Wiersema, D., Pol, L. H., and De Wit, J. (1996). Management of wastes from animal product processing. Livestock and environment, Finding a balance. International Agriculture Center, Wageningen, The Netherlands.

Wang, F., Yao, J., Si, Y., Chen, H., Russel, M., Chen, K., and Bramanti, E. (2010). Short-time effect of heavy metals upon microbial community activity. Journal of Hazardous Materials, 173(13), 510-516.

WHO (World Health Organization). (2006). Air quality guidelines: global update 2005: particulate matter, ozone, nitrogen dioxide, and sulfur dioxide. World Health Organization.

World Bank. (1995). Nigeria's strategic options for redressing industrial pollution. World Bank, industry and energy division. 1st edition, West Central Africa Department; Annexes: 1995; pp 60-62.

Zahoor, A., and Abdul, R. (2009). Enumeration of Coliforms. Journal of Environmental Sciences. 21, 814-820 


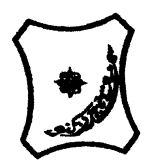

Bayero Journal of Pure and Applied Sciences, 13(2): 1 - 12

Received: November, 2020

Accepted: December, 2020

ISSN $2006-6996$

\title{
BIODEGRADATION POTENTIAL OF IMMOBILIZED BACTERIA IN THE TREATMENT OF TANNERY INDUSTRIAL EFFLUENTS FROM INDUSTRIAL ESTATES IN KANO STATE, NIGERIA
}

\author{
Abdullateef, B., ${ }^{1 *}$ Shuaibu, T. G., ${ }^{1}$ Babagana, K., ${ }^{1}$ Suleman, H. B. ${ }^{2}$ and Dauda, B. ${ }^{3}$ \\ ${ }^{1}$ Department of Pure and Applied Chemistry, Faculty of Science, University of Maiduguri, Borno State, \\ Nigeria \\ ${ }^{2}$ Department of Microbiology, Faculty of Science, University of Maiduguri, Borno State, Nigeria \\ ${ }^{3}$ Department of Chemical Engineering, Faculty of Engineering, University of Maiduguri, Borno State, \\ Nigeria \\ *Corresponding author: babslega@gmail.com; abelega2007@yahoo.com; +2348061309753
}

\section{ABSTRACT}

Industrial Effluents Samples from Gashash Tanneries (TAN1) in Bompai Industrial estate, Larabee Tannery Industry (TAN2) in Sharada Industrial estate and Z Tannery Industries (TAN3) in Challawa Industrial estate, Kano State, Nigeria were collected over a period of six months (August 2017 to January 2018) for assessing the biodegradation potentials of bacteria in the treatment of organic pollutants within the effluents. Bacteria were isolated from the effluents and immobilized on agar-agar. Different masses (5 g, $10 \mathrm{gr}, 15$ $\mathrm{g}, 20 \mathrm{~g}$, and $25 \mathrm{~g}$ ) of the bacteria were used in the treatment of $250 \mathrm{ml}$ of the effluents for ten days in a shaker incubator (Gallenkamp-OC-4364-L) at the temperature $30{ }^{\circ} \mathrm{C}$ and speed of $60 \mathrm{rpm}$. Pre-treatment analysis of the effluents for Temperature, pH, Biochemical Oxygen Demand (BOD), Chemical Oxygen Demand (COD), Suspended Solid (SS) and Total Dissolved Solids (TDS) gives the following results; temperature $\left({ }^{\circ} \mathrm{C}\right.$ )

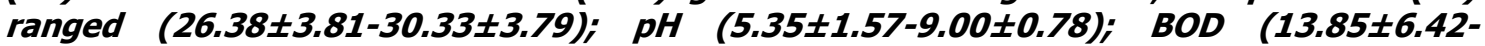
$38.75 \pm 16.20) ;$ COD (1406 $\pm 208-3532 \pm 1373) ;$ SS (208 $\pm 235-780 \pm 739)$ and TDS (266 $\pm 253-5276 \pm 2971)$. No statistical differences ( $p \leq 0.05)$ was observed for all the results among the different industries. The bacterial isolates were identified as Neisseria spp, Bacillus cereus, and Staphylococcus aureus, in TAN1, TAN2, and TAN3, respectively. After treatment of the effluent with the different masses of the isolated bacteria, the mean level of BOD was found to range as (0.55 $\pm 0.36-6.92 \pm 5.49) ; C O D$ (ND-3134 \pm 1595$)$;

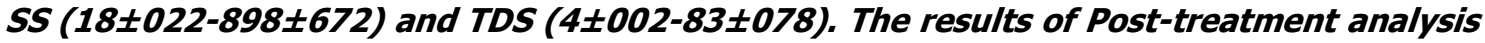
showed that there is overall decrease in the levels of the parameters determined when compared with that of the pre-treatment. The overall percentage reduction of the immobilised bacteria in the treatment of the respective effluents was in the order TAN2 (72\%)>TAN1 (70\%)>TAN3 (62\%). Hence, the immobilized bacteria are having higher biodegradation potential for the treatment of the tannery effluents.

Keywords: Biodegradation, bacteria, effluent, immobilization, tannery.

\section{INTRODUCTION}

Tannery industrial wastewater is a serious consequence of the pollution point of view for streams, freshwater, and land used for agriculture. The lack of awareness in the modern industrial practice has resulted in the discharge of tannery effluents which exhibit very high value of chromium ( $\mathrm{Cr}$ ), Sulfide, and chloride, Total Dissolved Solid (TDS), Total Suspended Solid (TSS), Biochemical Oxygen Demand (BOD) and Chemical Oxygen Demand (COD) in the water stream or land (Mohammed et al., 2001). Tanning is the process, which One ton of skin generally leads to the production of 20 to $80 \mathrm{~m}^{3}$ of turbid and foul-smelling converts the protein of the rawhide or skin into a stable material, which will not putrefy and is suitable for a wide variety of end applications (Elsheikh, 2009). The highly polluting chromium is the most commonly used tanning material producing leather that is more flexible and pliable than vegetable-tanned leather and does not discolor or lose shape in water as drastically as vegetable-tan (Elsheikh, 2009). Tannery effluent is among the most hazardous industrial pollutants due to its huge organic and inorganic load, which is highly toxic to human life and the environment (Kongjao et al., 2008). wastewater including chromium (100-400 mg/l), sulfide $(200-800 \mathrm{mg} / \mathrm{l})$, high levels of fat and 
BAJOPAS Volume 13 Number 2, December, 2020 other solid wastes, and notable pathogen contamination as well as pesticides added for skin conservation during transport (Elsheikh, 2009). There are more than 6000 tanneries in Nigeria with an annual processing capacity of 700,000 tons of hides and skins (Omoleke, 2004; Singh et al., 2008). It was reported that the total amount of waste produced per animal slaughtered is approximately $35 \%$ of its weight (World Bank, 1995). Also, for every $1000 \mathrm{~kg}$ of carcass weight, a slaughtered beef produces 5.5 $\mathrm{kg}$ of manure (excluding rumen contents or stockyard manure) and $100 \mathrm{~kg}$ of paunch manure (undigested food) (Verheijen et al., 1996). Tanneries generate wastewater in the range of 30-35 $\mathrm{L} \mathrm{kg}^{-1}$ skin/hide processed with variable $\mathrm{pH}$, Biological Oxygen Demand (BOD), Chemical Oxygen Demand (COD), high concentrations of suspended solids (SS), and tannins as well as chromium (Zahoor and Abdul, 2009).

Being heterogeneous and composed of a wide variety of compounds, it is very difficult to select a unique direct method for estimating the biodegradability of organic contents and biokinetic parameters for a wastewater sample (Rajor, 2004). For this purpose, some indirect estimation such as determination of biochemical oxygen demand (BOD) and chemical oxygen demand (COD) are applied as common laboratory investigations [9]. During retanning procedures, synthetic tannins (Syntan), oils and resins are added to form softer leather at varying doses (Munz et al., 2009). One of the refractory groups of chemicals in tannery effluents derives mainly from tannins (Ramasami et al., 2004). Syntans are characterized by complex chemical structures, because they are composed of an extended set of chemicals such as phenol-, naphthalene-, formaldehyde- and melamine-based syntans, and acrylic resins (Beem, 1994). Organic pollutants (proteic and lipidic components) are originated from skins (it is calculated that the raw skin has $30 \%$ loss of organic material during the working cycle) or they are introduced during processes (Hugo Springer, 1994).

Many conventional processes such as oxidation, chemical and biological processes were carried out to treat tanneries wastewater (Ebtesam et al, 2013). Biological processes have received more attention because of their costeffectiveness, lower sludge production and environmental friendliness (Noorjahan, 2014). Naturally occurring micro-organisms degrade the hazardous organic wastes including xenobiotic compounds, such as pesticides, polycyclic aromatic hydrocarbons (PAHs) and polychlorinated biphenyls (PCBs) in due course of time (Ranen and Sharadinadra, 2009). Bioremediation is based on the idea that all organisms remove substances from the environment to carry outgrowth and metabolism (Bouwer and Zehnder, 1993). Bacteria, protista and fungi are found to be very good at degrading complex molecules and incorporating the breakdown products into their metabolism (Bouwer and Zehnder, 1993). The resultant metabolic wastes that they produce are generally safe and somehow recycled into other organisms (Ranen and Sharadinadra, 2009). An acclimatized indigenous population of microorganisms capable of degradation of the compounds of interest must exist at the site for a successful bioremediation mode (Ranen and Sharadinadra, 2009). It has been observed that for a successful bioremediation mode, an acclimatized indigenous population of microorganisms capable of degradation of the compounds of interest must exist at the site under investigation (Ranen and Sharadinadra, 2009). Even though there are numerous physical and chemical methods employed in the disposal of wastes the advantage in using bacterium is that they play a key role in the reduction of COD, BOD, total protein, total tannin and total phenol (Saravanan and Saravanan, 1998)

Baba et al. (2020) studied the bioremediation potential of immobilized corynebacterium kutsceri in the Treatment of tannery industrial effluent from Challawa Industrial Estate, Kano State, Nigeria. The aim of the work is to study the reduction in the level of the contaminants through the process of bioremediation using the isolated bacteria. Immobilized bacteria can withstand various temperatures, $\mathrm{pH}$ and substrate concentrations; consequently, increasing the efficiency and the lifespan of the bacteria. Immobilized bacteria are widely applied in the treatment of wastewater and can be separated and recovered after the treatment with the same efficiency (Baba et al., 2020).

\section{MATERIALS AND METHODS \\ Study Area}

This study was carried out in Bompai, Sharada and Challawa industrial estates in Kano, Figure 1. Kano lies on Latitude $11^{\circ} 30^{\prime} \mathrm{N}$ and $8^{\circ} 30^{\prime} \mathrm{E}$ and Longitude $11^{\circ} 5^{\prime} \mathrm{N}$ and $8^{\circ} 5^{\prime} \mathrm{E}$ in Northern Nigeria. It is one of the developed industrial cities in Nigeria. Tannery activities are the dominating industries and this could be one of the reasons for her high population density (Dan'Azumi and Bichi, 2010). Many researchers have studied biodegradation of tannery effluent using microorganisms. However, limited literature is available on the biodegradation of tannery effluent in Kano industrial estates using 
BAJOPAS Volume 13 Number 2, December, 2020 immobilized bacterial cells. This research work focuses on the potential of the use of the indigenous immobilized bacterial isolates in the treatment of tannery effluents in the industrial estates.

\section{Sample Collection}

Effluents were collected from the Tannery Industries from Bompai, Challawa and Sharada Industrial Estates, Kano, Nigeria. The effluents were collected over a period of six months (August 2017 to January 2018). Samples collected in a sterile 4-liter plastic container with a unique identification number were preserved using an ice-box that was transported to the Microbiology Laboratory, Department of Microbiology, Bayero University of Kano for analysis

\section{Sample Preparation and Sample Analysis}

Immediately after the collection of the effluent, $\mathrm{pH}$, TSS, TDS, COD, BOD levels were determined before treatment (Pre-treatment determination) and ten days after treatment (Post-treatment determination) as described in
APHA (1989) standard methods. $\mathrm{pH}$ was determined using Ecotests $\mathrm{pH}$ meter and TDS was determined using AQUALYTIC TDS Salinometer. BOD was determined as described by the standard method (APHA, 1992). COD and SS were determined using DR/2010 HACH portable data logging spectrophotometer (DWAF, 1992)

\section{Identification and Biochemical} Characterization of the Bacterial Isolates

The bacteria were isolated from the effluents using Serial Dilution according to the method described by APHA (1989). The biochemical tests such as oxidase, catalase, coagulase, indole (from $1 \%$ tryptone broth), citrate (Simmons citrate agar), methyl red/VogesProskauer (MR/VP), nitrate reduction, Starch Hydrolysis, Glucose, Maltose, and Lactose tests were carried out on the bacterial isolates to identify the bacteria through the bacteria biochemical characteristics according to Ajao et al. (2011).

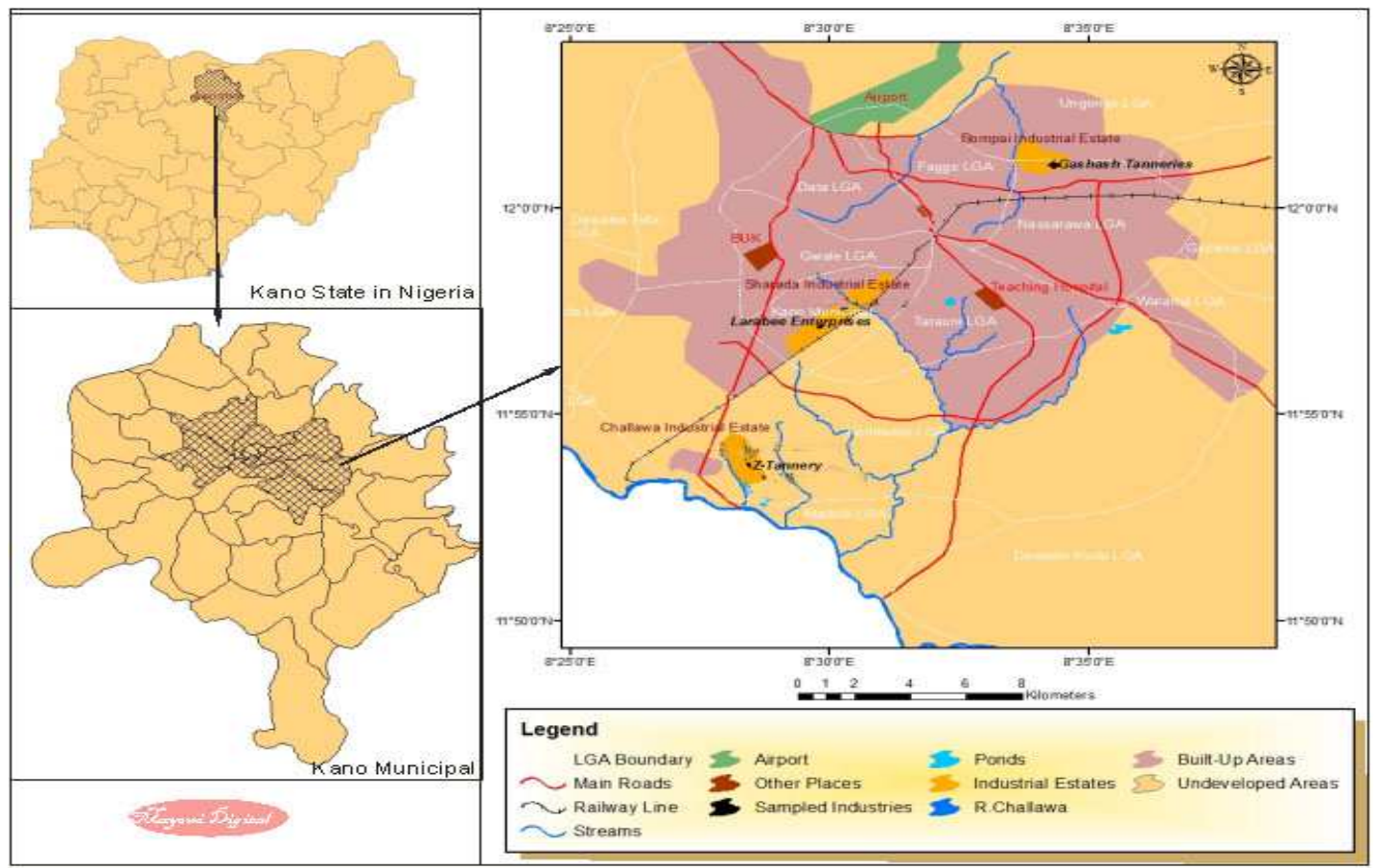

Fig. 1 Map showing the study areas

Source: Mayomi Digital Productions, GIS Laboratory, Department of Geography, UNIMAID (2017)

\section{Determination of Growth Rate of the Bacteria in Effluent Sample}

The bacteria growth rates were determined by transferring $2 \mathrm{~mL}$ of the bacterial isolates from the tannery effluent in broth medium into 100 $\mathrm{mL}$ sterile effluents in conical flasks and kept in an incubator (Giffrin cool) for 10 days. Control was also set up by incubating another $100 \mathrm{~mL}$ each of the sterile effluents without the bacteria. The optical density of the content was determined at the wavelength of $600 \mathrm{~nm}$ on a daily interval and recorded. 
BAJOPAS Volume 13 Number 2, December, 2020 Immobilization of Bacteria

Agar solution and inoculi were prepared separately. Fifty milliliters $(50 \mathrm{~mL})$ of nutrient broth each of the inoculi was prepared in a McCartney bottle and incubated for 24 hours. A solution of agar-agar was prepared by dissolving $10 \mathrm{~g}$ of the powder in distilled water and made up to $500 \mathrm{~mL}$ mark in an Erlenmeyer flask and was sterilized in an autoclave (280A) for 15 minutes and allowed to cool to $40-45^{\circ} \mathrm{C}$ (Ajao et al., 2011). Four milliliters ( $4 \mathrm{~mL})$ of the bacterial isolates in the nutrient broth was mixed with 36 $\mathrm{ml}$ of the prepared agar-agar media in petri-dish plates and then allowed to solidify. This was kept in the refrigerator for bioremediation.

\section{Bioremediation (Treatment) of the Effluents}

The solidified agar block (immobilized bacteria) was cut into cubes using a sterile knife; $0.1 \mathrm{~mL}$ phosphate buffer ( $\mathrm{pH} \mathrm{7.0)}$ was added and kept in the refrigerator for 1 hour for curing. The phosphate buffer was decanted after 1 hour and the cubes were washed with sterile distilled water 3-4 times before it was used (Ajao et al., 2011). Two liters (2 L) of the effluent was supplemented with the minimum basal medium in $\mathrm{g} / \mathrm{L}: \mathrm{NaCl}(0.8), \mathrm{MgSO}_{4} .7 \mathrm{H}_{2} \mathrm{O}(0.001), \mathrm{KH}_{2} \mathrm{PO}_{4}$ (2), $\mathrm{NaNO}_{3}$ (2), $\quad \mathrm{CaCl}_{2} .2 \mathrm{H}_{2} \mathrm{O} \quad(0.5)$ and $\mathrm{NaHPO}_{4} .12 \mathrm{H}_{2} \mathrm{O}(2)$ and sterilized in an autoclave at $121^{\circ} \mathrm{C}$ for 15 minutes (Margesin and Schinner, 2001). Two hundred and fifty milliliters $(250 \mathrm{~mL})$ of the effluents were transferred into different $250 \mathrm{ml}$ conical flasks. The content was covered with a cotton-wool ramped with foil paper to avoid contamination. Five grams $(5 \mathrm{~g})$ of the immobilized bacteria were quickly transferred into each of the effluents in the conical flasks in an inoculating chamber. The same procedures were carried out for the $10 \mathrm{~g}, 15 \mathrm{~g}, 20 \mathrm{~g}$ and 25 $\mathrm{g}$ of the immobilized bacteria in separate $250 \mathrm{~mL}$ effluents in conical flasks and agitated for ten days in a shaker incubator (Gallenkamp-OC4364-L) at a temperature $30^{\circ} \mathrm{C}$ and speed of 60 rpm. The treated effluent samples were taken on the tenth day and analyzed for the parameters $\mathrm{pH}$, SS, TDS, COD, and BOD, (Posttreatment determination) for the different grams of bacteria to evaluate and compare the biodegradation potential. (Baba et al., 2020).

\section{Statistical Analysis}

The data were represented as Mean \pm Standard deviation and analyzed statistically using oneway Analysis of Variance (ANOVA) and Tukey's HSD as Post Hoc Tests with the aid of SPSS 16.0. The correlation coefficient was also used to measure the strength of the relationship between the different masses of the bacteria and the parameters. All $\mathrm{p} \leq 0.05$ were considered as statistically significant.

\section{RESULTS AND DISCUSSION Physico-chemical parameters in the Industrial Effluents before the Biodegradation.}

Results of the Physico-chemical parameters in the industrial effluents before the Biodegradation is shown in table 1 . The mean temperatures $\left({ }^{\circ} \mathrm{C}\right)$ observed in TAN1, TAN2, and TAN3 samples were $28.07 \pm 0.65 ; 27.77 \pm 0.64$ and $26.38 \pm 3.81$ respectively. The order of the mean temperature of the samples from the three industries can be arranged as TAN1 > TAN2>TAN3. The temperature observed at TAN1, TAN2, and TAN3 samples were found below the WHO $\left(35^{\circ} \mathrm{C}\right)$ and NESREA $\left(40^{\circ} \mathrm{C}\right)$ limits. The low values of temperature might be due to the processes used at the time of sampling. High temperature brings down the solubility of gases in water that ultimately expresses as high BOD and COD. Statistical analysis shows that there is no significant difference $(p<0.05)$ between the mean values of temperature among the industries. This might be due to similar tannery activities involved in the tannery industries at the time of sampling. The average values of temperature observed in this present study are less than those observed by Akan et al. (2007), Akan et al. (2009) and Baba et al. (2020).

The mean level of $\mathrm{pH}$ observed in TAN1, TAN2 and TAN3, samples were $7.77 \pm 2.93$; $8.35 \pm 0.28$ and $7.52 \pm 0.76$ respectively. The order of the mean $\mathrm{pH}$ of the samples from the three industries can be arranged as TAN2> TAN1 $>$ TAN3. The $\mathrm{pH}$ of the samples falls within the WHO (7.0-8.5) and NESREA (6-9) standard limits. Statistical analysis shows that there is no significant difference $(p<0.05)$ between the mean values of $\mathrm{pH}$ among the industries. This might be due to similar tannery activities involved in the tannery industries at the time of sampling. Maheshwari et al. (2017) reported that the level of $\mathrm{pH}$ in the effluents from the tannery industry in Vaniyambadi, India was 6.5 which was lower than that observed in the present study. The $\mathrm{pH}$ in the effluents from the tannery industries in Kano and Kaduna were reported to be 7.64 and 6.89, respectively (Akan et al., 2007; Mohammed et al., 2017). The average values of $\mathrm{pH}$ observed in this present study are less than those observed by Mohammed et al. (2017) and Baba et al. (2020). The mean level of SS $(\mathrm{mg} / \mathrm{l})$ observed in TAN1, TAN2, and TAN3 samples were 374 \pm 124 ; $358 \pm 335$ and $780 \pm 739$ respectively. The order of the mean SS in the samples from the three industries can be arranged as TAN3 > TAN1 $>$ TAN2. 
The SS observed in the samples were far above the recommended standard limits of regulating bodies WHO $(30 \mathrm{mg} / \mathrm{l})$ and NESREA $(10 \mathrm{mg} / \mathrm{l})$. Statistical analysis shows that there is no significant difference $(p<0.05)$ between the mean values of SS among the industries. This might be due to similar tannery activities involved in the tannery industries at the time of sampling. The average values of SS observed in this present study are less than that observed $(3700 \pm 122 \mathrm{mg} / \mathrm{l})$ by Akan et al. (2009) for tanneries in Kano. Also, the average values of SS observed in this present study are less than that observed by Mohammed et al. (2017) and Baba et al. (2020) with the exception in TAN3.

The mean level of TDS (mg/l) observed in TAN1, TAN2, and TAN3 samples were $3941 \pm 3703$; $3300 \pm 1714$ and $2653 \pm 1240$ respectively. The order of the mean TDS in the samples from the three industries can be arranged as TAN1>TAN2>TAN3. The TDS observed in the samples were far above the recommended standard limits of WHO $(250 \mathrm{mg} / \mathrm{l})$ and NESREA $(500 \mathrm{mg} / \mathrm{l})$. Statistical analysis shows that there is no significant difference $(p<0.05)$ between the mean values of TDS among the industries. This might be due to similar tannery activities involved in the tannery industries at the time of sampling. TDS in the effluents from the tannery industries in Kano, Nigeria was reported to be $1281 \mathrm{mg} / \mathrm{l}$ (Akan et al., 2007). The average values of SS observed in this present study are less than those observed by Mohammed et al. (2017) and Baba et al. 2020)

The mean level of COD (mg/l) observed in TAN1, TAN2 and TAN3 samples seasons were $2372 \pm 938 ; \quad 1406 \pm 208$ and $3532 \pm 1373$ respectively. The order of the mean COD of the samples from the three industries can be arranged as TAN3>TAN1> TAN2. The COD observed in TAN1, TAN2 and TAN3 samples were far above the recommended standard limits of regulating bodies $\mathrm{WHO}(40 \mathrm{mg} / \mathrm{l})$ and NESREA (40 mg/l). Statistical analysis shows that there is no significant difference $(p<0.05)$ in COD among the industries. This might be due to similar tannery activities involved in the tannery industries as at the time of sampling. The Chemical Oxygen demand (COD) is the amount of oxygen, in $\mathrm{mg} / \mathrm{L}$, required for the degradation of the compound of wastewater to occur. In comparison, the average values of COD observed in this present study were higher than that observed by Mohammed et al. (2017) but lower than that observed by Baba et al. (2020).

The mean levels of BOD $(\mathrm{mg} / \mathrm{l})$ observed in TAN1, TAN2 and TAN3 samples were $13.85 \pm 6.42 ; \quad 19.46 \pm 0.50$ and $17.13 \pm 3.14$ respectively. The order of the mean BOD in the samples from the three industries can be arranged as TAN2>TAN3>TAN1. The BOD observed in TAN1, TAN2 and TAN3 samples were found below the recommended limits of NESREA (200 mg/l) but above WHO (10 mg/l). Statistical analysis shows that there is no significant difference $(p<0.05)$ between the mean values of BOD among the industries. This might be due to similar tannery activities involved in the tannery industries at the time of sampling. The low level of BOD recorded in this study is an indication of the low level of biodegradable organic solids in the effluent. The average values of BOD observed in this present study were lower than those observed by Mohammed et al. (2017) and Baba et al. (2020).

Table 1: Mean Values \pm S.D of Physico-chemical parameters of effluents from the Tannery Industries before Treatment.

\begin{tabular}{llllllll}
\hline Parameter & Tannery 1 & Tannery 2 & Tannery 3 & $\mathrm{a}$ & $\mathrm{b}$ & $\mathrm{c}$ & $\mathrm{d}$ \\
\cline { 2 - 7 } Temperature $\left({ }^{\circ} \mathrm{C}\right)$ & $28.07 \mathrm{a} \pm 0.65$ & $27.77 \mathrm{a} \pm 0.64$ & $26.38 \mathrm{a} \pm 3.81$ & & $29.50 \pm 4.68$ & 35 & 40 \\
pH & $7.77 \mathrm{a} \pm 2.93$ & $8.35 \mathrm{a} \pm 0.28$ & $7.52 \mathrm{a} \pm 0.76$ & 6.89 & $5.35 \pm 1.57$ & $7.0-8.5$ & $6.0-9.0$ \\
$\mathrm{COD}(\mathrm{mg} / \mathrm{l})$ & $2372 \mathrm{a} \pm 938$ & $1406 \mathrm{a} \pm 208$ & $3532 \mathrm{a} \pm 1373$ & 2.2 & $3106 \pm 2753$ & 40 & 40 \\
$\mathrm{BOD}(\mathrm{mg} / \mathrm{l})$ & $13.85 \mathrm{a} \pm 6.42$ & $19.46 \mathrm{a} \pm 0.50$ & $17.13 \mathrm{a} \pm 3.14$ & 1032 & $26.17 \pm 9.49$ & 10 & 200 \\
$\mathrm{SS}(\mathrm{mg} / \mathrm{l})$ & $374 \mathrm{a} \pm 124$ & $358 \mathrm{a} \pm 335$ & $780 \mathrm{a} \pm 739$ & 501 & $562 \pm 482$ & 30 & 10 \\
TDS $(\mathrm{mg} / \mathrm{l})$ & $3941 \mathrm{a} \pm 3703$ & $3300 \mathrm{a} \pm 1714$ & $2653 \mathrm{a} \pm 1240$ & 532.7 & $444 \pm 507$ & 250 & 500 \\
\hline
\end{tabular}

The values given in the table above are means of 6 replicate values, $\mathrm{n}=6$ ( 1 sample was taken monthly for 6 months). Within the rows, means with different alphabets are statistically different $(p<0.05)$. WHO: World Health Organisation. NESREA: National Environmental Standard and Regulatory Enforcement Agency. a = Mohammed et al.(2017), b = Baba et al. (2020), c = WHO (2006), $d=$ NESSRA (2009) 
BAJOPAS Volume 13 Number 2, December, 2020

Identification, Biochemical Characterization and growth rates of the Bacterial Isolates

Results of identification and biochemical characterization of the bacterial isolates were shown in table 2. After 24 hours of incubation, the nutrient agar media plates were checked for bacterial growth. The results showed the presence of different strains in the samples. The TAN1 bacteria isolate was found to be gramnegative cocci while TAN3 was gram-positive cocci. TAN2 bacteria isolate was found to be gram-positive, rod-shaped. TAN1, TAN2, and TAN3 bacteria isolates recorded positive results for spore former.

The results of the biochemical tests indicated that all the bacteria were positive for catalase, oxidase, citrate, maltose, glucose, lactose (negative in TAN1), mannitol (negative in TAN2), starch hydrolysis and coagulase (negative in TAN2) tests. The bacteria showed negative results for nitrate reduction, $M R$ (positive in TAN2), VP (positive in TAN1), Indole (positive in TAN2) tests. Base on the morphological and biochemical test results, TAN1, TAN2, and TAN3 bacteria isolates were identified to be Nesseria spp, Bacillus cereus, and Staphylococcus aureus respectively.

The growth rate of the TAN1, TAN2 and TAN3 Isolates were shown in figure 2. Generally, the optical density increase with the increase in time (day) and decrease as time goes on. The highest optical density was shown by bacillus cereus in TAN2 while the lowest was shown by Staphylococcus aureus in TAN3.

The initial growth phase of TAN1 Isolate bacteria occurred within 2-day of incubation as the growth rate increases up to the 6th-day incubation when the maximum growth was observed. Beyond the 6th day, the growth of the bacteria declined (which might be due to a shortage of nutrients in the effluents) until it reached its death phase (which might be due to the unavailability of nutrients in the effluents).

A similar trend of growth was also observed for TAN2 Isolate as the initial growth phase also occurred within 2-day of incubation but maximum growth rate observed on the 4th day of incubation. The stationary stage occurred between the 4th day and the 8th day. Beyond the 8th day, the growth of the bacteria declined (which might be due to a shortage of nutrients in the effluents) until it reached its death phase (which might be due to the unavailability of nutrients in the effluents).

The initial growth phase of TAN3 bacterial Isolate occurred within the 3-day incubation as the growth rate increases up to the 6th-day incubation when the maximum growth was observed. Beyond the 6th day, the growth of the bacteria declined (which might be due to a shortage of nutrients in the effluents) until it reached its death phase (which might be due to the unavailability of nutrients in the effluents).

Table 2: Morphological and Biochemical characteristics of bacterial isolates

\begin{tabular}{lllll} 
Bacterial Isolates & & TAN1 & TAN2 & TAN3 \\
\hline $\begin{array}{lllll}\text { Morphological } \\
\text { characteristics }\end{array}$ & Shape & Cocci & Rod & Cocci \\
& Spore & & & \\
& former & + & + & + \\
Gram & & & \\
Biochemical characteristics & reaction & - & + & + \\
& Citrate & + & + & + \\
& Catalase & + & + & + \\
& Coagulase & + & - & + \\
Starch & + & + & + \\
& Glucose & + & + & + \\
Oxidase & + & + & + \\
& Indo & - & + & - \\
Lactose & - & + & + \\
Manitol & + & - & + \\
Maltose & + & + & + \\
MR & - & + & - \\
VP & + & - & - \\
& Nitrate & - & - & - \\
Reduction & - Neisseria & Bacillus & Staphylococcus \\
& Bacterial & cereus & aureus \\
& name & spp & cas
\end{tabular}

+ = Positive; - = Negative; MR=Methyl Red; VP= Voges-Proskauer 


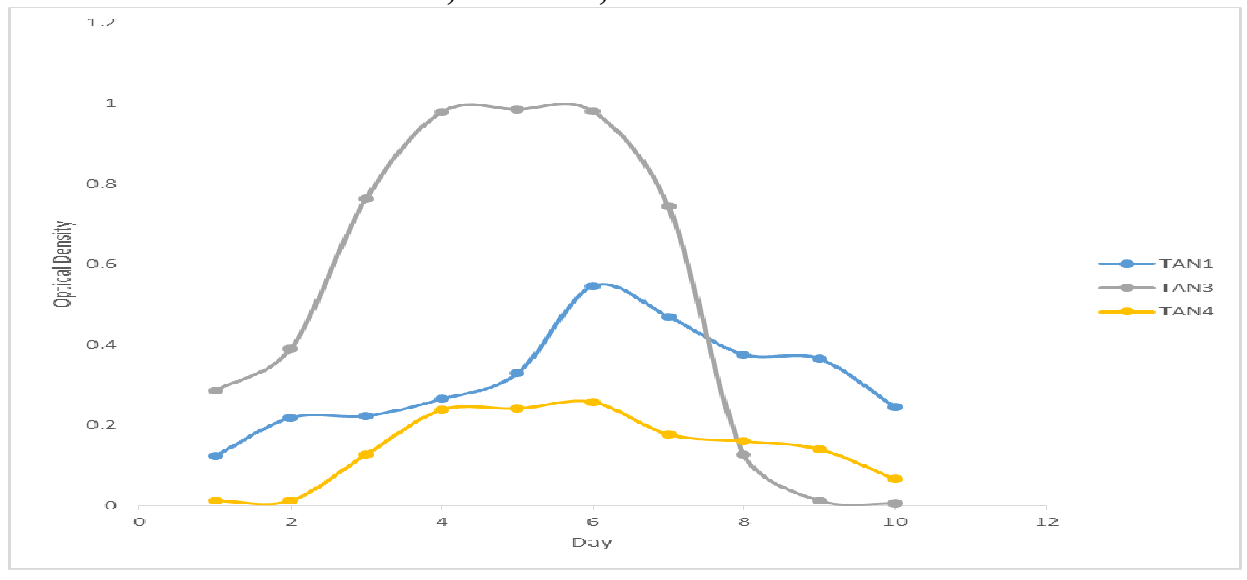

Fig. 2 Growth rates of the isolates in the effluents from the Tannery Industries

\section{Physico-chemical Parameters in the Industrial Effluents after the biodegradation.}

Table 3 shows the mean results of the physicochemical parameter before and after bioremediation using the different masses $(5 \mathrm{~g}$, $10 \mathrm{~g}, 15 \mathrm{~g}, 20 \mathrm{~g}$, and $25 \mathrm{~g}$ ) of the respective immobilized bacteria. Also, Table 4 shows the mean results of correlation coefficient ( $r$ ) between different masses of bacteria and physicochemical parameters.

The mean values $(\mathrm{mg} / \mathrm{l})$ of the SS after the bioremediation varies between $243 \pm 45$ and $898 \pm 672$. The mean concentration $(\mathrm{mg} / \mathrm{l})$ of SS remediated by the different masses $(5 \mathrm{~g}, 10 \mathrm{~g}$, $15 \mathrm{~g}, 20 \mathrm{~g}$, and $25 \mathrm{~g}$ ) of the bacteria varies. The SS in the samples fluctuates up and down after the bioremediation process when compared with the SS of the raw samples before the bioremediation. The increase in the levels of the SS might be due to the aggregation of the TDS which are large enough to result into SS. The increase in the levels of the SS might be also due to the influence of the nutrients which was added into the effluents in order to make the microorganisms more active and viable for fast degradation of organic contaminants in the effluent. The relative potential or efficiency of the different masses of the bacteria in remediating SS in TAN1 samples was in the order $25 \mathrm{~g}>20 \mathrm{~g}>15 \mathrm{~g}>10 \mathrm{~g}>5 \mathrm{~g}$. For TAN2 and TAN3 samples, the order was $25 \mathrm{~g}>20 \mathrm{~g}>15$ $\mathrm{g}>10 \mathrm{~g}>5 \mathrm{~g}$. These might be due to the variations in the surface areas of the different masses of the immobilized bacteria. Statistical analysis shows that there is no significant difference $(p<0.05)$ between the mean values of SS among the masses in the respective industries. Positive and significant correlations exist between the masses of bacteria and Suspended Solid (SS). This showed that there is general increase in the levels of the SS as the masses of the immobilized bacteria increases. TAN3 (90\%) and TAN1 (80\%) showed a very high correlation with the masses of the bacteria while TAN2 (61\%) showed a very low correlation.

The mean values $(\mathrm{mg} / \mathrm{l})$ of the TDS after the bioremediation varies between $46 \pm 11$ and $83 \pm 78$. The mean concentration $(\mathrm{mg} / \mathrm{l})$ of TDS remediated by the different masses $(5 \mathrm{~g}, 10 \mathrm{~g}$, $15 \mathrm{~g}, 20 \mathrm{~g}$, and $25 \mathrm{~g}$ ) of the bacteria varies. There is a reduction in all the TDS of all the samples after the bioremediation process compared with the TDS of the raw samples before the bioremediation. The relative potential or efficiency of the different masses of the bacteria in remediating TDS in TAN1 and TAN3 samples was in the order $5 \mathrm{~g}>10 \mathrm{~g}>15 \mathrm{~g}>20$ $\mathrm{g}>25 \mathrm{~g}$. For TAN2 samples, the order was 20 $g>10 \quad g>25 \quad g>15 \quad g>5 \quad g$. Statistical analysis shows that there is no significant difference $(p<0.05)$ between the mean values of TDS among the masses in the respective industries. These might be due to the variations in the surface areas of the different masses of the immobilized bacteria. Positive and significant correlations exist between the masses of bacteria and TDS with the exception in TAN2 (negative and insignificant correlation). The positive correlations showed that there is general increase in the levels of the TDS as the masses of the immobilized bacteria increases. TAN1 $(96 \%)$ showed a very high correlation with the masses of the bacteria while TAN2 (47\%) showed a very low correlation.

The mean values $(\mathrm{mg} / \mathrm{l})$ of the BOD after the bioremediation varies between $1.56 \pm 0.20 \mathrm{mg} / \mathrm{l}$ and $6.92 \pm 5.49 \mathrm{mg} / \mathrm{l}$. The mean concentration $(\mathrm{mg} / \mathrm{l})$ of BOD remediated by the different masses $(5 \mathrm{~g}, 10 \mathrm{~g}, 15 \mathrm{~g}, 20 \mathrm{~g}$, and $25 \mathrm{~g}$ ) of the bacteria varies. There is a reduction in all the BOD of all the samples after the bioremediation process compared with the $\mathrm{BOD}$ of the raw 
BAJOPAS Volume 13 Number 2, December, 2020 samples before the bioremediation. The relative potential or efficiency of the different masses of the bacteria in remediating BOD in TAN1, TAN2 and TAN3 samples were in the order $25 \mathrm{~g}>20$ $\mathrm{g}>15 \mathrm{~g}>10 \mathrm{~g}>5 \mathrm{~g}, 25 \mathrm{~g}>15 \mathrm{~g}>5 \mathrm{~g}>10 \mathrm{~g}>20 \mathrm{~g}$ and $20 \mathrm{~g}>10 \mathrm{~g}>25 \mathrm{~g}>15 \mathrm{~g}>5 \mathrm{~g}$ respectively. Statistical analysis shows that there is significant difference $(p<0.05)$ between the mean values of BOD among the masses in the respective industries. These might be due to the variations in the surface areas of the different masses of the immobilized bacteria. Negative and significant correlations exist between the masses of bacteria and BOD. This showed that there is general decrease in the levels of the BOD as the masses of the immobilized bacteria increases. TAN1 (94\%) showed a very high correlation with the masses of the bacteria while TAN2 (4\%) showed a very low correlation.

The mean values $(\mathrm{mg} / \mathrm{l})$ of the COD after the bioremediation varies between $250 \pm 154$ and $3134 \pm 1595$. The mean concentration $(\mathrm{mg} / \mathrm{l})$ of COD remediated by the different masses $(5 \mathrm{~g}$, $10 \mathrm{~g}, 15 \mathrm{~g} 20 \mathrm{~g}$, and $25 \mathrm{~g}$ ) of the bacteria varies. There is a reduction in all the COD of all the samples after the bioremediation process compared with the COD of the raw samples before the bioremediation. The relative potential or efficiency of the different masses of the bacteria in remediating COD in TAN1, TAN2 and TAN3 samples were in the order $25 \mathrm{~g}>20 \mathrm{~g}>15$ $\mathrm{g}>5 \mathrm{~g}>10 \mathrm{~g}, 25 \mathrm{~g}>20 \mathrm{~g}>15 \mathrm{~g}>10 \mathrm{~g}>5 \mathrm{~g}$ and 10 g>5 g>25 g>15 g>20 g respectively. Statistical analysis shows that there were significant difference $(p<0.05)$ between the mean values of COD among the masses in the respective industries except for effluents treated with $25 \mathrm{~g}$. These might be due to the variations in the surface areas of the different masses of the immobilized bacteria. Negative and insignificant correlations exist between the masses of bacteria and COD with the exception in TAN3 (positive and significant correlation). The negative correlations showed that there is general decrease in the levels of the COD as the masses of the immobilized bacteria increases. TAN2 (100\%) showed a very high correlation with the masses of the bacteria while TAN3 (36\%) showed a very low correlation.

Generally, there was an overall decrease in the concentration of these physicochemical parameters after the bioremediation using the different masses of the bacterial isolates. These might be due to the variations in the surface areas of the different masses of the immobilized bacteria. This is in line with the work of Jimoh et al. (2018) and Baba et al. (2020).

Table 3: Mean Values $(\mathrm{mg} / \mathrm{l}) \pm$ S.D of Physicochemical parameters in effluents from the Tannery Industries before and after Treatment of the effluents $(250 \mathrm{ml})$ with the different masses $(5 \mathrm{~g}, 10 \mathrm{~g}$, $15 \mathrm{~g}, 20 \mathrm{~g}$, and $25 \mathrm{~g}$ ) of the bacteria.

\begin{tabular}{llllllll}
\hline $\mathrm{P}$ & IND & Before & \multicolumn{5}{c}{ After } \\
\cline { 4 - 7 } & & & $5 \mathrm{~g}$ & $10 \mathrm{~g}$ & $15 \mathrm{~g}$ & $20 \mathrm{~g}$ & $25 \mathrm{~g}$ \\
\hline \multirow{2}{*}{ COD } & TAN1 & $2372 \pm 938$ & $1708 \mathrm{a} \pm 861$ & $2045 \mathrm{a} \pm 1205$ & $845 \mathrm{a} \pm 369$ & $300 \mathrm{a} \pm 167$ & $250 \mathrm{a} \pm 154$ \\
& TAN2 & $1406 \pm 208$ & $1195 \mathrm{a} \pm 208$ & $1125 \mathrm{a} \pm 384$ & $1055 \mathrm{a} \pm 317$ & $956 \mathrm{a} \pm 310$ & $870 \mathrm{ab} \pm 240$ \\
& TAN3 & $3532 \pm 1373$ & $2374 \mathrm{a} \pm 1344$ & $1976 \mathrm{a} \pm 1405$ & $2757 \mathrm{a} \pm 1266$ & $3134 \mathrm{a} \pm 1595$ & $2614 \mathrm{~b} \pm 1105$ \\
BOD & TAN1 & $13.85 \pm 6.42$ & $6.92 \mathrm{a} \pm 5.49$ & $6.42 \mathrm{a} \pm 5.07$ & $5.72 \mathrm{a} \pm 5.35$ & $4.62 \mathrm{a} \pm 4.37$ & $2.82 \mathrm{ab} \pm 1.26$ \\
& TAN2 & $19.46 \pm 0.50$ & $1.75 \mathrm{~b} \pm 0.22$ & $1.73 \mathrm{~b} \pm 0.18$ & $1.58 \mathrm{a} \pm 0.16$ & $1.91 \mathrm{a} \pm 0.22$ & $1.56 \mathrm{~b} \pm 0.20$ \\
& TAN3 & $17.13 \pm 3.14$ & $4.24 \mathrm{ab} \pm 0.77$ & $3.29 \mathrm{ab} \pm 0.37$ & $4.11 \mathrm{a} \pm 0.07$ & $3.23 \mathrm{a} \pm 0.91$ & $3.33 \mathrm{a} \pm 1.28$ \\
SS & TAN1 & $374 \pm 124$ & $243 \mathrm{a} \pm 45$ & $471 \mathrm{a} \pm 226$ & $475 \mathrm{a} \pm 182$ & $492 \mathrm{a} \pm 128$ & $611 \mathrm{a} \pm 217$ \\
& TAN2 & $358 \pm 335$ & $460 \mathrm{a} \pm 400$ & $543 \mathrm{a} \pm 414$ & $544 \mathrm{a} \pm 402$ & $551 \mathrm{a} \pm 414$ & $554 \mathrm{a} \pm 405$ \\
& TAN3 & $780 \pm 739$ & $586 \mathrm{a} \pm 594$ & $758 \mathrm{a} \pm 656$ & $787 \mathrm{a} \pm 676$ & $861 \mathrm{a} \pm 635$ & $898 \mathrm{a} \pm 672$ \\
TDS & TAN1 & $3941 \pm 3703$ & $51 \mathrm{a} \pm 10$ & $53 \mathrm{a} \pm 10$ & $55 \mathrm{a} \pm 15$ & $61 \mathrm{a} \pm 20$ & $63 \mathrm{a} \pm 26$ \\
& TAN2 & $3300 \pm 1714$ & $83 \mathrm{a} \pm 78$ & $47 \mathrm{a} \pm 20$ & $48 \mathrm{a} \pm 22$ & $47 \mathrm{a} \pm 17$ & $48 \mathrm{a} \pm 17$ \\
& TAN3 & $2653 \pm 1240$ & $46 \mathrm{a} \pm 11$ & $55 \mathrm{a} \pm 24$ & $55 \mathrm{a} \pm 25$ & $58 \mathrm{a} \pm 23$ & $61 \mathrm{a} \pm 28$ \\
\hline
\end{tabular}

Replicate $=6$ (months)

Within the rows, for the same parameter, means with different alphabets are statistically different $(p<0.05)$.

$\mathrm{P}=$ parameter, IND = Industries 
BAJOPAS Volume 13 Number 2, December, 2020

Table 4: Correlation coefficient $(r)$ between different masses of the bacteria and the physicochemical parameters.

\begin{tabular}{llll}
\hline Industries & Parameter & Correlation coefficient $(r)$ & $\begin{array}{l}\text { Percent dependence (rxrx100) } \\
(\%)\end{array}$ \\
\hline TAN1 & COD & -0.9 & 82 \\
& BOD & -0.97 & 94 \\
& SS & $0.90^{*}$ & 80 \\
TAN2 & TDS & $0.98^{*}$ & 96 \\
& COD & -1 & 100 \\
& BOD & -0.21 & 4 \\
& SS & $0.78^{*}$ & 61 \\
& TDS & -0.69 & 47 \\
& COD & $0.60^{*}$ & 36 \\
& BOD & -0.6 & 37 \\
& SS & $0.95^{*}$ & 90 \\
& TDS & $0.94^{*}$ & 89 \\
\hline
\end{tabular}

The correlation coefficient $(r)$ with * is statistically significant $(p<0.05)$.

Percentage reduction of the Parameters

Table 5 shows the percentage reduction of Parameters in industrial samples before and after the treatment of the effluents $(250 \mathrm{ml})$ with the different masses $(5 \mathrm{~g}, 10 \mathrm{~g}, 15 \mathrm{~g}, 20 \mathrm{~g}$, and $25 \mathrm{~g}$ ) of the Immobilized Bacteria.

In TAN1 samples, the percentage reduction (\%) of COD ranged (14-89); BOD (50-80); SS (-32$35)$ and TDS (98-99). In TAN2 samples, the percentage decrease $(\%)$ of COD ranged (15$38) ;$ BOD (90-92); SS [-28-(-55)] and TDS (9798). In TAN3 samples, the percentage decrease (\%) of COD ranged (11-44); BOD (76-81); SS (15-25) and TDS (98). The percentage increase in the levels COD, BOD and TDS might be due to the increase in the surface area of the different masses of the immobilized bacteria. However, the percentage decrease in the levels of the SS might be due to the aggregation of the TDS which are large enough to result into SS. The percentage decrease in the levels of the SS might be also due to the influence of the nutrients which was added into the effluents in order to make the microorganisms more active and viable for fast degradation of organic contaminants in the effluent. This is in line with the work of Jimoh et al. (2018) in which the concentration of the SS increase after the bioremediation of effluents.

Sreemoyee and Priti (2013) assessed and reduced several Physico-chemical parameters of dairy wastewater using Niesseria $s p$. and concluded that the species are well known to degrade organic compounds. This is in agreement with the current study in which the immobilized Niesseria $s p$ degrade the organic contaminants as indicated by the BOD, COD and TDS.

Jimoh et al. (2018) observed that TSS of the effluents was increased after treatment with immobilized bacteria and concluded that it might be due to the biostimulation method adopted for the research.

The optimum $\mathrm{pH}$ Biosorption of Chromium by Bacillus spp and Staphylococcus spp. from tannery effluent was investigated by Mythili and Karthikeyan (2011). The maximum adsorption of Chromium $(86.4 \mathrm{mg} / \mathrm{L})$ was showed by Bacillus spp and Staphylococcus spp showed $70.6 \mathrm{mg} / \mathrm{L}$ at an initial concentration of $100 \mathrm{mg} / \mathrm{L}$. In the present study, immobilised Bacillus spp and Staphylococcus spp. from the tannery industrial effluents reduced the levels of the organic pollutants with high potential as indicated by the percentage reduction of BOD, COD and TDS.

Enzymes often can work in multiple environments especially if they are immobilized. This makes the microorganisms' enzymes even more resistant to harsh environments and enables the enzymes to be recovered and recycled after they are no longer needed (Gianfreda and Rao 2004). Ramesh and Singh (1993) reported that the immobilized bacteria having more efficiency to remove the suspended particles than free cells. Using the immobilized cell is preferable due to its capability for using several times with the same efficiency, which makes it more economical. Similar work was done by Sikander et al. (2007) showing the higher reduction with permeabilized cells of Ochrobactrum intermedium strain SDCr-5. 
BAJOPAS Volume 13 Number 2, December, 2020

The results revealed the isolation and identification of isolates with the potential for the reduction of $\mathrm{Cr}$ (VI) to $\mathrm{Cr}$ (III). Results indicated that immobilized $B$. cereus could be efficiently used for the reduction of $\mathrm{Cr}$ (VI).

Table 5: Percentage reduction of the tested Parameters from the tannery industrial samples of the Immobilized Bacteria.

\begin{tabular}{lllllll}
\hline \multirow{2}{*}{ Industries } & & \multicolumn{5}{c}{ Percentage Reduction $(\%)$} \\
\cline { 3 - 7 } & & $5 \mathrm{~g}$ & $10 \mathrm{~g}$ & $15 \mathrm{~g}$ & $20 \mathrm{~g}$ & $25 \mathrm{~g}$ \\
\hline TAN1 & COD & 28 & 14 & 64 & 87 & 89 \\
& BOD & 50 & 54 & 59 & 67 & 80 \\
& SS & 35 & -26 & -27 & -32 & -63 \\
& TDS & 99 & 99 & 99 & 98 & 98 \\
TAN2 & COD & 15 & 20 & 25 & 32 & 38 \\
& BOD & 91 & 91 & 92 & 90 & 92 \\
& SS & -28 & -52 & -52 & -54 & -55 \\
& TDS & 97 & 99 & 99 & 99 & 99 \\
& COD & 33 & 44 & 22 & 11 & 26 \\
& BOD & 75 & 81 & 76 & 81 & 81 \\
& SS & 25 & 3 & -1 & -10 & -15 \\
& TDS & 98 & 98 & 98 & 98 & 98 \\
\hline
\end{tabular}

Percentage Reduction $=(B-A) / B \times 100 \%$

$A=$ Concentration of the parameter after treatment

$\mathrm{B}=$ Concentration of the parameter before treatment

$+=$ percentage decrease

- = percentage increase

In general, immobilization makes the enzyme more resistant to temperature, $\mathrm{pH}$, and substrate concentration swings giving it a longer lifetime and higher productivity per active unit (Gianfreda and Rao, 2004; FuIlbrook, 1996; Russell et al, 2003; Kandelbauer et al., 2004). Immobilized cells have been used and studied extensively for the production of useful chemicals (Ohtake and Silver, 1994), the treatment of wastewaters (Chen et al., 2003; Wang et al., 2010). Although many workers described microbial degradation of tannery effluent, limited literature is available on the bioremediation of tannery effluent using immobilized bacterial cells in the Kano Industrial Estates.

\section{CONCLUSION}

The samples contained variable levels of the physicochemical parameters. The results of the Analysis of variance revealed that, no statistical difference $(p<0.05)$ was observed for the temperature, $\mathrm{pH}, \mathrm{SS}, \mathrm{TDS}, \mathrm{BOD}$ and $\mathrm{COD}$ among the three tannery industries before the treatment. The levels of some of the parameters
(SS, TDS and COD) observed in the samples were found above the recommended limits of WHO and NESREA, which called for the treatment of the effluents before discharge into the environment. Base on the morphological and biochemical test results, TAN1, TAN2, and TAN3 bacterial isolates were identified to be Neisseria spp, Bacillus cereus, and Staphylococcus aureus respectively. The results of Post-treatment analysis showed that there is overall decrease in the levels of the parameters determined when compared with that of the pre-treatment. The overall percentage reduction of the immobilised bacteria in the treatment of the respective effluents was in the order TAN2 (72\%)>TAN1 $(70 \%)>$ TAN3 $(62 \%)$. Hence, the immobilized bacteria are having higher biodegradation potential for the treatment of the tannery effluents.

\section{Acknowledgments}

The authors wish to acknowledge the University of Maiduguri for the financial support. The authors are grateful to the Kano State Ministry of Environment for their support in obtaining the effluent samples. 


\section{REFERENCES}

Ajao, A. T., Adebayo, G. B., and Yakubu, S. E. (2011). Bioremediation of textile industrial effluent using mixed culture of Pseudomonas aeruginosa and Bacillus subtilis immobilized on agar-agar in a bioreactor. J. Microbiol. Biotech. Res, 1(3), 50-56.

Akan, J. C., Moses, E. A., Ogugbuaja, V. O., and Abah, J. (2007). Assessment of tannery industrial effluents from Kano metropolis, Kano State, Nigeria. Journal of Applied Sciences, 7(19), 2788-2793.

Akan, J. C., Ogugbuaja, V. O., Abdulrahman, F. I., and Ayodele, J. T. (2009). Pollutant levels in effluent samples from tanneries and textiles of Kano industrial areas, Nigeria. Global journal of pure and applied sciences, 15(3-4).

APHA (1989). Standard methods for Examination of Will bete and Will betewater.15 $5^{\text {th }}$ edition. Brydpass Springfield Will behington DC. pp. 164-176

APHA (1992). Standard Methods for the Examination of Water and Wastewater. Health, 69, 1116-9.

Baba, A., Garba, S. T., and Bello, H. S. (2020). Bioremediation Potential of Immobilized corynebacterium kutsceri in the Treatment of Tannery Industrial Effluent from Challawa Industrial Estate, Kano State, Nigeria. Journal of the Turkish Chemical Society Section A: Chemistry, $7(2), 335-350$.

Beem, E. I. V. (1994). reduction of solvent VOC emission. J. Oil Col. Chem. Ass, 77, 158.

Bouwer, E. J., and Zehnder, A. J. (1993). Bioremediation of organic compoundsputting microbial metabolism to work. Trends in biotechnology, 11(8), 360367.

Chen, K. C., Wu, J. Y., Liou, D. J., and Hwang, S. C. J. (2003). Decolorization of the textile dyes by newly isolated bacterial strains. Journal of Biotechnology, 101(1), 57-68.

Dan'Azumi, S., and Bichi, M. H. (2010). INDUSTRIAL POLLUTION AND HEAVY METALS PROFILE OF CHALLAWA RIVER IN KANO, NIGERIA. Journal of Applied Sciences in Environmental Sanitation, $5(1)$.

DWAF. (1992). Analytical Methods Manual, TR 151. Department of Water Affairs and Forestry, Pretoria.

El-Bestawy, E. (2013). Biological treatment of leather-tanning industrial wastewater using free living bacteria.
Elsheikh, M. A. S. (2009). Tannery wastewater pre-treatment. Water Science and Technology, 60(2), 433-440.

FuIlbrook, P. D. (1996). "Kinetics." Industrial enzymology: The application of enzymes in Industry. 2nd Ed. T. Godfrey and J Reichelt. eds.. Nature. New York.

Gianfreda, L., and Rao, M. A. (2004). Potential of extra cellular enzymes in remediation of polluted soils: a review. Enzyme and microbial technology, 35(4), 339354.

Hugo Springer. (1994). John Arthur Wilson Memorial Lecture "Treatment of Industrial Wastes of the Leather Industry - is it still a Major Problem". JALCA, 89, 153-185

Jimoh, A. A., Ganiyu, B. A., Baba, D., and Baba, A. (2018) Bioremediation Process of Effluent from Detergent and Food Industries in Jos, Nigeria: Kinetics and Thermodynamics. International Journal of Engineering Science Invention (IJESI), 762-73

Kandelbauer, A., Maute, O., Kessler, R. W., Erlacher, A., and Gübitz, G. M. (2004). Study of dye decolorization in an immobilized laccase enzyme-reactor using online spectroscopy. Biotechnology and bioengineering, 87(4), 552-563.

Kongjao, S., Damronglerd, S., and Hunsom, M. (2008). Simultaneous removal of organic and inorganic Pollutants in tannery wastewater using electrocoagulation technique. Korean Journal of chemical engineering, 25(4), 703.

Maheshwari, U. M., Aruna, S., Gomathi, M., and AbdulJaffar, A. H. (2017). Bioremediation by Free and Immobilized Bacteria Isolated from Tannery Effluent. International Journal of Research in Applied, Natural and Social Sciences. 5(7), 75-90

Margesin, R., and Schinner, F. (2001). Bioremediation (natural attenuation and biostimulation) of diesel-oilcontaminated soil in an alpine glacier skiing area. Applied and environmental microbiology, 677), 3127-3133.

Mohammed, A., Sekar, P., and George, J. (2011). Efficacy of microbes in bioremediation of tannery effluent. Inter. J. Curr. Res, 3(4), 324-326.

Mohammed, S. S. D., Orukotan, A. A., and Abdullahi, H. (2017). Physicochemical and Bacteriological Assessment of Tannery Effluent from Samaru-Zaria, 
BAJOPAS Volume 13 Number 2, December, 2020 Kaduna State, Nigeria. Journal of Applied

Sciences and Environmental Management, 21(4), 734-740.

Munz, G., De Angelis, D., Gori, R., Mori, G., Casarci, M., and Lubello, C. (2009). The role of tannins in conventional and membrane treatment of tannery wastewater. Journal of hazardous materials, 164(2-3), 733-739

Mythili, K., and Karthikeyan, B. (2011). Bioremediation of $\mathrm{Cr}$ (VI) from tannery effluent using Bacillus spp and Staphylococcus spp. International Multidisciplinary Research Journal, 1(6).

NESREA (2009). National Environmental Standards for Effluent Limitations and Regulation. 1233-1236

Noorjahan, C. M. (2014). Physicochemical characteristics, identification of bacteria and biodegradation of industrial effluent. Journal of bioremediation and Biodegradation, 5(3).

Ohtake, H. I., and Silver, A. O. (1994). Bacterial reduction of toxic chromate. Biological degradation and bioremediation of toxic chemicals, 403-415.

Omoleke, I. I. (2004). Management of environmental pollution in Ibadan, an African city: the challenges of health hazard facing government and the people. Journal of Human Ecology, 15(4), 265-275.

Rajor, A., Reddy, A.S., and Singh, B. (2004). Determination of BOD kinetic Parameters and evaluation of alternate methods, M.Sc. Thesis, Department of biotechnology \& environmental Science, Thapar Institute of Engineering and Technology, Patiala

Ramasami, T., Rajamani, S., and Rao, J. R. (1994, March). Pollution control in leather industry: Emerging technological options. In International symposium on surface and colloidal science and its relevance to soil pollution, madras.

Ramesh, J. V. S., and Singh, S. P. (1993). Yearly variation in certain physicochemical parameters of pond at eastern Doon Valley. Uttar Pradesh J. Zoo, 12 (1), 7577.

Ranen, S., and Sharadinadra, C. (2009). Biotechnology applications to environmental remediation in resource exploitation. Current science, 97, 6-25
Russell, A. J., Berberich, J. A., Drevon, G. F., and Koepsel, R. R. (2003). Biomaterials for mediation of

chemical and biological warfare agents. Annual review of biomedical engineering, 5(1), 1-27.

Saravanan, P., and Saravanan, A. (1999). Decolourization of tannery effluent by Flavobacterium sp. EK 1. Indian Journal of Environmental Protection, 19, 19-24.

Sikander, S., and Shahida, H. (2007). Reduction of toxic hexavalent chromium by Ochrobactrum intermedium strain SDCr5 stimulated by heavy metals. Bioresource Technol, 98, 340-344.

Singh, N., Sharma, B. K., and Bohra, P. C. (2000). Impact assessment of industrial effluent of arid soils by using satellite imageries. Journal of the Indian Society of Remote Sensing, 28(2-3), 79.

Sreemoyee, C., and Priti, P. (2013). Assessment of physico-chemical parameters of dairy waste water and isolation and characterization of bacterial strains in terms of cod reduction. Int J Sci, 2(3), 395-400.

Verheijen, L. A. H. M., Wiersema, D., Pol, L. H., and De Wit, J. (1996). Management of wastes from animal product processing. Livestock and environment, Finding a balance. International Agriculture Center, Wageningen, The Netherlands.

Wang, F., Yao, J., Si, Y., Chen, H., Russel, M., Chen, K., and Bramanti, E. (2010). Short-time effect of heavy metals upon microbial community activity. Journal of Hazardous Materials, 173(13), 510-516.

WHO (World Health Organization). (2006). Air quality guidelines: global update 2005: particulate matter, ozone, nitrogen dioxide, and sulfur dioxide. World Health Organization.

World Bank. (1995). Nigeria's strategic options for redressing industrial pollution. World Bank, industry and energy division. 1st edition, West Central Africa Department; Annexes: 1995; pp 60-62.

Zahoor, A., and Abdul, R. (2009). Enumeration of Coliforms. Journal of Environmental Sciences. 21, 814-820 


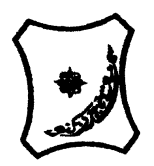

Bayero Journal of Pure and Applied Sciences, 13(2): 1 - 12

Received: November, 2020

Accepted: December, 2020

ISSN $2006-6996$

\title{
BIODEGRADATION POTENTIAL OF IMMOBILIZED BACTERIA IN THE TREATMENT OF TANNERY INDUSTRIAL EFFLUENTS FROM INDUSTRIAL ESTATES IN KANO STATE, NIGERIA
}

\author{
Abdullateef, B., ${ }^{1 *}$ Shuaibu, T. G., ${ }^{1}$ Babagana, K., ${ }^{1}$ Suleman, H. B. ${ }^{2}$ and Dauda, B. ${ }^{3}$ \\ ${ }^{1}$ Department of Pure and Applied Chemistry, Faculty of Science, University of Maiduguri, Borno State, \\ Nigeria \\ ${ }^{2}$ Department of Microbiology, Faculty of Science, University of Maiduguri, Borno State, Nigeria \\ ${ }^{3}$ Department of Chemical Engineering, Faculty of Engineering, University of Maiduguri, Borno State, \\ Nigeria \\ *Corresponding author: babslega@gmail.com; abelega2007@yahoo.com; +2348061309753
}

\section{ABSTRACT}

Industrial Effluents Samples from Gashash Tanneries (TAN1) in Bompai Industrial estate, Larabee Tannery Industry (TAN2) in Sharada Industrial estate and Z Tannery Industries (TAN3) in Challawa Industrial estate, Kano State, Nigeria were collected over a period of six months (August 2017 to January 2018) for assessing the biodegradation potentials of bacteria in the treatment of organic pollutants within the effluents. Bacteria were isolated from the effluents and immobilized on agar-agar. Different masses (5 g, $10 \mathrm{gr}, 15$ $\mathrm{g}, 20 \mathrm{~g}$, and $25 \mathrm{~g}$ ) of the bacteria were used in the treatment of $250 \mathrm{ml}$ of the effluents for ten days in a shaker incubator (Gallenkamp-OC-4364-L) at the temperature $30{ }^{\circ} \mathrm{C}$ and speed of $60 \mathrm{rpm}$. Pre-treatment analysis of the effluents for Temperature, pH, Biochemical Oxygen Demand (BOD), Chemical Oxygen Demand (COD), Suspended Solid (SS) and Total Dissolved Solids (TDS) gives the following results; temperature $\left({ }^{\circ} \mathrm{C}\right.$ )

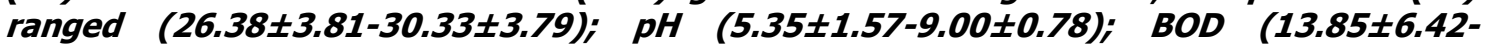
$38.75 \pm 16.20) ;$ COD (1406 $\pm 208-3532 \pm 1373) ;$ SS (208 $\pm 235-780 \pm 739)$ and TDS (266 $\pm 253-5276 \pm 2971)$. No statistical differences ( $p \leq 0.05)$ was observed for all the results among the different industries. The bacterial isolates were identified as Neisseria spp, Bacillus cereus, and Staphylococcus aureus, in TAN1, TAN2, and TAN3, respectively. After treatment of the effluent with the different masses of the isolated bacteria, the mean level of BOD was found to range as (0.55 $\pm 0.36-6.92 \pm 5.49) ; C O D$ (ND-3134 \pm 1595$)$;

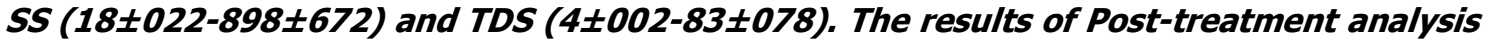
showed that there is overall decrease in the levels of the parameters determined when compared with that of the pre-treatment. The overall percentage reduction of the immobilised bacteria in the treatment of the respective effluents was in the order TAN2 (72\%)>TAN1 (70\%)>TAN3 (62\%). Hence, the immobilized bacteria are having higher biodegradation potential for the treatment of the tannery effluents.

Keywords: Biodegradation, bacteria, effluent, immobilization, tannery.

\section{INTRODUCTION}

Tannery industrial wastewater is a serious consequence of the pollution point of view for streams, freshwater, and land used for agriculture. The lack of awareness in the modern industrial practice has resulted in the discharge of tannery effluents which exhibit very high value of chromium ( $\mathrm{Cr}$ ), Sulfide, and chloride, Total Dissolved Solid (TDS), Total Suspended Solid (TSS), Biochemical Oxygen Demand (BOD) and Chemical Oxygen Demand (COD) in the water stream or land (Mohammed et al., 2001). Tanning is the process, which One ton of skin generally leads to the production of 20 to $80 \mathrm{~m}^{3}$ of turbid and foul-smelling converts the protein of the rawhide or skin into a stable material, which will not putrefy and is suitable for a wide variety of end applications (Elsheikh, 2009). The highly polluting chromium is the most commonly used tanning material producing leather that is more flexible and pliable than vegetable-tanned leather and does not discolor or lose shape in water as drastically as vegetable-tan (Elsheikh, 2009). Tannery effluent is among the most hazardous industrial pollutants due to its huge organic and inorganic load, which is highly toxic to human life and the environment (Kongjao et al., 2008). wastewater including chromium (100-400 mg/l), sulfide $(200-800 \mathrm{mg} / \mathrm{l})$, high levels of fat and 
BAJOPAS Volume 13 Number 2, December, 2020 other solid wastes, and notable pathogen contamination as well as pesticides added for skin conservation during transport (Elsheikh, 2009). There are more than 6000 tanneries in Nigeria with an annual processing capacity of 700,000 tons of hides and skins (Omoleke, 2004; Singh et al., 2008). It was reported that the total amount of waste produced per animal slaughtered is approximately $35 \%$ of its weight (World Bank, 1995). Also, for every $1000 \mathrm{~kg}$ of carcass weight, a slaughtered beef produces 5.5 $\mathrm{kg}$ of manure (excluding rumen contents or stockyard manure) and $100 \mathrm{~kg}$ of paunch manure (undigested food) (Verheijen et al., 1996). Tanneries generate wastewater in the range of 30-35 $\mathrm{L} \mathrm{kg}^{-1}$ skin/hide processed with variable $\mathrm{pH}$, Biological Oxygen Demand (BOD), Chemical Oxygen Demand (COD), high concentrations of suspended solids (SS), and tannins as well as chromium (Zahoor and Abdul, 2009).

Being heterogeneous and composed of a wide variety of compounds, it is very difficult to select a unique direct method for estimating the biodegradability of organic contents and biokinetic parameters for a wastewater sample (Rajor, 2004). For this purpose, some indirect estimation such as determination of biochemical oxygen demand (BOD) and chemical oxygen demand (COD) are applied as common laboratory investigations [9]. During retanning procedures, synthetic tannins (Syntan), oils and resins are added to form softer leather at varying doses (Munz et al., 2009). One of the refractory groups of chemicals in tannery effluents derives mainly from tannins (Ramasami et al., 2004). Syntans are characterized by complex chemical structures, because they are composed of an extended set of chemicals such as phenol-, naphthalene-, formaldehyde- and melamine-based syntans, and acrylic resins (Beem, 1994). Organic pollutants (proteic and lipidic components) are originated from skins (it is calculated that the raw skin has $30 \%$ loss of organic material during the working cycle) or they are introduced during processes (Hugo Springer, 1994).

Many conventional processes such as oxidation, chemical and biological processes were carried out to treat tanneries wastewater (Ebtesam et al, 2013). Biological processes have received more attention because of their costeffectiveness, lower sludge production and environmental friendliness (Noorjahan, 2014). Naturally occurring micro-organisms degrade the hazardous organic wastes including xenobiotic compounds, such as pesticides, polycyclic aromatic hydrocarbons (PAHs) and polychlorinated biphenyls (PCBs) in due course of time (Ranen and Sharadinadra, 2009). Bioremediation is based on the idea that all organisms remove substances from the environment to carry outgrowth and metabolism (Bouwer and Zehnder, 1993). Bacteria, protista and fungi are found to be very good at degrading complex molecules and incorporating the breakdown products into their metabolism (Bouwer and Zehnder, 1993). The resultant metabolic wastes that they produce are generally safe and somehow recycled into other organisms (Ranen and Sharadinadra, 2009). An acclimatized indigenous population of microorganisms capable of degradation of the compounds of interest must exist at the site for a successful bioremediation mode (Ranen and Sharadinadra, 2009). It has been observed that for a successful bioremediation mode, an acclimatized indigenous population of microorganisms capable of degradation of the compounds of interest must exist at the site under investigation (Ranen and Sharadinadra, 2009). Even though there are numerous physical and chemical methods employed in the disposal of wastes the advantage in using bacterium is that they play a key role in the reduction of COD, BOD, total protein, total tannin and total phenol (Saravanan and Saravanan, 1998)

Baba et al. (2020) studied the bioremediation potential of immobilized corynebacterium kutsceri in the Treatment of tannery industrial effluent from Challawa Industrial Estate, Kano State, Nigeria. The aim of the work is to study the reduction in the level of the contaminants through the process of bioremediation using the isolated bacteria. Immobilized bacteria can withstand various temperatures, $\mathrm{pH}$ and substrate concentrations; consequently, increasing the efficiency and the lifespan of the bacteria. Immobilized bacteria are widely applied in the treatment of wastewater and can be separated and recovered after the treatment with the same efficiency (Baba et al., 2020).

\section{MATERIALS AND METHODS \\ Study Area}

This study was carried out in Bompai, Sharada and Challawa industrial estates in Kano, Figure 1. Kano lies on Latitude $11^{\circ} 30^{\prime} \mathrm{N}$ and $8^{\circ} 30^{\prime} \mathrm{E}$ and Longitude $11^{\circ} 5^{\prime} \mathrm{N}$ and $8^{\circ} 5^{\prime} \mathrm{E}$ in Northern Nigeria. It is one of the developed industrial cities in Nigeria. Tannery activities are the dominating industries and this could be one of the reasons for her high population density (Dan'Azumi and Bichi, 2010). Many researchers have studied biodegradation of tannery effluent using microorganisms. However, limited literature is available on the biodegradation of tannery effluent in Kano industrial estates using 
BAJOPAS Volume 13 Number 2, December, 2020 immobilized bacterial cells. This research work focuses on the potential of the use of the indigenous immobilized bacterial isolates in the treatment of tannery effluents in the industrial estates.

\section{Sample Collection}

Effluents were collected from the Tannery Industries from Bompai, Challawa and Sharada Industrial Estates, Kano, Nigeria. The effluents were collected over a period of six months (August 2017 to January 2018). Samples collected in a sterile 4-liter plastic container with a unique identification number were preserved using an ice-box that was transported to the Microbiology Laboratory, Department of Microbiology, Bayero University of Kano for analysis

\section{Sample Preparation and Sample Analysis}

Immediately after the collection of the effluent, $\mathrm{pH}$, TSS, TDS, COD, BOD levels were determined before treatment (Pre-treatment determination) and ten days after treatment (Post-treatment determination) as described in
APHA (1989) standard methods. $\mathrm{pH}$ was determined using Ecotests $\mathrm{pH}$ meter and TDS was determined using AQUALYTIC TDS Salinometer. BOD was determined as described by the standard method (APHA, 1992). COD and SS were determined using DR/2010 HACH portable data logging spectrophotometer (DWAF, 1992)

\section{Identification and Biochemical} Characterization of the Bacterial Isolates

The bacteria were isolated from the effluents using Serial Dilution according to the method described by APHA (1989). The biochemical tests such as oxidase, catalase, coagulase, indole (from $1 \%$ tryptone broth), citrate (Simmons citrate agar), methyl red/VogesProskauer (MR/VP), nitrate reduction, Starch Hydrolysis, Glucose, Maltose, and Lactose tests were carried out on the bacterial isolates to identify the bacteria through the bacteria biochemical characteristics according to Ajao et al. (2011).

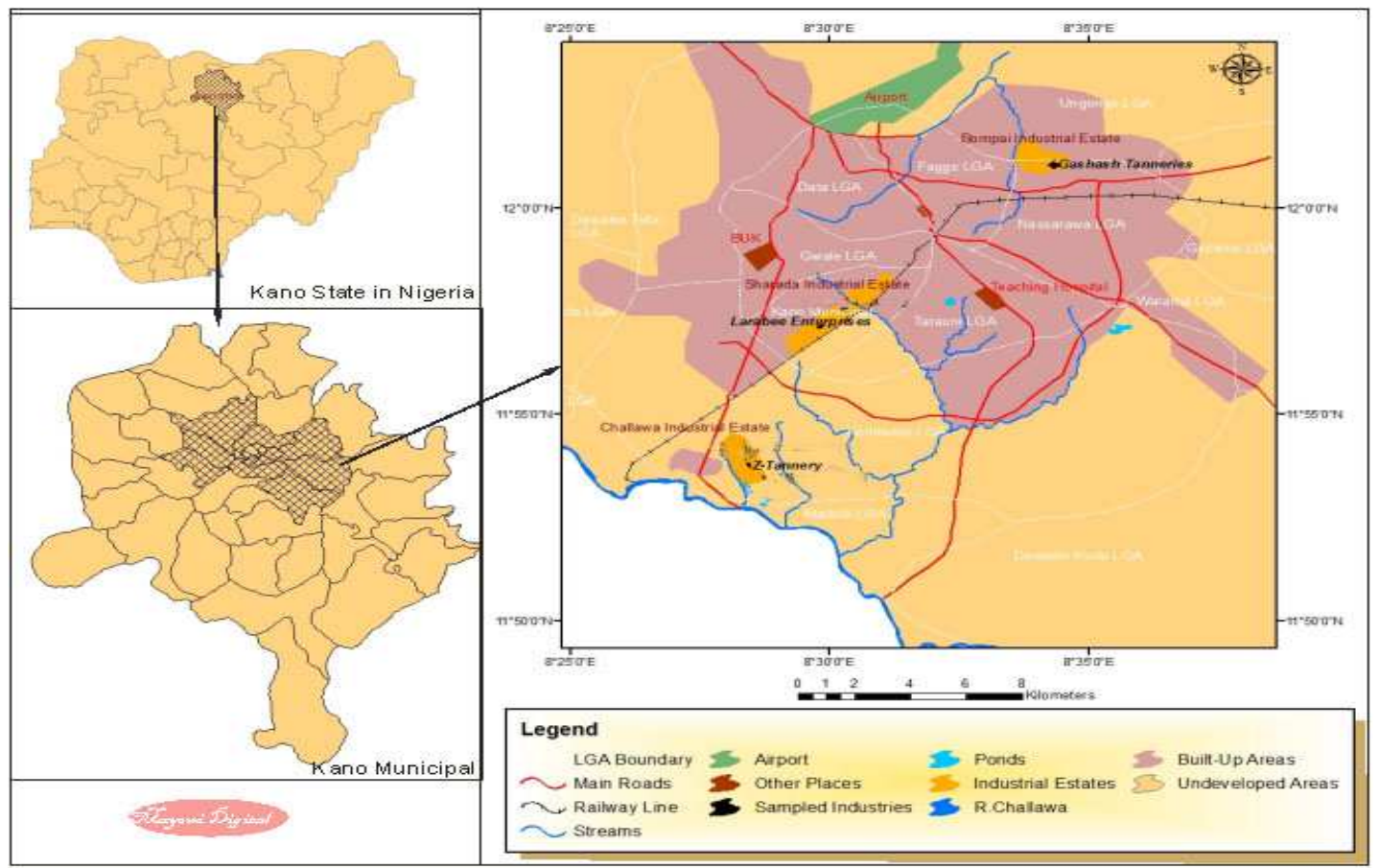

Fig. 1 Map showing the study areas

Source: Mayomi Digital Productions, GIS Laboratory, Department of Geography, UNIMAID (2017)

\section{Determination of Growth Rate of the Bacteria in Effluent Sample}

The bacteria growth rates were determined by transferring $2 \mathrm{~mL}$ of the bacterial isolates from the tannery effluent in broth medium into 100 $\mathrm{mL}$ sterile effluents in conical flasks and kept in an incubator (Giffrin cool) for 10 days. Control was also set up by incubating another $100 \mathrm{~mL}$ each of the sterile effluents without the bacteria. The optical density of the content was determined at the wavelength of $600 \mathrm{~nm}$ on a daily interval and recorded. 
BAJOPAS Volume 13 Number 2, December, 2020 Immobilization of Bacteria

Agar solution and inoculi were prepared separately. Fifty milliliters $(50 \mathrm{~mL})$ of nutrient broth each of the inoculi was prepared in a McCartney bottle and incubated for 24 hours. A solution of agar-agar was prepared by dissolving $10 \mathrm{~g}$ of the powder in distilled water and made up to $500 \mathrm{~mL}$ mark in an Erlenmeyer flask and was sterilized in an autoclave (280A) for 15 minutes and allowed to cool to $40-45^{\circ} \mathrm{C}$ (Ajao et al., 2011). Four milliliters ( $4 \mathrm{~mL})$ of the bacterial isolates in the nutrient broth was mixed with 36 $\mathrm{ml}$ of the prepared agar-agar media in petri-dish plates and then allowed to solidify. This was kept in the refrigerator for bioremediation.

\section{Bioremediation (Treatment) of the Effluents}

The solidified agar block (immobilized bacteria) was cut into cubes using a sterile knife; $0.1 \mathrm{~mL}$ phosphate buffer ( $\mathrm{pH} \mathrm{7.0)}$ was added and kept in the refrigerator for 1 hour for curing. The phosphate buffer was decanted after 1 hour and the cubes were washed with sterile distilled water 3-4 times before it was used (Ajao et al., 2011). Two liters (2 L) of the effluent was supplemented with the minimum basal medium in $\mathrm{g} / \mathrm{L}: \mathrm{NaCl}(0.8), \mathrm{MgSO}_{4} .7 \mathrm{H}_{2} \mathrm{O}(0.001), \mathrm{KH}_{2} \mathrm{PO}_{4}$ (2), $\mathrm{NaNO}_{3}$ (2), $\quad \mathrm{CaCl}_{2} .2 \mathrm{H}_{2} \mathrm{O} \quad(0.5)$ and $\mathrm{NaHPO}_{4} .12 \mathrm{H}_{2} \mathrm{O}(2)$ and sterilized in an autoclave at $121^{\circ} \mathrm{C}$ for 15 minutes (Margesin and Schinner, 2001). Two hundred and fifty milliliters $(250 \mathrm{~mL})$ of the effluents were transferred into different $250 \mathrm{ml}$ conical flasks. The content was covered with a cotton-wool ramped with foil paper to avoid contamination. Five grams $(5 \mathrm{~g})$ of the immobilized bacteria were quickly transferred into each of the effluents in the conical flasks in an inoculating chamber. The same procedures were carried out for the $10 \mathrm{~g}, 15 \mathrm{~g}, 20 \mathrm{~g}$ and 25 $\mathrm{g}$ of the immobilized bacteria in separate $250 \mathrm{~mL}$ effluents in conical flasks and agitated for ten days in a shaker incubator (Gallenkamp-OC4364-L) at a temperature $30^{\circ} \mathrm{C}$ and speed of 60 rpm. The treated effluent samples were taken on the tenth day and analyzed for the parameters $\mathrm{pH}$, SS, TDS, COD, and BOD, (Posttreatment determination) for the different grams of bacteria to evaluate and compare the biodegradation potential. (Baba et al., 2020).

\section{Statistical Analysis}

The data were represented as Mean \pm Standard deviation and analyzed statistically using oneway Analysis of Variance (ANOVA) and Tukey's HSD as Post Hoc Tests with the aid of SPSS 16.0. The correlation coefficient was also used to measure the strength of the relationship between the different masses of the bacteria and the parameters. All $\mathrm{p} \leq 0.05$ were considered as statistically significant.

\section{RESULTS AND DISCUSSION Physico-chemical parameters in the Industrial Effluents before the Biodegradation.}

Results of the Physico-chemical parameters in the industrial effluents before the Biodegradation is shown in table 1 . The mean temperatures $\left({ }^{\circ} \mathrm{C}\right)$ observed in TAN1, TAN2, and TAN3 samples were $28.07 \pm 0.65 ; 27.77 \pm 0.64$ and $26.38 \pm 3.81$ respectively. The order of the mean temperature of the samples from the three industries can be arranged as TAN1 > TAN2>TAN3. The temperature observed at TAN1, TAN2, and TAN3 samples were found below the WHO $\left(35^{\circ} \mathrm{C}\right)$ and NESREA $\left(40^{\circ} \mathrm{C}\right)$ limits. The low values of temperature might be due to the processes used at the time of sampling. High temperature brings down the solubility of gases in water that ultimately expresses as high BOD and COD. Statistical analysis shows that there is no significant difference $(p<0.05)$ between the mean values of temperature among the industries. This might be due to similar tannery activities involved in the tannery industries at the time of sampling. The average values of temperature observed in this present study are less than those observed by Akan et al. (2007), Akan et al. (2009) and Baba et al. (2020).

The mean level of $\mathrm{pH}$ observed in TAN1, TAN2 and TAN3, samples were $7.77 \pm 2.93$; $8.35 \pm 0.28$ and $7.52 \pm 0.76$ respectively. The order of the mean $\mathrm{pH}$ of the samples from the three industries can be arranged as TAN2> TAN1 $>$ TAN3. The $\mathrm{pH}$ of the samples falls within the WHO (7.0-8.5) and NESREA (6-9) standard limits. Statistical analysis shows that there is no significant difference $(p<0.05)$ between the mean values of $\mathrm{pH}$ among the industries. This might be due to similar tannery activities involved in the tannery industries at the time of sampling. Maheshwari et al. (2017) reported that the level of $\mathrm{pH}$ in the effluents from the tannery industry in Vaniyambadi, India was 6.5 which was lower than that observed in the present study. The $\mathrm{pH}$ in the effluents from the tannery industries in Kano and Kaduna were reported to be 7.64 and 6.89, respectively (Akan et al., 2007; Mohammed et al., 2017). The average values of $\mathrm{pH}$ observed in this present study are less than those observed by Mohammed et al. (2017) and Baba et al. (2020). The mean level of SS $(\mathrm{mg} / \mathrm{l})$ observed in TAN1, TAN2, and TAN3 samples were 374 \pm 124 ; $358 \pm 335$ and $780 \pm 739$ respectively. The order of the mean SS in the samples from the three industries can be arranged as TAN3 > TAN1 $>$ TAN2. 
The SS observed in the samples were far above the recommended standard limits of regulating bodies WHO $(30 \mathrm{mg} / \mathrm{l})$ and NESREA $(10 \mathrm{mg} / \mathrm{l})$. Statistical analysis shows that there is no significant difference $(p<0.05)$ between the mean values of SS among the industries. This might be due to similar tannery activities involved in the tannery industries at the time of sampling. The average values of SS observed in this present study are less than that observed $(3700 \pm 122 \mathrm{mg} / \mathrm{l})$ by Akan et al. (2009) for tanneries in Kano. Also, the average values of SS observed in this present study are less than that observed by Mohammed et al. (2017) and Baba et al. (2020) with the exception in TAN3.

The mean level of TDS (mg/l) observed in TAN1, TAN2, and TAN3 samples were $3941 \pm 3703$; $3300 \pm 1714$ and $2653 \pm 1240$ respectively. The order of the mean TDS in the samples from the three industries can be arranged as TAN1>TAN2>TAN3. The TDS observed in the samples were far above the recommended standard limits of WHO $(250 \mathrm{mg} / \mathrm{l})$ and NESREA $(500 \mathrm{mg} / \mathrm{l})$. Statistical analysis shows that there is no significant difference $(p<0.05)$ between the mean values of TDS among the industries. This might be due to similar tannery activities involved in the tannery industries at the time of sampling. TDS in the effluents from the tannery industries in Kano, Nigeria was reported to be $1281 \mathrm{mg} / \mathrm{l}$ (Akan et al., 2007). The average values of SS observed in this present study are less than those observed by Mohammed et al. (2017) and Baba et al. 2020)

The mean level of COD (mg/l) observed in TAN1, TAN2 and TAN3 samples seasons were $2372 \pm 938 ; \quad 1406 \pm 208$ and $3532 \pm 1373$ respectively. The order of the mean COD of the samples from the three industries can be arranged as TAN3>TAN1> TAN2. The COD observed in TAN1, TAN2 and TAN3 samples were far above the recommended standard limits of regulating bodies $\mathrm{WHO}(40 \mathrm{mg} / \mathrm{l})$ and NESREA (40 mg/l). Statistical analysis shows that there is no significant difference $(p<0.05)$ in COD among the industries. This might be due to similar tannery activities involved in the tannery industries as at the time of sampling. The Chemical Oxygen demand (COD) is the amount of oxygen, in $\mathrm{mg} / \mathrm{L}$, required for the degradation of the compound of wastewater to occur. In comparison, the average values of COD observed in this present study were higher than that observed by Mohammed et al. (2017) but lower than that observed by Baba et al. (2020).

The mean levels of BOD $(\mathrm{mg} / \mathrm{l})$ observed in TAN1, TAN2 and TAN3 samples were $13.85 \pm 6.42 ; \quad 19.46 \pm 0.50$ and $17.13 \pm 3.14$ respectively. The order of the mean BOD in the samples from the three industries can be arranged as TAN2>TAN3>TAN1. The BOD observed in TAN1, TAN2 and TAN3 samples were found below the recommended limits of NESREA (200 mg/l) but above WHO (10 mg/l). Statistical analysis shows that there is no significant difference $(p<0.05)$ between the mean values of BOD among the industries. This might be due to similar tannery activities involved in the tannery industries at the time of sampling. The low level of BOD recorded in this study is an indication of the low level of biodegradable organic solids in the effluent. The average values of BOD observed in this present study were lower than those observed by Mohammed et al. (2017) and Baba et al. (2020).

Table 1: Mean Values \pm S.D of Physico-chemical parameters of effluents from the Tannery Industries before Treatment.

\begin{tabular}{llllllll}
\hline Parameter & Tannery 1 & Tannery 2 & Tannery 3 & $\mathrm{a}$ & $\mathrm{b}$ & $\mathrm{c}$ & $\mathrm{d}$ \\
\cline { 2 - 7 } Temperature $\left({ }^{\circ} \mathrm{C}\right)$ & $28.07 \mathrm{a} \pm 0.65$ & $27.77 \mathrm{a} \pm 0.64$ & $26.38 \mathrm{a} \pm 3.81$ & & $29.50 \pm 4.68$ & 35 & 40 \\
pH & $7.77 \mathrm{a} \pm 2.93$ & $8.35 \mathrm{a} \pm 0.28$ & $7.52 \mathrm{a} \pm 0.76$ & 6.89 & $5.35 \pm 1.57$ & $7.0-8.5$ & $6.0-9.0$ \\
$\mathrm{COD}(\mathrm{mg} / \mathrm{l})$ & $2372 \mathrm{a} \pm 938$ & $1406 \mathrm{a} \pm 208$ & $3532 \mathrm{a} \pm 1373$ & 2.2 & $3106 \pm 2753$ & 40 & 40 \\
$\mathrm{BOD}(\mathrm{mg} / \mathrm{l})$ & $13.85 \mathrm{a} \pm 6.42$ & $19.46 \mathrm{a} \pm 0.50$ & $17.13 \mathrm{a} \pm 3.14$ & 1032 & $26.17 \pm 9.49$ & 10 & 200 \\
$\mathrm{SS}(\mathrm{mg} / \mathrm{l})$ & $374 \mathrm{a} \pm 124$ & $358 \mathrm{a} \pm 335$ & $780 \mathrm{a} \pm 739$ & 501 & $562 \pm 482$ & 30 & 10 \\
TDS $(\mathrm{mg} / \mathrm{l})$ & $3941 \mathrm{a} \pm 3703$ & $3300 \mathrm{a} \pm 1714$ & $2653 \mathrm{a} \pm 1240$ & 532.7 & $444 \pm 507$ & 250 & 500 \\
\hline
\end{tabular}

The values given in the table above are means of 6 replicate values, $\mathrm{n}=6$ ( 1 sample was taken monthly for 6 months). Within the rows, means with different alphabets are statistically different $(p<0.05)$. WHO: World Health Organisation. NESREA: National Environmental Standard and Regulatory Enforcement Agency. a = Mohammed et al.(2017), b = Baba et al. (2020), c = WHO (2006), $d=$ NESSRA (2009) 
BAJOPAS Volume 13 Number 2, December, 2020

Identification, Biochemical Characterization and growth rates of the Bacterial Isolates

Results of identification and biochemical characterization of the bacterial isolates were shown in table 2. After 24 hours of incubation, the nutrient agar media plates were checked for bacterial growth. The results showed the presence of different strains in the samples. The TAN1 bacteria isolate was found to be gramnegative cocci while TAN3 was gram-positive cocci. TAN2 bacteria isolate was found to be gram-positive, rod-shaped. TAN1, TAN2, and TAN3 bacteria isolates recorded positive results for spore former.

The results of the biochemical tests indicated that all the bacteria were positive for catalase, oxidase, citrate, maltose, glucose, lactose (negative in TAN1), mannitol (negative in TAN2), starch hydrolysis and coagulase (negative in TAN2) tests. The bacteria showed negative results for nitrate reduction, $M R$ (positive in TAN2), VP (positive in TAN1), Indole (positive in TAN2) tests. Base on the morphological and biochemical test results, TAN1, TAN2, and TAN3 bacteria isolates were identified to be Nesseria spp, Bacillus cereus, and Staphylococcus aureus respectively.

The growth rate of the TAN1, TAN2 and TAN3 Isolates were shown in figure 2. Generally, the optical density increase with the increase in time (day) and decrease as time goes on. The highest optical density was shown by bacillus cereus in TAN2 while the lowest was shown by Staphylococcus aureus in TAN3.

The initial growth phase of TAN1 Isolate bacteria occurred within 2-day of incubation as the growth rate increases up to the 6th-day incubation when the maximum growth was observed. Beyond the 6th day, the growth of the bacteria declined (which might be due to a shortage of nutrients in the effluents) until it reached its death phase (which might be due to the unavailability of nutrients in the effluents).

A similar trend of growth was also observed for TAN2 Isolate as the initial growth phase also occurred within 2-day of incubation but maximum growth rate observed on the 4th day of incubation. The stationary stage occurred between the 4th day and the 8th day. Beyond the 8th day, the growth of the bacteria declined (which might be due to a shortage of nutrients in the effluents) until it reached its death phase (which might be due to the unavailability of nutrients in the effluents).

The initial growth phase of TAN3 bacterial Isolate occurred within the 3-day incubation as the growth rate increases up to the 6th-day incubation when the maximum growth was observed. Beyond the 6th day, the growth of the bacteria declined (which might be due to a shortage of nutrients in the effluents) until it reached its death phase (which might be due to the unavailability of nutrients in the effluents).

Table 2: Morphological and Biochemical characteristics of bacterial isolates

\begin{tabular}{lllll} 
Bacterial Isolates & & TAN1 & TAN2 & TAN3 \\
\hline $\begin{array}{lllll}\text { Morphological } \\
\text { characteristics }\end{array}$ & Shape & Cocci & Rod & Cocci \\
& Spore & & & \\
& former & + & + & + \\
Gram & & & \\
Biochemical characteristics & reaction & - & + & + \\
& Citrate & + & + & + \\
& Catalase & + & + & + \\
& Coagulase & + & - & + \\
Starch & + & + & + \\
& Glucose & + & + & + \\
Oxidase & + & + & + \\
& Indo & - & + & - \\
Lactose & - & + & + \\
Manitol & + & - & + \\
Maltose & + & + & + \\
MR & - & + & - \\
VP & + & - & - \\
& Nitrate & - & - & - \\
Reduction & - Neisseria & Bacillus & Staphylococcus \\
& Bacterial & cereus & aureus \\
& name & spp & cas
\end{tabular}

+ = Positive; - = Negative; MR=Methyl Red; VP= Voges-Proskauer 


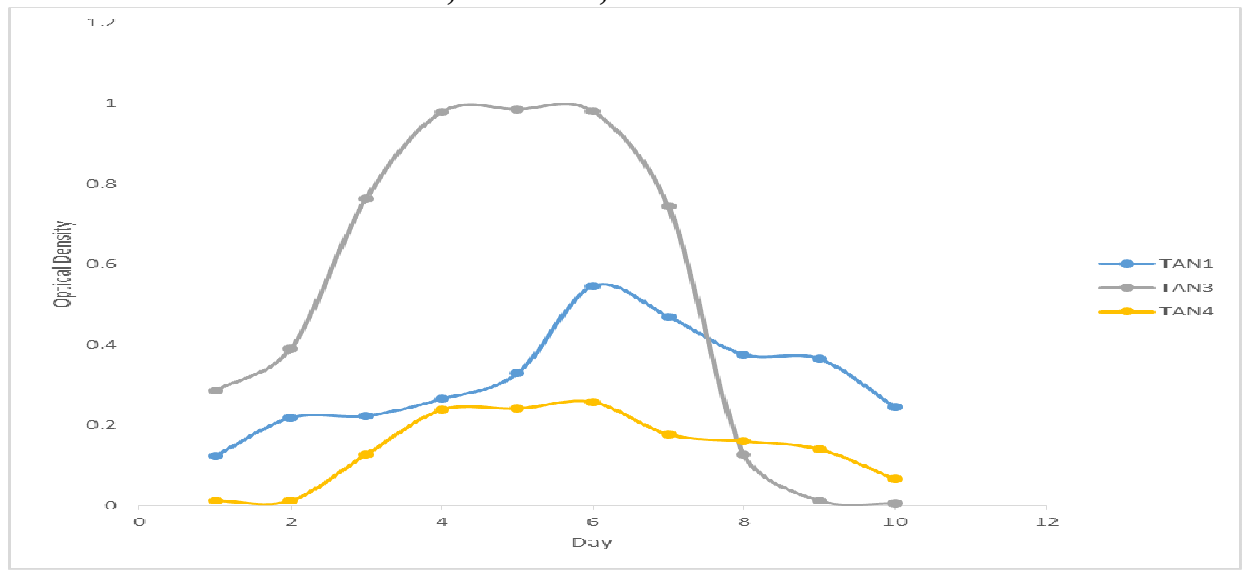

Fig. 2 Growth rates of the isolates in the effluents from the Tannery Industries

\section{Physico-chemical Parameters in the Industrial Effluents after the biodegradation.}

Table 3 shows the mean results of the physicochemical parameter before and after bioremediation using the different masses $(5 \mathrm{~g}$, $10 \mathrm{~g}, 15 \mathrm{~g}, 20 \mathrm{~g}$, and $25 \mathrm{~g}$ ) of the respective immobilized bacteria. Also, Table 4 shows the mean results of correlation coefficient ( $r$ ) between different masses of bacteria and physicochemical parameters.

The mean values $(\mathrm{mg} / \mathrm{l})$ of the SS after the bioremediation varies between $243 \pm 45$ and $898 \pm 672$. The mean concentration $(\mathrm{mg} / \mathrm{l})$ of SS remediated by the different masses $(5 \mathrm{~g}, 10 \mathrm{~g}$, $15 \mathrm{~g}, 20 \mathrm{~g}$, and $25 \mathrm{~g}$ ) of the bacteria varies. The SS in the samples fluctuates up and down after the bioremediation process when compared with the SS of the raw samples before the bioremediation. The increase in the levels of the SS might be due to the aggregation of the TDS which are large enough to result into SS. The increase in the levels of the SS might be also due to the influence of the nutrients which was added into the effluents in order to make the microorganisms more active and viable for fast degradation of organic contaminants in the effluent. The relative potential or efficiency of the different masses of the bacteria in remediating SS in TAN1 samples was in the order $25 \mathrm{~g}>20 \mathrm{~g}>15 \mathrm{~g}>10 \mathrm{~g}>5 \mathrm{~g}$. For TAN2 and TAN3 samples, the order was $25 \mathrm{~g}>20 \mathrm{~g}>15$ $\mathrm{g}>10 \mathrm{~g}>5 \mathrm{~g}$. These might be due to the variations in the surface areas of the different masses of the immobilized bacteria. Statistical analysis shows that there is no significant difference $(p<0.05)$ between the mean values of SS among the masses in the respective industries. Positive and significant correlations exist between the masses of bacteria and Suspended Solid (SS). This showed that there is general increase in the levels of the SS as the masses of the immobilized bacteria increases. TAN3 (90\%) and TAN1 (80\%) showed a very high correlation with the masses of the bacteria while TAN2 (61\%) showed a very low correlation.

The mean values $(\mathrm{mg} / \mathrm{l})$ of the TDS after the bioremediation varies between $46 \pm 11$ and $83 \pm 78$. The mean concentration $(\mathrm{mg} / \mathrm{l})$ of TDS remediated by the different masses $(5 \mathrm{~g}, 10 \mathrm{~g}$, $15 \mathrm{~g}, 20 \mathrm{~g}$, and $25 \mathrm{~g}$ ) of the bacteria varies. There is a reduction in all the TDS of all the samples after the bioremediation process compared with the TDS of the raw samples before the bioremediation. The relative potential or efficiency of the different masses of the bacteria in remediating TDS in TAN1 and TAN3 samples was in the order $5 \mathrm{~g}>10 \mathrm{~g}>15 \mathrm{~g}>20$ $\mathrm{g}>25 \mathrm{~g}$. For TAN2 samples, the order was 20 $g>10 \quad g>25 \quad g>15 \quad g>5 \quad g$. Statistical analysis shows that there is no significant difference $(p<0.05)$ between the mean values of TDS among the masses in the respective industries. These might be due to the variations in the surface areas of the different masses of the immobilized bacteria. Positive and significant correlations exist between the masses of bacteria and TDS with the exception in TAN2 (negative and insignificant correlation). The positive correlations showed that there is general increase in the levels of the TDS as the masses of the immobilized bacteria increases. TAN1 $(96 \%)$ showed a very high correlation with the masses of the bacteria while TAN2 (47\%) showed a very low correlation.

The mean values $(\mathrm{mg} / \mathrm{l})$ of the BOD after the bioremediation varies between $1.56 \pm 0.20 \mathrm{mg} / \mathrm{l}$ and $6.92 \pm 5.49 \mathrm{mg} / \mathrm{l}$. The mean concentration $(\mathrm{mg} / \mathrm{l})$ of BOD remediated by the different masses $(5 \mathrm{~g}, 10 \mathrm{~g}, 15 \mathrm{~g}, 20 \mathrm{~g}$, and $25 \mathrm{~g}$ ) of the bacteria varies. There is a reduction in all the BOD of all the samples after the bioremediation process compared with the $\mathrm{BOD}$ of the raw 
BAJOPAS Volume 13 Number 2, December, 2020 samples before the bioremediation. The relative potential or efficiency of the different masses of the bacteria in remediating BOD in TAN1, TAN2 and TAN3 samples were in the order $25 \mathrm{~g}>20$ $\mathrm{g}>15 \mathrm{~g}>10 \mathrm{~g}>5 \mathrm{~g}, 25 \mathrm{~g}>15 \mathrm{~g}>5 \mathrm{~g}>10 \mathrm{~g}>20 \mathrm{~g}$ and $20 \mathrm{~g}>10 \mathrm{~g}>25 \mathrm{~g}>15 \mathrm{~g}>5 \mathrm{~g}$ respectively. Statistical analysis shows that there is significant difference $(p<0.05)$ between the mean values of BOD among the masses in the respective industries. These might be due to the variations in the surface areas of the different masses of the immobilized bacteria. Negative and significant correlations exist between the masses of bacteria and BOD. This showed that there is general decrease in the levels of the BOD as the masses of the immobilized bacteria increases. TAN1 (94\%) showed a very high correlation with the masses of the bacteria while TAN2 (4\%) showed a very low correlation.

The mean values $(\mathrm{mg} / \mathrm{l})$ of the COD after the bioremediation varies between $250 \pm 154$ and $3134 \pm 1595$. The mean concentration $(\mathrm{mg} / \mathrm{l})$ of COD remediated by the different masses $(5 \mathrm{~g}$, $10 \mathrm{~g}, 15 \mathrm{~g} 20 \mathrm{~g}$, and $25 \mathrm{~g}$ ) of the bacteria varies. There is a reduction in all the COD of all the samples after the bioremediation process compared with the COD of the raw samples before the bioremediation. The relative potential or efficiency of the different masses of the bacteria in remediating COD in TAN1, TAN2 and TAN3 samples were in the order $25 \mathrm{~g}>20 \mathrm{~g}>15$ $\mathrm{g}>5 \mathrm{~g}>10 \mathrm{~g}, 25 \mathrm{~g}>20 \mathrm{~g}>15 \mathrm{~g}>10 \mathrm{~g}>5 \mathrm{~g}$ and 10 g>5 g>25 g>15 g>20 g respectively. Statistical analysis shows that there were significant difference $(p<0.05)$ between the mean values of COD among the masses in the respective industries except for effluents treated with $25 \mathrm{~g}$. These might be due to the variations in the surface areas of the different masses of the immobilized bacteria. Negative and insignificant correlations exist between the masses of bacteria and COD with the exception in TAN3 (positive and significant correlation). The negative correlations showed that there is general decrease in the levels of the COD as the masses of the immobilized bacteria increases. TAN2 (100\%) showed a very high correlation with the masses of the bacteria while TAN3 (36\%) showed a very low correlation.

Generally, there was an overall decrease in the concentration of these physicochemical parameters after the bioremediation using the different masses of the bacterial isolates. These might be due to the variations in the surface areas of the different masses of the immobilized bacteria. This is in line with the work of Jimoh et al. (2018) and Baba et al. (2020).

Table 3: Mean Values $(\mathrm{mg} / \mathrm{l}) \pm$ S.D of Physicochemical parameters in effluents from the Tannery Industries before and after Treatment of the effluents $(250 \mathrm{ml})$ with the different masses $(5 \mathrm{~g}, 10 \mathrm{~g}$, $15 \mathrm{~g}, 20 \mathrm{~g}$, and $25 \mathrm{~g}$ ) of the bacteria.

\begin{tabular}{llllllll}
\hline $\mathrm{P}$ & IND & Before & \multicolumn{5}{c}{ After } \\
\cline { 4 - 7 } & & & $5 \mathrm{~g}$ & $10 \mathrm{~g}$ & $15 \mathrm{~g}$ & $20 \mathrm{~g}$ & $25 \mathrm{~g}$ \\
\hline \multirow{2}{*}{ COD } & TAN1 & $2372 \pm 938$ & $1708 \mathrm{a} \pm 861$ & $2045 \mathrm{a} \pm 1205$ & $845 \mathrm{a} \pm 369$ & $300 \mathrm{a} \pm 167$ & $250 \mathrm{a} \pm 154$ \\
& TAN2 & $1406 \pm 208$ & $1195 \mathrm{a} \pm 208$ & $1125 \mathrm{a} \pm 384$ & $1055 \mathrm{a} \pm 317$ & $956 \mathrm{a} \pm 310$ & $870 \mathrm{ab} \pm 240$ \\
& TAN3 & $3532 \pm 1373$ & $2374 \mathrm{a} \pm 1344$ & $1976 \mathrm{a} \pm 1405$ & $2757 \mathrm{a} \pm 1266$ & $3134 \mathrm{a} \pm 1595$ & $2614 \mathrm{~b} \pm 1105$ \\
BOD & TAN1 & $13.85 \pm 6.42$ & $6.92 \mathrm{a} \pm 5.49$ & $6.42 \mathrm{a} \pm 5.07$ & $5.72 \mathrm{a} \pm 5.35$ & $4.62 \mathrm{a} \pm 4.37$ & $2.82 \mathrm{ab} \pm 1.26$ \\
& TAN2 & $19.46 \pm 0.50$ & $1.75 \mathrm{~b} \pm 0.22$ & $1.73 \mathrm{~b} \pm 0.18$ & $1.58 \mathrm{a} \pm 0.16$ & $1.91 \mathrm{a} \pm 0.22$ & $1.56 \mathrm{~b} \pm 0.20$ \\
& TAN3 & $17.13 \pm 3.14$ & $4.24 \mathrm{ab} \pm 0.77$ & $3.29 \mathrm{ab} \pm 0.37$ & $4.11 \mathrm{a} \pm 0.07$ & $3.23 \mathrm{a} \pm 0.91$ & $3.33 \mathrm{a} \pm 1.28$ \\
SS & TAN1 & $374 \pm 124$ & $243 \mathrm{a} \pm 45$ & $471 \mathrm{a} \pm 226$ & $475 \mathrm{a} \pm 182$ & $492 \mathrm{a} \pm 128$ & $611 \mathrm{a} \pm 217$ \\
& TAN2 & $358 \pm 335$ & $460 \mathrm{a} \pm 400$ & $543 \mathrm{a} \pm 414$ & $544 \mathrm{a} \pm 402$ & $551 \mathrm{a} \pm 414$ & $554 \mathrm{a} \pm 405$ \\
& TAN3 & $780 \pm 739$ & $586 \mathrm{a} \pm 594$ & $758 \mathrm{a} \pm 656$ & $787 \mathrm{a} \pm 676$ & $861 \mathrm{a} \pm 635$ & $898 \mathrm{a} \pm 672$ \\
TDS & TAN1 & $3941 \pm 3703$ & $51 \mathrm{a} \pm 10$ & $53 \mathrm{a} \pm 10$ & $55 \mathrm{a} \pm 15$ & $61 \mathrm{a} \pm 20$ & $63 \mathrm{a} \pm 26$ \\
& TAN2 & $3300 \pm 1714$ & $83 \mathrm{a} \pm 78$ & $47 \mathrm{a} \pm 20$ & $48 \mathrm{a} \pm 22$ & $47 \mathrm{a} \pm 17$ & $48 \mathrm{a} \pm 17$ \\
& TAN3 & $2653 \pm 1240$ & $46 \mathrm{a} \pm 11$ & $55 \mathrm{a} \pm 24$ & $55 \mathrm{a} \pm 25$ & $58 \mathrm{a} \pm 23$ & $61 \mathrm{a} \pm 28$ \\
\hline
\end{tabular}

Replicate $=6$ (months)

Within the rows, for the same parameter, means with different alphabets are statistically different $(p<0.05)$.

$\mathrm{P}=$ parameter, IND = Industries 
BAJOPAS Volume 13 Number 2, December, 2020

Table 4: Correlation coefficient $(r)$ between different masses of the bacteria and the physicochemical parameters.

\begin{tabular}{llll}
\hline Industries & Parameter & Correlation coefficient $(r)$ & $\begin{array}{l}\text { Percent dependence (rxrx100) } \\
(\%)\end{array}$ \\
\hline TAN1 & COD & -0.9 & 82 \\
& BOD & -0.97 & 94 \\
& SS & $0.90^{*}$ & 80 \\
TAN2 & TDS & $0.98^{*}$ & 96 \\
& COD & -1 & 100 \\
& BOD & -0.21 & 4 \\
& SS & $0.78^{*}$ & 61 \\
& TDS & -0.69 & 47 \\
& COD & $0.60^{*}$ & 36 \\
& BOD & -0.6 & 37 \\
& SS & $0.95^{*}$ & 90 \\
& TDS & $0.94^{*}$ & 89 \\
\hline
\end{tabular}

The correlation coefficient $(r)$ with * is statistically significant $(p<0.05)$.

Percentage reduction of the Parameters

Table 5 shows the percentage reduction of Parameters in industrial samples before and after the treatment of the effluents $(250 \mathrm{ml})$ with the different masses $(5 \mathrm{~g}, 10 \mathrm{~g}, 15 \mathrm{~g}, 20 \mathrm{~g}$, and $25 \mathrm{~g}$ ) of the Immobilized Bacteria.

In TAN1 samples, the percentage reduction (\%) of COD ranged (14-89); BOD (50-80); SS (-32$35)$ and TDS (98-99). In TAN2 samples, the percentage decrease $(\%)$ of COD ranged (15$38) ;$ BOD (90-92); SS [-28-(-55)] and TDS (9798). In TAN3 samples, the percentage decrease (\%) of COD ranged (11-44); BOD (76-81); SS (15-25) and TDS (98). The percentage increase in the levels COD, BOD and TDS might be due to the increase in the surface area of the different masses of the immobilized bacteria. However, the percentage decrease in the levels of the SS might be due to the aggregation of the TDS which are large enough to result into SS. The percentage decrease in the levels of the SS might be also due to the influence of the nutrients which was added into the effluents in order to make the microorganisms more active and viable for fast degradation of organic contaminants in the effluent. This is in line with the work of Jimoh et al. (2018) in which the concentration of the SS increase after the bioremediation of effluents.

Sreemoyee and Priti (2013) assessed and reduced several Physico-chemical parameters of dairy wastewater using Niesseria $s p$. and concluded that the species are well known to degrade organic compounds. This is in agreement with the current study in which the immobilized Niesseria $s p$ degrade the organic contaminants as indicated by the BOD, COD and TDS.

Jimoh et al. (2018) observed that TSS of the effluents was increased after treatment with immobilized bacteria and concluded that it might be due to the biostimulation method adopted for the research.

The optimum $\mathrm{pH}$ Biosorption of Chromium by Bacillus spp and Staphylococcus spp. from tannery effluent was investigated by Mythili and Karthikeyan (2011). The maximum adsorption of Chromium $(86.4 \mathrm{mg} / \mathrm{L})$ was showed by Bacillus spp and Staphylococcus spp showed $70.6 \mathrm{mg} / \mathrm{L}$ at an initial concentration of $100 \mathrm{mg} / \mathrm{L}$. In the present study, immobilised Bacillus spp and Staphylococcus spp. from the tannery industrial effluents reduced the levels of the organic pollutants with high potential as indicated by the percentage reduction of BOD, COD and TDS.

Enzymes often can work in multiple environments especially if they are immobilized. This makes the microorganisms' enzymes even more resistant to harsh environments and enables the enzymes to be recovered and recycled after they are no longer needed (Gianfreda and Rao 2004). Ramesh and Singh (1993) reported that the immobilized bacteria having more efficiency to remove the suspended particles than free cells. Using the immobilized cell is preferable due to its capability for using several times with the same efficiency, which makes it more economical. Similar work was done by Sikander et al. (2007) showing the higher reduction with permeabilized cells of Ochrobactrum intermedium strain SDCr-5. 
BAJOPAS Volume 13 Number 2, December, 2020

The results revealed the isolation and identification of isolates with the potential for the reduction of $\mathrm{Cr}$ (VI) to $\mathrm{Cr}$ (III). Results indicated that immobilized $B$. cereus could be efficiently used for the reduction of $\mathrm{Cr}$ (VI).

Table 5: Percentage reduction of the tested Parameters from the tannery industrial samples of the Immobilized Bacteria.

\begin{tabular}{lllllll}
\hline \multirow{2}{*}{ Industries } & & \multicolumn{5}{c}{ Percentage Reduction $(\%)$} \\
\cline { 3 - 7 } & & $5 \mathrm{~g}$ & $10 \mathrm{~g}$ & $15 \mathrm{~g}$ & $20 \mathrm{~g}$ & $25 \mathrm{~g}$ \\
\hline TAN1 & COD & 28 & 14 & 64 & 87 & 89 \\
& BOD & 50 & 54 & 59 & 67 & 80 \\
& SS & 35 & -26 & -27 & -32 & -63 \\
& TDS & 99 & 99 & 99 & 98 & 98 \\
TAN2 & COD & 15 & 20 & 25 & 32 & 38 \\
& BOD & 91 & 91 & 92 & 90 & 92 \\
& SS & -28 & -52 & -52 & -54 & -55 \\
& TDS & 97 & 99 & 99 & 99 & 99 \\
& COD & 33 & 44 & 22 & 11 & 26 \\
& BOD & 75 & 81 & 76 & 81 & 81 \\
& SS & 25 & 3 & -1 & -10 & -15 \\
& TDS & 98 & 98 & 98 & 98 & 98 \\
\hline
\end{tabular}

Percentage Reduction $=(B-A) / B \times 100 \%$

$A=$ Concentration of the parameter after treatment

$\mathrm{B}=$ Concentration of the parameter before treatment

$+=$ percentage decrease

- = percentage increase

In general, immobilization makes the enzyme more resistant to temperature, $\mathrm{pH}$, and substrate concentration swings giving it a longer lifetime and higher productivity per active unit (Gianfreda and Rao, 2004; FuIlbrook, 1996; Russell et al, 2003; Kandelbauer et al., 2004). Immobilized cells have been used and studied extensively for the production of useful chemicals (Ohtake and Silver, 1994), the treatment of wastewaters (Chen et al., 2003; Wang et al., 2010). Although many workers described microbial degradation of tannery effluent, limited literature is available on the bioremediation of tannery effluent using immobilized bacterial cells in the Kano Industrial Estates.

\section{CONCLUSION}

The samples contained variable levels of the physicochemical parameters. The results of the Analysis of variance revealed that, no statistical difference $(p<0.05)$ was observed for the temperature, $\mathrm{pH}, \mathrm{SS}, \mathrm{TDS}, \mathrm{BOD}$ and $\mathrm{COD}$ among the three tannery industries before the treatment. The levels of some of the parameters
(SS, TDS and COD) observed in the samples were found above the recommended limits of WHO and NESREA, which called for the treatment of the effluents before discharge into the environment. Base on the morphological and biochemical test results, TAN1, TAN2, and TAN3 bacterial isolates were identified to be Neisseria spp, Bacillus cereus, and Staphylococcus aureus respectively. The results of Post-treatment analysis showed that there is overall decrease in the levels of the parameters determined when compared with that of the pre-treatment. The overall percentage reduction of the immobilised bacteria in the treatment of the respective effluents was in the order TAN2 (72\%)>TAN1 $(70 \%)>$ TAN3 $(62 \%)$. Hence, the immobilized bacteria are having higher biodegradation potential for the treatment of the tannery effluents.

\section{Acknowledgments}

The authors wish to acknowledge the University of Maiduguri for the financial support. The authors are grateful to the Kano State Ministry of Environment for their support in obtaining the effluent samples. 


\section{REFERENCES}

Ajao, A. T., Adebayo, G. B., and Yakubu, S. E. (2011). Bioremediation of textile industrial effluent using mixed culture of Pseudomonas aeruginosa and Bacillus subtilis immobilized on agar-agar in a bioreactor. J. Microbiol. Biotech. Res, 1(3), 50-56.

Akan, J. C., Moses, E. A., Ogugbuaja, V. O., and Abah, J. (2007). Assessment of tannery industrial effluents from Kano metropolis, Kano State, Nigeria. Journal of Applied Sciences, 7(19), 2788-2793.

Akan, J. C., Ogugbuaja, V. O., Abdulrahman, F. I., and Ayodele, J. T. (2009). Pollutant levels in effluent samples from tanneries and textiles of Kano industrial areas, Nigeria. Global journal of pure and applied sciences, 15(3-4).

APHA (1989). Standard methods for Examination of Will bete and Will betewater.15 $5^{\text {th }}$ edition. Brydpass Springfield Will behington DC. pp. 164-176

APHA (1992). Standard Methods for the Examination of Water and Wastewater. Health, 69, 1116-9.

Baba, A., Garba, S. T., and Bello, H. S. (2020). Bioremediation Potential of Immobilized corynebacterium kutsceri in the Treatment of Tannery Industrial Effluent from Challawa Industrial Estate, Kano State, Nigeria. Journal of the Turkish Chemical Society Section A: Chemistry, $7(2), 335-350$.

Beem, E. I. V. (1994). reduction of solvent VOC emission. J. Oil Col. Chem. Ass, 77, 158.

Bouwer, E. J., and Zehnder, A. J. (1993). Bioremediation of organic compoundsputting microbial metabolism to work. Trends in biotechnology, 11(8), 360367.

Chen, K. C., Wu, J. Y., Liou, D. J., and Hwang, S. C. J. (2003). Decolorization of the textile dyes by newly isolated bacterial strains. Journal of Biotechnology, 101(1), 57-68.

Dan'Azumi, S., and Bichi, M. H. (2010). INDUSTRIAL POLLUTION AND HEAVY METALS PROFILE OF CHALLAWA RIVER IN KANO, NIGERIA. Journal of Applied Sciences in Environmental Sanitation, $5(1)$.

DWAF. (1992). Analytical Methods Manual, TR 151. Department of Water Affairs and Forestry, Pretoria.

El-Bestawy, E. (2013). Biological treatment of leather-tanning industrial wastewater using free living bacteria.
Elsheikh, M. A. S. (2009). Tannery wastewater pre-treatment. Water Science and Technology, 60(2), 433-440.

FuIlbrook, P. D. (1996). "Kinetics." Industrial enzymology: The application of enzymes in Industry. 2nd Ed. T. Godfrey and J Reichelt. eds.. Nature. New York.

Gianfreda, L., and Rao, M. A. (2004). Potential of extra cellular enzymes in remediation of polluted soils: a review. Enzyme and microbial technology, 35(4), 339354.

Hugo Springer. (1994). John Arthur Wilson Memorial Lecture "Treatment of Industrial Wastes of the Leather Industry - is it still a Major Problem". JALCA, 89, 153-185

Jimoh, A. A., Ganiyu, B. A., Baba, D., and Baba, A. (2018) Bioremediation Process of Effluent from Detergent and Food Industries in Jos, Nigeria: Kinetics and Thermodynamics. International Journal of Engineering Science Invention (IJESI), 762-73

Kandelbauer, A., Maute, O., Kessler, R. W., Erlacher, A., and Gübitz, G. M. (2004). Study of dye decolorization in an immobilized laccase enzyme-reactor using online spectroscopy. Biotechnology and bioengineering, 87(4), 552-563.

Kongjao, S., Damronglerd, S., and Hunsom, M. (2008). Simultaneous removal of organic and inorganic Pollutants in tannery wastewater using electrocoagulation technique. Korean Journal of chemical engineering, 25(4), 703.

Maheshwari, U. M., Aruna, S., Gomathi, M., and AbdulJaffar, A. H. (2017). Bioremediation by Free and Immobilized Bacteria Isolated from Tannery Effluent. International Journal of Research in Applied, Natural and Social Sciences. 5(7), 75-90

Margesin, R., and Schinner, F. (2001). Bioremediation (natural attenuation and biostimulation) of diesel-oilcontaminated soil in an alpine glacier skiing area. Applied and environmental microbiology, 677), 3127-3133.

Mohammed, A., Sekar, P., and George, J. (2011). Efficacy of microbes in bioremediation of tannery effluent. Inter. J. Curr. Res, 3(4), 324-326.

Mohammed, S. S. D., Orukotan, A. A., and Abdullahi, H. (2017). Physicochemical and Bacteriological Assessment of Tannery Effluent from Samaru-Zaria, 
BAJOPAS Volume 13 Number 2, December, 2020 Kaduna State, Nigeria. Journal of Applied

Sciences and Environmental Management, 21(4), 734-740.

Munz, G., De Angelis, D., Gori, R., Mori, G., Casarci, M., and Lubello, C. (2009). The role of tannins in conventional and membrane treatment of tannery wastewater. Journal of hazardous materials, 164(2-3), 733-739

Mythili, K., and Karthikeyan, B. (2011). Bioremediation of $\mathrm{Cr}$ (VI) from tannery effluent using Bacillus spp and Staphylococcus spp. International Multidisciplinary Research Journal, 1(6).

NESREA (2009). National Environmental Standards for Effluent Limitations and Regulation. 1233-1236

Noorjahan, C. M. (2014). Physicochemical characteristics, identification of bacteria and biodegradation of industrial effluent. Journal of bioremediation and Biodegradation, 5(3).

Ohtake, H. I., and Silver, A. O. (1994). Bacterial reduction of toxic chromate. Biological degradation and bioremediation of toxic chemicals, 403-415.

Omoleke, I. I. (2004). Management of environmental pollution in Ibadan, an African city: the challenges of health hazard facing government and the people. Journal of Human Ecology, 15(4), 265-275.

Rajor, A., Reddy, A.S., and Singh, B. (2004). Determination of BOD kinetic Parameters and evaluation of alternate methods, M.Sc. Thesis, Department of biotechnology \& environmental Science, Thapar Institute of Engineering and Technology, Patiala

Ramasami, T., Rajamani, S., and Rao, J. R. (1994, March). Pollution control in leather industry: Emerging technological options. In International symposium on surface and colloidal science and its relevance to soil pollution, madras.

Ramesh, J. V. S., and Singh, S. P. (1993). Yearly variation in certain physicochemical parameters of pond at eastern Doon Valley. Uttar Pradesh J. Zoo, 12 (1), 7577.

Ranen, S., and Sharadinadra, C. (2009). Biotechnology applications to environmental remediation in resource exploitation. Current science, 97, 6-25
Russell, A. J., Berberich, J. A., Drevon, G. F., and Koepsel, R. R. (2003). Biomaterials for mediation of

chemical and biological warfare agents. Annual review of biomedical engineering, 5(1), 1-27.

Saravanan, P., and Saravanan, A. (1999). Decolourization of tannery effluent by Flavobacterium sp. EK 1. Indian Journal of Environmental Protection, 19, 19-24.

Sikander, S., and Shahida, H. (2007). Reduction of toxic hexavalent chromium by Ochrobactrum intermedium strain SDCr5 stimulated by heavy metals. Bioresource Technol, 98, 340-344.

Singh, N., Sharma, B. K., and Bohra, P. C. (2000). Impact assessment of industrial effluent of arid soils by using satellite imageries. Journal of the Indian Society of Remote Sensing, 28(2-3), 79.

Sreemoyee, C., and Priti, P. (2013). Assessment of physico-chemical parameters of dairy waste water and isolation and characterization of bacterial strains in terms of cod reduction. Int J Sci, 2(3), 395-400.

Verheijen, L. A. H. M., Wiersema, D., Pol, L. H., and De Wit, J. (1996). Management of wastes from animal product processing. Livestock and environment, Finding a balance. International Agriculture Center, Wageningen, The Netherlands.

Wang, F., Yao, J., Si, Y., Chen, H., Russel, M., Chen, K., and Bramanti, E. (2010). Short-time effect of heavy metals upon microbial community activity. Journal of Hazardous Materials, 173(13), 510-516.

WHO (World Health Organization). (2006). Air quality guidelines: global update 2005: particulate matter, ozone, nitrogen dioxide, and sulfur dioxide. World Health Organization.

World Bank. (1995). Nigeria's strategic options for redressing industrial pollution. World Bank, industry and energy division. 1st edition, West Central Africa Department; Annexes: 1995; pp 60-62.

Zahoor, A., and Abdul, R. (2009). Enumeration of Coliforms. Journal of Environmental Sciences. 21, 814-820 


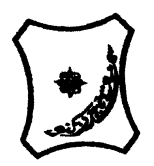

Bayero Journal of Pure and Applied Sciences, 13(2): 1 - 12

Received: November, 2020

Accepted: December, 2020

ISSN $2006-6996$

\title{
BIODEGRADATION POTENTIAL OF IMMOBILIZED BACTERIA IN THE TREATMENT OF TANNERY INDUSTRIAL EFFLUENTS FROM INDUSTRIAL ESTATES IN KANO STATE, NIGERIA
}

\author{
Abdullateef, B., ${ }^{1 *}$ Shuaibu, T. G., ${ }^{1}$ Babagana, K., ${ }^{1}$ Suleman, H. B. ${ }^{2}$ and Dauda, B. ${ }^{3}$ \\ ${ }^{1}$ Department of Pure and Applied Chemistry, Faculty of Science, University of Maiduguri, Borno State, \\ Nigeria \\ ${ }^{2}$ Department of Microbiology, Faculty of Science, University of Maiduguri, Borno State, Nigeria \\ ${ }^{3}$ Department of Chemical Engineering, Faculty of Engineering, University of Maiduguri, Borno State, \\ Nigeria \\ *Corresponding author: babslega@gmail.com; abelega2007@yahoo.com; +2348061309753
}

\section{ABSTRACT}

Industrial Effluents Samples from Gashash Tanneries (TAN1) in Bompai Industrial estate, Larabee Tannery Industry (TAN2) in Sharada Industrial estate and Z Tannery Industries (TAN3) in Challawa Industrial estate, Kano State, Nigeria were collected over a period of six months (August 2017 to January 2018) for assessing the biodegradation potentials of bacteria in the treatment of organic pollutants within the effluents. Bacteria were isolated from the effluents and immobilized on agar-agar. Different masses (5 g, $10 \mathrm{gr}, 15$ $\mathrm{g}, 20 \mathrm{~g}$, and $25 \mathrm{~g}$ ) of the bacteria were used in the treatment of $250 \mathrm{ml}$ of the effluents for ten days in a shaker incubator (Gallenkamp-OC-4364-L) at the temperature $30{ }^{\circ} \mathrm{C}$ and speed of $60 \mathrm{rpm}$. Pre-treatment analysis of the effluents for Temperature, pH, Biochemical Oxygen Demand (BOD), Chemical Oxygen Demand (COD), Suspended Solid (SS) and Total Dissolved Solids (TDS) gives the following results; temperature $\left({ }^{\circ} \mathrm{C}\right.$ )

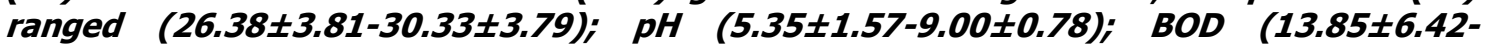
$38.75 \pm 16.20) ;$ COD (1406 $\pm 208-3532 \pm 1373) ;$ SS (208 $\pm 235-780 \pm 739)$ and TDS (266 $\pm 253-5276 \pm 2971)$. No statistical differences ( $p \leq 0.05)$ was observed for all the results among the different industries. The bacterial isolates were identified as Neisseria spp, Bacillus cereus, and Staphylococcus aureus, in TAN1, TAN2, and TAN3, respectively. After treatment of the effluent with the different masses of the isolated bacteria, the mean level of BOD was found to range as (0.55 $\pm 0.36-6.92 \pm 5.49) ; C O D$ (ND-3134 \pm 1595$)$;

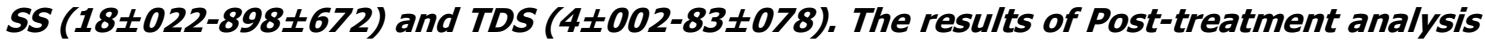
showed that there is overall decrease in the levels of the parameters determined when compared with that of the pre-treatment. The overall percentage reduction of the immobilised bacteria in the treatment of the respective effluents was in the order TAN2 (72\%)>TAN1 (70\%)>TAN3 (62\%). Hence, the immobilized bacteria are having higher biodegradation potential for the treatment of the tannery effluents.

Keywords: Biodegradation, bacteria, effluent, immobilization, tannery.

\section{INTRODUCTION}

Tannery industrial wastewater is a serious consequence of the pollution point of view for streams, freshwater, and land used for agriculture. The lack of awareness in the modern industrial practice has resulted in the discharge of tannery effluents which exhibit very high value of chromium ( $\mathrm{Cr}$ ), Sulfide, and chloride, Total Dissolved Solid (TDS), Total Suspended Solid (TSS), Biochemical Oxygen Demand (BOD) and Chemical Oxygen Demand (COD) in the water stream or land (Mohammed et al., 2001). Tanning is the process, which One ton of skin generally leads to the production of 20 to $80 \mathrm{~m}^{3}$ of turbid and foul-smelling converts the protein of the rawhide or skin into a stable material, which will not putrefy and is suitable for a wide variety of end applications (Elsheikh, 2009). The highly polluting chromium is the most commonly used tanning material producing leather that is more flexible and pliable than vegetable-tanned leather and does not discolor or lose shape in water as drastically as vegetable-tan (Elsheikh, 2009). Tannery effluent is among the most hazardous industrial pollutants due to its huge organic and inorganic load, which is highly toxic to human life and the environment (Kongjao et al., 2008). wastewater including chromium (100-400 mg/l), sulfide $(200-800 \mathrm{mg} / \mathrm{l})$, high levels of fat and 
BAJOPAS Volume 13 Number 2, December, 2020 other solid wastes, and notable pathogen contamination as well as pesticides added for skin conservation during transport (Elsheikh, 2009). There are more than 6000 tanneries in Nigeria with an annual processing capacity of 700,000 tons of hides and skins (Omoleke, 2004; Singh et al., 2008). It was reported that the total amount of waste produced per animal slaughtered is approximately $35 \%$ of its weight (World Bank, 1995). Also, for every $1000 \mathrm{~kg}$ of carcass weight, a slaughtered beef produces 5.5 $\mathrm{kg}$ of manure (excluding rumen contents or stockyard manure) and $100 \mathrm{~kg}$ of paunch manure (undigested food) (Verheijen et al., 1996). Tanneries generate wastewater in the range of 30-35 $\mathrm{L} \mathrm{kg}^{-1}$ skin/hide processed with variable $\mathrm{pH}$, Biological Oxygen Demand (BOD), Chemical Oxygen Demand (COD), high concentrations of suspended solids (SS), and tannins as well as chromium (Zahoor and Abdul, 2009).

Being heterogeneous and composed of a wide variety of compounds, it is very difficult to select a unique direct method for estimating the biodegradability of organic contents and biokinetic parameters for a wastewater sample (Rajor, 2004). For this purpose, some indirect estimation such as determination of biochemical oxygen demand (BOD) and chemical oxygen demand (COD) are applied as common laboratory investigations [9]. During retanning procedures, synthetic tannins (Syntan), oils and resins are added to form softer leather at varying doses (Munz et al., 2009). One of the refractory groups of chemicals in tannery effluents derives mainly from tannins (Ramasami et al., 2004). Syntans are characterized by complex chemical structures, because they are composed of an extended set of chemicals such as phenol-, naphthalene-, formaldehyde- and melamine-based syntans, and acrylic resins (Beem, 1994). Organic pollutants (proteic and lipidic components) are originated from skins (it is calculated that the raw skin has $30 \%$ loss of organic material during the working cycle) or they are introduced during processes (Hugo Springer, 1994).

Many conventional processes such as oxidation, chemical and biological processes were carried out to treat tanneries wastewater (Ebtesam et al, 2013). Biological processes have received more attention because of their costeffectiveness, lower sludge production and environmental friendliness (Noorjahan, 2014). Naturally occurring micro-organisms degrade the hazardous organic wastes including xenobiotic compounds, such as pesticides, polycyclic aromatic hydrocarbons (PAHs) and polychlorinated biphenyls (PCBs) in due course of time (Ranen and Sharadinadra, 2009). Bioremediation is based on the idea that all organisms remove substances from the environment to carry outgrowth and metabolism (Bouwer and Zehnder, 1993). Bacteria, protista and fungi are found to be very good at degrading complex molecules and incorporating the breakdown products into their metabolism (Bouwer and Zehnder, 1993). The resultant metabolic wastes that they produce are generally safe and somehow recycled into other organisms (Ranen and Sharadinadra, 2009). An acclimatized indigenous population of microorganisms capable of degradation of the compounds of interest must exist at the site for a successful bioremediation mode (Ranen and Sharadinadra, 2009). It has been observed that for a successful bioremediation mode, an acclimatized indigenous population of microorganisms capable of degradation of the compounds of interest must exist at the site under investigation (Ranen and Sharadinadra, 2009). Even though there are numerous physical and chemical methods employed in the disposal of wastes the advantage in using bacterium is that they play a key role in the reduction of COD, BOD, total protein, total tannin and total phenol (Saravanan and Saravanan, 1998)

Baba et al. (2020) studied the bioremediation potential of immobilized corynebacterium kutsceri in the Treatment of tannery industrial effluent from Challawa Industrial Estate, Kano State, Nigeria. The aim of the work is to study the reduction in the level of the contaminants through the process of bioremediation using the isolated bacteria. Immobilized bacteria can withstand various temperatures, $\mathrm{pH}$ and substrate concentrations; consequently, increasing the efficiency and the lifespan of the bacteria. Immobilized bacteria are widely applied in the treatment of wastewater and can be separated and recovered after the treatment with the same efficiency (Baba et al., 2020).

\section{MATERIALS AND METHODS \\ Study Area}

This study was carried out in Bompai, Sharada and Challawa industrial estates in Kano, Figure 1. Kano lies on Latitude $11^{\circ} 30^{\prime} \mathrm{N}$ and $8^{\circ} 30^{\prime} \mathrm{E}$ and Longitude $11^{\circ} 5^{\prime} \mathrm{N}$ and $8^{\circ} 5^{\prime} \mathrm{E}$ in Northern Nigeria. It is one of the developed industrial cities in Nigeria. Tannery activities are the dominating industries and this could be one of the reasons for her high population density (Dan'Azumi and Bichi, 2010). Many researchers have studied biodegradation of tannery effluent using microorganisms. However, limited literature is available on the biodegradation of tannery effluent in Kano industrial estates using 
BAJOPAS Volume 13 Number 2, December, 2020 immobilized bacterial cells. This research work focuses on the potential of the use of the indigenous immobilized bacterial isolates in the treatment of tannery effluents in the industrial estates.

\section{Sample Collection}

Effluents were collected from the Tannery Industries from Bompai, Challawa and Sharada Industrial Estates, Kano, Nigeria. The effluents were collected over a period of six months (August 2017 to January 2018). Samples collected in a sterile 4-liter plastic container with a unique identification number were preserved using an ice-box that was transported to the Microbiology Laboratory, Department of Microbiology, Bayero University of Kano for analysis

\section{Sample Preparation and Sample Analysis}

Immediately after the collection of the effluent, $\mathrm{pH}$, TSS, TDS, COD, BOD levels were determined before treatment (Pre-treatment determination) and ten days after treatment (Post-treatment determination) as described in
APHA (1989) standard methods. $\mathrm{pH}$ was determined using Ecotests $\mathrm{pH}$ meter and TDS was determined using AQUALYTIC TDS Salinometer. BOD was determined as described by the standard method (APHA, 1992). COD and SS were determined using DR/2010 HACH portable data logging spectrophotometer (DWAF, 1992)

\section{Identification and Biochemical} Characterization of the Bacterial Isolates

The bacteria were isolated from the effluents using Serial Dilution according to the method described by APHA (1989). The biochemical tests such as oxidase, catalase, coagulase, indole (from $1 \%$ tryptone broth), citrate (Simmons citrate agar), methyl red/VogesProskauer (MR/VP), nitrate reduction, Starch Hydrolysis, Glucose, Maltose, and Lactose tests were carried out on the bacterial isolates to identify the bacteria through the bacteria biochemical characteristics according to Ajao et al. (2011).

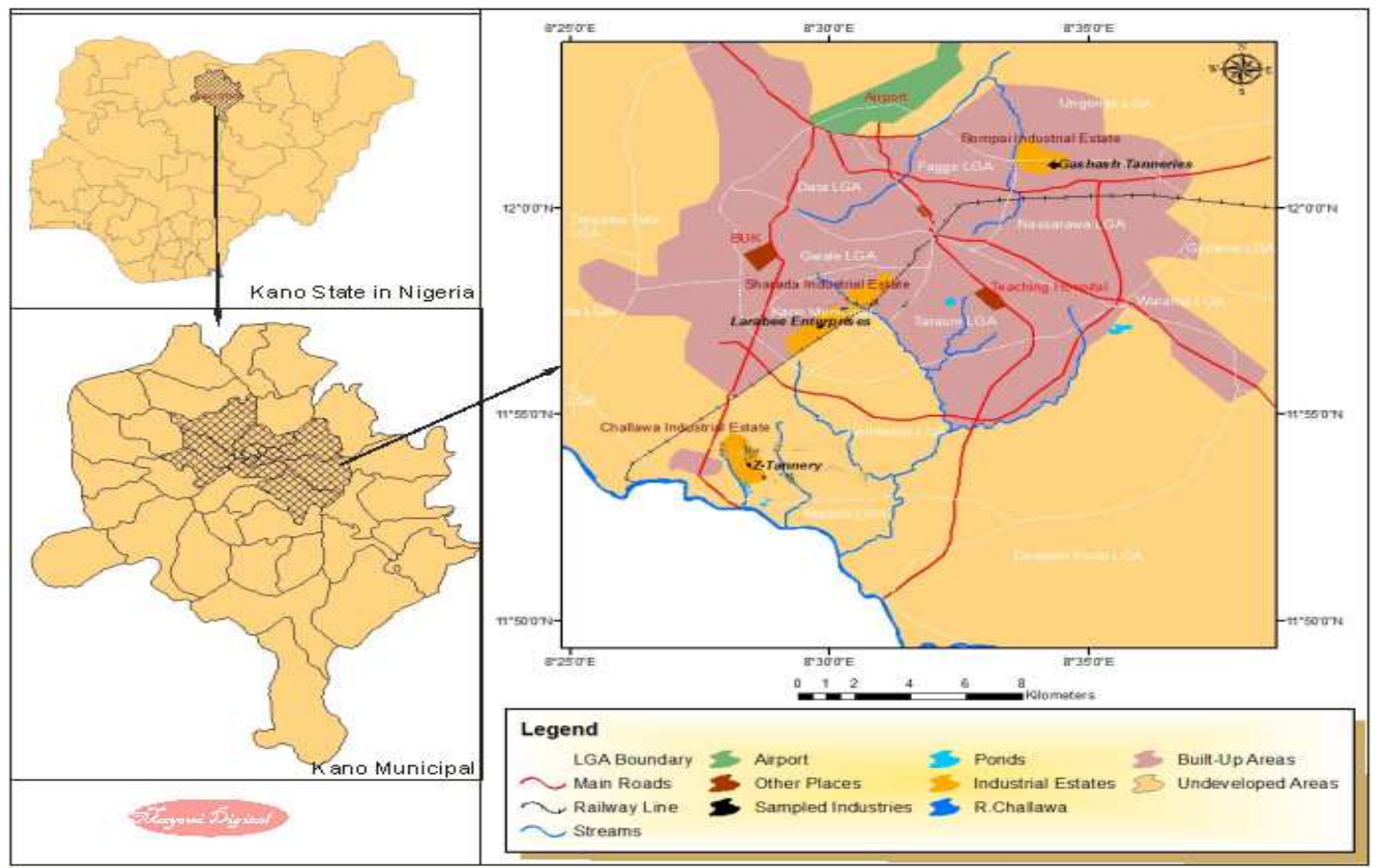

Fig. 1 Map showing the study areas

Source: Mayomi Digital Productions, GIS Laboratory, Department of Geography, UNIMAID (2017)

\section{Determination of Growth Rate of the Bacteria in Effluent Sample}

The bacteria growth rates were determined by transferring $2 \mathrm{~mL}$ of the bacterial isolates from the tannery effluent in broth medium into 100 $\mathrm{mL}$ sterile effluents in conical flasks and kept in an incubator (Giffrin cool) for 10 days. Control was also set up by incubating another $100 \mathrm{~mL}$ each of the sterile effluents without the bacteria. The optical density of the content was determined at the wavelength of $600 \mathrm{~nm}$ on a daily interval and recorded. 
BAJOPAS Volume 13 Number 2, December, 2020 Immobilization of Bacteria

Agar solution and inoculi were prepared separately. Fifty milliliters $(50 \mathrm{~mL})$ of nutrient broth each of the inoculi was prepared in a McCartney bottle and incubated for 24 hours. A solution of agar-agar was prepared by dissolving $10 \mathrm{~g}$ of the powder in distilled water and made up to $500 \mathrm{~mL}$ mark in an Erlenmeyer flask and was sterilized in an autoclave (280A) for 15 minutes and allowed to cool to $40-45^{\circ} \mathrm{C}$ (Ajao et al., 2011). Four milliliters ( $4 \mathrm{~mL})$ of the bacterial isolates in the nutrient broth was mixed with 36 $\mathrm{ml}$ of the prepared agar-agar media in petri-dish plates and then allowed to solidify. This was kept in the refrigerator for bioremediation.

\section{Bioremediation (Treatment) of the Effluents}

The solidified agar block (immobilized bacteria) was cut into cubes using a sterile knife; $0.1 \mathrm{~mL}$ phosphate buffer ( $\mathrm{pH} \mathrm{7.0)}$ was added and kept in the refrigerator for 1 hour for curing. The phosphate buffer was decanted after 1 hour and the cubes were washed with sterile distilled water 3-4 times before it was used (Ajao et al., 2011). Two liters (2 L) of the effluent was supplemented with the minimum basal medium in $\mathrm{g} / \mathrm{L}: \mathrm{NaCl}(0.8), \mathrm{MgSO}_{4} .7 \mathrm{H}_{2} \mathrm{O}(0.001), \mathrm{KH}_{2} \mathrm{PO}_{4}$ (2), $\mathrm{NaNO}_{3}$ (2), $\quad \mathrm{CaCl}_{2} .2 \mathrm{H}_{2} \mathrm{O} \quad(0.5)$ and $\mathrm{NaHPO}_{4} .12 \mathrm{H}_{2} \mathrm{O}(2)$ and sterilized in an autoclave at $121^{\circ} \mathrm{C}$ for 15 minutes (Margesin and Schinner, 2001). Two hundred and fifty milliliters $(250 \mathrm{~mL})$ of the effluents were transferred into different $250 \mathrm{ml}$ conical flasks. The content was covered with a cotton-wool ramped with foil paper to avoid contamination. Five grams $(5 \mathrm{~g})$ of the immobilized bacteria were quickly transferred into each of the effluents in the conical flasks in an inoculating chamber. The same procedures were carried out for the $10 \mathrm{~g}, 15 \mathrm{~g}, 20 \mathrm{~g}$ and 25 $\mathrm{g}$ of the immobilized bacteria in separate $250 \mathrm{~mL}$ effluents in conical flasks and agitated for ten days in a shaker incubator (Gallenkamp-OC4364-L) at a temperature $30^{\circ} \mathrm{C}$ and speed of 60 rpm. The treated effluent samples were taken on the tenth day and analyzed for the parameters $\mathrm{pH}$, SS, TDS, COD, and BOD, (Posttreatment determination) for the different grams of bacteria to evaluate and compare the biodegradation potential. (Baba et al., 2020).

\section{Statistical Analysis}

The data were represented as Mean \pm Standard deviation and analyzed statistically using oneway Analysis of Variance (ANOVA) and Tukey's HSD as Post Hoc Tests with the aid of SPSS 16.0. The correlation coefficient was also used to measure the strength of the relationship between the different masses of the bacteria and the parameters. All $\mathrm{p} \leq 0.05$ were considered as statistically significant.

\section{RESULTS AND DISCUSSION Physico-chemical parameters in the Industrial Effluents before the Biodegradation.}

Results of the Physico-chemical parameters in the industrial effluents before the Biodegradation is shown in table 1 . The mean temperatures $\left({ }^{\circ} \mathrm{C}\right)$ observed in TAN1, TAN2, and TAN3 samples were $28.07 \pm 0.65 ; 27.77 \pm 0.64$ and $26.38 \pm 3.81$ respectively. The order of the mean temperature of the samples from the three industries can be arranged as TAN1 > TAN2>TAN3. The temperature observed at TAN1, TAN2, and TAN3 samples were found below the WHO $\left(35^{\circ} \mathrm{C}\right)$ and NESREA $\left(40^{\circ} \mathrm{C}\right)$ limits. The low values of temperature might be due to the processes used at the time of sampling. High temperature brings down the solubility of gases in water that ultimately expresses as high BOD and COD. Statistical analysis shows that there is no significant difference $(p<0.05)$ between the mean values of temperature among the industries. This might be due to similar tannery activities involved in the tannery industries at the time of sampling. The average values of temperature observed in this present study are less than those observed by Akan et al. (2007), Akan et al. (2009) and Baba et al. (2020).

The mean level of $\mathrm{pH}$ observed in TAN1, TAN2 and TAN3, samples were $7.77 \pm 2.93$; $8.35 \pm 0.28$ and $7.52 \pm 0.76$ respectively. The order of the mean $\mathrm{pH}$ of the samples from the three industries can be arranged as TAN2> TAN1 $>$ TAN3. The $\mathrm{pH}$ of the samples falls within the WHO (7.0-8.5) and NESREA (6-9) standard limits. Statistical analysis shows that there is no significant difference $(p<0.05)$ between the mean values of $\mathrm{pH}$ among the industries. This might be due to similar tannery activities involved in the tannery industries at the time of sampling. Maheshwari et al. (2017) reported that the level of $\mathrm{pH}$ in the effluents from the tannery industry in Vaniyambadi, India was 6.5 which was lower than that observed in the present study. The $\mathrm{pH}$ in the effluents from the tannery industries in Kano and Kaduna were reported to be 7.64 and 6.89, respectively (Akan et al., 2007; Mohammed et al., 2017). The average values of $\mathrm{pH}$ observed in this present study are less than those observed by Mohammed et al. (2017) and Baba et al. (2020). The mean level of SS $(\mathrm{mg} / \mathrm{l})$ observed in TAN1, TAN2, and TAN3 samples were 374 \pm 124 ; $358 \pm 335$ and $780 \pm 739$ respectively. The order of the mean SS in the samples from the three industries can be arranged as TAN3 > TAN1 $>$ TAN2. 
The SS observed in the samples were far above the recommended standard limits of regulating bodies WHO $(30 \mathrm{mg} / \mathrm{l})$ and NESREA $(10 \mathrm{mg} / \mathrm{l})$. Statistical analysis shows that there is no significant difference $(p<0.05)$ between the mean values of SS among the industries. This might be due to similar tannery activities involved in the tannery industries at the time of sampling. The average values of SS observed in this present study are less than that observed $(3700 \pm 122 \mathrm{mg} / \mathrm{l})$ by Akan et al. (2009) for tanneries in Kano. Also, the average values of SS observed in this present study are less than that observed by Mohammed et al. (2017) and Baba et al. (2020) with the exception in TAN3.

The mean level of TDS (mg/l) observed in TAN1, TAN2, and TAN3 samples were $3941 \pm 3703$; $3300 \pm 1714$ and $2653 \pm 1240$ respectively. The order of the mean TDS in the samples from the three industries can be arranged as TAN1>TAN2>TAN3. The TDS observed in the samples were far above the recommended standard limits of WHO $(250 \mathrm{mg} / \mathrm{l})$ and NESREA $(500 \mathrm{mg} / \mathrm{l})$. Statistical analysis shows that there is no significant difference $(p<0.05)$ between the mean values of TDS among the industries. This might be due to similar tannery activities involved in the tannery industries at the time of sampling. TDS in the effluents from the tannery industries in Kano, Nigeria was reported to be $1281 \mathrm{mg} / \mathrm{l}$ (Akan et al., 2007). The average values of SS observed in this present study are less than those observed by Mohammed et al. (2017) and Baba et al. 2020)

The mean level of COD (mg/l) observed in TAN1, TAN2 and TAN3 samples seasons were $2372 \pm 938 ; \quad 1406 \pm 208$ and $3532 \pm 1373$ respectively. The order of the mean COD of the samples from the three industries can be arranged as TAN3>TAN1> TAN2. The COD observed in TAN1, TAN2 and TAN3 samples were far above the recommended standard limits of regulating bodies $\mathrm{WHO}(40 \mathrm{mg} / \mathrm{l})$ and NESREA (40 mg/l). Statistical analysis shows that there is no significant difference $(p<0.05)$ in COD among the industries. This might be due to similar tannery activities involved in the tannery industries as at the time of sampling. The Chemical Oxygen demand (COD) is the amount of oxygen, in $\mathrm{mg} / \mathrm{L}$, required for the degradation of the compound of wastewater to occur. In comparison, the average values of COD observed in this present study were higher than that observed by Mohammed et al. (2017) but lower than that observed by Baba et al. (2020).

The mean levels of BOD $(\mathrm{mg} / \mathrm{l})$ observed in TAN1, TAN2 and TAN3 samples were $13.85 \pm 6.42 ; \quad 19.46 \pm 0.50$ and $17.13 \pm 3.14$ respectively. The order of the mean BOD in the samples from the three industries can be arranged as TAN2>TAN3>TAN1. The BOD observed in TAN1, TAN2 and TAN3 samples were found below the recommended limits of NESREA (200 mg/l) but above WHO (10 mg/l). Statistical analysis shows that there is no significant difference $(p<0.05)$ between the mean values of BOD among the industries. This might be due to similar tannery activities involved in the tannery industries at the time of sampling. The low level of BOD recorded in this study is an indication of the low level of biodegradable organic solids in the effluent. The average values of BOD observed in this present study were lower than those observed by Mohammed et al. (2017) and Baba et al. (2020).

Table 1: Mean Values \pm S.D of Physico-chemical parameters of effluents from the Tannery Industries before Treatment.

\begin{tabular}{llllllll}
\hline Parameter & Tannery 1 & Tannery 2 & Tannery 3 & $\mathrm{a}$ & $\mathrm{b}$ & $\mathrm{c}$ & $\mathrm{d}$ \\
\cline { 2 - 7 } Temperature $\left({ }^{\circ} \mathrm{C}\right)$ & $28.07 \mathrm{a} \pm 0.65$ & $27.77 \mathrm{a} \pm 0.64$ & $26.38 \mathrm{a} \pm 3.81$ & & $29.50 \pm 4.68$ & 35 & 40 \\
pH & $7.77 \mathrm{a} \pm 2.93$ & $8.35 \mathrm{a} \pm 0.28$ & $7.52 \mathrm{a} \pm 0.76$ & 6.89 & $5.35 \pm 1.57$ & $7.0-8.5$ & $6.0-9.0$ \\
$\mathrm{COD}(\mathrm{mg} / \mathrm{l})$ & $2372 \mathrm{a} \pm 938$ & $1406 \mathrm{a} \pm 208$ & $3532 \mathrm{a} \pm 1373$ & 2.2 & $3106 \pm 2753$ & 40 & 40 \\
$\mathrm{BOD}(\mathrm{mg} / \mathrm{l})$ & $13.85 \mathrm{a} \pm 6.42$ & $19.46 \mathrm{a} \pm 0.50$ & $17.13 \mathrm{a} \pm 3.14$ & 1032 & $26.17 \pm 9.49$ & 10 & 200 \\
$\mathrm{SS}(\mathrm{mg} / \mathrm{l})$ & $374 \mathrm{a} \pm 124$ & $358 \mathrm{a} \pm 335$ & $780 \mathrm{a} \pm 739$ & 501 & $562 \pm 482$ & 30 & 10 \\
TDS $(\mathrm{mg} / \mathrm{l})$ & $3941 \mathrm{a} \pm 3703$ & $3300 \mathrm{a} \pm 1714$ & $2653 \mathrm{a} \pm 1240$ & 532.7 & $444 \pm 507$ & 250 & 500 \\
\hline
\end{tabular}

The values given in the table above are means of 6 replicate values, $\mathrm{n}=6$ ( 1 sample was taken monthly for 6 months). Within the rows, means with different alphabets are statistically different $(p<0.05)$. WHO: World Health Organisation. NESREA: National Environmental Standard and Regulatory Enforcement Agency. a = Mohammed et al.(2017), b = Baba et al. (2020), c = WHO (2006), $d=$ NESSRA (2009) 
BAJOPAS Volume 13 Number 2, December, 2020

Identification, Biochemical Characterization and growth rates of the Bacterial Isolates

Results of identification and biochemical characterization of the bacterial isolates were shown in table 2. After 24 hours of incubation, the nutrient agar media plates were checked for bacterial growth. The results showed the presence of different strains in the samples. The TAN1 bacteria isolate was found to be gramnegative cocci while TAN3 was gram-positive cocci. TAN2 bacteria isolate was found to be gram-positive, rod-shaped. TAN1, TAN2, and TAN3 bacteria isolates recorded positive results for spore former.

The results of the biochemical tests indicated that all the bacteria were positive for catalase, oxidase, citrate, maltose, glucose, lactose (negative in TAN1), mannitol (negative in TAN2), starch hydrolysis and coagulase (negative in TAN2) tests. The bacteria showed negative results for nitrate reduction, $M R$ (positive in TAN2), VP (positive in TAN1), Indole (positive in TAN2) tests. Base on the morphological and biochemical test results, TAN1, TAN2, and TAN3 bacteria isolates were identified to be Nesseria spp, Bacillus cereus, and Staphylococcus aureus respectively.

The growth rate of the TAN1, TAN2 and TAN3 Isolates were shown in figure 2. Generally, the optical density increase with the increase in time (day) and decrease as time goes on. The highest optical density was shown by bacillus cereus in TAN2 while the lowest was shown by Staphylococcus aureus in TAN3.

The initial growth phase of TAN1 Isolate bacteria occurred within 2-day of incubation as the growth rate increases up to the 6th-day incubation when the maximum growth was observed. Beyond the 6th day, the growth of the bacteria declined (which might be due to a shortage of nutrients in the effluents) until it reached its death phase (which might be due to the unavailability of nutrients in the effluents).

A similar trend of growth was also observed for TAN2 Isolate as the initial growth phase also occurred within 2-day of incubation but maximum growth rate observed on the 4th day of incubation. The stationary stage occurred between the 4th day and the 8th day. Beyond the 8th day, the growth of the bacteria declined (which might be due to a shortage of nutrients in the effluents) until it reached its death phase (which might be due to the unavailability of nutrients in the effluents).

The initial growth phase of TAN3 bacterial Isolate occurred within the 3-day incubation as the growth rate increases up to the 6th-day incubation when the maximum growth was observed. Beyond the 6th day, the growth of the bacteria declined (which might be due to a shortage of nutrients in the effluents) until it reached its death phase (which might be due to the unavailability of nutrients in the effluents).

Table 2: Morphological and Biochemical characteristics of bacterial isolates

\begin{tabular}{lllll} 
Bacterial Isolates & & TAN1 & TAN2 & TAN3 \\
\hline $\begin{array}{lllll}\text { Morphological } \\
\text { characteristics }\end{array}$ & Shape & Cocci & Rod & Cocci \\
& Spore & & & \\
& former & + & + & + \\
Gram & & & \\
Biochemical characteristics & reaction & - & + & + \\
& Citrate & + & + & + \\
& Catalase & + & + & + \\
& Coagulase & + & - & + \\
Starch & + & + & + \\
& Glucose & + & + & + \\
Oxidase & + & + & + \\
& Indo & - & + & - \\
Lactose & - & + & + \\
Manitol & + & - & + \\
Maltose & + & + & + \\
MR & - & + & - \\
VP & + & - & - \\
& Nitrate & - & - & - \\
Reduction & - Neisseria & Bacillus & Staphylococcus \\
& Bacterial & cereus & aureus \\
& name & spp & cas
\end{tabular}

+ = Positive; - = Negative; MR=Methyl Red; VP= Voges-Proskauer 


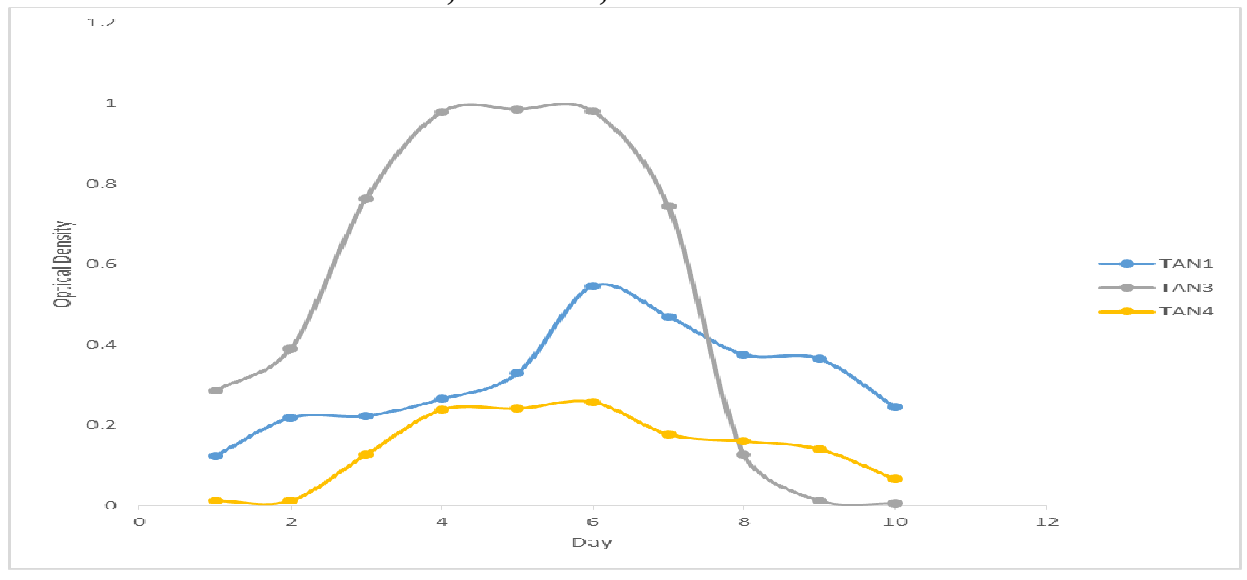

Fig. 2 Growth rates of the isolates in the effluents from the Tannery Industries

\section{Physico-chemical Parameters in the Industrial Effluents after the biodegradation.}

Table 3 shows the mean results of the physicochemical parameter before and after bioremediation using the different masses $(5 \mathrm{~g}$, $10 \mathrm{~g}, 15 \mathrm{~g}, 20 \mathrm{~g}$, and $25 \mathrm{~g}$ ) of the respective immobilized bacteria. Also, Table 4 shows the mean results of correlation coefficient ( $r$ ) between different masses of bacteria and physicochemical parameters.

The mean values $(\mathrm{mg} / \mathrm{l})$ of the SS after the bioremediation varies between $243 \pm 45$ and $898 \pm 672$. The mean concentration $(\mathrm{mg} / \mathrm{l})$ of SS remediated by the different masses $(5 \mathrm{~g}, 10 \mathrm{~g}$, $15 \mathrm{~g}, 20 \mathrm{~g}$, and $25 \mathrm{~g}$ ) of the bacteria varies. The SS in the samples fluctuates up and down after the bioremediation process when compared with the SS of the raw samples before the bioremediation. The increase in the levels of the SS might be due to the aggregation of the TDS which are large enough to result into SS. The increase in the levels of the SS might be also due to the influence of the nutrients which was added into the effluents in order to make the microorganisms more active and viable for fast degradation of organic contaminants in the effluent. The relative potential or efficiency of the different masses of the bacteria in remediating SS in TAN1 samples was in the order $25 \mathrm{~g}>20 \mathrm{~g}>15 \mathrm{~g}>10 \mathrm{~g}>5 \mathrm{~g}$. For TAN2 and TAN3 samples, the order was $25 \mathrm{~g}>20 \mathrm{~g}>15$ $\mathrm{g}>10 \mathrm{~g}>5 \mathrm{~g}$. These might be due to the variations in the surface areas of the different masses of the immobilized bacteria. Statistical analysis shows that there is no significant difference $(p<0.05)$ between the mean values of SS among the masses in the respective industries. Positive and significant correlations exist between the masses of bacteria and Suspended Solid (SS). This showed that there is general increase in the levels of the SS as the masses of the immobilized bacteria increases. TAN3 (90\%) and TAN1 (80\%) showed a very high correlation with the masses of the bacteria while TAN2 (61\%) showed a very low correlation.

The mean values $(\mathrm{mg} / \mathrm{l})$ of the TDS after the bioremediation varies between $46 \pm 11$ and $83 \pm 78$. The mean concentration $(\mathrm{mg} / \mathrm{l})$ of TDS remediated by the different masses $(5 \mathrm{~g}, 10 \mathrm{~g}$, $15 \mathrm{~g}, 20 \mathrm{~g}$, and $25 \mathrm{~g}$ ) of the bacteria varies. There is a reduction in all the TDS of all the samples after the bioremediation process compared with the TDS of the raw samples before the bioremediation. The relative potential or efficiency of the different masses of the bacteria in remediating TDS in TAN1 and TAN3 samples was in the order $5 \mathrm{~g}>10 \mathrm{~g}>15 \mathrm{~g}>20$ $\mathrm{g}>25 \mathrm{~g}$. For TAN2 samples, the order was 20 $g>10 \quad g>25 \quad g>15 \quad g>5 \quad g$. Statistical analysis shows that there is no significant difference $(p<0.05)$ between the mean values of TDS among the masses in the respective industries. These might be due to the variations in the surface areas of the different masses of the immobilized bacteria. Positive and significant correlations exist between the masses of bacteria and TDS with the exception in TAN2 (negative and insignificant correlation). The positive correlations showed that there is general increase in the levels of the TDS as the masses of the immobilized bacteria increases. TAN1 $(96 \%)$ showed a very high correlation with the masses of the bacteria while TAN2 (47\%) showed a very low correlation.

The mean values $(\mathrm{mg} / \mathrm{l})$ of the BOD after the bioremediation varies between $1.56 \pm 0.20 \mathrm{mg} / \mathrm{l}$ and $6.92 \pm 5.49 \mathrm{mg} / \mathrm{l}$. The mean concentration $(\mathrm{mg} / \mathrm{l})$ of BOD remediated by the different masses $(5 \mathrm{~g}, 10 \mathrm{~g}, 15 \mathrm{~g}, 20 \mathrm{~g}$, and $25 \mathrm{~g}$ ) of the bacteria varies. There is a reduction in all the BOD of all the samples after the bioremediation process compared with the $\mathrm{BOD}$ of the raw 
BAJOPAS Volume 13 Number 2, December, 2020 samples before the bioremediation. The relative potential or efficiency of the different masses of the bacteria in remediating BOD in TAN1, TAN2 and TAN3 samples were in the order $25 \mathrm{~g}>20$ $\mathrm{g}>15 \mathrm{~g}>10 \mathrm{~g}>5 \mathrm{~g}, 25 \mathrm{~g}>15 \mathrm{~g}>5 \mathrm{~g}>10 \mathrm{~g}>20 \mathrm{~g}$ and $20 \mathrm{~g}>10 \mathrm{~g}>25 \mathrm{~g}>15 \mathrm{~g}>5 \mathrm{~g}$ respectively. Statistical analysis shows that there is significant difference $(p<0.05)$ between the mean values of BOD among the masses in the respective industries. These might be due to the variations in the surface areas of the different masses of the immobilized bacteria. Negative and significant correlations exist between the masses of bacteria and BOD. This showed that there is general decrease in the levels of the BOD as the masses of the immobilized bacteria increases. TAN1 (94\%) showed a very high correlation with the masses of the bacteria while TAN2 (4\%) showed a very low correlation.

The mean values $(\mathrm{mg} / \mathrm{l})$ of the COD after the bioremediation varies between $250 \pm 154$ and $3134 \pm 1595$. The mean concentration $(\mathrm{mg} / \mathrm{l})$ of COD remediated by the different masses $(5 \mathrm{~g}$, $10 \mathrm{~g}, 15 \mathrm{~g} 20 \mathrm{~g}$, and $25 \mathrm{~g}$ ) of the bacteria varies. There is a reduction in all the COD of all the samples after the bioremediation process compared with the COD of the raw samples before the bioremediation. The relative potential or efficiency of the different masses of the bacteria in remediating COD in TAN1, TAN2 and TAN3 samples were in the order $25 \mathrm{~g}>20 \mathrm{~g}>15$ $\mathrm{g}>5 \mathrm{~g}>10 \mathrm{~g}, 25 \mathrm{~g}>20 \mathrm{~g}>15 \mathrm{~g}>10 \mathrm{~g}>5 \mathrm{~g}$ and 10 g>5 g>25 g>15 g>20 g respectively. Statistical analysis shows that there were significant difference $(p<0.05)$ between the mean values of COD among the masses in the respective industries except for effluents treated with $25 \mathrm{~g}$. These might be due to the variations in the surface areas of the different masses of the immobilized bacteria. Negative and insignificant correlations exist between the masses of bacteria and COD with the exception in TAN3 (positive and significant correlation). The negative correlations showed that there is general decrease in the levels of the COD as the masses of the immobilized bacteria increases. TAN2 (100\%) showed a very high correlation with the masses of the bacteria while TAN3 (36\%) showed a very low correlation.

Generally, there was an overall decrease in the concentration of these physicochemical parameters after the bioremediation using the different masses of the bacterial isolates. These might be due to the variations in the surface areas of the different masses of the immobilized bacteria. This is in line with the work of Jimoh et al. (2018) and Baba et al. (2020).

Table 3: Mean Values $(\mathrm{mg} / \mathrm{l}) \pm$ S.D of Physicochemical parameters in effluents from the Tannery Industries before and after Treatment of the effluents $(250 \mathrm{ml})$ with the different masses $(5 \mathrm{~g}, 10 \mathrm{~g}$, $15 \mathrm{~g}, 20 \mathrm{~g}$, and $25 \mathrm{~g}$ ) of the bacteria.

\begin{tabular}{llllllll}
\hline $\mathrm{P}$ & IND & Before & \multicolumn{5}{c}{ After } \\
\cline { 4 - 7 } & & & $5 \mathrm{~g}$ & $10 \mathrm{~g}$ & $15 \mathrm{~g}$ & $20 \mathrm{~g}$ & $25 \mathrm{~g}$ \\
\hline \multirow{2}{*}{ COD } & TAN1 & $2372 \pm 938$ & $1708 \mathrm{a} \pm 861$ & $2045 \mathrm{a} \pm 1205$ & $845 \mathrm{a} \pm 369$ & $300 \mathrm{a} \pm 167$ & $250 \mathrm{a} \pm 154$ \\
& TAN2 & $1406 \pm 208$ & $1195 \mathrm{a} \pm 208$ & $1125 \mathrm{a} \pm 384$ & $1055 \mathrm{a} \pm 317$ & $956 \mathrm{a} \pm 310$ & $870 \mathrm{ab} \pm 240$ \\
& TAN3 & $3532 \pm 1373$ & $2374 \mathrm{a} \pm 1344$ & $1976 \mathrm{a} \pm 1405$ & $2757 \mathrm{a} \pm 1266$ & $3134 \mathrm{a} \pm 1595$ & $2614 \mathrm{~b} \pm 1105$ \\
BOD & TAN1 & $13.85 \pm 6.42$ & $6.92 \mathrm{a} \pm 5.49$ & $6.42 \mathrm{a} \pm 5.07$ & $5.72 \mathrm{a} \pm 5.35$ & $4.62 \mathrm{a} \pm 4.37$ & $2.82 \mathrm{ab} \pm 1.26$ \\
& TAN2 & $19.46 \pm 0.50$ & $1.75 \mathrm{~b} \pm 0.22$ & $1.73 \mathrm{~b} \pm 0.18$ & $1.58 \mathrm{a} \pm 0.16$ & $1.91 \mathrm{a} \pm 0.22$ & $1.56 \mathrm{~b} \pm 0.20$ \\
& TAN3 & $17.13 \pm 3.14$ & $4.24 \mathrm{ab} \pm 0.77$ & $3.29 \mathrm{ab} \pm 0.37$ & $4.11 \mathrm{a} \pm 0.07$ & $3.23 \mathrm{a} \pm 0.91$ & $3.33 \mathrm{a} \pm 1.28$ \\
SS & TAN1 & $374 \pm 124$ & $243 \mathrm{a} \pm 45$ & $471 \mathrm{a} \pm 226$ & $475 \mathrm{a} \pm 182$ & $492 \mathrm{a} \pm 128$ & $611 \mathrm{a} \pm 217$ \\
& TAN2 & $358 \pm 335$ & $460 \mathrm{a} \pm 400$ & $543 \mathrm{a} \pm 414$ & $544 \mathrm{a} \pm 402$ & $551 \mathrm{a} \pm 414$ & $554 \mathrm{a} \pm 405$ \\
& TAN3 & $780 \pm 739$ & $586 \mathrm{a} \pm 594$ & $758 \mathrm{a} \pm 656$ & $787 \mathrm{a} \pm 676$ & $861 \mathrm{a} \pm 635$ & $898 \mathrm{a} \pm 672$ \\
TDS & TAN1 & $3941 \pm 3703$ & $51 \mathrm{a} \pm 10$ & $53 \mathrm{a} \pm 10$ & $55 \mathrm{a} \pm 15$ & $61 \mathrm{a} \pm 20$ & $63 \mathrm{a} \pm 26$ \\
& TAN2 & $3300 \pm 1714$ & $83 \mathrm{a} \pm 78$ & $47 \mathrm{a} \pm 20$ & $48 \mathrm{a} \pm 22$ & $47 \mathrm{a} \pm 17$ & $48 \mathrm{a} \pm 17$ \\
& TAN3 & $2653 \pm 1240$ & $46 \mathrm{a} \pm 11$ & $55 \mathrm{a} \pm 24$ & $55 \mathrm{a} \pm 25$ & $58 \mathrm{a} \pm 23$ & $61 \mathrm{a} \pm 28$ \\
\hline
\end{tabular}

Replicate $=6$ (months)

Within the rows, for the same parameter, means with different alphabets are statistically different $(p<0.05)$.

$\mathrm{P}=$ parameter, IND = Industries 
BAJOPAS Volume 13 Number 2, December, 2020

Table 4: Correlation coefficient $(r)$ between different masses of the bacteria and the physicochemical parameters.

\begin{tabular}{llll}
\hline Industries & Parameter & Correlation coefficient $(r)$ & $\begin{array}{l}\text { Percent dependence (rxrx100) } \\
(\%)\end{array}$ \\
\hline TAN1 & COD & -0.9 & 82 \\
& BOD & -0.97 & 94 \\
& SS & $0.90^{*}$ & 80 \\
TAN2 & TDS & $0.98^{*}$ & 96 \\
& COD & -1 & 100 \\
& BOD & -0.21 & 4 \\
& SS & $0.78^{*}$ & 61 \\
& TDS & -0.69 & 47 \\
& COD & $0.60^{*}$ & 36 \\
& BOD & -0.6 & 37 \\
& SS & $0.95^{*}$ & 90 \\
& TDS & $0.94^{*}$ & 89 \\
\hline
\end{tabular}

The correlation coefficient $(r)$ with * is statistically significant $(p<0.05)$.

Percentage reduction of the Parameters

Table 5 shows the percentage reduction of Parameters in industrial samples before and after the treatment of the effluents $(250 \mathrm{ml})$ with the different masses $(5 \mathrm{~g}, 10 \mathrm{~g}, 15 \mathrm{~g}, 20 \mathrm{~g}$, and $25 \mathrm{~g}$ ) of the Immobilized Bacteria.

In TAN1 samples, the percentage reduction (\%) of COD ranged (14-89); BOD (50-80); SS (-32$35)$ and TDS (98-99). In TAN2 samples, the percentage decrease $(\%)$ of COD ranged (15$38) ;$ BOD (90-92); SS [-28-(-55)] and TDS (9798). In TAN3 samples, the percentage decrease (\%) of COD ranged (11-44); BOD (76-81); SS (15-25) and TDS (98). The percentage increase in the levels COD, BOD and TDS might be due to the increase in the surface area of the different masses of the immobilized bacteria. However, the percentage decrease in the levels of the SS might be due to the aggregation of the TDS which are large enough to result into SS. The percentage decrease in the levels of the SS might be also due to the influence of the nutrients which was added into the effluents in order to make the microorganisms more active and viable for fast degradation of organic contaminants in the effluent. This is in line with the work of Jimoh et al. (2018) in which the concentration of the SS increase after the bioremediation of effluents.

Sreemoyee and Priti (2013) assessed and reduced several Physico-chemical parameters of dairy wastewater using Niesseria $s p$. and concluded that the species are well known to degrade organic compounds. This is in agreement with the current study in which the immobilized Niesseria $s p$ degrade the organic contaminants as indicated by the BOD, COD and TDS.

Jimoh et al. (2018) observed that TSS of the effluents was increased after treatment with immobilized bacteria and concluded that it might be due to the biostimulation method adopted for the research.

The optimum $\mathrm{pH}$ Biosorption of Chromium by Bacillus spp and Staphylococcus spp. from tannery effluent was investigated by Mythili and Karthikeyan (2011). The maximum adsorption of Chromium $(86.4 \mathrm{mg} / \mathrm{L})$ was showed by Bacillus spp and Staphylococcus spp showed $70.6 \mathrm{mg} / \mathrm{L}$ at an initial concentration of $100 \mathrm{mg} / \mathrm{L}$. In the present study, immobilised Bacillus spp and Staphylococcus spp. from the tannery industrial effluents reduced the levels of the organic pollutants with high potential as indicated by the percentage reduction of BOD, COD and TDS.

Enzymes often can work in multiple environments especially if they are immobilized. This makes the microorganisms' enzymes even more resistant to harsh environments and enables the enzymes to be recovered and recycled after they are no longer needed (Gianfreda and Rao 2004). Ramesh and Singh (1993) reported that the immobilized bacteria having more efficiency to remove the suspended particles than free cells. Using the immobilized cell is preferable due to its capability for using several times with the same efficiency, which makes it more economical. Similar work was done by Sikander et al. (2007) showing the higher reduction with permeabilized cells of Ochrobactrum intermedium strain SDCr-5. 
BAJOPAS Volume 13 Number 2, December, 2020

The results revealed the isolation and identification of isolates with the potential for the reduction of $\mathrm{Cr}$ (VI) to $\mathrm{Cr}$ (III). Results indicated that immobilized $B$. cereus could be efficiently used for the reduction of $\mathrm{Cr}$ (VI).

Table 5: Percentage reduction of the tested Parameters from the tannery industrial samples of the Immobilized Bacteria.

\begin{tabular}{lllllll}
\hline \multirow{2}{*}{ Industries } & & \multicolumn{5}{c}{ Percentage Reduction $(\%)$} \\
\cline { 3 - 7 } & & $5 \mathrm{~g}$ & $10 \mathrm{~g}$ & $15 \mathrm{~g}$ & $20 \mathrm{~g}$ & $25 \mathrm{~g}$ \\
\hline TAN1 & COD & 28 & 14 & 64 & 87 & 89 \\
& BOD & 50 & 54 & 59 & 67 & 80 \\
& SS & 35 & -26 & -27 & -32 & -63 \\
& TDS & 99 & 99 & 99 & 98 & 98 \\
TAN2 & COD & 15 & 20 & 25 & 32 & 38 \\
& BOD & 91 & 91 & 92 & 90 & 92 \\
& SS & -28 & -52 & -52 & -54 & -55 \\
& TDS & 97 & 99 & 99 & 99 & 99 \\
& COD & 33 & 44 & 22 & 11 & 26 \\
& BOD & 75 & 81 & 76 & 81 & 81 \\
& SS & 25 & 3 & -1 & -10 & -15 \\
& TDS & 98 & 98 & 98 & 98 & 98 \\
\hline
\end{tabular}

Percentage Reduction $=(B-A) / B \times 100 \%$

$A=$ Concentration of the parameter after treatment

$\mathrm{B}=$ Concentration of the parameter before treatment

$+=$ percentage decrease

- = percentage increase

In general, immobilization makes the enzyme more resistant to temperature, $\mathrm{pH}$, and substrate concentration swings giving it a longer lifetime and higher productivity per active unit (Gianfreda and Rao, 2004; FuIlbrook, 1996; Russell et al, 2003; Kandelbauer et al., 2004). Immobilized cells have been used and studied extensively for the production of useful chemicals (Ohtake and Silver, 1994), the treatment of wastewaters (Chen et al., 2003; Wang et al., 2010). Although many workers described microbial degradation of tannery effluent, limited literature is available on the bioremediation of tannery effluent using immobilized bacterial cells in the Kano Industrial Estates.

\section{CONCLUSION}

The samples contained variable levels of the physicochemical parameters. The results of the Analysis of variance revealed that, no statistical difference $(p<0.05)$ was observed for the temperature, $\mathrm{pH}, \mathrm{SS}, \mathrm{TDS}, \mathrm{BOD}$ and $\mathrm{COD}$ among the three tannery industries before the treatment. The levels of some of the parameters
(SS, TDS and COD) observed in the samples were found above the recommended limits of WHO and NESREA, which called for the treatment of the effluents before discharge into the environment. Base on the morphological and biochemical test results, TAN1, TAN2, and TAN3 bacterial isolates were identified to be Neisseria spp, Bacillus cereus, and Staphylococcus aureus respectively. The results of Post-treatment analysis showed that there is overall decrease in the levels of the parameters determined when compared with that of the pre-treatment. The overall percentage reduction of the immobilised bacteria in the treatment of the respective effluents was in the order TAN2 (72\%)>TAN1 $(70 \%)>$ TAN3 $(62 \%)$. Hence, the immobilized bacteria are having higher biodegradation potential for the treatment of the tannery effluents.

\section{Acknowledgments}

The authors wish to acknowledge the University of Maiduguri for the financial support. The authors are grateful to the Kano State Ministry of Environment for their support in obtaining the effluent samples. 


\section{REFERENCES}

Ajao, A. T., Adebayo, G. B., and Yakubu, S. E. (2011). Bioremediation of textile industrial effluent using mixed culture of Pseudomonas aeruginosa and Bacillus subtilis immobilized on agar-agar in a bioreactor. J. Microbiol. Biotech. Res, 1(3), 50-56.

Akan, J. C., Moses, E. A., Ogugbuaja, V. O., and Abah, J. (2007). Assessment of tannery industrial effluents from Kano metropolis, Kano State, Nigeria. Journal of Applied Sciences, 7(19), 2788-2793.

Akan, J. C., Ogugbuaja, V. O., Abdulrahman, F. I., and Ayodele, J. T. (2009). Pollutant levels in effluent samples from tanneries and textiles of Kano industrial areas, Nigeria. Global journal of pure and applied sciences, 15(3-4).

APHA (1989). Standard methods for Examination of Will bete and Will betewater.15 $5^{\text {th }}$ edition. Brydpass Springfield Will behington DC. pp. 164-176

APHA (1992). Standard Methods for the Examination of Water and Wastewater. Health, 69, 1116-9.

Baba, A., Garba, S. T., and Bello, H. S. (2020). Bioremediation Potential of Immobilized corynebacterium kutsceri in the Treatment of Tannery Industrial Effluent from Challawa Industrial Estate, Kano State, Nigeria. Journal of the Turkish Chemical Society Section A: Chemistry, $7(2), 335-350$.

Beem, E. I. V. (1994). reduction of solvent VOC emission. J. Oil Col. Chem. Ass, 77, 158.

Bouwer, E. J., and Zehnder, A. J. (1993). Bioremediation of organic compoundsputting microbial metabolism to work. Trends in biotechnology, 11(8), 360367.

Chen, K. C., Wu, J. Y., Liou, D. J., and Hwang, S. C. J. (2003). Decolorization of the textile dyes by newly isolated bacterial strains. Journal of Biotechnology, 101(1), 57-68.

Dan'Azumi, S., and Bichi, M. H. (2010). INDUSTRIAL POLLUTION AND HEAVY METALS PROFILE OF CHALLAWA RIVER IN KANO, NIGERIA. Journal of Applied Sciences in Environmental Sanitation, $5(1)$.

DWAF. (1992). Analytical Methods Manual, TR 151. Department of Water Affairs and Forestry, Pretoria.

El-Bestawy, E. (2013). Biological treatment of leather-tanning industrial wastewater using free living bacteria.
Elsheikh, M. A. S. (2009). Tannery wastewater pre-treatment. Water Science and Technology, 60(2), 433-440.

FuIlbrook, P. D. (1996). "Kinetics." Industrial enzymology: The application of enzymes in Industry. 2nd Ed. T. Godfrey and J Reichelt. eds.. Nature. New York.

Gianfreda, L., and Rao, M. A. (2004). Potential of extra cellular enzymes in remediation of polluted soils: a review. Enzyme and microbial technology, 35(4), 339354.

Hugo Springer. (1994). John Arthur Wilson Memorial Lecture "Treatment of Industrial Wastes of the Leather Industry - is it still a Major Problem". JALCA, 89, 153-185

Jimoh, A. A., Ganiyu, B. A., Baba, D., and Baba, A. (2018) Bioremediation Process of Effluent from Detergent and Food Industries in Jos, Nigeria: Kinetics and Thermodynamics. International Journal of Engineering Science Invention (IJESI), 762-73

Kandelbauer, A., Maute, O., Kessler, R. W., Erlacher, A., and Gübitz, G. M. (2004). Study of dye decolorization in an immobilized laccase enzyme-reactor using online spectroscopy. Biotechnology and bioengineering, 87(4), 552-563.

Kongjao, S., Damronglerd, S., and Hunsom, M. (2008). Simultaneous removal of organic and inorganic Pollutants in tannery wastewater using electrocoagulation technique. Korean Journal of chemical engineering, 25(4), 703.

Maheshwari, U. M., Aruna, S., Gomathi, M., and AbdulJaffar, A. H. (2017). Bioremediation by Free and Immobilized Bacteria Isolated from Tannery Effluent. International Journal of Research in Applied, Natural and Social Sciences. 5(7), 75-90

Margesin, R., and Schinner, F. (2001). Bioremediation (natural attenuation and biostimulation) of diesel-oilcontaminated soil in an alpine glacier skiing area. Applied and environmental microbiology, 677), 3127-3133.

Mohammed, A., Sekar, P., and George, J. (2011). Efficacy of microbes in bioremediation of tannery effluent. Inter. J. Curr. Res, 3(4), 324-326.

Mohammed, S. S. D., Orukotan, A. A., and Abdullahi, H. (2017). Physicochemical and Bacteriological Assessment of Tannery Effluent from Samaru-Zaria, 
BAJOPAS Volume 13 Number 2, December, 2020 Kaduna State, Nigeria. Journal of Applied

Sciences and Environmental Management, 21(4), 734-740.

Munz, G., De Angelis, D., Gori, R., Mori, G., Casarci, M., and Lubello, C. (2009). The role of tannins in conventional and membrane treatment of tannery wastewater. Journal of hazardous materials, 164(2-3), 733-739

Mythili, K., and Karthikeyan, B. (2011). Bioremediation of $\mathrm{Cr}$ (VI) from tannery effluent using Bacillus spp and Staphylococcus spp. International Multidisciplinary Research Journal, 1(6).

NESREA (2009). National Environmental Standards for Effluent Limitations and Regulation. 1233-1236

Noorjahan, C. M. (2014). Physicochemical characteristics, identification of bacteria and biodegradation of industrial effluent. Journal of bioremediation and Biodegradation, 5(3).

Ohtake, H. I., and Silver, A. O. (1994). Bacterial reduction of toxic chromate. Biological degradation and bioremediation of toxic chemicals, 403-415.

Omoleke, I. I. (2004). Management of environmental pollution in Ibadan, an African city: the challenges of health hazard facing government and the people. Journal of Human Ecology, 15(4), 265-275.

Rajor, A., Reddy, A.S., and Singh, B. (2004). Determination of BOD kinetic Parameters and evaluation of alternate methods, M.Sc. Thesis, Department of biotechnology \& environmental Science, Thapar Institute of Engineering and Technology, Patiala

Ramasami, T., Rajamani, S., and Rao, J. R. (1994, March). Pollution control in leather industry: Emerging technological options. In International symposium on surface and colloidal science and its relevance to soil pollution, madras.

Ramesh, J. V. S., and Singh, S. P. (1993). Yearly variation in certain physicochemical parameters of pond at eastern Doon Valley. Uttar Pradesh J. Zoo, 12 (1), 7577.

Ranen, S., and Sharadinadra, C. (2009). Biotechnology applications to environmental remediation in resource exploitation. Current science, 97, 6-25
Russell, A. J., Berberich, J. A., Drevon, G. F., and Koepsel, R. R. (2003). Biomaterials for mediation of

chemical and biological warfare agents. Annual review of biomedical engineering, 5(1), 1-27.

Saravanan, P., and Saravanan, A. (1999). Decolourization of tannery effluent by Flavobacterium sp. EK 1. Indian Journal of Environmental Protection, 19, 19-24.

Sikander, S., and Shahida, H. (2007). Reduction of toxic hexavalent chromium by Ochrobactrum intermedium strain SDCr5 stimulated by heavy metals. Bioresource Technol, 98, 340-344.

Singh, N., Sharma, B. K., and Bohra, P. C. (2000). Impact assessment of industrial effluent of arid soils by using satellite imageries. Journal of the Indian Society of Remote Sensing, 28(2-3), 79.

Sreemoyee, C., and Priti, P. (2013). Assessment of physico-chemical parameters of dairy waste water and isolation and characterization of bacterial strains in terms of cod reduction. Int J Sci, 2(3), 395-400.

Verheijen, L. A. H. M., Wiersema, D., Pol, L. H., and De Wit, J. (1996). Management of wastes from animal product processing. Livestock and environment, Finding a balance. International Agriculture Center, Wageningen, The Netherlands.

Wang, F., Yao, J., Si, Y., Chen, H., Russel, M., Chen, K., and Bramanti, E. (2010). Short-time effect of heavy metals upon microbial community activity. Journal of Hazardous Materials, 173(13), 510-516.

WHO (World Health Organization). (2006). Air quality guidelines: global update 2005: particulate matter, ozone, nitrogen dioxide, and sulfur dioxide. World Health Organization.

World Bank. (1995). Nigeria's strategic options for redressing industrial pollution. World Bank, industry and energy division. 1st edition, West Central Africa Department; Annexes: 1995; pp 60-62.

Zahoor, A., and Abdul, R. (2009). Enumeration of Coliforms. Journal of Environmental Sciences. 21, 814-820 


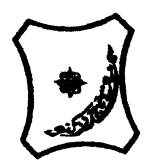

Bayero Journal of Pure and Applied Sciences, 13(2): 1 - 12

Received: November, 2020

Accepted: December, 2020

ISSN $2006-6996$

\title{
BIODEGRADATION POTENTIAL OF IMMOBILIZED BACTERIA IN THE TREATMENT OF TANNERY INDUSTRIAL EFFLUENTS FROM INDUSTRIAL ESTATES IN KANO STATE, NIGERIA
}

\author{
Abdullateef, B., ${ }^{1 *}$ Shuaibu, T. G., ${ }^{1}$ Babagana, K., ${ }^{1}$ Suleman, H. B. ${ }^{2}$ and Dauda, B. ${ }^{3}$ \\ ${ }^{1}$ Department of Pure and Applied Chemistry, Faculty of Science, University of Maiduguri, Borno State, \\ Nigeria \\ ${ }^{2}$ Department of Microbiology, Faculty of Science, University of Maiduguri, Borno State, Nigeria \\ ${ }^{3}$ Department of Chemical Engineering, Faculty of Engineering, University of Maiduguri, Borno State, \\ Nigeria \\ *Corresponding author: babslega@gmail.com; abelega2007@yahoo.com; +2348061309753
}

\section{ABSTRACT}

Industrial Effluents Samples from Gashash Tanneries (TAN1) in Bompai Industrial estate, Larabee Tannery Industry (TAN2) in Sharada Industrial estate and Z Tannery Industries (TAN3) in Challawa Industrial estate, Kano State, Nigeria were collected over a period of six months (August 2017 to January 2018) for assessing the biodegradation potentials of bacteria in the treatment of organic pollutants within the effluents. Bacteria were isolated from the effluents and immobilized on agar-agar. Different masses (5 g, $10 \mathrm{gr}, 15$ $\mathrm{g}, 20 \mathrm{~g}$, and $25 \mathrm{~g}$ ) of the bacteria were used in the treatment of $250 \mathrm{ml}$ of the effluents for ten days in a shaker incubator (Gallenkamp-OC-4364-L) at the temperature $30{ }^{\circ} \mathrm{C}$ and speed of $60 \mathrm{rpm}$. Pre-treatment analysis of the effluents for Temperature, pH, Biochemical Oxygen Demand (BOD), Chemical Oxygen Demand (COD), Suspended Solid (SS) and Total Dissolved Solids (TDS) gives the following results; temperature $\left({ }^{\circ} \mathrm{C}\right.$ )

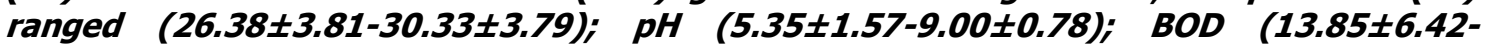
$38.75 \pm 16.20) ;$ COD (1406 $\pm 208-3532 \pm 1373) ;$ SS (208 $\pm 235-780 \pm 739)$ and TDS (266 $\pm 253-5276 \pm 2971)$. No statistical differences ( $p \leq 0.05)$ was observed for all the results among the different industries. The bacterial isolates were identified as Neisseria spp, Bacillus cereus, and Staphylococcus aureus, in TAN1, TAN2, and TAN3, respectively. After treatment of the effluent with the different masses of the isolated bacteria, the mean level of BOD was found to range as (0.55 $\pm 0.36-6.92 \pm 5.49) ; C O D$ (ND-3134 \pm 1595$)$;

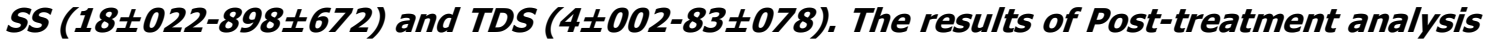
showed that there is overall decrease in the levels of the parameters determined when compared with that of the pre-treatment. The overall percentage reduction of the immobilised bacteria in the treatment of the respective effluents was in the order TAN2 (72\%)>TAN1 (70\%)>TAN3 (62\%). Hence, the immobilized bacteria are having higher biodegradation potential for the treatment of the tannery effluents.

Keywords: Biodegradation, bacteria, effluent, immobilization, tannery.

\section{INTRODUCTION}

Tannery industrial wastewater is a serious consequence of the pollution point of view for streams, freshwater, and land used for agriculture. The lack of awareness in the modern industrial practice has resulted in the discharge of tannery effluents which exhibit very high value of chromium ( $\mathrm{Cr}$ ), Sulfide, and chloride, Total Dissolved Solid (TDS), Total Suspended Solid (TSS), Biochemical Oxygen Demand (BOD) and Chemical Oxygen Demand (COD) in the water stream or land (Mohammed et al., 2001). Tanning is the process, which One ton of skin generally leads to the production of 20 to $80 \mathrm{~m}^{3}$ of turbid and foul-smelling converts the protein of the rawhide or skin into a stable material, which will not putrefy and is suitable for a wide variety of end applications (Elsheikh, 2009). The highly polluting chromium is the most commonly used tanning material producing leather that is more flexible and pliable than vegetable-tanned leather and does not discolor or lose shape in water as drastically as vegetable-tan (Elsheikh, 2009). Tannery effluent is among the most hazardous industrial pollutants due to its huge organic and inorganic load, which is highly toxic to human life and the environment (Kongjao et al., 2008). wastewater including chromium (100-400 mg/l), sulfide $(200-800 \mathrm{mg} / \mathrm{l})$, high levels of fat and 
BAJOPAS Volume 13 Number 2, December, 2020 other solid wastes, and notable pathogen contamination as well as pesticides added for skin conservation during transport (Elsheikh, 2009). There are more than 6000 tanneries in Nigeria with an annual processing capacity of 700,000 tons of hides and skins (Omoleke, 2004; Singh et al., 2008). It was reported that the total amount of waste produced per animal slaughtered is approximately $35 \%$ of its weight (World Bank, 1995). Also, for every $1000 \mathrm{~kg}$ of carcass weight, a slaughtered beef produces 5.5 $\mathrm{kg}$ of manure (excluding rumen contents or stockyard manure) and $100 \mathrm{~kg}$ of paunch manure (undigested food) (Verheijen et al., 1996). Tanneries generate wastewater in the range of 30-35 $\mathrm{L} \mathrm{kg}^{-1}$ skin/hide processed with variable $\mathrm{pH}$, Biological Oxygen Demand (BOD), Chemical Oxygen Demand (COD), high concentrations of suspended solids (SS), and tannins as well as chromium (Zahoor and Abdul, 2009).

Being heterogeneous and composed of a wide variety of compounds, it is very difficult to select a unique direct method for estimating the biodegradability of organic contents and biokinetic parameters for a wastewater sample (Rajor, 2004). For this purpose, some indirect estimation such as determination of biochemical oxygen demand (BOD) and chemical oxygen demand (COD) are applied as common laboratory investigations [9]. During retanning procedures, synthetic tannins (Syntan), oils and resins are added to form softer leather at varying doses (Munz et al., 2009). One of the refractory groups of chemicals in tannery effluents derives mainly from tannins (Ramasami et al., 2004). Syntans are characterized by complex chemical structures, because they are composed of an extended set of chemicals such as phenol-, naphthalene-, formaldehyde- and melamine-based syntans, and acrylic resins (Beem, 1994). Organic pollutants (proteic and lipidic components) are originated from skins (it is calculated that the raw skin has $30 \%$ loss of organic material during the working cycle) or they are introduced during processes (Hugo Springer, 1994).

Many conventional processes such as oxidation, chemical and biological processes were carried out to treat tanneries wastewater (Ebtesam et al, 2013). Biological processes have received more attention because of their costeffectiveness, lower sludge production and environmental friendliness (Noorjahan, 2014). Naturally occurring micro-organisms degrade the hazardous organic wastes including xenobiotic compounds, such as pesticides, polycyclic aromatic hydrocarbons (PAHs) and polychlorinated biphenyls (PCBs) in due course of time (Ranen and Sharadinadra, 2009). Bioremediation is based on the idea that all organisms remove substances from the environment to carry outgrowth and metabolism (Bouwer and Zehnder, 1993). Bacteria, protista and fungi are found to be very good at degrading complex molecules and incorporating the breakdown products into their metabolism (Bouwer and Zehnder, 1993). The resultant metabolic wastes that they produce are generally safe and somehow recycled into other organisms (Ranen and Sharadinadra, 2009). An acclimatized indigenous population of microorganisms capable of degradation of the compounds of interest must exist at the site for a successful bioremediation mode (Ranen and Sharadinadra, 2009). It has been observed that for a successful bioremediation mode, an acclimatized indigenous population of microorganisms capable of degradation of the compounds of interest must exist at the site under investigation (Ranen and Sharadinadra, 2009). Even though there are numerous physical and chemical methods employed in the disposal of wastes the advantage in using bacterium is that they play a key role in the reduction of COD, BOD, total protein, total tannin and total phenol (Saravanan and Saravanan, 1998)

Baba et al. (2020) studied the bioremediation potential of immobilized corynebacterium kutsceri in the Treatment of tannery industrial effluent from Challawa Industrial Estate, Kano State, Nigeria. The aim of the work is to study the reduction in the level of the contaminants through the process of bioremediation using the isolated bacteria. Immobilized bacteria can withstand various temperatures, $\mathrm{pH}$ and substrate concentrations; consequently, increasing the efficiency and the lifespan of the bacteria. Immobilized bacteria are widely applied in the treatment of wastewater and can be separated and recovered after the treatment with the same efficiency (Baba et al., 2020).

\section{MATERIALS AND METHODS \\ Study Area}

This study was carried out in Bompai, Sharada and Challawa industrial estates in Kano, Figure 1. Kano lies on Latitude $11^{\circ} 30^{\prime} \mathrm{N}$ and $8^{\circ} 30^{\prime} \mathrm{E}$ and Longitude $11^{\circ} 5^{\prime} \mathrm{N}$ and $8^{\circ} 5^{\prime} \mathrm{E}$ in Northern Nigeria. It is one of the developed industrial cities in Nigeria. Tannery activities are the dominating industries and this could be one of the reasons for her high population density (Dan'Azumi and Bichi, 2010). Many researchers have studied biodegradation of tannery effluent using microorganisms. However, limited literature is available on the biodegradation of tannery effluent in Kano industrial estates using 
BAJOPAS Volume 13 Number 2, December, 2020 immobilized bacterial cells. This research work focuses on the potential of the use of the indigenous immobilized bacterial isolates in the treatment of tannery effluents in the industrial estates.

\section{Sample Collection}

Effluents were collected from the Tannery Industries from Bompai, Challawa and Sharada Industrial Estates, Kano, Nigeria. The effluents were collected over a period of six months (August 2017 to January 2018). Samples collected in a sterile 4-liter plastic container with a unique identification number were preserved using an ice-box that was transported to the Microbiology Laboratory, Department of Microbiology, Bayero University of Kano for analysis

\section{Sample Preparation and Sample Analysis}

Immediately after the collection of the effluent, $\mathrm{pH}$, TSS, TDS, COD, BOD levels were determined before treatment (Pre-treatment determination) and ten days after treatment (Post-treatment determination) as described in
APHA (1989) standard methods. $\mathrm{pH}$ was determined using Ecotests $\mathrm{pH}$ meter and TDS was determined using AQUALYTIC TDS Salinometer. BOD was determined as described by the standard method (APHA, 1992). COD and SS were determined using DR/2010 HACH portable data logging spectrophotometer (DWAF, 1992)

\section{Identification and Biochemical} Characterization of the Bacterial Isolates

The bacteria were isolated from the effluents using Serial Dilution according to the method described by APHA (1989). The biochemical tests such as oxidase, catalase, coagulase, indole (from $1 \%$ tryptone broth), citrate (Simmons citrate agar), methyl red/VogesProskauer (MR/VP), nitrate reduction, Starch Hydrolysis, Glucose, Maltose, and Lactose tests were carried out on the bacterial isolates to identify the bacteria through the bacteria biochemical characteristics according to Ajao et al. (2011).

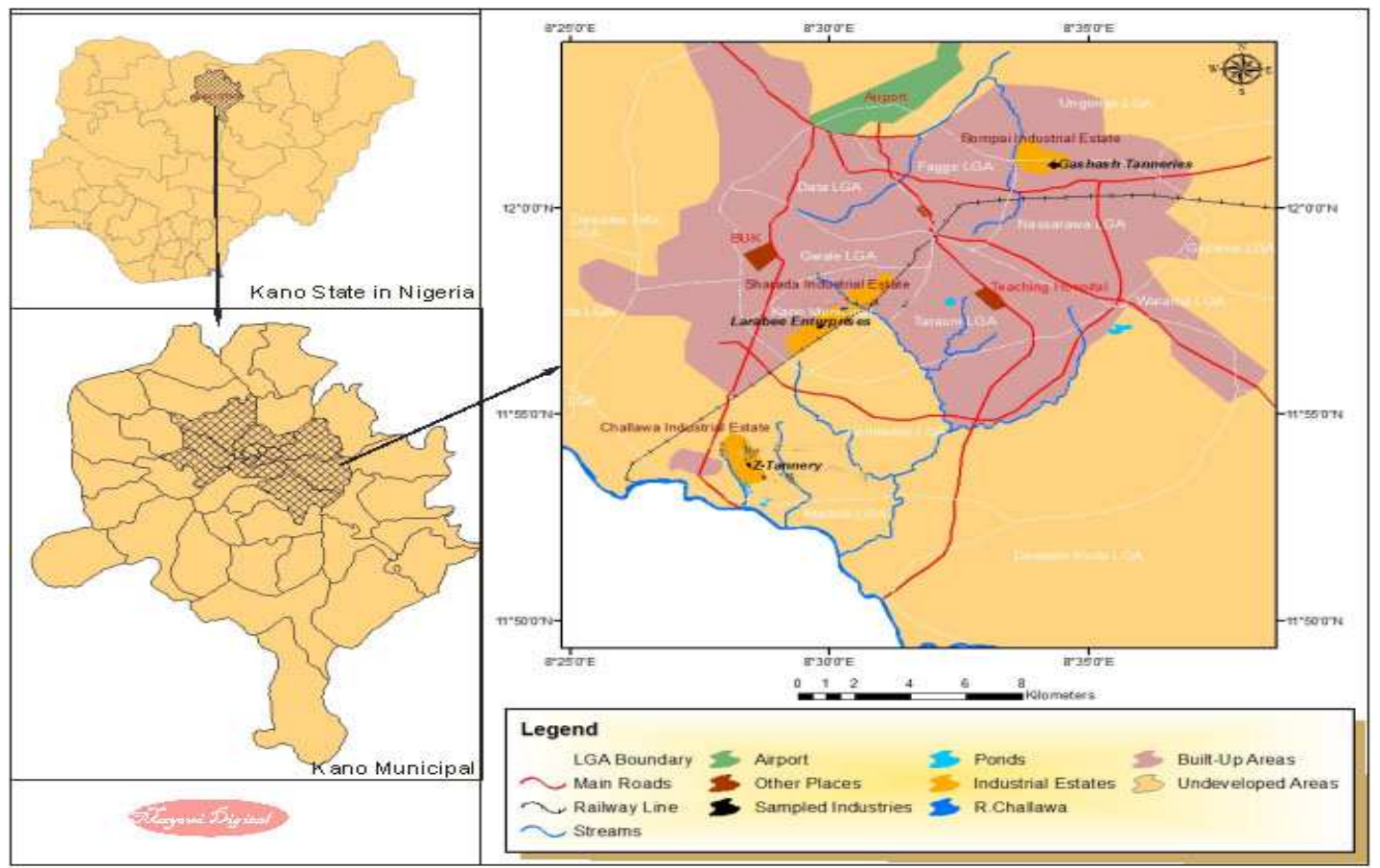

Fig. 1 Map showing the study areas

Source: Mayomi Digital Productions, GIS Laboratory, Department of Geography, UNIMAID (2017)

\section{Determination of Growth Rate of the Bacteria in Effluent Sample}

The bacteria growth rates were determined by transferring $2 \mathrm{~mL}$ of the bacterial isolates from the tannery effluent in broth medium into 100 $\mathrm{mL}$ sterile effluents in conical flasks and kept in an incubator (Giffrin cool) for 10 days. Control was also set up by incubating another $100 \mathrm{~mL}$ each of the sterile effluents without the bacteria. The optical density of the content was determined at the wavelength of $600 \mathrm{~nm}$ on a daily interval and recorded. 
BAJOPAS Volume 13 Number 2, December, 2020 Immobilization of Bacteria

Agar solution and inoculi were prepared separately. Fifty milliliters $(50 \mathrm{~mL})$ of nutrient broth each of the inoculi was prepared in a McCartney bottle and incubated for 24 hours. A solution of agar-agar was prepared by dissolving $10 \mathrm{~g}$ of the powder in distilled water and made up to $500 \mathrm{~mL}$ mark in an Erlenmeyer flask and was sterilized in an autoclave (280A) for 15 minutes and allowed to cool to $40-45^{\circ} \mathrm{C}$ (Ajao et al., 2011). Four milliliters ( $4 \mathrm{~mL})$ of the bacterial isolates in the nutrient broth was mixed with 36 $\mathrm{ml}$ of the prepared agar-agar media in petri-dish plates and then allowed to solidify. This was kept in the refrigerator for bioremediation.

\section{Bioremediation (Treatment) of the Effluents}

The solidified agar block (immobilized bacteria) was cut into cubes using a sterile knife; $0.1 \mathrm{~mL}$ phosphate buffer ( $\mathrm{pH} \mathrm{7.0)}$ was added and kept in the refrigerator for 1 hour for curing. The phosphate buffer was decanted after 1 hour and the cubes were washed with sterile distilled water 3-4 times before it was used (Ajao et al., 2011). Two liters (2 L) of the effluent was supplemented with the minimum basal medium in $\mathrm{g} / \mathrm{L}: \mathrm{NaCl}(0.8), \mathrm{MgSO}_{4} .7 \mathrm{H}_{2} \mathrm{O}(0.001), \mathrm{KH}_{2} \mathrm{PO}_{4}$ (2), $\mathrm{NaNO}_{3}$ (2), $\quad \mathrm{CaCl}_{2} .2 \mathrm{H}_{2} \mathrm{O} \quad(0.5)$ and $\mathrm{NaHPO}_{4} .12 \mathrm{H}_{2} \mathrm{O}(2)$ and sterilized in an autoclave at $121^{\circ} \mathrm{C}$ for 15 minutes (Margesin and Schinner, 2001). Two hundred and fifty milliliters $(250 \mathrm{~mL})$ of the effluents were transferred into different $250 \mathrm{ml}$ conical flasks. The content was covered with a cotton-wool ramped with foil paper to avoid contamination. Five grams $(5 \mathrm{~g})$ of the immobilized bacteria were quickly transferred into each of the effluents in the conical flasks in an inoculating chamber. The same procedures were carried out for the $10 \mathrm{~g}, 15 \mathrm{~g}, 20 \mathrm{~g}$ and 25 $\mathrm{g}$ of the immobilized bacteria in separate $250 \mathrm{~mL}$ effluents in conical flasks and agitated for ten days in a shaker incubator (Gallenkamp-OC4364-L) at a temperature $30^{\circ} \mathrm{C}$ and speed of 60 rpm. The treated effluent samples were taken on the tenth day and analyzed for the parameters $\mathrm{pH}$, SS, TDS, COD, and BOD, (Posttreatment determination) for the different grams of bacteria to evaluate and compare the biodegradation potential. (Baba et al., 2020).

\section{Statistical Analysis}

The data were represented as Mean \pm Standard deviation and analyzed statistically using oneway Analysis of Variance (ANOVA) and Tukey's HSD as Post Hoc Tests with the aid of SPSS 16.0. The correlation coefficient was also used to measure the strength of the relationship between the different masses of the bacteria and the parameters. All $\mathrm{p} \leq 0.05$ were considered as statistically significant.

\section{RESULTS AND DISCUSSION Physico-chemical parameters in the Industrial Effluents before the Biodegradation.}

Results of the Physico-chemical parameters in the industrial effluents before the Biodegradation is shown in table 1 . The mean temperatures $\left({ }^{\circ} \mathrm{C}\right)$ observed in TAN1, TAN2, and TAN3 samples were $28.07 \pm 0.65 ; 27.77 \pm 0.64$ and $26.38 \pm 3.81$ respectively. The order of the mean temperature of the samples from the three industries can be arranged as TAN1 > TAN2>TAN3. The temperature observed at TAN1, TAN2, and TAN3 samples were found below the WHO $\left(35^{\circ} \mathrm{C}\right)$ and NESREA $\left(40^{\circ} \mathrm{C}\right)$ limits. The low values of temperature might be due to the processes used at the time of sampling. High temperature brings down the solubility of gases in water that ultimately expresses as high BOD and COD. Statistical analysis shows that there is no significant difference $(p<0.05)$ between the mean values of temperature among the industries. This might be due to similar tannery activities involved in the tannery industries at the time of sampling. The average values of temperature observed in this present study are less than those observed by Akan et al. (2007), Akan et al. (2009) and Baba et al. (2020).

The mean level of $\mathrm{pH}$ observed in TAN1, TAN2 and TAN3, samples were $7.77 \pm 2.93$; $8.35 \pm 0.28$ and $7.52 \pm 0.76$ respectively. The order of the mean $\mathrm{pH}$ of the samples from the three industries can be arranged as TAN2> TAN1 $>$ TAN3. The $\mathrm{pH}$ of the samples falls within the WHO (7.0-8.5) and NESREA (6-9) standard limits. Statistical analysis shows that there is no significant difference $(p<0.05)$ between the mean values of $\mathrm{pH}$ among the industries. This might be due to similar tannery activities involved in the tannery industries at the time of sampling. Maheshwari et al. (2017) reported that the level of $\mathrm{pH}$ in the effluents from the tannery industry in Vaniyambadi, India was 6.5 which was lower than that observed in the present study. The $\mathrm{pH}$ in the effluents from the tannery industries in Kano and Kaduna were reported to be 7.64 and 6.89, respectively (Akan et al., 2007; Mohammed et al., 2017). The average values of $\mathrm{pH}$ observed in this present study are less than those observed by Mohammed et al. (2017) and Baba et al. (2020). The mean level of SS $(\mathrm{mg} / \mathrm{l})$ observed in TAN1, TAN2, and TAN3 samples were 374 \pm 124 ; $358 \pm 335$ and $780 \pm 739$ respectively. The order of the mean SS in the samples from the three industries can be arranged as TAN3 > TAN1 $>$ TAN2. 
The SS observed in the samples were far above the recommended standard limits of regulating bodies WHO $(30 \mathrm{mg} / \mathrm{l})$ and NESREA $(10 \mathrm{mg} / \mathrm{l})$. Statistical analysis shows that there is no significant difference $(p<0.05)$ between the mean values of SS among the industries. This might be due to similar tannery activities involved in the tannery industries at the time of sampling. The average values of SS observed in this present study are less than that observed $(3700 \pm 122 \mathrm{mg} / \mathrm{l})$ by Akan et al. (2009) for tanneries in Kano. Also, the average values of SS observed in this present study are less than that observed by Mohammed et al. (2017) and Baba et al. (2020) with the exception in TAN3.

The mean level of TDS (mg/l) observed in TAN1, TAN2, and TAN3 samples were $3941 \pm 3703$; $3300 \pm 1714$ and $2653 \pm 1240$ respectively. The order of the mean TDS in the samples from the three industries can be arranged as TAN1>TAN2>TAN3. The TDS observed in the samples were far above the recommended standard limits of WHO $(250 \mathrm{mg} / \mathrm{l})$ and NESREA $(500 \mathrm{mg} / \mathrm{l})$. Statistical analysis shows that there is no significant difference $(p<0.05)$ between the mean values of TDS among the industries. This might be due to similar tannery activities involved in the tannery industries at the time of sampling. TDS in the effluents from the tannery industries in Kano, Nigeria was reported to be $1281 \mathrm{mg} / \mathrm{l}$ (Akan et al., 2007). The average values of SS observed in this present study are less than those observed by Mohammed et al. (2017) and Baba et al. 2020)

The mean level of COD (mg/l) observed in TAN1, TAN2 and TAN3 samples seasons were $2372 \pm 938 ; \quad 1406 \pm 208$ and $3532 \pm 1373$ respectively. The order of the mean COD of the samples from the three industries can be arranged as TAN3>TAN1> TAN2. The COD observed in TAN1, TAN2 and TAN3 samples were far above the recommended standard limits of regulating bodies $\mathrm{WHO}(40 \mathrm{mg} / \mathrm{l})$ and NESREA (40 mg/l). Statistical analysis shows that there is no significant difference $(p<0.05)$ in COD among the industries. This might be due to similar tannery activities involved in the tannery industries as at the time of sampling. The Chemical Oxygen demand (COD) is the amount of oxygen, in $\mathrm{mg} / \mathrm{L}$, required for the degradation of the compound of wastewater to occur. In comparison, the average values of COD observed in this present study were higher than that observed by Mohammed et al. (2017) but lower than that observed by Baba et al. (2020).

The mean levels of BOD $(\mathrm{mg} / \mathrm{l})$ observed in TAN1, TAN2 and TAN3 samples were $13.85 \pm 6.42 ; \quad 19.46 \pm 0.50$ and $17.13 \pm 3.14$ respectively. The order of the mean BOD in the samples from the three industries can be arranged as TAN2>TAN3>TAN1. The BOD observed in TAN1, TAN2 and TAN3 samples were found below the recommended limits of NESREA (200 mg/l) but above WHO (10 mg/l). Statistical analysis shows that there is no significant difference $(p<0.05)$ between the mean values of BOD among the industries. This might be due to similar tannery activities involved in the tannery industries at the time of sampling. The low level of BOD recorded in this study is an indication of the low level of biodegradable organic solids in the effluent. The average values of BOD observed in this present study were lower than those observed by Mohammed et al. (2017) and Baba et al. (2020).

Table 1: Mean Values \pm S.D of Physico-chemical parameters of effluents from the Tannery Industries before Treatment.

\begin{tabular}{llllllll}
\hline Parameter & Tannery 1 & Tannery 2 & Tannery 3 & $\mathrm{a}$ & $\mathrm{b}$ & $\mathrm{c}$ & $\mathrm{d}$ \\
\cline { 2 - 7 } Temperature $\left({ }^{\circ} \mathrm{C}\right)$ & $28.07 \mathrm{a} \pm 0.65$ & $27.77 \mathrm{a} \pm 0.64$ & $26.38 \mathrm{a} \pm 3.81$ & & $29.50 \pm 4.68$ & 35 & 40 \\
pH & $7.77 \mathrm{a} \pm 2.93$ & $8.35 \mathrm{a} \pm 0.28$ & $7.52 \mathrm{a} \pm 0.76$ & 6.89 & $5.35 \pm 1.57$ & $7.0-8.5$ & $6.0-9.0$ \\
$\mathrm{COD}(\mathrm{mg} / \mathrm{l})$ & $2372 \mathrm{a} \pm 938$ & $1406 \mathrm{a} \pm 208$ & $3532 \mathrm{a} \pm 1373$ & 2.2 & $3106 \pm 2753$ & 40 & 40 \\
$\mathrm{BOD}(\mathrm{mg} / \mathrm{l})$ & $13.85 \mathrm{a} \pm 6.42$ & $19.46 \mathrm{a} \pm 0.50$ & $17.13 \mathrm{a} \pm 3.14$ & 1032 & $26.17 \pm 9.49$ & 10 & 200 \\
$\mathrm{SS}(\mathrm{mg} / \mathrm{l})$ & $374 \mathrm{a} \pm 124$ & $358 \mathrm{a} \pm 335$ & $780 \mathrm{a} \pm 739$ & 501 & $562 \pm 482$ & 30 & 10 \\
TDS $(\mathrm{mg} / \mathrm{l})$ & $3941 \mathrm{a} \pm 3703$ & $3300 \mathrm{a} \pm 1714$ & $2653 \mathrm{a} \pm 1240$ & 532.7 & $444 \pm 507$ & 250 & 500 \\
\hline
\end{tabular}

The values given in the table above are means of 6 replicate values, $\mathrm{n}=6$ ( 1 sample was taken monthly for 6 months). Within the rows, means with different alphabets are statistically different $(p<0.05)$. WHO: World Health Organisation. NESREA: National Environmental Standard and Regulatory Enforcement Agency. a = Mohammed et al.(2017), b = Baba et al. (2020), c = WHO (2006), $d=$ NESSRA (2009) 
BAJOPAS Volume 13 Number 2, December, 2020

Identification, Biochemical Characterization and growth rates of the Bacterial Isolates

Results of identification and biochemical characterization of the bacterial isolates were shown in table 2. After 24 hours of incubation, the nutrient agar media plates were checked for bacterial growth. The results showed the presence of different strains in the samples. The TAN1 bacteria isolate was found to be gramnegative cocci while TAN3 was gram-positive cocci. TAN2 bacteria isolate was found to be gram-positive, rod-shaped. TAN1, TAN2, and TAN3 bacteria isolates recorded positive results for spore former.

The results of the biochemical tests indicated that all the bacteria were positive for catalase, oxidase, citrate, maltose, glucose, lactose (negative in TAN1), mannitol (negative in TAN2), starch hydrolysis and coagulase (negative in TAN2) tests. The bacteria showed negative results for nitrate reduction, $M R$ (positive in TAN2), VP (positive in TAN1), Indole (positive in TAN2) tests. Base on the morphological and biochemical test results, TAN1, TAN2, and TAN3 bacteria isolates were identified to be Nesseria spp, Bacillus cereus, and Staphylococcus aureus respectively.

The growth rate of the TAN1, TAN2 and TAN3 Isolates were shown in figure 2. Generally, the optical density increase with the increase in time (day) and decrease as time goes on. The highest optical density was shown by bacillus cereus in TAN2 while the lowest was shown by Staphylococcus aureus in TAN3.

The initial growth phase of TAN1 Isolate bacteria occurred within 2-day of incubation as the growth rate increases up to the 6th-day incubation when the maximum growth was observed. Beyond the 6th day, the growth of the bacteria declined (which might be due to a shortage of nutrients in the effluents) until it reached its death phase (which might be due to the unavailability of nutrients in the effluents).

A similar trend of growth was also observed for TAN2 Isolate as the initial growth phase also occurred within 2-day of incubation but maximum growth rate observed on the 4th day of incubation. The stationary stage occurred between the 4th day and the 8th day. Beyond the 8th day, the growth of the bacteria declined (which might be due to a shortage of nutrients in the effluents) until it reached its death phase (which might be due to the unavailability of nutrients in the effluents).

The initial growth phase of TAN3 bacterial Isolate occurred within the 3-day incubation as the growth rate increases up to the 6th-day incubation when the maximum growth was observed. Beyond the 6th day, the growth of the bacteria declined (which might be due to a shortage of nutrients in the effluents) until it reached its death phase (which might be due to the unavailability of nutrients in the effluents).

Table 2: Morphological and Biochemical characteristics of bacterial isolates

\begin{tabular}{lllll} 
Bacterial Isolates & & TAN1 & TAN2 & TAN3 \\
\hline $\begin{array}{lllll}\text { Morphological } \\
\text { characteristics }\end{array}$ & Shape & Cocci & Rod & Cocci \\
& Spore & & & \\
& former & + & + & + \\
Gram & & & \\
Biochemical characteristics & reaction & - & + & + \\
& Citrate & + & + & + \\
& Catalase & + & + & + \\
& Coagulase & + & - & + \\
Starch & + & + & + \\
& Glucose & + & + & + \\
Oxidase & + & + & + \\
& Indo & - & + & - \\
Lactose & - & + & + \\
Manitol & + & - & + \\
Maltose & + & + & + \\
MR & - & + & - \\
VP & + & - & - \\
& Nitrate & - & - & - \\
Reduction & - Neisseria & Bacillus & Staphylococcus \\
& Bacterial & cereus & aureus \\
& name & spp & cas
\end{tabular}

+ = Positive; - = Negative; MR=Methyl Red; VP= Voges-Proskauer 


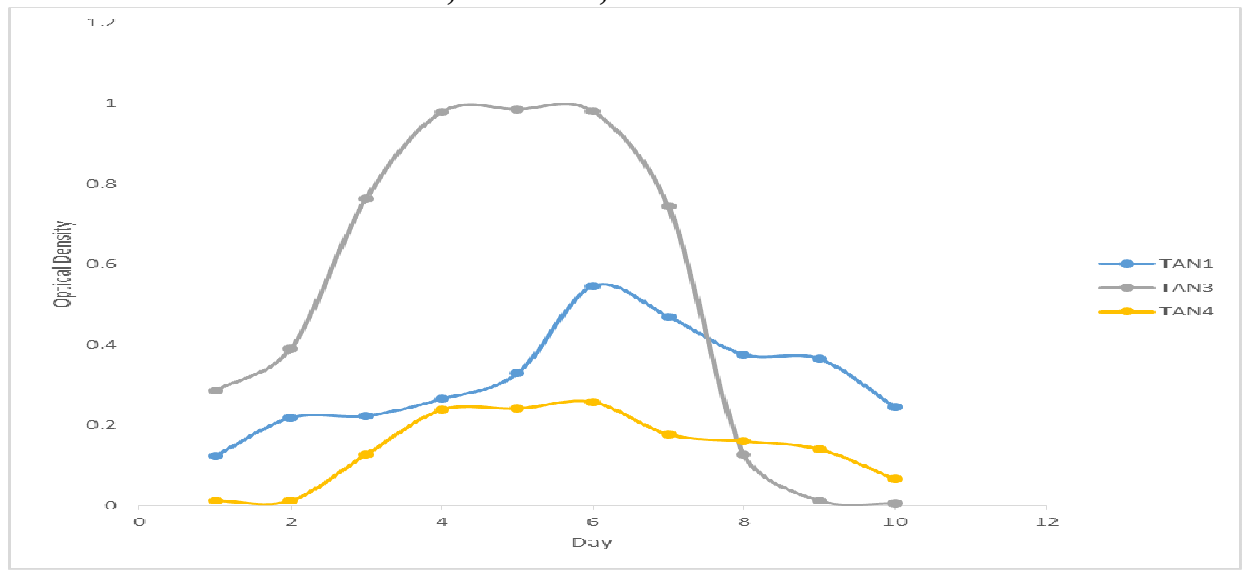

Fig. 2 Growth rates of the isolates in the effluents from the Tannery Industries

\section{Physico-chemical Parameters in the Industrial Effluents after the biodegradation.}

Table 3 shows the mean results of the physicochemical parameter before and after bioremediation using the different masses $(5 \mathrm{~g}$, $10 \mathrm{~g}, 15 \mathrm{~g}, 20 \mathrm{~g}$, and $25 \mathrm{~g}$ ) of the respective immobilized bacteria. Also, Table 4 shows the mean results of correlation coefficient ( $r$ ) between different masses of bacteria and physicochemical parameters.

The mean values $(\mathrm{mg} / \mathrm{l})$ of the SS after the bioremediation varies between $243 \pm 45$ and $898 \pm 672$. The mean concentration $(\mathrm{mg} / \mathrm{l})$ of SS remediated by the different masses $(5 \mathrm{~g}, 10 \mathrm{~g}$, $15 \mathrm{~g}, 20 \mathrm{~g}$, and $25 \mathrm{~g}$ ) of the bacteria varies. The SS in the samples fluctuates up and down after the bioremediation process when compared with the SS of the raw samples before the bioremediation. The increase in the levels of the SS might be due to the aggregation of the TDS which are large enough to result into SS. The increase in the levels of the SS might be also due to the influence of the nutrients which was added into the effluents in order to make the microorganisms more active and viable for fast degradation of organic contaminants in the effluent. The relative potential or efficiency of the different masses of the bacteria in remediating SS in TAN1 samples was in the order $25 \mathrm{~g}>20 \mathrm{~g}>15 \mathrm{~g}>10 \mathrm{~g}>5 \mathrm{~g}$. For TAN2 and TAN3 samples, the order was $25 \mathrm{~g}>20 \mathrm{~g}>15$ $\mathrm{g}>10 \mathrm{~g}>5 \mathrm{~g}$. These might be due to the variations in the surface areas of the different masses of the immobilized bacteria. Statistical analysis shows that there is no significant difference $(p<0.05)$ between the mean values of SS among the masses in the respective industries. Positive and significant correlations exist between the masses of bacteria and Suspended Solid (SS). This showed that there is general increase in the levels of the SS as the masses of the immobilized bacteria increases. TAN3 (90\%) and TAN1 (80\%) showed a very high correlation with the masses of the bacteria while TAN2 (61\%) showed a very low correlation.

The mean values $(\mathrm{mg} / \mathrm{l})$ of the TDS after the bioremediation varies between $46 \pm 11$ and $83 \pm 78$. The mean concentration $(\mathrm{mg} / \mathrm{l})$ of TDS remediated by the different masses $(5 \mathrm{~g}, 10 \mathrm{~g}$, $15 \mathrm{~g}, 20 \mathrm{~g}$, and $25 \mathrm{~g}$ ) of the bacteria varies. There is a reduction in all the TDS of all the samples after the bioremediation process compared with the TDS of the raw samples before the bioremediation. The relative potential or efficiency of the different masses of the bacteria in remediating TDS in TAN1 and TAN3 samples was in the order $5 \mathrm{~g}>10 \mathrm{~g}>15 \mathrm{~g}>20$ $\mathrm{g}>25 \mathrm{~g}$. For TAN2 samples, the order was 20 $g>10 \quad g>25 \quad g>15 \quad g>5 \quad g$. Statistical analysis shows that there is no significant difference $(p<0.05)$ between the mean values of TDS among the masses in the respective industries. These might be due to the variations in the surface areas of the different masses of the immobilized bacteria. Positive and significant correlations exist between the masses of bacteria and TDS with the exception in TAN2 (negative and insignificant correlation). The positive correlations showed that there is general increase in the levels of the TDS as the masses of the immobilized bacteria increases. TAN1 $(96 \%)$ showed a very high correlation with the masses of the bacteria while TAN2 (47\%) showed a very low correlation.

The mean values $(\mathrm{mg} / \mathrm{l})$ of the BOD after the bioremediation varies between $1.56 \pm 0.20 \mathrm{mg} / \mathrm{l}$ and $6.92 \pm 5.49 \mathrm{mg} / \mathrm{l}$. The mean concentration $(\mathrm{mg} / \mathrm{l})$ of BOD remediated by the different masses $(5 \mathrm{~g}, 10 \mathrm{~g}, 15 \mathrm{~g}, 20 \mathrm{~g}$, and $25 \mathrm{~g}$ ) of the bacteria varies. There is a reduction in all the BOD of all the samples after the bioremediation process compared with the $\mathrm{BOD}$ of the raw 
BAJOPAS Volume 13 Number 2, December, 2020 samples before the bioremediation. The relative potential or efficiency of the different masses of the bacteria in remediating BOD in TAN1, TAN2 and TAN3 samples were in the order $25 \mathrm{~g}>20$ $\mathrm{g}>15 \mathrm{~g}>10 \mathrm{~g}>5 \mathrm{~g}, 25 \mathrm{~g}>15 \mathrm{~g}>5 \mathrm{~g}>10 \mathrm{~g}>20 \mathrm{~g}$ and $20 \mathrm{~g}>10 \mathrm{~g}>25 \mathrm{~g}>15 \mathrm{~g}>5 \mathrm{~g}$ respectively. Statistical analysis shows that there is significant difference $(p<0.05)$ between the mean values of BOD among the masses in the respective industries. These might be due to the variations in the surface areas of the different masses of the immobilized bacteria. Negative and significant correlations exist between the masses of bacteria and BOD. This showed that there is general decrease in the levels of the BOD as the masses of the immobilized bacteria increases. TAN1 (94\%) showed a very high correlation with the masses of the bacteria while TAN2 (4\%) showed a very low correlation.

The mean values $(\mathrm{mg} / \mathrm{l})$ of the COD after the bioremediation varies between $250 \pm 154$ and $3134 \pm 1595$. The mean concentration $(\mathrm{mg} / \mathrm{l})$ of COD remediated by the different masses $(5 \mathrm{~g}$, $10 \mathrm{~g}, 15 \mathrm{~g} 20 \mathrm{~g}$, and $25 \mathrm{~g}$ ) of the bacteria varies. There is a reduction in all the COD of all the samples after the bioremediation process compared with the COD of the raw samples before the bioremediation. The relative potential or efficiency of the different masses of the bacteria in remediating COD in TAN1, TAN2 and TAN3 samples were in the order $25 \mathrm{~g}>20 \mathrm{~g}>15$ $\mathrm{g}>5 \mathrm{~g}>10 \mathrm{~g}, 25 \mathrm{~g}>20 \mathrm{~g}>15 \mathrm{~g}>10 \mathrm{~g}>5 \mathrm{~g}$ and 10 g>5 g>25 g>15 g>20 g respectively. Statistical analysis shows that there were significant difference $(p<0.05)$ between the mean values of COD among the masses in the respective industries except for effluents treated with $25 \mathrm{~g}$. These might be due to the variations in the surface areas of the different masses of the immobilized bacteria. Negative and insignificant correlations exist between the masses of bacteria and COD with the exception in TAN3 (positive and significant correlation). The negative correlations showed that there is general decrease in the levels of the COD as the masses of the immobilized bacteria increases. TAN2 (100\%) showed a very high correlation with the masses of the bacteria while TAN3 (36\%) showed a very low correlation.

Generally, there was an overall decrease in the concentration of these physicochemical parameters after the bioremediation using the different masses of the bacterial isolates. These might be due to the variations in the surface areas of the different masses of the immobilized bacteria. This is in line with the work of Jimoh et al. (2018) and Baba et al. (2020).

Table 3: Mean Values $(\mathrm{mg} / \mathrm{l}) \pm$ S.D of Physicochemical parameters in effluents from the Tannery Industries before and after Treatment of the effluents $(250 \mathrm{ml})$ with the different masses $(5 \mathrm{~g}, 10 \mathrm{~g}$, $15 \mathrm{~g}, 20 \mathrm{~g}$, and $25 \mathrm{~g}$ ) of the bacteria.

\begin{tabular}{llllllll}
\hline $\mathrm{P}$ & IND & Before & \multicolumn{5}{c}{ After } \\
\cline { 4 - 7 } & & & $5 \mathrm{~g}$ & $10 \mathrm{~g}$ & $15 \mathrm{~g}$ & $20 \mathrm{~g}$ & $25 \mathrm{~g}$ \\
\hline \multirow{2}{*}{ COD } & TAN1 & $2372 \pm 938$ & $1708 \mathrm{a} \pm 861$ & $2045 \mathrm{a} \pm 1205$ & $845 \mathrm{a} \pm 369$ & $300 \mathrm{a} \pm 167$ & $250 \mathrm{a} \pm 154$ \\
& TAN2 & $1406 \pm 208$ & $1195 \mathrm{a} \pm 208$ & $1125 \mathrm{a} \pm 384$ & $1055 \mathrm{a} \pm 317$ & $956 \mathrm{a} \pm 310$ & $870 \mathrm{ab} \pm 240$ \\
& TAN3 & $3532 \pm 1373$ & $2374 \mathrm{a} \pm 1344$ & $1976 \mathrm{a} \pm 1405$ & $2757 \mathrm{a} \pm 1266$ & $3134 \mathrm{a} \pm 1595$ & $2614 \mathrm{~b} \pm 1105$ \\
BOD & TAN1 & $13.85 \pm 6.42$ & $6.92 \mathrm{a} \pm 5.49$ & $6.42 \mathrm{a} \pm 5.07$ & $5.72 \mathrm{a} \pm 5.35$ & $4.62 \mathrm{a} \pm 4.37$ & $2.82 \mathrm{ab} \pm 1.26$ \\
& TAN2 & $19.46 \pm 0.50$ & $1.75 \mathrm{~b} \pm 0.22$ & $1.73 \mathrm{~b} \pm 0.18$ & $1.58 \mathrm{a} \pm 0.16$ & $1.91 \mathrm{a} \pm 0.22$ & $1.56 \mathrm{~b} \pm 0.20$ \\
& TAN3 & $17.13 \pm 3.14$ & $4.24 \mathrm{ab} \pm 0.77$ & $3.29 \mathrm{ab} \pm 0.37$ & $4.11 \mathrm{a} \pm 0.07$ & $3.23 \mathrm{a} \pm 0.91$ & $3.33 \mathrm{a} \pm 1.28$ \\
SS & TAN1 & $374 \pm 124$ & $243 \mathrm{a} \pm 45$ & $471 \mathrm{a} \pm 226$ & $475 \mathrm{a} \pm 182$ & $492 \mathrm{a} \pm 128$ & $611 \mathrm{a} \pm 217$ \\
& TAN2 & $358 \pm 335$ & $460 \mathrm{a} \pm 400$ & $543 \mathrm{a} \pm 414$ & $544 \mathrm{a} \pm 402$ & $551 \mathrm{a} \pm 414$ & $554 \mathrm{a} \pm 405$ \\
& TAN3 & $780 \pm 739$ & $586 \mathrm{a} \pm 594$ & $758 \mathrm{a} \pm 656$ & $787 \mathrm{a} \pm 676$ & $861 \mathrm{a} \pm 635$ & $898 \mathrm{a} \pm 672$ \\
TDS & TAN1 & $3941 \pm 3703$ & $51 \mathrm{a} \pm 10$ & $53 \mathrm{a} \pm 10$ & $55 \mathrm{a} \pm 15$ & $61 \mathrm{a} \pm 20$ & $63 \mathrm{a} \pm 26$ \\
& TAN2 & $3300 \pm 1714$ & $83 \mathrm{a} \pm 78$ & $47 \mathrm{a} \pm 20$ & $48 \mathrm{a} \pm 22$ & $47 \mathrm{a} \pm 17$ & $48 \mathrm{a} \pm 17$ \\
& TAN3 & $2653 \pm 1240$ & $46 \mathrm{a} \pm 11$ & $55 \mathrm{a} \pm 24$ & $55 \mathrm{a} \pm 25$ & $58 \mathrm{a} \pm 23$ & $61 \mathrm{a} \pm 28$ \\
\hline
\end{tabular}

Replicate $=6$ (months)

Within the rows, for the same parameter, means with different alphabets are statistically different $(p<0.05)$.

$\mathrm{P}=$ parameter, IND = Industries 
BAJOPAS Volume 13 Number 2, December, 2020

Table 4: Correlation coefficient $(r)$ between different masses of the bacteria and the physicochemical parameters.

\begin{tabular}{llll}
\hline Industries & Parameter & Correlation coefficient $(r)$ & $\begin{array}{l}\text { Percent dependence (rxrx100) } \\
(\%)\end{array}$ \\
\hline TAN1 & COD & -0.9 & 82 \\
& BOD & -0.97 & 94 \\
& SS & $0.90^{*}$ & 80 \\
TAN2 & TDS & $0.98^{*}$ & 96 \\
& COD & -1 & 100 \\
& BOD & -0.21 & 4 \\
& SS & $0.78^{*}$ & 61 \\
& TDS & -0.69 & 47 \\
& COD & $0.60^{*}$ & 36 \\
& BOD & -0.6 & 37 \\
& SS & $0.95^{*}$ & 90 \\
& TDS & $0.94^{*}$ & 89 \\
\hline
\end{tabular}

The correlation coefficient $(r)$ with * is statistically significant $(p<0.05)$.

Percentage reduction of the Parameters

Table 5 shows the percentage reduction of Parameters in industrial samples before and after the treatment of the effluents $(250 \mathrm{ml})$ with the different masses $(5 \mathrm{~g}, 10 \mathrm{~g}, 15 \mathrm{~g}, 20 \mathrm{~g}$, and $25 \mathrm{~g}$ ) of the Immobilized Bacteria.

In TAN1 samples, the percentage reduction (\%) of COD ranged (14-89); BOD (50-80); SS (-32$35)$ and TDS (98-99). In TAN2 samples, the percentage decrease $(\%)$ of COD ranged (15$38) ;$ BOD (90-92); SS [-28-(-55)] and TDS (9798). In TAN3 samples, the percentage decrease (\%) of COD ranged (11-44); BOD (76-81); SS (15-25) and TDS (98). The percentage increase in the levels COD, BOD and TDS might be due to the increase in the surface area of the different masses of the immobilized bacteria. However, the percentage decrease in the levels of the SS might be due to the aggregation of the TDS which are large enough to result into SS. The percentage decrease in the levels of the SS might be also due to the influence of the nutrients which was added into the effluents in order to make the microorganisms more active and viable for fast degradation of organic contaminants in the effluent. This is in line with the work of Jimoh et al. (2018) in which the concentration of the SS increase after the bioremediation of effluents.

Sreemoyee and Priti (2013) assessed and reduced several Physico-chemical parameters of dairy wastewater using Niesseria $s p$. and concluded that the species are well known to degrade organic compounds. This is in agreement with the current study in which the immobilized Niesseria $s p$ degrade the organic contaminants as indicated by the BOD, COD and TDS.

Jimoh et al. (2018) observed that TSS of the effluents was increased after treatment with immobilized bacteria and concluded that it might be due to the biostimulation method adopted for the research.

The optimum $\mathrm{pH}$ Biosorption of Chromium by Bacillus spp and Staphylococcus spp. from tannery effluent was investigated by Mythili and Karthikeyan (2011). The maximum adsorption of Chromium $(86.4 \mathrm{mg} / \mathrm{L})$ was showed by Bacillus spp and Staphylococcus spp showed $70.6 \mathrm{mg} / \mathrm{L}$ at an initial concentration of $100 \mathrm{mg} / \mathrm{L}$. In the present study, immobilised Bacillus spp and Staphylococcus spp. from the tannery industrial effluents reduced the levels of the organic pollutants with high potential as indicated by the percentage reduction of BOD, COD and TDS.

Enzymes often can work in multiple environments especially if they are immobilized. This makes the microorganisms' enzymes even more resistant to harsh environments and enables the enzymes to be recovered and recycled after they are no longer needed (Gianfreda and Rao 2004). Ramesh and Singh (1993) reported that the immobilized bacteria having more efficiency to remove the suspended particles than free cells. Using the immobilized cell is preferable due to its capability for using several times with the same efficiency, which makes it more economical. Similar work was done by Sikander et al. (2007) showing the higher reduction with permeabilized cells of Ochrobactrum intermedium strain SDCr-5. 
BAJOPAS Volume 13 Number 2, December, 2020

The results revealed the isolation and identification of isolates with the potential for the reduction of $\mathrm{Cr}$ (VI) to $\mathrm{Cr}$ (III). Results indicated that immobilized $B$. cereus could be efficiently used for the reduction of $\mathrm{Cr}$ (VI).

Table 5: Percentage reduction of the tested Parameters from the tannery industrial samples of the Immobilized Bacteria.

\begin{tabular}{lllllll}
\hline \multirow{2}{*}{ Industries } & & \multicolumn{5}{c}{ Percentage Reduction $(\%)$} \\
\cline { 3 - 7 } & & $5 \mathrm{~g}$ & $10 \mathrm{~g}$ & $15 \mathrm{~g}$ & $20 \mathrm{~g}$ & $25 \mathrm{~g}$ \\
\hline TAN1 & COD & 28 & 14 & 64 & 87 & 89 \\
& BOD & 50 & 54 & 59 & 67 & 80 \\
& SS & 35 & -26 & -27 & -32 & -63 \\
& TDS & 99 & 99 & 99 & 98 & 98 \\
TAN2 & COD & 15 & 20 & 25 & 32 & 38 \\
& BOD & 91 & 91 & 92 & 90 & 92 \\
& SS & -28 & -52 & -52 & -54 & -55 \\
& TDS & 97 & 99 & 99 & 99 & 99 \\
& COD & 33 & 44 & 22 & 11 & 26 \\
& BOD & 75 & 81 & 76 & 81 & 81 \\
& SS & 25 & 3 & -1 & -10 & -15 \\
& TDS & 98 & 98 & 98 & 98 & 98 \\
\hline
\end{tabular}

Percentage Reduction $=(B-A) / B \times 100 \%$

$A=$ Concentration of the parameter after treatment

$\mathrm{B}=$ Concentration of the parameter before treatment

$+=$ percentage decrease

- = percentage increase

In general, immobilization makes the enzyme more resistant to temperature, $\mathrm{pH}$, and substrate concentration swings giving it a longer lifetime and higher productivity per active unit (Gianfreda and Rao, 2004; FuIlbrook, 1996; Russell et al, 2003; Kandelbauer et al., 2004). Immobilized cells have been used and studied extensively for the production of useful chemicals (Ohtake and Silver, 1994), the treatment of wastewaters (Chen et al., 2003; Wang et al., 2010). Although many workers described microbial degradation of tannery effluent, limited literature is available on the bioremediation of tannery effluent using immobilized bacterial cells in the Kano Industrial Estates.

\section{CONCLUSION}

The samples contained variable levels of the physicochemical parameters. The results of the Analysis of variance revealed that, no statistical difference $(p<0.05)$ was observed for the temperature, $\mathrm{pH}, \mathrm{SS}, \mathrm{TDS}, \mathrm{BOD}$ and $\mathrm{COD}$ among the three tannery industries before the treatment. The levels of some of the parameters
(SS, TDS and COD) observed in the samples were found above the recommended limits of WHO and NESREA, which called for the treatment of the effluents before discharge into the environment. Base on the morphological and biochemical test results, TAN1, TAN2, and TAN3 bacterial isolates were identified to be Neisseria spp, Bacillus cereus, and Staphylococcus aureus respectively. The results of Post-treatment analysis showed that there is overall decrease in the levels of the parameters determined when compared with that of the pre-treatment. The overall percentage reduction of the immobilised bacteria in the treatment of the respective effluents was in the order TAN2 (72\%)>TAN1 $(70 \%)>$ TAN3 $(62 \%)$. Hence, the immobilized bacteria are having higher biodegradation potential for the treatment of the tannery effluents.

\section{Acknowledgments}

The authors wish to acknowledge the University of Maiduguri for the financial support. The authors are grateful to the Kano State Ministry of Environment for their support in obtaining the effluent samples. 


\section{REFERENCES}

Ajao, A. T., Adebayo, G. B., and Yakubu, S. E. (2011). Bioremediation of textile industrial effluent using mixed culture of Pseudomonas aeruginosa and Bacillus subtilis immobilized on agar-agar in a bioreactor. J. Microbiol. Biotech. Res, 1(3), 50-56.

Akan, J. C., Moses, E. A., Ogugbuaja, V. O., and Abah, J. (2007). Assessment of tannery industrial effluents from Kano metropolis, Kano State, Nigeria. Journal of Applied Sciences, 7(19), 2788-2793.

Akan, J. C., Ogugbuaja, V. O., Abdulrahman, F. I., and Ayodele, J. T. (2009). Pollutant levels in effluent samples from tanneries and textiles of Kano industrial areas, Nigeria. Global journal of pure and applied sciences, 15(3-4).

APHA (1989). Standard methods for Examination of Will bete and Will betewater.15 $5^{\text {th }}$ edition. Brydpass Springfield Will behington DC. pp. 164-176

APHA (1992). Standard Methods for the Examination of Water and Wastewater. Health, 69, 1116-9.

Baba, A., Garba, S. T., and Bello, H. S. (2020). Bioremediation Potential of Immobilized corynebacterium kutsceri in the Treatment of Tannery Industrial Effluent from Challawa Industrial Estate, Kano State, Nigeria. Journal of the Turkish Chemical Society Section A: Chemistry, $7(2), 335-350$.

Beem, E. I. V. (1994). reduction of solvent VOC emission. J. Oil Col. Chem. Ass, 77, 158.

Bouwer, E. J., and Zehnder, A. J. (1993). Bioremediation of organic compoundsputting microbial metabolism to work. Trends in biotechnology, 11(8), 360367.

Chen, K. C., Wu, J. Y., Liou, D. J., and Hwang, S. C. J. (2003). Decolorization of the textile dyes by newly isolated bacterial strains. Journal of Biotechnology, 101(1), 57-68.

Dan'Azumi, S., and Bichi, M. H. (2010). INDUSTRIAL POLLUTION AND HEAVY METALS PROFILE OF CHALLAWA RIVER IN KANO, NIGERIA. Journal of Applied Sciences in Environmental Sanitation, $5(1)$.

DWAF. (1992). Analytical Methods Manual, TR 151. Department of Water Affairs and Forestry, Pretoria.

El-Bestawy, E. (2013). Biological treatment of leather-tanning industrial wastewater using free living bacteria.
Elsheikh, M. A. S. (2009). Tannery wastewater pre-treatment. Water Science and Technology, 60(2), 433-440.

FuIlbrook, P. D. (1996). "Kinetics." Industrial enzymology: The application of enzymes in Industry. 2nd Ed. T. Godfrey and J Reichelt. eds.. Nature. New York.

Gianfreda, L., and Rao, M. A. (2004). Potential of extra cellular enzymes in remediation of polluted soils: a review. Enzyme and microbial technology, 35(4), 339354.

Hugo Springer. (1994). John Arthur Wilson Memorial Lecture "Treatment of Industrial Wastes of the Leather Industry - is it still a Major Problem". JALCA, 89, 153-185

Jimoh, A. A., Ganiyu, B. A., Baba, D., and Baba, A. (2018) Bioremediation Process of Effluent from Detergent and Food Industries in Jos, Nigeria: Kinetics and Thermodynamics. International Journal of Engineering Science Invention (IJESI), 762-73

Kandelbauer, A., Maute, O., Kessler, R. W., Erlacher, A., and Gübitz, G. M. (2004). Study of dye decolorization in an immobilized laccase enzyme-reactor using online spectroscopy. Biotechnology and bioengineering, 87(4), 552-563.

Kongjao, S., Damronglerd, S., and Hunsom, M. (2008). Simultaneous removal of organic and inorganic Pollutants in tannery wastewater using electrocoagulation technique. Korean Journal of chemical engineering, 25(4), 703.

Maheshwari, U. M., Aruna, S., Gomathi, M., and AbdulJaffar, A. H. (2017). Bioremediation by Free and Immobilized Bacteria Isolated from Tannery Effluent. International Journal of Research in Applied, Natural and Social Sciences. 5(7), 75-90

Margesin, R., and Schinner, F. (2001). Bioremediation (natural attenuation and biostimulation) of diesel-oilcontaminated soil in an alpine glacier skiing area. Applied and environmental microbiology, 677), 3127-3133.

Mohammed, A., Sekar, P., and George, J. (2011). Efficacy of microbes in bioremediation of tannery effluent. Inter. J. Curr. Res, 3(4), 324-326.

Mohammed, S. S. D., Orukotan, A. A., and Abdullahi, H. (2017). Physicochemical and Bacteriological Assessment of Tannery Effluent from Samaru-Zaria, 
BAJOPAS Volume 13 Number 2, December, 2020 Kaduna State, Nigeria. Journal of Applied

Sciences and Environmental Management, 21(4), 734-740.

Munz, G., De Angelis, D., Gori, R., Mori, G., Casarci, M., and Lubello, C. (2009). The role of tannins in conventional and membrane treatment of tannery wastewater. Journal of hazardous materials, 164(2-3), 733-739

Mythili, K., and Karthikeyan, B. (2011). Bioremediation of $\mathrm{Cr}$ (VI) from tannery effluent using Bacillus spp and Staphylococcus spp. International Multidisciplinary Research Journal, 1(6).

NESREA (2009). National Environmental Standards for Effluent Limitations and Regulation. 1233-1236

Noorjahan, C. M. (2014). Physicochemical characteristics, identification of bacteria and biodegradation of industrial effluent. Journal of bioremediation and Biodegradation, 5(3).

Ohtake, H. I., and Silver, A. O. (1994). Bacterial reduction of toxic chromate. Biological degradation and bioremediation of toxic chemicals, 403-415.

Omoleke, I. I. (2004). Management of environmental pollution in Ibadan, an African city: the challenges of health hazard facing government and the people. Journal of Human Ecology, 15(4), 265-275.

Rajor, A., Reddy, A.S., and Singh, B. (2004). Determination of BOD kinetic Parameters and evaluation of alternate methods, M.Sc. Thesis, Department of biotechnology \& environmental Science, Thapar Institute of Engineering and Technology, Patiala

Ramasami, T., Rajamani, S., and Rao, J. R. (1994, March). Pollution control in leather industry: Emerging technological options. In International symposium on surface and colloidal science and its relevance to soil pollution, madras.

Ramesh, J. V. S., and Singh, S. P. (1993). Yearly variation in certain physicochemical parameters of pond at eastern Doon Valley. Uttar Pradesh J. Zoo, 12 (1), 7577.

Ranen, S., and Sharadinadra, C. (2009). Biotechnology applications to environmental remediation in resource exploitation. Current science, 97, 6-25
Russell, A. J., Berberich, J. A., Drevon, G. F., and Koepsel, R. R. (2003). Biomaterials for mediation of

chemical and biological warfare agents. Annual review of biomedical engineering, 5(1), 1-27.

Saravanan, P., and Saravanan, A. (1999). Decolourization of tannery effluent by Flavobacterium sp. EK 1. Indian Journal of Environmental Protection, 19, 19-24.

Sikander, S., and Shahida, H. (2007). Reduction of toxic hexavalent chromium by Ochrobactrum intermedium strain SDCr5 stimulated by heavy metals. Bioresource Technol, 98, 340-344.

Singh, N., Sharma, B. K., and Bohra, P. C. (2000). Impact assessment of industrial effluent of arid soils by using satellite imageries. Journal of the Indian Society of Remote Sensing, 28(2-3), 79.

Sreemoyee, C., and Priti, P. (2013). Assessment of physico-chemical parameters of dairy waste water and isolation and characterization of bacterial strains in terms of cod reduction. Int J Sci, 2(3), 395-400.

Verheijen, L. A. H. M., Wiersema, D., Pol, L. H., and De Wit, J. (1996). Management of wastes from animal product processing. Livestock and environment, Finding a balance. International Agriculture Center, Wageningen, The Netherlands.

Wang, F., Yao, J., Si, Y., Chen, H., Russel, M., Chen, K., and Bramanti, E. (2010). Short-time effect of heavy metals upon microbial community activity. Journal of Hazardous Materials, 173(13), 510-516.

WHO (World Health Organization). (2006). Air quality guidelines: global update 2005: particulate matter, ozone, nitrogen dioxide, and sulfur dioxide. World Health Organization.

World Bank. (1995). Nigeria's strategic options for redressing industrial pollution. World Bank, industry and energy division. 1st edition, West Central Africa Department; Annexes: 1995; pp 60-62.

Zahoor, A., and Abdul, R. (2009). Enumeration of Coliforms. Journal of Environmental Sciences. 21, 814-820 


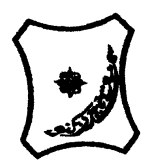

Bayero Journal of Pure and Applied Sciences, 13(2): 1 - 12

Received: November, 2020

Accepted: December, 2020

ISSN $2006-6996$

\title{
BIODEGRADATION POTENTIAL OF IMMOBILIZED BACTERIA IN THE TREATMENT OF TANNERY INDUSTRIAL EFFLUENTS FROM INDUSTRIAL ESTATES IN KANO STATE, NIGERIA
}

\author{
Abdullateef, B., ${ }^{1 *}$ Shuaibu, T. G., ${ }^{1}$ Babagana, K., ${ }^{1}$ Suleman, H. B. ${ }^{2}$ and Dauda, B. ${ }^{3}$ \\ ${ }^{1}$ Department of Pure and Applied Chemistry, Faculty of Science, University of Maiduguri, Borno State, \\ Nigeria \\ ${ }^{2}$ Department of Microbiology, Faculty of Science, University of Maiduguri, Borno State, Nigeria \\ ${ }^{3}$ Department of Chemical Engineering, Faculty of Engineering, University of Maiduguri, Borno State, \\ Nigeria \\ *Corresponding author: babslega@gmail.com; abelega2007@yahoo.com; +2348061309753
}

\section{ABSTRACT}

Industrial Effluents Samples from Gashash Tanneries (TAN1) in Bompai Industrial estate, Larabee Tannery Industry (TAN2) in Sharada Industrial estate and Z Tannery Industries (TAN3) in Challawa Industrial estate, Kano State, Nigeria were collected over a period of six months (August 2017 to January 2018) for assessing the biodegradation potentials of bacteria in the treatment of organic pollutants within the effluents. Bacteria were isolated from the effluents and immobilized on agar-agar. Different masses (5 g, $10 \mathrm{gr}, 15$ $\mathrm{g}, 20 \mathrm{~g}$, and $25 \mathrm{~g}$ ) of the bacteria were used in the treatment of $250 \mathrm{ml}$ of the effluents for ten days in a shaker incubator (Gallenkamp-OC-4364-L) at the temperature $30{ }^{\circ} \mathrm{C}$ and speed of $60 \mathrm{rpm}$. Pre-treatment analysis of the effluents for Temperature, pH, Biochemical Oxygen Demand (BOD), Chemical Oxygen Demand (COD), Suspended Solid (SS) and Total Dissolved Solids (TDS) gives the following results; temperature $\left({ }^{\circ} \mathrm{C}\right.$ )

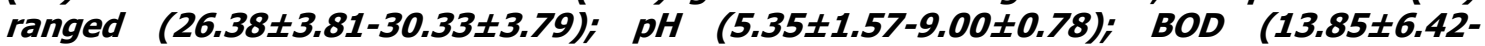
$38.75 \pm 16.20) ;$ COD (1406 $\pm 208-3532 \pm 1373) ;$ SS (208 $\pm 235-780 \pm 739)$ and TDS (266 $\pm 253-5276 \pm 2971)$. No statistical differences ( $p \leq 0.05)$ was observed for all the results among the different industries. The bacterial isolates were identified as Neisseria spp, Bacillus cereus, and Staphylococcus aureus, in TAN1, TAN2, and TAN3, respectively. After treatment of the effluent with the different masses of the isolated bacteria, the mean level of BOD was found to range as (0.55 $\pm 0.36-6.92 \pm 5.49) ; C O D$ (ND-3134 \pm 1595$)$;

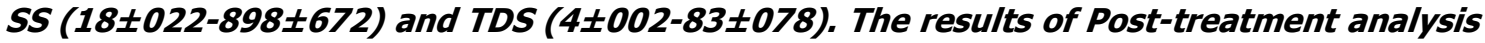
showed that there is overall decrease in the levels of the parameters determined when compared with that of the pre-treatment. The overall percentage reduction of the immobilised bacteria in the treatment of the respective effluents was in the order TAN2 (72\%)>TAN1 (70\%)>TAN3 (62\%). Hence, the immobilized bacteria are having higher biodegradation potential for the treatment of the tannery effluents.

Keywords: Biodegradation, bacteria, effluent, immobilization, tannery.

\section{INTRODUCTION}

Tannery industrial wastewater is a serious consequence of the pollution point of view for streams, freshwater, and land used for agriculture. The lack of awareness in the modern industrial practice has resulted in the discharge of tannery effluents which exhibit very high value of chromium ( $\mathrm{Cr}$ ), Sulfide, and chloride, Total Dissolved Solid (TDS), Total Suspended Solid (TSS), Biochemical Oxygen Demand (BOD) and Chemical Oxygen Demand (COD) in the water stream or land (Mohammed et al., 2001). Tanning is the process, which One ton of skin generally leads to the production of 20 to $80 \mathrm{~m}^{3}$ of turbid and foul-smelling converts the protein of the rawhide or skin into a stable material, which will not putrefy and is suitable for a wide variety of end applications (Elsheikh, 2009). The highly polluting chromium is the most commonly used tanning material producing leather that is more flexible and pliable than vegetable-tanned leather and does not discolor or lose shape in water as drastically as vegetable-tan (Elsheikh, 2009). Tannery effluent is among the most hazardous industrial pollutants due to its huge organic and inorganic load, which is highly toxic to human life and the environment (Kongjao et al., 2008). wastewater including chromium (100-400 mg/l), sulfide $(200-800 \mathrm{mg} / \mathrm{l})$, high levels of fat and 
BAJOPAS Volume 13 Number 2, December, 2020 other solid wastes, and notable pathogen contamination as well as pesticides added for skin conservation during transport (Elsheikh, 2009). There are more than 6000 tanneries in Nigeria with an annual processing capacity of 700,000 tons of hides and skins (Omoleke, 2004; Singh et al., 2008). It was reported that the total amount of waste produced per animal slaughtered is approximately $35 \%$ of its weight (World Bank, 1995). Also, for every $1000 \mathrm{~kg}$ of carcass weight, a slaughtered beef produces 5.5 $\mathrm{kg}$ of manure (excluding rumen contents or stockyard manure) and $100 \mathrm{~kg}$ of paunch manure (undigested food) (Verheijen et al., 1996). Tanneries generate wastewater in the range of 30-35 $\mathrm{L} \mathrm{kg}^{-1}$ skin/hide processed with variable $\mathrm{pH}$, Biological Oxygen Demand (BOD), Chemical Oxygen Demand (COD), high concentrations of suspended solids (SS), and tannins as well as chromium (Zahoor and Abdul, 2009).

Being heterogeneous and composed of a wide variety of compounds, it is very difficult to select a unique direct method for estimating the biodegradability of organic contents and biokinetic parameters for a wastewater sample (Rajor, 2004). For this purpose, some indirect estimation such as determination of biochemical oxygen demand (BOD) and chemical oxygen demand (COD) are applied as common laboratory investigations [9]. During retanning procedures, synthetic tannins (Syntan), oils and resins are added to form softer leather at varying doses (Munz et al., 2009). One of the refractory groups of chemicals in tannery effluents derives mainly from tannins (Ramasami et al., 2004). Syntans are characterized by complex chemical structures, because they are composed of an extended set of chemicals such as phenol-, naphthalene-, formaldehyde- and melamine-based syntans, and acrylic resins (Beem, 1994). Organic pollutants (proteic and lipidic components) are originated from skins (it is calculated that the raw skin has $30 \%$ loss of organic material during the working cycle) or they are introduced during processes (Hugo Springer, 1994).

Many conventional processes such as oxidation, chemical and biological processes were carried out to treat tanneries wastewater (Ebtesam et al, 2013). Biological processes have received more attention because of their costeffectiveness, lower sludge production and environmental friendliness (Noorjahan, 2014). Naturally occurring micro-organisms degrade the hazardous organic wastes including xenobiotic compounds, such as pesticides, polycyclic aromatic hydrocarbons (PAHs) and polychlorinated biphenyls (PCBs) in due course of time (Ranen and Sharadinadra, 2009). Bioremediation is based on the idea that all organisms remove substances from the environment to carry outgrowth and metabolism (Bouwer and Zehnder, 1993). Bacteria, protista and fungi are found to be very good at degrading complex molecules and incorporating the breakdown products into their metabolism (Bouwer and Zehnder, 1993). The resultant metabolic wastes that they produce are generally safe and somehow recycled into other organisms (Ranen and Sharadinadra, 2009). An acclimatized indigenous population of microorganisms capable of degradation of the compounds of interest must exist at the site for a successful bioremediation mode (Ranen and Sharadinadra, 2009). It has been observed that for a successful bioremediation mode, an acclimatized indigenous population of microorganisms capable of degradation of the compounds of interest must exist at the site under investigation (Ranen and Sharadinadra, 2009). Even though there are numerous physical and chemical methods employed in the disposal of wastes the advantage in using bacterium is that they play a key role in the reduction of COD, BOD, total protein, total tannin and total phenol (Saravanan and Saravanan, 1998)

Baba et al. (2020) studied the bioremediation potential of immobilized corynebacterium kutsceri in the Treatment of tannery industrial effluent from Challawa Industrial Estate, Kano State, Nigeria. The aim of the work is to study the reduction in the level of the contaminants through the process of bioremediation using the isolated bacteria. Immobilized bacteria can withstand various temperatures, $\mathrm{pH}$ and substrate concentrations; consequently, increasing the efficiency and the lifespan of the bacteria. Immobilized bacteria are widely applied in the treatment of wastewater and can be separated and recovered after the treatment with the same efficiency (Baba et al., 2020).

\section{MATERIALS AND METHODS \\ Study Area}

This study was carried out in Bompai, Sharada and Challawa industrial estates in Kano, Figure 1. Kano lies on Latitude $11^{\circ} 30^{\prime} \mathrm{N}$ and $8^{\circ} 30^{\prime} \mathrm{E}$ and Longitude $11^{\circ} 5^{\prime} \mathrm{N}$ and $8^{\circ} 5^{\prime} \mathrm{E}$ in Northern Nigeria. It is one of the developed industrial cities in Nigeria. Tannery activities are the dominating industries and this could be one of the reasons for her high population density (Dan'Azumi and Bichi, 2010). Many researchers have studied biodegradation of tannery effluent using microorganisms. However, limited literature is available on the biodegradation of tannery effluent in Kano industrial estates using 
BAJOPAS Volume 13 Number 2, December, 2020 immobilized bacterial cells. This research work focuses on the potential of the use of the indigenous immobilized bacterial isolates in the treatment of tannery effluents in the industrial estates.

\section{Sample Collection}

Effluents were collected from the Tannery Industries from Bompai, Challawa and Sharada Industrial Estates, Kano, Nigeria. The effluents were collected over a period of six months (August 2017 to January 2018). Samples collected in a sterile 4-liter plastic container with a unique identification number were preserved using an ice-box that was transported to the Microbiology Laboratory, Department of Microbiology, Bayero University of Kano for analysis

\section{Sample Preparation and Sample Analysis}

Immediately after the collection of the effluent, $\mathrm{pH}$, TSS, TDS, COD, BOD levels were determined before treatment (Pre-treatment determination) and ten days after treatment (Post-treatment determination) as described in
APHA (1989) standard methods. $\mathrm{pH}$ was determined using Ecotests $\mathrm{pH}$ meter and TDS was determined using AQUALYTIC TDS Salinometer. BOD was determined as described by the standard method (APHA, 1992). COD and SS were determined using DR/2010 HACH portable data logging spectrophotometer (DWAF, 1992)

\section{Identification and Biochemical} Characterization of the Bacterial Isolates

The bacteria were isolated from the effluents using Serial Dilution according to the method described by APHA (1989). The biochemical tests such as oxidase, catalase, coagulase, indole (from $1 \%$ tryptone broth), citrate (Simmons citrate agar), methyl red/VogesProskauer (MR/VP), nitrate reduction, Starch Hydrolysis, Glucose, Maltose, and Lactose tests were carried out on the bacterial isolates to identify the bacteria through the bacteria biochemical characteristics according to Ajao et al. (2011).

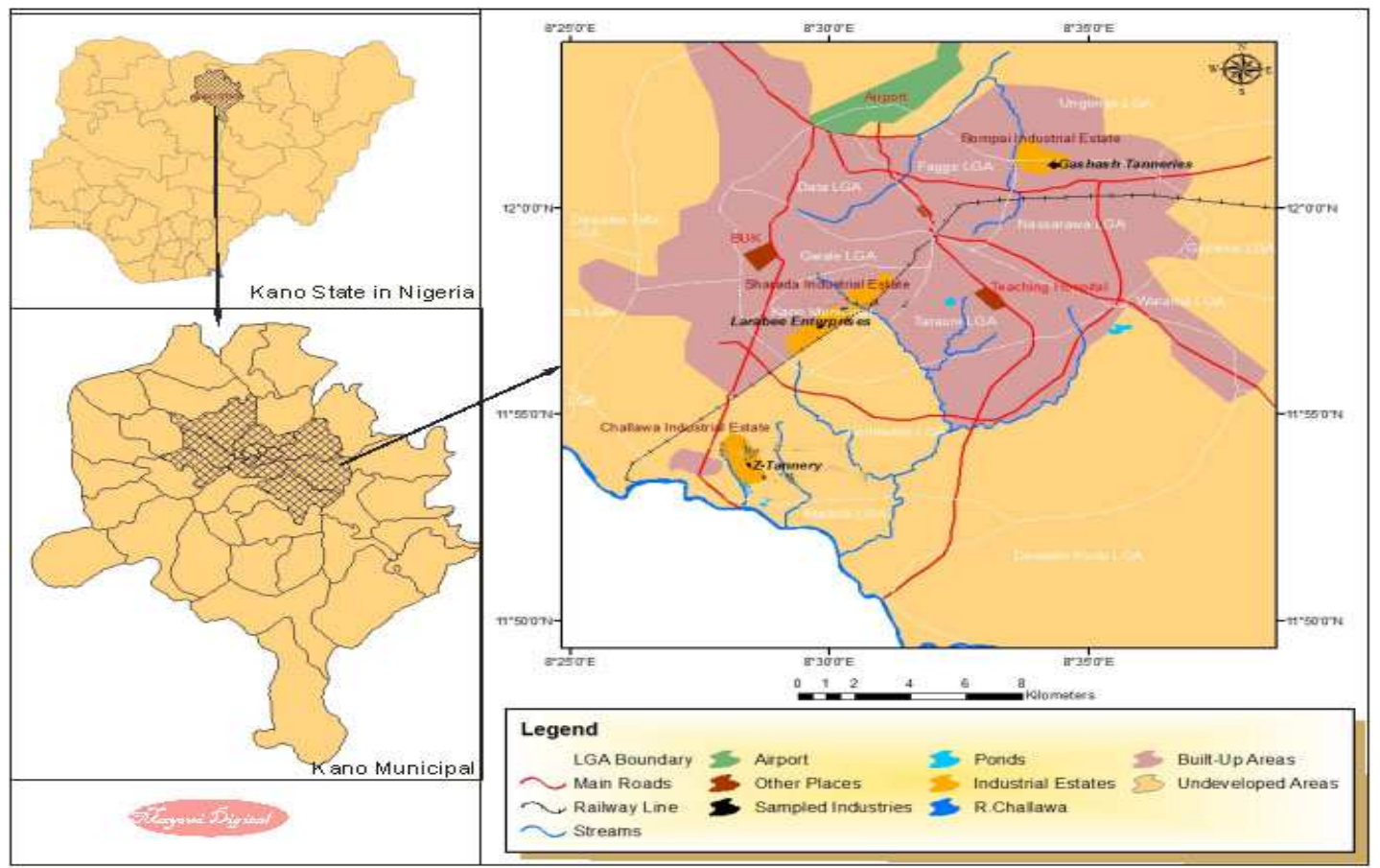

Fig. 1 Map showing the study areas

Source: Mayomi Digital Productions, GIS Laboratory, Department of Geography, UNIMAID (2017)

\section{Determination of Growth Rate of the Bacteria in Effluent Sample}

The bacteria growth rates were determined by transferring $2 \mathrm{~mL}$ of the bacterial isolates from the tannery effluent in broth medium into 100 $\mathrm{mL}$ sterile effluents in conical flasks and kept in an incubator (Giffrin cool) for 10 days. Control was also set up by incubating another $100 \mathrm{~mL}$ each of the sterile effluents without the bacteria. The optical density of the content was determined at the wavelength of $600 \mathrm{~nm}$ on a daily interval and recorded. 
BAJOPAS Volume 13 Number 2, December, 2020 Immobilization of Bacteria

Agar solution and inoculi were prepared separately. Fifty milliliters $(50 \mathrm{~mL})$ of nutrient broth each of the inoculi was prepared in a McCartney bottle and incubated for 24 hours. A solution of agar-agar was prepared by dissolving $10 \mathrm{~g}$ of the powder in distilled water and made up to $500 \mathrm{~mL}$ mark in an Erlenmeyer flask and was sterilized in an autoclave (280A) for 15 minutes and allowed to cool to $40-45^{\circ} \mathrm{C}$ (Ajao et al., 2011). Four milliliters ( $4 \mathrm{~mL})$ of the bacterial isolates in the nutrient broth was mixed with 36 $\mathrm{ml}$ of the prepared agar-agar media in petri-dish plates and then allowed to solidify. This was kept in the refrigerator for bioremediation.

\section{Bioremediation (Treatment) of the Effluents}

The solidified agar block (immobilized bacteria) was cut into cubes using a sterile knife; $0.1 \mathrm{~mL}$ phosphate buffer ( $\mathrm{pH} \mathrm{7.0)}$ was added and kept in the refrigerator for 1 hour for curing. The phosphate buffer was decanted after 1 hour and the cubes were washed with sterile distilled water 3-4 times before it was used (Ajao et al., 2011). Two liters (2 L) of the effluent was supplemented with the minimum basal medium in $\mathrm{g} / \mathrm{L}: \mathrm{NaCl}(0.8), \mathrm{MgSO}_{4} .7 \mathrm{H}_{2} \mathrm{O}(0.001), \mathrm{KH}_{2} \mathrm{PO}_{4}$ (2), $\mathrm{NaNO}_{3}$ (2), $\quad \mathrm{CaCl}_{2} .2 \mathrm{H}_{2} \mathrm{O} \quad(0.5)$ and $\mathrm{NaHPO}_{4} .12 \mathrm{H}_{2} \mathrm{O}(2)$ and sterilized in an autoclave at $121^{\circ} \mathrm{C}$ for 15 minutes (Margesin and Schinner, 2001). Two hundred and fifty milliliters $(250 \mathrm{~mL})$ of the effluents were transferred into different $250 \mathrm{ml}$ conical flasks. The content was covered with a cotton-wool ramped with foil paper to avoid contamination. Five grams $(5 \mathrm{~g})$ of the immobilized bacteria were quickly transferred into each of the effluents in the conical flasks in an inoculating chamber. The same procedures were carried out for the $10 \mathrm{~g}, 15 \mathrm{~g}, 20 \mathrm{~g}$ and 25 $\mathrm{g}$ of the immobilized bacteria in separate $250 \mathrm{~mL}$ effluents in conical flasks and agitated for ten days in a shaker incubator (Gallenkamp-OC4364-L) at a temperature $30^{\circ} \mathrm{C}$ and speed of 60 rpm. The treated effluent samples were taken on the tenth day and analyzed for the parameters $\mathrm{pH}$, SS, TDS, COD, and BOD, (Posttreatment determination) for the different grams of bacteria to evaluate and compare the biodegradation potential. (Baba et al., 2020).

\section{Statistical Analysis}

The data were represented as Mean \pm Standard deviation and analyzed statistically using oneway Analysis of Variance (ANOVA) and Tukey's HSD as Post Hoc Tests with the aid of SPSS 16.0. The correlation coefficient was also used to measure the strength of the relationship between the different masses of the bacteria and the parameters. All $\mathrm{p} \leq 0.05$ were considered as statistically significant.

\section{RESULTS AND DISCUSSION Physico-chemical parameters in the Industrial Effluents before the Biodegradation.}

Results of the Physico-chemical parameters in the industrial effluents before the Biodegradation is shown in table 1 . The mean temperatures $\left({ }^{\circ} \mathrm{C}\right)$ observed in TAN1, TAN2, and TAN3 samples were $28.07 \pm 0.65 ; 27.77 \pm 0.64$ and $26.38 \pm 3.81$ respectively. The order of the mean temperature of the samples from the three industries can be arranged as TAN1 > TAN2>TAN3. The temperature observed at TAN1, TAN2, and TAN3 samples were found below the WHO $\left(35^{\circ} \mathrm{C}\right)$ and NESREA $\left(40^{\circ} \mathrm{C}\right)$ limits. The low values of temperature might be due to the processes used at the time of sampling. High temperature brings down the solubility of gases in water that ultimately expresses as high BOD and COD. Statistical analysis shows that there is no significant difference $(p<0.05)$ between the mean values of temperature among the industries. This might be due to similar tannery activities involved in the tannery industries at the time of sampling. The average values of temperature observed in this present study are less than those observed by Akan et al. (2007), Akan et al. (2009) and Baba et al. (2020).

The mean level of $\mathrm{pH}$ observed in TAN1, TAN2 and TAN3, samples were $7.77 \pm 2.93$; $8.35 \pm 0.28$ and $7.52 \pm 0.76$ respectively. The order of the mean $\mathrm{pH}$ of the samples from the three industries can be arranged as TAN2> TAN1 $>$ TAN3. The $\mathrm{pH}$ of the samples falls within the WHO (7.0-8.5) and NESREA (6-9) standard limits. Statistical analysis shows that there is no significant difference $(p<0.05)$ between the mean values of $\mathrm{pH}$ among the industries. This might be due to similar tannery activities involved in the tannery industries at the time of sampling. Maheshwari et al. (2017) reported that the level of $\mathrm{pH}$ in the effluents from the tannery industry in Vaniyambadi, India was 6.5 which was lower than that observed in the present study. The $\mathrm{pH}$ in the effluents from the tannery industries in Kano and Kaduna were reported to be 7.64 and 6.89, respectively (Akan et al., 2007; Mohammed et al., 2017). The average values of $\mathrm{pH}$ observed in this present study are less than those observed by Mohammed et al. (2017) and Baba et al. (2020). The mean level of SS $(\mathrm{mg} / \mathrm{l})$ observed in TAN1, TAN2, and TAN3 samples were 374 \pm 124 ; $358 \pm 335$ and $780 \pm 739$ respectively. The order of the mean SS in the samples from the three industries can be arranged as TAN3 > TAN1 $>$ TAN2. 
The SS observed in the samples were far above the recommended standard limits of regulating bodies WHO $(30 \mathrm{mg} / \mathrm{l})$ and NESREA $(10 \mathrm{mg} / \mathrm{l})$. Statistical analysis shows that there is no significant difference $(p<0.05)$ between the mean values of SS among the industries. This might be due to similar tannery activities involved in the tannery industries at the time of sampling. The average values of SS observed in this present study are less than that observed $(3700 \pm 122 \mathrm{mg} / \mathrm{l})$ by Akan et al. (2009) for tanneries in Kano. Also, the average values of SS observed in this present study are less than that observed by Mohammed et al. (2017) and Baba et al. (2020) with the exception in TAN3.

The mean level of TDS (mg/l) observed in TAN1, TAN2, and TAN3 samples were $3941 \pm 3703$; $3300 \pm 1714$ and $2653 \pm 1240$ respectively. The order of the mean TDS in the samples from the three industries can be arranged as TAN1>TAN2>TAN3. The TDS observed in the samples were far above the recommended standard limits of WHO $(250 \mathrm{mg} / \mathrm{l})$ and NESREA $(500 \mathrm{mg} / \mathrm{l})$. Statistical analysis shows that there is no significant difference $(p<0.05)$ between the mean values of TDS among the industries. This might be due to similar tannery activities involved in the tannery industries at the time of sampling. TDS in the effluents from the tannery industries in Kano, Nigeria was reported to be $1281 \mathrm{mg} / \mathrm{l}$ (Akan et al., 2007). The average values of SS observed in this present study are less than those observed by Mohammed et al. (2017) and Baba et al. 2020)

The mean level of COD (mg/l) observed in TAN1, TAN2 and TAN3 samples seasons were $2372 \pm 938 ; \quad 1406 \pm 208$ and $3532 \pm 1373$ respectively. The order of the mean COD of the samples from the three industries can be arranged as TAN3>TAN1> TAN2. The COD observed in TAN1, TAN2 and TAN3 samples were far above the recommended standard limits of regulating bodies $\mathrm{WHO}(40 \mathrm{mg} / \mathrm{l})$ and NESREA (40 mg/l). Statistical analysis shows that there is no significant difference $(p<0.05)$ in COD among the industries. This might be due to similar tannery activities involved in the tannery industries as at the time of sampling. The Chemical Oxygen demand (COD) is the amount of oxygen, in $\mathrm{mg} / \mathrm{L}$, required for the degradation of the compound of wastewater to occur. In comparison, the average values of COD observed in this present study were higher than that observed by Mohammed et al. (2017) but lower than that observed by Baba et al. (2020).

The mean levels of BOD $(\mathrm{mg} / \mathrm{l})$ observed in TAN1, TAN2 and TAN3 samples were $13.85 \pm 6.42 ; \quad 19.46 \pm 0.50$ and $17.13 \pm 3.14$ respectively. The order of the mean BOD in the samples from the three industries can be arranged as TAN2>TAN3>TAN1. The BOD observed in TAN1, TAN2 and TAN3 samples were found below the recommended limits of NESREA (200 mg/l) but above WHO (10 mg/l). Statistical analysis shows that there is no significant difference $(p<0.05)$ between the mean values of BOD among the industries. This might be due to similar tannery activities involved in the tannery industries at the time of sampling. The low level of BOD recorded in this study is an indication of the low level of biodegradable organic solids in the effluent. The average values of BOD observed in this present study were lower than those observed by Mohammed et al. (2017) and Baba et al. (2020).

Table 1: Mean Values \pm S.D of Physico-chemical parameters of effluents from the Tannery Industries before Treatment.

\begin{tabular}{llllllll}
\hline Parameter & Tannery 1 & Tannery 2 & Tannery 3 & $\mathrm{a}$ & $\mathrm{b}$ & $\mathrm{c}$ & $\mathrm{d}$ \\
\cline { 2 - 7 } Temperature $\left({ }^{\circ} \mathrm{C}\right)$ & $28.07 \mathrm{a} \pm 0.65$ & $27.77 \mathrm{a} \pm 0.64$ & $26.38 \mathrm{a} \pm 3.81$ & & $29.50 \pm 4.68$ & 35 & 40 \\
pH & $7.77 \mathrm{a} \pm 2.93$ & $8.35 \mathrm{a} \pm 0.28$ & $7.52 \mathrm{a} \pm 0.76$ & 6.89 & $5.35 \pm 1.57$ & $7.0-8.5$ & $6.0-9.0$ \\
$\mathrm{COD}(\mathrm{mg} / \mathrm{l})$ & $2372 \mathrm{a} \pm 938$ & $1406 \mathrm{a} \pm 208$ & $3532 \mathrm{a} \pm 1373$ & 2.2 & $3106 \pm 2753$ & 40 & 40 \\
$\mathrm{BOD}(\mathrm{mg} / \mathrm{l})$ & $13.85 \mathrm{a} \pm 6.42$ & $19.46 \mathrm{a} \pm 0.50$ & $17.13 \mathrm{a} \pm 3.14$ & 1032 & $26.17 \pm 9.49$ & 10 & 200 \\
$\mathrm{SS}(\mathrm{mg} / \mathrm{l})$ & $374 \mathrm{a} \pm 124$ & $358 \mathrm{a} \pm 335$ & $780 \mathrm{a} \pm 739$ & 501 & $562 \pm 482$ & 30 & 10 \\
TDS $(\mathrm{mg} / \mathrm{l})$ & $3941 \mathrm{a} \pm 3703$ & $3300 \mathrm{a} \pm 1714$ & $2653 \mathrm{a} \pm 1240$ & 532.7 & $444 \pm 507$ & 250 & 500 \\
\hline
\end{tabular}

The values given in the table above are means of 6 replicate values, $\mathrm{n}=6$ ( 1 sample was taken monthly for 6 months). Within the rows, means with different alphabets are statistically different $(p<0.05)$. WHO: World Health Organisation. NESREA: National Environmental Standard and Regulatory Enforcement Agency. a = Mohammed et al.(2017), b = Baba et al. (2020), c = WHO (2006), $d=$ NESSRA (2009) 
BAJOPAS Volume 13 Number 2, December, 2020

Identification, Biochemical Characterization and growth rates of the Bacterial Isolates

Results of identification and biochemical characterization of the bacterial isolates were shown in table 2. After 24 hours of incubation, the nutrient agar media plates were checked for bacterial growth. The results showed the presence of different strains in the samples. The TAN1 bacteria isolate was found to be gramnegative cocci while TAN3 was gram-positive cocci. TAN2 bacteria isolate was found to be gram-positive, rod-shaped. TAN1, TAN2, and TAN3 bacteria isolates recorded positive results for spore former.

The results of the biochemical tests indicated that all the bacteria were positive for catalase, oxidase, citrate, maltose, glucose, lactose (negative in TAN1), mannitol (negative in TAN2), starch hydrolysis and coagulase (negative in TAN2) tests. The bacteria showed negative results for nitrate reduction, $M R$ (positive in TAN2), VP (positive in TAN1), Indole (positive in TAN2) tests. Base on the morphological and biochemical test results, TAN1, TAN2, and TAN3 bacteria isolates were identified to be Nesseria spp, Bacillus cereus, and Staphylococcus aureus respectively.

The growth rate of the TAN1, TAN2 and TAN3 Isolates were shown in figure 2. Generally, the optical density increase with the increase in time (day) and decrease as time goes on. The highest optical density was shown by bacillus cereus in TAN2 while the lowest was shown by Staphylococcus aureus in TAN3.

The initial growth phase of TAN1 Isolate bacteria occurred within 2-day of incubation as the growth rate increases up to the 6th-day incubation when the maximum growth was observed. Beyond the 6th day, the growth of the bacteria declined (which might be due to a shortage of nutrients in the effluents) until it reached its death phase (which might be due to the unavailability of nutrients in the effluents).

A similar trend of growth was also observed for TAN2 Isolate as the initial growth phase also occurred within 2-day of incubation but maximum growth rate observed on the 4th day of incubation. The stationary stage occurred between the 4th day and the 8th day. Beyond the 8th day, the growth of the bacteria declined (which might be due to a shortage of nutrients in the effluents) until it reached its death phase (which might be due to the unavailability of nutrients in the effluents).

The initial growth phase of TAN3 bacterial Isolate occurred within the 3-day incubation as the growth rate increases up to the 6th-day incubation when the maximum growth was observed. Beyond the 6th day, the growth of the bacteria declined (which might be due to a shortage of nutrients in the effluents) until it reached its death phase (which might be due to the unavailability of nutrients in the effluents).

Table 2: Morphological and Biochemical characteristics of bacterial isolates

\begin{tabular}{lllll} 
Bacterial Isolates & & TAN1 & TAN2 & TAN3 \\
\hline $\begin{array}{lllll}\text { Morphological } \\
\text { characteristics }\end{array}$ & Shape & Cocci & Rod & Cocci \\
& Spore & & & \\
& former & + & + & + \\
Gram & & & \\
Biochemical characteristics & reaction & - & + & + \\
& Citrate & + & + & + \\
& Catalase & + & + & + \\
& Coagulase & + & - & + \\
Starch & + & + & + \\
& Glucose & + & + & + \\
Oxidase & + & + & + \\
& Indo & - & + & - \\
Lactose & - & + & + \\
Manitol & + & - & + \\
Maltose & + & + & + \\
MR & - & + & - \\
VP & + & - & - \\
& Nitrate & - & - & - \\
Reduction & - Neisseria & Bacillus & Staphylococcus \\
& Bacterial & cereus & aureus \\
& name & spp & cas
\end{tabular}

+ = Positive; - = Negative; MR=Methyl Red; VP= Voges-Proskauer 


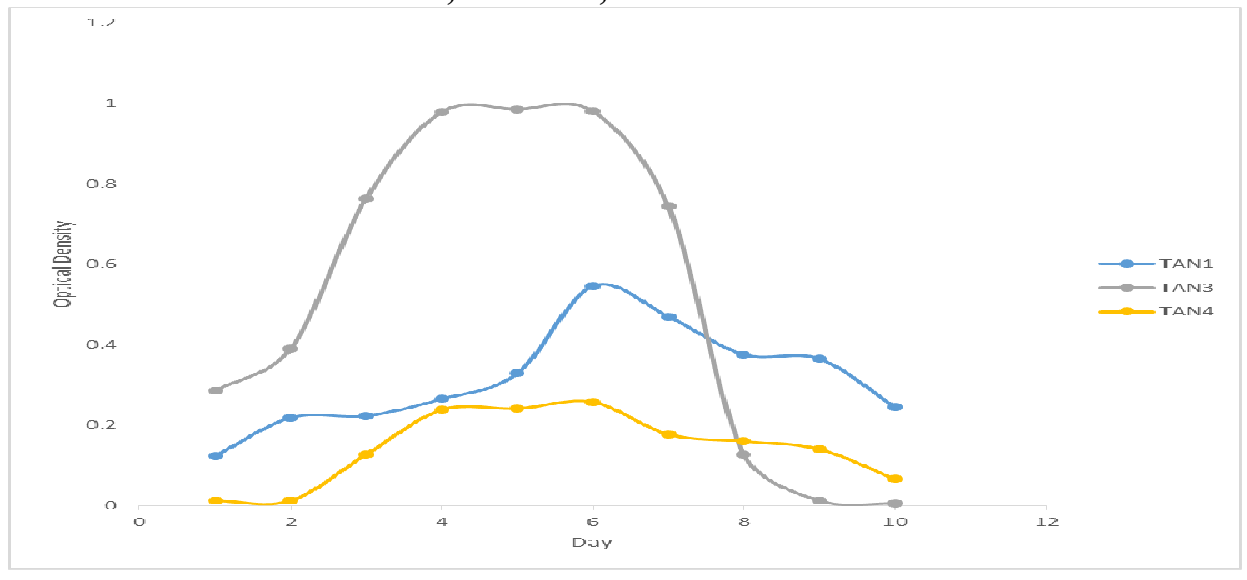

Fig. 2 Growth rates of the isolates in the effluents from the Tannery Industries

\section{Physico-chemical Parameters in the Industrial Effluents after the biodegradation.}

Table 3 shows the mean results of the physicochemical parameter before and after bioremediation using the different masses $(5 \mathrm{~g}$, $10 \mathrm{~g}, 15 \mathrm{~g}, 20 \mathrm{~g}$, and $25 \mathrm{~g}$ ) of the respective immobilized bacteria. Also, Table 4 shows the mean results of correlation coefficient ( $r$ ) between different masses of bacteria and physicochemical parameters.

The mean values $(\mathrm{mg} / \mathrm{l})$ of the SS after the bioremediation varies between $243 \pm 45$ and $898 \pm 672$. The mean concentration $(\mathrm{mg} / \mathrm{l})$ of SS remediated by the different masses $(5 \mathrm{~g}, 10 \mathrm{~g}$, $15 \mathrm{~g}, 20 \mathrm{~g}$, and $25 \mathrm{~g}$ ) of the bacteria varies. The SS in the samples fluctuates up and down after the bioremediation process when compared with the SS of the raw samples before the bioremediation. The increase in the levels of the SS might be due to the aggregation of the TDS which are large enough to result into SS. The increase in the levels of the SS might be also due to the influence of the nutrients which was added into the effluents in order to make the microorganisms more active and viable for fast degradation of organic contaminants in the effluent. The relative potential or efficiency of the different masses of the bacteria in remediating SS in TAN1 samples was in the order $25 \mathrm{~g}>20 \mathrm{~g}>15 \mathrm{~g}>10 \mathrm{~g}>5 \mathrm{~g}$. For TAN2 and TAN3 samples, the order was $25 \mathrm{~g}>20 \mathrm{~g}>15$ $\mathrm{g}>10 \mathrm{~g}>5 \mathrm{~g}$. These might be due to the variations in the surface areas of the different masses of the immobilized bacteria. Statistical analysis shows that there is no significant difference $(p<0.05)$ between the mean values of SS among the masses in the respective industries. Positive and significant correlations exist between the masses of bacteria and Suspended Solid (SS). This showed that there is general increase in the levels of the SS as the masses of the immobilized bacteria increases. TAN3 (90\%) and TAN1 (80\%) showed a very high correlation with the masses of the bacteria while TAN2 (61\%) showed a very low correlation.

The mean values $(\mathrm{mg} / \mathrm{l})$ of the TDS after the bioremediation varies between $46 \pm 11$ and $83 \pm 78$. The mean concentration $(\mathrm{mg} / \mathrm{l})$ of TDS remediated by the different masses $(5 \mathrm{~g}, 10 \mathrm{~g}$, $15 \mathrm{~g}, 20 \mathrm{~g}$, and $25 \mathrm{~g}$ ) of the bacteria varies. There is a reduction in all the TDS of all the samples after the bioremediation process compared with the TDS of the raw samples before the bioremediation. The relative potential or efficiency of the different masses of the bacteria in remediating TDS in TAN1 and TAN3 samples was in the order $5 \mathrm{~g}>10 \mathrm{~g}>15 \mathrm{~g}>20$ $\mathrm{g}>25 \mathrm{~g}$. For TAN2 samples, the order was 20 $g>10 \quad g>25 \quad g>15 \quad g>5 \quad g$. Statistical analysis shows that there is no significant difference $(p<0.05)$ between the mean values of TDS among the masses in the respective industries. These might be due to the variations in the surface areas of the different masses of the immobilized bacteria. Positive and significant correlations exist between the masses of bacteria and TDS with the exception in TAN2 (negative and insignificant correlation). The positive correlations showed that there is general increase in the levels of the TDS as the masses of the immobilized bacteria increases. TAN1 $(96 \%)$ showed a very high correlation with the masses of the bacteria while TAN2 (47\%) showed a very low correlation.

The mean values $(\mathrm{mg} / \mathrm{l})$ of the BOD after the bioremediation varies between $1.56 \pm 0.20 \mathrm{mg} / \mathrm{l}$ and $6.92 \pm 5.49 \mathrm{mg} / \mathrm{l}$. The mean concentration $(\mathrm{mg} / \mathrm{l})$ of BOD remediated by the different masses $(5 \mathrm{~g}, 10 \mathrm{~g}, 15 \mathrm{~g}, 20 \mathrm{~g}$, and $25 \mathrm{~g}$ ) of the bacteria varies. There is a reduction in all the BOD of all the samples after the bioremediation process compared with the $\mathrm{BOD}$ of the raw 
BAJOPAS Volume 13 Number 2, December, 2020 samples before the bioremediation. The relative potential or efficiency of the different masses of the bacteria in remediating BOD in TAN1, TAN2 and TAN3 samples were in the order $25 \mathrm{~g}>20$ $\mathrm{g}>15 \mathrm{~g}>10 \mathrm{~g}>5 \mathrm{~g}, 25 \mathrm{~g}>15 \mathrm{~g}>5 \mathrm{~g}>10 \mathrm{~g}>20 \mathrm{~g}$ and $20 \mathrm{~g}>10 \mathrm{~g}>25 \mathrm{~g}>15 \mathrm{~g}>5 \mathrm{~g}$ respectively. Statistical analysis shows that there is significant difference $(p<0.05)$ between the mean values of BOD among the masses in the respective industries. These might be due to the variations in the surface areas of the different masses of the immobilized bacteria. Negative and significant correlations exist between the masses of bacteria and BOD. This showed that there is general decrease in the levels of the BOD as the masses of the immobilized bacteria increases. TAN1 (94\%) showed a very high correlation with the masses of the bacteria while TAN2 (4\%) showed a very low correlation.

The mean values $(\mathrm{mg} / \mathrm{l})$ of the COD after the bioremediation varies between $250 \pm 154$ and $3134 \pm 1595$. The mean concentration $(\mathrm{mg} / \mathrm{l})$ of COD remediated by the different masses $(5 \mathrm{~g}$, $10 \mathrm{~g}, 15 \mathrm{~g} 20 \mathrm{~g}$, and $25 \mathrm{~g}$ ) of the bacteria varies. There is a reduction in all the COD of all the samples after the bioremediation process compared with the COD of the raw samples before the bioremediation. The relative potential or efficiency of the different masses of the bacteria in remediating COD in TAN1, TAN2 and TAN3 samples were in the order $25 \mathrm{~g}>20 \mathrm{~g}>15$ $\mathrm{g}>5 \mathrm{~g}>10 \mathrm{~g}, 25 \mathrm{~g}>20 \mathrm{~g}>15 \mathrm{~g}>10 \mathrm{~g}>5 \mathrm{~g}$ and 10 g>5 g>25 g>15 g>20 g respectively. Statistical analysis shows that there were significant difference $(p<0.05)$ between the mean values of COD among the masses in the respective industries except for effluents treated with $25 \mathrm{~g}$. These might be due to the variations in the surface areas of the different masses of the immobilized bacteria. Negative and insignificant correlations exist between the masses of bacteria and COD with the exception in TAN3 (positive and significant correlation). The negative correlations showed that there is general decrease in the levels of the COD as the masses of the immobilized bacteria increases. TAN2 (100\%) showed a very high correlation with the masses of the bacteria while TAN3 (36\%) showed a very low correlation.

Generally, there was an overall decrease in the concentration of these physicochemical parameters after the bioremediation using the different masses of the bacterial isolates. These might be due to the variations in the surface areas of the different masses of the immobilized bacteria. This is in line with the work of Jimoh et al. (2018) and Baba et al. (2020).

Table 3: Mean Values $(\mathrm{mg} / \mathrm{l}) \pm$ S.D of Physicochemical parameters in effluents from the Tannery Industries before and after Treatment of the effluents $(250 \mathrm{ml})$ with the different masses $(5 \mathrm{~g}, 10 \mathrm{~g}$, $15 \mathrm{~g}, 20 \mathrm{~g}$, and $25 \mathrm{~g}$ ) of the bacteria.

\begin{tabular}{llllllll}
\hline $\mathrm{P}$ & IND & Before & \multicolumn{5}{c}{ After } \\
\cline { 4 - 7 } & & & $5 \mathrm{~g}$ & $10 \mathrm{~g}$ & $15 \mathrm{~g}$ & $20 \mathrm{~g}$ & $25 \mathrm{~g}$ \\
\hline \multirow{2}{*}{ COD } & TAN1 & $2372 \pm 938$ & $1708 \mathrm{a} \pm 861$ & $2045 \mathrm{a} \pm 1205$ & $845 \mathrm{a} \pm 369$ & $300 \mathrm{a} \pm 167$ & $250 \mathrm{a} \pm 154$ \\
& TAN2 & $1406 \pm 208$ & $1195 \mathrm{a} \pm 208$ & $1125 \mathrm{a} \pm 384$ & $1055 \mathrm{a} \pm 317$ & $956 \mathrm{a} \pm 310$ & $870 \mathrm{ab} \pm 240$ \\
& TAN3 & $3532 \pm 1373$ & $2374 \mathrm{a} \pm 1344$ & $1976 \mathrm{a} \pm 1405$ & $2757 \mathrm{a} \pm 1266$ & $3134 \mathrm{a} \pm 1595$ & $2614 \mathrm{~b} \pm 1105$ \\
BOD & TAN1 & $13.85 \pm 6.42$ & $6.92 \mathrm{a} \pm 5.49$ & $6.42 \mathrm{a} \pm 5.07$ & $5.72 \mathrm{a} \pm 5.35$ & $4.62 \mathrm{a} \pm 4.37$ & $2.82 \mathrm{ab} \pm 1.26$ \\
& TAN2 & $19.46 \pm 0.50$ & $1.75 \mathrm{~b} \pm 0.22$ & $1.73 \mathrm{~b} \pm 0.18$ & $1.58 \mathrm{a} \pm 0.16$ & $1.91 \mathrm{a} \pm 0.22$ & $1.56 \mathrm{~b} \pm 0.20$ \\
& TAN3 & $17.13 \pm 3.14$ & $4.24 \mathrm{ab} \pm 0.77$ & $3.29 \mathrm{ab} \pm 0.37$ & $4.11 \mathrm{a} \pm 0.07$ & $3.23 \mathrm{a} \pm 0.91$ & $3.33 \mathrm{a} \pm 1.28$ \\
SS & TAN1 & $374 \pm 124$ & $243 \mathrm{a} \pm 45$ & $471 \mathrm{a} \pm 226$ & $475 \mathrm{a} \pm 182$ & $492 \mathrm{a} \pm 128$ & $611 \mathrm{a} \pm 217$ \\
& TAN2 & $358 \pm 335$ & $460 \mathrm{a} \pm 400$ & $543 \mathrm{a} \pm 414$ & $544 \mathrm{a} \pm 402$ & $551 \mathrm{a} \pm 414$ & $554 \mathrm{a} \pm 405$ \\
& TAN3 & $780 \pm 739$ & $586 \mathrm{a} \pm 594$ & $758 \mathrm{a} \pm 656$ & $787 \mathrm{a} \pm 676$ & $861 \mathrm{a} \pm 635$ & $898 \mathrm{a} \pm 672$ \\
TDS & TAN1 & $3941 \pm 3703$ & $51 \mathrm{a} \pm 10$ & $53 \mathrm{a} \pm 10$ & $55 \mathrm{a} \pm 15$ & $61 \mathrm{a} \pm 20$ & $63 \mathrm{a} \pm 26$ \\
& TAN2 & $3300 \pm 1714$ & $83 \mathrm{a} \pm 78$ & $47 \mathrm{a} \pm 20$ & $48 \mathrm{a} \pm 22$ & $47 \mathrm{a} \pm 17$ & $48 \mathrm{a} \pm 17$ \\
& TAN3 & $2653 \pm 1240$ & $46 \mathrm{a} \pm 11$ & $55 \mathrm{a} \pm 24$ & $55 \mathrm{a} \pm 25$ & $58 \mathrm{a} \pm 23$ & $61 \mathrm{a} \pm 28$ \\
\hline
\end{tabular}

Replicate $=6$ (months)

Within the rows, for the same parameter, means with different alphabets are statistically different $(p<0.05)$.

$\mathrm{P}=$ parameter, IND = Industries 
BAJOPAS Volume 13 Number 2, December, 2020

Table 4: Correlation coefficient $(r)$ between different masses of the bacteria and the physicochemical parameters.

\begin{tabular}{llll}
\hline Industries & Parameter & Correlation coefficient $(r)$ & $\begin{array}{l}\text { Percent dependence (rxrx100) } \\
(\%)\end{array}$ \\
\hline TAN1 & COD & -0.9 & 82 \\
& BOD & -0.97 & 94 \\
& SS & $0.90^{*}$ & 80 \\
TAN2 & TDS & $0.98^{*}$ & 96 \\
& COD & -1 & 100 \\
& BOD & -0.21 & 4 \\
& SS & $0.78^{*}$ & 61 \\
& TDS & -0.69 & 47 \\
& COD & $0.60^{*}$ & 36 \\
& BOD & -0.6 & 37 \\
& SS & $0.95^{*}$ & 90 \\
& TDS & $0.94^{*}$ & 89 \\
\hline
\end{tabular}

The correlation coefficient $(r)$ with * is statistically significant $(p<0.05)$.

Percentage reduction of the Parameters

Table 5 shows the percentage reduction of Parameters in industrial samples before and after the treatment of the effluents $(250 \mathrm{ml})$ with the different masses $(5 \mathrm{~g}, 10 \mathrm{~g}, 15 \mathrm{~g}, 20 \mathrm{~g}$, and $25 \mathrm{~g}$ ) of the Immobilized Bacteria.

In TAN1 samples, the percentage reduction (\%) of COD ranged (14-89); BOD (50-80); SS (-32$35)$ and TDS (98-99). In TAN2 samples, the percentage decrease $(\%)$ of COD ranged (15$38) ;$ BOD (90-92); SS [-28-(-55)] and TDS (9798). In TAN3 samples, the percentage decrease (\%) of COD ranged (11-44); BOD (76-81); SS (15-25) and TDS (98). The percentage increase in the levels COD, BOD and TDS might be due to the increase in the surface area of the different masses of the immobilized bacteria. However, the percentage decrease in the levels of the SS might be due to the aggregation of the TDS which are large enough to result into SS. The percentage decrease in the levels of the SS might be also due to the influence of the nutrients which was added into the effluents in order to make the microorganisms more active and viable for fast degradation of organic contaminants in the effluent. This is in line with the work of Jimoh et al. (2018) in which the concentration of the SS increase after the bioremediation of effluents.

Sreemoyee and Priti (2013) assessed and reduced several Physico-chemical parameters of dairy wastewater using Niesseria $s p$. and concluded that the species are well known to degrade organic compounds. This is in agreement with the current study in which the immobilized Niesseria $s p$ degrade the organic contaminants as indicated by the BOD, COD and TDS.

Jimoh et al. (2018) observed that TSS of the effluents was increased after treatment with immobilized bacteria and concluded that it might be due to the biostimulation method adopted for the research.

The optimum $\mathrm{pH}$ Biosorption of Chromium by Bacillus spp and Staphylococcus spp. from tannery effluent was investigated by Mythili and Karthikeyan (2011). The maximum adsorption of Chromium $(86.4 \mathrm{mg} / \mathrm{L})$ was showed by Bacillus spp and Staphylococcus spp showed $70.6 \mathrm{mg} / \mathrm{L}$ at an initial concentration of $100 \mathrm{mg} / \mathrm{L}$. In the present study, immobilised Bacillus spp and Staphylococcus spp. from the tannery industrial effluents reduced the levels of the organic pollutants with high potential as indicated by the percentage reduction of BOD, COD and TDS.

Enzymes often can work in multiple environments especially if they are immobilized. This makes the microorganisms' enzymes even more resistant to harsh environments and enables the enzymes to be recovered and recycled after they are no longer needed (Gianfreda and Rao 2004). Ramesh and Singh (1993) reported that the immobilized bacteria having more efficiency to remove the suspended particles than free cells. Using the immobilized cell is preferable due to its capability for using several times with the same efficiency, which makes it more economical. Similar work was done by Sikander et al. (2007) showing the higher reduction with permeabilized cells of Ochrobactrum intermedium strain SDCr-5. 
BAJOPAS Volume 13 Number 2, December, 2020

The results revealed the isolation and identification of isolates with the potential for the reduction of $\mathrm{Cr}$ (VI) to $\mathrm{Cr}$ (III). Results indicated that immobilized $B$. cereus could be efficiently used for the reduction of $\mathrm{Cr}$ (VI).

Table 5: Percentage reduction of the tested Parameters from the tannery industrial samples of the Immobilized Bacteria.

\begin{tabular}{lllllll}
\hline \multirow{2}{*}{ Industries } & & \multicolumn{5}{c}{ Percentage Reduction $(\%)$} \\
\cline { 3 - 7 } & & $5 \mathrm{~g}$ & $10 \mathrm{~g}$ & $15 \mathrm{~g}$ & $20 \mathrm{~g}$ & $25 \mathrm{~g}$ \\
\hline TAN1 & COD & 28 & 14 & 64 & 87 & 89 \\
& BOD & 50 & 54 & 59 & 67 & 80 \\
& SS & 35 & -26 & -27 & -32 & -63 \\
& TDS & 99 & 99 & 99 & 98 & 98 \\
TAN2 & COD & 15 & 20 & 25 & 32 & 38 \\
& BOD & 91 & 91 & 92 & 90 & 92 \\
& SS & -28 & -52 & -52 & -54 & -55 \\
& TDS & 97 & 99 & 99 & 99 & 99 \\
& COD & 33 & 44 & 22 & 11 & 26 \\
& BOD & 75 & 81 & 76 & 81 & 81 \\
& SS & 25 & 3 & -1 & -10 & -15 \\
& TDS & 98 & 98 & 98 & 98 & 98 \\
\hline
\end{tabular}

Percentage Reduction $=(B-A) / B \times 100 \%$

$A=$ Concentration of the parameter after treatment

$\mathrm{B}=$ Concentration of the parameter before treatment

$+=$ percentage decrease

- = percentage increase

In general, immobilization makes the enzyme more resistant to temperature, $\mathrm{pH}$, and substrate concentration swings giving it a longer lifetime and higher productivity per active unit (Gianfreda and Rao, 2004; FuIlbrook, 1996; Russell et al, 2003; Kandelbauer et al., 2004). Immobilized cells have been used and studied extensively for the production of useful chemicals (Ohtake and Silver, 1994), the treatment of wastewaters (Chen et al., 2003; Wang et al., 2010). Although many workers described microbial degradation of tannery effluent, limited literature is available on the bioremediation of tannery effluent using immobilized bacterial cells in the Kano Industrial Estates.

\section{CONCLUSION}

The samples contained variable levels of the physicochemical parameters. The results of the Analysis of variance revealed that, no statistical difference $(p<0.05)$ was observed for the temperature, $\mathrm{pH}, \mathrm{SS}, \mathrm{TDS}, \mathrm{BOD}$ and $\mathrm{COD}$ among the three tannery industries before the treatment. The levels of some of the parameters
(SS, TDS and COD) observed in the samples were found above the recommended limits of WHO and NESREA, which called for the treatment of the effluents before discharge into the environment. Base on the morphological and biochemical test results, TAN1, TAN2, and TAN3 bacterial isolates were identified to be Neisseria spp, Bacillus cereus, and Staphylococcus aureus respectively. The results of Post-treatment analysis showed that there is overall decrease in the levels of the parameters determined when compared with that of the pre-treatment. The overall percentage reduction of the immobilised bacteria in the treatment of the respective effluents was in the order TAN2 (72\%)>TAN1 $(70 \%)>$ TAN3 $(62 \%)$. Hence, the immobilized bacteria are having higher biodegradation potential for the treatment of the tannery effluents.

\section{Acknowledgments}

The authors wish to acknowledge the University of Maiduguri for the financial support. The authors are grateful to the Kano State Ministry of Environment for their support in obtaining the effluent samples. 


\section{REFERENCES}

Ajao, A. T., Adebayo, G. B., and Yakubu, S. E. (2011). Bioremediation of textile industrial effluent using mixed culture of Pseudomonas aeruginosa and Bacillus subtilis immobilized on agar-agar in a bioreactor. J. Microbiol. Biotech. Res, 1(3), 50-56.

Akan, J. C., Moses, E. A., Ogugbuaja, V. O., and Abah, J. (2007). Assessment of tannery industrial effluents from Kano metropolis, Kano State, Nigeria. Journal of Applied Sciences, 7(19), 2788-2793.

Akan, J. C., Ogugbuaja, V. O., Abdulrahman, F. I., and Ayodele, J. T. (2009). Pollutant levels in effluent samples from tanneries and textiles of Kano industrial areas, Nigeria. Global journal of pure and applied sciences, 15(3-4).

APHA (1989). Standard methods for Examination of Will bete and Will betewater.15 $5^{\text {th }}$ edition. Brydpass Springfield Will behington DC. pp. 164-176

APHA (1992). Standard Methods for the Examination of Water and Wastewater. Health, 69, 1116-9.

Baba, A., Garba, S. T., and Bello, H. S. (2020). Bioremediation Potential of Immobilized corynebacterium kutsceri in the Treatment of Tannery Industrial Effluent from Challawa Industrial Estate, Kano State, Nigeria. Journal of the Turkish Chemical Society Section A: Chemistry, $7(2), 335-350$.

Beem, E. I. V. (1994). reduction of solvent VOC emission. J. Oil Col. Chem. Ass, 77, 158.

Bouwer, E. J., and Zehnder, A. J. (1993). Bioremediation of organic compoundsputting microbial metabolism to work. Trends in biotechnology, 11(8), 360367.

Chen, K. C., Wu, J. Y., Liou, D. J., and Hwang, S. C. J. (2003). Decolorization of the textile dyes by newly isolated bacterial strains. Journal of Biotechnology, 101(1), 57-68.

Dan'Azumi, S., and Bichi, M. H. (2010). INDUSTRIAL POLLUTION AND HEAVY METALS PROFILE OF CHALLAWA RIVER IN KANO, NIGERIA. Journal of Applied Sciences in Environmental Sanitation, $5(1)$.

DWAF. (1992). Analytical Methods Manual, TR 151. Department of Water Affairs and Forestry, Pretoria.

El-Bestawy, E. (2013). Biological treatment of leather-tanning industrial wastewater using free living bacteria.
Elsheikh, M. A. S. (2009). Tannery wastewater pre-treatment. Water Science and Technology, 60(2), 433-440.

FuIlbrook, P. D. (1996). "Kinetics." Industrial enzymology: The application of enzymes in Industry. 2nd Ed. T. Godfrey and J Reichelt. eds.. Nature. New York.

Gianfreda, L., and Rao, M. A. (2004). Potential of extra cellular enzymes in remediation of polluted soils: a review. Enzyme and microbial technology, 35(4), 339354.

Hugo Springer. (1994). John Arthur Wilson Memorial Lecture "Treatment of Industrial Wastes of the Leather Industry - is it still a Major Problem". JALCA, 89, 153-185

Jimoh, A. A., Ganiyu, B. A., Baba, D., and Baba, A. (2018) Bioremediation Process of Effluent from Detergent and Food Industries in Jos, Nigeria: Kinetics and Thermodynamics. International Journal of Engineering Science Invention (IJESI), 762-73

Kandelbauer, A., Maute, O., Kessler, R. W., Erlacher, A., and Gübitz, G. M. (2004). Study of dye decolorization in an immobilized laccase enzyme-reactor using online spectroscopy. Biotechnology and bioengineering, 87(4), 552-563.

Kongjao, S., Damronglerd, S., and Hunsom, M. (2008). Simultaneous removal of organic and inorganic Pollutants in tannery wastewater using electrocoagulation technique. Korean Journal of chemical engineering, 25(4), 703.

Maheshwari, U. M., Aruna, S., Gomathi, M., and AbdulJaffar, A. H. (2017). Bioremediation by Free and Immobilized Bacteria Isolated from Tannery Effluent. International Journal of Research in Applied, Natural and Social Sciences. 5(7), 75-90

Margesin, R., and Schinner, F. (2001). Bioremediation (natural attenuation and biostimulation) of diesel-oilcontaminated soil in an alpine glacier skiing area. Applied and environmental microbiology, 677), 3127-3133.

Mohammed, A., Sekar, P., and George, J. (2011). Efficacy of microbes in bioremediation of tannery effluent. Inter. J. Curr. Res, 3(4), 324-326.

Mohammed, S. S. D., Orukotan, A. A., and Abdullahi, H. (2017). Physicochemical and Bacteriological Assessment of Tannery Effluent from Samaru-Zaria, 
BAJOPAS Volume 13 Number 2, December, 2020 Kaduna State, Nigeria. Journal of Applied

Sciences and Environmental Management, 21(4), 734-740.

Munz, G., De Angelis, D., Gori, R., Mori, G., Casarci, M., and Lubello, C. (2009). The role of tannins in conventional and membrane treatment of tannery wastewater. Journal of hazardous materials, 164(2-3), 733-739

Mythili, K., and Karthikeyan, B. (2011). Bioremediation of $\mathrm{Cr}$ (VI) from tannery effluent using Bacillus spp and Staphylococcus spp. International Multidisciplinary Research Journal, 1(6).

NESREA (2009). National Environmental Standards for Effluent Limitations and Regulation. 1233-1236

Noorjahan, C. M. (2014). Physicochemical characteristics, identification of bacteria and biodegradation of industrial effluent. Journal of bioremediation and Biodegradation, 5(3).

Ohtake, H. I., and Silver, A. O. (1994). Bacterial reduction of toxic chromate. Biological degradation and bioremediation of toxic chemicals, 403-415.

Omoleke, I. I. (2004). Management of environmental pollution in Ibadan, an African city: the challenges of health hazard facing government and the people. Journal of Human Ecology, 15(4), 265-275.

Rajor, A., Reddy, A.S., and Singh, B. (2004). Determination of BOD kinetic Parameters and evaluation of alternate methods, M.Sc. Thesis, Department of biotechnology \& environmental Science, Thapar Institute of Engineering and Technology, Patiala

Ramasami, T., Rajamani, S., and Rao, J. R. (1994, March). Pollution control in leather industry: Emerging technological options. In International symposium on surface and colloidal science and its relevance to soil pollution, madras.

Ramesh, J. V. S., and Singh, S. P. (1993). Yearly variation in certain physicochemical parameters of pond at eastern Doon Valley. Uttar Pradesh J. Zoo, 12 (1), 7577.

Ranen, S., and Sharadinadra, C. (2009). Biotechnology applications to environmental remediation in resource exploitation. Current science, 97, 6-25
Russell, A. J., Berberich, J. A., Drevon, G. F., and Koepsel, R. R. (2003). Biomaterials for mediation of

chemical and biological warfare agents. Annual review of biomedical engineering, 5(1), 1-27.

Saravanan, P., and Saravanan, A. (1999). Decolourization of tannery effluent by Flavobacterium sp. EK 1. Indian Journal of Environmental Protection, 19, 19-24.

Sikander, S., and Shahida, H. (2007). Reduction of toxic hexavalent chromium by Ochrobactrum intermedium strain SDCr5 stimulated by heavy metals. Bioresource Technol, 98, 340-344.

Singh, N., Sharma, B. K., and Bohra, P. C. (2000). Impact assessment of industrial effluent of arid soils by using satellite imageries. Journal of the Indian Society of Remote Sensing, 28(2-3), 79.

Sreemoyee, C., and Priti, P. (2013). Assessment of physico-chemical parameters of dairy waste water and isolation and characterization of bacterial strains in terms of cod reduction. Int J Sci, 2(3), 395-400.

Verheijen, L. A. H. M., Wiersema, D., Pol, L. H., and De Wit, J. (1996). Management of wastes from animal product processing. Livestock and environment, Finding a balance. International Agriculture Center, Wageningen, The Netherlands.

Wang, F., Yao, J., Si, Y., Chen, H., Russel, M., Chen, K., and Bramanti, E. (2010). Short-time effect of heavy metals upon microbial community activity. Journal of Hazardous Materials, 173(13), 510-516.

WHO (World Health Organization). (2006). Air quality guidelines: global update 2005: particulate matter, ozone, nitrogen dioxide, and sulfur dioxide. World Health Organization.

World Bank. (1995). Nigeria's strategic options for redressing industrial pollution. World Bank, industry and energy division. 1st edition, West Central Africa Department; Annexes: 1995; pp 60-62.

Zahoor, A., and Abdul, R. (2009). Enumeration of Coliforms. Journal of Environmental Sciences. 21, 814-820 


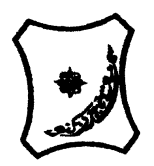

Bayero Journal of Pure and Applied Sciences, 13(2): 1 - 12

Received: November, 2020

Accepted: December, 2020

ISSN $2006-6996$

\title{
BIODEGRADATION POTENTIAL OF IMMOBILIZED BACTERIA IN THE TREATMENT OF TANNERY INDUSTRIAL EFFLUENTS FROM INDUSTRIAL ESTATES IN KANO STATE, NIGERIA
}

\author{
Abdullateef, B., ${ }^{1 *}$ Shuaibu, T. G., ${ }^{1}$ Babagana, K., ${ }^{1}$ Suleman, H. B. ${ }^{2}$ and Dauda, B. ${ }^{3}$ \\ ${ }^{1}$ Department of Pure and Applied Chemistry, Faculty of Science, University of Maiduguri, Borno State, \\ Nigeria \\ ${ }^{2}$ Department of Microbiology, Faculty of Science, University of Maiduguri, Borno State, Nigeria \\ ${ }^{3}$ Department of Chemical Engineering, Faculty of Engineering, University of Maiduguri, Borno State, \\ Nigeria \\ *Corresponding author: babslega@gmail.com; abelega2007@yahoo.com; +2348061309753
}

\section{ABSTRACT}

Industrial Effluents Samples from Gashash Tanneries (TAN1) in Bompai Industrial estate, Larabee Tannery Industry (TAN2) in Sharada Industrial estate and Z Tannery Industries (TAN3) in Challawa Industrial estate, Kano State, Nigeria were collected over a period of six months (August 2017 to January 2018) for assessing the biodegradation potentials of bacteria in the treatment of organic pollutants within the effluents. Bacteria were isolated from the effluents and immobilized on agar-agar. Different masses (5 g, $10 \mathrm{gr}, 15$ $\mathrm{g}, 20 \mathrm{~g}$, and $25 \mathrm{~g}$ ) of the bacteria were used in the treatment of $250 \mathrm{ml}$ of the effluents for ten days in a shaker incubator (Gallenkamp-OC-4364-L) at the temperature $30{ }^{\circ} \mathrm{C}$ and speed of $60 \mathrm{rpm}$. Pre-treatment analysis of the effluents for Temperature, pH, Biochemical Oxygen Demand (BOD), Chemical Oxygen Demand (COD), Suspended Solid (SS) and Total Dissolved Solids (TDS) gives the following results; temperature $\left({ }^{\circ} \mathrm{C}\right.$ )

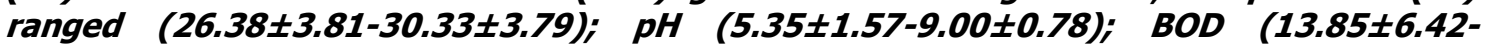
$38.75 \pm 16.20) ;$ COD (1406 $\pm 208-3532 \pm 1373) ;$ SS (208 $\pm 235-780 \pm 739)$ and TDS (266 $\pm 253-5276 \pm 2971)$. No statistical differences ( $p \leq 0.05)$ was observed for all the results among the different industries. The bacterial isolates were identified as Neisseria spp, Bacillus cereus, and Staphylococcus aureus, in TAN1, TAN2, and TAN3, respectively. After treatment of the effluent with the different masses of the isolated bacteria, the mean level of BOD was found to range as (0.55 $\pm 0.36-6.92 \pm 5.49) ; C O D$ (ND-3134 \pm 1595$)$;

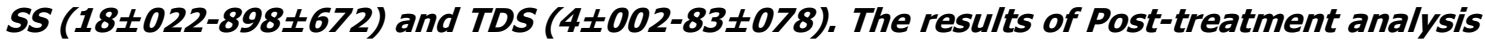
showed that there is overall decrease in the levels of the parameters determined when compared with that of the pre-treatment. The overall percentage reduction of the immobilised bacteria in the treatment of the respective effluents was in the order TAN2 (72\%)>TAN1 (70\%)>TAN3 (62\%). Hence, the immobilized bacteria are having higher biodegradation potential for the treatment of the tannery effluents.

Keywords: Biodegradation, bacteria, effluent, immobilization, tannery.

\section{INTRODUCTION}

Tannery industrial wastewater is a serious consequence of the pollution point of view for streams, freshwater, and land used for agriculture. The lack of awareness in the modern industrial practice has resulted in the discharge of tannery effluents which exhibit very high value of chromium ( $\mathrm{Cr}$ ), Sulfide, and chloride, Total Dissolved Solid (TDS), Total Suspended Solid (TSS), Biochemical Oxygen Demand (BOD) and Chemical Oxygen Demand (COD) in the water stream or land (Mohammed et al., 2001). Tanning is the process, which One ton of skin generally leads to the production of 20 to $80 \mathrm{~m}^{3}$ of turbid and foul-smelling converts the protein of the rawhide or skin into a stable material, which will not putrefy and is suitable for a wide variety of end applications (Elsheikh, 2009). The highly polluting chromium is the most commonly used tanning material producing leather that is more flexible and pliable than vegetable-tanned leather and does not discolor or lose shape in water as drastically as vegetable-tan (Elsheikh, 2009). Tannery effluent is among the most hazardous industrial pollutants due to its huge organic and inorganic load, which is highly toxic to human life and the environment (Kongjao et al., 2008). wastewater including chromium (100-400 mg/l), sulfide $(200-800 \mathrm{mg} / \mathrm{l})$, high levels of fat and 
BAJOPAS Volume 13 Number 2, December, 2020 other solid wastes, and notable pathogen contamination as well as pesticides added for skin conservation during transport (Elsheikh, 2009). There are more than 6000 tanneries in Nigeria with an annual processing capacity of 700,000 tons of hides and skins (Omoleke, 2004; Singh et al., 2008). It was reported that the total amount of waste produced per animal slaughtered is approximately $35 \%$ of its weight (World Bank, 1995). Also, for every $1000 \mathrm{~kg}$ of carcass weight, a slaughtered beef produces 5.5 $\mathrm{kg}$ of manure (excluding rumen contents or stockyard manure) and $100 \mathrm{~kg}$ of paunch manure (undigested food) (Verheijen et al., 1996). Tanneries generate wastewater in the range of 30-35 $\mathrm{L} \mathrm{kg}^{-1}$ skin/hide processed with variable $\mathrm{pH}$, Biological Oxygen Demand (BOD), Chemical Oxygen Demand (COD), high concentrations of suspended solids (SS), and tannins as well as chromium (Zahoor and Abdul, 2009).

Being heterogeneous and composed of a wide variety of compounds, it is very difficult to select a unique direct method for estimating the biodegradability of organic contents and biokinetic parameters for a wastewater sample (Rajor, 2004). For this purpose, some indirect estimation such as determination of biochemical oxygen demand (BOD) and chemical oxygen demand (COD) are applied as common laboratory investigations [9]. During retanning procedures, synthetic tannins (Syntan), oils and resins are added to form softer leather at varying doses (Munz et al., 2009). One of the refractory groups of chemicals in tannery effluents derives mainly from tannins (Ramasami et al., 2004). Syntans are characterized by complex chemical structures, because they are composed of an extended set of chemicals such as phenol-, naphthalene-, formaldehyde- and melamine-based syntans, and acrylic resins (Beem, 1994). Organic pollutants (proteic and lipidic components) are originated from skins (it is calculated that the raw skin has $30 \%$ loss of organic material during the working cycle) or they are introduced during processes (Hugo Springer, 1994).

Many conventional processes such as oxidation, chemical and biological processes were carried out to treat tanneries wastewater (Ebtesam et al, 2013). Biological processes have received more attention because of their costeffectiveness, lower sludge production and environmental friendliness (Noorjahan, 2014). Naturally occurring micro-organisms degrade the hazardous organic wastes including xenobiotic compounds, such as pesticides, polycyclic aromatic hydrocarbons (PAHs) and polychlorinated biphenyls (PCBs) in due course of time (Ranen and Sharadinadra, 2009). Bioremediation is based on the idea that all organisms remove substances from the environment to carry outgrowth and metabolism (Bouwer and Zehnder, 1993). Bacteria, protista and fungi are found to be very good at degrading complex molecules and incorporating the breakdown products into their metabolism (Bouwer and Zehnder, 1993). The resultant metabolic wastes that they produce are generally safe and somehow recycled into other organisms (Ranen and Sharadinadra, 2009). An acclimatized indigenous population of microorganisms capable of degradation of the compounds of interest must exist at the site for a successful bioremediation mode (Ranen and Sharadinadra, 2009). It has been observed that for a successful bioremediation mode, an acclimatized indigenous population of microorganisms capable of degradation of the compounds of interest must exist at the site under investigation (Ranen and Sharadinadra, 2009). Even though there are numerous physical and chemical methods employed in the disposal of wastes the advantage in using bacterium is that they play a key role in the reduction of COD, BOD, total protein, total tannin and total phenol (Saravanan and Saravanan, 1998)

Baba et al. (2020) studied the bioremediation potential of immobilized corynebacterium kutsceri in the Treatment of tannery industrial effluent from Challawa Industrial Estate, Kano State, Nigeria. The aim of the work is to study the reduction in the level of the contaminants through the process of bioremediation using the isolated bacteria. Immobilized bacteria can withstand various temperatures, $\mathrm{pH}$ and substrate concentrations; consequently, increasing the efficiency and the lifespan of the bacteria. Immobilized bacteria are widely applied in the treatment of wastewater and can be separated and recovered after the treatment with the same efficiency (Baba et al., 2020).

\section{MATERIALS AND METHODS \\ Study Area}

This study was carried out in Bompai, Sharada and Challawa industrial estates in Kano, Figure 1. Kano lies on Latitude $11^{\circ} 30^{\prime} \mathrm{N}$ and $8^{\circ} 30^{\prime} \mathrm{E}$ and Longitude $11^{\circ} 5^{\prime} \mathrm{N}$ and $8^{\circ} 5^{\prime} \mathrm{E}$ in Northern Nigeria. It is one of the developed industrial cities in Nigeria. Tannery activities are the dominating industries and this could be one of the reasons for her high population density (Dan'Azumi and Bichi, 2010). Many researchers have studied biodegradation of tannery effluent using microorganisms. However, limited literature is available on the biodegradation of tannery effluent in Kano industrial estates using 
BAJOPAS Volume 13 Number 2, December, 2020 immobilized bacterial cells. This research work focuses on the potential of the use of the indigenous immobilized bacterial isolates in the treatment of tannery effluents in the industrial estates.

\section{Sample Collection}

Effluents were collected from the Tannery Industries from Bompai, Challawa and Sharada Industrial Estates, Kano, Nigeria. The effluents were collected over a period of six months (August 2017 to January 2018). Samples collected in a sterile 4-liter plastic container with a unique identification number were preserved using an ice-box that was transported to the Microbiology Laboratory, Department of Microbiology, Bayero University of Kano for analysis

\section{Sample Preparation and Sample Analysis}

Immediately after the collection of the effluent, $\mathrm{pH}$, TSS, TDS, COD, BOD levels were determined before treatment (Pre-treatment determination) and ten days after treatment (Post-treatment determination) as described in
APHA (1989) standard methods. $\mathrm{pH}$ was determined using Ecotests $\mathrm{pH}$ meter and TDS was determined using AQUALYTIC TDS Salinometer. BOD was determined as described by the standard method (APHA, 1992). COD and SS were determined using DR/2010 HACH portable data logging spectrophotometer (DWAF, 1992)

\section{Identification and Biochemical} Characterization of the Bacterial Isolates

The bacteria were isolated from the effluents using Serial Dilution according to the method described by APHA (1989). The biochemical tests such as oxidase, catalase, coagulase, indole (from $1 \%$ tryptone broth), citrate (Simmons citrate agar), methyl red/VogesProskauer (MR/VP), nitrate reduction, Starch Hydrolysis, Glucose, Maltose, and Lactose tests were carried out on the bacterial isolates to identify the bacteria through the bacteria biochemical characteristics according to Ajao et al. (2011).

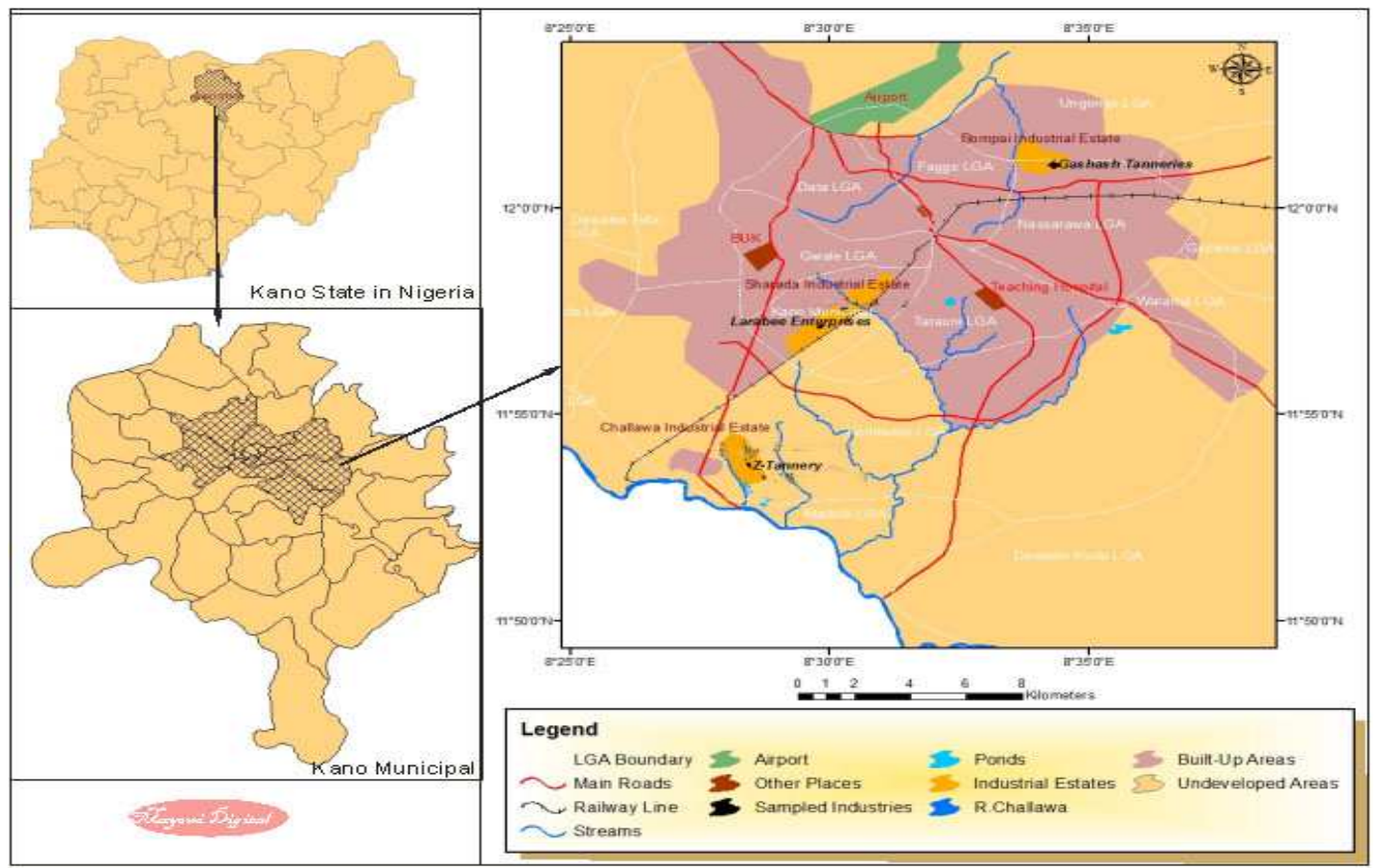

Fig. 1 Map showing the study areas

Source: Mayomi Digital Productions, GIS Laboratory, Department of Geography, UNIMAID (2017)

\section{Determination of Growth Rate of the Bacteria in Effluent Sample}

The bacteria growth rates were determined by transferring $2 \mathrm{~mL}$ of the bacterial isolates from the tannery effluent in broth medium into 100 $\mathrm{mL}$ sterile effluents in conical flasks and kept in an incubator (Giffrin cool) for 10 days. Control was also set up by incubating another $100 \mathrm{~mL}$ each of the sterile effluents without the bacteria. The optical density of the content was determined at the wavelength of $600 \mathrm{~nm}$ on a daily interval and recorded. 
BAJOPAS Volume 13 Number 2, December, 2020 Immobilization of Bacteria

Agar solution and inoculi were prepared separately. Fifty milliliters $(50 \mathrm{~mL})$ of nutrient broth each of the inoculi was prepared in a McCartney bottle and incubated for 24 hours. A solution of agar-agar was prepared by dissolving $10 \mathrm{~g}$ of the powder in distilled water and made up to $500 \mathrm{~mL}$ mark in an Erlenmeyer flask and was sterilized in an autoclave (280A) for 15 minutes and allowed to cool to $40-45^{\circ} \mathrm{C}$ (Ajao et al., 2011). Four milliliters ( $4 \mathrm{~mL})$ of the bacterial isolates in the nutrient broth was mixed with 36 $\mathrm{ml}$ of the prepared agar-agar media in petri-dish plates and then allowed to solidify. This was kept in the refrigerator for bioremediation.

\section{Bioremediation (Treatment) of the Effluents}

The solidified agar block (immobilized bacteria) was cut into cubes using a sterile knife; $0.1 \mathrm{~mL}$ phosphate buffer ( $\mathrm{pH} \mathrm{7.0)}$ was added and kept in the refrigerator for 1 hour for curing. The phosphate buffer was decanted after 1 hour and the cubes were washed with sterile distilled water 3-4 times before it was used (Ajao et al., 2011). Two liters (2 L) of the effluent was supplemented with the minimum basal medium in $\mathrm{g} / \mathrm{L}: \mathrm{NaCl}(0.8), \mathrm{MgSO}_{4} .7 \mathrm{H}_{2} \mathrm{O}(0.001), \mathrm{KH}_{2} \mathrm{PO}_{4}$ (2), $\mathrm{NaNO}_{3}$ (2), $\quad \mathrm{CaCl}_{2} .2 \mathrm{H}_{2} \mathrm{O} \quad(0.5)$ and $\mathrm{NaHPO}_{4} .12 \mathrm{H}_{2} \mathrm{O}(2)$ and sterilized in an autoclave at $121^{\circ} \mathrm{C}$ for 15 minutes (Margesin and Schinner, 2001). Two hundred and fifty milliliters $(250 \mathrm{~mL})$ of the effluents were transferred into different $250 \mathrm{ml}$ conical flasks. The content was covered with a cotton-wool ramped with foil paper to avoid contamination. Five grams $(5 \mathrm{~g})$ of the immobilized bacteria were quickly transferred into each of the effluents in the conical flasks in an inoculating chamber. The same procedures were carried out for the $10 \mathrm{~g}, 15 \mathrm{~g}, 20 \mathrm{~g}$ and 25 $\mathrm{g}$ of the immobilized bacteria in separate $250 \mathrm{~mL}$ effluents in conical flasks and agitated for ten days in a shaker incubator (Gallenkamp-OC4364-L) at a temperature $30^{\circ} \mathrm{C}$ and speed of 60 rpm. The treated effluent samples were taken on the tenth day and analyzed for the parameters $\mathrm{pH}$, SS, TDS, COD, and BOD, (Posttreatment determination) for the different grams of bacteria to evaluate and compare the biodegradation potential. (Baba et al., 2020).

\section{Statistical Analysis}

The data were represented as Mean \pm Standard deviation and analyzed statistically using oneway Analysis of Variance (ANOVA) and Tukey's HSD as Post Hoc Tests with the aid of SPSS 16.0. The correlation coefficient was also used to measure the strength of the relationship between the different masses of the bacteria and the parameters. All $\mathrm{p} \leq 0.05$ were considered as statistically significant.

\section{RESULTS AND DISCUSSION Physico-chemical parameters in the Industrial Effluents before the Biodegradation.}

Results of the Physico-chemical parameters in the industrial effluents before the Biodegradation is shown in table 1 . The mean temperatures $\left({ }^{\circ} \mathrm{C}\right)$ observed in TAN1, TAN2, and TAN3 samples were $28.07 \pm 0.65 ; 27.77 \pm 0.64$ and $26.38 \pm 3.81$ respectively. The order of the mean temperature of the samples from the three industries can be arranged as TAN1 > TAN2>TAN3. The temperature observed at TAN1, TAN2, and TAN3 samples were found below the WHO $\left(35^{\circ} \mathrm{C}\right)$ and NESREA $\left(40^{\circ} \mathrm{C}\right)$ limits. The low values of temperature might be due to the processes used at the time of sampling. High temperature brings down the solubility of gases in water that ultimately expresses as high BOD and COD. Statistical analysis shows that there is no significant difference $(p<0.05)$ between the mean values of temperature among the industries. This might be due to similar tannery activities involved in the tannery industries at the time of sampling. The average values of temperature observed in this present study are less than those observed by Akan et al. (2007), Akan et al. (2009) and Baba et al. (2020).

The mean level of $\mathrm{pH}$ observed in TAN1, TAN2 and TAN3, samples were $7.77 \pm 2.93$; $8.35 \pm 0.28$ and $7.52 \pm 0.76$ respectively. The order of the mean $\mathrm{pH}$ of the samples from the three industries can be arranged as TAN2> TAN1 $>$ TAN3. The $\mathrm{pH}$ of the samples falls within the WHO (7.0-8.5) and NESREA (6-9) standard limits. Statistical analysis shows that there is no significant difference $(p<0.05)$ between the mean values of $\mathrm{pH}$ among the industries. This might be due to similar tannery activities involved in the tannery industries at the time of sampling. Maheshwari et al. (2017) reported that the level of $\mathrm{pH}$ in the effluents from the tannery industry in Vaniyambadi, India was 6.5 which was lower than that observed in the present study. The $\mathrm{pH}$ in the effluents from the tannery industries in Kano and Kaduna were reported to be 7.64 and 6.89, respectively (Akan et al., 2007; Mohammed et al., 2017). The average values of $\mathrm{pH}$ observed in this present study are less than those observed by Mohammed et al. (2017) and Baba et al. (2020). The mean level of SS $(\mathrm{mg} / \mathrm{l})$ observed in TAN1, TAN2, and TAN3 samples were 374 \pm 124 ; $358 \pm 335$ and $780 \pm 739$ respectively. The order of the mean SS in the samples from the three industries can be arranged as TAN3 > TAN1 $>$ TAN2. 
The SS observed in the samples were far above the recommended standard limits of regulating bodies WHO $(30 \mathrm{mg} / \mathrm{l})$ and NESREA $(10 \mathrm{mg} / \mathrm{l})$. Statistical analysis shows that there is no significant difference $(p<0.05)$ between the mean values of SS among the industries. This might be due to similar tannery activities involved in the tannery industries at the time of sampling. The average values of SS observed in this present study are less than that observed $(3700 \pm 122 \mathrm{mg} / \mathrm{l})$ by Akan et al. (2009) for tanneries in Kano. Also, the average values of SS observed in this present study are less than that observed by Mohammed et al. (2017) and Baba et al. (2020) with the exception in TAN3.

The mean level of TDS (mg/l) observed in TAN1, TAN2, and TAN3 samples were $3941 \pm 3703$; $3300 \pm 1714$ and $2653 \pm 1240$ respectively. The order of the mean TDS in the samples from the three industries can be arranged as TAN1>TAN2>TAN3. The TDS observed in the samples were far above the recommended standard limits of WHO $(250 \mathrm{mg} / \mathrm{l})$ and NESREA $(500 \mathrm{mg} / \mathrm{l})$. Statistical analysis shows that there is no significant difference $(p<0.05)$ between the mean values of TDS among the industries. This might be due to similar tannery activities involved in the tannery industries at the time of sampling. TDS in the effluents from the tannery industries in Kano, Nigeria was reported to be $1281 \mathrm{mg} / \mathrm{l}$ (Akan et al., 2007). The average values of SS observed in this present study are less than those observed by Mohammed et al. (2017) and Baba et al. 2020)

The mean level of COD (mg/l) observed in TAN1, TAN2 and TAN3 samples seasons were $2372 \pm 938 ; \quad 1406 \pm 208$ and $3532 \pm 1373$ respectively. The order of the mean COD of the samples from the three industries can be arranged as TAN3>TAN1> TAN2. The COD observed in TAN1, TAN2 and TAN3 samples were far above the recommended standard limits of regulating bodies $\mathrm{WHO}(40 \mathrm{mg} / \mathrm{l})$ and NESREA (40 mg/l). Statistical analysis shows that there is no significant difference $(p<0.05)$ in COD among the industries. This might be due to similar tannery activities involved in the tannery industries as at the time of sampling. The Chemical Oxygen demand (COD) is the amount of oxygen, in $\mathrm{mg} / \mathrm{L}$, required for the degradation of the compound of wastewater to occur. In comparison, the average values of COD observed in this present study were higher than that observed by Mohammed et al. (2017) but lower than that observed by Baba et al. (2020).

The mean levels of BOD $(\mathrm{mg} / \mathrm{l})$ observed in TAN1, TAN2 and TAN3 samples were $13.85 \pm 6.42 ; \quad 19.46 \pm 0.50$ and $17.13 \pm 3.14$ respectively. The order of the mean BOD in the samples from the three industries can be arranged as TAN2>TAN3>TAN1. The BOD observed in TAN1, TAN2 and TAN3 samples were found below the recommended limits of NESREA (200 mg/l) but above WHO (10 mg/l). Statistical analysis shows that there is no significant difference $(p<0.05)$ between the mean values of BOD among the industries. This might be due to similar tannery activities involved in the tannery industries at the time of sampling. The low level of BOD recorded in this study is an indication of the low level of biodegradable organic solids in the effluent. The average values of BOD observed in this present study were lower than those observed by Mohammed et al. (2017) and Baba et al. (2020).

Table 1: Mean Values \pm S.D of Physico-chemical parameters of effluents from the Tannery Industries before Treatment.

\begin{tabular}{llllllll}
\hline Parameter & Tannery 1 & Tannery 2 & Tannery 3 & $\mathrm{a}$ & $\mathrm{b}$ & $\mathrm{c}$ & $\mathrm{d}$ \\
\cline { 2 - 7 } Temperature $\left({ }^{\circ} \mathrm{C}\right)$ & $28.07 \mathrm{a} \pm 0.65$ & $27.77 \mathrm{a} \pm 0.64$ & $26.38 \mathrm{a} \pm 3.81$ & & $29.50 \pm 4.68$ & 35 & 40 \\
pH & $7.77 \mathrm{a} \pm 2.93$ & $8.35 \mathrm{a} \pm 0.28$ & $7.52 \mathrm{a} \pm 0.76$ & 6.89 & $5.35 \pm 1.57$ & $7.0-8.5$ & $6.0-9.0$ \\
$\mathrm{COD}(\mathrm{mg} / \mathrm{l})$ & $2372 \mathrm{a} \pm 938$ & $1406 \mathrm{a} \pm 208$ & $3532 \mathrm{a} \pm 1373$ & 2.2 & $3106 \pm 2753$ & 40 & 40 \\
$\mathrm{BOD}(\mathrm{mg} / \mathrm{l})$ & $13.85 \mathrm{a} \pm 6.42$ & $19.46 \mathrm{a} \pm 0.50$ & $17.13 \mathrm{a} \pm 3.14$ & 1032 & $26.17 \pm 9.49$ & 10 & 200 \\
$\mathrm{SS}(\mathrm{mg} / \mathrm{l})$ & $374 \mathrm{a} \pm 124$ & $358 \mathrm{a} \pm 335$ & $780 \mathrm{a} \pm 739$ & 501 & $562 \pm 482$ & 30 & 10 \\
TDS $(\mathrm{mg} / \mathrm{l})$ & $3941 \mathrm{a} \pm 3703$ & $3300 \mathrm{a} \pm 1714$ & $2653 \mathrm{a} \pm 1240$ & 532.7 & $444 \pm 507$ & 250 & 500 \\
\hline
\end{tabular}

The values given in the table above are means of 6 replicate values, $\mathrm{n}=6$ ( 1 sample was taken monthly for 6 months). Within the rows, means with different alphabets are statistically different $(p<0.05)$. WHO: World Health Organisation. NESREA: National Environmental Standard and Regulatory Enforcement Agency. a = Mohammed et al.(2017), b = Baba et al. (2020), c = WHO (2006), $d=$ NESSRA (2009) 
BAJOPAS Volume 13 Number 2, December, 2020

Identification, Biochemical Characterization and growth rates of the Bacterial Isolates

Results of identification and biochemical characterization of the bacterial isolates were shown in table 2. After 24 hours of incubation, the nutrient agar media plates were checked for bacterial growth. The results showed the presence of different strains in the samples. The TAN1 bacteria isolate was found to be gramnegative cocci while TAN3 was gram-positive cocci. TAN2 bacteria isolate was found to be gram-positive, rod-shaped. TAN1, TAN2, and TAN3 bacteria isolates recorded positive results for spore former.

The results of the biochemical tests indicated that all the bacteria were positive for catalase, oxidase, citrate, maltose, glucose, lactose (negative in TAN1), mannitol (negative in TAN2), starch hydrolysis and coagulase (negative in TAN2) tests. The bacteria showed negative results for nitrate reduction, $M R$ (positive in TAN2), VP (positive in TAN1), Indole (positive in TAN2) tests. Base on the morphological and biochemical test results, TAN1, TAN2, and TAN3 bacteria isolates were identified to be Nesseria spp, Bacillus cereus, and Staphylococcus aureus respectively.

The growth rate of the TAN1, TAN2 and TAN3 Isolates were shown in figure 2. Generally, the optical density increase with the increase in time (day) and decrease as time goes on. The highest optical density was shown by bacillus cereus in TAN2 while the lowest was shown by Staphylococcus aureus in TAN3.

The initial growth phase of TAN1 Isolate bacteria occurred within 2-day of incubation as the growth rate increases up to the 6th-day incubation when the maximum growth was observed. Beyond the 6th day, the growth of the bacteria declined (which might be due to a shortage of nutrients in the effluents) until it reached its death phase (which might be due to the unavailability of nutrients in the effluents).

A similar trend of growth was also observed for TAN2 Isolate as the initial growth phase also occurred within 2-day of incubation but maximum growth rate observed on the 4th day of incubation. The stationary stage occurred between the 4th day and the 8th day. Beyond the 8th day, the growth of the bacteria declined (which might be due to a shortage of nutrients in the effluents) until it reached its death phase (which might be due to the unavailability of nutrients in the effluents).

The initial growth phase of TAN3 bacterial Isolate occurred within the 3-day incubation as the growth rate increases up to the 6th-day incubation when the maximum growth was observed. Beyond the 6th day, the growth of the bacteria declined (which might be due to a shortage of nutrients in the effluents) until it reached its death phase (which might be due to the unavailability of nutrients in the effluents).

Table 2: Morphological and Biochemical characteristics of bacterial isolates

\begin{tabular}{lllll} 
Bacterial Isolates & & TAN1 & TAN2 & TAN3 \\
\hline $\begin{array}{lllll}\text { Morphological } \\
\text { characteristics }\end{array}$ & Shape & Cocci & Rod & Cocci \\
& Spore & & & \\
& former & + & + & + \\
Gram & & & \\
Biochemical characteristics & reaction & - & + & + \\
& Citrate & + & + & + \\
& Catalase & + & + & + \\
& Coagulase & + & - & + \\
Starch & + & + & + \\
& Glucose & + & + & + \\
Oxidase & + & + & + \\
& Indo & - & + & - \\
Lactose & - & + & + \\
Manitol & + & - & + \\
Maltose & + & + & + \\
MR & - & + & - \\
VP & + & - & - \\
& Nitrate & - & - & - \\
Reduction & - Neisseria & Bacillus & Staphylococcus \\
& Bacterial & cereus & aureus \\
& name & spp & cas
\end{tabular}

+ = Positive; - = Negative; MR=Methyl Red; VP= Voges-Proskauer 


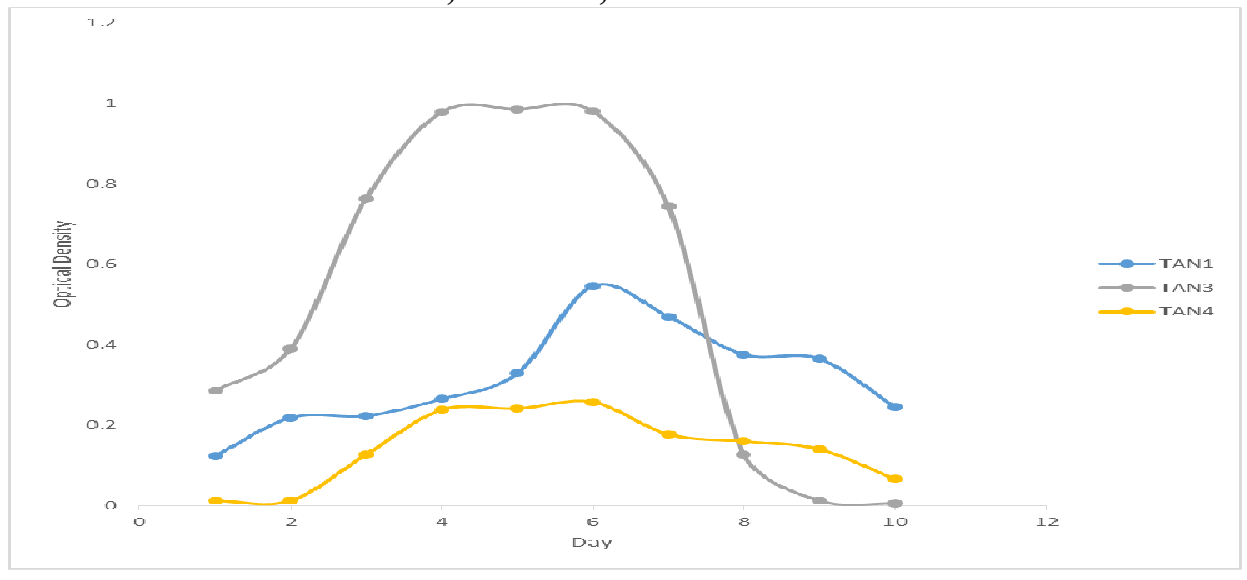

Fig. 2 Growth rates of the isolates in the effluents from the Tannery Industries

\section{Physico-chemical Parameters in the Industrial Effluents after the biodegradation.}

Table 3 shows the mean results of the physicochemical parameter before and after bioremediation using the different masses $(5 \mathrm{~g}$, $10 \mathrm{~g}, 15 \mathrm{~g}, 20 \mathrm{~g}$, and $25 \mathrm{~g}$ ) of the respective immobilized bacteria. Also, Table 4 shows the mean results of correlation coefficient ( $r$ ) between different masses of bacteria and physicochemical parameters.

The mean values $(\mathrm{mg} / \mathrm{l})$ of the SS after the bioremediation varies between $243 \pm 45$ and $898 \pm 672$. The mean concentration $(\mathrm{mg} / \mathrm{l})$ of SS remediated by the different masses $(5 \mathrm{~g}, 10 \mathrm{~g}$, $15 \mathrm{~g}, 20 \mathrm{~g}$, and $25 \mathrm{~g}$ ) of the bacteria varies. The SS in the samples fluctuates up and down after the bioremediation process when compared with the SS of the raw samples before the bioremediation. The increase in the levels of the SS might be due to the aggregation of the TDS which are large enough to result into SS. The increase in the levels of the SS might be also due to the influence of the nutrients which was added into the effluents in order to make the microorganisms more active and viable for fast degradation of organic contaminants in the effluent. The relative potential or efficiency of the different masses of the bacteria in remediating SS in TAN1 samples was in the order $25 \mathrm{~g}>20 \mathrm{~g}>15 \mathrm{~g}>10 \mathrm{~g}>5 \mathrm{~g}$. For TAN2 and TAN3 samples, the order was $25 \mathrm{~g}>20 \mathrm{~g}>15$ $\mathrm{g}>10 \mathrm{~g}>5 \mathrm{~g}$. These might be due to the variations in the surface areas of the different masses of the immobilized bacteria. Statistical analysis shows that there is no significant difference $(p<0.05)$ between the mean values of SS among the masses in the respective industries. Positive and significant correlations exist between the masses of bacteria and Suspended Solid (SS). This showed that there is general increase in the levels of the SS as the masses of the immobilized bacteria increases. TAN3 (90\%) and TAN1 (80\%) showed a very high correlation with the masses of the bacteria while TAN2 (61\%) showed a very low correlation.

The mean values $(\mathrm{mg} / \mathrm{l})$ of the TDS after the bioremediation varies between $46 \pm 11$ and $83 \pm 78$. The mean concentration $(\mathrm{mg} / \mathrm{l})$ of TDS remediated by the different masses $(5 \mathrm{~g}, 10 \mathrm{~g}$, $15 \mathrm{~g}, 20 \mathrm{~g}$, and $25 \mathrm{~g}$ ) of the bacteria varies. There is a reduction in all the TDS of all the samples after the bioremediation process compared with the TDS of the raw samples before the bioremediation. The relative potential or efficiency of the different masses of the bacteria in remediating TDS in TAN1 and TAN3 samples was in the order $5 \mathrm{~g}>10 \mathrm{~g}>15 \mathrm{~g}>20$ $\mathrm{g}>25 \mathrm{~g}$. For TAN2 samples, the order was 20 $g>10 \quad g>25 \quad g>15 \quad g>5 \quad g$. Statistical analysis shows that there is no significant difference $(p<0.05)$ between the mean values of TDS among the masses in the respective industries. These might be due to the variations in the surface areas of the different masses of the immobilized bacteria. Positive and significant correlations exist between the masses of bacteria and TDS with the exception in TAN2 (negative and insignificant correlation). The positive correlations showed that there is general increase in the levels of the TDS as the masses of the immobilized bacteria increases. TAN1 $(96 \%)$ showed a very high correlation with the masses of the bacteria while TAN2 (47\%) showed a very low correlation.

The mean values $(\mathrm{mg} / \mathrm{l})$ of the BOD after the bioremediation varies between $1.56 \pm 0.20 \mathrm{mg} / \mathrm{l}$ and $6.92 \pm 5.49 \mathrm{mg} / \mathrm{l}$. The mean concentration $(\mathrm{mg} / \mathrm{l})$ of BOD remediated by the different masses $(5 \mathrm{~g}, 10 \mathrm{~g}, 15 \mathrm{~g}, 20 \mathrm{~g}$, and $25 \mathrm{~g}$ ) of the bacteria varies. There is a reduction in all the BOD of all the samples after the bioremediation process compared with the $\mathrm{BOD}$ of the raw 
BAJOPAS Volume 13 Number 2, December, 2020 samples before the bioremediation. The relative potential or efficiency of the different masses of the bacteria in remediating BOD in TAN1, TAN2 and TAN3 samples were in the order $25 \mathrm{~g}>20$ $\mathrm{g}>15 \mathrm{~g}>10 \mathrm{~g}>5 \mathrm{~g}, 25 \mathrm{~g}>15 \mathrm{~g}>5 \mathrm{~g}>10 \mathrm{~g}>20 \mathrm{~g}$ and $20 \mathrm{~g}>10 \mathrm{~g}>25 \mathrm{~g}>15 \mathrm{~g}>5 \mathrm{~g}$ respectively. Statistical analysis shows that there is significant difference $(p<0.05)$ between the mean values of BOD among the masses in the respective industries. These might be due to the variations in the surface areas of the different masses of the immobilized bacteria. Negative and significant correlations exist between the masses of bacteria and BOD. This showed that there is general decrease in the levels of the BOD as the masses of the immobilized bacteria increases. TAN1 (94\%) showed a very high correlation with the masses of the bacteria while TAN2 (4\%) showed a very low correlation.

The mean values $(\mathrm{mg} / \mathrm{l})$ of the COD after the bioremediation varies between $250 \pm 154$ and $3134 \pm 1595$. The mean concentration $(\mathrm{mg} / \mathrm{l})$ of COD remediated by the different masses $(5 \mathrm{~g}$, $10 \mathrm{~g}, 15 \mathrm{~g} 20 \mathrm{~g}$, and $25 \mathrm{~g}$ ) of the bacteria varies. There is a reduction in all the COD of all the samples after the bioremediation process compared with the COD of the raw samples before the bioremediation. The relative potential or efficiency of the different masses of the bacteria in remediating COD in TAN1, TAN2 and TAN3 samples were in the order $25 \mathrm{~g}>20 \mathrm{~g}>15$ $\mathrm{g}>5 \mathrm{~g}>10 \mathrm{~g}, 25 \mathrm{~g}>20 \mathrm{~g}>15 \mathrm{~g}>10 \mathrm{~g}>5 \mathrm{~g}$ and 10 g>5 g>25 g>15 g>20 g respectively. Statistical analysis shows that there were significant difference $(p<0.05)$ between the mean values of COD among the masses in the respective industries except for effluents treated with $25 \mathrm{~g}$. These might be due to the variations in the surface areas of the different masses of the immobilized bacteria. Negative and insignificant correlations exist between the masses of bacteria and COD with the exception in TAN3 (positive and significant correlation). The negative correlations showed that there is general decrease in the levels of the COD as the masses of the immobilized bacteria increases. TAN2 (100\%) showed a very high correlation with the masses of the bacteria while TAN3 (36\%) showed a very low correlation.

Generally, there was an overall decrease in the concentration of these physicochemical parameters after the bioremediation using the different masses of the bacterial isolates. These might be due to the variations in the surface areas of the different masses of the immobilized bacteria. This is in line with the work of Jimoh et al. (2018) and Baba et al. (2020).

Table 3: Mean Values $(\mathrm{mg} / \mathrm{l}) \pm$ S.D of Physicochemical parameters in effluents from the Tannery Industries before and after Treatment of the effluents $(250 \mathrm{ml})$ with the different masses $(5 \mathrm{~g}, 10 \mathrm{~g}$, $15 \mathrm{~g}, 20 \mathrm{~g}$, and $25 \mathrm{~g}$ ) of the bacteria.

\begin{tabular}{llllllll}
\hline $\mathrm{P}$ & IND & Before & \multicolumn{5}{c}{ After } \\
\cline { 4 - 7 } & & & $5 \mathrm{~g}$ & $10 \mathrm{~g}$ & $15 \mathrm{~g}$ & $20 \mathrm{~g}$ & $25 \mathrm{~g}$ \\
\hline \multirow{2}{*}{ COD } & TAN1 & $2372 \pm 938$ & $1708 \mathrm{a} \pm 861$ & $2045 \mathrm{a} \pm 1205$ & $845 \mathrm{a} \pm 369$ & $300 \mathrm{a} \pm 167$ & $250 \mathrm{a} \pm 154$ \\
& TAN2 & $1406 \pm 208$ & $1195 \mathrm{a} \pm 208$ & $1125 \mathrm{a} \pm 384$ & $1055 \mathrm{a} \pm 317$ & $956 \mathrm{a} \pm 310$ & $870 \mathrm{ab} \pm 240$ \\
& TAN3 & $3532 \pm 1373$ & $2374 \mathrm{a} \pm 1344$ & $1976 \mathrm{a} \pm 1405$ & $2757 \mathrm{a} \pm 1266$ & $3134 \mathrm{a} \pm 1595$ & $2614 \mathrm{~b} \pm 1105$ \\
BOD & TAN1 & $13.85 \pm 6.42$ & $6.92 \mathrm{a} \pm 5.49$ & $6.42 \mathrm{a} \pm 5.07$ & $5.72 \mathrm{a} \pm 5.35$ & $4.62 \mathrm{a} \pm 4.37$ & $2.82 \mathrm{ab} \pm 1.26$ \\
& TAN2 & $19.46 \pm 0.50$ & $1.75 \mathrm{~b} \pm 0.22$ & $1.73 \mathrm{~b} \pm 0.18$ & $1.58 \mathrm{a} \pm 0.16$ & $1.91 \mathrm{a} \pm 0.22$ & $1.56 \mathrm{~b} \pm 0.20$ \\
& TAN3 & $17.13 \pm 3.14$ & $4.24 \mathrm{ab} \pm 0.77$ & $3.29 \mathrm{ab} \pm 0.37$ & $4.11 \mathrm{a} \pm 0.07$ & $3.23 \mathrm{a} \pm 0.91$ & $3.33 \mathrm{a} \pm 1.28$ \\
SS & TAN1 & $374 \pm 124$ & $243 \mathrm{a} \pm 45$ & $471 \mathrm{a} \pm 226$ & $475 \mathrm{a} \pm 182$ & $492 \mathrm{a} \pm 128$ & $611 \mathrm{a} \pm 217$ \\
& TAN2 & $358 \pm 335$ & $460 \mathrm{a} \pm 400$ & $543 \mathrm{a} \pm 414$ & $544 \mathrm{a} \pm 402$ & $551 \mathrm{a} \pm 414$ & $554 \mathrm{a} \pm 405$ \\
& TAN3 & $780 \pm 739$ & $586 \mathrm{a} \pm 594$ & $758 \mathrm{a} \pm 656$ & $787 \mathrm{a} \pm 676$ & $861 \mathrm{a} \pm 635$ & $898 \mathrm{a} \pm 672$ \\
TDS & TAN1 & $3941 \pm 3703$ & $51 \mathrm{a} \pm 10$ & $53 \mathrm{a} \pm 10$ & $55 \mathrm{a} \pm 15$ & $61 \mathrm{a} \pm 20$ & $63 \mathrm{a} \pm 26$ \\
& TAN2 & $3300 \pm 1714$ & $83 \mathrm{a} \pm 78$ & $47 \mathrm{a} \pm 20$ & $48 \mathrm{a} \pm 22$ & $47 \mathrm{a} \pm 17$ & $48 \mathrm{a} \pm 17$ \\
& TAN3 & $2653 \pm 1240$ & $46 \mathrm{a} \pm 11$ & $55 \mathrm{a} \pm 24$ & $55 \mathrm{a} \pm 25$ & $58 \mathrm{a} \pm 23$ & $61 \mathrm{a} \pm 28$ \\
\hline
\end{tabular}

Replicate $=6$ (months)

Within the rows, for the same parameter, means with different alphabets are statistically different $(p<0.05)$.

$\mathrm{P}=$ parameter, IND = Industries 
BAJOPAS Volume 13 Number 2, December, 2020

Table 4: Correlation coefficient $(r)$ between different masses of the bacteria and the physicochemical parameters.

\begin{tabular}{llll}
\hline Industries & Parameter & Correlation coefficient $(r)$ & $\begin{array}{l}\text { Percent dependence (rxrx100) } \\
(\%)\end{array}$ \\
\hline TAN1 & COD & -0.9 & 82 \\
& BOD & -0.97 & 94 \\
& SS & $0.90^{*}$ & 80 \\
TAN2 & TDS & $0.98^{*}$ & 96 \\
& COD & -1 & 100 \\
& BOD & -0.21 & 4 \\
& SS & $0.78^{*}$ & 61 \\
& TDS & -0.69 & 47 \\
& COD & $0.60^{*}$ & 36 \\
& BOD & -0.6 & 37 \\
& SS & $0.95^{*}$ & 90 \\
& TDS & $0.94^{*}$ & 89 \\
\hline
\end{tabular}

The correlation coefficient $(r)$ with * is statistically significant $(p<0.05)$.

Percentage reduction of the Parameters

Table 5 shows the percentage reduction of Parameters in industrial samples before and after the treatment of the effluents $(250 \mathrm{ml})$ with the different masses $(5 \mathrm{~g}, 10 \mathrm{~g}, 15 \mathrm{~g}, 20 \mathrm{~g}$, and $25 \mathrm{~g}$ ) of the Immobilized Bacteria.

In TAN1 samples, the percentage reduction (\%) of COD ranged (14-89); BOD (50-80); SS (-32$35)$ and TDS (98-99). In TAN2 samples, the percentage decrease $(\%)$ of COD ranged (15$38) ;$ BOD (90-92); SS [-28-(-55)] and TDS (9798). In TAN3 samples, the percentage decrease (\%) of COD ranged (11-44); BOD (76-81); SS (15-25) and TDS (98). The percentage increase in the levels COD, BOD and TDS might be due to the increase in the surface area of the different masses of the immobilized bacteria. However, the percentage decrease in the levels of the SS might be due to the aggregation of the TDS which are large enough to result into SS. The percentage decrease in the levels of the SS might be also due to the influence of the nutrients which was added into the effluents in order to make the microorganisms more active and viable for fast degradation of organic contaminants in the effluent. This is in line with the work of Jimoh et al. (2018) in which the concentration of the SS increase after the bioremediation of effluents.

Sreemoyee and Priti (2013) assessed and reduced several Physico-chemical parameters of dairy wastewater using Niesseria $s p$. and concluded that the species are well known to degrade organic compounds. This is in agreement with the current study in which the immobilized Niesseria $s p$ degrade the organic contaminants as indicated by the BOD, COD and TDS.

Jimoh et al. (2018) observed that TSS of the effluents was increased after treatment with immobilized bacteria and concluded that it might be due to the biostimulation method adopted for the research.

The optimum $\mathrm{pH}$ Biosorption of Chromium by Bacillus spp and Staphylococcus spp. from tannery effluent was investigated by Mythili and Karthikeyan (2011). The maximum adsorption of Chromium $(86.4 \mathrm{mg} / \mathrm{L})$ was showed by Bacillus spp and Staphylococcus spp showed $70.6 \mathrm{mg} / \mathrm{L}$ at an initial concentration of $100 \mathrm{mg} / \mathrm{L}$. In the present study, immobilised Bacillus spp and Staphylococcus spp. from the tannery industrial effluents reduced the levels of the organic pollutants with high potential as indicated by the percentage reduction of BOD, COD and TDS.

Enzymes often can work in multiple environments especially if they are immobilized. This makes the microorganisms' enzymes even more resistant to harsh environments and enables the enzymes to be recovered and recycled after they are no longer needed (Gianfreda and Rao 2004). Ramesh and Singh (1993) reported that the immobilized bacteria having more efficiency to remove the suspended particles than free cells. Using the immobilized cell is preferable due to its capability for using several times with the same efficiency, which makes it more economical. Similar work was done by Sikander et al. (2007) showing the higher reduction with permeabilized cells of Ochrobactrum intermedium strain SDCr-5. 
BAJOPAS Volume 13 Number 2, December, 2020

The results revealed the isolation and identification of isolates with the potential for the reduction of $\mathrm{Cr}$ (VI) to $\mathrm{Cr}$ (III). Results indicated that immobilized $B$. cereus could be efficiently used for the reduction of $\mathrm{Cr}$ (VI).

Table 5: Percentage reduction of the tested Parameters from the tannery industrial samples of the Immobilized Bacteria.

\begin{tabular}{lllllll}
\hline \multirow{2}{*}{ Industries } & & \multicolumn{5}{c}{ Percentage Reduction $(\%)$} \\
\cline { 3 - 7 } & & $5 \mathrm{~g}$ & $10 \mathrm{~g}$ & $15 \mathrm{~g}$ & $20 \mathrm{~g}$ & $25 \mathrm{~g}$ \\
\hline TAN1 & COD & 28 & 14 & 64 & 87 & 89 \\
& BOD & 50 & 54 & 59 & 67 & 80 \\
& SS & 35 & -26 & -27 & -32 & -63 \\
& TDS & 99 & 99 & 99 & 98 & 98 \\
TAN2 & COD & 15 & 20 & 25 & 32 & 38 \\
& BOD & 91 & 91 & 92 & 90 & 92 \\
& SS & -28 & -52 & -52 & -54 & -55 \\
& TDS & 97 & 99 & 99 & 99 & 99 \\
& COD & 33 & 44 & 22 & 11 & 26 \\
& BOD & 75 & 81 & 76 & 81 & 81 \\
& SS & 25 & 3 & -1 & -10 & -15 \\
& TDS & 98 & 98 & 98 & 98 & 98 \\
\hline
\end{tabular}

Percentage Reduction $=(B-A) / B \times 100 \%$

$A=$ Concentration of the parameter after treatment

$\mathrm{B}=$ Concentration of the parameter before treatment

$+=$ percentage decrease

- = percentage increase

In general, immobilization makes the enzyme more resistant to temperature, $\mathrm{pH}$, and substrate concentration swings giving it a longer lifetime and higher productivity per active unit (Gianfreda and Rao, 2004; FuIlbrook, 1996; Russell et al, 2003; Kandelbauer et al., 2004). Immobilized cells have been used and studied extensively for the production of useful chemicals (Ohtake and Silver, 1994), the treatment of wastewaters (Chen et al., 2003; Wang et al., 2010). Although many workers described microbial degradation of tannery effluent, limited literature is available on the bioremediation of tannery effluent using immobilized bacterial cells in the Kano Industrial Estates.

\section{CONCLUSION}

The samples contained variable levels of the physicochemical parameters. The results of the Analysis of variance revealed that, no statistical difference $(p<0.05)$ was observed for the temperature, $\mathrm{pH}, \mathrm{SS}, \mathrm{TDS}, \mathrm{BOD}$ and $\mathrm{COD}$ among the three tannery industries before the treatment. The levels of some of the parameters
(SS, TDS and COD) observed in the samples were found above the recommended limits of WHO and NESREA, which called for the treatment of the effluents before discharge into the environment. Base on the morphological and biochemical test results, TAN1, TAN2, and TAN3 bacterial isolates were identified to be Neisseria spp, Bacillus cereus, and Staphylococcus aureus respectively. The results of Post-treatment analysis showed that there is overall decrease in the levels of the parameters determined when compared with that of the pre-treatment. The overall percentage reduction of the immobilised bacteria in the treatment of the respective effluents was in the order TAN2 (72\%)>TAN1 $(70 \%)>$ TAN3 $(62 \%)$. Hence, the immobilized bacteria are having higher biodegradation potential for the treatment of the tannery effluents.

\section{Acknowledgments}

The authors wish to acknowledge the University of Maiduguri for the financial support. The authors are grateful to the Kano State Ministry of Environment for their support in obtaining the effluent samples. 


\section{REFERENCES}

Ajao, A. T., Adebayo, G. B., and Yakubu, S. E. (2011). Bioremediation of textile industrial effluent using mixed culture of Pseudomonas aeruginosa and Bacillus subtilis immobilized on agar-agar in a bioreactor. J. Microbiol. Biotech. Res, 1(3), 50-56.

Akan, J. C., Moses, E. A., Ogugbuaja, V. O., and Abah, J. (2007). Assessment of tannery industrial effluents from Kano metropolis, Kano State, Nigeria. Journal of Applied Sciences, 7(19), 2788-2793.

Akan, J. C., Ogugbuaja, V. O., Abdulrahman, F. I., and Ayodele, J. T. (2009). Pollutant levels in effluent samples from tanneries and textiles of Kano industrial areas, Nigeria. Global journal of pure and applied sciences, 15(3-4).

APHA (1989). Standard methods for Examination of Will bete and Will betewater.15 $5^{\text {th }}$ edition. Brydpass Springfield Will behington DC. pp. 164-176

APHA (1992). Standard Methods for the Examination of Water and Wastewater. Health, 69, 1116-9.

Baba, A., Garba, S. T., and Bello, H. S. (2020). Bioremediation Potential of Immobilized corynebacterium kutsceri in the Treatment of Tannery Industrial Effluent from Challawa Industrial Estate, Kano State, Nigeria. Journal of the Turkish Chemical Society Section A: Chemistry, $7(2), 335-350$.

Beem, E. I. V. (1994). reduction of solvent VOC emission. J. Oil Col. Chem. Ass, 77, 158.

Bouwer, E. J., and Zehnder, A. J. (1993). Bioremediation of organic compoundsputting microbial metabolism to work. Trends in biotechnology, 11(8), 360367.

Chen, K. C., Wu, J. Y., Liou, D. J., and Hwang, S. C. J. (2003). Decolorization of the textile dyes by newly isolated bacterial strains. Journal of Biotechnology, 101(1), 57-68.

Dan'Azumi, S., and Bichi, M. H. (2010). INDUSTRIAL POLLUTION AND HEAVY METALS PROFILE OF CHALLAWA RIVER IN KANO, NIGERIA. Journal of Applied Sciences in Environmental Sanitation, $5(1)$.

DWAF. (1992). Analytical Methods Manual, TR 151. Department of Water Affairs and Forestry, Pretoria.

El-Bestawy, E. (2013). Biological treatment of leather-tanning industrial wastewater using free living bacteria.
Elsheikh, M. A. S. (2009). Tannery wastewater pre-treatment. Water Science and Technology, 60(2), 433-440.

FuIlbrook, P. D. (1996). "Kinetics." Industrial enzymology: The application of enzymes in Industry. 2nd Ed. T. Godfrey and J Reichelt. eds.. Nature. New York.

Gianfreda, L., and Rao, M. A. (2004). Potential of extra cellular enzymes in remediation of polluted soils: a review. Enzyme and microbial technology, 35(4), 339354.

Hugo Springer. (1994). John Arthur Wilson Memorial Lecture "Treatment of Industrial Wastes of the Leather Industry - is it still a Major Problem". JALCA, 89, 153-185

Jimoh, A. A., Ganiyu, B. A., Baba, D., and Baba, A. (2018) Bioremediation Process of Effluent from Detergent and Food Industries in Jos, Nigeria: Kinetics and Thermodynamics. International Journal of Engineering Science Invention (IJESI), 762-73

Kandelbauer, A., Maute, O., Kessler, R. W., Erlacher, A., and Gübitz, G. M. (2004). Study of dye decolorization in an immobilized laccase enzyme-reactor using online spectroscopy. Biotechnology and bioengineering, 87(4), 552-563.

Kongjao, S., Damronglerd, S., and Hunsom, M. (2008). Simultaneous removal of organic and inorganic Pollutants in tannery wastewater using electrocoagulation technique. Korean Journal of chemical engineering, 25(4), 703.

Maheshwari, U. M., Aruna, S., Gomathi, M., and AbdulJaffar, A. H. (2017). Bioremediation by Free and Immobilized Bacteria Isolated from Tannery Effluent. International Journal of Research in Applied, Natural and Social Sciences. 5(7), 75-90

Margesin, R., and Schinner, F. (2001). Bioremediation (natural attenuation and biostimulation) of diesel-oilcontaminated soil in an alpine glacier skiing area. Applied and environmental microbiology, 677), 3127-3133.

Mohammed, A., Sekar, P., and George, J. (2011). Efficacy of microbes in bioremediation of tannery effluent. Inter. J. Curr. Res, 3(4), 324-326.

Mohammed, S. S. D., Orukotan, A. A., and Abdullahi, H. (2017). Physicochemical and Bacteriological Assessment of Tannery Effluent from Samaru-Zaria, 
BAJOPAS Volume 13 Number 2, December, 2020 Kaduna State, Nigeria. Journal of Applied

Sciences and Environmental Management, 21(4), 734-740.

Munz, G., De Angelis, D., Gori, R., Mori, G., Casarci, M., and Lubello, C. (2009). The role of tannins in conventional and membrane treatment of tannery wastewater. Journal of hazardous materials, 164(2-3), 733-739

Mythili, K., and Karthikeyan, B. (2011). Bioremediation of $\mathrm{Cr}$ (VI) from tannery effluent using Bacillus spp and Staphylococcus spp. International Multidisciplinary Research Journal, 1(6).

NESREA (2009). National Environmental Standards for Effluent Limitations and Regulation. 1233-1236

Noorjahan, C. M. (2014). Physicochemical characteristics, identification of bacteria and biodegradation of industrial effluent. Journal of bioremediation and Biodegradation, 5(3).

Ohtake, H. I., and Silver, A. O. (1994). Bacterial reduction of toxic chromate. Biological degradation and bioremediation of toxic chemicals, 403-415.

Omoleke, I. I. (2004). Management of environmental pollution in Ibadan, an African city: the challenges of health hazard facing government and the people. Journal of Human Ecology, 15(4), 265-275.

Rajor, A., Reddy, A.S., and Singh, B. (2004). Determination of BOD kinetic Parameters and evaluation of alternate methods, M.Sc. Thesis, Department of biotechnology \& environmental Science, Thapar Institute of Engineering and Technology, Patiala

Ramasami, T., Rajamani, S., and Rao, J. R. (1994, March). Pollution control in leather industry: Emerging technological options. In International symposium on surface and colloidal science and its relevance to soil pollution, madras.

Ramesh, J. V. S., and Singh, S. P. (1993). Yearly variation in certain physicochemical parameters of pond at eastern Doon Valley. Uttar Pradesh J. Zoo, 12 (1), 7577.

Ranen, S., and Sharadinadra, C. (2009). Biotechnology applications to environmental remediation in resource exploitation. Current science, 97, 6-25
Russell, A. J., Berberich, J. A., Drevon, G. F., and Koepsel, R. R. (2003). Biomaterials for mediation of

chemical and biological warfare agents. Annual review of biomedical engineering, 5(1), 1-27.

Saravanan, P., and Saravanan, A. (1999). Decolourization of tannery effluent by Flavobacterium sp. EK 1. Indian Journal of Environmental Protection, 19, 19-24.

Sikander, S., and Shahida, H. (2007). Reduction of toxic hexavalent chromium by Ochrobactrum intermedium strain SDCr5 stimulated by heavy metals. Bioresource Technol, 98, 340-344.

Singh, N., Sharma, B. K., and Bohra, P. C. (2000). Impact assessment of industrial effluent of arid soils by using satellite imageries. Journal of the Indian Society of Remote Sensing, 28(2-3), 79.

Sreemoyee, C., and Priti, P. (2013). Assessment of physico-chemical parameters of dairy waste water and isolation and characterization of bacterial strains in terms of cod reduction. Int J Sci, 2(3), 395-400.

Verheijen, L. A. H. M., Wiersema, D., Pol, L. H., and De Wit, J. (1996). Management of wastes from animal product processing. Livestock and environment, Finding a balance. International Agriculture Center, Wageningen, The Netherlands.

Wang, F., Yao, J., Si, Y., Chen, H., Russel, M., Chen, K., and Bramanti, E. (2010). Short-time effect of heavy metals upon microbial community activity. Journal of Hazardous Materials, 173(13), 510-516.

WHO (World Health Organization). (2006). Air quality guidelines: global update 2005: particulate matter, ozone, nitrogen dioxide, and sulfur dioxide. World Health Organization.

World Bank. (1995). Nigeria's strategic options for redressing industrial pollution. World Bank, industry and energy division. 1st edition, West Central Africa Department; Annexes: 1995; pp 60-62.

Zahoor, A., and Abdul, R. (2009). Enumeration of Coliforms. Journal of Environmental Sciences. 21, 814-820 


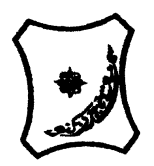

Bayero Journal of Pure and Applied Sciences, 13(2): 1 - 12

Received: November, 2020

Accepted: December, 2020

ISSN $2006-6996$

\title{
BIODEGRADATION POTENTIAL OF IMMOBILIZED BACTERIA IN THE TREATMENT OF TANNERY INDUSTRIAL EFFLUENTS FROM INDUSTRIAL ESTATES IN KANO STATE, NIGERIA
}

\author{
Abdullateef, B., ${ }^{1 *}$ Shuaibu, T. G., ${ }^{1}$ Babagana, K., ${ }^{1}$ Suleman, H. B. ${ }^{2}$ and Dauda, B. ${ }^{3}$ \\ ${ }^{1}$ Department of Pure and Applied Chemistry, Faculty of Science, University of Maiduguri, Borno State, \\ Nigeria \\ ${ }^{2}$ Department of Microbiology, Faculty of Science, University of Maiduguri, Borno State, Nigeria \\ ${ }^{3}$ Department of Chemical Engineering, Faculty of Engineering, University of Maiduguri, Borno State, \\ Nigeria \\ *Corresponding author: babslega@gmail.com; abelega2007@yahoo.com; +2348061309753
}

\section{ABSTRACT}

Industrial Effluents Samples from Gashash Tanneries (TAN1) in Bompai Industrial estate, Larabee Tannery Industry (TAN2) in Sharada Industrial estate and Z Tannery Industries (TAN3) in Challawa Industrial estate, Kano State, Nigeria were collected over a period of six months (August 2017 to January 2018) for assessing the biodegradation potentials of bacteria in the treatment of organic pollutants within the effluents. Bacteria were isolated from the effluents and immobilized on agar-agar. Different masses (5 g, $10 \mathrm{gr}, 15$ $\mathrm{g}, 20 \mathrm{~g}$, and $25 \mathrm{~g}$ ) of the bacteria were used in the treatment of $250 \mathrm{ml}$ of the effluents for ten days in a shaker incubator (Gallenkamp-OC-4364-L) at the temperature $30{ }^{\circ} \mathrm{C}$ and speed of $60 \mathrm{rpm}$. Pre-treatment analysis of the effluents for Temperature, pH, Biochemical Oxygen Demand (BOD), Chemical Oxygen Demand (COD), Suspended Solid (SS) and Total Dissolved Solids (TDS) gives the following results; temperature $\left({ }^{\circ} \mathrm{C}\right.$ )

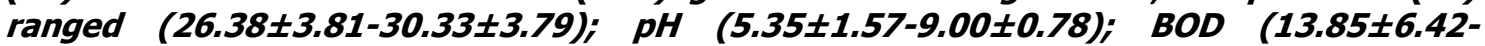
$38.75 \pm 16.20) ;$ COD (1406 $\pm 208-3532 \pm 1373) ;$ SS (208 $\pm 235-780 \pm 739)$ and TDS (266 $\pm 253-5276 \pm 2971)$. No statistical differences ( $p \leq 0.05)$ was observed for all the results among the different industries. The bacterial isolates were identified as Neisseria spp, Bacillus cereus, and Staphylococcus aureus, in TAN1, TAN2, and TAN3, respectively. After treatment of the effluent with the different masses of the isolated bacteria, the mean level of BOD was found to range as (0.55 $\pm 0.36-6.92 \pm 5.49) ; C O D$ (ND-3134 \pm 1595$)$;

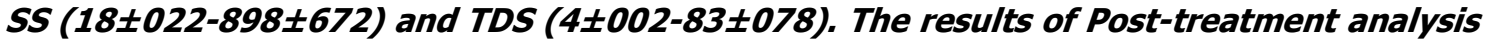
showed that there is overall decrease in the levels of the parameters determined when compared with that of the pre-treatment. The overall percentage reduction of the immobilised bacteria in the treatment of the respective effluents was in the order TAN2 (72\%)>TAN1 (70\%)>TAN3 (62\%). Hence, the immobilized bacteria are having higher biodegradation potential for the treatment of the tannery effluents.

Keywords: Biodegradation, bacteria, effluent, immobilization, tannery.

\section{INTRODUCTION}

Tannery industrial wastewater is a serious consequence of the pollution point of view for streams, freshwater, and land used for agriculture. The lack of awareness in the modern industrial practice has resulted in the discharge of tannery effluents which exhibit very high value of chromium ( $\mathrm{Cr}$ ), Sulfide, and chloride, Total Dissolved Solid (TDS), Total Suspended Solid (TSS), Biochemical Oxygen Demand (BOD) and Chemical Oxygen Demand (COD) in the water stream or land (Mohammed et al., 2001). Tanning is the process, which One ton of skin generally leads to the production of 20 to $80 \mathrm{~m}^{3}$ of turbid and foul-smelling converts the protein of the rawhide or skin into a stable material, which will not putrefy and is suitable for a wide variety of end applications (Elsheikh, 2009). The highly polluting chromium is the most commonly used tanning material producing leather that is more flexible and pliable than vegetable-tanned leather and does not discolor or lose shape in water as drastically as vegetable-tan (Elsheikh, 2009). Tannery effluent is among the most hazardous industrial pollutants due to its huge organic and inorganic load, which is highly toxic to human life and the environment (Kongjao et al., 2008). wastewater including chromium (100-400 mg/l), sulfide $(200-800 \mathrm{mg} / \mathrm{l})$, high levels of fat and 
BAJOPAS Volume 13 Number 2, December, 2020 other solid wastes, and notable pathogen contamination as well as pesticides added for skin conservation during transport (Elsheikh, 2009). There are more than 6000 tanneries in Nigeria with an annual processing capacity of 700,000 tons of hides and skins (Omoleke, 2004; Singh et al., 2008). It was reported that the total amount of waste produced per animal slaughtered is approximately $35 \%$ of its weight (World Bank, 1995). Also, for every $1000 \mathrm{~kg}$ of carcass weight, a slaughtered beef produces 5.5 $\mathrm{kg}$ of manure (excluding rumen contents or stockyard manure) and $100 \mathrm{~kg}$ of paunch manure (undigested food) (Verheijen et al., 1996). Tanneries generate wastewater in the range of 30-35 $\mathrm{L} \mathrm{kg}^{-1}$ skin/hide processed with variable $\mathrm{pH}$, Biological Oxygen Demand (BOD), Chemical Oxygen Demand (COD), high concentrations of suspended solids (SS), and tannins as well as chromium (Zahoor and Abdul, 2009).

Being heterogeneous and composed of a wide variety of compounds, it is very difficult to select a unique direct method for estimating the biodegradability of organic contents and biokinetic parameters for a wastewater sample (Rajor, 2004). For this purpose, some indirect estimation such as determination of biochemical oxygen demand (BOD) and chemical oxygen demand (COD) are applied as common laboratory investigations [9]. During retanning procedures, synthetic tannins (Syntan), oils and resins are added to form softer leather at varying doses (Munz et al., 2009). One of the refractory groups of chemicals in tannery effluents derives mainly from tannins (Ramasami et al., 2004). Syntans are characterized by complex chemical structures, because they are composed of an extended set of chemicals such as phenol-, naphthalene-, formaldehyde- and melamine-based syntans, and acrylic resins (Beem, 1994). Organic pollutants (proteic and lipidic components) are originated from skins (it is calculated that the raw skin has $30 \%$ loss of organic material during the working cycle) or they are introduced during processes (Hugo Springer, 1994).

Many conventional processes such as oxidation, chemical and biological processes were carried out to treat tanneries wastewater (Ebtesam et al, 2013). Biological processes have received more attention because of their costeffectiveness, lower sludge production and environmental friendliness (Noorjahan, 2014). Naturally occurring micro-organisms degrade the hazardous organic wastes including xenobiotic compounds, such as pesticides, polycyclic aromatic hydrocarbons (PAHs) and polychlorinated biphenyls (PCBs) in due course of time (Ranen and Sharadinadra, 2009). Bioremediation is based on the idea that all organisms remove substances from the environment to carry outgrowth and metabolism (Bouwer and Zehnder, 1993). Bacteria, protista and fungi are found to be very good at degrading complex molecules and incorporating the breakdown products into their metabolism (Bouwer and Zehnder, 1993). The resultant metabolic wastes that they produce are generally safe and somehow recycled into other organisms (Ranen and Sharadinadra, 2009). An acclimatized indigenous population of microorganisms capable of degradation of the compounds of interest must exist at the site for a successful bioremediation mode (Ranen and Sharadinadra, 2009). It has been observed that for a successful bioremediation mode, an acclimatized indigenous population of microorganisms capable of degradation of the compounds of interest must exist at the site under investigation (Ranen and Sharadinadra, 2009). Even though there are numerous physical and chemical methods employed in the disposal of wastes the advantage in using bacterium is that they play a key role in the reduction of COD, BOD, total protein, total tannin and total phenol (Saravanan and Saravanan, 1998)

Baba et al. (2020) studied the bioremediation potential of immobilized corynebacterium kutsceri in the Treatment of tannery industrial effluent from Challawa Industrial Estate, Kano State, Nigeria. The aim of the work is to study the reduction in the level of the contaminants through the process of bioremediation using the isolated bacteria. Immobilized bacteria can withstand various temperatures, $\mathrm{pH}$ and substrate concentrations; consequently, increasing the efficiency and the lifespan of the bacteria. Immobilized bacteria are widely applied in the treatment of wastewater and can be separated and recovered after the treatment with the same efficiency (Baba et al., 2020).

\section{MATERIALS AND METHODS \\ Study Area}

This study was carried out in Bompai, Sharada and Challawa industrial estates in Kano, Figure 1. Kano lies on Latitude $11^{\circ} 30^{\prime} \mathrm{N}$ and $8^{\circ} 30^{\prime} \mathrm{E}$ and Longitude $11^{\circ} 5^{\prime} \mathrm{N}$ and $8^{\circ} 5^{\prime} \mathrm{E}$ in Northern Nigeria. It is one of the developed industrial cities in Nigeria. Tannery activities are the dominating industries and this could be one of the reasons for her high population density (Dan'Azumi and Bichi, 2010). Many researchers have studied biodegradation of tannery effluent using microorganisms. However, limited literature is available on the biodegradation of tannery effluent in Kano industrial estates using 
BAJOPAS Volume 13 Number 2, December, 2020 immobilized bacterial cells. This research work focuses on the potential of the use of the indigenous immobilized bacterial isolates in the treatment of tannery effluents in the industrial estates.

\section{Sample Collection}

Effluents were collected from the Tannery Industries from Bompai, Challawa and Sharada Industrial Estates, Kano, Nigeria. The effluents were collected over a period of six months (August 2017 to January 2018). Samples collected in a sterile 4-liter plastic container with a unique identification number were preserved using an ice-box that was transported to the Microbiology Laboratory, Department of Microbiology, Bayero University of Kano for analysis

\section{Sample Preparation and Sample Analysis}

Immediately after the collection of the effluent, $\mathrm{pH}$, TSS, TDS, COD, BOD levels were determined before treatment (Pre-treatment determination) and ten days after treatment (Post-treatment determination) as described in
APHA (1989) standard methods. $\mathrm{pH}$ was determined using Ecotests $\mathrm{pH}$ meter and TDS was determined using AQUALYTIC TDS Salinometer. BOD was determined as described by the standard method (APHA, 1992). COD and SS were determined using DR/2010 HACH portable data logging spectrophotometer (DWAF, 1992)

\section{Identification and Biochemical} Characterization of the Bacterial Isolates

The bacteria were isolated from the effluents using Serial Dilution according to the method described by APHA (1989). The biochemical tests such as oxidase, catalase, coagulase, indole (from $1 \%$ tryptone broth), citrate (Simmons citrate agar), methyl red/VogesProskauer (MR/VP), nitrate reduction, Starch Hydrolysis, Glucose, Maltose, and Lactose tests were carried out on the bacterial isolates to identify the bacteria through the bacteria biochemical characteristics according to Ajao et al. (2011).

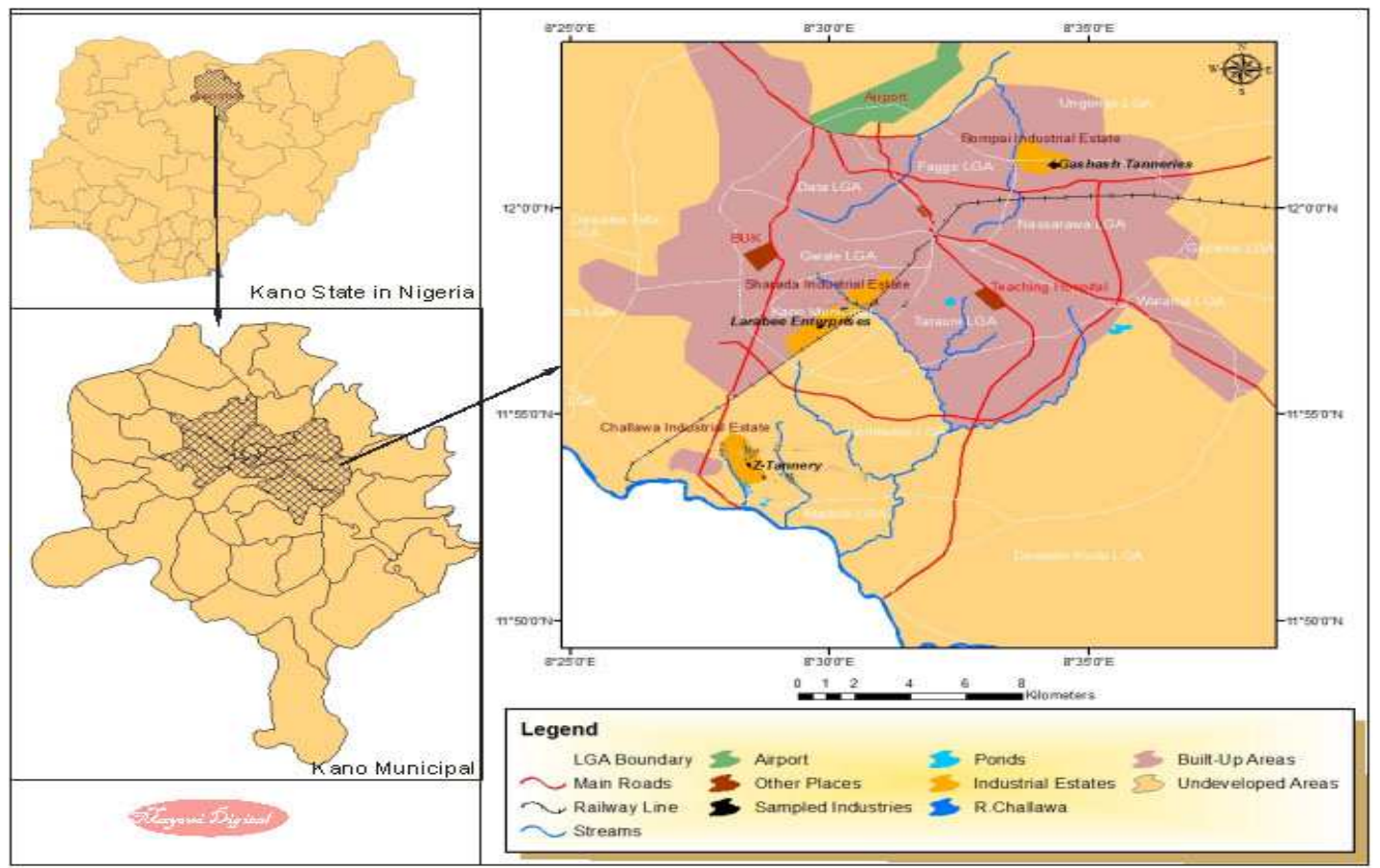

Fig. 1 Map showing the study areas

Source: Mayomi Digital Productions, GIS Laboratory, Department of Geography, UNIMAID (2017)

\section{Determination of Growth Rate of the Bacteria in Effluent Sample}

The bacteria growth rates were determined by transferring $2 \mathrm{~mL}$ of the bacterial isolates from the tannery effluent in broth medium into 100 $\mathrm{mL}$ sterile effluents in conical flasks and kept in an incubator (Giffrin cool) for 10 days. Control was also set up by incubating another $100 \mathrm{~mL}$ each of the sterile effluents without the bacteria. The optical density of the content was determined at the wavelength of $600 \mathrm{~nm}$ on a daily interval and recorded. 
BAJOPAS Volume 13 Number 2, December, 2020 Immobilization of Bacteria

Agar solution and inoculi were prepared separately. Fifty milliliters $(50 \mathrm{~mL})$ of nutrient broth each of the inoculi was prepared in a McCartney bottle and incubated for 24 hours. A solution of agar-agar was prepared by dissolving $10 \mathrm{~g}$ of the powder in distilled water and made up to $500 \mathrm{~mL}$ mark in an Erlenmeyer flask and was sterilized in an autoclave (280A) for 15 minutes and allowed to cool to $40-45^{\circ} \mathrm{C}$ (Ajao et al., 2011). Four milliliters ( $4 \mathrm{~mL})$ of the bacterial isolates in the nutrient broth was mixed with 36 $\mathrm{ml}$ of the prepared agar-agar media in petri-dish plates and then allowed to solidify. This was kept in the refrigerator for bioremediation.

\section{Bioremediation (Treatment) of the Effluents}

The solidified agar block (immobilized bacteria) was cut into cubes using a sterile knife; $0.1 \mathrm{~mL}$ phosphate buffer ( $\mathrm{pH} \mathrm{7.0)}$ was added and kept in the refrigerator for 1 hour for curing. The phosphate buffer was decanted after 1 hour and the cubes were washed with sterile distilled water 3-4 times before it was used (Ajao et al., 2011). Two liters (2 L) of the effluent was supplemented with the minimum basal medium in $\mathrm{g} / \mathrm{L}: \mathrm{NaCl}(0.8), \mathrm{MgSO}_{4} .7 \mathrm{H}_{2} \mathrm{O}(0.001), \mathrm{KH}_{2} \mathrm{PO}_{4}$ (2), $\mathrm{NaNO}_{3}$ (2), $\quad \mathrm{CaCl}_{2} .2 \mathrm{H}_{2} \mathrm{O} \quad(0.5)$ and $\mathrm{NaHPO}_{4} .12 \mathrm{H}_{2} \mathrm{O}(2)$ and sterilized in an autoclave at $121^{\circ} \mathrm{C}$ for 15 minutes (Margesin and Schinner, 2001). Two hundred and fifty milliliters $(250 \mathrm{~mL})$ of the effluents were transferred into different $250 \mathrm{ml}$ conical flasks. The content was covered with a cotton-wool ramped with foil paper to avoid contamination. Five grams $(5 \mathrm{~g})$ of the immobilized bacteria were quickly transferred into each of the effluents in the conical flasks in an inoculating chamber. The same procedures were carried out for the $10 \mathrm{~g}, 15 \mathrm{~g}, 20 \mathrm{~g}$ and 25 $\mathrm{g}$ of the immobilized bacteria in separate $250 \mathrm{~mL}$ effluents in conical flasks and agitated for ten days in a shaker incubator (Gallenkamp-OC4364-L) at a temperature $30^{\circ} \mathrm{C}$ and speed of 60 rpm. The treated effluent samples were taken on the tenth day and analyzed for the parameters $\mathrm{pH}$, SS, TDS, COD, and BOD, (Posttreatment determination) for the different grams of bacteria to evaluate and compare the biodegradation potential. (Baba et al., 2020).

\section{Statistical Analysis}

The data were represented as Mean \pm Standard deviation and analyzed statistically using oneway Analysis of Variance (ANOVA) and Tukey's HSD as Post Hoc Tests with the aid of SPSS 16.0. The correlation coefficient was also used to measure the strength of the relationship between the different masses of the bacteria and the parameters. All $\mathrm{p} \leq 0.05$ were considered as statistically significant.

\section{RESULTS AND DISCUSSION Physico-chemical parameters in the Industrial Effluents before the Biodegradation.}

Results of the Physico-chemical parameters in the industrial effluents before the Biodegradation is shown in table 1 . The mean temperatures $\left({ }^{\circ} \mathrm{C}\right)$ observed in TAN1, TAN2, and TAN3 samples were $28.07 \pm 0.65 ; 27.77 \pm 0.64$ and $26.38 \pm 3.81$ respectively. The order of the mean temperature of the samples from the three industries can be arranged as TAN1 > TAN2>TAN3. The temperature observed at TAN1, TAN2, and TAN3 samples were found below the WHO $\left(35^{\circ} \mathrm{C}\right)$ and NESREA $\left(40^{\circ} \mathrm{C}\right)$ limits. The low values of temperature might be due to the processes used at the time of sampling. High temperature brings down the solubility of gases in water that ultimately expresses as high BOD and COD. Statistical analysis shows that there is no significant difference $(p<0.05)$ between the mean values of temperature among the industries. This might be due to similar tannery activities involved in the tannery industries at the time of sampling. The average values of temperature observed in this present study are less than those observed by Akan et al. (2007), Akan et al. (2009) and Baba et al. (2020).

The mean level of $\mathrm{pH}$ observed in TAN1, TAN2 and TAN3, samples were $7.77 \pm 2.93$; $8.35 \pm 0.28$ and $7.52 \pm 0.76$ respectively. The order of the mean $\mathrm{pH}$ of the samples from the three industries can be arranged as TAN2> TAN1 $>$ TAN3. The $\mathrm{pH}$ of the samples falls within the WHO (7.0-8.5) and NESREA (6-9) standard limits. Statistical analysis shows that there is no significant difference $(p<0.05)$ between the mean values of $\mathrm{pH}$ among the industries. This might be due to similar tannery activities involved in the tannery industries at the time of sampling. Maheshwari et al. (2017) reported that the level of $\mathrm{pH}$ in the effluents from the tannery industry in Vaniyambadi, India was 6.5 which was lower than that observed in the present study. The $\mathrm{pH}$ in the effluents from the tannery industries in Kano and Kaduna were reported to be 7.64 and 6.89, respectively (Akan et al., 2007; Mohammed et al., 2017). The average values of $\mathrm{pH}$ observed in this present study are less than those observed by Mohammed et al. (2017) and Baba et al. (2020). The mean level of SS $(\mathrm{mg} / \mathrm{l})$ observed in TAN1, TAN2, and TAN3 samples were 374 \pm 124 ; $358 \pm 335$ and $780 \pm 739$ respectively. The order of the mean SS in the samples from the three industries can be arranged as TAN3 > TAN1 $>$ TAN2. 
The SS observed in the samples were far above the recommended standard limits of regulating bodies WHO $(30 \mathrm{mg} / \mathrm{l})$ and NESREA $(10 \mathrm{mg} / \mathrm{l})$. Statistical analysis shows that there is no significant difference $(p<0.05)$ between the mean values of SS among the industries. This might be due to similar tannery activities involved in the tannery industries at the time of sampling. The average values of SS observed in this present study are less than that observed $(3700 \pm 122 \mathrm{mg} / \mathrm{l})$ by Akan et al. (2009) for tanneries in Kano. Also, the average values of SS observed in this present study are less than that observed by Mohammed et al. (2017) and Baba et al. (2020) with the exception in TAN3.

The mean level of TDS (mg/l) observed in TAN1, TAN2, and TAN3 samples were $3941 \pm 3703$; $3300 \pm 1714$ and $2653 \pm 1240$ respectively. The order of the mean TDS in the samples from the three industries can be arranged as TAN1>TAN2>TAN3. The TDS observed in the samples were far above the recommended standard limits of WHO $(250 \mathrm{mg} / \mathrm{l})$ and NESREA $(500 \mathrm{mg} / \mathrm{l})$. Statistical analysis shows that there is no significant difference $(p<0.05)$ between the mean values of TDS among the industries. This might be due to similar tannery activities involved in the tannery industries at the time of sampling. TDS in the effluents from the tannery industries in Kano, Nigeria was reported to be $1281 \mathrm{mg} / \mathrm{l}$ (Akan et al., 2007). The average values of SS observed in this present study are less than those observed by Mohammed et al. (2017) and Baba et al. 2020)

The mean level of COD (mg/l) observed in TAN1, TAN2 and TAN3 samples seasons were $2372 \pm 938 ; \quad 1406 \pm 208$ and $3532 \pm 1373$ respectively. The order of the mean COD of the samples from the three industries can be arranged as TAN3>TAN1> TAN2. The COD observed in TAN1, TAN2 and TAN3 samples were far above the recommended standard limits of regulating bodies $\mathrm{WHO}(40 \mathrm{mg} / \mathrm{l})$ and NESREA (40 mg/l). Statistical analysis shows that there is no significant difference $(p<0.05)$ in COD among the industries. This might be due to similar tannery activities involved in the tannery industries as at the time of sampling. The Chemical Oxygen demand (COD) is the amount of oxygen, in $\mathrm{mg} / \mathrm{L}$, required for the degradation of the compound of wastewater to occur. In comparison, the average values of COD observed in this present study were higher than that observed by Mohammed et al. (2017) but lower than that observed by Baba et al. (2020).

The mean levels of BOD $(\mathrm{mg} / \mathrm{l})$ observed in TAN1, TAN2 and TAN3 samples were $13.85 \pm 6.42 ; \quad 19.46 \pm 0.50$ and $17.13 \pm 3.14$ respectively. The order of the mean BOD in the samples from the three industries can be arranged as TAN2>TAN3>TAN1. The BOD observed in TAN1, TAN2 and TAN3 samples were found below the recommended limits of NESREA (200 mg/l) but above WHO (10 mg/l). Statistical analysis shows that there is no significant difference $(p<0.05)$ between the mean values of BOD among the industries. This might be due to similar tannery activities involved in the tannery industries at the time of sampling. The low level of BOD recorded in this study is an indication of the low level of biodegradable organic solids in the effluent. The average values of BOD observed in this present study were lower than those observed by Mohammed et al. (2017) and Baba et al. (2020).

Table 1: Mean Values \pm S.D of Physico-chemical parameters of effluents from the Tannery Industries before Treatment.

\begin{tabular}{llllllll}
\hline Parameter & Tannery 1 & Tannery 2 & Tannery 3 & $\mathrm{a}$ & $\mathrm{b}$ & $\mathrm{c}$ & $\mathrm{d}$ \\
\cline { 2 - 7 } Temperature $\left({ }^{\circ} \mathrm{C}\right)$ & $28.07 \mathrm{a} \pm 0.65$ & $27.77 \mathrm{a} \pm 0.64$ & $26.38 \mathrm{a} \pm 3.81$ & & $29.50 \pm 4.68$ & 35 & 40 \\
pH & $7.77 \mathrm{a} \pm 2.93$ & $8.35 \mathrm{a} \pm 0.28$ & $7.52 \mathrm{a} \pm 0.76$ & 6.89 & $5.35 \pm 1.57$ & $7.0-8.5$ & $6.0-9.0$ \\
$\mathrm{COD}(\mathrm{mg} / \mathrm{l})$ & $2372 \mathrm{a} \pm 938$ & $1406 \mathrm{a} \pm 208$ & $3532 \mathrm{a} \pm 1373$ & 2.2 & $3106 \pm 2753$ & 40 & 40 \\
$\mathrm{BOD}(\mathrm{mg} / \mathrm{l})$ & $13.85 \mathrm{a} \pm 6.42$ & $19.46 \mathrm{a} \pm 0.50$ & $17.13 \mathrm{a} \pm 3.14$ & 1032 & $26.17 \pm 9.49$ & 10 & 200 \\
$\mathrm{SS}(\mathrm{mg} / \mathrm{l})$ & $374 \mathrm{a} \pm 124$ & $358 \mathrm{a} \pm 335$ & $780 \mathrm{a} \pm 739$ & 501 & $562 \pm 482$ & 30 & 10 \\
TDS $(\mathrm{mg} / \mathrm{l})$ & $3941 \mathrm{a} \pm 3703$ & $3300 \mathrm{a} \pm 1714$ & $2653 \mathrm{a} \pm 1240$ & 532.7 & $444 \pm 507$ & 250 & 500 \\
\hline
\end{tabular}

The values given in the table above are means of 6 replicate values, $\mathrm{n}=6$ ( 1 sample was taken monthly for 6 months). Within the rows, means with different alphabets are statistically different $(p<0.05)$. WHO: World Health Organisation. NESREA: National Environmental Standard and Regulatory Enforcement Agency. a = Mohammed et al.(2017), b = Baba et al. (2020), c = WHO (2006), $d=$ NESSRA (2009) 
BAJOPAS Volume 13 Number 2, December, 2020

Identification, Biochemical Characterization and growth rates of the Bacterial Isolates

Results of identification and biochemical characterization of the bacterial isolates were shown in table 2. After 24 hours of incubation, the nutrient agar media plates were checked for bacterial growth. The results showed the presence of different strains in the samples. The TAN1 bacteria isolate was found to be gramnegative cocci while TAN3 was gram-positive cocci. TAN2 bacteria isolate was found to be gram-positive, rod-shaped. TAN1, TAN2, and TAN3 bacteria isolates recorded positive results for spore former.

The results of the biochemical tests indicated that all the bacteria were positive for catalase, oxidase, citrate, maltose, glucose, lactose (negative in TAN1), mannitol (negative in TAN2), starch hydrolysis and coagulase (negative in TAN2) tests. The bacteria showed negative results for nitrate reduction, $M R$ (positive in TAN2), VP (positive in TAN1), Indole (positive in TAN2) tests. Base on the morphological and biochemical test results, TAN1, TAN2, and TAN3 bacteria isolates were identified to be Nesseria spp, Bacillus cereus, and Staphylococcus aureus respectively.

The growth rate of the TAN1, TAN2 and TAN3 Isolates were shown in figure 2. Generally, the optical density increase with the increase in time (day) and decrease as time goes on. The highest optical density was shown by bacillus cereus in TAN2 while the lowest was shown by Staphylococcus aureus in TAN3.

The initial growth phase of TAN1 Isolate bacteria occurred within 2-day of incubation as the growth rate increases up to the 6th-day incubation when the maximum growth was observed. Beyond the 6th day, the growth of the bacteria declined (which might be due to a shortage of nutrients in the effluents) until it reached its death phase (which might be due to the unavailability of nutrients in the effluents).

A similar trend of growth was also observed for TAN2 Isolate as the initial growth phase also occurred within 2-day of incubation but maximum growth rate observed on the 4th day of incubation. The stationary stage occurred between the 4th day and the 8th day. Beyond the 8th day, the growth of the bacteria declined (which might be due to a shortage of nutrients in the effluents) until it reached its death phase (which might be due to the unavailability of nutrients in the effluents).

The initial growth phase of TAN3 bacterial Isolate occurred within the 3-day incubation as the growth rate increases up to the 6th-day incubation when the maximum growth was observed. Beyond the 6th day, the growth of the bacteria declined (which might be due to a shortage of nutrients in the effluents) until it reached its death phase (which might be due to the unavailability of nutrients in the effluents).

Table 2: Morphological and Biochemical characteristics of bacterial isolates

\begin{tabular}{lllll} 
Bacterial Isolates & & TAN1 & TAN2 & TAN3 \\
\hline $\begin{array}{lllll}\text { Morphological } \\
\text { characteristics }\end{array}$ & Shape & Cocci & Rod & Cocci \\
& Spore & & & \\
& former & + & + & + \\
Gram & & & \\
Biochemical characteristics & reaction & - & + & + \\
& Citrate & + & + & + \\
& Catalase & + & + & + \\
& Coagulase & + & - & + \\
Starch & + & + & + \\
& Glucose & + & + & + \\
Oxidase & + & + & + \\
& Indo & - & + & - \\
Lactose & - & + & + \\
Manitol & + & - & + \\
Maltose & + & + & + \\
MR & - & + & - \\
VP & + & - & - \\
& Nitrate & - & - & - \\
Reduction & - Neisseria & Bacillus & Staphylococcus \\
& Bacterial & cereus & aureus \\
& name & spp & cas
\end{tabular}

+ = Positive; - = Negative; MR=Methyl Red; VP= Voges-Proskauer 


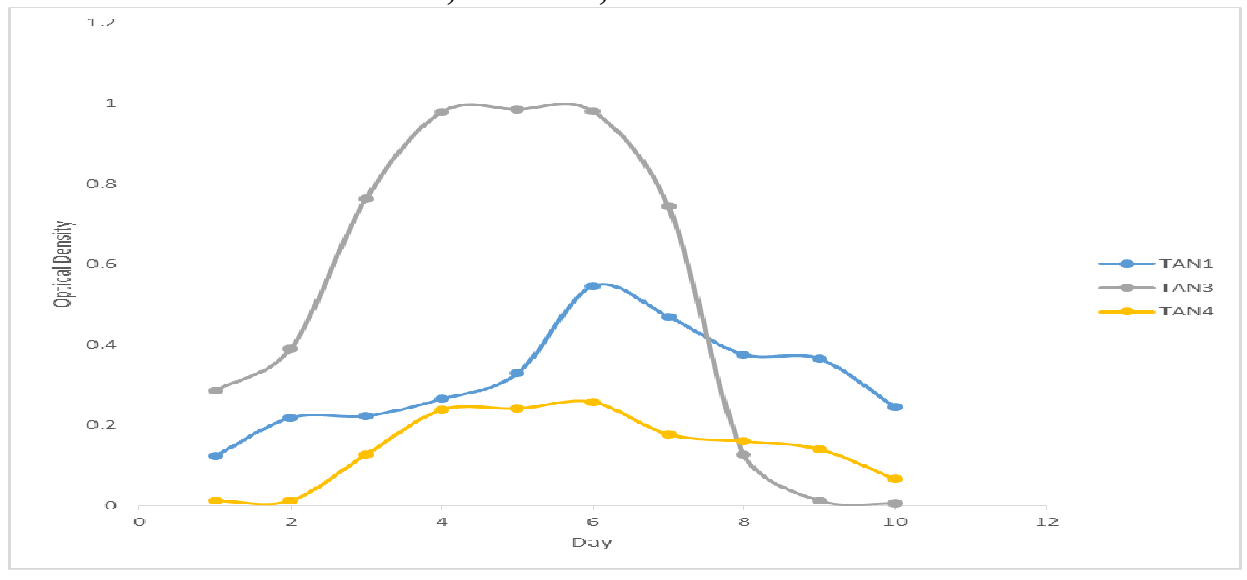

Fig. 2 Growth rates of the isolates in the effluents from the Tannery Industries

\section{Physico-chemical Parameters in the Industrial Effluents after the biodegradation.}

Table 3 shows the mean results of the physicochemical parameter before and after bioremediation using the different masses $(5 \mathrm{~g}$, $10 \mathrm{~g}, 15 \mathrm{~g}, 20 \mathrm{~g}$, and $25 \mathrm{~g}$ ) of the respective immobilized bacteria. Also, Table 4 shows the mean results of correlation coefficient ( $r$ ) between different masses of bacteria and physicochemical parameters.

The mean values $(\mathrm{mg} / \mathrm{l})$ of the SS after the bioremediation varies between $243 \pm 45$ and $898 \pm 672$. The mean concentration $(\mathrm{mg} / \mathrm{l})$ of SS remediated by the different masses $(5 \mathrm{~g}, 10 \mathrm{~g}$, $15 \mathrm{~g}, 20 \mathrm{~g}$, and $25 \mathrm{~g}$ ) of the bacteria varies. The SS in the samples fluctuates up and down after the bioremediation process when compared with the SS of the raw samples before the bioremediation. The increase in the levels of the SS might be due to the aggregation of the TDS which are large enough to result into SS. The increase in the levels of the SS might be also due to the influence of the nutrients which was added into the effluents in order to make the microorganisms more active and viable for fast degradation of organic contaminants in the effluent. The relative potential or efficiency of the different masses of the bacteria in remediating SS in TAN1 samples was in the order $25 \mathrm{~g}>20 \mathrm{~g}>15 \mathrm{~g}>10 \mathrm{~g}>5 \mathrm{~g}$. For TAN2 and TAN3 samples, the order was $25 \mathrm{~g}>20 \mathrm{~g}>15$ $\mathrm{g}>10 \mathrm{~g}>5 \mathrm{~g}$. These might be due to the variations in the surface areas of the different masses of the immobilized bacteria. Statistical analysis shows that there is no significant difference $(p<0.05)$ between the mean values of SS among the masses in the respective industries. Positive and significant correlations exist between the masses of bacteria and Suspended Solid (SS). This showed that there is general increase in the levels of the SS as the masses of the immobilized bacteria increases. TAN3 (90\%) and TAN1 (80\%) showed a very high correlation with the masses of the bacteria while TAN2 (61\%) showed a very low correlation.

The mean values $(\mathrm{mg} / \mathrm{l})$ of the TDS after the bioremediation varies between $46 \pm 11$ and $83 \pm 78$. The mean concentration $(\mathrm{mg} / \mathrm{l})$ of TDS remediated by the different masses $(5 \mathrm{~g}, 10 \mathrm{~g}$, $15 \mathrm{~g}, 20 \mathrm{~g}$, and $25 \mathrm{~g}$ ) of the bacteria varies. There is a reduction in all the TDS of all the samples after the bioremediation process compared with the TDS of the raw samples before the bioremediation. The relative potential or efficiency of the different masses of the bacteria in remediating TDS in TAN1 and TAN3 samples was in the order $5 \mathrm{~g}>10 \mathrm{~g}>15 \mathrm{~g}>20$ $\mathrm{g}>25 \mathrm{~g}$. For TAN2 samples, the order was 20 $g>10 \quad g>25 \quad g>15 \quad g>5 \quad g$. Statistical analysis shows that there is no significant difference $(p<0.05)$ between the mean values of TDS among the masses in the respective industries. These might be due to the variations in the surface areas of the different masses of the immobilized bacteria. Positive and significant correlations exist between the masses of bacteria and TDS with the exception in TAN2 (negative and insignificant correlation). The positive correlations showed that there is general increase in the levels of the TDS as the masses of the immobilized bacteria increases. TAN1 $(96 \%)$ showed a very high correlation with the masses of the bacteria while TAN2 (47\%) showed a very low correlation.

The mean values $(\mathrm{mg} / \mathrm{l})$ of the BOD after the bioremediation varies between $1.56 \pm 0.20 \mathrm{mg} / \mathrm{l}$ and $6.92 \pm 5.49 \mathrm{mg} / \mathrm{l}$. The mean concentration $(\mathrm{mg} / \mathrm{l})$ of BOD remediated by the different masses $(5 \mathrm{~g}, 10 \mathrm{~g}, 15 \mathrm{~g}, 20 \mathrm{~g}$, and $25 \mathrm{~g}$ ) of the bacteria varies. There is a reduction in all the BOD of all the samples after the bioremediation process compared with the $\mathrm{BOD}$ of the raw 
BAJOPAS Volume 13 Number 2, December, 2020 samples before the bioremediation. The relative potential or efficiency of the different masses of the bacteria in remediating BOD in TAN1, TAN2 and TAN3 samples were in the order $25 \mathrm{~g}>20$ $\mathrm{g}>15 \mathrm{~g}>10 \mathrm{~g}>5 \mathrm{~g}, 25 \mathrm{~g}>15 \mathrm{~g}>5 \mathrm{~g}>10 \mathrm{~g}>20 \mathrm{~g}$ and $20 \mathrm{~g}>10 \mathrm{~g}>25 \mathrm{~g}>15 \mathrm{~g}>5 \mathrm{~g}$ respectively. Statistical analysis shows that there is significant difference $(p<0.05)$ between the mean values of BOD among the masses in the respective industries. These might be due to the variations in the surface areas of the different masses of the immobilized bacteria. Negative and significant correlations exist between the masses of bacteria and BOD. This showed that there is general decrease in the levels of the BOD as the masses of the immobilized bacteria increases. TAN1 (94\%) showed a very high correlation with the masses of the bacteria while TAN2 (4\%) showed a very low correlation.

The mean values $(\mathrm{mg} / \mathrm{l})$ of the COD after the bioremediation varies between $250 \pm 154$ and $3134 \pm 1595$. The mean concentration $(\mathrm{mg} / \mathrm{l})$ of COD remediated by the different masses $(5 \mathrm{~g}$, $10 \mathrm{~g}, 15 \mathrm{~g} 20 \mathrm{~g}$, and $25 \mathrm{~g}$ ) of the bacteria varies. There is a reduction in all the COD of all the samples after the bioremediation process compared with the COD of the raw samples before the bioremediation. The relative potential or efficiency of the different masses of the bacteria in remediating COD in TAN1, TAN2 and TAN3 samples were in the order $25 \mathrm{~g}>20 \mathrm{~g}>15$ $\mathrm{g}>5 \mathrm{~g}>10 \mathrm{~g}, 25 \mathrm{~g}>20 \mathrm{~g}>15 \mathrm{~g}>10 \mathrm{~g}>5 \mathrm{~g}$ and 10 g>5 g>25 g>15 g>20 g respectively. Statistical analysis shows that there were significant difference $(p<0.05)$ between the mean values of COD among the masses in the respective industries except for effluents treated with $25 \mathrm{~g}$. These might be due to the variations in the surface areas of the different masses of the immobilized bacteria. Negative and insignificant correlations exist between the masses of bacteria and COD with the exception in TAN3 (positive and significant correlation). The negative correlations showed that there is general decrease in the levels of the COD as the masses of the immobilized bacteria increases. TAN2 (100\%) showed a very high correlation with the masses of the bacteria while TAN3 (36\%) showed a very low correlation.

Generally, there was an overall decrease in the concentration of these physicochemical parameters after the bioremediation using the different masses of the bacterial isolates. These might be due to the variations in the surface areas of the different masses of the immobilized bacteria. This is in line with the work of Jimoh et al. (2018) and Baba et al. (2020).

Table 3: Mean Values $(\mathrm{mg} / \mathrm{l}) \pm$ S.D of Physicochemical parameters in effluents from the Tannery Industries before and after Treatment of the effluents $(250 \mathrm{ml})$ with the different masses $(5 \mathrm{~g}, 10 \mathrm{~g}$, $15 \mathrm{~g}, 20 \mathrm{~g}$, and $25 \mathrm{~g}$ ) of the bacteria.

\begin{tabular}{llllllll}
\hline $\mathrm{P}$ & IND & Before & \multicolumn{5}{c}{ After } \\
\cline { 4 - 7 } & & & $5 \mathrm{~g}$ & $10 \mathrm{~g}$ & $15 \mathrm{~g}$ & $20 \mathrm{~g}$ & $25 \mathrm{~g}$ \\
\hline \multirow{2}{*}{ COD } & TAN1 & $2372 \pm 938$ & $1708 \mathrm{a} \pm 861$ & $2045 \mathrm{a} \pm 1205$ & $845 \mathrm{a} \pm 369$ & $300 \mathrm{a} \pm 167$ & $250 \mathrm{a} \pm 154$ \\
& TAN2 & $1406 \pm 208$ & $1195 \mathrm{a} \pm 208$ & $1125 \mathrm{a} \pm 384$ & $1055 \mathrm{a} \pm 317$ & $956 \mathrm{a} \pm 310$ & $870 \mathrm{ab} \pm 240$ \\
& TAN3 & $3532 \pm 1373$ & $2374 \mathrm{a} \pm 1344$ & $1976 \mathrm{a} \pm 1405$ & $2757 \mathrm{a} \pm 1266$ & $3134 \mathrm{a} \pm 1595$ & $2614 \mathrm{~b} \pm 1105$ \\
BOD & TAN1 & $13.85 \pm 6.42$ & $6.92 \mathrm{a} \pm 5.49$ & $6.42 \mathrm{a} \pm 5.07$ & $5.72 \mathrm{a} \pm 5.35$ & $4.62 \mathrm{a} \pm 4.37$ & $2.82 \mathrm{ab} \pm 1.26$ \\
& TAN2 & $19.46 \pm 0.50$ & $1.75 \mathrm{~b} \pm 0.22$ & $1.73 \mathrm{~b} \pm 0.18$ & $1.58 \mathrm{a} \pm 0.16$ & $1.91 \mathrm{a} \pm 0.22$ & $1.56 \mathrm{~b} \pm 0.20$ \\
& TAN3 & $17.13 \pm 3.14$ & $4.24 \mathrm{ab} \pm 0.77$ & $3.29 \mathrm{ab} \pm 0.37$ & $4.11 \mathrm{a} \pm 0.07$ & $3.23 \mathrm{a} \pm 0.91$ & $3.33 \mathrm{a} \pm 1.28$ \\
SS & TAN1 & $374 \pm 124$ & $243 \mathrm{a} \pm 45$ & $471 \mathrm{a} \pm 226$ & $475 \mathrm{a} \pm 182$ & $492 \mathrm{a} \pm 128$ & $611 \mathrm{a} \pm 217$ \\
& TAN2 & $358 \pm 335$ & $460 \mathrm{a} \pm 400$ & $543 \mathrm{a} \pm 414$ & $544 \mathrm{a} \pm 402$ & $551 \mathrm{a} \pm 414$ & $554 \mathrm{a} \pm 405$ \\
& TAN3 & $780 \pm 739$ & $586 \mathrm{a} \pm 594$ & $758 \mathrm{a} \pm 656$ & $787 \mathrm{a} \pm 676$ & $861 \mathrm{a} \pm 635$ & $898 \mathrm{a} \pm 672$ \\
TDS & TAN1 & $3941 \pm 3703$ & $51 \mathrm{a} \pm 10$ & $53 \mathrm{a} \pm 10$ & $55 \mathrm{a} \pm 15$ & $61 \mathrm{a} \pm 20$ & $63 \mathrm{a} \pm 26$ \\
& TAN2 & $3300 \pm 1714$ & $83 \mathrm{a} \pm 78$ & $47 \mathrm{a} \pm 20$ & $48 \mathrm{a} \pm 22$ & $47 \mathrm{a} \pm 17$ & $48 \mathrm{a} \pm 17$ \\
& TAN3 & $2653 \pm 1240$ & $46 \mathrm{a} \pm 11$ & $55 \mathrm{a} \pm 24$ & $55 \mathrm{a} \pm 25$ & $58 \mathrm{a} \pm 23$ & $61 \mathrm{a} \pm 28$ \\
\hline
\end{tabular}

Replicate $=6$ (months)

Within the rows, for the same parameter, means with different alphabets are statistically different $(p<0.05)$.

$\mathrm{P}=$ parameter, IND = Industries 
BAJOPAS Volume 13 Number 2, December, 2020

Table 4: Correlation coefficient $(r)$ between different masses of the bacteria and the physicochemical parameters.

\begin{tabular}{llll}
\hline Industries & Parameter & Correlation coefficient $(r)$ & $\begin{array}{l}\text { Percent dependence (rxrx100) } \\
(\%)\end{array}$ \\
\hline TAN1 & COD & -0.9 & 82 \\
& BOD & -0.97 & 94 \\
& SS & $0.90^{*}$ & 80 \\
TAN2 & TDS & $0.98^{*}$ & 96 \\
& COD & -1 & 100 \\
& BOD & -0.21 & 4 \\
& SS & $0.78^{*}$ & 61 \\
& TDS & -0.69 & 47 \\
& COD & $0.60^{*}$ & 36 \\
& BOD & -0.6 & 37 \\
& SS & $0.95^{*}$ & 90 \\
& TDS & $0.94^{*}$ & 89 \\
\hline
\end{tabular}

The correlation coefficient $(r)$ with * is statistically significant $(p<0.05)$.

Percentage reduction of the Parameters

Table 5 shows the percentage reduction of Parameters in industrial samples before and after the treatment of the effluents $(250 \mathrm{ml})$ with the different masses $(5 \mathrm{~g}, 10 \mathrm{~g}, 15 \mathrm{~g}, 20 \mathrm{~g}$, and $25 \mathrm{~g}$ ) of the Immobilized Bacteria.

In TAN1 samples, the percentage reduction (\%) of COD ranged (14-89); BOD (50-80); SS (-32$35)$ and TDS (98-99). In TAN2 samples, the percentage decrease $(\%)$ of COD ranged (15$38) ;$ BOD (90-92); SS [-28-(-55)] and TDS (9798). In TAN3 samples, the percentage decrease (\%) of COD ranged (11-44); BOD (76-81); SS (15-25) and TDS (98). The percentage increase in the levels COD, BOD and TDS might be due to the increase in the surface area of the different masses of the immobilized bacteria. However, the percentage decrease in the levels of the SS might be due to the aggregation of the TDS which are large enough to result into SS. The percentage decrease in the levels of the SS might be also due to the influence of the nutrients which was added into the effluents in order to make the microorganisms more active and viable for fast degradation of organic contaminants in the effluent. This is in line with the work of Jimoh et al. (2018) in which the concentration of the SS increase after the bioremediation of effluents.

Sreemoyee and Priti (2013) assessed and reduced several Physico-chemical parameters of dairy wastewater using Niesseria $s p$. and concluded that the species are well known to degrade organic compounds. This is in agreement with the current study in which the immobilized Niesseria $s p$ degrade the organic contaminants as indicated by the BOD, COD and TDS.

Jimoh et al. (2018) observed that TSS of the effluents was increased after treatment with immobilized bacteria and concluded that it might be due to the biostimulation method adopted for the research.

The optimum $\mathrm{pH}$ Biosorption of Chromium by Bacillus spp and Staphylococcus spp. from tannery effluent was investigated by Mythili and Karthikeyan (2011). The maximum adsorption of Chromium $(86.4 \mathrm{mg} / \mathrm{L})$ was showed by Bacillus spp and Staphylococcus spp showed $70.6 \mathrm{mg} / \mathrm{L}$ at an initial concentration of $100 \mathrm{mg} / \mathrm{L}$. In the present study, immobilised Bacillus spp and Staphylococcus spp. from the tannery industrial effluents reduced the levels of the organic pollutants with high potential as indicated by the percentage reduction of BOD, COD and TDS.

Enzymes often can work in multiple environments especially if they are immobilized. This makes the microorganisms' enzymes even more resistant to harsh environments and enables the enzymes to be recovered and recycled after they are no longer needed (Gianfreda and Rao 2004). Ramesh and Singh (1993) reported that the immobilized bacteria having more efficiency to remove the suspended particles than free cells. Using the immobilized cell is preferable due to its capability for using several times with the same efficiency, which makes it more economical. Similar work was done by Sikander et al. (2007) showing the higher reduction with permeabilized cells of Ochrobactrum intermedium strain SDCr-5. 
BAJOPAS Volume 13 Number 2, December, 2020

The results revealed the isolation and identification of isolates with the potential for the reduction of $\mathrm{Cr}$ (VI) to $\mathrm{Cr}$ (III). Results indicated that immobilized $B$. cereus could be efficiently used for the reduction of $\mathrm{Cr}$ (VI).

Table 5: Percentage reduction of the tested Parameters from the tannery industrial samples of the Immobilized Bacteria.

\begin{tabular}{lllllll}
\hline \multirow{2}{*}{ Industries } & & \multicolumn{5}{c}{ Percentage Reduction $(\%)$} \\
\cline { 3 - 7 } & & $5 \mathrm{~g}$ & $10 \mathrm{~g}$ & $15 \mathrm{~g}$ & $20 \mathrm{~g}$ & $25 \mathrm{~g}$ \\
\hline TAN1 & COD & 28 & 14 & 64 & 87 & 89 \\
& BOD & 50 & 54 & 59 & 67 & 80 \\
& SS & 35 & -26 & -27 & -32 & -63 \\
& TDS & 99 & 99 & 99 & 98 & 98 \\
TAN2 & COD & 15 & 20 & 25 & 32 & 38 \\
& BOD & 91 & 91 & 92 & 90 & 92 \\
& SS & -28 & -52 & -52 & -54 & -55 \\
& TDS & 97 & 99 & 99 & 99 & 99 \\
& COD & 33 & 44 & 22 & 11 & 26 \\
& BOD & 75 & 81 & 76 & 81 & 81 \\
& SS & 25 & 3 & -1 & -10 & -15 \\
& TDS & 98 & 98 & 98 & 98 & 98 \\
\hline
\end{tabular}

Percentage Reduction $=(B-A) / B \times 100 \%$

$A=$ Concentration of the parameter after treatment

$\mathrm{B}=$ Concentration of the parameter before treatment

$+=$ percentage decrease

- = percentage increase

In general, immobilization makes the enzyme more resistant to temperature, $\mathrm{pH}$, and substrate concentration swings giving it a longer lifetime and higher productivity per active unit (Gianfreda and Rao, 2004; FuIlbrook, 1996; Russell et al, 2003; Kandelbauer et al., 2004). Immobilized cells have been used and studied extensively for the production of useful chemicals (Ohtake and Silver, 1994), the treatment of wastewaters (Chen et al., 2003; Wang et al., 2010). Although many workers described microbial degradation of tannery effluent, limited literature is available on the bioremediation of tannery effluent using immobilized bacterial cells in the Kano Industrial Estates.

\section{CONCLUSION}

The samples contained variable levels of the physicochemical parameters. The results of the Analysis of variance revealed that, no statistical difference $(p<0.05)$ was observed for the temperature, $\mathrm{pH}, \mathrm{SS}, \mathrm{TDS}, \mathrm{BOD}$ and $\mathrm{COD}$ among the three tannery industries before the treatment. The levels of some of the parameters
(SS, TDS and COD) observed in the samples were found above the recommended limits of WHO and NESREA, which called for the treatment of the effluents before discharge into the environment. Base on the morphological and biochemical test results, TAN1, TAN2, and TAN3 bacterial isolates were identified to be Neisseria spp, Bacillus cereus, and Staphylococcus aureus respectively. The results of Post-treatment analysis showed that there is overall decrease in the levels of the parameters determined when compared with that of the pre-treatment. The overall percentage reduction of the immobilised bacteria in the treatment of the respective effluents was in the order TAN2 (72\%)>TAN1 $(70 \%)>$ TAN3 $(62 \%)$. Hence, the immobilized bacteria are having higher biodegradation potential for the treatment of the tannery effluents.

\section{Acknowledgments}

The authors wish to acknowledge the University of Maiduguri for the financial support. The authors are grateful to the Kano State Ministry of Environment for their support in obtaining the effluent samples. 


\section{REFERENCES}

Ajao, A. T., Adebayo, G. B., and Yakubu, S. E. (2011). Bioremediation of textile industrial effluent using mixed culture of Pseudomonas aeruginosa and Bacillus subtilis immobilized on agar-agar in a bioreactor. J. Microbiol. Biotech. Res, 1(3), 50-56.

Akan, J. C., Moses, E. A., Ogugbuaja, V. O., and Abah, J. (2007). Assessment of tannery industrial effluents from Kano metropolis, Kano State, Nigeria. Journal of Applied Sciences, 7(19), 2788-2793.

Akan, J. C., Ogugbuaja, V. O., Abdulrahman, F. I., and Ayodele, J. T. (2009). Pollutant levels in effluent samples from tanneries and textiles of Kano industrial areas, Nigeria. Global journal of pure and applied sciences, 15(3-4).

APHA (1989). Standard methods for Examination of Will bete and Will betewater.15 $5^{\text {th }}$ edition. Brydpass Springfield Will behington DC. pp. 164-176

APHA (1992). Standard Methods for the Examination of Water and Wastewater. Health, 69, 1116-9.

Baba, A., Garba, S. T., and Bello, H. S. (2020). Bioremediation Potential of Immobilized corynebacterium kutsceri in the Treatment of Tannery Industrial Effluent from Challawa Industrial Estate, Kano State, Nigeria. Journal of the Turkish Chemical Society Section A: Chemistry, $7(2), 335-350$.

Beem, E. I. V. (1994). reduction of solvent VOC emission. J. Oil Col. Chem. Ass, 77, 158.

Bouwer, E. J., and Zehnder, A. J. (1993). Bioremediation of organic compoundsputting microbial metabolism to work. Trends in biotechnology, 11(8), 360367.

Chen, K. C., Wu, J. Y., Liou, D. J., and Hwang, S. C. J. (2003). Decolorization of the textile dyes by newly isolated bacterial strains. Journal of Biotechnology, 101(1), 57-68.

Dan'Azumi, S., and Bichi, M. H. (2010). INDUSTRIAL POLLUTION AND HEAVY METALS PROFILE OF CHALLAWA RIVER IN KANO, NIGERIA. Journal of Applied Sciences in Environmental Sanitation, $5(1)$.

DWAF. (1992). Analytical Methods Manual, TR 151. Department of Water Affairs and Forestry, Pretoria.

El-Bestawy, E. (2013). Biological treatment of leather-tanning industrial wastewater using free living bacteria.
Elsheikh, M. A. S. (2009). Tannery wastewater pre-treatment. Water Science and Technology, 60(2), 433-440.

FuIlbrook, P. D. (1996). "Kinetics." Industrial enzymology: The application of enzymes in Industry. 2nd Ed. T. Godfrey and J Reichelt. eds.. Nature. New York.

Gianfreda, L., and Rao, M. A. (2004). Potential of extra cellular enzymes in remediation of polluted soils: a review. Enzyme and microbial technology, 35(4), 339354.

Hugo Springer. (1994). John Arthur Wilson Memorial Lecture "Treatment of Industrial Wastes of the Leather Industry - is it still a Major Problem". JALCA, 89, 153-185

Jimoh, A. A., Ganiyu, B. A., Baba, D., and Baba, A. (2018) Bioremediation Process of Effluent from Detergent and Food Industries in Jos, Nigeria: Kinetics and Thermodynamics. International Journal of Engineering Science Invention (IJESI), 762-73

Kandelbauer, A., Maute, O., Kessler, R. W., Erlacher, A., and Gübitz, G. M. (2004). Study of dye decolorization in an immobilized laccase enzyme-reactor using online spectroscopy. Biotechnology and bioengineering, 87(4), 552-563.

Kongjao, S., Damronglerd, S., and Hunsom, M. (2008). Simultaneous removal of organic and inorganic Pollutants in tannery wastewater using electrocoagulation technique. Korean Journal of chemical engineering, 25(4), 703.

Maheshwari, U. M., Aruna, S., Gomathi, M., and AbdulJaffar, A. H. (2017). Bioremediation by Free and Immobilized Bacteria Isolated from Tannery Effluent. International Journal of Research in Applied, Natural and Social Sciences. 5(7), 75-90

Margesin, R., and Schinner, F. (2001). Bioremediation (natural attenuation and biostimulation) of diesel-oilcontaminated soil in an alpine glacier skiing area. Applied and environmental microbiology, 677), 3127-3133.

Mohammed, A., Sekar, P., and George, J. (2011). Efficacy of microbes in bioremediation of tannery effluent. Inter. J. Curr. Res, 3(4), 324-326.

Mohammed, S. S. D., Orukotan, A. A., and Abdullahi, H. (2017). Physicochemical and Bacteriological Assessment of Tannery Effluent from Samaru-Zaria, 
BAJOPAS Volume 13 Number 2, December, 2020 Kaduna State, Nigeria. Journal of Applied

Sciences and Environmental Management, 21(4), 734-740.

Munz, G., De Angelis, D., Gori, R., Mori, G., Casarci, M., and Lubello, C. (2009). The role of tannins in conventional and membrane treatment of tannery wastewater. Journal of hazardous materials, 164(2-3), 733-739

Mythili, K., and Karthikeyan, B. (2011). Bioremediation of $\mathrm{Cr}$ (VI) from tannery effluent using Bacillus spp and Staphylococcus spp. International Multidisciplinary Research Journal, 1(6).

NESREA (2009). National Environmental Standards for Effluent Limitations and Regulation. 1233-1236

Noorjahan, C. M. (2014). Physicochemical characteristics, identification of bacteria and biodegradation of industrial effluent. Journal of bioremediation and Biodegradation, 5(3).

Ohtake, H. I., and Silver, A. O. (1994). Bacterial reduction of toxic chromate. Biological degradation and bioremediation of toxic chemicals, 403-415.

Omoleke, I. I. (2004). Management of environmental pollution in Ibadan, an African city: the challenges of health hazard facing government and the people. Journal of Human Ecology, 15(4), 265-275.

Rajor, A., Reddy, A.S., and Singh, B. (2004). Determination of BOD kinetic Parameters and evaluation of alternate methods, M.Sc. Thesis, Department of biotechnology \& environmental Science, Thapar Institute of Engineering and Technology, Patiala

Ramasami, T., Rajamani, S., and Rao, J. R. (1994, March). Pollution control in leather industry: Emerging technological options. In International symposium on surface and colloidal science and its relevance to soil pollution, madras.

Ramesh, J. V. S., and Singh, S. P. (1993). Yearly variation in certain physicochemical parameters of pond at eastern Doon Valley. Uttar Pradesh J. Zoo, 12 (1), 7577.

Ranen, S., and Sharadinadra, C. (2009). Biotechnology applications to environmental remediation in resource exploitation. Current science, 97, 6-25
Russell, A. J., Berberich, J. A., Drevon, G. F., and Koepsel, R. R. (2003). Biomaterials for mediation of

chemical and biological warfare agents. Annual review of biomedical engineering, 5(1), 1-27.

Saravanan, P., and Saravanan, A. (1999). Decolourization of tannery effluent by Flavobacterium sp. EK 1. Indian Journal of Environmental Protection, 19, 19-24.

Sikander, S., and Shahida, H. (2007). Reduction of toxic hexavalent chromium by Ochrobactrum intermedium strain SDCr5 stimulated by heavy metals. Bioresource Technol, 98, 340-344.

Singh, N., Sharma, B. K., and Bohra, P. C. (2000). Impact assessment of industrial effluent of arid soils by using satellite imageries. Journal of the Indian Society of Remote Sensing, 28(2-3), 79.

Sreemoyee, C., and Priti, P. (2013). Assessment of physico-chemical parameters of dairy waste water and isolation and characterization of bacterial strains in terms of cod reduction. Int J Sci, 2(3), 395-400.

Verheijen, L. A. H. M., Wiersema, D., Pol, L. H., and De Wit, J. (1996). Management of wastes from animal product processing. Livestock and environment, Finding a balance. International Agriculture Center, Wageningen, The Netherlands.

Wang, F., Yao, J., Si, Y., Chen, H., Russel, M., Chen, K., and Bramanti, E. (2010). Short-time effect of heavy metals upon microbial community activity. Journal of Hazardous Materials, 173(13), 510-516.

WHO (World Health Organization). (2006). Air quality guidelines: global update 2005: particulate matter, ozone, nitrogen dioxide, and sulfur dioxide. World Health Organization.

World Bank. (1995). Nigeria's strategic options for redressing industrial pollution. World Bank, industry and energy division. 1st edition, West Central Africa Department; Annexes: 1995; pp 60-62.

Zahoor, A., and Abdul, R. (2009). Enumeration of Coliforms. Journal of Environmental Sciences. 21, 814-820 


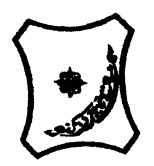

Bayero Journal of Pure and Applied Sciences, 13(2): 1 - 12

Received: November, 2020

Accepted: December, 2020

ISSN $2006-6996$

\title{
BIODEGRADATION POTENTIAL OF IMMOBILIZED BACTERIA IN THE TREATMENT OF TANNERY INDUSTRIAL EFFLUENTS FROM INDUSTRIAL ESTATES IN KANO STATE, NIGERIA
}

\author{
Abdullateef, B., ${ }^{1 *}$ Shuaibu, T. G., ${ }^{1}$ Babagana, K., ${ }^{1}$ Suleman, H. B. ${ }^{2}$ and Dauda, B. ${ }^{3}$ \\ ${ }^{1}$ Department of Pure and Applied Chemistry, Faculty of Science, University of Maiduguri, Borno State, \\ Nigeria \\ ${ }^{2}$ Department of Microbiology, Faculty of Science, University of Maiduguri, Borno State, Nigeria \\ ${ }^{3}$ Department of Chemical Engineering, Faculty of Engineering, University of Maiduguri, Borno State, \\ Nigeria \\ *Corresponding author: babslega@gmail.com; abelega2007@yahoo.com; +2348061309753
}

\section{ABSTRACT}

Industrial Effluents Samples from Gashash Tanneries (TAN1) in Bompai Industrial estate, Larabee Tannery Industry (TAN2) in Sharada Industrial estate and Z Tannery Industries (TAN3) in Challawa Industrial estate, Kano State, Nigeria were collected over a period of six months (August 2017 to January 2018) for assessing the biodegradation potentials of bacteria in the treatment of organic pollutants within the effluents. Bacteria were isolated from the effluents and immobilized on agar-agar. Different masses (5 g, $10 \mathrm{gr}, 15$ $\mathrm{g}, 20 \mathrm{~g}$, and $25 \mathrm{~g}$ ) of the bacteria were used in the treatment of $250 \mathrm{ml}$ of the effluents for ten days in a shaker incubator (Gallenkamp-OC-4364-L) at the temperature $30{ }^{\circ} \mathrm{C}$ and speed of $60 \mathrm{rpm}$. Pre-treatment analysis of the effluents for Temperature, pH, Biochemical Oxygen Demand (BOD), Chemical Oxygen Demand (COD), Suspended Solid (SS) and Total Dissolved Solids (TDS) gives the following results; temperature $\left({ }^{\circ} \mathrm{C}\right.$ )

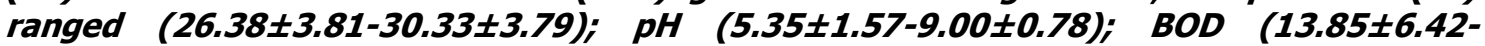
$38.75 \pm 16.20) ;$ COD (1406 $\pm 208-3532 \pm 1373) ;$ SS (208 $\pm 235-780 \pm 739)$ and TDS (266 $\pm 253-5276 \pm 2971)$. No statistical differences ( $p \leq 0.05)$ was observed for all the results among the different industries. The bacterial isolates were identified as Neisseria spp, Bacillus cereus, and Staphylococcus aureus, in TAN1, TAN2, and TAN3, respectively. After treatment of the effluent with the different masses of the isolated bacteria, the mean level of BOD was found to range as (0.55 $\pm 0.36-6.92 \pm 5.49) ; C O D$ (ND-3134 \pm 1595$)$;

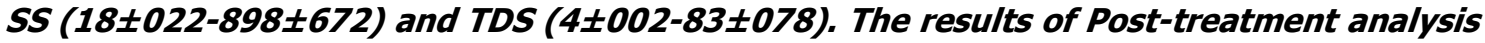
showed that there is overall decrease in the levels of the parameters determined when compared with that of the pre-treatment. The overall percentage reduction of the immobilised bacteria in the treatment of the respective effluents was in the order TAN2 (72\%)>TAN1 (70\%)>TAN3 (62\%). Hence, the immobilized bacteria are having higher biodegradation potential for the treatment of the tannery effluents.

Keywords: Biodegradation, bacteria, effluent, immobilization, tannery.

\section{INTRODUCTION}

Tannery industrial wastewater is a serious consequence of the pollution point of view for streams, freshwater, and land used for agriculture. The lack of awareness in the modern industrial practice has resulted in the discharge of tannery effluents which exhibit very high value of chromium ( $\mathrm{Cr}$ ), Sulfide, and chloride, Total Dissolved Solid (TDS), Total Suspended Solid (TSS), Biochemical Oxygen Demand (BOD) and Chemical Oxygen Demand (COD) in the water stream or land (Mohammed et al., 2001). Tanning is the process, which One ton of skin generally leads to the production of 20 to $80 \mathrm{~m}^{3}$ of turbid and foul-smelling converts the protein of the rawhide or skin into a stable material, which will not putrefy and is suitable for a wide variety of end applications (Elsheikh, 2009). The highly polluting chromium is the most commonly used tanning material producing leather that is more flexible and pliable than vegetable-tanned leather and does not discolor or lose shape in water as drastically as vegetable-tan (Elsheikh, 2009). Tannery effluent is among the most hazardous industrial pollutants due to its huge organic and inorganic load, which is highly toxic to human life and the environment (Kongjao et al., 2008). wastewater including chromium (100-400 mg/l), sulfide $(200-800 \mathrm{mg} / \mathrm{l})$, high levels of fat and 
BAJOPAS Volume 13 Number 2, December, 2020 other solid wastes, and notable pathogen contamination as well as pesticides added for skin conservation during transport (Elsheikh, 2009). There are more than 6000 tanneries in Nigeria with an annual processing capacity of 700,000 tons of hides and skins (Omoleke, 2004; Singh et al., 2008). It was reported that the total amount of waste produced per animal slaughtered is approximately $35 \%$ of its weight (World Bank, 1995). Also, for every $1000 \mathrm{~kg}$ of carcass weight, a slaughtered beef produces 5.5 $\mathrm{kg}$ of manure (excluding rumen contents or stockyard manure) and $100 \mathrm{~kg}$ of paunch manure (undigested food) (Verheijen et al., 1996). Tanneries generate wastewater in the range of 30-35 $\mathrm{L} \mathrm{kg}^{-1}$ skin/hide processed with variable $\mathrm{pH}$, Biological Oxygen Demand (BOD), Chemical Oxygen Demand (COD), high concentrations of suspended solids (SS), and tannins as well as chromium (Zahoor and Abdul, 2009).

Being heterogeneous and composed of a wide variety of compounds, it is very difficult to select a unique direct method for estimating the biodegradability of organic contents and biokinetic parameters for a wastewater sample (Rajor, 2004). For this purpose, some indirect estimation such as determination of biochemical oxygen demand (BOD) and chemical oxygen demand (COD) are applied as common laboratory investigations [9]. During retanning procedures, synthetic tannins (Syntan), oils and resins are added to form softer leather at varying doses (Munz et al., 2009). One of the refractory groups of chemicals in tannery effluents derives mainly from tannins (Ramasami et al., 2004). Syntans are characterized by complex chemical structures, because they are composed of an extended set of chemicals such as phenol-, naphthalene-, formaldehyde- and melamine-based syntans, and acrylic resins (Beem, 1994). Organic pollutants (proteic and lipidic components) are originated from skins (it is calculated that the raw skin has $30 \%$ loss of organic material during the working cycle) or they are introduced during processes (Hugo Springer, 1994).

Many conventional processes such as oxidation, chemical and biological processes were carried out to treat tanneries wastewater (Ebtesam et al, 2013). Biological processes have received more attention because of their costeffectiveness, lower sludge production and environmental friendliness (Noorjahan, 2014). Naturally occurring micro-organisms degrade the hazardous organic wastes including xenobiotic compounds, such as pesticides, polycyclic aromatic hydrocarbons (PAHs) and polychlorinated biphenyls (PCBs) in due course of time (Ranen and Sharadinadra, 2009). Bioremediation is based on the idea that all organisms remove substances from the environment to carry outgrowth and metabolism (Bouwer and Zehnder, 1993). Bacteria, protista and fungi are found to be very good at degrading complex molecules and incorporating the breakdown products into their metabolism (Bouwer and Zehnder, 1993). The resultant metabolic wastes that they produce are generally safe and somehow recycled into other organisms (Ranen and Sharadinadra, 2009). An acclimatized indigenous population of microorganisms capable of degradation of the compounds of interest must exist at the site for a successful bioremediation mode (Ranen and Sharadinadra, 2009). It has been observed that for a successful bioremediation mode, an acclimatized indigenous population of microorganisms capable of degradation of the compounds of interest must exist at the site under investigation (Ranen and Sharadinadra, 2009). Even though there are numerous physical and chemical methods employed in the disposal of wastes the advantage in using bacterium is that they play a key role in the reduction of COD, BOD, total protein, total tannin and total phenol (Saravanan and Saravanan, 1998)

Baba et al. (2020) studied the bioremediation potential of immobilized corynebacterium kutsceri in the Treatment of tannery industrial effluent from Challawa Industrial Estate, Kano State, Nigeria. The aim of the work is to study the reduction in the level of the contaminants through the process of bioremediation using the isolated bacteria. Immobilized bacteria can withstand various temperatures, $\mathrm{pH}$ and substrate concentrations; consequently, increasing the efficiency and the lifespan of the bacteria. Immobilized bacteria are widely applied in the treatment of wastewater and can be separated and recovered after the treatment with the same efficiency (Baba et al., 2020).

\section{MATERIALS AND METHODS \\ Study Area}

This study was carried out in Bompai, Sharada and Challawa industrial estates in Kano, Figure 1. Kano lies on Latitude $11^{\circ} 30^{\prime} \mathrm{N}$ and $8^{\circ} 30^{\prime} \mathrm{E}$ and Longitude $11^{\circ} 5^{\prime} \mathrm{N}$ and $8^{\circ} 5^{\prime} \mathrm{E}$ in Northern Nigeria. It is one of the developed industrial cities in Nigeria. Tannery activities are the dominating industries and this could be one of the reasons for her high population density (Dan'Azumi and Bichi, 2010). Many researchers have studied biodegradation of tannery effluent using microorganisms. However, limited literature is available on the biodegradation of tannery effluent in Kano industrial estates using 
BAJOPAS Volume 13 Number 2, December, 2020 immobilized bacterial cells. This research work focuses on the potential of the use of the indigenous immobilized bacterial isolates in the treatment of tannery effluents in the industrial estates.

\section{Sample Collection}

Effluents were collected from the Tannery Industries from Bompai, Challawa and Sharada Industrial Estates, Kano, Nigeria. The effluents were collected over a period of six months (August 2017 to January 2018). Samples collected in a sterile 4-liter plastic container with a unique identification number were preserved using an ice-box that was transported to the Microbiology Laboratory, Department of Microbiology, Bayero University of Kano for analysis

\section{Sample Preparation and Sample Analysis}

Immediately after the collection of the effluent, $\mathrm{pH}$, TSS, TDS, COD, BOD levels were determined before treatment (Pre-treatment determination) and ten days after treatment (Post-treatment determination) as described in
APHA (1989) standard methods. $\mathrm{pH}$ was determined using Ecotests $\mathrm{pH}$ meter and TDS was determined using AQUALYTIC TDS Salinometer. BOD was determined as described by the standard method (APHA, 1992). COD and SS were determined using DR/2010 HACH portable data logging spectrophotometer (DWAF, 1992)

\section{Identification and Biochemical} Characterization of the Bacterial Isolates

The bacteria were isolated from the effluents using Serial Dilution according to the method described by APHA (1989). The biochemical tests such as oxidase, catalase, coagulase, indole (from $1 \%$ tryptone broth), citrate (Simmons citrate agar), methyl red/VogesProskauer (MR/VP), nitrate reduction, Starch Hydrolysis, Glucose, Maltose, and Lactose tests were carried out on the bacterial isolates to identify the bacteria through the bacteria biochemical characteristics according to Ajao et al. (2011).

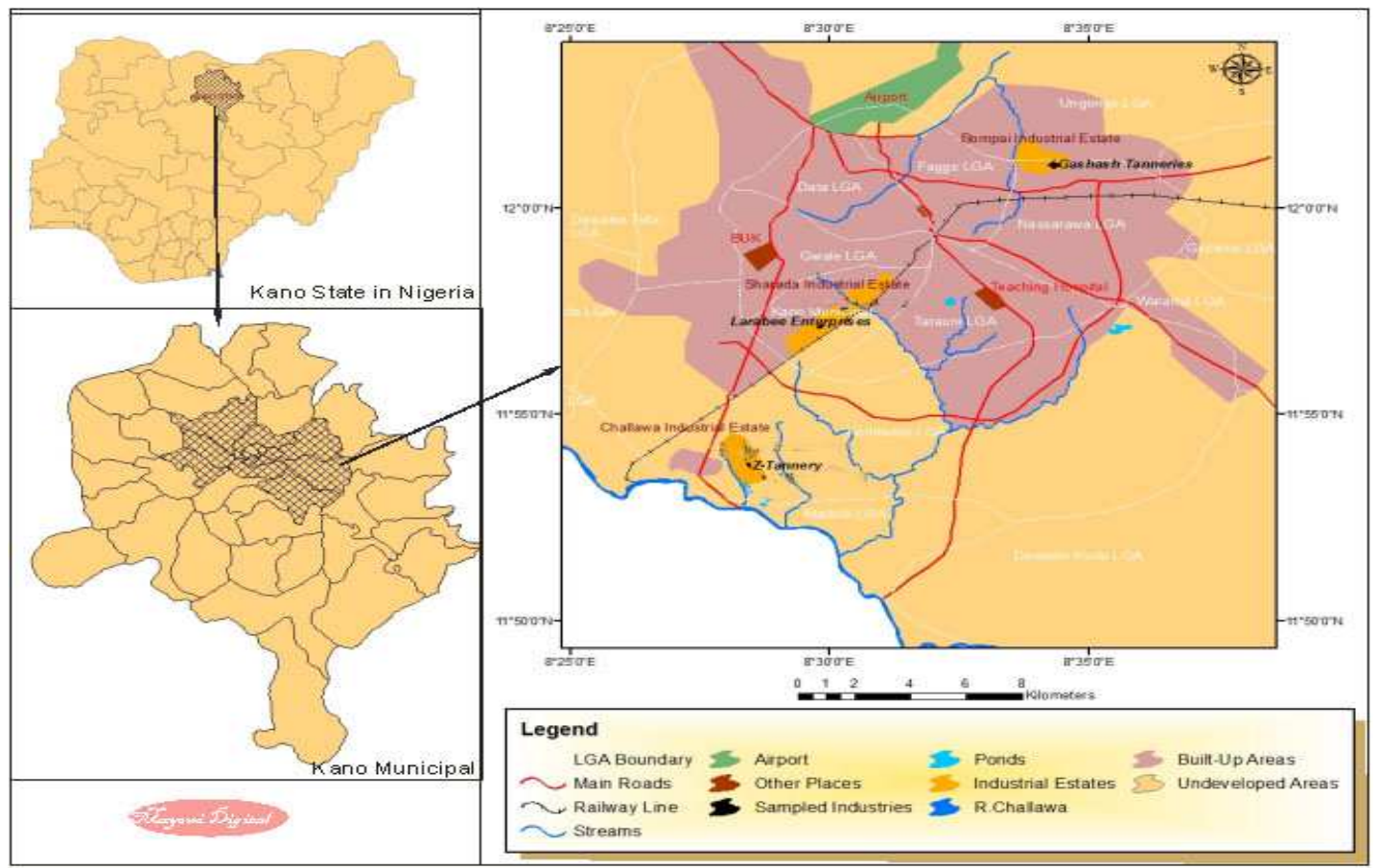

Fig. 1 Map showing the study areas

Source: Mayomi Digital Productions, GIS Laboratory, Department of Geography, UNIMAID (2017)

\section{Determination of Growth Rate of the Bacteria in Effluent Sample}

The bacteria growth rates were determined by transferring $2 \mathrm{~mL}$ of the bacterial isolates from the tannery effluent in broth medium into 100 $\mathrm{mL}$ sterile effluents in conical flasks and kept in an incubator (Giffrin cool) for 10 days. Control was also set up by incubating another $100 \mathrm{~mL}$ each of the sterile effluents without the bacteria. The optical density of the content was determined at the wavelength of $600 \mathrm{~nm}$ on a daily interval and recorded. 
BAJOPAS Volume 13 Number 2, December, 2020 Immobilization of Bacteria

Agar solution and inoculi were prepared separately. Fifty milliliters $(50 \mathrm{~mL})$ of nutrient broth each of the inoculi was prepared in a McCartney bottle and incubated for 24 hours. A solution of agar-agar was prepared by dissolving $10 \mathrm{~g}$ of the powder in distilled water and made up to $500 \mathrm{~mL}$ mark in an Erlenmeyer flask and was sterilized in an autoclave (280A) for 15 minutes and allowed to cool to $40-45^{\circ} \mathrm{C}$ (Ajao et al., 2011). Four milliliters ( $4 \mathrm{~mL})$ of the bacterial isolates in the nutrient broth was mixed with 36 $\mathrm{ml}$ of the prepared agar-agar media in petri-dish plates and then allowed to solidify. This was kept in the refrigerator for bioremediation.

\section{Bioremediation (Treatment) of the Effluents}

The solidified agar block (immobilized bacteria) was cut into cubes using a sterile knife; $0.1 \mathrm{~mL}$ phosphate buffer ( $\mathrm{pH} \mathrm{7.0)}$ was added and kept in the refrigerator for 1 hour for curing. The phosphate buffer was decanted after 1 hour and the cubes were washed with sterile distilled water 3-4 times before it was used (Ajao et al., 2011). Two liters (2 L) of the effluent was supplemented with the minimum basal medium in $\mathrm{g} / \mathrm{L}: \mathrm{NaCl}(0.8), \mathrm{MgSO}_{4} .7 \mathrm{H}_{2} \mathrm{O}(0.001), \mathrm{KH}_{2} \mathrm{PO}_{4}$ (2), $\mathrm{NaNO}_{3}$ (2), $\quad \mathrm{CaCl}_{2} .2 \mathrm{H}_{2} \mathrm{O} \quad(0.5)$ and $\mathrm{NaHPO}_{4} .12 \mathrm{H}_{2} \mathrm{O}(2)$ and sterilized in an autoclave at $121^{\circ} \mathrm{C}$ for 15 minutes (Margesin and Schinner, 2001). Two hundred and fifty milliliters $(250 \mathrm{~mL})$ of the effluents were transferred into different $250 \mathrm{ml}$ conical flasks. The content was covered with a cotton-wool ramped with foil paper to avoid contamination. Five grams $(5 \mathrm{~g})$ of the immobilized bacteria were quickly transferred into each of the effluents in the conical flasks in an inoculating chamber. The same procedures were carried out for the $10 \mathrm{~g}, 15 \mathrm{~g}, 20 \mathrm{~g}$ and 25 $\mathrm{g}$ of the immobilized bacteria in separate $250 \mathrm{~mL}$ effluents in conical flasks and agitated for ten days in a shaker incubator (Gallenkamp-OC4364-L) at a temperature $30^{\circ} \mathrm{C}$ and speed of 60 rpm. The treated effluent samples were taken on the tenth day and analyzed for the parameters $\mathrm{pH}$, SS, TDS, COD, and BOD, (Posttreatment determination) for the different grams of bacteria to evaluate and compare the biodegradation potential. (Baba et al., 2020).

\section{Statistical Analysis}

The data were represented as Mean \pm Standard deviation and analyzed statistically using oneway Analysis of Variance (ANOVA) and Tukey's HSD as Post Hoc Tests with the aid of SPSS 16.0. The correlation coefficient was also used to measure the strength of the relationship between the different masses of the bacteria and the parameters. All $\mathrm{p} \leq 0.05$ were considered as statistically significant.

\section{RESULTS AND DISCUSSION Physico-chemical parameters in the Industrial Effluents before the Biodegradation.}

Results of the Physico-chemical parameters in the industrial effluents before the Biodegradation is shown in table 1 . The mean temperatures $\left({ }^{\circ} \mathrm{C}\right)$ observed in TAN1, TAN2, and TAN3 samples were $28.07 \pm 0.65 ; 27.77 \pm 0.64$ and $26.38 \pm 3.81$ respectively. The order of the mean temperature of the samples from the three industries can be arranged as TAN1 > TAN2>TAN3. The temperature observed at TAN1, TAN2, and TAN3 samples were found below the WHO $\left(35^{\circ} \mathrm{C}\right)$ and NESREA $\left(40^{\circ} \mathrm{C}\right)$ limits. The low values of temperature might be due to the processes used at the time of sampling. High temperature brings down the solubility of gases in water that ultimately expresses as high BOD and COD. Statistical analysis shows that there is no significant difference $(p<0.05)$ between the mean values of temperature among the industries. This might be due to similar tannery activities involved in the tannery industries at the time of sampling. The average values of temperature observed in this present study are less than those observed by Akan et al. (2007), Akan et al. (2009) and Baba et al. (2020).

The mean level of $\mathrm{pH}$ observed in TAN1, TAN2 and TAN3, samples were $7.77 \pm 2.93$; $8.35 \pm 0.28$ and $7.52 \pm 0.76$ respectively. The order of the mean $\mathrm{pH}$ of the samples from the three industries can be arranged as TAN2> TAN1 $>$ TAN3. The $\mathrm{pH}$ of the samples falls within the WHO (7.0-8.5) and NESREA (6-9) standard limits. Statistical analysis shows that there is no significant difference $(p<0.05)$ between the mean values of $\mathrm{pH}$ among the industries. This might be due to similar tannery activities involved in the tannery industries at the time of sampling. Maheshwari et al. (2017) reported that the level of $\mathrm{pH}$ in the effluents from the tannery industry in Vaniyambadi, India was 6.5 which was lower than that observed in the present study. The $\mathrm{pH}$ in the effluents from the tannery industries in Kano and Kaduna were reported to be 7.64 and 6.89, respectively (Akan et al., 2007; Mohammed et al., 2017). The average values of $\mathrm{pH}$ observed in this present study are less than those observed by Mohammed et al. (2017) and Baba et al. (2020). The mean level of SS $(\mathrm{mg} / \mathrm{l})$ observed in TAN1, TAN2, and TAN3 samples were 374 \pm 124 ; $358 \pm 335$ and $780 \pm 739$ respectively. The order of the mean SS in the samples from the three industries can be arranged as TAN3 > TAN1 $>$ TAN2. 
The SS observed in the samples were far above the recommended standard limits of regulating bodies WHO $(30 \mathrm{mg} / \mathrm{l})$ and NESREA $(10 \mathrm{mg} / \mathrm{l})$. Statistical analysis shows that there is no significant difference $(p<0.05)$ between the mean values of SS among the industries. This might be due to similar tannery activities involved in the tannery industries at the time of sampling. The average values of SS observed in this present study are less than that observed $(3700 \pm 122 \mathrm{mg} / \mathrm{l})$ by Akan et al. (2009) for tanneries in Kano. Also, the average values of SS observed in this present study are less than that observed by Mohammed et al. (2017) and Baba et al. (2020) with the exception in TAN3.

The mean level of TDS (mg/l) observed in TAN1, TAN2, and TAN3 samples were $3941 \pm 3703$; $3300 \pm 1714$ and $2653 \pm 1240$ respectively. The order of the mean TDS in the samples from the three industries can be arranged as TAN1>TAN2>TAN3. The TDS observed in the samples were far above the recommended standard limits of WHO $(250 \mathrm{mg} / \mathrm{l})$ and NESREA $(500 \mathrm{mg} / \mathrm{l})$. Statistical analysis shows that there is no significant difference $(p<0.05)$ between the mean values of TDS among the industries. This might be due to similar tannery activities involved in the tannery industries at the time of sampling. TDS in the effluents from the tannery industries in Kano, Nigeria was reported to be $1281 \mathrm{mg} / \mathrm{l}$ (Akan et al., 2007). The average values of SS observed in this present study are less than those observed by Mohammed et al. (2017) and Baba et al. 2020)

The mean level of COD (mg/l) observed in TAN1, TAN2 and TAN3 samples seasons were $2372 \pm 938 ; \quad 1406 \pm 208$ and $3532 \pm 1373$ respectively. The order of the mean COD of the samples from the three industries can be arranged as TAN3>TAN1> TAN2. The COD observed in TAN1, TAN2 and TAN3 samples were far above the recommended standard limits of regulating bodies $\mathrm{WHO}(40 \mathrm{mg} / \mathrm{l})$ and NESREA (40 mg/l). Statistical analysis shows that there is no significant difference $(p<0.05)$ in COD among the industries. This might be due to similar tannery activities involved in the tannery industries as at the time of sampling. The Chemical Oxygen demand (COD) is the amount of oxygen, in $\mathrm{mg} / \mathrm{L}$, required for the degradation of the compound of wastewater to occur. In comparison, the average values of COD observed in this present study were higher than that observed by Mohammed et al. (2017) but lower than that observed by Baba et al. (2020).

The mean levels of BOD $(\mathrm{mg} / \mathrm{l})$ observed in TAN1, TAN2 and TAN3 samples were $13.85 \pm 6.42 ; \quad 19.46 \pm 0.50$ and $17.13 \pm 3.14$ respectively. The order of the mean BOD in the samples from the three industries can be arranged as TAN2>TAN3>TAN1. The BOD observed in TAN1, TAN2 and TAN3 samples were found below the recommended limits of NESREA (200 mg/l) but above WHO (10 mg/l). Statistical analysis shows that there is no significant difference $(p<0.05)$ between the mean values of BOD among the industries. This might be due to similar tannery activities involved in the tannery industries at the time of sampling. The low level of BOD recorded in this study is an indication of the low level of biodegradable organic solids in the effluent. The average values of BOD observed in this present study were lower than those observed by Mohammed et al. (2017) and Baba et al. (2020).

Table 1: Mean Values \pm S.D of Physico-chemical parameters of effluents from the Tannery Industries before Treatment.

\begin{tabular}{llllllll}
\hline Parameter & Tannery 1 & Tannery 2 & Tannery 3 & $\mathrm{a}$ & $\mathrm{b}$ & $\mathrm{c}$ & $\mathrm{d}$ \\
\cline { 2 - 7 } Temperature $\left({ }^{\circ} \mathrm{C}\right)$ & $28.07 \mathrm{a} \pm 0.65$ & $27.77 \mathrm{a} \pm 0.64$ & $26.38 \mathrm{a} \pm 3.81$ & & $29.50 \pm 4.68$ & 35 & 40 \\
pH & $7.77 \mathrm{a} \pm 2.93$ & $8.35 \mathrm{a} \pm 0.28$ & $7.52 \mathrm{a} \pm 0.76$ & 6.89 & $5.35 \pm 1.57$ & $7.0-8.5$ & $6.0-9.0$ \\
$\mathrm{COD}(\mathrm{mg} / \mathrm{l})$ & $2372 \mathrm{a} \pm 938$ & $1406 \mathrm{a} \pm 208$ & $3532 \mathrm{a} \pm 1373$ & 2.2 & $3106 \pm 2753$ & 40 & 40 \\
$\mathrm{BOD}(\mathrm{mg} / \mathrm{l})$ & $13.85 \mathrm{a} \pm 6.42$ & $19.46 \mathrm{a} \pm 0.50$ & $17.13 \mathrm{a} \pm 3.14$ & 1032 & $26.17 \pm 9.49$ & 10 & 200 \\
$\mathrm{SS}(\mathrm{mg} / \mathrm{l})$ & $374 \mathrm{a} \pm 124$ & $358 \mathrm{a} \pm 335$ & $780 \mathrm{a} \pm 739$ & 501 & $562 \pm 482$ & 30 & 10 \\
TDS $(\mathrm{mg} / \mathrm{l})$ & $3941 \mathrm{a} \pm 3703$ & $3300 \mathrm{a} \pm 1714$ & $2653 \mathrm{a} \pm 1240$ & 532.7 & $444 \pm 507$ & 250 & 500 \\
\hline
\end{tabular}

The values given in the table above are means of 6 replicate values, $\mathrm{n}=6$ ( 1 sample was taken monthly for 6 months). Within the rows, means with different alphabets are statistically different $(p<0.05)$. WHO: World Health Organisation. NESREA: National Environmental Standard and Regulatory Enforcement Agency. a = Mohammed et al.(2017), b = Baba et al. (2020), c = WHO (2006), $d=$ NESSRA (2009) 
BAJOPAS Volume 13 Number 2, December, 2020

Identification, Biochemical Characterization and growth rates of the Bacterial Isolates

Results of identification and biochemical characterization of the bacterial isolates were shown in table 2. After 24 hours of incubation, the nutrient agar media plates were checked for bacterial growth. The results showed the presence of different strains in the samples. The TAN1 bacteria isolate was found to be gramnegative cocci while TAN3 was gram-positive cocci. TAN2 bacteria isolate was found to be gram-positive, rod-shaped. TAN1, TAN2, and TAN3 bacteria isolates recorded positive results for spore former.

The results of the biochemical tests indicated that all the bacteria were positive for catalase, oxidase, citrate, maltose, glucose, lactose (negative in TAN1), mannitol (negative in TAN2), starch hydrolysis and coagulase (negative in TAN2) tests. The bacteria showed negative results for nitrate reduction, $M R$ (positive in TAN2), VP (positive in TAN1), Indole (positive in TAN2) tests. Base on the morphological and biochemical test results, TAN1, TAN2, and TAN3 bacteria isolates were identified to be Nesseria spp, Bacillus cereus, and Staphylococcus aureus respectively.

The growth rate of the TAN1, TAN2 and TAN3 Isolates were shown in figure 2. Generally, the optical density increase with the increase in time (day) and decrease as time goes on. The highest optical density was shown by bacillus cereus in TAN2 while the lowest was shown by Staphylococcus aureus in TAN3.

The initial growth phase of TAN1 Isolate bacteria occurred within 2-day of incubation as the growth rate increases up to the 6th-day incubation when the maximum growth was observed. Beyond the 6th day, the growth of the bacteria declined (which might be due to a shortage of nutrients in the effluents) until it reached its death phase (which might be due to the unavailability of nutrients in the effluents).

A similar trend of growth was also observed for TAN2 Isolate as the initial growth phase also occurred within 2-day of incubation but maximum growth rate observed on the 4th day of incubation. The stationary stage occurred between the 4th day and the 8th day. Beyond the 8th day, the growth of the bacteria declined (which might be due to a shortage of nutrients in the effluents) until it reached its death phase (which might be due to the unavailability of nutrients in the effluents).

The initial growth phase of TAN3 bacterial Isolate occurred within the 3-day incubation as the growth rate increases up to the 6th-day incubation when the maximum growth was observed. Beyond the 6th day, the growth of the bacteria declined (which might be due to a shortage of nutrients in the effluents) until it reached its death phase (which might be due to the unavailability of nutrients in the effluents).

Table 2: Morphological and Biochemical characteristics of bacterial isolates

\begin{tabular}{lllll} 
Bacterial Isolates & & TAN1 & TAN2 & TAN3 \\
\hline $\begin{array}{lllll}\text { Morphological } \\
\text { characteristics }\end{array}$ & Shape & Cocci & Rod & Cocci \\
& Spore & & & \\
& former & + & + & + \\
Gram & & & \\
Biochemical characteristics & reaction & - & + & + \\
& Citrate & + & + & + \\
& Catalase & + & + & + \\
& Coagulase & + & - & + \\
Starch & + & + & + \\
& Glucose & + & + & + \\
Oxidase & + & + & + \\
& Indo & - & + & - \\
Lactose & - & + & + \\
Manitol & + & - & + \\
Maltose & + & + & + \\
MR & - & + & - \\
VP & + & - & - \\
& Nitrate & - & - & - \\
Reduction & - Neisseria & Bacillus & Staphylococcus \\
& Bacterial & cereus & aureus \\
& name & spp & cas
\end{tabular}

+ = Positive; - = Negative; MR=Methyl Red; VP= Voges-Proskauer 


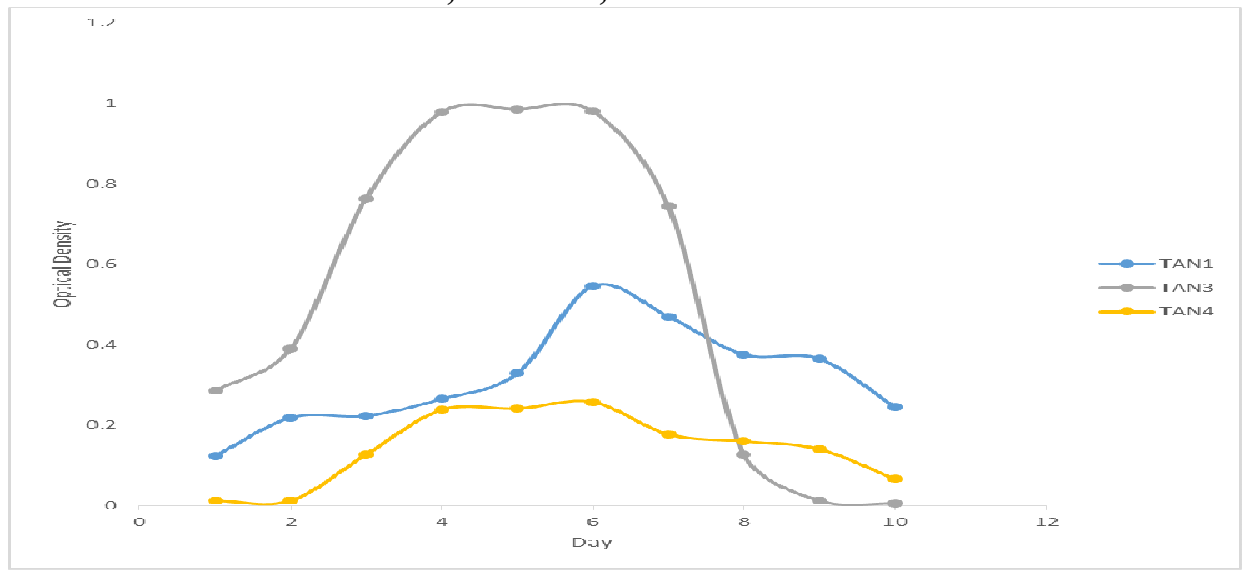

Fig. 2 Growth rates of the isolates in the effluents from the Tannery Industries

\section{Physico-chemical Parameters in the Industrial Effluents after the biodegradation.}

Table 3 shows the mean results of the physicochemical parameter before and after bioremediation using the different masses $(5 \mathrm{~g}$, $10 \mathrm{~g}, 15 \mathrm{~g}, 20 \mathrm{~g}$, and $25 \mathrm{~g}$ ) of the respective immobilized bacteria. Also, Table 4 shows the mean results of correlation coefficient ( $r$ ) between different masses of bacteria and physicochemical parameters.

The mean values $(\mathrm{mg} / \mathrm{l})$ of the SS after the bioremediation varies between $243 \pm 45$ and $898 \pm 672$. The mean concentration $(\mathrm{mg} / \mathrm{l})$ of SS remediated by the different masses $(5 \mathrm{~g}, 10 \mathrm{~g}$, $15 \mathrm{~g}, 20 \mathrm{~g}$, and $25 \mathrm{~g}$ ) of the bacteria varies. The SS in the samples fluctuates up and down after the bioremediation process when compared with the SS of the raw samples before the bioremediation. The increase in the levels of the SS might be due to the aggregation of the TDS which are large enough to result into SS. The increase in the levels of the SS might be also due to the influence of the nutrients which was added into the effluents in order to make the microorganisms more active and viable for fast degradation of organic contaminants in the effluent. The relative potential or efficiency of the different masses of the bacteria in remediating SS in TAN1 samples was in the order $25 \mathrm{~g}>20 \mathrm{~g}>15 \mathrm{~g}>10 \mathrm{~g}>5 \mathrm{~g}$. For TAN2 and TAN3 samples, the order was $25 \mathrm{~g}>20 \mathrm{~g}>15$ $\mathrm{g}>10 \mathrm{~g}>5 \mathrm{~g}$. These might be due to the variations in the surface areas of the different masses of the immobilized bacteria. Statistical analysis shows that there is no significant difference $(p<0.05)$ between the mean values of SS among the masses in the respective industries. Positive and significant correlations exist between the masses of bacteria and Suspended Solid (SS). This showed that there is general increase in the levels of the SS as the masses of the immobilized bacteria increases. TAN3 (90\%) and TAN1 (80\%) showed a very high correlation with the masses of the bacteria while TAN2 (61\%) showed a very low correlation.

The mean values $(\mathrm{mg} / \mathrm{l})$ of the TDS after the bioremediation varies between $46 \pm 11$ and $83 \pm 78$. The mean concentration $(\mathrm{mg} / \mathrm{l})$ of TDS remediated by the different masses $(5 \mathrm{~g}, 10 \mathrm{~g}$, $15 \mathrm{~g}, 20 \mathrm{~g}$, and $25 \mathrm{~g}$ ) of the bacteria varies. There is a reduction in all the TDS of all the samples after the bioremediation process compared with the TDS of the raw samples before the bioremediation. The relative potential or efficiency of the different masses of the bacteria in remediating TDS in TAN1 and TAN3 samples was in the order $5 \mathrm{~g}>10 \mathrm{~g}>15 \mathrm{~g}>20$ $\mathrm{g}>25 \mathrm{~g}$. For TAN2 samples, the order was 20 $g>10 \quad g>25 \quad g>15 \quad g>5 \quad g$. Statistical analysis shows that there is no significant difference $(p<0.05)$ between the mean values of TDS among the masses in the respective industries. These might be due to the variations in the surface areas of the different masses of the immobilized bacteria. Positive and significant correlations exist between the masses of bacteria and TDS with the exception in TAN2 (negative and insignificant correlation). The positive correlations showed that there is general increase in the levels of the TDS as the masses of the immobilized bacteria increases. TAN1 $(96 \%)$ showed a very high correlation with the masses of the bacteria while TAN2 (47\%) showed a very low correlation.

The mean values $(\mathrm{mg} / \mathrm{l})$ of the BOD after the bioremediation varies between $1.56 \pm 0.20 \mathrm{mg} / \mathrm{l}$ and $6.92 \pm 5.49 \mathrm{mg} / \mathrm{l}$. The mean concentration $(\mathrm{mg} / \mathrm{l})$ of BOD remediated by the different masses $(5 \mathrm{~g}, 10 \mathrm{~g}, 15 \mathrm{~g}, 20 \mathrm{~g}$, and $25 \mathrm{~g}$ ) of the bacteria varies. There is a reduction in all the BOD of all the samples after the bioremediation process compared with the $\mathrm{BOD}$ of the raw 
BAJOPAS Volume 13 Number 2, December, 2020 samples before the bioremediation. The relative potential or efficiency of the different masses of the bacteria in remediating BOD in TAN1, TAN2 and TAN3 samples were in the order $25 \mathrm{~g}>20$ $\mathrm{g}>15 \mathrm{~g}>10 \mathrm{~g}>5 \mathrm{~g}, 25 \mathrm{~g}>15 \mathrm{~g}>5 \mathrm{~g}>10 \mathrm{~g}>20 \mathrm{~g}$ and $20 \mathrm{~g}>10 \mathrm{~g}>25 \mathrm{~g}>15 \mathrm{~g}>5 \mathrm{~g}$ respectively. Statistical analysis shows that there is significant difference $(p<0.05)$ between the mean values of BOD among the masses in the respective industries. These might be due to the variations in the surface areas of the different masses of the immobilized bacteria. Negative and significant correlations exist between the masses of bacteria and BOD. This showed that there is general decrease in the levels of the BOD as the masses of the immobilized bacteria increases. TAN1 (94\%) showed a very high correlation with the masses of the bacteria while TAN2 (4\%) showed a very low correlation.

The mean values $(\mathrm{mg} / \mathrm{l})$ of the COD after the bioremediation varies between $250 \pm 154$ and $3134 \pm 1595$. The mean concentration $(\mathrm{mg} / \mathrm{l})$ of COD remediated by the different masses $(5 \mathrm{~g}$, $10 \mathrm{~g}, 15 \mathrm{~g} 20 \mathrm{~g}$, and $25 \mathrm{~g}$ ) of the bacteria varies. There is a reduction in all the COD of all the samples after the bioremediation process compared with the COD of the raw samples before the bioremediation. The relative potential or efficiency of the different masses of the bacteria in remediating COD in TAN1, TAN2 and TAN3 samples were in the order $25 \mathrm{~g}>20 \mathrm{~g}>15$ $\mathrm{g}>5 \mathrm{~g}>10 \mathrm{~g}, 25 \mathrm{~g}>20 \mathrm{~g}>15 \mathrm{~g}>10 \mathrm{~g}>5 \mathrm{~g}$ and 10 g>5 g>25 g>15 g>20 g respectively. Statistical analysis shows that there were significant difference $(p<0.05)$ between the mean values of COD among the masses in the respective industries except for effluents treated with $25 \mathrm{~g}$. These might be due to the variations in the surface areas of the different masses of the immobilized bacteria. Negative and insignificant correlations exist between the masses of bacteria and COD with the exception in TAN3 (positive and significant correlation). The negative correlations showed that there is general decrease in the levels of the COD as the masses of the immobilized bacteria increases. TAN2 (100\%) showed a very high correlation with the masses of the bacteria while TAN3 (36\%) showed a very low correlation.

Generally, there was an overall decrease in the concentration of these physicochemical parameters after the bioremediation using the different masses of the bacterial isolates. These might be due to the variations in the surface areas of the different masses of the immobilized bacteria. This is in line with the work of Jimoh et al. (2018) and Baba et al. (2020).

Table 3: Mean Values $(\mathrm{mg} / \mathrm{l}) \pm$ S.D of Physicochemical parameters in effluents from the Tannery Industries before and after Treatment of the effluents $(250 \mathrm{ml})$ with the different masses $(5 \mathrm{~g}, 10 \mathrm{~g}$, $15 \mathrm{~g}, 20 \mathrm{~g}$, and $25 \mathrm{~g}$ ) of the bacteria.

\begin{tabular}{llllllll}
\hline $\mathrm{P}$ & IND & Before & \multicolumn{5}{c}{ After } \\
\cline { 4 - 7 } & & & $5 \mathrm{~g}$ & $10 \mathrm{~g}$ & $15 \mathrm{~g}$ & $20 \mathrm{~g}$ & $25 \mathrm{~g}$ \\
\hline \multirow{2}{*}{ COD } & TAN1 & $2372 \pm 938$ & $1708 \mathrm{a} \pm 861$ & $2045 \mathrm{a} \pm 1205$ & $845 \mathrm{a} \pm 369$ & $300 \mathrm{a} \pm 167$ & $250 \mathrm{a} \pm 154$ \\
& TAN2 & $1406 \pm 208$ & $1195 \mathrm{a} \pm 208$ & $1125 \mathrm{a} \pm 384$ & $1055 \mathrm{a} \pm 317$ & $956 \mathrm{a} \pm 310$ & $870 \mathrm{ab} \pm 240$ \\
& TAN3 & $3532 \pm 1373$ & $2374 \mathrm{a} \pm 1344$ & $1976 \mathrm{a} \pm 1405$ & $2757 \mathrm{a} \pm 1266$ & $3134 \mathrm{a} \pm 1595$ & $2614 \mathrm{~b} \pm 1105$ \\
BOD & TAN1 & $13.85 \pm 6.42$ & $6.92 \mathrm{a} \pm 5.49$ & $6.42 \mathrm{a} \pm 5.07$ & $5.72 \mathrm{a} \pm 5.35$ & $4.62 \mathrm{a} \pm 4.37$ & $2.82 \mathrm{ab} \pm 1.26$ \\
& TAN2 & $19.46 \pm 0.50$ & $1.75 \mathrm{~b} \pm 0.22$ & $1.73 \mathrm{~b} \pm 0.18$ & $1.58 \mathrm{a} \pm 0.16$ & $1.91 \mathrm{a} \pm 0.22$ & $1.56 \mathrm{~b} \pm 0.20$ \\
& TAN3 & $17.13 \pm 3.14$ & $4.24 \mathrm{ab} \pm 0.77$ & $3.29 \mathrm{ab} \pm 0.37$ & $4.11 \mathrm{a} \pm 0.07$ & $3.23 \mathrm{a} \pm 0.91$ & $3.33 \mathrm{a} \pm 1.28$ \\
SS & TAN1 & $374 \pm 124$ & $243 \mathrm{a} \pm 45$ & $471 \mathrm{a} \pm 226$ & $475 \mathrm{a} \pm 182$ & $492 \mathrm{a} \pm 128$ & $611 \mathrm{a} \pm 217$ \\
& TAN2 & $358 \pm 335$ & $460 \mathrm{a} \pm 400$ & $543 \mathrm{a} \pm 414$ & $544 \mathrm{a} \pm 402$ & $551 \mathrm{a} \pm 414$ & $554 \mathrm{a} \pm 405$ \\
& TAN3 & $780 \pm 739$ & $586 \mathrm{a} \pm 594$ & $758 \mathrm{a} \pm 656$ & $787 \mathrm{a} \pm 676$ & $861 \mathrm{a} \pm 635$ & $898 \mathrm{a} \pm 672$ \\
TDS & TAN1 & $3941 \pm 3703$ & $51 \mathrm{a} \pm 10$ & $53 \mathrm{a} \pm 10$ & $55 \mathrm{a} \pm 15$ & $61 \mathrm{a} \pm 20$ & $63 \mathrm{a} \pm 26$ \\
& TAN2 & $3300 \pm 1714$ & $83 \mathrm{a} \pm 78$ & $47 \mathrm{a} \pm 20$ & $48 \mathrm{a} \pm 22$ & $47 \mathrm{a} \pm 17$ & $48 \mathrm{a} \pm 17$ \\
& TAN3 & $2653 \pm 1240$ & $46 \mathrm{a} \pm 11$ & $55 \mathrm{a} \pm 24$ & $55 \mathrm{a} \pm 25$ & $58 \mathrm{a} \pm 23$ & $61 \mathrm{a} \pm 28$ \\
\hline
\end{tabular}

Replicate $=6$ (months)

Within the rows, for the same parameter, means with different alphabets are statistically different $(p<0.05)$.

$\mathrm{P}=$ parameter, IND = Industries 
BAJOPAS Volume 13 Number 2, December, 2020

Table 4: Correlation coefficient $(r)$ between different masses of the bacteria and the physicochemical parameters.

\begin{tabular}{llll}
\hline Industries & Parameter & Correlation coefficient $(r)$ & $\begin{array}{l}\text { Percent dependence (rxrx100) } \\
(\%)\end{array}$ \\
\hline TAN1 & COD & -0.9 & 82 \\
& BOD & -0.97 & 94 \\
& SS & $0.90^{*}$ & 80 \\
TAN2 & TDS & $0.98^{*}$ & 96 \\
& COD & -1 & 100 \\
& BOD & -0.21 & 4 \\
& SS & $0.78^{*}$ & 61 \\
& TDS & -0.69 & 47 \\
& COD & $0.60^{*}$ & 36 \\
& BOD & -0.6 & 37 \\
& SS & $0.95^{*}$ & 90 \\
& TDS & $0.94^{*}$ & 89 \\
\hline
\end{tabular}

The correlation coefficient $(r)$ with * is statistically significant $(p<0.05)$.

Percentage reduction of the Parameters

Table 5 shows the percentage reduction of Parameters in industrial samples before and after the treatment of the effluents $(250 \mathrm{ml})$ with the different masses $(5 \mathrm{~g}, 10 \mathrm{~g}, 15 \mathrm{~g}, 20 \mathrm{~g}$, and $25 \mathrm{~g}$ ) of the Immobilized Bacteria.

In TAN1 samples, the percentage reduction (\%) of COD ranged (14-89); BOD (50-80); SS (-32$35)$ and TDS (98-99). In TAN2 samples, the percentage decrease $(\%)$ of COD ranged (15$38) ;$ BOD (90-92); SS [-28-(-55)] and TDS (9798). In TAN3 samples, the percentage decrease (\%) of COD ranged (11-44); BOD (76-81); SS (15-25) and TDS (98). The percentage increase in the levels COD, BOD and TDS might be due to the increase in the surface area of the different masses of the immobilized bacteria. However, the percentage decrease in the levels of the SS might be due to the aggregation of the TDS which are large enough to result into SS. The percentage decrease in the levels of the SS might be also due to the influence of the nutrients which was added into the effluents in order to make the microorganisms more active and viable for fast degradation of organic contaminants in the effluent. This is in line with the work of Jimoh et al. (2018) in which the concentration of the SS increase after the bioremediation of effluents.

Sreemoyee and Priti (2013) assessed and reduced several Physico-chemical parameters of dairy wastewater using Niesseria $s p$. and concluded that the species are well known to degrade organic compounds. This is in agreement with the current study in which the immobilized Niesseria $s p$ degrade the organic contaminants as indicated by the BOD, COD and TDS.

Jimoh et al. (2018) observed that TSS of the effluents was increased after treatment with immobilized bacteria and concluded that it might be due to the biostimulation method adopted for the research.

The optimum $\mathrm{pH}$ Biosorption of Chromium by Bacillus spp and Staphylococcus spp. from tannery effluent was investigated by Mythili and Karthikeyan (2011). The maximum adsorption of Chromium $(86.4 \mathrm{mg} / \mathrm{L})$ was showed by Bacillus spp and Staphylococcus spp showed $70.6 \mathrm{mg} / \mathrm{L}$ at an initial concentration of $100 \mathrm{mg} / \mathrm{L}$. In the present study, immobilised Bacillus spp and Staphylococcus spp. from the tannery industrial effluents reduced the levels of the organic pollutants with high potential as indicated by the percentage reduction of BOD, COD and TDS.

Enzymes often can work in multiple environments especially if they are immobilized. This makes the microorganisms' enzymes even more resistant to harsh environments and enables the enzymes to be recovered and recycled after they are no longer needed (Gianfreda and Rao 2004). Ramesh and Singh (1993) reported that the immobilized bacteria having more efficiency to remove the suspended particles than free cells. Using the immobilized cell is preferable due to its capability for using several times with the same efficiency, which makes it more economical. Similar work was done by Sikander et al. (2007) showing the higher reduction with permeabilized cells of Ochrobactrum intermedium strain SDCr-5. 
BAJOPAS Volume 13 Number 2, December, 2020

The results revealed the isolation and identification of isolates with the potential for the reduction of $\mathrm{Cr}$ (VI) to $\mathrm{Cr}$ (III). Results indicated that immobilized $B$. cereus could be efficiently used for the reduction of $\mathrm{Cr}$ (VI).

Table 5: Percentage reduction of the tested Parameters from the tannery industrial samples of the Immobilized Bacteria.

\begin{tabular}{lllllll}
\hline \multirow{2}{*}{ Industries } & & \multicolumn{5}{c}{ Percentage Reduction $(\%)$} \\
\cline { 3 - 7 } & & $5 \mathrm{~g}$ & $10 \mathrm{~g}$ & $15 \mathrm{~g}$ & $20 \mathrm{~g}$ & $25 \mathrm{~g}$ \\
\hline TAN1 & COD & 28 & 14 & 64 & 87 & 89 \\
& BOD & 50 & 54 & 59 & 67 & 80 \\
& SS & 35 & -26 & -27 & -32 & -63 \\
& TDS & 99 & 99 & 99 & 98 & 98 \\
TAN2 & COD & 15 & 20 & 25 & 32 & 38 \\
& BOD & 91 & 91 & 92 & 90 & 92 \\
& SS & -28 & -52 & -52 & -54 & -55 \\
& TDS & 97 & 99 & 99 & 99 & 99 \\
& COD & 33 & 44 & 22 & 11 & 26 \\
& BOD & 75 & 81 & 76 & 81 & 81 \\
& SS & 25 & 3 & -1 & -10 & -15 \\
& TDS & 98 & 98 & 98 & 98 & 98 \\
\hline
\end{tabular}

Percentage Reduction $=(B-A) / B \times 100 \%$

$A=$ Concentration of the parameter after treatment

$\mathrm{B}=$ Concentration of the parameter before treatment

$+=$ percentage decrease

- = percentage increase

In general, immobilization makes the enzyme more resistant to temperature, $\mathrm{pH}$, and substrate concentration swings giving it a longer lifetime and higher productivity per active unit (Gianfreda and Rao, 2004; FuIlbrook, 1996; Russell et al, 2003; Kandelbauer et al., 2004). Immobilized cells have been used and studied extensively for the production of useful chemicals (Ohtake and Silver, 1994), the treatment of wastewaters (Chen et al., 2003; Wang et al., 2010). Although many workers described microbial degradation of tannery effluent, limited literature is available on the bioremediation of tannery effluent using immobilized bacterial cells in the Kano Industrial Estates.

\section{CONCLUSION}

The samples contained variable levels of the physicochemical parameters. The results of the Analysis of variance revealed that, no statistical difference $(p<0.05)$ was observed for the temperature, $\mathrm{pH}, \mathrm{SS}, \mathrm{TDS}, \mathrm{BOD}$ and $\mathrm{COD}$ among the three tannery industries before the treatment. The levels of some of the parameters
(SS, TDS and COD) observed in the samples were found above the recommended limits of WHO and NESREA, which called for the treatment of the effluents before discharge into the environment. Base on the morphological and biochemical test results, TAN1, TAN2, and TAN3 bacterial isolates were identified to be Neisseria spp, Bacillus cereus, and Staphylococcus aureus respectively. The results of Post-treatment analysis showed that there is overall decrease in the levels of the parameters determined when compared with that of the pre-treatment. The overall percentage reduction of the immobilised bacteria in the treatment of the respective effluents was in the order TAN2 (72\%)>TAN1 $(70 \%)>$ TAN3 $(62 \%)$. Hence, the immobilized bacteria are having higher biodegradation potential for the treatment of the tannery effluents.

\section{Acknowledgments}

The authors wish to acknowledge the University of Maiduguri for the financial support. The authors are grateful to the Kano State Ministry of Environment for their support in obtaining the effluent samples. 


\section{REFERENCES}

Ajao, A. T., Adebayo, G. B., and Yakubu, S. E. (2011). Bioremediation of textile industrial effluent using mixed culture of Pseudomonas aeruginosa and Bacillus subtilis immobilized on agar-agar in a bioreactor. J. Microbiol. Biotech. Res, 1(3), 50-56.

Akan, J. C., Moses, E. A., Ogugbuaja, V. O., and Abah, J. (2007). Assessment of tannery industrial effluents from Kano metropolis, Kano State, Nigeria. Journal of Applied Sciences, 7(19), 2788-2793.

Akan, J. C., Ogugbuaja, V. O., Abdulrahman, F. I., and Ayodele, J. T. (2009). Pollutant levels in effluent samples from tanneries and textiles of Kano industrial areas, Nigeria. Global journal of pure and applied sciences, 15(3-4).

APHA (1989). Standard methods for Examination of Will bete and Will betewater.15 $5^{\text {th }}$ edition. Brydpass Springfield Will behington DC. pp. 164-176

APHA (1992). Standard Methods for the Examination of Water and Wastewater. Health, 69, 1116-9.

Baba, A., Garba, S. T., and Bello, H. S. (2020). Bioremediation Potential of Immobilized corynebacterium kutsceri in the Treatment of Tannery Industrial Effluent from Challawa Industrial Estate, Kano State, Nigeria. Journal of the Turkish Chemical Society Section A: Chemistry, $7(2), 335-350$.

Beem, E. I. V. (1994). reduction of solvent VOC emission. J. Oil Col. Chem. Ass, 77, 158.

Bouwer, E. J., and Zehnder, A. J. (1993). Bioremediation of organic compoundsputting microbial metabolism to work. Trends in biotechnology, 11(8), 360367.

Chen, K. C., Wu, J. Y., Liou, D. J., and Hwang, S. C. J. (2003). Decolorization of the textile dyes by newly isolated bacterial strains. Journal of Biotechnology, 101(1), 57-68.

Dan'Azumi, S., and Bichi, M. H. (2010). INDUSTRIAL POLLUTION AND HEAVY METALS PROFILE OF CHALLAWA RIVER IN KANO, NIGERIA. Journal of Applied Sciences in Environmental Sanitation, $5(1)$.

DWAF. (1992). Analytical Methods Manual, TR 151. Department of Water Affairs and Forestry, Pretoria.

El-Bestawy, E. (2013). Biological treatment of leather-tanning industrial wastewater using free living bacteria.
Elsheikh, M. A. S. (2009). Tannery wastewater pre-treatment. Water Science and Technology, 60(2), 433-440.

FuIlbrook, P. D. (1996). "Kinetics." Industrial enzymology: The application of enzymes in Industry. 2nd Ed. T. Godfrey and J Reichelt. eds.. Nature. New York.

Gianfreda, L., and Rao, M. A. (2004). Potential of extra cellular enzymes in remediation of polluted soils: a review. Enzyme and microbial technology, 35(4), 339354.

Hugo Springer. (1994). John Arthur Wilson Memorial Lecture "Treatment of Industrial Wastes of the Leather Industry - is it still a Major Problem". JALCA, 89, 153-185

Jimoh, A. A., Ganiyu, B. A., Baba, D., and Baba, A. (2018) Bioremediation Process of Effluent from Detergent and Food Industries in Jos, Nigeria: Kinetics and Thermodynamics. International Journal of Engineering Science Invention (IJESI), 762-73

Kandelbauer, A., Maute, O., Kessler, R. W., Erlacher, A., and Gübitz, G. M. (2004). Study of dye decolorization in an immobilized laccase enzyme-reactor using online spectroscopy. Biotechnology and bioengineering, 87(4), 552-563.

Kongjao, S., Damronglerd, S., and Hunsom, M. (2008). Simultaneous removal of organic and inorganic Pollutants in tannery wastewater using electrocoagulation technique. Korean Journal of chemical engineering, 25(4), 703.

Maheshwari, U. M., Aruna, S., Gomathi, M., and AbdulJaffar, A. H. (2017). Bioremediation by Free and Immobilized Bacteria Isolated from Tannery Effluent. International Journal of Research in Applied, Natural and Social Sciences. 5(7), 75-90

Margesin, R., and Schinner, F. (2001). Bioremediation (natural attenuation and biostimulation) of diesel-oilcontaminated soil in an alpine glacier skiing area. Applied and environmental microbiology, 677), 3127-3133.

Mohammed, A., Sekar, P., and George, J. (2011). Efficacy of microbes in bioremediation of tannery effluent. Inter. J. Curr. Res, 3(4), 324-326.

Mohammed, S. S. D., Orukotan, A. A., and Abdullahi, H. (2017). Physicochemical and Bacteriological Assessment of Tannery Effluent from Samaru-Zaria, 
BAJOPAS Volume 13 Number 2, December, 2020 Kaduna State, Nigeria. Journal of Applied

Sciences and Environmental Management, 21(4), 734-740.

Munz, G., De Angelis, D., Gori, R., Mori, G., Casarci, M., and Lubello, C. (2009). The role of tannins in conventional and membrane treatment of tannery wastewater. Journal of hazardous materials, 164(2-3), 733-739

Mythili, K., and Karthikeyan, B. (2011). Bioremediation of $\mathrm{Cr}$ (VI) from tannery effluent using Bacillus spp and Staphylococcus spp. International Multidisciplinary Research Journal, 1(6).

NESREA (2009). National Environmental Standards for Effluent Limitations and Regulation. 1233-1236

Noorjahan, C. M. (2014). Physicochemical characteristics, identification of bacteria and biodegradation of industrial effluent. Journal of bioremediation and Biodegradation, 5(3).

Ohtake, H. I., and Silver, A. O. (1994). Bacterial reduction of toxic chromate. Biological degradation and bioremediation of toxic chemicals, 403-415.

Omoleke, I. I. (2004). Management of environmental pollution in Ibadan, an African city: the challenges of health hazard facing government and the people. Journal of Human Ecology, 15(4), 265-275.

Rajor, A., Reddy, A.S., and Singh, B. (2004). Determination of BOD kinetic Parameters and evaluation of alternate methods, M.Sc. Thesis, Department of biotechnology \& environmental Science, Thapar Institute of Engineering and Technology, Patiala

Ramasami, T., Rajamani, S., and Rao, J. R. (1994, March). Pollution control in leather industry: Emerging technological options. In International symposium on surface and colloidal science and its relevance to soil pollution, madras.

Ramesh, J. V. S., and Singh, S. P. (1993). Yearly variation in certain physicochemical parameters of pond at eastern Doon Valley. Uttar Pradesh J. Zoo, 12 (1), 7577.

Ranen, S., and Sharadinadra, C. (2009). Biotechnology applications to environmental remediation in resource exploitation. Current science, 97, 6-25
Russell, A. J., Berberich, J. A., Drevon, G. F., and Koepsel, R. R. (2003). Biomaterials for mediation of

chemical and biological warfare agents. Annual review of biomedical engineering, 5(1), 1-27.

Saravanan, P., and Saravanan, A. (1999). Decolourization of tannery effluent by Flavobacterium sp. EK 1. Indian Journal of Environmental Protection, 19, 19-24.

Sikander, S., and Shahida, H. (2007). Reduction of toxic hexavalent chromium by Ochrobactrum intermedium strain SDCr5 stimulated by heavy metals. Bioresource Technol, 98, 340-344.

Singh, N., Sharma, B. K., and Bohra, P. C. (2000). Impact assessment of industrial effluent of arid soils by using satellite imageries. Journal of the Indian Society of Remote Sensing, 28(2-3), 79.

Sreemoyee, C., and Priti, P. (2013). Assessment of physico-chemical parameters of dairy waste water and isolation and characterization of bacterial strains in terms of cod reduction. Int J Sci, 2(3), 395-400.

Verheijen, L. A. H. M., Wiersema, D., Pol, L. H., and De Wit, J. (1996). Management of wastes from animal product processing. Livestock and environment, Finding a balance. International Agriculture Center, Wageningen, The Netherlands.

Wang, F., Yao, J., Si, Y., Chen, H., Russel, M., Chen, K., and Bramanti, E. (2010). Short-time effect of heavy metals upon microbial community activity. Journal of Hazardous Materials, 173(13), 510-516.

WHO (World Health Organization). (2006). Air quality guidelines: global update 2005: particulate matter, ozone, nitrogen dioxide, and sulfur dioxide. World Health Organization.

World Bank. (1995). Nigeria's strategic options for redressing industrial pollution. World Bank, industry and energy division. 1st edition, West Central Africa Department; Annexes: 1995; pp 60-62.

Zahoor, A., and Abdul, R. (2009). Enumeration of Coliforms. Journal of Environmental Sciences. 21, 814-820 


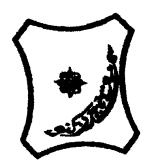

Bayero Journal of Pure and Applied Sciences, 13(2): 1 - 12

Received: November, 2020

Accepted: December, 2020

ISSN $2006-6996$

\title{
BIODEGRADATION POTENTIAL OF IMMOBILIZED BACTERIA IN THE TREATMENT OF TANNERY INDUSTRIAL EFFLUENTS FROM INDUSTRIAL ESTATES IN KANO STATE, NIGERIA
}

\author{
Abdullateef, B., ${ }^{1 *}$ Shuaibu, T. G., ${ }^{1}$ Babagana, K., ${ }^{1}$ Suleman, H. B. ${ }^{2}$ and Dauda, B. ${ }^{3}$ \\ ${ }^{1}$ Department of Pure and Applied Chemistry, Faculty of Science, University of Maiduguri, Borno State, \\ Nigeria \\ ${ }^{2}$ Department of Microbiology, Faculty of Science, University of Maiduguri, Borno State, Nigeria \\ ${ }^{3}$ Department of Chemical Engineering, Faculty of Engineering, University of Maiduguri, Borno State, \\ Nigeria \\ *Corresponding author: babslega@gmail.com; abelega2007@yahoo.com; +2348061309753
}

\section{ABSTRACT}

Industrial Effluents Samples from Gashash Tanneries (TAN1) in Bompai Industrial estate, Larabee Tannery Industry (TAN2) in Sharada Industrial estate and Z Tannery Industries (TAN3) in Challawa Industrial estate, Kano State, Nigeria were collected over a period of six months (August 2017 to January 2018) for assessing the biodegradation potentials of bacteria in the treatment of organic pollutants within the effluents. Bacteria were isolated from the effluents and immobilized on agar-agar. Different masses (5 g, $10 \mathrm{gr}, 15$ $\mathrm{g}, 20 \mathrm{~g}$, and $25 \mathrm{~g}$ ) of the bacteria were used in the treatment of $250 \mathrm{ml}$ of the effluents for ten days in a shaker incubator (Gallenkamp-OC-4364-L) at the temperature $30{ }^{\circ} \mathrm{C}$ and speed of $60 \mathrm{rpm}$. Pre-treatment analysis of the effluents for Temperature, pH, Biochemical Oxygen Demand (BOD), Chemical Oxygen Demand (COD), Suspended Solid (SS) and Total Dissolved Solids (TDS) gives the following results; temperature $\left({ }^{\circ} \mathrm{C}\right.$ )

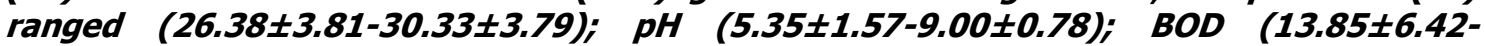
$38.75 \pm 16.20) ;$ COD (1406 $\pm 208-3532 \pm 1373) ;$ SS (208 $\pm 235-780 \pm 739)$ and TDS (266 $\pm 253-5276 \pm 2971)$. No statistical differences ( $p \leq 0.05)$ was observed for all the results among the different industries. The bacterial isolates were identified as Neisseria spp, Bacillus cereus, and Staphylococcus aureus, in TAN1, TAN2, and TAN3, respectively. After treatment of the effluent with the different masses of the isolated bacteria, the mean level of BOD was found to range as (0.55 $\pm 0.36-6.92 \pm 5.49) ; C O D$ (ND-3134 \pm 1595$)$;

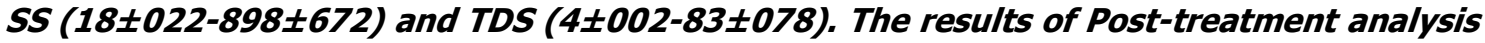
showed that there is overall decrease in the levels of the parameters determined when compared with that of the pre-treatment. The overall percentage reduction of the immobilised bacteria in the treatment of the respective effluents was in the order TAN2 (72\%)>TAN1 (70\%)>TAN3 (62\%). Hence, the immobilized bacteria are having higher biodegradation potential for the treatment of the tannery effluents.

Keywords: Biodegradation, bacteria, effluent, immobilization, tannery.

\section{INTRODUCTION}

Tannery industrial wastewater is a serious consequence of the pollution point of view for streams, freshwater, and land used for agriculture. The lack of awareness in the modern industrial practice has resulted in the discharge of tannery effluents which exhibit very high value of chromium ( $\mathrm{Cr}$ ), Sulfide, and chloride, Total Dissolved Solid (TDS), Total Suspended Solid (TSS), Biochemical Oxygen Demand (BOD) and Chemical Oxygen Demand (COD) in the water stream or land (Mohammed et al., 2001). Tanning is the process, which One ton of skin generally leads to the production of 20 to $80 \mathrm{~m}^{3}$ of turbid and foul-smelling converts the protein of the rawhide or skin into a stable material, which will not putrefy and is suitable for a wide variety of end applications (Elsheikh, 2009). The highly polluting chromium is the most commonly used tanning material producing leather that is more flexible and pliable than vegetable-tanned leather and does not discolor or lose shape in water as drastically as vegetable-tan (Elsheikh, 2009). Tannery effluent is among the most hazardous industrial pollutants due to its huge organic and inorganic load, which is highly toxic to human life and the environment (Kongjao et al., 2008). wastewater including chromium (100-400 mg/l), sulfide $(200-800 \mathrm{mg} / \mathrm{l})$, high levels of fat and 
BAJOPAS Volume 13 Number 2, December, 2020 other solid wastes, and notable pathogen contamination as well as pesticides added for skin conservation during transport (Elsheikh, 2009). There are more than 6000 tanneries in Nigeria with an annual processing capacity of 700,000 tons of hides and skins (Omoleke, 2004; Singh et al., 2008). It was reported that the total amount of waste produced per animal slaughtered is approximately $35 \%$ of its weight (World Bank, 1995). Also, for every $1000 \mathrm{~kg}$ of carcass weight, a slaughtered beef produces 5.5 $\mathrm{kg}$ of manure (excluding rumen contents or stockyard manure) and $100 \mathrm{~kg}$ of paunch manure (undigested food) (Verheijen et al., 1996). Tanneries generate wastewater in the range of 30-35 $\mathrm{L} \mathrm{kg}^{-1}$ skin/hide processed with variable $\mathrm{pH}$, Biological Oxygen Demand (BOD), Chemical Oxygen Demand (COD), high concentrations of suspended solids (SS), and tannins as well as chromium (Zahoor and Abdul, 2009).

Being heterogeneous and composed of a wide variety of compounds, it is very difficult to select a unique direct method for estimating the biodegradability of organic contents and biokinetic parameters for a wastewater sample (Rajor, 2004). For this purpose, some indirect estimation such as determination of biochemical oxygen demand (BOD) and chemical oxygen demand (COD) are applied as common laboratory investigations [9]. During retanning procedures, synthetic tannins (Syntan), oils and resins are added to form softer leather at varying doses (Munz et al., 2009). One of the refractory groups of chemicals in tannery effluents derives mainly from tannins (Ramasami et al., 2004). Syntans are characterized by complex chemical structures, because they are composed of an extended set of chemicals such as phenol-, naphthalene-, formaldehyde- and melamine-based syntans, and acrylic resins (Beem, 1994). Organic pollutants (proteic and lipidic components) are originated from skins (it is calculated that the raw skin has $30 \%$ loss of organic material during the working cycle) or they are introduced during processes (Hugo Springer, 1994).

Many conventional processes such as oxidation, chemical and biological processes were carried out to treat tanneries wastewater (Ebtesam et al, 2013). Biological processes have received more attention because of their costeffectiveness, lower sludge production and environmental friendliness (Noorjahan, 2014). Naturally occurring micro-organisms degrade the hazardous organic wastes including xenobiotic compounds, such as pesticides, polycyclic aromatic hydrocarbons (PAHs) and polychlorinated biphenyls (PCBs) in due course of time (Ranen and Sharadinadra, 2009). Bioremediation is based on the idea that all organisms remove substances from the environment to carry outgrowth and metabolism (Bouwer and Zehnder, 1993). Bacteria, protista and fungi are found to be very good at degrading complex molecules and incorporating the breakdown products into their metabolism (Bouwer and Zehnder, 1993). The resultant metabolic wastes that they produce are generally safe and somehow recycled into other organisms (Ranen and Sharadinadra, 2009). An acclimatized indigenous population of microorganisms capable of degradation of the compounds of interest must exist at the site for a successful bioremediation mode (Ranen and Sharadinadra, 2009). It has been observed that for a successful bioremediation mode, an acclimatized indigenous population of microorganisms capable of degradation of the compounds of interest must exist at the site under investigation (Ranen and Sharadinadra, 2009). Even though there are numerous physical and chemical methods employed in the disposal of wastes the advantage in using bacterium is that they play a key role in the reduction of COD, BOD, total protein, total tannin and total phenol (Saravanan and Saravanan, 1998)

Baba et al. (2020) studied the bioremediation potential of immobilized corynebacterium kutsceri in the Treatment of tannery industrial effluent from Challawa Industrial Estate, Kano State, Nigeria. The aim of the work is to study the reduction in the level of the contaminants through the process of bioremediation using the isolated bacteria. Immobilized bacteria can withstand various temperatures, $\mathrm{pH}$ and substrate concentrations; consequently, increasing the efficiency and the lifespan of the bacteria. Immobilized bacteria are widely applied in the treatment of wastewater and can be separated and recovered after the treatment with the same efficiency (Baba et al., 2020).

\section{MATERIALS AND METHODS \\ Study Area}

This study was carried out in Bompai, Sharada and Challawa industrial estates in Kano, Figure 1. Kano lies on Latitude $11^{\circ} 30^{\prime} \mathrm{N}$ and $8^{\circ} 30^{\prime} \mathrm{E}$ and Longitude $11^{\circ} 5^{\prime} \mathrm{N}$ and $8^{\circ} 5^{\prime} \mathrm{E}$ in Northern Nigeria. It is one of the developed industrial cities in Nigeria. Tannery activities are the dominating industries and this could be one of the reasons for her high population density (Dan'Azumi and Bichi, 2010). Many researchers have studied biodegradation of tannery effluent using microorganisms. However, limited literature is available on the biodegradation of tannery effluent in Kano industrial estates using 
BAJOPAS Volume 13 Number 2, December, 2020 immobilized bacterial cells. This research work focuses on the potential of the use of the indigenous immobilized bacterial isolates in the treatment of tannery effluents in the industrial estates.

\section{Sample Collection}

Effluents were collected from the Tannery Industries from Bompai, Challawa and Sharada Industrial Estates, Kano, Nigeria. The effluents were collected over a period of six months (August 2017 to January 2018). Samples collected in a sterile 4-liter plastic container with a unique identification number were preserved using an ice-box that was transported to the Microbiology Laboratory, Department of Microbiology, Bayero University of Kano for analysis

\section{Sample Preparation and Sample Analysis}

Immediately after the collection of the effluent, $\mathrm{pH}$, TSS, TDS, COD, BOD levels were determined before treatment (Pre-treatment determination) and ten days after treatment (Post-treatment determination) as described in
APHA (1989) standard methods. $\mathrm{pH}$ was determined using Ecotests $\mathrm{pH}$ meter and TDS was determined using AQUALYTIC TDS Salinometer. BOD was determined as described by the standard method (APHA, 1992). COD and SS were determined using DR/2010 HACH portable data logging spectrophotometer (DWAF, 1992)

\section{Identification and Biochemical} Characterization of the Bacterial Isolates

The bacteria were isolated from the effluents using Serial Dilution according to the method described by APHA (1989). The biochemical tests such as oxidase, catalase, coagulase, indole (from $1 \%$ tryptone broth), citrate (Simmons citrate agar), methyl red/VogesProskauer (MR/VP), nitrate reduction, Starch Hydrolysis, Glucose, Maltose, and Lactose tests were carried out on the bacterial isolates to identify the bacteria through the bacteria biochemical characteristics according to Ajao et al. (2011).

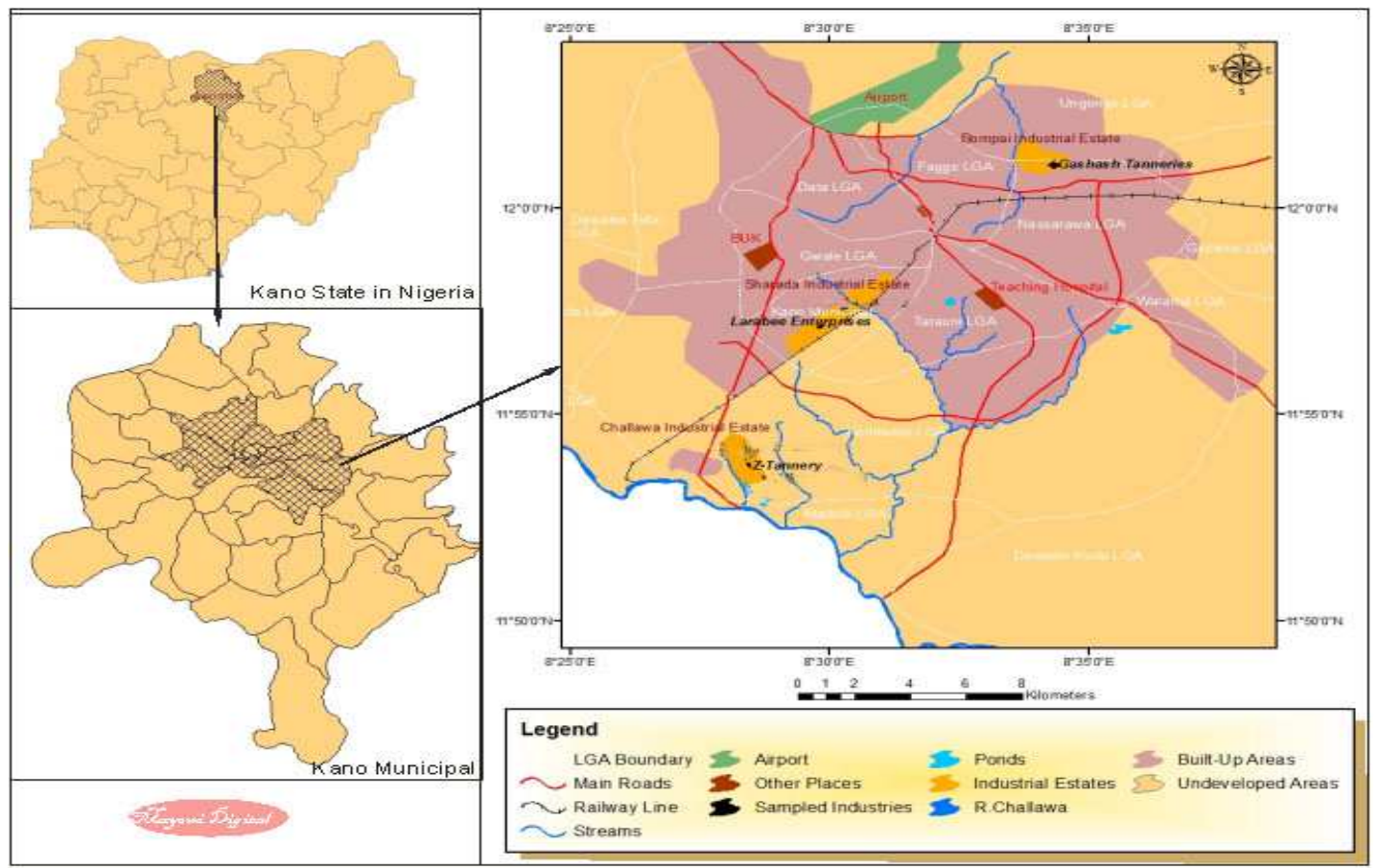

Fig. 1 Map showing the study areas

Source: Mayomi Digital Productions, GIS Laboratory, Department of Geography, UNIMAID (2017)

\section{Determination of Growth Rate of the Bacteria in Effluent Sample}

The bacteria growth rates were determined by transferring $2 \mathrm{~mL}$ of the bacterial isolates from the tannery effluent in broth medium into 100 $\mathrm{mL}$ sterile effluents in conical flasks and kept in an incubator (Giffrin cool) for 10 days. Control was also set up by incubating another $100 \mathrm{~mL}$ each of the sterile effluents without the bacteria. The optical density of the content was determined at the wavelength of $600 \mathrm{~nm}$ on a daily interval and recorded. 
BAJOPAS Volume 13 Number 2, December, 2020 Immobilization of Bacteria

Agar solution and inoculi were prepared separately. Fifty milliliters $(50 \mathrm{~mL})$ of nutrient broth each of the inoculi was prepared in a McCartney bottle and incubated for 24 hours. A solution of agar-agar was prepared by dissolving $10 \mathrm{~g}$ of the powder in distilled water and made up to $500 \mathrm{~mL}$ mark in an Erlenmeyer flask and was sterilized in an autoclave (280A) for 15 minutes and allowed to cool to $40-45^{\circ} \mathrm{C}$ (Ajao et al., 2011). Four milliliters ( $4 \mathrm{~mL})$ of the bacterial isolates in the nutrient broth was mixed with 36 $\mathrm{ml}$ of the prepared agar-agar media in petri-dish plates and then allowed to solidify. This was kept in the refrigerator for bioremediation.

\section{Bioremediation (Treatment) of the Effluents}

The solidified agar block (immobilized bacteria) was cut into cubes using a sterile knife; $0.1 \mathrm{~mL}$ phosphate buffer ( $\mathrm{pH} \mathrm{7.0)}$ was added and kept in the refrigerator for 1 hour for curing. The phosphate buffer was decanted after 1 hour and the cubes were washed with sterile distilled water 3-4 times before it was used (Ajao et al., 2011). Two liters (2 L) of the effluent was supplemented with the minimum basal medium in $\mathrm{g} / \mathrm{L}: \mathrm{NaCl}(0.8), \mathrm{MgSO}_{4} .7 \mathrm{H}_{2} \mathrm{O}(0.001), \mathrm{KH}_{2} \mathrm{PO}_{4}$ (2), $\mathrm{NaNO}_{3}$ (2), $\quad \mathrm{CaCl}_{2} .2 \mathrm{H}_{2} \mathrm{O} \quad(0.5)$ and $\mathrm{NaHPO}_{4} .12 \mathrm{H}_{2} \mathrm{O}(2)$ and sterilized in an autoclave at $121^{\circ} \mathrm{C}$ for 15 minutes (Margesin and Schinner, 2001). Two hundred and fifty milliliters $(250 \mathrm{~mL})$ of the effluents were transferred into different $250 \mathrm{ml}$ conical flasks. The content was covered with a cotton-wool ramped with foil paper to avoid contamination. Five grams $(5 \mathrm{~g})$ of the immobilized bacteria were quickly transferred into each of the effluents in the conical flasks in an inoculating chamber. The same procedures were carried out for the $10 \mathrm{~g}, 15 \mathrm{~g}, 20 \mathrm{~g}$ and 25 $\mathrm{g}$ of the immobilized bacteria in separate $250 \mathrm{~mL}$ effluents in conical flasks and agitated for ten days in a shaker incubator (Gallenkamp-OC4364-L) at a temperature $30^{\circ} \mathrm{C}$ and speed of 60 rpm. The treated effluent samples were taken on the tenth day and analyzed for the parameters $\mathrm{pH}$, SS, TDS, COD, and BOD, (Posttreatment determination) for the different grams of bacteria to evaluate and compare the biodegradation potential. (Baba et al., 2020).

\section{Statistical Analysis}

The data were represented as Mean \pm Standard deviation and analyzed statistically using oneway Analysis of Variance (ANOVA) and Tukey's HSD as Post Hoc Tests with the aid of SPSS 16.0. The correlation coefficient was also used to measure the strength of the relationship between the different masses of the bacteria and the parameters. All $\mathrm{p} \leq 0.05$ were considered as statistically significant.

\section{RESULTS AND DISCUSSION Physico-chemical parameters in the Industrial Effluents before the Biodegradation.}

Results of the Physico-chemical parameters in the industrial effluents before the Biodegradation is shown in table 1 . The mean temperatures $\left({ }^{\circ} \mathrm{C}\right)$ observed in TAN1, TAN2, and TAN3 samples were $28.07 \pm 0.65 ; 27.77 \pm 0.64$ and $26.38 \pm 3.81$ respectively. The order of the mean temperature of the samples from the three industries can be arranged as TAN1 > TAN2>TAN3. The temperature observed at TAN1, TAN2, and TAN3 samples were found below the WHO $\left(35^{\circ} \mathrm{C}\right)$ and NESREA $\left(40^{\circ} \mathrm{C}\right)$ limits. The low values of temperature might be due to the processes used at the time of sampling. High temperature brings down the solubility of gases in water that ultimately expresses as high BOD and COD. Statistical analysis shows that there is no significant difference $(p<0.05)$ between the mean values of temperature among the industries. This might be due to similar tannery activities involved in the tannery industries at the time of sampling. The average values of temperature observed in this present study are less than those observed by Akan et al. (2007), Akan et al. (2009) and Baba et al. (2020).

The mean level of $\mathrm{pH}$ observed in TAN1, TAN2 and TAN3, samples were $7.77 \pm 2.93$; $8.35 \pm 0.28$ and $7.52 \pm 0.76$ respectively. The order of the mean $\mathrm{pH}$ of the samples from the three industries can be arranged as TAN2> TAN1 $>$ TAN3. The $\mathrm{pH}$ of the samples falls within the WHO (7.0-8.5) and NESREA (6-9) standard limits. Statistical analysis shows that there is no significant difference $(p<0.05)$ between the mean values of $\mathrm{pH}$ among the industries. This might be due to similar tannery activities involved in the tannery industries at the time of sampling. Maheshwari et al. (2017) reported that the level of $\mathrm{pH}$ in the effluents from the tannery industry in Vaniyambadi, India was 6.5 which was lower than that observed in the present study. The $\mathrm{pH}$ in the effluents from the tannery industries in Kano and Kaduna were reported to be 7.64 and 6.89, respectively (Akan et al., 2007; Mohammed et al., 2017). The average values of $\mathrm{pH}$ observed in this present study are less than those observed by Mohammed et al. (2017) and Baba et al. (2020). The mean level of SS $(\mathrm{mg} / \mathrm{l})$ observed in TAN1, TAN2, and TAN3 samples were 374 \pm 124 ; $358 \pm 335$ and $780 \pm 739$ respectively. The order of the mean SS in the samples from the three industries can be arranged as TAN3 > TAN1 $>$ TAN2. 
The SS observed in the samples were far above the recommended standard limits of regulating bodies WHO $(30 \mathrm{mg} / \mathrm{l})$ and NESREA $(10 \mathrm{mg} / \mathrm{l})$. Statistical analysis shows that there is no significant difference $(p<0.05)$ between the mean values of SS among the industries. This might be due to similar tannery activities involved in the tannery industries at the time of sampling. The average values of SS observed in this present study are less than that observed $(3700 \pm 122 \mathrm{mg} / \mathrm{l})$ by Akan et al. (2009) for tanneries in Kano. Also, the average values of SS observed in this present study are less than that observed by Mohammed et al. (2017) and Baba et al. (2020) with the exception in TAN3.

The mean level of TDS (mg/l) observed in TAN1, TAN2, and TAN3 samples were $3941 \pm 3703$; $3300 \pm 1714$ and $2653 \pm 1240$ respectively. The order of the mean TDS in the samples from the three industries can be arranged as TAN1>TAN2>TAN3. The TDS observed in the samples were far above the recommended standard limits of WHO $(250 \mathrm{mg} / \mathrm{l})$ and NESREA $(500 \mathrm{mg} / \mathrm{l})$. Statistical analysis shows that there is no significant difference $(p<0.05)$ between the mean values of TDS among the industries. This might be due to similar tannery activities involved in the tannery industries at the time of sampling. TDS in the effluents from the tannery industries in Kano, Nigeria was reported to be $1281 \mathrm{mg} / \mathrm{l}$ (Akan et al., 2007). The average values of SS observed in this present study are less than those observed by Mohammed et al. (2017) and Baba et al. 2020)

The mean level of COD (mg/l) observed in TAN1, TAN2 and TAN3 samples seasons were $2372 \pm 938 ; \quad 1406 \pm 208$ and $3532 \pm 1373$ respectively. The order of the mean COD of the samples from the three industries can be arranged as TAN3>TAN1> TAN2. The COD observed in TAN1, TAN2 and TAN3 samples were far above the recommended standard limits of regulating bodies $\mathrm{WHO}(40 \mathrm{mg} / \mathrm{l})$ and NESREA (40 mg/l). Statistical analysis shows that there is no significant difference $(p<0.05)$ in COD among the industries. This might be due to similar tannery activities involved in the tannery industries as at the time of sampling. The Chemical Oxygen demand (COD) is the amount of oxygen, in $\mathrm{mg} / \mathrm{L}$, required for the degradation of the compound of wastewater to occur. In comparison, the average values of COD observed in this present study were higher than that observed by Mohammed et al. (2017) but lower than that observed by Baba et al. (2020).

The mean levels of BOD $(\mathrm{mg} / \mathrm{l})$ observed in TAN1, TAN2 and TAN3 samples were $13.85 \pm 6.42 ; \quad 19.46 \pm 0.50$ and $17.13 \pm 3.14$ respectively. The order of the mean BOD in the samples from the three industries can be arranged as TAN2>TAN3>TAN1. The BOD observed in TAN1, TAN2 and TAN3 samples were found below the recommended limits of NESREA (200 mg/l) but above WHO (10 mg/l). Statistical analysis shows that there is no significant difference $(p<0.05)$ between the mean values of BOD among the industries. This might be due to similar tannery activities involved in the tannery industries at the time of sampling. The low level of BOD recorded in this study is an indication of the low level of biodegradable organic solids in the effluent. The average values of BOD observed in this present study were lower than those observed by Mohammed et al. (2017) and Baba et al. (2020).

Table 1: Mean Values \pm S.D of Physico-chemical parameters of effluents from the Tannery Industries before Treatment.

\begin{tabular}{llllllll}
\hline Parameter & Tannery 1 & Tannery 2 & Tannery 3 & $\mathrm{a}$ & $\mathrm{b}$ & $\mathrm{c}$ & $\mathrm{d}$ \\
\cline { 2 - 7 } Temperature $\left({ }^{\circ} \mathrm{C}\right)$ & $28.07 \mathrm{a} \pm 0.65$ & $27.77 \mathrm{a} \pm 0.64$ & $26.38 \mathrm{a} \pm 3.81$ & & $29.50 \pm 4.68$ & 35 & 40 \\
pH & $7.77 \mathrm{a} \pm 2.93$ & $8.35 \mathrm{a} \pm 0.28$ & $7.52 \mathrm{a} \pm 0.76$ & 6.89 & $5.35 \pm 1.57$ & $7.0-8.5$ & $6.0-9.0$ \\
$\mathrm{COD}(\mathrm{mg} / \mathrm{l})$ & $2372 \mathrm{a} \pm 938$ & $1406 \mathrm{a} \pm 208$ & $3532 \mathrm{a} \pm 1373$ & 2.2 & $3106 \pm 2753$ & 40 & 40 \\
$\mathrm{BOD}(\mathrm{mg} / \mathrm{l})$ & $13.85 \mathrm{a} \pm 6.42$ & $19.46 \mathrm{a} \pm 0.50$ & $17.13 \mathrm{a} \pm 3.14$ & 1032 & $26.17 \pm 9.49$ & 10 & 200 \\
$\mathrm{SS}(\mathrm{mg} / \mathrm{l})$ & $374 \mathrm{a} \pm 124$ & $358 \mathrm{a} \pm 335$ & $780 \mathrm{a} \pm 739$ & 501 & $562 \pm 482$ & 30 & 10 \\
TDS $(\mathrm{mg} / \mathrm{l})$ & $3941 \mathrm{a} \pm 3703$ & $3300 \mathrm{a} \pm 1714$ & $2653 \mathrm{a} \pm 1240$ & 532.7 & $444 \pm 507$ & 250 & 500 \\
\hline
\end{tabular}

The values given in the table above are means of 6 replicate values, $\mathrm{n}=6$ ( 1 sample was taken monthly for 6 months). Within the rows, means with different alphabets are statistically different $(p<0.05)$. WHO: World Health Organisation. NESREA: National Environmental Standard and Regulatory Enforcement Agency. a = Mohammed et al.(2017), b = Baba et al. (2020), c = WHO (2006), $d=$ NESSRA (2009) 
BAJOPAS Volume 13 Number 2, December, 2020

Identification, Biochemical Characterization and growth rates of the Bacterial Isolates

Results of identification and biochemical characterization of the bacterial isolates were shown in table 2. After 24 hours of incubation, the nutrient agar media plates were checked for bacterial growth. The results showed the presence of different strains in the samples. The TAN1 bacteria isolate was found to be gramnegative cocci while TAN3 was gram-positive cocci. TAN2 bacteria isolate was found to be gram-positive, rod-shaped. TAN1, TAN2, and TAN3 bacteria isolates recorded positive results for spore former.

The results of the biochemical tests indicated that all the bacteria were positive for catalase, oxidase, citrate, maltose, glucose, lactose (negative in TAN1), mannitol (negative in TAN2), starch hydrolysis and coagulase (negative in TAN2) tests. The bacteria showed negative results for nitrate reduction, $M R$ (positive in TAN2), VP (positive in TAN1), Indole (positive in TAN2) tests. Base on the morphological and biochemical test results, TAN1, TAN2, and TAN3 bacteria isolates were identified to be Nesseria spp, Bacillus cereus, and Staphylococcus aureus respectively.

The growth rate of the TAN1, TAN2 and TAN3 Isolates were shown in figure 2. Generally, the optical density increase with the increase in time (day) and decrease as time goes on. The highest optical density was shown by bacillus cereus in TAN2 while the lowest was shown by Staphylococcus aureus in TAN3.

The initial growth phase of TAN1 Isolate bacteria occurred within 2-day of incubation as the growth rate increases up to the 6th-day incubation when the maximum growth was observed. Beyond the 6th day, the growth of the bacteria declined (which might be due to a shortage of nutrients in the effluents) until it reached its death phase (which might be due to the unavailability of nutrients in the effluents).

A similar trend of growth was also observed for TAN2 Isolate as the initial growth phase also occurred within 2-day of incubation but maximum growth rate observed on the 4th day of incubation. The stationary stage occurred between the 4th day and the 8th day. Beyond the 8th day, the growth of the bacteria declined (which might be due to a shortage of nutrients in the effluents) until it reached its death phase (which might be due to the unavailability of nutrients in the effluents).

The initial growth phase of TAN3 bacterial Isolate occurred within the 3-day incubation as the growth rate increases up to the 6th-day incubation when the maximum growth was observed. Beyond the 6th day, the growth of the bacteria declined (which might be due to a shortage of nutrients in the effluents) until it reached its death phase (which might be due to the unavailability of nutrients in the effluents).

Table 2: Morphological and Biochemical characteristics of bacterial isolates

\begin{tabular}{lllll} 
Bacterial Isolates & & TAN1 & TAN2 & TAN3 \\
\hline $\begin{array}{lllll}\text { Morphological } \\
\text { characteristics }\end{array}$ & Shape & Cocci & Rod & Cocci \\
& Spore & & & \\
& former & + & + & + \\
Gram & & & \\
Biochemical characteristics & reaction & - & + & + \\
& Citrate & + & + & + \\
& Catalase & + & + & + \\
& Coagulase & + & - & + \\
Starch & + & + & + \\
& Glucose & + & + & + \\
Oxidase & + & + & + \\
& Indo & - & + & - \\
Lactose & - & + & + \\
Manitol & + & - & + \\
Maltose & + & + & + \\
MR & - & + & - \\
VP & + & - & - \\
& Nitrate & - & - & - \\
Reduction & - Neisseria & Bacillus & Staphylococcus \\
& Bacterial & cereus & aureus \\
& name & spp & cas
\end{tabular}

+ = Positive; - = Negative; MR=Methyl Red; VP= Voges-Proskauer 


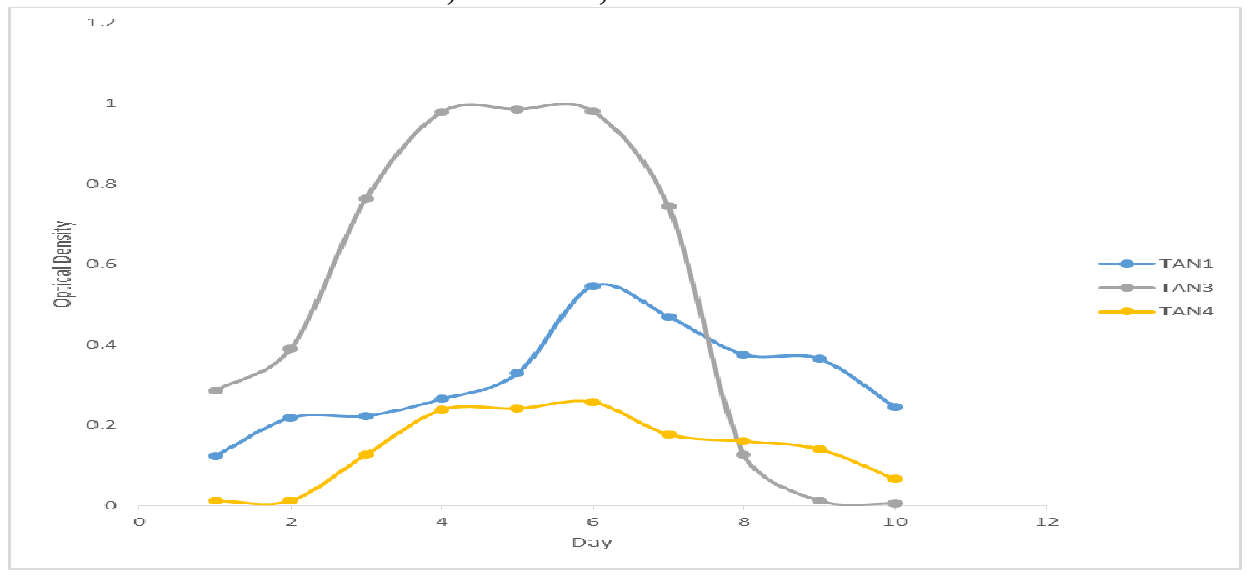

Fig. 2 Growth rates of the isolates in the effluents from the Tannery Industries

\section{Physico-chemical Parameters in the Industrial Effluents after the biodegradation.}

Table 3 shows the mean results of the physicochemical parameter before and after bioremediation using the different masses $(5 \mathrm{~g}$, $10 \mathrm{~g}, 15 \mathrm{~g}, 20 \mathrm{~g}$, and $25 \mathrm{~g}$ ) of the respective immobilized bacteria. Also, Table 4 shows the mean results of correlation coefficient ( $r$ ) between different masses of bacteria and physicochemical parameters.

The mean values $(\mathrm{mg} / \mathrm{l})$ of the SS after the bioremediation varies between $243 \pm 45$ and $898 \pm 672$. The mean concentration $(\mathrm{mg} / \mathrm{l})$ of SS remediated by the different masses $(5 \mathrm{~g}, 10 \mathrm{~g}$, $15 \mathrm{~g}, 20 \mathrm{~g}$, and $25 \mathrm{~g}$ ) of the bacteria varies. The SS in the samples fluctuates up and down after the bioremediation process when compared with the SS of the raw samples before the bioremediation. The increase in the levels of the SS might be due to the aggregation of the TDS which are large enough to result into SS. The increase in the levels of the SS might be also due to the influence of the nutrients which was added into the effluents in order to make the microorganisms more active and viable for fast degradation of organic contaminants in the effluent. The relative potential or efficiency of the different masses of the bacteria in remediating SS in TAN1 samples was in the order $25 \mathrm{~g}>20 \mathrm{~g}>15 \mathrm{~g}>10 \mathrm{~g}>5 \mathrm{~g}$. For TAN2 and TAN3 samples, the order was $25 \mathrm{~g}>20 \mathrm{~g}>15$ $\mathrm{g}>10 \mathrm{~g}>5 \mathrm{~g}$. These might be due to the variations in the surface areas of the different masses of the immobilized bacteria. Statistical analysis shows that there is no significant difference $(p<0.05)$ between the mean values of SS among the masses in the respective industries. Positive and significant correlations exist between the masses of bacteria and Suspended Solid (SS). This showed that there is general increase in the levels of the SS as the masses of the immobilized bacteria increases. TAN3 (90\%) and TAN1 (80\%) showed a very high correlation with the masses of the bacteria while TAN2 (61\%) showed a very low correlation.

The mean values $(\mathrm{mg} / \mathrm{l})$ of the TDS after the bioremediation varies between $46 \pm 11$ and $83 \pm 78$. The mean concentration $(\mathrm{mg} / \mathrm{l})$ of TDS remediated by the different masses $(5 \mathrm{~g}, 10 \mathrm{~g}$, $15 \mathrm{~g}, 20 \mathrm{~g}$, and $25 \mathrm{~g}$ ) of the bacteria varies. There is a reduction in all the TDS of all the samples after the bioremediation process compared with the TDS of the raw samples before the bioremediation. The relative potential or efficiency of the different masses of the bacteria in remediating TDS in TAN1 and TAN3 samples was in the order $5 \mathrm{~g}>10 \mathrm{~g}>15 \mathrm{~g}>20$ $\mathrm{g}>25 \mathrm{~g}$. For TAN2 samples, the order was 20 $g>10 \quad g>25 \quad g>15 \quad g>5 \quad g$. Statistical analysis shows that there is no significant difference $(p<0.05)$ between the mean values of TDS among the masses in the respective industries. These might be due to the variations in the surface areas of the different masses of the immobilized bacteria. Positive and significant correlations exist between the masses of bacteria and TDS with the exception in TAN2 (negative and insignificant correlation). The positive correlations showed that there is general increase in the levels of the TDS as the masses of the immobilized bacteria increases. TAN1 $(96 \%)$ showed a very high correlation with the masses of the bacteria while TAN2 (47\%) showed a very low correlation.

The mean values $(\mathrm{mg} / \mathrm{l})$ of the BOD after the bioremediation varies between $1.56 \pm 0.20 \mathrm{mg} / \mathrm{l}$ and $6.92 \pm 5.49 \mathrm{mg} / \mathrm{l}$. The mean concentration $(\mathrm{mg} / \mathrm{l})$ of BOD remediated by the different masses $(5 \mathrm{~g}, 10 \mathrm{~g}, 15 \mathrm{~g}, 20 \mathrm{~g}$, and $25 \mathrm{~g}$ ) of the bacteria varies. There is a reduction in all the BOD of all the samples after the bioremediation process compared with the $\mathrm{BOD}$ of the raw 
BAJOPAS Volume 13 Number 2, December, 2020 samples before the bioremediation. The relative potential or efficiency of the different masses of the bacteria in remediating BOD in TAN1, TAN2 and TAN3 samples were in the order $25 \mathrm{~g}>20$ $\mathrm{g}>15 \mathrm{~g}>10 \mathrm{~g}>5 \mathrm{~g}, 25 \mathrm{~g}>15 \mathrm{~g}>5 \mathrm{~g}>10 \mathrm{~g}>20 \mathrm{~g}$ and $20 \mathrm{~g}>10 \mathrm{~g}>25 \mathrm{~g}>15 \mathrm{~g}>5 \mathrm{~g}$ respectively. Statistical analysis shows that there is significant difference $(p<0.05)$ between the mean values of BOD among the masses in the respective industries. These might be due to the variations in the surface areas of the different masses of the immobilized bacteria. Negative and significant correlations exist between the masses of bacteria and BOD. This showed that there is general decrease in the levels of the BOD as the masses of the immobilized bacteria increases. TAN1 (94\%) showed a very high correlation with the masses of the bacteria while TAN2 (4\%) showed a very low correlation.

The mean values $(\mathrm{mg} / \mathrm{l})$ of the COD after the bioremediation varies between $250 \pm 154$ and $3134 \pm 1595$. The mean concentration $(\mathrm{mg} / \mathrm{l})$ of COD remediated by the different masses $(5 \mathrm{~g}$, $10 \mathrm{~g}, 15 \mathrm{~g} 20 \mathrm{~g}$, and $25 \mathrm{~g}$ ) of the bacteria varies. There is a reduction in all the COD of all the samples after the bioremediation process compared with the COD of the raw samples before the bioremediation. The relative potential or efficiency of the different masses of the bacteria in remediating COD in TAN1, TAN2 and TAN3 samples were in the order $25 \mathrm{~g}>20 \mathrm{~g}>15$ $\mathrm{g}>5 \mathrm{~g}>10 \mathrm{~g}, 25 \mathrm{~g}>20 \mathrm{~g}>15 \mathrm{~g}>10 \mathrm{~g}>5 \mathrm{~g}$ and 10 g>5 g>25 g>15 g>20 g respectively. Statistical analysis shows that there were significant difference $(p<0.05)$ between the mean values of COD among the masses in the respective industries except for effluents treated with $25 \mathrm{~g}$. These might be due to the variations in the surface areas of the different masses of the immobilized bacteria. Negative and insignificant correlations exist between the masses of bacteria and COD with the exception in TAN3 (positive and significant correlation). The negative correlations showed that there is general decrease in the levels of the COD as the masses of the immobilized bacteria increases. TAN2 (100\%) showed a very high correlation with the masses of the bacteria while TAN3 (36\%) showed a very low correlation.

Generally, there was an overall decrease in the concentration of these physicochemical parameters after the bioremediation using the different masses of the bacterial isolates. These might be due to the variations in the surface areas of the different masses of the immobilized bacteria. This is in line with the work of Jimoh et al. (2018) and Baba et al. (2020).

Table 3: Mean Values $(\mathrm{mg} / \mathrm{l}) \pm$ S.D of Physicochemical parameters in effluents from the Tannery Industries before and after Treatment of the effluents $(250 \mathrm{ml})$ with the different masses $(5 \mathrm{~g}, 10 \mathrm{~g}$, $15 \mathrm{~g}, 20 \mathrm{~g}$, and $25 \mathrm{~g}$ ) of the bacteria.

\begin{tabular}{llllllll}
\hline $\mathrm{P}$ & IND & Before & \multicolumn{5}{c}{ After } \\
\cline { 4 - 7 } & & & $5 \mathrm{~g}$ & $10 \mathrm{~g}$ & $15 \mathrm{~g}$ & $20 \mathrm{~g}$ & $25 \mathrm{~g}$ \\
\hline \multirow{2}{*}{ COD } & TAN1 & $2372 \pm 938$ & $1708 \mathrm{a} \pm 861$ & $2045 \mathrm{a} \pm 1205$ & $845 \mathrm{a} \pm 369$ & $300 \mathrm{a} \pm 167$ & $250 \mathrm{a} \pm 154$ \\
& TAN2 & $1406 \pm 208$ & $1195 \mathrm{a} \pm 208$ & $1125 \mathrm{a} \pm 384$ & $1055 \mathrm{a} \pm 317$ & $956 \mathrm{a} \pm 310$ & $870 \mathrm{ab} \pm 240$ \\
& TAN3 & $3532 \pm 1373$ & $2374 \mathrm{a} \pm 1344$ & $1976 \mathrm{a} \pm 1405$ & $2757 \mathrm{a} \pm 1266$ & $3134 \mathrm{a} \pm 1595$ & $2614 \mathrm{~b} \pm 1105$ \\
BOD & TAN1 & $13.85 \pm 6.42$ & $6.92 \mathrm{a} \pm 5.49$ & $6.42 \mathrm{a} \pm 5.07$ & $5.72 \mathrm{a} \pm 5.35$ & $4.62 \mathrm{a} \pm 4.37$ & $2.82 \mathrm{ab} \pm 1.26$ \\
& TAN2 & $19.46 \pm 0.50$ & $1.75 \mathrm{~b} \pm 0.22$ & $1.73 \mathrm{~b} \pm 0.18$ & $1.58 \mathrm{a} \pm 0.16$ & $1.91 \mathrm{a} \pm 0.22$ & $1.56 \mathrm{~b} \pm 0.20$ \\
& TAN3 & $17.13 \pm 3.14$ & $4.24 \mathrm{ab} \pm 0.77$ & $3.29 \mathrm{ab} \pm 0.37$ & $4.11 \mathrm{a} \pm 0.07$ & $3.23 \mathrm{a} \pm 0.91$ & $3.33 \mathrm{a} \pm 1.28$ \\
SS & TAN1 & $374 \pm 124$ & $243 \mathrm{a} \pm 45$ & $471 \mathrm{a} \pm 226$ & $475 \mathrm{a} \pm 182$ & $492 \mathrm{a} \pm 128$ & $611 \mathrm{a} \pm 217$ \\
& TAN2 & $358 \pm 335$ & $460 \mathrm{a} \pm 400$ & $543 \mathrm{a} \pm 414$ & $544 \mathrm{a} \pm 402$ & $551 \mathrm{a} \pm 414$ & $554 \mathrm{a} \pm 405$ \\
& TAN3 & $780 \pm 739$ & $586 \mathrm{a} \pm 594$ & $758 \mathrm{a} \pm 656$ & $787 \mathrm{a} \pm 676$ & $861 \mathrm{a} \pm 635$ & $898 \mathrm{a} \pm 672$ \\
TDS & TAN1 & $3941 \pm 3703$ & $51 \mathrm{a} \pm 10$ & $53 \mathrm{a} \pm 10$ & $55 \mathrm{a} \pm 15$ & $61 \mathrm{a} \pm 20$ & $63 \mathrm{a} \pm 26$ \\
& TAN2 & $3300 \pm 1714$ & $83 \mathrm{a} \pm 78$ & $47 \mathrm{a} \pm 20$ & $48 \mathrm{a} \pm 22$ & $47 \mathrm{a} \pm 17$ & $48 \mathrm{a} \pm 17$ \\
& TAN3 & $2653 \pm 1240$ & $46 \mathrm{a} \pm 11$ & $55 \mathrm{a} \pm 24$ & $55 \mathrm{a} \pm 25$ & $58 \mathrm{a} \pm 23$ & $61 \mathrm{a} \pm 28$ \\
\hline
\end{tabular}

Replicate $=6$ (months)

Within the rows, for the same parameter, means with different alphabets are statistically different $(p<0.05)$.

$\mathrm{P}=$ parameter, IND = Industries 
BAJOPAS Volume 13 Number 2, December, 2020

Table 4: Correlation coefficient $(r)$ between different masses of the bacteria and the physicochemical parameters.

\begin{tabular}{llll}
\hline Industries & Parameter & Correlation coefficient $(r)$ & $\begin{array}{l}\text { Percent dependence (rxrx100) } \\
(\%)\end{array}$ \\
\hline TAN1 & COD & -0.9 & 82 \\
& BOD & -0.97 & 94 \\
& SS & $0.90^{*}$ & 80 \\
TAN2 & TDS & $0.98^{*}$ & 96 \\
& COD & -1 & 100 \\
& BOD & -0.21 & 4 \\
& SS & $0.78^{*}$ & 61 \\
& TDS & -0.69 & 47 \\
& COD & $0.60^{*}$ & 36 \\
& BOD & -0.6 & 37 \\
& SS & $0.95^{*}$ & 90 \\
& TDS & $0.94^{*}$ & 89 \\
\hline
\end{tabular}

The correlation coefficient $(r)$ with * is statistically significant $(p<0.05)$.

Percentage reduction of the Parameters

Table 5 shows the percentage reduction of Parameters in industrial samples before and after the treatment of the effluents $(250 \mathrm{ml})$ with the different masses $(5 \mathrm{~g}, 10 \mathrm{~g}, 15 \mathrm{~g}, 20 \mathrm{~g}$, and $25 \mathrm{~g}$ ) of the Immobilized Bacteria.

In TAN1 samples, the percentage reduction (\%) of COD ranged (14-89); BOD (50-80); SS (-32$35)$ and TDS (98-99). In TAN2 samples, the percentage decrease $(\%)$ of COD ranged (15$38) ;$ BOD (90-92); SS [-28-(-55)] and TDS (9798). In TAN3 samples, the percentage decrease (\%) of COD ranged (11-44); BOD (76-81); SS (15-25) and TDS (98). The percentage increase in the levels COD, BOD and TDS might be due to the increase in the surface area of the different masses of the immobilized bacteria. However, the percentage decrease in the levels of the SS might be due to the aggregation of the TDS which are large enough to result into SS. The percentage decrease in the levels of the SS might be also due to the influence of the nutrients which was added into the effluents in order to make the microorganisms more active and viable for fast degradation of organic contaminants in the effluent. This is in line with the work of Jimoh et al. (2018) in which the concentration of the SS increase after the bioremediation of effluents.

Sreemoyee and Priti (2013) assessed and reduced several Physico-chemical parameters of dairy wastewater using Niesseria $s p$. and concluded that the species are well known to degrade organic compounds. This is in agreement with the current study in which the immobilized Niesseria $s p$ degrade the organic contaminants as indicated by the BOD, COD and TDS.

Jimoh et al. (2018) observed that TSS of the effluents was increased after treatment with immobilized bacteria and concluded that it might be due to the biostimulation method adopted for the research.

The optimum $\mathrm{pH}$ Biosorption of Chromium by Bacillus spp and Staphylococcus spp. from tannery effluent was investigated by Mythili and Karthikeyan (2011). The maximum adsorption of Chromium $(86.4 \mathrm{mg} / \mathrm{L})$ was showed by Bacillus spp and Staphylococcus spp showed $70.6 \mathrm{mg} / \mathrm{L}$ at an initial concentration of $100 \mathrm{mg} / \mathrm{L}$. In the present study, immobilised Bacillus spp and Staphylococcus spp. from the tannery industrial effluents reduced the levels of the organic pollutants with high potential as indicated by the percentage reduction of BOD, COD and TDS.

Enzymes often can work in multiple environments especially if they are immobilized. This makes the microorganisms' enzymes even more resistant to harsh environments and enables the enzymes to be recovered and recycled after they are no longer needed (Gianfreda and Rao 2004). Ramesh and Singh (1993) reported that the immobilized bacteria having more efficiency to remove the suspended particles than free cells. Using the immobilized cell is preferable due to its capability for using several times with the same efficiency, which makes it more economical. Similar work was done by Sikander et al. (2007) showing the higher reduction with permeabilized cells of Ochrobactrum intermedium strain SDCr-5. 
BAJOPAS Volume 13 Number 2, December, 2020

The results revealed the isolation and identification of isolates with the potential for the reduction of $\mathrm{Cr}$ (VI) to $\mathrm{Cr}$ (III). Results indicated that immobilized $B$. cereus could be efficiently used for the reduction of $\mathrm{Cr}$ (VI).

Table 5: Percentage reduction of the tested Parameters from the tannery industrial samples of the Immobilized Bacteria.

\begin{tabular}{lllllll}
\hline \multirow{2}{*}{ Industries } & & \multicolumn{5}{c}{ Percentage Reduction $(\%)$} \\
\cline { 3 - 7 } & & $5 \mathrm{~g}$ & $10 \mathrm{~g}$ & $15 \mathrm{~g}$ & $20 \mathrm{~g}$ & $25 \mathrm{~g}$ \\
\hline TAN1 & COD & 28 & 14 & 64 & 87 & 89 \\
& BOD & 50 & 54 & 59 & 67 & 80 \\
& SS & 35 & -26 & -27 & -32 & -63 \\
& TDS & 99 & 99 & 99 & 98 & 98 \\
TAN2 & COD & 15 & 20 & 25 & 32 & 38 \\
& BOD & 91 & 91 & 92 & 90 & 92 \\
& SS & -28 & -52 & -52 & -54 & -55 \\
& TDS & 97 & 99 & 99 & 99 & 99 \\
& COD & 33 & 44 & 22 & 11 & 26 \\
& BOD & 75 & 81 & 76 & 81 & 81 \\
& SS & 25 & 3 & -1 & -10 & -15 \\
& TDS & 98 & 98 & 98 & 98 & 98 \\
\hline
\end{tabular}

Percentage Reduction $=(B-A) / B \times 100 \%$

$A=$ Concentration of the parameter after treatment

$\mathrm{B}=$ Concentration of the parameter before treatment

$+=$ percentage decrease

- = percentage increase

In general, immobilization makes the enzyme more resistant to temperature, $\mathrm{pH}$, and substrate concentration swings giving it a longer lifetime and higher productivity per active unit (Gianfreda and Rao, 2004; FuIlbrook, 1996; Russell et al, 2003; Kandelbauer et al., 2004). Immobilized cells have been used and studied extensively for the production of useful chemicals (Ohtake and Silver, 1994), the treatment of wastewaters (Chen et al., 2003; Wang et al., 2010). Although many workers described microbial degradation of tannery effluent, limited literature is available on the bioremediation of tannery effluent using immobilized bacterial cells in the Kano Industrial Estates.

\section{CONCLUSION}

The samples contained variable levels of the physicochemical parameters. The results of the Analysis of variance revealed that, no statistical difference $(p<0.05)$ was observed for the temperature, $\mathrm{pH}, \mathrm{SS}, \mathrm{TDS}, \mathrm{BOD}$ and $\mathrm{COD}$ among the three tannery industries before the treatment. The levels of some of the parameters
(SS, TDS and COD) observed in the samples were found above the recommended limits of WHO and NESREA, which called for the treatment of the effluents before discharge into the environment. Base on the morphological and biochemical test results, TAN1, TAN2, and TAN3 bacterial isolates were identified to be Neisseria spp, Bacillus cereus, and Staphylococcus aureus respectively. The results of Post-treatment analysis showed that there is overall decrease in the levels of the parameters determined when compared with that of the pre-treatment. The overall percentage reduction of the immobilised bacteria in the treatment of the respective effluents was in the order TAN2 (72\%)>TAN1 $(70 \%)>$ TAN3 $(62 \%)$. Hence, the immobilized bacteria are having higher biodegradation potential for the treatment of the tannery effluents.

\section{Acknowledgments}

The authors wish to acknowledge the University of Maiduguri for the financial support. The authors are grateful to the Kano State Ministry of Environment for their support in obtaining the effluent samples. 


\section{REFERENCES}

Ajao, A. T., Adebayo, G. B., and Yakubu, S. E. (2011). Bioremediation of textile industrial effluent using mixed culture of Pseudomonas aeruginosa and Bacillus subtilis immobilized on agar-agar in a bioreactor. J. Microbiol. Biotech. Res, 1(3), 50-56.

Akan, J. C., Moses, E. A., Ogugbuaja, V. O., and Abah, J. (2007). Assessment of tannery industrial effluents from Kano metropolis, Kano State, Nigeria. Journal of Applied Sciences, 7(19), 2788-2793.

Akan, J. C., Ogugbuaja, V. O., Abdulrahman, F. I., and Ayodele, J. T. (2009). Pollutant levels in effluent samples from tanneries and textiles of Kano industrial areas, Nigeria. Global journal of pure and applied sciences, 15(3-4).

APHA (1989). Standard methods for Examination of Will bete and Will betewater.15 $5^{\text {th }}$ edition. Brydpass Springfield Will behington DC. pp. 164-176

APHA (1992). Standard Methods for the Examination of Water and Wastewater. Health, 69, 1116-9.

Baba, A., Garba, S. T., and Bello, H. S. (2020). Bioremediation Potential of Immobilized corynebacterium kutsceri in the Treatment of Tannery Industrial Effluent from Challawa Industrial Estate, Kano State, Nigeria. Journal of the Turkish Chemical Society Section A: Chemistry, $7(2), 335-350$.

Beem, E. I. V. (1994). reduction of solvent VOC emission. J. Oil Col. Chem. Ass, 77, 158.

Bouwer, E. J., and Zehnder, A. J. (1993). Bioremediation of organic compoundsputting microbial metabolism to work. Trends in biotechnology, 11(8), 360367.

Chen, K. C., Wu, J. Y., Liou, D. J., and Hwang, S. C. J. (2003). Decolorization of the textile dyes by newly isolated bacterial strains. Journal of Biotechnology, 101(1), 57-68.

Dan'Azumi, S., and Bichi, M. H. (2010). INDUSTRIAL POLLUTION AND HEAVY METALS PROFILE OF CHALLAWA RIVER IN KANO, NIGERIA. Journal of Applied Sciences in Environmental Sanitation, $5(1)$.

DWAF. (1992). Analytical Methods Manual, TR 151. Department of Water Affairs and Forestry, Pretoria.

El-Bestawy, E. (2013). Biological treatment of leather-tanning industrial wastewater using free living bacteria.
Elsheikh, M. A. S. (2009). Tannery wastewater pre-treatment. Water Science and Technology, 60(2), 433-440.

FuIlbrook, P. D. (1996). "Kinetics." Industrial enzymology: The application of enzymes in Industry. 2nd Ed. T. Godfrey and J Reichelt. eds.. Nature. New York.

Gianfreda, L., and Rao, M. A. (2004). Potential of extra cellular enzymes in remediation of polluted soils: a review. Enzyme and microbial technology, 35(4), 339354.

Hugo Springer. (1994). John Arthur Wilson Memorial Lecture "Treatment of Industrial Wastes of the Leather Industry - is it still a Major Problem". JALCA, 89, 153-185

Jimoh, A. A., Ganiyu, B. A., Baba, D., and Baba, A. (2018) Bioremediation Process of Effluent from Detergent and Food Industries in Jos, Nigeria: Kinetics and Thermodynamics. International Journal of Engineering Science Invention (IJESI), 762-73

Kandelbauer, A., Maute, O., Kessler, R. W., Erlacher, A., and Gübitz, G. M. (2004). Study of dye decolorization in an immobilized laccase enzyme-reactor using online spectroscopy. Biotechnology and bioengineering, 87(4), 552-563.

Kongjao, S., Damronglerd, S., and Hunsom, M. (2008). Simultaneous removal of organic and inorganic Pollutants in tannery wastewater using electrocoagulation technique. Korean Journal of chemical engineering, 25(4), 703.

Maheshwari, U. M., Aruna, S., Gomathi, M., and AbdulJaffar, A. H. (2017). Bioremediation by Free and Immobilized Bacteria Isolated from Tannery Effluent. International Journal of Research in Applied, Natural and Social Sciences. 5(7), 75-90

Margesin, R., and Schinner, F. (2001). Bioremediation (natural attenuation and biostimulation) of diesel-oilcontaminated soil in an alpine glacier skiing area. Applied and environmental microbiology, 677), 3127-3133.

Mohammed, A., Sekar, P., and George, J. (2011). Efficacy of microbes in bioremediation of tannery effluent. Inter. J. Curr. Res, 3(4), 324-326.

Mohammed, S. S. D., Orukotan, A. A., and Abdullahi, H. (2017). Physicochemical and Bacteriological Assessment of Tannery Effluent from Samaru-Zaria, 
BAJOPAS Volume 13 Number 2, December, 2020 Kaduna State, Nigeria. Journal of Applied

Sciences and Environmental Management, 21(4), 734-740.

Munz, G., De Angelis, D., Gori, R., Mori, G., Casarci, M., and Lubello, C. (2009). The role of tannins in conventional and membrane treatment of tannery wastewater. Journal of hazardous materials, 164(2-3), 733-739

Mythili, K., and Karthikeyan, B. (2011). Bioremediation of $\mathrm{Cr}$ (VI) from tannery effluent using Bacillus spp and Staphylococcus spp. International Multidisciplinary Research Journal, 1(6).

NESREA (2009). National Environmental Standards for Effluent Limitations and Regulation. 1233-1236

Noorjahan, C. M. (2014). Physicochemical characteristics, identification of bacteria and biodegradation of industrial effluent. Journal of bioremediation and Biodegradation, 5(3).

Ohtake, H. I., and Silver, A. O. (1994). Bacterial reduction of toxic chromate. Biological degradation and bioremediation of toxic chemicals, 403-415.

Omoleke, I. I. (2004). Management of environmental pollution in Ibadan, an African city: the challenges of health hazard facing government and the people. Journal of Human Ecology, 15(4), 265-275.

Rajor, A., Reddy, A.S., and Singh, B. (2004). Determination of BOD kinetic Parameters and evaluation of alternate methods, M.Sc. Thesis, Department of biotechnology \& environmental Science, Thapar Institute of Engineering and Technology, Patiala

Ramasami, T., Rajamani, S., and Rao, J. R. (1994, March). Pollution control in leather industry: Emerging technological options. In International symposium on surface and colloidal science and its relevance to soil pollution, madras.

Ramesh, J. V. S., and Singh, S. P. (1993). Yearly variation in certain physicochemical parameters of pond at eastern Doon Valley. Uttar Pradesh J. Zoo, 12 (1), 7577.

Ranen, S., and Sharadinadra, C. (2009). Biotechnology applications to environmental remediation in resource exploitation. Current science, 97, 6-25
Russell, A. J., Berberich, J. A., Drevon, G. F., and Koepsel, R. R. (2003). Biomaterials for mediation of

chemical and biological warfare agents. Annual review of biomedical engineering, 5(1), 1-27.

Saravanan, P., and Saravanan, A. (1999). Decolourization of tannery effluent by Flavobacterium sp. EK 1. Indian Journal of Environmental Protection, 19, 19-24.

Sikander, S., and Shahida, H. (2007). Reduction of toxic hexavalent chromium by Ochrobactrum intermedium strain SDCr5 stimulated by heavy metals. Bioresource Technol, 98, 340-344.

Singh, N., Sharma, B. K., and Bohra, P. C. (2000). Impact assessment of industrial effluent of arid soils by using satellite imageries. Journal of the Indian Society of Remote Sensing, 28(2-3), 79.

Sreemoyee, C., and Priti, P. (2013). Assessment of physico-chemical parameters of dairy waste water and isolation and characterization of bacterial strains in terms of cod reduction. Int J Sci, 2(3), 395-400.

Verheijen, L. A. H. M., Wiersema, D., Pol, L. H., and De Wit, J. (1996). Management of wastes from animal product processing. Livestock and environment, Finding a balance. International Agriculture Center, Wageningen, The Netherlands.

Wang, F., Yao, J., Si, Y., Chen, H., Russel, M., Chen, K., and Bramanti, E. (2010). Short-time effect of heavy metals upon microbial community activity. Journal of Hazardous Materials, 173(13), 510-516.

WHO (World Health Organization). (2006). Air quality guidelines: global update 2005: particulate matter, ozone, nitrogen dioxide, and sulfur dioxide. World Health Organization.

World Bank. (1995). Nigeria's strategic options for redressing industrial pollution. World Bank, industry and energy division. 1st edition, West Central Africa Department; Annexes: 1995; pp 60-62.

Zahoor, A., and Abdul, R. (2009). Enumeration of Coliforms. Journal of Environmental Sciences. 21, 814-820 


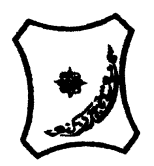

Bayero Journal of Pure and Applied Sciences, 13(2): 1 - 12

Received: November, 2020

Accepted: December, 2020

ISSN $2006-6996$

\title{
BIODEGRADATION POTENTIAL OF IMMOBILIZED BACTERIA IN THE TREATMENT OF TANNERY INDUSTRIAL EFFLUENTS FROM INDUSTRIAL ESTATES IN KANO STATE, NIGERIA
}

\author{
Abdullateef, B., ${ }^{1 *}$ Shuaibu, T. G., ${ }^{1}$ Babagana, K., ${ }^{1}$ Suleman, H. B. ${ }^{2}$ and Dauda, B. ${ }^{3}$ \\ ${ }^{1}$ Department of Pure and Applied Chemistry, Faculty of Science, University of Maiduguri, Borno State, \\ Nigeria \\ ${ }^{2}$ Department of Microbiology, Faculty of Science, University of Maiduguri, Borno State, Nigeria \\ ${ }^{3}$ Department of Chemical Engineering, Faculty of Engineering, University of Maiduguri, Borno State, \\ Nigeria \\ *Corresponding author: babslega@gmail.com; abelega2007@yahoo.com; +2348061309753
}

\section{ABSTRACT}

Industrial Effluents Samples from Gashash Tanneries (TAN1) in Bompai Industrial estate, Larabee Tannery Industry (TAN2) in Sharada Industrial estate and Z Tannery Industries (TAN3) in Challawa Industrial estate, Kano State, Nigeria were collected over a period of six months (August 2017 to January 2018) for assessing the biodegradation potentials of bacteria in the treatment of organic pollutants within the effluents. Bacteria were isolated from the effluents and immobilized on agar-agar. Different masses (5 g, $10 \mathrm{gr}, 15$ $\mathrm{g}, 20 \mathrm{~g}$, and $25 \mathrm{~g}$ ) of the bacteria were used in the treatment of $250 \mathrm{ml}$ of the effluents for ten days in a shaker incubator (Gallenkamp-OC-4364-L) at the temperature $30{ }^{\circ} \mathrm{C}$ and speed of $60 \mathrm{rpm}$. Pre-treatment analysis of the effluents for Temperature, pH, Biochemical Oxygen Demand (BOD), Chemical Oxygen Demand (COD), Suspended Solid (SS) and Total Dissolved Solids (TDS) gives the following results; temperature $\left({ }^{\circ} \mathrm{C}\right.$ )

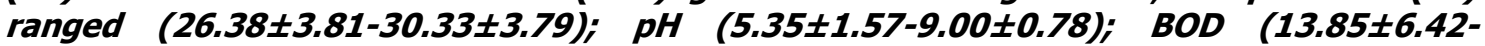
$38.75 \pm 16.20) ;$ COD (1406 $\pm 208-3532 \pm 1373) ;$ SS (208 $\pm 235-780 \pm 739)$ and TDS (266 $\pm 253-5276 \pm 2971)$. No statistical differences ( $p \leq 0.05)$ was observed for all the results among the different industries. The bacterial isolates were identified as Neisseria spp, Bacillus cereus, and Staphylococcus aureus, in TAN1, TAN2, and TAN3, respectively. After treatment of the effluent with the different masses of the isolated bacteria, the mean level of BOD was found to range as (0.55 $\pm 0.36-6.92 \pm 5.49) ; C O D$ (ND-3134 \pm 1595$)$;

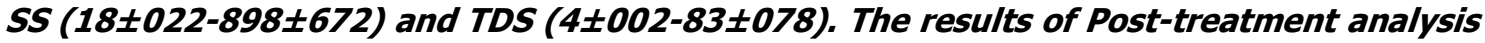
showed that there is overall decrease in the levels of the parameters determined when compared with that of the pre-treatment. The overall percentage reduction of the immobilised bacteria in the treatment of the respective effluents was in the order TAN2 (72\%)>TAN1 (70\%)>TAN3 (62\%). Hence, the immobilized bacteria are having higher biodegradation potential for the treatment of the tannery effluents.

Keywords: Biodegradation, bacteria, effluent, immobilization, tannery.

\section{INTRODUCTION}

Tannery industrial wastewater is a serious consequence of the pollution point of view for streams, freshwater, and land used for agriculture. The lack of awareness in the modern industrial practice has resulted in the discharge of tannery effluents which exhibit very high value of chromium ( $\mathrm{Cr}$ ), Sulfide, and chloride, Total Dissolved Solid (TDS), Total Suspended Solid (TSS), Biochemical Oxygen Demand (BOD) and Chemical Oxygen Demand (COD) in the water stream or land (Mohammed et al., 2001). Tanning is the process, which One ton of skin generally leads to the production of 20 to $80 \mathrm{~m}^{3}$ of turbid and foul-smelling converts the protein of the rawhide or skin into a stable material, which will not putrefy and is suitable for a wide variety of end applications (Elsheikh, 2009). The highly polluting chromium is the most commonly used tanning material producing leather that is more flexible and pliable than vegetable-tanned leather and does not discolor or lose shape in water as drastically as vegetable-tan (Elsheikh, 2009). Tannery effluent is among the most hazardous industrial pollutants due to its huge organic and inorganic load, which is highly toxic to human life and the environment (Kongjao et al., 2008). wastewater including chromium (100-400 mg/l), sulfide $(200-800 \mathrm{mg} / \mathrm{l})$, high levels of fat and 
BAJOPAS Volume 13 Number 2, December, 2020 other solid wastes, and notable pathogen contamination as well as pesticides added for skin conservation during transport (Elsheikh, 2009). There are more than 6000 tanneries in Nigeria with an annual processing capacity of 700,000 tons of hides and skins (Omoleke, 2004; Singh et al., 2008). It was reported that the total amount of waste produced per animal slaughtered is approximately $35 \%$ of its weight (World Bank, 1995). Also, for every $1000 \mathrm{~kg}$ of carcass weight, a slaughtered beef produces 5.5 $\mathrm{kg}$ of manure (excluding rumen contents or stockyard manure) and $100 \mathrm{~kg}$ of paunch manure (undigested food) (Verheijen et al., 1996). Tanneries generate wastewater in the range of 30-35 $\mathrm{L} \mathrm{kg}^{-1}$ skin/hide processed with variable $\mathrm{pH}$, Biological Oxygen Demand (BOD), Chemical Oxygen Demand (COD), high concentrations of suspended solids (SS), and tannins as well as chromium (Zahoor and Abdul, 2009).

Being heterogeneous and composed of a wide variety of compounds, it is very difficult to select a unique direct method for estimating the biodegradability of organic contents and biokinetic parameters for a wastewater sample (Rajor, 2004). For this purpose, some indirect estimation such as determination of biochemical oxygen demand (BOD) and chemical oxygen demand (COD) are applied as common laboratory investigations [9]. During retanning procedures, synthetic tannins (Syntan), oils and resins are added to form softer leather at varying doses (Munz et al., 2009). One of the refractory groups of chemicals in tannery effluents derives mainly from tannins (Ramasami et al., 2004). Syntans are characterized by complex chemical structures, because they are composed of an extended set of chemicals such as phenol-, naphthalene-, formaldehyde- and melamine-based syntans, and acrylic resins (Beem, 1994). Organic pollutants (proteic and lipidic components) are originated from skins (it is calculated that the raw skin has $30 \%$ loss of organic material during the working cycle) or they are introduced during processes (Hugo Springer, 1994).

Many conventional processes such as oxidation, chemical and biological processes were carried out to treat tanneries wastewater (Ebtesam et al, 2013). Biological processes have received more attention because of their costeffectiveness, lower sludge production and environmental friendliness (Noorjahan, 2014). Naturally occurring micro-organisms degrade the hazardous organic wastes including xenobiotic compounds, such as pesticides, polycyclic aromatic hydrocarbons (PAHs) and polychlorinated biphenyls (PCBs) in due course of time (Ranen and Sharadinadra, 2009). Bioremediation is based on the idea that all organisms remove substances from the environment to carry outgrowth and metabolism (Bouwer and Zehnder, 1993). Bacteria, protista and fungi are found to be very good at degrading complex molecules and incorporating the breakdown products into their metabolism (Bouwer and Zehnder, 1993). The resultant metabolic wastes that they produce are generally safe and somehow recycled into other organisms (Ranen and Sharadinadra, 2009). An acclimatized indigenous population of microorganisms capable of degradation of the compounds of interest must exist at the site for a successful bioremediation mode (Ranen and Sharadinadra, 2009). It has been observed that for a successful bioremediation mode, an acclimatized indigenous population of microorganisms capable of degradation of the compounds of interest must exist at the site under investigation (Ranen and Sharadinadra, 2009). Even though there are numerous physical and chemical methods employed in the disposal of wastes the advantage in using bacterium is that they play a key role in the reduction of COD, BOD, total protein, total tannin and total phenol (Saravanan and Saravanan, 1998)

Baba et al. (2020) studied the bioremediation potential of immobilized corynebacterium kutsceri in the Treatment of tannery industrial effluent from Challawa Industrial Estate, Kano State, Nigeria. The aim of the work is to study the reduction in the level of the contaminants through the process of bioremediation using the isolated bacteria. Immobilized bacteria can withstand various temperatures, $\mathrm{pH}$ and substrate concentrations; consequently, increasing the efficiency and the lifespan of the bacteria. Immobilized bacteria are widely applied in the treatment of wastewater and can be separated and recovered after the treatment with the same efficiency (Baba et al., 2020).

\section{MATERIALS AND METHODS \\ Study Area}

This study was carried out in Bompai, Sharada and Challawa industrial estates in Kano, Figure 1. Kano lies on Latitude $11^{\circ} 30^{\prime} \mathrm{N}$ and $8^{\circ} 30^{\prime} \mathrm{E}$ and Longitude $11^{\circ} 5^{\prime} \mathrm{N}$ and $8^{\circ} 5^{\prime} \mathrm{E}$ in Northern Nigeria. It is one of the developed industrial cities in Nigeria. Tannery activities are the dominating industries and this could be one of the reasons for her high population density (Dan'Azumi and Bichi, 2010). Many researchers have studied biodegradation of tannery effluent using microorganisms. However, limited literature is available on the biodegradation of tannery effluent in Kano industrial estates using 
BAJOPAS Volume 13 Number 2, December, 2020 immobilized bacterial cells. This research work focuses on the potential of the use of the indigenous immobilized bacterial isolates in the treatment of tannery effluents in the industrial estates.

\section{Sample Collection}

Effluents were collected from the Tannery Industries from Bompai, Challawa and Sharada Industrial Estates, Kano, Nigeria. The effluents were collected over a period of six months (August 2017 to January 2018). Samples collected in a sterile 4-liter plastic container with a unique identification number were preserved using an ice-box that was transported to the Microbiology Laboratory, Department of Microbiology, Bayero University of Kano for analysis

\section{Sample Preparation and Sample Analysis}

Immediately after the collection of the effluent, $\mathrm{pH}$, TSS, TDS, COD, BOD levels were determined before treatment (Pre-treatment determination) and ten days after treatment (Post-treatment determination) as described in
APHA (1989) standard methods. $\mathrm{pH}$ was determined using Ecotests $\mathrm{pH}$ meter and TDS was determined using AQUALYTIC TDS Salinometer. BOD was determined as described by the standard method (APHA, 1992). COD and SS were determined using DR/2010 HACH portable data logging spectrophotometer (DWAF, 1992)

\section{Identification and Biochemical} Characterization of the Bacterial Isolates

The bacteria were isolated from the effluents using Serial Dilution according to the method described by APHA (1989). The biochemical tests such as oxidase, catalase, coagulase, indole (from $1 \%$ tryptone broth), citrate (Simmons citrate agar), methyl red/VogesProskauer (MR/VP), nitrate reduction, Starch Hydrolysis, Glucose, Maltose, and Lactose tests were carried out on the bacterial isolates to identify the bacteria through the bacteria biochemical characteristics according to Ajao et al. (2011).

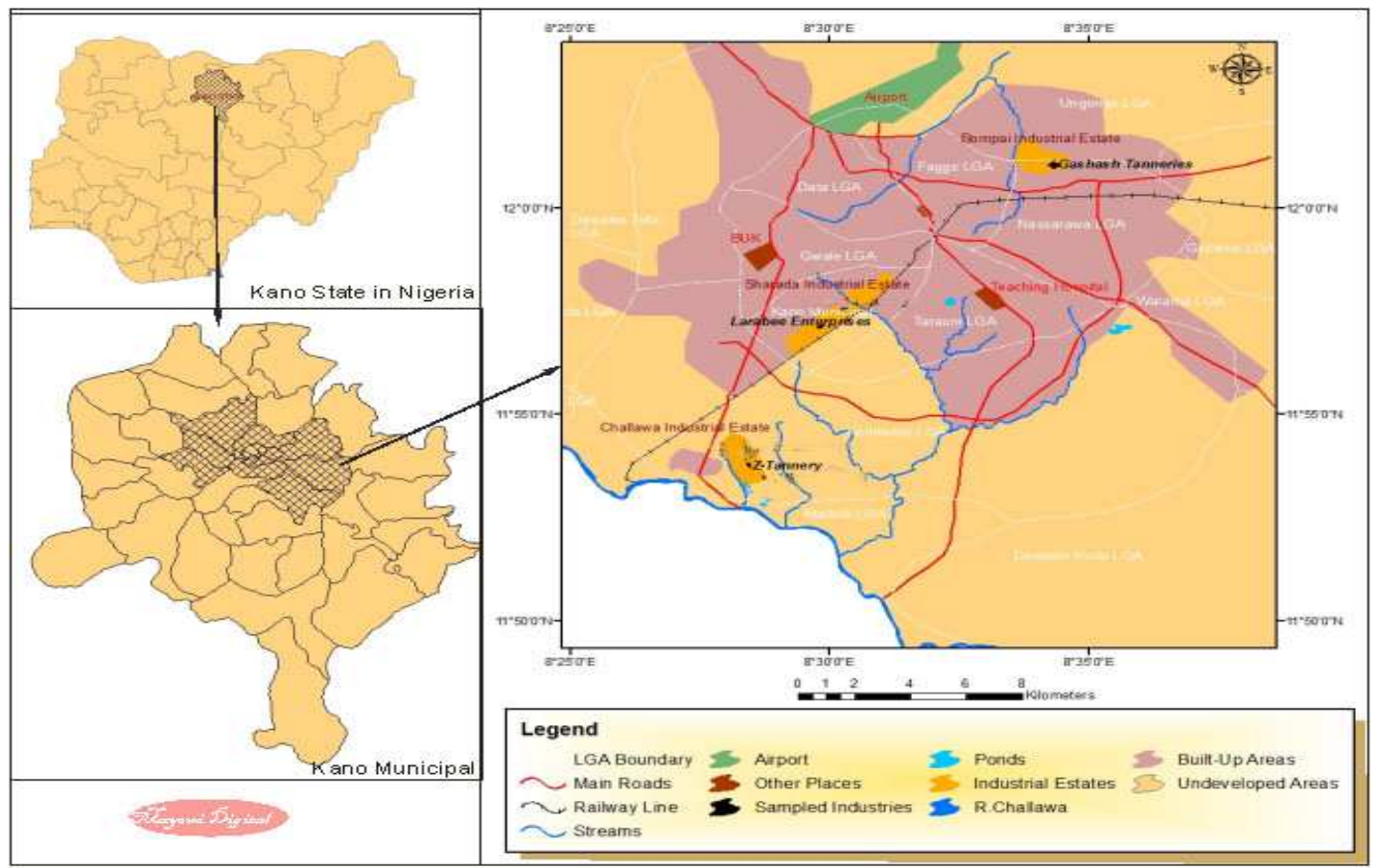

Fig. 1 Map showing the study areas

Source: Mayomi Digital Productions, GIS Laboratory, Department of Geography, UNIMAID (2017)

\section{Determination of Growth Rate of the Bacteria in Effluent Sample}

The bacteria growth rates were determined by transferring $2 \mathrm{~mL}$ of the bacterial isolates from the tannery effluent in broth medium into 100 $\mathrm{mL}$ sterile effluents in conical flasks and kept in an incubator (Giffrin cool) for 10 days. Control was also set up by incubating another $100 \mathrm{~mL}$ each of the sterile effluents without the bacteria. The optical density of the content was determined at the wavelength of $600 \mathrm{~nm}$ on a daily interval and recorded. 
BAJOPAS Volume 13 Number 2, December, 2020 Immobilization of Bacteria

Agar solution and inoculi were prepared separately. Fifty milliliters $(50 \mathrm{~mL})$ of nutrient broth each of the inoculi was prepared in a McCartney bottle and incubated for 24 hours. A solution of agar-agar was prepared by dissolving $10 \mathrm{~g}$ of the powder in distilled water and made up to $500 \mathrm{~mL}$ mark in an Erlenmeyer flask and was sterilized in an autoclave (280A) for 15 minutes and allowed to cool to $40-45^{\circ} \mathrm{C}$ (Ajao et al., 2011). Four milliliters ( $4 \mathrm{~mL})$ of the bacterial isolates in the nutrient broth was mixed with 36 $\mathrm{ml}$ of the prepared agar-agar media in petri-dish plates and then allowed to solidify. This was kept in the refrigerator for bioremediation.

\section{Bioremediation (Treatment) of the Effluents}

The solidified agar block (immobilized bacteria) was cut into cubes using a sterile knife; $0.1 \mathrm{~mL}$ phosphate buffer ( $\mathrm{pH} \mathrm{7.0)}$ was added and kept in the refrigerator for 1 hour for curing. The phosphate buffer was decanted after 1 hour and the cubes were washed with sterile distilled water 3-4 times before it was used (Ajao et al., 2011). Two liters (2 L) of the effluent was supplemented with the minimum basal medium in $\mathrm{g} / \mathrm{L}: \mathrm{NaCl}(0.8), \mathrm{MgSO}_{4} .7 \mathrm{H}_{2} \mathrm{O}(0.001), \mathrm{KH}_{2} \mathrm{PO}_{4}$ (2), $\mathrm{NaNO}_{3}$ (2), $\quad \mathrm{CaCl}_{2} .2 \mathrm{H}_{2} \mathrm{O} \quad(0.5)$ and $\mathrm{NaHPO}_{4} .12 \mathrm{H}_{2} \mathrm{O}(2)$ and sterilized in an autoclave at $121^{\circ} \mathrm{C}$ for 15 minutes (Margesin and Schinner, 2001). Two hundred and fifty milliliters $(250 \mathrm{~mL})$ of the effluents were transferred into different $250 \mathrm{ml}$ conical flasks. The content was covered with a cotton-wool ramped with foil paper to avoid contamination. Five grams $(5 \mathrm{~g})$ of the immobilized bacteria were quickly transferred into each of the effluents in the conical flasks in an inoculating chamber. The same procedures were carried out for the $10 \mathrm{~g}, 15 \mathrm{~g}, 20 \mathrm{~g}$ and 25 $\mathrm{g}$ of the immobilized bacteria in separate $250 \mathrm{~mL}$ effluents in conical flasks and agitated for ten days in a shaker incubator (Gallenkamp-OC4364-L) at a temperature $30^{\circ} \mathrm{C}$ and speed of 60 rpm. The treated effluent samples were taken on the tenth day and analyzed for the parameters $\mathrm{pH}$, SS, TDS, COD, and BOD, (Posttreatment determination) for the different grams of bacteria to evaluate and compare the biodegradation potential. (Baba et al., 2020).

\section{Statistical Analysis}

The data were represented as Mean \pm Standard deviation and analyzed statistically using oneway Analysis of Variance (ANOVA) and Tukey's HSD as Post Hoc Tests with the aid of SPSS 16.0. The correlation coefficient was also used to measure the strength of the relationship between the different masses of the bacteria and the parameters. All $\mathrm{p} \leq 0.05$ were considered as statistically significant.

\section{RESULTS AND DISCUSSION Physico-chemical parameters in the Industrial Effluents before the Biodegradation.}

Results of the Physico-chemical parameters in the industrial effluents before the Biodegradation is shown in table 1 . The mean temperatures $\left({ }^{\circ} \mathrm{C}\right)$ observed in TAN1, TAN2, and TAN3 samples were $28.07 \pm 0.65 ; 27.77 \pm 0.64$ and $26.38 \pm 3.81$ respectively. The order of the mean temperature of the samples from the three industries can be arranged as TAN1 > TAN2>TAN3. The temperature observed at TAN1, TAN2, and TAN3 samples were found below the WHO $\left(35^{\circ} \mathrm{C}\right)$ and NESREA $\left(40^{\circ} \mathrm{C}\right)$ limits. The low values of temperature might be due to the processes used at the time of sampling. High temperature brings down the solubility of gases in water that ultimately expresses as high BOD and COD. Statistical analysis shows that there is no significant difference $(p<0.05)$ between the mean values of temperature among the industries. This might be due to similar tannery activities involved in the tannery industries at the time of sampling. The average values of temperature observed in this present study are less than those observed by Akan et al. (2007), Akan et al. (2009) and Baba et al. (2020).

The mean level of $\mathrm{pH}$ observed in TAN1, TAN2 and TAN3, samples were $7.77 \pm 2.93$; $8.35 \pm 0.28$ and $7.52 \pm 0.76$ respectively. The order of the mean $\mathrm{pH}$ of the samples from the three industries can be arranged as TAN2> TAN1 $>$ TAN3. The $\mathrm{pH}$ of the samples falls within the WHO (7.0-8.5) and NESREA (6-9) standard limits. Statistical analysis shows that there is no significant difference $(p<0.05)$ between the mean values of $\mathrm{pH}$ among the industries. This might be due to similar tannery activities involved in the tannery industries at the time of sampling. Maheshwari et al. (2017) reported that the level of $\mathrm{pH}$ in the effluents from the tannery industry in Vaniyambadi, India was 6.5 which was lower than that observed in the present study. The $\mathrm{pH}$ in the effluents from the tannery industries in Kano and Kaduna were reported to be 7.64 and 6.89, respectively (Akan et al., 2007; Mohammed et al., 2017). The average values of $\mathrm{pH}$ observed in this present study are less than those observed by Mohammed et al. (2017) and Baba et al. (2020). The mean level of SS $(\mathrm{mg} / \mathrm{l})$ observed in TAN1, TAN2, and TAN3 samples were 374 \pm 124 ; $358 \pm 335$ and $780 \pm 739$ respectively. The order of the mean SS in the samples from the three industries can be arranged as TAN3 > TAN1 $>$ TAN2. 
The SS observed in the samples were far above the recommended standard limits of regulating bodies WHO $(30 \mathrm{mg} / \mathrm{l})$ and NESREA $(10 \mathrm{mg} / \mathrm{l})$. Statistical analysis shows that there is no significant difference $(p<0.05)$ between the mean values of SS among the industries. This might be due to similar tannery activities involved in the tannery industries at the time of sampling. The average values of SS observed in this present study are less than that observed $(3700 \pm 122 \mathrm{mg} / \mathrm{l})$ by Akan et al. (2009) for tanneries in Kano. Also, the average values of SS observed in this present study are less than that observed by Mohammed et al. (2017) and Baba et al. (2020) with the exception in TAN3.

The mean level of TDS (mg/l) observed in TAN1, TAN2, and TAN3 samples were $3941 \pm 3703$; $3300 \pm 1714$ and $2653 \pm 1240$ respectively. The order of the mean TDS in the samples from the three industries can be arranged as TAN1>TAN2>TAN3. The TDS observed in the samples were far above the recommended standard limits of WHO $(250 \mathrm{mg} / \mathrm{l})$ and NESREA $(500 \mathrm{mg} / \mathrm{l})$. Statistical analysis shows that there is no significant difference $(p<0.05)$ between the mean values of TDS among the industries. This might be due to similar tannery activities involved in the tannery industries at the time of sampling. TDS in the effluents from the tannery industries in Kano, Nigeria was reported to be $1281 \mathrm{mg} / \mathrm{l}$ (Akan et al., 2007). The average values of SS observed in this present study are less than those observed by Mohammed et al. (2017) and Baba et al. 2020)

The mean level of COD (mg/l) observed in TAN1, TAN2 and TAN3 samples seasons were $2372 \pm 938 ; \quad 1406 \pm 208$ and $3532 \pm 1373$ respectively. The order of the mean COD of the samples from the three industries can be arranged as TAN3>TAN1> TAN2. The COD observed in TAN1, TAN2 and TAN3 samples were far above the recommended standard limits of regulating bodies $\mathrm{WHO}(40 \mathrm{mg} / \mathrm{l})$ and NESREA (40 mg/l). Statistical analysis shows that there is no significant difference $(p<0.05)$ in COD among the industries. This might be due to similar tannery activities involved in the tannery industries as at the time of sampling. The Chemical Oxygen demand (COD) is the amount of oxygen, in $\mathrm{mg} / \mathrm{L}$, required for the degradation of the compound of wastewater to occur. In comparison, the average values of COD observed in this present study were higher than that observed by Mohammed et al. (2017) but lower than that observed by Baba et al. (2020).

The mean levels of BOD $(\mathrm{mg} / \mathrm{l})$ observed in TAN1, TAN2 and TAN3 samples were $13.85 \pm 6.42 ; \quad 19.46 \pm 0.50$ and $17.13 \pm 3.14$ respectively. The order of the mean BOD in the samples from the three industries can be arranged as TAN2>TAN3>TAN1. The BOD observed in TAN1, TAN2 and TAN3 samples were found below the recommended limits of NESREA (200 mg/l) but above WHO (10 mg/l). Statistical analysis shows that there is no significant difference $(p<0.05)$ between the mean values of BOD among the industries. This might be due to similar tannery activities involved in the tannery industries at the time of sampling. The low level of BOD recorded in this study is an indication of the low level of biodegradable organic solids in the effluent. The average values of BOD observed in this present study were lower than those observed by Mohammed et al. (2017) and Baba et al. (2020).

Table 1: Mean Values \pm S.D of Physico-chemical parameters of effluents from the Tannery Industries before Treatment.

\begin{tabular}{llllllll}
\hline Parameter & Tannery 1 & Tannery 2 & Tannery 3 & $\mathrm{a}$ & $\mathrm{b}$ & $\mathrm{c}$ & $\mathrm{d}$ \\
\cline { 2 - 7 } Temperature $\left({ }^{\circ} \mathrm{C}\right)$ & $28.07 \mathrm{a} \pm 0.65$ & $27.77 \mathrm{a} \pm 0.64$ & $26.38 \mathrm{a} \pm 3.81$ & & $29.50 \pm 4.68$ & 35 & 40 \\
pH & $7.77 \mathrm{a} \pm 2.93$ & $8.35 \mathrm{a} \pm 0.28$ & $7.52 \mathrm{a} \pm 0.76$ & 6.89 & $5.35 \pm 1.57$ & $7.0-8.5$ & $6.0-9.0$ \\
$\mathrm{COD}(\mathrm{mg} / \mathrm{l})$ & $2372 \mathrm{a} \pm 938$ & $1406 \mathrm{a} \pm 208$ & $3532 \mathrm{a} \pm 1373$ & 2.2 & $3106 \pm 2753$ & 40 & 40 \\
$\mathrm{BOD}(\mathrm{mg} / \mathrm{l})$ & $13.85 \mathrm{a} \pm 6.42$ & $19.46 \mathrm{a} \pm 0.50$ & $17.13 \mathrm{a} \pm 3.14$ & 1032 & $26.17 \pm 9.49$ & 10 & 200 \\
$\mathrm{SS}(\mathrm{mg} / \mathrm{l})$ & $374 \mathrm{a} \pm 124$ & $358 \mathrm{a} \pm 335$ & $780 \mathrm{a} \pm 739$ & 501 & $562 \pm 482$ & 30 & 10 \\
TDS $(\mathrm{mg} / \mathrm{l})$ & $3941 \mathrm{a} \pm 3703$ & $3300 \mathrm{a} \pm 1714$ & $2653 \mathrm{a} \pm 1240$ & 532.7 & $444 \pm 507$ & 250 & 500 \\
\hline
\end{tabular}

The values given in the table above are means of 6 replicate values, $\mathrm{n}=6$ ( 1 sample was taken monthly for 6 months). Within the rows, means with different alphabets are statistically different $(p<0.05)$. WHO: World Health Organisation. NESREA: National Environmental Standard and Regulatory Enforcement Agency. a = Mohammed et al.(2017), b = Baba et al. (2020), c = WHO (2006), $d=$ NESSRA (2009) 
BAJOPAS Volume 13 Number 2, December, 2020

Identification, Biochemical Characterization and growth rates of the Bacterial Isolates

Results of identification and biochemical characterization of the bacterial isolates were shown in table 2. After 24 hours of incubation, the nutrient agar media plates were checked for bacterial growth. The results showed the presence of different strains in the samples. The TAN1 bacteria isolate was found to be gramnegative cocci while TAN3 was gram-positive cocci. TAN2 bacteria isolate was found to be gram-positive, rod-shaped. TAN1, TAN2, and TAN3 bacteria isolates recorded positive results for spore former.

The results of the biochemical tests indicated that all the bacteria were positive for catalase, oxidase, citrate, maltose, glucose, lactose (negative in TAN1), mannitol (negative in TAN2), starch hydrolysis and coagulase (negative in TAN2) tests. The bacteria showed negative results for nitrate reduction, $M R$ (positive in TAN2), VP (positive in TAN1), Indole (positive in TAN2) tests. Base on the morphological and biochemical test results, TAN1, TAN2, and TAN3 bacteria isolates were identified to be Nesseria spp, Bacillus cereus, and Staphylococcus aureus respectively.

The growth rate of the TAN1, TAN2 and TAN3 Isolates were shown in figure 2. Generally, the optical density increase with the increase in time (day) and decrease as time goes on. The highest optical density was shown by bacillus cereus in TAN2 while the lowest was shown by Staphylococcus aureus in TAN3.

The initial growth phase of TAN1 Isolate bacteria occurred within 2-day of incubation as the growth rate increases up to the 6th-day incubation when the maximum growth was observed. Beyond the 6th day, the growth of the bacteria declined (which might be due to a shortage of nutrients in the effluents) until it reached its death phase (which might be due to the unavailability of nutrients in the effluents).

A similar trend of growth was also observed for TAN2 Isolate as the initial growth phase also occurred within 2-day of incubation but maximum growth rate observed on the 4th day of incubation. The stationary stage occurred between the 4th day and the 8th day. Beyond the 8th day, the growth of the bacteria declined (which might be due to a shortage of nutrients in the effluents) until it reached its death phase (which might be due to the unavailability of nutrients in the effluents).

The initial growth phase of TAN3 bacterial Isolate occurred within the 3-day incubation as the growth rate increases up to the 6th-day incubation when the maximum growth was observed. Beyond the 6th day, the growth of the bacteria declined (which might be due to a shortage of nutrients in the effluents) until it reached its death phase (which might be due to the unavailability of nutrients in the effluents).

Table 2: Morphological and Biochemical characteristics of bacterial isolates

\begin{tabular}{lllll} 
Bacterial Isolates & & TAN1 & TAN2 & TAN3 \\
\hline $\begin{array}{lllll}\text { Morphological } \\
\text { characteristics }\end{array}$ & Shape & Cocci & Rod & Cocci \\
& Spore & & & \\
& former & + & + & + \\
Gram & & & \\
Biochemical characteristics & reaction & - & + & + \\
& Citrate & + & + & + \\
& Catalase & + & + & + \\
& Coagulase & + & - & + \\
Starch & + & + & + \\
& Glucose & + & + & + \\
Oxidase & + & + & + \\
& Indo & - & + & - \\
Lactose & - & + & + \\
Manitol & + & - & + \\
Maltose & + & + & + \\
MR & - & + & - \\
VP & + & - & - \\
& Nitrate & - & - & - \\
Reduction & - Neisseria & Bacillus & Staphylococcus \\
& Bacterial & cereus & aureus \\
& name & spp & cas
\end{tabular}

+ = Positive; - = Negative; MR=Methyl Red; VP= Voges-Proskauer 


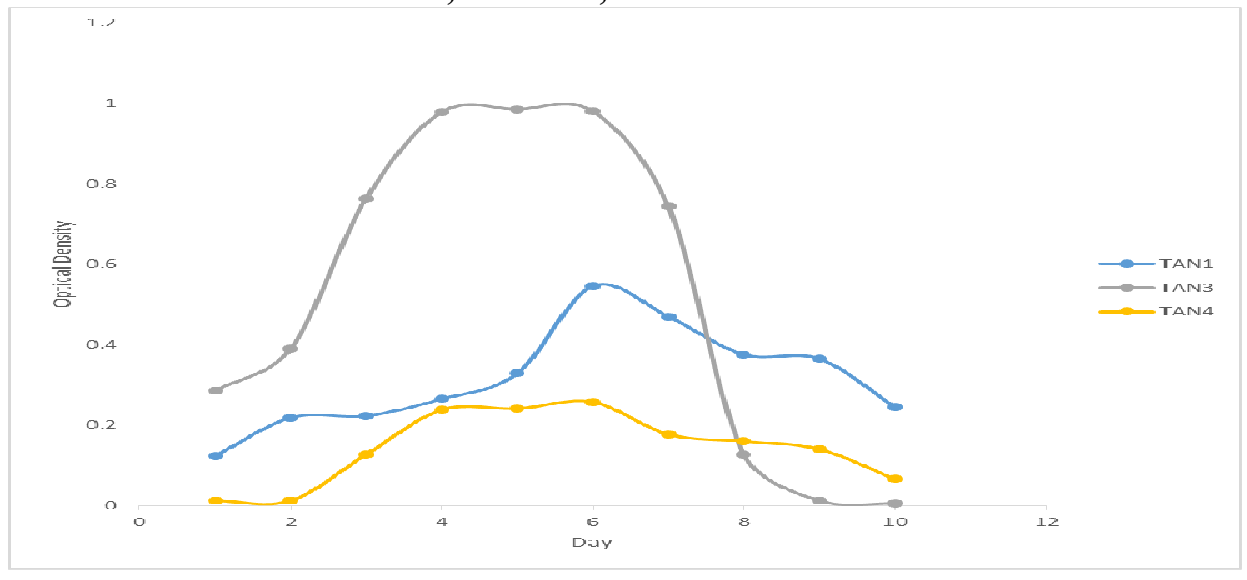

Fig. 2 Growth rates of the isolates in the effluents from the Tannery Industries

\section{Physico-chemical Parameters in the Industrial Effluents after the biodegradation.}

Table 3 shows the mean results of the physicochemical parameter before and after bioremediation using the different masses $(5 \mathrm{~g}$, $10 \mathrm{~g}, 15 \mathrm{~g}, 20 \mathrm{~g}$, and $25 \mathrm{~g}$ ) of the respective immobilized bacteria. Also, Table 4 shows the mean results of correlation coefficient ( $r$ ) between different masses of bacteria and physicochemical parameters.

The mean values $(\mathrm{mg} / \mathrm{l})$ of the SS after the bioremediation varies between $243 \pm 45$ and $898 \pm 672$. The mean concentration $(\mathrm{mg} / \mathrm{l})$ of SS remediated by the different masses $(5 \mathrm{~g}, 10 \mathrm{~g}$, $15 \mathrm{~g}, 20 \mathrm{~g}$, and $25 \mathrm{~g}$ ) of the bacteria varies. The SS in the samples fluctuates up and down after the bioremediation process when compared with the SS of the raw samples before the bioremediation. The increase in the levels of the SS might be due to the aggregation of the TDS which are large enough to result into SS. The increase in the levels of the SS might be also due to the influence of the nutrients which was added into the effluents in order to make the microorganisms more active and viable for fast degradation of organic contaminants in the effluent. The relative potential or efficiency of the different masses of the bacteria in remediating SS in TAN1 samples was in the order $25 \mathrm{~g}>20 \mathrm{~g}>15 \mathrm{~g}>10 \mathrm{~g}>5 \mathrm{~g}$. For TAN2 and TAN3 samples, the order was $25 \mathrm{~g}>20 \mathrm{~g}>15$ $\mathrm{g}>10 \mathrm{~g}>5 \mathrm{~g}$. These might be due to the variations in the surface areas of the different masses of the immobilized bacteria. Statistical analysis shows that there is no significant difference $(p<0.05)$ between the mean values of SS among the masses in the respective industries. Positive and significant correlations exist between the masses of bacteria and Suspended Solid (SS). This showed that there is general increase in the levels of the SS as the masses of the immobilized bacteria increases. TAN3 (90\%) and TAN1 (80\%) showed a very high correlation with the masses of the bacteria while TAN2 (61\%) showed a very low correlation.

The mean values $(\mathrm{mg} / \mathrm{l})$ of the TDS after the bioremediation varies between $46 \pm 11$ and $83 \pm 78$. The mean concentration $(\mathrm{mg} / \mathrm{l})$ of TDS remediated by the different masses $(5 \mathrm{~g}, 10 \mathrm{~g}$, $15 \mathrm{~g}, 20 \mathrm{~g}$, and $25 \mathrm{~g}$ ) of the bacteria varies. There is a reduction in all the TDS of all the samples after the bioremediation process compared with the TDS of the raw samples before the bioremediation. The relative potential or efficiency of the different masses of the bacteria in remediating TDS in TAN1 and TAN3 samples was in the order $5 \mathrm{~g}>10 \mathrm{~g}>15 \mathrm{~g}>20$ $\mathrm{g}>25 \mathrm{~g}$. For TAN2 samples, the order was 20 $g>10 \quad g>25 \quad g>15 \quad g>5 \quad g$. Statistical analysis shows that there is no significant difference $(p<0.05)$ between the mean values of TDS among the masses in the respective industries. These might be due to the variations in the surface areas of the different masses of the immobilized bacteria. Positive and significant correlations exist between the masses of bacteria and TDS with the exception in TAN2 (negative and insignificant correlation). The positive correlations showed that there is general increase in the levels of the TDS as the masses of the immobilized bacteria increases. TAN1 $(96 \%)$ showed a very high correlation with the masses of the bacteria while TAN2 (47\%) showed a very low correlation.

The mean values $(\mathrm{mg} / \mathrm{l})$ of the BOD after the bioremediation varies between $1.56 \pm 0.20 \mathrm{mg} / \mathrm{l}$ and $6.92 \pm 5.49 \mathrm{mg} / \mathrm{l}$. The mean concentration $(\mathrm{mg} / \mathrm{l})$ of BOD remediated by the different masses $(5 \mathrm{~g}, 10 \mathrm{~g}, 15 \mathrm{~g}, 20 \mathrm{~g}$, and $25 \mathrm{~g}$ ) of the bacteria varies. There is a reduction in all the BOD of all the samples after the bioremediation process compared with the $\mathrm{BOD}$ of the raw 
BAJOPAS Volume 13 Number 2, December, 2020 samples before the bioremediation. The relative potential or efficiency of the different masses of the bacteria in remediating BOD in TAN1, TAN2 and TAN3 samples were in the order $25 \mathrm{~g}>20$ $\mathrm{g}>15 \mathrm{~g}>10 \mathrm{~g}>5 \mathrm{~g}, 25 \mathrm{~g}>15 \mathrm{~g}>5 \mathrm{~g}>10 \mathrm{~g}>20 \mathrm{~g}$ and $20 \mathrm{~g}>10 \mathrm{~g}>25 \mathrm{~g}>15 \mathrm{~g}>5 \mathrm{~g}$ respectively. Statistical analysis shows that there is significant difference $(p<0.05)$ between the mean values of BOD among the masses in the respective industries. These might be due to the variations in the surface areas of the different masses of the immobilized bacteria. Negative and significant correlations exist between the masses of bacteria and BOD. This showed that there is general decrease in the levels of the BOD as the masses of the immobilized bacteria increases. TAN1 (94\%) showed a very high correlation with the masses of the bacteria while TAN2 (4\%) showed a very low correlation.

The mean values $(\mathrm{mg} / \mathrm{l})$ of the COD after the bioremediation varies between $250 \pm 154$ and $3134 \pm 1595$. The mean concentration $(\mathrm{mg} / \mathrm{l})$ of COD remediated by the different masses $(5 \mathrm{~g}$, $10 \mathrm{~g}, 15 \mathrm{~g} 20 \mathrm{~g}$, and $25 \mathrm{~g}$ ) of the bacteria varies. There is a reduction in all the COD of all the samples after the bioremediation process compared with the COD of the raw samples before the bioremediation. The relative potential or efficiency of the different masses of the bacteria in remediating COD in TAN1, TAN2 and TAN3 samples were in the order $25 \mathrm{~g}>20 \mathrm{~g}>15$ $\mathrm{g}>5 \mathrm{~g}>10 \mathrm{~g}, 25 \mathrm{~g}>20 \mathrm{~g}>15 \mathrm{~g}>10 \mathrm{~g}>5 \mathrm{~g}$ and 10 g>5 g>25 g>15 g>20 g respectively. Statistical analysis shows that there were significant difference $(p<0.05)$ between the mean values of COD among the masses in the respective industries except for effluents treated with $25 \mathrm{~g}$. These might be due to the variations in the surface areas of the different masses of the immobilized bacteria. Negative and insignificant correlations exist between the masses of bacteria and COD with the exception in TAN3 (positive and significant correlation). The negative correlations showed that there is general decrease in the levels of the COD as the masses of the immobilized bacteria increases. TAN2 (100\%) showed a very high correlation with the masses of the bacteria while TAN3 (36\%) showed a very low correlation.

Generally, there was an overall decrease in the concentration of these physicochemical parameters after the bioremediation using the different masses of the bacterial isolates. These might be due to the variations in the surface areas of the different masses of the immobilized bacteria. This is in line with the work of Jimoh et al. (2018) and Baba et al. (2020).

Table 3: Mean Values $(\mathrm{mg} / \mathrm{l}) \pm$ S.D of Physicochemical parameters in effluents from the Tannery Industries before and after Treatment of the effluents $(250 \mathrm{ml})$ with the different masses $(5 \mathrm{~g}, 10 \mathrm{~g}$, $15 \mathrm{~g}, 20 \mathrm{~g}$, and $25 \mathrm{~g}$ ) of the bacteria.

\begin{tabular}{llllllll}
\hline $\mathrm{P}$ & IND & Before & \multicolumn{5}{c}{ After } \\
\cline { 4 - 7 } & & & $5 \mathrm{~g}$ & $10 \mathrm{~g}$ & $15 \mathrm{~g}$ & $20 \mathrm{~g}$ & $25 \mathrm{~g}$ \\
\hline \multirow{2}{*}{ COD } & TAN1 & $2372 \pm 938$ & $1708 \mathrm{a} \pm 861$ & $2045 \mathrm{a} \pm 1205$ & $845 \mathrm{a} \pm 369$ & $300 \mathrm{a} \pm 167$ & $250 \mathrm{a} \pm 154$ \\
& TAN2 & $1406 \pm 208$ & $1195 \mathrm{a} \pm 208$ & $1125 \mathrm{a} \pm 384$ & $1055 \mathrm{a} \pm 317$ & $956 \mathrm{a} \pm 310$ & $870 \mathrm{ab} \pm 240$ \\
& TAN3 & $3532 \pm 1373$ & $2374 \mathrm{a} \pm 1344$ & $1976 \mathrm{a} \pm 1405$ & $2757 \mathrm{a} \pm 1266$ & $3134 \mathrm{a} \pm 1595$ & $2614 \mathrm{~b} \pm 1105$ \\
BOD & TAN1 & $13.85 \pm 6.42$ & $6.92 \mathrm{a} \pm 5.49$ & $6.42 \mathrm{a} \pm 5.07$ & $5.72 \mathrm{a} \pm 5.35$ & $4.62 \mathrm{a} \pm 4.37$ & $2.82 \mathrm{ab} \pm 1.26$ \\
& TAN2 & $19.46 \pm 0.50$ & $1.75 \mathrm{~b} \pm 0.22$ & $1.73 \mathrm{~b} \pm 0.18$ & $1.58 \mathrm{a} \pm 0.16$ & $1.91 \mathrm{a} \pm 0.22$ & $1.56 \mathrm{~b} \pm 0.20$ \\
& TAN3 & $17.13 \pm 3.14$ & $4.24 \mathrm{ab} \pm 0.77$ & $3.29 \mathrm{ab} \pm 0.37$ & $4.11 \mathrm{a} \pm 0.07$ & $3.23 \mathrm{a} \pm 0.91$ & $3.33 \mathrm{a} \pm 1.28$ \\
SS & TAN1 & $374 \pm 124$ & $243 \mathrm{a} \pm 45$ & $471 \mathrm{a} \pm 226$ & $475 \mathrm{a} \pm 182$ & $492 \mathrm{a} \pm 128$ & $611 \mathrm{a} \pm 217$ \\
& TAN2 & $358 \pm 335$ & $460 \mathrm{a} \pm 400$ & $543 \mathrm{a} \pm 414$ & $544 \mathrm{a} \pm 402$ & $551 \mathrm{a} \pm 414$ & $554 \mathrm{a} \pm 405$ \\
& TAN3 & $780 \pm 739$ & $586 \mathrm{a} \pm 594$ & $758 \mathrm{a} \pm 656$ & $787 \mathrm{a} \pm 676$ & $861 \mathrm{a} \pm 635$ & $898 \mathrm{a} \pm 672$ \\
TDS & TAN1 & $3941 \pm 3703$ & $51 \mathrm{a} \pm 10$ & $53 \mathrm{a} \pm 10$ & $55 \mathrm{a} \pm 15$ & $61 \mathrm{a} \pm 20$ & $63 \mathrm{a} \pm 26$ \\
& TAN2 & $3300 \pm 1714$ & $83 \mathrm{a} \pm 78$ & $47 \mathrm{a} \pm 20$ & $48 \mathrm{a} \pm 22$ & $47 \mathrm{a} \pm 17$ & $48 \mathrm{a} \pm 17$ \\
& TAN3 & $2653 \pm 1240$ & $46 \mathrm{a} \pm 11$ & $55 \mathrm{a} \pm 24$ & $55 \mathrm{a} \pm 25$ & $58 \mathrm{a} \pm 23$ & $61 \mathrm{a} \pm 28$ \\
\hline
\end{tabular}

Replicate $=6$ (months)

Within the rows, for the same parameter, means with different alphabets are statistically different $(p<0.05)$.

$\mathrm{P}=$ parameter, IND = Industries 
BAJOPAS Volume 13 Number 2, December, 2020

Table 4: Correlation coefficient $(r)$ between different masses of the bacteria and the physicochemical parameters.

\begin{tabular}{llll}
\hline Industries & Parameter & Correlation coefficient $(r)$ & $\begin{array}{l}\text { Percent dependence (rxrx100) } \\
(\%)\end{array}$ \\
\hline TAN1 & COD & -0.9 & 82 \\
& BOD & -0.97 & 94 \\
& SS & $0.90^{*}$ & 80 \\
TAN2 & TDS & $0.98^{*}$ & 96 \\
& COD & -1 & 100 \\
& BOD & -0.21 & 4 \\
& SS & $0.78^{*}$ & 61 \\
& TDS & -0.69 & 47 \\
& COD & $0.60^{*}$ & 36 \\
& BOD & -0.6 & 37 \\
& SS & $0.95^{*}$ & 90 \\
& TDS & $0.94^{*}$ & 89 \\
\hline
\end{tabular}

The correlation coefficient $(r)$ with * is statistically significant $(p<0.05)$.

Percentage reduction of the Parameters

Table 5 shows the percentage reduction of Parameters in industrial samples before and after the treatment of the effluents $(250 \mathrm{ml})$ with the different masses $(5 \mathrm{~g}, 10 \mathrm{~g}, 15 \mathrm{~g}, 20 \mathrm{~g}$, and $25 \mathrm{~g}$ ) of the Immobilized Bacteria.

In TAN1 samples, the percentage reduction (\%) of COD ranged (14-89); BOD (50-80); SS (-32$35)$ and TDS (98-99). In TAN2 samples, the percentage decrease $(\%)$ of COD ranged (15$38) ;$ BOD (90-92); SS [-28-(-55)] and TDS (9798). In TAN3 samples, the percentage decrease (\%) of COD ranged (11-44); BOD (76-81); SS (15-25) and TDS (98). The percentage increase in the levels COD, BOD and TDS might be due to the increase in the surface area of the different masses of the immobilized bacteria. However, the percentage decrease in the levels of the SS might be due to the aggregation of the TDS which are large enough to result into SS. The percentage decrease in the levels of the SS might be also due to the influence of the nutrients which was added into the effluents in order to make the microorganisms more active and viable for fast degradation of organic contaminants in the effluent. This is in line with the work of Jimoh et al. (2018) in which the concentration of the SS increase after the bioremediation of effluents.

Sreemoyee and Priti (2013) assessed and reduced several Physico-chemical parameters of dairy wastewater using Niesseria $s p$. and concluded that the species are well known to degrade organic compounds. This is in agreement with the current study in which the immobilized Niesseria $s p$ degrade the organic contaminants as indicated by the BOD, COD and TDS.

Jimoh et al. (2018) observed that TSS of the effluents was increased after treatment with immobilized bacteria and concluded that it might be due to the biostimulation method adopted for the research.

The optimum $\mathrm{pH}$ Biosorption of Chromium by Bacillus spp and Staphylococcus spp. from tannery effluent was investigated by Mythili and Karthikeyan (2011). The maximum adsorption of Chromium $(86.4 \mathrm{mg} / \mathrm{L})$ was showed by Bacillus spp and Staphylococcus spp showed $70.6 \mathrm{mg} / \mathrm{L}$ at an initial concentration of $100 \mathrm{mg} / \mathrm{L}$. In the present study, immobilised Bacillus spp and Staphylococcus spp. from the tannery industrial effluents reduced the levels of the organic pollutants with high potential as indicated by the percentage reduction of BOD, COD and TDS.

Enzymes often can work in multiple environments especially if they are immobilized. This makes the microorganisms' enzymes even more resistant to harsh environments and enables the enzymes to be recovered and recycled after they are no longer needed (Gianfreda and Rao 2004). Ramesh and Singh (1993) reported that the immobilized bacteria having more efficiency to remove the suspended particles than free cells. Using the immobilized cell is preferable due to its capability for using several times with the same efficiency, which makes it more economical. Similar work was done by Sikander et al. (2007) showing the higher reduction with permeabilized cells of Ochrobactrum intermedium strain SDCr-5. 
BAJOPAS Volume 13 Number 2, December, 2020

The results revealed the isolation and identification of isolates with the potential for the reduction of $\mathrm{Cr}$ (VI) to $\mathrm{Cr}$ (III). Results indicated that immobilized $B$. cereus could be efficiently used for the reduction of $\mathrm{Cr}$ (VI).

Table 5: Percentage reduction of the tested Parameters from the tannery industrial samples of the Immobilized Bacteria.

\begin{tabular}{lllllll}
\hline \multirow{2}{*}{ Industries } & & \multicolumn{5}{c}{ Percentage Reduction $(\%)$} \\
\cline { 3 - 7 } & & $5 \mathrm{~g}$ & $10 \mathrm{~g}$ & $15 \mathrm{~g}$ & $20 \mathrm{~g}$ & $25 \mathrm{~g}$ \\
\hline TAN1 & COD & 28 & 14 & 64 & 87 & 89 \\
& BOD & 50 & 54 & 59 & 67 & 80 \\
& SS & 35 & -26 & -27 & -32 & -63 \\
& TDS & 99 & 99 & 99 & 98 & 98 \\
TAN2 & COD & 15 & 20 & 25 & 32 & 38 \\
& BOD & 91 & 91 & 92 & 90 & 92 \\
& SS & -28 & -52 & -52 & -54 & -55 \\
& TDS & 97 & 99 & 99 & 99 & 99 \\
& COD & 33 & 44 & 22 & 11 & 26 \\
& BOD & 75 & 81 & 76 & 81 & 81 \\
& SS & 25 & 3 & -1 & -10 & -15 \\
& TDS & 98 & 98 & 98 & 98 & 98 \\
\hline
\end{tabular}

Percentage Reduction $=(B-A) / B \times 100 \%$

$A=$ Concentration of the parameter after treatment

$\mathrm{B}=$ Concentration of the parameter before treatment

$+=$ percentage decrease

- = percentage increase

In general, immobilization makes the enzyme more resistant to temperature, $\mathrm{pH}$, and substrate concentration swings giving it a longer lifetime and higher productivity per active unit (Gianfreda and Rao, 2004; FuIlbrook, 1996; Russell et al, 2003; Kandelbauer et al., 2004). Immobilized cells have been used and studied extensively for the production of useful chemicals (Ohtake and Silver, 1994), the treatment of wastewaters (Chen et al., 2003; Wang et al., 2010). Although many workers described microbial degradation of tannery effluent, limited literature is available on the bioremediation of tannery effluent using immobilized bacterial cells in the Kano Industrial Estates.

\section{CONCLUSION}

The samples contained variable levels of the physicochemical parameters. The results of the Analysis of variance revealed that, no statistical difference $(p<0.05)$ was observed for the temperature, $\mathrm{pH}, \mathrm{SS}, \mathrm{TDS}, \mathrm{BOD}$ and $\mathrm{COD}$ among the three tannery industries before the treatment. The levels of some of the parameters
(SS, TDS and COD) observed in the samples were found above the recommended limits of WHO and NESREA, which called for the treatment of the effluents before discharge into the environment. Base on the morphological and biochemical test results, TAN1, TAN2, and TAN3 bacterial isolates were identified to be Neisseria spp, Bacillus cereus, and Staphylococcus aureus respectively. The results of Post-treatment analysis showed that there is overall decrease in the levels of the parameters determined when compared with that of the pre-treatment. The overall percentage reduction of the immobilised bacteria in the treatment of the respective effluents was in the order TAN2 (72\%)>TAN1 $(70 \%)>$ TAN3 $(62 \%)$. Hence, the immobilized bacteria are having higher biodegradation potential for the treatment of the tannery effluents.

\section{Acknowledgments}

The authors wish to acknowledge the University of Maiduguri for the financial support. The authors are grateful to the Kano State Ministry of Environment for their support in obtaining the effluent samples. 


\section{REFERENCES}

Ajao, A. T., Adebayo, G. B., and Yakubu, S. E. (2011). Bioremediation of textile industrial effluent using mixed culture of Pseudomonas aeruginosa and Bacillus subtilis immobilized on agar-agar in a bioreactor. J. Microbiol. Biotech. Res, 1(3), 50-56.

Akan, J. C., Moses, E. A., Ogugbuaja, V. O., and Abah, J. (2007). Assessment of tannery industrial effluents from Kano metropolis, Kano State, Nigeria. Journal of Applied Sciences, 7(19), 2788-2793.

Akan, J. C., Ogugbuaja, V. O., Abdulrahman, F. I., and Ayodele, J. T. (2009). Pollutant levels in effluent samples from tanneries and textiles of Kano industrial areas, Nigeria. Global journal of pure and applied sciences, 15(3-4).

APHA (1989). Standard methods for Examination of Will bete and Will betewater.15 $5^{\text {th }}$ edition. Brydpass Springfield Will behington DC. pp. 164-176

APHA (1992). Standard Methods for the Examination of Water and Wastewater. Health, 69, 1116-9.

Baba, A., Garba, S. T., and Bello, H. S. (2020). Bioremediation Potential of Immobilized corynebacterium kutsceri in the Treatment of Tannery Industrial Effluent from Challawa Industrial Estate, Kano State, Nigeria. Journal of the Turkish Chemical Society Section A: Chemistry, $7(2), 335-350$.

Beem, E. I. V. (1994). reduction of solvent VOC emission. J. Oil Col. Chem. Ass, 77, 158.

Bouwer, E. J., and Zehnder, A. J. (1993). Bioremediation of organic compoundsputting microbial metabolism to work. Trends in biotechnology, 11(8), 360367.

Chen, K. C., Wu, J. Y., Liou, D. J., and Hwang, S. C. J. (2003). Decolorization of the textile dyes by newly isolated bacterial strains. Journal of Biotechnology, 101(1), 57-68.

Dan'Azumi, S., and Bichi, M. H. (2010). INDUSTRIAL POLLUTION AND HEAVY METALS PROFILE OF CHALLAWA RIVER IN KANO, NIGERIA. Journal of Applied Sciences in Environmental Sanitation, $5(1)$.

DWAF. (1992). Analytical Methods Manual, TR 151. Department of Water Affairs and Forestry, Pretoria.

El-Bestawy, E. (2013). Biological treatment of leather-tanning industrial wastewater using free living bacteria.
Elsheikh, M. A. S. (2009). Tannery wastewater pre-treatment. Water Science and Technology, 60(2), 433-440.

FuIlbrook, P. D. (1996). "Kinetics." Industrial enzymology: The application of enzymes in Industry. 2nd Ed. T. Godfrey and J Reichelt. eds.. Nature. New York.

Gianfreda, L., and Rao, M. A. (2004). Potential of extra cellular enzymes in remediation of polluted soils: a review. Enzyme and microbial technology, 35(4), 339354.

Hugo Springer. (1994). John Arthur Wilson Memorial Lecture "Treatment of Industrial Wastes of the Leather Industry - is it still a Major Problem". JALCA, 89, 153-185

Jimoh, A. A., Ganiyu, B. A., Baba, D., and Baba, A. (2018) Bioremediation Process of Effluent from Detergent and Food Industries in Jos, Nigeria: Kinetics and Thermodynamics. International Journal of Engineering Science Invention (IJESI), 762-73

Kandelbauer, A., Maute, O., Kessler, R. W., Erlacher, A., and Gübitz, G. M. (2004). Study of dye decolorization in an immobilized laccase enzyme-reactor using online spectroscopy. Biotechnology and bioengineering, 87(4), 552-563.

Kongjao, S., Damronglerd, S., and Hunsom, M. (2008). Simultaneous removal of organic and inorganic Pollutants in tannery wastewater using electrocoagulation technique. Korean Journal of chemical engineering, 25(4), 703.

Maheshwari, U. M., Aruna, S., Gomathi, M., and AbdulJaffar, A. H. (2017). Bioremediation by Free and Immobilized Bacteria Isolated from Tannery Effluent. International Journal of Research in Applied, Natural and Social Sciences. 5(7), 75-90

Margesin, R., and Schinner, F. (2001). Bioremediation (natural attenuation and biostimulation) of diesel-oilcontaminated soil in an alpine glacier skiing area. Applied and environmental microbiology, 677), 3127-3133.

Mohammed, A., Sekar, P., and George, J. (2011). Efficacy of microbes in bioremediation of tannery effluent. Inter. J. Curr. Res, 3(4), 324-326.

Mohammed, S. S. D., Orukotan, A. A., and Abdullahi, H. (2017). Physicochemical and Bacteriological Assessment of Tannery Effluent from Samaru-Zaria, 
BAJOPAS Volume 13 Number 2, December, 2020 Kaduna State, Nigeria. Journal of Applied

Sciences and Environmental Management, 21(4), 734-740.

Munz, G., De Angelis, D., Gori, R., Mori, G., Casarci, M., and Lubello, C. (2009). The role of tannins in conventional and membrane treatment of tannery wastewater. Journal of hazardous materials, 164(2-3), 733-739

Mythili, K., and Karthikeyan, B. (2011). Bioremediation of $\mathrm{Cr}$ (VI) from tannery effluent using Bacillus spp and Staphylococcus spp. International Multidisciplinary Research Journal, 1(6).

NESREA (2009). National Environmental Standards for Effluent Limitations and Regulation. 1233-1236

Noorjahan, C. M. (2014). Physicochemical characteristics, identification of bacteria and biodegradation of industrial effluent. Journal of bioremediation and Biodegradation, 5(3).

Ohtake, H. I., and Silver, A. O. (1994). Bacterial reduction of toxic chromate. Biological degradation and bioremediation of toxic chemicals, 403-415.

Omoleke, I. I. (2004). Management of environmental pollution in Ibadan, an African city: the challenges of health hazard facing government and the people. Journal of Human Ecology, 15(4), 265-275.

Rajor, A., Reddy, A.S., and Singh, B. (2004). Determination of BOD kinetic Parameters and evaluation of alternate methods, M.Sc. Thesis, Department of biotechnology \& environmental Science, Thapar Institute of Engineering and Technology, Patiala

Ramasami, T., Rajamani, S., and Rao, J. R. (1994, March). Pollution control in leather industry: Emerging technological options. In International symposium on surface and colloidal science and its relevance to soil pollution, madras.

Ramesh, J. V. S., and Singh, S. P. (1993). Yearly variation in certain physicochemical parameters of pond at eastern Doon Valley. Uttar Pradesh J. Zoo, 12 (1), 7577.

Ranen, S., and Sharadinadra, C. (2009). Biotechnology applications to environmental remediation in resource exploitation. Current science, 97, 6-25
Russell, A. J., Berberich, J. A., Drevon, G. F., and Koepsel, R. R. (2003). Biomaterials for mediation of

chemical and biological warfare agents. Annual review of biomedical engineering, 5(1), 1-27.

Saravanan, P., and Saravanan, A. (1999). Decolourization of tannery effluent by Flavobacterium sp. EK 1. Indian Journal of Environmental Protection, 19, 19-24.

Sikander, S., and Shahida, H. (2007). Reduction of toxic hexavalent chromium by Ochrobactrum intermedium strain SDCr5 stimulated by heavy metals. Bioresource Technol, 98, 340-344.

Singh, N., Sharma, B. K., and Bohra, P. C. (2000). Impact assessment of industrial effluent of arid soils by using satellite imageries. Journal of the Indian Society of Remote Sensing, 28(2-3), 79.

Sreemoyee, C., and Priti, P. (2013). Assessment of physico-chemical parameters of dairy waste water and isolation and characterization of bacterial strains in terms of cod reduction. Int J Sci, 2(3), 395-400.

Verheijen, L. A. H. M., Wiersema, D., Pol, L. H., and De Wit, J. (1996). Management of wastes from animal product processing. Livestock and environment, Finding a balance. International Agriculture Center, Wageningen, The Netherlands.

Wang, F., Yao, J., Si, Y., Chen, H., Russel, M., Chen, K., and Bramanti, E. (2010). Short-time effect of heavy metals upon microbial community activity. Journal of Hazardous Materials, 173(13), 510-516.

WHO (World Health Organization). (2006). Air quality guidelines: global update 2005: particulate matter, ozone, nitrogen dioxide, and sulfur dioxide. World Health Organization.

World Bank. (1995). Nigeria's strategic options for redressing industrial pollution. World Bank, industry and energy division. 1st edition, West Central Africa Department; Annexes: 1995; pp 60-62.

Zahoor, A., and Abdul, R. (2009). Enumeration of Coliforms. Journal of Environmental Sciences. 21, 814-820 


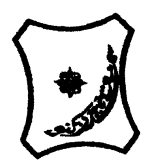

Bayero Journal of Pure and Applied Sciences, 13(2): 1 - 12

Received: November, 2020

Accepted: December, 2020

ISSN $2006-6996$

\title{
BIODEGRADATION POTENTIAL OF IMMOBILIZED BACTERIA IN THE TREATMENT OF TANNERY INDUSTRIAL EFFLUENTS FROM INDUSTRIAL ESTATES IN KANO STATE, NIGERIA
}

\author{
Abdullateef, B., ${ }^{1 *}$ Shuaibu, T. G., ${ }^{1}$ Babagana, K., ${ }^{1}$ Suleman, H. B. ${ }^{2}$ and Dauda, B. ${ }^{3}$ \\ ${ }^{1}$ Department of Pure and Applied Chemistry, Faculty of Science, University of Maiduguri, Borno State, \\ Nigeria \\ ${ }^{2}$ Department of Microbiology, Faculty of Science, University of Maiduguri, Borno State, Nigeria \\ ${ }^{3}$ Department of Chemical Engineering, Faculty of Engineering, University of Maiduguri, Borno State, \\ Nigeria \\ *Corresponding author: babslega@gmail.com; abelega2007@yahoo.com; +2348061309753
}

\section{ABSTRACT}

Industrial Effluents Samples from Gashash Tanneries (TAN1) in Bompai Industrial estate, Larabee Tannery Industry (TAN2) in Sharada Industrial estate and Z Tannery Industries (TAN3) in Challawa Industrial estate, Kano State, Nigeria were collected over a period of six months (August 2017 to January 2018) for assessing the biodegradation potentials of bacteria in the treatment of organic pollutants within the effluents. Bacteria were isolated from the effluents and immobilized on agar-agar. Different masses (5 g, $10 \mathrm{gr}, 15$ $\mathrm{g}, 20 \mathrm{~g}$, and $25 \mathrm{~g}$ ) of the bacteria were used in the treatment of $250 \mathrm{ml}$ of the effluents for ten days in a shaker incubator (Gallenkamp-OC-4364-L) at the temperature $30{ }^{\circ} \mathrm{C}$ and speed of $60 \mathrm{rpm}$. Pre-treatment analysis of the effluents for Temperature, pH, Biochemical Oxygen Demand (BOD), Chemical Oxygen Demand (COD), Suspended Solid (SS) and Total Dissolved Solids (TDS) gives the following results; temperature $\left({ }^{\circ} \mathrm{C}\right.$ )

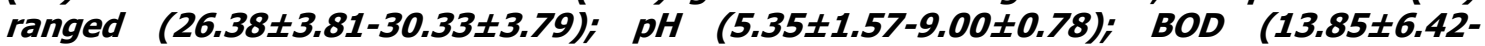
$38.75 \pm 16.20) ;$ COD (1406 $\pm 208-3532 \pm 1373) ;$ SS (208 $\pm 235-780 \pm 739)$ and TDS (266 $\pm 253-5276 \pm 2971)$. No statistical differences ( $p \leq 0.05)$ was observed for all the results among the different industries. The bacterial isolates were identified as Neisseria spp, Bacillus cereus, and Staphylococcus aureus, in TAN1, TAN2, and TAN3, respectively. After treatment of the effluent with the different masses of the isolated bacteria, the mean level of BOD was found to range as (0.55 $\pm 0.36-6.92 \pm 5.49) ; C O D$ (ND-3134 \pm 1595$)$;

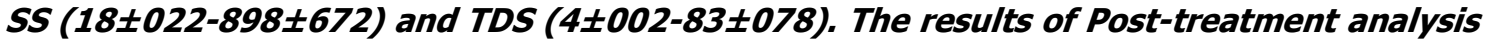
showed that there is overall decrease in the levels of the parameters determined when compared with that of the pre-treatment. The overall percentage reduction of the immobilised bacteria in the treatment of the respective effluents was in the order TAN2 (72\%)>TAN1 (70\%)>TAN3 (62\%). Hence, the immobilized bacteria are having higher biodegradation potential for the treatment of the tannery effluents.

Keywords: Biodegradation, bacteria, effluent, immobilization, tannery.

\section{INTRODUCTION}

Tannery industrial wastewater is a serious consequence of the pollution point of view for streams, freshwater, and land used for agriculture. The lack of awareness in the modern industrial practice has resulted in the discharge of tannery effluents which exhibit very high value of chromium ( $\mathrm{Cr}$ ), Sulfide, and chloride, Total Dissolved Solid (TDS), Total Suspended Solid (TSS), Biochemical Oxygen Demand (BOD) and Chemical Oxygen Demand (COD) in the water stream or land (Mohammed et al., 2001). Tanning is the process, which One ton of skin generally leads to the production of 20 to $80 \mathrm{~m}^{3}$ of turbid and foul-smelling converts the protein of the rawhide or skin into a stable material, which will not putrefy and is suitable for a wide variety of end applications (Elsheikh, 2009). The highly polluting chromium is the most commonly used tanning material producing leather that is more flexible and pliable than vegetable-tanned leather and does not discolor or lose shape in water as drastically as vegetable-tan (Elsheikh, 2009). Tannery effluent is among the most hazardous industrial pollutants due to its huge organic and inorganic load, which is highly toxic to human life and the environment (Kongjao et al., 2008). wastewater including chromium (100-400 mg/l), sulfide $(200-800 \mathrm{mg} / \mathrm{l})$, high levels of fat and 
BAJOPAS Volume 13 Number 2, December, 2020 other solid wastes, and notable pathogen contamination as well as pesticides added for skin conservation during transport (Elsheikh, 2009). There are more than 6000 tanneries in Nigeria with an annual processing capacity of 700,000 tons of hides and skins (Omoleke, 2004; Singh et al., 2008). It was reported that the total amount of waste produced per animal slaughtered is approximately $35 \%$ of its weight (World Bank, 1995). Also, for every $1000 \mathrm{~kg}$ of carcass weight, a slaughtered beef produces 5.5 $\mathrm{kg}$ of manure (excluding rumen contents or stockyard manure) and $100 \mathrm{~kg}$ of paunch manure (undigested food) (Verheijen et al., 1996). Tanneries generate wastewater in the range of 30-35 $\mathrm{L} \mathrm{kg}^{-1}$ skin/hide processed with variable $\mathrm{pH}$, Biological Oxygen Demand (BOD), Chemical Oxygen Demand (COD), high concentrations of suspended solids (SS), and tannins as well as chromium (Zahoor and Abdul, 2009).

Being heterogeneous and composed of a wide variety of compounds, it is very difficult to select a unique direct method for estimating the biodegradability of organic contents and biokinetic parameters for a wastewater sample (Rajor, 2004). For this purpose, some indirect estimation such as determination of biochemical oxygen demand (BOD) and chemical oxygen demand (COD) are applied as common laboratory investigations [9]. During retanning procedures, synthetic tannins (Syntan), oils and resins are added to form softer leather at varying doses (Munz et al., 2009). One of the refractory groups of chemicals in tannery effluents derives mainly from tannins (Ramasami et al., 2004). Syntans are characterized by complex chemical structures, because they are composed of an extended set of chemicals such as phenol-, naphthalene-, formaldehyde- and melamine-based syntans, and acrylic resins (Beem, 1994). Organic pollutants (proteic and lipidic components) are originated from skins (it is calculated that the raw skin has $30 \%$ loss of organic material during the working cycle) or they are introduced during processes (Hugo Springer, 1994).

Many conventional processes such as oxidation, chemical and biological processes were carried out to treat tanneries wastewater (Ebtesam et al, 2013). Biological processes have received more attention because of their costeffectiveness, lower sludge production and environmental friendliness (Noorjahan, 2014). Naturally occurring micro-organisms degrade the hazardous organic wastes including xenobiotic compounds, such as pesticides, polycyclic aromatic hydrocarbons (PAHs) and polychlorinated biphenyls (PCBs) in due course of time (Ranen and Sharadinadra, 2009). Bioremediation is based on the idea that all organisms remove substances from the environment to carry outgrowth and metabolism (Bouwer and Zehnder, 1993). Bacteria, protista and fungi are found to be very good at degrading complex molecules and incorporating the breakdown products into their metabolism (Bouwer and Zehnder, 1993). The resultant metabolic wastes that they produce are generally safe and somehow recycled into other organisms (Ranen and Sharadinadra, 2009). An acclimatized indigenous population of microorganisms capable of degradation of the compounds of interest must exist at the site for a successful bioremediation mode (Ranen and Sharadinadra, 2009). It has been observed that for a successful bioremediation mode, an acclimatized indigenous population of microorganisms capable of degradation of the compounds of interest must exist at the site under investigation (Ranen and Sharadinadra, 2009). Even though there are numerous physical and chemical methods employed in the disposal of wastes the advantage in using bacterium is that they play a key role in the reduction of COD, BOD, total protein, total tannin and total phenol (Saravanan and Saravanan, 1998)

Baba et al. (2020) studied the bioremediation potential of immobilized corynebacterium kutsceri in the Treatment of tannery industrial effluent from Challawa Industrial Estate, Kano State, Nigeria. The aim of the work is to study the reduction in the level of the contaminants through the process of bioremediation using the isolated bacteria. Immobilized bacteria can withstand various temperatures, $\mathrm{pH}$ and substrate concentrations; consequently, increasing the efficiency and the lifespan of the bacteria. Immobilized bacteria are widely applied in the treatment of wastewater and can be separated and recovered after the treatment with the same efficiency (Baba et al., 2020).

\section{MATERIALS AND METHODS \\ Study Area}

This study was carried out in Bompai, Sharada and Challawa industrial estates in Kano, Figure 1. Kano lies on Latitude $11^{\circ} 30^{\prime} \mathrm{N}$ and $8^{\circ} 30^{\prime} \mathrm{E}$ and Longitude $11^{\circ} 5^{\prime} \mathrm{N}$ and $8^{\circ} 5^{\prime} \mathrm{E}$ in Northern Nigeria. It is one of the developed industrial cities in Nigeria. Tannery activities are the dominating industries and this could be one of the reasons for her high population density (Dan'Azumi and Bichi, 2010). Many researchers have studied biodegradation of tannery effluent using microorganisms. However, limited literature is available on the biodegradation of tannery effluent in Kano industrial estates using 
BAJOPAS Volume 13 Number 2, December, 2020 immobilized bacterial cells. This research work focuses on the potential of the use of the indigenous immobilized bacterial isolates in the treatment of tannery effluents in the industrial estates.

\section{Sample Collection}

Effluents were collected from the Tannery Industries from Bompai, Challawa and Sharada Industrial Estates, Kano, Nigeria. The effluents were collected over a period of six months (August 2017 to January 2018). Samples collected in a sterile 4-liter plastic container with a unique identification number were preserved using an ice-box that was transported to the Microbiology Laboratory, Department of Microbiology, Bayero University of Kano for analysis

\section{Sample Preparation and Sample Analysis}

Immediately after the collection of the effluent, $\mathrm{pH}$, TSS, TDS, COD, BOD levels were determined before treatment (Pre-treatment determination) and ten days after treatment (Post-treatment determination) as described in
APHA (1989) standard methods. $\mathrm{pH}$ was determined using Ecotests $\mathrm{pH}$ meter and TDS was determined using AQUALYTIC TDS Salinometer. BOD was determined as described by the standard method (APHA, 1992). COD and SS were determined using DR/2010 HACH portable data logging spectrophotometer (DWAF, 1992)

\section{Identification and Biochemical} Characterization of the Bacterial Isolates

The bacteria were isolated from the effluents using Serial Dilution according to the method described by APHA (1989). The biochemical tests such as oxidase, catalase, coagulase, indole (from $1 \%$ tryptone broth), citrate (Simmons citrate agar), methyl red/VogesProskauer (MR/VP), nitrate reduction, Starch Hydrolysis, Glucose, Maltose, and Lactose tests were carried out on the bacterial isolates to identify the bacteria through the bacteria biochemical characteristics according to Ajao et al. (2011).

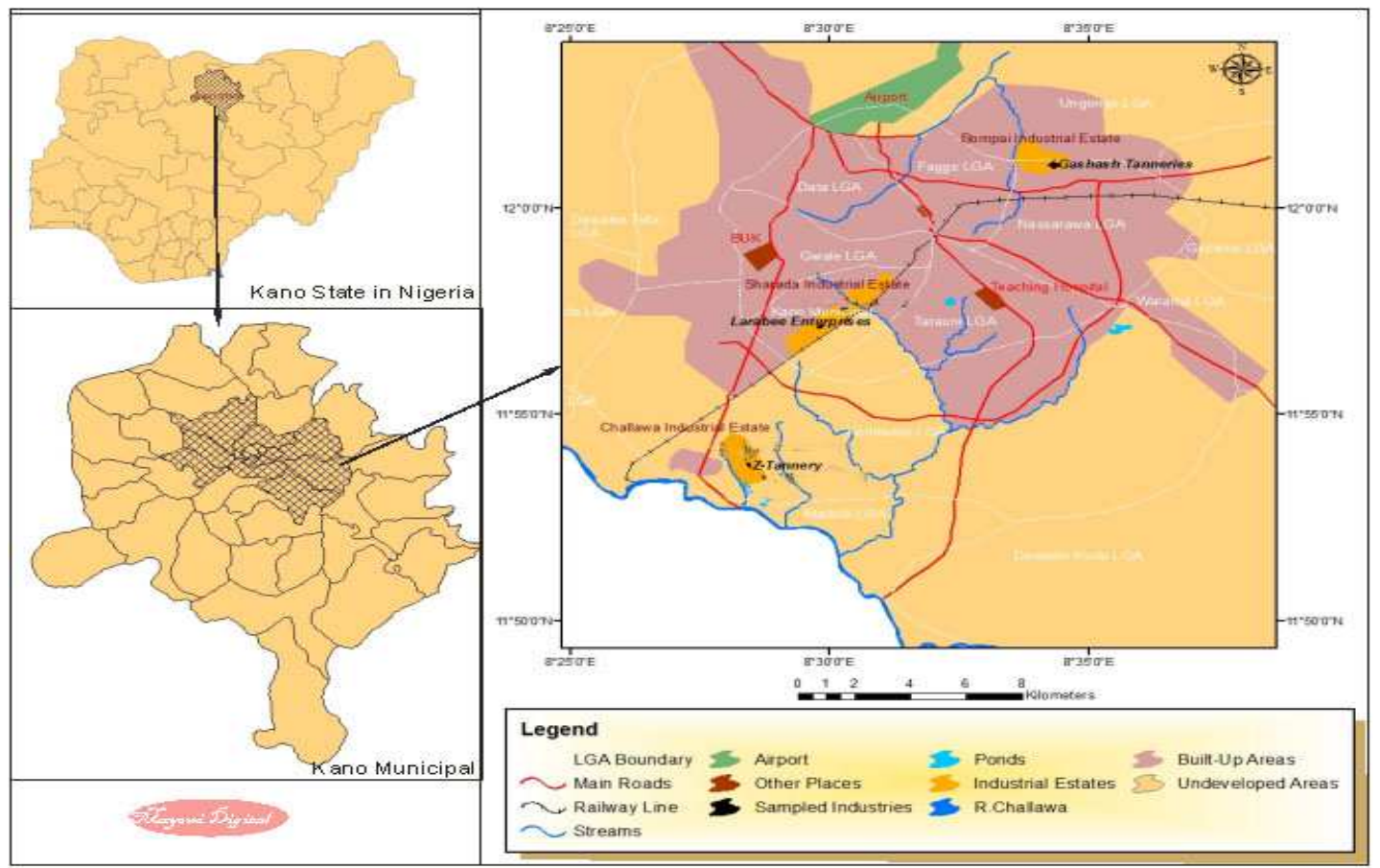

Fig. 1 Map showing the study areas

Source: Mayomi Digital Productions, GIS Laboratory, Department of Geography, UNIMAID (2017)

\section{Determination of Growth Rate of the Bacteria in Effluent Sample}

The bacteria growth rates were determined by transferring $2 \mathrm{~mL}$ of the bacterial isolates from the tannery effluent in broth medium into 100 $\mathrm{mL}$ sterile effluents in conical flasks and kept in an incubator (Giffrin cool) for 10 days. Control was also set up by incubating another $100 \mathrm{~mL}$ each of the sterile effluents without the bacteria. The optical density of the content was determined at the wavelength of $600 \mathrm{~nm}$ on a daily interval and recorded. 
BAJOPAS Volume 13 Number 2, December, 2020 Immobilization of Bacteria

Agar solution and inoculi were prepared separately. Fifty milliliters $(50 \mathrm{~mL})$ of nutrient broth each of the inoculi was prepared in a McCartney bottle and incubated for 24 hours. A solution of agar-agar was prepared by dissolving $10 \mathrm{~g}$ of the powder in distilled water and made up to $500 \mathrm{~mL}$ mark in an Erlenmeyer flask and was sterilized in an autoclave (280A) for 15 minutes and allowed to cool to $40-45^{\circ} \mathrm{C}$ (Ajao et al., 2011). Four milliliters ( $4 \mathrm{~mL})$ of the bacterial isolates in the nutrient broth was mixed with 36 $\mathrm{ml}$ of the prepared agar-agar media in petri-dish plates and then allowed to solidify. This was kept in the refrigerator for bioremediation.

\section{Bioremediation (Treatment) of the Effluents}

The solidified agar block (immobilized bacteria) was cut into cubes using a sterile knife; $0.1 \mathrm{~mL}$ phosphate buffer ( $\mathrm{pH} \mathrm{7.0)}$ was added and kept in the refrigerator for 1 hour for curing. The phosphate buffer was decanted after 1 hour and the cubes were washed with sterile distilled water 3-4 times before it was used (Ajao et al., 2011). Two liters (2 L) of the effluent was supplemented with the minimum basal medium in $\mathrm{g} / \mathrm{L}: \mathrm{NaCl}(0.8), \mathrm{MgSO}_{4} .7 \mathrm{H}_{2} \mathrm{O}(0.001), \mathrm{KH}_{2} \mathrm{PO}_{4}$ (2), $\mathrm{NaNO}_{3}$ (2), $\quad \mathrm{CaCl}_{2} .2 \mathrm{H}_{2} \mathrm{O} \quad(0.5)$ and $\mathrm{NaHPO}_{4} .12 \mathrm{H}_{2} \mathrm{O}(2)$ and sterilized in an autoclave at $121^{\circ} \mathrm{C}$ for 15 minutes (Margesin and Schinner, 2001). Two hundred and fifty milliliters $(250 \mathrm{~mL})$ of the effluents were transferred into different $250 \mathrm{ml}$ conical flasks. The content was covered with a cotton-wool ramped with foil paper to avoid contamination. Five grams $(5 \mathrm{~g})$ of the immobilized bacteria were quickly transferred into each of the effluents in the conical flasks in an inoculating chamber. The same procedures were carried out for the $10 \mathrm{~g}, 15 \mathrm{~g}, 20 \mathrm{~g}$ and 25 $\mathrm{g}$ of the immobilized bacteria in separate $250 \mathrm{~mL}$ effluents in conical flasks and agitated for ten days in a shaker incubator (Gallenkamp-OC4364-L) at a temperature $30^{\circ} \mathrm{C}$ and speed of 60 rpm. The treated effluent samples were taken on the tenth day and analyzed for the parameters $\mathrm{pH}$, SS, TDS, COD, and BOD, (Posttreatment determination) for the different grams of bacteria to evaluate and compare the biodegradation potential. (Baba et al., 2020).

\section{Statistical Analysis}

The data were represented as Mean \pm Standard deviation and analyzed statistically using oneway Analysis of Variance (ANOVA) and Tukey's HSD as Post Hoc Tests with the aid of SPSS 16.0. The correlation coefficient was also used to measure the strength of the relationship between the different masses of the bacteria and the parameters. All $\mathrm{p} \leq 0.05$ were considered as statistically significant.

\section{RESULTS AND DISCUSSION Physico-chemical parameters in the Industrial Effluents before the Biodegradation.}

Results of the Physico-chemical parameters in the industrial effluents before the Biodegradation is shown in table 1 . The mean temperatures $\left({ }^{\circ} \mathrm{C}\right)$ observed in TAN1, TAN2, and TAN3 samples were $28.07 \pm 0.65 ; 27.77 \pm 0.64$ and $26.38 \pm 3.81$ respectively. The order of the mean temperature of the samples from the three industries can be arranged as TAN1 > TAN2>TAN3. The temperature observed at TAN1, TAN2, and TAN3 samples were found below the WHO $\left(35^{\circ} \mathrm{C}\right)$ and NESREA $\left(40^{\circ} \mathrm{C}\right)$ limits. The low values of temperature might be due to the processes used at the time of sampling. High temperature brings down the solubility of gases in water that ultimately expresses as high BOD and COD. Statistical analysis shows that there is no significant difference $(p<0.05)$ between the mean values of temperature among the industries. This might be due to similar tannery activities involved in the tannery industries at the time of sampling. The average values of temperature observed in this present study are less than those observed by Akan et al. (2007), Akan et al. (2009) and Baba et al. (2020).

The mean level of $\mathrm{pH}$ observed in TAN1, TAN2 and TAN3, samples were $7.77 \pm 2.93$; $8.35 \pm 0.28$ and $7.52 \pm 0.76$ respectively. The order of the mean $\mathrm{pH}$ of the samples from the three industries can be arranged as TAN2> TAN1 $>$ TAN3. The $\mathrm{pH}$ of the samples falls within the WHO (7.0-8.5) and NESREA (6-9) standard limits. Statistical analysis shows that there is no significant difference $(p<0.05)$ between the mean values of $\mathrm{pH}$ among the industries. This might be due to similar tannery activities involved in the tannery industries at the time of sampling. Maheshwari et al. (2017) reported that the level of $\mathrm{pH}$ in the effluents from the tannery industry in Vaniyambadi, India was 6.5 which was lower than that observed in the present study. The $\mathrm{pH}$ in the effluents from the tannery industries in Kano and Kaduna were reported to be 7.64 and 6.89, respectively (Akan et al., 2007; Mohammed et al., 2017). The average values of $\mathrm{pH}$ observed in this present study are less than those observed by Mohammed et al. (2017) and Baba et al. (2020). The mean level of SS $(\mathrm{mg} / \mathrm{l})$ observed in TAN1, TAN2, and TAN3 samples were 374 \pm 124 ; $358 \pm 335$ and $780 \pm 739$ respectively. The order of the mean SS in the samples from the three industries can be arranged as TAN3 > TAN1 $>$ TAN2. 
The SS observed in the samples were far above the recommended standard limits of regulating bodies WHO $(30 \mathrm{mg} / \mathrm{l})$ and NESREA $(10 \mathrm{mg} / \mathrm{l})$. Statistical analysis shows that there is no significant difference $(p<0.05)$ between the mean values of SS among the industries. This might be due to similar tannery activities involved in the tannery industries at the time of sampling. The average values of SS observed in this present study are less than that observed $(3700 \pm 122 \mathrm{mg} / \mathrm{l})$ by Akan et al. (2009) for tanneries in Kano. Also, the average values of SS observed in this present study are less than that observed by Mohammed et al. (2017) and Baba et al. (2020) with the exception in TAN3.

The mean level of TDS (mg/l) observed in TAN1, TAN2, and TAN3 samples were $3941 \pm 3703$; $3300 \pm 1714$ and $2653 \pm 1240$ respectively. The order of the mean TDS in the samples from the three industries can be arranged as TAN1>TAN2>TAN3. The TDS observed in the samples were far above the recommended standard limits of WHO $(250 \mathrm{mg} / \mathrm{l})$ and NESREA $(500 \mathrm{mg} / \mathrm{l})$. Statistical analysis shows that there is no significant difference $(p<0.05)$ between the mean values of TDS among the industries. This might be due to similar tannery activities involved in the tannery industries at the time of sampling. TDS in the effluents from the tannery industries in Kano, Nigeria was reported to be $1281 \mathrm{mg} / \mathrm{l}$ (Akan et al., 2007). The average values of SS observed in this present study are less than those observed by Mohammed et al. (2017) and Baba et al. 2020)

The mean level of COD (mg/l) observed in TAN1, TAN2 and TAN3 samples seasons were $2372 \pm 938 ; \quad 1406 \pm 208$ and $3532 \pm 1373$ respectively. The order of the mean COD of the samples from the three industries can be arranged as TAN3>TAN1> TAN2. The COD observed in TAN1, TAN2 and TAN3 samples were far above the recommended standard limits of regulating bodies $\mathrm{WHO}(40 \mathrm{mg} / \mathrm{l})$ and NESREA (40 mg/l). Statistical analysis shows that there is no significant difference $(p<0.05)$ in COD among the industries. This might be due to similar tannery activities involved in the tannery industries as at the time of sampling. The Chemical Oxygen demand (COD) is the amount of oxygen, in $\mathrm{mg} / \mathrm{L}$, required for the degradation of the compound of wastewater to occur. In comparison, the average values of COD observed in this present study were higher than that observed by Mohammed et al. (2017) but lower than that observed by Baba et al. (2020).

The mean levels of BOD $(\mathrm{mg} / \mathrm{l})$ observed in TAN1, TAN2 and TAN3 samples were $13.85 \pm 6.42 ; \quad 19.46 \pm 0.50$ and $17.13 \pm 3.14$ respectively. The order of the mean BOD in the samples from the three industries can be arranged as TAN2>TAN3>TAN1. The BOD observed in TAN1, TAN2 and TAN3 samples were found below the recommended limits of NESREA (200 mg/l) but above WHO (10 mg/l). Statistical analysis shows that there is no significant difference $(p<0.05)$ between the mean values of BOD among the industries. This might be due to similar tannery activities involved in the tannery industries at the time of sampling. The low level of BOD recorded in this study is an indication of the low level of biodegradable organic solids in the effluent. The average values of BOD observed in this present study were lower than those observed by Mohammed et al. (2017) and Baba et al. (2020).

Table 1: Mean Values \pm S.D of Physico-chemical parameters of effluents from the Tannery Industries before Treatment.

\begin{tabular}{llllllll}
\hline Parameter & Tannery 1 & Tannery 2 & Tannery 3 & $\mathrm{a}$ & $\mathrm{b}$ & $\mathrm{c}$ & $\mathrm{d}$ \\
\cline { 2 - 7 } Temperature $\left({ }^{\circ} \mathrm{C}\right)$ & $28.07 \mathrm{a} \pm 0.65$ & $27.77 \mathrm{a} \pm 0.64$ & $26.38 \mathrm{a} \pm 3.81$ & & $29.50 \pm 4.68$ & 35 & 40 \\
pH & $7.77 \mathrm{a} \pm 2.93$ & $8.35 \mathrm{a} \pm 0.28$ & $7.52 \mathrm{a} \pm 0.76$ & 6.89 & $5.35 \pm 1.57$ & $7.0-8.5$ & $6.0-9.0$ \\
$\mathrm{COD}(\mathrm{mg} / \mathrm{l})$ & $2372 \mathrm{a} \pm 938$ & $1406 \mathrm{a} \pm 208$ & $3532 \mathrm{a} \pm 1373$ & 2.2 & $3106 \pm 2753$ & 40 & 40 \\
$\mathrm{BOD}(\mathrm{mg} / \mathrm{l})$ & $13.85 \mathrm{a} \pm 6.42$ & $19.46 \mathrm{a} \pm 0.50$ & $17.13 \mathrm{a} \pm 3.14$ & 1032 & $26.17 \pm 9.49$ & 10 & 200 \\
$\mathrm{SS}(\mathrm{mg} / \mathrm{l})$ & $374 \mathrm{a} \pm 124$ & $358 \mathrm{a} \pm 335$ & $780 \mathrm{a} \pm 739$ & 501 & $562 \pm 482$ & 30 & 10 \\
TDS $(\mathrm{mg} / \mathrm{l})$ & $3941 \mathrm{a} \pm 3703$ & $3300 \mathrm{a} \pm 1714$ & $2653 \mathrm{a} \pm 1240$ & 532.7 & $444 \pm 507$ & 250 & 500 \\
\hline
\end{tabular}

The values given in the table above are means of 6 replicate values, $\mathrm{n}=6$ ( 1 sample was taken monthly for 6 months). Within the rows, means with different alphabets are statistically different $(p<0.05)$. WHO: World Health Organisation. NESREA: National Environmental Standard and Regulatory Enforcement Agency. a = Mohammed et al.(2017), b = Baba et al. (2020), c = WHO (2006), $d=$ NESSRA (2009) 
BAJOPAS Volume 13 Number 2, December, 2020

Identification, Biochemical Characterization and growth rates of the Bacterial Isolates

Results of identification and biochemical characterization of the bacterial isolates were shown in table 2. After 24 hours of incubation, the nutrient agar media plates were checked for bacterial growth. The results showed the presence of different strains in the samples. The TAN1 bacteria isolate was found to be gramnegative cocci while TAN3 was gram-positive cocci. TAN2 bacteria isolate was found to be gram-positive, rod-shaped. TAN1, TAN2, and TAN3 bacteria isolates recorded positive results for spore former.

The results of the biochemical tests indicated that all the bacteria were positive for catalase, oxidase, citrate, maltose, glucose, lactose (negative in TAN1), mannitol (negative in TAN2), starch hydrolysis and coagulase (negative in TAN2) tests. The bacteria showed negative results for nitrate reduction, $M R$ (positive in TAN2), VP (positive in TAN1), Indole (positive in TAN2) tests. Base on the morphological and biochemical test results, TAN1, TAN2, and TAN3 bacteria isolates were identified to be Nesseria spp, Bacillus cereus, and Staphylococcus aureus respectively.

The growth rate of the TAN1, TAN2 and TAN3 Isolates were shown in figure 2. Generally, the optical density increase with the increase in time (day) and decrease as time goes on. The highest optical density was shown by bacillus cereus in TAN2 while the lowest was shown by Staphylococcus aureus in TAN3.

The initial growth phase of TAN1 Isolate bacteria occurred within 2-day of incubation as the growth rate increases up to the 6th-day incubation when the maximum growth was observed. Beyond the 6th day, the growth of the bacteria declined (which might be due to a shortage of nutrients in the effluents) until it reached its death phase (which might be due to the unavailability of nutrients in the effluents).

A similar trend of growth was also observed for TAN2 Isolate as the initial growth phase also occurred within 2-day of incubation but maximum growth rate observed on the 4th day of incubation. The stationary stage occurred between the 4th day and the 8th day. Beyond the 8th day, the growth of the bacteria declined (which might be due to a shortage of nutrients in the effluents) until it reached its death phase (which might be due to the unavailability of nutrients in the effluents).

The initial growth phase of TAN3 bacterial Isolate occurred within the 3-day incubation as the growth rate increases up to the 6th-day incubation when the maximum growth was observed. Beyond the 6th day, the growth of the bacteria declined (which might be due to a shortage of nutrients in the effluents) until it reached its death phase (which might be due to the unavailability of nutrients in the effluents).

Table 2: Morphological and Biochemical characteristics of bacterial isolates

\begin{tabular}{lllll} 
Bacterial Isolates & & TAN1 & TAN2 & TAN3 \\
\hline $\begin{array}{lllll}\text { Morphological } \\
\text { characteristics }\end{array}$ & Shape & Cocci & Rod & Cocci \\
& Spore & & & \\
& former & + & + & + \\
Gram & & & \\
Biochemical characteristics & reaction & - & + & + \\
& Citrate & + & + & + \\
& Catalase & + & + & + \\
& Coagulase & + & - & + \\
Starch & + & + & + \\
& Glucose & + & + & + \\
Oxidase & + & + & + \\
& Indo & - & + & - \\
Lactose & - & + & + \\
Manitol & + & - & + \\
Maltose & + & + & + \\
MR & - & + & - \\
VP & + & - & - \\
& Nitrate & - & - & - \\
Reduction & - Neisseria & Bacillus & Staphylococcus \\
& Bacterial & cereus & aureus \\
& name & spp & cas
\end{tabular}

+ = Positive; - = Negative; MR=Methyl Red; VP= Voges-Proskauer 


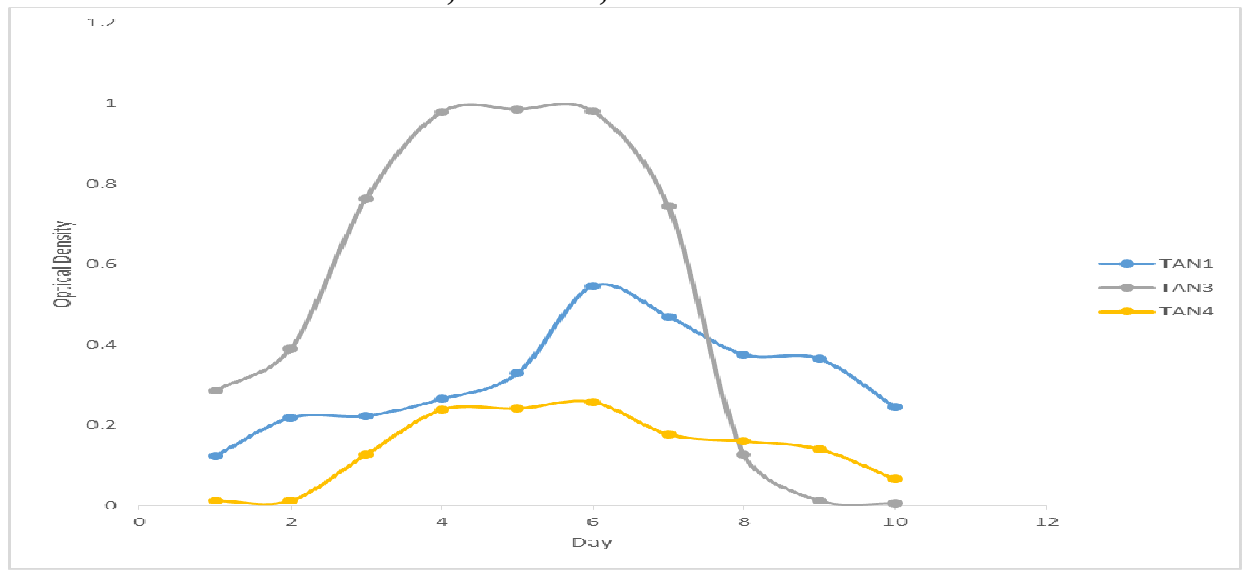

Fig. 2 Growth rates of the isolates in the effluents from the Tannery Industries

\section{Physico-chemical Parameters in the Industrial Effluents after the biodegradation.}

Table 3 shows the mean results of the physicochemical parameter before and after bioremediation using the different masses $(5 \mathrm{~g}$, $10 \mathrm{~g}, 15 \mathrm{~g}, 20 \mathrm{~g}$, and $25 \mathrm{~g}$ ) of the respective immobilized bacteria. Also, Table 4 shows the mean results of correlation coefficient ( $r$ ) between different masses of bacteria and physicochemical parameters.

The mean values $(\mathrm{mg} / \mathrm{l})$ of the SS after the bioremediation varies between $243 \pm 45$ and $898 \pm 672$. The mean concentration $(\mathrm{mg} / \mathrm{l})$ of SS remediated by the different masses $(5 \mathrm{~g}, 10 \mathrm{~g}$, $15 \mathrm{~g}, 20 \mathrm{~g}$, and $25 \mathrm{~g}$ ) of the bacteria varies. The SS in the samples fluctuates up and down after the bioremediation process when compared with the SS of the raw samples before the bioremediation. The increase in the levels of the SS might be due to the aggregation of the TDS which are large enough to result into SS. The increase in the levels of the SS might be also due to the influence of the nutrients which was added into the effluents in order to make the microorganisms more active and viable for fast degradation of organic contaminants in the effluent. The relative potential or efficiency of the different masses of the bacteria in remediating SS in TAN1 samples was in the order $25 \mathrm{~g}>20 \mathrm{~g}>15 \mathrm{~g}>10 \mathrm{~g}>5 \mathrm{~g}$. For TAN2 and TAN3 samples, the order was $25 \mathrm{~g}>20 \mathrm{~g}>15$ $\mathrm{g}>10 \mathrm{~g}>5 \mathrm{~g}$. These might be due to the variations in the surface areas of the different masses of the immobilized bacteria. Statistical analysis shows that there is no significant difference $(p<0.05)$ between the mean values of SS among the masses in the respective industries. Positive and significant correlations exist between the masses of bacteria and Suspended Solid (SS). This showed that there is general increase in the levels of the SS as the masses of the immobilized bacteria increases. TAN3 (90\%) and TAN1 (80\%) showed a very high correlation with the masses of the bacteria while TAN2 (61\%) showed a very low correlation.

The mean values $(\mathrm{mg} / \mathrm{l})$ of the TDS after the bioremediation varies between $46 \pm 11$ and $83 \pm 78$. The mean concentration $(\mathrm{mg} / \mathrm{l})$ of TDS remediated by the different masses $(5 \mathrm{~g}, 10 \mathrm{~g}$, $15 \mathrm{~g}, 20 \mathrm{~g}$, and $25 \mathrm{~g}$ ) of the bacteria varies. There is a reduction in all the TDS of all the samples after the bioremediation process compared with the TDS of the raw samples before the bioremediation. The relative potential or efficiency of the different masses of the bacteria in remediating TDS in TAN1 and TAN3 samples was in the order $5 \mathrm{~g}>10 \mathrm{~g}>15 \mathrm{~g}>20$ $\mathrm{g}>25 \mathrm{~g}$. For TAN2 samples, the order was 20 $g>10 \quad g>25 \quad g>15 \quad g>5 \quad g$. Statistical analysis shows that there is no significant difference $(p<0.05)$ between the mean values of TDS among the masses in the respective industries. These might be due to the variations in the surface areas of the different masses of the immobilized bacteria. Positive and significant correlations exist between the masses of bacteria and TDS with the exception in TAN2 (negative and insignificant correlation). The positive correlations showed that there is general increase in the levels of the TDS as the masses of the immobilized bacteria increases. TAN1 $(96 \%)$ showed a very high correlation with the masses of the bacteria while TAN2 (47\%) showed a very low correlation.

The mean values $(\mathrm{mg} / \mathrm{l})$ of the BOD after the bioremediation varies between $1.56 \pm 0.20 \mathrm{mg} / \mathrm{l}$ and $6.92 \pm 5.49 \mathrm{mg} / \mathrm{l}$. The mean concentration $(\mathrm{mg} / \mathrm{l})$ of BOD remediated by the different masses $(5 \mathrm{~g}, 10 \mathrm{~g}, 15 \mathrm{~g}, 20 \mathrm{~g}$, and $25 \mathrm{~g}$ ) of the bacteria varies. There is a reduction in all the BOD of all the samples after the bioremediation process compared with the $\mathrm{BOD}$ of the raw 
BAJOPAS Volume 13 Number 2, December, 2020 samples before the bioremediation. The relative potential or efficiency of the different masses of the bacteria in remediating BOD in TAN1, TAN2 and TAN3 samples were in the order $25 \mathrm{~g}>20$ $\mathrm{g}>15 \mathrm{~g}>10 \mathrm{~g}>5 \mathrm{~g}, 25 \mathrm{~g}>15 \mathrm{~g}>5 \mathrm{~g}>10 \mathrm{~g}>20 \mathrm{~g}$ and $20 \mathrm{~g}>10 \mathrm{~g}>25 \mathrm{~g}>15 \mathrm{~g}>5 \mathrm{~g}$ respectively. Statistical analysis shows that there is significant difference $(p<0.05)$ between the mean values of BOD among the masses in the respective industries. These might be due to the variations in the surface areas of the different masses of the immobilized bacteria. Negative and significant correlations exist between the masses of bacteria and BOD. This showed that there is general decrease in the levels of the BOD as the masses of the immobilized bacteria increases. TAN1 (94\%) showed a very high correlation with the masses of the bacteria while TAN2 (4\%) showed a very low correlation.

The mean values $(\mathrm{mg} / \mathrm{l})$ of the COD after the bioremediation varies between $250 \pm 154$ and $3134 \pm 1595$. The mean concentration $(\mathrm{mg} / \mathrm{l})$ of COD remediated by the different masses $(5 \mathrm{~g}$, $10 \mathrm{~g}, 15 \mathrm{~g} 20 \mathrm{~g}$, and $25 \mathrm{~g}$ ) of the bacteria varies. There is a reduction in all the COD of all the samples after the bioremediation process compared with the COD of the raw samples before the bioremediation. The relative potential or efficiency of the different masses of the bacteria in remediating COD in TAN1, TAN2 and TAN3 samples were in the order $25 \mathrm{~g}>20 \mathrm{~g}>15$ $\mathrm{g}>5 \mathrm{~g}>10 \mathrm{~g}, 25 \mathrm{~g}>20 \mathrm{~g}>15 \mathrm{~g}>10 \mathrm{~g}>5 \mathrm{~g}$ and 10 g>5 g>25 g>15 g>20 g respectively. Statistical analysis shows that there were significant difference $(p<0.05)$ between the mean values of COD among the masses in the respective industries except for effluents treated with $25 \mathrm{~g}$. These might be due to the variations in the surface areas of the different masses of the immobilized bacteria. Negative and insignificant correlations exist between the masses of bacteria and COD with the exception in TAN3 (positive and significant correlation). The negative correlations showed that there is general decrease in the levels of the COD as the masses of the immobilized bacteria increases. TAN2 (100\%) showed a very high correlation with the masses of the bacteria while TAN3 (36\%) showed a very low correlation.

Generally, there was an overall decrease in the concentration of these physicochemical parameters after the bioremediation using the different masses of the bacterial isolates. These might be due to the variations in the surface areas of the different masses of the immobilized bacteria. This is in line with the work of Jimoh et al. (2018) and Baba et al. (2020).

Table 3: Mean Values $(\mathrm{mg} / \mathrm{l}) \pm$ S.D of Physicochemical parameters in effluents from the Tannery Industries before and after Treatment of the effluents $(250 \mathrm{ml})$ with the different masses $(5 \mathrm{~g}, 10 \mathrm{~g}$, $15 \mathrm{~g}, 20 \mathrm{~g}$, and $25 \mathrm{~g}$ ) of the bacteria.

\begin{tabular}{llllllll}
\hline $\mathrm{P}$ & IND & Before & \multicolumn{5}{c}{ After } \\
\cline { 4 - 7 } & & & $5 \mathrm{~g}$ & $10 \mathrm{~g}$ & $15 \mathrm{~g}$ & $20 \mathrm{~g}$ & $25 \mathrm{~g}$ \\
\hline \multirow{2}{*}{ COD } & TAN1 & $2372 \pm 938$ & $1708 \mathrm{a} \pm 861$ & $2045 \mathrm{a} \pm 1205$ & $845 \mathrm{a} \pm 369$ & $300 \mathrm{a} \pm 167$ & $250 \mathrm{a} \pm 154$ \\
& TAN2 & $1406 \pm 208$ & $1195 \mathrm{a} \pm 208$ & $1125 \mathrm{a} \pm 384$ & $1055 \mathrm{a} \pm 317$ & $956 \mathrm{a} \pm 310$ & $870 \mathrm{ab} \pm 240$ \\
& TAN3 & $3532 \pm 1373$ & $2374 \mathrm{a} \pm 1344$ & $1976 \mathrm{a} \pm 1405$ & $2757 \mathrm{a} \pm 1266$ & $3134 \mathrm{a} \pm 1595$ & $2614 \mathrm{~b} \pm 1105$ \\
BOD & TAN1 & $13.85 \pm 6.42$ & $6.92 \mathrm{a} \pm 5.49$ & $6.42 \mathrm{a} \pm 5.07$ & $5.72 \mathrm{a} \pm 5.35$ & $4.62 \mathrm{a} \pm 4.37$ & $2.82 \mathrm{ab} \pm 1.26$ \\
& TAN2 & $19.46 \pm 0.50$ & $1.75 \mathrm{~b} \pm 0.22$ & $1.73 \mathrm{~b} \pm 0.18$ & $1.58 \mathrm{a} \pm 0.16$ & $1.91 \mathrm{a} \pm 0.22$ & $1.56 \mathrm{~b} \pm 0.20$ \\
& TAN3 & $17.13 \pm 3.14$ & $4.24 \mathrm{ab} \pm 0.77$ & $3.29 \mathrm{ab} \pm 0.37$ & $4.11 \mathrm{a} \pm 0.07$ & $3.23 \mathrm{a} \pm 0.91$ & $3.33 \mathrm{a} \pm 1.28$ \\
SS & TAN1 & $374 \pm 124$ & $243 \mathrm{a} \pm 45$ & $471 \mathrm{a} \pm 226$ & $475 \mathrm{a} \pm 182$ & $492 \mathrm{a} \pm 128$ & $611 \mathrm{a} \pm 217$ \\
& TAN2 & $358 \pm 335$ & $460 \mathrm{a} \pm 400$ & $543 \mathrm{a} \pm 414$ & $544 \mathrm{a} \pm 402$ & $551 \mathrm{a} \pm 414$ & $554 \mathrm{a} \pm 405$ \\
& TAN3 & $780 \pm 739$ & $586 \mathrm{a} \pm 594$ & $758 \mathrm{a} \pm 656$ & $787 \mathrm{a} \pm 676$ & $861 \mathrm{a} \pm 635$ & $898 \mathrm{a} \pm 672$ \\
TDS & TAN1 & $3941 \pm 3703$ & $51 \mathrm{a} \pm 10$ & $53 \mathrm{a} \pm 10$ & $55 \mathrm{a} \pm 15$ & $61 \mathrm{a} \pm 20$ & $63 \mathrm{a} \pm 26$ \\
& TAN2 & $3300 \pm 1714$ & $83 \mathrm{a} \pm 78$ & $47 \mathrm{a} \pm 20$ & $48 \mathrm{a} \pm 22$ & $47 \mathrm{a} \pm 17$ & $48 \mathrm{a} \pm 17$ \\
& TAN3 & $2653 \pm 1240$ & $46 \mathrm{a} \pm 11$ & $55 \mathrm{a} \pm 24$ & $55 \mathrm{a} \pm 25$ & $58 \mathrm{a} \pm 23$ & $61 \mathrm{a} \pm 28$ \\
\hline
\end{tabular}

Replicate $=6$ (months)

Within the rows, for the same parameter, means with different alphabets are statistically different $(p<0.05)$.

$\mathrm{P}=$ parameter, IND = Industries 
BAJOPAS Volume 13 Number 2, December, 2020

Table 4: Correlation coefficient $(r)$ between different masses of the bacteria and the physicochemical parameters.

\begin{tabular}{llll}
\hline Industries & Parameter & Correlation coefficient $(r)$ & $\begin{array}{l}\text { Percent dependence (rxrx100) } \\
(\%)\end{array}$ \\
\hline TAN1 & COD & -0.9 & 82 \\
& BOD & -0.97 & 94 \\
& SS & $0.90^{*}$ & 80 \\
TAN2 & TDS & $0.98^{*}$ & 96 \\
& COD & -1 & 100 \\
& BOD & -0.21 & 4 \\
& SS & $0.78^{*}$ & 61 \\
& TDS & -0.69 & 47 \\
& COD & $0.60^{*}$ & 36 \\
& BOD & -0.6 & 37 \\
& SS & $0.95^{*}$ & 90 \\
& TDS & $0.94^{*}$ & 89 \\
\hline
\end{tabular}

The correlation coefficient $(r)$ with * is statistically significant $(p<0.05)$.

Percentage reduction of the Parameters

Table 5 shows the percentage reduction of Parameters in industrial samples before and after the treatment of the effluents $(250 \mathrm{ml})$ with the different masses $(5 \mathrm{~g}, 10 \mathrm{~g}, 15 \mathrm{~g}, 20 \mathrm{~g}$, and $25 \mathrm{~g}$ ) of the Immobilized Bacteria.

In TAN1 samples, the percentage reduction (\%) of COD ranged (14-89); BOD (50-80); SS (-32$35)$ and TDS (98-99). In TAN2 samples, the percentage decrease $(\%)$ of COD ranged (15$38) ;$ BOD (90-92); SS [-28-(-55)] and TDS (9798). In TAN3 samples, the percentage decrease (\%) of COD ranged (11-44); BOD (76-81); SS (15-25) and TDS (98). The percentage increase in the levels COD, BOD and TDS might be due to the increase in the surface area of the different masses of the immobilized bacteria. However, the percentage decrease in the levels of the SS might be due to the aggregation of the TDS which are large enough to result into SS. The percentage decrease in the levels of the SS might be also due to the influence of the nutrients which was added into the effluents in order to make the microorganisms more active and viable for fast degradation of organic contaminants in the effluent. This is in line with the work of Jimoh et al. (2018) in which the concentration of the SS increase after the bioremediation of effluents.

Sreemoyee and Priti (2013) assessed and reduced several Physico-chemical parameters of dairy wastewater using Niesseria $s p$. and concluded that the species are well known to degrade organic compounds. This is in agreement with the current study in which the immobilized Niesseria $s p$ degrade the organic contaminants as indicated by the BOD, COD and TDS.

Jimoh et al. (2018) observed that TSS of the effluents was increased after treatment with immobilized bacteria and concluded that it might be due to the biostimulation method adopted for the research.

The optimum $\mathrm{pH}$ Biosorption of Chromium by Bacillus spp and Staphylococcus spp. from tannery effluent was investigated by Mythili and Karthikeyan (2011). The maximum adsorption of Chromium $(86.4 \mathrm{mg} / \mathrm{L})$ was showed by Bacillus spp and Staphylococcus spp showed $70.6 \mathrm{mg} / \mathrm{L}$ at an initial concentration of $100 \mathrm{mg} / \mathrm{L}$. In the present study, immobilised Bacillus spp and Staphylococcus spp. from the tannery industrial effluents reduced the levels of the organic pollutants with high potential as indicated by the percentage reduction of BOD, COD and TDS.

Enzymes often can work in multiple environments especially if they are immobilized. This makes the microorganisms' enzymes even more resistant to harsh environments and enables the enzymes to be recovered and recycled after they are no longer needed (Gianfreda and Rao 2004). Ramesh and Singh (1993) reported that the immobilized bacteria having more efficiency to remove the suspended particles than free cells. Using the immobilized cell is preferable due to its capability for using several times with the same efficiency, which makes it more economical. Similar work was done by Sikander et al. (2007) showing the higher reduction with permeabilized cells of Ochrobactrum intermedium strain SDCr-5. 
BAJOPAS Volume 13 Number 2, December, 2020

The results revealed the isolation and identification of isolates with the potential for the reduction of $\mathrm{Cr}$ (VI) to $\mathrm{Cr}$ (III). Results indicated that immobilized $B$. cereus could be efficiently used for the reduction of $\mathrm{Cr}$ (VI).

Table 5: Percentage reduction of the tested Parameters from the tannery industrial samples of the Immobilized Bacteria.

\begin{tabular}{lllllll}
\hline \multirow{2}{*}{ Industries } & & \multicolumn{5}{c}{ Percentage Reduction $(\%)$} \\
\cline { 3 - 7 } & & $5 \mathrm{~g}$ & $10 \mathrm{~g}$ & $15 \mathrm{~g}$ & $20 \mathrm{~g}$ & $25 \mathrm{~g}$ \\
\hline TAN1 & COD & 28 & 14 & 64 & 87 & 89 \\
& BOD & 50 & 54 & 59 & 67 & 80 \\
& SS & 35 & -26 & -27 & -32 & -63 \\
& TDS & 99 & 99 & 99 & 98 & 98 \\
TAN2 & COD & 15 & 20 & 25 & 32 & 38 \\
& BOD & 91 & 91 & 92 & 90 & 92 \\
& SS & -28 & -52 & -52 & -54 & -55 \\
& TDS & 97 & 99 & 99 & 99 & 99 \\
& COD & 33 & 44 & 22 & 11 & 26 \\
& BOD & 75 & 81 & 76 & 81 & 81 \\
& SS & 25 & 3 & -1 & -10 & -15 \\
& TDS & 98 & 98 & 98 & 98 & 98 \\
\hline
\end{tabular}

Percentage Reduction $=(B-A) / B \times 100 \%$

$A=$ Concentration of the parameter after treatment

$\mathrm{B}=$ Concentration of the parameter before treatment

$+=$ percentage decrease

- = percentage increase

In general, immobilization makes the enzyme more resistant to temperature, $\mathrm{pH}$, and substrate concentration swings giving it a longer lifetime and higher productivity per active unit (Gianfreda and Rao, 2004; FuIlbrook, 1996; Russell et al, 2003; Kandelbauer et al., 2004). Immobilized cells have been used and studied extensively for the production of useful chemicals (Ohtake and Silver, 1994), the treatment of wastewaters (Chen et al., 2003; Wang et al., 2010). Although many workers described microbial degradation of tannery effluent, limited literature is available on the bioremediation of tannery effluent using immobilized bacterial cells in the Kano Industrial Estates.

\section{CONCLUSION}

The samples contained variable levels of the physicochemical parameters. The results of the Analysis of variance revealed that, no statistical difference $(p<0.05)$ was observed for the temperature, $\mathrm{pH}, \mathrm{SS}, \mathrm{TDS}, \mathrm{BOD}$ and $\mathrm{COD}$ among the three tannery industries before the treatment. The levels of some of the parameters
(SS, TDS and COD) observed in the samples were found above the recommended limits of WHO and NESREA, which called for the treatment of the effluents before discharge into the environment. Base on the morphological and biochemical test results, TAN1, TAN2, and TAN3 bacterial isolates were identified to be Neisseria spp, Bacillus cereus, and Staphylococcus aureus respectively. The results of Post-treatment analysis showed that there is overall decrease in the levels of the parameters determined when compared with that of the pre-treatment. The overall percentage reduction of the immobilised bacteria in the treatment of the respective effluents was in the order TAN2 (72\%)>TAN1 $(70 \%)>$ TAN3 $(62 \%)$. Hence, the immobilized bacteria are having higher biodegradation potential for the treatment of the tannery effluents.

\section{Acknowledgments}

The authors wish to acknowledge the University of Maiduguri for the financial support. The authors are grateful to the Kano State Ministry of Environment for their support in obtaining the effluent samples. 


\section{REFERENCES}

Ajao, A. T., Adebayo, G. B., and Yakubu, S. E. (2011). Bioremediation of textile industrial effluent using mixed culture of Pseudomonas aeruginosa and Bacillus subtilis immobilized on agar-agar in a bioreactor. J. Microbiol. Biotech. Res, 1(3), 50-56.

Akan, J. C., Moses, E. A., Ogugbuaja, V. O., and Abah, J. (2007). Assessment of tannery industrial effluents from Kano metropolis, Kano State, Nigeria. Journal of Applied Sciences, 7(19), 2788-2793.

Akan, J. C., Ogugbuaja, V. O., Abdulrahman, F. I., and Ayodele, J. T. (2009). Pollutant levels in effluent samples from tanneries and textiles of Kano industrial areas, Nigeria. Global journal of pure and applied sciences, 15(3-4).

APHA (1989). Standard methods for Examination of Will bete and Will betewater.15 $5^{\text {th }}$ edition. Brydpass Springfield Will behington DC. pp. 164-176

APHA (1992). Standard Methods for the Examination of Water and Wastewater. Health, 69, 1116-9.

Baba, A., Garba, S. T., and Bello, H. S. (2020). Bioremediation Potential of Immobilized corynebacterium kutsceri in the Treatment of Tannery Industrial Effluent from Challawa Industrial Estate, Kano State, Nigeria. Journal of the Turkish Chemical Society Section A: Chemistry, $7(2), 335-350$.

Beem, E. I. V. (1994). reduction of solvent VOC emission. J. Oil Col. Chem. Ass, 77, 158.

Bouwer, E. J., and Zehnder, A. J. (1993). Bioremediation of organic compoundsputting microbial metabolism to work. Trends in biotechnology, 11(8), 360367.

Chen, K. C., Wu, J. Y., Liou, D. J., and Hwang, S. C. J. (2003). Decolorization of the textile dyes by newly isolated bacterial strains. Journal of Biotechnology, 101(1), 57-68.

Dan'Azumi, S., and Bichi, M. H. (2010). INDUSTRIAL POLLUTION AND HEAVY METALS PROFILE OF CHALLAWA RIVER IN KANO, NIGERIA. Journal of Applied Sciences in Environmental Sanitation, $5(1)$.

DWAF. (1992). Analytical Methods Manual, TR 151. Department of Water Affairs and Forestry, Pretoria.

El-Bestawy, E. (2013). Biological treatment of leather-tanning industrial wastewater using free living bacteria.
Elsheikh, M. A. S. (2009). Tannery wastewater pre-treatment. Water Science and Technology, 60(2), 433-440.

FuIlbrook, P. D. (1996). "Kinetics." Industrial enzymology: The application of enzymes in Industry. 2nd Ed. T. Godfrey and J Reichelt. eds.. Nature. New York.

Gianfreda, L., and Rao, M. A. (2004). Potential of extra cellular enzymes in remediation of polluted soils: a review. Enzyme and microbial technology, 35(4), 339354.

Hugo Springer. (1994). John Arthur Wilson Memorial Lecture "Treatment of Industrial Wastes of the Leather Industry - is it still a Major Problem". JALCA, 89, 153-185

Jimoh, A. A., Ganiyu, B. A., Baba, D., and Baba, A. (2018) Bioremediation Process of Effluent from Detergent and Food Industries in Jos, Nigeria: Kinetics and Thermodynamics. International Journal of Engineering Science Invention (IJESI), 762-73

Kandelbauer, A., Maute, O., Kessler, R. W., Erlacher, A., and Gübitz, G. M. (2004). Study of dye decolorization in an immobilized laccase enzyme-reactor using online spectroscopy. Biotechnology and bioengineering, 87(4), 552-563.

Kongjao, S., Damronglerd, S., and Hunsom, M. (2008). Simultaneous removal of organic and inorganic Pollutants in tannery wastewater using electrocoagulation technique. Korean Journal of chemical engineering, 25(4), 703.

Maheshwari, U. M., Aruna, S., Gomathi, M., and AbdulJaffar, A. H. (2017). Bioremediation by Free and Immobilized Bacteria Isolated from Tannery Effluent. International Journal of Research in Applied, Natural and Social Sciences. 5(7), 75-90

Margesin, R., and Schinner, F. (2001). Bioremediation (natural attenuation and biostimulation) of diesel-oilcontaminated soil in an alpine glacier skiing area. Applied and environmental microbiology, 677), 3127-3133.

Mohammed, A., Sekar, P., and George, J. (2011). Efficacy of microbes in bioremediation of tannery effluent. Inter. J. Curr. Res, 3(4), 324-326.

Mohammed, S. S. D., Orukotan, A. A., and Abdullahi, H. (2017). Physicochemical and Bacteriological Assessment of Tannery Effluent from Samaru-Zaria, 
BAJOPAS Volume 13 Number 2, December, 2020 Kaduna State, Nigeria. Journal of Applied

Sciences and Environmental Management, 21(4), 734-740.

Munz, G., De Angelis, D., Gori, R., Mori, G., Casarci, M., and Lubello, C. (2009). The role of tannins in conventional and membrane treatment of tannery wastewater. Journal of hazardous materials, 164(2-3), 733-739

Mythili, K., and Karthikeyan, B. (2011). Bioremediation of $\mathrm{Cr}$ (VI) from tannery effluent using Bacillus spp and Staphylococcus spp. International Multidisciplinary Research Journal, 1(6).

NESREA (2009). National Environmental Standards for Effluent Limitations and Regulation. 1233-1236

Noorjahan, C. M. (2014). Physicochemical characteristics, identification of bacteria and biodegradation of industrial effluent. Journal of bioremediation and Biodegradation, 5(3).

Ohtake, H. I., and Silver, A. O. (1994). Bacterial reduction of toxic chromate. Biological degradation and bioremediation of toxic chemicals, 403-415.

Omoleke, I. I. (2004). Management of environmental pollution in Ibadan, an African city: the challenges of health hazard facing government and the people. Journal of Human Ecology, 15(4), 265-275.

Rajor, A., Reddy, A.S., and Singh, B. (2004). Determination of BOD kinetic Parameters and evaluation of alternate methods, M.Sc. Thesis, Department of biotechnology \& environmental Science, Thapar Institute of Engineering and Technology, Patiala

Ramasami, T., Rajamani, S., and Rao, J. R. (1994, March). Pollution control in leather industry: Emerging technological options. In International symposium on surface and colloidal science and its relevance to soil pollution, madras.

Ramesh, J. V. S., and Singh, S. P. (1993). Yearly variation in certain physicochemical parameters of pond at eastern Doon Valley. Uttar Pradesh J. Zoo, 12 (1), 7577.

Ranen, S., and Sharadinadra, C. (2009). Biotechnology applications to environmental remediation in resource exploitation. Current science, 97, 6-25
Russell, A. J., Berberich, J. A., Drevon, G. F., and Koepsel, R. R. (2003). Biomaterials for mediation of

chemical and biological warfare agents. Annual review of biomedical engineering, 5(1), 1-27.

Saravanan, P., and Saravanan, A. (1999). Decolourization of tannery effluent by Flavobacterium sp. EK 1. Indian Journal of Environmental Protection, 19, 19-24.

Sikander, S., and Shahida, H. (2007). Reduction of toxic hexavalent chromium by Ochrobactrum intermedium strain SDCr5 stimulated by heavy metals. Bioresource Technol, 98, 340-344.

Singh, N., Sharma, B. K., and Bohra, P. C. (2000). Impact assessment of industrial effluent of arid soils by using satellite imageries. Journal of the Indian Society of Remote Sensing, 28(2-3), 79.

Sreemoyee, C., and Priti, P. (2013). Assessment of physico-chemical parameters of dairy waste water and isolation and characterization of bacterial strains in terms of cod reduction. Int J Sci, 2(3), 395-400.

Verheijen, L. A. H. M., Wiersema, D., Pol, L. H., and De Wit, J. (1996). Management of wastes from animal product processing. Livestock and environment, Finding a balance. International Agriculture Center, Wageningen, The Netherlands.

Wang, F., Yao, J., Si, Y., Chen, H., Russel, M., Chen, K., and Bramanti, E. (2010). Short-time effect of heavy metals upon microbial community activity. Journal of Hazardous Materials, 173(13), 510-516.

WHO (World Health Organization). (2006). Air quality guidelines: global update 2005: particulate matter, ozone, nitrogen dioxide, and sulfur dioxide. World Health Organization.

World Bank. (1995). Nigeria's strategic options for redressing industrial pollution. World Bank, industry and energy division. 1st edition, West Central Africa Department; Annexes: 1995; pp 60-62.

Zahoor, A., and Abdul, R. (2009). Enumeration of Coliforms. Journal of Environmental Sciences. 21, 814-820 


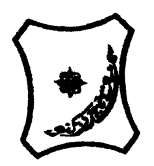

Bayero Journal of Pure and Applied Sciences, 13(2): 1 - 12

Received: November, 2020

Accepted: December, 2020

ISSN $2006-6996$

\title{
BIODEGRADATION POTENTIAL OF IMMOBILIZED BACTERIA IN THE TREATMENT OF TANNERY INDUSTRIAL EFFLUENTS FROM INDUSTRIAL ESTATES IN KANO STATE, NIGERIA
}

\author{
Abdullateef, B., ${ }^{1 *}$ Shuaibu, T. G., ${ }^{1}$ Babagana, K., ${ }^{1}$ Suleman, H. B. ${ }^{2}$ and Dauda, B. ${ }^{3}$ \\ ${ }^{1}$ Department of Pure and Applied Chemistry, Faculty of Science, University of Maiduguri, Borno State, \\ Nigeria \\ ${ }^{2}$ Department of Microbiology, Faculty of Science, University of Maiduguri, Borno State, Nigeria \\ ${ }^{3}$ Department of Chemical Engineering, Faculty of Engineering, University of Maiduguri, Borno State, \\ Nigeria \\ *Corresponding author: babslega@gmail.com; abelega2007@yahoo.com; +2348061309753
}

\section{ABSTRACT}

Industrial Effluents Samples from Gashash Tanneries (TAN1) in Bompai Industrial estate, Larabee Tannery Industry (TAN2) in Sharada Industrial estate and Z Tannery Industries (TAN3) in Challawa Industrial estate, Kano State, Nigeria were collected over a period of six months (August 2017 to January 2018) for assessing the biodegradation potentials of bacteria in the treatment of organic pollutants within the effluents. Bacteria were isolated from the effluents and immobilized on agar-agar. Different masses (5 g, $10 \mathrm{gr}, 15$ $\mathrm{g}, 20 \mathrm{~g}$, and $25 \mathrm{~g}$ ) of the bacteria were used in the treatment of $250 \mathrm{ml}$ of the effluents for ten days in a shaker incubator (Gallenkamp-OC-4364-L) at the temperature $30{ }^{\circ} \mathrm{C}$ and speed of $60 \mathrm{rpm}$. Pre-treatment analysis of the effluents for Temperature, pH, Biochemical Oxygen Demand (BOD), Chemical Oxygen Demand (COD), Suspended Solid (SS) and Total Dissolved Solids (TDS) gives the following results; temperature $\left({ }^{\circ} \mathrm{C}\right.$ )

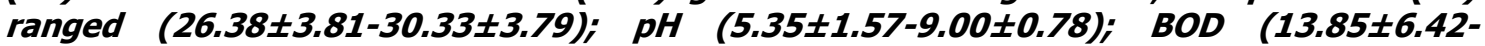
$38.75 \pm 16.20) ;$ COD (1406 $\pm 208-3532 \pm 1373) ;$ SS (208 $\pm 235-780 \pm 739)$ and TDS (266 $\pm 253-5276 \pm 2971)$. No statistical differences ( $p \leq 0.05)$ was observed for all the results among the different industries. The bacterial isolates were identified as Neisseria spp, Bacillus cereus, and Staphylococcus aureus, in TAN1, TAN2, and TAN3, respectively. After treatment of the effluent with the different masses of the isolated bacteria, the mean level of BOD was found to range as (0.55 $\pm 0.36-6.92 \pm 5.49) ; C O D$ (ND-3134 \pm 1595$)$;

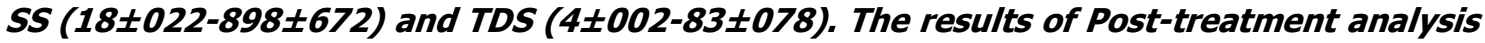
showed that there is overall decrease in the levels of the parameters determined when compared with that of the pre-treatment. The overall percentage reduction of the immobilised bacteria in the treatment of the respective effluents was in the order TAN2 (72\%)>TAN1 (70\%)>TAN3 (62\%). Hence, the immobilized bacteria are having higher biodegradation potential for the treatment of the tannery effluents.

Keywords: Biodegradation, bacteria, effluent, immobilization, tannery.

\section{INTRODUCTION}

Tannery industrial wastewater is a serious consequence of the pollution point of view for streams, freshwater, and land used for agriculture. The lack of awareness in the modern industrial practice has resulted in the discharge of tannery effluents which exhibit very high value of chromium ( $\mathrm{Cr}$ ), Sulfide, and chloride, Total Dissolved Solid (TDS), Total Suspended Solid (TSS), Biochemical Oxygen Demand (BOD) and Chemical Oxygen Demand (COD) in the water stream or land (Mohammed et al., 2001). Tanning is the process, which One ton of skin generally leads to the production of 20 to $80 \mathrm{~m}^{3}$ of turbid and foul-smelling converts the protein of the rawhide or skin into a stable material, which will not putrefy and is suitable for a wide variety of end applications (Elsheikh, 2009). The highly polluting chromium is the most commonly used tanning material producing leather that is more flexible and pliable than vegetable-tanned leather and does not discolor or lose shape in water as drastically as vegetable-tan (Elsheikh, 2009). Tannery effluent is among the most hazardous industrial pollutants due to its huge organic and inorganic load, which is highly toxic to human life and the environment (Kongjao et al., 2008). wastewater including chromium (100-400 mg/l), sulfide $(200-800 \mathrm{mg} / \mathrm{l})$, high levels of fat and 
BAJOPAS Volume 13 Number 2, December, 2020 other solid wastes, and notable pathogen contamination as well as pesticides added for skin conservation during transport (Elsheikh, 2009). There are more than 6000 tanneries in Nigeria with an annual processing capacity of 700,000 tons of hides and skins (Omoleke, 2004; Singh et al., 2008). It was reported that the total amount of waste produced per animal slaughtered is approximately $35 \%$ of its weight (World Bank, 1995). Also, for every $1000 \mathrm{~kg}$ of carcass weight, a slaughtered beef produces 5.5 $\mathrm{kg}$ of manure (excluding rumen contents or stockyard manure) and $100 \mathrm{~kg}$ of paunch manure (undigested food) (Verheijen et al., 1996). Tanneries generate wastewater in the range of 30-35 $\mathrm{L} \mathrm{kg}^{-1}$ skin/hide processed with variable $\mathrm{pH}$, Biological Oxygen Demand (BOD), Chemical Oxygen Demand (COD), high concentrations of suspended solids (SS), and tannins as well as chromium (Zahoor and Abdul, 2009).

Being heterogeneous and composed of a wide variety of compounds, it is very difficult to select a unique direct method for estimating the biodegradability of organic contents and biokinetic parameters for a wastewater sample (Rajor, 2004). For this purpose, some indirect estimation such as determination of biochemical oxygen demand (BOD) and chemical oxygen demand (COD) are applied as common laboratory investigations [9]. During retanning procedures, synthetic tannins (Syntan), oils and resins are added to form softer leather at varying doses (Munz et al., 2009). One of the refractory groups of chemicals in tannery effluents derives mainly from tannins (Ramasami et al., 2004). Syntans are characterized by complex chemical structures, because they are composed of an extended set of chemicals such as phenol-, naphthalene-, formaldehyde- and melamine-based syntans, and acrylic resins (Beem, 1994). Organic pollutants (proteic and lipidic components) are originated from skins (it is calculated that the raw skin has $30 \%$ loss of organic material during the working cycle) or they are introduced during processes (Hugo Springer, 1994).

Many conventional processes such as oxidation, chemical and biological processes were carried out to treat tanneries wastewater (Ebtesam et al, 2013). Biological processes have received more attention because of their costeffectiveness, lower sludge production and environmental friendliness (Noorjahan, 2014). Naturally occurring micro-organisms degrade the hazardous organic wastes including xenobiotic compounds, such as pesticides, polycyclic aromatic hydrocarbons (PAHs) and polychlorinated biphenyls (PCBs) in due course of time (Ranen and Sharadinadra, 2009). Bioremediation is based on the idea that all organisms remove substances from the environment to carry outgrowth and metabolism (Bouwer and Zehnder, 1993). Bacteria, protista and fungi are found to be very good at degrading complex molecules and incorporating the breakdown products into their metabolism (Bouwer and Zehnder, 1993). The resultant metabolic wastes that they produce are generally safe and somehow recycled into other organisms (Ranen and Sharadinadra, 2009). An acclimatized indigenous population of microorganisms capable of degradation of the compounds of interest must exist at the site for a successful bioremediation mode (Ranen and Sharadinadra, 2009). It has been observed that for a successful bioremediation mode, an acclimatized indigenous population of microorganisms capable of degradation of the compounds of interest must exist at the site under investigation (Ranen and Sharadinadra, 2009). Even though there are numerous physical and chemical methods employed in the disposal of wastes the advantage in using bacterium is that they play a key role in the reduction of COD, BOD, total protein, total tannin and total phenol (Saravanan and Saravanan, 1998)

Baba et al. (2020) studied the bioremediation potential of immobilized corynebacterium kutsceri in the Treatment of tannery industrial effluent from Challawa Industrial Estate, Kano State, Nigeria. The aim of the work is to study the reduction in the level of the contaminants through the process of bioremediation using the isolated bacteria. Immobilized bacteria can withstand various temperatures, $\mathrm{pH}$ and substrate concentrations; consequently, increasing the efficiency and the lifespan of the bacteria. Immobilized bacteria are widely applied in the treatment of wastewater and can be separated and recovered after the treatment with the same efficiency (Baba et al., 2020).

\section{MATERIALS AND METHODS \\ Study Area}

This study was carried out in Bompai, Sharada and Challawa industrial estates in Kano, Figure 1. Kano lies on Latitude $11^{\circ} 30^{\prime} \mathrm{N}$ and $8^{\circ} 30^{\prime} \mathrm{E}$ and Longitude $11^{\circ} 5^{\prime} \mathrm{N}$ and $8^{\circ} 5^{\prime} \mathrm{E}$ in Northern Nigeria. It is one of the developed industrial cities in Nigeria. Tannery activities are the dominating industries and this could be one of the reasons for her high population density (Dan'Azumi and Bichi, 2010). Many researchers have studied biodegradation of tannery effluent using microorganisms. However, limited literature is available on the biodegradation of tannery effluent in Kano industrial estates using 
BAJOPAS Volume 13 Number 2, December, 2020 immobilized bacterial cells. This research work focuses on the potential of the use of the indigenous immobilized bacterial isolates in the treatment of tannery effluents in the industrial estates.

\section{Sample Collection}

Effluents were collected from the Tannery Industries from Bompai, Challawa and Sharada Industrial Estates, Kano, Nigeria. The effluents were collected over a period of six months (August 2017 to January 2018). Samples collected in a sterile 4-liter plastic container with a unique identification number were preserved using an ice-box that was transported to the Microbiology Laboratory, Department of Microbiology, Bayero University of Kano for analysis

\section{Sample Preparation and Sample Analysis}

Immediately after the collection of the effluent, $\mathrm{pH}$, TSS, TDS, COD, BOD levels were determined before treatment (Pre-treatment determination) and ten days after treatment (Post-treatment determination) as described in
APHA (1989) standard methods. $\mathrm{pH}$ was determined using Ecotests $\mathrm{pH}$ meter and TDS was determined using AQUALYTIC TDS Salinometer. BOD was determined as described by the standard method (APHA, 1992). COD and SS were determined using DR/2010 HACH portable data logging spectrophotometer (DWAF, 1992)

\section{Identification and Biochemical} Characterization of the Bacterial Isolates

The bacteria were isolated from the effluents using Serial Dilution according to the method described by APHA (1989). The biochemical tests such as oxidase, catalase, coagulase, indole (from $1 \%$ tryptone broth), citrate (Simmons citrate agar), methyl red/VogesProskauer (MR/VP), nitrate reduction, Starch Hydrolysis, Glucose, Maltose, and Lactose tests were carried out on the bacterial isolates to identify the bacteria through the bacteria biochemical characteristics according to Ajao et al. (2011).

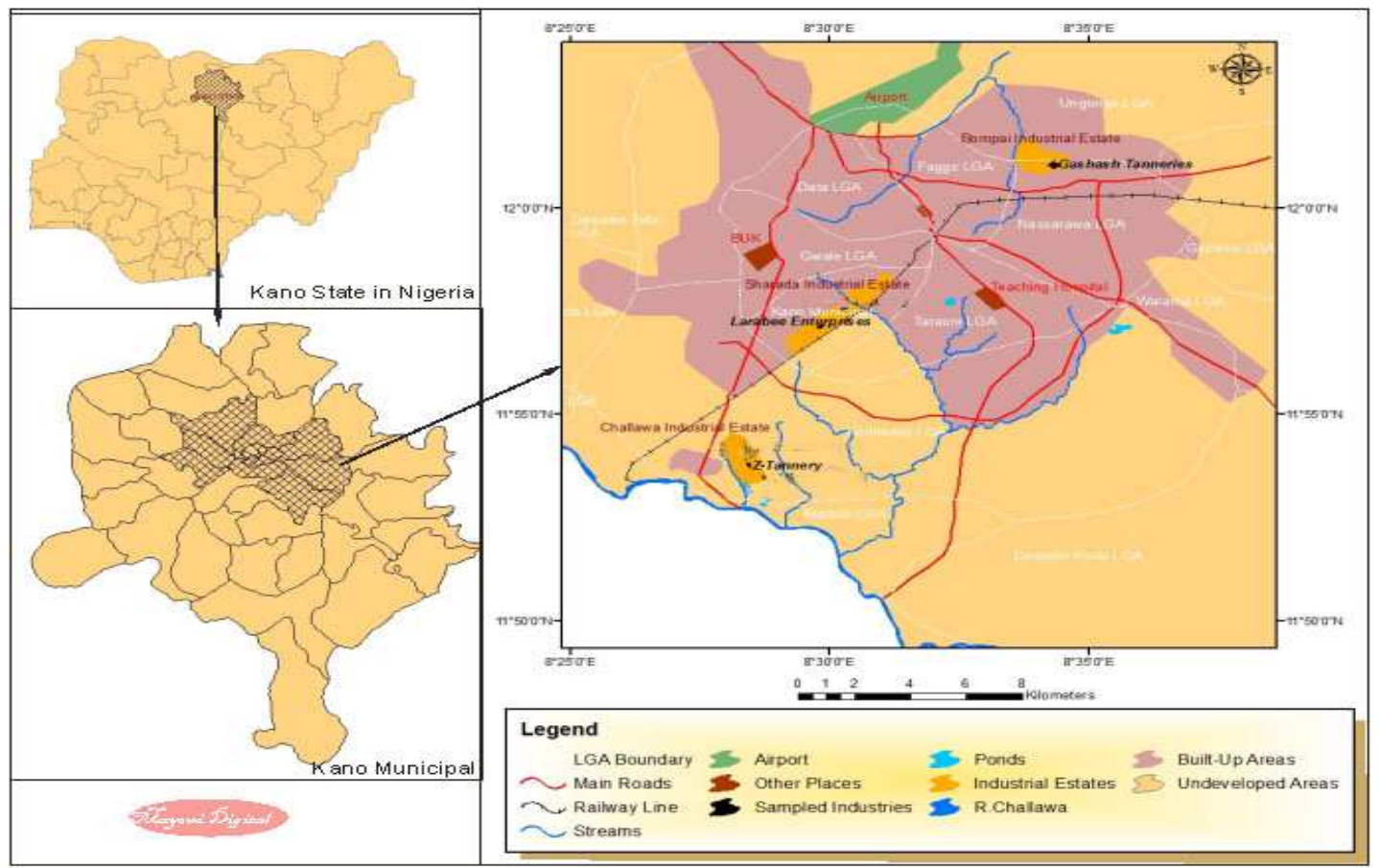

Fig. 1 Map showing the study areas

Source: Mayomi Digital Productions, GIS Laboratory, Department of Geography, UNIMAID (2017)

\section{Determination of Growth Rate of the Bacteria in Effluent Sample}

The bacteria growth rates were determined by transferring $2 \mathrm{~mL}$ of the bacterial isolates from the tannery effluent in broth medium into 100 $\mathrm{mL}$ sterile effluents in conical flasks and kept in an incubator (Giffrin cool) for 10 days. Control was also set up by incubating another $100 \mathrm{~mL}$ each of the sterile effluents without the bacteria. The optical density of the content was determined at the wavelength of $600 \mathrm{~nm}$ on a daily interval and recorded. 
BAJOPAS Volume 13 Number 2, December, 2020 Immobilization of Bacteria

Agar solution and inoculi were prepared separately. Fifty milliliters $(50 \mathrm{~mL})$ of nutrient broth each of the inoculi was prepared in a McCartney bottle and incubated for 24 hours. A solution of agar-agar was prepared by dissolving $10 \mathrm{~g}$ of the powder in distilled water and made up to $500 \mathrm{~mL}$ mark in an Erlenmeyer flask and was sterilized in an autoclave (280A) for 15 minutes and allowed to cool to $40-45^{\circ} \mathrm{C}$ (Ajao et al., 2011). Four milliliters ( $4 \mathrm{~mL})$ of the bacterial isolates in the nutrient broth was mixed with 36 $\mathrm{ml}$ of the prepared agar-agar media in petri-dish plates and then allowed to solidify. This was kept in the refrigerator for bioremediation.

\section{Bioremediation (Treatment) of the Effluents}

The solidified agar block (immobilized bacteria) was cut into cubes using a sterile knife; $0.1 \mathrm{~mL}$ phosphate buffer ( $\mathrm{pH} \mathrm{7.0)}$ was added and kept in the refrigerator for 1 hour for curing. The phosphate buffer was decanted after 1 hour and the cubes were washed with sterile distilled water 3-4 times before it was used (Ajao et al., 2011). Two liters (2 L) of the effluent was supplemented with the minimum basal medium in $\mathrm{g} / \mathrm{L}: \mathrm{NaCl}(0.8), \mathrm{MgSO}_{4} .7 \mathrm{H}_{2} \mathrm{O}(0.001), \mathrm{KH}_{2} \mathrm{PO}_{4}$ (2), $\mathrm{NaNO}_{3}$ (2), $\quad \mathrm{CaCl}_{2} .2 \mathrm{H}_{2} \mathrm{O} \quad(0.5)$ and $\mathrm{NaHPO}_{4} .12 \mathrm{H}_{2} \mathrm{O}(2)$ and sterilized in an autoclave at $121^{\circ} \mathrm{C}$ for 15 minutes (Margesin and Schinner, 2001). Two hundred and fifty milliliters $(250 \mathrm{~mL})$ of the effluents were transferred into different $250 \mathrm{ml}$ conical flasks. The content was covered with a cotton-wool ramped with foil paper to avoid contamination. Five grams $(5 \mathrm{~g})$ of the immobilized bacteria were quickly transferred into each of the effluents in the conical flasks in an inoculating chamber. The same procedures were carried out for the $10 \mathrm{~g}, 15 \mathrm{~g}, 20 \mathrm{~g}$ and 25 $\mathrm{g}$ of the immobilized bacteria in separate $250 \mathrm{~mL}$ effluents in conical flasks and agitated for ten days in a shaker incubator (Gallenkamp-OC4364-L) at a temperature $30^{\circ} \mathrm{C}$ and speed of 60 rpm. The treated effluent samples were taken on the tenth day and analyzed for the parameters $\mathrm{pH}$, SS, TDS, COD, and BOD, (Posttreatment determination) for the different grams of bacteria to evaluate and compare the biodegradation potential. (Baba et al., 2020).

\section{Statistical Analysis}

The data were represented as Mean \pm Standard deviation and analyzed statistically using oneway Analysis of Variance (ANOVA) and Tukey's HSD as Post Hoc Tests with the aid of SPSS 16.0. The correlation coefficient was also used to measure the strength of the relationship between the different masses of the bacteria and the parameters. All $\mathrm{p} \leq 0.05$ were considered as statistically significant.

\section{RESULTS AND DISCUSSION Physico-chemical parameters in the Industrial Effluents before the Biodegradation.}

Results of the Physico-chemical parameters in the industrial effluents before the Biodegradation is shown in table 1 . The mean temperatures $\left({ }^{\circ} \mathrm{C}\right)$ observed in TAN1, TAN2, and TAN3 samples were $28.07 \pm 0.65 ; 27.77 \pm 0.64$ and $26.38 \pm 3.81$ respectively. The order of the mean temperature of the samples from the three industries can be arranged as TAN1 > TAN2>TAN3. The temperature observed at TAN1, TAN2, and TAN3 samples were found below the WHO $\left(35^{\circ} \mathrm{C}\right)$ and NESREA $\left(40^{\circ} \mathrm{C}\right)$ limits. The low values of temperature might be due to the processes used at the time of sampling. High temperature brings down the solubility of gases in water that ultimately expresses as high BOD and COD. Statistical analysis shows that there is no significant difference $(p<0.05)$ between the mean values of temperature among the industries. This might be due to similar tannery activities involved in the tannery industries at the time of sampling. The average values of temperature observed in this present study are less than those observed by Akan et al. (2007), Akan et al. (2009) and Baba et al. (2020).

The mean level of $\mathrm{pH}$ observed in TAN1, TAN2 and TAN3, samples were $7.77 \pm 2.93$; $8.35 \pm 0.28$ and $7.52 \pm 0.76$ respectively. The order of the mean $\mathrm{pH}$ of the samples from the three industries can be arranged as TAN2> TAN1 $>$ TAN3. The $\mathrm{pH}$ of the samples falls within the WHO (7.0-8.5) and NESREA (6-9) standard limits. Statistical analysis shows that there is no significant difference $(p<0.05)$ between the mean values of $\mathrm{pH}$ among the industries. This might be due to similar tannery activities involved in the tannery industries at the time of sampling. Maheshwari et al. (2017) reported that the level of $\mathrm{pH}$ in the effluents from the tannery industry in Vaniyambadi, India was 6.5 which was lower than that observed in the present study. The $\mathrm{pH}$ in the effluents from the tannery industries in Kano and Kaduna were reported to be 7.64 and 6.89, respectively (Akan et al., 2007; Mohammed et al., 2017). The average values of $\mathrm{pH}$ observed in this present study are less than those observed by Mohammed et al. (2017) and Baba et al. (2020). The mean level of SS $(\mathrm{mg} / \mathrm{l})$ observed in TAN1, TAN2, and TAN3 samples were 374 \pm 124 ; $358 \pm 335$ and $780 \pm 739$ respectively. The order of the mean SS in the samples from the three industries can be arranged as TAN3 > TAN1 $>$ TAN2. 
The SS observed in the samples were far above the recommended standard limits of regulating bodies WHO $(30 \mathrm{mg} / \mathrm{l})$ and NESREA $(10 \mathrm{mg} / \mathrm{l})$. Statistical analysis shows that there is no significant difference $(p<0.05)$ between the mean values of SS among the industries. This might be due to similar tannery activities involved in the tannery industries at the time of sampling. The average values of SS observed in this present study are less than that observed $(3700 \pm 122 \mathrm{mg} / \mathrm{l})$ by Akan et al. (2009) for tanneries in Kano. Also, the average values of SS observed in this present study are less than that observed by Mohammed et al. (2017) and Baba et al. (2020) with the exception in TAN3.

The mean level of TDS (mg/l) observed in TAN1, TAN2, and TAN3 samples were $3941 \pm 3703$; $3300 \pm 1714$ and $2653 \pm 1240$ respectively. The order of the mean TDS in the samples from the three industries can be arranged as TAN1>TAN2>TAN3. The TDS observed in the samples were far above the recommended standard limits of WHO $(250 \mathrm{mg} / \mathrm{l})$ and NESREA $(500 \mathrm{mg} / \mathrm{l})$. Statistical analysis shows that there is no significant difference $(p<0.05)$ between the mean values of TDS among the industries. This might be due to similar tannery activities involved in the tannery industries at the time of sampling. TDS in the effluents from the tannery industries in Kano, Nigeria was reported to be $1281 \mathrm{mg} / \mathrm{l}$ (Akan et al., 2007). The average values of SS observed in this present study are less than those observed by Mohammed et al. (2017) and Baba et al. 2020)

The mean level of COD (mg/l) observed in TAN1, TAN2 and TAN3 samples seasons were $2372 \pm 938 ; \quad 1406 \pm 208$ and $3532 \pm 1373$ respectively. The order of the mean COD of the samples from the three industries can be arranged as TAN3>TAN1> TAN2. The COD observed in TAN1, TAN2 and TAN3 samples were far above the recommended standard limits of regulating bodies $\mathrm{WHO}(40 \mathrm{mg} / \mathrm{l})$ and NESREA (40 mg/l). Statistical analysis shows that there is no significant difference $(p<0.05)$ in COD among the industries. This might be due to similar tannery activities involved in the tannery industries as at the time of sampling. The Chemical Oxygen demand (COD) is the amount of oxygen, in $\mathrm{mg} / \mathrm{L}$, required for the degradation of the compound of wastewater to occur. In comparison, the average values of COD observed in this present study were higher than that observed by Mohammed et al. (2017) but lower than that observed by Baba et al. (2020).

The mean levels of BOD $(\mathrm{mg} / \mathrm{l})$ observed in TAN1, TAN2 and TAN3 samples were $13.85 \pm 6.42 ; \quad 19.46 \pm 0.50$ and $17.13 \pm 3.14$ respectively. The order of the mean BOD in the samples from the three industries can be arranged as TAN2>TAN3>TAN1. The BOD observed in TAN1, TAN2 and TAN3 samples were found below the recommended limits of NESREA (200 mg/l) but above WHO (10 mg/l). Statistical analysis shows that there is no significant difference $(p<0.05)$ between the mean values of BOD among the industries. This might be due to similar tannery activities involved in the tannery industries at the time of sampling. The low level of BOD recorded in this study is an indication of the low level of biodegradable organic solids in the effluent. The average values of BOD observed in this present study were lower than those observed by Mohammed et al. (2017) and Baba et al. (2020).

Table 1: Mean Values \pm S.D of Physico-chemical parameters of effluents from the Tannery Industries before Treatment.

\begin{tabular}{llllllll}
\hline Parameter & Tannery 1 & Tannery 2 & Tannery 3 & $\mathrm{a}$ & $\mathrm{b}$ & $\mathrm{c}$ & $\mathrm{d}$ \\
\cline { 2 - 7 } Temperature $\left({ }^{\circ} \mathrm{C}\right)$ & $28.07 \mathrm{a} \pm 0.65$ & $27.77 \mathrm{a} \pm 0.64$ & $26.38 \mathrm{a} \pm 3.81$ & & $29.50 \pm 4.68$ & 35 & 40 \\
pH & $7.77 \mathrm{a} \pm 2.93$ & $8.35 \mathrm{a} \pm 0.28$ & $7.52 \mathrm{a} \pm 0.76$ & 6.89 & $5.35 \pm 1.57$ & $7.0-8.5$ & $6.0-9.0$ \\
$\mathrm{COD}(\mathrm{mg} / \mathrm{l})$ & $2372 \mathrm{a} \pm 938$ & $1406 \mathrm{a} \pm 208$ & $3532 \mathrm{a} \pm 1373$ & 2.2 & $3106 \pm 2753$ & 40 & 40 \\
$\mathrm{BOD}(\mathrm{mg} / \mathrm{l})$ & $13.85 \mathrm{a} \pm 6.42$ & $19.46 \mathrm{a} \pm 0.50$ & $17.13 \mathrm{a} \pm 3.14$ & 1032 & $26.17 \pm 9.49$ & 10 & 200 \\
$\mathrm{SS}(\mathrm{mg} / \mathrm{l})$ & $374 \mathrm{a} \pm 124$ & $358 \mathrm{a} \pm 335$ & $780 \mathrm{a} \pm 739$ & 501 & $562 \pm 482$ & 30 & 10 \\
TDS $(\mathrm{mg} / \mathrm{l})$ & $3941 \mathrm{a} \pm 3703$ & $3300 \mathrm{a} \pm 1714$ & $2653 \mathrm{a} \pm 1240$ & 532.7 & $444 \pm 507$ & 250 & 500 \\
\hline
\end{tabular}

The values given in the table above are means of 6 replicate values, $\mathrm{n}=6$ ( 1 sample was taken monthly for 6 months). Within the rows, means with different alphabets are statistically different $(p<0.05)$. WHO: World Health Organisation. NESREA: National Environmental Standard and Regulatory Enforcement Agency. a = Mohammed et al.(2017), b = Baba et al. (2020), c = WHO (2006), $d=$ NESSRA (2009) 
BAJOPAS Volume 13 Number 2, December, 2020

Identification, Biochemical Characterization and growth rates of the Bacterial Isolates

Results of identification and biochemical characterization of the bacterial isolates were shown in table 2. After 24 hours of incubation, the nutrient agar media plates were checked for bacterial growth. The results showed the presence of different strains in the samples. The TAN1 bacteria isolate was found to be gramnegative cocci while TAN3 was gram-positive cocci. TAN2 bacteria isolate was found to be gram-positive, rod-shaped. TAN1, TAN2, and TAN3 bacteria isolates recorded positive results for spore former.

The results of the biochemical tests indicated that all the bacteria were positive for catalase, oxidase, citrate, maltose, glucose, lactose (negative in TAN1), mannitol (negative in TAN2), starch hydrolysis and coagulase (negative in TAN2) tests. The bacteria showed negative results for nitrate reduction, $M R$ (positive in TAN2), VP (positive in TAN1), Indole (positive in TAN2) tests. Base on the morphological and biochemical test results, TAN1, TAN2, and TAN3 bacteria isolates were identified to be Nesseria spp, Bacillus cereus, and Staphylococcus aureus respectively.

The growth rate of the TAN1, TAN2 and TAN3 Isolates were shown in figure 2. Generally, the optical density increase with the increase in time (day) and decrease as time goes on. The highest optical density was shown by bacillus cereus in TAN2 while the lowest was shown by Staphylococcus aureus in TAN3.

The initial growth phase of TAN1 Isolate bacteria occurred within 2-day of incubation as the growth rate increases up to the 6th-day incubation when the maximum growth was observed. Beyond the 6th day, the growth of the bacteria declined (which might be due to a shortage of nutrients in the effluents) until it reached its death phase (which might be due to the unavailability of nutrients in the effluents).

A similar trend of growth was also observed for TAN2 Isolate as the initial growth phase also occurred within 2-day of incubation but maximum growth rate observed on the 4th day of incubation. The stationary stage occurred between the 4th day and the 8th day. Beyond the 8th day, the growth of the bacteria declined (which might be due to a shortage of nutrients in the effluents) until it reached its death phase (which might be due to the unavailability of nutrients in the effluents).

The initial growth phase of TAN3 bacterial Isolate occurred within the 3-day incubation as the growth rate increases up to the 6th-day incubation when the maximum growth was observed. Beyond the 6th day, the growth of the bacteria declined (which might be due to a shortage of nutrients in the effluents) until it reached its death phase (which might be due to the unavailability of nutrients in the effluents).

Table 2: Morphological and Biochemical characteristics of bacterial isolates

\begin{tabular}{lllll} 
Bacterial Isolates & & TAN1 & TAN2 & TAN3 \\
\hline $\begin{array}{lllll}\text { Morphological } \\
\text { characteristics }\end{array}$ & Shape & Cocci & Rod & Cocci \\
& Spore & & & \\
& former & + & + & + \\
Gram & & & \\
Biochemical characteristics & reaction & - & + & + \\
& Citrate & + & + & + \\
& Catalase & + & + & + \\
& Coagulase & + & - & + \\
Starch & + & + & + \\
& Glucose & + & + & + \\
Oxidase & + & + & + \\
& Indo & - & + & - \\
Lactose & - & + & + \\
Manitol & + & - & + \\
Maltose & + & + & + \\
MR & - & + & - \\
VP & + & - & - \\
& Nitrate & - & - & - \\
Reduction & - Neisseria & Bacillus & Staphylococcus \\
& Bacterial & cereus & aureus \\
& name & spp & cas
\end{tabular}

+ = Positive; - = Negative; MR=Methyl Red; VP= Voges-Proskauer 


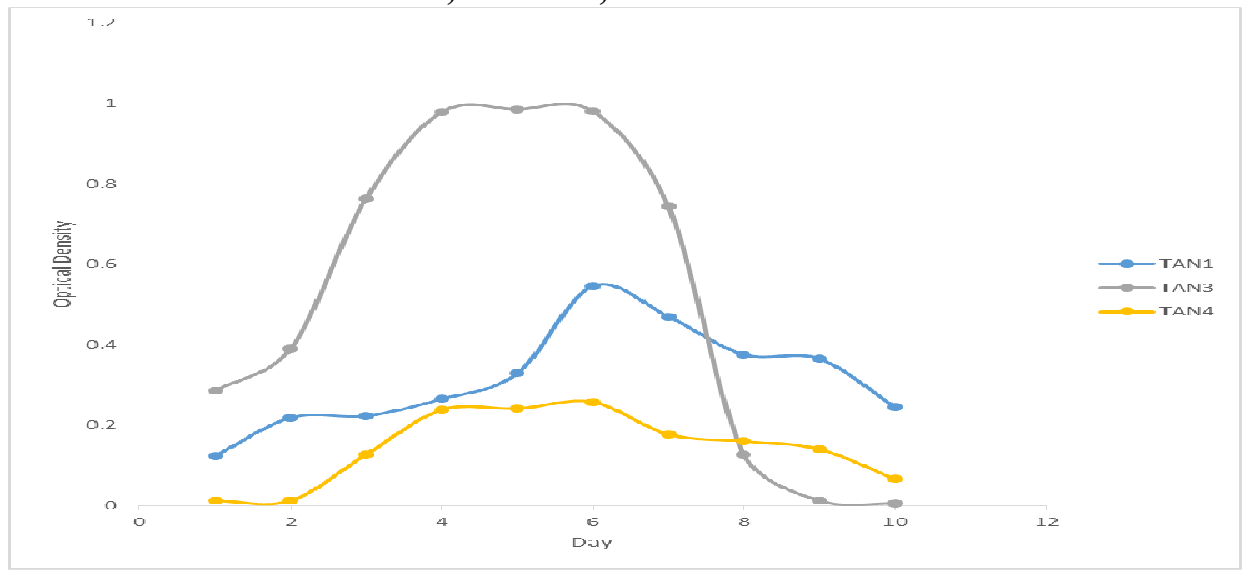

Fig. 2 Growth rates of the isolates in the effluents from the Tannery Industries

\section{Physico-chemical Parameters in the Industrial Effluents after the biodegradation.}

Table 3 shows the mean results of the physicochemical parameter before and after bioremediation using the different masses $(5 \mathrm{~g}$, $10 \mathrm{~g}, 15 \mathrm{~g}, 20 \mathrm{~g}$, and $25 \mathrm{~g}$ ) of the respective immobilized bacteria. Also, Table 4 shows the mean results of correlation coefficient ( $r$ ) between different masses of bacteria and physicochemical parameters.

The mean values $(\mathrm{mg} / \mathrm{l})$ of the SS after the bioremediation varies between $243 \pm 45$ and $898 \pm 672$. The mean concentration $(\mathrm{mg} / \mathrm{l})$ of SS remediated by the different masses $(5 \mathrm{~g}, 10 \mathrm{~g}$, $15 \mathrm{~g}, 20 \mathrm{~g}$, and $25 \mathrm{~g}$ ) of the bacteria varies. The SS in the samples fluctuates up and down after the bioremediation process when compared with the SS of the raw samples before the bioremediation. The increase in the levels of the SS might be due to the aggregation of the TDS which are large enough to result into SS. The increase in the levels of the SS might be also due to the influence of the nutrients which was added into the effluents in order to make the microorganisms more active and viable for fast degradation of organic contaminants in the effluent. The relative potential or efficiency of the different masses of the bacteria in remediating SS in TAN1 samples was in the order $25 \mathrm{~g}>20 \mathrm{~g}>15 \mathrm{~g}>10 \mathrm{~g}>5 \mathrm{~g}$. For TAN2 and TAN3 samples, the order was $25 \mathrm{~g}>20 \mathrm{~g}>15$ $\mathrm{g}>10 \mathrm{~g}>5 \mathrm{~g}$. These might be due to the variations in the surface areas of the different masses of the immobilized bacteria. Statistical analysis shows that there is no significant difference $(p<0.05)$ between the mean values of SS among the masses in the respective industries. Positive and significant correlations exist between the masses of bacteria and Suspended Solid (SS). This showed that there is general increase in the levels of the SS as the masses of the immobilized bacteria increases. TAN3 (90\%) and TAN1 (80\%) showed a very high correlation with the masses of the bacteria while TAN2 (61\%) showed a very low correlation.

The mean values $(\mathrm{mg} / \mathrm{l})$ of the TDS after the bioremediation varies between $46 \pm 11$ and $83 \pm 78$. The mean concentration $(\mathrm{mg} / \mathrm{l})$ of TDS remediated by the different masses $(5 \mathrm{~g}, 10 \mathrm{~g}$, $15 \mathrm{~g}, 20 \mathrm{~g}$, and $25 \mathrm{~g}$ ) of the bacteria varies. There is a reduction in all the TDS of all the samples after the bioremediation process compared with the TDS of the raw samples before the bioremediation. The relative potential or efficiency of the different masses of the bacteria in remediating TDS in TAN1 and TAN3 samples was in the order $5 \mathrm{~g}>10 \mathrm{~g}>15 \mathrm{~g}>20$ $\mathrm{g}>25 \mathrm{~g}$. For TAN2 samples, the order was 20 $g>10 \quad g>25 \quad g>15 \quad g>5 \quad g$. Statistical analysis shows that there is no significant difference $(p<0.05)$ between the mean values of TDS among the masses in the respective industries. These might be due to the variations in the surface areas of the different masses of the immobilized bacteria. Positive and significant correlations exist between the masses of bacteria and TDS with the exception in TAN2 (negative and insignificant correlation). The positive correlations showed that there is general increase in the levels of the TDS as the masses of the immobilized bacteria increases. TAN1 $(96 \%)$ showed a very high correlation with the masses of the bacteria while TAN2 (47\%) showed a very low correlation.

The mean values $(\mathrm{mg} / \mathrm{l})$ of the BOD after the bioremediation varies between $1.56 \pm 0.20 \mathrm{mg} / \mathrm{l}$ and $6.92 \pm 5.49 \mathrm{mg} / \mathrm{l}$. The mean concentration $(\mathrm{mg} / \mathrm{l})$ of BOD remediated by the different masses $(5 \mathrm{~g}, 10 \mathrm{~g}, 15 \mathrm{~g}, 20 \mathrm{~g}$, and $25 \mathrm{~g}$ ) of the bacteria varies. There is a reduction in all the BOD of all the samples after the bioremediation process compared with the $\mathrm{BOD}$ of the raw 
BAJOPAS Volume 13 Number 2, December, 2020 samples before the bioremediation. The relative potential or efficiency of the different masses of the bacteria in remediating BOD in TAN1, TAN2 and TAN3 samples were in the order $25 \mathrm{~g}>20$ $\mathrm{g}>15 \mathrm{~g}>10 \mathrm{~g}>5 \mathrm{~g}, 25 \mathrm{~g}>15 \mathrm{~g}>5 \mathrm{~g}>10 \mathrm{~g}>20 \mathrm{~g}$ and $20 \mathrm{~g}>10 \mathrm{~g}>25 \mathrm{~g}>15 \mathrm{~g}>5 \mathrm{~g}$ respectively. Statistical analysis shows that there is significant difference $(p<0.05)$ between the mean values of BOD among the masses in the respective industries. These might be due to the variations in the surface areas of the different masses of the immobilized bacteria. Negative and significant correlations exist between the masses of bacteria and BOD. This showed that there is general decrease in the levels of the BOD as the masses of the immobilized bacteria increases. TAN1 (94\%) showed a very high correlation with the masses of the bacteria while TAN2 (4\%) showed a very low correlation.

The mean values $(\mathrm{mg} / \mathrm{l})$ of the COD after the bioremediation varies between $250 \pm 154$ and $3134 \pm 1595$. The mean concentration $(\mathrm{mg} / \mathrm{l})$ of COD remediated by the different masses $(5 \mathrm{~g}$, $10 \mathrm{~g}, 15 \mathrm{~g} 20 \mathrm{~g}$, and $25 \mathrm{~g}$ ) of the bacteria varies. There is a reduction in all the COD of all the samples after the bioremediation process compared with the COD of the raw samples before the bioremediation. The relative potential or efficiency of the different masses of the bacteria in remediating COD in TAN1, TAN2 and TAN3 samples were in the order $25 \mathrm{~g}>20 \mathrm{~g}>15$ $\mathrm{g}>5 \mathrm{~g}>10 \mathrm{~g}, 25 \mathrm{~g}>20 \mathrm{~g}>15 \mathrm{~g}>10 \mathrm{~g}>5 \mathrm{~g}$ and 10 g>5 g>25 g>15 g>20 g respectively. Statistical analysis shows that there were significant difference $(p<0.05)$ between the mean values of COD among the masses in the respective industries except for effluents treated with $25 \mathrm{~g}$. These might be due to the variations in the surface areas of the different masses of the immobilized bacteria. Negative and insignificant correlations exist between the masses of bacteria and COD with the exception in TAN3 (positive and significant correlation). The negative correlations showed that there is general decrease in the levels of the COD as the masses of the immobilized bacteria increases. TAN2 (100\%) showed a very high correlation with the masses of the bacteria while TAN3 (36\%) showed a very low correlation.

Generally, there was an overall decrease in the concentration of these physicochemical parameters after the bioremediation using the different masses of the bacterial isolates. These might be due to the variations in the surface areas of the different masses of the immobilized bacteria. This is in line with the work of Jimoh et al. (2018) and Baba et al. (2020).

Table 3: Mean Values $(\mathrm{mg} / \mathrm{l}) \pm$ S.D of Physicochemical parameters in effluents from the Tannery Industries before and after Treatment of the effluents $(250 \mathrm{ml})$ with the different masses $(5 \mathrm{~g}, 10 \mathrm{~g}$, $15 \mathrm{~g}, 20 \mathrm{~g}$, and $25 \mathrm{~g}$ ) of the bacteria.

\begin{tabular}{llllllll}
\hline $\mathrm{P}$ & IND & Before & \multicolumn{5}{c}{ After } \\
\cline { 4 - 7 } & & & $5 \mathrm{~g}$ & $10 \mathrm{~g}$ & $15 \mathrm{~g}$ & $20 \mathrm{~g}$ & $25 \mathrm{~g}$ \\
\hline \multirow{2}{*}{ COD } & TAN1 & $2372 \pm 938$ & $1708 \mathrm{a} \pm 861$ & $2045 \mathrm{a} \pm 1205$ & $845 \mathrm{a} \pm 369$ & $300 \mathrm{a} \pm 167$ & $250 \mathrm{a} \pm 154$ \\
& TAN2 & $1406 \pm 208$ & $1195 \mathrm{a} \pm 208$ & $1125 \mathrm{a} \pm 384$ & $1055 \mathrm{a} \pm 317$ & $956 \mathrm{a} \pm 310$ & $870 \mathrm{ab} \pm 240$ \\
& TAN3 & $3532 \pm 1373$ & $2374 \mathrm{a} \pm 1344$ & $1976 \mathrm{a} \pm 1405$ & $2757 \mathrm{a} \pm 1266$ & $3134 \mathrm{a} \pm 1595$ & $2614 \mathrm{~b} \pm 1105$ \\
BOD & TAN1 & $13.85 \pm 6.42$ & $6.92 \mathrm{a} \pm 5.49$ & $6.42 \mathrm{a} \pm 5.07$ & $5.72 \mathrm{a} \pm 5.35$ & $4.62 \mathrm{a} \pm 4.37$ & $2.82 \mathrm{ab} \pm 1.26$ \\
& TAN2 & $19.46 \pm 0.50$ & $1.75 \mathrm{~b} \pm 0.22$ & $1.73 \mathrm{~b} \pm 0.18$ & $1.58 \mathrm{a} \pm 0.16$ & $1.91 \mathrm{a} \pm 0.22$ & $1.56 \mathrm{~b} \pm 0.20$ \\
& TAN3 & $17.13 \pm 3.14$ & $4.24 \mathrm{ab} \pm 0.77$ & $3.29 \mathrm{ab} \pm 0.37$ & $4.11 \mathrm{a} \pm 0.07$ & $3.23 \mathrm{a} \pm 0.91$ & $3.33 \mathrm{a} \pm 1.28$ \\
SS & TAN1 & $374 \pm 124$ & $243 \mathrm{a} \pm 45$ & $471 \mathrm{a} \pm 226$ & $475 \mathrm{a} \pm 182$ & $492 \mathrm{a} \pm 128$ & $611 \mathrm{a} \pm 217$ \\
& TAN2 & $358 \pm 335$ & $460 \mathrm{a} \pm 400$ & $543 \mathrm{a} \pm 414$ & $544 \mathrm{a} \pm 402$ & $551 \mathrm{a} \pm 414$ & $554 \mathrm{a} \pm 405$ \\
& TAN3 & $780 \pm 739$ & $586 \mathrm{a} \pm 594$ & $758 \mathrm{a} \pm 656$ & $787 \mathrm{a} \pm 676$ & $861 \mathrm{a} \pm 635$ & $898 \mathrm{a} \pm 672$ \\
TDS & TAN1 & $3941 \pm 3703$ & $51 \mathrm{a} \pm 10$ & $53 \mathrm{a} \pm 10$ & $55 \mathrm{a} \pm 15$ & $61 \mathrm{a} \pm 20$ & $63 \mathrm{a} \pm 26$ \\
& TAN2 & $3300 \pm 1714$ & $83 \mathrm{a} \pm 78$ & $47 \mathrm{a} \pm 20$ & $48 \mathrm{a} \pm 22$ & $47 \mathrm{a} \pm 17$ & $48 \mathrm{a} \pm 17$ \\
& TAN3 & $2653 \pm 1240$ & $46 \mathrm{a} \pm 11$ & $55 \mathrm{a} \pm 24$ & $55 \mathrm{a} \pm 25$ & $58 \mathrm{a} \pm 23$ & $61 \mathrm{a} \pm 28$ \\
\hline
\end{tabular}

Replicate $=6$ (months)

Within the rows, for the same parameter, means with different alphabets are statistically different $(p<0.05)$.

$\mathrm{P}=$ parameter, IND = Industries 
BAJOPAS Volume 13 Number 2, December, 2020

Table 4: Correlation coefficient $(r)$ between different masses of the bacteria and the physicochemical parameters.

\begin{tabular}{llll}
\hline Industries & Parameter & Correlation coefficient $(r)$ & $\begin{array}{l}\text { Percent dependence (rxrx100) } \\
(\%)\end{array}$ \\
\hline TAN1 & COD & -0.9 & 82 \\
& BOD & -0.97 & 94 \\
& SS & $0.90^{*}$ & 80 \\
TAN2 & TDS & $0.98^{*}$ & 96 \\
& COD & -1 & 100 \\
& BOD & -0.21 & 4 \\
& SS & $0.78^{*}$ & 61 \\
& TDS & -0.69 & 47 \\
& COD & $0.60^{*}$ & 36 \\
& BOD & -0.6 & 37 \\
& SS & $0.95^{*}$ & 90 \\
& TDS & $0.94^{*}$ & 89 \\
\hline
\end{tabular}

The correlation coefficient $(r)$ with * is statistically significant $(p<0.05)$.

Percentage reduction of the Parameters

Table 5 shows the percentage reduction of Parameters in industrial samples before and after the treatment of the effluents $(250 \mathrm{ml})$ with the different masses $(5 \mathrm{~g}, 10 \mathrm{~g}, 15 \mathrm{~g}, 20 \mathrm{~g}$, and $25 \mathrm{~g}$ ) of the Immobilized Bacteria.

In TAN1 samples, the percentage reduction (\%) of COD ranged (14-89); BOD (50-80); SS (-32$35)$ and TDS (98-99). In TAN2 samples, the percentage decrease $(\%)$ of COD ranged (15$38) ;$ BOD (90-92); SS [-28-(-55)] and TDS (9798). In TAN3 samples, the percentage decrease (\%) of COD ranged (11-44); BOD (76-81); SS (15-25) and TDS (98). The percentage increase in the levels COD, BOD and TDS might be due to the increase in the surface area of the different masses of the immobilized bacteria. However, the percentage decrease in the levels of the SS might be due to the aggregation of the TDS which are large enough to result into SS. The percentage decrease in the levels of the SS might be also due to the influence of the nutrients which was added into the effluents in order to make the microorganisms more active and viable for fast degradation of organic contaminants in the effluent. This is in line with the work of Jimoh et al. (2018) in which the concentration of the SS increase after the bioremediation of effluents.

Sreemoyee and Priti (2013) assessed and reduced several Physico-chemical parameters of dairy wastewater using Niesseria $s p$. and concluded that the species are well known to degrade organic compounds. This is in agreement with the current study in which the immobilized Niesseria $s p$ degrade the organic contaminants as indicated by the BOD, COD and TDS.

Jimoh et al. (2018) observed that TSS of the effluents was increased after treatment with immobilized bacteria and concluded that it might be due to the biostimulation method adopted for the research.

The optimum $\mathrm{pH}$ Biosorption of Chromium by Bacillus spp and Staphylococcus spp. from tannery effluent was investigated by Mythili and Karthikeyan (2011). The maximum adsorption of Chromium $(86.4 \mathrm{mg} / \mathrm{L})$ was showed by Bacillus spp and Staphylococcus spp showed $70.6 \mathrm{mg} / \mathrm{L}$ at an initial concentration of $100 \mathrm{mg} / \mathrm{L}$. In the present study, immobilised Bacillus spp and Staphylococcus spp. from the tannery industrial effluents reduced the levels of the organic pollutants with high potential as indicated by the percentage reduction of BOD, COD and TDS.

Enzymes often can work in multiple environments especially if they are immobilized. This makes the microorganisms' enzymes even more resistant to harsh environments and enables the enzymes to be recovered and recycled after they are no longer needed (Gianfreda and Rao 2004). Ramesh and Singh (1993) reported that the immobilized bacteria having more efficiency to remove the suspended particles than free cells. Using the immobilized cell is preferable due to its capability for using several times with the same efficiency, which makes it more economical. Similar work was done by Sikander et al. (2007) showing the higher reduction with permeabilized cells of Ochrobactrum intermedium strain SDCr-5. 
BAJOPAS Volume 13 Number 2, December, 2020

The results revealed the isolation and identification of isolates with the potential for the reduction of $\mathrm{Cr}$ (VI) to $\mathrm{Cr}$ (III). Results indicated that immobilized $B$. cereus could be efficiently used for the reduction of $\mathrm{Cr}$ (VI).

Table 5: Percentage reduction of the tested Parameters from the tannery industrial samples of the Immobilized Bacteria.

\begin{tabular}{lllllll}
\hline \multirow{2}{*}{ Industries } & & \multicolumn{5}{c}{ Percentage Reduction $(\%)$} \\
\cline { 3 - 7 } & & $5 \mathrm{~g}$ & $10 \mathrm{~g}$ & $15 \mathrm{~g}$ & $20 \mathrm{~g}$ & $25 \mathrm{~g}$ \\
\hline TAN1 & COD & 28 & 14 & 64 & 87 & 89 \\
& BOD & 50 & 54 & 59 & 67 & 80 \\
& SS & 35 & -26 & -27 & -32 & -63 \\
& TDS & 99 & 99 & 99 & 98 & 98 \\
TAN2 & COD & 15 & 20 & 25 & 32 & 38 \\
& BOD & 91 & 91 & 92 & 90 & 92 \\
& SS & -28 & -52 & -52 & -54 & -55 \\
& TDS & 97 & 99 & 99 & 99 & 99 \\
& COD & 33 & 44 & 22 & 11 & 26 \\
& BOD & 75 & 81 & 76 & 81 & 81 \\
& SS & 25 & 3 & -1 & -10 & -15 \\
& TDS & 98 & 98 & 98 & 98 & 98 \\
\hline
\end{tabular}

Percentage Reduction $=(B-A) / B \times 100 \%$

$A=$ Concentration of the parameter after treatment

$\mathrm{B}=$ Concentration of the parameter before treatment

$+=$ percentage decrease

- = percentage increase

In general, immobilization makes the enzyme more resistant to temperature, $\mathrm{pH}$, and substrate concentration swings giving it a longer lifetime and higher productivity per active unit (Gianfreda and Rao, 2004; FuIlbrook, 1996; Russell et al, 2003; Kandelbauer et al., 2004). Immobilized cells have been used and studied extensively for the production of useful chemicals (Ohtake and Silver, 1994), the treatment of wastewaters (Chen et al., 2003; Wang et al., 2010). Although many workers described microbial degradation of tannery effluent, limited literature is available on the bioremediation of tannery effluent using immobilized bacterial cells in the Kano Industrial Estates.

\section{CONCLUSION}

The samples contained variable levels of the physicochemical parameters. The results of the Analysis of variance revealed that, no statistical difference $(p<0.05)$ was observed for the temperature, $\mathrm{pH}, \mathrm{SS}, \mathrm{TDS}, \mathrm{BOD}$ and $\mathrm{COD}$ among the three tannery industries before the treatment. The levels of some of the parameters
(SS, TDS and COD) observed in the samples were found above the recommended limits of WHO and NESREA, which called for the treatment of the effluents before discharge into the environment. Base on the morphological and biochemical test results, TAN1, TAN2, and TAN3 bacterial isolates were identified to be Neisseria spp, Bacillus cereus, and Staphylococcus aureus respectively. The results of Post-treatment analysis showed that there is overall decrease in the levels of the parameters determined when compared with that of the pre-treatment. The overall percentage reduction of the immobilised bacteria in the treatment of the respective effluents was in the order TAN2 (72\%)>TAN1 $(70 \%)>$ TAN3 $(62 \%)$. Hence, the immobilized bacteria are having higher biodegradation potential for the treatment of the tannery effluents.

\section{Acknowledgments}

The authors wish to acknowledge the University of Maiduguri for the financial support. The authors are grateful to the Kano State Ministry of Environment for their support in obtaining the effluent samples. 


\section{REFERENCES}

Ajao, A. T., Adebayo, G. B., and Yakubu, S. E. (2011). Bioremediation of textile industrial effluent using mixed culture of Pseudomonas aeruginosa and Bacillus subtilis immobilized on agar-agar in a bioreactor. J. Microbiol. Biotech. Res, 1(3), 50-56.

Akan, J. C., Moses, E. A., Ogugbuaja, V. O., and Abah, J. (2007). Assessment of tannery industrial effluents from Kano metropolis, Kano State, Nigeria. Journal of Applied Sciences, 7(19), 2788-2793.

Akan, J. C., Ogugbuaja, V. O., Abdulrahman, F. I., and Ayodele, J. T. (2009). Pollutant levels in effluent samples from tanneries and textiles of Kano industrial areas, Nigeria. Global journal of pure and applied sciences, 15(3-4).

APHA (1989). Standard methods for Examination of Will bete and Will betewater.15 $5^{\text {th }}$ edition. Brydpass Springfield Will behington DC. pp. 164-176

APHA (1992). Standard Methods for the Examination of Water and Wastewater. Health, 69, 1116-9.

Baba, A., Garba, S. T., and Bello, H. S. (2020). Bioremediation Potential of Immobilized corynebacterium kutsceri in the Treatment of Tannery Industrial Effluent from Challawa Industrial Estate, Kano State, Nigeria. Journal of the Turkish Chemical Society Section A: Chemistry, $7(2), 335-350$.

Beem, E. I. V. (1994). reduction of solvent VOC emission. J. Oil Col. Chem. Ass, 77, 158.

Bouwer, E. J., and Zehnder, A. J. (1993). Bioremediation of organic compoundsputting microbial metabolism to work. Trends in biotechnology, 11(8), 360367.

Chen, K. C., Wu, J. Y., Liou, D. J., and Hwang, S. C. J. (2003). Decolorization of the textile dyes by newly isolated bacterial strains. Journal of Biotechnology, 101(1), 57-68.

Dan'Azumi, S., and Bichi, M. H. (2010). INDUSTRIAL POLLUTION AND HEAVY METALS PROFILE OF CHALLAWA RIVER IN KANO, NIGERIA. Journal of Applied Sciences in Environmental Sanitation, $5(1)$.

DWAF. (1992). Analytical Methods Manual, TR 151. Department of Water Affairs and Forestry, Pretoria.

El-Bestawy, E. (2013). Biological treatment of leather-tanning industrial wastewater using free living bacteria.
Elsheikh, M. A. S. (2009). Tannery wastewater pre-treatment. Water Science and Technology, 60(2), 433-440.

FuIlbrook, P. D. (1996). "Kinetics." Industrial enzymology: The application of enzymes in Industry. 2nd Ed. T. Godfrey and J Reichelt. eds.. Nature. New York.

Gianfreda, L., and Rao, M. A. (2004). Potential of extra cellular enzymes in remediation of polluted soils: a review. Enzyme and microbial technology, 35(4), 339354.

Hugo Springer. (1994). John Arthur Wilson Memorial Lecture "Treatment of Industrial Wastes of the Leather Industry - is it still a Major Problem". JALCA, 89, 153-185

Jimoh, A. A., Ganiyu, B. A., Baba, D., and Baba, A. (2018) Bioremediation Process of Effluent from Detergent and Food Industries in Jos, Nigeria: Kinetics and Thermodynamics. International Journal of Engineering Science Invention (IJESI), 762-73

Kandelbauer, A., Maute, O., Kessler, R. W., Erlacher, A., and Gübitz, G. M. (2004). Study of dye decolorization in an immobilized laccase enzyme-reactor using online spectroscopy. Biotechnology and bioengineering, 87(4), 552-563.

Kongjao, S., Damronglerd, S., and Hunsom, M. (2008). Simultaneous removal of organic and inorganic Pollutants in tannery wastewater using electrocoagulation technique. Korean Journal of chemical engineering, 25(4), 703.

Maheshwari, U. M., Aruna, S., Gomathi, M., and AbdulJaffar, A. H. (2017). Bioremediation by Free and Immobilized Bacteria Isolated from Tannery Effluent. International Journal of Research in Applied, Natural and Social Sciences. 5(7), 75-90

Margesin, R., and Schinner, F. (2001). Bioremediation (natural attenuation and biostimulation) of diesel-oilcontaminated soil in an alpine glacier skiing area. Applied and environmental microbiology, 677), 3127-3133.

Mohammed, A., Sekar, P., and George, J. (2011). Efficacy of microbes in bioremediation of tannery effluent. Inter. J. Curr. Res, 3(4), 324-326.

Mohammed, S. S. D., Orukotan, A. A., and Abdullahi, H. (2017). Physicochemical and Bacteriological Assessment of Tannery Effluent from Samaru-Zaria, 
BAJOPAS Volume 13 Number 2, December, 2020 Kaduna State, Nigeria. Journal of Applied

Sciences and Environmental Management, 21(4), 734-740.

Munz, G., De Angelis, D., Gori, R., Mori, G., Casarci, M., and Lubello, C. (2009). The role of tannins in conventional and membrane treatment of tannery wastewater. Journal of hazardous materials, 164(2-3), 733-739

Mythili, K., and Karthikeyan, B. (2011). Bioremediation of $\mathrm{Cr}$ (VI) from tannery effluent using Bacillus spp and Staphylococcus spp. International Multidisciplinary Research Journal, 1(6).

NESREA (2009). National Environmental Standards for Effluent Limitations and Regulation. 1233-1236

Noorjahan, C. M. (2014). Physicochemical characteristics, identification of bacteria and biodegradation of industrial effluent. Journal of bioremediation and Biodegradation, 5(3).

Ohtake, H. I., and Silver, A. O. (1994). Bacterial reduction of toxic chromate. Biological degradation and bioremediation of toxic chemicals, 403-415.

Omoleke, I. I. (2004). Management of environmental pollution in Ibadan, an African city: the challenges of health hazard facing government and the people. Journal of Human Ecology, 15(4), 265-275.

Rajor, A., Reddy, A.S., and Singh, B. (2004). Determination of BOD kinetic Parameters and evaluation of alternate methods, M.Sc. Thesis, Department of biotechnology \& environmental Science, Thapar Institute of Engineering and Technology, Patiala

Ramasami, T., Rajamani, S., and Rao, J. R. (1994, March). Pollution control in leather industry: Emerging technological options. In International symposium on surface and colloidal science and its relevance to soil pollution, madras.

Ramesh, J. V. S., and Singh, S. P. (1993). Yearly variation in certain physicochemical parameters of pond at eastern Doon Valley. Uttar Pradesh J. Zoo, 12 (1), 7577.

Ranen, S., and Sharadinadra, C. (2009). Biotechnology applications to environmental remediation in resource exploitation. Current science, 97, 6-25
Russell, A. J., Berberich, J. A., Drevon, G. F., and Koepsel, R. R. (2003). Biomaterials for mediation of

chemical and biological warfare agents. Annual review of biomedical engineering, 5(1), 1-27.

Saravanan, P., and Saravanan, A. (1999). Decolourization of tannery effluent by Flavobacterium sp. EK 1. Indian Journal of Environmental Protection, 19, 19-24.

Sikander, S., and Shahida, H. (2007). Reduction of toxic hexavalent chromium by Ochrobactrum intermedium strain SDCr5 stimulated by heavy metals. Bioresource Technol, 98, 340-344.

Singh, N., Sharma, B. K., and Bohra, P. C. (2000). Impact assessment of industrial effluent of arid soils by using satellite imageries. Journal of the Indian Society of Remote Sensing, 28(2-3), 79.

Sreemoyee, C., and Priti, P. (2013). Assessment of physico-chemical parameters of dairy waste water and isolation and characterization of bacterial strains in terms of cod reduction. Int J Sci, 2(3), 395-400.

Verheijen, L. A. H. M., Wiersema, D., Pol, L. H., and De Wit, J. (1996). Management of wastes from animal product processing. Livestock and environment, Finding a balance. International Agriculture Center, Wageningen, The Netherlands.

Wang, F., Yao, J., Si, Y., Chen, H., Russel, M., Chen, K., and Bramanti, E. (2010). Short-time effect of heavy metals upon microbial community activity. Journal of Hazardous Materials, 173(13), 510-516.

WHO (World Health Organization). (2006). Air quality guidelines: global update 2005: particulate matter, ozone, nitrogen dioxide, and sulfur dioxide. World Health Organization.

World Bank. (1995). Nigeria's strategic options for redressing industrial pollution. World Bank, industry and energy division. 1st edition, West Central Africa Department; Annexes: 1995; pp 60-62.

Zahoor, A., and Abdul, R. (2009). Enumeration of Coliforms. Journal of Environmental Sciences. 21, 814-820 


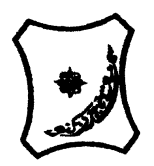

Bayero Journal of Pure and Applied Sciences, 13(2): 1 - 12

Received: November, 2020

Accepted: December, 2020

ISSN $2006-6996$

\title{
BIODEGRADATION POTENTIAL OF IMMOBILIZED BACTERIA IN THE TREATMENT OF TANNERY INDUSTRIAL EFFLUENTS FROM INDUSTRIAL ESTATES IN KANO STATE, NIGERIA
}

\author{
Abdullateef, B., ${ }^{1 *}$ Shuaibu, T. G., ${ }^{1}$ Babagana, K., ${ }^{1}$ Suleman, H. B. ${ }^{2}$ and Dauda, B. ${ }^{3}$ \\ ${ }^{1}$ Department of Pure and Applied Chemistry, Faculty of Science, University of Maiduguri, Borno State, \\ Nigeria \\ ${ }^{2}$ Department of Microbiology, Faculty of Science, University of Maiduguri, Borno State, Nigeria \\ ${ }^{3}$ Department of Chemical Engineering, Faculty of Engineering, University of Maiduguri, Borno State, \\ Nigeria \\ *Corresponding author: babslega@gmail.com; abelega2007@yahoo.com; +2348061309753
}

\section{ABSTRACT}

Industrial Effluents Samples from Gashash Tanneries (TAN1) in Bompai Industrial estate, Larabee Tannery Industry (TAN2) in Sharada Industrial estate and Z Tannery Industries (TAN3) in Challawa Industrial estate, Kano State, Nigeria were collected over a period of six months (August 2017 to January 2018) for assessing the biodegradation potentials of bacteria in the treatment of organic pollutants within the effluents. Bacteria were isolated from the effluents and immobilized on agar-agar. Different masses (5 g, $10 \mathrm{gr}, 15$ $\mathrm{g}, 20 \mathrm{~g}$, and $25 \mathrm{~g}$ ) of the bacteria were used in the treatment of $250 \mathrm{ml}$ of the effluents for ten days in a shaker incubator (Gallenkamp-OC-4364-L) at the temperature $30{ }^{\circ} \mathrm{C}$ and speed of $60 \mathrm{rpm}$. Pre-treatment analysis of the effluents for Temperature, pH, Biochemical Oxygen Demand (BOD), Chemical Oxygen Demand (COD), Suspended Solid (SS) and Total Dissolved Solids (TDS) gives the following results; temperature $\left({ }^{\circ} \mathrm{C}\right.$ )

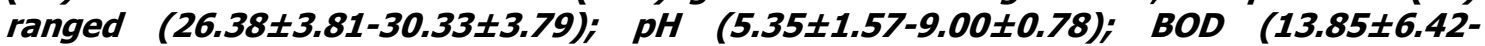
$38.75 \pm 16.20) ;$ COD (1406 $\pm 208-3532 \pm 1373) ;$ SS (208 $\pm 235-780 \pm 739)$ and TDS (266 $\pm 253-5276 \pm 2971)$. No statistical differences ( $p \leq 0.05)$ was observed for all the results among the different industries. The bacterial isolates were identified as Neisseria spp, Bacillus cereus, and Staphylococcus aureus, in TAN1, TAN2, and TAN3, respectively. After treatment of the effluent with the different masses of the isolated bacteria, the mean level of BOD was found to range as (0.55 $\pm 0.36-6.92 \pm 5.49) ; C O D$ (ND-3134 \pm 1595$)$;

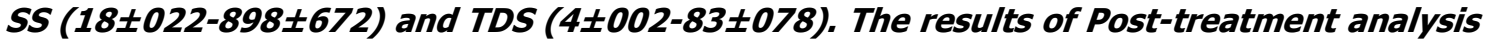
showed that there is overall decrease in the levels of the parameters determined when compared with that of the pre-treatment. The overall percentage reduction of the immobilised bacteria in the treatment of the respective effluents was in the order TAN2 (72\%)>TAN1 (70\%)>TAN3 (62\%). Hence, the immobilized bacteria are having higher biodegradation potential for the treatment of the tannery effluents.

Keywords: Biodegradation, bacteria, effluent, immobilization, tannery.

\section{INTRODUCTION}

Tannery industrial wastewater is a serious consequence of the pollution point of view for streams, freshwater, and land used for agriculture. The lack of awareness in the modern industrial practice has resulted in the discharge of tannery effluents which exhibit very high value of chromium ( $\mathrm{Cr}$ ), Sulfide, and chloride, Total Dissolved Solid (TDS), Total Suspended Solid (TSS), Biochemical Oxygen Demand (BOD) and Chemical Oxygen Demand (COD) in the water stream or land (Mohammed et al., 2001). Tanning is the process, which One ton of skin generally leads to the production of 20 to $80 \mathrm{~m}^{3}$ of turbid and foul-smelling converts the protein of the rawhide or skin into a stable material, which will not putrefy and is suitable for a wide variety of end applications (Elsheikh, 2009). The highly polluting chromium is the most commonly used tanning material producing leather that is more flexible and pliable than vegetable-tanned leather and does not discolor or lose shape in water as drastically as vegetable-tan (Elsheikh, 2009). Tannery effluent is among the most hazardous industrial pollutants due to its huge organic and inorganic load, which is highly toxic to human life and the environment (Kongjao et al., 2008). wastewater including chromium (100-400 mg/l), sulfide $(200-800 \mathrm{mg} / \mathrm{l})$, high levels of fat and 
BAJOPAS Volume 13 Number 2, December, 2020 other solid wastes, and notable pathogen contamination as well as pesticides added for skin conservation during transport (Elsheikh, 2009). There are more than 6000 tanneries in Nigeria with an annual processing capacity of 700,000 tons of hides and skins (Omoleke, 2004; Singh et al., 2008). It was reported that the total amount of waste produced per animal slaughtered is approximately $35 \%$ of its weight (World Bank, 1995). Also, for every $1000 \mathrm{~kg}$ of carcass weight, a slaughtered beef produces 5.5 $\mathrm{kg}$ of manure (excluding rumen contents or stockyard manure) and $100 \mathrm{~kg}$ of paunch manure (undigested food) (Verheijen et al., 1996). Tanneries generate wastewater in the range of 30-35 $\mathrm{L} \mathrm{kg}^{-1}$ skin/hide processed with variable $\mathrm{pH}$, Biological Oxygen Demand (BOD), Chemical Oxygen Demand (COD), high concentrations of suspended solids (SS), and tannins as well as chromium (Zahoor and Abdul, 2009).

Being heterogeneous and composed of a wide variety of compounds, it is very difficult to select a unique direct method for estimating the biodegradability of organic contents and biokinetic parameters for a wastewater sample (Rajor, 2004). For this purpose, some indirect estimation such as determination of biochemical oxygen demand (BOD) and chemical oxygen demand (COD) are applied as common laboratory investigations [9]. During retanning procedures, synthetic tannins (Syntan), oils and resins are added to form softer leather at varying doses (Munz et al., 2009). One of the refractory groups of chemicals in tannery effluents derives mainly from tannins (Ramasami et al., 2004). Syntans are characterized by complex chemical structures, because they are composed of an extended set of chemicals such as phenol-, naphthalene-, formaldehyde- and melamine-based syntans, and acrylic resins (Beem, 1994). Organic pollutants (proteic and lipidic components) are originated from skins (it is calculated that the raw skin has $30 \%$ loss of organic material during the working cycle) or they are introduced during processes (Hugo Springer, 1994).

Many conventional processes such as oxidation, chemical and biological processes were carried out to treat tanneries wastewater (Ebtesam et al, 2013). Biological processes have received more attention because of their costeffectiveness, lower sludge production and environmental friendliness (Noorjahan, 2014). Naturally occurring micro-organisms degrade the hazardous organic wastes including xenobiotic compounds, such as pesticides, polycyclic aromatic hydrocarbons (PAHs) and polychlorinated biphenyls (PCBs) in due course of time (Ranen and Sharadinadra, 2009). Bioremediation is based on the idea that all organisms remove substances from the environment to carry outgrowth and metabolism (Bouwer and Zehnder, 1993). Bacteria, protista and fungi are found to be very good at degrading complex molecules and incorporating the breakdown products into their metabolism (Bouwer and Zehnder, 1993). The resultant metabolic wastes that they produce are generally safe and somehow recycled into other organisms (Ranen and Sharadinadra, 2009). An acclimatized indigenous population of microorganisms capable of degradation of the compounds of interest must exist at the site for a successful bioremediation mode (Ranen and Sharadinadra, 2009). It has been observed that for a successful bioremediation mode, an acclimatized indigenous population of microorganisms capable of degradation of the compounds of interest must exist at the site under investigation (Ranen and Sharadinadra, 2009). Even though there are numerous physical and chemical methods employed in the disposal of wastes the advantage in using bacterium is that they play a key role in the reduction of COD, BOD, total protein, total tannin and total phenol (Saravanan and Saravanan, 1998)

Baba et al. (2020) studied the bioremediation potential of immobilized corynebacterium kutsceri in the Treatment of tannery industrial effluent from Challawa Industrial Estate, Kano State, Nigeria. The aim of the work is to study the reduction in the level of the contaminants through the process of bioremediation using the isolated bacteria. Immobilized bacteria can withstand various temperatures, $\mathrm{pH}$ and substrate concentrations; consequently, increasing the efficiency and the lifespan of the bacteria. Immobilized bacteria are widely applied in the treatment of wastewater and can be separated and recovered after the treatment with the same efficiency (Baba et al., 2020).

\section{MATERIALS AND METHODS \\ Study Area}

This study was carried out in Bompai, Sharada and Challawa industrial estates in Kano, Figure 1. Kano lies on Latitude $11^{\circ} 30^{\prime} \mathrm{N}$ and $8^{\circ} 30^{\prime} \mathrm{E}$ and Longitude $11^{\circ} 5^{\prime} \mathrm{N}$ and $8^{\circ} 5^{\prime} \mathrm{E}$ in Northern Nigeria. It is one of the developed industrial cities in Nigeria. Tannery activities are the dominating industries and this could be one of the reasons for her high population density (Dan'Azumi and Bichi, 2010). Many researchers have studied biodegradation of tannery effluent using microorganisms. However, limited literature is available on the biodegradation of tannery effluent in Kano industrial estates using 
BAJOPAS Volume 13 Number 2, December, 2020 immobilized bacterial cells. This research work focuses on the potential of the use of the indigenous immobilized bacterial isolates in the treatment of tannery effluents in the industrial estates.

\section{Sample Collection}

Effluents were collected from the Tannery Industries from Bompai, Challawa and Sharada Industrial Estates, Kano, Nigeria. The effluents were collected over a period of six months (August 2017 to January 2018). Samples collected in a sterile 4-liter plastic container with a unique identification number were preserved using an ice-box that was transported to the Microbiology Laboratory, Department of Microbiology, Bayero University of Kano for analysis

\section{Sample Preparation and Sample Analysis}

Immediately after the collection of the effluent, $\mathrm{pH}$, TSS, TDS, COD, BOD levels were determined before treatment (Pre-treatment determination) and ten days after treatment (Post-treatment determination) as described in
APHA (1989) standard methods. $\mathrm{pH}$ was determined using Ecotests $\mathrm{pH}$ meter and TDS was determined using AQUALYTIC TDS Salinometer. BOD was determined as described by the standard method (APHA, 1992). COD and SS were determined using DR/2010 HACH portable data logging spectrophotometer (DWAF, 1992)

\section{Identification and Biochemical} Characterization of the Bacterial Isolates

The bacteria were isolated from the effluents using Serial Dilution according to the method described by APHA (1989). The biochemical tests such as oxidase, catalase, coagulase, indole (from $1 \%$ tryptone broth), citrate (Simmons citrate agar), methyl red/VogesProskauer (MR/VP), nitrate reduction, Starch Hydrolysis, Glucose, Maltose, and Lactose tests were carried out on the bacterial isolates to identify the bacteria through the bacteria biochemical characteristics according to Ajao et al. (2011).

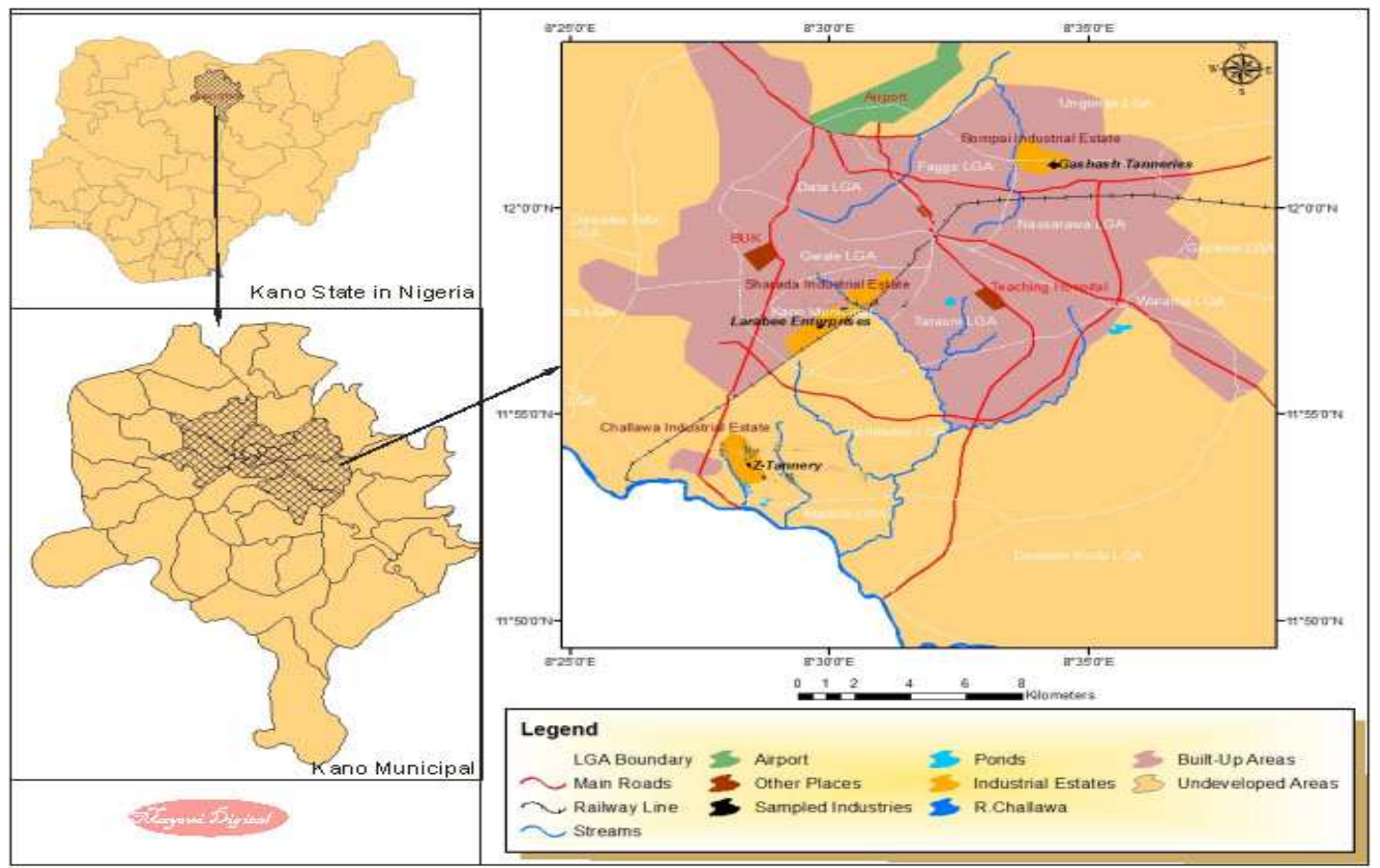

Fig. 1 Map showing the study areas

Source: Mayomi Digital Productions, GIS Laboratory, Department of Geography, UNIMAID (2017)

\section{Determination of Growth Rate of the Bacteria in Effluent Sample}

The bacteria growth rates were determined by transferring $2 \mathrm{~mL}$ of the bacterial isolates from the tannery effluent in broth medium into 100 $\mathrm{mL}$ sterile effluents in conical flasks and kept in an incubator (Giffrin cool) for 10 days. Control was also set up by incubating another $100 \mathrm{~mL}$ each of the sterile effluents without the bacteria. The optical density of the content was determined at the wavelength of $600 \mathrm{~nm}$ on a daily interval and recorded. 
BAJOPAS Volume 13 Number 2, December, 2020 Immobilization of Bacteria

Agar solution and inoculi were prepared separately. Fifty milliliters $(50 \mathrm{~mL})$ of nutrient broth each of the inoculi was prepared in a McCartney bottle and incubated for 24 hours. A solution of agar-agar was prepared by dissolving $10 \mathrm{~g}$ of the powder in distilled water and made up to $500 \mathrm{~mL}$ mark in an Erlenmeyer flask and was sterilized in an autoclave (280A) for 15 minutes and allowed to cool to $40-45^{\circ} \mathrm{C}$ (Ajao et al., 2011). Four milliliters ( $4 \mathrm{~mL})$ of the bacterial isolates in the nutrient broth was mixed with 36 $\mathrm{ml}$ of the prepared agar-agar media in petri-dish plates and then allowed to solidify. This was kept in the refrigerator for bioremediation.

\section{Bioremediation (Treatment) of the Effluents}

The solidified agar block (immobilized bacteria) was cut into cubes using a sterile knife; $0.1 \mathrm{~mL}$ phosphate buffer ( $\mathrm{pH} \mathrm{7.0)}$ was added and kept in the refrigerator for 1 hour for curing. The phosphate buffer was decanted after 1 hour and the cubes were washed with sterile distilled water 3-4 times before it was used (Ajao et al., 2011). Two liters (2 L) of the effluent was supplemented with the minimum basal medium in $\mathrm{g} / \mathrm{L}: \mathrm{NaCl}(0.8), \mathrm{MgSO}_{4} .7 \mathrm{H}_{2} \mathrm{O}(0.001), \mathrm{KH}_{2} \mathrm{PO}_{4}$ (2), $\mathrm{NaNO}_{3}$ (2), $\quad \mathrm{CaCl}_{2} .2 \mathrm{H}_{2} \mathrm{O} \quad(0.5)$ and $\mathrm{NaHPO}_{4} .12 \mathrm{H}_{2} \mathrm{O}(2)$ and sterilized in an autoclave at $121^{\circ} \mathrm{C}$ for 15 minutes (Margesin and Schinner, 2001). Two hundred and fifty milliliters $(250 \mathrm{~mL})$ of the effluents were transferred into different $250 \mathrm{ml}$ conical flasks. The content was covered with a cotton-wool ramped with foil paper to avoid contamination. Five grams $(5 \mathrm{~g})$ of the immobilized bacteria were quickly transferred into each of the effluents in the conical flasks in an inoculating chamber. The same procedures were carried out for the $10 \mathrm{~g}, 15 \mathrm{~g}, 20 \mathrm{~g}$ and 25 $\mathrm{g}$ of the immobilized bacteria in separate $250 \mathrm{~mL}$ effluents in conical flasks and agitated for ten days in a shaker incubator (Gallenkamp-OC4364-L) at a temperature $30^{\circ} \mathrm{C}$ and speed of 60 rpm. The treated effluent samples were taken on the tenth day and analyzed for the parameters $\mathrm{pH}$, SS, TDS, COD, and BOD, (Posttreatment determination) for the different grams of bacteria to evaluate and compare the biodegradation potential. (Baba et al., 2020).

\section{Statistical Analysis}

The data were represented as Mean \pm Standard deviation and analyzed statistically using oneway Analysis of Variance (ANOVA) and Tukey's HSD as Post Hoc Tests with the aid of SPSS 16.0. The correlation coefficient was also used to measure the strength of the relationship between the different masses of the bacteria and the parameters. All $\mathrm{p} \leq 0.05$ were considered as statistically significant.

\section{RESULTS AND DISCUSSION Physico-chemical parameters in the Industrial Effluents before the Biodegradation.}

Results of the Physico-chemical parameters in the industrial effluents before the Biodegradation is shown in table 1 . The mean temperatures $\left({ }^{\circ} \mathrm{C}\right)$ observed in TAN1, TAN2, and TAN3 samples were $28.07 \pm 0.65 ; 27.77 \pm 0.64$ and $26.38 \pm 3.81$ respectively. The order of the mean temperature of the samples from the three industries can be arranged as TAN1 > TAN2>TAN3. The temperature observed at TAN1, TAN2, and TAN3 samples were found below the WHO $\left(35^{\circ} \mathrm{C}\right)$ and NESREA $\left(40^{\circ} \mathrm{C}\right)$ limits. The low values of temperature might be due to the processes used at the time of sampling. High temperature brings down the solubility of gases in water that ultimately expresses as high BOD and COD. Statistical analysis shows that there is no significant difference $(p<0.05)$ between the mean values of temperature among the industries. This might be due to similar tannery activities involved in the tannery industries at the time of sampling. The average values of temperature observed in this present study are less than those observed by Akan et al. (2007), Akan et al. (2009) and Baba et al. (2020).

The mean level of $\mathrm{pH}$ observed in TAN1, TAN2 and TAN3, samples were $7.77 \pm 2.93$; $8.35 \pm 0.28$ and $7.52 \pm 0.76$ respectively. The order of the mean $\mathrm{pH}$ of the samples from the three industries can be arranged as TAN2> TAN1 $>$ TAN3. The $\mathrm{pH}$ of the samples falls within the WHO (7.0-8.5) and NESREA (6-9) standard limits. Statistical analysis shows that there is no significant difference $(p<0.05)$ between the mean values of $\mathrm{pH}$ among the industries. This might be due to similar tannery activities involved in the tannery industries at the time of sampling. Maheshwari et al. (2017) reported that the level of $\mathrm{pH}$ in the effluents from the tannery industry in Vaniyambadi, India was 6.5 which was lower than that observed in the present study. The $\mathrm{pH}$ in the effluents from the tannery industries in Kano and Kaduna were reported to be 7.64 and 6.89, respectively (Akan et al., 2007; Mohammed et al., 2017). The average values of $\mathrm{pH}$ observed in this present study are less than those observed by Mohammed et al. (2017) and Baba et al. (2020). The mean level of SS $(\mathrm{mg} / \mathrm{l})$ observed in TAN1, TAN2, and TAN3 samples were 374 \pm 124 ; $358 \pm 335$ and $780 \pm 739$ respectively. The order of the mean SS in the samples from the three industries can be arranged as TAN3 > TAN1 $>$ TAN2. 
The SS observed in the samples were far above the recommended standard limits of regulating bodies WHO $(30 \mathrm{mg} / \mathrm{l})$ and NESREA $(10 \mathrm{mg} / \mathrm{l})$. Statistical analysis shows that there is no significant difference $(p<0.05)$ between the mean values of SS among the industries. This might be due to similar tannery activities involved in the tannery industries at the time of sampling. The average values of SS observed in this present study are less than that observed $(3700 \pm 122 \mathrm{mg} / \mathrm{l})$ by Akan et al. (2009) for tanneries in Kano. Also, the average values of SS observed in this present study are less than that observed by Mohammed et al. (2017) and Baba et al. (2020) with the exception in TAN3.

The mean level of TDS (mg/l) observed in TAN1, TAN2, and TAN3 samples were $3941 \pm 3703$; $3300 \pm 1714$ and $2653 \pm 1240$ respectively. The order of the mean TDS in the samples from the three industries can be arranged as TAN1>TAN2>TAN3. The TDS observed in the samples were far above the recommended standard limits of WHO $(250 \mathrm{mg} / \mathrm{l})$ and NESREA $(500 \mathrm{mg} / \mathrm{l})$. Statistical analysis shows that there is no significant difference $(p<0.05)$ between the mean values of TDS among the industries. This might be due to similar tannery activities involved in the tannery industries at the time of sampling. TDS in the effluents from the tannery industries in Kano, Nigeria was reported to be $1281 \mathrm{mg} / \mathrm{l}$ (Akan et al., 2007). The average values of SS observed in this present study are less than those observed by Mohammed et al. (2017) and Baba et al. 2020)

The mean level of COD (mg/l) observed in TAN1, TAN2 and TAN3 samples seasons were $2372 \pm 938 ; \quad 1406 \pm 208$ and $3532 \pm 1373$ respectively. The order of the mean COD of the samples from the three industries can be arranged as TAN3>TAN1> TAN2. The COD observed in TAN1, TAN2 and TAN3 samples were far above the recommended standard limits of regulating bodies $\mathrm{WHO}(40 \mathrm{mg} / \mathrm{l})$ and NESREA (40 mg/l). Statistical analysis shows that there is no significant difference $(p<0.05)$ in COD among the industries. This might be due to similar tannery activities involved in the tannery industries as at the time of sampling. The Chemical Oxygen demand (COD) is the amount of oxygen, in $\mathrm{mg} / \mathrm{L}$, required for the degradation of the compound of wastewater to occur. In comparison, the average values of COD observed in this present study were higher than that observed by Mohammed et al. (2017) but lower than that observed by Baba et al. (2020).

The mean levels of BOD $(\mathrm{mg} / \mathrm{l})$ observed in TAN1, TAN2 and TAN3 samples were $13.85 \pm 6.42 ; \quad 19.46 \pm 0.50$ and $17.13 \pm 3.14$ respectively. The order of the mean BOD in the samples from the three industries can be arranged as TAN2>TAN3>TAN1. The BOD observed in TAN1, TAN2 and TAN3 samples were found below the recommended limits of NESREA (200 mg/l) but above WHO (10 mg/l). Statistical analysis shows that there is no significant difference $(p<0.05)$ between the mean values of BOD among the industries. This might be due to similar tannery activities involved in the tannery industries at the time of sampling. The low level of BOD recorded in this study is an indication of the low level of biodegradable organic solids in the effluent. The average values of BOD observed in this present study were lower than those observed by Mohammed et al. (2017) and Baba et al. (2020).

Table 1: Mean Values \pm S.D of Physico-chemical parameters of effluents from the Tannery Industries before Treatment.

\begin{tabular}{llllllll}
\hline Parameter & Tannery 1 & Tannery 2 & Tannery 3 & $\mathrm{a}$ & $\mathrm{b}$ & $\mathrm{c}$ & $\mathrm{d}$ \\
\cline { 2 - 7 } Temperature $\left({ }^{\circ} \mathrm{C}\right)$ & $28.07 \mathrm{a} \pm 0.65$ & $27.77 \mathrm{a} \pm 0.64$ & $26.38 \mathrm{a} \pm 3.81$ & & $29.50 \pm 4.68$ & 35 & 40 \\
pH & $7.77 \mathrm{a} \pm 2.93$ & $8.35 \mathrm{a} \pm 0.28$ & $7.52 \mathrm{a} \pm 0.76$ & 6.89 & $5.35 \pm 1.57$ & $7.0-8.5$ & $6.0-9.0$ \\
$\mathrm{COD}(\mathrm{mg} / \mathrm{l})$ & $2372 \mathrm{a} \pm 938$ & $1406 \mathrm{a} \pm 208$ & $3532 \mathrm{a} \pm 1373$ & 2.2 & $3106 \pm 2753$ & 40 & 40 \\
$\mathrm{BOD}(\mathrm{mg} / \mathrm{l})$ & $13.85 \mathrm{a} \pm 6.42$ & $19.46 \mathrm{a} \pm 0.50$ & $17.13 \mathrm{a} \pm 3.14$ & 1032 & $26.17 \pm 9.49$ & 10 & 200 \\
$\mathrm{SS}(\mathrm{mg} / \mathrm{l})$ & $374 \mathrm{a} \pm 124$ & $358 \mathrm{a} \pm 335$ & $780 \mathrm{a} \pm 739$ & 501 & $562 \pm 482$ & 30 & 10 \\
TDS $(\mathrm{mg} / \mathrm{l})$ & $3941 \mathrm{a} \pm 3703$ & $3300 \mathrm{a} \pm 1714$ & $2653 \mathrm{a} \pm 1240$ & 532.7 & $444 \pm 507$ & 250 & 500 \\
\hline
\end{tabular}

The values given in the table above are means of 6 replicate values, $\mathrm{n}=6$ ( 1 sample was taken monthly for 6 months). Within the rows, means with different alphabets are statistically different $(p<0.05)$. WHO: World Health Organisation. NESREA: National Environmental Standard and Regulatory Enforcement Agency. a = Mohammed et al.(2017), b = Baba et al. (2020), c = WHO (2006), $d=$ NESSRA (2009) 
BAJOPAS Volume 13 Number 2, December, 2020

Identification, Biochemical Characterization and growth rates of the Bacterial Isolates

Results of identification and biochemical characterization of the bacterial isolates were shown in table 2. After 24 hours of incubation, the nutrient agar media plates were checked for bacterial growth. The results showed the presence of different strains in the samples. The TAN1 bacteria isolate was found to be gramnegative cocci while TAN3 was gram-positive cocci. TAN2 bacteria isolate was found to be gram-positive, rod-shaped. TAN1, TAN2, and TAN3 bacteria isolates recorded positive results for spore former.

The results of the biochemical tests indicated that all the bacteria were positive for catalase, oxidase, citrate, maltose, glucose, lactose (negative in TAN1), mannitol (negative in TAN2), starch hydrolysis and coagulase (negative in TAN2) tests. The bacteria showed negative results for nitrate reduction, $M R$ (positive in TAN2), VP (positive in TAN1), Indole (positive in TAN2) tests. Base on the morphological and biochemical test results, TAN1, TAN2, and TAN3 bacteria isolates were identified to be Nesseria spp, Bacillus cereus, and Staphylococcus aureus respectively.

The growth rate of the TAN1, TAN2 and TAN3 Isolates were shown in figure 2. Generally, the optical density increase with the increase in time (day) and decrease as time goes on. The highest optical density was shown by bacillus cereus in TAN2 while the lowest was shown by Staphylococcus aureus in TAN3.

The initial growth phase of TAN1 Isolate bacteria occurred within 2-day of incubation as the growth rate increases up to the 6th-day incubation when the maximum growth was observed. Beyond the 6th day, the growth of the bacteria declined (which might be due to a shortage of nutrients in the effluents) until it reached its death phase (which might be due to the unavailability of nutrients in the effluents).

A similar trend of growth was also observed for TAN2 Isolate as the initial growth phase also occurred within 2-day of incubation but maximum growth rate observed on the 4th day of incubation. The stationary stage occurred between the 4th day and the 8th day. Beyond the 8th day, the growth of the bacteria declined (which might be due to a shortage of nutrients in the effluents) until it reached its death phase (which might be due to the unavailability of nutrients in the effluents).

The initial growth phase of TAN3 bacterial Isolate occurred within the 3-day incubation as the growth rate increases up to the 6th-day incubation when the maximum growth was observed. Beyond the 6th day, the growth of the bacteria declined (which might be due to a shortage of nutrients in the effluents) until it reached its death phase (which might be due to the unavailability of nutrients in the effluents).

Table 2: Morphological and Biochemical characteristics of bacterial isolates

\begin{tabular}{lllll} 
Bacterial Isolates & & TAN1 & TAN2 & TAN3 \\
\hline $\begin{array}{lllll}\text { Morphological } \\
\text { characteristics }\end{array}$ & Shape & Cocci & Rod & Cocci \\
& Spore & & & \\
& former & + & + & + \\
Gram & & & \\
Biochemical characteristics & reaction & - & + & + \\
& Citrate & + & + & + \\
& Catalase & + & + & + \\
& Coagulase & + & - & + \\
Starch & + & + & + \\
& Glucose & + & + & + \\
Oxidase & + & + & + \\
& Indo & - & + & - \\
Lactose & - & + & + \\
Manitol & + & - & + \\
Maltose & + & + & + \\
MR & - & + & - \\
VP & + & - & - \\
& Nitrate & - & - & - \\
Reduction & - Neisseria & Bacillus & Staphylococcus \\
& Bacterial & cereus & aureus \\
& name & spp & cas
\end{tabular}

+ = Positive; - = Negative; MR=Methyl Red; VP= Voges-Proskauer 


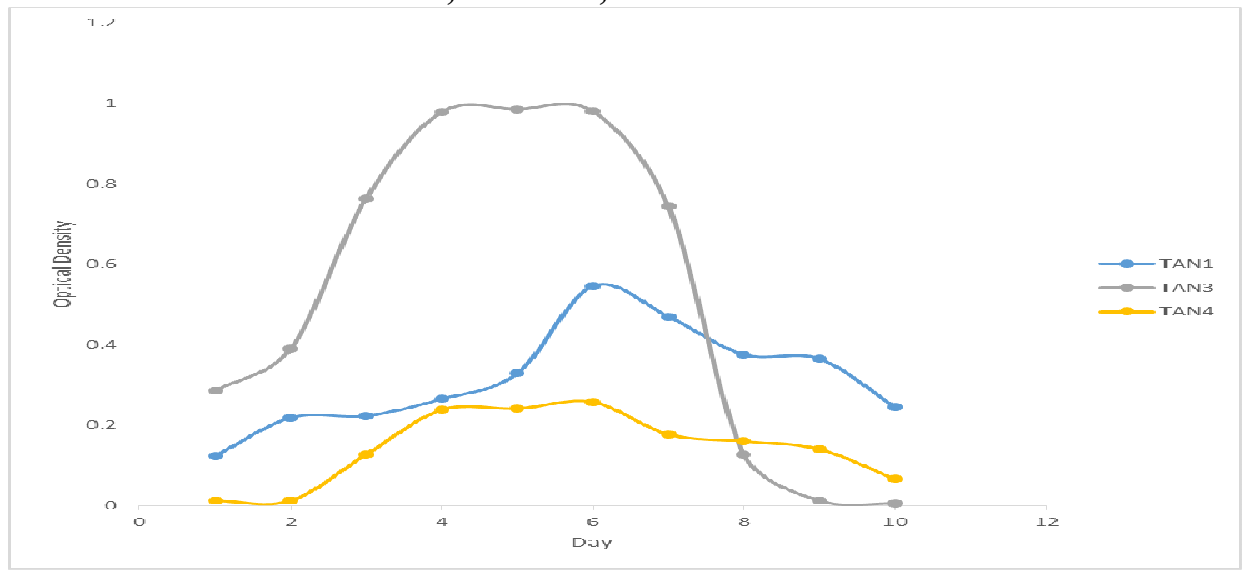

Fig. 2 Growth rates of the isolates in the effluents from the Tannery Industries

\section{Physico-chemical Parameters in the Industrial Effluents after the biodegradation.}

Table 3 shows the mean results of the physicochemical parameter before and after bioremediation using the different masses $(5 \mathrm{~g}$, $10 \mathrm{~g}, 15 \mathrm{~g}, 20 \mathrm{~g}$, and $25 \mathrm{~g}$ ) of the respective immobilized bacteria. Also, Table 4 shows the mean results of correlation coefficient ( $r$ ) between different masses of bacteria and physicochemical parameters.

The mean values $(\mathrm{mg} / \mathrm{l})$ of the SS after the bioremediation varies between $243 \pm 45$ and $898 \pm 672$. The mean concentration $(\mathrm{mg} / \mathrm{l})$ of SS remediated by the different masses $(5 \mathrm{~g}, 10 \mathrm{~g}$, $15 \mathrm{~g}, 20 \mathrm{~g}$, and $25 \mathrm{~g}$ ) of the bacteria varies. The SS in the samples fluctuates up and down after the bioremediation process when compared with the SS of the raw samples before the bioremediation. The increase in the levels of the SS might be due to the aggregation of the TDS which are large enough to result into SS. The increase in the levels of the SS might be also due to the influence of the nutrients which was added into the effluents in order to make the microorganisms more active and viable for fast degradation of organic contaminants in the effluent. The relative potential or efficiency of the different masses of the bacteria in remediating SS in TAN1 samples was in the order $25 \mathrm{~g}>20 \mathrm{~g}>15 \mathrm{~g}>10 \mathrm{~g}>5 \mathrm{~g}$. For TAN2 and TAN3 samples, the order was $25 \mathrm{~g}>20 \mathrm{~g}>15$ $\mathrm{g}>10 \mathrm{~g}>5 \mathrm{~g}$. These might be due to the variations in the surface areas of the different masses of the immobilized bacteria. Statistical analysis shows that there is no significant difference $(p<0.05)$ between the mean values of SS among the masses in the respective industries. Positive and significant correlations exist between the masses of bacteria and Suspended Solid (SS). This showed that there is general increase in the levels of the SS as the masses of the immobilized bacteria increases. TAN3 (90\%) and TAN1 (80\%) showed a very high correlation with the masses of the bacteria while TAN2 (61\%) showed a very low correlation.

The mean values $(\mathrm{mg} / \mathrm{l})$ of the TDS after the bioremediation varies between $46 \pm 11$ and $83 \pm 78$. The mean concentration $(\mathrm{mg} / \mathrm{l})$ of TDS remediated by the different masses $(5 \mathrm{~g}, 10 \mathrm{~g}$, $15 \mathrm{~g}, 20 \mathrm{~g}$, and $25 \mathrm{~g}$ ) of the bacteria varies. There is a reduction in all the TDS of all the samples after the bioremediation process compared with the TDS of the raw samples before the bioremediation. The relative potential or efficiency of the different masses of the bacteria in remediating TDS in TAN1 and TAN3 samples was in the order $5 \mathrm{~g}>10 \mathrm{~g}>15 \mathrm{~g}>20$ $\mathrm{g}>25 \mathrm{~g}$. For TAN2 samples, the order was 20 $g>10 \quad g>25 \quad g>15 \quad g>5 \quad g$. Statistical analysis shows that there is no significant difference $(p<0.05)$ between the mean values of TDS among the masses in the respective industries. These might be due to the variations in the surface areas of the different masses of the immobilized bacteria. Positive and significant correlations exist between the masses of bacteria and TDS with the exception in TAN2 (negative and insignificant correlation). The positive correlations showed that there is general increase in the levels of the TDS as the masses of the immobilized bacteria increases. TAN1 $(96 \%)$ showed a very high correlation with the masses of the bacteria while TAN2 (47\%) showed a very low correlation.

The mean values $(\mathrm{mg} / \mathrm{l})$ of the BOD after the bioremediation varies between $1.56 \pm 0.20 \mathrm{mg} / \mathrm{l}$ and $6.92 \pm 5.49 \mathrm{mg} / \mathrm{l}$. The mean concentration $(\mathrm{mg} / \mathrm{l})$ of BOD remediated by the different masses $(5 \mathrm{~g}, 10 \mathrm{~g}, 15 \mathrm{~g}, 20 \mathrm{~g}$, and $25 \mathrm{~g}$ ) of the bacteria varies. There is a reduction in all the BOD of all the samples after the bioremediation process compared with the $\mathrm{BOD}$ of the raw 
BAJOPAS Volume 13 Number 2, December, 2020 samples before the bioremediation. The relative potential or efficiency of the different masses of the bacteria in remediating BOD in TAN1, TAN2 and TAN3 samples were in the order $25 \mathrm{~g}>20$ $\mathrm{g}>15 \mathrm{~g}>10 \mathrm{~g}>5 \mathrm{~g}, 25 \mathrm{~g}>15 \mathrm{~g}>5 \mathrm{~g}>10 \mathrm{~g}>20 \mathrm{~g}$ and $20 \mathrm{~g}>10 \mathrm{~g}>25 \mathrm{~g}>15 \mathrm{~g}>5 \mathrm{~g}$ respectively. Statistical analysis shows that there is significant difference $(p<0.05)$ between the mean values of BOD among the masses in the respective industries. These might be due to the variations in the surface areas of the different masses of the immobilized bacteria. Negative and significant correlations exist between the masses of bacteria and BOD. This showed that there is general decrease in the levels of the BOD as the masses of the immobilized bacteria increases. TAN1 (94\%) showed a very high correlation with the masses of the bacteria while TAN2 (4\%) showed a very low correlation.

The mean values $(\mathrm{mg} / \mathrm{l})$ of the COD after the bioremediation varies between $250 \pm 154$ and $3134 \pm 1595$. The mean concentration $(\mathrm{mg} / \mathrm{l})$ of COD remediated by the different masses $(5 \mathrm{~g}$, $10 \mathrm{~g}, 15 \mathrm{~g} 20 \mathrm{~g}$, and $25 \mathrm{~g}$ ) of the bacteria varies. There is a reduction in all the COD of all the samples after the bioremediation process compared with the COD of the raw samples before the bioremediation. The relative potential or efficiency of the different masses of the bacteria in remediating COD in TAN1, TAN2 and TAN3 samples were in the order $25 \mathrm{~g}>20 \mathrm{~g}>15$ $\mathrm{g}>5 \mathrm{~g}>10 \mathrm{~g}, 25 \mathrm{~g}>20 \mathrm{~g}>15 \mathrm{~g}>10 \mathrm{~g}>5 \mathrm{~g}$ and 10 g>5 g>25 g>15 g>20 g respectively. Statistical analysis shows that there were significant difference $(p<0.05)$ between the mean values of COD among the masses in the respective industries except for effluents treated with $25 \mathrm{~g}$. These might be due to the variations in the surface areas of the different masses of the immobilized bacteria. Negative and insignificant correlations exist between the masses of bacteria and COD with the exception in TAN3 (positive and significant correlation). The negative correlations showed that there is general decrease in the levels of the COD as the masses of the immobilized bacteria increases. TAN2 (100\%) showed a very high correlation with the masses of the bacteria while TAN3 (36\%) showed a very low correlation.

Generally, there was an overall decrease in the concentration of these physicochemical parameters after the bioremediation using the different masses of the bacterial isolates. These might be due to the variations in the surface areas of the different masses of the immobilized bacteria. This is in line with the work of Jimoh et al. (2018) and Baba et al. (2020).

Table 3: Mean Values $(\mathrm{mg} / \mathrm{l}) \pm$ S.D of Physicochemical parameters in effluents from the Tannery Industries before and after Treatment of the effluents $(250 \mathrm{ml})$ with the different masses $(5 \mathrm{~g}, 10 \mathrm{~g}$, $15 \mathrm{~g}, 20 \mathrm{~g}$, and $25 \mathrm{~g}$ ) of the bacteria.

\begin{tabular}{llllllll}
\hline $\mathrm{P}$ & IND & Before & \multicolumn{5}{c}{ After } \\
\cline { 4 - 7 } & & & $5 \mathrm{~g}$ & $10 \mathrm{~g}$ & $15 \mathrm{~g}$ & $20 \mathrm{~g}$ & $25 \mathrm{~g}$ \\
\hline \multirow{2}{*}{ COD } & TAN1 & $2372 \pm 938$ & $1708 \mathrm{a} \pm 861$ & $2045 \mathrm{a} \pm 1205$ & $845 \mathrm{a} \pm 369$ & $300 \mathrm{a} \pm 167$ & $250 \mathrm{a} \pm 154$ \\
& TAN2 & $1406 \pm 208$ & $1195 \mathrm{a} \pm 208$ & $1125 \mathrm{a} \pm 384$ & $1055 \mathrm{a} \pm 317$ & $956 \mathrm{a} \pm 310$ & $870 \mathrm{ab} \pm 240$ \\
& TAN3 & $3532 \pm 1373$ & $2374 \mathrm{a} \pm 1344$ & $1976 \mathrm{a} \pm 1405$ & $2757 \mathrm{a} \pm 1266$ & $3134 \mathrm{a} \pm 1595$ & $2614 \mathrm{~b} \pm 1105$ \\
BOD & TAN1 & $13.85 \pm 6.42$ & $6.92 \mathrm{a} \pm 5.49$ & $6.42 \mathrm{a} \pm 5.07$ & $5.72 \mathrm{a} \pm 5.35$ & $4.62 \mathrm{a} \pm 4.37$ & $2.82 \mathrm{ab} \pm 1.26$ \\
& TAN2 & $19.46 \pm 0.50$ & $1.75 \mathrm{~b} \pm 0.22$ & $1.73 \mathrm{~b} \pm 0.18$ & $1.58 \mathrm{a} \pm 0.16$ & $1.91 \mathrm{a} \pm 0.22$ & $1.56 \mathrm{~b} \pm 0.20$ \\
& TAN3 & $17.13 \pm 3.14$ & $4.24 \mathrm{ab} \pm 0.77$ & $3.29 \mathrm{ab} \pm 0.37$ & $4.11 \mathrm{a} \pm 0.07$ & $3.23 \mathrm{a} \pm 0.91$ & $3.33 \mathrm{a} \pm 1.28$ \\
SS & TAN1 & $374 \pm 124$ & $243 \mathrm{a} \pm 45$ & $471 \mathrm{a} \pm 226$ & $475 \mathrm{a} \pm 182$ & $492 \mathrm{a} \pm 128$ & $611 \mathrm{a} \pm 217$ \\
& TAN2 & $358 \pm 335$ & $460 \mathrm{a} \pm 400$ & $543 \mathrm{a} \pm 414$ & $544 \mathrm{a} \pm 402$ & $551 \mathrm{a} \pm 414$ & $554 \mathrm{a} \pm 405$ \\
& TAN3 & $780 \pm 739$ & $586 \mathrm{a} \pm 594$ & $758 \mathrm{a} \pm 656$ & $787 \mathrm{a} \pm 676$ & $861 \mathrm{a} \pm 635$ & $898 \mathrm{a} \pm 672$ \\
TDS & TAN1 & $3941 \pm 3703$ & $51 \mathrm{a} \pm 10$ & $53 \mathrm{a} \pm 10$ & $55 \mathrm{a} \pm 15$ & $61 \mathrm{a} \pm 20$ & $63 \mathrm{a} \pm 26$ \\
& TAN2 & $3300 \pm 1714$ & $83 \mathrm{a} \pm 78$ & $47 \mathrm{a} \pm 20$ & $48 \mathrm{a} \pm 22$ & $47 \mathrm{a} \pm 17$ & $48 \mathrm{a} \pm 17$ \\
& TAN3 & $2653 \pm 1240$ & $46 \mathrm{a} \pm 11$ & $55 \mathrm{a} \pm 24$ & $55 \mathrm{a} \pm 25$ & $58 \mathrm{a} \pm 23$ & $61 \mathrm{a} \pm 28$ \\
\hline
\end{tabular}

Replicate $=6$ (months)

Within the rows, for the same parameter, means with different alphabets are statistically different $(p<0.05)$.

$\mathrm{P}=$ parameter, IND = Industries 
BAJOPAS Volume 13 Number 2, December, 2020

Table 4: Correlation coefficient $(r)$ between different masses of the bacteria and the physicochemical parameters.

\begin{tabular}{llll}
\hline Industries & Parameter & Correlation coefficient $(r)$ & $\begin{array}{l}\text { Percent dependence (rxrx100) } \\
(\%)\end{array}$ \\
\hline TAN1 & COD & -0.9 & 82 \\
& BOD & -0.97 & 94 \\
& SS & $0.90^{*}$ & 80 \\
TAN2 & TDS & $0.98^{*}$ & 96 \\
& COD & -1 & 100 \\
& BOD & -0.21 & 4 \\
& SS & $0.78^{*}$ & 61 \\
& TDS & -0.69 & 47 \\
& COD & $0.60^{*}$ & 36 \\
& BOD & -0.6 & 37 \\
& SS & $0.95^{*}$ & 90 \\
& TDS & $0.94^{*}$ & 89 \\
\hline
\end{tabular}

The correlation coefficient $(r)$ with * is statistically significant $(p<0.05)$.

Percentage reduction of the Parameters

Table 5 shows the percentage reduction of Parameters in industrial samples before and after the treatment of the effluents $(250 \mathrm{ml})$ with the different masses $(5 \mathrm{~g}, 10 \mathrm{~g}, 15 \mathrm{~g}, 20 \mathrm{~g}$, and $25 \mathrm{~g}$ ) of the Immobilized Bacteria.

In TAN1 samples, the percentage reduction (\%) of COD ranged (14-89); BOD (50-80); SS (-32$35)$ and TDS (98-99). In TAN2 samples, the percentage decrease $(\%)$ of COD ranged (15$38) ;$ BOD (90-92); SS [-28-(-55)] and TDS (9798). In TAN3 samples, the percentage decrease (\%) of COD ranged (11-44); BOD (76-81); SS (15-25) and TDS (98). The percentage increase in the levels COD, BOD and TDS might be due to the increase in the surface area of the different masses of the immobilized bacteria. However, the percentage decrease in the levels of the SS might be due to the aggregation of the TDS which are large enough to result into SS. The percentage decrease in the levels of the SS might be also due to the influence of the nutrients which was added into the effluents in order to make the microorganisms more active and viable for fast degradation of organic contaminants in the effluent. This is in line with the work of Jimoh et al. (2018) in which the concentration of the SS increase after the bioremediation of effluents.

Sreemoyee and Priti (2013) assessed and reduced several Physico-chemical parameters of dairy wastewater using Niesseria $s p$. and concluded that the species are well known to degrade organic compounds. This is in agreement with the current study in which the immobilized Niesseria $s p$ degrade the organic contaminants as indicated by the BOD, COD and TDS.

Jimoh et al. (2018) observed that TSS of the effluents was increased after treatment with immobilized bacteria and concluded that it might be due to the biostimulation method adopted for the research.

The optimum $\mathrm{pH}$ Biosorption of Chromium by Bacillus spp and Staphylococcus spp. from tannery effluent was investigated by Mythili and Karthikeyan (2011). The maximum adsorption of Chromium $(86.4 \mathrm{mg} / \mathrm{L})$ was showed by Bacillus spp and Staphylococcus spp showed $70.6 \mathrm{mg} / \mathrm{L}$ at an initial concentration of $100 \mathrm{mg} / \mathrm{L}$. In the present study, immobilised Bacillus spp and Staphylococcus spp. from the tannery industrial effluents reduced the levels of the organic pollutants with high potential as indicated by the percentage reduction of BOD, COD and TDS.

Enzymes often can work in multiple environments especially if they are immobilized. This makes the microorganisms' enzymes even more resistant to harsh environments and enables the enzymes to be recovered and recycled after they are no longer needed (Gianfreda and Rao 2004). Ramesh and Singh (1993) reported that the immobilized bacteria having more efficiency to remove the suspended particles than free cells. Using the immobilized cell is preferable due to its capability for using several times with the same efficiency, which makes it more economical. Similar work was done by Sikander et al. (2007) showing the higher reduction with permeabilized cells of Ochrobactrum intermedium strain SDCr-5. 
BAJOPAS Volume 13 Number 2, December, 2020

The results revealed the isolation and identification of isolates with the potential for the reduction of $\mathrm{Cr}$ (VI) to $\mathrm{Cr}$ (III). Results indicated that immobilized $B$. cereus could be efficiently used for the reduction of $\mathrm{Cr}$ (VI).

Table 5: Percentage reduction of the tested Parameters from the tannery industrial samples of the Immobilized Bacteria.

\begin{tabular}{lllllll}
\hline \multirow{2}{*}{ Industries } & & \multicolumn{5}{c}{ Percentage Reduction $(\%)$} \\
\cline { 3 - 7 } & & $5 \mathrm{~g}$ & $10 \mathrm{~g}$ & $15 \mathrm{~g}$ & $20 \mathrm{~g}$ & $25 \mathrm{~g}$ \\
\hline TAN1 & COD & 28 & 14 & 64 & 87 & 89 \\
& BOD & 50 & 54 & 59 & 67 & 80 \\
& SS & 35 & -26 & -27 & -32 & -63 \\
& TDS & 99 & 99 & 99 & 98 & 98 \\
TAN2 & COD & 15 & 20 & 25 & 32 & 38 \\
& BOD & 91 & 91 & 92 & 90 & 92 \\
& SS & -28 & -52 & -52 & -54 & -55 \\
& TDS & 97 & 99 & 99 & 99 & 99 \\
& COD & 33 & 44 & 22 & 11 & 26 \\
& BOD & 75 & 81 & 76 & 81 & 81 \\
& SS & 25 & 3 & -1 & -10 & -15 \\
& TDS & 98 & 98 & 98 & 98 & 98 \\
\hline
\end{tabular}

Percentage Reduction $=(B-A) / B \times 100 \%$

$A=$ Concentration of the parameter after treatment

$\mathrm{B}=$ Concentration of the parameter before treatment

$+=$ percentage decrease

- = percentage increase

In general, immobilization makes the enzyme more resistant to temperature, $\mathrm{pH}$, and substrate concentration swings giving it a longer lifetime and higher productivity per active unit (Gianfreda and Rao, 2004; FuIlbrook, 1996; Russell et al, 2003; Kandelbauer et al., 2004). Immobilized cells have been used and studied extensively for the production of useful chemicals (Ohtake and Silver, 1994), the treatment of wastewaters (Chen et al., 2003; Wang et al., 2010). Although many workers described microbial degradation of tannery effluent, limited literature is available on the bioremediation of tannery effluent using immobilized bacterial cells in the Kano Industrial Estates.

\section{CONCLUSION}

The samples contained variable levels of the physicochemical parameters. The results of the Analysis of variance revealed that, no statistical difference $(p<0.05)$ was observed for the temperature, $\mathrm{pH}, \mathrm{SS}, \mathrm{TDS}, \mathrm{BOD}$ and $\mathrm{COD}$ among the three tannery industries before the treatment. The levels of some of the parameters
(SS, TDS and COD) observed in the samples were found above the recommended limits of WHO and NESREA, which called for the treatment of the effluents before discharge into the environment. Base on the morphological and biochemical test results, TAN1, TAN2, and TAN3 bacterial isolates were identified to be Neisseria spp, Bacillus cereus, and Staphylococcus aureus respectively. The results of Post-treatment analysis showed that there is overall decrease in the levels of the parameters determined when compared with that of the pre-treatment. The overall percentage reduction of the immobilised bacteria in the treatment of the respective effluents was in the order TAN2 (72\%)>TAN1 $(70 \%)>$ TAN3 $(62 \%)$. Hence, the immobilized bacteria are having higher biodegradation potential for the treatment of the tannery effluents.

\section{Acknowledgments}

The authors wish to acknowledge the University of Maiduguri for the financial support. The authors are grateful to the Kano State Ministry of Environment for their support in obtaining the effluent samples. 


\section{REFERENCES}

Ajao, A. T., Adebayo, G. B., and Yakubu, S. E. (2011). Bioremediation of textile industrial effluent using mixed culture of Pseudomonas aeruginosa and Bacillus subtilis immobilized on agar-agar in a bioreactor. J. Microbiol. Biotech. Res, 1(3), 50-56.

Akan, J. C., Moses, E. A., Ogugbuaja, V. O., and Abah, J. (2007). Assessment of tannery industrial effluents from Kano metropolis, Kano State, Nigeria. Journal of Applied Sciences, 7(19), 2788-2793.

Akan, J. C., Ogugbuaja, V. O., Abdulrahman, F. I., and Ayodele, J. T. (2009). Pollutant levels in effluent samples from tanneries and textiles of Kano industrial areas, Nigeria. Global journal of pure and applied sciences, 15(3-4).

APHA (1989). Standard methods for Examination of Will bete and Will betewater.15 $5^{\text {th }}$ edition. Brydpass Springfield Will behington DC. pp. 164-176

APHA (1992). Standard Methods for the Examination of Water and Wastewater. Health, 69, 1116-9.

Baba, A., Garba, S. T., and Bello, H. S. (2020). Bioremediation Potential of Immobilized corynebacterium kutsceri in the Treatment of Tannery Industrial Effluent from Challawa Industrial Estate, Kano State, Nigeria. Journal of the Turkish Chemical Society Section A: Chemistry, $7(2), 335-350$.

Beem, E. I. V. (1994). reduction of solvent VOC emission. J. Oil Col. Chem. Ass, 77, 158.

Bouwer, E. J., and Zehnder, A. J. (1993). Bioremediation of organic compoundsputting microbial metabolism to work. Trends in biotechnology, 11(8), 360367.

Chen, K. C., Wu, J. Y., Liou, D. J., and Hwang, S. C. J. (2003). Decolorization of the textile dyes by newly isolated bacterial strains. Journal of Biotechnology, 101(1), 57-68.

Dan'Azumi, S., and Bichi, M. H. (2010). INDUSTRIAL POLLUTION AND HEAVY METALS PROFILE OF CHALLAWA RIVER IN KANO, NIGERIA. Journal of Applied Sciences in Environmental Sanitation, $5(1)$.

DWAF. (1992). Analytical Methods Manual, TR 151. Department of Water Affairs and Forestry, Pretoria.

El-Bestawy, E. (2013). Biological treatment of leather-tanning industrial wastewater using free living bacteria.
Elsheikh, M. A. S. (2009). Tannery wastewater pre-treatment. Water Science and Technology, 60(2), 433-440.

FuIlbrook, P. D. (1996). "Kinetics." Industrial enzymology: The application of enzymes in Industry. 2nd Ed. T. Godfrey and J Reichelt. eds.. Nature. New York.

Gianfreda, L., and Rao, M. A. (2004). Potential of extra cellular enzymes in remediation of polluted soils: a review. Enzyme and microbial technology, 35(4), 339354.

Hugo Springer. (1994). John Arthur Wilson Memorial Lecture "Treatment of Industrial Wastes of the Leather Industry - is it still a Major Problem". JALCA, 89, 153-185

Jimoh, A. A., Ganiyu, B. A., Baba, D., and Baba, A. (2018) Bioremediation Process of Effluent from Detergent and Food Industries in Jos, Nigeria: Kinetics and Thermodynamics. International Journal of Engineering Science Invention (IJESI), 762-73

Kandelbauer, A., Maute, O., Kessler, R. W., Erlacher, A., and Gübitz, G. M. (2004). Study of dye decolorization in an immobilized laccase enzyme-reactor using online spectroscopy. Biotechnology and bioengineering, 87(4), 552-563.

Kongjao, S., Damronglerd, S., and Hunsom, M. (2008). Simultaneous removal of organic and inorganic Pollutants in tannery wastewater using electrocoagulation technique. Korean Journal of chemical engineering, 25(4), 703.

Maheshwari, U. M., Aruna, S., Gomathi, M., and AbdulJaffar, A. H. (2017). Bioremediation by Free and Immobilized Bacteria Isolated from Tannery Effluent. International Journal of Research in Applied, Natural and Social Sciences. 5(7), 75-90

Margesin, R., and Schinner, F. (2001). Bioremediation (natural attenuation and biostimulation) of diesel-oilcontaminated soil in an alpine glacier skiing area. Applied and environmental microbiology, 677), 3127-3133.

Mohammed, A., Sekar, P., and George, J. (2011). Efficacy of microbes in bioremediation of tannery effluent. Inter. J. Curr. Res, 3(4), 324-326.

Mohammed, S. S. D., Orukotan, A. A., and Abdullahi, H. (2017). Physicochemical and Bacteriological Assessment of Tannery Effluent from Samaru-Zaria, 
BAJOPAS Volume 13 Number 2, December, 2020 Kaduna State, Nigeria. Journal of Applied

Sciences and Environmental Management, 21(4), 734-740.

Munz, G., De Angelis, D., Gori, R., Mori, G., Casarci, M., and Lubello, C. (2009). The role of tannins in conventional and membrane treatment of tannery wastewater. Journal of hazardous materials, 164(2-3), 733-739

Mythili, K., and Karthikeyan, B. (2011). Bioremediation of $\mathrm{Cr}$ (VI) from tannery effluent using Bacillus spp and Staphylococcus spp. International Multidisciplinary Research Journal, 1(6).

NESREA (2009). National Environmental Standards for Effluent Limitations and Regulation. 1233-1236

Noorjahan, C. M. (2014). Physicochemical characteristics, identification of bacteria and biodegradation of industrial effluent. Journal of bioremediation and Biodegradation, 5(3).

Ohtake, H. I., and Silver, A. O. (1994). Bacterial reduction of toxic chromate. Biological degradation and bioremediation of toxic chemicals, 403-415.

Omoleke, I. I. (2004). Management of environmental pollution in Ibadan, an African city: the challenges of health hazard facing government and the people. Journal of Human Ecology, 15(4), 265-275.

Rajor, A., Reddy, A.S., and Singh, B. (2004). Determination of BOD kinetic Parameters and evaluation of alternate methods, M.Sc. Thesis, Department of biotechnology \& environmental Science, Thapar Institute of Engineering and Technology, Patiala

Ramasami, T., Rajamani, S., and Rao, J. R. (1994, March). Pollution control in leather industry: Emerging technological options. In International symposium on surface and colloidal science and its relevance to soil pollution, madras.

Ramesh, J. V. S., and Singh, S. P. (1993). Yearly variation in certain physicochemical parameters of pond at eastern Doon Valley. Uttar Pradesh J. Zoo, 12 (1), 7577.

Ranen, S., and Sharadinadra, C. (2009). Biotechnology applications to environmental remediation in resource exploitation. Current science, 97, 6-25
Russell, A. J., Berberich, J. A., Drevon, G. F., and Koepsel, R. R. (2003). Biomaterials for mediation of

chemical and biological warfare agents. Annual review of biomedical engineering, 5(1), 1-27.

Saravanan, P., and Saravanan, A. (1999). Decolourization of tannery effluent by Flavobacterium sp. EK 1. Indian Journal of Environmental Protection, 19, 19-24.

Sikander, S., and Shahida, H. (2007). Reduction of toxic hexavalent chromium by Ochrobactrum intermedium strain SDCr5 stimulated by heavy metals. Bioresource Technol, 98, 340-344.

Singh, N., Sharma, B. K., and Bohra, P. C. (2000). Impact assessment of industrial effluent of arid soils by using satellite imageries. Journal of the Indian Society of Remote Sensing, 28(2-3), 79.

Sreemoyee, C., and Priti, P. (2013). Assessment of physico-chemical parameters of dairy waste water and isolation and characterization of bacterial strains in terms of cod reduction. Int J Sci, 2(3), 395-400.

Verheijen, L. A. H. M., Wiersema, D., Pol, L. H., and De Wit, J. (1996). Management of wastes from animal product processing. Livestock and environment, Finding a balance. International Agriculture Center, Wageningen, The Netherlands.

Wang, F., Yao, J., Si, Y., Chen, H., Russel, M., Chen, K., and Bramanti, E. (2010). Short-time effect of heavy metals upon microbial community activity. Journal of Hazardous Materials, 173(13), 510-516.

WHO (World Health Organization). (2006). Air quality guidelines: global update 2005: particulate matter, ozone, nitrogen dioxide, and sulfur dioxide. World Health Organization.

World Bank. (1995). Nigeria's strategic options for redressing industrial pollution. World Bank, industry and energy division. 1st edition, West Central Africa Department; Annexes: 1995; pp 60-62.

Zahoor, A., and Abdul, R. (2009). Enumeration of Coliforms. Journal of Environmental Sciences. 21, 814-820 


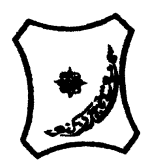

Bayero Journal of Pure and Applied Sciences, 13(2): 1 - 12

Received: November, 2020

Accepted: December, 2020

ISSN $2006-6996$

\title{
BIODEGRADATION POTENTIAL OF IMMOBILIZED BACTERIA IN THE TREATMENT OF TANNERY INDUSTRIAL EFFLUENTS FROM INDUSTRIAL ESTATES IN KANO STATE, NIGERIA
}

\author{
Abdullateef, B., ${ }^{1 *}$ Shuaibu, T. G., ${ }^{1}$ Babagana, K., ${ }^{1}$ Suleman, H. B. ${ }^{2}$ and Dauda, B. ${ }^{3}$ \\ ${ }^{1}$ Department of Pure and Applied Chemistry, Faculty of Science, University of Maiduguri, Borno State, \\ Nigeria \\ ${ }^{2}$ Department of Microbiology, Faculty of Science, University of Maiduguri, Borno State, Nigeria \\ ${ }^{3}$ Department of Chemical Engineering, Faculty of Engineering, University of Maiduguri, Borno State, \\ Nigeria \\ *Corresponding author: babslega@gmail.com; abelega2007@yahoo.com; +2348061309753
}

\section{ABSTRACT}

Industrial Effluents Samples from Gashash Tanneries (TAN1) in Bompai Industrial estate, Larabee Tannery Industry (TAN2) in Sharada Industrial estate and Z Tannery Industries (TAN3) in Challawa Industrial estate, Kano State, Nigeria were collected over a period of six months (August 2017 to January 2018) for assessing the biodegradation potentials of bacteria in the treatment of organic pollutants within the effluents. Bacteria were isolated from the effluents and immobilized on agar-agar. Different masses (5 g, $10 \mathrm{gr}, 15$ $\mathrm{g}, 20 \mathrm{~g}$, and $25 \mathrm{~g}$ ) of the bacteria were used in the treatment of $250 \mathrm{ml}$ of the effluents for ten days in a shaker incubator (Gallenkamp-OC-4364-L) at the temperature $30{ }^{\circ} \mathrm{C}$ and speed of $60 \mathrm{rpm}$. Pre-treatment analysis of the effluents for Temperature, pH, Biochemical Oxygen Demand (BOD), Chemical Oxygen Demand (COD), Suspended Solid (SS) and Total Dissolved Solids (TDS) gives the following results; temperature $\left({ }^{\circ} \mathrm{C}\right.$ )

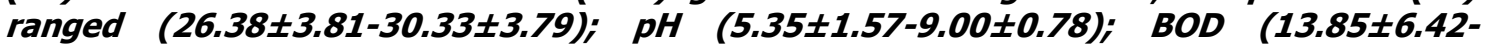
$38.75 \pm 16.20) ;$ COD (1406 $\pm 208-3532 \pm 1373) ;$ SS (208 $\pm 235-780 \pm 739)$ and TDS (266 $\pm 253-5276 \pm 2971)$. No statistical differences ( $p \leq 0.05)$ was observed for all the results among the different industries. The bacterial isolates were identified as Neisseria spp, Bacillus cereus, and Staphylococcus aureus, in TAN1, TAN2, and TAN3, respectively. After treatment of the effluent with the different masses of the isolated bacteria, the mean level of BOD was found to range as (0.55 $\pm 0.36-6.92 \pm 5.49) ; C O D$ (ND-3134 \pm 1595$)$;

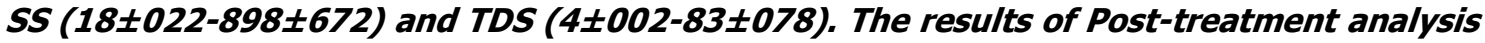
showed that there is overall decrease in the levels of the parameters determined when compared with that of the pre-treatment. The overall percentage reduction of the immobilised bacteria in the treatment of the respective effluents was in the order TAN2 (72\%)>TAN1 (70\%)>TAN3 (62\%). Hence, the immobilized bacteria are having higher biodegradation potential for the treatment of the tannery effluents.

Keywords: Biodegradation, bacteria, effluent, immobilization, tannery.

\section{INTRODUCTION}

Tannery industrial wastewater is a serious consequence of the pollution point of view for streams, freshwater, and land used for agriculture. The lack of awareness in the modern industrial practice has resulted in the discharge of tannery effluents which exhibit very high value of chromium ( $\mathrm{Cr}$ ), Sulfide, and chloride, Total Dissolved Solid (TDS), Total Suspended Solid (TSS), Biochemical Oxygen Demand (BOD) and Chemical Oxygen Demand (COD) in the water stream or land (Mohammed et al., 2001). Tanning is the process, which One ton of skin generally leads to the production of 20 to $80 \mathrm{~m}^{3}$ of turbid and foul-smelling converts the protein of the rawhide or skin into a stable material, which will not putrefy and is suitable for a wide variety of end applications (Elsheikh, 2009). The highly polluting chromium is the most commonly used tanning material producing leather that is more flexible and pliable than vegetable-tanned leather and does not discolor or lose shape in water as drastically as vegetable-tan (Elsheikh, 2009). Tannery effluent is among the most hazardous industrial pollutants due to its huge organic and inorganic load, which is highly toxic to human life and the environment (Kongjao et al., 2008). wastewater including chromium (100-400 mg/l), sulfide $(200-800 \mathrm{mg} / \mathrm{l})$, high levels of fat and 
BAJOPAS Volume 13 Number 2, December, 2020 other solid wastes, and notable pathogen contamination as well as pesticides added for skin conservation during transport (Elsheikh, 2009). There are more than 6000 tanneries in Nigeria with an annual processing capacity of 700,000 tons of hides and skins (Omoleke, 2004; Singh et al., 2008). It was reported that the total amount of waste produced per animal slaughtered is approximately $35 \%$ of its weight (World Bank, 1995). Also, for every $1000 \mathrm{~kg}$ of carcass weight, a slaughtered beef produces 5.5 $\mathrm{kg}$ of manure (excluding rumen contents or stockyard manure) and $100 \mathrm{~kg}$ of paunch manure (undigested food) (Verheijen et al., 1996). Tanneries generate wastewater in the range of 30-35 $\mathrm{L} \mathrm{kg}^{-1}$ skin/hide processed with variable $\mathrm{pH}$, Biological Oxygen Demand (BOD), Chemical Oxygen Demand (COD), high concentrations of suspended solids (SS), and tannins as well as chromium (Zahoor and Abdul, 2009).

Being heterogeneous and composed of a wide variety of compounds, it is very difficult to select a unique direct method for estimating the biodegradability of organic contents and biokinetic parameters for a wastewater sample (Rajor, 2004). For this purpose, some indirect estimation such as determination of biochemical oxygen demand (BOD) and chemical oxygen demand (COD) are applied as common laboratory investigations [9]. During retanning procedures, synthetic tannins (Syntan), oils and resins are added to form softer leather at varying doses (Munz et al., 2009). One of the refractory groups of chemicals in tannery effluents derives mainly from tannins (Ramasami et al., 2004). Syntans are characterized by complex chemical structures, because they are composed of an extended set of chemicals such as phenol-, naphthalene-, formaldehyde- and melamine-based syntans, and acrylic resins (Beem, 1994). Organic pollutants (proteic and lipidic components) are originated from skins (it is calculated that the raw skin has $30 \%$ loss of organic material during the working cycle) or they are introduced during processes (Hugo Springer, 1994).

Many conventional processes such as oxidation, chemical and biological processes were carried out to treat tanneries wastewater (Ebtesam et al, 2013). Biological processes have received more attention because of their costeffectiveness, lower sludge production and environmental friendliness (Noorjahan, 2014). Naturally occurring micro-organisms degrade the hazardous organic wastes including xenobiotic compounds, such as pesticides, polycyclic aromatic hydrocarbons (PAHs) and polychlorinated biphenyls (PCBs) in due course of time (Ranen and Sharadinadra, 2009). Bioremediation is based on the idea that all organisms remove substances from the environment to carry outgrowth and metabolism (Bouwer and Zehnder, 1993). Bacteria, protista and fungi are found to be very good at degrading complex molecules and incorporating the breakdown products into their metabolism (Bouwer and Zehnder, 1993). The resultant metabolic wastes that they produce are generally safe and somehow recycled into other organisms (Ranen and Sharadinadra, 2009). An acclimatized indigenous population of microorganisms capable of degradation of the compounds of interest must exist at the site for a successful bioremediation mode (Ranen and Sharadinadra, 2009). It has been observed that for a successful bioremediation mode, an acclimatized indigenous population of microorganisms capable of degradation of the compounds of interest must exist at the site under investigation (Ranen and Sharadinadra, 2009). Even though there are numerous physical and chemical methods employed in the disposal of wastes the advantage in using bacterium is that they play a key role in the reduction of COD, BOD, total protein, total tannin and total phenol (Saravanan and Saravanan, 1998)

Baba et al. (2020) studied the bioremediation potential of immobilized corynebacterium kutsceri in the Treatment of tannery industrial effluent from Challawa Industrial Estate, Kano State, Nigeria. The aim of the work is to study the reduction in the level of the contaminants through the process of bioremediation using the isolated bacteria. Immobilized bacteria can withstand various temperatures, $\mathrm{pH}$ and substrate concentrations; consequently, increasing the efficiency and the lifespan of the bacteria. Immobilized bacteria are widely applied in the treatment of wastewater and can be separated and recovered after the treatment with the same efficiency (Baba et al., 2020).

\section{MATERIALS AND METHODS \\ Study Area}

This study was carried out in Bompai, Sharada and Challawa industrial estates in Kano, Figure 1. Kano lies on Latitude $11^{\circ} 30^{\prime} \mathrm{N}$ and $8^{\circ} 30^{\prime} \mathrm{E}$ and Longitude $11^{\circ} 5^{\prime} \mathrm{N}$ and $8^{\circ} 5^{\prime} \mathrm{E}$ in Northern Nigeria. It is one of the developed industrial cities in Nigeria. Tannery activities are the dominating industries and this could be one of the reasons for her high population density (Dan'Azumi and Bichi, 2010). Many researchers have studied biodegradation of tannery effluent using microorganisms. However, limited literature is available on the biodegradation of tannery effluent in Kano industrial estates using 
BAJOPAS Volume 13 Number 2, December, 2020 immobilized bacterial cells. This research work focuses on the potential of the use of the indigenous immobilized bacterial isolates in the treatment of tannery effluents in the industrial estates.

\section{Sample Collection}

Effluents were collected from the Tannery Industries from Bompai, Challawa and Sharada Industrial Estates, Kano, Nigeria. The effluents were collected over a period of six months (August 2017 to January 2018). Samples collected in a sterile 4-liter plastic container with a unique identification number were preserved using an ice-box that was transported to the Microbiology Laboratory, Department of Microbiology, Bayero University of Kano for analysis

\section{Sample Preparation and Sample Analysis}

Immediately after the collection of the effluent, $\mathrm{pH}$, TSS, TDS, COD, BOD levels were determined before treatment (Pre-treatment determination) and ten days after treatment (Post-treatment determination) as described in
APHA (1989) standard methods. $\mathrm{pH}$ was determined using Ecotests $\mathrm{pH}$ meter and TDS was determined using AQUALYTIC TDS Salinometer. BOD was determined as described by the standard method (APHA, 1992). COD and SS were determined using DR/2010 HACH portable data logging spectrophotometer (DWAF, 1992)

\section{Identification and Biochemical} Characterization of the Bacterial Isolates

The bacteria were isolated from the effluents using Serial Dilution according to the method described by APHA (1989). The biochemical tests such as oxidase, catalase, coagulase, indole (from $1 \%$ tryptone broth), citrate (Simmons citrate agar), methyl red/VogesProskauer (MR/VP), nitrate reduction, Starch Hydrolysis, Glucose, Maltose, and Lactose tests were carried out on the bacterial isolates to identify the bacteria through the bacteria biochemical characteristics according to Ajao et al. (2011).

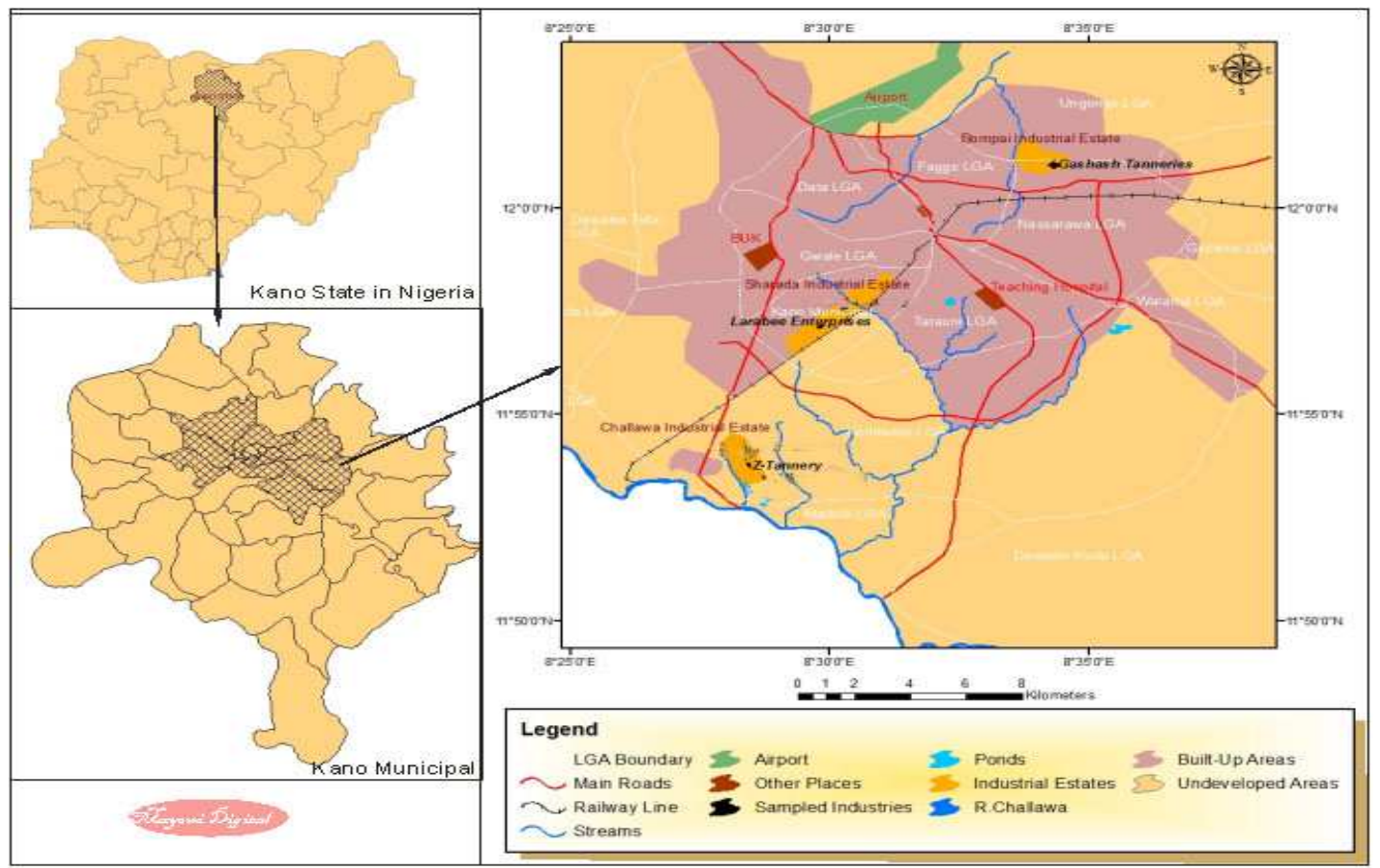

Fig. 1 Map showing the study areas

Source: Mayomi Digital Productions, GIS Laboratory, Department of Geography, UNIMAID (2017)

\section{Determination of Growth Rate of the Bacteria in Effluent Sample}

The bacteria growth rates were determined by transferring $2 \mathrm{~mL}$ of the bacterial isolates from the tannery effluent in broth medium into 100 $\mathrm{mL}$ sterile effluents in conical flasks and kept in an incubator (Giffrin cool) for 10 days. Control was also set up by incubating another $100 \mathrm{~mL}$ each of the sterile effluents without the bacteria. The optical density of the content was determined at the wavelength of $600 \mathrm{~nm}$ on a daily interval and recorded. 
BAJOPAS Volume 13 Number 2, December, 2020 Immobilization of Bacteria

Agar solution and inoculi were prepared separately. Fifty milliliters $(50 \mathrm{~mL})$ of nutrient broth each of the inoculi was prepared in a McCartney bottle and incubated for 24 hours. A solution of agar-agar was prepared by dissolving $10 \mathrm{~g}$ of the powder in distilled water and made up to $500 \mathrm{~mL}$ mark in an Erlenmeyer flask and was sterilized in an autoclave (280A) for 15 minutes and allowed to cool to $40-45^{\circ} \mathrm{C}$ (Ajao et al., 2011). Four milliliters ( $4 \mathrm{~mL})$ of the bacterial isolates in the nutrient broth was mixed with 36 $\mathrm{ml}$ of the prepared agar-agar media in petri-dish plates and then allowed to solidify. This was kept in the refrigerator for bioremediation.

\section{Bioremediation (Treatment) of the Effluents}

The solidified agar block (immobilized bacteria) was cut into cubes using a sterile knife; $0.1 \mathrm{~mL}$ phosphate buffer ( $\mathrm{pH} \mathrm{7.0)}$ was added and kept in the refrigerator for 1 hour for curing. The phosphate buffer was decanted after 1 hour and the cubes were washed with sterile distilled water 3-4 times before it was used (Ajao et al., 2011). Two liters (2 L) of the effluent was supplemented with the minimum basal medium in $\mathrm{g} / \mathrm{L}: \mathrm{NaCl}(0.8), \mathrm{MgSO}_{4} .7 \mathrm{H}_{2} \mathrm{O}(0.001), \mathrm{KH}_{2} \mathrm{PO}_{4}$ (2), $\mathrm{NaNO}_{3}$ (2), $\quad \mathrm{CaCl}_{2} .2 \mathrm{H}_{2} \mathrm{O} \quad(0.5)$ and $\mathrm{NaHPO}_{4} .12 \mathrm{H}_{2} \mathrm{O}(2)$ and sterilized in an autoclave at $121^{\circ} \mathrm{C}$ for 15 minutes (Margesin and Schinner, 2001). Two hundred and fifty milliliters $(250 \mathrm{~mL})$ of the effluents were transferred into different $250 \mathrm{ml}$ conical flasks. The content was covered with a cotton-wool ramped with foil paper to avoid contamination. Five grams $(5 \mathrm{~g})$ of the immobilized bacteria were quickly transferred into each of the effluents in the conical flasks in an inoculating chamber. The same procedures were carried out for the $10 \mathrm{~g}, 15 \mathrm{~g}, 20 \mathrm{~g}$ and 25 $\mathrm{g}$ of the immobilized bacteria in separate $250 \mathrm{~mL}$ effluents in conical flasks and agitated for ten days in a shaker incubator (Gallenkamp-OC4364-L) at a temperature $30^{\circ} \mathrm{C}$ and speed of 60 rpm. The treated effluent samples were taken on the tenth day and analyzed for the parameters $\mathrm{pH}$, SS, TDS, COD, and BOD, (Posttreatment determination) for the different grams of bacteria to evaluate and compare the biodegradation potential. (Baba et al., 2020).

\section{Statistical Analysis}

The data were represented as Mean \pm Standard deviation and analyzed statistically using oneway Analysis of Variance (ANOVA) and Tukey's HSD as Post Hoc Tests with the aid of SPSS 16.0. The correlation coefficient was also used to measure the strength of the relationship between the different masses of the bacteria and the parameters. All $\mathrm{p} \leq 0.05$ were considered as statistically significant.

\section{RESULTS AND DISCUSSION Physico-chemical parameters in the Industrial Effluents before the Biodegradation.}

Results of the Physico-chemical parameters in the industrial effluents before the Biodegradation is shown in table 1 . The mean temperatures $\left({ }^{\circ} \mathrm{C}\right)$ observed in TAN1, TAN2, and TAN3 samples were $28.07 \pm 0.65 ; 27.77 \pm 0.64$ and $26.38 \pm 3.81$ respectively. The order of the mean temperature of the samples from the three industries can be arranged as TAN1 > TAN2>TAN3. The temperature observed at TAN1, TAN2, and TAN3 samples were found below the WHO $\left(35^{\circ} \mathrm{C}\right)$ and NESREA $\left(40^{\circ} \mathrm{C}\right)$ limits. The low values of temperature might be due to the processes used at the time of sampling. High temperature brings down the solubility of gases in water that ultimately expresses as high BOD and COD. Statistical analysis shows that there is no significant difference $(p<0.05)$ between the mean values of temperature among the industries. This might be due to similar tannery activities involved in the tannery industries at the time of sampling. The average values of temperature observed in this present study are less than those observed by Akan et al. (2007), Akan et al. (2009) and Baba et al. (2020).

The mean level of $\mathrm{pH}$ observed in TAN1, TAN2 and TAN3, samples were $7.77 \pm 2.93$; $8.35 \pm 0.28$ and $7.52 \pm 0.76$ respectively. The order of the mean $\mathrm{pH}$ of the samples from the three industries can be arranged as TAN2> TAN1 $>$ TAN3. The $\mathrm{pH}$ of the samples falls within the WHO (7.0-8.5) and NESREA (6-9) standard limits. Statistical analysis shows that there is no significant difference $(p<0.05)$ between the mean values of $\mathrm{pH}$ among the industries. This might be due to similar tannery activities involved in the tannery industries at the time of sampling. Maheshwari et al. (2017) reported that the level of $\mathrm{pH}$ in the effluents from the tannery industry in Vaniyambadi, India was 6.5 which was lower than that observed in the present study. The $\mathrm{pH}$ in the effluents from the tannery industries in Kano and Kaduna were reported to be 7.64 and 6.89, respectively (Akan et al., 2007; Mohammed et al., 2017). The average values of $\mathrm{pH}$ observed in this present study are less than those observed by Mohammed et al. (2017) and Baba et al. (2020). The mean level of SS $(\mathrm{mg} / \mathrm{l})$ observed in TAN1, TAN2, and TAN3 samples were 374 \pm 124 ; $358 \pm 335$ and $780 \pm 739$ respectively. The order of the mean SS in the samples from the three industries can be arranged as TAN3 > TAN1 $>$ TAN2. 
The SS observed in the samples were far above the recommended standard limits of regulating bodies WHO $(30 \mathrm{mg} / \mathrm{l})$ and NESREA $(10 \mathrm{mg} / \mathrm{l})$. Statistical analysis shows that there is no significant difference $(p<0.05)$ between the mean values of SS among the industries. This might be due to similar tannery activities involved in the tannery industries at the time of sampling. The average values of SS observed in this present study are less than that observed $(3700 \pm 122 \mathrm{mg} / \mathrm{l})$ by Akan et al. (2009) for tanneries in Kano. Also, the average values of SS observed in this present study are less than that observed by Mohammed et al. (2017) and Baba et al. (2020) with the exception in TAN3.

The mean level of TDS (mg/l) observed in TAN1, TAN2, and TAN3 samples were $3941 \pm 3703$; $3300 \pm 1714$ and $2653 \pm 1240$ respectively. The order of the mean TDS in the samples from the three industries can be arranged as TAN1>TAN2>TAN3. The TDS observed in the samples were far above the recommended standard limits of WHO $(250 \mathrm{mg} / \mathrm{l})$ and NESREA $(500 \mathrm{mg} / \mathrm{l})$. Statistical analysis shows that there is no significant difference $(p<0.05)$ between the mean values of TDS among the industries. This might be due to similar tannery activities involved in the tannery industries at the time of sampling. TDS in the effluents from the tannery industries in Kano, Nigeria was reported to be $1281 \mathrm{mg} / \mathrm{l}$ (Akan et al., 2007). The average values of SS observed in this present study are less than those observed by Mohammed et al. (2017) and Baba et al. 2020)

The mean level of COD (mg/l) observed in TAN1, TAN2 and TAN3 samples seasons were $2372 \pm 938 ; \quad 1406 \pm 208$ and $3532 \pm 1373$ respectively. The order of the mean COD of the samples from the three industries can be arranged as TAN3>TAN1> TAN2. The COD observed in TAN1, TAN2 and TAN3 samples were far above the recommended standard limits of regulating bodies $\mathrm{WHO}(40 \mathrm{mg} / \mathrm{l})$ and NESREA (40 mg/l). Statistical analysis shows that there is no significant difference $(p<0.05)$ in COD among the industries. This might be due to similar tannery activities involved in the tannery industries as at the time of sampling. The Chemical Oxygen demand (COD) is the amount of oxygen, in $\mathrm{mg} / \mathrm{L}$, required for the degradation of the compound of wastewater to occur. In comparison, the average values of COD observed in this present study were higher than that observed by Mohammed et al. (2017) but lower than that observed by Baba et al. (2020).

The mean levels of BOD $(\mathrm{mg} / \mathrm{l})$ observed in TAN1, TAN2 and TAN3 samples were $13.85 \pm 6.42 ; \quad 19.46 \pm 0.50$ and $17.13 \pm 3.14$ respectively. The order of the mean BOD in the samples from the three industries can be arranged as TAN2>TAN3>TAN1. The BOD observed in TAN1, TAN2 and TAN3 samples were found below the recommended limits of NESREA (200 mg/l) but above WHO (10 mg/l). Statistical analysis shows that there is no significant difference $(p<0.05)$ between the mean values of BOD among the industries. This might be due to similar tannery activities involved in the tannery industries at the time of sampling. The low level of BOD recorded in this study is an indication of the low level of biodegradable organic solids in the effluent. The average values of BOD observed in this present study were lower than those observed by Mohammed et al. (2017) and Baba et al. (2020).

Table 1: Mean Values \pm S.D of Physico-chemical parameters of effluents from the Tannery Industries before Treatment.

\begin{tabular}{llllllll}
\hline Parameter & Tannery 1 & Tannery 2 & Tannery 3 & $\mathrm{a}$ & $\mathrm{b}$ & $\mathrm{c}$ & $\mathrm{d}$ \\
\cline { 2 - 7 } Temperature $\left({ }^{\circ} \mathrm{C}\right)$ & $28.07 \mathrm{a} \pm 0.65$ & $27.77 \mathrm{a} \pm 0.64$ & $26.38 \mathrm{a} \pm 3.81$ & & $29.50 \pm 4.68$ & 35 & 40 \\
pH & $7.77 \mathrm{a} \pm 2.93$ & $8.35 \mathrm{a} \pm 0.28$ & $7.52 \mathrm{a} \pm 0.76$ & 6.89 & $5.35 \pm 1.57$ & $7.0-8.5$ & $6.0-9.0$ \\
$\mathrm{COD}(\mathrm{mg} / \mathrm{l})$ & $2372 \mathrm{a} \pm 938$ & $1406 \mathrm{a} \pm 208$ & $3532 \mathrm{a} \pm 1373$ & 2.2 & $3106 \pm 2753$ & 40 & 40 \\
$\mathrm{BOD}(\mathrm{mg} / \mathrm{l})$ & $13.85 \mathrm{a} \pm 6.42$ & $19.46 \mathrm{a} \pm 0.50$ & $17.13 \mathrm{a} \pm 3.14$ & 1032 & $26.17 \pm 9.49$ & 10 & 200 \\
$\mathrm{SS}(\mathrm{mg} / \mathrm{l})$ & $374 \mathrm{a} \pm 124$ & $358 \mathrm{a} \pm 335$ & $780 \mathrm{a} \pm 739$ & 501 & $562 \pm 482$ & 30 & 10 \\
TDS $(\mathrm{mg} / \mathrm{l})$ & $3941 \mathrm{a} \pm 3703$ & $3300 \mathrm{a} \pm 1714$ & $2653 \mathrm{a} \pm 1240$ & 532.7 & $444 \pm 507$ & 250 & 500 \\
\hline
\end{tabular}

The values given in the table above are means of 6 replicate values, $\mathrm{n}=6$ ( 1 sample was taken monthly for 6 months). Within the rows, means with different alphabets are statistically different $(p<0.05)$. WHO: World Health Organisation. NESREA: National Environmental Standard and Regulatory Enforcement Agency. a = Mohammed et al.(2017), b = Baba et al. (2020), c = WHO (2006), $d=$ NESSRA (2009) 
BAJOPAS Volume 13 Number 2, December, 2020

Identification, Biochemical Characterization and growth rates of the Bacterial Isolates

Results of identification and biochemical characterization of the bacterial isolates were shown in table 2. After 24 hours of incubation, the nutrient agar media plates were checked for bacterial growth. The results showed the presence of different strains in the samples. The TAN1 bacteria isolate was found to be gramnegative cocci while TAN3 was gram-positive cocci. TAN2 bacteria isolate was found to be gram-positive, rod-shaped. TAN1, TAN2, and TAN3 bacteria isolates recorded positive results for spore former.

The results of the biochemical tests indicated that all the bacteria were positive for catalase, oxidase, citrate, maltose, glucose, lactose (negative in TAN1), mannitol (negative in TAN2), starch hydrolysis and coagulase (negative in TAN2) tests. The bacteria showed negative results for nitrate reduction, $M R$ (positive in TAN2), VP (positive in TAN1), Indole (positive in TAN2) tests. Base on the morphological and biochemical test results, TAN1, TAN2, and TAN3 bacteria isolates were identified to be Nesseria spp, Bacillus cereus, and Staphylococcus aureus respectively.

The growth rate of the TAN1, TAN2 and TAN3 Isolates were shown in figure 2. Generally, the optical density increase with the increase in time (day) and decrease as time goes on. The highest optical density was shown by bacillus cereus in TAN2 while the lowest was shown by Staphylococcus aureus in TAN3.

The initial growth phase of TAN1 Isolate bacteria occurred within 2-day of incubation as the growth rate increases up to the 6th-day incubation when the maximum growth was observed. Beyond the 6th day, the growth of the bacteria declined (which might be due to a shortage of nutrients in the effluents) until it reached its death phase (which might be due to the unavailability of nutrients in the effluents).

A similar trend of growth was also observed for TAN2 Isolate as the initial growth phase also occurred within 2-day of incubation but maximum growth rate observed on the 4th day of incubation. The stationary stage occurred between the 4th day and the 8th day. Beyond the 8th day, the growth of the bacteria declined (which might be due to a shortage of nutrients in the effluents) until it reached its death phase (which might be due to the unavailability of nutrients in the effluents).

The initial growth phase of TAN3 bacterial Isolate occurred within the 3-day incubation as the growth rate increases up to the 6th-day incubation when the maximum growth was observed. Beyond the 6th day, the growth of the bacteria declined (which might be due to a shortage of nutrients in the effluents) until it reached its death phase (which might be due to the unavailability of nutrients in the effluents).

Table 2: Morphological and Biochemical characteristics of bacterial isolates

\begin{tabular}{lllll} 
Bacterial Isolates & & TAN1 & TAN2 & TAN3 \\
\hline $\begin{array}{lllll}\text { Morphological } \\
\text { characteristics }\end{array}$ & Shape & Cocci & Rod & Cocci \\
& Spore & & & \\
& former & + & + & + \\
Gram & & & \\
Biochemical characteristics & reaction & - & + & + \\
& Citrate & + & + & + \\
& Catalase & + & + & + \\
& Coagulase & + & - & + \\
Starch & + & + & + \\
& Glucose & + & + & + \\
Oxidase & + & + & + \\
& Indo & - & + & - \\
Lactose & - & + & + \\
Manitol & + & - & + \\
Maltose & + & + & + \\
MR & - & + & - \\
VP & + & - & - \\
& Nitrate & - & - & - \\
Reduction & - Neisseria & Bacillus & Staphylococcus \\
& Bacterial & cereus & aureus \\
& name & spp & cas
\end{tabular}

+ = Positive; - = Negative; MR=Methyl Red; VP= Voges-Proskauer 


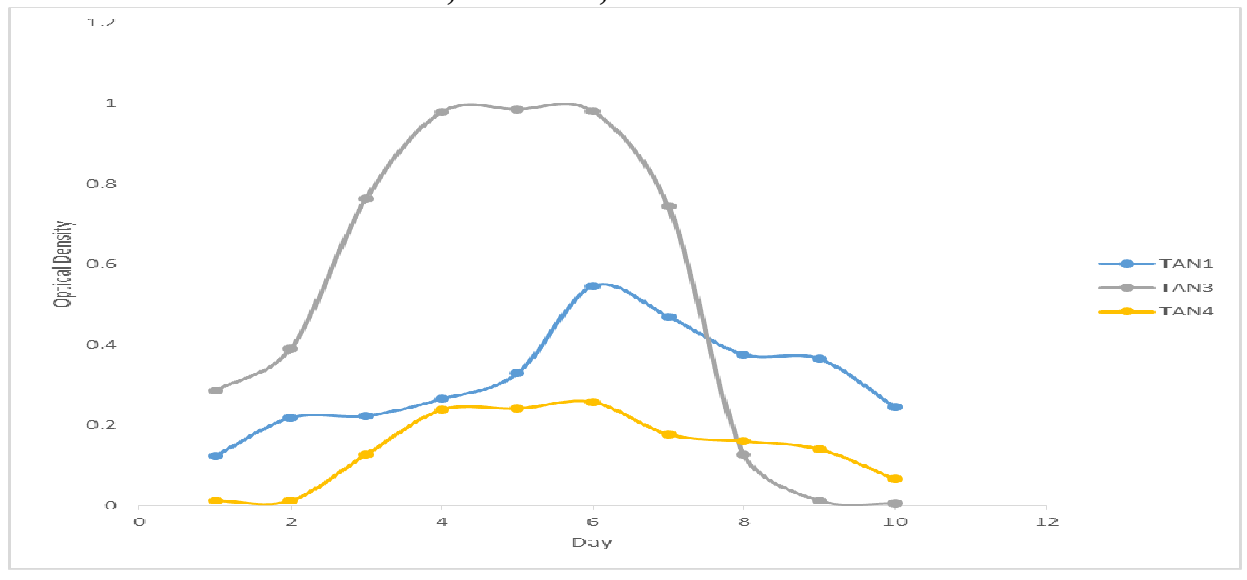

Fig. 2 Growth rates of the isolates in the effluents from the Tannery Industries

\section{Physico-chemical Parameters in the Industrial Effluents after the biodegradation.}

Table 3 shows the mean results of the physicochemical parameter before and after bioremediation using the different masses $(5 \mathrm{~g}$, $10 \mathrm{~g}, 15 \mathrm{~g}, 20 \mathrm{~g}$, and $25 \mathrm{~g}$ ) of the respective immobilized bacteria. Also, Table 4 shows the mean results of correlation coefficient ( $r$ ) between different masses of bacteria and physicochemical parameters.

The mean values $(\mathrm{mg} / \mathrm{l})$ of the SS after the bioremediation varies between $243 \pm 45$ and $898 \pm 672$. The mean concentration $(\mathrm{mg} / \mathrm{l})$ of SS remediated by the different masses $(5 \mathrm{~g}, 10 \mathrm{~g}$, $15 \mathrm{~g}, 20 \mathrm{~g}$, and $25 \mathrm{~g}$ ) of the bacteria varies. The SS in the samples fluctuates up and down after the bioremediation process when compared with the SS of the raw samples before the bioremediation. The increase in the levels of the SS might be due to the aggregation of the TDS which are large enough to result into SS. The increase in the levels of the SS might be also due to the influence of the nutrients which was added into the effluents in order to make the microorganisms more active and viable for fast degradation of organic contaminants in the effluent. The relative potential or efficiency of the different masses of the bacteria in remediating SS in TAN1 samples was in the order $25 \mathrm{~g}>20 \mathrm{~g}>15 \mathrm{~g}>10 \mathrm{~g}>5 \mathrm{~g}$. For TAN2 and TAN3 samples, the order was $25 \mathrm{~g}>20 \mathrm{~g}>15$ $\mathrm{g}>10 \mathrm{~g}>5 \mathrm{~g}$. These might be due to the variations in the surface areas of the different masses of the immobilized bacteria. Statistical analysis shows that there is no significant difference $(p<0.05)$ between the mean values of SS among the masses in the respective industries. Positive and significant correlations exist between the masses of bacteria and Suspended Solid (SS). This showed that there is general increase in the levels of the SS as the masses of the immobilized bacteria increases. TAN3 (90\%) and TAN1 (80\%) showed a very high correlation with the masses of the bacteria while TAN2 (61\%) showed a very low correlation.

The mean values $(\mathrm{mg} / \mathrm{l})$ of the TDS after the bioremediation varies between $46 \pm 11$ and $83 \pm 78$. The mean concentration $(\mathrm{mg} / \mathrm{l})$ of TDS remediated by the different masses $(5 \mathrm{~g}, 10 \mathrm{~g}$, $15 \mathrm{~g}, 20 \mathrm{~g}$, and $25 \mathrm{~g}$ ) of the bacteria varies. There is a reduction in all the TDS of all the samples after the bioremediation process compared with the TDS of the raw samples before the bioremediation. The relative potential or efficiency of the different masses of the bacteria in remediating TDS in TAN1 and TAN3 samples was in the order $5 \mathrm{~g}>10 \mathrm{~g}>15 \mathrm{~g}>20$ $\mathrm{g}>25 \mathrm{~g}$. For TAN2 samples, the order was 20 $g>10 \quad g>25 \quad g>15 \quad g>5 \quad g$. Statistical analysis shows that there is no significant difference $(p<0.05)$ between the mean values of TDS among the masses in the respective industries. These might be due to the variations in the surface areas of the different masses of the immobilized bacteria. Positive and significant correlations exist between the masses of bacteria and TDS with the exception in TAN2 (negative and insignificant correlation). The positive correlations showed that there is general increase in the levels of the TDS as the masses of the immobilized bacteria increases. TAN1 $(96 \%)$ showed a very high correlation with the masses of the bacteria while TAN2 (47\%) showed a very low correlation.

The mean values $(\mathrm{mg} / \mathrm{l})$ of the BOD after the bioremediation varies between $1.56 \pm 0.20 \mathrm{mg} / \mathrm{l}$ and $6.92 \pm 5.49 \mathrm{mg} / \mathrm{l}$. The mean concentration $(\mathrm{mg} / \mathrm{l})$ of BOD remediated by the different masses $(5 \mathrm{~g}, 10 \mathrm{~g}, 15 \mathrm{~g}, 20 \mathrm{~g}$, and $25 \mathrm{~g}$ ) of the bacteria varies. There is a reduction in all the BOD of all the samples after the bioremediation process compared with the $\mathrm{BOD}$ of the raw 
BAJOPAS Volume 13 Number 2, December, 2020 samples before the bioremediation. The relative potential or efficiency of the different masses of the bacteria in remediating BOD in TAN1, TAN2 and TAN3 samples were in the order $25 \mathrm{~g}>20$ $\mathrm{g}>15 \mathrm{~g}>10 \mathrm{~g}>5 \mathrm{~g}, 25 \mathrm{~g}>15 \mathrm{~g}>5 \mathrm{~g}>10 \mathrm{~g}>20 \mathrm{~g}$ and $20 \mathrm{~g}>10 \mathrm{~g}>25 \mathrm{~g}>15 \mathrm{~g}>5 \mathrm{~g}$ respectively. Statistical analysis shows that there is significant difference $(p<0.05)$ between the mean values of BOD among the masses in the respective industries. These might be due to the variations in the surface areas of the different masses of the immobilized bacteria. Negative and significant correlations exist between the masses of bacteria and BOD. This showed that there is general decrease in the levels of the BOD as the masses of the immobilized bacteria increases. TAN1 (94\%) showed a very high correlation with the masses of the bacteria while TAN2 (4\%) showed a very low correlation.

The mean values $(\mathrm{mg} / \mathrm{l})$ of the COD after the bioremediation varies between $250 \pm 154$ and $3134 \pm 1595$. The mean concentration $(\mathrm{mg} / \mathrm{l})$ of COD remediated by the different masses $(5 \mathrm{~g}$, $10 \mathrm{~g}, 15 \mathrm{~g} 20 \mathrm{~g}$, and $25 \mathrm{~g}$ ) of the bacteria varies. There is a reduction in all the COD of all the samples after the bioremediation process compared with the COD of the raw samples before the bioremediation. The relative potential or efficiency of the different masses of the bacteria in remediating COD in TAN1, TAN2 and TAN3 samples were in the order $25 \mathrm{~g}>20 \mathrm{~g}>15$ $\mathrm{g}>5 \mathrm{~g}>10 \mathrm{~g}, 25 \mathrm{~g}>20 \mathrm{~g}>15 \mathrm{~g}>10 \mathrm{~g}>5 \mathrm{~g}$ and 10 g>5 g>25 g>15 g>20 g respectively. Statistical analysis shows that there were significant difference $(p<0.05)$ between the mean values of COD among the masses in the respective industries except for effluents treated with $25 \mathrm{~g}$. These might be due to the variations in the surface areas of the different masses of the immobilized bacteria. Negative and insignificant correlations exist between the masses of bacteria and COD with the exception in TAN3 (positive and significant correlation). The negative correlations showed that there is general decrease in the levels of the COD as the masses of the immobilized bacteria increases. TAN2 (100\%) showed a very high correlation with the masses of the bacteria while TAN3 (36\%) showed a very low correlation.

Generally, there was an overall decrease in the concentration of these physicochemical parameters after the bioremediation using the different masses of the bacterial isolates. These might be due to the variations in the surface areas of the different masses of the immobilized bacteria. This is in line with the work of Jimoh et al. (2018) and Baba et al. (2020).

Table 3: Mean Values $(\mathrm{mg} / \mathrm{l}) \pm$ S.D of Physicochemical parameters in effluents from the Tannery Industries before and after Treatment of the effluents $(250 \mathrm{ml})$ with the different masses $(5 \mathrm{~g}, 10 \mathrm{~g}$, $15 \mathrm{~g}, 20 \mathrm{~g}$, and $25 \mathrm{~g}$ ) of the bacteria.

\begin{tabular}{llllllll}
\hline $\mathrm{P}$ & IND & Before & \multicolumn{5}{c}{ After } \\
\cline { 4 - 7 } & & & $5 \mathrm{~g}$ & $10 \mathrm{~g}$ & $15 \mathrm{~g}$ & $20 \mathrm{~g}$ & $25 \mathrm{~g}$ \\
\hline \multirow{2}{*}{ COD } & TAN1 & $2372 \pm 938$ & $1708 \mathrm{a} \pm 861$ & $2045 \mathrm{a} \pm 1205$ & $845 \mathrm{a} \pm 369$ & $300 \mathrm{a} \pm 167$ & $250 \mathrm{a} \pm 154$ \\
& TAN2 & $1406 \pm 208$ & $1195 \mathrm{a} \pm 208$ & $1125 \mathrm{a} \pm 384$ & $1055 \mathrm{a} \pm 317$ & $956 \mathrm{a} \pm 310$ & $870 \mathrm{ab} \pm 240$ \\
& TAN3 & $3532 \pm 1373$ & $2374 \mathrm{a} \pm 1344$ & $1976 \mathrm{a} \pm 1405$ & $2757 \mathrm{a} \pm 1266$ & $3134 \mathrm{a} \pm 1595$ & $2614 \mathrm{~b} \pm 1105$ \\
BOD & TAN1 & $13.85 \pm 6.42$ & $6.92 \mathrm{a} \pm 5.49$ & $6.42 \mathrm{a} \pm 5.07$ & $5.72 \mathrm{a} \pm 5.35$ & $4.62 \mathrm{a} \pm 4.37$ & $2.82 \mathrm{ab} \pm 1.26$ \\
& TAN2 & $19.46 \pm 0.50$ & $1.75 \mathrm{~b} \pm 0.22$ & $1.73 \mathrm{~b} \pm 0.18$ & $1.58 \mathrm{a} \pm 0.16$ & $1.91 \mathrm{a} \pm 0.22$ & $1.56 \mathrm{~b} \pm 0.20$ \\
& TAN3 & $17.13 \pm 3.14$ & $4.24 \mathrm{ab} \pm 0.77$ & $3.29 \mathrm{ab} \pm 0.37$ & $4.11 \mathrm{a} \pm 0.07$ & $3.23 \mathrm{a} \pm 0.91$ & $3.33 \mathrm{a} \pm 1.28$ \\
SS & TAN1 & $374 \pm 124$ & $243 \mathrm{a} \pm 45$ & $471 \mathrm{a} \pm 226$ & $475 \mathrm{a} \pm 182$ & $492 \mathrm{a} \pm 128$ & $611 \mathrm{a} \pm 217$ \\
& TAN2 & $358 \pm 335$ & $460 \mathrm{a} \pm 400$ & $543 \mathrm{a} \pm 414$ & $544 \mathrm{a} \pm 402$ & $551 \mathrm{a} \pm 414$ & $554 \mathrm{a} \pm 405$ \\
& TAN3 & $780 \pm 739$ & $586 \mathrm{a} \pm 594$ & $758 \mathrm{a} \pm 656$ & $787 \mathrm{a} \pm 676$ & $861 \mathrm{a} \pm 635$ & $898 \mathrm{a} \pm 672$ \\
TDS & TAN1 & $3941 \pm 3703$ & $51 \mathrm{a} \pm 10$ & $53 \mathrm{a} \pm 10$ & $55 \mathrm{a} \pm 15$ & $61 \mathrm{a} \pm 20$ & $63 \mathrm{a} \pm 26$ \\
& TAN2 & $3300 \pm 1714$ & $83 \mathrm{a} \pm 78$ & $47 \mathrm{a} \pm 20$ & $48 \mathrm{a} \pm 22$ & $47 \mathrm{a} \pm 17$ & $48 \mathrm{a} \pm 17$ \\
& TAN3 & $2653 \pm 1240$ & $46 \mathrm{a} \pm 11$ & $55 \mathrm{a} \pm 24$ & $55 \mathrm{a} \pm 25$ & $58 \mathrm{a} \pm 23$ & $61 \mathrm{a} \pm 28$ \\
\hline
\end{tabular}

Replicate $=6$ (months)

Within the rows, for the same parameter, means with different alphabets are statistically different $(p<0.05)$.

$\mathrm{P}=$ parameter, IND = Industries 
BAJOPAS Volume 13 Number 2, December, 2020

Table 4: Correlation coefficient $(r)$ between different masses of the bacteria and the physicochemical parameters.

\begin{tabular}{llll}
\hline Industries & Parameter & Correlation coefficient $(r)$ & $\begin{array}{l}\text { Percent dependence (rxrx100) } \\
(\%)\end{array}$ \\
\hline TAN1 & COD & -0.9 & 82 \\
& BOD & -0.97 & 94 \\
& SS & $0.90^{*}$ & 80 \\
TAN2 & TDS & $0.98^{*}$ & 96 \\
& COD & -1 & 100 \\
& BOD & -0.21 & 4 \\
& SS & $0.78^{*}$ & 61 \\
& TDS & -0.69 & 47 \\
& COD & $0.60^{*}$ & 36 \\
& BOD & -0.6 & 37 \\
& SS & $0.95^{*}$ & 90 \\
& TDS & $0.94^{*}$ & 89 \\
\hline
\end{tabular}

The correlation coefficient $(r)$ with * is statistically significant $(p<0.05)$.

Percentage reduction of the Parameters

Table 5 shows the percentage reduction of Parameters in industrial samples before and after the treatment of the effluents $(250 \mathrm{ml})$ with the different masses $(5 \mathrm{~g}, 10 \mathrm{~g}, 15 \mathrm{~g}, 20 \mathrm{~g}$, and $25 \mathrm{~g}$ ) of the Immobilized Bacteria.

In TAN1 samples, the percentage reduction (\%) of COD ranged (14-89); BOD (50-80); SS (-32$35)$ and TDS (98-99). In TAN2 samples, the percentage decrease $(\%)$ of COD ranged (15$38) ;$ BOD (90-92); SS [-28-(-55)] and TDS (9798). In TAN3 samples, the percentage decrease (\%) of COD ranged (11-44); BOD (76-81); SS (15-25) and TDS (98). The percentage increase in the levels COD, BOD and TDS might be due to the increase in the surface area of the different masses of the immobilized bacteria. However, the percentage decrease in the levels of the SS might be due to the aggregation of the TDS which are large enough to result into SS. The percentage decrease in the levels of the SS might be also due to the influence of the nutrients which was added into the effluents in order to make the microorganisms more active and viable for fast degradation of organic contaminants in the effluent. This is in line with the work of Jimoh et al. (2018) in which the concentration of the SS increase after the bioremediation of effluents.

Sreemoyee and Priti (2013) assessed and reduced several Physico-chemical parameters of dairy wastewater using Niesseria $s p$. and concluded that the species are well known to degrade organic compounds. This is in agreement with the current study in which the immobilized Niesseria $s p$ degrade the organic contaminants as indicated by the BOD, COD and TDS.

Jimoh et al. (2018) observed that TSS of the effluents was increased after treatment with immobilized bacteria and concluded that it might be due to the biostimulation method adopted for the research.

The optimum $\mathrm{pH}$ Biosorption of Chromium by Bacillus spp and Staphylococcus spp. from tannery effluent was investigated by Mythili and Karthikeyan (2011). The maximum adsorption of Chromium $(86.4 \mathrm{mg} / \mathrm{L})$ was showed by Bacillus spp and Staphylococcus spp showed $70.6 \mathrm{mg} / \mathrm{L}$ at an initial concentration of $100 \mathrm{mg} / \mathrm{L}$. In the present study, immobilised Bacillus spp and Staphylococcus spp. from the tannery industrial effluents reduced the levels of the organic pollutants with high potential as indicated by the percentage reduction of BOD, COD and TDS.

Enzymes often can work in multiple environments especially if they are immobilized. This makes the microorganisms' enzymes even more resistant to harsh environments and enables the enzymes to be recovered and recycled after they are no longer needed (Gianfreda and Rao 2004). Ramesh and Singh (1993) reported that the immobilized bacteria having more efficiency to remove the suspended particles than free cells. Using the immobilized cell is preferable due to its capability for using several times with the same efficiency, which makes it more economical. Similar work was done by Sikander et al. (2007) showing the higher reduction with permeabilized cells of Ochrobactrum intermedium strain SDCr-5. 
BAJOPAS Volume 13 Number 2, December, 2020

The results revealed the isolation and identification of isolates with the potential for the reduction of $\mathrm{Cr}$ (VI) to $\mathrm{Cr}$ (III). Results indicated that immobilized $B$. cereus could be efficiently used for the reduction of $\mathrm{Cr}$ (VI).

Table 5: Percentage reduction of the tested Parameters from the tannery industrial samples of the Immobilized Bacteria.

\begin{tabular}{lllllll}
\hline \multirow{2}{*}{ Industries } & & \multicolumn{5}{c}{ Percentage Reduction $(\%)$} \\
\cline { 3 - 7 } & & $5 \mathrm{~g}$ & $10 \mathrm{~g}$ & $15 \mathrm{~g}$ & $20 \mathrm{~g}$ & $25 \mathrm{~g}$ \\
\hline TAN1 & COD & 28 & 14 & 64 & 87 & 89 \\
& BOD & 50 & 54 & 59 & 67 & 80 \\
& SS & 35 & -26 & -27 & -32 & -63 \\
& TDS & 99 & 99 & 99 & 98 & 98 \\
TAN2 & COD & 15 & 20 & 25 & 32 & 38 \\
& BOD & 91 & 91 & 92 & 90 & 92 \\
& SS & -28 & -52 & -52 & -54 & -55 \\
& TDS & 97 & 99 & 99 & 99 & 99 \\
& COD & 33 & 44 & 22 & 11 & 26 \\
& BOD & 75 & 81 & 76 & 81 & 81 \\
& SS & 25 & 3 & -1 & -10 & -15 \\
& TDS & 98 & 98 & 98 & 98 & 98 \\
\hline
\end{tabular}

Percentage Reduction $=(B-A) / B \times 100 \%$

$A=$ Concentration of the parameter after treatment

$\mathrm{B}=$ Concentration of the parameter before treatment

$+=$ percentage decrease

- = percentage increase

In general, immobilization makes the enzyme more resistant to temperature, $\mathrm{pH}$, and substrate concentration swings giving it a longer lifetime and higher productivity per active unit (Gianfreda and Rao, 2004; FuIlbrook, 1996; Russell et al, 2003; Kandelbauer et al., 2004). Immobilized cells have been used and studied extensively for the production of useful chemicals (Ohtake and Silver, 1994), the treatment of wastewaters (Chen et al., 2003; Wang et al., 2010). Although many workers described microbial degradation of tannery effluent, limited literature is available on the bioremediation of tannery effluent using immobilized bacterial cells in the Kano Industrial Estates.

\section{CONCLUSION}

The samples contained variable levels of the physicochemical parameters. The results of the Analysis of variance revealed that, no statistical difference $(p<0.05)$ was observed for the temperature, $\mathrm{pH}, \mathrm{SS}, \mathrm{TDS}, \mathrm{BOD}$ and $\mathrm{COD}$ among the three tannery industries before the treatment. The levels of some of the parameters
(SS, TDS and COD) observed in the samples were found above the recommended limits of WHO and NESREA, which called for the treatment of the effluents before discharge into the environment. Base on the morphological and biochemical test results, TAN1, TAN2, and TAN3 bacterial isolates were identified to be Neisseria spp, Bacillus cereus, and Staphylococcus aureus respectively. The results of Post-treatment analysis showed that there is overall decrease in the levels of the parameters determined when compared with that of the pre-treatment. The overall percentage reduction of the immobilised bacteria in the treatment of the respective effluents was in the order TAN2 (72\%)>TAN1 $(70 \%)>$ TAN3 $(62 \%)$. Hence, the immobilized bacteria are having higher biodegradation potential for the treatment of the tannery effluents.

\section{Acknowledgments}

The authors wish to acknowledge the University of Maiduguri for the financial support. The authors are grateful to the Kano State Ministry of Environment for their support in obtaining the effluent samples. 


\section{REFERENCES}

Ajao, A. T., Adebayo, G. B., and Yakubu, S. E. (2011). Bioremediation of textile industrial effluent using mixed culture of Pseudomonas aeruginosa and Bacillus subtilis immobilized on agar-agar in a bioreactor. J. Microbiol. Biotech. Res, 1(3), 50-56.

Akan, J. C., Moses, E. A., Ogugbuaja, V. O., and Abah, J. (2007). Assessment of tannery industrial effluents from Kano metropolis, Kano State, Nigeria. Journal of Applied Sciences, 7(19), 2788-2793.

Akan, J. C., Ogugbuaja, V. O., Abdulrahman, F. I., and Ayodele, J. T. (2009). Pollutant levels in effluent samples from tanneries and textiles of Kano industrial areas, Nigeria. Global journal of pure and applied sciences, 15(3-4).

APHA (1989). Standard methods for Examination of Will bete and Will betewater.15 $5^{\text {th }}$ edition. Brydpass Springfield Will behington DC. pp. 164-176

APHA (1992). Standard Methods for the Examination of Water and Wastewater. Health, 69, 1116-9.

Baba, A., Garba, S. T., and Bello, H. S. (2020). Bioremediation Potential of Immobilized corynebacterium kutsceri in the Treatment of Tannery Industrial Effluent from Challawa Industrial Estate, Kano State, Nigeria. Journal of the Turkish Chemical Society Section A: Chemistry, $7(2), 335-350$.

Beem, E. I. V. (1994). reduction of solvent VOC emission. J. Oil Col. Chem. Ass, 77, 158.

Bouwer, E. J., and Zehnder, A. J. (1993). Bioremediation of organic compoundsputting microbial metabolism to work. Trends in biotechnology, 11(8), 360367.

Chen, K. C., Wu, J. Y., Liou, D. J., and Hwang, S. C. J. (2003). Decolorization of the textile dyes by newly isolated bacterial strains. Journal of Biotechnology, 101(1), 57-68.

Dan'Azumi, S., and Bichi, M. H. (2010). INDUSTRIAL POLLUTION AND HEAVY METALS PROFILE OF CHALLAWA RIVER IN KANO, NIGERIA. Journal of Applied Sciences in Environmental Sanitation, $5(1)$.

DWAF. (1992). Analytical Methods Manual, TR 151. Department of Water Affairs and Forestry, Pretoria.

El-Bestawy, E. (2013). Biological treatment of leather-tanning industrial wastewater using free living bacteria.
Elsheikh, M. A. S. (2009). Tannery wastewater pre-treatment. Water Science and Technology, 60(2), 433-440.

FuIlbrook, P. D. (1996). "Kinetics." Industrial enzymology: The application of enzymes in Industry. 2nd Ed. T. Godfrey and J Reichelt. eds.. Nature. New York.

Gianfreda, L., and Rao, M. A. (2004). Potential of extra cellular enzymes in remediation of polluted soils: a review. Enzyme and microbial technology, 35(4), 339354.

Hugo Springer. (1994). John Arthur Wilson Memorial Lecture "Treatment of Industrial Wastes of the Leather Industry - is it still a Major Problem". JALCA, 89, 153-185

Jimoh, A. A., Ganiyu, B. A., Baba, D., and Baba, A. (2018) Bioremediation Process of Effluent from Detergent and Food Industries in Jos, Nigeria: Kinetics and Thermodynamics. International Journal of Engineering Science Invention (IJESI), 762-73

Kandelbauer, A., Maute, O., Kessler, R. W., Erlacher, A., and Gübitz, G. M. (2004). Study of dye decolorization in an immobilized laccase enzyme-reactor using online spectroscopy. Biotechnology and bioengineering, 87(4), 552-563.

Kongjao, S., Damronglerd, S., and Hunsom, M. (2008). Simultaneous removal of organic and inorganic Pollutants in tannery wastewater using electrocoagulation technique. Korean Journal of chemical engineering, 25(4), 703.

Maheshwari, U. M., Aruna, S., Gomathi, M., and AbdulJaffar, A. H. (2017). Bioremediation by Free and Immobilized Bacteria Isolated from Tannery Effluent. International Journal of Research in Applied, Natural and Social Sciences. 5(7), 75-90

Margesin, R., and Schinner, F. (2001). Bioremediation (natural attenuation and biostimulation) of diesel-oilcontaminated soil in an alpine glacier skiing area. Applied and environmental microbiology, 677), 3127-3133.

Mohammed, A., Sekar, P., and George, J. (2011). Efficacy of microbes in bioremediation of tannery effluent. Inter. J. Curr. Res, 3(4), 324-326.

Mohammed, S. S. D., Orukotan, A. A., and Abdullahi, H. (2017). Physicochemical and Bacteriological Assessment of Tannery Effluent from Samaru-Zaria, 
BAJOPAS Volume 13 Number 2, December, 2020 Kaduna State, Nigeria. Journal of Applied

Sciences and Environmental Management, 21(4), 734-740.

Munz, G., De Angelis, D., Gori, R., Mori, G., Casarci, M., and Lubello, C. (2009). The role of tannins in conventional and membrane treatment of tannery wastewater. Journal of hazardous materials, 164(2-3), 733-739

Mythili, K., and Karthikeyan, B. (2011). Bioremediation of $\mathrm{Cr}$ (VI) from tannery effluent using Bacillus spp and Staphylococcus spp. International Multidisciplinary Research Journal, 1(6).

NESREA (2009). National Environmental Standards for Effluent Limitations and Regulation. 1233-1236

Noorjahan, C. M. (2014). Physicochemical characteristics, identification of bacteria and biodegradation of industrial effluent. Journal of bioremediation and Biodegradation, 5(3).

Ohtake, H. I., and Silver, A. O. (1994). Bacterial reduction of toxic chromate. Biological degradation and bioremediation of toxic chemicals, 403-415.

Omoleke, I. I. (2004). Management of environmental pollution in Ibadan, an African city: the challenges of health hazard facing government and the people. Journal of Human Ecology, 15(4), 265-275.

Rajor, A., Reddy, A.S., and Singh, B. (2004). Determination of BOD kinetic Parameters and evaluation of alternate methods, M.Sc. Thesis, Department of biotechnology \& environmental Science, Thapar Institute of Engineering and Technology, Patiala

Ramasami, T., Rajamani, S., and Rao, J. R. (1994, March). Pollution control in leather industry: Emerging technological options. In International symposium on surface and colloidal science and its relevance to soil pollution, madras.

Ramesh, J. V. S., and Singh, S. P. (1993). Yearly variation in certain physicochemical parameters of pond at eastern Doon Valley. Uttar Pradesh J. Zoo, 12 (1), 7577.

Ranen, S., and Sharadinadra, C. (2009). Biotechnology applications to environmental remediation in resource exploitation. Current science, 97, 6-25
Russell, A. J., Berberich, J. A., Drevon, G. F., and Koepsel, R. R. (2003). Biomaterials for mediation of

chemical and biological warfare agents. Annual review of biomedical engineering, 5(1), 1-27.

Saravanan, P., and Saravanan, A. (1999). Decolourization of tannery effluent by Flavobacterium sp. EK 1. Indian Journal of Environmental Protection, 19, 19-24.

Sikander, S., and Shahida, H. (2007). Reduction of toxic hexavalent chromium by Ochrobactrum intermedium strain SDCr5 stimulated by heavy metals. Bioresource Technol, 98, 340-344.

Singh, N., Sharma, B. K., and Bohra, P. C. (2000). Impact assessment of industrial effluent of arid soils by using satellite imageries. Journal of the Indian Society of Remote Sensing, 28(2-3), 79.

Sreemoyee, C., and Priti, P. (2013). Assessment of physico-chemical parameters of dairy waste water and isolation and characterization of bacterial strains in terms of cod reduction. Int J Sci, 2(3), 395-400.

Verheijen, L. A. H. M., Wiersema, D., Pol, L. H., and De Wit, J. (1996). Management of wastes from animal product processing. Livestock and environment, Finding a balance. International Agriculture Center, Wageningen, The Netherlands.

Wang, F., Yao, J., Si, Y., Chen, H., Russel, M., Chen, K., and Bramanti, E. (2010). Short-time effect of heavy metals upon microbial community activity. Journal of Hazardous Materials, 173(13), 510-516.

WHO (World Health Organization). (2006). Air quality guidelines: global update 2005: particulate matter, ozone, nitrogen dioxide, and sulfur dioxide. World Health Organization.

World Bank. (1995). Nigeria's strategic options for redressing industrial pollution. World Bank, industry and energy division. 1st edition, West Central Africa Department; Annexes: 1995; pp 60-62.

Zahoor, A., and Abdul, R. (2009). Enumeration of Coliforms. Journal of Environmental Sciences. 21, 814-820 


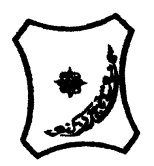

Bayero Journal of Pure and Applied Sciences, 13(2): 1 - 12

Received: November, 2020

Accepted: December, 2020

ISSN $2006-6996$

\title{
BIODEGRADATION POTENTIAL OF IMMOBILIZED BACTERIA IN THE TREATMENT OF TANNERY INDUSTRIAL EFFLUENTS FROM INDUSTRIAL ESTATES IN KANO STATE, NIGERIA
}

\author{
Abdullateef, B., ${ }^{1 *}$ Shuaibu, T. G., ${ }^{1}$ Babagana, K., ${ }^{1}$ Suleman, H. B. ${ }^{2}$ and Dauda, B. ${ }^{3}$ \\ ${ }^{1}$ Department of Pure and Applied Chemistry, Faculty of Science, University of Maiduguri, Borno State, \\ Nigeria \\ ${ }^{2}$ Department of Microbiology, Faculty of Science, University of Maiduguri, Borno State, Nigeria \\ ${ }^{3}$ Department of Chemical Engineering, Faculty of Engineering, University of Maiduguri, Borno State, \\ Nigeria \\ *Corresponding author: babslega@gmail.com; abelega2007@yahoo.com; +2348061309753
}

\section{ABSTRACT}

Industrial Effluents Samples from Gashash Tanneries (TAN1) in Bompai Industrial estate, Larabee Tannery Industry (TAN2) in Sharada Industrial estate and Z Tannery Industries (TAN3) in Challawa Industrial estate, Kano State, Nigeria were collected over a period of six months (August 2017 to January 2018) for assessing the biodegradation potentials of bacteria in the treatment of organic pollutants within the effluents. Bacteria were isolated from the effluents and immobilized on agar-agar. Different masses (5 g, $10 \mathrm{gr}, 15$ $\mathrm{g}, 20 \mathrm{~g}$, and $25 \mathrm{~g}$ ) of the bacteria were used in the treatment of $250 \mathrm{ml}$ of the effluents for ten days in a shaker incubator (Gallenkamp-OC-4364-L) at the temperature $30{ }^{\circ} \mathrm{C}$ and speed of $60 \mathrm{rpm}$. Pre-treatment analysis of the effluents for Temperature, pH, Biochemical Oxygen Demand (BOD), Chemical Oxygen Demand (COD), Suspended Solid (SS) and Total Dissolved Solids (TDS) gives the following results; temperature $\left({ }^{\circ} \mathrm{C}\right.$ )

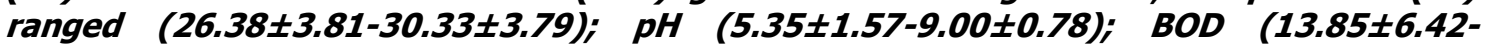
$38.75 \pm 16.20) ;$ COD (1406 $\pm 208-3532 \pm 1373) ;$ SS (208 $\pm 235-780 \pm 739)$ and TDS (266 $\pm 253-5276 \pm 2971)$. No statistical differences ( $p \leq 0.05)$ was observed for all the results among the different industries. The bacterial isolates were identified as Neisseria spp, Bacillus cereus, and Staphylococcus aureus, in TAN1, TAN2, and TAN3, respectively. After treatment of the effluent with the different masses of the isolated bacteria, the mean level of BOD was found to range as (0.55 $\pm 0.36-6.92 \pm 5.49) ; C O D$ (ND-3134 \pm 1595$)$;

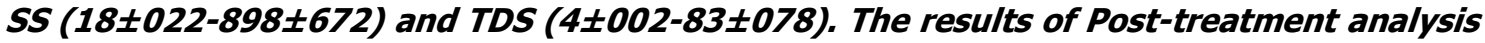
showed that there is overall decrease in the levels of the parameters determined when compared with that of the pre-treatment. The overall percentage reduction of the immobilised bacteria in the treatment of the respective effluents was in the order TAN2 (72\%)>TAN1 (70\%)>TAN3 (62\%). Hence, the immobilized bacteria are having higher biodegradation potential for the treatment of the tannery effluents.

Keywords: Biodegradation, bacteria, effluent, immobilization, tannery.

\section{INTRODUCTION}

Tannery industrial wastewater is a serious consequence of the pollution point of view for streams, freshwater, and land used for agriculture. The lack of awareness in the modern industrial practice has resulted in the discharge of tannery effluents which exhibit very high value of chromium ( $\mathrm{Cr}$ ), Sulfide, and chloride, Total Dissolved Solid (TDS), Total Suspended Solid (TSS), Biochemical Oxygen Demand (BOD) and Chemical Oxygen Demand (COD) in the water stream or land (Mohammed et al., 2001). Tanning is the process, which One ton of skin generally leads to the production of 20 to $80 \mathrm{~m}^{3}$ of turbid and foul-smelling converts the protein of the rawhide or skin into a stable material, which will not putrefy and is suitable for a wide variety of end applications (Elsheikh, 2009). The highly polluting chromium is the most commonly used tanning material producing leather that is more flexible and pliable than vegetable-tanned leather and does not discolor or lose shape in water as drastically as vegetable-tan (Elsheikh, 2009). Tannery effluent is among the most hazardous industrial pollutants due to its huge organic and inorganic load, which is highly toxic to human life and the environment (Kongjao et al., 2008). wastewater including chromium (100-400 mg/l), sulfide $(200-800 \mathrm{mg} / \mathrm{l})$, high levels of fat and 
BAJOPAS Volume 13 Number 2, December, 2020 other solid wastes, and notable pathogen contamination as well as pesticides added for skin conservation during transport (Elsheikh, 2009). There are more than 6000 tanneries in Nigeria with an annual processing capacity of 700,000 tons of hides and skins (Omoleke, 2004; Singh et al., 2008). It was reported that the total amount of waste produced per animal slaughtered is approximately $35 \%$ of its weight (World Bank, 1995). Also, for every $1000 \mathrm{~kg}$ of carcass weight, a slaughtered beef produces 5.5 $\mathrm{kg}$ of manure (excluding rumen contents or stockyard manure) and $100 \mathrm{~kg}$ of paunch manure (undigested food) (Verheijen et al., 1996). Tanneries generate wastewater in the range of 30-35 $\mathrm{L} \mathrm{kg}^{-1}$ skin/hide processed with variable $\mathrm{pH}$, Biological Oxygen Demand (BOD), Chemical Oxygen Demand (COD), high concentrations of suspended solids (SS), and tannins as well as chromium (Zahoor and Abdul, 2009).

Being heterogeneous and composed of a wide variety of compounds, it is very difficult to select a unique direct method for estimating the biodegradability of organic contents and biokinetic parameters for a wastewater sample (Rajor, 2004). For this purpose, some indirect estimation such as determination of biochemical oxygen demand (BOD) and chemical oxygen demand (COD) are applied as common laboratory investigations [9]. During retanning procedures, synthetic tannins (Syntan), oils and resins are added to form softer leather at varying doses (Munz et al., 2009). One of the refractory groups of chemicals in tannery effluents derives mainly from tannins (Ramasami et al., 2004). Syntans are characterized by complex chemical structures, because they are composed of an extended set of chemicals such as phenol-, naphthalene-, formaldehyde- and melamine-based syntans, and acrylic resins (Beem, 1994). Organic pollutants (proteic and lipidic components) are originated from skins (it is calculated that the raw skin has $30 \%$ loss of organic material during the working cycle) or they are introduced during processes (Hugo Springer, 1994).

Many conventional processes such as oxidation, chemical and biological processes were carried out to treat tanneries wastewater (Ebtesam et al, 2013). Biological processes have received more attention because of their costeffectiveness, lower sludge production and environmental friendliness (Noorjahan, 2014). Naturally occurring micro-organisms degrade the hazardous organic wastes including xenobiotic compounds, such as pesticides, polycyclic aromatic hydrocarbons (PAHs) and polychlorinated biphenyls (PCBs) in due course of time (Ranen and Sharadinadra, 2009). Bioremediation is based on the idea that all organisms remove substances from the environment to carry outgrowth and metabolism (Bouwer and Zehnder, 1993). Bacteria, protista and fungi are found to be very good at degrading complex molecules and incorporating the breakdown products into their metabolism (Bouwer and Zehnder, 1993). The resultant metabolic wastes that they produce are generally safe and somehow recycled into other organisms (Ranen and Sharadinadra, 2009). An acclimatized indigenous population of microorganisms capable of degradation of the compounds of interest must exist at the site for a successful bioremediation mode (Ranen and Sharadinadra, 2009). It has been observed that for a successful bioremediation mode, an acclimatized indigenous population of microorganisms capable of degradation of the compounds of interest must exist at the site under investigation (Ranen and Sharadinadra, 2009). Even though there are numerous physical and chemical methods employed in the disposal of wastes the advantage in using bacterium is that they play a key role in the reduction of COD, BOD, total protein, total tannin and total phenol (Saravanan and Saravanan, 1998)

Baba et al. (2020) studied the bioremediation potential of immobilized corynebacterium kutsceri in the Treatment of tannery industrial effluent from Challawa Industrial Estate, Kano State, Nigeria. The aim of the work is to study the reduction in the level of the contaminants through the process of bioremediation using the isolated bacteria. Immobilized bacteria can withstand various temperatures, $\mathrm{pH}$ and substrate concentrations; consequently, increasing the efficiency and the lifespan of the bacteria. Immobilized bacteria are widely applied in the treatment of wastewater and can be separated and recovered after the treatment with the same efficiency (Baba et al., 2020).

\section{MATERIALS AND METHODS \\ Study Area}

This study was carried out in Bompai, Sharada and Challawa industrial estates in Kano, Figure 1. Kano lies on Latitude $11^{\circ} 30^{\prime} \mathrm{N}$ and $8^{\circ} 30^{\prime} \mathrm{E}$ and Longitude $11^{\circ} 5^{\prime} \mathrm{N}$ and $8^{\circ} 5^{\prime} \mathrm{E}$ in Northern Nigeria. It is one of the developed industrial cities in Nigeria. Tannery activities are the dominating industries and this could be one of the reasons for her high population density (Dan'Azumi and Bichi, 2010). Many researchers have studied biodegradation of tannery effluent using microorganisms. However, limited literature is available on the biodegradation of tannery effluent in Kano industrial estates using 
BAJOPAS Volume 13 Number 2, December, 2020 immobilized bacterial cells. This research work focuses on the potential of the use of the indigenous immobilized bacterial isolates in the treatment of tannery effluents in the industrial estates.

\section{Sample Collection}

Effluents were collected from the Tannery Industries from Bompai, Challawa and Sharada Industrial Estates, Kano, Nigeria. The effluents were collected over a period of six months (August 2017 to January 2018). Samples collected in a sterile 4-liter plastic container with a unique identification number were preserved using an ice-box that was transported to the Microbiology Laboratory, Department of Microbiology, Bayero University of Kano for analysis

\section{Sample Preparation and Sample Analysis}

Immediately after the collection of the effluent, $\mathrm{pH}$, TSS, TDS, COD, BOD levels were determined before treatment (Pre-treatment determination) and ten days after treatment (Post-treatment determination) as described in
APHA (1989) standard methods. $\mathrm{pH}$ was determined using Ecotests $\mathrm{pH}$ meter and TDS was determined using AQUALYTIC TDS Salinometer. BOD was determined as described by the standard method (APHA, 1992). COD and SS were determined using DR/2010 HACH portable data logging spectrophotometer (DWAF, 1992)

\section{Identification and Biochemical} Characterization of the Bacterial Isolates

The bacteria were isolated from the effluents using Serial Dilution according to the method described by APHA (1989). The biochemical tests such as oxidase, catalase, coagulase, indole (from $1 \%$ tryptone broth), citrate (Simmons citrate agar), methyl red/VogesProskauer (MR/VP), nitrate reduction, Starch Hydrolysis, Glucose, Maltose, and Lactose tests were carried out on the bacterial isolates to identify the bacteria through the bacteria biochemical characteristics according to Ajao et al. (2011).

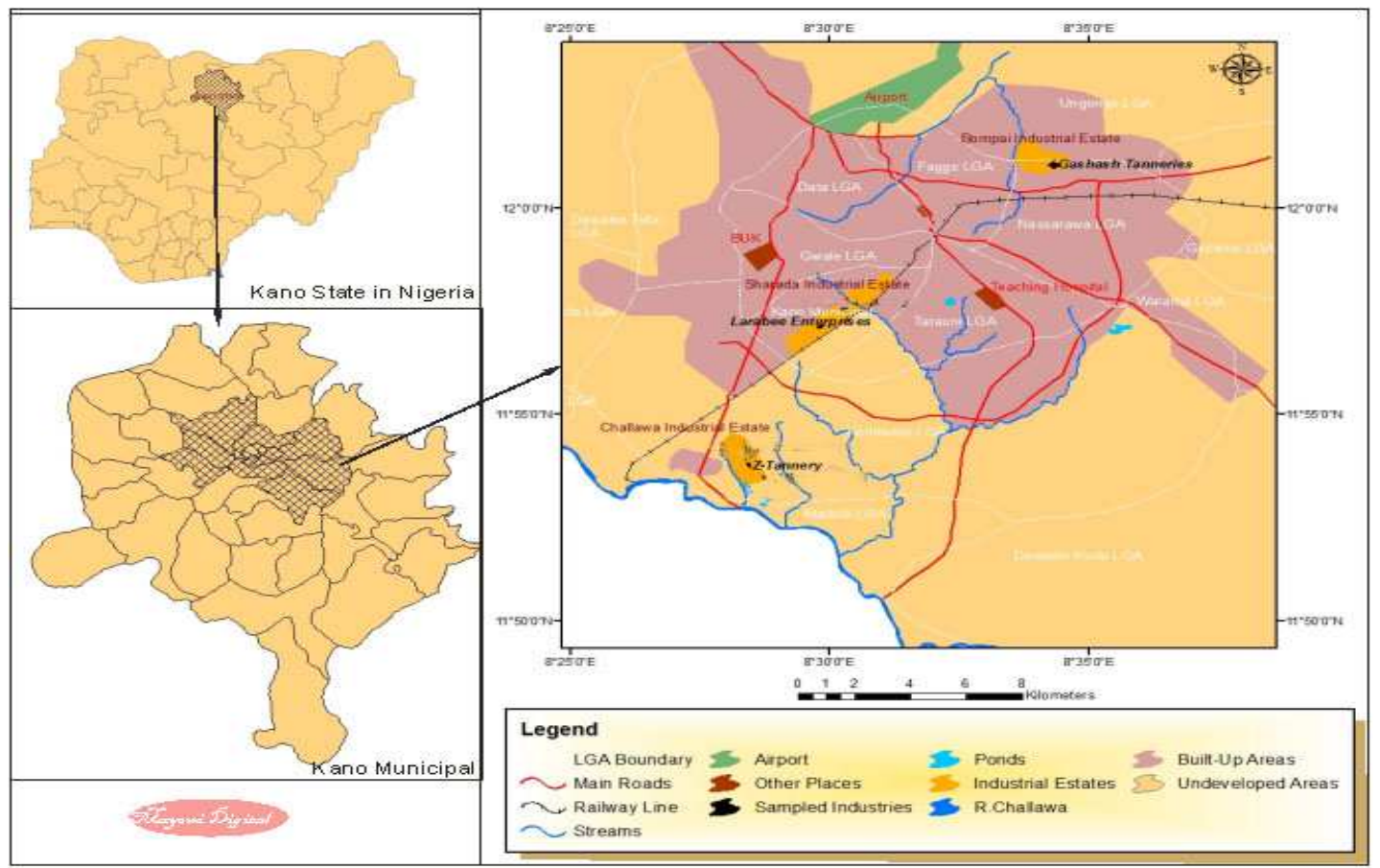

Fig. 1 Map showing the study areas

Source: Mayomi Digital Productions, GIS Laboratory, Department of Geography, UNIMAID (2017)

\section{Determination of Growth Rate of the Bacteria in Effluent Sample}

The bacteria growth rates were determined by transferring $2 \mathrm{~mL}$ of the bacterial isolates from the tannery effluent in broth medium into 100 $\mathrm{mL}$ sterile effluents in conical flasks and kept in an incubator (Giffrin cool) for 10 days. Control was also set up by incubating another $100 \mathrm{~mL}$ each of the sterile effluents without the bacteria. The optical density of the content was determined at the wavelength of $600 \mathrm{~nm}$ on a daily interval and recorded. 
BAJOPAS Volume 13 Number 2, December, 2020 Immobilization of Bacteria

Agar solution and inoculi were prepared separately. Fifty milliliters $(50 \mathrm{~mL})$ of nutrient broth each of the inoculi was prepared in a McCartney bottle and incubated for 24 hours. A solution of agar-agar was prepared by dissolving $10 \mathrm{~g}$ of the powder in distilled water and made up to $500 \mathrm{~mL}$ mark in an Erlenmeyer flask and was sterilized in an autoclave (280A) for 15 minutes and allowed to cool to $40-45^{\circ} \mathrm{C}$ (Ajao et al., 2011). Four milliliters ( $4 \mathrm{~mL})$ of the bacterial isolates in the nutrient broth was mixed with 36 $\mathrm{ml}$ of the prepared agar-agar media in petri-dish plates and then allowed to solidify. This was kept in the refrigerator for bioremediation.

\section{Bioremediation (Treatment) of the Effluents}

The solidified agar block (immobilized bacteria) was cut into cubes using a sterile knife; $0.1 \mathrm{~mL}$ phosphate buffer ( $\mathrm{pH} \mathrm{7.0)}$ was added and kept in the refrigerator for 1 hour for curing. The phosphate buffer was decanted after 1 hour and the cubes were washed with sterile distilled water 3-4 times before it was used (Ajao et al., 2011). Two liters (2 L) of the effluent was supplemented with the minimum basal medium in $\mathrm{g} / \mathrm{L}: \mathrm{NaCl}(0.8), \mathrm{MgSO}_{4} .7 \mathrm{H}_{2} \mathrm{O}(0.001), \mathrm{KH}_{2} \mathrm{PO}_{4}$ (2), $\mathrm{NaNO}_{3}$ (2), $\quad \mathrm{CaCl}_{2} .2 \mathrm{H}_{2} \mathrm{O} \quad(0.5)$ and $\mathrm{NaHPO}_{4} .12 \mathrm{H}_{2} \mathrm{O}(2)$ and sterilized in an autoclave at $121^{\circ} \mathrm{C}$ for 15 minutes (Margesin and Schinner, 2001). Two hundred and fifty milliliters $(250 \mathrm{~mL})$ of the effluents were transferred into different $250 \mathrm{ml}$ conical flasks. The content was covered with a cotton-wool ramped with foil paper to avoid contamination. Five grams $(5 \mathrm{~g})$ of the immobilized bacteria were quickly transferred into each of the effluents in the conical flasks in an inoculating chamber. The same procedures were carried out for the $10 \mathrm{~g}, 15 \mathrm{~g}, 20 \mathrm{~g}$ and 25 $\mathrm{g}$ of the immobilized bacteria in separate $250 \mathrm{~mL}$ effluents in conical flasks and agitated for ten days in a shaker incubator (Gallenkamp-OC4364-L) at a temperature $30^{\circ} \mathrm{C}$ and speed of 60 rpm. The treated effluent samples were taken on the tenth day and analyzed for the parameters $\mathrm{pH}$, SS, TDS, COD, and BOD, (Posttreatment determination) for the different grams of bacteria to evaluate and compare the biodegradation potential. (Baba et al., 2020).

\section{Statistical Analysis}

The data were represented as Mean \pm Standard deviation and analyzed statistically using oneway Analysis of Variance (ANOVA) and Tukey's HSD as Post Hoc Tests with the aid of SPSS 16.0. The correlation coefficient was also used to measure the strength of the relationship between the different masses of the bacteria and the parameters. All $\mathrm{p} \leq 0.05$ were considered as statistically significant.

\section{RESULTS AND DISCUSSION Physico-chemical parameters in the Industrial Effluents before the Biodegradation.}

Results of the Physico-chemical parameters in the industrial effluents before the Biodegradation is shown in table 1 . The mean temperatures $\left({ }^{\circ} \mathrm{C}\right)$ observed in TAN1, TAN2, and TAN3 samples were $28.07 \pm 0.65 ; 27.77 \pm 0.64$ and $26.38 \pm 3.81$ respectively. The order of the mean temperature of the samples from the three industries can be arranged as TAN1 > TAN2>TAN3. The temperature observed at TAN1, TAN2, and TAN3 samples were found below the WHO $\left(35^{\circ} \mathrm{C}\right)$ and NESREA $\left(40^{\circ} \mathrm{C}\right)$ limits. The low values of temperature might be due to the processes used at the time of sampling. High temperature brings down the solubility of gases in water that ultimately expresses as high BOD and COD. Statistical analysis shows that there is no significant difference $(p<0.05)$ between the mean values of temperature among the industries. This might be due to similar tannery activities involved in the tannery industries at the time of sampling. The average values of temperature observed in this present study are less than those observed by Akan et al. (2007), Akan et al. (2009) and Baba et al. (2020).

The mean level of $\mathrm{pH}$ observed in TAN1, TAN2 and TAN3, samples were $7.77 \pm 2.93$; $8.35 \pm 0.28$ and $7.52 \pm 0.76$ respectively. The order of the mean $\mathrm{pH}$ of the samples from the three industries can be arranged as TAN2> TAN1 $>$ TAN3. The $\mathrm{pH}$ of the samples falls within the WHO (7.0-8.5) and NESREA (6-9) standard limits. Statistical analysis shows that there is no significant difference $(p<0.05)$ between the mean values of $\mathrm{pH}$ among the industries. This might be due to similar tannery activities involved in the tannery industries at the time of sampling. Maheshwari et al. (2017) reported that the level of $\mathrm{pH}$ in the effluents from the tannery industry in Vaniyambadi, India was 6.5 which was lower than that observed in the present study. The $\mathrm{pH}$ in the effluents from the tannery industries in Kano and Kaduna were reported to be 7.64 and 6.89, respectively (Akan et al., 2007; Mohammed et al., 2017). The average values of $\mathrm{pH}$ observed in this present study are less than those observed by Mohammed et al. (2017) and Baba et al. (2020). The mean level of SS $(\mathrm{mg} / \mathrm{l})$ observed in TAN1, TAN2, and TAN3 samples were 374 \pm 124 ; $358 \pm 335$ and $780 \pm 739$ respectively. The order of the mean SS in the samples from the three industries can be arranged as TAN3 > TAN1 $>$ TAN2. 
The SS observed in the samples were far above the recommended standard limits of regulating bodies WHO $(30 \mathrm{mg} / \mathrm{l})$ and NESREA $(10 \mathrm{mg} / \mathrm{l})$. Statistical analysis shows that there is no significant difference $(p<0.05)$ between the mean values of SS among the industries. This might be due to similar tannery activities involved in the tannery industries at the time of sampling. The average values of SS observed in this present study are less than that observed $(3700 \pm 122 \mathrm{mg} / \mathrm{l})$ by Akan et al. (2009) for tanneries in Kano. Also, the average values of SS observed in this present study are less than that observed by Mohammed et al. (2017) and Baba et al. (2020) with the exception in TAN3.

The mean level of TDS (mg/l) observed in TAN1, TAN2, and TAN3 samples were $3941 \pm 3703$; $3300 \pm 1714$ and $2653 \pm 1240$ respectively. The order of the mean TDS in the samples from the three industries can be arranged as TAN1>TAN2>TAN3. The TDS observed in the samples were far above the recommended standard limits of WHO $(250 \mathrm{mg} / \mathrm{l})$ and NESREA $(500 \mathrm{mg} / \mathrm{l})$. Statistical analysis shows that there is no significant difference $(p<0.05)$ between the mean values of TDS among the industries. This might be due to similar tannery activities involved in the tannery industries at the time of sampling. TDS in the effluents from the tannery industries in Kano, Nigeria was reported to be $1281 \mathrm{mg} / \mathrm{l}$ (Akan et al., 2007). The average values of SS observed in this present study are less than those observed by Mohammed et al. (2017) and Baba et al. 2020)

The mean level of COD (mg/l) observed in TAN1, TAN2 and TAN3 samples seasons were $2372 \pm 938 ; \quad 1406 \pm 208$ and $3532 \pm 1373$ respectively. The order of the mean COD of the samples from the three industries can be arranged as TAN3>TAN1> TAN2. The COD observed in TAN1, TAN2 and TAN3 samples were far above the recommended standard limits of regulating bodies $\mathrm{WHO}(40 \mathrm{mg} / \mathrm{l})$ and NESREA (40 mg/l). Statistical analysis shows that there is no significant difference $(p<0.05)$ in COD among the industries. This might be due to similar tannery activities involved in the tannery industries as at the time of sampling. The Chemical Oxygen demand (COD) is the amount of oxygen, in $\mathrm{mg} / \mathrm{L}$, required for the degradation of the compound of wastewater to occur. In comparison, the average values of COD observed in this present study were higher than that observed by Mohammed et al. (2017) but lower than that observed by Baba et al. (2020).

The mean levels of BOD $(\mathrm{mg} / \mathrm{l})$ observed in TAN1, TAN2 and TAN3 samples were $13.85 \pm 6.42 ; \quad 19.46 \pm 0.50$ and $17.13 \pm 3.14$ respectively. The order of the mean BOD in the samples from the three industries can be arranged as TAN2>TAN3>TAN1. The BOD observed in TAN1, TAN2 and TAN3 samples were found below the recommended limits of NESREA (200 mg/l) but above WHO (10 mg/l). Statistical analysis shows that there is no significant difference $(p<0.05)$ between the mean values of BOD among the industries. This might be due to similar tannery activities involved in the tannery industries at the time of sampling. The low level of BOD recorded in this study is an indication of the low level of biodegradable organic solids in the effluent. The average values of BOD observed in this present study were lower than those observed by Mohammed et al. (2017) and Baba et al. (2020).

Table 1: Mean Values \pm S.D of Physico-chemical parameters of effluents from the Tannery Industries before Treatment.

\begin{tabular}{llllllll}
\hline Parameter & Tannery 1 & Tannery 2 & Tannery 3 & $\mathrm{a}$ & $\mathrm{b}$ & $\mathrm{c}$ & $\mathrm{d}$ \\
\cline { 2 - 7 } Temperature $\left({ }^{\circ} \mathrm{C}\right)$ & $28.07 \mathrm{a} \pm 0.65$ & $27.77 \mathrm{a} \pm 0.64$ & $26.38 \mathrm{a} \pm 3.81$ & & $29.50 \pm 4.68$ & 35 & 40 \\
pH & $7.77 \mathrm{a} \pm 2.93$ & $8.35 \mathrm{a} \pm 0.28$ & $7.52 \mathrm{a} \pm 0.76$ & 6.89 & $5.35 \pm 1.57$ & $7.0-8.5$ & $6.0-9.0$ \\
$\mathrm{COD}(\mathrm{mg} / \mathrm{l})$ & $2372 \mathrm{a} \pm 938$ & $1406 \mathrm{a} \pm 208$ & $3532 \mathrm{a} \pm 1373$ & 2.2 & $3106 \pm 2753$ & 40 & 40 \\
$\mathrm{BOD}(\mathrm{mg} / \mathrm{l})$ & $13.85 \mathrm{a} \pm 6.42$ & $19.46 \mathrm{a} \pm 0.50$ & $17.13 \mathrm{a} \pm 3.14$ & 1032 & $26.17 \pm 9.49$ & 10 & 200 \\
$\mathrm{SS}(\mathrm{mg} / \mathrm{l})$ & $374 \mathrm{a} \pm 124$ & $358 \mathrm{a} \pm 335$ & $780 \mathrm{a} \pm 739$ & 501 & $562 \pm 482$ & 30 & 10 \\
TDS $(\mathrm{mg} / \mathrm{l})$ & $3941 \mathrm{a} \pm 3703$ & $3300 \mathrm{a} \pm 1714$ & $2653 \mathrm{a} \pm 1240$ & 532.7 & $444 \pm 507$ & 250 & 500 \\
\hline
\end{tabular}

The values given in the table above are means of 6 replicate values, $\mathrm{n}=6$ ( 1 sample was taken monthly for 6 months). Within the rows, means with different alphabets are statistically different $(p<0.05)$. WHO: World Health Organisation. NESREA: National Environmental Standard and Regulatory Enforcement Agency. a = Mohammed et al.(2017), b = Baba et al. (2020), c = WHO (2006), $d=$ NESSRA (2009) 
BAJOPAS Volume 13 Number 2, December, 2020

Identification, Biochemical Characterization and growth rates of the Bacterial Isolates

Results of identification and biochemical characterization of the bacterial isolates were shown in table 2. After 24 hours of incubation, the nutrient agar media plates were checked for bacterial growth. The results showed the presence of different strains in the samples. The TAN1 bacteria isolate was found to be gramnegative cocci while TAN3 was gram-positive cocci. TAN2 bacteria isolate was found to be gram-positive, rod-shaped. TAN1, TAN2, and TAN3 bacteria isolates recorded positive results for spore former.

The results of the biochemical tests indicated that all the bacteria were positive for catalase, oxidase, citrate, maltose, glucose, lactose (negative in TAN1), mannitol (negative in TAN2), starch hydrolysis and coagulase (negative in TAN2) tests. The bacteria showed negative results for nitrate reduction, $M R$ (positive in TAN2), VP (positive in TAN1), Indole (positive in TAN2) tests. Base on the morphological and biochemical test results, TAN1, TAN2, and TAN3 bacteria isolates were identified to be Nesseria spp, Bacillus cereus, and Staphylococcus aureus respectively.

The growth rate of the TAN1, TAN2 and TAN3 Isolates were shown in figure 2. Generally, the optical density increase with the increase in time (day) and decrease as time goes on. The highest optical density was shown by bacillus cereus in TAN2 while the lowest was shown by Staphylococcus aureus in TAN3.

The initial growth phase of TAN1 Isolate bacteria occurred within 2-day of incubation as the growth rate increases up to the 6th-day incubation when the maximum growth was observed. Beyond the 6th day, the growth of the bacteria declined (which might be due to a shortage of nutrients in the effluents) until it reached its death phase (which might be due to the unavailability of nutrients in the effluents).

A similar trend of growth was also observed for TAN2 Isolate as the initial growth phase also occurred within 2-day of incubation but maximum growth rate observed on the 4th day of incubation. The stationary stage occurred between the 4th day and the 8th day. Beyond the 8th day, the growth of the bacteria declined (which might be due to a shortage of nutrients in the effluents) until it reached its death phase (which might be due to the unavailability of nutrients in the effluents).

The initial growth phase of TAN3 bacterial Isolate occurred within the 3-day incubation as the growth rate increases up to the 6th-day incubation when the maximum growth was observed. Beyond the 6th day, the growth of the bacteria declined (which might be due to a shortage of nutrients in the effluents) until it reached its death phase (which might be due to the unavailability of nutrients in the effluents).

Table 2: Morphological and Biochemical characteristics of bacterial isolates

\begin{tabular}{lllll} 
Bacterial Isolates & & TAN1 & TAN2 & TAN3 \\
\hline $\begin{array}{lllll}\text { Morphological } \\
\text { characteristics }\end{array}$ & Shape & Cocci & Rod & Cocci \\
& Spore & & & \\
& former & + & + & + \\
Gram & & & \\
Biochemical characteristics & reaction & - & + & + \\
& Citrate & + & + & + \\
& Catalase & + & + & + \\
& Coagulase & + & - & + \\
Starch & + & + & + \\
& Glucose & + & + & + \\
Oxidase & + & + & + \\
& Indo & - & + & - \\
Lactose & - & + & + \\
Manitol & + & - & + \\
Maltose & + & + & + \\
MR & - & + & - \\
VP & + & - & - \\
& Nitrate & - & - & - \\
Reduction & - Neisseria & Bacillus & Staphylococcus \\
& Bacterial & cereus & aureus \\
& name & spp & cas
\end{tabular}

+ = Positive; - = Negative; MR=Methyl Red; VP= Voges-Proskauer 


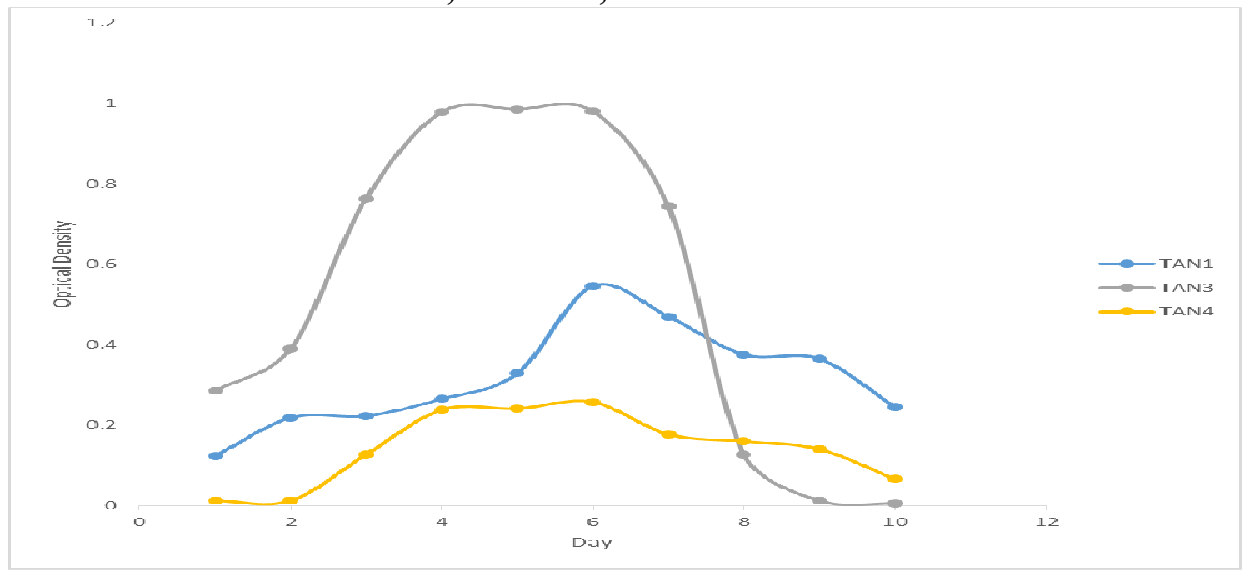

Fig. 2 Growth rates of the isolates in the effluents from the Tannery Industries

\section{Physico-chemical Parameters in the Industrial Effluents after the biodegradation.}

Table 3 shows the mean results of the physicochemical parameter before and after bioremediation using the different masses $(5 \mathrm{~g}$, $10 \mathrm{~g}, 15 \mathrm{~g}, 20 \mathrm{~g}$, and $25 \mathrm{~g}$ ) of the respective immobilized bacteria. Also, Table 4 shows the mean results of correlation coefficient ( $r$ ) between different masses of bacteria and physicochemical parameters.

The mean values $(\mathrm{mg} / \mathrm{l})$ of the SS after the bioremediation varies between $243 \pm 45$ and $898 \pm 672$. The mean concentration $(\mathrm{mg} / \mathrm{l})$ of SS remediated by the different masses $(5 \mathrm{~g}, 10 \mathrm{~g}$, $15 \mathrm{~g}, 20 \mathrm{~g}$, and $25 \mathrm{~g}$ ) of the bacteria varies. The SS in the samples fluctuates up and down after the bioremediation process when compared with the SS of the raw samples before the bioremediation. The increase in the levels of the SS might be due to the aggregation of the TDS which are large enough to result into SS. The increase in the levels of the SS might be also due to the influence of the nutrients which was added into the effluents in order to make the microorganisms more active and viable for fast degradation of organic contaminants in the effluent. The relative potential or efficiency of the different masses of the bacteria in remediating SS in TAN1 samples was in the order $25 \mathrm{~g}>20 \mathrm{~g}>15 \mathrm{~g}>10 \mathrm{~g}>5 \mathrm{~g}$. For TAN2 and TAN3 samples, the order was $25 \mathrm{~g}>20 \mathrm{~g}>15$ $\mathrm{g}>10 \mathrm{~g}>5 \mathrm{~g}$. These might be due to the variations in the surface areas of the different masses of the immobilized bacteria. Statistical analysis shows that there is no significant difference $(p<0.05)$ between the mean values of SS among the masses in the respective industries. Positive and significant correlations exist between the masses of bacteria and Suspended Solid (SS). This showed that there is general increase in the levels of the SS as the masses of the immobilized bacteria increases. TAN3 (90\%) and TAN1 (80\%) showed a very high correlation with the masses of the bacteria while TAN2 (61\%) showed a very low correlation.

The mean values $(\mathrm{mg} / \mathrm{l})$ of the TDS after the bioremediation varies between $46 \pm 11$ and $83 \pm 78$. The mean concentration $(\mathrm{mg} / \mathrm{l})$ of TDS remediated by the different masses $(5 \mathrm{~g}, 10 \mathrm{~g}$, $15 \mathrm{~g}, 20 \mathrm{~g}$, and $25 \mathrm{~g}$ ) of the bacteria varies. There is a reduction in all the TDS of all the samples after the bioremediation process compared with the TDS of the raw samples before the bioremediation. The relative potential or efficiency of the different masses of the bacteria in remediating TDS in TAN1 and TAN3 samples was in the order $5 \mathrm{~g}>10 \mathrm{~g}>15 \mathrm{~g}>20$ $\mathrm{g}>25 \mathrm{~g}$. For TAN2 samples, the order was 20 $g>10 \quad g>25 \quad g>15 \quad g>5 \quad g$. Statistical analysis shows that there is no significant difference $(p<0.05)$ between the mean values of TDS among the masses in the respective industries. These might be due to the variations in the surface areas of the different masses of the immobilized bacteria. Positive and significant correlations exist between the masses of bacteria and TDS with the exception in TAN2 (negative and insignificant correlation). The positive correlations showed that there is general increase in the levels of the TDS as the masses of the immobilized bacteria increases. TAN1 $(96 \%)$ showed a very high correlation with the masses of the bacteria while TAN2 (47\%) showed a very low correlation.

The mean values $(\mathrm{mg} / \mathrm{l})$ of the BOD after the bioremediation varies between $1.56 \pm 0.20 \mathrm{mg} / \mathrm{l}$ and $6.92 \pm 5.49 \mathrm{mg} / \mathrm{l}$. The mean concentration $(\mathrm{mg} / \mathrm{l})$ of BOD remediated by the different masses $(5 \mathrm{~g}, 10 \mathrm{~g}, 15 \mathrm{~g}, 20 \mathrm{~g}$, and $25 \mathrm{~g}$ ) of the bacteria varies. There is a reduction in all the BOD of all the samples after the bioremediation process compared with the $\mathrm{BOD}$ of the raw 
BAJOPAS Volume 13 Number 2, December, 2020 samples before the bioremediation. The relative potential or efficiency of the different masses of the bacteria in remediating BOD in TAN1, TAN2 and TAN3 samples were in the order $25 \mathrm{~g}>20$ $\mathrm{g}>15 \mathrm{~g}>10 \mathrm{~g}>5 \mathrm{~g}, 25 \mathrm{~g}>15 \mathrm{~g}>5 \mathrm{~g}>10 \mathrm{~g}>20 \mathrm{~g}$ and $20 \mathrm{~g}>10 \mathrm{~g}>25 \mathrm{~g}>15 \mathrm{~g}>5 \mathrm{~g}$ respectively. Statistical analysis shows that there is significant difference $(p<0.05)$ between the mean values of BOD among the masses in the respective industries. These might be due to the variations in the surface areas of the different masses of the immobilized bacteria. Negative and significant correlations exist between the masses of bacteria and BOD. This showed that there is general decrease in the levels of the BOD as the masses of the immobilized bacteria increases. TAN1 (94\%) showed a very high correlation with the masses of the bacteria while TAN2 (4\%) showed a very low correlation.

The mean values $(\mathrm{mg} / \mathrm{l})$ of the COD after the bioremediation varies between $250 \pm 154$ and $3134 \pm 1595$. The mean concentration $(\mathrm{mg} / \mathrm{l})$ of COD remediated by the different masses $(5 \mathrm{~g}$, $10 \mathrm{~g}, 15 \mathrm{~g} 20 \mathrm{~g}$, and $25 \mathrm{~g}$ ) of the bacteria varies. There is a reduction in all the COD of all the samples after the bioremediation process compared with the COD of the raw samples before the bioremediation. The relative potential or efficiency of the different masses of the bacteria in remediating COD in TAN1, TAN2 and TAN3 samples were in the order $25 \mathrm{~g}>20 \mathrm{~g}>15$ $\mathrm{g}>5 \mathrm{~g}>10 \mathrm{~g}, 25 \mathrm{~g}>20 \mathrm{~g}>15 \mathrm{~g}>10 \mathrm{~g}>5 \mathrm{~g}$ and 10 g>5 g>25 g>15 g>20 g respectively. Statistical analysis shows that there were significant difference $(p<0.05)$ between the mean values of COD among the masses in the respective industries except for effluents treated with $25 \mathrm{~g}$. These might be due to the variations in the surface areas of the different masses of the immobilized bacteria. Negative and insignificant correlations exist between the masses of bacteria and COD with the exception in TAN3 (positive and significant correlation). The negative correlations showed that there is general decrease in the levels of the COD as the masses of the immobilized bacteria increases. TAN2 (100\%) showed a very high correlation with the masses of the bacteria while TAN3 (36\%) showed a very low correlation.

Generally, there was an overall decrease in the concentration of these physicochemical parameters after the bioremediation using the different masses of the bacterial isolates. These might be due to the variations in the surface areas of the different masses of the immobilized bacteria. This is in line with the work of Jimoh et al. (2018) and Baba et al. (2020).

Table 3: Mean Values $(\mathrm{mg} / \mathrm{l}) \pm$ S.D of Physicochemical parameters in effluents from the Tannery Industries before and after Treatment of the effluents $(250 \mathrm{ml})$ with the different masses $(5 \mathrm{~g}, 10 \mathrm{~g}$, $15 \mathrm{~g}, 20 \mathrm{~g}$, and $25 \mathrm{~g}$ ) of the bacteria.

\begin{tabular}{llllllll}
\hline $\mathrm{P}$ & IND & Before & \multicolumn{5}{c}{ After } \\
\cline { 4 - 7 } & & & $5 \mathrm{~g}$ & $10 \mathrm{~g}$ & $15 \mathrm{~g}$ & $20 \mathrm{~g}$ & $25 \mathrm{~g}$ \\
\hline \multirow{2}{*}{ COD } & TAN1 & $2372 \pm 938$ & $1708 \mathrm{a} \pm 861$ & $2045 \mathrm{a} \pm 1205$ & $845 \mathrm{a} \pm 369$ & $300 \mathrm{a} \pm 167$ & $250 \mathrm{a} \pm 154$ \\
& TAN2 & $1406 \pm 208$ & $1195 \mathrm{a} \pm 208$ & $1125 \mathrm{a} \pm 384$ & $1055 \mathrm{a} \pm 317$ & $956 \mathrm{a} \pm 310$ & $870 \mathrm{ab} \pm 240$ \\
& TAN3 & $3532 \pm 1373$ & $2374 \mathrm{a} \pm 1344$ & $1976 \mathrm{a} \pm 1405$ & $2757 \mathrm{a} \pm 1266$ & $3134 \mathrm{a} \pm 1595$ & $2614 \mathrm{~b} \pm 1105$ \\
BOD & TAN1 & $13.85 \pm 6.42$ & $6.92 \mathrm{a} \pm 5.49$ & $6.42 \mathrm{a} \pm 5.07$ & $5.72 \mathrm{a} \pm 5.35$ & $4.62 \mathrm{a} \pm 4.37$ & $2.82 \mathrm{ab} \pm 1.26$ \\
& TAN2 & $19.46 \pm 0.50$ & $1.75 \mathrm{~b} \pm 0.22$ & $1.73 \mathrm{~b} \pm 0.18$ & $1.58 \mathrm{a} \pm 0.16$ & $1.91 \mathrm{a} \pm 0.22$ & $1.56 \mathrm{~b} \pm 0.20$ \\
& TAN3 & $17.13 \pm 3.14$ & $4.24 \mathrm{ab} \pm 0.77$ & $3.29 \mathrm{ab} \pm 0.37$ & $4.11 \mathrm{a} \pm 0.07$ & $3.23 \mathrm{a} \pm 0.91$ & $3.33 \mathrm{a} \pm 1.28$ \\
SS & TAN1 & $374 \pm 124$ & $243 \mathrm{a} \pm 45$ & $471 \mathrm{a} \pm 226$ & $475 \mathrm{a} \pm 182$ & $492 \mathrm{a} \pm 128$ & $611 \mathrm{a} \pm 217$ \\
& TAN2 & $358 \pm 335$ & $460 \mathrm{a} \pm 400$ & $543 \mathrm{a} \pm 414$ & $544 \mathrm{a} \pm 402$ & $551 \mathrm{a} \pm 414$ & $554 \mathrm{a} \pm 405$ \\
& TAN3 & $780 \pm 739$ & $586 \mathrm{a} \pm 594$ & $758 \mathrm{a} \pm 656$ & $787 \mathrm{a} \pm 676$ & $861 \mathrm{a} \pm 635$ & $898 \mathrm{a} \pm 672$ \\
TDS & TAN1 & $3941 \pm 3703$ & $51 \mathrm{a} \pm 10$ & $53 \mathrm{a} \pm 10$ & $55 \mathrm{a} \pm 15$ & $61 \mathrm{a} \pm 20$ & $63 \mathrm{a} \pm 26$ \\
& TAN2 & $3300 \pm 1714$ & $83 \mathrm{a} \pm 78$ & $47 \mathrm{a} \pm 20$ & $48 \mathrm{a} \pm 22$ & $47 \mathrm{a} \pm 17$ & $48 \mathrm{a} \pm 17$ \\
& TAN3 & $2653 \pm 1240$ & $46 \mathrm{a} \pm 11$ & $55 \mathrm{a} \pm 24$ & $55 \mathrm{a} \pm 25$ & $58 \mathrm{a} \pm 23$ & $61 \mathrm{a} \pm 28$ \\
\hline
\end{tabular}

Replicate $=6$ (months)

Within the rows, for the same parameter, means with different alphabets are statistically different $(p<0.05)$.

$\mathrm{P}=$ parameter, IND = Industries 
BAJOPAS Volume 13 Number 2, December, 2020

Table 4: Correlation coefficient $(r)$ between different masses of the bacteria and the physicochemical parameters.

\begin{tabular}{llll}
\hline Industries & Parameter & Correlation coefficient $(r)$ & $\begin{array}{l}\text { Percent dependence (rxrx100) } \\
(\%)\end{array}$ \\
\hline TAN1 & COD & -0.9 & 82 \\
& BOD & -0.97 & 94 \\
& SS & $0.90^{*}$ & 80 \\
TAN2 & TDS & $0.98^{*}$ & 96 \\
& COD & -1 & 100 \\
& BOD & -0.21 & 4 \\
& SS & $0.78^{*}$ & 61 \\
& TDS & -0.69 & 47 \\
& COD & $0.60^{*}$ & 36 \\
& BOD & -0.6 & 37 \\
& SS & $0.95^{*}$ & 90 \\
& TDS & $0.94^{*}$ & 89 \\
\hline
\end{tabular}

The correlation coefficient $(r)$ with * is statistically significant $(p<0.05)$.

Percentage reduction of the Parameters

Table 5 shows the percentage reduction of Parameters in industrial samples before and after the treatment of the effluents $(250 \mathrm{ml})$ with the different masses $(5 \mathrm{~g}, 10 \mathrm{~g}, 15 \mathrm{~g}, 20 \mathrm{~g}$, and $25 \mathrm{~g}$ ) of the Immobilized Bacteria.

In TAN1 samples, the percentage reduction (\%) of COD ranged (14-89); BOD (50-80); SS (-32$35)$ and TDS (98-99). In TAN2 samples, the percentage decrease $(\%)$ of COD ranged (15$38) ;$ BOD (90-92); SS [-28-(-55)] and TDS (9798). In TAN3 samples, the percentage decrease (\%) of COD ranged (11-44); BOD (76-81); SS (15-25) and TDS (98). The percentage increase in the levels COD, BOD and TDS might be due to the increase in the surface area of the different masses of the immobilized bacteria. However, the percentage decrease in the levels of the SS might be due to the aggregation of the TDS which are large enough to result into SS. The percentage decrease in the levels of the SS might be also due to the influence of the nutrients which was added into the effluents in order to make the microorganisms more active and viable for fast degradation of organic contaminants in the effluent. This is in line with the work of Jimoh et al. (2018) in which the concentration of the SS increase after the bioremediation of effluents.

Sreemoyee and Priti (2013) assessed and reduced several Physico-chemical parameters of dairy wastewater using Niesseria $s p$. and concluded that the species are well known to degrade organic compounds. This is in agreement with the current study in which the immobilized Niesseria $s p$ degrade the organic contaminants as indicated by the BOD, COD and TDS.

Jimoh et al. (2018) observed that TSS of the effluents was increased after treatment with immobilized bacteria and concluded that it might be due to the biostimulation method adopted for the research.

The optimum $\mathrm{pH}$ Biosorption of Chromium by Bacillus spp and Staphylococcus spp. from tannery effluent was investigated by Mythili and Karthikeyan (2011). The maximum adsorption of Chromium $(86.4 \mathrm{mg} / \mathrm{L})$ was showed by Bacillus spp and Staphylococcus spp showed $70.6 \mathrm{mg} / \mathrm{L}$ at an initial concentration of $100 \mathrm{mg} / \mathrm{L}$. In the present study, immobilised Bacillus spp and Staphylococcus spp. from the tannery industrial effluents reduced the levels of the organic pollutants with high potential as indicated by the percentage reduction of BOD, COD and TDS.

Enzymes often can work in multiple environments especially if they are immobilized. This makes the microorganisms' enzymes even more resistant to harsh environments and enables the enzymes to be recovered and recycled after they are no longer needed (Gianfreda and Rao 2004). Ramesh and Singh (1993) reported that the immobilized bacteria having more efficiency to remove the suspended particles than free cells. Using the immobilized cell is preferable due to its capability for using several times with the same efficiency, which makes it more economical. Similar work was done by Sikander et al. (2007) showing the higher reduction with permeabilized cells of Ochrobactrum intermedium strain SDCr-5. 
BAJOPAS Volume 13 Number 2, December, 2020

The results revealed the isolation and identification of isolates with the potential for the reduction of $\mathrm{Cr}$ (VI) to $\mathrm{Cr}$ (III). Results indicated that immobilized $B$. cereus could be efficiently used for the reduction of $\mathrm{Cr}$ (VI).

Table 5: Percentage reduction of the tested Parameters from the tannery industrial samples of the Immobilized Bacteria.

\begin{tabular}{lllllll}
\hline \multirow{2}{*}{ Industries } & & \multicolumn{5}{c}{ Percentage Reduction $(\%)$} \\
\cline { 3 - 7 } & & $5 \mathrm{~g}$ & $10 \mathrm{~g}$ & $15 \mathrm{~g}$ & $20 \mathrm{~g}$ & $25 \mathrm{~g}$ \\
\hline TAN1 & COD & 28 & 14 & 64 & 87 & 89 \\
& BOD & 50 & 54 & 59 & 67 & 80 \\
& SS & 35 & -26 & -27 & -32 & -63 \\
& TDS & 99 & 99 & 99 & 98 & 98 \\
TAN2 & COD & 15 & 20 & 25 & 32 & 38 \\
& BOD & 91 & 91 & 92 & 90 & 92 \\
& SS & -28 & -52 & -52 & -54 & -55 \\
& TDS & 97 & 99 & 99 & 99 & 99 \\
& COD & 33 & 44 & 22 & 11 & 26 \\
& BOD & 75 & 81 & 76 & 81 & 81 \\
& SS & 25 & 3 & -1 & -10 & -15 \\
& TDS & 98 & 98 & 98 & 98 & 98 \\
\hline
\end{tabular}

Percentage Reduction $=(B-A) / B \times 100 \%$

$A=$ Concentration of the parameter after treatment

$\mathrm{B}=$ Concentration of the parameter before treatment

$+=$ percentage decrease

- = percentage increase

In general, immobilization makes the enzyme more resistant to temperature, $\mathrm{pH}$, and substrate concentration swings giving it a longer lifetime and higher productivity per active unit (Gianfreda and Rao, 2004; FuIlbrook, 1996; Russell et al, 2003; Kandelbauer et al., 2004). Immobilized cells have been used and studied extensively for the production of useful chemicals (Ohtake and Silver, 1994), the treatment of wastewaters (Chen et al., 2003; Wang et al., 2010). Although many workers described microbial degradation of tannery effluent, limited literature is available on the bioremediation of tannery effluent using immobilized bacterial cells in the Kano Industrial Estates.

\section{CONCLUSION}

The samples contained variable levels of the physicochemical parameters. The results of the Analysis of variance revealed that, no statistical difference $(p<0.05)$ was observed for the temperature, $\mathrm{pH}, \mathrm{SS}, \mathrm{TDS}, \mathrm{BOD}$ and $\mathrm{COD}$ among the three tannery industries before the treatment. The levels of some of the parameters
(SS, TDS and COD) observed in the samples were found above the recommended limits of WHO and NESREA, which called for the treatment of the effluents before discharge into the environment. Base on the morphological and biochemical test results, TAN1, TAN2, and TAN3 bacterial isolates were identified to be Neisseria spp, Bacillus cereus, and Staphylococcus aureus respectively. The results of Post-treatment analysis showed that there is overall decrease in the levels of the parameters determined when compared with that of the pre-treatment. The overall percentage reduction of the immobilised bacteria in the treatment of the respective effluents was in the order TAN2 (72\%)>TAN1 $(70 \%)>$ TAN3 $(62 \%)$. Hence, the immobilized bacteria are having higher biodegradation potential for the treatment of the tannery effluents.

\section{Acknowledgments}

The authors wish to acknowledge the University of Maiduguri for the financial support. The authors are grateful to the Kano State Ministry of Environment for their support in obtaining the effluent samples. 


\section{REFERENCES}

Ajao, A. T., Adebayo, G. B., and Yakubu, S. E. (2011). Bioremediation of textile industrial effluent using mixed culture of Pseudomonas aeruginosa and Bacillus subtilis immobilized on agar-agar in a bioreactor. J. Microbiol. Biotech. Res, 1(3), 50-56.

Akan, J. C., Moses, E. A., Ogugbuaja, V. O., and Abah, J. (2007). Assessment of tannery industrial effluents from Kano metropolis, Kano State, Nigeria. Journal of Applied Sciences, 7(19), 2788-2793.

Akan, J. C., Ogugbuaja, V. O., Abdulrahman, F. I., and Ayodele, J. T. (2009). Pollutant levels in effluent samples from tanneries and textiles of Kano industrial areas, Nigeria. Global journal of pure and applied sciences, 15(3-4).

APHA (1989). Standard methods for Examination of Will bete and Will betewater.15 $5^{\text {th }}$ edition. Brydpass Springfield Will behington DC. pp. 164-176

APHA (1992). Standard Methods for the Examination of Water and Wastewater. Health, 69, 1116-9.

Baba, A., Garba, S. T., and Bello, H. S. (2020). Bioremediation Potential of Immobilized corynebacterium kutsceri in the Treatment of Tannery Industrial Effluent from Challawa Industrial Estate, Kano State, Nigeria. Journal of the Turkish Chemical Society Section A: Chemistry, $7(2), 335-350$.

Beem, E. I. V. (1994). reduction of solvent VOC emission. J. Oil Col. Chem. Ass, 77, 158.

Bouwer, E. J., and Zehnder, A. J. (1993). Bioremediation of organic compoundsputting microbial metabolism to work. Trends in biotechnology, 11(8), 360367.

Chen, K. C., Wu, J. Y., Liou, D. J., and Hwang, S. C. J. (2003). Decolorization of the textile dyes by newly isolated bacterial strains. Journal of Biotechnology, 101(1), 57-68.

Dan'Azumi, S., and Bichi, M. H. (2010). INDUSTRIAL POLLUTION AND HEAVY METALS PROFILE OF CHALLAWA RIVER IN KANO, NIGERIA. Journal of Applied Sciences in Environmental Sanitation, $5(1)$.

DWAF. (1992). Analytical Methods Manual, TR 151. Department of Water Affairs and Forestry, Pretoria.

El-Bestawy, E. (2013). Biological treatment of leather-tanning industrial wastewater using free living bacteria.
Elsheikh, M. A. S. (2009). Tannery wastewater pre-treatment. Water Science and Technology, 60(2), 433-440.

FuIlbrook, P. D. (1996). "Kinetics." Industrial enzymology: The application of enzymes in Industry. 2nd Ed. T. Godfrey and J Reichelt. eds.. Nature. New York.

Gianfreda, L., and Rao, M. A. (2004). Potential of extra cellular enzymes in remediation of polluted soils: a review. Enzyme and microbial technology, 35(4), 339354.

Hugo Springer. (1994). John Arthur Wilson Memorial Lecture "Treatment of Industrial Wastes of the Leather Industry - is it still a Major Problem". JALCA, 89, 153-185

Jimoh, A. A., Ganiyu, B. A., Baba, D., and Baba, A. (2018) Bioremediation Process of Effluent from Detergent and Food Industries in Jos, Nigeria: Kinetics and Thermodynamics. International Journal of Engineering Science Invention (IJESI), 762-73

Kandelbauer, A., Maute, O., Kessler, R. W., Erlacher, A., and Gübitz, G. M. (2004). Study of dye decolorization in an immobilized laccase enzyme-reactor using online spectroscopy. Biotechnology and bioengineering, 87(4), 552-563.

Kongjao, S., Damronglerd, S., and Hunsom, M. (2008). Simultaneous removal of organic and inorganic Pollutants in tannery wastewater using electrocoagulation technique. Korean Journal of chemical engineering, 25(4), 703.

Maheshwari, U. M., Aruna, S., Gomathi, M., and AbdulJaffar, A. H. (2017). Bioremediation by Free and Immobilized Bacteria Isolated from Tannery Effluent. International Journal of Research in Applied, Natural and Social Sciences. 5(7), 75-90

Margesin, R., and Schinner, F. (2001). Bioremediation (natural attenuation and biostimulation) of diesel-oilcontaminated soil in an alpine glacier skiing area. Applied and environmental microbiology, 677), 3127-3133.

Mohammed, A., Sekar, P., and George, J. (2011). Efficacy of microbes in bioremediation of tannery effluent. Inter. J. Curr. Res, 3(4), 324-326.

Mohammed, S. S. D., Orukotan, A. A., and Abdullahi, H. (2017). Physicochemical and Bacteriological Assessment of Tannery Effluent from Samaru-Zaria, 
BAJOPAS Volume 13 Number 2, December, 2020 Kaduna State, Nigeria. Journal of Applied

Sciences and Environmental Management, 21(4), 734-740.

Munz, G., De Angelis, D., Gori, R., Mori, G., Casarci, M., and Lubello, C. (2009). The role of tannins in conventional and membrane treatment of tannery wastewater. Journal of hazardous materials, 164(2-3), 733-739

Mythili, K., and Karthikeyan, B. (2011). Bioremediation of $\mathrm{Cr}$ (VI) from tannery effluent using Bacillus spp and Staphylococcus spp. International Multidisciplinary Research Journal, 1(6).

NESREA (2009). National Environmental Standards for Effluent Limitations and Regulation. 1233-1236

Noorjahan, C. M. (2014). Physicochemical characteristics, identification of bacteria and biodegradation of industrial effluent. Journal of bioremediation and Biodegradation, 5(3).

Ohtake, H. I., and Silver, A. O. (1994). Bacterial reduction of toxic chromate. Biological degradation and bioremediation of toxic chemicals, 403-415.

Omoleke, I. I. (2004). Management of environmental pollution in Ibadan, an African city: the challenges of health hazard facing government and the people. Journal of Human Ecology, 15(4), 265-275.

Rajor, A., Reddy, A.S., and Singh, B. (2004). Determination of BOD kinetic Parameters and evaluation of alternate methods, M.Sc. Thesis, Department of biotechnology \& environmental Science, Thapar Institute of Engineering and Technology, Patiala

Ramasami, T., Rajamani, S., and Rao, J. R. (1994, March). Pollution control in leather industry: Emerging technological options. In International symposium on surface and colloidal science and its relevance to soil pollution, madras.

Ramesh, J. V. S., and Singh, S. P. (1993). Yearly variation in certain physicochemical parameters of pond at eastern Doon Valley. Uttar Pradesh J. Zoo, 12 (1), 7577.

Ranen, S., and Sharadinadra, C. (2009). Biotechnology applications to environmental remediation in resource exploitation. Current science, 97, 6-25
Russell, A. J., Berberich, J. A., Drevon, G. F., and Koepsel, R. R. (2003). Biomaterials for mediation of

chemical and biological warfare agents. Annual review of biomedical engineering, 5(1), 1-27.

Saravanan, P., and Saravanan, A. (1999). Decolourization of tannery effluent by Flavobacterium sp. EK 1. Indian Journal of Environmental Protection, 19, 19-24.

Sikander, S., and Shahida, H. (2007). Reduction of toxic hexavalent chromium by Ochrobactrum intermedium strain SDCr5 stimulated by heavy metals. Bioresource Technol, 98, 340-344.

Singh, N., Sharma, B. K., and Bohra, P. C. (2000). Impact assessment of industrial effluent of arid soils by using satellite imageries. Journal of the Indian Society of Remote Sensing, 28(2-3), 79.

Sreemoyee, C., and Priti, P. (2013). Assessment of physico-chemical parameters of dairy waste water and isolation and characterization of bacterial strains in terms of cod reduction. Int J Sci, 2(3), 395-400.

Verheijen, L. A. H. M., Wiersema, D., Pol, L. H., and De Wit, J. (1996). Management of wastes from animal product processing. Livestock and environment, Finding a balance. International Agriculture Center, Wageningen, The Netherlands.

Wang, F., Yao, J., Si, Y., Chen, H., Russel, M., Chen, K., and Bramanti, E. (2010). Short-time effect of heavy metals upon microbial community activity. Journal of Hazardous Materials, 173(13), 510-516.

WHO (World Health Organization). (2006). Air quality guidelines: global update 2005: particulate matter, ozone, nitrogen dioxide, and sulfur dioxide. World Health Organization.

World Bank. (1995). Nigeria's strategic options for redressing industrial pollution. World Bank, industry and energy division. 1st edition, West Central Africa Department; Annexes: 1995; pp 60-62.

Zahoor, A., and Abdul, R. (2009). Enumeration of Coliforms. Journal of Environmental Sciences. 21, 814-820 


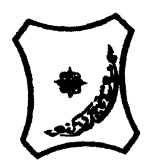

Bayero Journal of Pure and Applied Sciences, 13(2): 1 - 12

Received: November, 2020

Accepted: December, 2020

ISSN $2006-6996$

\title{
BIODEGRADATION POTENTIAL OF IMMOBILIZED BACTERIA IN THE TREATMENT OF TANNERY INDUSTRIAL EFFLUENTS FROM INDUSTRIAL ESTATES IN KANO STATE, NIGERIA
}

\author{
Abdullateef, B., ${ }^{1 *}$ Shuaibu, T. G., ${ }^{1}$ Babagana, K., ${ }^{1}$ Suleman, H. B. ${ }^{2}$ and Dauda, B. ${ }^{3}$ \\ ${ }^{1}$ Department of Pure and Applied Chemistry, Faculty of Science, University of Maiduguri, Borno State, \\ Nigeria \\ ${ }^{2}$ Department of Microbiology, Faculty of Science, University of Maiduguri, Borno State, Nigeria \\ ${ }^{3}$ Department of Chemical Engineering, Faculty of Engineering, University of Maiduguri, Borno State, \\ Nigeria \\ *Corresponding author: babslega@gmail.com; abelega2007@yahoo.com; +2348061309753
}

\section{ABSTRACT}

Industrial Effluents Samples from Gashash Tanneries (TAN1) in Bompai Industrial estate, Larabee Tannery Industry (TAN2) in Sharada Industrial estate and Z Tannery Industries (TAN3) in Challawa Industrial estate, Kano State, Nigeria were collected over a period of six months (August 2017 to January 2018) for assessing the biodegradation potentials of bacteria in the treatment of organic pollutants within the effluents. Bacteria were isolated from the effluents and immobilized on agar-agar. Different masses (5 g, $10 \mathrm{gr}, 15$ $\mathrm{g}, 20 \mathrm{~g}$, and $25 \mathrm{~g}$ ) of the bacteria were used in the treatment of $250 \mathrm{ml}$ of the effluents for ten days in a shaker incubator (Gallenkamp-OC-4364-L) at the temperature $30{ }^{\circ} \mathrm{C}$ and speed of $60 \mathrm{rpm}$. Pre-treatment analysis of the effluents for Temperature, pH, Biochemical Oxygen Demand (BOD), Chemical Oxygen Demand (COD), Suspended Solid (SS) and Total Dissolved Solids (TDS) gives the following results; temperature $\left({ }^{\circ} \mathrm{C}\right.$ )

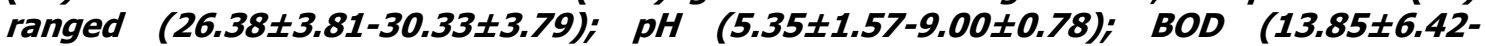
$38.75 \pm 16.20) ;$ COD (1406 $\pm 208-3532 \pm 1373) ;$ SS (208 $\pm 235-780 \pm 739)$ and TDS (266 $\pm 253-5276 \pm 2971)$. No statistical differences ( $p \leq 0.05)$ was observed for all the results among the different industries. The bacterial isolates were identified as Neisseria spp, Bacillus cereus, and Staphylococcus aureus, in TAN1, TAN2, and TAN3, respectively. After treatment of the effluent with the different masses of the isolated bacteria, the mean level of BOD was found to range as (0.55 $\pm 0.36-6.92 \pm 5.49) ; C O D$ (ND-3134 \pm 1595$)$;

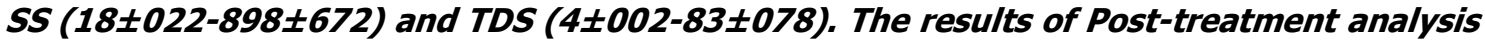
showed that there is overall decrease in the levels of the parameters determined when compared with that of the pre-treatment. The overall percentage reduction of the immobilised bacteria in the treatment of the respective effluents was in the order TAN2 (72\%)>TAN1 (70\%)>TAN3 (62\%). Hence, the immobilized bacteria are having higher biodegradation potential for the treatment of the tannery effluents.

Keywords: Biodegradation, bacteria, effluent, immobilization, tannery.

\section{INTRODUCTION}

Tannery industrial wastewater is a serious consequence of the pollution point of view for streams, freshwater, and land used for agriculture. The lack of awareness in the modern industrial practice has resulted in the discharge of tannery effluents which exhibit very high value of chromium ( $\mathrm{Cr}$ ), Sulfide, and chloride, Total Dissolved Solid (TDS), Total Suspended Solid (TSS), Biochemical Oxygen Demand (BOD) and Chemical Oxygen Demand (COD) in the water stream or land (Mohammed et al., 2001). Tanning is the process, which One ton of skin generally leads to the production of 20 to $80 \mathrm{~m}^{3}$ of turbid and foul-smelling converts the protein of the rawhide or skin into a stable material, which will not putrefy and is suitable for a wide variety of end applications (Elsheikh, 2009). The highly polluting chromium is the most commonly used tanning material producing leather that is more flexible and pliable than vegetable-tanned leather and does not discolor or lose shape in water as drastically as vegetable-tan (Elsheikh, 2009). Tannery effluent is among the most hazardous industrial pollutants due to its huge organic and inorganic load, which is highly toxic to human life and the environment (Kongjao et al., 2008). wastewater including chromium (100-400 mg/l), sulfide $(200-800 \mathrm{mg} / \mathrm{l})$, high levels of fat and 
BAJOPAS Volume 13 Number 2, December, 2020 other solid wastes, and notable pathogen contamination as well as pesticides added for skin conservation during transport (Elsheikh, 2009). There are more than 6000 tanneries in Nigeria with an annual processing capacity of 700,000 tons of hides and skins (Omoleke, 2004; Singh et al., 2008). It was reported that the total amount of waste produced per animal slaughtered is approximately $35 \%$ of its weight (World Bank, 1995). Also, for every $1000 \mathrm{~kg}$ of carcass weight, a slaughtered beef produces 5.5 $\mathrm{kg}$ of manure (excluding rumen contents or stockyard manure) and $100 \mathrm{~kg}$ of paunch manure (undigested food) (Verheijen et al., 1996). Tanneries generate wastewater in the range of 30-35 $\mathrm{L} \mathrm{kg}^{-1}$ skin/hide processed with variable $\mathrm{pH}$, Biological Oxygen Demand (BOD), Chemical Oxygen Demand (COD), high concentrations of suspended solids (SS), and tannins as well as chromium (Zahoor and Abdul, 2009).

Being heterogeneous and composed of a wide variety of compounds, it is very difficult to select a unique direct method for estimating the biodegradability of organic contents and biokinetic parameters for a wastewater sample (Rajor, 2004). For this purpose, some indirect estimation such as determination of biochemical oxygen demand (BOD) and chemical oxygen demand (COD) are applied as common laboratory investigations [9]. During retanning procedures, synthetic tannins (Syntan), oils and resins are added to form softer leather at varying doses (Munz et al., 2009). One of the refractory groups of chemicals in tannery effluents derives mainly from tannins (Ramasami et al., 2004). Syntans are characterized by complex chemical structures, because they are composed of an extended set of chemicals such as phenol-, naphthalene-, formaldehyde- and melamine-based syntans, and acrylic resins (Beem, 1994). Organic pollutants (proteic and lipidic components) are originated from skins (it is calculated that the raw skin has $30 \%$ loss of organic material during the working cycle) or they are introduced during processes (Hugo Springer, 1994).

Many conventional processes such as oxidation, chemical and biological processes were carried out to treat tanneries wastewater (Ebtesam et al, 2013). Biological processes have received more attention because of their costeffectiveness, lower sludge production and environmental friendliness (Noorjahan, 2014). Naturally occurring micro-organisms degrade the hazardous organic wastes including xenobiotic compounds, such as pesticides, polycyclic aromatic hydrocarbons (PAHs) and polychlorinated biphenyls (PCBs) in due course of time (Ranen and Sharadinadra, 2009). Bioremediation is based on the idea that all organisms remove substances from the environment to carry outgrowth and metabolism (Bouwer and Zehnder, 1993). Bacteria, protista and fungi are found to be very good at degrading complex molecules and incorporating the breakdown products into their metabolism (Bouwer and Zehnder, 1993). The resultant metabolic wastes that they produce are generally safe and somehow recycled into other organisms (Ranen and Sharadinadra, 2009). An acclimatized indigenous population of microorganisms capable of degradation of the compounds of interest must exist at the site for a successful bioremediation mode (Ranen and Sharadinadra, 2009). It has been observed that for a successful bioremediation mode, an acclimatized indigenous population of microorganisms capable of degradation of the compounds of interest must exist at the site under investigation (Ranen and Sharadinadra, 2009). Even though there are numerous physical and chemical methods employed in the disposal of wastes the advantage in using bacterium is that they play a key role in the reduction of COD, BOD, total protein, total tannin and total phenol (Saravanan and Saravanan, 1998)

Baba et al. (2020) studied the bioremediation potential of immobilized corynebacterium kutsceri in the Treatment of tannery industrial effluent from Challawa Industrial Estate, Kano State, Nigeria. The aim of the work is to study the reduction in the level of the contaminants through the process of bioremediation using the isolated bacteria. Immobilized bacteria can withstand various temperatures, $\mathrm{pH}$ and substrate concentrations; consequently, increasing the efficiency and the lifespan of the bacteria. Immobilized bacteria are widely applied in the treatment of wastewater and can be separated and recovered after the treatment with the same efficiency (Baba et al., 2020).

\section{MATERIALS AND METHODS \\ Study Area}

This study was carried out in Bompai, Sharada and Challawa industrial estates in Kano, Figure 1. Kano lies on Latitude $11^{\circ} 30^{\prime} \mathrm{N}$ and $8^{\circ} 30^{\prime} \mathrm{E}$ and Longitude $11^{\circ} 5^{\prime} \mathrm{N}$ and $8^{\circ} 5^{\prime} \mathrm{E}$ in Northern Nigeria. It is one of the developed industrial cities in Nigeria. Tannery activities are the dominating industries and this could be one of the reasons for her high population density (Dan'Azumi and Bichi, 2010). Many researchers have studied biodegradation of tannery effluent using microorganisms. However, limited literature is available on the biodegradation of tannery effluent in Kano industrial estates using 
BAJOPAS Volume 13 Number 2, December, 2020 immobilized bacterial cells. This research work focuses on the potential of the use of the indigenous immobilized bacterial isolates in the treatment of tannery effluents in the industrial estates.

\section{Sample Collection}

Effluents were collected from the Tannery Industries from Bompai, Challawa and Sharada Industrial Estates, Kano, Nigeria. The effluents were collected over a period of six months (August 2017 to January 2018). Samples collected in a sterile 4-liter plastic container with a unique identification number were preserved using an ice-box that was transported to the Microbiology Laboratory, Department of Microbiology, Bayero University of Kano for analysis

\section{Sample Preparation and Sample Analysis}

Immediately after the collection of the effluent, $\mathrm{pH}$, TSS, TDS, COD, BOD levels were determined before treatment (Pre-treatment determination) and ten days after treatment (Post-treatment determination) as described in
APHA (1989) standard methods. $\mathrm{pH}$ was determined using Ecotests $\mathrm{pH}$ meter and TDS was determined using AQUALYTIC TDS Salinometer. BOD was determined as described by the standard method (APHA, 1992). COD and SS were determined using DR/2010 HACH portable data logging spectrophotometer (DWAF, 1992)

\section{Identification and Biochemical} Characterization of the Bacterial Isolates

The bacteria were isolated from the effluents using Serial Dilution according to the method described by APHA (1989). The biochemical tests such as oxidase, catalase, coagulase, indole (from $1 \%$ tryptone broth), citrate (Simmons citrate agar), methyl red/VogesProskauer (MR/VP), nitrate reduction, Starch Hydrolysis, Glucose, Maltose, and Lactose tests were carried out on the bacterial isolates to identify the bacteria through the bacteria biochemical characteristics according to Ajao et al. (2011).

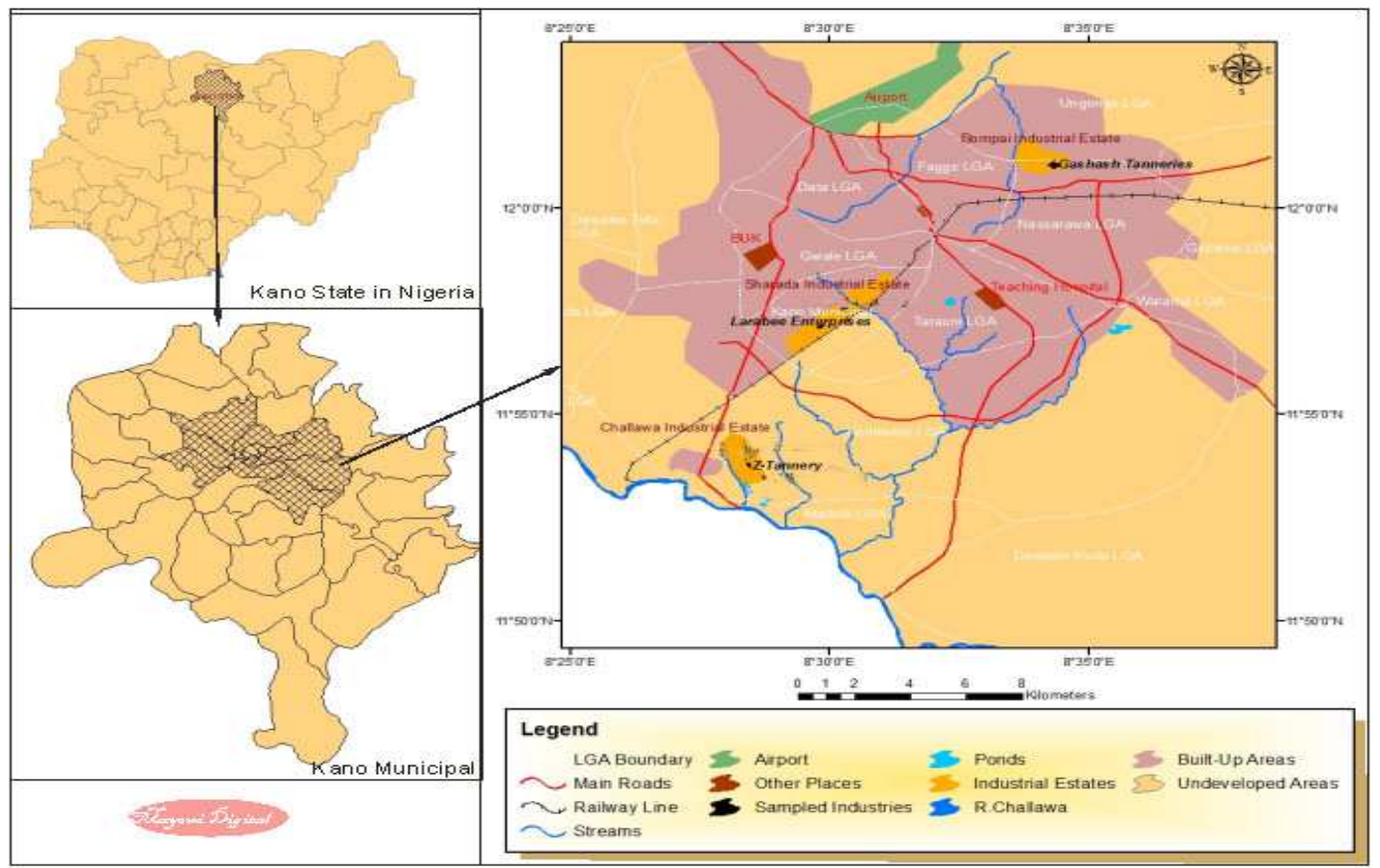

Fig. 1 Map showing the study areas

Source: Mayomi Digital Productions, GIS Laboratory, Department of Geography, UNIMAID (2017)

\section{Determination of Growth Rate of the Bacteria in Effluent Sample}

The bacteria growth rates were determined by transferring $2 \mathrm{~mL}$ of the bacterial isolates from the tannery effluent in broth medium into 100 $\mathrm{mL}$ sterile effluents in conical flasks and kept in an incubator (Giffrin cool) for 10 days. Control was also set up by incubating another $100 \mathrm{~mL}$ each of the sterile effluents without the bacteria. The optical density of the content was determined at the wavelength of $600 \mathrm{~nm}$ on a daily interval and recorded. 
BAJOPAS Volume 13 Number 2, December, 2020 Immobilization of Bacteria

Agar solution and inoculi were prepared separately. Fifty milliliters $(50 \mathrm{~mL})$ of nutrient broth each of the inoculi was prepared in a McCartney bottle and incubated for 24 hours. A solution of agar-agar was prepared by dissolving $10 \mathrm{~g}$ of the powder in distilled water and made up to $500 \mathrm{~mL}$ mark in an Erlenmeyer flask and was sterilized in an autoclave (280A) for 15 minutes and allowed to cool to $40-45^{\circ} \mathrm{C}$ (Ajao et al., 2011). Four milliliters ( $4 \mathrm{~mL})$ of the bacterial isolates in the nutrient broth was mixed with 36 $\mathrm{ml}$ of the prepared agar-agar media in petri-dish plates and then allowed to solidify. This was kept in the refrigerator for bioremediation.

\section{Bioremediation (Treatment) of the Effluents}

The solidified agar block (immobilized bacteria) was cut into cubes using a sterile knife; $0.1 \mathrm{~mL}$ phosphate buffer ( $\mathrm{pH} \mathrm{7.0)}$ was added and kept in the refrigerator for 1 hour for curing. The phosphate buffer was decanted after 1 hour and the cubes were washed with sterile distilled water 3-4 times before it was used (Ajao et al., 2011). Two liters (2 L) of the effluent was supplemented with the minimum basal medium in $\mathrm{g} / \mathrm{L}: \mathrm{NaCl}(0.8), \mathrm{MgSO}_{4} .7 \mathrm{H}_{2} \mathrm{O}(0.001), \mathrm{KH}_{2} \mathrm{PO}_{4}$ (2), $\mathrm{NaNO}_{3}$ (2), $\quad \mathrm{CaCl}_{2} .2 \mathrm{H}_{2} \mathrm{O} \quad(0.5)$ and $\mathrm{NaHPO}_{4} .12 \mathrm{H}_{2} \mathrm{O}(2)$ and sterilized in an autoclave at $121^{\circ} \mathrm{C}$ for 15 minutes (Margesin and Schinner, 2001). Two hundred and fifty milliliters $(250 \mathrm{~mL})$ of the effluents were transferred into different $250 \mathrm{ml}$ conical flasks. The content was covered with a cotton-wool ramped with foil paper to avoid contamination. Five grams $(5 \mathrm{~g})$ of the immobilized bacteria were quickly transferred into each of the effluents in the conical flasks in an inoculating chamber. The same procedures were carried out for the $10 \mathrm{~g}, 15 \mathrm{~g}, 20 \mathrm{~g}$ and 25 $\mathrm{g}$ of the immobilized bacteria in separate $250 \mathrm{~mL}$ effluents in conical flasks and agitated for ten days in a shaker incubator (Gallenkamp-OC4364-L) at a temperature $30^{\circ} \mathrm{C}$ and speed of 60 rpm. The treated effluent samples were taken on the tenth day and analyzed for the parameters $\mathrm{pH}$, SS, TDS, COD, and BOD, (Posttreatment determination) for the different grams of bacteria to evaluate and compare the biodegradation potential. (Baba et al., 2020).

\section{Statistical Analysis}

The data were represented as Mean \pm Standard deviation and analyzed statistically using oneway Analysis of Variance (ANOVA) and Tukey's HSD as Post Hoc Tests with the aid of SPSS 16.0. The correlation coefficient was also used to measure the strength of the relationship between the different masses of the bacteria and the parameters. All $\mathrm{p} \leq 0.05$ were considered as statistically significant.

\section{RESULTS AND DISCUSSION Physico-chemical parameters in the Industrial Effluents before the Biodegradation.}

Results of the Physico-chemical parameters in the industrial effluents before the Biodegradation is shown in table 1 . The mean temperatures $\left({ }^{\circ} \mathrm{C}\right)$ observed in TAN1, TAN2, and TAN3 samples were $28.07 \pm 0.65 ; 27.77 \pm 0.64$ and $26.38 \pm 3.81$ respectively. The order of the mean temperature of the samples from the three industries can be arranged as TAN1 > TAN2>TAN3. The temperature observed at TAN1, TAN2, and TAN3 samples were found below the WHO $\left(35^{\circ} \mathrm{C}\right)$ and NESREA $\left(40^{\circ} \mathrm{C}\right)$ limits. The low values of temperature might be due to the processes used at the time of sampling. High temperature brings down the solubility of gases in water that ultimately expresses as high BOD and COD. Statistical analysis shows that there is no significant difference $(p<0.05)$ between the mean values of temperature among the industries. This might be due to similar tannery activities involved in the tannery industries at the time of sampling. The average values of temperature observed in this present study are less than those observed by Akan et al. (2007), Akan et al. (2009) and Baba et al. (2020).

The mean level of $\mathrm{pH}$ observed in TAN1, TAN2 and TAN3, samples were $7.77 \pm 2.93$; $8.35 \pm 0.28$ and $7.52 \pm 0.76$ respectively. The order of the mean $\mathrm{pH}$ of the samples from the three industries can be arranged as TAN2> TAN1 $>$ TAN3. The $\mathrm{pH}$ of the samples falls within the WHO (7.0-8.5) and NESREA (6-9) standard limits. Statistical analysis shows that there is no significant difference $(p<0.05)$ between the mean values of $\mathrm{pH}$ among the industries. This might be due to similar tannery activities involved in the tannery industries at the time of sampling. Maheshwari et al. (2017) reported that the level of $\mathrm{pH}$ in the effluents from the tannery industry in Vaniyambadi, India was 6.5 which was lower than that observed in the present study. The $\mathrm{pH}$ in the effluents from the tannery industries in Kano and Kaduna were reported to be 7.64 and 6.89, respectively (Akan et al., 2007; Mohammed et al., 2017). The average values of $\mathrm{pH}$ observed in this present study are less than those observed by Mohammed et al. (2017) and Baba et al. (2020). The mean level of SS $(\mathrm{mg} / \mathrm{l})$ observed in TAN1, TAN2, and TAN3 samples were 374 \pm 124 ; $358 \pm 335$ and $780 \pm 739$ respectively. The order of the mean SS in the samples from the three industries can be arranged as TAN3 > TAN1 $>$ TAN2. 
The SS observed in the samples were far above the recommended standard limits of regulating bodies WHO $(30 \mathrm{mg} / \mathrm{l})$ and NESREA $(10 \mathrm{mg} / \mathrm{l})$. Statistical analysis shows that there is no significant difference $(p<0.05)$ between the mean values of SS among the industries. This might be due to similar tannery activities involved in the tannery industries at the time of sampling. The average values of SS observed in this present study are less than that observed $(3700 \pm 122 \mathrm{mg} / \mathrm{l})$ by Akan et al. (2009) for tanneries in Kano. Also, the average values of SS observed in this present study are less than that observed by Mohammed et al. (2017) and Baba et al. (2020) with the exception in TAN3.

The mean level of TDS (mg/l) observed in TAN1, TAN2, and TAN3 samples were $3941 \pm 3703$; $3300 \pm 1714$ and $2653 \pm 1240$ respectively. The order of the mean TDS in the samples from the three industries can be arranged as TAN1>TAN2>TAN3. The TDS observed in the samples were far above the recommended standard limits of WHO $(250 \mathrm{mg} / \mathrm{l})$ and NESREA $(500 \mathrm{mg} / \mathrm{l})$. Statistical analysis shows that there is no significant difference $(p<0.05)$ between the mean values of TDS among the industries. This might be due to similar tannery activities involved in the tannery industries at the time of sampling. TDS in the effluents from the tannery industries in Kano, Nigeria was reported to be $1281 \mathrm{mg} / \mathrm{l}$ (Akan et al., 2007). The average values of SS observed in this present study are less than those observed by Mohammed et al. (2017) and Baba et al. 2020)

The mean level of COD (mg/l) observed in TAN1, TAN2 and TAN3 samples seasons were $2372 \pm 938 ; \quad 1406 \pm 208$ and $3532 \pm 1373$ respectively. The order of the mean COD of the samples from the three industries can be arranged as TAN3>TAN1> TAN2. The COD observed in TAN1, TAN2 and TAN3 samples were far above the recommended standard limits of regulating bodies $\mathrm{WHO}(40 \mathrm{mg} / \mathrm{l})$ and NESREA (40 mg/l). Statistical analysis shows that there is no significant difference $(p<0.05)$ in COD among the industries. This might be due to similar tannery activities involved in the tannery industries as at the time of sampling. The Chemical Oxygen demand (COD) is the amount of oxygen, in $\mathrm{mg} / \mathrm{L}$, required for the degradation of the compound of wastewater to occur. In comparison, the average values of COD observed in this present study were higher than that observed by Mohammed et al. (2017) but lower than that observed by Baba et al. (2020).

The mean levels of BOD $(\mathrm{mg} / \mathrm{l})$ observed in TAN1, TAN2 and TAN3 samples were $13.85 \pm 6.42 ; \quad 19.46 \pm 0.50$ and $17.13 \pm 3.14$ respectively. The order of the mean BOD in the samples from the three industries can be arranged as TAN2>TAN3>TAN1. The BOD observed in TAN1, TAN2 and TAN3 samples were found below the recommended limits of NESREA (200 mg/l) but above WHO (10 mg/l). Statistical analysis shows that there is no significant difference $(p<0.05)$ between the mean values of BOD among the industries. This might be due to similar tannery activities involved in the tannery industries at the time of sampling. The low level of BOD recorded in this study is an indication of the low level of biodegradable organic solids in the effluent. The average values of BOD observed in this present study were lower than those observed by Mohammed et al. (2017) and Baba et al. (2020).

Table 1: Mean Values \pm S.D of Physico-chemical parameters of effluents from the Tannery Industries before Treatment.

\begin{tabular}{llllllll}
\hline Parameter & Tannery 1 & Tannery 2 & Tannery 3 & $\mathrm{a}$ & $\mathrm{b}$ & $\mathrm{c}$ & $\mathrm{d}$ \\
\cline { 2 - 7 } Temperature $\left({ }^{\circ} \mathrm{C}\right)$ & $28.07 \mathrm{a} \pm 0.65$ & $27.77 \mathrm{a} \pm 0.64$ & $26.38 \mathrm{a} \pm 3.81$ & & $29.50 \pm 4.68$ & 35 & 40 \\
pH & $7.77 \mathrm{a} \pm 2.93$ & $8.35 \mathrm{a} \pm 0.28$ & $7.52 \mathrm{a} \pm 0.76$ & 6.89 & $5.35 \pm 1.57$ & $7.0-8.5$ & $6.0-9.0$ \\
$\mathrm{COD}(\mathrm{mg} / \mathrm{l})$ & $2372 \mathrm{a} \pm 938$ & $1406 \mathrm{a} \pm 208$ & $3532 \mathrm{a} \pm 1373$ & 2.2 & $3106 \pm 2753$ & 40 & 40 \\
$\mathrm{BOD}(\mathrm{mg} / \mathrm{l})$ & $13.85 \mathrm{a} \pm 6.42$ & $19.46 \mathrm{a} \pm 0.50$ & $17.13 \mathrm{a} \pm 3.14$ & 1032 & $26.17 \pm 9.49$ & 10 & 200 \\
$\mathrm{SS}(\mathrm{mg} / \mathrm{l})$ & $374 \mathrm{a} \pm 124$ & $358 \mathrm{a} \pm 335$ & $780 \mathrm{a} \pm 739$ & 501 & $562 \pm 482$ & 30 & 10 \\
TDS $(\mathrm{mg} / \mathrm{l})$ & $3941 \mathrm{a} \pm 3703$ & $3300 \mathrm{a} \pm 1714$ & $2653 \mathrm{a} \pm 1240$ & 532.7 & $444 \pm 507$ & 250 & 500 \\
\hline
\end{tabular}

The values given in the table above are means of 6 replicate values, $\mathrm{n}=6$ ( 1 sample was taken monthly for 6 months). Within the rows, means with different alphabets are statistically different $(p<0.05)$. WHO: World Health Organisation. NESREA: National Environmental Standard and Regulatory Enforcement Agency. a = Mohammed et al.(2017), b = Baba et al. (2020), c = WHO (2006), $d=$ NESSRA (2009) 
BAJOPAS Volume 13 Number 2, December, 2020

Identification, Biochemical Characterization and growth rates of the Bacterial Isolates

Results of identification and biochemical characterization of the bacterial isolates were shown in table 2. After 24 hours of incubation, the nutrient agar media plates were checked for bacterial growth. The results showed the presence of different strains in the samples. The TAN1 bacteria isolate was found to be gramnegative cocci while TAN3 was gram-positive cocci. TAN2 bacteria isolate was found to be gram-positive, rod-shaped. TAN1, TAN2, and TAN3 bacteria isolates recorded positive results for spore former.

The results of the biochemical tests indicated that all the bacteria were positive for catalase, oxidase, citrate, maltose, glucose, lactose (negative in TAN1), mannitol (negative in TAN2), starch hydrolysis and coagulase (negative in TAN2) tests. The bacteria showed negative results for nitrate reduction, $M R$ (positive in TAN2), VP (positive in TAN1), Indole (positive in TAN2) tests. Base on the morphological and biochemical test results, TAN1, TAN2, and TAN3 bacteria isolates were identified to be Nesseria spp, Bacillus cereus, and Staphylococcus aureus respectively.

The growth rate of the TAN1, TAN2 and TAN3 Isolates were shown in figure 2. Generally, the optical density increase with the increase in time (day) and decrease as time goes on. The highest optical density was shown by bacillus cereus in TAN2 while the lowest was shown by Staphylococcus aureus in TAN3.

The initial growth phase of TAN1 Isolate bacteria occurred within 2-day of incubation as the growth rate increases up to the 6th-day incubation when the maximum growth was observed. Beyond the 6th day, the growth of the bacteria declined (which might be due to a shortage of nutrients in the effluents) until it reached its death phase (which might be due to the unavailability of nutrients in the effluents).

A similar trend of growth was also observed for TAN2 Isolate as the initial growth phase also occurred within 2-day of incubation but maximum growth rate observed on the 4th day of incubation. The stationary stage occurred between the 4th day and the 8th day. Beyond the 8th day, the growth of the bacteria declined (which might be due to a shortage of nutrients in the effluents) until it reached its death phase (which might be due to the unavailability of nutrients in the effluents).

The initial growth phase of TAN3 bacterial Isolate occurred within the 3-day incubation as the growth rate increases up to the 6th-day incubation when the maximum growth was observed. Beyond the 6th day, the growth of the bacteria declined (which might be due to a shortage of nutrients in the effluents) until it reached its death phase (which might be due to the unavailability of nutrients in the effluents).

Table 2: Morphological and Biochemical characteristics of bacterial isolates

\begin{tabular}{lllll} 
Bacterial Isolates & & TAN1 & TAN2 & TAN3 \\
\hline $\begin{array}{lllll}\text { Morphological } \\
\text { characteristics }\end{array}$ & Shape & Cocci & Rod & Cocci \\
& Spore & & & \\
& former & + & + & + \\
Gram & & & \\
Biochemical characteristics & reaction & - & + & + \\
& Citrate & + & + & + \\
& Catalase & + & + & + \\
& Coagulase & + & - & + \\
Starch & + & + & + \\
& Glucose & + & + & + \\
Oxidase & + & + & + \\
& Indo & - & + & - \\
Lactose & - & + & + \\
Manitol & + & - & + \\
Maltose & + & + & + \\
MR & - & + & - \\
VP & + & - & - \\
& Nitrate & - & - & - \\
Reduction & - Neisseria & Bacillus & Staphylococcus \\
& Bacterial & cereus & aureus \\
& name & spp & cas
\end{tabular}

+ = Positive; - = Negative; MR=Methyl Red; VP= Voges-Proskauer 


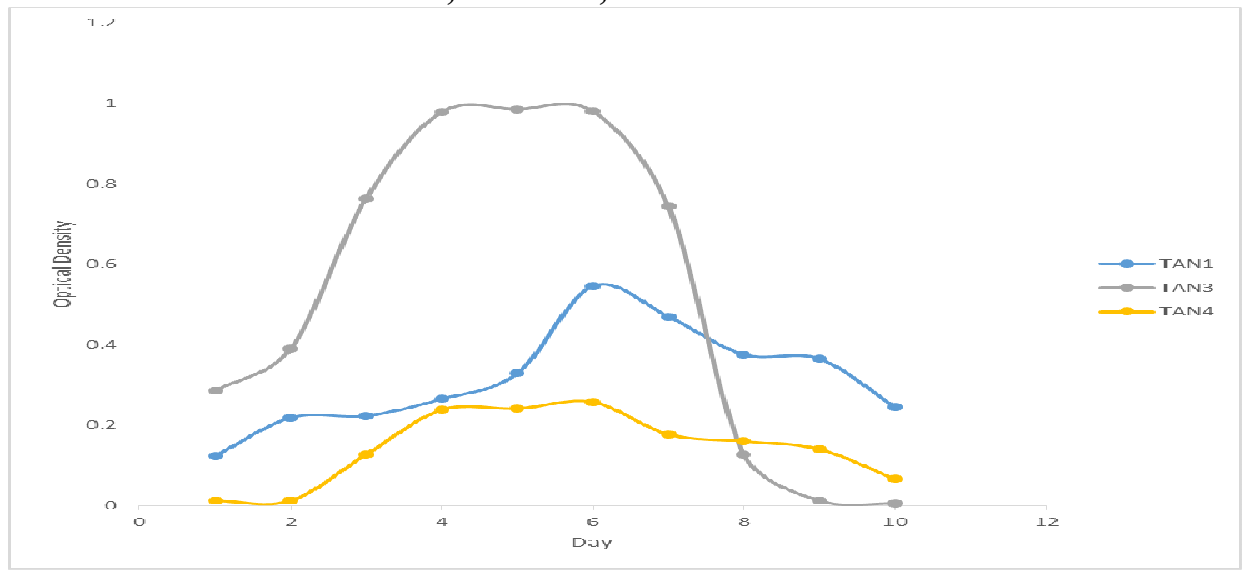

Fig. 2 Growth rates of the isolates in the effluents from the Tannery Industries

\section{Physico-chemical Parameters in the Industrial Effluents after the biodegradation.}

Table 3 shows the mean results of the physicochemical parameter before and after bioremediation using the different masses $(5 \mathrm{~g}$, $10 \mathrm{~g}, 15 \mathrm{~g}, 20 \mathrm{~g}$, and $25 \mathrm{~g}$ ) of the respective immobilized bacteria. Also, Table 4 shows the mean results of correlation coefficient ( $r$ ) between different masses of bacteria and physicochemical parameters.

The mean values $(\mathrm{mg} / \mathrm{l})$ of the SS after the bioremediation varies between $243 \pm 45$ and $898 \pm 672$. The mean concentration $(\mathrm{mg} / \mathrm{l})$ of SS remediated by the different masses $(5 \mathrm{~g}, 10 \mathrm{~g}$, $15 \mathrm{~g}, 20 \mathrm{~g}$, and $25 \mathrm{~g}$ ) of the bacteria varies. The SS in the samples fluctuates up and down after the bioremediation process when compared with the SS of the raw samples before the bioremediation. The increase in the levels of the SS might be due to the aggregation of the TDS which are large enough to result into SS. The increase in the levels of the SS might be also due to the influence of the nutrients which was added into the effluents in order to make the microorganisms more active and viable for fast degradation of organic contaminants in the effluent. The relative potential or efficiency of the different masses of the bacteria in remediating SS in TAN1 samples was in the order $25 \mathrm{~g}>20 \mathrm{~g}>15 \mathrm{~g}>10 \mathrm{~g}>5 \mathrm{~g}$. For TAN2 and TAN3 samples, the order was $25 \mathrm{~g}>20 \mathrm{~g}>15$ $\mathrm{g}>10 \mathrm{~g}>5 \mathrm{~g}$. These might be due to the variations in the surface areas of the different masses of the immobilized bacteria. Statistical analysis shows that there is no significant difference $(p<0.05)$ between the mean values of SS among the masses in the respective industries. Positive and significant correlations exist between the masses of bacteria and Suspended Solid (SS). This showed that there is general increase in the levels of the SS as the masses of the immobilized bacteria increases. TAN3 (90\%) and TAN1 (80\%) showed a very high correlation with the masses of the bacteria while TAN2 (61\%) showed a very low correlation.

The mean values $(\mathrm{mg} / \mathrm{l})$ of the TDS after the bioremediation varies between $46 \pm 11$ and $83 \pm 78$. The mean concentration $(\mathrm{mg} / \mathrm{l})$ of TDS remediated by the different masses $(5 \mathrm{~g}, 10 \mathrm{~g}$, $15 \mathrm{~g}, 20 \mathrm{~g}$, and $25 \mathrm{~g}$ ) of the bacteria varies. There is a reduction in all the TDS of all the samples after the bioremediation process compared with the TDS of the raw samples before the bioremediation. The relative potential or efficiency of the different masses of the bacteria in remediating TDS in TAN1 and TAN3 samples was in the order $5 \mathrm{~g}>10 \mathrm{~g}>15 \mathrm{~g}>20$ $\mathrm{g}>25 \mathrm{~g}$. For TAN2 samples, the order was 20 $g>10 \quad g>25 \quad g>15 \quad g>5 \quad g$. Statistical analysis shows that there is no significant difference $(p<0.05)$ between the mean values of TDS among the masses in the respective industries. These might be due to the variations in the surface areas of the different masses of the immobilized bacteria. Positive and significant correlations exist between the masses of bacteria and TDS with the exception in TAN2 (negative and insignificant correlation). The positive correlations showed that there is general increase in the levels of the TDS as the masses of the immobilized bacteria increases. TAN1 $(96 \%)$ showed a very high correlation with the masses of the bacteria while TAN2 (47\%) showed a very low correlation.

The mean values $(\mathrm{mg} / \mathrm{l})$ of the BOD after the bioremediation varies between $1.56 \pm 0.20 \mathrm{mg} / \mathrm{l}$ and $6.92 \pm 5.49 \mathrm{mg} / \mathrm{l}$. The mean concentration $(\mathrm{mg} / \mathrm{l})$ of BOD remediated by the different masses $(5 \mathrm{~g}, 10 \mathrm{~g}, 15 \mathrm{~g}, 20 \mathrm{~g}$, and $25 \mathrm{~g}$ ) of the bacteria varies. There is a reduction in all the BOD of all the samples after the bioremediation process compared with the $\mathrm{BOD}$ of the raw 
BAJOPAS Volume 13 Number 2, December, 2020 samples before the bioremediation. The relative potential or efficiency of the different masses of the bacteria in remediating BOD in TAN1, TAN2 and TAN3 samples were in the order $25 \mathrm{~g}>20$ $\mathrm{g}>15 \mathrm{~g}>10 \mathrm{~g}>5 \mathrm{~g}, 25 \mathrm{~g}>15 \mathrm{~g}>5 \mathrm{~g}>10 \mathrm{~g}>20 \mathrm{~g}$ and $20 \mathrm{~g}>10 \mathrm{~g}>25 \mathrm{~g}>15 \mathrm{~g}>5 \mathrm{~g}$ respectively. Statistical analysis shows that there is significant difference $(p<0.05)$ between the mean values of BOD among the masses in the respective industries. These might be due to the variations in the surface areas of the different masses of the immobilized bacteria. Negative and significant correlations exist between the masses of bacteria and BOD. This showed that there is general decrease in the levels of the BOD as the masses of the immobilized bacteria increases. TAN1 (94\%) showed a very high correlation with the masses of the bacteria while TAN2 (4\%) showed a very low correlation.

The mean values $(\mathrm{mg} / \mathrm{l})$ of the COD after the bioremediation varies between $250 \pm 154$ and $3134 \pm 1595$. The mean concentration $(\mathrm{mg} / \mathrm{l})$ of COD remediated by the different masses $(5 \mathrm{~g}$, $10 \mathrm{~g}, 15 \mathrm{~g} 20 \mathrm{~g}$, and $25 \mathrm{~g}$ ) of the bacteria varies. There is a reduction in all the COD of all the samples after the bioremediation process compared with the COD of the raw samples before the bioremediation. The relative potential or efficiency of the different masses of the bacteria in remediating COD in TAN1, TAN2 and TAN3 samples were in the order $25 \mathrm{~g}>20 \mathrm{~g}>15$ $\mathrm{g}>5 \mathrm{~g}>10 \mathrm{~g}, 25 \mathrm{~g}>20 \mathrm{~g}>15 \mathrm{~g}>10 \mathrm{~g}>5 \mathrm{~g}$ and 10 g>5 g>25 g>15 g>20 g respectively. Statistical analysis shows that there were significant difference $(p<0.05)$ between the mean values of COD among the masses in the respective industries except for effluents treated with $25 \mathrm{~g}$. These might be due to the variations in the surface areas of the different masses of the immobilized bacteria. Negative and insignificant correlations exist between the masses of bacteria and COD with the exception in TAN3 (positive and significant correlation). The negative correlations showed that there is general decrease in the levels of the COD as the masses of the immobilized bacteria increases. TAN2 (100\%) showed a very high correlation with the masses of the bacteria while TAN3 (36\%) showed a very low correlation.

Generally, there was an overall decrease in the concentration of these physicochemical parameters after the bioremediation using the different masses of the bacterial isolates. These might be due to the variations in the surface areas of the different masses of the immobilized bacteria. This is in line with the work of Jimoh et al. (2018) and Baba et al. (2020).

Table 3: Mean Values $(\mathrm{mg} / \mathrm{l}) \pm$ S.D of Physicochemical parameters in effluents from the Tannery Industries before and after Treatment of the effluents $(250 \mathrm{ml})$ with the different masses $(5 \mathrm{~g}, 10 \mathrm{~g}$, $15 \mathrm{~g}, 20 \mathrm{~g}$, and $25 \mathrm{~g}$ ) of the bacteria.

\begin{tabular}{llllllll}
\hline $\mathrm{P}$ & IND & Before & \multicolumn{5}{c}{ After } \\
\cline { 4 - 7 } & & & $5 \mathrm{~g}$ & $10 \mathrm{~g}$ & $15 \mathrm{~g}$ & $20 \mathrm{~g}$ & $25 \mathrm{~g}$ \\
\hline \multirow{2}{*}{ COD } & TAN1 & $2372 \pm 938$ & $1708 \mathrm{a} \pm 861$ & $2045 \mathrm{a} \pm 1205$ & $845 \mathrm{a} \pm 369$ & $300 \mathrm{a} \pm 167$ & $250 \mathrm{a} \pm 154$ \\
& TAN2 & $1406 \pm 208$ & $1195 \mathrm{a} \pm 208$ & $1125 \mathrm{a} \pm 384$ & $1055 \mathrm{a} \pm 317$ & $956 \mathrm{a} \pm 310$ & $870 \mathrm{ab} \pm 240$ \\
& TAN3 & $3532 \pm 1373$ & $2374 \mathrm{a} \pm 1344$ & $1976 \mathrm{a} \pm 1405$ & $2757 \mathrm{a} \pm 1266$ & $3134 \mathrm{a} \pm 1595$ & $2614 \mathrm{~b} \pm 1105$ \\
BOD & TAN1 & $13.85 \pm 6.42$ & $6.92 \mathrm{a} \pm 5.49$ & $6.42 \mathrm{a} \pm 5.07$ & $5.72 \mathrm{a} \pm 5.35$ & $4.62 \mathrm{a} \pm 4.37$ & $2.82 \mathrm{ab} \pm 1.26$ \\
& TAN2 & $19.46 \pm 0.50$ & $1.75 \mathrm{~b} \pm 0.22$ & $1.73 \mathrm{~b} \pm 0.18$ & $1.58 \mathrm{a} \pm 0.16$ & $1.91 \mathrm{a} \pm 0.22$ & $1.56 \mathrm{~b} \pm 0.20$ \\
& TAN3 & $17.13 \pm 3.14$ & $4.24 \mathrm{ab} \pm 0.77$ & $3.29 \mathrm{ab} \pm 0.37$ & $4.11 \mathrm{a} \pm 0.07$ & $3.23 \mathrm{a} \pm 0.91$ & $3.33 \mathrm{a} \pm 1.28$ \\
SS & TAN1 & $374 \pm 124$ & $243 \mathrm{a} \pm 45$ & $471 \mathrm{a} \pm 226$ & $475 \mathrm{a} \pm 182$ & $492 \mathrm{a} \pm 128$ & $611 \mathrm{a} \pm 217$ \\
& TAN2 & $358 \pm 335$ & $460 \mathrm{a} \pm 400$ & $543 \mathrm{a} \pm 414$ & $544 \mathrm{a} \pm 402$ & $551 \mathrm{a} \pm 414$ & $554 \mathrm{a} \pm 405$ \\
& TAN3 & $780 \pm 739$ & $586 \mathrm{a} \pm 594$ & $758 \mathrm{a} \pm 656$ & $787 \mathrm{a} \pm 676$ & $861 \mathrm{a} \pm 635$ & $898 \mathrm{a} \pm 672$ \\
TDS & TAN1 & $3941 \pm 3703$ & $51 \mathrm{a} \pm 10$ & $53 \mathrm{a} \pm 10$ & $55 \mathrm{a} \pm 15$ & $61 \mathrm{a} \pm 20$ & $63 \mathrm{a} \pm 26$ \\
& TAN2 & $3300 \pm 1714$ & $83 \mathrm{a} \pm 78$ & $47 \mathrm{a} \pm 20$ & $48 \mathrm{a} \pm 22$ & $47 \mathrm{a} \pm 17$ & $48 \mathrm{a} \pm 17$ \\
& TAN3 & $2653 \pm 1240$ & $46 \mathrm{a} \pm 11$ & $55 \mathrm{a} \pm 24$ & $55 \mathrm{a} \pm 25$ & $58 \mathrm{a} \pm 23$ & $61 \mathrm{a} \pm 28$ \\
\hline
\end{tabular}

Replicate $=6$ (months)

Within the rows, for the same parameter, means with different alphabets are statistically different $(p<0.05)$.

$\mathrm{P}=$ parameter, IND = Industries 
BAJOPAS Volume 13 Number 2, December, 2020

Table 4: Correlation coefficient $(r)$ between different masses of the bacteria and the physicochemical parameters.

\begin{tabular}{llll}
\hline Industries & Parameter & Correlation coefficient $(r)$ & $\begin{array}{l}\text { Percent dependence (rxrx100) } \\
(\%)\end{array}$ \\
\hline TAN1 & COD & -0.9 & 82 \\
& BOD & -0.97 & 94 \\
& SS & $0.90^{*}$ & 80 \\
TAN2 & TDS & $0.98^{*}$ & 96 \\
& COD & -1 & 100 \\
& BOD & -0.21 & 4 \\
& SS & $0.78^{*}$ & 61 \\
& TDS & -0.69 & 47 \\
& COD & $0.60^{*}$ & 36 \\
& BOD & -0.6 & 37 \\
& SS & $0.95^{*}$ & 90 \\
& TDS & $0.94^{*}$ & 89 \\
\hline
\end{tabular}

The correlation coefficient $(r)$ with * is statistically significant $(p<0.05)$.

Percentage reduction of the Parameters

Table 5 shows the percentage reduction of Parameters in industrial samples before and after the treatment of the effluents $(250 \mathrm{ml})$ with the different masses $(5 \mathrm{~g}, 10 \mathrm{~g}, 15 \mathrm{~g}, 20 \mathrm{~g}$, and $25 \mathrm{~g}$ ) of the Immobilized Bacteria.

In TAN1 samples, the percentage reduction (\%) of COD ranged (14-89); BOD (50-80); SS (-32$35)$ and TDS (98-99). In TAN2 samples, the percentage decrease $(\%)$ of COD ranged (15$38) ;$ BOD (90-92); SS [-28-(-55)] and TDS (9798). In TAN3 samples, the percentage decrease (\%) of COD ranged (11-44); BOD (76-81); SS (15-25) and TDS (98). The percentage increase in the levels COD, BOD and TDS might be due to the increase in the surface area of the different masses of the immobilized bacteria. However, the percentage decrease in the levels of the SS might be due to the aggregation of the TDS which are large enough to result into SS. The percentage decrease in the levels of the SS might be also due to the influence of the nutrients which was added into the effluents in order to make the microorganisms more active and viable for fast degradation of organic contaminants in the effluent. This is in line with the work of Jimoh et al. (2018) in which the concentration of the SS increase after the bioremediation of effluents.

Sreemoyee and Priti (2013) assessed and reduced several Physico-chemical parameters of dairy wastewater using Niesseria $s p$. and concluded that the species are well known to degrade organic compounds. This is in agreement with the current study in which the immobilized Niesseria $s p$ degrade the organic contaminants as indicated by the BOD, COD and TDS.

Jimoh et al. (2018) observed that TSS of the effluents was increased after treatment with immobilized bacteria and concluded that it might be due to the biostimulation method adopted for the research.

The optimum $\mathrm{pH}$ Biosorption of Chromium by Bacillus spp and Staphylococcus spp. from tannery effluent was investigated by Mythili and Karthikeyan (2011). The maximum adsorption of Chromium $(86.4 \mathrm{mg} / \mathrm{L})$ was showed by Bacillus spp and Staphylococcus spp showed $70.6 \mathrm{mg} / \mathrm{L}$ at an initial concentration of $100 \mathrm{mg} / \mathrm{L}$. In the present study, immobilised Bacillus spp and Staphylococcus spp. from the tannery industrial effluents reduced the levels of the organic pollutants with high potential as indicated by the percentage reduction of BOD, COD and TDS.

Enzymes often can work in multiple environments especially if they are immobilized. This makes the microorganisms' enzymes even more resistant to harsh environments and enables the enzymes to be recovered and recycled after they are no longer needed (Gianfreda and Rao 2004). Ramesh and Singh (1993) reported that the immobilized bacteria having more efficiency to remove the suspended particles than free cells. Using the immobilized cell is preferable due to its capability for using several times with the same efficiency, which makes it more economical. Similar work was done by Sikander et al. (2007) showing the higher reduction with permeabilized cells of Ochrobactrum intermedium strain SDCr-5. 
BAJOPAS Volume 13 Number 2, December, 2020

The results revealed the isolation and identification of isolates with the potential for the reduction of $\mathrm{Cr}$ (VI) to $\mathrm{Cr}$ (III). Results indicated that immobilized $B$. cereus could be efficiently used for the reduction of $\mathrm{Cr}$ (VI).

Table 5: Percentage reduction of the tested Parameters from the tannery industrial samples of the Immobilized Bacteria.

\begin{tabular}{lllllll}
\hline \multirow{2}{*}{ Industries } & & \multicolumn{5}{c}{ Percentage Reduction $(\%)$} \\
\cline { 3 - 7 } & & $5 \mathrm{~g}$ & $10 \mathrm{~g}$ & $15 \mathrm{~g}$ & $20 \mathrm{~g}$ & $25 \mathrm{~g}$ \\
\hline TAN1 & COD & 28 & 14 & 64 & 87 & 89 \\
& BOD & 50 & 54 & 59 & 67 & 80 \\
& SS & 35 & -26 & -27 & -32 & -63 \\
& TDS & 99 & 99 & 99 & 98 & 98 \\
TAN2 & COD & 15 & 20 & 25 & 32 & 38 \\
& BOD & 91 & 91 & 92 & 90 & 92 \\
& SS & -28 & -52 & -52 & -54 & -55 \\
& TDS & 97 & 99 & 99 & 99 & 99 \\
& COD & 33 & 44 & 22 & 11 & 26 \\
& BOD & 75 & 81 & 76 & 81 & 81 \\
& SS & 25 & 3 & -1 & -10 & -15 \\
& TDS & 98 & 98 & 98 & 98 & 98 \\
\hline
\end{tabular}

Percentage Reduction $=(B-A) / B \times 100 \%$

$A=$ Concentration of the parameter after treatment

$\mathrm{B}=$ Concentration of the parameter before treatment

$+=$ percentage decrease

- = percentage increase

In general, immobilization makes the enzyme more resistant to temperature, $\mathrm{pH}$, and substrate concentration swings giving it a longer lifetime and higher productivity per active unit (Gianfreda and Rao, 2004; FuIlbrook, 1996; Russell et al, 2003; Kandelbauer et al., 2004). Immobilized cells have been used and studied extensively for the production of useful chemicals (Ohtake and Silver, 1994), the treatment of wastewaters (Chen et al., 2003; Wang et al., 2010). Although many workers described microbial degradation of tannery effluent, limited literature is available on the bioremediation of tannery effluent using immobilized bacterial cells in the Kano Industrial Estates.

\section{CONCLUSION}

The samples contained variable levels of the physicochemical parameters. The results of the Analysis of variance revealed that, no statistical difference $(p<0.05)$ was observed for the temperature, $\mathrm{pH}, \mathrm{SS}, \mathrm{TDS}, \mathrm{BOD}$ and $\mathrm{COD}$ among the three tannery industries before the treatment. The levels of some of the parameters
(SS, TDS and COD) observed in the samples were found above the recommended limits of WHO and NESREA, which called for the treatment of the effluents before discharge into the environment. Base on the morphological and biochemical test results, TAN1, TAN2, and TAN3 bacterial isolates were identified to be Neisseria spp, Bacillus cereus, and Staphylococcus aureus respectively. The results of Post-treatment analysis showed that there is overall decrease in the levels of the parameters determined when compared with that of the pre-treatment. The overall percentage reduction of the immobilised bacteria in the treatment of the respective effluents was in the order TAN2 (72\%)>TAN1 $(70 \%)>$ TAN3 $(62 \%)$. Hence, the immobilized bacteria are having higher biodegradation potential for the treatment of the tannery effluents.

\section{Acknowledgments}

The authors wish to acknowledge the University of Maiduguri for the financial support. The authors are grateful to the Kano State Ministry of Environment for their support in obtaining the effluent samples. 


\section{REFERENCES}

Ajao, A. T., Adebayo, G. B., and Yakubu, S. E. (2011). Bioremediation of textile industrial effluent using mixed culture of Pseudomonas aeruginosa and Bacillus subtilis immobilized on agar-agar in a bioreactor. J. Microbiol. Biotech. Res, 1(3), 50-56.

Akan, J. C., Moses, E. A., Ogugbuaja, V. O., and Abah, J. (2007). Assessment of tannery industrial effluents from Kano metropolis, Kano State, Nigeria. Journal of Applied Sciences, 7(19), 2788-2793.

Akan, J. C., Ogugbuaja, V. O., Abdulrahman, F. I., and Ayodele, J. T. (2009). Pollutant levels in effluent samples from tanneries and textiles of Kano industrial areas, Nigeria. Global journal of pure and applied sciences, 15(3-4).

APHA (1989). Standard methods for Examination of Will bete and Will betewater.15 $5^{\text {th }}$ edition. Brydpass Springfield Will behington DC. pp. 164-176

APHA (1992). Standard Methods for the Examination of Water and Wastewater. Health, 69, 1116-9.

Baba, A., Garba, S. T., and Bello, H. S. (2020). Bioremediation Potential of Immobilized corynebacterium kutsceri in the Treatment of Tannery Industrial Effluent from Challawa Industrial Estate, Kano State, Nigeria. Journal of the Turkish Chemical Society Section A: Chemistry, $7(2), 335-350$.

Beem, E. I. V. (1994). reduction of solvent VOC emission. J. Oil Col. Chem. Ass, 77, 158.

Bouwer, E. J., and Zehnder, A. J. (1993). Bioremediation of organic compoundsputting microbial metabolism to work. Trends in biotechnology, 11(8), 360367.

Chen, K. C., Wu, J. Y., Liou, D. J., and Hwang, S. C. J. (2003). Decolorization of the textile dyes by newly isolated bacterial strains. Journal of Biotechnology, 101(1), 57-68.

Dan'Azumi, S., and Bichi, M. H. (2010). INDUSTRIAL POLLUTION AND HEAVY METALS PROFILE OF CHALLAWA RIVER IN KANO, NIGERIA. Journal of Applied Sciences in Environmental Sanitation, $5(1)$.

DWAF. (1992). Analytical Methods Manual, TR 151. Department of Water Affairs and Forestry, Pretoria.

El-Bestawy, E. (2013). Biological treatment of leather-tanning industrial wastewater using free living bacteria.
Elsheikh, M. A. S. (2009). Tannery wastewater pre-treatment. Water Science and Technology, 60(2), 433-440.

FuIlbrook, P. D. (1996). "Kinetics." Industrial enzymology: The application of enzymes in Industry. 2nd Ed. T. Godfrey and J Reichelt. eds.. Nature. New York.

Gianfreda, L., and Rao, M. A. (2004). Potential of extra cellular enzymes in remediation of polluted soils: a review. Enzyme and microbial technology, 35(4), 339354.

Hugo Springer. (1994). John Arthur Wilson Memorial Lecture "Treatment of Industrial Wastes of the Leather Industry - is it still a Major Problem". JALCA, 89, 153-185

Jimoh, A. A., Ganiyu, B. A., Baba, D., and Baba, A. (2018) Bioremediation Process of Effluent from Detergent and Food Industries in Jos, Nigeria: Kinetics and Thermodynamics. International Journal of Engineering Science Invention (IJESI), 762-73

Kandelbauer, A., Maute, O., Kessler, R. W., Erlacher, A., and Gübitz, G. M. (2004). Study of dye decolorization in an immobilized laccase enzyme-reactor using online spectroscopy. Biotechnology and bioengineering, 87(4), 552-563.

Kongjao, S., Damronglerd, S., and Hunsom, M. (2008). Simultaneous removal of organic and inorganic Pollutants in tannery wastewater using electrocoagulation technique. Korean Journal of chemical engineering, 25(4), 703.

Maheshwari, U. M., Aruna, S., Gomathi, M., and AbdulJaffar, A. H. (2017). Bioremediation by Free and Immobilized Bacteria Isolated from Tannery Effluent. International Journal of Research in Applied, Natural and Social Sciences. 5(7), 75-90

Margesin, R., and Schinner, F. (2001). Bioremediation (natural attenuation and biostimulation) of diesel-oilcontaminated soil in an alpine glacier skiing area. Applied and environmental microbiology, 677), 3127-3133.

Mohammed, A., Sekar, P., and George, J. (2011). Efficacy of microbes in bioremediation of tannery effluent. Inter. J. Curr. Res, 3(4), 324-326.

Mohammed, S. S. D., Orukotan, A. A., and Abdullahi, H. (2017). Physicochemical and Bacteriological Assessment of Tannery Effluent from Samaru-Zaria, 
BAJOPAS Volume 13 Number 2, December, 2020 Kaduna State, Nigeria. Journal of Applied

Sciences and Environmental Management, 21(4), 734-740.

Munz, G., De Angelis, D., Gori, R., Mori, G., Casarci, M., and Lubello, C. (2009). The role of tannins in conventional and membrane treatment of tannery wastewater. Journal of hazardous materials, 164(2-3), 733-739

Mythili, K., and Karthikeyan, B. (2011). Bioremediation of $\mathrm{Cr}$ (VI) from tannery effluent using Bacillus spp and Staphylococcus spp. International Multidisciplinary Research Journal, 1(6).

NESREA (2009). National Environmental Standards for Effluent Limitations and Regulation. 1233-1236

Noorjahan, C. M. (2014). Physicochemical characteristics, identification of bacteria and biodegradation of industrial effluent. Journal of bioremediation and Biodegradation, 5(3).

Ohtake, H. I., and Silver, A. O. (1994). Bacterial reduction of toxic chromate. Biological degradation and bioremediation of toxic chemicals, 403-415.

Omoleke, I. I. (2004). Management of environmental pollution in Ibadan, an African city: the challenges of health hazard facing government and the people. Journal of Human Ecology, 15(4), 265-275.

Rajor, A., Reddy, A.S., and Singh, B. (2004). Determination of BOD kinetic Parameters and evaluation of alternate methods, M.Sc. Thesis, Department of biotechnology \& environmental Science, Thapar Institute of Engineering and Technology, Patiala

Ramasami, T., Rajamani, S., and Rao, J. R. (1994, March). Pollution control in leather industry: Emerging technological options. In International symposium on surface and colloidal science and its relevance to soil pollution, madras.

Ramesh, J. V. S., and Singh, S. P. (1993). Yearly variation in certain physicochemical parameters of pond at eastern Doon Valley. Uttar Pradesh J. Zoo, 12 (1), 7577.

Ranen, S., and Sharadinadra, C. (2009). Biotechnology applications to environmental remediation in resource exploitation. Current science, 97, 6-25
Russell, A. J., Berberich, J. A., Drevon, G. F., and Koepsel, R. R. (2003). Biomaterials for mediation of

chemical and biological warfare agents. Annual review of biomedical engineering, 5(1), 1-27.

Saravanan, P., and Saravanan, A. (1999). Decolourization of tannery effluent by Flavobacterium sp. EK 1. Indian Journal of Environmental Protection, 19, 19-24.

Sikander, S., and Shahida, H. (2007). Reduction of toxic hexavalent chromium by Ochrobactrum intermedium strain SDCr5 stimulated by heavy metals. Bioresource Technol, 98, 340-344.

Singh, N., Sharma, B. K., and Bohra, P. C. (2000). Impact assessment of industrial effluent of arid soils by using satellite imageries. Journal of the Indian Society of Remote Sensing, 28(2-3), 79.

Sreemoyee, C., and Priti, P. (2013). Assessment of physico-chemical parameters of dairy waste water and isolation and characterization of bacterial strains in terms of cod reduction. Int J Sci, 2(3), 395-400.

Verheijen, L. A. H. M., Wiersema, D., Pol, L. H., and De Wit, J. (1996). Management of wastes from animal product processing. Livestock and environment, Finding a balance. International Agriculture Center, Wageningen, The Netherlands.

Wang, F., Yao, J., Si, Y., Chen, H., Russel, M., Chen, K., and Bramanti, E. (2010). Short-time effect of heavy metals upon microbial community activity. Journal of Hazardous Materials, 173(13), 510-516.

WHO (World Health Organization). (2006). Air quality guidelines: global update 2005: particulate matter, ozone, nitrogen dioxide, and sulfur dioxide. World Health Organization.

World Bank. (1995). Nigeria's strategic options for redressing industrial pollution. World Bank, industry and energy division. 1st edition, West Central Africa Department; Annexes: 1995; pp 60-62.

Zahoor, A., and Abdul, R. (2009). Enumeration of Coliforms. Journal of Environmental Sciences. 21, 814-820 


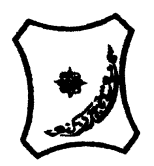

Bayero Journal of Pure and Applied Sciences, 13(2): 1 - 12

Received: November, 2020

Accepted: December, 2020

ISSN $2006-6996$

\title{
BIODEGRADATION POTENTIAL OF IMMOBILIZED BACTERIA IN THE TREATMENT OF TANNERY INDUSTRIAL EFFLUENTS FROM INDUSTRIAL ESTATES IN KANO STATE, NIGERIA
}

\author{
Abdullateef, B., ${ }^{1 *}$ Shuaibu, T. G., ${ }^{1}$ Babagana, K., ${ }^{1}$ Suleman, H. B. ${ }^{2}$ and Dauda, B. ${ }^{3}$ \\ ${ }^{1}$ Department of Pure and Applied Chemistry, Faculty of Science, University of Maiduguri, Borno State, \\ Nigeria \\ ${ }^{2}$ Department of Microbiology, Faculty of Science, University of Maiduguri, Borno State, Nigeria \\ ${ }^{3}$ Department of Chemical Engineering, Faculty of Engineering, University of Maiduguri, Borno State, \\ Nigeria \\ *Corresponding author: babslega@gmail.com; abelega2007@yahoo.com; +2348061309753
}

\section{ABSTRACT}

Industrial Effluents Samples from Gashash Tanneries (TAN1) in Bompai Industrial estate, Larabee Tannery Industry (TAN2) in Sharada Industrial estate and Z Tannery Industries (TAN3) in Challawa Industrial estate, Kano State, Nigeria were collected over a period of six months (August 2017 to January 2018) for assessing the biodegradation potentials of bacteria in the treatment of organic pollutants within the effluents. Bacteria were isolated from the effluents and immobilized on agar-agar. Different masses (5 g, $10 \mathrm{gr}, 15$ $\mathrm{g}, 20 \mathrm{~g}$, and $25 \mathrm{~g}$ ) of the bacteria were used in the treatment of $250 \mathrm{ml}$ of the effluents for ten days in a shaker incubator (Gallenkamp-OC-4364-L) at the temperature $30{ }^{\circ} \mathrm{C}$ and speed of $60 \mathrm{rpm}$. Pre-treatment analysis of the effluents for Temperature, pH, Biochemical Oxygen Demand (BOD), Chemical Oxygen Demand (COD), Suspended Solid (SS) and Total Dissolved Solids (TDS) gives the following results; temperature $\left({ }^{\circ} \mathrm{C}\right.$ )

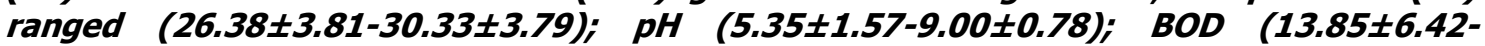
$38.75 \pm 16.20) ;$ COD (1406 $\pm 208-3532 \pm 1373) ;$ SS (208 $\pm 235-780 \pm 739)$ and TDS (266 $\pm 253-5276 \pm 2971)$. No statistical differences ( $p \leq 0.05)$ was observed for all the results among the different industries. The bacterial isolates were identified as Neisseria spp, Bacillus cereus, and Staphylococcus aureus, in TAN1, TAN2, and TAN3, respectively. After treatment of the effluent with the different masses of the isolated bacteria, the mean level of BOD was found to range as (0.55 $\pm 0.36-6.92 \pm 5.49) ; C O D$ (ND-3134 \pm 1595$)$;

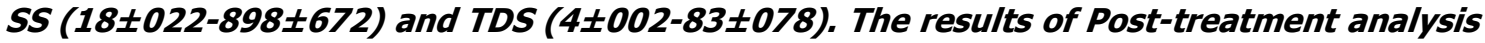
showed that there is overall decrease in the levels of the parameters determined when compared with that of the pre-treatment. The overall percentage reduction of the immobilised bacteria in the treatment of the respective effluents was in the order TAN2 (72\%)>TAN1 (70\%)>TAN3 (62\%). Hence, the immobilized bacteria are having higher biodegradation potential for the treatment of the tannery effluents.

Keywords: Biodegradation, bacteria, effluent, immobilization, tannery.

\section{INTRODUCTION}

Tannery industrial wastewater is a serious consequence of the pollution point of view for streams, freshwater, and land used for agriculture. The lack of awareness in the modern industrial practice has resulted in the discharge of tannery effluents which exhibit very high value of chromium ( $\mathrm{Cr}$ ), Sulfide, and chloride, Total Dissolved Solid (TDS), Total Suspended Solid (TSS), Biochemical Oxygen Demand (BOD) and Chemical Oxygen Demand (COD) in the water stream or land (Mohammed et al., 2001). Tanning is the process, which One ton of skin generally leads to the production of 20 to $80 \mathrm{~m}^{3}$ of turbid and foul-smelling converts the protein of the rawhide or skin into a stable material, which will not putrefy and is suitable for a wide variety of end applications (Elsheikh, 2009). The highly polluting chromium is the most commonly used tanning material producing leather that is more flexible and pliable than vegetable-tanned leather and does not discolor or lose shape in water as drastically as vegetable-tan (Elsheikh, 2009). Tannery effluent is among the most hazardous industrial pollutants due to its huge organic and inorganic load, which is highly toxic to human life and the environment (Kongjao et al., 2008). wastewater including chromium (100-400 mg/l), sulfide $(200-800 \mathrm{mg} / \mathrm{l})$, high levels of fat and 
BAJOPAS Volume 13 Number 2, December, 2020 other solid wastes, and notable pathogen contamination as well as pesticides added for skin conservation during transport (Elsheikh, 2009). There are more than 6000 tanneries in Nigeria with an annual processing capacity of 700,000 tons of hides and skins (Omoleke, 2004; Singh et al., 2008). It was reported that the total amount of waste produced per animal slaughtered is approximately $35 \%$ of its weight (World Bank, 1995). Also, for every $1000 \mathrm{~kg}$ of carcass weight, a slaughtered beef produces 5.5 $\mathrm{kg}$ of manure (excluding rumen contents or stockyard manure) and $100 \mathrm{~kg}$ of paunch manure (undigested food) (Verheijen et al., 1996). Tanneries generate wastewater in the range of 30-35 $\mathrm{L} \mathrm{kg}^{-1}$ skin/hide processed with variable $\mathrm{pH}$, Biological Oxygen Demand (BOD), Chemical Oxygen Demand (COD), high concentrations of suspended solids (SS), and tannins as well as chromium (Zahoor and Abdul, 2009).

Being heterogeneous and composed of a wide variety of compounds, it is very difficult to select a unique direct method for estimating the biodegradability of organic contents and biokinetic parameters for a wastewater sample (Rajor, 2004). For this purpose, some indirect estimation such as determination of biochemical oxygen demand (BOD) and chemical oxygen demand (COD) are applied as common laboratory investigations [9]. During retanning procedures, synthetic tannins (Syntan), oils and resins are added to form softer leather at varying doses (Munz et al., 2009). One of the refractory groups of chemicals in tannery effluents derives mainly from tannins (Ramasami et al., 2004). Syntans are characterized by complex chemical structures, because they are composed of an extended set of chemicals such as phenol-, naphthalene-, formaldehyde- and melamine-based syntans, and acrylic resins (Beem, 1994). Organic pollutants (proteic and lipidic components) are originated from skins (it is calculated that the raw skin has $30 \%$ loss of organic material during the working cycle) or they are introduced during processes (Hugo Springer, 1994).

Many conventional processes such as oxidation, chemical and biological processes were carried out to treat tanneries wastewater (Ebtesam et al, 2013). Biological processes have received more attention because of their costeffectiveness, lower sludge production and environmental friendliness (Noorjahan, 2014). Naturally occurring micro-organisms degrade the hazardous organic wastes including xenobiotic compounds, such as pesticides, polycyclic aromatic hydrocarbons (PAHs) and polychlorinated biphenyls (PCBs) in due course of time (Ranen and Sharadinadra, 2009). Bioremediation is based on the idea that all organisms remove substances from the environment to carry outgrowth and metabolism (Bouwer and Zehnder, 1993). Bacteria, protista and fungi are found to be very good at degrading complex molecules and incorporating the breakdown products into their metabolism (Bouwer and Zehnder, 1993). The resultant metabolic wastes that they produce are generally safe and somehow recycled into other organisms (Ranen and Sharadinadra, 2009). An acclimatized indigenous population of microorganisms capable of degradation of the compounds of interest must exist at the site for a successful bioremediation mode (Ranen and Sharadinadra, 2009). It has been observed that for a successful bioremediation mode, an acclimatized indigenous population of microorganisms capable of degradation of the compounds of interest must exist at the site under investigation (Ranen and Sharadinadra, 2009). Even though there are numerous physical and chemical methods employed in the disposal of wastes the advantage in using bacterium is that they play a key role in the reduction of COD, BOD, total protein, total tannin and total phenol (Saravanan and Saravanan, 1998)

Baba et al. (2020) studied the bioremediation potential of immobilized corynebacterium kutsceri in the Treatment of tannery industrial effluent from Challawa Industrial Estate, Kano State, Nigeria. The aim of the work is to study the reduction in the level of the contaminants through the process of bioremediation using the isolated bacteria. Immobilized bacteria can withstand various temperatures, $\mathrm{pH}$ and substrate concentrations; consequently, increasing the efficiency and the lifespan of the bacteria. Immobilized bacteria are widely applied in the treatment of wastewater and can be separated and recovered after the treatment with the same efficiency (Baba et al., 2020).

\section{MATERIALS AND METHODS \\ Study Area}

This study was carried out in Bompai, Sharada and Challawa industrial estates in Kano, Figure 1. Kano lies on Latitude $11^{\circ} 30^{\prime} \mathrm{N}$ and $8^{\circ} 30^{\prime} \mathrm{E}$ and Longitude $11^{\circ} 5^{\prime} \mathrm{N}$ and $8^{\circ} 5^{\prime} \mathrm{E}$ in Northern Nigeria. It is one of the developed industrial cities in Nigeria. Tannery activities are the dominating industries and this could be one of the reasons for her high population density (Dan'Azumi and Bichi, 2010). Many researchers have studied biodegradation of tannery effluent using microorganisms. However, limited literature is available on the biodegradation of tannery effluent in Kano industrial estates using 
BAJOPAS Volume 13 Number 2, December, 2020 immobilized bacterial cells. This research work focuses on the potential of the use of the indigenous immobilized bacterial isolates in the treatment of tannery effluents in the industrial estates.

\section{Sample Collection}

Effluents were collected from the Tannery Industries from Bompai, Challawa and Sharada Industrial Estates, Kano, Nigeria. The effluents were collected over a period of six months (August 2017 to January 2018). Samples collected in a sterile 4-liter plastic container with a unique identification number were preserved using an ice-box that was transported to the Microbiology Laboratory, Department of Microbiology, Bayero University of Kano for analysis

\section{Sample Preparation and Sample Analysis}

Immediately after the collection of the effluent, $\mathrm{pH}$, TSS, TDS, COD, BOD levels were determined before treatment (Pre-treatment determination) and ten days after treatment (Post-treatment determination) as described in
APHA (1989) standard methods. $\mathrm{pH}$ was determined using Ecotests $\mathrm{pH}$ meter and TDS was determined using AQUALYTIC TDS Salinometer. BOD was determined as described by the standard method (APHA, 1992). COD and SS were determined using DR/2010 HACH portable data logging spectrophotometer (DWAF, 1992)

\section{Identification and Biochemical} Characterization of the Bacterial Isolates

The bacteria were isolated from the effluents using Serial Dilution according to the method described by APHA (1989). The biochemical tests such as oxidase, catalase, coagulase, indole (from $1 \%$ tryptone broth), citrate (Simmons citrate agar), methyl red/VogesProskauer (MR/VP), nitrate reduction, Starch Hydrolysis, Glucose, Maltose, and Lactose tests were carried out on the bacterial isolates to identify the bacteria through the bacteria biochemical characteristics according to Ajao et al. (2011).

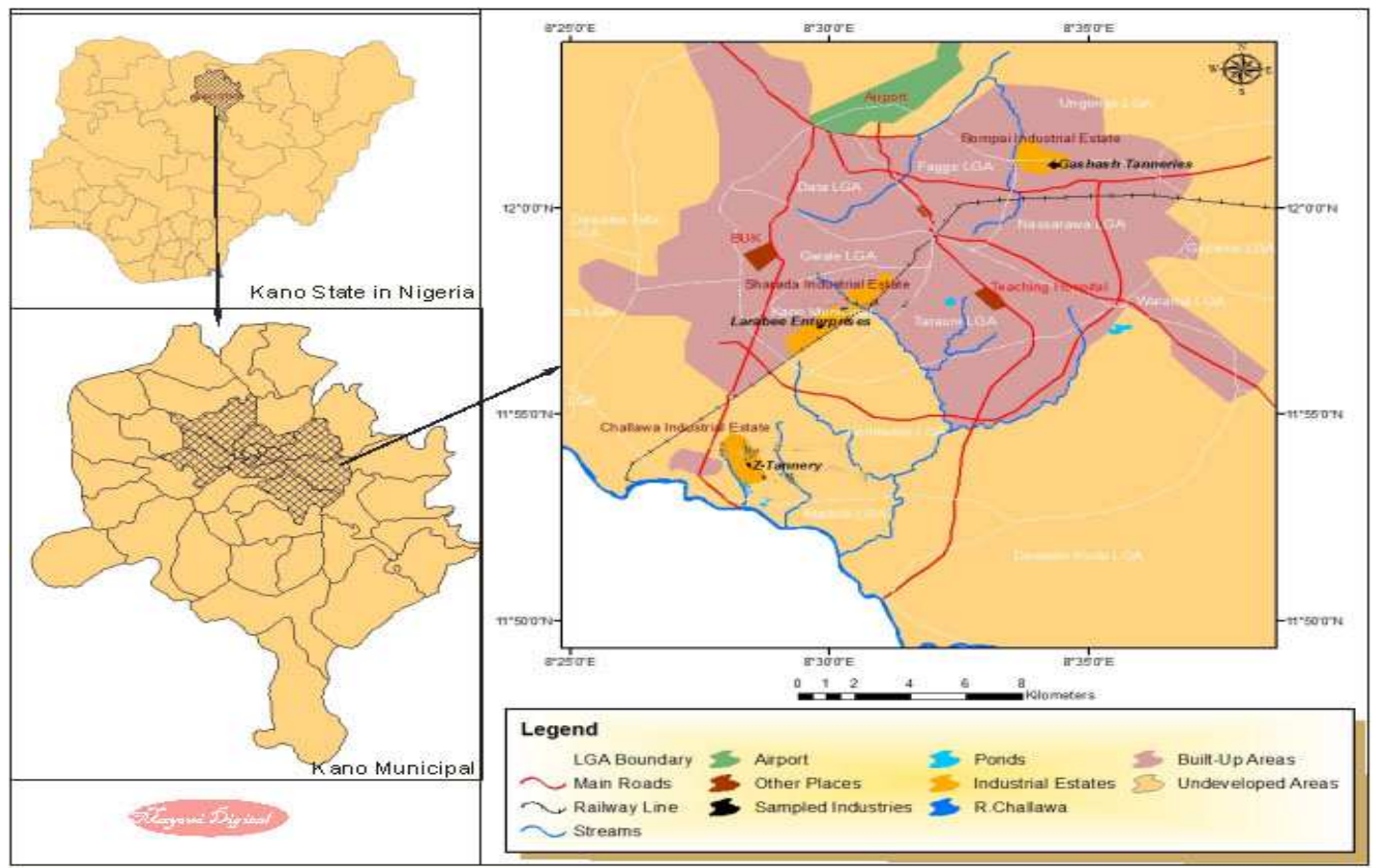

Fig. 1 Map showing the study areas

Source: Mayomi Digital Productions, GIS Laboratory, Department of Geography, UNIMAID (2017)

\section{Determination of Growth Rate of the Bacteria in Effluent Sample}

The bacteria growth rates were determined by transferring $2 \mathrm{~mL}$ of the bacterial isolates from the tannery effluent in broth medium into 100 $\mathrm{mL}$ sterile effluents in conical flasks and kept in an incubator (Giffrin cool) for 10 days. Control was also set up by incubating another $100 \mathrm{~mL}$ each of the sterile effluents without the bacteria. The optical density of the content was determined at the wavelength of $600 \mathrm{~nm}$ on a daily interval and recorded. 
BAJOPAS Volume 13 Number 2, December, 2020 Immobilization of Bacteria

Agar solution and inoculi were prepared separately. Fifty milliliters $(50 \mathrm{~mL})$ of nutrient broth each of the inoculi was prepared in a McCartney bottle and incubated for 24 hours. A solution of agar-agar was prepared by dissolving $10 \mathrm{~g}$ of the powder in distilled water and made up to $500 \mathrm{~mL}$ mark in an Erlenmeyer flask and was sterilized in an autoclave (280A) for 15 minutes and allowed to cool to $40-45^{\circ} \mathrm{C}$ (Ajao et al., 2011). Four milliliters ( $4 \mathrm{~mL})$ of the bacterial isolates in the nutrient broth was mixed with 36 $\mathrm{ml}$ of the prepared agar-agar media in petri-dish plates and then allowed to solidify. This was kept in the refrigerator for bioremediation.

\section{Bioremediation (Treatment) of the Effluents}

The solidified agar block (immobilized bacteria) was cut into cubes using a sterile knife; $0.1 \mathrm{~mL}$ phosphate buffer ( $\mathrm{pH} \mathrm{7.0)}$ was added and kept in the refrigerator for 1 hour for curing. The phosphate buffer was decanted after 1 hour and the cubes were washed with sterile distilled water 3-4 times before it was used (Ajao et al., 2011). Two liters (2 L) of the effluent was supplemented with the minimum basal medium in $\mathrm{g} / \mathrm{L}: \mathrm{NaCl}(0.8), \mathrm{MgSO}_{4} .7 \mathrm{H}_{2} \mathrm{O}(0.001), \mathrm{KH}_{2} \mathrm{PO}_{4}$ (2), $\mathrm{NaNO}_{3}$ (2), $\quad \mathrm{CaCl}_{2} .2 \mathrm{H}_{2} \mathrm{O} \quad(0.5)$ and $\mathrm{NaHPO}_{4} .12 \mathrm{H}_{2} \mathrm{O}(2)$ and sterilized in an autoclave at $121^{\circ} \mathrm{C}$ for 15 minutes (Margesin and Schinner, 2001). Two hundred and fifty milliliters $(250 \mathrm{~mL})$ of the effluents were transferred into different $250 \mathrm{ml}$ conical flasks. The content was covered with a cotton-wool ramped with foil paper to avoid contamination. Five grams $(5 \mathrm{~g})$ of the immobilized bacteria were quickly transferred into each of the effluents in the conical flasks in an inoculating chamber. The same procedures were carried out for the $10 \mathrm{~g}, 15 \mathrm{~g}, 20 \mathrm{~g}$ and 25 $\mathrm{g}$ of the immobilized bacteria in separate $250 \mathrm{~mL}$ effluents in conical flasks and agitated for ten days in a shaker incubator (Gallenkamp-OC4364-L) at a temperature $30^{\circ} \mathrm{C}$ and speed of 60 rpm. The treated effluent samples were taken on the tenth day and analyzed for the parameters $\mathrm{pH}$, SS, TDS, COD, and BOD, (Posttreatment determination) for the different grams of bacteria to evaluate and compare the biodegradation potential. (Baba et al., 2020).

\section{Statistical Analysis}

The data were represented as Mean \pm Standard deviation and analyzed statistically using oneway Analysis of Variance (ANOVA) and Tukey's HSD as Post Hoc Tests with the aid of SPSS 16.0. The correlation coefficient was also used to measure the strength of the relationship between the different masses of the bacteria and the parameters. All $\mathrm{p} \leq 0.05$ were considered as statistically significant.

\section{RESULTS AND DISCUSSION Physico-chemical parameters in the Industrial Effluents before the Biodegradation.}

Results of the Physico-chemical parameters in the industrial effluents before the Biodegradation is shown in table 1 . The mean temperatures $\left({ }^{\circ} \mathrm{C}\right)$ observed in TAN1, TAN2, and TAN3 samples were $28.07 \pm 0.65 ; 27.77 \pm 0.64$ and $26.38 \pm 3.81$ respectively. The order of the mean temperature of the samples from the three industries can be arranged as TAN1 > TAN2>TAN3. The temperature observed at TAN1, TAN2, and TAN3 samples were found below the WHO $\left(35^{\circ} \mathrm{C}\right)$ and NESREA $\left(40^{\circ} \mathrm{C}\right)$ limits. The low values of temperature might be due to the processes used at the time of sampling. High temperature brings down the solubility of gases in water that ultimately expresses as high BOD and COD. Statistical analysis shows that there is no significant difference $(p<0.05)$ between the mean values of temperature among the industries. This might be due to similar tannery activities involved in the tannery industries at the time of sampling. The average values of temperature observed in this present study are less than those observed by Akan et al. (2007), Akan et al. (2009) and Baba et al. (2020).

The mean level of $\mathrm{pH}$ observed in TAN1, TAN2 and TAN3, samples were $7.77 \pm 2.93$; $8.35 \pm 0.28$ and $7.52 \pm 0.76$ respectively. The order of the mean $\mathrm{pH}$ of the samples from the three industries can be arranged as TAN2> TAN1 $>$ TAN3. The $\mathrm{pH}$ of the samples falls within the WHO (7.0-8.5) and NESREA (6-9) standard limits. Statistical analysis shows that there is no significant difference $(p<0.05)$ between the mean values of $\mathrm{pH}$ among the industries. This might be due to similar tannery activities involved in the tannery industries at the time of sampling. Maheshwari et al. (2017) reported that the level of $\mathrm{pH}$ in the effluents from the tannery industry in Vaniyambadi, India was 6.5 which was lower than that observed in the present study. The $\mathrm{pH}$ in the effluents from the tannery industries in Kano and Kaduna were reported to be 7.64 and 6.89, respectively (Akan et al., 2007; Mohammed et al., 2017). The average values of $\mathrm{pH}$ observed in this present study are less than those observed by Mohammed et al. (2017) and Baba et al. (2020). The mean level of SS $(\mathrm{mg} / \mathrm{l})$ observed in TAN1, TAN2, and TAN3 samples were 374 \pm 124 ; $358 \pm 335$ and $780 \pm 739$ respectively. The order of the mean SS in the samples from the three industries can be arranged as TAN3 > TAN1 $>$ TAN2. 
The SS observed in the samples were far above the recommended standard limits of regulating bodies WHO $(30 \mathrm{mg} / \mathrm{l})$ and NESREA $(10 \mathrm{mg} / \mathrm{l})$. Statistical analysis shows that there is no significant difference $(p<0.05)$ between the mean values of SS among the industries. This might be due to similar tannery activities involved in the tannery industries at the time of sampling. The average values of SS observed in this present study are less than that observed $(3700 \pm 122 \mathrm{mg} / \mathrm{l})$ by Akan et al. (2009) for tanneries in Kano. Also, the average values of SS observed in this present study are less than that observed by Mohammed et al. (2017) and Baba et al. (2020) with the exception in TAN3.

The mean level of TDS (mg/l) observed in TAN1, TAN2, and TAN3 samples were $3941 \pm 3703$; $3300 \pm 1714$ and $2653 \pm 1240$ respectively. The order of the mean TDS in the samples from the three industries can be arranged as TAN1>TAN2>TAN3. The TDS observed in the samples were far above the recommended standard limits of WHO $(250 \mathrm{mg} / \mathrm{l})$ and NESREA $(500 \mathrm{mg} / \mathrm{l})$. Statistical analysis shows that there is no significant difference $(p<0.05)$ between the mean values of TDS among the industries. This might be due to similar tannery activities involved in the tannery industries at the time of sampling. TDS in the effluents from the tannery industries in Kano, Nigeria was reported to be $1281 \mathrm{mg} / \mathrm{l}$ (Akan et al., 2007). The average values of SS observed in this present study are less than those observed by Mohammed et al. (2017) and Baba et al. 2020)

The mean level of COD (mg/l) observed in TAN1, TAN2 and TAN3 samples seasons were $2372 \pm 938 ; \quad 1406 \pm 208$ and $3532 \pm 1373$ respectively. The order of the mean COD of the samples from the three industries can be arranged as TAN3>TAN1> TAN2. The COD observed in TAN1, TAN2 and TAN3 samples were far above the recommended standard limits of regulating bodies $\mathrm{WHO}(40 \mathrm{mg} / \mathrm{l})$ and NESREA (40 mg/l). Statistical analysis shows that there is no significant difference $(p<0.05)$ in COD among the industries. This might be due to similar tannery activities involved in the tannery industries as at the time of sampling. The Chemical Oxygen demand (COD) is the amount of oxygen, in $\mathrm{mg} / \mathrm{L}$, required for the degradation of the compound of wastewater to occur. In comparison, the average values of COD observed in this present study were higher than that observed by Mohammed et al. (2017) but lower than that observed by Baba et al. (2020).

The mean levels of BOD $(\mathrm{mg} / \mathrm{l})$ observed in TAN1, TAN2 and TAN3 samples were $13.85 \pm 6.42 ; \quad 19.46 \pm 0.50$ and $17.13 \pm 3.14$ respectively. The order of the mean BOD in the samples from the three industries can be arranged as TAN2>TAN3>TAN1. The BOD observed in TAN1, TAN2 and TAN3 samples were found below the recommended limits of NESREA (200 mg/l) but above WHO (10 mg/l). Statistical analysis shows that there is no significant difference $(p<0.05)$ between the mean values of BOD among the industries. This might be due to similar tannery activities involved in the tannery industries at the time of sampling. The low level of BOD recorded in this study is an indication of the low level of biodegradable organic solids in the effluent. The average values of BOD observed in this present study were lower than those observed by Mohammed et al. (2017) and Baba et al. (2020).

Table 1: Mean Values \pm S.D of Physico-chemical parameters of effluents from the Tannery Industries before Treatment.

\begin{tabular}{llllllll}
\hline Parameter & Tannery 1 & Tannery 2 & Tannery 3 & $\mathrm{a}$ & $\mathrm{b}$ & $\mathrm{c}$ & $\mathrm{d}$ \\
\cline { 2 - 7 } Temperature $\left({ }^{\circ} \mathrm{C}\right)$ & $28.07 \mathrm{a} \pm 0.65$ & $27.77 \mathrm{a} \pm 0.64$ & $26.38 \mathrm{a} \pm 3.81$ & & $29.50 \pm 4.68$ & 35 & 40 \\
pH & $7.77 \mathrm{a} \pm 2.93$ & $8.35 \mathrm{a} \pm 0.28$ & $7.52 \mathrm{a} \pm 0.76$ & 6.89 & $5.35 \pm 1.57$ & $7.0-8.5$ & $6.0-9.0$ \\
$\mathrm{COD}(\mathrm{mg} / \mathrm{l})$ & $2372 \mathrm{a} \pm 938$ & $1406 \mathrm{a} \pm 208$ & $3532 \mathrm{a} \pm 1373$ & 2.2 & $3106 \pm 2753$ & 40 & 40 \\
$\mathrm{BOD}(\mathrm{mg} / \mathrm{l})$ & $13.85 \mathrm{a} \pm 6.42$ & $19.46 \mathrm{a} \pm 0.50$ & $17.13 \mathrm{a} \pm 3.14$ & 1032 & $26.17 \pm 9.49$ & 10 & 200 \\
$\mathrm{SS}(\mathrm{mg} / \mathrm{l})$ & $374 \mathrm{a} \pm 124$ & $358 \mathrm{a} \pm 335$ & $780 \mathrm{a} \pm 739$ & 501 & $562 \pm 482$ & 30 & 10 \\
TDS $(\mathrm{mg} / \mathrm{l})$ & $3941 \mathrm{a} \pm 3703$ & $3300 \mathrm{a} \pm 1714$ & $2653 \mathrm{a} \pm 1240$ & 532.7 & $444 \pm 507$ & 250 & 500 \\
\hline
\end{tabular}

The values given in the table above are means of 6 replicate values, $\mathrm{n}=6$ ( 1 sample was taken monthly for 6 months). Within the rows, means with different alphabets are statistically different $(p<0.05)$. WHO: World Health Organisation. NESREA: National Environmental Standard and Regulatory Enforcement Agency. a = Mohammed et al.(2017), b = Baba et al. (2020), c = WHO (2006), $d=$ NESSRA (2009) 
BAJOPAS Volume 13 Number 2, December, 2020

Identification, Biochemical Characterization and growth rates of the Bacterial Isolates

Results of identification and biochemical characterization of the bacterial isolates were shown in table 2. After 24 hours of incubation, the nutrient agar media plates were checked for bacterial growth. The results showed the presence of different strains in the samples. The TAN1 bacteria isolate was found to be gramnegative cocci while TAN3 was gram-positive cocci. TAN2 bacteria isolate was found to be gram-positive, rod-shaped. TAN1, TAN2, and TAN3 bacteria isolates recorded positive results for spore former.

The results of the biochemical tests indicated that all the bacteria were positive for catalase, oxidase, citrate, maltose, glucose, lactose (negative in TAN1), mannitol (negative in TAN2), starch hydrolysis and coagulase (negative in TAN2) tests. The bacteria showed negative results for nitrate reduction, $M R$ (positive in TAN2), VP (positive in TAN1), Indole (positive in TAN2) tests. Base on the morphological and biochemical test results, TAN1, TAN2, and TAN3 bacteria isolates were identified to be Nesseria spp, Bacillus cereus, and Staphylococcus aureus respectively.

The growth rate of the TAN1, TAN2 and TAN3 Isolates were shown in figure 2. Generally, the optical density increase with the increase in time (day) and decrease as time goes on. The highest optical density was shown by bacillus cereus in TAN2 while the lowest was shown by Staphylococcus aureus in TAN3.

The initial growth phase of TAN1 Isolate bacteria occurred within 2-day of incubation as the growth rate increases up to the 6th-day incubation when the maximum growth was observed. Beyond the 6th day, the growth of the bacteria declined (which might be due to a shortage of nutrients in the effluents) until it reached its death phase (which might be due to the unavailability of nutrients in the effluents).

A similar trend of growth was also observed for TAN2 Isolate as the initial growth phase also occurred within 2-day of incubation but maximum growth rate observed on the 4th day of incubation. The stationary stage occurred between the 4th day and the 8th day. Beyond the 8th day, the growth of the bacteria declined (which might be due to a shortage of nutrients in the effluents) until it reached its death phase (which might be due to the unavailability of nutrients in the effluents).

The initial growth phase of TAN3 bacterial Isolate occurred within the 3-day incubation as the growth rate increases up to the 6th-day incubation when the maximum growth was observed. Beyond the 6th day, the growth of the bacteria declined (which might be due to a shortage of nutrients in the effluents) until it reached its death phase (which might be due to the unavailability of nutrients in the effluents).

Table 2: Morphological and Biochemical characteristics of bacterial isolates

\begin{tabular}{lllll} 
Bacterial Isolates & & TAN1 & TAN2 & TAN3 \\
\hline $\begin{array}{lllll}\text { Morphological } \\
\text { characteristics }\end{array}$ & Shape & Cocci & Rod & Cocci \\
& Spore & & & \\
& former & + & + & + \\
Gram & & & \\
Biochemical characteristics & reaction & - & + & + \\
& Citrate & + & + & + \\
& Catalase & + & + & + \\
& Coagulase & + & - & + \\
Starch & + & + & + \\
& Glucose & + & + & + \\
Oxidase & + & + & + \\
& Indo & - & + & - \\
Lactose & - & + & + \\
Manitol & + & - & + \\
Maltose & + & + & + \\
MR & - & + & - \\
VP & + & - & - \\
& Nitrate & - & - & - \\
Reduction & - Neisseria & Bacillus & Staphylococcus \\
& Bacterial & cereus & aureus \\
& name & spp & cas
\end{tabular}

+ = Positive; - = Negative; MR=Methyl Red; VP= Voges-Proskauer 


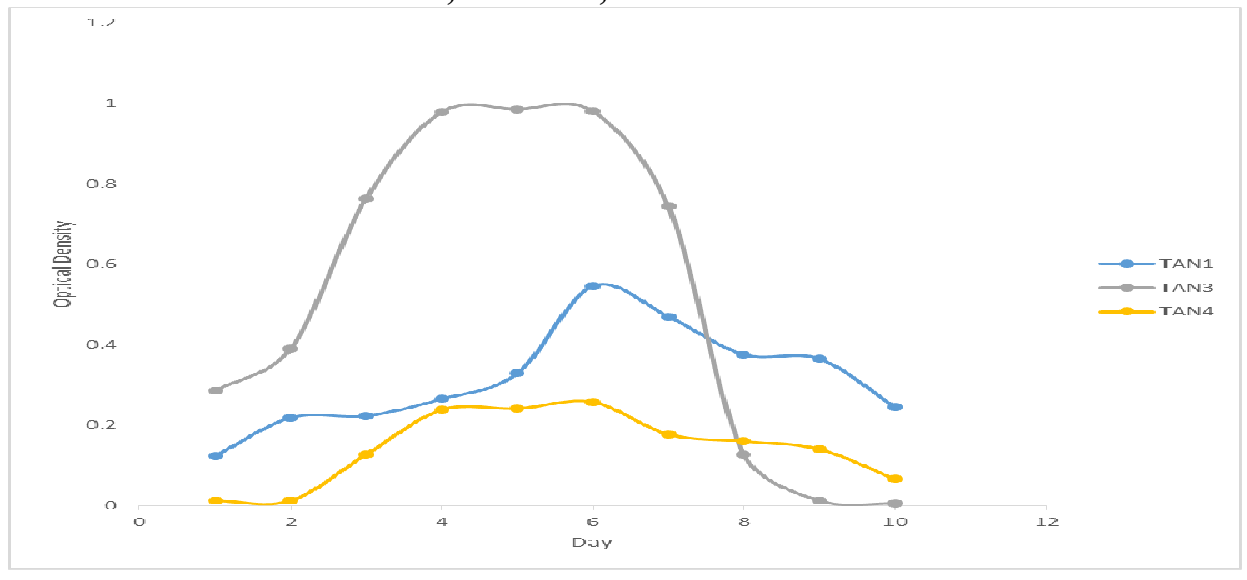

Fig. 2 Growth rates of the isolates in the effluents from the Tannery Industries

\section{Physico-chemical Parameters in the Industrial Effluents after the biodegradation.}

Table 3 shows the mean results of the physicochemical parameter before and after bioremediation using the different masses $(5 \mathrm{~g}$, $10 \mathrm{~g}, 15 \mathrm{~g}, 20 \mathrm{~g}$, and $25 \mathrm{~g}$ ) of the respective immobilized bacteria. Also, Table 4 shows the mean results of correlation coefficient ( $r$ ) between different masses of bacteria and physicochemical parameters.

The mean values $(\mathrm{mg} / \mathrm{l})$ of the SS after the bioremediation varies between $243 \pm 45$ and $898 \pm 672$. The mean concentration $(\mathrm{mg} / \mathrm{l})$ of SS remediated by the different masses $(5 \mathrm{~g}, 10 \mathrm{~g}$, $15 \mathrm{~g}, 20 \mathrm{~g}$, and $25 \mathrm{~g}$ ) of the bacteria varies. The SS in the samples fluctuates up and down after the bioremediation process when compared with the SS of the raw samples before the bioremediation. The increase in the levels of the SS might be due to the aggregation of the TDS which are large enough to result into SS. The increase in the levels of the SS might be also due to the influence of the nutrients which was added into the effluents in order to make the microorganisms more active and viable for fast degradation of organic contaminants in the effluent. The relative potential or efficiency of the different masses of the bacteria in remediating SS in TAN1 samples was in the order $25 \mathrm{~g}>20 \mathrm{~g}>15 \mathrm{~g}>10 \mathrm{~g}>5 \mathrm{~g}$. For TAN2 and TAN3 samples, the order was $25 \mathrm{~g}>20 \mathrm{~g}>15$ $\mathrm{g}>10 \mathrm{~g}>5 \mathrm{~g}$. These might be due to the variations in the surface areas of the different masses of the immobilized bacteria. Statistical analysis shows that there is no significant difference $(p<0.05)$ between the mean values of SS among the masses in the respective industries. Positive and significant correlations exist between the masses of bacteria and Suspended Solid (SS). This showed that there is general increase in the levels of the SS as the masses of the immobilized bacteria increases. TAN3 (90\%) and TAN1 (80\%) showed a very high correlation with the masses of the bacteria while TAN2 (61\%) showed a very low correlation.

The mean values $(\mathrm{mg} / \mathrm{l})$ of the TDS after the bioremediation varies between $46 \pm 11$ and $83 \pm 78$. The mean concentration $(\mathrm{mg} / \mathrm{l})$ of TDS remediated by the different masses $(5 \mathrm{~g}, 10 \mathrm{~g}$, $15 \mathrm{~g}, 20 \mathrm{~g}$, and $25 \mathrm{~g}$ ) of the bacteria varies. There is a reduction in all the TDS of all the samples after the bioremediation process compared with the TDS of the raw samples before the bioremediation. The relative potential or efficiency of the different masses of the bacteria in remediating TDS in TAN1 and TAN3 samples was in the order $5 \mathrm{~g}>10 \mathrm{~g}>15 \mathrm{~g}>20$ $\mathrm{g}>25 \mathrm{~g}$. For TAN2 samples, the order was 20 $g>10 \quad g>25 \quad g>15 \quad g>5 \quad g$. Statistical analysis shows that there is no significant difference $(p<0.05)$ between the mean values of TDS among the masses in the respective industries. These might be due to the variations in the surface areas of the different masses of the immobilized bacteria. Positive and significant correlations exist between the masses of bacteria and TDS with the exception in TAN2 (negative and insignificant correlation). The positive correlations showed that there is general increase in the levels of the TDS as the masses of the immobilized bacteria increases. TAN1 $(96 \%)$ showed a very high correlation with the masses of the bacteria while TAN2 (47\%) showed a very low correlation.

The mean values $(\mathrm{mg} / \mathrm{l})$ of the BOD after the bioremediation varies between $1.56 \pm 0.20 \mathrm{mg} / \mathrm{l}$ and $6.92 \pm 5.49 \mathrm{mg} / \mathrm{l}$. The mean concentration $(\mathrm{mg} / \mathrm{l})$ of BOD remediated by the different masses $(5 \mathrm{~g}, 10 \mathrm{~g}, 15 \mathrm{~g}, 20 \mathrm{~g}$, and $25 \mathrm{~g}$ ) of the bacteria varies. There is a reduction in all the BOD of all the samples after the bioremediation process compared with the $\mathrm{BOD}$ of the raw 
BAJOPAS Volume 13 Number 2, December, 2020 samples before the bioremediation. The relative potential or efficiency of the different masses of the bacteria in remediating BOD in TAN1, TAN2 and TAN3 samples were in the order $25 \mathrm{~g}>20$ $\mathrm{g}>15 \mathrm{~g}>10 \mathrm{~g}>5 \mathrm{~g}, 25 \mathrm{~g}>15 \mathrm{~g}>5 \mathrm{~g}>10 \mathrm{~g}>20 \mathrm{~g}$ and $20 \mathrm{~g}>10 \mathrm{~g}>25 \mathrm{~g}>15 \mathrm{~g}>5 \mathrm{~g}$ respectively. Statistical analysis shows that there is significant difference $(p<0.05)$ between the mean values of BOD among the masses in the respective industries. These might be due to the variations in the surface areas of the different masses of the immobilized bacteria. Negative and significant correlations exist between the masses of bacteria and BOD. This showed that there is general decrease in the levels of the BOD as the masses of the immobilized bacteria increases. TAN1 (94\%) showed a very high correlation with the masses of the bacteria while TAN2 (4\%) showed a very low correlation.

The mean values $(\mathrm{mg} / \mathrm{l})$ of the COD after the bioremediation varies between $250 \pm 154$ and $3134 \pm 1595$. The mean concentration $(\mathrm{mg} / \mathrm{l})$ of COD remediated by the different masses $(5 \mathrm{~g}$, $10 \mathrm{~g}, 15 \mathrm{~g} 20 \mathrm{~g}$, and $25 \mathrm{~g}$ ) of the bacteria varies. There is a reduction in all the COD of all the samples after the bioremediation process compared with the COD of the raw samples before the bioremediation. The relative potential or efficiency of the different masses of the bacteria in remediating COD in TAN1, TAN2 and TAN3 samples were in the order $25 \mathrm{~g}>20 \mathrm{~g}>15$ $\mathrm{g}>5 \mathrm{~g}>10 \mathrm{~g}, 25 \mathrm{~g}>20 \mathrm{~g}>15 \mathrm{~g}>10 \mathrm{~g}>5 \mathrm{~g}$ and 10 g>5 g>25 g>15 g>20 g respectively. Statistical analysis shows that there were significant difference $(p<0.05)$ between the mean values of COD among the masses in the respective industries except for effluents treated with $25 \mathrm{~g}$. These might be due to the variations in the surface areas of the different masses of the immobilized bacteria. Negative and insignificant correlations exist between the masses of bacteria and COD with the exception in TAN3 (positive and significant correlation). The negative correlations showed that there is general decrease in the levels of the COD as the masses of the immobilized bacteria increases. TAN2 (100\%) showed a very high correlation with the masses of the bacteria while TAN3 (36\%) showed a very low correlation.

Generally, there was an overall decrease in the concentration of these physicochemical parameters after the bioremediation using the different masses of the bacterial isolates. These might be due to the variations in the surface areas of the different masses of the immobilized bacteria. This is in line with the work of Jimoh et al. (2018) and Baba et al. (2020).

Table 3: Mean Values $(\mathrm{mg} / \mathrm{l}) \pm$ S.D of Physicochemical parameters in effluents from the Tannery Industries before and after Treatment of the effluents $(250 \mathrm{ml})$ with the different masses $(5 \mathrm{~g}, 10 \mathrm{~g}$, $15 \mathrm{~g}, 20 \mathrm{~g}$, and $25 \mathrm{~g}$ ) of the bacteria.

\begin{tabular}{llllllll}
\hline $\mathrm{P}$ & IND & Before & \multicolumn{5}{c}{ After } \\
\cline { 4 - 7 } & & & $5 \mathrm{~g}$ & $10 \mathrm{~g}$ & $15 \mathrm{~g}$ & $20 \mathrm{~g}$ & $25 \mathrm{~g}$ \\
\hline \multirow{2}{*}{ COD } & TAN1 & $2372 \pm 938$ & $1708 \mathrm{a} \pm 861$ & $2045 \mathrm{a} \pm 1205$ & $845 \mathrm{a} \pm 369$ & $300 \mathrm{a} \pm 167$ & $250 \mathrm{a} \pm 154$ \\
& TAN2 & $1406 \pm 208$ & $1195 \mathrm{a} \pm 208$ & $1125 \mathrm{a} \pm 384$ & $1055 \mathrm{a} \pm 317$ & $956 \mathrm{a} \pm 310$ & $870 \mathrm{ab} \pm 240$ \\
& TAN3 & $3532 \pm 1373$ & $2374 \mathrm{a} \pm 1344$ & $1976 \mathrm{a} \pm 1405$ & $2757 \mathrm{a} \pm 1266$ & $3134 \mathrm{a} \pm 1595$ & $2614 \mathrm{~b} \pm 1105$ \\
BOD & TAN1 & $13.85 \pm 6.42$ & $6.92 \mathrm{a} \pm 5.49$ & $6.42 \mathrm{a} \pm 5.07$ & $5.72 \mathrm{a} \pm 5.35$ & $4.62 \mathrm{a} \pm 4.37$ & $2.82 \mathrm{ab} \pm 1.26$ \\
& TAN2 & $19.46 \pm 0.50$ & $1.75 \mathrm{~b} \pm 0.22$ & $1.73 \mathrm{~b} \pm 0.18$ & $1.58 \mathrm{a} \pm 0.16$ & $1.91 \mathrm{a} \pm 0.22$ & $1.56 \mathrm{~b} \pm 0.20$ \\
& TAN3 & $17.13 \pm 3.14$ & $4.24 \mathrm{ab} \pm 0.77$ & $3.29 \mathrm{ab} \pm 0.37$ & $4.11 \mathrm{a} \pm 0.07$ & $3.23 \mathrm{a} \pm 0.91$ & $3.33 \mathrm{a} \pm 1.28$ \\
SS & TAN1 & $374 \pm 124$ & $243 \mathrm{a} \pm 45$ & $471 \mathrm{a} \pm 226$ & $475 \mathrm{a} \pm 182$ & $492 \mathrm{a} \pm 128$ & $611 \mathrm{a} \pm 217$ \\
& TAN2 & $358 \pm 335$ & $460 \mathrm{a} \pm 400$ & $543 \mathrm{a} \pm 414$ & $544 \mathrm{a} \pm 402$ & $551 \mathrm{a} \pm 414$ & $554 \mathrm{a} \pm 405$ \\
& TAN3 & $780 \pm 739$ & $586 \mathrm{a} \pm 594$ & $758 \mathrm{a} \pm 656$ & $787 \mathrm{a} \pm 676$ & $861 \mathrm{a} \pm 635$ & $898 \mathrm{a} \pm 672$ \\
TDS & TAN1 & $3941 \pm 3703$ & $51 \mathrm{a} \pm 10$ & $53 \mathrm{a} \pm 10$ & $55 \mathrm{a} \pm 15$ & $61 \mathrm{a} \pm 20$ & $63 \mathrm{a} \pm 26$ \\
& TAN2 & $3300 \pm 1714$ & $83 \mathrm{a} \pm 78$ & $47 \mathrm{a} \pm 20$ & $48 \mathrm{a} \pm 22$ & $47 \mathrm{a} \pm 17$ & $48 \mathrm{a} \pm 17$ \\
& TAN3 & $2653 \pm 1240$ & $46 \mathrm{a} \pm 11$ & $55 \mathrm{a} \pm 24$ & $55 \mathrm{a} \pm 25$ & $58 \mathrm{a} \pm 23$ & $61 \mathrm{a} \pm 28$ \\
\hline
\end{tabular}

Replicate $=6$ (months)

Within the rows, for the same parameter, means with different alphabets are statistically different $(p<0.05)$.

$\mathrm{P}=$ parameter, IND = Industries 
BAJOPAS Volume 13 Number 2, December, 2020

Table 4: Correlation coefficient $(r)$ between different masses of the bacteria and the physicochemical parameters.

\begin{tabular}{llll}
\hline Industries & Parameter & Correlation coefficient $(r)$ & $\begin{array}{l}\text { Percent dependence (rxrx100) } \\
(\%)\end{array}$ \\
\hline TAN1 & COD & -0.9 & 82 \\
& BOD & -0.97 & 94 \\
& SS & $0.90^{*}$ & 80 \\
TAN2 & TDS & $0.98^{*}$ & 96 \\
& COD & -1 & 100 \\
& BOD & -0.21 & 4 \\
& SS & $0.78^{*}$ & 61 \\
& TDS & -0.69 & 47 \\
& COD & $0.60^{*}$ & 36 \\
& BOD & -0.6 & 37 \\
& SS & $0.95^{*}$ & 90 \\
& TDS & $0.94^{*}$ & 89 \\
\hline
\end{tabular}

The correlation coefficient $(r)$ with * is statistically significant $(p<0.05)$.

Percentage reduction of the Parameters

Table 5 shows the percentage reduction of Parameters in industrial samples before and after the treatment of the effluents $(250 \mathrm{ml})$ with the different masses $(5 \mathrm{~g}, 10 \mathrm{~g}, 15 \mathrm{~g}, 20 \mathrm{~g}$, and $25 \mathrm{~g}$ ) of the Immobilized Bacteria.

In TAN1 samples, the percentage reduction (\%) of COD ranged (14-89); BOD (50-80); SS (-32$35)$ and TDS (98-99). In TAN2 samples, the percentage decrease $(\%)$ of COD ranged (15$38) ;$ BOD (90-92); SS [-28-(-55)] and TDS (9798). In TAN3 samples, the percentage decrease (\%) of COD ranged (11-44); BOD (76-81); SS (15-25) and TDS (98). The percentage increase in the levels COD, BOD and TDS might be due to the increase in the surface area of the different masses of the immobilized bacteria. However, the percentage decrease in the levels of the SS might be due to the aggregation of the TDS which are large enough to result into SS. The percentage decrease in the levels of the SS might be also due to the influence of the nutrients which was added into the effluents in order to make the microorganisms more active and viable for fast degradation of organic contaminants in the effluent. This is in line with the work of Jimoh et al. (2018) in which the concentration of the SS increase after the bioremediation of effluents.

Sreemoyee and Priti (2013) assessed and reduced several Physico-chemical parameters of dairy wastewater using Niesseria $s p$. and concluded that the species are well known to degrade organic compounds. This is in agreement with the current study in which the immobilized Niesseria $s p$ degrade the organic contaminants as indicated by the BOD, COD and TDS.

Jimoh et al. (2018) observed that TSS of the effluents was increased after treatment with immobilized bacteria and concluded that it might be due to the biostimulation method adopted for the research.

The optimum $\mathrm{pH}$ Biosorption of Chromium by Bacillus spp and Staphylococcus spp. from tannery effluent was investigated by Mythili and Karthikeyan (2011). The maximum adsorption of Chromium $(86.4 \mathrm{mg} / \mathrm{L})$ was showed by Bacillus spp and Staphylococcus spp showed $70.6 \mathrm{mg} / \mathrm{L}$ at an initial concentration of $100 \mathrm{mg} / \mathrm{L}$. In the present study, immobilised Bacillus spp and Staphylococcus spp. from the tannery industrial effluents reduced the levels of the organic pollutants with high potential as indicated by the percentage reduction of BOD, COD and TDS.

Enzymes often can work in multiple environments especially if they are immobilized. This makes the microorganisms' enzymes even more resistant to harsh environments and enables the enzymes to be recovered and recycled after they are no longer needed (Gianfreda and Rao 2004). Ramesh and Singh (1993) reported that the immobilized bacteria having more efficiency to remove the suspended particles than free cells. Using the immobilized cell is preferable due to its capability for using several times with the same efficiency, which makes it more economical. Similar work was done by Sikander et al. (2007) showing the higher reduction with permeabilized cells of Ochrobactrum intermedium strain SDCr-5. 
BAJOPAS Volume 13 Number 2, December, 2020

The results revealed the isolation and identification of isolates with the potential for the reduction of $\mathrm{Cr}$ (VI) to $\mathrm{Cr}$ (III). Results indicated that immobilized $B$. cereus could be efficiently used for the reduction of $\mathrm{Cr}$ (VI).

Table 5: Percentage reduction of the tested Parameters from the tannery industrial samples of the Immobilized Bacteria.

\begin{tabular}{lllllll}
\hline \multirow{2}{*}{ Industries } & & \multicolumn{5}{c}{ Percentage Reduction $(\%)$} \\
\cline { 3 - 7 } & & $5 \mathrm{~g}$ & $10 \mathrm{~g}$ & $15 \mathrm{~g}$ & $20 \mathrm{~g}$ & $25 \mathrm{~g}$ \\
\hline TAN1 & COD & 28 & 14 & 64 & 87 & 89 \\
& BOD & 50 & 54 & 59 & 67 & 80 \\
& SS & 35 & -26 & -27 & -32 & -63 \\
& TDS & 99 & 99 & 99 & 98 & 98 \\
TAN2 & COD & 15 & 20 & 25 & 32 & 38 \\
& BOD & 91 & 91 & 92 & 90 & 92 \\
& SS & -28 & -52 & -52 & -54 & -55 \\
& TDS & 97 & 99 & 99 & 99 & 99 \\
& COD & 33 & 44 & 22 & 11 & 26 \\
& BOD & 75 & 81 & 76 & 81 & 81 \\
& SS & 25 & 3 & -1 & -10 & -15 \\
& TDS & 98 & 98 & 98 & 98 & 98 \\
\hline
\end{tabular}

Percentage Reduction $=(B-A) / B \times 100 \%$

$A=$ Concentration of the parameter after treatment

$\mathrm{B}=$ Concentration of the parameter before treatment

$+=$ percentage decrease

- = percentage increase

In general, immobilization makes the enzyme more resistant to temperature, $\mathrm{pH}$, and substrate concentration swings giving it a longer lifetime and higher productivity per active unit (Gianfreda and Rao, 2004; FuIlbrook, 1996; Russell et al, 2003; Kandelbauer et al., 2004). Immobilized cells have been used and studied extensively for the production of useful chemicals (Ohtake and Silver, 1994), the treatment of wastewaters (Chen et al., 2003; Wang et al., 2010). Although many workers described microbial degradation of tannery effluent, limited literature is available on the bioremediation of tannery effluent using immobilized bacterial cells in the Kano Industrial Estates.

\section{CONCLUSION}

The samples contained variable levels of the physicochemical parameters. The results of the Analysis of variance revealed that, no statistical difference $(p<0.05)$ was observed for the temperature, $\mathrm{pH}, \mathrm{SS}, \mathrm{TDS}, \mathrm{BOD}$ and $\mathrm{COD}$ among the three tannery industries before the treatment. The levels of some of the parameters
(SS, TDS and COD) observed in the samples were found above the recommended limits of WHO and NESREA, which called for the treatment of the effluents before discharge into the environment. Base on the morphological and biochemical test results, TAN1, TAN2, and TAN3 bacterial isolates were identified to be Neisseria spp, Bacillus cereus, and Staphylococcus aureus respectively. The results of Post-treatment analysis showed that there is overall decrease in the levels of the parameters determined when compared with that of the pre-treatment. The overall percentage reduction of the immobilised bacteria in the treatment of the respective effluents was in the order TAN2 (72\%)>TAN1 $(70 \%)>$ TAN3 $(62 \%)$. Hence, the immobilized bacteria are having higher biodegradation potential for the treatment of the tannery effluents.

\section{Acknowledgments}

The authors wish to acknowledge the University of Maiduguri for the financial support. The authors are grateful to the Kano State Ministry of Environment for their support in obtaining the effluent samples. 


\section{REFERENCES}

Ajao, A. T., Adebayo, G. B., and Yakubu, S. E. (2011). Bioremediation of textile industrial effluent using mixed culture of Pseudomonas aeruginosa and Bacillus subtilis immobilized on agar-agar in a bioreactor. J. Microbiol. Biotech. Res, 1(3), 50-56.

Akan, J. C., Moses, E. A., Ogugbuaja, V. O., and Abah, J. (2007). Assessment of tannery industrial effluents from Kano metropolis, Kano State, Nigeria. Journal of Applied Sciences, 7(19), 2788-2793.

Akan, J. C., Ogugbuaja, V. O., Abdulrahman, F. I., and Ayodele, J. T. (2009). Pollutant levels in effluent samples from tanneries and textiles of Kano industrial areas, Nigeria. Global journal of pure and applied sciences, 15(3-4).

APHA (1989). Standard methods for Examination of Will bete and Will betewater.15 $5^{\text {th }}$ edition. Brydpass Springfield Will behington DC. pp. 164-176

APHA (1992). Standard Methods for the Examination of Water and Wastewater. Health, 69, 1116-9.

Baba, A., Garba, S. T., and Bello, H. S. (2020). Bioremediation Potential of Immobilized corynebacterium kutsceri in the Treatment of Tannery Industrial Effluent from Challawa Industrial Estate, Kano State, Nigeria. Journal of the Turkish Chemical Society Section A: Chemistry, $7(2), 335-350$.

Beem, E. I. V. (1994). reduction of solvent VOC emission. J. Oil Col. Chem. Ass, 77, 158.

Bouwer, E. J., and Zehnder, A. J. (1993). Bioremediation of organic compoundsputting microbial metabolism to work. Trends in biotechnology, 11(8), 360367.

Chen, K. C., Wu, J. Y., Liou, D. J., and Hwang, S. C. J. (2003). Decolorization of the textile dyes by newly isolated bacterial strains. Journal of Biotechnology, 101(1), 57-68.

Dan'Azumi, S., and Bichi, M. H. (2010). INDUSTRIAL POLLUTION AND HEAVY METALS PROFILE OF CHALLAWA RIVER IN KANO, NIGERIA. Journal of Applied Sciences in Environmental Sanitation, $5(1)$.

DWAF. (1992). Analytical Methods Manual, TR 151. Department of Water Affairs and Forestry, Pretoria.

El-Bestawy, E. (2013). Biological treatment of leather-tanning industrial wastewater using free living bacteria.
Elsheikh, M. A. S. (2009). Tannery wastewater pre-treatment. Water Science and Technology, 60(2), 433-440.

FuIlbrook, P. D. (1996). "Kinetics." Industrial enzymology: The application of enzymes in Industry. 2nd Ed. T. Godfrey and J Reichelt. eds.. Nature. New York.

Gianfreda, L., and Rao, M. A. (2004). Potential of extra cellular enzymes in remediation of polluted soils: a review. Enzyme and microbial technology, 35(4), 339354.

Hugo Springer. (1994). John Arthur Wilson Memorial Lecture "Treatment of Industrial Wastes of the Leather Industry - is it still a Major Problem". JALCA, 89, 153-185

Jimoh, A. A., Ganiyu, B. A., Baba, D., and Baba, A. (2018) Bioremediation Process of Effluent from Detergent and Food Industries in Jos, Nigeria: Kinetics and Thermodynamics. International Journal of Engineering Science Invention (IJESI), 762-73

Kandelbauer, A., Maute, O., Kessler, R. W., Erlacher, A., and Gübitz, G. M. (2004). Study of dye decolorization in an immobilized laccase enzyme-reactor using online spectroscopy. Biotechnology and bioengineering, 87(4), 552-563.

Kongjao, S., Damronglerd, S., and Hunsom, M. (2008). Simultaneous removal of organic and inorganic Pollutants in tannery wastewater using electrocoagulation technique. Korean Journal of chemical engineering, 25(4), 703.

Maheshwari, U. M., Aruna, S., Gomathi, M., and AbdulJaffar, A. H. (2017). Bioremediation by Free and Immobilized Bacteria Isolated from Tannery Effluent. International Journal of Research in Applied, Natural and Social Sciences. 5(7), 75-90

Margesin, R., and Schinner, F. (2001). Bioremediation (natural attenuation and biostimulation) of diesel-oilcontaminated soil in an alpine glacier skiing area. Applied and environmental microbiology, 677), 3127-3133.

Mohammed, A., Sekar, P., and George, J. (2011). Efficacy of microbes in bioremediation of tannery effluent. Inter. J. Curr. Res, 3(4), 324-326.

Mohammed, S. S. D., Orukotan, A. A., and Abdullahi, H. (2017). Physicochemical and Bacteriological Assessment of Tannery Effluent from Samaru-Zaria, 
BAJOPAS Volume 13 Number 2, December, 2020 Kaduna State, Nigeria. Journal of Applied

Sciences and Environmental Management, 21(4), 734-740.

Munz, G., De Angelis, D., Gori, R., Mori, G., Casarci, M., and Lubello, C. (2009). The role of tannins in conventional and membrane treatment of tannery wastewater. Journal of hazardous materials, 164(2-3), 733-739

Mythili, K., and Karthikeyan, B. (2011). Bioremediation of $\mathrm{Cr}$ (VI) from tannery effluent using Bacillus spp and Staphylococcus spp. International Multidisciplinary Research Journal, 1(6).

NESREA (2009). National Environmental Standards for Effluent Limitations and Regulation. 1233-1236

Noorjahan, C. M. (2014). Physicochemical characteristics, identification of bacteria and biodegradation of industrial effluent. Journal of bioremediation and Biodegradation, 5(3).

Ohtake, H. I., and Silver, A. O. (1994). Bacterial reduction of toxic chromate. Biological degradation and bioremediation of toxic chemicals, 403-415.

Omoleke, I. I. (2004). Management of environmental pollution in Ibadan, an African city: the challenges of health hazard facing government and the people. Journal of Human Ecology, 15(4), 265-275.

Rajor, A., Reddy, A.S., and Singh, B. (2004). Determination of BOD kinetic Parameters and evaluation of alternate methods, M.Sc. Thesis, Department of biotechnology \& environmental Science, Thapar Institute of Engineering and Technology, Patiala

Ramasami, T., Rajamani, S., and Rao, J. R. (1994, March). Pollution control in leather industry: Emerging technological options. In International symposium on surface and colloidal science and its relevance to soil pollution, madras.

Ramesh, J. V. S., and Singh, S. P. (1993). Yearly variation in certain physicochemical parameters of pond at eastern Doon Valley. Uttar Pradesh J. Zoo, 12 (1), 7577.

Ranen, S., and Sharadinadra, C. (2009). Biotechnology applications to environmental remediation in resource exploitation. Current science, 97, 6-25
Russell, A. J., Berberich, J. A., Drevon, G. F., and Koepsel, R. R. (2003). Biomaterials for mediation of

chemical and biological warfare agents. Annual review of biomedical engineering, 5(1), 1-27.

Saravanan, P., and Saravanan, A. (1999). Decolourization of tannery effluent by Flavobacterium sp. EK 1. Indian Journal of Environmental Protection, 19, 19-24.

Sikander, S., and Shahida, H. (2007). Reduction of toxic hexavalent chromium by Ochrobactrum intermedium strain SDCr5 stimulated by heavy metals. Bioresource Technol, 98, 340-344.

Singh, N., Sharma, B. K., and Bohra, P. C. (2000). Impact assessment of industrial effluent of arid soils by using satellite imageries. Journal of the Indian Society of Remote Sensing, 28(2-3), 79.

Sreemoyee, C., and Priti, P. (2013). Assessment of physico-chemical parameters of dairy waste water and isolation and characterization of bacterial strains in terms of cod reduction. Int J Sci, 2(3), 395-400.

Verheijen, L. A. H. M., Wiersema, D., Pol, L. H., and De Wit, J. (1996). Management of wastes from animal product processing. Livestock and environment, Finding a balance. International Agriculture Center, Wageningen, The Netherlands.

Wang, F., Yao, J., Si, Y., Chen, H., Russel, M., Chen, K., and Bramanti, E. (2010). Short-time effect of heavy metals upon microbial community activity. Journal of Hazardous Materials, 173(13), 510-516.

WHO (World Health Organization). (2006). Air quality guidelines: global update 2005: particulate matter, ozone, nitrogen dioxide, and sulfur dioxide. World Health Organization.

World Bank. (1995). Nigeria's strategic options for redressing industrial pollution. World Bank, industry and energy division. 1st edition, West Central Africa Department; Annexes: 1995; pp 60-62.

Zahoor, A., and Abdul, R. (2009). Enumeration of Coliforms. Journal of Environmental Sciences. 21, 814-820 


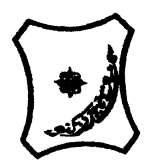

Bayero Journal of Pure and Applied Sciences, 13(2): 1 - 12

Received: November, 2020

Accepted: December, 2020

ISSN $2006-6996$

\title{
BIODEGRADATION POTENTIAL OF IMMOBILIZED BACTERIA IN THE TREATMENT OF TANNERY INDUSTRIAL EFFLUENTS FROM INDUSTRIAL ESTATES IN KANO STATE, NIGERIA
}

\author{
Abdullateef, B., ${ }^{1 *}$ Shuaibu, T. G., ${ }^{1}$ Babagana, K., ${ }^{1}$ Suleman, H. B. ${ }^{2}$ and Dauda, B. ${ }^{3}$ \\ ${ }^{1}$ Department of Pure and Applied Chemistry, Faculty of Science, University of Maiduguri, Borno State, \\ Nigeria \\ ${ }^{2}$ Department of Microbiology, Faculty of Science, University of Maiduguri, Borno State, Nigeria \\ ${ }^{3}$ Department of Chemical Engineering, Faculty of Engineering, University of Maiduguri, Borno State, \\ Nigeria \\ *Corresponding author: babslega@gmail.com; abelega2007@yahoo.com; +2348061309753
}

\section{ABSTRACT}

Industrial Effluents Samples from Gashash Tanneries (TAN1) in Bompai Industrial estate, Larabee Tannery Industry (TAN2) in Sharada Industrial estate and Z Tannery Industries (TAN3) in Challawa Industrial estate, Kano State, Nigeria were collected over a period of six months (August 2017 to January 2018) for assessing the biodegradation potentials of bacteria in the treatment of organic pollutants within the effluents. Bacteria were isolated from the effluents and immobilized on agar-agar. Different masses (5 g, $10 \mathrm{gr}, 15$ $\mathrm{g}, 20 \mathrm{~g}$, and $25 \mathrm{~g}$ ) of the bacteria were used in the treatment of $250 \mathrm{ml}$ of the effluents for ten days in a shaker incubator (Gallenkamp-OC-4364-L) at the temperature $30{ }^{\circ} \mathrm{C}$ and speed of $60 \mathrm{rpm}$. Pre-treatment analysis of the effluents for Temperature, pH, Biochemical Oxygen Demand (BOD), Chemical Oxygen Demand (COD), Suspended Solid (SS) and Total Dissolved Solids (TDS) gives the following results; temperature $\left({ }^{\circ} \mathrm{C}\right.$ )

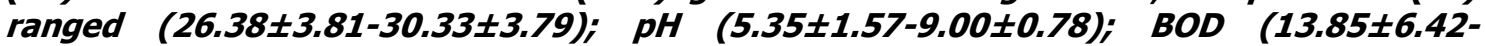
$38.75 \pm 16.20) ;$ COD (1406 $\pm 208-3532 \pm 1373) ;$ SS (208 $\pm 235-780 \pm 739)$ and TDS (266 $\pm 253-5276 \pm 2971)$. No statistical differences ( $p \leq 0.05)$ was observed for all the results among the different industries. The bacterial isolates were identified as Neisseria spp, Bacillus cereus, and Staphylococcus aureus, in TAN1, TAN2, and TAN3, respectively. After treatment of the effluent with the different masses of the isolated bacteria, the mean level of BOD was found to range as (0.55 $\pm 0.36-6.92 \pm 5.49) ; C O D$ (ND-3134 \pm 1595$)$;

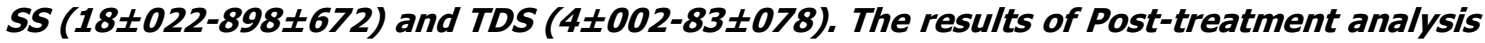
showed that there is overall decrease in the levels of the parameters determined when compared with that of the pre-treatment. The overall percentage reduction of the immobilised bacteria in the treatment of the respective effluents was in the order TAN2 (72\%)>TAN1 (70\%)>TAN3 (62\%). Hence, the immobilized bacteria are having higher biodegradation potential for the treatment of the tannery effluents.

Keywords: Biodegradation, bacteria, effluent, immobilization, tannery.

\section{INTRODUCTION}

Tannery industrial wastewater is a serious consequence of the pollution point of view for streams, freshwater, and land used for agriculture. The lack of awareness in the modern industrial practice has resulted in the discharge of tannery effluents which exhibit very high value of chromium ( $\mathrm{Cr}$ ), Sulfide, and chloride, Total Dissolved Solid (TDS), Total Suspended Solid (TSS), Biochemical Oxygen Demand (BOD) and Chemical Oxygen Demand (COD) in the water stream or land (Mohammed et al., 2001). Tanning is the process, which One ton of skin generally leads to the production of 20 to $80 \mathrm{~m}^{3}$ of turbid and foul-smelling converts the protein of the rawhide or skin into a stable material, which will not putrefy and is suitable for a wide variety of end applications (Elsheikh, 2009). The highly polluting chromium is the most commonly used tanning material producing leather that is more flexible and pliable than vegetable-tanned leather and does not discolor or lose shape in water as drastically as vegetable-tan (Elsheikh, 2009). Tannery effluent is among the most hazardous industrial pollutants due to its huge organic and inorganic load, which is highly toxic to human life and the environment (Kongjao et al., 2008). wastewater including chromium (100-400 mg/l), sulfide $(200-800 \mathrm{mg} / \mathrm{l})$, high levels of fat and 
BAJOPAS Volume 13 Number 2, December, 2020 other solid wastes, and notable pathogen contamination as well as pesticides added for skin conservation during transport (Elsheikh, 2009). There are more than 6000 tanneries in Nigeria with an annual processing capacity of 700,000 tons of hides and skins (Omoleke, 2004; Singh et al., 2008). It was reported that the total amount of waste produced per animal slaughtered is approximately $35 \%$ of its weight (World Bank, 1995). Also, for every $1000 \mathrm{~kg}$ of carcass weight, a slaughtered beef produces 5.5 $\mathrm{kg}$ of manure (excluding rumen contents or stockyard manure) and $100 \mathrm{~kg}$ of paunch manure (undigested food) (Verheijen et al., 1996). Tanneries generate wastewater in the range of 30-35 $\mathrm{L} \mathrm{kg}^{-1}$ skin/hide processed with variable $\mathrm{pH}$, Biological Oxygen Demand (BOD), Chemical Oxygen Demand (COD), high concentrations of suspended solids (SS), and tannins as well as chromium (Zahoor and Abdul, 2009).

Being heterogeneous and composed of a wide variety of compounds, it is very difficult to select a unique direct method for estimating the biodegradability of organic contents and biokinetic parameters for a wastewater sample (Rajor, 2004). For this purpose, some indirect estimation such as determination of biochemical oxygen demand (BOD) and chemical oxygen demand (COD) are applied as common laboratory investigations [9]. During retanning procedures, synthetic tannins (Syntan), oils and resins are added to form softer leather at varying doses (Munz et al., 2009). One of the refractory groups of chemicals in tannery effluents derives mainly from tannins (Ramasami et al., 2004). Syntans are characterized by complex chemical structures, because they are composed of an extended set of chemicals such as phenol-, naphthalene-, formaldehyde- and melamine-based syntans, and acrylic resins (Beem, 1994). Organic pollutants (proteic and lipidic components) are originated from skins (it is calculated that the raw skin has $30 \%$ loss of organic material during the working cycle) or they are introduced during processes (Hugo Springer, 1994).

Many conventional processes such as oxidation, chemical and biological processes were carried out to treat tanneries wastewater (Ebtesam et al, 2013). Biological processes have received more attention because of their costeffectiveness, lower sludge production and environmental friendliness (Noorjahan, 2014). Naturally occurring micro-organisms degrade the hazardous organic wastes including xenobiotic compounds, such as pesticides, polycyclic aromatic hydrocarbons (PAHs) and polychlorinated biphenyls (PCBs) in due course of time (Ranen and Sharadinadra, 2009). Bioremediation is based on the idea that all organisms remove substances from the environment to carry outgrowth and metabolism (Bouwer and Zehnder, 1993). Bacteria, protista and fungi are found to be very good at degrading complex molecules and incorporating the breakdown products into their metabolism (Bouwer and Zehnder, 1993). The resultant metabolic wastes that they produce are generally safe and somehow recycled into other organisms (Ranen and Sharadinadra, 2009). An acclimatized indigenous population of microorganisms capable of degradation of the compounds of interest must exist at the site for a successful bioremediation mode (Ranen and Sharadinadra, 2009). It has been observed that for a successful bioremediation mode, an acclimatized indigenous population of microorganisms capable of degradation of the compounds of interest must exist at the site under investigation (Ranen and Sharadinadra, 2009). Even though there are numerous physical and chemical methods employed in the disposal of wastes the advantage in using bacterium is that they play a key role in the reduction of COD, BOD, total protein, total tannin and total phenol (Saravanan and Saravanan, 1998)

Baba et al. (2020) studied the bioremediation potential of immobilized corynebacterium kutsceri in the Treatment of tannery industrial effluent from Challawa Industrial Estate, Kano State, Nigeria. The aim of the work is to study the reduction in the level of the contaminants through the process of bioremediation using the isolated bacteria. Immobilized bacteria can withstand various temperatures, $\mathrm{pH}$ and substrate concentrations; consequently, increasing the efficiency and the lifespan of the bacteria. Immobilized bacteria are widely applied in the treatment of wastewater and can be separated and recovered after the treatment with the same efficiency (Baba et al., 2020).

\section{MATERIALS AND METHODS \\ Study Area}

This study was carried out in Bompai, Sharada and Challawa industrial estates in Kano, Figure 1. Kano lies on Latitude $11^{\circ} 30^{\prime} \mathrm{N}$ and $8^{\circ} 30^{\prime} \mathrm{E}$ and Longitude $11^{\circ} 5^{\prime} \mathrm{N}$ and $8^{\circ} 5^{\prime} \mathrm{E}$ in Northern Nigeria. It is one of the developed industrial cities in Nigeria. Tannery activities are the dominating industries and this could be one of the reasons for her high population density (Dan'Azumi and Bichi, 2010). Many researchers have studied biodegradation of tannery effluent using microorganisms. However, limited literature is available on the biodegradation of tannery effluent in Kano industrial estates using 
BAJOPAS Volume 13 Number 2, December, 2020 immobilized bacterial cells. This research work focuses on the potential of the use of the indigenous immobilized bacterial isolates in the treatment of tannery effluents in the industrial estates.

\section{Sample Collection}

Effluents were collected from the Tannery Industries from Bompai, Challawa and Sharada Industrial Estates, Kano, Nigeria. The effluents were collected over a period of six months (August 2017 to January 2018). Samples collected in a sterile 4-liter plastic container with a unique identification number were preserved using an ice-box that was transported to the Microbiology Laboratory, Department of Microbiology, Bayero University of Kano for analysis

\section{Sample Preparation and Sample Analysis}

Immediately after the collection of the effluent, $\mathrm{pH}$, TSS, TDS, COD, BOD levels were determined before treatment (Pre-treatment determination) and ten days after treatment (Post-treatment determination) as described in
APHA (1989) standard methods. $\mathrm{pH}$ was determined using Ecotests $\mathrm{pH}$ meter and TDS was determined using AQUALYTIC TDS Salinometer. BOD was determined as described by the standard method (APHA, 1992). COD and SS were determined using DR/2010 HACH portable data logging spectrophotometer (DWAF, 1992)

\section{Identification and Biochemical} Characterization of the Bacterial Isolates

The bacteria were isolated from the effluents using Serial Dilution according to the method described by APHA (1989). The biochemical tests such as oxidase, catalase, coagulase, indole (from $1 \%$ tryptone broth), citrate (Simmons citrate agar), methyl red/VogesProskauer (MR/VP), nitrate reduction, Starch Hydrolysis, Glucose, Maltose, and Lactose tests were carried out on the bacterial isolates to identify the bacteria through the bacteria biochemical characteristics according to Ajao et al. (2011).

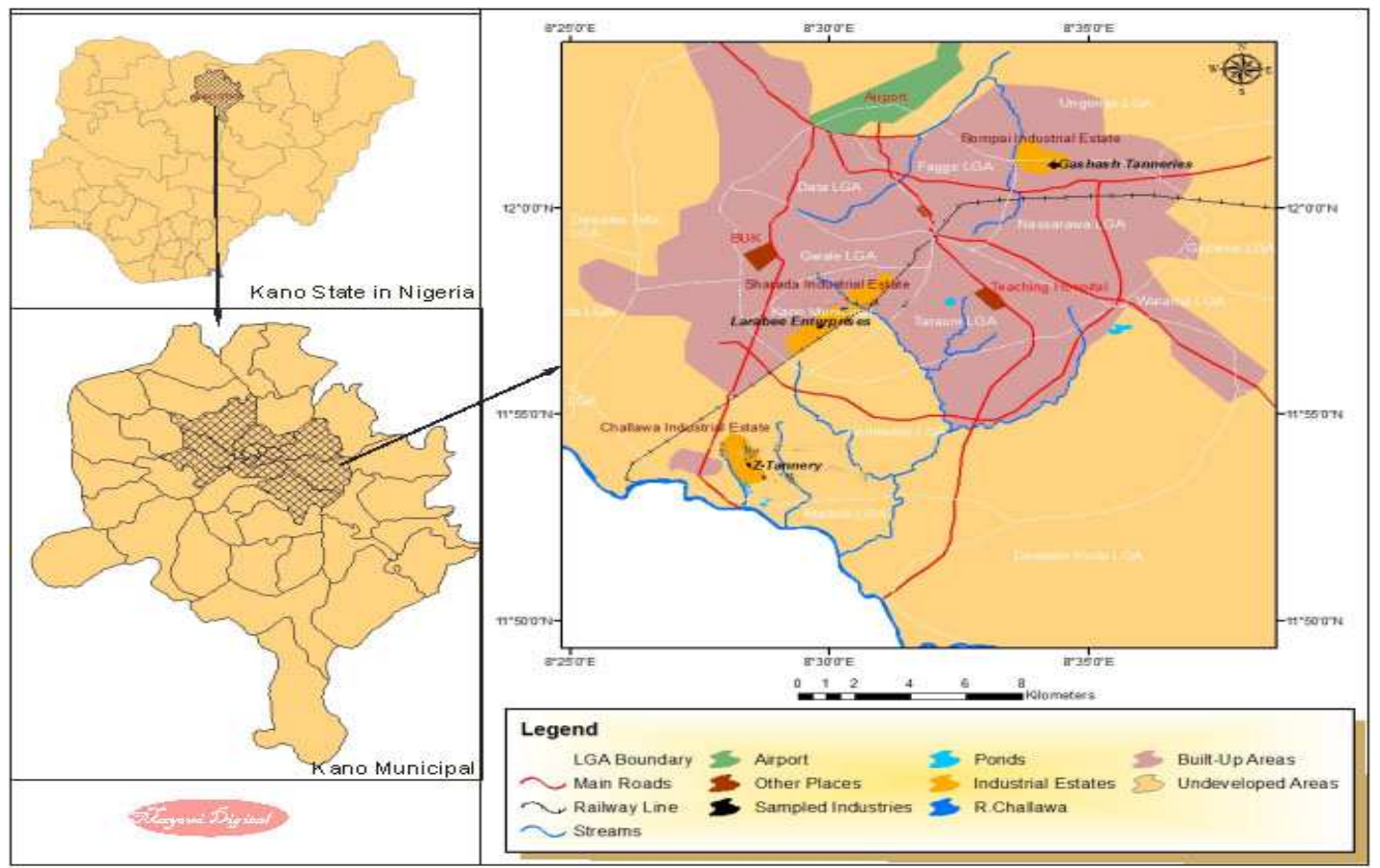

Fig. 1 Map showing the study areas

Source: Mayomi Digital Productions, GIS Laboratory, Department of Geography, UNIMAID (2017)

\section{Determination of Growth Rate of the Bacteria in Effluent Sample}

The bacteria growth rates were determined by transferring $2 \mathrm{~mL}$ of the bacterial isolates from the tannery effluent in broth medium into 100 $\mathrm{mL}$ sterile effluents in conical flasks and kept in an incubator (Giffrin cool) for 10 days. Control was also set up by incubating another $100 \mathrm{~mL}$ each of the sterile effluents without the bacteria. The optical density of the content was determined at the wavelength of $600 \mathrm{~nm}$ on a daily interval and recorded. 
BAJOPAS Volume 13 Number 2, December, 2020 Immobilization of Bacteria

Agar solution and inoculi were prepared separately. Fifty milliliters $(50 \mathrm{~mL})$ of nutrient broth each of the inoculi was prepared in a McCartney bottle and incubated for 24 hours. A solution of agar-agar was prepared by dissolving $10 \mathrm{~g}$ of the powder in distilled water and made up to $500 \mathrm{~mL}$ mark in an Erlenmeyer flask and was sterilized in an autoclave (280A) for 15 minutes and allowed to cool to $40-45^{\circ} \mathrm{C}$ (Ajao et al., 2011). Four milliliters ( $4 \mathrm{~mL})$ of the bacterial isolates in the nutrient broth was mixed with 36 $\mathrm{ml}$ of the prepared agar-agar media in petri-dish plates and then allowed to solidify. This was kept in the refrigerator for bioremediation.

\section{Bioremediation (Treatment) of the Effluents}

The solidified agar block (immobilized bacteria) was cut into cubes using a sterile knife; $0.1 \mathrm{~mL}$ phosphate buffer ( $\mathrm{pH} \mathrm{7.0)}$ was added and kept in the refrigerator for 1 hour for curing. The phosphate buffer was decanted after 1 hour and the cubes were washed with sterile distilled water 3-4 times before it was used (Ajao et al., 2011). Two liters (2 L) of the effluent was supplemented with the minimum basal medium in $\mathrm{g} / \mathrm{L}: \mathrm{NaCl}(0.8), \mathrm{MgSO}_{4} .7 \mathrm{H}_{2} \mathrm{O}(0.001), \mathrm{KH}_{2} \mathrm{PO}_{4}$ (2), $\mathrm{NaNO}_{3}$ (2), $\quad \mathrm{CaCl}_{2} .2 \mathrm{H}_{2} \mathrm{O} \quad(0.5)$ and $\mathrm{NaHPO}_{4} .12 \mathrm{H}_{2} \mathrm{O}(2)$ and sterilized in an autoclave at $121^{\circ} \mathrm{C}$ for 15 minutes (Margesin and Schinner, 2001). Two hundred and fifty milliliters $(250 \mathrm{~mL})$ of the effluents were transferred into different $250 \mathrm{ml}$ conical flasks. The content was covered with a cotton-wool ramped with foil paper to avoid contamination. Five grams $(5 \mathrm{~g})$ of the immobilized bacteria were quickly transferred into each of the effluents in the conical flasks in an inoculating chamber. The same procedures were carried out for the $10 \mathrm{~g}, 15 \mathrm{~g}, 20 \mathrm{~g}$ and 25 $\mathrm{g}$ of the immobilized bacteria in separate $250 \mathrm{~mL}$ effluents in conical flasks and agitated for ten days in a shaker incubator (Gallenkamp-OC4364-L) at a temperature $30^{\circ} \mathrm{C}$ and speed of 60 rpm. The treated effluent samples were taken on the tenth day and analyzed for the parameters $\mathrm{pH}$, SS, TDS, COD, and BOD, (Posttreatment determination) for the different grams of bacteria to evaluate and compare the biodegradation potential. (Baba et al., 2020).

\section{Statistical Analysis}

The data were represented as Mean \pm Standard deviation and analyzed statistically using oneway Analysis of Variance (ANOVA) and Tukey's HSD as Post Hoc Tests with the aid of SPSS 16.0. The correlation coefficient was also used to measure the strength of the relationship between the different masses of the bacteria and the parameters. All $\mathrm{p} \leq 0.05$ were considered as statistically significant.

\section{RESULTS AND DISCUSSION Physico-chemical parameters in the Industrial Effluents before the Biodegradation.}

Results of the Physico-chemical parameters in the industrial effluents before the Biodegradation is shown in table 1 . The mean temperatures $\left({ }^{\circ} \mathrm{C}\right)$ observed in TAN1, TAN2, and TAN3 samples were $28.07 \pm 0.65 ; 27.77 \pm 0.64$ and $26.38 \pm 3.81$ respectively. The order of the mean temperature of the samples from the three industries can be arranged as TAN1 > TAN2>TAN3. The temperature observed at TAN1, TAN2, and TAN3 samples were found below the WHO $\left(35^{\circ} \mathrm{C}\right)$ and NESREA $\left(40^{\circ} \mathrm{C}\right)$ limits. The low values of temperature might be due to the processes used at the time of sampling. High temperature brings down the solubility of gases in water that ultimately expresses as high BOD and COD. Statistical analysis shows that there is no significant difference $(p<0.05)$ between the mean values of temperature among the industries. This might be due to similar tannery activities involved in the tannery industries at the time of sampling. The average values of temperature observed in this present study are less than those observed by Akan et al. (2007), Akan et al. (2009) and Baba et al. (2020).

The mean level of $\mathrm{pH}$ observed in TAN1, TAN2 and TAN3, samples were $7.77 \pm 2.93$; $8.35 \pm 0.28$ and $7.52 \pm 0.76$ respectively. The order of the mean $\mathrm{pH}$ of the samples from the three industries can be arranged as TAN2> TAN1 $>$ TAN3. The $\mathrm{pH}$ of the samples falls within the WHO (7.0-8.5) and NESREA (6-9) standard limits. Statistical analysis shows that there is no significant difference $(p<0.05)$ between the mean values of $\mathrm{pH}$ among the industries. This might be due to similar tannery activities involved in the tannery industries at the time of sampling. Maheshwari et al. (2017) reported that the level of $\mathrm{pH}$ in the effluents from the tannery industry in Vaniyambadi, India was 6.5 which was lower than that observed in the present study. The $\mathrm{pH}$ in the effluents from the tannery industries in Kano and Kaduna were reported to be 7.64 and 6.89, respectively (Akan et al., 2007; Mohammed et al., 2017). The average values of $\mathrm{pH}$ observed in this present study are less than those observed by Mohammed et al. (2017) and Baba et al. (2020). The mean level of SS $(\mathrm{mg} / \mathrm{l})$ observed in TAN1, TAN2, and TAN3 samples were 374 \pm 124 ; $358 \pm 335$ and $780 \pm 739$ respectively. The order of the mean SS in the samples from the three industries can be arranged as TAN3 > TAN1 $>$ TAN2. 
The SS observed in the samples were far above the recommended standard limits of regulating bodies WHO $(30 \mathrm{mg} / \mathrm{l})$ and NESREA $(10 \mathrm{mg} / \mathrm{l})$. Statistical analysis shows that there is no significant difference $(p<0.05)$ between the mean values of SS among the industries. This might be due to similar tannery activities involved in the tannery industries at the time of sampling. The average values of SS observed in this present study are less than that observed $(3700 \pm 122 \mathrm{mg} / \mathrm{l})$ by Akan et al. (2009) for tanneries in Kano. Also, the average values of SS observed in this present study are less than that observed by Mohammed et al. (2017) and Baba et al. (2020) with the exception in TAN3.

The mean level of TDS (mg/l) observed in TAN1, TAN2, and TAN3 samples were $3941 \pm 3703$; $3300 \pm 1714$ and $2653 \pm 1240$ respectively. The order of the mean TDS in the samples from the three industries can be arranged as TAN1>TAN2>TAN3. The TDS observed in the samples were far above the recommended standard limits of WHO $(250 \mathrm{mg} / \mathrm{l})$ and NESREA $(500 \mathrm{mg} / \mathrm{l})$. Statistical analysis shows that there is no significant difference $(p<0.05)$ between the mean values of TDS among the industries. This might be due to similar tannery activities involved in the tannery industries at the time of sampling. TDS in the effluents from the tannery industries in Kano, Nigeria was reported to be $1281 \mathrm{mg} / \mathrm{l}$ (Akan et al., 2007). The average values of SS observed in this present study are less than those observed by Mohammed et al. (2017) and Baba et al. 2020)

The mean level of COD (mg/l) observed in TAN1, TAN2 and TAN3 samples seasons were $2372 \pm 938 ; \quad 1406 \pm 208$ and $3532 \pm 1373$ respectively. The order of the mean COD of the samples from the three industries can be arranged as TAN3>TAN1> TAN2. The COD observed in TAN1, TAN2 and TAN3 samples were far above the recommended standard limits of regulating bodies $\mathrm{WHO}(40 \mathrm{mg} / \mathrm{l})$ and NESREA (40 mg/l). Statistical analysis shows that there is no significant difference $(p<0.05)$ in COD among the industries. This might be due to similar tannery activities involved in the tannery industries as at the time of sampling. The Chemical Oxygen demand (COD) is the amount of oxygen, in $\mathrm{mg} / \mathrm{L}$, required for the degradation of the compound of wastewater to occur. In comparison, the average values of COD observed in this present study were higher than that observed by Mohammed et al. (2017) but lower than that observed by Baba et al. (2020).

The mean levels of BOD $(\mathrm{mg} / \mathrm{l})$ observed in TAN1, TAN2 and TAN3 samples were $13.85 \pm 6.42 ; \quad 19.46 \pm 0.50$ and $17.13 \pm 3.14$ respectively. The order of the mean BOD in the samples from the three industries can be arranged as TAN2>TAN3>TAN1. The BOD observed in TAN1, TAN2 and TAN3 samples were found below the recommended limits of NESREA (200 mg/l) but above WHO (10 mg/l). Statistical analysis shows that there is no significant difference $(p<0.05)$ between the mean values of BOD among the industries. This might be due to similar tannery activities involved in the tannery industries at the time of sampling. The low level of BOD recorded in this study is an indication of the low level of biodegradable organic solids in the effluent. The average values of BOD observed in this present study were lower than those observed by Mohammed et al. (2017) and Baba et al. (2020).

Table 1: Mean Values \pm S.D of Physico-chemical parameters of effluents from the Tannery Industries before Treatment.

\begin{tabular}{llllllll}
\hline Parameter & Tannery 1 & Tannery 2 & Tannery 3 & $\mathrm{a}$ & $\mathrm{b}$ & $\mathrm{c}$ & $\mathrm{d}$ \\
\cline { 2 - 7 } Temperature $\left({ }^{\circ} \mathrm{C}\right)$ & $28.07 \mathrm{a} \pm 0.65$ & $27.77 \mathrm{a} \pm 0.64$ & $26.38 \mathrm{a} \pm 3.81$ & & $29.50 \pm 4.68$ & 35 & 40 \\
pH & $7.77 \mathrm{a} \pm 2.93$ & $8.35 \mathrm{a} \pm 0.28$ & $7.52 \mathrm{a} \pm 0.76$ & 6.89 & $5.35 \pm 1.57$ & $7.0-8.5$ & $6.0-9.0$ \\
$\mathrm{COD}(\mathrm{mg} / \mathrm{l})$ & $2372 \mathrm{a} \pm 938$ & $1406 \mathrm{a} \pm 208$ & $3532 \mathrm{a} \pm 1373$ & 2.2 & $3106 \pm 2753$ & 40 & 40 \\
$\mathrm{BOD}(\mathrm{mg} / \mathrm{l})$ & $13.85 \mathrm{a} \pm 6.42$ & $19.46 \mathrm{a} \pm 0.50$ & $17.13 \mathrm{a} \pm 3.14$ & 1032 & $26.17 \pm 9.49$ & 10 & 200 \\
$\mathrm{SS}(\mathrm{mg} / \mathrm{l})$ & $374 \mathrm{a} \pm 124$ & $358 \mathrm{a} \pm 335$ & $780 \mathrm{a} \pm 739$ & 501 & $562 \pm 482$ & 30 & 10 \\
TDS $(\mathrm{mg} / \mathrm{l})$ & $3941 \mathrm{a} \pm 3703$ & $3300 \mathrm{a} \pm 1714$ & $2653 \mathrm{a} \pm 1240$ & 532.7 & $444 \pm 507$ & 250 & 500 \\
\hline
\end{tabular}

The values given in the table above are means of 6 replicate values, $\mathrm{n}=6$ ( 1 sample was taken monthly for 6 months). Within the rows, means with different alphabets are statistically different $(p<0.05)$. WHO: World Health Organisation. NESREA: National Environmental Standard and Regulatory Enforcement Agency. a = Mohammed et al.(2017), b = Baba et al. (2020), c = WHO (2006), $d=$ NESSRA (2009) 
BAJOPAS Volume 13 Number 2, December, 2020

Identification, Biochemical Characterization and growth rates of the Bacterial Isolates

Results of identification and biochemical characterization of the bacterial isolates were shown in table 2. After 24 hours of incubation, the nutrient agar media plates were checked for bacterial growth. The results showed the presence of different strains in the samples. The TAN1 bacteria isolate was found to be gramnegative cocci while TAN3 was gram-positive cocci. TAN2 bacteria isolate was found to be gram-positive, rod-shaped. TAN1, TAN2, and TAN3 bacteria isolates recorded positive results for spore former.

The results of the biochemical tests indicated that all the bacteria were positive for catalase, oxidase, citrate, maltose, glucose, lactose (negative in TAN1), mannitol (negative in TAN2), starch hydrolysis and coagulase (negative in TAN2) tests. The bacteria showed negative results for nitrate reduction, $M R$ (positive in TAN2), VP (positive in TAN1), Indole (positive in TAN2) tests. Base on the morphological and biochemical test results, TAN1, TAN2, and TAN3 bacteria isolates were identified to be Nesseria spp, Bacillus cereus, and Staphylococcus aureus respectively.

The growth rate of the TAN1, TAN2 and TAN3 Isolates were shown in figure 2. Generally, the optical density increase with the increase in time (day) and decrease as time goes on. The highest optical density was shown by bacillus cereus in TAN2 while the lowest was shown by Staphylococcus aureus in TAN3.

The initial growth phase of TAN1 Isolate bacteria occurred within 2-day of incubation as the growth rate increases up to the 6th-day incubation when the maximum growth was observed. Beyond the 6th day, the growth of the bacteria declined (which might be due to a shortage of nutrients in the effluents) until it reached its death phase (which might be due to the unavailability of nutrients in the effluents).

A similar trend of growth was also observed for TAN2 Isolate as the initial growth phase also occurred within 2-day of incubation but maximum growth rate observed on the 4th day of incubation. The stationary stage occurred between the 4th day and the 8th day. Beyond the 8th day, the growth of the bacteria declined (which might be due to a shortage of nutrients in the effluents) until it reached its death phase (which might be due to the unavailability of nutrients in the effluents).

The initial growth phase of TAN3 bacterial Isolate occurred within the 3-day incubation as the growth rate increases up to the 6th-day incubation when the maximum growth was observed. Beyond the 6th day, the growth of the bacteria declined (which might be due to a shortage of nutrients in the effluents) until it reached its death phase (which might be due to the unavailability of nutrients in the effluents).

Table 2: Morphological and Biochemical characteristics of bacterial isolates

\begin{tabular}{lllll} 
Bacterial Isolates & & TAN1 & TAN2 & TAN3 \\
\hline $\begin{array}{lllll}\text { Morphological } \\
\text { characteristics }\end{array}$ & Shape & Cocci & Rod & Cocci \\
& Spore & & & \\
& former & + & + & + \\
Gram & & & \\
Biochemical characteristics & reaction & - & + & + \\
& Citrate & + & + & + \\
& Catalase & + & + & + \\
& Coagulase & + & - & + \\
Starch & + & + & + \\
& Glucose & + & + & + \\
Oxidase & + & + & + \\
& Indo & - & + & - \\
Lactose & - & + & + \\
Manitol & + & - & + \\
Maltose & + & + & + \\
MR & - & + & - \\
VP & + & - & - \\
& Nitrate & - & - & - \\
Reduction & - Neisseria & Bacillus & Staphylococcus \\
& Bacterial & cereus & aureus \\
& name & spp & cas
\end{tabular}

+ = Positive; - = Negative; MR=Methyl Red; VP= Voges-Proskauer 


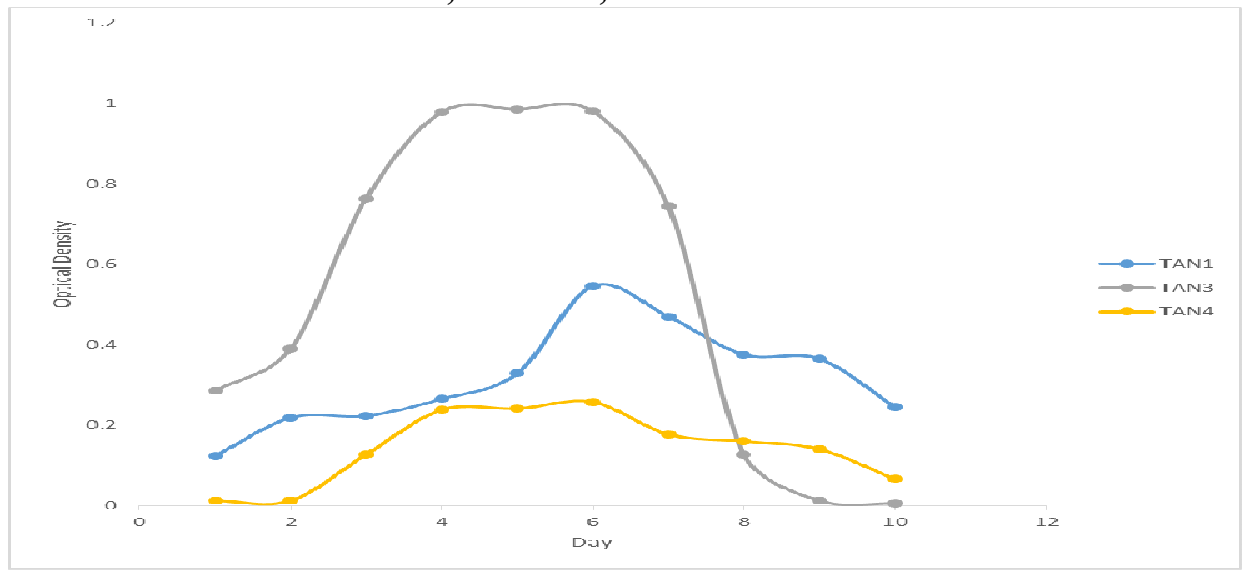

Fig. 2 Growth rates of the isolates in the effluents from the Tannery Industries

\section{Physico-chemical Parameters in the Industrial Effluents after the biodegradation.}

Table 3 shows the mean results of the physicochemical parameter before and after bioremediation using the different masses $(5 \mathrm{~g}$, $10 \mathrm{~g}, 15 \mathrm{~g}, 20 \mathrm{~g}$, and $25 \mathrm{~g}$ ) of the respective immobilized bacteria. Also, Table 4 shows the mean results of correlation coefficient ( $r$ ) between different masses of bacteria and physicochemical parameters.

The mean values $(\mathrm{mg} / \mathrm{l})$ of the SS after the bioremediation varies between $243 \pm 45$ and $898 \pm 672$. The mean concentration $(\mathrm{mg} / \mathrm{l})$ of SS remediated by the different masses $(5 \mathrm{~g}, 10 \mathrm{~g}$, $15 \mathrm{~g}, 20 \mathrm{~g}$, and $25 \mathrm{~g}$ ) of the bacteria varies. The SS in the samples fluctuates up and down after the bioremediation process when compared with the SS of the raw samples before the bioremediation. The increase in the levels of the SS might be due to the aggregation of the TDS which are large enough to result into SS. The increase in the levels of the SS might be also due to the influence of the nutrients which was added into the effluents in order to make the microorganisms more active and viable for fast degradation of organic contaminants in the effluent. The relative potential or efficiency of the different masses of the bacteria in remediating SS in TAN1 samples was in the order $25 \mathrm{~g}>20 \mathrm{~g}>15 \mathrm{~g}>10 \mathrm{~g}>5 \mathrm{~g}$. For TAN2 and TAN3 samples, the order was $25 \mathrm{~g}>20 \mathrm{~g}>15$ $\mathrm{g}>10 \mathrm{~g}>5 \mathrm{~g}$. These might be due to the variations in the surface areas of the different masses of the immobilized bacteria. Statistical analysis shows that there is no significant difference $(p<0.05)$ between the mean values of SS among the masses in the respective industries. Positive and significant correlations exist between the masses of bacteria and Suspended Solid (SS). This showed that there is general increase in the levels of the SS as the masses of the immobilized bacteria increases. TAN3 (90\%) and TAN1 (80\%) showed a very high correlation with the masses of the bacteria while TAN2 (61\%) showed a very low correlation.

The mean values $(\mathrm{mg} / \mathrm{l})$ of the TDS after the bioremediation varies between $46 \pm 11$ and $83 \pm 78$. The mean concentration $(\mathrm{mg} / \mathrm{l})$ of TDS remediated by the different masses $(5 \mathrm{~g}, 10 \mathrm{~g}$, $15 \mathrm{~g}, 20 \mathrm{~g}$, and $25 \mathrm{~g}$ ) of the bacteria varies. There is a reduction in all the TDS of all the samples after the bioremediation process compared with the TDS of the raw samples before the bioremediation. The relative potential or efficiency of the different masses of the bacteria in remediating TDS in TAN1 and TAN3 samples was in the order $5 \mathrm{~g}>10 \mathrm{~g}>15 \mathrm{~g}>20$ $\mathrm{g}>25 \mathrm{~g}$. For TAN2 samples, the order was 20 $g>10 \quad g>25 \quad g>15 \quad g>5 \quad g$. Statistical analysis shows that there is no significant difference $(p<0.05)$ between the mean values of TDS among the masses in the respective industries. These might be due to the variations in the surface areas of the different masses of the immobilized bacteria. Positive and significant correlations exist between the masses of bacteria and TDS with the exception in TAN2 (negative and insignificant correlation). The positive correlations showed that there is general increase in the levels of the TDS as the masses of the immobilized bacteria increases. TAN1 $(96 \%)$ showed a very high correlation with the masses of the bacteria while TAN2 (47\%) showed a very low correlation.

The mean values $(\mathrm{mg} / \mathrm{l})$ of the BOD after the bioremediation varies between $1.56 \pm 0.20 \mathrm{mg} / \mathrm{l}$ and $6.92 \pm 5.49 \mathrm{mg} / \mathrm{l}$. The mean concentration $(\mathrm{mg} / \mathrm{l})$ of BOD remediated by the different masses $(5 \mathrm{~g}, 10 \mathrm{~g}, 15 \mathrm{~g}, 20 \mathrm{~g}$, and $25 \mathrm{~g}$ ) of the bacteria varies. There is a reduction in all the BOD of all the samples after the bioremediation process compared with the $\mathrm{BOD}$ of the raw 
BAJOPAS Volume 13 Number 2, December, 2020 samples before the bioremediation. The relative potential or efficiency of the different masses of the bacteria in remediating BOD in TAN1, TAN2 and TAN3 samples were in the order $25 \mathrm{~g}>20$ $\mathrm{g}>15 \mathrm{~g}>10 \mathrm{~g}>5 \mathrm{~g}, 25 \mathrm{~g}>15 \mathrm{~g}>5 \mathrm{~g}>10 \mathrm{~g}>20 \mathrm{~g}$ and $20 \mathrm{~g}>10 \mathrm{~g}>25 \mathrm{~g}>15 \mathrm{~g}>5 \mathrm{~g}$ respectively. Statistical analysis shows that there is significant difference $(p<0.05)$ between the mean values of BOD among the masses in the respective industries. These might be due to the variations in the surface areas of the different masses of the immobilized bacteria. Negative and significant correlations exist between the masses of bacteria and BOD. This showed that there is general decrease in the levels of the BOD as the masses of the immobilized bacteria increases. TAN1 (94\%) showed a very high correlation with the masses of the bacteria while TAN2 (4\%) showed a very low correlation.

The mean values $(\mathrm{mg} / \mathrm{l})$ of the COD after the bioremediation varies between $250 \pm 154$ and $3134 \pm 1595$. The mean concentration $(\mathrm{mg} / \mathrm{l})$ of COD remediated by the different masses $(5 \mathrm{~g}$, $10 \mathrm{~g}, 15 \mathrm{~g} 20 \mathrm{~g}$, and $25 \mathrm{~g}$ ) of the bacteria varies. There is a reduction in all the COD of all the samples after the bioremediation process compared with the COD of the raw samples before the bioremediation. The relative potential or efficiency of the different masses of the bacteria in remediating COD in TAN1, TAN2 and TAN3 samples were in the order $25 \mathrm{~g}>20 \mathrm{~g}>15$ $\mathrm{g}>5 \mathrm{~g}>10 \mathrm{~g}, 25 \mathrm{~g}>20 \mathrm{~g}>15 \mathrm{~g}>10 \mathrm{~g}>5 \mathrm{~g}$ and 10 g>5 g>25 g>15 g>20 g respectively. Statistical analysis shows that there were significant difference $(p<0.05)$ between the mean values of COD among the masses in the respective industries except for effluents treated with $25 \mathrm{~g}$. These might be due to the variations in the surface areas of the different masses of the immobilized bacteria. Negative and insignificant correlations exist between the masses of bacteria and COD with the exception in TAN3 (positive and significant correlation). The negative correlations showed that there is general decrease in the levels of the COD as the masses of the immobilized bacteria increases. TAN2 (100\%) showed a very high correlation with the masses of the bacteria while TAN3 (36\%) showed a very low correlation.

Generally, there was an overall decrease in the concentration of these physicochemical parameters after the bioremediation using the different masses of the bacterial isolates. These might be due to the variations in the surface areas of the different masses of the immobilized bacteria. This is in line with the work of Jimoh et al. (2018) and Baba et al. (2020).

Table 3: Mean Values $(\mathrm{mg} / \mathrm{l}) \pm$ S.D of Physicochemical parameters in effluents from the Tannery Industries before and after Treatment of the effluents $(250 \mathrm{ml})$ with the different masses $(5 \mathrm{~g}, 10 \mathrm{~g}$, $15 \mathrm{~g}, 20 \mathrm{~g}$, and $25 \mathrm{~g}$ ) of the bacteria.

\begin{tabular}{llllllll}
\hline $\mathrm{P}$ & IND & Before & \multicolumn{5}{c}{ After } \\
\cline { 4 - 7 } & & & $5 \mathrm{~g}$ & $10 \mathrm{~g}$ & $15 \mathrm{~g}$ & $20 \mathrm{~g}$ & $25 \mathrm{~g}$ \\
\hline \multirow{2}{*}{ COD } & TAN1 & $2372 \pm 938$ & $1708 \mathrm{a} \pm 861$ & $2045 \mathrm{a} \pm 1205$ & $845 \mathrm{a} \pm 369$ & $300 \mathrm{a} \pm 167$ & $250 \mathrm{a} \pm 154$ \\
& TAN2 & $1406 \pm 208$ & $1195 \mathrm{a} \pm 208$ & $1125 \mathrm{a} \pm 384$ & $1055 \mathrm{a} \pm 317$ & $956 \mathrm{a} \pm 310$ & $870 \mathrm{ab} \pm 240$ \\
& TAN3 & $3532 \pm 1373$ & $2374 \mathrm{a} \pm 1344$ & $1976 \mathrm{a} \pm 1405$ & $2757 \mathrm{a} \pm 1266$ & $3134 \mathrm{a} \pm 1595$ & $2614 \mathrm{~b} \pm 1105$ \\
BOD & TAN1 & $13.85 \pm 6.42$ & $6.92 \mathrm{a} \pm 5.49$ & $6.42 \mathrm{a} \pm 5.07$ & $5.72 \mathrm{a} \pm 5.35$ & $4.62 \mathrm{a} \pm 4.37$ & $2.82 \mathrm{ab} \pm 1.26$ \\
& TAN2 & $19.46 \pm 0.50$ & $1.75 \mathrm{~b} \pm 0.22$ & $1.73 \mathrm{~b} \pm 0.18$ & $1.58 \mathrm{a} \pm 0.16$ & $1.91 \mathrm{a} \pm 0.22$ & $1.56 \mathrm{~b} \pm 0.20$ \\
& TAN3 & $17.13 \pm 3.14$ & $4.24 \mathrm{ab} \pm 0.77$ & $3.29 \mathrm{ab} \pm 0.37$ & $4.11 \mathrm{a} \pm 0.07$ & $3.23 \mathrm{a} \pm 0.91$ & $3.33 \mathrm{a} \pm 1.28$ \\
SS & TAN1 & $374 \pm 124$ & $243 \mathrm{a} \pm 45$ & $471 \mathrm{a} \pm 226$ & $475 \mathrm{a} \pm 182$ & $492 \mathrm{a} \pm 128$ & $611 \mathrm{a} \pm 217$ \\
& TAN2 & $358 \pm 335$ & $460 \mathrm{a} \pm 400$ & $543 \mathrm{a} \pm 414$ & $544 \mathrm{a} \pm 402$ & $551 \mathrm{a} \pm 414$ & $554 \mathrm{a} \pm 405$ \\
& TAN3 & $780 \pm 739$ & $586 \mathrm{a} \pm 594$ & $758 \mathrm{a} \pm 656$ & $787 \mathrm{a} \pm 676$ & $861 \mathrm{a} \pm 635$ & $898 \mathrm{a} \pm 672$ \\
TDS & TAN1 & $3941 \pm 3703$ & $51 \mathrm{a} \pm 10$ & $53 \mathrm{a} \pm 10$ & $55 \mathrm{a} \pm 15$ & $61 \mathrm{a} \pm 20$ & $63 \mathrm{a} \pm 26$ \\
& TAN2 & $3300 \pm 1714$ & $83 \mathrm{a} \pm 78$ & $47 \mathrm{a} \pm 20$ & $48 \mathrm{a} \pm 22$ & $47 \mathrm{a} \pm 17$ & $48 \mathrm{a} \pm 17$ \\
& TAN3 & $2653 \pm 1240$ & $46 \mathrm{a} \pm 11$ & $55 \mathrm{a} \pm 24$ & $55 \mathrm{a} \pm 25$ & $58 \mathrm{a} \pm 23$ & $61 \mathrm{a} \pm 28$ \\
\hline
\end{tabular}

Replicate $=6$ (months)

Within the rows, for the same parameter, means with different alphabets are statistically different $(p<0.05)$.

$\mathrm{P}=$ parameter, IND = Industries 
BAJOPAS Volume 13 Number 2, December, 2020

Table 4: Correlation coefficient $(r)$ between different masses of the bacteria and the physicochemical parameters.

\begin{tabular}{llll}
\hline Industries & Parameter & Correlation coefficient $(r)$ & $\begin{array}{l}\text { Percent dependence (rxrx100) } \\
(\%)\end{array}$ \\
\hline TAN1 & COD & -0.9 & 82 \\
& BOD & -0.97 & 94 \\
& SS & $0.90^{*}$ & 80 \\
TAN2 & TDS & $0.98^{*}$ & 96 \\
& COD & -1 & 100 \\
& BOD & -0.21 & 4 \\
& SS & $0.78^{*}$ & 61 \\
& TDS & -0.69 & 47 \\
& COD & $0.60^{*}$ & 36 \\
& BOD & -0.6 & 37 \\
& SS & $0.95^{*}$ & 90 \\
& TDS & $0.94^{*}$ & 89 \\
\hline
\end{tabular}

The correlation coefficient $(r)$ with * is statistically significant $(p<0.05)$.

Percentage reduction of the Parameters

Table 5 shows the percentage reduction of Parameters in industrial samples before and after the treatment of the effluents $(250 \mathrm{ml})$ with the different masses $(5 \mathrm{~g}, 10 \mathrm{~g}, 15 \mathrm{~g}, 20 \mathrm{~g}$, and $25 \mathrm{~g}$ ) of the Immobilized Bacteria.

In TAN1 samples, the percentage reduction (\%) of COD ranged (14-89); BOD (50-80); SS (-32$35)$ and TDS (98-99). In TAN2 samples, the percentage decrease $(\%)$ of COD ranged (15$38) ;$ BOD (90-92); SS [-28-(-55)] and TDS (9798). In TAN3 samples, the percentage decrease (\%) of COD ranged (11-44); BOD (76-81); SS (15-25) and TDS (98). The percentage increase in the levels COD, BOD and TDS might be due to the increase in the surface area of the different masses of the immobilized bacteria. However, the percentage decrease in the levels of the SS might be due to the aggregation of the TDS which are large enough to result into SS. The percentage decrease in the levels of the SS might be also due to the influence of the nutrients which was added into the effluents in order to make the microorganisms more active and viable for fast degradation of organic contaminants in the effluent. This is in line with the work of Jimoh et al. (2018) in which the concentration of the SS increase after the bioremediation of effluents.

Sreemoyee and Priti (2013) assessed and reduced several Physico-chemical parameters of dairy wastewater using Niesseria $s p$. and concluded that the species are well known to degrade organic compounds. This is in agreement with the current study in which the immobilized Niesseria $s p$ degrade the organic contaminants as indicated by the BOD, COD and TDS.

Jimoh et al. (2018) observed that TSS of the effluents was increased after treatment with immobilized bacteria and concluded that it might be due to the biostimulation method adopted for the research.

The optimum $\mathrm{pH}$ Biosorption of Chromium by Bacillus spp and Staphylococcus spp. from tannery effluent was investigated by Mythili and Karthikeyan (2011). The maximum adsorption of Chromium $(86.4 \mathrm{mg} / \mathrm{L})$ was showed by Bacillus spp and Staphylococcus spp showed $70.6 \mathrm{mg} / \mathrm{L}$ at an initial concentration of $100 \mathrm{mg} / \mathrm{L}$. In the present study, immobilised Bacillus spp and Staphylococcus spp. from the tannery industrial effluents reduced the levels of the organic pollutants with high potential as indicated by the percentage reduction of BOD, COD and TDS.

Enzymes often can work in multiple environments especially if they are immobilized. This makes the microorganisms' enzymes even more resistant to harsh environments and enables the enzymes to be recovered and recycled after they are no longer needed (Gianfreda and Rao 2004). Ramesh and Singh (1993) reported that the immobilized bacteria having more efficiency to remove the suspended particles than free cells. Using the immobilized cell is preferable due to its capability for using several times with the same efficiency, which makes it more economical. Similar work was done by Sikander et al. (2007) showing the higher reduction with permeabilized cells of Ochrobactrum intermedium strain SDCr-5. 
BAJOPAS Volume 13 Number 2, December, 2020

The results revealed the isolation and identification of isolates with the potential for the reduction of $\mathrm{Cr}$ (VI) to $\mathrm{Cr}$ (III). Results indicated that immobilized $B$. cereus could be efficiently used for the reduction of $\mathrm{Cr}$ (VI).

Table 5: Percentage reduction of the tested Parameters from the tannery industrial samples of the Immobilized Bacteria.

\begin{tabular}{lllllll}
\hline \multirow{2}{*}{ Industries } & & \multicolumn{5}{c}{ Percentage Reduction $(\%)$} \\
\cline { 3 - 7 } & & $5 \mathrm{~g}$ & $10 \mathrm{~g}$ & $15 \mathrm{~g}$ & $20 \mathrm{~g}$ & $25 \mathrm{~g}$ \\
\hline TAN1 & COD & 28 & 14 & 64 & 87 & 89 \\
& BOD & 50 & 54 & 59 & 67 & 80 \\
& SS & 35 & -26 & -27 & -32 & -63 \\
& TDS & 99 & 99 & 99 & 98 & 98 \\
TAN2 & COD & 15 & 20 & 25 & 32 & 38 \\
& BOD & 91 & 91 & 92 & 90 & 92 \\
& SS & -28 & -52 & -52 & -54 & -55 \\
& TDS & 97 & 99 & 99 & 99 & 99 \\
& COD & 33 & 44 & 22 & 11 & 26 \\
& BOD & 75 & 81 & 76 & 81 & 81 \\
& SS & 25 & 3 & -1 & -10 & -15 \\
& TDS & 98 & 98 & 98 & 98 & 98 \\
\hline
\end{tabular}

Percentage Reduction $=(B-A) / B \times 100 \%$

$A=$ Concentration of the parameter after treatment

$\mathrm{B}=$ Concentration of the parameter before treatment

$+=$ percentage decrease

- = percentage increase

In general, immobilization makes the enzyme more resistant to temperature, $\mathrm{pH}$, and substrate concentration swings giving it a longer lifetime and higher productivity per active unit (Gianfreda and Rao, 2004; FuIlbrook, 1996; Russell et al, 2003; Kandelbauer et al., 2004). Immobilized cells have been used and studied extensively for the production of useful chemicals (Ohtake and Silver, 1994), the treatment of wastewaters (Chen et al., 2003; Wang et al., 2010). Although many workers described microbial degradation of tannery effluent, limited literature is available on the bioremediation of tannery effluent using immobilized bacterial cells in the Kano Industrial Estates.

\section{CONCLUSION}

The samples contained variable levels of the physicochemical parameters. The results of the Analysis of variance revealed that, no statistical difference $(p<0.05)$ was observed for the temperature, $\mathrm{pH}, \mathrm{SS}, \mathrm{TDS}, \mathrm{BOD}$ and $\mathrm{COD}$ among the three tannery industries before the treatment. The levels of some of the parameters
(SS, TDS and COD) observed in the samples were found above the recommended limits of WHO and NESREA, which called for the treatment of the effluents before discharge into the environment. Base on the morphological and biochemical test results, TAN1, TAN2, and TAN3 bacterial isolates were identified to be Neisseria spp, Bacillus cereus, and Staphylococcus aureus respectively. The results of Post-treatment analysis showed that there is overall decrease in the levels of the parameters determined when compared with that of the pre-treatment. The overall percentage reduction of the immobilised bacteria in the treatment of the respective effluents was in the order TAN2 (72\%)>TAN1 $(70 \%)>$ TAN3 $(62 \%)$. Hence, the immobilized bacteria are having higher biodegradation potential for the treatment of the tannery effluents.

\section{Acknowledgments}

The authors wish to acknowledge the University of Maiduguri for the financial support. The authors are grateful to the Kano State Ministry of Environment for their support in obtaining the effluent samples. 


\section{REFERENCES}

Ajao, A. T., Adebayo, G. B., and Yakubu, S. E. (2011). Bioremediation of textile industrial effluent using mixed culture of Pseudomonas aeruginosa and Bacillus subtilis immobilized on agar-agar in a bioreactor. J. Microbiol. Biotech. Res, 1(3), 50-56.

Akan, J. C., Moses, E. A., Ogugbuaja, V. O., and Abah, J. (2007). Assessment of tannery industrial effluents from Kano metropolis, Kano State, Nigeria. Journal of Applied Sciences, 7(19), 2788-2793.

Akan, J. C., Ogugbuaja, V. O., Abdulrahman, F. I., and Ayodele, J. T. (2009). Pollutant levels in effluent samples from tanneries and textiles of Kano industrial areas, Nigeria. Global journal of pure and applied sciences, 15(3-4).

APHA (1989). Standard methods for Examination of Will bete and Will betewater.15 $5^{\text {th }}$ edition. Brydpass Springfield Will behington DC. pp. 164-176

APHA (1992). Standard Methods for the Examination of Water and Wastewater. Health, 69, 1116-9.

Baba, A., Garba, S. T., and Bello, H. S. (2020). Bioremediation Potential of Immobilized corynebacterium kutsceri in the Treatment of Tannery Industrial Effluent from Challawa Industrial Estate, Kano State, Nigeria. Journal of the Turkish Chemical Society Section A: Chemistry, $7(2), 335-350$.

Beem, E. I. V. (1994). reduction of solvent VOC emission. J. Oil Col. Chem. Ass, 77, 158.

Bouwer, E. J., and Zehnder, A. J. (1993). Bioremediation of organic compoundsputting microbial metabolism to work. Trends in biotechnology, 11(8), 360367.

Chen, K. C., Wu, J. Y., Liou, D. J., and Hwang, S. C. J. (2003). Decolorization of the textile dyes by newly isolated bacterial strains. Journal of Biotechnology, 101(1), 57-68.

Dan'Azumi, S., and Bichi, M. H. (2010). INDUSTRIAL POLLUTION AND HEAVY METALS PROFILE OF CHALLAWA RIVER IN KANO, NIGERIA. Journal of Applied Sciences in Environmental Sanitation, $5(1)$.

DWAF. (1992). Analytical Methods Manual, TR 151. Department of Water Affairs and Forestry, Pretoria.

El-Bestawy, E. (2013). Biological treatment of leather-tanning industrial wastewater using free living bacteria.
Elsheikh, M. A. S. (2009). Tannery wastewater pre-treatment. Water Science and Technology, 60(2), 433-440.

FuIlbrook, P. D. (1996). "Kinetics." Industrial enzymology: The application of enzymes in Industry. 2nd Ed. T. Godfrey and J Reichelt. eds.. Nature. New York.

Gianfreda, L., and Rao, M. A. (2004). Potential of extra cellular enzymes in remediation of polluted soils: a review. Enzyme and microbial technology, 35(4), 339354.

Hugo Springer. (1994). John Arthur Wilson Memorial Lecture "Treatment of Industrial Wastes of the Leather Industry - is it still a Major Problem". JALCA, 89, 153-185

Jimoh, A. A., Ganiyu, B. A., Baba, D., and Baba, A. (2018) Bioremediation Process of Effluent from Detergent and Food Industries in Jos, Nigeria: Kinetics and Thermodynamics. International Journal of Engineering Science Invention (IJESI), 762-73

Kandelbauer, A., Maute, O., Kessler, R. W., Erlacher, A., and Gübitz, G. M. (2004). Study of dye decolorization in an immobilized laccase enzyme-reactor using online spectroscopy. Biotechnology and bioengineering, 87(4), 552-563.

Kongjao, S., Damronglerd, S., and Hunsom, M. (2008). Simultaneous removal of organic and inorganic Pollutants in tannery wastewater using electrocoagulation technique. Korean Journal of chemical engineering, 25(4), 703.

Maheshwari, U. M., Aruna, S., Gomathi, M., and AbdulJaffar, A. H. (2017). Bioremediation by Free and Immobilized Bacteria Isolated from Tannery Effluent. International Journal of Research in Applied, Natural and Social Sciences. 5(7), 75-90

Margesin, R., and Schinner, F. (2001). Bioremediation (natural attenuation and biostimulation) of diesel-oilcontaminated soil in an alpine glacier skiing area. Applied and environmental microbiology, 677), 3127-3133.

Mohammed, A., Sekar, P., and George, J. (2011). Efficacy of microbes in bioremediation of tannery effluent. Inter. J. Curr. Res, 3(4), 324-326.

Mohammed, S. S. D., Orukotan, A. A., and Abdullahi, H. (2017). Physicochemical and Bacteriological Assessment of Tannery Effluent from Samaru-Zaria, 
BAJOPAS Volume 13 Number 2, December, 2020 Kaduna State, Nigeria. Journal of Applied

Sciences and Environmental Management, 21(4), 734-740.

Munz, G., De Angelis, D., Gori, R., Mori, G., Casarci, M., and Lubello, C. (2009). The role of tannins in conventional and membrane treatment of tannery wastewater. Journal of hazardous materials, 164(2-3), 733-739

Mythili, K., and Karthikeyan, B. (2011). Bioremediation of $\mathrm{Cr}$ (VI) from tannery effluent using Bacillus spp and Staphylococcus spp. International Multidisciplinary Research Journal, 1(6).

NESREA (2009). National Environmental Standards for Effluent Limitations and Regulation. 1233-1236

Noorjahan, C. M. (2014). Physicochemical characteristics, identification of bacteria and biodegradation of industrial effluent. Journal of bioremediation and Biodegradation, 5(3).

Ohtake, H. I., and Silver, A. O. (1994). Bacterial reduction of toxic chromate. Biological degradation and bioremediation of toxic chemicals, 403-415.

Omoleke, I. I. (2004). Management of environmental pollution in Ibadan, an African city: the challenges of health hazard facing government and the people. Journal of Human Ecology, 15(4), 265-275.

Rajor, A., Reddy, A.S., and Singh, B. (2004). Determination of BOD kinetic Parameters and evaluation of alternate methods, M.Sc. Thesis, Department of biotechnology \& environmental Science, Thapar Institute of Engineering and Technology, Patiala

Ramasami, T., Rajamani, S., and Rao, J. R. (1994, March). Pollution control in leather industry: Emerging technological options. In International symposium on surface and colloidal science and its relevance to soil pollution, madras.

Ramesh, J. V. S., and Singh, S. P. (1993). Yearly variation in certain physicochemical parameters of pond at eastern Doon Valley. Uttar Pradesh J. Zoo, 12 (1), 7577.

Ranen, S., and Sharadinadra, C. (2009). Biotechnology applications to environmental remediation in resource exploitation. Current science, 97, 6-25
Russell, A. J., Berberich, J. A., Drevon, G. F., and Koepsel, R. R. (2003). Biomaterials for mediation of

chemical and biological warfare agents. Annual review of biomedical engineering, 5(1), 1-27.

Saravanan, P., and Saravanan, A. (1999). Decolourization of tannery effluent by Flavobacterium sp. EK 1. Indian Journal of Environmental Protection, 19, 19-24.

Sikander, S., and Shahida, H. (2007). Reduction of toxic hexavalent chromium by Ochrobactrum intermedium strain SDCr5 stimulated by heavy metals. Bioresource Technol, 98, 340-344.

Singh, N., Sharma, B. K., and Bohra, P. C. (2000). Impact assessment of industrial effluent of arid soils by using satellite imageries. Journal of the Indian Society of Remote Sensing, 28(2-3), 79.

Sreemoyee, C., and Priti, P. (2013). Assessment of physico-chemical parameters of dairy waste water and isolation and characterization of bacterial strains in terms of cod reduction. Int J Sci, 2(3), 395-400.

Verheijen, L. A. H. M., Wiersema, D., Pol, L. H., and De Wit, J. (1996). Management of wastes from animal product processing. Livestock and environment, Finding a balance. International Agriculture Center, Wageningen, The Netherlands.

Wang, F., Yao, J., Si, Y., Chen, H., Russel, M., Chen, K., and Bramanti, E. (2010). Short-time effect of heavy metals upon microbial community activity. Journal of Hazardous Materials, 173(13), 510-516.

WHO (World Health Organization). (2006). Air quality guidelines: global update 2005: particulate matter, ozone, nitrogen dioxide, and sulfur dioxide. World Health Organization.

World Bank. (1995). Nigeria's strategic options for redressing industrial pollution. World Bank, industry and energy division. 1st edition, West Central Africa Department; Annexes: 1995; pp 60-62.

Zahoor, A., and Abdul, R. (2009). Enumeration of Coliforms. Journal of Environmental Sciences. 21, 814-820 


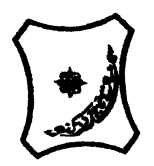

Bayero Journal of Pure and Applied Sciences, 13(2): 1 - 12

Received: November, 2020

Accepted: December, 2020

ISSN $2006-6996$

\title{
BIODEGRADATION POTENTIAL OF IMMOBILIZED BACTERIA IN THE TREATMENT OF TANNERY INDUSTRIAL EFFLUENTS FROM INDUSTRIAL ESTATES IN KANO STATE, NIGERIA
}

\author{
Abdullateef, B., ${ }^{1 *}$ Shuaibu, T. G., ${ }^{1}$ Babagana, K., ${ }^{1}$ Suleman, H. B. ${ }^{2}$ and Dauda, B. ${ }^{3}$ \\ ${ }^{1}$ Department of Pure and Applied Chemistry, Faculty of Science, University of Maiduguri, Borno State, \\ Nigeria \\ ${ }^{2}$ Department of Microbiology, Faculty of Science, University of Maiduguri, Borno State, Nigeria \\ ${ }^{3}$ Department of Chemical Engineering, Faculty of Engineering, University of Maiduguri, Borno State, \\ Nigeria \\ *Corresponding author: babslega@gmail.com; abelega2007@yahoo.com; +2348061309753
}

\section{ABSTRACT}

Industrial Effluents Samples from Gashash Tanneries (TAN1) in Bompai Industrial estate, Larabee Tannery Industry (TAN2) in Sharada Industrial estate and Z Tannery Industries (TAN3) in Challawa Industrial estate, Kano State, Nigeria were collected over a period of six months (August 2017 to January 2018) for assessing the biodegradation potentials of bacteria in the treatment of organic pollutants within the effluents. Bacteria were isolated from the effluents and immobilized on agar-agar. Different masses (5 g, $10 \mathrm{gr}, 15$ $\mathrm{g}, 20 \mathrm{~g}$, and $25 \mathrm{~g}$ ) of the bacteria were used in the treatment of $250 \mathrm{ml}$ of the effluents for ten days in a shaker incubator (Gallenkamp-OC-4364-L) at the temperature $30{ }^{\circ} \mathrm{C}$ and speed of $60 \mathrm{rpm}$. Pre-treatment analysis of the effluents for Temperature, pH, Biochemical Oxygen Demand (BOD), Chemical Oxygen Demand (COD), Suspended Solid (SS) and Total Dissolved Solids (TDS) gives the following results; temperature $\left({ }^{\circ} \mathrm{C}\right.$ )

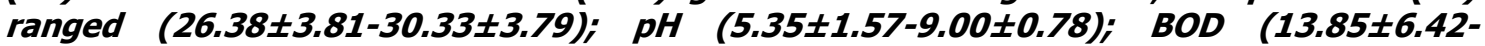
$38.75 \pm 16.20) ;$ COD (1406 $\pm 208-3532 \pm 1373) ;$ SS (208 $\pm 235-780 \pm 739)$ and TDS (266 $\pm 253-5276 \pm 2971)$. No statistical differences ( $p \leq 0.05)$ was observed for all the results among the different industries. The bacterial isolates were identified as Neisseria spp, Bacillus cereus, and Staphylococcus aureus, in TAN1, TAN2, and TAN3, respectively. After treatment of the effluent with the different masses of the isolated bacteria, the mean level of BOD was found to range as (0.55 $\pm 0.36-6.92 \pm 5.49) ; C O D$ (ND-3134 \pm 1595$)$;

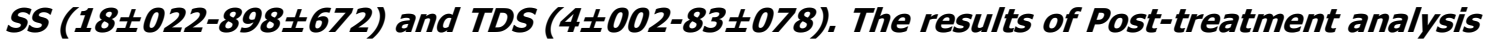
showed that there is overall decrease in the levels of the parameters determined when compared with that of the pre-treatment. The overall percentage reduction of the immobilised bacteria in the treatment of the respective effluents was in the order TAN2 (72\%)>TAN1 (70\%)>TAN3 (62\%). Hence, the immobilized bacteria are having higher biodegradation potential for the treatment of the tannery effluents.

Keywords: Biodegradation, bacteria, effluent, immobilization, tannery.

\section{INTRODUCTION}

Tannery industrial wastewater is a serious consequence of the pollution point of view for streams, freshwater, and land used for agriculture. The lack of awareness in the modern industrial practice has resulted in the discharge of tannery effluents which exhibit very high value of chromium ( $\mathrm{Cr}$ ), Sulfide, and chloride, Total Dissolved Solid (TDS), Total Suspended Solid (TSS), Biochemical Oxygen Demand (BOD) and Chemical Oxygen Demand (COD) in the water stream or land (Mohammed et al., 2001). Tanning is the process, which One ton of skin generally leads to the production of 20 to $80 \mathrm{~m}^{3}$ of turbid and foul-smelling converts the protein of the rawhide or skin into a stable material, which will not putrefy and is suitable for a wide variety of end applications (Elsheikh, 2009). The highly polluting chromium is the most commonly used tanning material producing leather that is more flexible and pliable than vegetable-tanned leather and does not discolor or lose shape in water as drastically as vegetable-tan (Elsheikh, 2009). Tannery effluent is among the most hazardous industrial pollutants due to its huge organic and inorganic load, which is highly toxic to human life and the environment (Kongjao et al., 2008). wastewater including chromium (100-400 mg/l), sulfide $(200-800 \mathrm{mg} / \mathrm{l})$, high levels of fat and 
BAJOPAS Volume 13 Number 2, December, 2020 other solid wastes, and notable pathogen contamination as well as pesticides added for skin conservation during transport (Elsheikh, 2009). There are more than 6000 tanneries in Nigeria with an annual processing capacity of 700,000 tons of hides and skins (Omoleke, 2004; Singh et al., 2008). It was reported that the total amount of waste produced per animal slaughtered is approximately $35 \%$ of its weight (World Bank, 1995). Also, for every $1000 \mathrm{~kg}$ of carcass weight, a slaughtered beef produces 5.5 $\mathrm{kg}$ of manure (excluding rumen contents or stockyard manure) and $100 \mathrm{~kg}$ of paunch manure (undigested food) (Verheijen et al., 1996). Tanneries generate wastewater in the range of 30-35 $\mathrm{L} \mathrm{kg}^{-1}$ skin/hide processed with variable $\mathrm{pH}$, Biological Oxygen Demand (BOD), Chemical Oxygen Demand (COD), high concentrations of suspended solids (SS), and tannins as well as chromium (Zahoor and Abdul, 2009).

Being heterogeneous and composed of a wide variety of compounds, it is very difficult to select a unique direct method for estimating the biodegradability of organic contents and biokinetic parameters for a wastewater sample (Rajor, 2004). For this purpose, some indirect estimation such as determination of biochemical oxygen demand (BOD) and chemical oxygen demand (COD) are applied as common laboratory investigations [9]. During retanning procedures, synthetic tannins (Syntan), oils and resins are added to form softer leather at varying doses (Munz et al., 2009). One of the refractory groups of chemicals in tannery effluents derives mainly from tannins (Ramasami et al., 2004). Syntans are characterized by complex chemical structures, because they are composed of an extended set of chemicals such as phenol-, naphthalene-, formaldehyde- and melamine-based syntans, and acrylic resins (Beem, 1994). Organic pollutants (proteic and lipidic components) are originated from skins (it is calculated that the raw skin has $30 \%$ loss of organic material during the working cycle) or they are introduced during processes (Hugo Springer, 1994).

Many conventional processes such as oxidation, chemical and biological processes were carried out to treat tanneries wastewater (Ebtesam et al, 2013). Biological processes have received more attention because of their costeffectiveness, lower sludge production and environmental friendliness (Noorjahan, 2014). Naturally occurring micro-organisms degrade the hazardous organic wastes including xenobiotic compounds, such as pesticides, polycyclic aromatic hydrocarbons (PAHs) and polychlorinated biphenyls (PCBs) in due course of time (Ranen and Sharadinadra, 2009). Bioremediation is based on the idea that all organisms remove substances from the environment to carry outgrowth and metabolism (Bouwer and Zehnder, 1993). Bacteria, protista and fungi are found to be very good at degrading complex molecules and incorporating the breakdown products into their metabolism (Bouwer and Zehnder, 1993). The resultant metabolic wastes that they produce are generally safe and somehow recycled into other organisms (Ranen and Sharadinadra, 2009). An acclimatized indigenous population of microorganisms capable of degradation of the compounds of interest must exist at the site for a successful bioremediation mode (Ranen and Sharadinadra, 2009). It has been observed that for a successful bioremediation mode, an acclimatized indigenous population of microorganisms capable of degradation of the compounds of interest must exist at the site under investigation (Ranen and Sharadinadra, 2009). Even though there are numerous physical and chemical methods employed in the disposal of wastes the advantage in using bacterium is that they play a key role in the reduction of COD, BOD, total protein, total tannin and total phenol (Saravanan and Saravanan, 1998)

Baba et al. (2020) studied the bioremediation potential of immobilized corynebacterium kutsceri in the Treatment of tannery industrial effluent from Challawa Industrial Estate, Kano State, Nigeria. The aim of the work is to study the reduction in the level of the contaminants through the process of bioremediation using the isolated bacteria. Immobilized bacteria can withstand various temperatures, $\mathrm{pH}$ and substrate concentrations; consequently, increasing the efficiency and the lifespan of the bacteria. Immobilized bacteria are widely applied in the treatment of wastewater and can be separated and recovered after the treatment with the same efficiency (Baba et al., 2020).

\section{MATERIALS AND METHODS \\ Study Area}

This study was carried out in Bompai, Sharada and Challawa industrial estates in Kano, Figure 1. Kano lies on Latitude $11^{\circ} 30^{\prime} \mathrm{N}$ and $8^{\circ} 30^{\prime} \mathrm{E}$ and Longitude $11^{\circ} 5^{\prime} \mathrm{N}$ and $8^{\circ} 5^{\prime} \mathrm{E}$ in Northern Nigeria. It is one of the developed industrial cities in Nigeria. Tannery activities are the dominating industries and this could be one of the reasons for her high population density (Dan'Azumi and Bichi, 2010). Many researchers have studied biodegradation of tannery effluent using microorganisms. However, limited literature is available on the biodegradation of tannery effluent in Kano industrial estates using 
BAJOPAS Volume 13 Number 2, December, 2020 immobilized bacterial cells. This research work focuses on the potential of the use of the indigenous immobilized bacterial isolates in the treatment of tannery effluents in the industrial estates.

\section{Sample Collection}

Effluents were collected from the Tannery Industries from Bompai, Challawa and Sharada Industrial Estates, Kano, Nigeria. The effluents were collected over a period of six months (August 2017 to January 2018). Samples collected in a sterile 4-liter plastic container with a unique identification number were preserved using an ice-box that was transported to the Microbiology Laboratory, Department of Microbiology, Bayero University of Kano for analysis

\section{Sample Preparation and Sample Analysis}

Immediately after the collection of the effluent, $\mathrm{pH}$, TSS, TDS, COD, BOD levels were determined before treatment (Pre-treatment determination) and ten days after treatment (Post-treatment determination) as described in
APHA (1989) standard methods. $\mathrm{pH}$ was determined using Ecotests $\mathrm{pH}$ meter and TDS was determined using AQUALYTIC TDS Salinometer. BOD was determined as described by the standard method (APHA, 1992). COD and SS were determined using DR/2010 HACH portable data logging spectrophotometer (DWAF, 1992)

\section{Identification and Biochemical} Characterization of the Bacterial Isolates

The bacteria were isolated from the effluents using Serial Dilution according to the method described by APHA (1989). The biochemical tests such as oxidase, catalase, coagulase, indole (from $1 \%$ tryptone broth), citrate (Simmons citrate agar), methyl red/VogesProskauer (MR/VP), nitrate reduction, Starch Hydrolysis, Glucose, Maltose, and Lactose tests were carried out on the bacterial isolates to identify the bacteria through the bacteria biochemical characteristics according to Ajao et al. (2011).

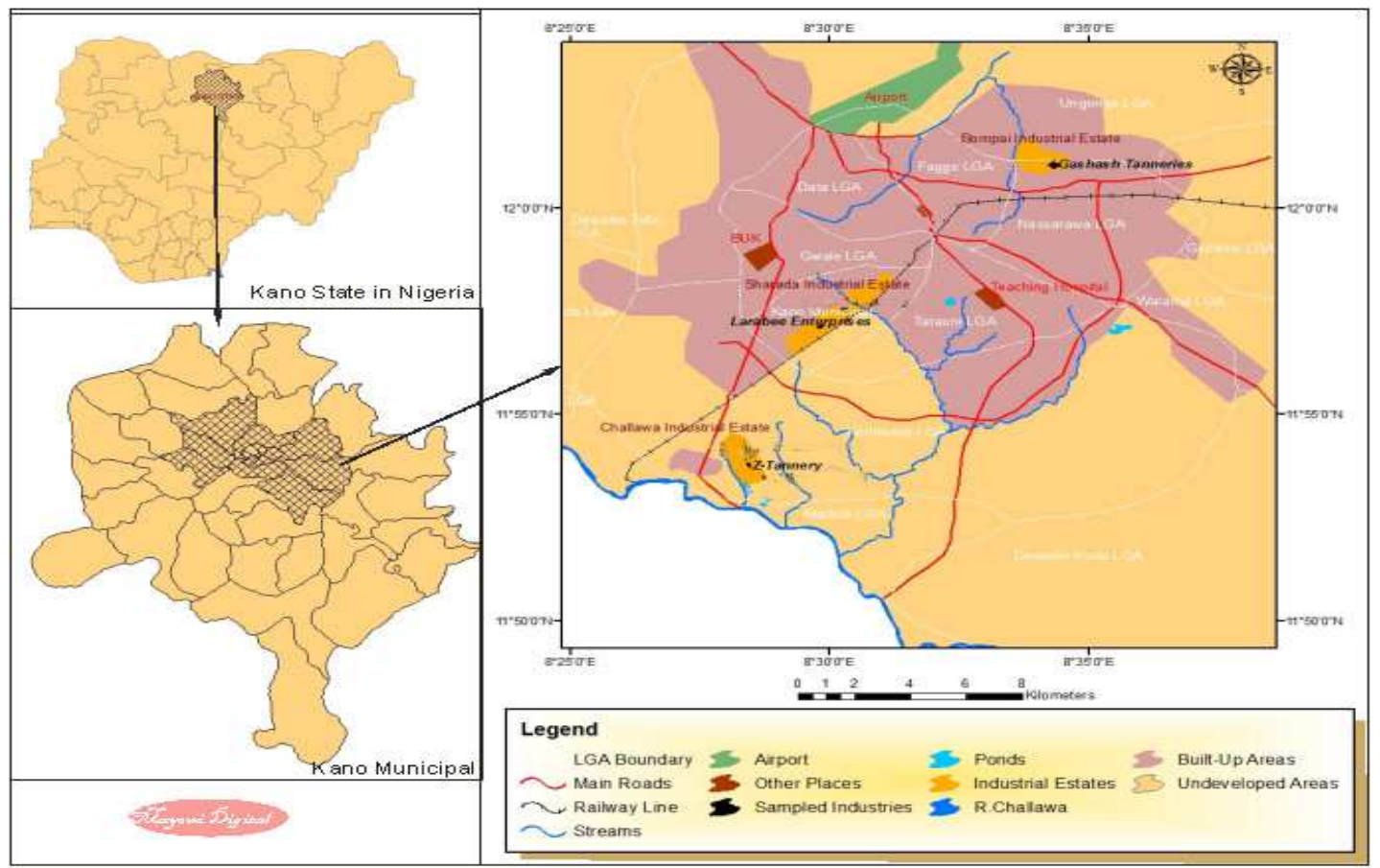

Fig. 1 Map showing the study areas

Source: Mayomi Digital Productions, GIS Laboratory, Department of Geography, UNIMAID (2017)

\section{Determination of Growth Rate of the Bacteria in Effluent Sample}

The bacteria growth rates were determined by transferring $2 \mathrm{~mL}$ of the bacterial isolates from the tannery effluent in broth medium into 100 $\mathrm{mL}$ sterile effluents in conical flasks and kept in an incubator (Giffrin cool) for 10 days. Control was also set up by incubating another $100 \mathrm{~mL}$ each of the sterile effluents without the bacteria. The optical density of the content was determined at the wavelength of $600 \mathrm{~nm}$ on a daily interval and recorded. 
BAJOPAS Volume 13 Number 2, December, 2020 Immobilization of Bacteria

Agar solution and inoculi were prepared separately. Fifty milliliters $(50 \mathrm{~mL})$ of nutrient broth each of the inoculi was prepared in a McCartney bottle and incubated for 24 hours. A solution of agar-agar was prepared by dissolving $10 \mathrm{~g}$ of the powder in distilled water and made up to $500 \mathrm{~mL}$ mark in an Erlenmeyer flask and was sterilized in an autoclave (280A) for 15 minutes and allowed to cool to $40-45^{\circ} \mathrm{C}$ (Ajao et al., 2011). Four milliliters ( $4 \mathrm{~mL})$ of the bacterial isolates in the nutrient broth was mixed with 36 $\mathrm{ml}$ of the prepared agar-agar media in petri-dish plates and then allowed to solidify. This was kept in the refrigerator for bioremediation.

\section{Bioremediation (Treatment) of the Effluents}

The solidified agar block (immobilized bacteria) was cut into cubes using a sterile knife; $0.1 \mathrm{~mL}$ phosphate buffer ( $\mathrm{pH} \mathrm{7.0)}$ was added and kept in the refrigerator for 1 hour for curing. The phosphate buffer was decanted after 1 hour and the cubes were washed with sterile distilled water 3-4 times before it was used (Ajao et al., 2011). Two liters (2 L) of the effluent was supplemented with the minimum basal medium in $\mathrm{g} / \mathrm{L}: \mathrm{NaCl}(0.8), \mathrm{MgSO}_{4} .7 \mathrm{H}_{2} \mathrm{O}(0.001), \mathrm{KH}_{2} \mathrm{PO}_{4}$ (2), $\mathrm{NaNO}_{3}$ (2), $\quad \mathrm{CaCl}_{2} .2 \mathrm{H}_{2} \mathrm{O} \quad(0.5)$ and $\mathrm{NaHPO}_{4} .12 \mathrm{H}_{2} \mathrm{O}(2)$ and sterilized in an autoclave at $121^{\circ} \mathrm{C}$ for 15 minutes (Margesin and Schinner, 2001). Two hundred and fifty milliliters $(250 \mathrm{~mL})$ of the effluents were transferred into different $250 \mathrm{ml}$ conical flasks. The content was covered with a cotton-wool ramped with foil paper to avoid contamination. Five grams $(5 \mathrm{~g})$ of the immobilized bacteria were quickly transferred into each of the effluents in the conical flasks in an inoculating chamber. The same procedures were carried out for the $10 \mathrm{~g}, 15 \mathrm{~g}, 20 \mathrm{~g}$ and 25 $\mathrm{g}$ of the immobilized bacteria in separate $250 \mathrm{~mL}$ effluents in conical flasks and agitated for ten days in a shaker incubator (Gallenkamp-OC4364-L) at a temperature $30^{\circ} \mathrm{C}$ and speed of 60 rpm. The treated effluent samples were taken on the tenth day and analyzed for the parameters $\mathrm{pH}$, SS, TDS, COD, and BOD, (Posttreatment determination) for the different grams of bacteria to evaluate and compare the biodegradation potential. (Baba et al., 2020).

\section{Statistical Analysis}

The data were represented as Mean \pm Standard deviation and analyzed statistically using oneway Analysis of Variance (ANOVA) and Tukey's HSD as Post Hoc Tests with the aid of SPSS 16.0. The correlation coefficient was also used to measure the strength of the relationship between the different masses of the bacteria and the parameters. All $\mathrm{p} \leq 0.05$ were considered as statistically significant.

\section{RESULTS AND DISCUSSION Physico-chemical parameters in the Industrial Effluents before the Biodegradation.}

Results of the Physico-chemical parameters in the industrial effluents before the Biodegradation is shown in table 1 . The mean temperatures $\left({ }^{\circ} \mathrm{C}\right)$ observed in TAN1, TAN2, and TAN3 samples were $28.07 \pm 0.65 ; 27.77 \pm 0.64$ and $26.38 \pm 3.81$ respectively. The order of the mean temperature of the samples from the three industries can be arranged as TAN1 > TAN2>TAN3. The temperature observed at TAN1, TAN2, and TAN3 samples were found below the WHO $\left(35^{\circ} \mathrm{C}\right)$ and NESREA $\left(40^{\circ} \mathrm{C}\right)$ limits. The low values of temperature might be due to the processes used at the time of sampling. High temperature brings down the solubility of gases in water that ultimately expresses as high BOD and COD. Statistical analysis shows that there is no significant difference $(p<0.05)$ between the mean values of temperature among the industries. This might be due to similar tannery activities involved in the tannery industries at the time of sampling. The average values of temperature observed in this present study are less than those observed by Akan et al. (2007), Akan et al. (2009) and Baba et al. (2020).

The mean level of $\mathrm{pH}$ observed in TAN1, TAN2 and TAN3, samples were $7.77 \pm 2.93$; $8.35 \pm 0.28$ and $7.52 \pm 0.76$ respectively. The order of the mean $\mathrm{pH}$ of the samples from the three industries can be arranged as TAN2> TAN1 $>$ TAN3. The $\mathrm{pH}$ of the samples falls within the WHO (7.0-8.5) and NESREA (6-9) standard limits. Statistical analysis shows that there is no significant difference $(p<0.05)$ between the mean values of $\mathrm{pH}$ among the industries. This might be due to similar tannery activities involved in the tannery industries at the time of sampling. Maheshwari et al. (2017) reported that the level of $\mathrm{pH}$ in the effluents from the tannery industry in Vaniyambadi, India was 6.5 which was lower than that observed in the present study. The $\mathrm{pH}$ in the effluents from the tannery industries in Kano and Kaduna were reported to be 7.64 and 6.89, respectively (Akan et al., 2007; Mohammed et al., 2017). The average values of $\mathrm{pH}$ observed in this present study are less than those observed by Mohammed et al. (2017) and Baba et al. (2020). The mean level of SS $(\mathrm{mg} / \mathrm{l})$ observed in TAN1, TAN2, and TAN3 samples were 374 \pm 124 ; $358 \pm 335$ and $780 \pm 739$ respectively. The order of the mean SS in the samples from the three industries can be arranged as TAN3 > TAN1 $>$ TAN2. 
The SS observed in the samples were far above the recommended standard limits of regulating bodies WHO $(30 \mathrm{mg} / \mathrm{l})$ and NESREA $(10 \mathrm{mg} / \mathrm{l})$. Statistical analysis shows that there is no significant difference $(p<0.05)$ between the mean values of SS among the industries. This might be due to similar tannery activities involved in the tannery industries at the time of sampling. The average values of SS observed in this present study are less than that observed $(3700 \pm 122 \mathrm{mg} / \mathrm{l})$ by Akan et al. (2009) for tanneries in Kano. Also, the average values of SS observed in this present study are less than that observed by Mohammed et al. (2017) and Baba et al. (2020) with the exception in TAN3.

The mean level of TDS (mg/l) observed in TAN1, TAN2, and TAN3 samples were $3941 \pm 3703$; $3300 \pm 1714$ and $2653 \pm 1240$ respectively. The order of the mean TDS in the samples from the three industries can be arranged as TAN1>TAN2>TAN3. The TDS observed in the samples were far above the recommended standard limits of WHO $(250 \mathrm{mg} / \mathrm{l})$ and NESREA $(500 \mathrm{mg} / \mathrm{l})$. Statistical analysis shows that there is no significant difference $(p<0.05)$ between the mean values of TDS among the industries. This might be due to similar tannery activities involved in the tannery industries at the time of sampling. TDS in the effluents from the tannery industries in Kano, Nigeria was reported to be $1281 \mathrm{mg} / \mathrm{l}$ (Akan et al., 2007). The average values of SS observed in this present study are less than those observed by Mohammed et al. (2017) and Baba et al. 2020)

The mean level of COD (mg/l) observed in TAN1, TAN2 and TAN3 samples seasons were $2372 \pm 938 ; \quad 1406 \pm 208$ and $3532 \pm 1373$ respectively. The order of the mean COD of the samples from the three industries can be arranged as TAN3>TAN1> TAN2. The COD observed in TAN1, TAN2 and TAN3 samples were far above the recommended standard limits of regulating bodies $\mathrm{WHO}(40 \mathrm{mg} / \mathrm{l})$ and NESREA (40 mg/l). Statistical analysis shows that there is no significant difference $(p<0.05)$ in COD among the industries. This might be due to similar tannery activities involved in the tannery industries as at the time of sampling. The Chemical Oxygen demand (COD) is the amount of oxygen, in $\mathrm{mg} / \mathrm{L}$, required for the degradation of the compound of wastewater to occur. In comparison, the average values of COD observed in this present study were higher than that observed by Mohammed et al. (2017) but lower than that observed by Baba et al. (2020).

The mean levels of BOD $(\mathrm{mg} / \mathrm{l})$ observed in TAN1, TAN2 and TAN3 samples were $13.85 \pm 6.42 ; \quad 19.46 \pm 0.50$ and $17.13 \pm 3.14$ respectively. The order of the mean BOD in the samples from the three industries can be arranged as TAN2>TAN3>TAN1. The BOD observed in TAN1, TAN2 and TAN3 samples were found below the recommended limits of NESREA (200 mg/l) but above WHO (10 mg/l). Statistical analysis shows that there is no significant difference $(p<0.05)$ between the mean values of BOD among the industries. This might be due to similar tannery activities involved in the tannery industries at the time of sampling. The low level of BOD recorded in this study is an indication of the low level of biodegradable organic solids in the effluent. The average values of BOD observed in this present study were lower than those observed by Mohammed et al. (2017) and Baba et al. (2020).

Table 1: Mean Values \pm S.D of Physico-chemical parameters of effluents from the Tannery Industries before Treatment.

\begin{tabular}{llllllll}
\hline Parameter & Tannery 1 & Tannery 2 & Tannery 3 & $\mathrm{a}$ & $\mathrm{b}$ & $\mathrm{c}$ & $\mathrm{d}$ \\
\cline { 2 - 7 } Temperature $\left({ }^{\circ} \mathrm{C}\right)$ & $28.07 \mathrm{a} \pm 0.65$ & $27.77 \mathrm{a} \pm 0.64$ & $26.38 \mathrm{a} \pm 3.81$ & & $29.50 \pm 4.68$ & 35 & 40 \\
pH & $7.77 \mathrm{a} \pm 2.93$ & $8.35 \mathrm{a} \pm 0.28$ & $7.52 \mathrm{a} \pm 0.76$ & 6.89 & $5.35 \pm 1.57$ & $7.0-8.5$ & $6.0-9.0$ \\
$\mathrm{COD}(\mathrm{mg} / \mathrm{l})$ & $2372 \mathrm{a} \pm 938$ & $1406 \mathrm{a} \pm 208$ & $3532 \mathrm{a} \pm 1373$ & 2.2 & $3106 \pm 2753$ & 40 & 40 \\
$\mathrm{BOD}(\mathrm{mg} / \mathrm{l})$ & $13.85 \mathrm{a} \pm 6.42$ & $19.46 \mathrm{a} \pm 0.50$ & $17.13 \mathrm{a} \pm 3.14$ & 1032 & $26.17 \pm 9.49$ & 10 & 200 \\
$\mathrm{SS}(\mathrm{mg} / \mathrm{l})$ & $374 \mathrm{a} \pm 124$ & $358 \mathrm{a} \pm 335$ & $780 \mathrm{a} \pm 739$ & 501 & $562 \pm 482$ & 30 & 10 \\
TDS $(\mathrm{mg} / \mathrm{l})$ & $3941 \mathrm{a} \pm 3703$ & $3300 \mathrm{a} \pm 1714$ & $2653 \mathrm{a} \pm 1240$ & 532.7 & $444 \pm 507$ & 250 & 500 \\
\hline
\end{tabular}

The values given in the table above are means of 6 replicate values, $\mathrm{n}=6$ ( 1 sample was taken monthly for 6 months). Within the rows, means with different alphabets are statistically different $(p<0.05)$. WHO: World Health Organisation. NESREA: National Environmental Standard and Regulatory Enforcement Agency. a = Mohammed et al.(2017), b = Baba et al. (2020), c = WHO (2006), $d=$ NESSRA (2009) 
BAJOPAS Volume 13 Number 2, December, 2020

Identification, Biochemical Characterization and growth rates of the Bacterial Isolates

Results of identification and biochemical characterization of the bacterial isolates were shown in table 2. After 24 hours of incubation, the nutrient agar media plates were checked for bacterial growth. The results showed the presence of different strains in the samples. The TAN1 bacteria isolate was found to be gramnegative cocci while TAN3 was gram-positive cocci. TAN2 bacteria isolate was found to be gram-positive, rod-shaped. TAN1, TAN2, and TAN3 bacteria isolates recorded positive results for spore former.

The results of the biochemical tests indicated that all the bacteria were positive for catalase, oxidase, citrate, maltose, glucose, lactose (negative in TAN1), mannitol (negative in TAN2), starch hydrolysis and coagulase (negative in TAN2) tests. The bacteria showed negative results for nitrate reduction, $M R$ (positive in TAN2), VP (positive in TAN1), Indole (positive in TAN2) tests. Base on the morphological and biochemical test results, TAN1, TAN2, and TAN3 bacteria isolates were identified to be Nesseria spp, Bacillus cereus, and Staphylococcus aureus respectively.

The growth rate of the TAN1, TAN2 and TAN3 Isolates were shown in figure 2. Generally, the optical density increase with the increase in time (day) and decrease as time goes on. The highest optical density was shown by bacillus cereus in TAN2 while the lowest was shown by Staphylococcus aureus in TAN3.

The initial growth phase of TAN1 Isolate bacteria occurred within 2-day of incubation as the growth rate increases up to the 6th-day incubation when the maximum growth was observed. Beyond the 6th day, the growth of the bacteria declined (which might be due to a shortage of nutrients in the effluents) until it reached its death phase (which might be due to the unavailability of nutrients in the effluents).

A similar trend of growth was also observed for TAN2 Isolate as the initial growth phase also occurred within 2-day of incubation but maximum growth rate observed on the 4th day of incubation. The stationary stage occurred between the 4th day and the 8th day. Beyond the 8th day, the growth of the bacteria declined (which might be due to a shortage of nutrients in the effluents) until it reached its death phase (which might be due to the unavailability of nutrients in the effluents).

The initial growth phase of TAN3 bacterial Isolate occurred within the 3-day incubation as the growth rate increases up to the 6th-day incubation when the maximum growth was observed. Beyond the 6th day, the growth of the bacteria declined (which might be due to a shortage of nutrients in the effluents) until it reached its death phase (which might be due to the unavailability of nutrients in the effluents).

Table 2: Morphological and Biochemical characteristics of bacterial isolates

\begin{tabular}{lllll} 
Bacterial Isolates & & TAN1 & TAN2 & TAN3 \\
\hline $\begin{array}{lllll}\text { Morphological } \\
\text { characteristics }\end{array}$ & Shape & Cocci & Rod & Cocci \\
& Spore & & & \\
& former & + & + & + \\
Gram & & & \\
Biochemical characteristics & reaction & - & + & + \\
& Citrate & + & + & + \\
& Catalase & + & + & + \\
& Coagulase & + & - & + \\
Starch & + & + & + \\
& Glucose & + & + & + \\
Oxidase & + & + & + \\
& Indo & - & + & - \\
Lactose & - & + & + \\
Manitol & + & - & + \\
Maltose & + & + & + \\
MR & - & + & - \\
VP & + & - & - \\
& Nitrate & - & - & - \\
Reduction & - Neisseria & Bacillus & Staphylococcus \\
& Bacterial & cereus & aureus \\
& name & spp & cas
\end{tabular}

+ = Positive; - = Negative; MR=Methyl Red; VP= Voges-Proskauer 


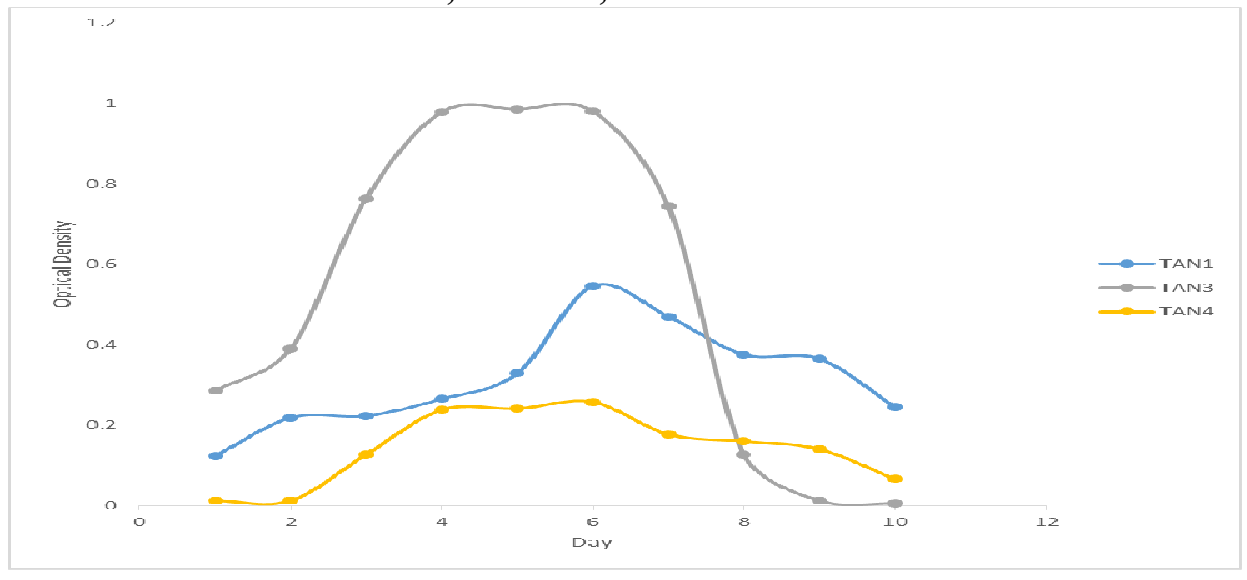

Fig. 2 Growth rates of the isolates in the effluents from the Tannery Industries

\section{Physico-chemical Parameters in the Industrial Effluents after the biodegradation.}

Table 3 shows the mean results of the physicochemical parameter before and after bioremediation using the different masses $(5 \mathrm{~g}$, $10 \mathrm{~g}, 15 \mathrm{~g}, 20 \mathrm{~g}$, and $25 \mathrm{~g}$ ) of the respective immobilized bacteria. Also, Table 4 shows the mean results of correlation coefficient ( $r$ ) between different masses of bacteria and physicochemical parameters.

The mean values $(\mathrm{mg} / \mathrm{l})$ of the SS after the bioremediation varies between $243 \pm 45$ and $898 \pm 672$. The mean concentration $(\mathrm{mg} / \mathrm{l})$ of SS remediated by the different masses $(5 \mathrm{~g}, 10 \mathrm{~g}$, $15 \mathrm{~g}, 20 \mathrm{~g}$, and $25 \mathrm{~g}$ ) of the bacteria varies. The SS in the samples fluctuates up and down after the bioremediation process when compared with the SS of the raw samples before the bioremediation. The increase in the levels of the SS might be due to the aggregation of the TDS which are large enough to result into SS. The increase in the levels of the SS might be also due to the influence of the nutrients which was added into the effluents in order to make the microorganisms more active and viable for fast degradation of organic contaminants in the effluent. The relative potential or efficiency of the different masses of the bacteria in remediating SS in TAN1 samples was in the order $25 \mathrm{~g}>20 \mathrm{~g}>15 \mathrm{~g}>10 \mathrm{~g}>5 \mathrm{~g}$. For TAN2 and TAN3 samples, the order was $25 \mathrm{~g}>20 \mathrm{~g}>15$ $\mathrm{g}>10 \mathrm{~g}>5 \mathrm{~g}$. These might be due to the variations in the surface areas of the different masses of the immobilized bacteria. Statistical analysis shows that there is no significant difference $(p<0.05)$ between the mean values of SS among the masses in the respective industries. Positive and significant correlations exist between the masses of bacteria and Suspended Solid (SS). This showed that there is general increase in the levels of the SS as the masses of the immobilized bacteria increases. TAN3 (90\%) and TAN1 (80\%) showed a very high correlation with the masses of the bacteria while TAN2 (61\%) showed a very low correlation.

The mean values $(\mathrm{mg} / \mathrm{l})$ of the TDS after the bioremediation varies between $46 \pm 11$ and $83 \pm 78$. The mean concentration $(\mathrm{mg} / \mathrm{l})$ of TDS remediated by the different masses $(5 \mathrm{~g}, 10 \mathrm{~g}$, $15 \mathrm{~g}, 20 \mathrm{~g}$, and $25 \mathrm{~g}$ ) of the bacteria varies. There is a reduction in all the TDS of all the samples after the bioremediation process compared with the TDS of the raw samples before the bioremediation. The relative potential or efficiency of the different masses of the bacteria in remediating TDS in TAN1 and TAN3 samples was in the order $5 \mathrm{~g}>10 \mathrm{~g}>15 \mathrm{~g}>20$ $\mathrm{g}>25 \mathrm{~g}$. For TAN2 samples, the order was 20 $g>10 \quad g>25 \quad g>15 \quad g>5 \quad g$. Statistical analysis shows that there is no significant difference $(p<0.05)$ between the mean values of TDS among the masses in the respective industries. These might be due to the variations in the surface areas of the different masses of the immobilized bacteria. Positive and significant correlations exist between the masses of bacteria and TDS with the exception in TAN2 (negative and insignificant correlation). The positive correlations showed that there is general increase in the levels of the TDS as the masses of the immobilized bacteria increases. TAN1 $(96 \%)$ showed a very high correlation with the masses of the bacteria while TAN2 (47\%) showed a very low correlation.

The mean values $(\mathrm{mg} / \mathrm{l})$ of the BOD after the bioremediation varies between $1.56 \pm 0.20 \mathrm{mg} / \mathrm{l}$ and $6.92 \pm 5.49 \mathrm{mg} / \mathrm{l}$. The mean concentration $(\mathrm{mg} / \mathrm{l})$ of BOD remediated by the different masses $(5 \mathrm{~g}, 10 \mathrm{~g}, 15 \mathrm{~g}, 20 \mathrm{~g}$, and $25 \mathrm{~g}$ ) of the bacteria varies. There is a reduction in all the BOD of all the samples after the bioremediation process compared with the $\mathrm{BOD}$ of the raw 
BAJOPAS Volume 13 Number 2, December, 2020 samples before the bioremediation. The relative potential or efficiency of the different masses of the bacteria in remediating BOD in TAN1, TAN2 and TAN3 samples were in the order $25 \mathrm{~g}>20$ $\mathrm{g}>15 \mathrm{~g}>10 \mathrm{~g}>5 \mathrm{~g}, 25 \mathrm{~g}>15 \mathrm{~g}>5 \mathrm{~g}>10 \mathrm{~g}>20 \mathrm{~g}$ and $20 \mathrm{~g}>10 \mathrm{~g}>25 \mathrm{~g}>15 \mathrm{~g}>5 \mathrm{~g}$ respectively. Statistical analysis shows that there is significant difference $(p<0.05)$ between the mean values of BOD among the masses in the respective industries. These might be due to the variations in the surface areas of the different masses of the immobilized bacteria. Negative and significant correlations exist between the masses of bacteria and BOD. This showed that there is general decrease in the levels of the BOD as the masses of the immobilized bacteria increases. TAN1 (94\%) showed a very high correlation with the masses of the bacteria while TAN2 (4\%) showed a very low correlation.

The mean values $(\mathrm{mg} / \mathrm{l})$ of the COD after the bioremediation varies between $250 \pm 154$ and $3134 \pm 1595$. The mean concentration $(\mathrm{mg} / \mathrm{l})$ of COD remediated by the different masses $(5 \mathrm{~g}$, $10 \mathrm{~g}, 15 \mathrm{~g} 20 \mathrm{~g}$, and $25 \mathrm{~g}$ ) of the bacteria varies. There is a reduction in all the COD of all the samples after the bioremediation process compared with the COD of the raw samples before the bioremediation. The relative potential or efficiency of the different masses of the bacteria in remediating COD in TAN1, TAN2 and TAN3 samples were in the order $25 \mathrm{~g}>20 \mathrm{~g}>15$ $\mathrm{g}>5 \mathrm{~g}>10 \mathrm{~g}, 25 \mathrm{~g}>20 \mathrm{~g}>15 \mathrm{~g}>10 \mathrm{~g}>5 \mathrm{~g}$ and 10 g>5 g>25 g>15 g>20 g respectively. Statistical analysis shows that there were significant difference $(p<0.05)$ between the mean values of COD among the masses in the respective industries except for effluents treated with $25 \mathrm{~g}$. These might be due to the variations in the surface areas of the different masses of the immobilized bacteria. Negative and insignificant correlations exist between the masses of bacteria and COD with the exception in TAN3 (positive and significant correlation). The negative correlations showed that there is general decrease in the levels of the COD as the masses of the immobilized bacteria increases. TAN2 (100\%) showed a very high correlation with the masses of the bacteria while TAN3 (36\%) showed a very low correlation.

Generally, there was an overall decrease in the concentration of these physicochemical parameters after the bioremediation using the different masses of the bacterial isolates. These might be due to the variations in the surface areas of the different masses of the immobilized bacteria. This is in line with the work of Jimoh et al. (2018) and Baba et al. (2020).

Table 3: Mean Values $(\mathrm{mg} / \mathrm{l}) \pm$ S.D of Physicochemical parameters in effluents from the Tannery Industries before and after Treatment of the effluents $(250 \mathrm{ml})$ with the different masses $(5 \mathrm{~g}, 10 \mathrm{~g}$, $15 \mathrm{~g}, 20 \mathrm{~g}$, and $25 \mathrm{~g}$ ) of the bacteria.

\begin{tabular}{llllllll}
\hline $\mathrm{P}$ & IND & Before & \multicolumn{5}{c}{ After } \\
\cline { 4 - 7 } & & & $5 \mathrm{~g}$ & $10 \mathrm{~g}$ & $15 \mathrm{~g}$ & $20 \mathrm{~g}$ & $25 \mathrm{~g}$ \\
\hline \multirow{2}{*}{ COD } & TAN1 & $2372 \pm 938$ & $1708 \mathrm{a} \pm 861$ & $2045 \mathrm{a} \pm 1205$ & $845 \mathrm{a} \pm 369$ & $300 \mathrm{a} \pm 167$ & $250 \mathrm{a} \pm 154$ \\
& TAN2 & $1406 \pm 208$ & $1195 \mathrm{a} \pm 208$ & $1125 \mathrm{a} \pm 384$ & $1055 \mathrm{a} \pm 317$ & $956 \mathrm{a} \pm 310$ & $870 \mathrm{ab} \pm 240$ \\
& TAN3 & $3532 \pm 1373$ & $2374 \mathrm{a} \pm 1344$ & $1976 \mathrm{a} \pm 1405$ & $2757 \mathrm{a} \pm 1266$ & $3134 \mathrm{a} \pm 1595$ & $2614 \mathrm{~b} \pm 1105$ \\
BOD & TAN1 & $13.85 \pm 6.42$ & $6.92 \mathrm{a} \pm 5.49$ & $6.42 \mathrm{a} \pm 5.07$ & $5.72 \mathrm{a} \pm 5.35$ & $4.62 \mathrm{a} \pm 4.37$ & $2.82 \mathrm{ab} \pm 1.26$ \\
& TAN2 & $19.46 \pm 0.50$ & $1.75 \mathrm{~b} \pm 0.22$ & $1.73 \mathrm{~b} \pm 0.18$ & $1.58 \mathrm{a} \pm 0.16$ & $1.91 \mathrm{a} \pm 0.22$ & $1.56 \mathrm{~b} \pm 0.20$ \\
& TAN3 & $17.13 \pm 3.14$ & $4.24 \mathrm{ab} \pm 0.77$ & $3.29 \mathrm{ab} \pm 0.37$ & $4.11 \mathrm{a} \pm 0.07$ & $3.23 \mathrm{a} \pm 0.91$ & $3.33 \mathrm{a} \pm 1.28$ \\
SS & TAN1 & $374 \pm 124$ & $243 \mathrm{a} \pm 45$ & $471 \mathrm{a} \pm 226$ & $475 \mathrm{a} \pm 182$ & $492 \mathrm{a} \pm 128$ & $611 \mathrm{a} \pm 217$ \\
& TAN2 & $358 \pm 335$ & $460 \mathrm{a} \pm 400$ & $543 \mathrm{a} \pm 414$ & $544 \mathrm{a} \pm 402$ & $551 \mathrm{a} \pm 414$ & $554 \mathrm{a} \pm 405$ \\
& TAN3 & $780 \pm 739$ & $586 \mathrm{a} \pm 594$ & $758 \mathrm{a} \pm 656$ & $787 \mathrm{a} \pm 676$ & $861 \mathrm{a} \pm 635$ & $898 \mathrm{a} \pm 672$ \\
TDS & TAN1 & $3941 \pm 3703$ & $51 \mathrm{a} \pm 10$ & $53 \mathrm{a} \pm 10$ & $55 \mathrm{a} \pm 15$ & $61 \mathrm{a} \pm 20$ & $63 \mathrm{a} \pm 26$ \\
& TAN2 & $3300 \pm 1714$ & $83 \mathrm{a} \pm 78$ & $47 \mathrm{a} \pm 20$ & $48 \mathrm{a} \pm 22$ & $47 \mathrm{a} \pm 17$ & $48 \mathrm{a} \pm 17$ \\
& TAN3 & $2653 \pm 1240$ & $46 \mathrm{a} \pm 11$ & $55 \mathrm{a} \pm 24$ & $55 \mathrm{a} \pm 25$ & $58 \mathrm{a} \pm 23$ & $61 \mathrm{a} \pm 28$ \\
\hline
\end{tabular}

Replicate $=6$ (months)

Within the rows, for the same parameter, means with different alphabets are statistically different $(p<0.05)$.

$\mathrm{P}=$ parameter, IND = Industries 
BAJOPAS Volume 13 Number 2, December, 2020

Table 4: Correlation coefficient $(r)$ between different masses of the bacteria and the physicochemical parameters.

\begin{tabular}{llll}
\hline Industries & Parameter & Correlation coefficient $(r)$ & $\begin{array}{l}\text { Percent dependence (rxrx100) } \\
(\%)\end{array}$ \\
\hline TAN1 & COD & -0.9 & 82 \\
& BOD & -0.97 & 94 \\
& SS & $0.90^{*}$ & 80 \\
TAN2 & TDS & $0.98^{*}$ & 96 \\
& COD & -1 & 100 \\
& BOD & -0.21 & 4 \\
& SS & $0.78^{*}$ & 61 \\
& TDS & -0.69 & 47 \\
& COD & $0.60^{*}$ & 36 \\
& BOD & -0.6 & 37 \\
& SS & $0.95^{*}$ & 90 \\
& TDS & $0.94^{*}$ & 89 \\
\hline
\end{tabular}

The correlation coefficient $(r)$ with * is statistically significant $(p<0.05)$.

Percentage reduction of the Parameters

Table 5 shows the percentage reduction of Parameters in industrial samples before and after the treatment of the effluents $(250 \mathrm{ml})$ with the different masses $(5 \mathrm{~g}, 10 \mathrm{~g}, 15 \mathrm{~g}, 20 \mathrm{~g}$, and $25 \mathrm{~g}$ ) of the Immobilized Bacteria.

In TAN1 samples, the percentage reduction (\%) of COD ranged (14-89); BOD (50-80); SS (-32$35)$ and TDS (98-99). In TAN2 samples, the percentage decrease $(\%)$ of COD ranged (15$38) ;$ BOD (90-92); SS [-28-(-55)] and TDS (9798). In TAN3 samples, the percentage decrease (\%) of COD ranged (11-44); BOD (76-81); SS (15-25) and TDS (98). The percentage increase in the levels COD, BOD and TDS might be due to the increase in the surface area of the different masses of the immobilized bacteria. However, the percentage decrease in the levels of the SS might be due to the aggregation of the TDS which are large enough to result into SS. The percentage decrease in the levels of the SS might be also due to the influence of the nutrients which was added into the effluents in order to make the microorganisms more active and viable for fast degradation of organic contaminants in the effluent. This is in line with the work of Jimoh et al. (2018) in which the concentration of the SS increase after the bioremediation of effluents.

Sreemoyee and Priti (2013) assessed and reduced several Physico-chemical parameters of dairy wastewater using Niesseria $s p$. and concluded that the species are well known to degrade organic compounds. This is in agreement with the current study in which the immobilized Niesseria $s p$ degrade the organic contaminants as indicated by the BOD, COD and TDS.

Jimoh et al. (2018) observed that TSS of the effluents was increased after treatment with immobilized bacteria and concluded that it might be due to the biostimulation method adopted for the research.

The optimum $\mathrm{pH}$ Biosorption of Chromium by Bacillus spp and Staphylococcus spp. from tannery effluent was investigated by Mythili and Karthikeyan (2011). The maximum adsorption of Chromium $(86.4 \mathrm{mg} / \mathrm{L})$ was showed by Bacillus spp and Staphylococcus spp showed $70.6 \mathrm{mg} / \mathrm{L}$ at an initial concentration of $100 \mathrm{mg} / \mathrm{L}$. In the present study, immobilised Bacillus spp and Staphylococcus spp. from the tannery industrial effluents reduced the levels of the organic pollutants with high potential as indicated by the percentage reduction of BOD, COD and TDS.

Enzymes often can work in multiple environments especially if they are immobilized. This makes the microorganisms' enzymes even more resistant to harsh environments and enables the enzymes to be recovered and recycled after they are no longer needed (Gianfreda and Rao 2004). Ramesh and Singh (1993) reported that the immobilized bacteria having more efficiency to remove the suspended particles than free cells. Using the immobilized cell is preferable due to its capability for using several times with the same efficiency, which makes it more economical. Similar work was done by Sikander et al. (2007) showing the higher reduction with permeabilized cells of Ochrobactrum intermedium strain SDCr-5. 
BAJOPAS Volume 13 Number 2, December, 2020

The results revealed the isolation and identification of isolates with the potential for the reduction of $\mathrm{Cr}$ (VI) to $\mathrm{Cr}$ (III). Results indicated that immobilized $B$. cereus could be efficiently used for the reduction of $\mathrm{Cr}$ (VI).

Table 5: Percentage reduction of the tested Parameters from the tannery industrial samples of the Immobilized Bacteria.

\begin{tabular}{lllllll}
\hline \multirow{2}{*}{ Industries } & & \multicolumn{5}{c}{ Percentage Reduction $(\%)$} \\
\cline { 3 - 7 } & & $5 \mathrm{~g}$ & $10 \mathrm{~g}$ & $15 \mathrm{~g}$ & $20 \mathrm{~g}$ & $25 \mathrm{~g}$ \\
\hline TAN1 & COD & 28 & 14 & 64 & 87 & 89 \\
& BOD & 50 & 54 & 59 & 67 & 80 \\
& SS & 35 & -26 & -27 & -32 & -63 \\
& TDS & 99 & 99 & 99 & 98 & 98 \\
TAN2 & COD & 15 & 20 & 25 & 32 & 38 \\
& BOD & 91 & 91 & 92 & 90 & 92 \\
& SS & -28 & -52 & -52 & -54 & -55 \\
& TDS & 97 & 99 & 99 & 99 & 99 \\
& COD & 33 & 44 & 22 & 11 & 26 \\
& BOD & 75 & 81 & 76 & 81 & 81 \\
& SS & 25 & 3 & -1 & -10 & -15 \\
& TDS & 98 & 98 & 98 & 98 & 98 \\
\hline
\end{tabular}

Percentage Reduction $=(B-A) / B \times 100 \%$

$A=$ Concentration of the parameter after treatment

$\mathrm{B}=$ Concentration of the parameter before treatment

$+=$ percentage decrease

- = percentage increase

In general, immobilization makes the enzyme more resistant to temperature, $\mathrm{pH}$, and substrate concentration swings giving it a longer lifetime and higher productivity per active unit (Gianfreda and Rao, 2004; FuIlbrook, 1996; Russell et al, 2003; Kandelbauer et al., 2004). Immobilized cells have been used and studied extensively for the production of useful chemicals (Ohtake and Silver, 1994), the treatment of wastewaters (Chen et al., 2003; Wang et al., 2010). Although many workers described microbial degradation of tannery effluent, limited literature is available on the bioremediation of tannery effluent using immobilized bacterial cells in the Kano Industrial Estates.

\section{CONCLUSION}

The samples contained variable levels of the physicochemical parameters. The results of the Analysis of variance revealed that, no statistical difference $(p<0.05)$ was observed for the temperature, $\mathrm{pH}, \mathrm{SS}, \mathrm{TDS}, \mathrm{BOD}$ and $\mathrm{COD}$ among the three tannery industries before the treatment. The levels of some of the parameters
(SS, TDS and COD) observed in the samples were found above the recommended limits of WHO and NESREA, which called for the treatment of the effluents before discharge into the environment. Base on the morphological and biochemical test results, TAN1, TAN2, and TAN3 bacterial isolates were identified to be Neisseria spp, Bacillus cereus, and Staphylococcus aureus respectively. The results of Post-treatment analysis showed that there is overall decrease in the levels of the parameters determined when compared with that of the pre-treatment. The overall percentage reduction of the immobilised bacteria in the treatment of the respective effluents was in the order TAN2 (72\%)>TAN1 $(70 \%)>$ TAN3 $(62 \%)$. Hence, the immobilized bacteria are having higher biodegradation potential for the treatment of the tannery effluents.

\section{Acknowledgments}

The authors wish to acknowledge the University of Maiduguri for the financial support. The authors are grateful to the Kano State Ministry of Environment for their support in obtaining the effluent samples. 


\section{REFERENCES}

Ajao, A. T., Adebayo, G. B., and Yakubu, S. E. (2011). Bioremediation of textile industrial effluent using mixed culture of Pseudomonas aeruginosa and Bacillus subtilis immobilized on agar-agar in a bioreactor. J. Microbiol. Biotech. Res, 1(3), 50-56.

Akan, J. C., Moses, E. A., Ogugbuaja, V. O., and Abah, J. (2007). Assessment of tannery industrial effluents from Kano metropolis, Kano State, Nigeria. Journal of Applied Sciences, 7(19), 2788-2793.

Akan, J. C., Ogugbuaja, V. O., Abdulrahman, F. I., and Ayodele, J. T. (2009). Pollutant levels in effluent samples from tanneries and textiles of Kano industrial areas, Nigeria. Global journal of pure and applied sciences, 15(3-4).

APHA (1989). Standard methods for Examination of Will bete and Will betewater.15 $5^{\text {th }}$ edition. Brydpass Springfield Will behington DC. pp. 164-176

APHA (1992). Standard Methods for the Examination of Water and Wastewater. Health, 69, 1116-9.

Baba, A., Garba, S. T., and Bello, H. S. (2020). Bioremediation Potential of Immobilized corynebacterium kutsceri in the Treatment of Tannery Industrial Effluent from Challawa Industrial Estate, Kano State, Nigeria. Journal of the Turkish Chemical Society Section A: Chemistry, $7(2), 335-350$.

Beem, E. I. V. (1994). reduction of solvent VOC emission. J. Oil Col. Chem. Ass, 77, 158.

Bouwer, E. J., and Zehnder, A. J. (1993). Bioremediation of organic compoundsputting microbial metabolism to work. Trends in biotechnology, 11(8), 360367.

Chen, K. C., Wu, J. Y., Liou, D. J., and Hwang, S. C. J. (2003). Decolorization of the textile dyes by newly isolated bacterial strains. Journal of Biotechnology, 101(1), 57-68.

Dan'Azumi, S., and Bichi, M. H. (2010). INDUSTRIAL POLLUTION AND HEAVY METALS PROFILE OF CHALLAWA RIVER IN KANO, NIGERIA. Journal of Applied Sciences in Environmental Sanitation, $5(1)$.

DWAF. (1992). Analytical Methods Manual, TR 151. Department of Water Affairs and Forestry, Pretoria.

El-Bestawy, E. (2013). Biological treatment of leather-tanning industrial wastewater using free living bacteria.
Elsheikh, M. A. S. (2009). Tannery wastewater pre-treatment. Water Science and Technology, 60(2), 433-440.

FuIlbrook, P. D. (1996). "Kinetics." Industrial enzymology: The application of enzymes in Industry. 2nd Ed. T. Godfrey and J Reichelt. eds.. Nature. New York.

Gianfreda, L., and Rao, M. A. (2004). Potential of extra cellular enzymes in remediation of polluted soils: a review. Enzyme and microbial technology, 35(4), 339354.

Hugo Springer. (1994). John Arthur Wilson Memorial Lecture "Treatment of Industrial Wastes of the Leather Industry - is it still a Major Problem". JALCA, 89, 153-185

Jimoh, A. A., Ganiyu, B. A., Baba, D., and Baba, A. (2018) Bioremediation Process of Effluent from Detergent and Food Industries in Jos, Nigeria: Kinetics and Thermodynamics. International Journal of Engineering Science Invention (IJESI), 762-73

Kandelbauer, A., Maute, O., Kessler, R. W., Erlacher, A., and Gübitz, G. M. (2004). Study of dye decolorization in an immobilized laccase enzyme-reactor using online spectroscopy. Biotechnology and bioengineering, 87(4), 552-563.

Kongjao, S., Damronglerd, S., and Hunsom, M. (2008). Simultaneous removal of organic and inorganic Pollutants in tannery wastewater using electrocoagulation technique. Korean Journal of chemical engineering, 25(4), 703.

Maheshwari, U. M., Aruna, S., Gomathi, M., and AbdulJaffar, A. H. (2017). Bioremediation by Free and Immobilized Bacteria Isolated from Tannery Effluent. International Journal of Research in Applied, Natural and Social Sciences. 5(7), 75-90

Margesin, R., and Schinner, F. (2001). Bioremediation (natural attenuation and biostimulation) of diesel-oilcontaminated soil in an alpine glacier skiing area. Applied and environmental microbiology, 677), 3127-3133.

Mohammed, A., Sekar, P., and George, J. (2011). Efficacy of microbes in bioremediation of tannery effluent. Inter. J. Curr. Res, 3(4), 324-326.

Mohammed, S. S. D., Orukotan, A. A., and Abdullahi, H. (2017). Physicochemical and Bacteriological Assessment of Tannery Effluent from Samaru-Zaria, 
BAJOPAS Volume 13 Number 2, December, 2020 Kaduna State, Nigeria. Journal of Applied

Sciences and Environmental Management, 21(4), 734-740.

Munz, G., De Angelis, D., Gori, R., Mori, G., Casarci, M., and Lubello, C. (2009). The role of tannins in conventional and membrane treatment of tannery wastewater. Journal of hazardous materials, 164(2-3), 733-739

Mythili, K., and Karthikeyan, B. (2011). Bioremediation of $\mathrm{Cr}$ (VI) from tannery effluent using Bacillus spp and Staphylococcus spp. International Multidisciplinary Research Journal, 1(6).

NESREA (2009). National Environmental Standards for Effluent Limitations and Regulation. 1233-1236

Noorjahan, C. M. (2014). Physicochemical characteristics, identification of bacteria and biodegradation of industrial effluent. Journal of bioremediation and Biodegradation, 5(3).

Ohtake, H. I., and Silver, A. O. (1994). Bacterial reduction of toxic chromate. Biological degradation and bioremediation of toxic chemicals, 403-415.

Omoleke, I. I. (2004). Management of environmental pollution in Ibadan, an African city: the challenges of health hazard facing government and the people. Journal of Human Ecology, 15(4), 265-275.

Rajor, A., Reddy, A.S., and Singh, B. (2004). Determination of BOD kinetic Parameters and evaluation of alternate methods, M.Sc. Thesis, Department of biotechnology \& environmental Science, Thapar Institute of Engineering and Technology, Patiala

Ramasami, T., Rajamani, S., and Rao, J. R. (1994, March). Pollution control in leather industry: Emerging technological options. In International symposium on surface and colloidal science and its relevance to soil pollution, madras.

Ramesh, J. V. S., and Singh, S. P. (1993). Yearly variation in certain physicochemical parameters of pond at eastern Doon Valley. Uttar Pradesh J. Zoo, 12 (1), 7577.

Ranen, S., and Sharadinadra, C. (2009). Biotechnology applications to environmental remediation in resource exploitation. Current science, 97, 6-25
Russell, A. J., Berberich, J. A., Drevon, G. F., and Koepsel, R. R. (2003). Biomaterials for mediation of

chemical and biological warfare agents. Annual review of biomedical engineering, 5(1), 1-27.

Saravanan, P., and Saravanan, A. (1999). Decolourization of tannery effluent by Flavobacterium sp. EK 1. Indian Journal of Environmental Protection, 19, 19-24.

Sikander, S., and Shahida, H. (2007). Reduction of toxic hexavalent chromium by Ochrobactrum intermedium strain SDCr5 stimulated by heavy metals. Bioresource Technol, 98, 340-344.

Singh, N., Sharma, B. K., and Bohra, P. C. (2000). Impact assessment of industrial effluent of arid soils by using satellite imageries. Journal of the Indian Society of Remote Sensing, 28(2-3), 79.

Sreemoyee, C., and Priti, P. (2013). Assessment of physico-chemical parameters of dairy waste water and isolation and characterization of bacterial strains in terms of cod reduction. Int J Sci, 2(3), 395-400.

Verheijen, L. A. H. M., Wiersema, D., Pol, L. H., and De Wit, J. (1996). Management of wastes from animal product processing. Livestock and environment, Finding a balance. International Agriculture Center, Wageningen, The Netherlands.

Wang, F., Yao, J., Si, Y., Chen, H., Russel, M., Chen, K., and Bramanti, E. (2010). Short-time effect of heavy metals upon microbial community activity. Journal of Hazardous Materials, 173(13), 510-516.

WHO (World Health Organization). (2006). Air quality guidelines: global update 2005: particulate matter, ozone, nitrogen dioxide, and sulfur dioxide. World Health Organization.

World Bank. (1995). Nigeria's strategic options for redressing industrial pollution. World Bank, industry and energy division. 1st edition, West Central Africa Department; Annexes: 1995; pp 60-62.

Zahoor, A., and Abdul, R. (2009). Enumeration of Coliforms. Journal of Environmental Sciences. 21, 814-820 


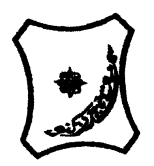

Bayero Journal of Pure and Applied Sciences, 13(2): 1 - 12

Received: November, 2020

Accepted: December, 2020

ISSN $2006-6996$

\title{
BIODEGRADATION POTENTIAL OF IMMOBILIZED BACTERIA IN THE TREATMENT OF TANNERY INDUSTRIAL EFFLUENTS FROM INDUSTRIAL ESTATES IN KANO STATE, NIGERIA
}

\author{
Abdullateef, B., ${ }^{1 *}$ Shuaibu, T. G., ${ }^{1}$ Babagana, K., ${ }^{1}$ Suleman, H. B. ${ }^{2}$ and Dauda, B. ${ }^{3}$ \\ ${ }^{1}$ Department of Pure and Applied Chemistry, Faculty of Science, University of Maiduguri, Borno State, \\ Nigeria \\ ${ }^{2}$ Department of Microbiology, Faculty of Science, University of Maiduguri, Borno State, Nigeria \\ ${ }^{3}$ Department of Chemical Engineering, Faculty of Engineering, University of Maiduguri, Borno State, \\ Nigeria \\ *Corresponding author: babslega@gmail.com; abelega2007@yahoo.com; +2348061309753
}

\section{ABSTRACT}

Industrial Effluents Samples from Gashash Tanneries (TAN1) in Bompai Industrial estate, Larabee Tannery Industry (TAN2) in Sharada Industrial estate and Z Tannery Industries (TAN3) in Challawa Industrial estate, Kano State, Nigeria were collected over a period of six months (August 2017 to January 2018) for assessing the biodegradation potentials of bacteria in the treatment of organic pollutants within the effluents. Bacteria were isolated from the effluents and immobilized on agar-agar. Different masses (5 g, $10 \mathrm{gr}, 15$ $\mathrm{g}, 20 \mathrm{~g}$, and $25 \mathrm{~g}$ ) of the bacteria were used in the treatment of $250 \mathrm{ml}$ of the effluents for ten days in a shaker incubator (Gallenkamp-OC-4364-L) at the temperature $30{ }^{\circ} \mathrm{C}$ and speed of $60 \mathrm{rpm}$. Pre-treatment analysis of the effluents for Temperature, pH, Biochemical Oxygen Demand (BOD), Chemical Oxygen Demand (COD), Suspended Solid (SS) and Total Dissolved Solids (TDS) gives the following results; temperature $\left({ }^{\circ} \mathrm{C}\right.$ )

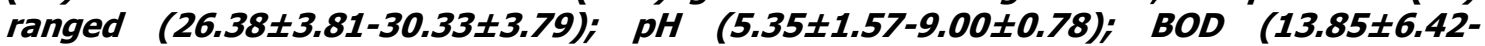
$38.75 \pm 16.20) ;$ COD (1406 $\pm 208-3532 \pm 1373) ;$ SS (208 $\pm 235-780 \pm 739)$ and TDS (266 $\pm 253-5276 \pm 2971)$. No statistical differences ( $p \leq 0.05)$ was observed for all the results among the different industries. The bacterial isolates were identified as Neisseria spp, Bacillus cereus, and Staphylococcus aureus, in TAN1, TAN2, and TAN3, respectively. After treatment of the effluent with the different masses of the isolated bacteria, the mean level of BOD was found to range as (0.55 $\pm 0.36-6.92 \pm 5.49) ; C O D$ (ND-3134 \pm 1595$)$;

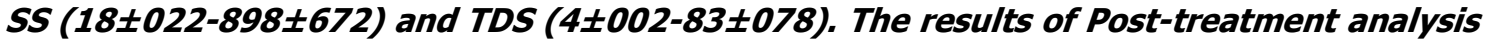
showed that there is overall decrease in the levels of the parameters determined when compared with that of the pre-treatment. The overall percentage reduction of the immobilised bacteria in the treatment of the respective effluents was in the order TAN2 (72\%)>TAN1 (70\%)>TAN3 (62\%). Hence, the immobilized bacteria are having higher biodegradation potential for the treatment of the tannery effluents.

Keywords: Biodegradation, bacteria, effluent, immobilization, tannery.

\section{INTRODUCTION}

Tannery industrial wastewater is a serious consequence of the pollution point of view for streams, freshwater, and land used for agriculture. The lack of awareness in the modern industrial practice has resulted in the discharge of tannery effluents which exhibit very high value of chromium ( $\mathrm{Cr}$ ), Sulfide, and chloride, Total Dissolved Solid (TDS), Total Suspended Solid (TSS), Biochemical Oxygen Demand (BOD) and Chemical Oxygen Demand (COD) in the water stream or land (Mohammed et al., 2001). Tanning is the process, which One ton of skin generally leads to the production of 20 to $80 \mathrm{~m}^{3}$ of turbid and foul-smelling converts the protein of the rawhide or skin into a stable material, which will not putrefy and is suitable for a wide variety of end applications (Elsheikh, 2009). The highly polluting chromium is the most commonly used tanning material producing leather that is more flexible and pliable than vegetable-tanned leather and does not discolor or lose shape in water as drastically as vegetable-tan (Elsheikh, 2009). Tannery effluent is among the most hazardous industrial pollutants due to its huge organic and inorganic load, which is highly toxic to human life and the environment (Kongjao et al., 2008). wastewater including chromium (100-400 mg/l), sulfide $(200-800 \mathrm{mg} / \mathrm{l})$, high levels of fat and 
BAJOPAS Volume 13 Number 2, December, 2020 other solid wastes, and notable pathogen contamination as well as pesticides added for skin conservation during transport (Elsheikh, 2009). There are more than 6000 tanneries in Nigeria with an annual processing capacity of 700,000 tons of hides and skins (Omoleke, 2004; Singh et al., 2008). It was reported that the total amount of waste produced per animal slaughtered is approximately $35 \%$ of its weight (World Bank, 1995). Also, for every $1000 \mathrm{~kg}$ of carcass weight, a slaughtered beef produces 5.5 $\mathrm{kg}$ of manure (excluding rumen contents or stockyard manure) and $100 \mathrm{~kg}$ of paunch manure (undigested food) (Verheijen et al., 1996). Tanneries generate wastewater in the range of 30-35 $\mathrm{L} \mathrm{kg}^{-1}$ skin/hide processed with variable $\mathrm{pH}$, Biological Oxygen Demand (BOD), Chemical Oxygen Demand (COD), high concentrations of suspended solids (SS), and tannins as well as chromium (Zahoor and Abdul, 2009).

Being heterogeneous and composed of a wide variety of compounds, it is very difficult to select a unique direct method for estimating the biodegradability of organic contents and biokinetic parameters for a wastewater sample (Rajor, 2004). For this purpose, some indirect estimation such as determination of biochemical oxygen demand (BOD) and chemical oxygen demand (COD) are applied as common laboratory investigations [9]. During retanning procedures, synthetic tannins (Syntan), oils and resins are added to form softer leather at varying doses (Munz et al., 2009). One of the refractory groups of chemicals in tannery effluents derives mainly from tannins (Ramasami et al., 2004). Syntans are characterized by complex chemical structures, because they are composed of an extended set of chemicals such as phenol-, naphthalene-, formaldehyde- and melamine-based syntans, and acrylic resins (Beem, 1994). Organic pollutants (proteic and lipidic components) are originated from skins (it is calculated that the raw skin has $30 \%$ loss of organic material during the working cycle) or they are introduced during processes (Hugo Springer, 1994).

Many conventional processes such as oxidation, chemical and biological processes were carried out to treat tanneries wastewater (Ebtesam et al, 2013). Biological processes have received more attention because of their costeffectiveness, lower sludge production and environmental friendliness (Noorjahan, 2014). Naturally occurring micro-organisms degrade the hazardous organic wastes including xenobiotic compounds, such as pesticides, polycyclic aromatic hydrocarbons (PAHs) and polychlorinated biphenyls (PCBs) in due course of time (Ranen and Sharadinadra, 2009). Bioremediation is based on the idea that all organisms remove substances from the environment to carry outgrowth and metabolism (Bouwer and Zehnder, 1993). Bacteria, protista and fungi are found to be very good at degrading complex molecules and incorporating the breakdown products into their metabolism (Bouwer and Zehnder, 1993). The resultant metabolic wastes that they produce are generally safe and somehow recycled into other organisms (Ranen and Sharadinadra, 2009). An acclimatized indigenous population of microorganisms capable of degradation of the compounds of interest must exist at the site for a successful bioremediation mode (Ranen and Sharadinadra, 2009). It has been observed that for a successful bioremediation mode, an acclimatized indigenous population of microorganisms capable of degradation of the compounds of interest must exist at the site under investigation (Ranen and Sharadinadra, 2009). Even though there are numerous physical and chemical methods employed in the disposal of wastes the advantage in using bacterium is that they play a key role in the reduction of COD, BOD, total protein, total tannin and total phenol (Saravanan and Saravanan, 1998)

Baba et al. (2020) studied the bioremediation potential of immobilized corynebacterium kutsceri in the Treatment of tannery industrial effluent from Challawa Industrial Estate, Kano State, Nigeria. The aim of the work is to study the reduction in the level of the contaminants through the process of bioremediation using the isolated bacteria. Immobilized bacteria can withstand various temperatures, $\mathrm{pH}$ and substrate concentrations; consequently, increasing the efficiency and the lifespan of the bacteria. Immobilized bacteria are widely applied in the treatment of wastewater and can be separated and recovered after the treatment with the same efficiency (Baba et al., 2020).

\section{MATERIALS AND METHODS \\ Study Area}

This study was carried out in Bompai, Sharada and Challawa industrial estates in Kano, Figure 1. Kano lies on Latitude $11^{\circ} 30^{\prime} \mathrm{N}$ and $8^{\circ} 30^{\prime} \mathrm{E}$ and Longitude $11^{\circ} 5^{\prime} \mathrm{N}$ and $8^{\circ} 5^{\prime} \mathrm{E}$ in Northern Nigeria. It is one of the developed industrial cities in Nigeria. Tannery activities are the dominating industries and this could be one of the reasons for her high population density (Dan'Azumi and Bichi, 2010). Many researchers have studied biodegradation of tannery effluent using microorganisms. However, limited literature is available on the biodegradation of tannery effluent in Kano industrial estates using 
BAJOPAS Volume 13 Number 2, December, 2020 immobilized bacterial cells. This research work focuses on the potential of the use of the indigenous immobilized bacterial isolates in the treatment of tannery effluents in the industrial estates.

\section{Sample Collection}

Effluents were collected from the Tannery Industries from Bompai, Challawa and Sharada Industrial Estates, Kano, Nigeria. The effluents were collected over a period of six months (August 2017 to January 2018). Samples collected in a sterile 4-liter plastic container with a unique identification number were preserved using an ice-box that was transported to the Microbiology Laboratory, Department of Microbiology, Bayero University of Kano for analysis

\section{Sample Preparation and Sample Analysis}

Immediately after the collection of the effluent, $\mathrm{pH}$, TSS, TDS, COD, BOD levels were determined before treatment (Pre-treatment determination) and ten days after treatment (Post-treatment determination) as described in
APHA (1989) standard methods. $\mathrm{pH}$ was determined using Ecotests $\mathrm{pH}$ meter and TDS was determined using AQUALYTIC TDS Salinometer. BOD was determined as described by the standard method (APHA, 1992). COD and SS were determined using DR/2010 HACH portable data logging spectrophotometer (DWAF, 1992)

\section{Identification and Biochemical} Characterization of the Bacterial Isolates

The bacteria were isolated from the effluents using Serial Dilution according to the method described by APHA (1989). The biochemical tests such as oxidase, catalase, coagulase, indole (from $1 \%$ tryptone broth), citrate (Simmons citrate agar), methyl red/VogesProskauer (MR/VP), nitrate reduction, Starch Hydrolysis, Glucose, Maltose, and Lactose tests were carried out on the bacterial isolates to identify the bacteria through the bacteria biochemical characteristics according to Ajao et al. (2011).

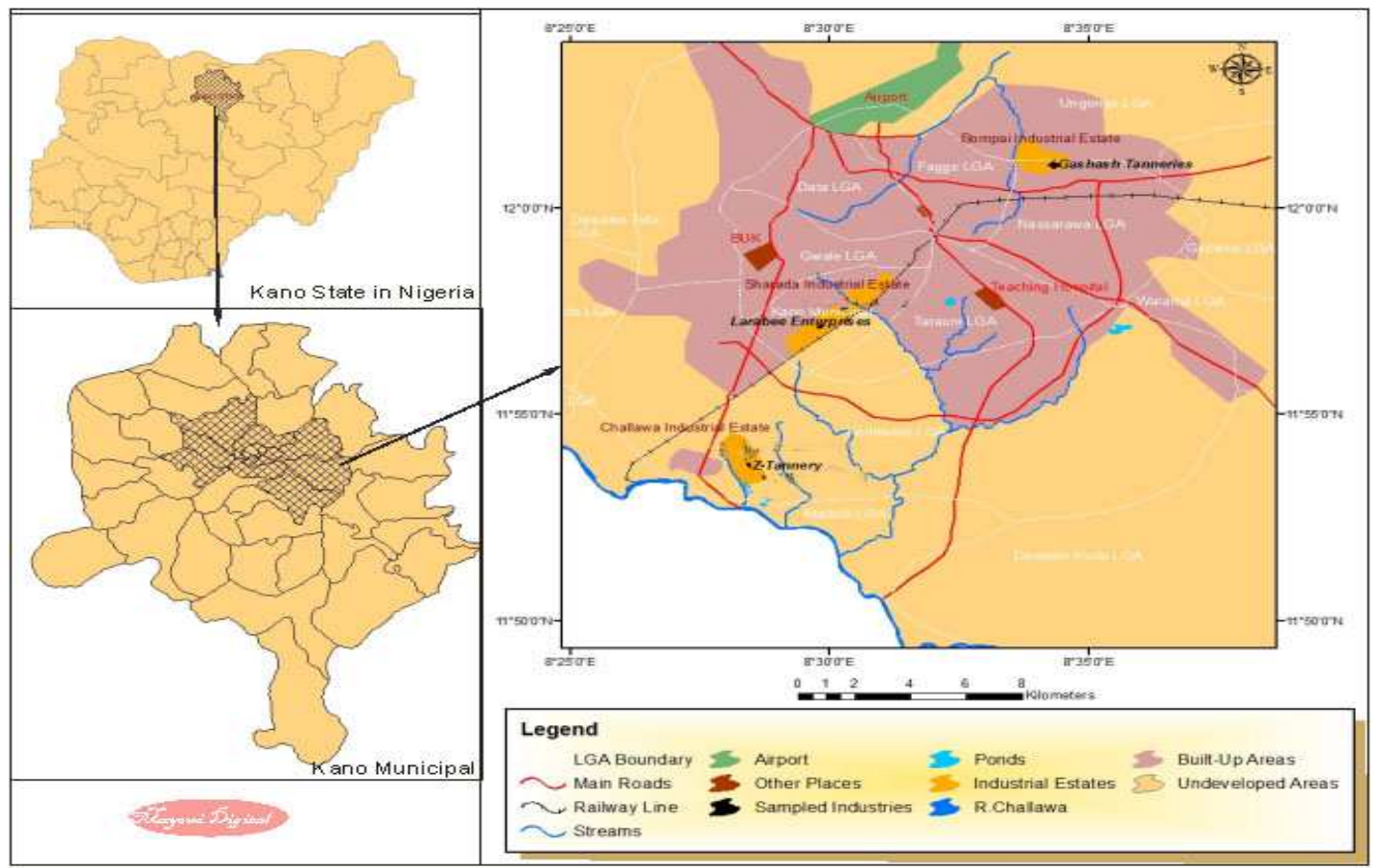

Fig. 1 Map showing the study areas

Source: Mayomi Digital Productions, GIS Laboratory, Department of Geography, UNIMAID (2017)

\section{Determination of Growth Rate of the Bacteria in Effluent Sample}

The bacteria growth rates were determined by transferring $2 \mathrm{~mL}$ of the bacterial isolates from the tannery effluent in broth medium into 100 $\mathrm{mL}$ sterile effluents in conical flasks and kept in an incubator (Giffrin cool) for 10 days. Control was also set up by incubating another $100 \mathrm{~mL}$ each of the sterile effluents without the bacteria. The optical density of the content was determined at the wavelength of $600 \mathrm{~nm}$ on a daily interval and recorded. 
BAJOPAS Volume 13 Number 2, December, 2020 Immobilization of Bacteria

Agar solution and inoculi were prepared separately. Fifty milliliters $(50 \mathrm{~mL})$ of nutrient broth each of the inoculi was prepared in a McCartney bottle and incubated for 24 hours. A solution of agar-agar was prepared by dissolving $10 \mathrm{~g}$ of the powder in distilled water and made up to $500 \mathrm{~mL}$ mark in an Erlenmeyer flask and was sterilized in an autoclave (280A) for 15 minutes and allowed to cool to $40-45^{\circ} \mathrm{C}$ (Ajao et al., 2011). Four milliliters ( $4 \mathrm{~mL})$ of the bacterial isolates in the nutrient broth was mixed with 36 $\mathrm{ml}$ of the prepared agar-agar media in petri-dish plates and then allowed to solidify. This was kept in the refrigerator for bioremediation.

\section{Bioremediation (Treatment) of the Effluents}

The solidified agar block (immobilized bacteria) was cut into cubes using a sterile knife; $0.1 \mathrm{~mL}$ phosphate buffer ( $\mathrm{pH} \mathrm{7.0)}$ was added and kept in the refrigerator for 1 hour for curing. The phosphate buffer was decanted after 1 hour and the cubes were washed with sterile distilled water 3-4 times before it was used (Ajao et al., 2011). Two liters (2 L) of the effluent was supplemented with the minimum basal medium in $\mathrm{g} / \mathrm{L}: \mathrm{NaCl}(0.8), \mathrm{MgSO}_{4} .7 \mathrm{H}_{2} \mathrm{O}(0.001), \mathrm{KH}_{2} \mathrm{PO}_{4}$ (2), $\mathrm{NaNO}_{3}$ (2), $\quad \mathrm{CaCl}_{2} .2 \mathrm{H}_{2} \mathrm{O} \quad(0.5)$ and $\mathrm{NaHPO}_{4} .12 \mathrm{H}_{2} \mathrm{O}(2)$ and sterilized in an autoclave at $121^{\circ} \mathrm{C}$ for 15 minutes (Margesin and Schinner, 2001). Two hundred and fifty milliliters $(250 \mathrm{~mL})$ of the effluents were transferred into different $250 \mathrm{ml}$ conical flasks. The content was covered with a cotton-wool ramped with foil paper to avoid contamination. Five grams $(5 \mathrm{~g})$ of the immobilized bacteria were quickly transferred into each of the effluents in the conical flasks in an inoculating chamber. The same procedures were carried out for the $10 \mathrm{~g}, 15 \mathrm{~g}, 20 \mathrm{~g}$ and 25 $\mathrm{g}$ of the immobilized bacteria in separate $250 \mathrm{~mL}$ effluents in conical flasks and agitated for ten days in a shaker incubator (Gallenkamp-OC4364-L) at a temperature $30^{\circ} \mathrm{C}$ and speed of 60 rpm. The treated effluent samples were taken on the tenth day and analyzed for the parameters $\mathrm{pH}$, SS, TDS, COD, and BOD, (Posttreatment determination) for the different grams of bacteria to evaluate and compare the biodegradation potential. (Baba et al., 2020).

\section{Statistical Analysis}

The data were represented as Mean \pm Standard deviation and analyzed statistically using oneway Analysis of Variance (ANOVA) and Tukey's HSD as Post Hoc Tests with the aid of SPSS 16.0. The correlation coefficient was also used to measure the strength of the relationship between the different masses of the bacteria and the parameters. All $\mathrm{p} \leq 0.05$ were considered as statistically significant.

\section{RESULTS AND DISCUSSION Physico-chemical parameters in the Industrial Effluents before the Biodegradation.}

Results of the Physico-chemical parameters in the industrial effluents before the Biodegradation is shown in table 1 . The mean temperatures $\left({ }^{\circ} \mathrm{C}\right)$ observed in TAN1, TAN2, and TAN3 samples were $28.07 \pm 0.65 ; 27.77 \pm 0.64$ and $26.38 \pm 3.81$ respectively. The order of the mean temperature of the samples from the three industries can be arranged as TAN1 > TAN2>TAN3. The temperature observed at TAN1, TAN2, and TAN3 samples were found below the WHO $\left(35^{\circ} \mathrm{C}\right)$ and NESREA $\left(40^{\circ} \mathrm{C}\right)$ limits. The low values of temperature might be due to the processes used at the time of sampling. High temperature brings down the solubility of gases in water that ultimately expresses as high BOD and COD. Statistical analysis shows that there is no significant difference $(p<0.05)$ between the mean values of temperature among the industries. This might be due to similar tannery activities involved in the tannery industries at the time of sampling. The average values of temperature observed in this present study are less than those observed by Akan et al. (2007), Akan et al. (2009) and Baba et al. (2020).

The mean level of $\mathrm{pH}$ observed in TAN1, TAN2 and TAN3, samples were $7.77 \pm 2.93$; $8.35 \pm 0.28$ and $7.52 \pm 0.76$ respectively. The order of the mean $\mathrm{pH}$ of the samples from the three industries can be arranged as TAN2> TAN1 $>$ TAN3. The $\mathrm{pH}$ of the samples falls within the WHO (7.0-8.5) and NESREA (6-9) standard limits. Statistical analysis shows that there is no significant difference $(p<0.05)$ between the mean values of $\mathrm{pH}$ among the industries. This might be due to similar tannery activities involved in the tannery industries at the time of sampling. Maheshwari et al. (2017) reported that the level of $\mathrm{pH}$ in the effluents from the tannery industry in Vaniyambadi, India was 6.5 which was lower than that observed in the present study. The $\mathrm{pH}$ in the effluents from the tannery industries in Kano and Kaduna were reported to be 7.64 and 6.89, respectively (Akan et al., 2007; Mohammed et al., 2017). The average values of $\mathrm{pH}$ observed in this present study are less than those observed by Mohammed et al. (2017) and Baba et al. (2020). The mean level of SS $(\mathrm{mg} / \mathrm{l})$ observed in TAN1, TAN2, and TAN3 samples were 374 \pm 124 ; $358 \pm 335$ and $780 \pm 739$ respectively. The order of the mean SS in the samples from the three industries can be arranged as TAN3 > TAN1 $>$ TAN2. 
The SS observed in the samples were far above the recommended standard limits of regulating bodies WHO $(30 \mathrm{mg} / \mathrm{l})$ and NESREA $(10 \mathrm{mg} / \mathrm{l})$. Statistical analysis shows that there is no significant difference $(p<0.05)$ between the mean values of SS among the industries. This might be due to similar tannery activities involved in the tannery industries at the time of sampling. The average values of SS observed in this present study are less than that observed $(3700 \pm 122 \mathrm{mg} / \mathrm{l})$ by Akan et al. (2009) for tanneries in Kano. Also, the average values of SS observed in this present study are less than that observed by Mohammed et al. (2017) and Baba et al. (2020) with the exception in TAN3.

The mean level of TDS (mg/l) observed in TAN1, TAN2, and TAN3 samples were $3941 \pm 3703$; $3300 \pm 1714$ and $2653 \pm 1240$ respectively. The order of the mean TDS in the samples from the three industries can be arranged as TAN1>TAN2>TAN3. The TDS observed in the samples were far above the recommended standard limits of WHO $(250 \mathrm{mg} / \mathrm{l})$ and NESREA $(500 \mathrm{mg} / \mathrm{l})$. Statistical analysis shows that there is no significant difference $(p<0.05)$ between the mean values of TDS among the industries. This might be due to similar tannery activities involved in the tannery industries at the time of sampling. TDS in the effluents from the tannery industries in Kano, Nigeria was reported to be $1281 \mathrm{mg} / \mathrm{l}$ (Akan et al., 2007). The average values of SS observed in this present study are less than those observed by Mohammed et al. (2017) and Baba et al. 2020)

The mean level of COD (mg/l) observed in TAN1, TAN2 and TAN3 samples seasons were $2372 \pm 938 ; \quad 1406 \pm 208$ and $3532 \pm 1373$ respectively. The order of the mean COD of the samples from the three industries can be arranged as TAN3>TAN1> TAN2. The COD observed in TAN1, TAN2 and TAN3 samples were far above the recommended standard limits of regulating bodies $\mathrm{WHO}(40 \mathrm{mg} / \mathrm{l})$ and NESREA (40 mg/l). Statistical analysis shows that there is no significant difference $(p<0.05)$ in COD among the industries. This might be due to similar tannery activities involved in the tannery industries as at the time of sampling. The Chemical Oxygen demand (COD) is the amount of oxygen, in $\mathrm{mg} / \mathrm{L}$, required for the degradation of the compound of wastewater to occur. In comparison, the average values of COD observed in this present study were higher than that observed by Mohammed et al. (2017) but lower than that observed by Baba et al. (2020).

The mean levels of BOD $(\mathrm{mg} / \mathrm{l})$ observed in TAN1, TAN2 and TAN3 samples were $13.85 \pm 6.42 ; \quad 19.46 \pm 0.50$ and $17.13 \pm 3.14$ respectively. The order of the mean BOD in the samples from the three industries can be arranged as TAN2>TAN3>TAN1. The BOD observed in TAN1, TAN2 and TAN3 samples were found below the recommended limits of NESREA (200 mg/l) but above WHO (10 mg/l). Statistical analysis shows that there is no significant difference $(p<0.05)$ between the mean values of BOD among the industries. This might be due to similar tannery activities involved in the tannery industries at the time of sampling. The low level of BOD recorded in this study is an indication of the low level of biodegradable organic solids in the effluent. The average values of BOD observed in this present study were lower than those observed by Mohammed et al. (2017) and Baba et al. (2020).

Table 1: Mean Values \pm S.D of Physico-chemical parameters of effluents from the Tannery Industries before Treatment.

\begin{tabular}{llllllll}
\hline Parameter & Tannery 1 & Tannery 2 & Tannery 3 & $\mathrm{a}$ & $\mathrm{b}$ & $\mathrm{c}$ & $\mathrm{d}$ \\
\cline { 2 - 7 } Temperature $\left({ }^{\circ} \mathrm{C}\right)$ & $28.07 \mathrm{a} \pm 0.65$ & $27.77 \mathrm{a} \pm 0.64$ & $26.38 \mathrm{a} \pm 3.81$ & & $29.50 \pm 4.68$ & 35 & 40 \\
pH & $7.77 \mathrm{a} \pm 2.93$ & $8.35 \mathrm{a} \pm 0.28$ & $7.52 \mathrm{a} \pm 0.76$ & 6.89 & $5.35 \pm 1.57$ & $7.0-8.5$ & $6.0-9.0$ \\
$\mathrm{COD}(\mathrm{mg} / \mathrm{l})$ & $2372 \mathrm{a} \pm 938$ & $1406 \mathrm{a} \pm 208$ & $3532 \mathrm{a} \pm 1373$ & 2.2 & $3106 \pm 2753$ & 40 & 40 \\
$\mathrm{BOD}(\mathrm{mg} / \mathrm{l})$ & $13.85 \mathrm{a} \pm 6.42$ & $19.46 \mathrm{a} \pm 0.50$ & $17.13 \mathrm{a} \pm 3.14$ & 1032 & $26.17 \pm 9.49$ & 10 & 200 \\
$\mathrm{SS}(\mathrm{mg} / \mathrm{l})$ & $374 \mathrm{a} \pm 124$ & $358 \mathrm{a} \pm 335$ & $780 \mathrm{a} \pm 739$ & 501 & $562 \pm 482$ & 30 & 10 \\
TDS $(\mathrm{mg} / \mathrm{l})$ & $3941 \mathrm{a} \pm 3703$ & $3300 \mathrm{a} \pm 1714$ & $2653 \mathrm{a} \pm 1240$ & 532.7 & $444 \pm 507$ & 250 & 500 \\
\hline
\end{tabular}

The values given in the table above are means of 6 replicate values, $\mathrm{n}=6$ ( 1 sample was taken monthly for 6 months). Within the rows, means with different alphabets are statistically different $(p<0.05)$. WHO: World Health Organisation. NESREA: National Environmental Standard and Regulatory Enforcement Agency. a = Mohammed et al.(2017), b = Baba et al. (2020), c = WHO (2006), $d=$ NESSRA (2009) 
BAJOPAS Volume 13 Number 2, December, 2020

Identification, Biochemical Characterization and growth rates of the Bacterial Isolates

Results of identification and biochemical characterization of the bacterial isolates were shown in table 2. After 24 hours of incubation, the nutrient agar media plates were checked for bacterial growth. The results showed the presence of different strains in the samples. The TAN1 bacteria isolate was found to be gramnegative cocci while TAN3 was gram-positive cocci. TAN2 bacteria isolate was found to be gram-positive, rod-shaped. TAN1, TAN2, and TAN3 bacteria isolates recorded positive results for spore former.

The results of the biochemical tests indicated that all the bacteria were positive for catalase, oxidase, citrate, maltose, glucose, lactose (negative in TAN1), mannitol (negative in TAN2), starch hydrolysis and coagulase (negative in TAN2) tests. The bacteria showed negative results for nitrate reduction, $M R$ (positive in TAN2), VP (positive in TAN1), Indole (positive in TAN2) tests. Base on the morphological and biochemical test results, TAN1, TAN2, and TAN3 bacteria isolates were identified to be Nesseria spp, Bacillus cereus, and Staphylococcus aureus respectively.

The growth rate of the TAN1, TAN2 and TAN3 Isolates were shown in figure 2. Generally, the optical density increase with the increase in time (day) and decrease as time goes on. The highest optical density was shown by bacillus cereus in TAN2 while the lowest was shown by Staphylococcus aureus in TAN3.

The initial growth phase of TAN1 Isolate bacteria occurred within 2-day of incubation as the growth rate increases up to the 6th-day incubation when the maximum growth was observed. Beyond the 6th day, the growth of the bacteria declined (which might be due to a shortage of nutrients in the effluents) until it reached its death phase (which might be due to the unavailability of nutrients in the effluents).

A similar trend of growth was also observed for TAN2 Isolate as the initial growth phase also occurred within 2-day of incubation but maximum growth rate observed on the 4th day of incubation. The stationary stage occurred between the 4th day and the 8th day. Beyond the 8th day, the growth of the bacteria declined (which might be due to a shortage of nutrients in the effluents) until it reached its death phase (which might be due to the unavailability of nutrients in the effluents).

The initial growth phase of TAN3 bacterial Isolate occurred within the 3-day incubation as the growth rate increases up to the 6th-day incubation when the maximum growth was observed. Beyond the 6th day, the growth of the bacteria declined (which might be due to a shortage of nutrients in the effluents) until it reached its death phase (which might be due to the unavailability of nutrients in the effluents).

Table 2: Morphological and Biochemical characteristics of bacterial isolates

\begin{tabular}{lllll} 
Bacterial Isolates & & TAN1 & TAN2 & TAN3 \\
\hline $\begin{array}{lllll}\text { Morphological } \\
\text { characteristics }\end{array}$ & Shape & Cocci & Rod & Cocci \\
& Spore & & & \\
& former & + & + & + \\
Gram & & & \\
Biochemical characteristics & reaction & - & + & + \\
& Citrate & + & + & + \\
& Catalase & + & + & + \\
& Coagulase & + & - & + \\
Starch & + & + & + \\
& Glucose & + & + & + \\
Oxidase & + & + & + \\
& Indo & - & + & - \\
Lactose & - & + & + \\
Manitol & + & - & + \\
Maltose & + & + & + \\
MR & - & + & - \\
VP & + & - & - \\
& Nitrate & - & - & - \\
Reduction & - Neisseria & Bacillus & Staphylococcus \\
& Bacterial & cereus & aureus \\
& name & spp & cas
\end{tabular}

+ = Positive; - = Negative; MR=Methyl Red; VP= Voges-Proskauer 


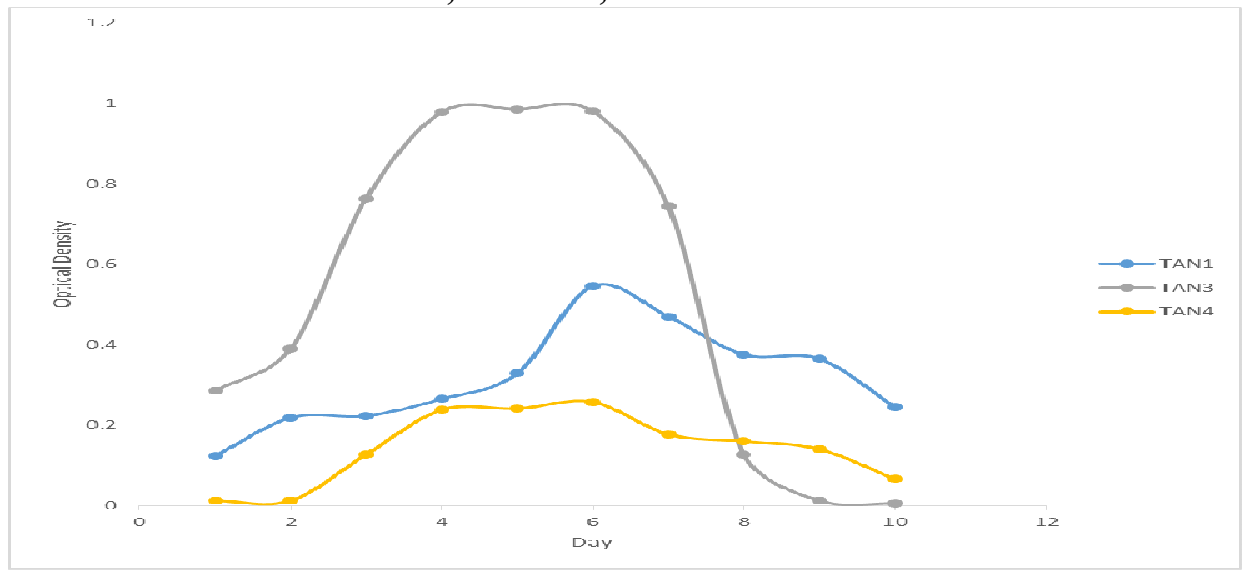

Fig. 2 Growth rates of the isolates in the effluents from the Tannery Industries

\section{Physico-chemical Parameters in the Industrial Effluents after the biodegradation.}

Table 3 shows the mean results of the physicochemical parameter before and after bioremediation using the different masses $(5 \mathrm{~g}$, $10 \mathrm{~g}, 15 \mathrm{~g}, 20 \mathrm{~g}$, and $25 \mathrm{~g}$ ) of the respective immobilized bacteria. Also, Table 4 shows the mean results of correlation coefficient ( $r$ ) between different masses of bacteria and physicochemical parameters.

The mean values $(\mathrm{mg} / \mathrm{l})$ of the SS after the bioremediation varies between $243 \pm 45$ and $898 \pm 672$. The mean concentration $(\mathrm{mg} / \mathrm{l})$ of SS remediated by the different masses $(5 \mathrm{~g}, 10 \mathrm{~g}$, $15 \mathrm{~g}, 20 \mathrm{~g}$, and $25 \mathrm{~g}$ ) of the bacteria varies. The SS in the samples fluctuates up and down after the bioremediation process when compared with the SS of the raw samples before the bioremediation. The increase in the levels of the SS might be due to the aggregation of the TDS which are large enough to result into SS. The increase in the levels of the SS might be also due to the influence of the nutrients which was added into the effluents in order to make the microorganisms more active and viable for fast degradation of organic contaminants in the effluent. The relative potential or efficiency of the different masses of the bacteria in remediating SS in TAN1 samples was in the order $25 \mathrm{~g}>20 \mathrm{~g}>15 \mathrm{~g}>10 \mathrm{~g}>5 \mathrm{~g}$. For TAN2 and TAN3 samples, the order was $25 \mathrm{~g}>20 \mathrm{~g}>15$ $\mathrm{g}>10 \mathrm{~g}>5 \mathrm{~g}$. These might be due to the variations in the surface areas of the different masses of the immobilized bacteria. Statistical analysis shows that there is no significant difference $(p<0.05)$ between the mean values of SS among the masses in the respective industries. Positive and significant correlations exist between the masses of bacteria and Suspended Solid (SS). This showed that there is general increase in the levels of the SS as the masses of the immobilized bacteria increases. TAN3 (90\%) and TAN1 (80\%) showed a very high correlation with the masses of the bacteria while TAN2 (61\%) showed a very low correlation.

The mean values $(\mathrm{mg} / \mathrm{l})$ of the TDS after the bioremediation varies between $46 \pm 11$ and $83 \pm 78$. The mean concentration $(\mathrm{mg} / \mathrm{l})$ of TDS remediated by the different masses $(5 \mathrm{~g}, 10 \mathrm{~g}$, $15 \mathrm{~g}, 20 \mathrm{~g}$, and $25 \mathrm{~g}$ ) of the bacteria varies. There is a reduction in all the TDS of all the samples after the bioremediation process compared with the TDS of the raw samples before the bioremediation. The relative potential or efficiency of the different masses of the bacteria in remediating TDS in TAN1 and TAN3 samples was in the order $5 \mathrm{~g}>10 \mathrm{~g}>15 \mathrm{~g}>20$ $\mathrm{g}>25 \mathrm{~g}$. For TAN2 samples, the order was 20 $g>10 \quad g>25 \quad g>15 \quad g>5 \quad g$. Statistical analysis shows that there is no significant difference $(p<0.05)$ between the mean values of TDS among the masses in the respective industries. These might be due to the variations in the surface areas of the different masses of the immobilized bacteria. Positive and significant correlations exist between the masses of bacteria and TDS with the exception in TAN2 (negative and insignificant correlation). The positive correlations showed that there is general increase in the levels of the TDS as the masses of the immobilized bacteria increases. TAN1 $(96 \%)$ showed a very high correlation with the masses of the bacteria while TAN2 (47\%) showed a very low correlation.

The mean values $(\mathrm{mg} / \mathrm{l})$ of the BOD after the bioremediation varies between $1.56 \pm 0.20 \mathrm{mg} / \mathrm{l}$ and $6.92 \pm 5.49 \mathrm{mg} / \mathrm{l}$. The mean concentration $(\mathrm{mg} / \mathrm{l})$ of BOD remediated by the different masses $(5 \mathrm{~g}, 10 \mathrm{~g}, 15 \mathrm{~g}, 20 \mathrm{~g}$, and $25 \mathrm{~g}$ ) of the bacteria varies. There is a reduction in all the BOD of all the samples after the bioremediation process compared with the $\mathrm{BOD}$ of the raw 
BAJOPAS Volume 13 Number 2, December, 2020 samples before the bioremediation. The relative potential or efficiency of the different masses of the bacteria in remediating BOD in TAN1, TAN2 and TAN3 samples were in the order $25 \mathrm{~g}>20$ $\mathrm{g}>15 \mathrm{~g}>10 \mathrm{~g}>5 \mathrm{~g}, 25 \mathrm{~g}>15 \mathrm{~g}>5 \mathrm{~g}>10 \mathrm{~g}>20 \mathrm{~g}$ and $20 \mathrm{~g}>10 \mathrm{~g}>25 \mathrm{~g}>15 \mathrm{~g}>5 \mathrm{~g}$ respectively. Statistical analysis shows that there is significant difference $(p<0.05)$ between the mean values of BOD among the masses in the respective industries. These might be due to the variations in the surface areas of the different masses of the immobilized bacteria. Negative and significant correlations exist between the masses of bacteria and BOD. This showed that there is general decrease in the levels of the BOD as the masses of the immobilized bacteria increases. TAN1 (94\%) showed a very high correlation with the masses of the bacteria while TAN2 (4\%) showed a very low correlation.

The mean values $(\mathrm{mg} / \mathrm{l})$ of the COD after the bioremediation varies between $250 \pm 154$ and $3134 \pm 1595$. The mean concentration $(\mathrm{mg} / \mathrm{l})$ of COD remediated by the different masses $(5 \mathrm{~g}$, $10 \mathrm{~g}, 15 \mathrm{~g} 20 \mathrm{~g}$, and $25 \mathrm{~g}$ ) of the bacteria varies. There is a reduction in all the COD of all the samples after the bioremediation process compared with the COD of the raw samples before the bioremediation. The relative potential or efficiency of the different masses of the bacteria in remediating COD in TAN1, TAN2 and TAN3 samples were in the order $25 \mathrm{~g}>20 \mathrm{~g}>15$ $\mathrm{g}>5 \mathrm{~g}>10 \mathrm{~g}, 25 \mathrm{~g}>20 \mathrm{~g}>15 \mathrm{~g}>10 \mathrm{~g}>5 \mathrm{~g}$ and 10 g>5 g>25 g>15 g>20 g respectively. Statistical analysis shows that there were significant difference $(p<0.05)$ between the mean values of COD among the masses in the respective industries except for effluents treated with $25 \mathrm{~g}$. These might be due to the variations in the surface areas of the different masses of the immobilized bacteria. Negative and insignificant correlations exist between the masses of bacteria and COD with the exception in TAN3 (positive and significant correlation). The negative correlations showed that there is general decrease in the levels of the COD as the masses of the immobilized bacteria increases. TAN2 (100\%) showed a very high correlation with the masses of the bacteria while TAN3 (36\%) showed a very low correlation.

Generally, there was an overall decrease in the concentration of these physicochemical parameters after the bioremediation using the different masses of the bacterial isolates. These might be due to the variations in the surface areas of the different masses of the immobilized bacteria. This is in line with the work of Jimoh et al. (2018) and Baba et al. (2020).

Table 3: Mean Values $(\mathrm{mg} / \mathrm{l}) \pm$ S.D of Physicochemical parameters in effluents from the Tannery Industries before and after Treatment of the effluents $(250 \mathrm{ml})$ with the different masses $(5 \mathrm{~g}, 10 \mathrm{~g}$, $15 \mathrm{~g}, 20 \mathrm{~g}$, and $25 \mathrm{~g}$ ) of the bacteria.

\begin{tabular}{llllllll}
\hline $\mathrm{P}$ & IND & Before & \multicolumn{5}{c}{ After } \\
\cline { 4 - 7 } & & & $5 \mathrm{~g}$ & $10 \mathrm{~g}$ & $15 \mathrm{~g}$ & $20 \mathrm{~g}$ & $25 \mathrm{~g}$ \\
\hline \multirow{2}{*}{ COD } & TAN1 & $2372 \pm 938$ & $1708 \mathrm{a} \pm 861$ & $2045 \mathrm{a} \pm 1205$ & $845 \mathrm{a} \pm 369$ & $300 \mathrm{a} \pm 167$ & $250 \mathrm{a} \pm 154$ \\
& TAN2 & $1406 \pm 208$ & $1195 \mathrm{a} \pm 208$ & $1125 \mathrm{a} \pm 384$ & $1055 \mathrm{a} \pm 317$ & $956 \mathrm{a} \pm 310$ & $870 \mathrm{ab} \pm 240$ \\
& TAN3 & $3532 \pm 1373$ & $2374 \mathrm{a} \pm 1344$ & $1976 \mathrm{a} \pm 1405$ & $2757 \mathrm{a} \pm 1266$ & $3134 \mathrm{a} \pm 1595$ & $2614 \mathrm{~b} \pm 1105$ \\
BOD & TAN1 & $13.85 \pm 6.42$ & $6.92 \mathrm{a} \pm 5.49$ & $6.42 \mathrm{a} \pm 5.07$ & $5.72 \mathrm{a} \pm 5.35$ & $4.62 \mathrm{a} \pm 4.37$ & $2.82 \mathrm{ab} \pm 1.26$ \\
& TAN2 & $19.46 \pm 0.50$ & $1.75 \mathrm{~b} \pm 0.22$ & $1.73 \mathrm{~b} \pm 0.18$ & $1.58 \mathrm{a} \pm 0.16$ & $1.91 \mathrm{a} \pm 0.22$ & $1.56 \mathrm{~b} \pm 0.20$ \\
& TAN3 & $17.13 \pm 3.14$ & $4.24 \mathrm{ab} \pm 0.77$ & $3.29 \mathrm{ab} \pm 0.37$ & $4.11 \mathrm{a} \pm 0.07$ & $3.23 \mathrm{a} \pm 0.91$ & $3.33 \mathrm{a} \pm 1.28$ \\
SS & TAN1 & $374 \pm 124$ & $243 \mathrm{a} \pm 45$ & $471 \mathrm{a} \pm 226$ & $475 \mathrm{a} \pm 182$ & $492 \mathrm{a} \pm 128$ & $611 \mathrm{a} \pm 217$ \\
& TAN2 & $358 \pm 335$ & $460 \mathrm{a} \pm 400$ & $543 \mathrm{a} \pm 414$ & $544 \mathrm{a} \pm 402$ & $551 \mathrm{a} \pm 414$ & $554 \mathrm{a} \pm 405$ \\
& TAN3 & $780 \pm 739$ & $586 \mathrm{a} \pm 594$ & $758 \mathrm{a} \pm 656$ & $787 \mathrm{a} \pm 676$ & $861 \mathrm{a} \pm 635$ & $898 \mathrm{a} \pm 672$ \\
TDS & TAN1 & $3941 \pm 3703$ & $51 \mathrm{a} \pm 10$ & $53 \mathrm{a} \pm 10$ & $55 \mathrm{a} \pm 15$ & $61 \mathrm{a} \pm 20$ & $63 \mathrm{a} \pm 26$ \\
& TAN2 & $3300 \pm 1714$ & $83 \mathrm{a} \pm 78$ & $47 \mathrm{a} \pm 20$ & $48 \mathrm{a} \pm 22$ & $47 \mathrm{a} \pm 17$ & $48 \mathrm{a} \pm 17$ \\
& TAN3 & $2653 \pm 1240$ & $46 \mathrm{a} \pm 11$ & $55 \mathrm{a} \pm 24$ & $55 \mathrm{a} \pm 25$ & $58 \mathrm{a} \pm 23$ & $61 \mathrm{a} \pm 28$ \\
\hline
\end{tabular}

Replicate $=6$ (months)

Within the rows, for the same parameter, means with different alphabets are statistically different $(p<0.05)$.

$\mathrm{P}=$ parameter, IND = Industries 
BAJOPAS Volume 13 Number 2, December, 2020

Table 4: Correlation coefficient $(r)$ between different masses of the bacteria and the physicochemical parameters.

\begin{tabular}{llll}
\hline Industries & Parameter & Correlation coefficient $(r)$ & $\begin{array}{l}\text { Percent dependence (rxrx100) } \\
(\%)\end{array}$ \\
\hline TAN1 & COD & -0.9 & 82 \\
& BOD & -0.97 & 94 \\
& SS & $0.90^{*}$ & 80 \\
TAN2 & TDS & $0.98^{*}$ & 96 \\
& COD & -1 & 100 \\
& BOD & -0.21 & 4 \\
& SS & $0.78^{*}$ & 61 \\
& TDS & -0.69 & 47 \\
& COD & $0.60^{*}$ & 36 \\
& BOD & -0.6 & 37 \\
& SS & $0.95^{*}$ & 90 \\
& TDS & $0.94^{*}$ & 89 \\
\hline
\end{tabular}

The correlation coefficient $(r)$ with * is statistically significant $(p<0.05)$.

Percentage reduction of the Parameters

Table 5 shows the percentage reduction of Parameters in industrial samples before and after the treatment of the effluents $(250 \mathrm{ml})$ with the different masses $(5 \mathrm{~g}, 10 \mathrm{~g}, 15 \mathrm{~g}, 20 \mathrm{~g}$, and $25 \mathrm{~g}$ ) of the Immobilized Bacteria.

In TAN1 samples, the percentage reduction (\%) of COD ranged (14-89); BOD (50-80); SS (-32$35)$ and TDS (98-99). In TAN2 samples, the percentage decrease $(\%)$ of COD ranged (15$38) ;$ BOD (90-92); SS [-28-(-55)] and TDS (9798). In TAN3 samples, the percentage decrease (\%) of COD ranged (11-44); BOD (76-81); SS (15-25) and TDS (98). The percentage increase in the levels COD, BOD and TDS might be due to the increase in the surface area of the different masses of the immobilized bacteria. However, the percentage decrease in the levels of the SS might be due to the aggregation of the TDS which are large enough to result into SS. The percentage decrease in the levels of the SS might be also due to the influence of the nutrients which was added into the effluents in order to make the microorganisms more active and viable for fast degradation of organic contaminants in the effluent. This is in line with the work of Jimoh et al. (2018) in which the concentration of the SS increase after the bioremediation of effluents.

Sreemoyee and Priti (2013) assessed and reduced several Physico-chemical parameters of dairy wastewater using Niesseria $s p$. and concluded that the species are well known to degrade organic compounds. This is in agreement with the current study in which the immobilized Niesseria $s p$ degrade the organic contaminants as indicated by the BOD, COD and TDS.

Jimoh et al. (2018) observed that TSS of the effluents was increased after treatment with immobilized bacteria and concluded that it might be due to the biostimulation method adopted for the research.

The optimum $\mathrm{pH}$ Biosorption of Chromium by Bacillus spp and Staphylococcus spp. from tannery effluent was investigated by Mythili and Karthikeyan (2011). The maximum adsorption of Chromium $(86.4 \mathrm{mg} / \mathrm{L})$ was showed by Bacillus spp and Staphylococcus spp showed $70.6 \mathrm{mg} / \mathrm{L}$ at an initial concentration of $100 \mathrm{mg} / \mathrm{L}$. In the present study, immobilised Bacillus spp and Staphylococcus spp. from the tannery industrial effluents reduced the levels of the organic pollutants with high potential as indicated by the percentage reduction of BOD, COD and TDS.

Enzymes often can work in multiple environments especially if they are immobilized. This makes the microorganisms' enzymes even more resistant to harsh environments and enables the enzymes to be recovered and recycled after they are no longer needed (Gianfreda and Rao 2004). Ramesh and Singh (1993) reported that the immobilized bacteria having more efficiency to remove the suspended particles than free cells. Using the immobilized cell is preferable due to its capability for using several times with the same efficiency, which makes it more economical. Similar work was done by Sikander et al. (2007) showing the higher reduction with permeabilized cells of Ochrobactrum intermedium strain SDCr-5. 
BAJOPAS Volume 13 Number 2, December, 2020

The results revealed the isolation and identification of isolates with the potential for the reduction of $\mathrm{Cr}$ (VI) to $\mathrm{Cr}$ (III). Results indicated that immobilized $B$. cereus could be efficiently used for the reduction of $\mathrm{Cr}$ (VI).

Table 5: Percentage reduction of the tested Parameters from the tannery industrial samples of the Immobilized Bacteria.

\begin{tabular}{lllllll}
\hline \multirow{2}{*}{ Industries } & & \multicolumn{5}{c}{ Percentage Reduction $(\%)$} \\
\cline { 3 - 7 } & & $5 \mathrm{~g}$ & $10 \mathrm{~g}$ & $15 \mathrm{~g}$ & $20 \mathrm{~g}$ & $25 \mathrm{~g}$ \\
\hline TAN1 & COD & 28 & 14 & 64 & 87 & 89 \\
& BOD & 50 & 54 & 59 & 67 & 80 \\
& SS & 35 & -26 & -27 & -32 & -63 \\
& TDS & 99 & 99 & 99 & 98 & 98 \\
TAN2 & COD & 15 & 20 & 25 & 32 & 38 \\
& BOD & 91 & 91 & 92 & 90 & 92 \\
& SS & -28 & -52 & -52 & -54 & -55 \\
& TDS & 97 & 99 & 99 & 99 & 99 \\
& COD & 33 & 44 & 22 & 11 & 26 \\
& BOD & 75 & 81 & 76 & 81 & 81 \\
& SS & 25 & 3 & -1 & -10 & -15 \\
& TDS & 98 & 98 & 98 & 98 & 98 \\
\hline
\end{tabular}

Percentage Reduction $=(B-A) / B \times 100 \%$

$A=$ Concentration of the parameter after treatment

$\mathrm{B}=$ Concentration of the parameter before treatment

$+=$ percentage decrease

- = percentage increase

In general, immobilization makes the enzyme more resistant to temperature, $\mathrm{pH}$, and substrate concentration swings giving it a longer lifetime and higher productivity per active unit (Gianfreda and Rao, 2004; FuIlbrook, 1996; Russell et al, 2003; Kandelbauer et al., 2004). Immobilized cells have been used and studied extensively for the production of useful chemicals (Ohtake and Silver, 1994), the treatment of wastewaters (Chen et al., 2003; Wang et al., 2010). Although many workers described microbial degradation of tannery effluent, limited literature is available on the bioremediation of tannery effluent using immobilized bacterial cells in the Kano Industrial Estates.

\section{CONCLUSION}

The samples contained variable levels of the physicochemical parameters. The results of the Analysis of variance revealed that, no statistical difference $(p<0.05)$ was observed for the temperature, $\mathrm{pH}, \mathrm{SS}, \mathrm{TDS}, \mathrm{BOD}$ and $\mathrm{COD}$ among the three tannery industries before the treatment. The levels of some of the parameters
(SS, TDS and COD) observed in the samples were found above the recommended limits of WHO and NESREA, which called for the treatment of the effluents before discharge into the environment. Base on the morphological and biochemical test results, TAN1, TAN2, and TAN3 bacterial isolates were identified to be Neisseria spp, Bacillus cereus, and Staphylococcus aureus respectively. The results of Post-treatment analysis showed that there is overall decrease in the levels of the parameters determined when compared with that of the pre-treatment. The overall percentage reduction of the immobilised bacteria in the treatment of the respective effluents was in the order TAN2 (72\%)>TAN1 $(70 \%)>$ TAN3 $(62 \%)$. Hence, the immobilized bacteria are having higher biodegradation potential for the treatment of the tannery effluents.

\section{Acknowledgments}

The authors wish to acknowledge the University of Maiduguri for the financial support. The authors are grateful to the Kano State Ministry of Environment for their support in obtaining the effluent samples. 


\section{REFERENCES}

Ajao, A. T., Adebayo, G. B., and Yakubu, S. E. (2011). Bioremediation of textile industrial effluent using mixed culture of Pseudomonas aeruginosa and Bacillus subtilis immobilized on agar-agar in a bioreactor. J. Microbiol. Biotech. Res, 1(3), 50-56.

Akan, J. C., Moses, E. A., Ogugbuaja, V. O., and Abah, J. (2007). Assessment of tannery industrial effluents from Kano metropolis, Kano State, Nigeria. Journal of Applied Sciences, 7(19), 2788-2793.

Akan, J. C., Ogugbuaja, V. O., Abdulrahman, F. I., and Ayodele, J. T. (2009). Pollutant levels in effluent samples from tanneries and textiles of Kano industrial areas, Nigeria. Global journal of pure and applied sciences, 15(3-4).

APHA (1989). Standard methods for Examination of Will bete and Will betewater.15 $5^{\text {th }}$ edition. Brydpass Springfield Will behington DC. pp. 164-176

APHA (1992). Standard Methods for the Examination of Water and Wastewater. Health, 69, 1116-9.

Baba, A., Garba, S. T., and Bello, H. S. (2020). Bioremediation Potential of Immobilized corynebacterium kutsceri in the Treatment of Tannery Industrial Effluent from Challawa Industrial Estate, Kano State, Nigeria. Journal of the Turkish Chemical Society Section A: Chemistry, $7(2), 335-350$.

Beem, E. I. V. (1994). reduction of solvent VOC emission. J. Oil Col. Chem. Ass, 77, 158.

Bouwer, E. J., and Zehnder, A. J. (1993). Bioremediation of organic compoundsputting microbial metabolism to work. Trends in biotechnology, 11(8), 360367.

Chen, K. C., Wu, J. Y., Liou, D. J., and Hwang, S. C. J. (2003). Decolorization of the textile dyes by newly isolated bacterial strains. Journal of Biotechnology, 101(1), 57-68.

Dan'Azumi, S., and Bichi, M. H. (2010). INDUSTRIAL POLLUTION AND HEAVY METALS PROFILE OF CHALLAWA RIVER IN KANO, NIGERIA. Journal of Applied Sciences in Environmental Sanitation, $5(1)$.

DWAF. (1992). Analytical Methods Manual, TR 151. Department of Water Affairs and Forestry, Pretoria.

El-Bestawy, E. (2013). Biological treatment of leather-tanning industrial wastewater using free living bacteria.
Elsheikh, M. A. S. (2009). Tannery wastewater pre-treatment. Water Science and Technology, 60(2), 433-440.

FuIlbrook, P. D. (1996). "Kinetics." Industrial enzymology: The application of enzymes in Industry. 2nd Ed. T. Godfrey and J Reichelt. eds.. Nature. New York.

Gianfreda, L., and Rao, M. A. (2004). Potential of extra cellular enzymes in remediation of polluted soils: a review. Enzyme and microbial technology, 35(4), 339354.

Hugo Springer. (1994). John Arthur Wilson Memorial Lecture "Treatment of Industrial Wastes of the Leather Industry - is it still a Major Problem". JALCA, 89, 153-185

Jimoh, A. A., Ganiyu, B. A., Baba, D., and Baba, A. (2018) Bioremediation Process of Effluent from Detergent and Food Industries in Jos, Nigeria: Kinetics and Thermodynamics. International Journal of Engineering Science Invention (IJESI), 762-73

Kandelbauer, A., Maute, O., Kessler, R. W., Erlacher, A., and Gübitz, G. M. (2004). Study of dye decolorization in an immobilized laccase enzyme-reactor using online spectroscopy. Biotechnology and bioengineering, 87(4), 552-563.

Kongjao, S., Damronglerd, S., and Hunsom, M. (2008). Simultaneous removal of organic and inorganic Pollutants in tannery wastewater using electrocoagulation technique. Korean Journal of chemical engineering, 25(4), 703.

Maheshwari, U. M., Aruna, S., Gomathi, M., and AbdulJaffar, A. H. (2017). Bioremediation by Free and Immobilized Bacteria Isolated from Tannery Effluent. International Journal of Research in Applied, Natural and Social Sciences. 5(7), 75-90

Margesin, R., and Schinner, F. (2001). Bioremediation (natural attenuation and biostimulation) of diesel-oilcontaminated soil in an alpine glacier skiing area. Applied and environmental microbiology, 677), 3127-3133.

Mohammed, A., Sekar, P., and George, J. (2011). Efficacy of microbes in bioremediation of tannery effluent. Inter. J. Curr. Res, 3(4), 324-326.

Mohammed, S. S. D., Orukotan, A. A., and Abdullahi, H. (2017). Physicochemical and Bacteriological Assessment of Tannery Effluent from Samaru-Zaria, 
BAJOPAS Volume 13 Number 2, December, 2020 Kaduna State, Nigeria. Journal of Applied

Sciences and Environmental Management, 21(4), 734-740.

Munz, G., De Angelis, D., Gori, R., Mori, G., Casarci, M., and Lubello, C. (2009). The role of tannins in conventional and membrane treatment of tannery wastewater. Journal of hazardous materials, 164(2-3), 733-739

Mythili, K., and Karthikeyan, B. (2011). Bioremediation of $\mathrm{Cr}$ (VI) from tannery effluent using Bacillus spp and Staphylococcus spp. International Multidisciplinary Research Journal, 1(6).

NESREA (2009). National Environmental Standards for Effluent Limitations and Regulation. 1233-1236

Noorjahan, C. M. (2014). Physicochemical characteristics, identification of bacteria and biodegradation of industrial effluent. Journal of bioremediation and Biodegradation, 5(3).

Ohtake, H. I., and Silver, A. O. (1994). Bacterial reduction of toxic chromate. Biological degradation and bioremediation of toxic chemicals, 403-415.

Omoleke, I. I. (2004). Management of environmental pollution in Ibadan, an African city: the challenges of health hazard facing government and the people. Journal of Human Ecology, 15(4), 265-275.

Rajor, A., Reddy, A.S., and Singh, B. (2004). Determination of BOD kinetic Parameters and evaluation of alternate methods, M.Sc. Thesis, Department of biotechnology \& environmental Science, Thapar Institute of Engineering and Technology, Patiala

Ramasami, T., Rajamani, S., and Rao, J. R. (1994, March). Pollution control in leather industry: Emerging technological options. In International symposium on surface and colloidal science and its relevance to soil pollution, madras.

Ramesh, J. V. S., and Singh, S. P. (1993). Yearly variation in certain physicochemical parameters of pond at eastern Doon Valley. Uttar Pradesh J. Zoo, 12 (1), 7577.

Ranen, S., and Sharadinadra, C. (2009). Biotechnology applications to environmental remediation in resource exploitation. Current science, 97, 6-25
Russell, A. J., Berberich, J. A., Drevon, G. F., and Koepsel, R. R. (2003). Biomaterials for mediation of

chemical and biological warfare agents. Annual review of biomedical engineering, 5(1), 1-27.

Saravanan, P., and Saravanan, A. (1999). Decolourization of tannery effluent by Flavobacterium sp. EK 1. Indian Journal of Environmental Protection, 19, 19-24.

Sikander, S., and Shahida, H. (2007). Reduction of toxic hexavalent chromium by Ochrobactrum intermedium strain SDCr5 stimulated by heavy metals. Bioresource Technol, 98, 340-344.

Singh, N., Sharma, B. K., and Bohra, P. C. (2000). Impact assessment of industrial effluent of arid soils by using satellite imageries. Journal of the Indian Society of Remote Sensing, 28(2-3), 79.

Sreemoyee, C., and Priti, P. (2013). Assessment of physico-chemical parameters of dairy waste water and isolation and characterization of bacterial strains in terms of cod reduction. Int J Sci, 2(3), 395-400.

Verheijen, L. A. H. M., Wiersema, D., Pol, L. H., and De Wit, J. (1996). Management of wastes from animal product processing. Livestock and environment, Finding a balance. International Agriculture Center, Wageningen, The Netherlands.

Wang, F., Yao, J., Si, Y., Chen, H., Russel, M., Chen, K., and Bramanti, E. (2010). Short-time effect of heavy metals upon microbial community activity. Journal of Hazardous Materials, 173(13), 510-516.

WHO (World Health Organization). (2006). Air quality guidelines: global update 2005: particulate matter, ozone, nitrogen dioxide, and sulfur dioxide. World Health Organization.

World Bank. (1995). Nigeria's strategic options for redressing industrial pollution. World Bank, industry and energy division. 1st edition, West Central Africa Department; Annexes: 1995; pp 60-62.

Zahoor, A., and Abdul, R. (2009). Enumeration of Coliforms. Journal of Environmental Sciences. 21, 814-820 


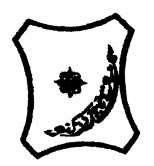

Bayero Journal of Pure and Applied Sciences, 13(2): 1 - 12

Received: November, 2020

Accepted: December, 2020

ISSN $2006-6996$

\title{
BIODEGRADATION POTENTIAL OF IMMOBILIZED BACTERIA IN THE TREATMENT OF TANNERY INDUSTRIAL EFFLUENTS FROM INDUSTRIAL ESTATES IN KANO STATE, NIGERIA
}

\author{
Abdullateef, B., ${ }^{1 *}$ Shuaibu, T. G., ${ }^{1}$ Babagana, K., ${ }^{1}$ Suleman, H. B. ${ }^{2}$ and Dauda, B. ${ }^{3}$ \\ ${ }^{1}$ Department of Pure and Applied Chemistry, Faculty of Science, University of Maiduguri, Borno State, \\ Nigeria \\ ${ }^{2}$ Department of Microbiology, Faculty of Science, University of Maiduguri, Borno State, Nigeria \\ ${ }^{3}$ Department of Chemical Engineering, Faculty of Engineering, University of Maiduguri, Borno State, \\ Nigeria \\ *Corresponding author: babslega@gmail.com; abelega2007@yahoo.com; +2348061309753
}

\section{ABSTRACT}

Industrial Effluents Samples from Gashash Tanneries (TAN1) in Bompai Industrial estate, Larabee Tannery Industry (TAN2) in Sharada Industrial estate and Z Tannery Industries (TAN3) in Challawa Industrial estate, Kano State, Nigeria were collected over a period of six months (August 2017 to January 2018) for assessing the biodegradation potentials of bacteria in the treatment of organic pollutants within the effluents. Bacteria were isolated from the effluents and immobilized on agar-agar. Different masses (5 g, $10 \mathrm{gr}, 15$ $\mathrm{g}, 20 \mathrm{~g}$, and $25 \mathrm{~g}$ ) of the bacteria were used in the treatment of $250 \mathrm{ml}$ of the effluents for ten days in a shaker incubator (Gallenkamp-OC-4364-L) at the temperature $30{ }^{\circ} \mathrm{C}$ and speed of $60 \mathrm{rpm}$. Pre-treatment analysis of the effluents for Temperature, pH, Biochemical Oxygen Demand (BOD), Chemical Oxygen Demand (COD), Suspended Solid (SS) and Total Dissolved Solids (TDS) gives the following results; temperature $\left({ }^{\circ} \mathrm{C}\right.$ )

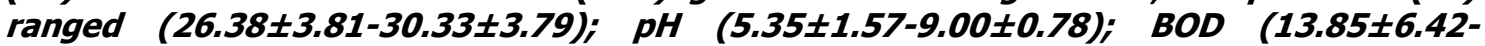
$38.75 \pm 16.20) ;$ COD (1406 $\pm 208-3532 \pm 1373) ;$ SS (208 $\pm 235-780 \pm 739)$ and TDS (266 $\pm 253-5276 \pm 2971)$. No statistical differences ( $p \leq 0.05)$ was observed for all the results among the different industries. The bacterial isolates were identified as Neisseria spp, Bacillus cereus, and Staphylococcus aureus, in TAN1, TAN2, and TAN3, respectively. After treatment of the effluent with the different masses of the isolated bacteria, the mean level of BOD was found to range as (0.55 $\pm 0.36-6.92 \pm 5.49) ; C O D$ (ND-3134 \pm 1595$)$;

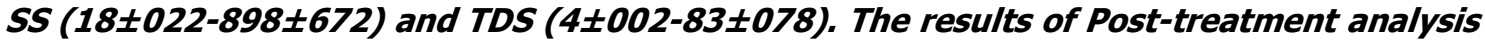
showed that there is overall decrease in the levels of the parameters determined when compared with that of the pre-treatment. The overall percentage reduction of the immobilised bacteria in the treatment of the respective effluents was in the order TAN2 (72\%)>TAN1 (70\%)>TAN3 (62\%). Hence, the immobilized bacteria are having higher biodegradation potential for the treatment of the tannery effluents.

Keywords: Biodegradation, bacteria, effluent, immobilization, tannery.

\section{INTRODUCTION}

Tannery industrial wastewater is a serious consequence of the pollution point of view for streams, freshwater, and land used for agriculture. The lack of awareness in the modern industrial practice has resulted in the discharge of tannery effluents which exhibit very high value of chromium ( $\mathrm{Cr}$ ), Sulfide, and chloride, Total Dissolved Solid (TDS), Total Suspended Solid (TSS), Biochemical Oxygen Demand (BOD) and Chemical Oxygen Demand (COD) in the water stream or land (Mohammed et al., 2001). Tanning is the process, which One ton of skin generally leads to the production of 20 to $80 \mathrm{~m}^{3}$ of turbid and foul-smelling converts the protein of the rawhide or skin into a stable material, which will not putrefy and is suitable for a wide variety of end applications (Elsheikh, 2009). The highly polluting chromium is the most commonly used tanning material producing leather that is more flexible and pliable than vegetable-tanned leather and does not discolor or lose shape in water as drastically as vegetable-tan (Elsheikh, 2009). Tannery effluent is among the most hazardous industrial pollutants due to its huge organic and inorganic load, which is highly toxic to human life and the environment (Kongjao et al., 2008). wastewater including chromium (100-400 mg/l), sulfide $(200-800 \mathrm{mg} / \mathrm{l})$, high levels of fat and 
BAJOPAS Volume 13 Number 2, December, 2020 other solid wastes, and notable pathogen contamination as well as pesticides added for skin conservation during transport (Elsheikh, 2009). There are more than 6000 tanneries in Nigeria with an annual processing capacity of 700,000 tons of hides and skins (Omoleke, 2004; Singh et al., 2008). It was reported that the total amount of waste produced per animal slaughtered is approximately $35 \%$ of its weight (World Bank, 1995). Also, for every $1000 \mathrm{~kg}$ of carcass weight, a slaughtered beef produces 5.5 $\mathrm{kg}$ of manure (excluding rumen contents or stockyard manure) and $100 \mathrm{~kg}$ of paunch manure (undigested food) (Verheijen et al., 1996). Tanneries generate wastewater in the range of 30-35 $\mathrm{L} \mathrm{kg}^{-1}$ skin/hide processed with variable $\mathrm{pH}$, Biological Oxygen Demand (BOD), Chemical Oxygen Demand (COD), high concentrations of suspended solids (SS), and tannins as well as chromium (Zahoor and Abdul, 2009).

Being heterogeneous and composed of a wide variety of compounds, it is very difficult to select a unique direct method for estimating the biodegradability of organic contents and biokinetic parameters for a wastewater sample (Rajor, 2004). For this purpose, some indirect estimation such as determination of biochemical oxygen demand (BOD) and chemical oxygen demand (COD) are applied as common laboratory investigations [9]. During retanning procedures, synthetic tannins (Syntan), oils and resins are added to form softer leather at varying doses (Munz et al., 2009). One of the refractory groups of chemicals in tannery effluents derives mainly from tannins (Ramasami et al., 2004). Syntans are characterized by complex chemical structures, because they are composed of an extended set of chemicals such as phenol-, naphthalene-, formaldehyde- and melamine-based syntans, and acrylic resins (Beem, 1994). Organic pollutants (proteic and lipidic components) are originated from skins (it is calculated that the raw skin has $30 \%$ loss of organic material during the working cycle) or they are introduced during processes (Hugo Springer, 1994).

Many conventional processes such as oxidation, chemical and biological processes were carried out to treat tanneries wastewater (Ebtesam et al, 2013). Biological processes have received more attention because of their costeffectiveness, lower sludge production and environmental friendliness (Noorjahan, 2014). Naturally occurring micro-organisms degrade the hazardous organic wastes including xenobiotic compounds, such as pesticides, polycyclic aromatic hydrocarbons (PAHs) and polychlorinated biphenyls (PCBs) in due course of time (Ranen and Sharadinadra, 2009). Bioremediation is based on the idea that all organisms remove substances from the environment to carry outgrowth and metabolism (Bouwer and Zehnder, 1993). Bacteria, protista and fungi are found to be very good at degrading complex molecules and incorporating the breakdown products into their metabolism (Bouwer and Zehnder, 1993). The resultant metabolic wastes that they produce are generally safe and somehow recycled into other organisms (Ranen and Sharadinadra, 2009). An acclimatized indigenous population of microorganisms capable of degradation of the compounds of interest must exist at the site for a successful bioremediation mode (Ranen and Sharadinadra, 2009). It has been observed that for a successful bioremediation mode, an acclimatized indigenous population of microorganisms capable of degradation of the compounds of interest must exist at the site under investigation (Ranen and Sharadinadra, 2009). Even though there are numerous physical and chemical methods employed in the disposal of wastes the advantage in using bacterium is that they play a key role in the reduction of COD, BOD, total protein, total tannin and total phenol (Saravanan and Saravanan, 1998)

Baba et al. (2020) studied the bioremediation potential of immobilized corynebacterium kutsceri in the Treatment of tannery industrial effluent from Challawa Industrial Estate, Kano State, Nigeria. The aim of the work is to study the reduction in the level of the contaminants through the process of bioremediation using the isolated bacteria. Immobilized bacteria can withstand various temperatures, $\mathrm{pH}$ and substrate concentrations; consequently, increasing the efficiency and the lifespan of the bacteria. Immobilized bacteria are widely applied in the treatment of wastewater and can be separated and recovered after the treatment with the same efficiency (Baba et al., 2020).

\section{MATERIALS AND METHODS \\ Study Area}

This study was carried out in Bompai, Sharada and Challawa industrial estates in Kano, Figure 1. Kano lies on Latitude $11^{\circ} 30^{\prime} \mathrm{N}$ and $8^{\circ} 30^{\prime} \mathrm{E}$ and Longitude $11^{\circ} 5^{\prime} \mathrm{N}$ and $8^{\circ} 5^{\prime} \mathrm{E}$ in Northern Nigeria. It is one of the developed industrial cities in Nigeria. Tannery activities are the dominating industries and this could be one of the reasons for her high population density (Dan'Azumi and Bichi, 2010). Many researchers have studied biodegradation of tannery effluent using microorganisms. However, limited literature is available on the biodegradation of tannery effluent in Kano industrial estates using 
BAJOPAS Volume 13 Number 2, December, 2020 immobilized bacterial cells. This research work focuses on the potential of the use of the indigenous immobilized bacterial isolates in the treatment of tannery effluents in the industrial estates.

\section{Sample Collection}

Effluents were collected from the Tannery Industries from Bompai, Challawa and Sharada Industrial Estates, Kano, Nigeria. The effluents were collected over a period of six months (August 2017 to January 2018). Samples collected in a sterile 4-liter plastic container with a unique identification number were preserved using an ice-box that was transported to the Microbiology Laboratory, Department of Microbiology, Bayero University of Kano for analysis

\section{Sample Preparation and Sample Analysis}

Immediately after the collection of the effluent, $\mathrm{pH}$, TSS, TDS, COD, BOD levels were determined before treatment (Pre-treatment determination) and ten days after treatment (Post-treatment determination) as described in
APHA (1989) standard methods. $\mathrm{pH}$ was determined using Ecotests $\mathrm{pH}$ meter and TDS was determined using AQUALYTIC TDS Salinometer. BOD was determined as described by the standard method (APHA, 1992). COD and SS were determined using DR/2010 HACH portable data logging spectrophotometer (DWAF, 1992)

\section{Identification and Biochemical} Characterization of the Bacterial Isolates

The bacteria were isolated from the effluents using Serial Dilution according to the method described by APHA (1989). The biochemical tests such as oxidase, catalase, coagulase, indole (from $1 \%$ tryptone broth), citrate (Simmons citrate agar), methyl red/VogesProskauer (MR/VP), nitrate reduction, Starch Hydrolysis, Glucose, Maltose, and Lactose tests were carried out on the bacterial isolates to identify the bacteria through the bacteria biochemical characteristics according to Ajao et al. (2011).

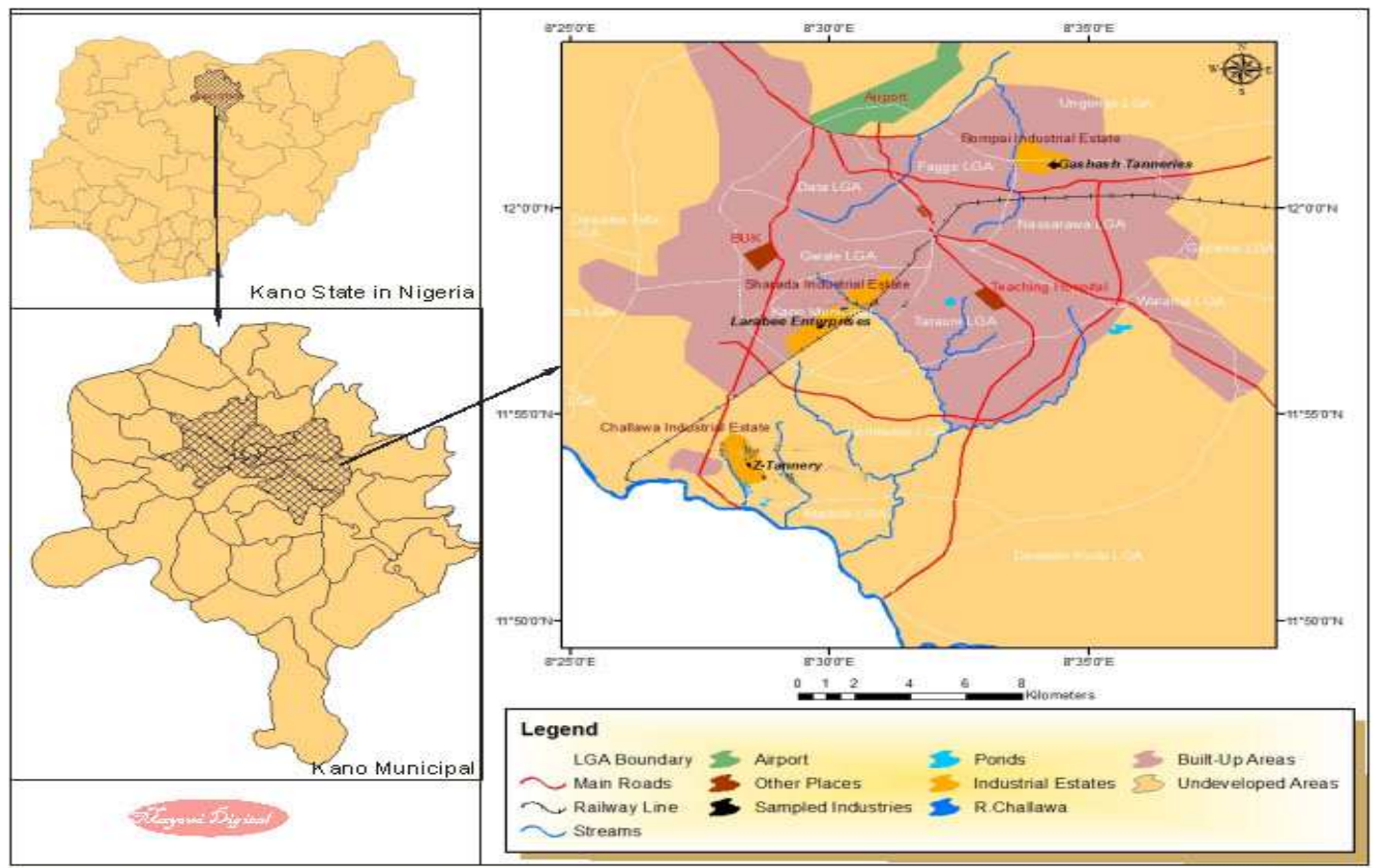

Fig. 1 Map showing the study areas

Source: Mayomi Digital Productions, GIS Laboratory, Department of Geography, UNIMAID (2017)

\section{Determination of Growth Rate of the Bacteria in Effluent Sample}

The bacteria growth rates were determined by transferring $2 \mathrm{~mL}$ of the bacterial isolates from the tannery effluent in broth medium into 100 $\mathrm{mL}$ sterile effluents in conical flasks and kept in an incubator (Giffrin cool) for 10 days. Control was also set up by incubating another $100 \mathrm{~mL}$ each of the sterile effluents without the bacteria. The optical density of the content was determined at the wavelength of $600 \mathrm{~nm}$ on a daily interval and recorded. 
BAJOPAS Volume 13 Number 2, December, 2020 Immobilization of Bacteria

Agar solution and inoculi were prepared separately. Fifty milliliters $(50 \mathrm{~mL})$ of nutrient broth each of the inoculi was prepared in a McCartney bottle and incubated for 24 hours. A solution of agar-agar was prepared by dissolving $10 \mathrm{~g}$ of the powder in distilled water and made up to $500 \mathrm{~mL}$ mark in an Erlenmeyer flask and was sterilized in an autoclave (280A) for 15 minutes and allowed to cool to $40-45^{\circ} \mathrm{C}$ (Ajao et al., 2011). Four milliliters ( $4 \mathrm{~mL})$ of the bacterial isolates in the nutrient broth was mixed with 36 $\mathrm{ml}$ of the prepared agar-agar media in petri-dish plates and then allowed to solidify. This was kept in the refrigerator for bioremediation.

\section{Bioremediation (Treatment) of the Effluents}

The solidified agar block (immobilized bacteria) was cut into cubes using a sterile knife; $0.1 \mathrm{~mL}$ phosphate buffer ( $\mathrm{pH} \mathrm{7.0)}$ was added and kept in the refrigerator for 1 hour for curing. The phosphate buffer was decanted after 1 hour and the cubes were washed with sterile distilled water 3-4 times before it was used (Ajao et al., 2011). Two liters (2 L) of the effluent was supplemented with the minimum basal medium in $\mathrm{g} / \mathrm{L}: \mathrm{NaCl}(0.8), \mathrm{MgSO}_{4} .7 \mathrm{H}_{2} \mathrm{O}(0.001), \mathrm{KH}_{2} \mathrm{PO}_{4}$ (2), $\mathrm{NaNO}_{3}$ (2), $\quad \mathrm{CaCl}_{2} .2 \mathrm{H}_{2} \mathrm{O} \quad(0.5)$ and $\mathrm{NaHPO}_{4} .12 \mathrm{H}_{2} \mathrm{O}(2)$ and sterilized in an autoclave at $121^{\circ} \mathrm{C}$ for 15 minutes (Margesin and Schinner, 2001). Two hundred and fifty milliliters $(250 \mathrm{~mL})$ of the effluents were transferred into different $250 \mathrm{ml}$ conical flasks. The content was covered with a cotton-wool ramped with foil paper to avoid contamination. Five grams $(5 \mathrm{~g})$ of the immobilized bacteria were quickly transferred into each of the effluents in the conical flasks in an inoculating chamber. The same procedures were carried out for the $10 \mathrm{~g}, 15 \mathrm{~g}, 20 \mathrm{~g}$ and 25 $\mathrm{g}$ of the immobilized bacteria in separate $250 \mathrm{~mL}$ effluents in conical flasks and agitated for ten days in a shaker incubator (Gallenkamp-OC4364-L) at a temperature $30^{\circ} \mathrm{C}$ and speed of 60 rpm. The treated effluent samples were taken on the tenth day and analyzed for the parameters $\mathrm{pH}$, SS, TDS, COD, and BOD, (Posttreatment determination) for the different grams of bacteria to evaluate and compare the biodegradation potential. (Baba et al., 2020).

\section{Statistical Analysis}

The data were represented as Mean \pm Standard deviation and analyzed statistically using oneway Analysis of Variance (ANOVA) and Tukey's HSD as Post Hoc Tests with the aid of SPSS 16.0. The correlation coefficient was also used to measure the strength of the relationship between the different masses of the bacteria and the parameters. All $\mathrm{p} \leq 0.05$ were considered as statistically significant.

\section{RESULTS AND DISCUSSION Physico-chemical parameters in the Industrial Effluents before the Biodegradation.}

Results of the Physico-chemical parameters in the industrial effluents before the Biodegradation is shown in table 1 . The mean temperatures $\left({ }^{\circ} \mathrm{C}\right)$ observed in TAN1, TAN2, and TAN3 samples were $28.07 \pm 0.65 ; 27.77 \pm 0.64$ and $26.38 \pm 3.81$ respectively. The order of the mean temperature of the samples from the three industries can be arranged as TAN1 > TAN2>TAN3. The temperature observed at TAN1, TAN2, and TAN3 samples were found below the WHO $\left(35^{\circ} \mathrm{C}\right)$ and NESREA $\left(40^{\circ} \mathrm{C}\right)$ limits. The low values of temperature might be due to the processes used at the time of sampling. High temperature brings down the solubility of gases in water that ultimately expresses as high BOD and COD. Statistical analysis shows that there is no significant difference $(p<0.05)$ between the mean values of temperature among the industries. This might be due to similar tannery activities involved in the tannery industries at the time of sampling. The average values of temperature observed in this present study are less than those observed by Akan et al. (2007), Akan et al. (2009) and Baba et al. (2020).

The mean level of $\mathrm{pH}$ observed in TAN1, TAN2 and TAN3, samples were $7.77 \pm 2.93$; $8.35 \pm 0.28$ and $7.52 \pm 0.76$ respectively. The order of the mean $\mathrm{pH}$ of the samples from the three industries can be arranged as TAN2> TAN1 $>$ TAN3. The $\mathrm{pH}$ of the samples falls within the WHO (7.0-8.5) and NESREA (6-9) standard limits. Statistical analysis shows that there is no significant difference $(p<0.05)$ between the mean values of $\mathrm{pH}$ among the industries. This might be due to similar tannery activities involved in the tannery industries at the time of sampling. Maheshwari et al. (2017) reported that the level of $\mathrm{pH}$ in the effluents from the tannery industry in Vaniyambadi, India was 6.5 which was lower than that observed in the present study. The $\mathrm{pH}$ in the effluents from the tannery industries in Kano and Kaduna were reported to be 7.64 and 6.89, respectively (Akan et al., 2007; Mohammed et al., 2017). The average values of $\mathrm{pH}$ observed in this present study are less than those observed by Mohammed et al. (2017) and Baba et al. (2020). The mean level of SS $(\mathrm{mg} / \mathrm{l})$ observed in TAN1, TAN2, and TAN3 samples were 374 \pm 124 ; $358 \pm 335$ and $780 \pm 739$ respectively. The order of the mean SS in the samples from the three industries can be arranged as TAN3 > TAN1 $>$ TAN2. 
The SS observed in the samples were far above the recommended standard limits of regulating bodies WHO $(30 \mathrm{mg} / \mathrm{l})$ and NESREA $(10 \mathrm{mg} / \mathrm{l})$. Statistical analysis shows that there is no significant difference $(p<0.05)$ between the mean values of SS among the industries. This might be due to similar tannery activities involved in the tannery industries at the time of sampling. The average values of SS observed in this present study are less than that observed $(3700 \pm 122 \mathrm{mg} / \mathrm{l})$ by Akan et al. (2009) for tanneries in Kano. Also, the average values of SS observed in this present study are less than that observed by Mohammed et al. (2017) and Baba et al. (2020) with the exception in TAN3.

The mean level of TDS (mg/l) observed in TAN1, TAN2, and TAN3 samples were $3941 \pm 3703$; $3300 \pm 1714$ and $2653 \pm 1240$ respectively. The order of the mean TDS in the samples from the three industries can be arranged as TAN1>TAN2>TAN3. The TDS observed in the samples were far above the recommended standard limits of WHO $(250 \mathrm{mg} / \mathrm{l})$ and NESREA $(500 \mathrm{mg} / \mathrm{l})$. Statistical analysis shows that there is no significant difference $(p<0.05)$ between the mean values of TDS among the industries. This might be due to similar tannery activities involved in the tannery industries at the time of sampling. TDS in the effluents from the tannery industries in Kano, Nigeria was reported to be $1281 \mathrm{mg} / \mathrm{l}$ (Akan et al., 2007). The average values of SS observed in this present study are less than those observed by Mohammed et al. (2017) and Baba et al. 2020)

The mean level of COD (mg/l) observed in TAN1, TAN2 and TAN3 samples seasons were $2372 \pm 938 ; \quad 1406 \pm 208$ and $3532 \pm 1373$ respectively. The order of the mean COD of the samples from the three industries can be arranged as TAN3>TAN1> TAN2. The COD observed in TAN1, TAN2 and TAN3 samples were far above the recommended standard limits of regulating bodies $\mathrm{WHO}(40 \mathrm{mg} / \mathrm{l})$ and NESREA (40 mg/l). Statistical analysis shows that there is no significant difference $(p<0.05)$ in COD among the industries. This might be due to similar tannery activities involved in the tannery industries as at the time of sampling. The Chemical Oxygen demand (COD) is the amount of oxygen, in $\mathrm{mg} / \mathrm{L}$, required for the degradation of the compound of wastewater to occur. In comparison, the average values of COD observed in this present study were higher than that observed by Mohammed et al. (2017) but lower than that observed by Baba et al. (2020).

The mean levels of BOD $(\mathrm{mg} / \mathrm{l})$ observed in TAN1, TAN2 and TAN3 samples were $13.85 \pm 6.42 ; \quad 19.46 \pm 0.50$ and $17.13 \pm 3.14$ respectively. The order of the mean BOD in the samples from the three industries can be arranged as TAN2>TAN3>TAN1. The BOD observed in TAN1, TAN2 and TAN3 samples were found below the recommended limits of NESREA (200 mg/l) but above WHO (10 mg/l). Statistical analysis shows that there is no significant difference $(p<0.05)$ between the mean values of BOD among the industries. This might be due to similar tannery activities involved in the tannery industries at the time of sampling. The low level of BOD recorded in this study is an indication of the low level of biodegradable organic solids in the effluent. The average values of BOD observed in this present study were lower than those observed by Mohammed et al. (2017) and Baba et al. (2020).

Table 1: Mean Values \pm S.D of Physico-chemical parameters of effluents from the Tannery Industries before Treatment.

\begin{tabular}{llllllll}
\hline Parameter & Tannery 1 & Tannery 2 & Tannery 3 & $\mathrm{a}$ & $\mathrm{b}$ & $\mathrm{c}$ & $\mathrm{d}$ \\
\cline { 2 - 7 } Temperature $\left({ }^{\circ} \mathrm{C}\right)$ & $28.07 \mathrm{a} \pm 0.65$ & $27.77 \mathrm{a} \pm 0.64$ & $26.38 \mathrm{a} \pm 3.81$ & & $29.50 \pm 4.68$ & 35 & 40 \\
pH & $7.77 \mathrm{a} \pm 2.93$ & $8.35 \mathrm{a} \pm 0.28$ & $7.52 \mathrm{a} \pm 0.76$ & 6.89 & $5.35 \pm 1.57$ & $7.0-8.5$ & $6.0-9.0$ \\
$\mathrm{COD}(\mathrm{mg} / \mathrm{l})$ & $2372 \mathrm{a} \pm 938$ & $1406 \mathrm{a} \pm 208$ & $3532 \mathrm{a} \pm 1373$ & 2.2 & $3106 \pm 2753$ & 40 & 40 \\
$\mathrm{BOD}(\mathrm{mg} / \mathrm{l})$ & $13.85 \mathrm{a} \pm 6.42$ & $19.46 \mathrm{a} \pm 0.50$ & $17.13 \mathrm{a} \pm 3.14$ & 1032 & $26.17 \pm 9.49$ & 10 & 200 \\
$\mathrm{SS}(\mathrm{mg} / \mathrm{l})$ & $374 \mathrm{a} \pm 124$ & $358 \mathrm{a} \pm 335$ & $780 \mathrm{a} \pm 739$ & 501 & $562 \pm 482$ & 30 & 10 \\
TDS $(\mathrm{mg} / \mathrm{l})$ & $3941 \mathrm{a} \pm 3703$ & $3300 \mathrm{a} \pm 1714$ & $2653 \mathrm{a} \pm 1240$ & 532.7 & $444 \pm 507$ & 250 & 500 \\
\hline
\end{tabular}

The values given in the table above are means of 6 replicate values, $\mathrm{n}=6$ ( 1 sample was taken monthly for 6 months). Within the rows, means with different alphabets are statistically different $(p<0.05)$. WHO: World Health Organisation. NESREA: National Environmental Standard and Regulatory Enforcement Agency. a = Mohammed et al.(2017), b = Baba et al. (2020), c = WHO (2006), $d=$ NESSRA (2009) 
BAJOPAS Volume 13 Number 2, December, 2020

Identification, Biochemical Characterization and growth rates of the Bacterial Isolates

Results of identification and biochemical characterization of the bacterial isolates were shown in table 2. After 24 hours of incubation, the nutrient agar media plates were checked for bacterial growth. The results showed the presence of different strains in the samples. The TAN1 bacteria isolate was found to be gramnegative cocci while TAN3 was gram-positive cocci. TAN2 bacteria isolate was found to be gram-positive, rod-shaped. TAN1, TAN2, and TAN3 bacteria isolates recorded positive results for spore former.

The results of the biochemical tests indicated that all the bacteria were positive for catalase, oxidase, citrate, maltose, glucose, lactose (negative in TAN1), mannitol (negative in TAN2), starch hydrolysis and coagulase (negative in TAN2) tests. The bacteria showed negative results for nitrate reduction, $M R$ (positive in TAN2), VP (positive in TAN1), Indole (positive in TAN2) tests. Base on the morphological and biochemical test results, TAN1, TAN2, and TAN3 bacteria isolates were identified to be Nesseria spp, Bacillus cereus, and Staphylococcus aureus respectively.

The growth rate of the TAN1, TAN2 and TAN3 Isolates were shown in figure 2. Generally, the optical density increase with the increase in time (day) and decrease as time goes on. The highest optical density was shown by bacillus cereus in TAN2 while the lowest was shown by Staphylococcus aureus in TAN3.

The initial growth phase of TAN1 Isolate bacteria occurred within 2-day of incubation as the growth rate increases up to the 6th-day incubation when the maximum growth was observed. Beyond the 6th day, the growth of the bacteria declined (which might be due to a shortage of nutrients in the effluents) until it reached its death phase (which might be due to the unavailability of nutrients in the effluents).

A similar trend of growth was also observed for TAN2 Isolate as the initial growth phase also occurred within 2-day of incubation but maximum growth rate observed on the 4th day of incubation. The stationary stage occurred between the 4th day and the 8th day. Beyond the 8th day, the growth of the bacteria declined (which might be due to a shortage of nutrients in the effluents) until it reached its death phase (which might be due to the unavailability of nutrients in the effluents).

The initial growth phase of TAN3 bacterial Isolate occurred within the 3-day incubation as the growth rate increases up to the 6th-day incubation when the maximum growth was observed. Beyond the 6th day, the growth of the bacteria declined (which might be due to a shortage of nutrients in the effluents) until it reached its death phase (which might be due to the unavailability of nutrients in the effluents).

Table 2: Morphological and Biochemical characteristics of bacterial isolates

\begin{tabular}{lllll} 
Bacterial Isolates & & TAN1 & TAN2 & TAN3 \\
\hline $\begin{array}{lllll}\text { Morphological } \\
\text { characteristics }\end{array}$ & Shape & Cocci & Rod & Cocci \\
& Spore & & & \\
& former & + & + & + \\
Gram & & & \\
Biochemical characteristics & reaction & - & + & + \\
& Citrate & + & + & + \\
& Catalase & + & + & + \\
& Coagulase & + & - & + \\
Starch & + & + & + \\
& Glucose & + & + & + \\
Oxidase & + & + & + \\
& Indo & - & + & - \\
Lactose & - & + & + \\
Manitol & + & - & + \\
Maltose & + & + & + \\
MR & - & + & - \\
VP & + & - & - \\
& Nitrate & - & - & - \\
Reduction & - Neisseria & Bacillus & Staphylococcus \\
& Bacterial & cereus & aureus \\
& name & spp & cas
\end{tabular}

+ = Positive; - = Negative; MR=Methyl Red; VP= Voges-Proskauer 


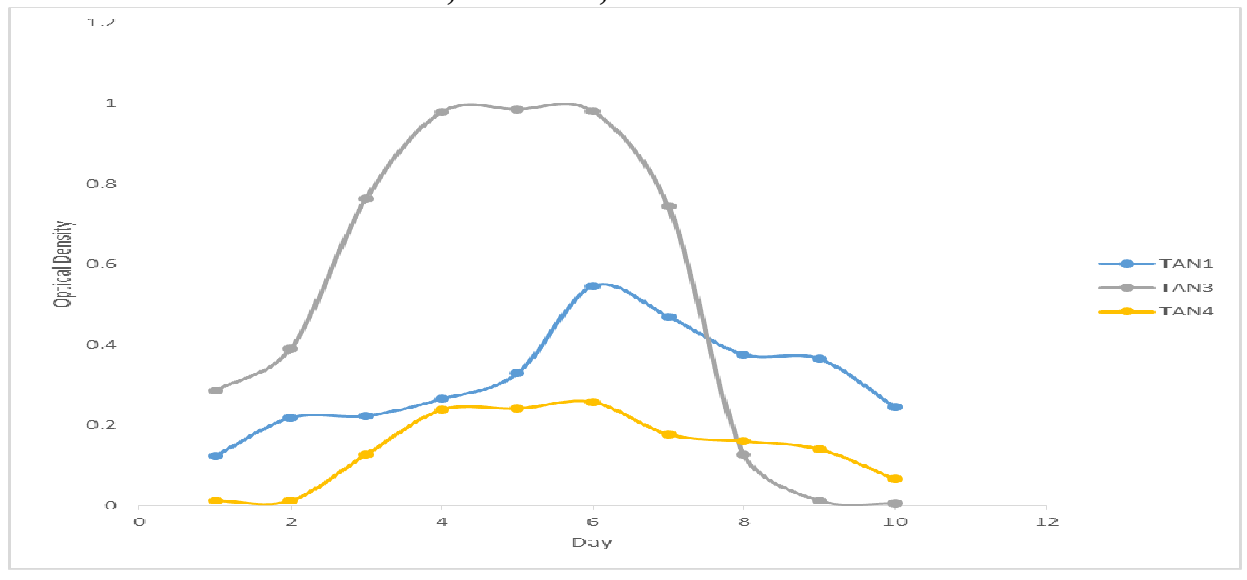

Fig. 2 Growth rates of the isolates in the effluents from the Tannery Industries

\section{Physico-chemical Parameters in the Industrial Effluents after the biodegradation.}

Table 3 shows the mean results of the physicochemical parameter before and after bioremediation using the different masses $(5 \mathrm{~g}$, $10 \mathrm{~g}, 15 \mathrm{~g}, 20 \mathrm{~g}$, and $25 \mathrm{~g}$ ) of the respective immobilized bacteria. Also, Table 4 shows the mean results of correlation coefficient ( $r$ ) between different masses of bacteria and physicochemical parameters.

The mean values $(\mathrm{mg} / \mathrm{l})$ of the SS after the bioremediation varies between $243 \pm 45$ and $898 \pm 672$. The mean concentration $(\mathrm{mg} / \mathrm{l})$ of SS remediated by the different masses $(5 \mathrm{~g}, 10 \mathrm{~g}$, $15 \mathrm{~g}, 20 \mathrm{~g}$, and $25 \mathrm{~g}$ ) of the bacteria varies. The SS in the samples fluctuates up and down after the bioremediation process when compared with the SS of the raw samples before the bioremediation. The increase in the levels of the SS might be due to the aggregation of the TDS which are large enough to result into SS. The increase in the levels of the SS might be also due to the influence of the nutrients which was added into the effluents in order to make the microorganisms more active and viable for fast degradation of organic contaminants in the effluent. The relative potential or efficiency of the different masses of the bacteria in remediating SS in TAN1 samples was in the order $25 \mathrm{~g}>20 \mathrm{~g}>15 \mathrm{~g}>10 \mathrm{~g}>5 \mathrm{~g}$. For TAN2 and TAN3 samples, the order was $25 \mathrm{~g}>20 \mathrm{~g}>15$ $\mathrm{g}>10 \mathrm{~g}>5 \mathrm{~g}$. These might be due to the variations in the surface areas of the different masses of the immobilized bacteria. Statistical analysis shows that there is no significant difference $(p<0.05)$ between the mean values of SS among the masses in the respective industries. Positive and significant correlations exist between the masses of bacteria and Suspended Solid (SS). This showed that there is general increase in the levels of the SS as the masses of the immobilized bacteria increases. TAN3 (90\%) and TAN1 (80\%) showed a very high correlation with the masses of the bacteria while TAN2 (61\%) showed a very low correlation.

The mean values $(\mathrm{mg} / \mathrm{l})$ of the TDS after the bioremediation varies between $46 \pm 11$ and $83 \pm 78$. The mean concentration $(\mathrm{mg} / \mathrm{l})$ of TDS remediated by the different masses $(5 \mathrm{~g}, 10 \mathrm{~g}$, $15 \mathrm{~g}, 20 \mathrm{~g}$, and $25 \mathrm{~g}$ ) of the bacteria varies. There is a reduction in all the TDS of all the samples after the bioremediation process compared with the TDS of the raw samples before the bioremediation. The relative potential or efficiency of the different masses of the bacteria in remediating TDS in TAN1 and TAN3 samples was in the order $5 \mathrm{~g}>10 \mathrm{~g}>15 \mathrm{~g}>20$ $\mathrm{g}>25 \mathrm{~g}$. For TAN2 samples, the order was 20 $g>10 \quad g>25 \quad g>15 \quad g>5 \quad g$. Statistical analysis shows that there is no significant difference $(p<0.05)$ between the mean values of TDS among the masses in the respective industries. These might be due to the variations in the surface areas of the different masses of the immobilized bacteria. Positive and significant correlations exist between the masses of bacteria and TDS with the exception in TAN2 (negative and insignificant correlation). The positive correlations showed that there is general increase in the levels of the TDS as the masses of the immobilized bacteria increases. TAN1 $(96 \%)$ showed a very high correlation with the masses of the bacteria while TAN2 (47\%) showed a very low correlation.

The mean values $(\mathrm{mg} / \mathrm{l})$ of the BOD after the bioremediation varies between $1.56 \pm 0.20 \mathrm{mg} / \mathrm{l}$ and $6.92 \pm 5.49 \mathrm{mg} / \mathrm{l}$. The mean concentration $(\mathrm{mg} / \mathrm{l})$ of BOD remediated by the different masses $(5 \mathrm{~g}, 10 \mathrm{~g}, 15 \mathrm{~g}, 20 \mathrm{~g}$, and $25 \mathrm{~g}$ ) of the bacteria varies. There is a reduction in all the BOD of all the samples after the bioremediation process compared with the $\mathrm{BOD}$ of the raw 
BAJOPAS Volume 13 Number 2, December, 2020 samples before the bioremediation. The relative potential or efficiency of the different masses of the bacteria in remediating BOD in TAN1, TAN2 and TAN3 samples were in the order $25 \mathrm{~g}>20$ $\mathrm{g}>15 \mathrm{~g}>10 \mathrm{~g}>5 \mathrm{~g}, 25 \mathrm{~g}>15 \mathrm{~g}>5 \mathrm{~g}>10 \mathrm{~g}>20 \mathrm{~g}$ and $20 \mathrm{~g}>10 \mathrm{~g}>25 \mathrm{~g}>15 \mathrm{~g}>5 \mathrm{~g}$ respectively. Statistical analysis shows that there is significant difference $(p<0.05)$ between the mean values of BOD among the masses in the respective industries. These might be due to the variations in the surface areas of the different masses of the immobilized bacteria. Negative and significant correlations exist between the masses of bacteria and BOD. This showed that there is general decrease in the levels of the BOD as the masses of the immobilized bacteria increases. TAN1 (94\%) showed a very high correlation with the masses of the bacteria while TAN2 (4\%) showed a very low correlation.

The mean values $(\mathrm{mg} / \mathrm{l})$ of the COD after the bioremediation varies between $250 \pm 154$ and $3134 \pm 1595$. The mean concentration $(\mathrm{mg} / \mathrm{l})$ of COD remediated by the different masses $(5 \mathrm{~g}$, $10 \mathrm{~g}, 15 \mathrm{~g} 20 \mathrm{~g}$, and $25 \mathrm{~g}$ ) of the bacteria varies. There is a reduction in all the COD of all the samples after the bioremediation process compared with the COD of the raw samples before the bioremediation. The relative potential or efficiency of the different masses of the bacteria in remediating COD in TAN1, TAN2 and TAN3 samples were in the order $25 \mathrm{~g}>20 \mathrm{~g}>15$ $\mathrm{g}>5 \mathrm{~g}>10 \mathrm{~g}, 25 \mathrm{~g}>20 \mathrm{~g}>15 \mathrm{~g}>10 \mathrm{~g}>5 \mathrm{~g}$ and 10 g>5 g>25 g>15 g>20 g respectively. Statistical analysis shows that there were significant difference $(p<0.05)$ between the mean values of COD among the masses in the respective industries except for effluents treated with $25 \mathrm{~g}$. These might be due to the variations in the surface areas of the different masses of the immobilized bacteria. Negative and insignificant correlations exist between the masses of bacteria and COD with the exception in TAN3 (positive and significant correlation). The negative correlations showed that there is general decrease in the levels of the COD as the masses of the immobilized bacteria increases. TAN2 (100\%) showed a very high correlation with the masses of the bacteria while TAN3 (36\%) showed a very low correlation.

Generally, there was an overall decrease in the concentration of these physicochemical parameters after the bioremediation using the different masses of the bacterial isolates. These might be due to the variations in the surface areas of the different masses of the immobilized bacteria. This is in line with the work of Jimoh et al. (2018) and Baba et al. (2020).

Table 3: Mean Values $(\mathrm{mg} / \mathrm{l}) \pm$ S.D of Physicochemical parameters in effluents from the Tannery Industries before and after Treatment of the effluents $(250 \mathrm{ml})$ with the different masses $(5 \mathrm{~g}, 10 \mathrm{~g}$, $15 \mathrm{~g}, 20 \mathrm{~g}$, and $25 \mathrm{~g}$ ) of the bacteria.

\begin{tabular}{llllllll}
\hline $\mathrm{P}$ & IND & Before & \multicolumn{5}{c}{ After } \\
\cline { 4 - 7 } & & & $5 \mathrm{~g}$ & $10 \mathrm{~g}$ & $15 \mathrm{~g}$ & $20 \mathrm{~g}$ & $25 \mathrm{~g}$ \\
\hline \multirow{2}{*}{ COD } & TAN1 & $2372 \pm 938$ & $1708 \mathrm{a} \pm 861$ & $2045 \mathrm{a} \pm 1205$ & $845 \mathrm{a} \pm 369$ & $300 \mathrm{a} \pm 167$ & $250 \mathrm{a} \pm 154$ \\
& TAN2 & $1406 \pm 208$ & $1195 \mathrm{a} \pm 208$ & $1125 \mathrm{a} \pm 384$ & $1055 \mathrm{a} \pm 317$ & $956 \mathrm{a} \pm 310$ & $870 \mathrm{ab} \pm 240$ \\
& TAN3 & $3532 \pm 1373$ & $2374 \mathrm{a} \pm 1344$ & $1976 \mathrm{a} \pm 1405$ & $2757 \mathrm{a} \pm 1266$ & $3134 \mathrm{a} \pm 1595$ & $2614 \mathrm{~b} \pm 1105$ \\
BOD & TAN1 & $13.85 \pm 6.42$ & $6.92 \mathrm{a} \pm 5.49$ & $6.42 \mathrm{a} \pm 5.07$ & $5.72 \mathrm{a} \pm 5.35$ & $4.62 \mathrm{a} \pm 4.37$ & $2.82 \mathrm{ab} \pm 1.26$ \\
& TAN2 & $19.46 \pm 0.50$ & $1.75 \mathrm{~b} \pm 0.22$ & $1.73 \mathrm{~b} \pm 0.18$ & $1.58 \mathrm{a} \pm 0.16$ & $1.91 \mathrm{a} \pm 0.22$ & $1.56 \mathrm{~b} \pm 0.20$ \\
& TAN3 & $17.13 \pm 3.14$ & $4.24 \mathrm{ab} \pm 0.77$ & $3.29 \mathrm{ab} \pm 0.37$ & $4.11 \mathrm{a} \pm 0.07$ & $3.23 \mathrm{a} \pm 0.91$ & $3.33 \mathrm{a} \pm 1.28$ \\
SS & TAN1 & $374 \pm 124$ & $243 \mathrm{a} \pm 45$ & $471 \mathrm{a} \pm 226$ & $475 \mathrm{a} \pm 182$ & $492 \mathrm{a} \pm 128$ & $611 \mathrm{a} \pm 217$ \\
& TAN2 & $358 \pm 335$ & $460 \mathrm{a} \pm 400$ & $543 \mathrm{a} \pm 414$ & $544 \mathrm{a} \pm 402$ & $551 \mathrm{a} \pm 414$ & $554 \mathrm{a} \pm 405$ \\
& TAN3 & $780 \pm 739$ & $586 \mathrm{a} \pm 594$ & $758 \mathrm{a} \pm 656$ & $787 \mathrm{a} \pm 676$ & $861 \mathrm{a} \pm 635$ & $898 \mathrm{a} \pm 672$ \\
TDS & TAN1 & $3941 \pm 3703$ & $51 \mathrm{a} \pm 10$ & $53 \mathrm{a} \pm 10$ & $55 \mathrm{a} \pm 15$ & $61 \mathrm{a} \pm 20$ & $63 \mathrm{a} \pm 26$ \\
& TAN2 & $3300 \pm 1714$ & $83 \mathrm{a} \pm 78$ & $47 \mathrm{a} \pm 20$ & $48 \mathrm{a} \pm 22$ & $47 \mathrm{a} \pm 17$ & $48 \mathrm{a} \pm 17$ \\
& TAN3 & $2653 \pm 1240$ & $46 \mathrm{a} \pm 11$ & $55 \mathrm{a} \pm 24$ & $55 \mathrm{a} \pm 25$ & $58 \mathrm{a} \pm 23$ & $61 \mathrm{a} \pm 28$ \\
\hline
\end{tabular}

Replicate $=6$ (months)

Within the rows, for the same parameter, means with different alphabets are statistically different $(p<0.05)$.

$\mathrm{P}=$ parameter, IND = Industries 
BAJOPAS Volume 13 Number 2, December, 2020

Table 4: Correlation coefficient $(r)$ between different masses of the bacteria and the physicochemical parameters.

\begin{tabular}{llll}
\hline Industries & Parameter & Correlation coefficient $(r)$ & $\begin{array}{l}\text { Percent dependence (rxrx100) } \\
(\%)\end{array}$ \\
\hline TAN1 & COD & -0.9 & 82 \\
& BOD & -0.97 & 94 \\
& SS & $0.90^{*}$ & 80 \\
TAN2 & TDS & $0.98^{*}$ & 96 \\
& COD & -1 & 100 \\
& BOD & -0.21 & 4 \\
& SS & $0.78^{*}$ & 61 \\
& TDS & -0.69 & 47 \\
& COD & $0.60^{*}$ & 36 \\
& BOD & -0.6 & 37 \\
& SS & $0.95^{*}$ & 90 \\
& TDS & $0.94^{*}$ & 89 \\
\hline
\end{tabular}

The correlation coefficient $(r)$ with * is statistically significant $(p<0.05)$.

Percentage reduction of the Parameters

Table 5 shows the percentage reduction of Parameters in industrial samples before and after the treatment of the effluents $(250 \mathrm{ml})$ with the different masses $(5 \mathrm{~g}, 10 \mathrm{~g}, 15 \mathrm{~g}, 20 \mathrm{~g}$, and $25 \mathrm{~g}$ ) of the Immobilized Bacteria.

In TAN1 samples, the percentage reduction (\%) of COD ranged (14-89); BOD (50-80); SS (-32$35)$ and TDS (98-99). In TAN2 samples, the percentage decrease $(\%)$ of COD ranged (15$38) ;$ BOD (90-92); SS [-28-(-55)] and TDS (9798). In TAN3 samples, the percentage decrease (\%) of COD ranged (11-44); BOD (76-81); SS (15-25) and TDS (98). The percentage increase in the levels COD, BOD and TDS might be due to the increase in the surface area of the different masses of the immobilized bacteria. However, the percentage decrease in the levels of the SS might be due to the aggregation of the TDS which are large enough to result into SS. The percentage decrease in the levels of the SS might be also due to the influence of the nutrients which was added into the effluents in order to make the microorganisms more active and viable for fast degradation of organic contaminants in the effluent. This is in line with the work of Jimoh et al. (2018) in which the concentration of the SS increase after the bioremediation of effluents.

Sreemoyee and Priti (2013) assessed and reduced several Physico-chemical parameters of dairy wastewater using Niesseria $s p$. and concluded that the species are well known to degrade organic compounds. This is in agreement with the current study in which the immobilized Niesseria $s p$ degrade the organic contaminants as indicated by the BOD, COD and TDS.

Jimoh et al. (2018) observed that TSS of the effluents was increased after treatment with immobilized bacteria and concluded that it might be due to the biostimulation method adopted for the research.

The optimum $\mathrm{pH}$ Biosorption of Chromium by Bacillus spp and Staphylococcus spp. from tannery effluent was investigated by Mythili and Karthikeyan (2011). The maximum adsorption of Chromium $(86.4 \mathrm{mg} / \mathrm{L})$ was showed by Bacillus spp and Staphylococcus spp showed $70.6 \mathrm{mg} / \mathrm{L}$ at an initial concentration of $100 \mathrm{mg} / \mathrm{L}$. In the present study, immobilised Bacillus spp and Staphylococcus spp. from the tannery industrial effluents reduced the levels of the organic pollutants with high potential as indicated by the percentage reduction of BOD, COD and TDS.

Enzymes often can work in multiple environments especially if they are immobilized. This makes the microorganisms' enzymes even more resistant to harsh environments and enables the enzymes to be recovered and recycled after they are no longer needed (Gianfreda and Rao 2004). Ramesh and Singh (1993) reported that the immobilized bacteria having more efficiency to remove the suspended particles than free cells. Using the immobilized cell is preferable due to its capability for using several times with the same efficiency, which makes it more economical. Similar work was done by Sikander et al. (2007) showing the higher reduction with permeabilized cells of Ochrobactrum intermedium strain SDCr-5. 
BAJOPAS Volume 13 Number 2, December, 2020

The results revealed the isolation and identification of isolates with the potential for the reduction of $\mathrm{Cr}$ (VI) to $\mathrm{Cr}$ (III). Results indicated that immobilized $B$. cereus could be efficiently used for the reduction of $\mathrm{Cr}$ (VI).

Table 5: Percentage reduction of the tested Parameters from the tannery industrial samples of the Immobilized Bacteria.

\begin{tabular}{lllllll}
\hline \multirow{2}{*}{ Industries } & & \multicolumn{5}{c}{ Percentage Reduction $(\%)$} \\
\cline { 3 - 7 } & & $5 \mathrm{~g}$ & $10 \mathrm{~g}$ & $15 \mathrm{~g}$ & $20 \mathrm{~g}$ & $25 \mathrm{~g}$ \\
\hline TAN1 & COD & 28 & 14 & 64 & 87 & 89 \\
& BOD & 50 & 54 & 59 & 67 & 80 \\
& SS & 35 & -26 & -27 & -32 & -63 \\
& TDS & 99 & 99 & 99 & 98 & 98 \\
TAN2 & COD & 15 & 20 & 25 & 32 & 38 \\
& BOD & 91 & 91 & 92 & 90 & 92 \\
& SS & -28 & -52 & -52 & -54 & -55 \\
& TDS & 97 & 99 & 99 & 99 & 99 \\
& COD & 33 & 44 & 22 & 11 & 26 \\
& BOD & 75 & 81 & 76 & 81 & 81 \\
& SS & 25 & 3 & -1 & -10 & -15 \\
& TDS & 98 & 98 & 98 & 98 & 98 \\
\hline
\end{tabular}

Percentage Reduction $=(B-A) / B \times 100 \%$

$A=$ Concentration of the parameter after treatment

$\mathrm{B}=$ Concentration of the parameter before treatment

$+=$ percentage decrease

- = percentage increase

In general, immobilization makes the enzyme more resistant to temperature, $\mathrm{pH}$, and substrate concentration swings giving it a longer lifetime and higher productivity per active unit (Gianfreda and Rao, 2004; FuIlbrook, 1996; Russell et al, 2003; Kandelbauer et al., 2004). Immobilized cells have been used and studied extensively for the production of useful chemicals (Ohtake and Silver, 1994), the treatment of wastewaters (Chen et al., 2003; Wang et al., 2010). Although many workers described microbial degradation of tannery effluent, limited literature is available on the bioremediation of tannery effluent using immobilized bacterial cells in the Kano Industrial Estates.

\section{CONCLUSION}

The samples contained variable levels of the physicochemical parameters. The results of the Analysis of variance revealed that, no statistical difference $(p<0.05)$ was observed for the temperature, $\mathrm{pH}, \mathrm{SS}, \mathrm{TDS}, \mathrm{BOD}$ and $\mathrm{COD}$ among the three tannery industries before the treatment. The levels of some of the parameters
(SS, TDS and COD) observed in the samples were found above the recommended limits of WHO and NESREA, which called for the treatment of the effluents before discharge into the environment. Base on the morphological and biochemical test results, TAN1, TAN2, and TAN3 bacterial isolates were identified to be Neisseria spp, Bacillus cereus, and Staphylococcus aureus respectively. The results of Post-treatment analysis showed that there is overall decrease in the levels of the parameters determined when compared with that of the pre-treatment. The overall percentage reduction of the immobilised bacteria in the treatment of the respective effluents was in the order TAN2 (72\%)>TAN1 $(70 \%)>$ TAN3 $(62 \%)$. Hence, the immobilized bacteria are having higher biodegradation potential for the treatment of the tannery effluents.

\section{Acknowledgments}

The authors wish to acknowledge the University of Maiduguri for the financial support. The authors are grateful to the Kano State Ministry of Environment for their support in obtaining the effluent samples. 


\section{REFERENCES}

Ajao, A. T., Adebayo, G. B., and Yakubu, S. E. (2011). Bioremediation of textile industrial effluent using mixed culture of Pseudomonas aeruginosa and Bacillus subtilis immobilized on agar-agar in a bioreactor. J. Microbiol. Biotech. Res, 1(3), 50-56.

Akan, J. C., Moses, E. A., Ogugbuaja, V. O., and Abah, J. (2007). Assessment of tannery industrial effluents from Kano metropolis, Kano State, Nigeria. Journal of Applied Sciences, 7(19), 2788-2793.

Akan, J. C., Ogugbuaja, V. O., Abdulrahman, F. I., and Ayodele, J. T. (2009). Pollutant levels in effluent samples from tanneries and textiles of Kano industrial areas, Nigeria. Global journal of pure and applied sciences, 15(3-4).

APHA (1989). Standard methods for Examination of Will bete and Will betewater.15 $5^{\text {th }}$ edition. Brydpass Springfield Will behington DC. pp. 164-176

APHA (1992). Standard Methods for the Examination of Water and Wastewater. Health, 69, 1116-9.

Baba, A., Garba, S. T., and Bello, H. S. (2020). Bioremediation Potential of Immobilized corynebacterium kutsceri in the Treatment of Tannery Industrial Effluent from Challawa Industrial Estate, Kano State, Nigeria. Journal of the Turkish Chemical Society Section A: Chemistry, $7(2), 335-350$.

Beem, E. I. V. (1994). reduction of solvent VOC emission. J. Oil Col. Chem. Ass, 77, 158.

Bouwer, E. J., and Zehnder, A. J. (1993). Bioremediation of organic compoundsputting microbial metabolism to work. Trends in biotechnology, 11(8), 360367.

Chen, K. C., Wu, J. Y., Liou, D. J., and Hwang, S. C. J. (2003). Decolorization of the textile dyes by newly isolated bacterial strains. Journal of Biotechnology, 101(1), 57-68.

Dan'Azumi, S., and Bichi, M. H. (2010). INDUSTRIAL POLLUTION AND HEAVY METALS PROFILE OF CHALLAWA RIVER IN KANO, NIGERIA. Journal of Applied Sciences in Environmental Sanitation, $5(1)$.

DWAF. (1992). Analytical Methods Manual, TR 151. Department of Water Affairs and Forestry, Pretoria.

El-Bestawy, E. (2013). Biological treatment of leather-tanning industrial wastewater using free living bacteria.
Elsheikh, M. A. S. (2009). Tannery wastewater pre-treatment. Water Science and Technology, 60(2), 433-440.

FuIlbrook, P. D. (1996). "Kinetics." Industrial enzymology: The application of enzymes in Industry. 2nd Ed. T. Godfrey and J Reichelt. eds.. Nature. New York.

Gianfreda, L., and Rao, M. A. (2004). Potential of extra cellular enzymes in remediation of polluted soils: a review. Enzyme and microbial technology, 35(4), 339354.

Hugo Springer. (1994). John Arthur Wilson Memorial Lecture "Treatment of Industrial Wastes of the Leather Industry - is it still a Major Problem". JALCA, 89, 153-185

Jimoh, A. A., Ganiyu, B. A., Baba, D., and Baba, A. (2018) Bioremediation Process of Effluent from Detergent and Food Industries in Jos, Nigeria: Kinetics and Thermodynamics. International Journal of Engineering Science Invention (IJESI), 762-73

Kandelbauer, A., Maute, O., Kessler, R. W., Erlacher, A., and Gübitz, G. M. (2004). Study of dye decolorization in an immobilized laccase enzyme-reactor using online spectroscopy. Biotechnology and bioengineering, 87(4), 552-563.

Kongjao, S., Damronglerd, S., and Hunsom, M. (2008). Simultaneous removal of organic and inorganic Pollutants in tannery wastewater using electrocoagulation technique. Korean Journal of chemical engineering, 25(4), 703.

Maheshwari, U. M., Aruna, S., Gomathi, M., and AbdulJaffar, A. H. (2017). Bioremediation by Free and Immobilized Bacteria Isolated from Tannery Effluent. International Journal of Research in Applied, Natural and Social Sciences. 5(7), 75-90

Margesin, R., and Schinner, F. (2001). Bioremediation (natural attenuation and biostimulation) of diesel-oilcontaminated soil in an alpine glacier skiing area. Applied and environmental microbiology, 677), 3127-3133.

Mohammed, A., Sekar, P., and George, J. (2011). Efficacy of microbes in bioremediation of tannery effluent. Inter. J. Curr. Res, 3(4), 324-326.

Mohammed, S. S. D., Orukotan, A. A., and Abdullahi, H. (2017). Physicochemical and Bacteriological Assessment of Tannery Effluent from Samaru-Zaria, 
BAJOPAS Volume 13 Number 2, December, 2020 Kaduna State, Nigeria. Journal of Applied

Sciences and Environmental Management, 21(4), 734-740.

Munz, G., De Angelis, D., Gori, R., Mori, G., Casarci, M., and Lubello, C. (2009). The role of tannins in conventional and membrane treatment of tannery wastewater. Journal of hazardous materials, 164(2-3), 733-739

Mythili, K., and Karthikeyan, B. (2011). Bioremediation of $\mathrm{Cr}$ (VI) from tannery effluent using Bacillus spp and Staphylococcus spp. International Multidisciplinary Research Journal, 1(6).

NESREA (2009). National Environmental Standards for Effluent Limitations and Regulation. 1233-1236

Noorjahan, C. M. (2014). Physicochemical characteristics, identification of bacteria and biodegradation of industrial effluent. Journal of bioremediation and Biodegradation, 5(3).

Ohtake, H. I., and Silver, A. O. (1994). Bacterial reduction of toxic chromate. Biological degradation and bioremediation of toxic chemicals, 403-415.

Omoleke, I. I. (2004). Management of environmental pollution in Ibadan, an African city: the challenges of health hazard facing government and the people. Journal of Human Ecology, 15(4), 265-275.

Rajor, A., Reddy, A.S., and Singh, B. (2004). Determination of BOD kinetic Parameters and evaluation of alternate methods, M.Sc. Thesis, Department of biotechnology \& environmental Science, Thapar Institute of Engineering and Technology, Patiala

Ramasami, T., Rajamani, S., and Rao, J. R. (1994, March). Pollution control in leather industry: Emerging technological options. In International symposium on surface and colloidal science and its relevance to soil pollution, madras.

Ramesh, J. V. S., and Singh, S. P. (1993). Yearly variation in certain physicochemical parameters of pond at eastern Doon Valley. Uttar Pradesh J. Zoo, 12 (1), 7577.

Ranen, S., and Sharadinadra, C. (2009). Biotechnology applications to environmental remediation in resource exploitation. Current science, 97, 6-25
Russell, A. J., Berberich, J. A., Drevon, G. F., and Koepsel, R. R. (2003). Biomaterials for mediation of

chemical and biological warfare agents. Annual review of biomedical engineering, 5(1), 1-27.

Saravanan, P., and Saravanan, A. (1999). Decolourization of tannery effluent by Flavobacterium sp. EK 1. Indian Journal of Environmental Protection, 19, 19-24.

Sikander, S., and Shahida, H. (2007). Reduction of toxic hexavalent chromium by Ochrobactrum intermedium strain SDCr5 stimulated by heavy metals. Bioresource Technol, 98, 340-344.

Singh, N., Sharma, B. K., and Bohra, P. C. (2000). Impact assessment of industrial effluent of arid soils by using satellite imageries. Journal of the Indian Society of Remote Sensing, 28(2-3), 79.

Sreemoyee, C., and Priti, P. (2013). Assessment of physico-chemical parameters of dairy waste water and isolation and characterization of bacterial strains in terms of cod reduction. Int J Sci, 2(3), 395-400.

Verheijen, L. A. H. M., Wiersema, D., Pol, L. H., and De Wit, J. (1996). Management of wastes from animal product processing. Livestock and environment, Finding a balance. International Agriculture Center, Wageningen, The Netherlands.

Wang, F., Yao, J., Si, Y., Chen, H., Russel, M., Chen, K., and Bramanti, E. (2010). Short-time effect of heavy metals upon microbial community activity. Journal of Hazardous Materials, 173(13), 510-516.

WHO (World Health Organization). (2006). Air quality guidelines: global update 2005: particulate matter, ozone, nitrogen dioxide, and sulfur dioxide. World Health Organization.

World Bank. (1995). Nigeria's strategic options for redressing industrial pollution. World Bank, industry and energy division. 1st edition, West Central Africa Department; Annexes: 1995; pp 60-62.

Zahoor, A., and Abdul, R. (2009). Enumeration of Coliforms. Journal of Environmental Sciences. 21, 814-820 


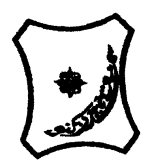

Bayero Journal of Pure and Applied Sciences, 13(2): 1 - 12

Received: November, 2020

Accepted: December, 2020

ISSN $2006-6996$

\title{
BIODEGRADATION POTENTIAL OF IMMOBILIZED BACTERIA IN THE TREATMENT OF TANNERY INDUSTRIAL EFFLUENTS FROM INDUSTRIAL ESTATES IN KANO STATE, NIGERIA
}

\author{
Abdullateef, B., ${ }^{1 *}$ Shuaibu, T. G., ${ }^{1}$ Babagana, K., ${ }^{1}$ Suleman, H. B. ${ }^{2}$ and Dauda, B. ${ }^{3}$ \\ ${ }^{1}$ Department of Pure and Applied Chemistry, Faculty of Science, University of Maiduguri, Borno State, \\ Nigeria \\ ${ }^{2}$ Department of Microbiology, Faculty of Science, University of Maiduguri, Borno State, Nigeria \\ ${ }^{3}$ Department of Chemical Engineering, Faculty of Engineering, University of Maiduguri, Borno State, \\ Nigeria \\ *Corresponding author: babslega@gmail.com; abelega2007@yahoo.com; +2348061309753
}

\section{ABSTRACT}

Industrial Effluents Samples from Gashash Tanneries (TAN1) in Bompai Industrial estate, Larabee Tannery Industry (TAN2) in Sharada Industrial estate and Z Tannery Industries (TAN3) in Challawa Industrial estate, Kano State, Nigeria were collected over a period of six months (August 2017 to January 2018) for assessing the biodegradation potentials of bacteria in the treatment of organic pollutants within the effluents. Bacteria were isolated from the effluents and immobilized on agar-agar. Different masses (5 g, $10 \mathrm{gr}, 15$ $\mathrm{g}, 20 \mathrm{~g}$, and $25 \mathrm{~g}$ ) of the bacteria were used in the treatment of $250 \mathrm{ml}$ of the effluents for ten days in a shaker incubator (Gallenkamp-OC-4364-L) at the temperature $30{ }^{\circ} \mathrm{C}$ and speed of $60 \mathrm{rpm}$. Pre-treatment analysis of the effluents for Temperature, pH, Biochemical Oxygen Demand (BOD), Chemical Oxygen Demand (COD), Suspended Solid (SS) and Total Dissolved Solids (TDS) gives the following results; temperature $\left({ }^{\circ} \mathrm{C}\right.$ )

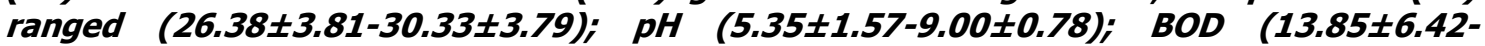
$38.75 \pm 16.20) ;$ COD (1406 $\pm 208-3532 \pm 1373) ;$ SS (208 $\pm 235-780 \pm 739)$ and TDS (266 $\pm 253-5276 \pm 2971)$. No statistical differences ( $p \leq 0.05)$ was observed for all the results among the different industries. The bacterial isolates were identified as Neisseria spp, Bacillus cereus, and Staphylococcus aureus, in TAN1, TAN2, and TAN3, respectively. After treatment of the effluent with the different masses of the isolated bacteria, the mean level of BOD was found to range as (0.55 $\pm 0.36-6.92 \pm 5.49) ; C O D$ (ND-3134 \pm 1595$)$;

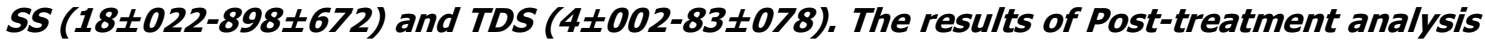
showed that there is overall decrease in the levels of the parameters determined when compared with that of the pre-treatment. The overall percentage reduction of the immobilised bacteria in the treatment of the respective effluents was in the order TAN2 (72\%)>TAN1 (70\%)>TAN3 (62\%). Hence, the immobilized bacteria are having higher biodegradation potential for the treatment of the tannery effluents.

Keywords: Biodegradation, bacteria, effluent, immobilization, tannery.

\section{INTRODUCTION}

Tannery industrial wastewater is a serious consequence of the pollution point of view for streams, freshwater, and land used for agriculture. The lack of awareness in the modern industrial practice has resulted in the discharge of tannery effluents which exhibit very high value of chromium ( $\mathrm{Cr}$ ), Sulfide, and chloride, Total Dissolved Solid (TDS), Total Suspended Solid (TSS), Biochemical Oxygen Demand (BOD) and Chemical Oxygen Demand (COD) in the water stream or land (Mohammed et al., 2001). Tanning is the process, which One ton of skin generally leads to the production of 20 to $80 \mathrm{~m}^{3}$ of turbid and foul-smelling converts the protein of the rawhide or skin into a stable material, which will not putrefy and is suitable for a wide variety of end applications (Elsheikh, 2009). The highly polluting chromium is the most commonly used tanning material producing leather that is more flexible and pliable than vegetable-tanned leather and does not discolor or lose shape in water as drastically as vegetable-tan (Elsheikh, 2009). Tannery effluent is among the most hazardous industrial pollutants due to its huge organic and inorganic load, which is highly toxic to human life and the environment (Kongjao et al., 2008). wastewater including chromium (100-400 mg/l), sulfide $(200-800 \mathrm{mg} / \mathrm{l})$, high levels of fat and 
BAJOPAS Volume 13 Number 2, December, 2020 other solid wastes, and notable pathogen contamination as well as pesticides added for skin conservation during transport (Elsheikh, 2009). There are more than 6000 tanneries in Nigeria with an annual processing capacity of 700,000 tons of hides and skins (Omoleke, 2004; Singh et al., 2008). It was reported that the total amount of waste produced per animal slaughtered is approximately $35 \%$ of its weight (World Bank, 1995). Also, for every $1000 \mathrm{~kg}$ of carcass weight, a slaughtered beef produces 5.5 $\mathrm{kg}$ of manure (excluding rumen contents or stockyard manure) and $100 \mathrm{~kg}$ of paunch manure (undigested food) (Verheijen et al., 1996). Tanneries generate wastewater in the range of 30-35 $\mathrm{L} \mathrm{kg}^{-1}$ skin/hide processed with variable $\mathrm{pH}$, Biological Oxygen Demand (BOD), Chemical Oxygen Demand (COD), high concentrations of suspended solids (SS), and tannins as well as chromium (Zahoor and Abdul, 2009).

Being heterogeneous and composed of a wide variety of compounds, it is very difficult to select a unique direct method for estimating the biodegradability of organic contents and biokinetic parameters for a wastewater sample (Rajor, 2004). For this purpose, some indirect estimation such as determination of biochemical oxygen demand (BOD) and chemical oxygen demand (COD) are applied as common laboratory investigations [9]. During retanning procedures, synthetic tannins (Syntan), oils and resins are added to form softer leather at varying doses (Munz et al., 2009). One of the refractory groups of chemicals in tannery effluents derives mainly from tannins (Ramasami et al., 2004). Syntans are characterized by complex chemical structures, because they are composed of an extended set of chemicals such as phenol-, naphthalene-, formaldehyde- and melamine-based syntans, and acrylic resins (Beem, 1994). Organic pollutants (proteic and lipidic components) are originated from skins (it is calculated that the raw skin has $30 \%$ loss of organic material during the working cycle) or they are introduced during processes (Hugo Springer, 1994).

Many conventional processes such as oxidation, chemical and biological processes were carried out to treat tanneries wastewater (Ebtesam et al, 2013). Biological processes have received more attention because of their costeffectiveness, lower sludge production and environmental friendliness (Noorjahan, 2014). Naturally occurring micro-organisms degrade the hazardous organic wastes including xenobiotic compounds, such as pesticides, polycyclic aromatic hydrocarbons (PAHs) and polychlorinated biphenyls (PCBs) in due course of time (Ranen and Sharadinadra, 2009). Bioremediation is based on the idea that all organisms remove substances from the environment to carry outgrowth and metabolism (Bouwer and Zehnder, 1993). Bacteria, protista and fungi are found to be very good at degrading complex molecules and incorporating the breakdown products into their metabolism (Bouwer and Zehnder, 1993). The resultant metabolic wastes that they produce are generally safe and somehow recycled into other organisms (Ranen and Sharadinadra, 2009). An acclimatized indigenous population of microorganisms capable of degradation of the compounds of interest must exist at the site for a successful bioremediation mode (Ranen and Sharadinadra, 2009). It has been observed that for a successful bioremediation mode, an acclimatized indigenous population of microorganisms capable of degradation of the compounds of interest must exist at the site under investigation (Ranen and Sharadinadra, 2009). Even though there are numerous physical and chemical methods employed in the disposal of wastes the advantage in using bacterium is that they play a key role in the reduction of COD, BOD, total protein, total tannin and total phenol (Saravanan and Saravanan, 1998)

Baba et al. (2020) studied the bioremediation potential of immobilized corynebacterium kutsceri in the Treatment of tannery industrial effluent from Challawa Industrial Estate, Kano State, Nigeria. The aim of the work is to study the reduction in the level of the contaminants through the process of bioremediation using the isolated bacteria. Immobilized bacteria can withstand various temperatures, $\mathrm{pH}$ and substrate concentrations; consequently, increasing the efficiency and the lifespan of the bacteria. Immobilized bacteria are widely applied in the treatment of wastewater and can be separated and recovered after the treatment with the same efficiency (Baba et al., 2020).

\section{MATERIALS AND METHODS \\ Study Area}

This study was carried out in Bompai, Sharada and Challawa industrial estates in Kano, Figure 1. Kano lies on Latitude $11^{\circ} 30^{\prime} \mathrm{N}$ and $8^{\circ} 30^{\prime} \mathrm{E}$ and Longitude $11^{\circ} 5^{\prime} \mathrm{N}$ and $8^{\circ} 5^{\prime} \mathrm{E}$ in Northern Nigeria. It is one of the developed industrial cities in Nigeria. Tannery activities are the dominating industries and this could be one of the reasons for her high population density (Dan'Azumi and Bichi, 2010). Many researchers have studied biodegradation of tannery effluent using microorganisms. However, limited literature is available on the biodegradation of tannery effluent in Kano industrial estates using 
BAJOPAS Volume 13 Number 2, December, 2020 immobilized bacterial cells. This research work focuses on the potential of the use of the indigenous immobilized bacterial isolates in the treatment of tannery effluents in the industrial estates.

\section{Sample Collection}

Effluents were collected from the Tannery Industries from Bompai, Challawa and Sharada Industrial Estates, Kano, Nigeria. The effluents were collected over a period of six months (August 2017 to January 2018). Samples collected in a sterile 4-liter plastic container with a unique identification number were preserved using an ice-box that was transported to the Microbiology Laboratory, Department of Microbiology, Bayero University of Kano for analysis

\section{Sample Preparation and Sample Analysis}

Immediately after the collection of the effluent, $\mathrm{pH}$, TSS, TDS, COD, BOD levels were determined before treatment (Pre-treatment determination) and ten days after treatment (Post-treatment determination) as described in
APHA (1989) standard methods. $\mathrm{pH}$ was determined using Ecotests $\mathrm{pH}$ meter and TDS was determined using AQUALYTIC TDS Salinometer. BOD was determined as described by the standard method (APHA, 1992). COD and SS were determined using DR/2010 HACH portable data logging spectrophotometer (DWAF, 1992)

\section{Identification and Biochemical} Characterization of the Bacterial Isolates

The bacteria were isolated from the effluents using Serial Dilution according to the method described by APHA (1989). The biochemical tests such as oxidase, catalase, coagulase, indole (from $1 \%$ tryptone broth), citrate (Simmons citrate agar), methyl red/VogesProskauer (MR/VP), nitrate reduction, Starch Hydrolysis, Glucose, Maltose, and Lactose tests were carried out on the bacterial isolates to identify the bacteria through the bacteria biochemical characteristics according to Ajao et al. (2011).

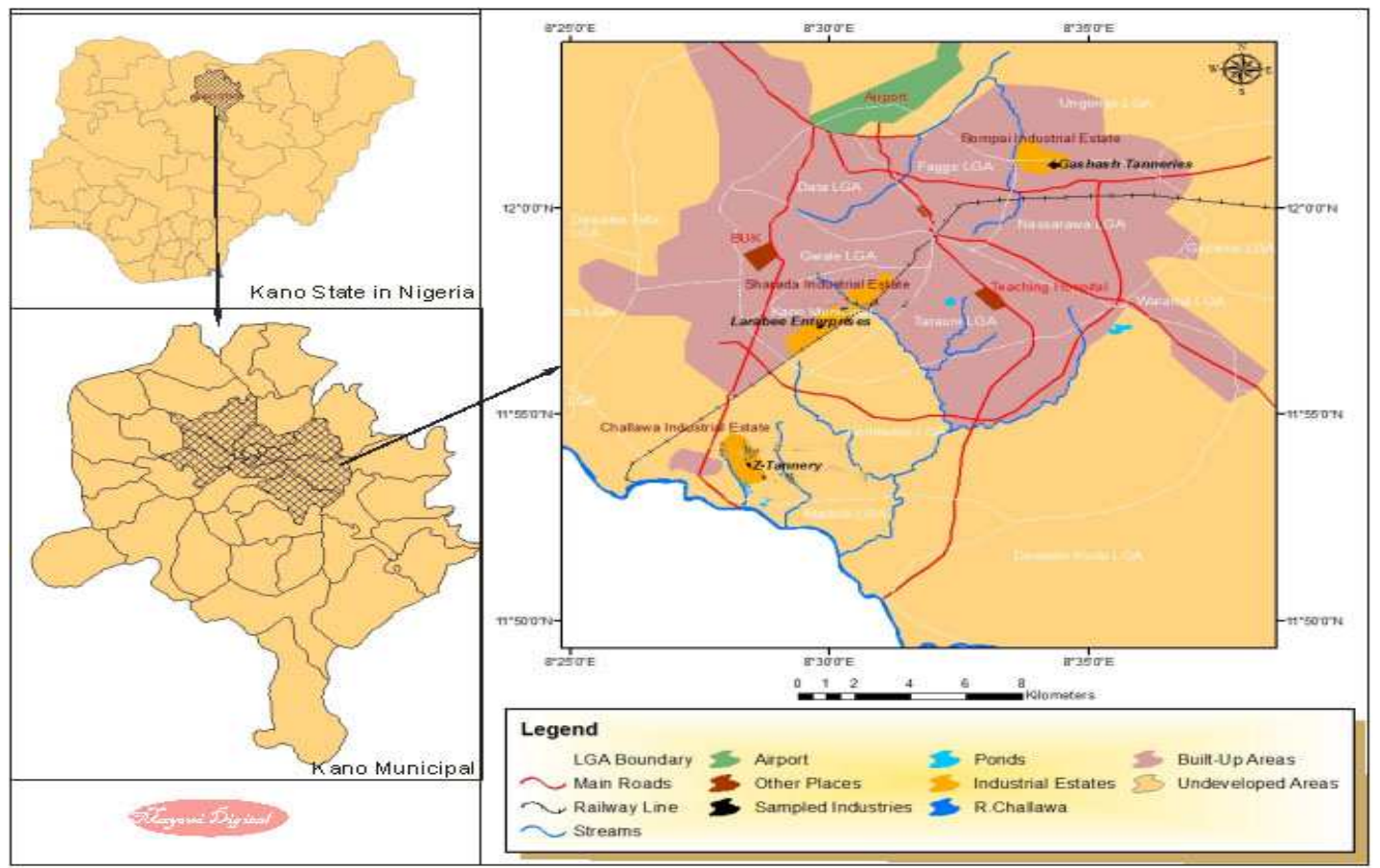

Fig. 1 Map showing the study areas

Source: Mayomi Digital Productions, GIS Laboratory, Department of Geography, UNIMAID (2017)

\section{Determination of Growth Rate of the Bacteria in Effluent Sample}

The bacteria growth rates were determined by transferring $2 \mathrm{~mL}$ of the bacterial isolates from the tannery effluent in broth medium into 100 $\mathrm{mL}$ sterile effluents in conical flasks and kept in an incubator (Giffrin cool) for 10 days. Control was also set up by incubating another $100 \mathrm{~mL}$ each of the sterile effluents without the bacteria. The optical density of the content was determined at the wavelength of $600 \mathrm{~nm}$ on a daily interval and recorded. 
BAJOPAS Volume 13 Number 2, December, 2020 Immobilization of Bacteria

Agar solution and inoculi were prepared separately. Fifty milliliters $(50 \mathrm{~mL})$ of nutrient broth each of the inoculi was prepared in a McCartney bottle and incubated for 24 hours. A solution of agar-agar was prepared by dissolving $10 \mathrm{~g}$ of the powder in distilled water and made up to $500 \mathrm{~mL}$ mark in an Erlenmeyer flask and was sterilized in an autoclave (280A) for 15 minutes and allowed to cool to $40-45^{\circ} \mathrm{C}$ (Ajao et al., 2011). Four milliliters ( $4 \mathrm{~mL})$ of the bacterial isolates in the nutrient broth was mixed with 36 $\mathrm{ml}$ of the prepared agar-agar media in petri-dish plates and then allowed to solidify. This was kept in the refrigerator for bioremediation.

\section{Bioremediation (Treatment) of the Effluents}

The solidified agar block (immobilized bacteria) was cut into cubes using a sterile knife; $0.1 \mathrm{~mL}$ phosphate buffer ( $\mathrm{pH} \mathrm{7.0)}$ was added and kept in the refrigerator for 1 hour for curing. The phosphate buffer was decanted after 1 hour and the cubes were washed with sterile distilled water 3-4 times before it was used (Ajao et al., 2011). Two liters (2 L) of the effluent was supplemented with the minimum basal medium in $\mathrm{g} / \mathrm{L}: \mathrm{NaCl}(0.8), \mathrm{MgSO}_{4} .7 \mathrm{H}_{2} \mathrm{O}(0.001), \mathrm{KH}_{2} \mathrm{PO}_{4}$ (2), $\mathrm{NaNO}_{3}$ (2), $\quad \mathrm{CaCl}_{2} .2 \mathrm{H}_{2} \mathrm{O} \quad(0.5)$ and $\mathrm{NaHPO}_{4} .12 \mathrm{H}_{2} \mathrm{O}(2)$ and sterilized in an autoclave at $121^{\circ} \mathrm{C}$ for 15 minutes (Margesin and Schinner, 2001). Two hundred and fifty milliliters $(250 \mathrm{~mL})$ of the effluents were transferred into different $250 \mathrm{ml}$ conical flasks. The content was covered with a cotton-wool ramped with foil paper to avoid contamination. Five grams $(5 \mathrm{~g})$ of the immobilized bacteria were quickly transferred into each of the effluents in the conical flasks in an inoculating chamber. The same procedures were carried out for the $10 \mathrm{~g}, 15 \mathrm{~g}, 20 \mathrm{~g}$ and 25 $\mathrm{g}$ of the immobilized bacteria in separate $250 \mathrm{~mL}$ effluents in conical flasks and agitated for ten days in a shaker incubator (Gallenkamp-OC4364-L) at a temperature $30^{\circ} \mathrm{C}$ and speed of 60 rpm. The treated effluent samples were taken on the tenth day and analyzed for the parameters $\mathrm{pH}$, SS, TDS, COD, and BOD, (Posttreatment determination) for the different grams of bacteria to evaluate and compare the biodegradation potential. (Baba et al., 2020).

\section{Statistical Analysis}

The data were represented as Mean \pm Standard deviation and analyzed statistically using oneway Analysis of Variance (ANOVA) and Tukey's HSD as Post Hoc Tests with the aid of SPSS 16.0. The correlation coefficient was also used to measure the strength of the relationship between the different masses of the bacteria and the parameters. All $\mathrm{p} \leq 0.05$ were considered as statistically significant.

\section{RESULTS AND DISCUSSION Physico-chemical parameters in the Industrial Effluents before the Biodegradation.}

Results of the Physico-chemical parameters in the industrial effluents before the Biodegradation is shown in table 1 . The mean temperatures $\left({ }^{\circ} \mathrm{C}\right)$ observed in TAN1, TAN2, and TAN3 samples were $28.07 \pm 0.65 ; 27.77 \pm 0.64$ and $26.38 \pm 3.81$ respectively. The order of the mean temperature of the samples from the three industries can be arranged as TAN1 > TAN2>TAN3. The temperature observed at TAN1, TAN2, and TAN3 samples were found below the WHO $\left(35^{\circ} \mathrm{C}\right)$ and NESREA $\left(40^{\circ} \mathrm{C}\right)$ limits. The low values of temperature might be due to the processes used at the time of sampling. High temperature brings down the solubility of gases in water that ultimately expresses as high BOD and COD. Statistical analysis shows that there is no significant difference $(p<0.05)$ between the mean values of temperature among the industries. This might be due to similar tannery activities involved in the tannery industries at the time of sampling. The average values of temperature observed in this present study are less than those observed by Akan et al. (2007), Akan et al. (2009) and Baba et al. (2020).

The mean level of $\mathrm{pH}$ observed in TAN1, TAN2 and TAN3, samples were $7.77 \pm 2.93$; $8.35 \pm 0.28$ and $7.52 \pm 0.76$ respectively. The order of the mean $\mathrm{pH}$ of the samples from the three industries can be arranged as TAN2> TAN1 $>$ TAN3. The $\mathrm{pH}$ of the samples falls within the WHO (7.0-8.5) and NESREA (6-9) standard limits. Statistical analysis shows that there is no significant difference $(p<0.05)$ between the mean values of $\mathrm{pH}$ among the industries. This might be due to similar tannery activities involved in the tannery industries at the time of sampling. Maheshwari et al. (2017) reported that the level of $\mathrm{pH}$ in the effluents from the tannery industry in Vaniyambadi, India was 6.5 which was lower than that observed in the present study. The $\mathrm{pH}$ in the effluents from the tannery industries in Kano and Kaduna were reported to be 7.64 and 6.89, respectively (Akan et al., 2007; Mohammed et al., 2017). The average values of $\mathrm{pH}$ observed in this present study are less than those observed by Mohammed et al. (2017) and Baba et al. (2020). The mean level of SS $(\mathrm{mg} / \mathrm{l})$ observed in TAN1, TAN2, and TAN3 samples were 374 \pm 124 ; $358 \pm 335$ and $780 \pm 739$ respectively. The order of the mean SS in the samples from the three industries can be arranged as TAN3 > TAN1 $>$ TAN2. 
The SS observed in the samples were far above the recommended standard limits of regulating bodies WHO $(30 \mathrm{mg} / \mathrm{l})$ and NESREA $(10 \mathrm{mg} / \mathrm{l})$. Statistical analysis shows that there is no significant difference $(p<0.05)$ between the mean values of SS among the industries. This might be due to similar tannery activities involved in the tannery industries at the time of sampling. The average values of SS observed in this present study are less than that observed $(3700 \pm 122 \mathrm{mg} / \mathrm{l})$ by Akan et al. (2009) for tanneries in Kano. Also, the average values of SS observed in this present study are less than that observed by Mohammed et al. (2017) and Baba et al. (2020) with the exception in TAN3.

The mean level of TDS (mg/l) observed in TAN1, TAN2, and TAN3 samples were $3941 \pm 3703$; $3300 \pm 1714$ and $2653 \pm 1240$ respectively. The order of the mean TDS in the samples from the three industries can be arranged as TAN1>TAN2>TAN3. The TDS observed in the samples were far above the recommended standard limits of WHO $(250 \mathrm{mg} / \mathrm{l})$ and NESREA $(500 \mathrm{mg} / \mathrm{l})$. Statistical analysis shows that there is no significant difference $(p<0.05)$ between the mean values of TDS among the industries. This might be due to similar tannery activities involved in the tannery industries at the time of sampling. TDS in the effluents from the tannery industries in Kano, Nigeria was reported to be $1281 \mathrm{mg} / \mathrm{l}$ (Akan et al., 2007). The average values of SS observed in this present study are less than those observed by Mohammed et al. (2017) and Baba et al. 2020)

The mean level of COD (mg/l) observed in TAN1, TAN2 and TAN3 samples seasons were $2372 \pm 938 ; \quad 1406 \pm 208$ and $3532 \pm 1373$ respectively. The order of the mean COD of the samples from the three industries can be arranged as TAN3>TAN1> TAN2. The COD observed in TAN1, TAN2 and TAN3 samples were far above the recommended standard limits of regulating bodies $\mathrm{WHO}(40 \mathrm{mg} / \mathrm{l})$ and NESREA (40 mg/l). Statistical analysis shows that there is no significant difference $(p<0.05)$ in COD among the industries. This might be due to similar tannery activities involved in the tannery industries as at the time of sampling. The Chemical Oxygen demand (COD) is the amount of oxygen, in $\mathrm{mg} / \mathrm{L}$, required for the degradation of the compound of wastewater to occur. In comparison, the average values of COD observed in this present study were higher than that observed by Mohammed et al. (2017) but lower than that observed by Baba et al. (2020).

The mean levels of BOD $(\mathrm{mg} / \mathrm{l})$ observed in TAN1, TAN2 and TAN3 samples were $13.85 \pm 6.42 ; \quad 19.46 \pm 0.50$ and $17.13 \pm 3.14$ respectively. The order of the mean BOD in the samples from the three industries can be arranged as TAN2>TAN3>TAN1. The BOD observed in TAN1, TAN2 and TAN3 samples were found below the recommended limits of NESREA (200 mg/l) but above WHO (10 mg/l). Statistical analysis shows that there is no significant difference $(p<0.05)$ between the mean values of BOD among the industries. This might be due to similar tannery activities involved in the tannery industries at the time of sampling. The low level of BOD recorded in this study is an indication of the low level of biodegradable organic solids in the effluent. The average values of BOD observed in this present study were lower than those observed by Mohammed et al. (2017) and Baba et al. (2020).

Table 1: Mean Values \pm S.D of Physico-chemical parameters of effluents from the Tannery Industries before Treatment.

\begin{tabular}{llllllll}
\hline Parameter & Tannery 1 & Tannery 2 & Tannery 3 & $\mathrm{a}$ & $\mathrm{b}$ & $\mathrm{c}$ & $\mathrm{d}$ \\
\cline { 2 - 7 } Temperature $\left({ }^{\circ} \mathrm{C}\right)$ & $28.07 \mathrm{a} \pm 0.65$ & $27.77 \mathrm{a} \pm 0.64$ & $26.38 \mathrm{a} \pm 3.81$ & & $29.50 \pm 4.68$ & 35 & 40 \\
pH & $7.77 \mathrm{a} \pm 2.93$ & $8.35 \mathrm{a} \pm 0.28$ & $7.52 \mathrm{a} \pm 0.76$ & 6.89 & $5.35 \pm 1.57$ & $7.0-8.5$ & $6.0-9.0$ \\
$\mathrm{COD}(\mathrm{mg} / \mathrm{l})$ & $2372 \mathrm{a} \pm 938$ & $1406 \mathrm{a} \pm 208$ & $3532 \mathrm{a} \pm 1373$ & 2.2 & $3106 \pm 2753$ & 40 & 40 \\
$\mathrm{BOD}(\mathrm{mg} / \mathrm{l})$ & $13.85 \mathrm{a} \pm 6.42$ & $19.46 \mathrm{a} \pm 0.50$ & $17.13 \mathrm{a} \pm 3.14$ & 1032 & $26.17 \pm 9.49$ & 10 & 200 \\
$\mathrm{SS}(\mathrm{mg} / \mathrm{l})$ & $374 \mathrm{a} \pm 124$ & $358 \mathrm{a} \pm 335$ & $780 \mathrm{a} \pm 739$ & 501 & $562 \pm 482$ & 30 & 10 \\
TDS $(\mathrm{mg} / \mathrm{l})$ & $3941 \mathrm{a} \pm 3703$ & $3300 \mathrm{a} \pm 1714$ & $2653 \mathrm{a} \pm 1240$ & 532.7 & $444 \pm 507$ & 250 & 500 \\
\hline
\end{tabular}

The values given in the table above are means of 6 replicate values, $\mathrm{n}=6$ ( 1 sample was taken monthly for 6 months). Within the rows, means with different alphabets are statistically different $(p<0.05)$. WHO: World Health Organisation. NESREA: National Environmental Standard and Regulatory Enforcement Agency. a = Mohammed et al.(2017), b = Baba et al. (2020), c = WHO (2006), $d=$ NESSRA (2009) 
BAJOPAS Volume 13 Number 2, December, 2020

Identification, Biochemical Characterization and growth rates of the Bacterial Isolates

Results of identification and biochemical characterization of the bacterial isolates were shown in table 2. After 24 hours of incubation, the nutrient agar media plates were checked for bacterial growth. The results showed the presence of different strains in the samples. The TAN1 bacteria isolate was found to be gramnegative cocci while TAN3 was gram-positive cocci. TAN2 bacteria isolate was found to be gram-positive, rod-shaped. TAN1, TAN2, and TAN3 bacteria isolates recorded positive results for spore former.

The results of the biochemical tests indicated that all the bacteria were positive for catalase, oxidase, citrate, maltose, glucose, lactose (negative in TAN1), mannitol (negative in TAN2), starch hydrolysis and coagulase (negative in TAN2) tests. The bacteria showed negative results for nitrate reduction, $M R$ (positive in TAN2), VP (positive in TAN1), Indole (positive in TAN2) tests. Base on the morphological and biochemical test results, TAN1, TAN2, and TAN3 bacteria isolates were identified to be Nesseria spp, Bacillus cereus, and Staphylococcus aureus respectively.

The growth rate of the TAN1, TAN2 and TAN3 Isolates were shown in figure 2. Generally, the optical density increase with the increase in time (day) and decrease as time goes on. The highest optical density was shown by bacillus cereus in TAN2 while the lowest was shown by Staphylococcus aureus in TAN3.

The initial growth phase of TAN1 Isolate bacteria occurred within 2-day of incubation as the growth rate increases up to the 6th-day incubation when the maximum growth was observed. Beyond the 6th day, the growth of the bacteria declined (which might be due to a shortage of nutrients in the effluents) until it reached its death phase (which might be due to the unavailability of nutrients in the effluents).

A similar trend of growth was also observed for TAN2 Isolate as the initial growth phase also occurred within 2-day of incubation but maximum growth rate observed on the 4th day of incubation. The stationary stage occurred between the 4th day and the 8th day. Beyond the 8th day, the growth of the bacteria declined (which might be due to a shortage of nutrients in the effluents) until it reached its death phase (which might be due to the unavailability of nutrients in the effluents).

The initial growth phase of TAN3 bacterial Isolate occurred within the 3-day incubation as the growth rate increases up to the 6th-day incubation when the maximum growth was observed. Beyond the 6th day, the growth of the bacteria declined (which might be due to a shortage of nutrients in the effluents) until it reached its death phase (which might be due to the unavailability of nutrients in the effluents).

Table 2: Morphological and Biochemical characteristics of bacterial isolates

\begin{tabular}{lllll} 
Bacterial Isolates & & TAN1 & TAN2 & TAN3 \\
\hline $\begin{array}{lllll}\text { Morphological } \\
\text { characteristics }\end{array}$ & Shape & Cocci & Rod & Cocci \\
& Spore & & & \\
& former & + & + & + \\
Gram & & & \\
Biochemical characteristics & reaction & - & + & + \\
& Citrate & + & + & + \\
& Catalase & + & + & + \\
& Coagulase & + & - & + \\
Starch & + & + & + \\
& Glucose & + & + & + \\
Oxidase & + & + & + \\
& Indo & - & + & - \\
Lactose & - & + & + \\
Manitol & + & - & + \\
Maltose & + & + & + \\
MR & - & + & - \\
VP & + & - & - \\
& Nitrate & - & - & - \\
Reduction & - Neisseria & Bacillus & Staphylococcus \\
& Bacterial & cereus & aureus \\
& name & spp & cas
\end{tabular}

+ = Positive; - = Negative; MR=Methyl Red; VP= Voges-Proskauer 


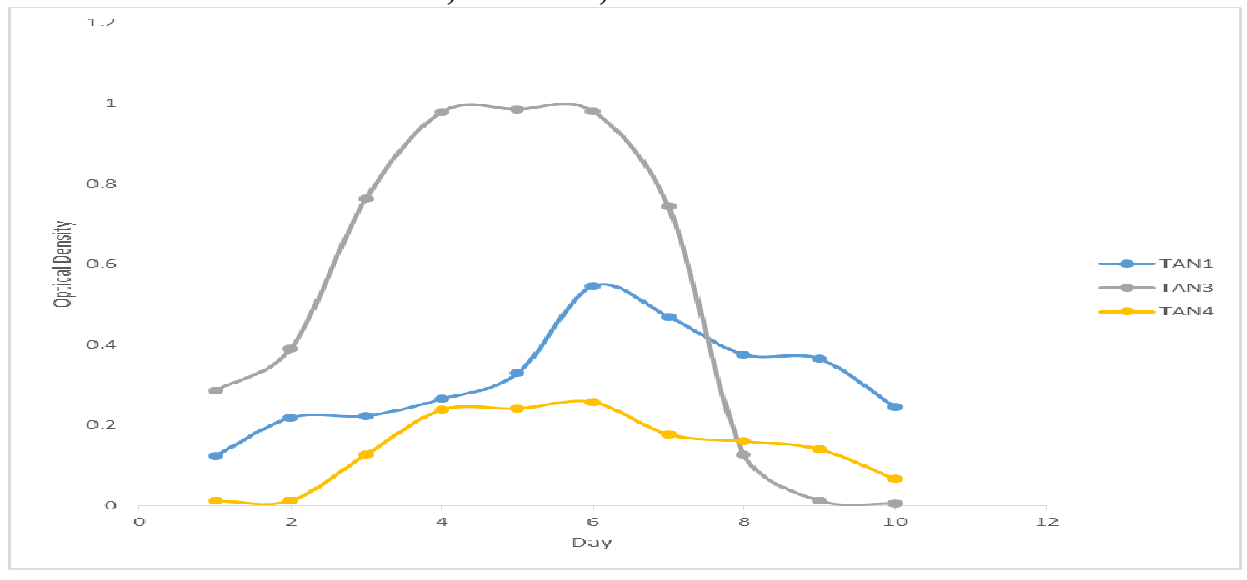

Fig. 2 Growth rates of the isolates in the effluents from the Tannery Industries

\section{Physico-chemical Parameters in the Industrial Effluents after the biodegradation.}

Table 3 shows the mean results of the physicochemical parameter before and after bioremediation using the different masses $(5 \mathrm{~g}$, $10 \mathrm{~g}, 15 \mathrm{~g}, 20 \mathrm{~g}$, and $25 \mathrm{~g}$ ) of the respective immobilized bacteria. Also, Table 4 shows the mean results of correlation coefficient ( $r$ ) between different masses of bacteria and physicochemical parameters.

The mean values $(\mathrm{mg} / \mathrm{l})$ of the SS after the bioremediation varies between $243 \pm 45$ and $898 \pm 672$. The mean concentration $(\mathrm{mg} / \mathrm{l})$ of SS remediated by the different masses $(5 \mathrm{~g}, 10 \mathrm{~g}$, $15 \mathrm{~g}, 20 \mathrm{~g}$, and $25 \mathrm{~g}$ ) of the bacteria varies. The SS in the samples fluctuates up and down after the bioremediation process when compared with the SS of the raw samples before the bioremediation. The increase in the levels of the SS might be due to the aggregation of the TDS which are large enough to result into SS. The increase in the levels of the SS might be also due to the influence of the nutrients which was added into the effluents in order to make the microorganisms more active and viable for fast degradation of organic contaminants in the effluent. The relative potential or efficiency of the different masses of the bacteria in remediating SS in TAN1 samples was in the order $25 \mathrm{~g}>20 \mathrm{~g}>15 \mathrm{~g}>10 \mathrm{~g}>5 \mathrm{~g}$. For TAN2 and TAN3 samples, the order was $25 \mathrm{~g}>20 \mathrm{~g}>15$ $\mathrm{g}>10 \mathrm{~g}>5 \mathrm{~g}$. These might be due to the variations in the surface areas of the different masses of the immobilized bacteria. Statistical analysis shows that there is no significant difference $(p<0.05)$ between the mean values of SS among the masses in the respective industries. Positive and significant correlations exist between the masses of bacteria and Suspended Solid (SS). This showed that there is general increase in the levels of the SS as the masses of the immobilized bacteria increases. TAN3 (90\%) and TAN1 (80\%) showed a very high correlation with the masses of the bacteria while TAN2 (61\%) showed a very low correlation.

The mean values $(\mathrm{mg} / \mathrm{l})$ of the TDS after the bioremediation varies between $46 \pm 11$ and $83 \pm 78$. The mean concentration $(\mathrm{mg} / \mathrm{l})$ of TDS remediated by the different masses $(5 \mathrm{~g}, 10 \mathrm{~g}$, $15 \mathrm{~g}, 20 \mathrm{~g}$, and $25 \mathrm{~g}$ ) of the bacteria varies. There is a reduction in all the TDS of all the samples after the bioremediation process compared with the TDS of the raw samples before the bioremediation. The relative potential or efficiency of the different masses of the bacteria in remediating TDS in TAN1 and TAN3 samples was in the order $5 \mathrm{~g}>10 \mathrm{~g}>15 \mathrm{~g}>20$ $\mathrm{g}>25 \mathrm{~g}$. For TAN2 samples, the order was 20 $g>10 \quad g>25 \quad g>15 \quad g>5 \quad g$. Statistical analysis shows that there is no significant difference $(p<0.05)$ between the mean values of TDS among the masses in the respective industries. These might be due to the variations in the surface areas of the different masses of the immobilized bacteria. Positive and significant correlations exist between the masses of bacteria and TDS with the exception in TAN2 (negative and insignificant correlation). The positive correlations showed that there is general increase in the levels of the TDS as the masses of the immobilized bacteria increases. TAN1 $(96 \%)$ showed a very high correlation with the masses of the bacteria while TAN2 (47\%) showed a very low correlation.

The mean values $(\mathrm{mg} / \mathrm{l})$ of the BOD after the bioremediation varies between $1.56 \pm 0.20 \mathrm{mg} / \mathrm{l}$ and $6.92 \pm 5.49 \mathrm{mg} / \mathrm{l}$. The mean concentration $(\mathrm{mg} / \mathrm{l})$ of BOD remediated by the different masses $(5 \mathrm{~g}, 10 \mathrm{~g}, 15 \mathrm{~g}, 20 \mathrm{~g}$, and $25 \mathrm{~g}$ ) of the bacteria varies. There is a reduction in all the BOD of all the samples after the bioremediation process compared with the $\mathrm{BOD}$ of the raw 
BAJOPAS Volume 13 Number 2, December, 2020 samples before the bioremediation. The relative potential or efficiency of the different masses of the bacteria in remediating BOD in TAN1, TAN2 and TAN3 samples were in the order $25 \mathrm{~g}>20$ $\mathrm{g}>15 \mathrm{~g}>10 \mathrm{~g}>5 \mathrm{~g}, 25 \mathrm{~g}>15 \mathrm{~g}>5 \mathrm{~g}>10 \mathrm{~g}>20 \mathrm{~g}$ and $20 \mathrm{~g}>10 \mathrm{~g}>25 \mathrm{~g}>15 \mathrm{~g}>5 \mathrm{~g}$ respectively. Statistical analysis shows that there is significant difference $(p<0.05)$ between the mean values of BOD among the masses in the respective industries. These might be due to the variations in the surface areas of the different masses of the immobilized bacteria. Negative and significant correlations exist between the masses of bacteria and BOD. This showed that there is general decrease in the levels of the BOD as the masses of the immobilized bacteria increases. TAN1 (94\%) showed a very high correlation with the masses of the bacteria while TAN2 (4\%) showed a very low correlation.

The mean values $(\mathrm{mg} / \mathrm{l})$ of the COD after the bioremediation varies between $250 \pm 154$ and $3134 \pm 1595$. The mean concentration $(\mathrm{mg} / \mathrm{l})$ of COD remediated by the different masses $(5 \mathrm{~g}$, $10 \mathrm{~g}, 15 \mathrm{~g} 20 \mathrm{~g}$, and $25 \mathrm{~g}$ ) of the bacteria varies. There is a reduction in all the COD of all the samples after the bioremediation process compared with the COD of the raw samples before the bioremediation. The relative potential or efficiency of the different masses of the bacteria in remediating COD in TAN1, TAN2 and TAN3 samples were in the order $25 \mathrm{~g}>20 \mathrm{~g}>15$ $\mathrm{g}>5 \mathrm{~g}>10 \mathrm{~g}, 25 \mathrm{~g}>20 \mathrm{~g}>15 \mathrm{~g}>10 \mathrm{~g}>5 \mathrm{~g}$ and 10 g>5 g>25 g>15 g>20 g respectively. Statistical analysis shows that there were significant difference $(p<0.05)$ between the mean values of COD among the masses in the respective industries except for effluents treated with $25 \mathrm{~g}$. These might be due to the variations in the surface areas of the different masses of the immobilized bacteria. Negative and insignificant correlations exist between the masses of bacteria and COD with the exception in TAN3 (positive and significant correlation). The negative correlations showed that there is general decrease in the levels of the COD as the masses of the immobilized bacteria increases. TAN2 (100\%) showed a very high correlation with the masses of the bacteria while TAN3 (36\%) showed a very low correlation.

Generally, there was an overall decrease in the concentration of these physicochemical parameters after the bioremediation using the different masses of the bacterial isolates. These might be due to the variations in the surface areas of the different masses of the immobilized bacteria. This is in line with the work of Jimoh et al. (2018) and Baba et al. (2020).

Table 3: Mean Values $(\mathrm{mg} / \mathrm{l}) \pm$ S.D of Physicochemical parameters in effluents from the Tannery Industries before and after Treatment of the effluents $(250 \mathrm{ml})$ with the different masses $(5 \mathrm{~g}, 10 \mathrm{~g}$, $15 \mathrm{~g}, 20 \mathrm{~g}$, and $25 \mathrm{~g}$ ) of the bacteria.

\begin{tabular}{llllllll}
\hline $\mathrm{P}$ & IND & Before & \multicolumn{5}{c}{ After } \\
\cline { 4 - 7 } & & & $5 \mathrm{~g}$ & $10 \mathrm{~g}$ & $15 \mathrm{~g}$ & $20 \mathrm{~g}$ & $25 \mathrm{~g}$ \\
\hline \multirow{2}{*}{ COD } & TAN1 & $2372 \pm 938$ & $1708 \mathrm{a} \pm 861$ & $2045 \mathrm{a} \pm 1205$ & $845 \mathrm{a} \pm 369$ & $300 \mathrm{a} \pm 167$ & $250 \mathrm{a} \pm 154$ \\
& TAN2 & $1406 \pm 208$ & $1195 \mathrm{a} \pm 208$ & $1125 \mathrm{a} \pm 384$ & $1055 \mathrm{a} \pm 317$ & $956 \mathrm{a} \pm 310$ & $870 \mathrm{ab} \pm 240$ \\
& TAN3 & $3532 \pm 1373$ & $2374 \mathrm{a} \pm 1344$ & $1976 \mathrm{a} \pm 1405$ & $2757 \mathrm{a} \pm 1266$ & $3134 \mathrm{a} \pm 1595$ & $2614 \mathrm{~b} \pm 1105$ \\
BOD & TAN1 & $13.85 \pm 6.42$ & $6.92 \mathrm{a} \pm 5.49$ & $6.42 \mathrm{a} \pm 5.07$ & $5.72 \mathrm{a} \pm 5.35$ & $4.62 \mathrm{a} \pm 4.37$ & $2.82 \mathrm{ab} \pm 1.26$ \\
& TAN2 & $19.46 \pm 0.50$ & $1.75 \mathrm{~b} \pm 0.22$ & $1.73 \mathrm{~b} \pm 0.18$ & $1.58 \mathrm{a} \pm 0.16$ & $1.91 \mathrm{a} \pm 0.22$ & $1.56 \mathrm{~b} \pm 0.20$ \\
& TAN3 & $17.13 \pm 3.14$ & $4.24 \mathrm{ab} \pm 0.77$ & $3.29 \mathrm{ab} \pm 0.37$ & $4.11 \mathrm{a} \pm 0.07$ & $3.23 \mathrm{a} \pm 0.91$ & $3.33 \mathrm{a} \pm 1.28$ \\
SS & TAN1 & $374 \pm 124$ & $243 \mathrm{a} \pm 45$ & $471 \mathrm{a} \pm 226$ & $475 \mathrm{a} \pm 182$ & $492 \mathrm{a} \pm 128$ & $611 \mathrm{a} \pm 217$ \\
& TAN2 & $358 \pm 335$ & $460 \mathrm{a} \pm 400$ & $543 \mathrm{a} \pm 414$ & $544 \mathrm{a} \pm 402$ & $551 \mathrm{a} \pm 414$ & $554 \mathrm{a} \pm 405$ \\
& TAN3 & $780 \pm 739$ & $586 \mathrm{a} \pm 594$ & $758 \mathrm{a} \pm 656$ & $787 \mathrm{a} \pm 676$ & $861 \mathrm{a} \pm 635$ & $898 \mathrm{a} \pm 672$ \\
TDS & TAN1 & $3941 \pm 3703$ & $51 \mathrm{a} \pm 10$ & $53 \mathrm{a} \pm 10$ & $55 \mathrm{a} \pm 15$ & $61 \mathrm{a} \pm 20$ & $63 \mathrm{a} \pm 26$ \\
& TAN2 & $3300 \pm 1714$ & $83 \mathrm{a} \pm 78$ & $47 \mathrm{a} \pm 20$ & $48 \mathrm{a} \pm 22$ & $47 \mathrm{a} \pm 17$ & $48 \mathrm{a} \pm 17$ \\
& TAN3 & $2653 \pm 1240$ & $46 \mathrm{a} \pm 11$ & $55 \mathrm{a} \pm 24$ & $55 \mathrm{a} \pm 25$ & $58 \mathrm{a} \pm 23$ & $61 \mathrm{a} \pm 28$ \\
\hline
\end{tabular}

Replicate $=6$ (months)

Within the rows, for the same parameter, means with different alphabets are statistically different $(p<0.05)$.

$\mathrm{P}=$ parameter, IND = Industries 
BAJOPAS Volume 13 Number 2, December, 2020

Table 4: Correlation coefficient $(r)$ between different masses of the bacteria and the physicochemical parameters.

\begin{tabular}{llll}
\hline Industries & Parameter & Correlation coefficient $(r)$ & $\begin{array}{l}\text { Percent dependence (rxrx100) } \\
(\%)\end{array}$ \\
\hline TAN1 & COD & -0.9 & 82 \\
& BOD & -0.97 & 94 \\
& SS & $0.90^{*}$ & 80 \\
TAN2 & TDS & $0.98^{*}$ & 96 \\
& COD & -1 & 100 \\
& BOD & -0.21 & 4 \\
& SS & $0.78^{*}$ & 61 \\
& TDS & -0.69 & 47 \\
& COD & $0.60^{*}$ & 36 \\
& BOD & -0.6 & 37 \\
& SS & $0.95^{*}$ & 90 \\
& TDS & $0.94^{*}$ & 89 \\
\hline
\end{tabular}

The correlation coefficient $(r)$ with * is statistically significant $(p<0.05)$.

Percentage reduction of the Parameters

Table 5 shows the percentage reduction of Parameters in industrial samples before and after the treatment of the effluents $(250 \mathrm{ml})$ with the different masses $(5 \mathrm{~g}, 10 \mathrm{~g}, 15 \mathrm{~g}, 20 \mathrm{~g}$, and $25 \mathrm{~g}$ ) of the Immobilized Bacteria.

In TAN1 samples, the percentage reduction (\%) of COD ranged (14-89); BOD (50-80); SS (-32$35)$ and TDS (98-99). In TAN2 samples, the percentage decrease $(\%)$ of COD ranged (15$38) ;$ BOD (90-92); SS [-28-(-55)] and TDS (9798). In TAN3 samples, the percentage decrease (\%) of COD ranged (11-44); BOD (76-81); SS (15-25) and TDS (98). The percentage increase in the levels COD, BOD and TDS might be due to the increase in the surface area of the different masses of the immobilized bacteria. However, the percentage decrease in the levels of the SS might be due to the aggregation of the TDS which are large enough to result into SS. The percentage decrease in the levels of the SS might be also due to the influence of the nutrients which was added into the effluents in order to make the microorganisms more active and viable for fast degradation of organic contaminants in the effluent. This is in line with the work of Jimoh et al. (2018) in which the concentration of the SS increase after the bioremediation of effluents.

Sreemoyee and Priti (2013) assessed and reduced several Physico-chemical parameters of dairy wastewater using Niesseria $s p$. and concluded that the species are well known to degrade organic compounds. This is in agreement with the current study in which the immobilized Niesseria $s p$ degrade the organic contaminants as indicated by the BOD, COD and TDS.

Jimoh et al. (2018) observed that TSS of the effluents was increased after treatment with immobilized bacteria and concluded that it might be due to the biostimulation method adopted for the research.

The optimum $\mathrm{pH}$ Biosorption of Chromium by Bacillus spp and Staphylococcus spp. from tannery effluent was investigated by Mythili and Karthikeyan (2011). The maximum adsorption of Chromium $(86.4 \mathrm{mg} / \mathrm{L})$ was showed by Bacillus spp and Staphylococcus spp showed $70.6 \mathrm{mg} / \mathrm{L}$ at an initial concentration of $100 \mathrm{mg} / \mathrm{L}$. In the present study, immobilised Bacillus spp and Staphylococcus spp. from the tannery industrial effluents reduced the levels of the organic pollutants with high potential as indicated by the percentage reduction of BOD, COD and TDS.

Enzymes often can work in multiple environments especially if they are immobilized. This makes the microorganisms' enzymes even more resistant to harsh environments and enables the enzymes to be recovered and recycled after they are no longer needed (Gianfreda and Rao 2004). Ramesh and Singh (1993) reported that the immobilized bacteria having more efficiency to remove the suspended particles than free cells. Using the immobilized cell is preferable due to its capability for using several times with the same efficiency, which makes it more economical. Similar work was done by Sikander et al. (2007) showing the higher reduction with permeabilized cells of Ochrobactrum intermedium strain SDCr-5. 
BAJOPAS Volume 13 Number 2, December, 2020

The results revealed the isolation and identification of isolates with the potential for the reduction of $\mathrm{Cr}$ (VI) to $\mathrm{Cr}$ (III). Results indicated that immobilized $B$. cereus could be efficiently used for the reduction of $\mathrm{Cr}$ (VI).

Table 5: Percentage reduction of the tested Parameters from the tannery industrial samples of the Immobilized Bacteria.

\begin{tabular}{lllllll}
\hline \multirow{2}{*}{ Industries } & & \multicolumn{5}{c}{ Percentage Reduction $(\%)$} \\
\cline { 3 - 7 } & & $5 \mathrm{~g}$ & $10 \mathrm{~g}$ & $15 \mathrm{~g}$ & $20 \mathrm{~g}$ & $25 \mathrm{~g}$ \\
\hline TAN1 & COD & 28 & 14 & 64 & 87 & 89 \\
& BOD & 50 & 54 & 59 & 67 & 80 \\
& SS & 35 & -26 & -27 & -32 & -63 \\
& TDS & 99 & 99 & 99 & 98 & 98 \\
TAN2 & COD & 15 & 20 & 25 & 32 & 38 \\
& BOD & 91 & 91 & 92 & 90 & 92 \\
& SS & -28 & -52 & -52 & -54 & -55 \\
& TDS & 97 & 99 & 99 & 99 & 99 \\
& COD & 33 & 44 & 22 & 11 & 26 \\
& BOD & 75 & 81 & 76 & 81 & 81 \\
& SS & 25 & 3 & -1 & -10 & -15 \\
& TDS & 98 & 98 & 98 & 98 & 98 \\
\hline
\end{tabular}

Percentage Reduction $=(B-A) / B \times 100 \%$

$A=$ Concentration of the parameter after treatment

$\mathrm{B}=$ Concentration of the parameter before treatment

$+=$ percentage decrease

- = percentage increase

In general, immobilization makes the enzyme more resistant to temperature, $\mathrm{pH}$, and substrate concentration swings giving it a longer lifetime and higher productivity per active unit (Gianfreda and Rao, 2004; FuIlbrook, 1996; Russell et al, 2003; Kandelbauer et al., 2004). Immobilized cells have been used and studied extensively for the production of useful chemicals (Ohtake and Silver, 1994), the treatment of wastewaters (Chen et al., 2003; Wang et al., 2010). Although many workers described microbial degradation of tannery effluent, limited literature is available on the bioremediation of tannery effluent using immobilized bacterial cells in the Kano Industrial Estates.

\section{CONCLUSION}

The samples contained variable levels of the physicochemical parameters. The results of the Analysis of variance revealed that, no statistical difference $(p<0.05)$ was observed for the temperature, $\mathrm{pH}, \mathrm{SS}, \mathrm{TDS}, \mathrm{BOD}$ and $\mathrm{COD}$ among the three tannery industries before the treatment. The levels of some of the parameters
(SS, TDS and COD) observed in the samples were found above the recommended limits of WHO and NESREA, which called for the treatment of the effluents before discharge into the environment. Base on the morphological and biochemical test results, TAN1, TAN2, and TAN3 bacterial isolates were identified to be Neisseria spp, Bacillus cereus, and Staphylococcus aureus respectively. The results of Post-treatment analysis showed that there is overall decrease in the levels of the parameters determined when compared with that of the pre-treatment. The overall percentage reduction of the immobilised bacteria in the treatment of the respective effluents was in the order TAN2 (72\%)>TAN1 $(70 \%)>$ TAN3 $(62 \%)$. Hence, the immobilized bacteria are having higher biodegradation potential for the treatment of the tannery effluents.

\section{Acknowledgments}

The authors wish to acknowledge the University of Maiduguri for the financial support. The authors are grateful to the Kano State Ministry of Environment for their support in obtaining the effluent samples. 


\section{REFERENCES}

Ajao, A. T., Adebayo, G. B., and Yakubu, S. E. (2011). Bioremediation of textile industrial effluent using mixed culture of Pseudomonas aeruginosa and Bacillus subtilis immobilized on agar-agar in a bioreactor. J. Microbiol. Biotech. Res, 1(3), 50-56.

Akan, J. C., Moses, E. A., Ogugbuaja, V. O., and Abah, J. (2007). Assessment of tannery industrial effluents from Kano metropolis, Kano State, Nigeria. Journal of Applied Sciences, 7(19), 2788-2793.

Akan, J. C., Ogugbuaja, V. O., Abdulrahman, F. I., and Ayodele, J. T. (2009). Pollutant levels in effluent samples from tanneries and textiles of Kano industrial areas, Nigeria. Global journal of pure and applied sciences, 15(3-4).

APHA (1989). Standard methods for Examination of Will bete and Will betewater.15 $5^{\text {th }}$ edition. Brydpass Springfield Will behington DC. pp. 164-176

APHA (1992). Standard Methods for the Examination of Water and Wastewater. Health, 69, 1116-9.

Baba, A., Garba, S. T., and Bello, H. S. (2020). Bioremediation Potential of Immobilized corynebacterium kutsceri in the Treatment of Tannery Industrial Effluent from Challawa Industrial Estate, Kano State, Nigeria. Journal of the Turkish Chemical Society Section A: Chemistry, $7(2), 335-350$.

Beem, E. I. V. (1994). reduction of solvent VOC emission. J. Oil Col. Chem. Ass, 77, 158.

Bouwer, E. J., and Zehnder, A. J. (1993). Bioremediation of organic compoundsputting microbial metabolism to work. Trends in biotechnology, 11(8), 360367.

Chen, K. C., Wu, J. Y., Liou, D. J., and Hwang, S. C. J. (2003). Decolorization of the textile dyes by newly isolated bacterial strains. Journal of Biotechnology, 101(1), 57-68.

Dan'Azumi, S., and Bichi, M. H. (2010). INDUSTRIAL POLLUTION AND HEAVY METALS PROFILE OF CHALLAWA RIVER IN KANO, NIGERIA. Journal of Applied Sciences in Environmental Sanitation, $5(1)$.

DWAF. (1992). Analytical Methods Manual, TR 151. Department of Water Affairs and Forestry, Pretoria.

El-Bestawy, E. (2013). Biological treatment of leather-tanning industrial wastewater using free living bacteria.
Elsheikh, M. A. S. (2009). Tannery wastewater pre-treatment. Water Science and Technology, 60(2), 433-440.

FuIlbrook, P. D. (1996). "Kinetics." Industrial enzymology: The application of enzymes in Industry. 2nd Ed. T. Godfrey and J Reichelt. eds.. Nature. New York.

Gianfreda, L., and Rao, M. A. (2004). Potential of extra cellular enzymes in remediation of polluted soils: a review. Enzyme and microbial technology, 35(4), 339354.

Hugo Springer. (1994). John Arthur Wilson Memorial Lecture "Treatment of Industrial Wastes of the Leather Industry - is it still a Major Problem". JALCA, 89, 153-185

Jimoh, A. A., Ganiyu, B. A., Baba, D., and Baba, A. (2018) Bioremediation Process of Effluent from Detergent and Food Industries in Jos, Nigeria: Kinetics and Thermodynamics. International Journal of Engineering Science Invention (IJESI), 762-73

Kandelbauer, A., Maute, O., Kessler, R. W., Erlacher, A., and Gübitz, G. M. (2004). Study of dye decolorization in an immobilized laccase enzyme-reactor using online spectroscopy. Biotechnology and bioengineering, 87(4), 552-563.

Kongjao, S., Damronglerd, S., and Hunsom, M. (2008). Simultaneous removal of organic and inorganic Pollutants in tannery wastewater using electrocoagulation technique. Korean Journal of chemical engineering, 25(4), 703.

Maheshwari, U. M., Aruna, S., Gomathi, M., and AbdulJaffar, A. H. (2017). Bioremediation by Free and Immobilized Bacteria Isolated from Tannery Effluent. International Journal of Research in Applied, Natural and Social Sciences. 5(7), 75-90

Margesin, R., and Schinner, F. (2001). Bioremediation (natural attenuation and biostimulation) of diesel-oilcontaminated soil in an alpine glacier skiing area. Applied and environmental microbiology, 677), 3127-3133.

Mohammed, A., Sekar, P., and George, J. (2011). Efficacy of microbes in bioremediation of tannery effluent. Inter. J. Curr. Res, 3(4), 324-326.

Mohammed, S. S. D., Orukotan, A. A., and Abdullahi, H. (2017). Physicochemical and Bacteriological Assessment of Tannery Effluent from Samaru-Zaria, 
BAJOPAS Volume 13 Number 2, December, 2020 Kaduna State, Nigeria. Journal of Applied

Sciences and Environmental Management, 21(4), 734-740.

Munz, G., De Angelis, D., Gori, R., Mori, G., Casarci, M., and Lubello, C. (2009). The role of tannins in conventional and membrane treatment of tannery wastewater. Journal of hazardous materials, 164(2-3), 733-739

Mythili, K., and Karthikeyan, B. (2011). Bioremediation of $\mathrm{Cr}$ (VI) from tannery effluent using Bacillus spp and Staphylococcus spp. International Multidisciplinary Research Journal, 1(6).

NESREA (2009). National Environmental Standards for Effluent Limitations and Regulation. 1233-1236

Noorjahan, C. M. (2014). Physicochemical characteristics, identification of bacteria and biodegradation of industrial effluent. Journal of bioremediation and Biodegradation, 5(3).

Ohtake, H. I., and Silver, A. O. (1994). Bacterial reduction of toxic chromate. Biological degradation and bioremediation of toxic chemicals, 403-415.

Omoleke, I. I. (2004). Management of environmental pollution in Ibadan, an African city: the challenges of health hazard facing government and the people. Journal of Human Ecology, 15(4), 265-275.

Rajor, A., Reddy, A.S., and Singh, B. (2004). Determination of BOD kinetic Parameters and evaluation of alternate methods, M.Sc. Thesis, Department of biotechnology \& environmental Science, Thapar Institute of Engineering and Technology, Patiala

Ramasami, T., Rajamani, S., and Rao, J. R. (1994, March). Pollution control in leather industry: Emerging technological options. In International symposium on surface and colloidal science and its relevance to soil pollution, madras.

Ramesh, J. V. S., and Singh, S. P. (1993). Yearly variation in certain physicochemical parameters of pond at eastern Doon Valley. Uttar Pradesh J. Zoo, 12 (1), 7577.

Ranen, S., and Sharadinadra, C. (2009). Biotechnology applications to environmental remediation in resource exploitation. Current science, 97, 6-25
Russell, A. J., Berberich, J. A., Drevon, G. F., and Koepsel, R. R. (2003). Biomaterials for mediation of

chemical and biological warfare agents. Annual review of biomedical engineering, 5(1), 1-27.

Saravanan, P., and Saravanan, A. (1999). Decolourization of tannery effluent by Flavobacterium sp. EK 1. Indian Journal of Environmental Protection, 19, 19-24.

Sikander, S., and Shahida, H. (2007). Reduction of toxic hexavalent chromium by Ochrobactrum intermedium strain SDCr5 stimulated by heavy metals. Bioresource Technol, 98, 340-344.

Singh, N., Sharma, B. K., and Bohra, P. C. (2000). Impact assessment of industrial effluent of arid soils by using satellite imageries. Journal of the Indian Society of Remote Sensing, 28(2-3), 79.

Sreemoyee, C., and Priti, P. (2013). Assessment of physico-chemical parameters of dairy waste water and isolation and characterization of bacterial strains in terms of cod reduction. Int J Sci, 2(3), 395-400.

Verheijen, L. A. H. M., Wiersema, D., Pol, L. H., and De Wit, J. (1996). Management of wastes from animal product processing. Livestock and environment, Finding a balance. International Agriculture Center, Wageningen, The Netherlands.

Wang, F., Yao, J., Si, Y., Chen, H., Russel, M., Chen, K., and Bramanti, E. (2010). Short-time effect of heavy metals upon microbial community activity. Journal of Hazardous Materials, 173(13), 510-516.

WHO (World Health Organization). (2006). Air quality guidelines: global update 2005: particulate matter, ozone, nitrogen dioxide, and sulfur dioxide. World Health Organization.

World Bank. (1995). Nigeria's strategic options for redressing industrial pollution. World Bank, industry and energy division. 1st edition, West Central Africa Department; Annexes: 1995; pp 60-62.

Zahoor, A., and Abdul, R. (2009). Enumeration of Coliforms. Journal of Environmental Sciences. 21, 814-820 


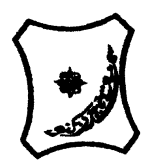

Bayero Journal of Pure and Applied Sciences, 13(2): 1 - 12

Received: November, 2020

Accepted: December, 2020

ISSN $2006-6996$

\title{
BIODEGRADATION POTENTIAL OF IMMOBILIZED BACTERIA IN THE TREATMENT OF TANNERY INDUSTRIAL EFFLUENTS FROM INDUSTRIAL ESTATES IN KANO STATE, NIGERIA
}

\author{
Abdullateef, B., ${ }^{1 *}$ Shuaibu, T. G., ${ }^{1}$ Babagana, K., ${ }^{1}$ Suleman, H. B. ${ }^{2}$ and Dauda, B. ${ }^{3}$ \\ ${ }^{1}$ Department of Pure and Applied Chemistry, Faculty of Science, University of Maiduguri, Borno State, \\ Nigeria \\ ${ }^{2}$ Department of Microbiology, Faculty of Science, University of Maiduguri, Borno State, Nigeria \\ ${ }^{3}$ Department of Chemical Engineering, Faculty of Engineering, University of Maiduguri, Borno State, \\ Nigeria \\ *Corresponding author: babslega@gmail.com; abelega2007@yahoo.com; +2348061309753
}

\section{ABSTRACT}

Industrial Effluents Samples from Gashash Tanneries (TAN1) in Bompai Industrial estate, Larabee Tannery Industry (TAN2) in Sharada Industrial estate and Z Tannery Industries (TAN3) in Challawa Industrial estate, Kano State, Nigeria were collected over a period of six months (August 2017 to January 2018) for assessing the biodegradation potentials of bacteria in the treatment of organic pollutants within the effluents. Bacteria were isolated from the effluents and immobilized on agar-agar. Different masses (5 g, $10 \mathrm{gr}, 15$ $\mathrm{g}, 20 \mathrm{~g}$, and $25 \mathrm{~g}$ ) of the bacteria were used in the treatment of $250 \mathrm{ml}$ of the effluents for ten days in a shaker incubator (Gallenkamp-OC-4364-L) at the temperature $30{ }^{\circ} \mathrm{C}$ and speed of $60 \mathrm{rpm}$. Pre-treatment analysis of the effluents for Temperature, pH, Biochemical Oxygen Demand (BOD), Chemical Oxygen Demand (COD), Suspended Solid (SS) and Total Dissolved Solids (TDS) gives the following results; temperature $\left({ }^{\circ} \mathrm{C}\right.$ )

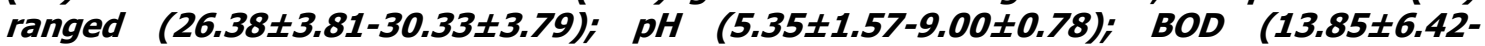
$38.75 \pm 16.20) ;$ COD (1406 $\pm 208-3532 \pm 1373) ;$ SS (208 $\pm 235-780 \pm 739)$ and TDS (266 $\pm 253-5276 \pm 2971)$. No statistical differences ( $p \leq 0.05)$ was observed for all the results among the different industries. The bacterial isolates were identified as Neisseria spp, Bacillus cereus, and Staphylococcus aureus, in TAN1, TAN2, and TAN3, respectively. After treatment of the effluent with the different masses of the isolated bacteria, the mean level of BOD was found to range as (0.55 $\pm 0.36-6.92 \pm 5.49) ; C O D$ (ND-3134 \pm 1595$)$;

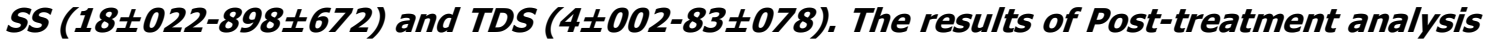
showed that there is overall decrease in the levels of the parameters determined when compared with that of the pre-treatment. The overall percentage reduction of the immobilised bacteria in the treatment of the respective effluents was in the order TAN2 (72\%)>TAN1 (70\%)>TAN3 (62\%). Hence, the immobilized bacteria are having higher biodegradation potential for the treatment of the tannery effluents.

Keywords: Biodegradation, bacteria, effluent, immobilization, tannery.

\section{INTRODUCTION}

Tannery industrial wastewater is a serious consequence of the pollution point of view for streams, freshwater, and land used for agriculture. The lack of awareness in the modern industrial practice has resulted in the discharge of tannery effluents which exhibit very high value of chromium ( $\mathrm{Cr}$ ), Sulfide, and chloride, Total Dissolved Solid (TDS), Total Suspended Solid (TSS), Biochemical Oxygen Demand (BOD) and Chemical Oxygen Demand (COD) in the water stream or land (Mohammed et al., 2001). Tanning is the process, which One ton of skin generally leads to the production of 20 to $80 \mathrm{~m}^{3}$ of turbid and foul-smelling converts the protein of the rawhide or skin into a stable material, which will not putrefy and is suitable for a wide variety of end applications (Elsheikh, 2009). The highly polluting chromium is the most commonly used tanning material producing leather that is more flexible and pliable than vegetable-tanned leather and does not discolor or lose shape in water as drastically as vegetable-tan (Elsheikh, 2009). Tannery effluent is among the most hazardous industrial pollutants due to its huge organic and inorganic load, which is highly toxic to human life and the environment (Kongjao et al., 2008). wastewater including chromium (100-400 mg/l), sulfide $(200-800 \mathrm{mg} / \mathrm{l})$, high levels of fat and 
BAJOPAS Volume 13 Number 2, December, 2020 other solid wastes, and notable pathogen contamination as well as pesticides added for skin conservation during transport (Elsheikh, 2009). There are more than 6000 tanneries in Nigeria with an annual processing capacity of 700,000 tons of hides and skins (Omoleke, 2004; Singh et al., 2008). It was reported that the total amount of waste produced per animal slaughtered is approximately $35 \%$ of its weight (World Bank, 1995). Also, for every $1000 \mathrm{~kg}$ of carcass weight, a slaughtered beef produces 5.5 $\mathrm{kg}$ of manure (excluding rumen contents or stockyard manure) and $100 \mathrm{~kg}$ of paunch manure (undigested food) (Verheijen et al., 1996). Tanneries generate wastewater in the range of 30-35 $\mathrm{L} \mathrm{kg}^{-1}$ skin/hide processed with variable $\mathrm{pH}$, Biological Oxygen Demand (BOD), Chemical Oxygen Demand (COD), high concentrations of suspended solids (SS), and tannins as well as chromium (Zahoor and Abdul, 2009).

Being heterogeneous and composed of a wide variety of compounds, it is very difficult to select a unique direct method for estimating the biodegradability of organic contents and biokinetic parameters for a wastewater sample (Rajor, 2004). For this purpose, some indirect estimation such as determination of biochemical oxygen demand (BOD) and chemical oxygen demand (COD) are applied as common laboratory investigations [9]. During retanning procedures, synthetic tannins (Syntan), oils and resins are added to form softer leather at varying doses (Munz et al., 2009). One of the refractory groups of chemicals in tannery effluents derives mainly from tannins (Ramasami et al., 2004). Syntans are characterized by complex chemical structures, because they are composed of an extended set of chemicals such as phenol-, naphthalene-, formaldehyde- and melamine-based syntans, and acrylic resins (Beem, 1994). Organic pollutants (proteic and lipidic components) are originated from skins (it is calculated that the raw skin has $30 \%$ loss of organic material during the working cycle) or they are introduced during processes (Hugo Springer, 1994).

Many conventional processes such as oxidation, chemical and biological processes were carried out to treat tanneries wastewater (Ebtesam et al, 2013). Biological processes have received more attention because of their costeffectiveness, lower sludge production and environmental friendliness (Noorjahan, 2014). Naturally occurring micro-organisms degrade the hazardous organic wastes including xenobiotic compounds, such as pesticides, polycyclic aromatic hydrocarbons (PAHs) and polychlorinated biphenyls (PCBs) in due course of time (Ranen and Sharadinadra, 2009). Bioremediation is based on the idea that all organisms remove substances from the environment to carry outgrowth and metabolism (Bouwer and Zehnder, 1993). Bacteria, protista and fungi are found to be very good at degrading complex molecules and incorporating the breakdown products into their metabolism (Bouwer and Zehnder, 1993). The resultant metabolic wastes that they produce are generally safe and somehow recycled into other organisms (Ranen and Sharadinadra, 2009). An acclimatized indigenous population of microorganisms capable of degradation of the compounds of interest must exist at the site for a successful bioremediation mode (Ranen and Sharadinadra, 2009). It has been observed that for a successful bioremediation mode, an acclimatized indigenous population of microorganisms capable of degradation of the compounds of interest must exist at the site under investigation (Ranen and Sharadinadra, 2009). Even though there are numerous physical and chemical methods employed in the disposal of wastes the advantage in using bacterium is that they play a key role in the reduction of COD, BOD, total protein, total tannin and total phenol (Saravanan and Saravanan, 1998)

Baba et al. (2020) studied the bioremediation potential of immobilized corynebacterium kutsceri in the Treatment of tannery industrial effluent from Challawa Industrial Estate, Kano State, Nigeria. The aim of the work is to study the reduction in the level of the contaminants through the process of bioremediation using the isolated bacteria. Immobilized bacteria can withstand various temperatures, $\mathrm{pH}$ and substrate concentrations; consequently, increasing the efficiency and the lifespan of the bacteria. Immobilized bacteria are widely applied in the treatment of wastewater and can be separated and recovered after the treatment with the same efficiency (Baba et al., 2020).

\section{MATERIALS AND METHODS \\ Study Area}

This study was carried out in Bompai, Sharada and Challawa industrial estates in Kano, Figure 1. Kano lies on Latitude $11^{\circ} 30^{\prime} \mathrm{N}$ and $8^{\circ} 30^{\prime} \mathrm{E}$ and Longitude $11^{\circ} 5^{\prime} \mathrm{N}$ and $8^{\circ} 5^{\prime} \mathrm{E}$ in Northern Nigeria. It is one of the developed industrial cities in Nigeria. Tannery activities are the dominating industries and this could be one of the reasons for her high population density (Dan'Azumi and Bichi, 2010). Many researchers have studied biodegradation of tannery effluent using microorganisms. However, limited literature is available on the biodegradation of tannery effluent in Kano industrial estates using 
BAJOPAS Volume 13 Number 2, December, 2020 immobilized bacterial cells. This research work focuses on the potential of the use of the indigenous immobilized bacterial isolates in the treatment of tannery effluents in the industrial estates.

\section{Sample Collection}

Effluents were collected from the Tannery Industries from Bompai, Challawa and Sharada Industrial Estates, Kano, Nigeria. The effluents were collected over a period of six months (August 2017 to January 2018). Samples collected in a sterile 4-liter plastic container with a unique identification number were preserved using an ice-box that was transported to the Microbiology Laboratory, Department of Microbiology, Bayero University of Kano for analysis

\section{Sample Preparation and Sample Analysis}

Immediately after the collection of the effluent, $\mathrm{pH}$, TSS, TDS, COD, BOD levels were determined before treatment (Pre-treatment determination) and ten days after treatment (Post-treatment determination) as described in
APHA (1989) standard methods. $\mathrm{pH}$ was determined using Ecotests $\mathrm{pH}$ meter and TDS was determined using AQUALYTIC TDS Salinometer. BOD was determined as described by the standard method (APHA, 1992). COD and SS were determined using DR/2010 HACH portable data logging spectrophotometer (DWAF, 1992)

\section{Identification and Biochemical} Characterization of the Bacterial Isolates

The bacteria were isolated from the effluents using Serial Dilution according to the method described by APHA (1989). The biochemical tests such as oxidase, catalase, coagulase, indole (from $1 \%$ tryptone broth), citrate (Simmons citrate agar), methyl red/VogesProskauer (MR/VP), nitrate reduction, Starch Hydrolysis, Glucose, Maltose, and Lactose tests were carried out on the bacterial isolates to identify the bacteria through the bacteria biochemical characteristics according to Ajao et al. (2011).

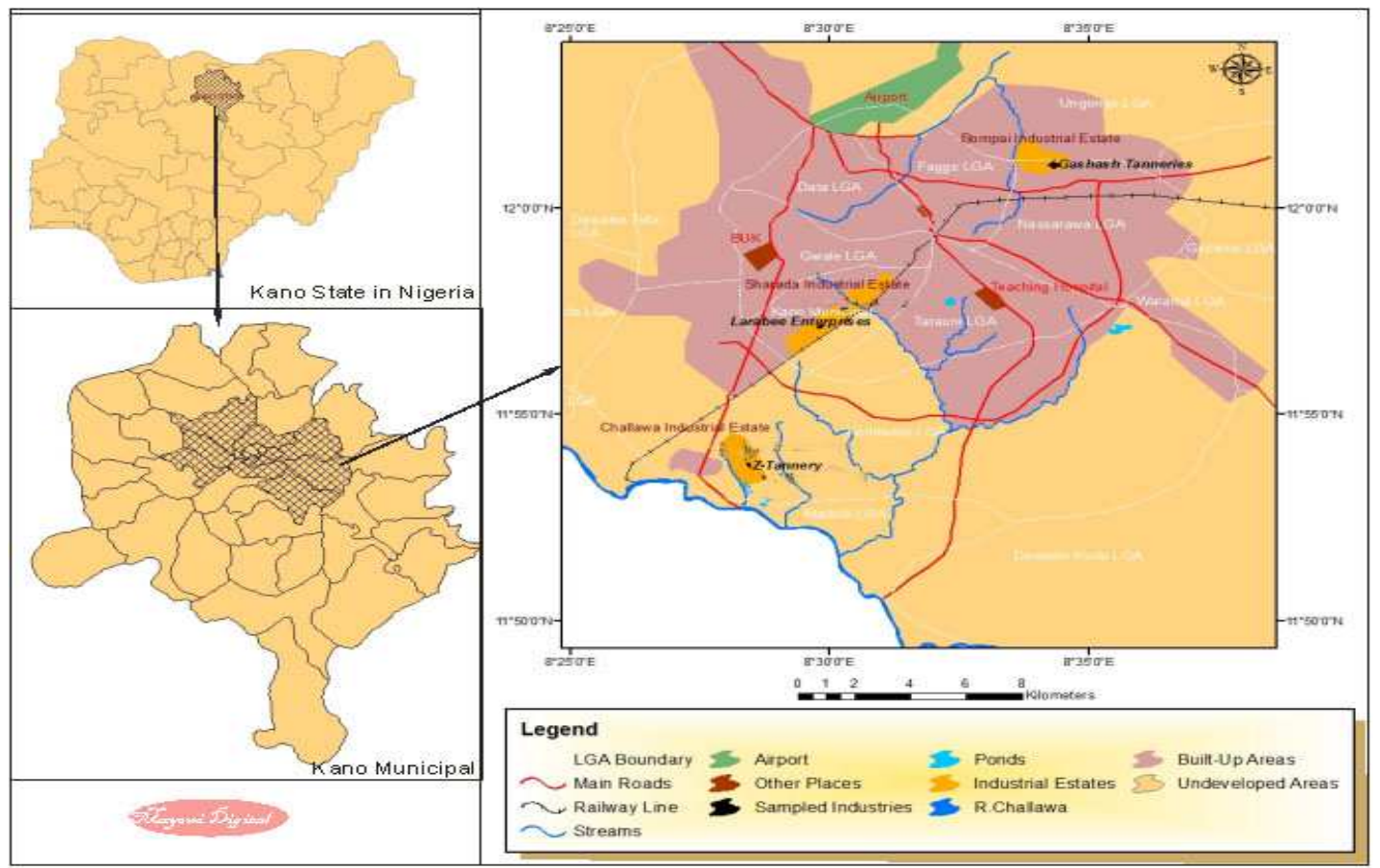

Fig. 1 Map showing the study areas

Source: Mayomi Digital Productions, GIS Laboratory, Department of Geography, UNIMAID (2017)

\section{Determination of Growth Rate of the Bacteria in Effluent Sample}

The bacteria growth rates were determined by transferring $2 \mathrm{~mL}$ of the bacterial isolates from the tannery effluent in broth medium into 100 $\mathrm{mL}$ sterile effluents in conical flasks and kept in an incubator (Giffrin cool) for 10 days. Control was also set up by incubating another $100 \mathrm{~mL}$ each of the sterile effluents without the bacteria. The optical density of the content was determined at the wavelength of $600 \mathrm{~nm}$ on a daily interval and recorded. 
BAJOPAS Volume 13 Number 2, December, 2020 Immobilization of Bacteria

Agar solution and inoculi were prepared separately. Fifty milliliters $(50 \mathrm{~mL})$ of nutrient broth each of the inoculi was prepared in a McCartney bottle and incubated for 24 hours. A solution of agar-agar was prepared by dissolving $10 \mathrm{~g}$ of the powder in distilled water and made up to $500 \mathrm{~mL}$ mark in an Erlenmeyer flask and was sterilized in an autoclave (280A) for 15 minutes and allowed to cool to $40-45^{\circ} \mathrm{C}$ (Ajao et al., 2011). Four milliliters ( $4 \mathrm{~mL})$ of the bacterial isolates in the nutrient broth was mixed with 36 $\mathrm{ml}$ of the prepared agar-agar media in petri-dish plates and then allowed to solidify. This was kept in the refrigerator for bioremediation.

\section{Bioremediation (Treatment) of the Effluents}

The solidified agar block (immobilized bacteria) was cut into cubes using a sterile knife; $0.1 \mathrm{~mL}$ phosphate buffer ( $\mathrm{pH} \mathrm{7.0)}$ was added and kept in the refrigerator for 1 hour for curing. The phosphate buffer was decanted after 1 hour and the cubes were washed with sterile distilled water 3-4 times before it was used (Ajao et al., 2011). Two liters (2 L) of the effluent was supplemented with the minimum basal medium in $\mathrm{g} / \mathrm{L}: \mathrm{NaCl}(0.8), \mathrm{MgSO}_{4} .7 \mathrm{H}_{2} \mathrm{O}(0.001), \mathrm{KH}_{2} \mathrm{PO}_{4}$ (2), $\mathrm{NaNO}_{3}$ (2), $\quad \mathrm{CaCl}_{2} .2 \mathrm{H}_{2} \mathrm{O} \quad(0.5)$ and $\mathrm{NaHPO}_{4} .12 \mathrm{H}_{2} \mathrm{O}(2)$ and sterilized in an autoclave at $121^{\circ} \mathrm{C}$ for 15 minutes (Margesin and Schinner, 2001). Two hundred and fifty milliliters $(250 \mathrm{~mL})$ of the effluents were transferred into different $250 \mathrm{ml}$ conical flasks. The content was covered with a cotton-wool ramped with foil paper to avoid contamination. Five grams $(5 \mathrm{~g})$ of the immobilized bacteria were quickly transferred into each of the effluents in the conical flasks in an inoculating chamber. The same procedures were carried out for the $10 \mathrm{~g}, 15 \mathrm{~g}, 20 \mathrm{~g}$ and 25 $\mathrm{g}$ of the immobilized bacteria in separate $250 \mathrm{~mL}$ effluents in conical flasks and agitated for ten days in a shaker incubator (Gallenkamp-OC4364-L) at a temperature $30^{\circ} \mathrm{C}$ and speed of 60 rpm. The treated effluent samples were taken on the tenth day and analyzed for the parameters $\mathrm{pH}$, SS, TDS, COD, and BOD, (Posttreatment determination) for the different grams of bacteria to evaluate and compare the biodegradation potential. (Baba et al., 2020).

\section{Statistical Analysis}

The data were represented as Mean \pm Standard deviation and analyzed statistically using oneway Analysis of Variance (ANOVA) and Tukey's HSD as Post Hoc Tests with the aid of SPSS 16.0. The correlation coefficient was also used to measure the strength of the relationship between the different masses of the bacteria and the parameters. All $\mathrm{p} \leq 0.05$ were considered as statistically significant.

\section{RESULTS AND DISCUSSION Physico-chemical parameters in the Industrial Effluents before the Biodegradation.}

Results of the Physico-chemical parameters in the industrial effluents before the Biodegradation is shown in table 1 . The mean temperatures $\left({ }^{\circ} \mathrm{C}\right)$ observed in TAN1, TAN2, and TAN3 samples were $28.07 \pm 0.65 ; 27.77 \pm 0.64$ and $26.38 \pm 3.81$ respectively. The order of the mean temperature of the samples from the three industries can be arranged as TAN1 > TAN2>TAN3. The temperature observed at TAN1, TAN2, and TAN3 samples were found below the WHO $\left(35^{\circ} \mathrm{C}\right)$ and NESREA $\left(40^{\circ} \mathrm{C}\right)$ limits. The low values of temperature might be due to the processes used at the time of sampling. High temperature brings down the solubility of gases in water that ultimately expresses as high BOD and COD. Statistical analysis shows that there is no significant difference $(p<0.05)$ between the mean values of temperature among the industries. This might be due to similar tannery activities involved in the tannery industries at the time of sampling. The average values of temperature observed in this present study are less than those observed by Akan et al. (2007), Akan et al. (2009) and Baba et al. (2020).

The mean level of $\mathrm{pH}$ observed in TAN1, TAN2 and TAN3, samples were $7.77 \pm 2.93$; $8.35 \pm 0.28$ and $7.52 \pm 0.76$ respectively. The order of the mean $\mathrm{pH}$ of the samples from the three industries can be arranged as TAN2> TAN1 $>$ TAN3. The $\mathrm{pH}$ of the samples falls within the WHO (7.0-8.5) and NESREA (6-9) standard limits. Statistical analysis shows that there is no significant difference $(p<0.05)$ between the mean values of $\mathrm{pH}$ among the industries. This might be due to similar tannery activities involved in the tannery industries at the time of sampling. Maheshwari et al. (2017) reported that the level of $\mathrm{pH}$ in the effluents from the tannery industry in Vaniyambadi, India was 6.5 which was lower than that observed in the present study. The $\mathrm{pH}$ in the effluents from the tannery industries in Kano and Kaduna were reported to be 7.64 and 6.89, respectively (Akan et al., 2007; Mohammed et al., 2017). The average values of $\mathrm{pH}$ observed in this present study are less than those observed by Mohammed et al. (2017) and Baba et al. (2020). The mean level of SS $(\mathrm{mg} / \mathrm{l})$ observed in TAN1, TAN2, and TAN3 samples were 374 \pm 124 ; $358 \pm 335$ and $780 \pm 739$ respectively. The order of the mean SS in the samples from the three industries can be arranged as TAN3 > TAN1 $>$ TAN2. 
The SS observed in the samples were far above the recommended standard limits of regulating bodies WHO $(30 \mathrm{mg} / \mathrm{l})$ and NESREA $(10 \mathrm{mg} / \mathrm{l})$. Statistical analysis shows that there is no significant difference $(p<0.05)$ between the mean values of SS among the industries. This might be due to similar tannery activities involved in the tannery industries at the time of sampling. The average values of SS observed in this present study are less than that observed $(3700 \pm 122 \mathrm{mg} / \mathrm{l})$ by Akan et al. (2009) for tanneries in Kano. Also, the average values of SS observed in this present study are less than that observed by Mohammed et al. (2017) and Baba et al. (2020) with the exception in TAN3.

The mean level of TDS (mg/l) observed in TAN1, TAN2, and TAN3 samples were $3941 \pm 3703$; $3300 \pm 1714$ and $2653 \pm 1240$ respectively. The order of the mean TDS in the samples from the three industries can be arranged as TAN1>TAN2>TAN3. The TDS observed in the samples were far above the recommended standard limits of WHO $(250 \mathrm{mg} / \mathrm{l})$ and NESREA $(500 \mathrm{mg} / \mathrm{l})$. Statistical analysis shows that there is no significant difference $(p<0.05)$ between the mean values of TDS among the industries. This might be due to similar tannery activities involved in the tannery industries at the time of sampling. TDS in the effluents from the tannery industries in Kano, Nigeria was reported to be $1281 \mathrm{mg} / \mathrm{l}$ (Akan et al., 2007). The average values of SS observed in this present study are less than those observed by Mohammed et al. (2017) and Baba et al. 2020)

The mean level of COD (mg/l) observed in TAN1, TAN2 and TAN3 samples seasons were $2372 \pm 938 ; \quad 1406 \pm 208$ and $3532 \pm 1373$ respectively. The order of the mean COD of the samples from the three industries can be arranged as TAN3>TAN1> TAN2. The COD observed in TAN1, TAN2 and TAN3 samples were far above the recommended standard limits of regulating bodies $\mathrm{WHO}(40 \mathrm{mg} / \mathrm{l})$ and NESREA (40 mg/l). Statistical analysis shows that there is no significant difference $(p<0.05)$ in COD among the industries. This might be due to similar tannery activities involved in the tannery industries as at the time of sampling. The Chemical Oxygen demand (COD) is the amount of oxygen, in $\mathrm{mg} / \mathrm{L}$, required for the degradation of the compound of wastewater to occur. In comparison, the average values of COD observed in this present study were higher than that observed by Mohammed et al. (2017) but lower than that observed by Baba et al. (2020).

The mean levels of BOD $(\mathrm{mg} / \mathrm{l})$ observed in TAN1, TAN2 and TAN3 samples were $13.85 \pm 6.42 ; \quad 19.46 \pm 0.50$ and $17.13 \pm 3.14$ respectively. The order of the mean BOD in the samples from the three industries can be arranged as TAN2>TAN3>TAN1. The BOD observed in TAN1, TAN2 and TAN3 samples were found below the recommended limits of NESREA (200 mg/l) but above WHO (10 mg/l). Statistical analysis shows that there is no significant difference $(p<0.05)$ between the mean values of BOD among the industries. This might be due to similar tannery activities involved in the tannery industries at the time of sampling. The low level of BOD recorded in this study is an indication of the low level of biodegradable organic solids in the effluent. The average values of BOD observed in this present study were lower than those observed by Mohammed et al. (2017) and Baba et al. (2020).

Table 1: Mean Values \pm S.D of Physico-chemical parameters of effluents from the Tannery Industries before Treatment.

\begin{tabular}{llllllll}
\hline Parameter & Tannery 1 & Tannery 2 & Tannery 3 & $\mathrm{a}$ & $\mathrm{b}$ & $\mathrm{c}$ & $\mathrm{d}$ \\
\cline { 2 - 7 } Temperature $\left({ }^{\circ} \mathrm{C}\right)$ & $28.07 \mathrm{a} \pm 0.65$ & $27.77 \mathrm{a} \pm 0.64$ & $26.38 \mathrm{a} \pm 3.81$ & & $29.50 \pm 4.68$ & 35 & 40 \\
pH & $7.77 \mathrm{a} \pm 2.93$ & $8.35 \mathrm{a} \pm 0.28$ & $7.52 \mathrm{a} \pm 0.76$ & 6.89 & $5.35 \pm 1.57$ & $7.0-8.5$ & $6.0-9.0$ \\
$\mathrm{COD}(\mathrm{mg} / \mathrm{l})$ & $2372 \mathrm{a} \pm 938$ & $1406 \mathrm{a} \pm 208$ & $3532 \mathrm{a} \pm 1373$ & 2.2 & $3106 \pm 2753$ & 40 & 40 \\
$\mathrm{BOD}(\mathrm{mg} / \mathrm{l})$ & $13.85 \mathrm{a} \pm 6.42$ & $19.46 \mathrm{a} \pm 0.50$ & $17.13 \mathrm{a} \pm 3.14$ & 1032 & $26.17 \pm 9.49$ & 10 & 200 \\
$\mathrm{SS}(\mathrm{mg} / \mathrm{l})$ & $374 \mathrm{a} \pm 124$ & $358 \mathrm{a} \pm 335$ & $780 \mathrm{a} \pm 739$ & 501 & $562 \pm 482$ & 30 & 10 \\
TDS $(\mathrm{mg} / \mathrm{l})$ & $3941 \mathrm{a} \pm 3703$ & $3300 \mathrm{a} \pm 1714$ & $2653 \mathrm{a} \pm 1240$ & 532.7 & $444 \pm 507$ & 250 & 500 \\
\hline
\end{tabular}

The values given in the table above are means of 6 replicate values, $\mathrm{n}=6$ ( 1 sample was taken monthly for 6 months). Within the rows, means with different alphabets are statistically different $(p<0.05)$. WHO: World Health Organisation. NESREA: National Environmental Standard and Regulatory Enforcement Agency. a = Mohammed et al.(2017), b = Baba et al. (2020), c = WHO (2006), $d=$ NESSRA (2009) 
BAJOPAS Volume 13 Number 2, December, 2020

Identification, Biochemical Characterization and growth rates of the Bacterial Isolates

Results of identification and biochemical characterization of the bacterial isolates were shown in table 2. After 24 hours of incubation, the nutrient agar media plates were checked for bacterial growth. The results showed the presence of different strains in the samples. The TAN1 bacteria isolate was found to be gramnegative cocci while TAN3 was gram-positive cocci. TAN2 bacteria isolate was found to be gram-positive, rod-shaped. TAN1, TAN2, and TAN3 bacteria isolates recorded positive results for spore former.

The results of the biochemical tests indicated that all the bacteria were positive for catalase, oxidase, citrate, maltose, glucose, lactose (negative in TAN1), mannitol (negative in TAN2), starch hydrolysis and coagulase (negative in TAN2) tests. The bacteria showed negative results for nitrate reduction, $M R$ (positive in TAN2), VP (positive in TAN1), Indole (positive in TAN2) tests. Base on the morphological and biochemical test results, TAN1, TAN2, and TAN3 bacteria isolates were identified to be Nesseria spp, Bacillus cereus, and Staphylococcus aureus respectively.

The growth rate of the TAN1, TAN2 and TAN3 Isolates were shown in figure 2. Generally, the optical density increase with the increase in time (day) and decrease as time goes on. The highest optical density was shown by bacillus cereus in TAN2 while the lowest was shown by Staphylococcus aureus in TAN3.

The initial growth phase of TAN1 Isolate bacteria occurred within 2-day of incubation as the growth rate increases up to the 6th-day incubation when the maximum growth was observed. Beyond the 6th day, the growth of the bacteria declined (which might be due to a shortage of nutrients in the effluents) until it reached its death phase (which might be due to the unavailability of nutrients in the effluents).

A similar trend of growth was also observed for TAN2 Isolate as the initial growth phase also occurred within 2-day of incubation but maximum growth rate observed on the 4th day of incubation. The stationary stage occurred between the 4th day and the 8th day. Beyond the 8th day, the growth of the bacteria declined (which might be due to a shortage of nutrients in the effluents) until it reached its death phase (which might be due to the unavailability of nutrients in the effluents).

The initial growth phase of TAN3 bacterial Isolate occurred within the 3-day incubation as the growth rate increases up to the 6th-day incubation when the maximum growth was observed. Beyond the 6th day, the growth of the bacteria declined (which might be due to a shortage of nutrients in the effluents) until it reached its death phase (which might be due to the unavailability of nutrients in the effluents).

Table 2: Morphological and Biochemical characteristics of bacterial isolates

\begin{tabular}{lllll} 
Bacterial Isolates & & TAN1 & TAN2 & TAN3 \\
\hline $\begin{array}{lllll}\text { Morphological } \\
\text { characteristics }\end{array}$ & Shape & Cocci & Rod & Cocci \\
& Spore & & & \\
& former & + & + & + \\
Gram & & & \\
Biochemical characteristics & reaction & - & + & + \\
& Citrate & + & + & + \\
& Catalase & + & + & + \\
& Coagulase & + & - & + \\
Starch & + & + & + \\
& Glucose & + & + & + \\
Oxidase & + & + & + \\
& Indo & - & + & - \\
Lactose & - & + & + \\
Manitol & + & - & + \\
Maltose & + & + & + \\
MR & - & + & - \\
VP & + & - & - \\
& Nitrate & - & - & - \\
Reduction & - Neisseria & Bacillus & Staphylococcus \\
& Bacterial & cereus & aureus \\
& name & spp & cas
\end{tabular}

+ = Positive; - = Negative; MR=Methyl Red; VP= Voges-Proskauer 


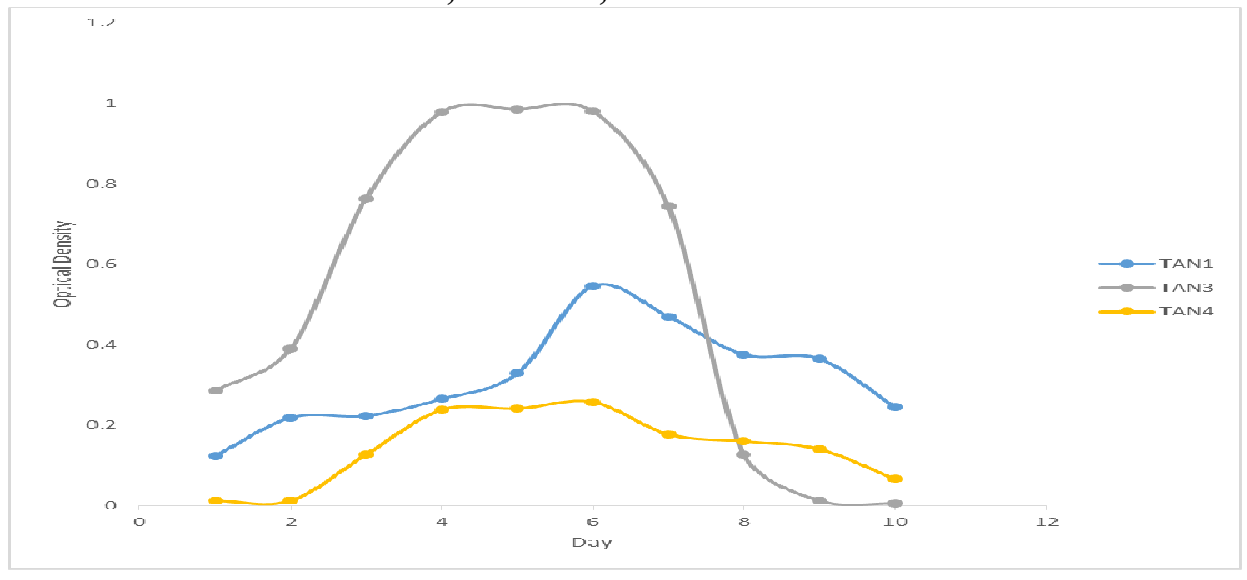

Fig. 2 Growth rates of the isolates in the effluents from the Tannery Industries

\section{Physico-chemical Parameters in the Industrial Effluents after the biodegradation.}

Table 3 shows the mean results of the physicochemical parameter before and after bioremediation using the different masses $(5 \mathrm{~g}$, $10 \mathrm{~g}, 15 \mathrm{~g}, 20 \mathrm{~g}$, and $25 \mathrm{~g}$ ) of the respective immobilized bacteria. Also, Table 4 shows the mean results of correlation coefficient ( $r$ ) between different masses of bacteria and physicochemical parameters.

The mean values $(\mathrm{mg} / \mathrm{l})$ of the SS after the bioremediation varies between $243 \pm 45$ and $898 \pm 672$. The mean concentration $(\mathrm{mg} / \mathrm{l})$ of SS remediated by the different masses $(5 \mathrm{~g}, 10 \mathrm{~g}$, $15 \mathrm{~g}, 20 \mathrm{~g}$, and $25 \mathrm{~g}$ ) of the bacteria varies. The SS in the samples fluctuates up and down after the bioremediation process when compared with the SS of the raw samples before the bioremediation. The increase in the levels of the SS might be due to the aggregation of the TDS which are large enough to result into SS. The increase in the levels of the SS might be also due to the influence of the nutrients which was added into the effluents in order to make the microorganisms more active and viable for fast degradation of organic contaminants in the effluent. The relative potential or efficiency of the different masses of the bacteria in remediating SS in TAN1 samples was in the order $25 \mathrm{~g}>20 \mathrm{~g}>15 \mathrm{~g}>10 \mathrm{~g}>5 \mathrm{~g}$. For TAN2 and TAN3 samples, the order was $25 \mathrm{~g}>20 \mathrm{~g}>15$ $\mathrm{g}>10 \mathrm{~g}>5 \mathrm{~g}$. These might be due to the variations in the surface areas of the different masses of the immobilized bacteria. Statistical analysis shows that there is no significant difference $(p<0.05)$ between the mean values of SS among the masses in the respective industries. Positive and significant correlations exist between the masses of bacteria and Suspended Solid (SS). This showed that there is general increase in the levels of the SS as the masses of the immobilized bacteria increases. TAN3 (90\%) and TAN1 (80\%) showed a very high correlation with the masses of the bacteria while TAN2 (61\%) showed a very low correlation.

The mean values $(\mathrm{mg} / \mathrm{l})$ of the TDS after the bioremediation varies between $46 \pm 11$ and $83 \pm 78$. The mean concentration $(\mathrm{mg} / \mathrm{l})$ of TDS remediated by the different masses $(5 \mathrm{~g}, 10 \mathrm{~g}$, $15 \mathrm{~g}, 20 \mathrm{~g}$, and $25 \mathrm{~g}$ ) of the bacteria varies. There is a reduction in all the TDS of all the samples after the bioremediation process compared with the TDS of the raw samples before the bioremediation. The relative potential or efficiency of the different masses of the bacteria in remediating TDS in TAN1 and TAN3 samples was in the order $5 \mathrm{~g}>10 \mathrm{~g}>15 \mathrm{~g}>20$ $\mathrm{g}>25 \mathrm{~g}$. For TAN2 samples, the order was 20 $g>10 \quad g>25 \quad g>15 \quad g>5 \quad g$. Statistical analysis shows that there is no significant difference $(p<0.05)$ between the mean values of TDS among the masses in the respective industries. These might be due to the variations in the surface areas of the different masses of the immobilized bacteria. Positive and significant correlations exist between the masses of bacteria and TDS with the exception in TAN2 (negative and insignificant correlation). The positive correlations showed that there is general increase in the levels of the TDS as the masses of the immobilized bacteria increases. TAN1 $(96 \%)$ showed a very high correlation with the masses of the bacteria while TAN2 (47\%) showed a very low correlation.

The mean values $(\mathrm{mg} / \mathrm{l})$ of the BOD after the bioremediation varies between $1.56 \pm 0.20 \mathrm{mg} / \mathrm{l}$ and $6.92 \pm 5.49 \mathrm{mg} / \mathrm{l}$. The mean concentration $(\mathrm{mg} / \mathrm{l})$ of BOD remediated by the different masses $(5 \mathrm{~g}, 10 \mathrm{~g}, 15 \mathrm{~g}, 20 \mathrm{~g}$, and $25 \mathrm{~g}$ ) of the bacteria varies. There is a reduction in all the BOD of all the samples after the bioremediation process compared with the $\mathrm{BOD}$ of the raw 
BAJOPAS Volume 13 Number 2, December, 2020 samples before the bioremediation. The relative potential or efficiency of the different masses of the bacteria in remediating BOD in TAN1, TAN2 and TAN3 samples were in the order $25 \mathrm{~g}>20$ $\mathrm{g}>15 \mathrm{~g}>10 \mathrm{~g}>5 \mathrm{~g}, 25 \mathrm{~g}>15 \mathrm{~g}>5 \mathrm{~g}>10 \mathrm{~g}>20 \mathrm{~g}$ and $20 \mathrm{~g}>10 \mathrm{~g}>25 \mathrm{~g}>15 \mathrm{~g}>5 \mathrm{~g}$ respectively. Statistical analysis shows that there is significant difference $(p<0.05)$ between the mean values of BOD among the masses in the respective industries. These might be due to the variations in the surface areas of the different masses of the immobilized bacteria. Negative and significant correlations exist between the masses of bacteria and BOD. This showed that there is general decrease in the levels of the BOD as the masses of the immobilized bacteria increases. TAN1 (94\%) showed a very high correlation with the masses of the bacteria while TAN2 (4\%) showed a very low correlation.

The mean values $(\mathrm{mg} / \mathrm{l})$ of the COD after the bioremediation varies between $250 \pm 154$ and $3134 \pm 1595$. The mean concentration $(\mathrm{mg} / \mathrm{l})$ of COD remediated by the different masses $(5 \mathrm{~g}$, $10 \mathrm{~g}, 15 \mathrm{~g} 20 \mathrm{~g}$, and $25 \mathrm{~g}$ ) of the bacteria varies. There is a reduction in all the COD of all the samples after the bioremediation process compared with the COD of the raw samples before the bioremediation. The relative potential or efficiency of the different masses of the bacteria in remediating COD in TAN1, TAN2 and TAN3 samples were in the order $25 \mathrm{~g}>20 \mathrm{~g}>15$ $\mathrm{g}>5 \mathrm{~g}>10 \mathrm{~g}, 25 \mathrm{~g}>20 \mathrm{~g}>15 \mathrm{~g}>10 \mathrm{~g}>5 \mathrm{~g}$ and 10 g>5 g>25 g>15 g>20 g respectively. Statistical analysis shows that there were significant difference $(p<0.05)$ between the mean values of COD among the masses in the respective industries except for effluents treated with $25 \mathrm{~g}$. These might be due to the variations in the surface areas of the different masses of the immobilized bacteria. Negative and insignificant correlations exist between the masses of bacteria and COD with the exception in TAN3 (positive and significant correlation). The negative correlations showed that there is general decrease in the levels of the COD as the masses of the immobilized bacteria increases. TAN2 (100\%) showed a very high correlation with the masses of the bacteria while TAN3 (36\%) showed a very low correlation.

Generally, there was an overall decrease in the concentration of these physicochemical parameters after the bioremediation using the different masses of the bacterial isolates. These might be due to the variations in the surface areas of the different masses of the immobilized bacteria. This is in line with the work of Jimoh et al. (2018) and Baba et al. (2020).

Table 3: Mean Values $(\mathrm{mg} / \mathrm{l}) \pm$ S.D of Physicochemical parameters in effluents from the Tannery Industries before and after Treatment of the effluents $(250 \mathrm{ml})$ with the different masses $(5 \mathrm{~g}, 10 \mathrm{~g}$, $15 \mathrm{~g}, 20 \mathrm{~g}$, and $25 \mathrm{~g}$ ) of the bacteria.

\begin{tabular}{llllllll}
\hline $\mathrm{P}$ & IND & Before & \multicolumn{5}{c}{ After } \\
\cline { 4 - 7 } & & & $5 \mathrm{~g}$ & $10 \mathrm{~g}$ & $15 \mathrm{~g}$ & $20 \mathrm{~g}$ & $25 \mathrm{~g}$ \\
\hline \multirow{2}{*}{ COD } & TAN1 & $2372 \pm 938$ & $1708 \mathrm{a} \pm 861$ & $2045 \mathrm{a} \pm 1205$ & $845 \mathrm{a} \pm 369$ & $300 \mathrm{a} \pm 167$ & $250 \mathrm{a} \pm 154$ \\
& TAN2 & $1406 \pm 208$ & $1195 \mathrm{a} \pm 208$ & $1125 \mathrm{a} \pm 384$ & $1055 \mathrm{a} \pm 317$ & $956 \mathrm{a} \pm 310$ & $870 \mathrm{ab} \pm 240$ \\
& TAN3 & $3532 \pm 1373$ & $2374 \mathrm{a} \pm 1344$ & $1976 \mathrm{a} \pm 1405$ & $2757 \mathrm{a} \pm 1266$ & $3134 \mathrm{a} \pm 1595$ & $2614 \mathrm{~b} \pm 1105$ \\
BOD & TAN1 & $13.85 \pm 6.42$ & $6.92 \mathrm{a} \pm 5.49$ & $6.42 \mathrm{a} \pm 5.07$ & $5.72 \mathrm{a} \pm 5.35$ & $4.62 \mathrm{a} \pm 4.37$ & $2.82 \mathrm{ab} \pm 1.26$ \\
& TAN2 & $19.46 \pm 0.50$ & $1.75 \mathrm{~b} \pm 0.22$ & $1.73 \mathrm{~b} \pm 0.18$ & $1.58 \mathrm{a} \pm 0.16$ & $1.91 \mathrm{a} \pm 0.22$ & $1.56 \mathrm{~b} \pm 0.20$ \\
& TAN3 & $17.13 \pm 3.14$ & $4.24 \mathrm{ab} \pm 0.77$ & $3.29 \mathrm{ab} \pm 0.37$ & $4.11 \mathrm{a} \pm 0.07$ & $3.23 \mathrm{a} \pm 0.91$ & $3.33 \mathrm{a} \pm 1.28$ \\
SS & TAN1 & $374 \pm 124$ & $243 \mathrm{a} \pm 45$ & $471 \mathrm{a} \pm 226$ & $475 \mathrm{a} \pm 182$ & $492 \mathrm{a} \pm 128$ & $611 \mathrm{a} \pm 217$ \\
& TAN2 & $358 \pm 335$ & $460 \mathrm{a} \pm 400$ & $543 \mathrm{a} \pm 414$ & $544 \mathrm{a} \pm 402$ & $551 \mathrm{a} \pm 414$ & $554 \mathrm{a} \pm 405$ \\
& TAN3 & $780 \pm 739$ & $586 \mathrm{a} \pm 594$ & $758 \mathrm{a} \pm 656$ & $787 \mathrm{a} \pm 676$ & $861 \mathrm{a} \pm 635$ & $898 \mathrm{a} \pm 672$ \\
TDS & TAN1 & $3941 \pm 3703$ & $51 \mathrm{a} \pm 10$ & $53 \mathrm{a} \pm 10$ & $55 \mathrm{a} \pm 15$ & $61 \mathrm{a} \pm 20$ & $63 \mathrm{a} \pm 26$ \\
& TAN2 & $3300 \pm 1714$ & $83 \mathrm{a} \pm 78$ & $47 \mathrm{a} \pm 20$ & $48 \mathrm{a} \pm 22$ & $47 \mathrm{a} \pm 17$ & $48 \mathrm{a} \pm 17$ \\
& TAN3 & $2653 \pm 1240$ & $46 \mathrm{a} \pm 11$ & $55 \mathrm{a} \pm 24$ & $55 \mathrm{a} \pm 25$ & $58 \mathrm{a} \pm 23$ & $61 \mathrm{a} \pm 28$ \\
\hline
\end{tabular}

Replicate $=6$ (months)

Within the rows, for the same parameter, means with different alphabets are statistically different $(p<0.05)$.

$\mathrm{P}=$ parameter, IND = Industries 
BAJOPAS Volume 13 Number 2, December, 2020

Table 4: Correlation coefficient $(r)$ between different masses of the bacteria and the physicochemical parameters.

\begin{tabular}{llll}
\hline Industries & Parameter & Correlation coefficient $(r)$ & $\begin{array}{l}\text { Percent dependence (rxrx100) } \\
(\%)\end{array}$ \\
\hline TAN1 & COD & -0.9 & 82 \\
& BOD & -0.97 & 94 \\
& SS & $0.90^{*}$ & 80 \\
TAN2 & TDS & $0.98^{*}$ & 96 \\
& COD & -1 & 100 \\
& BOD & -0.21 & 4 \\
& SS & $0.78^{*}$ & 61 \\
& TDS & -0.69 & 47 \\
& COD & $0.60^{*}$ & 36 \\
& BOD & -0.6 & 37 \\
& SS & $0.95^{*}$ & 90 \\
& TDS & $0.94^{*}$ & 89 \\
\hline
\end{tabular}

The correlation coefficient $(r)$ with * is statistically significant $(p<0.05)$.

Percentage reduction of the Parameters

Table 5 shows the percentage reduction of Parameters in industrial samples before and after the treatment of the effluents $(250 \mathrm{ml})$ with the different masses $(5 \mathrm{~g}, 10 \mathrm{~g}, 15 \mathrm{~g}, 20 \mathrm{~g}$, and $25 \mathrm{~g}$ ) of the Immobilized Bacteria.

In TAN1 samples, the percentage reduction (\%) of COD ranged (14-89); BOD (50-80); SS (-32$35)$ and TDS (98-99). In TAN2 samples, the percentage decrease $(\%)$ of COD ranged (15$38) ;$ BOD (90-92); SS [-28-(-55)] and TDS (9798). In TAN3 samples, the percentage decrease (\%) of COD ranged (11-44); BOD (76-81); SS (15-25) and TDS (98). The percentage increase in the levels COD, BOD and TDS might be due to the increase in the surface area of the different masses of the immobilized bacteria. However, the percentage decrease in the levels of the SS might be due to the aggregation of the TDS which are large enough to result into SS. The percentage decrease in the levels of the SS might be also due to the influence of the nutrients which was added into the effluents in order to make the microorganisms more active and viable for fast degradation of organic contaminants in the effluent. This is in line with the work of Jimoh et al. (2018) in which the concentration of the SS increase after the bioremediation of effluents.

Sreemoyee and Priti (2013) assessed and reduced several Physico-chemical parameters of dairy wastewater using Niesseria $s p$. and concluded that the species are well known to degrade organic compounds. This is in agreement with the current study in which the immobilized Niesseria $s p$ degrade the organic contaminants as indicated by the BOD, COD and TDS.

Jimoh et al. (2018) observed that TSS of the effluents was increased after treatment with immobilized bacteria and concluded that it might be due to the biostimulation method adopted for the research.

The optimum $\mathrm{pH}$ Biosorption of Chromium by Bacillus spp and Staphylococcus spp. from tannery effluent was investigated by Mythili and Karthikeyan (2011). The maximum adsorption of Chromium $(86.4 \mathrm{mg} / \mathrm{L})$ was showed by Bacillus spp and Staphylococcus spp showed $70.6 \mathrm{mg} / \mathrm{L}$ at an initial concentration of $100 \mathrm{mg} / \mathrm{L}$. In the present study, immobilised Bacillus spp and Staphylococcus spp. from the tannery industrial effluents reduced the levels of the organic pollutants with high potential as indicated by the percentage reduction of BOD, COD and TDS.

Enzymes often can work in multiple environments especially if they are immobilized. This makes the microorganisms' enzymes even more resistant to harsh environments and enables the enzymes to be recovered and recycled after they are no longer needed (Gianfreda and Rao 2004). Ramesh and Singh (1993) reported that the immobilized bacteria having more efficiency to remove the suspended particles than free cells. Using the immobilized cell is preferable due to its capability for using several times with the same efficiency, which makes it more economical. Similar work was done by Sikander et al. (2007) showing the higher reduction with permeabilized cells of Ochrobactrum intermedium strain SDCr-5. 
BAJOPAS Volume 13 Number 2, December, 2020

The results revealed the isolation and identification of isolates with the potential for the reduction of $\mathrm{Cr}$ (VI) to $\mathrm{Cr}$ (III). Results indicated that immobilized $B$. cereus could be efficiently used for the reduction of $\mathrm{Cr}$ (VI).

Table 5: Percentage reduction of the tested Parameters from the tannery industrial samples of the Immobilized Bacteria.

\begin{tabular}{lllllll}
\hline \multirow{2}{*}{ Industries } & & \multicolumn{5}{c}{ Percentage Reduction $(\%)$} \\
\cline { 3 - 7 } & & $5 \mathrm{~g}$ & $10 \mathrm{~g}$ & $15 \mathrm{~g}$ & $20 \mathrm{~g}$ & $25 \mathrm{~g}$ \\
\hline TAN1 & COD & 28 & 14 & 64 & 87 & 89 \\
& BOD & 50 & 54 & 59 & 67 & 80 \\
& SS & 35 & -26 & -27 & -32 & -63 \\
& TDS & 99 & 99 & 99 & 98 & 98 \\
TAN2 & COD & 15 & 20 & 25 & 32 & 38 \\
& BOD & 91 & 91 & 92 & 90 & 92 \\
& SS & -28 & -52 & -52 & -54 & -55 \\
& TDS & 97 & 99 & 99 & 99 & 99 \\
& COD & 33 & 44 & 22 & 11 & 26 \\
& BOD & 75 & 81 & 76 & 81 & 81 \\
& SS & 25 & 3 & -1 & -10 & -15 \\
& TDS & 98 & 98 & 98 & 98 & 98 \\
\hline
\end{tabular}

Percentage Reduction $=(B-A) / B \times 100 \%$

$A=$ Concentration of the parameter after treatment

$\mathrm{B}=$ Concentration of the parameter before treatment

$+=$ percentage decrease

- = percentage increase

In general, immobilization makes the enzyme more resistant to temperature, $\mathrm{pH}$, and substrate concentration swings giving it a longer lifetime and higher productivity per active unit (Gianfreda and Rao, 2004; FuIlbrook, 1996; Russell et al, 2003; Kandelbauer et al., 2004). Immobilized cells have been used and studied extensively for the production of useful chemicals (Ohtake and Silver, 1994), the treatment of wastewaters (Chen et al., 2003; Wang et al., 2010). Although many workers described microbial degradation of tannery effluent, limited literature is available on the bioremediation of tannery effluent using immobilized bacterial cells in the Kano Industrial Estates.

\section{CONCLUSION}

The samples contained variable levels of the physicochemical parameters. The results of the Analysis of variance revealed that, no statistical difference $(p<0.05)$ was observed for the temperature, $\mathrm{pH}, \mathrm{SS}, \mathrm{TDS}, \mathrm{BOD}$ and $\mathrm{COD}$ among the three tannery industries before the treatment. The levels of some of the parameters
(SS, TDS and COD) observed in the samples were found above the recommended limits of WHO and NESREA, which called for the treatment of the effluents before discharge into the environment. Base on the morphological and biochemical test results, TAN1, TAN2, and TAN3 bacterial isolates were identified to be Neisseria spp, Bacillus cereus, and Staphylococcus aureus respectively. The results of Post-treatment analysis showed that there is overall decrease in the levels of the parameters determined when compared with that of the pre-treatment. The overall percentage reduction of the immobilised bacteria in the treatment of the respective effluents was in the order TAN2 (72\%)>TAN1 $(70 \%)>$ TAN3 $(62 \%)$. Hence, the immobilized bacteria are having higher biodegradation potential for the treatment of the tannery effluents.

\section{Acknowledgments}

The authors wish to acknowledge the University of Maiduguri for the financial support. The authors are grateful to the Kano State Ministry of Environment for their support in obtaining the effluent samples. 


\section{REFERENCES}

Ajao, A. T., Adebayo, G. B., and Yakubu, S. E. (2011). Bioremediation of textile industrial effluent using mixed culture of Pseudomonas aeruginosa and Bacillus subtilis immobilized on agar-agar in a bioreactor. J. Microbiol. Biotech. Res, 1(3), 50-56.

Akan, J. C., Moses, E. A., Ogugbuaja, V. O., and Abah, J. (2007). Assessment of tannery industrial effluents from Kano metropolis, Kano State, Nigeria. Journal of Applied Sciences, 7(19), 2788-2793.

Akan, J. C., Ogugbuaja, V. O., Abdulrahman, F. I., and Ayodele, J. T. (2009). Pollutant levels in effluent samples from tanneries and textiles of Kano industrial areas, Nigeria. Global journal of pure and applied sciences, 15(3-4).

APHA (1989). Standard methods for Examination of Will bete and Will betewater.15 $5^{\text {th }}$ edition. Brydpass Springfield Will behington DC. pp. 164-176

APHA (1992). Standard Methods for the Examination of Water and Wastewater. Health, 69, 1116-9.

Baba, A., Garba, S. T., and Bello, H. S. (2020). Bioremediation Potential of Immobilized corynebacterium kutsceri in the Treatment of Tannery Industrial Effluent from Challawa Industrial Estate, Kano State, Nigeria. Journal of the Turkish Chemical Society Section A: Chemistry, $7(2), 335-350$.

Beem, E. I. V. (1994). reduction of solvent VOC emission. J. Oil Col. Chem. Ass, 77, 158.

Bouwer, E. J., and Zehnder, A. J. (1993). Bioremediation of organic compoundsputting microbial metabolism to work. Trends in biotechnology, 11(8), 360367.

Chen, K. C., Wu, J. Y., Liou, D. J., and Hwang, S. C. J. (2003). Decolorization of the textile dyes by newly isolated bacterial strains. Journal of Biotechnology, 101(1), 57-68.

Dan'Azumi, S., and Bichi, M. H. (2010). INDUSTRIAL POLLUTION AND HEAVY METALS PROFILE OF CHALLAWA RIVER IN KANO, NIGERIA. Journal of Applied Sciences in Environmental Sanitation, $5(1)$.

DWAF. (1992). Analytical Methods Manual, TR 151. Department of Water Affairs and Forestry, Pretoria.

El-Bestawy, E. (2013). Biological treatment of leather-tanning industrial wastewater using free living bacteria.
Elsheikh, M. A. S. (2009). Tannery wastewater pre-treatment. Water Science and Technology, 60(2), 433-440.

FuIlbrook, P. D. (1996). "Kinetics." Industrial enzymology: The application of enzymes in Industry. 2nd Ed. T. Godfrey and J Reichelt. eds.. Nature. New York.

Gianfreda, L., and Rao, M. A. (2004). Potential of extra cellular enzymes in remediation of polluted soils: a review. Enzyme and microbial technology, 35(4), 339354.

Hugo Springer. (1994). John Arthur Wilson Memorial Lecture "Treatment of Industrial Wastes of the Leather Industry - is it still a Major Problem". JALCA, 89, 153-185

Jimoh, A. A., Ganiyu, B. A., Baba, D., and Baba, A. (2018) Bioremediation Process of Effluent from Detergent and Food Industries in Jos, Nigeria: Kinetics and Thermodynamics. International Journal of Engineering Science Invention (IJESI), 762-73

Kandelbauer, A., Maute, O., Kessler, R. W., Erlacher, A., and Gübitz, G. M. (2004). Study of dye decolorization in an immobilized laccase enzyme-reactor using online spectroscopy. Biotechnology and bioengineering, 87(4), 552-563.

Kongjao, S., Damronglerd, S., and Hunsom, M. (2008). Simultaneous removal of organic and inorganic Pollutants in tannery wastewater using electrocoagulation technique. Korean Journal of chemical engineering, 25(4), 703.

Maheshwari, U. M., Aruna, S., Gomathi, M., and AbdulJaffar, A. H. (2017). Bioremediation by Free and Immobilized Bacteria Isolated from Tannery Effluent. International Journal of Research in Applied, Natural and Social Sciences. 5(7), 75-90

Margesin, R., and Schinner, F. (2001). Bioremediation (natural attenuation and biostimulation) of diesel-oilcontaminated soil in an alpine glacier skiing area. Applied and environmental microbiology, 677), 3127-3133.

Mohammed, A., Sekar, P., and George, J. (2011). Efficacy of microbes in bioremediation of tannery effluent. Inter. J. Curr. Res, 3(4), 324-326.

Mohammed, S. S. D., Orukotan, A. A., and Abdullahi, H. (2017). Physicochemical and Bacteriological Assessment of Tannery Effluent from Samaru-Zaria, 
BAJOPAS Volume 13 Number 2, December, 2020 Kaduna State, Nigeria. Journal of Applied

Sciences and Environmental Management, 21(4), 734-740.

Munz, G., De Angelis, D., Gori, R., Mori, G., Casarci, M., and Lubello, C. (2009). The role of tannins in conventional and membrane treatment of tannery wastewater. Journal of hazardous materials, 164(2-3), 733-739

Mythili, K., and Karthikeyan, B. (2011). Bioremediation of $\mathrm{Cr}$ (VI) from tannery effluent using Bacillus spp and Staphylococcus spp. International Multidisciplinary Research Journal, 1(6).

NESREA (2009). National Environmental Standards for Effluent Limitations and Regulation. 1233-1236

Noorjahan, C. M. (2014). Physicochemical characteristics, identification of bacteria and biodegradation of industrial effluent. Journal of bioremediation and Biodegradation, 5(3).

Ohtake, H. I., and Silver, A. O. (1994). Bacterial reduction of toxic chromate. Biological degradation and bioremediation of toxic chemicals, 403-415.

Omoleke, I. I. (2004). Management of environmental pollution in Ibadan, an African city: the challenges of health hazard facing government and the people. Journal of Human Ecology, 15(4), 265-275.

Rajor, A., Reddy, A.S., and Singh, B. (2004). Determination of BOD kinetic Parameters and evaluation of alternate methods, M.Sc. Thesis, Department of biotechnology \& environmental Science, Thapar Institute of Engineering and Technology, Patiala

Ramasami, T., Rajamani, S., and Rao, J. R. (1994, March). Pollution control in leather industry: Emerging technological options. In International symposium on surface and colloidal science and its relevance to soil pollution, madras.

Ramesh, J. V. S., and Singh, S. P. (1993). Yearly variation in certain physicochemical parameters of pond at eastern Doon Valley. Uttar Pradesh J. Zoo, 12 (1), 7577.

Ranen, S., and Sharadinadra, C. (2009). Biotechnology applications to environmental remediation in resource exploitation. Current science, 97, 6-25
Russell, A. J., Berberich, J. A., Drevon, G. F., and Koepsel, R. R. (2003). Biomaterials for mediation of

chemical and biological warfare agents. Annual review of biomedical engineering, 5(1), 1-27.

Saravanan, P., and Saravanan, A. (1999). Decolourization of tannery effluent by Flavobacterium sp. EK 1. Indian Journal of Environmental Protection, 19, 19-24.

Sikander, S., and Shahida, H. (2007). Reduction of toxic hexavalent chromium by Ochrobactrum intermedium strain SDCr5 stimulated by heavy metals. Bioresource Technol, 98, 340-344.

Singh, N., Sharma, B. K., and Bohra, P. C. (2000). Impact assessment of industrial effluent of arid soils by using satellite imageries. Journal of the Indian Society of Remote Sensing, 28(2-3), 79.

Sreemoyee, C., and Priti, P. (2013). Assessment of physico-chemical parameters of dairy waste water and isolation and characterization of bacterial strains in terms of cod reduction. Int J Sci, 2(3), 395-400.

Verheijen, L. A. H. M., Wiersema, D., Pol, L. H., and De Wit, J. (1996). Management of wastes from animal product processing. Livestock and environment, Finding a balance. International Agriculture Center, Wageningen, The Netherlands.

Wang, F., Yao, J., Si, Y., Chen, H., Russel, M., Chen, K., and Bramanti, E. (2010). Short-time effect of heavy metals upon microbial community activity. Journal of Hazardous Materials, 173(13), 510-516.

WHO (World Health Organization). (2006). Air quality guidelines: global update 2005: particulate matter, ozone, nitrogen dioxide, and sulfur dioxide. World Health Organization.

World Bank. (1995). Nigeria's strategic options for redressing industrial pollution. World Bank, industry and energy division. 1st edition, West Central Africa Department; Annexes: 1995; pp 60-62.

Zahoor, A., and Abdul, R. (2009). Enumeration of Coliforms. Journal of Environmental Sciences. 21, 814-820 


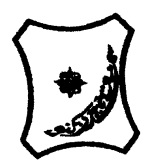

Bayero Journal of Pure and Applied Sciences, 13(2): 1 - 12

Received: November, 2020

Accepted: December, 2020

ISSN $2006-6996$

\title{
BIODEGRADATION POTENTIAL OF IMMOBILIZED BACTERIA IN THE TREATMENT OF TANNERY INDUSTRIAL EFFLUENTS FROM INDUSTRIAL ESTATES IN KANO STATE, NIGERIA
}

\author{
Abdullateef, B., ${ }^{1 *}$ Shuaibu, T. G., ${ }^{1}$ Babagana, K., ${ }^{1}$ Suleman, H. B. ${ }^{2}$ and Dauda, B. ${ }^{3}$ \\ ${ }^{1}$ Department of Pure and Applied Chemistry, Faculty of Science, University of Maiduguri, Borno State, \\ Nigeria \\ ${ }^{2}$ Department of Microbiology, Faculty of Science, University of Maiduguri, Borno State, Nigeria \\ ${ }^{3}$ Department of Chemical Engineering, Faculty of Engineering, University of Maiduguri, Borno State, \\ Nigeria \\ *Corresponding author: babslega@gmail.com; abelega2007@yahoo.com; +2348061309753
}

\section{ABSTRACT}

Industrial Effluents Samples from Gashash Tanneries (TAN1) in Bompai Industrial estate, Larabee Tannery Industry (TAN2) in Sharada Industrial estate and Z Tannery Industries (TAN3) in Challawa Industrial estate, Kano State, Nigeria were collected over a period of six months (August 2017 to January 2018) for assessing the biodegradation potentials of bacteria in the treatment of organic pollutants within the effluents. Bacteria were isolated from the effluents and immobilized on agar-agar. Different masses (5 g, $10 \mathrm{gr}, 15$ $\mathrm{g}, 20 \mathrm{~g}$, and $25 \mathrm{~g}$ ) of the bacteria were used in the treatment of $250 \mathrm{ml}$ of the effluents for ten days in a shaker incubator (Gallenkamp-OC-4364-L) at the temperature $30{ }^{\circ} \mathrm{C}$ and speed of $60 \mathrm{rpm}$. Pre-treatment analysis of the effluents for Temperature, pH, Biochemical Oxygen Demand (BOD), Chemical Oxygen Demand (COD), Suspended Solid (SS) and Total Dissolved Solids (TDS) gives the following results; temperature $\left({ }^{\circ} \mathrm{C}\right.$ )

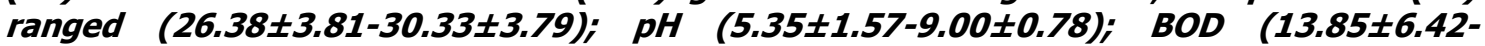
$38.75 \pm 16.20) ;$ COD (1406 $\pm 208-3532 \pm 1373) ;$ SS (208 $\pm 235-780 \pm 739)$ and TDS (266 $\pm 253-5276 \pm 2971)$. No statistical differences ( $p \leq 0.05)$ was observed for all the results among the different industries. The bacterial isolates were identified as Neisseria spp, Bacillus cereus, and Staphylococcus aureus, in TAN1, TAN2, and TAN3, respectively. After treatment of the effluent with the different masses of the isolated bacteria, the mean level of BOD was found to range as (0.55 $\pm 0.36-6.92 \pm 5.49) ; C O D$ (ND-3134 \pm 1595$)$;

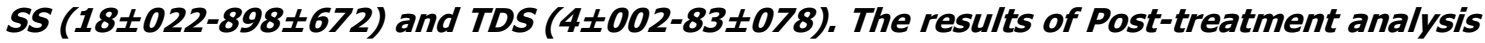
showed that there is overall decrease in the levels of the parameters determined when compared with that of the pre-treatment. The overall percentage reduction of the immobilised bacteria in the treatment of the respective effluents was in the order TAN2 (72\%)>TAN1 (70\%)>TAN3 (62\%). Hence, the immobilized bacteria are having higher biodegradation potential for the treatment of the tannery effluents.

Keywords: Biodegradation, bacteria, effluent, immobilization, tannery.

\section{INTRODUCTION}

Tannery industrial wastewater is a serious consequence of the pollution point of view for streams, freshwater, and land used for agriculture. The lack of awareness in the modern industrial practice has resulted in the discharge of tannery effluents which exhibit very high value of chromium ( $\mathrm{Cr}$ ), Sulfide, and chloride, Total Dissolved Solid (TDS), Total Suspended Solid (TSS), Biochemical Oxygen Demand (BOD) and Chemical Oxygen Demand (COD) in the water stream or land (Mohammed et al., 2001). Tanning is the process, which One ton of skin generally leads to the production of 20 to $80 \mathrm{~m}^{3}$ of turbid and foul-smelling converts the protein of the rawhide or skin into a stable material, which will not putrefy and is suitable for a wide variety of end applications (Elsheikh, 2009). The highly polluting chromium is the most commonly used tanning material producing leather that is more flexible and pliable than vegetable-tanned leather and does not discolor or lose shape in water as drastically as vegetable-tan (Elsheikh, 2009). Tannery effluent is among the most hazardous industrial pollutants due to its huge organic and inorganic load, which is highly toxic to human life and the environment (Kongjao et al., 2008). wastewater including chromium (100-400 mg/l), sulfide $(200-800 \mathrm{mg} / \mathrm{l})$, high levels of fat and 
BAJOPAS Volume 13 Number 2, December, 2020 other solid wastes, and notable pathogen contamination as well as pesticides added for skin conservation during transport (Elsheikh, 2009). There are more than 6000 tanneries in Nigeria with an annual processing capacity of 700,000 tons of hides and skins (Omoleke, 2004; Singh et al., 2008). It was reported that the total amount of waste produced per animal slaughtered is approximately $35 \%$ of its weight (World Bank, 1995). Also, for every $1000 \mathrm{~kg}$ of carcass weight, a slaughtered beef produces 5.5 $\mathrm{kg}$ of manure (excluding rumen contents or stockyard manure) and $100 \mathrm{~kg}$ of paunch manure (undigested food) (Verheijen et al., 1996). Tanneries generate wastewater in the range of 30-35 $\mathrm{L} \mathrm{kg}^{-1}$ skin/hide processed with variable $\mathrm{pH}$, Biological Oxygen Demand (BOD), Chemical Oxygen Demand (COD), high concentrations of suspended solids (SS), and tannins as well as chromium (Zahoor and Abdul, 2009).

Being heterogeneous and composed of a wide variety of compounds, it is very difficult to select a unique direct method for estimating the biodegradability of organic contents and biokinetic parameters for a wastewater sample (Rajor, 2004). For this purpose, some indirect estimation such as determination of biochemical oxygen demand (BOD) and chemical oxygen demand (COD) are applied as common laboratory investigations [9]. During retanning procedures, synthetic tannins (Syntan), oils and resins are added to form softer leather at varying doses (Munz et al., 2009). One of the refractory groups of chemicals in tannery effluents derives mainly from tannins (Ramasami et al., 2004). Syntans are characterized by complex chemical structures, because they are composed of an extended set of chemicals such as phenol-, naphthalene-, formaldehyde- and melamine-based syntans, and acrylic resins (Beem, 1994). Organic pollutants (proteic and lipidic components) are originated from skins (it is calculated that the raw skin has $30 \%$ loss of organic material during the working cycle) or they are introduced during processes (Hugo Springer, 1994).

Many conventional processes such as oxidation, chemical and biological processes were carried out to treat tanneries wastewater (Ebtesam et al, 2013). Biological processes have received more attention because of their costeffectiveness, lower sludge production and environmental friendliness (Noorjahan, 2014). Naturally occurring micro-organisms degrade the hazardous organic wastes including xenobiotic compounds, such as pesticides, polycyclic aromatic hydrocarbons (PAHs) and polychlorinated biphenyls (PCBs) in due course of time (Ranen and Sharadinadra, 2009). Bioremediation is based on the idea that all organisms remove substances from the environment to carry outgrowth and metabolism (Bouwer and Zehnder, 1993). Bacteria, protista and fungi are found to be very good at degrading complex molecules and incorporating the breakdown products into their metabolism (Bouwer and Zehnder, 1993). The resultant metabolic wastes that they produce are generally safe and somehow recycled into other organisms (Ranen and Sharadinadra, 2009). An acclimatized indigenous population of microorganisms capable of degradation of the compounds of interest must exist at the site for a successful bioremediation mode (Ranen and Sharadinadra, 2009). It has been observed that for a successful bioremediation mode, an acclimatized indigenous population of microorganisms capable of degradation of the compounds of interest must exist at the site under investigation (Ranen and Sharadinadra, 2009). Even though there are numerous physical and chemical methods employed in the disposal of wastes the advantage in using bacterium is that they play a key role in the reduction of COD, BOD, total protein, total tannin and total phenol (Saravanan and Saravanan, 1998)

Baba et al. (2020) studied the bioremediation potential of immobilized corynebacterium kutsceri in the Treatment of tannery industrial effluent from Challawa Industrial Estate, Kano State, Nigeria. The aim of the work is to study the reduction in the level of the contaminants through the process of bioremediation using the isolated bacteria. Immobilized bacteria can withstand various temperatures, $\mathrm{pH}$ and substrate concentrations; consequently, increasing the efficiency and the lifespan of the bacteria. Immobilized bacteria are widely applied in the treatment of wastewater and can be separated and recovered after the treatment with the same efficiency (Baba et al., 2020).

\section{MATERIALS AND METHODS \\ Study Area}

This study was carried out in Bompai, Sharada and Challawa industrial estates in Kano, Figure 1. Kano lies on Latitude $11^{\circ} 30^{\prime} \mathrm{N}$ and $8^{\circ} 30^{\prime} \mathrm{E}$ and Longitude $11^{\circ} 5^{\prime} \mathrm{N}$ and $8^{\circ} 5^{\prime} \mathrm{E}$ in Northern Nigeria. It is one of the developed industrial cities in Nigeria. Tannery activities are the dominating industries and this could be one of the reasons for her high population density (Dan'Azumi and Bichi, 2010). Many researchers have studied biodegradation of tannery effluent using microorganisms. However, limited literature is available on the biodegradation of tannery effluent in Kano industrial estates using 
BAJOPAS Volume 13 Number 2, December, 2020 immobilized bacterial cells. This research work focuses on the potential of the use of the indigenous immobilized bacterial isolates in the treatment of tannery effluents in the industrial estates.

\section{Sample Collection}

Effluents were collected from the Tannery Industries from Bompai, Challawa and Sharada Industrial Estates, Kano, Nigeria. The effluents were collected over a period of six months (August 2017 to January 2018). Samples collected in a sterile 4-liter plastic container with a unique identification number were preserved using an ice-box that was transported to the Microbiology Laboratory, Department of Microbiology, Bayero University of Kano for analysis

\section{Sample Preparation and Sample Analysis}

Immediately after the collection of the effluent, $\mathrm{pH}$, TSS, TDS, COD, BOD levels were determined before treatment (Pre-treatment determination) and ten days after treatment (Post-treatment determination) as described in
APHA (1989) standard methods. $\mathrm{pH}$ was determined using Ecotests $\mathrm{pH}$ meter and TDS was determined using AQUALYTIC TDS Salinometer. BOD was determined as described by the standard method (APHA, 1992). COD and SS were determined using DR/2010 HACH portable data logging spectrophotometer (DWAF, 1992)

\section{Identification and Biochemical} Characterization of the Bacterial Isolates

The bacteria were isolated from the effluents using Serial Dilution according to the method described by APHA (1989). The biochemical tests such as oxidase, catalase, coagulase, indole (from $1 \%$ tryptone broth), citrate (Simmons citrate agar), methyl red/VogesProskauer (MR/VP), nitrate reduction, Starch Hydrolysis, Glucose, Maltose, and Lactose tests were carried out on the bacterial isolates to identify the bacteria through the bacteria biochemical characteristics according to Ajao et al. (2011).

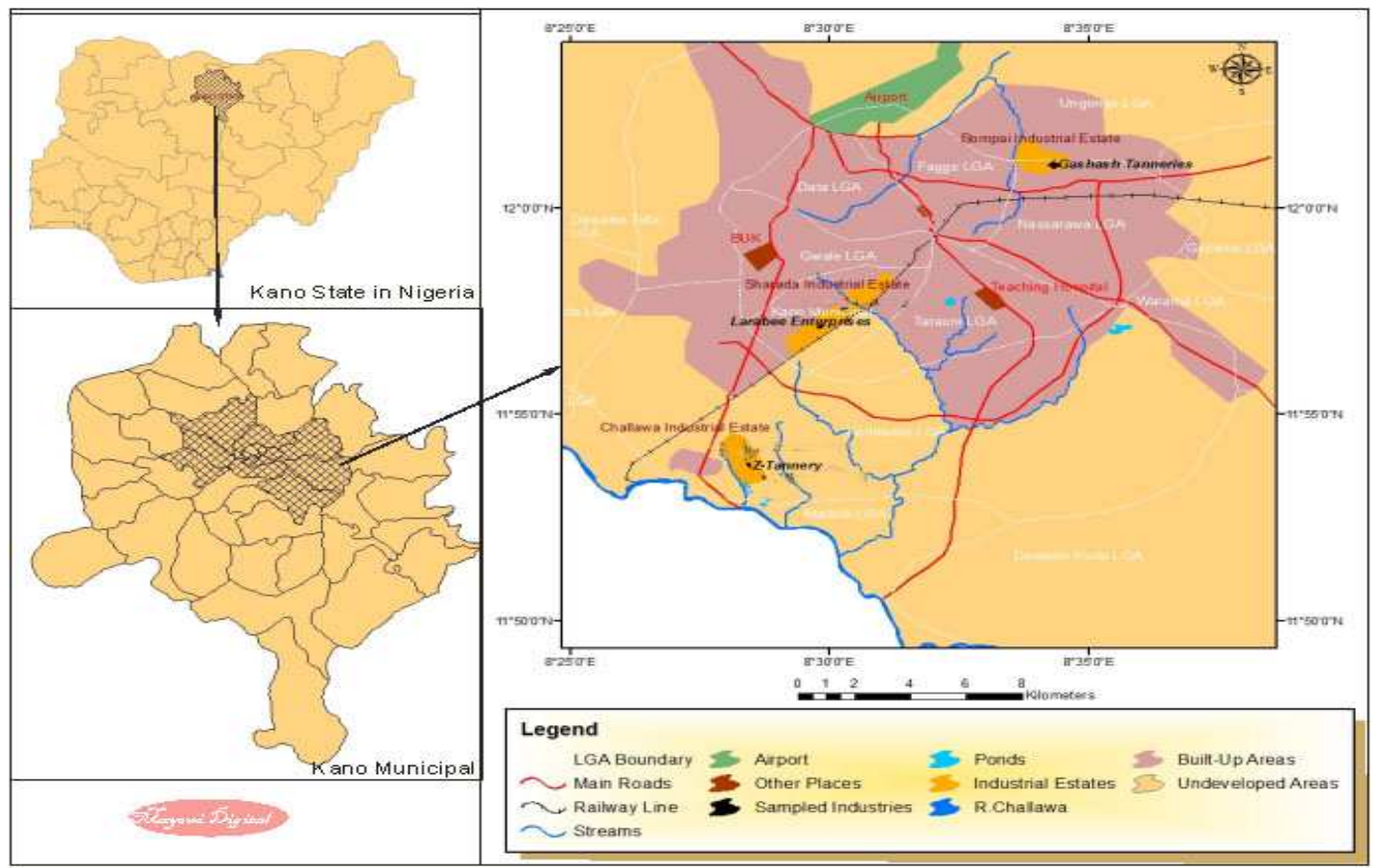

Fig. 1 Map showing the study areas

Source: Mayomi Digital Productions, GIS Laboratory, Department of Geography, UNIMAID (2017)

\section{Determination of Growth Rate of the Bacteria in Effluent Sample}

The bacteria growth rates were determined by transferring $2 \mathrm{~mL}$ of the bacterial isolates from the tannery effluent in broth medium into 100 $\mathrm{mL}$ sterile effluents in conical flasks and kept in an incubator (Giffrin cool) for 10 days. Control was also set up by incubating another $100 \mathrm{~mL}$ each of the sterile effluents without the bacteria. The optical density of the content was determined at the wavelength of $600 \mathrm{~nm}$ on a daily interval and recorded. 
BAJOPAS Volume 13 Number 2, December, 2020 Immobilization of Bacteria

Agar solution and inoculi were prepared separately. Fifty milliliters $(50 \mathrm{~mL})$ of nutrient broth each of the inoculi was prepared in a McCartney bottle and incubated for 24 hours. A solution of agar-agar was prepared by dissolving $10 \mathrm{~g}$ of the powder in distilled water and made up to $500 \mathrm{~mL}$ mark in an Erlenmeyer flask and was sterilized in an autoclave (280A) for 15 minutes and allowed to cool to $40-45^{\circ} \mathrm{C}$ (Ajao et al., 2011). Four milliliters ( $4 \mathrm{~mL})$ of the bacterial isolates in the nutrient broth was mixed with 36 $\mathrm{ml}$ of the prepared agar-agar media in petri-dish plates and then allowed to solidify. This was kept in the refrigerator for bioremediation.

\section{Bioremediation (Treatment) of the Effluents}

The solidified agar block (immobilized bacteria) was cut into cubes using a sterile knife; $0.1 \mathrm{~mL}$ phosphate buffer ( $\mathrm{pH} \mathrm{7.0)}$ was added and kept in the refrigerator for 1 hour for curing. The phosphate buffer was decanted after 1 hour and the cubes were washed with sterile distilled water 3-4 times before it was used (Ajao et al., 2011). Two liters (2 L) of the effluent was supplemented with the minimum basal medium in $\mathrm{g} / \mathrm{L}: \mathrm{NaCl}(0.8), \mathrm{MgSO}_{4} .7 \mathrm{H}_{2} \mathrm{O}(0.001), \mathrm{KH}_{2} \mathrm{PO}_{4}$ (2), $\mathrm{NaNO}_{3}$ (2), $\quad \mathrm{CaCl}_{2} .2 \mathrm{H}_{2} \mathrm{O} \quad(0.5)$ and $\mathrm{NaHPO}_{4} .12 \mathrm{H}_{2} \mathrm{O}(2)$ and sterilized in an autoclave at $121^{\circ} \mathrm{C}$ for 15 minutes (Margesin and Schinner, 2001). Two hundred and fifty milliliters $(250 \mathrm{~mL})$ of the effluents were transferred into different $250 \mathrm{ml}$ conical flasks. The content was covered with a cotton-wool ramped with foil paper to avoid contamination. Five grams $(5 \mathrm{~g})$ of the immobilized bacteria were quickly transferred into each of the effluents in the conical flasks in an inoculating chamber. The same procedures were carried out for the $10 \mathrm{~g}, 15 \mathrm{~g}, 20 \mathrm{~g}$ and 25 $\mathrm{g}$ of the immobilized bacteria in separate $250 \mathrm{~mL}$ effluents in conical flasks and agitated for ten days in a shaker incubator (Gallenkamp-OC4364-L) at a temperature $30^{\circ} \mathrm{C}$ and speed of 60 rpm. The treated effluent samples were taken on the tenth day and analyzed for the parameters $\mathrm{pH}$, SS, TDS, COD, and BOD, (Posttreatment determination) for the different grams of bacteria to evaluate and compare the biodegradation potential. (Baba et al., 2020).

\section{Statistical Analysis}

The data were represented as Mean \pm Standard deviation and analyzed statistically using oneway Analysis of Variance (ANOVA) and Tukey's HSD as Post Hoc Tests with the aid of SPSS 16.0. The correlation coefficient was also used to measure the strength of the relationship between the different masses of the bacteria and the parameters. All $\mathrm{p} \leq 0.05$ were considered as statistically significant.

\section{RESULTS AND DISCUSSION Physico-chemical parameters in the Industrial Effluents before the Biodegradation.}

Results of the Physico-chemical parameters in the industrial effluents before the Biodegradation is shown in table 1 . The mean temperatures $\left({ }^{\circ} \mathrm{C}\right)$ observed in TAN1, TAN2, and TAN3 samples were $28.07 \pm 0.65 ; 27.77 \pm 0.64$ and $26.38 \pm 3.81$ respectively. The order of the mean temperature of the samples from the three industries can be arranged as TAN1 > TAN2>TAN3. The temperature observed at TAN1, TAN2, and TAN3 samples were found below the WHO $\left(35^{\circ} \mathrm{C}\right)$ and NESREA $\left(40^{\circ} \mathrm{C}\right)$ limits. The low values of temperature might be due to the processes used at the time of sampling. High temperature brings down the solubility of gases in water that ultimately expresses as high BOD and COD. Statistical analysis shows that there is no significant difference $(p<0.05)$ between the mean values of temperature among the industries. This might be due to similar tannery activities involved in the tannery industries at the time of sampling. The average values of temperature observed in this present study are less than those observed by Akan et al. (2007), Akan et al. (2009) and Baba et al. (2020).

The mean level of $\mathrm{pH}$ observed in TAN1, TAN2 and TAN3, samples were $7.77 \pm 2.93$; $8.35 \pm 0.28$ and $7.52 \pm 0.76$ respectively. The order of the mean $\mathrm{pH}$ of the samples from the three industries can be arranged as TAN2> TAN1 $>$ TAN3. The $\mathrm{pH}$ of the samples falls within the WHO (7.0-8.5) and NESREA (6-9) standard limits. Statistical analysis shows that there is no significant difference $(p<0.05)$ between the mean values of $\mathrm{pH}$ among the industries. This might be due to similar tannery activities involved in the tannery industries at the time of sampling. Maheshwari et al. (2017) reported that the level of $\mathrm{pH}$ in the effluents from the tannery industry in Vaniyambadi, India was 6.5 which was lower than that observed in the present study. The $\mathrm{pH}$ in the effluents from the tannery industries in Kano and Kaduna were reported to be 7.64 and 6.89, respectively (Akan et al., 2007; Mohammed et al., 2017). The average values of $\mathrm{pH}$ observed in this present study are less than those observed by Mohammed et al. (2017) and Baba et al. (2020). The mean level of SS $(\mathrm{mg} / \mathrm{l})$ observed in TAN1, TAN2, and TAN3 samples were 374 \pm 124 ; $358 \pm 335$ and $780 \pm 739$ respectively. The order of the mean SS in the samples from the three industries can be arranged as TAN3 > TAN1 $>$ TAN2. 
The SS observed in the samples were far above the recommended standard limits of regulating bodies WHO $(30 \mathrm{mg} / \mathrm{l})$ and NESREA $(10 \mathrm{mg} / \mathrm{l})$. Statistical analysis shows that there is no significant difference $(p<0.05)$ between the mean values of SS among the industries. This might be due to similar tannery activities involved in the tannery industries at the time of sampling. The average values of SS observed in this present study are less than that observed $(3700 \pm 122 \mathrm{mg} / \mathrm{l})$ by Akan et al. (2009) for tanneries in Kano. Also, the average values of SS observed in this present study are less than that observed by Mohammed et al. (2017) and Baba et al. (2020) with the exception in TAN3.

The mean level of TDS (mg/l) observed in TAN1, TAN2, and TAN3 samples were $3941 \pm 3703$; $3300 \pm 1714$ and $2653 \pm 1240$ respectively. The order of the mean TDS in the samples from the three industries can be arranged as TAN1>TAN2>TAN3. The TDS observed in the samples were far above the recommended standard limits of WHO $(250 \mathrm{mg} / \mathrm{l})$ and NESREA $(500 \mathrm{mg} / \mathrm{l})$. Statistical analysis shows that there is no significant difference $(p<0.05)$ between the mean values of TDS among the industries. This might be due to similar tannery activities involved in the tannery industries at the time of sampling. TDS in the effluents from the tannery industries in Kano, Nigeria was reported to be $1281 \mathrm{mg} / \mathrm{l}$ (Akan et al., 2007). The average values of SS observed in this present study are less than those observed by Mohammed et al. (2017) and Baba et al. 2020)

The mean level of COD (mg/l) observed in TAN1, TAN2 and TAN3 samples seasons were $2372 \pm 938 ; \quad 1406 \pm 208$ and $3532 \pm 1373$ respectively. The order of the mean COD of the samples from the three industries can be arranged as TAN3>TAN1> TAN2. The COD observed in TAN1, TAN2 and TAN3 samples were far above the recommended standard limits of regulating bodies $\mathrm{WHO}(40 \mathrm{mg} / \mathrm{l})$ and NESREA (40 mg/l). Statistical analysis shows that there is no significant difference $(p<0.05)$ in COD among the industries. This might be due to similar tannery activities involved in the tannery industries as at the time of sampling. The Chemical Oxygen demand (COD) is the amount of oxygen, in $\mathrm{mg} / \mathrm{L}$, required for the degradation of the compound of wastewater to occur. In comparison, the average values of COD observed in this present study were higher than that observed by Mohammed et al. (2017) but lower than that observed by Baba et al. (2020).

The mean levels of BOD $(\mathrm{mg} / \mathrm{l})$ observed in TAN1, TAN2 and TAN3 samples were $13.85 \pm 6.42 ; \quad 19.46 \pm 0.50$ and $17.13 \pm 3.14$ respectively. The order of the mean BOD in the samples from the three industries can be arranged as TAN2>TAN3>TAN1. The BOD observed in TAN1, TAN2 and TAN3 samples were found below the recommended limits of NESREA (200 mg/l) but above WHO (10 mg/l). Statistical analysis shows that there is no significant difference $(p<0.05)$ between the mean values of BOD among the industries. This might be due to similar tannery activities involved in the tannery industries at the time of sampling. The low level of BOD recorded in this study is an indication of the low level of biodegradable organic solids in the effluent. The average values of BOD observed in this present study were lower than those observed by Mohammed et al. (2017) and Baba et al. (2020).

Table 1: Mean Values \pm S.D of Physico-chemical parameters of effluents from the Tannery Industries before Treatment.

\begin{tabular}{llllllll}
\hline Parameter & Tannery 1 & Tannery 2 & Tannery 3 & $\mathrm{a}$ & $\mathrm{b}$ & $\mathrm{c}$ & $\mathrm{d}$ \\
\cline { 2 - 7 } Temperature $\left({ }^{\circ} \mathrm{C}\right)$ & $28.07 \mathrm{a} \pm 0.65$ & $27.77 \mathrm{a} \pm 0.64$ & $26.38 \mathrm{a} \pm 3.81$ & & $29.50 \pm 4.68$ & 35 & 40 \\
pH & $7.77 \mathrm{a} \pm 2.93$ & $8.35 \mathrm{a} \pm 0.28$ & $7.52 \mathrm{a} \pm 0.76$ & 6.89 & $5.35 \pm 1.57$ & $7.0-8.5$ & $6.0-9.0$ \\
$\mathrm{COD}(\mathrm{mg} / \mathrm{l})$ & $2372 \mathrm{a} \pm 938$ & $1406 \mathrm{a} \pm 208$ & $3532 \mathrm{a} \pm 1373$ & 2.2 & $3106 \pm 2753$ & 40 & 40 \\
$\mathrm{BOD}(\mathrm{mg} / \mathrm{l})$ & $13.85 \mathrm{a} \pm 6.42$ & $19.46 \mathrm{a} \pm 0.50$ & $17.13 \mathrm{a} \pm 3.14$ & 1032 & $26.17 \pm 9.49$ & 10 & 200 \\
$\mathrm{SS}(\mathrm{mg} / \mathrm{l})$ & $374 \mathrm{a} \pm 124$ & $358 \mathrm{a} \pm 335$ & $780 \mathrm{a} \pm 739$ & 501 & $562 \pm 482$ & 30 & 10 \\
TDS $(\mathrm{mg} / \mathrm{l})$ & $3941 \mathrm{a} \pm 3703$ & $3300 \mathrm{a} \pm 1714$ & $2653 \mathrm{a} \pm 1240$ & 532.7 & $444 \pm 507$ & 250 & 500 \\
\hline
\end{tabular}

The values given in the table above are means of 6 replicate values, $\mathrm{n}=6$ ( 1 sample was taken monthly for 6 months). Within the rows, means with different alphabets are statistically different $(p<0.05)$. WHO: World Health Organisation. NESREA: National Environmental Standard and Regulatory Enforcement Agency. a = Mohammed et al.(2017), b = Baba et al. (2020), c = WHO (2006), $d=$ NESSRA (2009) 
BAJOPAS Volume 13 Number 2, December, 2020

Identification, Biochemical Characterization and growth rates of the Bacterial Isolates

Results of identification and biochemical characterization of the bacterial isolates were shown in table 2. After 24 hours of incubation, the nutrient agar media plates were checked for bacterial growth. The results showed the presence of different strains in the samples. The TAN1 bacteria isolate was found to be gramnegative cocci while TAN3 was gram-positive cocci. TAN2 bacteria isolate was found to be gram-positive, rod-shaped. TAN1, TAN2, and TAN3 bacteria isolates recorded positive results for spore former.

The results of the biochemical tests indicated that all the bacteria were positive for catalase, oxidase, citrate, maltose, glucose, lactose (negative in TAN1), mannitol (negative in TAN2), starch hydrolysis and coagulase (negative in TAN2) tests. The bacteria showed negative results for nitrate reduction, $M R$ (positive in TAN2), VP (positive in TAN1), Indole (positive in TAN2) tests. Base on the morphological and biochemical test results, TAN1, TAN2, and TAN3 bacteria isolates were identified to be Nesseria spp, Bacillus cereus, and Staphylococcus aureus respectively.

The growth rate of the TAN1, TAN2 and TAN3 Isolates were shown in figure 2. Generally, the optical density increase with the increase in time (day) and decrease as time goes on. The highest optical density was shown by bacillus cereus in TAN2 while the lowest was shown by Staphylococcus aureus in TAN3.

The initial growth phase of TAN1 Isolate bacteria occurred within 2-day of incubation as the growth rate increases up to the 6th-day incubation when the maximum growth was observed. Beyond the 6th day, the growth of the bacteria declined (which might be due to a shortage of nutrients in the effluents) until it reached its death phase (which might be due to the unavailability of nutrients in the effluents).

A similar trend of growth was also observed for TAN2 Isolate as the initial growth phase also occurred within 2-day of incubation but maximum growth rate observed on the 4th day of incubation. The stationary stage occurred between the 4th day and the 8th day. Beyond the 8th day, the growth of the bacteria declined (which might be due to a shortage of nutrients in the effluents) until it reached its death phase (which might be due to the unavailability of nutrients in the effluents).

The initial growth phase of TAN3 bacterial Isolate occurred within the 3-day incubation as the growth rate increases up to the 6th-day incubation when the maximum growth was observed. Beyond the 6th day, the growth of the bacteria declined (which might be due to a shortage of nutrients in the effluents) until it reached its death phase (which might be due to the unavailability of nutrients in the effluents).

Table 2: Morphological and Biochemical characteristics of bacterial isolates

\begin{tabular}{lllll} 
Bacterial Isolates & & TAN1 & TAN2 & TAN3 \\
\hline $\begin{array}{lllll}\text { Morphological } \\
\text { characteristics }\end{array}$ & Shape & Cocci & Rod & Cocci \\
& Spore & & & \\
& former & + & + & + \\
Gram & & & \\
Biochemical characteristics & reaction & - & + & + \\
& Citrate & + & + & + \\
& Catalase & + & + & + \\
& Coagulase & + & - & + \\
Starch & + & + & + \\
& Glucose & + & + & + \\
Oxidase & + & + & + \\
& Indo & - & + & - \\
Lactose & - & + & + \\
Manitol & + & - & + \\
Maltose & + & + & + \\
MR & - & + & - \\
VP & + & - & - \\
& Nitrate & - & - & - \\
Reduction & - Neisseria & Bacillus & Staphylococcus \\
& Bacterial & cereus & aureus \\
& name & spp & cas
\end{tabular}

+ = Positive; - = Negative; MR=Methyl Red; VP= Voges-Proskauer 


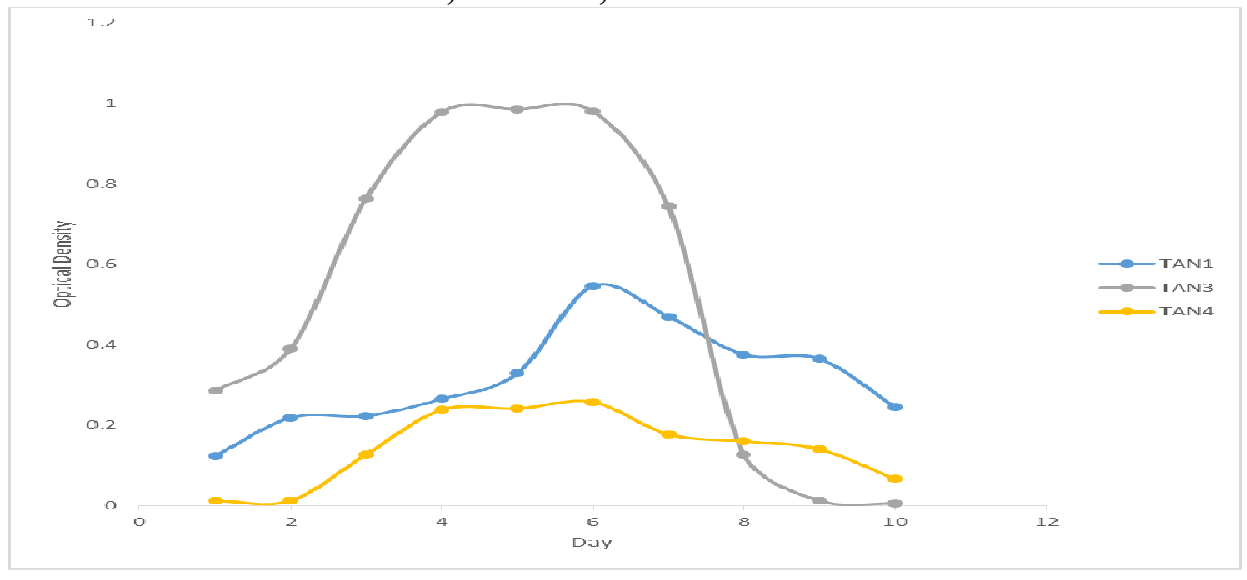

Fig. 2 Growth rates of the isolates in the effluents from the Tannery Industries

\section{Physico-chemical Parameters in the Industrial Effluents after the biodegradation.}

Table 3 shows the mean results of the physicochemical parameter before and after bioremediation using the different masses $(5 \mathrm{~g}$, $10 \mathrm{~g}, 15 \mathrm{~g}, 20 \mathrm{~g}$, and $25 \mathrm{~g}$ ) of the respective immobilized bacteria. Also, Table 4 shows the mean results of correlation coefficient ( $r$ ) between different masses of bacteria and physicochemical parameters.

The mean values $(\mathrm{mg} / \mathrm{l})$ of the SS after the bioremediation varies between $243 \pm 45$ and $898 \pm 672$. The mean concentration $(\mathrm{mg} / \mathrm{l})$ of SS remediated by the different masses $(5 \mathrm{~g}, 10 \mathrm{~g}$, $15 \mathrm{~g}, 20 \mathrm{~g}$, and $25 \mathrm{~g}$ ) of the bacteria varies. The SS in the samples fluctuates up and down after the bioremediation process when compared with the SS of the raw samples before the bioremediation. The increase in the levels of the SS might be due to the aggregation of the TDS which are large enough to result into SS. The increase in the levels of the SS might be also due to the influence of the nutrients which was added into the effluents in order to make the microorganisms more active and viable for fast degradation of organic contaminants in the effluent. The relative potential or efficiency of the different masses of the bacteria in remediating SS in TAN1 samples was in the order $25 \mathrm{~g}>20 \mathrm{~g}>15 \mathrm{~g}>10 \mathrm{~g}>5 \mathrm{~g}$. For TAN2 and TAN3 samples, the order was $25 \mathrm{~g}>20 \mathrm{~g}>15$ $\mathrm{g}>10 \mathrm{~g}>5 \mathrm{~g}$. These might be due to the variations in the surface areas of the different masses of the immobilized bacteria. Statistical analysis shows that there is no significant difference $(p<0.05)$ between the mean values of SS among the masses in the respective industries. Positive and significant correlations exist between the masses of bacteria and Suspended Solid (SS). This showed that there is general increase in the levels of the SS as the masses of the immobilized bacteria increases. TAN3 (90\%) and TAN1 (80\%) showed a very high correlation with the masses of the bacteria while TAN2 (61\%) showed a very low correlation.

The mean values $(\mathrm{mg} / \mathrm{l})$ of the TDS after the bioremediation varies between $46 \pm 11$ and $83 \pm 78$. The mean concentration $(\mathrm{mg} / \mathrm{l})$ of TDS remediated by the different masses $(5 \mathrm{~g}, 10 \mathrm{~g}$, $15 \mathrm{~g}, 20 \mathrm{~g}$, and $25 \mathrm{~g}$ ) of the bacteria varies. There is a reduction in all the TDS of all the samples after the bioremediation process compared with the TDS of the raw samples before the bioremediation. The relative potential or efficiency of the different masses of the bacteria in remediating TDS in TAN1 and TAN3 samples was in the order $5 \mathrm{~g}>10 \mathrm{~g}>15 \mathrm{~g}>20$ $\mathrm{g}>25 \mathrm{~g}$. For TAN2 samples, the order was 20 $g>10 \quad g>25 \quad g>15 \quad g>5 \quad g$. Statistical analysis shows that there is no significant difference $(p<0.05)$ between the mean values of TDS among the masses in the respective industries. These might be due to the variations in the surface areas of the different masses of the immobilized bacteria. Positive and significant correlations exist between the masses of bacteria and TDS with the exception in TAN2 (negative and insignificant correlation). The positive correlations showed that there is general increase in the levels of the TDS as the masses of the immobilized bacteria increases. TAN1 $(96 \%)$ showed a very high correlation with the masses of the bacteria while TAN2 (47\%) showed a very low correlation.

The mean values $(\mathrm{mg} / \mathrm{l})$ of the BOD after the bioremediation varies between $1.56 \pm 0.20 \mathrm{mg} / \mathrm{l}$ and $6.92 \pm 5.49 \mathrm{mg} / \mathrm{l}$. The mean concentration $(\mathrm{mg} / \mathrm{l})$ of BOD remediated by the different masses $(5 \mathrm{~g}, 10 \mathrm{~g}, 15 \mathrm{~g}, 20 \mathrm{~g}$, and $25 \mathrm{~g}$ ) of the bacteria varies. There is a reduction in all the BOD of all the samples after the bioremediation process compared with the $\mathrm{BOD}$ of the raw 
BAJOPAS Volume 13 Number 2, December, 2020 samples before the bioremediation. The relative potential or efficiency of the different masses of the bacteria in remediating BOD in TAN1, TAN2 and TAN3 samples were in the order $25 \mathrm{~g}>20$ $\mathrm{g}>15 \mathrm{~g}>10 \mathrm{~g}>5 \mathrm{~g}, 25 \mathrm{~g}>15 \mathrm{~g}>5 \mathrm{~g}>10 \mathrm{~g}>20 \mathrm{~g}$ and $20 \mathrm{~g}>10 \mathrm{~g}>25 \mathrm{~g}>15 \mathrm{~g}>5 \mathrm{~g}$ respectively. Statistical analysis shows that there is significant difference $(p<0.05)$ between the mean values of BOD among the masses in the respective industries. These might be due to the variations in the surface areas of the different masses of the immobilized bacteria. Negative and significant correlations exist between the masses of bacteria and BOD. This showed that there is general decrease in the levels of the BOD as the masses of the immobilized bacteria increases. TAN1 (94\%) showed a very high correlation with the masses of the bacteria while TAN2 (4\%) showed a very low correlation.

The mean values $(\mathrm{mg} / \mathrm{l})$ of the COD after the bioremediation varies between $250 \pm 154$ and $3134 \pm 1595$. The mean concentration $(\mathrm{mg} / \mathrm{l})$ of COD remediated by the different masses $(5 \mathrm{~g}$, $10 \mathrm{~g}, 15 \mathrm{~g} 20 \mathrm{~g}$, and $25 \mathrm{~g}$ ) of the bacteria varies. There is a reduction in all the COD of all the samples after the bioremediation process compared with the COD of the raw samples before the bioremediation. The relative potential or efficiency of the different masses of the bacteria in remediating COD in TAN1, TAN2 and TAN3 samples were in the order $25 \mathrm{~g}>20 \mathrm{~g}>15$ $\mathrm{g}>5 \mathrm{~g}>10 \mathrm{~g}, 25 \mathrm{~g}>20 \mathrm{~g}>15 \mathrm{~g}>10 \mathrm{~g}>5 \mathrm{~g}$ and 10 g>5 g>25 g>15 g>20 g respectively. Statistical analysis shows that there were significant difference $(p<0.05)$ between the mean values of COD among the masses in the respective industries except for effluents treated with $25 \mathrm{~g}$. These might be due to the variations in the surface areas of the different masses of the immobilized bacteria. Negative and insignificant correlations exist between the masses of bacteria and COD with the exception in TAN3 (positive and significant correlation). The negative correlations showed that there is general decrease in the levels of the COD as the masses of the immobilized bacteria increases. TAN2 (100\%) showed a very high correlation with the masses of the bacteria while TAN3 (36\%) showed a very low correlation.

Generally, there was an overall decrease in the concentration of these physicochemical parameters after the bioremediation using the different masses of the bacterial isolates. These might be due to the variations in the surface areas of the different masses of the immobilized bacteria. This is in line with the work of Jimoh et al. (2018) and Baba et al. (2020).

Table 3: Mean Values $(\mathrm{mg} / \mathrm{l}) \pm$ S.D of Physicochemical parameters in effluents from the Tannery Industries before and after Treatment of the effluents $(250 \mathrm{ml})$ with the different masses $(5 \mathrm{~g}, 10 \mathrm{~g}$, $15 \mathrm{~g}, 20 \mathrm{~g}$, and $25 \mathrm{~g}$ ) of the bacteria.

\begin{tabular}{llllllll}
\hline $\mathrm{P}$ & IND & Before & \multicolumn{5}{c}{ After } \\
\cline { 4 - 7 } & & & $5 \mathrm{~g}$ & $10 \mathrm{~g}$ & $15 \mathrm{~g}$ & $20 \mathrm{~g}$ & $25 \mathrm{~g}$ \\
\hline \multirow{2}{*}{ COD } & TAN1 & $2372 \pm 938$ & $1708 \mathrm{a} \pm 861$ & $2045 \mathrm{a} \pm 1205$ & $845 \mathrm{a} \pm 369$ & $300 \mathrm{a} \pm 167$ & $250 \mathrm{a} \pm 154$ \\
& TAN2 & $1406 \pm 208$ & $1195 \mathrm{a} \pm 208$ & $1125 \mathrm{a} \pm 384$ & $1055 \mathrm{a} \pm 317$ & $956 \mathrm{a} \pm 310$ & $870 \mathrm{ab} \pm 240$ \\
& TAN3 & $3532 \pm 1373$ & $2374 \mathrm{a} \pm 1344$ & $1976 \mathrm{a} \pm 1405$ & $2757 \mathrm{a} \pm 1266$ & $3134 \mathrm{a} \pm 1595$ & $2614 \mathrm{~b} \pm 1105$ \\
BOD & TAN1 & $13.85 \pm 6.42$ & $6.92 \mathrm{a} \pm 5.49$ & $6.42 \mathrm{a} \pm 5.07$ & $5.72 \mathrm{a} \pm 5.35$ & $4.62 \mathrm{a} \pm 4.37$ & $2.82 \mathrm{ab} \pm 1.26$ \\
& TAN2 & $19.46 \pm 0.50$ & $1.75 \mathrm{~b} \pm 0.22$ & $1.73 \mathrm{~b} \pm 0.18$ & $1.58 \mathrm{a} \pm 0.16$ & $1.91 \mathrm{a} \pm 0.22$ & $1.56 \mathrm{~b} \pm 0.20$ \\
& TAN3 & $17.13 \pm 3.14$ & $4.24 \mathrm{ab} \pm 0.77$ & $3.29 \mathrm{ab} \pm 0.37$ & $4.11 \mathrm{a} \pm 0.07$ & $3.23 \mathrm{a} \pm 0.91$ & $3.33 \mathrm{a} \pm 1.28$ \\
SS & TAN1 & $374 \pm 124$ & $243 \mathrm{a} \pm 45$ & $471 \mathrm{a} \pm 226$ & $475 \mathrm{a} \pm 182$ & $492 \mathrm{a} \pm 128$ & $611 \mathrm{a} \pm 217$ \\
& TAN2 & $358 \pm 335$ & $460 \mathrm{a} \pm 400$ & $543 \mathrm{a} \pm 414$ & $544 \mathrm{a} \pm 402$ & $551 \mathrm{a} \pm 414$ & $554 \mathrm{a} \pm 405$ \\
& TAN3 & $780 \pm 739$ & $586 \mathrm{a} \pm 594$ & $758 \mathrm{a} \pm 656$ & $787 \mathrm{a} \pm 676$ & $861 \mathrm{a} \pm 635$ & $898 \mathrm{a} \pm 672$ \\
TDS & TAN1 & $3941 \pm 3703$ & $51 \mathrm{a} \pm 10$ & $53 \mathrm{a} \pm 10$ & $55 \mathrm{a} \pm 15$ & $61 \mathrm{a} \pm 20$ & $63 \mathrm{a} \pm 26$ \\
& TAN2 & $3300 \pm 1714$ & $83 \mathrm{a} \pm 78$ & $47 \mathrm{a} \pm 20$ & $48 \mathrm{a} \pm 22$ & $47 \mathrm{a} \pm 17$ & $48 \mathrm{a} \pm 17$ \\
& TAN3 & $2653 \pm 1240$ & $46 \mathrm{a} \pm 11$ & $55 \mathrm{a} \pm 24$ & $55 \mathrm{a} \pm 25$ & $58 \mathrm{a} \pm 23$ & $61 \mathrm{a} \pm 28$ \\
\hline
\end{tabular}

Replicate $=6$ (months)

Within the rows, for the same parameter, means with different alphabets are statistically different $(p<0.05)$.

$\mathrm{P}=$ parameter, IND = Industries 
BAJOPAS Volume 13 Number 2, December, 2020

Table 4: Correlation coefficient $(r)$ between different masses of the bacteria and the physicochemical parameters.

\begin{tabular}{llll}
\hline Industries & Parameter & Correlation coefficient $(r)$ & $\begin{array}{l}\text { Percent dependence (rxrx100) } \\
(\%)\end{array}$ \\
\hline TAN1 & COD & -0.9 & 82 \\
& BOD & -0.97 & 94 \\
& SS & $0.90^{*}$ & 80 \\
TAN2 & TDS & $0.98^{*}$ & 96 \\
& COD & -1 & 100 \\
& BOD & -0.21 & 4 \\
& SS & $0.78^{*}$ & 61 \\
& TDS & -0.69 & 47 \\
& COD & $0.60^{*}$ & 36 \\
& BOD & -0.6 & 37 \\
& SS & $0.95^{*}$ & 90 \\
& TDS & $0.94^{*}$ & 89 \\
\hline
\end{tabular}

The correlation coefficient $(r)$ with * is statistically significant $(p<0.05)$.

Percentage reduction of the Parameters

Table 5 shows the percentage reduction of Parameters in industrial samples before and after the treatment of the effluents $(250 \mathrm{ml})$ with the different masses $(5 \mathrm{~g}, 10 \mathrm{~g}, 15 \mathrm{~g}, 20 \mathrm{~g}$, and $25 \mathrm{~g}$ ) of the Immobilized Bacteria.

In TAN1 samples, the percentage reduction (\%) of COD ranged (14-89); BOD (50-80); SS (-32$35)$ and TDS (98-99). In TAN2 samples, the percentage decrease $(\%)$ of COD ranged (15$38) ;$ BOD (90-92); SS [-28-(-55)] and TDS (9798). In TAN3 samples, the percentage decrease (\%) of COD ranged (11-44); BOD (76-81); SS (15-25) and TDS (98). The percentage increase in the levels COD, BOD and TDS might be due to the increase in the surface area of the different masses of the immobilized bacteria. However, the percentage decrease in the levels of the SS might be due to the aggregation of the TDS which are large enough to result into SS. The percentage decrease in the levels of the SS might be also due to the influence of the nutrients which was added into the effluents in order to make the microorganisms more active and viable for fast degradation of organic contaminants in the effluent. This is in line with the work of Jimoh et al. (2018) in which the concentration of the SS increase after the bioremediation of effluents.

Sreemoyee and Priti (2013) assessed and reduced several Physico-chemical parameters of dairy wastewater using Niesseria $s p$. and concluded that the species are well known to degrade organic compounds. This is in agreement with the current study in which the immobilized Niesseria $s p$ degrade the organic contaminants as indicated by the BOD, COD and TDS.

Jimoh et al. (2018) observed that TSS of the effluents was increased after treatment with immobilized bacteria and concluded that it might be due to the biostimulation method adopted for the research.

The optimum $\mathrm{pH}$ Biosorption of Chromium by Bacillus spp and Staphylococcus spp. from tannery effluent was investigated by Mythili and Karthikeyan (2011). The maximum adsorption of Chromium $(86.4 \mathrm{mg} / \mathrm{L})$ was showed by Bacillus spp and Staphylococcus spp showed $70.6 \mathrm{mg} / \mathrm{L}$ at an initial concentration of $100 \mathrm{mg} / \mathrm{L}$. In the present study, immobilised Bacillus spp and Staphylococcus spp. from the tannery industrial effluents reduced the levels of the organic pollutants with high potential as indicated by the percentage reduction of BOD, COD and TDS.

Enzymes often can work in multiple environments especially if they are immobilized. This makes the microorganisms' enzymes even more resistant to harsh environments and enables the enzymes to be recovered and recycled after they are no longer needed (Gianfreda and Rao 2004). Ramesh and Singh (1993) reported that the immobilized bacteria having more efficiency to remove the suspended particles than free cells. Using the immobilized cell is preferable due to its capability for using several times with the same efficiency, which makes it more economical. Similar work was done by Sikander et al. (2007) showing the higher reduction with permeabilized cells of Ochrobactrum intermedium strain SDCr-5. 
BAJOPAS Volume 13 Number 2, December, 2020

The results revealed the isolation and identification of isolates with the potential for the reduction of $\mathrm{Cr}$ (VI) to $\mathrm{Cr}$ (III). Results indicated that immobilized $B$. cereus could be efficiently used for the reduction of $\mathrm{Cr}$ (VI).

Table 5: Percentage reduction of the tested Parameters from the tannery industrial samples of the Immobilized Bacteria.

\begin{tabular}{lllllll}
\hline \multirow{2}{*}{ Industries } & & \multicolumn{5}{c}{ Percentage Reduction $(\%)$} \\
\cline { 3 - 7 } & & $5 \mathrm{~g}$ & $10 \mathrm{~g}$ & $15 \mathrm{~g}$ & $20 \mathrm{~g}$ & $25 \mathrm{~g}$ \\
\hline TAN1 & COD & 28 & 14 & 64 & 87 & 89 \\
& BOD & 50 & 54 & 59 & 67 & 80 \\
& SS & 35 & -26 & -27 & -32 & -63 \\
& TDS & 99 & 99 & 99 & 98 & 98 \\
TAN2 & COD & 15 & 20 & 25 & 32 & 38 \\
& BOD & 91 & 91 & 92 & 90 & 92 \\
& SS & -28 & -52 & -52 & -54 & -55 \\
& TDS & 97 & 99 & 99 & 99 & 99 \\
& COD & 33 & 44 & 22 & 11 & 26 \\
& BOD & 75 & 81 & 76 & 81 & 81 \\
& SS & 25 & 3 & -1 & -10 & -15 \\
& TDS & 98 & 98 & 98 & 98 & 98 \\
\hline
\end{tabular}

Percentage Reduction $=(B-A) / B \times 100 \%$

$A=$ Concentration of the parameter after treatment

$\mathrm{B}=$ Concentration of the parameter before treatment

$+=$ percentage decrease

- = percentage increase

In general, immobilization makes the enzyme more resistant to temperature, $\mathrm{pH}$, and substrate concentration swings giving it a longer lifetime and higher productivity per active unit (Gianfreda and Rao, 2004; FuIlbrook, 1996; Russell et al, 2003; Kandelbauer et al., 2004). Immobilized cells have been used and studied extensively for the production of useful chemicals (Ohtake and Silver, 1994), the treatment of wastewaters (Chen et al., 2003; Wang et al., 2010). Although many workers described microbial degradation of tannery effluent, limited literature is available on the bioremediation of tannery effluent using immobilized bacterial cells in the Kano Industrial Estates.

\section{CONCLUSION}

The samples contained variable levels of the physicochemical parameters. The results of the Analysis of variance revealed that, no statistical difference $(p<0.05)$ was observed for the temperature, $\mathrm{pH}, \mathrm{SS}, \mathrm{TDS}, \mathrm{BOD}$ and $\mathrm{COD}$ among the three tannery industries before the treatment. The levels of some of the parameters
(SS, TDS and COD) observed in the samples were found above the recommended limits of WHO and NESREA, which called for the treatment of the effluents before discharge into the environment. Base on the morphological and biochemical test results, TAN1, TAN2, and TAN3 bacterial isolates were identified to be Neisseria spp, Bacillus cereus, and Staphylococcus aureus respectively. The results of Post-treatment analysis showed that there is overall decrease in the levels of the parameters determined when compared with that of the pre-treatment. The overall percentage reduction of the immobilised bacteria in the treatment of the respective effluents was in the order TAN2 (72\%)>TAN1 $(70 \%)>$ TAN3 $(62 \%)$. Hence, the immobilized bacteria are having higher biodegradation potential for the treatment of the tannery effluents.

\section{Acknowledgments}

The authors wish to acknowledge the University of Maiduguri for the financial support. The authors are grateful to the Kano State Ministry of Environment for their support in obtaining the effluent samples. 


\section{REFERENCES}

Ajao, A. T., Adebayo, G. B., and Yakubu, S. E. (2011). Bioremediation of textile industrial effluent using mixed culture of Pseudomonas aeruginosa and Bacillus subtilis immobilized on agar-agar in a bioreactor. J. Microbiol. Biotech. Res, 1(3), 50-56.

Akan, J. C., Moses, E. A., Ogugbuaja, V. O., and Abah, J. (2007). Assessment of tannery industrial effluents from Kano metropolis, Kano State, Nigeria. Journal of Applied Sciences, 7(19), 2788-2793.

Akan, J. C., Ogugbuaja, V. O., Abdulrahman, F. I., and Ayodele, J. T. (2009). Pollutant levels in effluent samples from tanneries and textiles of Kano industrial areas, Nigeria. Global journal of pure and applied sciences, 15(3-4).

APHA (1989). Standard methods for Examination of Will bete and Will betewater.15 $5^{\text {th }}$ edition. Brydpass Springfield Will behington DC. pp. 164-176

APHA (1992). Standard Methods for the Examination of Water and Wastewater. Health, 69, 1116-9.

Baba, A., Garba, S. T., and Bello, H. S. (2020). Bioremediation Potential of Immobilized corynebacterium kutsceri in the Treatment of Tannery Industrial Effluent from Challawa Industrial Estate, Kano State, Nigeria. Journal of the Turkish Chemical Society Section A: Chemistry, $7(2), 335-350$.

Beem, E. I. V. (1994). reduction of solvent VOC emission. J. Oil Col. Chem. Ass, 77, 158.

Bouwer, E. J., and Zehnder, A. J. (1993). Bioremediation of organic compoundsputting microbial metabolism to work. Trends in biotechnology, 11(8), 360367.

Chen, K. C., Wu, J. Y., Liou, D. J., and Hwang, S. C. J. (2003). Decolorization of the textile dyes by newly isolated bacterial strains. Journal of Biotechnology, 101(1), 57-68.

Dan'Azumi, S., and Bichi, M. H. (2010). INDUSTRIAL POLLUTION AND HEAVY METALS PROFILE OF CHALLAWA RIVER IN KANO, NIGERIA. Journal of Applied Sciences in Environmental Sanitation, $5(1)$.

DWAF. (1992). Analytical Methods Manual, TR 151. Department of Water Affairs and Forestry, Pretoria.

El-Bestawy, E. (2013). Biological treatment of leather-tanning industrial wastewater using free living bacteria.
Elsheikh, M. A. S. (2009). Tannery wastewater pre-treatment. Water Science and Technology, 60(2), 433-440.

FuIlbrook, P. D. (1996). "Kinetics." Industrial enzymology: The application of enzymes in Industry. 2nd Ed. T. Godfrey and J Reichelt. eds.. Nature. New York.

Gianfreda, L., and Rao, M. A. (2004). Potential of extra cellular enzymes in remediation of polluted soils: a review. Enzyme and microbial technology, 35(4), 339354.

Hugo Springer. (1994). John Arthur Wilson Memorial Lecture "Treatment of Industrial Wastes of the Leather Industry - is it still a Major Problem". JALCA, 89, 153-185

Jimoh, A. A., Ganiyu, B. A., Baba, D., and Baba, A. (2018) Bioremediation Process of Effluent from Detergent and Food Industries in Jos, Nigeria: Kinetics and Thermodynamics. International Journal of Engineering Science Invention (IJESI), 762-73

Kandelbauer, A., Maute, O., Kessler, R. W., Erlacher, A., and Gübitz, G. M. (2004). Study of dye decolorization in an immobilized laccase enzyme-reactor using online spectroscopy. Biotechnology and bioengineering, 87(4), 552-563.

Kongjao, S., Damronglerd, S., and Hunsom, M. (2008). Simultaneous removal of organic and inorganic Pollutants in tannery wastewater using electrocoagulation technique. Korean Journal of chemical engineering, 25(4), 703.

Maheshwari, U. M., Aruna, S., Gomathi, M., and AbdulJaffar, A. H. (2017). Bioremediation by Free and Immobilized Bacteria Isolated from Tannery Effluent. International Journal of Research in Applied, Natural and Social Sciences. 5(7), 75-90

Margesin, R., and Schinner, F. (2001). Bioremediation (natural attenuation and biostimulation) of diesel-oilcontaminated soil in an alpine glacier skiing area. Applied and environmental microbiology, 677), 3127-3133.

Mohammed, A., Sekar, P., and George, J. (2011). Efficacy of microbes in bioremediation of tannery effluent. Inter. J. Curr. Res, 3(4), 324-326.

Mohammed, S. S. D., Orukotan, A. A., and Abdullahi, H. (2017). Physicochemical and Bacteriological Assessment of Tannery Effluent from Samaru-Zaria, 
BAJOPAS Volume 13 Number 2, December, 2020 Kaduna State, Nigeria. Journal of Applied

Sciences and Environmental Management, 21(4), 734-740.

Munz, G., De Angelis, D., Gori, R., Mori, G., Casarci, M., and Lubello, C. (2009). The role of tannins in conventional and membrane treatment of tannery wastewater. Journal of hazardous materials, 164(2-3), 733-739

Mythili, K., and Karthikeyan, B. (2011). Bioremediation of $\mathrm{Cr}$ (VI) from tannery effluent using Bacillus spp and Staphylococcus spp. International Multidisciplinary Research Journal, 1(6).

NESREA (2009). National Environmental Standards for Effluent Limitations and Regulation. 1233-1236

Noorjahan, C. M. (2014). Physicochemical characteristics, identification of bacteria and biodegradation of industrial effluent. Journal of bioremediation and Biodegradation, 5(3).

Ohtake, H. I., and Silver, A. O. (1994). Bacterial reduction of toxic chromate. Biological degradation and bioremediation of toxic chemicals, 403-415.

Omoleke, I. I. (2004). Management of environmental pollution in Ibadan, an African city: the challenges of health hazard facing government and the people. Journal of Human Ecology, 15(4), 265-275.

Rajor, A., Reddy, A.S., and Singh, B. (2004). Determination of BOD kinetic Parameters and evaluation of alternate methods, M.Sc. Thesis, Department of biotechnology \& environmental Science, Thapar Institute of Engineering and Technology, Patiala

Ramasami, T., Rajamani, S., and Rao, J. R. (1994, March). Pollution control in leather industry: Emerging technological options. In International symposium on surface and colloidal science and its relevance to soil pollution, madras.

Ramesh, J. V. S., and Singh, S. P. (1993). Yearly variation in certain physicochemical parameters of pond at eastern Doon Valley. Uttar Pradesh J. Zoo, 12 (1), 7577.

Ranen, S., and Sharadinadra, C. (2009). Biotechnology applications to environmental remediation in resource exploitation. Current science, 97, 6-25
Russell, A. J., Berberich, J. A., Drevon, G. F., and Koepsel, R. R. (2003). Biomaterials for mediation of

chemical and biological warfare agents. Annual review of biomedical engineering, 5(1), 1-27.

Saravanan, P., and Saravanan, A. (1999). Decolourization of tannery effluent by Flavobacterium sp. EK 1. Indian Journal of Environmental Protection, 19, 19-24.

Sikander, S., and Shahida, H. (2007). Reduction of toxic hexavalent chromium by Ochrobactrum intermedium strain SDCr5 stimulated by heavy metals. Bioresource Technol, 98, 340-344.

Singh, N., Sharma, B. K., and Bohra, P. C. (2000). Impact assessment of industrial effluent of arid soils by using satellite imageries. Journal of the Indian Society of Remote Sensing, 28(2-3), 79.

Sreemoyee, C., and Priti, P. (2013). Assessment of physico-chemical parameters of dairy waste water and isolation and characterization of bacterial strains in terms of cod reduction. Int J Sci, 2(3), 395-400.

Verheijen, L. A. H. M., Wiersema, D., Pol, L. H., and De Wit, J. (1996). Management of wastes from animal product processing. Livestock and environment, Finding a balance. International Agriculture Center, Wageningen, The Netherlands.

Wang, F., Yao, J., Si, Y., Chen, H., Russel, M., Chen, K., and Bramanti, E. (2010). Short-time effect of heavy metals upon microbial community activity. Journal of Hazardous Materials, 173(13), 510-516.

WHO (World Health Organization). (2006). Air quality guidelines: global update 2005: particulate matter, ozone, nitrogen dioxide, and sulfur dioxide. World Health Organization.

World Bank. (1995). Nigeria's strategic options for redressing industrial pollution. World Bank, industry and energy division. 1st edition, West Central Africa Department; Annexes: 1995; pp 60-62.

Zahoor, A., and Abdul, R. (2009). Enumeration of Coliforms. Journal of Environmental Sciences. 21, 814-820 


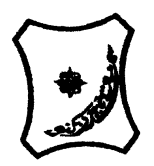

Bayero Journal of Pure and Applied Sciences, 13(2): 1 - 12

Received: November, 2020

Accepted: December, 2020

ISSN $2006-6996$

\title{
BIODEGRADATION POTENTIAL OF IMMOBILIZED BACTERIA IN THE TREATMENT OF TANNERY INDUSTRIAL EFFLUENTS FROM INDUSTRIAL ESTATES IN KANO STATE, NIGERIA
}

\author{
Abdullateef, B., ${ }^{1 *}$ Shuaibu, T. G., ${ }^{1}$ Babagana, K., ${ }^{1}$ Suleman, H. B. ${ }^{2}$ and Dauda, B. ${ }^{3}$ \\ ${ }^{1}$ Department of Pure and Applied Chemistry, Faculty of Science, University of Maiduguri, Borno State, \\ Nigeria \\ ${ }^{2}$ Department of Microbiology, Faculty of Science, University of Maiduguri, Borno State, Nigeria \\ ${ }^{3}$ Department of Chemical Engineering, Faculty of Engineering, University of Maiduguri, Borno State, \\ Nigeria \\ *Corresponding author: babslega@gmail.com; abelega2007@yahoo.com; +2348061309753
}

\section{ABSTRACT}

Industrial Effluents Samples from Gashash Tanneries (TAN1) in Bompai Industrial estate, Larabee Tannery Industry (TAN2) in Sharada Industrial estate and Z Tannery Industries (TAN3) in Challawa Industrial estate, Kano State, Nigeria were collected over a period of six months (August 2017 to January 2018) for assessing the biodegradation potentials of bacteria in the treatment of organic pollutants within the effluents. Bacteria were isolated from the effluents and immobilized on agar-agar. Different masses (5 g, $10 \mathrm{gr}, 15$ $\mathrm{g}, 20 \mathrm{~g}$, and $25 \mathrm{~g}$ ) of the bacteria were used in the treatment of $250 \mathrm{ml}$ of the effluents for ten days in a shaker incubator (Gallenkamp-OC-4364-L) at the temperature $30{ }^{\circ} \mathrm{C}$ and speed of $60 \mathrm{rpm}$. Pre-treatment analysis of the effluents for Temperature, pH, Biochemical Oxygen Demand (BOD), Chemical Oxygen Demand (COD), Suspended Solid (SS) and Total Dissolved Solids (TDS) gives the following results; temperature $\left({ }^{\circ} \mathrm{C}\right.$ )

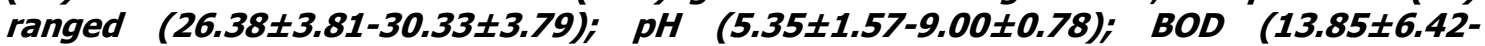
$38.75 \pm 16.20) ;$ COD (1406 $\pm 208-3532 \pm 1373) ;$ SS (208 $\pm 235-780 \pm 739)$ and TDS (266 $\pm 253-5276 \pm 2971)$. No statistical differences ( $p \leq 0.05)$ was observed for all the results among the different industries. The bacterial isolates were identified as Neisseria spp, Bacillus cereus, and Staphylococcus aureus, in TAN1, TAN2, and TAN3, respectively. After treatment of the effluent with the different masses of the isolated bacteria, the mean level of BOD was found to range as (0.55 $\pm 0.36-6.92 \pm 5.49) ; C O D$ (ND-3134 \pm 1595$)$;

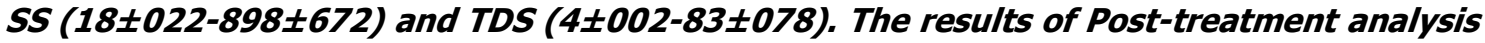
showed that there is overall decrease in the levels of the parameters determined when compared with that of the pre-treatment. The overall percentage reduction of the immobilised bacteria in the treatment of the respective effluents was in the order TAN2 (72\%)>TAN1 (70\%)>TAN3 (62\%). Hence, the immobilized bacteria are having higher biodegradation potential for the treatment of the tannery effluents.

Keywords: Biodegradation, bacteria, effluent, immobilization, tannery.

\section{INTRODUCTION}

Tannery industrial wastewater is a serious consequence of the pollution point of view for streams, freshwater, and land used for agriculture. The lack of awareness in the modern industrial practice has resulted in the discharge of tannery effluents which exhibit very high value of chromium ( $\mathrm{Cr}$ ), Sulfide, and chloride, Total Dissolved Solid (TDS), Total Suspended Solid (TSS), Biochemical Oxygen Demand (BOD) and Chemical Oxygen Demand (COD) in the water stream or land (Mohammed et al., 2001). Tanning is the process, which One ton of skin generally leads to the production of 20 to $80 \mathrm{~m}^{3}$ of turbid and foul-smelling converts the protein of the rawhide or skin into a stable material, which will not putrefy and is suitable for a wide variety of end applications (Elsheikh, 2009). The highly polluting chromium is the most commonly used tanning material producing leather that is more flexible and pliable than vegetable-tanned leather and does not discolor or lose shape in water as drastically as vegetable-tan (Elsheikh, 2009). Tannery effluent is among the most hazardous industrial pollutants due to its huge organic and inorganic load, which is highly toxic to human life and the environment (Kongjao et al., 2008). wastewater including chromium (100-400 mg/l), sulfide $(200-800 \mathrm{mg} / \mathrm{l})$, high levels of fat and 
BAJOPAS Volume 13 Number 2, December, 2020 other solid wastes, and notable pathogen contamination as well as pesticides added for skin conservation during transport (Elsheikh, 2009). There are more than 6000 tanneries in Nigeria with an annual processing capacity of 700,000 tons of hides and skins (Omoleke, 2004; Singh et al., 2008). It was reported that the total amount of waste produced per animal slaughtered is approximately $35 \%$ of its weight (World Bank, 1995). Also, for every $1000 \mathrm{~kg}$ of carcass weight, a slaughtered beef produces 5.5 $\mathrm{kg}$ of manure (excluding rumen contents or stockyard manure) and $100 \mathrm{~kg}$ of paunch manure (undigested food) (Verheijen et al., 1996). Tanneries generate wastewater in the range of 30-35 $\mathrm{L} \mathrm{kg}^{-1}$ skin/hide processed with variable $\mathrm{pH}$, Biological Oxygen Demand (BOD), Chemical Oxygen Demand (COD), high concentrations of suspended solids (SS), and tannins as well as chromium (Zahoor and Abdul, 2009).

Being heterogeneous and composed of a wide variety of compounds, it is very difficult to select a unique direct method for estimating the biodegradability of organic contents and biokinetic parameters for a wastewater sample (Rajor, 2004). For this purpose, some indirect estimation such as determination of biochemical oxygen demand (BOD) and chemical oxygen demand (COD) are applied as common laboratory investigations [9]. During retanning procedures, synthetic tannins (Syntan), oils and resins are added to form softer leather at varying doses (Munz et al., 2009). One of the refractory groups of chemicals in tannery effluents derives mainly from tannins (Ramasami et al., 2004). Syntans are characterized by complex chemical structures, because they are composed of an extended set of chemicals such as phenol-, naphthalene-, formaldehyde- and melamine-based syntans, and acrylic resins (Beem, 1994). Organic pollutants (proteic and lipidic components) are originated from skins (it is calculated that the raw skin has $30 \%$ loss of organic material during the working cycle) or they are introduced during processes (Hugo Springer, 1994).

Many conventional processes such as oxidation, chemical and biological processes were carried out to treat tanneries wastewater (Ebtesam et al, 2013). Biological processes have received more attention because of their costeffectiveness, lower sludge production and environmental friendliness (Noorjahan, 2014). Naturally occurring micro-organisms degrade the hazardous organic wastes including xenobiotic compounds, such as pesticides, polycyclic aromatic hydrocarbons (PAHs) and polychlorinated biphenyls (PCBs) in due course of time (Ranen and Sharadinadra, 2009). Bioremediation is based on the idea that all organisms remove substances from the environment to carry outgrowth and metabolism (Bouwer and Zehnder, 1993). Bacteria, protista and fungi are found to be very good at degrading complex molecules and incorporating the breakdown products into their metabolism (Bouwer and Zehnder, 1993). The resultant metabolic wastes that they produce are generally safe and somehow recycled into other organisms (Ranen and Sharadinadra, 2009). An acclimatized indigenous population of microorganisms capable of degradation of the compounds of interest must exist at the site for a successful bioremediation mode (Ranen and Sharadinadra, 2009). It has been observed that for a successful bioremediation mode, an acclimatized indigenous population of microorganisms capable of degradation of the compounds of interest must exist at the site under investigation (Ranen and Sharadinadra, 2009). Even though there are numerous physical and chemical methods employed in the disposal of wastes the advantage in using bacterium is that they play a key role in the reduction of COD, BOD, total protein, total tannin and total phenol (Saravanan and Saravanan, 1998)

Baba et al. (2020) studied the bioremediation potential of immobilized corynebacterium kutsceri in the Treatment of tannery industrial effluent from Challawa Industrial Estate, Kano State, Nigeria. The aim of the work is to study the reduction in the level of the contaminants through the process of bioremediation using the isolated bacteria. Immobilized bacteria can withstand various temperatures, $\mathrm{pH}$ and substrate concentrations; consequently, increasing the efficiency and the lifespan of the bacteria. Immobilized bacteria are widely applied in the treatment of wastewater and can be separated and recovered after the treatment with the same efficiency (Baba et al., 2020).

\section{MATERIALS AND METHODS \\ Study Area}

This study was carried out in Bompai, Sharada and Challawa industrial estates in Kano, Figure 1. Kano lies on Latitude $11^{\circ} 30^{\prime} \mathrm{N}$ and $8^{\circ} 30^{\prime} \mathrm{E}$ and Longitude $11^{\circ} 5^{\prime} \mathrm{N}$ and $8^{\circ} 5^{\prime} \mathrm{E}$ in Northern Nigeria. It is one of the developed industrial cities in Nigeria. Tannery activities are the dominating industries and this could be one of the reasons for her high population density (Dan'Azumi and Bichi, 2010). Many researchers have studied biodegradation of tannery effluent using microorganisms. However, limited literature is available on the biodegradation of tannery effluent in Kano industrial estates using 
BAJOPAS Volume 13 Number 2, December, 2020 immobilized bacterial cells. This research work focuses on the potential of the use of the indigenous immobilized bacterial isolates in the treatment of tannery effluents in the industrial estates.

\section{Sample Collection}

Effluents were collected from the Tannery Industries from Bompai, Challawa and Sharada Industrial Estates, Kano, Nigeria. The effluents were collected over a period of six months (August 2017 to January 2018). Samples collected in a sterile 4-liter plastic container with a unique identification number were preserved using an ice-box that was transported to the Microbiology Laboratory, Department of Microbiology, Bayero University of Kano for analysis

\section{Sample Preparation and Sample Analysis}

Immediately after the collection of the effluent, $\mathrm{pH}$, TSS, TDS, COD, BOD levels were determined before treatment (Pre-treatment determination) and ten days after treatment (Post-treatment determination) as described in
APHA (1989) standard methods. $\mathrm{pH}$ was determined using Ecotests $\mathrm{pH}$ meter and TDS was determined using AQUALYTIC TDS Salinometer. BOD was determined as described by the standard method (APHA, 1992). COD and SS were determined using DR/2010 HACH portable data logging spectrophotometer (DWAF, 1992)

\section{Identification and Biochemical} Characterization of the Bacterial Isolates

The bacteria were isolated from the effluents using Serial Dilution according to the method described by APHA (1989). The biochemical tests such as oxidase, catalase, coagulase, indole (from $1 \%$ tryptone broth), citrate (Simmons citrate agar), methyl red/VogesProskauer (MR/VP), nitrate reduction, Starch Hydrolysis, Glucose, Maltose, and Lactose tests were carried out on the bacterial isolates to identify the bacteria through the bacteria biochemical characteristics according to Ajao et al. (2011).

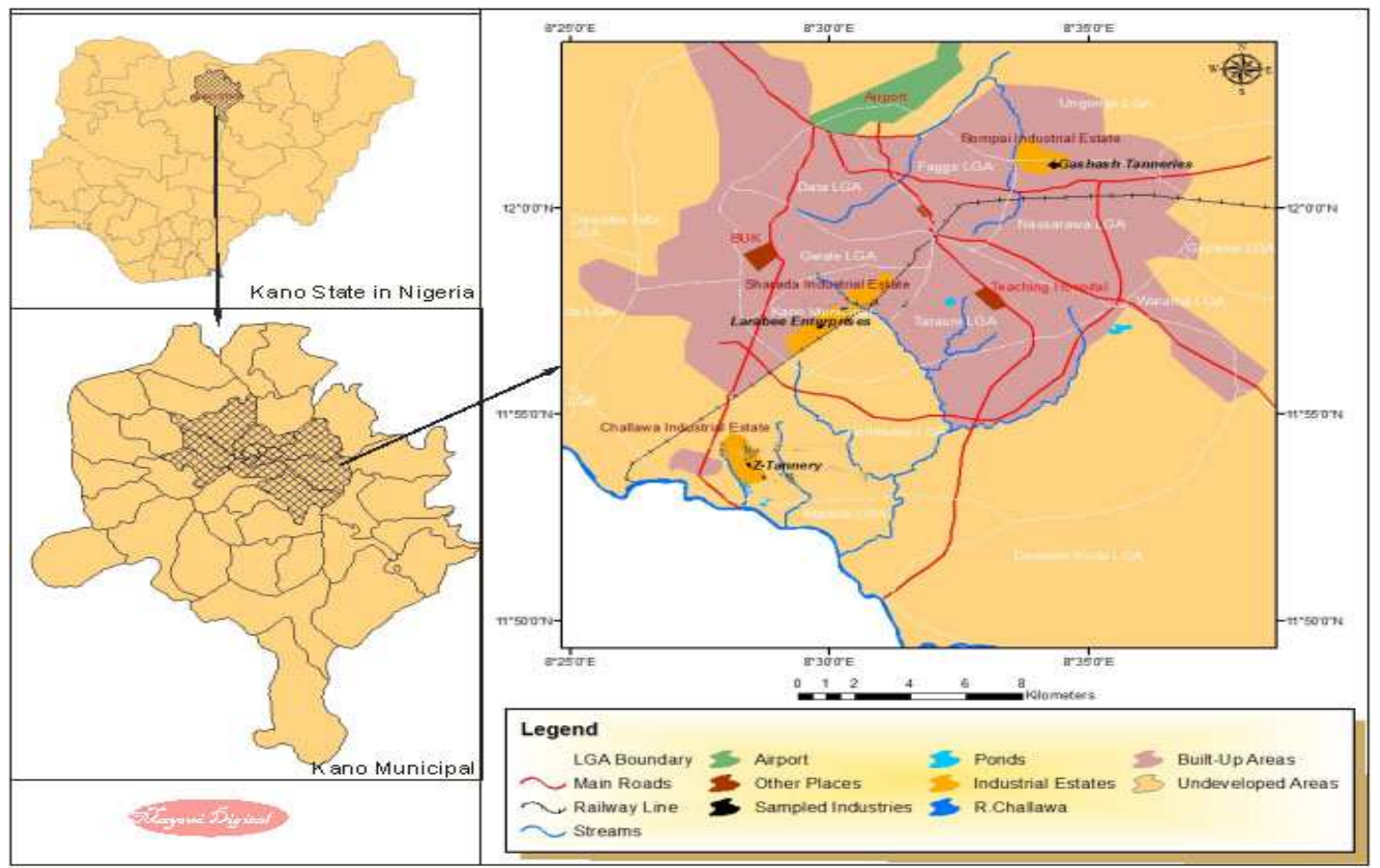

Fig. 1 Map showing the study areas

Source: Mayomi Digital Productions, GIS Laboratory, Department of Geography, UNIMAID (2017)

\section{Determination of Growth Rate of the Bacteria in Effluent Sample}

The bacteria growth rates were determined by transferring $2 \mathrm{~mL}$ of the bacterial isolates from the tannery effluent in broth medium into 100 $\mathrm{mL}$ sterile effluents in conical flasks and kept in an incubator (Giffrin cool) for 10 days. Control was also set up by incubating another $100 \mathrm{~mL}$ each of the sterile effluents without the bacteria. The optical density of the content was determined at the wavelength of $600 \mathrm{~nm}$ on a daily interval and recorded. 
BAJOPAS Volume 13 Number 2, December, 2020 Immobilization of Bacteria

Agar solution and inoculi were prepared separately. Fifty milliliters $(50 \mathrm{~mL})$ of nutrient broth each of the inoculi was prepared in a McCartney bottle and incubated for 24 hours. A solution of agar-agar was prepared by dissolving $10 \mathrm{~g}$ of the powder in distilled water and made up to $500 \mathrm{~mL}$ mark in an Erlenmeyer flask and was sterilized in an autoclave (280A) for 15 minutes and allowed to cool to $40-45^{\circ} \mathrm{C}$ (Ajao et al., 2011). Four milliliters ( $4 \mathrm{~mL})$ of the bacterial isolates in the nutrient broth was mixed with 36 $\mathrm{ml}$ of the prepared agar-agar media in petri-dish plates and then allowed to solidify. This was kept in the refrigerator for bioremediation.

\section{Bioremediation (Treatment) of the Effluents}

The solidified agar block (immobilized bacteria) was cut into cubes using a sterile knife; $0.1 \mathrm{~mL}$ phosphate buffer ( $\mathrm{pH} \mathrm{7.0)}$ was added and kept in the refrigerator for 1 hour for curing. The phosphate buffer was decanted after 1 hour and the cubes were washed with sterile distilled water 3-4 times before it was used (Ajao et al., 2011). Two liters (2 L) of the effluent was supplemented with the minimum basal medium in $\mathrm{g} / \mathrm{L}: \mathrm{NaCl}(0.8), \mathrm{MgSO}_{4} .7 \mathrm{H}_{2} \mathrm{O}(0.001), \mathrm{KH}_{2} \mathrm{PO}_{4}$ (2), $\mathrm{NaNO}_{3}$ (2), $\quad \mathrm{CaCl}_{2} .2 \mathrm{H}_{2} \mathrm{O} \quad(0.5)$ and $\mathrm{NaHPO}_{4} .12 \mathrm{H}_{2} \mathrm{O}(2)$ and sterilized in an autoclave at $121^{\circ} \mathrm{C}$ for 15 minutes (Margesin and Schinner, 2001). Two hundred and fifty milliliters $(250 \mathrm{~mL})$ of the effluents were transferred into different $250 \mathrm{ml}$ conical flasks. The content was covered with a cotton-wool ramped with foil paper to avoid contamination. Five grams $(5 \mathrm{~g})$ of the immobilized bacteria were quickly transferred into each of the effluents in the conical flasks in an inoculating chamber. The same procedures were carried out for the $10 \mathrm{~g}, 15 \mathrm{~g}, 20 \mathrm{~g}$ and 25 $\mathrm{g}$ of the immobilized bacteria in separate $250 \mathrm{~mL}$ effluents in conical flasks and agitated for ten days in a shaker incubator (Gallenkamp-OC4364-L) at a temperature $30^{\circ} \mathrm{C}$ and speed of 60 rpm. The treated effluent samples were taken on the tenth day and analyzed for the parameters $\mathrm{pH}$, SS, TDS, COD, and BOD, (Posttreatment determination) for the different grams of bacteria to evaluate and compare the biodegradation potential. (Baba et al., 2020).

\section{Statistical Analysis}

The data were represented as Mean \pm Standard deviation and analyzed statistically using oneway Analysis of Variance (ANOVA) and Tukey's HSD as Post Hoc Tests with the aid of SPSS 16.0. The correlation coefficient was also used to measure the strength of the relationship between the different masses of the bacteria and the parameters. All $\mathrm{p} \leq 0.05$ were considered as statistically significant.

\section{RESULTS AND DISCUSSION Physico-chemical parameters in the Industrial Effluents before the Biodegradation.}

Results of the Physico-chemical parameters in the industrial effluents before the Biodegradation is shown in table 1 . The mean temperatures $\left({ }^{\circ} \mathrm{C}\right)$ observed in TAN1, TAN2, and TAN3 samples were $28.07 \pm 0.65 ; 27.77 \pm 0.64$ and $26.38 \pm 3.81$ respectively. The order of the mean temperature of the samples from the three industries can be arranged as TAN1 > TAN2>TAN3. The temperature observed at TAN1, TAN2, and TAN3 samples were found below the WHO $\left(35^{\circ} \mathrm{C}\right)$ and NESREA $\left(40^{\circ} \mathrm{C}\right)$ limits. The low values of temperature might be due to the processes used at the time of sampling. High temperature brings down the solubility of gases in water that ultimately expresses as high BOD and COD. Statistical analysis shows that there is no significant difference $(p<0.05)$ between the mean values of temperature among the industries. This might be due to similar tannery activities involved in the tannery industries at the time of sampling. The average values of temperature observed in this present study are less than those observed by Akan et al. (2007), Akan et al. (2009) and Baba et al. (2020).

The mean level of $\mathrm{pH}$ observed in TAN1, TAN2 and TAN3, samples were $7.77 \pm 2.93$; $8.35 \pm 0.28$ and $7.52 \pm 0.76$ respectively. The order of the mean $\mathrm{pH}$ of the samples from the three industries can be arranged as TAN2> TAN1 $>$ TAN3. The $\mathrm{pH}$ of the samples falls within the WHO (7.0-8.5) and NESREA (6-9) standard limits. Statistical analysis shows that there is no significant difference $(p<0.05)$ between the mean values of $\mathrm{pH}$ among the industries. This might be due to similar tannery activities involved in the tannery industries at the time of sampling. Maheshwari et al. (2017) reported that the level of $\mathrm{pH}$ in the effluents from the tannery industry in Vaniyambadi, India was 6.5 which was lower than that observed in the present study. The $\mathrm{pH}$ in the effluents from the tannery industries in Kano and Kaduna were reported to be 7.64 and 6.89, respectively (Akan et al., 2007; Mohammed et al., 2017). The average values of $\mathrm{pH}$ observed in this present study are less than those observed by Mohammed et al. (2017) and Baba et al. (2020). The mean level of SS $(\mathrm{mg} / \mathrm{l})$ observed in TAN1, TAN2, and TAN3 samples were 374 \pm 124 ; $358 \pm 335$ and $780 \pm 739$ respectively. The order of the mean SS in the samples from the three industries can be arranged as TAN3 > TAN1 $>$ TAN2. 
The SS observed in the samples were far above the recommended standard limits of regulating bodies WHO $(30 \mathrm{mg} / \mathrm{l})$ and NESREA $(10 \mathrm{mg} / \mathrm{l})$. Statistical analysis shows that there is no significant difference $(p<0.05)$ between the mean values of SS among the industries. This might be due to similar tannery activities involved in the tannery industries at the time of sampling. The average values of SS observed in this present study are less than that observed $(3700 \pm 122 \mathrm{mg} / \mathrm{l})$ by Akan et al. (2009) for tanneries in Kano. Also, the average values of SS observed in this present study are less than that observed by Mohammed et al. (2017) and Baba et al. (2020) with the exception in TAN3.

The mean level of TDS (mg/l) observed in TAN1, TAN2, and TAN3 samples were $3941 \pm 3703$; $3300 \pm 1714$ and $2653 \pm 1240$ respectively. The order of the mean TDS in the samples from the three industries can be arranged as TAN1>TAN2>TAN3. The TDS observed in the samples were far above the recommended standard limits of WHO $(250 \mathrm{mg} / \mathrm{l})$ and NESREA $(500 \mathrm{mg} / \mathrm{l})$. Statistical analysis shows that there is no significant difference $(p<0.05)$ between the mean values of TDS among the industries. This might be due to similar tannery activities involved in the tannery industries at the time of sampling. TDS in the effluents from the tannery industries in Kano, Nigeria was reported to be $1281 \mathrm{mg} / \mathrm{l}$ (Akan et al., 2007). The average values of SS observed in this present study are less than those observed by Mohammed et al. (2017) and Baba et al. 2020)

The mean level of COD (mg/l) observed in TAN1, TAN2 and TAN3 samples seasons were $2372 \pm 938 ; \quad 1406 \pm 208$ and $3532 \pm 1373$ respectively. The order of the mean COD of the samples from the three industries can be arranged as TAN3>TAN1> TAN2. The COD observed in TAN1, TAN2 and TAN3 samples were far above the recommended standard limits of regulating bodies $\mathrm{WHO}(40 \mathrm{mg} / \mathrm{l})$ and NESREA (40 mg/l). Statistical analysis shows that there is no significant difference $(p<0.05)$ in COD among the industries. This might be due to similar tannery activities involved in the tannery industries as at the time of sampling. The Chemical Oxygen demand (COD) is the amount of oxygen, in $\mathrm{mg} / \mathrm{L}$, required for the degradation of the compound of wastewater to occur. In comparison, the average values of COD observed in this present study were higher than that observed by Mohammed et al. (2017) but lower than that observed by Baba et al. (2020).

The mean levels of BOD $(\mathrm{mg} / \mathrm{l})$ observed in TAN1, TAN2 and TAN3 samples were $13.85 \pm 6.42 ; \quad 19.46 \pm 0.50$ and $17.13 \pm 3.14$ respectively. The order of the mean BOD in the samples from the three industries can be arranged as TAN2>TAN3>TAN1. The BOD observed in TAN1, TAN2 and TAN3 samples were found below the recommended limits of NESREA (200 mg/l) but above WHO (10 mg/l). Statistical analysis shows that there is no significant difference $(p<0.05)$ between the mean values of BOD among the industries. This might be due to similar tannery activities involved in the tannery industries at the time of sampling. The low level of BOD recorded in this study is an indication of the low level of biodegradable organic solids in the effluent. The average values of BOD observed in this present study were lower than those observed by Mohammed et al. (2017) and Baba et al. (2020).

Table 1: Mean Values \pm S.D of Physico-chemical parameters of effluents from the Tannery Industries before Treatment.

\begin{tabular}{llllllll}
\hline Parameter & Tannery 1 & Tannery 2 & Tannery 3 & $\mathrm{a}$ & $\mathrm{b}$ & $\mathrm{c}$ & $\mathrm{d}$ \\
\cline { 2 - 7 } Temperature $\left({ }^{\circ} \mathrm{C}\right)$ & $28.07 \mathrm{a} \pm 0.65$ & $27.77 \mathrm{a} \pm 0.64$ & $26.38 \mathrm{a} \pm 3.81$ & & $29.50 \pm 4.68$ & 35 & 40 \\
pH & $7.77 \mathrm{a} \pm 2.93$ & $8.35 \mathrm{a} \pm 0.28$ & $7.52 \mathrm{a} \pm 0.76$ & 6.89 & $5.35 \pm 1.57$ & $7.0-8.5$ & $6.0-9.0$ \\
$\mathrm{COD}(\mathrm{mg} / \mathrm{l})$ & $2372 \mathrm{a} \pm 938$ & $1406 \mathrm{a} \pm 208$ & $3532 \mathrm{a} \pm 1373$ & 2.2 & $3106 \pm 2753$ & 40 & 40 \\
$\mathrm{BOD}(\mathrm{mg} / \mathrm{l})$ & $13.85 \mathrm{a} \pm 6.42$ & $19.46 \mathrm{a} \pm 0.50$ & $17.13 \mathrm{a} \pm 3.14$ & 1032 & $26.17 \pm 9.49$ & 10 & 200 \\
$\mathrm{SS}(\mathrm{mg} / \mathrm{l})$ & $374 \mathrm{a} \pm 124$ & $358 \mathrm{a} \pm 335$ & $780 \mathrm{a} \pm 739$ & 501 & $562 \pm 482$ & 30 & 10 \\
TDS $(\mathrm{mg} / \mathrm{l})$ & $3941 \mathrm{a} \pm 3703$ & $3300 \mathrm{a} \pm 1714$ & $2653 \mathrm{a} \pm 1240$ & 532.7 & $444 \pm 507$ & 250 & 500 \\
\hline
\end{tabular}

The values given in the table above are means of 6 replicate values, $\mathrm{n}=6$ ( 1 sample was taken monthly for 6 months). Within the rows, means with different alphabets are statistically different $(p<0.05)$. WHO: World Health Organisation. NESREA: National Environmental Standard and Regulatory Enforcement Agency. a = Mohammed et al.(2017), b = Baba et al. (2020), c = WHO (2006), $d=$ NESSRA (2009) 
BAJOPAS Volume 13 Number 2, December, 2020

Identification, Biochemical Characterization and growth rates of the Bacterial Isolates

Results of identification and biochemical characterization of the bacterial isolates were shown in table 2. After 24 hours of incubation, the nutrient agar media plates were checked for bacterial growth. The results showed the presence of different strains in the samples. The TAN1 bacteria isolate was found to be gramnegative cocci while TAN3 was gram-positive cocci. TAN2 bacteria isolate was found to be gram-positive, rod-shaped. TAN1, TAN2, and TAN3 bacteria isolates recorded positive results for spore former.

The results of the biochemical tests indicated that all the bacteria were positive for catalase, oxidase, citrate, maltose, glucose, lactose (negative in TAN1), mannitol (negative in TAN2), starch hydrolysis and coagulase (negative in TAN2) tests. The bacteria showed negative results for nitrate reduction, $M R$ (positive in TAN2), VP (positive in TAN1), Indole (positive in TAN2) tests. Base on the morphological and biochemical test results, TAN1, TAN2, and TAN3 bacteria isolates were identified to be Nesseria spp, Bacillus cereus, and Staphylococcus aureus respectively.

The growth rate of the TAN1, TAN2 and TAN3 Isolates were shown in figure 2. Generally, the optical density increase with the increase in time (day) and decrease as time goes on. The highest optical density was shown by bacillus cereus in TAN2 while the lowest was shown by Staphylococcus aureus in TAN3.

The initial growth phase of TAN1 Isolate bacteria occurred within 2-day of incubation as the growth rate increases up to the 6th-day incubation when the maximum growth was observed. Beyond the 6th day, the growth of the bacteria declined (which might be due to a shortage of nutrients in the effluents) until it reached its death phase (which might be due to the unavailability of nutrients in the effluents).

A similar trend of growth was also observed for TAN2 Isolate as the initial growth phase also occurred within 2-day of incubation but maximum growth rate observed on the 4th day of incubation. The stationary stage occurred between the 4th day and the 8th day. Beyond the 8th day, the growth of the bacteria declined (which might be due to a shortage of nutrients in the effluents) until it reached its death phase (which might be due to the unavailability of nutrients in the effluents).

The initial growth phase of TAN3 bacterial Isolate occurred within the 3-day incubation as the growth rate increases up to the 6th-day incubation when the maximum growth was observed. Beyond the 6th day, the growth of the bacteria declined (which might be due to a shortage of nutrients in the effluents) until it reached its death phase (which might be due to the unavailability of nutrients in the effluents).

Table 2: Morphological and Biochemical characteristics of bacterial isolates

\begin{tabular}{lllll} 
Bacterial Isolates & & TAN1 & TAN2 & TAN3 \\
\hline $\begin{array}{lllll}\text { Morphological } \\
\text { characteristics }\end{array}$ & Shape & Cocci & Rod & Cocci \\
& Spore & & & \\
& former & + & + & + \\
Gram & & & \\
Biochemical characteristics & reaction & - & + & + \\
& Citrate & + & + & + \\
& Catalase & + & + & + \\
& Coagulase & + & - & + \\
Starch & + & + & + \\
& Glucose & + & + & + \\
Oxidase & + & + & + \\
& Indo & - & + & - \\
Lactose & - & + & + \\
Manitol & + & - & + \\
Maltose & + & + & + \\
MR & - & + & - \\
VP & + & - & - \\
& Nitrate & - & - & - \\
Reduction & - Neisseria & Bacillus & Staphylococcus \\
& Bacterial & cereus & aureus \\
& name & spp & cas
\end{tabular}

+ = Positive; - = Negative; MR=Methyl Red; VP= Voges-Proskauer 


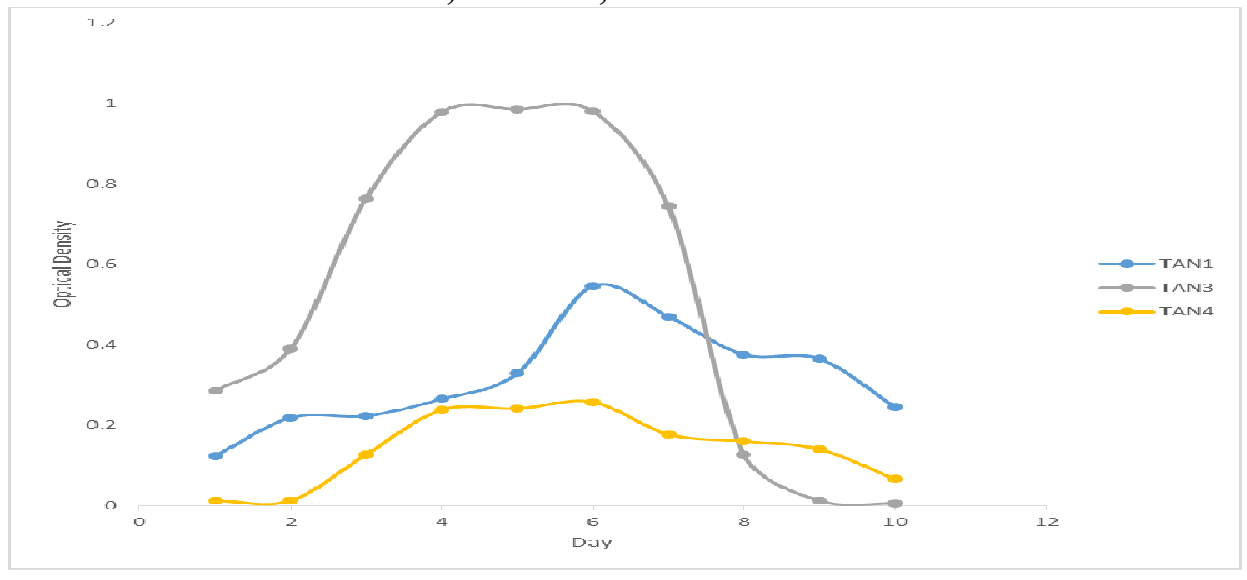

Fig. 2 Growth rates of the isolates in the effluents from the Tannery Industries

\section{Physico-chemical Parameters in the Industrial Effluents after the biodegradation.}

Table 3 shows the mean results of the physicochemical parameter before and after bioremediation using the different masses $(5 \mathrm{~g}$, $10 \mathrm{~g}, 15 \mathrm{~g}, 20 \mathrm{~g}$, and $25 \mathrm{~g}$ ) of the respective immobilized bacteria. Also, Table 4 shows the mean results of correlation coefficient ( $r$ ) between different masses of bacteria and physicochemical parameters.

The mean values $(\mathrm{mg} / \mathrm{l})$ of the SS after the bioremediation varies between $243 \pm 45$ and $898 \pm 672$. The mean concentration $(\mathrm{mg} / \mathrm{l})$ of SS remediated by the different masses $(5 \mathrm{~g}, 10 \mathrm{~g}$, $15 \mathrm{~g}, 20 \mathrm{~g}$, and $25 \mathrm{~g}$ ) of the bacteria varies. The SS in the samples fluctuates up and down after the bioremediation process when compared with the SS of the raw samples before the bioremediation. The increase in the levels of the SS might be due to the aggregation of the TDS which are large enough to result into SS. The increase in the levels of the SS might be also due to the influence of the nutrients which was added into the effluents in order to make the microorganisms more active and viable for fast degradation of organic contaminants in the effluent. The relative potential or efficiency of the different masses of the bacteria in remediating SS in TAN1 samples was in the order $25 \mathrm{~g}>20 \mathrm{~g}>15 \mathrm{~g}>10 \mathrm{~g}>5 \mathrm{~g}$. For TAN2 and TAN3 samples, the order was $25 \mathrm{~g}>20 \mathrm{~g}>15$ $\mathrm{g}>10 \mathrm{~g}>5 \mathrm{~g}$. These might be due to the variations in the surface areas of the different masses of the immobilized bacteria. Statistical analysis shows that there is no significant difference $(p<0.05)$ between the mean values of SS among the masses in the respective industries. Positive and significant correlations exist between the masses of bacteria and Suspended Solid (SS). This showed that there is general increase in the levels of the SS as the masses of the immobilized bacteria increases. TAN3 (90\%) and TAN1 (80\%) showed a very high correlation with the masses of the bacteria while TAN2 (61\%) showed a very low correlation.

The mean values $(\mathrm{mg} / \mathrm{l})$ of the TDS after the bioremediation varies between $46 \pm 11$ and $83 \pm 78$. The mean concentration $(\mathrm{mg} / \mathrm{l})$ of TDS remediated by the different masses $(5 \mathrm{~g}, 10 \mathrm{~g}$, $15 \mathrm{~g}, 20 \mathrm{~g}$, and $25 \mathrm{~g}$ ) of the bacteria varies. There is a reduction in all the TDS of all the samples after the bioremediation process compared with the TDS of the raw samples before the bioremediation. The relative potential or efficiency of the different masses of the bacteria in remediating TDS in TAN1 and TAN3 samples was in the order $5 \mathrm{~g}>10 \mathrm{~g}>15 \mathrm{~g}>20$ $\mathrm{g}>25 \mathrm{~g}$. For TAN2 samples, the order was 20 $g>10 \quad g>25 \quad g>15 \quad g>5 \quad g$. Statistical analysis shows that there is no significant difference $(p<0.05)$ between the mean values of TDS among the masses in the respective industries. These might be due to the variations in the surface areas of the different masses of the immobilized bacteria. Positive and significant correlations exist between the masses of bacteria and TDS with the exception in TAN2 (negative and insignificant correlation). The positive correlations showed that there is general increase in the levels of the TDS as the masses of the immobilized bacteria increases. TAN1 $(96 \%)$ showed a very high correlation with the masses of the bacteria while TAN2 (47\%) showed a very low correlation.

The mean values $(\mathrm{mg} / \mathrm{l})$ of the BOD after the bioremediation varies between $1.56 \pm 0.20 \mathrm{mg} / \mathrm{l}$ and $6.92 \pm 5.49 \mathrm{mg} / \mathrm{l}$. The mean concentration $(\mathrm{mg} / \mathrm{l})$ of BOD remediated by the different masses $(5 \mathrm{~g}, 10 \mathrm{~g}, 15 \mathrm{~g}, 20 \mathrm{~g}$, and $25 \mathrm{~g}$ ) of the bacteria varies. There is a reduction in all the BOD of all the samples after the bioremediation process compared with the $\mathrm{BOD}$ of the raw 
BAJOPAS Volume 13 Number 2, December, 2020 samples before the bioremediation. The relative potential or efficiency of the different masses of the bacteria in remediating BOD in TAN1, TAN2 and TAN3 samples were in the order $25 \mathrm{~g}>20$ $\mathrm{g}>15 \mathrm{~g}>10 \mathrm{~g}>5 \mathrm{~g}, 25 \mathrm{~g}>15 \mathrm{~g}>5 \mathrm{~g}>10 \mathrm{~g}>20 \mathrm{~g}$ and $20 \mathrm{~g}>10 \mathrm{~g}>25 \mathrm{~g}>15 \mathrm{~g}>5 \mathrm{~g}$ respectively. Statistical analysis shows that there is significant difference $(p<0.05)$ between the mean values of BOD among the masses in the respective industries. These might be due to the variations in the surface areas of the different masses of the immobilized bacteria. Negative and significant correlations exist between the masses of bacteria and BOD. This showed that there is general decrease in the levels of the BOD as the masses of the immobilized bacteria increases. TAN1 (94\%) showed a very high correlation with the masses of the bacteria while TAN2 (4\%) showed a very low correlation.

The mean values $(\mathrm{mg} / \mathrm{l})$ of the COD after the bioremediation varies between $250 \pm 154$ and $3134 \pm 1595$. The mean concentration $(\mathrm{mg} / \mathrm{l})$ of COD remediated by the different masses $(5 \mathrm{~g}$, $10 \mathrm{~g}, 15 \mathrm{~g} 20 \mathrm{~g}$, and $25 \mathrm{~g}$ ) of the bacteria varies. There is a reduction in all the COD of all the samples after the bioremediation process compared with the COD of the raw samples before the bioremediation. The relative potential or efficiency of the different masses of the bacteria in remediating COD in TAN1, TAN2 and TAN3 samples were in the order $25 \mathrm{~g}>20 \mathrm{~g}>15$ $\mathrm{g}>5 \mathrm{~g}>10 \mathrm{~g}, 25 \mathrm{~g}>20 \mathrm{~g}>15 \mathrm{~g}>10 \mathrm{~g}>5 \mathrm{~g}$ and 10 g>5 g>25 g>15 g>20 g respectively. Statistical analysis shows that there were significant difference $(p<0.05)$ between the mean values of COD among the masses in the respective industries except for effluents treated with $25 \mathrm{~g}$. These might be due to the variations in the surface areas of the different masses of the immobilized bacteria. Negative and insignificant correlations exist between the masses of bacteria and COD with the exception in TAN3 (positive and significant correlation). The negative correlations showed that there is general decrease in the levels of the COD as the masses of the immobilized bacteria increases. TAN2 (100\%) showed a very high correlation with the masses of the bacteria while TAN3 (36\%) showed a very low correlation.

Generally, there was an overall decrease in the concentration of these physicochemical parameters after the bioremediation using the different masses of the bacterial isolates. These might be due to the variations in the surface areas of the different masses of the immobilized bacteria. This is in line with the work of Jimoh et al. (2018) and Baba et al. (2020).

Table 3: Mean Values $(\mathrm{mg} / \mathrm{l}) \pm$ S.D of Physicochemical parameters in effluents from the Tannery Industries before and after Treatment of the effluents $(250 \mathrm{ml})$ with the different masses $(5 \mathrm{~g}, 10 \mathrm{~g}$, $15 \mathrm{~g}, 20 \mathrm{~g}$, and $25 \mathrm{~g}$ ) of the bacteria.

\begin{tabular}{llllllll}
\hline $\mathrm{P}$ & IND & Before & \multicolumn{5}{c}{ After } \\
\cline { 4 - 7 } & & & $5 \mathrm{~g}$ & $10 \mathrm{~g}$ & $15 \mathrm{~g}$ & $20 \mathrm{~g}$ & $25 \mathrm{~g}$ \\
\hline \multirow{2}{*}{ COD } & TAN1 & $2372 \pm 938$ & $1708 \mathrm{a} \pm 861$ & $2045 \mathrm{a} \pm 1205$ & $845 \mathrm{a} \pm 369$ & $300 \mathrm{a} \pm 167$ & $250 \mathrm{a} \pm 154$ \\
& TAN2 & $1406 \pm 208$ & $1195 \mathrm{a} \pm 208$ & $1125 \mathrm{a} \pm 384$ & $1055 \mathrm{a} \pm 317$ & $956 \mathrm{a} \pm 310$ & $870 \mathrm{ab} \pm 240$ \\
& TAN3 & $3532 \pm 1373$ & $2374 \mathrm{a} \pm 1344$ & $1976 \mathrm{a} \pm 1405$ & $2757 \mathrm{a} \pm 1266$ & $3134 \mathrm{a} \pm 1595$ & $2614 \mathrm{~b} \pm 1105$ \\
BOD & TAN1 & $13.85 \pm 6.42$ & $6.92 \mathrm{a} \pm 5.49$ & $6.42 \mathrm{a} \pm 5.07$ & $5.72 \mathrm{a} \pm 5.35$ & $4.62 \mathrm{a} \pm 4.37$ & $2.82 \mathrm{ab} \pm 1.26$ \\
& TAN2 & $19.46 \pm 0.50$ & $1.75 \mathrm{~b} \pm 0.22$ & $1.73 \mathrm{~b} \pm 0.18$ & $1.58 \mathrm{a} \pm 0.16$ & $1.91 \mathrm{a} \pm 0.22$ & $1.56 \mathrm{~b} \pm 0.20$ \\
& TAN3 & $17.13 \pm 3.14$ & $4.24 \mathrm{ab} \pm 0.77$ & $3.29 \mathrm{ab} \pm 0.37$ & $4.11 \mathrm{a} \pm 0.07$ & $3.23 \mathrm{a} \pm 0.91$ & $3.33 \mathrm{a} \pm 1.28$ \\
SS & TAN1 & $374 \pm 124$ & $243 \mathrm{a} \pm 45$ & $471 \mathrm{a} \pm 226$ & $475 \mathrm{a} \pm 182$ & $492 \mathrm{a} \pm 128$ & $611 \mathrm{a} \pm 217$ \\
& TAN2 & $358 \pm 335$ & $460 \mathrm{a} \pm 400$ & $543 \mathrm{a} \pm 414$ & $544 \mathrm{a} \pm 402$ & $551 \mathrm{a} \pm 414$ & $554 \mathrm{a} \pm 405$ \\
& TAN3 & $780 \pm 739$ & $586 \mathrm{a} \pm 594$ & $758 \mathrm{a} \pm 656$ & $787 \mathrm{a} \pm 676$ & $861 \mathrm{a} \pm 635$ & $898 \mathrm{a} \pm 672$ \\
TDS & TAN1 & $3941 \pm 3703$ & $51 \mathrm{a} \pm 10$ & $53 \mathrm{a} \pm 10$ & $55 \mathrm{a} \pm 15$ & $61 \mathrm{a} \pm 20$ & $63 \mathrm{a} \pm 26$ \\
& TAN2 & $3300 \pm 1714$ & $83 \mathrm{a} \pm 78$ & $47 \mathrm{a} \pm 20$ & $48 \mathrm{a} \pm 22$ & $47 \mathrm{a} \pm 17$ & $48 \mathrm{a} \pm 17$ \\
& TAN3 & $2653 \pm 1240$ & $46 \mathrm{a} \pm 11$ & $55 \mathrm{a} \pm 24$ & $55 \mathrm{a} \pm 25$ & $58 \mathrm{a} \pm 23$ & $61 \mathrm{a} \pm 28$ \\
\hline
\end{tabular}

Replicate $=6$ (months)

Within the rows, for the same parameter, means with different alphabets are statistically different $(p<0.05)$.

$\mathrm{P}=$ parameter, IND = Industries 
BAJOPAS Volume 13 Number 2, December, 2020

Table 4: Correlation coefficient $(r)$ between different masses of the bacteria and the physicochemical parameters.

\begin{tabular}{llll}
\hline Industries & Parameter & Correlation coefficient $(r)$ & $\begin{array}{l}\text { Percent dependence (rxrx100) } \\
(\%)\end{array}$ \\
\hline TAN1 & COD & -0.9 & 82 \\
& BOD & -0.97 & 94 \\
& SS & $0.90^{*}$ & 80 \\
TAN2 & TDS & $0.98^{*}$ & 96 \\
& COD & -1 & 100 \\
& BOD & -0.21 & 4 \\
& SS & $0.78^{*}$ & 61 \\
& TDS & -0.69 & 47 \\
& COD & $0.60^{*}$ & 36 \\
& BOD & -0.6 & 37 \\
& SS & $0.95^{*}$ & 90 \\
& TDS & $0.94^{*}$ & 89 \\
\hline
\end{tabular}

The correlation coefficient $(r)$ with * is statistically significant $(p<0.05)$.

Percentage reduction of the Parameters

Table 5 shows the percentage reduction of Parameters in industrial samples before and after the treatment of the effluents $(250 \mathrm{ml})$ with the different masses $(5 \mathrm{~g}, 10 \mathrm{~g}, 15 \mathrm{~g}, 20 \mathrm{~g}$, and $25 \mathrm{~g}$ ) of the Immobilized Bacteria.

In TAN1 samples, the percentage reduction (\%) of COD ranged (14-89); BOD (50-80); SS (-32$35)$ and TDS (98-99). In TAN2 samples, the percentage decrease $(\%)$ of COD ranged (15$38) ;$ BOD (90-92); SS [-28-(-55)] and TDS (9798). In TAN3 samples, the percentage decrease (\%) of COD ranged (11-44); BOD (76-81); SS (15-25) and TDS (98). The percentage increase in the levels COD, BOD and TDS might be due to the increase in the surface area of the different masses of the immobilized bacteria. However, the percentage decrease in the levels of the SS might be due to the aggregation of the TDS which are large enough to result into SS. The percentage decrease in the levels of the SS might be also due to the influence of the nutrients which was added into the effluents in order to make the microorganisms more active and viable for fast degradation of organic contaminants in the effluent. This is in line with the work of Jimoh et al. (2018) in which the concentration of the SS increase after the bioremediation of effluents.

Sreemoyee and Priti (2013) assessed and reduced several Physico-chemical parameters of dairy wastewater using Niesseria $s p$. and concluded that the species are well known to degrade organic compounds. This is in agreement with the current study in which the immobilized Niesseria $s p$ degrade the organic contaminants as indicated by the BOD, COD and TDS.

Jimoh et al. (2018) observed that TSS of the effluents was increased after treatment with immobilized bacteria and concluded that it might be due to the biostimulation method adopted for the research.

The optimum $\mathrm{pH}$ Biosorption of Chromium by Bacillus spp and Staphylococcus spp. from tannery effluent was investigated by Mythili and Karthikeyan (2011). The maximum adsorption of Chromium $(86.4 \mathrm{mg} / \mathrm{L})$ was showed by Bacillus spp and Staphylococcus spp showed $70.6 \mathrm{mg} / \mathrm{L}$ at an initial concentration of $100 \mathrm{mg} / \mathrm{L}$. In the present study, immobilised Bacillus spp and Staphylococcus spp. from the tannery industrial effluents reduced the levels of the organic pollutants with high potential as indicated by the percentage reduction of BOD, COD and TDS.

Enzymes often can work in multiple environments especially if they are immobilized. This makes the microorganisms' enzymes even more resistant to harsh environments and enables the enzymes to be recovered and recycled after they are no longer needed (Gianfreda and Rao 2004). Ramesh and Singh (1993) reported that the immobilized bacteria having more efficiency to remove the suspended particles than free cells. Using the immobilized cell is preferable due to its capability for using several times with the same efficiency, which makes it more economical. Similar work was done by Sikander et al. (2007) showing the higher reduction with permeabilized cells of Ochrobactrum intermedium strain SDCr-5. 
BAJOPAS Volume 13 Number 2, December, 2020

The results revealed the isolation and identification of isolates with the potential for the reduction of $\mathrm{Cr}$ (VI) to $\mathrm{Cr}$ (III). Results indicated that immobilized $B$. cereus could be efficiently used for the reduction of $\mathrm{Cr}$ (VI).

Table 5: Percentage reduction of the tested Parameters from the tannery industrial samples of the Immobilized Bacteria.

\begin{tabular}{lllllll}
\hline \multirow{2}{*}{ Industries } & & \multicolumn{5}{c}{ Percentage Reduction $(\%)$} \\
\cline { 3 - 7 } & & $5 \mathrm{~g}$ & $10 \mathrm{~g}$ & $15 \mathrm{~g}$ & $20 \mathrm{~g}$ & $25 \mathrm{~g}$ \\
\hline TAN1 & COD & 28 & 14 & 64 & 87 & 89 \\
& BOD & 50 & 54 & 59 & 67 & 80 \\
& SS & 35 & -26 & -27 & -32 & -63 \\
& TDS & 99 & 99 & 99 & 98 & 98 \\
TAN2 & COD & 15 & 20 & 25 & 32 & 38 \\
& BOD & 91 & 91 & 92 & 90 & 92 \\
& SS & -28 & -52 & -52 & -54 & -55 \\
& TDS & 97 & 99 & 99 & 99 & 99 \\
& COD & 33 & 44 & 22 & 11 & 26 \\
& BOD & 75 & 81 & 76 & 81 & 81 \\
& SS & 25 & 3 & -1 & -10 & -15 \\
& TDS & 98 & 98 & 98 & 98 & 98 \\
\hline
\end{tabular}

Percentage Reduction $=(B-A) / B \times 100 \%$

$A=$ Concentration of the parameter after treatment

$\mathrm{B}=$ Concentration of the parameter before treatment

$+=$ percentage decrease

- = percentage increase

In general, immobilization makes the enzyme more resistant to temperature, $\mathrm{pH}$, and substrate concentration swings giving it a longer lifetime and higher productivity per active unit (Gianfreda and Rao, 2004; FuIlbrook, 1996; Russell et al, 2003; Kandelbauer et al., 2004). Immobilized cells have been used and studied extensively for the production of useful chemicals (Ohtake and Silver, 1994), the treatment of wastewaters (Chen et al., 2003; Wang et al., 2010). Although many workers described microbial degradation of tannery effluent, limited literature is available on the bioremediation of tannery effluent using immobilized bacterial cells in the Kano Industrial Estates.

\section{CONCLUSION}

The samples contained variable levels of the physicochemical parameters. The results of the Analysis of variance revealed that, no statistical difference $(p<0.05)$ was observed for the temperature, $\mathrm{pH}, \mathrm{SS}, \mathrm{TDS}, \mathrm{BOD}$ and $\mathrm{COD}$ among the three tannery industries before the treatment. The levels of some of the parameters
(SS, TDS and COD) observed in the samples were found above the recommended limits of WHO and NESREA, which called for the treatment of the effluents before discharge into the environment. Base on the morphological and biochemical test results, TAN1, TAN2, and TAN3 bacterial isolates were identified to be Neisseria spp, Bacillus cereus, and Staphylococcus aureus respectively. The results of Post-treatment analysis showed that there is overall decrease in the levels of the parameters determined when compared with that of the pre-treatment. The overall percentage reduction of the immobilised bacteria in the treatment of the respective effluents was in the order TAN2 (72\%)>TAN1 $(70 \%)>$ TAN3 $(62 \%)$. Hence, the immobilized bacteria are having higher biodegradation potential for the treatment of the tannery effluents.

\section{Acknowledgments}

The authors wish to acknowledge the University of Maiduguri for the financial support. The authors are grateful to the Kano State Ministry of Environment for their support in obtaining the effluent samples. 


\section{REFERENCES}

Ajao, A. T., Adebayo, G. B., and Yakubu, S. E. (2011). Bioremediation of textile industrial effluent using mixed culture of Pseudomonas aeruginosa and Bacillus subtilis immobilized on agar-agar in a bioreactor. J. Microbiol. Biotech. Res, 1(3), 50-56.

Akan, J. C., Moses, E. A., Ogugbuaja, V. O., and Abah, J. (2007). Assessment of tannery industrial effluents from Kano metropolis, Kano State, Nigeria. Journal of Applied Sciences, 7(19), 2788-2793.

Akan, J. C., Ogugbuaja, V. O., Abdulrahman, F. I., and Ayodele, J. T. (2009). Pollutant levels in effluent samples from tanneries and textiles of Kano industrial areas, Nigeria. Global journal of pure and applied sciences, 15(3-4).

APHA (1989). Standard methods for Examination of Will bete and Will betewater.15 $5^{\text {th }}$ edition. Brydpass Springfield Will behington DC. pp. 164-176

APHA (1992). Standard Methods for the Examination of Water and Wastewater. Health, 69, 1116-9.

Baba, A., Garba, S. T., and Bello, H. S. (2020). Bioremediation Potential of Immobilized corynebacterium kutsceri in the Treatment of Tannery Industrial Effluent from Challawa Industrial Estate, Kano State, Nigeria. Journal of the Turkish Chemical Society Section A: Chemistry, $7(2), 335-350$.

Beem, E. I. V. (1994). reduction of solvent VOC emission. J. Oil Col. Chem. Ass, 77, 158.

Bouwer, E. J., and Zehnder, A. J. (1993). Bioremediation of organic compoundsputting microbial metabolism to work. Trends in biotechnology, 11(8), 360367.

Chen, K. C., Wu, J. Y., Liou, D. J., and Hwang, S. C. J. (2003). Decolorization of the textile dyes by newly isolated bacterial strains. Journal of Biotechnology, 101(1), 57-68.

Dan'Azumi, S., and Bichi, M. H. (2010). INDUSTRIAL POLLUTION AND HEAVY METALS PROFILE OF CHALLAWA RIVER IN KANO, NIGERIA. Journal of Applied Sciences in Environmental Sanitation, $5(1)$.

DWAF. (1992). Analytical Methods Manual, TR 151. Department of Water Affairs and Forestry, Pretoria.

El-Bestawy, E. (2013). Biological treatment of leather-tanning industrial wastewater using free living bacteria.
Elsheikh, M. A. S. (2009). Tannery wastewater pre-treatment. Water Science and Technology, 60(2), 433-440.

FuIlbrook, P. D. (1996). "Kinetics." Industrial enzymology: The application of enzymes in Industry. 2nd Ed. T. Godfrey and J Reichelt. eds.. Nature. New York.

Gianfreda, L., and Rao, M. A. (2004). Potential of extra cellular enzymes in remediation of polluted soils: a review. Enzyme and microbial technology, 35(4), 339354.

Hugo Springer. (1994). John Arthur Wilson Memorial Lecture "Treatment of Industrial Wastes of the Leather Industry - is it still a Major Problem". JALCA, 89, 153-185

Jimoh, A. A., Ganiyu, B. A., Baba, D., and Baba, A. (2018) Bioremediation Process of Effluent from Detergent and Food Industries in Jos, Nigeria: Kinetics and Thermodynamics. International Journal of Engineering Science Invention (IJESI), 762-73

Kandelbauer, A., Maute, O., Kessler, R. W., Erlacher, A., and Gübitz, G. M. (2004). Study of dye decolorization in an immobilized laccase enzyme-reactor using online spectroscopy. Biotechnology and bioengineering, 87(4), 552-563.

Kongjao, S., Damronglerd, S., and Hunsom, M. (2008). Simultaneous removal of organic and inorganic Pollutants in tannery wastewater using electrocoagulation technique. Korean Journal of chemical engineering, 25(4), 703.

Maheshwari, U. M., Aruna, S., Gomathi, M., and AbdulJaffar, A. H. (2017). Bioremediation by Free and Immobilized Bacteria Isolated from Tannery Effluent. International Journal of Research in Applied, Natural and Social Sciences. 5(7), 75-90

Margesin, R., and Schinner, F. (2001). Bioremediation (natural attenuation and biostimulation) of diesel-oilcontaminated soil in an alpine glacier skiing area. Applied and environmental microbiology, 677), 3127-3133.

Mohammed, A., Sekar, P., and George, J. (2011). Efficacy of microbes in bioremediation of tannery effluent. Inter. J. Curr. Res, 3(4), 324-326.

Mohammed, S. S. D., Orukotan, A. A., and Abdullahi, H. (2017). Physicochemical and Bacteriological Assessment of Tannery Effluent from Samaru-Zaria, 
BAJOPAS Volume 13 Number 2, December, 2020 Kaduna State, Nigeria. Journal of Applied

Sciences and Environmental Management, 21(4), 734-740.

Munz, G., De Angelis, D., Gori, R., Mori, G., Casarci, M., and Lubello, C. (2009). The role of tannins in conventional and membrane treatment of tannery wastewater. Journal of hazardous materials, 164(2-3), 733-739

Mythili, K., and Karthikeyan, B. (2011). Bioremediation of $\mathrm{Cr}$ (VI) from tannery effluent using Bacillus spp and Staphylococcus spp. International Multidisciplinary Research Journal, 1(6).

NESREA (2009). National Environmental Standards for Effluent Limitations and Regulation. 1233-1236

Noorjahan, C. M. (2014). Physicochemical characteristics, identification of bacteria and biodegradation of industrial effluent. Journal of bioremediation and Biodegradation, 5(3).

Ohtake, H. I., and Silver, A. O. (1994). Bacterial reduction of toxic chromate. Biological degradation and bioremediation of toxic chemicals, 403-415.

Omoleke, I. I. (2004). Management of environmental pollution in Ibadan, an African city: the challenges of health hazard facing government and the people. Journal of Human Ecology, 15(4), 265-275.

Rajor, A., Reddy, A.S., and Singh, B. (2004). Determination of BOD kinetic Parameters and evaluation of alternate methods, M.Sc. Thesis, Department of biotechnology \& environmental Science, Thapar Institute of Engineering and Technology, Patiala

Ramasami, T., Rajamani, S., and Rao, J. R. (1994, March). Pollution control in leather industry: Emerging technological options. In International symposium on surface and colloidal science and its relevance to soil pollution, madras.

Ramesh, J. V. S., and Singh, S. P. (1993). Yearly variation in certain physicochemical parameters of pond at eastern Doon Valley. Uttar Pradesh J. Zoo, 12 (1), 7577.

Ranen, S., and Sharadinadra, C. (2009). Biotechnology applications to environmental remediation in resource exploitation. Current science, 97, 6-25
Russell, A. J., Berberich, J. A., Drevon, G. F., and Koepsel, R. R. (2003). Biomaterials for mediation of

chemical and biological warfare agents. Annual review of biomedical engineering, 5(1), 1-27.

Saravanan, P., and Saravanan, A. (1999). Decolourization of tannery effluent by Flavobacterium sp. EK 1. Indian Journal of Environmental Protection, 19, 19-24.

Sikander, S., and Shahida, H. (2007). Reduction of toxic hexavalent chromium by Ochrobactrum intermedium strain SDCr5 stimulated by heavy metals. Bioresource Technol, 98, 340-344.

Singh, N., Sharma, B. K., and Bohra, P. C. (2000). Impact assessment of industrial effluent of arid soils by using satellite imageries. Journal of the Indian Society of Remote Sensing, 28(2-3), 79.

Sreemoyee, C., and Priti, P. (2013). Assessment of physico-chemical parameters of dairy waste water and isolation and characterization of bacterial strains in terms of cod reduction. Int J Sci, 2(3), 395-400.

Verheijen, L. A. H. M., Wiersema, D., Pol, L. H., and De Wit, J. (1996). Management of wastes from animal product processing. Livestock and environment, Finding a balance. International Agriculture Center, Wageningen, The Netherlands.

Wang, F., Yao, J., Si, Y., Chen, H., Russel, M., Chen, K., and Bramanti, E. (2010). Short-time effect of heavy metals upon microbial community activity. Journal of Hazardous Materials, 173(13), 510-516.

WHO (World Health Organization). (2006). Air quality guidelines: global update 2005: particulate matter, ozone, nitrogen dioxide, and sulfur dioxide. World Health Organization.

World Bank. (1995). Nigeria's strategic options for redressing industrial pollution. World Bank, industry and energy division. 1st edition, West Central Africa Department; Annexes: 1995; pp 60-62.

Zahoor, A., and Abdul, R. (2009). Enumeration of Coliforms. Journal of Environmental Sciences. 21, 814-820 


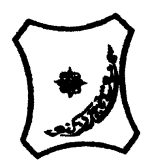

Bayero Journal of Pure and Applied Sciences, 13(2): 1 - 12

Received: November, 2020

Accepted: December, 2020

ISSN $2006-6996$

\title{
BIODEGRADATION POTENTIAL OF IMMOBILIZED BACTERIA IN THE TREATMENT OF TANNERY INDUSTRIAL EFFLUENTS FROM INDUSTRIAL ESTATES IN KANO STATE, NIGERIA
}

\author{
Abdullateef, B., ${ }^{1 *}$ Shuaibu, T. G., ${ }^{1}$ Babagana, K., ${ }^{1}$ Suleman, H. B. ${ }^{2}$ and Dauda, B. ${ }^{3}$ \\ ${ }^{1}$ Department of Pure and Applied Chemistry, Faculty of Science, University of Maiduguri, Borno State, \\ Nigeria \\ ${ }^{2}$ Department of Microbiology, Faculty of Science, University of Maiduguri, Borno State, Nigeria \\ ${ }^{3}$ Department of Chemical Engineering, Faculty of Engineering, University of Maiduguri, Borno State, \\ Nigeria \\ *Corresponding author: babslega@gmail.com; abelega2007@yahoo.com; +2348061309753
}

\section{ABSTRACT}

Industrial Effluents Samples from Gashash Tanneries (TAN1) in Bompai Industrial estate, Larabee Tannery Industry (TAN2) in Sharada Industrial estate and Z Tannery Industries (TAN3) in Challawa Industrial estate, Kano State, Nigeria were collected over a period of six months (August 2017 to January 2018) for assessing the biodegradation potentials of bacteria in the treatment of organic pollutants within the effluents. Bacteria were isolated from the effluents and immobilized on agar-agar. Different masses (5 g, $10 \mathrm{gr}, 15$ $\mathrm{g}, 20 \mathrm{~g}$, and $25 \mathrm{~g}$ ) of the bacteria were used in the treatment of $250 \mathrm{ml}$ of the effluents for ten days in a shaker incubator (Gallenkamp-OC-4364-L) at the temperature $30{ }^{\circ} \mathrm{C}$ and speed of $60 \mathrm{rpm}$. Pre-treatment analysis of the effluents for Temperature, pH, Biochemical Oxygen Demand (BOD), Chemical Oxygen Demand (COD), Suspended Solid (SS) and Total Dissolved Solids (TDS) gives the following results; temperature $\left({ }^{\circ} \mathrm{C}\right.$ )

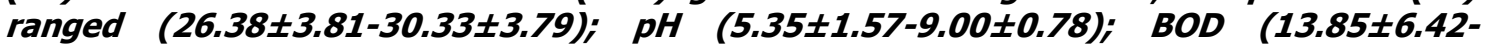
$38.75 \pm 16.20) ;$ COD (1406 $\pm 208-3532 \pm 1373) ;$ SS (208 $\pm 235-780 \pm 739)$ and TDS (266 $\pm 253-5276 \pm 2971)$. No statistical differences ( $p \leq 0.05)$ was observed for all the results among the different industries. The bacterial isolates were identified as Neisseria spp, Bacillus cereus, and Staphylococcus aureus, in TAN1, TAN2, and TAN3, respectively. After treatment of the effluent with the different masses of the isolated bacteria, the mean level of BOD was found to range as (0.55 $\pm 0.36-6.92 \pm 5.49) ; C O D$ (ND-3134 \pm 1595$)$;

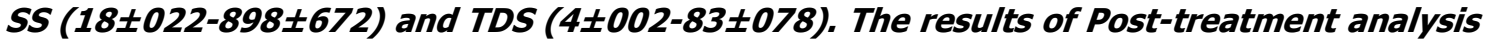
showed that there is overall decrease in the levels of the parameters determined when compared with that of the pre-treatment. The overall percentage reduction of the immobilised bacteria in the treatment of the respective effluents was in the order TAN2 (72\%)>TAN1 (70\%)>TAN3 (62\%). Hence, the immobilized bacteria are having higher biodegradation potential for the treatment of the tannery effluents.

Keywords: Biodegradation, bacteria, effluent, immobilization, tannery.

\section{INTRODUCTION}

Tannery industrial wastewater is a serious consequence of the pollution point of view for streams, freshwater, and land used for agriculture. The lack of awareness in the modern industrial practice has resulted in the discharge of tannery effluents which exhibit very high value of chromium ( $\mathrm{Cr}$ ), Sulfide, and chloride, Total Dissolved Solid (TDS), Total Suspended Solid (TSS), Biochemical Oxygen Demand (BOD) and Chemical Oxygen Demand (COD) in the water stream or land (Mohammed et al., 2001). Tanning is the process, which One ton of skin generally leads to the production of 20 to $80 \mathrm{~m}^{3}$ of turbid and foul-smelling converts the protein of the rawhide or skin into a stable material, which will not putrefy and is suitable for a wide variety of end applications (Elsheikh, 2009). The highly polluting chromium is the most commonly used tanning material producing leather that is more flexible and pliable than vegetable-tanned leather and does not discolor or lose shape in water as drastically as vegetable-tan (Elsheikh, 2009). Tannery effluent is among the most hazardous industrial pollutants due to its huge organic and inorganic load, which is highly toxic to human life and the environment (Kongjao et al., 2008). wastewater including chromium (100-400 mg/l), sulfide $(200-800 \mathrm{mg} / \mathrm{l})$, high levels of fat and 
BAJOPAS Volume 13 Number 2, December, 2020 other solid wastes, and notable pathogen contamination as well as pesticides added for skin conservation during transport (Elsheikh, 2009). There are more than 6000 tanneries in Nigeria with an annual processing capacity of 700,000 tons of hides and skins (Omoleke, 2004; Singh et al., 2008). It was reported that the total amount of waste produced per animal slaughtered is approximately $35 \%$ of its weight (World Bank, 1995). Also, for every $1000 \mathrm{~kg}$ of carcass weight, a slaughtered beef produces 5.5 $\mathrm{kg}$ of manure (excluding rumen contents or stockyard manure) and $100 \mathrm{~kg}$ of paunch manure (undigested food) (Verheijen et al., 1996). Tanneries generate wastewater in the range of 30-35 $\mathrm{L} \mathrm{kg}^{-1}$ skin/hide processed with variable $\mathrm{pH}$, Biological Oxygen Demand (BOD), Chemical Oxygen Demand (COD), high concentrations of suspended solids (SS), and tannins as well as chromium (Zahoor and Abdul, 2009).

Being heterogeneous and composed of a wide variety of compounds, it is very difficult to select a unique direct method for estimating the biodegradability of organic contents and biokinetic parameters for a wastewater sample (Rajor, 2004). For this purpose, some indirect estimation such as determination of biochemical oxygen demand (BOD) and chemical oxygen demand (COD) are applied as common laboratory investigations [9]. During retanning procedures, synthetic tannins (Syntan), oils and resins are added to form softer leather at varying doses (Munz et al., 2009). One of the refractory groups of chemicals in tannery effluents derives mainly from tannins (Ramasami et al., 2004). Syntans are characterized by complex chemical structures, because they are composed of an extended set of chemicals such as phenol-, naphthalene-, formaldehyde- and melamine-based syntans, and acrylic resins (Beem, 1994). Organic pollutants (proteic and lipidic components) are originated from skins (it is calculated that the raw skin has $30 \%$ loss of organic material during the working cycle) or they are introduced during processes (Hugo Springer, 1994).

Many conventional processes such as oxidation, chemical and biological processes were carried out to treat tanneries wastewater (Ebtesam et al, 2013). Biological processes have received more attention because of their costeffectiveness, lower sludge production and environmental friendliness (Noorjahan, 2014). Naturally occurring micro-organisms degrade the hazardous organic wastes including xenobiotic compounds, such as pesticides, polycyclic aromatic hydrocarbons (PAHs) and polychlorinated biphenyls (PCBs) in due course of time (Ranen and Sharadinadra, 2009). Bioremediation is based on the idea that all organisms remove substances from the environment to carry outgrowth and metabolism (Bouwer and Zehnder, 1993). Bacteria, protista and fungi are found to be very good at degrading complex molecules and incorporating the breakdown products into their metabolism (Bouwer and Zehnder, 1993). The resultant metabolic wastes that they produce are generally safe and somehow recycled into other organisms (Ranen and Sharadinadra, 2009). An acclimatized indigenous population of microorganisms capable of degradation of the compounds of interest must exist at the site for a successful bioremediation mode (Ranen and Sharadinadra, 2009). It has been observed that for a successful bioremediation mode, an acclimatized indigenous population of microorganisms capable of degradation of the compounds of interest must exist at the site under investigation (Ranen and Sharadinadra, 2009). Even though there are numerous physical and chemical methods employed in the disposal of wastes the advantage in using bacterium is that they play a key role in the reduction of COD, BOD, total protein, total tannin and total phenol (Saravanan and Saravanan, 1998)

Baba et al. (2020) studied the bioremediation potential of immobilized corynebacterium kutsceri in the Treatment of tannery industrial effluent from Challawa Industrial Estate, Kano State, Nigeria. The aim of the work is to study the reduction in the level of the contaminants through the process of bioremediation using the isolated bacteria. Immobilized bacteria can withstand various temperatures, $\mathrm{pH}$ and substrate concentrations; consequently, increasing the efficiency and the lifespan of the bacteria. Immobilized bacteria are widely applied in the treatment of wastewater and can be separated and recovered after the treatment with the same efficiency (Baba et al., 2020).

\section{MATERIALS AND METHODS \\ Study Area}

This study was carried out in Bompai, Sharada and Challawa industrial estates in Kano, Figure 1. Kano lies on Latitude $11^{\circ} 30^{\prime} \mathrm{N}$ and $8^{\circ} 30^{\prime} \mathrm{E}$ and Longitude $11^{\circ} 5^{\prime} \mathrm{N}$ and $8^{\circ} 5^{\prime} \mathrm{E}$ in Northern Nigeria. It is one of the developed industrial cities in Nigeria. Tannery activities are the dominating industries and this could be one of the reasons for her high population density (Dan'Azumi and Bichi, 2010). Many researchers have studied biodegradation of tannery effluent using microorganisms. However, limited literature is available on the biodegradation of tannery effluent in Kano industrial estates using 
BAJOPAS Volume 13 Number 2, December, 2020 immobilized bacterial cells. This research work focuses on the potential of the use of the indigenous immobilized bacterial isolates in the treatment of tannery effluents in the industrial estates.

\section{Sample Collection}

Effluents were collected from the Tannery Industries from Bompai, Challawa and Sharada Industrial Estates, Kano, Nigeria. The effluents were collected over a period of six months (August 2017 to January 2018). Samples collected in a sterile 4-liter plastic container with a unique identification number were preserved using an ice-box that was transported to the Microbiology Laboratory, Department of Microbiology, Bayero University of Kano for analysis

\section{Sample Preparation and Sample Analysis}

Immediately after the collection of the effluent, $\mathrm{pH}$, TSS, TDS, COD, BOD levels were determined before treatment (Pre-treatment determination) and ten days after treatment (Post-treatment determination) as described in
APHA (1989) standard methods. $\mathrm{pH}$ was determined using Ecotests $\mathrm{pH}$ meter and TDS was determined using AQUALYTIC TDS Salinometer. BOD was determined as described by the standard method (APHA, 1992). COD and SS were determined using DR/2010 HACH portable data logging spectrophotometer (DWAF, 1992)

\section{Identification and Biochemical} Characterization of the Bacterial Isolates

The bacteria were isolated from the effluents using Serial Dilution according to the method described by APHA (1989). The biochemical tests such as oxidase, catalase, coagulase, indole (from $1 \%$ tryptone broth), citrate (Simmons citrate agar), methyl red/VogesProskauer (MR/VP), nitrate reduction, Starch Hydrolysis, Glucose, Maltose, and Lactose tests were carried out on the bacterial isolates to identify the bacteria through the bacteria biochemical characteristics according to Ajao et al. (2011).

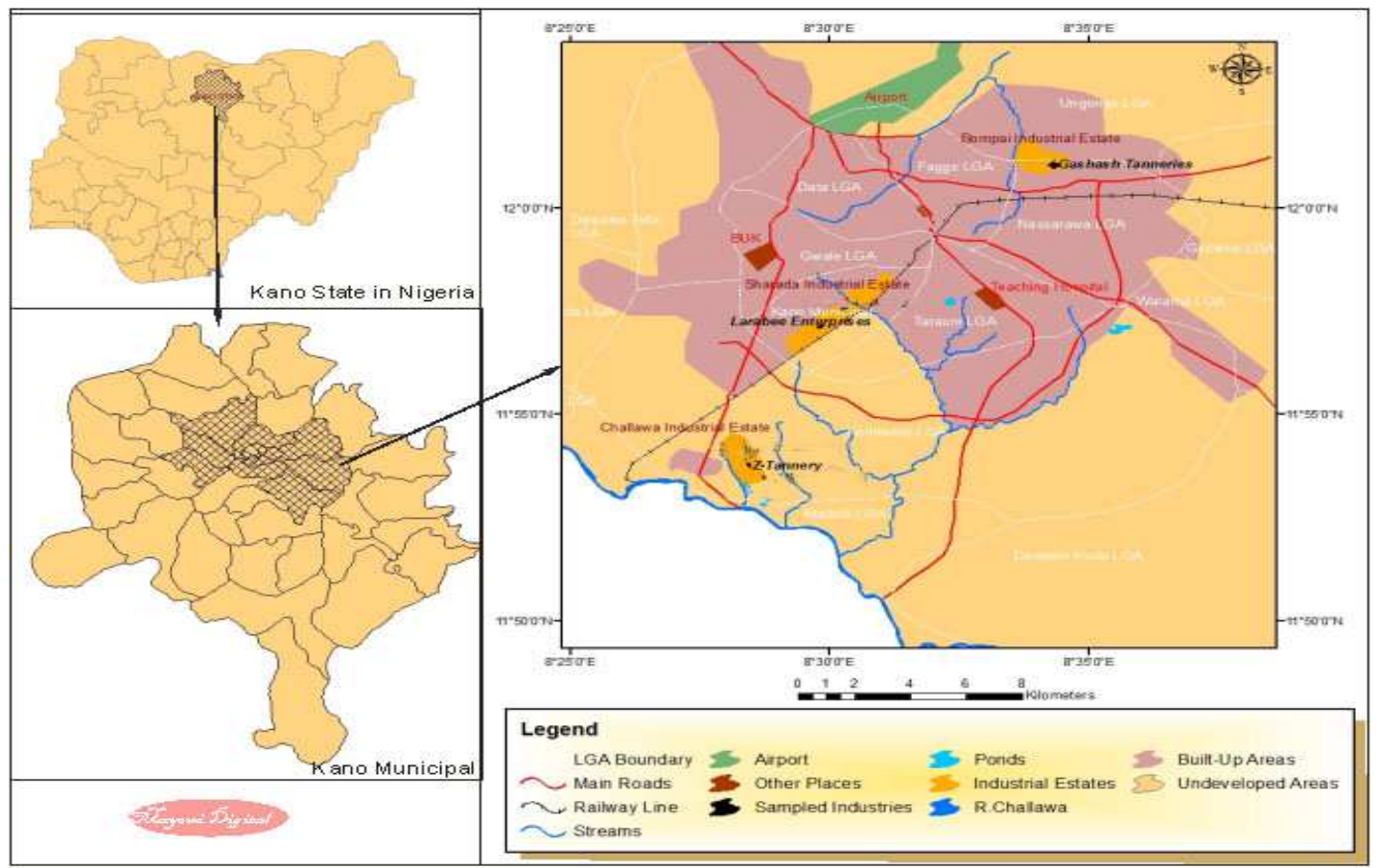

Fig. 1 Map showing the study areas

Source: Mayomi Digital Productions, GIS Laboratory, Department of Geography, UNIMAID (2017)

\section{Determination of Growth Rate of the Bacteria in Effluent Sample}

The bacteria growth rates were determined by transferring $2 \mathrm{~mL}$ of the bacterial isolates from the tannery effluent in broth medium into 100 $\mathrm{mL}$ sterile effluents in conical flasks and kept in an incubator (Giffrin cool) for 10 days. Control was also set up by incubating another $100 \mathrm{~mL}$ each of the sterile effluents without the bacteria. The optical density of the content was determined at the wavelength of $600 \mathrm{~nm}$ on a daily interval and recorded. 
BAJOPAS Volume 13 Number 2, December, 2020 Immobilization of Bacteria

Agar solution and inoculi were prepared separately. Fifty milliliters $(50 \mathrm{~mL})$ of nutrient broth each of the inoculi was prepared in a McCartney bottle and incubated for 24 hours. A solution of agar-agar was prepared by dissolving $10 \mathrm{~g}$ of the powder in distilled water and made up to $500 \mathrm{~mL}$ mark in an Erlenmeyer flask and was sterilized in an autoclave (280A) for 15 minutes and allowed to cool to $40-45^{\circ} \mathrm{C}$ (Ajao et al., 2011). Four milliliters ( $4 \mathrm{~mL})$ of the bacterial isolates in the nutrient broth was mixed with 36 $\mathrm{ml}$ of the prepared agar-agar media in petri-dish plates and then allowed to solidify. This was kept in the refrigerator for bioremediation.

\section{Bioremediation (Treatment) of the Effluents}

The solidified agar block (immobilized bacteria) was cut into cubes using a sterile knife; $0.1 \mathrm{~mL}$ phosphate buffer ( $\mathrm{pH} \mathrm{7.0)}$ was added and kept in the refrigerator for 1 hour for curing. The phosphate buffer was decanted after 1 hour and the cubes were washed with sterile distilled water 3-4 times before it was used (Ajao et al., 2011). Two liters (2 L) of the effluent was supplemented with the minimum basal medium in $\mathrm{g} / \mathrm{L}: \mathrm{NaCl}(0.8), \mathrm{MgSO}_{4} .7 \mathrm{H}_{2} \mathrm{O}(0.001), \mathrm{KH}_{2} \mathrm{PO}_{4}$ (2), $\mathrm{NaNO}_{3}$ (2), $\quad \mathrm{CaCl}_{2} .2 \mathrm{H}_{2} \mathrm{O} \quad(0.5)$ and $\mathrm{NaHPO}_{4} .12 \mathrm{H}_{2} \mathrm{O}(2)$ and sterilized in an autoclave at $121^{\circ} \mathrm{C}$ for 15 minutes (Margesin and Schinner, 2001). Two hundred and fifty milliliters $(250 \mathrm{~mL})$ of the effluents were transferred into different $250 \mathrm{ml}$ conical flasks. The content was covered with a cotton-wool ramped with foil paper to avoid contamination. Five grams $(5 \mathrm{~g})$ of the immobilized bacteria were quickly transferred into each of the effluents in the conical flasks in an inoculating chamber. The same procedures were carried out for the $10 \mathrm{~g}, 15 \mathrm{~g}, 20 \mathrm{~g}$ and 25 $\mathrm{g}$ of the immobilized bacteria in separate $250 \mathrm{~mL}$ effluents in conical flasks and agitated for ten days in a shaker incubator (Gallenkamp-OC4364-L) at a temperature $30^{\circ} \mathrm{C}$ and speed of 60 rpm. The treated effluent samples were taken on the tenth day and analyzed for the parameters $\mathrm{pH}$, SS, TDS, COD, and BOD, (Posttreatment determination) for the different grams of bacteria to evaluate and compare the biodegradation potential. (Baba et al., 2020).

\section{Statistical Analysis}

The data were represented as Mean \pm Standard deviation and analyzed statistically using oneway Analysis of Variance (ANOVA) and Tukey's HSD as Post Hoc Tests with the aid of SPSS 16.0. The correlation coefficient was also used to measure the strength of the relationship between the different masses of the bacteria and the parameters. All $\mathrm{p} \leq 0.05$ were considered as statistically significant.

\section{RESULTS AND DISCUSSION Physico-chemical parameters in the Industrial Effluents before the Biodegradation.}

Results of the Physico-chemical parameters in the industrial effluents before the Biodegradation is shown in table 1 . The mean temperatures $\left({ }^{\circ} \mathrm{C}\right)$ observed in TAN1, TAN2, and TAN3 samples were $28.07 \pm 0.65 ; 27.77 \pm 0.64$ and $26.38 \pm 3.81$ respectively. The order of the mean temperature of the samples from the three industries can be arranged as TAN1 > TAN2>TAN3. The temperature observed at TAN1, TAN2, and TAN3 samples were found below the WHO $\left(35^{\circ} \mathrm{C}\right)$ and NESREA $\left(40^{\circ} \mathrm{C}\right)$ limits. The low values of temperature might be due to the processes used at the time of sampling. High temperature brings down the solubility of gases in water that ultimately expresses as high BOD and COD. Statistical analysis shows that there is no significant difference $(p<0.05)$ between the mean values of temperature among the industries. This might be due to similar tannery activities involved in the tannery industries at the time of sampling. The average values of temperature observed in this present study are less than those observed by Akan et al. (2007), Akan et al. (2009) and Baba et al. (2020).

The mean level of $\mathrm{pH}$ observed in TAN1, TAN2 and TAN3, samples were $7.77 \pm 2.93$; $8.35 \pm 0.28$ and $7.52 \pm 0.76$ respectively. The order of the mean $\mathrm{pH}$ of the samples from the three industries can be arranged as TAN2> TAN1 $>$ TAN3. The $\mathrm{pH}$ of the samples falls within the WHO (7.0-8.5) and NESREA (6-9) standard limits. Statistical analysis shows that there is no significant difference $(p<0.05)$ between the mean values of $\mathrm{pH}$ among the industries. This might be due to similar tannery activities involved in the tannery industries at the time of sampling. Maheshwari et al. (2017) reported that the level of $\mathrm{pH}$ in the effluents from the tannery industry in Vaniyambadi, India was 6.5 which was lower than that observed in the present study. The $\mathrm{pH}$ in the effluents from the tannery industries in Kano and Kaduna were reported to be 7.64 and 6.89, respectively (Akan et al., 2007; Mohammed et al., 2017). The average values of $\mathrm{pH}$ observed in this present study are less than those observed by Mohammed et al. (2017) and Baba et al. (2020). The mean level of SS $(\mathrm{mg} / \mathrm{l})$ observed in TAN1, TAN2, and TAN3 samples were 374 \pm 124 ; $358 \pm 335$ and $780 \pm 739$ respectively. The order of the mean SS in the samples from the three industries can be arranged as TAN3 > TAN1 $>$ TAN2. 
The SS observed in the samples were far above the recommended standard limits of regulating bodies WHO $(30 \mathrm{mg} / \mathrm{l})$ and NESREA $(10 \mathrm{mg} / \mathrm{l})$. Statistical analysis shows that there is no significant difference $(p<0.05)$ between the mean values of SS among the industries. This might be due to similar tannery activities involved in the tannery industries at the time of sampling. The average values of SS observed in this present study are less than that observed $(3700 \pm 122 \mathrm{mg} / \mathrm{l})$ by Akan et al. (2009) for tanneries in Kano. Also, the average values of SS observed in this present study are less than that observed by Mohammed et al. (2017) and Baba et al. (2020) with the exception in TAN3.

The mean level of TDS (mg/l) observed in TAN1, TAN2, and TAN3 samples were $3941 \pm 3703$; $3300 \pm 1714$ and $2653 \pm 1240$ respectively. The order of the mean TDS in the samples from the three industries can be arranged as TAN1>TAN2>TAN3. The TDS observed in the samples were far above the recommended standard limits of WHO $(250 \mathrm{mg} / \mathrm{l})$ and NESREA $(500 \mathrm{mg} / \mathrm{l})$. Statistical analysis shows that there is no significant difference $(p<0.05)$ between the mean values of TDS among the industries. This might be due to similar tannery activities involved in the tannery industries at the time of sampling. TDS in the effluents from the tannery industries in Kano, Nigeria was reported to be $1281 \mathrm{mg} / \mathrm{l}$ (Akan et al., 2007). The average values of SS observed in this present study are less than those observed by Mohammed et al. (2017) and Baba et al. 2020)

The mean level of COD (mg/l) observed in TAN1, TAN2 and TAN3 samples seasons were $2372 \pm 938 ; \quad 1406 \pm 208$ and $3532 \pm 1373$ respectively. The order of the mean COD of the samples from the three industries can be arranged as TAN3>TAN1> TAN2. The COD observed in TAN1, TAN2 and TAN3 samples were far above the recommended standard limits of regulating bodies $\mathrm{WHO}(40 \mathrm{mg} / \mathrm{l})$ and NESREA (40 mg/l). Statistical analysis shows that there is no significant difference $(p<0.05)$ in COD among the industries. This might be due to similar tannery activities involved in the tannery industries as at the time of sampling. The Chemical Oxygen demand (COD) is the amount of oxygen, in $\mathrm{mg} / \mathrm{L}$, required for the degradation of the compound of wastewater to occur. In comparison, the average values of COD observed in this present study were higher than that observed by Mohammed et al. (2017) but lower than that observed by Baba et al. (2020).

The mean levels of BOD $(\mathrm{mg} / \mathrm{l})$ observed in TAN1, TAN2 and TAN3 samples were $13.85 \pm 6.42 ; \quad 19.46 \pm 0.50$ and $17.13 \pm 3.14$ respectively. The order of the mean BOD in the samples from the three industries can be arranged as TAN2>TAN3>TAN1. The BOD observed in TAN1, TAN2 and TAN3 samples were found below the recommended limits of NESREA (200 mg/l) but above WHO (10 mg/l). Statistical analysis shows that there is no significant difference $(p<0.05)$ between the mean values of BOD among the industries. This might be due to similar tannery activities involved in the tannery industries at the time of sampling. The low level of BOD recorded in this study is an indication of the low level of biodegradable organic solids in the effluent. The average values of BOD observed in this present study were lower than those observed by Mohammed et al. (2017) and Baba et al. (2020).

Table 1: Mean Values \pm S.D of Physico-chemical parameters of effluents from the Tannery Industries before Treatment.

\begin{tabular}{llllllll}
\hline Parameter & Tannery 1 & Tannery 2 & Tannery 3 & $\mathrm{a}$ & $\mathrm{b}$ & $\mathrm{c}$ & $\mathrm{d}$ \\
\cline { 2 - 7 } Temperature $\left({ }^{\circ} \mathrm{C}\right)$ & $28.07 \mathrm{a} \pm 0.65$ & $27.77 \mathrm{a} \pm 0.64$ & $26.38 \mathrm{a} \pm 3.81$ & & $29.50 \pm 4.68$ & 35 & 40 \\
pH & $7.77 \mathrm{a} \pm 2.93$ & $8.35 \mathrm{a} \pm 0.28$ & $7.52 \mathrm{a} \pm 0.76$ & 6.89 & $5.35 \pm 1.57$ & $7.0-8.5$ & $6.0-9.0$ \\
$\mathrm{COD}(\mathrm{mg} / \mathrm{l})$ & $2372 \mathrm{a} \pm 938$ & $1406 \mathrm{a} \pm 208$ & $3532 \mathrm{a} \pm 1373$ & 2.2 & $3106 \pm 2753$ & 40 & 40 \\
$\mathrm{BOD}(\mathrm{mg} / \mathrm{l})$ & $13.85 \mathrm{a} \pm 6.42$ & $19.46 \mathrm{a} \pm 0.50$ & $17.13 \mathrm{a} \pm 3.14$ & 1032 & $26.17 \pm 9.49$ & 10 & 200 \\
$\mathrm{SS}(\mathrm{mg} / \mathrm{l})$ & $374 \mathrm{a} \pm 124$ & $358 \mathrm{a} \pm 335$ & $780 \mathrm{a} \pm 739$ & 501 & $562 \pm 482$ & 30 & 10 \\
TDS $(\mathrm{mg} / \mathrm{l})$ & $3941 \mathrm{a} \pm 3703$ & $3300 \mathrm{a} \pm 1714$ & $2653 \mathrm{a} \pm 1240$ & 532.7 & $444 \pm 507$ & 250 & 500 \\
\hline
\end{tabular}

The values given in the table above are means of 6 replicate values, $\mathrm{n}=6$ ( 1 sample was taken monthly for 6 months). Within the rows, means with different alphabets are statistically different $(p<0.05)$. WHO: World Health Organisation. NESREA: National Environmental Standard and Regulatory Enforcement Agency. a = Mohammed et al.(2017), b = Baba et al. (2020), c = WHO (2006), $d=$ NESSRA (2009) 
BAJOPAS Volume 13 Number 2, December, 2020

Identification, Biochemical Characterization and growth rates of the Bacterial Isolates

Results of identification and biochemical characterization of the bacterial isolates were shown in table 2. After 24 hours of incubation, the nutrient agar media plates were checked for bacterial growth. The results showed the presence of different strains in the samples. The TAN1 bacteria isolate was found to be gramnegative cocci while TAN3 was gram-positive cocci. TAN2 bacteria isolate was found to be gram-positive, rod-shaped. TAN1, TAN2, and TAN3 bacteria isolates recorded positive results for spore former.

The results of the biochemical tests indicated that all the bacteria were positive for catalase, oxidase, citrate, maltose, glucose, lactose (negative in TAN1), mannitol (negative in TAN2), starch hydrolysis and coagulase (negative in TAN2) tests. The bacteria showed negative results for nitrate reduction, $M R$ (positive in TAN2), VP (positive in TAN1), Indole (positive in TAN2) tests. Base on the morphological and biochemical test results, TAN1, TAN2, and TAN3 bacteria isolates were identified to be Nesseria spp, Bacillus cereus, and Staphylococcus aureus respectively.

The growth rate of the TAN1, TAN2 and TAN3 Isolates were shown in figure 2. Generally, the optical density increase with the increase in time (day) and decrease as time goes on. The highest optical density was shown by bacillus cereus in TAN2 while the lowest was shown by Staphylococcus aureus in TAN3.

The initial growth phase of TAN1 Isolate bacteria occurred within 2-day of incubation as the growth rate increases up to the 6th-day incubation when the maximum growth was observed. Beyond the 6th day, the growth of the bacteria declined (which might be due to a shortage of nutrients in the effluents) until it reached its death phase (which might be due to the unavailability of nutrients in the effluents).

A similar trend of growth was also observed for TAN2 Isolate as the initial growth phase also occurred within 2-day of incubation but maximum growth rate observed on the 4th day of incubation. The stationary stage occurred between the 4th day and the 8th day. Beyond the 8th day, the growth of the bacteria declined (which might be due to a shortage of nutrients in the effluents) until it reached its death phase (which might be due to the unavailability of nutrients in the effluents).

The initial growth phase of TAN3 bacterial Isolate occurred within the 3-day incubation as the growth rate increases up to the 6th-day incubation when the maximum growth was observed. Beyond the 6th day, the growth of the bacteria declined (which might be due to a shortage of nutrients in the effluents) until it reached its death phase (which might be due to the unavailability of nutrients in the effluents).

Table 2: Morphological and Biochemical characteristics of bacterial isolates

\begin{tabular}{lllll} 
Bacterial Isolates & & TAN1 & TAN2 & TAN3 \\
\hline $\begin{array}{lllll}\text { Morphological } \\
\text { characteristics }\end{array}$ & Shape & Cocci & Rod & Cocci \\
& Spore & & & \\
& former & + & + & + \\
Gram & & & \\
Biochemical characteristics & reaction & - & + & + \\
& Citrate & + & + & + \\
& Catalase & + & + & + \\
& Coagulase & + & - & + \\
Starch & + & + & + \\
& Glucose & + & + & + \\
Oxidase & + & + & + \\
& Indo & - & + & - \\
Lactose & - & + & + \\
Manitol & + & - & + \\
Maltose & + & + & + \\
MR & - & + & - \\
VP & + & - & - \\
& Nitrate & - & - & - \\
Reduction & - Neisseria & Bacillus & Staphylococcus \\
& Bacterial & cereus & aureus \\
& name & spp & cas
\end{tabular}

+ = Positive; - = Negative; MR=Methyl Red; VP= Voges-Proskauer 


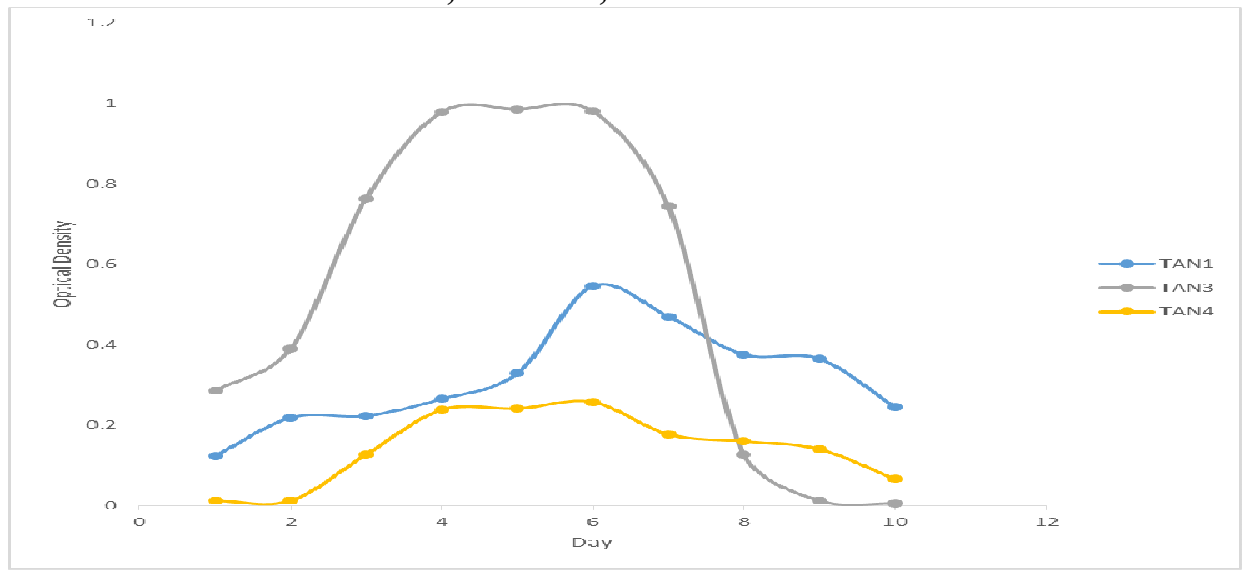

Fig. 2 Growth rates of the isolates in the effluents from the Tannery Industries

\section{Physico-chemical Parameters in the Industrial Effluents after the biodegradation.}

Table 3 shows the mean results of the physicochemical parameter before and after bioremediation using the different masses $(5 \mathrm{~g}$, $10 \mathrm{~g}, 15 \mathrm{~g}, 20 \mathrm{~g}$, and $25 \mathrm{~g}$ ) of the respective immobilized bacteria. Also, Table 4 shows the mean results of correlation coefficient ( $r$ ) between different masses of bacteria and physicochemical parameters.

The mean values $(\mathrm{mg} / \mathrm{l})$ of the SS after the bioremediation varies between $243 \pm 45$ and $898 \pm 672$. The mean concentration $(\mathrm{mg} / \mathrm{l})$ of SS remediated by the different masses $(5 \mathrm{~g}, 10 \mathrm{~g}$, $15 \mathrm{~g}, 20 \mathrm{~g}$, and $25 \mathrm{~g}$ ) of the bacteria varies. The SS in the samples fluctuates up and down after the bioremediation process when compared with the SS of the raw samples before the bioremediation. The increase in the levels of the SS might be due to the aggregation of the TDS which are large enough to result into SS. The increase in the levels of the SS might be also due to the influence of the nutrients which was added into the effluents in order to make the microorganisms more active and viable for fast degradation of organic contaminants in the effluent. The relative potential or efficiency of the different masses of the bacteria in remediating SS in TAN1 samples was in the order $25 \mathrm{~g}>20 \mathrm{~g}>15 \mathrm{~g}>10 \mathrm{~g}>5 \mathrm{~g}$. For TAN2 and TAN3 samples, the order was $25 \mathrm{~g}>20 \mathrm{~g}>15$ $\mathrm{g}>10 \mathrm{~g}>5 \mathrm{~g}$. These might be due to the variations in the surface areas of the different masses of the immobilized bacteria. Statistical analysis shows that there is no significant difference $(p<0.05)$ between the mean values of SS among the masses in the respective industries. Positive and significant correlations exist between the masses of bacteria and Suspended Solid (SS). This showed that there is general increase in the levels of the SS as the masses of the immobilized bacteria increases. TAN3 (90\%) and TAN1 (80\%) showed a very high correlation with the masses of the bacteria while TAN2 (61\%) showed a very low correlation.

The mean values $(\mathrm{mg} / \mathrm{l})$ of the TDS after the bioremediation varies between $46 \pm 11$ and $83 \pm 78$. The mean concentration $(\mathrm{mg} / \mathrm{l})$ of TDS remediated by the different masses $(5 \mathrm{~g}, 10 \mathrm{~g}$, $15 \mathrm{~g}, 20 \mathrm{~g}$, and $25 \mathrm{~g}$ ) of the bacteria varies. There is a reduction in all the TDS of all the samples after the bioremediation process compared with the TDS of the raw samples before the bioremediation. The relative potential or efficiency of the different masses of the bacteria in remediating TDS in TAN1 and TAN3 samples was in the order $5 \mathrm{~g}>10 \mathrm{~g}>15 \mathrm{~g}>20$ $\mathrm{g}>25 \mathrm{~g}$. For TAN2 samples, the order was 20 $g>10 \quad g>25 \quad g>15 \quad g>5 \quad g$. Statistical analysis shows that there is no significant difference $(p<0.05)$ between the mean values of TDS among the masses in the respective industries. These might be due to the variations in the surface areas of the different masses of the immobilized bacteria. Positive and significant correlations exist between the masses of bacteria and TDS with the exception in TAN2 (negative and insignificant correlation). The positive correlations showed that there is general increase in the levels of the TDS as the masses of the immobilized bacteria increases. TAN1 $(96 \%)$ showed a very high correlation with the masses of the bacteria while TAN2 (47\%) showed a very low correlation.

The mean values $(\mathrm{mg} / \mathrm{l})$ of the BOD after the bioremediation varies between $1.56 \pm 0.20 \mathrm{mg} / \mathrm{l}$ and $6.92 \pm 5.49 \mathrm{mg} / \mathrm{l}$. The mean concentration $(\mathrm{mg} / \mathrm{l})$ of BOD remediated by the different masses $(5 \mathrm{~g}, 10 \mathrm{~g}, 15 \mathrm{~g}, 20 \mathrm{~g}$, and $25 \mathrm{~g}$ ) of the bacteria varies. There is a reduction in all the BOD of all the samples after the bioremediation process compared with the $\mathrm{BOD}$ of the raw 
BAJOPAS Volume 13 Number 2, December, 2020 samples before the bioremediation. The relative potential or efficiency of the different masses of the bacteria in remediating BOD in TAN1, TAN2 and TAN3 samples were in the order $25 \mathrm{~g}>20$ $\mathrm{g}>15 \mathrm{~g}>10 \mathrm{~g}>5 \mathrm{~g}, 25 \mathrm{~g}>15 \mathrm{~g}>5 \mathrm{~g}>10 \mathrm{~g}>20 \mathrm{~g}$ and $20 \mathrm{~g}>10 \mathrm{~g}>25 \mathrm{~g}>15 \mathrm{~g}>5 \mathrm{~g}$ respectively. Statistical analysis shows that there is significant difference $(p<0.05)$ between the mean values of BOD among the masses in the respective industries. These might be due to the variations in the surface areas of the different masses of the immobilized bacteria. Negative and significant correlations exist between the masses of bacteria and BOD. This showed that there is general decrease in the levels of the BOD as the masses of the immobilized bacteria increases. TAN1 (94\%) showed a very high correlation with the masses of the bacteria while TAN2 (4\%) showed a very low correlation.

The mean values $(\mathrm{mg} / \mathrm{l})$ of the COD after the bioremediation varies between $250 \pm 154$ and $3134 \pm 1595$. The mean concentration $(\mathrm{mg} / \mathrm{l})$ of COD remediated by the different masses $(5 \mathrm{~g}$, $10 \mathrm{~g}, 15 \mathrm{~g} 20 \mathrm{~g}$, and $25 \mathrm{~g}$ ) of the bacteria varies. There is a reduction in all the COD of all the samples after the bioremediation process compared with the COD of the raw samples before the bioremediation. The relative potential or efficiency of the different masses of the bacteria in remediating COD in TAN1, TAN2 and TAN3 samples were in the order $25 \mathrm{~g}>20 \mathrm{~g}>15$ $\mathrm{g}>5 \mathrm{~g}>10 \mathrm{~g}, 25 \mathrm{~g}>20 \mathrm{~g}>15 \mathrm{~g}>10 \mathrm{~g}>5 \mathrm{~g}$ and 10 g>5 g>25 g>15 g>20 g respectively. Statistical analysis shows that there were significant difference $(p<0.05)$ between the mean values of COD among the masses in the respective industries except for effluents treated with $25 \mathrm{~g}$. These might be due to the variations in the surface areas of the different masses of the immobilized bacteria. Negative and insignificant correlations exist between the masses of bacteria and COD with the exception in TAN3 (positive and significant correlation). The negative correlations showed that there is general decrease in the levels of the COD as the masses of the immobilized bacteria increases. TAN2 (100\%) showed a very high correlation with the masses of the bacteria while TAN3 (36\%) showed a very low correlation.

Generally, there was an overall decrease in the concentration of these physicochemical parameters after the bioremediation using the different masses of the bacterial isolates. These might be due to the variations in the surface areas of the different masses of the immobilized bacteria. This is in line with the work of Jimoh et al. (2018) and Baba et al. (2020).

Table 3: Mean Values $(\mathrm{mg} / \mathrm{l}) \pm$ S.D of Physicochemical parameters in effluents from the Tannery Industries before and after Treatment of the effluents $(250 \mathrm{ml})$ with the different masses $(5 \mathrm{~g}, 10 \mathrm{~g}$, $15 \mathrm{~g}, 20 \mathrm{~g}$, and $25 \mathrm{~g}$ ) of the bacteria.

\begin{tabular}{llllllll}
\hline $\mathrm{P}$ & IND & Before & \multicolumn{5}{c}{ After } \\
\cline { 4 - 7 } & & & $5 \mathrm{~g}$ & $10 \mathrm{~g}$ & $15 \mathrm{~g}$ & $20 \mathrm{~g}$ & $25 \mathrm{~g}$ \\
\hline \multirow{2}{*}{ COD } & TAN1 & $2372 \pm 938$ & $1708 \mathrm{a} \pm 861$ & $2045 \mathrm{a} \pm 1205$ & $845 \mathrm{a} \pm 369$ & $300 \mathrm{a} \pm 167$ & $250 \mathrm{a} \pm 154$ \\
& TAN2 & $1406 \pm 208$ & $1195 \mathrm{a} \pm 208$ & $1125 \mathrm{a} \pm 384$ & $1055 \mathrm{a} \pm 317$ & $956 \mathrm{a} \pm 310$ & $870 \mathrm{ab} \pm 240$ \\
& TAN3 & $3532 \pm 1373$ & $2374 \mathrm{a} \pm 1344$ & $1976 \mathrm{a} \pm 1405$ & $2757 \mathrm{a} \pm 1266$ & $3134 \mathrm{a} \pm 1595$ & $2614 \mathrm{~b} \pm 1105$ \\
BOD & TAN1 & $13.85 \pm 6.42$ & $6.92 \mathrm{a} \pm 5.49$ & $6.42 \mathrm{a} \pm 5.07$ & $5.72 \mathrm{a} \pm 5.35$ & $4.62 \mathrm{a} \pm 4.37$ & $2.82 \mathrm{ab} \pm 1.26$ \\
& TAN2 & $19.46 \pm 0.50$ & $1.75 \mathrm{~b} \pm 0.22$ & $1.73 \mathrm{~b} \pm 0.18$ & $1.58 \mathrm{a} \pm 0.16$ & $1.91 \mathrm{a} \pm 0.22$ & $1.56 \mathrm{~b} \pm 0.20$ \\
& TAN3 & $17.13 \pm 3.14$ & $4.24 \mathrm{ab} \pm 0.77$ & $3.29 \mathrm{ab} \pm 0.37$ & $4.11 \mathrm{a} \pm 0.07$ & $3.23 \mathrm{a} \pm 0.91$ & $3.33 \mathrm{a} \pm 1.28$ \\
SS & TAN1 & $374 \pm 124$ & $243 \mathrm{a} \pm 45$ & $471 \mathrm{a} \pm 226$ & $475 \mathrm{a} \pm 182$ & $492 \mathrm{a} \pm 128$ & $611 \mathrm{a} \pm 217$ \\
& TAN2 & $358 \pm 335$ & $460 \mathrm{a} \pm 400$ & $543 \mathrm{a} \pm 414$ & $544 \mathrm{a} \pm 402$ & $551 \mathrm{a} \pm 414$ & $554 \mathrm{a} \pm 405$ \\
& TAN3 & $780 \pm 739$ & $586 \mathrm{a} \pm 594$ & $758 \mathrm{a} \pm 656$ & $787 \mathrm{a} \pm 676$ & $861 \mathrm{a} \pm 635$ & $898 \mathrm{a} \pm 672$ \\
TDS & TAN1 & $3941 \pm 3703$ & $51 \mathrm{a} \pm 10$ & $53 \mathrm{a} \pm 10$ & $55 \mathrm{a} \pm 15$ & $61 \mathrm{a} \pm 20$ & $63 \mathrm{a} \pm 26$ \\
& TAN2 & $3300 \pm 1714$ & $83 \mathrm{a} \pm 78$ & $47 \mathrm{a} \pm 20$ & $48 \mathrm{a} \pm 22$ & $47 \mathrm{a} \pm 17$ & $48 \mathrm{a} \pm 17$ \\
& TAN3 & $2653 \pm 1240$ & $46 \mathrm{a} \pm 11$ & $55 \mathrm{a} \pm 24$ & $55 \mathrm{a} \pm 25$ & $58 \mathrm{a} \pm 23$ & $61 \mathrm{a} \pm 28$ \\
\hline
\end{tabular}

Replicate $=6$ (months)

Within the rows, for the same parameter, means with different alphabets are statistically different $(p<0.05)$.

$\mathrm{P}=$ parameter, IND = Industries 
BAJOPAS Volume 13 Number 2, December, 2020

Table 4: Correlation coefficient $(r)$ between different masses of the bacteria and the physicochemical parameters.

\begin{tabular}{llll}
\hline Industries & Parameter & Correlation coefficient $(r)$ & $\begin{array}{l}\text { Percent dependence (rxrx100) } \\
(\%)\end{array}$ \\
\hline TAN1 & COD & -0.9 & 82 \\
& BOD & -0.97 & 94 \\
& SS & $0.90^{*}$ & 80 \\
TAN2 & TDS & $0.98^{*}$ & 96 \\
& COD & -1 & 100 \\
& BOD & -0.21 & 4 \\
& SS & $0.78^{*}$ & 61 \\
& TDS & -0.69 & 47 \\
& COD & $0.60^{*}$ & 36 \\
& BOD & -0.6 & 37 \\
& SS & $0.95^{*}$ & 90 \\
& TDS & $0.94^{*}$ & 89 \\
\hline
\end{tabular}

The correlation coefficient $(r)$ with * is statistically significant $(p<0.05)$.

Percentage reduction of the Parameters

Table 5 shows the percentage reduction of Parameters in industrial samples before and after the treatment of the effluents $(250 \mathrm{ml})$ with the different masses $(5 \mathrm{~g}, 10 \mathrm{~g}, 15 \mathrm{~g}, 20 \mathrm{~g}$, and $25 \mathrm{~g}$ ) of the Immobilized Bacteria.

In TAN1 samples, the percentage reduction (\%) of COD ranged (14-89); BOD (50-80); SS (-32$35)$ and TDS (98-99). In TAN2 samples, the percentage decrease $(\%)$ of COD ranged (15$38) ;$ BOD (90-92); SS [-28-(-55)] and TDS (9798). In TAN3 samples, the percentage decrease (\%) of COD ranged (11-44); BOD (76-81); SS (15-25) and TDS (98). The percentage increase in the levels COD, BOD and TDS might be due to the increase in the surface area of the different masses of the immobilized bacteria. However, the percentage decrease in the levels of the SS might be due to the aggregation of the TDS which are large enough to result into SS. The percentage decrease in the levels of the SS might be also due to the influence of the nutrients which was added into the effluents in order to make the microorganisms more active and viable for fast degradation of organic contaminants in the effluent. This is in line with the work of Jimoh et al. (2018) in which the concentration of the SS increase after the bioremediation of effluents.

Sreemoyee and Priti (2013) assessed and reduced several Physico-chemical parameters of dairy wastewater using Niesseria $s p$. and concluded that the species are well known to degrade organic compounds. This is in agreement with the current study in which the immobilized Niesseria $s p$ degrade the organic contaminants as indicated by the BOD, COD and TDS.

Jimoh et al. (2018) observed that TSS of the effluents was increased after treatment with immobilized bacteria and concluded that it might be due to the biostimulation method adopted for the research.

The optimum $\mathrm{pH}$ Biosorption of Chromium by Bacillus spp and Staphylococcus spp. from tannery effluent was investigated by Mythili and Karthikeyan (2011). The maximum adsorption of Chromium $(86.4 \mathrm{mg} / \mathrm{L})$ was showed by Bacillus spp and Staphylococcus spp showed $70.6 \mathrm{mg} / \mathrm{L}$ at an initial concentration of $100 \mathrm{mg} / \mathrm{L}$. In the present study, immobilised Bacillus spp and Staphylococcus spp. from the tannery industrial effluents reduced the levels of the organic pollutants with high potential as indicated by the percentage reduction of BOD, COD and TDS.

Enzymes often can work in multiple environments especially if they are immobilized. This makes the microorganisms' enzymes even more resistant to harsh environments and enables the enzymes to be recovered and recycled after they are no longer needed (Gianfreda and Rao 2004). Ramesh and Singh (1993) reported that the immobilized bacteria having more efficiency to remove the suspended particles than free cells. Using the immobilized cell is preferable due to its capability for using several times with the same efficiency, which makes it more economical. Similar work was done by Sikander et al. (2007) showing the higher reduction with permeabilized cells of Ochrobactrum intermedium strain SDCr-5. 
BAJOPAS Volume 13 Number 2, December, 2020

The results revealed the isolation and identification of isolates with the potential for the reduction of $\mathrm{Cr}$ (VI) to $\mathrm{Cr}$ (III). Results indicated that immobilized $B$. cereus could be efficiently used for the reduction of $\mathrm{Cr}$ (VI).

Table 5: Percentage reduction of the tested Parameters from the tannery industrial samples of the Immobilized Bacteria.

\begin{tabular}{lllllll}
\hline \multirow{2}{*}{ Industries } & & \multicolumn{5}{c}{ Percentage Reduction $(\%)$} \\
\cline { 3 - 7 } & & $5 \mathrm{~g}$ & $10 \mathrm{~g}$ & $15 \mathrm{~g}$ & $20 \mathrm{~g}$ & $25 \mathrm{~g}$ \\
\hline TAN1 & COD & 28 & 14 & 64 & 87 & 89 \\
& BOD & 50 & 54 & 59 & 67 & 80 \\
& SS & 35 & -26 & -27 & -32 & -63 \\
& TDS & 99 & 99 & 99 & 98 & 98 \\
TAN2 & COD & 15 & 20 & 25 & 32 & 38 \\
& BOD & 91 & 91 & 92 & 90 & 92 \\
& SS & -28 & -52 & -52 & -54 & -55 \\
& TDS & 97 & 99 & 99 & 99 & 99 \\
& COD & 33 & 44 & 22 & 11 & 26 \\
& BOD & 75 & 81 & 76 & 81 & 81 \\
& SS & 25 & 3 & -1 & -10 & -15 \\
& TDS & 98 & 98 & 98 & 98 & 98 \\
\hline
\end{tabular}

Percentage Reduction $=(B-A) / B \times 100 \%$

$A=$ Concentration of the parameter after treatment

$\mathrm{B}=$ Concentration of the parameter before treatment

$+=$ percentage decrease

- = percentage increase

In general, immobilization makes the enzyme more resistant to temperature, $\mathrm{pH}$, and substrate concentration swings giving it a longer lifetime and higher productivity per active unit (Gianfreda and Rao, 2004; FuIlbrook, 1996; Russell et al, 2003; Kandelbauer et al., 2004). Immobilized cells have been used and studied extensively for the production of useful chemicals (Ohtake and Silver, 1994), the treatment of wastewaters (Chen et al., 2003; Wang et al., 2010). Although many workers described microbial degradation of tannery effluent, limited literature is available on the bioremediation of tannery effluent using immobilized bacterial cells in the Kano Industrial Estates.

\section{CONCLUSION}

The samples contained variable levels of the physicochemical parameters. The results of the Analysis of variance revealed that, no statistical difference $(p<0.05)$ was observed for the temperature, $\mathrm{pH}, \mathrm{SS}, \mathrm{TDS}, \mathrm{BOD}$ and $\mathrm{COD}$ among the three tannery industries before the treatment. The levels of some of the parameters
(SS, TDS and COD) observed in the samples were found above the recommended limits of WHO and NESREA, which called for the treatment of the effluents before discharge into the environment. Base on the morphological and biochemical test results, TAN1, TAN2, and TAN3 bacterial isolates were identified to be Neisseria spp, Bacillus cereus, and Staphylococcus aureus respectively. The results of Post-treatment analysis showed that there is overall decrease in the levels of the parameters determined when compared with that of the pre-treatment. The overall percentage reduction of the immobilised bacteria in the treatment of the respective effluents was in the order TAN2 (72\%)>TAN1 $(70 \%)>$ TAN3 $(62 \%)$. Hence, the immobilized bacteria are having higher biodegradation potential for the treatment of the tannery effluents.

\section{Acknowledgments}

The authors wish to acknowledge the University of Maiduguri for the financial support. The authors are grateful to the Kano State Ministry of Environment for their support in obtaining the effluent samples. 


\section{REFERENCES}

Ajao, A. T., Adebayo, G. B., and Yakubu, S. E. (2011). Bioremediation of textile industrial effluent using mixed culture of Pseudomonas aeruginosa and Bacillus subtilis immobilized on agar-agar in a bioreactor. J. Microbiol. Biotech. Res, 1(3), 50-56.

Akan, J. C., Moses, E. A., Ogugbuaja, V. O., and Abah, J. (2007). Assessment of tannery industrial effluents from Kano metropolis, Kano State, Nigeria. Journal of Applied Sciences, 7(19), 2788-2793.

Akan, J. C., Ogugbuaja, V. O., Abdulrahman, F. I., and Ayodele, J. T. (2009). Pollutant levels in effluent samples from tanneries and textiles of Kano industrial areas, Nigeria. Global journal of pure and applied sciences, 15(3-4).

APHA (1989). Standard methods for Examination of Will bete and Will betewater.15 $5^{\text {th }}$ edition. Brydpass Springfield Will behington DC. pp. 164-176

APHA (1992). Standard Methods for the Examination of Water and Wastewater. Health, 69, 1116-9.

Baba, A., Garba, S. T., and Bello, H. S. (2020). Bioremediation Potential of Immobilized corynebacterium kutsceri in the Treatment of Tannery Industrial Effluent from Challawa Industrial Estate, Kano State, Nigeria. Journal of the Turkish Chemical Society Section A: Chemistry, $7(2), 335-350$.

Beem, E. I. V. (1994). reduction of solvent VOC emission. J. Oil Col. Chem. Ass, 77, 158.

Bouwer, E. J., and Zehnder, A. J. (1993). Bioremediation of organic compoundsputting microbial metabolism to work. Trends in biotechnology, 11(8), 360367.

Chen, K. C., Wu, J. Y., Liou, D. J., and Hwang, S. C. J. (2003). Decolorization of the textile dyes by newly isolated bacterial strains. Journal of Biotechnology, 101(1), 57-68.

Dan'Azumi, S., and Bichi, M. H. (2010). INDUSTRIAL POLLUTION AND HEAVY METALS PROFILE OF CHALLAWA RIVER IN KANO, NIGERIA. Journal of Applied Sciences in Environmental Sanitation, $5(1)$.

DWAF. (1992). Analytical Methods Manual, TR 151. Department of Water Affairs and Forestry, Pretoria.

El-Bestawy, E. (2013). Biological treatment of leather-tanning industrial wastewater using free living bacteria.
Elsheikh, M. A. S. (2009). Tannery wastewater pre-treatment. Water Science and Technology, 60(2), 433-440.

FuIlbrook, P. D. (1996). "Kinetics." Industrial enzymology: The application of enzymes in Industry. 2nd Ed. T. Godfrey and J Reichelt. eds.. Nature. New York.

Gianfreda, L., and Rao, M. A. (2004). Potential of extra cellular enzymes in remediation of polluted soils: a review. Enzyme and microbial technology, 35(4), 339354.

Hugo Springer. (1994). John Arthur Wilson Memorial Lecture "Treatment of Industrial Wastes of the Leather Industry - is it still a Major Problem". JALCA, 89, 153-185

Jimoh, A. A., Ganiyu, B. A., Baba, D., and Baba, A. (2018) Bioremediation Process of Effluent from Detergent and Food Industries in Jos, Nigeria: Kinetics and Thermodynamics. International Journal of Engineering Science Invention (IJESI), 762-73

Kandelbauer, A., Maute, O., Kessler, R. W., Erlacher, A., and Gübitz, G. M. (2004). Study of dye decolorization in an immobilized laccase enzyme-reactor using online spectroscopy. Biotechnology and bioengineering, 87(4), 552-563.

Kongjao, S., Damronglerd, S., and Hunsom, M. (2008). Simultaneous removal of organic and inorganic Pollutants in tannery wastewater using electrocoagulation technique. Korean Journal of chemical engineering, 25(4), 703.

Maheshwari, U. M., Aruna, S., Gomathi, M., and AbdulJaffar, A. H. (2017). Bioremediation by Free and Immobilized Bacteria Isolated from Tannery Effluent. International Journal of Research in Applied, Natural and Social Sciences. 5(7), 75-90

Margesin, R., and Schinner, F. (2001). Bioremediation (natural attenuation and biostimulation) of diesel-oilcontaminated soil in an alpine glacier skiing area. Applied and environmental microbiology, 677), 3127-3133.

Mohammed, A., Sekar, P., and George, J. (2011). Efficacy of microbes in bioremediation of tannery effluent. Inter. J. Curr. Res, 3(4), 324-326.

Mohammed, S. S. D., Orukotan, A. A., and Abdullahi, H. (2017). Physicochemical and Bacteriological Assessment of Tannery Effluent from Samaru-Zaria, 
BAJOPAS Volume 13 Number 2, December, 2020 Kaduna State, Nigeria. Journal of Applied

Sciences and Environmental Management, 21(4), 734-740.

Munz, G., De Angelis, D., Gori, R., Mori, G., Casarci, M., and Lubello, C. (2009). The role of tannins in conventional and membrane treatment of tannery wastewater. Journal of hazardous materials, 164(2-3), 733-739

Mythili, K., and Karthikeyan, B. (2011). Bioremediation of $\mathrm{Cr}$ (VI) from tannery effluent using Bacillus spp and Staphylococcus spp. International Multidisciplinary Research Journal, 1(6).

NESREA (2009). National Environmental Standards for Effluent Limitations and Regulation. 1233-1236

Noorjahan, C. M. (2014). Physicochemical characteristics, identification of bacteria and biodegradation of industrial effluent. Journal of bioremediation and Biodegradation, 5(3).

Ohtake, H. I., and Silver, A. O. (1994). Bacterial reduction of toxic chromate. Biological degradation and bioremediation of toxic chemicals, 403-415.

Omoleke, I. I. (2004). Management of environmental pollution in Ibadan, an African city: the challenges of health hazard facing government and the people. Journal of Human Ecology, 15(4), 265-275.

Rajor, A., Reddy, A.S., and Singh, B. (2004). Determination of BOD kinetic Parameters and evaluation of alternate methods, M.Sc. Thesis, Department of biotechnology \& environmental Science, Thapar Institute of Engineering and Technology, Patiala

Ramasami, T., Rajamani, S., and Rao, J. R. (1994, March). Pollution control in leather industry: Emerging technological options. In International symposium on surface and colloidal science and its relevance to soil pollution, madras.

Ramesh, J. V. S., and Singh, S. P. (1993). Yearly variation in certain physicochemical parameters of pond at eastern Doon Valley. Uttar Pradesh J. Zoo, 12 (1), 7577.

Ranen, S., and Sharadinadra, C. (2009). Biotechnology applications to environmental remediation in resource exploitation. Current science, 97, 6-25
Russell, A. J., Berberich, J. A., Drevon, G. F., and Koepsel, R. R. (2003). Biomaterials for mediation of

chemical and biological warfare agents. Annual review of biomedical engineering, 5(1), 1-27.

Saravanan, P., and Saravanan, A. (1999). Decolourization of tannery effluent by Flavobacterium sp. EK 1. Indian Journal of Environmental Protection, 19, 19-24.

Sikander, S., and Shahida, H. (2007). Reduction of toxic hexavalent chromium by Ochrobactrum intermedium strain SDCr5 stimulated by heavy metals. Bioresource Technol, 98, 340-344.

Singh, N., Sharma, B. K., and Bohra, P. C. (2000). Impact assessment of industrial effluent of arid soils by using satellite imageries. Journal of the Indian Society of Remote Sensing, 28(2-3), 79.

Sreemoyee, C., and Priti, P. (2013). Assessment of physico-chemical parameters of dairy waste water and isolation and characterization of bacterial strains in terms of cod reduction. Int J Sci, 2(3), 395-400.

Verheijen, L. A. H. M., Wiersema, D., Pol, L. H., and De Wit, J. (1996). Management of wastes from animal product processing. Livestock and environment, Finding a balance. International Agriculture Center, Wageningen, The Netherlands.

Wang, F., Yao, J., Si, Y., Chen, H., Russel, M., Chen, K., and Bramanti, E. (2010). Short-time effect of heavy metals upon microbial community activity. Journal of Hazardous Materials, 173(13), 510-516.

WHO (World Health Organization). (2006). Air quality guidelines: global update 2005: particulate matter, ozone, nitrogen dioxide, and sulfur dioxide. World Health Organization.

World Bank. (1995). Nigeria's strategic options for redressing industrial pollution. World Bank, industry and energy division. 1st edition, West Central Africa Department; Annexes: 1995; pp 60-62.

Zahoor, A., and Abdul, R. (2009). Enumeration of Coliforms. Journal of Environmental Sciences. 21, 814-820 


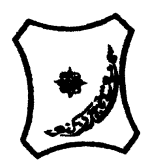

Bayero Journal of Pure and Applied Sciences, 13(2): 1 - 12

Received: November, 2020

Accepted: December, 2020

ISSN $2006-6996$

\title{
BIODEGRADATION POTENTIAL OF IMMOBILIZED BACTERIA IN THE TREATMENT OF TANNERY INDUSTRIAL EFFLUENTS FROM INDUSTRIAL ESTATES IN KANO STATE, NIGERIA
}

\author{
Abdullateef, B., ${ }^{1 *}$ Shuaibu, T. G., ${ }^{1}$ Babagana, K., ${ }^{1}$ Suleman, H. B. ${ }^{2}$ and Dauda, B. ${ }^{3}$ \\ ${ }^{1}$ Department of Pure and Applied Chemistry, Faculty of Science, University of Maiduguri, Borno State, \\ Nigeria \\ ${ }^{2}$ Department of Microbiology, Faculty of Science, University of Maiduguri, Borno State, Nigeria \\ ${ }^{3}$ Department of Chemical Engineering, Faculty of Engineering, University of Maiduguri, Borno State, \\ Nigeria \\ *Corresponding author: babslega@gmail.com; abelega2007@yahoo.com; +2348061309753
}

\section{ABSTRACT}

Industrial Effluents Samples from Gashash Tanneries (TAN1) in Bompai Industrial estate, Larabee Tannery Industry (TAN2) in Sharada Industrial estate and Z Tannery Industries (TAN3) in Challawa Industrial estate, Kano State, Nigeria were collected over a period of six months (August 2017 to January 2018) for assessing the biodegradation potentials of bacteria in the treatment of organic pollutants within the effluents. Bacteria were isolated from the effluents and immobilized on agar-agar. Different masses (5 g, $10 \mathrm{gr}, 15$ $\mathrm{g}, 20 \mathrm{~g}$, and $25 \mathrm{~g}$ ) of the bacteria were used in the treatment of $250 \mathrm{ml}$ of the effluents for ten days in a shaker incubator (Gallenkamp-OC-4364-L) at the temperature $30{ }^{\circ} \mathrm{C}$ and speed of $60 \mathrm{rpm}$. Pre-treatment analysis of the effluents for Temperature, pH, Biochemical Oxygen Demand (BOD), Chemical Oxygen Demand (COD), Suspended Solid (SS) and Total Dissolved Solids (TDS) gives the following results; temperature $\left({ }^{\circ} \mathrm{C}\right.$ )

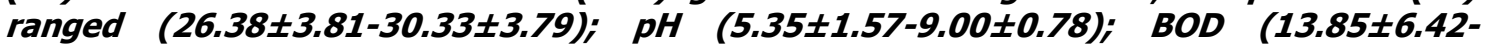
$38.75 \pm 16.20) ;$ COD (1406 $\pm 208-3532 \pm 1373) ;$ SS (208 $\pm 235-780 \pm 739)$ and TDS (266 $\pm 253-5276 \pm 2971)$. No statistical differences ( $p \leq 0.05)$ was observed for all the results among the different industries. The bacterial isolates were identified as Neisseria spp, Bacillus cereus, and Staphylococcus aureus, in TAN1, TAN2, and TAN3, respectively. After treatment of the effluent with the different masses of the isolated bacteria, the mean level of BOD was found to range as (0.55 $\pm 0.36-6.92 \pm 5.49) ; C O D$ (ND-3134 \pm 1595$)$;

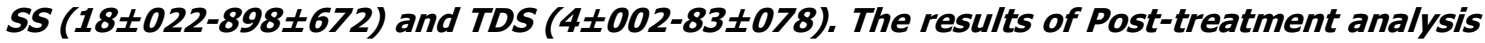
showed that there is overall decrease in the levels of the parameters determined when compared with that of the pre-treatment. The overall percentage reduction of the immobilised bacteria in the treatment of the respective effluents was in the order TAN2 (72\%)>TAN1 (70\%)>TAN3 (62\%). Hence, the immobilized bacteria are having higher biodegradation potential for the treatment of the tannery effluents.

Keywords: Biodegradation, bacteria, effluent, immobilization, tannery.

\section{INTRODUCTION}

Tannery industrial wastewater is a serious consequence of the pollution point of view for streams, freshwater, and land used for agriculture. The lack of awareness in the modern industrial practice has resulted in the discharge of tannery effluents which exhibit very high value of chromium ( $\mathrm{Cr}$ ), Sulfide, and chloride, Total Dissolved Solid (TDS), Total Suspended Solid (TSS), Biochemical Oxygen Demand (BOD) and Chemical Oxygen Demand (COD) in the water stream or land (Mohammed et al., 2001). Tanning is the process, which One ton of skin generally leads to the production of 20 to $80 \mathrm{~m}^{3}$ of turbid and foul-smelling converts the protein of the rawhide or skin into a stable material, which will not putrefy and is suitable for a wide variety of end applications (Elsheikh, 2009). The highly polluting chromium is the most commonly used tanning material producing leather that is more flexible and pliable than vegetable-tanned leather and does not discolor or lose shape in water as drastically as vegetable-tan (Elsheikh, 2009). Tannery effluent is among the most hazardous industrial pollutants due to its huge organic and inorganic load, which is highly toxic to human life and the environment (Kongjao et al., 2008). wastewater including chromium (100-400 mg/l), sulfide $(200-800 \mathrm{mg} / \mathrm{l})$, high levels of fat and 
BAJOPAS Volume 13 Number 2, December, 2020 other solid wastes, and notable pathogen contamination as well as pesticides added for skin conservation during transport (Elsheikh, 2009). There are more than 6000 tanneries in Nigeria with an annual processing capacity of 700,000 tons of hides and skins (Omoleke, 2004; Singh et al., 2008). It was reported that the total amount of waste produced per animal slaughtered is approximately $35 \%$ of its weight (World Bank, 1995). Also, for every $1000 \mathrm{~kg}$ of carcass weight, a slaughtered beef produces 5.5 $\mathrm{kg}$ of manure (excluding rumen contents or stockyard manure) and $100 \mathrm{~kg}$ of paunch manure (undigested food) (Verheijen et al., 1996). Tanneries generate wastewater in the range of 30-35 $\mathrm{L} \mathrm{kg}^{-1}$ skin/hide processed with variable $\mathrm{pH}$, Biological Oxygen Demand (BOD), Chemical Oxygen Demand (COD), high concentrations of suspended solids (SS), and tannins as well as chromium (Zahoor and Abdul, 2009).

Being heterogeneous and composed of a wide variety of compounds, it is very difficult to select a unique direct method for estimating the biodegradability of organic contents and biokinetic parameters for a wastewater sample (Rajor, 2004). For this purpose, some indirect estimation such as determination of biochemical oxygen demand (BOD) and chemical oxygen demand (COD) are applied as common laboratory investigations [9]. During retanning procedures, synthetic tannins (Syntan), oils and resins are added to form softer leather at varying doses (Munz et al., 2009). One of the refractory groups of chemicals in tannery effluents derives mainly from tannins (Ramasami et al., 2004). Syntans are characterized by complex chemical structures, because they are composed of an extended set of chemicals such as phenol-, naphthalene-, formaldehyde- and melamine-based syntans, and acrylic resins (Beem, 1994). Organic pollutants (proteic and lipidic components) are originated from skins (it is calculated that the raw skin has $30 \%$ loss of organic material during the working cycle) or they are introduced during processes (Hugo Springer, 1994).

Many conventional processes such as oxidation, chemical and biological processes were carried out to treat tanneries wastewater (Ebtesam et al, 2013). Biological processes have received more attention because of their costeffectiveness, lower sludge production and environmental friendliness (Noorjahan, 2014). Naturally occurring micro-organisms degrade the hazardous organic wastes including xenobiotic compounds, such as pesticides, polycyclic aromatic hydrocarbons (PAHs) and polychlorinated biphenyls (PCBs) in due course of time (Ranen and Sharadinadra, 2009). Bioremediation is based on the idea that all organisms remove substances from the environment to carry outgrowth and metabolism (Bouwer and Zehnder, 1993). Bacteria, protista and fungi are found to be very good at degrading complex molecules and incorporating the breakdown products into their metabolism (Bouwer and Zehnder, 1993). The resultant metabolic wastes that they produce are generally safe and somehow recycled into other organisms (Ranen and Sharadinadra, 2009). An acclimatized indigenous population of microorganisms capable of degradation of the compounds of interest must exist at the site for a successful bioremediation mode (Ranen and Sharadinadra, 2009). It has been observed that for a successful bioremediation mode, an acclimatized indigenous population of microorganisms capable of degradation of the compounds of interest must exist at the site under investigation (Ranen and Sharadinadra, 2009). Even though there are numerous physical and chemical methods employed in the disposal of wastes the advantage in using bacterium is that they play a key role in the reduction of COD, BOD, total protein, total tannin and total phenol (Saravanan and Saravanan, 1998)

Baba et al. (2020) studied the bioremediation potential of immobilized corynebacterium kutsceri in the Treatment of tannery industrial effluent from Challawa Industrial Estate, Kano State, Nigeria. The aim of the work is to study the reduction in the level of the contaminants through the process of bioremediation using the isolated bacteria. Immobilized bacteria can withstand various temperatures, $\mathrm{pH}$ and substrate concentrations; consequently, increasing the efficiency and the lifespan of the bacteria. Immobilized bacteria are widely applied in the treatment of wastewater and can be separated and recovered after the treatment with the same efficiency (Baba et al., 2020).

\section{MATERIALS AND METHODS \\ Study Area}

This study was carried out in Bompai, Sharada and Challawa industrial estates in Kano, Figure 1. Kano lies on Latitude $11^{\circ} 30^{\prime} \mathrm{N}$ and $8^{\circ} 30^{\prime} \mathrm{E}$ and Longitude $11^{\circ} 5^{\prime} \mathrm{N}$ and $8^{\circ} 5^{\prime} \mathrm{E}$ in Northern Nigeria. It is one of the developed industrial cities in Nigeria. Tannery activities are the dominating industries and this could be one of the reasons for her high population density (Dan'Azumi and Bichi, 2010). Many researchers have studied biodegradation of tannery effluent using microorganisms. However, limited literature is available on the biodegradation of tannery effluent in Kano industrial estates using 
BAJOPAS Volume 13 Number 2, December, 2020 immobilized bacterial cells. This research work focuses on the potential of the use of the indigenous immobilized bacterial isolates in the treatment of tannery effluents in the industrial estates.

\section{Sample Collection}

Effluents were collected from the Tannery Industries from Bompai, Challawa and Sharada Industrial Estates, Kano, Nigeria. The effluents were collected over a period of six months (August 2017 to January 2018). Samples collected in a sterile 4-liter plastic container with a unique identification number were preserved using an ice-box that was transported to the Microbiology Laboratory, Department of Microbiology, Bayero University of Kano for analysis

\section{Sample Preparation and Sample Analysis}

Immediately after the collection of the effluent, $\mathrm{pH}$, TSS, TDS, COD, BOD levels were determined before treatment (Pre-treatment determination) and ten days after treatment (Post-treatment determination) as described in
APHA (1989) standard methods. $\mathrm{pH}$ was determined using Ecotests $\mathrm{pH}$ meter and TDS was determined using AQUALYTIC TDS Salinometer. BOD was determined as described by the standard method (APHA, 1992). COD and SS were determined using DR/2010 HACH portable data logging spectrophotometer (DWAF, 1992)

\section{Identification and Biochemical} Characterization of the Bacterial Isolates

The bacteria were isolated from the effluents using Serial Dilution according to the method described by APHA (1989). The biochemical tests such as oxidase, catalase, coagulase, indole (from $1 \%$ tryptone broth), citrate (Simmons citrate agar), methyl red/VogesProskauer (MR/VP), nitrate reduction, Starch Hydrolysis, Glucose, Maltose, and Lactose tests were carried out on the bacterial isolates to identify the bacteria through the bacteria biochemical characteristics according to Ajao et al. (2011).

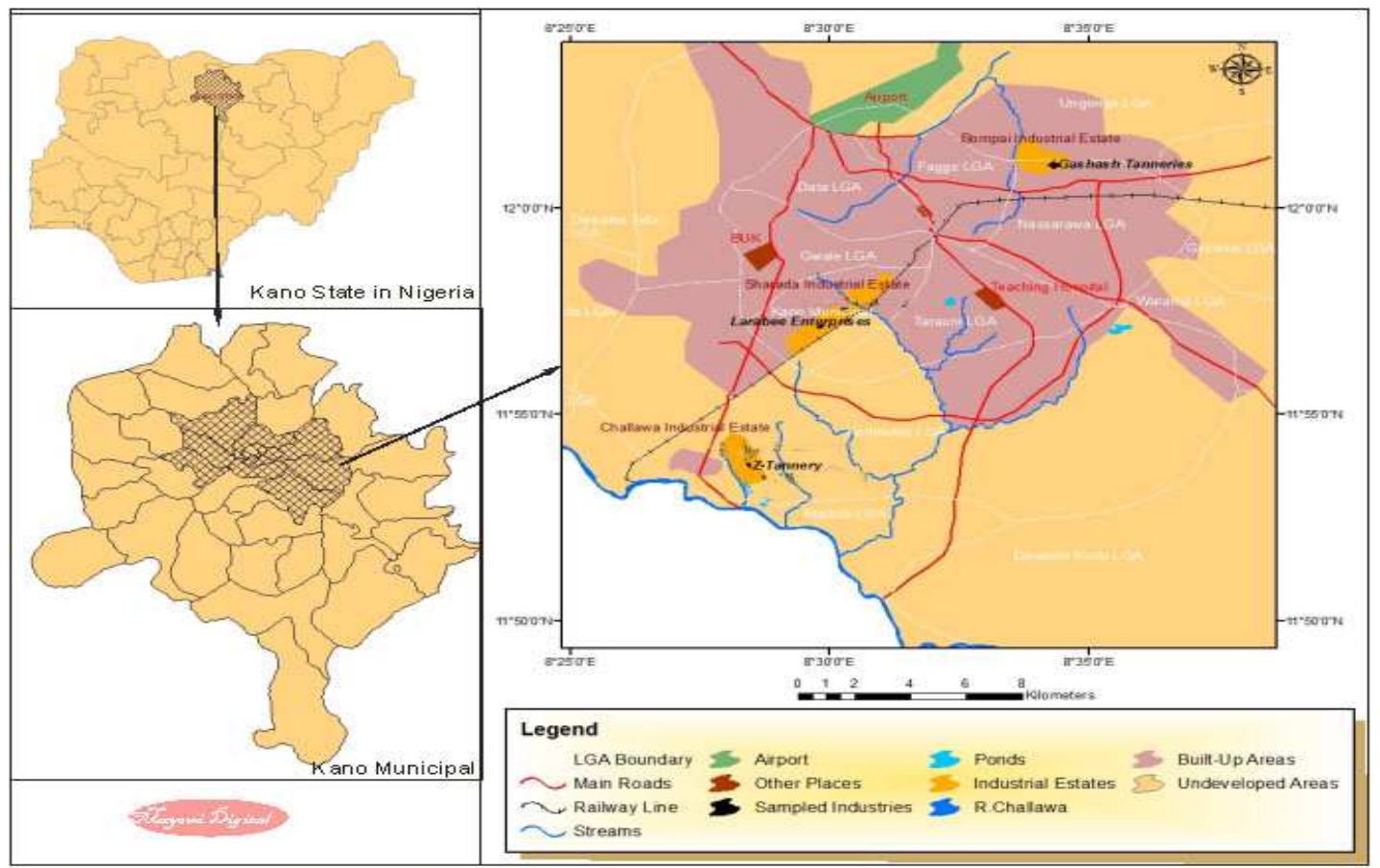

Fig. 1 Map showing the study areas

Source: Mayomi Digital Productions, GIS Laboratory, Department of Geography, UNIMAID (2017)

\section{Determination of Growth Rate of the Bacteria in Effluent Sample}

The bacteria growth rates were determined by transferring $2 \mathrm{~mL}$ of the bacterial isolates from the tannery effluent in broth medium into 100 $\mathrm{mL}$ sterile effluents in conical flasks and kept in an incubator (Giffrin cool) for 10 days. Control was also set up by incubating another $100 \mathrm{~mL}$ each of the sterile effluents without the bacteria. The optical density of the content was determined at the wavelength of $600 \mathrm{~nm}$ on a daily interval and recorded. 
BAJOPAS Volume 13 Number 2, December, 2020 Immobilization of Bacteria

Agar solution and inoculi were prepared separately. Fifty milliliters $(50 \mathrm{~mL})$ of nutrient broth each of the inoculi was prepared in a McCartney bottle and incubated for 24 hours. A solution of agar-agar was prepared by dissolving $10 \mathrm{~g}$ of the powder in distilled water and made up to $500 \mathrm{~mL}$ mark in an Erlenmeyer flask and was sterilized in an autoclave (280A) for 15 minutes and allowed to cool to $40-45^{\circ} \mathrm{C}$ (Ajao et al., 2011). Four milliliters ( $4 \mathrm{~mL})$ of the bacterial isolates in the nutrient broth was mixed with 36 $\mathrm{ml}$ of the prepared agar-agar media in petri-dish plates and then allowed to solidify. This was kept in the refrigerator for bioremediation.

\section{Bioremediation (Treatment) of the Effluents}

The solidified agar block (immobilized bacteria) was cut into cubes using a sterile knife; $0.1 \mathrm{~mL}$ phosphate buffer ( $\mathrm{pH} \mathrm{7.0)}$ was added and kept in the refrigerator for 1 hour for curing. The phosphate buffer was decanted after 1 hour and the cubes were washed with sterile distilled water 3-4 times before it was used (Ajao et al., 2011). Two liters (2 L) of the effluent was supplemented with the minimum basal medium in $\mathrm{g} / \mathrm{L}: \mathrm{NaCl}(0.8), \mathrm{MgSO}_{4} .7 \mathrm{H}_{2} \mathrm{O}(0.001), \mathrm{KH}_{2} \mathrm{PO}_{4}$ (2), $\mathrm{NaNO}_{3}$ (2), $\quad \mathrm{CaCl}_{2} .2 \mathrm{H}_{2} \mathrm{O} \quad(0.5)$ and $\mathrm{NaHPO}_{4} .12 \mathrm{H}_{2} \mathrm{O}(2)$ and sterilized in an autoclave at $121^{\circ} \mathrm{C}$ for 15 minutes (Margesin and Schinner, 2001). Two hundred and fifty milliliters $(250 \mathrm{~mL})$ of the effluents were transferred into different $250 \mathrm{ml}$ conical flasks. The content was covered with a cotton-wool ramped with foil paper to avoid contamination. Five grams $(5 \mathrm{~g})$ of the immobilized bacteria were quickly transferred into each of the effluents in the conical flasks in an inoculating chamber. The same procedures were carried out for the $10 \mathrm{~g}, 15 \mathrm{~g}, 20 \mathrm{~g}$ and 25 $\mathrm{g}$ of the immobilized bacteria in separate $250 \mathrm{~mL}$ effluents in conical flasks and agitated for ten days in a shaker incubator (Gallenkamp-OC4364-L) at a temperature $30^{\circ} \mathrm{C}$ and speed of 60 rpm. The treated effluent samples were taken on the tenth day and analyzed for the parameters $\mathrm{pH}$, SS, TDS, COD, and BOD, (Posttreatment determination) for the different grams of bacteria to evaluate and compare the biodegradation potential. (Baba et al., 2020).

\section{Statistical Analysis}

The data were represented as Mean \pm Standard deviation and analyzed statistically using oneway Analysis of Variance (ANOVA) and Tukey's HSD as Post Hoc Tests with the aid of SPSS 16.0. The correlation coefficient was also used to measure the strength of the relationship between the different masses of the bacteria and the parameters. All $\mathrm{p} \leq 0.05$ were considered as statistically significant.

\section{RESULTS AND DISCUSSION Physico-chemical parameters in the Industrial Effluents before the Biodegradation.}

Results of the Physico-chemical parameters in the industrial effluents before the Biodegradation is shown in table 1 . The mean temperatures $\left({ }^{\circ} \mathrm{C}\right)$ observed in TAN1, TAN2, and TAN3 samples were $28.07 \pm 0.65 ; 27.77 \pm 0.64$ and $26.38 \pm 3.81$ respectively. The order of the mean temperature of the samples from the three industries can be arranged as TAN1 > TAN2>TAN3. The temperature observed at TAN1, TAN2, and TAN3 samples were found below the WHO $\left(35^{\circ} \mathrm{C}\right)$ and NESREA $\left(40^{\circ} \mathrm{C}\right)$ limits. The low values of temperature might be due to the processes used at the time of sampling. High temperature brings down the solubility of gases in water that ultimately expresses as high BOD and COD. Statistical analysis shows that there is no significant difference $(p<0.05)$ between the mean values of temperature among the industries. This might be due to similar tannery activities involved in the tannery industries at the time of sampling. The average values of temperature observed in this present study are less than those observed by Akan et al. (2007), Akan et al. (2009) and Baba et al. (2020).

The mean level of $\mathrm{pH}$ observed in TAN1, TAN2 and TAN3, samples were $7.77 \pm 2.93$; $8.35 \pm 0.28$ and $7.52 \pm 0.76$ respectively. The order of the mean $\mathrm{pH}$ of the samples from the three industries can be arranged as TAN2> TAN1 $>$ TAN3. The $\mathrm{pH}$ of the samples falls within the WHO (7.0-8.5) and NESREA (6-9) standard limits. Statistical analysis shows that there is no significant difference $(p<0.05)$ between the mean values of $\mathrm{pH}$ among the industries. This might be due to similar tannery activities involved in the tannery industries at the time of sampling. Maheshwari et al. (2017) reported that the level of $\mathrm{pH}$ in the effluents from the tannery industry in Vaniyambadi, India was 6.5 which was lower than that observed in the present study. The $\mathrm{pH}$ in the effluents from the tannery industries in Kano and Kaduna were reported to be 7.64 and 6.89, respectively (Akan et al., 2007; Mohammed et al., 2017). The average values of $\mathrm{pH}$ observed in this present study are less than those observed by Mohammed et al. (2017) and Baba et al. (2020). The mean level of SS $(\mathrm{mg} / \mathrm{l})$ observed in TAN1, TAN2, and TAN3 samples were 374 \pm 124 ; $358 \pm 335$ and $780 \pm 739$ respectively. The order of the mean SS in the samples from the three industries can be arranged as TAN3 > TAN1 $>$ TAN2. 
The SS observed in the samples were far above the recommended standard limits of regulating bodies WHO $(30 \mathrm{mg} / \mathrm{l})$ and NESREA $(10 \mathrm{mg} / \mathrm{l})$. Statistical analysis shows that there is no significant difference $(p<0.05)$ between the mean values of SS among the industries. This might be due to similar tannery activities involved in the tannery industries at the time of sampling. The average values of SS observed in this present study are less than that observed $(3700 \pm 122 \mathrm{mg} / \mathrm{l})$ by Akan et al. (2009) for tanneries in Kano. Also, the average values of SS observed in this present study are less than that observed by Mohammed et al. (2017) and Baba et al. (2020) with the exception in TAN3.

The mean level of TDS (mg/l) observed in TAN1, TAN2, and TAN3 samples were $3941 \pm 3703$; $3300 \pm 1714$ and $2653 \pm 1240$ respectively. The order of the mean TDS in the samples from the three industries can be arranged as TAN1>TAN2>TAN3. The TDS observed in the samples were far above the recommended standard limits of WHO $(250 \mathrm{mg} / \mathrm{l})$ and NESREA $(500 \mathrm{mg} / \mathrm{l})$. Statistical analysis shows that there is no significant difference $(p<0.05)$ between the mean values of TDS among the industries. This might be due to similar tannery activities involved in the tannery industries at the time of sampling. TDS in the effluents from the tannery industries in Kano, Nigeria was reported to be $1281 \mathrm{mg} / \mathrm{l}$ (Akan et al., 2007). The average values of SS observed in this present study are less than those observed by Mohammed et al. (2017) and Baba et al. 2020)

The mean level of COD (mg/l) observed in TAN1, TAN2 and TAN3 samples seasons were $2372 \pm 938 ; \quad 1406 \pm 208$ and $3532 \pm 1373$ respectively. The order of the mean COD of the samples from the three industries can be arranged as TAN3>TAN1> TAN2. The COD observed in TAN1, TAN2 and TAN3 samples were far above the recommended standard limits of regulating bodies $\mathrm{WHO}(40 \mathrm{mg} / \mathrm{l})$ and NESREA (40 mg/l). Statistical analysis shows that there is no significant difference $(p<0.05)$ in COD among the industries. This might be due to similar tannery activities involved in the tannery industries as at the time of sampling. The Chemical Oxygen demand (COD) is the amount of oxygen, in $\mathrm{mg} / \mathrm{L}$, required for the degradation of the compound of wastewater to occur. In comparison, the average values of COD observed in this present study were higher than that observed by Mohammed et al. (2017) but lower than that observed by Baba et al. (2020).

The mean levels of BOD $(\mathrm{mg} / \mathrm{l})$ observed in TAN1, TAN2 and TAN3 samples were $13.85 \pm 6.42 ; \quad 19.46 \pm 0.50$ and $17.13 \pm 3.14$ respectively. The order of the mean BOD in the samples from the three industries can be arranged as TAN2>TAN3>TAN1. The BOD observed in TAN1, TAN2 and TAN3 samples were found below the recommended limits of NESREA (200 mg/l) but above WHO (10 mg/l). Statistical analysis shows that there is no significant difference $(p<0.05)$ between the mean values of BOD among the industries. This might be due to similar tannery activities involved in the tannery industries at the time of sampling. The low level of BOD recorded in this study is an indication of the low level of biodegradable organic solids in the effluent. The average values of BOD observed in this present study were lower than those observed by Mohammed et al. (2017) and Baba et al. (2020).

Table 1: Mean Values \pm S.D of Physico-chemical parameters of effluents from the Tannery Industries before Treatment.

\begin{tabular}{llllllll}
\hline Parameter & Tannery 1 & Tannery 2 & Tannery 3 & $\mathrm{a}$ & $\mathrm{b}$ & $\mathrm{c}$ & $\mathrm{d}$ \\
\cline { 2 - 7 } Temperature $\left({ }^{\circ} \mathrm{C}\right)$ & $28.07 \mathrm{a} \pm 0.65$ & $27.77 \mathrm{a} \pm 0.64$ & $26.38 \mathrm{a} \pm 3.81$ & & $29.50 \pm 4.68$ & 35 & 40 \\
pH & $7.77 \mathrm{a} \pm 2.93$ & $8.35 \mathrm{a} \pm 0.28$ & $7.52 \mathrm{a} \pm 0.76$ & 6.89 & $5.35 \pm 1.57$ & $7.0-8.5$ & $6.0-9.0$ \\
$\mathrm{COD}(\mathrm{mg} / \mathrm{l})$ & $2372 \mathrm{a} \pm 938$ & $1406 \mathrm{a} \pm 208$ & $3532 \mathrm{a} \pm 1373$ & 2.2 & $3106 \pm 2753$ & 40 & 40 \\
$\mathrm{BOD}(\mathrm{mg} / \mathrm{l})$ & $13.85 \mathrm{a} \pm 6.42$ & $19.46 \mathrm{a} \pm 0.50$ & $17.13 \mathrm{a} \pm 3.14$ & 1032 & $26.17 \pm 9.49$ & 10 & 200 \\
$\mathrm{SS}(\mathrm{mg} / \mathrm{l})$ & $374 \mathrm{a} \pm 124$ & $358 \mathrm{a} \pm 335$ & $780 \mathrm{a} \pm 739$ & 501 & $562 \pm 482$ & 30 & 10 \\
TDS $(\mathrm{mg} / \mathrm{l})$ & $3941 \mathrm{a} \pm 3703$ & $3300 \mathrm{a} \pm 1714$ & $2653 \mathrm{a} \pm 1240$ & 532.7 & $444 \pm 507$ & 250 & 500 \\
\hline
\end{tabular}

The values given in the table above are means of 6 replicate values, $\mathrm{n}=6$ ( 1 sample was taken monthly for 6 months). Within the rows, means with different alphabets are statistically different $(p<0.05)$. WHO: World Health Organisation. NESREA: National Environmental Standard and Regulatory Enforcement Agency. a = Mohammed et al.(2017), b = Baba et al. (2020), c = WHO (2006), $d=$ NESSRA (2009) 
BAJOPAS Volume 13 Number 2, December, 2020

Identification, Biochemical Characterization and growth rates of the Bacterial Isolates

Results of identification and biochemical characterization of the bacterial isolates were shown in table 2. After 24 hours of incubation, the nutrient agar media plates were checked for bacterial growth. The results showed the presence of different strains in the samples. The TAN1 bacteria isolate was found to be gramnegative cocci while TAN3 was gram-positive cocci. TAN2 bacteria isolate was found to be gram-positive, rod-shaped. TAN1, TAN2, and TAN3 bacteria isolates recorded positive results for spore former.

The results of the biochemical tests indicated that all the bacteria were positive for catalase, oxidase, citrate, maltose, glucose, lactose (negative in TAN1), mannitol (negative in TAN2), starch hydrolysis and coagulase (negative in TAN2) tests. The bacteria showed negative results for nitrate reduction, $M R$ (positive in TAN2), VP (positive in TAN1), Indole (positive in TAN2) tests. Base on the morphological and biochemical test results, TAN1, TAN2, and TAN3 bacteria isolates were identified to be Nesseria spp, Bacillus cereus, and Staphylococcus aureus respectively.

The growth rate of the TAN1, TAN2 and TAN3 Isolates were shown in figure 2. Generally, the optical density increase with the increase in time (day) and decrease as time goes on. The highest optical density was shown by bacillus cereus in TAN2 while the lowest was shown by Staphylococcus aureus in TAN3.

The initial growth phase of TAN1 Isolate bacteria occurred within 2-day of incubation as the growth rate increases up to the 6th-day incubation when the maximum growth was observed. Beyond the 6th day, the growth of the bacteria declined (which might be due to a shortage of nutrients in the effluents) until it reached its death phase (which might be due to the unavailability of nutrients in the effluents).

A similar trend of growth was also observed for TAN2 Isolate as the initial growth phase also occurred within 2-day of incubation but maximum growth rate observed on the 4th day of incubation. The stationary stage occurred between the 4th day and the 8th day. Beyond the 8th day, the growth of the bacteria declined (which might be due to a shortage of nutrients in the effluents) until it reached its death phase (which might be due to the unavailability of nutrients in the effluents).

The initial growth phase of TAN3 bacterial Isolate occurred within the 3-day incubation as the growth rate increases up to the 6th-day incubation when the maximum growth was observed. Beyond the 6th day, the growth of the bacteria declined (which might be due to a shortage of nutrients in the effluents) until it reached its death phase (which might be due to the unavailability of nutrients in the effluents).

Table 2: Morphological and Biochemical characteristics of bacterial isolates

\begin{tabular}{lllll} 
Bacterial Isolates & & TAN1 & TAN2 & TAN3 \\
\hline $\begin{array}{lllll}\text { Morphological } \\
\text { characteristics }\end{array}$ & Shape & Cocci & Rod & Cocci \\
& Spore & & & \\
& former & + & + & + \\
Gram & & & \\
Biochemical characteristics & reaction & - & + & + \\
& Citrate & + & + & + \\
& Catalase & + & + & + \\
& Coagulase & + & - & + \\
Starch & + & + & + \\
& Glucose & + & + & + \\
Oxidase & + & + & + \\
& Indo & - & + & - \\
Lactose & - & + & + \\
Manitol & + & - & + \\
Maltose & + & + & + \\
MR & - & + & - \\
VP & + & - & - \\
& Nitrate & - & - & - \\
Reduction & - Neisseria & Bacillus & Staphylococcus \\
& Bacterial & cereus & aureus \\
& name & spp & cas
\end{tabular}

+ = Positive; - = Negative; MR=Methyl Red; VP= Voges-Proskauer 


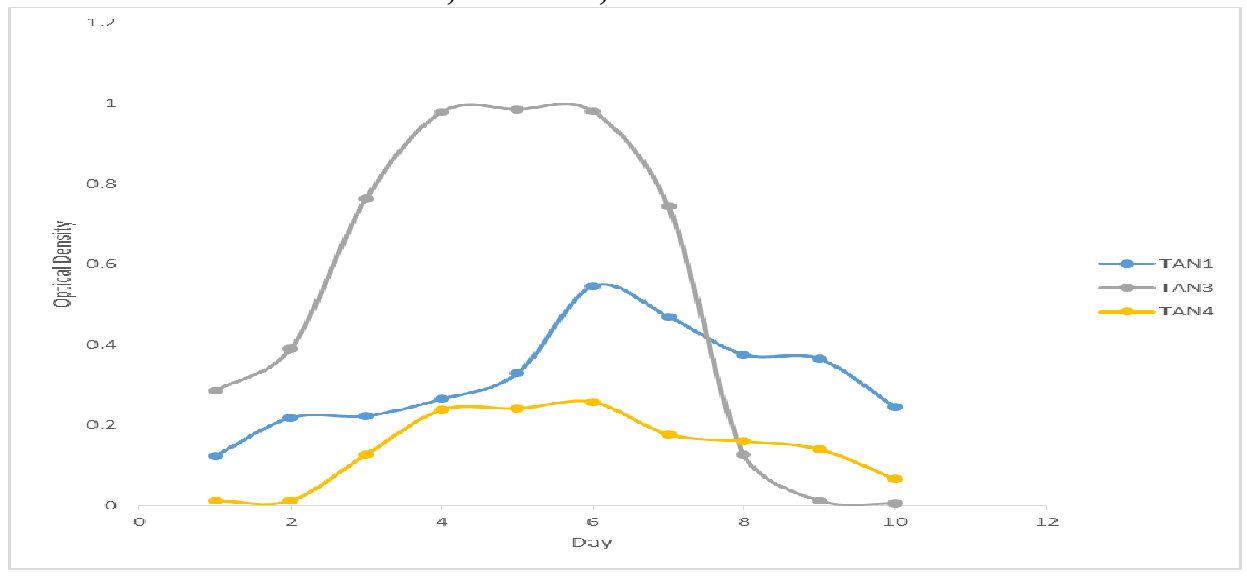

Fig. 2 Growth rates of the isolates in the effluents from the Tannery Industries

\section{Physico-chemical Parameters in the Industrial Effluents after the biodegradation.}

Table 3 shows the mean results of the physicochemical parameter before and after bioremediation using the different masses $(5 \mathrm{~g}$, $10 \mathrm{~g}, 15 \mathrm{~g}, 20 \mathrm{~g}$, and $25 \mathrm{~g}$ ) of the respective immobilized bacteria. Also, Table 4 shows the mean results of correlation coefficient ( $r$ ) between different masses of bacteria and physicochemical parameters.

The mean values $(\mathrm{mg} / \mathrm{l})$ of the SS after the bioremediation varies between $243 \pm 45$ and $898 \pm 672$. The mean concentration $(\mathrm{mg} / \mathrm{l})$ of SS remediated by the different masses $(5 \mathrm{~g}, 10 \mathrm{~g}$, $15 \mathrm{~g}, 20 \mathrm{~g}$, and $25 \mathrm{~g}$ ) of the bacteria varies. The SS in the samples fluctuates up and down after the bioremediation process when compared with the SS of the raw samples before the bioremediation. The increase in the levels of the SS might be due to the aggregation of the TDS which are large enough to result into SS. The increase in the levels of the SS might be also due to the influence of the nutrients which was added into the effluents in order to make the microorganisms more active and viable for fast degradation of organic contaminants in the effluent. The relative potential or efficiency of the different masses of the bacteria in remediating SS in TAN1 samples was in the order $25 \mathrm{~g}>20 \mathrm{~g}>15 \mathrm{~g}>10 \mathrm{~g}>5 \mathrm{~g}$. For TAN2 and TAN3 samples, the order was $25 \mathrm{~g}>20 \mathrm{~g}>15$ $\mathrm{g}>10 \mathrm{~g}>5 \mathrm{~g}$. These might be due to the variations in the surface areas of the different masses of the immobilized bacteria. Statistical analysis shows that there is no significant difference $(p<0.05)$ between the mean values of SS among the masses in the respective industries. Positive and significant correlations exist between the masses of bacteria and Suspended Solid (SS). This showed that there is general increase in the levels of the SS as the masses of the immobilized bacteria increases. TAN3 (90\%) and TAN1 (80\%) showed a very high correlation with the masses of the bacteria while TAN2 (61\%) showed a very low correlation.

The mean values $(\mathrm{mg} / \mathrm{l})$ of the TDS after the bioremediation varies between $46 \pm 11$ and $83 \pm 78$. The mean concentration $(\mathrm{mg} / \mathrm{l})$ of TDS remediated by the different masses $(5 \mathrm{~g}, 10 \mathrm{~g}$, $15 \mathrm{~g}, 20 \mathrm{~g}$, and $25 \mathrm{~g}$ ) of the bacteria varies. There is a reduction in all the TDS of all the samples after the bioremediation process compared with the TDS of the raw samples before the bioremediation. The relative potential or efficiency of the different masses of the bacteria in remediating TDS in TAN1 and TAN3 samples was in the order $5 \mathrm{~g}>10 \mathrm{~g}>15 \mathrm{~g}>20$ $\mathrm{g}>25 \mathrm{~g}$. For TAN2 samples, the order was 20 $g>10 \quad g>25 \quad g>15 \quad g>5 \quad g$. Statistical analysis shows that there is no significant difference $(p<0.05)$ between the mean values of TDS among the masses in the respective industries. These might be due to the variations in the surface areas of the different masses of the immobilized bacteria. Positive and significant correlations exist between the masses of bacteria and TDS with the exception in TAN2 (negative and insignificant correlation). The positive correlations showed that there is general increase in the levels of the TDS as the masses of the immobilized bacteria increases. TAN1 $(96 \%)$ showed a very high correlation with the masses of the bacteria while TAN2 (47\%) showed a very low correlation.

The mean values $(\mathrm{mg} / \mathrm{l})$ of the BOD after the bioremediation varies between $1.56 \pm 0.20 \mathrm{mg} / \mathrm{l}$ and $6.92 \pm 5.49 \mathrm{mg} / \mathrm{l}$. The mean concentration $(\mathrm{mg} / \mathrm{l})$ of BOD remediated by the different masses $(5 \mathrm{~g}, 10 \mathrm{~g}, 15 \mathrm{~g}, 20 \mathrm{~g}$, and $25 \mathrm{~g}$ ) of the bacteria varies. There is a reduction in all the BOD of all the samples after the bioremediation process compared with the $\mathrm{BOD}$ of the raw 
BAJOPAS Volume 13 Number 2, December, 2020 samples before the bioremediation. The relative potential or efficiency of the different masses of the bacteria in remediating BOD in TAN1, TAN2 and TAN3 samples were in the order $25 \mathrm{~g}>20$ $\mathrm{g}>15 \mathrm{~g}>10 \mathrm{~g}>5 \mathrm{~g}, 25 \mathrm{~g}>15 \mathrm{~g}>5 \mathrm{~g}>10 \mathrm{~g}>20 \mathrm{~g}$ and $20 \mathrm{~g}>10 \mathrm{~g}>25 \mathrm{~g}>15 \mathrm{~g}>5 \mathrm{~g}$ respectively. Statistical analysis shows that there is significant difference $(p<0.05)$ between the mean values of BOD among the masses in the respective industries. These might be due to the variations in the surface areas of the different masses of the immobilized bacteria. Negative and significant correlations exist between the masses of bacteria and BOD. This showed that there is general decrease in the levels of the BOD as the masses of the immobilized bacteria increases. TAN1 (94\%) showed a very high correlation with the masses of the bacteria while TAN2 (4\%) showed a very low correlation.

The mean values $(\mathrm{mg} / \mathrm{l})$ of the COD after the bioremediation varies between $250 \pm 154$ and $3134 \pm 1595$. The mean concentration $(\mathrm{mg} / \mathrm{l})$ of COD remediated by the different masses $(5 \mathrm{~g}$, $10 \mathrm{~g}, 15 \mathrm{~g} 20 \mathrm{~g}$, and $25 \mathrm{~g}$ ) of the bacteria varies. There is a reduction in all the COD of all the samples after the bioremediation process compared with the COD of the raw samples before the bioremediation. The relative potential or efficiency of the different masses of the bacteria in remediating COD in TAN1, TAN2 and TAN3 samples were in the order $25 \mathrm{~g}>20 \mathrm{~g}>15$ $\mathrm{g}>5 \mathrm{~g}>10 \mathrm{~g}, 25 \mathrm{~g}>20 \mathrm{~g}>15 \mathrm{~g}>10 \mathrm{~g}>5 \mathrm{~g}$ and 10 g>5 g>25 g>15 g>20 g respectively. Statistical analysis shows that there were significant difference $(p<0.05)$ between the mean values of COD among the masses in the respective industries except for effluents treated with $25 \mathrm{~g}$. These might be due to the variations in the surface areas of the different masses of the immobilized bacteria. Negative and insignificant correlations exist between the masses of bacteria and COD with the exception in TAN3 (positive and significant correlation). The negative correlations showed that there is general decrease in the levels of the COD as the masses of the immobilized bacteria increases. TAN2 (100\%) showed a very high correlation with the masses of the bacteria while TAN3 (36\%) showed a very low correlation.

Generally, there was an overall decrease in the concentration of these physicochemical parameters after the bioremediation using the different masses of the bacterial isolates. These might be due to the variations in the surface areas of the different masses of the immobilized bacteria. This is in line with the work of Jimoh et al. (2018) and Baba et al. (2020).

Table 3: Mean Values $(\mathrm{mg} / \mathrm{l}) \pm$ S.D of Physicochemical parameters in effluents from the Tannery Industries before and after Treatment of the effluents $(250 \mathrm{ml})$ with the different masses $(5 \mathrm{~g}, 10 \mathrm{~g}$, $15 \mathrm{~g}, 20 \mathrm{~g}$, and $25 \mathrm{~g}$ ) of the bacteria.

\begin{tabular}{llllllll}
\hline $\mathrm{P}$ & IND & Before & \multicolumn{5}{c}{ After } \\
\cline { 4 - 7 } & & & $5 \mathrm{~g}$ & $10 \mathrm{~g}$ & $15 \mathrm{~g}$ & $20 \mathrm{~g}$ & $25 \mathrm{~g}$ \\
\hline \multirow{2}{*}{ COD } & TAN1 & $2372 \pm 938$ & $1708 \mathrm{a} \pm 861$ & $2045 \mathrm{a} \pm 1205$ & $845 \mathrm{a} \pm 369$ & $300 \mathrm{a} \pm 167$ & $250 \mathrm{a} \pm 154$ \\
& TAN2 & $1406 \pm 208$ & $1195 \mathrm{a} \pm 208$ & $1125 \mathrm{a} \pm 384$ & $1055 \mathrm{a} \pm 317$ & $956 \mathrm{a} \pm 310$ & $870 \mathrm{ab} \pm 240$ \\
& TAN3 & $3532 \pm 1373$ & $2374 \mathrm{a} \pm 1344$ & $1976 \mathrm{a} \pm 1405$ & $2757 \mathrm{a} \pm 1266$ & $3134 \mathrm{a} \pm 1595$ & $2614 \mathrm{~b} \pm 1105$ \\
BOD & TAN1 & $13.85 \pm 6.42$ & $6.92 \mathrm{a} \pm 5.49$ & $6.42 \mathrm{a} \pm 5.07$ & $5.72 \mathrm{a} \pm 5.35$ & $4.62 \mathrm{a} \pm 4.37$ & $2.82 \mathrm{ab} \pm 1.26$ \\
& TAN2 & $19.46 \pm 0.50$ & $1.75 \mathrm{~b} \pm 0.22$ & $1.73 \mathrm{~b} \pm 0.18$ & $1.58 \mathrm{a} \pm 0.16$ & $1.91 \mathrm{a} \pm 0.22$ & $1.56 \mathrm{~b} \pm 0.20$ \\
& TAN3 & $17.13 \pm 3.14$ & $4.24 \mathrm{ab} \pm 0.77$ & $3.29 \mathrm{ab} \pm 0.37$ & $4.11 \mathrm{a} \pm 0.07$ & $3.23 \mathrm{a} \pm 0.91$ & $3.33 \mathrm{a} \pm 1.28$ \\
SS & TAN1 & $374 \pm 124$ & $243 \mathrm{a} \pm 45$ & $471 \mathrm{a} \pm 226$ & $475 \mathrm{a} \pm 182$ & $492 \mathrm{a} \pm 128$ & $611 \mathrm{a} \pm 217$ \\
& TAN2 & $358 \pm 335$ & $460 \mathrm{a} \pm 400$ & $543 \mathrm{a} \pm 414$ & $544 \mathrm{a} \pm 402$ & $551 \mathrm{a} \pm 414$ & $554 \mathrm{a} \pm 405$ \\
& TAN3 & $780 \pm 739$ & $586 \mathrm{a} \pm 594$ & $758 \mathrm{a} \pm 656$ & $787 \mathrm{a} \pm 676$ & $861 \mathrm{a} \pm 635$ & $898 \mathrm{a} \pm 672$ \\
TDS & TAN1 & $3941 \pm 3703$ & $51 \mathrm{a} \pm 10$ & $53 \mathrm{a} \pm 10$ & $55 \mathrm{a} \pm 15$ & $61 \mathrm{a} \pm 20$ & $63 \mathrm{a} \pm 26$ \\
& TAN2 & $3300 \pm 1714$ & $83 \mathrm{a} \pm 78$ & $47 \mathrm{a} \pm 20$ & $48 \mathrm{a} \pm 22$ & $47 \mathrm{a} \pm 17$ & $48 \mathrm{a} \pm 17$ \\
& TAN3 & $2653 \pm 1240$ & $46 \mathrm{a} \pm 11$ & $55 \mathrm{a} \pm 24$ & $55 \mathrm{a} \pm 25$ & $58 \mathrm{a} \pm 23$ & $61 \mathrm{a} \pm 28$ \\
\hline
\end{tabular}

Replicate $=6$ (months)

Within the rows, for the same parameter, means with different alphabets are statistically different $(p<0.05)$.

$\mathrm{P}=$ parameter, IND = Industries 
BAJOPAS Volume 13 Number 2, December, 2020

Table 4: Correlation coefficient $(r)$ between different masses of the bacteria and the physicochemical parameters.

\begin{tabular}{llll}
\hline Industries & Parameter & Correlation coefficient $(r)$ & $\begin{array}{l}\text { Percent dependence (rxrx100) } \\
(\%)\end{array}$ \\
\hline TAN1 & COD & -0.9 & 82 \\
& BOD & -0.97 & 94 \\
& SS & $0.90^{*}$ & 80 \\
TAN2 & TDS & $0.98^{*}$ & 96 \\
& COD & -1 & 100 \\
& BOD & -0.21 & 4 \\
& SS & $0.78^{*}$ & 61 \\
& TDS & -0.69 & 47 \\
& COD & $0.60^{*}$ & 36 \\
& BOD & -0.6 & 37 \\
& SS & $0.95^{*}$ & 90 \\
& TDS & $0.94^{*}$ & 89 \\
\hline
\end{tabular}

The correlation coefficient $(r)$ with * is statistically significant $(p<0.05)$.

Percentage reduction of the Parameters

Table 5 shows the percentage reduction of Parameters in industrial samples before and after the treatment of the effluents $(250 \mathrm{ml})$ with the different masses $(5 \mathrm{~g}, 10 \mathrm{~g}, 15 \mathrm{~g}, 20 \mathrm{~g}$, and $25 \mathrm{~g}$ ) of the Immobilized Bacteria.

In TAN1 samples, the percentage reduction (\%) of COD ranged (14-89); BOD (50-80); SS (-32$35)$ and TDS (98-99). In TAN2 samples, the percentage decrease $(\%)$ of COD ranged (15$38) ;$ BOD (90-92); SS [-28-(-55)] and TDS (9798). In TAN3 samples, the percentage decrease (\%) of COD ranged (11-44); BOD (76-81); SS (15-25) and TDS (98). The percentage increase in the levels COD, BOD and TDS might be due to the increase in the surface area of the different masses of the immobilized bacteria. However, the percentage decrease in the levels of the SS might be due to the aggregation of the TDS which are large enough to result into SS. The percentage decrease in the levels of the SS might be also due to the influence of the nutrients which was added into the effluents in order to make the microorganisms more active and viable for fast degradation of organic contaminants in the effluent. This is in line with the work of Jimoh et al. (2018) in which the concentration of the SS increase after the bioremediation of effluents.

Sreemoyee and Priti (2013) assessed and reduced several Physico-chemical parameters of dairy wastewater using Niesseria $s p$. and concluded that the species are well known to degrade organic compounds. This is in agreement with the current study in which the immobilized Niesseria $s p$ degrade the organic contaminants as indicated by the BOD, COD and TDS.

Jimoh et al. (2018) observed that TSS of the effluents was increased after treatment with immobilized bacteria and concluded that it might be due to the biostimulation method adopted for the research.

The optimum $\mathrm{pH}$ Biosorption of Chromium by Bacillus spp and Staphylococcus spp. from tannery effluent was investigated by Mythili and Karthikeyan (2011). The maximum adsorption of Chromium $(86.4 \mathrm{mg} / \mathrm{L})$ was showed by Bacillus spp and Staphylococcus spp showed $70.6 \mathrm{mg} / \mathrm{L}$ at an initial concentration of $100 \mathrm{mg} / \mathrm{L}$. In the present study, immobilised Bacillus spp and Staphylococcus spp. from the tannery industrial effluents reduced the levels of the organic pollutants with high potential as indicated by the percentage reduction of BOD, COD and TDS.

Enzymes often can work in multiple environments especially if they are immobilized. This makes the microorganisms' enzymes even more resistant to harsh environments and enables the enzymes to be recovered and recycled after they are no longer needed (Gianfreda and Rao 2004). Ramesh and Singh (1993) reported that the immobilized bacteria having more efficiency to remove the suspended particles than free cells. Using the immobilized cell is preferable due to its capability for using several times with the same efficiency, which makes it more economical. Similar work was done by Sikander et al. (2007) showing the higher reduction with permeabilized cells of Ochrobactrum intermedium strain SDCr-5. 
BAJOPAS Volume 13 Number 2, December, 2020

The results revealed the isolation and identification of isolates with the potential for the reduction of $\mathrm{Cr}$ (VI) to $\mathrm{Cr}$ (III). Results indicated that immobilized $B$. cereus could be efficiently used for the reduction of $\mathrm{Cr}$ (VI).

Table 5: Percentage reduction of the tested Parameters from the tannery industrial samples of the Immobilized Bacteria.

\begin{tabular}{lllllll}
\hline \multirow{2}{*}{ Industries } & & \multicolumn{5}{c}{ Percentage Reduction $(\%)$} \\
\cline { 3 - 7 } & & $5 \mathrm{~g}$ & $10 \mathrm{~g}$ & $15 \mathrm{~g}$ & $20 \mathrm{~g}$ & $25 \mathrm{~g}$ \\
\hline TAN1 & COD & 28 & 14 & 64 & 87 & 89 \\
& BOD & 50 & 54 & 59 & 67 & 80 \\
& SS & 35 & -26 & -27 & -32 & -63 \\
& TDS & 99 & 99 & 99 & 98 & 98 \\
TAN2 & COD & 15 & 20 & 25 & 32 & 38 \\
& BOD & 91 & 91 & 92 & 90 & 92 \\
& SS & -28 & -52 & -52 & -54 & -55 \\
& TDS & 97 & 99 & 99 & 99 & 99 \\
& COD & 33 & 44 & 22 & 11 & 26 \\
& BOD & 75 & 81 & 76 & 81 & 81 \\
& SS & 25 & 3 & -1 & -10 & -15 \\
& TDS & 98 & 98 & 98 & 98 & 98 \\
\hline
\end{tabular}

Percentage Reduction $=(B-A) / B \times 100 \%$

$A=$ Concentration of the parameter after treatment

$\mathrm{B}=$ Concentration of the parameter before treatment

$+=$ percentage decrease

- = percentage increase

In general, immobilization makes the enzyme more resistant to temperature, $\mathrm{pH}$, and substrate concentration swings giving it a longer lifetime and higher productivity per active unit (Gianfreda and Rao, 2004; FuIlbrook, 1996; Russell et al, 2003; Kandelbauer et al., 2004). Immobilized cells have been used and studied extensively for the production of useful chemicals (Ohtake and Silver, 1994), the treatment of wastewaters (Chen et al., 2003; Wang et al., 2010). Although many workers described microbial degradation of tannery effluent, limited literature is available on the bioremediation of tannery effluent using immobilized bacterial cells in the Kano Industrial Estates.

\section{CONCLUSION}

The samples contained variable levels of the physicochemical parameters. The results of the Analysis of variance revealed that, no statistical difference $(p<0.05)$ was observed for the temperature, $\mathrm{pH}, \mathrm{SS}, \mathrm{TDS}, \mathrm{BOD}$ and $\mathrm{COD}$ among the three tannery industries before the treatment. The levels of some of the parameters
(SS, TDS and COD) observed in the samples were found above the recommended limits of WHO and NESREA, which called for the treatment of the effluents before discharge into the environment. Base on the morphological and biochemical test results, TAN1, TAN2, and TAN3 bacterial isolates were identified to be Neisseria spp, Bacillus cereus, and Staphylococcus aureus respectively. The results of Post-treatment analysis showed that there is overall decrease in the levels of the parameters determined when compared with that of the pre-treatment. The overall percentage reduction of the immobilised bacteria in the treatment of the respective effluents was in the order TAN2 (72\%)>TAN1 $(70 \%)>$ TAN3 $(62 \%)$. Hence, the immobilized bacteria are having higher biodegradation potential for the treatment of the tannery effluents.

\section{Acknowledgments}

The authors wish to acknowledge the University of Maiduguri for the financial support. The authors are grateful to the Kano State Ministry of Environment for their support in obtaining the effluent samples. 


\section{REFERENCES}

Ajao, A. T., Adebayo, G. B., and Yakubu, S. E. (2011). Bioremediation of textile industrial effluent using mixed culture of Pseudomonas aeruginosa and Bacillus subtilis immobilized on agar-agar in a bioreactor. J. Microbiol. Biotech. Res, 1(3), 50-56.

Akan, J. C., Moses, E. A., Ogugbuaja, V. O., and Abah, J. (2007). Assessment of tannery industrial effluents from Kano metropolis, Kano State, Nigeria. Journal of Applied Sciences, 7(19), 2788-2793.

Akan, J. C., Ogugbuaja, V. O., Abdulrahman, F. I., and Ayodele, J. T. (2009). Pollutant levels in effluent samples from tanneries and textiles of Kano industrial areas, Nigeria. Global journal of pure and applied sciences, 15(3-4).

APHA (1989). Standard methods for Examination of Will bete and Will betewater.15 $5^{\text {th }}$ edition. Brydpass Springfield Will behington DC. pp. 164-176

APHA (1992). Standard Methods for the Examination of Water and Wastewater. Health, 69, 1116-9.

Baba, A., Garba, S. T., and Bello, H. S. (2020). Bioremediation Potential of Immobilized corynebacterium kutsceri in the Treatment of Tannery Industrial Effluent from Challawa Industrial Estate, Kano State, Nigeria. Journal of the Turkish Chemical Society Section A: Chemistry, $7(2), 335-350$.

Beem, E. I. V. (1994). reduction of solvent VOC emission. J. Oil Col. Chem. Ass, 77, 158.

Bouwer, E. J., and Zehnder, A. J. (1993). Bioremediation of organic compoundsputting microbial metabolism to work. Trends in biotechnology, 11(8), 360367.

Chen, K. C., Wu, J. Y., Liou, D. J., and Hwang, S. C. J. (2003). Decolorization of the textile dyes by newly isolated bacterial strains. Journal of Biotechnology, 101(1), 57-68.

Dan'Azumi, S., and Bichi, M. H. (2010). INDUSTRIAL POLLUTION AND HEAVY METALS PROFILE OF CHALLAWA RIVER IN KANO, NIGERIA. Journal of Applied Sciences in Environmental Sanitation, $5(1)$.

DWAF. (1992). Analytical Methods Manual, TR 151. Department of Water Affairs and Forestry, Pretoria.

El-Bestawy, E. (2013). Biological treatment of leather-tanning industrial wastewater using free living bacteria.
Elsheikh, M. A. S. (2009). Tannery wastewater pre-treatment. Water Science and Technology, 60(2), 433-440.

FuIlbrook, P. D. (1996). "Kinetics." Industrial enzymology: The application of enzymes in Industry. 2nd Ed. T. Godfrey and J Reichelt. eds.. Nature. New York.

Gianfreda, L., and Rao, M. A. (2004). Potential of extra cellular enzymes in remediation of polluted soils: a review. Enzyme and microbial technology, 35(4), 339354.

Hugo Springer. (1994). John Arthur Wilson Memorial Lecture "Treatment of Industrial Wastes of the Leather Industry - is it still a Major Problem". JALCA, 89, 153-185

Jimoh, A. A., Ganiyu, B. A., Baba, D., and Baba, A. (2018) Bioremediation Process of Effluent from Detergent and Food Industries in Jos, Nigeria: Kinetics and Thermodynamics. International Journal of Engineering Science Invention (IJESI), 762-73

Kandelbauer, A., Maute, O., Kessler, R. W., Erlacher, A., and Gübitz, G. M. (2004). Study of dye decolorization in an immobilized laccase enzyme-reactor using online spectroscopy. Biotechnology and bioengineering, 87(4), 552-563.

Kongjao, S., Damronglerd, S., and Hunsom, M. (2008). Simultaneous removal of organic and inorganic Pollutants in tannery wastewater using electrocoagulation technique. Korean Journal of chemical engineering, 25(4), 703.

Maheshwari, U. M., Aruna, S., Gomathi, M., and AbdulJaffar, A. H. (2017). Bioremediation by Free and Immobilized Bacteria Isolated from Tannery Effluent. International Journal of Research in Applied, Natural and Social Sciences. 5(7), 75-90

Margesin, R., and Schinner, F. (2001). Bioremediation (natural attenuation and biostimulation) of diesel-oilcontaminated soil in an alpine glacier skiing area. Applied and environmental microbiology, 677), 3127-3133.

Mohammed, A., Sekar, P., and George, J. (2011). Efficacy of microbes in bioremediation of tannery effluent. Inter. J. Curr. Res, 3(4), 324-326.

Mohammed, S. S. D., Orukotan, A. A., and Abdullahi, H. (2017). Physicochemical and Bacteriological Assessment of Tannery Effluent from Samaru-Zaria, 
BAJOPAS Volume 13 Number 2, December, 2020 Kaduna State, Nigeria. Journal of Applied

Sciences and Environmental Management, 21(4), 734-740.

Munz, G., De Angelis, D., Gori, R., Mori, G., Casarci, M., and Lubello, C. (2009). The role of tannins in conventional and membrane treatment of tannery wastewater. Journal of hazardous materials, 164(2-3), 733-739

Mythili, K., and Karthikeyan, B. (2011). Bioremediation of $\mathrm{Cr}$ (VI) from tannery effluent using Bacillus spp and Staphylococcus spp. International Multidisciplinary Research Journal, 1(6).

NESREA (2009). National Environmental Standards for Effluent Limitations and Regulation. 1233-1236

Noorjahan, C. M. (2014). Physicochemical characteristics, identification of bacteria and biodegradation of industrial effluent. Journal of bioremediation and Biodegradation, 5(3).

Ohtake, H. I., and Silver, A. O. (1994). Bacterial reduction of toxic chromate. Biological degradation and bioremediation of toxic chemicals, 403-415.

Omoleke, I. I. (2004). Management of environmental pollution in Ibadan, an African city: the challenges of health hazard facing government and the people. Journal of Human Ecology, 15(4), 265-275.

Rajor, A., Reddy, A.S., and Singh, B. (2004). Determination of BOD kinetic Parameters and evaluation of alternate methods, M.Sc. Thesis, Department of biotechnology \& environmental Science, Thapar Institute of Engineering and Technology, Patiala

Ramasami, T., Rajamani, S., and Rao, J. R. (1994, March). Pollution control in leather industry: Emerging technological options. In International symposium on surface and colloidal science and its relevance to soil pollution, madras.

Ramesh, J. V. S., and Singh, S. P. (1993). Yearly variation in certain physicochemical parameters of pond at eastern Doon Valley. Uttar Pradesh J. Zoo, 12 (1), 7577.

Ranen, S., and Sharadinadra, C. (2009). Biotechnology applications to environmental remediation in resource exploitation. Current science, 97, 6-25
Russell, A. J., Berberich, J. A., Drevon, G. F., and Koepsel, R. R. (2003). Biomaterials for mediation of

chemical and biological warfare agents. Annual review of biomedical engineering, 5(1), 1-27.

Saravanan, P., and Saravanan, A. (1999). Decolourization of tannery effluent by Flavobacterium sp. EK 1. Indian Journal of Environmental Protection, 19, 19-24.

Sikander, S., and Shahida, H. (2007). Reduction of toxic hexavalent chromium by Ochrobactrum intermedium strain SDCr5 stimulated by heavy metals. Bioresource Technol, 98, 340-344.

Singh, N., Sharma, B. K., and Bohra, P. C. (2000). Impact assessment of industrial effluent of arid soils by using satellite imageries. Journal of the Indian Society of Remote Sensing, 28(2-3), 79.

Sreemoyee, C., and Priti, P. (2013). Assessment of physico-chemical parameters of dairy waste water and isolation and characterization of bacterial strains in terms of cod reduction. Int J Sci, 2(3), 395-400.

Verheijen, L. A. H. M., Wiersema, D., Pol, L. H., and De Wit, J. (1996). Management of wastes from animal product processing. Livestock and environment, Finding a balance. International Agriculture Center, Wageningen, The Netherlands.

Wang, F., Yao, J., Si, Y., Chen, H., Russel, M., Chen, K., and Bramanti, E. (2010). Short-time effect of heavy metals upon microbial community activity. Journal of Hazardous Materials, 173(13), 510-516.

WHO (World Health Organization). (2006). Air quality guidelines: global update 2005: particulate matter, ozone, nitrogen dioxide, and sulfur dioxide. World Health Organization.

World Bank. (1995). Nigeria's strategic options for redressing industrial pollution. World Bank, industry and energy division. 1st edition, West Central Africa Department; Annexes: 1995; pp 60-62.

Zahoor, A., and Abdul, R. (2009). Enumeration of Coliforms. Journal of Environmental Sciences. 21, 814-820 


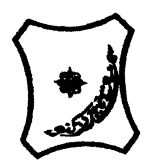

Bayero Journal of Pure and Applied Sciences, 13(2): 1 - 12

Received: November, 2020

Accepted: December, 2020

ISSN $2006-6996$

\title{
BIODEGRADATION POTENTIAL OF IMMOBILIZED BACTERIA IN THE TREATMENT OF TANNERY INDUSTRIAL EFFLUENTS FROM INDUSTRIAL ESTATES IN KANO STATE, NIGERIA
}

\author{
Abdullateef, B., ${ }^{1 *}$ Shuaibu, T. G., ${ }^{1}$ Babagana, K., ${ }^{1}$ Suleman, H. B. ${ }^{2}$ and Dauda, B. ${ }^{3}$ \\ ${ }^{1}$ Department of Pure and Applied Chemistry, Faculty of Science, University of Maiduguri, Borno State, \\ Nigeria \\ ${ }^{2}$ Department of Microbiology, Faculty of Science, University of Maiduguri, Borno State, Nigeria \\ ${ }^{3}$ Department of Chemical Engineering, Faculty of Engineering, University of Maiduguri, Borno State, \\ Nigeria \\ *Corresponding author: babslega@gmail.com; abelega2007@yahoo.com; +2348061309753
}

\section{ABSTRACT}

Industrial Effluents Samples from Gashash Tanneries (TAN1) in Bompai Industrial estate, Larabee Tannery Industry (TAN2) in Sharada Industrial estate and Z Tannery Industries (TAN3) in Challawa Industrial estate, Kano State, Nigeria were collected over a period of six months (August 2017 to January 2018) for assessing the biodegradation potentials of bacteria in the treatment of organic pollutants within the effluents. Bacteria were isolated from the effluents and immobilized on agar-agar. Different masses (5 g, $10 \mathrm{gr}, 15$ $\mathrm{g}, 20 \mathrm{~g}$, and $25 \mathrm{~g}$ ) of the bacteria were used in the treatment of $250 \mathrm{ml}$ of the effluents for ten days in a shaker incubator (Gallenkamp-OC-4364-L) at the temperature $30{ }^{\circ} \mathrm{C}$ and speed of $60 \mathrm{rpm}$. Pre-treatment analysis of the effluents for Temperature, pH, Biochemical Oxygen Demand (BOD), Chemical Oxygen Demand (COD), Suspended Solid (SS) and Total Dissolved Solids (TDS) gives the following results; temperature $\left({ }^{\circ} \mathrm{C}\right.$ )

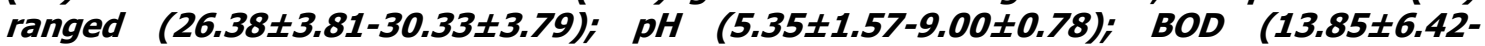
$38.75 \pm 16.20) ;$ COD (1406 $\pm 208-3532 \pm 1373) ;$ SS (208 $\pm 235-780 \pm 739)$ and TDS (266 $\pm 253-5276 \pm 2971)$. No statistical differences ( $p \leq 0.05)$ was observed for all the results among the different industries. The bacterial isolates were identified as Neisseria spp, Bacillus cereus, and Staphylococcus aureus, in TAN1, TAN2, and TAN3, respectively. After treatment of the effluent with the different masses of the isolated bacteria, the mean level of BOD was found to range as (0.55 $\pm 0.36-6.92 \pm 5.49) ; C O D$ (ND-3134 \pm 1595$)$;

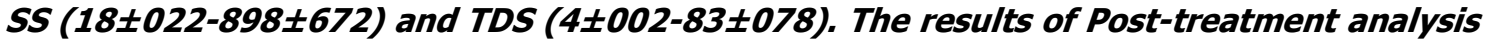
showed that there is overall decrease in the levels of the parameters determined when compared with that of the pre-treatment. The overall percentage reduction of the immobilised bacteria in the treatment of the respective effluents was in the order TAN2 (72\%)>TAN1 (70\%)>TAN3 (62\%). Hence, the immobilized bacteria are having higher biodegradation potential for the treatment of the tannery effluents.

Keywords: Biodegradation, bacteria, effluent, immobilization, tannery.

\section{INTRODUCTION}

Tannery industrial wastewater is a serious consequence of the pollution point of view for streams, freshwater, and land used for agriculture. The lack of awareness in the modern industrial practice has resulted in the discharge of tannery effluents which exhibit very high value of chromium ( $\mathrm{Cr}$ ), Sulfide, and chloride, Total Dissolved Solid (TDS), Total Suspended Solid (TSS), Biochemical Oxygen Demand (BOD) and Chemical Oxygen Demand (COD) in the water stream or land (Mohammed et al., 2001). Tanning is the process, which One ton of skin generally leads to the production of 20 to $80 \mathrm{~m}^{3}$ of turbid and foul-smelling converts the protein of the rawhide or skin into a stable material, which will not putrefy and is suitable for a wide variety of end applications (Elsheikh, 2009). The highly polluting chromium is the most commonly used tanning material producing leather that is more flexible and pliable than vegetable-tanned leather and does not discolor or lose shape in water as drastically as vegetable-tan (Elsheikh, 2009). Tannery effluent is among the most hazardous industrial pollutants due to its huge organic and inorganic load, which is highly toxic to human life and the environment (Kongjao et al., 2008). wastewater including chromium (100-400 mg/l), sulfide $(200-800 \mathrm{mg} / \mathrm{l})$, high levels of fat and 
BAJOPAS Volume 13 Number 2, December, 2020 other solid wastes, and notable pathogen contamination as well as pesticides added for skin conservation during transport (Elsheikh, 2009). There are more than 6000 tanneries in Nigeria with an annual processing capacity of 700,000 tons of hides and skins (Omoleke, 2004; Singh et al., 2008). It was reported that the total amount of waste produced per animal slaughtered is approximately $35 \%$ of its weight (World Bank, 1995). Also, for every $1000 \mathrm{~kg}$ of carcass weight, a slaughtered beef produces 5.5 $\mathrm{kg}$ of manure (excluding rumen contents or stockyard manure) and $100 \mathrm{~kg}$ of paunch manure (undigested food) (Verheijen et al., 1996). Tanneries generate wastewater in the range of 30-35 $\mathrm{L} \mathrm{kg}^{-1}$ skin/hide processed with variable $\mathrm{pH}$, Biological Oxygen Demand (BOD), Chemical Oxygen Demand (COD), high concentrations of suspended solids (SS), and tannins as well as chromium (Zahoor and Abdul, 2009).

Being heterogeneous and composed of a wide variety of compounds, it is very difficult to select a unique direct method for estimating the biodegradability of organic contents and biokinetic parameters for a wastewater sample (Rajor, 2004). For this purpose, some indirect estimation such as determination of biochemical oxygen demand (BOD) and chemical oxygen demand (COD) are applied as common laboratory investigations [9]. During retanning procedures, synthetic tannins (Syntan), oils and resins are added to form softer leather at varying doses (Munz et al., 2009). One of the refractory groups of chemicals in tannery effluents derives mainly from tannins (Ramasami et al., 2004). Syntans are characterized by complex chemical structures, because they are composed of an extended set of chemicals such as phenol-, naphthalene-, formaldehyde- and melamine-based syntans, and acrylic resins (Beem, 1994). Organic pollutants (proteic and lipidic components) are originated from skins (it is calculated that the raw skin has $30 \%$ loss of organic material during the working cycle) or they are introduced during processes (Hugo Springer, 1994).

Many conventional processes such as oxidation, chemical and biological processes were carried out to treat tanneries wastewater (Ebtesam et al, 2013). Biological processes have received more attention because of their costeffectiveness, lower sludge production and environmental friendliness (Noorjahan, 2014). Naturally occurring micro-organisms degrade the hazardous organic wastes including xenobiotic compounds, such as pesticides, polycyclic aromatic hydrocarbons (PAHs) and polychlorinated biphenyls (PCBs) in due course of time (Ranen and Sharadinadra, 2009). Bioremediation is based on the idea that all organisms remove substances from the environment to carry outgrowth and metabolism (Bouwer and Zehnder, 1993). Bacteria, protista and fungi are found to be very good at degrading complex molecules and incorporating the breakdown products into their metabolism (Bouwer and Zehnder, 1993). The resultant metabolic wastes that they produce are generally safe and somehow recycled into other organisms (Ranen and Sharadinadra, 2009). An acclimatized indigenous population of microorganisms capable of degradation of the compounds of interest must exist at the site for a successful bioremediation mode (Ranen and Sharadinadra, 2009). It has been observed that for a successful bioremediation mode, an acclimatized indigenous population of microorganisms capable of degradation of the compounds of interest must exist at the site under investigation (Ranen and Sharadinadra, 2009). Even though there are numerous physical and chemical methods employed in the disposal of wastes the advantage in using bacterium is that they play a key role in the reduction of COD, BOD, total protein, total tannin and total phenol (Saravanan and Saravanan, 1998)

Baba et al. (2020) studied the bioremediation potential of immobilized corynebacterium kutsceri in the Treatment of tannery industrial effluent from Challawa Industrial Estate, Kano State, Nigeria. The aim of the work is to study the reduction in the level of the contaminants through the process of bioremediation using the isolated bacteria. Immobilized bacteria can withstand various temperatures, $\mathrm{pH}$ and substrate concentrations; consequently, increasing the efficiency and the lifespan of the bacteria. Immobilized bacteria are widely applied in the treatment of wastewater and can be separated and recovered after the treatment with the same efficiency (Baba et al., 2020).

\section{MATERIALS AND METHODS \\ Study Area}

This study was carried out in Bompai, Sharada and Challawa industrial estates in Kano, Figure 1. Kano lies on Latitude $11^{\circ} 30^{\prime} \mathrm{N}$ and $8^{\circ} 30^{\prime} \mathrm{E}$ and Longitude $11^{\circ} 5^{\prime} \mathrm{N}$ and $8^{\circ} 5^{\prime} \mathrm{E}$ in Northern Nigeria. It is one of the developed industrial cities in Nigeria. Tannery activities are the dominating industries and this could be one of the reasons for her high population density (Dan'Azumi and Bichi, 2010). Many researchers have studied biodegradation of tannery effluent using microorganisms. However, limited literature is available on the biodegradation of tannery effluent in Kano industrial estates using 
BAJOPAS Volume 13 Number 2, December, 2020 immobilized bacterial cells. This research work focuses on the potential of the use of the indigenous immobilized bacterial isolates in the treatment of tannery effluents in the industrial estates.

\section{Sample Collection}

Effluents were collected from the Tannery Industries from Bompai, Challawa and Sharada Industrial Estates, Kano, Nigeria. The effluents were collected over a period of six months (August 2017 to January 2018). Samples collected in a sterile 4-liter plastic container with a unique identification number were preserved using an ice-box that was transported to the Microbiology Laboratory, Department of Microbiology, Bayero University of Kano for analysis

\section{Sample Preparation and Sample Analysis}

Immediately after the collection of the effluent, $\mathrm{pH}$, TSS, TDS, COD, BOD levels were determined before treatment (Pre-treatment determination) and ten days after treatment (Post-treatment determination) as described in
APHA (1989) standard methods. $\mathrm{pH}$ was determined using Ecotests $\mathrm{pH}$ meter and TDS was determined using AQUALYTIC TDS Salinometer. BOD was determined as described by the standard method (APHA, 1992). COD and SS were determined using DR/2010 HACH portable data logging spectrophotometer (DWAF, 1992)

\section{Identification and Biochemical} Characterization of the Bacterial Isolates

The bacteria were isolated from the effluents using Serial Dilution according to the method described by APHA (1989). The biochemical tests such as oxidase, catalase, coagulase, indole (from $1 \%$ tryptone broth), citrate (Simmons citrate agar), methyl red/VogesProskauer (MR/VP), nitrate reduction, Starch Hydrolysis, Glucose, Maltose, and Lactose tests were carried out on the bacterial isolates to identify the bacteria through the bacteria biochemical characteristics according to Ajao et al. (2011).

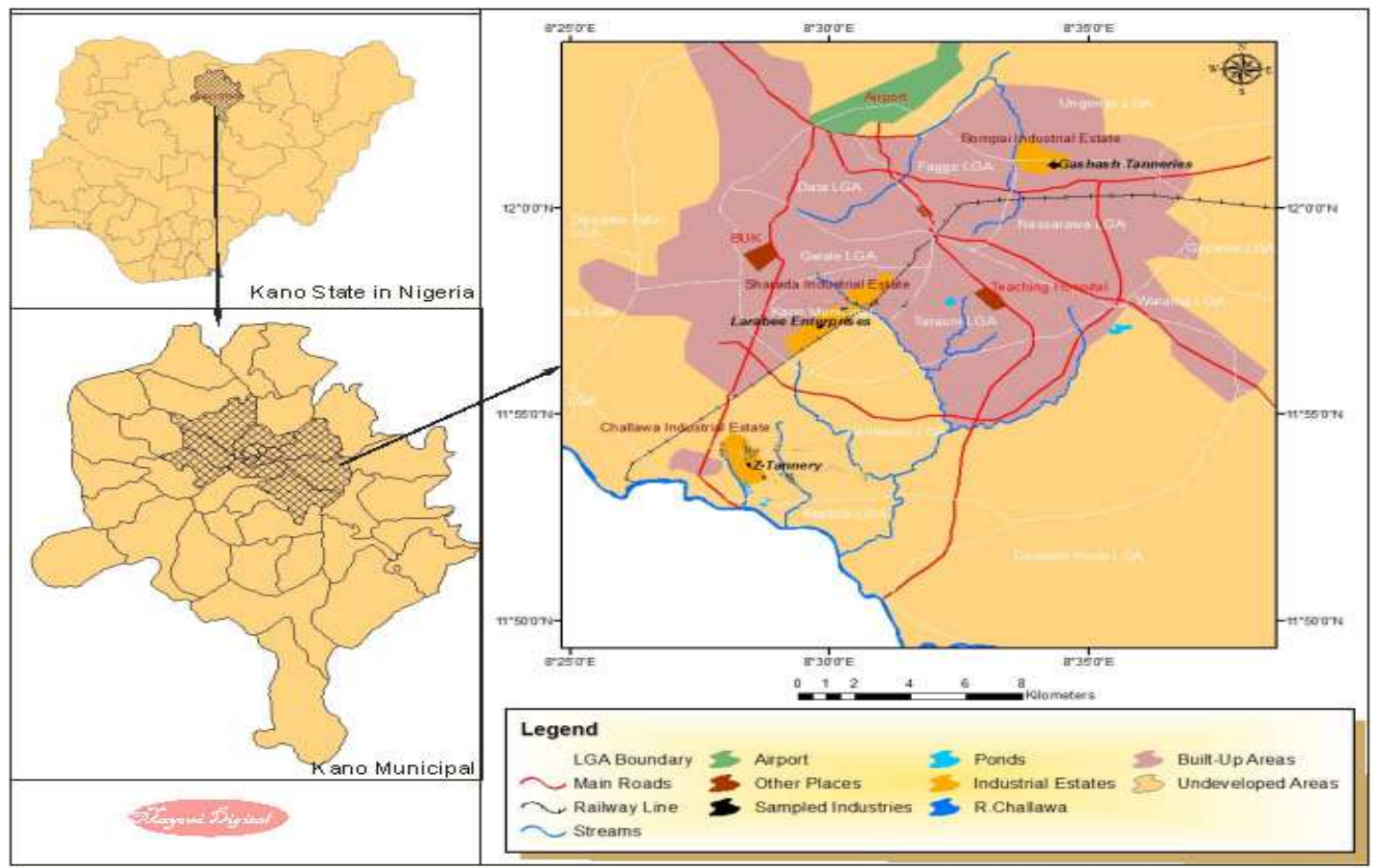

Fig. 1 Map showing the study areas

Source: Mayomi Digital Productions, GIS Laboratory, Department of Geography, UNIMAID (2017)

\section{Determination of Growth Rate of the Bacteria in Effluent Sample}

The bacteria growth rates were determined by transferring $2 \mathrm{~mL}$ of the bacterial isolates from the tannery effluent in broth medium into 100 $\mathrm{mL}$ sterile effluents in conical flasks and kept in an incubator (Giffrin cool) for 10 days. Control was also set up by incubating another $100 \mathrm{~mL}$ each of the sterile effluents without the bacteria. The optical density of the content was determined at the wavelength of $600 \mathrm{~nm}$ on a daily interval and recorded. 
BAJOPAS Volume 13 Number 2, December, 2020 Immobilization of Bacteria

Agar solution and inoculi were prepared separately. Fifty milliliters $(50 \mathrm{~mL})$ of nutrient broth each of the inoculi was prepared in a McCartney bottle and incubated for 24 hours. A solution of agar-agar was prepared by dissolving $10 \mathrm{~g}$ of the powder in distilled water and made up to $500 \mathrm{~mL}$ mark in an Erlenmeyer flask and was sterilized in an autoclave (280A) for 15 minutes and allowed to cool to $40-45^{\circ} \mathrm{C}$ (Ajao et al., 2011). Four milliliters ( $4 \mathrm{~mL})$ of the bacterial isolates in the nutrient broth was mixed with 36 $\mathrm{ml}$ of the prepared agar-agar media in petri-dish plates and then allowed to solidify. This was kept in the refrigerator for bioremediation.

\section{Bioremediation (Treatment) of the Effluents}

The solidified agar block (immobilized bacteria) was cut into cubes using a sterile knife; $0.1 \mathrm{~mL}$ phosphate buffer ( $\mathrm{pH} \mathrm{7.0)}$ was added and kept in the refrigerator for 1 hour for curing. The phosphate buffer was decanted after 1 hour and the cubes were washed with sterile distilled water 3-4 times before it was used (Ajao et al., 2011). Two liters (2 L) of the effluent was supplemented with the minimum basal medium in $\mathrm{g} / \mathrm{L}: \mathrm{NaCl}(0.8), \mathrm{MgSO}_{4} .7 \mathrm{H}_{2} \mathrm{O}(0.001), \mathrm{KH}_{2} \mathrm{PO}_{4}$ (2), $\mathrm{NaNO}_{3}$ (2), $\quad \mathrm{CaCl}_{2} .2 \mathrm{H}_{2} \mathrm{O} \quad(0.5)$ and $\mathrm{NaHPO}_{4} .12 \mathrm{H}_{2} \mathrm{O}(2)$ and sterilized in an autoclave at $121^{\circ} \mathrm{C}$ for 15 minutes (Margesin and Schinner, 2001). Two hundred and fifty milliliters $(250 \mathrm{~mL})$ of the effluents were transferred into different $250 \mathrm{ml}$ conical flasks. The content was covered with a cotton-wool ramped with foil paper to avoid contamination. Five grams $(5 \mathrm{~g})$ of the immobilized bacteria were quickly transferred into each of the effluents in the conical flasks in an inoculating chamber. The same procedures were carried out for the $10 \mathrm{~g}, 15 \mathrm{~g}, 20 \mathrm{~g}$ and 25 $\mathrm{g}$ of the immobilized bacteria in separate $250 \mathrm{~mL}$ effluents in conical flasks and agitated for ten days in a shaker incubator (Gallenkamp-OC4364-L) at a temperature $30^{\circ} \mathrm{C}$ and speed of 60 rpm. The treated effluent samples were taken on the tenth day and analyzed for the parameters $\mathrm{pH}$, SS, TDS, COD, and BOD, (Posttreatment determination) for the different grams of bacteria to evaluate and compare the biodegradation potential. (Baba et al., 2020).

\section{Statistical Analysis}

The data were represented as Mean \pm Standard deviation and analyzed statistically using oneway Analysis of Variance (ANOVA) and Tukey's HSD as Post Hoc Tests with the aid of SPSS 16.0. The correlation coefficient was also used to measure the strength of the relationship between the different masses of the bacteria and the parameters. All $\mathrm{p} \leq 0.05$ were considered as statistically significant.

\section{RESULTS AND DISCUSSION Physico-chemical parameters in the Industrial Effluents before the Biodegradation.}

Results of the Physico-chemical parameters in the industrial effluents before the Biodegradation is shown in table 1 . The mean temperatures $\left({ }^{\circ} \mathrm{C}\right)$ observed in TAN1, TAN2, and TAN3 samples were $28.07 \pm 0.65 ; 27.77 \pm 0.64$ and $26.38 \pm 3.81$ respectively. The order of the mean temperature of the samples from the three industries can be arranged as TAN1 > TAN2>TAN3. The temperature observed at TAN1, TAN2, and TAN3 samples were found below the WHO $\left(35^{\circ} \mathrm{C}\right)$ and NESREA $\left(40^{\circ} \mathrm{C}\right)$ limits. The low values of temperature might be due to the processes used at the time of sampling. High temperature brings down the solubility of gases in water that ultimately expresses as high BOD and COD. Statistical analysis shows that there is no significant difference $(p<0.05)$ between the mean values of temperature among the industries. This might be due to similar tannery activities involved in the tannery industries at the time of sampling. The average values of temperature observed in this present study are less than those observed by Akan et al. (2007), Akan et al. (2009) and Baba et al. (2020).

The mean level of $\mathrm{pH}$ observed in TAN1, TAN2 and TAN3, samples were $7.77 \pm 2.93$; $8.35 \pm 0.28$ and $7.52 \pm 0.76$ respectively. The order of the mean $\mathrm{pH}$ of the samples from the three industries can be arranged as TAN2> TAN1 $>$ TAN3. The $\mathrm{pH}$ of the samples falls within the WHO (7.0-8.5) and NESREA (6-9) standard limits. Statistical analysis shows that there is no significant difference $(p<0.05)$ between the mean values of $\mathrm{pH}$ among the industries. This might be due to similar tannery activities involved in the tannery industries at the time of sampling. Maheshwari et al. (2017) reported that the level of $\mathrm{pH}$ in the effluents from the tannery industry in Vaniyambadi, India was 6.5 which was lower than that observed in the present study. The $\mathrm{pH}$ in the effluents from the tannery industries in Kano and Kaduna were reported to be 7.64 and 6.89, respectively (Akan et al., 2007; Mohammed et al., 2017). The average values of $\mathrm{pH}$ observed in this present study are less than those observed by Mohammed et al. (2017) and Baba et al. (2020). The mean level of SS $(\mathrm{mg} / \mathrm{l})$ observed in TAN1, TAN2, and TAN3 samples were 374 \pm 124 ; $358 \pm 335$ and $780 \pm 739$ respectively. The order of the mean SS in the samples from the three industries can be arranged as TAN3 > TAN1 $>$ TAN2. 
The SS observed in the samples were far above the recommended standard limits of regulating bodies WHO $(30 \mathrm{mg} / \mathrm{l})$ and NESREA $(10 \mathrm{mg} / \mathrm{l})$. Statistical analysis shows that there is no significant difference $(p<0.05)$ between the mean values of SS among the industries. This might be due to similar tannery activities involved in the tannery industries at the time of sampling. The average values of SS observed in this present study are less than that observed $(3700 \pm 122 \mathrm{mg} / \mathrm{l})$ by Akan et al. (2009) for tanneries in Kano. Also, the average values of SS observed in this present study are less than that observed by Mohammed et al. (2017) and Baba et al. (2020) with the exception in TAN3.

The mean level of TDS (mg/l) observed in TAN1, TAN2, and TAN3 samples were $3941 \pm 3703$; $3300 \pm 1714$ and $2653 \pm 1240$ respectively. The order of the mean TDS in the samples from the three industries can be arranged as TAN1>TAN2>TAN3. The TDS observed in the samples were far above the recommended standard limits of WHO $(250 \mathrm{mg} / \mathrm{l})$ and NESREA $(500 \mathrm{mg} / \mathrm{l})$. Statistical analysis shows that there is no significant difference $(p<0.05)$ between the mean values of TDS among the industries. This might be due to similar tannery activities involved in the tannery industries at the time of sampling. TDS in the effluents from the tannery industries in Kano, Nigeria was reported to be $1281 \mathrm{mg} / \mathrm{l}$ (Akan et al., 2007). The average values of SS observed in this present study are less than those observed by Mohammed et al. (2017) and Baba et al. 2020)

The mean level of COD (mg/l) observed in TAN1, TAN2 and TAN3 samples seasons were $2372 \pm 938 ; \quad 1406 \pm 208$ and $3532 \pm 1373$ respectively. The order of the mean COD of the samples from the three industries can be arranged as TAN3>TAN1> TAN2. The COD observed in TAN1, TAN2 and TAN3 samples were far above the recommended standard limits of regulating bodies $\mathrm{WHO}(40 \mathrm{mg} / \mathrm{l})$ and NESREA (40 mg/l). Statistical analysis shows that there is no significant difference $(p<0.05)$ in COD among the industries. This might be due to similar tannery activities involved in the tannery industries as at the time of sampling. The Chemical Oxygen demand (COD) is the amount of oxygen, in $\mathrm{mg} / \mathrm{L}$, required for the degradation of the compound of wastewater to occur. In comparison, the average values of COD observed in this present study were higher than that observed by Mohammed et al. (2017) but lower than that observed by Baba et al. (2020).

The mean levels of BOD $(\mathrm{mg} / \mathrm{l})$ observed in TAN1, TAN2 and TAN3 samples were $13.85 \pm 6.42 ; \quad 19.46 \pm 0.50$ and $17.13 \pm 3.14$ respectively. The order of the mean BOD in the samples from the three industries can be arranged as TAN2>TAN3>TAN1. The BOD observed in TAN1, TAN2 and TAN3 samples were found below the recommended limits of NESREA (200 mg/l) but above WHO (10 mg/l). Statistical analysis shows that there is no significant difference $(p<0.05)$ between the mean values of BOD among the industries. This might be due to similar tannery activities involved in the tannery industries at the time of sampling. The low level of BOD recorded in this study is an indication of the low level of biodegradable organic solids in the effluent. The average values of BOD observed in this present study were lower than those observed by Mohammed et al. (2017) and Baba et al. (2020).

Table 1: Mean Values \pm S.D of Physico-chemical parameters of effluents from the Tannery Industries before Treatment.

\begin{tabular}{llllllll}
\hline Parameter & Tannery 1 & Tannery 2 & Tannery 3 & $\mathrm{a}$ & $\mathrm{b}$ & $\mathrm{c}$ & $\mathrm{d}$ \\
\cline { 2 - 7 } Temperature $\left({ }^{\circ} \mathrm{C}\right)$ & $28.07 \mathrm{a} \pm 0.65$ & $27.77 \mathrm{a} \pm 0.64$ & $26.38 \mathrm{a} \pm 3.81$ & & $29.50 \pm 4.68$ & 35 & 40 \\
pH & $7.77 \mathrm{a} \pm 2.93$ & $8.35 \mathrm{a} \pm 0.28$ & $7.52 \mathrm{a} \pm 0.76$ & 6.89 & $5.35 \pm 1.57$ & $7.0-8.5$ & $6.0-9.0$ \\
$\mathrm{COD}(\mathrm{mg} / \mathrm{l})$ & $2372 \mathrm{a} \pm 938$ & $1406 \mathrm{a} \pm 208$ & $3532 \mathrm{a} \pm 1373$ & 2.2 & $3106 \pm 2753$ & 40 & 40 \\
$\mathrm{BOD}(\mathrm{mg} / \mathrm{l})$ & $13.85 \mathrm{a} \pm 6.42$ & $19.46 \mathrm{a} \pm 0.50$ & $17.13 \mathrm{a} \pm 3.14$ & 1032 & $26.17 \pm 9.49$ & 10 & 200 \\
$\mathrm{SS}(\mathrm{mg} / \mathrm{l})$ & $374 \mathrm{a} \pm 124$ & $358 \mathrm{a} \pm 335$ & $780 \mathrm{a} \pm 739$ & 501 & $562 \pm 482$ & 30 & 10 \\
TDS $(\mathrm{mg} / \mathrm{l})$ & $3941 \mathrm{a} \pm 3703$ & $3300 \mathrm{a} \pm 1714$ & $2653 \mathrm{a} \pm 1240$ & 532.7 & $444 \pm 507$ & 250 & 500 \\
\hline
\end{tabular}

The values given in the table above are means of 6 replicate values, $\mathrm{n}=6$ ( 1 sample was taken monthly for 6 months). Within the rows, means with different alphabets are statistically different $(p<0.05)$. WHO: World Health Organisation. NESREA: National Environmental Standard and Regulatory Enforcement Agency. a = Mohammed et al.(2017), b = Baba et al. (2020), c = WHO (2006), $d=$ NESSRA (2009) 
BAJOPAS Volume 13 Number 2, December, 2020

Identification, Biochemical Characterization and growth rates of the Bacterial Isolates

Results of identification and biochemical characterization of the bacterial isolates were shown in table 2. After 24 hours of incubation, the nutrient agar media plates were checked for bacterial growth. The results showed the presence of different strains in the samples. The TAN1 bacteria isolate was found to be gramnegative cocci while TAN3 was gram-positive cocci. TAN2 bacteria isolate was found to be gram-positive, rod-shaped. TAN1, TAN2, and TAN3 bacteria isolates recorded positive results for spore former.

The results of the biochemical tests indicated that all the bacteria were positive for catalase, oxidase, citrate, maltose, glucose, lactose (negative in TAN1), mannitol (negative in TAN2), starch hydrolysis and coagulase (negative in TAN2) tests. The bacteria showed negative results for nitrate reduction, $M R$ (positive in TAN2), VP (positive in TAN1), Indole (positive in TAN2) tests. Base on the morphological and biochemical test results, TAN1, TAN2, and TAN3 bacteria isolates were identified to be Nesseria spp, Bacillus cereus, and Staphylococcus aureus respectively.

The growth rate of the TAN1, TAN2 and TAN3 Isolates were shown in figure 2. Generally, the optical density increase with the increase in time (day) and decrease as time goes on. The highest optical density was shown by bacillus cereus in TAN2 while the lowest was shown by Staphylococcus aureus in TAN3.

The initial growth phase of TAN1 Isolate bacteria occurred within 2-day of incubation as the growth rate increases up to the 6th-day incubation when the maximum growth was observed. Beyond the 6th day, the growth of the bacteria declined (which might be due to a shortage of nutrients in the effluents) until it reached its death phase (which might be due to the unavailability of nutrients in the effluents).

A similar trend of growth was also observed for TAN2 Isolate as the initial growth phase also occurred within 2-day of incubation but maximum growth rate observed on the 4th day of incubation. The stationary stage occurred between the 4th day and the 8th day. Beyond the 8th day, the growth of the bacteria declined (which might be due to a shortage of nutrients in the effluents) until it reached its death phase (which might be due to the unavailability of nutrients in the effluents).

The initial growth phase of TAN3 bacterial Isolate occurred within the 3-day incubation as the growth rate increases up to the 6th-day incubation when the maximum growth was observed. Beyond the 6th day, the growth of the bacteria declined (which might be due to a shortage of nutrients in the effluents) until it reached its death phase (which might be due to the unavailability of nutrients in the effluents).

Table 2: Morphological and Biochemical characteristics of bacterial isolates

\begin{tabular}{lllll} 
Bacterial Isolates & & TAN1 & TAN2 & TAN3 \\
\hline $\begin{array}{lllll}\text { Morphological } \\
\text { characteristics }\end{array}$ & Shape & Cocci & Rod & Cocci \\
& Spore & & & \\
& former & + & + & + \\
Gram & & & \\
Biochemical characteristics & reaction & - & + & + \\
& Citrate & + & + & + \\
& Catalase & + & + & + \\
& Coagulase & + & - & + \\
Starch & + & + & + \\
& Glucose & + & + & + \\
Oxidase & + & + & + \\
& Indo & - & + & - \\
Lactose & - & + & + \\
Manitol & + & - & + \\
Maltose & + & + & + \\
MR & - & + & - \\
VP & + & - & - \\
& Nitrate & - & - & - \\
Reduction & - Neisseria & Bacillus & Staphylococcus \\
& Bacterial & cereus & aureus \\
& name & spp & cas
\end{tabular}

+ = Positive; - = Negative; MR=Methyl Red; VP= Voges-Proskauer 


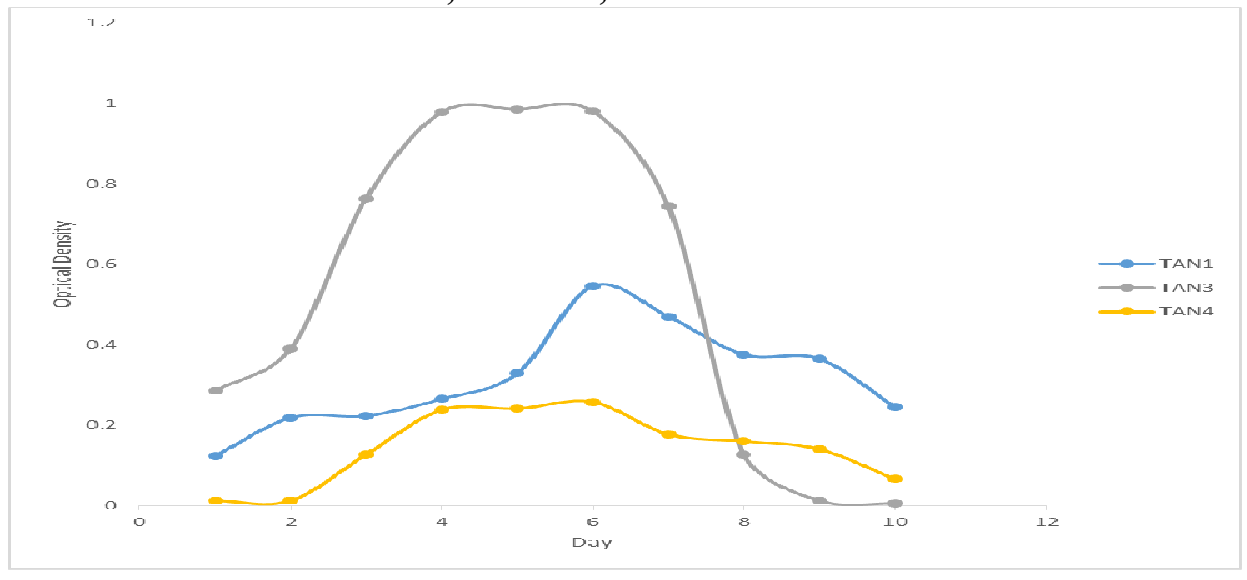

Fig. 2 Growth rates of the isolates in the effluents from the Tannery Industries

\section{Physico-chemical Parameters in the Industrial Effluents after the biodegradation.}

Table 3 shows the mean results of the physicochemical parameter before and after bioremediation using the different masses $(5 \mathrm{~g}$, $10 \mathrm{~g}, 15 \mathrm{~g}, 20 \mathrm{~g}$, and $25 \mathrm{~g}$ ) of the respective immobilized bacteria. Also, Table 4 shows the mean results of correlation coefficient ( $r$ ) between different masses of bacteria and physicochemical parameters.

The mean values $(\mathrm{mg} / \mathrm{l})$ of the SS after the bioremediation varies between $243 \pm 45$ and $898 \pm 672$. The mean concentration $(\mathrm{mg} / \mathrm{l})$ of SS remediated by the different masses $(5 \mathrm{~g}, 10 \mathrm{~g}$, $15 \mathrm{~g}, 20 \mathrm{~g}$, and $25 \mathrm{~g}$ ) of the bacteria varies. The SS in the samples fluctuates up and down after the bioremediation process when compared with the SS of the raw samples before the bioremediation. The increase in the levels of the SS might be due to the aggregation of the TDS which are large enough to result into SS. The increase in the levels of the SS might be also due to the influence of the nutrients which was added into the effluents in order to make the microorganisms more active and viable for fast degradation of organic contaminants in the effluent. The relative potential or efficiency of the different masses of the bacteria in remediating SS in TAN1 samples was in the order $25 \mathrm{~g}>20 \mathrm{~g}>15 \mathrm{~g}>10 \mathrm{~g}>5 \mathrm{~g}$. For TAN2 and TAN3 samples, the order was $25 \mathrm{~g}>20 \mathrm{~g}>15$ $\mathrm{g}>10 \mathrm{~g}>5 \mathrm{~g}$. These might be due to the variations in the surface areas of the different masses of the immobilized bacteria. Statistical analysis shows that there is no significant difference $(p<0.05)$ between the mean values of SS among the masses in the respective industries. Positive and significant correlations exist between the masses of bacteria and Suspended Solid (SS). This showed that there is general increase in the levels of the SS as the masses of the immobilized bacteria increases. TAN3 (90\%) and TAN1 (80\%) showed a very high correlation with the masses of the bacteria while TAN2 (61\%) showed a very low correlation.

The mean values $(\mathrm{mg} / \mathrm{l})$ of the TDS after the bioremediation varies between $46 \pm 11$ and $83 \pm 78$. The mean concentration $(\mathrm{mg} / \mathrm{l})$ of TDS remediated by the different masses $(5 \mathrm{~g}, 10 \mathrm{~g}$, $15 \mathrm{~g}, 20 \mathrm{~g}$, and $25 \mathrm{~g}$ ) of the bacteria varies. There is a reduction in all the TDS of all the samples after the bioremediation process compared with the TDS of the raw samples before the bioremediation. The relative potential or efficiency of the different masses of the bacteria in remediating TDS in TAN1 and TAN3 samples was in the order $5 \mathrm{~g}>10 \mathrm{~g}>15 \mathrm{~g}>20$ $\mathrm{g}>25 \mathrm{~g}$. For TAN2 samples, the order was 20 $g>10 \quad g>25 \quad g>15 \quad g>5 \quad g$. Statistical analysis shows that there is no significant difference $(p<0.05)$ between the mean values of TDS among the masses in the respective industries. These might be due to the variations in the surface areas of the different masses of the immobilized bacteria. Positive and significant correlations exist between the masses of bacteria and TDS with the exception in TAN2 (negative and insignificant correlation). The positive correlations showed that there is general increase in the levels of the TDS as the masses of the immobilized bacteria increases. TAN1 $(96 \%)$ showed a very high correlation with the masses of the bacteria while TAN2 (47\%) showed a very low correlation.

The mean values $(\mathrm{mg} / \mathrm{l})$ of the BOD after the bioremediation varies between $1.56 \pm 0.20 \mathrm{mg} / \mathrm{l}$ and $6.92 \pm 5.49 \mathrm{mg} / \mathrm{l}$. The mean concentration $(\mathrm{mg} / \mathrm{l})$ of BOD remediated by the different masses $(5 \mathrm{~g}, 10 \mathrm{~g}, 15 \mathrm{~g}, 20 \mathrm{~g}$, and $25 \mathrm{~g}$ ) of the bacteria varies. There is a reduction in all the BOD of all the samples after the bioremediation process compared with the $\mathrm{BOD}$ of the raw 
BAJOPAS Volume 13 Number 2, December, 2020 samples before the bioremediation. The relative potential or efficiency of the different masses of the bacteria in remediating BOD in TAN1, TAN2 and TAN3 samples were in the order $25 \mathrm{~g}>20$ $\mathrm{g}>15 \mathrm{~g}>10 \mathrm{~g}>5 \mathrm{~g}, 25 \mathrm{~g}>15 \mathrm{~g}>5 \mathrm{~g}>10 \mathrm{~g}>20 \mathrm{~g}$ and $20 \mathrm{~g}>10 \mathrm{~g}>25 \mathrm{~g}>15 \mathrm{~g}>5 \mathrm{~g}$ respectively. Statistical analysis shows that there is significant difference $(p<0.05)$ between the mean values of BOD among the masses in the respective industries. These might be due to the variations in the surface areas of the different masses of the immobilized bacteria. Negative and significant correlations exist between the masses of bacteria and BOD. This showed that there is general decrease in the levels of the BOD as the masses of the immobilized bacteria increases. TAN1 (94\%) showed a very high correlation with the masses of the bacteria while TAN2 (4\%) showed a very low correlation.

The mean values $(\mathrm{mg} / \mathrm{l})$ of the COD after the bioremediation varies between $250 \pm 154$ and $3134 \pm 1595$. The mean concentration $(\mathrm{mg} / \mathrm{l})$ of COD remediated by the different masses $(5 \mathrm{~g}$, $10 \mathrm{~g}, 15 \mathrm{~g} 20 \mathrm{~g}$, and $25 \mathrm{~g}$ ) of the bacteria varies. There is a reduction in all the COD of all the samples after the bioremediation process compared with the COD of the raw samples before the bioremediation. The relative potential or efficiency of the different masses of the bacteria in remediating COD in TAN1, TAN2 and TAN3 samples were in the order $25 \mathrm{~g}>20 \mathrm{~g}>15$ $\mathrm{g}>5 \mathrm{~g}>10 \mathrm{~g}, 25 \mathrm{~g}>20 \mathrm{~g}>15 \mathrm{~g}>10 \mathrm{~g}>5 \mathrm{~g}$ and 10 g>5 g>25 g>15 g>20 g respectively. Statistical analysis shows that there were significant difference $(p<0.05)$ between the mean values of COD among the masses in the respective industries except for effluents treated with $25 \mathrm{~g}$. These might be due to the variations in the surface areas of the different masses of the immobilized bacteria. Negative and insignificant correlations exist between the masses of bacteria and COD with the exception in TAN3 (positive and significant correlation). The negative correlations showed that there is general decrease in the levels of the COD as the masses of the immobilized bacteria increases. TAN2 (100\%) showed a very high correlation with the masses of the bacteria while TAN3 (36\%) showed a very low correlation.

Generally, there was an overall decrease in the concentration of these physicochemical parameters after the bioremediation using the different masses of the bacterial isolates. These might be due to the variations in the surface areas of the different masses of the immobilized bacteria. This is in line with the work of Jimoh et al. (2018) and Baba et al. (2020).

Table 3: Mean Values $(\mathrm{mg} / \mathrm{l}) \pm$ S.D of Physicochemical parameters in effluents from the Tannery Industries before and after Treatment of the effluents $(250 \mathrm{ml})$ with the different masses $(5 \mathrm{~g}, 10 \mathrm{~g}$, $15 \mathrm{~g}, 20 \mathrm{~g}$, and $25 \mathrm{~g}$ ) of the bacteria.

\begin{tabular}{llllllll}
\hline $\mathrm{P}$ & IND & Before & \multicolumn{5}{c}{ After } \\
\cline { 4 - 7 } & & & $5 \mathrm{~g}$ & $10 \mathrm{~g}$ & $15 \mathrm{~g}$ & $20 \mathrm{~g}$ & $25 \mathrm{~g}$ \\
\hline \multirow{2}{*}{ COD } & TAN1 & $2372 \pm 938$ & $1708 \mathrm{a} \pm 861$ & $2045 \mathrm{a} \pm 1205$ & $845 \mathrm{a} \pm 369$ & $300 \mathrm{a} \pm 167$ & $250 \mathrm{a} \pm 154$ \\
& TAN2 & $1406 \pm 208$ & $1195 \mathrm{a} \pm 208$ & $1125 \mathrm{a} \pm 384$ & $1055 \mathrm{a} \pm 317$ & $956 \mathrm{a} \pm 310$ & $870 \mathrm{ab} \pm 240$ \\
& TAN3 & $3532 \pm 1373$ & $2374 \mathrm{a} \pm 1344$ & $1976 \mathrm{a} \pm 1405$ & $2757 \mathrm{a} \pm 1266$ & $3134 \mathrm{a} \pm 1595$ & $2614 \mathrm{~b} \pm 1105$ \\
BOD & TAN1 & $13.85 \pm 6.42$ & $6.92 \mathrm{a} \pm 5.49$ & $6.42 \mathrm{a} \pm 5.07$ & $5.72 \mathrm{a} \pm 5.35$ & $4.62 \mathrm{a} \pm 4.37$ & $2.82 \mathrm{ab} \pm 1.26$ \\
& TAN2 & $19.46 \pm 0.50$ & $1.75 \mathrm{~b} \pm 0.22$ & $1.73 \mathrm{~b} \pm 0.18$ & $1.58 \mathrm{a} \pm 0.16$ & $1.91 \mathrm{a} \pm 0.22$ & $1.56 \mathrm{~b} \pm 0.20$ \\
& TAN3 & $17.13 \pm 3.14$ & $4.24 \mathrm{ab} \pm 0.77$ & $3.29 \mathrm{ab} \pm 0.37$ & $4.11 \mathrm{a} \pm 0.07$ & $3.23 \mathrm{a} \pm 0.91$ & $3.33 \mathrm{a} \pm 1.28$ \\
SS & TAN1 & $374 \pm 124$ & $243 \mathrm{a} \pm 45$ & $471 \mathrm{a} \pm 226$ & $475 \mathrm{a} \pm 182$ & $492 \mathrm{a} \pm 128$ & $611 \mathrm{a} \pm 217$ \\
& TAN2 & $358 \pm 335$ & $460 \mathrm{a} \pm 400$ & $543 \mathrm{a} \pm 414$ & $544 \mathrm{a} \pm 402$ & $551 \mathrm{a} \pm 414$ & $554 \mathrm{a} \pm 405$ \\
& TAN3 & $780 \pm 739$ & $586 \mathrm{a} \pm 594$ & $758 \mathrm{a} \pm 656$ & $787 \mathrm{a} \pm 676$ & $861 \mathrm{a} \pm 635$ & $898 \mathrm{a} \pm 672$ \\
TDS & TAN1 & $3941 \pm 3703$ & $51 \mathrm{a} \pm 10$ & $53 \mathrm{a} \pm 10$ & $55 \mathrm{a} \pm 15$ & $61 \mathrm{a} \pm 20$ & $63 \mathrm{a} \pm 26$ \\
& TAN2 & $3300 \pm 1714$ & $83 \mathrm{a} \pm 78$ & $47 \mathrm{a} \pm 20$ & $48 \mathrm{a} \pm 22$ & $47 \mathrm{a} \pm 17$ & $48 \mathrm{a} \pm 17$ \\
& TAN3 & $2653 \pm 1240$ & $46 \mathrm{a} \pm 11$ & $55 \mathrm{a} \pm 24$ & $55 \mathrm{a} \pm 25$ & $58 \mathrm{a} \pm 23$ & $61 \mathrm{a} \pm 28$ \\
\hline
\end{tabular}

Replicate $=6$ (months)

Within the rows, for the same parameter, means with different alphabets are statistically different $(p<0.05)$.

$\mathrm{P}=$ parameter, IND = Industries 
BAJOPAS Volume 13 Number 2, December, 2020

Table 4: Correlation coefficient $(r)$ between different masses of the bacteria and the physicochemical parameters.

\begin{tabular}{llll}
\hline Industries & Parameter & Correlation coefficient $(r)$ & $\begin{array}{l}\text { Percent dependence (rxrx100) } \\
(\%)\end{array}$ \\
\hline TAN1 & COD & -0.9 & 82 \\
& BOD & -0.97 & 94 \\
& SS & $0.90^{*}$ & 80 \\
TAN2 & TDS & $0.98^{*}$ & 96 \\
& COD & -1 & 100 \\
& BOD & -0.21 & 4 \\
& SS & $0.78^{*}$ & 61 \\
& TDS & -0.69 & 47 \\
& COD & $0.60^{*}$ & 36 \\
& BOD & -0.6 & 37 \\
& SS & $0.95^{*}$ & 90 \\
& TDS & $0.94^{*}$ & 89 \\
\hline
\end{tabular}

The correlation coefficient $(r)$ with * is statistically significant $(p<0.05)$.

Percentage reduction of the Parameters

Table 5 shows the percentage reduction of Parameters in industrial samples before and after the treatment of the effluents $(250 \mathrm{ml})$ with the different masses $(5 \mathrm{~g}, 10 \mathrm{~g}, 15 \mathrm{~g}, 20 \mathrm{~g}$, and $25 \mathrm{~g}$ ) of the Immobilized Bacteria.

In TAN1 samples, the percentage reduction (\%) of COD ranged (14-89); BOD (50-80); SS (-32$35)$ and TDS (98-99). In TAN2 samples, the percentage decrease $(\%)$ of COD ranged (15$38) ;$ BOD (90-92); SS [-28-(-55)] and TDS (9798). In TAN3 samples, the percentage decrease (\%) of COD ranged (11-44); BOD (76-81); SS (15-25) and TDS (98). The percentage increase in the levels COD, BOD and TDS might be due to the increase in the surface area of the different masses of the immobilized bacteria. However, the percentage decrease in the levels of the SS might be due to the aggregation of the TDS which are large enough to result into SS. The percentage decrease in the levels of the SS might be also due to the influence of the nutrients which was added into the effluents in order to make the microorganisms more active and viable for fast degradation of organic contaminants in the effluent. This is in line with the work of Jimoh et al. (2018) in which the concentration of the SS increase after the bioremediation of effluents.

Sreemoyee and Priti (2013) assessed and reduced several Physico-chemical parameters of dairy wastewater using Niesseria $s p$. and concluded that the species are well known to degrade organic compounds. This is in agreement with the current study in which the immobilized Niesseria $s p$ degrade the organic contaminants as indicated by the BOD, COD and TDS.

Jimoh et al. (2018) observed that TSS of the effluents was increased after treatment with immobilized bacteria and concluded that it might be due to the biostimulation method adopted for the research.

The optimum $\mathrm{pH}$ Biosorption of Chromium by Bacillus spp and Staphylococcus spp. from tannery effluent was investigated by Mythili and Karthikeyan (2011). The maximum adsorption of Chromium $(86.4 \mathrm{mg} / \mathrm{L})$ was showed by Bacillus spp and Staphylococcus spp showed $70.6 \mathrm{mg} / \mathrm{L}$ at an initial concentration of $100 \mathrm{mg} / \mathrm{L}$. In the present study, immobilised Bacillus spp and Staphylococcus spp. from the tannery industrial effluents reduced the levels of the organic pollutants with high potential as indicated by the percentage reduction of BOD, COD and TDS.

Enzymes often can work in multiple environments especially if they are immobilized. This makes the microorganisms' enzymes even more resistant to harsh environments and enables the enzymes to be recovered and recycled after they are no longer needed (Gianfreda and Rao 2004). Ramesh and Singh (1993) reported that the immobilized bacteria having more efficiency to remove the suspended particles than free cells. Using the immobilized cell is preferable due to its capability for using several times with the same efficiency, which makes it more economical. Similar work was done by Sikander et al. (2007) showing the higher reduction with permeabilized cells of Ochrobactrum intermedium strain SDCr-5. 
BAJOPAS Volume 13 Number 2, December, 2020

The results revealed the isolation and identification of isolates with the potential for the reduction of $\mathrm{Cr}$ (VI) to $\mathrm{Cr}$ (III). Results indicated that immobilized $B$. cereus could be efficiently used for the reduction of $\mathrm{Cr}$ (VI).

Table 5: Percentage reduction of the tested Parameters from the tannery industrial samples of the Immobilized Bacteria.

\begin{tabular}{lllllll}
\hline \multirow{2}{*}{ Industries } & & \multicolumn{5}{c}{ Percentage Reduction $(\%)$} \\
\cline { 3 - 7 } & & $5 \mathrm{~g}$ & $10 \mathrm{~g}$ & $15 \mathrm{~g}$ & $20 \mathrm{~g}$ & $25 \mathrm{~g}$ \\
\hline TAN1 & COD & 28 & 14 & 64 & 87 & 89 \\
& BOD & 50 & 54 & 59 & 67 & 80 \\
& SS & 35 & -26 & -27 & -32 & -63 \\
& TDS & 99 & 99 & 99 & 98 & 98 \\
TAN2 & COD & 15 & 20 & 25 & 32 & 38 \\
& BOD & 91 & 91 & 92 & 90 & 92 \\
& SS & -28 & -52 & -52 & -54 & -55 \\
& TDS & 97 & 99 & 99 & 99 & 99 \\
& COD & 33 & 44 & 22 & 11 & 26 \\
& BOD & 75 & 81 & 76 & 81 & 81 \\
& SS & 25 & 3 & -1 & -10 & -15 \\
& TDS & 98 & 98 & 98 & 98 & 98 \\
\hline
\end{tabular}

Percentage Reduction $=(B-A) / B \times 100 \%$

$A=$ Concentration of the parameter after treatment

$\mathrm{B}=$ Concentration of the parameter before treatment

$+=$ percentage decrease

- = percentage increase

In general, immobilization makes the enzyme more resistant to temperature, $\mathrm{pH}$, and substrate concentration swings giving it a longer lifetime and higher productivity per active unit (Gianfreda and Rao, 2004; FuIlbrook, 1996; Russell et al, 2003; Kandelbauer et al., 2004). Immobilized cells have been used and studied extensively for the production of useful chemicals (Ohtake and Silver, 1994), the treatment of wastewaters (Chen et al., 2003; Wang et al., 2010). Although many workers described microbial degradation of tannery effluent, limited literature is available on the bioremediation of tannery effluent using immobilized bacterial cells in the Kano Industrial Estates.

\section{CONCLUSION}

The samples contained variable levels of the physicochemical parameters. The results of the Analysis of variance revealed that, no statistical difference $(p<0.05)$ was observed for the temperature, $\mathrm{pH}, \mathrm{SS}, \mathrm{TDS}, \mathrm{BOD}$ and $\mathrm{COD}$ among the three tannery industries before the treatment. The levels of some of the parameters
(SS, TDS and COD) observed in the samples were found above the recommended limits of WHO and NESREA, which called for the treatment of the effluents before discharge into the environment. Base on the morphological and biochemical test results, TAN1, TAN2, and TAN3 bacterial isolates were identified to be Neisseria spp, Bacillus cereus, and Staphylococcus aureus respectively. The results of Post-treatment analysis showed that there is overall decrease in the levels of the parameters determined when compared with that of the pre-treatment. The overall percentage reduction of the immobilised bacteria in the treatment of the respective effluents was in the order TAN2 (72\%)>TAN1 $(70 \%)>$ TAN3 $(62 \%)$. Hence, the immobilized bacteria are having higher biodegradation potential for the treatment of the tannery effluents.

\section{Acknowledgments}

The authors wish to acknowledge the University of Maiduguri for the financial support. The authors are grateful to the Kano State Ministry of Environment for their support in obtaining the effluent samples. 


\section{REFERENCES}

Ajao, A. T., Adebayo, G. B., and Yakubu, S. E. (2011). Bioremediation of textile industrial effluent using mixed culture of Pseudomonas aeruginosa and Bacillus subtilis immobilized on agar-agar in a bioreactor. J. Microbiol. Biotech. Res, 1(3), 50-56.

Akan, J. C., Moses, E. A., Ogugbuaja, V. O., and Abah, J. (2007). Assessment of tannery industrial effluents from Kano metropolis, Kano State, Nigeria. Journal of Applied Sciences, 7(19), 2788-2793.

Akan, J. C., Ogugbuaja, V. O., Abdulrahman, F. I., and Ayodele, J. T. (2009). Pollutant levels in effluent samples from tanneries and textiles of Kano industrial areas, Nigeria. Global journal of pure and applied sciences, 15(3-4).

APHA (1989). Standard methods for Examination of Will bete and Will betewater.15 $5^{\text {th }}$ edition. Brydpass Springfield Will behington DC. pp. 164-176

APHA (1992). Standard Methods for the Examination of Water and Wastewater. Health, 69, 1116-9.

Baba, A., Garba, S. T., and Bello, H. S. (2020). Bioremediation Potential of Immobilized corynebacterium kutsceri in the Treatment of Tannery Industrial Effluent from Challawa Industrial Estate, Kano State, Nigeria. Journal of the Turkish Chemical Society Section A: Chemistry, $7(2), 335-350$.

Beem, E. I. V. (1994). reduction of solvent VOC emission. J. Oil Col. Chem. Ass, 77, 158.

Bouwer, E. J., and Zehnder, A. J. (1993). Bioremediation of organic compoundsputting microbial metabolism to work. Trends in biotechnology, 11(8), 360367.

Chen, K. C., Wu, J. Y., Liou, D. J., and Hwang, S. C. J. (2003). Decolorization of the textile dyes by newly isolated bacterial strains. Journal of Biotechnology, 101(1), 57-68.

Dan'Azumi, S., and Bichi, M. H. (2010). INDUSTRIAL POLLUTION AND HEAVY METALS PROFILE OF CHALLAWA RIVER IN KANO, NIGERIA. Journal of Applied Sciences in Environmental Sanitation, $5(1)$.

DWAF. (1992). Analytical Methods Manual, TR 151. Department of Water Affairs and Forestry, Pretoria.

El-Bestawy, E. (2013). Biological treatment of leather-tanning industrial wastewater using free living bacteria.
Elsheikh, M. A. S. (2009). Tannery wastewater pre-treatment. Water Science and Technology, 60(2), 433-440.

FuIlbrook, P. D. (1996). "Kinetics." Industrial enzymology: The application of enzymes in Industry. 2nd Ed. T. Godfrey and J Reichelt. eds.. Nature. New York.

Gianfreda, L., and Rao, M. A. (2004). Potential of extra cellular enzymes in remediation of polluted soils: a review. Enzyme and microbial technology, 35(4), 339354.

Hugo Springer. (1994). John Arthur Wilson Memorial Lecture "Treatment of Industrial Wastes of the Leather Industry - is it still a Major Problem". JALCA, 89, 153-185

Jimoh, A. A., Ganiyu, B. A., Baba, D., and Baba, A. (2018) Bioremediation Process of Effluent from Detergent and Food Industries in Jos, Nigeria: Kinetics and Thermodynamics. International Journal of Engineering Science Invention (IJESI), 762-73

Kandelbauer, A., Maute, O., Kessler, R. W., Erlacher, A., and Gübitz, G. M. (2004). Study of dye decolorization in an immobilized laccase enzyme-reactor using online spectroscopy. Biotechnology and bioengineering, 87(4), 552-563.

Kongjao, S., Damronglerd, S., and Hunsom, M. (2008). Simultaneous removal of organic and inorganic Pollutants in tannery wastewater using electrocoagulation technique. Korean Journal of chemical engineering, 25(4), 703.

Maheshwari, U. M., Aruna, S., Gomathi, M., and AbdulJaffar, A. H. (2017). Bioremediation by Free and Immobilized Bacteria Isolated from Tannery Effluent. International Journal of Research in Applied, Natural and Social Sciences. 5(7), 75-90

Margesin, R., and Schinner, F. (2001). Bioremediation (natural attenuation and biostimulation) of diesel-oilcontaminated soil in an alpine glacier skiing area. Applied and environmental microbiology, 677), 3127-3133.

Mohammed, A., Sekar, P., and George, J. (2011). Efficacy of microbes in bioremediation of tannery effluent. Inter. J. Curr. Res, 3(4), 324-326.

Mohammed, S. S. D., Orukotan, A. A., and Abdullahi, H. (2017). Physicochemical and Bacteriological Assessment of Tannery Effluent from Samaru-Zaria, 
BAJOPAS Volume 13 Number 2, December, 2020 Kaduna State, Nigeria. Journal of Applied

Sciences and Environmental Management, 21(4), 734-740.

Munz, G., De Angelis, D., Gori, R., Mori, G., Casarci, M., and Lubello, C. (2009). The role of tannins in conventional and membrane treatment of tannery wastewater. Journal of hazardous materials, 164(2-3), 733-739

Mythili, K., and Karthikeyan, B. (2011). Bioremediation of $\mathrm{Cr}$ (VI) from tannery effluent using Bacillus spp and Staphylococcus spp. International Multidisciplinary Research Journal, 1(6).

NESREA (2009). National Environmental Standards for Effluent Limitations and Regulation. 1233-1236

Noorjahan, C. M. (2014). Physicochemical characteristics, identification of bacteria and biodegradation of industrial effluent. Journal of bioremediation and Biodegradation, 5(3).

Ohtake, H. I., and Silver, A. O. (1994). Bacterial reduction of toxic chromate. Biological degradation and bioremediation of toxic chemicals, 403-415.

Omoleke, I. I. (2004). Management of environmental pollution in Ibadan, an African city: the challenges of health hazard facing government and the people. Journal of Human Ecology, 15(4), 265-275.

Rajor, A., Reddy, A.S., and Singh, B. (2004). Determination of BOD kinetic Parameters and evaluation of alternate methods, M.Sc. Thesis, Department of biotechnology \& environmental Science, Thapar Institute of Engineering and Technology, Patiala

Ramasami, T., Rajamani, S., and Rao, J. R. (1994, March). Pollution control in leather industry: Emerging technological options. In International symposium on surface and colloidal science and its relevance to soil pollution, madras.

Ramesh, J. V. S., and Singh, S. P. (1993). Yearly variation in certain physicochemical parameters of pond at eastern Doon Valley. Uttar Pradesh J. Zoo, 12 (1), 7577.

Ranen, S., and Sharadinadra, C. (2009). Biotechnology applications to environmental remediation in resource exploitation. Current science, 97, 6-25
Russell, A. J., Berberich, J. A., Drevon, G. F., and Koepsel, R. R. (2003). Biomaterials for mediation of

chemical and biological warfare agents. Annual review of biomedical engineering, 5(1), 1-27.

Saravanan, P., and Saravanan, A. (1999). Decolourization of tannery effluent by Flavobacterium sp. EK 1. Indian Journal of Environmental Protection, 19, 19-24.

Sikander, S., and Shahida, H. (2007). Reduction of toxic hexavalent chromium by Ochrobactrum intermedium strain SDCr5 stimulated by heavy metals. Bioresource Technol, 98, 340-344.

Singh, N., Sharma, B. K., and Bohra, P. C. (2000). Impact assessment of industrial effluent of arid soils by using satellite imageries. Journal of the Indian Society of Remote Sensing, 28(2-3), 79.

Sreemoyee, C., and Priti, P. (2013). Assessment of physico-chemical parameters of dairy waste water and isolation and characterization of bacterial strains in terms of cod reduction. Int J Sci, 2(3), 395-400.

Verheijen, L. A. H. M., Wiersema, D., Pol, L. H., and De Wit, J. (1996). Management of wastes from animal product processing. Livestock and environment, Finding a balance. International Agriculture Center, Wageningen, The Netherlands.

Wang, F., Yao, J., Si, Y., Chen, H., Russel, M., Chen, K., and Bramanti, E. (2010). Short-time effect of heavy metals upon microbial community activity. Journal of Hazardous Materials, 173(13), 510-516.

WHO (World Health Organization). (2006). Air quality guidelines: global update 2005: particulate matter, ozone, nitrogen dioxide, and sulfur dioxide. World Health Organization.

World Bank. (1995). Nigeria's strategic options for redressing industrial pollution. World Bank, industry and energy division. 1st edition, West Central Africa Department; Annexes: 1995; pp 60-62.

Zahoor, A., and Abdul, R. (2009). Enumeration of Coliforms. Journal of Environmental Sciences. 21, 814-820 


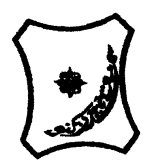

Bayero Journal of Pure and Applied Sciences, 13(2): 1 - 12

Received: November, 2020

Accepted: December, 2020

ISSN $2006-6996$

\title{
BIODEGRADATION POTENTIAL OF IMMOBILIZED BACTERIA IN THE TREATMENT OF TANNERY INDUSTRIAL EFFLUENTS FROM INDUSTRIAL ESTATES IN KANO STATE, NIGERIA
}

\author{
Abdullateef, B., ${ }^{1 *}$ Shuaibu, T. G., ${ }^{1}$ Babagana, K., ${ }^{1}$ Suleman, H. B. ${ }^{2}$ and Dauda, B. ${ }^{3}$ \\ ${ }^{1}$ Department of Pure and Applied Chemistry, Faculty of Science, University of Maiduguri, Borno State, \\ Nigeria \\ ${ }^{2}$ Department of Microbiology, Faculty of Science, University of Maiduguri, Borno State, Nigeria \\ ${ }^{3}$ Department of Chemical Engineering, Faculty of Engineering, University of Maiduguri, Borno State, \\ Nigeria \\ *Corresponding author: babslega@gmail.com; abelega2007@yahoo.com; +2348061309753
}

\section{ABSTRACT}

Industrial Effluents Samples from Gashash Tanneries (TAN1) in Bompai Industrial estate, Larabee Tannery Industry (TAN2) in Sharada Industrial estate and Z Tannery Industries (TAN3) in Challawa Industrial estate, Kano State, Nigeria were collected over a period of six months (August 2017 to January 2018) for assessing the biodegradation potentials of bacteria in the treatment of organic pollutants within the effluents. Bacteria were isolated from the effluents and immobilized on agar-agar. Different masses (5 g, $10 \mathrm{gr}, 15$ $\mathrm{g}, 20 \mathrm{~g}$, and $25 \mathrm{~g}$ ) of the bacteria were used in the treatment of $250 \mathrm{ml}$ of the effluents for ten days in a shaker incubator (Gallenkamp-OC-4364-L) at the temperature $30{ }^{\circ} \mathrm{C}$ and speed of $60 \mathrm{rpm}$. Pre-treatment analysis of the effluents for Temperature, pH, Biochemical Oxygen Demand (BOD), Chemical Oxygen Demand (COD), Suspended Solid (SS) and Total Dissolved Solids (TDS) gives the following results; temperature $\left({ }^{\circ} \mathrm{C}\right.$ )

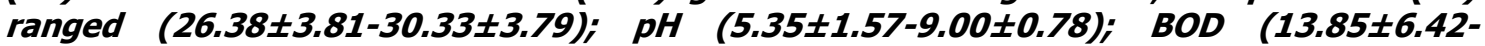
$38.75 \pm 16.20) ;$ COD (1406 $\pm 208-3532 \pm 1373) ;$ SS (208 $\pm 235-780 \pm 739)$ and TDS (266 $\pm 253-5276 \pm 2971)$. No statistical differences ( $p \leq 0.05)$ was observed for all the results among the different industries. The bacterial isolates were identified as Neisseria spp, Bacillus cereus, and Staphylococcus aureus, in TAN1, TAN2, and TAN3, respectively. After treatment of the effluent with the different masses of the isolated bacteria, the mean level of BOD was found to range as (0.55 $\pm 0.36-6.92 \pm 5.49) ; C O D$ (ND-3134 \pm 1595$)$;

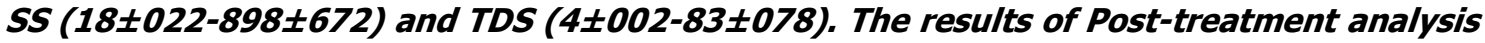
showed that there is overall decrease in the levels of the parameters determined when compared with that of the pre-treatment. The overall percentage reduction of the immobilised bacteria in the treatment of the respective effluents was in the order TAN2 (72\%)>TAN1 (70\%)>TAN3 (62\%). Hence, the immobilized bacteria are having higher biodegradation potential for the treatment of the tannery effluents.

Keywords: Biodegradation, bacteria, effluent, immobilization, tannery.

\section{INTRODUCTION}

Tannery industrial wastewater is a serious consequence of the pollution point of view for streams, freshwater, and land used for agriculture. The lack of awareness in the modern industrial practice has resulted in the discharge of tannery effluents which exhibit very high value of chromium ( $\mathrm{Cr}$ ), Sulfide, and chloride, Total Dissolved Solid (TDS), Total Suspended Solid (TSS), Biochemical Oxygen Demand (BOD) and Chemical Oxygen Demand (COD) in the water stream or land (Mohammed et al., 2001). Tanning is the process, which One ton of skin generally leads to the production of 20 to $80 \mathrm{~m}^{3}$ of turbid and foul-smelling converts the protein of the rawhide or skin into a stable material, which will not putrefy and is suitable for a wide variety of end applications (Elsheikh, 2009). The highly polluting chromium is the most commonly used tanning material producing leather that is more flexible and pliable than vegetable-tanned leather and does not discolor or lose shape in water as drastically as vegetable-tan (Elsheikh, 2009). Tannery effluent is among the most hazardous industrial pollutants due to its huge organic and inorganic load, which is highly toxic to human life and the environment (Kongjao et al., 2008). wastewater including chromium (100-400 mg/l), sulfide $(200-800 \mathrm{mg} / \mathrm{l})$, high levels of fat and 
BAJOPAS Volume 13 Number 2, December, 2020 other solid wastes, and notable pathogen contamination as well as pesticides added for skin conservation during transport (Elsheikh, 2009). There are more than 6000 tanneries in Nigeria with an annual processing capacity of 700,000 tons of hides and skins (Omoleke, 2004; Singh et al., 2008). It was reported that the total amount of waste produced per animal slaughtered is approximately $35 \%$ of its weight (World Bank, 1995). Also, for every $1000 \mathrm{~kg}$ of carcass weight, a slaughtered beef produces 5.5 $\mathrm{kg}$ of manure (excluding rumen contents or stockyard manure) and $100 \mathrm{~kg}$ of paunch manure (undigested food) (Verheijen et al., 1996). Tanneries generate wastewater in the range of 30-35 $\mathrm{L} \mathrm{kg}^{-1}$ skin/hide processed with variable $\mathrm{pH}$, Biological Oxygen Demand (BOD), Chemical Oxygen Demand (COD), high concentrations of suspended solids (SS), and tannins as well as chromium (Zahoor and Abdul, 2009).

Being heterogeneous and composed of a wide variety of compounds, it is very difficult to select a unique direct method for estimating the biodegradability of organic contents and biokinetic parameters for a wastewater sample (Rajor, 2004). For this purpose, some indirect estimation such as determination of biochemical oxygen demand (BOD) and chemical oxygen demand (COD) are applied as common laboratory investigations [9]. During retanning procedures, synthetic tannins (Syntan), oils and resins are added to form softer leather at varying doses (Munz et al., 2009). One of the refractory groups of chemicals in tannery effluents derives mainly from tannins (Ramasami et al., 2004). Syntans are characterized by complex chemical structures, because they are composed of an extended set of chemicals such as phenol-, naphthalene-, formaldehyde- and melamine-based syntans, and acrylic resins (Beem, 1994). Organic pollutants (proteic and lipidic components) are originated from skins (it is calculated that the raw skin has $30 \%$ loss of organic material during the working cycle) or they are introduced during processes (Hugo Springer, 1994).

Many conventional processes such as oxidation, chemical and biological processes were carried out to treat tanneries wastewater (Ebtesam et al, 2013). Biological processes have received more attention because of their costeffectiveness, lower sludge production and environmental friendliness (Noorjahan, 2014). Naturally occurring micro-organisms degrade the hazardous organic wastes including xenobiotic compounds, such as pesticides, polycyclic aromatic hydrocarbons (PAHs) and polychlorinated biphenyls (PCBs) in due course of time (Ranen and Sharadinadra, 2009). Bioremediation is based on the idea that all organisms remove substances from the environment to carry outgrowth and metabolism (Bouwer and Zehnder, 1993). Bacteria, protista and fungi are found to be very good at degrading complex molecules and incorporating the breakdown products into their metabolism (Bouwer and Zehnder, 1993). The resultant metabolic wastes that they produce are generally safe and somehow recycled into other organisms (Ranen and Sharadinadra, 2009). An acclimatized indigenous population of microorganisms capable of degradation of the compounds of interest must exist at the site for a successful bioremediation mode (Ranen and Sharadinadra, 2009). It has been observed that for a successful bioremediation mode, an acclimatized indigenous population of microorganisms capable of degradation of the compounds of interest must exist at the site under investigation (Ranen and Sharadinadra, 2009). Even though there are numerous physical and chemical methods employed in the disposal of wastes the advantage in using bacterium is that they play a key role in the reduction of COD, BOD, total protein, total tannin and total phenol (Saravanan and Saravanan, 1998)

Baba et al. (2020) studied the bioremediation potential of immobilized corynebacterium kutsceri in the Treatment of tannery industrial effluent from Challawa Industrial Estate, Kano State, Nigeria. The aim of the work is to study the reduction in the level of the contaminants through the process of bioremediation using the isolated bacteria. Immobilized bacteria can withstand various temperatures, $\mathrm{pH}$ and substrate concentrations; consequently, increasing the efficiency and the lifespan of the bacteria. Immobilized bacteria are widely applied in the treatment of wastewater and can be separated and recovered after the treatment with the same efficiency (Baba et al., 2020).

\section{MATERIALS AND METHODS \\ Study Area}

This study was carried out in Bompai, Sharada and Challawa industrial estates in Kano, Figure 1. Kano lies on Latitude $11^{\circ} 30^{\prime} \mathrm{N}$ and $8^{\circ} 30^{\prime} \mathrm{E}$ and Longitude $11^{\circ} 5^{\prime} \mathrm{N}$ and $8^{\circ} 5^{\prime} \mathrm{E}$ in Northern Nigeria. It is one of the developed industrial cities in Nigeria. Tannery activities are the dominating industries and this could be one of the reasons for her high population density (Dan'Azumi and Bichi, 2010). Many researchers have studied biodegradation of tannery effluent using microorganisms. However, limited literature is available on the biodegradation of tannery effluent in Kano industrial estates using 
BAJOPAS Volume 13 Number 2, December, 2020 immobilized bacterial cells. This research work focuses on the potential of the use of the indigenous immobilized bacterial isolates in the treatment of tannery effluents in the industrial estates.

\section{Sample Collection}

Effluents were collected from the Tannery Industries from Bompai, Challawa and Sharada Industrial Estates, Kano, Nigeria. The effluents were collected over a period of six months (August 2017 to January 2018). Samples collected in a sterile 4-liter plastic container with a unique identification number were preserved using an ice-box that was transported to the Microbiology Laboratory, Department of Microbiology, Bayero University of Kano for analysis

\section{Sample Preparation and Sample Analysis}

Immediately after the collection of the effluent, $\mathrm{pH}$, TSS, TDS, COD, BOD levels were determined before treatment (Pre-treatment determination) and ten days after treatment (Post-treatment determination) as described in
APHA (1989) standard methods. $\mathrm{pH}$ was determined using Ecotests $\mathrm{pH}$ meter and TDS was determined using AQUALYTIC TDS Salinometer. BOD was determined as described by the standard method (APHA, 1992). COD and SS were determined using DR/2010 HACH portable data logging spectrophotometer (DWAF, 1992)

\section{Identification and Biochemical} Characterization of the Bacterial Isolates

The bacteria were isolated from the effluents using Serial Dilution according to the method described by APHA (1989). The biochemical tests such as oxidase, catalase, coagulase, indole (from $1 \%$ tryptone broth), citrate (Simmons citrate agar), methyl red/VogesProskauer (MR/VP), nitrate reduction, Starch Hydrolysis, Glucose, Maltose, and Lactose tests were carried out on the bacterial isolates to identify the bacteria through the bacteria biochemical characteristics according to Ajao et al. (2011).

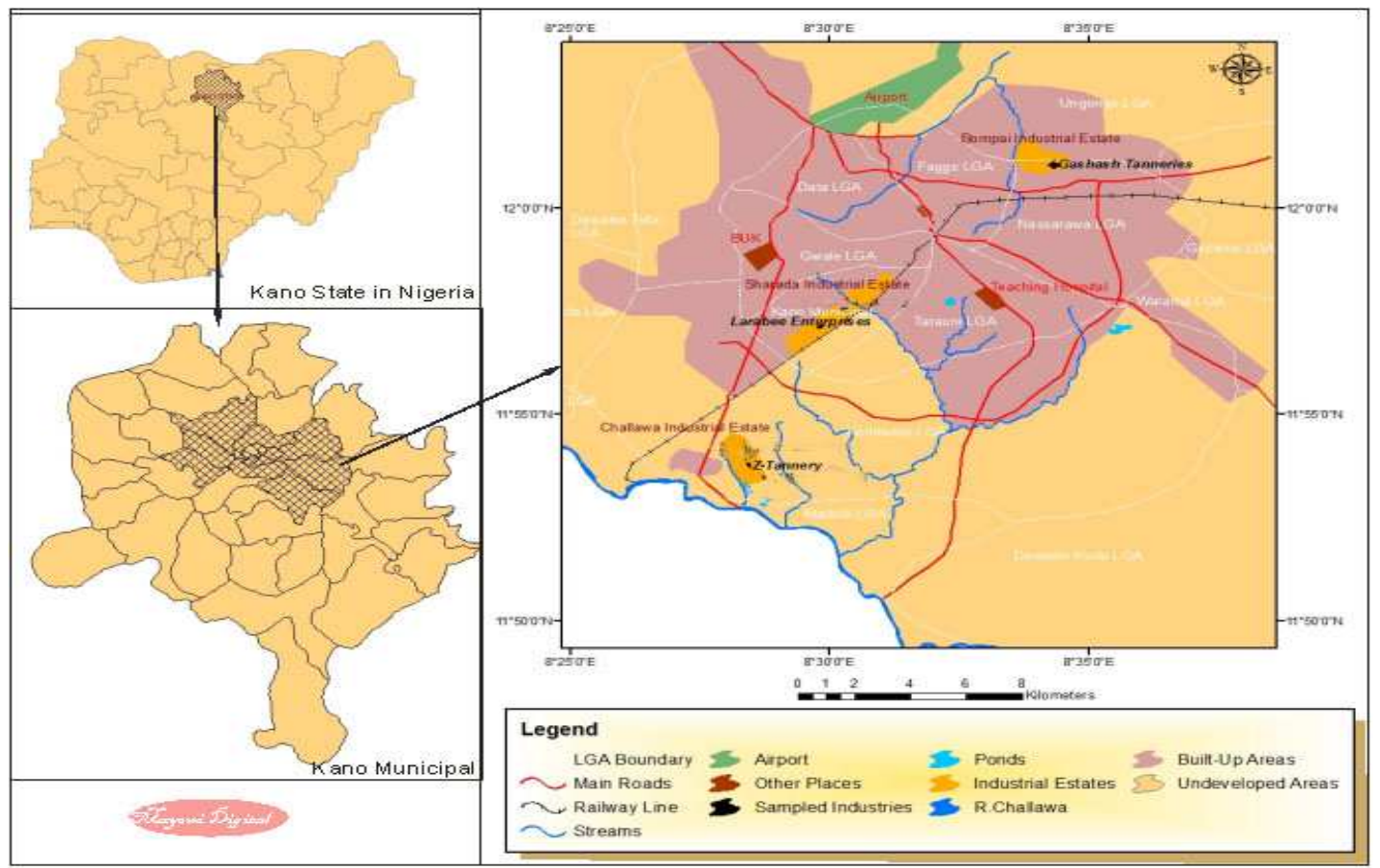

Fig. 1 Map showing the study areas

Source: Mayomi Digital Productions, GIS Laboratory, Department of Geography, UNIMAID (2017)

\section{Determination of Growth Rate of the Bacteria in Effluent Sample}

The bacteria growth rates were determined by transferring $2 \mathrm{~mL}$ of the bacterial isolates from the tannery effluent in broth medium into 100 $\mathrm{mL}$ sterile effluents in conical flasks and kept in an incubator (Giffrin cool) for 10 days. Control was also set up by incubating another $100 \mathrm{~mL}$ each of the sterile effluents without the bacteria. The optical density of the content was determined at the wavelength of $600 \mathrm{~nm}$ on a daily interval and recorded. 
BAJOPAS Volume 13 Number 2, December, 2020 Immobilization of Bacteria

Agar solution and inoculi were prepared separately. Fifty milliliters $(50 \mathrm{~mL})$ of nutrient broth each of the inoculi was prepared in a McCartney bottle and incubated for 24 hours. A solution of agar-agar was prepared by dissolving $10 \mathrm{~g}$ of the powder in distilled water and made up to $500 \mathrm{~mL}$ mark in an Erlenmeyer flask and was sterilized in an autoclave (280A) for 15 minutes and allowed to cool to $40-45^{\circ} \mathrm{C}$ (Ajao et al., 2011). Four milliliters ( $4 \mathrm{~mL})$ of the bacterial isolates in the nutrient broth was mixed with 36 $\mathrm{ml}$ of the prepared agar-agar media in petri-dish plates and then allowed to solidify. This was kept in the refrigerator for bioremediation.

\section{Bioremediation (Treatment) of the Effluents}

The solidified agar block (immobilized bacteria) was cut into cubes using a sterile knife; $0.1 \mathrm{~mL}$ phosphate buffer ( $\mathrm{pH} \mathrm{7.0)}$ was added and kept in the refrigerator for 1 hour for curing. The phosphate buffer was decanted after 1 hour and the cubes were washed with sterile distilled water 3-4 times before it was used (Ajao et al., 2011). Two liters (2 L) of the effluent was supplemented with the minimum basal medium in $\mathrm{g} / \mathrm{L}: \mathrm{NaCl}(0.8), \mathrm{MgSO}_{4} .7 \mathrm{H}_{2} \mathrm{O}(0.001), \mathrm{KH}_{2} \mathrm{PO}_{4}$ (2), $\mathrm{NaNO}_{3}$ (2), $\quad \mathrm{CaCl}_{2} .2 \mathrm{H}_{2} \mathrm{O} \quad(0.5)$ and $\mathrm{NaHPO}_{4} .12 \mathrm{H}_{2} \mathrm{O}(2)$ and sterilized in an autoclave at $121^{\circ} \mathrm{C}$ for 15 minutes (Margesin and Schinner, 2001). Two hundred and fifty milliliters $(250 \mathrm{~mL})$ of the effluents were transferred into different $250 \mathrm{ml}$ conical flasks. The content was covered with a cotton-wool ramped with foil paper to avoid contamination. Five grams $(5 \mathrm{~g})$ of the immobilized bacteria were quickly transferred into each of the effluents in the conical flasks in an inoculating chamber. The same procedures were carried out for the $10 \mathrm{~g}, 15 \mathrm{~g}, 20 \mathrm{~g}$ and 25 $\mathrm{g}$ of the immobilized bacteria in separate $250 \mathrm{~mL}$ effluents in conical flasks and agitated for ten days in a shaker incubator (Gallenkamp-OC4364-L) at a temperature $30^{\circ} \mathrm{C}$ and speed of 60 rpm. The treated effluent samples were taken on the tenth day and analyzed for the parameters $\mathrm{pH}$, SS, TDS, COD, and BOD, (Posttreatment determination) for the different grams of bacteria to evaluate and compare the biodegradation potential. (Baba et al., 2020).

\section{Statistical Analysis}

The data were represented as Mean \pm Standard deviation and analyzed statistically using oneway Analysis of Variance (ANOVA) and Tukey's HSD as Post Hoc Tests with the aid of SPSS 16.0. The correlation coefficient was also used to measure the strength of the relationship between the different masses of the bacteria and the parameters. All $\mathrm{p} \leq 0.05$ were considered as statistically significant.

\section{RESULTS AND DISCUSSION Physico-chemical parameters in the Industrial Effluents before the Biodegradation.}

Results of the Physico-chemical parameters in the industrial effluents before the Biodegradation is shown in table 1 . The mean temperatures $\left({ }^{\circ} \mathrm{C}\right)$ observed in TAN1, TAN2, and TAN3 samples were $28.07 \pm 0.65 ; 27.77 \pm 0.64$ and $26.38 \pm 3.81$ respectively. The order of the mean temperature of the samples from the three industries can be arranged as TAN1 > TAN2>TAN3. The temperature observed at TAN1, TAN2, and TAN3 samples were found below the WHO $\left(35^{\circ} \mathrm{C}\right)$ and NESREA $\left(40^{\circ} \mathrm{C}\right)$ limits. The low values of temperature might be due to the processes used at the time of sampling. High temperature brings down the solubility of gases in water that ultimately expresses as high BOD and COD. Statistical analysis shows that there is no significant difference $(p<0.05)$ between the mean values of temperature among the industries. This might be due to similar tannery activities involved in the tannery industries at the time of sampling. The average values of temperature observed in this present study are less than those observed by Akan et al. (2007), Akan et al. (2009) and Baba et al. (2020).

The mean level of $\mathrm{pH}$ observed in TAN1, TAN2 and TAN3, samples were $7.77 \pm 2.93$; $8.35 \pm 0.28$ and $7.52 \pm 0.76$ respectively. The order of the mean $\mathrm{pH}$ of the samples from the three industries can be arranged as TAN2> TAN1 $>$ TAN3. The $\mathrm{pH}$ of the samples falls within the WHO (7.0-8.5) and NESREA (6-9) standard limits. Statistical analysis shows that there is no significant difference $(p<0.05)$ between the mean values of $\mathrm{pH}$ among the industries. This might be due to similar tannery activities involved in the tannery industries at the time of sampling. Maheshwari et al. (2017) reported that the level of $\mathrm{pH}$ in the effluents from the tannery industry in Vaniyambadi, India was 6.5 which was lower than that observed in the present study. The $\mathrm{pH}$ in the effluents from the tannery industries in Kano and Kaduna were reported to be 7.64 and 6.89, respectively (Akan et al., 2007; Mohammed et al., 2017). The average values of $\mathrm{pH}$ observed in this present study are less than those observed by Mohammed et al. (2017) and Baba et al. (2020). The mean level of SS $(\mathrm{mg} / \mathrm{l})$ observed in TAN1, TAN2, and TAN3 samples were 374 \pm 124 ; $358 \pm 335$ and $780 \pm 739$ respectively. The order of the mean SS in the samples from the three industries can be arranged as TAN3 > TAN1 $>$ TAN2. 
The SS observed in the samples were far above the recommended standard limits of regulating bodies WHO $(30 \mathrm{mg} / \mathrm{l})$ and NESREA $(10 \mathrm{mg} / \mathrm{l})$. Statistical analysis shows that there is no significant difference $(p<0.05)$ between the mean values of SS among the industries. This might be due to similar tannery activities involved in the tannery industries at the time of sampling. The average values of SS observed in this present study are less than that observed $(3700 \pm 122 \mathrm{mg} / \mathrm{l})$ by Akan et al. (2009) for tanneries in Kano. Also, the average values of SS observed in this present study are less than that observed by Mohammed et al. (2017) and Baba et al. (2020) with the exception in TAN3.

The mean level of TDS (mg/l) observed in TAN1, TAN2, and TAN3 samples were $3941 \pm 3703$; $3300 \pm 1714$ and $2653 \pm 1240$ respectively. The order of the mean TDS in the samples from the three industries can be arranged as TAN1>TAN2>TAN3. The TDS observed in the samples were far above the recommended standard limits of WHO $(250 \mathrm{mg} / \mathrm{l})$ and NESREA $(500 \mathrm{mg} / \mathrm{l})$. Statistical analysis shows that there is no significant difference $(p<0.05)$ between the mean values of TDS among the industries. This might be due to similar tannery activities involved in the tannery industries at the time of sampling. TDS in the effluents from the tannery industries in Kano, Nigeria was reported to be $1281 \mathrm{mg} / \mathrm{l}$ (Akan et al., 2007). The average values of SS observed in this present study are less than those observed by Mohammed et al. (2017) and Baba et al. 2020)

The mean level of COD (mg/l) observed in TAN1, TAN2 and TAN3 samples seasons were $2372 \pm 938 ; \quad 1406 \pm 208$ and $3532 \pm 1373$ respectively. The order of the mean COD of the samples from the three industries can be arranged as TAN3>TAN1> TAN2. The COD observed in TAN1, TAN2 and TAN3 samples were far above the recommended standard limits of regulating bodies $\mathrm{WHO}(40 \mathrm{mg} / \mathrm{l})$ and NESREA (40 mg/l). Statistical analysis shows that there is no significant difference $(p<0.05)$ in COD among the industries. This might be due to similar tannery activities involved in the tannery industries as at the time of sampling. The Chemical Oxygen demand (COD) is the amount of oxygen, in $\mathrm{mg} / \mathrm{L}$, required for the degradation of the compound of wastewater to occur. In comparison, the average values of COD observed in this present study were higher than that observed by Mohammed et al. (2017) but lower than that observed by Baba et al. (2020).

The mean levels of BOD $(\mathrm{mg} / \mathrm{l})$ observed in TAN1, TAN2 and TAN3 samples were $13.85 \pm 6.42 ; \quad 19.46 \pm 0.50$ and $17.13 \pm 3.14$ respectively. The order of the mean BOD in the samples from the three industries can be arranged as TAN2>TAN3>TAN1. The BOD observed in TAN1, TAN2 and TAN3 samples were found below the recommended limits of NESREA (200 mg/l) but above WHO (10 mg/l). Statistical analysis shows that there is no significant difference $(p<0.05)$ between the mean values of BOD among the industries. This might be due to similar tannery activities involved in the tannery industries at the time of sampling. The low level of BOD recorded in this study is an indication of the low level of biodegradable organic solids in the effluent. The average values of BOD observed in this present study were lower than those observed by Mohammed et al. (2017) and Baba et al. (2020).

Table 1: Mean Values \pm S.D of Physico-chemical parameters of effluents from the Tannery Industries before Treatment.

\begin{tabular}{llllllll}
\hline Parameter & Tannery 1 & Tannery 2 & Tannery 3 & $\mathrm{a}$ & $\mathrm{b}$ & $\mathrm{c}$ & $\mathrm{d}$ \\
\cline { 2 - 7 } Temperature $\left({ }^{\circ} \mathrm{C}\right)$ & $28.07 \mathrm{a} \pm 0.65$ & $27.77 \mathrm{a} \pm 0.64$ & $26.38 \mathrm{a} \pm 3.81$ & & $29.50 \pm 4.68$ & 35 & 40 \\
pH & $7.77 \mathrm{a} \pm 2.93$ & $8.35 \mathrm{a} \pm 0.28$ & $7.52 \mathrm{a} \pm 0.76$ & 6.89 & $5.35 \pm 1.57$ & $7.0-8.5$ & $6.0-9.0$ \\
$\mathrm{COD}(\mathrm{mg} / \mathrm{l})$ & $2372 \mathrm{a} \pm 938$ & $1406 \mathrm{a} \pm 208$ & $3532 \mathrm{a} \pm 1373$ & 2.2 & $3106 \pm 2753$ & 40 & 40 \\
$\mathrm{BOD}(\mathrm{mg} / \mathrm{l})$ & $13.85 \mathrm{a} \pm 6.42$ & $19.46 \mathrm{a} \pm 0.50$ & $17.13 \mathrm{a} \pm 3.14$ & 1032 & $26.17 \pm 9.49$ & 10 & 200 \\
$\mathrm{SS}(\mathrm{mg} / \mathrm{l})$ & $374 \mathrm{a} \pm 124$ & $358 \mathrm{a} \pm 335$ & $780 \mathrm{a} \pm 739$ & 501 & $562 \pm 482$ & 30 & 10 \\
TDS $(\mathrm{mg} / \mathrm{l})$ & $3941 \mathrm{a} \pm 3703$ & $3300 \mathrm{a} \pm 1714$ & $2653 \mathrm{a} \pm 1240$ & 532.7 & $444 \pm 507$ & 250 & 500 \\
\hline
\end{tabular}

The values given in the table above are means of 6 replicate values, $\mathrm{n}=6$ ( 1 sample was taken monthly for 6 months). Within the rows, means with different alphabets are statistically different $(p<0.05)$. WHO: World Health Organisation. NESREA: National Environmental Standard and Regulatory Enforcement Agency. a = Mohammed et al.(2017), b = Baba et al. (2020), c = WHO (2006), $d=$ NESSRA (2009) 
BAJOPAS Volume 13 Number 2, December, 2020

Identification, Biochemical Characterization and growth rates of the Bacterial Isolates

Results of identification and biochemical characterization of the bacterial isolates were shown in table 2. After 24 hours of incubation, the nutrient agar media plates were checked for bacterial growth. The results showed the presence of different strains in the samples. The TAN1 bacteria isolate was found to be gramnegative cocci while TAN3 was gram-positive cocci. TAN2 bacteria isolate was found to be gram-positive, rod-shaped. TAN1, TAN2, and TAN3 bacteria isolates recorded positive results for spore former.

The results of the biochemical tests indicated that all the bacteria were positive for catalase, oxidase, citrate, maltose, glucose, lactose (negative in TAN1), mannitol (negative in TAN2), starch hydrolysis and coagulase (negative in TAN2) tests. The bacteria showed negative results for nitrate reduction, $M R$ (positive in TAN2), VP (positive in TAN1), Indole (positive in TAN2) tests. Base on the morphological and biochemical test results, TAN1, TAN2, and TAN3 bacteria isolates were identified to be Nesseria spp, Bacillus cereus, and Staphylococcus aureus respectively.

The growth rate of the TAN1, TAN2 and TAN3 Isolates were shown in figure 2. Generally, the optical density increase with the increase in time (day) and decrease as time goes on. The highest optical density was shown by bacillus cereus in TAN2 while the lowest was shown by Staphylococcus aureus in TAN3.

The initial growth phase of TAN1 Isolate bacteria occurred within 2-day of incubation as the growth rate increases up to the 6th-day incubation when the maximum growth was observed. Beyond the 6th day, the growth of the bacteria declined (which might be due to a shortage of nutrients in the effluents) until it reached its death phase (which might be due to the unavailability of nutrients in the effluents).

A similar trend of growth was also observed for TAN2 Isolate as the initial growth phase also occurred within 2-day of incubation but maximum growth rate observed on the 4th day of incubation. The stationary stage occurred between the 4th day and the 8th day. Beyond the 8th day, the growth of the bacteria declined (which might be due to a shortage of nutrients in the effluents) until it reached its death phase (which might be due to the unavailability of nutrients in the effluents).

The initial growth phase of TAN3 bacterial Isolate occurred within the 3-day incubation as the growth rate increases up to the 6th-day incubation when the maximum growth was observed. Beyond the 6th day, the growth of the bacteria declined (which might be due to a shortage of nutrients in the effluents) until it reached its death phase (which might be due to the unavailability of nutrients in the effluents).

Table 2: Morphological and Biochemical characteristics of bacterial isolates

\begin{tabular}{lllll} 
Bacterial Isolates & & TAN1 & TAN2 & TAN3 \\
\hline $\begin{array}{lllll}\text { Morphological } \\
\text { characteristics }\end{array}$ & Shape & Cocci & Rod & Cocci \\
& Spore & & & \\
& former & + & + & + \\
Gram & & & \\
Biochemical characteristics & reaction & - & + & + \\
& Citrate & + & + & + \\
& Catalase & + & + & + \\
& Coagulase & + & - & + \\
Starch & + & + & + \\
& Glucose & + & + & + \\
Oxidase & + & + & + \\
& Indo & - & + & - \\
Lactose & - & + & + \\
Manitol & + & - & + \\
Maltose & + & + & + \\
MR & - & + & - \\
VP & + & - & - \\
& Nitrate & - & - & - \\
Reduction & - Neisseria & Bacillus & Staphylococcus \\
& Bacterial & cereus & aureus \\
& name & spp & cas
\end{tabular}

+ = Positive; - = Negative; MR=Methyl Red; VP= Voges-Proskauer 


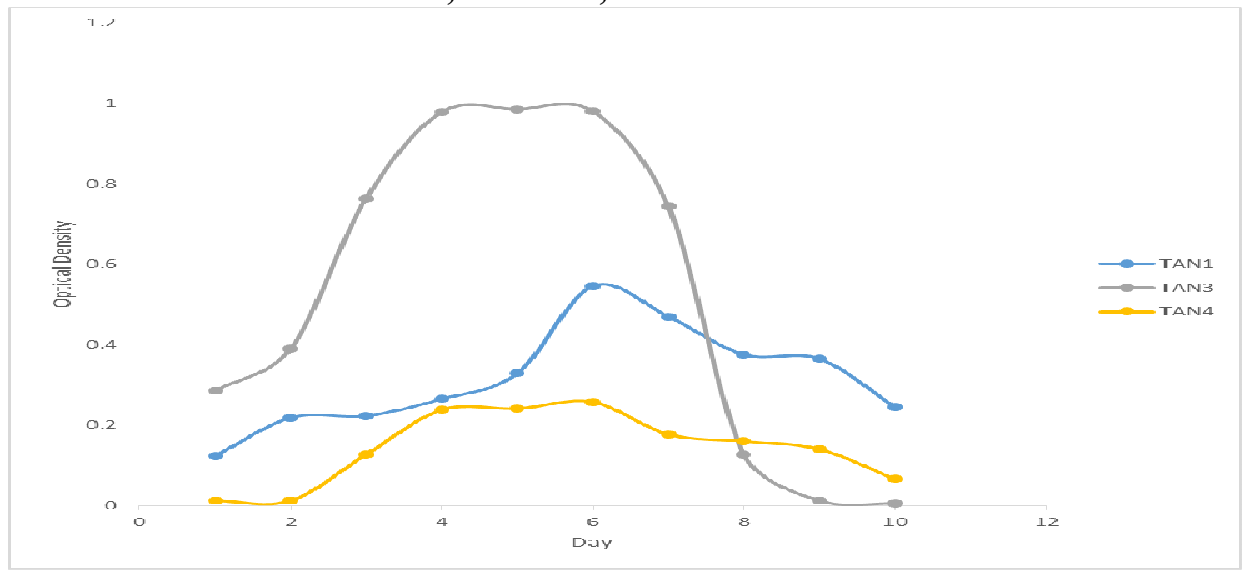

Fig. 2 Growth rates of the isolates in the effluents from the Tannery Industries

\section{Physico-chemical Parameters in the Industrial Effluents after the biodegradation.}

Table 3 shows the mean results of the physicochemical parameter before and after bioremediation using the different masses $(5 \mathrm{~g}$, $10 \mathrm{~g}, 15 \mathrm{~g}, 20 \mathrm{~g}$, and $25 \mathrm{~g}$ ) of the respective immobilized bacteria. Also, Table 4 shows the mean results of correlation coefficient ( $r$ ) between different masses of bacteria and physicochemical parameters.

The mean values $(\mathrm{mg} / \mathrm{l})$ of the SS after the bioremediation varies between $243 \pm 45$ and $898 \pm 672$. The mean concentration $(\mathrm{mg} / \mathrm{l})$ of SS remediated by the different masses $(5 \mathrm{~g}, 10 \mathrm{~g}$, $15 \mathrm{~g}, 20 \mathrm{~g}$, and $25 \mathrm{~g}$ ) of the bacteria varies. The SS in the samples fluctuates up and down after the bioremediation process when compared with the SS of the raw samples before the bioremediation. The increase in the levels of the SS might be due to the aggregation of the TDS which are large enough to result into SS. The increase in the levels of the SS might be also due to the influence of the nutrients which was added into the effluents in order to make the microorganisms more active and viable for fast degradation of organic contaminants in the effluent. The relative potential or efficiency of the different masses of the bacteria in remediating SS in TAN1 samples was in the order $25 \mathrm{~g}>20 \mathrm{~g}>15 \mathrm{~g}>10 \mathrm{~g}>5 \mathrm{~g}$. For TAN2 and TAN3 samples, the order was $25 \mathrm{~g}>20 \mathrm{~g}>15$ $\mathrm{g}>10 \mathrm{~g}>5 \mathrm{~g}$. These might be due to the variations in the surface areas of the different masses of the immobilized bacteria. Statistical analysis shows that there is no significant difference $(p<0.05)$ between the mean values of SS among the masses in the respective industries. Positive and significant correlations exist between the masses of bacteria and Suspended Solid (SS). This showed that there is general increase in the levels of the SS as the masses of the immobilized bacteria increases. TAN3 (90\%) and TAN1 (80\%) showed a very high correlation with the masses of the bacteria while TAN2 (61\%) showed a very low correlation.

The mean values $(\mathrm{mg} / \mathrm{l})$ of the TDS after the bioremediation varies between $46 \pm 11$ and $83 \pm 78$. The mean concentration $(\mathrm{mg} / \mathrm{l})$ of TDS remediated by the different masses $(5 \mathrm{~g}, 10 \mathrm{~g}$, $15 \mathrm{~g}, 20 \mathrm{~g}$, and $25 \mathrm{~g}$ ) of the bacteria varies. There is a reduction in all the TDS of all the samples after the bioremediation process compared with the TDS of the raw samples before the bioremediation. The relative potential or efficiency of the different masses of the bacteria in remediating TDS in TAN1 and TAN3 samples was in the order $5 \mathrm{~g}>10 \mathrm{~g}>15 \mathrm{~g}>20$ $\mathrm{g}>25 \mathrm{~g}$. For TAN2 samples, the order was 20 $g>10 \quad g>25 \quad g>15 \quad g>5 \quad g$. Statistical analysis shows that there is no significant difference $(p<0.05)$ between the mean values of TDS among the masses in the respective industries. These might be due to the variations in the surface areas of the different masses of the immobilized bacteria. Positive and significant correlations exist between the masses of bacteria and TDS with the exception in TAN2 (negative and insignificant correlation). The positive correlations showed that there is general increase in the levels of the TDS as the masses of the immobilized bacteria increases. TAN1 $(96 \%)$ showed a very high correlation with the masses of the bacteria while TAN2 (47\%) showed a very low correlation.

The mean values $(\mathrm{mg} / \mathrm{l})$ of the BOD after the bioremediation varies between $1.56 \pm 0.20 \mathrm{mg} / \mathrm{l}$ and $6.92 \pm 5.49 \mathrm{mg} / \mathrm{l}$. The mean concentration $(\mathrm{mg} / \mathrm{l})$ of BOD remediated by the different masses $(5 \mathrm{~g}, 10 \mathrm{~g}, 15 \mathrm{~g}, 20 \mathrm{~g}$, and $25 \mathrm{~g}$ ) of the bacteria varies. There is a reduction in all the BOD of all the samples after the bioremediation process compared with the $\mathrm{BOD}$ of the raw 
BAJOPAS Volume 13 Number 2, December, 2020 samples before the bioremediation. The relative potential or efficiency of the different masses of the bacteria in remediating BOD in TAN1, TAN2 and TAN3 samples were in the order $25 \mathrm{~g}>20$ $\mathrm{g}>15 \mathrm{~g}>10 \mathrm{~g}>5 \mathrm{~g}, 25 \mathrm{~g}>15 \mathrm{~g}>5 \mathrm{~g}>10 \mathrm{~g}>20 \mathrm{~g}$ and $20 \mathrm{~g}>10 \mathrm{~g}>25 \mathrm{~g}>15 \mathrm{~g}>5 \mathrm{~g}$ respectively. Statistical analysis shows that there is significant difference $(p<0.05)$ between the mean values of BOD among the masses in the respective industries. These might be due to the variations in the surface areas of the different masses of the immobilized bacteria. Negative and significant correlations exist between the masses of bacteria and BOD. This showed that there is general decrease in the levels of the BOD as the masses of the immobilized bacteria increases. TAN1 (94\%) showed a very high correlation with the masses of the bacteria while TAN2 (4\%) showed a very low correlation.

The mean values $(\mathrm{mg} / \mathrm{l})$ of the COD after the bioremediation varies between $250 \pm 154$ and $3134 \pm 1595$. The mean concentration $(\mathrm{mg} / \mathrm{l})$ of COD remediated by the different masses $(5 \mathrm{~g}$, $10 \mathrm{~g}, 15 \mathrm{~g} 20 \mathrm{~g}$, and $25 \mathrm{~g}$ ) of the bacteria varies. There is a reduction in all the COD of all the samples after the bioremediation process compared with the COD of the raw samples before the bioremediation. The relative potential or efficiency of the different masses of the bacteria in remediating COD in TAN1, TAN2 and TAN3 samples were in the order $25 \mathrm{~g}>20 \mathrm{~g}>15$ $\mathrm{g}>5 \mathrm{~g}>10 \mathrm{~g}, 25 \mathrm{~g}>20 \mathrm{~g}>15 \mathrm{~g}>10 \mathrm{~g}>5 \mathrm{~g}$ and 10 g>5 g>25 g>15 g>20 g respectively. Statistical analysis shows that there were significant difference $(p<0.05)$ between the mean values of COD among the masses in the respective industries except for effluents treated with $25 \mathrm{~g}$. These might be due to the variations in the surface areas of the different masses of the immobilized bacteria. Negative and insignificant correlations exist between the masses of bacteria and COD with the exception in TAN3 (positive and significant correlation). The negative correlations showed that there is general decrease in the levels of the COD as the masses of the immobilized bacteria increases. TAN2 (100\%) showed a very high correlation with the masses of the bacteria while TAN3 (36\%) showed a very low correlation.

Generally, there was an overall decrease in the concentration of these physicochemical parameters after the bioremediation using the different masses of the bacterial isolates. These might be due to the variations in the surface areas of the different masses of the immobilized bacteria. This is in line with the work of Jimoh et al. (2018) and Baba et al. (2020).

Table 3: Mean Values $(\mathrm{mg} / \mathrm{l}) \pm$ S.D of Physicochemical parameters in effluents from the Tannery Industries before and after Treatment of the effluents $(250 \mathrm{ml})$ with the different masses $(5 \mathrm{~g}, 10 \mathrm{~g}$, $15 \mathrm{~g}, 20 \mathrm{~g}$, and $25 \mathrm{~g}$ ) of the bacteria.

\begin{tabular}{llllllll}
\hline $\mathrm{P}$ & IND & Before & \multicolumn{5}{c}{ After } \\
\cline { 4 - 7 } & & & $5 \mathrm{~g}$ & $10 \mathrm{~g}$ & $15 \mathrm{~g}$ & $20 \mathrm{~g}$ & $25 \mathrm{~g}$ \\
\hline \multirow{2}{*}{ COD } & TAN1 & $2372 \pm 938$ & $1708 \mathrm{a} \pm 861$ & $2045 \mathrm{a} \pm 1205$ & $845 \mathrm{a} \pm 369$ & $300 \mathrm{a} \pm 167$ & $250 \mathrm{a} \pm 154$ \\
& TAN2 & $1406 \pm 208$ & $1195 \mathrm{a} \pm 208$ & $1125 \mathrm{a} \pm 384$ & $1055 \mathrm{a} \pm 317$ & $956 \mathrm{a} \pm 310$ & $870 \mathrm{ab} \pm 240$ \\
& TAN3 & $3532 \pm 1373$ & $2374 \mathrm{a} \pm 1344$ & $1976 \mathrm{a} \pm 1405$ & $2757 \mathrm{a} \pm 1266$ & $3134 \mathrm{a} \pm 1595$ & $2614 \mathrm{~b} \pm 1105$ \\
BOD & TAN1 & $13.85 \pm 6.42$ & $6.92 \mathrm{a} \pm 5.49$ & $6.42 \mathrm{a} \pm 5.07$ & $5.72 \mathrm{a} \pm 5.35$ & $4.62 \mathrm{a} \pm 4.37$ & $2.82 \mathrm{ab} \pm 1.26$ \\
& TAN2 & $19.46 \pm 0.50$ & $1.75 \mathrm{~b} \pm 0.22$ & $1.73 \mathrm{~b} \pm 0.18$ & $1.58 \mathrm{a} \pm 0.16$ & $1.91 \mathrm{a} \pm 0.22$ & $1.56 \mathrm{~b} \pm 0.20$ \\
& TAN3 & $17.13 \pm 3.14$ & $4.24 \mathrm{ab} \pm 0.77$ & $3.29 \mathrm{ab} \pm 0.37$ & $4.11 \mathrm{a} \pm 0.07$ & $3.23 \mathrm{a} \pm 0.91$ & $3.33 \mathrm{a} \pm 1.28$ \\
SS & TAN1 & $374 \pm 124$ & $243 \mathrm{a} \pm 45$ & $471 \mathrm{a} \pm 226$ & $475 \mathrm{a} \pm 182$ & $492 \mathrm{a} \pm 128$ & $611 \mathrm{a} \pm 217$ \\
& TAN2 & $358 \pm 335$ & $460 \mathrm{a} \pm 400$ & $543 \mathrm{a} \pm 414$ & $544 \mathrm{a} \pm 402$ & $551 \mathrm{a} \pm 414$ & $554 \mathrm{a} \pm 405$ \\
& TAN3 & $780 \pm 739$ & $586 \mathrm{a} \pm 594$ & $758 \mathrm{a} \pm 656$ & $787 \mathrm{a} \pm 676$ & $861 \mathrm{a} \pm 635$ & $898 \mathrm{a} \pm 672$ \\
TDS & TAN1 & $3941 \pm 3703$ & $51 \mathrm{a} \pm 10$ & $53 \mathrm{a} \pm 10$ & $55 \mathrm{a} \pm 15$ & $61 \mathrm{a} \pm 20$ & $63 \mathrm{a} \pm 26$ \\
& TAN2 & $3300 \pm 1714$ & $83 \mathrm{a} \pm 78$ & $47 \mathrm{a} \pm 20$ & $48 \mathrm{a} \pm 22$ & $47 \mathrm{a} \pm 17$ & $48 \mathrm{a} \pm 17$ \\
& TAN3 & $2653 \pm 1240$ & $46 \mathrm{a} \pm 11$ & $55 \mathrm{a} \pm 24$ & $55 \mathrm{a} \pm 25$ & $58 \mathrm{a} \pm 23$ & $61 \mathrm{a} \pm 28$ \\
\hline
\end{tabular}

Replicate $=6$ (months)

Within the rows, for the same parameter, means with different alphabets are statistically different $(p<0.05)$.

$\mathrm{P}=$ parameter, IND = Industries 
BAJOPAS Volume 13 Number 2, December, 2020

Table 4: Correlation coefficient $(r)$ between different masses of the bacteria and the physicochemical parameters.

\begin{tabular}{llll}
\hline Industries & Parameter & Correlation coefficient $(r)$ & $\begin{array}{l}\text { Percent dependence (rxrx100) } \\
(\%)\end{array}$ \\
\hline TAN1 & COD & -0.9 & 82 \\
& BOD & -0.97 & 94 \\
& SS & $0.90^{*}$ & 80 \\
TAN2 & TDS & $0.98^{*}$ & 96 \\
& COD & -1 & 100 \\
& BOD & -0.21 & 4 \\
& SS & $0.78^{*}$ & 61 \\
& TDS & -0.69 & 47 \\
& COD & $0.60^{*}$ & 36 \\
& BOD & -0.6 & 37 \\
& SS & $0.95^{*}$ & 90 \\
& TDS & $0.94^{*}$ & 89 \\
\hline
\end{tabular}

The correlation coefficient $(r)$ with * is statistically significant $(p<0.05)$.

Percentage reduction of the Parameters

Table 5 shows the percentage reduction of Parameters in industrial samples before and after the treatment of the effluents $(250 \mathrm{ml})$ with the different masses $(5 \mathrm{~g}, 10 \mathrm{~g}, 15 \mathrm{~g}, 20 \mathrm{~g}$, and $25 \mathrm{~g}$ ) of the Immobilized Bacteria.

In TAN1 samples, the percentage reduction (\%) of COD ranged (14-89); BOD (50-80); SS (-32$35)$ and TDS (98-99). In TAN2 samples, the percentage decrease $(\%)$ of COD ranged (15$38) ;$ BOD (90-92); SS [-28-(-55)] and TDS (9798). In TAN3 samples, the percentage decrease (\%) of COD ranged (11-44); BOD (76-81); SS (15-25) and TDS (98). The percentage increase in the levels COD, BOD and TDS might be due to the increase in the surface area of the different masses of the immobilized bacteria. However, the percentage decrease in the levels of the SS might be due to the aggregation of the TDS which are large enough to result into SS. The percentage decrease in the levels of the SS might be also due to the influence of the nutrients which was added into the effluents in order to make the microorganisms more active and viable for fast degradation of organic contaminants in the effluent. This is in line with the work of Jimoh et al. (2018) in which the concentration of the SS increase after the bioremediation of effluents.

Sreemoyee and Priti (2013) assessed and reduced several Physico-chemical parameters of dairy wastewater using Niesseria $s p$. and concluded that the species are well known to degrade organic compounds. This is in agreement with the current study in which the immobilized Niesseria $s p$ degrade the organic contaminants as indicated by the BOD, COD and TDS.

Jimoh et al. (2018) observed that TSS of the effluents was increased after treatment with immobilized bacteria and concluded that it might be due to the biostimulation method adopted for the research.

The optimum $\mathrm{pH}$ Biosorption of Chromium by Bacillus spp and Staphylococcus spp. from tannery effluent was investigated by Mythili and Karthikeyan (2011). The maximum adsorption of Chromium $(86.4 \mathrm{mg} / \mathrm{L})$ was showed by Bacillus spp and Staphylococcus spp showed $70.6 \mathrm{mg} / \mathrm{L}$ at an initial concentration of $100 \mathrm{mg} / \mathrm{L}$. In the present study, immobilised Bacillus spp and Staphylococcus spp. from the tannery industrial effluents reduced the levels of the organic pollutants with high potential as indicated by the percentage reduction of BOD, COD and TDS.

Enzymes often can work in multiple environments especially if they are immobilized. This makes the microorganisms' enzymes even more resistant to harsh environments and enables the enzymes to be recovered and recycled after they are no longer needed (Gianfreda and Rao 2004). Ramesh and Singh (1993) reported that the immobilized bacteria having more efficiency to remove the suspended particles than free cells. Using the immobilized cell is preferable due to its capability for using several times with the same efficiency, which makes it more economical. Similar work was done by Sikander et al. (2007) showing the higher reduction with permeabilized cells of Ochrobactrum intermedium strain SDCr-5. 
BAJOPAS Volume 13 Number 2, December, 2020

The results revealed the isolation and identification of isolates with the potential for the reduction of $\mathrm{Cr}$ (VI) to $\mathrm{Cr}$ (III). Results indicated that immobilized $B$. cereus could be efficiently used for the reduction of $\mathrm{Cr}$ (VI).

Table 5: Percentage reduction of the tested Parameters from the tannery industrial samples of the Immobilized Bacteria.

\begin{tabular}{lllllll}
\hline \multirow{2}{*}{ Industries } & & \multicolumn{5}{c}{ Percentage Reduction $(\%)$} \\
\cline { 3 - 7 } & & $5 \mathrm{~g}$ & $10 \mathrm{~g}$ & $15 \mathrm{~g}$ & $20 \mathrm{~g}$ & $25 \mathrm{~g}$ \\
\hline TAN1 & COD & 28 & 14 & 64 & 87 & 89 \\
& BOD & 50 & 54 & 59 & 67 & 80 \\
& SS & 35 & -26 & -27 & -32 & -63 \\
& TDS & 99 & 99 & 99 & 98 & 98 \\
TAN2 & COD & 15 & 20 & 25 & 32 & 38 \\
& BOD & 91 & 91 & 92 & 90 & 92 \\
& SS & -28 & -52 & -52 & -54 & -55 \\
& TDS & 97 & 99 & 99 & 99 & 99 \\
& COD & 33 & 44 & 22 & 11 & 26 \\
& BOD & 75 & 81 & 76 & 81 & 81 \\
& SS & 25 & 3 & -1 & -10 & -15 \\
& TDS & 98 & 98 & 98 & 98 & 98 \\
\hline
\end{tabular}

Percentage Reduction $=(B-A) / B \times 100 \%$

$A=$ Concentration of the parameter after treatment

$\mathrm{B}=$ Concentration of the parameter before treatment

$+=$ percentage decrease

- = percentage increase

In general, immobilization makes the enzyme more resistant to temperature, $\mathrm{pH}$, and substrate concentration swings giving it a longer lifetime and higher productivity per active unit (Gianfreda and Rao, 2004; FuIlbrook, 1996; Russell et al, 2003; Kandelbauer et al., 2004). Immobilized cells have been used and studied extensively for the production of useful chemicals (Ohtake and Silver, 1994), the treatment of wastewaters (Chen et al., 2003; Wang et al., 2010). Although many workers described microbial degradation of tannery effluent, limited literature is available on the bioremediation of tannery effluent using immobilized bacterial cells in the Kano Industrial Estates.

\section{CONCLUSION}

The samples contained variable levels of the physicochemical parameters. The results of the Analysis of variance revealed that, no statistical difference $(p<0.05)$ was observed for the temperature, $\mathrm{pH}, \mathrm{SS}, \mathrm{TDS}, \mathrm{BOD}$ and $\mathrm{COD}$ among the three tannery industries before the treatment. The levels of some of the parameters
(SS, TDS and COD) observed in the samples were found above the recommended limits of WHO and NESREA, which called for the treatment of the effluents before discharge into the environment. Base on the morphological and biochemical test results, TAN1, TAN2, and TAN3 bacterial isolates were identified to be Neisseria spp, Bacillus cereus, and Staphylococcus aureus respectively. The results of Post-treatment analysis showed that there is overall decrease in the levels of the parameters determined when compared with that of the pre-treatment. The overall percentage reduction of the immobilised bacteria in the treatment of the respective effluents was in the order TAN2 (72\%)>TAN1 $(70 \%)>$ TAN3 $(62 \%)$. Hence, the immobilized bacteria are having higher biodegradation potential for the treatment of the tannery effluents.

\section{Acknowledgments}

The authors wish to acknowledge the University of Maiduguri for the financial support. The authors are grateful to the Kano State Ministry of Environment for their support in obtaining the effluent samples. 


\section{REFERENCES}

Ajao, A. T., Adebayo, G. B., and Yakubu, S. E. (2011). Bioremediation of textile industrial effluent using mixed culture of Pseudomonas aeruginosa and Bacillus subtilis immobilized on agar-agar in a bioreactor. J. Microbiol. Biotech. Res, 1(3), 50-56.

Akan, J. C., Moses, E. A., Ogugbuaja, V. O., and Abah, J. (2007). Assessment of tannery industrial effluents from Kano metropolis, Kano State, Nigeria. Journal of Applied Sciences, 7(19), 2788-2793.

Akan, J. C., Ogugbuaja, V. O., Abdulrahman, F. I., and Ayodele, J. T. (2009). Pollutant levels in effluent samples from tanneries and textiles of Kano industrial areas, Nigeria. Global journal of pure and applied sciences, 15(3-4).

APHA (1989). Standard methods for Examination of Will bete and Will betewater.15 $5^{\text {th }}$ edition. Brydpass Springfield Will behington DC. pp. 164-176

APHA (1992). Standard Methods for the Examination of Water and Wastewater. Health, 69, 1116-9.

Baba, A., Garba, S. T., and Bello, H. S. (2020). Bioremediation Potential of Immobilized corynebacterium kutsceri in the Treatment of Tannery Industrial Effluent from Challawa Industrial Estate, Kano State, Nigeria. Journal of the Turkish Chemical Society Section A: Chemistry, $7(2), 335-350$.

Beem, E. I. V. (1994). reduction of solvent VOC emission. J. Oil Col. Chem. Ass, 77, 158.

Bouwer, E. J., and Zehnder, A. J. (1993). Bioremediation of organic compoundsputting microbial metabolism to work. Trends in biotechnology, 11(8), 360367.

Chen, K. C., Wu, J. Y., Liou, D. J., and Hwang, S. C. J. (2003). Decolorization of the textile dyes by newly isolated bacterial strains. Journal of Biotechnology, 101(1), 57-68.

Dan'Azumi, S., and Bichi, M. H. (2010). INDUSTRIAL POLLUTION AND HEAVY METALS PROFILE OF CHALLAWA RIVER IN KANO, NIGERIA. Journal of Applied Sciences in Environmental Sanitation, $5(1)$.

DWAF. (1992). Analytical Methods Manual, TR 151. Department of Water Affairs and Forestry, Pretoria.

El-Bestawy, E. (2013). Biological treatment of leather-tanning industrial wastewater using free living bacteria.
Elsheikh, M. A. S. (2009). Tannery wastewater pre-treatment. Water Science and Technology, 60(2), 433-440.

FuIlbrook, P. D. (1996). "Kinetics." Industrial enzymology: The application of enzymes in Industry. 2nd Ed. T. Godfrey and J Reichelt. eds.. Nature. New York.

Gianfreda, L., and Rao, M. A. (2004). Potential of extra cellular enzymes in remediation of polluted soils: a review. Enzyme and microbial technology, 35(4), 339354.

Hugo Springer. (1994). John Arthur Wilson Memorial Lecture "Treatment of Industrial Wastes of the Leather Industry - is it still a Major Problem". JALCA, 89, 153-185

Jimoh, A. A., Ganiyu, B. A., Baba, D., and Baba, A. (2018) Bioremediation Process of Effluent from Detergent and Food Industries in Jos, Nigeria: Kinetics and Thermodynamics. International Journal of Engineering Science Invention (IJESI), 762-73

Kandelbauer, A., Maute, O., Kessler, R. W., Erlacher, A., and Gübitz, G. M. (2004). Study of dye decolorization in an immobilized laccase enzyme-reactor using online spectroscopy. Biotechnology and bioengineering, 87(4), 552-563.

Kongjao, S., Damronglerd, S., and Hunsom, M. (2008). Simultaneous removal of organic and inorganic Pollutants in tannery wastewater using electrocoagulation technique. Korean Journal of chemical engineering, 25(4), 703.

Maheshwari, U. M., Aruna, S., Gomathi, M., and AbdulJaffar, A. H. (2017). Bioremediation by Free and Immobilized Bacteria Isolated from Tannery Effluent. International Journal of Research in Applied, Natural and Social Sciences. 5(7), 75-90

Margesin, R., and Schinner, F. (2001). Bioremediation (natural attenuation and biostimulation) of diesel-oilcontaminated soil in an alpine glacier skiing area. Applied and environmental microbiology, 677), 3127-3133.

Mohammed, A., Sekar, P., and George, J. (2011). Efficacy of microbes in bioremediation of tannery effluent. Inter. J. Curr. Res, 3(4), 324-326.

Mohammed, S. S. D., Orukotan, A. A., and Abdullahi, H. (2017). Physicochemical and Bacteriological Assessment of Tannery Effluent from Samaru-Zaria, 
BAJOPAS Volume 13 Number 2, December, 2020 Kaduna State, Nigeria. Journal of Applied

Sciences and Environmental Management, 21(4), 734-740.

Munz, G., De Angelis, D., Gori, R., Mori, G., Casarci, M., and Lubello, C. (2009). The role of tannins in conventional and membrane treatment of tannery wastewater. Journal of hazardous materials, 164(2-3), 733-739

Mythili, K., and Karthikeyan, B. (2011). Bioremediation of $\mathrm{Cr}$ (VI) from tannery effluent using Bacillus spp and Staphylococcus spp. International Multidisciplinary Research Journal, 1(6).

NESREA (2009). National Environmental Standards for Effluent Limitations and Regulation. 1233-1236

Noorjahan, C. M. (2014). Physicochemical characteristics, identification of bacteria and biodegradation of industrial effluent. Journal of bioremediation and Biodegradation, 5(3).

Ohtake, H. I., and Silver, A. O. (1994). Bacterial reduction of toxic chromate. Biological degradation and bioremediation of toxic chemicals, 403-415.

Omoleke, I. I. (2004). Management of environmental pollution in Ibadan, an African city: the challenges of health hazard facing government and the people. Journal of Human Ecology, 15(4), 265-275.

Rajor, A., Reddy, A.S., and Singh, B. (2004). Determination of BOD kinetic Parameters and evaluation of alternate methods, M.Sc. Thesis, Department of biotechnology \& environmental Science, Thapar Institute of Engineering and Technology, Patiala

Ramasami, T., Rajamani, S., and Rao, J. R. (1994, March). Pollution control in leather industry: Emerging technological options. In International symposium on surface and colloidal science and its relevance to soil pollution, madras.

Ramesh, J. V. S., and Singh, S. P. (1993). Yearly variation in certain physicochemical parameters of pond at eastern Doon Valley. Uttar Pradesh J. Zoo, 12 (1), 7577.

Ranen, S., and Sharadinadra, C. (2009). Biotechnology applications to environmental remediation in resource exploitation. Current science, 97, 6-25
Russell, A. J., Berberich, J. A., Drevon, G. F., and Koepsel, R. R. (2003). Biomaterials for mediation of

chemical and biological warfare agents. Annual review of biomedical engineering, 5(1), 1-27.

Saravanan, P., and Saravanan, A. (1999). Decolourization of tannery effluent by Flavobacterium sp. EK 1. Indian Journal of Environmental Protection, 19, 19-24.

Sikander, S., and Shahida, H. (2007). Reduction of toxic hexavalent chromium by Ochrobactrum intermedium strain SDCr5 stimulated by heavy metals. Bioresource Technol, 98, 340-344.

Singh, N., Sharma, B. K., and Bohra, P. C. (2000). Impact assessment of industrial effluent of arid soils by using satellite imageries. Journal of the Indian Society of Remote Sensing, 28(2-3), 79.

Sreemoyee, C., and Priti, P. (2013). Assessment of physico-chemical parameters of dairy waste water and isolation and characterization of bacterial strains in terms of cod reduction. Int J Sci, 2(3), 395-400.

Verheijen, L. A. H. M., Wiersema, D., Pol, L. H., and De Wit, J. (1996). Management of wastes from animal product processing. Livestock and environment, Finding a balance. International Agriculture Center, Wageningen, The Netherlands.

Wang, F., Yao, J., Si, Y., Chen, H., Russel, M., Chen, K., and Bramanti, E. (2010). Short-time effect of heavy metals upon microbial community activity. Journal of Hazardous Materials, 173(13), 510-516.

WHO (World Health Organization). (2006). Air quality guidelines: global update 2005: particulate matter, ozone, nitrogen dioxide, and sulfur dioxide. World Health Organization.

World Bank. (1995). Nigeria's strategic options for redressing industrial pollution. World Bank, industry and energy division. 1st edition, West Central Africa Department; Annexes: 1995; pp 60-62.

Zahoor, A., and Abdul, R. (2009). Enumeration of Coliforms. Journal of Environmental Sciences. 21, 814-820 


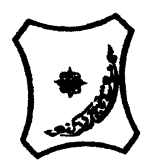

Bayero Journal of Pure and Applied Sciences, 13(2): 1 - 12

Received: November, 2020

Accepted: December, 2020

ISSN $2006-6996$

\title{
BIODEGRADATION POTENTIAL OF IMMOBILIZED BACTERIA IN THE TREATMENT OF TANNERY INDUSTRIAL EFFLUENTS FROM INDUSTRIAL ESTATES IN KANO STATE, NIGERIA
}

\author{
Abdullateef, B., ${ }^{1 *}$ Shuaibu, T. G., ${ }^{1}$ Babagana, K., ${ }^{1}$ Suleman, H. B. ${ }^{2}$ and Dauda, B. ${ }^{3}$ \\ ${ }^{1}$ Department of Pure and Applied Chemistry, Faculty of Science, University of Maiduguri, Borno State, \\ Nigeria \\ ${ }^{2}$ Department of Microbiology, Faculty of Science, University of Maiduguri, Borno State, Nigeria \\ ${ }^{3}$ Department of Chemical Engineering, Faculty of Engineering, University of Maiduguri, Borno State, \\ Nigeria \\ *Corresponding author: babslega@gmail.com; abelega2007@yahoo.com; +2348061309753
}

\section{ABSTRACT}

Industrial Effluents Samples from Gashash Tanneries (TAN1) in Bompai Industrial estate, Larabee Tannery Industry (TAN2) in Sharada Industrial estate and Z Tannery Industries (TAN3) in Challawa Industrial estate, Kano State, Nigeria were collected over a period of six months (August 2017 to January 2018) for assessing the biodegradation potentials of bacteria in the treatment of organic pollutants within the effluents. Bacteria were isolated from the effluents and immobilized on agar-agar. Different masses (5 g, $10 \mathrm{gr}, 15$ $\mathrm{g}, 20 \mathrm{~g}$, and $25 \mathrm{~g}$ ) of the bacteria were used in the treatment of $250 \mathrm{ml}$ of the effluents for ten days in a shaker incubator (Gallenkamp-OC-4364-L) at the temperature $30{ }^{\circ} \mathrm{C}$ and speed of $60 \mathrm{rpm}$. Pre-treatment analysis of the effluents for Temperature, pH, Biochemical Oxygen Demand (BOD), Chemical Oxygen Demand (COD), Suspended Solid (SS) and Total Dissolved Solids (TDS) gives the following results; temperature $\left({ }^{\circ} \mathrm{C}\right.$ )

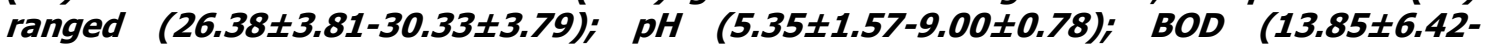
$38.75 \pm 16.20) ;$ COD (1406 $\pm 208-3532 \pm 1373) ;$ SS (208 $\pm 235-780 \pm 739)$ and TDS (266 $\pm 253-5276 \pm 2971)$. No statistical differences ( $p \leq 0.05)$ was observed for all the results among the different industries. The bacterial isolates were identified as Neisseria spp, Bacillus cereus, and Staphylococcus aureus, in TAN1, TAN2, and TAN3, respectively. After treatment of the effluent with the different masses of the isolated bacteria, the mean level of BOD was found to range as (0.55 $\pm 0.36-6.92 \pm 5.49) ; C O D$ (ND-3134 \pm 1595$)$;

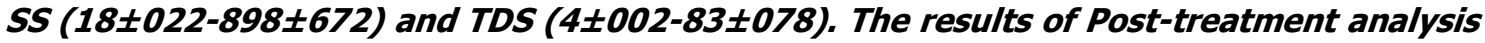
showed that there is overall decrease in the levels of the parameters determined when compared with that of the pre-treatment. The overall percentage reduction of the immobilised bacteria in the treatment of the respective effluents was in the order TAN2 (72\%)>TAN1 (70\%)>TAN3 (62\%). Hence, the immobilized bacteria are having higher biodegradation potential for the treatment of the tannery effluents.

Keywords: Biodegradation, bacteria, effluent, immobilization, tannery.

\section{INTRODUCTION}

Tannery industrial wastewater is a serious consequence of the pollution point of view for streams, freshwater, and land used for agriculture. The lack of awareness in the modern industrial practice has resulted in the discharge of tannery effluents which exhibit very high value of chromium ( $\mathrm{Cr}$ ), Sulfide, and chloride, Total Dissolved Solid (TDS), Total Suspended Solid (TSS), Biochemical Oxygen Demand (BOD) and Chemical Oxygen Demand (COD) in the water stream or land (Mohammed et al., 2001). Tanning is the process, which One ton of skin generally leads to the production of 20 to $80 \mathrm{~m}^{3}$ of turbid and foul-smelling converts the protein of the rawhide or skin into a stable material, which will not putrefy and is suitable for a wide variety of end applications (Elsheikh, 2009). The highly polluting chromium is the most commonly used tanning material producing leather that is more flexible and pliable than vegetable-tanned leather and does not discolor or lose shape in water as drastically as vegetable-tan (Elsheikh, 2009). Tannery effluent is among the most hazardous industrial pollutants due to its huge organic and inorganic load, which is highly toxic to human life and the environment (Kongjao et al., 2008). wastewater including chromium (100-400 mg/l), sulfide $(200-800 \mathrm{mg} / \mathrm{l})$, high levels of fat and 
BAJOPAS Volume 13 Number 2, December, 2020 other solid wastes, and notable pathogen contamination as well as pesticides added for skin conservation during transport (Elsheikh, 2009). There are more than 6000 tanneries in Nigeria with an annual processing capacity of 700,000 tons of hides and skins (Omoleke, 2004; Singh et al., 2008). It was reported that the total amount of waste produced per animal slaughtered is approximately $35 \%$ of its weight (World Bank, 1995). Also, for every $1000 \mathrm{~kg}$ of carcass weight, a slaughtered beef produces 5.5 $\mathrm{kg}$ of manure (excluding rumen contents or stockyard manure) and $100 \mathrm{~kg}$ of paunch manure (undigested food) (Verheijen et al., 1996). Tanneries generate wastewater in the range of 30-35 $\mathrm{L} \mathrm{kg}^{-1}$ skin/hide processed with variable $\mathrm{pH}$, Biological Oxygen Demand (BOD), Chemical Oxygen Demand (COD), high concentrations of suspended solids (SS), and tannins as well as chromium (Zahoor and Abdul, 2009).

Being heterogeneous and composed of a wide variety of compounds, it is very difficult to select a unique direct method for estimating the biodegradability of organic contents and biokinetic parameters for a wastewater sample (Rajor, 2004). For this purpose, some indirect estimation such as determination of biochemical oxygen demand (BOD) and chemical oxygen demand (COD) are applied as common laboratory investigations [9]. During retanning procedures, synthetic tannins (Syntan), oils and resins are added to form softer leather at varying doses (Munz et al., 2009). One of the refractory groups of chemicals in tannery effluents derives mainly from tannins (Ramasami et al., 2004). Syntans are characterized by complex chemical structures, because they are composed of an extended set of chemicals such as phenol-, naphthalene-, formaldehyde- and melamine-based syntans, and acrylic resins (Beem, 1994). Organic pollutants (proteic and lipidic components) are originated from skins (it is calculated that the raw skin has $30 \%$ loss of organic material during the working cycle) or they are introduced during processes (Hugo Springer, 1994).

Many conventional processes such as oxidation, chemical and biological processes were carried out to treat tanneries wastewater (Ebtesam et al, 2013). Biological processes have received more attention because of their costeffectiveness, lower sludge production and environmental friendliness (Noorjahan, 2014). Naturally occurring micro-organisms degrade the hazardous organic wastes including xenobiotic compounds, such as pesticides, polycyclic aromatic hydrocarbons (PAHs) and polychlorinated biphenyls (PCBs) in due course of time (Ranen and Sharadinadra, 2009). Bioremediation is based on the idea that all organisms remove substances from the environment to carry outgrowth and metabolism (Bouwer and Zehnder, 1993). Bacteria, protista and fungi are found to be very good at degrading complex molecules and incorporating the breakdown products into their metabolism (Bouwer and Zehnder, 1993). The resultant metabolic wastes that they produce are generally safe and somehow recycled into other organisms (Ranen and Sharadinadra, 2009). An acclimatized indigenous population of microorganisms capable of degradation of the compounds of interest must exist at the site for a successful bioremediation mode (Ranen and Sharadinadra, 2009). It has been observed that for a successful bioremediation mode, an acclimatized indigenous population of microorganisms capable of degradation of the compounds of interest must exist at the site under investigation (Ranen and Sharadinadra, 2009). Even though there are numerous physical and chemical methods employed in the disposal of wastes the advantage in using bacterium is that they play a key role in the reduction of COD, BOD, total protein, total tannin and total phenol (Saravanan and Saravanan, 1998)

Baba et al. (2020) studied the bioremediation potential of immobilized corynebacterium kutsceri in the Treatment of tannery industrial effluent from Challawa Industrial Estate, Kano State, Nigeria. The aim of the work is to study the reduction in the level of the contaminants through the process of bioremediation using the isolated bacteria. Immobilized bacteria can withstand various temperatures, $\mathrm{pH}$ and substrate concentrations; consequently, increasing the efficiency and the lifespan of the bacteria. Immobilized bacteria are widely applied in the treatment of wastewater and can be separated and recovered after the treatment with the same efficiency (Baba et al., 2020).

\section{MATERIALS AND METHODS \\ Study Area}

This study was carried out in Bompai, Sharada and Challawa industrial estates in Kano, Figure 1. Kano lies on Latitude $11^{\circ} 30^{\prime} \mathrm{N}$ and $8^{\circ} 30^{\prime} \mathrm{E}$ and Longitude $11^{\circ} 5^{\prime} \mathrm{N}$ and $8^{\circ} 5^{\prime} \mathrm{E}$ in Northern Nigeria. It is one of the developed industrial cities in Nigeria. Tannery activities are the dominating industries and this could be one of the reasons for her high population density (Dan'Azumi and Bichi, 2010). Many researchers have studied biodegradation of tannery effluent using microorganisms. However, limited literature is available on the biodegradation of tannery effluent in Kano industrial estates using 
BAJOPAS Volume 13 Number 2, December, 2020 immobilized bacterial cells. This research work focuses on the potential of the use of the indigenous immobilized bacterial isolates in the treatment of tannery effluents in the industrial estates.

\section{Sample Collection}

Effluents were collected from the Tannery Industries from Bompai, Challawa and Sharada Industrial Estates, Kano, Nigeria. The effluents were collected over a period of six months (August 2017 to January 2018). Samples collected in a sterile 4-liter plastic container with a unique identification number were preserved using an ice-box that was transported to the Microbiology Laboratory, Department of Microbiology, Bayero University of Kano for analysis

\section{Sample Preparation and Sample Analysis}

Immediately after the collection of the effluent, $\mathrm{pH}$, TSS, TDS, COD, BOD levels were determined before treatment (Pre-treatment determination) and ten days after treatment (Post-treatment determination) as described in
APHA (1989) standard methods. $\mathrm{pH}$ was determined using Ecotests $\mathrm{pH}$ meter and TDS was determined using AQUALYTIC TDS Salinometer. BOD was determined as described by the standard method (APHA, 1992). COD and SS were determined using DR/2010 HACH portable data logging spectrophotometer (DWAF, 1992)

\section{Identification and Biochemical} Characterization of the Bacterial Isolates

The bacteria were isolated from the effluents using Serial Dilution according to the method described by APHA (1989). The biochemical tests such as oxidase, catalase, coagulase, indole (from $1 \%$ tryptone broth), citrate (Simmons citrate agar), methyl red/VogesProskauer (MR/VP), nitrate reduction, Starch Hydrolysis, Glucose, Maltose, and Lactose tests were carried out on the bacterial isolates to identify the bacteria through the bacteria biochemical characteristics according to Ajao et al. (2011).

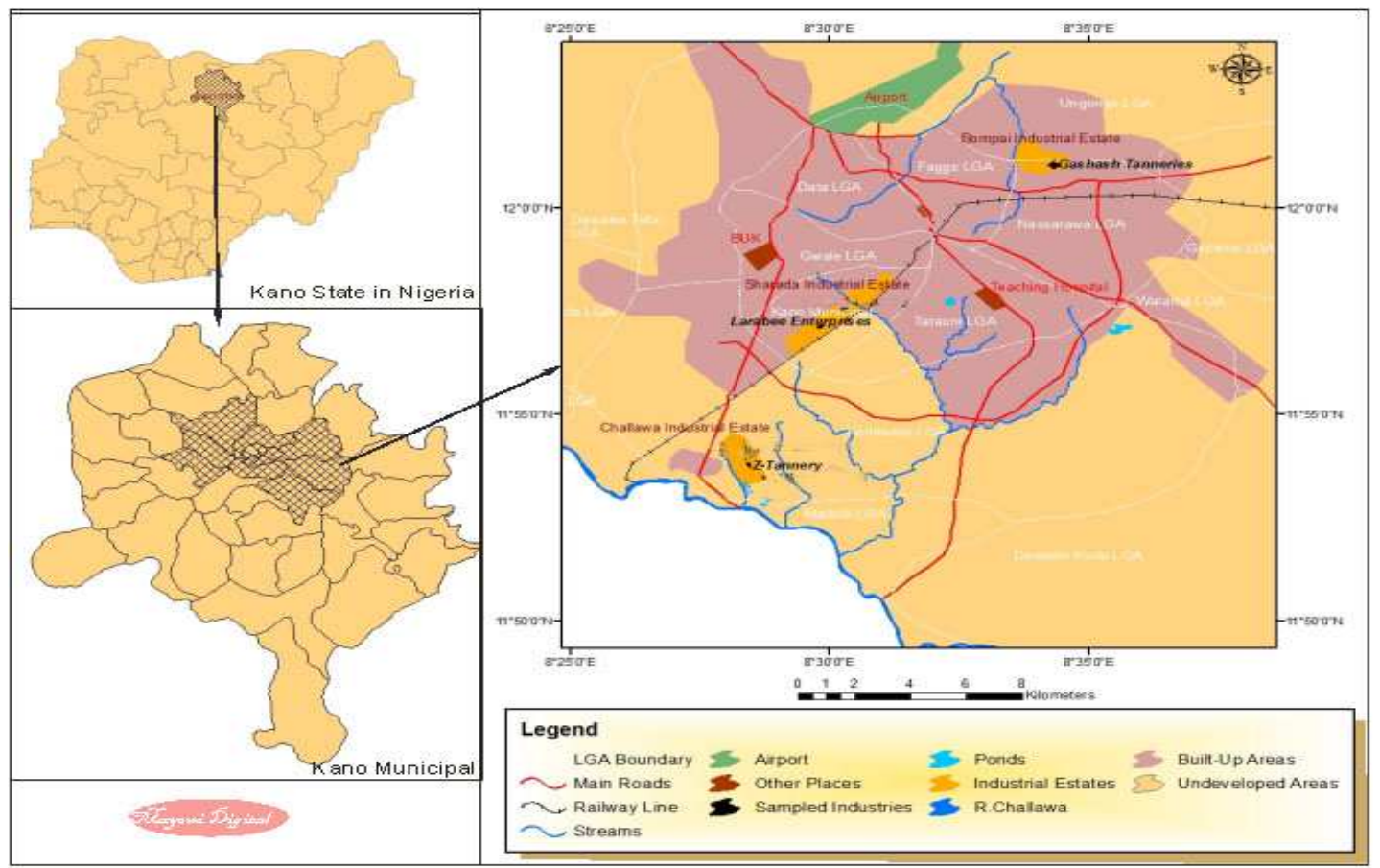

Fig. 1 Map showing the study areas

Source: Mayomi Digital Productions, GIS Laboratory, Department of Geography, UNIMAID (2017)

\section{Determination of Growth Rate of the Bacteria in Effluent Sample}

The bacteria growth rates were determined by transferring $2 \mathrm{~mL}$ of the bacterial isolates from the tannery effluent in broth medium into 100 $\mathrm{mL}$ sterile effluents in conical flasks and kept in an incubator (Giffrin cool) for 10 days. Control was also set up by incubating another $100 \mathrm{~mL}$ each of the sterile effluents without the bacteria. The optical density of the content was determined at the wavelength of $600 \mathrm{~nm}$ on a daily interval and recorded. 
BAJOPAS Volume 13 Number 2, December, 2020 Immobilization of Bacteria

Agar solution and inoculi were prepared separately. Fifty milliliters $(50 \mathrm{~mL})$ of nutrient broth each of the inoculi was prepared in a McCartney bottle and incubated for 24 hours. A solution of agar-agar was prepared by dissolving $10 \mathrm{~g}$ of the powder in distilled water and made up to $500 \mathrm{~mL}$ mark in an Erlenmeyer flask and was sterilized in an autoclave (280A) for 15 minutes and allowed to cool to $40-45^{\circ} \mathrm{C}$ (Ajao et al., 2011). Four milliliters ( $4 \mathrm{~mL})$ of the bacterial isolates in the nutrient broth was mixed with 36 $\mathrm{ml}$ of the prepared agar-agar media in petri-dish plates and then allowed to solidify. This was kept in the refrigerator for bioremediation.

\section{Bioremediation (Treatment) of the Effluents}

The solidified agar block (immobilized bacteria) was cut into cubes using a sterile knife; $0.1 \mathrm{~mL}$ phosphate buffer ( $\mathrm{pH} \mathrm{7.0)}$ was added and kept in the refrigerator for 1 hour for curing. The phosphate buffer was decanted after 1 hour and the cubes were washed with sterile distilled water 3-4 times before it was used (Ajao et al., 2011). Two liters (2 L) of the effluent was supplemented with the minimum basal medium in $\mathrm{g} / \mathrm{L}: \mathrm{NaCl}(0.8), \mathrm{MgSO}_{4} .7 \mathrm{H}_{2} \mathrm{O}(0.001), \mathrm{KH}_{2} \mathrm{PO}_{4}$ (2), $\mathrm{NaNO}_{3}$ (2), $\quad \mathrm{CaCl}_{2} .2 \mathrm{H}_{2} \mathrm{O} \quad(0.5)$ and $\mathrm{NaHPO}_{4} .12 \mathrm{H}_{2} \mathrm{O}(2)$ and sterilized in an autoclave at $121^{\circ} \mathrm{C}$ for 15 minutes (Margesin and Schinner, 2001). Two hundred and fifty milliliters $(250 \mathrm{~mL})$ of the effluents were transferred into different $250 \mathrm{ml}$ conical flasks. The content was covered with a cotton-wool ramped with foil paper to avoid contamination. Five grams $(5 \mathrm{~g})$ of the immobilized bacteria were quickly transferred into each of the effluents in the conical flasks in an inoculating chamber. The same procedures were carried out for the $10 \mathrm{~g}, 15 \mathrm{~g}, 20 \mathrm{~g}$ and 25 $\mathrm{g}$ of the immobilized bacteria in separate $250 \mathrm{~mL}$ effluents in conical flasks and agitated for ten days in a shaker incubator (Gallenkamp-OC4364-L) at a temperature $30^{\circ} \mathrm{C}$ and speed of 60 rpm. The treated effluent samples were taken on the tenth day and analyzed for the parameters $\mathrm{pH}$, SS, TDS, COD, and BOD, (Posttreatment determination) for the different grams of bacteria to evaluate and compare the biodegradation potential. (Baba et al., 2020).

\section{Statistical Analysis}

The data were represented as Mean \pm Standard deviation and analyzed statistically using oneway Analysis of Variance (ANOVA) and Tukey's HSD as Post Hoc Tests with the aid of SPSS 16.0. The correlation coefficient was also used to measure the strength of the relationship between the different masses of the bacteria and the parameters. All $\mathrm{p} \leq 0.05$ were considered as statistically significant.

\section{RESULTS AND DISCUSSION Physico-chemical parameters in the Industrial Effluents before the Biodegradation.}

Results of the Physico-chemical parameters in the industrial effluents before the Biodegradation is shown in table 1 . The mean temperatures $\left({ }^{\circ} \mathrm{C}\right)$ observed in TAN1, TAN2, and TAN3 samples were $28.07 \pm 0.65 ; 27.77 \pm 0.64$ and $26.38 \pm 3.81$ respectively. The order of the mean temperature of the samples from the three industries can be arranged as TAN1 > TAN2>TAN3. The temperature observed at TAN1, TAN2, and TAN3 samples were found below the WHO $\left(35^{\circ} \mathrm{C}\right)$ and NESREA $\left(40^{\circ} \mathrm{C}\right)$ limits. The low values of temperature might be due to the processes used at the time of sampling. High temperature brings down the solubility of gases in water that ultimately expresses as high BOD and COD. Statistical analysis shows that there is no significant difference $(p<0.05)$ between the mean values of temperature among the industries. This might be due to similar tannery activities involved in the tannery industries at the time of sampling. The average values of temperature observed in this present study are less than those observed by Akan et al. (2007), Akan et al. (2009) and Baba et al. (2020).

The mean level of $\mathrm{pH}$ observed in TAN1, TAN2 and TAN3, samples were $7.77 \pm 2.93$; $8.35 \pm 0.28$ and $7.52 \pm 0.76$ respectively. The order of the mean $\mathrm{pH}$ of the samples from the three industries can be arranged as TAN2> TAN1 $>$ TAN3. The $\mathrm{pH}$ of the samples falls within the WHO (7.0-8.5) and NESREA (6-9) standard limits. Statistical analysis shows that there is no significant difference $(p<0.05)$ between the mean values of $\mathrm{pH}$ among the industries. This might be due to similar tannery activities involved in the tannery industries at the time of sampling. Maheshwari et al. (2017) reported that the level of $\mathrm{pH}$ in the effluents from the tannery industry in Vaniyambadi, India was 6.5 which was lower than that observed in the present study. The $\mathrm{pH}$ in the effluents from the tannery industries in Kano and Kaduna were reported to be 7.64 and 6.89, respectively (Akan et al., 2007; Mohammed et al., 2017). The average values of $\mathrm{pH}$ observed in this present study are less than those observed by Mohammed et al. (2017) and Baba et al. (2020). The mean level of SS $(\mathrm{mg} / \mathrm{l})$ observed in TAN1, TAN2, and TAN3 samples were 374 \pm 124 ; $358 \pm 335$ and $780 \pm 739$ respectively. The order of the mean SS in the samples from the three industries can be arranged as TAN3 > TAN1 $>$ TAN2. 
The SS observed in the samples were far above the recommended standard limits of regulating bodies WHO $(30 \mathrm{mg} / \mathrm{l})$ and NESREA $(10 \mathrm{mg} / \mathrm{l})$. Statistical analysis shows that there is no significant difference $(p<0.05)$ between the mean values of SS among the industries. This might be due to similar tannery activities involved in the tannery industries at the time of sampling. The average values of SS observed in this present study are less than that observed $(3700 \pm 122 \mathrm{mg} / \mathrm{l})$ by Akan et al. (2009) for tanneries in Kano. Also, the average values of SS observed in this present study are less than that observed by Mohammed et al. (2017) and Baba et al. (2020) with the exception in TAN3.

The mean level of TDS (mg/l) observed in TAN1, TAN2, and TAN3 samples were $3941 \pm 3703$; $3300 \pm 1714$ and $2653 \pm 1240$ respectively. The order of the mean TDS in the samples from the three industries can be arranged as TAN1>TAN2>TAN3. The TDS observed in the samples were far above the recommended standard limits of WHO $(250 \mathrm{mg} / \mathrm{l})$ and NESREA $(500 \mathrm{mg} / \mathrm{l})$. Statistical analysis shows that there is no significant difference $(p<0.05)$ between the mean values of TDS among the industries. This might be due to similar tannery activities involved in the tannery industries at the time of sampling. TDS in the effluents from the tannery industries in Kano, Nigeria was reported to be $1281 \mathrm{mg} / \mathrm{l}$ (Akan et al., 2007). The average values of SS observed in this present study are less than those observed by Mohammed et al. (2017) and Baba et al. 2020)

The mean level of COD (mg/l) observed in TAN1, TAN2 and TAN3 samples seasons were $2372 \pm 938 ; \quad 1406 \pm 208$ and $3532 \pm 1373$ respectively. The order of the mean COD of the samples from the three industries can be arranged as TAN3>TAN1> TAN2. The COD observed in TAN1, TAN2 and TAN3 samples were far above the recommended standard limits of regulating bodies $\mathrm{WHO}(40 \mathrm{mg} / \mathrm{l})$ and NESREA (40 mg/l). Statistical analysis shows that there is no significant difference $(p<0.05)$ in COD among the industries. This might be due to similar tannery activities involved in the tannery industries as at the time of sampling. The Chemical Oxygen demand (COD) is the amount of oxygen, in $\mathrm{mg} / \mathrm{L}$, required for the degradation of the compound of wastewater to occur. In comparison, the average values of COD observed in this present study were higher than that observed by Mohammed et al. (2017) but lower than that observed by Baba et al. (2020).

The mean levels of BOD $(\mathrm{mg} / \mathrm{l})$ observed in TAN1, TAN2 and TAN3 samples were $13.85 \pm 6.42 ; \quad 19.46 \pm 0.50$ and $17.13 \pm 3.14$ respectively. The order of the mean BOD in the samples from the three industries can be arranged as TAN2>TAN3>TAN1. The BOD observed in TAN1, TAN2 and TAN3 samples were found below the recommended limits of NESREA (200 mg/l) but above WHO (10 mg/l). Statistical analysis shows that there is no significant difference $(p<0.05)$ between the mean values of BOD among the industries. This might be due to similar tannery activities involved in the tannery industries at the time of sampling. The low level of BOD recorded in this study is an indication of the low level of biodegradable organic solids in the effluent. The average values of BOD observed in this present study were lower than those observed by Mohammed et al. (2017) and Baba et al. (2020).

Table 1: Mean Values \pm S.D of Physico-chemical parameters of effluents from the Tannery Industries before Treatment.

\begin{tabular}{llllllll}
\hline Parameter & Tannery 1 & Tannery 2 & Tannery 3 & $\mathrm{a}$ & $\mathrm{b}$ & $\mathrm{c}$ & $\mathrm{d}$ \\
\cline { 2 - 7 } Temperature $\left({ }^{\circ} \mathrm{C}\right)$ & $28.07 \mathrm{a} \pm 0.65$ & $27.77 \mathrm{a} \pm 0.64$ & $26.38 \mathrm{a} \pm 3.81$ & & $29.50 \pm 4.68$ & 35 & 40 \\
pH & $7.77 \mathrm{a} \pm 2.93$ & $8.35 \mathrm{a} \pm 0.28$ & $7.52 \mathrm{a} \pm 0.76$ & 6.89 & $5.35 \pm 1.57$ & $7.0-8.5$ & $6.0-9.0$ \\
$\mathrm{COD}(\mathrm{mg} / \mathrm{l})$ & $2372 \mathrm{a} \pm 938$ & $1406 \mathrm{a} \pm 208$ & $3532 \mathrm{a} \pm 1373$ & 2.2 & $3106 \pm 2753$ & 40 & 40 \\
$\mathrm{BOD}(\mathrm{mg} / \mathrm{l})$ & $13.85 \mathrm{a} \pm 6.42$ & $19.46 \mathrm{a} \pm 0.50$ & $17.13 \mathrm{a} \pm 3.14$ & 1032 & $26.17 \pm 9.49$ & 10 & 200 \\
$\mathrm{SS}(\mathrm{mg} / \mathrm{l})$ & $374 \mathrm{a} \pm 124$ & $358 \mathrm{a} \pm 335$ & $780 \mathrm{a} \pm 739$ & 501 & $562 \pm 482$ & 30 & 10 \\
TDS $(\mathrm{mg} / \mathrm{l})$ & $3941 \mathrm{a} \pm 3703$ & $3300 \mathrm{a} \pm 1714$ & $2653 \mathrm{a} \pm 1240$ & 532.7 & $444 \pm 507$ & 250 & 500 \\
\hline
\end{tabular}

The values given in the table above are means of 6 replicate values, $\mathrm{n}=6$ ( 1 sample was taken monthly for 6 months). Within the rows, means with different alphabets are statistically different $(p<0.05)$. WHO: World Health Organisation. NESREA: National Environmental Standard and Regulatory Enforcement Agency. a = Mohammed et al.(2017), b = Baba et al. (2020), c = WHO (2006), $d=$ NESSRA (2009) 
BAJOPAS Volume 13 Number 2, December, 2020

Identification, Biochemical Characterization and growth rates of the Bacterial Isolates

Results of identification and biochemical characterization of the bacterial isolates were shown in table 2. After 24 hours of incubation, the nutrient agar media plates were checked for bacterial growth. The results showed the presence of different strains in the samples. The TAN1 bacteria isolate was found to be gramnegative cocci while TAN3 was gram-positive cocci. TAN2 bacteria isolate was found to be gram-positive, rod-shaped. TAN1, TAN2, and TAN3 bacteria isolates recorded positive results for spore former.

The results of the biochemical tests indicated that all the bacteria were positive for catalase, oxidase, citrate, maltose, glucose, lactose (negative in TAN1), mannitol (negative in TAN2), starch hydrolysis and coagulase (negative in TAN2) tests. The bacteria showed negative results for nitrate reduction, $M R$ (positive in TAN2), VP (positive in TAN1), Indole (positive in TAN2) tests. Base on the morphological and biochemical test results, TAN1, TAN2, and TAN3 bacteria isolates were identified to be Nesseria spp, Bacillus cereus, and Staphylococcus aureus respectively.

The growth rate of the TAN1, TAN2 and TAN3 Isolates were shown in figure 2. Generally, the optical density increase with the increase in time (day) and decrease as time goes on. The highest optical density was shown by bacillus cereus in TAN2 while the lowest was shown by Staphylococcus aureus in TAN3.

The initial growth phase of TAN1 Isolate bacteria occurred within 2-day of incubation as the growth rate increases up to the 6th-day incubation when the maximum growth was observed. Beyond the 6th day, the growth of the bacteria declined (which might be due to a shortage of nutrients in the effluents) until it reached its death phase (which might be due to the unavailability of nutrients in the effluents).

A similar trend of growth was also observed for TAN2 Isolate as the initial growth phase also occurred within 2-day of incubation but maximum growth rate observed on the 4th day of incubation. The stationary stage occurred between the 4th day and the 8th day. Beyond the 8th day, the growth of the bacteria declined (which might be due to a shortage of nutrients in the effluents) until it reached its death phase (which might be due to the unavailability of nutrients in the effluents).

The initial growth phase of TAN3 bacterial Isolate occurred within the 3-day incubation as the growth rate increases up to the 6th-day incubation when the maximum growth was observed. Beyond the 6th day, the growth of the bacteria declined (which might be due to a shortage of nutrients in the effluents) until it reached its death phase (which might be due to the unavailability of nutrients in the effluents).

Table 2: Morphological and Biochemical characteristics of bacterial isolates

\begin{tabular}{lllll} 
Bacterial Isolates & & TAN1 & TAN2 & TAN3 \\
\hline $\begin{array}{lllll}\text { Morphological } \\
\text { characteristics }\end{array}$ & Shape & Cocci & Rod & Cocci \\
& Spore & & & \\
& former & + & + & + \\
Gram & & & \\
Biochemical characteristics & reaction & - & + & + \\
& Citrate & + & + & + \\
& Catalase & + & + & + \\
& Coagulase & + & - & + \\
Starch & + & + & + \\
& Glucose & + & + & + \\
Oxidase & + & + & + \\
& Indo & - & + & - \\
Lactose & - & + & + \\
Manitol & + & - & + \\
Maltose & + & + & + \\
MR & - & + & - \\
VP & + & - & - \\
& Nitrate & - & - & - \\
Reduction & - Neisseria & Bacillus & Staphylococcus \\
& Bacterial & cereus & aureus \\
& name & spp & cas
\end{tabular}

+ = Positive; - = Negative; MR=Methyl Red; VP= Voges-Proskauer 


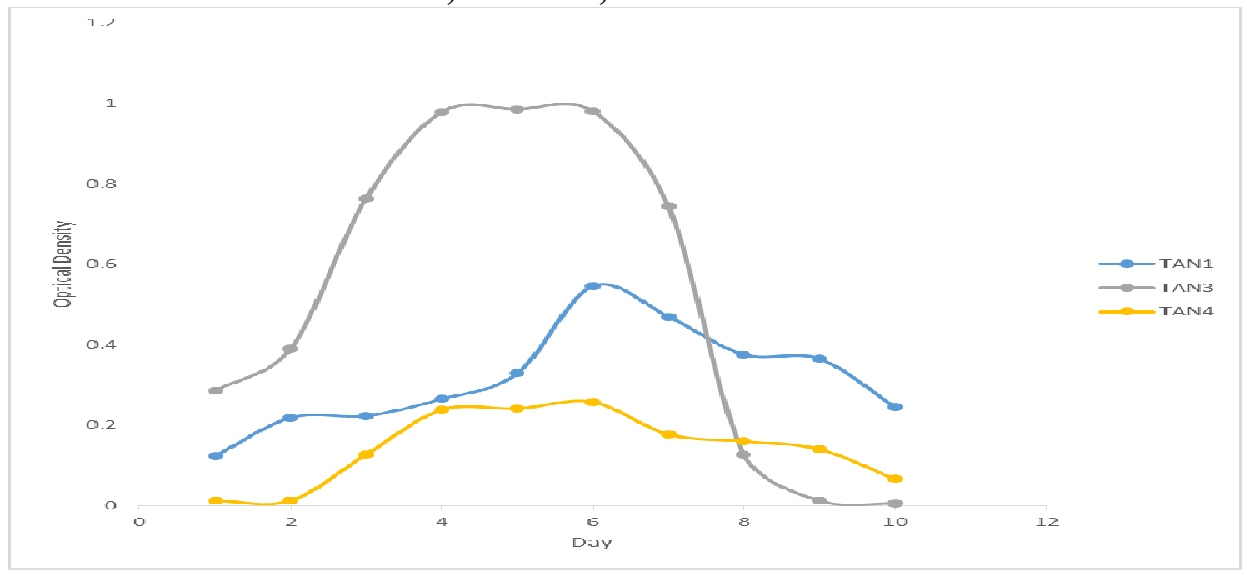

Fig. 2 Growth rates of the isolates in the effluents from the Tannery Industries

\section{Physico-chemical Parameters in the Industrial Effluents after the biodegradation.}

Table 3 shows the mean results of the physicochemical parameter before and after bioremediation using the different masses $(5 \mathrm{~g}$, $10 \mathrm{~g}, 15 \mathrm{~g}, 20 \mathrm{~g}$, and $25 \mathrm{~g}$ ) of the respective immobilized bacteria. Also, Table 4 shows the mean results of correlation coefficient ( $r$ ) between different masses of bacteria and physicochemical parameters.

The mean values $(\mathrm{mg} / \mathrm{l})$ of the SS after the bioremediation varies between $243 \pm 45$ and $898 \pm 672$. The mean concentration $(\mathrm{mg} / \mathrm{l})$ of SS remediated by the different masses $(5 \mathrm{~g}, 10 \mathrm{~g}$, $15 \mathrm{~g}, 20 \mathrm{~g}$, and $25 \mathrm{~g}$ ) of the bacteria varies. The SS in the samples fluctuates up and down after the bioremediation process when compared with the SS of the raw samples before the bioremediation. The increase in the levels of the SS might be due to the aggregation of the TDS which are large enough to result into SS. The increase in the levels of the SS might be also due to the influence of the nutrients which was added into the effluents in order to make the microorganisms more active and viable for fast degradation of organic contaminants in the effluent. The relative potential or efficiency of the different masses of the bacteria in remediating SS in TAN1 samples was in the order $25 \mathrm{~g}>20 \mathrm{~g}>15 \mathrm{~g}>10 \mathrm{~g}>5 \mathrm{~g}$. For TAN2 and TAN3 samples, the order was $25 \mathrm{~g}>20 \mathrm{~g}>15$ $\mathrm{g}>10 \mathrm{~g}>5 \mathrm{~g}$. These might be due to the variations in the surface areas of the different masses of the immobilized bacteria. Statistical analysis shows that there is no significant difference $(p<0.05)$ between the mean values of SS among the masses in the respective industries. Positive and significant correlations exist between the masses of bacteria and Suspended Solid (SS). This showed that there is general increase in the levels of the SS as the masses of the immobilized bacteria increases. TAN3 (90\%) and TAN1 (80\%) showed a very high correlation with the masses of the bacteria while TAN2 (61\%) showed a very low correlation.

The mean values $(\mathrm{mg} / \mathrm{l})$ of the TDS after the bioremediation varies between $46 \pm 11$ and $83 \pm 78$. The mean concentration $(\mathrm{mg} / \mathrm{l})$ of TDS remediated by the different masses $(5 \mathrm{~g}, 10 \mathrm{~g}$, $15 \mathrm{~g}, 20 \mathrm{~g}$, and $25 \mathrm{~g}$ ) of the bacteria varies. There is a reduction in all the TDS of all the samples after the bioremediation process compared with the TDS of the raw samples before the bioremediation. The relative potential or efficiency of the different masses of the bacteria in remediating TDS in TAN1 and TAN3 samples was in the order $5 \mathrm{~g}>10 \mathrm{~g}>15 \mathrm{~g}>20$ $\mathrm{g}>25 \mathrm{~g}$. For TAN2 samples, the order was 20 $g>10 \quad g>25 \quad g>15 \quad g>5 \quad g$. Statistical analysis shows that there is no significant difference $(p<0.05)$ between the mean values of TDS among the masses in the respective industries. These might be due to the variations in the surface areas of the different masses of the immobilized bacteria. Positive and significant correlations exist between the masses of bacteria and TDS with the exception in TAN2 (negative and insignificant correlation). The positive correlations showed that there is general increase in the levels of the TDS as the masses of the immobilized bacteria increases. TAN1 $(96 \%)$ showed a very high correlation with the masses of the bacteria while TAN2 (47\%) showed a very low correlation.

The mean values $(\mathrm{mg} / \mathrm{l})$ of the BOD after the bioremediation varies between $1.56 \pm 0.20 \mathrm{mg} / \mathrm{l}$ and $6.92 \pm 5.49 \mathrm{mg} / \mathrm{l}$. The mean concentration $(\mathrm{mg} / \mathrm{l})$ of BOD remediated by the different masses $(5 \mathrm{~g}, 10 \mathrm{~g}, 15 \mathrm{~g}, 20 \mathrm{~g}$, and $25 \mathrm{~g}$ ) of the bacteria varies. There is a reduction in all the BOD of all the samples after the bioremediation process compared with the $\mathrm{BOD}$ of the raw 
BAJOPAS Volume 13 Number 2, December, 2020 samples before the bioremediation. The relative potential or efficiency of the different masses of the bacteria in remediating BOD in TAN1, TAN2 and TAN3 samples were in the order $25 \mathrm{~g}>20$ $\mathrm{g}>15 \mathrm{~g}>10 \mathrm{~g}>5 \mathrm{~g}, 25 \mathrm{~g}>15 \mathrm{~g}>5 \mathrm{~g}>10 \mathrm{~g}>20 \mathrm{~g}$ and $20 \mathrm{~g}>10 \mathrm{~g}>25 \mathrm{~g}>15 \mathrm{~g}>5 \mathrm{~g}$ respectively. Statistical analysis shows that there is significant difference $(p<0.05)$ between the mean values of BOD among the masses in the respective industries. These might be due to the variations in the surface areas of the different masses of the immobilized bacteria. Negative and significant correlations exist between the masses of bacteria and BOD. This showed that there is general decrease in the levels of the BOD as the masses of the immobilized bacteria increases. TAN1 (94\%) showed a very high correlation with the masses of the bacteria while TAN2 (4\%) showed a very low correlation.

The mean values $(\mathrm{mg} / \mathrm{l})$ of the COD after the bioremediation varies between $250 \pm 154$ and $3134 \pm 1595$. The mean concentration $(\mathrm{mg} / \mathrm{l})$ of COD remediated by the different masses $(5 \mathrm{~g}$, $10 \mathrm{~g}, 15 \mathrm{~g} 20 \mathrm{~g}$, and $25 \mathrm{~g}$ ) of the bacteria varies. There is a reduction in all the COD of all the samples after the bioremediation process compared with the COD of the raw samples before the bioremediation. The relative potential or efficiency of the different masses of the bacteria in remediating COD in TAN1, TAN2 and TAN3 samples were in the order $25 \mathrm{~g}>20 \mathrm{~g}>15$ $\mathrm{g}>5 \mathrm{~g}>10 \mathrm{~g}, 25 \mathrm{~g}>20 \mathrm{~g}>15 \mathrm{~g}>10 \mathrm{~g}>5 \mathrm{~g}$ and 10 g>5 g>25 g>15 g>20 g respectively. Statistical analysis shows that there were significant difference $(p<0.05)$ between the mean values of COD among the masses in the respective industries except for effluents treated with $25 \mathrm{~g}$. These might be due to the variations in the surface areas of the different masses of the immobilized bacteria. Negative and insignificant correlations exist between the masses of bacteria and COD with the exception in TAN3 (positive and significant correlation). The negative correlations showed that there is general decrease in the levels of the COD as the masses of the immobilized bacteria increases. TAN2 (100\%) showed a very high correlation with the masses of the bacteria while TAN3 (36\%) showed a very low correlation.

Generally, there was an overall decrease in the concentration of these physicochemical parameters after the bioremediation using the different masses of the bacterial isolates. These might be due to the variations in the surface areas of the different masses of the immobilized bacteria. This is in line with the work of Jimoh et al. (2018) and Baba et al. (2020).

Table 3: Mean Values $(\mathrm{mg} / \mathrm{l}) \pm$ S.D of Physicochemical parameters in effluents from the Tannery Industries before and after Treatment of the effluents $(250 \mathrm{ml})$ with the different masses $(5 \mathrm{~g}, 10 \mathrm{~g}$, $15 \mathrm{~g}, 20 \mathrm{~g}$, and $25 \mathrm{~g}$ ) of the bacteria.

\begin{tabular}{llllllll}
\hline $\mathrm{P}$ & IND & Before & \multicolumn{5}{c}{ After } \\
\cline { 4 - 7 } & & & $5 \mathrm{~g}$ & $10 \mathrm{~g}$ & $15 \mathrm{~g}$ & $20 \mathrm{~g}$ & $25 \mathrm{~g}$ \\
\hline \multirow{2}{*}{ COD } & TAN1 & $2372 \pm 938$ & $1708 \mathrm{a} \pm 861$ & $2045 \mathrm{a} \pm 1205$ & $845 \mathrm{a} \pm 369$ & $300 \mathrm{a} \pm 167$ & $250 \mathrm{a} \pm 154$ \\
& TAN2 & $1406 \pm 208$ & $1195 \mathrm{a} \pm 208$ & $1125 \mathrm{a} \pm 384$ & $1055 \mathrm{a} \pm 317$ & $956 \mathrm{a} \pm 310$ & $870 \mathrm{ab} \pm 240$ \\
& TAN3 & $3532 \pm 1373$ & $2374 \mathrm{a} \pm 1344$ & $1976 \mathrm{a} \pm 1405$ & $2757 \mathrm{a} \pm 1266$ & $3134 \mathrm{a} \pm 1595$ & $2614 \mathrm{~b} \pm 1105$ \\
BOD & TAN1 & $13.85 \pm 6.42$ & $6.92 \mathrm{a} \pm 5.49$ & $6.42 \mathrm{a} \pm 5.07$ & $5.72 \mathrm{a} \pm 5.35$ & $4.62 \mathrm{a} \pm 4.37$ & $2.82 \mathrm{ab} \pm 1.26$ \\
& TAN2 & $19.46 \pm 0.50$ & $1.75 \mathrm{~b} \pm 0.22$ & $1.73 \mathrm{~b} \pm 0.18$ & $1.58 \mathrm{a} \pm 0.16$ & $1.91 \mathrm{a} \pm 0.22$ & $1.56 \mathrm{~b} \pm 0.20$ \\
& TAN3 & $17.13 \pm 3.14$ & $4.24 \mathrm{ab} \pm 0.77$ & $3.29 \mathrm{ab} \pm 0.37$ & $4.11 \mathrm{a} \pm 0.07$ & $3.23 \mathrm{a} \pm 0.91$ & $3.33 \mathrm{a} \pm 1.28$ \\
SS & TAN1 & $374 \pm 124$ & $243 \mathrm{a} \pm 45$ & $471 \mathrm{a} \pm 226$ & $475 \mathrm{a} \pm 182$ & $492 \mathrm{a} \pm 128$ & $611 \mathrm{a} \pm 217$ \\
& TAN2 & $358 \pm 335$ & $460 \mathrm{a} \pm 400$ & $543 \mathrm{a} \pm 414$ & $544 \mathrm{a} \pm 402$ & $551 \mathrm{a} \pm 414$ & $554 \mathrm{a} \pm 405$ \\
& TAN3 & $780 \pm 739$ & $586 \mathrm{a} \pm 594$ & $758 \mathrm{a} \pm 656$ & $787 \mathrm{a} \pm 676$ & $861 \mathrm{a} \pm 635$ & $898 \mathrm{a} \pm 672$ \\
TDS & TAN1 & $3941 \pm 3703$ & $51 \mathrm{a} \pm 10$ & $53 \mathrm{a} \pm 10$ & $55 \mathrm{a} \pm 15$ & $61 \mathrm{a} \pm 20$ & $63 \mathrm{a} \pm 26$ \\
& TAN2 & $3300 \pm 1714$ & $83 \mathrm{a} \pm 78$ & $47 \mathrm{a} \pm 20$ & $48 \mathrm{a} \pm 22$ & $47 \mathrm{a} \pm 17$ & $48 \mathrm{a} \pm 17$ \\
& TAN3 & $2653 \pm 1240$ & $46 \mathrm{a} \pm 11$ & $55 \mathrm{a} \pm 24$ & $55 \mathrm{a} \pm 25$ & $58 \mathrm{a} \pm 23$ & $61 \mathrm{a} \pm 28$ \\
\hline
\end{tabular}

Replicate $=6$ (months)

Within the rows, for the same parameter, means with different alphabets are statistically different $(p<0.05)$.

$\mathrm{P}=$ parameter, IND = Industries 
BAJOPAS Volume 13 Number 2, December, 2020

Table 4: Correlation coefficient $(r)$ between different masses of the bacteria and the physicochemical parameters.

\begin{tabular}{llll}
\hline Industries & Parameter & Correlation coefficient $(r)$ & $\begin{array}{l}\text { Percent dependence (rxrx100) } \\
(\%)\end{array}$ \\
\hline TAN1 & COD & -0.9 & 82 \\
& BOD & -0.97 & 94 \\
& SS & $0.90^{*}$ & 80 \\
TAN2 & TDS & $0.98^{*}$ & 96 \\
& COD & -1 & 100 \\
& BOD & -0.21 & 4 \\
& SS & $0.78^{*}$ & 61 \\
& TDS & -0.69 & 47 \\
& COD & $0.60^{*}$ & 36 \\
& BOD & -0.6 & 37 \\
& SS & $0.95^{*}$ & 90 \\
& TDS & $0.94^{*}$ & 89 \\
\hline
\end{tabular}

The correlation coefficient $(r)$ with * is statistically significant $(p<0.05)$.

Percentage reduction of the Parameters

Table 5 shows the percentage reduction of Parameters in industrial samples before and after the treatment of the effluents $(250 \mathrm{ml})$ with the different masses $(5 \mathrm{~g}, 10 \mathrm{~g}, 15 \mathrm{~g}, 20 \mathrm{~g}$, and $25 \mathrm{~g}$ ) of the Immobilized Bacteria.

In TAN1 samples, the percentage reduction (\%) of COD ranged (14-89); BOD (50-80); SS (-32$35)$ and TDS (98-99). In TAN2 samples, the percentage decrease $(\%)$ of COD ranged (15$38) ;$ BOD (90-92); SS [-28-(-55)] and TDS (9798). In TAN3 samples, the percentage decrease (\%) of COD ranged (11-44); BOD (76-81); SS (15-25) and TDS (98). The percentage increase in the levels COD, BOD and TDS might be due to the increase in the surface area of the different masses of the immobilized bacteria. However, the percentage decrease in the levels of the SS might be due to the aggregation of the TDS which are large enough to result into SS. The percentage decrease in the levels of the SS might be also due to the influence of the nutrients which was added into the effluents in order to make the microorganisms more active and viable for fast degradation of organic contaminants in the effluent. This is in line with the work of Jimoh et al. (2018) in which the concentration of the SS increase after the bioremediation of effluents.

Sreemoyee and Priti (2013) assessed and reduced several Physico-chemical parameters of dairy wastewater using Niesseria $s p$. and concluded that the species are well known to degrade organic compounds. This is in agreement with the current study in which the immobilized Niesseria $s p$ degrade the organic contaminants as indicated by the BOD, COD and TDS.

Jimoh et al. (2018) observed that TSS of the effluents was increased after treatment with immobilized bacteria and concluded that it might be due to the biostimulation method adopted for the research.

The optimum $\mathrm{pH}$ Biosorption of Chromium by Bacillus spp and Staphylococcus spp. from tannery effluent was investigated by Mythili and Karthikeyan (2011). The maximum adsorption of Chromium $(86.4 \mathrm{mg} / \mathrm{L})$ was showed by Bacillus spp and Staphylococcus spp showed $70.6 \mathrm{mg} / \mathrm{L}$ at an initial concentration of $100 \mathrm{mg} / \mathrm{L}$. In the present study, immobilised Bacillus spp and Staphylococcus spp. from the tannery industrial effluents reduced the levels of the organic pollutants with high potential as indicated by the percentage reduction of BOD, COD and TDS.

Enzymes often can work in multiple environments especially if they are immobilized. This makes the microorganisms' enzymes even more resistant to harsh environments and enables the enzymes to be recovered and recycled after they are no longer needed (Gianfreda and Rao 2004). Ramesh and Singh (1993) reported that the immobilized bacteria having more efficiency to remove the suspended particles than free cells. Using the immobilized cell is preferable due to its capability for using several times with the same efficiency, which makes it more economical. Similar work was done by Sikander et al. (2007) showing the higher reduction with permeabilized cells of Ochrobactrum intermedium strain SDCr-5. 
BAJOPAS Volume 13 Number 2, December, 2020

The results revealed the isolation and identification of isolates with the potential for the reduction of $\mathrm{Cr}$ (VI) to $\mathrm{Cr}$ (III). Results indicated that immobilized $B$. cereus could be efficiently used for the reduction of $\mathrm{Cr}$ (VI).

Table 5: Percentage reduction of the tested Parameters from the tannery industrial samples of the Immobilized Bacteria.

\begin{tabular}{lllllll}
\hline \multirow{2}{*}{ Industries } & & \multicolumn{5}{c}{ Percentage Reduction $(\%)$} \\
\cline { 3 - 7 } & & $5 \mathrm{~g}$ & $10 \mathrm{~g}$ & $15 \mathrm{~g}$ & $20 \mathrm{~g}$ & $25 \mathrm{~g}$ \\
\hline TAN1 & COD & 28 & 14 & 64 & 87 & 89 \\
& BOD & 50 & 54 & 59 & 67 & 80 \\
& SS & 35 & -26 & -27 & -32 & -63 \\
& TDS & 99 & 99 & 99 & 98 & 98 \\
TAN2 & COD & 15 & 20 & 25 & 32 & 38 \\
& BOD & 91 & 91 & 92 & 90 & 92 \\
& SS & -28 & -52 & -52 & -54 & -55 \\
& TDS & 97 & 99 & 99 & 99 & 99 \\
& COD & 33 & 44 & 22 & 11 & 26 \\
& BOD & 75 & 81 & 76 & 81 & 81 \\
& SS & 25 & 3 & -1 & -10 & -15 \\
& TDS & 98 & 98 & 98 & 98 & 98 \\
\hline
\end{tabular}

Percentage Reduction $=(B-A) / B \times 100 \%$

$A=$ Concentration of the parameter after treatment

$\mathrm{B}=$ Concentration of the parameter before treatment

$+=$ percentage decrease

- = percentage increase

In general, immobilization makes the enzyme more resistant to temperature, $\mathrm{pH}$, and substrate concentration swings giving it a longer lifetime and higher productivity per active unit (Gianfreda and Rao, 2004; FuIlbrook, 1996; Russell et al, 2003; Kandelbauer et al., 2004). Immobilized cells have been used and studied extensively for the production of useful chemicals (Ohtake and Silver, 1994), the treatment of wastewaters (Chen et al., 2003; Wang et al., 2010). Although many workers described microbial degradation of tannery effluent, limited literature is available on the bioremediation of tannery effluent using immobilized bacterial cells in the Kano Industrial Estates.

\section{CONCLUSION}

The samples contained variable levels of the physicochemical parameters. The results of the Analysis of variance revealed that, no statistical difference $(p<0.05)$ was observed for the temperature, $\mathrm{pH}, \mathrm{SS}, \mathrm{TDS}, \mathrm{BOD}$ and $\mathrm{COD}$ among the three tannery industries before the treatment. The levels of some of the parameters
(SS, TDS and COD) observed in the samples were found above the recommended limits of WHO and NESREA, which called for the treatment of the effluents before discharge into the environment. Base on the morphological and biochemical test results, TAN1, TAN2, and TAN3 bacterial isolates were identified to be Neisseria spp, Bacillus cereus, and Staphylococcus aureus respectively. The results of Post-treatment analysis showed that there is overall decrease in the levels of the parameters determined when compared with that of the pre-treatment. The overall percentage reduction of the immobilised bacteria in the treatment of the respective effluents was in the order TAN2 (72\%)>TAN1 $(70 \%)>$ TAN3 $(62 \%)$. Hence, the immobilized bacteria are having higher biodegradation potential for the treatment of the tannery effluents.

\section{Acknowledgments}

The authors wish to acknowledge the University of Maiduguri for the financial support. The authors are grateful to the Kano State Ministry of Environment for their support in obtaining the effluent samples. 


\section{REFERENCES}

Ajao, A. T., Adebayo, G. B., and Yakubu, S. E. (2011). Bioremediation of textile industrial effluent using mixed culture of Pseudomonas aeruginosa and Bacillus subtilis immobilized on agar-agar in a bioreactor. J. Microbiol. Biotech. Res, 1(3), 50-56.

Akan, J. C., Moses, E. A., Ogugbuaja, V. O., and Abah, J. (2007). Assessment of tannery industrial effluents from Kano metropolis, Kano State, Nigeria. Journal of Applied Sciences, 7(19), 2788-2793.

Akan, J. C., Ogugbuaja, V. O., Abdulrahman, F. I., and Ayodele, J. T. (2009). Pollutant levels in effluent samples from tanneries and textiles of Kano industrial areas, Nigeria. Global journal of pure and applied sciences, 15(3-4).

APHA (1989). Standard methods for Examination of Will bete and Will betewater.15 $5^{\text {th }}$ edition. Brydpass Springfield Will behington DC. pp. 164-176

APHA (1992). Standard Methods for the Examination of Water and Wastewater. Health, 69, 1116-9.

Baba, A., Garba, S. T., and Bello, H. S. (2020). Bioremediation Potential of Immobilized corynebacterium kutsceri in the Treatment of Tannery Industrial Effluent from Challawa Industrial Estate, Kano State, Nigeria. Journal of the Turkish Chemical Society Section A: Chemistry, $7(2), 335-350$.

Beem, E. I. V. (1994). reduction of solvent VOC emission. J. Oil Col. Chem. Ass, 77, 158.

Bouwer, E. J., and Zehnder, A. J. (1993). Bioremediation of organic compoundsputting microbial metabolism to work. Trends in biotechnology, 11(8), 360367.

Chen, K. C., Wu, J. Y., Liou, D. J., and Hwang, S. C. J. (2003). Decolorization of the textile dyes by newly isolated bacterial strains. Journal of Biotechnology, 101(1), 57-68.

Dan'Azumi, S., and Bichi, M. H. (2010). INDUSTRIAL POLLUTION AND HEAVY METALS PROFILE OF CHALLAWA RIVER IN KANO, NIGERIA. Journal of Applied Sciences in Environmental Sanitation, $5(1)$.

DWAF. (1992). Analytical Methods Manual, TR 151. Department of Water Affairs and Forestry, Pretoria.

El-Bestawy, E. (2013). Biological treatment of leather-tanning industrial wastewater using free living bacteria.
Elsheikh, M. A. S. (2009). Tannery wastewater pre-treatment. Water Science and Technology, 60(2), 433-440.

FuIlbrook, P. D. (1996). "Kinetics." Industrial enzymology: The application of enzymes in Industry. 2nd Ed. T. Godfrey and J Reichelt. eds.. Nature. New York.

Gianfreda, L., and Rao, M. A. (2004). Potential of extra cellular enzymes in remediation of polluted soils: a review. Enzyme and microbial technology, 35(4), 339354.

Hugo Springer. (1994). John Arthur Wilson Memorial Lecture "Treatment of Industrial Wastes of the Leather Industry - is it still a Major Problem". JALCA, 89, 153-185

Jimoh, A. A., Ganiyu, B. A., Baba, D., and Baba, A. (2018) Bioremediation Process of Effluent from Detergent and Food Industries in Jos, Nigeria: Kinetics and Thermodynamics. International Journal of Engineering Science Invention (IJESI), 762-73

Kandelbauer, A., Maute, O., Kessler, R. W., Erlacher, A., and Gübitz, G. M. (2004). Study of dye decolorization in an immobilized laccase enzyme-reactor using online spectroscopy. Biotechnology and bioengineering, 87(4), 552-563.

Kongjao, S., Damronglerd, S., and Hunsom, M. (2008). Simultaneous removal of organic and inorganic Pollutants in tannery wastewater using electrocoagulation technique. Korean Journal of chemical engineering, 25(4), 703.

Maheshwari, U. M., Aruna, S., Gomathi, M., and AbdulJaffar, A. H. (2017). Bioremediation by Free and Immobilized Bacteria Isolated from Tannery Effluent. International Journal of Research in Applied, Natural and Social Sciences. 5(7), 75-90

Margesin, R., and Schinner, F. (2001). Bioremediation (natural attenuation and biostimulation) of diesel-oilcontaminated soil in an alpine glacier skiing area. Applied and environmental microbiology, 677), 3127-3133.

Mohammed, A., Sekar, P., and George, J. (2011). Efficacy of microbes in bioremediation of tannery effluent. Inter. J. Curr. Res, 3(4), 324-326.

Mohammed, S. S. D., Orukotan, A. A., and Abdullahi, H. (2017). Physicochemical and Bacteriological Assessment of Tannery Effluent from Samaru-Zaria, 
BAJOPAS Volume 13 Number 2, December, 2020 Kaduna State, Nigeria. Journal of Applied

Sciences and Environmental Management, 21(4), 734-740.

Munz, G., De Angelis, D., Gori, R., Mori, G., Casarci, M., and Lubello, C. (2009). The role of tannins in conventional and membrane treatment of tannery wastewater. Journal of hazardous materials, 164(2-3), 733-739

Mythili, K., and Karthikeyan, B. (2011). Bioremediation of $\mathrm{Cr}$ (VI) from tannery effluent using Bacillus spp and Staphylococcus spp. International Multidisciplinary Research Journal, 1(6).

NESREA (2009). National Environmental Standards for Effluent Limitations and Regulation. 1233-1236

Noorjahan, C. M. (2014). Physicochemical characteristics, identification of bacteria and biodegradation of industrial effluent. Journal of bioremediation and Biodegradation, 5(3).

Ohtake, H. I., and Silver, A. O. (1994). Bacterial reduction of toxic chromate. Biological degradation and bioremediation of toxic chemicals, 403-415.

Omoleke, I. I. (2004). Management of environmental pollution in Ibadan, an African city: the challenges of health hazard facing government and the people. Journal of Human Ecology, 15(4), 265-275.

Rajor, A., Reddy, A.S., and Singh, B. (2004). Determination of BOD kinetic Parameters and evaluation of alternate methods, M.Sc. Thesis, Department of biotechnology \& environmental Science, Thapar Institute of Engineering and Technology, Patiala

Ramasami, T., Rajamani, S., and Rao, J. R. (1994, March). Pollution control in leather industry: Emerging technological options. In International symposium on surface and colloidal science and its relevance to soil pollution, madras.

Ramesh, J. V. S., and Singh, S. P. (1993). Yearly variation in certain physicochemical parameters of pond at eastern Doon Valley. Uttar Pradesh J. Zoo, 12 (1), 7577.

Ranen, S., and Sharadinadra, C. (2009). Biotechnology applications to environmental remediation in resource exploitation. Current science, 97, 6-25
Russell, A. J., Berberich, J. A., Drevon, G. F., and Koepsel, R. R. (2003). Biomaterials for mediation of

chemical and biological warfare agents. Annual review of biomedical engineering, 5(1), 1-27.

Saravanan, P., and Saravanan, A. (1999). Decolourization of tannery effluent by Flavobacterium sp. EK 1. Indian Journal of Environmental Protection, 19, 19-24.

Sikander, S., and Shahida, H. (2007). Reduction of toxic hexavalent chromium by Ochrobactrum intermedium strain SDCr5 stimulated by heavy metals. Bioresource Technol, 98, 340-344.

Singh, N., Sharma, B. K., and Bohra, P. C. (2000). Impact assessment of industrial effluent of arid soils by using satellite imageries. Journal of the Indian Society of Remote Sensing, 28(2-3), 79.

Sreemoyee, C., and Priti, P. (2013). Assessment of physico-chemical parameters of dairy waste water and isolation and characterization of bacterial strains in terms of cod reduction. Int J Sci, 2(3), 395-400.

Verheijen, L. A. H. M., Wiersema, D., Pol, L. H., and De Wit, J. (1996). Management of wastes from animal product processing. Livestock and environment, Finding a balance. International Agriculture Center, Wageningen, The Netherlands.

Wang, F., Yao, J., Si, Y., Chen, H., Russel, M., Chen, K., and Bramanti, E. (2010). Short-time effect of heavy metals upon microbial community activity. Journal of Hazardous Materials, 173(13), 510-516.

WHO (World Health Organization). (2006). Air quality guidelines: global update 2005: particulate matter, ozone, nitrogen dioxide, and sulfur dioxide. World Health Organization.

World Bank. (1995). Nigeria's strategic options for redressing industrial pollution. World Bank, industry and energy division. 1st edition, West Central Africa Department; Annexes: 1995; pp 60-62.

Zahoor, A., and Abdul, R. (2009). Enumeration of Coliforms. Journal of Environmental Sciences. 21, 814-820 


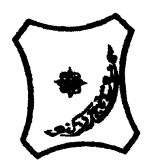

Bayero Journal of Pure and Applied Sciences, 13(2): 1 - 12

Received: November, 2020

Accepted: December, 2020

ISSN $2006-6996$

\title{
BIODEGRADATION POTENTIAL OF IMMOBILIZED BACTERIA IN THE TREATMENT OF TANNERY INDUSTRIAL EFFLUENTS FROM INDUSTRIAL ESTATES IN KANO STATE, NIGERIA
}

\author{
Abdullateef, B., ${ }^{1 *}$ Shuaibu, T. G., ${ }^{1}$ Babagana, K., ${ }^{1}$ Suleman, H. B. ${ }^{2}$ and Dauda, B. ${ }^{3}$ \\ ${ }^{1}$ Department of Pure and Applied Chemistry, Faculty of Science, University of Maiduguri, Borno State, \\ Nigeria \\ ${ }^{2}$ Department of Microbiology, Faculty of Science, University of Maiduguri, Borno State, Nigeria \\ ${ }^{3}$ Department of Chemical Engineering, Faculty of Engineering, University of Maiduguri, Borno State, \\ Nigeria \\ *Corresponding author: babslega@gmail.com; abelega2007@yahoo.com; +2348061309753
}

\section{ABSTRACT}

Industrial Effluents Samples from Gashash Tanneries (TAN1) in Bompai Industrial estate, Larabee Tannery Industry (TAN2) in Sharada Industrial estate and Z Tannery Industries (TAN3) in Challawa Industrial estate, Kano State, Nigeria were collected over a period of six months (August 2017 to January 2018) for assessing the biodegradation potentials of bacteria in the treatment of organic pollutants within the effluents. Bacteria were isolated from the effluents and immobilized on agar-agar. Different masses (5 g, $10 \mathrm{gr}, 15$ $\mathrm{g}, 20 \mathrm{~g}$, and $25 \mathrm{~g}$ ) of the bacteria were used in the treatment of $250 \mathrm{ml}$ of the effluents for ten days in a shaker incubator (Gallenkamp-OC-4364-L) at the temperature $30{ }^{\circ} \mathrm{C}$ and speed of $60 \mathrm{rpm}$. Pre-treatment analysis of the effluents for Temperature, pH, Biochemical Oxygen Demand (BOD), Chemical Oxygen Demand (COD), Suspended Solid (SS) and Total Dissolved Solids (TDS) gives the following results; temperature $\left({ }^{\circ} \mathrm{C}\right.$ )

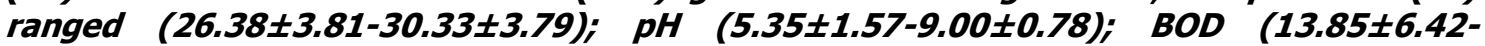
$38.75 \pm 16.20) ;$ COD (1406 $\pm 208-3532 \pm 1373) ;$ SS (208 $\pm 235-780 \pm 739)$ and TDS (266 $\pm 253-5276 \pm 2971)$. No statistical differences ( $p \leq 0.05)$ was observed for all the results among the different industries. The bacterial isolates were identified as Neisseria spp, Bacillus cereus, and Staphylococcus aureus, in TAN1, TAN2, and TAN3, respectively. After treatment of the effluent with the different masses of the isolated bacteria, the mean level of BOD was found to range as (0.55 $\pm 0.36-6.92 \pm 5.49) ; C O D$ (ND-3134 \pm 1595$)$;

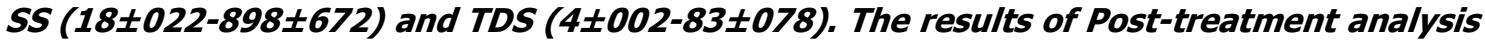
showed that there is overall decrease in the levels of the parameters determined when compared with that of the pre-treatment. The overall percentage reduction of the immobilised bacteria in the treatment of the respective effluents was in the order TAN2 (72\%)>TAN1 (70\%)>TAN3 (62\%). Hence, the immobilized bacteria are having higher biodegradation potential for the treatment of the tannery effluents.

Keywords: Biodegradation, bacteria, effluent, immobilization, tannery.

\section{INTRODUCTION}

Tannery industrial wastewater is a serious consequence of the pollution point of view for streams, freshwater, and land used for agriculture. The lack of awareness in the modern industrial practice has resulted in the discharge of tannery effluents which exhibit very high value of chromium ( $\mathrm{Cr}$ ), Sulfide, and chloride, Total Dissolved Solid (TDS), Total Suspended Solid (TSS), Biochemical Oxygen Demand (BOD) and Chemical Oxygen Demand (COD) in the water stream or land (Mohammed et al., 2001). Tanning is the process, which One ton of skin generally leads to the production of 20 to $80 \mathrm{~m}^{3}$ of turbid and foul-smelling converts the protein of the rawhide or skin into a stable material, which will not putrefy and is suitable for a wide variety of end applications (Elsheikh, 2009). The highly polluting chromium is the most commonly used tanning material producing leather that is more flexible and pliable than vegetable-tanned leather and does not discolor or lose shape in water as drastically as vegetable-tan (Elsheikh, 2009). Tannery effluent is among the most hazardous industrial pollutants due to its huge organic and inorganic load, which is highly toxic to human life and the environment (Kongjao et al., 2008). wastewater including chromium (100-400 mg/l), sulfide $(200-800 \mathrm{mg} / \mathrm{l})$, high levels of fat and 
BAJOPAS Volume 13 Number 2, December, 2020 other solid wastes, and notable pathogen contamination as well as pesticides added for skin conservation during transport (Elsheikh, 2009). There are more than 6000 tanneries in Nigeria with an annual processing capacity of 700,000 tons of hides and skins (Omoleke, 2004; Singh et al., 2008). It was reported that the total amount of waste produced per animal slaughtered is approximately $35 \%$ of its weight (World Bank, 1995). Also, for every $1000 \mathrm{~kg}$ of carcass weight, a slaughtered beef produces 5.5 $\mathrm{kg}$ of manure (excluding rumen contents or stockyard manure) and $100 \mathrm{~kg}$ of paunch manure (undigested food) (Verheijen et al., 1996). Tanneries generate wastewater in the range of 30-35 $\mathrm{L} \mathrm{kg}^{-1}$ skin/hide processed with variable $\mathrm{pH}$, Biological Oxygen Demand (BOD), Chemical Oxygen Demand (COD), high concentrations of suspended solids (SS), and tannins as well as chromium (Zahoor and Abdul, 2009).

Being heterogeneous and composed of a wide variety of compounds, it is very difficult to select a unique direct method for estimating the biodegradability of organic contents and biokinetic parameters for a wastewater sample (Rajor, 2004). For this purpose, some indirect estimation such as determination of biochemical oxygen demand (BOD) and chemical oxygen demand (COD) are applied as common laboratory investigations [9]. During retanning procedures, synthetic tannins (Syntan), oils and resins are added to form softer leather at varying doses (Munz et al., 2009). One of the refractory groups of chemicals in tannery effluents derives mainly from tannins (Ramasami et al., 2004). Syntans are characterized by complex chemical structures, because they are composed of an extended set of chemicals such as phenol-, naphthalene-, formaldehyde- and melamine-based syntans, and acrylic resins (Beem, 1994). Organic pollutants (proteic and lipidic components) are originated from skins (it is calculated that the raw skin has $30 \%$ loss of organic material during the working cycle) or they are introduced during processes (Hugo Springer, 1994).

Many conventional processes such as oxidation, chemical and biological processes were carried out to treat tanneries wastewater (Ebtesam et al, 2013). Biological processes have received more attention because of their costeffectiveness, lower sludge production and environmental friendliness (Noorjahan, 2014). Naturally occurring micro-organisms degrade the hazardous organic wastes including xenobiotic compounds, such as pesticides, polycyclic aromatic hydrocarbons (PAHs) and polychlorinated biphenyls (PCBs) in due course of time (Ranen and Sharadinadra, 2009). Bioremediation is based on the idea that all organisms remove substances from the environment to carry outgrowth and metabolism (Bouwer and Zehnder, 1993). Bacteria, protista and fungi are found to be very good at degrading complex molecules and incorporating the breakdown products into their metabolism (Bouwer and Zehnder, 1993). The resultant metabolic wastes that they produce are generally safe and somehow recycled into other organisms (Ranen and Sharadinadra, 2009). An acclimatized indigenous population of microorganisms capable of degradation of the compounds of interest must exist at the site for a successful bioremediation mode (Ranen and Sharadinadra, 2009). It has been observed that for a successful bioremediation mode, an acclimatized indigenous population of microorganisms capable of degradation of the compounds of interest must exist at the site under investigation (Ranen and Sharadinadra, 2009). Even though there are numerous physical and chemical methods employed in the disposal of wastes the advantage in using bacterium is that they play a key role in the reduction of COD, BOD, total protein, total tannin and total phenol (Saravanan and Saravanan, 1998)

Baba et al. (2020) studied the bioremediation potential of immobilized corynebacterium kutsceri in the Treatment of tannery industrial effluent from Challawa Industrial Estate, Kano State, Nigeria. The aim of the work is to study the reduction in the level of the contaminants through the process of bioremediation using the isolated bacteria. Immobilized bacteria can withstand various temperatures, $\mathrm{pH}$ and substrate concentrations; consequently, increasing the efficiency and the lifespan of the bacteria. Immobilized bacteria are widely applied in the treatment of wastewater and can be separated and recovered after the treatment with the same efficiency (Baba et al., 2020).

\section{MATERIALS AND METHODS \\ Study Area}

This study was carried out in Bompai, Sharada and Challawa industrial estates in Kano, Figure 1. Kano lies on Latitude $11^{\circ} 30^{\prime} \mathrm{N}$ and $8^{\circ} 30^{\prime} \mathrm{E}$ and Longitude $11^{\circ} 5^{\prime} \mathrm{N}$ and $8^{\circ} 5^{\prime} \mathrm{E}$ in Northern Nigeria. It is one of the developed industrial cities in Nigeria. Tannery activities are the dominating industries and this could be one of the reasons for her high population density (Dan'Azumi and Bichi, 2010). Many researchers have studied biodegradation of tannery effluent using microorganisms. However, limited literature is available on the biodegradation of tannery effluent in Kano industrial estates using 
BAJOPAS Volume 13 Number 2, December, 2020 immobilized bacterial cells. This research work focuses on the potential of the use of the indigenous immobilized bacterial isolates in the treatment of tannery effluents in the industrial estates.

\section{Sample Collection}

Effluents were collected from the Tannery Industries from Bompai, Challawa and Sharada Industrial Estates, Kano, Nigeria. The effluents were collected over a period of six months (August 2017 to January 2018). Samples collected in a sterile 4-liter plastic container with a unique identification number were preserved using an ice-box that was transported to the Microbiology Laboratory, Department of Microbiology, Bayero University of Kano for analysis

\section{Sample Preparation and Sample Analysis}

Immediately after the collection of the effluent, $\mathrm{pH}$, TSS, TDS, COD, BOD levels were determined before treatment (Pre-treatment determination) and ten days after treatment (Post-treatment determination) as described in
APHA (1989) standard methods. $\mathrm{pH}$ was determined using Ecotests $\mathrm{pH}$ meter and TDS was determined using AQUALYTIC TDS Salinometer. BOD was determined as described by the standard method (APHA, 1992). COD and SS were determined using DR/2010 HACH portable data logging spectrophotometer (DWAF, 1992)

\section{Identification and Biochemical} Characterization of the Bacterial Isolates

The bacteria were isolated from the effluents using Serial Dilution according to the method described by APHA (1989). The biochemical tests such as oxidase, catalase, coagulase, indole (from $1 \%$ tryptone broth), citrate (Simmons citrate agar), methyl red/VogesProskauer (MR/VP), nitrate reduction, Starch Hydrolysis, Glucose, Maltose, and Lactose tests were carried out on the bacterial isolates to identify the bacteria through the bacteria biochemical characteristics according to Ajao et al. (2011).

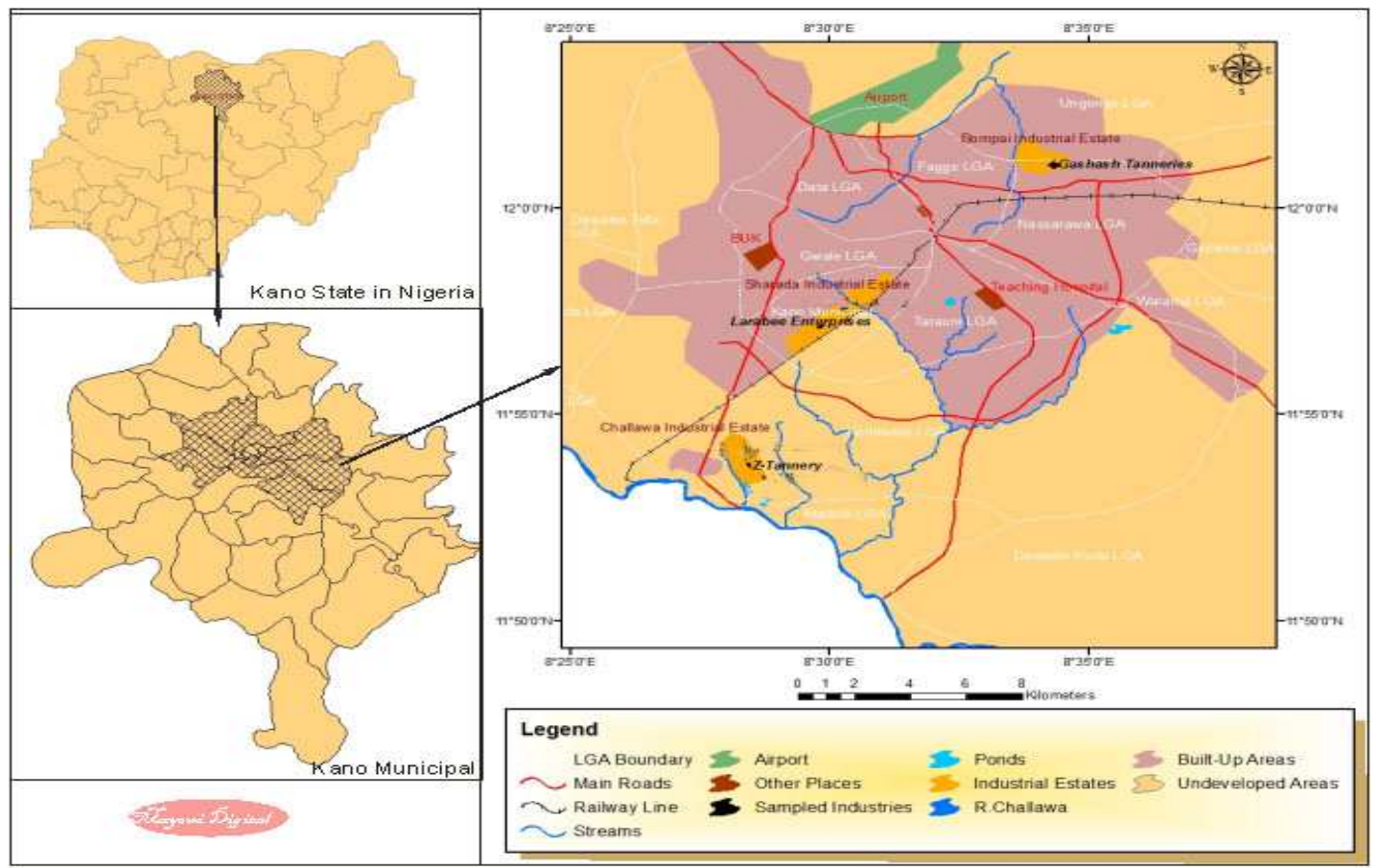

Fig. 1 Map showing the study areas

Source: Mayomi Digital Productions, GIS Laboratory, Department of Geography, UNIMAID (2017)

\section{Determination of Growth Rate of the Bacteria in Effluent Sample}

The bacteria growth rates were determined by transferring $2 \mathrm{~mL}$ of the bacterial isolates from the tannery effluent in broth medium into 100 $\mathrm{mL}$ sterile effluents in conical flasks and kept in an incubator (Giffrin cool) for 10 days. Control was also set up by incubating another $100 \mathrm{~mL}$ each of the sterile effluents without the bacteria. The optical density of the content was determined at the wavelength of $600 \mathrm{~nm}$ on a daily interval and recorded. 
BAJOPAS Volume 13 Number 2, December, 2020 Immobilization of Bacteria

Agar solution and inoculi were prepared separately. Fifty milliliters $(50 \mathrm{~mL})$ of nutrient broth each of the inoculi was prepared in a McCartney bottle and incubated for 24 hours. A solution of agar-agar was prepared by dissolving $10 \mathrm{~g}$ of the powder in distilled water and made up to $500 \mathrm{~mL}$ mark in an Erlenmeyer flask and was sterilized in an autoclave (280A) for 15 minutes and allowed to cool to $40-45^{\circ} \mathrm{C}$ (Ajao et al., 2011). Four milliliters ( $4 \mathrm{~mL})$ of the bacterial isolates in the nutrient broth was mixed with 36 $\mathrm{ml}$ of the prepared agar-agar media in petri-dish plates and then allowed to solidify. This was kept in the refrigerator for bioremediation.

\section{Bioremediation (Treatment) of the Effluents}

The solidified agar block (immobilized bacteria) was cut into cubes using a sterile knife; $0.1 \mathrm{~mL}$ phosphate buffer ( $\mathrm{pH} \mathrm{7.0)}$ was added and kept in the refrigerator for 1 hour for curing. The phosphate buffer was decanted after 1 hour and the cubes were washed with sterile distilled water 3-4 times before it was used (Ajao et al., 2011). Two liters (2 L) of the effluent was supplemented with the minimum basal medium in $\mathrm{g} / \mathrm{L}: \mathrm{NaCl}(0.8), \mathrm{MgSO}_{4} .7 \mathrm{H}_{2} \mathrm{O}(0.001), \mathrm{KH}_{2} \mathrm{PO}_{4}$ (2), $\mathrm{NaNO}_{3}$ (2), $\quad \mathrm{CaCl}_{2} .2 \mathrm{H}_{2} \mathrm{O} \quad(0.5)$ and $\mathrm{NaHPO}_{4} .12 \mathrm{H}_{2} \mathrm{O}(2)$ and sterilized in an autoclave at $121^{\circ} \mathrm{C}$ for 15 minutes (Margesin and Schinner, 2001). Two hundred and fifty milliliters $(250 \mathrm{~mL})$ of the effluents were transferred into different $250 \mathrm{ml}$ conical flasks. The content was covered with a cotton-wool ramped with foil paper to avoid contamination. Five grams $(5 \mathrm{~g})$ of the immobilized bacteria were quickly transferred into each of the effluents in the conical flasks in an inoculating chamber. The same procedures were carried out for the $10 \mathrm{~g}, 15 \mathrm{~g}, 20 \mathrm{~g}$ and 25 $\mathrm{g}$ of the immobilized bacteria in separate $250 \mathrm{~mL}$ effluents in conical flasks and agitated for ten days in a shaker incubator (Gallenkamp-OC4364-L) at a temperature $30^{\circ} \mathrm{C}$ and speed of 60 rpm. The treated effluent samples were taken on the tenth day and analyzed for the parameters $\mathrm{pH}$, SS, TDS, COD, and BOD, (Posttreatment determination) for the different grams of bacteria to evaluate and compare the biodegradation potential. (Baba et al., 2020).

\section{Statistical Analysis}

The data were represented as Mean \pm Standard deviation and analyzed statistically using oneway Analysis of Variance (ANOVA) and Tukey's HSD as Post Hoc Tests with the aid of SPSS 16.0. The correlation coefficient was also used to measure the strength of the relationship between the different masses of the bacteria and the parameters. All $\mathrm{p} \leq 0.05$ were considered as statistically significant.

\section{RESULTS AND DISCUSSION Physico-chemical parameters in the Industrial Effluents before the Biodegradation.}

Results of the Physico-chemical parameters in the industrial effluents before the Biodegradation is shown in table 1 . The mean temperatures $\left({ }^{\circ} \mathrm{C}\right)$ observed in TAN1, TAN2, and TAN3 samples were $28.07 \pm 0.65 ; 27.77 \pm 0.64$ and $26.38 \pm 3.81$ respectively. The order of the mean temperature of the samples from the three industries can be arranged as TAN1 > TAN2>TAN3. The temperature observed at TAN1, TAN2, and TAN3 samples were found below the WHO $\left(35^{\circ} \mathrm{C}\right)$ and NESREA $\left(40^{\circ} \mathrm{C}\right)$ limits. The low values of temperature might be due to the processes used at the time of sampling. High temperature brings down the solubility of gases in water that ultimately expresses as high BOD and COD. Statistical analysis shows that there is no significant difference $(p<0.05)$ between the mean values of temperature among the industries. This might be due to similar tannery activities involved in the tannery industries at the time of sampling. The average values of temperature observed in this present study are less than those observed by Akan et al. (2007), Akan et al. (2009) and Baba et al. (2020).

The mean level of $\mathrm{pH}$ observed in TAN1, TAN2 and TAN3, samples were $7.77 \pm 2.93$; $8.35 \pm 0.28$ and $7.52 \pm 0.76$ respectively. The order of the mean $\mathrm{pH}$ of the samples from the three industries can be arranged as TAN2> TAN1 $>$ TAN3. The $\mathrm{pH}$ of the samples falls within the WHO (7.0-8.5) and NESREA (6-9) standard limits. Statistical analysis shows that there is no significant difference $(p<0.05)$ between the mean values of $\mathrm{pH}$ among the industries. This might be due to similar tannery activities involved in the tannery industries at the time of sampling. Maheshwari et al. (2017) reported that the level of $\mathrm{pH}$ in the effluents from the tannery industry in Vaniyambadi, India was 6.5 which was lower than that observed in the present study. The $\mathrm{pH}$ in the effluents from the tannery industries in Kano and Kaduna were reported to be 7.64 and 6.89, respectively (Akan et al., 2007; Mohammed et al., 2017). The average values of $\mathrm{pH}$ observed in this present study are less than those observed by Mohammed et al. (2017) and Baba et al. (2020). The mean level of SS $(\mathrm{mg} / \mathrm{l})$ observed in TAN1, TAN2, and TAN3 samples were 374 \pm 124 ; $358 \pm 335$ and $780 \pm 739$ respectively. The order of the mean SS in the samples from the three industries can be arranged as TAN3 > TAN1 $>$ TAN2. 
The SS observed in the samples were far above the recommended standard limits of regulating bodies WHO $(30 \mathrm{mg} / \mathrm{l})$ and NESREA $(10 \mathrm{mg} / \mathrm{l})$. Statistical analysis shows that there is no significant difference $(p<0.05)$ between the mean values of SS among the industries. This might be due to similar tannery activities involved in the tannery industries at the time of sampling. The average values of SS observed in this present study are less than that observed $(3700 \pm 122 \mathrm{mg} / \mathrm{l})$ by Akan et al. (2009) for tanneries in Kano. Also, the average values of SS observed in this present study are less than that observed by Mohammed et al. (2017) and Baba et al. (2020) with the exception in TAN3.

The mean level of TDS (mg/l) observed in TAN1, TAN2, and TAN3 samples were $3941 \pm 3703$; $3300 \pm 1714$ and $2653 \pm 1240$ respectively. The order of the mean TDS in the samples from the three industries can be arranged as TAN1>TAN2>TAN3. The TDS observed in the samples were far above the recommended standard limits of WHO $(250 \mathrm{mg} / \mathrm{l})$ and NESREA $(500 \mathrm{mg} / \mathrm{l})$. Statistical analysis shows that there is no significant difference $(p<0.05)$ between the mean values of TDS among the industries. This might be due to similar tannery activities involved in the tannery industries at the time of sampling. TDS in the effluents from the tannery industries in Kano, Nigeria was reported to be $1281 \mathrm{mg} / \mathrm{l}$ (Akan et al., 2007). The average values of SS observed in this present study are less than those observed by Mohammed et al. (2017) and Baba et al. 2020)

The mean level of COD (mg/l) observed in TAN1, TAN2 and TAN3 samples seasons were $2372 \pm 938 ; \quad 1406 \pm 208$ and $3532 \pm 1373$ respectively. The order of the mean COD of the samples from the three industries can be arranged as TAN3>TAN1> TAN2. The COD observed in TAN1, TAN2 and TAN3 samples were far above the recommended standard limits of regulating bodies $\mathrm{WHO}(40 \mathrm{mg} / \mathrm{l})$ and NESREA (40 mg/l). Statistical analysis shows that there is no significant difference $(p<0.05)$ in COD among the industries. This might be due to similar tannery activities involved in the tannery industries as at the time of sampling. The Chemical Oxygen demand (COD) is the amount of oxygen, in $\mathrm{mg} / \mathrm{L}$, required for the degradation of the compound of wastewater to occur. In comparison, the average values of COD observed in this present study were higher than that observed by Mohammed et al. (2017) but lower than that observed by Baba et al. (2020).

The mean levels of BOD $(\mathrm{mg} / \mathrm{l})$ observed in TAN1, TAN2 and TAN3 samples were $13.85 \pm 6.42 ; \quad 19.46 \pm 0.50$ and $17.13 \pm 3.14$ respectively. The order of the mean BOD in the samples from the three industries can be arranged as TAN2>TAN3>TAN1. The BOD observed in TAN1, TAN2 and TAN3 samples were found below the recommended limits of NESREA (200 mg/l) but above WHO (10 mg/l). Statistical analysis shows that there is no significant difference $(p<0.05)$ between the mean values of BOD among the industries. This might be due to similar tannery activities involved in the tannery industries at the time of sampling. The low level of BOD recorded in this study is an indication of the low level of biodegradable organic solids in the effluent. The average values of BOD observed in this present study were lower than those observed by Mohammed et al. (2017) and Baba et al. (2020).

Table 1: Mean Values \pm S.D of Physico-chemical parameters of effluents from the Tannery Industries before Treatment.

\begin{tabular}{llllllll}
\hline Parameter & Tannery 1 & Tannery 2 & Tannery 3 & $\mathrm{a}$ & $\mathrm{b}$ & $\mathrm{c}$ & $\mathrm{d}$ \\
\cline { 2 - 7 } Temperature $\left({ }^{\circ} \mathrm{C}\right)$ & $28.07 \mathrm{a} \pm 0.65$ & $27.77 \mathrm{a} \pm 0.64$ & $26.38 \mathrm{a} \pm 3.81$ & & $29.50 \pm 4.68$ & 35 & 40 \\
pH & $7.77 \mathrm{a} \pm 2.93$ & $8.35 \mathrm{a} \pm 0.28$ & $7.52 \mathrm{a} \pm 0.76$ & 6.89 & $5.35 \pm 1.57$ & $7.0-8.5$ & $6.0-9.0$ \\
$\mathrm{COD}(\mathrm{mg} / \mathrm{l})$ & $2372 \mathrm{a} \pm 938$ & $1406 \mathrm{a} \pm 208$ & $3532 \mathrm{a} \pm 1373$ & 2.2 & $3106 \pm 2753$ & 40 & 40 \\
$\mathrm{BOD}(\mathrm{mg} / \mathrm{l})$ & $13.85 \mathrm{a} \pm 6.42$ & $19.46 \mathrm{a} \pm 0.50$ & $17.13 \mathrm{a} \pm 3.14$ & 1032 & $26.17 \pm 9.49$ & 10 & 200 \\
$\mathrm{SS}(\mathrm{mg} / \mathrm{l})$ & $374 \mathrm{a} \pm 124$ & $358 \mathrm{a} \pm 335$ & $780 \mathrm{a} \pm 739$ & 501 & $562 \pm 482$ & 30 & 10 \\
TDS $(\mathrm{mg} / \mathrm{l})$ & $3941 \mathrm{a} \pm 3703$ & $3300 \mathrm{a} \pm 1714$ & $2653 \mathrm{a} \pm 1240$ & 532.7 & $444 \pm 507$ & 250 & 500 \\
\hline
\end{tabular}

The values given in the table above are means of 6 replicate values, $\mathrm{n}=6$ ( 1 sample was taken monthly for 6 months). Within the rows, means with different alphabets are statistically different $(p<0.05)$. WHO: World Health Organisation. NESREA: National Environmental Standard and Regulatory Enforcement Agency. a = Mohammed et al.(2017), b = Baba et al. (2020), c = WHO (2006), $d=$ NESSRA (2009) 
BAJOPAS Volume 13 Number 2, December, 2020

Identification, Biochemical Characterization and growth rates of the Bacterial Isolates

Results of identification and biochemical characterization of the bacterial isolates were shown in table 2. After 24 hours of incubation, the nutrient agar media plates were checked for bacterial growth. The results showed the presence of different strains in the samples. The TAN1 bacteria isolate was found to be gramnegative cocci while TAN3 was gram-positive cocci. TAN2 bacteria isolate was found to be gram-positive, rod-shaped. TAN1, TAN2, and TAN3 bacteria isolates recorded positive results for spore former.

The results of the biochemical tests indicated that all the bacteria were positive for catalase, oxidase, citrate, maltose, glucose, lactose (negative in TAN1), mannitol (negative in TAN2), starch hydrolysis and coagulase (negative in TAN2) tests. The bacteria showed negative results for nitrate reduction, $M R$ (positive in TAN2), VP (positive in TAN1), Indole (positive in TAN2) tests. Base on the morphological and biochemical test results, TAN1, TAN2, and TAN3 bacteria isolates were identified to be Nesseria spp, Bacillus cereus, and Staphylococcus aureus respectively.

The growth rate of the TAN1, TAN2 and TAN3 Isolates were shown in figure 2. Generally, the optical density increase with the increase in time (day) and decrease as time goes on. The highest optical density was shown by bacillus cereus in TAN2 while the lowest was shown by Staphylococcus aureus in TAN3.

The initial growth phase of TAN1 Isolate bacteria occurred within 2-day of incubation as the growth rate increases up to the 6th-day incubation when the maximum growth was observed. Beyond the 6th day, the growth of the bacteria declined (which might be due to a shortage of nutrients in the effluents) until it reached its death phase (which might be due to the unavailability of nutrients in the effluents).

A similar trend of growth was also observed for TAN2 Isolate as the initial growth phase also occurred within 2-day of incubation but maximum growth rate observed on the 4th day of incubation. The stationary stage occurred between the 4th day and the 8th day. Beyond the 8th day, the growth of the bacteria declined (which might be due to a shortage of nutrients in the effluents) until it reached its death phase (which might be due to the unavailability of nutrients in the effluents).

The initial growth phase of TAN3 bacterial Isolate occurred within the 3-day incubation as the growth rate increases up to the 6th-day incubation when the maximum growth was observed. Beyond the 6th day, the growth of the bacteria declined (which might be due to a shortage of nutrients in the effluents) until it reached its death phase (which might be due to the unavailability of nutrients in the effluents).

Table 2: Morphological and Biochemical characteristics of bacterial isolates

\begin{tabular}{lllll} 
Bacterial Isolates & & TAN1 & TAN2 & TAN3 \\
\hline $\begin{array}{lllll}\text { Morphological } \\
\text { characteristics }\end{array}$ & Shape & Cocci & Rod & Cocci \\
& Spore & & & \\
& former & + & + & + \\
Gram & & & \\
Biochemical characteristics & reaction & - & + & + \\
& Citrate & + & + & + \\
& Catalase & + & + & + \\
& Coagulase & + & - & + \\
Starch & + & + & + \\
& Glucose & + & + & + \\
Oxidase & + & + & + \\
& Indo & - & + & - \\
Lactose & - & + & + \\
Manitol & + & - & + \\
Maltose & + & + & + \\
MR & - & + & - \\
VP & + & - & - \\
& Nitrate & - & - & - \\
Reduction & - Neisseria & Bacillus & Staphylococcus \\
& Bacterial & cereus & aureus \\
& name & spp & cas
\end{tabular}

+ = Positive; - = Negative; MR=Methyl Red; VP= Voges-Proskauer 


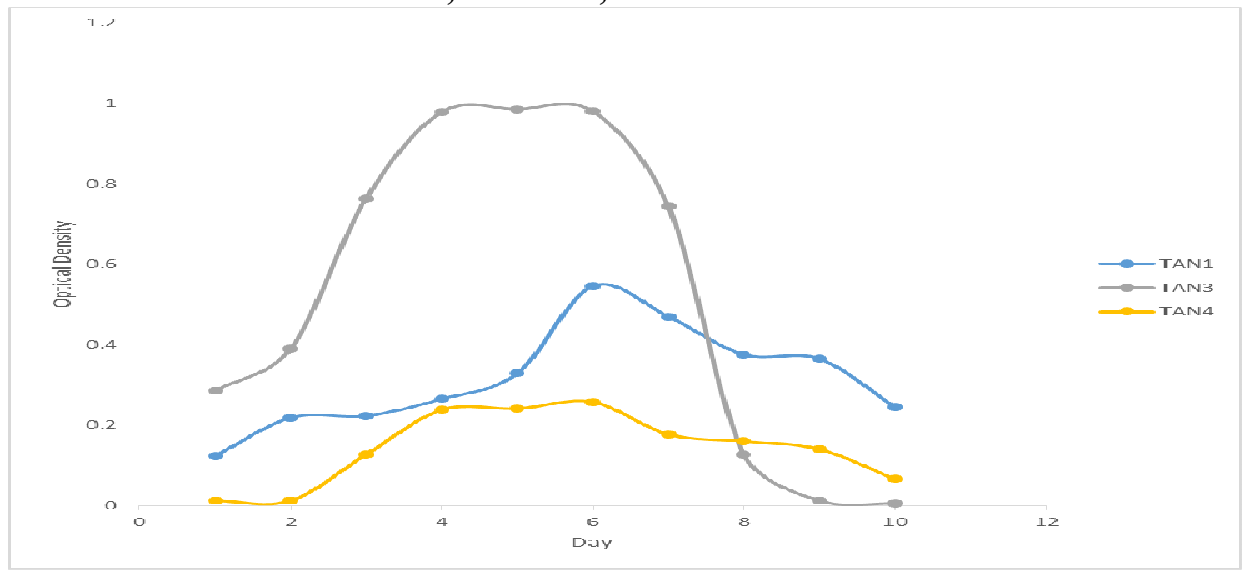

Fig. 2 Growth rates of the isolates in the effluents from the Tannery Industries

\section{Physico-chemical Parameters in the Industrial Effluents after the biodegradation.}

Table 3 shows the mean results of the physicochemical parameter before and after bioremediation using the different masses $(5 \mathrm{~g}$, $10 \mathrm{~g}, 15 \mathrm{~g}, 20 \mathrm{~g}$, and $25 \mathrm{~g}$ ) of the respective immobilized bacteria. Also, Table 4 shows the mean results of correlation coefficient ( $r$ ) between different masses of bacteria and physicochemical parameters.

The mean values $(\mathrm{mg} / \mathrm{l})$ of the SS after the bioremediation varies between $243 \pm 45$ and $898 \pm 672$. The mean concentration $(\mathrm{mg} / \mathrm{l})$ of SS remediated by the different masses $(5 \mathrm{~g}, 10 \mathrm{~g}$, $15 \mathrm{~g}, 20 \mathrm{~g}$, and $25 \mathrm{~g}$ ) of the bacteria varies. The SS in the samples fluctuates up and down after the bioremediation process when compared with the SS of the raw samples before the bioremediation. The increase in the levels of the SS might be due to the aggregation of the TDS which are large enough to result into SS. The increase in the levels of the SS might be also due to the influence of the nutrients which was added into the effluents in order to make the microorganisms more active and viable for fast degradation of organic contaminants in the effluent. The relative potential or efficiency of the different masses of the bacteria in remediating SS in TAN1 samples was in the order $25 \mathrm{~g}>20 \mathrm{~g}>15 \mathrm{~g}>10 \mathrm{~g}>5 \mathrm{~g}$. For TAN2 and TAN3 samples, the order was $25 \mathrm{~g}>20 \mathrm{~g}>15$ $\mathrm{g}>10 \mathrm{~g}>5 \mathrm{~g}$. These might be due to the variations in the surface areas of the different masses of the immobilized bacteria. Statistical analysis shows that there is no significant difference $(p<0.05)$ between the mean values of SS among the masses in the respective industries. Positive and significant correlations exist between the masses of bacteria and Suspended Solid (SS). This showed that there is general increase in the levels of the SS as the masses of the immobilized bacteria increases. TAN3 (90\%) and TAN1 (80\%) showed a very high correlation with the masses of the bacteria while TAN2 (61\%) showed a very low correlation.

The mean values $(\mathrm{mg} / \mathrm{l})$ of the TDS after the bioremediation varies between $46 \pm 11$ and $83 \pm 78$. The mean concentration $(\mathrm{mg} / \mathrm{l})$ of TDS remediated by the different masses $(5 \mathrm{~g}, 10 \mathrm{~g}$, $15 \mathrm{~g}, 20 \mathrm{~g}$, and $25 \mathrm{~g}$ ) of the bacteria varies. There is a reduction in all the TDS of all the samples after the bioremediation process compared with the TDS of the raw samples before the bioremediation. The relative potential or efficiency of the different masses of the bacteria in remediating TDS in TAN1 and TAN3 samples was in the order $5 \mathrm{~g}>10 \mathrm{~g}>15 \mathrm{~g}>20$ $\mathrm{g}>25 \mathrm{~g}$. For TAN2 samples, the order was 20 $g>10 \quad g>25 \quad g>15 \quad g>5 \quad g$. Statistical analysis shows that there is no significant difference $(p<0.05)$ between the mean values of TDS among the masses in the respective industries. These might be due to the variations in the surface areas of the different masses of the immobilized bacteria. Positive and significant correlations exist between the masses of bacteria and TDS with the exception in TAN2 (negative and insignificant correlation). The positive correlations showed that there is general increase in the levels of the TDS as the masses of the immobilized bacteria increases. TAN1 $(96 \%)$ showed a very high correlation with the masses of the bacteria while TAN2 (47\%) showed a very low correlation.

The mean values $(\mathrm{mg} / \mathrm{l})$ of the BOD after the bioremediation varies between $1.56 \pm 0.20 \mathrm{mg} / \mathrm{l}$ and $6.92 \pm 5.49 \mathrm{mg} / \mathrm{l}$. The mean concentration $(\mathrm{mg} / \mathrm{l})$ of BOD remediated by the different masses $(5 \mathrm{~g}, 10 \mathrm{~g}, 15 \mathrm{~g}, 20 \mathrm{~g}$, and $25 \mathrm{~g}$ ) of the bacteria varies. There is a reduction in all the BOD of all the samples after the bioremediation process compared with the $\mathrm{BOD}$ of the raw 
BAJOPAS Volume 13 Number 2, December, 2020 samples before the bioremediation. The relative potential or efficiency of the different masses of the bacteria in remediating BOD in TAN1, TAN2 and TAN3 samples were in the order $25 \mathrm{~g}>20$ $\mathrm{g}>15 \mathrm{~g}>10 \mathrm{~g}>5 \mathrm{~g}, 25 \mathrm{~g}>15 \mathrm{~g}>5 \mathrm{~g}>10 \mathrm{~g}>20 \mathrm{~g}$ and $20 \mathrm{~g}>10 \mathrm{~g}>25 \mathrm{~g}>15 \mathrm{~g}>5 \mathrm{~g}$ respectively. Statistical analysis shows that there is significant difference $(p<0.05)$ between the mean values of BOD among the masses in the respective industries. These might be due to the variations in the surface areas of the different masses of the immobilized bacteria. Negative and significant correlations exist between the masses of bacteria and BOD. This showed that there is general decrease in the levels of the BOD as the masses of the immobilized bacteria increases. TAN1 (94\%) showed a very high correlation with the masses of the bacteria while TAN2 (4\%) showed a very low correlation.

The mean values $(\mathrm{mg} / \mathrm{l})$ of the COD after the bioremediation varies between $250 \pm 154$ and $3134 \pm 1595$. The mean concentration $(\mathrm{mg} / \mathrm{l})$ of COD remediated by the different masses $(5 \mathrm{~g}$, $10 \mathrm{~g}, 15 \mathrm{~g} 20 \mathrm{~g}$, and $25 \mathrm{~g}$ ) of the bacteria varies. There is a reduction in all the COD of all the samples after the bioremediation process compared with the COD of the raw samples before the bioremediation. The relative potential or efficiency of the different masses of the bacteria in remediating COD in TAN1, TAN2 and TAN3 samples were in the order $25 \mathrm{~g}>20 \mathrm{~g}>15$ $\mathrm{g}>5 \mathrm{~g}>10 \mathrm{~g}, 25 \mathrm{~g}>20 \mathrm{~g}>15 \mathrm{~g}>10 \mathrm{~g}>5 \mathrm{~g}$ and 10 g>5 g>25 g>15 g>20 g respectively. Statistical analysis shows that there were significant difference $(p<0.05)$ between the mean values of COD among the masses in the respective industries except for effluents treated with $25 \mathrm{~g}$. These might be due to the variations in the surface areas of the different masses of the immobilized bacteria. Negative and insignificant correlations exist between the masses of bacteria and COD with the exception in TAN3 (positive and significant correlation). The negative correlations showed that there is general decrease in the levels of the COD as the masses of the immobilized bacteria increases. TAN2 (100\%) showed a very high correlation with the masses of the bacteria while TAN3 (36\%) showed a very low correlation.

Generally, there was an overall decrease in the concentration of these physicochemical parameters after the bioremediation using the different masses of the bacterial isolates. These might be due to the variations in the surface areas of the different masses of the immobilized bacteria. This is in line with the work of Jimoh et al. (2018) and Baba et al. (2020).

Table 3: Mean Values $(\mathrm{mg} / \mathrm{l}) \pm$ S.D of Physicochemical parameters in effluents from the Tannery Industries before and after Treatment of the effluents $(250 \mathrm{ml})$ with the different masses $(5 \mathrm{~g}, 10 \mathrm{~g}$, $15 \mathrm{~g}, 20 \mathrm{~g}$, and $25 \mathrm{~g}$ ) of the bacteria.

\begin{tabular}{llllllll}
\hline $\mathrm{P}$ & IND & Before & \multicolumn{5}{c}{ After } \\
\cline { 4 - 7 } & & & $5 \mathrm{~g}$ & $10 \mathrm{~g}$ & $15 \mathrm{~g}$ & $20 \mathrm{~g}$ & $25 \mathrm{~g}$ \\
\hline \multirow{2}{*}{ COD } & TAN1 & $2372 \pm 938$ & $1708 \mathrm{a} \pm 861$ & $2045 \mathrm{a} \pm 1205$ & $845 \mathrm{a} \pm 369$ & $300 \mathrm{a} \pm 167$ & $250 \mathrm{a} \pm 154$ \\
& TAN2 & $1406 \pm 208$ & $1195 \mathrm{a} \pm 208$ & $1125 \mathrm{a} \pm 384$ & $1055 \mathrm{a} \pm 317$ & $956 \mathrm{a} \pm 310$ & $870 \mathrm{ab} \pm 240$ \\
& TAN3 & $3532 \pm 1373$ & $2374 \mathrm{a} \pm 1344$ & $1976 \mathrm{a} \pm 1405$ & $2757 \mathrm{a} \pm 1266$ & $3134 \mathrm{a} \pm 1595$ & $2614 \mathrm{~b} \pm 1105$ \\
BOD & TAN1 & $13.85 \pm 6.42$ & $6.92 \mathrm{a} \pm 5.49$ & $6.42 \mathrm{a} \pm 5.07$ & $5.72 \mathrm{a} \pm 5.35$ & $4.62 \mathrm{a} \pm 4.37$ & $2.82 \mathrm{ab} \pm 1.26$ \\
& TAN2 & $19.46 \pm 0.50$ & $1.75 \mathrm{~b} \pm 0.22$ & $1.73 \mathrm{~b} \pm 0.18$ & $1.58 \mathrm{a} \pm 0.16$ & $1.91 \mathrm{a} \pm 0.22$ & $1.56 \mathrm{~b} \pm 0.20$ \\
& TAN3 & $17.13 \pm 3.14$ & $4.24 \mathrm{ab} \pm 0.77$ & $3.29 \mathrm{ab} \pm 0.37$ & $4.11 \mathrm{a} \pm 0.07$ & $3.23 \mathrm{a} \pm 0.91$ & $3.33 \mathrm{a} \pm 1.28$ \\
SS & TAN1 & $374 \pm 124$ & $243 \mathrm{a} \pm 45$ & $471 \mathrm{a} \pm 226$ & $475 \mathrm{a} \pm 182$ & $492 \mathrm{a} \pm 128$ & $611 \mathrm{a} \pm 217$ \\
& TAN2 & $358 \pm 335$ & $460 \mathrm{a} \pm 400$ & $543 \mathrm{a} \pm 414$ & $544 \mathrm{a} \pm 402$ & $551 \mathrm{a} \pm 414$ & $554 \mathrm{a} \pm 405$ \\
& TAN3 & $780 \pm 739$ & $586 \mathrm{a} \pm 594$ & $758 \mathrm{a} \pm 656$ & $787 \mathrm{a} \pm 676$ & $861 \mathrm{a} \pm 635$ & $898 \mathrm{a} \pm 672$ \\
TDS & TAN1 & $3941 \pm 3703$ & $51 \mathrm{a} \pm 10$ & $53 \mathrm{a} \pm 10$ & $55 \mathrm{a} \pm 15$ & $61 \mathrm{a} \pm 20$ & $63 \mathrm{a} \pm 26$ \\
& TAN2 & $3300 \pm 1714$ & $83 \mathrm{a} \pm 78$ & $47 \mathrm{a} \pm 20$ & $48 \mathrm{a} \pm 22$ & $47 \mathrm{a} \pm 17$ & $48 \mathrm{a} \pm 17$ \\
& TAN3 & $2653 \pm 1240$ & $46 \mathrm{a} \pm 11$ & $55 \mathrm{a} \pm 24$ & $55 \mathrm{a} \pm 25$ & $58 \mathrm{a} \pm 23$ & $61 \mathrm{a} \pm 28$ \\
\hline
\end{tabular}

Replicate $=6$ (months)

Within the rows, for the same parameter, means with different alphabets are statistically different $(p<0.05)$.

$\mathrm{P}=$ parameter, IND = Industries 
BAJOPAS Volume 13 Number 2, December, 2020

Table 4: Correlation coefficient $(r)$ between different masses of the bacteria and the physicochemical parameters.

\begin{tabular}{llll}
\hline Industries & Parameter & Correlation coefficient $(r)$ & $\begin{array}{l}\text { Percent dependence (rxrx100) } \\
(\%)\end{array}$ \\
\hline TAN1 & COD & -0.9 & 82 \\
& BOD & -0.97 & 94 \\
& SS & $0.90^{*}$ & 80 \\
TAN2 & TDS & $0.98^{*}$ & 96 \\
& COD & -1 & 100 \\
& BOD & -0.21 & 4 \\
& SS & $0.78^{*}$ & 61 \\
& TDS & -0.69 & 47 \\
& COD & $0.60^{*}$ & 36 \\
& BOD & -0.6 & 37 \\
& SS & $0.95^{*}$ & 90 \\
& TDS & $0.94^{*}$ & 89 \\
\hline
\end{tabular}

The correlation coefficient $(r)$ with * is statistically significant $(p<0.05)$.

Percentage reduction of the Parameters

Table 5 shows the percentage reduction of Parameters in industrial samples before and after the treatment of the effluents $(250 \mathrm{ml})$ with the different masses $(5 \mathrm{~g}, 10 \mathrm{~g}, 15 \mathrm{~g}, 20 \mathrm{~g}$, and $25 \mathrm{~g}$ ) of the Immobilized Bacteria.

In TAN1 samples, the percentage reduction (\%) of COD ranged (14-89); BOD (50-80); SS (-32$35)$ and TDS (98-99). In TAN2 samples, the percentage decrease $(\%)$ of COD ranged (15$38) ;$ BOD (90-92); SS [-28-(-55)] and TDS (9798). In TAN3 samples, the percentage decrease (\%) of COD ranged (11-44); BOD (76-81); SS (15-25) and TDS (98). The percentage increase in the levels COD, BOD and TDS might be due to the increase in the surface area of the different masses of the immobilized bacteria. However, the percentage decrease in the levels of the SS might be due to the aggregation of the TDS which are large enough to result into SS. The percentage decrease in the levels of the SS might be also due to the influence of the nutrients which was added into the effluents in order to make the microorganisms more active and viable for fast degradation of organic contaminants in the effluent. This is in line with the work of Jimoh et al. (2018) in which the concentration of the SS increase after the bioremediation of effluents.

Sreemoyee and Priti (2013) assessed and reduced several Physico-chemical parameters of dairy wastewater using Niesseria $s p$. and concluded that the species are well known to degrade organic compounds. This is in agreement with the current study in which the immobilized Niesseria $s p$ degrade the organic contaminants as indicated by the BOD, COD and TDS.

Jimoh et al. (2018) observed that TSS of the effluents was increased after treatment with immobilized bacteria and concluded that it might be due to the biostimulation method adopted for the research.

The optimum $\mathrm{pH}$ Biosorption of Chromium by Bacillus spp and Staphylococcus spp. from tannery effluent was investigated by Mythili and Karthikeyan (2011). The maximum adsorption of Chromium $(86.4 \mathrm{mg} / \mathrm{L})$ was showed by Bacillus spp and Staphylococcus spp showed $70.6 \mathrm{mg} / \mathrm{L}$ at an initial concentration of $100 \mathrm{mg} / \mathrm{L}$. In the present study, immobilised Bacillus spp and Staphylococcus spp. from the tannery industrial effluents reduced the levels of the organic pollutants with high potential as indicated by the percentage reduction of BOD, COD and TDS.

Enzymes often can work in multiple environments especially if they are immobilized. This makes the microorganisms' enzymes even more resistant to harsh environments and enables the enzymes to be recovered and recycled after they are no longer needed (Gianfreda and Rao 2004). Ramesh and Singh (1993) reported that the immobilized bacteria having more efficiency to remove the suspended particles than free cells. Using the immobilized cell is preferable due to its capability for using several times with the same efficiency, which makes it more economical. Similar work was done by Sikander et al. (2007) showing the higher reduction with permeabilized cells of Ochrobactrum intermedium strain SDCr-5. 
BAJOPAS Volume 13 Number 2, December, 2020

The results revealed the isolation and identification of isolates with the potential for the reduction of $\mathrm{Cr}$ (VI) to $\mathrm{Cr}$ (III). Results indicated that immobilized $B$. cereus could be efficiently used for the reduction of $\mathrm{Cr}$ (VI).

Table 5: Percentage reduction of the tested Parameters from the tannery industrial samples of the Immobilized Bacteria.

\begin{tabular}{lllllll}
\hline \multirow{2}{*}{ Industries } & & \multicolumn{5}{c}{ Percentage Reduction $(\%)$} \\
\cline { 3 - 7 } & & $5 \mathrm{~g}$ & $10 \mathrm{~g}$ & $15 \mathrm{~g}$ & $20 \mathrm{~g}$ & $25 \mathrm{~g}$ \\
\hline TAN1 & COD & 28 & 14 & 64 & 87 & 89 \\
& BOD & 50 & 54 & 59 & 67 & 80 \\
& SS & 35 & -26 & -27 & -32 & -63 \\
& TDS & 99 & 99 & 99 & 98 & 98 \\
TAN2 & COD & 15 & 20 & 25 & 32 & 38 \\
& BOD & 91 & 91 & 92 & 90 & 92 \\
& SS & -28 & -52 & -52 & -54 & -55 \\
& TDS & 97 & 99 & 99 & 99 & 99 \\
& COD & 33 & 44 & 22 & 11 & 26 \\
& BOD & 75 & 81 & 76 & 81 & 81 \\
& SS & 25 & 3 & -1 & -10 & -15 \\
& TDS & 98 & 98 & 98 & 98 & 98 \\
\hline
\end{tabular}

Percentage Reduction $=(B-A) / B \times 100 \%$

$A=$ Concentration of the parameter after treatment

$\mathrm{B}=$ Concentration of the parameter before treatment

$+=$ percentage decrease

- = percentage increase

In general, immobilization makes the enzyme more resistant to temperature, $\mathrm{pH}$, and substrate concentration swings giving it a longer lifetime and higher productivity per active unit (Gianfreda and Rao, 2004; FuIlbrook, 1996; Russell et al, 2003; Kandelbauer et al., 2004). Immobilized cells have been used and studied extensively for the production of useful chemicals (Ohtake and Silver, 1994), the treatment of wastewaters (Chen et al., 2003; Wang et al., 2010). Although many workers described microbial degradation of tannery effluent, limited literature is available on the bioremediation of tannery effluent using immobilized bacterial cells in the Kano Industrial Estates.

\section{CONCLUSION}

The samples contained variable levels of the physicochemical parameters. The results of the Analysis of variance revealed that, no statistical difference $(p<0.05)$ was observed for the temperature, $\mathrm{pH}, \mathrm{SS}, \mathrm{TDS}, \mathrm{BOD}$ and $\mathrm{COD}$ among the three tannery industries before the treatment. The levels of some of the parameters
(SS, TDS and COD) observed in the samples were found above the recommended limits of WHO and NESREA, which called for the treatment of the effluents before discharge into the environment. Base on the morphological and biochemical test results, TAN1, TAN2, and TAN3 bacterial isolates were identified to be Neisseria spp, Bacillus cereus, and Staphylococcus aureus respectively. The results of Post-treatment analysis showed that there is overall decrease in the levels of the parameters determined when compared with that of the pre-treatment. The overall percentage reduction of the immobilised bacteria in the treatment of the respective effluents was in the order TAN2 (72\%)>TAN1 $(70 \%)>$ TAN3 $(62 \%)$. Hence, the immobilized bacteria are having higher biodegradation potential for the treatment of the tannery effluents.

\section{Acknowledgments}

The authors wish to acknowledge the University of Maiduguri for the financial support. The authors are grateful to the Kano State Ministry of Environment for their support in obtaining the effluent samples. 


\section{REFERENCES}

Ajao, A. T., Adebayo, G. B., and Yakubu, S. E. (2011). Bioremediation of textile industrial effluent using mixed culture of Pseudomonas aeruginosa and Bacillus subtilis immobilized on agar-agar in a bioreactor. J. Microbiol. Biotech. Res, 1(3), 50-56.

Akan, J. C., Moses, E. A., Ogugbuaja, V. O., and Abah, J. (2007). Assessment of tannery industrial effluents from Kano metropolis, Kano State, Nigeria. Journal of Applied Sciences, 7(19), 2788-2793.

Akan, J. C., Ogugbuaja, V. O., Abdulrahman, F. I., and Ayodele, J. T. (2009). Pollutant levels in effluent samples from tanneries and textiles of Kano industrial areas, Nigeria. Global journal of pure and applied sciences, 15(3-4).

APHA (1989). Standard methods for Examination of Will bete and Will betewater.15 $5^{\text {th }}$ edition. Brydpass Springfield Will behington DC. pp. 164-176

APHA (1992). Standard Methods for the Examination of Water and Wastewater. Health, 69, 1116-9.

Baba, A., Garba, S. T., and Bello, H. S. (2020). Bioremediation Potential of Immobilized corynebacterium kutsceri in the Treatment of Tannery Industrial Effluent from Challawa Industrial Estate, Kano State, Nigeria. Journal of the Turkish Chemical Society Section A: Chemistry, $7(2), 335-350$.

Beem, E. I. V. (1994). reduction of solvent VOC emission. J. Oil Col. Chem. Ass, 77, 158.

Bouwer, E. J., and Zehnder, A. J. (1993). Bioremediation of organic compoundsputting microbial metabolism to work. Trends in biotechnology, 11(8), 360367.

Chen, K. C., Wu, J. Y., Liou, D. J., and Hwang, S. C. J. (2003). Decolorization of the textile dyes by newly isolated bacterial strains. Journal of Biotechnology, 101(1), 57-68.

Dan'Azumi, S., and Bichi, M. H. (2010). INDUSTRIAL POLLUTION AND HEAVY METALS PROFILE OF CHALLAWA RIVER IN KANO, NIGERIA. Journal of Applied Sciences in Environmental Sanitation, $5(1)$.

DWAF. (1992). Analytical Methods Manual, TR 151. Department of Water Affairs and Forestry, Pretoria.

El-Bestawy, E. (2013). Biological treatment of leather-tanning industrial wastewater using free living bacteria.
Elsheikh, M. A. S. (2009). Tannery wastewater pre-treatment. Water Science and Technology, 60(2), 433-440.

FuIlbrook, P. D. (1996). "Kinetics." Industrial enzymology: The application of enzymes in Industry. 2nd Ed. T. Godfrey and J Reichelt. eds.. Nature. New York.

Gianfreda, L., and Rao, M. A. (2004). Potential of extra cellular enzymes in remediation of polluted soils: a review. Enzyme and microbial technology, 35(4), 339354.

Hugo Springer. (1994). John Arthur Wilson Memorial Lecture "Treatment of Industrial Wastes of the Leather Industry - is it still a Major Problem". JALCA, 89, 153-185

Jimoh, A. A., Ganiyu, B. A., Baba, D., and Baba, A. (2018) Bioremediation Process of Effluent from Detergent and Food Industries in Jos, Nigeria: Kinetics and Thermodynamics. International Journal of Engineering Science Invention (IJESI), 762-73

Kandelbauer, A., Maute, O., Kessler, R. W., Erlacher, A., and Gübitz, G. M. (2004). Study of dye decolorization in an immobilized laccase enzyme-reactor using online spectroscopy. Biotechnology and bioengineering, 87(4), 552-563.

Kongjao, S., Damronglerd, S., and Hunsom, M. (2008). Simultaneous removal of organic and inorganic Pollutants in tannery wastewater using electrocoagulation technique. Korean Journal of chemical engineering, 25(4), 703.

Maheshwari, U. M., Aruna, S., Gomathi, M., and AbdulJaffar, A. H. (2017). Bioremediation by Free and Immobilized Bacteria Isolated from Tannery Effluent. International Journal of Research in Applied, Natural and Social Sciences. 5(7), 75-90

Margesin, R., and Schinner, F. (2001). Bioremediation (natural attenuation and biostimulation) of diesel-oilcontaminated soil in an alpine glacier skiing area. Applied and environmental microbiology, 677), 3127-3133.

Mohammed, A., Sekar, P., and George, J. (2011). Efficacy of microbes in bioremediation of tannery effluent. Inter. J. Curr. Res, 3(4), 324-326.

Mohammed, S. S. D., Orukotan, A. A., and Abdullahi, H. (2017). Physicochemical and Bacteriological Assessment of Tannery Effluent from Samaru-Zaria, 
BAJOPAS Volume 13 Number 2, December, 2020 Kaduna State, Nigeria. Journal of Applied

Sciences and Environmental Management, 21(4), 734-740.

Munz, G., De Angelis, D., Gori, R., Mori, G., Casarci, M., and Lubello, C. (2009). The role of tannins in conventional and membrane treatment of tannery wastewater. Journal of hazardous materials, 164(2-3), 733-739

Mythili, K., and Karthikeyan, B. (2011). Bioremediation of $\mathrm{Cr}$ (VI) from tannery effluent using Bacillus spp and Staphylococcus spp. International Multidisciplinary Research Journal, 1(6).

NESREA (2009). National Environmental Standards for Effluent Limitations and Regulation. 1233-1236

Noorjahan, C. M. (2014). Physicochemical characteristics, identification of bacteria and biodegradation of industrial effluent. Journal of bioremediation and Biodegradation, 5(3).

Ohtake, H. I., and Silver, A. O. (1994). Bacterial reduction of toxic chromate. Biological degradation and bioremediation of toxic chemicals, 403-415.

Omoleke, I. I. (2004). Management of environmental pollution in Ibadan, an African city: the challenges of health hazard facing government and the people. Journal of Human Ecology, 15(4), 265-275.

Rajor, A., Reddy, A.S., and Singh, B. (2004). Determination of BOD kinetic Parameters and evaluation of alternate methods, M.Sc. Thesis, Department of biotechnology \& environmental Science, Thapar Institute of Engineering and Technology, Patiala

Ramasami, T., Rajamani, S., and Rao, J. R. (1994, March). Pollution control in leather industry: Emerging technological options. In International symposium on surface and colloidal science and its relevance to soil pollution, madras.

Ramesh, J. V. S., and Singh, S. P. (1993). Yearly variation in certain physicochemical parameters of pond at eastern Doon Valley. Uttar Pradesh J. Zoo, 12 (1), 7577.

Ranen, S., and Sharadinadra, C. (2009). Biotechnology applications to environmental remediation in resource exploitation. Current science, 97, 6-25
Russell, A. J., Berberich, J. A., Drevon, G. F., and Koepsel, R. R. (2003). Biomaterials for mediation of

chemical and biological warfare agents. Annual review of biomedical engineering, 5(1), 1-27.

Saravanan, P., and Saravanan, A. (1999). Decolourization of tannery effluent by Flavobacterium sp. EK 1. Indian Journal of Environmental Protection, 19, 19-24.

Sikander, S., and Shahida, H. (2007). Reduction of toxic hexavalent chromium by Ochrobactrum intermedium strain SDCr5 stimulated by heavy metals. Bioresource Technol, 98, 340-344.

Singh, N., Sharma, B. K., and Bohra, P. C. (2000). Impact assessment of industrial effluent of arid soils by using satellite imageries. Journal of the Indian Society of Remote Sensing, 28(2-3), 79.

Sreemoyee, C., and Priti, P. (2013). Assessment of physico-chemical parameters of dairy waste water and isolation and characterization of bacterial strains in terms of cod reduction. Int J Sci, 2(3), 395-400.

Verheijen, L. A. H. M., Wiersema, D., Pol, L. H., and De Wit, J. (1996). Management of wastes from animal product processing. Livestock and environment, Finding a balance. International Agriculture Center, Wageningen, The Netherlands.

Wang, F., Yao, J., Si, Y., Chen, H., Russel, M., Chen, K., and Bramanti, E. (2010). Short-time effect of heavy metals upon microbial community activity. Journal of Hazardous Materials, 173(13), 510-516.

WHO (World Health Organization). (2006). Air quality guidelines: global update 2005: particulate matter, ozone, nitrogen dioxide, and sulfur dioxide. World Health Organization.

World Bank. (1995). Nigeria's strategic options for redressing industrial pollution. World Bank, industry and energy division. 1st edition, West Central Africa Department; Annexes: 1995; pp 60-62.

Zahoor, A., and Abdul, R. (2009). Enumeration of Coliforms. Journal of Environmental Sciences. 21, 814-820 


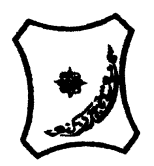

Bayero Journal of Pure and Applied Sciences, 13(2): 1 - 12

Received: November, 2020

Accepted: December, 2020

ISSN $2006-6996$

\title{
BIODEGRADATION POTENTIAL OF IMMOBILIZED BACTERIA IN THE TREATMENT OF TANNERY INDUSTRIAL EFFLUENTS FROM INDUSTRIAL ESTATES IN KANO STATE, NIGERIA
}

\author{
Abdullateef, B., ${ }^{1 *}$ Shuaibu, T. G., ${ }^{1}$ Babagana, K., ${ }^{1}$ Suleman, H. B. ${ }^{2}$ and Dauda, B. ${ }^{3}$ \\ ${ }^{1}$ Department of Pure and Applied Chemistry, Faculty of Science, University of Maiduguri, Borno State, \\ Nigeria \\ ${ }^{2}$ Department of Microbiology, Faculty of Science, University of Maiduguri, Borno State, Nigeria \\ ${ }^{3}$ Department of Chemical Engineering, Faculty of Engineering, University of Maiduguri, Borno State, \\ Nigeria \\ *Corresponding author: babslega@gmail.com; abelega2007@yahoo.com; +2348061309753
}

\section{ABSTRACT}

Industrial Effluents Samples from Gashash Tanneries (TAN1) in Bompai Industrial estate, Larabee Tannery Industry (TAN2) in Sharada Industrial estate and Z Tannery Industries (TAN3) in Challawa Industrial estate, Kano State, Nigeria were collected over a period of six months (August 2017 to January 2018) for assessing the biodegradation potentials of bacteria in the treatment of organic pollutants within the effluents. Bacteria were isolated from the effluents and immobilized on agar-agar. Different masses (5 g, $10 \mathrm{gr}, 15$ $\mathrm{g}, 20 \mathrm{~g}$, and $25 \mathrm{~g}$ ) of the bacteria were used in the treatment of $250 \mathrm{ml}$ of the effluents for ten days in a shaker incubator (Gallenkamp-OC-4364-L) at the temperature $30{ }^{\circ} \mathrm{C}$ and speed of $60 \mathrm{rpm}$. Pre-treatment analysis of the effluents for Temperature, pH, Biochemical Oxygen Demand (BOD), Chemical Oxygen Demand (COD), Suspended Solid (SS) and Total Dissolved Solids (TDS) gives the following results; temperature $\left({ }^{\circ} \mathrm{C}\right.$ )

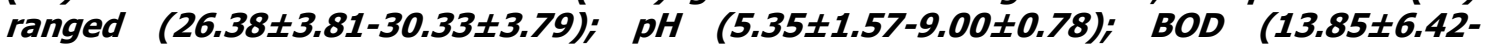
$38.75 \pm 16.20) ;$ COD (1406 $\pm 208-3532 \pm 1373) ;$ SS (208 $\pm 235-780 \pm 739)$ and TDS (266 $\pm 253-5276 \pm 2971)$. No statistical differences ( $p \leq 0.05)$ was observed for all the results among the different industries. The bacterial isolates were identified as Neisseria spp, Bacillus cereus, and Staphylococcus aureus, in TAN1, TAN2, and TAN3, respectively. After treatment of the effluent with the different masses of the isolated bacteria, the mean level of BOD was found to range as (0.55 $\pm 0.36-6.92 \pm 5.49) ; C O D$ (ND-3134 \pm 1595$)$;

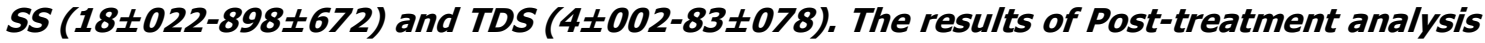
showed that there is overall decrease in the levels of the parameters determined when compared with that of the pre-treatment. The overall percentage reduction of the immobilised bacteria in the treatment of the respective effluents was in the order TAN2 (72\%)>TAN1 (70\%)>TAN3 (62\%). Hence, the immobilized bacteria are having higher biodegradation potential for the treatment of the tannery effluents.

Keywords: Biodegradation, bacteria, effluent, immobilization, tannery.

\section{INTRODUCTION}

Tannery industrial wastewater is a serious consequence of the pollution point of view for streams, freshwater, and land used for agriculture. The lack of awareness in the modern industrial practice has resulted in the discharge of tannery effluents which exhibit very high value of chromium ( $\mathrm{Cr}$ ), Sulfide, and chloride, Total Dissolved Solid (TDS), Total Suspended Solid (TSS), Biochemical Oxygen Demand (BOD) and Chemical Oxygen Demand (COD) in the water stream or land (Mohammed et al., 2001). Tanning is the process, which One ton of skin generally leads to the production of 20 to $80 \mathrm{~m}^{3}$ of turbid and foul-smelling converts the protein of the rawhide or skin into a stable material, which will not putrefy and is suitable for a wide variety of end applications (Elsheikh, 2009). The highly polluting chromium is the most commonly used tanning material producing leather that is more flexible and pliable than vegetable-tanned leather and does not discolor or lose shape in water as drastically as vegetable-tan (Elsheikh, 2009). Tannery effluent is among the most hazardous industrial pollutants due to its huge organic and inorganic load, which is highly toxic to human life and the environment (Kongjao et al., 2008). wastewater including chromium (100-400 mg/l), sulfide $(200-800 \mathrm{mg} / \mathrm{l})$, high levels of fat and 
BAJOPAS Volume 13 Number 2, December, 2020 other solid wastes, and notable pathogen contamination as well as pesticides added for skin conservation during transport (Elsheikh, 2009). There are more than 6000 tanneries in Nigeria with an annual processing capacity of 700,000 tons of hides and skins (Omoleke, 2004; Singh et al., 2008). It was reported that the total amount of waste produced per animal slaughtered is approximately $35 \%$ of its weight (World Bank, 1995). Also, for every $1000 \mathrm{~kg}$ of carcass weight, a slaughtered beef produces 5.5 $\mathrm{kg}$ of manure (excluding rumen contents or stockyard manure) and $100 \mathrm{~kg}$ of paunch manure (undigested food) (Verheijen et al., 1996). Tanneries generate wastewater in the range of 30-35 $\mathrm{L} \mathrm{kg}^{-1}$ skin/hide processed with variable $\mathrm{pH}$, Biological Oxygen Demand (BOD), Chemical Oxygen Demand (COD), high concentrations of suspended solids (SS), and tannins as well as chromium (Zahoor and Abdul, 2009).

Being heterogeneous and composed of a wide variety of compounds, it is very difficult to select a unique direct method for estimating the biodegradability of organic contents and biokinetic parameters for a wastewater sample (Rajor, 2004). For this purpose, some indirect estimation such as determination of biochemical oxygen demand (BOD) and chemical oxygen demand (COD) are applied as common laboratory investigations [9]. During retanning procedures, synthetic tannins (Syntan), oils and resins are added to form softer leather at varying doses (Munz et al., 2009). One of the refractory groups of chemicals in tannery effluents derives mainly from tannins (Ramasami et al., 2004). Syntans are characterized by complex chemical structures, because they are composed of an extended set of chemicals such as phenol-, naphthalene-, formaldehyde- and melamine-based syntans, and acrylic resins (Beem, 1994). Organic pollutants (proteic and lipidic components) are originated from skins (it is calculated that the raw skin has $30 \%$ loss of organic material during the working cycle) or they are introduced during processes (Hugo Springer, 1994).

Many conventional processes such as oxidation, chemical and biological processes were carried out to treat tanneries wastewater (Ebtesam et al, 2013). Biological processes have received more attention because of their costeffectiveness, lower sludge production and environmental friendliness (Noorjahan, 2014). Naturally occurring micro-organisms degrade the hazardous organic wastes including xenobiotic compounds, such as pesticides, polycyclic aromatic hydrocarbons (PAHs) and polychlorinated biphenyls (PCBs) in due course of time (Ranen and Sharadinadra, 2009). Bioremediation is based on the idea that all organisms remove substances from the environment to carry outgrowth and metabolism (Bouwer and Zehnder, 1993). Bacteria, protista and fungi are found to be very good at degrading complex molecules and incorporating the breakdown products into their metabolism (Bouwer and Zehnder, 1993). The resultant metabolic wastes that they produce are generally safe and somehow recycled into other organisms (Ranen and Sharadinadra, 2009). An acclimatized indigenous population of microorganisms capable of degradation of the compounds of interest must exist at the site for a successful bioremediation mode (Ranen and Sharadinadra, 2009). It has been observed that for a successful bioremediation mode, an acclimatized indigenous population of microorganisms capable of degradation of the compounds of interest must exist at the site under investigation (Ranen and Sharadinadra, 2009). Even though there are numerous physical and chemical methods employed in the disposal of wastes the advantage in using bacterium is that they play a key role in the reduction of COD, BOD, total protein, total tannin and total phenol (Saravanan and Saravanan, 1998)

Baba et al. (2020) studied the bioremediation potential of immobilized corynebacterium kutsceri in the Treatment of tannery industrial effluent from Challawa Industrial Estate, Kano State, Nigeria. The aim of the work is to study the reduction in the level of the contaminants through the process of bioremediation using the isolated bacteria. Immobilized bacteria can withstand various temperatures, $\mathrm{pH}$ and substrate concentrations; consequently, increasing the efficiency and the lifespan of the bacteria. Immobilized bacteria are widely applied in the treatment of wastewater and can be separated and recovered after the treatment with the same efficiency (Baba et al., 2020).

\section{MATERIALS AND METHODS \\ Study Area}

This study was carried out in Bompai, Sharada and Challawa industrial estates in Kano, Figure 1. Kano lies on Latitude $11^{\circ} 30^{\prime} \mathrm{N}$ and $8^{\circ} 30^{\prime} \mathrm{E}$ and Longitude $11^{\circ} 5^{\prime} \mathrm{N}$ and $8^{\circ} 5^{\prime} \mathrm{E}$ in Northern Nigeria. It is one of the developed industrial cities in Nigeria. Tannery activities are the dominating industries and this could be one of the reasons for her high population density (Dan'Azumi and Bichi, 2010). Many researchers have studied biodegradation of tannery effluent using microorganisms. However, limited literature is available on the biodegradation of tannery effluent in Kano industrial estates using 
BAJOPAS Volume 13 Number 2, December, 2020 immobilized bacterial cells. This research work focuses on the potential of the use of the indigenous immobilized bacterial isolates in the treatment of tannery effluents in the industrial estates.

\section{Sample Collection}

Effluents were collected from the Tannery Industries from Bompai, Challawa and Sharada Industrial Estates, Kano, Nigeria. The effluents were collected over a period of six months (August 2017 to January 2018). Samples collected in a sterile 4-liter plastic container with a unique identification number were preserved using an ice-box that was transported to the Microbiology Laboratory, Department of Microbiology, Bayero University of Kano for analysis

\section{Sample Preparation and Sample Analysis}

Immediately after the collection of the effluent, $\mathrm{pH}$, TSS, TDS, COD, BOD levels were determined before treatment (Pre-treatment determination) and ten days after treatment (Post-treatment determination) as described in
APHA (1989) standard methods. $\mathrm{pH}$ was determined using Ecotests $\mathrm{pH}$ meter and TDS was determined using AQUALYTIC TDS Salinometer. BOD was determined as described by the standard method (APHA, 1992). COD and SS were determined using DR/2010 HACH portable data logging spectrophotometer (DWAF, 1992)

\section{Identification and Biochemical} Characterization of the Bacterial Isolates

The bacteria were isolated from the effluents using Serial Dilution according to the method described by APHA (1989). The biochemical tests such as oxidase, catalase, coagulase, indole (from $1 \%$ tryptone broth), citrate (Simmons citrate agar), methyl red/VogesProskauer (MR/VP), nitrate reduction, Starch Hydrolysis, Glucose, Maltose, and Lactose tests were carried out on the bacterial isolates to identify the bacteria through the bacteria biochemical characteristics according to Ajao et al. (2011).

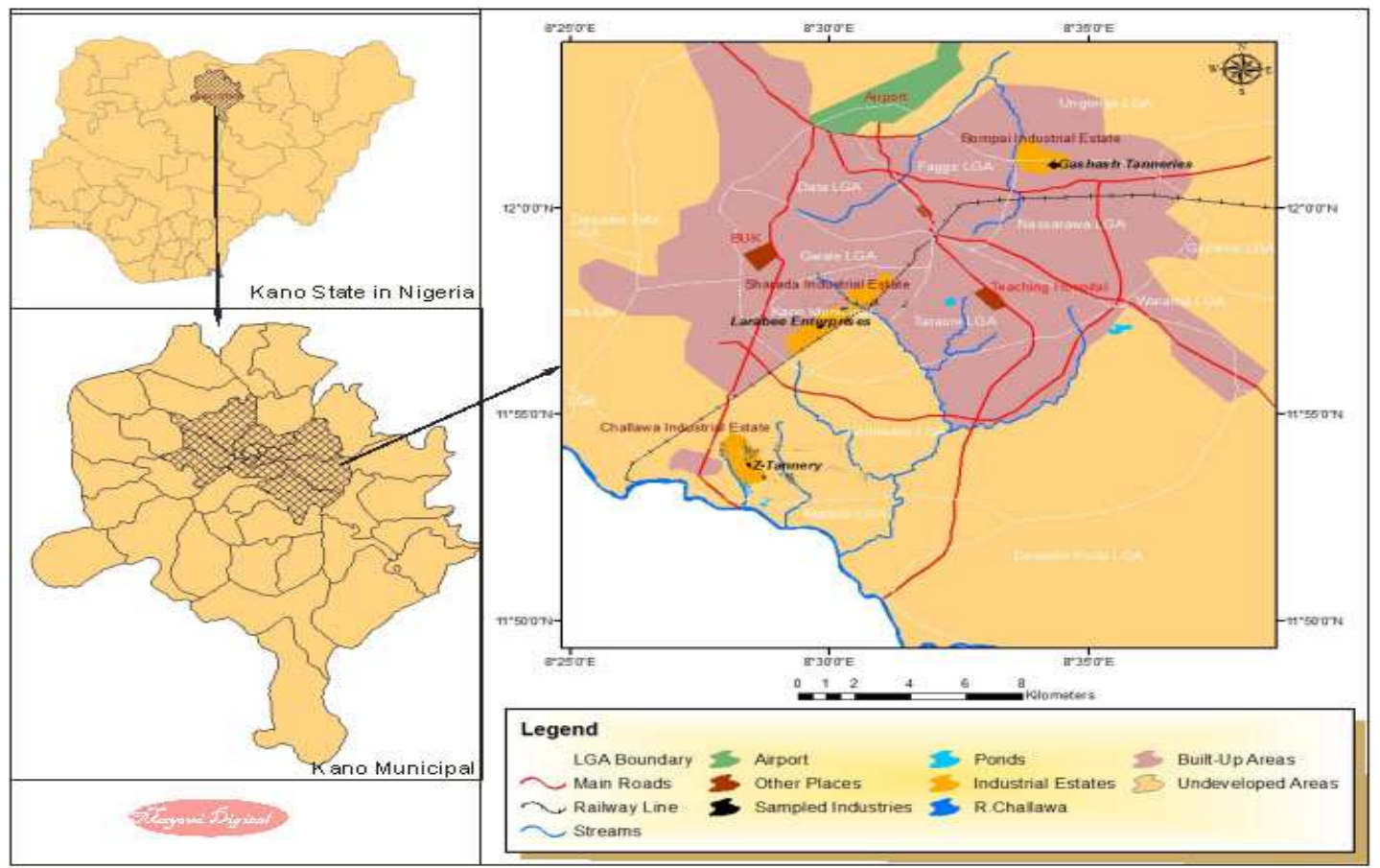

Fig. 1 Map showing the study areas

Source: Mayomi Digital Productions, GIS Laboratory, Department of Geography, UNIMAID (2017)

\section{Determination of Growth Rate of the Bacteria in Effluent Sample}

The bacteria growth rates were determined by transferring $2 \mathrm{~mL}$ of the bacterial isolates from the tannery effluent in broth medium into 100 $\mathrm{mL}$ sterile effluents in conical flasks and kept in an incubator (Giffrin cool) for 10 days. Control was also set up by incubating another $100 \mathrm{~mL}$ each of the sterile effluents without the bacteria. The optical density of the content was determined at the wavelength of $600 \mathrm{~nm}$ on a daily interval and recorded. 
BAJOPAS Volume 13 Number 2, December, 2020 Immobilization of Bacteria

Agar solution and inoculi were prepared separately. Fifty milliliters $(50 \mathrm{~mL})$ of nutrient broth each of the inoculi was prepared in a McCartney bottle and incubated for 24 hours. A solution of agar-agar was prepared by dissolving $10 \mathrm{~g}$ of the powder in distilled water and made up to $500 \mathrm{~mL}$ mark in an Erlenmeyer flask and was sterilized in an autoclave (280A) for 15 minutes and allowed to cool to $40-45^{\circ} \mathrm{C}$ (Ajao et al., 2011). Four milliliters ( $4 \mathrm{~mL})$ of the bacterial isolates in the nutrient broth was mixed with 36 $\mathrm{ml}$ of the prepared agar-agar media in petri-dish plates and then allowed to solidify. This was kept in the refrigerator for bioremediation.

\section{Bioremediation (Treatment) of the Effluents}

The solidified agar block (immobilized bacteria) was cut into cubes using a sterile knife; $0.1 \mathrm{~mL}$ phosphate buffer ( $\mathrm{pH} \mathrm{7.0)}$ was added and kept in the refrigerator for 1 hour for curing. The phosphate buffer was decanted after 1 hour and the cubes were washed with sterile distilled water 3-4 times before it was used (Ajao et al., 2011). Two liters (2 L) of the effluent was supplemented with the minimum basal medium in $\mathrm{g} / \mathrm{L}: \mathrm{NaCl}(0.8), \mathrm{MgSO}_{4} .7 \mathrm{H}_{2} \mathrm{O}(0.001), \mathrm{KH}_{2} \mathrm{PO}_{4}$ (2), $\mathrm{NaNO}_{3}$ (2), $\quad \mathrm{CaCl}_{2} .2 \mathrm{H}_{2} \mathrm{O} \quad(0.5)$ and $\mathrm{NaHPO}_{4} .12 \mathrm{H}_{2} \mathrm{O}(2)$ and sterilized in an autoclave at $121^{\circ} \mathrm{C}$ for 15 minutes (Margesin and Schinner, 2001). Two hundred and fifty milliliters $(250 \mathrm{~mL})$ of the effluents were transferred into different $250 \mathrm{ml}$ conical flasks. The content was covered with a cotton-wool ramped with foil paper to avoid contamination. Five grams $(5 \mathrm{~g})$ of the immobilized bacteria were quickly transferred into each of the effluents in the conical flasks in an inoculating chamber. The same procedures were carried out for the $10 \mathrm{~g}, 15 \mathrm{~g}, 20 \mathrm{~g}$ and 25 $\mathrm{g}$ of the immobilized bacteria in separate $250 \mathrm{~mL}$ effluents in conical flasks and agitated for ten days in a shaker incubator (Gallenkamp-OC4364-L) at a temperature $30^{\circ} \mathrm{C}$ and speed of 60 rpm. The treated effluent samples were taken on the tenth day and analyzed for the parameters $\mathrm{pH}$, SS, TDS, COD, and BOD, (Posttreatment determination) for the different grams of bacteria to evaluate and compare the biodegradation potential. (Baba et al., 2020).

\section{Statistical Analysis}

The data were represented as Mean \pm Standard deviation and analyzed statistically using oneway Analysis of Variance (ANOVA) and Tukey's HSD as Post Hoc Tests with the aid of SPSS 16.0. The correlation coefficient was also used to measure the strength of the relationship between the different masses of the bacteria and the parameters. All $\mathrm{p} \leq 0.05$ were considered as statistically significant.

\section{RESULTS AND DISCUSSION Physico-chemical parameters in the Industrial Effluents before the Biodegradation.}

Results of the Physico-chemical parameters in the industrial effluents before the Biodegradation is shown in table 1 . The mean temperatures $\left({ }^{\circ} \mathrm{C}\right)$ observed in TAN1, TAN2, and TAN3 samples were $28.07 \pm 0.65 ; 27.77 \pm 0.64$ and $26.38 \pm 3.81$ respectively. The order of the mean temperature of the samples from the three industries can be arranged as TAN1 > TAN2>TAN3. The temperature observed at TAN1, TAN2, and TAN3 samples were found below the WHO $\left(35^{\circ} \mathrm{C}\right)$ and NESREA $\left(40^{\circ} \mathrm{C}\right)$ limits. The low values of temperature might be due to the processes used at the time of sampling. High temperature brings down the solubility of gases in water that ultimately expresses as high BOD and COD. Statistical analysis shows that there is no significant difference $(p<0.05)$ between the mean values of temperature among the industries. This might be due to similar tannery activities involved in the tannery industries at the time of sampling. The average values of temperature observed in this present study are less than those observed by Akan et al. (2007), Akan et al. (2009) and Baba et al. (2020).

The mean level of $\mathrm{pH}$ observed in TAN1, TAN2 and TAN3, samples were $7.77 \pm 2.93$; $8.35 \pm 0.28$ and $7.52 \pm 0.76$ respectively. The order of the mean $\mathrm{pH}$ of the samples from the three industries can be arranged as TAN2> TAN1 $>$ TAN3. The $\mathrm{pH}$ of the samples falls within the WHO (7.0-8.5) and NESREA (6-9) standard limits. Statistical analysis shows that there is no significant difference $(p<0.05)$ between the mean values of $\mathrm{pH}$ among the industries. This might be due to similar tannery activities involved in the tannery industries at the time of sampling. Maheshwari et al. (2017) reported that the level of $\mathrm{pH}$ in the effluents from the tannery industry in Vaniyambadi, India was 6.5 which was lower than that observed in the present study. The $\mathrm{pH}$ in the effluents from the tannery industries in Kano and Kaduna were reported to be 7.64 and 6.89, respectively (Akan et al., 2007; Mohammed et al., 2017). The average values of $\mathrm{pH}$ observed in this present study are less than those observed by Mohammed et al. (2017) and Baba et al. (2020). The mean level of SS $(\mathrm{mg} / \mathrm{l})$ observed in TAN1, TAN2, and TAN3 samples were 374 \pm 124 ; $358 \pm 335$ and $780 \pm 739$ respectively. The order of the mean SS in the samples from the three industries can be arranged as TAN3 > TAN1 $>$ TAN2. 
The SS observed in the samples were far above the recommended standard limits of regulating bodies WHO $(30 \mathrm{mg} / \mathrm{l})$ and NESREA $(10 \mathrm{mg} / \mathrm{l})$. Statistical analysis shows that there is no significant difference $(p<0.05)$ between the mean values of SS among the industries. This might be due to similar tannery activities involved in the tannery industries at the time of sampling. The average values of SS observed in this present study are less than that observed $(3700 \pm 122 \mathrm{mg} / \mathrm{l})$ by Akan et al. (2009) for tanneries in Kano. Also, the average values of SS observed in this present study are less than that observed by Mohammed et al. (2017) and Baba et al. (2020) with the exception in TAN3.

The mean level of TDS (mg/l) observed in TAN1, TAN2, and TAN3 samples were $3941 \pm 3703$; $3300 \pm 1714$ and $2653 \pm 1240$ respectively. The order of the mean TDS in the samples from the three industries can be arranged as TAN1>TAN2>TAN3. The TDS observed in the samples were far above the recommended standard limits of WHO $(250 \mathrm{mg} / \mathrm{l})$ and NESREA $(500 \mathrm{mg} / \mathrm{l})$. Statistical analysis shows that there is no significant difference $(p<0.05)$ between the mean values of TDS among the industries. This might be due to similar tannery activities involved in the tannery industries at the time of sampling. TDS in the effluents from the tannery industries in Kano, Nigeria was reported to be $1281 \mathrm{mg} / \mathrm{l}$ (Akan et al., 2007). The average values of SS observed in this present study are less than those observed by Mohammed et al. (2017) and Baba et al. 2020)

The mean level of COD (mg/l) observed in TAN1, TAN2 and TAN3 samples seasons were $2372 \pm 938 ; \quad 1406 \pm 208$ and $3532 \pm 1373$ respectively. The order of the mean COD of the samples from the three industries can be arranged as TAN3>TAN1> TAN2. The COD observed in TAN1, TAN2 and TAN3 samples were far above the recommended standard limits of regulating bodies $\mathrm{WHO}(40 \mathrm{mg} / \mathrm{l})$ and NESREA (40 mg/l). Statistical analysis shows that there is no significant difference $(p<0.05)$ in COD among the industries. This might be due to similar tannery activities involved in the tannery industries as at the time of sampling. The Chemical Oxygen demand (COD) is the amount of oxygen, in $\mathrm{mg} / \mathrm{L}$, required for the degradation of the compound of wastewater to occur. In comparison, the average values of COD observed in this present study were higher than that observed by Mohammed et al. (2017) but lower than that observed by Baba et al. (2020).

The mean levels of BOD $(\mathrm{mg} / \mathrm{l})$ observed in TAN1, TAN2 and TAN3 samples were $13.85 \pm 6.42 ; \quad 19.46 \pm 0.50$ and $17.13 \pm 3.14$ respectively. The order of the mean BOD in the samples from the three industries can be arranged as TAN2>TAN3>TAN1. The BOD observed in TAN1, TAN2 and TAN3 samples were found below the recommended limits of NESREA (200 mg/l) but above WHO (10 mg/l). Statistical analysis shows that there is no significant difference $(p<0.05)$ between the mean values of BOD among the industries. This might be due to similar tannery activities involved in the tannery industries at the time of sampling. The low level of BOD recorded in this study is an indication of the low level of biodegradable organic solids in the effluent. The average values of BOD observed in this present study were lower than those observed by Mohammed et al. (2017) and Baba et al. (2020).

Table 1: Mean Values \pm S.D of Physico-chemical parameters of effluents from the Tannery Industries before Treatment.

\begin{tabular}{llllllll}
\hline Parameter & Tannery 1 & Tannery 2 & Tannery 3 & $\mathrm{a}$ & $\mathrm{b}$ & $\mathrm{c}$ & $\mathrm{d}$ \\
\cline { 2 - 7 } Temperature $\left({ }^{\circ} \mathrm{C}\right)$ & $28.07 \mathrm{a} \pm 0.65$ & $27.77 \mathrm{a} \pm 0.64$ & $26.38 \mathrm{a} \pm 3.81$ & & $29.50 \pm 4.68$ & 35 & 40 \\
pH & $7.77 \mathrm{a} \pm 2.93$ & $8.35 \mathrm{a} \pm 0.28$ & $7.52 \mathrm{a} \pm 0.76$ & 6.89 & $5.35 \pm 1.57$ & $7.0-8.5$ & $6.0-9.0$ \\
$\mathrm{COD}(\mathrm{mg} / \mathrm{l})$ & $2372 \mathrm{a} \pm 938$ & $1406 \mathrm{a} \pm 208$ & $3532 \mathrm{a} \pm 1373$ & 2.2 & $3106 \pm 2753$ & 40 & 40 \\
$\mathrm{BOD}(\mathrm{mg} / \mathrm{l})$ & $13.85 \mathrm{a} \pm 6.42$ & $19.46 \mathrm{a} \pm 0.50$ & $17.13 \mathrm{a} \pm 3.14$ & 1032 & $26.17 \pm 9.49$ & 10 & 200 \\
$\mathrm{SS}(\mathrm{mg} / \mathrm{l})$ & $374 \mathrm{a} \pm 124$ & $358 \mathrm{a} \pm 335$ & $780 \mathrm{a} \pm 739$ & 501 & $562 \pm 482$ & 30 & 10 \\
TDS $(\mathrm{mg} / \mathrm{l})$ & $3941 \mathrm{a} \pm 3703$ & $3300 \mathrm{a} \pm 1714$ & $2653 \mathrm{a} \pm 1240$ & 532.7 & $444 \pm 507$ & 250 & 500 \\
\hline
\end{tabular}

The values given in the table above are means of 6 replicate values, $\mathrm{n}=6$ ( 1 sample was taken monthly for 6 months). Within the rows, means with different alphabets are statistically different $(p<0.05)$. WHO: World Health Organisation. NESREA: National Environmental Standard and Regulatory Enforcement Agency. a = Mohammed et al.(2017), b = Baba et al. (2020), c = WHO (2006), $d=$ NESSRA (2009) 
BAJOPAS Volume 13 Number 2, December, 2020

Identification, Biochemical Characterization and growth rates of the Bacterial Isolates

Results of identification and biochemical characterization of the bacterial isolates were shown in table 2. After 24 hours of incubation, the nutrient agar media plates were checked for bacterial growth. The results showed the presence of different strains in the samples. The TAN1 bacteria isolate was found to be gramnegative cocci while TAN3 was gram-positive cocci. TAN2 bacteria isolate was found to be gram-positive, rod-shaped. TAN1, TAN2, and TAN3 bacteria isolates recorded positive results for spore former.

The results of the biochemical tests indicated that all the bacteria were positive for catalase, oxidase, citrate, maltose, glucose, lactose (negative in TAN1), mannitol (negative in TAN2), starch hydrolysis and coagulase (negative in TAN2) tests. The bacteria showed negative results for nitrate reduction, $M R$ (positive in TAN2), VP (positive in TAN1), Indole (positive in TAN2) tests. Base on the morphological and biochemical test results, TAN1, TAN2, and TAN3 bacteria isolates were identified to be Nesseria spp, Bacillus cereus, and Staphylococcus aureus respectively.

The growth rate of the TAN1, TAN2 and TAN3 Isolates were shown in figure 2. Generally, the optical density increase with the increase in time (day) and decrease as time goes on. The highest optical density was shown by bacillus cereus in TAN2 while the lowest was shown by Staphylococcus aureus in TAN3.

The initial growth phase of TAN1 Isolate bacteria occurred within 2-day of incubation as the growth rate increases up to the 6th-day incubation when the maximum growth was observed. Beyond the 6th day, the growth of the bacteria declined (which might be due to a shortage of nutrients in the effluents) until it reached its death phase (which might be due to the unavailability of nutrients in the effluents).

A similar trend of growth was also observed for TAN2 Isolate as the initial growth phase also occurred within 2-day of incubation but maximum growth rate observed on the 4th day of incubation. The stationary stage occurred between the 4th day and the 8th day. Beyond the 8th day, the growth of the bacteria declined (which might be due to a shortage of nutrients in the effluents) until it reached its death phase (which might be due to the unavailability of nutrients in the effluents).

The initial growth phase of TAN3 bacterial Isolate occurred within the 3-day incubation as the growth rate increases up to the 6th-day incubation when the maximum growth was observed. Beyond the 6th day, the growth of the bacteria declined (which might be due to a shortage of nutrients in the effluents) until it reached its death phase (which might be due to the unavailability of nutrients in the effluents).

Table 2: Morphological and Biochemical characteristics of bacterial isolates

\begin{tabular}{lllll} 
Bacterial Isolates & & TAN1 & TAN2 & TAN3 \\
\hline $\begin{array}{lllll}\text { Morphological } \\
\text { characteristics }\end{array}$ & Shape & Cocci & Rod & Cocci \\
& Spore & & & \\
& former & + & + & + \\
Gram & & & \\
Biochemical characteristics & reaction & - & + & + \\
& Citrate & + & + & + \\
& Catalase & + & + & + \\
& Coagulase & + & - & + \\
Starch & + & + & + \\
& Glucose & + & + & + \\
Oxidase & + & + & + \\
& Indo & - & + & - \\
Lactose & - & + & + \\
Manitol & + & - & + \\
Maltose & + & + & + \\
MR & - & + & - \\
VP & + & - & - \\
& Nitrate & - & - & - \\
Reduction & - Neisseria & Bacillus & Staphylococcus \\
& Bacterial & cereus & aureus \\
& name & spp & cas
\end{tabular}

+ = Positive; - = Negative; MR=Methyl Red; VP= Voges-Proskauer 


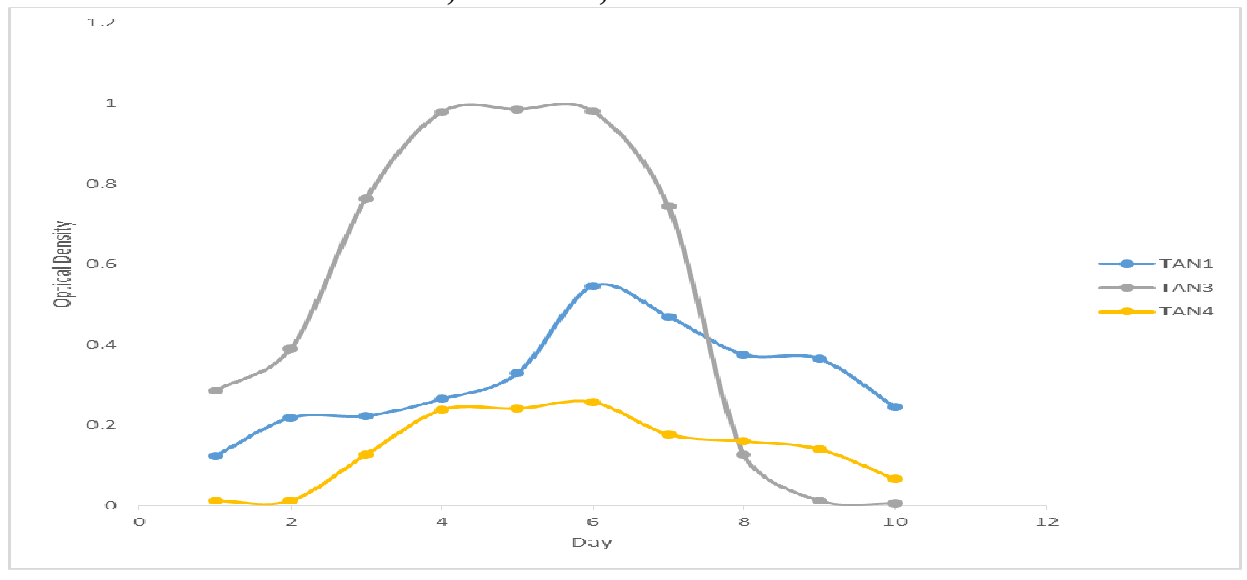

Fig. 2 Growth rates of the isolates in the effluents from the Tannery Industries

\section{Physico-chemical Parameters in the Industrial Effluents after the biodegradation.}

Table 3 shows the mean results of the physicochemical parameter before and after bioremediation using the different masses $(5 \mathrm{~g}$, $10 \mathrm{~g}, 15 \mathrm{~g}, 20 \mathrm{~g}$, and $25 \mathrm{~g}$ ) of the respective immobilized bacteria. Also, Table 4 shows the mean results of correlation coefficient ( $r$ ) between different masses of bacteria and physicochemical parameters.

The mean values $(\mathrm{mg} / \mathrm{l})$ of the SS after the bioremediation varies between $243 \pm 45$ and $898 \pm 672$. The mean concentration $(\mathrm{mg} / \mathrm{l})$ of SS remediated by the different masses $(5 \mathrm{~g}, 10 \mathrm{~g}$, $15 \mathrm{~g}, 20 \mathrm{~g}$, and $25 \mathrm{~g}$ ) of the bacteria varies. The SS in the samples fluctuates up and down after the bioremediation process when compared with the SS of the raw samples before the bioremediation. The increase in the levels of the SS might be due to the aggregation of the TDS which are large enough to result into SS. The increase in the levels of the SS might be also due to the influence of the nutrients which was added into the effluents in order to make the microorganisms more active and viable for fast degradation of organic contaminants in the effluent. The relative potential or efficiency of the different masses of the bacteria in remediating SS in TAN1 samples was in the order $25 \mathrm{~g}>20 \mathrm{~g}>15 \mathrm{~g}>10 \mathrm{~g}>5 \mathrm{~g}$. For TAN2 and TAN3 samples, the order was $25 \mathrm{~g}>20 \mathrm{~g}>15$ $\mathrm{g}>10 \mathrm{~g}>5 \mathrm{~g}$. These might be due to the variations in the surface areas of the different masses of the immobilized bacteria. Statistical analysis shows that there is no significant difference $(p<0.05)$ between the mean values of SS among the masses in the respective industries. Positive and significant correlations exist between the masses of bacteria and Suspended Solid (SS). This showed that there is general increase in the levels of the SS as the masses of the immobilized bacteria increases. TAN3 (90\%) and TAN1 (80\%) showed a very high correlation with the masses of the bacteria while TAN2 (61\%) showed a very low correlation.

The mean values $(\mathrm{mg} / \mathrm{l})$ of the TDS after the bioremediation varies between $46 \pm 11$ and $83 \pm 78$. The mean concentration $(\mathrm{mg} / \mathrm{l})$ of TDS remediated by the different masses $(5 \mathrm{~g}, 10 \mathrm{~g}$, $15 \mathrm{~g}, 20 \mathrm{~g}$, and $25 \mathrm{~g}$ ) of the bacteria varies. There is a reduction in all the TDS of all the samples after the bioremediation process compared with the TDS of the raw samples before the bioremediation. The relative potential or efficiency of the different masses of the bacteria in remediating TDS in TAN1 and TAN3 samples was in the order $5 \mathrm{~g}>10 \mathrm{~g}>15 \mathrm{~g}>20$ $\mathrm{g}>25 \mathrm{~g}$. For TAN2 samples, the order was 20 $g>10 \quad g>25 \quad g>15 \quad g>5 \quad g$. Statistical analysis shows that there is no significant difference $(p<0.05)$ between the mean values of TDS among the masses in the respective industries. These might be due to the variations in the surface areas of the different masses of the immobilized bacteria. Positive and significant correlations exist between the masses of bacteria and TDS with the exception in TAN2 (negative and insignificant correlation). The positive correlations showed that there is general increase in the levels of the TDS as the masses of the immobilized bacteria increases. TAN1 $(96 \%)$ showed a very high correlation with the masses of the bacteria while TAN2 (47\%) showed a very low correlation.

The mean values $(\mathrm{mg} / \mathrm{l})$ of the BOD after the bioremediation varies between $1.56 \pm 0.20 \mathrm{mg} / \mathrm{l}$ and $6.92 \pm 5.49 \mathrm{mg} / \mathrm{l}$. The mean concentration $(\mathrm{mg} / \mathrm{l})$ of BOD remediated by the different masses $(5 \mathrm{~g}, 10 \mathrm{~g}, 15 \mathrm{~g}, 20 \mathrm{~g}$, and $25 \mathrm{~g}$ ) of the bacteria varies. There is a reduction in all the BOD of all the samples after the bioremediation process compared with the $\mathrm{BOD}$ of the raw 
BAJOPAS Volume 13 Number 2, December, 2020 samples before the bioremediation. The relative potential or efficiency of the different masses of the bacteria in remediating BOD in TAN1, TAN2 and TAN3 samples were in the order $25 \mathrm{~g}>20$ $\mathrm{g}>15 \mathrm{~g}>10 \mathrm{~g}>5 \mathrm{~g}, 25 \mathrm{~g}>15 \mathrm{~g}>5 \mathrm{~g}>10 \mathrm{~g}>20 \mathrm{~g}$ and $20 \mathrm{~g}>10 \mathrm{~g}>25 \mathrm{~g}>15 \mathrm{~g}>5 \mathrm{~g}$ respectively. Statistical analysis shows that there is significant difference $(p<0.05)$ between the mean values of BOD among the masses in the respective industries. These might be due to the variations in the surface areas of the different masses of the immobilized bacteria. Negative and significant correlations exist between the masses of bacteria and BOD. This showed that there is general decrease in the levels of the BOD as the masses of the immobilized bacteria increases. TAN1 (94\%) showed a very high correlation with the masses of the bacteria while TAN2 (4\%) showed a very low correlation.

The mean values $(\mathrm{mg} / \mathrm{l})$ of the COD after the bioremediation varies between $250 \pm 154$ and $3134 \pm 1595$. The mean concentration $(\mathrm{mg} / \mathrm{l})$ of COD remediated by the different masses $(5 \mathrm{~g}$, $10 \mathrm{~g}, 15 \mathrm{~g} 20 \mathrm{~g}$, and $25 \mathrm{~g}$ ) of the bacteria varies. There is a reduction in all the COD of all the samples after the bioremediation process compared with the COD of the raw samples before the bioremediation. The relative potential or efficiency of the different masses of the bacteria in remediating COD in TAN1, TAN2 and TAN3 samples were in the order $25 \mathrm{~g}>20 \mathrm{~g}>15$ $\mathrm{g}>5 \mathrm{~g}>10 \mathrm{~g}, 25 \mathrm{~g}>20 \mathrm{~g}>15 \mathrm{~g}>10 \mathrm{~g}>5 \mathrm{~g}$ and 10 g>5 g>25 g>15 g>20 g respectively. Statistical analysis shows that there were significant difference $(p<0.05)$ between the mean values of COD among the masses in the respective industries except for effluents treated with $25 \mathrm{~g}$. These might be due to the variations in the surface areas of the different masses of the immobilized bacteria. Negative and insignificant correlations exist between the masses of bacteria and COD with the exception in TAN3 (positive and significant correlation). The negative correlations showed that there is general decrease in the levels of the COD as the masses of the immobilized bacteria increases. TAN2 (100\%) showed a very high correlation with the masses of the bacteria while TAN3 (36\%) showed a very low correlation.

Generally, there was an overall decrease in the concentration of these physicochemical parameters after the bioremediation using the different masses of the bacterial isolates. These might be due to the variations in the surface areas of the different masses of the immobilized bacteria. This is in line with the work of Jimoh et al. (2018) and Baba et al. (2020).

Table 3: Mean Values $(\mathrm{mg} / \mathrm{l}) \pm$ S.D of Physicochemical parameters in effluents from the Tannery Industries before and after Treatment of the effluents $(250 \mathrm{ml})$ with the different masses $(5 \mathrm{~g}, 10 \mathrm{~g}$, $15 \mathrm{~g}, 20 \mathrm{~g}$, and $25 \mathrm{~g}$ ) of the bacteria.

\begin{tabular}{llllllll}
\hline $\mathrm{P}$ & IND & Before & \multicolumn{5}{c}{ After } \\
\cline { 4 - 7 } & & & $5 \mathrm{~g}$ & $10 \mathrm{~g}$ & $15 \mathrm{~g}$ & $20 \mathrm{~g}$ & $25 \mathrm{~g}$ \\
\hline \multirow{2}{*}{ COD } & TAN1 & $2372 \pm 938$ & $1708 \mathrm{a} \pm 861$ & $2045 \mathrm{a} \pm 1205$ & $845 \mathrm{a} \pm 369$ & $300 \mathrm{a} \pm 167$ & $250 \mathrm{a} \pm 154$ \\
& TAN2 & $1406 \pm 208$ & $1195 \mathrm{a} \pm 208$ & $1125 \mathrm{a} \pm 384$ & $1055 \mathrm{a} \pm 317$ & $956 \mathrm{a} \pm 310$ & $870 \mathrm{ab} \pm 240$ \\
& TAN3 & $3532 \pm 1373$ & $2374 \mathrm{a} \pm 1344$ & $1976 \mathrm{a} \pm 1405$ & $2757 \mathrm{a} \pm 1266$ & $3134 \mathrm{a} \pm 1595$ & $2614 \mathrm{~b} \pm 1105$ \\
BOD & TAN1 & $13.85 \pm 6.42$ & $6.92 \mathrm{a} \pm 5.49$ & $6.42 \mathrm{a} \pm 5.07$ & $5.72 \mathrm{a} \pm 5.35$ & $4.62 \mathrm{a} \pm 4.37$ & $2.82 \mathrm{ab} \pm 1.26$ \\
& TAN2 & $19.46 \pm 0.50$ & $1.75 \mathrm{~b} \pm 0.22$ & $1.73 \mathrm{~b} \pm 0.18$ & $1.58 \mathrm{a} \pm 0.16$ & $1.91 \mathrm{a} \pm 0.22$ & $1.56 \mathrm{~b} \pm 0.20$ \\
& TAN3 & $17.13 \pm 3.14$ & $4.24 \mathrm{ab} \pm 0.77$ & $3.29 \mathrm{ab} \pm 0.37$ & $4.11 \mathrm{a} \pm 0.07$ & $3.23 \mathrm{a} \pm 0.91$ & $3.33 \mathrm{a} \pm 1.28$ \\
SS & TAN1 & $374 \pm 124$ & $243 \mathrm{a} \pm 45$ & $471 \mathrm{a} \pm 226$ & $475 \mathrm{a} \pm 182$ & $492 \mathrm{a} \pm 128$ & $611 \mathrm{a} \pm 217$ \\
& TAN2 & $358 \pm 335$ & $460 \mathrm{a} \pm 400$ & $543 \mathrm{a} \pm 414$ & $544 \mathrm{a} \pm 402$ & $551 \mathrm{a} \pm 414$ & $554 \mathrm{a} \pm 405$ \\
& TAN3 & $780 \pm 739$ & $586 \mathrm{a} \pm 594$ & $758 \mathrm{a} \pm 656$ & $787 \mathrm{a} \pm 676$ & $861 \mathrm{a} \pm 635$ & $898 \mathrm{a} \pm 672$ \\
TDS & TAN1 & $3941 \pm 3703$ & $51 \mathrm{a} \pm 10$ & $53 \mathrm{a} \pm 10$ & $55 \mathrm{a} \pm 15$ & $61 \mathrm{a} \pm 20$ & $63 \mathrm{a} \pm 26$ \\
& TAN2 & $3300 \pm 1714$ & $83 \mathrm{a} \pm 78$ & $47 \mathrm{a} \pm 20$ & $48 \mathrm{a} \pm 22$ & $47 \mathrm{a} \pm 17$ & $48 \mathrm{a} \pm 17$ \\
& TAN3 & $2653 \pm 1240$ & $46 \mathrm{a} \pm 11$ & $55 \mathrm{a} \pm 24$ & $55 \mathrm{a} \pm 25$ & $58 \mathrm{a} \pm 23$ & $61 \mathrm{a} \pm 28$ \\
\hline
\end{tabular}

Replicate $=6$ (months)

Within the rows, for the same parameter, means with different alphabets are statistically different $(p<0.05)$.

$\mathrm{P}=$ parameter, IND = Industries 
BAJOPAS Volume 13 Number 2, December, 2020

Table 4: Correlation coefficient $(r)$ between different masses of the bacteria and the physicochemical parameters.

\begin{tabular}{llll}
\hline Industries & Parameter & Correlation coefficient $(r)$ & $\begin{array}{l}\text { Percent dependence (rxrx100) } \\
(\%)\end{array}$ \\
\hline TAN1 & COD & -0.9 & 82 \\
& BOD & -0.97 & 94 \\
& SS & $0.90^{*}$ & 80 \\
TAN2 & TDS & $0.98^{*}$ & 96 \\
& COD & -1 & 100 \\
& BOD & -0.21 & 4 \\
& SS & $0.78^{*}$ & 61 \\
& TDS & -0.69 & 47 \\
& COD & $0.60^{*}$ & 36 \\
& BOD & -0.6 & 37 \\
& SS & $0.95^{*}$ & 90 \\
& TDS & $0.94^{*}$ & 89 \\
\hline
\end{tabular}

The correlation coefficient $(r)$ with * is statistically significant $(p<0.05)$.

Percentage reduction of the Parameters

Table 5 shows the percentage reduction of Parameters in industrial samples before and after the treatment of the effluents $(250 \mathrm{ml})$ with the different masses $(5 \mathrm{~g}, 10 \mathrm{~g}, 15 \mathrm{~g}, 20 \mathrm{~g}$, and $25 \mathrm{~g}$ ) of the Immobilized Bacteria.

In TAN1 samples, the percentage reduction (\%) of COD ranged (14-89); BOD (50-80); SS (-32$35)$ and TDS (98-99). In TAN2 samples, the percentage decrease $(\%)$ of COD ranged (15$38) ;$ BOD (90-92); SS [-28-(-55)] and TDS (9798). In TAN3 samples, the percentage decrease (\%) of COD ranged (11-44); BOD (76-81); SS (15-25) and TDS (98). The percentage increase in the levels COD, BOD and TDS might be due to the increase in the surface area of the different masses of the immobilized bacteria. However, the percentage decrease in the levels of the SS might be due to the aggregation of the TDS which are large enough to result into SS. The percentage decrease in the levels of the SS might be also due to the influence of the nutrients which was added into the effluents in order to make the microorganisms more active and viable for fast degradation of organic contaminants in the effluent. This is in line with the work of Jimoh et al. (2018) in which the concentration of the SS increase after the bioremediation of effluents.

Sreemoyee and Priti (2013) assessed and reduced several Physico-chemical parameters of dairy wastewater using Niesseria $s p$. and concluded that the species are well known to degrade organic compounds. This is in agreement with the current study in which the immobilized Niesseria $s p$ degrade the organic contaminants as indicated by the BOD, COD and TDS.

Jimoh et al. (2018) observed that TSS of the effluents was increased after treatment with immobilized bacteria and concluded that it might be due to the biostimulation method adopted for the research.

The optimum $\mathrm{pH}$ Biosorption of Chromium by Bacillus spp and Staphylococcus spp. from tannery effluent was investigated by Mythili and Karthikeyan (2011). The maximum adsorption of Chromium $(86.4 \mathrm{mg} / \mathrm{L})$ was showed by Bacillus spp and Staphylococcus spp showed $70.6 \mathrm{mg} / \mathrm{L}$ at an initial concentration of $100 \mathrm{mg} / \mathrm{L}$. In the present study, immobilised Bacillus spp and Staphylococcus spp. from the tannery industrial effluents reduced the levels of the organic pollutants with high potential as indicated by the percentage reduction of BOD, COD and TDS.

Enzymes often can work in multiple environments especially if they are immobilized. This makes the microorganisms' enzymes even more resistant to harsh environments and enables the enzymes to be recovered and recycled after they are no longer needed (Gianfreda and Rao 2004). Ramesh and Singh (1993) reported that the immobilized bacteria having more efficiency to remove the suspended particles than free cells. Using the immobilized cell is preferable due to its capability for using several times with the same efficiency, which makes it more economical. Similar work was done by Sikander et al. (2007) showing the higher reduction with permeabilized cells of Ochrobactrum intermedium strain SDCr-5. 
BAJOPAS Volume 13 Number 2, December, 2020

The results revealed the isolation and identification of isolates with the potential for the reduction of $\mathrm{Cr}$ (VI) to $\mathrm{Cr}$ (III). Results indicated that immobilized $B$. cereus could be efficiently used for the reduction of $\mathrm{Cr}$ (VI).

Table 5: Percentage reduction of the tested Parameters from the tannery industrial samples of the Immobilized Bacteria.

\begin{tabular}{lllllll}
\hline \multirow{2}{*}{ Industries } & & \multicolumn{5}{c}{ Percentage Reduction $(\%)$} \\
\cline { 3 - 7 } & & $5 \mathrm{~g}$ & $10 \mathrm{~g}$ & $15 \mathrm{~g}$ & $20 \mathrm{~g}$ & $25 \mathrm{~g}$ \\
\hline TAN1 & COD & 28 & 14 & 64 & 87 & 89 \\
& BOD & 50 & 54 & 59 & 67 & 80 \\
& SS & 35 & -26 & -27 & -32 & -63 \\
& TDS & 99 & 99 & 99 & 98 & 98 \\
TAN2 & COD & 15 & 20 & 25 & 32 & 38 \\
& BOD & 91 & 91 & 92 & 90 & 92 \\
& SS & -28 & -52 & -52 & -54 & -55 \\
& TDS & 97 & 99 & 99 & 99 & 99 \\
& COD & 33 & 44 & 22 & 11 & 26 \\
& BOD & 75 & 81 & 76 & 81 & 81 \\
& SS & 25 & 3 & -1 & -10 & -15 \\
& TDS & 98 & 98 & 98 & 98 & 98 \\
\hline
\end{tabular}

Percentage Reduction $=(B-A) / B \times 100 \%$

$A=$ Concentration of the parameter after treatment

$\mathrm{B}=$ Concentration of the parameter before treatment

$+=$ percentage decrease

- = percentage increase

In general, immobilization makes the enzyme more resistant to temperature, $\mathrm{pH}$, and substrate concentration swings giving it a longer lifetime and higher productivity per active unit (Gianfreda and Rao, 2004; FuIlbrook, 1996; Russell et al, 2003; Kandelbauer et al., 2004). Immobilized cells have been used and studied extensively for the production of useful chemicals (Ohtake and Silver, 1994), the treatment of wastewaters (Chen et al., 2003; Wang et al., 2010). Although many workers described microbial degradation of tannery effluent, limited literature is available on the bioremediation of tannery effluent using immobilized bacterial cells in the Kano Industrial Estates.

\section{CONCLUSION}

The samples contained variable levels of the physicochemical parameters. The results of the Analysis of variance revealed that, no statistical difference $(p<0.05)$ was observed for the temperature, $\mathrm{pH}, \mathrm{SS}, \mathrm{TDS}, \mathrm{BOD}$ and $\mathrm{COD}$ among the three tannery industries before the treatment. The levels of some of the parameters
(SS, TDS and COD) observed in the samples were found above the recommended limits of WHO and NESREA, which called for the treatment of the effluents before discharge into the environment. Base on the morphological and biochemical test results, TAN1, TAN2, and TAN3 bacterial isolates were identified to be Neisseria spp, Bacillus cereus, and Staphylococcus aureus respectively. The results of Post-treatment analysis showed that there is overall decrease in the levels of the parameters determined when compared with that of the pre-treatment. The overall percentage reduction of the immobilised bacteria in the treatment of the respective effluents was in the order TAN2 (72\%)>TAN1 $(70 \%)>$ TAN3 $(62 \%)$. Hence, the immobilized bacteria are having higher biodegradation potential for the treatment of the tannery effluents.

\section{Acknowledgments}

The authors wish to acknowledge the University of Maiduguri for the financial support. The authors are grateful to the Kano State Ministry of Environment for their support in obtaining the effluent samples. 


\section{REFERENCES}

Ajao, A. T., Adebayo, G. B., and Yakubu, S. E. (2011). Bioremediation of textile industrial effluent using mixed culture of Pseudomonas aeruginosa and Bacillus subtilis immobilized on agar-agar in a bioreactor. J. Microbiol. Biotech. Res, 1(3), 50-56.

Akan, J. C., Moses, E. A., Ogugbuaja, V. O., and Abah, J. (2007). Assessment of tannery industrial effluents from Kano metropolis, Kano State, Nigeria. Journal of Applied Sciences, 7(19), 2788-2793.

Akan, J. C., Ogugbuaja, V. O., Abdulrahman, F. I., and Ayodele, J. T. (2009). Pollutant levels in effluent samples from tanneries and textiles of Kano industrial areas, Nigeria. Global journal of pure and applied sciences, 15(3-4).

APHA (1989). Standard methods for Examination of Will bete and Will betewater.15 $5^{\text {th }}$ edition. Brydpass Springfield Will behington DC. pp. 164-176

APHA (1992). Standard Methods for the Examination of Water and Wastewater. Health, 69, 1116-9.

Baba, A., Garba, S. T., and Bello, H. S. (2020). Bioremediation Potential of Immobilized corynebacterium kutsceri in the Treatment of Tannery Industrial Effluent from Challawa Industrial Estate, Kano State, Nigeria. Journal of the Turkish Chemical Society Section A: Chemistry, $7(2), 335-350$.

Beem, E. I. V. (1994). reduction of solvent VOC emission. J. Oil Col. Chem. Ass, 77, 158.

Bouwer, E. J., and Zehnder, A. J. (1993). Bioremediation of organic compoundsputting microbial metabolism to work. Trends in biotechnology, 11(8), 360367.

Chen, K. C., Wu, J. Y., Liou, D. J., and Hwang, S. C. J. (2003). Decolorization of the textile dyes by newly isolated bacterial strains. Journal of Biotechnology, 101(1), 57-68.

Dan'Azumi, S., and Bichi, M. H. (2010). INDUSTRIAL POLLUTION AND HEAVY METALS PROFILE OF CHALLAWA RIVER IN KANO, NIGERIA. Journal of Applied Sciences in Environmental Sanitation, $5(1)$.

DWAF. (1992). Analytical Methods Manual, TR 151. Department of Water Affairs and Forestry, Pretoria.

El-Bestawy, E. (2013). Biological treatment of leather-tanning industrial wastewater using free living bacteria.
Elsheikh, M. A. S. (2009). Tannery wastewater pre-treatment. Water Science and Technology, 60(2), 433-440.

FuIlbrook, P. D. (1996). "Kinetics." Industrial enzymology: The application of enzymes in Industry. 2nd Ed. T. Godfrey and J Reichelt. eds.. Nature. New York.

Gianfreda, L., and Rao, M. A. (2004). Potential of extra cellular enzymes in remediation of polluted soils: a review. Enzyme and microbial technology, 35(4), 339354.

Hugo Springer. (1994). John Arthur Wilson Memorial Lecture "Treatment of Industrial Wastes of the Leather Industry - is it still a Major Problem". JALCA, 89, 153-185

Jimoh, A. A., Ganiyu, B. A., Baba, D., and Baba, A. (2018) Bioremediation Process of Effluent from Detergent and Food Industries in Jos, Nigeria: Kinetics and Thermodynamics. International Journal of Engineering Science Invention (IJESI), 762-73

Kandelbauer, A., Maute, O., Kessler, R. W., Erlacher, A., and Gübitz, G. M. (2004). Study of dye decolorization in an immobilized laccase enzyme-reactor using online spectroscopy. Biotechnology and bioengineering, 87(4), 552-563.

Kongjao, S., Damronglerd, S., and Hunsom, M. (2008). Simultaneous removal of organic and inorganic Pollutants in tannery wastewater using electrocoagulation technique. Korean Journal of chemical engineering, 25(4), 703.

Maheshwari, U. M., Aruna, S., Gomathi, M., and AbdulJaffar, A. H. (2017). Bioremediation by Free and Immobilized Bacteria Isolated from Tannery Effluent. International Journal of Research in Applied, Natural and Social Sciences. 5(7), 75-90

Margesin, R., and Schinner, F. (2001). Bioremediation (natural attenuation and biostimulation) of diesel-oilcontaminated soil in an alpine glacier skiing area. Applied and environmental microbiology, 677), 3127-3133.

Mohammed, A., Sekar, P., and George, J. (2011). Efficacy of microbes in bioremediation of tannery effluent. Inter. J. Curr. Res, 3(4), 324-326.

Mohammed, S. S. D., Orukotan, A. A., and Abdullahi, H. (2017). Physicochemical and Bacteriological Assessment of Tannery Effluent from Samaru-Zaria, 
BAJOPAS Volume 13 Number 2, December, 2020 Kaduna State, Nigeria. Journal of Applied

Sciences and Environmental Management, 21(4), 734-740.

Munz, G., De Angelis, D., Gori, R., Mori, G., Casarci, M., and Lubello, C. (2009). The role of tannins in conventional and membrane treatment of tannery wastewater. Journal of hazardous materials, 164(2-3), 733-739

Mythili, K., and Karthikeyan, B. (2011). Bioremediation of $\mathrm{Cr}$ (VI) from tannery effluent using Bacillus spp and Staphylococcus spp. International Multidisciplinary Research Journal, 1(6).

NESREA (2009). National Environmental Standards for Effluent Limitations and Regulation. 1233-1236

Noorjahan, C. M. (2014). Physicochemical characteristics, identification of bacteria and biodegradation of industrial effluent. Journal of bioremediation and Biodegradation, 5(3).

Ohtake, H. I., and Silver, A. O. (1994). Bacterial reduction of toxic chromate. Biological degradation and bioremediation of toxic chemicals, 403-415.

Omoleke, I. I. (2004). Management of environmental pollution in Ibadan, an African city: the challenges of health hazard facing government and the people. Journal of Human Ecology, 15(4), 265-275.

Rajor, A., Reddy, A.S., and Singh, B. (2004). Determination of BOD kinetic Parameters and evaluation of alternate methods, M.Sc. Thesis, Department of biotechnology \& environmental Science, Thapar Institute of Engineering and Technology, Patiala

Ramasami, T., Rajamani, S., and Rao, J. R. (1994, March). Pollution control in leather industry: Emerging technological options. In International symposium on surface and colloidal science and its relevance to soil pollution, madras.

Ramesh, J. V. S., and Singh, S. P. (1993). Yearly variation in certain physicochemical parameters of pond at eastern Doon Valley. Uttar Pradesh J. Zoo, 12 (1), 7577.

Ranen, S., and Sharadinadra, C. (2009). Biotechnology applications to environmental remediation in resource exploitation. Current science, 97, 6-25
Russell, A. J., Berberich, J. A., Drevon, G. F., and Koepsel, R. R. (2003). Biomaterials for mediation of

chemical and biological warfare agents. Annual review of biomedical engineering, 5(1), 1-27.

Saravanan, P., and Saravanan, A. (1999). Decolourization of tannery effluent by Flavobacterium sp. EK 1. Indian Journal of Environmental Protection, 19, 19-24.

Sikander, S., and Shahida, H. (2007). Reduction of toxic hexavalent chromium by Ochrobactrum intermedium strain SDCr5 stimulated by heavy metals. Bioresource Technol, 98, 340-344.

Singh, N., Sharma, B. K., and Bohra, P. C. (2000). Impact assessment of industrial effluent of arid soils by using satellite imageries. Journal of the Indian Society of Remote Sensing, 28(2-3), 79.

Sreemoyee, C., and Priti, P. (2013). Assessment of physico-chemical parameters of dairy waste water and isolation and characterization of bacterial strains in terms of cod reduction. Int J Sci, 2(3), 395-400.

Verheijen, L. A. H. M., Wiersema, D., Pol, L. H., and De Wit, J. (1996). Management of wastes from animal product processing. Livestock and environment, Finding a balance. International Agriculture Center, Wageningen, The Netherlands.

Wang, F., Yao, J., Si, Y., Chen, H., Russel, M., Chen, K., and Bramanti, E. (2010). Short-time effect of heavy metals upon microbial community activity. Journal of Hazardous Materials, 173(13), 510-516.

WHO (World Health Organization). (2006). Air quality guidelines: global update 2005: particulate matter, ozone, nitrogen dioxide, and sulfur dioxide. World Health Organization.

World Bank. (1995). Nigeria's strategic options for redressing industrial pollution. World Bank, industry and energy division. 1st edition, West Central Africa Department; Annexes: 1995; pp 60-62.

Zahoor, A., and Abdul, R. (2009). Enumeration of Coliforms. Journal of Environmental Sciences. 21, 814-820 


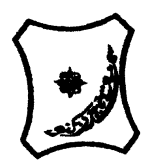

Bayero Journal of Pure and Applied Sciences, 13(2): 1 - 12

Received: November, 2020

Accepted: December, 2020

ISSN $2006-6996$

\title{
BIODEGRADATION POTENTIAL OF IMMOBILIZED BACTERIA IN THE TREATMENT OF TANNERY INDUSTRIAL EFFLUENTS FROM INDUSTRIAL ESTATES IN KANO STATE, NIGERIA
}

\author{
Abdullateef, B., ${ }^{1 *}$ Shuaibu, T. G., ${ }^{1}$ Babagana, K., ${ }^{1}$ Suleman, H. B. ${ }^{2}$ and Dauda, B. ${ }^{3}$ \\ ${ }^{1}$ Department of Pure and Applied Chemistry, Faculty of Science, University of Maiduguri, Borno State, \\ Nigeria \\ ${ }^{2}$ Department of Microbiology, Faculty of Science, University of Maiduguri, Borno State, Nigeria \\ ${ }^{3}$ Department of Chemical Engineering, Faculty of Engineering, University of Maiduguri, Borno State, \\ Nigeria \\ *Corresponding author: babslega@gmail.com; abelega2007@yahoo.com; +2348061309753
}

\section{ABSTRACT}

Industrial Effluents Samples from Gashash Tanneries (TAN1) in Bompai Industrial estate, Larabee Tannery Industry (TAN2) in Sharada Industrial estate and Z Tannery Industries (TAN3) in Challawa Industrial estate, Kano State, Nigeria were collected over a period of six months (August 2017 to January 2018) for assessing the biodegradation potentials of bacteria in the treatment of organic pollutants within the effluents. Bacteria were isolated from the effluents and immobilized on agar-agar. Different masses (5 g, $10 \mathrm{gr}, 15$ $\mathrm{g}, 20 \mathrm{~g}$, and $25 \mathrm{~g}$ ) of the bacteria were used in the treatment of $250 \mathrm{ml}$ of the effluents for ten days in a shaker incubator (Gallenkamp-OC-4364-L) at the temperature $30{ }^{\circ} \mathrm{C}$ and speed of $60 \mathrm{rpm}$. Pre-treatment analysis of the effluents for Temperature, pH, Biochemical Oxygen Demand (BOD), Chemical Oxygen Demand (COD), Suspended Solid (SS) and Total Dissolved Solids (TDS) gives the following results; temperature $\left({ }^{\circ} \mathrm{C}\right.$ )

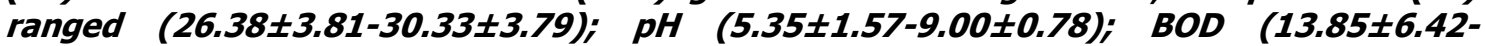
$38.75 \pm 16.20) ;$ COD (1406 $\pm 208-3532 \pm 1373) ;$ SS (208 $\pm 235-780 \pm 739)$ and TDS (266 $\pm 253-5276 \pm 2971)$. No statistical differences ( $p \leq 0.05)$ was observed for all the results among the different industries. The bacterial isolates were identified as Neisseria spp, Bacillus cereus, and Staphylococcus aureus, in TAN1, TAN2, and TAN3, respectively. After treatment of the effluent with the different masses of the isolated bacteria, the mean level of BOD was found to range as (0.55 $\pm 0.36-6.92 \pm 5.49) ; C O D$ (ND-3134 \pm 1595$)$;

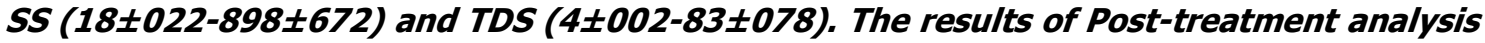
showed that there is overall decrease in the levels of the parameters determined when compared with that of the pre-treatment. The overall percentage reduction of the immobilised bacteria in the treatment of the respective effluents was in the order TAN2 (72\%)>TAN1 (70\%)>TAN3 (62\%). Hence, the immobilized bacteria are having higher biodegradation potential for the treatment of the tannery effluents.

Keywords: Biodegradation, bacteria, effluent, immobilization, tannery.

\section{INTRODUCTION}

Tannery industrial wastewater is a serious consequence of the pollution point of view for streams, freshwater, and land used for agriculture. The lack of awareness in the modern industrial practice has resulted in the discharge of tannery effluents which exhibit very high value of chromium ( $\mathrm{Cr}$ ), Sulfide, and chloride, Total Dissolved Solid (TDS), Total Suspended Solid (TSS), Biochemical Oxygen Demand (BOD) and Chemical Oxygen Demand (COD) in the water stream or land (Mohammed et al., 2001). Tanning is the process, which One ton of skin generally leads to the production of 20 to $80 \mathrm{~m}^{3}$ of turbid and foul-smelling converts the protein of the rawhide or skin into a stable material, which will not putrefy and is suitable for a wide variety of end applications (Elsheikh, 2009). The highly polluting chromium is the most commonly used tanning material producing leather that is more flexible and pliable than vegetable-tanned leather and does not discolor or lose shape in water as drastically as vegetable-tan (Elsheikh, 2009). Tannery effluent is among the most hazardous industrial pollutants due to its huge organic and inorganic load, which is highly toxic to human life and the environment (Kongjao et al., 2008). wastewater including chromium (100-400 mg/l), sulfide $(200-800 \mathrm{mg} / \mathrm{l})$, high levels of fat and 
BAJOPAS Volume 13 Number 2, December, 2020 other solid wastes, and notable pathogen contamination as well as pesticides added for skin conservation during transport (Elsheikh, 2009). There are more than 6000 tanneries in Nigeria with an annual processing capacity of 700,000 tons of hides and skins (Omoleke, 2004; Singh et al., 2008). It was reported that the total amount of waste produced per animal slaughtered is approximately $35 \%$ of its weight (World Bank, 1995). Also, for every $1000 \mathrm{~kg}$ of carcass weight, a slaughtered beef produces 5.5 $\mathrm{kg}$ of manure (excluding rumen contents or stockyard manure) and $100 \mathrm{~kg}$ of paunch manure (undigested food) (Verheijen et al., 1996). Tanneries generate wastewater in the range of 30-35 $\mathrm{L} \mathrm{kg}^{-1}$ skin/hide processed with variable $\mathrm{pH}$, Biological Oxygen Demand (BOD), Chemical Oxygen Demand (COD), high concentrations of suspended solids (SS), and tannins as well as chromium (Zahoor and Abdul, 2009).

Being heterogeneous and composed of a wide variety of compounds, it is very difficult to select a unique direct method for estimating the biodegradability of organic contents and biokinetic parameters for a wastewater sample (Rajor, 2004). For this purpose, some indirect estimation such as determination of biochemical oxygen demand (BOD) and chemical oxygen demand (COD) are applied as common laboratory investigations [9]. During retanning procedures, synthetic tannins (Syntan), oils and resins are added to form softer leather at varying doses (Munz et al., 2009). One of the refractory groups of chemicals in tannery effluents derives mainly from tannins (Ramasami et al., 2004). Syntans are characterized by complex chemical structures, because they are composed of an extended set of chemicals such as phenol-, naphthalene-, formaldehyde- and melamine-based syntans, and acrylic resins (Beem, 1994). Organic pollutants (proteic and lipidic components) are originated from skins (it is calculated that the raw skin has $30 \%$ loss of organic material during the working cycle) or they are introduced during processes (Hugo Springer, 1994).

Many conventional processes such as oxidation, chemical and biological processes were carried out to treat tanneries wastewater (Ebtesam et al, 2013). Biological processes have received more attention because of their costeffectiveness, lower sludge production and environmental friendliness (Noorjahan, 2014). Naturally occurring micro-organisms degrade the hazardous organic wastes including xenobiotic compounds, such as pesticides, polycyclic aromatic hydrocarbons (PAHs) and polychlorinated biphenyls (PCBs) in due course of time (Ranen and Sharadinadra, 2009). Bioremediation is based on the idea that all organisms remove substances from the environment to carry outgrowth and metabolism (Bouwer and Zehnder, 1993). Bacteria, protista and fungi are found to be very good at degrading complex molecules and incorporating the breakdown products into their metabolism (Bouwer and Zehnder, 1993). The resultant metabolic wastes that they produce are generally safe and somehow recycled into other organisms (Ranen and Sharadinadra, 2009). An acclimatized indigenous population of microorganisms capable of degradation of the compounds of interest must exist at the site for a successful bioremediation mode (Ranen and Sharadinadra, 2009). It has been observed that for a successful bioremediation mode, an acclimatized indigenous population of microorganisms capable of degradation of the compounds of interest must exist at the site under investigation (Ranen and Sharadinadra, 2009). Even though there are numerous physical and chemical methods employed in the disposal of wastes the advantage in using bacterium is that they play a key role in the reduction of COD, BOD, total protein, total tannin and total phenol (Saravanan and Saravanan, 1998)

Baba et al. (2020) studied the bioremediation potential of immobilized corynebacterium kutsceri in the Treatment of tannery industrial effluent from Challawa Industrial Estate, Kano State, Nigeria. The aim of the work is to study the reduction in the level of the contaminants through the process of bioremediation using the isolated bacteria. Immobilized bacteria can withstand various temperatures, $\mathrm{pH}$ and substrate concentrations; consequently, increasing the efficiency and the lifespan of the bacteria. Immobilized bacteria are widely applied in the treatment of wastewater and can be separated and recovered after the treatment with the same efficiency (Baba et al., 2020).

\section{MATERIALS AND METHODS \\ Study Area}

This study was carried out in Bompai, Sharada and Challawa industrial estates in Kano, Figure 1. Kano lies on Latitude $11^{\circ} 30^{\prime} \mathrm{N}$ and $8^{\circ} 30^{\prime} \mathrm{E}$ and Longitude $11^{\circ} 5^{\prime} \mathrm{N}$ and $8^{\circ} 5^{\prime} \mathrm{E}$ in Northern Nigeria. It is one of the developed industrial cities in Nigeria. Tannery activities are the dominating industries and this could be one of the reasons for her high population density (Dan'Azumi and Bichi, 2010). Many researchers have studied biodegradation of tannery effluent using microorganisms. However, limited literature is available on the biodegradation of tannery effluent in Kano industrial estates using 
BAJOPAS Volume 13 Number 2, December, 2020 immobilized bacterial cells. This research work focuses on the potential of the use of the indigenous immobilized bacterial isolates in the treatment of tannery effluents in the industrial estates.

\section{Sample Collection}

Effluents were collected from the Tannery Industries from Bompai, Challawa and Sharada Industrial Estates, Kano, Nigeria. The effluents were collected over a period of six months (August 2017 to January 2018). Samples collected in a sterile 4-liter plastic container with a unique identification number were preserved using an ice-box that was transported to the Microbiology Laboratory, Department of Microbiology, Bayero University of Kano for analysis

\section{Sample Preparation and Sample Analysis}

Immediately after the collection of the effluent, $\mathrm{pH}$, TSS, TDS, COD, BOD levels were determined before treatment (Pre-treatment determination) and ten days after treatment (Post-treatment determination) as described in
APHA (1989) standard methods. $\mathrm{pH}$ was determined using Ecotests $\mathrm{pH}$ meter and TDS was determined using AQUALYTIC TDS Salinometer. BOD was determined as described by the standard method (APHA, 1992). COD and SS were determined using DR/2010 HACH portable data logging spectrophotometer (DWAF, 1992)

\section{Identification and Biochemical} Characterization of the Bacterial Isolates

The bacteria were isolated from the effluents using Serial Dilution according to the method described by APHA (1989). The biochemical tests such as oxidase, catalase, coagulase, indole (from $1 \%$ tryptone broth), citrate (Simmons citrate agar), methyl red/VogesProskauer (MR/VP), nitrate reduction, Starch Hydrolysis, Glucose, Maltose, and Lactose tests were carried out on the bacterial isolates to identify the bacteria through the bacteria biochemical characteristics according to Ajao et al. (2011).

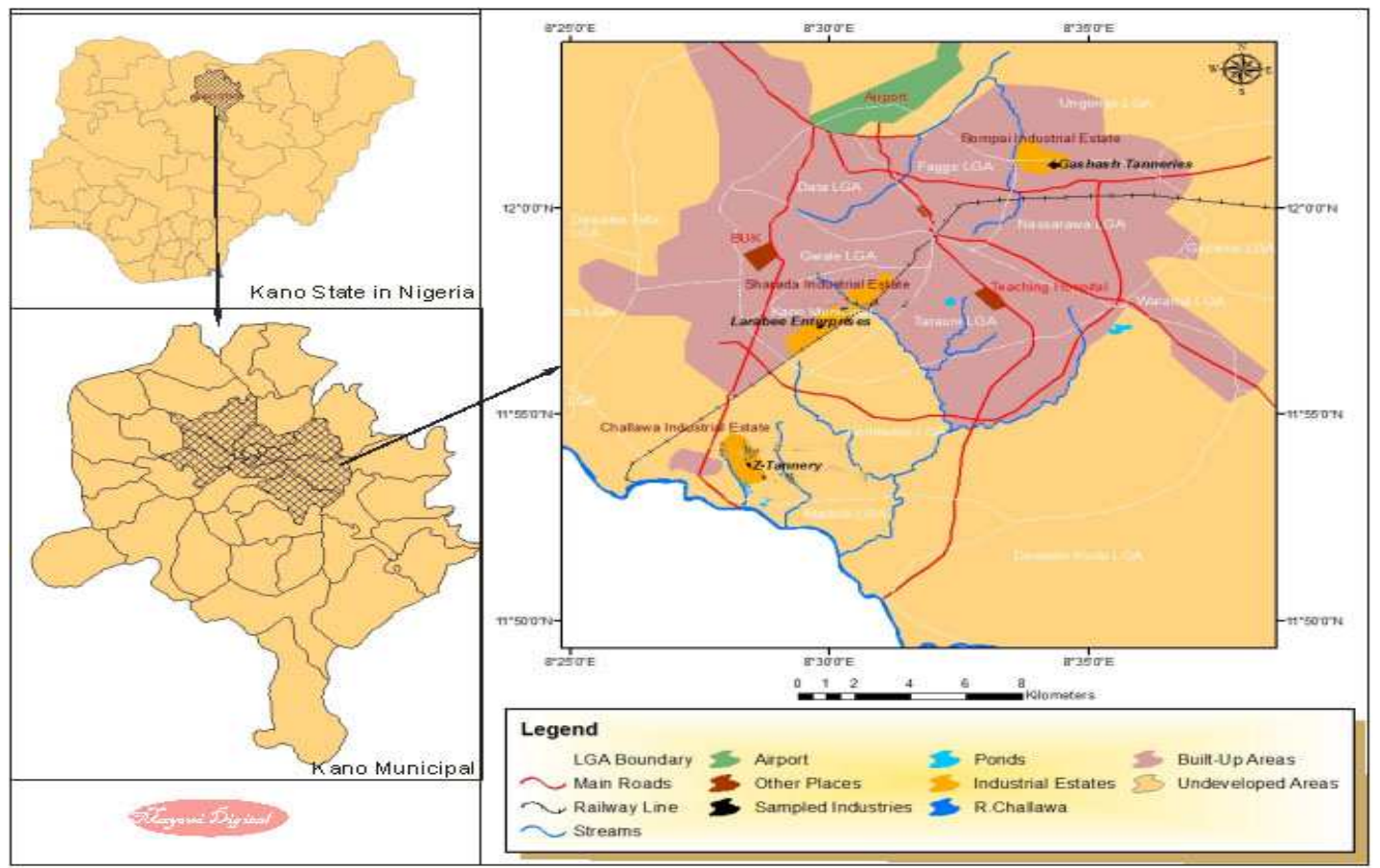

Fig. 1 Map showing the study areas

Source: Mayomi Digital Productions, GIS Laboratory, Department of Geography, UNIMAID (2017)

\section{Determination of Growth Rate of the Bacteria in Effluent Sample}

The bacteria growth rates were determined by transferring $2 \mathrm{~mL}$ of the bacterial isolates from the tannery effluent in broth medium into 100 $\mathrm{mL}$ sterile effluents in conical flasks and kept in an incubator (Giffrin cool) for 10 days. Control was also set up by incubating another $100 \mathrm{~mL}$ each of the sterile effluents without the bacteria. The optical density of the content was determined at the wavelength of $600 \mathrm{~nm}$ on a daily interval and recorded. 
BAJOPAS Volume 13 Number 2, December, 2020 Immobilization of Bacteria

Agar solution and inoculi were prepared separately. Fifty milliliters $(50 \mathrm{~mL})$ of nutrient broth each of the inoculi was prepared in a McCartney bottle and incubated for 24 hours. A solution of agar-agar was prepared by dissolving $10 \mathrm{~g}$ of the powder in distilled water and made up to $500 \mathrm{~mL}$ mark in an Erlenmeyer flask and was sterilized in an autoclave (280A) for 15 minutes and allowed to cool to $40-45^{\circ} \mathrm{C}$ (Ajao et al., 2011). Four milliliters ( $4 \mathrm{~mL})$ of the bacterial isolates in the nutrient broth was mixed with 36 $\mathrm{ml}$ of the prepared agar-agar media in petri-dish plates and then allowed to solidify. This was kept in the refrigerator for bioremediation.

\section{Bioremediation (Treatment) of the Effluents}

The solidified agar block (immobilized bacteria) was cut into cubes using a sterile knife; $0.1 \mathrm{~mL}$ phosphate buffer ( $\mathrm{pH} \mathrm{7.0)}$ was added and kept in the refrigerator for 1 hour for curing. The phosphate buffer was decanted after 1 hour and the cubes were washed with sterile distilled water 3-4 times before it was used (Ajao et al., 2011). Two liters (2 L) of the effluent was supplemented with the minimum basal medium in $\mathrm{g} / \mathrm{L}: \mathrm{NaCl}(0.8), \mathrm{MgSO}_{4} .7 \mathrm{H}_{2} \mathrm{O}(0.001), \mathrm{KH}_{2} \mathrm{PO}_{4}$ (2), $\mathrm{NaNO}_{3}$ (2), $\quad \mathrm{CaCl}_{2} .2 \mathrm{H}_{2} \mathrm{O} \quad(0.5)$ and $\mathrm{NaHPO}_{4} .12 \mathrm{H}_{2} \mathrm{O}(2)$ and sterilized in an autoclave at $121^{\circ} \mathrm{C}$ for 15 minutes (Margesin and Schinner, 2001). Two hundred and fifty milliliters $(250 \mathrm{~mL})$ of the effluents were transferred into different $250 \mathrm{ml}$ conical flasks. The content was covered with a cotton-wool ramped with foil paper to avoid contamination. Five grams $(5 \mathrm{~g})$ of the immobilized bacteria were quickly transferred into each of the effluents in the conical flasks in an inoculating chamber. The same procedures were carried out for the $10 \mathrm{~g}, 15 \mathrm{~g}, 20 \mathrm{~g}$ and 25 $\mathrm{g}$ of the immobilized bacteria in separate $250 \mathrm{~mL}$ effluents in conical flasks and agitated for ten days in a shaker incubator (Gallenkamp-OC4364-L) at a temperature $30^{\circ} \mathrm{C}$ and speed of 60 rpm. The treated effluent samples were taken on the tenth day and analyzed for the parameters $\mathrm{pH}$, SS, TDS, COD, and BOD, (Posttreatment determination) for the different grams of bacteria to evaluate and compare the biodegradation potential. (Baba et al., 2020).

\section{Statistical Analysis}

The data were represented as Mean \pm Standard deviation and analyzed statistically using oneway Analysis of Variance (ANOVA) and Tukey's HSD as Post Hoc Tests with the aid of SPSS 16.0. The correlation coefficient was also used to measure the strength of the relationship between the different masses of the bacteria and the parameters. All $\mathrm{p} \leq 0.05$ were considered as statistically significant.

\section{RESULTS AND DISCUSSION Physico-chemical parameters in the Industrial Effluents before the Biodegradation.}

Results of the Physico-chemical parameters in the industrial effluents before the Biodegradation is shown in table 1 . The mean temperatures $\left({ }^{\circ} \mathrm{C}\right)$ observed in TAN1, TAN2, and TAN3 samples were $28.07 \pm 0.65 ; 27.77 \pm 0.64$ and $26.38 \pm 3.81$ respectively. The order of the mean temperature of the samples from the three industries can be arranged as TAN1 > TAN2>TAN3. The temperature observed at TAN1, TAN2, and TAN3 samples were found below the WHO $\left(35^{\circ} \mathrm{C}\right)$ and NESREA $\left(40^{\circ} \mathrm{C}\right)$ limits. The low values of temperature might be due to the processes used at the time of sampling. High temperature brings down the solubility of gases in water that ultimately expresses as high BOD and COD. Statistical analysis shows that there is no significant difference $(p<0.05)$ between the mean values of temperature among the industries. This might be due to similar tannery activities involved in the tannery industries at the time of sampling. The average values of temperature observed in this present study are less than those observed by Akan et al. (2007), Akan et al. (2009) and Baba et al. (2020).

The mean level of $\mathrm{pH}$ observed in TAN1, TAN2 and TAN3, samples were $7.77 \pm 2.93$; $8.35 \pm 0.28$ and $7.52 \pm 0.76$ respectively. The order of the mean $\mathrm{pH}$ of the samples from the three industries can be arranged as TAN2> TAN1 $>$ TAN3. The $\mathrm{pH}$ of the samples falls within the WHO (7.0-8.5) and NESREA (6-9) standard limits. Statistical analysis shows that there is no significant difference $(p<0.05)$ between the mean values of $\mathrm{pH}$ among the industries. This might be due to similar tannery activities involved in the tannery industries at the time of sampling. Maheshwari et al. (2017) reported that the level of $\mathrm{pH}$ in the effluents from the tannery industry in Vaniyambadi, India was 6.5 which was lower than that observed in the present study. The $\mathrm{pH}$ in the effluents from the tannery industries in Kano and Kaduna were reported to be 7.64 and 6.89, respectively (Akan et al., 2007; Mohammed et al., 2017). The average values of $\mathrm{pH}$ observed in this present study are less than those observed by Mohammed et al. (2017) and Baba et al. (2020). The mean level of SS $(\mathrm{mg} / \mathrm{l})$ observed in TAN1, TAN2, and TAN3 samples were 374 \pm 124 ; $358 \pm 335$ and $780 \pm 739$ respectively. The order of the mean SS in the samples from the three industries can be arranged as TAN3 > TAN1 $>$ TAN2. 
The SS observed in the samples were far above the recommended standard limits of regulating bodies WHO $(30 \mathrm{mg} / \mathrm{l})$ and NESREA $(10 \mathrm{mg} / \mathrm{l})$. Statistical analysis shows that there is no significant difference $(p<0.05)$ between the mean values of SS among the industries. This might be due to similar tannery activities involved in the tannery industries at the time of sampling. The average values of SS observed in this present study are less than that observed $(3700 \pm 122 \mathrm{mg} / \mathrm{l})$ by Akan et al. (2009) for tanneries in Kano. Also, the average values of SS observed in this present study are less than that observed by Mohammed et al. (2017) and Baba et al. (2020) with the exception in TAN3.

The mean level of TDS (mg/l) observed in TAN1, TAN2, and TAN3 samples were $3941 \pm 3703$; $3300 \pm 1714$ and $2653 \pm 1240$ respectively. The order of the mean TDS in the samples from the three industries can be arranged as TAN1>TAN2>TAN3. The TDS observed in the samples were far above the recommended standard limits of WHO $(250 \mathrm{mg} / \mathrm{l})$ and NESREA $(500 \mathrm{mg} / \mathrm{l})$. Statistical analysis shows that there is no significant difference $(p<0.05)$ between the mean values of TDS among the industries. This might be due to similar tannery activities involved in the tannery industries at the time of sampling. TDS in the effluents from the tannery industries in Kano, Nigeria was reported to be $1281 \mathrm{mg} / \mathrm{l}$ (Akan et al., 2007). The average values of SS observed in this present study are less than those observed by Mohammed et al. (2017) and Baba et al. 2020)

The mean level of COD (mg/l) observed in TAN1, TAN2 and TAN3 samples seasons were $2372 \pm 938 ; \quad 1406 \pm 208$ and $3532 \pm 1373$ respectively. The order of the mean COD of the samples from the three industries can be arranged as TAN3>TAN1> TAN2. The COD observed in TAN1, TAN2 and TAN3 samples were far above the recommended standard limits of regulating bodies $\mathrm{WHO}(40 \mathrm{mg} / \mathrm{l})$ and NESREA (40 mg/l). Statistical analysis shows that there is no significant difference $(p<0.05)$ in COD among the industries. This might be due to similar tannery activities involved in the tannery industries as at the time of sampling. The Chemical Oxygen demand (COD) is the amount of oxygen, in $\mathrm{mg} / \mathrm{L}$, required for the degradation of the compound of wastewater to occur. In comparison, the average values of COD observed in this present study were higher than that observed by Mohammed et al. (2017) but lower than that observed by Baba et al. (2020).

The mean levels of BOD $(\mathrm{mg} / \mathrm{l})$ observed in TAN1, TAN2 and TAN3 samples were $13.85 \pm 6.42 ; \quad 19.46 \pm 0.50$ and $17.13 \pm 3.14$ respectively. The order of the mean BOD in the samples from the three industries can be arranged as TAN2>TAN3>TAN1. The BOD observed in TAN1, TAN2 and TAN3 samples were found below the recommended limits of NESREA (200 mg/l) but above WHO (10 mg/l). Statistical analysis shows that there is no significant difference $(p<0.05)$ between the mean values of BOD among the industries. This might be due to similar tannery activities involved in the tannery industries at the time of sampling. The low level of BOD recorded in this study is an indication of the low level of biodegradable organic solids in the effluent. The average values of BOD observed in this present study were lower than those observed by Mohammed et al. (2017) and Baba et al. (2020).

Table 1: Mean Values \pm S.D of Physico-chemical parameters of effluents from the Tannery Industries before Treatment.

\begin{tabular}{llllllll}
\hline Parameter & Tannery 1 & Tannery 2 & Tannery 3 & $\mathrm{a}$ & $\mathrm{b}$ & $\mathrm{c}$ & $\mathrm{d}$ \\
\cline { 2 - 7 } Temperature $\left({ }^{\circ} \mathrm{C}\right)$ & $28.07 \mathrm{a} \pm 0.65$ & $27.77 \mathrm{a} \pm 0.64$ & $26.38 \mathrm{a} \pm 3.81$ & & $29.50 \pm 4.68$ & 35 & 40 \\
pH & $7.77 \mathrm{a} \pm 2.93$ & $8.35 \mathrm{a} \pm 0.28$ & $7.52 \mathrm{a} \pm 0.76$ & 6.89 & $5.35 \pm 1.57$ & $7.0-8.5$ & $6.0-9.0$ \\
$\mathrm{COD}(\mathrm{mg} / \mathrm{l})$ & $2372 \mathrm{a} \pm 938$ & $1406 \mathrm{a} \pm 208$ & $3532 \mathrm{a} \pm 1373$ & 2.2 & $3106 \pm 2753$ & 40 & 40 \\
$\mathrm{BOD}(\mathrm{mg} / \mathrm{l})$ & $13.85 \mathrm{a} \pm 6.42$ & $19.46 \mathrm{a} \pm 0.50$ & $17.13 \mathrm{a} \pm 3.14$ & 1032 & $26.17 \pm 9.49$ & 10 & 200 \\
$\mathrm{SS}(\mathrm{mg} / \mathrm{l})$ & $374 \mathrm{a} \pm 124$ & $358 \mathrm{a} \pm 335$ & $780 \mathrm{a} \pm 739$ & 501 & $562 \pm 482$ & 30 & 10 \\
TDS $(\mathrm{mg} / \mathrm{l})$ & $3941 \mathrm{a} \pm 3703$ & $3300 \mathrm{a} \pm 1714$ & $2653 \mathrm{a} \pm 1240$ & 532.7 & $444 \pm 507$ & 250 & 500 \\
\hline
\end{tabular}

The values given in the table above are means of 6 replicate values, $\mathrm{n}=6$ ( 1 sample was taken monthly for 6 months). Within the rows, means with different alphabets are statistically different $(p<0.05)$. WHO: World Health Organisation. NESREA: National Environmental Standard and Regulatory Enforcement Agency. a = Mohammed et al.(2017), b = Baba et al. (2020), c = WHO (2006), $d=$ NESSRA (2009) 
BAJOPAS Volume 13 Number 2, December, 2020

Identification, Biochemical Characterization and growth rates of the Bacterial Isolates

Results of identification and biochemical characterization of the bacterial isolates were shown in table 2. After 24 hours of incubation, the nutrient agar media plates were checked for bacterial growth. The results showed the presence of different strains in the samples. The TAN1 bacteria isolate was found to be gramnegative cocci while TAN3 was gram-positive cocci. TAN2 bacteria isolate was found to be gram-positive, rod-shaped. TAN1, TAN2, and TAN3 bacteria isolates recorded positive results for spore former.

The results of the biochemical tests indicated that all the bacteria were positive for catalase, oxidase, citrate, maltose, glucose, lactose (negative in TAN1), mannitol (negative in TAN2), starch hydrolysis and coagulase (negative in TAN2) tests. The bacteria showed negative results for nitrate reduction, $M R$ (positive in TAN2), VP (positive in TAN1), Indole (positive in TAN2) tests. Base on the morphological and biochemical test results, TAN1, TAN2, and TAN3 bacteria isolates were identified to be Nesseria spp, Bacillus cereus, and Staphylococcus aureus respectively.

The growth rate of the TAN1, TAN2 and TAN3 Isolates were shown in figure 2. Generally, the optical density increase with the increase in time (day) and decrease as time goes on. The highest optical density was shown by bacillus cereus in TAN2 while the lowest was shown by Staphylococcus aureus in TAN3.

The initial growth phase of TAN1 Isolate bacteria occurred within 2-day of incubation as the growth rate increases up to the 6th-day incubation when the maximum growth was observed. Beyond the 6th day, the growth of the bacteria declined (which might be due to a shortage of nutrients in the effluents) until it reached its death phase (which might be due to the unavailability of nutrients in the effluents).

A similar trend of growth was also observed for TAN2 Isolate as the initial growth phase also occurred within 2-day of incubation but maximum growth rate observed on the 4th day of incubation. The stationary stage occurred between the 4th day and the 8th day. Beyond the 8th day, the growth of the bacteria declined (which might be due to a shortage of nutrients in the effluents) until it reached its death phase (which might be due to the unavailability of nutrients in the effluents).

The initial growth phase of TAN3 bacterial Isolate occurred within the 3-day incubation as the growth rate increases up to the 6th-day incubation when the maximum growth was observed. Beyond the 6th day, the growth of the bacteria declined (which might be due to a shortage of nutrients in the effluents) until it reached its death phase (which might be due to the unavailability of nutrients in the effluents).

Table 2: Morphological and Biochemical characteristics of bacterial isolates

\begin{tabular}{lllll} 
Bacterial Isolates & & TAN1 & TAN2 & TAN3 \\
\hline $\begin{array}{lllll}\text { Morphological } \\
\text { characteristics }\end{array}$ & Shape & Cocci & Rod & Cocci \\
& Spore & & & \\
& former & + & + & + \\
Gram & & & \\
Biochemical characteristics & reaction & - & + & + \\
& Citrate & + & + & + \\
& Catalase & + & + & + \\
& Coagulase & + & - & + \\
Starch & + & + & + \\
& Glucose & + & + & + \\
Oxidase & + & + & + \\
& Indo & - & + & - \\
Lactose & - & + & + \\
Manitol & + & - & + \\
Maltose & + & + & + \\
MR & - & + & - \\
VP & + & - & - \\
& Nitrate & - & - & - \\
Reduction & - Neisseria & Bacillus & Staphylococcus \\
& Bacterial & cereus & aureus \\
& name & spp & cas
\end{tabular}

+ = Positive; - = Negative; MR=Methyl Red; VP= Voges-Proskauer 


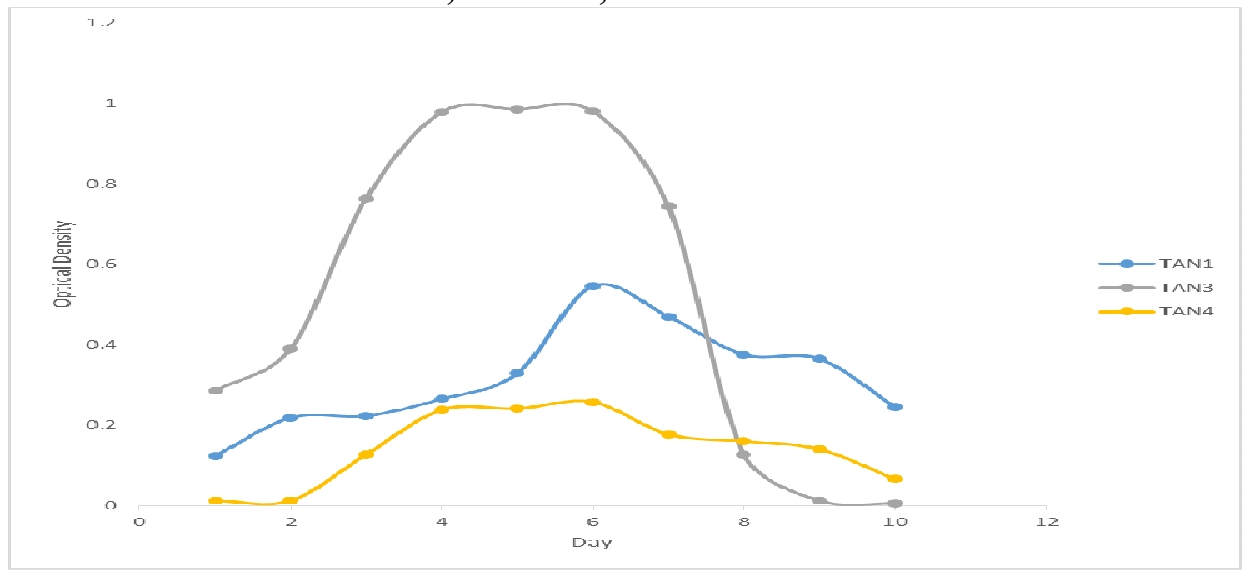

Fig. 2 Growth rates of the isolates in the effluents from the Tannery Industries

\section{Physico-chemical Parameters in the Industrial Effluents after the biodegradation.}

Table 3 shows the mean results of the physicochemical parameter before and after bioremediation using the different masses $(5 \mathrm{~g}$, $10 \mathrm{~g}, 15 \mathrm{~g}, 20 \mathrm{~g}$, and $25 \mathrm{~g}$ ) of the respective immobilized bacteria. Also, Table 4 shows the mean results of correlation coefficient ( $r$ ) between different masses of bacteria and physicochemical parameters.

The mean values $(\mathrm{mg} / \mathrm{l})$ of the SS after the bioremediation varies between $243 \pm 45$ and $898 \pm 672$. The mean concentration $(\mathrm{mg} / \mathrm{l})$ of SS remediated by the different masses $(5 \mathrm{~g}, 10 \mathrm{~g}$, $15 \mathrm{~g}, 20 \mathrm{~g}$, and $25 \mathrm{~g}$ ) of the bacteria varies. The SS in the samples fluctuates up and down after the bioremediation process when compared with the SS of the raw samples before the bioremediation. The increase in the levels of the SS might be due to the aggregation of the TDS which are large enough to result into SS. The increase in the levels of the SS might be also due to the influence of the nutrients which was added into the effluents in order to make the microorganisms more active and viable for fast degradation of organic contaminants in the effluent. The relative potential or efficiency of the different masses of the bacteria in remediating SS in TAN1 samples was in the order $25 \mathrm{~g}>20 \mathrm{~g}>15 \mathrm{~g}>10 \mathrm{~g}>5 \mathrm{~g}$. For TAN2 and TAN3 samples, the order was $25 \mathrm{~g}>20 \mathrm{~g}>15$ $\mathrm{g}>10 \mathrm{~g}>5 \mathrm{~g}$. These might be due to the variations in the surface areas of the different masses of the immobilized bacteria. Statistical analysis shows that there is no significant difference $(p<0.05)$ between the mean values of SS among the masses in the respective industries. Positive and significant correlations exist between the masses of bacteria and Suspended Solid (SS). This showed that there is general increase in the levels of the SS as the masses of the immobilized bacteria increases. TAN3 (90\%) and TAN1 (80\%) showed a very high correlation with the masses of the bacteria while TAN2 (61\%) showed a very low correlation.

The mean values $(\mathrm{mg} / \mathrm{l})$ of the TDS after the bioremediation varies between $46 \pm 11$ and $83 \pm 78$. The mean concentration $(\mathrm{mg} / \mathrm{l})$ of TDS remediated by the different masses $(5 \mathrm{~g}, 10 \mathrm{~g}$, $15 \mathrm{~g}, 20 \mathrm{~g}$, and $25 \mathrm{~g}$ ) of the bacteria varies. There is a reduction in all the TDS of all the samples after the bioremediation process compared with the TDS of the raw samples before the bioremediation. The relative potential or efficiency of the different masses of the bacteria in remediating TDS in TAN1 and TAN3 samples was in the order $5 \mathrm{~g}>10 \mathrm{~g}>15 \mathrm{~g}>20$ $\mathrm{g}>25 \mathrm{~g}$. For TAN2 samples, the order was 20 $g>10 \quad g>25 \quad g>15 \quad g>5 \quad g$. Statistical analysis shows that there is no significant difference $(p<0.05)$ between the mean values of TDS among the masses in the respective industries. These might be due to the variations in the surface areas of the different masses of the immobilized bacteria. Positive and significant correlations exist between the masses of bacteria and TDS with the exception in TAN2 (negative and insignificant correlation). The positive correlations showed that there is general increase in the levels of the TDS as the masses of the immobilized bacteria increases. TAN1 $(96 \%)$ showed a very high correlation with the masses of the bacteria while TAN2 (47\%) showed a very low correlation.

The mean values $(\mathrm{mg} / \mathrm{l})$ of the BOD after the bioremediation varies between $1.56 \pm 0.20 \mathrm{mg} / \mathrm{l}$ and $6.92 \pm 5.49 \mathrm{mg} / \mathrm{l}$. The mean concentration $(\mathrm{mg} / \mathrm{l})$ of BOD remediated by the different masses $(5 \mathrm{~g}, 10 \mathrm{~g}, 15 \mathrm{~g}, 20 \mathrm{~g}$, and $25 \mathrm{~g}$ ) of the bacteria varies. There is a reduction in all the BOD of all the samples after the bioremediation process compared with the $\mathrm{BOD}$ of the raw 
BAJOPAS Volume 13 Number 2, December, 2020 samples before the bioremediation. The relative potential or efficiency of the different masses of the bacteria in remediating BOD in TAN1, TAN2 and TAN3 samples were in the order $25 \mathrm{~g}>20$ $\mathrm{g}>15 \mathrm{~g}>10 \mathrm{~g}>5 \mathrm{~g}, 25 \mathrm{~g}>15 \mathrm{~g}>5 \mathrm{~g}>10 \mathrm{~g}>20 \mathrm{~g}$ and $20 \mathrm{~g}>10 \mathrm{~g}>25 \mathrm{~g}>15 \mathrm{~g}>5 \mathrm{~g}$ respectively. Statistical analysis shows that there is significant difference $(p<0.05)$ between the mean values of BOD among the masses in the respective industries. These might be due to the variations in the surface areas of the different masses of the immobilized bacteria. Negative and significant correlations exist between the masses of bacteria and BOD. This showed that there is general decrease in the levels of the BOD as the masses of the immobilized bacteria increases. TAN1 (94\%) showed a very high correlation with the masses of the bacteria while TAN2 (4\%) showed a very low correlation.

The mean values $(\mathrm{mg} / \mathrm{l})$ of the COD after the bioremediation varies between $250 \pm 154$ and $3134 \pm 1595$. The mean concentration $(\mathrm{mg} / \mathrm{l})$ of COD remediated by the different masses $(5 \mathrm{~g}$, $10 \mathrm{~g}, 15 \mathrm{~g} 20 \mathrm{~g}$, and $25 \mathrm{~g}$ ) of the bacteria varies. There is a reduction in all the COD of all the samples after the bioremediation process compared with the COD of the raw samples before the bioremediation. The relative potential or efficiency of the different masses of the bacteria in remediating COD in TAN1, TAN2 and TAN3 samples were in the order $25 \mathrm{~g}>20 \mathrm{~g}>15$ $\mathrm{g}>5 \mathrm{~g}>10 \mathrm{~g}, 25 \mathrm{~g}>20 \mathrm{~g}>15 \mathrm{~g}>10 \mathrm{~g}>5 \mathrm{~g}$ and 10 g>5 g>25 g>15 g>20 g respectively. Statistical analysis shows that there were significant difference $(p<0.05)$ between the mean values of COD among the masses in the respective industries except for effluents treated with $25 \mathrm{~g}$. These might be due to the variations in the surface areas of the different masses of the immobilized bacteria. Negative and insignificant correlations exist between the masses of bacteria and COD with the exception in TAN3 (positive and significant correlation). The negative correlations showed that there is general decrease in the levels of the COD as the masses of the immobilized bacteria increases. TAN2 (100\%) showed a very high correlation with the masses of the bacteria while TAN3 (36\%) showed a very low correlation.

Generally, there was an overall decrease in the concentration of these physicochemical parameters after the bioremediation using the different masses of the bacterial isolates. These might be due to the variations in the surface areas of the different masses of the immobilized bacteria. This is in line with the work of Jimoh et al. (2018) and Baba et al. (2020).

Table 3: Mean Values $(\mathrm{mg} / \mathrm{l}) \pm$ S.D of Physicochemical parameters in effluents from the Tannery Industries before and after Treatment of the effluents $(250 \mathrm{ml})$ with the different masses $(5 \mathrm{~g}, 10 \mathrm{~g}$, $15 \mathrm{~g}, 20 \mathrm{~g}$, and $25 \mathrm{~g}$ ) of the bacteria.

\begin{tabular}{llllllll}
\hline $\mathrm{P}$ & IND & Before & \multicolumn{5}{c}{ After } \\
\cline { 4 - 7 } & & & $5 \mathrm{~g}$ & $10 \mathrm{~g}$ & $15 \mathrm{~g}$ & $20 \mathrm{~g}$ & $25 \mathrm{~g}$ \\
\hline \multirow{2}{*}{ COD } & TAN1 & $2372 \pm 938$ & $1708 \mathrm{a} \pm 861$ & $2045 \mathrm{a} \pm 1205$ & $845 \mathrm{a} \pm 369$ & $300 \mathrm{a} \pm 167$ & $250 \mathrm{a} \pm 154$ \\
& TAN2 & $1406 \pm 208$ & $1195 \mathrm{a} \pm 208$ & $1125 \mathrm{a} \pm 384$ & $1055 \mathrm{a} \pm 317$ & $956 \mathrm{a} \pm 310$ & $870 \mathrm{ab} \pm 240$ \\
& TAN3 & $3532 \pm 1373$ & $2374 \mathrm{a} \pm 1344$ & $1976 \mathrm{a} \pm 1405$ & $2757 \mathrm{a} \pm 1266$ & $3134 \mathrm{a} \pm 1595$ & $2614 \mathrm{~b} \pm 1105$ \\
BOD & TAN1 & $13.85 \pm 6.42$ & $6.92 \mathrm{a} \pm 5.49$ & $6.42 \mathrm{a} \pm 5.07$ & $5.72 \mathrm{a} \pm 5.35$ & $4.62 \mathrm{a} \pm 4.37$ & $2.82 \mathrm{ab} \pm 1.26$ \\
& TAN2 & $19.46 \pm 0.50$ & $1.75 \mathrm{~b} \pm 0.22$ & $1.73 \mathrm{~b} \pm 0.18$ & $1.58 \mathrm{a} \pm 0.16$ & $1.91 \mathrm{a} \pm 0.22$ & $1.56 \mathrm{~b} \pm 0.20$ \\
& TAN3 & $17.13 \pm 3.14$ & $4.24 \mathrm{ab} \pm 0.77$ & $3.29 \mathrm{ab} \pm 0.37$ & $4.11 \mathrm{a} \pm 0.07$ & $3.23 \mathrm{a} \pm 0.91$ & $3.33 \mathrm{a} \pm 1.28$ \\
SS & TAN1 & $374 \pm 124$ & $243 \mathrm{a} \pm 45$ & $471 \mathrm{a} \pm 226$ & $475 \mathrm{a} \pm 182$ & $492 \mathrm{a} \pm 128$ & $611 \mathrm{a} \pm 217$ \\
& TAN2 & $358 \pm 335$ & $460 \mathrm{a} \pm 400$ & $543 \mathrm{a} \pm 414$ & $544 \mathrm{a} \pm 402$ & $551 \mathrm{a} \pm 414$ & $554 \mathrm{a} \pm 405$ \\
& TAN3 & $780 \pm 739$ & $586 \mathrm{a} \pm 594$ & $758 \mathrm{a} \pm 656$ & $787 \mathrm{a} \pm 676$ & $861 \mathrm{a} \pm 635$ & $898 \mathrm{a} \pm 672$ \\
TDS & TAN1 & $3941 \pm 3703$ & $51 \mathrm{a} \pm 10$ & $53 \mathrm{a} \pm 10$ & $55 \mathrm{a} \pm 15$ & $61 \mathrm{a} \pm 20$ & $63 \mathrm{a} \pm 26$ \\
& TAN2 & $3300 \pm 1714$ & $83 \mathrm{a} \pm 78$ & $47 \mathrm{a} \pm 20$ & $48 \mathrm{a} \pm 22$ & $47 \mathrm{a} \pm 17$ & $48 \mathrm{a} \pm 17$ \\
& TAN3 & $2653 \pm 1240$ & $46 \mathrm{a} \pm 11$ & $55 \mathrm{a} \pm 24$ & $55 \mathrm{a} \pm 25$ & $58 \mathrm{a} \pm 23$ & $61 \mathrm{a} \pm 28$ \\
\hline
\end{tabular}

Replicate $=6$ (months)

Within the rows, for the same parameter, means with different alphabets are statistically different $(p<0.05)$.

$\mathrm{P}=$ parameter, IND = Industries 
BAJOPAS Volume 13 Number 2, December, 2020

Table 4: Correlation coefficient $(r)$ between different masses of the bacteria and the physicochemical parameters.

\begin{tabular}{llll}
\hline Industries & Parameter & Correlation coefficient $(r)$ & $\begin{array}{l}\text { Percent dependence (rxrx100) } \\
(\%)\end{array}$ \\
\hline TAN1 & COD & -0.9 & 82 \\
& BOD & -0.97 & 94 \\
& SS & $0.90^{*}$ & 80 \\
TAN2 & TDS & $0.98^{*}$ & 96 \\
& COD & -1 & 100 \\
& BOD & -0.21 & 4 \\
& SS & $0.78^{*}$ & 61 \\
& TDS & -0.69 & 47 \\
& COD & $0.60^{*}$ & 36 \\
& BOD & -0.6 & 37 \\
& SS & $0.95^{*}$ & 90 \\
& TDS & $0.94^{*}$ & 89 \\
\hline
\end{tabular}

The correlation coefficient $(r)$ with * is statistically significant $(p<0.05)$.

Percentage reduction of the Parameters

Table 5 shows the percentage reduction of Parameters in industrial samples before and after the treatment of the effluents $(250 \mathrm{ml})$ with the different masses $(5 \mathrm{~g}, 10 \mathrm{~g}, 15 \mathrm{~g}, 20 \mathrm{~g}$, and $25 \mathrm{~g}$ ) of the Immobilized Bacteria.

In TAN1 samples, the percentage reduction (\%) of COD ranged (14-89); BOD (50-80); SS (-32$35)$ and TDS (98-99). In TAN2 samples, the percentage decrease $(\%)$ of COD ranged (15$38) ;$ BOD (90-92); SS [-28-(-55)] and TDS (9798). In TAN3 samples, the percentage decrease (\%) of COD ranged (11-44); BOD (76-81); SS (15-25) and TDS (98). The percentage increase in the levels COD, BOD and TDS might be due to the increase in the surface area of the different masses of the immobilized bacteria. However, the percentage decrease in the levels of the SS might be due to the aggregation of the TDS which are large enough to result into SS. The percentage decrease in the levels of the SS might be also due to the influence of the nutrients which was added into the effluents in order to make the microorganisms more active and viable for fast degradation of organic contaminants in the effluent. This is in line with the work of Jimoh et al. (2018) in which the concentration of the SS increase after the bioremediation of effluents.

Sreemoyee and Priti (2013) assessed and reduced several Physico-chemical parameters of dairy wastewater using Niesseria $s p$. and concluded that the species are well known to degrade organic compounds. This is in agreement with the current study in which the immobilized Niesseria $s p$ degrade the organic contaminants as indicated by the BOD, COD and TDS.

Jimoh et al. (2018) observed that TSS of the effluents was increased after treatment with immobilized bacteria and concluded that it might be due to the biostimulation method adopted for the research.

The optimum $\mathrm{pH}$ Biosorption of Chromium by Bacillus spp and Staphylococcus spp. from tannery effluent was investigated by Mythili and Karthikeyan (2011). The maximum adsorption of Chromium $(86.4 \mathrm{mg} / \mathrm{L})$ was showed by Bacillus spp and Staphylococcus spp showed $70.6 \mathrm{mg} / \mathrm{L}$ at an initial concentration of $100 \mathrm{mg} / \mathrm{L}$. In the present study, immobilised Bacillus spp and Staphylococcus spp. from the tannery industrial effluents reduced the levels of the organic pollutants with high potential as indicated by the percentage reduction of BOD, COD and TDS.

Enzymes often can work in multiple environments especially if they are immobilized. This makes the microorganisms' enzymes even more resistant to harsh environments and enables the enzymes to be recovered and recycled after they are no longer needed (Gianfreda and Rao 2004). Ramesh and Singh (1993) reported that the immobilized bacteria having more efficiency to remove the suspended particles than free cells. Using the immobilized cell is preferable due to its capability for using several times with the same efficiency, which makes it more economical. Similar work was done by Sikander et al. (2007) showing the higher reduction with permeabilized cells of Ochrobactrum intermedium strain SDCr-5. 
BAJOPAS Volume 13 Number 2, December, 2020

The results revealed the isolation and identification of isolates with the potential for the reduction of $\mathrm{Cr}$ (VI) to $\mathrm{Cr}$ (III). Results indicated that immobilized $B$. cereus could be efficiently used for the reduction of $\mathrm{Cr}$ (VI).

Table 5: Percentage reduction of the tested Parameters from the tannery industrial samples of the Immobilized Bacteria.

\begin{tabular}{lllllll}
\hline \multirow{2}{*}{ Industries } & & \multicolumn{5}{c}{ Percentage Reduction $(\%)$} \\
\cline { 3 - 7 } & & $5 \mathrm{~g}$ & $10 \mathrm{~g}$ & $15 \mathrm{~g}$ & $20 \mathrm{~g}$ & $25 \mathrm{~g}$ \\
\hline TAN1 & COD & 28 & 14 & 64 & 87 & 89 \\
& BOD & 50 & 54 & 59 & 67 & 80 \\
& SS & 35 & -26 & -27 & -32 & -63 \\
& TDS & 99 & 99 & 99 & 98 & 98 \\
TAN2 & COD & 15 & 20 & 25 & 32 & 38 \\
& BOD & 91 & 91 & 92 & 90 & 92 \\
& SS & -28 & -52 & -52 & -54 & -55 \\
& TDS & 97 & 99 & 99 & 99 & 99 \\
& COD & 33 & 44 & 22 & 11 & 26 \\
& BOD & 75 & 81 & 76 & 81 & 81 \\
& SS & 25 & 3 & -1 & -10 & -15 \\
& TDS & 98 & 98 & 98 & 98 & 98 \\
\hline
\end{tabular}

Percentage Reduction $=(B-A) / B \times 100 \%$

$A=$ Concentration of the parameter after treatment

$\mathrm{B}=$ Concentration of the parameter before treatment

$+=$ percentage decrease

- = percentage increase

In general, immobilization makes the enzyme more resistant to temperature, $\mathrm{pH}$, and substrate concentration swings giving it a longer lifetime and higher productivity per active unit (Gianfreda and Rao, 2004; FuIlbrook, 1996; Russell et al, 2003; Kandelbauer et al., 2004). Immobilized cells have been used and studied extensively for the production of useful chemicals (Ohtake and Silver, 1994), the treatment of wastewaters (Chen et al., 2003; Wang et al., 2010). Although many workers described microbial degradation of tannery effluent, limited literature is available on the bioremediation of tannery effluent using immobilized bacterial cells in the Kano Industrial Estates.

\section{CONCLUSION}

The samples contained variable levels of the physicochemical parameters. The results of the Analysis of variance revealed that, no statistical difference $(p<0.05)$ was observed for the temperature, $\mathrm{pH}, \mathrm{SS}, \mathrm{TDS}, \mathrm{BOD}$ and $\mathrm{COD}$ among the three tannery industries before the treatment. The levels of some of the parameters
(SS, TDS and COD) observed in the samples were found above the recommended limits of WHO and NESREA, which called for the treatment of the effluents before discharge into the environment. Base on the morphological and biochemical test results, TAN1, TAN2, and TAN3 bacterial isolates were identified to be Neisseria spp, Bacillus cereus, and Staphylococcus aureus respectively. The results of Post-treatment analysis showed that there is overall decrease in the levels of the parameters determined when compared with that of the pre-treatment. The overall percentage reduction of the immobilised bacteria in the treatment of the respective effluents was in the order TAN2 (72\%)>TAN1 $(70 \%)>$ TAN3 $(62 \%)$. Hence, the immobilized bacteria are having higher biodegradation potential for the treatment of the tannery effluents.

\section{Acknowledgments}

The authors wish to acknowledge the University of Maiduguri for the financial support. The authors are grateful to the Kano State Ministry of Environment for their support in obtaining the effluent samples. 


\section{REFERENCES}

Ajao, A. T., Adebayo, G. B., and Yakubu, S. E. (2011). Bioremediation of textile industrial effluent using mixed culture of Pseudomonas aeruginosa and Bacillus subtilis immobilized on agar-agar in a bioreactor. J. Microbiol. Biotech. Res, 1(3), 50-56.

Akan, J. C., Moses, E. A., Ogugbuaja, V. O., and Abah, J. (2007). Assessment of tannery industrial effluents from Kano metropolis, Kano State, Nigeria. Journal of Applied Sciences, 7(19), 2788-2793.

Akan, J. C., Ogugbuaja, V. O., Abdulrahman, F. I., and Ayodele, J. T. (2009). Pollutant levels in effluent samples from tanneries and textiles of Kano industrial areas, Nigeria. Global journal of pure and applied sciences, 15(3-4).

APHA (1989). Standard methods for Examination of Will bete and Will betewater.15 $5^{\text {th }}$ edition. Brydpass Springfield Will behington DC. pp. 164-176

APHA (1992). Standard Methods for the Examination of Water and Wastewater. Health, 69, 1116-9.

Baba, A., Garba, S. T., and Bello, H. S. (2020). Bioremediation Potential of Immobilized corynebacterium kutsceri in the Treatment of Tannery Industrial Effluent from Challawa Industrial Estate, Kano State, Nigeria. Journal of the Turkish Chemical Society Section A: Chemistry, $7(2), 335-350$.

Beem, E. I. V. (1994). reduction of solvent VOC emission. J. Oil Col. Chem. Ass, 77, 158.

Bouwer, E. J., and Zehnder, A. J. (1993). Bioremediation of organic compoundsputting microbial metabolism to work. Trends in biotechnology, 11(8), 360367.

Chen, K. C., Wu, J. Y., Liou, D. J., and Hwang, S. C. J. (2003). Decolorization of the textile dyes by newly isolated bacterial strains. Journal of Biotechnology, 101(1), 57-68.

Dan'Azumi, S., and Bichi, M. H. (2010). INDUSTRIAL POLLUTION AND HEAVY METALS PROFILE OF CHALLAWA RIVER IN KANO, NIGERIA. Journal of Applied Sciences in Environmental Sanitation, $5(1)$.

DWAF. (1992). Analytical Methods Manual, TR 151. Department of Water Affairs and Forestry, Pretoria.

El-Bestawy, E. (2013). Biological treatment of leather-tanning industrial wastewater using free living bacteria.
Elsheikh, M. A. S. (2009). Tannery wastewater pre-treatment. Water Science and Technology, 60(2), 433-440.

FuIlbrook, P. D. (1996). "Kinetics." Industrial enzymology: The application of enzymes in Industry. 2nd Ed. T. Godfrey and J Reichelt. eds.. Nature. New York.

Gianfreda, L., and Rao, M. A. (2004). Potential of extra cellular enzymes in remediation of polluted soils: a review. Enzyme and microbial technology, 35(4), 339354.

Hugo Springer. (1994). John Arthur Wilson Memorial Lecture "Treatment of Industrial Wastes of the Leather Industry - is it still a Major Problem". JALCA, 89, 153-185

Jimoh, A. A., Ganiyu, B. A., Baba, D., and Baba, A. (2018) Bioremediation Process of Effluent from Detergent and Food Industries in Jos, Nigeria: Kinetics and Thermodynamics. International Journal of Engineering Science Invention (IJESI), 762-73

Kandelbauer, A., Maute, O., Kessler, R. W., Erlacher, A., and Gübitz, G. M. (2004). Study of dye decolorization in an immobilized laccase enzyme-reactor using online spectroscopy. Biotechnology and bioengineering, 87(4), 552-563.

Kongjao, S., Damronglerd, S., and Hunsom, M. (2008). Simultaneous removal of organic and inorganic Pollutants in tannery wastewater using electrocoagulation technique. Korean Journal of chemical engineering, 25(4), 703.

Maheshwari, U. M., Aruna, S., Gomathi, M., and AbdulJaffar, A. H. (2017). Bioremediation by Free and Immobilized Bacteria Isolated from Tannery Effluent. International Journal of Research in Applied, Natural and Social Sciences. 5(7), 75-90

Margesin, R., and Schinner, F. (2001). Bioremediation (natural attenuation and biostimulation) of diesel-oilcontaminated soil in an alpine glacier skiing area. Applied and environmental microbiology, 677), 3127-3133.

Mohammed, A., Sekar, P., and George, J. (2011). Efficacy of microbes in bioremediation of tannery effluent. Inter. J. Curr. Res, 3(4), 324-326.

Mohammed, S. S. D., Orukotan, A. A., and Abdullahi, H. (2017). Physicochemical and Bacteriological Assessment of Tannery Effluent from Samaru-Zaria, 
BAJOPAS Volume 13 Number 2, December, 2020 Kaduna State, Nigeria. Journal of Applied

Sciences and Environmental Management, 21(4), 734-740.

Munz, G., De Angelis, D., Gori, R., Mori, G., Casarci, M., and Lubello, C. (2009). The role of tannins in conventional and membrane treatment of tannery wastewater. Journal of hazardous materials, 164(2-3), 733-739

Mythili, K., and Karthikeyan, B. (2011). Bioremediation of $\mathrm{Cr}$ (VI) from tannery effluent using Bacillus spp and Staphylococcus spp. International Multidisciplinary Research Journal, 1(6).

NESREA (2009). National Environmental Standards for Effluent Limitations and Regulation. 1233-1236

Noorjahan, C. M. (2014). Physicochemical characteristics, identification of bacteria and biodegradation of industrial effluent. Journal of bioremediation and Biodegradation, 5(3).

Ohtake, H. I., and Silver, A. O. (1994). Bacterial reduction of toxic chromate. Biological degradation and bioremediation of toxic chemicals, 403-415.

Omoleke, I. I. (2004). Management of environmental pollution in Ibadan, an African city: the challenges of health hazard facing government and the people. Journal of Human Ecology, 15(4), 265-275.

Rajor, A., Reddy, A.S., and Singh, B. (2004). Determination of BOD kinetic Parameters and evaluation of alternate methods, M.Sc. Thesis, Department of biotechnology \& environmental Science, Thapar Institute of Engineering and Technology, Patiala

Ramasami, T., Rajamani, S., and Rao, J. R. (1994, March). Pollution control in leather industry: Emerging technological options. In International symposium on surface and colloidal science and its relevance to soil pollution, madras.

Ramesh, J. V. S., and Singh, S. P. (1993). Yearly variation in certain physicochemical parameters of pond at eastern Doon Valley. Uttar Pradesh J. Zoo, 12 (1), 7577.

Ranen, S., and Sharadinadra, C. (2009). Biotechnology applications to environmental remediation in resource exploitation. Current science, 97, 6-25
Russell, A. J., Berberich, J. A., Drevon, G. F., and Koepsel, R. R. (2003). Biomaterials for mediation of

chemical and biological warfare agents. Annual review of biomedical engineering, 5(1), 1-27.

Saravanan, P., and Saravanan, A. (1999). Decolourization of tannery effluent by Flavobacterium sp. EK 1. Indian Journal of Environmental Protection, 19, 19-24.

Sikander, S., and Shahida, H. (2007). Reduction of toxic hexavalent chromium by Ochrobactrum intermedium strain SDCr5 stimulated by heavy metals. Bioresource Technol, 98, 340-344.

Singh, N., Sharma, B. K., and Bohra, P. C. (2000). Impact assessment of industrial effluent of arid soils by using satellite imageries. Journal of the Indian Society of Remote Sensing, 28(2-3), 79.

Sreemoyee, C., and Priti, P. (2013). Assessment of physico-chemical parameters of dairy waste water and isolation and characterization of bacterial strains in terms of cod reduction. Int J Sci, 2(3), 395-400.

Verheijen, L. A. H. M., Wiersema, D., Pol, L. H., and De Wit, J. (1996). Management of wastes from animal product processing. Livestock and environment, Finding a balance. International Agriculture Center, Wageningen, The Netherlands.

Wang, F., Yao, J., Si, Y., Chen, H., Russel, M., Chen, K., and Bramanti, E. (2010). Short-time effect of heavy metals upon microbial community activity. Journal of Hazardous Materials, 173(13), 510-516.

WHO (World Health Organization). (2006). Air quality guidelines: global update 2005: particulate matter, ozone, nitrogen dioxide, and sulfur dioxide. World Health Organization.

World Bank. (1995). Nigeria's strategic options for redressing industrial pollution. World Bank, industry and energy division. 1st edition, West Central Africa Department; Annexes: 1995; pp 60-62.

Zahoor, A., and Abdul, R. (2009). Enumeration of Coliforms. Journal of Environmental Sciences. 21, 814-820 


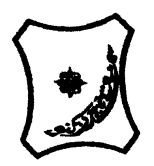

Bayero Journal of Pure and Applied Sciences, 13(2): 1 - 12

Received: November, 2020

Accepted: December, 2020

ISSN $2006-6996$

\title{
BIODEGRADATION POTENTIAL OF IMMOBILIZED BACTERIA IN THE TREATMENT OF TANNERY INDUSTRIAL EFFLUENTS FROM INDUSTRIAL ESTATES IN KANO STATE, NIGERIA
}

\author{
Abdullateef, B., ${ }^{1 *}$ Shuaibu, T. G., ${ }^{1}$ Babagana, K., ${ }^{1}$ Suleman, H. B. ${ }^{2}$ and Dauda, B. ${ }^{3}$ \\ ${ }^{1}$ Department of Pure and Applied Chemistry, Faculty of Science, University of Maiduguri, Borno State, \\ Nigeria \\ ${ }^{2}$ Department of Microbiology, Faculty of Science, University of Maiduguri, Borno State, Nigeria \\ ${ }^{3}$ Department of Chemical Engineering, Faculty of Engineering, University of Maiduguri, Borno State, \\ Nigeria \\ *Corresponding author: babslega@gmail.com; abelega2007@yahoo.com; +2348061309753
}

\section{ABSTRACT}

Industrial Effluents Samples from Gashash Tanneries (TAN1) in Bompai Industrial estate, Larabee Tannery Industry (TAN2) in Sharada Industrial estate and Z Tannery Industries (TAN3) in Challawa Industrial estate, Kano State, Nigeria were collected over a period of six months (August 2017 to January 2018) for assessing the biodegradation potentials of bacteria in the treatment of organic pollutants within the effluents. Bacteria were isolated from the effluents and immobilized on agar-agar. Different masses (5 g, $10 \mathrm{gr}, 15$ $\mathrm{g}, 20 \mathrm{~g}$, and $25 \mathrm{~g}$ ) of the bacteria were used in the treatment of $250 \mathrm{ml}$ of the effluents for ten days in a shaker incubator (Gallenkamp-OC-4364-L) at the temperature $30{ }^{\circ} \mathrm{C}$ and speed of $60 \mathrm{rpm}$. Pre-treatment analysis of the effluents for Temperature, pH, Biochemical Oxygen Demand (BOD), Chemical Oxygen Demand (COD), Suspended Solid (SS) and Total Dissolved Solids (TDS) gives the following results; temperature $\left({ }^{\circ} \mathrm{C}\right.$ )

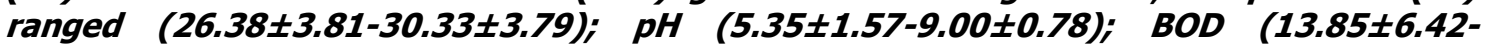
$38.75 \pm 16.20) ;$ COD (1406 $\pm 208-3532 \pm 1373) ;$ SS (208 $\pm 235-780 \pm 739)$ and TDS (266 $\pm 253-5276 \pm 2971)$. No statistical differences ( $p \leq 0.05)$ was observed for all the results among the different industries. The bacterial isolates were identified as Neisseria spp, Bacillus cereus, and Staphylococcus aureus, in TAN1, TAN2, and TAN3, respectively. After treatment of the effluent with the different masses of the isolated bacteria, the mean level of BOD was found to range as (0.55 $\pm 0.36-6.92 \pm 5.49) ; C O D$ (ND-3134 \pm 1595$)$;

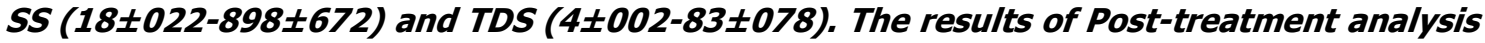
showed that there is overall decrease in the levels of the parameters determined when compared with that of the pre-treatment. The overall percentage reduction of the immobilised bacteria in the treatment of the respective effluents was in the order TAN2 (72\%)>TAN1 (70\%)>TAN3 (62\%). Hence, the immobilized bacteria are having higher biodegradation potential for the treatment of the tannery effluents.

Keywords: Biodegradation, bacteria, effluent, immobilization, tannery.

\section{INTRODUCTION}

Tannery industrial wastewater is a serious consequence of the pollution point of view for streams, freshwater, and land used for agriculture. The lack of awareness in the modern industrial practice has resulted in the discharge of tannery effluents which exhibit very high value of chromium ( $\mathrm{Cr}$ ), Sulfide, and chloride, Total Dissolved Solid (TDS), Total Suspended Solid (TSS), Biochemical Oxygen Demand (BOD) and Chemical Oxygen Demand (COD) in the water stream or land (Mohammed et al., 2001). Tanning is the process, which One ton of skin generally leads to the production of 20 to $80 \mathrm{~m}^{3}$ of turbid and foul-smelling converts the protein of the rawhide or skin into a stable material, which will not putrefy and is suitable for a wide variety of end applications (Elsheikh, 2009). The highly polluting chromium is the most commonly used tanning material producing leather that is more flexible and pliable than vegetable-tanned leather and does not discolor or lose shape in water as drastically as vegetable-tan (Elsheikh, 2009). Tannery effluent is among the most hazardous industrial pollutants due to its huge organic and inorganic load, which is highly toxic to human life and the environment (Kongjao et al., 2008). wastewater including chromium (100-400 mg/l), sulfide $(200-800 \mathrm{mg} / \mathrm{l})$, high levels of fat and 
BAJOPAS Volume 13 Number 2, December, 2020 other solid wastes, and notable pathogen contamination as well as pesticides added for skin conservation during transport (Elsheikh, 2009). There are more than 6000 tanneries in Nigeria with an annual processing capacity of 700,000 tons of hides and skins (Omoleke, 2004; Singh et al., 2008). It was reported that the total amount of waste produced per animal slaughtered is approximately $35 \%$ of its weight (World Bank, 1995). Also, for every $1000 \mathrm{~kg}$ of carcass weight, a slaughtered beef produces 5.5 $\mathrm{kg}$ of manure (excluding rumen contents or stockyard manure) and $100 \mathrm{~kg}$ of paunch manure (undigested food) (Verheijen et al., 1996). Tanneries generate wastewater in the range of 30-35 $\mathrm{L} \mathrm{kg}^{-1}$ skin/hide processed with variable $\mathrm{pH}$, Biological Oxygen Demand (BOD), Chemical Oxygen Demand (COD), high concentrations of suspended solids (SS), and tannins as well as chromium (Zahoor and Abdul, 2009).

Being heterogeneous and composed of a wide variety of compounds, it is very difficult to select a unique direct method for estimating the biodegradability of organic contents and biokinetic parameters for a wastewater sample (Rajor, 2004). For this purpose, some indirect estimation such as determination of biochemical oxygen demand (BOD) and chemical oxygen demand (COD) are applied as common laboratory investigations [9]. During retanning procedures, synthetic tannins (Syntan), oils and resins are added to form softer leather at varying doses (Munz et al., 2009). One of the refractory groups of chemicals in tannery effluents derives mainly from tannins (Ramasami et al., 2004). Syntans are characterized by complex chemical structures, because they are composed of an extended set of chemicals such as phenol-, naphthalene-, formaldehyde- and melamine-based syntans, and acrylic resins (Beem, 1994). Organic pollutants (proteic and lipidic components) are originated from skins (it is calculated that the raw skin has $30 \%$ loss of organic material during the working cycle) or they are introduced during processes (Hugo Springer, 1994).

Many conventional processes such as oxidation, chemical and biological processes were carried out to treat tanneries wastewater (Ebtesam et al, 2013). Biological processes have received more attention because of their costeffectiveness, lower sludge production and environmental friendliness (Noorjahan, 2014). Naturally occurring micro-organisms degrade the hazardous organic wastes including xenobiotic compounds, such as pesticides, polycyclic aromatic hydrocarbons (PAHs) and polychlorinated biphenyls (PCBs) in due course of time (Ranen and Sharadinadra, 2009). Bioremediation is based on the idea that all organisms remove substances from the environment to carry outgrowth and metabolism (Bouwer and Zehnder, 1993). Bacteria, protista and fungi are found to be very good at degrading complex molecules and incorporating the breakdown products into their metabolism (Bouwer and Zehnder, 1993). The resultant metabolic wastes that they produce are generally safe and somehow recycled into other organisms (Ranen and Sharadinadra, 2009). An acclimatized indigenous population of microorganisms capable of degradation of the compounds of interest must exist at the site for a successful bioremediation mode (Ranen and Sharadinadra, 2009). It has been observed that for a successful bioremediation mode, an acclimatized indigenous population of microorganisms capable of degradation of the compounds of interest must exist at the site under investigation (Ranen and Sharadinadra, 2009). Even though there are numerous physical and chemical methods employed in the disposal of wastes the advantage in using bacterium is that they play a key role in the reduction of COD, BOD, total protein, total tannin and total phenol (Saravanan and Saravanan, 1998)

Baba et al. (2020) studied the bioremediation potential of immobilized corynebacterium kutsceri in the Treatment of tannery industrial effluent from Challawa Industrial Estate, Kano State, Nigeria. The aim of the work is to study the reduction in the level of the contaminants through the process of bioremediation using the isolated bacteria. Immobilized bacteria can withstand various temperatures, $\mathrm{pH}$ and substrate concentrations; consequently, increasing the efficiency and the lifespan of the bacteria. Immobilized bacteria are widely applied in the treatment of wastewater and can be separated and recovered after the treatment with the same efficiency (Baba et al., 2020).

\section{MATERIALS AND METHODS \\ Study Area}

This study was carried out in Bompai, Sharada and Challawa industrial estates in Kano, Figure 1. Kano lies on Latitude $11^{\circ} 30^{\prime} \mathrm{N}$ and $8^{\circ} 30^{\prime} \mathrm{E}$ and Longitude $11^{\circ} 5^{\prime} \mathrm{N}$ and $8^{\circ} 5^{\prime} \mathrm{E}$ in Northern Nigeria. It is one of the developed industrial cities in Nigeria. Tannery activities are the dominating industries and this could be one of the reasons for her high population density (Dan'Azumi and Bichi, 2010). Many researchers have studied biodegradation of tannery effluent using microorganisms. However, limited literature is available on the biodegradation of tannery effluent in Kano industrial estates using 
BAJOPAS Volume 13 Number 2, December, 2020 immobilized bacterial cells. This research work focuses on the potential of the use of the indigenous immobilized bacterial isolates in the treatment of tannery effluents in the industrial estates.

\section{Sample Collection}

Effluents were collected from the Tannery Industries from Bompai, Challawa and Sharada Industrial Estates, Kano, Nigeria. The effluents were collected over a period of six months (August 2017 to January 2018). Samples collected in a sterile 4-liter plastic container with a unique identification number were preserved using an ice-box that was transported to the Microbiology Laboratory, Department of Microbiology, Bayero University of Kano for analysis

\section{Sample Preparation and Sample Analysis}

Immediately after the collection of the effluent, $\mathrm{pH}$, TSS, TDS, COD, BOD levels were determined before treatment (Pre-treatment determination) and ten days after treatment (Post-treatment determination) as described in
APHA (1989) standard methods. $\mathrm{pH}$ was determined using Ecotests $\mathrm{pH}$ meter and TDS was determined using AQUALYTIC TDS Salinometer. BOD was determined as described by the standard method (APHA, 1992). COD and SS were determined using DR/2010 HACH portable data logging spectrophotometer (DWAF, 1992)

\section{Identification and Biochemical} Characterization of the Bacterial Isolates

The bacteria were isolated from the effluents using Serial Dilution according to the method described by APHA (1989). The biochemical tests such as oxidase, catalase, coagulase, indole (from $1 \%$ tryptone broth), citrate (Simmons citrate agar), methyl red/VogesProskauer (MR/VP), nitrate reduction, Starch Hydrolysis, Glucose, Maltose, and Lactose tests were carried out on the bacterial isolates to identify the bacteria through the bacteria biochemical characteristics according to Ajao et al. (2011).

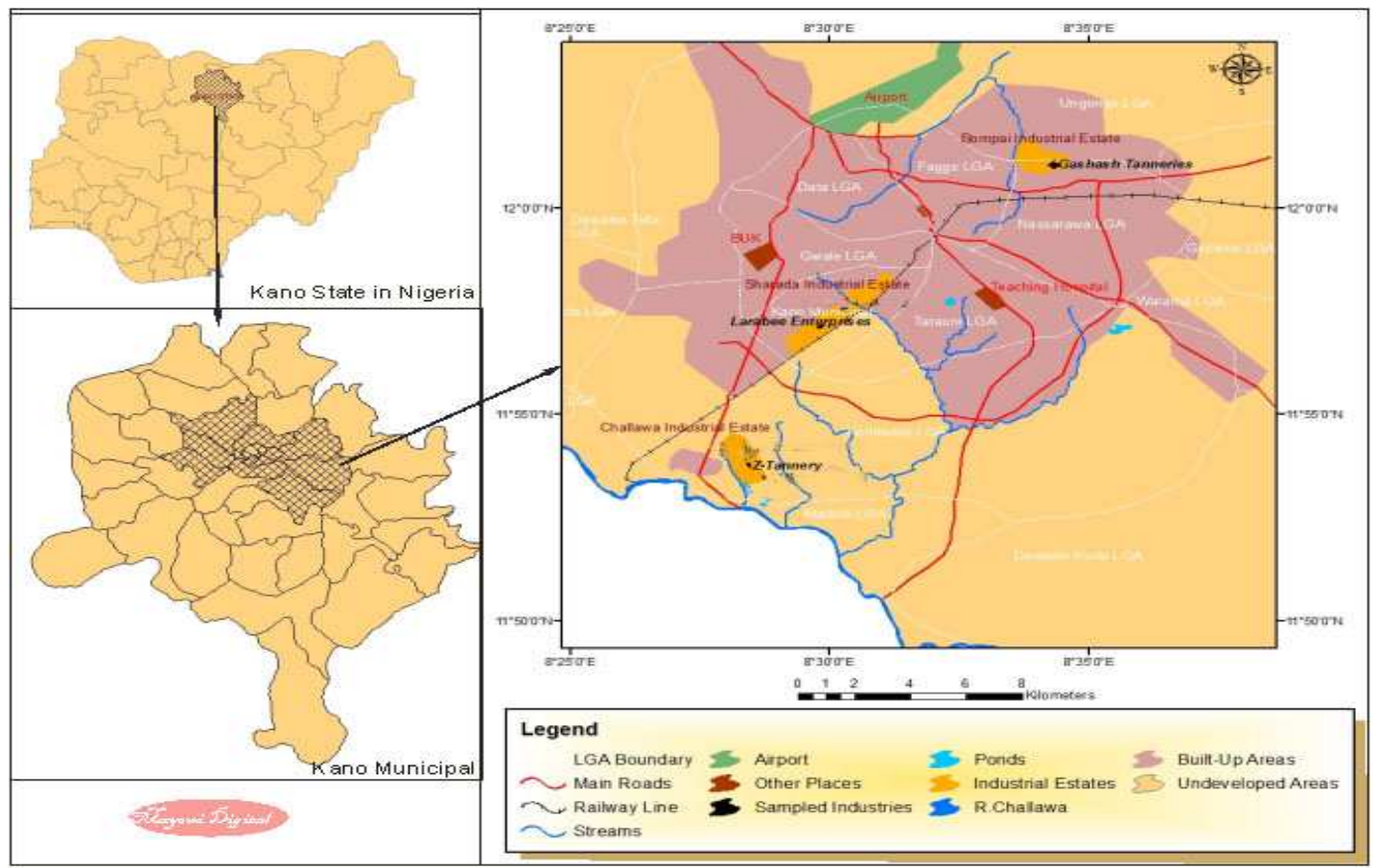

Fig. 1 Map showing the study areas

Source: Mayomi Digital Productions, GIS Laboratory, Department of Geography, UNIMAID (2017)

\section{Determination of Growth Rate of the Bacteria in Effluent Sample}

The bacteria growth rates were determined by transferring $2 \mathrm{~mL}$ of the bacterial isolates from the tannery effluent in broth medium into 100 $\mathrm{mL}$ sterile effluents in conical flasks and kept in an incubator (Giffrin cool) for 10 days. Control was also set up by incubating another $100 \mathrm{~mL}$ each of the sterile effluents without the bacteria. The optical density of the content was determined at the wavelength of $600 \mathrm{~nm}$ on a daily interval and recorded. 
BAJOPAS Volume 13 Number 2, December, 2020 Immobilization of Bacteria

Agar solution and inoculi were prepared separately. Fifty milliliters $(50 \mathrm{~mL})$ of nutrient broth each of the inoculi was prepared in a McCartney bottle and incubated for 24 hours. A solution of agar-agar was prepared by dissolving $10 \mathrm{~g}$ of the powder in distilled water and made up to $500 \mathrm{~mL}$ mark in an Erlenmeyer flask and was sterilized in an autoclave (280A) for 15 minutes and allowed to cool to $40-45^{\circ} \mathrm{C}$ (Ajao et al., 2011). Four milliliters ( $4 \mathrm{~mL})$ of the bacterial isolates in the nutrient broth was mixed with 36 $\mathrm{ml}$ of the prepared agar-agar media in petri-dish plates and then allowed to solidify. This was kept in the refrigerator for bioremediation.

\section{Bioremediation (Treatment) of the Effluents}

The solidified agar block (immobilized bacteria) was cut into cubes using a sterile knife; $0.1 \mathrm{~mL}$ phosphate buffer ( $\mathrm{pH} \mathrm{7.0)}$ was added and kept in the refrigerator for 1 hour for curing. The phosphate buffer was decanted after 1 hour and the cubes were washed with sterile distilled water 3-4 times before it was used (Ajao et al., 2011). Two liters (2 L) of the effluent was supplemented with the minimum basal medium in $\mathrm{g} / \mathrm{L}: \mathrm{NaCl}(0.8), \mathrm{MgSO}_{4} .7 \mathrm{H}_{2} \mathrm{O}(0.001), \mathrm{KH}_{2} \mathrm{PO}_{4}$ (2), $\mathrm{NaNO}_{3}$ (2), $\quad \mathrm{CaCl}_{2} .2 \mathrm{H}_{2} \mathrm{O} \quad(0.5)$ and $\mathrm{NaHPO}_{4} .12 \mathrm{H}_{2} \mathrm{O}(2)$ and sterilized in an autoclave at $121^{\circ} \mathrm{C}$ for 15 minutes (Margesin and Schinner, 2001). Two hundred and fifty milliliters $(250 \mathrm{~mL})$ of the effluents were transferred into different $250 \mathrm{ml}$ conical flasks. The content was covered with a cotton-wool ramped with foil paper to avoid contamination. Five grams $(5 \mathrm{~g})$ of the immobilized bacteria were quickly transferred into each of the effluents in the conical flasks in an inoculating chamber. The same procedures were carried out for the $10 \mathrm{~g}, 15 \mathrm{~g}, 20 \mathrm{~g}$ and 25 $\mathrm{g}$ of the immobilized bacteria in separate $250 \mathrm{~mL}$ effluents in conical flasks and agitated for ten days in a shaker incubator (Gallenkamp-OC4364-L) at a temperature $30^{\circ} \mathrm{C}$ and speed of 60 rpm. The treated effluent samples were taken on the tenth day and analyzed for the parameters $\mathrm{pH}$, SS, TDS, COD, and BOD, (Posttreatment determination) for the different grams of bacteria to evaluate and compare the biodegradation potential. (Baba et al., 2020).

\section{Statistical Analysis}

The data were represented as Mean \pm Standard deviation and analyzed statistically using oneway Analysis of Variance (ANOVA) and Tukey's HSD as Post Hoc Tests with the aid of SPSS 16.0. The correlation coefficient was also used to measure the strength of the relationship between the different masses of the bacteria and the parameters. All $\mathrm{p} \leq 0.05$ were considered as statistically significant.

\section{RESULTS AND DISCUSSION Physico-chemical parameters in the Industrial Effluents before the Biodegradation.}

Results of the Physico-chemical parameters in the industrial effluents before the Biodegradation is shown in table 1 . The mean temperatures $\left({ }^{\circ} \mathrm{C}\right)$ observed in TAN1, TAN2, and TAN3 samples were $28.07 \pm 0.65 ; 27.77 \pm 0.64$ and $26.38 \pm 3.81$ respectively. The order of the mean temperature of the samples from the three industries can be arranged as TAN1 > TAN2>TAN3. The temperature observed at TAN1, TAN2, and TAN3 samples were found below the WHO $\left(35^{\circ} \mathrm{C}\right)$ and NESREA $\left(40^{\circ} \mathrm{C}\right)$ limits. The low values of temperature might be due to the processes used at the time of sampling. High temperature brings down the solubility of gases in water that ultimately expresses as high BOD and COD. Statistical analysis shows that there is no significant difference $(p<0.05)$ between the mean values of temperature among the industries. This might be due to similar tannery activities involved in the tannery industries at the time of sampling. The average values of temperature observed in this present study are less than those observed by Akan et al. (2007), Akan et al. (2009) and Baba et al. (2020).

The mean level of $\mathrm{pH}$ observed in TAN1, TAN2 and TAN3, samples were $7.77 \pm 2.93$; $8.35 \pm 0.28$ and $7.52 \pm 0.76$ respectively. The order of the mean $\mathrm{pH}$ of the samples from the three industries can be arranged as TAN2> TAN1 $>$ TAN3. The $\mathrm{pH}$ of the samples falls within the WHO (7.0-8.5) and NESREA (6-9) standard limits. Statistical analysis shows that there is no significant difference $(p<0.05)$ between the mean values of $\mathrm{pH}$ among the industries. This might be due to similar tannery activities involved in the tannery industries at the time of sampling. Maheshwari et al. (2017) reported that the level of $\mathrm{pH}$ in the effluents from the tannery industry in Vaniyambadi, India was 6.5 which was lower than that observed in the present study. The $\mathrm{pH}$ in the effluents from the tannery industries in Kano and Kaduna were reported to be 7.64 and 6.89, respectively (Akan et al., 2007; Mohammed et al., 2017). The average values of $\mathrm{pH}$ observed in this present study are less than those observed by Mohammed et al. (2017) and Baba et al. (2020). The mean level of SS $(\mathrm{mg} / \mathrm{l})$ observed in TAN1, TAN2, and TAN3 samples were 374 \pm 124 ; $358 \pm 335$ and $780 \pm 739$ respectively. The order of the mean SS in the samples from the three industries can be arranged as TAN3 > TAN1 $>$ TAN2. 
The SS observed in the samples were far above the recommended standard limits of regulating bodies WHO $(30 \mathrm{mg} / \mathrm{l})$ and NESREA $(10 \mathrm{mg} / \mathrm{l})$. Statistical analysis shows that there is no significant difference $(p<0.05)$ between the mean values of SS among the industries. This might be due to similar tannery activities involved in the tannery industries at the time of sampling. The average values of SS observed in this present study are less than that observed $(3700 \pm 122 \mathrm{mg} / \mathrm{l})$ by Akan et al. (2009) for tanneries in Kano. Also, the average values of SS observed in this present study are less than that observed by Mohammed et al. (2017) and Baba et al. (2020) with the exception in TAN3.

The mean level of TDS (mg/l) observed in TAN1, TAN2, and TAN3 samples were $3941 \pm 3703$; $3300 \pm 1714$ and $2653 \pm 1240$ respectively. The order of the mean TDS in the samples from the three industries can be arranged as TAN1>TAN2>TAN3. The TDS observed in the samples were far above the recommended standard limits of WHO $(250 \mathrm{mg} / \mathrm{l})$ and NESREA $(500 \mathrm{mg} / \mathrm{l})$. Statistical analysis shows that there is no significant difference $(p<0.05)$ between the mean values of TDS among the industries. This might be due to similar tannery activities involved in the tannery industries at the time of sampling. TDS in the effluents from the tannery industries in Kano, Nigeria was reported to be $1281 \mathrm{mg} / \mathrm{l}$ (Akan et al., 2007). The average values of SS observed in this present study are less than those observed by Mohammed et al. (2017) and Baba et al. 2020)

The mean level of COD (mg/l) observed in TAN1, TAN2 and TAN3 samples seasons were $2372 \pm 938 ; \quad 1406 \pm 208$ and $3532 \pm 1373$ respectively. The order of the mean COD of the samples from the three industries can be arranged as TAN3>TAN1> TAN2. The COD observed in TAN1, TAN2 and TAN3 samples were far above the recommended standard limits of regulating bodies $\mathrm{WHO}(40 \mathrm{mg} / \mathrm{l})$ and NESREA (40 mg/l). Statistical analysis shows that there is no significant difference $(p<0.05)$ in COD among the industries. This might be due to similar tannery activities involved in the tannery industries as at the time of sampling. The Chemical Oxygen demand (COD) is the amount of oxygen, in $\mathrm{mg} / \mathrm{L}$, required for the degradation of the compound of wastewater to occur. In comparison, the average values of COD observed in this present study were higher than that observed by Mohammed et al. (2017) but lower than that observed by Baba et al. (2020).

The mean levels of BOD $(\mathrm{mg} / \mathrm{l})$ observed in TAN1, TAN2 and TAN3 samples were $13.85 \pm 6.42 ; \quad 19.46 \pm 0.50$ and $17.13 \pm 3.14$ respectively. The order of the mean BOD in the samples from the three industries can be arranged as TAN2>TAN3>TAN1. The BOD observed in TAN1, TAN2 and TAN3 samples were found below the recommended limits of NESREA (200 mg/l) but above WHO (10 mg/l). Statistical analysis shows that there is no significant difference $(p<0.05)$ between the mean values of BOD among the industries. This might be due to similar tannery activities involved in the tannery industries at the time of sampling. The low level of BOD recorded in this study is an indication of the low level of biodegradable organic solids in the effluent. The average values of BOD observed in this present study were lower than those observed by Mohammed et al. (2017) and Baba et al. (2020).

Table 1: Mean Values \pm S.D of Physico-chemical parameters of effluents from the Tannery Industries before Treatment.

\begin{tabular}{llllllll}
\hline Parameter & Tannery 1 & Tannery 2 & Tannery 3 & $\mathrm{a}$ & $\mathrm{b}$ & $\mathrm{c}$ & $\mathrm{d}$ \\
\cline { 2 - 7 } Temperature $\left({ }^{\circ} \mathrm{C}\right)$ & $28.07 \mathrm{a} \pm 0.65$ & $27.77 \mathrm{a} \pm 0.64$ & $26.38 \mathrm{a} \pm 3.81$ & & $29.50 \pm 4.68$ & 35 & 40 \\
pH & $7.77 \mathrm{a} \pm 2.93$ & $8.35 \mathrm{a} \pm 0.28$ & $7.52 \mathrm{a} \pm 0.76$ & 6.89 & $5.35 \pm 1.57$ & $7.0-8.5$ & $6.0-9.0$ \\
$\mathrm{COD}(\mathrm{mg} / \mathrm{l})$ & $2372 \mathrm{a} \pm 938$ & $1406 \mathrm{a} \pm 208$ & $3532 \mathrm{a} \pm 1373$ & 2.2 & $3106 \pm 2753$ & 40 & 40 \\
$\mathrm{BOD}(\mathrm{mg} / \mathrm{l})$ & $13.85 \mathrm{a} \pm 6.42$ & $19.46 \mathrm{a} \pm 0.50$ & $17.13 \mathrm{a} \pm 3.14$ & 1032 & $26.17 \pm 9.49$ & 10 & 200 \\
$\mathrm{SS}(\mathrm{mg} / \mathrm{l})$ & $374 \mathrm{a} \pm 124$ & $358 \mathrm{a} \pm 335$ & $780 \mathrm{a} \pm 739$ & 501 & $562 \pm 482$ & 30 & 10 \\
TDS $(\mathrm{mg} / \mathrm{l})$ & $3941 \mathrm{a} \pm 3703$ & $3300 \mathrm{a} \pm 1714$ & $2653 \mathrm{a} \pm 1240$ & 532.7 & $444 \pm 507$ & 250 & 500 \\
\hline
\end{tabular}

The values given in the table above are means of 6 replicate values, $\mathrm{n}=6$ ( 1 sample was taken monthly for 6 months). Within the rows, means with different alphabets are statistically different $(p<0.05)$. WHO: World Health Organisation. NESREA: National Environmental Standard and Regulatory Enforcement Agency. a = Mohammed et al.(2017), b = Baba et al. (2020), c = WHO (2006), $d=$ NESSRA (2009) 
BAJOPAS Volume 13 Number 2, December, 2020

Identification, Biochemical Characterization and growth rates of the Bacterial Isolates

Results of identification and biochemical characterization of the bacterial isolates were shown in table 2. After 24 hours of incubation, the nutrient agar media plates were checked for bacterial growth. The results showed the presence of different strains in the samples. The TAN1 bacteria isolate was found to be gramnegative cocci while TAN3 was gram-positive cocci. TAN2 bacteria isolate was found to be gram-positive, rod-shaped. TAN1, TAN2, and TAN3 bacteria isolates recorded positive results for spore former.

The results of the biochemical tests indicated that all the bacteria were positive for catalase, oxidase, citrate, maltose, glucose, lactose (negative in TAN1), mannitol (negative in TAN2), starch hydrolysis and coagulase (negative in TAN2) tests. The bacteria showed negative results for nitrate reduction, $M R$ (positive in TAN2), VP (positive in TAN1), Indole (positive in TAN2) tests. Base on the morphological and biochemical test results, TAN1, TAN2, and TAN3 bacteria isolates were identified to be Nesseria spp, Bacillus cereus, and Staphylococcus aureus respectively.

The growth rate of the TAN1, TAN2 and TAN3 Isolates were shown in figure 2. Generally, the optical density increase with the increase in time (day) and decrease as time goes on. The highest optical density was shown by bacillus cereus in TAN2 while the lowest was shown by Staphylococcus aureus in TAN3.

The initial growth phase of TAN1 Isolate bacteria occurred within 2-day of incubation as the growth rate increases up to the 6th-day incubation when the maximum growth was observed. Beyond the 6th day, the growth of the bacteria declined (which might be due to a shortage of nutrients in the effluents) until it reached its death phase (which might be due to the unavailability of nutrients in the effluents).

A similar trend of growth was also observed for TAN2 Isolate as the initial growth phase also occurred within 2-day of incubation but maximum growth rate observed on the 4th day of incubation. The stationary stage occurred between the 4th day and the 8th day. Beyond the 8th day, the growth of the bacteria declined (which might be due to a shortage of nutrients in the effluents) until it reached its death phase (which might be due to the unavailability of nutrients in the effluents).

The initial growth phase of TAN3 bacterial Isolate occurred within the 3-day incubation as the growth rate increases up to the 6th-day incubation when the maximum growth was observed. Beyond the 6th day, the growth of the bacteria declined (which might be due to a shortage of nutrients in the effluents) until it reached its death phase (which might be due to the unavailability of nutrients in the effluents).

Table 2: Morphological and Biochemical characteristics of bacterial isolates

\begin{tabular}{lllll} 
Bacterial Isolates & & TAN1 & TAN2 & TAN3 \\
\hline $\begin{array}{lllll}\text { Morphological } \\
\text { characteristics }\end{array}$ & Shape & Cocci & Rod & Cocci \\
& Spore & & & \\
& former & + & + & + \\
Gram & & & \\
Biochemical characteristics & reaction & - & + & + \\
& Citrate & + & + & + \\
& Catalase & + & + & + \\
& Coagulase & + & - & + \\
Starch & + & + & + \\
& Glucose & + & + & + \\
Oxidase & + & + & + \\
& Indo & - & + & - \\
Lactose & - & + & + \\
Manitol & + & - & + \\
Maltose & + & + & + \\
MR & - & + & - \\
VP & + & - & - \\
& Nitrate & - & - & - \\
Reduction & - Neisseria & Bacillus & Staphylococcus \\
& Bacterial & cereus & aureus \\
& name & spp & cas
\end{tabular}

+ = Positive; - = Negative; MR=Methyl Red; VP= Voges-Proskauer 


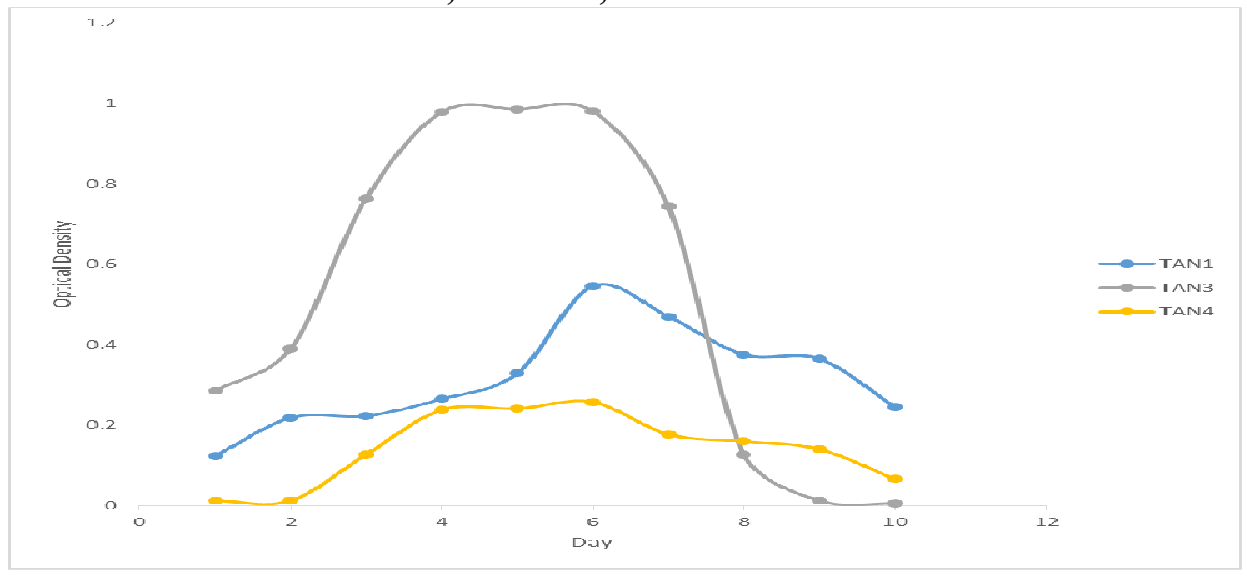

Fig. 2 Growth rates of the isolates in the effluents from the Tannery Industries

\section{Physico-chemical Parameters in the Industrial Effluents after the biodegradation.}

Table 3 shows the mean results of the physicochemical parameter before and after bioremediation using the different masses $(5 \mathrm{~g}$, $10 \mathrm{~g}, 15 \mathrm{~g}, 20 \mathrm{~g}$, and $25 \mathrm{~g}$ ) of the respective immobilized bacteria. Also, Table 4 shows the mean results of correlation coefficient ( $r$ ) between different masses of bacteria and physicochemical parameters.

The mean values $(\mathrm{mg} / \mathrm{l})$ of the SS after the bioremediation varies between $243 \pm 45$ and $898 \pm 672$. The mean concentration $(\mathrm{mg} / \mathrm{l})$ of SS remediated by the different masses $(5 \mathrm{~g}, 10 \mathrm{~g}$, $15 \mathrm{~g}, 20 \mathrm{~g}$, and $25 \mathrm{~g}$ ) of the bacteria varies. The SS in the samples fluctuates up and down after the bioremediation process when compared with the SS of the raw samples before the bioremediation. The increase in the levels of the SS might be due to the aggregation of the TDS which are large enough to result into SS. The increase in the levels of the SS might be also due to the influence of the nutrients which was added into the effluents in order to make the microorganisms more active and viable for fast degradation of organic contaminants in the effluent. The relative potential or efficiency of the different masses of the bacteria in remediating SS in TAN1 samples was in the order $25 \mathrm{~g}>20 \mathrm{~g}>15 \mathrm{~g}>10 \mathrm{~g}>5 \mathrm{~g}$. For TAN2 and TAN3 samples, the order was $25 \mathrm{~g}>20 \mathrm{~g}>15$ $\mathrm{g}>10 \mathrm{~g}>5 \mathrm{~g}$. These might be due to the variations in the surface areas of the different masses of the immobilized bacteria. Statistical analysis shows that there is no significant difference $(p<0.05)$ between the mean values of SS among the masses in the respective industries. Positive and significant correlations exist between the masses of bacteria and Suspended Solid (SS). This showed that there is general increase in the levels of the SS as the masses of the immobilized bacteria increases. TAN3 (90\%) and TAN1 (80\%) showed a very high correlation with the masses of the bacteria while TAN2 (61\%) showed a very low correlation.

The mean values $(\mathrm{mg} / \mathrm{l})$ of the TDS after the bioremediation varies between $46 \pm 11$ and $83 \pm 78$. The mean concentration $(\mathrm{mg} / \mathrm{l})$ of TDS remediated by the different masses $(5 \mathrm{~g}, 10 \mathrm{~g}$, $15 \mathrm{~g}, 20 \mathrm{~g}$, and $25 \mathrm{~g}$ ) of the bacteria varies. There is a reduction in all the TDS of all the samples after the bioremediation process compared with the TDS of the raw samples before the bioremediation. The relative potential or efficiency of the different masses of the bacteria in remediating TDS in TAN1 and TAN3 samples was in the order $5 \mathrm{~g}>10 \mathrm{~g}>15 \mathrm{~g}>20$ $\mathrm{g}>25 \mathrm{~g}$. For TAN2 samples, the order was 20 $g>10 \quad g>25 \quad g>15 \quad g>5 \quad g$. Statistical analysis shows that there is no significant difference $(p<0.05)$ between the mean values of TDS among the masses in the respective industries. These might be due to the variations in the surface areas of the different masses of the immobilized bacteria. Positive and significant correlations exist between the masses of bacteria and TDS with the exception in TAN2 (negative and insignificant correlation). The positive correlations showed that there is general increase in the levels of the TDS as the masses of the immobilized bacteria increases. TAN1 $(96 \%)$ showed a very high correlation with the masses of the bacteria while TAN2 (47\%) showed a very low correlation.

The mean values $(\mathrm{mg} / \mathrm{l})$ of the BOD after the bioremediation varies between $1.56 \pm 0.20 \mathrm{mg} / \mathrm{l}$ and $6.92 \pm 5.49 \mathrm{mg} / \mathrm{l}$. The mean concentration $(\mathrm{mg} / \mathrm{l})$ of BOD remediated by the different masses $(5 \mathrm{~g}, 10 \mathrm{~g}, 15 \mathrm{~g}, 20 \mathrm{~g}$, and $25 \mathrm{~g}$ ) of the bacteria varies. There is a reduction in all the BOD of all the samples after the bioremediation process compared with the $\mathrm{BOD}$ of the raw 
BAJOPAS Volume 13 Number 2, December, 2020 samples before the bioremediation. The relative potential or efficiency of the different masses of the bacteria in remediating BOD in TAN1, TAN2 and TAN3 samples were in the order $25 \mathrm{~g}>20$ $\mathrm{g}>15 \mathrm{~g}>10 \mathrm{~g}>5 \mathrm{~g}, 25 \mathrm{~g}>15 \mathrm{~g}>5 \mathrm{~g}>10 \mathrm{~g}>20 \mathrm{~g}$ and $20 \mathrm{~g}>10 \mathrm{~g}>25 \mathrm{~g}>15 \mathrm{~g}>5 \mathrm{~g}$ respectively. Statistical analysis shows that there is significant difference $(p<0.05)$ between the mean values of BOD among the masses in the respective industries. These might be due to the variations in the surface areas of the different masses of the immobilized bacteria. Negative and significant correlations exist between the masses of bacteria and BOD. This showed that there is general decrease in the levels of the BOD as the masses of the immobilized bacteria increases. TAN1 (94\%) showed a very high correlation with the masses of the bacteria while TAN2 (4\%) showed a very low correlation.

The mean values $(\mathrm{mg} / \mathrm{l})$ of the COD after the bioremediation varies between $250 \pm 154$ and $3134 \pm 1595$. The mean concentration $(\mathrm{mg} / \mathrm{l})$ of COD remediated by the different masses $(5 \mathrm{~g}$, $10 \mathrm{~g}, 15 \mathrm{~g} 20 \mathrm{~g}$, and $25 \mathrm{~g}$ ) of the bacteria varies. There is a reduction in all the COD of all the samples after the bioremediation process compared with the COD of the raw samples before the bioremediation. The relative potential or efficiency of the different masses of the bacteria in remediating COD in TAN1, TAN2 and TAN3 samples were in the order $25 \mathrm{~g}>20 \mathrm{~g}>15$ $\mathrm{g}>5 \mathrm{~g}>10 \mathrm{~g}, 25 \mathrm{~g}>20 \mathrm{~g}>15 \mathrm{~g}>10 \mathrm{~g}>5 \mathrm{~g}$ and 10 g>5 g>25 g>15 g>20 g respectively. Statistical analysis shows that there were significant difference $(p<0.05)$ between the mean values of COD among the masses in the respective industries except for effluents treated with $25 \mathrm{~g}$. These might be due to the variations in the surface areas of the different masses of the immobilized bacteria. Negative and insignificant correlations exist between the masses of bacteria and COD with the exception in TAN3 (positive and significant correlation). The negative correlations showed that there is general decrease in the levels of the COD as the masses of the immobilized bacteria increases. TAN2 (100\%) showed a very high correlation with the masses of the bacteria while TAN3 (36\%) showed a very low correlation.

Generally, there was an overall decrease in the concentration of these physicochemical parameters after the bioremediation using the different masses of the bacterial isolates. These might be due to the variations in the surface areas of the different masses of the immobilized bacteria. This is in line with the work of Jimoh et al. (2018) and Baba et al. (2020).

Table 3: Mean Values $(\mathrm{mg} / \mathrm{l}) \pm$ S.D of Physicochemical parameters in effluents from the Tannery Industries before and after Treatment of the effluents $(250 \mathrm{ml})$ with the different masses $(5 \mathrm{~g}, 10 \mathrm{~g}$, $15 \mathrm{~g}, 20 \mathrm{~g}$, and $25 \mathrm{~g}$ ) of the bacteria.

\begin{tabular}{llllllll}
\hline $\mathrm{P}$ & IND & Before & \multicolumn{5}{c}{ After } \\
\cline { 4 - 7 } & & & $5 \mathrm{~g}$ & $10 \mathrm{~g}$ & $15 \mathrm{~g}$ & $20 \mathrm{~g}$ & $25 \mathrm{~g}$ \\
\hline \multirow{2}{*}{ COD } & TAN1 & $2372 \pm 938$ & $1708 \mathrm{a} \pm 861$ & $2045 \mathrm{a} \pm 1205$ & $845 \mathrm{a} \pm 369$ & $300 \mathrm{a} \pm 167$ & $250 \mathrm{a} \pm 154$ \\
& TAN2 & $1406 \pm 208$ & $1195 \mathrm{a} \pm 208$ & $1125 \mathrm{a} \pm 384$ & $1055 \mathrm{a} \pm 317$ & $956 \mathrm{a} \pm 310$ & $870 \mathrm{ab} \pm 240$ \\
& TAN3 & $3532 \pm 1373$ & $2374 \mathrm{a} \pm 1344$ & $1976 \mathrm{a} \pm 1405$ & $2757 \mathrm{a} \pm 1266$ & $3134 \mathrm{a} \pm 1595$ & $2614 \mathrm{~b} \pm 1105$ \\
BOD & TAN1 & $13.85 \pm 6.42$ & $6.92 \mathrm{a} \pm 5.49$ & $6.42 \mathrm{a} \pm 5.07$ & $5.72 \mathrm{a} \pm 5.35$ & $4.62 \mathrm{a} \pm 4.37$ & $2.82 \mathrm{ab} \pm 1.26$ \\
& TAN2 & $19.46 \pm 0.50$ & $1.75 \mathrm{~b} \pm 0.22$ & $1.73 \mathrm{~b} \pm 0.18$ & $1.58 \mathrm{a} \pm 0.16$ & $1.91 \mathrm{a} \pm 0.22$ & $1.56 \mathrm{~b} \pm 0.20$ \\
& TAN3 & $17.13 \pm 3.14$ & $4.24 \mathrm{ab} \pm 0.77$ & $3.29 \mathrm{ab} \pm 0.37$ & $4.11 \mathrm{a} \pm 0.07$ & $3.23 \mathrm{a} \pm 0.91$ & $3.33 \mathrm{a} \pm 1.28$ \\
SS & TAN1 & $374 \pm 124$ & $243 \mathrm{a} \pm 45$ & $471 \mathrm{a} \pm 226$ & $475 \mathrm{a} \pm 182$ & $492 \mathrm{a} \pm 128$ & $611 \mathrm{a} \pm 217$ \\
& TAN2 & $358 \pm 335$ & $460 \mathrm{a} \pm 400$ & $543 \mathrm{a} \pm 414$ & $544 \mathrm{a} \pm 402$ & $551 \mathrm{a} \pm 414$ & $554 \mathrm{a} \pm 405$ \\
& TAN3 & $780 \pm 739$ & $586 \mathrm{a} \pm 594$ & $758 \mathrm{a} \pm 656$ & $787 \mathrm{a} \pm 676$ & $861 \mathrm{a} \pm 635$ & $898 \mathrm{a} \pm 672$ \\
TDS & TAN1 & $3941 \pm 3703$ & $51 \mathrm{a} \pm 10$ & $53 \mathrm{a} \pm 10$ & $55 \mathrm{a} \pm 15$ & $61 \mathrm{a} \pm 20$ & $63 \mathrm{a} \pm 26$ \\
& TAN2 & $3300 \pm 1714$ & $83 \mathrm{a} \pm 78$ & $47 \mathrm{a} \pm 20$ & $48 \mathrm{a} \pm 22$ & $47 \mathrm{a} \pm 17$ & $48 \mathrm{a} \pm 17$ \\
& TAN3 & $2653 \pm 1240$ & $46 \mathrm{a} \pm 11$ & $55 \mathrm{a} \pm 24$ & $55 \mathrm{a} \pm 25$ & $58 \mathrm{a} \pm 23$ & $61 \mathrm{a} \pm 28$ \\
\hline
\end{tabular}

Replicate $=6$ (months)

Within the rows, for the same parameter, means with different alphabets are statistically different $(p<0.05)$.

$\mathrm{P}=$ parameter, IND = Industries 
BAJOPAS Volume 13 Number 2, December, 2020

Table 4: Correlation coefficient $(r)$ between different masses of the bacteria and the physicochemical parameters.

\begin{tabular}{llll}
\hline Industries & Parameter & Correlation coefficient $(r)$ & $\begin{array}{l}\text { Percent dependence (rxrx100) } \\
(\%)\end{array}$ \\
\hline TAN1 & COD & -0.9 & 82 \\
& BOD & -0.97 & 94 \\
& SS & $0.90^{*}$ & 80 \\
TAN2 & TDS & $0.98^{*}$ & 96 \\
& COD & -1 & 100 \\
& BOD & -0.21 & 4 \\
& SS & $0.78^{*}$ & 61 \\
& TDS & -0.69 & 47 \\
& COD & $0.60^{*}$ & 36 \\
& BOD & -0.6 & 37 \\
& SS & $0.95^{*}$ & 90 \\
& TDS & $0.94^{*}$ & 89 \\
\hline
\end{tabular}

The correlation coefficient $(r)$ with * is statistically significant $(p<0.05)$.

Percentage reduction of the Parameters

Table 5 shows the percentage reduction of Parameters in industrial samples before and after the treatment of the effluents $(250 \mathrm{ml})$ with the different masses $(5 \mathrm{~g}, 10 \mathrm{~g}, 15 \mathrm{~g}, 20 \mathrm{~g}$, and $25 \mathrm{~g}$ ) of the Immobilized Bacteria.

In TAN1 samples, the percentage reduction (\%) of COD ranged (14-89); BOD (50-80); SS (-32$35)$ and TDS (98-99). In TAN2 samples, the percentage decrease $(\%)$ of COD ranged (15$38) ;$ BOD (90-92); SS [-28-(-55)] and TDS (9798). In TAN3 samples, the percentage decrease (\%) of COD ranged (11-44); BOD (76-81); SS (15-25) and TDS (98). The percentage increase in the levels COD, BOD and TDS might be due to the increase in the surface area of the different masses of the immobilized bacteria. However, the percentage decrease in the levels of the SS might be due to the aggregation of the TDS which are large enough to result into SS. The percentage decrease in the levels of the SS might be also due to the influence of the nutrients which was added into the effluents in order to make the microorganisms more active and viable for fast degradation of organic contaminants in the effluent. This is in line with the work of Jimoh et al. (2018) in which the concentration of the SS increase after the bioremediation of effluents.

Sreemoyee and Priti (2013) assessed and reduced several Physico-chemical parameters of dairy wastewater using Niesseria $s p$. and concluded that the species are well known to degrade organic compounds. This is in agreement with the current study in which the immobilized Niesseria $s p$ degrade the organic contaminants as indicated by the BOD, COD and TDS.

Jimoh et al. (2018) observed that TSS of the effluents was increased after treatment with immobilized bacteria and concluded that it might be due to the biostimulation method adopted for the research.

The optimum $\mathrm{pH}$ Biosorption of Chromium by Bacillus spp and Staphylococcus spp. from tannery effluent was investigated by Mythili and Karthikeyan (2011). The maximum adsorption of Chromium $(86.4 \mathrm{mg} / \mathrm{L})$ was showed by Bacillus spp and Staphylococcus spp showed $70.6 \mathrm{mg} / \mathrm{L}$ at an initial concentration of $100 \mathrm{mg} / \mathrm{L}$. In the present study, immobilised Bacillus spp and Staphylococcus spp. from the tannery industrial effluents reduced the levels of the organic pollutants with high potential as indicated by the percentage reduction of BOD, COD and TDS.

Enzymes often can work in multiple environments especially if they are immobilized. This makes the microorganisms' enzymes even more resistant to harsh environments and enables the enzymes to be recovered and recycled after they are no longer needed (Gianfreda and Rao 2004). Ramesh and Singh (1993) reported that the immobilized bacteria having more efficiency to remove the suspended particles than free cells. Using the immobilized cell is preferable due to its capability for using several times with the same efficiency, which makes it more economical. Similar work was done by Sikander et al. (2007) showing the higher reduction with permeabilized cells of Ochrobactrum intermedium strain SDCr-5. 
BAJOPAS Volume 13 Number 2, December, 2020

The results revealed the isolation and identification of isolates with the potential for the reduction of $\mathrm{Cr}$ (VI) to $\mathrm{Cr}$ (III). Results indicated that immobilized $B$. cereus could be efficiently used for the reduction of $\mathrm{Cr}$ (VI).

Table 5: Percentage reduction of the tested Parameters from the tannery industrial samples of the Immobilized Bacteria.

\begin{tabular}{lllllll}
\hline \multirow{2}{*}{ Industries } & & \multicolumn{5}{c}{ Percentage Reduction $(\%)$} \\
\cline { 3 - 7 } & & $5 \mathrm{~g}$ & $10 \mathrm{~g}$ & $15 \mathrm{~g}$ & $20 \mathrm{~g}$ & $25 \mathrm{~g}$ \\
\hline TAN1 & COD & 28 & 14 & 64 & 87 & 89 \\
& BOD & 50 & 54 & 59 & 67 & 80 \\
& SS & 35 & -26 & -27 & -32 & -63 \\
& TDS & 99 & 99 & 99 & 98 & 98 \\
TAN2 & COD & 15 & 20 & 25 & 32 & 38 \\
& BOD & 91 & 91 & 92 & 90 & 92 \\
& SS & -28 & -52 & -52 & -54 & -55 \\
& TDS & 97 & 99 & 99 & 99 & 99 \\
& COD & 33 & 44 & 22 & 11 & 26 \\
& BOD & 75 & 81 & 76 & 81 & 81 \\
& SS & 25 & 3 & -1 & -10 & -15 \\
& TDS & 98 & 98 & 98 & 98 & 98 \\
\hline
\end{tabular}

Percentage Reduction $=(B-A) / B \times 100 \%$

$A=$ Concentration of the parameter after treatment

$\mathrm{B}=$ Concentration of the parameter before treatment

$+=$ percentage decrease

- = percentage increase

In general, immobilization makes the enzyme more resistant to temperature, $\mathrm{pH}$, and substrate concentration swings giving it a longer lifetime and higher productivity per active unit (Gianfreda and Rao, 2004; FuIlbrook, 1996; Russell et al, 2003; Kandelbauer et al., 2004). Immobilized cells have been used and studied extensively for the production of useful chemicals (Ohtake and Silver, 1994), the treatment of wastewaters (Chen et al., 2003; Wang et al., 2010). Although many workers described microbial degradation of tannery effluent, limited literature is available on the bioremediation of tannery effluent using immobilized bacterial cells in the Kano Industrial Estates.

\section{CONCLUSION}

The samples contained variable levels of the physicochemical parameters. The results of the Analysis of variance revealed that, no statistical difference $(p<0.05)$ was observed for the temperature, $\mathrm{pH}, \mathrm{SS}, \mathrm{TDS}, \mathrm{BOD}$ and $\mathrm{COD}$ among the three tannery industries before the treatment. The levels of some of the parameters
(SS, TDS and COD) observed in the samples were found above the recommended limits of WHO and NESREA, which called for the treatment of the effluents before discharge into the environment. Base on the morphological and biochemical test results, TAN1, TAN2, and TAN3 bacterial isolates were identified to be Neisseria spp, Bacillus cereus, and Staphylococcus aureus respectively. The results of Post-treatment analysis showed that there is overall decrease in the levels of the parameters determined when compared with that of the pre-treatment. The overall percentage reduction of the immobilised bacteria in the treatment of the respective effluents was in the order TAN2 (72\%)>TAN1 $(70 \%)>$ TAN3 $(62 \%)$. Hence, the immobilized bacteria are having higher biodegradation potential for the treatment of the tannery effluents.

\section{Acknowledgments}

The authors wish to acknowledge the University of Maiduguri for the financial support. The authors are grateful to the Kano State Ministry of Environment for their support in obtaining the effluent samples. 


\section{REFERENCES}

Ajao, A. T., Adebayo, G. B., and Yakubu, S. E. (2011). Bioremediation of textile industrial effluent using mixed culture of Pseudomonas aeruginosa and Bacillus subtilis immobilized on agar-agar in a bioreactor. J. Microbiol. Biotech. Res, 1(3), 50-56.

Akan, J. C., Moses, E. A., Ogugbuaja, V. O., and Abah, J. (2007). Assessment of tannery industrial effluents from Kano metropolis, Kano State, Nigeria. Journal of Applied Sciences, 7(19), 2788-2793.

Akan, J. C., Ogugbuaja, V. O., Abdulrahman, F. I., and Ayodele, J. T. (2009). Pollutant levels in effluent samples from tanneries and textiles of Kano industrial areas, Nigeria. Global journal of pure and applied sciences, 15(3-4).

APHA (1989). Standard methods for Examination of Will bete and Will betewater.15 $5^{\text {th }}$ edition. Brydpass Springfield Will behington DC. pp. 164-176

APHA (1992). Standard Methods for the Examination of Water and Wastewater. Health, 69, 1116-9.

Baba, A., Garba, S. T., and Bello, H. S. (2020). Bioremediation Potential of Immobilized corynebacterium kutsceri in the Treatment of Tannery Industrial Effluent from Challawa Industrial Estate, Kano State, Nigeria. Journal of the Turkish Chemical Society Section A: Chemistry, $7(2), 335-350$.

Beem, E. I. V. (1994). reduction of solvent VOC emission. J. Oil Col. Chem. Ass, 77, 158.

Bouwer, E. J., and Zehnder, A. J. (1993). Bioremediation of organic compoundsputting microbial metabolism to work. Trends in biotechnology, 11(8), 360367.

Chen, K. C., Wu, J. Y., Liou, D. J., and Hwang, S. C. J. (2003). Decolorization of the textile dyes by newly isolated bacterial strains. Journal of Biotechnology, 101(1), 57-68.

Dan'Azumi, S., and Bichi, M. H. (2010). INDUSTRIAL POLLUTION AND HEAVY METALS PROFILE OF CHALLAWA RIVER IN KANO, NIGERIA. Journal of Applied Sciences in Environmental Sanitation, $5(1)$.

DWAF. (1992). Analytical Methods Manual, TR 151. Department of Water Affairs and Forestry, Pretoria.

El-Bestawy, E. (2013). Biological treatment of leather-tanning industrial wastewater using free living bacteria.
Elsheikh, M. A. S. (2009). Tannery wastewater pre-treatment. Water Science and Technology, 60(2), 433-440.

FuIlbrook, P. D. (1996). "Kinetics." Industrial enzymology: The application of enzymes in Industry. 2nd Ed. T. Godfrey and J Reichelt. eds.. Nature. New York.

Gianfreda, L., and Rao, M. A. (2004). Potential of extra cellular enzymes in remediation of polluted soils: a review. Enzyme and microbial technology, 35(4), 339354.

Hugo Springer. (1994). John Arthur Wilson Memorial Lecture "Treatment of Industrial Wastes of the Leather Industry - is it still a Major Problem". JALCA, 89, 153-185

Jimoh, A. A., Ganiyu, B. A., Baba, D., and Baba, A. (2018) Bioremediation Process of Effluent from Detergent and Food Industries in Jos, Nigeria: Kinetics and Thermodynamics. International Journal of Engineering Science Invention (IJESI), 762-73

Kandelbauer, A., Maute, O., Kessler, R. W., Erlacher, A., and Gübitz, G. M. (2004). Study of dye decolorization in an immobilized laccase enzyme-reactor using online spectroscopy. Biotechnology and bioengineering, 87(4), 552-563.

Kongjao, S., Damronglerd, S., and Hunsom, M. (2008). Simultaneous removal of organic and inorganic Pollutants in tannery wastewater using electrocoagulation technique. Korean Journal of chemical engineering, 25(4), 703.

Maheshwari, U. M., Aruna, S., Gomathi, M., and AbdulJaffar, A. H. (2017). Bioremediation by Free and Immobilized Bacteria Isolated from Tannery Effluent. International Journal of Research in Applied, Natural and Social Sciences. 5(7), 75-90

Margesin, R., and Schinner, F. (2001). Bioremediation (natural attenuation and biostimulation) of diesel-oilcontaminated soil in an alpine glacier skiing area. Applied and environmental microbiology, 677), 3127-3133.

Mohammed, A., Sekar, P., and George, J. (2011). Efficacy of microbes in bioremediation of tannery effluent. Inter. J. Curr. Res, 3(4), 324-326.

Mohammed, S. S. D., Orukotan, A. A., and Abdullahi, H. (2017). Physicochemical and Bacteriological Assessment of Tannery Effluent from Samaru-Zaria, 
BAJOPAS Volume 13 Number 2, December, 2020 Kaduna State, Nigeria. Journal of Applied

Sciences and Environmental Management, 21(4), 734-740.

Munz, G., De Angelis, D., Gori, R., Mori, G., Casarci, M., and Lubello, C. (2009). The role of tannins in conventional and membrane treatment of tannery wastewater. Journal of hazardous materials, 164(2-3), 733-739

Mythili, K., and Karthikeyan, B. (2011). Bioremediation of $\mathrm{Cr}$ (VI) from tannery effluent using Bacillus spp and Staphylococcus spp. International Multidisciplinary Research Journal, 1(6).

NESREA (2009). National Environmental Standards for Effluent Limitations and Regulation. 1233-1236

Noorjahan, C. M. (2014). Physicochemical characteristics, identification of bacteria and biodegradation of industrial effluent. Journal of bioremediation and Biodegradation, 5(3).

Ohtake, H. I., and Silver, A. O. (1994). Bacterial reduction of toxic chromate. Biological degradation and bioremediation of toxic chemicals, 403-415.

Omoleke, I. I. (2004). Management of environmental pollution in Ibadan, an African city: the challenges of health hazard facing government and the people. Journal of Human Ecology, 15(4), 265-275.

Rajor, A., Reddy, A.S., and Singh, B. (2004). Determination of BOD kinetic Parameters and evaluation of alternate methods, M.Sc. Thesis, Department of biotechnology \& environmental Science, Thapar Institute of Engineering and Technology, Patiala

Ramasami, T., Rajamani, S., and Rao, J. R. (1994, March). Pollution control in leather industry: Emerging technological options. In International symposium on surface and colloidal science and its relevance to soil pollution, madras.

Ramesh, J. V. S., and Singh, S. P. (1993). Yearly variation in certain physicochemical parameters of pond at eastern Doon Valley. Uttar Pradesh J. Zoo, 12 (1), 7577.

Ranen, S., and Sharadinadra, C. (2009). Biotechnology applications to environmental remediation in resource exploitation. Current science, 97, 6-25
Russell, A. J., Berberich, J. A., Drevon, G. F., and Koepsel, R. R. (2003). Biomaterials for mediation of

chemical and biological warfare agents. Annual review of biomedical engineering, 5(1), 1-27.

Saravanan, P., and Saravanan, A. (1999). Decolourization of tannery effluent by Flavobacterium sp. EK 1. Indian Journal of Environmental Protection, 19, 19-24.

Sikander, S., and Shahida, H. (2007). Reduction of toxic hexavalent chromium by Ochrobactrum intermedium strain SDCr5 stimulated by heavy metals. Bioresource Technol, 98, 340-344.

Singh, N., Sharma, B. K., and Bohra, P. C. (2000). Impact assessment of industrial effluent of arid soils by using satellite imageries. Journal of the Indian Society of Remote Sensing, 28(2-3), 79.

Sreemoyee, C., and Priti, P. (2013). Assessment of physico-chemical parameters of dairy waste water and isolation and characterization of bacterial strains in terms of cod reduction. Int J Sci, 2(3), 395-400.

Verheijen, L. A. H. M., Wiersema, D., Pol, L. H., and De Wit, J. (1996). Management of wastes from animal product processing. Livestock and environment, Finding a balance. International Agriculture Center, Wageningen, The Netherlands.

Wang, F., Yao, J., Si, Y., Chen, H., Russel, M., Chen, K., and Bramanti, E. (2010). Short-time effect of heavy metals upon microbial community activity. Journal of Hazardous Materials, 173(13), 510-516.

WHO (World Health Organization). (2006). Air quality guidelines: global update 2005: particulate matter, ozone, nitrogen dioxide, and sulfur dioxide. World Health Organization.

World Bank. (1995). Nigeria's strategic options for redressing industrial pollution. World Bank, industry and energy division. 1st edition, West Central Africa Department; Annexes: 1995; pp 60-62.

Zahoor, A., and Abdul, R. (2009). Enumeration of Coliforms. Journal of Environmental Sciences. 21, 814-820 


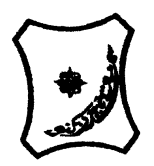

Bayero Journal of Pure and Applied Sciences, 13(2): 1 - 12

Received: November, 2020

Accepted: December, 2020

ISSN $2006-6996$

\title{
BIODEGRADATION POTENTIAL OF IMMOBILIZED BACTERIA IN THE TREATMENT OF TANNERY INDUSTRIAL EFFLUENTS FROM INDUSTRIAL ESTATES IN KANO STATE, NIGERIA
}

\author{
Abdullateef, B., ${ }^{1 *}$ Shuaibu, T. G., ${ }^{1}$ Babagana, K., ${ }^{1}$ Suleman, H. B. ${ }^{2}$ and Dauda, B. ${ }^{3}$ \\ ${ }^{1}$ Department of Pure and Applied Chemistry, Faculty of Science, University of Maiduguri, Borno State, \\ Nigeria \\ ${ }^{2}$ Department of Microbiology, Faculty of Science, University of Maiduguri, Borno State, Nigeria \\ ${ }^{3}$ Department of Chemical Engineering, Faculty of Engineering, University of Maiduguri, Borno State, \\ Nigeria \\ *Corresponding author: babslega@gmail.com; abelega2007@yahoo.com; +2348061309753
}

\section{ABSTRACT}

Industrial Effluents Samples from Gashash Tanneries (TAN1) in Bompai Industrial estate, Larabee Tannery Industry (TAN2) in Sharada Industrial estate and Z Tannery Industries (TAN3) in Challawa Industrial estate, Kano State, Nigeria were collected over a period of six months (August 2017 to January 2018) for assessing the biodegradation potentials of bacteria in the treatment of organic pollutants within the effluents. Bacteria were isolated from the effluents and immobilized on agar-agar. Different masses (5 g, $10 \mathrm{gr}, 15$ $\mathrm{g}, 20 \mathrm{~g}$, and $25 \mathrm{~g}$ ) of the bacteria were used in the treatment of $250 \mathrm{ml}$ of the effluents for ten days in a shaker incubator (Gallenkamp-OC-4364-L) at the temperature $30{ }^{\circ} \mathrm{C}$ and speed of $60 \mathrm{rpm}$. Pre-treatment analysis of the effluents for Temperature, pH, Biochemical Oxygen Demand (BOD), Chemical Oxygen Demand (COD), Suspended Solid (SS) and Total Dissolved Solids (TDS) gives the following results; temperature $\left({ }^{\circ} \mathrm{C}\right.$ )

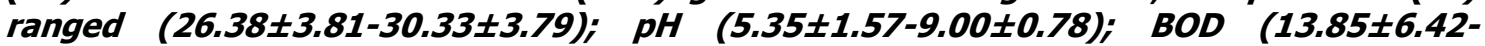
$38.75 \pm 16.20) ;$ COD (1406 $\pm 208-3532 \pm 1373) ;$ SS (208 $\pm 235-780 \pm 739)$ and TDS (266 $\pm 253-5276 \pm 2971)$. No statistical differences ( $p \leq 0.05)$ was observed for all the results among the different industries. The bacterial isolates were identified as Neisseria spp, Bacillus cereus, and Staphylococcus aureus, in TAN1, TAN2, and TAN3, respectively. After treatment of the effluent with the different masses of the isolated bacteria, the mean level of BOD was found to range as (0.55 $\pm 0.36-6.92 \pm 5.49) ; C O D$ (ND-3134 \pm 1595$)$;

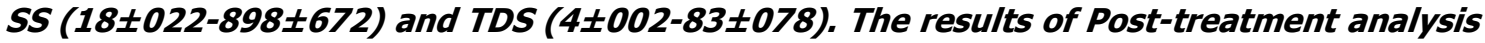
showed that there is overall decrease in the levels of the parameters determined when compared with that of the pre-treatment. The overall percentage reduction of the immobilised bacteria in the treatment of the respective effluents was in the order TAN2 (72\%)>TAN1 (70\%)>TAN3 (62\%). Hence, the immobilized bacteria are having higher biodegradation potential for the treatment of the tannery effluents.

Keywords: Biodegradation, bacteria, effluent, immobilization, tannery.

\section{INTRODUCTION}

Tannery industrial wastewater is a serious consequence of the pollution point of view for streams, freshwater, and land used for agriculture. The lack of awareness in the modern industrial practice has resulted in the discharge of tannery effluents which exhibit very high value of chromium ( $\mathrm{Cr}$ ), Sulfide, and chloride, Total Dissolved Solid (TDS), Total Suspended Solid (TSS), Biochemical Oxygen Demand (BOD) and Chemical Oxygen Demand (COD) in the water stream or land (Mohammed et al., 2001). Tanning is the process, which One ton of skin generally leads to the production of 20 to $80 \mathrm{~m}^{3}$ of turbid and foul-smelling converts the protein of the rawhide or skin into a stable material, which will not putrefy and is suitable for a wide variety of end applications (Elsheikh, 2009). The highly polluting chromium is the most commonly used tanning material producing leather that is more flexible and pliable than vegetable-tanned leather and does not discolor or lose shape in water as drastically as vegetable-tan (Elsheikh, 2009). Tannery effluent is among the most hazardous industrial pollutants due to its huge organic and inorganic load, which is highly toxic to human life and the environment (Kongjao et al., 2008). wastewater including chromium (100-400 mg/l), sulfide $(200-800 \mathrm{mg} / \mathrm{l})$, high levels of fat and 
BAJOPAS Volume 13 Number 2, December, 2020 other solid wastes, and notable pathogen contamination as well as pesticides added for skin conservation during transport (Elsheikh, 2009). There are more than 6000 tanneries in Nigeria with an annual processing capacity of 700,000 tons of hides and skins (Omoleke, 2004; Singh et al., 2008). It was reported that the total amount of waste produced per animal slaughtered is approximately $35 \%$ of its weight (World Bank, 1995). Also, for every $1000 \mathrm{~kg}$ of carcass weight, a slaughtered beef produces 5.5 $\mathrm{kg}$ of manure (excluding rumen contents or stockyard manure) and $100 \mathrm{~kg}$ of paunch manure (undigested food) (Verheijen et al., 1996). Tanneries generate wastewater in the range of 30-35 $\mathrm{L} \mathrm{kg}^{-1}$ skin/hide processed with variable $\mathrm{pH}$, Biological Oxygen Demand (BOD), Chemical Oxygen Demand (COD), high concentrations of suspended solids (SS), and tannins as well as chromium (Zahoor and Abdul, 2009).

Being heterogeneous and composed of a wide variety of compounds, it is very difficult to select a unique direct method for estimating the biodegradability of organic contents and biokinetic parameters for a wastewater sample (Rajor, 2004). For this purpose, some indirect estimation such as determination of biochemical oxygen demand (BOD) and chemical oxygen demand (COD) are applied as common laboratory investigations [9]. During retanning procedures, synthetic tannins (Syntan), oils and resins are added to form softer leather at varying doses (Munz et al., 2009). One of the refractory groups of chemicals in tannery effluents derives mainly from tannins (Ramasami et al., 2004). Syntans are characterized by complex chemical structures, because they are composed of an extended set of chemicals such as phenol-, naphthalene-, formaldehyde- and melamine-based syntans, and acrylic resins (Beem, 1994). Organic pollutants (proteic and lipidic components) are originated from skins (it is calculated that the raw skin has $30 \%$ loss of organic material during the working cycle) or they are introduced during processes (Hugo Springer, 1994).

Many conventional processes such as oxidation, chemical and biological processes were carried out to treat tanneries wastewater (Ebtesam et al, 2013). Biological processes have received more attention because of their costeffectiveness, lower sludge production and environmental friendliness (Noorjahan, 2014). Naturally occurring micro-organisms degrade the hazardous organic wastes including xenobiotic compounds, such as pesticides, polycyclic aromatic hydrocarbons (PAHs) and polychlorinated biphenyls (PCBs) in due course of time (Ranen and Sharadinadra, 2009). Bioremediation is based on the idea that all organisms remove substances from the environment to carry outgrowth and metabolism (Bouwer and Zehnder, 1993). Bacteria, protista and fungi are found to be very good at degrading complex molecules and incorporating the breakdown products into their metabolism (Bouwer and Zehnder, 1993). The resultant metabolic wastes that they produce are generally safe and somehow recycled into other organisms (Ranen and Sharadinadra, 2009). An acclimatized indigenous population of microorganisms capable of degradation of the compounds of interest must exist at the site for a successful bioremediation mode (Ranen and Sharadinadra, 2009). It has been observed that for a successful bioremediation mode, an acclimatized indigenous population of microorganisms capable of degradation of the compounds of interest must exist at the site under investigation (Ranen and Sharadinadra, 2009). Even though there are numerous physical and chemical methods employed in the disposal of wastes the advantage in using bacterium is that they play a key role in the reduction of COD, BOD, total protein, total tannin and total phenol (Saravanan and Saravanan, 1998)

Baba et al. (2020) studied the bioremediation potential of immobilized corynebacterium kutsceri in the Treatment of tannery industrial effluent from Challawa Industrial Estate, Kano State, Nigeria. The aim of the work is to study the reduction in the level of the contaminants through the process of bioremediation using the isolated bacteria. Immobilized bacteria can withstand various temperatures, $\mathrm{pH}$ and substrate concentrations; consequently, increasing the efficiency and the lifespan of the bacteria. Immobilized bacteria are widely applied in the treatment of wastewater and can be separated and recovered after the treatment with the same efficiency (Baba et al., 2020).

\section{MATERIALS AND METHODS \\ Study Area}

This study was carried out in Bompai, Sharada and Challawa industrial estates in Kano, Figure 1. Kano lies on Latitude $11^{\circ} 30^{\prime} \mathrm{N}$ and $8^{\circ} 30^{\prime} \mathrm{E}$ and Longitude $11^{\circ} 5^{\prime} \mathrm{N}$ and $8^{\circ} 5^{\prime} \mathrm{E}$ in Northern Nigeria. It is one of the developed industrial cities in Nigeria. Tannery activities are the dominating industries and this could be one of the reasons for her high population density (Dan'Azumi and Bichi, 2010). Many researchers have studied biodegradation of tannery effluent using microorganisms. However, limited literature is available on the biodegradation of tannery effluent in Kano industrial estates using 
BAJOPAS Volume 13 Number 2, December, 2020 immobilized bacterial cells. This research work focuses on the potential of the use of the indigenous immobilized bacterial isolates in the treatment of tannery effluents in the industrial estates.

\section{Sample Collection}

Effluents were collected from the Tannery Industries from Bompai, Challawa and Sharada Industrial Estates, Kano, Nigeria. The effluents were collected over a period of six months (August 2017 to January 2018). Samples collected in a sterile 4-liter plastic container with a unique identification number were preserved using an ice-box that was transported to the Microbiology Laboratory, Department of Microbiology, Bayero University of Kano for analysis

\section{Sample Preparation and Sample Analysis}

Immediately after the collection of the effluent, $\mathrm{pH}$, TSS, TDS, COD, BOD levels were determined before treatment (Pre-treatment determination) and ten days after treatment (Post-treatment determination) as described in
APHA (1989) standard methods. $\mathrm{pH}$ was determined using Ecotests $\mathrm{pH}$ meter and TDS was determined using AQUALYTIC TDS Salinometer. BOD was determined as described by the standard method (APHA, 1992). COD and SS were determined using DR/2010 HACH portable data logging spectrophotometer (DWAF, 1992)

\section{Identification and Biochemical} Characterization of the Bacterial Isolates

The bacteria were isolated from the effluents using Serial Dilution according to the method described by APHA (1989). The biochemical tests such as oxidase, catalase, coagulase, indole (from $1 \%$ tryptone broth), citrate (Simmons citrate agar), methyl red/VogesProskauer (MR/VP), nitrate reduction, Starch Hydrolysis, Glucose, Maltose, and Lactose tests were carried out on the bacterial isolates to identify the bacteria through the bacteria biochemical characteristics according to Ajao et al. (2011).

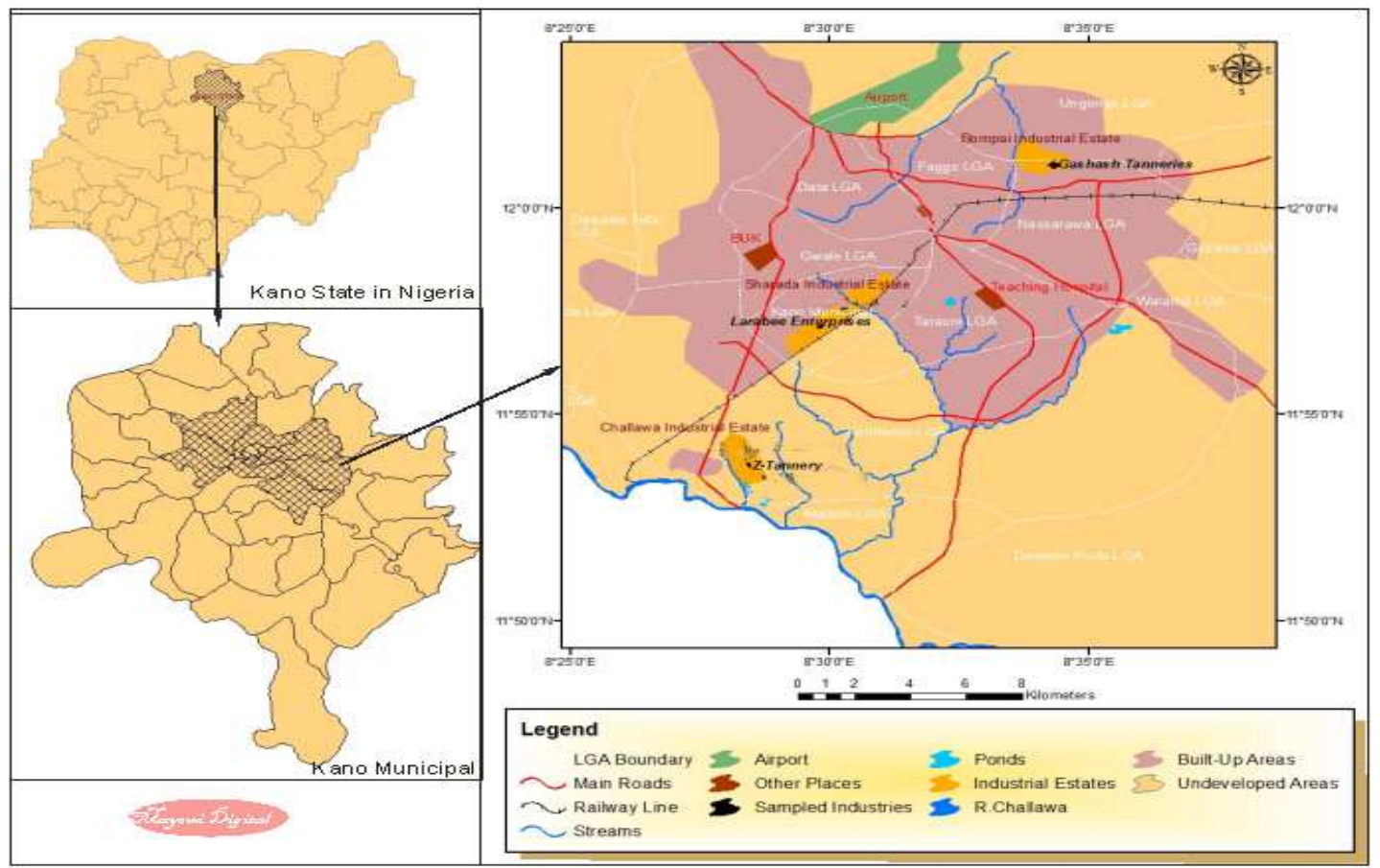

Fig. 1 Map showing the study areas

Source: Mayomi Digital Productions, GIS Laboratory, Department of Geography, UNIMAID (2017)

\section{Determination of Growth Rate of the Bacteria in Effluent Sample}

The bacteria growth rates were determined by transferring $2 \mathrm{~mL}$ of the bacterial isolates from the tannery effluent in broth medium into 100 $\mathrm{mL}$ sterile effluents in conical flasks and kept in an incubator (Giffrin cool) for 10 days. Control was also set up by incubating another $100 \mathrm{~mL}$ each of the sterile effluents without the bacteria. The optical density of the content was determined at the wavelength of $600 \mathrm{~nm}$ on a daily interval and recorded. 
BAJOPAS Volume 13 Number 2, December, 2020 Immobilization of Bacteria

Agar solution and inoculi were prepared separately. Fifty milliliters $(50 \mathrm{~mL})$ of nutrient broth each of the inoculi was prepared in a McCartney bottle and incubated for 24 hours. A solution of agar-agar was prepared by dissolving $10 \mathrm{~g}$ of the powder in distilled water and made up to $500 \mathrm{~mL}$ mark in an Erlenmeyer flask and was sterilized in an autoclave (280A) for 15 minutes and allowed to cool to $40-45^{\circ} \mathrm{C}$ (Ajao et al., 2011). Four milliliters ( $4 \mathrm{~mL})$ of the bacterial isolates in the nutrient broth was mixed with 36 $\mathrm{ml}$ of the prepared agar-agar media in petri-dish plates and then allowed to solidify. This was kept in the refrigerator for bioremediation.

\section{Bioremediation (Treatment) of the Effluents}

The solidified agar block (immobilized bacteria) was cut into cubes using a sterile knife; $0.1 \mathrm{~mL}$ phosphate buffer ( $\mathrm{pH} \mathrm{7.0)}$ was added and kept in the refrigerator for 1 hour for curing. The phosphate buffer was decanted after 1 hour and the cubes were washed with sterile distilled water 3-4 times before it was used (Ajao et al., 2011). Two liters (2 L) of the effluent was supplemented with the minimum basal medium in $\mathrm{g} / \mathrm{L}: \mathrm{NaCl}(0.8), \mathrm{MgSO}_{4} .7 \mathrm{H}_{2} \mathrm{O}(0.001), \mathrm{KH}_{2} \mathrm{PO}_{4}$ (2), $\mathrm{NaNO}_{3}$ (2), $\quad \mathrm{CaCl}_{2} .2 \mathrm{H}_{2} \mathrm{O} \quad(0.5)$ and $\mathrm{NaHPO}_{4} .12 \mathrm{H}_{2} \mathrm{O}(2)$ and sterilized in an autoclave at $121^{\circ} \mathrm{C}$ for 15 minutes (Margesin and Schinner, 2001). Two hundred and fifty milliliters $(250 \mathrm{~mL})$ of the effluents were transferred into different $250 \mathrm{ml}$ conical flasks. The content was covered with a cotton-wool ramped with foil paper to avoid contamination. Five grams $(5 \mathrm{~g})$ of the immobilized bacteria were quickly transferred into each of the effluents in the conical flasks in an inoculating chamber. The same procedures were carried out for the $10 \mathrm{~g}, 15 \mathrm{~g}, 20 \mathrm{~g}$ and 25 $\mathrm{g}$ of the immobilized bacteria in separate $250 \mathrm{~mL}$ effluents in conical flasks and agitated for ten days in a shaker incubator (Gallenkamp-OC4364-L) at a temperature $30^{\circ} \mathrm{C}$ and speed of 60 rpm. The treated effluent samples were taken on the tenth day and analyzed for the parameters $\mathrm{pH}$, SS, TDS, COD, and BOD, (Posttreatment determination) for the different grams of bacteria to evaluate and compare the biodegradation potential. (Baba et al., 2020).

\section{Statistical Analysis}

The data were represented as Mean \pm Standard deviation and analyzed statistically using oneway Analysis of Variance (ANOVA) and Tukey's HSD as Post Hoc Tests with the aid of SPSS 16.0. The correlation coefficient was also used to measure the strength of the relationship between the different masses of the bacteria and the parameters. All $\mathrm{p} \leq 0.05$ were considered as statistically significant.

\section{RESULTS AND DISCUSSION Physico-chemical parameters in the Industrial Effluents before the Biodegradation.}

Results of the Physico-chemical parameters in the industrial effluents before the Biodegradation is shown in table 1 . The mean temperatures $\left({ }^{\circ} \mathrm{C}\right)$ observed in TAN1, TAN2, and TAN3 samples were $28.07 \pm 0.65 ; 27.77 \pm 0.64$ and $26.38 \pm 3.81$ respectively. The order of the mean temperature of the samples from the three industries can be arranged as TAN1 > TAN2>TAN3. The temperature observed at TAN1, TAN2, and TAN3 samples were found below the WHO $\left(35^{\circ} \mathrm{C}\right)$ and NESREA $\left(40^{\circ} \mathrm{C}\right)$ limits. The low values of temperature might be due to the processes used at the time of sampling. High temperature brings down the solubility of gases in water that ultimately expresses as high BOD and COD. Statistical analysis shows that there is no significant difference $(p<0.05)$ between the mean values of temperature among the industries. This might be due to similar tannery activities involved in the tannery industries at the time of sampling. The average values of temperature observed in this present study are less than those observed by Akan et al. (2007), Akan et al. (2009) and Baba et al. (2020).

The mean level of $\mathrm{pH}$ observed in TAN1, TAN2 and TAN3, samples were $7.77 \pm 2.93$; $8.35 \pm 0.28$ and $7.52 \pm 0.76$ respectively. The order of the mean $\mathrm{pH}$ of the samples from the three industries can be arranged as TAN2> TAN1 $>$ TAN3. The $\mathrm{pH}$ of the samples falls within the WHO (7.0-8.5) and NESREA (6-9) standard limits. Statistical analysis shows that there is no significant difference $(p<0.05)$ between the mean values of $\mathrm{pH}$ among the industries. This might be due to similar tannery activities involved in the tannery industries at the time of sampling. Maheshwari et al. (2017) reported that the level of $\mathrm{pH}$ in the effluents from the tannery industry in Vaniyambadi, India was 6.5 which was lower than that observed in the present study. The $\mathrm{pH}$ in the effluents from the tannery industries in Kano and Kaduna were reported to be 7.64 and 6.89, respectively (Akan et al., 2007; Mohammed et al., 2017). The average values of $\mathrm{pH}$ observed in this present study are less than those observed by Mohammed et al. (2017) and Baba et al. (2020). The mean level of SS $(\mathrm{mg} / \mathrm{l})$ observed in TAN1, TAN2, and TAN3 samples were 374 \pm 124 ; $358 \pm 335$ and $780 \pm 739$ respectively. The order of the mean SS in the samples from the three industries can be arranged as TAN3 > TAN1 $>$ TAN2. 
The SS observed in the samples were far above the recommended standard limits of regulating bodies WHO $(30 \mathrm{mg} / \mathrm{l})$ and NESREA $(10 \mathrm{mg} / \mathrm{l})$. Statistical analysis shows that there is no significant difference $(p<0.05)$ between the mean values of SS among the industries. This might be due to similar tannery activities involved in the tannery industries at the time of sampling. The average values of SS observed in this present study are less than that observed $(3700 \pm 122 \mathrm{mg} / \mathrm{l})$ by Akan et al. (2009) for tanneries in Kano. Also, the average values of SS observed in this present study are less than that observed by Mohammed et al. (2017) and Baba et al. (2020) with the exception in TAN3.

The mean level of TDS (mg/l) observed in TAN1, TAN2, and TAN3 samples were $3941 \pm 3703$; $3300 \pm 1714$ and $2653 \pm 1240$ respectively. The order of the mean TDS in the samples from the three industries can be arranged as TAN1>TAN2>TAN3. The TDS observed in the samples were far above the recommended standard limits of WHO $(250 \mathrm{mg} / \mathrm{l})$ and NESREA $(500 \mathrm{mg} / \mathrm{l})$. Statistical analysis shows that there is no significant difference $(p<0.05)$ between the mean values of TDS among the industries. This might be due to similar tannery activities involved in the tannery industries at the time of sampling. TDS in the effluents from the tannery industries in Kano, Nigeria was reported to be $1281 \mathrm{mg} / \mathrm{l}$ (Akan et al., 2007). The average values of SS observed in this present study are less than those observed by Mohammed et al. (2017) and Baba et al. 2020)

The mean level of COD (mg/l) observed in TAN1, TAN2 and TAN3 samples seasons were $2372 \pm 938 ; \quad 1406 \pm 208$ and $3532 \pm 1373$ respectively. The order of the mean COD of the samples from the three industries can be arranged as TAN3>TAN1> TAN2. The COD observed in TAN1, TAN2 and TAN3 samples were far above the recommended standard limits of regulating bodies $\mathrm{WHO}(40 \mathrm{mg} / \mathrm{l})$ and NESREA (40 mg/l). Statistical analysis shows that there is no significant difference $(p<0.05)$ in COD among the industries. This might be due to similar tannery activities involved in the tannery industries as at the time of sampling. The Chemical Oxygen demand (COD) is the amount of oxygen, in $\mathrm{mg} / \mathrm{L}$, required for the degradation of the compound of wastewater to occur. In comparison, the average values of COD observed in this present study were higher than that observed by Mohammed et al. (2017) but lower than that observed by Baba et al. (2020).

The mean levels of BOD $(\mathrm{mg} / \mathrm{l})$ observed in TAN1, TAN2 and TAN3 samples were $13.85 \pm 6.42 ; \quad 19.46 \pm 0.50$ and $17.13 \pm 3.14$ respectively. The order of the mean BOD in the samples from the three industries can be arranged as TAN2>TAN3>TAN1. The BOD observed in TAN1, TAN2 and TAN3 samples were found below the recommended limits of NESREA (200 mg/l) but above WHO (10 mg/l). Statistical analysis shows that there is no significant difference $(p<0.05)$ between the mean values of BOD among the industries. This might be due to similar tannery activities involved in the tannery industries at the time of sampling. The low level of BOD recorded in this study is an indication of the low level of biodegradable organic solids in the effluent. The average values of BOD observed in this present study were lower than those observed by Mohammed et al. (2017) and Baba et al. (2020).

Table 1: Mean Values \pm S.D of Physico-chemical parameters of effluents from the Tannery Industries before Treatment.

\begin{tabular}{llllllll}
\hline Parameter & Tannery 1 & Tannery 2 & Tannery 3 & $\mathrm{a}$ & $\mathrm{b}$ & $\mathrm{c}$ & $\mathrm{d}$ \\
\cline { 2 - 7 } Temperature $\left({ }^{\circ} \mathrm{C}\right)$ & $28.07 \mathrm{a} \pm 0.65$ & $27.77 \mathrm{a} \pm 0.64$ & $26.38 \mathrm{a} \pm 3.81$ & & $29.50 \pm 4.68$ & 35 & 40 \\
pH & $7.77 \mathrm{a} \pm 2.93$ & $8.35 \mathrm{a} \pm 0.28$ & $7.52 \mathrm{a} \pm 0.76$ & 6.89 & $5.35 \pm 1.57$ & $7.0-8.5$ & $6.0-9.0$ \\
$\mathrm{COD}(\mathrm{mg} / \mathrm{l})$ & $2372 \mathrm{a} \pm 938$ & $1406 \mathrm{a} \pm 208$ & $3532 \mathrm{a} \pm 1373$ & 2.2 & $3106 \pm 2753$ & 40 & 40 \\
$\mathrm{BOD}(\mathrm{mg} / \mathrm{l})$ & $13.85 \mathrm{a} \pm 6.42$ & $19.46 \mathrm{a} \pm 0.50$ & $17.13 \mathrm{a} \pm 3.14$ & 1032 & $26.17 \pm 9.49$ & 10 & 200 \\
$\mathrm{SS}(\mathrm{mg} / \mathrm{l})$ & $374 \mathrm{a} \pm 124$ & $358 \mathrm{a} \pm 335$ & $780 \mathrm{a} \pm 739$ & 501 & $562 \pm 482$ & 30 & 10 \\
TDS $(\mathrm{mg} / \mathrm{l})$ & $3941 \mathrm{a} \pm 3703$ & $3300 \mathrm{a} \pm 1714$ & $2653 \mathrm{a} \pm 1240$ & 532.7 & $444 \pm 507$ & 250 & 500 \\
\hline
\end{tabular}

The values given in the table above are means of 6 replicate values, $\mathrm{n}=6$ ( 1 sample was taken monthly for 6 months). Within the rows, means with different alphabets are statistically different $(p<0.05)$. WHO: World Health Organisation. NESREA: National Environmental Standard and Regulatory Enforcement Agency. a = Mohammed et al.(2017), b = Baba et al. (2020), c = WHO (2006), $d=$ NESSRA (2009) 
BAJOPAS Volume 13 Number 2, December, 2020

Identification, Biochemical Characterization and growth rates of the Bacterial Isolates

Results of identification and biochemical characterization of the bacterial isolates were shown in table 2. After 24 hours of incubation, the nutrient agar media plates were checked for bacterial growth. The results showed the presence of different strains in the samples. The TAN1 bacteria isolate was found to be gramnegative cocci while TAN3 was gram-positive cocci. TAN2 bacteria isolate was found to be gram-positive, rod-shaped. TAN1, TAN2, and TAN3 bacteria isolates recorded positive results for spore former.

The results of the biochemical tests indicated that all the bacteria were positive for catalase, oxidase, citrate, maltose, glucose, lactose (negative in TAN1), mannitol (negative in TAN2), starch hydrolysis and coagulase (negative in TAN2) tests. The bacteria showed negative results for nitrate reduction, $M R$ (positive in TAN2), VP (positive in TAN1), Indole (positive in TAN2) tests. Base on the morphological and biochemical test results, TAN1, TAN2, and TAN3 bacteria isolates were identified to be Nesseria spp, Bacillus cereus, and Staphylococcus aureus respectively.

The growth rate of the TAN1, TAN2 and TAN3 Isolates were shown in figure 2. Generally, the optical density increase with the increase in time (day) and decrease as time goes on. The highest optical density was shown by bacillus cereus in TAN2 while the lowest was shown by Staphylococcus aureus in TAN3.

The initial growth phase of TAN1 Isolate bacteria occurred within 2-day of incubation as the growth rate increases up to the 6th-day incubation when the maximum growth was observed. Beyond the 6th day, the growth of the bacteria declined (which might be due to a shortage of nutrients in the effluents) until it reached its death phase (which might be due to the unavailability of nutrients in the effluents).

A similar trend of growth was also observed for TAN2 Isolate as the initial growth phase also occurred within 2-day of incubation but maximum growth rate observed on the 4th day of incubation. The stationary stage occurred between the 4th day and the 8th day. Beyond the 8th day, the growth of the bacteria declined (which might be due to a shortage of nutrients in the effluents) until it reached its death phase (which might be due to the unavailability of nutrients in the effluents).

The initial growth phase of TAN3 bacterial Isolate occurred within the 3-day incubation as the growth rate increases up to the 6th-day incubation when the maximum growth was observed. Beyond the 6th day, the growth of the bacteria declined (which might be due to a shortage of nutrients in the effluents) until it reached its death phase (which might be due to the unavailability of nutrients in the effluents).

Table 2: Morphological and Biochemical characteristics of bacterial isolates

\begin{tabular}{lllll} 
Bacterial Isolates & & TAN1 & TAN2 & TAN3 \\
\hline $\begin{array}{lllll}\text { Morphological } \\
\text { characteristics }\end{array}$ & Shape & Cocci & Rod & Cocci \\
& Spore & & & \\
& former & + & + & + \\
Gram & & & \\
Biochemical characteristics & reaction & - & + & + \\
& Citrate & + & + & + \\
& Catalase & + & + & + \\
& Coagulase & + & - & + \\
Starch & + & + & + \\
& Glucose & + & + & + \\
Oxidase & + & + & + \\
& Indo & - & + & - \\
Lactose & - & + & + \\
Manitol & + & - & + \\
Maltose & + & + & + \\
MR & - & + & - \\
VP & + & - & - \\
& Nitrate & - & - & - \\
Reduction & - Neisseria & Bacillus & Staphylococcus \\
& Bacterial & cereus & aureus \\
& name & spp & cas
\end{tabular}

+ = Positive; - = Negative; MR=Methyl Red; VP= Voges-Proskauer 


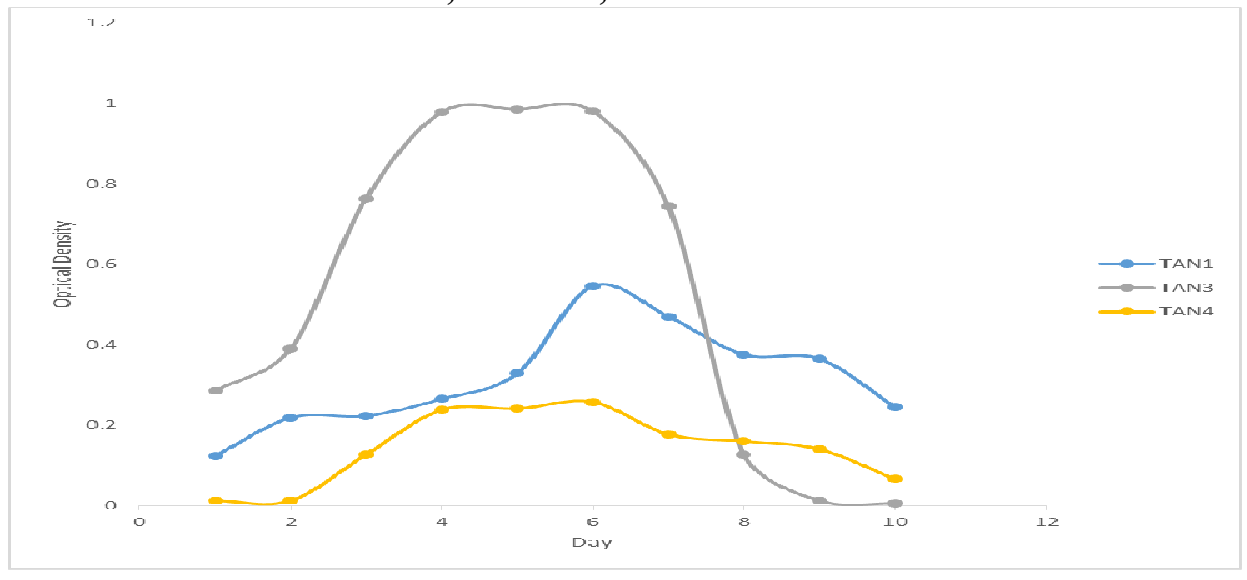

Fig. 2 Growth rates of the isolates in the effluents from the Tannery Industries

\section{Physico-chemical Parameters in the Industrial Effluents after the biodegradation.}

Table 3 shows the mean results of the physicochemical parameter before and after bioremediation using the different masses $(5 \mathrm{~g}$, $10 \mathrm{~g}, 15 \mathrm{~g}, 20 \mathrm{~g}$, and $25 \mathrm{~g}$ ) of the respective immobilized bacteria. Also, Table 4 shows the mean results of correlation coefficient ( $r$ ) between different masses of bacteria and physicochemical parameters.

The mean values $(\mathrm{mg} / \mathrm{l})$ of the SS after the bioremediation varies between $243 \pm 45$ and $898 \pm 672$. The mean concentration $(\mathrm{mg} / \mathrm{l})$ of SS remediated by the different masses $(5 \mathrm{~g}, 10 \mathrm{~g}$, $15 \mathrm{~g}, 20 \mathrm{~g}$, and $25 \mathrm{~g}$ ) of the bacteria varies. The SS in the samples fluctuates up and down after the bioremediation process when compared with the SS of the raw samples before the bioremediation. The increase in the levels of the SS might be due to the aggregation of the TDS which are large enough to result into SS. The increase in the levels of the SS might be also due to the influence of the nutrients which was added into the effluents in order to make the microorganisms more active and viable for fast degradation of organic contaminants in the effluent. The relative potential or efficiency of the different masses of the bacteria in remediating SS in TAN1 samples was in the order $25 \mathrm{~g}>20 \mathrm{~g}>15 \mathrm{~g}>10 \mathrm{~g}>5 \mathrm{~g}$. For TAN2 and TAN3 samples, the order was $25 \mathrm{~g}>20 \mathrm{~g}>15$ $\mathrm{g}>10 \mathrm{~g}>5 \mathrm{~g}$. These might be due to the variations in the surface areas of the different masses of the immobilized bacteria. Statistical analysis shows that there is no significant difference $(p<0.05)$ between the mean values of SS among the masses in the respective industries. Positive and significant correlations exist between the masses of bacteria and Suspended Solid (SS). This showed that there is general increase in the levels of the SS as the masses of the immobilized bacteria increases. TAN3 (90\%) and TAN1 (80\%) showed a very high correlation with the masses of the bacteria while TAN2 (61\%) showed a very low correlation.

The mean values $(\mathrm{mg} / \mathrm{l})$ of the TDS after the bioremediation varies between $46 \pm 11$ and $83 \pm 78$. The mean concentration $(\mathrm{mg} / \mathrm{l})$ of TDS remediated by the different masses $(5 \mathrm{~g}, 10 \mathrm{~g}$, $15 \mathrm{~g}, 20 \mathrm{~g}$, and $25 \mathrm{~g}$ ) of the bacteria varies. There is a reduction in all the TDS of all the samples after the bioremediation process compared with the TDS of the raw samples before the bioremediation. The relative potential or efficiency of the different masses of the bacteria in remediating TDS in TAN1 and TAN3 samples was in the order $5 \mathrm{~g}>10 \mathrm{~g}>15 \mathrm{~g}>20$ $\mathrm{g}>25 \mathrm{~g}$. For TAN2 samples, the order was 20 $g>10 \quad g>25 \quad g>15 \quad g>5 \quad g$. Statistical analysis shows that there is no significant difference $(p<0.05)$ between the mean values of TDS among the masses in the respective industries. These might be due to the variations in the surface areas of the different masses of the immobilized bacteria. Positive and significant correlations exist between the masses of bacteria and TDS with the exception in TAN2 (negative and insignificant correlation). The positive correlations showed that there is general increase in the levels of the TDS as the masses of the immobilized bacteria increases. TAN1 $(96 \%)$ showed a very high correlation with the masses of the bacteria while TAN2 (47\%) showed a very low correlation.

The mean values $(\mathrm{mg} / \mathrm{l})$ of the BOD after the bioremediation varies between $1.56 \pm 0.20 \mathrm{mg} / \mathrm{l}$ and $6.92 \pm 5.49 \mathrm{mg} / \mathrm{l}$. The mean concentration $(\mathrm{mg} / \mathrm{l})$ of BOD remediated by the different masses $(5 \mathrm{~g}, 10 \mathrm{~g}, 15 \mathrm{~g}, 20 \mathrm{~g}$, and $25 \mathrm{~g}$ ) of the bacteria varies. There is a reduction in all the BOD of all the samples after the bioremediation process compared with the $\mathrm{BOD}$ of the raw 
BAJOPAS Volume 13 Number 2, December, 2020 samples before the bioremediation. The relative potential or efficiency of the different masses of the bacteria in remediating BOD in TAN1, TAN2 and TAN3 samples were in the order $25 \mathrm{~g}>20$ $\mathrm{g}>15 \mathrm{~g}>10 \mathrm{~g}>5 \mathrm{~g}, 25 \mathrm{~g}>15 \mathrm{~g}>5 \mathrm{~g}>10 \mathrm{~g}>20 \mathrm{~g}$ and $20 \mathrm{~g}>10 \mathrm{~g}>25 \mathrm{~g}>15 \mathrm{~g}>5 \mathrm{~g}$ respectively. Statistical analysis shows that there is significant difference $(p<0.05)$ between the mean values of BOD among the masses in the respective industries. These might be due to the variations in the surface areas of the different masses of the immobilized bacteria. Negative and significant correlations exist between the masses of bacteria and BOD. This showed that there is general decrease in the levels of the BOD as the masses of the immobilized bacteria increases. TAN1 (94\%) showed a very high correlation with the masses of the bacteria while TAN2 (4\%) showed a very low correlation.

The mean values $(\mathrm{mg} / \mathrm{l})$ of the COD after the bioremediation varies between $250 \pm 154$ and $3134 \pm 1595$. The mean concentration $(\mathrm{mg} / \mathrm{l})$ of COD remediated by the different masses $(5 \mathrm{~g}$, $10 \mathrm{~g}, 15 \mathrm{~g} 20 \mathrm{~g}$, and $25 \mathrm{~g}$ ) of the bacteria varies. There is a reduction in all the COD of all the samples after the bioremediation process compared with the COD of the raw samples before the bioremediation. The relative potential or efficiency of the different masses of the bacteria in remediating COD in TAN1, TAN2 and TAN3 samples were in the order $25 \mathrm{~g}>20 \mathrm{~g}>15$ $\mathrm{g}>5 \mathrm{~g}>10 \mathrm{~g}, 25 \mathrm{~g}>20 \mathrm{~g}>15 \mathrm{~g}>10 \mathrm{~g}>5 \mathrm{~g}$ and 10 g>5 g>25 g>15 g>20 g respectively. Statistical analysis shows that there were significant difference $(p<0.05)$ between the mean values of COD among the masses in the respective industries except for effluents treated with $25 \mathrm{~g}$. These might be due to the variations in the surface areas of the different masses of the immobilized bacteria. Negative and insignificant correlations exist between the masses of bacteria and COD with the exception in TAN3 (positive and significant correlation). The negative correlations showed that there is general decrease in the levels of the COD as the masses of the immobilized bacteria increases. TAN2 (100\%) showed a very high correlation with the masses of the bacteria while TAN3 (36\%) showed a very low correlation.

Generally, there was an overall decrease in the concentration of these physicochemical parameters after the bioremediation using the different masses of the bacterial isolates. These might be due to the variations in the surface areas of the different masses of the immobilized bacteria. This is in line with the work of Jimoh et al. (2018) and Baba et al. (2020).

Table 3: Mean Values $(\mathrm{mg} / \mathrm{l}) \pm$ S.D of Physicochemical parameters in effluents from the Tannery Industries before and after Treatment of the effluents $(250 \mathrm{ml})$ with the different masses $(5 \mathrm{~g}, 10 \mathrm{~g}$, $15 \mathrm{~g}, 20 \mathrm{~g}$, and $25 \mathrm{~g}$ ) of the bacteria.

\begin{tabular}{llllllll}
\hline $\mathrm{P}$ & IND & Before & \multicolumn{5}{c}{ After } \\
\cline { 4 - 7 } & & & $5 \mathrm{~g}$ & $10 \mathrm{~g}$ & $15 \mathrm{~g}$ & $20 \mathrm{~g}$ & $25 \mathrm{~g}$ \\
\hline \multirow{2}{*}{ COD } & TAN1 & $2372 \pm 938$ & $1708 \mathrm{a} \pm 861$ & $2045 \mathrm{a} \pm 1205$ & $845 \mathrm{a} \pm 369$ & $300 \mathrm{a} \pm 167$ & $250 \mathrm{a} \pm 154$ \\
& TAN2 & $1406 \pm 208$ & $1195 \mathrm{a} \pm 208$ & $1125 \mathrm{a} \pm 384$ & $1055 \mathrm{a} \pm 317$ & $956 \mathrm{a} \pm 310$ & $870 \mathrm{ab} \pm 240$ \\
& TAN3 & $3532 \pm 1373$ & $2374 \mathrm{a} \pm 1344$ & $1976 \mathrm{a} \pm 1405$ & $2757 \mathrm{a} \pm 1266$ & $3134 \mathrm{a} \pm 1595$ & $2614 \mathrm{~b} \pm 1105$ \\
BOD & TAN1 & $13.85 \pm 6.42$ & $6.92 \mathrm{a} \pm 5.49$ & $6.42 \mathrm{a} \pm 5.07$ & $5.72 \mathrm{a} \pm 5.35$ & $4.62 \mathrm{a} \pm 4.37$ & $2.82 \mathrm{ab} \pm 1.26$ \\
& TAN2 & $19.46 \pm 0.50$ & $1.75 \mathrm{~b} \pm 0.22$ & $1.73 \mathrm{~b} \pm 0.18$ & $1.58 \mathrm{a} \pm 0.16$ & $1.91 \mathrm{a} \pm 0.22$ & $1.56 \mathrm{~b} \pm 0.20$ \\
& TAN3 & $17.13 \pm 3.14$ & $4.24 \mathrm{ab} \pm 0.77$ & $3.29 \mathrm{ab} \pm 0.37$ & $4.11 \mathrm{a} \pm 0.07$ & $3.23 \mathrm{a} \pm 0.91$ & $3.33 \mathrm{a} \pm 1.28$ \\
SS & TAN1 & $374 \pm 124$ & $243 \mathrm{a} \pm 45$ & $471 \mathrm{a} \pm 226$ & $475 \mathrm{a} \pm 182$ & $492 \mathrm{a} \pm 128$ & $611 \mathrm{a} \pm 217$ \\
& TAN2 & $358 \pm 335$ & $460 \mathrm{a} \pm 400$ & $543 \mathrm{a} \pm 414$ & $544 \mathrm{a} \pm 402$ & $551 \mathrm{a} \pm 414$ & $554 \mathrm{a} \pm 405$ \\
& TAN3 & $780 \pm 739$ & $586 \mathrm{a} \pm 594$ & $758 \mathrm{a} \pm 656$ & $787 \mathrm{a} \pm 676$ & $861 \mathrm{a} \pm 635$ & $898 \mathrm{a} \pm 672$ \\
TDS & TAN1 & $3941 \pm 3703$ & $51 \mathrm{a} \pm 10$ & $53 \mathrm{a} \pm 10$ & $55 \mathrm{a} \pm 15$ & $61 \mathrm{a} \pm 20$ & $63 \mathrm{a} \pm 26$ \\
& TAN2 & $3300 \pm 1714$ & $83 \mathrm{a} \pm 78$ & $47 \mathrm{a} \pm 20$ & $48 \mathrm{a} \pm 22$ & $47 \mathrm{a} \pm 17$ & $48 \mathrm{a} \pm 17$ \\
& TAN3 & $2653 \pm 1240$ & $46 \mathrm{a} \pm 11$ & $55 \mathrm{a} \pm 24$ & $55 \mathrm{a} \pm 25$ & $58 \mathrm{a} \pm 23$ & $61 \mathrm{a} \pm 28$ \\
\hline
\end{tabular}

Replicate $=6$ (months)

Within the rows, for the same parameter, means with different alphabets are statistically different $(p<0.05)$.

$\mathrm{P}=$ parameter, IND = Industries 
BAJOPAS Volume 13 Number 2, December, 2020

Table 4: Correlation coefficient $(r)$ between different masses of the bacteria and the physicochemical parameters.

\begin{tabular}{llll}
\hline Industries & Parameter & Correlation coefficient $(r)$ & $\begin{array}{l}\text { Percent dependence (rxrx100) } \\
(\%)\end{array}$ \\
\hline TAN1 & COD & -0.9 & 82 \\
& BOD & -0.97 & 94 \\
& SS & $0.90^{*}$ & 80 \\
TAN2 & TDS & $0.98^{*}$ & 96 \\
& COD & -1 & 100 \\
& BOD & -0.21 & 4 \\
& SS & $0.78^{*}$ & 61 \\
& TDS & -0.69 & 47 \\
& COD & $0.60^{*}$ & 36 \\
& BOD & -0.6 & 37 \\
& SS & $0.95^{*}$ & 90 \\
& TDS & $0.94^{*}$ & 89 \\
\hline
\end{tabular}

The correlation coefficient $(r)$ with * is statistically significant $(p<0.05)$.

Percentage reduction of the Parameters

Table 5 shows the percentage reduction of Parameters in industrial samples before and after the treatment of the effluents $(250 \mathrm{ml})$ with the different masses $(5 \mathrm{~g}, 10 \mathrm{~g}, 15 \mathrm{~g}, 20 \mathrm{~g}$, and $25 \mathrm{~g}$ ) of the Immobilized Bacteria.

In TAN1 samples, the percentage reduction (\%) of COD ranged (14-89); BOD (50-80); SS (-32$35)$ and TDS (98-99). In TAN2 samples, the percentage decrease $(\%)$ of COD ranged (15$38) ;$ BOD (90-92); SS [-28-(-55)] and TDS (9798). In TAN3 samples, the percentage decrease (\%) of COD ranged (11-44); BOD (76-81); SS (15-25) and TDS (98). The percentage increase in the levels COD, BOD and TDS might be due to the increase in the surface area of the different masses of the immobilized bacteria. However, the percentage decrease in the levels of the SS might be due to the aggregation of the TDS which are large enough to result into SS. The percentage decrease in the levels of the SS might be also due to the influence of the nutrients which was added into the effluents in order to make the microorganisms more active and viable for fast degradation of organic contaminants in the effluent. This is in line with the work of Jimoh et al. (2018) in which the concentration of the SS increase after the bioremediation of effluents.

Sreemoyee and Priti (2013) assessed and reduced several Physico-chemical parameters of dairy wastewater using Niesseria $s p$. and concluded that the species are well known to degrade organic compounds. This is in agreement with the current study in which the immobilized Niesseria $s p$ degrade the organic contaminants as indicated by the BOD, COD and TDS.

Jimoh et al. (2018) observed that TSS of the effluents was increased after treatment with immobilized bacteria and concluded that it might be due to the biostimulation method adopted for the research.

The optimum $\mathrm{pH}$ Biosorption of Chromium by Bacillus spp and Staphylococcus spp. from tannery effluent was investigated by Mythili and Karthikeyan (2011). The maximum adsorption of Chromium $(86.4 \mathrm{mg} / \mathrm{L})$ was showed by Bacillus spp and Staphylococcus spp showed $70.6 \mathrm{mg} / \mathrm{L}$ at an initial concentration of $100 \mathrm{mg} / \mathrm{L}$. In the present study, immobilised Bacillus spp and Staphylococcus spp. from the tannery industrial effluents reduced the levels of the organic pollutants with high potential as indicated by the percentage reduction of BOD, COD and TDS.

Enzymes often can work in multiple environments especially if they are immobilized. This makes the microorganisms' enzymes even more resistant to harsh environments and enables the enzymes to be recovered and recycled after they are no longer needed (Gianfreda and Rao 2004). Ramesh and Singh (1993) reported that the immobilized bacteria having more efficiency to remove the suspended particles than free cells. Using the immobilized cell is preferable due to its capability for using several times with the same efficiency, which makes it more economical. Similar work was done by Sikander et al. (2007) showing the higher reduction with permeabilized cells of Ochrobactrum intermedium strain SDCr-5. 
BAJOPAS Volume 13 Number 2, December, 2020

The results revealed the isolation and identification of isolates with the potential for the reduction of $\mathrm{Cr}$ (VI) to $\mathrm{Cr}$ (III). Results indicated that immobilized $B$. cereus could be efficiently used for the reduction of $\mathrm{Cr}$ (VI).

Table 5: Percentage reduction of the tested Parameters from the tannery industrial samples of the Immobilized Bacteria.

\begin{tabular}{lllllll}
\hline \multirow{2}{*}{ Industries } & & \multicolumn{5}{c}{ Percentage Reduction $(\%)$} \\
\cline { 3 - 7 } & & $5 \mathrm{~g}$ & $10 \mathrm{~g}$ & $15 \mathrm{~g}$ & $20 \mathrm{~g}$ & $25 \mathrm{~g}$ \\
\hline TAN1 & COD & 28 & 14 & 64 & 87 & 89 \\
& BOD & 50 & 54 & 59 & 67 & 80 \\
& SS & 35 & -26 & -27 & -32 & -63 \\
& TDS & 99 & 99 & 99 & 98 & 98 \\
TAN2 & COD & 15 & 20 & 25 & 32 & 38 \\
& BOD & 91 & 91 & 92 & 90 & 92 \\
& SS & -28 & -52 & -52 & -54 & -55 \\
& TDS & 97 & 99 & 99 & 99 & 99 \\
& COD & 33 & 44 & 22 & 11 & 26 \\
& BOD & 75 & 81 & 76 & 81 & 81 \\
& SS & 25 & 3 & -1 & -10 & -15 \\
& TDS & 98 & 98 & 98 & 98 & 98 \\
\hline
\end{tabular}

Percentage Reduction $=(B-A) / B \times 100 \%$

$A=$ Concentration of the parameter after treatment

$\mathrm{B}=$ Concentration of the parameter before treatment

$+=$ percentage decrease

- = percentage increase

In general, immobilization makes the enzyme more resistant to temperature, $\mathrm{pH}$, and substrate concentration swings giving it a longer lifetime and higher productivity per active unit (Gianfreda and Rao, 2004; FuIlbrook, 1996; Russell et al, 2003; Kandelbauer et al., 2004). Immobilized cells have been used and studied extensively for the production of useful chemicals (Ohtake and Silver, 1994), the treatment of wastewaters (Chen et al., 2003; Wang et al., 2010). Although many workers described microbial degradation of tannery effluent, limited literature is available on the bioremediation of tannery effluent using immobilized bacterial cells in the Kano Industrial Estates.

\section{CONCLUSION}

The samples contained variable levels of the physicochemical parameters. The results of the Analysis of variance revealed that, no statistical difference $(p<0.05)$ was observed for the temperature, $\mathrm{pH}, \mathrm{SS}, \mathrm{TDS}, \mathrm{BOD}$ and $\mathrm{COD}$ among the three tannery industries before the treatment. The levels of some of the parameters
(SS, TDS and COD) observed in the samples were found above the recommended limits of WHO and NESREA, which called for the treatment of the effluents before discharge into the environment. Base on the morphological and biochemical test results, TAN1, TAN2, and TAN3 bacterial isolates were identified to be Neisseria spp, Bacillus cereus, and Staphylococcus aureus respectively. The results of Post-treatment analysis showed that there is overall decrease in the levels of the parameters determined when compared with that of the pre-treatment. The overall percentage reduction of the immobilised bacteria in the treatment of the respective effluents was in the order TAN2 (72\%)>TAN1 $(70 \%)>$ TAN3 $(62 \%)$. Hence, the immobilized bacteria are having higher biodegradation potential for the treatment of the tannery effluents.

\section{Acknowledgments}

The authors wish to acknowledge the University of Maiduguri for the financial support. The authors are grateful to the Kano State Ministry of Environment for their support in obtaining the effluent samples. 


\section{REFERENCES}

Ajao, A. T., Adebayo, G. B., and Yakubu, S. E. (2011). Bioremediation of textile industrial effluent using mixed culture of Pseudomonas aeruginosa and Bacillus subtilis immobilized on agar-agar in a bioreactor. J. Microbiol. Biotech. Res, 1(3), 50-56.

Akan, J. C., Moses, E. A., Ogugbuaja, V. O., and Abah, J. (2007). Assessment of tannery industrial effluents from Kano metropolis, Kano State, Nigeria. Journal of Applied Sciences, 7(19), 2788-2793.

Akan, J. C., Ogugbuaja, V. O., Abdulrahman, F. I., and Ayodele, J. T. (2009). Pollutant levels in effluent samples from tanneries and textiles of Kano industrial areas, Nigeria. Global journal of pure and applied sciences, 15(3-4).

APHA (1989). Standard methods for Examination of Will bete and Will betewater.15 $5^{\text {th }}$ edition. Brydpass Springfield Will behington DC. pp. 164-176

APHA (1992). Standard Methods for the Examination of Water and Wastewater. Health, 69, 1116-9.

Baba, A., Garba, S. T., and Bello, H. S. (2020). Bioremediation Potential of Immobilized corynebacterium kutsceri in the Treatment of Tannery Industrial Effluent from Challawa Industrial Estate, Kano State, Nigeria. Journal of the Turkish Chemical Society Section A: Chemistry, $7(2), 335-350$.

Beem, E. I. V. (1994). reduction of solvent VOC emission. J. Oil Col. Chem. Ass, 77, 158.

Bouwer, E. J., and Zehnder, A. J. (1993). Bioremediation of organic compoundsputting microbial metabolism to work. Trends in biotechnology, 11(8), 360367.

Chen, K. C., Wu, J. Y., Liou, D. J., and Hwang, S. C. J. (2003). Decolorization of the textile dyes by newly isolated bacterial strains. Journal of Biotechnology, 101(1), 57-68.

Dan'Azumi, S., and Bichi, M. H. (2010). INDUSTRIAL POLLUTION AND HEAVY METALS PROFILE OF CHALLAWA RIVER IN KANO, NIGERIA. Journal of Applied Sciences in Environmental Sanitation, $5(1)$.

DWAF. (1992). Analytical Methods Manual, TR 151. Department of Water Affairs and Forestry, Pretoria.

El-Bestawy, E. (2013). Biological treatment of leather-tanning industrial wastewater using free living bacteria.
Elsheikh, M. A. S. (2009). Tannery wastewater pre-treatment. Water Science and Technology, 60(2), 433-440.

FuIlbrook, P. D. (1996). "Kinetics." Industrial enzymology: The application of enzymes in Industry. 2nd Ed. T. Godfrey and J Reichelt. eds.. Nature. New York.

Gianfreda, L., and Rao, M. A. (2004). Potential of extra cellular enzymes in remediation of polluted soils: a review. Enzyme and microbial technology, 35(4), 339354.

Hugo Springer. (1994). John Arthur Wilson Memorial Lecture "Treatment of Industrial Wastes of the Leather Industry - is it still a Major Problem". JALCA, 89, 153-185

Jimoh, A. A., Ganiyu, B. A., Baba, D., and Baba, A. (2018) Bioremediation Process of Effluent from Detergent and Food Industries in Jos, Nigeria: Kinetics and Thermodynamics. International Journal of Engineering Science Invention (IJESI), 762-73

Kandelbauer, A., Maute, O., Kessler, R. W., Erlacher, A., and Gübitz, G. M. (2004). Study of dye decolorization in an immobilized laccase enzyme-reactor using online spectroscopy. Biotechnology and bioengineering, 87(4), 552-563.

Kongjao, S., Damronglerd, S., and Hunsom, M. (2008). Simultaneous removal of organic and inorganic Pollutants in tannery wastewater using electrocoagulation technique. Korean Journal of chemical engineering, 25(4), 703.

Maheshwari, U. M., Aruna, S., Gomathi, M., and AbdulJaffar, A. H. (2017). Bioremediation by Free and Immobilized Bacteria Isolated from Tannery Effluent. International Journal of Research in Applied, Natural and Social Sciences. 5(7), 75-90

Margesin, R., and Schinner, F. (2001). Bioremediation (natural attenuation and biostimulation) of diesel-oilcontaminated soil in an alpine glacier skiing area. Applied and environmental microbiology, 677), 3127-3133.

Mohammed, A., Sekar, P., and George, J. (2011). Efficacy of microbes in bioremediation of tannery effluent. Inter. J. Curr. Res, 3(4), 324-326.

Mohammed, S. S. D., Orukotan, A. A., and Abdullahi, H. (2017). Physicochemical and Bacteriological Assessment of Tannery Effluent from Samaru-Zaria, 
BAJOPAS Volume 13 Number 2, December, 2020 Kaduna State, Nigeria. Journal of Applied

Sciences and Environmental Management, 21(4), 734-740.

Munz, G., De Angelis, D., Gori, R., Mori, G., Casarci, M., and Lubello, C. (2009). The role of tannins in conventional and membrane treatment of tannery wastewater. Journal of hazardous materials, 164(2-3), 733-739

Mythili, K., and Karthikeyan, B. (2011). Bioremediation of $\mathrm{Cr}$ (VI) from tannery effluent using Bacillus spp and Staphylococcus spp. International Multidisciplinary Research Journal, 1(6).

NESREA (2009). National Environmental Standards for Effluent Limitations and Regulation. 1233-1236

Noorjahan, C. M. (2014). Physicochemical characteristics, identification of bacteria and biodegradation of industrial effluent. Journal of bioremediation and Biodegradation, 5(3).

Ohtake, H. I., and Silver, A. O. (1994). Bacterial reduction of toxic chromate. Biological degradation and bioremediation of toxic chemicals, 403-415.

Omoleke, I. I. (2004). Management of environmental pollution in Ibadan, an African city: the challenges of health hazard facing government and the people. Journal of Human Ecology, 15(4), 265-275.

Rajor, A., Reddy, A.S., and Singh, B. (2004). Determination of BOD kinetic Parameters and evaluation of alternate methods, M.Sc. Thesis, Department of biotechnology \& environmental Science, Thapar Institute of Engineering and Technology, Patiala

Ramasami, T., Rajamani, S., and Rao, J. R. (1994, March). Pollution control in leather industry: Emerging technological options. In International symposium on surface and colloidal science and its relevance to soil pollution, madras.

Ramesh, J. V. S., and Singh, S. P. (1993). Yearly variation in certain physicochemical parameters of pond at eastern Doon Valley. Uttar Pradesh J. Zoo, 12 (1), 7577.

Ranen, S., and Sharadinadra, C. (2009). Biotechnology applications to environmental remediation in resource exploitation. Current science, 97, 6-25
Russell, A. J., Berberich, J. A., Drevon, G. F., and Koepsel, R. R. (2003). Biomaterials for mediation of

chemical and biological warfare agents. Annual review of biomedical engineering, 5(1), 1-27.

Saravanan, P., and Saravanan, A. (1999). Decolourization of tannery effluent by Flavobacterium sp. EK 1. Indian Journal of Environmental Protection, 19, 19-24.

Sikander, S., and Shahida, H. (2007). Reduction of toxic hexavalent chromium by Ochrobactrum intermedium strain SDCr5 stimulated by heavy metals. Bioresource Technol, 98, 340-344.

Singh, N., Sharma, B. K., and Bohra, P. C. (2000). Impact assessment of industrial effluent of arid soils by using satellite imageries. Journal of the Indian Society of Remote Sensing, 28(2-3), 79.

Sreemoyee, C., and Priti, P. (2013). Assessment of physico-chemical parameters of dairy waste water and isolation and characterization of bacterial strains in terms of cod reduction. Int J Sci, 2(3), 395-400.

Verheijen, L. A. H. M., Wiersema, D., Pol, L. H., and De Wit, J. (1996). Management of wastes from animal product processing. Livestock and environment, Finding a balance. International Agriculture Center, Wageningen, The Netherlands.

Wang, F., Yao, J., Si, Y., Chen, H., Russel, M., Chen, K., and Bramanti, E. (2010). Short-time effect of heavy metals upon microbial community activity. Journal of Hazardous Materials, 173(13), 510-516.

WHO (World Health Organization). (2006). Air quality guidelines: global update 2005: particulate matter, ozone, nitrogen dioxide, and sulfur dioxide. World Health Organization.

World Bank. (1995). Nigeria's strategic options for redressing industrial pollution. World Bank, industry and energy division. 1st edition, West Central Africa Department; Annexes: 1995; pp 60-62.

Zahoor, A., and Abdul, R. (2009). Enumeration of Coliforms. Journal of Environmental Sciences. 21, 814-820 


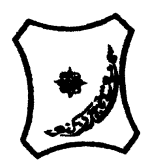

Bayero Journal of Pure and Applied Sciences, 13(2): 1 - 12

Received: November, 2020

Accepted: December, 2020

ISSN $2006-6996$

\title{
BIODEGRADATION POTENTIAL OF IMMOBILIZED BACTERIA IN THE TREATMENT OF TANNERY INDUSTRIAL EFFLUENTS FROM INDUSTRIAL ESTATES IN KANO STATE, NIGERIA
}

\author{
Abdullateef, B., ${ }^{1 *}$ Shuaibu, T. G., ${ }^{1}$ Babagana, K., ${ }^{1}$ Suleman, H. B. ${ }^{2}$ and Dauda, B. ${ }^{3}$ \\ ${ }^{1}$ Department of Pure and Applied Chemistry, Faculty of Science, University of Maiduguri, Borno State, \\ Nigeria \\ ${ }^{2}$ Department of Microbiology, Faculty of Science, University of Maiduguri, Borno State, Nigeria \\ ${ }^{3}$ Department of Chemical Engineering, Faculty of Engineering, University of Maiduguri, Borno State, \\ Nigeria \\ *Corresponding author: babslega@gmail.com; abelega2007@yahoo.com; +2348061309753
}

\section{ABSTRACT}

Industrial Effluents Samples from Gashash Tanneries (TAN1) in Bompai Industrial estate, Larabee Tannery Industry (TAN2) in Sharada Industrial estate and Z Tannery Industries (TAN3) in Challawa Industrial estate, Kano State, Nigeria were collected over a period of six months (August 2017 to January 2018) for assessing the biodegradation potentials of bacteria in the treatment of organic pollutants within the effluents. Bacteria were isolated from the effluents and immobilized on agar-agar. Different masses (5 g, $10 \mathrm{gr}, 15$ $\mathrm{g}, 20 \mathrm{~g}$, and $25 \mathrm{~g}$ ) of the bacteria were used in the treatment of $250 \mathrm{ml}$ of the effluents for ten days in a shaker incubator (Gallenkamp-OC-4364-L) at the temperature $30{ }^{\circ} \mathrm{C}$ and speed of $60 \mathrm{rpm}$. Pre-treatment analysis of the effluents for Temperature, pH, Biochemical Oxygen Demand (BOD), Chemical Oxygen Demand (COD), Suspended Solid (SS) and Total Dissolved Solids (TDS) gives the following results; temperature $\left({ }^{\circ} \mathrm{C}\right.$ )

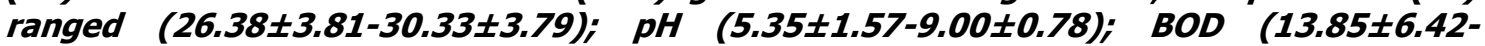
$38.75 \pm 16.20) ;$ COD (1406 $\pm 208-3532 \pm 1373) ;$ SS (208 $\pm 235-780 \pm 739)$ and TDS (266 $\pm 253-5276 \pm 2971)$. No statistical differences ( $p \leq 0.05)$ was observed for all the results among the different industries. The bacterial isolates were identified as Neisseria spp, Bacillus cereus, and Staphylococcus aureus, in TAN1, TAN2, and TAN3, respectively. After treatment of the effluent with the different masses of the isolated bacteria, the mean level of BOD was found to range as (0.55 $\pm 0.36-6.92 \pm 5.49) ; C O D$ (ND-3134 \pm 1595$)$;

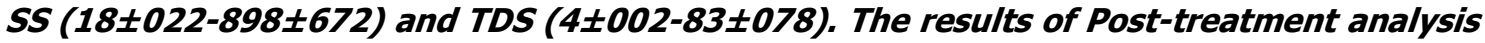
showed that there is overall decrease in the levels of the parameters determined when compared with that of the pre-treatment. The overall percentage reduction of the immobilised bacteria in the treatment of the respective effluents was in the order TAN2 (72\%)>TAN1 (70\%)>TAN3 (62\%). Hence, the immobilized bacteria are having higher biodegradation potential for the treatment of the tannery effluents.

Keywords: Biodegradation, bacteria, effluent, immobilization, tannery.

\section{INTRODUCTION}

Tannery industrial wastewater is a serious consequence of the pollution point of view for streams, freshwater, and land used for agriculture. The lack of awareness in the modern industrial practice has resulted in the discharge of tannery effluents which exhibit very high value of chromium ( $\mathrm{Cr}$ ), Sulfide, and chloride, Total Dissolved Solid (TDS), Total Suspended Solid (TSS), Biochemical Oxygen Demand (BOD) and Chemical Oxygen Demand (COD) in the water stream or land (Mohammed et al., 2001). Tanning is the process, which One ton of skin generally leads to the production of 20 to $80 \mathrm{~m}^{3}$ of turbid and foul-smelling converts the protein of the rawhide or skin into a stable material, which will not putrefy and is suitable for a wide variety of end applications (Elsheikh, 2009). The highly polluting chromium is the most commonly used tanning material producing leather that is more flexible and pliable than vegetable-tanned leather and does not discolor or lose shape in water as drastically as vegetable-tan (Elsheikh, 2009). Tannery effluent is among the most hazardous industrial pollutants due to its huge organic and inorganic load, which is highly toxic to human life and the environment (Kongjao et al., 2008). wastewater including chromium (100-400 mg/l), sulfide $(200-800 \mathrm{mg} / \mathrm{l})$, high levels of fat and 
BAJOPAS Volume 13 Number 2, December, 2020 other solid wastes, and notable pathogen contamination as well as pesticides added for skin conservation during transport (Elsheikh, 2009). There are more than 6000 tanneries in Nigeria with an annual processing capacity of 700,000 tons of hides and skins (Omoleke, 2004; Singh et al., 2008). It was reported that the total amount of waste produced per animal slaughtered is approximately $35 \%$ of its weight (World Bank, 1995). Also, for every $1000 \mathrm{~kg}$ of carcass weight, a slaughtered beef produces 5.5 $\mathrm{kg}$ of manure (excluding rumen contents or stockyard manure) and $100 \mathrm{~kg}$ of paunch manure (undigested food) (Verheijen et al., 1996). Tanneries generate wastewater in the range of 30-35 $\mathrm{L} \mathrm{kg}^{-1}$ skin/hide processed with variable $\mathrm{pH}$, Biological Oxygen Demand (BOD), Chemical Oxygen Demand (COD), high concentrations of suspended solids (SS), and tannins as well as chromium (Zahoor and Abdul, 2009).

Being heterogeneous and composed of a wide variety of compounds, it is very difficult to select a unique direct method for estimating the biodegradability of organic contents and biokinetic parameters for a wastewater sample (Rajor, 2004). For this purpose, some indirect estimation such as determination of biochemical oxygen demand (BOD) and chemical oxygen demand (COD) are applied as common laboratory investigations [9]. During retanning procedures, synthetic tannins (Syntan), oils and resins are added to form softer leather at varying doses (Munz et al., 2009). One of the refractory groups of chemicals in tannery effluents derives mainly from tannins (Ramasami et al., 2004). Syntans are characterized by complex chemical structures, because they are composed of an extended set of chemicals such as phenol-, naphthalene-, formaldehyde- and melamine-based syntans, and acrylic resins (Beem, 1994). Organic pollutants (proteic and lipidic components) are originated from skins (it is calculated that the raw skin has $30 \%$ loss of organic material during the working cycle) or they are introduced during processes (Hugo Springer, 1994).

Many conventional processes such as oxidation, chemical and biological processes were carried out to treat tanneries wastewater (Ebtesam et al, 2013). Biological processes have received more attention because of their costeffectiveness, lower sludge production and environmental friendliness (Noorjahan, 2014). Naturally occurring micro-organisms degrade the hazardous organic wastes including xenobiotic compounds, such as pesticides, polycyclic aromatic hydrocarbons (PAHs) and polychlorinated biphenyls (PCBs) in due course of time (Ranen and Sharadinadra, 2009). Bioremediation is based on the idea that all organisms remove substances from the environment to carry outgrowth and metabolism (Bouwer and Zehnder, 1993). Bacteria, protista and fungi are found to be very good at degrading complex molecules and incorporating the breakdown products into their metabolism (Bouwer and Zehnder, 1993). The resultant metabolic wastes that they produce are generally safe and somehow recycled into other organisms (Ranen and Sharadinadra, 2009). An acclimatized indigenous population of microorganisms capable of degradation of the compounds of interest must exist at the site for a successful bioremediation mode (Ranen and Sharadinadra, 2009). It has been observed that for a successful bioremediation mode, an acclimatized indigenous population of microorganisms capable of degradation of the compounds of interest must exist at the site under investigation (Ranen and Sharadinadra, 2009). Even though there are numerous physical and chemical methods employed in the disposal of wastes the advantage in using bacterium is that they play a key role in the reduction of COD, BOD, total protein, total tannin and total phenol (Saravanan and Saravanan, 1998)

Baba et al. (2020) studied the bioremediation potential of immobilized corynebacterium kutsceri in the Treatment of tannery industrial effluent from Challawa Industrial Estate, Kano State, Nigeria. The aim of the work is to study the reduction in the level of the contaminants through the process of bioremediation using the isolated bacteria. Immobilized bacteria can withstand various temperatures, $\mathrm{pH}$ and substrate concentrations; consequently, increasing the efficiency and the lifespan of the bacteria. Immobilized bacteria are widely applied in the treatment of wastewater and can be separated and recovered after the treatment with the same efficiency (Baba et al., 2020).

\section{MATERIALS AND METHODS \\ Study Area}

This study was carried out in Bompai, Sharada and Challawa industrial estates in Kano, Figure 1. Kano lies on Latitude $11^{\circ} 30^{\prime} \mathrm{N}$ and $8^{\circ} 30^{\prime} \mathrm{E}$ and Longitude $11^{\circ} 5^{\prime} \mathrm{N}$ and $8^{\circ} 5^{\prime} \mathrm{E}$ in Northern Nigeria. It is one of the developed industrial cities in Nigeria. Tannery activities are the dominating industries and this could be one of the reasons for her high population density (Dan'Azumi and Bichi, 2010). Many researchers have studied biodegradation of tannery effluent using microorganisms. However, limited literature is available on the biodegradation of tannery effluent in Kano industrial estates using 
BAJOPAS Volume 13 Number 2, December, 2020 immobilized bacterial cells. This research work focuses on the potential of the use of the indigenous immobilized bacterial isolates in the treatment of tannery effluents in the industrial estates.

\section{Sample Collection}

Effluents were collected from the Tannery Industries from Bompai, Challawa and Sharada Industrial Estates, Kano, Nigeria. The effluents were collected over a period of six months (August 2017 to January 2018). Samples collected in a sterile 4-liter plastic container with a unique identification number were preserved using an ice-box that was transported to the Microbiology Laboratory, Department of Microbiology, Bayero University of Kano for analysis

\section{Sample Preparation and Sample Analysis}

Immediately after the collection of the effluent, $\mathrm{pH}$, TSS, TDS, COD, BOD levels were determined before treatment (Pre-treatment determination) and ten days after treatment (Post-treatment determination) as described in
APHA (1989) standard methods. $\mathrm{pH}$ was determined using Ecotests $\mathrm{pH}$ meter and TDS was determined using AQUALYTIC TDS Salinometer. BOD was determined as described by the standard method (APHA, 1992). COD and SS were determined using DR/2010 HACH portable data logging spectrophotometer (DWAF, 1992)

\section{Identification and Biochemical} Characterization of the Bacterial Isolates

The bacteria were isolated from the effluents using Serial Dilution according to the method described by APHA (1989). The biochemical tests such as oxidase, catalase, coagulase, indole (from $1 \%$ tryptone broth), citrate (Simmons citrate agar), methyl red/VogesProskauer (MR/VP), nitrate reduction, Starch Hydrolysis, Glucose, Maltose, and Lactose tests were carried out on the bacterial isolates to identify the bacteria through the bacteria biochemical characteristics according to Ajao et al. (2011).

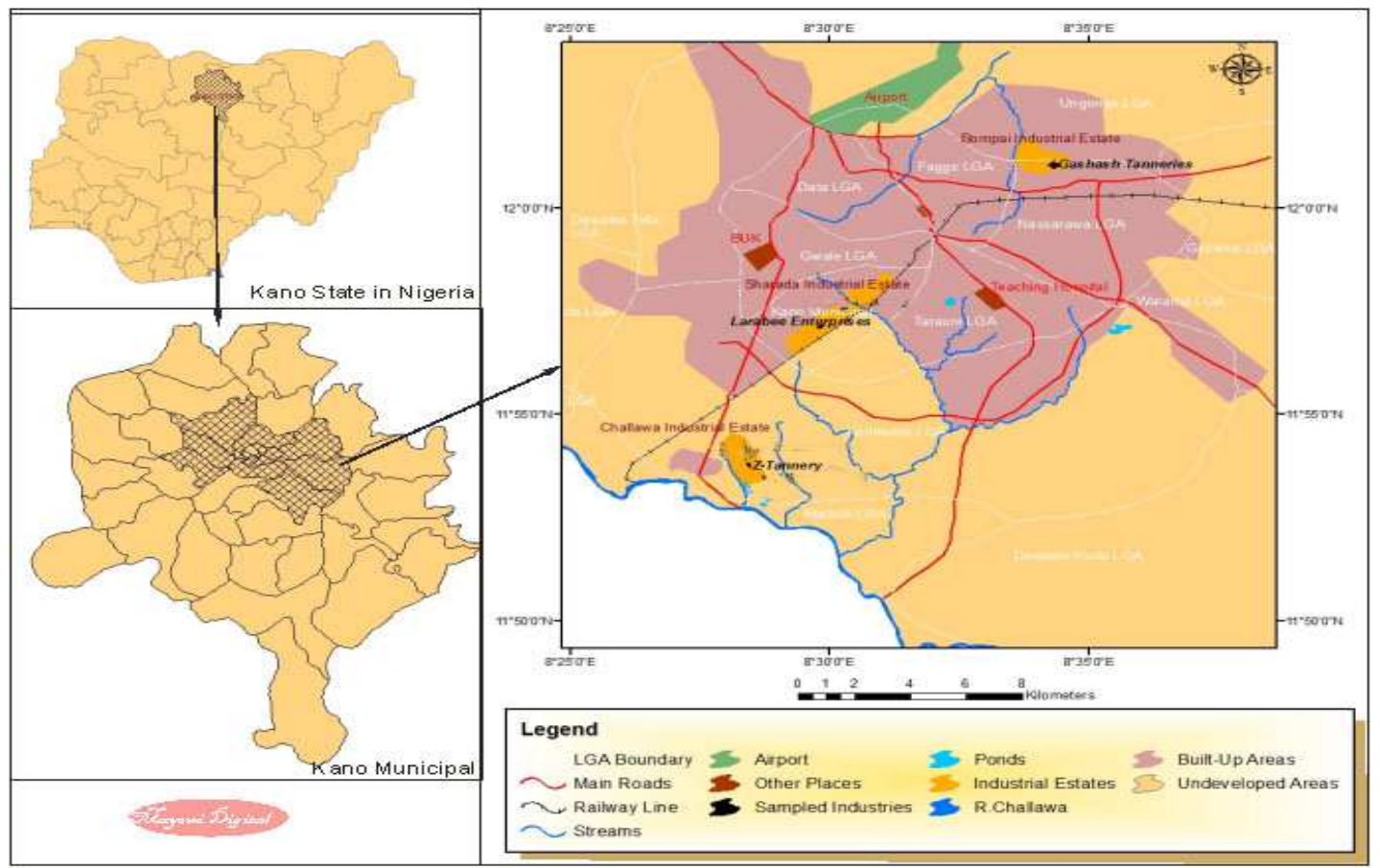

Fig. 1 Map showing the study areas

Source: Mayomi Digital Productions, GIS Laboratory, Department of Geography, UNIMAID (2017)

\section{Determination of Growth Rate of the Bacteria in Effluent Sample}

The bacteria growth rates were determined by transferring $2 \mathrm{~mL}$ of the bacterial isolates from the tannery effluent in broth medium into 100 $\mathrm{mL}$ sterile effluents in conical flasks and kept in an incubator (Giffrin cool) for 10 days. Control was also set up by incubating another $100 \mathrm{~mL}$ each of the sterile effluents without the bacteria. The optical density of the content was determined at the wavelength of $600 \mathrm{~nm}$ on a daily interval and recorded. 
BAJOPAS Volume 13 Number 2, December, 2020 Immobilization of Bacteria

Agar solution and inoculi were prepared separately. Fifty milliliters $(50 \mathrm{~mL})$ of nutrient broth each of the inoculi was prepared in a McCartney bottle and incubated for 24 hours. A solution of agar-agar was prepared by dissolving $10 \mathrm{~g}$ of the powder in distilled water and made up to $500 \mathrm{~mL}$ mark in an Erlenmeyer flask and was sterilized in an autoclave (280A) for 15 minutes and allowed to cool to $40-45^{\circ} \mathrm{C}$ (Ajao et al., 2011). Four milliliters ( $4 \mathrm{~mL})$ of the bacterial isolates in the nutrient broth was mixed with 36 $\mathrm{ml}$ of the prepared agar-agar media in petri-dish plates and then allowed to solidify. This was kept in the refrigerator for bioremediation.

\section{Bioremediation (Treatment) of the Effluents}

The solidified agar block (immobilized bacteria) was cut into cubes using a sterile knife; $0.1 \mathrm{~mL}$ phosphate buffer ( $\mathrm{pH} \mathrm{7.0)}$ was added and kept in the refrigerator for 1 hour for curing. The phosphate buffer was decanted after 1 hour and the cubes were washed with sterile distilled water 3-4 times before it was used (Ajao et al., 2011). Two liters (2 L) of the effluent was supplemented with the minimum basal medium in $\mathrm{g} / \mathrm{L}: \mathrm{NaCl}(0.8), \mathrm{MgSO}_{4} .7 \mathrm{H}_{2} \mathrm{O}(0.001), \mathrm{KH}_{2} \mathrm{PO}_{4}$ (2), $\mathrm{NaNO}_{3}$ (2), $\quad \mathrm{CaCl}_{2} .2 \mathrm{H}_{2} \mathrm{O} \quad(0.5)$ and $\mathrm{NaHPO}_{4} .12 \mathrm{H}_{2} \mathrm{O}(2)$ and sterilized in an autoclave at $121^{\circ} \mathrm{C}$ for 15 minutes (Margesin and Schinner, 2001). Two hundred and fifty milliliters $(250 \mathrm{~mL})$ of the effluents were transferred into different $250 \mathrm{ml}$ conical flasks. The content was covered with a cotton-wool ramped with foil paper to avoid contamination. Five grams $(5 \mathrm{~g})$ of the immobilized bacteria were quickly transferred into each of the effluents in the conical flasks in an inoculating chamber. The same procedures were carried out for the $10 \mathrm{~g}, 15 \mathrm{~g}, 20 \mathrm{~g}$ and 25 $\mathrm{g}$ of the immobilized bacteria in separate $250 \mathrm{~mL}$ effluents in conical flasks and agitated for ten days in a shaker incubator (Gallenkamp-OC4364-L) at a temperature $30^{\circ} \mathrm{C}$ and speed of 60 rpm. The treated effluent samples were taken on the tenth day and analyzed for the parameters $\mathrm{pH}$, SS, TDS, COD, and BOD, (Posttreatment determination) for the different grams of bacteria to evaluate and compare the biodegradation potential. (Baba et al., 2020).

\section{Statistical Analysis}

The data were represented as Mean \pm Standard deviation and analyzed statistically using oneway Analysis of Variance (ANOVA) and Tukey's HSD as Post Hoc Tests with the aid of SPSS 16.0. The correlation coefficient was also used to measure the strength of the relationship between the different masses of the bacteria and the parameters. All $\mathrm{p} \leq 0.05$ were considered as statistically significant.

\section{RESULTS AND DISCUSSION Physico-chemical parameters in the Industrial Effluents before the Biodegradation.}

Results of the Physico-chemical parameters in the industrial effluents before the Biodegradation is shown in table 1 . The mean temperatures $\left({ }^{\circ} \mathrm{C}\right)$ observed in TAN1, TAN2, and TAN3 samples were $28.07 \pm 0.65 ; 27.77 \pm 0.64$ and $26.38 \pm 3.81$ respectively. The order of the mean temperature of the samples from the three industries can be arranged as TAN1 > TAN2>TAN3. The temperature observed at TAN1, TAN2, and TAN3 samples were found below the WHO $\left(35^{\circ} \mathrm{C}\right)$ and NESREA $\left(40^{\circ} \mathrm{C}\right)$ limits. The low values of temperature might be due to the processes used at the time of sampling. High temperature brings down the solubility of gases in water that ultimately expresses as high BOD and COD. Statistical analysis shows that there is no significant difference $(p<0.05)$ between the mean values of temperature among the industries. This might be due to similar tannery activities involved in the tannery industries at the time of sampling. The average values of temperature observed in this present study are less than those observed by Akan et al. (2007), Akan et al. (2009) and Baba et al. (2020).

The mean level of $\mathrm{pH}$ observed in TAN1, TAN2 and TAN3, samples were $7.77 \pm 2.93$; $8.35 \pm 0.28$ and $7.52 \pm 0.76$ respectively. The order of the mean $\mathrm{pH}$ of the samples from the three industries can be arranged as TAN2> TAN1 $>$ TAN3. The $\mathrm{pH}$ of the samples falls within the WHO (7.0-8.5) and NESREA (6-9) standard limits. Statistical analysis shows that there is no significant difference $(p<0.05)$ between the mean values of $\mathrm{pH}$ among the industries. This might be due to similar tannery activities involved in the tannery industries at the time of sampling. Maheshwari et al. (2017) reported that the level of $\mathrm{pH}$ in the effluents from the tannery industry in Vaniyambadi, India was 6.5 which was lower than that observed in the present study. The $\mathrm{pH}$ in the effluents from the tannery industries in Kano and Kaduna were reported to be 7.64 and 6.89, respectively (Akan et al., 2007; Mohammed et al., 2017). The average values of $\mathrm{pH}$ observed in this present study are less than those observed by Mohammed et al. (2017) and Baba et al. (2020). The mean level of SS $(\mathrm{mg} / \mathrm{l})$ observed in TAN1, TAN2, and TAN3 samples were 374 \pm 124 ; $358 \pm 335$ and $780 \pm 739$ respectively. The order of the mean SS in the samples from the three industries can be arranged as TAN3 > TAN1 $>$ TAN2. 
The SS observed in the samples were far above the recommended standard limits of regulating bodies WHO $(30 \mathrm{mg} / \mathrm{l})$ and NESREA $(10 \mathrm{mg} / \mathrm{l})$. Statistical analysis shows that there is no significant difference $(p<0.05)$ between the mean values of SS among the industries. This might be due to similar tannery activities involved in the tannery industries at the time of sampling. The average values of SS observed in this present study are less than that observed $(3700 \pm 122 \mathrm{mg} / \mathrm{l})$ by Akan et al. (2009) for tanneries in Kano. Also, the average values of SS observed in this present study are less than that observed by Mohammed et al. (2017) and Baba et al. (2020) with the exception in TAN3.

The mean level of TDS (mg/l) observed in TAN1, TAN2, and TAN3 samples were $3941 \pm 3703$; $3300 \pm 1714$ and $2653 \pm 1240$ respectively. The order of the mean TDS in the samples from the three industries can be arranged as TAN1>TAN2>TAN3. The TDS observed in the samples were far above the recommended standard limits of WHO $(250 \mathrm{mg} / \mathrm{l})$ and NESREA $(500 \mathrm{mg} / \mathrm{l})$. Statistical analysis shows that there is no significant difference $(p<0.05)$ between the mean values of TDS among the industries. This might be due to similar tannery activities involved in the tannery industries at the time of sampling. TDS in the effluents from the tannery industries in Kano, Nigeria was reported to be $1281 \mathrm{mg} / \mathrm{l}$ (Akan et al., 2007). The average values of SS observed in this present study are less than those observed by Mohammed et al. (2017) and Baba et al. 2020)

The mean level of COD (mg/l) observed in TAN1, TAN2 and TAN3 samples seasons were $2372 \pm 938 ; \quad 1406 \pm 208$ and $3532 \pm 1373$ respectively. The order of the mean COD of the samples from the three industries can be arranged as TAN3>TAN1> TAN2. The COD observed in TAN1, TAN2 and TAN3 samples were far above the recommended standard limits of regulating bodies $\mathrm{WHO}(40 \mathrm{mg} / \mathrm{l})$ and NESREA (40 mg/l). Statistical analysis shows that there is no significant difference $(p<0.05)$ in COD among the industries. This might be due to similar tannery activities involved in the tannery industries as at the time of sampling. The Chemical Oxygen demand (COD) is the amount of oxygen, in $\mathrm{mg} / \mathrm{L}$, required for the degradation of the compound of wastewater to occur. In comparison, the average values of COD observed in this present study were higher than that observed by Mohammed et al. (2017) but lower than that observed by Baba et al. (2020).

The mean levels of BOD $(\mathrm{mg} / \mathrm{l})$ observed in TAN1, TAN2 and TAN3 samples were $13.85 \pm 6.42 ; \quad 19.46 \pm 0.50$ and $17.13 \pm 3.14$ respectively. The order of the mean BOD in the samples from the three industries can be arranged as TAN2>TAN3>TAN1. The BOD observed in TAN1, TAN2 and TAN3 samples were found below the recommended limits of NESREA (200 mg/l) but above WHO (10 mg/l). Statistical analysis shows that there is no significant difference $(p<0.05)$ between the mean values of BOD among the industries. This might be due to similar tannery activities involved in the tannery industries at the time of sampling. The low level of BOD recorded in this study is an indication of the low level of biodegradable organic solids in the effluent. The average values of BOD observed in this present study were lower than those observed by Mohammed et al. (2017) and Baba et al. (2020).

Table 1: Mean Values \pm S.D of Physico-chemical parameters of effluents from the Tannery Industries before Treatment.

\begin{tabular}{llllllll}
\hline Parameter & Tannery 1 & Tannery 2 & Tannery 3 & $\mathrm{a}$ & $\mathrm{b}$ & $\mathrm{c}$ & $\mathrm{d}$ \\
\cline { 2 - 7 } Temperature $\left({ }^{\circ} \mathrm{C}\right)$ & $28.07 \mathrm{a} \pm 0.65$ & $27.77 \mathrm{a} \pm 0.64$ & $26.38 \mathrm{a} \pm 3.81$ & & $29.50 \pm 4.68$ & 35 & 40 \\
pH & $7.77 \mathrm{a} \pm 2.93$ & $8.35 \mathrm{a} \pm 0.28$ & $7.52 \mathrm{a} \pm 0.76$ & 6.89 & $5.35 \pm 1.57$ & $7.0-8.5$ & $6.0-9.0$ \\
$\mathrm{COD}(\mathrm{mg} / \mathrm{l})$ & $2372 \mathrm{a} \pm 938$ & $1406 \mathrm{a} \pm 208$ & $3532 \mathrm{a} \pm 1373$ & 2.2 & $3106 \pm 2753$ & 40 & 40 \\
$\mathrm{BOD}(\mathrm{mg} / \mathrm{l})$ & $13.85 \mathrm{a} \pm 6.42$ & $19.46 \mathrm{a} \pm 0.50$ & $17.13 \mathrm{a} \pm 3.14$ & 1032 & $26.17 \pm 9.49$ & 10 & 200 \\
$\mathrm{SS}(\mathrm{mg} / \mathrm{l})$ & $374 \mathrm{a} \pm 124$ & $358 \mathrm{a} \pm 335$ & $780 \mathrm{a} \pm 739$ & 501 & $562 \pm 482$ & 30 & 10 \\
TDS $(\mathrm{mg} / \mathrm{l})$ & $3941 \mathrm{a} \pm 3703$ & $3300 \mathrm{a} \pm 1714$ & $2653 \mathrm{a} \pm 1240$ & 532.7 & $444 \pm 507$ & 250 & 500 \\
\hline
\end{tabular}

The values given in the table above are means of 6 replicate values, $\mathrm{n}=6$ ( 1 sample was taken monthly for 6 months). Within the rows, means with different alphabets are statistically different $(p<0.05)$. WHO: World Health Organisation. NESREA: National Environmental Standard and Regulatory Enforcement Agency. a = Mohammed et al.(2017), b = Baba et al. (2020), c = WHO (2006), $d=$ NESSRA (2009) 
BAJOPAS Volume 13 Number 2, December, 2020

Identification, Biochemical Characterization and growth rates of the Bacterial Isolates

Results of identification and biochemical characterization of the bacterial isolates were shown in table 2. After 24 hours of incubation, the nutrient agar media plates were checked for bacterial growth. The results showed the presence of different strains in the samples. The TAN1 bacteria isolate was found to be gramnegative cocci while TAN3 was gram-positive cocci. TAN2 bacteria isolate was found to be gram-positive, rod-shaped. TAN1, TAN2, and TAN3 bacteria isolates recorded positive results for spore former.

The results of the biochemical tests indicated that all the bacteria were positive for catalase, oxidase, citrate, maltose, glucose, lactose (negative in TAN1), mannitol (negative in TAN2), starch hydrolysis and coagulase (negative in TAN2) tests. The bacteria showed negative results for nitrate reduction, $M R$ (positive in TAN2), VP (positive in TAN1), Indole (positive in TAN2) tests. Base on the morphological and biochemical test results, TAN1, TAN2, and TAN3 bacteria isolates were identified to be Nesseria spp, Bacillus cereus, and Staphylococcus aureus respectively.

The growth rate of the TAN1, TAN2 and TAN3 Isolates were shown in figure 2. Generally, the optical density increase with the increase in time (day) and decrease as time goes on. The highest optical density was shown by bacillus cereus in TAN2 while the lowest was shown by Staphylococcus aureus in TAN3.

The initial growth phase of TAN1 Isolate bacteria occurred within 2-day of incubation as the growth rate increases up to the 6th-day incubation when the maximum growth was observed. Beyond the 6th day, the growth of the bacteria declined (which might be due to a shortage of nutrients in the effluents) until it reached its death phase (which might be due to the unavailability of nutrients in the effluents).

A similar trend of growth was also observed for TAN2 Isolate as the initial growth phase also occurred within 2-day of incubation but maximum growth rate observed on the 4th day of incubation. The stationary stage occurred between the 4th day and the 8th day. Beyond the 8th day, the growth of the bacteria declined (which might be due to a shortage of nutrients in the effluents) until it reached its death phase (which might be due to the unavailability of nutrients in the effluents).

The initial growth phase of TAN3 bacterial Isolate occurred within the 3-day incubation as the growth rate increases up to the 6th-day incubation when the maximum growth was observed. Beyond the 6th day, the growth of the bacteria declined (which might be due to a shortage of nutrients in the effluents) until it reached its death phase (which might be due to the unavailability of nutrients in the effluents).

Table 2: Morphological and Biochemical characteristics of bacterial isolates

\begin{tabular}{lllll} 
Bacterial Isolates & & TAN1 & TAN2 & TAN3 \\
\hline $\begin{array}{lllll}\text { Morphological } \\
\text { characteristics }\end{array}$ & Shape & Cocci & Rod & Cocci \\
& Spore & & & \\
& former & + & + & + \\
Gram & & & \\
Biochemical characteristics & reaction & - & + & + \\
& Citrate & + & + & + \\
& Catalase & + & + & + \\
& Coagulase & + & - & + \\
Starch & + & + & + \\
& Glucose & + & + & + \\
Oxidase & + & + & + \\
& Indo & - & + & - \\
Lactose & - & + & + \\
Manitol & + & - & + \\
Maltose & + & + & + \\
MR & - & + & - \\
VP & + & - & - \\
& Nitrate & - & - & - \\
Reduction & - Neisseria & Bacillus & Staphylococcus \\
& Bacterial & cereus & aureus \\
& name & spp & cas
\end{tabular}

+ = Positive; - = Negative; MR=Methyl Red; VP= Voges-Proskauer 


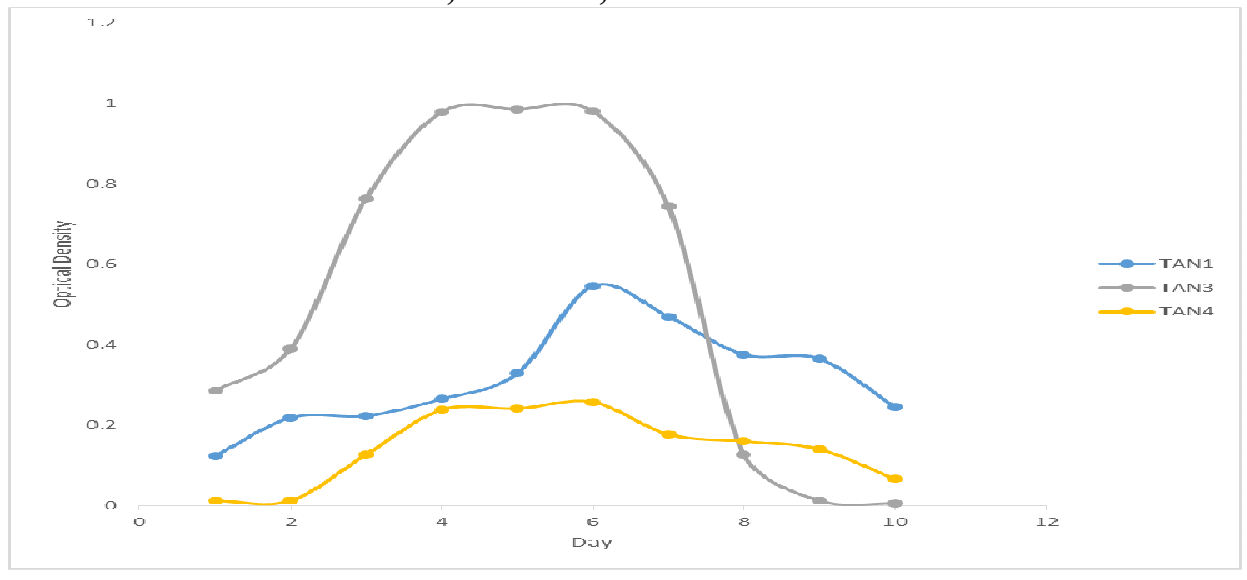

Fig. 2 Growth rates of the isolates in the effluents from the Tannery Industries

\section{Physico-chemical Parameters in the Industrial Effluents after the biodegradation.}

Table 3 shows the mean results of the physicochemical parameter before and after bioremediation using the different masses $(5 \mathrm{~g}$, $10 \mathrm{~g}, 15 \mathrm{~g}, 20 \mathrm{~g}$, and $25 \mathrm{~g}$ ) of the respective immobilized bacteria. Also, Table 4 shows the mean results of correlation coefficient ( $r$ ) between different masses of bacteria and physicochemical parameters.

The mean values $(\mathrm{mg} / \mathrm{l})$ of the SS after the bioremediation varies between $243 \pm 45$ and $898 \pm 672$. The mean concentration $(\mathrm{mg} / \mathrm{l})$ of SS remediated by the different masses $(5 \mathrm{~g}, 10 \mathrm{~g}$, $15 \mathrm{~g}, 20 \mathrm{~g}$, and $25 \mathrm{~g}$ ) of the bacteria varies. The SS in the samples fluctuates up and down after the bioremediation process when compared with the SS of the raw samples before the bioremediation. The increase in the levels of the SS might be due to the aggregation of the TDS which are large enough to result into SS. The increase in the levels of the SS might be also due to the influence of the nutrients which was added into the effluents in order to make the microorganisms more active and viable for fast degradation of organic contaminants in the effluent. The relative potential or efficiency of the different masses of the bacteria in remediating SS in TAN1 samples was in the order $25 \mathrm{~g}>20 \mathrm{~g}>15 \mathrm{~g}>10 \mathrm{~g}>5 \mathrm{~g}$. For TAN2 and TAN3 samples, the order was $25 \mathrm{~g}>20 \mathrm{~g}>15$ $\mathrm{g}>10 \mathrm{~g}>5 \mathrm{~g}$. These might be due to the variations in the surface areas of the different masses of the immobilized bacteria. Statistical analysis shows that there is no significant difference $(p<0.05)$ between the mean values of SS among the masses in the respective industries. Positive and significant correlations exist between the masses of bacteria and Suspended Solid (SS). This showed that there is general increase in the levels of the SS as the masses of the immobilized bacteria increases. TAN3 (90\%) and TAN1 (80\%) showed a very high correlation with the masses of the bacteria while TAN2 (61\%) showed a very low correlation.

The mean values $(\mathrm{mg} / \mathrm{l})$ of the TDS after the bioremediation varies between $46 \pm 11$ and $83 \pm 78$. The mean concentration $(\mathrm{mg} / \mathrm{l})$ of TDS remediated by the different masses $(5 \mathrm{~g}, 10 \mathrm{~g}$, $15 \mathrm{~g}, 20 \mathrm{~g}$, and $25 \mathrm{~g}$ ) of the bacteria varies. There is a reduction in all the TDS of all the samples after the bioremediation process compared with the TDS of the raw samples before the bioremediation. The relative potential or efficiency of the different masses of the bacteria in remediating TDS in TAN1 and TAN3 samples was in the order $5 \mathrm{~g}>10 \mathrm{~g}>15 \mathrm{~g}>20$ $\mathrm{g}>25 \mathrm{~g}$. For TAN2 samples, the order was 20 $g>10 \quad g>25 \quad g>15 \quad g>5 \quad g$. Statistical analysis shows that there is no significant difference $(p<0.05)$ between the mean values of TDS among the masses in the respective industries. These might be due to the variations in the surface areas of the different masses of the immobilized bacteria. Positive and significant correlations exist between the masses of bacteria and TDS with the exception in TAN2 (negative and insignificant correlation). The positive correlations showed that there is general increase in the levels of the TDS as the masses of the immobilized bacteria increases. TAN1 $(96 \%)$ showed a very high correlation with the masses of the bacteria while TAN2 (47\%) showed a very low correlation.

The mean values $(\mathrm{mg} / \mathrm{l})$ of the BOD after the bioremediation varies between $1.56 \pm 0.20 \mathrm{mg} / \mathrm{l}$ and $6.92 \pm 5.49 \mathrm{mg} / \mathrm{l}$. The mean concentration $(\mathrm{mg} / \mathrm{l})$ of BOD remediated by the different masses $(5 \mathrm{~g}, 10 \mathrm{~g}, 15 \mathrm{~g}, 20 \mathrm{~g}$, and $25 \mathrm{~g}$ ) of the bacteria varies. There is a reduction in all the BOD of all the samples after the bioremediation process compared with the $\mathrm{BOD}$ of the raw 
BAJOPAS Volume 13 Number 2, December, 2020 samples before the bioremediation. The relative potential or efficiency of the different masses of the bacteria in remediating BOD in TAN1, TAN2 and TAN3 samples were in the order $25 \mathrm{~g}>20$ $\mathrm{g}>15 \mathrm{~g}>10 \mathrm{~g}>5 \mathrm{~g}, 25 \mathrm{~g}>15 \mathrm{~g}>5 \mathrm{~g}>10 \mathrm{~g}>20 \mathrm{~g}$ and $20 \mathrm{~g}>10 \mathrm{~g}>25 \mathrm{~g}>15 \mathrm{~g}>5 \mathrm{~g}$ respectively. Statistical analysis shows that there is significant difference $(p<0.05)$ between the mean values of BOD among the masses in the respective industries. These might be due to the variations in the surface areas of the different masses of the immobilized bacteria. Negative and significant correlations exist between the masses of bacteria and BOD. This showed that there is general decrease in the levels of the BOD as the masses of the immobilized bacteria increases. TAN1 (94\%) showed a very high correlation with the masses of the bacteria while TAN2 (4\%) showed a very low correlation.

The mean values $(\mathrm{mg} / \mathrm{l})$ of the COD after the bioremediation varies between $250 \pm 154$ and $3134 \pm 1595$. The mean concentration $(\mathrm{mg} / \mathrm{l})$ of COD remediated by the different masses $(5 \mathrm{~g}$, $10 \mathrm{~g}, 15 \mathrm{~g} 20 \mathrm{~g}$, and $25 \mathrm{~g}$ ) of the bacteria varies. There is a reduction in all the COD of all the samples after the bioremediation process compared with the COD of the raw samples before the bioremediation. The relative potential or efficiency of the different masses of the bacteria in remediating COD in TAN1, TAN2 and TAN3 samples were in the order $25 \mathrm{~g}>20 \mathrm{~g}>15$ $\mathrm{g}>5 \mathrm{~g}>10 \mathrm{~g}, 25 \mathrm{~g}>20 \mathrm{~g}>15 \mathrm{~g}>10 \mathrm{~g}>5 \mathrm{~g}$ and 10 g>5 g>25 g>15 g>20 g respectively. Statistical analysis shows that there were significant difference $(p<0.05)$ between the mean values of COD among the masses in the respective industries except for effluents treated with $25 \mathrm{~g}$. These might be due to the variations in the surface areas of the different masses of the immobilized bacteria. Negative and insignificant correlations exist between the masses of bacteria and COD with the exception in TAN3 (positive and significant correlation). The negative correlations showed that there is general decrease in the levels of the COD as the masses of the immobilized bacteria increases. TAN2 (100\%) showed a very high correlation with the masses of the bacteria while TAN3 (36\%) showed a very low correlation.

Generally, there was an overall decrease in the concentration of these physicochemical parameters after the bioremediation using the different masses of the bacterial isolates. These might be due to the variations in the surface areas of the different masses of the immobilized bacteria. This is in line with the work of Jimoh et al. (2018) and Baba et al. (2020).

Table 3: Mean Values $(\mathrm{mg} / \mathrm{l}) \pm$ S.D of Physicochemical parameters in effluents from the Tannery Industries before and after Treatment of the effluents $(250 \mathrm{ml})$ with the different masses $(5 \mathrm{~g}, 10 \mathrm{~g}$, $15 \mathrm{~g}, 20 \mathrm{~g}$, and $25 \mathrm{~g}$ ) of the bacteria.

\begin{tabular}{llllllll}
\hline $\mathrm{P}$ & IND & Before & \multicolumn{5}{c}{ After } \\
\cline { 4 - 7 } & & & $5 \mathrm{~g}$ & $10 \mathrm{~g}$ & $15 \mathrm{~g}$ & $20 \mathrm{~g}$ & $25 \mathrm{~g}$ \\
\hline \multirow{2}{*}{ COD } & TAN1 & $2372 \pm 938$ & $1708 \mathrm{a} \pm 861$ & $2045 \mathrm{a} \pm 1205$ & $845 \mathrm{a} \pm 369$ & $300 \mathrm{a} \pm 167$ & $250 \mathrm{a} \pm 154$ \\
& TAN2 & $1406 \pm 208$ & $1195 \mathrm{a} \pm 208$ & $1125 \mathrm{a} \pm 384$ & $1055 \mathrm{a} \pm 317$ & $956 \mathrm{a} \pm 310$ & $870 \mathrm{ab} \pm 240$ \\
& TAN3 & $3532 \pm 1373$ & $2374 \mathrm{a} \pm 1344$ & $1976 \mathrm{a} \pm 1405$ & $2757 \mathrm{a} \pm 1266$ & $3134 \mathrm{a} \pm 1595$ & $2614 \mathrm{~b} \pm 1105$ \\
BOD & TAN1 & $13.85 \pm 6.42$ & $6.92 \mathrm{a} \pm 5.49$ & $6.42 \mathrm{a} \pm 5.07$ & $5.72 \mathrm{a} \pm 5.35$ & $4.62 \mathrm{a} \pm 4.37$ & $2.82 \mathrm{ab} \pm 1.26$ \\
& TAN2 & $19.46 \pm 0.50$ & $1.75 \mathrm{~b} \pm 0.22$ & $1.73 \mathrm{~b} \pm 0.18$ & $1.58 \mathrm{a} \pm 0.16$ & $1.91 \mathrm{a} \pm 0.22$ & $1.56 \mathrm{~b} \pm 0.20$ \\
& TAN3 & $17.13 \pm 3.14$ & $4.24 \mathrm{ab} \pm 0.77$ & $3.29 \mathrm{ab} \pm 0.37$ & $4.11 \mathrm{a} \pm 0.07$ & $3.23 \mathrm{a} \pm 0.91$ & $3.33 \mathrm{a} \pm 1.28$ \\
SS & TAN1 & $374 \pm 124$ & $243 \mathrm{a} \pm 45$ & $471 \mathrm{a} \pm 226$ & $475 \mathrm{a} \pm 182$ & $492 \mathrm{a} \pm 128$ & $611 \mathrm{a} \pm 217$ \\
& TAN2 & $358 \pm 335$ & $460 \mathrm{a} \pm 400$ & $543 \mathrm{a} \pm 414$ & $544 \mathrm{a} \pm 402$ & $551 \mathrm{a} \pm 414$ & $554 \mathrm{a} \pm 405$ \\
& TAN3 & $780 \pm 739$ & $586 \mathrm{a} \pm 594$ & $758 \mathrm{a} \pm 656$ & $787 \mathrm{a} \pm 676$ & $861 \mathrm{a} \pm 635$ & $898 \mathrm{a} \pm 672$ \\
TDS & TAN1 & $3941 \pm 3703$ & $51 \mathrm{a} \pm 10$ & $53 \mathrm{a} \pm 10$ & $55 \mathrm{a} \pm 15$ & $61 \mathrm{a} \pm 20$ & $63 \mathrm{a} \pm 26$ \\
& TAN2 & $3300 \pm 1714$ & $83 \mathrm{a} \pm 78$ & $47 \mathrm{a} \pm 20$ & $48 \mathrm{a} \pm 22$ & $47 \mathrm{a} \pm 17$ & $48 \mathrm{a} \pm 17$ \\
& TAN3 & $2653 \pm 1240$ & $46 \mathrm{a} \pm 11$ & $55 \mathrm{a} \pm 24$ & $55 \mathrm{a} \pm 25$ & $58 \mathrm{a} \pm 23$ & $61 \mathrm{a} \pm 28$ \\
\hline
\end{tabular}

Replicate $=6$ (months)

Within the rows, for the same parameter, means with different alphabets are statistically different $(p<0.05)$.

$\mathrm{P}=$ parameter, IND = Industries 
BAJOPAS Volume 13 Number 2, December, 2020

Table 4: Correlation coefficient $(r)$ between different masses of the bacteria and the physicochemical parameters.

\begin{tabular}{llll}
\hline Industries & Parameter & Correlation coefficient $(r)$ & $\begin{array}{l}\text { Percent dependence (rxrx100) } \\
(\%)\end{array}$ \\
\hline TAN1 & COD & -0.9 & 82 \\
& BOD & -0.97 & 94 \\
& SS & $0.90^{*}$ & 80 \\
TAN2 & TDS & $0.98^{*}$ & 96 \\
& COD & -1 & 100 \\
& BOD & -0.21 & 4 \\
& SS & $0.78^{*}$ & 61 \\
& TDS & -0.69 & 47 \\
& COD & $0.60^{*}$ & 36 \\
& BOD & -0.6 & 37 \\
& SS & $0.95^{*}$ & 90 \\
& TDS & $0.94^{*}$ & 89 \\
\hline
\end{tabular}

The correlation coefficient $(r)$ with * is statistically significant $(p<0.05)$.

Percentage reduction of the Parameters

Table 5 shows the percentage reduction of Parameters in industrial samples before and after the treatment of the effluents $(250 \mathrm{ml})$ with the different masses $(5 \mathrm{~g}, 10 \mathrm{~g}, 15 \mathrm{~g}, 20 \mathrm{~g}$, and $25 \mathrm{~g}$ ) of the Immobilized Bacteria.

In TAN1 samples, the percentage reduction (\%) of COD ranged (14-89); BOD (50-80); SS (-32$35)$ and TDS (98-99). In TAN2 samples, the percentage decrease $(\%)$ of COD ranged (15$38) ;$ BOD (90-92); SS [-28-(-55)] and TDS (9798). In TAN3 samples, the percentage decrease (\%) of COD ranged (11-44); BOD (76-81); SS (15-25) and TDS (98). The percentage increase in the levels COD, BOD and TDS might be due to the increase in the surface area of the different masses of the immobilized bacteria. However, the percentage decrease in the levels of the SS might be due to the aggregation of the TDS which are large enough to result into SS. The percentage decrease in the levels of the SS might be also due to the influence of the nutrients which was added into the effluents in order to make the microorganisms more active and viable for fast degradation of organic contaminants in the effluent. This is in line with the work of Jimoh et al. (2018) in which the concentration of the SS increase after the bioremediation of effluents.

Sreemoyee and Priti (2013) assessed and reduced several Physico-chemical parameters of dairy wastewater using Niesseria $s p$. and concluded that the species are well known to degrade organic compounds. This is in agreement with the current study in which the immobilized Niesseria $s p$ degrade the organic contaminants as indicated by the BOD, COD and TDS.

Jimoh et al. (2018) observed that TSS of the effluents was increased after treatment with immobilized bacteria and concluded that it might be due to the biostimulation method adopted for the research.

The optimum $\mathrm{pH}$ Biosorption of Chromium by Bacillus spp and Staphylococcus spp. from tannery effluent was investigated by Mythili and Karthikeyan (2011). The maximum adsorption of Chromium $(86.4 \mathrm{mg} / \mathrm{L})$ was showed by Bacillus spp and Staphylococcus spp showed $70.6 \mathrm{mg} / \mathrm{L}$ at an initial concentration of $100 \mathrm{mg} / \mathrm{L}$. In the present study, immobilised Bacillus spp and Staphylococcus spp. from the tannery industrial effluents reduced the levels of the organic pollutants with high potential as indicated by the percentage reduction of BOD, COD and TDS.

Enzymes often can work in multiple environments especially if they are immobilized. This makes the microorganisms' enzymes even more resistant to harsh environments and enables the enzymes to be recovered and recycled after they are no longer needed (Gianfreda and Rao 2004). Ramesh and Singh (1993) reported that the immobilized bacteria having more efficiency to remove the suspended particles than free cells. Using the immobilized cell is preferable due to its capability for using several times with the same efficiency, which makes it more economical. Similar work was done by Sikander et al. (2007) showing the higher reduction with permeabilized cells of Ochrobactrum intermedium strain SDCr-5. 
BAJOPAS Volume 13 Number 2, December, 2020

The results revealed the isolation and identification of isolates with the potential for the reduction of $\mathrm{Cr}$ (VI) to $\mathrm{Cr}$ (III). Results indicated that immobilized $B$. cereus could be efficiently used for the reduction of $\mathrm{Cr}$ (VI).

Table 5: Percentage reduction of the tested Parameters from the tannery industrial samples of the Immobilized Bacteria.

\begin{tabular}{lllllll}
\hline \multirow{2}{*}{ Industries } & & \multicolumn{5}{c}{ Percentage Reduction $(\%)$} \\
\cline { 3 - 7 } & & $5 \mathrm{~g}$ & $10 \mathrm{~g}$ & $15 \mathrm{~g}$ & $20 \mathrm{~g}$ & $25 \mathrm{~g}$ \\
\hline TAN1 & COD & 28 & 14 & 64 & 87 & 89 \\
& BOD & 50 & 54 & 59 & 67 & 80 \\
& SS & 35 & -26 & -27 & -32 & -63 \\
& TDS & 99 & 99 & 99 & 98 & 98 \\
TAN2 & COD & 15 & 20 & 25 & 32 & 38 \\
& BOD & 91 & 91 & 92 & 90 & 92 \\
& SS & -28 & -52 & -52 & -54 & -55 \\
& TDS & 97 & 99 & 99 & 99 & 99 \\
& COD & 33 & 44 & 22 & 11 & 26 \\
& BOD & 75 & 81 & 76 & 81 & 81 \\
& SS & 25 & 3 & -1 & -10 & -15 \\
& TDS & 98 & 98 & 98 & 98 & 98 \\
\hline
\end{tabular}

Percentage Reduction $=(B-A) / B \times 100 \%$

$A=$ Concentration of the parameter after treatment

$\mathrm{B}=$ Concentration of the parameter before treatment

$+=$ percentage decrease

- = percentage increase

In general, immobilization makes the enzyme more resistant to temperature, $\mathrm{pH}$, and substrate concentration swings giving it a longer lifetime and higher productivity per active unit (Gianfreda and Rao, 2004; FuIlbrook, 1996; Russell et al, 2003; Kandelbauer et al., 2004). Immobilized cells have been used and studied extensively for the production of useful chemicals (Ohtake and Silver, 1994), the treatment of wastewaters (Chen et al., 2003; Wang et al., 2010). Although many workers described microbial degradation of tannery effluent, limited literature is available on the bioremediation of tannery effluent using immobilized bacterial cells in the Kano Industrial Estates.

\section{CONCLUSION}

The samples contained variable levels of the physicochemical parameters. The results of the Analysis of variance revealed that, no statistical difference $(p<0.05)$ was observed for the temperature, $\mathrm{pH}, \mathrm{SS}, \mathrm{TDS}, \mathrm{BOD}$ and $\mathrm{COD}$ among the three tannery industries before the treatment. The levels of some of the parameters
(SS, TDS and COD) observed in the samples were found above the recommended limits of WHO and NESREA, which called for the treatment of the effluents before discharge into the environment. Base on the morphological and biochemical test results, TAN1, TAN2, and TAN3 bacterial isolates were identified to be Neisseria spp, Bacillus cereus, and Staphylococcus aureus respectively. The results of Post-treatment analysis showed that there is overall decrease in the levels of the parameters determined when compared with that of the pre-treatment. The overall percentage reduction of the immobilised bacteria in the treatment of the respective effluents was in the order TAN2 (72\%)>TAN1 $(70 \%)>$ TAN3 $(62 \%)$. Hence, the immobilized bacteria are having higher biodegradation potential for the treatment of the tannery effluents.

\section{Acknowledgments}

The authors wish to acknowledge the University of Maiduguri for the financial support. The authors are grateful to the Kano State Ministry of Environment for their support in obtaining the effluent samples. 


\section{REFERENCES}

Ajao, A. T., Adebayo, G. B., and Yakubu, S. E. (2011). Bioremediation of textile industrial effluent using mixed culture of Pseudomonas aeruginosa and Bacillus subtilis immobilized on agar-agar in a bioreactor. J. Microbiol. Biotech. Res, 1(3), 50-56.

Akan, J. C., Moses, E. A., Ogugbuaja, V. O., and Abah, J. (2007). Assessment of tannery industrial effluents from Kano metropolis, Kano State, Nigeria. Journal of Applied Sciences, 7(19), 2788-2793.

Akan, J. C., Ogugbuaja, V. O., Abdulrahman, F. I., and Ayodele, J. T. (2009). Pollutant levels in effluent samples from tanneries and textiles of Kano industrial areas, Nigeria. Global journal of pure and applied sciences, 15(3-4).

APHA (1989). Standard methods for Examination of Will bete and Will betewater.15 $5^{\text {th }}$ edition. Brydpass Springfield Will behington DC. pp. 164-176

APHA (1992). Standard Methods for the Examination of Water and Wastewater. Health, 69, 1116-9.

Baba, A., Garba, S. T., and Bello, H. S. (2020). Bioremediation Potential of Immobilized corynebacterium kutsceri in the Treatment of Tannery Industrial Effluent from Challawa Industrial Estate, Kano State, Nigeria. Journal of the Turkish Chemical Society Section A: Chemistry, $7(2), 335-350$.

Beem, E. I. V. (1994). reduction of solvent VOC emission. J. Oil Col. Chem. Ass, 77, 158.

Bouwer, E. J., and Zehnder, A. J. (1993). Bioremediation of organic compoundsputting microbial metabolism to work. Trends in biotechnology, 11(8), 360367.

Chen, K. C., Wu, J. Y., Liou, D. J., and Hwang, S. C. J. (2003). Decolorization of the textile dyes by newly isolated bacterial strains. Journal of Biotechnology, 101(1), 57-68.

Dan'Azumi, S., and Bichi, M. H. (2010). INDUSTRIAL POLLUTION AND HEAVY METALS PROFILE OF CHALLAWA RIVER IN KANO, NIGERIA. Journal of Applied Sciences in Environmental Sanitation, $5(1)$.

DWAF. (1992). Analytical Methods Manual, TR 151. Department of Water Affairs and Forestry, Pretoria.

El-Bestawy, E. (2013). Biological treatment of leather-tanning industrial wastewater using free living bacteria.
Elsheikh, M. A. S. (2009). Tannery wastewater pre-treatment. Water Science and Technology, 60(2), 433-440.

FuIlbrook, P. D. (1996). "Kinetics." Industrial enzymology: The application of enzymes in Industry. 2nd Ed. T. Godfrey and J Reichelt. eds.. Nature. New York.

Gianfreda, L., and Rao, M. A. (2004). Potential of extra cellular enzymes in remediation of polluted soils: a review. Enzyme and microbial technology, 35(4), 339354.

Hugo Springer. (1994). John Arthur Wilson Memorial Lecture "Treatment of Industrial Wastes of the Leather Industry - is it still a Major Problem". JALCA, 89, 153-185

Jimoh, A. A., Ganiyu, B. A., Baba, D., and Baba, A. (2018) Bioremediation Process of Effluent from Detergent and Food Industries in Jos, Nigeria: Kinetics and Thermodynamics. International Journal of Engineering Science Invention (IJESI), 762-73

Kandelbauer, A., Maute, O., Kessler, R. W., Erlacher, A., and Gübitz, G. M. (2004). Study of dye decolorization in an immobilized laccase enzyme-reactor using online spectroscopy. Biotechnology and bioengineering, 87(4), 552-563.

Kongjao, S., Damronglerd, S., and Hunsom, M. (2008). Simultaneous removal of organic and inorganic Pollutants in tannery wastewater using electrocoagulation technique. Korean Journal of chemical engineering, 25(4), 703.

Maheshwari, U. M., Aruna, S., Gomathi, M., and AbdulJaffar, A. H. (2017). Bioremediation by Free and Immobilized Bacteria Isolated from Tannery Effluent. International Journal of Research in Applied, Natural and Social Sciences. 5(7), 75-90

Margesin, R., and Schinner, F. (2001). Bioremediation (natural attenuation and biostimulation) of diesel-oilcontaminated soil in an alpine glacier skiing area. Applied and environmental microbiology, 677), 3127-3133.

Mohammed, A., Sekar, P., and George, J. (2011). Efficacy of microbes in bioremediation of tannery effluent. Inter. J. Curr. Res, 3(4), 324-326.

Mohammed, S. S. D., Orukotan, A. A., and Abdullahi, H. (2017). Physicochemical and Bacteriological Assessment of Tannery Effluent from Samaru-Zaria, 
BAJOPAS Volume 13 Number 2, December, 2020 Kaduna State, Nigeria. Journal of Applied

Sciences and Environmental Management, 21(4), 734-740.

Munz, G., De Angelis, D., Gori, R., Mori, G., Casarci, M., and Lubello, C. (2009). The role of tannins in conventional and membrane treatment of tannery wastewater. Journal of hazardous materials, 164(2-3), 733-739

Mythili, K., and Karthikeyan, B. (2011). Bioremediation of $\mathrm{Cr}$ (VI) from tannery effluent using Bacillus spp and Staphylococcus spp. International Multidisciplinary Research Journal, 1(6).

NESREA (2009). National Environmental Standards for Effluent Limitations and Regulation. 1233-1236

Noorjahan, C. M. (2014). Physicochemical characteristics, identification of bacteria and biodegradation of industrial effluent. Journal of bioremediation and Biodegradation, 5(3).

Ohtake, H. I., and Silver, A. O. (1994). Bacterial reduction of toxic chromate. Biological degradation and bioremediation of toxic chemicals, 403-415.

Omoleke, I. I. (2004). Management of environmental pollution in Ibadan, an African city: the challenges of health hazard facing government and the people. Journal of Human Ecology, 15(4), 265-275.

Rajor, A., Reddy, A.S., and Singh, B. (2004). Determination of BOD kinetic Parameters and evaluation of alternate methods, M.Sc. Thesis, Department of biotechnology \& environmental Science, Thapar Institute of Engineering and Technology, Patiala

Ramasami, T., Rajamani, S., and Rao, J. R. (1994, March). Pollution control in leather industry: Emerging technological options. In International symposium on surface and colloidal science and its relevance to soil pollution, madras.

Ramesh, J. V. S., and Singh, S. P. (1993). Yearly variation in certain physicochemical parameters of pond at eastern Doon Valley. Uttar Pradesh J. Zoo, 12 (1), 7577.

Ranen, S., and Sharadinadra, C. (2009). Biotechnology applications to environmental remediation in resource exploitation. Current science, 97, 6-25
Russell, A. J., Berberich, J. A., Drevon, G. F., and Koepsel, R. R. (2003). Biomaterials for mediation of

chemical and biological warfare agents. Annual review of biomedical engineering, 5(1), 1-27.

Saravanan, P., and Saravanan, A. (1999). Decolourization of tannery effluent by Flavobacterium sp. EK 1. Indian Journal of Environmental Protection, 19, 19-24.

Sikander, S., and Shahida, H. (2007). Reduction of toxic hexavalent chromium by Ochrobactrum intermedium strain SDCr5 stimulated by heavy metals. Bioresource Technol, 98, 340-344.

Singh, N., Sharma, B. K., and Bohra, P. C. (2000). Impact assessment of industrial effluent of arid soils by using satellite imageries. Journal of the Indian Society of Remote Sensing, 28(2-3), 79.

Sreemoyee, C., and Priti, P. (2013). Assessment of physico-chemical parameters of dairy waste water and isolation and characterization of bacterial strains in terms of cod reduction. Int J Sci, 2(3), 395-400.

Verheijen, L. A. H. M., Wiersema, D., Pol, L. H., and De Wit, J. (1996). Management of wastes from animal product processing. Livestock and environment, Finding a balance. International Agriculture Center, Wageningen, The Netherlands.

Wang, F., Yao, J., Si, Y., Chen, H., Russel, M., Chen, K., and Bramanti, E. (2010). Short-time effect of heavy metals upon microbial community activity. Journal of Hazardous Materials, 173(13), 510-516.

WHO (World Health Organization). (2006). Air quality guidelines: global update 2005: particulate matter, ozone, nitrogen dioxide, and sulfur dioxide. World Health Organization.

World Bank. (1995). Nigeria's strategic options for redressing industrial pollution. World Bank, industry and energy division. 1st edition, West Central Africa Department; Annexes: 1995; pp 60-62.

Zahoor, A., and Abdul, R. (2009). Enumeration of Coliforms. Journal of Environmental Sciences. 21, 814-820 


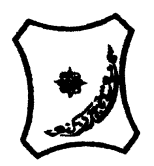

Bayero Journal of Pure and Applied Sciences, 13(2): 1 - 12

Received: November, 2020

Accepted: December, 2020

ISSN $2006-6996$

\title{
BIODEGRADATION POTENTIAL OF IMMOBILIZED BACTERIA IN THE TREATMENT OF TANNERY INDUSTRIAL EFFLUENTS FROM INDUSTRIAL ESTATES IN KANO STATE, NIGERIA
}

\author{
Abdullateef, B., ${ }^{1 *}$ Shuaibu, T. G., ${ }^{1}$ Babagana, K., ${ }^{1}$ Suleman, H. B. ${ }^{2}$ and Dauda, B. ${ }^{3}$ \\ ${ }^{1}$ Department of Pure and Applied Chemistry, Faculty of Science, University of Maiduguri, Borno State, \\ Nigeria \\ ${ }^{2}$ Department of Microbiology, Faculty of Science, University of Maiduguri, Borno State, Nigeria \\ ${ }^{3}$ Department of Chemical Engineering, Faculty of Engineering, University of Maiduguri, Borno State, \\ Nigeria \\ *Corresponding author: babslega@gmail.com; abelega2007@yahoo.com; +2348061309753
}

\section{ABSTRACT}

Industrial Effluents Samples from Gashash Tanneries (TAN1) in Bompai Industrial estate, Larabee Tannery Industry (TAN2) in Sharada Industrial estate and Z Tannery Industries (TAN3) in Challawa Industrial estate, Kano State, Nigeria were collected over a period of six months (August 2017 to January 2018) for assessing the biodegradation potentials of bacteria in the treatment of organic pollutants within the effluents. Bacteria were isolated from the effluents and immobilized on agar-agar. Different masses (5 g, $10 \mathrm{gr}, 15$ $\mathrm{g}, 20 \mathrm{~g}$, and $25 \mathrm{~g}$ ) of the bacteria were used in the treatment of $250 \mathrm{ml}$ of the effluents for ten days in a shaker incubator (Gallenkamp-OC-4364-L) at the temperature $30{ }^{\circ} \mathrm{C}$ and speed of $60 \mathrm{rpm}$. Pre-treatment analysis of the effluents for Temperature, pH, Biochemical Oxygen Demand (BOD), Chemical Oxygen Demand (COD), Suspended Solid (SS) and Total Dissolved Solids (TDS) gives the following results; temperature $\left({ }^{\circ} \mathrm{C}\right.$ )

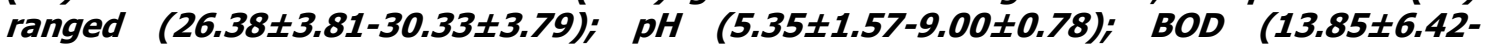
$38.75 \pm 16.20) ;$ COD (1406 $\pm 208-3532 \pm 1373) ;$ SS (208 $\pm 235-780 \pm 739)$ and TDS (266 $\pm 253-5276 \pm 2971)$. No statistical differences ( $p \leq 0.05)$ was observed for all the results among the different industries. The bacterial isolates were identified as Neisseria spp, Bacillus cereus, and Staphylococcus aureus, in TAN1, TAN2, and TAN3, respectively. After treatment of the effluent with the different masses of the isolated bacteria, the mean level of BOD was found to range as (0.55 $\pm 0.36-6.92 \pm 5.49) ; C O D$ (ND-3134 \pm 1595$)$;

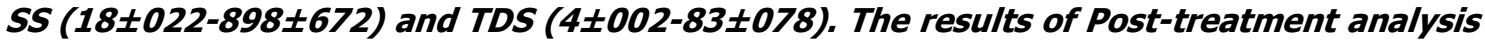
showed that there is overall decrease in the levels of the parameters determined when compared with that of the pre-treatment. The overall percentage reduction of the immobilised bacteria in the treatment of the respective effluents was in the order TAN2 (72\%)>TAN1 (70\%)>TAN3 (62\%). Hence, the immobilized bacteria are having higher biodegradation potential for the treatment of the tannery effluents.

Keywords: Biodegradation, bacteria, effluent, immobilization, tannery.

\section{INTRODUCTION}

Tannery industrial wastewater is a serious consequence of the pollution point of view for streams, freshwater, and land used for agriculture. The lack of awareness in the modern industrial practice has resulted in the discharge of tannery effluents which exhibit very high value of chromium ( $\mathrm{Cr}$ ), Sulfide, and chloride, Total Dissolved Solid (TDS), Total Suspended Solid (TSS), Biochemical Oxygen Demand (BOD) and Chemical Oxygen Demand (COD) in the water stream or land (Mohammed et al., 2001). Tanning is the process, which One ton of skin generally leads to the production of 20 to $80 \mathrm{~m}^{3}$ of turbid and foul-smelling converts the protein of the rawhide or skin into a stable material, which will not putrefy and is suitable for a wide variety of end applications (Elsheikh, 2009). The highly polluting chromium is the most commonly used tanning material producing leather that is more flexible and pliable than vegetable-tanned leather and does not discolor or lose shape in water as drastically as vegetable-tan (Elsheikh, 2009). Tannery effluent is among the most hazardous industrial pollutants due to its huge organic and inorganic load, which is highly toxic to human life and the environment (Kongjao et al., 2008). wastewater including chromium (100-400 mg/l), sulfide $(200-800 \mathrm{mg} / \mathrm{l})$, high levels of fat and 
BAJOPAS Volume 13 Number 2, December, 2020 other solid wastes, and notable pathogen contamination as well as pesticides added for skin conservation during transport (Elsheikh, 2009). There are more than 6000 tanneries in Nigeria with an annual processing capacity of 700,000 tons of hides and skins (Omoleke, 2004; Singh et al., 2008). It was reported that the total amount of waste produced per animal slaughtered is approximately $35 \%$ of its weight (World Bank, 1995). Also, for every $1000 \mathrm{~kg}$ of carcass weight, a slaughtered beef produces 5.5 $\mathrm{kg}$ of manure (excluding rumen contents or stockyard manure) and $100 \mathrm{~kg}$ of paunch manure (undigested food) (Verheijen et al., 1996). Tanneries generate wastewater in the range of 30-35 $\mathrm{L} \mathrm{kg}^{-1}$ skin/hide processed with variable $\mathrm{pH}$, Biological Oxygen Demand (BOD), Chemical Oxygen Demand (COD), high concentrations of suspended solids (SS), and tannins as well as chromium (Zahoor and Abdul, 2009).

Being heterogeneous and composed of a wide variety of compounds, it is very difficult to select a unique direct method for estimating the biodegradability of organic contents and biokinetic parameters for a wastewater sample (Rajor, 2004). For this purpose, some indirect estimation such as determination of biochemical oxygen demand (BOD) and chemical oxygen demand (COD) are applied as common laboratory investigations [9]. During retanning procedures, synthetic tannins (Syntan), oils and resins are added to form softer leather at varying doses (Munz et al., 2009). One of the refractory groups of chemicals in tannery effluents derives mainly from tannins (Ramasami et al., 2004). Syntans are characterized by complex chemical structures, because they are composed of an extended set of chemicals such as phenol-, naphthalene-, formaldehyde- and melamine-based syntans, and acrylic resins (Beem, 1994). Organic pollutants (proteic and lipidic components) are originated from skins (it is calculated that the raw skin has $30 \%$ loss of organic material during the working cycle) or they are introduced during processes (Hugo Springer, 1994).

Many conventional processes such as oxidation, chemical and biological processes were carried out to treat tanneries wastewater (Ebtesam et al, 2013). Biological processes have received more attention because of their costeffectiveness, lower sludge production and environmental friendliness (Noorjahan, 2014). Naturally occurring micro-organisms degrade the hazardous organic wastes including xenobiotic compounds, such as pesticides, polycyclic aromatic hydrocarbons (PAHs) and polychlorinated biphenyls (PCBs) in due course of time (Ranen and Sharadinadra, 2009). Bioremediation is based on the idea that all organisms remove substances from the environment to carry outgrowth and metabolism (Bouwer and Zehnder, 1993). Bacteria, protista and fungi are found to be very good at degrading complex molecules and incorporating the breakdown products into their metabolism (Bouwer and Zehnder, 1993). The resultant metabolic wastes that they produce are generally safe and somehow recycled into other organisms (Ranen and Sharadinadra, 2009). An acclimatized indigenous population of microorganisms capable of degradation of the compounds of interest must exist at the site for a successful bioremediation mode (Ranen and Sharadinadra, 2009). It has been observed that for a successful bioremediation mode, an acclimatized indigenous population of microorganisms capable of degradation of the compounds of interest must exist at the site under investigation (Ranen and Sharadinadra, 2009). Even though there are numerous physical and chemical methods employed in the disposal of wastes the advantage in using bacterium is that they play a key role in the reduction of COD, BOD, total protein, total tannin and total phenol (Saravanan and Saravanan, 1998)

Baba et al. (2020) studied the bioremediation potential of immobilized corynebacterium kutsceri in the Treatment of tannery industrial effluent from Challawa Industrial Estate, Kano State, Nigeria. The aim of the work is to study the reduction in the level of the contaminants through the process of bioremediation using the isolated bacteria. Immobilized bacteria can withstand various temperatures, $\mathrm{pH}$ and substrate concentrations; consequently, increasing the efficiency and the lifespan of the bacteria. Immobilized bacteria are widely applied in the treatment of wastewater and can be separated and recovered after the treatment with the same efficiency (Baba et al., 2020).

\section{MATERIALS AND METHODS \\ Study Area}

This study was carried out in Bompai, Sharada and Challawa industrial estates in Kano, Figure 1. Kano lies on Latitude $11^{\circ} 30^{\prime} \mathrm{N}$ and $8^{\circ} 30^{\prime} \mathrm{E}$ and Longitude $11^{\circ} 5^{\prime} \mathrm{N}$ and $8^{\circ} 5^{\prime} \mathrm{E}$ in Northern Nigeria. It is one of the developed industrial cities in Nigeria. Tannery activities are the dominating industries and this could be one of the reasons for her high population density (Dan'Azumi and Bichi, 2010). Many researchers have studied biodegradation of tannery effluent using microorganisms. However, limited literature is available on the biodegradation of tannery effluent in Kano industrial estates using 
BAJOPAS Volume 13 Number 2, December, 2020 immobilized bacterial cells. This research work focuses on the potential of the use of the indigenous immobilized bacterial isolates in the treatment of tannery effluents in the industrial estates.

\section{Sample Collection}

Effluents were collected from the Tannery Industries from Bompai, Challawa and Sharada Industrial Estates, Kano, Nigeria. The effluents were collected over a period of six months (August 2017 to January 2018). Samples collected in a sterile 4-liter plastic container with a unique identification number were preserved using an ice-box that was transported to the Microbiology Laboratory, Department of Microbiology, Bayero University of Kano for analysis

\section{Sample Preparation and Sample Analysis}

Immediately after the collection of the effluent, $\mathrm{pH}$, TSS, TDS, COD, BOD levels were determined before treatment (Pre-treatment determination) and ten days after treatment (Post-treatment determination) as described in
APHA (1989) standard methods. $\mathrm{pH}$ was determined using Ecotests $\mathrm{pH}$ meter and TDS was determined using AQUALYTIC TDS Salinometer. BOD was determined as described by the standard method (APHA, 1992). COD and SS were determined using DR/2010 HACH portable data logging spectrophotometer (DWAF, 1992)

\section{Identification and Biochemical} Characterization of the Bacterial Isolates

The bacteria were isolated from the effluents using Serial Dilution according to the method described by APHA (1989). The biochemical tests such as oxidase, catalase, coagulase, indole (from $1 \%$ tryptone broth), citrate (Simmons citrate agar), methyl red/VogesProskauer (MR/VP), nitrate reduction, Starch Hydrolysis, Glucose, Maltose, and Lactose tests were carried out on the bacterial isolates to identify the bacteria through the bacteria biochemical characteristics according to Ajao et al. (2011).

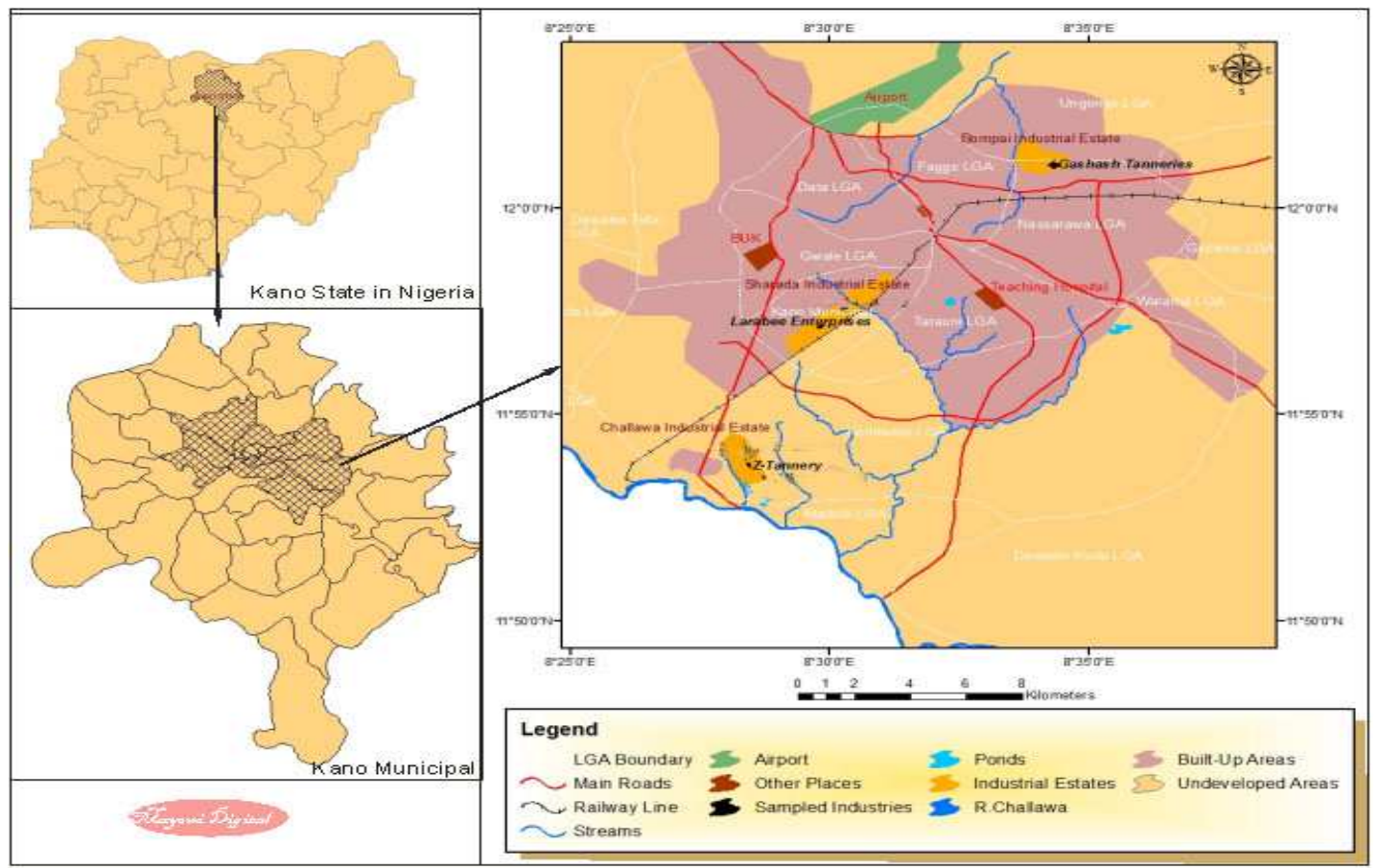

Fig. 1 Map showing the study areas

Source: Mayomi Digital Productions, GIS Laboratory, Department of Geography, UNIMAID (2017)

\section{Determination of Growth Rate of the Bacteria in Effluent Sample}

The bacteria growth rates were determined by transferring $2 \mathrm{~mL}$ of the bacterial isolates from the tannery effluent in broth medium into 100 $\mathrm{mL}$ sterile effluents in conical flasks and kept in an incubator (Giffrin cool) for 10 days. Control was also set up by incubating another $100 \mathrm{~mL}$ each of the sterile effluents without the bacteria. The optical density of the content was determined at the wavelength of $600 \mathrm{~nm}$ on a daily interval and recorded. 
BAJOPAS Volume 13 Number 2, December, 2020 Immobilization of Bacteria

Agar solution and inoculi were prepared separately. Fifty milliliters $(50 \mathrm{~mL})$ of nutrient broth each of the inoculi was prepared in a McCartney bottle and incubated for 24 hours. A solution of agar-agar was prepared by dissolving $10 \mathrm{~g}$ of the powder in distilled water and made up to $500 \mathrm{~mL}$ mark in an Erlenmeyer flask and was sterilized in an autoclave (280A) for 15 minutes and allowed to cool to $40-45^{\circ} \mathrm{C}$ (Ajao et al., 2011). Four milliliters ( $4 \mathrm{~mL})$ of the bacterial isolates in the nutrient broth was mixed with 36 $\mathrm{ml}$ of the prepared agar-agar media in petri-dish plates and then allowed to solidify. This was kept in the refrigerator for bioremediation.

\section{Bioremediation (Treatment) of the Effluents}

The solidified agar block (immobilized bacteria) was cut into cubes using a sterile knife; $0.1 \mathrm{~mL}$ phosphate buffer ( $\mathrm{pH} \mathrm{7.0)}$ was added and kept in the refrigerator for 1 hour for curing. The phosphate buffer was decanted after 1 hour and the cubes were washed with sterile distilled water 3-4 times before it was used (Ajao et al., 2011). Two liters (2 L) of the effluent was supplemented with the minimum basal medium in $\mathrm{g} / \mathrm{L}: \mathrm{NaCl}(0.8), \mathrm{MgSO}_{4} .7 \mathrm{H}_{2} \mathrm{O}(0.001), \mathrm{KH}_{2} \mathrm{PO}_{4}$ (2), $\mathrm{NaNO}_{3}$ (2), $\quad \mathrm{CaCl}_{2} .2 \mathrm{H}_{2} \mathrm{O} \quad(0.5)$ and $\mathrm{NaHPO}_{4} .12 \mathrm{H}_{2} \mathrm{O}(2)$ and sterilized in an autoclave at $121^{\circ} \mathrm{C}$ for 15 minutes (Margesin and Schinner, 2001). Two hundred and fifty milliliters $(250 \mathrm{~mL})$ of the effluents were transferred into different $250 \mathrm{ml}$ conical flasks. The content was covered with a cotton-wool ramped with foil paper to avoid contamination. Five grams $(5 \mathrm{~g})$ of the immobilized bacteria were quickly transferred into each of the effluents in the conical flasks in an inoculating chamber. The same procedures were carried out for the $10 \mathrm{~g}, 15 \mathrm{~g}, 20 \mathrm{~g}$ and 25 $\mathrm{g}$ of the immobilized bacteria in separate $250 \mathrm{~mL}$ effluents in conical flasks and agitated for ten days in a shaker incubator (Gallenkamp-OC4364-L) at a temperature $30^{\circ} \mathrm{C}$ and speed of 60 rpm. The treated effluent samples were taken on the tenth day and analyzed for the parameters $\mathrm{pH}$, SS, TDS, COD, and BOD, (Posttreatment determination) for the different grams of bacteria to evaluate and compare the biodegradation potential. (Baba et al., 2020).

\section{Statistical Analysis}

The data were represented as Mean \pm Standard deviation and analyzed statistically using oneway Analysis of Variance (ANOVA) and Tukey's HSD as Post Hoc Tests with the aid of SPSS 16.0. The correlation coefficient was also used to measure the strength of the relationship between the different masses of the bacteria and the parameters. All $\mathrm{p} \leq 0.05$ were considered as statistically significant.

\section{RESULTS AND DISCUSSION Physico-chemical parameters in the Industrial Effluents before the Biodegradation.}

Results of the Physico-chemical parameters in the industrial effluents before the Biodegradation is shown in table 1 . The mean temperatures $\left({ }^{\circ} \mathrm{C}\right)$ observed in TAN1, TAN2, and TAN3 samples were $28.07 \pm 0.65 ; 27.77 \pm 0.64$ and $26.38 \pm 3.81$ respectively. The order of the mean temperature of the samples from the three industries can be arranged as TAN1 > TAN2>TAN3. The temperature observed at TAN1, TAN2, and TAN3 samples were found below the WHO $\left(35^{\circ} \mathrm{C}\right)$ and NESREA $\left(40^{\circ} \mathrm{C}\right)$ limits. The low values of temperature might be due to the processes used at the time of sampling. High temperature brings down the solubility of gases in water that ultimately expresses as high BOD and COD. Statistical analysis shows that there is no significant difference $(p<0.05)$ between the mean values of temperature among the industries. This might be due to similar tannery activities involved in the tannery industries at the time of sampling. The average values of temperature observed in this present study are less than those observed by Akan et al. (2007), Akan et al. (2009) and Baba et al. (2020).

The mean level of $\mathrm{pH}$ observed in TAN1, TAN2 and TAN3, samples were $7.77 \pm 2.93$; $8.35 \pm 0.28$ and $7.52 \pm 0.76$ respectively. The order of the mean $\mathrm{pH}$ of the samples from the three industries can be arranged as TAN2> TAN1 $>$ TAN3. The $\mathrm{pH}$ of the samples falls within the WHO (7.0-8.5) and NESREA (6-9) standard limits. Statistical analysis shows that there is no significant difference $(p<0.05)$ between the mean values of $\mathrm{pH}$ among the industries. This might be due to similar tannery activities involved in the tannery industries at the time of sampling. Maheshwari et al. (2017) reported that the level of $\mathrm{pH}$ in the effluents from the tannery industry in Vaniyambadi, India was 6.5 which was lower than that observed in the present study. The $\mathrm{pH}$ in the effluents from the tannery industries in Kano and Kaduna were reported to be 7.64 and 6.89, respectively (Akan et al., 2007; Mohammed et al., 2017). The average values of $\mathrm{pH}$ observed in this present study are less than those observed by Mohammed et al. (2017) and Baba et al. (2020). The mean level of SS $(\mathrm{mg} / \mathrm{l})$ observed in TAN1, TAN2, and TAN3 samples were 374 \pm 124 ; $358 \pm 335$ and $780 \pm 739$ respectively. The order of the mean SS in the samples from the three industries can be arranged as TAN3 > TAN1 $>$ TAN2. 
The SS observed in the samples were far above the recommended standard limits of regulating bodies WHO $(30 \mathrm{mg} / \mathrm{l})$ and NESREA $(10 \mathrm{mg} / \mathrm{l})$. Statistical analysis shows that there is no significant difference $(p<0.05)$ between the mean values of SS among the industries. This might be due to similar tannery activities involved in the tannery industries at the time of sampling. The average values of SS observed in this present study are less than that observed $(3700 \pm 122 \mathrm{mg} / \mathrm{l})$ by Akan et al. (2009) for tanneries in Kano. Also, the average values of SS observed in this present study are less than that observed by Mohammed et al. (2017) and Baba et al. (2020) with the exception in TAN3.

The mean level of TDS (mg/l) observed in TAN1, TAN2, and TAN3 samples were $3941 \pm 3703$; $3300 \pm 1714$ and $2653 \pm 1240$ respectively. The order of the mean TDS in the samples from the three industries can be arranged as TAN1>TAN2>TAN3. The TDS observed in the samples were far above the recommended standard limits of WHO $(250 \mathrm{mg} / \mathrm{l})$ and NESREA $(500 \mathrm{mg} / \mathrm{l})$. Statistical analysis shows that there is no significant difference $(p<0.05)$ between the mean values of TDS among the industries. This might be due to similar tannery activities involved in the tannery industries at the time of sampling. TDS in the effluents from the tannery industries in Kano, Nigeria was reported to be $1281 \mathrm{mg} / \mathrm{l}$ (Akan et al., 2007). The average values of SS observed in this present study are less than those observed by Mohammed et al. (2017) and Baba et al. 2020)

The mean level of COD (mg/l) observed in TAN1, TAN2 and TAN3 samples seasons were $2372 \pm 938 ; \quad 1406 \pm 208$ and $3532 \pm 1373$ respectively. The order of the mean COD of the samples from the three industries can be arranged as TAN3>TAN1> TAN2. The COD observed in TAN1, TAN2 and TAN3 samples were far above the recommended standard limits of regulating bodies $\mathrm{WHO}(40 \mathrm{mg} / \mathrm{l})$ and NESREA (40 mg/l). Statistical analysis shows that there is no significant difference $(p<0.05)$ in COD among the industries. This might be due to similar tannery activities involved in the tannery industries as at the time of sampling. The Chemical Oxygen demand (COD) is the amount of oxygen, in $\mathrm{mg} / \mathrm{L}$, required for the degradation of the compound of wastewater to occur. In comparison, the average values of COD observed in this present study were higher than that observed by Mohammed et al. (2017) but lower than that observed by Baba et al. (2020).

The mean levels of BOD $(\mathrm{mg} / \mathrm{l})$ observed in TAN1, TAN2 and TAN3 samples were $13.85 \pm 6.42 ; \quad 19.46 \pm 0.50$ and $17.13 \pm 3.14$ respectively. The order of the mean BOD in the samples from the three industries can be arranged as TAN2>TAN3>TAN1. The BOD observed in TAN1, TAN2 and TAN3 samples were found below the recommended limits of NESREA (200 mg/l) but above WHO (10 mg/l). Statistical analysis shows that there is no significant difference $(p<0.05)$ between the mean values of BOD among the industries. This might be due to similar tannery activities involved in the tannery industries at the time of sampling. The low level of BOD recorded in this study is an indication of the low level of biodegradable organic solids in the effluent. The average values of BOD observed in this present study were lower than those observed by Mohammed et al. (2017) and Baba et al. (2020).

Table 1: Mean Values \pm S.D of Physico-chemical parameters of effluents from the Tannery Industries before Treatment.

\begin{tabular}{llllllll}
\hline Parameter & Tannery 1 & Tannery 2 & Tannery 3 & $\mathrm{a}$ & $\mathrm{b}$ & $\mathrm{c}$ & $\mathrm{d}$ \\
\cline { 2 - 7 } Temperature $\left({ }^{\circ} \mathrm{C}\right)$ & $28.07 \mathrm{a} \pm 0.65$ & $27.77 \mathrm{a} \pm 0.64$ & $26.38 \mathrm{a} \pm 3.81$ & & $29.50 \pm 4.68$ & 35 & 40 \\
pH & $7.77 \mathrm{a} \pm 2.93$ & $8.35 \mathrm{a} \pm 0.28$ & $7.52 \mathrm{a} \pm 0.76$ & 6.89 & $5.35 \pm 1.57$ & $7.0-8.5$ & $6.0-9.0$ \\
$\mathrm{COD}(\mathrm{mg} / \mathrm{l})$ & $2372 \mathrm{a} \pm 938$ & $1406 \mathrm{a} \pm 208$ & $3532 \mathrm{a} \pm 1373$ & 2.2 & $3106 \pm 2753$ & 40 & 40 \\
$\mathrm{BOD}(\mathrm{mg} / \mathrm{l})$ & $13.85 \mathrm{a} \pm 6.42$ & $19.46 \mathrm{a} \pm 0.50$ & $17.13 \mathrm{a} \pm 3.14$ & 1032 & $26.17 \pm 9.49$ & 10 & 200 \\
$\mathrm{SS}(\mathrm{mg} / \mathrm{l})$ & $374 \mathrm{a} \pm 124$ & $358 \mathrm{a} \pm 335$ & $780 \mathrm{a} \pm 739$ & 501 & $562 \pm 482$ & 30 & 10 \\
TDS $(\mathrm{mg} / \mathrm{l})$ & $3941 \mathrm{a} \pm 3703$ & $3300 \mathrm{a} \pm 1714$ & $2653 \mathrm{a} \pm 1240$ & 532.7 & $444 \pm 507$ & 250 & 500 \\
\hline
\end{tabular}

The values given in the table above are means of 6 replicate values, $\mathrm{n}=6$ ( 1 sample was taken monthly for 6 months). Within the rows, means with different alphabets are statistically different $(p<0.05)$. WHO: World Health Organisation. NESREA: National Environmental Standard and Regulatory Enforcement Agency. a = Mohammed et al.(2017), b = Baba et al. (2020), c = WHO (2006), $d=$ NESSRA (2009) 
BAJOPAS Volume 13 Number 2, December, 2020

Identification, Biochemical Characterization and growth rates of the Bacterial Isolates

Results of identification and biochemical characterization of the bacterial isolates were shown in table 2. After 24 hours of incubation, the nutrient agar media plates were checked for bacterial growth. The results showed the presence of different strains in the samples. The TAN1 bacteria isolate was found to be gramnegative cocci while TAN3 was gram-positive cocci. TAN2 bacteria isolate was found to be gram-positive, rod-shaped. TAN1, TAN2, and TAN3 bacteria isolates recorded positive results for spore former.

The results of the biochemical tests indicated that all the bacteria were positive for catalase, oxidase, citrate, maltose, glucose, lactose (negative in TAN1), mannitol (negative in TAN2), starch hydrolysis and coagulase (negative in TAN2) tests. The bacteria showed negative results for nitrate reduction, $M R$ (positive in TAN2), VP (positive in TAN1), Indole (positive in TAN2) tests. Base on the morphological and biochemical test results, TAN1, TAN2, and TAN3 bacteria isolates were identified to be Nesseria spp, Bacillus cereus, and Staphylococcus aureus respectively.

The growth rate of the TAN1, TAN2 and TAN3 Isolates were shown in figure 2. Generally, the optical density increase with the increase in time (day) and decrease as time goes on. The highest optical density was shown by bacillus cereus in TAN2 while the lowest was shown by Staphylococcus aureus in TAN3.

The initial growth phase of TAN1 Isolate bacteria occurred within 2-day of incubation as the growth rate increases up to the 6th-day incubation when the maximum growth was observed. Beyond the 6th day, the growth of the bacteria declined (which might be due to a shortage of nutrients in the effluents) until it reached its death phase (which might be due to the unavailability of nutrients in the effluents).

A similar trend of growth was also observed for TAN2 Isolate as the initial growth phase also occurred within 2-day of incubation but maximum growth rate observed on the 4th day of incubation. The stationary stage occurred between the 4th day and the 8th day. Beyond the 8th day, the growth of the bacteria declined (which might be due to a shortage of nutrients in the effluents) until it reached its death phase (which might be due to the unavailability of nutrients in the effluents).

The initial growth phase of TAN3 bacterial Isolate occurred within the 3-day incubation as the growth rate increases up to the 6th-day incubation when the maximum growth was observed. Beyond the 6th day, the growth of the bacteria declined (which might be due to a shortage of nutrients in the effluents) until it reached its death phase (which might be due to the unavailability of nutrients in the effluents).

Table 2: Morphological and Biochemical characteristics of bacterial isolates

\begin{tabular}{lllll} 
Bacterial Isolates & & TAN1 & TAN2 & TAN3 \\
\hline $\begin{array}{lllll}\text { Morphological } \\
\text { characteristics }\end{array}$ & Shape & Cocci & Rod & Cocci \\
& Spore & & & \\
& former & + & + & + \\
Gram & & & \\
Biochemical characteristics & reaction & - & + & + \\
& Citrate & + & + & + \\
& Catalase & + & + & + \\
& Coagulase & + & - & + \\
Starch & + & + & + \\
& Glucose & + & + & + \\
Oxidase & + & + & + \\
& Indo & - & + & - \\
Lactose & - & + & + \\
Manitol & + & - & + \\
Maltose & + & + & + \\
MR & - & + & - \\
VP & + & - & - \\
& Nitrate & - & - & - \\
Reduction & - Neisseria & Bacillus & Staphylococcus \\
& Bacterial & cereus & aureus \\
& name & spp & cas
\end{tabular}

+ = Positive; - = Negative; MR=Methyl Red; VP= Voges-Proskauer 


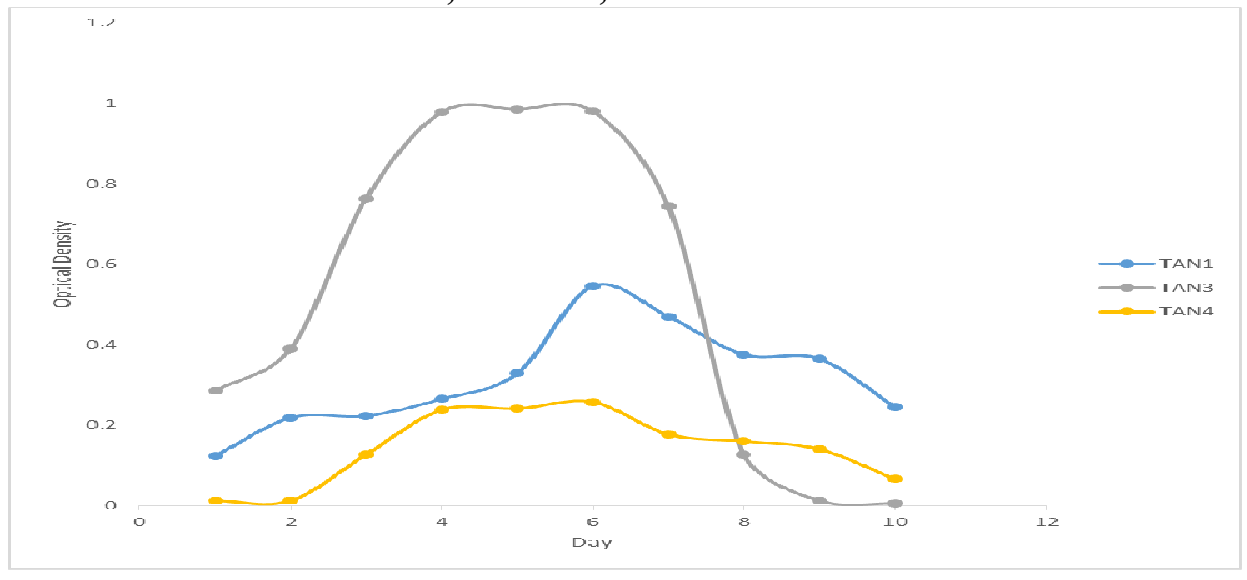

Fig. 2 Growth rates of the isolates in the effluents from the Tannery Industries

\section{Physico-chemical Parameters in the Industrial Effluents after the biodegradation.}

Table 3 shows the mean results of the physicochemical parameter before and after bioremediation using the different masses $(5 \mathrm{~g}$, $10 \mathrm{~g}, 15 \mathrm{~g}, 20 \mathrm{~g}$, and $25 \mathrm{~g}$ ) of the respective immobilized bacteria. Also, Table 4 shows the mean results of correlation coefficient ( $r$ ) between different masses of bacteria and physicochemical parameters.

The mean values $(\mathrm{mg} / \mathrm{l})$ of the SS after the bioremediation varies between $243 \pm 45$ and $898 \pm 672$. The mean concentration $(\mathrm{mg} / \mathrm{l})$ of SS remediated by the different masses $(5 \mathrm{~g}, 10 \mathrm{~g}$, $15 \mathrm{~g}, 20 \mathrm{~g}$, and $25 \mathrm{~g}$ ) of the bacteria varies. The SS in the samples fluctuates up and down after the bioremediation process when compared with the SS of the raw samples before the bioremediation. The increase in the levels of the SS might be due to the aggregation of the TDS which are large enough to result into SS. The increase in the levels of the SS might be also due to the influence of the nutrients which was added into the effluents in order to make the microorganisms more active and viable for fast degradation of organic contaminants in the effluent. The relative potential or efficiency of the different masses of the bacteria in remediating SS in TAN1 samples was in the order $25 \mathrm{~g}>20 \mathrm{~g}>15 \mathrm{~g}>10 \mathrm{~g}>5 \mathrm{~g}$. For TAN2 and TAN3 samples, the order was $25 \mathrm{~g}>20 \mathrm{~g}>15$ $\mathrm{g}>10 \mathrm{~g}>5 \mathrm{~g}$. These might be due to the variations in the surface areas of the different masses of the immobilized bacteria. Statistical analysis shows that there is no significant difference $(p<0.05)$ between the mean values of SS among the masses in the respective industries. Positive and significant correlations exist between the masses of bacteria and Suspended Solid (SS). This showed that there is general increase in the levels of the SS as the masses of the immobilized bacteria increases. TAN3 (90\%) and TAN1 (80\%) showed a very high correlation with the masses of the bacteria while TAN2 (61\%) showed a very low correlation.

The mean values $(\mathrm{mg} / \mathrm{l})$ of the TDS after the bioremediation varies between $46 \pm 11$ and $83 \pm 78$. The mean concentration $(\mathrm{mg} / \mathrm{l})$ of TDS remediated by the different masses $(5 \mathrm{~g}, 10 \mathrm{~g}$, $15 \mathrm{~g}, 20 \mathrm{~g}$, and $25 \mathrm{~g}$ ) of the bacteria varies. There is a reduction in all the TDS of all the samples after the bioremediation process compared with the TDS of the raw samples before the bioremediation. The relative potential or efficiency of the different masses of the bacteria in remediating TDS in TAN1 and TAN3 samples was in the order $5 \mathrm{~g}>10 \mathrm{~g}>15 \mathrm{~g}>20$ $\mathrm{g}>25 \mathrm{~g}$. For TAN2 samples, the order was 20 $g>10 \quad g>25 \quad g>15 \quad g>5 \quad g$. Statistical analysis shows that there is no significant difference $(p<0.05)$ between the mean values of TDS among the masses in the respective industries. These might be due to the variations in the surface areas of the different masses of the immobilized bacteria. Positive and significant correlations exist between the masses of bacteria and TDS with the exception in TAN2 (negative and insignificant correlation). The positive correlations showed that there is general increase in the levels of the TDS as the masses of the immobilized bacteria increases. TAN1 $(96 \%)$ showed a very high correlation with the masses of the bacteria while TAN2 (47\%) showed a very low correlation.

The mean values $(\mathrm{mg} / \mathrm{l})$ of the BOD after the bioremediation varies between $1.56 \pm 0.20 \mathrm{mg} / \mathrm{l}$ and $6.92 \pm 5.49 \mathrm{mg} / \mathrm{l}$. The mean concentration $(\mathrm{mg} / \mathrm{l})$ of BOD remediated by the different masses $(5 \mathrm{~g}, 10 \mathrm{~g}, 15 \mathrm{~g}, 20 \mathrm{~g}$, and $25 \mathrm{~g}$ ) of the bacteria varies. There is a reduction in all the BOD of all the samples after the bioremediation process compared with the $\mathrm{BOD}$ of the raw 
BAJOPAS Volume 13 Number 2, December, 2020 samples before the bioremediation. The relative potential or efficiency of the different masses of the bacteria in remediating BOD in TAN1, TAN2 and TAN3 samples were in the order $25 \mathrm{~g}>20$ $\mathrm{g}>15 \mathrm{~g}>10 \mathrm{~g}>5 \mathrm{~g}, 25 \mathrm{~g}>15 \mathrm{~g}>5 \mathrm{~g}>10 \mathrm{~g}>20 \mathrm{~g}$ and $20 \mathrm{~g}>10 \mathrm{~g}>25 \mathrm{~g}>15 \mathrm{~g}>5 \mathrm{~g}$ respectively. Statistical analysis shows that there is significant difference $(p<0.05)$ between the mean values of BOD among the masses in the respective industries. These might be due to the variations in the surface areas of the different masses of the immobilized bacteria. Negative and significant correlations exist between the masses of bacteria and BOD. This showed that there is general decrease in the levels of the BOD as the masses of the immobilized bacteria increases. TAN1 (94\%) showed a very high correlation with the masses of the bacteria while TAN2 (4\%) showed a very low correlation.

The mean values $(\mathrm{mg} / \mathrm{l})$ of the COD after the bioremediation varies between $250 \pm 154$ and $3134 \pm 1595$. The mean concentration $(\mathrm{mg} / \mathrm{l})$ of COD remediated by the different masses $(5 \mathrm{~g}$, $10 \mathrm{~g}, 15 \mathrm{~g} 20 \mathrm{~g}$, and $25 \mathrm{~g}$ ) of the bacteria varies. There is a reduction in all the COD of all the samples after the bioremediation process compared with the COD of the raw samples before the bioremediation. The relative potential or efficiency of the different masses of the bacteria in remediating COD in TAN1, TAN2 and TAN3 samples were in the order $25 \mathrm{~g}>20 \mathrm{~g}>15$ $\mathrm{g}>5 \mathrm{~g}>10 \mathrm{~g}, 25 \mathrm{~g}>20 \mathrm{~g}>15 \mathrm{~g}>10 \mathrm{~g}>5 \mathrm{~g}$ and 10 g>5 g>25 g>15 g>20 g respectively. Statistical analysis shows that there were significant difference $(p<0.05)$ between the mean values of COD among the masses in the respective industries except for effluents treated with $25 \mathrm{~g}$. These might be due to the variations in the surface areas of the different masses of the immobilized bacteria. Negative and insignificant correlations exist between the masses of bacteria and COD with the exception in TAN3 (positive and significant correlation). The negative correlations showed that there is general decrease in the levels of the COD as the masses of the immobilized bacteria increases. TAN2 (100\%) showed a very high correlation with the masses of the bacteria while TAN3 (36\%) showed a very low correlation.

Generally, there was an overall decrease in the concentration of these physicochemical parameters after the bioremediation using the different masses of the bacterial isolates. These might be due to the variations in the surface areas of the different masses of the immobilized bacteria. This is in line with the work of Jimoh et al. (2018) and Baba et al. (2020).

Table 3: Mean Values $(\mathrm{mg} / \mathrm{l}) \pm$ S.D of Physicochemical parameters in effluents from the Tannery Industries before and after Treatment of the effluents $(250 \mathrm{ml})$ with the different masses $(5 \mathrm{~g}, 10 \mathrm{~g}$, $15 \mathrm{~g}, 20 \mathrm{~g}$, and $25 \mathrm{~g}$ ) of the bacteria.

\begin{tabular}{llllllll}
\hline $\mathrm{P}$ & IND & Before & \multicolumn{5}{c}{ After } \\
\cline { 4 - 7 } & & & $5 \mathrm{~g}$ & $10 \mathrm{~g}$ & $15 \mathrm{~g}$ & $20 \mathrm{~g}$ & $25 \mathrm{~g}$ \\
\hline \multirow{2}{*}{ COD } & TAN1 & $2372 \pm 938$ & $1708 \mathrm{a} \pm 861$ & $2045 \mathrm{a} \pm 1205$ & $845 \mathrm{a} \pm 369$ & $300 \mathrm{a} \pm 167$ & $250 \mathrm{a} \pm 154$ \\
& TAN2 & $1406 \pm 208$ & $1195 \mathrm{a} \pm 208$ & $1125 \mathrm{a} \pm 384$ & $1055 \mathrm{a} \pm 317$ & $956 \mathrm{a} \pm 310$ & $870 \mathrm{ab} \pm 240$ \\
& TAN3 & $3532 \pm 1373$ & $2374 \mathrm{a} \pm 1344$ & $1976 \mathrm{a} \pm 1405$ & $2757 \mathrm{a} \pm 1266$ & $3134 \mathrm{a} \pm 1595$ & $2614 \mathrm{~b} \pm 1105$ \\
BOD & TAN1 & $13.85 \pm 6.42$ & $6.92 \mathrm{a} \pm 5.49$ & $6.42 \mathrm{a} \pm 5.07$ & $5.72 \mathrm{a} \pm 5.35$ & $4.62 \mathrm{a} \pm 4.37$ & $2.82 \mathrm{ab} \pm 1.26$ \\
& TAN2 & $19.46 \pm 0.50$ & $1.75 \mathrm{~b} \pm 0.22$ & $1.73 \mathrm{~b} \pm 0.18$ & $1.58 \mathrm{a} \pm 0.16$ & $1.91 \mathrm{a} \pm 0.22$ & $1.56 \mathrm{~b} \pm 0.20$ \\
& TAN3 & $17.13 \pm 3.14$ & $4.24 \mathrm{ab} \pm 0.77$ & $3.29 \mathrm{ab} \pm 0.37$ & $4.11 \mathrm{a} \pm 0.07$ & $3.23 \mathrm{a} \pm 0.91$ & $3.33 \mathrm{a} \pm 1.28$ \\
SS & TAN1 & $374 \pm 124$ & $243 \mathrm{a} \pm 45$ & $471 \mathrm{a} \pm 226$ & $475 \mathrm{a} \pm 182$ & $492 \mathrm{a} \pm 128$ & $611 \mathrm{a} \pm 217$ \\
& TAN2 & $358 \pm 335$ & $460 \mathrm{a} \pm 400$ & $543 \mathrm{a} \pm 414$ & $544 \mathrm{a} \pm 402$ & $551 \mathrm{a} \pm 414$ & $554 \mathrm{a} \pm 405$ \\
& TAN3 & $780 \pm 739$ & $586 \mathrm{a} \pm 594$ & $758 \mathrm{a} \pm 656$ & $787 \mathrm{a} \pm 676$ & $861 \mathrm{a} \pm 635$ & $898 \mathrm{a} \pm 672$ \\
TDS & TAN1 & $3941 \pm 3703$ & $51 \mathrm{a} \pm 10$ & $53 \mathrm{a} \pm 10$ & $55 \mathrm{a} \pm 15$ & $61 \mathrm{a} \pm 20$ & $63 \mathrm{a} \pm 26$ \\
& TAN2 & $3300 \pm 1714$ & $83 \mathrm{a} \pm 78$ & $47 \mathrm{a} \pm 20$ & $48 \mathrm{a} \pm 22$ & $47 \mathrm{a} \pm 17$ & $48 \mathrm{a} \pm 17$ \\
& TAN3 & $2653 \pm 1240$ & $46 \mathrm{a} \pm 11$ & $55 \mathrm{a} \pm 24$ & $55 \mathrm{a} \pm 25$ & $58 \mathrm{a} \pm 23$ & $61 \mathrm{a} \pm 28$ \\
\hline
\end{tabular}

Replicate $=6$ (months)

Within the rows, for the same parameter, means with different alphabets are statistically different $(p<0.05)$.

$\mathrm{P}=$ parameter, IND = Industries 
BAJOPAS Volume 13 Number 2, December, 2020

Table 4: Correlation coefficient $(r)$ between different masses of the bacteria and the physicochemical parameters.

\begin{tabular}{llll}
\hline Industries & Parameter & Correlation coefficient $(r)$ & $\begin{array}{l}\text { Percent dependence (rxrx100) } \\
(\%)\end{array}$ \\
\hline TAN1 & COD & -0.9 & 82 \\
& BOD & -0.97 & 94 \\
& SS & $0.90^{*}$ & 80 \\
TAN2 & TDS & $0.98^{*}$ & 96 \\
& COD & -1 & 100 \\
& BOD & -0.21 & 4 \\
& SS & $0.78^{*}$ & 61 \\
& TDS & -0.69 & 47 \\
& COD & $0.60^{*}$ & 36 \\
& BOD & -0.6 & 37 \\
& SS & $0.95^{*}$ & 90 \\
& TDS & $0.94^{*}$ & 89 \\
\hline
\end{tabular}

The correlation coefficient $(r)$ with * is statistically significant $(p<0.05)$.

Percentage reduction of the Parameters

Table 5 shows the percentage reduction of Parameters in industrial samples before and after the treatment of the effluents $(250 \mathrm{ml})$ with the different masses $(5 \mathrm{~g}, 10 \mathrm{~g}, 15 \mathrm{~g}, 20 \mathrm{~g}$, and $25 \mathrm{~g}$ ) of the Immobilized Bacteria.

In TAN1 samples, the percentage reduction (\%) of COD ranged (14-89); BOD (50-80); SS (-32$35)$ and TDS (98-99). In TAN2 samples, the percentage decrease $(\%)$ of COD ranged (15$38) ;$ BOD (90-92); SS [-28-(-55)] and TDS (9798). In TAN3 samples, the percentage decrease (\%) of COD ranged (11-44); BOD (76-81); SS (15-25) and TDS (98). The percentage increase in the levels COD, BOD and TDS might be due to the increase in the surface area of the different masses of the immobilized bacteria. However, the percentage decrease in the levels of the SS might be due to the aggregation of the TDS which are large enough to result into SS. The percentage decrease in the levels of the SS might be also due to the influence of the nutrients which was added into the effluents in order to make the microorganisms more active and viable for fast degradation of organic contaminants in the effluent. This is in line with the work of Jimoh et al. (2018) in which the concentration of the SS increase after the bioremediation of effluents.

Sreemoyee and Priti (2013) assessed and reduced several Physico-chemical parameters of dairy wastewater using Niesseria $s p$. and concluded that the species are well known to degrade organic compounds. This is in agreement with the current study in which the immobilized Niesseria $s p$ degrade the organic contaminants as indicated by the BOD, COD and TDS.

Jimoh et al. (2018) observed that TSS of the effluents was increased after treatment with immobilized bacteria and concluded that it might be due to the biostimulation method adopted for the research.

The optimum $\mathrm{pH}$ Biosorption of Chromium by Bacillus spp and Staphylococcus spp. from tannery effluent was investigated by Mythili and Karthikeyan (2011). The maximum adsorption of Chromium $(86.4 \mathrm{mg} / \mathrm{L})$ was showed by Bacillus spp and Staphylococcus spp showed $70.6 \mathrm{mg} / \mathrm{L}$ at an initial concentration of $100 \mathrm{mg} / \mathrm{L}$. In the present study, immobilised Bacillus spp and Staphylococcus spp. from the tannery industrial effluents reduced the levels of the organic pollutants with high potential as indicated by the percentage reduction of BOD, COD and TDS.

Enzymes often can work in multiple environments especially if they are immobilized. This makes the microorganisms' enzymes even more resistant to harsh environments and enables the enzymes to be recovered and recycled after they are no longer needed (Gianfreda and Rao 2004). Ramesh and Singh (1993) reported that the immobilized bacteria having more efficiency to remove the suspended particles than free cells. Using the immobilized cell is preferable due to its capability for using several times with the same efficiency, which makes it more economical. Similar work was done by Sikander et al. (2007) showing the higher reduction with permeabilized cells of Ochrobactrum intermedium strain SDCr-5. 
BAJOPAS Volume 13 Number 2, December, 2020

The results revealed the isolation and identification of isolates with the potential for the reduction of $\mathrm{Cr}$ (VI) to $\mathrm{Cr}$ (III). Results indicated that immobilized $B$. cereus could be efficiently used for the reduction of $\mathrm{Cr}$ (VI).

Table 5: Percentage reduction of the tested Parameters from the tannery industrial samples of the Immobilized Bacteria.

\begin{tabular}{lllllll}
\hline \multirow{2}{*}{ Industries } & & \multicolumn{5}{c}{ Percentage Reduction $(\%)$} \\
\cline { 3 - 7 } & & $5 \mathrm{~g}$ & $10 \mathrm{~g}$ & $15 \mathrm{~g}$ & $20 \mathrm{~g}$ & $25 \mathrm{~g}$ \\
\hline TAN1 & COD & 28 & 14 & 64 & 87 & 89 \\
& BOD & 50 & 54 & 59 & 67 & 80 \\
& SS & 35 & -26 & -27 & -32 & -63 \\
& TDS & 99 & 99 & 99 & 98 & 98 \\
TAN2 & COD & 15 & 20 & 25 & 32 & 38 \\
& BOD & 91 & 91 & 92 & 90 & 92 \\
& SS & -28 & -52 & -52 & -54 & -55 \\
& TDS & 97 & 99 & 99 & 99 & 99 \\
& COD & 33 & 44 & 22 & 11 & 26 \\
& BOD & 75 & 81 & 76 & 81 & 81 \\
& SS & 25 & 3 & -1 & -10 & -15 \\
& TDS & 98 & 98 & 98 & 98 & 98 \\
\hline
\end{tabular}

Percentage Reduction $=(B-A) / B \times 100 \%$

$A=$ Concentration of the parameter after treatment

$\mathrm{B}=$ Concentration of the parameter before treatment

$+=$ percentage decrease

- = percentage increase

In general, immobilization makes the enzyme more resistant to temperature, $\mathrm{pH}$, and substrate concentration swings giving it a longer lifetime and higher productivity per active unit (Gianfreda and Rao, 2004; FuIlbrook, 1996; Russell et al, 2003; Kandelbauer et al., 2004). Immobilized cells have been used and studied extensively for the production of useful chemicals (Ohtake and Silver, 1994), the treatment of wastewaters (Chen et al., 2003; Wang et al., 2010). Although many workers described microbial degradation of tannery effluent, limited literature is available on the bioremediation of tannery effluent using immobilized bacterial cells in the Kano Industrial Estates.

\section{CONCLUSION}

The samples contained variable levels of the physicochemical parameters. The results of the Analysis of variance revealed that, no statistical difference $(p<0.05)$ was observed for the temperature, $\mathrm{pH}, \mathrm{SS}, \mathrm{TDS}, \mathrm{BOD}$ and $\mathrm{COD}$ among the three tannery industries before the treatment. The levels of some of the parameters
(SS, TDS and COD) observed in the samples were found above the recommended limits of WHO and NESREA, which called for the treatment of the effluents before discharge into the environment. Base on the morphological and biochemical test results, TAN1, TAN2, and TAN3 bacterial isolates were identified to be Neisseria spp, Bacillus cereus, and Staphylococcus aureus respectively. The results of Post-treatment analysis showed that there is overall decrease in the levels of the parameters determined when compared with that of the pre-treatment. The overall percentage reduction of the immobilised bacteria in the treatment of the respective effluents was in the order TAN2 (72\%)>TAN1 $(70 \%)>$ TAN3 $(62 \%)$. Hence, the immobilized bacteria are having higher biodegradation potential for the treatment of the tannery effluents.

\section{Acknowledgments}

The authors wish to acknowledge the University of Maiduguri for the financial support. The authors are grateful to the Kano State Ministry of Environment for their support in obtaining the effluent samples. 


\section{REFERENCES}

Ajao, A. T., Adebayo, G. B., and Yakubu, S. E. (2011). Bioremediation of textile industrial effluent using mixed culture of Pseudomonas aeruginosa and Bacillus subtilis immobilized on agar-agar in a bioreactor. J. Microbiol. Biotech. Res, 1(3), 50-56.

Akan, J. C., Moses, E. A., Ogugbuaja, V. O., and Abah, J. (2007). Assessment of tannery industrial effluents from Kano metropolis, Kano State, Nigeria. Journal of Applied Sciences, 7(19), 2788-2793.

Akan, J. C., Ogugbuaja, V. O., Abdulrahman, F. I., and Ayodele, J. T. (2009). Pollutant levels in effluent samples from tanneries and textiles of Kano industrial areas, Nigeria. Global journal of pure and applied sciences, 15(3-4).

APHA (1989). Standard methods for Examination of Will bete and Will betewater.15 $5^{\text {th }}$ edition. Brydpass Springfield Will behington DC. pp. 164-176

APHA (1992). Standard Methods for the Examination of Water and Wastewater. Health, 69, 1116-9.

Baba, A., Garba, S. T., and Bello, H. S. (2020). Bioremediation Potential of Immobilized corynebacterium kutsceri in the Treatment of Tannery Industrial Effluent from Challawa Industrial Estate, Kano State, Nigeria. Journal of the Turkish Chemical Society Section A: Chemistry, $7(2), 335-350$.

Beem, E. I. V. (1994). reduction of solvent VOC emission. J. Oil Col. Chem. Ass, 77, 158.

Bouwer, E. J., and Zehnder, A. J. (1993). Bioremediation of organic compoundsputting microbial metabolism to work. Trends in biotechnology, 11(8), 360367.

Chen, K. C., Wu, J. Y., Liou, D. J., and Hwang, S. C. J. (2003). Decolorization of the textile dyes by newly isolated bacterial strains. Journal of Biotechnology, 101(1), 57-68.

Dan'Azumi, S., and Bichi, M. H. (2010). INDUSTRIAL POLLUTION AND HEAVY METALS PROFILE OF CHALLAWA RIVER IN KANO, NIGERIA. Journal of Applied Sciences in Environmental Sanitation, $5(1)$.

DWAF. (1992). Analytical Methods Manual, TR 151. Department of Water Affairs and Forestry, Pretoria.

El-Bestawy, E. (2013). Biological treatment of leather-tanning industrial wastewater using free living bacteria.
Elsheikh, M. A. S. (2009). Tannery wastewater pre-treatment. Water Science and Technology, 60(2), 433-440.

FuIlbrook, P. D. (1996). "Kinetics." Industrial enzymology: The application of enzymes in Industry. 2nd Ed. T. Godfrey and J Reichelt. eds.. Nature. New York.

Gianfreda, L., and Rao, M. A. (2004). Potential of extra cellular enzymes in remediation of polluted soils: a review. Enzyme and microbial technology, 35(4), 339354.

Hugo Springer. (1994). John Arthur Wilson Memorial Lecture "Treatment of Industrial Wastes of the Leather Industry - is it still a Major Problem". JALCA, 89, 153-185

Jimoh, A. A., Ganiyu, B. A., Baba, D., and Baba, A. (2018) Bioremediation Process of Effluent from Detergent and Food Industries in Jos, Nigeria: Kinetics and Thermodynamics. International Journal of Engineering Science Invention (IJESI), 762-73

Kandelbauer, A., Maute, O., Kessler, R. W., Erlacher, A., and Gübitz, G. M. (2004). Study of dye decolorization in an immobilized laccase enzyme-reactor using online spectroscopy. Biotechnology and bioengineering, 87(4), 552-563.

Kongjao, S., Damronglerd, S., and Hunsom, M. (2008). Simultaneous removal of organic and inorganic Pollutants in tannery wastewater using electrocoagulation technique. Korean Journal of chemical engineering, 25(4), 703.

Maheshwari, U. M., Aruna, S., Gomathi, M., and AbdulJaffar, A. H. (2017). Bioremediation by Free and Immobilized Bacteria Isolated from Tannery Effluent. International Journal of Research in Applied, Natural and Social Sciences. 5(7), 75-90

Margesin, R., and Schinner, F. (2001). Bioremediation (natural attenuation and biostimulation) of diesel-oilcontaminated soil in an alpine glacier skiing area. Applied and environmental microbiology, 677), 3127-3133.

Mohammed, A., Sekar, P., and George, J. (2011). Efficacy of microbes in bioremediation of tannery effluent. Inter. J. Curr. Res, 3(4), 324-326.

Mohammed, S. S. D., Orukotan, A. A., and Abdullahi, H. (2017). Physicochemical and Bacteriological Assessment of Tannery Effluent from Samaru-Zaria, 
BAJOPAS Volume 13 Number 2, December, 2020 Kaduna State, Nigeria. Journal of Applied

Sciences and Environmental Management, 21(4), 734-740.

Munz, G., De Angelis, D., Gori, R., Mori, G., Casarci, M., and Lubello, C. (2009). The role of tannins in conventional and membrane treatment of tannery wastewater. Journal of hazardous materials, 164(2-3), 733-739

Mythili, K., and Karthikeyan, B. (2011). Bioremediation of $\mathrm{Cr}$ (VI) from tannery effluent using Bacillus spp and Staphylococcus spp. International Multidisciplinary Research Journal, 1(6).

NESREA (2009). National Environmental Standards for Effluent Limitations and Regulation. 1233-1236

Noorjahan, C. M. (2014). Physicochemical characteristics, identification of bacteria and biodegradation of industrial effluent. Journal of bioremediation and Biodegradation, 5(3).

Ohtake, H. I., and Silver, A. O. (1994). Bacterial reduction of toxic chromate. Biological degradation and bioremediation of toxic chemicals, 403-415.

Omoleke, I. I. (2004). Management of environmental pollution in Ibadan, an African city: the challenges of health hazard facing government and the people. Journal of Human Ecology, 15(4), 265-275.

Rajor, A., Reddy, A.S., and Singh, B. (2004). Determination of BOD kinetic Parameters and evaluation of alternate methods, M.Sc. Thesis, Department of biotechnology \& environmental Science, Thapar Institute of Engineering and Technology, Patiala

Ramasami, T., Rajamani, S., and Rao, J. R. (1994, March). Pollution control in leather industry: Emerging technological options. In International symposium on surface and colloidal science and its relevance to soil pollution, madras.

Ramesh, J. V. S., and Singh, S. P. (1993). Yearly variation in certain physicochemical parameters of pond at eastern Doon Valley. Uttar Pradesh J. Zoo, 12 (1), 7577.

Ranen, S., and Sharadinadra, C. (2009). Biotechnology applications to environmental remediation in resource exploitation. Current science, 97, 6-25
Russell, A. J., Berberich, J. A., Drevon, G. F., and Koepsel, R. R. (2003). Biomaterials for mediation of

chemical and biological warfare agents. Annual review of biomedical engineering, 5(1), 1-27.

Saravanan, P., and Saravanan, A. (1999). Decolourization of tannery effluent by Flavobacterium sp. EK 1. Indian Journal of Environmental Protection, 19, 19-24.

Sikander, S., and Shahida, H. (2007). Reduction of toxic hexavalent chromium by Ochrobactrum intermedium strain SDCr5 stimulated by heavy metals. Bioresource Technol, 98, 340-344.

Singh, N., Sharma, B. K., and Bohra, P. C. (2000). Impact assessment of industrial effluent of arid soils by using satellite imageries. Journal of the Indian Society of Remote Sensing, 28(2-3), 79.

Sreemoyee, C., and Priti, P. (2013). Assessment of physico-chemical parameters of dairy waste water and isolation and characterization of bacterial strains in terms of cod reduction. Int J Sci, 2(3), 395-400.

Verheijen, L. A. H. M., Wiersema, D., Pol, L. H., and De Wit, J. (1996). Management of wastes from animal product processing. Livestock and environment, Finding a balance. International Agriculture Center, Wageningen, The Netherlands.

Wang, F., Yao, J., Si, Y., Chen, H., Russel, M., Chen, K., and Bramanti, E. (2010). Short-time effect of heavy metals upon microbial community activity. Journal of Hazardous Materials, 173(13), 510-516.

WHO (World Health Organization). (2006). Air quality guidelines: global update 2005: particulate matter, ozone, nitrogen dioxide, and sulfur dioxide. World Health Organization.

World Bank. (1995). Nigeria's strategic options for redressing industrial pollution. World Bank, industry and energy division. 1st edition, West Central Africa Department; Annexes: 1995; pp 60-62.

Zahoor, A., and Abdul, R. (2009). Enumeration of Coliforms. Journal of Environmental Sciences. 21, 814-820 


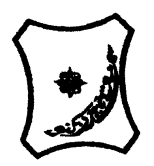

Bayero Journal of Pure and Applied Sciences, 13(2): 1 - 12

Received: November, 2020

Accepted: December, 2020

ISSN $2006-6996$

\title{
BIODEGRADATION POTENTIAL OF IMMOBILIZED BACTERIA IN THE TREATMENT OF TANNERY INDUSTRIAL EFFLUENTS FROM INDUSTRIAL ESTATES IN KANO STATE, NIGERIA
}

\author{
Abdullateef, B., ${ }^{1 *}$ Shuaibu, T. G., ${ }^{1}$ Babagana, K., ${ }^{1}$ Suleman, H. B. ${ }^{2}$ and Dauda, B. ${ }^{3}$ \\ ${ }^{1}$ Department of Pure and Applied Chemistry, Faculty of Science, University of Maiduguri, Borno State, \\ Nigeria \\ ${ }^{2}$ Department of Microbiology, Faculty of Science, University of Maiduguri, Borno State, Nigeria \\ ${ }^{3}$ Department of Chemical Engineering, Faculty of Engineering, University of Maiduguri, Borno State, \\ Nigeria \\ *Corresponding author: babslega@gmail.com; abelega2007@yahoo.com; +2348061309753
}

\section{ABSTRACT}

Industrial Effluents Samples from Gashash Tanneries (TAN1) in Bompai Industrial estate, Larabee Tannery Industry (TAN2) in Sharada Industrial estate and Z Tannery Industries (TAN3) in Challawa Industrial estate, Kano State, Nigeria were collected over a period of six months (August 2017 to January 2018) for assessing the biodegradation potentials of bacteria in the treatment of organic pollutants within the effluents. Bacteria were isolated from the effluents and immobilized on agar-agar. Different masses (5 g, $10 \mathrm{gr}, 15$ $\mathrm{g}, 20 \mathrm{~g}$, and $25 \mathrm{~g}$ ) of the bacteria were used in the treatment of $250 \mathrm{ml}$ of the effluents for ten days in a shaker incubator (Gallenkamp-OC-4364-L) at the temperature $30{ }^{\circ} \mathrm{C}$ and speed of $60 \mathrm{rpm}$. Pre-treatment analysis of the effluents for Temperature, pH, Biochemical Oxygen Demand (BOD), Chemical Oxygen Demand (COD), Suspended Solid (SS) and Total Dissolved Solids (TDS) gives the following results; temperature $\left({ }^{\circ} \mathrm{C}\right.$ )

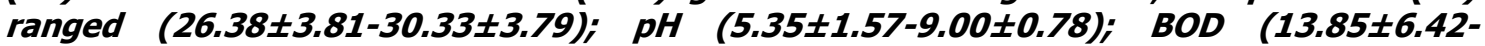
$38.75 \pm 16.20) ;$ COD (1406 $\pm 208-3532 \pm 1373) ;$ SS (208 $\pm 235-780 \pm 739)$ and TDS (266 $\pm 253-5276 \pm 2971)$. No statistical differences ( $p \leq 0.05)$ was observed for all the results among the different industries. The bacterial isolates were identified as Neisseria spp, Bacillus cereus, and Staphylococcus aureus, in TAN1, TAN2, and TAN3, respectively. After treatment of the effluent with the different masses of the isolated bacteria, the mean level of BOD was found to range as (0.55 $\pm 0.36-6.92 \pm 5.49) ; C O D$ (ND-3134 \pm 1595$)$;

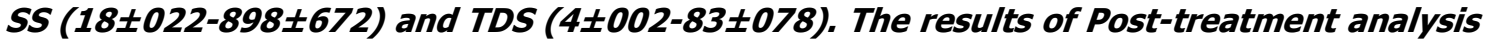
showed that there is overall decrease in the levels of the parameters determined when compared with that of the pre-treatment. The overall percentage reduction of the immobilised bacteria in the treatment of the respective effluents was in the order TAN2 (72\%)>TAN1 (70\%)>TAN3 (62\%). Hence, the immobilized bacteria are having higher biodegradation potential for the treatment of the tannery effluents.

Keywords: Biodegradation, bacteria, effluent, immobilization, tannery.

\section{INTRODUCTION}

Tannery industrial wastewater is a serious consequence of the pollution point of view for streams, freshwater, and land used for agriculture. The lack of awareness in the modern industrial practice has resulted in the discharge of tannery effluents which exhibit very high value of chromium ( $\mathrm{Cr}$ ), Sulfide, and chloride, Total Dissolved Solid (TDS), Total Suspended Solid (TSS), Biochemical Oxygen Demand (BOD) and Chemical Oxygen Demand (COD) in the water stream or land (Mohammed et al., 2001). Tanning is the process, which One ton of skin generally leads to the production of 20 to $80 \mathrm{~m}^{3}$ of turbid and foul-smelling converts the protein of the rawhide or skin into a stable material, which will not putrefy and is suitable for a wide variety of end applications (Elsheikh, 2009). The highly polluting chromium is the most commonly used tanning material producing leather that is more flexible and pliable than vegetable-tanned leather and does not discolor or lose shape in water as drastically as vegetable-tan (Elsheikh, 2009). Tannery effluent is among the most hazardous industrial pollutants due to its huge organic and inorganic load, which is highly toxic to human life and the environment (Kongjao et al., 2008). wastewater including chromium (100-400 mg/l), sulfide $(200-800 \mathrm{mg} / \mathrm{l})$, high levels of fat and 
BAJOPAS Volume 13 Number 2, December, 2020 other solid wastes, and notable pathogen contamination as well as pesticides added for skin conservation during transport (Elsheikh, 2009). There are more than 6000 tanneries in Nigeria with an annual processing capacity of 700,000 tons of hides and skins (Omoleke, 2004; Singh et al., 2008). It was reported that the total amount of waste produced per animal slaughtered is approximately $35 \%$ of its weight (World Bank, 1995). Also, for every $1000 \mathrm{~kg}$ of carcass weight, a slaughtered beef produces 5.5 $\mathrm{kg}$ of manure (excluding rumen contents or stockyard manure) and $100 \mathrm{~kg}$ of paunch manure (undigested food) (Verheijen et al., 1996). Tanneries generate wastewater in the range of 30-35 $\mathrm{L} \mathrm{kg}^{-1}$ skin/hide processed with variable $\mathrm{pH}$, Biological Oxygen Demand (BOD), Chemical Oxygen Demand (COD), high concentrations of suspended solids (SS), and tannins as well as chromium (Zahoor and Abdul, 2009).

Being heterogeneous and composed of a wide variety of compounds, it is very difficult to select a unique direct method for estimating the biodegradability of organic contents and biokinetic parameters for a wastewater sample (Rajor, 2004). For this purpose, some indirect estimation such as determination of biochemical oxygen demand (BOD) and chemical oxygen demand (COD) are applied as common laboratory investigations [9]. During retanning procedures, synthetic tannins (Syntan), oils and resins are added to form softer leather at varying doses (Munz et al., 2009). One of the refractory groups of chemicals in tannery effluents derives mainly from tannins (Ramasami et al., 2004). Syntans are characterized by complex chemical structures, because they are composed of an extended set of chemicals such as phenol-, naphthalene-, formaldehyde- and melamine-based syntans, and acrylic resins (Beem, 1994). Organic pollutants (proteic and lipidic components) are originated from skins (it is calculated that the raw skin has $30 \%$ loss of organic material during the working cycle) or they are introduced during processes (Hugo Springer, 1994).

Many conventional processes such as oxidation, chemical and biological processes were carried out to treat tanneries wastewater (Ebtesam et al, 2013). Biological processes have received more attention because of their costeffectiveness, lower sludge production and environmental friendliness (Noorjahan, 2014). Naturally occurring micro-organisms degrade the hazardous organic wastes including xenobiotic compounds, such as pesticides, polycyclic aromatic hydrocarbons (PAHs) and polychlorinated biphenyls (PCBs) in due course of time (Ranen and Sharadinadra, 2009). Bioremediation is based on the idea that all organisms remove substances from the environment to carry outgrowth and metabolism (Bouwer and Zehnder, 1993). Bacteria, protista and fungi are found to be very good at degrading complex molecules and incorporating the breakdown products into their metabolism (Bouwer and Zehnder, 1993). The resultant metabolic wastes that they produce are generally safe and somehow recycled into other organisms (Ranen and Sharadinadra, 2009). An acclimatized indigenous population of microorganisms capable of degradation of the compounds of interest must exist at the site for a successful bioremediation mode (Ranen and Sharadinadra, 2009). It has been observed that for a successful bioremediation mode, an acclimatized indigenous population of microorganisms capable of degradation of the compounds of interest must exist at the site under investigation (Ranen and Sharadinadra, 2009). Even though there are numerous physical and chemical methods employed in the disposal of wastes the advantage in using bacterium is that they play a key role in the reduction of COD, BOD, total protein, total tannin and total phenol (Saravanan and Saravanan, 1998)

Baba et al. (2020) studied the bioremediation potential of immobilized corynebacterium kutsceri in the Treatment of tannery industrial effluent from Challawa Industrial Estate, Kano State, Nigeria. The aim of the work is to study the reduction in the level of the contaminants through the process of bioremediation using the isolated bacteria. Immobilized bacteria can withstand various temperatures, $\mathrm{pH}$ and substrate concentrations; consequently, increasing the efficiency and the lifespan of the bacteria. Immobilized bacteria are widely applied in the treatment of wastewater and can be separated and recovered after the treatment with the same efficiency (Baba et al., 2020).

\section{MATERIALS AND METHODS \\ Study Area}

This study was carried out in Bompai, Sharada and Challawa industrial estates in Kano, Figure 1. Kano lies on Latitude $11^{\circ} 30^{\prime} \mathrm{N}$ and $8^{\circ} 30^{\prime} \mathrm{E}$ and Longitude $11^{\circ} 5^{\prime} \mathrm{N}$ and $8^{\circ} 5^{\prime} \mathrm{E}$ in Northern Nigeria. It is one of the developed industrial cities in Nigeria. Tannery activities are the dominating industries and this could be one of the reasons for her high population density (Dan'Azumi and Bichi, 2010). Many researchers have studied biodegradation of tannery effluent using microorganisms. However, limited literature is available on the biodegradation of tannery effluent in Kano industrial estates using 
BAJOPAS Volume 13 Number 2, December, 2020 immobilized bacterial cells. This research work focuses on the potential of the use of the indigenous immobilized bacterial isolates in the treatment of tannery effluents in the industrial estates.

\section{Sample Collection}

Effluents were collected from the Tannery Industries from Bompai, Challawa and Sharada Industrial Estates, Kano, Nigeria. The effluents were collected over a period of six months (August 2017 to January 2018). Samples collected in a sterile 4-liter plastic container with a unique identification number were preserved using an ice-box that was transported to the Microbiology Laboratory, Department of Microbiology, Bayero University of Kano for analysis

\section{Sample Preparation and Sample Analysis}

Immediately after the collection of the effluent, $\mathrm{pH}$, TSS, TDS, COD, BOD levels were determined before treatment (Pre-treatment determination) and ten days after treatment (Post-treatment determination) as described in
APHA (1989) standard methods. $\mathrm{pH}$ was determined using Ecotests $\mathrm{pH}$ meter and TDS was determined using AQUALYTIC TDS Salinometer. BOD was determined as described by the standard method (APHA, 1992). COD and SS were determined using DR/2010 HACH portable data logging spectrophotometer (DWAF, 1992)

\section{Identification and Biochemical} Characterization of the Bacterial Isolates

The bacteria were isolated from the effluents using Serial Dilution according to the method described by APHA (1989). The biochemical tests such as oxidase, catalase, coagulase, indole (from $1 \%$ tryptone broth), citrate (Simmons citrate agar), methyl red/VogesProskauer (MR/VP), nitrate reduction, Starch Hydrolysis, Glucose, Maltose, and Lactose tests were carried out on the bacterial isolates to identify the bacteria through the bacteria biochemical characteristics according to Ajao et al. (2011).

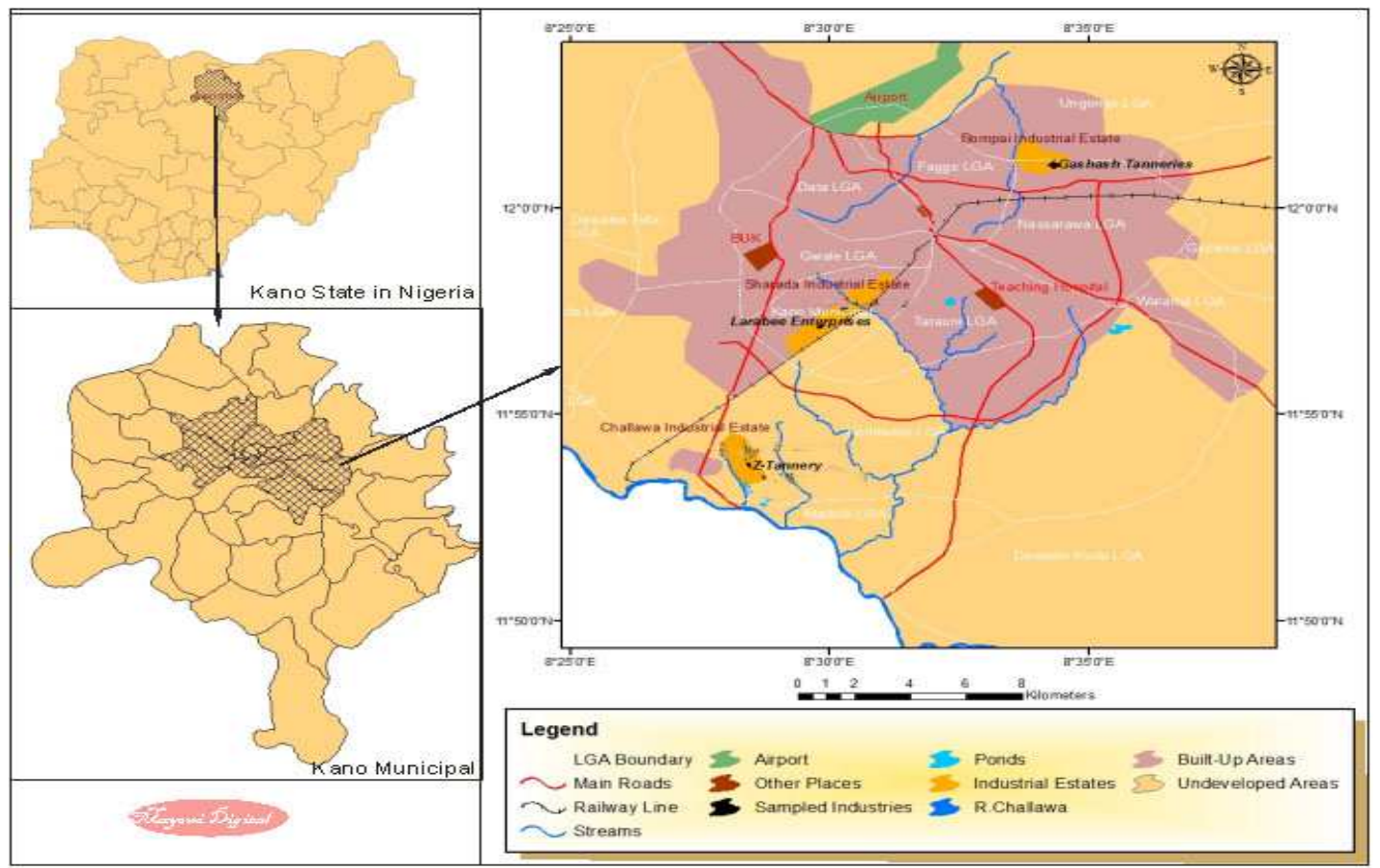

Fig. 1 Map showing the study areas

Source: Mayomi Digital Productions, GIS Laboratory, Department of Geography, UNIMAID (2017)

\section{Determination of Growth Rate of the Bacteria in Effluent Sample}

The bacteria growth rates were determined by transferring $2 \mathrm{~mL}$ of the bacterial isolates from the tannery effluent in broth medium into 100 $\mathrm{mL}$ sterile effluents in conical flasks and kept in an incubator (Giffrin cool) for 10 days. Control was also set up by incubating another $100 \mathrm{~mL}$ each of the sterile effluents without the bacteria. The optical density of the content was determined at the wavelength of $600 \mathrm{~nm}$ on a daily interval and recorded. 
BAJOPAS Volume 13 Number 2, December, 2020 Immobilization of Bacteria

Agar solution and inoculi were prepared separately. Fifty milliliters $(50 \mathrm{~mL})$ of nutrient broth each of the inoculi was prepared in a McCartney bottle and incubated for 24 hours. A solution of agar-agar was prepared by dissolving $10 \mathrm{~g}$ of the powder in distilled water and made up to $500 \mathrm{~mL}$ mark in an Erlenmeyer flask and was sterilized in an autoclave (280A) for 15 minutes and allowed to cool to $40-45^{\circ} \mathrm{C}$ (Ajao et al., 2011). Four milliliters ( $4 \mathrm{~mL})$ of the bacterial isolates in the nutrient broth was mixed with 36 $\mathrm{ml}$ of the prepared agar-agar media in petri-dish plates and then allowed to solidify. This was kept in the refrigerator for bioremediation.

\section{Bioremediation (Treatment) of the Effluents}

The solidified agar block (immobilized bacteria) was cut into cubes using a sterile knife; $0.1 \mathrm{~mL}$ phosphate buffer ( $\mathrm{pH} \mathrm{7.0)}$ was added and kept in the refrigerator for 1 hour for curing. The phosphate buffer was decanted after 1 hour and the cubes were washed with sterile distilled water 3-4 times before it was used (Ajao et al., 2011). Two liters (2 L) of the effluent was supplemented with the minimum basal medium in $\mathrm{g} / \mathrm{L}: \mathrm{NaCl}(0.8), \mathrm{MgSO}_{4} .7 \mathrm{H}_{2} \mathrm{O}(0.001), \mathrm{KH}_{2} \mathrm{PO}_{4}$ (2), $\mathrm{NaNO}_{3}$ (2), $\quad \mathrm{CaCl}_{2} .2 \mathrm{H}_{2} \mathrm{O} \quad(0.5)$ and $\mathrm{NaHPO}_{4} .12 \mathrm{H}_{2} \mathrm{O}(2)$ and sterilized in an autoclave at $121^{\circ} \mathrm{C}$ for 15 minutes (Margesin and Schinner, 2001). Two hundred and fifty milliliters $(250 \mathrm{~mL})$ of the effluents were transferred into different $250 \mathrm{ml}$ conical flasks. The content was covered with a cotton-wool ramped with foil paper to avoid contamination. Five grams $(5 \mathrm{~g})$ of the immobilized bacteria were quickly transferred into each of the effluents in the conical flasks in an inoculating chamber. The same procedures were carried out for the $10 \mathrm{~g}, 15 \mathrm{~g}, 20 \mathrm{~g}$ and 25 $\mathrm{g}$ of the immobilized bacteria in separate $250 \mathrm{~mL}$ effluents in conical flasks and agitated for ten days in a shaker incubator (Gallenkamp-OC4364-L) at a temperature $30^{\circ} \mathrm{C}$ and speed of 60 rpm. The treated effluent samples were taken on the tenth day and analyzed for the parameters $\mathrm{pH}$, SS, TDS, COD, and BOD, (Posttreatment determination) for the different grams of bacteria to evaluate and compare the biodegradation potential. (Baba et al., 2020).

\section{Statistical Analysis}

The data were represented as Mean \pm Standard deviation and analyzed statistically using oneway Analysis of Variance (ANOVA) and Tukey's HSD as Post Hoc Tests with the aid of SPSS 16.0. The correlation coefficient was also used to measure the strength of the relationship between the different masses of the bacteria and the parameters. All $\mathrm{p} \leq 0.05$ were considered as statistically significant.

\section{RESULTS AND DISCUSSION Physico-chemical parameters in the Industrial Effluents before the Biodegradation.}

Results of the Physico-chemical parameters in the industrial effluents before the Biodegradation is shown in table 1 . The mean temperatures $\left({ }^{\circ} \mathrm{C}\right)$ observed in TAN1, TAN2, and TAN3 samples were $28.07 \pm 0.65 ; 27.77 \pm 0.64$ and $26.38 \pm 3.81$ respectively. The order of the mean temperature of the samples from the three industries can be arranged as TAN1 > TAN2>TAN3. The temperature observed at TAN1, TAN2, and TAN3 samples were found below the WHO $\left(35^{\circ} \mathrm{C}\right)$ and NESREA $\left(40^{\circ} \mathrm{C}\right)$ limits. The low values of temperature might be due to the processes used at the time of sampling. High temperature brings down the solubility of gases in water that ultimately expresses as high BOD and COD. Statistical analysis shows that there is no significant difference $(p<0.05)$ between the mean values of temperature among the industries. This might be due to similar tannery activities involved in the tannery industries at the time of sampling. The average values of temperature observed in this present study are less than those observed by Akan et al. (2007), Akan et al. (2009) and Baba et al. (2020).

The mean level of $\mathrm{pH}$ observed in TAN1, TAN2 and TAN3, samples were $7.77 \pm 2.93$; $8.35 \pm 0.28$ and $7.52 \pm 0.76$ respectively. The order of the mean $\mathrm{pH}$ of the samples from the three industries can be arranged as TAN2> TAN1 $>$ TAN3. The $\mathrm{pH}$ of the samples falls within the WHO (7.0-8.5) and NESREA (6-9) standard limits. Statistical analysis shows that there is no significant difference $(p<0.05)$ between the mean values of $\mathrm{pH}$ among the industries. This might be due to similar tannery activities involved in the tannery industries at the time of sampling. Maheshwari et al. (2017) reported that the level of $\mathrm{pH}$ in the effluents from the tannery industry in Vaniyambadi, India was 6.5 which was lower than that observed in the present study. The $\mathrm{pH}$ in the effluents from the tannery industries in Kano and Kaduna were reported to be 7.64 and 6.89, respectively (Akan et al., 2007; Mohammed et al., 2017). The average values of $\mathrm{pH}$ observed in this present study are less than those observed by Mohammed et al. (2017) and Baba et al. (2020). The mean level of SS $(\mathrm{mg} / \mathrm{l})$ observed in TAN1, TAN2, and TAN3 samples were 374 \pm 124 ; $358 \pm 335$ and $780 \pm 739$ respectively. The order of the mean SS in the samples from the three industries can be arranged as TAN3 > TAN1 $>$ TAN2. 
The SS observed in the samples were far above the recommended standard limits of regulating bodies WHO $(30 \mathrm{mg} / \mathrm{l})$ and NESREA $(10 \mathrm{mg} / \mathrm{l})$. Statistical analysis shows that there is no significant difference $(p<0.05)$ between the mean values of SS among the industries. This might be due to similar tannery activities involved in the tannery industries at the time of sampling. The average values of SS observed in this present study are less than that observed $(3700 \pm 122 \mathrm{mg} / \mathrm{l})$ by Akan et al. (2009) for tanneries in Kano. Also, the average values of SS observed in this present study are less than that observed by Mohammed et al. (2017) and Baba et al. (2020) with the exception in TAN3.

The mean level of TDS (mg/l) observed in TAN1, TAN2, and TAN3 samples were $3941 \pm 3703$; $3300 \pm 1714$ and $2653 \pm 1240$ respectively. The order of the mean TDS in the samples from the three industries can be arranged as TAN1>TAN2>TAN3. The TDS observed in the samples were far above the recommended standard limits of WHO $(250 \mathrm{mg} / \mathrm{l})$ and NESREA $(500 \mathrm{mg} / \mathrm{l})$. Statistical analysis shows that there is no significant difference $(p<0.05)$ between the mean values of TDS among the industries. This might be due to similar tannery activities involved in the tannery industries at the time of sampling. TDS in the effluents from the tannery industries in Kano, Nigeria was reported to be $1281 \mathrm{mg} / \mathrm{l}$ (Akan et al., 2007). The average values of SS observed in this present study are less than those observed by Mohammed et al. (2017) and Baba et al. 2020)

The mean level of COD (mg/l) observed in TAN1, TAN2 and TAN3 samples seasons were $2372 \pm 938 ; \quad 1406 \pm 208$ and $3532 \pm 1373$ respectively. The order of the mean COD of the samples from the three industries can be arranged as TAN3>TAN1> TAN2. The COD observed in TAN1, TAN2 and TAN3 samples were far above the recommended standard limits of regulating bodies $\mathrm{WHO}(40 \mathrm{mg} / \mathrm{l})$ and NESREA (40 mg/l). Statistical analysis shows that there is no significant difference $(p<0.05)$ in COD among the industries. This might be due to similar tannery activities involved in the tannery industries as at the time of sampling. The Chemical Oxygen demand (COD) is the amount of oxygen, in $\mathrm{mg} / \mathrm{L}$, required for the degradation of the compound of wastewater to occur. In comparison, the average values of COD observed in this present study were higher than that observed by Mohammed et al. (2017) but lower than that observed by Baba et al. (2020).

The mean levels of BOD $(\mathrm{mg} / \mathrm{l})$ observed in TAN1, TAN2 and TAN3 samples were $13.85 \pm 6.42 ; \quad 19.46 \pm 0.50$ and $17.13 \pm 3.14$ respectively. The order of the mean BOD in the samples from the three industries can be arranged as TAN2>TAN3>TAN1. The BOD observed in TAN1, TAN2 and TAN3 samples were found below the recommended limits of NESREA (200 mg/l) but above WHO (10 mg/l). Statistical analysis shows that there is no significant difference $(p<0.05)$ between the mean values of BOD among the industries. This might be due to similar tannery activities involved in the tannery industries at the time of sampling. The low level of BOD recorded in this study is an indication of the low level of biodegradable organic solids in the effluent. The average values of BOD observed in this present study were lower than those observed by Mohammed et al. (2017) and Baba et al. (2020).

Table 1: Mean Values \pm S.D of Physico-chemical parameters of effluents from the Tannery Industries before Treatment.

\begin{tabular}{llllllll}
\hline Parameter & Tannery 1 & Tannery 2 & Tannery 3 & $\mathrm{a}$ & $\mathrm{b}$ & $\mathrm{c}$ & $\mathrm{d}$ \\
\cline { 2 - 7 } Temperature $\left({ }^{\circ} \mathrm{C}\right)$ & $28.07 \mathrm{a} \pm 0.65$ & $27.77 \mathrm{a} \pm 0.64$ & $26.38 \mathrm{a} \pm 3.81$ & & $29.50 \pm 4.68$ & 35 & 40 \\
pH & $7.77 \mathrm{a} \pm 2.93$ & $8.35 \mathrm{a} \pm 0.28$ & $7.52 \mathrm{a} \pm 0.76$ & 6.89 & $5.35 \pm 1.57$ & $7.0-8.5$ & $6.0-9.0$ \\
$\mathrm{COD}(\mathrm{mg} / \mathrm{l})$ & $2372 \mathrm{a} \pm 938$ & $1406 \mathrm{a} \pm 208$ & $3532 \mathrm{a} \pm 1373$ & 2.2 & $3106 \pm 2753$ & 40 & 40 \\
$\mathrm{BOD}(\mathrm{mg} / \mathrm{l})$ & $13.85 \mathrm{a} \pm 6.42$ & $19.46 \mathrm{a} \pm 0.50$ & $17.13 \mathrm{a} \pm 3.14$ & 1032 & $26.17 \pm 9.49$ & 10 & 200 \\
$\mathrm{SS}(\mathrm{mg} / \mathrm{l})$ & $374 \mathrm{a} \pm 124$ & $358 \mathrm{a} \pm 335$ & $780 \mathrm{a} \pm 739$ & 501 & $562 \pm 482$ & 30 & 10 \\
TDS $(\mathrm{mg} / \mathrm{l})$ & $3941 \mathrm{a} \pm 3703$ & $3300 \mathrm{a} \pm 1714$ & $2653 \mathrm{a} \pm 1240$ & 532.7 & $444 \pm 507$ & 250 & 500 \\
\hline
\end{tabular}

The values given in the table above are means of 6 replicate values, $\mathrm{n}=6$ ( 1 sample was taken monthly for 6 months). Within the rows, means with different alphabets are statistically different $(p<0.05)$. WHO: World Health Organisation. NESREA: National Environmental Standard and Regulatory Enforcement Agency. a = Mohammed et al.(2017), b = Baba et al. (2020), c = WHO (2006), $d=$ NESSRA (2009) 
BAJOPAS Volume 13 Number 2, December, 2020

Identification, Biochemical Characterization and growth rates of the Bacterial Isolates

Results of identification and biochemical characterization of the bacterial isolates were shown in table 2. After 24 hours of incubation, the nutrient agar media plates were checked for bacterial growth. The results showed the presence of different strains in the samples. The TAN1 bacteria isolate was found to be gramnegative cocci while TAN3 was gram-positive cocci. TAN2 bacteria isolate was found to be gram-positive, rod-shaped. TAN1, TAN2, and TAN3 bacteria isolates recorded positive results for spore former.

The results of the biochemical tests indicated that all the bacteria were positive for catalase, oxidase, citrate, maltose, glucose, lactose (negative in TAN1), mannitol (negative in TAN2), starch hydrolysis and coagulase (negative in TAN2) tests. The bacteria showed negative results for nitrate reduction, $M R$ (positive in TAN2), VP (positive in TAN1), Indole (positive in TAN2) tests. Base on the morphological and biochemical test results, TAN1, TAN2, and TAN3 bacteria isolates were identified to be Nesseria spp, Bacillus cereus, and Staphylococcus aureus respectively.

The growth rate of the TAN1, TAN2 and TAN3 Isolates were shown in figure 2. Generally, the optical density increase with the increase in time (day) and decrease as time goes on. The highest optical density was shown by bacillus cereus in TAN2 while the lowest was shown by Staphylococcus aureus in TAN3.

The initial growth phase of TAN1 Isolate bacteria occurred within 2-day of incubation as the growth rate increases up to the 6th-day incubation when the maximum growth was observed. Beyond the 6th day, the growth of the bacteria declined (which might be due to a shortage of nutrients in the effluents) until it reached its death phase (which might be due to the unavailability of nutrients in the effluents).

A similar trend of growth was also observed for TAN2 Isolate as the initial growth phase also occurred within 2-day of incubation but maximum growth rate observed on the 4th day of incubation. The stationary stage occurred between the 4th day and the 8th day. Beyond the 8th day, the growth of the bacteria declined (which might be due to a shortage of nutrients in the effluents) until it reached its death phase (which might be due to the unavailability of nutrients in the effluents).

The initial growth phase of TAN3 bacterial Isolate occurred within the 3-day incubation as the growth rate increases up to the 6th-day incubation when the maximum growth was observed. Beyond the 6th day, the growth of the bacteria declined (which might be due to a shortage of nutrients in the effluents) until it reached its death phase (which might be due to the unavailability of nutrients in the effluents).

Table 2: Morphological and Biochemical characteristics of bacterial isolates

\begin{tabular}{lllll} 
Bacterial Isolates & & TAN1 & TAN2 & TAN3 \\
\hline $\begin{array}{lllll}\text { Morphological } \\
\text { characteristics }\end{array}$ & Shape & Cocci & Rod & Cocci \\
& Spore & & & \\
& former & + & + & + \\
Gram & & & \\
Biochemical characteristics & reaction & - & + & + \\
& Citrate & + & + & + \\
& Catalase & + & + & + \\
& Coagulase & + & - & + \\
Starch & + & + & + \\
& Glucose & + & + & + \\
Oxidase & + & + & + \\
& Indo & - & + & - \\
Lactose & - & + & + \\
Manitol & + & - & + \\
Maltose & + & + & + \\
MR & - & + & - \\
VP & + & - & - \\
& Nitrate & - & - & - \\
Reduction & - Neisseria & Bacillus & Staphylococcus \\
& Bacterial & cereus & aureus \\
& name & spp & cas
\end{tabular}

+ = Positive; - = Negative; MR=Methyl Red; VP= Voges-Proskauer 


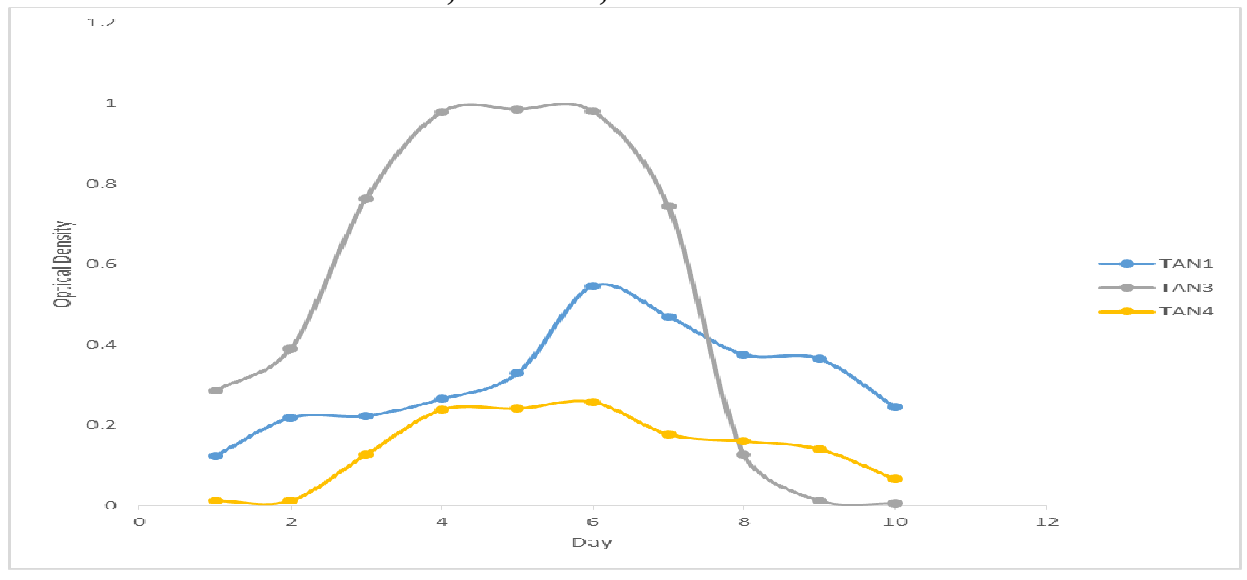

Fig. 2 Growth rates of the isolates in the effluents from the Tannery Industries

\section{Physico-chemical Parameters in the Industrial Effluents after the biodegradation.}

Table 3 shows the mean results of the physicochemical parameter before and after bioremediation using the different masses $(5 \mathrm{~g}$, $10 \mathrm{~g}, 15 \mathrm{~g}, 20 \mathrm{~g}$, and $25 \mathrm{~g}$ ) of the respective immobilized bacteria. Also, Table 4 shows the mean results of correlation coefficient ( $r$ ) between different masses of bacteria and physicochemical parameters.

The mean values $(\mathrm{mg} / \mathrm{l})$ of the SS after the bioremediation varies between $243 \pm 45$ and $898 \pm 672$. The mean concentration $(\mathrm{mg} / \mathrm{l})$ of SS remediated by the different masses $(5 \mathrm{~g}, 10 \mathrm{~g}$, $15 \mathrm{~g}, 20 \mathrm{~g}$, and $25 \mathrm{~g}$ ) of the bacteria varies. The SS in the samples fluctuates up and down after the bioremediation process when compared with the SS of the raw samples before the bioremediation. The increase in the levels of the SS might be due to the aggregation of the TDS which are large enough to result into SS. The increase in the levels of the SS might be also due to the influence of the nutrients which was added into the effluents in order to make the microorganisms more active and viable for fast degradation of organic contaminants in the effluent. The relative potential or efficiency of the different masses of the bacteria in remediating SS in TAN1 samples was in the order $25 \mathrm{~g}>20 \mathrm{~g}>15 \mathrm{~g}>10 \mathrm{~g}>5 \mathrm{~g}$. For TAN2 and TAN3 samples, the order was $25 \mathrm{~g}>20 \mathrm{~g}>15$ $\mathrm{g}>10 \mathrm{~g}>5 \mathrm{~g}$. These might be due to the variations in the surface areas of the different masses of the immobilized bacteria. Statistical analysis shows that there is no significant difference $(p<0.05)$ between the mean values of SS among the masses in the respective industries. Positive and significant correlations exist between the masses of bacteria and Suspended Solid (SS). This showed that there is general increase in the levels of the SS as the masses of the immobilized bacteria increases. TAN3 (90\%) and TAN1 (80\%) showed a very high correlation with the masses of the bacteria while TAN2 (61\%) showed a very low correlation.

The mean values $(\mathrm{mg} / \mathrm{l})$ of the TDS after the bioremediation varies between $46 \pm 11$ and $83 \pm 78$. The mean concentration $(\mathrm{mg} / \mathrm{l})$ of TDS remediated by the different masses $(5 \mathrm{~g}, 10 \mathrm{~g}$, $15 \mathrm{~g}, 20 \mathrm{~g}$, and $25 \mathrm{~g}$ ) of the bacteria varies. There is a reduction in all the TDS of all the samples after the bioremediation process compared with the TDS of the raw samples before the bioremediation. The relative potential or efficiency of the different masses of the bacteria in remediating TDS in TAN1 and TAN3 samples was in the order $5 \mathrm{~g}>10 \mathrm{~g}>15 \mathrm{~g}>20$ $\mathrm{g}>25 \mathrm{~g}$. For TAN2 samples, the order was 20 $g>10 \quad g>25 \quad g>15 \quad g>5 \quad g$. Statistical analysis shows that there is no significant difference $(p<0.05)$ between the mean values of TDS among the masses in the respective industries. These might be due to the variations in the surface areas of the different masses of the immobilized bacteria. Positive and significant correlations exist between the masses of bacteria and TDS with the exception in TAN2 (negative and insignificant correlation). The positive correlations showed that there is general increase in the levels of the TDS as the masses of the immobilized bacteria increases. TAN1 $(96 \%)$ showed a very high correlation with the masses of the bacteria while TAN2 (47\%) showed a very low correlation.

The mean values $(\mathrm{mg} / \mathrm{l})$ of the BOD after the bioremediation varies between $1.56 \pm 0.20 \mathrm{mg} / \mathrm{l}$ and $6.92 \pm 5.49 \mathrm{mg} / \mathrm{l}$. The mean concentration $(\mathrm{mg} / \mathrm{l})$ of BOD remediated by the different masses $(5 \mathrm{~g}, 10 \mathrm{~g}, 15 \mathrm{~g}, 20 \mathrm{~g}$, and $25 \mathrm{~g}$ ) of the bacteria varies. There is a reduction in all the BOD of all the samples after the bioremediation process compared with the $\mathrm{BOD}$ of the raw 
BAJOPAS Volume 13 Number 2, December, 2020 samples before the bioremediation. The relative potential or efficiency of the different masses of the bacteria in remediating BOD in TAN1, TAN2 and TAN3 samples were in the order $25 \mathrm{~g}>20$ $\mathrm{g}>15 \mathrm{~g}>10 \mathrm{~g}>5 \mathrm{~g}, 25 \mathrm{~g}>15 \mathrm{~g}>5 \mathrm{~g}>10 \mathrm{~g}>20 \mathrm{~g}$ and $20 \mathrm{~g}>10 \mathrm{~g}>25 \mathrm{~g}>15 \mathrm{~g}>5 \mathrm{~g}$ respectively. Statistical analysis shows that there is significant difference $(p<0.05)$ between the mean values of BOD among the masses in the respective industries. These might be due to the variations in the surface areas of the different masses of the immobilized bacteria. Negative and significant correlations exist between the masses of bacteria and BOD. This showed that there is general decrease in the levels of the BOD as the masses of the immobilized bacteria increases. TAN1 (94\%) showed a very high correlation with the masses of the bacteria while TAN2 (4\%) showed a very low correlation.

The mean values $(\mathrm{mg} / \mathrm{l})$ of the COD after the bioremediation varies between $250 \pm 154$ and $3134 \pm 1595$. The mean concentration $(\mathrm{mg} / \mathrm{l})$ of COD remediated by the different masses $(5 \mathrm{~g}$, $10 \mathrm{~g}, 15 \mathrm{~g} 20 \mathrm{~g}$, and $25 \mathrm{~g}$ ) of the bacteria varies. There is a reduction in all the COD of all the samples after the bioremediation process compared with the COD of the raw samples before the bioremediation. The relative potential or efficiency of the different masses of the bacteria in remediating COD in TAN1, TAN2 and TAN3 samples were in the order $25 \mathrm{~g}>20 \mathrm{~g}>15$ $\mathrm{g}>5 \mathrm{~g}>10 \mathrm{~g}, 25 \mathrm{~g}>20 \mathrm{~g}>15 \mathrm{~g}>10 \mathrm{~g}>5 \mathrm{~g}$ and 10 g>5 g>25 g>15 g>20 g respectively. Statistical analysis shows that there were significant difference $(p<0.05)$ between the mean values of COD among the masses in the respective industries except for effluents treated with $25 \mathrm{~g}$. These might be due to the variations in the surface areas of the different masses of the immobilized bacteria. Negative and insignificant correlations exist between the masses of bacteria and COD with the exception in TAN3 (positive and significant correlation). The negative correlations showed that there is general decrease in the levels of the COD as the masses of the immobilized bacteria increases. TAN2 (100\%) showed a very high correlation with the masses of the bacteria while TAN3 (36\%) showed a very low correlation.

Generally, there was an overall decrease in the concentration of these physicochemical parameters after the bioremediation using the different masses of the bacterial isolates. These might be due to the variations in the surface areas of the different masses of the immobilized bacteria. This is in line with the work of Jimoh et al. (2018) and Baba et al. (2020).

Table 3: Mean Values $(\mathrm{mg} / \mathrm{l}) \pm$ S.D of Physicochemical parameters in effluents from the Tannery Industries before and after Treatment of the effluents $(250 \mathrm{ml})$ with the different masses $(5 \mathrm{~g}, 10 \mathrm{~g}$, $15 \mathrm{~g}, 20 \mathrm{~g}$, and $25 \mathrm{~g}$ ) of the bacteria.

\begin{tabular}{llllllll}
\hline $\mathrm{P}$ & IND & Before & \multicolumn{5}{c}{ After } \\
\cline { 4 - 7 } & & & $5 \mathrm{~g}$ & $10 \mathrm{~g}$ & $15 \mathrm{~g}$ & $20 \mathrm{~g}$ & $25 \mathrm{~g}$ \\
\hline \multirow{2}{*}{ COD } & TAN1 & $2372 \pm 938$ & $1708 \mathrm{a} \pm 861$ & $2045 \mathrm{a} \pm 1205$ & $845 \mathrm{a} \pm 369$ & $300 \mathrm{a} \pm 167$ & $250 \mathrm{a} \pm 154$ \\
& TAN2 & $1406 \pm 208$ & $1195 \mathrm{a} \pm 208$ & $1125 \mathrm{a} \pm 384$ & $1055 \mathrm{a} \pm 317$ & $956 \mathrm{a} \pm 310$ & $870 \mathrm{ab} \pm 240$ \\
& TAN3 & $3532 \pm 1373$ & $2374 \mathrm{a} \pm 1344$ & $1976 \mathrm{a} \pm 1405$ & $2757 \mathrm{a} \pm 1266$ & $3134 \mathrm{a} \pm 1595$ & $2614 \mathrm{~b} \pm 1105$ \\
BOD & TAN1 & $13.85 \pm 6.42$ & $6.92 \mathrm{a} \pm 5.49$ & $6.42 \mathrm{a} \pm 5.07$ & $5.72 \mathrm{a} \pm 5.35$ & $4.62 \mathrm{a} \pm 4.37$ & $2.82 \mathrm{ab} \pm 1.26$ \\
& TAN2 & $19.46 \pm 0.50$ & $1.75 \mathrm{~b} \pm 0.22$ & $1.73 \mathrm{~b} \pm 0.18$ & $1.58 \mathrm{a} \pm 0.16$ & $1.91 \mathrm{a} \pm 0.22$ & $1.56 \mathrm{~b} \pm 0.20$ \\
& TAN3 & $17.13 \pm 3.14$ & $4.24 \mathrm{ab} \pm 0.77$ & $3.29 \mathrm{ab} \pm 0.37$ & $4.11 \mathrm{a} \pm 0.07$ & $3.23 \mathrm{a} \pm 0.91$ & $3.33 \mathrm{a} \pm 1.28$ \\
SS & TAN1 & $374 \pm 124$ & $243 \mathrm{a} \pm 45$ & $471 \mathrm{a} \pm 226$ & $475 \mathrm{a} \pm 182$ & $492 \mathrm{a} \pm 128$ & $611 \mathrm{a} \pm 217$ \\
& TAN2 & $358 \pm 335$ & $460 \mathrm{a} \pm 400$ & $543 \mathrm{a} \pm 414$ & $544 \mathrm{a} \pm 402$ & $551 \mathrm{a} \pm 414$ & $554 \mathrm{a} \pm 405$ \\
& TAN3 & $780 \pm 739$ & $586 \mathrm{a} \pm 594$ & $758 \mathrm{a} \pm 656$ & $787 \mathrm{a} \pm 676$ & $861 \mathrm{a} \pm 635$ & $898 \mathrm{a} \pm 672$ \\
TDS & TAN1 & $3941 \pm 3703$ & $51 \mathrm{a} \pm 10$ & $53 \mathrm{a} \pm 10$ & $55 \mathrm{a} \pm 15$ & $61 \mathrm{a} \pm 20$ & $63 \mathrm{a} \pm 26$ \\
& TAN2 & $3300 \pm 1714$ & $83 \mathrm{a} \pm 78$ & $47 \mathrm{a} \pm 20$ & $48 \mathrm{a} \pm 22$ & $47 \mathrm{a} \pm 17$ & $48 \mathrm{a} \pm 17$ \\
& TAN3 & $2653 \pm 1240$ & $46 \mathrm{a} \pm 11$ & $55 \mathrm{a} \pm 24$ & $55 \mathrm{a} \pm 25$ & $58 \mathrm{a} \pm 23$ & $61 \mathrm{a} \pm 28$ \\
\hline
\end{tabular}

Replicate $=6$ (months)

Within the rows, for the same parameter, means with different alphabets are statistically different $(p<0.05)$.

$\mathrm{P}=$ parameter, IND = Industries 
BAJOPAS Volume 13 Number 2, December, 2020

Table 4: Correlation coefficient $(r)$ between different masses of the bacteria and the physicochemical parameters.

\begin{tabular}{llll}
\hline Industries & Parameter & Correlation coefficient $(r)$ & $\begin{array}{l}\text { Percent dependence (rxrx100) } \\
(\%)\end{array}$ \\
\hline TAN1 & COD & -0.9 & 82 \\
& BOD & -0.97 & 94 \\
& SS & $0.90^{*}$ & 80 \\
TAN2 & TDS & $0.98^{*}$ & 96 \\
& COD & -1 & 100 \\
& BOD & -0.21 & 4 \\
& SS & $0.78^{*}$ & 61 \\
& TDS & -0.69 & 47 \\
& COD & $0.60^{*}$ & 36 \\
& BOD & -0.6 & 37 \\
& SS & $0.95^{*}$ & 90 \\
& TDS & $0.94^{*}$ & 89 \\
\hline
\end{tabular}

The correlation coefficient $(r)$ with * is statistically significant $(p<0.05)$.

Percentage reduction of the Parameters

Table 5 shows the percentage reduction of Parameters in industrial samples before and after the treatment of the effluents $(250 \mathrm{ml})$ with the different masses $(5 \mathrm{~g}, 10 \mathrm{~g}, 15 \mathrm{~g}, 20 \mathrm{~g}$, and $25 \mathrm{~g}$ ) of the Immobilized Bacteria.

In TAN1 samples, the percentage reduction (\%) of COD ranged (14-89); BOD (50-80); SS (-32$35)$ and TDS (98-99). In TAN2 samples, the percentage decrease $(\%)$ of COD ranged (15$38) ;$ BOD (90-92); SS [-28-(-55)] and TDS (9798). In TAN3 samples, the percentage decrease (\%) of COD ranged (11-44); BOD (76-81); SS (15-25) and TDS (98). The percentage increase in the levels COD, BOD and TDS might be due to the increase in the surface area of the different masses of the immobilized bacteria. However, the percentage decrease in the levels of the SS might be due to the aggregation of the TDS which are large enough to result into SS. The percentage decrease in the levels of the SS might be also due to the influence of the nutrients which was added into the effluents in order to make the microorganisms more active and viable for fast degradation of organic contaminants in the effluent. This is in line with the work of Jimoh et al. (2018) in which the concentration of the SS increase after the bioremediation of effluents.

Sreemoyee and Priti (2013) assessed and reduced several Physico-chemical parameters of dairy wastewater using Niesseria $s p$. and concluded that the species are well known to degrade organic compounds. This is in agreement with the current study in which the immobilized Niesseria $s p$ degrade the organic contaminants as indicated by the BOD, COD and TDS.

Jimoh et al. (2018) observed that TSS of the effluents was increased after treatment with immobilized bacteria and concluded that it might be due to the biostimulation method adopted for the research.

The optimum $\mathrm{pH}$ Biosorption of Chromium by Bacillus spp and Staphylococcus spp. from tannery effluent was investigated by Mythili and Karthikeyan (2011). The maximum adsorption of Chromium $(86.4 \mathrm{mg} / \mathrm{L})$ was showed by Bacillus spp and Staphylococcus spp showed $70.6 \mathrm{mg} / \mathrm{L}$ at an initial concentration of $100 \mathrm{mg} / \mathrm{L}$. In the present study, immobilised Bacillus spp and Staphylococcus spp. from the tannery industrial effluents reduced the levels of the organic pollutants with high potential as indicated by the percentage reduction of BOD, COD and TDS.

Enzymes often can work in multiple environments especially if they are immobilized. This makes the microorganisms' enzymes even more resistant to harsh environments and enables the enzymes to be recovered and recycled after they are no longer needed (Gianfreda and Rao 2004). Ramesh and Singh (1993) reported that the immobilized bacteria having more efficiency to remove the suspended particles than free cells. Using the immobilized cell is preferable due to its capability for using several times with the same efficiency, which makes it more economical. Similar work was done by Sikander et al. (2007) showing the higher reduction with permeabilized cells of Ochrobactrum intermedium strain SDCr-5. 
BAJOPAS Volume 13 Number 2, December, 2020

The results revealed the isolation and identification of isolates with the potential for the reduction of $\mathrm{Cr}$ (VI) to $\mathrm{Cr}$ (III). Results indicated that immobilized $B$. cereus could be efficiently used for the reduction of $\mathrm{Cr}$ (VI).

Table 5: Percentage reduction of the tested Parameters from the tannery industrial samples of the Immobilized Bacteria.

\begin{tabular}{lllllll}
\hline \multirow{2}{*}{ Industries } & & \multicolumn{5}{c}{ Percentage Reduction $(\%)$} \\
\cline { 3 - 7 } & & $5 \mathrm{~g}$ & $10 \mathrm{~g}$ & $15 \mathrm{~g}$ & $20 \mathrm{~g}$ & $25 \mathrm{~g}$ \\
\hline TAN1 & COD & 28 & 14 & 64 & 87 & 89 \\
& BOD & 50 & 54 & 59 & 67 & 80 \\
& SS & 35 & -26 & -27 & -32 & -63 \\
& TDS & 99 & 99 & 99 & 98 & 98 \\
TAN2 & COD & 15 & 20 & 25 & 32 & 38 \\
& BOD & 91 & 91 & 92 & 90 & 92 \\
& SS & -28 & -52 & -52 & -54 & -55 \\
& TDS & 97 & 99 & 99 & 99 & 99 \\
& COD & 33 & 44 & 22 & 11 & 26 \\
& BOD & 75 & 81 & 76 & 81 & 81 \\
& SS & 25 & 3 & -1 & -10 & -15 \\
& TDS & 98 & 98 & 98 & 98 & 98 \\
\hline
\end{tabular}

Percentage Reduction $=(B-A) / B \times 100 \%$

$A=$ Concentration of the parameter after treatment

$\mathrm{B}=$ Concentration of the parameter before treatment

$+=$ percentage decrease

- = percentage increase

In general, immobilization makes the enzyme more resistant to temperature, $\mathrm{pH}$, and substrate concentration swings giving it a longer lifetime and higher productivity per active unit (Gianfreda and Rao, 2004; FuIlbrook, 1996; Russell et al, 2003; Kandelbauer et al., 2004). Immobilized cells have been used and studied extensively for the production of useful chemicals (Ohtake and Silver, 1994), the treatment of wastewaters (Chen et al., 2003; Wang et al., 2010). Although many workers described microbial degradation of tannery effluent, limited literature is available on the bioremediation of tannery effluent using immobilized bacterial cells in the Kano Industrial Estates.

\section{CONCLUSION}

The samples contained variable levels of the physicochemical parameters. The results of the Analysis of variance revealed that, no statistical difference $(p<0.05)$ was observed for the temperature, $\mathrm{pH}, \mathrm{SS}, \mathrm{TDS}, \mathrm{BOD}$ and $\mathrm{COD}$ among the three tannery industries before the treatment. The levels of some of the parameters
(SS, TDS and COD) observed in the samples were found above the recommended limits of WHO and NESREA, which called for the treatment of the effluents before discharge into the environment. Base on the morphological and biochemical test results, TAN1, TAN2, and TAN3 bacterial isolates were identified to be Neisseria spp, Bacillus cereus, and Staphylococcus aureus respectively. The results of Post-treatment analysis showed that there is overall decrease in the levels of the parameters determined when compared with that of the pre-treatment. The overall percentage reduction of the immobilised bacteria in the treatment of the respective effluents was in the order TAN2 (72\%)>TAN1 $(70 \%)>$ TAN3 $(62 \%)$. Hence, the immobilized bacteria are having higher biodegradation potential for the treatment of the tannery effluents.

\section{Acknowledgments}

The authors wish to acknowledge the University of Maiduguri for the financial support. The authors are grateful to the Kano State Ministry of Environment for their support in obtaining the effluent samples. 


\section{REFERENCES}

Ajao, A. T., Adebayo, G. B., and Yakubu, S. E. (2011). Bioremediation of textile industrial effluent using mixed culture of Pseudomonas aeruginosa and Bacillus subtilis immobilized on agar-agar in a bioreactor. J. Microbiol. Biotech. Res, 1(3), 50-56.

Akan, J. C., Moses, E. A., Ogugbuaja, V. O., and Abah, J. (2007). Assessment of tannery industrial effluents from Kano metropolis, Kano State, Nigeria. Journal of Applied Sciences, 7(19), 2788-2793.

Akan, J. C., Ogugbuaja, V. O., Abdulrahman, F. I., and Ayodele, J. T. (2009). Pollutant levels in effluent samples from tanneries and textiles of Kano industrial areas, Nigeria. Global journal of pure and applied sciences, 15(3-4).

APHA (1989). Standard methods for Examination of Will bete and Will betewater.15 $5^{\text {th }}$ edition. Brydpass Springfield Will behington DC. pp. 164-176

APHA (1992). Standard Methods for the Examination of Water and Wastewater. Health, 69, 1116-9.

Baba, A., Garba, S. T., and Bello, H. S. (2020). Bioremediation Potential of Immobilized corynebacterium kutsceri in the Treatment of Tannery Industrial Effluent from Challawa Industrial Estate, Kano State, Nigeria. Journal of the Turkish Chemical Society Section A: Chemistry, $7(2), 335-350$.

Beem, E. I. V. (1994). reduction of solvent VOC emission. J. Oil Col. Chem. Ass, 77, 158.

Bouwer, E. J., and Zehnder, A. J. (1993). Bioremediation of organic compoundsputting microbial metabolism to work. Trends in biotechnology, 11(8), 360367.

Chen, K. C., Wu, J. Y., Liou, D. J., and Hwang, S. C. J. (2003). Decolorization of the textile dyes by newly isolated bacterial strains. Journal of Biotechnology, 101(1), 57-68.

Dan'Azumi, S., and Bichi, M. H. (2010). INDUSTRIAL POLLUTION AND HEAVY METALS PROFILE OF CHALLAWA RIVER IN KANO, NIGERIA. Journal of Applied Sciences in Environmental Sanitation, $5(1)$.

DWAF. (1992). Analytical Methods Manual, TR 151. Department of Water Affairs and Forestry, Pretoria.

El-Bestawy, E. (2013). Biological treatment of leather-tanning industrial wastewater using free living bacteria.
Elsheikh, M. A. S. (2009). Tannery wastewater pre-treatment. Water Science and Technology, 60(2), 433-440.

FuIlbrook, P. D. (1996). "Kinetics." Industrial enzymology: The application of enzymes in Industry. 2nd Ed. T. Godfrey and J Reichelt. eds.. Nature. New York.

Gianfreda, L., and Rao, M. A. (2004). Potential of extra cellular enzymes in remediation of polluted soils: a review. Enzyme and microbial technology, 35(4), 339354.

Hugo Springer. (1994). John Arthur Wilson Memorial Lecture "Treatment of Industrial Wastes of the Leather Industry - is it still a Major Problem". JALCA, 89, 153-185

Jimoh, A. A., Ganiyu, B. A., Baba, D., and Baba, A. (2018) Bioremediation Process of Effluent from Detergent and Food Industries in Jos, Nigeria: Kinetics and Thermodynamics. International Journal of Engineering Science Invention (IJESI), 762-73

Kandelbauer, A., Maute, O., Kessler, R. W., Erlacher, A., and Gübitz, G. M. (2004). Study of dye decolorization in an immobilized laccase enzyme-reactor using online spectroscopy. Biotechnology and bioengineering, 87(4), 552-563.

Kongjao, S., Damronglerd, S., and Hunsom, M. (2008). Simultaneous removal of organic and inorganic Pollutants in tannery wastewater using electrocoagulation technique. Korean Journal of chemical engineering, 25(4), 703.

Maheshwari, U. M., Aruna, S., Gomathi, M., and AbdulJaffar, A. H. (2017). Bioremediation by Free and Immobilized Bacteria Isolated from Tannery Effluent. International Journal of Research in Applied, Natural and Social Sciences. 5(7), 75-90

Margesin, R., and Schinner, F. (2001). Bioremediation (natural attenuation and biostimulation) of diesel-oilcontaminated soil in an alpine glacier skiing area. Applied and environmental microbiology, 677), 3127-3133.

Mohammed, A., Sekar, P., and George, J. (2011). Efficacy of microbes in bioremediation of tannery effluent. Inter. J. Curr. Res, 3(4), 324-326.

Mohammed, S. S. D., Orukotan, A. A., and Abdullahi, H. (2017). Physicochemical and Bacteriological Assessment of Tannery Effluent from Samaru-Zaria, 
BAJOPAS Volume 13 Number 2, December, 2020 Kaduna State, Nigeria. Journal of Applied

Sciences and Environmental Management, 21(4), 734-740.

Munz, G., De Angelis, D., Gori, R., Mori, G., Casarci, M., and Lubello, C. (2009). The role of tannins in conventional and membrane treatment of tannery wastewater. Journal of hazardous materials, 164(2-3), 733-739

Mythili, K., and Karthikeyan, B. (2011). Bioremediation of $\mathrm{Cr}$ (VI) from tannery effluent using Bacillus spp and Staphylococcus spp. International Multidisciplinary Research Journal, 1(6).

NESREA (2009). National Environmental Standards for Effluent Limitations and Regulation. 1233-1236

Noorjahan, C. M. (2014). Physicochemical characteristics, identification of bacteria and biodegradation of industrial effluent. Journal of bioremediation and Biodegradation, 5(3).

Ohtake, H. I., and Silver, A. O. (1994). Bacterial reduction of toxic chromate. Biological degradation and bioremediation of toxic chemicals, 403-415.

Omoleke, I. I. (2004). Management of environmental pollution in Ibadan, an African city: the challenges of health hazard facing government and the people. Journal of Human Ecology, 15(4), 265-275.

Rajor, A., Reddy, A.S., and Singh, B. (2004). Determination of BOD kinetic Parameters and evaluation of alternate methods, M.Sc. Thesis, Department of biotechnology \& environmental Science, Thapar Institute of Engineering and Technology, Patiala

Ramasami, T., Rajamani, S., and Rao, J. R. (1994, March). Pollution control in leather industry: Emerging technological options. In International symposium on surface and colloidal science and its relevance to soil pollution, madras.

Ramesh, J. V. S., and Singh, S. P. (1993). Yearly variation in certain physicochemical parameters of pond at eastern Doon Valley. Uttar Pradesh J. Zoo, 12 (1), 7577.

Ranen, S., and Sharadinadra, C. (2009). Biotechnology applications to environmental remediation in resource exploitation. Current science, 97, 6-25
Russell, A. J., Berberich, J. A., Drevon, G. F., and Koepsel, R. R. (2003). Biomaterials for mediation of

chemical and biological warfare agents. Annual review of biomedical engineering, 5(1), 1-27.

Saravanan, P., and Saravanan, A. (1999). Decolourization of tannery effluent by Flavobacterium sp. EK 1. Indian Journal of Environmental Protection, 19, 19-24.

Sikander, S., and Shahida, H. (2007). Reduction of toxic hexavalent chromium by Ochrobactrum intermedium strain SDCr5 stimulated by heavy metals. Bioresource Technol, 98, 340-344.

Singh, N., Sharma, B. K., and Bohra, P. C. (2000). Impact assessment of industrial effluent of arid soils by using satellite imageries. Journal of the Indian Society of Remote Sensing, 28(2-3), 79.

Sreemoyee, C., and Priti, P. (2013). Assessment of physico-chemical parameters of dairy waste water and isolation and characterization of bacterial strains in terms of cod reduction. Int J Sci, 2(3), 395-400.

Verheijen, L. A. H. M., Wiersema, D., Pol, L. H., and De Wit, J. (1996). Management of wastes from animal product processing. Livestock and environment, Finding a balance. International Agriculture Center, Wageningen, The Netherlands.

Wang, F., Yao, J., Si, Y., Chen, H., Russel, M., Chen, K., and Bramanti, E. (2010). Short-time effect of heavy metals upon microbial community activity. Journal of Hazardous Materials, 173(13), 510-516.

WHO (World Health Organization). (2006). Air quality guidelines: global update 2005: particulate matter, ozone, nitrogen dioxide, and sulfur dioxide. World Health Organization.

World Bank. (1995). Nigeria's strategic options for redressing industrial pollution. World Bank, industry and energy division. 1st edition, West Central Africa Department; Annexes: 1995; pp 60-62.

Zahoor, A., and Abdul, R. (2009). Enumeration of Coliforms. Journal of Environmental Sciences. 21, 814-820 


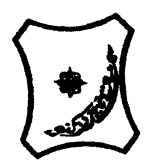

Bayero Journal of Pure and Applied Sciences, 13(2): 1 - 12

Received: November, 2020

Accepted: December, 2020

ISSN $2006-6996$

\title{
BIODEGRADATION POTENTIAL OF IMMOBILIZED BACTERIA IN THE TREATMENT OF TANNERY INDUSTRIAL EFFLUENTS FROM INDUSTRIAL ESTATES IN KANO STATE, NIGERIA
}

\author{
Abdullateef, B., ${ }^{1 *}$ Shuaibu, T. G., ${ }^{1}$ Babagana, K., ${ }^{1}$ Suleman, H. B. ${ }^{2}$ and Dauda, B. ${ }^{3}$ \\ ${ }^{1}$ Department of Pure and Applied Chemistry, Faculty of Science, University of Maiduguri, Borno State, \\ Nigeria \\ ${ }^{2}$ Department of Microbiology, Faculty of Science, University of Maiduguri, Borno State, Nigeria \\ ${ }^{3}$ Department of Chemical Engineering, Faculty of Engineering, University of Maiduguri, Borno State, \\ Nigeria \\ *Corresponding author: babslega@gmail.com; abelega2007@yahoo.com; +2348061309753
}

\section{ABSTRACT}

Industrial Effluents Samples from Gashash Tanneries (TAN1) in Bompai Industrial estate, Larabee Tannery Industry (TAN2) in Sharada Industrial estate and Z Tannery Industries (TAN3) in Challawa Industrial estate, Kano State, Nigeria were collected over a period of six months (August 2017 to January 2018) for assessing the biodegradation potentials of bacteria in the treatment of organic pollutants within the effluents. Bacteria were isolated from the effluents and immobilized on agar-agar. Different masses (5 g, $10 \mathrm{gr}, 15$ $\mathrm{g}, 20 \mathrm{~g}$, and $25 \mathrm{~g}$ ) of the bacteria were used in the treatment of $250 \mathrm{ml}$ of the effluents for ten days in a shaker incubator (Gallenkamp-OC-4364-L) at the temperature $30{ }^{\circ} \mathrm{C}$ and speed of $60 \mathrm{rpm}$. Pre-treatment analysis of the effluents for Temperature, pH, Biochemical Oxygen Demand (BOD), Chemical Oxygen Demand (COD), Suspended Solid (SS) and Total Dissolved Solids (TDS) gives the following results; temperature $\left({ }^{\circ} \mathrm{C}\right.$ )

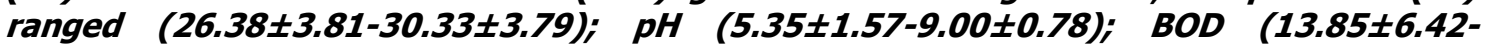
$38.75 \pm 16.20) ;$ COD (1406 $\pm 208-3532 \pm 1373) ;$ SS (208 $\pm 235-780 \pm 739)$ and TDS (266 $\pm 253-5276 \pm 2971)$. No statistical differences ( $p \leq 0.05)$ was observed for all the results among the different industries. The bacterial isolates were identified as Neisseria spp, Bacillus cereus, and Staphylococcus aureus, in TAN1, TAN2, and TAN3, respectively. After treatment of the effluent with the different masses of the isolated bacteria, the mean level of BOD was found to range as (0.55 $\pm 0.36-6.92 \pm 5.49) ; C O D$ (ND-3134 \pm 1595$)$;

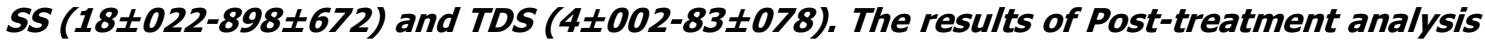
showed that there is overall decrease in the levels of the parameters determined when compared with that of the pre-treatment. The overall percentage reduction of the immobilised bacteria in the treatment of the respective effluents was in the order TAN2 (72\%)>TAN1 (70\%)>TAN3 (62\%). Hence, the immobilized bacteria are having higher biodegradation potential for the treatment of the tannery effluents.

Keywords: Biodegradation, bacteria, effluent, immobilization, tannery.

\section{INTRODUCTION}

Tannery industrial wastewater is a serious consequence of the pollution point of view for streams, freshwater, and land used for agriculture. The lack of awareness in the modern industrial practice has resulted in the discharge of tannery effluents which exhibit very high value of chromium ( $\mathrm{Cr}$ ), Sulfide, and chloride, Total Dissolved Solid (TDS), Total Suspended Solid (TSS), Biochemical Oxygen Demand (BOD) and Chemical Oxygen Demand (COD) in the water stream or land (Mohammed et al., 2001). Tanning is the process, which One ton of skin generally leads to the production of 20 to $80 \mathrm{~m}^{3}$ of turbid and foul-smelling converts the protein of the rawhide or skin into a stable material, which will not putrefy and is suitable for a wide variety of end applications (Elsheikh, 2009). The highly polluting chromium is the most commonly used tanning material producing leather that is more flexible and pliable than vegetable-tanned leather and does not discolor or lose shape in water as drastically as vegetable-tan (Elsheikh, 2009). Tannery effluent is among the most hazardous industrial pollutants due to its huge organic and inorganic load, which is highly toxic to human life and the environment (Kongjao et al., 2008). wastewater including chromium (100-400 mg/l), sulfide $(200-800 \mathrm{mg} / \mathrm{l})$, high levels of fat and 
BAJOPAS Volume 13 Number 2, December, 2020 other solid wastes, and notable pathogen contamination as well as pesticides added for skin conservation during transport (Elsheikh, 2009). There are more than 6000 tanneries in Nigeria with an annual processing capacity of 700,000 tons of hides and skins (Omoleke, 2004; Singh et al., 2008). It was reported that the total amount of waste produced per animal slaughtered is approximately $35 \%$ of its weight (World Bank, 1995). Also, for every $1000 \mathrm{~kg}$ of carcass weight, a slaughtered beef produces 5.5 $\mathrm{kg}$ of manure (excluding rumen contents or stockyard manure) and $100 \mathrm{~kg}$ of paunch manure (undigested food) (Verheijen et al., 1996). Tanneries generate wastewater in the range of 30-35 $\mathrm{L} \mathrm{kg}^{-1}$ skin/hide processed with variable $\mathrm{pH}$, Biological Oxygen Demand (BOD), Chemical Oxygen Demand (COD), high concentrations of suspended solids (SS), and tannins as well as chromium (Zahoor and Abdul, 2009).

Being heterogeneous and composed of a wide variety of compounds, it is very difficult to select a unique direct method for estimating the biodegradability of organic contents and biokinetic parameters for a wastewater sample (Rajor, 2004). For this purpose, some indirect estimation such as determination of biochemical oxygen demand (BOD) and chemical oxygen demand (COD) are applied as common laboratory investigations [9]. During retanning procedures, synthetic tannins (Syntan), oils and resins are added to form softer leather at varying doses (Munz et al., 2009). One of the refractory groups of chemicals in tannery effluents derives mainly from tannins (Ramasami et al., 2004). Syntans are characterized by complex chemical structures, because they are composed of an extended set of chemicals such as phenol-, naphthalene-, formaldehyde- and melamine-based syntans, and acrylic resins (Beem, 1994). Organic pollutants (proteic and lipidic components) are originated from skins (it is calculated that the raw skin has $30 \%$ loss of organic material during the working cycle) or they are introduced during processes (Hugo Springer, 1994).

Many conventional processes such as oxidation, chemical and biological processes were carried out to treat tanneries wastewater (Ebtesam et al, 2013). Biological processes have received more attention because of their costeffectiveness, lower sludge production and environmental friendliness (Noorjahan, 2014). Naturally occurring micro-organisms degrade the hazardous organic wastes including xenobiotic compounds, such as pesticides, polycyclic aromatic hydrocarbons (PAHs) and polychlorinated biphenyls (PCBs) in due course of time (Ranen and Sharadinadra, 2009). Bioremediation is based on the idea that all organisms remove substances from the environment to carry outgrowth and metabolism (Bouwer and Zehnder, 1993). Bacteria, protista and fungi are found to be very good at degrading complex molecules and incorporating the breakdown products into their metabolism (Bouwer and Zehnder, 1993). The resultant metabolic wastes that they produce are generally safe and somehow recycled into other organisms (Ranen and Sharadinadra, 2009). An acclimatized indigenous population of microorganisms capable of degradation of the compounds of interest must exist at the site for a successful bioremediation mode (Ranen and Sharadinadra, 2009). It has been observed that for a successful bioremediation mode, an acclimatized indigenous population of microorganisms capable of degradation of the compounds of interest must exist at the site under investigation (Ranen and Sharadinadra, 2009). Even though there are numerous physical and chemical methods employed in the disposal of wastes the advantage in using bacterium is that they play a key role in the reduction of COD, BOD, total protein, total tannin and total phenol (Saravanan and Saravanan, 1998)

Baba et al. (2020) studied the bioremediation potential of immobilized corynebacterium kutsceri in the Treatment of tannery industrial effluent from Challawa Industrial Estate, Kano State, Nigeria. The aim of the work is to study the reduction in the level of the contaminants through the process of bioremediation using the isolated bacteria. Immobilized bacteria can withstand various temperatures, $\mathrm{pH}$ and substrate concentrations; consequently, increasing the efficiency and the lifespan of the bacteria. Immobilized bacteria are widely applied in the treatment of wastewater and can be separated and recovered after the treatment with the same efficiency (Baba et al., 2020).

\section{MATERIALS AND METHODS \\ Study Area}

This study was carried out in Bompai, Sharada and Challawa industrial estates in Kano, Figure 1. Kano lies on Latitude $11^{\circ} 30^{\prime} \mathrm{N}$ and $8^{\circ} 30^{\prime} \mathrm{E}$ and Longitude $11^{\circ} 5^{\prime} \mathrm{N}$ and $8^{\circ} 5^{\prime} \mathrm{E}$ in Northern Nigeria. It is one of the developed industrial cities in Nigeria. Tannery activities are the dominating industries and this could be one of the reasons for her high population density (Dan'Azumi and Bichi, 2010). Many researchers have studied biodegradation of tannery effluent using microorganisms. However, limited literature is available on the biodegradation of tannery effluent in Kano industrial estates using 
BAJOPAS Volume 13 Number 2, December, 2020 immobilized bacterial cells. This research work focuses on the potential of the use of the indigenous immobilized bacterial isolates in the treatment of tannery effluents in the industrial estates.

\section{Sample Collection}

Effluents were collected from the Tannery Industries from Bompai, Challawa and Sharada Industrial Estates, Kano, Nigeria. The effluents were collected over a period of six months (August 2017 to January 2018). Samples collected in a sterile 4-liter plastic container with a unique identification number were preserved using an ice-box that was transported to the Microbiology Laboratory, Department of Microbiology, Bayero University of Kano for analysis

\section{Sample Preparation and Sample Analysis}

Immediately after the collection of the effluent, $\mathrm{pH}$, TSS, TDS, COD, BOD levels were determined before treatment (Pre-treatment determination) and ten days after treatment (Post-treatment determination) as described in
APHA (1989) standard methods. $\mathrm{pH}$ was determined using Ecotests $\mathrm{pH}$ meter and TDS was determined using AQUALYTIC TDS Salinometer. BOD was determined as described by the standard method (APHA, 1992). COD and SS were determined using DR/2010 HACH portable data logging spectrophotometer (DWAF, 1992)

\section{Identification and Biochemical} Characterization of the Bacterial Isolates

The bacteria were isolated from the effluents using Serial Dilution according to the method described by APHA (1989). The biochemical tests such as oxidase, catalase, coagulase, indole (from $1 \%$ tryptone broth), citrate (Simmons citrate agar), methyl red/VogesProskauer (MR/VP), nitrate reduction, Starch Hydrolysis, Glucose, Maltose, and Lactose tests were carried out on the bacterial isolates to identify the bacteria through the bacteria biochemical characteristics according to Ajao et al. (2011).

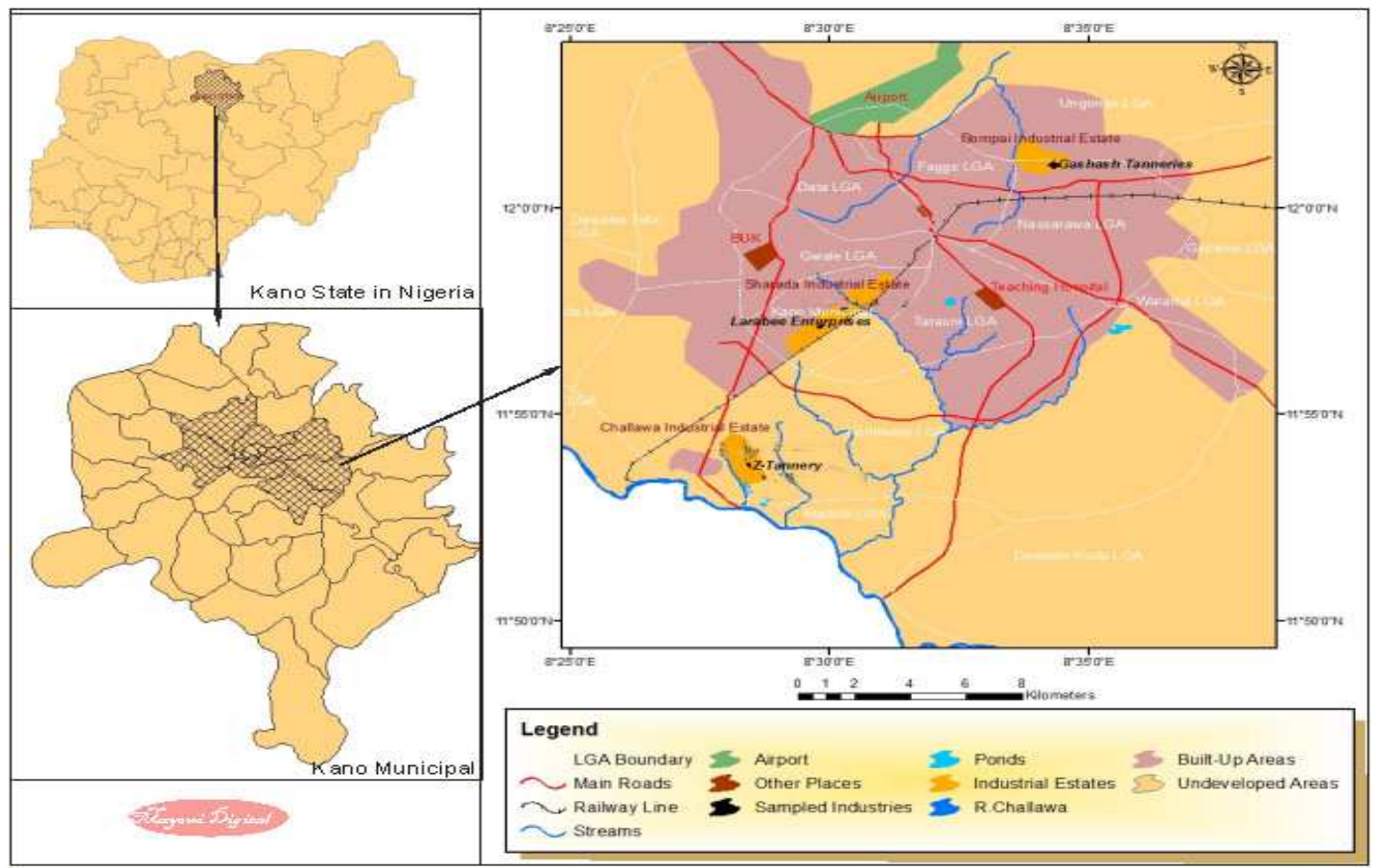

Fig. 1 Map showing the study areas

Source: Mayomi Digital Productions, GIS Laboratory, Department of Geography, UNIMAID (2017)

\section{Determination of Growth Rate of the Bacteria in Effluent Sample}

The bacteria growth rates were determined by transferring $2 \mathrm{~mL}$ of the bacterial isolates from the tannery effluent in broth medium into 100 $\mathrm{mL}$ sterile effluents in conical flasks and kept in an incubator (Giffrin cool) for 10 days. Control was also set up by incubating another $100 \mathrm{~mL}$ each of the sterile effluents without the bacteria. The optical density of the content was determined at the wavelength of $600 \mathrm{~nm}$ on a daily interval and recorded. 
BAJOPAS Volume 13 Number 2, December, 2020 Immobilization of Bacteria

Agar solution and inoculi were prepared separately. Fifty milliliters $(50 \mathrm{~mL})$ of nutrient broth each of the inoculi was prepared in a McCartney bottle and incubated for 24 hours. A solution of agar-agar was prepared by dissolving $10 \mathrm{~g}$ of the powder in distilled water and made up to $500 \mathrm{~mL}$ mark in an Erlenmeyer flask and was sterilized in an autoclave (280A) for 15 minutes and allowed to cool to $40-45^{\circ} \mathrm{C}$ (Ajao et al., 2011). Four milliliters ( $4 \mathrm{~mL})$ of the bacterial isolates in the nutrient broth was mixed with 36 $\mathrm{ml}$ of the prepared agar-agar media in petri-dish plates and then allowed to solidify. This was kept in the refrigerator for bioremediation.

\section{Bioremediation (Treatment) of the Effluents}

The solidified agar block (immobilized bacteria) was cut into cubes using a sterile knife; $0.1 \mathrm{~mL}$ phosphate buffer ( $\mathrm{pH} \mathrm{7.0)}$ was added and kept in the refrigerator for 1 hour for curing. The phosphate buffer was decanted after 1 hour and the cubes were washed with sterile distilled water 3-4 times before it was used (Ajao et al., 2011). Two liters (2 L) of the effluent was supplemented with the minimum basal medium in $\mathrm{g} / \mathrm{L}: \mathrm{NaCl}(0.8), \mathrm{MgSO}_{4} .7 \mathrm{H}_{2} \mathrm{O}(0.001), \mathrm{KH}_{2} \mathrm{PO}_{4}$ (2), $\mathrm{NaNO}_{3}$ (2), $\quad \mathrm{CaCl}_{2} .2 \mathrm{H}_{2} \mathrm{O} \quad(0.5)$ and $\mathrm{NaHPO}_{4} .12 \mathrm{H}_{2} \mathrm{O}(2)$ and sterilized in an autoclave at $121^{\circ} \mathrm{C}$ for 15 minutes (Margesin and Schinner, 2001). Two hundred and fifty milliliters $(250 \mathrm{~mL})$ of the effluents were transferred into different $250 \mathrm{ml}$ conical flasks. The content was covered with a cotton-wool ramped with foil paper to avoid contamination. Five grams $(5 \mathrm{~g})$ of the immobilized bacteria were quickly transferred into each of the effluents in the conical flasks in an inoculating chamber. The same procedures were carried out for the $10 \mathrm{~g}, 15 \mathrm{~g}, 20 \mathrm{~g}$ and 25 $\mathrm{g}$ of the immobilized bacteria in separate $250 \mathrm{~mL}$ effluents in conical flasks and agitated for ten days in a shaker incubator (Gallenkamp-OC4364-L) at a temperature $30^{\circ} \mathrm{C}$ and speed of 60 rpm. The treated effluent samples were taken on the tenth day and analyzed for the parameters $\mathrm{pH}$, SS, TDS, COD, and BOD, (Posttreatment determination) for the different grams of bacteria to evaluate and compare the biodegradation potential. (Baba et al., 2020).

\section{Statistical Analysis}

The data were represented as Mean \pm Standard deviation and analyzed statistically using oneway Analysis of Variance (ANOVA) and Tukey's HSD as Post Hoc Tests with the aid of SPSS 16.0. The correlation coefficient was also used to measure the strength of the relationship between the different masses of the bacteria and the parameters. All $\mathrm{p} \leq 0.05$ were considered as statistically significant.

\section{RESULTS AND DISCUSSION Physico-chemical parameters in the Industrial Effluents before the Biodegradation.}

Results of the Physico-chemical parameters in the industrial effluents before the Biodegradation is shown in table 1 . The mean temperatures $\left({ }^{\circ} \mathrm{C}\right)$ observed in TAN1, TAN2, and TAN3 samples were $28.07 \pm 0.65 ; 27.77 \pm 0.64$ and $26.38 \pm 3.81$ respectively. The order of the mean temperature of the samples from the three industries can be arranged as TAN1 > TAN2>TAN3. The temperature observed at TAN1, TAN2, and TAN3 samples were found below the WHO $\left(35^{\circ} \mathrm{C}\right)$ and NESREA $\left(40^{\circ} \mathrm{C}\right)$ limits. The low values of temperature might be due to the processes used at the time of sampling. High temperature brings down the solubility of gases in water that ultimately expresses as high BOD and COD. Statistical analysis shows that there is no significant difference $(p<0.05)$ between the mean values of temperature among the industries. This might be due to similar tannery activities involved in the tannery industries at the time of sampling. The average values of temperature observed in this present study are less than those observed by Akan et al. (2007), Akan et al. (2009) and Baba et al. (2020).

The mean level of $\mathrm{pH}$ observed in TAN1, TAN2 and TAN3, samples were $7.77 \pm 2.93$; $8.35 \pm 0.28$ and $7.52 \pm 0.76$ respectively. The order of the mean $\mathrm{pH}$ of the samples from the three industries can be arranged as TAN2> TAN1 $>$ TAN3. The $\mathrm{pH}$ of the samples falls within the WHO (7.0-8.5) and NESREA (6-9) standard limits. Statistical analysis shows that there is no significant difference $(p<0.05)$ between the mean values of $\mathrm{pH}$ among the industries. This might be due to similar tannery activities involved in the tannery industries at the time of sampling. Maheshwari et al. (2017) reported that the level of $\mathrm{pH}$ in the effluents from the tannery industry in Vaniyambadi, India was 6.5 which was lower than that observed in the present study. The $\mathrm{pH}$ in the effluents from the tannery industries in Kano and Kaduna were reported to be 7.64 and 6.89, respectively (Akan et al., 2007; Mohammed et al., 2017). The average values of $\mathrm{pH}$ observed in this present study are less than those observed by Mohammed et al. (2017) and Baba et al. (2020). The mean level of SS $(\mathrm{mg} / \mathrm{l})$ observed in TAN1, TAN2, and TAN3 samples were 374 \pm 124 ; $358 \pm 335$ and $780 \pm 739$ respectively. The order of the mean SS in the samples from the three industries can be arranged as TAN3 > TAN1 $>$ TAN2. 
The SS observed in the samples were far above the recommended standard limits of regulating bodies WHO $(30 \mathrm{mg} / \mathrm{l})$ and NESREA $(10 \mathrm{mg} / \mathrm{l})$. Statistical analysis shows that there is no significant difference $(p<0.05)$ between the mean values of SS among the industries. This might be due to similar tannery activities involved in the tannery industries at the time of sampling. The average values of SS observed in this present study are less than that observed $(3700 \pm 122 \mathrm{mg} / \mathrm{l})$ by Akan et al. (2009) for tanneries in Kano. Also, the average values of SS observed in this present study are less than that observed by Mohammed et al. (2017) and Baba et al. (2020) with the exception in TAN3.

The mean level of TDS (mg/l) observed in TAN1, TAN2, and TAN3 samples were $3941 \pm 3703$; $3300 \pm 1714$ and $2653 \pm 1240$ respectively. The order of the mean TDS in the samples from the three industries can be arranged as TAN1>TAN2>TAN3. The TDS observed in the samples were far above the recommended standard limits of WHO $(250 \mathrm{mg} / \mathrm{l})$ and NESREA $(500 \mathrm{mg} / \mathrm{l})$. Statistical analysis shows that there is no significant difference $(p<0.05)$ between the mean values of TDS among the industries. This might be due to similar tannery activities involved in the tannery industries at the time of sampling. TDS in the effluents from the tannery industries in Kano, Nigeria was reported to be $1281 \mathrm{mg} / \mathrm{l}$ (Akan et al., 2007). The average values of SS observed in this present study are less than those observed by Mohammed et al. (2017) and Baba et al. 2020)

The mean level of COD (mg/l) observed in TAN1, TAN2 and TAN3 samples seasons were $2372 \pm 938 ; \quad 1406 \pm 208$ and $3532 \pm 1373$ respectively. The order of the mean COD of the samples from the three industries can be arranged as TAN3>TAN1> TAN2. The COD observed in TAN1, TAN2 and TAN3 samples were far above the recommended standard limits of regulating bodies $\mathrm{WHO}(40 \mathrm{mg} / \mathrm{l})$ and NESREA (40 mg/l). Statistical analysis shows that there is no significant difference $(p<0.05)$ in COD among the industries. This might be due to similar tannery activities involved in the tannery industries as at the time of sampling. The Chemical Oxygen demand (COD) is the amount of oxygen, in $\mathrm{mg} / \mathrm{L}$, required for the degradation of the compound of wastewater to occur. In comparison, the average values of COD observed in this present study were higher than that observed by Mohammed et al. (2017) but lower than that observed by Baba et al. (2020).

The mean levels of BOD $(\mathrm{mg} / \mathrm{l})$ observed in TAN1, TAN2 and TAN3 samples were $13.85 \pm 6.42 ; \quad 19.46 \pm 0.50$ and $17.13 \pm 3.14$ respectively. The order of the mean BOD in the samples from the three industries can be arranged as TAN2>TAN3>TAN1. The BOD observed in TAN1, TAN2 and TAN3 samples were found below the recommended limits of NESREA (200 mg/l) but above WHO (10 mg/l). Statistical analysis shows that there is no significant difference $(p<0.05)$ between the mean values of BOD among the industries. This might be due to similar tannery activities involved in the tannery industries at the time of sampling. The low level of BOD recorded in this study is an indication of the low level of biodegradable organic solids in the effluent. The average values of BOD observed in this present study were lower than those observed by Mohammed et al. (2017) and Baba et al. (2020).

Table 1: Mean Values \pm S.D of Physico-chemical parameters of effluents from the Tannery Industries before Treatment.

\begin{tabular}{llllllll}
\hline Parameter & Tannery 1 & Tannery 2 & Tannery 3 & $\mathrm{a}$ & $\mathrm{b}$ & $\mathrm{c}$ & $\mathrm{d}$ \\
\cline { 2 - 7 } Temperature $\left({ }^{\circ} \mathrm{C}\right)$ & $28.07 \mathrm{a} \pm 0.65$ & $27.77 \mathrm{a} \pm 0.64$ & $26.38 \mathrm{a} \pm 3.81$ & & $29.50 \pm 4.68$ & 35 & 40 \\
pH & $7.77 \mathrm{a} \pm 2.93$ & $8.35 \mathrm{a} \pm 0.28$ & $7.52 \mathrm{a} \pm 0.76$ & 6.89 & $5.35 \pm 1.57$ & $7.0-8.5$ & $6.0-9.0$ \\
$\mathrm{COD}(\mathrm{mg} / \mathrm{l})$ & $2372 \mathrm{a} \pm 938$ & $1406 \mathrm{a} \pm 208$ & $3532 \mathrm{a} \pm 1373$ & 2.2 & $3106 \pm 2753$ & 40 & 40 \\
$\mathrm{BOD}(\mathrm{mg} / \mathrm{l})$ & $13.85 \mathrm{a} \pm 6.42$ & $19.46 \mathrm{a} \pm 0.50$ & $17.13 \mathrm{a} \pm 3.14$ & 1032 & $26.17 \pm 9.49$ & 10 & 200 \\
$\mathrm{SS}(\mathrm{mg} / \mathrm{l})$ & $374 \mathrm{a} \pm 124$ & $358 \mathrm{a} \pm 335$ & $780 \mathrm{a} \pm 739$ & 501 & $562 \pm 482$ & 30 & 10 \\
TDS $(\mathrm{mg} / \mathrm{l})$ & $3941 \mathrm{a} \pm 3703$ & $3300 \mathrm{a} \pm 1714$ & $2653 \mathrm{a} \pm 1240$ & 532.7 & $444 \pm 507$ & 250 & 500 \\
\hline
\end{tabular}

The values given in the table above are means of 6 replicate values, $\mathrm{n}=6$ ( 1 sample was taken monthly for 6 months). Within the rows, means with different alphabets are statistically different $(p<0.05)$. WHO: World Health Organisation. NESREA: National Environmental Standard and Regulatory Enforcement Agency. a = Mohammed et al.(2017), b = Baba et al. (2020), c = WHO (2006), $d=$ NESSRA (2009) 
BAJOPAS Volume 13 Number 2, December, 2020

Identification, Biochemical Characterization and growth rates of the Bacterial Isolates

Results of identification and biochemical characterization of the bacterial isolates were shown in table 2. After 24 hours of incubation, the nutrient agar media plates were checked for bacterial growth. The results showed the presence of different strains in the samples. The TAN1 bacteria isolate was found to be gramnegative cocci while TAN3 was gram-positive cocci. TAN2 bacteria isolate was found to be gram-positive, rod-shaped. TAN1, TAN2, and TAN3 bacteria isolates recorded positive results for spore former.

The results of the biochemical tests indicated that all the bacteria were positive for catalase, oxidase, citrate, maltose, glucose, lactose (negative in TAN1), mannitol (negative in TAN2), starch hydrolysis and coagulase (negative in TAN2) tests. The bacteria showed negative results for nitrate reduction, $M R$ (positive in TAN2), VP (positive in TAN1), Indole (positive in TAN2) tests. Base on the morphological and biochemical test results, TAN1, TAN2, and TAN3 bacteria isolates were identified to be Nesseria spp, Bacillus cereus, and Staphylococcus aureus respectively.

The growth rate of the TAN1, TAN2 and TAN3 Isolates were shown in figure 2. Generally, the optical density increase with the increase in time (day) and decrease as time goes on. The highest optical density was shown by bacillus cereus in TAN2 while the lowest was shown by Staphylococcus aureus in TAN3.

The initial growth phase of TAN1 Isolate bacteria occurred within 2-day of incubation as the growth rate increases up to the 6th-day incubation when the maximum growth was observed. Beyond the 6th day, the growth of the bacteria declined (which might be due to a shortage of nutrients in the effluents) until it reached its death phase (which might be due to the unavailability of nutrients in the effluents).

A similar trend of growth was also observed for TAN2 Isolate as the initial growth phase also occurred within 2-day of incubation but maximum growth rate observed on the 4th day of incubation. The stationary stage occurred between the 4th day and the 8th day. Beyond the 8th day, the growth of the bacteria declined (which might be due to a shortage of nutrients in the effluents) until it reached its death phase (which might be due to the unavailability of nutrients in the effluents).

The initial growth phase of TAN3 bacterial Isolate occurred within the 3-day incubation as the growth rate increases up to the 6th-day incubation when the maximum growth was observed. Beyond the 6th day, the growth of the bacteria declined (which might be due to a shortage of nutrients in the effluents) until it reached its death phase (which might be due to the unavailability of nutrients in the effluents).

Table 2: Morphological and Biochemical characteristics of bacterial isolates

\begin{tabular}{lllll} 
Bacterial Isolates & & TAN1 & TAN2 & TAN3 \\
\hline $\begin{array}{lllll}\text { Morphological } \\
\text { characteristics }\end{array}$ & Shape & Cocci & Rod & Cocci \\
& Spore & & & \\
& former & + & + & + \\
Gram & & & \\
Biochemical characteristics & reaction & - & + & + \\
& Citrate & + & + & + \\
& Catalase & + & + & + \\
& Coagulase & + & - & + \\
Starch & + & + & + \\
& Glucose & + & + & + \\
Oxidase & + & + & + \\
& Indo & - & + & - \\
Lactose & - & + & + \\
Manitol & + & - & + \\
Maltose & + & + & + \\
MR & - & + & - \\
VP & + & - & - \\
& Nitrate & - & - & - \\
Reduction & - Neisseria & Bacillus & Staphylococcus \\
& Bacterial & cereus & aureus \\
& name & spp & cas
\end{tabular}

+ = Positive; - = Negative; MR=Methyl Red; VP= Voges-Proskauer 


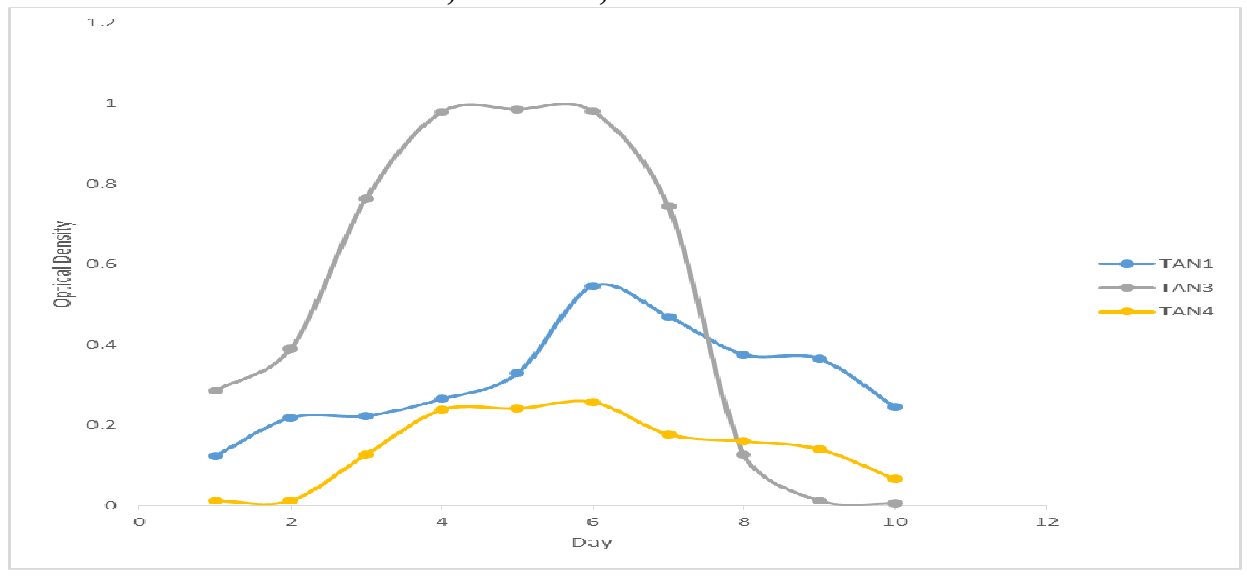

Fig. 2 Growth rates of the isolates in the effluents from the Tannery Industries

\section{Physico-chemical Parameters in the Industrial Effluents after the biodegradation.}

Table 3 shows the mean results of the physicochemical parameter before and after bioremediation using the different masses $(5 \mathrm{~g}$, $10 \mathrm{~g}, 15 \mathrm{~g}, 20 \mathrm{~g}$, and $25 \mathrm{~g}$ ) of the respective immobilized bacteria. Also, Table 4 shows the mean results of correlation coefficient ( $r$ ) between different masses of bacteria and physicochemical parameters.

The mean values $(\mathrm{mg} / \mathrm{l})$ of the SS after the bioremediation varies between $243 \pm 45$ and $898 \pm 672$. The mean concentration $(\mathrm{mg} / \mathrm{l})$ of SS remediated by the different masses $(5 \mathrm{~g}, 10 \mathrm{~g}$, $15 \mathrm{~g}, 20 \mathrm{~g}$, and $25 \mathrm{~g}$ ) of the bacteria varies. The SS in the samples fluctuates up and down after the bioremediation process when compared with the SS of the raw samples before the bioremediation. The increase in the levels of the SS might be due to the aggregation of the TDS which are large enough to result into SS. The increase in the levels of the SS might be also due to the influence of the nutrients which was added into the effluents in order to make the microorganisms more active and viable for fast degradation of organic contaminants in the effluent. The relative potential or efficiency of the different masses of the bacteria in remediating SS in TAN1 samples was in the order $25 \mathrm{~g}>20 \mathrm{~g}>15 \mathrm{~g}>10 \mathrm{~g}>5 \mathrm{~g}$. For TAN2 and TAN3 samples, the order was $25 \mathrm{~g}>20 \mathrm{~g}>15$ $\mathrm{g}>10 \mathrm{~g}>5 \mathrm{~g}$. These might be due to the variations in the surface areas of the different masses of the immobilized bacteria. Statistical analysis shows that there is no significant difference $(p<0.05)$ between the mean values of SS among the masses in the respective industries. Positive and significant correlations exist between the masses of bacteria and Suspended Solid (SS). This showed that there is general increase in the levels of the SS as the masses of the immobilized bacteria increases. TAN3 (90\%) and TAN1 (80\%) showed a very high correlation with the masses of the bacteria while TAN2 (61\%) showed a very low correlation.

The mean values $(\mathrm{mg} / \mathrm{l})$ of the TDS after the bioremediation varies between $46 \pm 11$ and $83 \pm 78$. The mean concentration $(\mathrm{mg} / \mathrm{l})$ of TDS remediated by the different masses $(5 \mathrm{~g}, 10 \mathrm{~g}$, $15 \mathrm{~g}, 20 \mathrm{~g}$, and $25 \mathrm{~g}$ ) of the bacteria varies. There is a reduction in all the TDS of all the samples after the bioremediation process compared with the TDS of the raw samples before the bioremediation. The relative potential or efficiency of the different masses of the bacteria in remediating TDS in TAN1 and TAN3 samples was in the order $5 \mathrm{~g}>10 \mathrm{~g}>15 \mathrm{~g}>20$ $\mathrm{g}>25 \mathrm{~g}$. For TAN2 samples, the order was 20 $g>10 \quad g>25 \quad g>15 \quad g>5 \quad g$. Statistical analysis shows that there is no significant difference $(p<0.05)$ between the mean values of TDS among the masses in the respective industries. These might be due to the variations in the surface areas of the different masses of the immobilized bacteria. Positive and significant correlations exist between the masses of bacteria and TDS with the exception in TAN2 (negative and insignificant correlation). The positive correlations showed that there is general increase in the levels of the TDS as the masses of the immobilized bacteria increases. TAN1 $(96 \%)$ showed a very high correlation with the masses of the bacteria while TAN2 (47\%) showed a very low correlation.

The mean values $(\mathrm{mg} / \mathrm{l})$ of the BOD after the bioremediation varies between $1.56 \pm 0.20 \mathrm{mg} / \mathrm{l}$ and $6.92 \pm 5.49 \mathrm{mg} / \mathrm{l}$. The mean concentration $(\mathrm{mg} / \mathrm{l})$ of BOD remediated by the different masses $(5 \mathrm{~g}, 10 \mathrm{~g}, 15 \mathrm{~g}, 20 \mathrm{~g}$, and $25 \mathrm{~g}$ ) of the bacteria varies. There is a reduction in all the BOD of all the samples after the bioremediation process compared with the $\mathrm{BOD}$ of the raw 
BAJOPAS Volume 13 Number 2, December, 2020 samples before the bioremediation. The relative potential or efficiency of the different masses of the bacteria in remediating BOD in TAN1, TAN2 and TAN3 samples were in the order $25 \mathrm{~g}>20$ $\mathrm{g}>15 \mathrm{~g}>10 \mathrm{~g}>5 \mathrm{~g}, 25 \mathrm{~g}>15 \mathrm{~g}>5 \mathrm{~g}>10 \mathrm{~g}>20 \mathrm{~g}$ and $20 \mathrm{~g}>10 \mathrm{~g}>25 \mathrm{~g}>15 \mathrm{~g}>5 \mathrm{~g}$ respectively. Statistical analysis shows that there is significant difference $(p<0.05)$ between the mean values of BOD among the masses in the respective industries. These might be due to the variations in the surface areas of the different masses of the immobilized bacteria. Negative and significant correlations exist between the masses of bacteria and BOD. This showed that there is general decrease in the levels of the BOD as the masses of the immobilized bacteria increases. TAN1 (94\%) showed a very high correlation with the masses of the bacteria while TAN2 (4\%) showed a very low correlation.

The mean values $(\mathrm{mg} / \mathrm{l})$ of the COD after the bioremediation varies between $250 \pm 154$ and $3134 \pm 1595$. The mean concentration $(\mathrm{mg} / \mathrm{l})$ of COD remediated by the different masses $(5 \mathrm{~g}$, $10 \mathrm{~g}, 15 \mathrm{~g} 20 \mathrm{~g}$, and $25 \mathrm{~g}$ ) of the bacteria varies. There is a reduction in all the COD of all the samples after the bioremediation process compared with the COD of the raw samples before the bioremediation. The relative potential or efficiency of the different masses of the bacteria in remediating COD in TAN1, TAN2 and TAN3 samples were in the order $25 \mathrm{~g}>20 \mathrm{~g}>15$ $\mathrm{g}>5 \mathrm{~g}>10 \mathrm{~g}, 25 \mathrm{~g}>20 \mathrm{~g}>15 \mathrm{~g}>10 \mathrm{~g}>5 \mathrm{~g}$ and 10 g>5 g>25 g>15 g>20 g respectively. Statistical analysis shows that there were significant difference $(p<0.05)$ between the mean values of COD among the masses in the respective industries except for effluents treated with $25 \mathrm{~g}$. These might be due to the variations in the surface areas of the different masses of the immobilized bacteria. Negative and insignificant correlations exist between the masses of bacteria and COD with the exception in TAN3 (positive and significant correlation). The negative correlations showed that there is general decrease in the levels of the COD as the masses of the immobilized bacteria increases. TAN2 (100\%) showed a very high correlation with the masses of the bacteria while TAN3 (36\%) showed a very low correlation.

Generally, there was an overall decrease in the concentration of these physicochemical parameters after the bioremediation using the different masses of the bacterial isolates. These might be due to the variations in the surface areas of the different masses of the immobilized bacteria. This is in line with the work of Jimoh et al. (2018) and Baba et al. (2020).

Table 3: Mean Values $(\mathrm{mg} / \mathrm{l}) \pm$ S.D of Physicochemical parameters in effluents from the Tannery Industries before and after Treatment of the effluents $(250 \mathrm{ml})$ with the different masses $(5 \mathrm{~g}, 10 \mathrm{~g}$, $15 \mathrm{~g}, 20 \mathrm{~g}$, and $25 \mathrm{~g}$ ) of the bacteria.

\begin{tabular}{llllllll}
\hline $\mathrm{P}$ & IND & Before & \multicolumn{5}{c}{ After } \\
\cline { 4 - 7 } & & & $5 \mathrm{~g}$ & $10 \mathrm{~g}$ & $15 \mathrm{~g}$ & $20 \mathrm{~g}$ & $25 \mathrm{~g}$ \\
\hline \multirow{2}{*}{ COD } & TAN1 & $2372 \pm 938$ & $1708 \mathrm{a} \pm 861$ & $2045 \mathrm{a} \pm 1205$ & $845 \mathrm{a} \pm 369$ & $300 \mathrm{a} \pm 167$ & $250 \mathrm{a} \pm 154$ \\
& TAN2 & $1406 \pm 208$ & $1195 \mathrm{a} \pm 208$ & $1125 \mathrm{a} \pm 384$ & $1055 \mathrm{a} \pm 317$ & $956 \mathrm{a} \pm 310$ & $870 \mathrm{ab} \pm 240$ \\
& TAN3 & $3532 \pm 1373$ & $2374 \mathrm{a} \pm 1344$ & $1976 \mathrm{a} \pm 1405$ & $2757 \mathrm{a} \pm 1266$ & $3134 \mathrm{a} \pm 1595$ & $2614 \mathrm{~b} \pm 1105$ \\
BOD & TAN1 & $13.85 \pm 6.42$ & $6.92 \mathrm{a} \pm 5.49$ & $6.42 \mathrm{a} \pm 5.07$ & $5.72 \mathrm{a} \pm 5.35$ & $4.62 \mathrm{a} \pm 4.37$ & $2.82 \mathrm{ab} \pm 1.26$ \\
& TAN2 & $19.46 \pm 0.50$ & $1.75 \mathrm{~b} \pm 0.22$ & $1.73 \mathrm{~b} \pm 0.18$ & $1.58 \mathrm{a} \pm 0.16$ & $1.91 \mathrm{a} \pm 0.22$ & $1.56 \mathrm{~b} \pm 0.20$ \\
& TAN3 & $17.13 \pm 3.14$ & $4.24 \mathrm{ab} \pm 0.77$ & $3.29 \mathrm{ab} \pm 0.37$ & $4.11 \mathrm{a} \pm 0.07$ & $3.23 \mathrm{a} \pm 0.91$ & $3.33 \mathrm{a} \pm 1.28$ \\
SS & TAN1 & $374 \pm 124$ & $243 \mathrm{a} \pm 45$ & $471 \mathrm{a} \pm 226$ & $475 \mathrm{a} \pm 182$ & $492 \mathrm{a} \pm 128$ & $611 \mathrm{a} \pm 217$ \\
& TAN2 & $358 \pm 335$ & $460 \mathrm{a} \pm 400$ & $543 \mathrm{a} \pm 414$ & $544 \mathrm{a} \pm 402$ & $551 \mathrm{a} \pm 414$ & $554 \mathrm{a} \pm 405$ \\
& TAN3 & $780 \pm 739$ & $586 \mathrm{a} \pm 594$ & $758 \mathrm{a} \pm 656$ & $787 \mathrm{a} \pm 676$ & $861 \mathrm{a} \pm 635$ & $898 \mathrm{a} \pm 672$ \\
TDS & TAN1 & $3941 \pm 3703$ & $51 \mathrm{a} \pm 10$ & $53 \mathrm{a} \pm 10$ & $55 \mathrm{a} \pm 15$ & $61 \mathrm{a} \pm 20$ & $63 \mathrm{a} \pm 26$ \\
& TAN2 & $3300 \pm 1714$ & $83 \mathrm{a} \pm 78$ & $47 \mathrm{a} \pm 20$ & $48 \mathrm{a} \pm 22$ & $47 \mathrm{a} \pm 17$ & $48 \mathrm{a} \pm 17$ \\
& TAN3 & $2653 \pm 1240$ & $46 \mathrm{a} \pm 11$ & $55 \mathrm{a} \pm 24$ & $55 \mathrm{a} \pm 25$ & $58 \mathrm{a} \pm 23$ & $61 \mathrm{a} \pm 28$ \\
\hline
\end{tabular}

Replicate $=6$ (months)

Within the rows, for the same parameter, means with different alphabets are statistically different $(p<0.05)$.

$\mathrm{P}=$ parameter, IND = Industries 
BAJOPAS Volume 13 Number 2, December, 2020

Table 4: Correlation coefficient $(r)$ between different masses of the bacteria and the physicochemical parameters.

\begin{tabular}{llll}
\hline Industries & Parameter & Correlation coefficient $(r)$ & $\begin{array}{l}\text { Percent dependence (rxrx100) } \\
(\%)\end{array}$ \\
\hline TAN1 & COD & -0.9 & 82 \\
& BOD & -0.97 & 94 \\
& SS & $0.90^{*}$ & 80 \\
TAN2 & TDS & $0.98^{*}$ & 96 \\
& COD & -1 & 100 \\
& BOD & -0.21 & 4 \\
& SS & $0.78^{*}$ & 61 \\
& TDS & -0.69 & 47 \\
& COD & $0.60^{*}$ & 36 \\
& BOD & -0.6 & 37 \\
& SS & $0.95^{*}$ & 90 \\
& TDS & $0.94^{*}$ & 89 \\
\hline
\end{tabular}

The correlation coefficient $(r)$ with * is statistically significant $(p<0.05)$.

Percentage reduction of the Parameters

Table 5 shows the percentage reduction of Parameters in industrial samples before and after the treatment of the effluents $(250 \mathrm{ml})$ with the different masses $(5 \mathrm{~g}, 10 \mathrm{~g}, 15 \mathrm{~g}, 20 \mathrm{~g}$, and $25 \mathrm{~g}$ ) of the Immobilized Bacteria.

In TAN1 samples, the percentage reduction (\%) of COD ranged (14-89); BOD (50-80); SS (-32$35)$ and TDS (98-99). In TAN2 samples, the percentage decrease $(\%)$ of COD ranged (15$38) ;$ BOD (90-92); SS [-28-(-55)] and TDS (9798). In TAN3 samples, the percentage decrease (\%) of COD ranged (11-44); BOD (76-81); SS (15-25) and TDS (98). The percentage increase in the levels COD, BOD and TDS might be due to the increase in the surface area of the different masses of the immobilized bacteria. However, the percentage decrease in the levels of the SS might be due to the aggregation of the TDS which are large enough to result into SS. The percentage decrease in the levels of the SS might be also due to the influence of the nutrients which was added into the effluents in order to make the microorganisms more active and viable for fast degradation of organic contaminants in the effluent. This is in line with the work of Jimoh et al. (2018) in which the concentration of the SS increase after the bioremediation of effluents.

Sreemoyee and Priti (2013) assessed and reduced several Physico-chemical parameters of dairy wastewater using Niesseria $s p$. and concluded that the species are well known to degrade organic compounds. This is in agreement with the current study in which the immobilized Niesseria $s p$ degrade the organic contaminants as indicated by the BOD, COD and TDS.

Jimoh et al. (2018) observed that TSS of the effluents was increased after treatment with immobilized bacteria and concluded that it might be due to the biostimulation method adopted for the research.

The optimum $\mathrm{pH}$ Biosorption of Chromium by Bacillus spp and Staphylococcus spp. from tannery effluent was investigated by Mythili and Karthikeyan (2011). The maximum adsorption of Chromium $(86.4 \mathrm{mg} / \mathrm{L})$ was showed by Bacillus spp and Staphylococcus spp showed $70.6 \mathrm{mg} / \mathrm{L}$ at an initial concentration of $100 \mathrm{mg} / \mathrm{L}$. In the present study, immobilised Bacillus spp and Staphylococcus spp. from the tannery industrial effluents reduced the levels of the organic pollutants with high potential as indicated by the percentage reduction of BOD, COD and TDS.

Enzymes often can work in multiple environments especially if they are immobilized. This makes the microorganisms' enzymes even more resistant to harsh environments and enables the enzymes to be recovered and recycled after they are no longer needed (Gianfreda and Rao 2004). Ramesh and Singh (1993) reported that the immobilized bacteria having more efficiency to remove the suspended particles than free cells. Using the immobilized cell is preferable due to its capability for using several times with the same efficiency, which makes it more economical. Similar work was done by Sikander et al. (2007) showing the higher reduction with permeabilized cells of Ochrobactrum intermedium strain SDCr-5. 
BAJOPAS Volume 13 Number 2, December, 2020

The results revealed the isolation and identification of isolates with the potential for the reduction of $\mathrm{Cr}$ (VI) to $\mathrm{Cr}$ (III). Results indicated that immobilized $B$. cereus could be efficiently used for the reduction of $\mathrm{Cr}$ (VI).

Table 5: Percentage reduction of the tested Parameters from the tannery industrial samples of the Immobilized Bacteria.

\begin{tabular}{lllllll}
\hline \multirow{2}{*}{ Industries } & & \multicolumn{5}{c}{ Percentage Reduction $(\%)$} \\
\cline { 3 - 7 } & & $5 \mathrm{~g}$ & $10 \mathrm{~g}$ & $15 \mathrm{~g}$ & $20 \mathrm{~g}$ & $25 \mathrm{~g}$ \\
\hline TAN1 & COD & 28 & 14 & 64 & 87 & 89 \\
& BOD & 50 & 54 & 59 & 67 & 80 \\
& SS & 35 & -26 & -27 & -32 & -63 \\
& TDS & 99 & 99 & 99 & 98 & 98 \\
TAN2 & COD & 15 & 20 & 25 & 32 & 38 \\
& BOD & 91 & 91 & 92 & 90 & 92 \\
& SS & -28 & -52 & -52 & -54 & -55 \\
& TDS & 97 & 99 & 99 & 99 & 99 \\
& COD & 33 & 44 & 22 & 11 & 26 \\
& BOD & 75 & 81 & 76 & 81 & 81 \\
& SS & 25 & 3 & -1 & -10 & -15 \\
& TDS & 98 & 98 & 98 & 98 & 98 \\
\hline
\end{tabular}

Percentage Reduction $=(B-A) / B \times 100 \%$

$A=$ Concentration of the parameter after treatment

$\mathrm{B}=$ Concentration of the parameter before treatment

$+=$ percentage decrease

- = percentage increase

In general, immobilization makes the enzyme more resistant to temperature, $\mathrm{pH}$, and substrate concentration swings giving it a longer lifetime and higher productivity per active unit (Gianfreda and Rao, 2004; FuIlbrook, 1996; Russell et al, 2003; Kandelbauer et al., 2004). Immobilized cells have been used and studied extensively for the production of useful chemicals (Ohtake and Silver, 1994), the treatment of wastewaters (Chen et al., 2003; Wang et al., 2010). Although many workers described microbial degradation of tannery effluent, limited literature is available on the bioremediation of tannery effluent using immobilized bacterial cells in the Kano Industrial Estates.

\section{CONCLUSION}

The samples contained variable levels of the physicochemical parameters. The results of the Analysis of variance revealed that, no statistical difference $(p<0.05)$ was observed for the temperature, $\mathrm{pH}, \mathrm{SS}, \mathrm{TDS}, \mathrm{BOD}$ and $\mathrm{COD}$ among the three tannery industries before the treatment. The levels of some of the parameters
(SS, TDS and COD) observed in the samples were found above the recommended limits of WHO and NESREA, which called for the treatment of the effluents before discharge into the environment. Base on the morphological and biochemical test results, TAN1, TAN2, and TAN3 bacterial isolates were identified to be Neisseria spp, Bacillus cereus, and Staphylococcus aureus respectively. The results of Post-treatment analysis showed that there is overall decrease in the levels of the parameters determined when compared with that of the pre-treatment. The overall percentage reduction of the immobilised bacteria in the treatment of the respective effluents was in the order TAN2 (72\%)>TAN1 $(70 \%)>$ TAN3 $(62 \%)$. Hence, the immobilized bacteria are having higher biodegradation potential for the treatment of the tannery effluents.

\section{Acknowledgments}

The authors wish to acknowledge the University of Maiduguri for the financial support. The authors are grateful to the Kano State Ministry of Environment for their support in obtaining the effluent samples. 


\section{REFERENCES}

Ajao, A. T., Adebayo, G. B., and Yakubu, S. E. (2011). Bioremediation of textile industrial effluent using mixed culture of Pseudomonas aeruginosa and Bacillus subtilis immobilized on agar-agar in a bioreactor. J. Microbiol. Biotech. Res, 1(3), 50-56.

Akan, J. C., Moses, E. A., Ogugbuaja, V. O., and Abah, J. (2007). Assessment of tannery industrial effluents from Kano metropolis, Kano State, Nigeria. Journal of Applied Sciences, 7(19), 2788-2793.

Akan, J. C., Ogugbuaja, V. O., Abdulrahman, F. I., and Ayodele, J. T. (2009). Pollutant levels in effluent samples from tanneries and textiles of Kano industrial areas, Nigeria. Global journal of pure and applied sciences, 15(3-4).

APHA (1989). Standard methods for Examination of Will bete and Will betewater.15 $5^{\text {th }}$ edition. Brydpass Springfield Will behington DC. pp. 164-176

APHA (1992). Standard Methods for the Examination of Water and Wastewater. Health, 69, 1116-9.

Baba, A., Garba, S. T., and Bello, H. S. (2020). Bioremediation Potential of Immobilized corynebacterium kutsceri in the Treatment of Tannery Industrial Effluent from Challawa Industrial Estate, Kano State, Nigeria. Journal of the Turkish Chemical Society Section A: Chemistry, $7(2), 335-350$.

Beem, E. I. V. (1994). reduction of solvent VOC emission. J. Oil Col. Chem. Ass, 77, 158.

Bouwer, E. J., and Zehnder, A. J. (1993). Bioremediation of organic compoundsputting microbial metabolism to work. Trends in biotechnology, 11(8), 360367.

Chen, K. C., Wu, J. Y., Liou, D. J., and Hwang, S. C. J. (2003). Decolorization of the textile dyes by newly isolated bacterial strains. Journal of Biotechnology, 101(1), 57-68.

Dan'Azumi, S., and Bichi, M. H. (2010). INDUSTRIAL POLLUTION AND HEAVY METALS PROFILE OF CHALLAWA RIVER IN KANO, NIGERIA. Journal of Applied Sciences in Environmental Sanitation, $5(1)$.

DWAF. (1992). Analytical Methods Manual, TR 151. Department of Water Affairs and Forestry, Pretoria.

El-Bestawy, E. (2013). Biological treatment of leather-tanning industrial wastewater using free living bacteria.
Elsheikh, M. A. S. (2009). Tannery wastewater pre-treatment. Water Science and Technology, 60(2), 433-440.

FuIlbrook, P. D. (1996). "Kinetics." Industrial enzymology: The application of enzymes in Industry. 2nd Ed. T. Godfrey and J Reichelt. eds.. Nature. New York.

Gianfreda, L., and Rao, M. A. (2004). Potential of extra cellular enzymes in remediation of polluted soils: a review. Enzyme and microbial technology, 35(4), 339354.

Hugo Springer. (1994). John Arthur Wilson Memorial Lecture "Treatment of Industrial Wastes of the Leather Industry - is it still a Major Problem". JALCA, 89, 153-185

Jimoh, A. A., Ganiyu, B. A., Baba, D., and Baba, A. (2018) Bioremediation Process of Effluent from Detergent and Food Industries in Jos, Nigeria: Kinetics and Thermodynamics. International Journal of Engineering Science Invention (IJESI), 762-73

Kandelbauer, A., Maute, O., Kessler, R. W., Erlacher, A., and Gübitz, G. M. (2004). Study of dye decolorization in an immobilized laccase enzyme-reactor using online spectroscopy. Biotechnology and bioengineering, 87(4), 552-563.

Kongjao, S., Damronglerd, S., and Hunsom, M. (2008). Simultaneous removal of organic and inorganic Pollutants in tannery wastewater using electrocoagulation technique. Korean Journal of chemical engineering, 25(4), 703.

Maheshwari, U. M., Aruna, S., Gomathi, M., and AbdulJaffar, A. H. (2017). Bioremediation by Free and Immobilized Bacteria Isolated from Tannery Effluent. International Journal of Research in Applied, Natural and Social Sciences. 5(7), 75-90

Margesin, R., and Schinner, F. (2001). Bioremediation (natural attenuation and biostimulation) of diesel-oilcontaminated soil in an alpine glacier skiing area. Applied and environmental microbiology, 677), 3127-3133.

Mohammed, A., Sekar, P., and George, J. (2011). Efficacy of microbes in bioremediation of tannery effluent. Inter. J. Curr. Res, 3(4), 324-326.

Mohammed, S. S. D., Orukotan, A. A., and Abdullahi, H. (2017). Physicochemical and Bacteriological Assessment of Tannery Effluent from Samaru-Zaria, 
BAJOPAS Volume 13 Number 2, December, 2020 Kaduna State, Nigeria. Journal of Applied

Sciences and Environmental Management, 21(4), 734-740.

Munz, G., De Angelis, D., Gori, R., Mori, G., Casarci, M., and Lubello, C. (2009). The role of tannins in conventional and membrane treatment of tannery wastewater. Journal of hazardous materials, 164(2-3), 733-739

Mythili, K., and Karthikeyan, B. (2011). Bioremediation of $\mathrm{Cr}$ (VI) from tannery effluent using Bacillus spp and Staphylococcus spp. International Multidisciplinary Research Journal, 1(6).

NESREA (2009). National Environmental Standards for Effluent Limitations and Regulation. 1233-1236

Noorjahan, C. M. (2014). Physicochemical characteristics, identification of bacteria and biodegradation of industrial effluent. Journal of bioremediation and Biodegradation, 5(3).

Ohtake, H. I., and Silver, A. O. (1994). Bacterial reduction of toxic chromate. Biological degradation and bioremediation of toxic chemicals, 403-415.

Omoleke, I. I. (2004). Management of environmental pollution in Ibadan, an African city: the challenges of health hazard facing government and the people. Journal of Human Ecology, 15(4), 265-275.

Rajor, A., Reddy, A.S., and Singh, B. (2004). Determination of BOD kinetic Parameters and evaluation of alternate methods, M.Sc. Thesis, Department of biotechnology \& environmental Science, Thapar Institute of Engineering and Technology, Patiala

Ramasami, T., Rajamani, S., and Rao, J. R. (1994, March). Pollution control in leather industry: Emerging technological options. In International symposium on surface and colloidal science and its relevance to soil pollution, madras.

Ramesh, J. V. S., and Singh, S. P. (1993). Yearly variation in certain physicochemical parameters of pond at eastern Doon Valley. Uttar Pradesh J. Zoo, 12 (1), 7577.

Ranen, S., and Sharadinadra, C. (2009). Biotechnology applications to environmental remediation in resource exploitation. Current science, 97, 6-25
Russell, A. J., Berberich, J. A., Drevon, G. F., and Koepsel, R. R. (2003). Biomaterials for mediation of

chemical and biological warfare agents. Annual review of biomedical engineering, 5(1), 1-27.

Saravanan, P., and Saravanan, A. (1999). Decolourization of tannery effluent by Flavobacterium sp. EK 1. Indian Journal of Environmental Protection, 19, 19-24.

Sikander, S., and Shahida, H. (2007). Reduction of toxic hexavalent chromium by Ochrobactrum intermedium strain SDCr5 stimulated by heavy metals. Bioresource Technol, 98, 340-344.

Singh, N., Sharma, B. K., and Bohra, P. C. (2000). Impact assessment of industrial effluent of arid soils by using satellite imageries. Journal of the Indian Society of Remote Sensing, 28(2-3), 79.

Sreemoyee, C., and Priti, P. (2013). Assessment of physico-chemical parameters of dairy waste water and isolation and characterization of bacterial strains in terms of cod reduction. Int J Sci, 2(3), 395-400.

Verheijen, L. A. H. M., Wiersema, D., Pol, L. H., and De Wit, J. (1996). Management of wastes from animal product processing. Livestock and environment, Finding a balance. International Agriculture Center, Wageningen, The Netherlands.

Wang, F., Yao, J., Si, Y., Chen, H., Russel, M., Chen, K., and Bramanti, E. (2010). Short-time effect of heavy metals upon microbial community activity. Journal of Hazardous Materials, 173(13), 510-516.

WHO (World Health Organization). (2006). Air quality guidelines: global update 2005: particulate matter, ozone, nitrogen dioxide, and sulfur dioxide. World Health Organization.

World Bank. (1995). Nigeria's strategic options for redressing industrial pollution. World Bank, industry and energy division. 1st edition, West Central Africa Department; Annexes: 1995; pp 60-62.

Zahoor, A., and Abdul, R. (2009). Enumeration of Coliforms. Journal of Environmental Sciences. 21, 814-820 


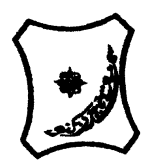

Bayero Journal of Pure and Applied Sciences, 13(2): 1 - 12

Received: November, 2020

Accepted: December, 2020

ISSN $2006-6996$

\title{
BIODEGRADATION POTENTIAL OF IMMOBILIZED BACTERIA IN THE TREATMENT OF TANNERY INDUSTRIAL EFFLUENTS FROM INDUSTRIAL ESTATES IN KANO STATE, NIGERIA
}

\author{
Abdullateef, B., ${ }^{1 *}$ Shuaibu, T. G., ${ }^{1}$ Babagana, K., ${ }^{1}$ Suleman, H. B. ${ }^{2}$ and Dauda, B. ${ }^{3}$ \\ ${ }^{1}$ Department of Pure and Applied Chemistry, Faculty of Science, University of Maiduguri, Borno State, \\ Nigeria \\ ${ }^{2}$ Department of Microbiology, Faculty of Science, University of Maiduguri, Borno State, Nigeria \\ ${ }^{3}$ Department of Chemical Engineering, Faculty of Engineering, University of Maiduguri, Borno State, \\ Nigeria \\ *Corresponding author: babslega@gmail.com; abelega2007@yahoo.com; +2348061309753
}

\section{ABSTRACT}

Industrial Effluents Samples from Gashash Tanneries (TAN1) in Bompai Industrial estate, Larabee Tannery Industry (TAN2) in Sharada Industrial estate and Z Tannery Industries (TAN3) in Challawa Industrial estate, Kano State, Nigeria were collected over a period of six months (August 2017 to January 2018) for assessing the biodegradation potentials of bacteria in the treatment of organic pollutants within the effluents. Bacteria were isolated from the effluents and immobilized on agar-agar. Different masses (5 g, $10 \mathrm{gr}, 15$ $\mathrm{g}, 20 \mathrm{~g}$, and $25 \mathrm{~g}$ ) of the bacteria were used in the treatment of $250 \mathrm{ml}$ of the effluents for ten days in a shaker incubator (Gallenkamp-OC-4364-L) at the temperature $30{ }^{\circ} \mathrm{C}$ and speed of $60 \mathrm{rpm}$. Pre-treatment analysis of the effluents for Temperature, pH, Biochemical Oxygen Demand (BOD), Chemical Oxygen Demand (COD), Suspended Solid (SS) and Total Dissolved Solids (TDS) gives the following results; temperature $\left({ }^{\circ} \mathrm{C}\right.$ )

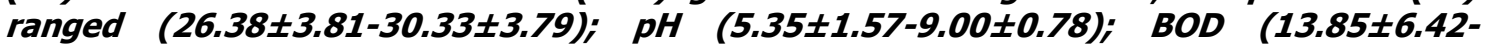
$38.75 \pm 16.20) ;$ COD (1406 $\pm 208-3532 \pm 1373) ;$ SS (208 $\pm 235-780 \pm 739)$ and TDS (266 $\pm 253-5276 \pm 2971)$. No statistical differences ( $p \leq 0.05)$ was observed for all the results among the different industries. The bacterial isolates were identified as Neisseria spp, Bacillus cereus, and Staphylococcus aureus, in TAN1, TAN2, and TAN3, respectively. After treatment of the effluent with the different masses of the isolated bacteria, the mean level of BOD was found to range as (0.55 $\pm 0.36-6.92 \pm 5.49) ; C O D$ (ND-3134 \pm 1595$)$;

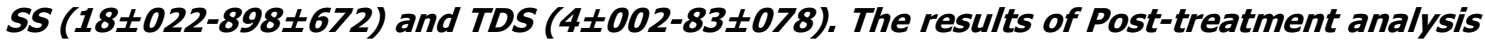
showed that there is overall decrease in the levels of the parameters determined when compared with that of the pre-treatment. The overall percentage reduction of the immobilised bacteria in the treatment of the respective effluents was in the order TAN2 (72\%)>TAN1 (70\%)>TAN3 (62\%). Hence, the immobilized bacteria are having higher biodegradation potential for the treatment of the tannery effluents.

Keywords: Biodegradation, bacteria, effluent, immobilization, tannery.

\section{INTRODUCTION}

Tannery industrial wastewater is a serious consequence of the pollution point of view for streams, freshwater, and land used for agriculture. The lack of awareness in the modern industrial practice has resulted in the discharge of tannery effluents which exhibit very high value of chromium ( $\mathrm{Cr}$ ), Sulfide, and chloride, Total Dissolved Solid (TDS), Total Suspended Solid (TSS), Biochemical Oxygen Demand (BOD) and Chemical Oxygen Demand (COD) in the water stream or land (Mohammed et al., 2001). Tanning is the process, which One ton of skin generally leads to the production of 20 to $80 \mathrm{~m}^{3}$ of turbid and foul-smelling converts the protein of the rawhide or skin into a stable material, which will not putrefy and is suitable for a wide variety of end applications (Elsheikh, 2009). The highly polluting chromium is the most commonly used tanning material producing leather that is more flexible and pliable than vegetable-tanned leather and does not discolor or lose shape in water as drastically as vegetable-tan (Elsheikh, 2009). Tannery effluent is among the most hazardous industrial pollutants due to its huge organic and inorganic load, which is highly toxic to human life and the environment (Kongjao et al., 2008). wastewater including chromium (100-400 mg/l), sulfide $(200-800 \mathrm{mg} / \mathrm{l})$, high levels of fat and 
BAJOPAS Volume 13 Number 2, December, 2020 other solid wastes, and notable pathogen contamination as well as pesticides added for skin conservation during transport (Elsheikh, 2009). There are more than 6000 tanneries in Nigeria with an annual processing capacity of 700,000 tons of hides and skins (Omoleke, 2004; Singh et al., 2008). It was reported that the total amount of waste produced per animal slaughtered is approximately $35 \%$ of its weight (World Bank, 1995). Also, for every $1000 \mathrm{~kg}$ of carcass weight, a slaughtered beef produces 5.5 $\mathrm{kg}$ of manure (excluding rumen contents or stockyard manure) and $100 \mathrm{~kg}$ of paunch manure (undigested food) (Verheijen et al., 1996). Tanneries generate wastewater in the range of 30-35 $\mathrm{L} \mathrm{kg}^{-1}$ skin/hide processed with variable $\mathrm{pH}$, Biological Oxygen Demand (BOD), Chemical Oxygen Demand (COD), high concentrations of suspended solids (SS), and tannins as well as chromium (Zahoor and Abdul, 2009).

Being heterogeneous and composed of a wide variety of compounds, it is very difficult to select a unique direct method for estimating the biodegradability of organic contents and biokinetic parameters for a wastewater sample (Rajor, 2004). For this purpose, some indirect estimation such as determination of biochemical oxygen demand (BOD) and chemical oxygen demand (COD) are applied as common laboratory investigations [9]. During retanning procedures, synthetic tannins (Syntan), oils and resins are added to form softer leather at varying doses (Munz et al., 2009). One of the refractory groups of chemicals in tannery effluents derives mainly from tannins (Ramasami et al., 2004). Syntans are characterized by complex chemical structures, because they are composed of an extended set of chemicals such as phenol-, naphthalene-, formaldehyde- and melamine-based syntans, and acrylic resins (Beem, 1994). Organic pollutants (proteic and lipidic components) are originated from skins (it is calculated that the raw skin has $30 \%$ loss of organic material during the working cycle) or they are introduced during processes (Hugo Springer, 1994).

Many conventional processes such as oxidation, chemical and biological processes were carried out to treat tanneries wastewater (Ebtesam et al, 2013). Biological processes have received more attention because of their costeffectiveness, lower sludge production and environmental friendliness (Noorjahan, 2014). Naturally occurring micro-organisms degrade the hazardous organic wastes including xenobiotic compounds, such as pesticides, polycyclic aromatic hydrocarbons (PAHs) and polychlorinated biphenyls (PCBs) in due course of time (Ranen and Sharadinadra, 2009). Bioremediation is based on the idea that all organisms remove substances from the environment to carry outgrowth and metabolism (Bouwer and Zehnder, 1993). Bacteria, protista and fungi are found to be very good at degrading complex molecules and incorporating the breakdown products into their metabolism (Bouwer and Zehnder, 1993). The resultant metabolic wastes that they produce are generally safe and somehow recycled into other organisms (Ranen and Sharadinadra, 2009). An acclimatized indigenous population of microorganisms capable of degradation of the compounds of interest must exist at the site for a successful bioremediation mode (Ranen and Sharadinadra, 2009). It has been observed that for a successful bioremediation mode, an acclimatized indigenous population of microorganisms capable of degradation of the compounds of interest must exist at the site under investigation (Ranen and Sharadinadra, 2009). Even though there are numerous physical and chemical methods employed in the disposal of wastes the advantage in using bacterium is that they play a key role in the reduction of COD, BOD, total protein, total tannin and total phenol (Saravanan and Saravanan, 1998)

Baba et al. (2020) studied the bioremediation potential of immobilized corynebacterium kutsceri in the Treatment of tannery industrial effluent from Challawa Industrial Estate, Kano State, Nigeria. The aim of the work is to study the reduction in the level of the contaminants through the process of bioremediation using the isolated bacteria. Immobilized bacteria can withstand various temperatures, $\mathrm{pH}$ and substrate concentrations; consequently, increasing the efficiency and the lifespan of the bacteria. Immobilized bacteria are widely applied in the treatment of wastewater and can be separated and recovered after the treatment with the same efficiency (Baba et al., 2020).

\section{MATERIALS AND METHODS \\ Study Area}

This study was carried out in Bompai, Sharada and Challawa industrial estates in Kano, Figure 1. Kano lies on Latitude $11^{\circ} 30^{\prime} \mathrm{N}$ and $8^{\circ} 30^{\prime} \mathrm{E}$ and Longitude $11^{\circ} 5^{\prime} \mathrm{N}$ and $8^{\circ} 5^{\prime} \mathrm{E}$ in Northern Nigeria. It is one of the developed industrial cities in Nigeria. Tannery activities are the dominating industries and this could be one of the reasons for her high population density (Dan'Azumi and Bichi, 2010). Many researchers have studied biodegradation of tannery effluent using microorganisms. However, limited literature is available on the biodegradation of tannery effluent in Kano industrial estates using 
BAJOPAS Volume 13 Number 2, December, 2020 immobilized bacterial cells. This research work focuses on the potential of the use of the indigenous immobilized bacterial isolates in the treatment of tannery effluents in the industrial estates.

\section{Sample Collection}

Effluents were collected from the Tannery Industries from Bompai, Challawa and Sharada Industrial Estates, Kano, Nigeria. The effluents were collected over a period of six months (August 2017 to January 2018). Samples collected in a sterile 4-liter plastic container with a unique identification number were preserved using an ice-box that was transported to the Microbiology Laboratory, Department of Microbiology, Bayero University of Kano for analysis

\section{Sample Preparation and Sample Analysis}

Immediately after the collection of the effluent, $\mathrm{pH}$, TSS, TDS, COD, BOD levels were determined before treatment (Pre-treatment determination) and ten days after treatment (Post-treatment determination) as described in
APHA (1989) standard methods. $\mathrm{pH}$ was determined using Ecotests $\mathrm{pH}$ meter and TDS was determined using AQUALYTIC TDS Salinometer. BOD was determined as described by the standard method (APHA, 1992). COD and SS were determined using DR/2010 HACH portable data logging spectrophotometer (DWAF, 1992)

\section{Identification and Biochemical} Characterization of the Bacterial Isolates

The bacteria were isolated from the effluents using Serial Dilution according to the method described by APHA (1989). The biochemical tests such as oxidase, catalase, coagulase, indole (from $1 \%$ tryptone broth), citrate (Simmons citrate agar), methyl red/VogesProskauer (MR/VP), nitrate reduction, Starch Hydrolysis, Glucose, Maltose, and Lactose tests were carried out on the bacterial isolates to identify the bacteria through the bacteria biochemical characteristics according to Ajao et al. (2011).

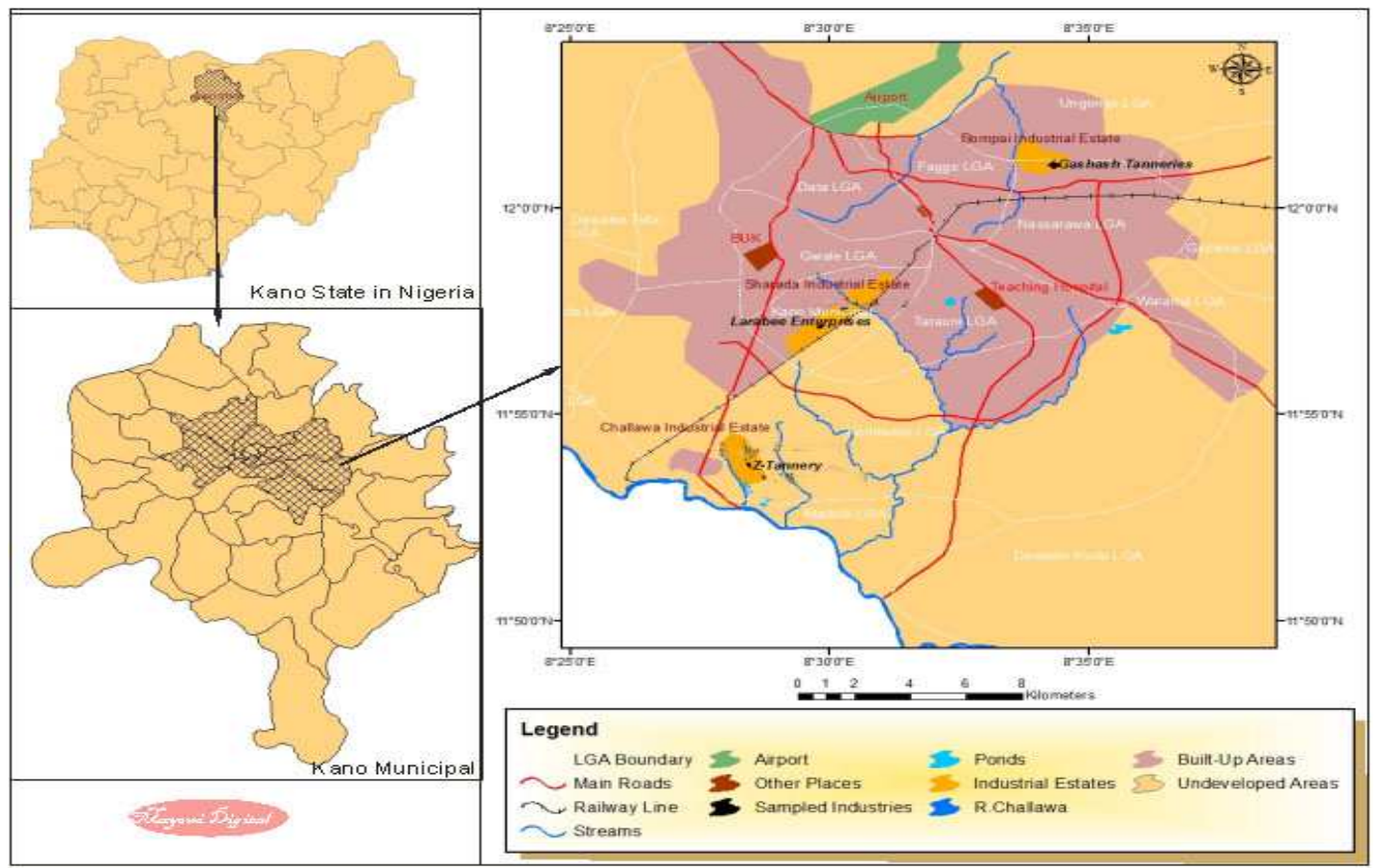

Fig. 1 Map showing the study areas

Source: Mayomi Digital Productions, GIS Laboratory, Department of Geography, UNIMAID (2017)

\section{Determination of Growth Rate of the Bacteria in Effluent Sample}

The bacteria growth rates were determined by transferring $2 \mathrm{~mL}$ of the bacterial isolates from the tannery effluent in broth medium into 100 $\mathrm{mL}$ sterile effluents in conical flasks and kept in an incubator (Giffrin cool) for 10 days. Control was also set up by incubating another $100 \mathrm{~mL}$ each of the sterile effluents without the bacteria. The optical density of the content was determined at the wavelength of $600 \mathrm{~nm}$ on a daily interval and recorded. 
BAJOPAS Volume 13 Number 2, December, 2020 Immobilization of Bacteria

Agar solution and inoculi were prepared separately. Fifty milliliters $(50 \mathrm{~mL})$ of nutrient broth each of the inoculi was prepared in a McCartney bottle and incubated for 24 hours. A solution of agar-agar was prepared by dissolving $10 \mathrm{~g}$ of the powder in distilled water and made up to $500 \mathrm{~mL}$ mark in an Erlenmeyer flask and was sterilized in an autoclave (280A) for 15 minutes and allowed to cool to $40-45^{\circ} \mathrm{C}$ (Ajao et al., 2011). Four milliliters ( $4 \mathrm{~mL})$ of the bacterial isolates in the nutrient broth was mixed with 36 $\mathrm{ml}$ of the prepared agar-agar media in petri-dish plates and then allowed to solidify. This was kept in the refrigerator for bioremediation.

\section{Bioremediation (Treatment) of the Effluents}

The solidified agar block (immobilized bacteria) was cut into cubes using a sterile knife; $0.1 \mathrm{~mL}$ phosphate buffer ( $\mathrm{pH} \mathrm{7.0)}$ was added and kept in the refrigerator for 1 hour for curing. The phosphate buffer was decanted after 1 hour and the cubes were washed with sterile distilled water 3-4 times before it was used (Ajao et al., 2011). Two liters (2 L) of the effluent was supplemented with the minimum basal medium in $\mathrm{g} / \mathrm{L}: \mathrm{NaCl}(0.8), \mathrm{MgSO}_{4} .7 \mathrm{H}_{2} \mathrm{O}(0.001), \mathrm{KH}_{2} \mathrm{PO}_{4}$ (2), $\mathrm{NaNO}_{3}$ (2), $\quad \mathrm{CaCl}_{2} .2 \mathrm{H}_{2} \mathrm{O} \quad(0.5)$ and $\mathrm{NaHPO}_{4} .12 \mathrm{H}_{2} \mathrm{O}(2)$ and sterilized in an autoclave at $121^{\circ} \mathrm{C}$ for 15 minutes (Margesin and Schinner, 2001). Two hundred and fifty milliliters $(250 \mathrm{~mL})$ of the effluents were transferred into different $250 \mathrm{ml}$ conical flasks. The content was covered with a cotton-wool ramped with foil paper to avoid contamination. Five grams $(5 \mathrm{~g})$ of the immobilized bacteria were quickly transferred into each of the effluents in the conical flasks in an inoculating chamber. The same procedures were carried out for the $10 \mathrm{~g}, 15 \mathrm{~g}, 20 \mathrm{~g}$ and 25 $\mathrm{g}$ of the immobilized bacteria in separate $250 \mathrm{~mL}$ effluents in conical flasks and agitated for ten days in a shaker incubator (Gallenkamp-OC4364-L) at a temperature $30^{\circ} \mathrm{C}$ and speed of 60 rpm. The treated effluent samples were taken on the tenth day and analyzed for the parameters $\mathrm{pH}$, SS, TDS, COD, and BOD, (Posttreatment determination) for the different grams of bacteria to evaluate and compare the biodegradation potential. (Baba et al., 2020).

\section{Statistical Analysis}

The data were represented as Mean \pm Standard deviation and analyzed statistically using oneway Analysis of Variance (ANOVA) and Tukey's HSD as Post Hoc Tests with the aid of SPSS 16.0. The correlation coefficient was also used to measure the strength of the relationship between the different masses of the bacteria and the parameters. All $\mathrm{p} \leq 0.05$ were considered as statistically significant.

\section{RESULTS AND DISCUSSION Physico-chemical parameters in the Industrial Effluents before the Biodegradation.}

Results of the Physico-chemical parameters in the industrial effluents before the Biodegradation is shown in table 1 . The mean temperatures $\left({ }^{\circ} \mathrm{C}\right)$ observed in TAN1, TAN2, and TAN3 samples were $28.07 \pm 0.65 ; 27.77 \pm 0.64$ and $26.38 \pm 3.81$ respectively. The order of the mean temperature of the samples from the three industries can be arranged as TAN1 > TAN2>TAN3. The temperature observed at TAN1, TAN2, and TAN3 samples were found below the WHO $\left(35^{\circ} \mathrm{C}\right)$ and NESREA $\left(40^{\circ} \mathrm{C}\right)$ limits. The low values of temperature might be due to the processes used at the time of sampling. High temperature brings down the solubility of gases in water that ultimately expresses as high BOD and COD. Statistical analysis shows that there is no significant difference $(p<0.05)$ between the mean values of temperature among the industries. This might be due to similar tannery activities involved in the tannery industries at the time of sampling. The average values of temperature observed in this present study are less than those observed by Akan et al. (2007), Akan et al. (2009) and Baba et al. (2020).

The mean level of $\mathrm{pH}$ observed in TAN1, TAN2 and TAN3, samples were $7.77 \pm 2.93$; $8.35 \pm 0.28$ and $7.52 \pm 0.76$ respectively. The order of the mean $\mathrm{pH}$ of the samples from the three industries can be arranged as TAN2> TAN1 $>$ TAN3. The $\mathrm{pH}$ of the samples falls within the WHO (7.0-8.5) and NESREA (6-9) standard limits. Statistical analysis shows that there is no significant difference $(p<0.05)$ between the mean values of $\mathrm{pH}$ among the industries. This might be due to similar tannery activities involved in the tannery industries at the time of sampling. Maheshwari et al. (2017) reported that the level of $\mathrm{pH}$ in the effluents from the tannery industry in Vaniyambadi, India was 6.5 which was lower than that observed in the present study. The $\mathrm{pH}$ in the effluents from the tannery industries in Kano and Kaduna were reported to be 7.64 and 6.89, respectively (Akan et al., 2007; Mohammed et al., 2017). The average values of $\mathrm{pH}$ observed in this present study are less than those observed by Mohammed et al. (2017) and Baba et al. (2020). The mean level of SS $(\mathrm{mg} / \mathrm{l})$ observed in TAN1, TAN2, and TAN3 samples were 374 \pm 124 ; $358 \pm 335$ and $780 \pm 739$ respectively. The order of the mean SS in the samples from the three industries can be arranged as TAN3 > TAN1 $>$ TAN2. 
The SS observed in the samples were far above the recommended standard limits of regulating bodies WHO $(30 \mathrm{mg} / \mathrm{l})$ and NESREA $(10 \mathrm{mg} / \mathrm{l})$. Statistical analysis shows that there is no significant difference $(p<0.05)$ between the mean values of SS among the industries. This might be due to similar tannery activities involved in the tannery industries at the time of sampling. The average values of SS observed in this present study are less than that observed $(3700 \pm 122 \mathrm{mg} / \mathrm{l})$ by Akan et al. (2009) for tanneries in Kano. Also, the average values of SS observed in this present study are less than that observed by Mohammed et al. (2017) and Baba et al. (2020) with the exception in TAN3.

The mean level of TDS (mg/l) observed in TAN1, TAN2, and TAN3 samples were $3941 \pm 3703$; $3300 \pm 1714$ and $2653 \pm 1240$ respectively. The order of the mean TDS in the samples from the three industries can be arranged as TAN1>TAN2>TAN3. The TDS observed in the samples were far above the recommended standard limits of WHO $(250 \mathrm{mg} / \mathrm{l})$ and NESREA $(500 \mathrm{mg} / \mathrm{l})$. Statistical analysis shows that there is no significant difference $(p<0.05)$ between the mean values of TDS among the industries. This might be due to similar tannery activities involved in the tannery industries at the time of sampling. TDS in the effluents from the tannery industries in Kano, Nigeria was reported to be $1281 \mathrm{mg} / \mathrm{l}$ (Akan et al., 2007). The average values of SS observed in this present study are less than those observed by Mohammed et al. (2017) and Baba et al. 2020)

The mean level of COD (mg/l) observed in TAN1, TAN2 and TAN3 samples seasons were $2372 \pm 938 ; \quad 1406 \pm 208$ and $3532 \pm 1373$ respectively. The order of the mean COD of the samples from the three industries can be arranged as TAN3>TAN1> TAN2. The COD observed in TAN1, TAN2 and TAN3 samples were far above the recommended standard limits of regulating bodies $\mathrm{WHO}(40 \mathrm{mg} / \mathrm{l})$ and NESREA (40 mg/l). Statistical analysis shows that there is no significant difference $(p<0.05)$ in COD among the industries. This might be due to similar tannery activities involved in the tannery industries as at the time of sampling. The Chemical Oxygen demand (COD) is the amount of oxygen, in $\mathrm{mg} / \mathrm{L}$, required for the degradation of the compound of wastewater to occur. In comparison, the average values of COD observed in this present study were higher than that observed by Mohammed et al. (2017) but lower than that observed by Baba et al. (2020).

The mean levels of BOD $(\mathrm{mg} / \mathrm{l})$ observed in TAN1, TAN2 and TAN3 samples were $13.85 \pm 6.42 ; \quad 19.46 \pm 0.50$ and $17.13 \pm 3.14$ respectively. The order of the mean BOD in the samples from the three industries can be arranged as TAN2>TAN3>TAN1. The BOD observed in TAN1, TAN2 and TAN3 samples were found below the recommended limits of NESREA (200 mg/l) but above WHO (10 mg/l). Statistical analysis shows that there is no significant difference $(p<0.05)$ between the mean values of BOD among the industries. This might be due to similar tannery activities involved in the tannery industries at the time of sampling. The low level of BOD recorded in this study is an indication of the low level of biodegradable organic solids in the effluent. The average values of BOD observed in this present study were lower than those observed by Mohammed et al. (2017) and Baba et al. (2020).

Table 1: Mean Values \pm S.D of Physico-chemical parameters of effluents from the Tannery Industries before Treatment.

\begin{tabular}{llllllll}
\hline Parameter & Tannery 1 & Tannery 2 & Tannery 3 & $\mathrm{a}$ & $\mathrm{b}$ & $\mathrm{c}$ & $\mathrm{d}$ \\
\cline { 2 - 7 } Temperature $\left({ }^{\circ} \mathrm{C}\right)$ & $28.07 \mathrm{a} \pm 0.65$ & $27.77 \mathrm{a} \pm 0.64$ & $26.38 \mathrm{a} \pm 3.81$ & & $29.50 \pm 4.68$ & 35 & 40 \\
pH & $7.77 \mathrm{a} \pm 2.93$ & $8.35 \mathrm{a} \pm 0.28$ & $7.52 \mathrm{a} \pm 0.76$ & 6.89 & $5.35 \pm 1.57$ & $7.0-8.5$ & $6.0-9.0$ \\
$\mathrm{COD}(\mathrm{mg} / \mathrm{l})$ & $2372 \mathrm{a} \pm 938$ & $1406 \mathrm{a} \pm 208$ & $3532 \mathrm{a} \pm 1373$ & 2.2 & $3106 \pm 2753$ & 40 & 40 \\
$\mathrm{BOD}(\mathrm{mg} / \mathrm{l})$ & $13.85 \mathrm{a} \pm 6.42$ & $19.46 \mathrm{a} \pm 0.50$ & $17.13 \mathrm{a} \pm 3.14$ & 1032 & $26.17 \pm 9.49$ & 10 & 200 \\
$\mathrm{SS}(\mathrm{mg} / \mathrm{l})$ & $374 \mathrm{a} \pm 124$ & $358 \mathrm{a} \pm 335$ & $780 \mathrm{a} \pm 739$ & 501 & $562 \pm 482$ & 30 & 10 \\
TDS $(\mathrm{mg} / \mathrm{l})$ & $3941 \mathrm{a} \pm 3703$ & $3300 \mathrm{a} \pm 1714$ & $2653 \mathrm{a} \pm 1240$ & 532.7 & $444 \pm 507$ & 250 & 500 \\
\hline
\end{tabular}

The values given in the table above are means of 6 replicate values, $\mathrm{n}=6$ ( 1 sample was taken monthly for 6 months). Within the rows, means with different alphabets are statistically different $(p<0.05)$. WHO: World Health Organisation. NESREA: National Environmental Standard and Regulatory Enforcement Agency. a = Mohammed et al.(2017), b = Baba et al. (2020), c = WHO (2006), $d=$ NESSRA (2009) 
BAJOPAS Volume 13 Number 2, December, 2020

Identification, Biochemical Characterization and growth rates of the Bacterial Isolates

Results of identification and biochemical characterization of the bacterial isolates were shown in table 2. After 24 hours of incubation, the nutrient agar media plates were checked for bacterial growth. The results showed the presence of different strains in the samples. The TAN1 bacteria isolate was found to be gramnegative cocci while TAN3 was gram-positive cocci. TAN2 bacteria isolate was found to be gram-positive, rod-shaped. TAN1, TAN2, and TAN3 bacteria isolates recorded positive results for spore former.

The results of the biochemical tests indicated that all the bacteria were positive for catalase, oxidase, citrate, maltose, glucose, lactose (negative in TAN1), mannitol (negative in TAN2), starch hydrolysis and coagulase (negative in TAN2) tests. The bacteria showed negative results for nitrate reduction, $M R$ (positive in TAN2), VP (positive in TAN1), Indole (positive in TAN2) tests. Base on the morphological and biochemical test results, TAN1, TAN2, and TAN3 bacteria isolates were identified to be Nesseria spp, Bacillus cereus, and Staphylococcus aureus respectively.

The growth rate of the TAN1, TAN2 and TAN3 Isolates were shown in figure 2. Generally, the optical density increase with the increase in time (day) and decrease as time goes on. The highest optical density was shown by bacillus cereus in TAN2 while the lowest was shown by Staphylococcus aureus in TAN3.

The initial growth phase of TAN1 Isolate bacteria occurred within 2-day of incubation as the growth rate increases up to the 6th-day incubation when the maximum growth was observed. Beyond the 6th day, the growth of the bacteria declined (which might be due to a shortage of nutrients in the effluents) until it reached its death phase (which might be due to the unavailability of nutrients in the effluents).

A similar trend of growth was also observed for TAN2 Isolate as the initial growth phase also occurred within 2-day of incubation but maximum growth rate observed on the 4th day of incubation. The stationary stage occurred between the 4th day and the 8th day. Beyond the 8th day, the growth of the bacteria declined (which might be due to a shortage of nutrients in the effluents) until it reached its death phase (which might be due to the unavailability of nutrients in the effluents).

The initial growth phase of TAN3 bacterial Isolate occurred within the 3-day incubation as the growth rate increases up to the 6th-day incubation when the maximum growth was observed. Beyond the 6th day, the growth of the bacteria declined (which might be due to a shortage of nutrients in the effluents) until it reached its death phase (which might be due to the unavailability of nutrients in the effluents).

Table 2: Morphological and Biochemical characteristics of bacterial isolates

\begin{tabular}{lllll} 
Bacterial Isolates & & TAN1 & TAN2 & TAN3 \\
\hline $\begin{array}{lllll}\text { Morphological } \\
\text { characteristics }\end{array}$ & Shape & Cocci & Rod & Cocci \\
& Spore & & & \\
& former & + & + & + \\
Gram & & & \\
Biochemical characteristics & reaction & - & + & + \\
& Citrate & + & + & + \\
& Catalase & + & + & + \\
& Coagulase & + & - & + \\
Starch & + & + & + \\
& Glucose & + & + & + \\
Oxidase & + & + & + \\
& Indo & - & + & - \\
Lactose & - & + & + \\
Manitol & + & - & + \\
Maltose & + & + & + \\
MR & - & + & - \\
VP & + & - & - \\
& Nitrate & - & - & - \\
Reduction & - Neisseria & Bacillus & Staphylococcus \\
& Bacterial & cereus & aureus \\
& name & spp & cas
\end{tabular}

+ = Positive; - = Negative; MR=Methyl Red; VP= Voges-Proskauer 


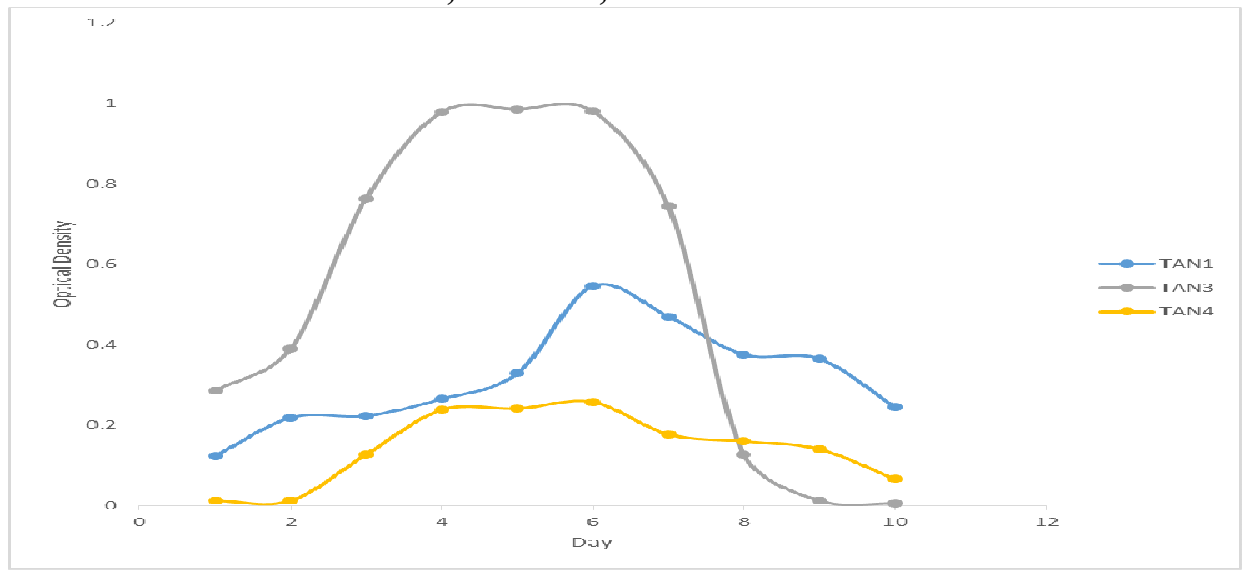

Fig. 2 Growth rates of the isolates in the effluents from the Tannery Industries

\section{Physico-chemical Parameters in the Industrial Effluents after the biodegradation.}

Table 3 shows the mean results of the physicochemical parameter before and after bioremediation using the different masses $(5 \mathrm{~g}$, $10 \mathrm{~g}, 15 \mathrm{~g}, 20 \mathrm{~g}$, and $25 \mathrm{~g}$ ) of the respective immobilized bacteria. Also, Table 4 shows the mean results of correlation coefficient ( $r$ ) between different masses of bacteria and physicochemical parameters.

The mean values $(\mathrm{mg} / \mathrm{l})$ of the SS after the bioremediation varies between $243 \pm 45$ and $898 \pm 672$. The mean concentration $(\mathrm{mg} / \mathrm{l})$ of SS remediated by the different masses $(5 \mathrm{~g}, 10 \mathrm{~g}$, $15 \mathrm{~g}, 20 \mathrm{~g}$, and $25 \mathrm{~g}$ ) of the bacteria varies. The SS in the samples fluctuates up and down after the bioremediation process when compared with the SS of the raw samples before the bioremediation. The increase in the levels of the SS might be due to the aggregation of the TDS which are large enough to result into SS. The increase in the levels of the SS might be also due to the influence of the nutrients which was added into the effluents in order to make the microorganisms more active and viable for fast degradation of organic contaminants in the effluent. The relative potential or efficiency of the different masses of the bacteria in remediating SS in TAN1 samples was in the order $25 \mathrm{~g}>20 \mathrm{~g}>15 \mathrm{~g}>10 \mathrm{~g}>5 \mathrm{~g}$. For TAN2 and TAN3 samples, the order was $25 \mathrm{~g}>20 \mathrm{~g}>15$ $\mathrm{g}>10 \mathrm{~g}>5 \mathrm{~g}$. These might be due to the variations in the surface areas of the different masses of the immobilized bacteria. Statistical analysis shows that there is no significant difference $(p<0.05)$ between the mean values of SS among the masses in the respective industries. Positive and significant correlations exist between the masses of bacteria and Suspended Solid (SS). This showed that there is general increase in the levels of the SS as the masses of the immobilized bacteria increases. TAN3 (90\%) and TAN1 (80\%) showed a very high correlation with the masses of the bacteria while TAN2 (61\%) showed a very low correlation.

The mean values $(\mathrm{mg} / \mathrm{l})$ of the TDS after the bioremediation varies between $46 \pm 11$ and $83 \pm 78$. The mean concentration $(\mathrm{mg} / \mathrm{l})$ of TDS remediated by the different masses $(5 \mathrm{~g}, 10 \mathrm{~g}$, $15 \mathrm{~g}, 20 \mathrm{~g}$, and $25 \mathrm{~g}$ ) of the bacteria varies. There is a reduction in all the TDS of all the samples after the bioremediation process compared with the TDS of the raw samples before the bioremediation. The relative potential or efficiency of the different masses of the bacteria in remediating TDS in TAN1 and TAN3 samples was in the order $5 \mathrm{~g}>10 \mathrm{~g}>15 \mathrm{~g}>20$ $\mathrm{g}>25 \mathrm{~g}$. For TAN2 samples, the order was 20 $g>10 \quad g>25 \quad g>15 \quad g>5 \quad g$. Statistical analysis shows that there is no significant difference $(p<0.05)$ between the mean values of TDS among the masses in the respective industries. These might be due to the variations in the surface areas of the different masses of the immobilized bacteria. Positive and significant correlations exist between the masses of bacteria and TDS with the exception in TAN2 (negative and insignificant correlation). The positive correlations showed that there is general increase in the levels of the TDS as the masses of the immobilized bacteria increases. TAN1 $(96 \%)$ showed a very high correlation with the masses of the bacteria while TAN2 (47\%) showed a very low correlation.

The mean values $(\mathrm{mg} / \mathrm{l})$ of the BOD after the bioremediation varies between $1.56 \pm 0.20 \mathrm{mg} / \mathrm{l}$ and $6.92 \pm 5.49 \mathrm{mg} / \mathrm{l}$. The mean concentration $(\mathrm{mg} / \mathrm{l})$ of BOD remediated by the different masses $(5 \mathrm{~g}, 10 \mathrm{~g}, 15 \mathrm{~g}, 20 \mathrm{~g}$, and $25 \mathrm{~g}$ ) of the bacteria varies. There is a reduction in all the BOD of all the samples after the bioremediation process compared with the $\mathrm{BOD}$ of the raw 
BAJOPAS Volume 13 Number 2, December, 2020 samples before the bioremediation. The relative potential or efficiency of the different masses of the bacteria in remediating BOD in TAN1, TAN2 and TAN3 samples were in the order $25 \mathrm{~g}>20$ $\mathrm{g}>15 \mathrm{~g}>10 \mathrm{~g}>5 \mathrm{~g}, 25 \mathrm{~g}>15 \mathrm{~g}>5 \mathrm{~g}>10 \mathrm{~g}>20 \mathrm{~g}$ and $20 \mathrm{~g}>10 \mathrm{~g}>25 \mathrm{~g}>15 \mathrm{~g}>5 \mathrm{~g}$ respectively. Statistical analysis shows that there is significant difference $(p<0.05)$ between the mean values of BOD among the masses in the respective industries. These might be due to the variations in the surface areas of the different masses of the immobilized bacteria. Negative and significant correlations exist between the masses of bacteria and BOD. This showed that there is general decrease in the levels of the BOD as the masses of the immobilized bacteria increases. TAN1 (94\%) showed a very high correlation with the masses of the bacteria while TAN2 (4\%) showed a very low correlation.

The mean values $(\mathrm{mg} / \mathrm{l})$ of the COD after the bioremediation varies between $250 \pm 154$ and $3134 \pm 1595$. The mean concentration $(\mathrm{mg} / \mathrm{l})$ of COD remediated by the different masses $(5 \mathrm{~g}$, $10 \mathrm{~g}, 15 \mathrm{~g} 20 \mathrm{~g}$, and $25 \mathrm{~g}$ ) of the bacteria varies. There is a reduction in all the COD of all the samples after the bioremediation process compared with the COD of the raw samples before the bioremediation. The relative potential or efficiency of the different masses of the bacteria in remediating COD in TAN1, TAN2 and TAN3 samples were in the order $25 \mathrm{~g}>20 \mathrm{~g}>15$ $\mathrm{g}>5 \mathrm{~g}>10 \mathrm{~g}, 25 \mathrm{~g}>20 \mathrm{~g}>15 \mathrm{~g}>10 \mathrm{~g}>5 \mathrm{~g}$ and 10 g>5 g>25 g>15 g>20 g respectively. Statistical analysis shows that there were significant difference $(p<0.05)$ between the mean values of COD among the masses in the respective industries except for effluents treated with $25 \mathrm{~g}$. These might be due to the variations in the surface areas of the different masses of the immobilized bacteria. Negative and insignificant correlations exist between the masses of bacteria and COD with the exception in TAN3 (positive and significant correlation). The negative correlations showed that there is general decrease in the levels of the COD as the masses of the immobilized bacteria increases. TAN2 (100\%) showed a very high correlation with the masses of the bacteria while TAN3 (36\%) showed a very low correlation.

Generally, there was an overall decrease in the concentration of these physicochemical parameters after the bioremediation using the different masses of the bacterial isolates. These might be due to the variations in the surface areas of the different masses of the immobilized bacteria. This is in line with the work of Jimoh et al. (2018) and Baba et al. (2020).

Table 3: Mean Values $(\mathrm{mg} / \mathrm{l}) \pm$ S.D of Physicochemical parameters in effluents from the Tannery Industries before and after Treatment of the effluents $(250 \mathrm{ml})$ with the different masses $(5 \mathrm{~g}, 10 \mathrm{~g}$, $15 \mathrm{~g}, 20 \mathrm{~g}$, and $25 \mathrm{~g}$ ) of the bacteria.

\begin{tabular}{llllllll}
\hline $\mathrm{P}$ & IND & Before & \multicolumn{5}{c}{ After } \\
\cline { 4 - 7 } & & & $5 \mathrm{~g}$ & $10 \mathrm{~g}$ & $15 \mathrm{~g}$ & $20 \mathrm{~g}$ & $25 \mathrm{~g}$ \\
\hline \multirow{2}{*}{ COD } & TAN1 & $2372 \pm 938$ & $1708 \mathrm{a} \pm 861$ & $2045 \mathrm{a} \pm 1205$ & $845 \mathrm{a} \pm 369$ & $300 \mathrm{a} \pm 167$ & $250 \mathrm{a} \pm 154$ \\
& TAN2 & $1406 \pm 208$ & $1195 \mathrm{a} \pm 208$ & $1125 \mathrm{a} \pm 384$ & $1055 \mathrm{a} \pm 317$ & $956 \mathrm{a} \pm 310$ & $870 \mathrm{ab} \pm 240$ \\
& TAN3 & $3532 \pm 1373$ & $2374 \mathrm{a} \pm 1344$ & $1976 \mathrm{a} \pm 1405$ & $2757 \mathrm{a} \pm 1266$ & $3134 \mathrm{a} \pm 1595$ & $2614 \mathrm{~b} \pm 1105$ \\
BOD & TAN1 & $13.85 \pm 6.42$ & $6.92 \mathrm{a} \pm 5.49$ & $6.42 \mathrm{a} \pm 5.07$ & $5.72 \mathrm{a} \pm 5.35$ & $4.62 \mathrm{a} \pm 4.37$ & $2.82 \mathrm{ab} \pm 1.26$ \\
& TAN2 & $19.46 \pm 0.50$ & $1.75 \mathrm{~b} \pm 0.22$ & $1.73 \mathrm{~b} \pm 0.18$ & $1.58 \mathrm{a} \pm 0.16$ & $1.91 \mathrm{a} \pm 0.22$ & $1.56 \mathrm{~b} \pm 0.20$ \\
& TAN3 & $17.13 \pm 3.14$ & $4.24 \mathrm{ab} \pm 0.77$ & $3.29 \mathrm{ab} \pm 0.37$ & $4.11 \mathrm{a} \pm 0.07$ & $3.23 \mathrm{a} \pm 0.91$ & $3.33 \mathrm{a} \pm 1.28$ \\
SS & TAN1 & $374 \pm 124$ & $243 \mathrm{a} \pm 45$ & $471 \mathrm{a} \pm 226$ & $475 \mathrm{a} \pm 182$ & $492 \mathrm{a} \pm 128$ & $611 \mathrm{a} \pm 217$ \\
& TAN2 & $358 \pm 335$ & $460 \mathrm{a} \pm 400$ & $543 \mathrm{a} \pm 414$ & $544 \mathrm{a} \pm 402$ & $551 \mathrm{a} \pm 414$ & $554 \mathrm{a} \pm 405$ \\
& TAN3 & $780 \pm 739$ & $586 \mathrm{a} \pm 594$ & $758 \mathrm{a} \pm 656$ & $787 \mathrm{a} \pm 676$ & $861 \mathrm{a} \pm 635$ & $898 \mathrm{a} \pm 672$ \\
TDS & TAN1 & $3941 \pm 3703$ & $51 \mathrm{a} \pm 10$ & $53 \mathrm{a} \pm 10$ & $55 \mathrm{a} \pm 15$ & $61 \mathrm{a} \pm 20$ & $63 \mathrm{a} \pm 26$ \\
& TAN2 & $3300 \pm 1714$ & $83 \mathrm{a} \pm 78$ & $47 \mathrm{a} \pm 20$ & $48 \mathrm{a} \pm 22$ & $47 \mathrm{a} \pm 17$ & $48 \mathrm{a} \pm 17$ \\
& TAN3 & $2653 \pm 1240$ & $46 \mathrm{a} \pm 11$ & $55 \mathrm{a} \pm 24$ & $55 \mathrm{a} \pm 25$ & $58 \mathrm{a} \pm 23$ & $61 \mathrm{a} \pm 28$ \\
\hline
\end{tabular}

Replicate $=6$ (months)

Within the rows, for the same parameter, means with different alphabets are statistically different $(p<0.05)$.

$\mathrm{P}=$ parameter, IND = Industries 
BAJOPAS Volume 13 Number 2, December, 2020

Table 4: Correlation coefficient $(r)$ between different masses of the bacteria and the physicochemical parameters.

\begin{tabular}{llll}
\hline Industries & Parameter & Correlation coefficient $(r)$ & $\begin{array}{l}\text { Percent dependence (rxrx100) } \\
(\%)\end{array}$ \\
\hline TAN1 & COD & -0.9 & 82 \\
& BOD & -0.97 & 94 \\
& SS & $0.90^{*}$ & 80 \\
TAN2 & TDS & $0.98^{*}$ & 96 \\
& COD & -1 & 100 \\
& BOD & -0.21 & 4 \\
& SS & $0.78^{*}$ & 61 \\
& TDS & -0.69 & 47 \\
& COD & $0.60^{*}$ & 36 \\
& BOD & -0.6 & 37 \\
& SS & $0.95^{*}$ & 90 \\
& TDS & $0.94^{*}$ & 89 \\
\hline
\end{tabular}

The correlation coefficient $(r)$ with * is statistically significant $(p<0.05)$.

Percentage reduction of the Parameters

Table 5 shows the percentage reduction of Parameters in industrial samples before and after the treatment of the effluents $(250 \mathrm{ml})$ with the different masses $(5 \mathrm{~g}, 10 \mathrm{~g}, 15 \mathrm{~g}, 20 \mathrm{~g}$, and $25 \mathrm{~g}$ ) of the Immobilized Bacteria.

In TAN1 samples, the percentage reduction (\%) of COD ranged (14-89); BOD (50-80); SS (-32$35)$ and TDS (98-99). In TAN2 samples, the percentage decrease $(\%)$ of COD ranged (15$38) ;$ BOD (90-92); SS [-28-(-55)] and TDS (9798). In TAN3 samples, the percentage decrease (\%) of COD ranged (11-44); BOD (76-81); SS (15-25) and TDS (98). The percentage increase in the levels COD, BOD and TDS might be due to the increase in the surface area of the different masses of the immobilized bacteria. However, the percentage decrease in the levels of the SS might be due to the aggregation of the TDS which are large enough to result into SS. The percentage decrease in the levels of the SS might be also due to the influence of the nutrients which was added into the effluents in order to make the microorganisms more active and viable for fast degradation of organic contaminants in the effluent. This is in line with the work of Jimoh et al. (2018) in which the concentration of the SS increase after the bioremediation of effluents.

Sreemoyee and Priti (2013) assessed and reduced several Physico-chemical parameters of dairy wastewater using Niesseria $s p$. and concluded that the species are well known to degrade organic compounds. This is in agreement with the current study in which the immobilized Niesseria $s p$ degrade the organic contaminants as indicated by the BOD, COD and TDS.

Jimoh et al. (2018) observed that TSS of the effluents was increased after treatment with immobilized bacteria and concluded that it might be due to the biostimulation method adopted for the research.

The optimum $\mathrm{pH}$ Biosorption of Chromium by Bacillus spp and Staphylococcus spp. from tannery effluent was investigated by Mythili and Karthikeyan (2011). The maximum adsorption of Chromium $(86.4 \mathrm{mg} / \mathrm{L})$ was showed by Bacillus spp and Staphylococcus spp showed $70.6 \mathrm{mg} / \mathrm{L}$ at an initial concentration of $100 \mathrm{mg} / \mathrm{L}$. In the present study, immobilised Bacillus spp and Staphylococcus spp. from the tannery industrial effluents reduced the levels of the organic pollutants with high potential as indicated by the percentage reduction of BOD, COD and TDS.

Enzymes often can work in multiple environments especially if they are immobilized. This makes the microorganisms' enzymes even more resistant to harsh environments and enables the enzymes to be recovered and recycled after they are no longer needed (Gianfreda and Rao 2004). Ramesh and Singh (1993) reported that the immobilized bacteria having more efficiency to remove the suspended particles than free cells. Using the immobilized cell is preferable due to its capability for using several times with the same efficiency, which makes it more economical. Similar work was done by Sikander et al. (2007) showing the higher reduction with permeabilized cells of Ochrobactrum intermedium strain SDCr-5. 
BAJOPAS Volume 13 Number 2, December, 2020

The results revealed the isolation and identification of isolates with the potential for the reduction of $\mathrm{Cr}$ (VI) to $\mathrm{Cr}$ (III). Results indicated that immobilized $B$. cereus could be efficiently used for the reduction of $\mathrm{Cr}$ (VI).

Table 5: Percentage reduction of the tested Parameters from the tannery industrial samples of the Immobilized Bacteria.

\begin{tabular}{lllllll}
\hline \multirow{2}{*}{ Industries } & & \multicolumn{5}{c}{ Percentage Reduction $(\%)$} \\
\cline { 3 - 7 } & & $5 \mathrm{~g}$ & $10 \mathrm{~g}$ & $15 \mathrm{~g}$ & $20 \mathrm{~g}$ & $25 \mathrm{~g}$ \\
\hline TAN1 & COD & 28 & 14 & 64 & 87 & 89 \\
& BOD & 50 & 54 & 59 & 67 & 80 \\
& SS & 35 & -26 & -27 & -32 & -63 \\
& TDS & 99 & 99 & 99 & 98 & 98 \\
TAN2 & COD & 15 & 20 & 25 & 32 & 38 \\
& BOD & 91 & 91 & 92 & 90 & 92 \\
& SS & -28 & -52 & -52 & -54 & -55 \\
& TDS & 97 & 99 & 99 & 99 & 99 \\
& COD & 33 & 44 & 22 & 11 & 26 \\
& BOD & 75 & 81 & 76 & 81 & 81 \\
& SS & 25 & 3 & -1 & -10 & -15 \\
& TDS & 98 & 98 & 98 & 98 & 98 \\
\hline
\end{tabular}

Percentage Reduction $=(B-A) / B \times 100 \%$

$A=$ Concentration of the parameter after treatment

$\mathrm{B}=$ Concentration of the parameter before treatment

$+=$ percentage decrease

- = percentage increase

In general, immobilization makes the enzyme more resistant to temperature, $\mathrm{pH}$, and substrate concentration swings giving it a longer lifetime and higher productivity per active unit (Gianfreda and Rao, 2004; FuIlbrook, 1996; Russell et al, 2003; Kandelbauer et al., 2004). Immobilized cells have been used and studied extensively for the production of useful chemicals (Ohtake and Silver, 1994), the treatment of wastewaters (Chen et al., 2003; Wang et al., 2010). Although many workers described microbial degradation of tannery effluent, limited literature is available on the bioremediation of tannery effluent using immobilized bacterial cells in the Kano Industrial Estates.

\section{CONCLUSION}

The samples contained variable levels of the physicochemical parameters. The results of the Analysis of variance revealed that, no statistical difference $(p<0.05)$ was observed for the temperature, $\mathrm{pH}, \mathrm{SS}, \mathrm{TDS}, \mathrm{BOD}$ and $\mathrm{COD}$ among the three tannery industries before the treatment. The levels of some of the parameters
(SS, TDS and COD) observed in the samples were found above the recommended limits of WHO and NESREA, which called for the treatment of the effluents before discharge into the environment. Base on the morphological and biochemical test results, TAN1, TAN2, and TAN3 bacterial isolates were identified to be Neisseria spp, Bacillus cereus, and Staphylococcus aureus respectively. The results of Post-treatment analysis showed that there is overall decrease in the levels of the parameters determined when compared with that of the pre-treatment. The overall percentage reduction of the immobilised bacteria in the treatment of the respective effluents was in the order TAN2 (72\%)>TAN1 $(70 \%)>$ TAN3 $(62 \%)$. Hence, the immobilized bacteria are having higher biodegradation potential for the treatment of the tannery effluents.

\section{Acknowledgments}

The authors wish to acknowledge the University of Maiduguri for the financial support. The authors are grateful to the Kano State Ministry of Environment for their support in obtaining the effluent samples. 


\section{REFERENCES}

Ajao, A. T., Adebayo, G. B., and Yakubu, S. E. (2011). Bioremediation of textile industrial effluent using mixed culture of Pseudomonas aeruginosa and Bacillus subtilis immobilized on agar-agar in a bioreactor. J. Microbiol. Biotech. Res, 1(3), 50-56.

Akan, J. C., Moses, E. A., Ogugbuaja, V. O., and Abah, J. (2007). Assessment of tannery industrial effluents from Kano metropolis, Kano State, Nigeria. Journal of Applied Sciences, 7(19), 2788-2793.

Akan, J. C., Ogugbuaja, V. O., Abdulrahman, F. I., and Ayodele, J. T. (2009). Pollutant levels in effluent samples from tanneries and textiles of Kano industrial areas, Nigeria. Global journal of pure and applied sciences, 15(3-4).

APHA (1989). Standard methods for Examination of Will bete and Will betewater.15 $5^{\text {th }}$ edition. Brydpass Springfield Will behington DC. pp. 164-176

APHA (1992). Standard Methods for the Examination of Water and Wastewater. Health, 69, 1116-9.

Baba, A., Garba, S. T., and Bello, H. S. (2020). Bioremediation Potential of Immobilized corynebacterium kutsceri in the Treatment of Tannery Industrial Effluent from Challawa Industrial Estate, Kano State, Nigeria. Journal of the Turkish Chemical Society Section A: Chemistry, $7(2), 335-350$.

Beem, E. I. V. (1994). reduction of solvent VOC emission. J. Oil Col. Chem. Ass, 77, 158.

Bouwer, E. J., and Zehnder, A. J. (1993). Bioremediation of organic compoundsputting microbial metabolism to work. Trends in biotechnology, 11(8), 360367.

Chen, K. C., Wu, J. Y., Liou, D. J., and Hwang, S. C. J. (2003). Decolorization of the textile dyes by newly isolated bacterial strains. Journal of Biotechnology, 101(1), 57-68.

Dan'Azumi, S., and Bichi, M. H. (2010). INDUSTRIAL POLLUTION AND HEAVY METALS PROFILE OF CHALLAWA RIVER IN KANO, NIGERIA. Journal of Applied Sciences in Environmental Sanitation, $5(1)$.

DWAF. (1992). Analytical Methods Manual, TR 151. Department of Water Affairs and Forestry, Pretoria.

El-Bestawy, E. (2013). Biological treatment of leather-tanning industrial wastewater using free living bacteria.
Elsheikh, M. A. S. (2009). Tannery wastewater pre-treatment. Water Science and Technology, 60(2), 433-440.

FuIlbrook, P. D. (1996). "Kinetics." Industrial enzymology: The application of enzymes in Industry. 2nd Ed. T. Godfrey and J Reichelt. eds.. Nature. New York.

Gianfreda, L., and Rao, M. A. (2004). Potential of extra cellular enzymes in remediation of polluted soils: a review. Enzyme and microbial technology, 35(4), 339354.

Hugo Springer. (1994). John Arthur Wilson Memorial Lecture "Treatment of Industrial Wastes of the Leather Industry - is it still a Major Problem". JALCA, 89, 153-185

Jimoh, A. A., Ganiyu, B. A., Baba, D., and Baba, A. (2018) Bioremediation Process of Effluent from Detergent and Food Industries in Jos, Nigeria: Kinetics and Thermodynamics. International Journal of Engineering Science Invention (IJESI), 762-73

Kandelbauer, A., Maute, O., Kessler, R. W., Erlacher, A., and Gübitz, G. M. (2004). Study of dye decolorization in an immobilized laccase enzyme-reactor using online spectroscopy. Biotechnology and bioengineering, 87(4), 552-563.

Kongjao, S., Damronglerd, S., and Hunsom, M. (2008). Simultaneous removal of organic and inorganic Pollutants in tannery wastewater using electrocoagulation technique. Korean Journal of chemical engineering, 25(4), 703.

Maheshwari, U. M., Aruna, S., Gomathi, M., and AbdulJaffar, A. H. (2017). Bioremediation by Free and Immobilized Bacteria Isolated from Tannery Effluent. International Journal of Research in Applied, Natural and Social Sciences. 5(7), 75-90

Margesin, R., and Schinner, F. (2001). Bioremediation (natural attenuation and biostimulation) of diesel-oilcontaminated soil in an alpine glacier skiing area. Applied and environmental microbiology, 677), 3127-3133.

Mohammed, A., Sekar, P., and George, J. (2011). Efficacy of microbes in bioremediation of tannery effluent. Inter. J. Curr. Res, 3(4), 324-326.

Mohammed, S. S. D., Orukotan, A. A., and Abdullahi, H. (2017). Physicochemical and Bacteriological Assessment of Tannery Effluent from Samaru-Zaria, 
BAJOPAS Volume 13 Number 2, December, 2020 Kaduna State, Nigeria. Journal of Applied

Sciences and Environmental Management, 21(4), 734-740.

Munz, G., De Angelis, D., Gori, R., Mori, G., Casarci, M., and Lubello, C. (2009). The role of tannins in conventional and membrane treatment of tannery wastewater. Journal of hazardous materials, 164(2-3), 733-739

Mythili, K., and Karthikeyan, B. (2011). Bioremediation of $\mathrm{Cr}$ (VI) from tannery effluent using Bacillus spp and Staphylococcus spp. International Multidisciplinary Research Journal, 1(6).

NESREA (2009). National Environmental Standards for Effluent Limitations and Regulation. 1233-1236

Noorjahan, C. M. (2014). Physicochemical characteristics, identification of bacteria and biodegradation of industrial effluent. Journal of bioremediation and Biodegradation, 5(3).

Ohtake, H. I., and Silver, A. O. (1994). Bacterial reduction of toxic chromate. Biological degradation and bioremediation of toxic chemicals, 403-415.

Omoleke, I. I. (2004). Management of environmental pollution in Ibadan, an African city: the challenges of health hazard facing government and the people. Journal of Human Ecology, 15(4), 265-275.

Rajor, A., Reddy, A.S., and Singh, B. (2004). Determination of BOD kinetic Parameters and evaluation of alternate methods, M.Sc. Thesis, Department of biotechnology \& environmental Science, Thapar Institute of Engineering and Technology, Patiala

Ramasami, T., Rajamani, S., and Rao, J. R. (1994, March). Pollution control in leather industry: Emerging technological options. In International symposium on surface and colloidal science and its relevance to soil pollution, madras.

Ramesh, J. V. S., and Singh, S. P. (1993). Yearly variation in certain physicochemical parameters of pond at eastern Doon Valley. Uttar Pradesh J. Zoo, 12 (1), 7577.

Ranen, S., and Sharadinadra, C. (2009). Biotechnology applications to environmental remediation in resource exploitation. Current science, 97, 6-25
Russell, A. J., Berberich, J. A., Drevon, G. F., and Koepsel, R. R. (2003). Biomaterials for mediation of

chemical and biological warfare agents. Annual review of biomedical engineering, 5(1), 1-27.

Saravanan, P., and Saravanan, A. (1999). Decolourization of tannery effluent by Flavobacterium sp. EK 1. Indian Journal of Environmental Protection, 19, 19-24.

Sikander, S., and Shahida, H. (2007). Reduction of toxic hexavalent chromium by Ochrobactrum intermedium strain SDCr5 stimulated by heavy metals. Bioresource Technol, 98, 340-344.

Singh, N., Sharma, B. K., and Bohra, P. C. (2000). Impact assessment of industrial effluent of arid soils by using satellite imageries. Journal of the Indian Society of Remote Sensing, 28(2-3), 79.

Sreemoyee, C., and Priti, P. (2013). Assessment of physico-chemical parameters of dairy waste water and isolation and characterization of bacterial strains in terms of cod reduction. Int J Sci, 2(3), 395-400.

Verheijen, L. A. H. M., Wiersema, D., Pol, L. H., and De Wit, J. (1996). Management of wastes from animal product processing. Livestock and environment, Finding a balance. International Agriculture Center, Wageningen, The Netherlands.

Wang, F., Yao, J., Si, Y., Chen, H., Russel, M., Chen, K., and Bramanti, E. (2010). Short-time effect of heavy metals upon microbial community activity. Journal of Hazardous Materials, 173(13), 510-516.

WHO (World Health Organization). (2006). Air quality guidelines: global update 2005: particulate matter, ozone, nitrogen dioxide, and sulfur dioxide. World Health Organization.

World Bank. (1995). Nigeria's strategic options for redressing industrial pollution. World Bank, industry and energy division. 1st edition, West Central Africa Department; Annexes: 1995; pp 60-62.

Zahoor, A., and Abdul, R. (2009). Enumeration of Coliforms. Journal of Environmental Sciences. 21, 814-820 


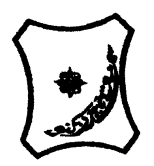

Bayero Journal of Pure and Applied Sciences, 13(2): 1 - 12

Received: November, 2020

Accepted: December, 2020

ISSN $2006-6996$

\title{
BIODEGRADATION POTENTIAL OF IMMOBILIZED BACTERIA IN THE TREATMENT OF TANNERY INDUSTRIAL EFFLUENTS FROM INDUSTRIAL ESTATES IN KANO STATE, NIGERIA
}

\author{
Abdullateef, B., ${ }^{1 *}$ Shuaibu, T. G., ${ }^{1}$ Babagana, K., ${ }^{1}$ Suleman, H. B. ${ }^{2}$ and Dauda, B. ${ }^{3}$ \\ ${ }^{1}$ Department of Pure and Applied Chemistry, Faculty of Science, University of Maiduguri, Borno State, \\ Nigeria \\ ${ }^{2}$ Department of Microbiology, Faculty of Science, University of Maiduguri, Borno State, Nigeria \\ ${ }^{3}$ Department of Chemical Engineering, Faculty of Engineering, University of Maiduguri, Borno State, \\ Nigeria \\ *Corresponding author: babslega@gmail.com; abelega2007@yahoo.com; +2348061309753
}

\section{ABSTRACT}

Industrial Effluents Samples from Gashash Tanneries (TAN1) in Bompai Industrial estate, Larabee Tannery Industry (TAN2) in Sharada Industrial estate and Z Tannery Industries (TAN3) in Challawa Industrial estate, Kano State, Nigeria were collected over a period of six months (August 2017 to January 2018) for assessing the biodegradation potentials of bacteria in the treatment of organic pollutants within the effluents. Bacteria were isolated from the effluents and immobilized on agar-agar. Different masses (5 g, $10 \mathrm{gr}, 15$ $\mathrm{g}, 20 \mathrm{~g}$, and $25 \mathrm{~g}$ ) of the bacteria were used in the treatment of $250 \mathrm{ml}$ of the effluents for ten days in a shaker incubator (Gallenkamp-OC-4364-L) at the temperature $30{ }^{\circ} \mathrm{C}$ and speed of $60 \mathrm{rpm}$. Pre-treatment analysis of the effluents for Temperature, pH, Biochemical Oxygen Demand (BOD), Chemical Oxygen Demand (COD), Suspended Solid (SS) and Total Dissolved Solids (TDS) gives the following results; temperature $\left({ }^{\circ} \mathrm{C}\right.$ )

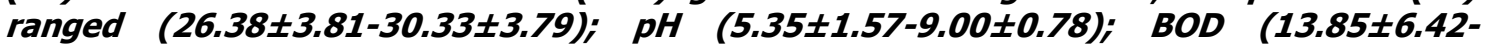
$38.75 \pm 16.20) ;$ COD (1406 $\pm 208-3532 \pm 1373) ;$ SS (208 $\pm 235-780 \pm 739)$ and TDS (266 $\pm 253-5276 \pm 2971)$. No statistical differences ( $p \leq 0.05)$ was observed for all the results among the different industries. The bacterial isolates were identified as Neisseria spp, Bacillus cereus, and Staphylococcus aureus, in TAN1, TAN2, and TAN3, respectively. After treatment of the effluent with the different masses of the isolated bacteria, the mean level of BOD was found to range as (0.55 $\pm 0.36-6.92 \pm 5.49) ; C O D$ (ND-3134 \pm 1595$)$;

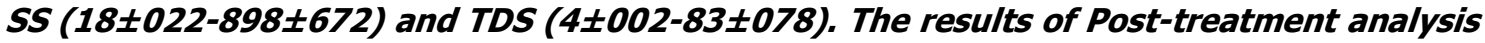
showed that there is overall decrease in the levels of the parameters determined when compared with that of the pre-treatment. The overall percentage reduction of the immobilised bacteria in the treatment of the respective effluents was in the order TAN2 (72\%)>TAN1 (70\%)>TAN3 (62\%). Hence, the immobilized bacteria are having higher biodegradation potential for the treatment of the tannery effluents.

Keywords: Biodegradation, bacteria, effluent, immobilization, tannery.

\section{INTRODUCTION}

Tannery industrial wastewater is a serious consequence of the pollution point of view for streams, freshwater, and land used for agriculture. The lack of awareness in the modern industrial practice has resulted in the discharge of tannery effluents which exhibit very high value of chromium ( $\mathrm{Cr}$ ), Sulfide, and chloride, Total Dissolved Solid (TDS), Total Suspended Solid (TSS), Biochemical Oxygen Demand (BOD) and Chemical Oxygen Demand (COD) in the water stream or land (Mohammed et al., 2001). Tanning is the process, which One ton of skin generally leads to the production of 20 to $80 \mathrm{~m}^{3}$ of turbid and foul-smelling converts the protein of the rawhide or skin into a stable material, which will not putrefy and is suitable for a wide variety of end applications (Elsheikh, 2009). The highly polluting chromium is the most commonly used tanning material producing leather that is more flexible and pliable than vegetable-tanned leather and does not discolor or lose shape in water as drastically as vegetable-tan (Elsheikh, 2009). Tannery effluent is among the most hazardous industrial pollutants due to its huge organic and inorganic load, which is highly toxic to human life and the environment (Kongjao et al., 2008). wastewater including chromium (100-400 mg/l), sulfide $(200-800 \mathrm{mg} / \mathrm{l})$, high levels of fat and 
BAJOPAS Volume 13 Number 2, December, 2020 other solid wastes, and notable pathogen contamination as well as pesticides added for skin conservation during transport (Elsheikh, 2009). There are more than 6000 tanneries in Nigeria with an annual processing capacity of 700,000 tons of hides and skins (Omoleke, 2004; Singh et al., 2008). It was reported that the total amount of waste produced per animal slaughtered is approximately $35 \%$ of its weight (World Bank, 1995). Also, for every $1000 \mathrm{~kg}$ of carcass weight, a slaughtered beef produces 5.5 $\mathrm{kg}$ of manure (excluding rumen contents or stockyard manure) and $100 \mathrm{~kg}$ of paunch manure (undigested food) (Verheijen et al., 1996). Tanneries generate wastewater in the range of 30-35 $\mathrm{L} \mathrm{kg}^{-1}$ skin/hide processed with variable $\mathrm{pH}$, Biological Oxygen Demand (BOD), Chemical Oxygen Demand (COD), high concentrations of suspended solids (SS), and tannins as well as chromium (Zahoor and Abdul, 2009).

Being heterogeneous and composed of a wide variety of compounds, it is very difficult to select a unique direct method for estimating the biodegradability of organic contents and biokinetic parameters for a wastewater sample (Rajor, 2004). For this purpose, some indirect estimation such as determination of biochemical oxygen demand (BOD) and chemical oxygen demand (COD) are applied as common laboratory investigations [9]. During retanning procedures, synthetic tannins (Syntan), oils and resins are added to form softer leather at varying doses (Munz et al., 2009). One of the refractory groups of chemicals in tannery effluents derives mainly from tannins (Ramasami et al., 2004). Syntans are characterized by complex chemical structures, because they are composed of an extended set of chemicals such as phenol-, naphthalene-, formaldehyde- and melamine-based syntans, and acrylic resins (Beem, 1994). Organic pollutants (proteic and lipidic components) are originated from skins (it is calculated that the raw skin has $30 \%$ loss of organic material during the working cycle) or they are introduced during processes (Hugo Springer, 1994).

Many conventional processes such as oxidation, chemical and biological processes were carried out to treat tanneries wastewater (Ebtesam et al, 2013). Biological processes have received more attention because of their costeffectiveness, lower sludge production and environmental friendliness (Noorjahan, 2014). Naturally occurring micro-organisms degrade the hazardous organic wastes including xenobiotic compounds, such as pesticides, polycyclic aromatic hydrocarbons (PAHs) and polychlorinated biphenyls (PCBs) in due course of time (Ranen and Sharadinadra, 2009). Bioremediation is based on the idea that all organisms remove substances from the environment to carry outgrowth and metabolism (Bouwer and Zehnder, 1993). Bacteria, protista and fungi are found to be very good at degrading complex molecules and incorporating the breakdown products into their metabolism (Bouwer and Zehnder, 1993). The resultant metabolic wastes that they produce are generally safe and somehow recycled into other organisms (Ranen and Sharadinadra, 2009). An acclimatized indigenous population of microorganisms capable of degradation of the compounds of interest must exist at the site for a successful bioremediation mode (Ranen and Sharadinadra, 2009). It has been observed that for a successful bioremediation mode, an acclimatized indigenous population of microorganisms capable of degradation of the compounds of interest must exist at the site under investigation (Ranen and Sharadinadra, 2009). Even though there are numerous physical and chemical methods employed in the disposal of wastes the advantage in using bacterium is that they play a key role in the reduction of COD, BOD, total protein, total tannin and total phenol (Saravanan and Saravanan, 1998)

Baba et al. (2020) studied the bioremediation potential of immobilized corynebacterium kutsceri in the Treatment of tannery industrial effluent from Challawa Industrial Estate, Kano State, Nigeria. The aim of the work is to study the reduction in the level of the contaminants through the process of bioremediation using the isolated bacteria. Immobilized bacteria can withstand various temperatures, $\mathrm{pH}$ and substrate concentrations; consequently, increasing the efficiency and the lifespan of the bacteria. Immobilized bacteria are widely applied in the treatment of wastewater and can be separated and recovered after the treatment with the same efficiency (Baba et al., 2020).

\section{MATERIALS AND METHODS \\ Study Area}

This study was carried out in Bompai, Sharada and Challawa industrial estates in Kano, Figure 1. Kano lies on Latitude $11^{\circ} 30^{\prime} \mathrm{N}$ and $8^{\circ} 30^{\prime} \mathrm{E}$ and Longitude $11^{\circ} 5^{\prime} \mathrm{N}$ and $8^{\circ} 5^{\prime} \mathrm{E}$ in Northern Nigeria. It is one of the developed industrial cities in Nigeria. Tannery activities are the dominating industries and this could be one of the reasons for her high population density (Dan'Azumi and Bichi, 2010). Many researchers have studied biodegradation of tannery effluent using microorganisms. However, limited literature is available on the biodegradation of tannery effluent in Kano industrial estates using 
BAJOPAS Volume 13 Number 2, December, 2020 immobilized bacterial cells. This research work focuses on the potential of the use of the indigenous immobilized bacterial isolates in the treatment of tannery effluents in the industrial estates.

\section{Sample Collection}

Effluents were collected from the Tannery Industries from Bompai, Challawa and Sharada Industrial Estates, Kano, Nigeria. The effluents were collected over a period of six months (August 2017 to January 2018). Samples collected in a sterile 4-liter plastic container with a unique identification number were preserved using an ice-box that was transported to the Microbiology Laboratory, Department of Microbiology, Bayero University of Kano for analysis

\section{Sample Preparation and Sample Analysis}

Immediately after the collection of the effluent, $\mathrm{pH}$, TSS, TDS, COD, BOD levels were determined before treatment (Pre-treatment determination) and ten days after treatment (Post-treatment determination) as described in
APHA (1989) standard methods. $\mathrm{pH}$ was determined using Ecotests $\mathrm{pH}$ meter and TDS was determined using AQUALYTIC TDS Salinometer. BOD was determined as described by the standard method (APHA, 1992). COD and SS were determined using DR/2010 HACH portable data logging spectrophotometer (DWAF, 1992)

\section{Identification and Biochemical} Characterization of the Bacterial Isolates

The bacteria were isolated from the effluents using Serial Dilution according to the method described by APHA (1989). The biochemical tests such as oxidase, catalase, coagulase, indole (from $1 \%$ tryptone broth), citrate (Simmons citrate agar), methyl red/VogesProskauer (MR/VP), nitrate reduction, Starch Hydrolysis, Glucose, Maltose, and Lactose tests were carried out on the bacterial isolates to identify the bacteria through the bacteria biochemical characteristics according to Ajao et al. (2011).

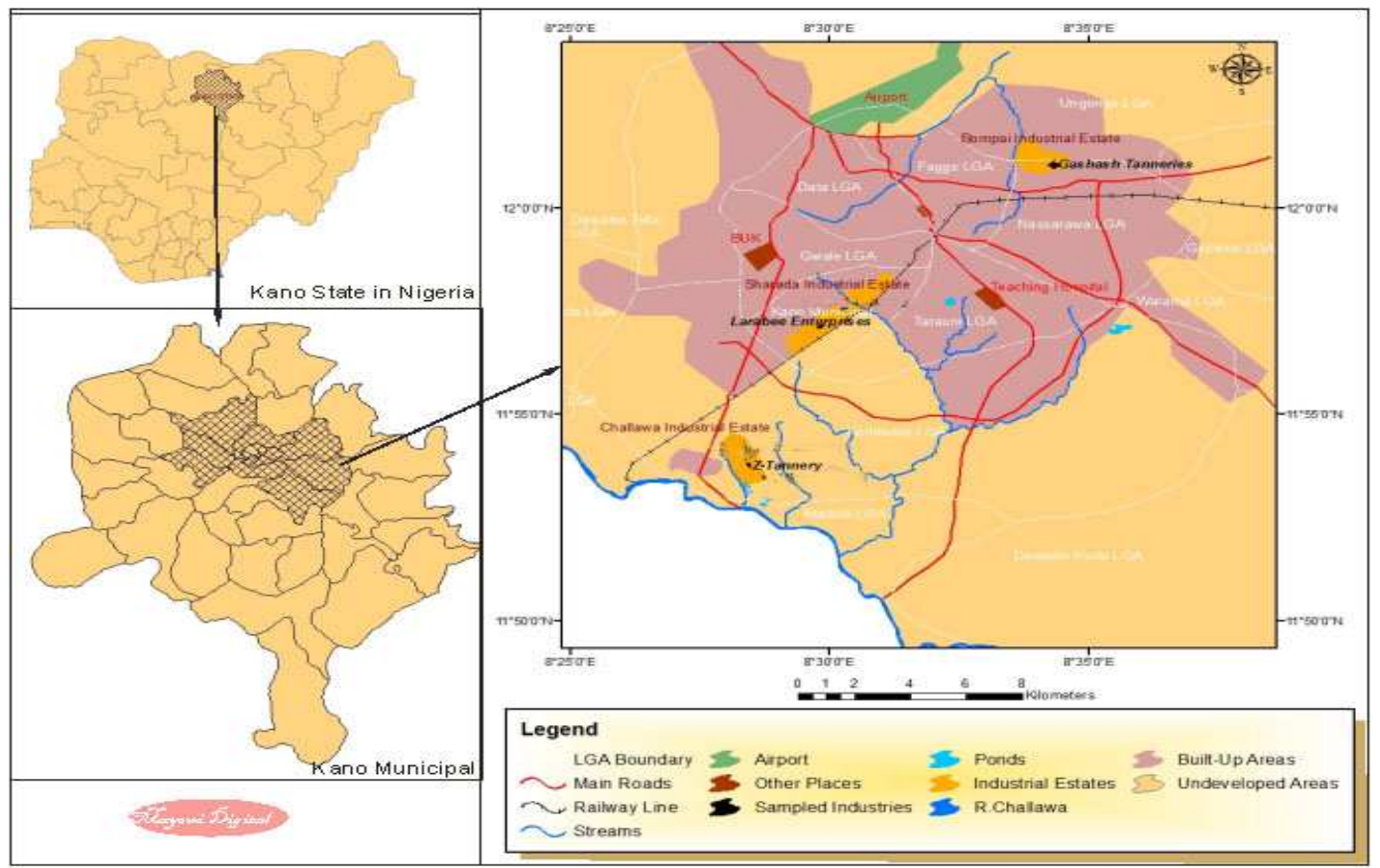

Fig. 1 Map showing the study areas

Source: Mayomi Digital Productions, GIS Laboratory, Department of Geography, UNIMAID (2017)

\section{Determination of Growth Rate of the Bacteria in Effluent Sample}

The bacteria growth rates were determined by transferring $2 \mathrm{~mL}$ of the bacterial isolates from the tannery effluent in broth medium into 100 $\mathrm{mL}$ sterile effluents in conical flasks and kept in an incubator (Giffrin cool) for 10 days. Control was also set up by incubating another $100 \mathrm{~mL}$ each of the sterile effluents without the bacteria. The optical density of the content was determined at the wavelength of $600 \mathrm{~nm}$ on a daily interval and recorded. 
BAJOPAS Volume 13 Number 2, December, 2020 Immobilization of Bacteria

Agar solution and inoculi were prepared separately. Fifty milliliters $(50 \mathrm{~mL})$ of nutrient broth each of the inoculi was prepared in a McCartney bottle and incubated for 24 hours. A solution of agar-agar was prepared by dissolving $10 \mathrm{~g}$ of the powder in distilled water and made up to $500 \mathrm{~mL}$ mark in an Erlenmeyer flask and was sterilized in an autoclave (280A) for 15 minutes and allowed to cool to $40-45^{\circ} \mathrm{C}$ (Ajao et al., 2011). Four milliliters ( $4 \mathrm{~mL})$ of the bacterial isolates in the nutrient broth was mixed with 36 $\mathrm{ml}$ of the prepared agar-agar media in petri-dish plates and then allowed to solidify. This was kept in the refrigerator for bioremediation.

\section{Bioremediation (Treatment) of the Effluents}

The solidified agar block (immobilized bacteria) was cut into cubes using a sterile knife; $0.1 \mathrm{~mL}$ phosphate buffer ( $\mathrm{pH} \mathrm{7.0)}$ was added and kept in the refrigerator for 1 hour for curing. The phosphate buffer was decanted after 1 hour and the cubes were washed with sterile distilled water 3-4 times before it was used (Ajao et al., 2011). Two liters (2 L) of the effluent was supplemented with the minimum basal medium in $\mathrm{g} / \mathrm{L}: \mathrm{NaCl}(0.8), \mathrm{MgSO}_{4} .7 \mathrm{H}_{2} \mathrm{O}(0.001), \mathrm{KH}_{2} \mathrm{PO}_{4}$ (2), $\mathrm{NaNO}_{3}$ (2), $\quad \mathrm{CaCl}_{2} .2 \mathrm{H}_{2} \mathrm{O} \quad(0.5)$ and $\mathrm{NaHPO}_{4} .12 \mathrm{H}_{2} \mathrm{O}(2)$ and sterilized in an autoclave at $121^{\circ} \mathrm{C}$ for 15 minutes (Margesin and Schinner, 2001). Two hundred and fifty milliliters $(250 \mathrm{~mL})$ of the effluents were transferred into different $250 \mathrm{ml}$ conical flasks. The content was covered with a cotton-wool ramped with foil paper to avoid contamination. Five grams $(5 \mathrm{~g})$ of the immobilized bacteria were quickly transferred into each of the effluents in the conical flasks in an inoculating chamber. The same procedures were carried out for the $10 \mathrm{~g}, 15 \mathrm{~g}, 20 \mathrm{~g}$ and 25 $\mathrm{g}$ of the immobilized bacteria in separate $250 \mathrm{~mL}$ effluents in conical flasks and agitated for ten days in a shaker incubator (Gallenkamp-OC4364-L) at a temperature $30^{\circ} \mathrm{C}$ and speed of 60 rpm. The treated effluent samples were taken on the tenth day and analyzed for the parameters $\mathrm{pH}$, SS, TDS, COD, and BOD, (Posttreatment determination) for the different grams of bacteria to evaluate and compare the biodegradation potential. (Baba et al., 2020).

\section{Statistical Analysis}

The data were represented as Mean \pm Standard deviation and analyzed statistically using oneway Analysis of Variance (ANOVA) and Tukey's HSD as Post Hoc Tests with the aid of SPSS 16.0. The correlation coefficient was also used to measure the strength of the relationship between the different masses of the bacteria and the parameters. All $\mathrm{p} \leq 0.05$ were considered as statistically significant.

\section{RESULTS AND DISCUSSION Physico-chemical parameters in the Industrial Effluents before the Biodegradation.}

Results of the Physico-chemical parameters in the industrial effluents before the Biodegradation is shown in table 1 . The mean temperatures $\left({ }^{\circ} \mathrm{C}\right)$ observed in TAN1, TAN2, and TAN3 samples were $28.07 \pm 0.65 ; 27.77 \pm 0.64$ and $26.38 \pm 3.81$ respectively. The order of the mean temperature of the samples from the three industries can be arranged as TAN1 > TAN2>TAN3. The temperature observed at TAN1, TAN2, and TAN3 samples were found below the WHO $\left(35^{\circ} \mathrm{C}\right)$ and NESREA $\left(40^{\circ} \mathrm{C}\right)$ limits. The low values of temperature might be due to the processes used at the time of sampling. High temperature brings down the solubility of gases in water that ultimately expresses as high BOD and COD. Statistical analysis shows that there is no significant difference $(p<0.05)$ between the mean values of temperature among the industries. This might be due to similar tannery activities involved in the tannery industries at the time of sampling. The average values of temperature observed in this present study are less than those observed by Akan et al. (2007), Akan et al. (2009) and Baba et al. (2020).

The mean level of $\mathrm{pH}$ observed in TAN1, TAN2 and TAN3, samples were $7.77 \pm 2.93$; $8.35 \pm 0.28$ and $7.52 \pm 0.76$ respectively. The order of the mean $\mathrm{pH}$ of the samples from the three industries can be arranged as TAN2> TAN1 $>$ TAN3. The $\mathrm{pH}$ of the samples falls within the WHO (7.0-8.5) and NESREA (6-9) standard limits. Statistical analysis shows that there is no significant difference $(p<0.05)$ between the mean values of $\mathrm{pH}$ among the industries. This might be due to similar tannery activities involved in the tannery industries at the time of sampling. Maheshwari et al. (2017) reported that the level of $\mathrm{pH}$ in the effluents from the tannery industry in Vaniyambadi, India was 6.5 which was lower than that observed in the present study. The $\mathrm{pH}$ in the effluents from the tannery industries in Kano and Kaduna were reported to be 7.64 and 6.89, respectively (Akan et al., 2007; Mohammed et al., 2017). The average values of $\mathrm{pH}$ observed in this present study are less than those observed by Mohammed et al. (2017) and Baba et al. (2020). The mean level of SS $(\mathrm{mg} / \mathrm{l})$ observed in TAN1, TAN2, and TAN3 samples were 374 \pm 124 ; $358 \pm 335$ and $780 \pm 739$ respectively. The order of the mean SS in the samples from the three industries can be arranged as TAN3 > TAN1 $>$ TAN2. 
The SS observed in the samples were far above the recommended standard limits of regulating bodies WHO $(30 \mathrm{mg} / \mathrm{l})$ and NESREA $(10 \mathrm{mg} / \mathrm{l})$. Statistical analysis shows that there is no significant difference $(p<0.05)$ between the mean values of SS among the industries. This might be due to similar tannery activities involved in the tannery industries at the time of sampling. The average values of SS observed in this present study are less than that observed $(3700 \pm 122 \mathrm{mg} / \mathrm{l})$ by Akan et al. (2009) for tanneries in Kano. Also, the average values of SS observed in this present study are less than that observed by Mohammed et al. (2017) and Baba et al. (2020) with the exception in TAN3.

The mean level of TDS (mg/l) observed in TAN1, TAN2, and TAN3 samples were $3941 \pm 3703$; $3300 \pm 1714$ and $2653 \pm 1240$ respectively. The order of the mean TDS in the samples from the three industries can be arranged as TAN1>TAN2>TAN3. The TDS observed in the samples were far above the recommended standard limits of WHO $(250 \mathrm{mg} / \mathrm{l})$ and NESREA $(500 \mathrm{mg} / \mathrm{l})$. Statistical analysis shows that there is no significant difference $(p<0.05)$ between the mean values of TDS among the industries. This might be due to similar tannery activities involved in the tannery industries at the time of sampling. TDS in the effluents from the tannery industries in Kano, Nigeria was reported to be $1281 \mathrm{mg} / \mathrm{l}$ (Akan et al., 2007). The average values of SS observed in this present study are less than those observed by Mohammed et al. (2017) and Baba et al. 2020)

The mean level of COD (mg/l) observed in TAN1, TAN2 and TAN3 samples seasons were $2372 \pm 938 ; \quad 1406 \pm 208$ and $3532 \pm 1373$ respectively. The order of the mean COD of the samples from the three industries can be arranged as TAN3>TAN1> TAN2. The COD observed in TAN1, TAN2 and TAN3 samples were far above the recommended standard limits of regulating bodies $\mathrm{WHO}(40 \mathrm{mg} / \mathrm{l})$ and NESREA (40 mg/l). Statistical analysis shows that there is no significant difference $(p<0.05)$ in COD among the industries. This might be due to similar tannery activities involved in the tannery industries as at the time of sampling. The Chemical Oxygen demand (COD) is the amount of oxygen, in $\mathrm{mg} / \mathrm{L}$, required for the degradation of the compound of wastewater to occur. In comparison, the average values of COD observed in this present study were higher than that observed by Mohammed et al. (2017) but lower than that observed by Baba et al. (2020).

The mean levels of BOD $(\mathrm{mg} / \mathrm{l})$ observed in TAN1, TAN2 and TAN3 samples were $13.85 \pm 6.42 ; \quad 19.46 \pm 0.50$ and $17.13 \pm 3.14$ respectively. The order of the mean BOD in the samples from the three industries can be arranged as TAN2>TAN3>TAN1. The BOD observed in TAN1, TAN2 and TAN3 samples were found below the recommended limits of NESREA (200 mg/l) but above WHO (10 mg/l). Statistical analysis shows that there is no significant difference $(p<0.05)$ between the mean values of BOD among the industries. This might be due to similar tannery activities involved in the tannery industries at the time of sampling. The low level of BOD recorded in this study is an indication of the low level of biodegradable organic solids in the effluent. The average values of BOD observed in this present study were lower than those observed by Mohammed et al. (2017) and Baba et al. (2020).

Table 1: Mean Values \pm S.D of Physico-chemical parameters of effluents from the Tannery Industries before Treatment.

\begin{tabular}{llllllll}
\hline Parameter & Tannery 1 & Tannery 2 & Tannery 3 & $\mathrm{a}$ & $\mathrm{b}$ & $\mathrm{c}$ & $\mathrm{d}$ \\
\cline { 2 - 7 } Temperature $\left({ }^{\circ} \mathrm{C}\right)$ & $28.07 \mathrm{a} \pm 0.65$ & $27.77 \mathrm{a} \pm 0.64$ & $26.38 \mathrm{a} \pm 3.81$ & & $29.50 \pm 4.68$ & 35 & 40 \\
pH & $7.77 \mathrm{a} \pm 2.93$ & $8.35 \mathrm{a} \pm 0.28$ & $7.52 \mathrm{a} \pm 0.76$ & 6.89 & $5.35 \pm 1.57$ & $7.0-8.5$ & $6.0-9.0$ \\
$\mathrm{COD}(\mathrm{mg} / \mathrm{l})$ & $2372 \mathrm{a} \pm 938$ & $1406 \mathrm{a} \pm 208$ & $3532 \mathrm{a} \pm 1373$ & 2.2 & $3106 \pm 2753$ & 40 & 40 \\
$\mathrm{BOD}(\mathrm{mg} / \mathrm{l})$ & $13.85 \mathrm{a} \pm 6.42$ & $19.46 \mathrm{a} \pm 0.50$ & $17.13 \mathrm{a} \pm 3.14$ & 1032 & $26.17 \pm 9.49$ & 10 & 200 \\
$\mathrm{SS}(\mathrm{mg} / \mathrm{l})$ & $374 \mathrm{a} \pm 124$ & $358 \mathrm{a} \pm 335$ & $780 \mathrm{a} \pm 739$ & 501 & $562 \pm 482$ & 30 & 10 \\
TDS $(\mathrm{mg} / \mathrm{l})$ & $3941 \mathrm{a} \pm 3703$ & $3300 \mathrm{a} \pm 1714$ & $2653 \mathrm{a} \pm 1240$ & 532.7 & $444 \pm 507$ & 250 & 500 \\
\hline
\end{tabular}

The values given in the table above are means of 6 replicate values, $\mathrm{n}=6$ ( 1 sample was taken monthly for 6 months). Within the rows, means with different alphabets are statistically different $(p<0.05)$. WHO: World Health Organisation. NESREA: National Environmental Standard and Regulatory Enforcement Agency. a = Mohammed et al.(2017), b = Baba et al. (2020), c = WHO (2006), $d=$ NESSRA (2009) 
BAJOPAS Volume 13 Number 2, December, 2020

Identification, Biochemical Characterization and growth rates of the Bacterial Isolates

Results of identification and biochemical characterization of the bacterial isolates were shown in table 2. After 24 hours of incubation, the nutrient agar media plates were checked for bacterial growth. The results showed the presence of different strains in the samples. The TAN1 bacteria isolate was found to be gramnegative cocci while TAN3 was gram-positive cocci. TAN2 bacteria isolate was found to be gram-positive, rod-shaped. TAN1, TAN2, and TAN3 bacteria isolates recorded positive results for spore former.

The results of the biochemical tests indicated that all the bacteria were positive for catalase, oxidase, citrate, maltose, glucose, lactose (negative in TAN1), mannitol (negative in TAN2), starch hydrolysis and coagulase (negative in TAN2) tests. The bacteria showed negative results for nitrate reduction, $M R$ (positive in TAN2), VP (positive in TAN1), Indole (positive in TAN2) tests. Base on the morphological and biochemical test results, TAN1, TAN2, and TAN3 bacteria isolates were identified to be Nesseria spp, Bacillus cereus, and Staphylococcus aureus respectively.

The growth rate of the TAN1, TAN2 and TAN3 Isolates were shown in figure 2. Generally, the optical density increase with the increase in time (day) and decrease as time goes on. The highest optical density was shown by bacillus cereus in TAN2 while the lowest was shown by Staphylococcus aureus in TAN3.

The initial growth phase of TAN1 Isolate bacteria occurred within 2-day of incubation as the growth rate increases up to the 6th-day incubation when the maximum growth was observed. Beyond the 6th day, the growth of the bacteria declined (which might be due to a shortage of nutrients in the effluents) until it reached its death phase (which might be due to the unavailability of nutrients in the effluents).

A similar trend of growth was also observed for TAN2 Isolate as the initial growth phase also occurred within 2-day of incubation but maximum growth rate observed on the 4th day of incubation. The stationary stage occurred between the 4th day and the 8th day. Beyond the 8th day, the growth of the bacteria declined (which might be due to a shortage of nutrients in the effluents) until it reached its death phase (which might be due to the unavailability of nutrients in the effluents).

The initial growth phase of TAN3 bacterial Isolate occurred within the 3-day incubation as the growth rate increases up to the 6th-day incubation when the maximum growth was observed. Beyond the 6th day, the growth of the bacteria declined (which might be due to a shortage of nutrients in the effluents) until it reached its death phase (which might be due to the unavailability of nutrients in the effluents).

Table 2: Morphological and Biochemical characteristics of bacterial isolates

\begin{tabular}{lllll} 
Bacterial Isolates & & TAN1 & TAN2 & TAN3 \\
\hline $\begin{array}{lllll}\text { Morphological } \\
\text { characteristics }\end{array}$ & Shape & Cocci & Rod & Cocci \\
& Spore & & & \\
& former & + & + & + \\
Gram & & & \\
Biochemical characteristics & reaction & - & + & + \\
& Citrate & + & + & + \\
& Catalase & + & + & + \\
& Coagulase & + & - & + \\
Starch & + & + & + \\
& Glucose & + & + & + \\
Oxidase & + & + & + \\
& Indo & - & + & - \\
Lactose & - & + & + \\
Manitol & + & - & + \\
Maltose & + & + & + \\
MR & - & + & - \\
VP & + & - & - \\
& Nitrate & - & - & - \\
Reduction & - Neisseria & Bacillus & Staphylococcus \\
& Bacterial & cereus & aureus \\
& name & spp & cas
\end{tabular}

+ = Positive; - = Negative; MR=Methyl Red; VP= Voges-Proskauer 


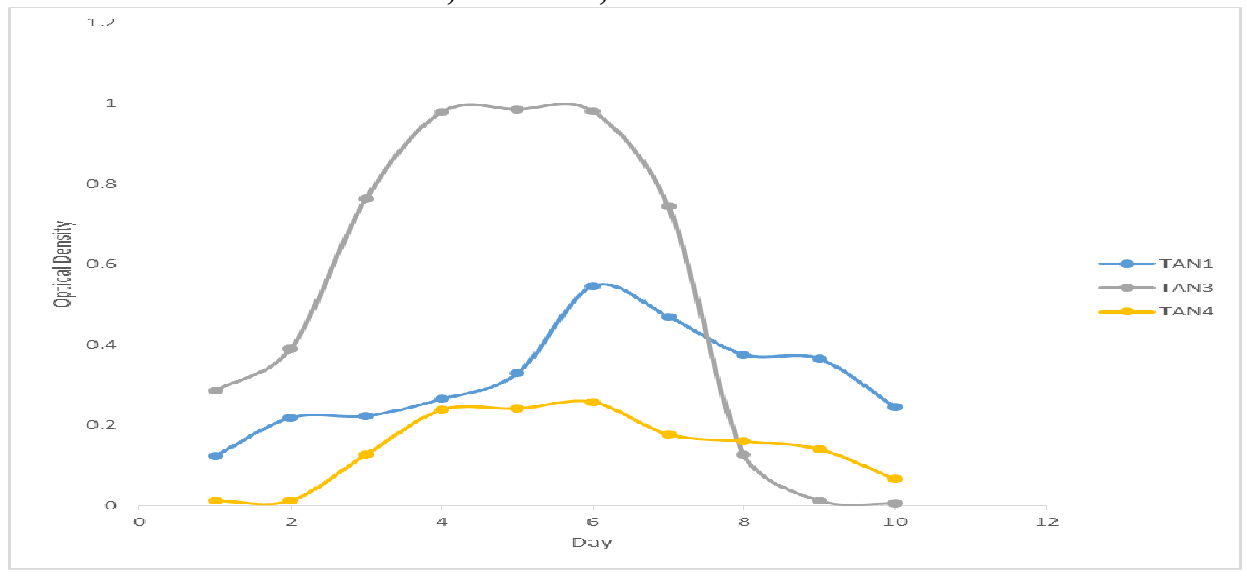

Fig. 2 Growth rates of the isolates in the effluents from the Tannery Industries

\section{Physico-chemical Parameters in the Industrial Effluents after the biodegradation.}

Table 3 shows the mean results of the physicochemical parameter before and after bioremediation using the different masses $(5 \mathrm{~g}$, $10 \mathrm{~g}, 15 \mathrm{~g}, 20 \mathrm{~g}$, and $25 \mathrm{~g}$ ) of the respective immobilized bacteria. Also, Table 4 shows the mean results of correlation coefficient ( $r$ ) between different masses of bacteria and physicochemical parameters.

The mean values $(\mathrm{mg} / \mathrm{l})$ of the SS after the bioremediation varies between $243 \pm 45$ and $898 \pm 672$. The mean concentration $(\mathrm{mg} / \mathrm{l})$ of SS remediated by the different masses $(5 \mathrm{~g}, 10 \mathrm{~g}$, $15 \mathrm{~g}, 20 \mathrm{~g}$, and $25 \mathrm{~g}$ ) of the bacteria varies. The SS in the samples fluctuates up and down after the bioremediation process when compared with the SS of the raw samples before the bioremediation. The increase in the levels of the SS might be due to the aggregation of the TDS which are large enough to result into SS. The increase in the levels of the SS might be also due to the influence of the nutrients which was added into the effluents in order to make the microorganisms more active and viable for fast degradation of organic contaminants in the effluent. The relative potential or efficiency of the different masses of the bacteria in remediating SS in TAN1 samples was in the order $25 \mathrm{~g}>20 \mathrm{~g}>15 \mathrm{~g}>10 \mathrm{~g}>5 \mathrm{~g}$. For TAN2 and TAN3 samples, the order was $25 \mathrm{~g}>20 \mathrm{~g}>15$ $\mathrm{g}>10 \mathrm{~g}>5 \mathrm{~g}$. These might be due to the variations in the surface areas of the different masses of the immobilized bacteria. Statistical analysis shows that there is no significant difference $(p<0.05)$ between the mean values of SS among the masses in the respective industries. Positive and significant correlations exist between the masses of bacteria and Suspended Solid (SS). This showed that there is general increase in the levels of the SS as the masses of the immobilized bacteria increases. TAN3 (90\%) and TAN1 (80\%) showed a very high correlation with the masses of the bacteria while TAN2 (61\%) showed a very low correlation.

The mean values $(\mathrm{mg} / \mathrm{l})$ of the TDS after the bioremediation varies between $46 \pm 11$ and $83 \pm 78$. The mean concentration $(\mathrm{mg} / \mathrm{l})$ of TDS remediated by the different masses $(5 \mathrm{~g}, 10 \mathrm{~g}$, $15 \mathrm{~g}, 20 \mathrm{~g}$, and $25 \mathrm{~g}$ ) of the bacteria varies. There is a reduction in all the TDS of all the samples after the bioremediation process compared with the TDS of the raw samples before the bioremediation. The relative potential or efficiency of the different masses of the bacteria in remediating TDS in TAN1 and TAN3 samples was in the order $5 \mathrm{~g}>10 \mathrm{~g}>15 \mathrm{~g}>20$ $\mathrm{g}>25 \mathrm{~g}$. For TAN2 samples, the order was 20 $g>10 \quad g>25 \quad g>15 \quad g>5 \quad g$. Statistical analysis shows that there is no significant difference $(p<0.05)$ between the mean values of TDS among the masses in the respective industries. These might be due to the variations in the surface areas of the different masses of the immobilized bacteria. Positive and significant correlations exist between the masses of bacteria and TDS with the exception in TAN2 (negative and insignificant correlation). The positive correlations showed that there is general increase in the levels of the TDS as the masses of the immobilized bacteria increases. TAN1 $(96 \%)$ showed a very high correlation with the masses of the bacteria while TAN2 (47\%) showed a very low correlation.

The mean values $(\mathrm{mg} / \mathrm{l})$ of the BOD after the bioremediation varies between $1.56 \pm 0.20 \mathrm{mg} / \mathrm{l}$ and $6.92 \pm 5.49 \mathrm{mg} / \mathrm{l}$. The mean concentration $(\mathrm{mg} / \mathrm{l})$ of BOD remediated by the different masses $(5 \mathrm{~g}, 10 \mathrm{~g}, 15 \mathrm{~g}, 20 \mathrm{~g}$, and $25 \mathrm{~g}$ ) of the bacteria varies. There is a reduction in all the BOD of all the samples after the bioremediation process compared with the $\mathrm{BOD}$ of the raw 
BAJOPAS Volume 13 Number 2, December, 2020 samples before the bioremediation. The relative potential or efficiency of the different masses of the bacteria in remediating BOD in TAN1, TAN2 and TAN3 samples were in the order $25 \mathrm{~g}>20$ $\mathrm{g}>15 \mathrm{~g}>10 \mathrm{~g}>5 \mathrm{~g}, 25 \mathrm{~g}>15 \mathrm{~g}>5 \mathrm{~g}>10 \mathrm{~g}>20 \mathrm{~g}$ and $20 \mathrm{~g}>10 \mathrm{~g}>25 \mathrm{~g}>15 \mathrm{~g}>5 \mathrm{~g}$ respectively. Statistical analysis shows that there is significant difference $(p<0.05)$ between the mean values of BOD among the masses in the respective industries. These might be due to the variations in the surface areas of the different masses of the immobilized bacteria. Negative and significant correlations exist between the masses of bacteria and BOD. This showed that there is general decrease in the levels of the BOD as the masses of the immobilized bacteria increases. TAN1 (94\%) showed a very high correlation with the masses of the bacteria while TAN2 (4\%) showed a very low correlation.

The mean values $(\mathrm{mg} / \mathrm{l})$ of the COD after the bioremediation varies between $250 \pm 154$ and $3134 \pm 1595$. The mean concentration $(\mathrm{mg} / \mathrm{l})$ of COD remediated by the different masses $(5 \mathrm{~g}$, $10 \mathrm{~g}, 15 \mathrm{~g} 20 \mathrm{~g}$, and $25 \mathrm{~g}$ ) of the bacteria varies. There is a reduction in all the COD of all the samples after the bioremediation process compared with the COD of the raw samples before the bioremediation. The relative potential or efficiency of the different masses of the bacteria in remediating COD in TAN1, TAN2 and TAN3 samples were in the order $25 \mathrm{~g}>20 \mathrm{~g}>15$ $\mathrm{g}>5 \mathrm{~g}>10 \mathrm{~g}, 25 \mathrm{~g}>20 \mathrm{~g}>15 \mathrm{~g}>10 \mathrm{~g}>5 \mathrm{~g}$ and 10 g>5 g>25 g>15 g>20 g respectively. Statistical analysis shows that there were significant difference $(p<0.05)$ between the mean values of COD among the masses in the respective industries except for effluents treated with $25 \mathrm{~g}$. These might be due to the variations in the surface areas of the different masses of the immobilized bacteria. Negative and insignificant correlations exist between the masses of bacteria and COD with the exception in TAN3 (positive and significant correlation). The negative correlations showed that there is general decrease in the levels of the COD as the masses of the immobilized bacteria increases. TAN2 (100\%) showed a very high correlation with the masses of the bacteria while TAN3 (36\%) showed a very low correlation.

Generally, there was an overall decrease in the concentration of these physicochemical parameters after the bioremediation using the different masses of the bacterial isolates. These might be due to the variations in the surface areas of the different masses of the immobilized bacteria. This is in line with the work of Jimoh et al. (2018) and Baba et al. (2020).

Table 3: Mean Values $(\mathrm{mg} / \mathrm{l}) \pm$ S.D of Physicochemical parameters in effluents from the Tannery Industries before and after Treatment of the effluents $(250 \mathrm{ml})$ with the different masses $(5 \mathrm{~g}, 10 \mathrm{~g}$, $15 \mathrm{~g}, 20 \mathrm{~g}$, and $25 \mathrm{~g}$ ) of the bacteria.

\begin{tabular}{llllllll}
\hline $\mathrm{P}$ & IND & Before & \multicolumn{5}{c}{ After } \\
\cline { 4 - 7 } & & & $5 \mathrm{~g}$ & $10 \mathrm{~g}$ & $15 \mathrm{~g}$ & $20 \mathrm{~g}$ & $25 \mathrm{~g}$ \\
\hline \multirow{2}{*}{ COD } & TAN1 & $2372 \pm 938$ & $1708 \mathrm{a} \pm 861$ & $2045 \mathrm{a} \pm 1205$ & $845 \mathrm{a} \pm 369$ & $300 \mathrm{a} \pm 167$ & $250 \mathrm{a} \pm 154$ \\
& TAN2 & $1406 \pm 208$ & $1195 \mathrm{a} \pm 208$ & $1125 \mathrm{a} \pm 384$ & $1055 \mathrm{a} \pm 317$ & $956 \mathrm{a} \pm 310$ & $870 \mathrm{ab} \pm 240$ \\
& TAN3 & $3532 \pm 1373$ & $2374 \mathrm{a} \pm 1344$ & $1976 \mathrm{a} \pm 1405$ & $2757 \mathrm{a} \pm 1266$ & $3134 \mathrm{a} \pm 1595$ & $2614 \mathrm{~b} \pm 1105$ \\
BOD & TAN1 & $13.85 \pm 6.42$ & $6.92 \mathrm{a} \pm 5.49$ & $6.42 \mathrm{a} \pm 5.07$ & $5.72 \mathrm{a} \pm 5.35$ & $4.62 \mathrm{a} \pm 4.37$ & $2.82 \mathrm{ab} \pm 1.26$ \\
& TAN2 & $19.46 \pm 0.50$ & $1.75 \mathrm{~b} \pm 0.22$ & $1.73 \mathrm{~b} \pm 0.18$ & $1.58 \mathrm{a} \pm 0.16$ & $1.91 \mathrm{a} \pm 0.22$ & $1.56 \mathrm{~b} \pm 0.20$ \\
& TAN3 & $17.13 \pm 3.14$ & $4.24 \mathrm{ab} \pm 0.77$ & $3.29 \mathrm{ab} \pm 0.37$ & $4.11 \mathrm{a} \pm 0.07$ & $3.23 \mathrm{a} \pm 0.91$ & $3.33 \mathrm{a} \pm 1.28$ \\
SS & TAN1 & $374 \pm 124$ & $243 \mathrm{a} \pm 45$ & $471 \mathrm{a} \pm 226$ & $475 \mathrm{a} \pm 182$ & $492 \mathrm{a} \pm 128$ & $611 \mathrm{a} \pm 217$ \\
& TAN2 & $358 \pm 335$ & $460 \mathrm{a} \pm 400$ & $543 \mathrm{a} \pm 414$ & $544 \mathrm{a} \pm 402$ & $551 \mathrm{a} \pm 414$ & $554 \mathrm{a} \pm 405$ \\
& TAN3 & $780 \pm 739$ & $586 \mathrm{a} \pm 594$ & $758 \mathrm{a} \pm 656$ & $787 \mathrm{a} \pm 676$ & $861 \mathrm{a} \pm 635$ & $898 \mathrm{a} \pm 672$ \\
TDS & TAN1 & $3941 \pm 3703$ & $51 \mathrm{a} \pm 10$ & $53 \mathrm{a} \pm 10$ & $55 \mathrm{a} \pm 15$ & $61 \mathrm{a} \pm 20$ & $63 \mathrm{a} \pm 26$ \\
& TAN2 & $3300 \pm 1714$ & $83 \mathrm{a} \pm 78$ & $47 \mathrm{a} \pm 20$ & $48 \mathrm{a} \pm 22$ & $47 \mathrm{a} \pm 17$ & $48 \mathrm{a} \pm 17$ \\
& TAN3 & $2653 \pm 1240$ & $46 \mathrm{a} \pm 11$ & $55 \mathrm{a} \pm 24$ & $55 \mathrm{a} \pm 25$ & $58 \mathrm{a} \pm 23$ & $61 \mathrm{a} \pm 28$ \\
\hline
\end{tabular}

Replicate $=6$ (months)

Within the rows, for the same parameter, means with different alphabets are statistically different $(p<0.05)$.

$\mathrm{P}=$ parameter, IND = Industries 
BAJOPAS Volume 13 Number 2, December, 2020

Table 4: Correlation coefficient $(r)$ between different masses of the bacteria and the physicochemical parameters.

\begin{tabular}{llll}
\hline Industries & Parameter & Correlation coefficient $(r)$ & $\begin{array}{l}\text { Percent dependence (rxrx100) } \\
(\%)\end{array}$ \\
\hline TAN1 & COD & -0.9 & 82 \\
& BOD & -0.97 & 94 \\
& SS & $0.90^{*}$ & 80 \\
TAN2 & TDS & $0.98^{*}$ & 96 \\
& COD & -1 & 100 \\
& BOD & -0.21 & 4 \\
& SS & $0.78^{*}$ & 61 \\
& TDS & -0.69 & 47 \\
& COD & $0.60^{*}$ & 36 \\
& BOD & -0.6 & 37 \\
& SS & $0.95^{*}$ & 90 \\
& TDS & $0.94^{*}$ & 89 \\
\hline
\end{tabular}

The correlation coefficient $(r)$ with * is statistically significant $(p<0.05)$.

Percentage reduction of the Parameters

Table 5 shows the percentage reduction of Parameters in industrial samples before and after the treatment of the effluents $(250 \mathrm{ml})$ with the different masses $(5 \mathrm{~g}, 10 \mathrm{~g}, 15 \mathrm{~g}, 20 \mathrm{~g}$, and $25 \mathrm{~g}$ ) of the Immobilized Bacteria.

In TAN1 samples, the percentage reduction (\%) of COD ranged (14-89); BOD (50-80); SS (-32$35)$ and TDS (98-99). In TAN2 samples, the percentage decrease $(\%)$ of COD ranged (15$38) ;$ BOD (90-92); SS [-28-(-55)] and TDS (9798). In TAN3 samples, the percentage decrease (\%) of COD ranged (11-44); BOD (76-81); SS (15-25) and TDS (98). The percentage increase in the levels COD, BOD and TDS might be due to the increase in the surface area of the different masses of the immobilized bacteria. However, the percentage decrease in the levels of the SS might be due to the aggregation of the TDS which are large enough to result into SS. The percentage decrease in the levels of the SS might be also due to the influence of the nutrients which was added into the effluents in order to make the microorganisms more active and viable for fast degradation of organic contaminants in the effluent. This is in line with the work of Jimoh et al. (2018) in which the concentration of the SS increase after the bioremediation of effluents.

Sreemoyee and Priti (2013) assessed and reduced several Physico-chemical parameters of dairy wastewater using Niesseria $s p$. and concluded that the species are well known to degrade organic compounds. This is in agreement with the current study in which the immobilized Niesseria $s p$ degrade the organic contaminants as indicated by the BOD, COD and TDS.

Jimoh et al. (2018) observed that TSS of the effluents was increased after treatment with immobilized bacteria and concluded that it might be due to the biostimulation method adopted for the research.

The optimum $\mathrm{pH}$ Biosorption of Chromium by Bacillus spp and Staphylococcus spp. from tannery effluent was investigated by Mythili and Karthikeyan (2011). The maximum adsorption of Chromium $(86.4 \mathrm{mg} / \mathrm{L})$ was showed by Bacillus spp and Staphylococcus spp showed $70.6 \mathrm{mg} / \mathrm{L}$ at an initial concentration of $100 \mathrm{mg} / \mathrm{L}$. In the present study, immobilised Bacillus spp and Staphylococcus spp. from the tannery industrial effluents reduced the levels of the organic pollutants with high potential as indicated by the percentage reduction of BOD, COD and TDS.

Enzymes often can work in multiple environments especially if they are immobilized. This makes the microorganisms' enzymes even more resistant to harsh environments and enables the enzymes to be recovered and recycled after they are no longer needed (Gianfreda and Rao 2004). Ramesh and Singh (1993) reported that the immobilized bacteria having more efficiency to remove the suspended particles than free cells. Using the immobilized cell is preferable due to its capability for using several times with the same efficiency, which makes it more economical. Similar work was done by Sikander et al. (2007) showing the higher reduction with permeabilized cells of Ochrobactrum intermedium strain SDCr-5. 
BAJOPAS Volume 13 Number 2, December, 2020

The results revealed the isolation and identification of isolates with the potential for the reduction of $\mathrm{Cr}$ (VI) to $\mathrm{Cr}$ (III). Results indicated that immobilized $B$. cereus could be efficiently used for the reduction of $\mathrm{Cr}$ (VI).

Table 5: Percentage reduction of the tested Parameters from the tannery industrial samples of the Immobilized Bacteria.

\begin{tabular}{lllllll}
\hline \multirow{2}{*}{ Industries } & & \multicolumn{5}{c}{ Percentage Reduction $(\%)$} \\
\cline { 3 - 7 } & & $5 \mathrm{~g}$ & $10 \mathrm{~g}$ & $15 \mathrm{~g}$ & $20 \mathrm{~g}$ & $25 \mathrm{~g}$ \\
\hline TAN1 & COD & 28 & 14 & 64 & 87 & 89 \\
& BOD & 50 & 54 & 59 & 67 & 80 \\
& SS & 35 & -26 & -27 & -32 & -63 \\
& TDS & 99 & 99 & 99 & 98 & 98 \\
TAN2 & COD & 15 & 20 & 25 & 32 & 38 \\
& BOD & 91 & 91 & 92 & 90 & 92 \\
& SS & -28 & -52 & -52 & -54 & -55 \\
& TDS & 97 & 99 & 99 & 99 & 99 \\
& COD & 33 & 44 & 22 & 11 & 26 \\
& BOD & 75 & 81 & 76 & 81 & 81 \\
& SS & 25 & 3 & -1 & -10 & -15 \\
& TDS & 98 & 98 & 98 & 98 & 98 \\
\hline
\end{tabular}

Percentage Reduction $=(B-A) / B \times 100 \%$

$A=$ Concentration of the parameter after treatment

$\mathrm{B}=$ Concentration of the parameter before treatment

$+=$ percentage decrease

- = percentage increase

In general, immobilization makes the enzyme more resistant to temperature, $\mathrm{pH}$, and substrate concentration swings giving it a longer lifetime and higher productivity per active unit (Gianfreda and Rao, 2004; FuIlbrook, 1996; Russell et al, 2003; Kandelbauer et al., 2004). Immobilized cells have been used and studied extensively for the production of useful chemicals (Ohtake and Silver, 1994), the treatment of wastewaters (Chen et al., 2003; Wang et al., 2010). Although many workers described microbial degradation of tannery effluent, limited literature is available on the bioremediation of tannery effluent using immobilized bacterial cells in the Kano Industrial Estates.

\section{CONCLUSION}

The samples contained variable levels of the physicochemical parameters. The results of the Analysis of variance revealed that, no statistical difference $(p<0.05)$ was observed for the temperature, $\mathrm{pH}, \mathrm{SS}, \mathrm{TDS}, \mathrm{BOD}$ and $\mathrm{COD}$ among the three tannery industries before the treatment. The levels of some of the parameters
(SS, TDS and COD) observed in the samples were found above the recommended limits of WHO and NESREA, which called for the treatment of the effluents before discharge into the environment. Base on the morphological and biochemical test results, TAN1, TAN2, and TAN3 bacterial isolates were identified to be Neisseria spp, Bacillus cereus, and Staphylococcus aureus respectively. The results of Post-treatment analysis showed that there is overall decrease in the levels of the parameters determined when compared with that of the pre-treatment. The overall percentage reduction of the immobilised bacteria in the treatment of the respective effluents was in the order TAN2 (72\%)>TAN1 $(70 \%)>$ TAN3 $(62 \%)$. Hence, the immobilized bacteria are having higher biodegradation potential for the treatment of the tannery effluents.

\section{Acknowledgments}

The authors wish to acknowledge the University of Maiduguri for the financial support. The authors are grateful to the Kano State Ministry of Environment for their support in obtaining the effluent samples. 


\section{REFERENCES}

Ajao, A. T., Adebayo, G. B., and Yakubu, S. E. (2011). Bioremediation of textile industrial effluent using mixed culture of Pseudomonas aeruginosa and Bacillus subtilis immobilized on agar-agar in a bioreactor. J. Microbiol. Biotech. Res, 1(3), 50-56.

Akan, J. C., Moses, E. A., Ogugbuaja, V. O., and Abah, J. (2007). Assessment of tannery industrial effluents from Kano metropolis, Kano State, Nigeria. Journal of Applied Sciences, 7(19), 2788-2793.

Akan, J. C., Ogugbuaja, V. O., Abdulrahman, F. I., and Ayodele, J. T. (2009). Pollutant levels in effluent samples from tanneries and textiles of Kano industrial areas, Nigeria. Global journal of pure and applied sciences, 15(3-4).

APHA (1989). Standard methods for Examination of Will bete and Will betewater.15 $5^{\text {th }}$ edition. Brydpass Springfield Will behington DC. pp. 164-176

APHA (1992). Standard Methods for the Examination of Water and Wastewater. Health, 69, 1116-9.

Baba, A., Garba, S. T., and Bello, H. S. (2020). Bioremediation Potential of Immobilized corynebacterium kutsceri in the Treatment of Tannery Industrial Effluent from Challawa Industrial Estate, Kano State, Nigeria. Journal of the Turkish Chemical Society Section A: Chemistry, $7(2), 335-350$.

Beem, E. I. V. (1994). reduction of solvent VOC emission. J. Oil Col. Chem. Ass, 77, 158.

Bouwer, E. J., and Zehnder, A. J. (1993). Bioremediation of organic compoundsputting microbial metabolism to work. Trends in biotechnology, 11(8), 360367.

Chen, K. C., Wu, J. Y., Liou, D. J., and Hwang, S. C. J. (2003). Decolorization of the textile dyes by newly isolated bacterial strains. Journal of Biotechnology, 101(1), 57-68.

Dan'Azumi, S., and Bichi, M. H. (2010). INDUSTRIAL POLLUTION AND HEAVY METALS PROFILE OF CHALLAWA RIVER IN KANO, NIGERIA. Journal of Applied Sciences in Environmental Sanitation, $5(1)$.

DWAF. (1992). Analytical Methods Manual, TR 151. Department of Water Affairs and Forestry, Pretoria.

El-Bestawy, E. (2013). Biological treatment of leather-tanning industrial wastewater using free living bacteria.
Elsheikh, M. A. S. (2009). Tannery wastewater pre-treatment. Water Science and Technology, 60(2), 433-440.

FuIlbrook, P. D. (1996). "Kinetics." Industrial enzymology: The application of enzymes in Industry. 2nd Ed. T. Godfrey and J Reichelt. eds.. Nature. New York.

Gianfreda, L., and Rao, M. A. (2004). Potential of extra cellular enzymes in remediation of polluted soils: a review. Enzyme and microbial technology, 35(4), 339354.

Hugo Springer. (1994). John Arthur Wilson Memorial Lecture "Treatment of Industrial Wastes of the Leather Industry - is it still a Major Problem". JALCA, 89, 153-185

Jimoh, A. A., Ganiyu, B. A., Baba, D., and Baba, A. (2018) Bioremediation Process of Effluent from Detergent and Food Industries in Jos, Nigeria: Kinetics and Thermodynamics. International Journal of Engineering Science Invention (IJESI), 762-73

Kandelbauer, A., Maute, O., Kessler, R. W., Erlacher, A., and Gübitz, G. M. (2004). Study of dye decolorization in an immobilized laccase enzyme-reactor using online spectroscopy. Biotechnology and bioengineering, 87(4), 552-563.

Kongjao, S., Damronglerd, S., and Hunsom, M. (2008). Simultaneous removal of organic and inorganic Pollutants in tannery wastewater using electrocoagulation technique. Korean Journal of chemical engineering, 25(4), 703.

Maheshwari, U. M., Aruna, S., Gomathi, M., and AbdulJaffar, A. H. (2017). Bioremediation by Free and Immobilized Bacteria Isolated from Tannery Effluent. International Journal of Research in Applied, Natural and Social Sciences. 5(7), 75-90

Margesin, R., and Schinner, F. (2001). Bioremediation (natural attenuation and biostimulation) of diesel-oilcontaminated soil in an alpine glacier skiing area. Applied and environmental microbiology, 677), 3127-3133.

Mohammed, A., Sekar, P., and George, J. (2011). Efficacy of microbes in bioremediation of tannery effluent. Inter. J. Curr. Res, 3(4), 324-326.

Mohammed, S. S. D., Orukotan, A. A., and Abdullahi, H. (2017). Physicochemical and Bacteriological Assessment of Tannery Effluent from Samaru-Zaria, 
BAJOPAS Volume 13 Number 2, December, 2020 Kaduna State, Nigeria. Journal of Applied

Sciences and Environmental Management, 21(4), 734-740.

Munz, G., De Angelis, D., Gori, R., Mori, G., Casarci, M., and Lubello, C. (2009). The role of tannins in conventional and membrane treatment of tannery wastewater. Journal of hazardous materials, 164(2-3), 733-739

Mythili, K., and Karthikeyan, B. (2011). Bioremediation of $\mathrm{Cr}$ (VI) from tannery effluent using Bacillus spp and Staphylococcus spp. International Multidisciplinary Research Journal, 1(6).

NESREA (2009). National Environmental Standards for Effluent Limitations and Regulation. 1233-1236

Noorjahan, C. M. (2014). Physicochemical characteristics, identification of bacteria and biodegradation of industrial effluent. Journal of bioremediation and Biodegradation, 5(3).

Ohtake, H. I., and Silver, A. O. (1994). Bacterial reduction of toxic chromate. Biological degradation and bioremediation of toxic chemicals, 403-415.

Omoleke, I. I. (2004). Management of environmental pollution in Ibadan, an African city: the challenges of health hazard facing government and the people. Journal of Human Ecology, 15(4), 265-275.

Rajor, A., Reddy, A.S., and Singh, B. (2004). Determination of BOD kinetic Parameters and evaluation of alternate methods, M.Sc. Thesis, Department of biotechnology \& environmental Science, Thapar Institute of Engineering and Technology, Patiala

Ramasami, T., Rajamani, S., and Rao, J. R. (1994, March). Pollution control in leather industry: Emerging technological options. In International symposium on surface and colloidal science and its relevance to soil pollution, madras.

Ramesh, J. V. S., and Singh, S. P. (1993). Yearly variation in certain physicochemical parameters of pond at eastern Doon Valley. Uttar Pradesh J. Zoo, 12 (1), 7577.

Ranen, S., and Sharadinadra, C. (2009). Biotechnology applications to environmental remediation in resource exploitation. Current science, 97, 6-25
Russell, A. J., Berberich, J. A., Drevon, G. F., and Koepsel, R. R. (2003). Biomaterials for mediation of

chemical and biological warfare agents. Annual review of biomedical engineering, 5(1), 1-27.

Saravanan, P., and Saravanan, A. (1999). Decolourization of tannery effluent by Flavobacterium sp. EK 1. Indian Journal of Environmental Protection, 19, 19-24.

Sikander, S., and Shahida, H. (2007). Reduction of toxic hexavalent chromium by Ochrobactrum intermedium strain SDCr5 stimulated by heavy metals. Bioresource Technol, 98, 340-344.

Singh, N., Sharma, B. K., and Bohra, P. C. (2000). Impact assessment of industrial effluent of arid soils by using satellite imageries. Journal of the Indian Society of Remote Sensing, 28(2-3), 79.

Sreemoyee, C., and Priti, P. (2013). Assessment of physico-chemical parameters of dairy waste water and isolation and characterization of bacterial strains in terms of cod reduction. Int J Sci, 2(3), 395-400.

Verheijen, L. A. H. M., Wiersema, D., Pol, L. H., and De Wit, J. (1996). Management of wastes from animal product processing. Livestock and environment, Finding a balance. International Agriculture Center, Wageningen, The Netherlands.

Wang, F., Yao, J., Si, Y., Chen, H., Russel, M., Chen, K., and Bramanti, E. (2010). Short-time effect of heavy metals upon microbial community activity. Journal of Hazardous Materials, 173(13), 510-516.

WHO (World Health Organization). (2006). Air quality guidelines: global update 2005: particulate matter, ozone, nitrogen dioxide, and sulfur dioxide. World Health Organization.

World Bank. (1995). Nigeria's strategic options for redressing industrial pollution. World Bank, industry and energy division. 1st edition, West Central Africa Department; Annexes: 1995; pp 60-62.

Zahoor, A., and Abdul, R. (2009). Enumeration of Coliforms. Journal of Environmental Sciences. 21, 814-820 


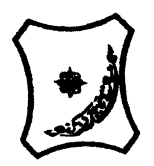

Bayero Journal of Pure and Applied Sciences, 13(2): 1 - 12

Received: November, 2020

Accepted: December, 2020

ISSN $2006-6996$

\title{
BIODEGRADATION POTENTIAL OF IMMOBILIZED BACTERIA IN THE TREATMENT OF TANNERY INDUSTRIAL EFFLUENTS FROM INDUSTRIAL ESTATES IN KANO STATE, NIGERIA
}

\author{
Abdullateef, B., ${ }^{1 *}$ Shuaibu, T. G., ${ }^{1}$ Babagana, K., ${ }^{1}$ Suleman, H. B. ${ }^{2}$ and Dauda, B. ${ }^{3}$ \\ ${ }^{1}$ Department of Pure and Applied Chemistry, Faculty of Science, University of Maiduguri, Borno State, \\ Nigeria \\ ${ }^{2}$ Department of Microbiology, Faculty of Science, University of Maiduguri, Borno State, Nigeria \\ ${ }^{3}$ Department of Chemical Engineering, Faculty of Engineering, University of Maiduguri, Borno State, \\ Nigeria \\ *Corresponding author: babslega@gmail.com; abelega2007@yahoo.com; +2348061309753
}

\section{ABSTRACT}

Industrial Effluents Samples from Gashash Tanneries (TAN1) in Bompai Industrial estate, Larabee Tannery Industry (TAN2) in Sharada Industrial estate and Z Tannery Industries (TAN3) in Challawa Industrial estate, Kano State, Nigeria were collected over a period of six months (August 2017 to January 2018) for assessing the biodegradation potentials of bacteria in the treatment of organic pollutants within the effluents. Bacteria were isolated from the effluents and immobilized on agar-agar. Different masses (5 g, $10 \mathrm{gr}, 15$ $\mathrm{g}, 20 \mathrm{~g}$, and $25 \mathrm{~g}$ ) of the bacteria were used in the treatment of $250 \mathrm{ml}$ of the effluents for ten days in a shaker incubator (Gallenkamp-OC-4364-L) at the temperature $30{ }^{\circ} \mathrm{C}$ and speed of $60 \mathrm{rpm}$. Pre-treatment analysis of the effluents for Temperature, pH, Biochemical Oxygen Demand (BOD), Chemical Oxygen Demand (COD), Suspended Solid (SS) and Total Dissolved Solids (TDS) gives the following results; temperature $\left({ }^{\circ} \mathrm{C}\right.$ )

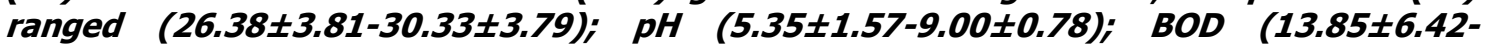
$38.75 \pm 16.20) ;$ COD (1406 $\pm 208-3532 \pm 1373) ;$ SS (208 $\pm 235-780 \pm 739)$ and TDS (266 $\pm 253-5276 \pm 2971)$. No statistical differences ( $p \leq 0.05)$ was observed for all the results among the different industries. The bacterial isolates were identified as Neisseria spp, Bacillus cereus, and Staphylococcus aureus, in TAN1, TAN2, and TAN3, respectively. After treatment of the effluent with the different masses of the isolated bacteria, the mean level of BOD was found to range as (0.55 $\pm 0.36-6.92 \pm 5.49) ; C O D$ (ND-3134 \pm 1595$)$;

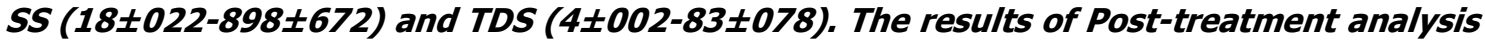
showed that there is overall decrease in the levels of the parameters determined when compared with that of the pre-treatment. The overall percentage reduction of the immobilised bacteria in the treatment of the respective effluents was in the order TAN2 (72\%)>TAN1 (70\%)>TAN3 (62\%). Hence, the immobilized bacteria are having higher biodegradation potential for the treatment of the tannery effluents.

Keywords: Biodegradation, bacteria, effluent, immobilization, tannery.

\section{INTRODUCTION}

Tannery industrial wastewater is a serious consequence of the pollution point of view for streams, freshwater, and land used for agriculture. The lack of awareness in the modern industrial practice has resulted in the discharge of tannery effluents which exhibit very high value of chromium ( $\mathrm{Cr}$ ), Sulfide, and chloride, Total Dissolved Solid (TDS), Total Suspended Solid (TSS), Biochemical Oxygen Demand (BOD) and Chemical Oxygen Demand (COD) in the water stream or land (Mohammed et al., 2001). Tanning is the process, which One ton of skin generally leads to the production of 20 to $80 \mathrm{~m}^{3}$ of turbid and foul-smelling converts the protein of the rawhide or skin into a stable material, which will not putrefy and is suitable for a wide variety of end applications (Elsheikh, 2009). The highly polluting chromium is the most commonly used tanning material producing leather that is more flexible and pliable than vegetable-tanned leather and does not discolor or lose shape in water as drastically as vegetable-tan (Elsheikh, 2009). Tannery effluent is among the most hazardous industrial pollutants due to its huge organic and inorganic load, which is highly toxic to human life and the environment (Kongjao et al., 2008). wastewater including chromium (100-400 mg/l), sulfide $(200-800 \mathrm{mg} / \mathrm{l})$, high levels of fat and 
BAJOPAS Volume 13 Number 2, December, 2020 other solid wastes, and notable pathogen contamination as well as pesticides added for skin conservation during transport (Elsheikh, 2009). There are more than 6000 tanneries in Nigeria with an annual processing capacity of 700,000 tons of hides and skins (Omoleke, 2004; Singh et al., 2008). It was reported that the total amount of waste produced per animal slaughtered is approximately $35 \%$ of its weight (World Bank, 1995). Also, for every $1000 \mathrm{~kg}$ of carcass weight, a slaughtered beef produces 5.5 $\mathrm{kg}$ of manure (excluding rumen contents or stockyard manure) and $100 \mathrm{~kg}$ of paunch manure (undigested food) (Verheijen et al., 1996). Tanneries generate wastewater in the range of 30-35 $\mathrm{L} \mathrm{kg}^{-1}$ skin/hide processed with variable $\mathrm{pH}$, Biological Oxygen Demand (BOD), Chemical Oxygen Demand (COD), high concentrations of suspended solids (SS), and tannins as well as chromium (Zahoor and Abdul, 2009).

Being heterogeneous and composed of a wide variety of compounds, it is very difficult to select a unique direct method for estimating the biodegradability of organic contents and biokinetic parameters for a wastewater sample (Rajor, 2004). For this purpose, some indirect estimation such as determination of biochemical oxygen demand (BOD) and chemical oxygen demand (COD) are applied as common laboratory investigations [9]. During retanning procedures, synthetic tannins (Syntan), oils and resins are added to form softer leather at varying doses (Munz et al., 2009). One of the refractory groups of chemicals in tannery effluents derives mainly from tannins (Ramasami et al., 2004). Syntans are characterized by complex chemical structures, because they are composed of an extended set of chemicals such as phenol-, naphthalene-, formaldehyde- and melamine-based syntans, and acrylic resins (Beem, 1994). Organic pollutants (proteic and lipidic components) are originated from skins (it is calculated that the raw skin has $30 \%$ loss of organic material during the working cycle) or they are introduced during processes (Hugo Springer, 1994).

Many conventional processes such as oxidation, chemical and biological processes were carried out to treat tanneries wastewater (Ebtesam et al, 2013). Biological processes have received more attention because of their costeffectiveness, lower sludge production and environmental friendliness (Noorjahan, 2014). Naturally occurring micro-organisms degrade the hazardous organic wastes including xenobiotic compounds, such as pesticides, polycyclic aromatic hydrocarbons (PAHs) and polychlorinated biphenyls (PCBs) in due course of time (Ranen and Sharadinadra, 2009). Bioremediation is based on the idea that all organisms remove substances from the environment to carry outgrowth and metabolism (Bouwer and Zehnder, 1993). Bacteria, protista and fungi are found to be very good at degrading complex molecules and incorporating the breakdown products into their metabolism (Bouwer and Zehnder, 1993). The resultant metabolic wastes that they produce are generally safe and somehow recycled into other organisms (Ranen and Sharadinadra, 2009). An acclimatized indigenous population of microorganisms capable of degradation of the compounds of interest must exist at the site for a successful bioremediation mode (Ranen and Sharadinadra, 2009). It has been observed that for a successful bioremediation mode, an acclimatized indigenous population of microorganisms capable of degradation of the compounds of interest must exist at the site under investigation (Ranen and Sharadinadra, 2009). Even though there are numerous physical and chemical methods employed in the disposal of wastes the advantage in using bacterium is that they play a key role in the reduction of COD, BOD, total protein, total tannin and total phenol (Saravanan and Saravanan, 1998)

Baba et al. (2020) studied the bioremediation potential of immobilized corynebacterium kutsceri in the Treatment of tannery industrial effluent from Challawa Industrial Estate, Kano State, Nigeria. The aim of the work is to study the reduction in the level of the contaminants through the process of bioremediation using the isolated bacteria. Immobilized bacteria can withstand various temperatures, $\mathrm{pH}$ and substrate concentrations; consequently, increasing the efficiency and the lifespan of the bacteria. Immobilized bacteria are widely applied in the treatment of wastewater and can be separated and recovered after the treatment with the same efficiency (Baba et al., 2020).

\section{MATERIALS AND METHODS \\ Study Area}

This study was carried out in Bompai, Sharada and Challawa industrial estates in Kano, Figure 1. Kano lies on Latitude $11^{\circ} 30^{\prime} \mathrm{N}$ and $8^{\circ} 30^{\prime} \mathrm{E}$ and Longitude $11^{\circ} 5^{\prime} \mathrm{N}$ and $8^{\circ} 5^{\prime} \mathrm{E}$ in Northern Nigeria. It is one of the developed industrial cities in Nigeria. Tannery activities are the dominating industries and this could be one of the reasons for her high population density (Dan'Azumi and Bichi, 2010). Many researchers have studied biodegradation of tannery effluent using microorganisms. However, limited literature is available on the biodegradation of tannery effluent in Kano industrial estates using 
BAJOPAS Volume 13 Number 2, December, 2020 immobilized bacterial cells. This research work focuses on the potential of the use of the indigenous immobilized bacterial isolates in the treatment of tannery effluents in the industrial estates.

\section{Sample Collection}

Effluents were collected from the Tannery Industries from Bompai, Challawa and Sharada Industrial Estates, Kano, Nigeria. The effluents were collected over a period of six months (August 2017 to January 2018). Samples collected in a sterile 4-liter plastic container with a unique identification number were preserved using an ice-box that was transported to the Microbiology Laboratory, Department of Microbiology, Bayero University of Kano for analysis

\section{Sample Preparation and Sample Analysis}

Immediately after the collection of the effluent, $\mathrm{pH}$, TSS, TDS, COD, BOD levels were determined before treatment (Pre-treatment determination) and ten days after treatment (Post-treatment determination) as described in
APHA (1989) standard methods. $\mathrm{pH}$ was determined using Ecotests $\mathrm{pH}$ meter and TDS was determined using AQUALYTIC TDS Salinometer. BOD was determined as described by the standard method (APHA, 1992). COD and SS were determined using DR/2010 HACH portable data logging spectrophotometer (DWAF, 1992)

\section{Identification and Biochemical} Characterization of the Bacterial Isolates

The bacteria were isolated from the effluents using Serial Dilution according to the method described by APHA (1989). The biochemical tests such as oxidase, catalase, coagulase, indole (from $1 \%$ tryptone broth), citrate (Simmons citrate agar), methyl red/VogesProskauer (MR/VP), nitrate reduction, Starch Hydrolysis, Glucose, Maltose, and Lactose tests were carried out on the bacterial isolates to identify the bacteria through the bacteria biochemical characteristics according to Ajao et al. (2011).

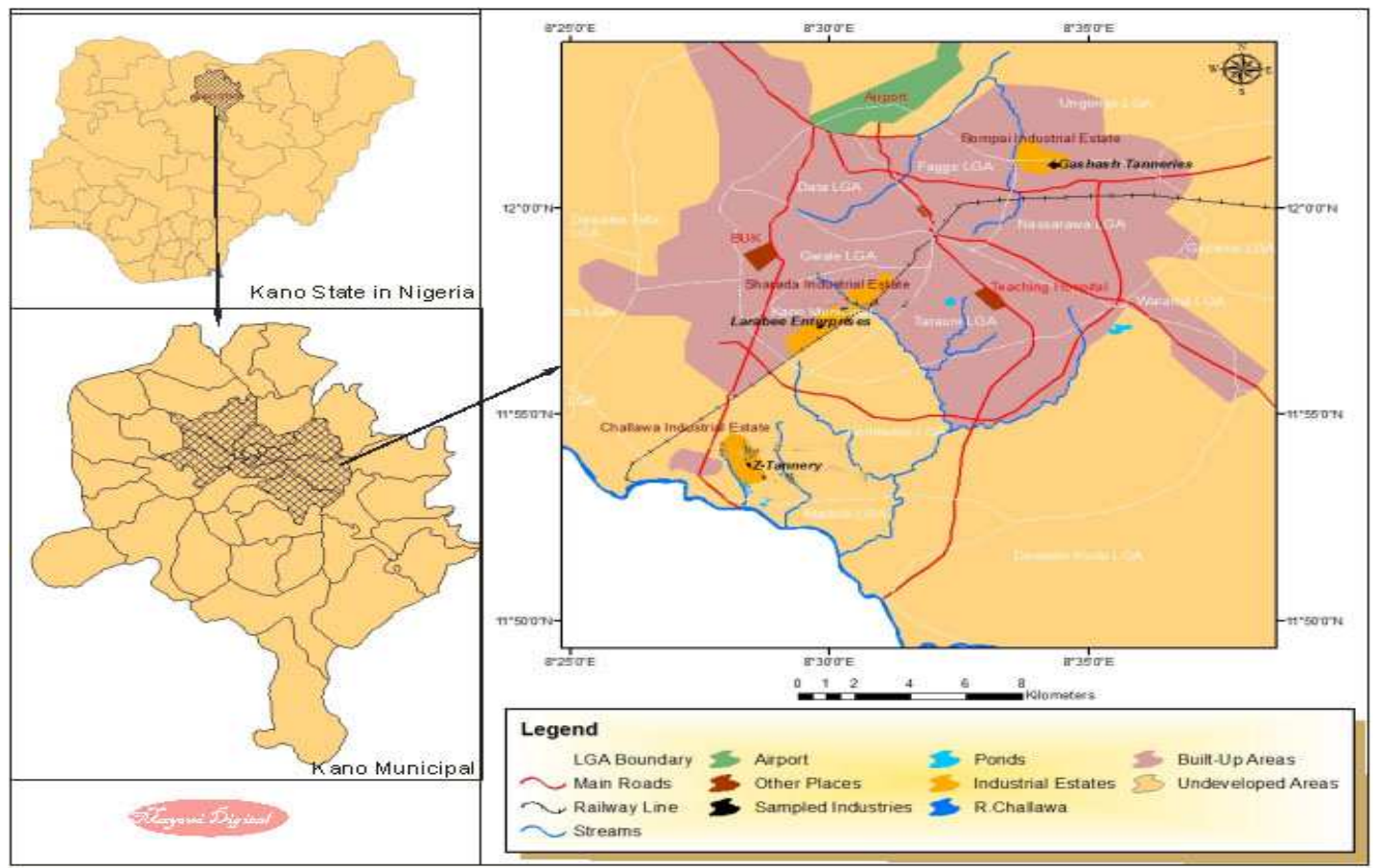

Fig. 1 Map showing the study areas

Source: Mayomi Digital Productions, GIS Laboratory, Department of Geography, UNIMAID (2017)

\section{Determination of Growth Rate of the Bacteria in Effluent Sample}

The bacteria growth rates were determined by transferring $2 \mathrm{~mL}$ of the bacterial isolates from the tannery effluent in broth medium into 100 $\mathrm{mL}$ sterile effluents in conical flasks and kept in an incubator (Giffrin cool) for 10 days. Control was also set up by incubating another $100 \mathrm{~mL}$ each of the sterile effluents without the bacteria. The optical density of the content was determined at the wavelength of $600 \mathrm{~nm}$ on a daily interval and recorded. 
BAJOPAS Volume 13 Number 2, December, 2020 Immobilization of Bacteria

Agar solution and inoculi were prepared separately. Fifty milliliters $(50 \mathrm{~mL})$ of nutrient broth each of the inoculi was prepared in a McCartney bottle and incubated for 24 hours. A solution of agar-agar was prepared by dissolving $10 \mathrm{~g}$ of the powder in distilled water and made up to $500 \mathrm{~mL}$ mark in an Erlenmeyer flask and was sterilized in an autoclave (280A) for 15 minutes and allowed to cool to $40-45^{\circ} \mathrm{C}$ (Ajao et al., 2011). Four milliliters ( $4 \mathrm{~mL})$ of the bacterial isolates in the nutrient broth was mixed with 36 $\mathrm{ml}$ of the prepared agar-agar media in petri-dish plates and then allowed to solidify. This was kept in the refrigerator for bioremediation.

\section{Bioremediation (Treatment) of the Effluents}

The solidified agar block (immobilized bacteria) was cut into cubes using a sterile knife; $0.1 \mathrm{~mL}$ phosphate buffer ( $\mathrm{pH} \mathrm{7.0)}$ was added and kept in the refrigerator for 1 hour for curing. The phosphate buffer was decanted after 1 hour and the cubes were washed with sterile distilled water 3-4 times before it was used (Ajao et al., 2011). Two liters (2 L) of the effluent was supplemented with the minimum basal medium in $\mathrm{g} / \mathrm{L}: \mathrm{NaCl}(0.8), \mathrm{MgSO}_{4} .7 \mathrm{H}_{2} \mathrm{O}(0.001), \mathrm{KH}_{2} \mathrm{PO}_{4}$ (2), $\mathrm{NaNO}_{3}$ (2), $\quad \mathrm{CaCl}_{2} .2 \mathrm{H}_{2} \mathrm{O} \quad(0.5)$ and $\mathrm{NaHPO}_{4} .12 \mathrm{H}_{2} \mathrm{O}(2)$ and sterilized in an autoclave at $121^{\circ} \mathrm{C}$ for 15 minutes (Margesin and Schinner, 2001). Two hundred and fifty milliliters $(250 \mathrm{~mL})$ of the effluents were transferred into different $250 \mathrm{ml}$ conical flasks. The content was covered with a cotton-wool ramped with foil paper to avoid contamination. Five grams $(5 \mathrm{~g})$ of the immobilized bacteria were quickly transferred into each of the effluents in the conical flasks in an inoculating chamber. The same procedures were carried out for the $10 \mathrm{~g}, 15 \mathrm{~g}, 20 \mathrm{~g}$ and 25 $\mathrm{g}$ of the immobilized bacteria in separate $250 \mathrm{~mL}$ effluents in conical flasks and agitated for ten days in a shaker incubator (Gallenkamp-OC4364-L) at a temperature $30^{\circ} \mathrm{C}$ and speed of 60 rpm. The treated effluent samples were taken on the tenth day and analyzed for the parameters $\mathrm{pH}$, SS, TDS, COD, and BOD, (Posttreatment determination) for the different grams of bacteria to evaluate and compare the biodegradation potential. (Baba et al., 2020).

\section{Statistical Analysis}

The data were represented as Mean \pm Standard deviation and analyzed statistically using oneway Analysis of Variance (ANOVA) and Tukey's HSD as Post Hoc Tests with the aid of SPSS 16.0. The correlation coefficient was also used to measure the strength of the relationship between the different masses of the bacteria and the parameters. All $\mathrm{p} \leq 0.05$ were considered as statistically significant.

\section{RESULTS AND DISCUSSION Physico-chemical parameters in the Industrial Effluents before the Biodegradation.}

Results of the Physico-chemical parameters in the industrial effluents before the Biodegradation is shown in table 1 . The mean temperatures $\left({ }^{\circ} \mathrm{C}\right)$ observed in TAN1, TAN2, and TAN3 samples were $28.07 \pm 0.65 ; 27.77 \pm 0.64$ and $26.38 \pm 3.81$ respectively. The order of the mean temperature of the samples from the three industries can be arranged as TAN1 > TAN2>TAN3. The temperature observed at TAN1, TAN2, and TAN3 samples were found below the WHO $\left(35^{\circ} \mathrm{C}\right)$ and NESREA $\left(40^{\circ} \mathrm{C}\right)$ limits. The low values of temperature might be due to the processes used at the time of sampling. High temperature brings down the solubility of gases in water that ultimately expresses as high BOD and COD. Statistical analysis shows that there is no significant difference $(p<0.05)$ between the mean values of temperature among the industries. This might be due to similar tannery activities involved in the tannery industries at the time of sampling. The average values of temperature observed in this present study are less than those observed by Akan et al. (2007), Akan et al. (2009) and Baba et al. (2020).

The mean level of $\mathrm{pH}$ observed in TAN1, TAN2 and TAN3, samples were $7.77 \pm 2.93$; $8.35 \pm 0.28$ and $7.52 \pm 0.76$ respectively. The order of the mean $\mathrm{pH}$ of the samples from the three industries can be arranged as TAN2> TAN1 $>$ TAN3. The $\mathrm{pH}$ of the samples falls within the WHO (7.0-8.5) and NESREA (6-9) standard limits. Statistical analysis shows that there is no significant difference $(p<0.05)$ between the mean values of $\mathrm{pH}$ among the industries. This might be due to similar tannery activities involved in the tannery industries at the time of sampling. Maheshwari et al. (2017) reported that the level of $\mathrm{pH}$ in the effluents from the tannery industry in Vaniyambadi, India was 6.5 which was lower than that observed in the present study. The $\mathrm{pH}$ in the effluents from the tannery industries in Kano and Kaduna were reported to be 7.64 and 6.89, respectively (Akan et al., 2007; Mohammed et al., 2017). The average values of $\mathrm{pH}$ observed in this present study are less than those observed by Mohammed et al. (2017) and Baba et al. (2020). The mean level of SS $(\mathrm{mg} / \mathrm{l})$ observed in TAN1, TAN2, and TAN3 samples were 374 \pm 124 ; $358 \pm 335$ and $780 \pm 739$ respectively. The order of the mean SS in the samples from the three industries can be arranged as TAN3 > TAN1 $>$ TAN2. 
The SS observed in the samples were far above the recommended standard limits of regulating bodies WHO $(30 \mathrm{mg} / \mathrm{l})$ and NESREA $(10 \mathrm{mg} / \mathrm{l})$. Statistical analysis shows that there is no significant difference $(p<0.05)$ between the mean values of SS among the industries. This might be due to similar tannery activities involved in the tannery industries at the time of sampling. The average values of SS observed in this present study are less than that observed $(3700 \pm 122 \mathrm{mg} / \mathrm{l})$ by Akan et al. (2009) for tanneries in Kano. Also, the average values of SS observed in this present study are less than that observed by Mohammed et al. (2017) and Baba et al. (2020) with the exception in TAN3.

The mean level of TDS (mg/l) observed in TAN1, TAN2, and TAN3 samples were $3941 \pm 3703$; $3300 \pm 1714$ and $2653 \pm 1240$ respectively. The order of the mean TDS in the samples from the three industries can be arranged as TAN1>TAN2>TAN3. The TDS observed in the samples were far above the recommended standard limits of WHO $(250 \mathrm{mg} / \mathrm{l})$ and NESREA $(500 \mathrm{mg} / \mathrm{l})$. Statistical analysis shows that there is no significant difference $(p<0.05)$ between the mean values of TDS among the industries. This might be due to similar tannery activities involved in the tannery industries at the time of sampling. TDS in the effluents from the tannery industries in Kano, Nigeria was reported to be $1281 \mathrm{mg} / \mathrm{l}$ (Akan et al., 2007). The average values of SS observed in this present study are less than those observed by Mohammed et al. (2017) and Baba et al. 2020)

The mean level of COD (mg/l) observed in TAN1, TAN2 and TAN3 samples seasons were $2372 \pm 938 ; \quad 1406 \pm 208$ and $3532 \pm 1373$ respectively. The order of the mean COD of the samples from the three industries can be arranged as TAN3>TAN1> TAN2. The COD observed in TAN1, TAN2 and TAN3 samples were far above the recommended standard limits of regulating bodies $\mathrm{WHO}(40 \mathrm{mg} / \mathrm{l})$ and NESREA (40 mg/l). Statistical analysis shows that there is no significant difference $(p<0.05)$ in COD among the industries. This might be due to similar tannery activities involved in the tannery industries as at the time of sampling. The Chemical Oxygen demand (COD) is the amount of oxygen, in $\mathrm{mg} / \mathrm{L}$, required for the degradation of the compound of wastewater to occur. In comparison, the average values of COD observed in this present study were higher than that observed by Mohammed et al. (2017) but lower than that observed by Baba et al. (2020).

The mean levels of BOD $(\mathrm{mg} / \mathrm{l})$ observed in TAN1, TAN2 and TAN3 samples were $13.85 \pm 6.42 ; \quad 19.46 \pm 0.50$ and $17.13 \pm 3.14$ respectively. The order of the mean BOD in the samples from the three industries can be arranged as TAN2>TAN3>TAN1. The BOD observed in TAN1, TAN2 and TAN3 samples were found below the recommended limits of NESREA (200 mg/l) but above WHO (10 mg/l). Statistical analysis shows that there is no significant difference $(p<0.05)$ between the mean values of BOD among the industries. This might be due to similar tannery activities involved in the tannery industries at the time of sampling. The low level of BOD recorded in this study is an indication of the low level of biodegradable organic solids in the effluent. The average values of BOD observed in this present study were lower than those observed by Mohammed et al. (2017) and Baba et al. (2020).

Table 1: Mean Values \pm S.D of Physico-chemical parameters of effluents from the Tannery Industries before Treatment.

\begin{tabular}{llllllll}
\hline Parameter & Tannery 1 & Tannery 2 & Tannery 3 & $\mathrm{a}$ & $\mathrm{b}$ & $\mathrm{c}$ & $\mathrm{d}$ \\
\cline { 2 - 7 } Temperature $\left({ }^{\circ} \mathrm{C}\right)$ & $28.07 \mathrm{a} \pm 0.65$ & $27.77 \mathrm{a} \pm 0.64$ & $26.38 \mathrm{a} \pm 3.81$ & & $29.50 \pm 4.68$ & 35 & 40 \\
pH & $7.77 \mathrm{a} \pm 2.93$ & $8.35 \mathrm{a} \pm 0.28$ & $7.52 \mathrm{a} \pm 0.76$ & 6.89 & $5.35 \pm 1.57$ & $7.0-8.5$ & $6.0-9.0$ \\
$\mathrm{COD}(\mathrm{mg} / \mathrm{l})$ & $2372 \mathrm{a} \pm 938$ & $1406 \mathrm{a} \pm 208$ & $3532 \mathrm{a} \pm 1373$ & 2.2 & $3106 \pm 2753$ & 40 & 40 \\
$\mathrm{BOD}(\mathrm{mg} / \mathrm{l})$ & $13.85 \mathrm{a} \pm 6.42$ & $19.46 \mathrm{a} \pm 0.50$ & $17.13 \mathrm{a} \pm 3.14$ & 1032 & $26.17 \pm 9.49$ & 10 & 200 \\
$\mathrm{SS}(\mathrm{mg} / \mathrm{l})$ & $374 \mathrm{a} \pm 124$ & $358 \mathrm{a} \pm 335$ & $780 \mathrm{a} \pm 739$ & 501 & $562 \pm 482$ & 30 & 10 \\
TDS $(\mathrm{mg} / \mathrm{l})$ & $3941 \mathrm{a} \pm 3703$ & $3300 \mathrm{a} \pm 1714$ & $2653 \mathrm{a} \pm 1240$ & 532.7 & $444 \pm 507$ & 250 & 500 \\
\hline
\end{tabular}

The values given in the table above are means of 6 replicate values, $\mathrm{n}=6$ ( 1 sample was taken monthly for 6 months). Within the rows, means with different alphabets are statistically different $(p<0.05)$. WHO: World Health Organisation. NESREA: National Environmental Standard and Regulatory Enforcement Agency. a = Mohammed et al.(2017), b = Baba et al. (2020), c = WHO (2006), $d=$ NESSRA (2009) 
BAJOPAS Volume 13 Number 2, December, 2020

Identification, Biochemical Characterization and growth rates of the Bacterial Isolates

Results of identification and biochemical characterization of the bacterial isolates were shown in table 2. After 24 hours of incubation, the nutrient agar media plates were checked for bacterial growth. The results showed the presence of different strains in the samples. The TAN1 bacteria isolate was found to be gramnegative cocci while TAN3 was gram-positive cocci. TAN2 bacteria isolate was found to be gram-positive, rod-shaped. TAN1, TAN2, and TAN3 bacteria isolates recorded positive results for spore former.

The results of the biochemical tests indicated that all the bacteria were positive for catalase, oxidase, citrate, maltose, glucose, lactose (negative in TAN1), mannitol (negative in TAN2), starch hydrolysis and coagulase (negative in TAN2) tests. The bacteria showed negative results for nitrate reduction, $M R$ (positive in TAN2), VP (positive in TAN1), Indole (positive in TAN2) tests. Base on the morphological and biochemical test results, TAN1, TAN2, and TAN3 bacteria isolates were identified to be Nesseria spp, Bacillus cereus, and Staphylococcus aureus respectively.

The growth rate of the TAN1, TAN2 and TAN3 Isolates were shown in figure 2. Generally, the optical density increase with the increase in time (day) and decrease as time goes on. The highest optical density was shown by bacillus cereus in TAN2 while the lowest was shown by Staphylococcus aureus in TAN3.

The initial growth phase of TAN1 Isolate bacteria occurred within 2-day of incubation as the growth rate increases up to the 6th-day incubation when the maximum growth was observed. Beyond the 6th day, the growth of the bacteria declined (which might be due to a shortage of nutrients in the effluents) until it reached its death phase (which might be due to the unavailability of nutrients in the effluents).

A similar trend of growth was also observed for TAN2 Isolate as the initial growth phase also occurred within 2-day of incubation but maximum growth rate observed on the 4th day of incubation. The stationary stage occurred between the 4th day and the 8th day. Beyond the 8th day, the growth of the bacteria declined (which might be due to a shortage of nutrients in the effluents) until it reached its death phase (which might be due to the unavailability of nutrients in the effluents).

The initial growth phase of TAN3 bacterial Isolate occurred within the 3-day incubation as the growth rate increases up to the 6th-day incubation when the maximum growth was observed. Beyond the 6th day, the growth of the bacteria declined (which might be due to a shortage of nutrients in the effluents) until it reached its death phase (which might be due to the unavailability of nutrients in the effluents).

Table 2: Morphological and Biochemical characteristics of bacterial isolates

\begin{tabular}{lllll} 
Bacterial Isolates & & TAN1 & TAN2 & TAN3 \\
\hline $\begin{array}{lllll}\text { Morphological } \\
\text { characteristics }\end{array}$ & Shape & Cocci & Rod & Cocci \\
& Spore & & & \\
& former & + & + & + \\
Gram & & & \\
Biochemical characteristics & reaction & - & + & + \\
& Citrate & + & + & + \\
& Catalase & + & + & + \\
& Coagulase & + & - & + \\
Starch & + & + & + \\
& Glucose & + & + & + \\
Oxidase & + & + & + \\
& Indo & - & + & - \\
Lactose & - & + & + \\
Manitol & + & - & + \\
Maltose & + & + & + \\
MR & - & + & - \\
VP & + & - & - \\
& Nitrate & - & - & - \\
Reduction & - Neisseria & Bacillus & Staphylococcus \\
& Bacterial & cereus & aureus \\
& name & spp & cas
\end{tabular}

+ = Positive; - = Negative; MR=Methyl Red; VP= Voges-Proskauer 


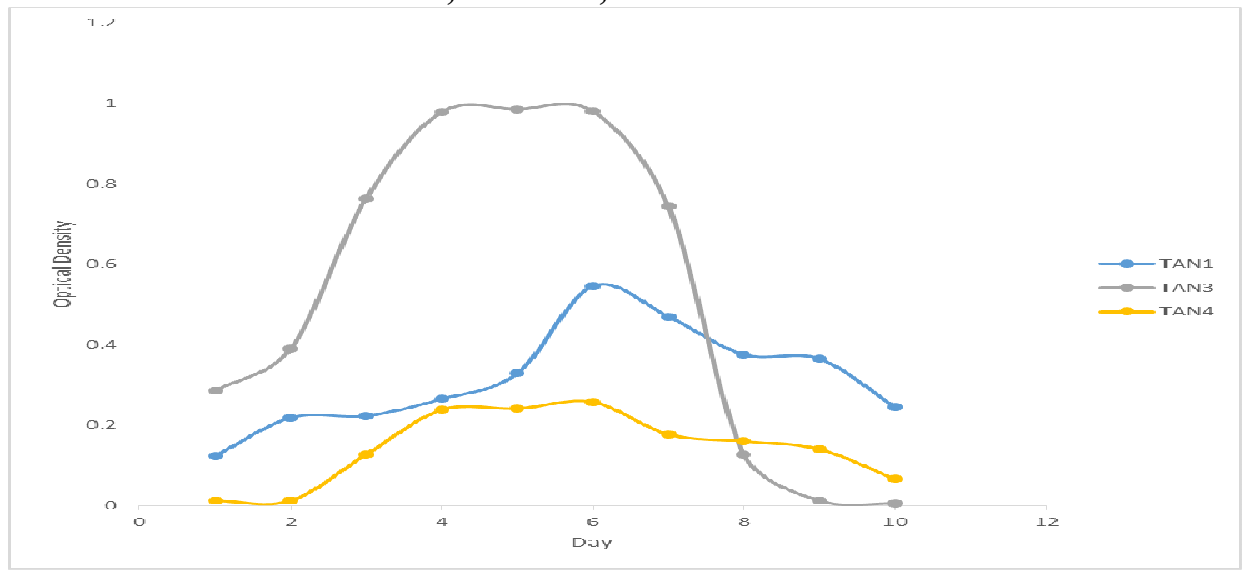

Fig. 2 Growth rates of the isolates in the effluents from the Tannery Industries

\section{Physico-chemical Parameters in the Industrial Effluents after the biodegradation.}

Table 3 shows the mean results of the physicochemical parameter before and after bioremediation using the different masses $(5 \mathrm{~g}$, $10 \mathrm{~g}, 15 \mathrm{~g}, 20 \mathrm{~g}$, and $25 \mathrm{~g}$ ) of the respective immobilized bacteria. Also, Table 4 shows the mean results of correlation coefficient ( $r$ ) between different masses of bacteria and physicochemical parameters.

The mean values $(\mathrm{mg} / \mathrm{l})$ of the SS after the bioremediation varies between $243 \pm 45$ and $898 \pm 672$. The mean concentration $(\mathrm{mg} / \mathrm{l})$ of SS remediated by the different masses $(5 \mathrm{~g}, 10 \mathrm{~g}$, $15 \mathrm{~g}, 20 \mathrm{~g}$, and $25 \mathrm{~g}$ ) of the bacteria varies. The SS in the samples fluctuates up and down after the bioremediation process when compared with the SS of the raw samples before the bioremediation. The increase in the levels of the SS might be due to the aggregation of the TDS which are large enough to result into SS. The increase in the levels of the SS might be also due to the influence of the nutrients which was added into the effluents in order to make the microorganisms more active and viable for fast degradation of organic contaminants in the effluent. The relative potential or efficiency of the different masses of the bacteria in remediating SS in TAN1 samples was in the order $25 \mathrm{~g}>20 \mathrm{~g}>15 \mathrm{~g}>10 \mathrm{~g}>5 \mathrm{~g}$. For TAN2 and TAN3 samples, the order was $25 \mathrm{~g}>20 \mathrm{~g}>15$ $\mathrm{g}>10 \mathrm{~g}>5 \mathrm{~g}$. These might be due to the variations in the surface areas of the different masses of the immobilized bacteria. Statistical analysis shows that there is no significant difference $(p<0.05)$ between the mean values of SS among the masses in the respective industries. Positive and significant correlations exist between the masses of bacteria and Suspended Solid (SS). This showed that there is general increase in the levels of the SS as the masses of the immobilized bacteria increases. TAN3 (90\%) and TAN1 (80\%) showed a very high correlation with the masses of the bacteria while TAN2 (61\%) showed a very low correlation.

The mean values $(\mathrm{mg} / \mathrm{l})$ of the TDS after the bioremediation varies between $46 \pm 11$ and $83 \pm 78$. The mean concentration $(\mathrm{mg} / \mathrm{l})$ of TDS remediated by the different masses $(5 \mathrm{~g}, 10 \mathrm{~g}$, $15 \mathrm{~g}, 20 \mathrm{~g}$, and $25 \mathrm{~g}$ ) of the bacteria varies. There is a reduction in all the TDS of all the samples after the bioremediation process compared with the TDS of the raw samples before the bioremediation. The relative potential or efficiency of the different masses of the bacteria in remediating TDS in TAN1 and TAN3 samples was in the order $5 \mathrm{~g}>10 \mathrm{~g}>15 \mathrm{~g}>20$ $\mathrm{g}>25 \mathrm{~g}$. For TAN2 samples, the order was 20 $g>10 \quad g>25 \quad g>15 \quad g>5 \quad g$. Statistical analysis shows that there is no significant difference $(p<0.05)$ between the mean values of TDS among the masses in the respective industries. These might be due to the variations in the surface areas of the different masses of the immobilized bacteria. Positive and significant correlations exist between the masses of bacteria and TDS with the exception in TAN2 (negative and insignificant correlation). The positive correlations showed that there is general increase in the levels of the TDS as the masses of the immobilized bacteria increases. TAN1 $(96 \%)$ showed a very high correlation with the masses of the bacteria while TAN2 (47\%) showed a very low correlation.

The mean values $(\mathrm{mg} / \mathrm{l})$ of the BOD after the bioremediation varies between $1.56 \pm 0.20 \mathrm{mg} / \mathrm{l}$ and $6.92 \pm 5.49 \mathrm{mg} / \mathrm{l}$. The mean concentration $(\mathrm{mg} / \mathrm{l})$ of BOD remediated by the different masses $(5 \mathrm{~g}, 10 \mathrm{~g}, 15 \mathrm{~g}, 20 \mathrm{~g}$, and $25 \mathrm{~g}$ ) of the bacteria varies. There is a reduction in all the BOD of all the samples after the bioremediation process compared with the $\mathrm{BOD}$ of the raw 
BAJOPAS Volume 13 Number 2, December, 2020 samples before the bioremediation. The relative potential or efficiency of the different masses of the bacteria in remediating BOD in TAN1, TAN2 and TAN3 samples were in the order $25 \mathrm{~g}>20$ $\mathrm{g}>15 \mathrm{~g}>10 \mathrm{~g}>5 \mathrm{~g}, 25 \mathrm{~g}>15 \mathrm{~g}>5 \mathrm{~g}>10 \mathrm{~g}>20 \mathrm{~g}$ and $20 \mathrm{~g}>10 \mathrm{~g}>25 \mathrm{~g}>15 \mathrm{~g}>5 \mathrm{~g}$ respectively. Statistical analysis shows that there is significant difference $(p<0.05)$ between the mean values of BOD among the masses in the respective industries. These might be due to the variations in the surface areas of the different masses of the immobilized bacteria. Negative and significant correlations exist between the masses of bacteria and BOD. This showed that there is general decrease in the levels of the BOD as the masses of the immobilized bacteria increases. TAN1 (94\%) showed a very high correlation with the masses of the bacteria while TAN2 (4\%) showed a very low correlation.

The mean values $(\mathrm{mg} / \mathrm{l})$ of the COD after the bioremediation varies between $250 \pm 154$ and $3134 \pm 1595$. The mean concentration $(\mathrm{mg} / \mathrm{l})$ of COD remediated by the different masses $(5 \mathrm{~g}$, $10 \mathrm{~g}, 15 \mathrm{~g} 20 \mathrm{~g}$, and $25 \mathrm{~g}$ ) of the bacteria varies. There is a reduction in all the COD of all the samples after the bioremediation process compared with the COD of the raw samples before the bioremediation. The relative potential or efficiency of the different masses of the bacteria in remediating COD in TAN1, TAN2 and TAN3 samples were in the order $25 \mathrm{~g}>20 \mathrm{~g}>15$ $\mathrm{g}>5 \mathrm{~g}>10 \mathrm{~g}, 25 \mathrm{~g}>20 \mathrm{~g}>15 \mathrm{~g}>10 \mathrm{~g}>5 \mathrm{~g}$ and 10 g>5 g>25 g>15 g>20 g respectively. Statistical analysis shows that there were significant difference $(p<0.05)$ between the mean values of COD among the masses in the respective industries except for effluents treated with $25 \mathrm{~g}$. These might be due to the variations in the surface areas of the different masses of the immobilized bacteria. Negative and insignificant correlations exist between the masses of bacteria and COD with the exception in TAN3 (positive and significant correlation). The negative correlations showed that there is general decrease in the levels of the COD as the masses of the immobilized bacteria increases. TAN2 (100\%) showed a very high correlation with the masses of the bacteria while TAN3 (36\%) showed a very low correlation.

Generally, there was an overall decrease in the concentration of these physicochemical parameters after the bioremediation using the different masses of the bacterial isolates. These might be due to the variations in the surface areas of the different masses of the immobilized bacteria. This is in line with the work of Jimoh et al. (2018) and Baba et al. (2020).

Table 3: Mean Values $(\mathrm{mg} / \mathrm{l}) \pm$ S.D of Physicochemical parameters in effluents from the Tannery Industries before and after Treatment of the effluents $(250 \mathrm{ml})$ with the different masses $(5 \mathrm{~g}, 10 \mathrm{~g}$, $15 \mathrm{~g}, 20 \mathrm{~g}$, and $25 \mathrm{~g}$ ) of the bacteria.

\begin{tabular}{llllllll}
\hline $\mathrm{P}$ & IND & Before & \multicolumn{5}{c}{ After } \\
\cline { 4 - 7 } & & & $5 \mathrm{~g}$ & $10 \mathrm{~g}$ & $15 \mathrm{~g}$ & $20 \mathrm{~g}$ & $25 \mathrm{~g}$ \\
\hline \multirow{2}{*}{ COD } & TAN1 & $2372 \pm 938$ & $1708 \mathrm{a} \pm 861$ & $2045 \mathrm{a} \pm 1205$ & $845 \mathrm{a} \pm 369$ & $300 \mathrm{a} \pm 167$ & $250 \mathrm{a} \pm 154$ \\
& TAN2 & $1406 \pm 208$ & $1195 \mathrm{a} \pm 208$ & $1125 \mathrm{a} \pm 384$ & $1055 \mathrm{a} \pm 317$ & $956 \mathrm{a} \pm 310$ & $870 \mathrm{ab} \pm 240$ \\
& TAN3 & $3532 \pm 1373$ & $2374 \mathrm{a} \pm 1344$ & $1976 \mathrm{a} \pm 1405$ & $2757 \mathrm{a} \pm 1266$ & $3134 \mathrm{a} \pm 1595$ & $2614 \mathrm{~b} \pm 1105$ \\
BOD & TAN1 & $13.85 \pm 6.42$ & $6.92 \mathrm{a} \pm 5.49$ & $6.42 \mathrm{a} \pm 5.07$ & $5.72 \mathrm{a} \pm 5.35$ & $4.62 \mathrm{a} \pm 4.37$ & $2.82 \mathrm{ab} \pm 1.26$ \\
& TAN2 & $19.46 \pm 0.50$ & $1.75 \mathrm{~b} \pm 0.22$ & $1.73 \mathrm{~b} \pm 0.18$ & $1.58 \mathrm{a} \pm 0.16$ & $1.91 \mathrm{a} \pm 0.22$ & $1.56 \mathrm{~b} \pm 0.20$ \\
& TAN3 & $17.13 \pm 3.14$ & $4.24 \mathrm{ab} \pm 0.77$ & $3.29 \mathrm{ab} \pm 0.37$ & $4.11 \mathrm{a} \pm 0.07$ & $3.23 \mathrm{a} \pm 0.91$ & $3.33 \mathrm{a} \pm 1.28$ \\
SS & TAN1 & $374 \pm 124$ & $243 \mathrm{a} \pm 45$ & $471 \mathrm{a} \pm 226$ & $475 \mathrm{a} \pm 182$ & $492 \mathrm{a} \pm 128$ & $611 \mathrm{a} \pm 217$ \\
& TAN2 & $358 \pm 335$ & $460 \mathrm{a} \pm 400$ & $543 \mathrm{a} \pm 414$ & $544 \mathrm{a} \pm 402$ & $551 \mathrm{a} \pm 414$ & $554 \mathrm{a} \pm 405$ \\
& TAN3 & $780 \pm 739$ & $586 \mathrm{a} \pm 594$ & $758 \mathrm{a} \pm 656$ & $787 \mathrm{a} \pm 676$ & $861 \mathrm{a} \pm 635$ & $898 \mathrm{a} \pm 672$ \\
TDS & TAN1 & $3941 \pm 3703$ & $51 \mathrm{a} \pm 10$ & $53 \mathrm{a} \pm 10$ & $55 \mathrm{a} \pm 15$ & $61 \mathrm{a} \pm 20$ & $63 \mathrm{a} \pm 26$ \\
& TAN2 & $3300 \pm 1714$ & $83 \mathrm{a} \pm 78$ & $47 \mathrm{a} \pm 20$ & $48 \mathrm{a} \pm 22$ & $47 \mathrm{a} \pm 17$ & $48 \mathrm{a} \pm 17$ \\
& TAN3 & $2653 \pm 1240$ & $46 \mathrm{a} \pm 11$ & $55 \mathrm{a} \pm 24$ & $55 \mathrm{a} \pm 25$ & $58 \mathrm{a} \pm 23$ & $61 \mathrm{a} \pm 28$ \\
\hline
\end{tabular}

Replicate $=6$ (months)

Within the rows, for the same parameter, means with different alphabets are statistically different $(p<0.05)$.

$\mathrm{P}=$ parameter, IND = Industries 
BAJOPAS Volume 13 Number 2, December, 2020

Table 4: Correlation coefficient $(r)$ between different masses of the bacteria and the physicochemical parameters.

\begin{tabular}{llll}
\hline Industries & Parameter & Correlation coefficient $(r)$ & $\begin{array}{l}\text { Percent dependence (rxrx100) } \\
(\%)\end{array}$ \\
\hline TAN1 & COD & -0.9 & 82 \\
& BOD & -0.97 & 94 \\
& SS & $0.90^{*}$ & 80 \\
TAN2 & TDS & $0.98^{*}$ & 96 \\
& COD & -1 & 100 \\
& BOD & -0.21 & 4 \\
& SS & $0.78^{*}$ & 61 \\
& TDS & -0.69 & 47 \\
& COD & $0.60^{*}$ & 36 \\
& BOD & -0.6 & 37 \\
& SS & $0.95^{*}$ & 90 \\
& TDS & $0.94^{*}$ & 89 \\
\hline
\end{tabular}

The correlation coefficient $(r)$ with * is statistically significant $(p<0.05)$.

Percentage reduction of the Parameters

Table 5 shows the percentage reduction of Parameters in industrial samples before and after the treatment of the effluents $(250 \mathrm{ml})$ with the different masses $(5 \mathrm{~g}, 10 \mathrm{~g}, 15 \mathrm{~g}, 20 \mathrm{~g}$, and $25 \mathrm{~g}$ ) of the Immobilized Bacteria.

In TAN1 samples, the percentage reduction (\%) of COD ranged (14-89); BOD (50-80); SS (-32$35)$ and TDS (98-99). In TAN2 samples, the percentage decrease $(\%)$ of COD ranged (15$38) ;$ BOD (90-92); SS [-28-(-55)] and TDS (9798). In TAN3 samples, the percentage decrease (\%) of COD ranged (11-44); BOD (76-81); SS (15-25) and TDS (98). The percentage increase in the levels COD, BOD and TDS might be due to the increase in the surface area of the different masses of the immobilized bacteria. However, the percentage decrease in the levels of the SS might be due to the aggregation of the TDS which are large enough to result into SS. The percentage decrease in the levels of the SS might be also due to the influence of the nutrients which was added into the effluents in order to make the microorganisms more active and viable for fast degradation of organic contaminants in the effluent. This is in line with the work of Jimoh et al. (2018) in which the concentration of the SS increase after the bioremediation of effluents.

Sreemoyee and Priti (2013) assessed and reduced several Physico-chemical parameters of dairy wastewater using Niesseria $s p$. and concluded that the species are well known to degrade organic compounds. This is in agreement with the current study in which the immobilized Niesseria $s p$ degrade the organic contaminants as indicated by the BOD, COD and TDS.

Jimoh et al. (2018) observed that TSS of the effluents was increased after treatment with immobilized bacteria and concluded that it might be due to the biostimulation method adopted for the research.

The optimum $\mathrm{pH}$ Biosorption of Chromium by Bacillus spp and Staphylococcus spp. from tannery effluent was investigated by Mythili and Karthikeyan (2011). The maximum adsorption of Chromium $(86.4 \mathrm{mg} / \mathrm{L})$ was showed by Bacillus spp and Staphylococcus spp showed $70.6 \mathrm{mg} / \mathrm{L}$ at an initial concentration of $100 \mathrm{mg} / \mathrm{L}$. In the present study, immobilised Bacillus spp and Staphylococcus spp. from the tannery industrial effluents reduced the levels of the organic pollutants with high potential as indicated by the percentage reduction of BOD, COD and TDS.

Enzymes often can work in multiple environments especially if they are immobilized. This makes the microorganisms' enzymes even more resistant to harsh environments and enables the enzymes to be recovered and recycled after they are no longer needed (Gianfreda and Rao 2004). Ramesh and Singh (1993) reported that the immobilized bacteria having more efficiency to remove the suspended particles than free cells. Using the immobilized cell is preferable due to its capability for using several times with the same efficiency, which makes it more economical. Similar work was done by Sikander et al. (2007) showing the higher reduction with permeabilized cells of Ochrobactrum intermedium strain SDCr-5. 
BAJOPAS Volume 13 Number 2, December, 2020

The results revealed the isolation and identification of isolates with the potential for the reduction of $\mathrm{Cr}$ (VI) to $\mathrm{Cr}$ (III). Results indicated that immobilized $B$. cereus could be efficiently used for the reduction of $\mathrm{Cr}$ (VI).

Table 5: Percentage reduction of the tested Parameters from the tannery industrial samples of the Immobilized Bacteria.

\begin{tabular}{lllllll}
\hline \multirow{2}{*}{ Industries } & & \multicolumn{5}{c}{ Percentage Reduction $(\%)$} \\
\cline { 3 - 7 } & & $5 \mathrm{~g}$ & $10 \mathrm{~g}$ & $15 \mathrm{~g}$ & $20 \mathrm{~g}$ & $25 \mathrm{~g}$ \\
\hline TAN1 & COD & 28 & 14 & 64 & 87 & 89 \\
& BOD & 50 & 54 & 59 & 67 & 80 \\
& SS & 35 & -26 & -27 & -32 & -63 \\
& TDS & 99 & 99 & 99 & 98 & 98 \\
TAN2 & COD & 15 & 20 & 25 & 32 & 38 \\
& BOD & 91 & 91 & 92 & 90 & 92 \\
& SS & -28 & -52 & -52 & -54 & -55 \\
& TDS & 97 & 99 & 99 & 99 & 99 \\
& COD & 33 & 44 & 22 & 11 & 26 \\
& BOD & 75 & 81 & 76 & 81 & 81 \\
& SS & 25 & 3 & -1 & -10 & -15 \\
& TDS & 98 & 98 & 98 & 98 & 98 \\
\hline
\end{tabular}

Percentage Reduction $=(B-A) / B \times 100 \%$

$A=$ Concentration of the parameter after treatment

$\mathrm{B}=$ Concentration of the parameter before treatment

$+=$ percentage decrease

- = percentage increase

In general, immobilization makes the enzyme more resistant to temperature, $\mathrm{pH}$, and substrate concentration swings giving it a longer lifetime and higher productivity per active unit (Gianfreda and Rao, 2004; FuIlbrook, 1996; Russell et al, 2003; Kandelbauer et al., 2004). Immobilized cells have been used and studied extensively for the production of useful chemicals (Ohtake and Silver, 1994), the treatment of wastewaters (Chen et al., 2003; Wang et al., 2010). Although many workers described microbial degradation of tannery effluent, limited literature is available on the bioremediation of tannery effluent using immobilized bacterial cells in the Kano Industrial Estates.

\section{CONCLUSION}

The samples contained variable levels of the physicochemical parameters. The results of the Analysis of variance revealed that, no statistical difference $(p<0.05)$ was observed for the temperature, $\mathrm{pH}, \mathrm{SS}, \mathrm{TDS}, \mathrm{BOD}$ and $\mathrm{COD}$ among the three tannery industries before the treatment. The levels of some of the parameters
(SS, TDS and COD) observed in the samples were found above the recommended limits of WHO and NESREA, which called for the treatment of the effluents before discharge into the environment. Base on the morphological and biochemical test results, TAN1, TAN2, and TAN3 bacterial isolates were identified to be Neisseria spp, Bacillus cereus, and Staphylococcus aureus respectively. The results of Post-treatment analysis showed that there is overall decrease in the levels of the parameters determined when compared with that of the pre-treatment. The overall percentage reduction of the immobilised bacteria in the treatment of the respective effluents was in the order TAN2 (72\%)>TAN1 $(70 \%)>$ TAN3 $(62 \%)$. Hence, the immobilized bacteria are having higher biodegradation potential for the treatment of the tannery effluents.

\section{Acknowledgments}

The authors wish to acknowledge the University of Maiduguri for the financial support. The authors are grateful to the Kano State Ministry of Environment for their support in obtaining the effluent samples. 


\section{REFERENCES}

Ajao, A. T., Adebayo, G. B., and Yakubu, S. E. (2011). Bioremediation of textile industrial effluent using mixed culture of Pseudomonas aeruginosa and Bacillus subtilis immobilized on agar-agar in a bioreactor. J. Microbiol. Biotech. Res, 1(3), 50-56.

Akan, J. C., Moses, E. A., Ogugbuaja, V. O., and Abah, J. (2007). Assessment of tannery industrial effluents from Kano metropolis, Kano State, Nigeria. Journal of Applied Sciences, 7(19), 2788-2793.

Akan, J. C., Ogugbuaja, V. O., Abdulrahman, F. I., and Ayodele, J. T. (2009). Pollutant levels in effluent samples from tanneries and textiles of Kano industrial areas, Nigeria. Global journal of pure and applied sciences, 15(3-4).

APHA (1989). Standard methods for Examination of Will bete and Will betewater.15 $5^{\text {th }}$ edition. Brydpass Springfield Will behington DC. pp. 164-176

APHA (1992). Standard Methods for the Examination of Water and Wastewater. Health, 69, 1116-9.

Baba, A., Garba, S. T., and Bello, H. S. (2020). Bioremediation Potential of Immobilized corynebacterium kutsceri in the Treatment of Tannery Industrial Effluent from Challawa Industrial Estate, Kano State, Nigeria. Journal of the Turkish Chemical Society Section A: Chemistry, $7(2), 335-350$.

Beem, E. I. V. (1994). reduction of solvent VOC emission. J. Oil Col. Chem. Ass, 77, 158.

Bouwer, E. J., and Zehnder, A. J. (1993). Bioremediation of organic compoundsputting microbial metabolism to work. Trends in biotechnology, 11(8), 360367.

Chen, K. C., Wu, J. Y., Liou, D. J., and Hwang, S. C. J. (2003). Decolorization of the textile dyes by newly isolated bacterial strains. Journal of Biotechnology, 101(1), 57-68.

Dan'Azumi, S., and Bichi, M. H. (2010). INDUSTRIAL POLLUTION AND HEAVY METALS PROFILE OF CHALLAWA RIVER IN KANO, NIGERIA. Journal of Applied Sciences in Environmental Sanitation, $5(1)$.

DWAF. (1992). Analytical Methods Manual, TR 151. Department of Water Affairs and Forestry, Pretoria.

El-Bestawy, E. (2013). Biological treatment of leather-tanning industrial wastewater using free living bacteria.
Elsheikh, M. A. S. (2009). Tannery wastewater pre-treatment. Water Science and Technology, 60(2), 433-440.

FuIlbrook, P. D. (1996). "Kinetics." Industrial enzymology: The application of enzymes in Industry. 2nd Ed. T. Godfrey and J Reichelt. eds.. Nature. New York.

Gianfreda, L., and Rao, M. A. (2004). Potential of extra cellular enzymes in remediation of polluted soils: a review. Enzyme and microbial technology, 35(4), 339354.

Hugo Springer. (1994). John Arthur Wilson Memorial Lecture "Treatment of Industrial Wastes of the Leather Industry - is it still a Major Problem". JALCA, 89, 153-185

Jimoh, A. A., Ganiyu, B. A., Baba, D., and Baba, A. (2018) Bioremediation Process of Effluent from Detergent and Food Industries in Jos, Nigeria: Kinetics and Thermodynamics. International Journal of Engineering Science Invention (IJESI), 762-73

Kandelbauer, A., Maute, O., Kessler, R. W., Erlacher, A., and Gübitz, G. M. (2004). Study of dye decolorization in an immobilized laccase enzyme-reactor using online spectroscopy. Biotechnology and bioengineering, 87(4), 552-563.

Kongjao, S., Damronglerd, S., and Hunsom, M. (2008). Simultaneous removal of organic and inorganic Pollutants in tannery wastewater using electrocoagulation technique. Korean Journal of chemical engineering, 25(4), 703.

Maheshwari, U. M., Aruna, S., Gomathi, M., and AbdulJaffar, A. H. (2017). Bioremediation by Free and Immobilized Bacteria Isolated from Tannery Effluent. International Journal of Research in Applied, Natural and Social Sciences. 5(7), 75-90

Margesin, R., and Schinner, F. (2001). Bioremediation (natural attenuation and biostimulation) of diesel-oilcontaminated soil in an alpine glacier skiing area. Applied and environmental microbiology, 677), 3127-3133.

Mohammed, A., Sekar, P., and George, J. (2011). Efficacy of microbes in bioremediation of tannery effluent. Inter. J. Curr. Res, 3(4), 324-326.

Mohammed, S. S. D., Orukotan, A. A., and Abdullahi, H. (2017). Physicochemical and Bacteriological Assessment of Tannery Effluent from Samaru-Zaria, 
BAJOPAS Volume 13 Number 2, December, 2020 Kaduna State, Nigeria. Journal of Applied

Sciences and Environmental Management, 21(4), 734-740.

Munz, G., De Angelis, D., Gori, R., Mori, G., Casarci, M., and Lubello, C. (2009). The role of tannins in conventional and membrane treatment of tannery wastewater. Journal of hazardous materials, 164(2-3), 733-739

Mythili, K., and Karthikeyan, B. (2011). Bioremediation of $\mathrm{Cr}$ (VI) from tannery effluent using Bacillus spp and Staphylococcus spp. International Multidisciplinary Research Journal, 1(6).

NESREA (2009). National Environmental Standards for Effluent Limitations and Regulation. 1233-1236

Noorjahan, C. M. (2014). Physicochemical characteristics, identification of bacteria and biodegradation of industrial effluent. Journal of bioremediation and Biodegradation, 5(3).

Ohtake, H. I., and Silver, A. O. (1994). Bacterial reduction of toxic chromate. Biological degradation and bioremediation of toxic chemicals, 403-415.

Omoleke, I. I. (2004). Management of environmental pollution in Ibadan, an African city: the challenges of health hazard facing government and the people. Journal of Human Ecology, 15(4), 265-275.

Rajor, A., Reddy, A.S., and Singh, B. (2004). Determination of BOD kinetic Parameters and evaluation of alternate methods, M.Sc. Thesis, Department of biotechnology \& environmental Science, Thapar Institute of Engineering and Technology, Patiala

Ramasami, T., Rajamani, S., and Rao, J. R. (1994, March). Pollution control in leather industry: Emerging technological options. In International symposium on surface and colloidal science and its relevance to soil pollution, madras.

Ramesh, J. V. S., and Singh, S. P. (1993). Yearly variation in certain physicochemical parameters of pond at eastern Doon Valley. Uttar Pradesh J. Zoo, 12 (1), 7577.

Ranen, S., and Sharadinadra, C. (2009). Biotechnology applications to environmental remediation in resource exploitation. Current science, 97, 6-25
Russell, A. J., Berberich, J. A., Drevon, G. F., and Koepsel, R. R. (2003). Biomaterials for mediation of

chemical and biological warfare agents. Annual review of biomedical engineering, 5(1), 1-27.

Saravanan, P., and Saravanan, A. (1999). Decolourization of tannery effluent by Flavobacterium sp. EK 1. Indian Journal of Environmental Protection, 19, 19-24.

Sikander, S., and Shahida, H. (2007). Reduction of toxic hexavalent chromium by Ochrobactrum intermedium strain SDCr5 stimulated by heavy metals. Bioresource Technol, 98, 340-344.

Singh, N., Sharma, B. K., and Bohra, P. C. (2000). Impact assessment of industrial effluent of arid soils by using satellite imageries. Journal of the Indian Society of Remote Sensing, 28(2-3), 79.

Sreemoyee, C., and Priti, P. (2013). Assessment of physico-chemical parameters of dairy waste water and isolation and characterization of bacterial strains in terms of cod reduction. Int J Sci, 2(3), 395-400.

Verheijen, L. A. H. M., Wiersema, D., Pol, L. H., and De Wit, J. (1996). Management of wastes from animal product processing. Livestock and environment, Finding a balance. International Agriculture Center, Wageningen, The Netherlands.

Wang, F., Yao, J., Si, Y., Chen, H., Russel, M., Chen, K., and Bramanti, E. (2010). Short-time effect of heavy metals upon microbial community activity. Journal of Hazardous Materials, 173(13), 510-516.

WHO (World Health Organization). (2006). Air quality guidelines: global update 2005: particulate matter, ozone, nitrogen dioxide, and sulfur dioxide. World Health Organization.

World Bank. (1995). Nigeria's strategic options for redressing industrial pollution. World Bank, industry and energy division. 1st edition, West Central Africa Department; Annexes: 1995; pp 60-62.

Zahoor, A., and Abdul, R. (2009). Enumeration of Coliforms. Journal of Environmental Sciences. 21, 814-820 


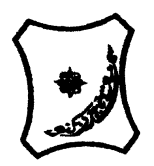

Bayero Journal of Pure and Applied Sciences, 13(2): 1 - 12

Received: November, 2020

Accepted: December, 2020

ISSN $2006-6996$

\title{
BIODEGRADATION POTENTIAL OF IMMOBILIZED BACTERIA IN THE TREATMENT OF TANNERY INDUSTRIAL EFFLUENTS FROM INDUSTRIAL ESTATES IN KANO STATE, NIGERIA
}

\author{
Abdullateef, B., ${ }^{1 *}$ Shuaibu, T. G., ${ }^{1}$ Babagana, K., ${ }^{1}$ Suleman, H. B. ${ }^{2}$ and Dauda, B. ${ }^{3}$ \\ ${ }^{1}$ Department of Pure and Applied Chemistry, Faculty of Science, University of Maiduguri, Borno State, \\ Nigeria \\ ${ }^{2}$ Department of Microbiology, Faculty of Science, University of Maiduguri, Borno State, Nigeria \\ ${ }^{3}$ Department of Chemical Engineering, Faculty of Engineering, University of Maiduguri, Borno State, \\ Nigeria \\ *Corresponding author: babslega@gmail.com; abelega2007@yahoo.com; +2348061309753
}

\section{ABSTRACT}

Industrial Effluents Samples from Gashash Tanneries (TAN1) in Bompai Industrial estate, Larabee Tannery Industry (TAN2) in Sharada Industrial estate and Z Tannery Industries (TAN3) in Challawa Industrial estate, Kano State, Nigeria were collected over a period of six months (August 2017 to January 2018) for assessing the biodegradation potentials of bacteria in the treatment of organic pollutants within the effluents. Bacteria were isolated from the effluents and immobilized on agar-agar. Different masses (5 g, $10 \mathrm{gr}, 15$ $\mathrm{g}, 20 \mathrm{~g}$, and $25 \mathrm{~g}$ ) of the bacteria were used in the treatment of $250 \mathrm{ml}$ of the effluents for ten days in a shaker incubator (Gallenkamp-OC-4364-L) at the temperature $30{ }^{\circ} \mathrm{C}$ and speed of $60 \mathrm{rpm}$. Pre-treatment analysis of the effluents for Temperature, pH, Biochemical Oxygen Demand (BOD), Chemical Oxygen Demand (COD), Suspended Solid (SS) and Total Dissolved Solids (TDS) gives the following results; temperature $\left({ }^{\circ} \mathrm{C}\right.$ )

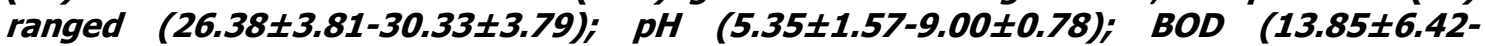
$38.75 \pm 16.20) ;$ COD (1406 $\pm 208-3532 \pm 1373) ;$ SS (208 $\pm 235-780 \pm 739)$ and TDS (266 $\pm 253-5276 \pm 2971)$. No statistical differences ( $p \leq 0.05)$ was observed for all the results among the different industries. The bacterial isolates were identified as Neisseria spp, Bacillus cereus, and Staphylococcus aureus, in TAN1, TAN2, and TAN3, respectively. After treatment of the effluent with the different masses of the isolated bacteria, the mean level of BOD was found to range as (0.55 $\pm 0.36-6.92 \pm 5.49) ; C O D$ (ND-3134 \pm 1595$)$;

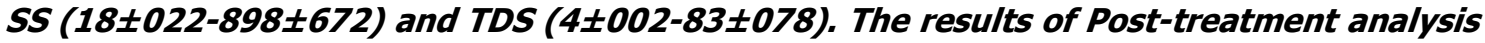
showed that there is overall decrease in the levels of the parameters determined when compared with that of the pre-treatment. The overall percentage reduction of the immobilised bacteria in the treatment of the respective effluents was in the order TAN2 (72\%)>TAN1 (70\%)>TAN3 (62\%). Hence, the immobilized bacteria are having higher biodegradation potential for the treatment of the tannery effluents.

Keywords: Biodegradation, bacteria, effluent, immobilization, tannery.

\section{INTRODUCTION}

Tannery industrial wastewater is a serious consequence of the pollution point of view for streams, freshwater, and land used for agriculture. The lack of awareness in the modern industrial practice has resulted in the discharge of tannery effluents which exhibit very high value of chromium ( $\mathrm{Cr}$ ), Sulfide, and chloride, Total Dissolved Solid (TDS), Total Suspended Solid (TSS), Biochemical Oxygen Demand (BOD) and Chemical Oxygen Demand (COD) in the water stream or land (Mohammed et al., 2001). Tanning is the process, which One ton of skin generally leads to the production of 20 to $80 \mathrm{~m}^{3}$ of turbid and foul-smelling converts the protein of the rawhide or skin into a stable material, which will not putrefy and is suitable for a wide variety of end applications (Elsheikh, 2009). The highly polluting chromium is the most commonly used tanning material producing leather that is more flexible and pliable than vegetable-tanned leather and does not discolor or lose shape in water as drastically as vegetable-tan (Elsheikh, 2009). Tannery effluent is among the most hazardous industrial pollutants due to its huge organic and inorganic load, which is highly toxic to human life and the environment (Kongjao et al., 2008). wastewater including chromium (100-400 mg/l), sulfide $(200-800 \mathrm{mg} / \mathrm{l})$, high levels of fat and 
BAJOPAS Volume 13 Number 2, December, 2020 other solid wastes, and notable pathogen contamination as well as pesticides added for skin conservation during transport (Elsheikh, 2009). There are more than 6000 tanneries in Nigeria with an annual processing capacity of 700,000 tons of hides and skins (Omoleke, 2004; Singh et al., 2008). It was reported that the total amount of waste produced per animal slaughtered is approximately $35 \%$ of its weight (World Bank, 1995). Also, for every $1000 \mathrm{~kg}$ of carcass weight, a slaughtered beef produces 5.5 $\mathrm{kg}$ of manure (excluding rumen contents or stockyard manure) and $100 \mathrm{~kg}$ of paunch manure (undigested food) (Verheijen et al., 1996). Tanneries generate wastewater in the range of 30-35 $\mathrm{L} \mathrm{kg}^{-1}$ skin/hide processed with variable $\mathrm{pH}$, Biological Oxygen Demand (BOD), Chemical Oxygen Demand (COD), high concentrations of suspended solids (SS), and tannins as well as chromium (Zahoor and Abdul, 2009).

Being heterogeneous and composed of a wide variety of compounds, it is very difficult to select a unique direct method for estimating the biodegradability of organic contents and biokinetic parameters for a wastewater sample (Rajor, 2004). For this purpose, some indirect estimation such as determination of biochemical oxygen demand (BOD) and chemical oxygen demand (COD) are applied as common laboratory investigations [9]. During retanning procedures, synthetic tannins (Syntan), oils and resins are added to form softer leather at varying doses (Munz et al., 2009). One of the refractory groups of chemicals in tannery effluents derives mainly from tannins (Ramasami et al., 2004). Syntans are characterized by complex chemical structures, because they are composed of an extended set of chemicals such as phenol-, naphthalene-, formaldehyde- and melamine-based syntans, and acrylic resins (Beem, 1994). Organic pollutants (proteic and lipidic components) are originated from skins (it is calculated that the raw skin has $30 \%$ loss of organic material during the working cycle) or they are introduced during processes (Hugo Springer, 1994).

Many conventional processes such as oxidation, chemical and biological processes were carried out to treat tanneries wastewater (Ebtesam et al, 2013). Biological processes have received more attention because of their costeffectiveness, lower sludge production and environmental friendliness (Noorjahan, 2014). Naturally occurring micro-organisms degrade the hazardous organic wastes including xenobiotic compounds, such as pesticides, polycyclic aromatic hydrocarbons (PAHs) and polychlorinated biphenyls (PCBs) in due course of time (Ranen and Sharadinadra, 2009). Bioremediation is based on the idea that all organisms remove substances from the environment to carry outgrowth and metabolism (Bouwer and Zehnder, 1993). Bacteria, protista and fungi are found to be very good at degrading complex molecules and incorporating the breakdown products into their metabolism (Bouwer and Zehnder, 1993). The resultant metabolic wastes that they produce are generally safe and somehow recycled into other organisms (Ranen and Sharadinadra, 2009). An acclimatized indigenous population of microorganisms capable of degradation of the compounds of interest must exist at the site for a successful bioremediation mode (Ranen and Sharadinadra, 2009). It has been observed that for a successful bioremediation mode, an acclimatized indigenous population of microorganisms capable of degradation of the compounds of interest must exist at the site under investigation (Ranen and Sharadinadra, 2009). Even though there are numerous physical and chemical methods employed in the disposal of wastes the advantage in using bacterium is that they play a key role in the reduction of COD, BOD, total protein, total tannin and total phenol (Saravanan and Saravanan, 1998)

Baba et al. (2020) studied the bioremediation potential of immobilized corynebacterium kutsceri in the Treatment of tannery industrial effluent from Challawa Industrial Estate, Kano State, Nigeria. The aim of the work is to study the reduction in the level of the contaminants through the process of bioremediation using the isolated bacteria. Immobilized bacteria can withstand various temperatures, $\mathrm{pH}$ and substrate concentrations; consequently, increasing the efficiency and the lifespan of the bacteria. Immobilized bacteria are widely applied in the treatment of wastewater and can be separated and recovered after the treatment with the same efficiency (Baba et al., 2020).

\section{MATERIALS AND METHODS \\ Study Area}

This study was carried out in Bompai, Sharada and Challawa industrial estates in Kano, Figure 1. Kano lies on Latitude $11^{\circ} 30^{\prime} \mathrm{N}$ and $8^{\circ} 30^{\prime} \mathrm{E}$ and Longitude $11^{\circ} 5^{\prime} \mathrm{N}$ and $8^{\circ} 5^{\prime} \mathrm{E}$ in Northern Nigeria. It is one of the developed industrial cities in Nigeria. Tannery activities are the dominating industries and this could be one of the reasons for her high population density (Dan'Azumi and Bichi, 2010). Many researchers have studied biodegradation of tannery effluent using microorganisms. However, limited literature is available on the biodegradation of tannery effluent in Kano industrial estates using 
BAJOPAS Volume 13 Number 2, December, 2020 immobilized bacterial cells. This research work focuses on the potential of the use of the indigenous immobilized bacterial isolates in the treatment of tannery effluents in the industrial estates.

\section{Sample Collection}

Effluents were collected from the Tannery Industries from Bompai, Challawa and Sharada Industrial Estates, Kano, Nigeria. The effluents were collected over a period of six months (August 2017 to January 2018). Samples collected in a sterile 4-liter plastic container with a unique identification number were preserved using an ice-box that was transported to the Microbiology Laboratory, Department of Microbiology, Bayero University of Kano for analysis

\section{Sample Preparation and Sample Analysis}

Immediately after the collection of the effluent, $\mathrm{pH}$, TSS, TDS, COD, BOD levels were determined before treatment (Pre-treatment determination) and ten days after treatment (Post-treatment determination) as described in
APHA (1989) standard methods. $\mathrm{pH}$ was determined using Ecotests $\mathrm{pH}$ meter and TDS was determined using AQUALYTIC TDS Salinometer. BOD was determined as described by the standard method (APHA, 1992). COD and SS were determined using DR/2010 HACH portable data logging spectrophotometer (DWAF, 1992)

\section{Identification and Biochemical} Characterization of the Bacterial Isolates

The bacteria were isolated from the effluents using Serial Dilution according to the method described by APHA (1989). The biochemical tests such as oxidase, catalase, coagulase, indole (from $1 \%$ tryptone broth), citrate (Simmons citrate agar), methyl red/VogesProskauer (MR/VP), nitrate reduction, Starch Hydrolysis, Glucose, Maltose, and Lactose tests were carried out on the bacterial isolates to identify the bacteria through the bacteria biochemical characteristics according to Ajao et al. (2011).

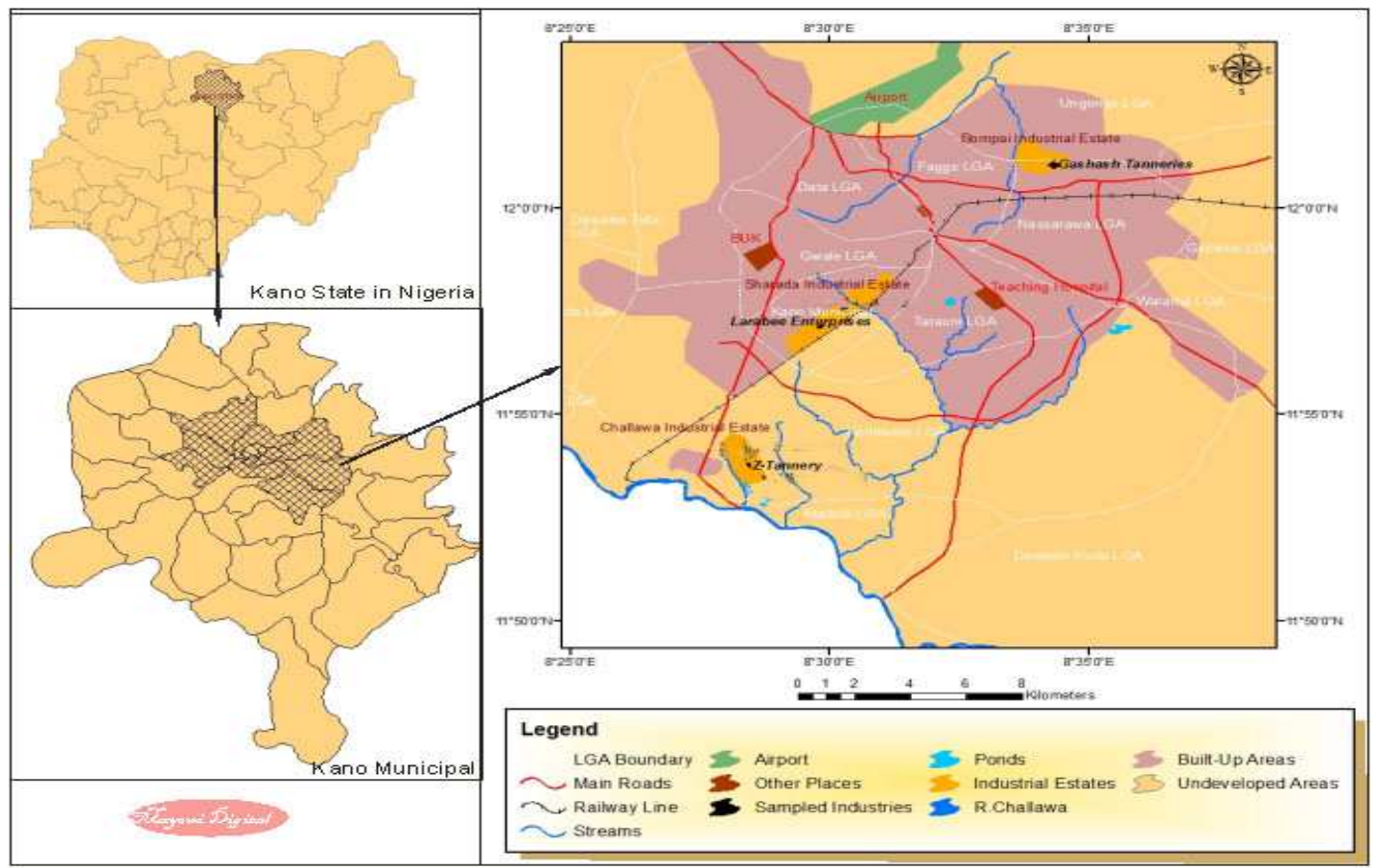

Fig. 1 Map showing the study areas

Source: Mayomi Digital Productions, GIS Laboratory, Department of Geography, UNIMAID (2017)

\section{Determination of Growth Rate of the Bacteria in Effluent Sample}

The bacteria growth rates were determined by transferring $2 \mathrm{~mL}$ of the bacterial isolates from the tannery effluent in broth medium into 100 $\mathrm{mL}$ sterile effluents in conical flasks and kept in an incubator (Giffrin cool) for 10 days. Control was also set up by incubating another $100 \mathrm{~mL}$ each of the sterile effluents without the bacteria. The optical density of the content was determined at the wavelength of $600 \mathrm{~nm}$ on a daily interval and recorded. 
BAJOPAS Volume 13 Number 2, December, 2020 Immobilization of Bacteria

Agar solution and inoculi were prepared separately. Fifty milliliters $(50 \mathrm{~mL})$ of nutrient broth each of the inoculi was prepared in a McCartney bottle and incubated for 24 hours. A solution of agar-agar was prepared by dissolving $10 \mathrm{~g}$ of the powder in distilled water and made up to $500 \mathrm{~mL}$ mark in an Erlenmeyer flask and was sterilized in an autoclave (280A) for 15 minutes and allowed to cool to $40-45^{\circ} \mathrm{C}$ (Ajao et al., 2011). Four milliliters ( $4 \mathrm{~mL})$ of the bacterial isolates in the nutrient broth was mixed with 36 $\mathrm{ml}$ of the prepared agar-agar media in petri-dish plates and then allowed to solidify. This was kept in the refrigerator for bioremediation.

\section{Bioremediation (Treatment) of the Effluents}

The solidified agar block (immobilized bacteria) was cut into cubes using a sterile knife; $0.1 \mathrm{~mL}$ phosphate buffer ( $\mathrm{pH} \mathrm{7.0)}$ was added and kept in the refrigerator for 1 hour for curing. The phosphate buffer was decanted after 1 hour and the cubes were washed with sterile distilled water 3-4 times before it was used (Ajao et al., 2011). Two liters (2 L) of the effluent was supplemented with the minimum basal medium in $\mathrm{g} / \mathrm{L}: \mathrm{NaCl}(0.8), \mathrm{MgSO}_{4} .7 \mathrm{H}_{2} \mathrm{O}(0.001), \mathrm{KH}_{2} \mathrm{PO}_{4}$ (2), $\mathrm{NaNO}_{3}$ (2), $\quad \mathrm{CaCl}_{2} .2 \mathrm{H}_{2} \mathrm{O} \quad(0.5)$ and $\mathrm{NaHPO}_{4} .12 \mathrm{H}_{2} \mathrm{O}(2)$ and sterilized in an autoclave at $121^{\circ} \mathrm{C}$ for 15 minutes (Margesin and Schinner, 2001). Two hundred and fifty milliliters $(250 \mathrm{~mL})$ of the effluents were transferred into different $250 \mathrm{ml}$ conical flasks. The content was covered with a cotton-wool ramped with foil paper to avoid contamination. Five grams $(5 \mathrm{~g})$ of the immobilized bacteria were quickly transferred into each of the effluents in the conical flasks in an inoculating chamber. The same procedures were carried out for the $10 \mathrm{~g}, 15 \mathrm{~g}, 20 \mathrm{~g}$ and 25 $\mathrm{g}$ of the immobilized bacteria in separate $250 \mathrm{~mL}$ effluents in conical flasks and agitated for ten days in a shaker incubator (Gallenkamp-OC4364-L) at a temperature $30^{\circ} \mathrm{C}$ and speed of 60 rpm. The treated effluent samples were taken on the tenth day and analyzed for the parameters $\mathrm{pH}$, SS, TDS, COD, and BOD, (Posttreatment determination) for the different grams of bacteria to evaluate and compare the biodegradation potential. (Baba et al., 2020).

\section{Statistical Analysis}

The data were represented as Mean \pm Standard deviation and analyzed statistically using oneway Analysis of Variance (ANOVA) and Tukey's HSD as Post Hoc Tests with the aid of SPSS 16.0. The correlation coefficient was also used to measure the strength of the relationship between the different masses of the bacteria and the parameters. All $\mathrm{p} \leq 0.05$ were considered as statistically significant.

\section{RESULTS AND DISCUSSION Physico-chemical parameters in the Industrial Effluents before the Biodegradation.}

Results of the Physico-chemical parameters in the industrial effluents before the Biodegradation is shown in table 1 . The mean temperatures $\left({ }^{\circ} \mathrm{C}\right)$ observed in TAN1, TAN2, and TAN3 samples were $28.07 \pm 0.65 ; 27.77 \pm 0.64$ and $26.38 \pm 3.81$ respectively. The order of the mean temperature of the samples from the three industries can be arranged as TAN1 > TAN2>TAN3. The temperature observed at TAN1, TAN2, and TAN3 samples were found below the WHO $\left(35^{\circ} \mathrm{C}\right)$ and NESREA $\left(40^{\circ} \mathrm{C}\right)$ limits. The low values of temperature might be due to the processes used at the time of sampling. High temperature brings down the solubility of gases in water that ultimately expresses as high BOD and COD. Statistical analysis shows that there is no significant difference $(p<0.05)$ between the mean values of temperature among the industries. This might be due to similar tannery activities involved in the tannery industries at the time of sampling. The average values of temperature observed in this present study are less than those observed by Akan et al. (2007), Akan et al. (2009) and Baba et al. (2020).

The mean level of $\mathrm{pH}$ observed in TAN1, TAN2 and TAN3, samples were $7.77 \pm 2.93$; $8.35 \pm 0.28$ and $7.52 \pm 0.76$ respectively. The order of the mean $\mathrm{pH}$ of the samples from the three industries can be arranged as TAN2> TAN1 $>$ TAN3. The $\mathrm{pH}$ of the samples falls within the WHO (7.0-8.5) and NESREA (6-9) standard limits. Statistical analysis shows that there is no significant difference $(p<0.05)$ between the mean values of $\mathrm{pH}$ among the industries. This might be due to similar tannery activities involved in the tannery industries at the time of sampling. Maheshwari et al. (2017) reported that the level of $\mathrm{pH}$ in the effluents from the tannery industry in Vaniyambadi, India was 6.5 which was lower than that observed in the present study. The $\mathrm{pH}$ in the effluents from the tannery industries in Kano and Kaduna were reported to be 7.64 and 6.89, respectively (Akan et al., 2007; Mohammed et al., 2017). The average values of $\mathrm{pH}$ observed in this present study are less than those observed by Mohammed et al. (2017) and Baba et al. (2020). The mean level of SS $(\mathrm{mg} / \mathrm{l})$ observed in TAN1, TAN2, and TAN3 samples were 374 \pm 124 ; $358 \pm 335$ and $780 \pm 739$ respectively. The order of the mean SS in the samples from the three industries can be arranged as TAN3 > TAN1 $>$ TAN2. 
The SS observed in the samples were far above the recommended standard limits of regulating bodies WHO $(30 \mathrm{mg} / \mathrm{l})$ and NESREA $(10 \mathrm{mg} / \mathrm{l})$. Statistical analysis shows that there is no significant difference $(p<0.05)$ between the mean values of SS among the industries. This might be due to similar tannery activities involved in the tannery industries at the time of sampling. The average values of SS observed in this present study are less than that observed $(3700 \pm 122 \mathrm{mg} / \mathrm{l})$ by Akan et al. (2009) for tanneries in Kano. Also, the average values of SS observed in this present study are less than that observed by Mohammed et al. (2017) and Baba et al. (2020) with the exception in TAN3.

The mean level of TDS (mg/l) observed in TAN1, TAN2, and TAN3 samples were $3941 \pm 3703$; $3300 \pm 1714$ and $2653 \pm 1240$ respectively. The order of the mean TDS in the samples from the three industries can be arranged as TAN1>TAN2>TAN3. The TDS observed in the samples were far above the recommended standard limits of WHO $(250 \mathrm{mg} / \mathrm{l})$ and NESREA $(500 \mathrm{mg} / \mathrm{l})$. Statistical analysis shows that there is no significant difference $(p<0.05)$ between the mean values of TDS among the industries. This might be due to similar tannery activities involved in the tannery industries at the time of sampling. TDS in the effluents from the tannery industries in Kano, Nigeria was reported to be $1281 \mathrm{mg} / \mathrm{l}$ (Akan et al., 2007). The average values of SS observed in this present study are less than those observed by Mohammed et al. (2017) and Baba et al. 2020)

The mean level of COD (mg/l) observed in TAN1, TAN2 and TAN3 samples seasons were $2372 \pm 938 ; \quad 1406 \pm 208$ and $3532 \pm 1373$ respectively. The order of the mean COD of the samples from the three industries can be arranged as TAN3>TAN1> TAN2. The COD observed in TAN1, TAN2 and TAN3 samples were far above the recommended standard limits of regulating bodies $\mathrm{WHO}(40 \mathrm{mg} / \mathrm{l})$ and NESREA (40 mg/l). Statistical analysis shows that there is no significant difference $(p<0.05)$ in COD among the industries. This might be due to similar tannery activities involved in the tannery industries as at the time of sampling. The Chemical Oxygen demand (COD) is the amount of oxygen, in $\mathrm{mg} / \mathrm{L}$, required for the degradation of the compound of wastewater to occur. In comparison, the average values of COD observed in this present study were higher than that observed by Mohammed et al. (2017) but lower than that observed by Baba et al. (2020).

The mean levels of BOD $(\mathrm{mg} / \mathrm{l})$ observed in TAN1, TAN2 and TAN3 samples were $13.85 \pm 6.42 ; \quad 19.46 \pm 0.50$ and $17.13 \pm 3.14$ respectively. The order of the mean BOD in the samples from the three industries can be arranged as TAN2>TAN3>TAN1. The BOD observed in TAN1, TAN2 and TAN3 samples were found below the recommended limits of NESREA (200 mg/l) but above WHO (10 mg/l). Statistical analysis shows that there is no significant difference $(p<0.05)$ between the mean values of BOD among the industries. This might be due to similar tannery activities involved in the tannery industries at the time of sampling. The low level of BOD recorded in this study is an indication of the low level of biodegradable organic solids in the effluent. The average values of BOD observed in this present study were lower than those observed by Mohammed et al. (2017) and Baba et al. (2020).

Table 1: Mean Values \pm S.D of Physico-chemical parameters of effluents from the Tannery Industries before Treatment.

\begin{tabular}{llllllll}
\hline Parameter & Tannery 1 & Tannery 2 & Tannery 3 & $\mathrm{a}$ & $\mathrm{b}$ & $\mathrm{c}$ & $\mathrm{d}$ \\
\cline { 2 - 7 } Temperature $\left({ }^{\circ} \mathrm{C}\right)$ & $28.07 \mathrm{a} \pm 0.65$ & $27.77 \mathrm{a} \pm 0.64$ & $26.38 \mathrm{a} \pm 3.81$ & & $29.50 \pm 4.68$ & 35 & 40 \\
pH & $7.77 \mathrm{a} \pm 2.93$ & $8.35 \mathrm{a} \pm 0.28$ & $7.52 \mathrm{a} \pm 0.76$ & 6.89 & $5.35 \pm 1.57$ & $7.0-8.5$ & $6.0-9.0$ \\
$\mathrm{COD}(\mathrm{mg} / \mathrm{l})$ & $2372 \mathrm{a} \pm 938$ & $1406 \mathrm{a} \pm 208$ & $3532 \mathrm{a} \pm 1373$ & 2.2 & $3106 \pm 2753$ & 40 & 40 \\
$\mathrm{BOD}(\mathrm{mg} / \mathrm{l})$ & $13.85 \mathrm{a} \pm 6.42$ & $19.46 \mathrm{a} \pm 0.50$ & $17.13 \mathrm{a} \pm 3.14$ & 1032 & $26.17 \pm 9.49$ & 10 & 200 \\
$\mathrm{SS}(\mathrm{mg} / \mathrm{l})$ & $374 \mathrm{a} \pm 124$ & $358 \mathrm{a} \pm 335$ & $780 \mathrm{a} \pm 739$ & 501 & $562 \pm 482$ & 30 & 10 \\
TDS $(\mathrm{mg} / \mathrm{l})$ & $3941 \mathrm{a} \pm 3703$ & $3300 \mathrm{a} \pm 1714$ & $2653 \mathrm{a} \pm 1240$ & 532.7 & $444 \pm 507$ & 250 & 500 \\
\hline
\end{tabular}

The values given in the table above are means of 6 replicate values, $\mathrm{n}=6$ ( 1 sample was taken monthly for 6 months). Within the rows, means with different alphabets are statistically different $(p<0.05)$. WHO: World Health Organisation. NESREA: National Environmental Standard and Regulatory Enforcement Agency. a = Mohammed et al.(2017), b = Baba et al. (2020), c = WHO (2006), $d=$ NESSRA (2009) 
BAJOPAS Volume 13 Number 2, December, 2020

Identification, Biochemical Characterization and growth rates of the Bacterial Isolates

Results of identification and biochemical characterization of the bacterial isolates were shown in table 2. After 24 hours of incubation, the nutrient agar media plates were checked for bacterial growth. The results showed the presence of different strains in the samples. The TAN1 bacteria isolate was found to be gramnegative cocci while TAN3 was gram-positive cocci. TAN2 bacteria isolate was found to be gram-positive, rod-shaped. TAN1, TAN2, and TAN3 bacteria isolates recorded positive results for spore former.

The results of the biochemical tests indicated that all the bacteria were positive for catalase, oxidase, citrate, maltose, glucose, lactose (negative in TAN1), mannitol (negative in TAN2), starch hydrolysis and coagulase (negative in TAN2) tests. The bacteria showed negative results for nitrate reduction, $M R$ (positive in TAN2), VP (positive in TAN1), Indole (positive in TAN2) tests. Base on the morphological and biochemical test results, TAN1, TAN2, and TAN3 bacteria isolates were identified to be Nesseria spp, Bacillus cereus, and Staphylococcus aureus respectively.

The growth rate of the TAN1, TAN2 and TAN3 Isolates were shown in figure 2. Generally, the optical density increase with the increase in time (day) and decrease as time goes on. The highest optical density was shown by bacillus cereus in TAN2 while the lowest was shown by Staphylococcus aureus in TAN3.

The initial growth phase of TAN1 Isolate bacteria occurred within 2-day of incubation as the growth rate increases up to the 6th-day incubation when the maximum growth was observed. Beyond the 6th day, the growth of the bacteria declined (which might be due to a shortage of nutrients in the effluents) until it reached its death phase (which might be due to the unavailability of nutrients in the effluents).

A similar trend of growth was also observed for TAN2 Isolate as the initial growth phase also occurred within 2-day of incubation but maximum growth rate observed on the 4th day of incubation. The stationary stage occurred between the 4th day and the 8th day. Beyond the 8th day, the growth of the bacteria declined (which might be due to a shortage of nutrients in the effluents) until it reached its death phase (which might be due to the unavailability of nutrients in the effluents).

The initial growth phase of TAN3 bacterial Isolate occurred within the 3-day incubation as the growth rate increases up to the 6th-day incubation when the maximum growth was observed. Beyond the 6th day, the growth of the bacteria declined (which might be due to a shortage of nutrients in the effluents) until it reached its death phase (which might be due to the unavailability of nutrients in the effluents).

Table 2: Morphological and Biochemical characteristics of bacterial isolates

\begin{tabular}{lllll} 
Bacterial Isolates & & TAN1 & TAN2 & TAN3 \\
\hline $\begin{array}{lllll}\text { Morphological } \\
\text { characteristics }\end{array}$ & Shape & Cocci & Rod & Cocci \\
& Spore & & & \\
& former & + & + & + \\
Gram & & & \\
Biochemical characteristics & reaction & - & + & + \\
& Citrate & + & + & + \\
& Catalase & + & + & + \\
& Coagulase & + & - & + \\
Starch & + & + & + \\
& Glucose & + & + & + \\
Oxidase & + & + & + \\
& Indo & - & + & - \\
Lactose & - & + & + \\
Manitol & + & - & + \\
Maltose & + & + & + \\
MR & - & + & - \\
VP & + & - & - \\
& Nitrate & - & - & - \\
Reduction & - Neisseria & Bacillus & Staphylococcus \\
& Bacterial & cereus & aureus \\
& name & spp & cas
\end{tabular}

+ = Positive; - = Negative; MR=Methyl Red; VP= Voges-Proskauer 


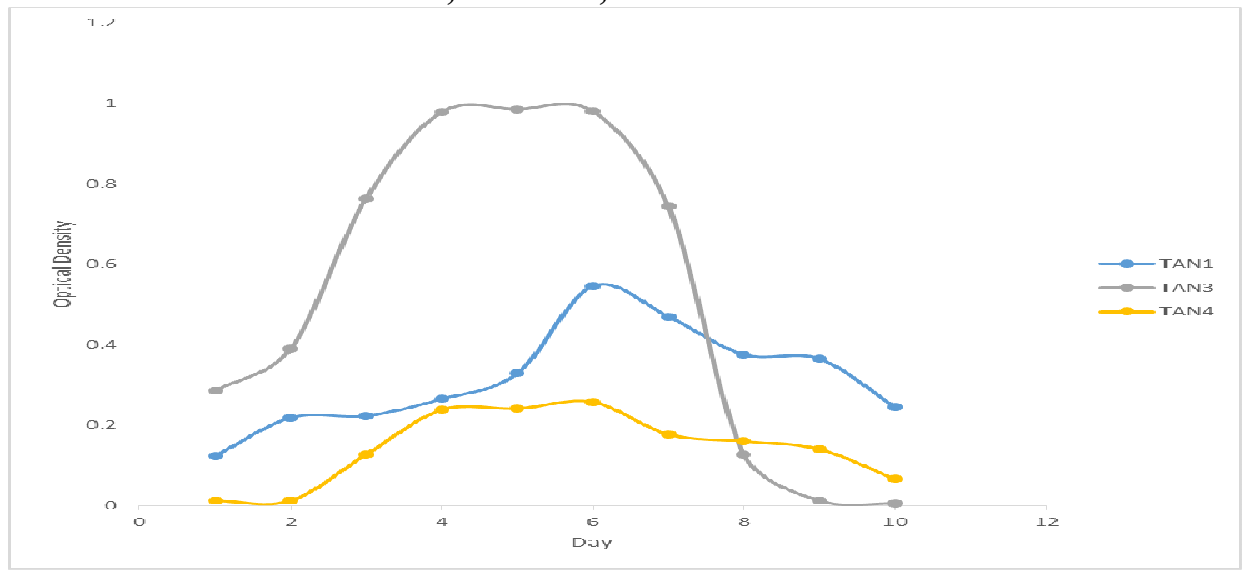

Fig. 2 Growth rates of the isolates in the effluents from the Tannery Industries

\section{Physico-chemical Parameters in the Industrial Effluents after the biodegradation.}

Table 3 shows the mean results of the physicochemical parameter before and after bioremediation using the different masses $(5 \mathrm{~g}$, $10 \mathrm{~g}, 15 \mathrm{~g}, 20 \mathrm{~g}$, and $25 \mathrm{~g}$ ) of the respective immobilized bacteria. Also, Table 4 shows the mean results of correlation coefficient ( $r$ ) between different masses of bacteria and physicochemical parameters.

The mean values $(\mathrm{mg} / \mathrm{l})$ of the SS after the bioremediation varies between $243 \pm 45$ and $898 \pm 672$. The mean concentration $(\mathrm{mg} / \mathrm{l})$ of SS remediated by the different masses $(5 \mathrm{~g}, 10 \mathrm{~g}$, $15 \mathrm{~g}, 20 \mathrm{~g}$, and $25 \mathrm{~g}$ ) of the bacteria varies. The SS in the samples fluctuates up and down after the bioremediation process when compared with the SS of the raw samples before the bioremediation. The increase in the levels of the SS might be due to the aggregation of the TDS which are large enough to result into SS. The increase in the levels of the SS might be also due to the influence of the nutrients which was added into the effluents in order to make the microorganisms more active and viable for fast degradation of organic contaminants in the effluent. The relative potential or efficiency of the different masses of the bacteria in remediating SS in TAN1 samples was in the order $25 \mathrm{~g}>20 \mathrm{~g}>15 \mathrm{~g}>10 \mathrm{~g}>5 \mathrm{~g}$. For TAN2 and TAN3 samples, the order was $25 \mathrm{~g}>20 \mathrm{~g}>15$ $\mathrm{g}>10 \mathrm{~g}>5 \mathrm{~g}$. These might be due to the variations in the surface areas of the different masses of the immobilized bacteria. Statistical analysis shows that there is no significant difference $(p<0.05)$ between the mean values of SS among the masses in the respective industries. Positive and significant correlations exist between the masses of bacteria and Suspended Solid (SS). This showed that there is general increase in the levels of the SS as the masses of the immobilized bacteria increases. TAN3 (90\%) and TAN1 (80\%) showed a very high correlation with the masses of the bacteria while TAN2 (61\%) showed a very low correlation.

The mean values $(\mathrm{mg} / \mathrm{l})$ of the TDS after the bioremediation varies between $46 \pm 11$ and $83 \pm 78$. The mean concentration $(\mathrm{mg} / \mathrm{l})$ of TDS remediated by the different masses $(5 \mathrm{~g}, 10 \mathrm{~g}$, $15 \mathrm{~g}, 20 \mathrm{~g}$, and $25 \mathrm{~g}$ ) of the bacteria varies. There is a reduction in all the TDS of all the samples after the bioremediation process compared with the TDS of the raw samples before the bioremediation. The relative potential or efficiency of the different masses of the bacteria in remediating TDS in TAN1 and TAN3 samples was in the order $5 \mathrm{~g}>10 \mathrm{~g}>15 \mathrm{~g}>20$ $\mathrm{g}>25 \mathrm{~g}$. For TAN2 samples, the order was 20 $g>10 \quad g>25 \quad g>15 \quad g>5 \quad g$. Statistical analysis shows that there is no significant difference $(p<0.05)$ between the mean values of TDS among the masses in the respective industries. These might be due to the variations in the surface areas of the different masses of the immobilized bacteria. Positive and significant correlations exist between the masses of bacteria and TDS with the exception in TAN2 (negative and insignificant correlation). The positive correlations showed that there is general increase in the levels of the TDS as the masses of the immobilized bacteria increases. TAN1 $(96 \%)$ showed a very high correlation with the masses of the bacteria while TAN2 (47\%) showed a very low correlation.

The mean values $(\mathrm{mg} / \mathrm{l})$ of the BOD after the bioremediation varies between $1.56 \pm 0.20 \mathrm{mg} / \mathrm{l}$ and $6.92 \pm 5.49 \mathrm{mg} / \mathrm{l}$. The mean concentration $(\mathrm{mg} / \mathrm{l})$ of BOD remediated by the different masses $(5 \mathrm{~g}, 10 \mathrm{~g}, 15 \mathrm{~g}, 20 \mathrm{~g}$, and $25 \mathrm{~g}$ ) of the bacteria varies. There is a reduction in all the BOD of all the samples after the bioremediation process compared with the $\mathrm{BOD}$ of the raw 
BAJOPAS Volume 13 Number 2, December, 2020 samples before the bioremediation. The relative potential or efficiency of the different masses of the bacteria in remediating BOD in TAN1, TAN2 and TAN3 samples were in the order $25 \mathrm{~g}>20$ $\mathrm{g}>15 \mathrm{~g}>10 \mathrm{~g}>5 \mathrm{~g}, 25 \mathrm{~g}>15 \mathrm{~g}>5 \mathrm{~g}>10 \mathrm{~g}>20 \mathrm{~g}$ and $20 \mathrm{~g}>10 \mathrm{~g}>25 \mathrm{~g}>15 \mathrm{~g}>5 \mathrm{~g}$ respectively. Statistical analysis shows that there is significant difference $(p<0.05)$ between the mean values of BOD among the masses in the respective industries. These might be due to the variations in the surface areas of the different masses of the immobilized bacteria. Negative and significant correlations exist between the masses of bacteria and BOD. This showed that there is general decrease in the levels of the BOD as the masses of the immobilized bacteria increases. TAN1 (94\%) showed a very high correlation with the masses of the bacteria while TAN2 (4\%) showed a very low correlation.

The mean values $(\mathrm{mg} / \mathrm{l})$ of the COD after the bioremediation varies between $250 \pm 154$ and $3134 \pm 1595$. The mean concentration $(\mathrm{mg} / \mathrm{l})$ of COD remediated by the different masses $(5 \mathrm{~g}$, $10 \mathrm{~g}, 15 \mathrm{~g} 20 \mathrm{~g}$, and $25 \mathrm{~g}$ ) of the bacteria varies. There is a reduction in all the COD of all the samples after the bioremediation process compared with the COD of the raw samples before the bioremediation. The relative potential or efficiency of the different masses of the bacteria in remediating COD in TAN1, TAN2 and TAN3 samples were in the order $25 \mathrm{~g}>20 \mathrm{~g}>15$ $\mathrm{g}>5 \mathrm{~g}>10 \mathrm{~g}, 25 \mathrm{~g}>20 \mathrm{~g}>15 \mathrm{~g}>10 \mathrm{~g}>5 \mathrm{~g}$ and 10 g>5 g>25 g>15 g>20 g respectively. Statistical analysis shows that there were significant difference $(p<0.05)$ between the mean values of COD among the masses in the respective industries except for effluents treated with $25 \mathrm{~g}$. These might be due to the variations in the surface areas of the different masses of the immobilized bacteria. Negative and insignificant correlations exist between the masses of bacteria and COD with the exception in TAN3 (positive and significant correlation). The negative correlations showed that there is general decrease in the levels of the COD as the masses of the immobilized bacteria increases. TAN2 (100\%) showed a very high correlation with the masses of the bacteria while TAN3 (36\%) showed a very low correlation.

Generally, there was an overall decrease in the concentration of these physicochemical parameters after the bioremediation using the different masses of the bacterial isolates. These might be due to the variations in the surface areas of the different masses of the immobilized bacteria. This is in line with the work of Jimoh et al. (2018) and Baba et al. (2020).

Table 3: Mean Values $(\mathrm{mg} / \mathrm{l}) \pm$ S.D of Physicochemical parameters in effluents from the Tannery Industries before and after Treatment of the effluents $(250 \mathrm{ml})$ with the different masses $(5 \mathrm{~g}, 10 \mathrm{~g}$, $15 \mathrm{~g}, 20 \mathrm{~g}$, and $25 \mathrm{~g}$ ) of the bacteria.

\begin{tabular}{llllllll}
\hline $\mathrm{P}$ & IND & Before & \multicolumn{5}{c}{ After } \\
\cline { 4 - 7 } & & & $5 \mathrm{~g}$ & $10 \mathrm{~g}$ & $15 \mathrm{~g}$ & $20 \mathrm{~g}$ & $25 \mathrm{~g}$ \\
\hline \multirow{2}{*}{ COD } & TAN1 & $2372 \pm 938$ & $1708 \mathrm{a} \pm 861$ & $2045 \mathrm{a} \pm 1205$ & $845 \mathrm{a} \pm 369$ & $300 \mathrm{a} \pm 167$ & $250 \mathrm{a} \pm 154$ \\
& TAN2 & $1406 \pm 208$ & $1195 \mathrm{a} \pm 208$ & $1125 \mathrm{a} \pm 384$ & $1055 \mathrm{a} \pm 317$ & $956 \mathrm{a} \pm 310$ & $870 \mathrm{ab} \pm 240$ \\
& TAN3 & $3532 \pm 1373$ & $2374 \mathrm{a} \pm 1344$ & $1976 \mathrm{a} \pm 1405$ & $2757 \mathrm{a} \pm 1266$ & $3134 \mathrm{a} \pm 1595$ & $2614 \mathrm{~b} \pm 1105$ \\
BOD & TAN1 & $13.85 \pm 6.42$ & $6.92 \mathrm{a} \pm 5.49$ & $6.42 \mathrm{a} \pm 5.07$ & $5.72 \mathrm{a} \pm 5.35$ & $4.62 \mathrm{a} \pm 4.37$ & $2.82 \mathrm{ab} \pm 1.26$ \\
& TAN2 & $19.46 \pm 0.50$ & $1.75 \mathrm{~b} \pm 0.22$ & $1.73 \mathrm{~b} \pm 0.18$ & $1.58 \mathrm{a} \pm 0.16$ & $1.91 \mathrm{a} \pm 0.22$ & $1.56 \mathrm{~b} \pm 0.20$ \\
& TAN3 & $17.13 \pm 3.14$ & $4.24 \mathrm{ab} \pm 0.77$ & $3.29 \mathrm{ab} \pm 0.37$ & $4.11 \mathrm{a} \pm 0.07$ & $3.23 \mathrm{a} \pm 0.91$ & $3.33 \mathrm{a} \pm 1.28$ \\
SS & TAN1 & $374 \pm 124$ & $243 \mathrm{a} \pm 45$ & $471 \mathrm{a} \pm 226$ & $475 \mathrm{a} \pm 182$ & $492 \mathrm{a} \pm 128$ & $611 \mathrm{a} \pm 217$ \\
& TAN2 & $358 \pm 335$ & $460 \mathrm{a} \pm 400$ & $543 \mathrm{a} \pm 414$ & $544 \mathrm{a} \pm 402$ & $551 \mathrm{a} \pm 414$ & $554 \mathrm{a} \pm 405$ \\
& TAN3 & $780 \pm 739$ & $586 \mathrm{a} \pm 594$ & $758 \mathrm{a} \pm 656$ & $787 \mathrm{a} \pm 676$ & $861 \mathrm{a} \pm 635$ & $898 \mathrm{a} \pm 672$ \\
TDS & TAN1 & $3941 \pm 3703$ & $51 \mathrm{a} \pm 10$ & $53 \mathrm{a} \pm 10$ & $55 \mathrm{a} \pm 15$ & $61 \mathrm{a} \pm 20$ & $63 \mathrm{a} \pm 26$ \\
& TAN2 & $3300 \pm 1714$ & $83 \mathrm{a} \pm 78$ & $47 \mathrm{a} \pm 20$ & $48 \mathrm{a} \pm 22$ & $47 \mathrm{a} \pm 17$ & $48 \mathrm{a} \pm 17$ \\
& TAN3 & $2653 \pm 1240$ & $46 \mathrm{a} \pm 11$ & $55 \mathrm{a} \pm 24$ & $55 \mathrm{a} \pm 25$ & $58 \mathrm{a} \pm 23$ & $61 \mathrm{a} \pm 28$ \\
\hline
\end{tabular}

Replicate $=6$ (months)

Within the rows, for the same parameter, means with different alphabets are statistically different $(p<0.05)$.

$\mathrm{P}=$ parameter, IND = Industries 
BAJOPAS Volume 13 Number 2, December, 2020

Table 4: Correlation coefficient $(r)$ between different masses of the bacteria and the physicochemical parameters.

\begin{tabular}{llll}
\hline Industries & Parameter & Correlation coefficient $(r)$ & $\begin{array}{l}\text { Percent dependence (rxrx100) } \\
(\%)\end{array}$ \\
\hline TAN1 & COD & -0.9 & 82 \\
& BOD & -0.97 & 94 \\
& SS & $0.90^{*}$ & 80 \\
TAN2 & TDS & $0.98^{*}$ & 96 \\
& COD & -1 & 100 \\
& BOD & -0.21 & 4 \\
& SS & $0.78^{*}$ & 61 \\
& TDS & -0.69 & 47 \\
& COD & $0.60^{*}$ & 36 \\
& BOD & -0.6 & 37 \\
& SS & $0.95^{*}$ & 90 \\
& TDS & $0.94^{*}$ & 89 \\
\hline
\end{tabular}

The correlation coefficient $(r)$ with * is statistically significant $(p<0.05)$.

Percentage reduction of the Parameters

Table 5 shows the percentage reduction of Parameters in industrial samples before and after the treatment of the effluents $(250 \mathrm{ml})$ with the different masses $(5 \mathrm{~g}, 10 \mathrm{~g}, 15 \mathrm{~g}, 20 \mathrm{~g}$, and $25 \mathrm{~g}$ ) of the Immobilized Bacteria.

In TAN1 samples, the percentage reduction (\%) of COD ranged (14-89); BOD (50-80); SS (-32$35)$ and TDS (98-99). In TAN2 samples, the percentage decrease $(\%)$ of COD ranged (15$38) ;$ BOD (90-92); SS [-28-(-55)] and TDS (9798). In TAN3 samples, the percentage decrease (\%) of COD ranged (11-44); BOD (76-81); SS (15-25) and TDS (98). The percentage increase in the levels COD, BOD and TDS might be due to the increase in the surface area of the different masses of the immobilized bacteria. However, the percentage decrease in the levels of the SS might be due to the aggregation of the TDS which are large enough to result into SS. The percentage decrease in the levels of the SS might be also due to the influence of the nutrients which was added into the effluents in order to make the microorganisms more active and viable for fast degradation of organic contaminants in the effluent. This is in line with the work of Jimoh et al. (2018) in which the concentration of the SS increase after the bioremediation of effluents.

Sreemoyee and Priti (2013) assessed and reduced several Physico-chemical parameters of dairy wastewater using Niesseria $s p$. and concluded that the species are well known to degrade organic compounds. This is in agreement with the current study in which the immobilized Niesseria $s p$ degrade the organic contaminants as indicated by the BOD, COD and TDS.

Jimoh et al. (2018) observed that TSS of the effluents was increased after treatment with immobilized bacteria and concluded that it might be due to the biostimulation method adopted for the research.

The optimum $\mathrm{pH}$ Biosorption of Chromium by Bacillus spp and Staphylococcus spp. from tannery effluent was investigated by Mythili and Karthikeyan (2011). The maximum adsorption of Chromium $(86.4 \mathrm{mg} / \mathrm{L})$ was showed by Bacillus spp and Staphylococcus spp showed $70.6 \mathrm{mg} / \mathrm{L}$ at an initial concentration of $100 \mathrm{mg} / \mathrm{L}$. In the present study, immobilised Bacillus spp and Staphylococcus spp. from the tannery industrial effluents reduced the levels of the organic pollutants with high potential as indicated by the percentage reduction of BOD, COD and TDS.

Enzymes often can work in multiple environments especially if they are immobilized. This makes the microorganisms' enzymes even more resistant to harsh environments and enables the enzymes to be recovered and recycled after they are no longer needed (Gianfreda and Rao 2004). Ramesh and Singh (1993) reported that the immobilized bacteria having more efficiency to remove the suspended particles than free cells. Using the immobilized cell is preferable due to its capability for using several times with the same efficiency, which makes it more economical. Similar work was done by Sikander et al. (2007) showing the higher reduction with permeabilized cells of Ochrobactrum intermedium strain SDCr-5. 
BAJOPAS Volume 13 Number 2, December, 2020

The results revealed the isolation and identification of isolates with the potential for the reduction of $\mathrm{Cr}$ (VI) to $\mathrm{Cr}$ (III). Results indicated that immobilized $B$. cereus could be efficiently used for the reduction of $\mathrm{Cr}$ (VI).

Table 5: Percentage reduction of the tested Parameters from the tannery industrial samples of the Immobilized Bacteria.

\begin{tabular}{lllllll}
\hline \multirow{2}{*}{ Industries } & & \multicolumn{5}{c}{ Percentage Reduction $(\%)$} \\
\cline { 3 - 7 } & & $5 \mathrm{~g}$ & $10 \mathrm{~g}$ & $15 \mathrm{~g}$ & $20 \mathrm{~g}$ & $25 \mathrm{~g}$ \\
\hline TAN1 & COD & 28 & 14 & 64 & 87 & 89 \\
& BOD & 50 & 54 & 59 & 67 & 80 \\
& SS & 35 & -26 & -27 & -32 & -63 \\
& TDS & 99 & 99 & 99 & 98 & 98 \\
TAN2 & COD & 15 & 20 & 25 & 32 & 38 \\
& BOD & 91 & 91 & 92 & 90 & 92 \\
& SS & -28 & -52 & -52 & -54 & -55 \\
& TDS & 97 & 99 & 99 & 99 & 99 \\
& COD & 33 & 44 & 22 & 11 & 26 \\
& BOD & 75 & 81 & 76 & 81 & 81 \\
& SS & 25 & 3 & -1 & -10 & -15 \\
& TDS & 98 & 98 & 98 & 98 & 98 \\
\hline
\end{tabular}

Percentage Reduction $=(B-A) / B \times 100 \%$

$A=$ Concentration of the parameter after treatment

$\mathrm{B}=$ Concentration of the parameter before treatment

$+=$ percentage decrease

- = percentage increase

In general, immobilization makes the enzyme more resistant to temperature, $\mathrm{pH}$, and substrate concentration swings giving it a longer lifetime and higher productivity per active unit (Gianfreda and Rao, 2004; FuIlbrook, 1996; Russell et al, 2003; Kandelbauer et al., 2004). Immobilized cells have been used and studied extensively for the production of useful chemicals (Ohtake and Silver, 1994), the treatment of wastewaters (Chen et al., 2003; Wang et al., 2010). Although many workers described microbial degradation of tannery effluent, limited literature is available on the bioremediation of tannery effluent using immobilized bacterial cells in the Kano Industrial Estates.

\section{CONCLUSION}

The samples contained variable levels of the physicochemical parameters. The results of the Analysis of variance revealed that, no statistical difference $(p<0.05)$ was observed for the temperature, $\mathrm{pH}, \mathrm{SS}, \mathrm{TDS}, \mathrm{BOD}$ and $\mathrm{COD}$ among the three tannery industries before the treatment. The levels of some of the parameters
(SS, TDS and COD) observed in the samples were found above the recommended limits of WHO and NESREA, which called for the treatment of the effluents before discharge into the environment. Base on the morphological and biochemical test results, TAN1, TAN2, and TAN3 bacterial isolates were identified to be Neisseria spp, Bacillus cereus, and Staphylococcus aureus respectively. The results of Post-treatment analysis showed that there is overall decrease in the levels of the parameters determined when compared with that of the pre-treatment. The overall percentage reduction of the immobilised bacteria in the treatment of the respective effluents was in the order TAN2 (72\%)>TAN1 $(70 \%)>$ TAN3 $(62 \%)$. Hence, the immobilized bacteria are having higher biodegradation potential for the treatment of the tannery effluents.

\section{Acknowledgments}

The authors wish to acknowledge the University of Maiduguri for the financial support. The authors are grateful to the Kano State Ministry of Environment for their support in obtaining the effluent samples. 


\section{REFERENCES}

Ajao, A. T., Adebayo, G. B., and Yakubu, S. E. (2011). Bioremediation of textile industrial effluent using mixed culture of Pseudomonas aeruginosa and Bacillus subtilis immobilized on agar-agar in a bioreactor. J. Microbiol. Biotech. Res, 1(3), 50-56.

Akan, J. C., Moses, E. A., Ogugbuaja, V. O., and Abah, J. (2007). Assessment of tannery industrial effluents from Kano metropolis, Kano State, Nigeria. Journal of Applied Sciences, 7(19), 2788-2793.

Akan, J. C., Ogugbuaja, V. O., Abdulrahman, F. I., and Ayodele, J. T. (2009). Pollutant levels in effluent samples from tanneries and textiles of Kano industrial areas, Nigeria. Global journal of pure and applied sciences, 15(3-4).

APHA (1989). Standard methods for Examination of Will bete and Will betewater.15 $5^{\text {th }}$ edition. Brydpass Springfield Will behington DC. pp. 164-176

APHA (1992). Standard Methods for the Examination of Water and Wastewater. Health, 69, 1116-9.

Baba, A., Garba, S. T., and Bello, H. S. (2020). Bioremediation Potential of Immobilized corynebacterium kutsceri in the Treatment of Tannery Industrial Effluent from Challawa Industrial Estate, Kano State, Nigeria. Journal of the Turkish Chemical Society Section A: Chemistry, $7(2), 335-350$.

Beem, E. I. V. (1994). reduction of solvent VOC emission. J. Oil Col. Chem. Ass, 77, 158.

Bouwer, E. J., and Zehnder, A. J. (1993). Bioremediation of organic compoundsputting microbial metabolism to work. Trends in biotechnology, 11(8), 360367.

Chen, K. C., Wu, J. Y., Liou, D. J., and Hwang, S. C. J. (2003). Decolorization of the textile dyes by newly isolated bacterial strains. Journal of Biotechnology, 101(1), 57-68.

Dan'Azumi, S., and Bichi, M. H. (2010). INDUSTRIAL POLLUTION AND HEAVY METALS PROFILE OF CHALLAWA RIVER IN KANO, NIGERIA. Journal of Applied Sciences in Environmental Sanitation, $5(1)$.

DWAF. (1992). Analytical Methods Manual, TR 151. Department of Water Affairs and Forestry, Pretoria.

El-Bestawy, E. (2013). Biological treatment of leather-tanning industrial wastewater using free living bacteria.
Elsheikh, M. A. S. (2009). Tannery wastewater pre-treatment. Water Science and Technology, 60(2), 433-440.

FuIlbrook, P. D. (1996). "Kinetics." Industrial enzymology: The application of enzymes in Industry. 2nd Ed. T. Godfrey and J Reichelt. eds.. Nature. New York.

Gianfreda, L., and Rao, M. A. (2004). Potential of extra cellular enzymes in remediation of polluted soils: a review. Enzyme and microbial technology, 35(4), 339354.

Hugo Springer. (1994). John Arthur Wilson Memorial Lecture "Treatment of Industrial Wastes of the Leather Industry - is it still a Major Problem". JALCA, 89, 153-185

Jimoh, A. A., Ganiyu, B. A., Baba, D., and Baba, A. (2018) Bioremediation Process of Effluent from Detergent and Food Industries in Jos, Nigeria: Kinetics and Thermodynamics. International Journal of Engineering Science Invention (IJESI), 762-73

Kandelbauer, A., Maute, O., Kessler, R. W., Erlacher, A., and Gübitz, G. M. (2004). Study of dye decolorization in an immobilized laccase enzyme-reactor using online spectroscopy. Biotechnology and bioengineering, 87(4), 552-563.

Kongjao, S., Damronglerd, S., and Hunsom, M. (2008). Simultaneous removal of organic and inorganic Pollutants in tannery wastewater using electrocoagulation technique. Korean Journal of chemical engineering, 25(4), 703.

Maheshwari, U. M., Aruna, S., Gomathi, M., and AbdulJaffar, A. H. (2017). Bioremediation by Free and Immobilized Bacteria Isolated from Tannery Effluent. International Journal of Research in Applied, Natural and Social Sciences. 5(7), 75-90

Margesin, R., and Schinner, F. (2001). Bioremediation (natural attenuation and biostimulation) of diesel-oilcontaminated soil in an alpine glacier skiing area. Applied and environmental microbiology, 677), 3127-3133.

Mohammed, A., Sekar, P., and George, J. (2011). Efficacy of microbes in bioremediation of tannery effluent. Inter. J. Curr. Res, 3(4), 324-326.

Mohammed, S. S. D., Orukotan, A. A., and Abdullahi, H. (2017). Physicochemical and Bacteriological Assessment of Tannery Effluent from Samaru-Zaria, 
BAJOPAS Volume 13 Number 2, December, 2020 Kaduna State, Nigeria. Journal of Applied

Sciences and Environmental Management, 21(4), 734-740.

Munz, G., De Angelis, D., Gori, R., Mori, G., Casarci, M., and Lubello, C. (2009). The role of tannins in conventional and membrane treatment of tannery wastewater. Journal of hazardous materials, 164(2-3), 733-739

Mythili, K., and Karthikeyan, B. (2011). Bioremediation of $\mathrm{Cr}$ (VI) from tannery effluent using Bacillus spp and Staphylococcus spp. International Multidisciplinary Research Journal, 1(6).

NESREA (2009). National Environmental Standards for Effluent Limitations and Regulation. 1233-1236

Noorjahan, C. M. (2014). Physicochemical characteristics, identification of bacteria and biodegradation of industrial effluent. Journal of bioremediation and Biodegradation, 5(3).

Ohtake, H. I., and Silver, A. O. (1994). Bacterial reduction of toxic chromate. Biological degradation and bioremediation of toxic chemicals, 403-415.

Omoleke, I. I. (2004). Management of environmental pollution in Ibadan, an African city: the challenges of health hazard facing government and the people. Journal of Human Ecology, 15(4), 265-275.

Rajor, A., Reddy, A.S., and Singh, B. (2004). Determination of BOD kinetic Parameters and evaluation of alternate methods, M.Sc. Thesis, Department of biotechnology \& environmental Science, Thapar Institute of Engineering and Technology, Patiala

Ramasami, T., Rajamani, S., and Rao, J. R. (1994, March). Pollution control in leather industry: Emerging technological options. In International symposium on surface and colloidal science and its relevance to soil pollution, madras.

Ramesh, J. V. S., and Singh, S. P. (1993). Yearly variation in certain physicochemical parameters of pond at eastern Doon Valley. Uttar Pradesh J. Zoo, 12 (1), 7577.

Ranen, S., and Sharadinadra, C. (2009). Biotechnology applications to environmental remediation in resource exploitation. Current science, 97, 6-25
Russell, A. J., Berberich, J. A., Drevon, G. F., and Koepsel, R. R. (2003). Biomaterials for mediation of

chemical and biological warfare agents. Annual review of biomedical engineering, 5(1), 1-27.

Saravanan, P., and Saravanan, A. (1999). Decolourization of tannery effluent by Flavobacterium sp. EK 1. Indian Journal of Environmental Protection, 19, 19-24.

Sikander, S., and Shahida, H. (2007). Reduction of toxic hexavalent chromium by Ochrobactrum intermedium strain SDCr5 stimulated by heavy metals. Bioresource Technol, 98, 340-344.

Singh, N., Sharma, B. K., and Bohra, P. C. (2000). Impact assessment of industrial effluent of arid soils by using satellite imageries. Journal of the Indian Society of Remote Sensing, 28(2-3), 79.

Sreemoyee, C., and Priti, P. (2013). Assessment of physico-chemical parameters of dairy waste water and isolation and characterization of bacterial strains in terms of cod reduction. Int J Sci, 2(3), 395-400.

Verheijen, L. A. H. M., Wiersema, D., Pol, L. H., and De Wit, J. (1996). Management of wastes from animal product processing. Livestock and environment, Finding a balance. International Agriculture Center, Wageningen, The Netherlands.

Wang, F., Yao, J., Si, Y., Chen, H., Russel, M., Chen, K., and Bramanti, E. (2010). Short-time effect of heavy metals upon microbial community activity. Journal of Hazardous Materials, 173(13), 510-516.

WHO (World Health Organization). (2006). Air quality guidelines: global update 2005: particulate matter, ozone, nitrogen dioxide, and sulfur dioxide. World Health Organization.

World Bank. (1995). Nigeria's strategic options for redressing industrial pollution. World Bank, industry and energy division. 1st edition, West Central Africa Department; Annexes: 1995; pp 60-62.

Zahoor, A., and Abdul, R. (2009). Enumeration of Coliforms. Journal of Environmental Sciences. 21, 814-820 


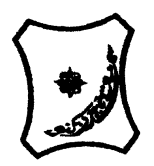

Bayero Journal of Pure and Applied Sciences, 13(2): 1 - 12

Received: November, 2020

Accepted: December, 2020

ISSN $2006-6996$

\title{
BIODEGRADATION POTENTIAL OF IMMOBILIZED BACTERIA IN THE TREATMENT OF TANNERY INDUSTRIAL EFFLUENTS FROM INDUSTRIAL ESTATES IN KANO STATE, NIGERIA
}

\author{
Abdullateef, B., ${ }^{1 *}$ Shuaibu, T. G., ${ }^{1}$ Babagana, K., ${ }^{1}$ Suleman, H. B. ${ }^{2}$ and Dauda, B. ${ }^{3}$ \\ ${ }^{1}$ Department of Pure and Applied Chemistry, Faculty of Science, University of Maiduguri, Borno State, \\ Nigeria \\ ${ }^{2}$ Department of Microbiology, Faculty of Science, University of Maiduguri, Borno State, Nigeria \\ ${ }^{3}$ Department of Chemical Engineering, Faculty of Engineering, University of Maiduguri, Borno State, \\ Nigeria \\ *Corresponding author: babslega@gmail.com; abelega2007@yahoo.com; +2348061309753
}

\section{ABSTRACT}

Industrial Effluents Samples from Gashash Tanneries (TAN1) in Bompai Industrial estate, Larabee Tannery Industry (TAN2) in Sharada Industrial estate and Z Tannery Industries (TAN3) in Challawa Industrial estate, Kano State, Nigeria were collected over a period of six months (August 2017 to January 2018) for assessing the biodegradation potentials of bacteria in the treatment of organic pollutants within the effluents. Bacteria were isolated from the effluents and immobilized on agar-agar. Different masses (5 g, $10 \mathrm{gr}, 15$ $\mathrm{g}, 20 \mathrm{~g}$, and $25 \mathrm{~g}$ ) of the bacteria were used in the treatment of $250 \mathrm{ml}$ of the effluents for ten days in a shaker incubator (Gallenkamp-OC-4364-L) at the temperature $30{ }^{\circ} \mathrm{C}$ and speed of $60 \mathrm{rpm}$. Pre-treatment analysis of the effluents for Temperature, pH, Biochemical Oxygen Demand (BOD), Chemical Oxygen Demand (COD), Suspended Solid (SS) and Total Dissolved Solids (TDS) gives the following results; temperature $\left({ }^{\circ} \mathrm{C}\right.$ )

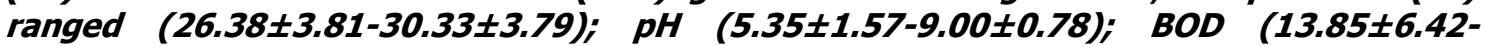
$38.75 \pm 16.20) ;$ COD (1406 $\pm 208-3532 \pm 1373) ;$ SS (208 $\pm 235-780 \pm 739)$ and TDS (266 $\pm 253-5276 \pm 2971)$. No statistical differences ( $p \leq 0.05)$ was observed for all the results among the different industries. The bacterial isolates were identified as Neisseria spp, Bacillus cereus, and Staphylococcus aureus, in TAN1, TAN2, and TAN3, respectively. After treatment of the effluent with the different masses of the isolated bacteria, the mean level of BOD was found to range as (0.55 $\pm 0.36-6.92 \pm 5.49) ; C O D$ (ND-3134 \pm 1595$)$;

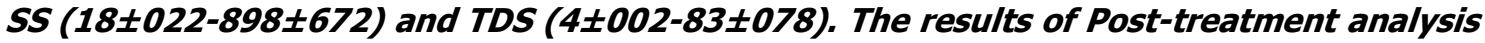
showed that there is overall decrease in the levels of the parameters determined when compared with that of the pre-treatment. The overall percentage reduction of the immobilised bacteria in the treatment of the respective effluents was in the order TAN2 (72\%)>TAN1 (70\%)>TAN3 (62\%). Hence, the immobilized bacteria are having higher biodegradation potential for the treatment of the tannery effluents.

Keywords: Biodegradation, bacteria, effluent, immobilization, tannery.

\section{INTRODUCTION}

Tannery industrial wastewater is a serious consequence of the pollution point of view for streams, freshwater, and land used for agriculture. The lack of awareness in the modern industrial practice has resulted in the discharge of tannery effluents which exhibit very high value of chromium ( $\mathrm{Cr}$ ), Sulfide, and chloride, Total Dissolved Solid (TDS), Total Suspended Solid (TSS), Biochemical Oxygen Demand (BOD) and Chemical Oxygen Demand (COD) in the water stream or land (Mohammed et al., 2001). Tanning is the process, which One ton of skin generally leads to the production of 20 to $80 \mathrm{~m}^{3}$ of turbid and foul-smelling converts the protein of the rawhide or skin into a stable material, which will not putrefy and is suitable for a wide variety of end applications (Elsheikh, 2009). The highly polluting chromium is the most commonly used tanning material producing leather that is more flexible and pliable than vegetable-tanned leather and does not discolor or lose shape in water as drastically as vegetable-tan (Elsheikh, 2009). Tannery effluent is among the most hazardous industrial pollutants due to its huge organic and inorganic load, which is highly toxic to human life and the environment (Kongjao et al., 2008). wastewater including chromium (100-400 mg/l), sulfide $(200-800 \mathrm{mg} / \mathrm{l})$, high levels of fat and 
BAJOPAS Volume 13 Number 2, December, 2020 other solid wastes, and notable pathogen contamination as well as pesticides added for skin conservation during transport (Elsheikh, 2009). There are more than 6000 tanneries in Nigeria with an annual processing capacity of 700,000 tons of hides and skins (Omoleke, 2004; Singh et al., 2008). It was reported that the total amount of waste produced per animal slaughtered is approximately $35 \%$ of its weight (World Bank, 1995). Also, for every $1000 \mathrm{~kg}$ of carcass weight, a slaughtered beef produces 5.5 $\mathrm{kg}$ of manure (excluding rumen contents or stockyard manure) and $100 \mathrm{~kg}$ of paunch manure (undigested food) (Verheijen et al., 1996). Tanneries generate wastewater in the range of 30-35 $\mathrm{L} \mathrm{kg}^{-1}$ skin/hide processed with variable $\mathrm{pH}$, Biological Oxygen Demand (BOD), Chemical Oxygen Demand (COD), high concentrations of suspended solids (SS), and tannins as well as chromium (Zahoor and Abdul, 2009).

Being heterogeneous and composed of a wide variety of compounds, it is very difficult to select a unique direct method for estimating the biodegradability of organic contents and biokinetic parameters for a wastewater sample (Rajor, 2004). For this purpose, some indirect estimation such as determination of biochemical oxygen demand (BOD) and chemical oxygen demand (COD) are applied as common laboratory investigations [9]. During retanning procedures, synthetic tannins (Syntan), oils and resins are added to form softer leather at varying doses (Munz et al., 2009). One of the refractory groups of chemicals in tannery effluents derives mainly from tannins (Ramasami et al., 2004). Syntans are characterized by complex chemical structures, because they are composed of an extended set of chemicals such as phenol-, naphthalene-, formaldehyde- and melamine-based syntans, and acrylic resins (Beem, 1994). Organic pollutants (proteic and lipidic components) are originated from skins (it is calculated that the raw skin has $30 \%$ loss of organic material during the working cycle) or they are introduced during processes (Hugo Springer, 1994).

Many conventional processes such as oxidation, chemical and biological processes were carried out to treat tanneries wastewater (Ebtesam et al, 2013). Biological processes have received more attention because of their costeffectiveness, lower sludge production and environmental friendliness (Noorjahan, 2014). Naturally occurring micro-organisms degrade the hazardous organic wastes including xenobiotic compounds, such as pesticides, polycyclic aromatic hydrocarbons (PAHs) and polychlorinated biphenyls (PCBs) in due course of time (Ranen and Sharadinadra, 2009). Bioremediation is based on the idea that all organisms remove substances from the environment to carry outgrowth and metabolism (Bouwer and Zehnder, 1993). Bacteria, protista and fungi are found to be very good at degrading complex molecules and incorporating the breakdown products into their metabolism (Bouwer and Zehnder, 1993). The resultant metabolic wastes that they produce are generally safe and somehow recycled into other organisms (Ranen and Sharadinadra, 2009). An acclimatized indigenous population of microorganisms capable of degradation of the compounds of interest must exist at the site for a successful bioremediation mode (Ranen and Sharadinadra, 2009). It has been observed that for a successful bioremediation mode, an acclimatized indigenous population of microorganisms capable of degradation of the compounds of interest must exist at the site under investigation (Ranen and Sharadinadra, 2009). Even though there are numerous physical and chemical methods employed in the disposal of wastes the advantage in using bacterium is that they play a key role in the reduction of COD, BOD, total protein, total tannin and total phenol (Saravanan and Saravanan, 1998)

Baba et al. (2020) studied the bioremediation potential of immobilized corynebacterium kutsceri in the Treatment of tannery industrial effluent from Challawa Industrial Estate, Kano State, Nigeria. The aim of the work is to study the reduction in the level of the contaminants through the process of bioremediation using the isolated bacteria. Immobilized bacteria can withstand various temperatures, $\mathrm{pH}$ and substrate concentrations; consequently, increasing the efficiency and the lifespan of the bacteria. Immobilized bacteria are widely applied in the treatment of wastewater and can be separated and recovered after the treatment with the same efficiency (Baba et al., 2020).

\section{MATERIALS AND METHODS \\ Study Area}

This study was carried out in Bompai, Sharada and Challawa industrial estates in Kano, Figure 1. Kano lies on Latitude $11^{\circ} 30^{\prime} \mathrm{N}$ and $8^{\circ} 30^{\prime} \mathrm{E}$ and Longitude $11^{\circ} 5^{\prime} \mathrm{N}$ and $8^{\circ} 5^{\prime} \mathrm{E}$ in Northern Nigeria. It is one of the developed industrial cities in Nigeria. Tannery activities are the dominating industries and this could be one of the reasons for her high population density (Dan'Azumi and Bichi, 2010). Many researchers have studied biodegradation of tannery effluent using microorganisms. However, limited literature is available on the biodegradation of tannery effluent in Kano industrial estates using 
BAJOPAS Volume 13 Number 2, December, 2020 immobilized bacterial cells. This research work focuses on the potential of the use of the indigenous immobilized bacterial isolates in the treatment of tannery effluents in the industrial estates.

\section{Sample Collection}

Effluents were collected from the Tannery Industries from Bompai, Challawa and Sharada Industrial Estates, Kano, Nigeria. The effluents were collected over a period of six months (August 2017 to January 2018). Samples collected in a sterile 4-liter plastic container with a unique identification number were preserved using an ice-box that was transported to the Microbiology Laboratory, Department of Microbiology, Bayero University of Kano for analysis

\section{Sample Preparation and Sample Analysis}

Immediately after the collection of the effluent, $\mathrm{pH}$, TSS, TDS, COD, BOD levels were determined before treatment (Pre-treatment determination) and ten days after treatment (Post-treatment determination) as described in
APHA (1989) standard methods. $\mathrm{pH}$ was determined using Ecotests $\mathrm{pH}$ meter and TDS was determined using AQUALYTIC TDS Salinometer. BOD was determined as described by the standard method (APHA, 1992). COD and SS were determined using DR/2010 HACH portable data logging spectrophotometer (DWAF, 1992)

\section{Identification and Biochemical} Characterization of the Bacterial Isolates

The bacteria were isolated from the effluents using Serial Dilution according to the method described by APHA (1989). The biochemical tests such as oxidase, catalase, coagulase, indole (from $1 \%$ tryptone broth), citrate (Simmons citrate agar), methyl red/VogesProskauer (MR/VP), nitrate reduction, Starch Hydrolysis, Glucose, Maltose, and Lactose tests were carried out on the bacterial isolates to identify the bacteria through the bacteria biochemical characteristics according to Ajao et al. (2011).

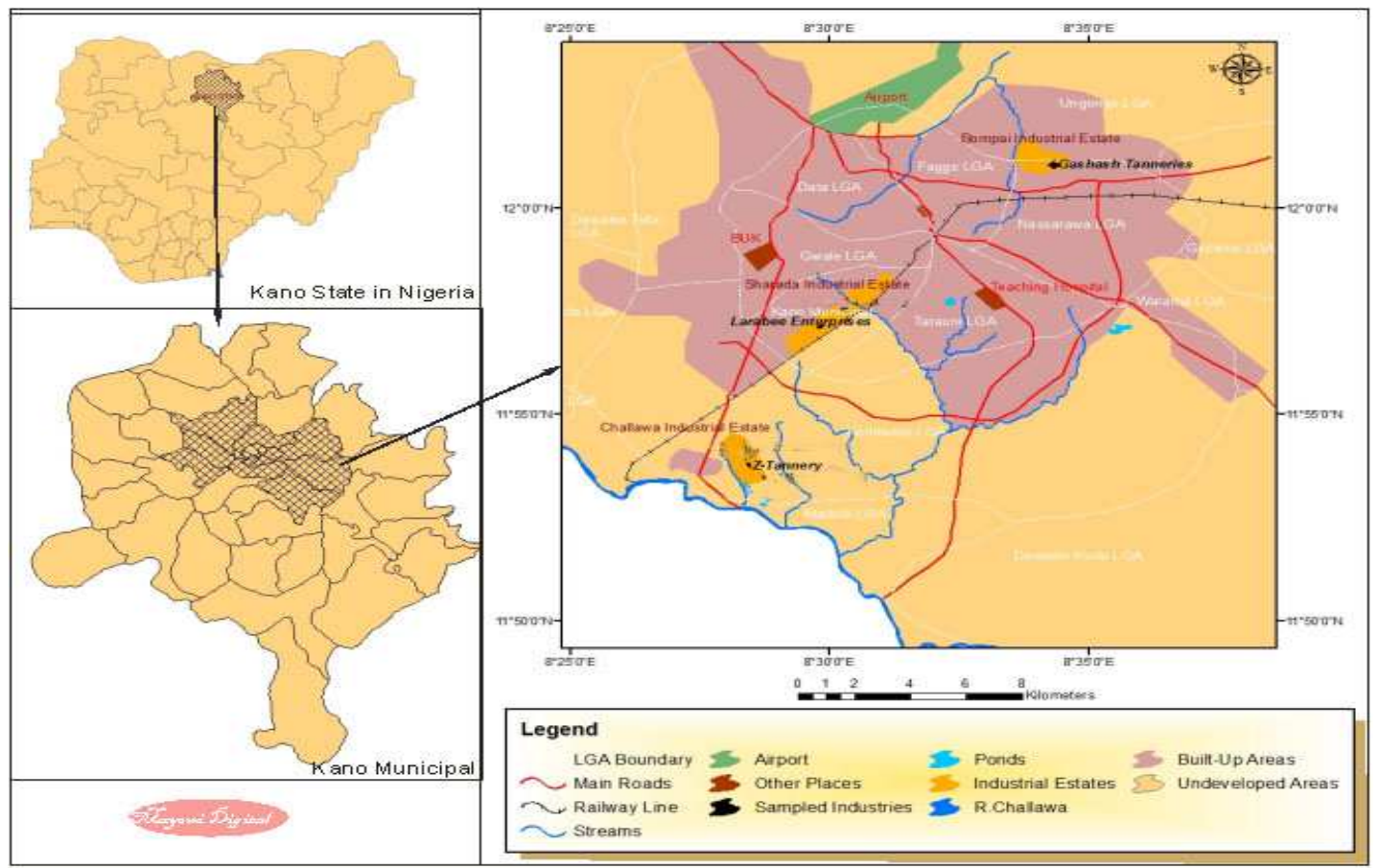

Fig. 1 Map showing the study areas

Source: Mayomi Digital Productions, GIS Laboratory, Department of Geography, UNIMAID (2017)

\section{Determination of Growth Rate of the Bacteria in Effluent Sample}

The bacteria growth rates were determined by transferring $2 \mathrm{~mL}$ of the bacterial isolates from the tannery effluent in broth medium into 100 $\mathrm{mL}$ sterile effluents in conical flasks and kept in an incubator (Giffrin cool) for 10 days. Control was also set up by incubating another $100 \mathrm{~mL}$ each of the sterile effluents without the bacteria. The optical density of the content was determined at the wavelength of $600 \mathrm{~nm}$ on a daily interval and recorded. 
BAJOPAS Volume 13 Number 2, December, 2020 Immobilization of Bacteria

Agar solution and inoculi were prepared separately. Fifty milliliters $(50 \mathrm{~mL})$ of nutrient broth each of the inoculi was prepared in a McCartney bottle and incubated for 24 hours. A solution of agar-agar was prepared by dissolving $10 \mathrm{~g}$ of the powder in distilled water and made up to $500 \mathrm{~mL}$ mark in an Erlenmeyer flask and was sterilized in an autoclave (280A) for 15 minutes and allowed to cool to $40-45^{\circ} \mathrm{C}$ (Ajao et al., 2011). Four milliliters ( $4 \mathrm{~mL})$ of the bacterial isolates in the nutrient broth was mixed with 36 $\mathrm{ml}$ of the prepared agar-agar media in petri-dish plates and then allowed to solidify. This was kept in the refrigerator for bioremediation.

\section{Bioremediation (Treatment) of the Effluents}

The solidified agar block (immobilized bacteria) was cut into cubes using a sterile knife; $0.1 \mathrm{~mL}$ phosphate buffer ( $\mathrm{pH} \mathrm{7.0)}$ was added and kept in the refrigerator for 1 hour for curing. The phosphate buffer was decanted after 1 hour and the cubes were washed with sterile distilled water 3-4 times before it was used (Ajao et al., 2011). Two liters (2 L) of the effluent was supplemented with the minimum basal medium in $\mathrm{g} / \mathrm{L}: \mathrm{NaCl}(0.8), \mathrm{MgSO}_{4} .7 \mathrm{H}_{2} \mathrm{O}(0.001), \mathrm{KH}_{2} \mathrm{PO}_{4}$ (2), $\mathrm{NaNO}_{3}$ (2), $\quad \mathrm{CaCl}_{2} .2 \mathrm{H}_{2} \mathrm{O} \quad(0.5)$ and $\mathrm{NaHPO}_{4} .12 \mathrm{H}_{2} \mathrm{O}(2)$ and sterilized in an autoclave at $121^{\circ} \mathrm{C}$ for 15 minutes (Margesin and Schinner, 2001). Two hundred and fifty milliliters $(250 \mathrm{~mL})$ of the effluents were transferred into different $250 \mathrm{ml}$ conical flasks. The content was covered with a cotton-wool ramped with foil paper to avoid contamination. Five grams $(5 \mathrm{~g})$ of the immobilized bacteria were quickly transferred into each of the effluents in the conical flasks in an inoculating chamber. The same procedures were carried out for the $10 \mathrm{~g}, 15 \mathrm{~g}, 20 \mathrm{~g}$ and 25 $\mathrm{g}$ of the immobilized bacteria in separate $250 \mathrm{~mL}$ effluents in conical flasks and agitated for ten days in a shaker incubator (Gallenkamp-OC4364-L) at a temperature $30^{\circ} \mathrm{C}$ and speed of 60 rpm. The treated effluent samples were taken on the tenth day and analyzed for the parameters $\mathrm{pH}$, SS, TDS, COD, and BOD, (Posttreatment determination) for the different grams of bacteria to evaluate and compare the biodegradation potential. (Baba et al., 2020).

\section{Statistical Analysis}

The data were represented as Mean \pm Standard deviation and analyzed statistically using oneway Analysis of Variance (ANOVA) and Tukey's HSD as Post Hoc Tests with the aid of SPSS 16.0. The correlation coefficient was also used to measure the strength of the relationship between the different masses of the bacteria and the parameters. All $\mathrm{p} \leq 0.05$ were considered as statistically significant.

\section{RESULTS AND DISCUSSION Physico-chemical parameters in the Industrial Effluents before the Biodegradation.}

Results of the Physico-chemical parameters in the industrial effluents before the Biodegradation is shown in table 1 . The mean temperatures $\left({ }^{\circ} \mathrm{C}\right)$ observed in TAN1, TAN2, and TAN3 samples were $28.07 \pm 0.65 ; 27.77 \pm 0.64$ and $26.38 \pm 3.81$ respectively. The order of the mean temperature of the samples from the three industries can be arranged as TAN1 > TAN2>TAN3. The temperature observed at TAN1, TAN2, and TAN3 samples were found below the WHO $\left(35^{\circ} \mathrm{C}\right)$ and NESREA $\left(40^{\circ} \mathrm{C}\right)$ limits. The low values of temperature might be due to the processes used at the time of sampling. High temperature brings down the solubility of gases in water that ultimately expresses as high BOD and COD. Statistical analysis shows that there is no significant difference $(p<0.05)$ between the mean values of temperature among the industries. This might be due to similar tannery activities involved in the tannery industries at the time of sampling. The average values of temperature observed in this present study are less than those observed by Akan et al. (2007), Akan et al. (2009) and Baba et al. (2020).

The mean level of $\mathrm{pH}$ observed in TAN1, TAN2 and TAN3, samples were $7.77 \pm 2.93$; $8.35 \pm 0.28$ and $7.52 \pm 0.76$ respectively. The order of the mean $\mathrm{pH}$ of the samples from the three industries can be arranged as TAN2> TAN1 $>$ TAN3. The $\mathrm{pH}$ of the samples falls within the WHO (7.0-8.5) and NESREA (6-9) standard limits. Statistical analysis shows that there is no significant difference $(p<0.05)$ between the mean values of $\mathrm{pH}$ among the industries. This might be due to similar tannery activities involved in the tannery industries at the time of sampling. Maheshwari et al. (2017) reported that the level of $\mathrm{pH}$ in the effluents from the tannery industry in Vaniyambadi, India was 6.5 which was lower than that observed in the present study. The $\mathrm{pH}$ in the effluents from the tannery industries in Kano and Kaduna were reported to be 7.64 and 6.89, respectively (Akan et al., 2007; Mohammed et al., 2017). The average values of $\mathrm{pH}$ observed in this present study are less than those observed by Mohammed et al. (2017) and Baba et al. (2020). The mean level of SS $(\mathrm{mg} / \mathrm{l})$ observed in TAN1, TAN2, and TAN3 samples were 374 \pm 124 ; $358 \pm 335$ and $780 \pm 739$ respectively. The order of the mean SS in the samples from the three industries can be arranged as TAN3 > TAN1 $>$ TAN2. 
The SS observed in the samples were far above the recommended standard limits of regulating bodies WHO $(30 \mathrm{mg} / \mathrm{l})$ and NESREA $(10 \mathrm{mg} / \mathrm{l})$. Statistical analysis shows that there is no significant difference $(p<0.05)$ between the mean values of SS among the industries. This might be due to similar tannery activities involved in the tannery industries at the time of sampling. The average values of SS observed in this present study are less than that observed $(3700 \pm 122 \mathrm{mg} / \mathrm{l})$ by Akan et al. (2009) for tanneries in Kano. Also, the average values of SS observed in this present study are less than that observed by Mohammed et al. (2017) and Baba et al. (2020) with the exception in TAN3.

The mean level of TDS (mg/l) observed in TAN1, TAN2, and TAN3 samples were $3941 \pm 3703$; $3300 \pm 1714$ and $2653 \pm 1240$ respectively. The order of the mean TDS in the samples from the three industries can be arranged as TAN1>TAN2>TAN3. The TDS observed in the samples were far above the recommended standard limits of WHO $(250 \mathrm{mg} / \mathrm{l})$ and NESREA $(500 \mathrm{mg} / \mathrm{l})$. Statistical analysis shows that there is no significant difference $(p<0.05)$ between the mean values of TDS among the industries. This might be due to similar tannery activities involved in the tannery industries at the time of sampling. TDS in the effluents from the tannery industries in Kano, Nigeria was reported to be $1281 \mathrm{mg} / \mathrm{l}$ (Akan et al., 2007). The average values of SS observed in this present study are less than those observed by Mohammed et al. (2017) and Baba et al. 2020)

The mean level of COD (mg/l) observed in TAN1, TAN2 and TAN3 samples seasons were $2372 \pm 938 ; \quad 1406 \pm 208$ and $3532 \pm 1373$ respectively. The order of the mean COD of the samples from the three industries can be arranged as TAN3>TAN1> TAN2. The COD observed in TAN1, TAN2 and TAN3 samples were far above the recommended standard limits of regulating bodies $\mathrm{WHO}(40 \mathrm{mg} / \mathrm{l})$ and NESREA (40 mg/l). Statistical analysis shows that there is no significant difference $(p<0.05)$ in COD among the industries. This might be due to similar tannery activities involved in the tannery industries as at the time of sampling. The Chemical Oxygen demand (COD) is the amount of oxygen, in $\mathrm{mg} / \mathrm{L}$, required for the degradation of the compound of wastewater to occur. In comparison, the average values of COD observed in this present study were higher than that observed by Mohammed et al. (2017) but lower than that observed by Baba et al. (2020).

The mean levels of BOD $(\mathrm{mg} / \mathrm{l})$ observed in TAN1, TAN2 and TAN3 samples were $13.85 \pm 6.42 ; \quad 19.46 \pm 0.50$ and $17.13 \pm 3.14$ respectively. The order of the mean BOD in the samples from the three industries can be arranged as TAN2>TAN3>TAN1. The BOD observed in TAN1, TAN2 and TAN3 samples were found below the recommended limits of NESREA (200 mg/l) but above WHO (10 mg/l). Statistical analysis shows that there is no significant difference $(p<0.05)$ between the mean values of BOD among the industries. This might be due to similar tannery activities involved in the tannery industries at the time of sampling. The low level of BOD recorded in this study is an indication of the low level of biodegradable organic solids in the effluent. The average values of BOD observed in this present study were lower than those observed by Mohammed et al. (2017) and Baba et al. (2020).

Table 1: Mean Values \pm S.D of Physico-chemical parameters of effluents from the Tannery Industries before Treatment.

\begin{tabular}{llllllll}
\hline Parameter & Tannery 1 & Tannery 2 & Tannery 3 & $\mathrm{a}$ & $\mathrm{b}$ & $\mathrm{c}$ & $\mathrm{d}$ \\
\cline { 2 - 7 } Temperature $\left({ }^{\circ} \mathrm{C}\right)$ & $28.07 \mathrm{a} \pm 0.65$ & $27.77 \mathrm{a} \pm 0.64$ & $26.38 \mathrm{a} \pm 3.81$ & & $29.50 \pm 4.68$ & 35 & 40 \\
pH & $7.77 \mathrm{a} \pm 2.93$ & $8.35 \mathrm{a} \pm 0.28$ & $7.52 \mathrm{a} \pm 0.76$ & 6.89 & $5.35 \pm 1.57$ & $7.0-8.5$ & $6.0-9.0$ \\
$\mathrm{COD}(\mathrm{mg} / \mathrm{l})$ & $2372 \mathrm{a} \pm 938$ & $1406 \mathrm{a} \pm 208$ & $3532 \mathrm{a} \pm 1373$ & 2.2 & $3106 \pm 2753$ & 40 & 40 \\
$\mathrm{BOD}(\mathrm{mg} / \mathrm{l})$ & $13.85 \mathrm{a} \pm 6.42$ & $19.46 \mathrm{a} \pm 0.50$ & $17.13 \mathrm{a} \pm 3.14$ & 1032 & $26.17 \pm 9.49$ & 10 & 200 \\
$\mathrm{SS}(\mathrm{mg} / \mathrm{l})$ & $374 \mathrm{a} \pm 124$ & $358 \mathrm{a} \pm 335$ & $780 \mathrm{a} \pm 739$ & 501 & $562 \pm 482$ & 30 & 10 \\
TDS $(\mathrm{mg} / \mathrm{l})$ & $3941 \mathrm{a} \pm 3703$ & $3300 \mathrm{a} \pm 1714$ & $2653 \mathrm{a} \pm 1240$ & 532.7 & $444 \pm 507$ & 250 & 500 \\
\hline
\end{tabular}

The values given in the table above are means of 6 replicate values, $\mathrm{n}=6$ ( 1 sample was taken monthly for 6 months). Within the rows, means with different alphabets are statistically different $(p<0.05)$. WHO: World Health Organisation. NESREA: National Environmental Standard and Regulatory Enforcement Agency. a = Mohammed et al.(2017), b = Baba et al. (2020), c = WHO (2006), $d=$ NESSRA (2009) 
BAJOPAS Volume 13 Number 2, December, 2020

Identification, Biochemical Characterization and growth rates of the Bacterial Isolates

Results of identification and biochemical characterization of the bacterial isolates were shown in table 2. After 24 hours of incubation, the nutrient agar media plates were checked for bacterial growth. The results showed the presence of different strains in the samples. The TAN1 bacteria isolate was found to be gramnegative cocci while TAN3 was gram-positive cocci. TAN2 bacteria isolate was found to be gram-positive, rod-shaped. TAN1, TAN2, and TAN3 bacteria isolates recorded positive results for spore former.

The results of the biochemical tests indicated that all the bacteria were positive for catalase, oxidase, citrate, maltose, glucose, lactose (negative in TAN1), mannitol (negative in TAN2), starch hydrolysis and coagulase (negative in TAN2) tests. The bacteria showed negative results for nitrate reduction, $M R$ (positive in TAN2), VP (positive in TAN1), Indole (positive in TAN2) tests. Base on the morphological and biochemical test results, TAN1, TAN2, and TAN3 bacteria isolates were identified to be Nesseria spp, Bacillus cereus, and Staphylococcus aureus respectively.

The growth rate of the TAN1, TAN2 and TAN3 Isolates were shown in figure 2. Generally, the optical density increase with the increase in time (day) and decrease as time goes on. The highest optical density was shown by bacillus cereus in TAN2 while the lowest was shown by Staphylococcus aureus in TAN3.

The initial growth phase of TAN1 Isolate bacteria occurred within 2-day of incubation as the growth rate increases up to the 6th-day incubation when the maximum growth was observed. Beyond the 6th day, the growth of the bacteria declined (which might be due to a shortage of nutrients in the effluents) until it reached its death phase (which might be due to the unavailability of nutrients in the effluents).

A similar trend of growth was also observed for TAN2 Isolate as the initial growth phase also occurred within 2-day of incubation but maximum growth rate observed on the 4th day of incubation. The stationary stage occurred between the 4th day and the 8th day. Beyond the 8th day, the growth of the bacteria declined (which might be due to a shortage of nutrients in the effluents) until it reached its death phase (which might be due to the unavailability of nutrients in the effluents).

The initial growth phase of TAN3 bacterial Isolate occurred within the 3-day incubation as the growth rate increases up to the 6th-day incubation when the maximum growth was observed. Beyond the 6th day, the growth of the bacteria declined (which might be due to a shortage of nutrients in the effluents) until it reached its death phase (which might be due to the unavailability of nutrients in the effluents).

Table 2: Morphological and Biochemical characteristics of bacterial isolates

\begin{tabular}{lllll} 
Bacterial Isolates & & TAN1 & TAN2 & TAN3 \\
\hline $\begin{array}{lllll}\text { Morphological } \\
\text { characteristics }\end{array}$ & Shape & Cocci & Rod & Cocci \\
& Spore & & & \\
& former & + & + & + \\
Gram & & & \\
Biochemical characteristics & reaction & - & + & + \\
& Citrate & + & + & + \\
& Catalase & + & + & + \\
& Coagulase & + & - & + \\
Starch & + & + & + \\
& Glucose & + & + & + \\
Oxidase & + & + & + \\
& Indo & - & + & - \\
Lactose & - & + & + \\
Manitol & + & - & + \\
Maltose & + & + & + \\
MR & - & + & - \\
VP & + & - & - \\
& Nitrate & - & - & - \\
Reduction & - Neisseria & Bacillus & Staphylococcus \\
& Bacterial & cereus & aureus \\
& name & spp & cas
\end{tabular}

+ = Positive; - = Negative; MR=Methyl Red; VP= Voges-Proskauer 


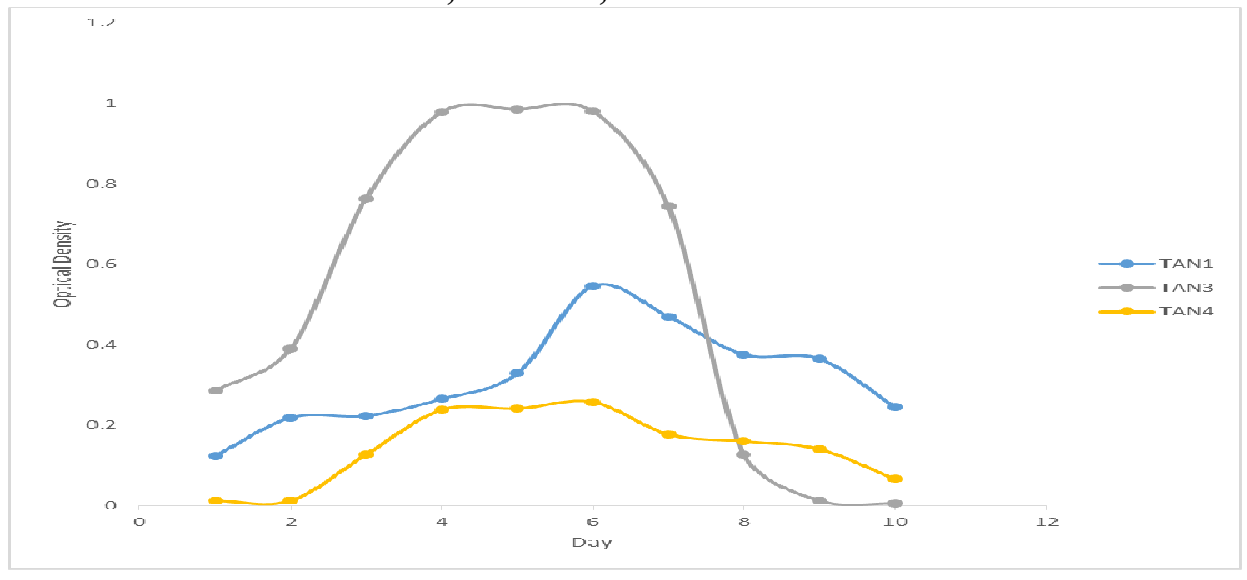

Fig. 2 Growth rates of the isolates in the effluents from the Tannery Industries

\section{Physico-chemical Parameters in the Industrial Effluents after the biodegradation.}

Table 3 shows the mean results of the physicochemical parameter before and after bioremediation using the different masses $(5 \mathrm{~g}$, $10 \mathrm{~g}, 15 \mathrm{~g}, 20 \mathrm{~g}$, and $25 \mathrm{~g}$ ) of the respective immobilized bacteria. Also, Table 4 shows the mean results of correlation coefficient ( $r$ ) between different masses of bacteria and physicochemical parameters.

The mean values $(\mathrm{mg} / \mathrm{l})$ of the SS after the bioremediation varies between $243 \pm 45$ and $898 \pm 672$. The mean concentration $(\mathrm{mg} / \mathrm{l})$ of SS remediated by the different masses $(5 \mathrm{~g}, 10 \mathrm{~g}$, $15 \mathrm{~g}, 20 \mathrm{~g}$, and $25 \mathrm{~g}$ ) of the bacteria varies. The SS in the samples fluctuates up and down after the bioremediation process when compared with the SS of the raw samples before the bioremediation. The increase in the levels of the SS might be due to the aggregation of the TDS which are large enough to result into SS. The increase in the levels of the SS might be also due to the influence of the nutrients which was added into the effluents in order to make the microorganisms more active and viable for fast degradation of organic contaminants in the effluent. The relative potential or efficiency of the different masses of the bacteria in remediating SS in TAN1 samples was in the order $25 \mathrm{~g}>20 \mathrm{~g}>15 \mathrm{~g}>10 \mathrm{~g}>5 \mathrm{~g}$. For TAN2 and TAN3 samples, the order was $25 \mathrm{~g}>20 \mathrm{~g}>15$ $\mathrm{g}>10 \mathrm{~g}>5 \mathrm{~g}$. These might be due to the variations in the surface areas of the different masses of the immobilized bacteria. Statistical analysis shows that there is no significant difference $(p<0.05)$ between the mean values of SS among the masses in the respective industries. Positive and significant correlations exist between the masses of bacteria and Suspended Solid (SS). This showed that there is general increase in the levels of the SS as the masses of the immobilized bacteria increases. TAN3 (90\%) and TAN1 (80\%) showed a very high correlation with the masses of the bacteria while TAN2 (61\%) showed a very low correlation.

The mean values $(\mathrm{mg} / \mathrm{l})$ of the TDS after the bioremediation varies between $46 \pm 11$ and $83 \pm 78$. The mean concentration $(\mathrm{mg} / \mathrm{l})$ of TDS remediated by the different masses $(5 \mathrm{~g}, 10 \mathrm{~g}$, $15 \mathrm{~g}, 20 \mathrm{~g}$, and $25 \mathrm{~g}$ ) of the bacteria varies. There is a reduction in all the TDS of all the samples after the bioremediation process compared with the TDS of the raw samples before the bioremediation. The relative potential or efficiency of the different masses of the bacteria in remediating TDS in TAN1 and TAN3 samples was in the order $5 \mathrm{~g}>10 \mathrm{~g}>15 \mathrm{~g}>20$ $\mathrm{g}>25 \mathrm{~g}$. For TAN2 samples, the order was 20 $g>10 \quad g>25 \quad g>15 \quad g>5 \quad g$. Statistical analysis shows that there is no significant difference $(p<0.05)$ between the mean values of TDS among the masses in the respective industries. These might be due to the variations in the surface areas of the different masses of the immobilized bacteria. Positive and significant correlations exist between the masses of bacteria and TDS with the exception in TAN2 (negative and insignificant correlation). The positive correlations showed that there is general increase in the levels of the TDS as the masses of the immobilized bacteria increases. TAN1 $(96 \%)$ showed a very high correlation with the masses of the bacteria while TAN2 (47\%) showed a very low correlation.

The mean values $(\mathrm{mg} / \mathrm{l})$ of the BOD after the bioremediation varies between $1.56 \pm 0.20 \mathrm{mg} / \mathrm{l}$ and $6.92 \pm 5.49 \mathrm{mg} / \mathrm{l}$. The mean concentration $(\mathrm{mg} / \mathrm{l})$ of BOD remediated by the different masses $(5 \mathrm{~g}, 10 \mathrm{~g}, 15 \mathrm{~g}, 20 \mathrm{~g}$, and $25 \mathrm{~g}$ ) of the bacteria varies. There is a reduction in all the BOD of all the samples after the bioremediation process compared with the $\mathrm{BOD}$ of the raw 
BAJOPAS Volume 13 Number 2, December, 2020 samples before the bioremediation. The relative potential or efficiency of the different masses of the bacteria in remediating BOD in TAN1, TAN2 and TAN3 samples were in the order $25 \mathrm{~g}>20$ $\mathrm{g}>15 \mathrm{~g}>10 \mathrm{~g}>5 \mathrm{~g}, 25 \mathrm{~g}>15 \mathrm{~g}>5 \mathrm{~g}>10 \mathrm{~g}>20 \mathrm{~g}$ and $20 \mathrm{~g}>10 \mathrm{~g}>25 \mathrm{~g}>15 \mathrm{~g}>5 \mathrm{~g}$ respectively. Statistical analysis shows that there is significant difference $(p<0.05)$ between the mean values of BOD among the masses in the respective industries. These might be due to the variations in the surface areas of the different masses of the immobilized bacteria. Negative and significant correlations exist between the masses of bacteria and BOD. This showed that there is general decrease in the levels of the BOD as the masses of the immobilized bacteria increases. TAN1 (94\%) showed a very high correlation with the masses of the bacteria while TAN2 (4\%) showed a very low correlation.

The mean values $(\mathrm{mg} / \mathrm{l})$ of the COD after the bioremediation varies between $250 \pm 154$ and $3134 \pm 1595$. The mean concentration $(\mathrm{mg} / \mathrm{l})$ of COD remediated by the different masses $(5 \mathrm{~g}$, $10 \mathrm{~g}, 15 \mathrm{~g} 20 \mathrm{~g}$, and $25 \mathrm{~g}$ ) of the bacteria varies. There is a reduction in all the COD of all the samples after the bioremediation process compared with the COD of the raw samples before the bioremediation. The relative potential or efficiency of the different masses of the bacteria in remediating COD in TAN1, TAN2 and TAN3 samples were in the order $25 \mathrm{~g}>20 \mathrm{~g}>15$ $\mathrm{g}>5 \mathrm{~g}>10 \mathrm{~g}, 25 \mathrm{~g}>20 \mathrm{~g}>15 \mathrm{~g}>10 \mathrm{~g}>5 \mathrm{~g}$ and 10 g>5 g>25 g>15 g>20 g respectively. Statistical analysis shows that there were significant difference $(p<0.05)$ between the mean values of COD among the masses in the respective industries except for effluents treated with $25 \mathrm{~g}$. These might be due to the variations in the surface areas of the different masses of the immobilized bacteria. Negative and insignificant correlations exist between the masses of bacteria and COD with the exception in TAN3 (positive and significant correlation). The negative correlations showed that there is general decrease in the levels of the COD as the masses of the immobilized bacteria increases. TAN2 (100\%) showed a very high correlation with the masses of the bacteria while TAN3 (36\%) showed a very low correlation.

Generally, there was an overall decrease in the concentration of these physicochemical parameters after the bioremediation using the different masses of the bacterial isolates. These might be due to the variations in the surface areas of the different masses of the immobilized bacteria. This is in line with the work of Jimoh et al. (2018) and Baba et al. (2020).

Table 3: Mean Values $(\mathrm{mg} / \mathrm{l}) \pm$ S.D of Physicochemical parameters in effluents from the Tannery Industries before and after Treatment of the effluents $(250 \mathrm{ml})$ with the different masses $(5 \mathrm{~g}, 10 \mathrm{~g}$, $15 \mathrm{~g}, 20 \mathrm{~g}$, and $25 \mathrm{~g}$ ) of the bacteria.

\begin{tabular}{llllllll}
\hline $\mathrm{P}$ & IND & Before & \multicolumn{5}{c}{ After } \\
\cline { 4 - 7 } & & & $5 \mathrm{~g}$ & $10 \mathrm{~g}$ & $15 \mathrm{~g}$ & $20 \mathrm{~g}$ & $25 \mathrm{~g}$ \\
\hline \multirow{2}{*}{ COD } & TAN1 & $2372 \pm 938$ & $1708 \mathrm{a} \pm 861$ & $2045 \mathrm{a} \pm 1205$ & $845 \mathrm{a} \pm 369$ & $300 \mathrm{a} \pm 167$ & $250 \mathrm{a} \pm 154$ \\
& TAN2 & $1406 \pm 208$ & $1195 \mathrm{a} \pm 208$ & $1125 \mathrm{a} \pm 384$ & $1055 \mathrm{a} \pm 317$ & $956 \mathrm{a} \pm 310$ & $870 \mathrm{ab} \pm 240$ \\
& TAN3 & $3532 \pm 1373$ & $2374 \mathrm{a} \pm 1344$ & $1976 \mathrm{a} \pm 1405$ & $2757 \mathrm{a} \pm 1266$ & $3134 \mathrm{a} \pm 1595$ & $2614 \mathrm{~b} \pm 1105$ \\
BOD & TAN1 & $13.85 \pm 6.42$ & $6.92 \mathrm{a} \pm 5.49$ & $6.42 \mathrm{a} \pm 5.07$ & $5.72 \mathrm{a} \pm 5.35$ & $4.62 \mathrm{a} \pm 4.37$ & $2.82 \mathrm{ab} \pm 1.26$ \\
& TAN2 & $19.46 \pm 0.50$ & $1.75 \mathrm{~b} \pm 0.22$ & $1.73 \mathrm{~b} \pm 0.18$ & $1.58 \mathrm{a} \pm 0.16$ & $1.91 \mathrm{a} \pm 0.22$ & $1.56 \mathrm{~b} \pm 0.20$ \\
& TAN3 & $17.13 \pm 3.14$ & $4.24 \mathrm{ab} \pm 0.77$ & $3.29 \mathrm{ab} \pm 0.37$ & $4.11 \mathrm{a} \pm 0.07$ & $3.23 \mathrm{a} \pm 0.91$ & $3.33 \mathrm{a} \pm 1.28$ \\
SS & TAN1 & $374 \pm 124$ & $243 \mathrm{a} \pm 45$ & $471 \mathrm{a} \pm 226$ & $475 \mathrm{a} \pm 182$ & $492 \mathrm{a} \pm 128$ & $611 \mathrm{a} \pm 217$ \\
& TAN2 & $358 \pm 335$ & $460 \mathrm{a} \pm 400$ & $543 \mathrm{a} \pm 414$ & $544 \mathrm{a} \pm 402$ & $551 \mathrm{a} \pm 414$ & $554 \mathrm{a} \pm 405$ \\
& TAN3 & $780 \pm 739$ & $586 \mathrm{a} \pm 594$ & $758 \mathrm{a} \pm 656$ & $787 \mathrm{a} \pm 676$ & $861 \mathrm{a} \pm 635$ & $898 \mathrm{a} \pm 672$ \\
TDS & TAN1 & $3941 \pm 3703$ & $51 \mathrm{a} \pm 10$ & $53 \mathrm{a} \pm 10$ & $55 \mathrm{a} \pm 15$ & $61 \mathrm{a} \pm 20$ & $63 \mathrm{a} \pm 26$ \\
& TAN2 & $3300 \pm 1714$ & $83 \mathrm{a} \pm 78$ & $47 \mathrm{a} \pm 20$ & $48 \mathrm{a} \pm 22$ & $47 \mathrm{a} \pm 17$ & $48 \mathrm{a} \pm 17$ \\
& TAN3 & $2653 \pm 1240$ & $46 \mathrm{a} \pm 11$ & $55 \mathrm{a} \pm 24$ & $55 \mathrm{a} \pm 25$ & $58 \mathrm{a} \pm 23$ & $61 \mathrm{a} \pm 28$ \\
\hline
\end{tabular}

Replicate $=6$ (months)

Within the rows, for the same parameter, means with different alphabets are statistically different $(p<0.05)$.

$\mathrm{P}=$ parameter, IND = Industries 
BAJOPAS Volume 13 Number 2, December, 2020

Table 4: Correlation coefficient $(r)$ between different masses of the bacteria and the physicochemical parameters.

\begin{tabular}{llll}
\hline Industries & Parameter & Correlation coefficient $(r)$ & $\begin{array}{l}\text { Percent dependence (rxrx100) } \\
(\%)\end{array}$ \\
\hline TAN1 & COD & -0.9 & 82 \\
& BOD & -0.97 & 94 \\
& SS & $0.90^{*}$ & 80 \\
TAN2 & TDS & $0.98^{*}$ & 96 \\
& COD & -1 & 100 \\
& BOD & -0.21 & 4 \\
& SS & $0.78^{*}$ & 61 \\
& TDS & -0.69 & 47 \\
& COD & $0.60^{*}$ & 36 \\
& BOD & -0.6 & 37 \\
& SS & $0.95^{*}$ & 90 \\
& TDS & $0.94^{*}$ & 89 \\
\hline
\end{tabular}

The correlation coefficient $(r)$ with * is statistically significant $(p<0.05)$.

Percentage reduction of the Parameters

Table 5 shows the percentage reduction of Parameters in industrial samples before and after the treatment of the effluents $(250 \mathrm{ml})$ with the different masses $(5 \mathrm{~g}, 10 \mathrm{~g}, 15 \mathrm{~g}, 20 \mathrm{~g}$, and $25 \mathrm{~g}$ ) of the Immobilized Bacteria.

In TAN1 samples, the percentage reduction (\%) of COD ranged (14-89); BOD (50-80); SS (-32$35)$ and TDS (98-99). In TAN2 samples, the percentage decrease $(\%)$ of COD ranged (15$38) ;$ BOD (90-92); SS [-28-(-55)] and TDS (9798). In TAN3 samples, the percentage decrease (\%) of COD ranged (11-44); BOD (76-81); SS (15-25) and TDS (98). The percentage increase in the levels COD, BOD and TDS might be due to the increase in the surface area of the different masses of the immobilized bacteria. However, the percentage decrease in the levels of the SS might be due to the aggregation of the TDS which are large enough to result into SS. The percentage decrease in the levels of the SS might be also due to the influence of the nutrients which was added into the effluents in order to make the microorganisms more active and viable for fast degradation of organic contaminants in the effluent. This is in line with the work of Jimoh et al. (2018) in which the concentration of the SS increase after the bioremediation of effluents.

Sreemoyee and Priti (2013) assessed and reduced several Physico-chemical parameters of dairy wastewater using Niesseria $s p$. and concluded that the species are well known to degrade organic compounds. This is in agreement with the current study in which the immobilized Niesseria $s p$ degrade the organic contaminants as indicated by the BOD, COD and TDS.

Jimoh et al. (2018) observed that TSS of the effluents was increased after treatment with immobilized bacteria and concluded that it might be due to the biostimulation method adopted for the research.

The optimum $\mathrm{pH}$ Biosorption of Chromium by Bacillus spp and Staphylococcus spp. from tannery effluent was investigated by Mythili and Karthikeyan (2011). The maximum adsorption of Chromium $(86.4 \mathrm{mg} / \mathrm{L})$ was showed by Bacillus spp and Staphylococcus spp showed $70.6 \mathrm{mg} / \mathrm{L}$ at an initial concentration of $100 \mathrm{mg} / \mathrm{L}$. In the present study, immobilised Bacillus spp and Staphylococcus spp. from the tannery industrial effluents reduced the levels of the organic pollutants with high potential as indicated by the percentage reduction of BOD, COD and TDS.

Enzymes often can work in multiple environments especially if they are immobilized. This makes the microorganisms' enzymes even more resistant to harsh environments and enables the enzymes to be recovered and recycled after they are no longer needed (Gianfreda and Rao 2004). Ramesh and Singh (1993) reported that the immobilized bacteria having more efficiency to remove the suspended particles than free cells. Using the immobilized cell is preferable due to its capability for using several times with the same efficiency, which makes it more economical. Similar work was done by Sikander et al. (2007) showing the higher reduction with permeabilized cells of Ochrobactrum intermedium strain SDCr-5. 
BAJOPAS Volume 13 Number 2, December, 2020

The results revealed the isolation and identification of isolates with the potential for the reduction of $\mathrm{Cr}$ (VI) to $\mathrm{Cr}$ (III). Results indicated that immobilized $B$. cereus could be efficiently used for the reduction of $\mathrm{Cr}$ (VI).

Table 5: Percentage reduction of the tested Parameters from the tannery industrial samples of the Immobilized Bacteria.

\begin{tabular}{lllllll}
\hline \multirow{2}{*}{ Industries } & & \multicolumn{5}{c}{ Percentage Reduction $(\%)$} \\
\cline { 3 - 7 } & & $5 \mathrm{~g}$ & $10 \mathrm{~g}$ & $15 \mathrm{~g}$ & $20 \mathrm{~g}$ & $25 \mathrm{~g}$ \\
\hline TAN1 & COD & 28 & 14 & 64 & 87 & 89 \\
& BOD & 50 & 54 & 59 & 67 & 80 \\
& SS & 35 & -26 & -27 & -32 & -63 \\
& TDS & 99 & 99 & 99 & 98 & 98 \\
TAN2 & COD & 15 & 20 & 25 & 32 & 38 \\
& BOD & 91 & 91 & 92 & 90 & 92 \\
& SS & -28 & -52 & -52 & -54 & -55 \\
& TDS & 97 & 99 & 99 & 99 & 99 \\
& COD & 33 & 44 & 22 & 11 & 26 \\
& BOD & 75 & 81 & 76 & 81 & 81 \\
& SS & 25 & 3 & -1 & -10 & -15 \\
& TDS & 98 & 98 & 98 & 98 & 98 \\
\hline
\end{tabular}

Percentage Reduction $=(B-A) / B \times 100 \%$

$A=$ Concentration of the parameter after treatment

$\mathrm{B}=$ Concentration of the parameter before treatment

$+=$ percentage decrease

- = percentage increase

In general, immobilization makes the enzyme more resistant to temperature, $\mathrm{pH}$, and substrate concentration swings giving it a longer lifetime and higher productivity per active unit (Gianfreda and Rao, 2004; FuIlbrook, 1996; Russell et al, 2003; Kandelbauer et al., 2004). Immobilized cells have been used and studied extensively for the production of useful chemicals (Ohtake and Silver, 1994), the treatment of wastewaters (Chen et al., 2003; Wang et al., 2010). Although many workers described microbial degradation of tannery effluent, limited literature is available on the bioremediation of tannery effluent using immobilized bacterial cells in the Kano Industrial Estates.

\section{CONCLUSION}

The samples contained variable levels of the physicochemical parameters. The results of the Analysis of variance revealed that, no statistical difference $(p<0.05)$ was observed for the temperature, $\mathrm{pH}, \mathrm{SS}, \mathrm{TDS}, \mathrm{BOD}$ and $\mathrm{COD}$ among the three tannery industries before the treatment. The levels of some of the parameters
(SS, TDS and COD) observed in the samples were found above the recommended limits of WHO and NESREA, which called for the treatment of the effluents before discharge into the environment. Base on the morphological and biochemical test results, TAN1, TAN2, and TAN3 bacterial isolates were identified to be Neisseria spp, Bacillus cereus, and Staphylococcus aureus respectively. The results of Post-treatment analysis showed that there is overall decrease in the levels of the parameters determined when compared with that of the pre-treatment. The overall percentage reduction of the immobilised bacteria in the treatment of the respective effluents was in the order TAN2 (72\%)>TAN1 $(70 \%)>$ TAN3 $(62 \%)$. Hence, the immobilized bacteria are having higher biodegradation potential for the treatment of the tannery effluents.

\section{Acknowledgments}

The authors wish to acknowledge the University of Maiduguri for the financial support. The authors are grateful to the Kano State Ministry of Environment for their support in obtaining the effluent samples. 


\section{REFERENCES}

Ajao, A. T., Adebayo, G. B., and Yakubu, S. E. (2011). Bioremediation of textile industrial effluent using mixed culture of Pseudomonas aeruginosa and Bacillus subtilis immobilized on agar-agar in a bioreactor. J. Microbiol. Biotech. Res, 1(3), 50-56.

Akan, J. C., Moses, E. A., Ogugbuaja, V. O., and Abah, J. (2007). Assessment of tannery industrial effluents from Kano metropolis, Kano State, Nigeria. Journal of Applied Sciences, 7(19), 2788-2793.

Akan, J. C., Ogugbuaja, V. O., Abdulrahman, F. I., and Ayodele, J. T. (2009). Pollutant levels in effluent samples from tanneries and textiles of Kano industrial areas, Nigeria. Global journal of pure and applied sciences, 15(3-4).

APHA (1989). Standard methods for Examination of Will bete and Will betewater.15 $5^{\text {th }}$ edition. Brydpass Springfield Will behington DC. pp. 164-176

APHA (1992). Standard Methods for the Examination of Water and Wastewater. Health, 69, 1116-9.

Baba, A., Garba, S. T., and Bello, H. S. (2020). Bioremediation Potential of Immobilized corynebacterium kutsceri in the Treatment of Tannery Industrial Effluent from Challawa Industrial Estate, Kano State, Nigeria. Journal of the Turkish Chemical Society Section A: Chemistry, $7(2), 335-350$.

Beem, E. I. V. (1994). reduction of solvent VOC emission. J. Oil Col. Chem. Ass, 77, 158.

Bouwer, E. J., and Zehnder, A. J. (1993). Bioremediation of organic compoundsputting microbial metabolism to work. Trends in biotechnology, 11(8), 360367.

Chen, K. C., Wu, J. Y., Liou, D. J., and Hwang, S. C. J. (2003). Decolorization of the textile dyes by newly isolated bacterial strains. Journal of Biotechnology, 101(1), 57-68.

Dan'Azumi, S., and Bichi, M. H. (2010). INDUSTRIAL POLLUTION AND HEAVY METALS PROFILE OF CHALLAWA RIVER IN KANO, NIGERIA. Journal of Applied Sciences in Environmental Sanitation, $5(1)$.

DWAF. (1992). Analytical Methods Manual, TR 151. Department of Water Affairs and Forestry, Pretoria.

El-Bestawy, E. (2013). Biological treatment of leather-tanning industrial wastewater using free living bacteria.
Elsheikh, M. A. S. (2009). Tannery wastewater pre-treatment. Water Science and Technology, 60(2), 433-440.

FuIlbrook, P. D. (1996). "Kinetics." Industrial enzymology: The application of enzymes in Industry. 2nd Ed. T. Godfrey and J Reichelt. eds.. Nature. New York.

Gianfreda, L., and Rao, M. A. (2004). Potential of extra cellular enzymes in remediation of polluted soils: a review. Enzyme and microbial technology, 35(4), 339354.

Hugo Springer. (1994). John Arthur Wilson Memorial Lecture "Treatment of Industrial Wastes of the Leather Industry - is it still a Major Problem". JALCA, 89, 153-185

Jimoh, A. A., Ganiyu, B. A., Baba, D., and Baba, A. (2018) Bioremediation Process of Effluent from Detergent and Food Industries in Jos, Nigeria: Kinetics and Thermodynamics. International Journal of Engineering Science Invention (IJESI), 762-73

Kandelbauer, A., Maute, O., Kessler, R. W., Erlacher, A., and Gübitz, G. M. (2004). Study of dye decolorization in an immobilized laccase enzyme-reactor using online spectroscopy. Biotechnology and bioengineering, 87(4), 552-563.

Kongjao, S., Damronglerd, S., and Hunsom, M. (2008). Simultaneous removal of organic and inorganic Pollutants in tannery wastewater using electrocoagulation technique. Korean Journal of chemical engineering, 25(4), 703.

Maheshwari, U. M., Aruna, S., Gomathi, M., and AbdulJaffar, A. H. (2017). Bioremediation by Free and Immobilized Bacteria Isolated from Tannery Effluent. International Journal of Research in Applied, Natural and Social Sciences. 5(7), 75-90

Margesin, R., and Schinner, F. (2001). Bioremediation (natural attenuation and biostimulation) of diesel-oilcontaminated soil in an alpine glacier skiing area. Applied and environmental microbiology, 677), 3127-3133.

Mohammed, A., Sekar, P., and George, J. (2011). Efficacy of microbes in bioremediation of tannery effluent. Inter. J. Curr. Res, 3(4), 324-326.

Mohammed, S. S. D., Orukotan, A. A., and Abdullahi, H. (2017). Physicochemical and Bacteriological Assessment of Tannery Effluent from Samaru-Zaria, 
BAJOPAS Volume 13 Number 2, December, 2020 Kaduna State, Nigeria. Journal of Applied

Sciences and Environmental Management, 21(4), 734-740.

Munz, G., De Angelis, D., Gori, R., Mori, G., Casarci, M., and Lubello, C. (2009). The role of tannins in conventional and membrane treatment of tannery wastewater. Journal of hazardous materials, 164(2-3), 733-739

Mythili, K., and Karthikeyan, B. (2011). Bioremediation of $\mathrm{Cr}$ (VI) from tannery effluent using Bacillus spp and Staphylococcus spp. International Multidisciplinary Research Journal, 1(6).

NESREA (2009). National Environmental Standards for Effluent Limitations and Regulation. 1233-1236

Noorjahan, C. M. (2014). Physicochemical characteristics, identification of bacteria and biodegradation of industrial effluent. Journal of bioremediation and Biodegradation, 5(3).

Ohtake, H. I., and Silver, A. O. (1994). Bacterial reduction of toxic chromate. Biological degradation and bioremediation of toxic chemicals, 403-415.

Omoleke, I. I. (2004). Management of environmental pollution in Ibadan, an African city: the challenges of health hazard facing government and the people. Journal of Human Ecology, 15(4), 265-275.

Rajor, A., Reddy, A.S., and Singh, B. (2004). Determination of BOD kinetic Parameters and evaluation of alternate methods, M.Sc. Thesis, Department of biotechnology \& environmental Science, Thapar Institute of Engineering and Technology, Patiala

Ramasami, T., Rajamani, S., and Rao, J. R. (1994, March). Pollution control in leather industry: Emerging technological options. In International symposium on surface and colloidal science and its relevance to soil pollution, madras.

Ramesh, J. V. S., and Singh, S. P. (1993). Yearly variation in certain physicochemical parameters of pond at eastern Doon Valley. Uttar Pradesh J. Zoo, 12 (1), 7577.

Ranen, S., and Sharadinadra, C. (2009). Biotechnology applications to environmental remediation in resource exploitation. Current science, 97, 6-25
Russell, A. J., Berberich, J. A., Drevon, G. F., and Koepsel, R. R. (2003). Biomaterials for mediation of

chemical and biological warfare agents. Annual review of biomedical engineering, 5(1), 1-27.

Saravanan, P., and Saravanan, A. (1999). Decolourization of tannery effluent by Flavobacterium sp. EK 1. Indian Journal of Environmental Protection, 19, 19-24.

Sikander, S., and Shahida, H. (2007). Reduction of toxic hexavalent chromium by Ochrobactrum intermedium strain SDCr5 stimulated by heavy metals. Bioresource Technol, 98, 340-344.

Singh, N., Sharma, B. K., and Bohra, P. C. (2000). Impact assessment of industrial effluent of arid soils by using satellite imageries. Journal of the Indian Society of Remote Sensing, 28(2-3), 79.

Sreemoyee, C., and Priti, P. (2013). Assessment of physico-chemical parameters of dairy waste water and isolation and characterization of bacterial strains in terms of cod reduction. Int J Sci, 2(3), 395-400.

Verheijen, L. A. H. M., Wiersema, D., Pol, L. H., and De Wit, J. (1996). Management of wastes from animal product processing. Livestock and environment, Finding a balance. International Agriculture Center, Wageningen, The Netherlands.

Wang, F., Yao, J., Si, Y., Chen, H., Russel, M., Chen, K., and Bramanti, E. (2010). Short-time effect of heavy metals upon microbial community activity. Journal of Hazardous Materials, 173(13), 510-516.

WHO (World Health Organization). (2006). Air quality guidelines: global update 2005: particulate matter, ozone, nitrogen dioxide, and sulfur dioxide. World Health Organization.

World Bank. (1995). Nigeria's strategic options for redressing industrial pollution. World Bank, industry and energy division. 1st edition, West Central Africa Department; Annexes: 1995; pp 60-62.

Zahoor, A., and Abdul, R. (2009). Enumeration of Coliforms. Journal of Environmental Sciences. 21, 814-820 


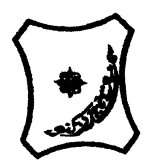

Bayero Journal of Pure and Applied Sciences, 13(2): 1 - 12

Received: November, 2020

Accepted: December, 2020

ISSN $2006-6996$

\title{
BIODEGRADATION POTENTIAL OF IMMOBILIZED BACTERIA IN THE TREATMENT OF TANNERY INDUSTRIAL EFFLUENTS FROM INDUSTRIAL ESTATES IN KANO STATE, NIGERIA
}

\author{
Abdullateef, B., ${ }^{1 *}$ Shuaibu, T. G., ${ }^{1}$ Babagana, K., ${ }^{1}$ Suleman, H. B. ${ }^{2}$ and Dauda, B. ${ }^{3}$ \\ ${ }^{1}$ Department of Pure and Applied Chemistry, Faculty of Science, University of Maiduguri, Borno State, \\ Nigeria \\ ${ }^{2}$ Department of Microbiology, Faculty of Science, University of Maiduguri, Borno State, Nigeria \\ ${ }^{3}$ Department of Chemical Engineering, Faculty of Engineering, University of Maiduguri, Borno State, \\ Nigeria \\ *Corresponding author: babslega@gmail.com; abelega2007@yahoo.com; +2348061309753
}

\section{ABSTRACT}

Industrial Effluents Samples from Gashash Tanneries (TAN1) in Bompai Industrial estate, Larabee Tannery Industry (TAN2) in Sharada Industrial estate and Z Tannery Industries (TAN3) in Challawa Industrial estate, Kano State, Nigeria were collected over a period of six months (August 2017 to January 2018) for assessing the biodegradation potentials of bacteria in the treatment of organic pollutants within the effluents. Bacteria were isolated from the effluents and immobilized on agar-agar. Different masses (5 g, $10 \mathrm{gr}, 15$ $\mathrm{g}, 20 \mathrm{~g}$, and $25 \mathrm{~g}$ ) of the bacteria were used in the treatment of $250 \mathrm{ml}$ of the effluents for ten days in a shaker incubator (Gallenkamp-OC-4364-L) at the temperature $30{ }^{\circ} \mathrm{C}$ and speed of $60 \mathrm{rpm}$. Pre-treatment analysis of the effluents for Temperature, pH, Biochemical Oxygen Demand (BOD), Chemical Oxygen Demand (COD), Suspended Solid (SS) and Total Dissolved Solids (TDS) gives the following results; temperature $\left({ }^{\circ} \mathrm{C}\right.$ )

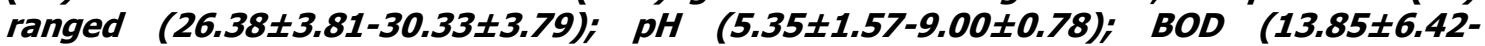
$38.75 \pm 16.20) ;$ COD (1406 $\pm 208-3532 \pm 1373) ;$ SS (208 $\pm 235-780 \pm 739)$ and TDS (266 $\pm 253-5276 \pm 2971)$. No statistical differences ( $p \leq 0.05)$ was observed for all the results among the different industries. The bacterial isolates were identified as Neisseria spp, Bacillus cereus, and Staphylococcus aureus, in TAN1, TAN2, and TAN3, respectively. After treatment of the effluent with the different masses of the isolated bacteria, the mean level of BOD was found to range as (0.55 $\pm 0.36-6.92 \pm 5.49) ; C O D$ (ND-3134 \pm 1595$)$;

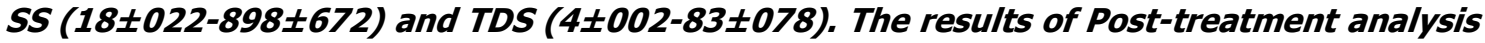
showed that there is overall decrease in the levels of the parameters determined when compared with that of the pre-treatment. The overall percentage reduction of the immobilised bacteria in the treatment of the respective effluents was in the order TAN2 (72\%)>TAN1 (70\%)>TAN3 (62\%). Hence, the immobilized bacteria are having higher biodegradation potential for the treatment of the tannery effluents.

Keywords: Biodegradation, bacteria, effluent, immobilization, tannery.

\section{INTRODUCTION}

Tannery industrial wastewater is a serious consequence of the pollution point of view for streams, freshwater, and land used for agriculture. The lack of awareness in the modern industrial practice has resulted in the discharge of tannery effluents which exhibit very high value of chromium ( $\mathrm{Cr}$ ), Sulfide, and chloride, Total Dissolved Solid (TDS), Total Suspended Solid (TSS), Biochemical Oxygen Demand (BOD) and Chemical Oxygen Demand (COD) in the water stream or land (Mohammed et al., 2001). Tanning is the process, which One ton of skin generally leads to the production of 20 to $80 \mathrm{~m}^{3}$ of turbid and foul-smelling converts the protein of the rawhide or skin into a stable material, which will not putrefy and is suitable for a wide variety of end applications (Elsheikh, 2009). The highly polluting chromium is the most commonly used tanning material producing leather that is more flexible and pliable than vegetable-tanned leather and does not discolor or lose shape in water as drastically as vegetable-tan (Elsheikh, 2009). Tannery effluent is among the most hazardous industrial pollutants due to its huge organic and inorganic load, which is highly toxic to human life and the environment (Kongjao et al., 2008). wastewater including chromium (100-400 mg/l), sulfide $(200-800 \mathrm{mg} / \mathrm{l})$, high levels of fat and 
BAJOPAS Volume 13 Number 2, December, 2020 other solid wastes, and notable pathogen contamination as well as pesticides added for skin conservation during transport (Elsheikh, 2009). There are more than 6000 tanneries in Nigeria with an annual processing capacity of 700,000 tons of hides and skins (Omoleke, 2004; Singh et al., 2008). It was reported that the total amount of waste produced per animal slaughtered is approximately $35 \%$ of its weight (World Bank, 1995). Also, for every $1000 \mathrm{~kg}$ of carcass weight, a slaughtered beef produces 5.5 $\mathrm{kg}$ of manure (excluding rumen contents or stockyard manure) and $100 \mathrm{~kg}$ of paunch manure (undigested food) (Verheijen et al., 1996). Tanneries generate wastewater in the range of 30-35 $\mathrm{L} \mathrm{kg}^{-1}$ skin/hide processed with variable $\mathrm{pH}$, Biological Oxygen Demand (BOD), Chemical Oxygen Demand (COD), high concentrations of suspended solids (SS), and tannins as well as chromium (Zahoor and Abdul, 2009).

Being heterogeneous and composed of a wide variety of compounds, it is very difficult to select a unique direct method for estimating the biodegradability of organic contents and biokinetic parameters for a wastewater sample (Rajor, 2004). For this purpose, some indirect estimation such as determination of biochemical oxygen demand (BOD) and chemical oxygen demand (COD) are applied as common laboratory investigations [9]. During retanning procedures, synthetic tannins (Syntan), oils and resins are added to form softer leather at varying doses (Munz et al., 2009). One of the refractory groups of chemicals in tannery effluents derives mainly from tannins (Ramasami et al., 2004). Syntans are characterized by complex chemical structures, because they are composed of an extended set of chemicals such as phenol-, naphthalene-, formaldehyde- and melamine-based syntans, and acrylic resins (Beem, 1994). Organic pollutants (proteic and lipidic components) are originated from skins (it is calculated that the raw skin has $30 \%$ loss of organic material during the working cycle) or they are introduced during processes (Hugo Springer, 1994).

Many conventional processes such as oxidation, chemical and biological processes were carried out to treat tanneries wastewater (Ebtesam et al, 2013). Biological processes have received more attention because of their costeffectiveness, lower sludge production and environmental friendliness (Noorjahan, 2014). Naturally occurring micro-organisms degrade the hazardous organic wastes including xenobiotic compounds, such as pesticides, polycyclic aromatic hydrocarbons (PAHs) and polychlorinated biphenyls (PCBs) in due course of time (Ranen and Sharadinadra, 2009). Bioremediation is based on the idea that all organisms remove substances from the environment to carry outgrowth and metabolism (Bouwer and Zehnder, 1993). Bacteria, protista and fungi are found to be very good at degrading complex molecules and incorporating the breakdown products into their metabolism (Bouwer and Zehnder, 1993). The resultant metabolic wastes that they produce are generally safe and somehow recycled into other organisms (Ranen and Sharadinadra, 2009). An acclimatized indigenous population of microorganisms capable of degradation of the compounds of interest must exist at the site for a successful bioremediation mode (Ranen and Sharadinadra, 2009). It has been observed that for a successful bioremediation mode, an acclimatized indigenous population of microorganisms capable of degradation of the compounds of interest must exist at the site under investigation (Ranen and Sharadinadra, 2009). Even though there are numerous physical and chemical methods employed in the disposal of wastes the advantage in using bacterium is that they play a key role in the reduction of COD, BOD, total protein, total tannin and total phenol (Saravanan and Saravanan, 1998)

Baba et al. (2020) studied the bioremediation potential of immobilized corynebacterium kutsceri in the Treatment of tannery industrial effluent from Challawa Industrial Estate, Kano State, Nigeria. The aim of the work is to study the reduction in the level of the contaminants through the process of bioremediation using the isolated bacteria. Immobilized bacteria can withstand various temperatures, $\mathrm{pH}$ and substrate concentrations; consequently, increasing the efficiency and the lifespan of the bacteria. Immobilized bacteria are widely applied in the treatment of wastewater and can be separated and recovered after the treatment with the same efficiency (Baba et al., 2020).

\section{MATERIALS AND METHODS \\ Study Area}

This study was carried out in Bompai, Sharada and Challawa industrial estates in Kano, Figure 1. Kano lies on Latitude $11^{\circ} 30^{\prime} \mathrm{N}$ and $8^{\circ} 30^{\prime} \mathrm{E}$ and Longitude $11^{\circ} 5^{\prime} \mathrm{N}$ and $8^{\circ} 5^{\prime} \mathrm{E}$ in Northern Nigeria. It is one of the developed industrial cities in Nigeria. Tannery activities are the dominating industries and this could be one of the reasons for her high population density (Dan'Azumi and Bichi, 2010). Many researchers have studied biodegradation of tannery effluent using microorganisms. However, limited literature is available on the biodegradation of tannery effluent in Kano industrial estates using 
BAJOPAS Volume 13 Number 2, December, 2020 immobilized bacterial cells. This research work focuses on the potential of the use of the indigenous immobilized bacterial isolates in the treatment of tannery effluents in the industrial estates.

\section{Sample Collection}

Effluents were collected from the Tannery Industries from Bompai, Challawa and Sharada Industrial Estates, Kano, Nigeria. The effluents were collected over a period of six months (August 2017 to January 2018). Samples collected in a sterile 4-liter plastic container with a unique identification number were preserved using an ice-box that was transported to the Microbiology Laboratory, Department of Microbiology, Bayero University of Kano for analysis

\section{Sample Preparation and Sample Analysis}

Immediately after the collection of the effluent, $\mathrm{pH}$, TSS, TDS, COD, BOD levels were determined before treatment (Pre-treatment determination) and ten days after treatment (Post-treatment determination) as described in
APHA (1989) standard methods. $\mathrm{pH}$ was determined using Ecotests $\mathrm{pH}$ meter and TDS was determined using AQUALYTIC TDS Salinometer. BOD was determined as described by the standard method (APHA, 1992). COD and SS were determined using DR/2010 HACH portable data logging spectrophotometer (DWAF, 1992)

\section{Identification and Biochemical} Characterization of the Bacterial Isolates

The bacteria were isolated from the effluents using Serial Dilution according to the method described by APHA (1989). The biochemical tests such as oxidase, catalase, coagulase, indole (from $1 \%$ tryptone broth), citrate (Simmons citrate agar), methyl red/VogesProskauer (MR/VP), nitrate reduction, Starch Hydrolysis, Glucose, Maltose, and Lactose tests were carried out on the bacterial isolates to identify the bacteria through the bacteria biochemical characteristics according to Ajao et al. (2011).

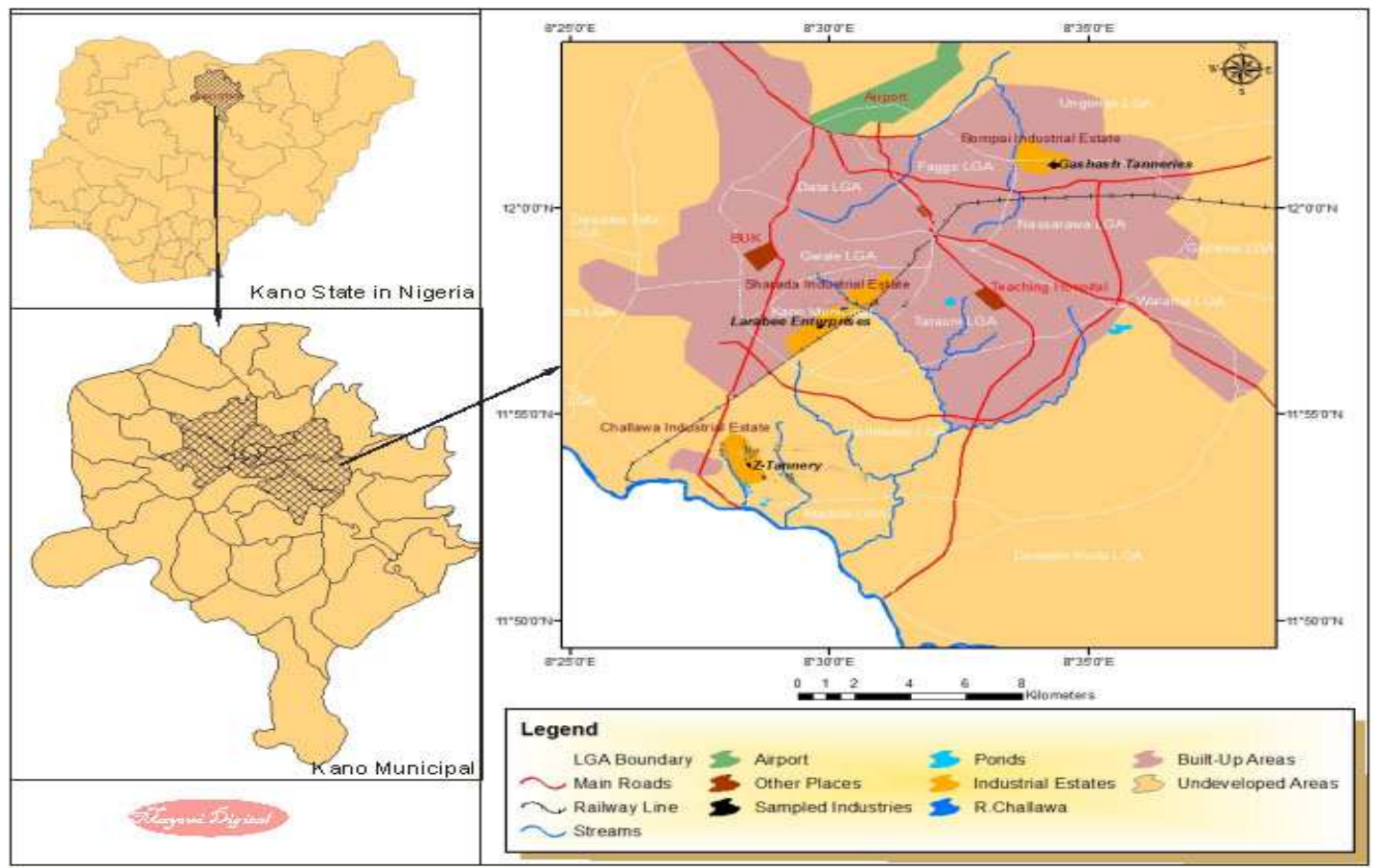

Fig. 1 Map showing the study areas

Source: Mayomi Digital Productions, GIS Laboratory, Department of Geography, UNIMAID (2017)

\section{Determination of Growth Rate of the Bacteria in Effluent Sample}

The bacteria growth rates were determined by transferring $2 \mathrm{~mL}$ of the bacterial isolates from the tannery effluent in broth medium into 100 $\mathrm{mL}$ sterile effluents in conical flasks and kept in an incubator (Giffrin cool) for 10 days. Control was also set up by incubating another $100 \mathrm{~mL}$ each of the sterile effluents without the bacteria. The optical density of the content was determined at the wavelength of $600 \mathrm{~nm}$ on a daily interval and recorded. 
BAJOPAS Volume 13 Number 2, December, 2020 Immobilization of Bacteria

Agar solution and inoculi were prepared separately. Fifty milliliters $(50 \mathrm{~mL})$ of nutrient broth each of the inoculi was prepared in a McCartney bottle and incubated for 24 hours. A solution of agar-agar was prepared by dissolving $10 \mathrm{~g}$ of the powder in distilled water and made up to $500 \mathrm{~mL}$ mark in an Erlenmeyer flask and was sterilized in an autoclave (280A) for 15 minutes and allowed to cool to $40-45^{\circ} \mathrm{C}$ (Ajao et al., 2011). Four milliliters ( $4 \mathrm{~mL})$ of the bacterial isolates in the nutrient broth was mixed with 36 $\mathrm{ml}$ of the prepared agar-agar media in petri-dish plates and then allowed to solidify. This was kept in the refrigerator for bioremediation.

\section{Bioremediation (Treatment) of the Effluents}

The solidified agar block (immobilized bacteria) was cut into cubes using a sterile knife; $0.1 \mathrm{~mL}$ phosphate buffer ( $\mathrm{pH} \mathrm{7.0)}$ was added and kept in the refrigerator for 1 hour for curing. The phosphate buffer was decanted after 1 hour and the cubes were washed with sterile distilled water 3-4 times before it was used (Ajao et al., 2011). Two liters (2 L) of the effluent was supplemented with the minimum basal medium in $\mathrm{g} / \mathrm{L}: \mathrm{NaCl}(0.8), \mathrm{MgSO}_{4} .7 \mathrm{H}_{2} \mathrm{O}(0.001), \mathrm{KH}_{2} \mathrm{PO}_{4}$ (2), $\mathrm{NaNO}_{3}$ (2), $\quad \mathrm{CaCl}_{2} .2 \mathrm{H}_{2} \mathrm{O} \quad(0.5)$ and $\mathrm{NaHPO}_{4} .12 \mathrm{H}_{2} \mathrm{O}(2)$ and sterilized in an autoclave at $121^{\circ} \mathrm{C}$ for 15 minutes (Margesin and Schinner, 2001). Two hundred and fifty milliliters $(250 \mathrm{~mL})$ of the effluents were transferred into different $250 \mathrm{ml}$ conical flasks. The content was covered with a cotton-wool ramped with foil paper to avoid contamination. Five grams $(5 \mathrm{~g})$ of the immobilized bacteria were quickly transferred into each of the effluents in the conical flasks in an inoculating chamber. The same procedures were carried out for the $10 \mathrm{~g}, 15 \mathrm{~g}, 20 \mathrm{~g}$ and 25 $\mathrm{g}$ of the immobilized bacteria in separate $250 \mathrm{~mL}$ effluents in conical flasks and agitated for ten days in a shaker incubator (Gallenkamp-OC4364-L) at a temperature $30^{\circ} \mathrm{C}$ and speed of 60 rpm. The treated effluent samples were taken on the tenth day and analyzed for the parameters $\mathrm{pH}$, SS, TDS, COD, and BOD, (Posttreatment determination) for the different grams of bacteria to evaluate and compare the biodegradation potential. (Baba et al., 2020).

\section{Statistical Analysis}

The data were represented as Mean \pm Standard deviation and analyzed statistically using oneway Analysis of Variance (ANOVA) and Tukey's HSD as Post Hoc Tests with the aid of SPSS 16.0. The correlation coefficient was also used to measure the strength of the relationship between the different masses of the bacteria and the parameters. All $\mathrm{p} \leq 0.05$ were considered as statistically significant.

\section{RESULTS AND DISCUSSION Physico-chemical parameters in the Industrial Effluents before the Biodegradation.}

Results of the Physico-chemical parameters in the industrial effluents before the Biodegradation is shown in table 1 . The mean temperatures $\left({ }^{\circ} \mathrm{C}\right)$ observed in TAN1, TAN2, and TAN3 samples were $28.07 \pm 0.65 ; 27.77 \pm 0.64$ and $26.38 \pm 3.81$ respectively. The order of the mean temperature of the samples from the three industries can be arranged as TAN1 > TAN2>TAN3. The temperature observed at TAN1, TAN2, and TAN3 samples were found below the WHO $\left(35^{\circ} \mathrm{C}\right)$ and NESREA $\left(40^{\circ} \mathrm{C}\right)$ limits. The low values of temperature might be due to the processes used at the time of sampling. High temperature brings down the solubility of gases in water that ultimately expresses as high BOD and COD. Statistical analysis shows that there is no significant difference $(p<0.05)$ between the mean values of temperature among the industries. This might be due to similar tannery activities involved in the tannery industries at the time of sampling. The average values of temperature observed in this present study are less than those observed by Akan et al. (2007), Akan et al. (2009) and Baba et al. (2020).

The mean level of $\mathrm{pH}$ observed in TAN1, TAN2 and TAN3, samples were $7.77 \pm 2.93$; $8.35 \pm 0.28$ and $7.52 \pm 0.76$ respectively. The order of the mean $\mathrm{pH}$ of the samples from the three industries can be arranged as TAN2> TAN1 $>$ TAN3. The $\mathrm{pH}$ of the samples falls within the WHO (7.0-8.5) and NESREA (6-9) standard limits. Statistical analysis shows that there is no significant difference $(p<0.05)$ between the mean values of $\mathrm{pH}$ among the industries. This might be due to similar tannery activities involved in the tannery industries at the time of sampling. Maheshwari et al. (2017) reported that the level of $\mathrm{pH}$ in the effluents from the tannery industry in Vaniyambadi, India was 6.5 which was lower than that observed in the present study. The $\mathrm{pH}$ in the effluents from the tannery industries in Kano and Kaduna were reported to be 7.64 and 6.89, respectively (Akan et al., 2007; Mohammed et al., 2017). The average values of $\mathrm{pH}$ observed in this present study are less than those observed by Mohammed et al. (2017) and Baba et al. (2020). The mean level of SS $(\mathrm{mg} / \mathrm{l})$ observed in TAN1, TAN2, and TAN3 samples were 374 \pm 124 ; $358 \pm 335$ and $780 \pm 739$ respectively. The order of the mean SS in the samples from the three industries can be arranged as TAN3 > TAN1 $>$ TAN2. 
The SS observed in the samples were far above the recommended standard limits of regulating bodies WHO $(30 \mathrm{mg} / \mathrm{l})$ and NESREA $(10 \mathrm{mg} / \mathrm{l})$. Statistical analysis shows that there is no significant difference $(p<0.05)$ between the mean values of SS among the industries. This might be due to similar tannery activities involved in the tannery industries at the time of sampling. The average values of SS observed in this present study are less than that observed $(3700 \pm 122 \mathrm{mg} / \mathrm{l})$ by Akan et al. (2009) for tanneries in Kano. Also, the average values of SS observed in this present study are less than that observed by Mohammed et al. (2017) and Baba et al. (2020) with the exception in TAN3.

The mean level of TDS (mg/l) observed in TAN1, TAN2, and TAN3 samples were $3941 \pm 3703$; $3300 \pm 1714$ and $2653 \pm 1240$ respectively. The order of the mean TDS in the samples from the three industries can be arranged as TAN1>TAN2>TAN3. The TDS observed in the samples were far above the recommended standard limits of WHO $(250 \mathrm{mg} / \mathrm{l})$ and NESREA $(500 \mathrm{mg} / \mathrm{l})$. Statistical analysis shows that there is no significant difference $(p<0.05)$ between the mean values of TDS among the industries. This might be due to similar tannery activities involved in the tannery industries at the time of sampling. TDS in the effluents from the tannery industries in Kano, Nigeria was reported to be $1281 \mathrm{mg} / \mathrm{l}$ (Akan et al., 2007). The average values of SS observed in this present study are less than those observed by Mohammed et al. (2017) and Baba et al. 2020)

The mean level of COD (mg/l) observed in TAN1, TAN2 and TAN3 samples seasons were $2372 \pm 938 ; \quad 1406 \pm 208$ and $3532 \pm 1373$ respectively. The order of the mean COD of the samples from the three industries can be arranged as TAN3>TAN1> TAN2. The COD observed in TAN1, TAN2 and TAN3 samples were far above the recommended standard limits of regulating bodies $\mathrm{WHO}(40 \mathrm{mg} / \mathrm{l})$ and NESREA (40 mg/l). Statistical analysis shows that there is no significant difference $(p<0.05)$ in COD among the industries. This might be due to similar tannery activities involved in the tannery industries as at the time of sampling. The Chemical Oxygen demand (COD) is the amount of oxygen, in $\mathrm{mg} / \mathrm{L}$, required for the degradation of the compound of wastewater to occur. In comparison, the average values of COD observed in this present study were higher than that observed by Mohammed et al. (2017) but lower than that observed by Baba et al. (2020).

The mean levels of BOD $(\mathrm{mg} / \mathrm{l})$ observed in TAN1, TAN2 and TAN3 samples were $13.85 \pm 6.42 ; \quad 19.46 \pm 0.50$ and $17.13 \pm 3.14$ respectively. The order of the mean BOD in the samples from the three industries can be arranged as TAN2>TAN3>TAN1. The BOD observed in TAN1, TAN2 and TAN3 samples were found below the recommended limits of NESREA (200 mg/l) but above WHO (10 mg/l). Statistical analysis shows that there is no significant difference $(p<0.05)$ between the mean values of BOD among the industries. This might be due to similar tannery activities involved in the tannery industries at the time of sampling. The low level of BOD recorded in this study is an indication of the low level of biodegradable organic solids in the effluent. The average values of BOD observed in this present study were lower than those observed by Mohammed et al. (2017) and Baba et al. (2020).

Table 1: Mean Values \pm S.D of Physico-chemical parameters of effluents from the Tannery Industries before Treatment.

\begin{tabular}{llllllll}
\hline Parameter & Tannery 1 & Tannery 2 & Tannery 3 & $\mathrm{a}$ & $\mathrm{b}$ & $\mathrm{c}$ & $\mathrm{d}$ \\
\cline { 2 - 7 } Temperature $\left({ }^{\circ} \mathrm{C}\right)$ & $28.07 \mathrm{a} \pm 0.65$ & $27.77 \mathrm{a} \pm 0.64$ & $26.38 \mathrm{a} \pm 3.81$ & & $29.50 \pm 4.68$ & 35 & 40 \\
pH & $7.77 \mathrm{a} \pm 2.93$ & $8.35 \mathrm{a} \pm 0.28$ & $7.52 \mathrm{a} \pm 0.76$ & 6.89 & $5.35 \pm 1.57$ & $7.0-8.5$ & $6.0-9.0$ \\
$\mathrm{COD}(\mathrm{mg} / \mathrm{l})$ & $2372 \mathrm{a} \pm 938$ & $1406 \mathrm{a} \pm 208$ & $3532 \mathrm{a} \pm 1373$ & 2.2 & $3106 \pm 2753$ & 40 & 40 \\
$\mathrm{BOD}(\mathrm{mg} / \mathrm{l})$ & $13.85 \mathrm{a} \pm 6.42$ & $19.46 \mathrm{a} \pm 0.50$ & $17.13 \mathrm{a} \pm 3.14$ & 1032 & $26.17 \pm 9.49$ & 10 & 200 \\
$\mathrm{SS}(\mathrm{mg} / \mathrm{l})$ & $374 \mathrm{a} \pm 124$ & $358 \mathrm{a} \pm 335$ & $780 \mathrm{a} \pm 739$ & 501 & $562 \pm 482$ & 30 & 10 \\
TDS $(\mathrm{mg} / \mathrm{l})$ & $3941 \mathrm{a} \pm 3703$ & $3300 \mathrm{a} \pm 1714$ & $2653 \mathrm{a} \pm 1240$ & 532.7 & $444 \pm 507$ & 250 & 500 \\
\hline
\end{tabular}

The values given in the table above are means of 6 replicate values, $\mathrm{n}=6$ ( 1 sample was taken monthly for 6 months). Within the rows, means with different alphabets are statistically different $(p<0.05)$. WHO: World Health Organisation. NESREA: National Environmental Standard and Regulatory Enforcement Agency. a = Mohammed et al.(2017), b = Baba et al. (2020), c = WHO (2006), $d=$ NESSRA (2009) 
BAJOPAS Volume 13 Number 2, December, 2020

Identification, Biochemical Characterization and growth rates of the Bacterial Isolates

Results of identification and biochemical characterization of the bacterial isolates were shown in table 2. After 24 hours of incubation, the nutrient agar media plates were checked for bacterial growth. The results showed the presence of different strains in the samples. The TAN1 bacteria isolate was found to be gramnegative cocci while TAN3 was gram-positive cocci. TAN2 bacteria isolate was found to be gram-positive, rod-shaped. TAN1, TAN2, and TAN3 bacteria isolates recorded positive results for spore former.

The results of the biochemical tests indicated that all the bacteria were positive for catalase, oxidase, citrate, maltose, glucose, lactose (negative in TAN1), mannitol (negative in TAN2), starch hydrolysis and coagulase (negative in TAN2) tests. The bacteria showed negative results for nitrate reduction, $M R$ (positive in TAN2), VP (positive in TAN1), Indole (positive in TAN2) tests. Base on the morphological and biochemical test results, TAN1, TAN2, and TAN3 bacteria isolates were identified to be Nesseria spp, Bacillus cereus, and Staphylococcus aureus respectively.

The growth rate of the TAN1, TAN2 and TAN3 Isolates were shown in figure 2. Generally, the optical density increase with the increase in time (day) and decrease as time goes on. The highest optical density was shown by bacillus cereus in TAN2 while the lowest was shown by Staphylococcus aureus in TAN3.

The initial growth phase of TAN1 Isolate bacteria occurred within 2-day of incubation as the growth rate increases up to the 6th-day incubation when the maximum growth was observed. Beyond the 6th day, the growth of the bacteria declined (which might be due to a shortage of nutrients in the effluents) until it reached its death phase (which might be due to the unavailability of nutrients in the effluents).

A similar trend of growth was also observed for TAN2 Isolate as the initial growth phase also occurred within 2-day of incubation but maximum growth rate observed on the 4th day of incubation. The stationary stage occurred between the 4th day and the 8th day. Beyond the 8th day, the growth of the bacteria declined (which might be due to a shortage of nutrients in the effluents) until it reached its death phase (which might be due to the unavailability of nutrients in the effluents).

The initial growth phase of TAN3 bacterial Isolate occurred within the 3-day incubation as the growth rate increases up to the 6th-day incubation when the maximum growth was observed. Beyond the 6th day, the growth of the bacteria declined (which might be due to a shortage of nutrients in the effluents) until it reached its death phase (which might be due to the unavailability of nutrients in the effluents).

Table 2: Morphological and Biochemical characteristics of bacterial isolates

\begin{tabular}{lllll} 
Bacterial Isolates & & TAN1 & TAN2 & TAN3 \\
\hline $\begin{array}{lllll}\text { Morphological } \\
\text { characteristics }\end{array}$ & Shape & Cocci & Rod & Cocci \\
& Spore & & & \\
& former & + & + & + \\
Gram & & & \\
Biochemical characteristics & reaction & - & + & + \\
& Citrate & + & + & + \\
& Catalase & + & + & + \\
& Coagulase & + & - & + \\
Starch & + & + & + \\
& Glucose & + & + & + \\
Oxidase & + & + & + \\
& Indo & - & + & - \\
Lactose & - & + & + \\
Manitol & + & - & + \\
Maltose & + & + & + \\
MR & - & + & - \\
VP & + & - & - \\
& Nitrate & - & - & - \\
Reduction & - Neisseria & Bacillus & Staphylococcus \\
& Bacterial & cereus & aureus \\
& name & spp & cas
\end{tabular}

+ = Positive; - = Negative; MR=Methyl Red; VP= Voges-Proskauer 


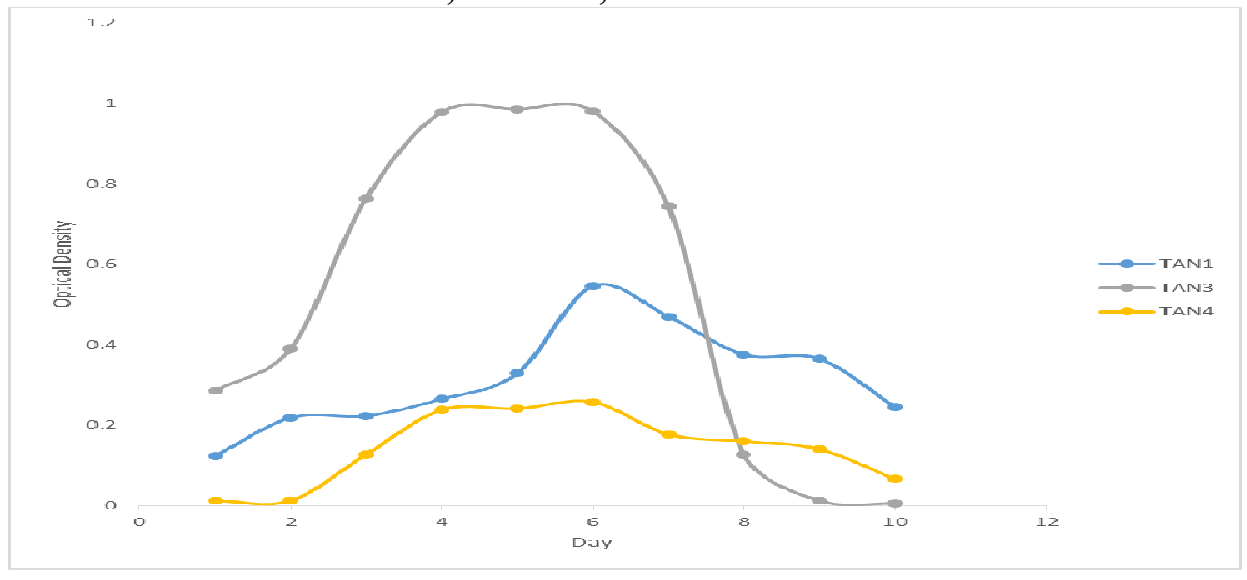

Fig. 2 Growth rates of the isolates in the effluents from the Tannery Industries

\section{Physico-chemical Parameters in the Industrial Effluents after the biodegradation.}

Table 3 shows the mean results of the physicochemical parameter before and after bioremediation using the different masses $(5 \mathrm{~g}$, $10 \mathrm{~g}, 15 \mathrm{~g}, 20 \mathrm{~g}$, and $25 \mathrm{~g}$ ) of the respective immobilized bacteria. Also, Table 4 shows the mean results of correlation coefficient ( $r$ ) between different masses of bacteria and physicochemical parameters.

The mean values $(\mathrm{mg} / \mathrm{l})$ of the SS after the bioremediation varies between $243 \pm 45$ and $898 \pm 672$. The mean concentration $(\mathrm{mg} / \mathrm{l})$ of SS remediated by the different masses $(5 \mathrm{~g}, 10 \mathrm{~g}$, $15 \mathrm{~g}, 20 \mathrm{~g}$, and $25 \mathrm{~g}$ ) of the bacteria varies. The SS in the samples fluctuates up and down after the bioremediation process when compared with the SS of the raw samples before the bioremediation. The increase in the levels of the SS might be due to the aggregation of the TDS which are large enough to result into SS. The increase in the levels of the SS might be also due to the influence of the nutrients which was added into the effluents in order to make the microorganisms more active and viable for fast degradation of organic contaminants in the effluent. The relative potential or efficiency of the different masses of the bacteria in remediating SS in TAN1 samples was in the order $25 \mathrm{~g}>20 \mathrm{~g}>15 \mathrm{~g}>10 \mathrm{~g}>5 \mathrm{~g}$. For TAN2 and TAN3 samples, the order was $25 \mathrm{~g}>20 \mathrm{~g}>15$ $\mathrm{g}>10 \mathrm{~g}>5 \mathrm{~g}$. These might be due to the variations in the surface areas of the different masses of the immobilized bacteria. Statistical analysis shows that there is no significant difference $(p<0.05)$ between the mean values of SS among the masses in the respective industries. Positive and significant correlations exist between the masses of bacteria and Suspended Solid (SS). This showed that there is general increase in the levels of the SS as the masses of the immobilized bacteria increases. TAN3 (90\%) and TAN1 (80\%) showed a very high correlation with the masses of the bacteria while TAN2 (61\%) showed a very low correlation.

The mean values $(\mathrm{mg} / \mathrm{l})$ of the TDS after the bioremediation varies between $46 \pm 11$ and $83 \pm 78$. The mean concentration $(\mathrm{mg} / \mathrm{l})$ of TDS remediated by the different masses $(5 \mathrm{~g}, 10 \mathrm{~g}$, $15 \mathrm{~g}, 20 \mathrm{~g}$, and $25 \mathrm{~g}$ ) of the bacteria varies. There is a reduction in all the TDS of all the samples after the bioremediation process compared with the TDS of the raw samples before the bioremediation. The relative potential or efficiency of the different masses of the bacteria in remediating TDS in TAN1 and TAN3 samples was in the order $5 \mathrm{~g}>10 \mathrm{~g}>15 \mathrm{~g}>20$ $\mathrm{g}>25 \mathrm{~g}$. For TAN2 samples, the order was 20 $g>10 \quad g>25 \quad g>15 \quad g>5 \quad g$. Statistical analysis shows that there is no significant difference $(p<0.05)$ between the mean values of TDS among the masses in the respective industries. These might be due to the variations in the surface areas of the different masses of the immobilized bacteria. Positive and significant correlations exist between the masses of bacteria and TDS with the exception in TAN2 (negative and insignificant correlation). The positive correlations showed that there is general increase in the levels of the TDS as the masses of the immobilized bacteria increases. TAN1 $(96 \%)$ showed a very high correlation with the masses of the bacteria while TAN2 (47\%) showed a very low correlation.

The mean values $(\mathrm{mg} / \mathrm{l})$ of the BOD after the bioremediation varies between $1.56 \pm 0.20 \mathrm{mg} / \mathrm{l}$ and $6.92 \pm 5.49 \mathrm{mg} / \mathrm{l}$. The mean concentration $(\mathrm{mg} / \mathrm{l})$ of BOD remediated by the different masses $(5 \mathrm{~g}, 10 \mathrm{~g}, 15 \mathrm{~g}, 20 \mathrm{~g}$, and $25 \mathrm{~g}$ ) of the bacteria varies. There is a reduction in all the BOD of all the samples after the bioremediation process compared with the $\mathrm{BOD}$ of the raw 
BAJOPAS Volume 13 Number 2, December, 2020 samples before the bioremediation. The relative potential or efficiency of the different masses of the bacteria in remediating BOD in TAN1, TAN2 and TAN3 samples were in the order $25 \mathrm{~g}>20$ $\mathrm{g}>15 \mathrm{~g}>10 \mathrm{~g}>5 \mathrm{~g}, 25 \mathrm{~g}>15 \mathrm{~g}>5 \mathrm{~g}>10 \mathrm{~g}>20 \mathrm{~g}$ and $20 \mathrm{~g}>10 \mathrm{~g}>25 \mathrm{~g}>15 \mathrm{~g}>5 \mathrm{~g}$ respectively. Statistical analysis shows that there is significant difference $(p<0.05)$ between the mean values of BOD among the masses in the respective industries. These might be due to the variations in the surface areas of the different masses of the immobilized bacteria. Negative and significant correlations exist between the masses of bacteria and BOD. This showed that there is general decrease in the levels of the BOD as the masses of the immobilized bacteria increases. TAN1 (94\%) showed a very high correlation with the masses of the bacteria while TAN2 (4\%) showed a very low correlation.

The mean values $(\mathrm{mg} / \mathrm{l})$ of the COD after the bioremediation varies between $250 \pm 154$ and $3134 \pm 1595$. The mean concentration $(\mathrm{mg} / \mathrm{l})$ of COD remediated by the different masses $(5 \mathrm{~g}$, $10 \mathrm{~g}, 15 \mathrm{~g} 20 \mathrm{~g}$, and $25 \mathrm{~g}$ ) of the bacteria varies. There is a reduction in all the COD of all the samples after the bioremediation process compared with the COD of the raw samples before the bioremediation. The relative potential or efficiency of the different masses of the bacteria in remediating COD in TAN1, TAN2 and TAN3 samples were in the order $25 \mathrm{~g}>20 \mathrm{~g}>15$ $\mathrm{g}>5 \mathrm{~g}>10 \mathrm{~g}, 25 \mathrm{~g}>20 \mathrm{~g}>15 \mathrm{~g}>10 \mathrm{~g}>5 \mathrm{~g}$ and 10 g>5 g>25 g>15 g>20 g respectively. Statistical analysis shows that there were significant difference $(p<0.05)$ between the mean values of COD among the masses in the respective industries except for effluents treated with $25 \mathrm{~g}$. These might be due to the variations in the surface areas of the different masses of the immobilized bacteria. Negative and insignificant correlations exist between the masses of bacteria and COD with the exception in TAN3 (positive and significant correlation). The negative correlations showed that there is general decrease in the levels of the COD as the masses of the immobilized bacteria increases. TAN2 (100\%) showed a very high correlation with the masses of the bacteria while TAN3 (36\%) showed a very low correlation.

Generally, there was an overall decrease in the concentration of these physicochemical parameters after the bioremediation using the different masses of the bacterial isolates. These might be due to the variations in the surface areas of the different masses of the immobilized bacteria. This is in line with the work of Jimoh et al. (2018) and Baba et al. (2020).

Table 3: Mean Values $(\mathrm{mg} / \mathrm{l}) \pm$ S.D of Physicochemical parameters in effluents from the Tannery Industries before and after Treatment of the effluents $(250 \mathrm{ml})$ with the different masses $(5 \mathrm{~g}, 10 \mathrm{~g}$, $15 \mathrm{~g}, 20 \mathrm{~g}$, and $25 \mathrm{~g}$ ) of the bacteria.

\begin{tabular}{llllllll}
\hline $\mathrm{P}$ & IND & Before & \multicolumn{5}{c}{ After } \\
\cline { 4 - 7 } & & & $5 \mathrm{~g}$ & $10 \mathrm{~g}$ & $15 \mathrm{~g}$ & $20 \mathrm{~g}$ & $25 \mathrm{~g}$ \\
\hline \multirow{2}{*}{ COD } & TAN1 & $2372 \pm 938$ & $1708 \mathrm{a} \pm 861$ & $2045 \mathrm{a} \pm 1205$ & $845 \mathrm{a} \pm 369$ & $300 \mathrm{a} \pm 167$ & $250 \mathrm{a} \pm 154$ \\
& TAN2 & $1406 \pm 208$ & $1195 \mathrm{a} \pm 208$ & $1125 \mathrm{a} \pm 384$ & $1055 \mathrm{a} \pm 317$ & $956 \mathrm{a} \pm 310$ & $870 \mathrm{ab} \pm 240$ \\
& TAN3 & $3532 \pm 1373$ & $2374 \mathrm{a} \pm 1344$ & $1976 \mathrm{a} \pm 1405$ & $2757 \mathrm{a} \pm 1266$ & $3134 \mathrm{a} \pm 1595$ & $2614 \mathrm{~b} \pm 1105$ \\
BOD & TAN1 & $13.85 \pm 6.42$ & $6.92 \mathrm{a} \pm 5.49$ & $6.42 \mathrm{a} \pm 5.07$ & $5.72 \mathrm{a} \pm 5.35$ & $4.62 \mathrm{a} \pm 4.37$ & $2.82 \mathrm{ab} \pm 1.26$ \\
& TAN2 & $19.46 \pm 0.50$ & $1.75 \mathrm{~b} \pm 0.22$ & $1.73 \mathrm{~b} \pm 0.18$ & $1.58 \mathrm{a} \pm 0.16$ & $1.91 \mathrm{a} \pm 0.22$ & $1.56 \mathrm{~b} \pm 0.20$ \\
& TAN3 & $17.13 \pm 3.14$ & $4.24 \mathrm{ab} \pm 0.77$ & $3.29 \mathrm{ab} \pm 0.37$ & $4.11 \mathrm{a} \pm 0.07$ & $3.23 \mathrm{a} \pm 0.91$ & $3.33 \mathrm{a} \pm 1.28$ \\
SS & TAN1 & $374 \pm 124$ & $243 \mathrm{a} \pm 45$ & $471 \mathrm{a} \pm 226$ & $475 \mathrm{a} \pm 182$ & $492 \mathrm{a} \pm 128$ & $611 \mathrm{a} \pm 217$ \\
& TAN2 & $358 \pm 335$ & $460 \mathrm{a} \pm 400$ & $543 \mathrm{a} \pm 414$ & $544 \mathrm{a} \pm 402$ & $551 \mathrm{a} \pm 414$ & $554 \mathrm{a} \pm 405$ \\
& TAN3 & $780 \pm 739$ & $586 \mathrm{a} \pm 594$ & $758 \mathrm{a} \pm 656$ & $787 \mathrm{a} \pm 676$ & $861 \mathrm{a} \pm 635$ & $898 \mathrm{a} \pm 672$ \\
TDS & TAN1 & $3941 \pm 3703$ & $51 \mathrm{a} \pm 10$ & $53 \mathrm{a} \pm 10$ & $55 \mathrm{a} \pm 15$ & $61 \mathrm{a} \pm 20$ & $63 \mathrm{a} \pm 26$ \\
& TAN2 & $3300 \pm 1714$ & $83 \mathrm{a} \pm 78$ & $47 \mathrm{a} \pm 20$ & $48 \mathrm{a} \pm 22$ & $47 \mathrm{a} \pm 17$ & $48 \mathrm{a} \pm 17$ \\
& TAN3 & $2653 \pm 1240$ & $46 \mathrm{a} \pm 11$ & $55 \mathrm{a} \pm 24$ & $55 \mathrm{a} \pm 25$ & $58 \mathrm{a} \pm 23$ & $61 \mathrm{a} \pm 28$ \\
\hline
\end{tabular}

Replicate $=6$ (months)

Within the rows, for the same parameter, means with different alphabets are statistically different $(p<0.05)$.

$\mathrm{P}=$ parameter, IND = Industries 
BAJOPAS Volume 13 Number 2, December, 2020

Table 4: Correlation coefficient $(r)$ between different masses of the bacteria and the physicochemical parameters.

\begin{tabular}{llll}
\hline Industries & Parameter & Correlation coefficient $(r)$ & $\begin{array}{l}\text { Percent dependence (rxrx100) } \\
(\%)\end{array}$ \\
\hline TAN1 & COD & -0.9 & 82 \\
& BOD & -0.97 & 94 \\
& SS & $0.90^{*}$ & 80 \\
TAN2 & TDS & $0.98^{*}$ & 96 \\
& COD & -1 & 100 \\
& BOD & -0.21 & 4 \\
& SS & $0.78^{*}$ & 61 \\
& TDS & -0.69 & 47 \\
& COD & $0.60^{*}$ & 36 \\
& BOD & -0.6 & 37 \\
& SS & $0.95^{*}$ & 90 \\
& TDS & $0.94^{*}$ & 89 \\
\hline
\end{tabular}

The correlation coefficient $(r)$ with * is statistically significant $(p<0.05)$.

Percentage reduction of the Parameters

Table 5 shows the percentage reduction of Parameters in industrial samples before and after the treatment of the effluents $(250 \mathrm{ml})$ with the different masses $(5 \mathrm{~g}, 10 \mathrm{~g}, 15 \mathrm{~g}, 20 \mathrm{~g}$, and $25 \mathrm{~g}$ ) of the Immobilized Bacteria.

In TAN1 samples, the percentage reduction (\%) of COD ranged (14-89); BOD (50-80); SS (-32$35)$ and TDS (98-99). In TAN2 samples, the percentage decrease $(\%)$ of COD ranged (15$38) ;$ BOD (90-92); SS [-28-(-55)] and TDS (9798). In TAN3 samples, the percentage decrease (\%) of COD ranged (11-44); BOD (76-81); SS (15-25) and TDS (98). The percentage increase in the levels COD, BOD and TDS might be due to the increase in the surface area of the different masses of the immobilized bacteria. However, the percentage decrease in the levels of the SS might be due to the aggregation of the TDS which are large enough to result into SS. The percentage decrease in the levels of the SS might be also due to the influence of the nutrients which was added into the effluents in order to make the microorganisms more active and viable for fast degradation of organic contaminants in the effluent. This is in line with the work of Jimoh et al. (2018) in which the concentration of the SS increase after the bioremediation of effluents.

Sreemoyee and Priti (2013) assessed and reduced several Physico-chemical parameters of dairy wastewater using Niesseria $s p$. and concluded that the species are well known to degrade organic compounds. This is in agreement with the current study in which the immobilized Niesseria $s p$ degrade the organic contaminants as indicated by the BOD, COD and TDS.

Jimoh et al. (2018) observed that TSS of the effluents was increased after treatment with immobilized bacteria and concluded that it might be due to the biostimulation method adopted for the research.

The optimum $\mathrm{pH}$ Biosorption of Chromium by Bacillus spp and Staphylococcus spp. from tannery effluent was investigated by Mythili and Karthikeyan (2011). The maximum adsorption of Chromium $(86.4 \mathrm{mg} / \mathrm{L})$ was showed by Bacillus spp and Staphylococcus spp showed $70.6 \mathrm{mg} / \mathrm{L}$ at an initial concentration of $100 \mathrm{mg} / \mathrm{L}$. In the present study, immobilised Bacillus spp and Staphylococcus spp. from the tannery industrial effluents reduced the levels of the organic pollutants with high potential as indicated by the percentage reduction of BOD, COD and TDS.

Enzymes often can work in multiple environments especially if they are immobilized. This makes the microorganisms' enzymes even more resistant to harsh environments and enables the enzymes to be recovered and recycled after they are no longer needed (Gianfreda and Rao 2004). Ramesh and Singh (1993) reported that the immobilized bacteria having more efficiency to remove the suspended particles than free cells. Using the immobilized cell is preferable due to its capability for using several times with the same efficiency, which makes it more economical. Similar work was done by Sikander et al. (2007) showing the higher reduction with permeabilized cells of Ochrobactrum intermedium strain SDCr-5. 
BAJOPAS Volume 13 Number 2, December, 2020

The results revealed the isolation and identification of isolates with the potential for the reduction of $\mathrm{Cr}$ (VI) to $\mathrm{Cr}$ (III). Results indicated that immobilized $B$. cereus could be efficiently used for the reduction of $\mathrm{Cr}$ (VI).

Table 5: Percentage reduction of the tested Parameters from the tannery industrial samples of the Immobilized Bacteria.

\begin{tabular}{lllllll}
\hline \multirow{2}{*}{ Industries } & & \multicolumn{5}{c}{ Percentage Reduction $(\%)$} \\
\cline { 3 - 7 } & & $5 \mathrm{~g}$ & $10 \mathrm{~g}$ & $15 \mathrm{~g}$ & $20 \mathrm{~g}$ & $25 \mathrm{~g}$ \\
\hline TAN1 & COD & 28 & 14 & 64 & 87 & 89 \\
& BOD & 50 & 54 & 59 & 67 & 80 \\
& SS & 35 & -26 & -27 & -32 & -63 \\
& TDS & 99 & 99 & 99 & 98 & 98 \\
TAN2 & COD & 15 & 20 & 25 & 32 & 38 \\
& BOD & 91 & 91 & 92 & 90 & 92 \\
& SS & -28 & -52 & -52 & -54 & -55 \\
& TDS & 97 & 99 & 99 & 99 & 99 \\
& COD & 33 & 44 & 22 & 11 & 26 \\
& BOD & 75 & 81 & 76 & 81 & 81 \\
& SS & 25 & 3 & -1 & -10 & -15 \\
& TDS & 98 & 98 & 98 & 98 & 98 \\
\hline
\end{tabular}

Percentage Reduction $=(B-A) / B \times 100 \%$

$A=$ Concentration of the parameter after treatment

$\mathrm{B}=$ Concentration of the parameter before treatment

$+=$ percentage decrease

- = percentage increase

In general, immobilization makes the enzyme more resistant to temperature, $\mathrm{pH}$, and substrate concentration swings giving it a longer lifetime and higher productivity per active unit (Gianfreda and Rao, 2004; FuIlbrook, 1996; Russell et al, 2003; Kandelbauer et al., 2004). Immobilized cells have been used and studied extensively for the production of useful chemicals (Ohtake and Silver, 1994), the treatment of wastewaters (Chen et al., 2003; Wang et al., 2010). Although many workers described microbial degradation of tannery effluent, limited literature is available on the bioremediation of tannery effluent using immobilized bacterial cells in the Kano Industrial Estates.

\section{CONCLUSION}

The samples contained variable levels of the physicochemical parameters. The results of the Analysis of variance revealed that, no statistical difference $(p<0.05)$ was observed for the temperature, $\mathrm{pH}, \mathrm{SS}, \mathrm{TDS}, \mathrm{BOD}$ and $\mathrm{COD}$ among the three tannery industries before the treatment. The levels of some of the parameters
(SS, TDS and COD) observed in the samples were found above the recommended limits of WHO and NESREA, which called for the treatment of the effluents before discharge into the environment. Base on the morphological and biochemical test results, TAN1, TAN2, and TAN3 bacterial isolates were identified to be Neisseria spp, Bacillus cereus, and Staphylococcus aureus respectively. The results of Post-treatment analysis showed that there is overall decrease in the levels of the parameters determined when compared with that of the pre-treatment. The overall percentage reduction of the immobilised bacteria in the treatment of the respective effluents was in the order TAN2 (72\%)>TAN1 $(70 \%)>$ TAN3 $(62 \%)$. Hence, the immobilized bacteria are having higher biodegradation potential for the treatment of the tannery effluents.

\section{Acknowledgments}

The authors wish to acknowledge the University of Maiduguri for the financial support. The authors are grateful to the Kano State Ministry of Environment for their support in obtaining the effluent samples. 


\section{REFERENCES}

Ajao, A. T., Adebayo, G. B., and Yakubu, S. E. (2011). Bioremediation of textile industrial effluent using mixed culture of Pseudomonas aeruginosa and Bacillus subtilis immobilized on agar-agar in a bioreactor. J. Microbiol. Biotech. Res, 1(3), 50-56.

Akan, J. C., Moses, E. A., Ogugbuaja, V. O., and Abah, J. (2007). Assessment of tannery industrial effluents from Kano metropolis, Kano State, Nigeria. Journal of Applied Sciences, 7(19), 2788-2793.

Akan, J. C., Ogugbuaja, V. O., Abdulrahman, F. I., and Ayodele, J. T. (2009). Pollutant levels in effluent samples from tanneries and textiles of Kano industrial areas, Nigeria. Global journal of pure and applied sciences, 15(3-4).

APHA (1989). Standard methods for Examination of Will bete and Will betewater.15 $5^{\text {th }}$ edition. Brydpass Springfield Will behington DC. pp. 164-176

APHA (1992). Standard Methods for the Examination of Water and Wastewater. Health, 69, 1116-9.

Baba, A., Garba, S. T., and Bello, H. S. (2020). Bioremediation Potential of Immobilized corynebacterium kutsceri in the Treatment of Tannery Industrial Effluent from Challawa Industrial Estate, Kano State, Nigeria. Journal of the Turkish Chemical Society Section A: Chemistry, $7(2), 335-350$.

Beem, E. I. V. (1994). reduction of solvent VOC emission. J. Oil Col. Chem. Ass, 77, 158.

Bouwer, E. J., and Zehnder, A. J. (1993). Bioremediation of organic compoundsputting microbial metabolism to work. Trends in biotechnology, 11(8), 360367.

Chen, K. C., Wu, J. Y., Liou, D. J., and Hwang, S. C. J. (2003). Decolorization of the textile dyes by newly isolated bacterial strains. Journal of Biotechnology, 101(1), 57-68.

Dan'Azumi, S., and Bichi, M. H. (2010). INDUSTRIAL POLLUTION AND HEAVY METALS PROFILE OF CHALLAWA RIVER IN KANO, NIGERIA. Journal of Applied Sciences in Environmental Sanitation, $5(1)$.

DWAF. (1992). Analytical Methods Manual, TR 151. Department of Water Affairs and Forestry, Pretoria.

El-Bestawy, E. (2013). Biological treatment of leather-tanning industrial wastewater using free living bacteria.
Elsheikh, M. A. S. (2009). Tannery wastewater pre-treatment. Water Science and Technology, 60(2), 433-440.

FuIlbrook, P. D. (1996). "Kinetics." Industrial enzymology: The application of enzymes in Industry. 2nd Ed. T. Godfrey and J Reichelt. eds.. Nature. New York.

Gianfreda, L., and Rao, M. A. (2004). Potential of extra cellular enzymes in remediation of polluted soils: a review. Enzyme and microbial technology, 35(4), 339354.

Hugo Springer. (1994). John Arthur Wilson Memorial Lecture "Treatment of Industrial Wastes of the Leather Industry - is it still a Major Problem". JALCA, 89, 153-185

Jimoh, A. A., Ganiyu, B. A., Baba, D., and Baba, A. (2018) Bioremediation Process of Effluent from Detergent and Food Industries in Jos, Nigeria: Kinetics and Thermodynamics. International Journal of Engineering Science Invention (IJESI), 762-73

Kandelbauer, A., Maute, O., Kessler, R. W., Erlacher, A., and Gübitz, G. M. (2004). Study of dye decolorization in an immobilized laccase enzyme-reactor using online spectroscopy. Biotechnology and bioengineering, 87(4), 552-563.

Kongjao, S., Damronglerd, S., and Hunsom, M. (2008). Simultaneous removal of organic and inorganic Pollutants in tannery wastewater using electrocoagulation technique. Korean Journal of chemical engineering, 25(4), 703.

Maheshwari, U. M., Aruna, S., Gomathi, M., and AbdulJaffar, A. H. (2017). Bioremediation by Free and Immobilized Bacteria Isolated from Tannery Effluent. International Journal of Research in Applied, Natural and Social Sciences. 5(7), 75-90

Margesin, R., and Schinner, F. (2001). Bioremediation (natural attenuation and biostimulation) of diesel-oilcontaminated soil in an alpine glacier skiing area. Applied and environmental microbiology, 677), 3127-3133.

Mohammed, A., Sekar, P., and George, J. (2011). Efficacy of microbes in bioremediation of tannery effluent. Inter. J. Curr. Res, 3(4), 324-326.

Mohammed, S. S. D., Orukotan, A. A., and Abdullahi, H. (2017). Physicochemical and Bacteriological Assessment of Tannery Effluent from Samaru-Zaria, 
BAJOPAS Volume 13 Number 2, December, 2020 Kaduna State, Nigeria. Journal of Applied

Sciences and Environmental Management, 21(4), 734-740.

Munz, G., De Angelis, D., Gori, R., Mori, G., Casarci, M., and Lubello, C. (2009). The role of tannins in conventional and membrane treatment of tannery wastewater. Journal of hazardous materials, 164(2-3), 733-739

Mythili, K., and Karthikeyan, B. (2011). Bioremediation of $\mathrm{Cr}$ (VI) from tannery effluent using Bacillus spp and Staphylococcus spp. International Multidisciplinary Research Journal, 1(6).

NESREA (2009). National Environmental Standards for Effluent Limitations and Regulation. 1233-1236

Noorjahan, C. M. (2014). Physicochemical characteristics, identification of bacteria and biodegradation of industrial effluent. Journal of bioremediation and Biodegradation, 5(3).

Ohtake, H. I., and Silver, A. O. (1994). Bacterial reduction of toxic chromate. Biological degradation and bioremediation of toxic chemicals, 403-415.

Omoleke, I. I. (2004). Management of environmental pollution in Ibadan, an African city: the challenges of health hazard facing government and the people. Journal of Human Ecology, 15(4), 265-275.

Rajor, A., Reddy, A.S., and Singh, B. (2004). Determination of BOD kinetic Parameters and evaluation of alternate methods, M.Sc. Thesis, Department of biotechnology \& environmental Science, Thapar Institute of Engineering and Technology, Patiala

Ramasami, T., Rajamani, S., and Rao, J. R. (1994, March). Pollution control in leather industry: Emerging technological options. In International symposium on surface and colloidal science and its relevance to soil pollution, madras.

Ramesh, J. V. S., and Singh, S. P. (1993). Yearly variation in certain physicochemical parameters of pond at eastern Doon Valley. Uttar Pradesh J. Zoo, 12 (1), 7577.

Ranen, S., and Sharadinadra, C. (2009). Biotechnology applications to environmental remediation in resource exploitation. Current science, 97, 6-25
Russell, A. J., Berberich, J. A., Drevon, G. F., and Koepsel, R. R. (2003). Biomaterials for mediation of

chemical and biological warfare agents. Annual review of biomedical engineering, 5(1), 1-27.

Saravanan, P., and Saravanan, A. (1999). Decolourization of tannery effluent by Flavobacterium sp. EK 1. Indian Journal of Environmental Protection, 19, 19-24.

Sikander, S., and Shahida, H. (2007). Reduction of toxic hexavalent chromium by Ochrobactrum intermedium strain SDCr5 stimulated by heavy metals. Bioresource Technol, 98, 340-344.

Singh, N., Sharma, B. K., and Bohra, P. C. (2000). Impact assessment of industrial effluent of arid soils by using satellite imageries. Journal of the Indian Society of Remote Sensing, 28(2-3), 79.

Sreemoyee, C., and Priti, P. (2013). Assessment of physico-chemical parameters of dairy waste water and isolation and characterization of bacterial strains in terms of cod reduction. Int J Sci, 2(3), 395-400.

Verheijen, L. A. H. M., Wiersema, D., Pol, L. H., and De Wit, J. (1996). Management of wastes from animal product processing. Livestock and environment, Finding a balance. International Agriculture Center, Wageningen, The Netherlands.

Wang, F., Yao, J., Si, Y., Chen, H., Russel, M., Chen, K., and Bramanti, E. (2010). Short-time effect of heavy metals upon microbial community activity. Journal of Hazardous Materials, 173(13), 510-516.

WHO (World Health Organization). (2006). Air quality guidelines: global update 2005: particulate matter, ozone, nitrogen dioxide, and sulfur dioxide. World Health Organization.

World Bank. (1995). Nigeria's strategic options for redressing industrial pollution. World Bank, industry and energy division. 1st edition, West Central Africa Department; Annexes: 1995; pp 60-62.

Zahoor, A., and Abdul, R. (2009). Enumeration of Coliforms. Journal of Environmental Sciences. 21, 814-820 


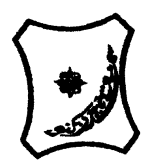

Bayero Journal of Pure and Applied Sciences, 13(2): 1 - 12

Received: November, 2020

Accepted: December, 2020

ISSN $2006-6996$

\title{
BIODEGRADATION POTENTIAL OF IMMOBILIZED BACTERIA IN THE TREATMENT OF TANNERY INDUSTRIAL EFFLUENTS FROM INDUSTRIAL ESTATES IN KANO STATE, NIGERIA
}

\author{
Abdullateef, B., ${ }^{1 *}$ Shuaibu, T. G., ${ }^{1}$ Babagana, K., ${ }^{1}$ Suleman, H. B. ${ }^{2}$ and Dauda, B. ${ }^{3}$ \\ ${ }^{1}$ Department of Pure and Applied Chemistry, Faculty of Science, University of Maiduguri, Borno State, \\ Nigeria \\ ${ }^{2}$ Department of Microbiology, Faculty of Science, University of Maiduguri, Borno State, Nigeria \\ ${ }^{3}$ Department of Chemical Engineering, Faculty of Engineering, University of Maiduguri, Borno State, \\ Nigeria \\ *Corresponding author: babslega@gmail.com; abelega2007@yahoo.com; +2348061309753
}

\section{ABSTRACT}

Industrial Effluents Samples from Gashash Tanneries (TAN1) in Bompai Industrial estate, Larabee Tannery Industry (TAN2) in Sharada Industrial estate and Z Tannery Industries (TAN3) in Challawa Industrial estate, Kano State, Nigeria were collected over a period of six months (August 2017 to January 2018) for assessing the biodegradation potentials of bacteria in the treatment of organic pollutants within the effluents. Bacteria were isolated from the effluents and immobilized on agar-agar. Different masses (5 g, $10 \mathrm{gr}, 15$ $\mathrm{g}, 20 \mathrm{~g}$, and $25 \mathrm{~g}$ ) of the bacteria were used in the treatment of $250 \mathrm{ml}$ of the effluents for ten days in a shaker incubator (Gallenkamp-OC-4364-L) at the temperature $30{ }^{\circ} \mathrm{C}$ and speed of $60 \mathrm{rpm}$. Pre-treatment analysis of the effluents for Temperature, pH, Biochemical Oxygen Demand (BOD), Chemical Oxygen Demand (COD), Suspended Solid (SS) and Total Dissolved Solids (TDS) gives the following results; temperature $\left({ }^{\circ} \mathrm{C}\right.$ )

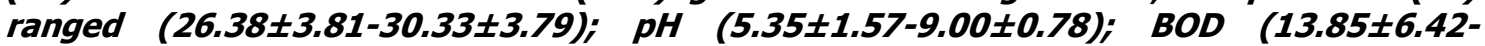
$38.75 \pm 16.20) ;$ COD (1406 $\pm 208-3532 \pm 1373) ;$ SS (208 $\pm 235-780 \pm 739)$ and TDS (266 $\pm 253-5276 \pm 2971)$. No statistical differences ( $p \leq 0.05)$ was observed for all the results among the different industries. The bacterial isolates were identified as Neisseria spp, Bacillus cereus, and Staphylococcus aureus, in TAN1, TAN2, and TAN3, respectively. After treatment of the effluent with the different masses of the isolated bacteria, the mean level of BOD was found to range as (0.55 $\pm 0.36-6.92 \pm 5.49) ; C O D$ (ND-3134 \pm 1595$)$;

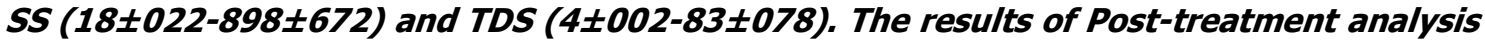
showed that there is overall decrease in the levels of the parameters determined when compared with that of the pre-treatment. The overall percentage reduction of the immobilised bacteria in the treatment of the respective effluents was in the order TAN2 (72\%)>TAN1 (70\%)>TAN3 (62\%). Hence, the immobilized bacteria are having higher biodegradation potential for the treatment of the tannery effluents.

Keywords: Biodegradation, bacteria, effluent, immobilization, tannery.

\section{INTRODUCTION}

Tannery industrial wastewater is a serious consequence of the pollution point of view for streams, freshwater, and land used for agriculture. The lack of awareness in the modern industrial practice has resulted in the discharge of tannery effluents which exhibit very high value of chromium ( $\mathrm{Cr}$ ), Sulfide, and chloride, Total Dissolved Solid (TDS), Total Suspended Solid (TSS), Biochemical Oxygen Demand (BOD) and Chemical Oxygen Demand (COD) in the water stream or land (Mohammed et al., 2001). Tanning is the process, which One ton of skin generally leads to the production of 20 to $80 \mathrm{~m}^{3}$ of turbid and foul-smelling converts the protein of the rawhide or skin into a stable material, which will not putrefy and is suitable for a wide variety of end applications (Elsheikh, 2009). The highly polluting chromium is the most commonly used tanning material producing leather that is more flexible and pliable than vegetable-tanned leather and does not discolor or lose shape in water as drastically as vegetable-tan (Elsheikh, 2009). Tannery effluent is among the most hazardous industrial pollutants due to its huge organic and inorganic load, which is highly toxic to human life and the environment (Kongjao et al., 2008). wastewater including chromium (100-400 mg/l), sulfide $(200-800 \mathrm{mg} / \mathrm{l})$, high levels of fat and 
BAJOPAS Volume 13 Number 2, December, 2020 other solid wastes, and notable pathogen contamination as well as pesticides added for skin conservation during transport (Elsheikh, 2009). There are more than 6000 tanneries in Nigeria with an annual processing capacity of 700,000 tons of hides and skins (Omoleke, 2004; Singh et al., 2008). It was reported that the total amount of waste produced per animal slaughtered is approximately $35 \%$ of its weight (World Bank, 1995). Also, for every $1000 \mathrm{~kg}$ of carcass weight, a slaughtered beef produces 5.5 $\mathrm{kg}$ of manure (excluding rumen contents or stockyard manure) and $100 \mathrm{~kg}$ of paunch manure (undigested food) (Verheijen et al., 1996). Tanneries generate wastewater in the range of 30-35 $\mathrm{L} \mathrm{kg}^{-1}$ skin/hide processed with variable $\mathrm{pH}$, Biological Oxygen Demand (BOD), Chemical Oxygen Demand (COD), high concentrations of suspended solids (SS), and tannins as well as chromium (Zahoor and Abdul, 2009).

Being heterogeneous and composed of a wide variety of compounds, it is very difficult to select a unique direct method for estimating the biodegradability of organic contents and biokinetic parameters for a wastewater sample (Rajor, 2004). For this purpose, some indirect estimation such as determination of biochemical oxygen demand (BOD) and chemical oxygen demand (COD) are applied as common laboratory investigations [9]. During retanning procedures, synthetic tannins (Syntan), oils and resins are added to form softer leather at varying doses (Munz et al., 2009). One of the refractory groups of chemicals in tannery effluents derives mainly from tannins (Ramasami et al., 2004). Syntans are characterized by complex chemical structures, because they are composed of an extended set of chemicals such as phenol-, naphthalene-, formaldehyde- and melamine-based syntans, and acrylic resins (Beem, 1994). Organic pollutants (proteic and lipidic components) are originated from skins (it is calculated that the raw skin has $30 \%$ loss of organic material during the working cycle) or they are introduced during processes (Hugo Springer, 1994).

Many conventional processes such as oxidation, chemical and biological processes were carried out to treat tanneries wastewater (Ebtesam et al, 2013). Biological processes have received more attention because of their costeffectiveness, lower sludge production and environmental friendliness (Noorjahan, 2014). Naturally occurring micro-organisms degrade the hazardous organic wastes including xenobiotic compounds, such as pesticides, polycyclic aromatic hydrocarbons (PAHs) and polychlorinated biphenyls (PCBs) in due course of time (Ranen and Sharadinadra, 2009). Bioremediation is based on the idea that all organisms remove substances from the environment to carry outgrowth and metabolism (Bouwer and Zehnder, 1993). Bacteria, protista and fungi are found to be very good at degrading complex molecules and incorporating the breakdown products into their metabolism (Bouwer and Zehnder, 1993). The resultant metabolic wastes that they produce are generally safe and somehow recycled into other organisms (Ranen and Sharadinadra, 2009). An acclimatized indigenous population of microorganisms capable of degradation of the compounds of interest must exist at the site for a successful bioremediation mode (Ranen and Sharadinadra, 2009). It has been observed that for a successful bioremediation mode, an acclimatized indigenous population of microorganisms capable of degradation of the compounds of interest must exist at the site under investigation (Ranen and Sharadinadra, 2009). Even though there are numerous physical and chemical methods employed in the disposal of wastes the advantage in using bacterium is that they play a key role in the reduction of COD, BOD, total protein, total tannin and total phenol (Saravanan and Saravanan, 1998)

Baba et al. (2020) studied the bioremediation potential of immobilized corynebacterium kutsceri in the Treatment of tannery industrial effluent from Challawa Industrial Estate, Kano State, Nigeria. The aim of the work is to study the reduction in the level of the contaminants through the process of bioremediation using the isolated bacteria. Immobilized bacteria can withstand various temperatures, $\mathrm{pH}$ and substrate concentrations; consequently, increasing the efficiency and the lifespan of the bacteria. Immobilized bacteria are widely applied in the treatment of wastewater and can be separated and recovered after the treatment with the same efficiency (Baba et al., 2020).

\section{MATERIALS AND METHODS \\ Study Area}

This study was carried out in Bompai, Sharada and Challawa industrial estates in Kano, Figure 1. Kano lies on Latitude $11^{\circ} 30^{\prime} \mathrm{N}$ and $8^{\circ} 30^{\prime} \mathrm{E}$ and Longitude $11^{\circ} 5^{\prime} \mathrm{N}$ and $8^{\circ} 5^{\prime} \mathrm{E}$ in Northern Nigeria. It is one of the developed industrial cities in Nigeria. Tannery activities are the dominating industries and this could be one of the reasons for her high population density (Dan'Azumi and Bichi, 2010). Many researchers have studied biodegradation of tannery effluent using microorganisms. However, limited literature is available on the biodegradation of tannery effluent in Kano industrial estates using 
BAJOPAS Volume 13 Number 2, December, 2020 immobilized bacterial cells. This research work focuses on the potential of the use of the indigenous immobilized bacterial isolates in the treatment of tannery effluents in the industrial estates.

\section{Sample Collection}

Effluents were collected from the Tannery Industries from Bompai, Challawa and Sharada Industrial Estates, Kano, Nigeria. The effluents were collected over a period of six months (August 2017 to January 2018). Samples collected in a sterile 4-liter plastic container with a unique identification number were preserved using an ice-box that was transported to the Microbiology Laboratory, Department of Microbiology, Bayero University of Kano for analysis

\section{Sample Preparation and Sample Analysis}

Immediately after the collection of the effluent, $\mathrm{pH}$, TSS, TDS, COD, BOD levels were determined before treatment (Pre-treatment determination) and ten days after treatment (Post-treatment determination) as described in
APHA (1989) standard methods. $\mathrm{pH}$ was determined using Ecotests $\mathrm{pH}$ meter and TDS was determined using AQUALYTIC TDS Salinometer. BOD was determined as described by the standard method (APHA, 1992). COD and SS were determined using DR/2010 HACH portable data logging spectrophotometer (DWAF, 1992)

\section{Identification and Biochemical} Characterization of the Bacterial Isolates

The bacteria were isolated from the effluents using Serial Dilution according to the method described by APHA (1989). The biochemical tests such as oxidase, catalase, coagulase, indole (from $1 \%$ tryptone broth), citrate (Simmons citrate agar), methyl red/VogesProskauer (MR/VP), nitrate reduction, Starch Hydrolysis, Glucose, Maltose, and Lactose tests were carried out on the bacterial isolates to identify the bacteria through the bacteria biochemical characteristics according to Ajao et al. (2011).

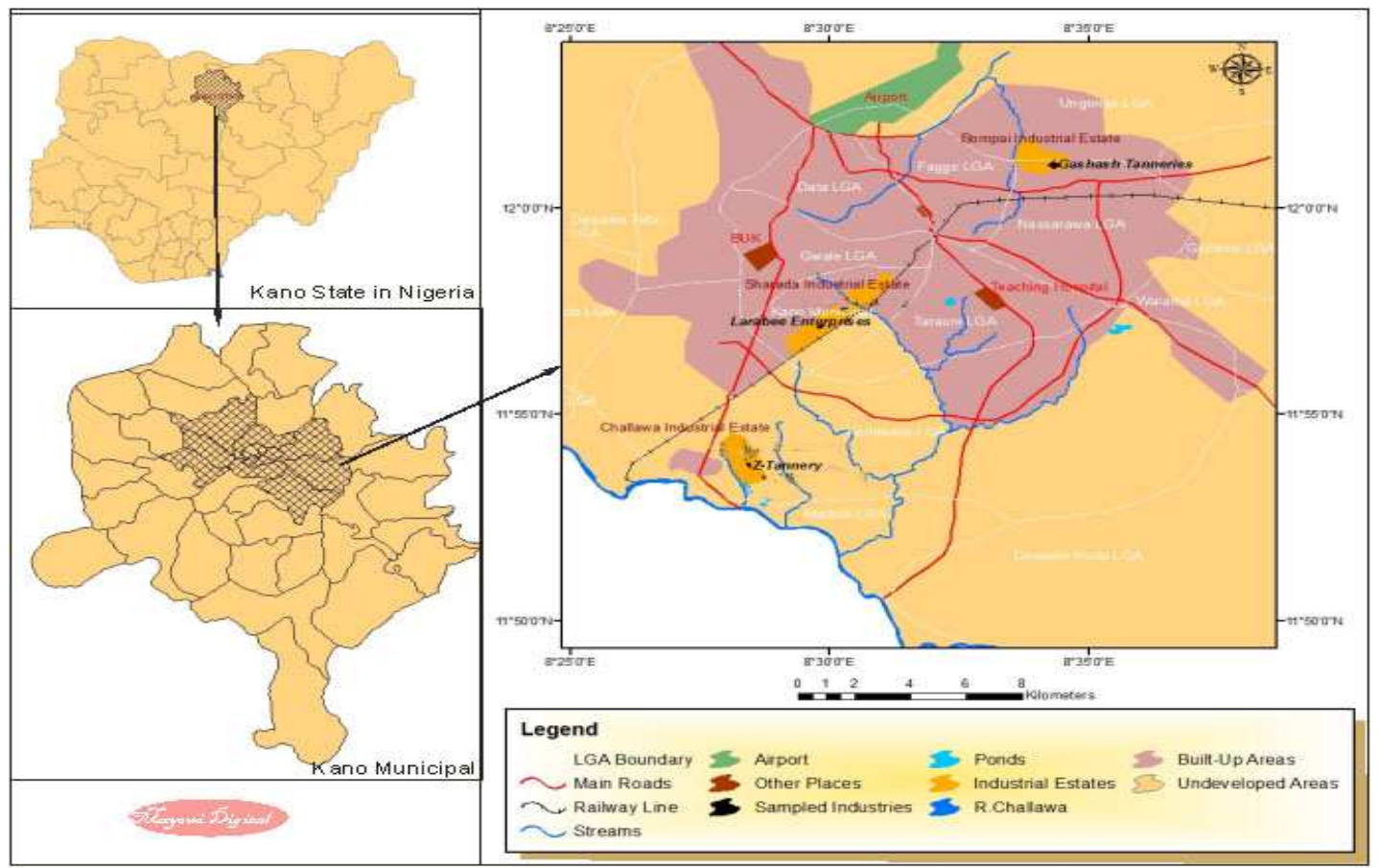

Fig. 1 Map showing the study areas

Source: Mayomi Digital Productions, GIS Laboratory, Department of Geography, UNIMAID (2017)

\section{Determination of Growth Rate of the Bacteria in Effluent Sample}

The bacteria growth rates were determined by transferring $2 \mathrm{~mL}$ of the bacterial isolates from the tannery effluent in broth medium into 100 $\mathrm{mL}$ sterile effluents in conical flasks and kept in an incubator (Giffrin cool) for 10 days. Control was also set up by incubating another $100 \mathrm{~mL}$ each of the sterile effluents without the bacteria. The optical density of the content was determined at the wavelength of $600 \mathrm{~nm}$ on a daily interval and recorded. 
BAJOPAS Volume 13 Number 2, December, 2020 Immobilization of Bacteria

Agar solution and inoculi were prepared separately. Fifty milliliters $(50 \mathrm{~mL})$ of nutrient broth each of the inoculi was prepared in a McCartney bottle and incubated for 24 hours. A solution of agar-agar was prepared by dissolving $10 \mathrm{~g}$ of the powder in distilled water and made up to $500 \mathrm{~mL}$ mark in an Erlenmeyer flask and was sterilized in an autoclave (280A) for 15 minutes and allowed to cool to $40-45^{\circ} \mathrm{C}$ (Ajao et al., 2011). Four milliliters ( $4 \mathrm{~mL})$ of the bacterial isolates in the nutrient broth was mixed with 36 $\mathrm{ml}$ of the prepared agar-agar media in petri-dish plates and then allowed to solidify. This was kept in the refrigerator for bioremediation.

\section{Bioremediation (Treatment) of the Effluents}

The solidified agar block (immobilized bacteria) was cut into cubes using a sterile knife; $0.1 \mathrm{~mL}$ phosphate buffer ( $\mathrm{pH} \mathrm{7.0)}$ was added and kept in the refrigerator for 1 hour for curing. The phosphate buffer was decanted after 1 hour and the cubes were washed with sterile distilled water 3-4 times before it was used (Ajao et al., 2011). Two liters (2 L) of the effluent was supplemented with the minimum basal medium in $\mathrm{g} / \mathrm{L}: \mathrm{NaCl}(0.8), \mathrm{MgSO}_{4} .7 \mathrm{H}_{2} \mathrm{O}(0.001), \mathrm{KH}_{2} \mathrm{PO}_{4}$ (2), $\mathrm{NaNO}_{3}$ (2), $\quad \mathrm{CaCl}_{2} .2 \mathrm{H}_{2} \mathrm{O} \quad(0.5)$ and $\mathrm{NaHPO}_{4} .12 \mathrm{H}_{2} \mathrm{O}(2)$ and sterilized in an autoclave at $121^{\circ} \mathrm{C}$ for 15 minutes (Margesin and Schinner, 2001). Two hundred and fifty milliliters $(250 \mathrm{~mL})$ of the effluents were transferred into different $250 \mathrm{ml}$ conical flasks. The content was covered with a cotton-wool ramped with foil paper to avoid contamination. Five grams $(5 \mathrm{~g})$ of the immobilized bacteria were quickly transferred into each of the effluents in the conical flasks in an inoculating chamber. The same procedures were carried out for the $10 \mathrm{~g}, 15 \mathrm{~g}, 20 \mathrm{~g}$ and 25 $\mathrm{g}$ of the immobilized bacteria in separate $250 \mathrm{~mL}$ effluents in conical flasks and agitated for ten days in a shaker incubator (Gallenkamp-OC4364-L) at a temperature $30^{\circ} \mathrm{C}$ and speed of 60 rpm. The treated effluent samples were taken on the tenth day and analyzed for the parameters $\mathrm{pH}$, SS, TDS, COD, and BOD, (Posttreatment determination) for the different grams of bacteria to evaluate and compare the biodegradation potential. (Baba et al., 2020).

\section{Statistical Analysis}

The data were represented as Mean \pm Standard deviation and analyzed statistically using oneway Analysis of Variance (ANOVA) and Tukey's HSD as Post Hoc Tests with the aid of SPSS 16.0. The correlation coefficient was also used to measure the strength of the relationship between the different masses of the bacteria and the parameters. All $\mathrm{p} \leq 0.05$ were considered as statistically significant.

\section{RESULTS AND DISCUSSION Physico-chemical parameters in the Industrial Effluents before the Biodegradation.}

Results of the Physico-chemical parameters in the industrial effluents before the Biodegradation is shown in table 1 . The mean temperatures $\left({ }^{\circ} \mathrm{C}\right)$ observed in TAN1, TAN2, and TAN3 samples were $28.07 \pm 0.65 ; 27.77 \pm 0.64$ and $26.38 \pm 3.81$ respectively. The order of the mean temperature of the samples from the three industries can be arranged as TAN1 > TAN2>TAN3. The temperature observed at TAN1, TAN2, and TAN3 samples were found below the WHO $\left(35^{\circ} \mathrm{C}\right)$ and NESREA $\left(40^{\circ} \mathrm{C}\right)$ limits. The low values of temperature might be due to the processes used at the time of sampling. High temperature brings down the solubility of gases in water that ultimately expresses as high BOD and COD. Statistical analysis shows that there is no significant difference $(p<0.05)$ between the mean values of temperature among the industries. This might be due to similar tannery activities involved in the tannery industries at the time of sampling. The average values of temperature observed in this present study are less than those observed by Akan et al. (2007), Akan et al. (2009) and Baba et al. (2020).

The mean level of $\mathrm{pH}$ observed in TAN1, TAN2 and TAN3, samples were $7.77 \pm 2.93$; $8.35 \pm 0.28$ and $7.52 \pm 0.76$ respectively. The order of the mean $\mathrm{pH}$ of the samples from the three industries can be arranged as TAN2> TAN1 $>$ TAN3. The $\mathrm{pH}$ of the samples falls within the WHO (7.0-8.5) and NESREA (6-9) standard limits. Statistical analysis shows that there is no significant difference $(p<0.05)$ between the mean values of $\mathrm{pH}$ among the industries. This might be due to similar tannery activities involved in the tannery industries at the time of sampling. Maheshwari et al. (2017) reported that the level of $\mathrm{pH}$ in the effluents from the tannery industry in Vaniyambadi, India was 6.5 which was lower than that observed in the present study. The $\mathrm{pH}$ in the effluents from the tannery industries in Kano and Kaduna were reported to be 7.64 and 6.89, respectively (Akan et al., 2007; Mohammed et al., 2017). The average values of $\mathrm{pH}$ observed in this present study are less than those observed by Mohammed et al. (2017) and Baba et al. (2020). The mean level of SS $(\mathrm{mg} / \mathrm{l})$ observed in TAN1, TAN2, and TAN3 samples were 374 \pm 124 ; $358 \pm 335$ and $780 \pm 739$ respectively. The order of the mean SS in the samples from the three industries can be arranged as TAN3 > TAN1 $>$ TAN2. 
The SS observed in the samples were far above the recommended standard limits of regulating bodies WHO $(30 \mathrm{mg} / \mathrm{l})$ and NESREA $(10 \mathrm{mg} / \mathrm{l})$. Statistical analysis shows that there is no significant difference $(p<0.05)$ between the mean values of SS among the industries. This might be due to similar tannery activities involved in the tannery industries at the time of sampling. The average values of SS observed in this present study are less than that observed $(3700 \pm 122 \mathrm{mg} / \mathrm{l})$ by Akan et al. (2009) for tanneries in Kano. Also, the average values of SS observed in this present study are less than that observed by Mohammed et al. (2017) and Baba et al. (2020) with the exception in TAN3.

The mean level of TDS (mg/l) observed in TAN1, TAN2, and TAN3 samples were $3941 \pm 3703$; $3300 \pm 1714$ and $2653 \pm 1240$ respectively. The order of the mean TDS in the samples from the three industries can be arranged as TAN1>TAN2>TAN3. The TDS observed in the samples were far above the recommended standard limits of WHO $(250 \mathrm{mg} / \mathrm{l})$ and NESREA $(500 \mathrm{mg} / \mathrm{l})$. Statistical analysis shows that there is no significant difference $(p<0.05)$ between the mean values of TDS among the industries. This might be due to similar tannery activities involved in the tannery industries at the time of sampling. TDS in the effluents from the tannery industries in Kano, Nigeria was reported to be $1281 \mathrm{mg} / \mathrm{l}$ (Akan et al., 2007). The average values of SS observed in this present study are less than those observed by Mohammed et al. (2017) and Baba et al. 2020)

The mean level of COD (mg/l) observed in TAN1, TAN2 and TAN3 samples seasons were $2372 \pm 938 ; \quad 1406 \pm 208$ and $3532 \pm 1373$ respectively. The order of the mean COD of the samples from the three industries can be arranged as TAN3>TAN1> TAN2. The COD observed in TAN1, TAN2 and TAN3 samples were far above the recommended standard limits of regulating bodies $\mathrm{WHO}(40 \mathrm{mg} / \mathrm{l})$ and NESREA (40 mg/l). Statistical analysis shows that there is no significant difference $(p<0.05)$ in COD among the industries. This might be due to similar tannery activities involved in the tannery industries as at the time of sampling. The Chemical Oxygen demand (COD) is the amount of oxygen, in $\mathrm{mg} / \mathrm{L}$, required for the degradation of the compound of wastewater to occur. In comparison, the average values of COD observed in this present study were higher than that observed by Mohammed et al. (2017) but lower than that observed by Baba et al. (2020).

The mean levels of BOD $(\mathrm{mg} / \mathrm{l})$ observed in TAN1, TAN2 and TAN3 samples were $13.85 \pm 6.42 ; \quad 19.46 \pm 0.50$ and $17.13 \pm 3.14$ respectively. The order of the mean BOD in the samples from the three industries can be arranged as TAN2>TAN3>TAN1. The BOD observed in TAN1, TAN2 and TAN3 samples were found below the recommended limits of NESREA (200 mg/l) but above WHO (10 mg/l). Statistical analysis shows that there is no significant difference $(p<0.05)$ between the mean values of BOD among the industries. This might be due to similar tannery activities involved in the tannery industries at the time of sampling. The low level of BOD recorded in this study is an indication of the low level of biodegradable organic solids in the effluent. The average values of BOD observed in this present study were lower than those observed by Mohammed et al. (2017) and Baba et al. (2020).

Table 1: Mean Values \pm S.D of Physico-chemical parameters of effluents from the Tannery Industries before Treatment.

\begin{tabular}{llllllll}
\hline Parameter & Tannery 1 & Tannery 2 & Tannery 3 & $\mathrm{a}$ & $\mathrm{b}$ & $\mathrm{c}$ & $\mathrm{d}$ \\
\cline { 2 - 7 } Temperature $\left({ }^{\circ} \mathrm{C}\right)$ & $28.07 \mathrm{a} \pm 0.65$ & $27.77 \mathrm{a} \pm 0.64$ & $26.38 \mathrm{a} \pm 3.81$ & & $29.50 \pm 4.68$ & 35 & 40 \\
pH & $7.77 \mathrm{a} \pm 2.93$ & $8.35 \mathrm{a} \pm 0.28$ & $7.52 \mathrm{a} \pm 0.76$ & 6.89 & $5.35 \pm 1.57$ & $7.0-8.5$ & $6.0-9.0$ \\
$\mathrm{COD}(\mathrm{mg} / \mathrm{l})$ & $2372 \mathrm{a} \pm 938$ & $1406 \mathrm{a} \pm 208$ & $3532 \mathrm{a} \pm 1373$ & 2.2 & $3106 \pm 2753$ & 40 & 40 \\
$\mathrm{BOD}(\mathrm{mg} / \mathrm{l})$ & $13.85 \mathrm{a} \pm 6.42$ & $19.46 \mathrm{a} \pm 0.50$ & $17.13 \mathrm{a} \pm 3.14$ & 1032 & $26.17 \pm 9.49$ & 10 & 200 \\
$\mathrm{SS}(\mathrm{mg} / \mathrm{l})$ & $374 \mathrm{a} \pm 124$ & $358 \mathrm{a} \pm 335$ & $780 \mathrm{a} \pm 739$ & 501 & $562 \pm 482$ & 30 & 10 \\
TDS $(\mathrm{mg} / \mathrm{l})$ & $3941 \mathrm{a} \pm 3703$ & $3300 \mathrm{a} \pm 1714$ & $2653 \mathrm{a} \pm 1240$ & 532.7 & $444 \pm 507$ & 250 & 500 \\
\hline
\end{tabular}

The values given in the table above are means of 6 replicate values, $\mathrm{n}=6$ ( 1 sample was taken monthly for 6 months). Within the rows, means with different alphabets are statistically different $(p<0.05)$. WHO: World Health Organisation. NESREA: National Environmental Standard and Regulatory Enforcement Agency. a = Mohammed et al.(2017), b = Baba et al. (2020), c = WHO (2006), $d=$ NESSRA (2009) 
BAJOPAS Volume 13 Number 2, December, 2020

Identification, Biochemical Characterization and growth rates of the Bacterial Isolates

Results of identification and biochemical characterization of the bacterial isolates were shown in table 2. After 24 hours of incubation, the nutrient agar media plates were checked for bacterial growth. The results showed the presence of different strains in the samples. The TAN1 bacteria isolate was found to be gramnegative cocci while TAN3 was gram-positive cocci. TAN2 bacteria isolate was found to be gram-positive, rod-shaped. TAN1, TAN2, and TAN3 bacteria isolates recorded positive results for spore former.

The results of the biochemical tests indicated that all the bacteria were positive for catalase, oxidase, citrate, maltose, glucose, lactose (negative in TAN1), mannitol (negative in TAN2), starch hydrolysis and coagulase (negative in TAN2) tests. The bacteria showed negative results for nitrate reduction, $M R$ (positive in TAN2), VP (positive in TAN1), Indole (positive in TAN2) tests. Base on the morphological and biochemical test results, TAN1, TAN2, and TAN3 bacteria isolates were identified to be Nesseria spp, Bacillus cereus, and Staphylococcus aureus respectively.

The growth rate of the TAN1, TAN2 and TAN3 Isolates were shown in figure 2. Generally, the optical density increase with the increase in time (day) and decrease as time goes on. The highest optical density was shown by bacillus cereus in TAN2 while the lowest was shown by Staphylococcus aureus in TAN3.

The initial growth phase of TAN1 Isolate bacteria occurred within 2-day of incubation as the growth rate increases up to the 6th-day incubation when the maximum growth was observed. Beyond the 6th day, the growth of the bacteria declined (which might be due to a shortage of nutrients in the effluents) until it reached its death phase (which might be due to the unavailability of nutrients in the effluents).

A similar trend of growth was also observed for TAN2 Isolate as the initial growth phase also occurred within 2-day of incubation but maximum growth rate observed on the 4th day of incubation. The stationary stage occurred between the 4th day and the 8th day. Beyond the 8th day, the growth of the bacteria declined (which might be due to a shortage of nutrients in the effluents) until it reached its death phase (which might be due to the unavailability of nutrients in the effluents).

The initial growth phase of TAN3 bacterial Isolate occurred within the 3-day incubation as the growth rate increases up to the 6th-day incubation when the maximum growth was observed. Beyond the 6th day, the growth of the bacteria declined (which might be due to a shortage of nutrients in the effluents) until it reached its death phase (which might be due to the unavailability of nutrients in the effluents).

Table 2: Morphological and Biochemical characteristics of bacterial isolates

\begin{tabular}{lllll} 
Bacterial Isolates & & TAN1 & TAN2 & TAN3 \\
\hline $\begin{array}{lllll}\text { Morphological } \\
\text { characteristics }\end{array}$ & Shape & Cocci & Rod & Cocci \\
& Spore & & & \\
& former & + & + & + \\
Gram & & & \\
Biochemical characteristics & reaction & - & + & + \\
& Citrate & + & + & + \\
& Catalase & + & + & + \\
& Coagulase & + & - & + \\
Starch & + & + & + \\
& Glucose & + & + & + \\
Oxidase & + & + & + \\
& Indo & - & + & - \\
Lactose & - & + & + \\
Manitol & + & - & + \\
Maltose & + & + & + \\
MR & - & + & - \\
VP & + & - & - \\
& Nitrate & - & - & - \\
Reduction & - Neisseria & Bacillus & Staphylococcus \\
& Bacterial & cereus & aureus \\
& name & spp & cas
\end{tabular}

+ = Positive; - = Negative; MR=Methyl Red; VP= Voges-Proskauer 


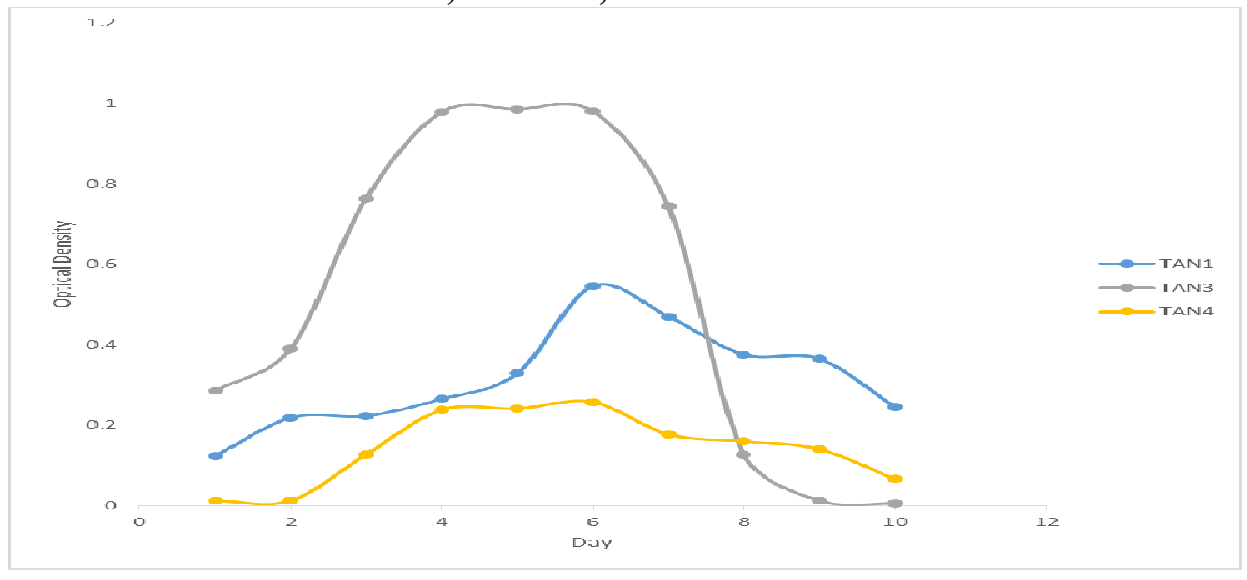

Fig. 2 Growth rates of the isolates in the effluents from the Tannery Industries

\section{Physico-chemical Parameters in the Industrial Effluents after the biodegradation.}

Table 3 shows the mean results of the physicochemical parameter before and after bioremediation using the different masses $(5 \mathrm{~g}$, $10 \mathrm{~g}, 15 \mathrm{~g}, 20 \mathrm{~g}$, and $25 \mathrm{~g}$ ) of the respective immobilized bacteria. Also, Table 4 shows the mean results of correlation coefficient ( $r$ ) between different masses of bacteria and physicochemical parameters.

The mean values $(\mathrm{mg} / \mathrm{l})$ of the SS after the bioremediation varies between $243 \pm 45$ and $898 \pm 672$. The mean concentration $(\mathrm{mg} / \mathrm{l})$ of SS remediated by the different masses $(5 \mathrm{~g}, 10 \mathrm{~g}$, $15 \mathrm{~g}, 20 \mathrm{~g}$, and $25 \mathrm{~g}$ ) of the bacteria varies. The SS in the samples fluctuates up and down after the bioremediation process when compared with the SS of the raw samples before the bioremediation. The increase in the levels of the SS might be due to the aggregation of the TDS which are large enough to result into SS. The increase in the levels of the SS might be also due to the influence of the nutrients which was added into the effluents in order to make the microorganisms more active and viable for fast degradation of organic contaminants in the effluent. The relative potential or efficiency of the different masses of the bacteria in remediating SS in TAN1 samples was in the order $25 \mathrm{~g}>20 \mathrm{~g}>15 \mathrm{~g}>10 \mathrm{~g}>5 \mathrm{~g}$. For TAN2 and TAN3 samples, the order was $25 \mathrm{~g}>20 \mathrm{~g}>15$ $\mathrm{g}>10 \mathrm{~g}>5 \mathrm{~g}$. These might be due to the variations in the surface areas of the different masses of the immobilized bacteria. Statistical analysis shows that there is no significant difference $(p<0.05)$ between the mean values of SS among the masses in the respective industries. Positive and significant correlations exist between the masses of bacteria and Suspended Solid (SS). This showed that there is general increase in the levels of the SS as the masses of the immobilized bacteria increases. TAN3 (90\%) and TAN1 (80\%) showed a very high correlation with the masses of the bacteria while TAN2 (61\%) showed a very low correlation.

The mean values $(\mathrm{mg} / \mathrm{l})$ of the TDS after the bioremediation varies between $46 \pm 11$ and $83 \pm 78$. The mean concentration $(\mathrm{mg} / \mathrm{l})$ of TDS remediated by the different masses $(5 \mathrm{~g}, 10 \mathrm{~g}$, $15 \mathrm{~g}, 20 \mathrm{~g}$, and $25 \mathrm{~g}$ ) of the bacteria varies. There is a reduction in all the TDS of all the samples after the bioremediation process compared with the TDS of the raw samples before the bioremediation. The relative potential or efficiency of the different masses of the bacteria in remediating TDS in TAN1 and TAN3 samples was in the order $5 \mathrm{~g}>10 \mathrm{~g}>15 \mathrm{~g}>20$ $\mathrm{g}>25 \mathrm{~g}$. For TAN2 samples, the order was 20 $g>10 \quad g>25 \quad g>15 \quad g>5 \quad g$. Statistical analysis shows that there is no significant difference $(p<0.05)$ between the mean values of TDS among the masses in the respective industries. These might be due to the variations in the surface areas of the different masses of the immobilized bacteria. Positive and significant correlations exist between the masses of bacteria and TDS with the exception in TAN2 (negative and insignificant correlation). The positive correlations showed that there is general increase in the levels of the TDS as the masses of the immobilized bacteria increases. TAN1 $(96 \%)$ showed a very high correlation with the masses of the bacteria while TAN2 (47\%) showed a very low correlation.

The mean values $(\mathrm{mg} / \mathrm{l})$ of the BOD after the bioremediation varies between $1.56 \pm 0.20 \mathrm{mg} / \mathrm{l}$ and $6.92 \pm 5.49 \mathrm{mg} / \mathrm{l}$. The mean concentration $(\mathrm{mg} / \mathrm{l})$ of BOD remediated by the different masses $(5 \mathrm{~g}, 10 \mathrm{~g}, 15 \mathrm{~g}, 20 \mathrm{~g}$, and $25 \mathrm{~g}$ ) of the bacteria varies. There is a reduction in all the BOD of all the samples after the bioremediation process compared with the $\mathrm{BOD}$ of the raw 
BAJOPAS Volume 13 Number 2, December, 2020 samples before the bioremediation. The relative potential or efficiency of the different masses of the bacteria in remediating BOD in TAN1, TAN2 and TAN3 samples were in the order $25 \mathrm{~g}>20$ $\mathrm{g}>15 \mathrm{~g}>10 \mathrm{~g}>5 \mathrm{~g}, 25 \mathrm{~g}>15 \mathrm{~g}>5 \mathrm{~g}>10 \mathrm{~g}>20 \mathrm{~g}$ and $20 \mathrm{~g}>10 \mathrm{~g}>25 \mathrm{~g}>15 \mathrm{~g}>5 \mathrm{~g}$ respectively. Statistical analysis shows that there is significant difference $(p<0.05)$ between the mean values of BOD among the masses in the respective industries. These might be due to the variations in the surface areas of the different masses of the immobilized bacteria. Negative and significant correlations exist between the masses of bacteria and BOD. This showed that there is general decrease in the levels of the BOD as the masses of the immobilized bacteria increases. TAN1 (94\%) showed a very high correlation with the masses of the bacteria while TAN2 (4\%) showed a very low correlation.

The mean values $(\mathrm{mg} / \mathrm{l})$ of the COD after the bioremediation varies between $250 \pm 154$ and $3134 \pm 1595$. The mean concentration $(\mathrm{mg} / \mathrm{l})$ of COD remediated by the different masses $(5 \mathrm{~g}$, $10 \mathrm{~g}, 15 \mathrm{~g} 20 \mathrm{~g}$, and $25 \mathrm{~g}$ ) of the bacteria varies. There is a reduction in all the COD of all the samples after the bioremediation process compared with the COD of the raw samples before the bioremediation. The relative potential or efficiency of the different masses of the bacteria in remediating COD in TAN1, TAN2 and TAN3 samples were in the order $25 \mathrm{~g}>20 \mathrm{~g}>15$ $\mathrm{g}>5 \mathrm{~g}>10 \mathrm{~g}, 25 \mathrm{~g}>20 \mathrm{~g}>15 \mathrm{~g}>10 \mathrm{~g}>5 \mathrm{~g}$ and 10 g>5 g>25 g>15 g>20 g respectively. Statistical analysis shows that there were significant difference $(p<0.05)$ between the mean values of COD among the masses in the respective industries except for effluents treated with $25 \mathrm{~g}$. These might be due to the variations in the surface areas of the different masses of the immobilized bacteria. Negative and insignificant correlations exist between the masses of bacteria and COD with the exception in TAN3 (positive and significant correlation). The negative correlations showed that there is general decrease in the levels of the COD as the masses of the immobilized bacteria increases. TAN2 (100\%) showed a very high correlation with the masses of the bacteria while TAN3 (36\%) showed a very low correlation.

Generally, there was an overall decrease in the concentration of these physicochemical parameters after the bioremediation using the different masses of the bacterial isolates. These might be due to the variations in the surface areas of the different masses of the immobilized bacteria. This is in line with the work of Jimoh et al. (2018) and Baba et al. (2020).

Table 3: Mean Values $(\mathrm{mg} / \mathrm{l}) \pm$ S.D of Physicochemical parameters in effluents from the Tannery Industries before and after Treatment of the effluents $(250 \mathrm{ml})$ with the different masses $(5 \mathrm{~g}, 10 \mathrm{~g}$, $15 \mathrm{~g}, 20 \mathrm{~g}$, and $25 \mathrm{~g}$ ) of the bacteria.

\begin{tabular}{llllllll}
\hline $\mathrm{P}$ & IND & Before & \multicolumn{5}{c}{ After } \\
\cline { 4 - 7 } & & & $5 \mathrm{~g}$ & $10 \mathrm{~g}$ & $15 \mathrm{~g}$ & $20 \mathrm{~g}$ & $25 \mathrm{~g}$ \\
\hline \multirow{2}{*}{ COD } & TAN1 & $2372 \pm 938$ & $1708 \mathrm{a} \pm 861$ & $2045 \mathrm{a} \pm 1205$ & $845 \mathrm{a} \pm 369$ & $300 \mathrm{a} \pm 167$ & $250 \mathrm{a} \pm 154$ \\
& TAN2 & $1406 \pm 208$ & $1195 \mathrm{a} \pm 208$ & $1125 \mathrm{a} \pm 384$ & $1055 \mathrm{a} \pm 317$ & $956 \mathrm{a} \pm 310$ & $870 \mathrm{ab} \pm 240$ \\
& TAN3 & $3532 \pm 1373$ & $2374 \mathrm{a} \pm 1344$ & $1976 \mathrm{a} \pm 1405$ & $2757 \mathrm{a} \pm 1266$ & $3134 \mathrm{a} \pm 1595$ & $2614 \mathrm{~b} \pm 1105$ \\
BOD & TAN1 & $13.85 \pm 6.42$ & $6.92 \mathrm{a} \pm 5.49$ & $6.42 \mathrm{a} \pm 5.07$ & $5.72 \mathrm{a} \pm 5.35$ & $4.62 \mathrm{a} \pm 4.37$ & $2.82 \mathrm{ab} \pm 1.26$ \\
& TAN2 & $19.46 \pm 0.50$ & $1.75 \mathrm{~b} \pm 0.22$ & $1.73 \mathrm{~b} \pm 0.18$ & $1.58 \mathrm{a} \pm 0.16$ & $1.91 \mathrm{a} \pm 0.22$ & $1.56 \mathrm{~b} \pm 0.20$ \\
& TAN3 & $17.13 \pm 3.14$ & $4.24 \mathrm{ab} \pm 0.77$ & $3.29 \mathrm{ab} \pm 0.37$ & $4.11 \mathrm{a} \pm 0.07$ & $3.23 \mathrm{a} \pm 0.91$ & $3.33 \mathrm{a} \pm 1.28$ \\
SS & TAN1 & $374 \pm 124$ & $243 \mathrm{a} \pm 45$ & $471 \mathrm{a} \pm 226$ & $475 \mathrm{a} \pm 182$ & $492 \mathrm{a} \pm 128$ & $611 \mathrm{a} \pm 217$ \\
& TAN2 & $358 \pm 335$ & $460 \mathrm{a} \pm 400$ & $543 \mathrm{a} \pm 414$ & $544 \mathrm{a} \pm 402$ & $551 \mathrm{a} \pm 414$ & $554 \mathrm{a} \pm 405$ \\
& TAN3 & $780 \pm 739$ & $586 \mathrm{a} \pm 594$ & $758 \mathrm{a} \pm 656$ & $787 \mathrm{a} \pm 676$ & $861 \mathrm{a} \pm 635$ & $898 \mathrm{a} \pm 672$ \\
TDS & TAN1 & $3941 \pm 3703$ & $51 \mathrm{a} \pm 10$ & $53 \mathrm{a} \pm 10$ & $55 \mathrm{a} \pm 15$ & $61 \mathrm{a} \pm 20$ & $63 \mathrm{a} \pm 26$ \\
& TAN2 & $3300 \pm 1714$ & $83 \mathrm{a} \pm 78$ & $47 \mathrm{a} \pm 20$ & $48 \mathrm{a} \pm 22$ & $47 \mathrm{a} \pm 17$ & $48 \mathrm{a} \pm 17$ \\
& TAN3 & $2653 \pm 1240$ & $46 \mathrm{a} \pm 11$ & $55 \mathrm{a} \pm 24$ & $55 \mathrm{a} \pm 25$ & $58 \mathrm{a} \pm 23$ & $61 \mathrm{a} \pm 28$ \\
\hline
\end{tabular}

Replicate $=6$ (months)

Within the rows, for the same parameter, means with different alphabets are statistically different $(p<0.05)$.

$\mathrm{P}=$ parameter, IND = Industries 
BAJOPAS Volume 13 Number 2, December, 2020

Table 4: Correlation coefficient $(r)$ between different masses of the bacteria and the physicochemical parameters.

\begin{tabular}{llll}
\hline Industries & Parameter & Correlation coefficient $(r)$ & $\begin{array}{l}\text { Percent dependence (rxrx100) } \\
(\%)\end{array}$ \\
\hline TAN1 & COD & -0.9 & 82 \\
& BOD & -0.97 & 94 \\
& SS & $0.90^{*}$ & 80 \\
TAN2 & TDS & $0.98^{*}$ & 96 \\
& COD & -1 & 100 \\
& BOD & -0.21 & 4 \\
& SS & $0.78^{*}$ & 61 \\
& TDS & -0.69 & 47 \\
& COD & $0.60^{*}$ & 36 \\
& BOD & -0.6 & 37 \\
& SS & $0.95^{*}$ & 90 \\
& TDS & $0.94^{*}$ & 89 \\
\hline
\end{tabular}

The correlation coefficient $(r)$ with * is statistically significant $(p<0.05)$.

Percentage reduction of the Parameters

Table 5 shows the percentage reduction of Parameters in industrial samples before and after the treatment of the effluents $(250 \mathrm{ml})$ with the different masses $(5 \mathrm{~g}, 10 \mathrm{~g}, 15 \mathrm{~g}, 20 \mathrm{~g}$, and $25 \mathrm{~g}$ ) of the Immobilized Bacteria.

In TAN1 samples, the percentage reduction (\%) of COD ranged (14-89); BOD (50-80); SS (-32$35)$ and TDS (98-99). In TAN2 samples, the percentage decrease $(\%)$ of COD ranged (15$38) ;$ BOD (90-92); SS [-28-(-55)] and TDS (9798). In TAN3 samples, the percentage decrease (\%) of COD ranged (11-44); BOD (76-81); SS (15-25) and TDS (98). The percentage increase in the levels COD, BOD and TDS might be due to the increase in the surface area of the different masses of the immobilized bacteria. However, the percentage decrease in the levels of the SS might be due to the aggregation of the TDS which are large enough to result into SS. The percentage decrease in the levels of the SS might be also due to the influence of the nutrients which was added into the effluents in order to make the microorganisms more active and viable for fast degradation of organic contaminants in the effluent. This is in line with the work of Jimoh et al. (2018) in which the concentration of the SS increase after the bioremediation of effluents.

Sreemoyee and Priti (2013) assessed and reduced several Physico-chemical parameters of dairy wastewater using Niesseria $s p$. and concluded that the species are well known to degrade organic compounds. This is in agreement with the current study in which the immobilized Niesseria $s p$ degrade the organic contaminants as indicated by the BOD, COD and TDS.

Jimoh et al. (2018) observed that TSS of the effluents was increased after treatment with immobilized bacteria and concluded that it might be due to the biostimulation method adopted for the research.

The optimum $\mathrm{pH}$ Biosorption of Chromium by Bacillus spp and Staphylococcus spp. from tannery effluent was investigated by Mythili and Karthikeyan (2011). The maximum adsorption of Chromium $(86.4 \mathrm{mg} / \mathrm{L})$ was showed by Bacillus spp and Staphylococcus spp showed $70.6 \mathrm{mg} / \mathrm{L}$ at an initial concentration of $100 \mathrm{mg} / \mathrm{L}$. In the present study, immobilised Bacillus spp and Staphylococcus spp. from the tannery industrial effluents reduced the levels of the organic pollutants with high potential as indicated by the percentage reduction of BOD, COD and TDS.

Enzymes often can work in multiple environments especially if they are immobilized. This makes the microorganisms' enzymes even more resistant to harsh environments and enables the enzymes to be recovered and recycled after they are no longer needed (Gianfreda and Rao 2004). Ramesh and Singh (1993) reported that the immobilized bacteria having more efficiency to remove the suspended particles than free cells. Using the immobilized cell is preferable due to its capability for using several times with the same efficiency, which makes it more economical. Similar work was done by Sikander et al. (2007) showing the higher reduction with permeabilized cells of Ochrobactrum intermedium strain SDCr-5. 
BAJOPAS Volume 13 Number 2, December, 2020

The results revealed the isolation and identification of isolates with the potential for the reduction of $\mathrm{Cr}$ (VI) to $\mathrm{Cr}$ (III). Results indicated that immobilized $B$. cereus could be efficiently used for the reduction of $\mathrm{Cr}$ (VI).

Table 5: Percentage reduction of the tested Parameters from the tannery industrial samples of the Immobilized Bacteria.

\begin{tabular}{lllllll}
\hline \multirow{2}{*}{ Industries } & & \multicolumn{5}{c}{ Percentage Reduction $(\%)$} \\
\cline { 3 - 7 } & & $5 \mathrm{~g}$ & $10 \mathrm{~g}$ & $15 \mathrm{~g}$ & $20 \mathrm{~g}$ & $25 \mathrm{~g}$ \\
\hline TAN1 & COD & 28 & 14 & 64 & 87 & 89 \\
& BOD & 50 & 54 & 59 & 67 & 80 \\
& SS & 35 & -26 & -27 & -32 & -63 \\
& TDS & 99 & 99 & 99 & 98 & 98 \\
TAN2 & COD & 15 & 20 & 25 & 32 & 38 \\
& BOD & 91 & 91 & 92 & 90 & 92 \\
& SS & -28 & -52 & -52 & -54 & -55 \\
& TDS & 97 & 99 & 99 & 99 & 99 \\
& COD & 33 & 44 & 22 & 11 & 26 \\
& BOD & 75 & 81 & 76 & 81 & 81 \\
& SS & 25 & 3 & -1 & -10 & -15 \\
& TDS & 98 & 98 & 98 & 98 & 98 \\
\hline
\end{tabular}

Percentage Reduction $=(B-A) / B \times 100 \%$

$A=$ Concentration of the parameter after treatment

$\mathrm{B}=$ Concentration of the parameter before treatment

$+=$ percentage decrease

- = percentage increase

In general, immobilization makes the enzyme more resistant to temperature, $\mathrm{pH}$, and substrate concentration swings giving it a longer lifetime and higher productivity per active unit (Gianfreda and Rao, 2004; FuIlbrook, 1996; Russell et al, 2003; Kandelbauer et al., 2004). Immobilized cells have been used and studied extensively for the production of useful chemicals (Ohtake and Silver, 1994), the treatment of wastewaters (Chen et al., 2003; Wang et al., 2010). Although many workers described microbial degradation of tannery effluent, limited literature is available on the bioremediation of tannery effluent using immobilized bacterial cells in the Kano Industrial Estates.

\section{CONCLUSION}

The samples contained variable levels of the physicochemical parameters. The results of the Analysis of variance revealed that, no statistical difference $(p<0.05)$ was observed for the temperature, $\mathrm{pH}, \mathrm{SS}, \mathrm{TDS}, \mathrm{BOD}$ and $\mathrm{COD}$ among the three tannery industries before the treatment. The levels of some of the parameters
(SS, TDS and COD) observed in the samples were found above the recommended limits of WHO and NESREA, which called for the treatment of the effluents before discharge into the environment. Base on the morphological and biochemical test results, TAN1, TAN2, and TAN3 bacterial isolates were identified to be Neisseria spp, Bacillus cereus, and Staphylococcus aureus respectively. The results of Post-treatment analysis showed that there is overall decrease in the levels of the parameters determined when compared with that of the pre-treatment. The overall percentage reduction of the immobilised bacteria in the treatment of the respective effluents was in the order TAN2 (72\%)>TAN1 $(70 \%)>$ TAN3 $(62 \%)$. Hence, the immobilized bacteria are having higher biodegradation potential for the treatment of the tannery effluents.

\section{Acknowledgments}

The authors wish to acknowledge the University of Maiduguri for the financial support. The authors are grateful to the Kano State Ministry of Environment for their support in obtaining the effluent samples. 


\section{REFERENCES}

Ajao, A. T., Adebayo, G. B., and Yakubu, S. E. (2011). Bioremediation of textile industrial effluent using mixed culture of Pseudomonas aeruginosa and Bacillus subtilis immobilized on agar-agar in a bioreactor. J. Microbiol. Biotech. Res, 1(3), 50-56.

Akan, J. C., Moses, E. A., Ogugbuaja, V. O., and Abah, J. (2007). Assessment of tannery industrial effluents from Kano metropolis, Kano State, Nigeria. Journal of Applied Sciences, 7(19), 2788-2793.

Akan, J. C., Ogugbuaja, V. O., Abdulrahman, F. I., and Ayodele, J. T. (2009). Pollutant levels in effluent samples from tanneries and textiles of Kano industrial areas, Nigeria. Global journal of pure and applied sciences, 15(3-4).

APHA (1989). Standard methods for Examination of Will bete and Will betewater.15 $5^{\text {th }}$ edition. Brydpass Springfield Will behington DC. pp. 164-176

APHA (1992). Standard Methods for the Examination of Water and Wastewater. Health, 69, 1116-9.

Baba, A., Garba, S. T., and Bello, H. S. (2020). Bioremediation Potential of Immobilized corynebacterium kutsceri in the Treatment of Tannery Industrial Effluent from Challawa Industrial Estate, Kano State, Nigeria. Journal of the Turkish Chemical Society Section A: Chemistry, $7(2), 335-350$.

Beem, E. I. V. (1994). reduction of solvent VOC emission. J. Oil Col. Chem. Ass, 77, 158.

Bouwer, E. J., and Zehnder, A. J. (1993). Bioremediation of organic compoundsputting microbial metabolism to work. Trends in biotechnology, 11(8), 360367.

Chen, K. C., Wu, J. Y., Liou, D. J., and Hwang, S. C. J. (2003). Decolorization of the textile dyes by newly isolated bacterial strains. Journal of Biotechnology, 101(1), 57-68.

Dan'Azumi, S., and Bichi, M. H. (2010). INDUSTRIAL POLLUTION AND HEAVY METALS PROFILE OF CHALLAWA RIVER IN KANO, NIGERIA. Journal of Applied Sciences in Environmental Sanitation, $5(1)$.

DWAF. (1992). Analytical Methods Manual, TR 151. Department of Water Affairs and Forestry, Pretoria.

El-Bestawy, E. (2013). Biological treatment of leather-tanning industrial wastewater using free living bacteria.
Elsheikh, M. A. S. (2009). Tannery wastewater pre-treatment. Water Science and Technology, 60(2), 433-440.

FuIlbrook, P. D. (1996). "Kinetics." Industrial enzymology: The application of enzymes in Industry. 2nd Ed. T. Godfrey and J Reichelt. eds.. Nature. New York.

Gianfreda, L., and Rao, M. A. (2004). Potential of extra cellular enzymes in remediation of polluted soils: a review. Enzyme and microbial technology, 35(4), 339354.

Hugo Springer. (1994). John Arthur Wilson Memorial Lecture "Treatment of Industrial Wastes of the Leather Industry - is it still a Major Problem". JALCA, 89, 153-185

Jimoh, A. A., Ganiyu, B. A., Baba, D., and Baba, A. (2018) Bioremediation Process of Effluent from Detergent and Food Industries in Jos, Nigeria: Kinetics and Thermodynamics. International Journal of Engineering Science Invention (IJESI), 762-73

Kandelbauer, A., Maute, O., Kessler, R. W., Erlacher, A., and Gübitz, G. M. (2004). Study of dye decolorization in an immobilized laccase enzyme-reactor using online spectroscopy. Biotechnology and bioengineering, 87(4), 552-563.

Kongjao, S., Damronglerd, S., and Hunsom, M. (2008). Simultaneous removal of organic and inorganic Pollutants in tannery wastewater using electrocoagulation technique. Korean Journal of chemical engineering, 25(4), 703.

Maheshwari, U. M., Aruna, S., Gomathi, M., and AbdulJaffar, A. H. (2017). Bioremediation by Free and Immobilized Bacteria Isolated from Tannery Effluent. International Journal of Research in Applied, Natural and Social Sciences. 5(7), 75-90

Margesin, R., and Schinner, F. (2001). Bioremediation (natural attenuation and biostimulation) of diesel-oilcontaminated soil in an alpine glacier skiing area. Applied and environmental microbiology, 677), 3127-3133.

Mohammed, A., Sekar, P., and George, J. (2011). Efficacy of microbes in bioremediation of tannery effluent. Inter. J. Curr. Res, 3(4), 324-326.

Mohammed, S. S. D., Orukotan, A. A., and Abdullahi, H. (2017). Physicochemical and Bacteriological Assessment of Tannery Effluent from Samaru-Zaria, 
BAJOPAS Volume 13 Number 2, December, 2020 Kaduna State, Nigeria. Journal of Applied

Sciences and Environmental Management, 21(4), 734-740.

Munz, G., De Angelis, D., Gori, R., Mori, G., Casarci, M., and Lubello, C. (2009). The role of tannins in conventional and membrane treatment of tannery wastewater. Journal of hazardous materials, 164(2-3), 733-739

Mythili, K., and Karthikeyan, B. (2011). Bioremediation of $\mathrm{Cr}$ (VI) from tannery effluent using Bacillus spp and Staphylococcus spp. International Multidisciplinary Research Journal, 1(6).

NESREA (2009). National Environmental Standards for Effluent Limitations and Regulation. 1233-1236

Noorjahan, C. M. (2014). Physicochemical characteristics, identification of bacteria and biodegradation of industrial effluent. Journal of bioremediation and Biodegradation, 5(3).

Ohtake, H. I., and Silver, A. O. (1994). Bacterial reduction of toxic chromate. Biological degradation and bioremediation of toxic chemicals, 403-415.

Omoleke, I. I. (2004). Management of environmental pollution in Ibadan, an African city: the challenges of health hazard facing government and the people. Journal of Human Ecology, 15(4), 265-275.

Rajor, A., Reddy, A.S., and Singh, B. (2004). Determination of BOD kinetic Parameters and evaluation of alternate methods, M.Sc. Thesis, Department of biotechnology \& environmental Science, Thapar Institute of Engineering and Technology, Patiala

Ramasami, T., Rajamani, S., and Rao, J. R. (1994, March). Pollution control in leather industry: Emerging technological options. In International symposium on surface and colloidal science and its relevance to soil pollution, madras.

Ramesh, J. V. S., and Singh, S. P. (1993). Yearly variation in certain physicochemical parameters of pond at eastern Doon Valley. Uttar Pradesh J. Zoo, 12 (1), 7577.

Ranen, S., and Sharadinadra, C. (2009). Biotechnology applications to environmental remediation in resource exploitation. Current science, 97, 6-25
Russell, A. J., Berberich, J. A., Drevon, G. F., and Koepsel, R. R. (2003). Biomaterials for mediation of

chemical and biological warfare agents. Annual review of biomedical engineering, 5(1), 1-27.

Saravanan, P., and Saravanan, A. (1999). Decolourization of tannery effluent by Flavobacterium sp. EK 1. Indian Journal of Environmental Protection, 19, 19-24.

Sikander, S., and Shahida, H. (2007). Reduction of toxic hexavalent chromium by Ochrobactrum intermedium strain SDCr5 stimulated by heavy metals. Bioresource Technol, 98, 340-344.

Singh, N., Sharma, B. K., and Bohra, P. C. (2000). Impact assessment of industrial effluent of arid soils by using satellite imageries. Journal of the Indian Society of Remote Sensing, 28(2-3), 79.

Sreemoyee, C., and Priti, P. (2013). Assessment of physico-chemical parameters of dairy waste water and isolation and characterization of bacterial strains in terms of cod reduction. Int J Sci, 2(3), 395-400.

Verheijen, L. A. H. M., Wiersema, D., Pol, L. H., and De Wit, J. (1996). Management of wastes from animal product processing. Livestock and environment, Finding a balance. International Agriculture Center, Wageningen, The Netherlands.

Wang, F., Yao, J., Si, Y., Chen, H., Russel, M., Chen, K., and Bramanti, E. (2010). Short-time effect of heavy metals upon microbial community activity. Journal of Hazardous Materials, 173(13), 510-516.

WHO (World Health Organization). (2006). Air quality guidelines: global update 2005: particulate matter, ozone, nitrogen dioxide, and sulfur dioxide. World Health Organization.

World Bank. (1995). Nigeria's strategic options for redressing industrial pollution. World Bank, industry and energy division. 1st edition, West Central Africa Department; Annexes: 1995; pp 60-62.

Zahoor, A., and Abdul, R. (2009). Enumeration of Coliforms. Journal of Environmental Sciences. 21, 814-820 


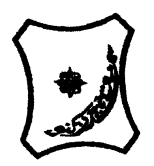

Bayero Journal of Pure and Applied Sciences, 13(2): 1 - 12

Received: November, 2020

Accepted: December, 2020

ISSN $2006-6996$

\title{
BIODEGRADATION POTENTIAL OF IMMOBILIZED BACTERIA IN THE TREATMENT OF TANNERY INDUSTRIAL EFFLUENTS FROM INDUSTRIAL ESTATES IN KANO STATE, NIGERIA
}

\author{
Abdullateef, B., ${ }^{1 *}$ Shuaibu, T. G., ${ }^{1}$ Babagana, K., ${ }^{1}$ Suleman, H. B. ${ }^{2}$ and Dauda, B. ${ }^{3}$ \\ ${ }^{1}$ Department of Pure and Applied Chemistry, Faculty of Science, University of Maiduguri, Borno State, \\ Nigeria \\ ${ }^{2}$ Department of Microbiology, Faculty of Science, University of Maiduguri, Borno State, Nigeria \\ ${ }^{3}$ Department of Chemical Engineering, Faculty of Engineering, University of Maiduguri, Borno State, \\ Nigeria \\ *Corresponding author: babslega@gmail.com; abelega2007@yahoo.com; +2348061309753
}

\section{ABSTRACT}

Industrial Effluents Samples from Gashash Tanneries (TAN1) in Bompai Industrial estate, Larabee Tannery Industry (TAN2) in Sharada Industrial estate and Z Tannery Industries (TAN3) in Challawa Industrial estate, Kano State, Nigeria were collected over a period of six months (August 2017 to January 2018) for assessing the biodegradation potentials of bacteria in the treatment of organic pollutants within the effluents. Bacteria were isolated from the effluents and immobilized on agar-agar. Different masses (5 g, $10 \mathrm{gr}, 15$ $\mathrm{g}, 20 \mathrm{~g}$, and $25 \mathrm{~g}$ ) of the bacteria were used in the treatment of $250 \mathrm{ml}$ of the effluents for ten days in a shaker incubator (Gallenkamp-OC-4364-L) at the temperature $30{ }^{\circ} \mathrm{C}$ and speed of $60 \mathrm{rpm}$. Pre-treatment analysis of the effluents for Temperature, pH, Biochemical Oxygen Demand (BOD), Chemical Oxygen Demand (COD), Suspended Solid (SS) and Total Dissolved Solids (TDS) gives the following results; temperature $\left({ }^{\circ} \mathrm{C}\right.$ )

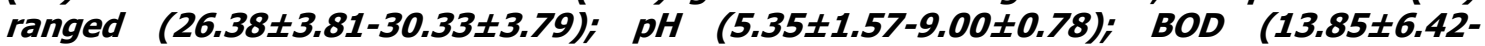
$38.75 \pm 16.20) ;$ COD (1406 $\pm 208-3532 \pm 1373) ;$ SS (208 $\pm 235-780 \pm 739)$ and TDS (266 $\pm 253-5276 \pm 2971)$. No statistical differences ( $p \leq 0.05)$ was observed for all the results among the different industries. The bacterial isolates were identified as Neisseria spp, Bacillus cereus, and Staphylococcus aureus, in TAN1, TAN2, and TAN3, respectively. After treatment of the effluent with the different masses of the isolated bacteria, the mean level of BOD was found to range as (0.55 $\pm 0.36-6.92 \pm 5.49) ; C O D$ (ND-3134 \pm 1595$)$;

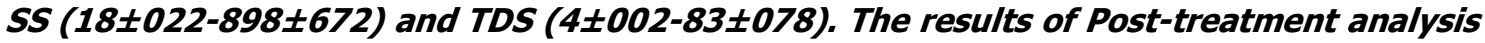
showed that there is overall decrease in the levels of the parameters determined when compared with that of the pre-treatment. The overall percentage reduction of the immobilised bacteria in the treatment of the respective effluents was in the order TAN2 (72\%)>TAN1 (70\%)>TAN3 (62\%). Hence, the immobilized bacteria are having higher biodegradation potential for the treatment of the tannery effluents.

Keywords: Biodegradation, bacteria, effluent, immobilization, tannery.

\section{INTRODUCTION}

Tannery industrial wastewater is a serious consequence of the pollution point of view for streams, freshwater, and land used for agriculture. The lack of awareness in the modern industrial practice has resulted in the discharge of tannery effluents which exhibit very high value of chromium ( $\mathrm{Cr}$ ), Sulfide, and chloride, Total Dissolved Solid (TDS), Total Suspended Solid (TSS), Biochemical Oxygen Demand (BOD) and Chemical Oxygen Demand (COD) in the water stream or land (Mohammed et al., 2001). Tanning is the process, which One ton of skin generally leads to the production of 20 to $80 \mathrm{~m}^{3}$ of turbid and foul-smelling converts the protein of the rawhide or skin into a stable material, which will not putrefy and is suitable for a wide variety of end applications (Elsheikh, 2009). The highly polluting chromium is the most commonly used tanning material producing leather that is more flexible and pliable than vegetable-tanned leather and does not discolor or lose shape in water as drastically as vegetable-tan (Elsheikh, 2009). Tannery effluent is among the most hazardous industrial pollutants due to its huge organic and inorganic load, which is highly toxic to human life and the environment (Kongjao et al., 2008). wastewater including chromium (100-400 mg/l), sulfide $(200-800 \mathrm{mg} / \mathrm{l})$, high levels of fat and 
BAJOPAS Volume 13 Number 2, December, 2020 other solid wastes, and notable pathogen contamination as well as pesticides added for skin conservation during transport (Elsheikh, 2009). There are more than 6000 tanneries in Nigeria with an annual processing capacity of 700,000 tons of hides and skins (Omoleke, 2004; Singh et al., 2008). It was reported that the total amount of waste produced per animal slaughtered is approximately $35 \%$ of its weight (World Bank, 1995). Also, for every $1000 \mathrm{~kg}$ of carcass weight, a slaughtered beef produces 5.5 $\mathrm{kg}$ of manure (excluding rumen contents or stockyard manure) and $100 \mathrm{~kg}$ of paunch manure (undigested food) (Verheijen et al., 1996). Tanneries generate wastewater in the range of 30-35 $\mathrm{L} \mathrm{kg}^{-1}$ skin/hide processed with variable $\mathrm{pH}$, Biological Oxygen Demand (BOD), Chemical Oxygen Demand (COD), high concentrations of suspended solids (SS), and tannins as well as chromium (Zahoor and Abdul, 2009).

Being heterogeneous and composed of a wide variety of compounds, it is very difficult to select a unique direct method for estimating the biodegradability of organic contents and biokinetic parameters for a wastewater sample (Rajor, 2004). For this purpose, some indirect estimation such as determination of biochemical oxygen demand (BOD) and chemical oxygen demand (COD) are applied as common laboratory investigations [9]. During retanning procedures, synthetic tannins (Syntan), oils and resins are added to form softer leather at varying doses (Munz et al., 2009). One of the refractory groups of chemicals in tannery effluents derives mainly from tannins (Ramasami et al., 2004). Syntans are characterized by complex chemical structures, because they are composed of an extended set of chemicals such as phenol-, naphthalene-, formaldehyde- and melamine-based syntans, and acrylic resins (Beem, 1994). Organic pollutants (proteic and lipidic components) are originated from skins (it is calculated that the raw skin has $30 \%$ loss of organic material during the working cycle) or they are introduced during processes (Hugo Springer, 1994).

Many conventional processes such as oxidation, chemical and biological processes were carried out to treat tanneries wastewater (Ebtesam et al, 2013). Biological processes have received more attention because of their costeffectiveness, lower sludge production and environmental friendliness (Noorjahan, 2014). Naturally occurring micro-organisms degrade the hazardous organic wastes including xenobiotic compounds, such as pesticides, polycyclic aromatic hydrocarbons (PAHs) and polychlorinated biphenyls (PCBs) in due course of time (Ranen and Sharadinadra, 2009). Bioremediation is based on the idea that all organisms remove substances from the environment to carry outgrowth and metabolism (Bouwer and Zehnder, 1993). Bacteria, protista and fungi are found to be very good at degrading complex molecules and incorporating the breakdown products into their metabolism (Bouwer and Zehnder, 1993). The resultant metabolic wastes that they produce are generally safe and somehow recycled into other organisms (Ranen and Sharadinadra, 2009). An acclimatized indigenous population of microorganisms capable of degradation of the compounds of interest must exist at the site for a successful bioremediation mode (Ranen and Sharadinadra, 2009). It has been observed that for a successful bioremediation mode, an acclimatized indigenous population of microorganisms capable of degradation of the compounds of interest must exist at the site under investigation (Ranen and Sharadinadra, 2009). Even though there are numerous physical and chemical methods employed in the disposal of wastes the advantage in using bacterium is that they play a key role in the reduction of COD, BOD, total protein, total tannin and total phenol (Saravanan and Saravanan, 1998)

Baba et al. (2020) studied the bioremediation potential of immobilized corynebacterium kutsceri in the Treatment of tannery industrial effluent from Challawa Industrial Estate, Kano State, Nigeria. The aim of the work is to study the reduction in the level of the contaminants through the process of bioremediation using the isolated bacteria. Immobilized bacteria can withstand various temperatures, $\mathrm{pH}$ and substrate concentrations; consequently, increasing the efficiency and the lifespan of the bacteria. Immobilized bacteria are widely applied in the treatment of wastewater and can be separated and recovered after the treatment with the same efficiency (Baba et al., 2020).

\section{MATERIALS AND METHODS \\ Study Area}

This study was carried out in Bompai, Sharada and Challawa industrial estates in Kano, Figure 1. Kano lies on Latitude $11^{\circ} 30^{\prime} \mathrm{N}$ and $8^{\circ} 30^{\prime} \mathrm{E}$ and Longitude $11^{\circ} 5^{\prime} \mathrm{N}$ and $8^{\circ} 5^{\prime} \mathrm{E}$ in Northern Nigeria. It is one of the developed industrial cities in Nigeria. Tannery activities are the dominating industries and this could be one of the reasons for her high population density (Dan'Azumi and Bichi, 2010). Many researchers have studied biodegradation of tannery effluent using microorganisms. However, limited literature is available on the biodegradation of tannery effluent in Kano industrial estates using 
BAJOPAS Volume 13 Number 2, December, 2020 immobilized bacterial cells. This research work focuses on the potential of the use of the indigenous immobilized bacterial isolates in the treatment of tannery effluents in the industrial estates.

\section{Sample Collection}

Effluents were collected from the Tannery Industries from Bompai, Challawa and Sharada Industrial Estates, Kano, Nigeria. The effluents were collected over a period of six months (August 2017 to January 2018). Samples collected in a sterile 4-liter plastic container with a unique identification number were preserved using an ice-box that was transported to the Microbiology Laboratory, Department of Microbiology, Bayero University of Kano for analysis

\section{Sample Preparation and Sample Analysis}

Immediately after the collection of the effluent, $\mathrm{pH}$, TSS, TDS, COD, BOD levels were determined before treatment (Pre-treatment determination) and ten days after treatment (Post-treatment determination) as described in
APHA (1989) standard methods. $\mathrm{pH}$ was determined using Ecotests $\mathrm{pH}$ meter and TDS was determined using AQUALYTIC TDS Salinometer. BOD was determined as described by the standard method (APHA, 1992). COD and SS were determined using DR/2010 HACH portable data logging spectrophotometer (DWAF, 1992)

\section{Identification and Biochemical} Characterization of the Bacterial Isolates

The bacteria were isolated from the effluents using Serial Dilution according to the method described by APHA (1989). The biochemical tests such as oxidase, catalase, coagulase, indole (from $1 \%$ tryptone broth), citrate (Simmons citrate agar), methyl red/VogesProskauer (MR/VP), nitrate reduction, Starch Hydrolysis, Glucose, Maltose, and Lactose tests were carried out on the bacterial isolates to identify the bacteria through the bacteria biochemical characteristics according to Ajao et al. (2011).

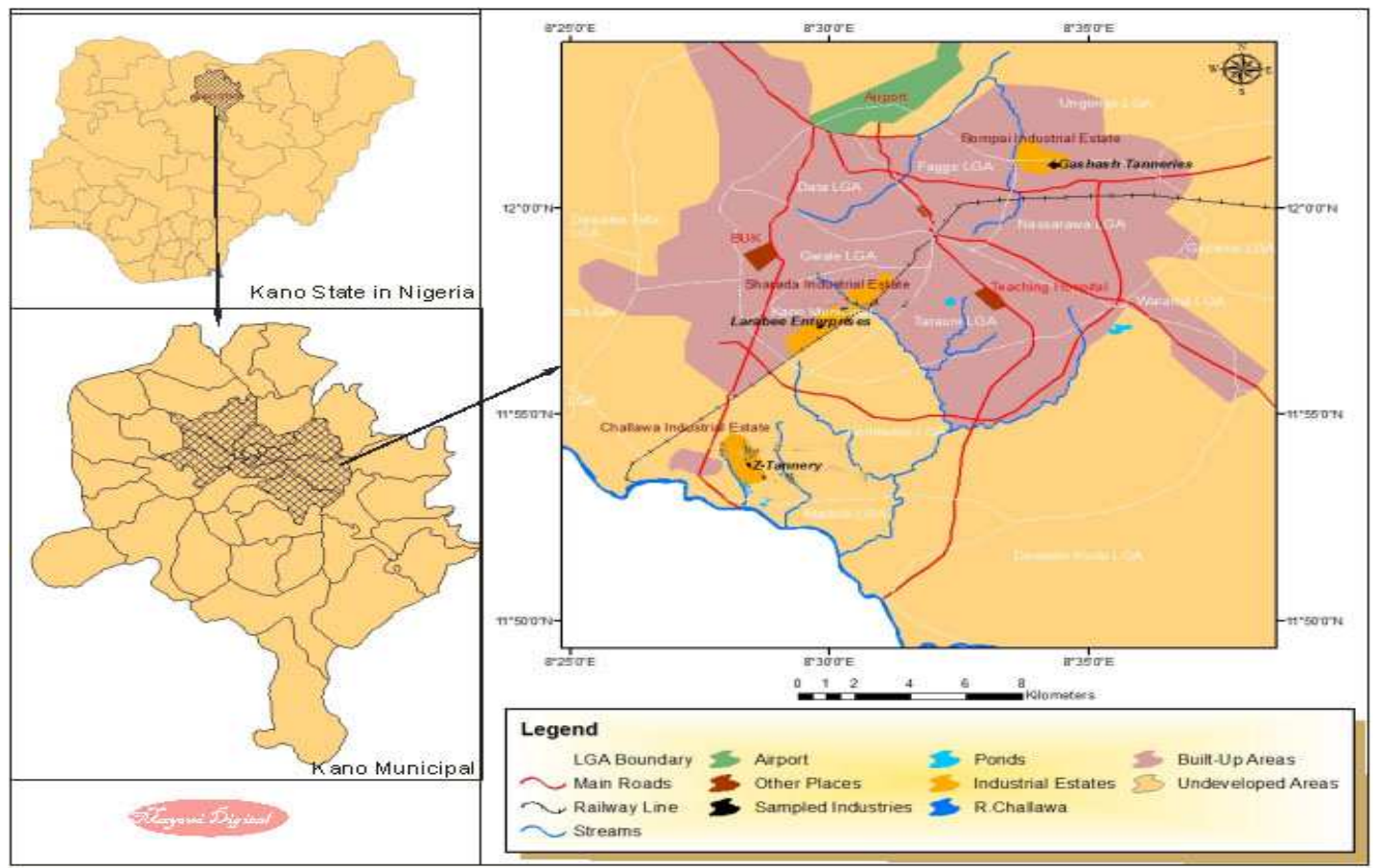

Fig. 1 Map showing the study areas

Source: Mayomi Digital Productions, GIS Laboratory, Department of Geography, UNIMAID (2017)

\section{Determination of Growth Rate of the Bacteria in Effluent Sample}

The bacteria growth rates were determined by transferring $2 \mathrm{~mL}$ of the bacterial isolates from the tannery effluent in broth medium into 100 $\mathrm{mL}$ sterile effluents in conical flasks and kept in an incubator (Giffrin cool) for 10 days. Control was also set up by incubating another $100 \mathrm{~mL}$ each of the sterile effluents without the bacteria. The optical density of the content was determined at the wavelength of $600 \mathrm{~nm}$ on a daily interval and recorded. 
BAJOPAS Volume 13 Number 2, December, 2020 Immobilization of Bacteria

Agar solution and inoculi were prepared separately. Fifty milliliters $(50 \mathrm{~mL})$ of nutrient broth each of the inoculi was prepared in a McCartney bottle and incubated for 24 hours. A solution of agar-agar was prepared by dissolving $10 \mathrm{~g}$ of the powder in distilled water and made up to $500 \mathrm{~mL}$ mark in an Erlenmeyer flask and was sterilized in an autoclave (280A) for 15 minutes and allowed to cool to $40-45^{\circ} \mathrm{C}$ (Ajao et al., 2011). Four milliliters ( $4 \mathrm{~mL})$ of the bacterial isolates in the nutrient broth was mixed with 36 $\mathrm{ml}$ of the prepared agar-agar media in petri-dish plates and then allowed to solidify. This was kept in the refrigerator for bioremediation.

\section{Bioremediation (Treatment) of the Effluents}

The solidified agar block (immobilized bacteria) was cut into cubes using a sterile knife; $0.1 \mathrm{~mL}$ phosphate buffer ( $\mathrm{pH} \mathrm{7.0)}$ was added and kept in the refrigerator for 1 hour for curing. The phosphate buffer was decanted after 1 hour and the cubes were washed with sterile distilled water 3-4 times before it was used (Ajao et al., 2011). Two liters (2 L) of the effluent was supplemented with the minimum basal medium in $\mathrm{g} / \mathrm{L}: \mathrm{NaCl}(0.8), \mathrm{MgSO}_{4} .7 \mathrm{H}_{2} \mathrm{O}(0.001), \mathrm{KH}_{2} \mathrm{PO}_{4}$ (2), $\mathrm{NaNO}_{3}$ (2), $\quad \mathrm{CaCl}_{2} .2 \mathrm{H}_{2} \mathrm{O} \quad(0.5)$ and $\mathrm{NaHPO}_{4} .12 \mathrm{H}_{2} \mathrm{O}(2)$ and sterilized in an autoclave at $121^{\circ} \mathrm{C}$ for 15 minutes (Margesin and Schinner, 2001). Two hundred and fifty milliliters $(250 \mathrm{~mL})$ of the effluents were transferred into different $250 \mathrm{ml}$ conical flasks. The content was covered with a cotton-wool ramped with foil paper to avoid contamination. Five grams $(5 \mathrm{~g})$ of the immobilized bacteria were quickly transferred into each of the effluents in the conical flasks in an inoculating chamber. The same procedures were carried out for the $10 \mathrm{~g}, 15 \mathrm{~g}, 20 \mathrm{~g}$ and 25 $\mathrm{g}$ of the immobilized bacteria in separate $250 \mathrm{~mL}$ effluents in conical flasks and agitated for ten days in a shaker incubator (Gallenkamp-OC4364-L) at a temperature $30^{\circ} \mathrm{C}$ and speed of 60 rpm. The treated effluent samples were taken on the tenth day and analyzed for the parameters $\mathrm{pH}$, SS, TDS, COD, and BOD, (Posttreatment determination) for the different grams of bacteria to evaluate and compare the biodegradation potential. (Baba et al., 2020).

\section{Statistical Analysis}

The data were represented as Mean \pm Standard deviation and analyzed statistically using oneway Analysis of Variance (ANOVA) and Tukey's HSD as Post Hoc Tests with the aid of SPSS 16.0. The correlation coefficient was also used to measure the strength of the relationship between the different masses of the bacteria and the parameters. All $\mathrm{p} \leq 0.05$ were considered as statistically significant.

\section{RESULTS AND DISCUSSION Physico-chemical parameters in the Industrial Effluents before the Biodegradation.}

Results of the Physico-chemical parameters in the industrial effluents before the Biodegradation is shown in table 1 . The mean temperatures $\left({ }^{\circ} \mathrm{C}\right)$ observed in TAN1, TAN2, and TAN3 samples were $28.07 \pm 0.65 ; 27.77 \pm 0.64$ and $26.38 \pm 3.81$ respectively. The order of the mean temperature of the samples from the three industries can be arranged as TAN1 > TAN2>TAN3. The temperature observed at TAN1, TAN2, and TAN3 samples were found below the WHO $\left(35^{\circ} \mathrm{C}\right)$ and NESREA $\left(40^{\circ} \mathrm{C}\right)$ limits. The low values of temperature might be due to the processes used at the time of sampling. High temperature brings down the solubility of gases in water that ultimately expresses as high BOD and COD. Statistical analysis shows that there is no significant difference $(p<0.05)$ between the mean values of temperature among the industries. This might be due to similar tannery activities involved in the tannery industries at the time of sampling. The average values of temperature observed in this present study are less than those observed by Akan et al. (2007), Akan et al. (2009) and Baba et al. (2020).

The mean level of $\mathrm{pH}$ observed in TAN1, TAN2 and TAN3, samples were $7.77 \pm 2.93$; $8.35 \pm 0.28$ and $7.52 \pm 0.76$ respectively. The order of the mean $\mathrm{pH}$ of the samples from the three industries can be arranged as TAN2> TAN1 $>$ TAN3. The $\mathrm{pH}$ of the samples falls within the WHO (7.0-8.5) and NESREA (6-9) standard limits. Statistical analysis shows that there is no significant difference $(p<0.05)$ between the mean values of $\mathrm{pH}$ among the industries. This might be due to similar tannery activities involved in the tannery industries at the time of sampling. Maheshwari et al. (2017) reported that the level of $\mathrm{pH}$ in the effluents from the tannery industry in Vaniyambadi, India was 6.5 which was lower than that observed in the present study. The $\mathrm{pH}$ in the effluents from the tannery industries in Kano and Kaduna were reported to be 7.64 and 6.89, respectively (Akan et al., 2007; Mohammed et al., 2017). The average values of $\mathrm{pH}$ observed in this present study are less than those observed by Mohammed et al. (2017) and Baba et al. (2020). The mean level of SS $(\mathrm{mg} / \mathrm{l})$ observed in TAN1, TAN2, and TAN3 samples were 374 \pm 124 ; $358 \pm 335$ and $780 \pm 739$ respectively. The order of the mean SS in the samples from the three industries can be arranged as TAN3 > TAN1 $>$ TAN2. 
The SS observed in the samples were far above the recommended standard limits of regulating bodies WHO $(30 \mathrm{mg} / \mathrm{l})$ and NESREA $(10 \mathrm{mg} / \mathrm{l})$. Statistical analysis shows that there is no significant difference $(p<0.05)$ between the mean values of SS among the industries. This might be due to similar tannery activities involved in the tannery industries at the time of sampling. The average values of SS observed in this present study are less than that observed $(3700 \pm 122 \mathrm{mg} / \mathrm{l})$ by Akan et al. (2009) for tanneries in Kano. Also, the average values of SS observed in this present study are less than that observed by Mohammed et al. (2017) and Baba et al. (2020) with the exception in TAN3.

The mean level of TDS (mg/l) observed in TAN1, TAN2, and TAN3 samples were $3941 \pm 3703$; $3300 \pm 1714$ and $2653 \pm 1240$ respectively. The order of the mean TDS in the samples from the three industries can be arranged as TAN1>TAN2>TAN3. The TDS observed in the samples were far above the recommended standard limits of WHO $(250 \mathrm{mg} / \mathrm{l})$ and NESREA $(500 \mathrm{mg} / \mathrm{l})$. Statistical analysis shows that there is no significant difference $(p<0.05)$ between the mean values of TDS among the industries. This might be due to similar tannery activities involved in the tannery industries at the time of sampling. TDS in the effluents from the tannery industries in Kano, Nigeria was reported to be $1281 \mathrm{mg} / \mathrm{l}$ (Akan et al., 2007). The average values of SS observed in this present study are less than those observed by Mohammed et al. (2017) and Baba et al. 2020)

The mean level of COD (mg/l) observed in TAN1, TAN2 and TAN3 samples seasons were $2372 \pm 938 ; \quad 1406 \pm 208$ and $3532 \pm 1373$ respectively. The order of the mean COD of the samples from the three industries can be arranged as TAN3>TAN1> TAN2. The COD observed in TAN1, TAN2 and TAN3 samples were far above the recommended standard limits of regulating bodies $\mathrm{WHO}(40 \mathrm{mg} / \mathrm{l})$ and NESREA (40 mg/l). Statistical analysis shows that there is no significant difference $(p<0.05)$ in COD among the industries. This might be due to similar tannery activities involved in the tannery industries as at the time of sampling. The Chemical Oxygen demand (COD) is the amount of oxygen, in $\mathrm{mg} / \mathrm{L}$, required for the degradation of the compound of wastewater to occur. In comparison, the average values of COD observed in this present study were higher than that observed by Mohammed et al. (2017) but lower than that observed by Baba et al. (2020).

The mean levels of BOD $(\mathrm{mg} / \mathrm{l})$ observed in TAN1, TAN2 and TAN3 samples were $13.85 \pm 6.42 ; \quad 19.46 \pm 0.50$ and $17.13 \pm 3.14$ respectively. The order of the mean BOD in the samples from the three industries can be arranged as TAN2>TAN3>TAN1. The BOD observed in TAN1, TAN2 and TAN3 samples were found below the recommended limits of NESREA (200 mg/l) but above WHO (10 mg/l). Statistical analysis shows that there is no significant difference $(p<0.05)$ between the mean values of BOD among the industries. This might be due to similar tannery activities involved in the tannery industries at the time of sampling. The low level of BOD recorded in this study is an indication of the low level of biodegradable organic solids in the effluent. The average values of BOD observed in this present study were lower than those observed by Mohammed et al. (2017) and Baba et al. (2020).

Table 1: Mean Values \pm S.D of Physico-chemical parameters of effluents from the Tannery Industries before Treatment.

\begin{tabular}{llllllll}
\hline Parameter & Tannery 1 & Tannery 2 & Tannery 3 & $\mathrm{a}$ & $\mathrm{b}$ & $\mathrm{c}$ & $\mathrm{d}$ \\
\cline { 2 - 7 } Temperature $\left({ }^{\circ} \mathrm{C}\right)$ & $28.07 \mathrm{a} \pm 0.65$ & $27.77 \mathrm{a} \pm 0.64$ & $26.38 \mathrm{a} \pm 3.81$ & & $29.50 \pm 4.68$ & 35 & 40 \\
pH & $7.77 \mathrm{a} \pm 2.93$ & $8.35 \mathrm{a} \pm 0.28$ & $7.52 \mathrm{a} \pm 0.76$ & 6.89 & $5.35 \pm 1.57$ & $7.0-8.5$ & $6.0-9.0$ \\
$\mathrm{COD}(\mathrm{mg} / \mathrm{l})$ & $2372 \mathrm{a} \pm 938$ & $1406 \mathrm{a} \pm 208$ & $3532 \mathrm{a} \pm 1373$ & 2.2 & $3106 \pm 2753$ & 40 & 40 \\
$\mathrm{BOD}(\mathrm{mg} / \mathrm{l})$ & $13.85 \mathrm{a} \pm 6.42$ & $19.46 \mathrm{a} \pm 0.50$ & $17.13 \mathrm{a} \pm 3.14$ & 1032 & $26.17 \pm 9.49$ & 10 & 200 \\
$\mathrm{SS}(\mathrm{mg} / \mathrm{l})$ & $374 \mathrm{a} \pm 124$ & $358 \mathrm{a} \pm 335$ & $780 \mathrm{a} \pm 739$ & 501 & $562 \pm 482$ & 30 & 10 \\
TDS $(\mathrm{mg} / \mathrm{l})$ & $3941 \mathrm{a} \pm 3703$ & $3300 \mathrm{a} \pm 1714$ & $2653 \mathrm{a} \pm 1240$ & 532.7 & $444 \pm 507$ & 250 & 500 \\
\hline
\end{tabular}

The values given in the table above are means of 6 replicate values, $\mathrm{n}=6$ ( 1 sample was taken monthly for 6 months). Within the rows, means with different alphabets are statistically different $(p<0.05)$. WHO: World Health Organisation. NESREA: National Environmental Standard and Regulatory Enforcement Agency. a = Mohammed et al.(2017), b = Baba et al. (2020), c = WHO (2006), $d=$ NESSRA (2009) 
BAJOPAS Volume 13 Number 2, December, 2020

Identification, Biochemical Characterization and growth rates of the Bacterial Isolates

Results of identification and biochemical characterization of the bacterial isolates were shown in table 2. After 24 hours of incubation, the nutrient agar media plates were checked for bacterial growth. The results showed the presence of different strains in the samples. The TAN1 bacteria isolate was found to be gramnegative cocci while TAN3 was gram-positive cocci. TAN2 bacteria isolate was found to be gram-positive, rod-shaped. TAN1, TAN2, and TAN3 bacteria isolates recorded positive results for spore former.

The results of the biochemical tests indicated that all the bacteria were positive for catalase, oxidase, citrate, maltose, glucose, lactose (negative in TAN1), mannitol (negative in TAN2), starch hydrolysis and coagulase (negative in TAN2) tests. The bacteria showed negative results for nitrate reduction, $M R$ (positive in TAN2), VP (positive in TAN1), Indole (positive in TAN2) tests. Base on the morphological and biochemical test results, TAN1, TAN2, and TAN3 bacteria isolates were identified to be Nesseria spp, Bacillus cereus, and Staphylococcus aureus respectively.

The growth rate of the TAN1, TAN2 and TAN3 Isolates were shown in figure 2. Generally, the optical density increase with the increase in time (day) and decrease as time goes on. The highest optical density was shown by bacillus cereus in TAN2 while the lowest was shown by Staphylococcus aureus in TAN3.

The initial growth phase of TAN1 Isolate bacteria occurred within 2-day of incubation as the growth rate increases up to the 6th-day incubation when the maximum growth was observed. Beyond the 6th day, the growth of the bacteria declined (which might be due to a shortage of nutrients in the effluents) until it reached its death phase (which might be due to the unavailability of nutrients in the effluents).

A similar trend of growth was also observed for TAN2 Isolate as the initial growth phase also occurred within 2-day of incubation but maximum growth rate observed on the 4th day of incubation. The stationary stage occurred between the 4th day and the 8th day. Beyond the 8th day, the growth of the bacteria declined (which might be due to a shortage of nutrients in the effluents) until it reached its death phase (which might be due to the unavailability of nutrients in the effluents).

The initial growth phase of TAN3 bacterial Isolate occurred within the 3-day incubation as the growth rate increases up to the 6th-day incubation when the maximum growth was observed. Beyond the 6th day, the growth of the bacteria declined (which might be due to a shortage of nutrients in the effluents) until it reached its death phase (which might be due to the unavailability of nutrients in the effluents).

Table 2: Morphological and Biochemical characteristics of bacterial isolates

\begin{tabular}{lllll} 
Bacterial Isolates & & TAN1 & TAN2 & TAN3 \\
\hline $\begin{array}{lllll}\text { Morphological } \\
\text { characteristics }\end{array}$ & Shape & Cocci & Rod & Cocci \\
& Spore & & & \\
& former & + & + & + \\
Gram & & & \\
Biochemical characteristics & reaction & - & + & + \\
& Citrate & + & + & + \\
& Catalase & + & + & + \\
& Coagulase & + & - & + \\
Starch & + & + & + \\
& Glucose & + & + & + \\
Oxidase & + & + & + \\
& Indo & - & + & - \\
Lactose & - & + & + \\
Manitol & + & - & + \\
Maltose & + & + & + \\
MR & - & + & - \\
VP & + & - & - \\
& Nitrate & - & - & - \\
Reduction & - Neisseria & Bacillus & Staphylococcus \\
& Bacterial & cereus & aureus \\
& name & spp & cas
\end{tabular}

+ = Positive; - = Negative; MR=Methyl Red; VP= Voges-Proskauer 


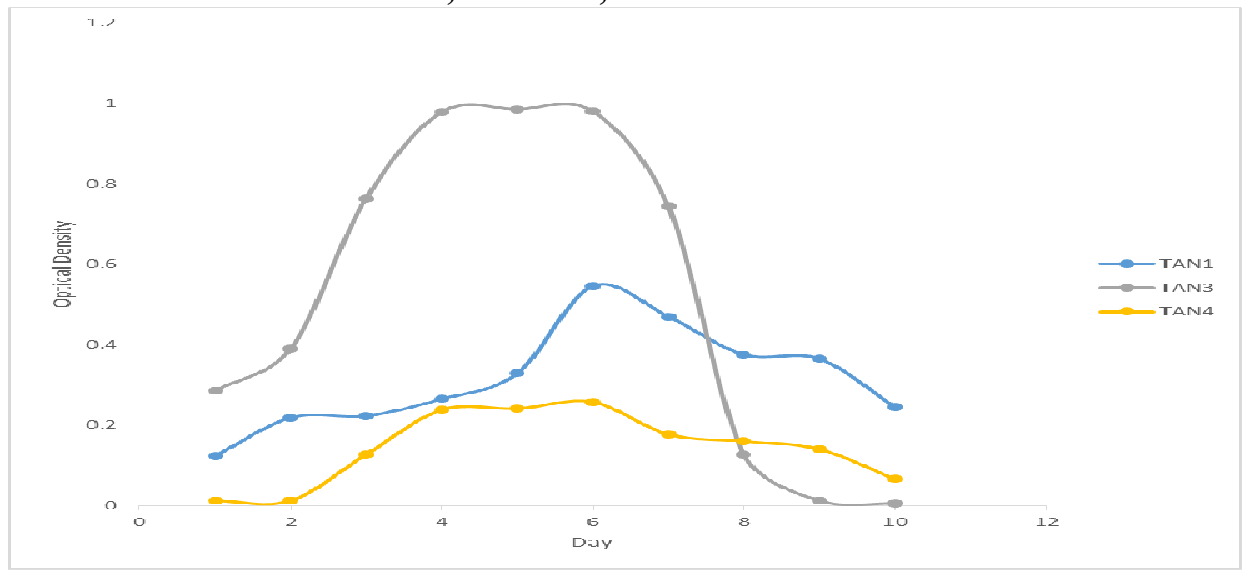

Fig. 2 Growth rates of the isolates in the effluents from the Tannery Industries

\section{Physico-chemical Parameters in the Industrial Effluents after the biodegradation.}

Table 3 shows the mean results of the physicochemical parameter before and after bioremediation using the different masses $(5 \mathrm{~g}$, $10 \mathrm{~g}, 15 \mathrm{~g}, 20 \mathrm{~g}$, and $25 \mathrm{~g}$ ) of the respective immobilized bacteria. Also, Table 4 shows the mean results of correlation coefficient ( $r$ ) between different masses of bacteria and physicochemical parameters.

The mean values $(\mathrm{mg} / \mathrm{l})$ of the SS after the bioremediation varies between $243 \pm 45$ and $898 \pm 672$. The mean concentration $(\mathrm{mg} / \mathrm{l})$ of SS remediated by the different masses $(5 \mathrm{~g}, 10 \mathrm{~g}$, $15 \mathrm{~g}, 20 \mathrm{~g}$, and $25 \mathrm{~g}$ ) of the bacteria varies. The SS in the samples fluctuates up and down after the bioremediation process when compared with the SS of the raw samples before the bioremediation. The increase in the levels of the SS might be due to the aggregation of the TDS which are large enough to result into SS. The increase in the levels of the SS might be also due to the influence of the nutrients which was added into the effluents in order to make the microorganisms more active and viable for fast degradation of organic contaminants in the effluent. The relative potential or efficiency of the different masses of the bacteria in remediating SS in TAN1 samples was in the order $25 \mathrm{~g}>20 \mathrm{~g}>15 \mathrm{~g}>10 \mathrm{~g}>5 \mathrm{~g}$. For TAN2 and TAN3 samples, the order was $25 \mathrm{~g}>20 \mathrm{~g}>15$ $\mathrm{g}>10 \mathrm{~g}>5 \mathrm{~g}$. These might be due to the variations in the surface areas of the different masses of the immobilized bacteria. Statistical analysis shows that there is no significant difference $(p<0.05)$ between the mean values of SS among the masses in the respective industries. Positive and significant correlations exist between the masses of bacteria and Suspended Solid (SS). This showed that there is general increase in the levels of the SS as the masses of the immobilized bacteria increases. TAN3 (90\%) and TAN1 (80\%) showed a very high correlation with the masses of the bacteria while TAN2 (61\%) showed a very low correlation.

The mean values $(\mathrm{mg} / \mathrm{l})$ of the TDS after the bioremediation varies between $46 \pm 11$ and $83 \pm 78$. The mean concentration $(\mathrm{mg} / \mathrm{l})$ of TDS remediated by the different masses $(5 \mathrm{~g}, 10 \mathrm{~g}$, $15 \mathrm{~g}, 20 \mathrm{~g}$, and $25 \mathrm{~g}$ ) of the bacteria varies. There is a reduction in all the TDS of all the samples after the bioremediation process compared with the TDS of the raw samples before the bioremediation. The relative potential or efficiency of the different masses of the bacteria in remediating TDS in TAN1 and TAN3 samples was in the order $5 \mathrm{~g}>10 \mathrm{~g}>15 \mathrm{~g}>20$ $\mathrm{g}>25 \mathrm{~g}$. For TAN2 samples, the order was 20 $g>10 \quad g>25 \quad g>15 \quad g>5 \quad g$. Statistical analysis shows that there is no significant difference $(p<0.05)$ between the mean values of TDS among the masses in the respective industries. These might be due to the variations in the surface areas of the different masses of the immobilized bacteria. Positive and significant correlations exist between the masses of bacteria and TDS with the exception in TAN2 (negative and insignificant correlation). The positive correlations showed that there is general increase in the levels of the TDS as the masses of the immobilized bacteria increases. TAN1 $(96 \%)$ showed a very high correlation with the masses of the bacteria while TAN2 (47\%) showed a very low correlation.

The mean values $(\mathrm{mg} / \mathrm{l})$ of the BOD after the bioremediation varies between $1.56 \pm 0.20 \mathrm{mg} / \mathrm{l}$ and $6.92 \pm 5.49 \mathrm{mg} / \mathrm{l}$. The mean concentration $(\mathrm{mg} / \mathrm{l})$ of BOD remediated by the different masses $(5 \mathrm{~g}, 10 \mathrm{~g}, 15 \mathrm{~g}, 20 \mathrm{~g}$, and $25 \mathrm{~g}$ ) of the bacteria varies. There is a reduction in all the BOD of all the samples after the bioremediation process compared with the $\mathrm{BOD}$ of the raw 
BAJOPAS Volume 13 Number 2, December, 2020 samples before the bioremediation. The relative potential or efficiency of the different masses of the bacteria in remediating BOD in TAN1, TAN2 and TAN3 samples were in the order $25 \mathrm{~g}>20$ $\mathrm{g}>15 \mathrm{~g}>10 \mathrm{~g}>5 \mathrm{~g}, 25 \mathrm{~g}>15 \mathrm{~g}>5 \mathrm{~g}>10 \mathrm{~g}>20 \mathrm{~g}$ and $20 \mathrm{~g}>10 \mathrm{~g}>25 \mathrm{~g}>15 \mathrm{~g}>5 \mathrm{~g}$ respectively. Statistical analysis shows that there is significant difference $(p<0.05)$ between the mean values of BOD among the masses in the respective industries. These might be due to the variations in the surface areas of the different masses of the immobilized bacteria. Negative and significant correlations exist between the masses of bacteria and BOD. This showed that there is general decrease in the levels of the BOD as the masses of the immobilized bacteria increases. TAN1 (94\%) showed a very high correlation with the masses of the bacteria while TAN2 (4\%) showed a very low correlation.

The mean values $(\mathrm{mg} / \mathrm{l})$ of the COD after the bioremediation varies between $250 \pm 154$ and $3134 \pm 1595$. The mean concentration $(\mathrm{mg} / \mathrm{l})$ of COD remediated by the different masses $(5 \mathrm{~g}$, $10 \mathrm{~g}, 15 \mathrm{~g} 20 \mathrm{~g}$, and $25 \mathrm{~g}$ ) of the bacteria varies. There is a reduction in all the COD of all the samples after the bioremediation process compared with the COD of the raw samples before the bioremediation. The relative potential or efficiency of the different masses of the bacteria in remediating COD in TAN1, TAN2 and TAN3 samples were in the order $25 \mathrm{~g}>20 \mathrm{~g}>15$ $\mathrm{g}>5 \mathrm{~g}>10 \mathrm{~g}, 25 \mathrm{~g}>20 \mathrm{~g}>15 \mathrm{~g}>10 \mathrm{~g}>5 \mathrm{~g}$ and 10 g>5 g>25 g>15 g>20 g respectively. Statistical analysis shows that there were significant difference $(p<0.05)$ between the mean values of COD among the masses in the respective industries except for effluents treated with $25 \mathrm{~g}$. These might be due to the variations in the surface areas of the different masses of the immobilized bacteria. Negative and insignificant correlations exist between the masses of bacteria and COD with the exception in TAN3 (positive and significant correlation). The negative correlations showed that there is general decrease in the levels of the COD as the masses of the immobilized bacteria increases. TAN2 (100\%) showed a very high correlation with the masses of the bacteria while TAN3 (36\%) showed a very low correlation.

Generally, there was an overall decrease in the concentration of these physicochemical parameters after the bioremediation using the different masses of the bacterial isolates. These might be due to the variations in the surface areas of the different masses of the immobilized bacteria. This is in line with the work of Jimoh et al. (2018) and Baba et al. (2020).

Table 3: Mean Values $(\mathrm{mg} / \mathrm{l}) \pm$ S.D of Physicochemical parameters in effluents from the Tannery Industries before and after Treatment of the effluents $(250 \mathrm{ml})$ with the different masses $(5 \mathrm{~g}, 10 \mathrm{~g}$, $15 \mathrm{~g}, 20 \mathrm{~g}$, and $25 \mathrm{~g}$ ) of the bacteria.

\begin{tabular}{llllllll}
\hline $\mathrm{P}$ & IND & Before & \multicolumn{5}{c}{ After } \\
\cline { 4 - 7 } & & & $5 \mathrm{~g}$ & $10 \mathrm{~g}$ & $15 \mathrm{~g}$ & $20 \mathrm{~g}$ & $25 \mathrm{~g}$ \\
\hline \multirow{2}{*}{ COD } & TAN1 & $2372 \pm 938$ & $1708 \mathrm{a} \pm 861$ & $2045 \mathrm{a} \pm 1205$ & $845 \mathrm{a} \pm 369$ & $300 \mathrm{a} \pm 167$ & $250 \mathrm{a} \pm 154$ \\
& TAN2 & $1406 \pm 208$ & $1195 \mathrm{a} \pm 208$ & $1125 \mathrm{a} \pm 384$ & $1055 \mathrm{a} \pm 317$ & $956 \mathrm{a} \pm 310$ & $870 \mathrm{ab} \pm 240$ \\
& TAN3 & $3532 \pm 1373$ & $2374 \mathrm{a} \pm 1344$ & $1976 \mathrm{a} \pm 1405$ & $2757 \mathrm{a} \pm 1266$ & $3134 \mathrm{a} \pm 1595$ & $2614 \mathrm{~b} \pm 1105$ \\
BOD & TAN1 & $13.85 \pm 6.42$ & $6.92 \mathrm{a} \pm 5.49$ & $6.42 \mathrm{a} \pm 5.07$ & $5.72 \mathrm{a} \pm 5.35$ & $4.62 \mathrm{a} \pm 4.37$ & $2.82 \mathrm{ab} \pm 1.26$ \\
& TAN2 & $19.46 \pm 0.50$ & $1.75 \mathrm{~b} \pm 0.22$ & $1.73 \mathrm{~b} \pm 0.18$ & $1.58 \mathrm{a} \pm 0.16$ & $1.91 \mathrm{a} \pm 0.22$ & $1.56 \mathrm{~b} \pm 0.20$ \\
& TAN3 & $17.13 \pm 3.14$ & $4.24 \mathrm{ab} \pm 0.77$ & $3.29 \mathrm{ab} \pm 0.37$ & $4.11 \mathrm{a} \pm 0.07$ & $3.23 \mathrm{a} \pm 0.91$ & $3.33 \mathrm{a} \pm 1.28$ \\
SS & TAN1 & $374 \pm 124$ & $243 \mathrm{a} \pm 45$ & $471 \mathrm{a} \pm 226$ & $475 \mathrm{a} \pm 182$ & $492 \mathrm{a} \pm 128$ & $611 \mathrm{a} \pm 217$ \\
& TAN2 & $358 \pm 335$ & $460 \mathrm{a} \pm 400$ & $543 \mathrm{a} \pm 414$ & $544 \mathrm{a} \pm 402$ & $551 \mathrm{a} \pm 414$ & $554 \mathrm{a} \pm 405$ \\
& TAN3 & $780 \pm 739$ & $586 \mathrm{a} \pm 594$ & $758 \mathrm{a} \pm 656$ & $787 \mathrm{a} \pm 676$ & $861 \mathrm{a} \pm 635$ & $898 \mathrm{a} \pm 672$ \\
TDS & TAN1 & $3941 \pm 3703$ & $51 \mathrm{a} \pm 10$ & $53 \mathrm{a} \pm 10$ & $55 \mathrm{a} \pm 15$ & $61 \mathrm{a} \pm 20$ & $63 \mathrm{a} \pm 26$ \\
& TAN2 & $3300 \pm 1714$ & $83 \mathrm{a} \pm 78$ & $47 \mathrm{a} \pm 20$ & $48 \mathrm{a} \pm 22$ & $47 \mathrm{a} \pm 17$ & $48 \mathrm{a} \pm 17$ \\
& TAN3 & $2653 \pm 1240$ & $46 \mathrm{a} \pm 11$ & $55 \mathrm{a} \pm 24$ & $55 \mathrm{a} \pm 25$ & $58 \mathrm{a} \pm 23$ & $61 \mathrm{a} \pm 28$ \\
\hline
\end{tabular}

Replicate $=6$ (months)

Within the rows, for the same parameter, means with different alphabets are statistically different $(p<0.05)$.

$\mathrm{P}=$ parameter, IND = Industries 
BAJOPAS Volume 13 Number 2, December, 2020

Table 4: Correlation coefficient $(r)$ between different masses of the bacteria and the physicochemical parameters.

\begin{tabular}{llll}
\hline Industries & Parameter & Correlation coefficient $(r)$ & $\begin{array}{l}\text { Percent dependence (rxrx100) } \\
(\%)\end{array}$ \\
\hline TAN1 & COD & -0.9 & 82 \\
& BOD & -0.97 & 94 \\
& SS & $0.90^{*}$ & 80 \\
TAN2 & TDS & $0.98^{*}$ & 96 \\
& COD & -1 & 100 \\
& BOD & -0.21 & 4 \\
& SS & $0.78^{*}$ & 61 \\
& TDS & -0.69 & 47 \\
& COD & $0.60^{*}$ & 36 \\
& BOD & -0.6 & 37 \\
& SS & $0.95^{*}$ & 90 \\
& TDS & $0.94^{*}$ & 89 \\
\hline
\end{tabular}

The correlation coefficient $(r)$ with * is statistically significant $(p<0.05)$.

Percentage reduction of the Parameters

Table 5 shows the percentage reduction of Parameters in industrial samples before and after the treatment of the effluents $(250 \mathrm{ml})$ with the different masses $(5 \mathrm{~g}, 10 \mathrm{~g}, 15 \mathrm{~g}, 20 \mathrm{~g}$, and $25 \mathrm{~g}$ ) of the Immobilized Bacteria.

In TAN1 samples, the percentage reduction (\%) of COD ranged (14-89); BOD (50-80); SS (-32$35)$ and TDS (98-99). In TAN2 samples, the percentage decrease $(\%)$ of COD ranged (15$38) ;$ BOD (90-92); SS [-28-(-55)] and TDS (9798). In TAN3 samples, the percentage decrease (\%) of COD ranged (11-44); BOD (76-81); SS (15-25) and TDS (98). The percentage increase in the levels COD, BOD and TDS might be due to the increase in the surface area of the different masses of the immobilized bacteria. However, the percentage decrease in the levels of the SS might be due to the aggregation of the TDS which are large enough to result into SS. The percentage decrease in the levels of the SS might be also due to the influence of the nutrients which was added into the effluents in order to make the microorganisms more active and viable for fast degradation of organic contaminants in the effluent. This is in line with the work of Jimoh et al. (2018) in which the concentration of the SS increase after the bioremediation of effluents.

Sreemoyee and Priti (2013) assessed and reduced several Physico-chemical parameters of dairy wastewater using Niesseria $s p$. and concluded that the species are well known to degrade organic compounds. This is in agreement with the current study in which the immobilized Niesseria $s p$ degrade the organic contaminants as indicated by the BOD, COD and TDS.

Jimoh et al. (2018) observed that TSS of the effluents was increased after treatment with immobilized bacteria and concluded that it might be due to the biostimulation method adopted for the research.

The optimum $\mathrm{pH}$ Biosorption of Chromium by Bacillus spp and Staphylococcus spp. from tannery effluent was investigated by Mythili and Karthikeyan (2011). The maximum adsorption of Chromium $(86.4 \mathrm{mg} / \mathrm{L})$ was showed by Bacillus spp and Staphylococcus spp showed $70.6 \mathrm{mg} / \mathrm{L}$ at an initial concentration of $100 \mathrm{mg} / \mathrm{L}$. In the present study, immobilised Bacillus spp and Staphylococcus spp. from the tannery industrial effluents reduced the levels of the organic pollutants with high potential as indicated by the percentage reduction of BOD, COD and TDS.

Enzymes often can work in multiple environments especially if they are immobilized. This makes the microorganisms' enzymes even more resistant to harsh environments and enables the enzymes to be recovered and recycled after they are no longer needed (Gianfreda and Rao 2004). Ramesh and Singh (1993) reported that the immobilized bacteria having more efficiency to remove the suspended particles than free cells. Using the immobilized cell is preferable due to its capability for using several times with the same efficiency, which makes it more economical. Similar work was done by Sikander et al. (2007) showing the higher reduction with permeabilized cells of Ochrobactrum intermedium strain SDCr-5. 
BAJOPAS Volume 13 Number 2, December, 2020

The results revealed the isolation and identification of isolates with the potential for the reduction of $\mathrm{Cr}$ (VI) to $\mathrm{Cr}$ (III). Results indicated that immobilized $B$. cereus could be efficiently used for the reduction of $\mathrm{Cr}$ (VI).

Table 5: Percentage reduction of the tested Parameters from the tannery industrial samples of the Immobilized Bacteria.

\begin{tabular}{lllllll}
\hline \multirow{2}{*}{ Industries } & & \multicolumn{5}{c}{ Percentage Reduction $(\%)$} \\
\cline { 3 - 7 } & & $5 \mathrm{~g}$ & $10 \mathrm{~g}$ & $15 \mathrm{~g}$ & $20 \mathrm{~g}$ & $25 \mathrm{~g}$ \\
\hline TAN1 & COD & 28 & 14 & 64 & 87 & 89 \\
& BOD & 50 & 54 & 59 & 67 & 80 \\
& SS & 35 & -26 & -27 & -32 & -63 \\
& TDS & 99 & 99 & 99 & 98 & 98 \\
TAN2 & COD & 15 & 20 & 25 & 32 & 38 \\
& BOD & 91 & 91 & 92 & 90 & 92 \\
& SS & -28 & -52 & -52 & -54 & -55 \\
& TDS & 97 & 99 & 99 & 99 & 99 \\
& COD & 33 & 44 & 22 & 11 & 26 \\
& BOD & 75 & 81 & 76 & 81 & 81 \\
& SS & 25 & 3 & -1 & -10 & -15 \\
& TDS & 98 & 98 & 98 & 98 & 98 \\
\hline
\end{tabular}

Percentage Reduction $=(B-A) / B \times 100 \%$

$A=$ Concentration of the parameter after treatment

$\mathrm{B}=$ Concentration of the parameter before treatment

$+=$ percentage decrease

- = percentage increase

In general, immobilization makes the enzyme more resistant to temperature, $\mathrm{pH}$, and substrate concentration swings giving it a longer lifetime and higher productivity per active unit (Gianfreda and Rao, 2004; FuIlbrook, 1996; Russell et al, 2003; Kandelbauer et al., 2004). Immobilized cells have been used and studied extensively for the production of useful chemicals (Ohtake and Silver, 1994), the treatment of wastewaters (Chen et al., 2003; Wang et al., 2010). Although many workers described microbial degradation of tannery effluent, limited literature is available on the bioremediation of tannery effluent using immobilized bacterial cells in the Kano Industrial Estates.

\section{CONCLUSION}

The samples contained variable levels of the physicochemical parameters. The results of the Analysis of variance revealed that, no statistical difference $(p<0.05)$ was observed for the temperature, $\mathrm{pH}, \mathrm{SS}, \mathrm{TDS}, \mathrm{BOD}$ and $\mathrm{COD}$ among the three tannery industries before the treatment. The levels of some of the parameters
(SS, TDS and COD) observed in the samples were found above the recommended limits of WHO and NESREA, which called for the treatment of the effluents before discharge into the environment. Base on the morphological and biochemical test results, TAN1, TAN2, and TAN3 bacterial isolates were identified to be Neisseria spp, Bacillus cereus, and Staphylococcus aureus respectively. The results of Post-treatment analysis showed that there is overall decrease in the levels of the parameters determined when compared with that of the pre-treatment. The overall percentage reduction of the immobilised bacteria in the treatment of the respective effluents was in the order TAN2 (72\%)>TAN1 $(70 \%)>$ TAN3 $(62 \%)$. Hence, the immobilized bacteria are having higher biodegradation potential for the treatment of the tannery effluents.

\section{Acknowledgments}

The authors wish to acknowledge the University of Maiduguri for the financial support. The authors are grateful to the Kano State Ministry of Environment for their support in obtaining the effluent samples. 


\section{REFERENCES}

Ajao, A. T., Adebayo, G. B., and Yakubu, S. E. (2011). Bioremediation of textile industrial effluent using mixed culture of Pseudomonas aeruginosa and Bacillus subtilis immobilized on agar-agar in a bioreactor. J. Microbiol. Biotech. Res, 1(3), 50-56.

Akan, J. C., Moses, E. A., Ogugbuaja, V. O., and Abah, J. (2007). Assessment of tannery industrial effluents from Kano metropolis, Kano State, Nigeria. Journal of Applied Sciences, 7(19), 2788-2793.

Akan, J. C., Ogugbuaja, V. O., Abdulrahman, F. I., and Ayodele, J. T. (2009). Pollutant levels in effluent samples from tanneries and textiles of Kano industrial areas, Nigeria. Global journal of pure and applied sciences, 15(3-4).

APHA (1989). Standard methods for Examination of Will bete and Will betewater.15 $5^{\text {th }}$ edition. Brydpass Springfield Will behington DC. pp. 164-176

APHA (1992). Standard Methods for the Examination of Water and Wastewater. Health, 69, 1116-9.

Baba, A., Garba, S. T., and Bello, H. S. (2020). Bioremediation Potential of Immobilized corynebacterium kutsceri in the Treatment of Tannery Industrial Effluent from Challawa Industrial Estate, Kano State, Nigeria. Journal of the Turkish Chemical Society Section A: Chemistry, $7(2), 335-350$.

Beem, E. I. V. (1994). reduction of solvent VOC emission. J. Oil Col. Chem. Ass, 77, 158.

Bouwer, E. J., and Zehnder, A. J. (1993). Bioremediation of organic compoundsputting microbial metabolism to work. Trends in biotechnology, 11(8), 360367.

Chen, K. C., Wu, J. Y., Liou, D. J., and Hwang, S. C. J. (2003). Decolorization of the textile dyes by newly isolated bacterial strains. Journal of Biotechnology, 101(1), 57-68.

Dan'Azumi, S., and Bichi, M. H. (2010). INDUSTRIAL POLLUTION AND HEAVY METALS PROFILE OF CHALLAWA RIVER IN KANO, NIGERIA. Journal of Applied Sciences in Environmental Sanitation, $5(1)$.

DWAF. (1992). Analytical Methods Manual, TR 151. Department of Water Affairs and Forestry, Pretoria.

El-Bestawy, E. (2013). Biological treatment of leather-tanning industrial wastewater using free living bacteria.
Elsheikh, M. A. S. (2009). Tannery wastewater pre-treatment. Water Science and Technology, 60(2), 433-440.

FuIlbrook, P. D. (1996). "Kinetics." Industrial enzymology: The application of enzymes in Industry. 2nd Ed. T. Godfrey and J Reichelt. eds.. Nature. New York.

Gianfreda, L., and Rao, M. A. (2004). Potential of extra cellular enzymes in remediation of polluted soils: a review. Enzyme and microbial technology, 35(4), 339354.

Hugo Springer. (1994). John Arthur Wilson Memorial Lecture "Treatment of Industrial Wastes of the Leather Industry - is it still a Major Problem". JALCA, 89, 153-185

Jimoh, A. A., Ganiyu, B. A., Baba, D., and Baba, A. (2018) Bioremediation Process of Effluent from Detergent and Food Industries in Jos, Nigeria: Kinetics and Thermodynamics. International Journal of Engineering Science Invention (IJESI), 762-73

Kandelbauer, A., Maute, O., Kessler, R. W., Erlacher, A., and Gübitz, G. M. (2004). Study of dye decolorization in an immobilized laccase enzyme-reactor using online spectroscopy. Biotechnology and bioengineering, 87(4), 552-563.

Kongjao, S., Damronglerd, S., and Hunsom, M. (2008). Simultaneous removal of organic and inorganic Pollutants in tannery wastewater using electrocoagulation technique. Korean Journal of chemical engineering, 25(4), 703.

Maheshwari, U. M., Aruna, S., Gomathi, M., and AbdulJaffar, A. H. (2017). Bioremediation by Free and Immobilized Bacteria Isolated from Tannery Effluent. International Journal of Research in Applied, Natural and Social Sciences. 5(7), 75-90

Margesin, R., and Schinner, F. (2001). Bioremediation (natural attenuation and biostimulation) of diesel-oilcontaminated soil in an alpine glacier skiing area. Applied and environmental microbiology, 677), 3127-3133.

Mohammed, A., Sekar, P., and George, J. (2011). Efficacy of microbes in bioremediation of tannery effluent. Inter. J. Curr. Res, 3(4), 324-326.

Mohammed, S. S. D., Orukotan, A. A., and Abdullahi, H. (2017). Physicochemical and Bacteriological Assessment of Tannery Effluent from Samaru-Zaria, 
BAJOPAS Volume 13 Number 2, December, 2020 Kaduna State, Nigeria. Journal of Applied

Sciences and Environmental Management, 21(4), 734-740.

Munz, G., De Angelis, D., Gori, R., Mori, G., Casarci, M., and Lubello, C. (2009). The role of tannins in conventional and membrane treatment of tannery wastewater. Journal of hazardous materials, 164(2-3), 733-739

Mythili, K., and Karthikeyan, B. (2011). Bioremediation of $\mathrm{Cr}$ (VI) from tannery effluent using Bacillus spp and Staphylococcus spp. International Multidisciplinary Research Journal, 1(6).

NESREA (2009). National Environmental Standards for Effluent Limitations and Regulation. 1233-1236

Noorjahan, C. M. (2014). Physicochemical characteristics, identification of bacteria and biodegradation of industrial effluent. Journal of bioremediation and Biodegradation, 5(3).

Ohtake, H. I., and Silver, A. O. (1994). Bacterial reduction of toxic chromate. Biological degradation and bioremediation of toxic chemicals, 403-415.

Omoleke, I. I. (2004). Management of environmental pollution in Ibadan, an African city: the challenges of health hazard facing government and the people. Journal of Human Ecology, 15(4), 265-275.

Rajor, A., Reddy, A.S., and Singh, B. (2004). Determination of BOD kinetic Parameters and evaluation of alternate methods, M.Sc. Thesis, Department of biotechnology \& environmental Science, Thapar Institute of Engineering and Technology, Patiala

Ramasami, T., Rajamani, S., and Rao, J. R. (1994, March). Pollution control in leather industry: Emerging technological options. In International symposium on surface and colloidal science and its relevance to soil pollution, madras.

Ramesh, J. V. S., and Singh, S. P. (1993). Yearly variation in certain physicochemical parameters of pond at eastern Doon Valley. Uttar Pradesh J. Zoo, 12 (1), 7577.

Ranen, S., and Sharadinadra, C. (2009). Biotechnology applications to environmental remediation in resource exploitation. Current science, 97, 6-25
Russell, A. J., Berberich, J. A., Drevon, G. F., and Koepsel, R. R. (2003). Biomaterials for mediation of

chemical and biological warfare agents. Annual review of biomedical engineering, 5(1), 1-27.

Saravanan, P., and Saravanan, A. (1999). Decolourization of tannery effluent by Flavobacterium sp. EK 1. Indian Journal of Environmental Protection, 19, 19-24.

Sikander, S., and Shahida, H. (2007). Reduction of toxic hexavalent chromium by Ochrobactrum intermedium strain SDCr5 stimulated by heavy metals. Bioresource Technol, 98, 340-344.

Singh, N., Sharma, B. K., and Bohra, P. C. (2000). Impact assessment of industrial effluent of arid soils by using satellite imageries. Journal of the Indian Society of Remote Sensing, 28(2-3), 79.

Sreemoyee, C., and Priti, P. (2013). Assessment of physico-chemical parameters of dairy waste water and isolation and characterization of bacterial strains in terms of cod reduction. Int J Sci, 2(3), 395-400.

Verheijen, L. A. H. M., Wiersema, D., Pol, L. H., and De Wit, J. (1996). Management of wastes from animal product processing. Livestock and environment, Finding a balance. International Agriculture Center, Wageningen, The Netherlands.

Wang, F., Yao, J., Si, Y., Chen, H., Russel, M., Chen, K., and Bramanti, E. (2010). Short-time effect of heavy metals upon microbial community activity. Journal of Hazardous Materials, 173(13), 510-516.

WHO (World Health Organization). (2006). Air quality guidelines: global update 2005: particulate matter, ozone, nitrogen dioxide, and sulfur dioxide. World Health Organization.

World Bank. (1995). Nigeria's strategic options for redressing industrial pollution. World Bank, industry and energy division. 1st edition, West Central Africa Department; Annexes: 1995; pp 60-62.

Zahoor, A., and Abdul, R. (2009). Enumeration of Coliforms. Journal of Environmental Sciences. 21, 814-820 


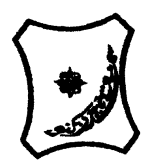

Bayero Journal of Pure and Applied Sciences, 13(2): 1 - 12

Received: November, 2020

Accepted: December, 2020

ISSN $2006-6996$

\title{
BIODEGRADATION POTENTIAL OF IMMOBILIZED BACTERIA IN THE TREATMENT OF TANNERY INDUSTRIAL EFFLUENTS FROM INDUSTRIAL ESTATES IN KANO STATE, NIGERIA
}

\author{
Abdullateef, B., ${ }^{1 *}$ Shuaibu, T. G., ${ }^{1}$ Babagana, K., ${ }^{1}$ Suleman, H. B. ${ }^{2}$ and Dauda, B. ${ }^{3}$ \\ ${ }^{1}$ Department of Pure and Applied Chemistry, Faculty of Science, University of Maiduguri, Borno State, \\ Nigeria \\ ${ }^{2}$ Department of Microbiology, Faculty of Science, University of Maiduguri, Borno State, Nigeria \\ ${ }^{3}$ Department of Chemical Engineering, Faculty of Engineering, University of Maiduguri, Borno State, \\ Nigeria \\ *Corresponding author: babslega@gmail.com; abelega2007@yahoo.com; +2348061309753
}

\section{ABSTRACT}

Industrial Effluents Samples from Gashash Tanneries (TAN1) in Bompai Industrial estate, Larabee Tannery Industry (TAN2) in Sharada Industrial estate and Z Tannery Industries (TAN3) in Challawa Industrial estate, Kano State, Nigeria were collected over a period of six months (August 2017 to January 2018) for assessing the biodegradation potentials of bacteria in the treatment of organic pollutants within the effluents. Bacteria were isolated from the effluents and immobilized on agar-agar. Different masses (5 g, $10 \mathrm{gr}, 15$ $\mathrm{g}, 20 \mathrm{~g}$, and $25 \mathrm{~g}$ ) of the bacteria were used in the treatment of $250 \mathrm{ml}$ of the effluents for ten days in a shaker incubator (Gallenkamp-OC-4364-L) at the temperature $30{ }^{\circ} \mathrm{C}$ and speed of $60 \mathrm{rpm}$. Pre-treatment analysis of the effluents for Temperature, pH, Biochemical Oxygen Demand (BOD), Chemical Oxygen Demand (COD), Suspended Solid (SS) and Total Dissolved Solids (TDS) gives the following results; temperature $\left({ }^{\circ} \mathrm{C}\right.$ )

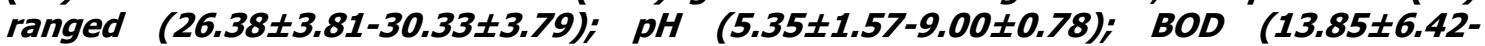
$38.75 \pm 16.20) ;$ COD (1406 $\pm 208-3532 \pm 1373) ;$ SS (208 $\pm 235-780 \pm 739)$ and TDS (266 $\pm 253-5276 \pm 2971)$. No statistical differences ( $p \leq 0.05)$ was observed for all the results among the different industries. The bacterial isolates were identified as Neisseria spp, Bacillus cereus, and Staphylococcus aureus, in TAN1, TAN2, and TAN3, respectively. After treatment of the effluent with the different masses of the isolated bacteria, the mean level of BOD was found to range as (0.55 $\pm 0.36-6.92 \pm 5.49) ; C O D$ (ND-3134 \pm 1595$)$;

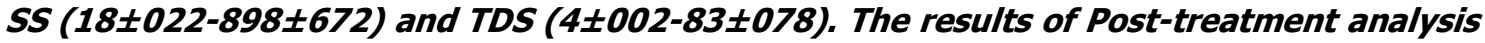
showed that there is overall decrease in the levels of the parameters determined when compared with that of the pre-treatment. The overall percentage reduction of the immobilised bacteria in the treatment of the respective effluents was in the order TAN2 (72\%)>TAN1 (70\%)>TAN3 (62\%). Hence, the immobilized bacteria are having higher biodegradation potential for the treatment of the tannery effluents.

Keywords: Biodegradation, bacteria, effluent, immobilization, tannery.

\section{INTRODUCTION}

Tannery industrial wastewater is a serious consequence of the pollution point of view for streams, freshwater, and land used for agriculture. The lack of awareness in the modern industrial practice has resulted in the discharge of tannery effluents which exhibit very high value of chromium ( $\mathrm{Cr}$ ), Sulfide, and chloride, Total Dissolved Solid (TDS), Total Suspended Solid (TSS), Biochemical Oxygen Demand (BOD) and Chemical Oxygen Demand (COD) in the water stream or land (Mohammed et al., 2001). Tanning is the process, which One ton of skin generally leads to the production of 20 to $80 \mathrm{~m}^{3}$ of turbid and foul-smelling converts the protein of the rawhide or skin into a stable material, which will not putrefy and is suitable for a wide variety of end applications (Elsheikh, 2009). The highly polluting chromium is the most commonly used tanning material producing leather that is more flexible and pliable than vegetable-tanned leather and does not discolor or lose shape in water as drastically as vegetable-tan (Elsheikh, 2009). Tannery effluent is among the most hazardous industrial pollutants due to its huge organic and inorganic load, which is highly toxic to human life and the environment (Kongjao et al., 2008). wastewater including chromium (100-400 mg/l), sulfide $(200-800 \mathrm{mg} / \mathrm{l})$, high levels of fat and 
BAJOPAS Volume 13 Number 2, December, 2020 other solid wastes, and notable pathogen contamination as well as pesticides added for skin conservation during transport (Elsheikh, 2009). There are more than 6000 tanneries in Nigeria with an annual processing capacity of 700,000 tons of hides and skins (Omoleke, 2004; Singh et al., 2008). It was reported that the total amount of waste produced per animal slaughtered is approximately $35 \%$ of its weight (World Bank, 1995). Also, for every $1000 \mathrm{~kg}$ of carcass weight, a slaughtered beef produces 5.5 $\mathrm{kg}$ of manure (excluding rumen contents or stockyard manure) and $100 \mathrm{~kg}$ of paunch manure (undigested food) (Verheijen et al., 1996). Tanneries generate wastewater in the range of 30-35 $\mathrm{L} \mathrm{kg}^{-1}$ skin/hide processed with variable $\mathrm{pH}$, Biological Oxygen Demand (BOD), Chemical Oxygen Demand (COD), high concentrations of suspended solids (SS), and tannins as well as chromium (Zahoor and Abdul, 2009).

Being heterogeneous and composed of a wide variety of compounds, it is very difficult to select a unique direct method for estimating the biodegradability of organic contents and biokinetic parameters for a wastewater sample (Rajor, 2004). For this purpose, some indirect estimation such as determination of biochemical oxygen demand (BOD) and chemical oxygen demand (COD) are applied as common laboratory investigations [9]. During retanning procedures, synthetic tannins (Syntan), oils and resins are added to form softer leather at varying doses (Munz et al., 2009). One of the refractory groups of chemicals in tannery effluents derives mainly from tannins (Ramasami et al., 2004). Syntans are characterized by complex chemical structures, because they are composed of an extended set of chemicals such as phenol-, naphthalene-, formaldehyde- and melamine-based syntans, and acrylic resins (Beem, 1994). Organic pollutants (proteic and lipidic components) are originated from skins (it is calculated that the raw skin has $30 \%$ loss of organic material during the working cycle) or they are introduced during processes (Hugo Springer, 1994).

Many conventional processes such as oxidation, chemical and biological processes were carried out to treat tanneries wastewater (Ebtesam et al, 2013). Biological processes have received more attention because of their costeffectiveness, lower sludge production and environmental friendliness (Noorjahan, 2014). Naturally occurring micro-organisms degrade the hazardous organic wastes including xenobiotic compounds, such as pesticides, polycyclic aromatic hydrocarbons (PAHs) and polychlorinated biphenyls (PCBs) in due course of time (Ranen and Sharadinadra, 2009). Bioremediation is based on the idea that all organisms remove substances from the environment to carry outgrowth and metabolism (Bouwer and Zehnder, 1993). Bacteria, protista and fungi are found to be very good at degrading complex molecules and incorporating the breakdown products into their metabolism (Bouwer and Zehnder, 1993). The resultant metabolic wastes that they produce are generally safe and somehow recycled into other organisms (Ranen and Sharadinadra, 2009). An acclimatized indigenous population of microorganisms capable of degradation of the compounds of interest must exist at the site for a successful bioremediation mode (Ranen and Sharadinadra, 2009). It has been observed that for a successful bioremediation mode, an acclimatized indigenous population of microorganisms capable of degradation of the compounds of interest must exist at the site under investigation (Ranen and Sharadinadra, 2009). Even though there are numerous physical and chemical methods employed in the disposal of wastes the advantage in using bacterium is that they play a key role in the reduction of COD, BOD, total protein, total tannin and total phenol (Saravanan and Saravanan, 1998)

Baba et al. (2020) studied the bioremediation potential of immobilized corynebacterium kutsceri in the Treatment of tannery industrial effluent from Challawa Industrial Estate, Kano State, Nigeria. The aim of the work is to study the reduction in the level of the contaminants through the process of bioremediation using the isolated bacteria. Immobilized bacteria can withstand various temperatures, $\mathrm{pH}$ and substrate concentrations; consequently, increasing the efficiency and the lifespan of the bacteria. Immobilized bacteria are widely applied in the treatment of wastewater and can be separated and recovered after the treatment with the same efficiency (Baba et al., 2020).

\section{MATERIALS AND METHODS \\ Study Area}

This study was carried out in Bompai, Sharada and Challawa industrial estates in Kano, Figure 1. Kano lies on Latitude $11^{\circ} 30^{\prime} \mathrm{N}$ and $8^{\circ} 30^{\prime} \mathrm{E}$ and Longitude $11^{\circ} 5^{\prime} \mathrm{N}$ and $8^{\circ} 5^{\prime} \mathrm{E}$ in Northern Nigeria. It is one of the developed industrial cities in Nigeria. Tannery activities are the dominating industries and this could be one of the reasons for her high population density (Dan'Azumi and Bichi, 2010). Many researchers have studied biodegradation of tannery effluent using microorganisms. However, limited literature is available on the biodegradation of tannery effluent in Kano industrial estates using 
BAJOPAS Volume 13 Number 2, December, 2020 immobilized bacterial cells. This research work focuses on the potential of the use of the indigenous immobilized bacterial isolates in the treatment of tannery effluents in the industrial estates.

\section{Sample Collection}

Effluents were collected from the Tannery Industries from Bompai, Challawa and Sharada Industrial Estates, Kano, Nigeria. The effluents were collected over a period of six months (August 2017 to January 2018). Samples collected in a sterile 4-liter plastic container with a unique identification number were preserved using an ice-box that was transported to the Microbiology Laboratory, Department of Microbiology, Bayero University of Kano for analysis

\section{Sample Preparation and Sample Analysis}

Immediately after the collection of the effluent, $\mathrm{pH}$, TSS, TDS, COD, BOD levels were determined before treatment (Pre-treatment determination) and ten days after treatment (Post-treatment determination) as described in
APHA (1989) standard methods. $\mathrm{pH}$ was determined using Ecotests $\mathrm{pH}$ meter and TDS was determined using AQUALYTIC TDS Salinometer. BOD was determined as described by the standard method (APHA, 1992). COD and SS were determined using DR/2010 HACH portable data logging spectrophotometer (DWAF, 1992)

\section{Identification and Biochemical} Characterization of the Bacterial Isolates

The bacteria were isolated from the effluents using Serial Dilution according to the method described by APHA (1989). The biochemical tests such as oxidase, catalase, coagulase, indole (from $1 \%$ tryptone broth), citrate (Simmons citrate agar), methyl red/VogesProskauer (MR/VP), nitrate reduction, Starch Hydrolysis, Glucose, Maltose, and Lactose tests were carried out on the bacterial isolates to identify the bacteria through the bacteria biochemical characteristics according to Ajao et al. (2011).

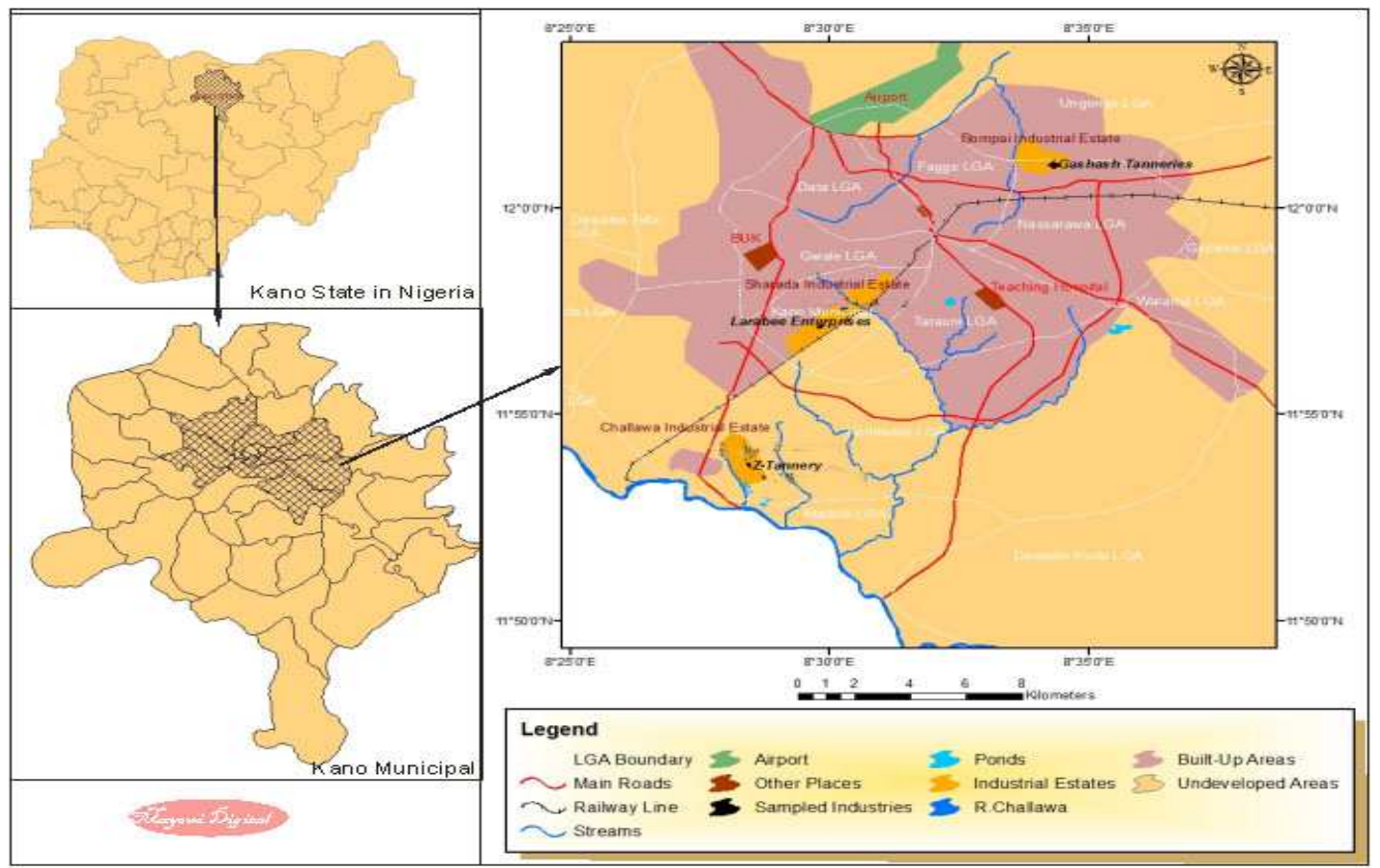

Fig. 1 Map showing the study areas

Source: Mayomi Digital Productions, GIS Laboratory, Department of Geography, UNIMAID (2017)

\section{Determination of Growth Rate of the Bacteria in Effluent Sample}

The bacteria growth rates were determined by transferring $2 \mathrm{~mL}$ of the bacterial isolates from the tannery effluent in broth medium into 100 $\mathrm{mL}$ sterile effluents in conical flasks and kept in an incubator (Giffrin cool) for 10 days. Control was also set up by incubating another $100 \mathrm{~mL}$ each of the sterile effluents without the bacteria. The optical density of the content was determined at the wavelength of $600 \mathrm{~nm}$ on a daily interval and recorded. 
BAJOPAS Volume 13 Number 2, December, 2020 Immobilization of Bacteria

Agar solution and inoculi were prepared separately. Fifty milliliters $(50 \mathrm{~mL})$ of nutrient broth each of the inoculi was prepared in a McCartney bottle and incubated for 24 hours. A solution of agar-agar was prepared by dissolving $10 \mathrm{~g}$ of the powder in distilled water and made up to $500 \mathrm{~mL}$ mark in an Erlenmeyer flask and was sterilized in an autoclave (280A) for 15 minutes and allowed to cool to $40-45^{\circ} \mathrm{C}$ (Ajao et al., 2011). Four milliliters ( $4 \mathrm{~mL})$ of the bacterial isolates in the nutrient broth was mixed with 36 $\mathrm{ml}$ of the prepared agar-agar media in petri-dish plates and then allowed to solidify. This was kept in the refrigerator for bioremediation.

\section{Bioremediation (Treatment) of the Effluents}

The solidified agar block (immobilized bacteria) was cut into cubes using a sterile knife; $0.1 \mathrm{~mL}$ phosphate buffer ( $\mathrm{pH} \mathrm{7.0)}$ was added and kept in the refrigerator for 1 hour for curing. The phosphate buffer was decanted after 1 hour and the cubes were washed with sterile distilled water 3-4 times before it was used (Ajao et al., 2011). Two liters (2 L) of the effluent was supplemented with the minimum basal medium in $\mathrm{g} / \mathrm{L}: \mathrm{NaCl}(0.8), \mathrm{MgSO}_{4} .7 \mathrm{H}_{2} \mathrm{O}(0.001), \mathrm{KH}_{2} \mathrm{PO}_{4}$ (2), $\mathrm{NaNO}_{3}$ (2), $\quad \mathrm{CaCl}_{2} .2 \mathrm{H}_{2} \mathrm{O} \quad(0.5)$ and $\mathrm{NaHPO}_{4} .12 \mathrm{H}_{2} \mathrm{O}(2)$ and sterilized in an autoclave at $121^{\circ} \mathrm{C}$ for 15 minutes (Margesin and Schinner, 2001). Two hundred and fifty milliliters $(250 \mathrm{~mL})$ of the effluents were transferred into different $250 \mathrm{ml}$ conical flasks. The content was covered with a cotton-wool ramped with foil paper to avoid contamination. Five grams $(5 \mathrm{~g})$ of the immobilized bacteria were quickly transferred into each of the effluents in the conical flasks in an inoculating chamber. The same procedures were carried out for the $10 \mathrm{~g}, 15 \mathrm{~g}, 20 \mathrm{~g}$ and 25 $\mathrm{g}$ of the immobilized bacteria in separate $250 \mathrm{~mL}$ effluents in conical flasks and agitated for ten days in a shaker incubator (Gallenkamp-OC4364-L) at a temperature $30^{\circ} \mathrm{C}$ and speed of 60 rpm. The treated effluent samples were taken on the tenth day and analyzed for the parameters $\mathrm{pH}$, SS, TDS, COD, and BOD, (Posttreatment determination) for the different grams of bacteria to evaluate and compare the biodegradation potential. (Baba et al., 2020).

\section{Statistical Analysis}

The data were represented as Mean \pm Standard deviation and analyzed statistically using oneway Analysis of Variance (ANOVA) and Tukey's HSD as Post Hoc Tests with the aid of SPSS 16.0. The correlation coefficient was also used to measure the strength of the relationship between the different masses of the bacteria and the parameters. All $\mathrm{p} \leq 0.05$ were considered as statistically significant.

\section{RESULTS AND DISCUSSION Physico-chemical parameters in the Industrial Effluents before the Biodegradation.}

Results of the Physico-chemical parameters in the industrial effluents before the Biodegradation is shown in table 1 . The mean temperatures $\left({ }^{\circ} \mathrm{C}\right)$ observed in TAN1, TAN2, and TAN3 samples were $28.07 \pm 0.65 ; 27.77 \pm 0.64$ and $26.38 \pm 3.81$ respectively. The order of the mean temperature of the samples from the three industries can be arranged as TAN1 > TAN2>TAN3. The temperature observed at TAN1, TAN2, and TAN3 samples were found below the WHO $\left(35^{\circ} \mathrm{C}\right)$ and NESREA $\left(40^{\circ} \mathrm{C}\right)$ limits. The low values of temperature might be due to the processes used at the time of sampling. High temperature brings down the solubility of gases in water that ultimately expresses as high BOD and COD. Statistical analysis shows that there is no significant difference $(p<0.05)$ between the mean values of temperature among the industries. This might be due to similar tannery activities involved in the tannery industries at the time of sampling. The average values of temperature observed in this present study are less than those observed by Akan et al. (2007), Akan et al. (2009) and Baba et al. (2020).

The mean level of $\mathrm{pH}$ observed in TAN1, TAN2 and TAN3, samples were $7.77 \pm 2.93$; $8.35 \pm 0.28$ and $7.52 \pm 0.76$ respectively. The order of the mean $\mathrm{pH}$ of the samples from the three industries can be arranged as TAN2> TAN1 $>$ TAN3. The $\mathrm{pH}$ of the samples falls within the WHO (7.0-8.5) and NESREA (6-9) standard limits. Statistical analysis shows that there is no significant difference $(p<0.05)$ between the mean values of $\mathrm{pH}$ among the industries. This might be due to similar tannery activities involved in the tannery industries at the time of sampling. Maheshwari et al. (2017) reported that the level of $\mathrm{pH}$ in the effluents from the tannery industry in Vaniyambadi, India was 6.5 which was lower than that observed in the present study. The $\mathrm{pH}$ in the effluents from the tannery industries in Kano and Kaduna were reported to be 7.64 and 6.89, respectively (Akan et al., 2007; Mohammed et al., 2017). The average values of $\mathrm{pH}$ observed in this present study are less than those observed by Mohammed et al. (2017) and Baba et al. (2020). The mean level of SS $(\mathrm{mg} / \mathrm{l})$ observed in TAN1, TAN2, and TAN3 samples were 374 \pm 124 ; $358 \pm 335$ and $780 \pm 739$ respectively. The order of the mean SS in the samples from the three industries can be arranged as TAN3 > TAN1 $>$ TAN2. 
The SS observed in the samples were far above the recommended standard limits of regulating bodies WHO $(30 \mathrm{mg} / \mathrm{l})$ and NESREA $(10 \mathrm{mg} / \mathrm{l})$. Statistical analysis shows that there is no significant difference $(p<0.05)$ between the mean values of SS among the industries. This might be due to similar tannery activities involved in the tannery industries at the time of sampling. The average values of SS observed in this present study are less than that observed $(3700 \pm 122 \mathrm{mg} / \mathrm{l})$ by Akan et al. (2009) for tanneries in Kano. Also, the average values of SS observed in this present study are less than that observed by Mohammed et al. (2017) and Baba et al. (2020) with the exception in TAN3.

The mean level of TDS (mg/l) observed in TAN1, TAN2, and TAN3 samples were $3941 \pm 3703$; $3300 \pm 1714$ and $2653 \pm 1240$ respectively. The order of the mean TDS in the samples from the three industries can be arranged as TAN1>TAN2>TAN3. The TDS observed in the samples were far above the recommended standard limits of WHO $(250 \mathrm{mg} / \mathrm{l})$ and NESREA $(500 \mathrm{mg} / \mathrm{l})$. Statistical analysis shows that there is no significant difference $(p<0.05)$ between the mean values of TDS among the industries. This might be due to similar tannery activities involved in the tannery industries at the time of sampling. TDS in the effluents from the tannery industries in Kano, Nigeria was reported to be $1281 \mathrm{mg} / \mathrm{l}$ (Akan et al., 2007). The average values of SS observed in this present study are less than those observed by Mohammed et al. (2017) and Baba et al. 2020)

The mean level of COD (mg/l) observed in TAN1, TAN2 and TAN3 samples seasons were $2372 \pm 938 ; \quad 1406 \pm 208$ and $3532 \pm 1373$ respectively. The order of the mean COD of the samples from the three industries can be arranged as TAN3>TAN1> TAN2. The COD observed in TAN1, TAN2 and TAN3 samples were far above the recommended standard limits of regulating bodies $\mathrm{WHO}(40 \mathrm{mg} / \mathrm{l})$ and NESREA (40 mg/l). Statistical analysis shows that there is no significant difference $(p<0.05)$ in COD among the industries. This might be due to similar tannery activities involved in the tannery industries as at the time of sampling. The Chemical Oxygen demand (COD) is the amount of oxygen, in $\mathrm{mg} / \mathrm{L}$, required for the degradation of the compound of wastewater to occur. In comparison, the average values of COD observed in this present study were higher than that observed by Mohammed et al. (2017) but lower than that observed by Baba et al. (2020).

The mean levels of BOD $(\mathrm{mg} / \mathrm{l})$ observed in TAN1, TAN2 and TAN3 samples were $13.85 \pm 6.42 ; \quad 19.46 \pm 0.50$ and $17.13 \pm 3.14$ respectively. The order of the mean BOD in the samples from the three industries can be arranged as TAN2>TAN3>TAN1. The BOD observed in TAN1, TAN2 and TAN3 samples were found below the recommended limits of NESREA (200 mg/l) but above WHO (10 mg/l). Statistical analysis shows that there is no significant difference $(p<0.05)$ between the mean values of BOD among the industries. This might be due to similar tannery activities involved in the tannery industries at the time of sampling. The low level of BOD recorded in this study is an indication of the low level of biodegradable organic solids in the effluent. The average values of BOD observed in this present study were lower than those observed by Mohammed et al. (2017) and Baba et al. (2020).

Table 1: Mean Values \pm S.D of Physico-chemical parameters of effluents from the Tannery Industries before Treatment.

\begin{tabular}{llllllll}
\hline Parameter & Tannery 1 & Tannery 2 & Tannery 3 & $\mathrm{a}$ & $\mathrm{b}$ & $\mathrm{c}$ & $\mathrm{d}$ \\
\cline { 2 - 7 } Temperature $\left({ }^{\circ} \mathrm{C}\right)$ & $28.07 \mathrm{a} \pm 0.65$ & $27.77 \mathrm{a} \pm 0.64$ & $26.38 \mathrm{a} \pm 3.81$ & & $29.50 \pm 4.68$ & 35 & 40 \\
pH & $7.77 \mathrm{a} \pm 2.93$ & $8.35 \mathrm{a} \pm 0.28$ & $7.52 \mathrm{a} \pm 0.76$ & 6.89 & $5.35 \pm 1.57$ & $7.0-8.5$ & $6.0-9.0$ \\
$\mathrm{COD}(\mathrm{mg} / \mathrm{l})$ & $2372 \mathrm{a} \pm 938$ & $1406 \mathrm{a} \pm 208$ & $3532 \mathrm{a} \pm 1373$ & 2.2 & $3106 \pm 2753$ & 40 & 40 \\
$\mathrm{BOD}(\mathrm{mg} / \mathrm{l})$ & $13.85 \mathrm{a} \pm 6.42$ & $19.46 \mathrm{a} \pm 0.50$ & $17.13 \mathrm{a} \pm 3.14$ & 1032 & $26.17 \pm 9.49$ & 10 & 200 \\
$\mathrm{SS}(\mathrm{mg} / \mathrm{l})$ & $374 \mathrm{a} \pm 124$ & $358 \mathrm{a} \pm 335$ & $780 \mathrm{a} \pm 739$ & 501 & $562 \pm 482$ & 30 & 10 \\
TDS $(\mathrm{mg} / \mathrm{l})$ & $3941 \mathrm{a} \pm 3703$ & $3300 \mathrm{a} \pm 1714$ & $2653 \mathrm{a} \pm 1240$ & 532.7 & $444 \pm 507$ & 250 & 500 \\
\hline
\end{tabular}

The values given in the table above are means of 6 replicate values, $\mathrm{n}=6$ ( 1 sample was taken monthly for 6 months). Within the rows, means with different alphabets are statistically different $(p<0.05)$. WHO: World Health Organisation. NESREA: National Environmental Standard and Regulatory Enforcement Agency. a = Mohammed et al.(2017), b = Baba et al. (2020), c = WHO (2006), $d=$ NESSRA (2009) 
BAJOPAS Volume 13 Number 2, December, 2020

Identification, Biochemical Characterization and growth rates of the Bacterial Isolates

Results of identification and biochemical characterization of the bacterial isolates were shown in table 2. After 24 hours of incubation, the nutrient agar media plates were checked for bacterial growth. The results showed the presence of different strains in the samples. The TAN1 bacteria isolate was found to be gramnegative cocci while TAN3 was gram-positive cocci. TAN2 bacteria isolate was found to be gram-positive, rod-shaped. TAN1, TAN2, and TAN3 bacteria isolates recorded positive results for spore former.

The results of the biochemical tests indicated that all the bacteria were positive for catalase, oxidase, citrate, maltose, glucose, lactose (negative in TAN1), mannitol (negative in TAN2), starch hydrolysis and coagulase (negative in TAN2) tests. The bacteria showed negative results for nitrate reduction, $M R$ (positive in TAN2), VP (positive in TAN1), Indole (positive in TAN2) tests. Base on the morphological and biochemical test results, TAN1, TAN2, and TAN3 bacteria isolates were identified to be Nesseria spp, Bacillus cereus, and Staphylococcus aureus respectively.

The growth rate of the TAN1, TAN2 and TAN3 Isolates were shown in figure 2. Generally, the optical density increase with the increase in time (day) and decrease as time goes on. The highest optical density was shown by bacillus cereus in TAN2 while the lowest was shown by Staphylococcus aureus in TAN3.

The initial growth phase of TAN1 Isolate bacteria occurred within 2-day of incubation as the growth rate increases up to the 6th-day incubation when the maximum growth was observed. Beyond the 6th day, the growth of the bacteria declined (which might be due to a shortage of nutrients in the effluents) until it reached its death phase (which might be due to the unavailability of nutrients in the effluents).

A similar trend of growth was also observed for TAN2 Isolate as the initial growth phase also occurred within 2-day of incubation but maximum growth rate observed on the 4th day of incubation. The stationary stage occurred between the 4th day and the 8th day. Beyond the 8th day, the growth of the bacteria declined (which might be due to a shortage of nutrients in the effluents) until it reached its death phase (which might be due to the unavailability of nutrients in the effluents).

The initial growth phase of TAN3 bacterial Isolate occurred within the 3-day incubation as the growth rate increases up to the 6th-day incubation when the maximum growth was observed. Beyond the 6th day, the growth of the bacteria declined (which might be due to a shortage of nutrients in the effluents) until it reached its death phase (which might be due to the unavailability of nutrients in the effluents).

Table 2: Morphological and Biochemical characteristics of bacterial isolates

\begin{tabular}{lllll} 
Bacterial Isolates & & TAN1 & TAN2 & TAN3 \\
\hline $\begin{array}{lllll}\text { Morphological } \\
\text { characteristics }\end{array}$ & Shape & Cocci & Rod & Cocci \\
& Spore & & & \\
& former & + & + & + \\
Gram & & & \\
Biochemical characteristics & reaction & - & + & + \\
& Citrate & + & + & + \\
& Catalase & + & + & + \\
& Coagulase & + & - & + \\
Starch & + & + & + \\
& Glucose & + & + & + \\
Oxidase & + & + & + \\
& Indo & - & + & - \\
Lactose & - & + & + \\
Manitol & + & - & + \\
Maltose & + & + & + \\
MR & - & + & - \\
VP & + & - & - \\
& Nitrate & - & - & - \\
Reduction & - Neisseria & Bacillus & Staphylococcus \\
& Bacterial & cereus & aureus \\
& name & spp & cas
\end{tabular}

+ = Positive; - = Negative; MR=Methyl Red; VP= Voges-Proskauer 


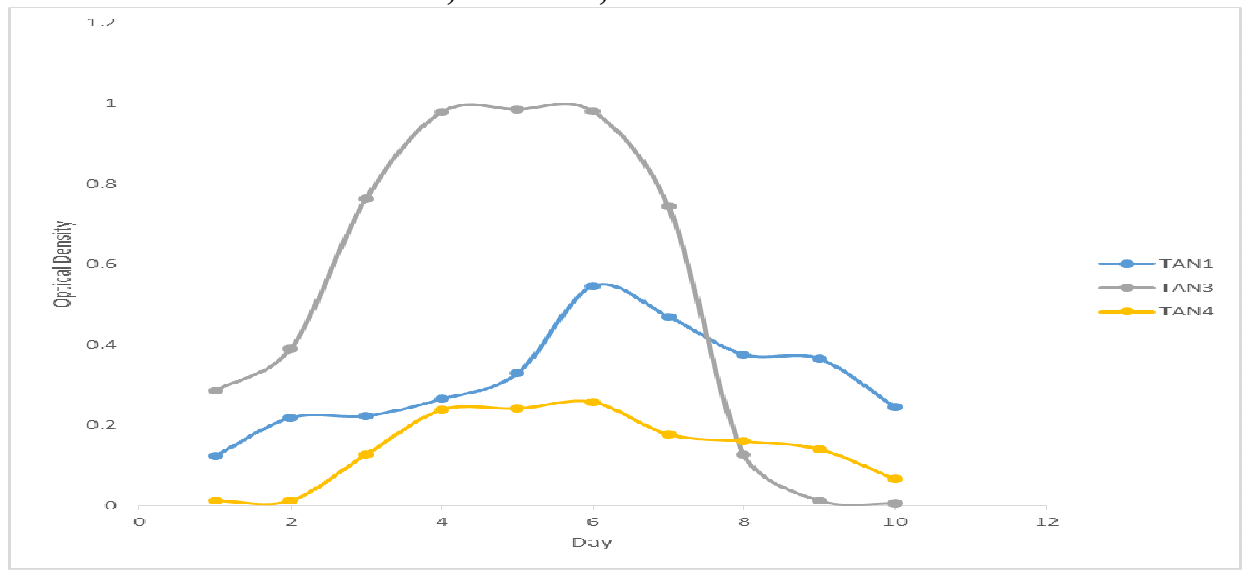

Fig. 2 Growth rates of the isolates in the effluents from the Tannery Industries

\section{Physico-chemical Parameters in the Industrial Effluents after the biodegradation.}

Table 3 shows the mean results of the physicochemical parameter before and after bioremediation using the different masses $(5 \mathrm{~g}$, $10 \mathrm{~g}, 15 \mathrm{~g}, 20 \mathrm{~g}$, and $25 \mathrm{~g}$ ) of the respective immobilized bacteria. Also, Table 4 shows the mean results of correlation coefficient ( $r$ ) between different masses of bacteria and physicochemical parameters.

The mean values $(\mathrm{mg} / \mathrm{l})$ of the SS after the bioremediation varies between $243 \pm 45$ and $898 \pm 672$. The mean concentration $(\mathrm{mg} / \mathrm{l})$ of SS remediated by the different masses $(5 \mathrm{~g}, 10 \mathrm{~g}$, $15 \mathrm{~g}, 20 \mathrm{~g}$, and $25 \mathrm{~g}$ ) of the bacteria varies. The SS in the samples fluctuates up and down after the bioremediation process when compared with the SS of the raw samples before the bioremediation. The increase in the levels of the SS might be due to the aggregation of the TDS which are large enough to result into SS. The increase in the levels of the SS might be also due to the influence of the nutrients which was added into the effluents in order to make the microorganisms more active and viable for fast degradation of organic contaminants in the effluent. The relative potential or efficiency of the different masses of the bacteria in remediating SS in TAN1 samples was in the order $25 \mathrm{~g}>20 \mathrm{~g}>15 \mathrm{~g}>10 \mathrm{~g}>5 \mathrm{~g}$. For TAN2 and TAN3 samples, the order was $25 \mathrm{~g}>20 \mathrm{~g}>15$ $\mathrm{g}>10 \mathrm{~g}>5 \mathrm{~g}$. These might be due to the variations in the surface areas of the different masses of the immobilized bacteria. Statistical analysis shows that there is no significant difference $(p<0.05)$ between the mean values of SS among the masses in the respective industries. Positive and significant correlations exist between the masses of bacteria and Suspended Solid (SS). This showed that there is general increase in the levels of the SS as the masses of the immobilized bacteria increases. TAN3 (90\%) and TAN1 (80\%) showed a very high correlation with the masses of the bacteria while TAN2 (61\%) showed a very low correlation.

The mean values $(\mathrm{mg} / \mathrm{l})$ of the TDS after the bioremediation varies between $46 \pm 11$ and $83 \pm 78$. The mean concentration $(\mathrm{mg} / \mathrm{l})$ of TDS remediated by the different masses $(5 \mathrm{~g}, 10 \mathrm{~g}$, $15 \mathrm{~g}, 20 \mathrm{~g}$, and $25 \mathrm{~g}$ ) of the bacteria varies. There is a reduction in all the TDS of all the samples after the bioremediation process compared with the TDS of the raw samples before the bioremediation. The relative potential or efficiency of the different masses of the bacteria in remediating TDS in TAN1 and TAN3 samples was in the order $5 \mathrm{~g}>10 \mathrm{~g}>15 \mathrm{~g}>20$ $\mathrm{g}>25 \mathrm{~g}$. For TAN2 samples, the order was 20 $g>10 \quad g>25 \quad g>15 \quad g>5 \quad g$. Statistical analysis shows that there is no significant difference $(p<0.05)$ between the mean values of TDS among the masses in the respective industries. These might be due to the variations in the surface areas of the different masses of the immobilized bacteria. Positive and significant correlations exist between the masses of bacteria and TDS with the exception in TAN2 (negative and insignificant correlation). The positive correlations showed that there is general increase in the levels of the TDS as the masses of the immobilized bacteria increases. TAN1 $(96 \%)$ showed a very high correlation with the masses of the bacteria while TAN2 (47\%) showed a very low correlation.

The mean values $(\mathrm{mg} / \mathrm{l})$ of the BOD after the bioremediation varies between $1.56 \pm 0.20 \mathrm{mg} / \mathrm{l}$ and $6.92 \pm 5.49 \mathrm{mg} / \mathrm{l}$. The mean concentration $(\mathrm{mg} / \mathrm{l})$ of BOD remediated by the different masses $(5 \mathrm{~g}, 10 \mathrm{~g}, 15 \mathrm{~g}, 20 \mathrm{~g}$, and $25 \mathrm{~g}$ ) of the bacteria varies. There is a reduction in all the BOD of all the samples after the bioremediation process compared with the $\mathrm{BOD}$ of the raw 
BAJOPAS Volume 13 Number 2, December, 2020 samples before the bioremediation. The relative potential or efficiency of the different masses of the bacteria in remediating BOD in TAN1, TAN2 and TAN3 samples were in the order $25 \mathrm{~g}>20$ $\mathrm{g}>15 \mathrm{~g}>10 \mathrm{~g}>5 \mathrm{~g}, 25 \mathrm{~g}>15 \mathrm{~g}>5 \mathrm{~g}>10 \mathrm{~g}>20 \mathrm{~g}$ and $20 \mathrm{~g}>10 \mathrm{~g}>25 \mathrm{~g}>15 \mathrm{~g}>5 \mathrm{~g}$ respectively. Statistical analysis shows that there is significant difference $(p<0.05)$ between the mean values of BOD among the masses in the respective industries. These might be due to the variations in the surface areas of the different masses of the immobilized bacteria. Negative and significant correlations exist between the masses of bacteria and BOD. This showed that there is general decrease in the levels of the BOD as the masses of the immobilized bacteria increases. TAN1 (94\%) showed a very high correlation with the masses of the bacteria while TAN2 (4\%) showed a very low correlation.

The mean values $(\mathrm{mg} / \mathrm{l})$ of the COD after the bioremediation varies between $250 \pm 154$ and $3134 \pm 1595$. The mean concentration $(\mathrm{mg} / \mathrm{l})$ of COD remediated by the different masses $(5 \mathrm{~g}$, $10 \mathrm{~g}, 15 \mathrm{~g} 20 \mathrm{~g}$, and $25 \mathrm{~g}$ ) of the bacteria varies. There is a reduction in all the COD of all the samples after the bioremediation process compared with the COD of the raw samples before the bioremediation. The relative potential or efficiency of the different masses of the bacteria in remediating COD in TAN1, TAN2 and TAN3 samples were in the order $25 \mathrm{~g}>20 \mathrm{~g}>15$ $\mathrm{g}>5 \mathrm{~g}>10 \mathrm{~g}, 25 \mathrm{~g}>20 \mathrm{~g}>15 \mathrm{~g}>10 \mathrm{~g}>5 \mathrm{~g}$ and 10 g>5 g>25 g>15 g>20 g respectively. Statistical analysis shows that there were significant difference $(p<0.05)$ between the mean values of COD among the masses in the respective industries except for effluents treated with $25 \mathrm{~g}$. These might be due to the variations in the surface areas of the different masses of the immobilized bacteria. Negative and insignificant correlations exist between the masses of bacteria and COD with the exception in TAN3 (positive and significant correlation). The negative correlations showed that there is general decrease in the levels of the COD as the masses of the immobilized bacteria increases. TAN2 (100\%) showed a very high correlation with the masses of the bacteria while TAN3 (36\%) showed a very low correlation.

Generally, there was an overall decrease in the concentration of these physicochemical parameters after the bioremediation using the different masses of the bacterial isolates. These might be due to the variations in the surface areas of the different masses of the immobilized bacteria. This is in line with the work of Jimoh et al. (2018) and Baba et al. (2020).

Table 3: Mean Values $(\mathrm{mg} / \mathrm{l}) \pm$ S.D of Physicochemical parameters in effluents from the Tannery Industries before and after Treatment of the effluents $(250 \mathrm{ml})$ with the different masses $(5 \mathrm{~g}, 10 \mathrm{~g}$, $15 \mathrm{~g}, 20 \mathrm{~g}$, and $25 \mathrm{~g}$ ) of the bacteria.

\begin{tabular}{llllllll}
\hline $\mathrm{P}$ & IND & Before & \multicolumn{5}{c}{ After } \\
\cline { 4 - 7 } & & & $5 \mathrm{~g}$ & $10 \mathrm{~g}$ & $15 \mathrm{~g}$ & $20 \mathrm{~g}$ & $25 \mathrm{~g}$ \\
\hline \multirow{2}{*}{ COD } & TAN1 & $2372 \pm 938$ & $1708 \mathrm{a} \pm 861$ & $2045 \mathrm{a} \pm 1205$ & $845 \mathrm{a} \pm 369$ & $300 \mathrm{a} \pm 167$ & $250 \mathrm{a} \pm 154$ \\
& TAN2 & $1406 \pm 208$ & $1195 \mathrm{a} \pm 208$ & $1125 \mathrm{a} \pm 384$ & $1055 \mathrm{a} \pm 317$ & $956 \mathrm{a} \pm 310$ & $870 \mathrm{ab} \pm 240$ \\
& TAN3 & $3532 \pm 1373$ & $2374 \mathrm{a} \pm 1344$ & $1976 \mathrm{a} \pm 1405$ & $2757 \mathrm{a} \pm 1266$ & $3134 \mathrm{a} \pm 1595$ & $2614 \mathrm{~b} \pm 1105$ \\
BOD & TAN1 & $13.85 \pm 6.42$ & $6.92 \mathrm{a} \pm 5.49$ & $6.42 \mathrm{a} \pm 5.07$ & $5.72 \mathrm{a} \pm 5.35$ & $4.62 \mathrm{a} \pm 4.37$ & $2.82 \mathrm{ab} \pm 1.26$ \\
& TAN2 & $19.46 \pm 0.50$ & $1.75 \mathrm{~b} \pm 0.22$ & $1.73 \mathrm{~b} \pm 0.18$ & $1.58 \mathrm{a} \pm 0.16$ & $1.91 \mathrm{a} \pm 0.22$ & $1.56 \mathrm{~b} \pm 0.20$ \\
& TAN3 & $17.13 \pm 3.14$ & $4.24 \mathrm{ab} \pm 0.77$ & $3.29 \mathrm{ab} \pm 0.37$ & $4.11 \mathrm{a} \pm 0.07$ & $3.23 \mathrm{a} \pm 0.91$ & $3.33 \mathrm{a} \pm 1.28$ \\
SS & TAN1 & $374 \pm 124$ & $243 \mathrm{a} \pm 45$ & $471 \mathrm{a} \pm 226$ & $475 \mathrm{a} \pm 182$ & $492 \mathrm{a} \pm 128$ & $611 \mathrm{a} \pm 217$ \\
& TAN2 & $358 \pm 335$ & $460 \mathrm{a} \pm 400$ & $543 \mathrm{a} \pm 414$ & $544 \mathrm{a} \pm 402$ & $551 \mathrm{a} \pm 414$ & $554 \mathrm{a} \pm 405$ \\
& TAN3 & $780 \pm 739$ & $586 \mathrm{a} \pm 594$ & $758 \mathrm{a} \pm 656$ & $787 \mathrm{a} \pm 676$ & $861 \mathrm{a} \pm 635$ & $898 \mathrm{a} \pm 672$ \\
TDS & TAN1 & $3941 \pm 3703$ & $51 \mathrm{a} \pm 10$ & $53 \mathrm{a} \pm 10$ & $55 \mathrm{a} \pm 15$ & $61 \mathrm{a} \pm 20$ & $63 \mathrm{a} \pm 26$ \\
& TAN2 & $3300 \pm 1714$ & $83 \mathrm{a} \pm 78$ & $47 \mathrm{a} \pm 20$ & $48 \mathrm{a} \pm 22$ & $47 \mathrm{a} \pm 17$ & $48 \mathrm{a} \pm 17$ \\
& TAN3 & $2653 \pm 1240$ & $46 \mathrm{a} \pm 11$ & $55 \mathrm{a} \pm 24$ & $55 \mathrm{a} \pm 25$ & $58 \mathrm{a} \pm 23$ & $61 \mathrm{a} \pm 28$ \\
\hline
\end{tabular}

Replicate $=6$ (months)

Within the rows, for the same parameter, means with different alphabets are statistically different $(p<0.05)$.

$\mathrm{P}=$ parameter, IND = Industries 
BAJOPAS Volume 13 Number 2, December, 2020

Table 4: Correlation coefficient $(r)$ between different masses of the bacteria and the physicochemical parameters.

\begin{tabular}{llll}
\hline Industries & Parameter & Correlation coefficient $(r)$ & $\begin{array}{l}\text { Percent dependence (rxrx100) } \\
(\%)\end{array}$ \\
\hline TAN1 & COD & -0.9 & 82 \\
& BOD & -0.97 & 94 \\
& SS & $0.90^{*}$ & 80 \\
TAN2 & TDS & $0.98^{*}$ & 96 \\
& COD & -1 & 100 \\
& BOD & -0.21 & 4 \\
& SS & $0.78^{*}$ & 61 \\
& TDS & -0.69 & 47 \\
& COD & $0.60^{*}$ & 36 \\
& BOD & -0.6 & 37 \\
& SS & $0.95^{*}$ & 90 \\
& TDS & $0.94^{*}$ & 89 \\
\hline
\end{tabular}

The correlation coefficient $(r)$ with * is statistically significant $(p<0.05)$.

Percentage reduction of the Parameters

Table 5 shows the percentage reduction of Parameters in industrial samples before and after the treatment of the effluents $(250 \mathrm{ml})$ with the different masses $(5 \mathrm{~g}, 10 \mathrm{~g}, 15 \mathrm{~g}, 20 \mathrm{~g}$, and $25 \mathrm{~g}$ ) of the Immobilized Bacteria.

In TAN1 samples, the percentage reduction (\%) of COD ranged (14-89); BOD (50-80); SS (-32$35)$ and TDS (98-99). In TAN2 samples, the percentage decrease $(\%)$ of COD ranged (15$38) ;$ BOD (90-92); SS [-28-(-55)] and TDS (9798). In TAN3 samples, the percentage decrease (\%) of COD ranged (11-44); BOD (76-81); SS (15-25) and TDS (98). The percentage increase in the levels COD, BOD and TDS might be due to the increase in the surface area of the different masses of the immobilized bacteria. However, the percentage decrease in the levels of the SS might be due to the aggregation of the TDS which are large enough to result into SS. The percentage decrease in the levels of the SS might be also due to the influence of the nutrients which was added into the effluents in order to make the microorganisms more active and viable for fast degradation of organic contaminants in the effluent. This is in line with the work of Jimoh et al. (2018) in which the concentration of the SS increase after the bioremediation of effluents.

Sreemoyee and Priti (2013) assessed and reduced several Physico-chemical parameters of dairy wastewater using Niesseria $s p$. and concluded that the species are well known to degrade organic compounds. This is in agreement with the current study in which the immobilized Niesseria $s p$ degrade the organic contaminants as indicated by the BOD, COD and TDS.

Jimoh et al. (2018) observed that TSS of the effluents was increased after treatment with immobilized bacteria and concluded that it might be due to the biostimulation method adopted for the research.

The optimum $\mathrm{pH}$ Biosorption of Chromium by Bacillus spp and Staphylococcus spp. from tannery effluent was investigated by Mythili and Karthikeyan (2011). The maximum adsorption of Chromium $(86.4 \mathrm{mg} / \mathrm{L})$ was showed by Bacillus spp and Staphylococcus spp showed $70.6 \mathrm{mg} / \mathrm{L}$ at an initial concentration of $100 \mathrm{mg} / \mathrm{L}$. In the present study, immobilised Bacillus spp and Staphylococcus spp. from the tannery industrial effluents reduced the levels of the organic pollutants with high potential as indicated by the percentage reduction of BOD, COD and TDS.

Enzymes often can work in multiple environments especially if they are immobilized. This makes the microorganisms' enzymes even more resistant to harsh environments and enables the enzymes to be recovered and recycled after they are no longer needed (Gianfreda and Rao 2004). Ramesh and Singh (1993) reported that the immobilized bacteria having more efficiency to remove the suspended particles than free cells. Using the immobilized cell is preferable due to its capability for using several times with the same efficiency, which makes it more economical. Similar work was done by Sikander et al. (2007) showing the higher reduction with permeabilized cells of Ochrobactrum intermedium strain SDCr-5. 
BAJOPAS Volume 13 Number 2, December, 2020

The results revealed the isolation and identification of isolates with the potential for the reduction of $\mathrm{Cr}$ (VI) to $\mathrm{Cr}$ (III). Results indicated that immobilized $B$. cereus could be efficiently used for the reduction of $\mathrm{Cr}$ (VI).

Table 5: Percentage reduction of the tested Parameters from the tannery industrial samples of the Immobilized Bacteria.

\begin{tabular}{lllllll}
\hline \multirow{2}{*}{ Industries } & & \multicolumn{5}{c}{ Percentage Reduction $(\%)$} \\
\cline { 3 - 7 } & & $5 \mathrm{~g}$ & $10 \mathrm{~g}$ & $15 \mathrm{~g}$ & $20 \mathrm{~g}$ & $25 \mathrm{~g}$ \\
\hline TAN1 & COD & 28 & 14 & 64 & 87 & 89 \\
& BOD & 50 & 54 & 59 & 67 & 80 \\
& SS & 35 & -26 & -27 & -32 & -63 \\
& TDS & 99 & 99 & 99 & 98 & 98 \\
TAN2 & COD & 15 & 20 & 25 & 32 & 38 \\
& BOD & 91 & 91 & 92 & 90 & 92 \\
& SS & -28 & -52 & -52 & -54 & -55 \\
& TDS & 97 & 99 & 99 & 99 & 99 \\
& COD & 33 & 44 & 22 & 11 & 26 \\
& BOD & 75 & 81 & 76 & 81 & 81 \\
& SS & 25 & 3 & -1 & -10 & -15 \\
& TDS & 98 & 98 & 98 & 98 & 98 \\
\hline
\end{tabular}

Percentage Reduction $=(B-A) / B \times 100 \%$

$A=$ Concentration of the parameter after treatment

$\mathrm{B}=$ Concentration of the parameter before treatment

$+=$ percentage decrease

- = percentage increase

In general, immobilization makes the enzyme more resistant to temperature, $\mathrm{pH}$, and substrate concentration swings giving it a longer lifetime and higher productivity per active unit (Gianfreda and Rao, 2004; FuIlbrook, 1996; Russell et al, 2003; Kandelbauer et al., 2004). Immobilized cells have been used and studied extensively for the production of useful chemicals (Ohtake and Silver, 1994), the treatment of wastewaters (Chen et al., 2003; Wang et al., 2010). Although many workers described microbial degradation of tannery effluent, limited literature is available on the bioremediation of tannery effluent using immobilized bacterial cells in the Kano Industrial Estates.

\section{CONCLUSION}

The samples contained variable levels of the physicochemical parameters. The results of the Analysis of variance revealed that, no statistical difference $(p<0.05)$ was observed for the temperature, $\mathrm{pH}, \mathrm{SS}, \mathrm{TDS}, \mathrm{BOD}$ and $\mathrm{COD}$ among the three tannery industries before the treatment. The levels of some of the parameters
(SS, TDS and COD) observed in the samples were found above the recommended limits of WHO and NESREA, which called for the treatment of the effluents before discharge into the environment. Base on the morphological and biochemical test results, TAN1, TAN2, and TAN3 bacterial isolates were identified to be Neisseria spp, Bacillus cereus, and Staphylococcus aureus respectively. The results of Post-treatment analysis showed that there is overall decrease in the levels of the parameters determined when compared with that of the pre-treatment. The overall percentage reduction of the immobilised bacteria in the treatment of the respective effluents was in the order TAN2 (72\%)>TAN1 $(70 \%)>$ TAN3 $(62 \%)$. Hence, the immobilized bacteria are having higher biodegradation potential for the treatment of the tannery effluents.

\section{Acknowledgments}

The authors wish to acknowledge the University of Maiduguri for the financial support. The authors are grateful to the Kano State Ministry of Environment for their support in obtaining the effluent samples. 


\section{REFERENCES}

Ajao, A. T., Adebayo, G. B., and Yakubu, S. E. (2011). Bioremediation of textile industrial effluent using mixed culture of Pseudomonas aeruginosa and Bacillus subtilis immobilized on agar-agar in a bioreactor. J. Microbiol. Biotech. Res, 1(3), 50-56.

Akan, J. C., Moses, E. A., Ogugbuaja, V. O., and Abah, J. (2007). Assessment of tannery industrial effluents from Kano metropolis, Kano State, Nigeria. Journal of Applied Sciences, 7(19), 2788-2793.

Akan, J. C., Ogugbuaja, V. O., Abdulrahman, F. I., and Ayodele, J. T. (2009). Pollutant levels in effluent samples from tanneries and textiles of Kano industrial areas, Nigeria. Global journal of pure and applied sciences, 15(3-4).

APHA (1989). Standard methods for Examination of Will bete and Will betewater.15 $5^{\text {th }}$ edition. Brydpass Springfield Will behington DC. pp. 164-176

APHA (1992). Standard Methods for the Examination of Water and Wastewater. Health, 69, 1116-9.

Baba, A., Garba, S. T., and Bello, H. S. (2020). Bioremediation Potential of Immobilized corynebacterium kutsceri in the Treatment of Tannery Industrial Effluent from Challawa Industrial Estate, Kano State, Nigeria. Journal of the Turkish Chemical Society Section A: Chemistry, $7(2), 335-350$.

Beem, E. I. V. (1994). reduction of solvent VOC emission. J. Oil Col. Chem. Ass, 77, 158.

Bouwer, E. J., and Zehnder, A. J. (1993). Bioremediation of organic compoundsputting microbial metabolism to work. Trends in biotechnology, 11(8), 360367.

Chen, K. C., Wu, J. Y., Liou, D. J., and Hwang, S. C. J. (2003). Decolorization of the textile dyes by newly isolated bacterial strains. Journal of Biotechnology, 101(1), 57-68.

Dan'Azumi, S., and Bichi, M. H. (2010). INDUSTRIAL POLLUTION AND HEAVY METALS PROFILE OF CHALLAWA RIVER IN KANO, NIGERIA. Journal of Applied Sciences in Environmental Sanitation, $5(1)$.

DWAF. (1992). Analytical Methods Manual, TR 151. Department of Water Affairs and Forestry, Pretoria.

El-Bestawy, E. (2013). Biological treatment of leather-tanning industrial wastewater using free living bacteria.
Elsheikh, M. A. S. (2009). Tannery wastewater pre-treatment. Water Science and Technology, 60(2), 433-440.

FuIlbrook, P. D. (1996). "Kinetics." Industrial enzymology: The application of enzymes in Industry. 2nd Ed. T. Godfrey and J Reichelt. eds.. Nature. New York.

Gianfreda, L., and Rao, M. A. (2004). Potential of extra cellular enzymes in remediation of polluted soils: a review. Enzyme and microbial technology, 35(4), 339354.

Hugo Springer. (1994). John Arthur Wilson Memorial Lecture "Treatment of Industrial Wastes of the Leather Industry - is it still a Major Problem". JALCA, 89, 153-185

Jimoh, A. A., Ganiyu, B. A., Baba, D., and Baba, A. (2018) Bioremediation Process of Effluent from Detergent and Food Industries in Jos, Nigeria: Kinetics and Thermodynamics. International Journal of Engineering Science Invention (IJESI), 762-73

Kandelbauer, A., Maute, O., Kessler, R. W., Erlacher, A., and Gübitz, G. M. (2004). Study of dye decolorization in an immobilized laccase enzyme-reactor using online spectroscopy. Biotechnology and bioengineering, 87(4), 552-563.

Kongjao, S., Damronglerd, S., and Hunsom, M. (2008). Simultaneous removal of organic and inorganic Pollutants in tannery wastewater using electrocoagulation technique. Korean Journal of chemical engineering, 25(4), 703.

Maheshwari, U. M., Aruna, S., Gomathi, M., and AbdulJaffar, A. H. (2017). Bioremediation by Free and Immobilized Bacteria Isolated from Tannery Effluent. International Journal of Research in Applied, Natural and Social Sciences. 5(7), 75-90

Margesin, R., and Schinner, F. (2001). Bioremediation (natural attenuation and biostimulation) of diesel-oilcontaminated soil in an alpine glacier skiing area. Applied and environmental microbiology, 677), 3127-3133.

Mohammed, A., Sekar, P., and George, J. (2011). Efficacy of microbes in bioremediation of tannery effluent. Inter. J. Curr. Res, 3(4), 324-326.

Mohammed, S. S. D., Orukotan, A. A., and Abdullahi, H. (2017). Physicochemical and Bacteriological Assessment of Tannery Effluent from Samaru-Zaria, 
BAJOPAS Volume 13 Number 2, December, 2020 Kaduna State, Nigeria. Journal of Applied

Sciences and Environmental Management, 21(4), 734-740.

Munz, G., De Angelis, D., Gori, R., Mori, G., Casarci, M., and Lubello, C. (2009). The role of tannins in conventional and membrane treatment of tannery wastewater. Journal of hazardous materials, 164(2-3), 733-739

Mythili, K., and Karthikeyan, B. (2011). Bioremediation of $\mathrm{Cr}$ (VI) from tannery effluent using Bacillus spp and Staphylococcus spp. International Multidisciplinary Research Journal, 1(6).

NESREA (2009). National Environmental Standards for Effluent Limitations and Regulation. 1233-1236

Noorjahan, C. M. (2014). Physicochemical characteristics, identification of bacteria and biodegradation of industrial effluent. Journal of bioremediation and Biodegradation, 5(3).

Ohtake, H. I., and Silver, A. O. (1994). Bacterial reduction of toxic chromate. Biological degradation and bioremediation of toxic chemicals, 403-415.

Omoleke, I. I. (2004). Management of environmental pollution in Ibadan, an African city: the challenges of health hazard facing government and the people. Journal of Human Ecology, 15(4), 265-275.

Rajor, A., Reddy, A.S., and Singh, B. (2004). Determination of BOD kinetic Parameters and evaluation of alternate methods, M.Sc. Thesis, Department of biotechnology \& environmental Science, Thapar Institute of Engineering and Technology, Patiala

Ramasami, T., Rajamani, S., and Rao, J. R. (1994, March). Pollution control in leather industry: Emerging technological options. In International symposium on surface and colloidal science and its relevance to soil pollution, madras.

Ramesh, J. V. S., and Singh, S. P. (1993). Yearly variation in certain physicochemical parameters of pond at eastern Doon Valley. Uttar Pradesh J. Zoo, 12 (1), 7577.

Ranen, S., and Sharadinadra, C. (2009). Biotechnology applications to environmental remediation in resource exploitation. Current science, 97, 6-25
Russell, A. J., Berberich, J. A., Drevon, G. F., and Koepsel, R. R. (2003). Biomaterials for mediation of

chemical and biological warfare agents. Annual review of biomedical engineering, 5(1), 1-27.

Saravanan, P., and Saravanan, A. (1999). Decolourization of tannery effluent by Flavobacterium sp. EK 1. Indian Journal of Environmental Protection, 19, 19-24.

Sikander, S., and Shahida, H. (2007). Reduction of toxic hexavalent chromium by Ochrobactrum intermedium strain SDCr5 stimulated by heavy metals. Bioresource Technol, 98, 340-344.

Singh, N., Sharma, B. K., and Bohra, P. C. (2000). Impact assessment of industrial effluent of arid soils by using satellite imageries. Journal of the Indian Society of Remote Sensing, 28(2-3), 79.

Sreemoyee, C., and Priti, P. (2013). Assessment of physico-chemical parameters of dairy waste water and isolation and characterization of bacterial strains in terms of cod reduction. Int J Sci, 2(3), 395-400.

Verheijen, L. A. H. M., Wiersema, D., Pol, L. H., and De Wit, J. (1996). Management of wastes from animal product processing. Livestock and environment, Finding a balance. International Agriculture Center, Wageningen, The Netherlands.

Wang, F., Yao, J., Si, Y., Chen, H., Russel, M., Chen, K., and Bramanti, E. (2010). Short-time effect of heavy metals upon microbial community activity. Journal of Hazardous Materials, 173(13), 510-516.

WHO (World Health Organization). (2006). Air quality guidelines: global update 2005: particulate matter, ozone, nitrogen dioxide, and sulfur dioxide. World Health Organization.

World Bank. (1995). Nigeria's strategic options for redressing industrial pollution. World Bank, industry and energy division. 1st edition, West Central Africa Department; Annexes: 1995; pp 60-62.

Zahoor, A., and Abdul, R. (2009). Enumeration of Coliforms. Journal of Environmental Sciences. 21, 814-820 


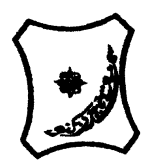

Bayero Journal of Pure and Applied Sciences, 13(2): 1 - 12

Received: November, 2020

Accepted: December, 2020

ISSN $2006-6996$

\title{
BIODEGRADATION POTENTIAL OF IMMOBILIZED BACTERIA IN THE TREATMENT OF TANNERY INDUSTRIAL EFFLUENTS FROM INDUSTRIAL ESTATES IN KANO STATE, NIGERIA
}

\author{
Abdullateef, B., ${ }^{1 *}$ Shuaibu, T. G., ${ }^{1}$ Babagana, K., ${ }^{1}$ Suleman, H. B. ${ }^{2}$ and Dauda, B. ${ }^{3}$ \\ ${ }^{1}$ Department of Pure and Applied Chemistry, Faculty of Science, University of Maiduguri, Borno State, \\ Nigeria \\ ${ }^{2}$ Department of Microbiology, Faculty of Science, University of Maiduguri, Borno State, Nigeria \\ ${ }^{3}$ Department of Chemical Engineering, Faculty of Engineering, University of Maiduguri, Borno State, \\ Nigeria \\ *Corresponding author: babslega@gmail.com; abelega2007@yahoo.com; +2348061309753
}

\section{ABSTRACT}

Industrial Effluents Samples from Gashash Tanneries (TAN1) in Bompai Industrial estate, Larabee Tannery Industry (TAN2) in Sharada Industrial estate and Z Tannery Industries (TAN3) in Challawa Industrial estate, Kano State, Nigeria were collected over a period of six months (August 2017 to January 2018) for assessing the biodegradation potentials of bacteria in the treatment of organic pollutants within the effluents. Bacteria were isolated from the effluents and immobilized on agar-agar. Different masses (5 g, $10 \mathrm{gr}, 15$ $\mathrm{g}, 20 \mathrm{~g}$, and $25 \mathrm{~g}$ ) of the bacteria were used in the treatment of $250 \mathrm{ml}$ of the effluents for ten days in a shaker incubator (Gallenkamp-OC-4364-L) at the temperature $30{ }^{\circ} \mathrm{C}$ and speed of $60 \mathrm{rpm}$. Pre-treatment analysis of the effluents for Temperature, pH, Biochemical Oxygen Demand (BOD), Chemical Oxygen Demand (COD), Suspended Solid (SS) and Total Dissolved Solids (TDS) gives the following results; temperature $\left({ }^{\circ} \mathrm{C}\right.$ )

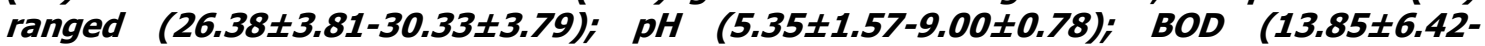
$38.75 \pm 16.20) ;$ COD (1406 $\pm 208-3532 \pm 1373) ;$ SS (208 $\pm 235-780 \pm 739)$ and TDS (266 $\pm 253-5276 \pm 2971)$. No statistical differences ( $p \leq 0.05)$ was observed for all the results among the different industries. The bacterial isolates were identified as Neisseria spp, Bacillus cereus, and Staphylococcus aureus, in TAN1, TAN2, and TAN3, respectively. After treatment of the effluent with the different masses of the isolated bacteria, the mean level of BOD was found to range as (0.55 $\pm 0.36-6.92 \pm 5.49) ; C O D$ (ND-3134 \pm 1595$)$;

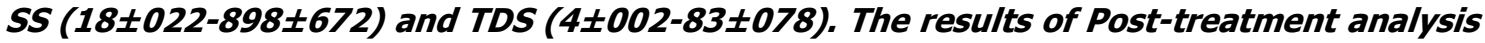
showed that there is overall decrease in the levels of the parameters determined when compared with that of the pre-treatment. The overall percentage reduction of the immobilised bacteria in the treatment of the respective effluents was in the order TAN2 (72\%)>TAN1 (70\%)>TAN3 (62\%). Hence, the immobilized bacteria are having higher biodegradation potential for the treatment of the tannery effluents.

Keywords: Biodegradation, bacteria, effluent, immobilization, tannery.

\section{INTRODUCTION}

Tannery industrial wastewater is a serious consequence of the pollution point of view for streams, freshwater, and land used for agriculture. The lack of awareness in the modern industrial practice has resulted in the discharge of tannery effluents which exhibit very high value of chromium ( $\mathrm{Cr}$ ), Sulfide, and chloride, Total Dissolved Solid (TDS), Total Suspended Solid (TSS), Biochemical Oxygen Demand (BOD) and Chemical Oxygen Demand (COD) in the water stream or land (Mohammed et al., 2001). Tanning is the process, which One ton of skin generally leads to the production of 20 to $80 \mathrm{~m}^{3}$ of turbid and foul-smelling converts the protein of the rawhide or skin into a stable material, which will not putrefy and is suitable for a wide variety of end applications (Elsheikh, 2009). The highly polluting chromium is the most commonly used tanning material producing leather that is more flexible and pliable than vegetable-tanned leather and does not discolor or lose shape in water as drastically as vegetable-tan (Elsheikh, 2009). Tannery effluent is among the most hazardous industrial pollutants due to its huge organic and inorganic load, which is highly toxic to human life and the environment (Kongjao et al., 2008). wastewater including chromium (100-400 mg/l), sulfide $(200-800 \mathrm{mg} / \mathrm{l})$, high levels of fat and 
BAJOPAS Volume 13 Number 2, December, 2020 other solid wastes, and notable pathogen contamination as well as pesticides added for skin conservation during transport (Elsheikh, 2009). There are more than 6000 tanneries in Nigeria with an annual processing capacity of 700,000 tons of hides and skins (Omoleke, 2004; Singh et al., 2008). It was reported that the total amount of waste produced per animal slaughtered is approximately $35 \%$ of its weight (World Bank, 1995). Also, for every $1000 \mathrm{~kg}$ of carcass weight, a slaughtered beef produces 5.5 $\mathrm{kg}$ of manure (excluding rumen contents or stockyard manure) and $100 \mathrm{~kg}$ of paunch manure (undigested food) (Verheijen et al., 1996). Tanneries generate wastewater in the range of 30-35 $\mathrm{L} \mathrm{kg}^{-1}$ skin/hide processed with variable $\mathrm{pH}$, Biological Oxygen Demand (BOD), Chemical Oxygen Demand (COD), high concentrations of suspended solids (SS), and tannins as well as chromium (Zahoor and Abdul, 2009).

Being heterogeneous and composed of a wide variety of compounds, it is very difficult to select a unique direct method for estimating the biodegradability of organic contents and biokinetic parameters for a wastewater sample (Rajor, 2004). For this purpose, some indirect estimation such as determination of biochemical oxygen demand (BOD) and chemical oxygen demand (COD) are applied as common laboratory investigations [9]. During retanning procedures, synthetic tannins (Syntan), oils and resins are added to form softer leather at varying doses (Munz et al., 2009). One of the refractory groups of chemicals in tannery effluents derives mainly from tannins (Ramasami et al., 2004). Syntans are characterized by complex chemical structures, because they are composed of an extended set of chemicals such as phenol-, naphthalene-, formaldehyde- and melamine-based syntans, and acrylic resins (Beem, 1994). Organic pollutants (proteic and lipidic components) are originated from skins (it is calculated that the raw skin has $30 \%$ loss of organic material during the working cycle) or they are introduced during processes (Hugo Springer, 1994).

Many conventional processes such as oxidation, chemical and biological processes were carried out to treat tanneries wastewater (Ebtesam et al, 2013). Biological processes have received more attention because of their costeffectiveness, lower sludge production and environmental friendliness (Noorjahan, 2014). Naturally occurring micro-organisms degrade the hazardous organic wastes including xenobiotic compounds, such as pesticides, polycyclic aromatic hydrocarbons (PAHs) and polychlorinated biphenyls (PCBs) in due course of time (Ranen and Sharadinadra, 2009). Bioremediation is based on the idea that all organisms remove substances from the environment to carry outgrowth and metabolism (Bouwer and Zehnder, 1993). Bacteria, protista and fungi are found to be very good at degrading complex molecules and incorporating the breakdown products into their metabolism (Bouwer and Zehnder, 1993). The resultant metabolic wastes that they produce are generally safe and somehow recycled into other organisms (Ranen and Sharadinadra, 2009). An acclimatized indigenous population of microorganisms capable of degradation of the compounds of interest must exist at the site for a successful bioremediation mode (Ranen and Sharadinadra, 2009). It has been observed that for a successful bioremediation mode, an acclimatized indigenous population of microorganisms capable of degradation of the compounds of interest must exist at the site under investigation (Ranen and Sharadinadra, 2009). Even though there are numerous physical and chemical methods employed in the disposal of wastes the advantage in using bacterium is that they play a key role in the reduction of COD, BOD, total protein, total tannin and total phenol (Saravanan and Saravanan, 1998)

Baba et al. (2020) studied the bioremediation potential of immobilized corynebacterium kutsceri in the Treatment of tannery industrial effluent from Challawa Industrial Estate, Kano State, Nigeria. The aim of the work is to study the reduction in the level of the contaminants through the process of bioremediation using the isolated bacteria. Immobilized bacteria can withstand various temperatures, $\mathrm{pH}$ and substrate concentrations; consequently, increasing the efficiency and the lifespan of the bacteria. Immobilized bacteria are widely applied in the treatment of wastewater and can be separated and recovered after the treatment with the same efficiency (Baba et al., 2020).

\section{MATERIALS AND METHODS \\ Study Area}

This study was carried out in Bompai, Sharada and Challawa industrial estates in Kano, Figure 1. Kano lies on Latitude $11^{\circ} 30^{\prime} \mathrm{N}$ and $8^{\circ} 30^{\prime} \mathrm{E}$ and Longitude $11^{\circ} 5^{\prime} \mathrm{N}$ and $8^{\circ} 5^{\prime} \mathrm{E}$ in Northern Nigeria. It is one of the developed industrial cities in Nigeria. Tannery activities are the dominating industries and this could be one of the reasons for her high population density (Dan'Azumi and Bichi, 2010). Many researchers have studied biodegradation of tannery effluent using microorganisms. However, limited literature is available on the biodegradation of tannery effluent in Kano industrial estates using 
BAJOPAS Volume 13 Number 2, December, 2020 immobilized bacterial cells. This research work focuses on the potential of the use of the indigenous immobilized bacterial isolates in the treatment of tannery effluents in the industrial estates.

\section{Sample Collection}

Effluents were collected from the Tannery Industries from Bompai, Challawa and Sharada Industrial Estates, Kano, Nigeria. The effluents were collected over a period of six months (August 2017 to January 2018). Samples collected in a sterile 4-liter plastic container with a unique identification number were preserved using an ice-box that was transported to the Microbiology Laboratory, Department of Microbiology, Bayero University of Kano for analysis

\section{Sample Preparation and Sample Analysis}

Immediately after the collection of the effluent, $\mathrm{pH}$, TSS, TDS, COD, BOD levels were determined before treatment (Pre-treatment determination) and ten days after treatment (Post-treatment determination) as described in
APHA (1989) standard methods. $\mathrm{pH}$ was determined using Ecotests $\mathrm{pH}$ meter and TDS was determined using AQUALYTIC TDS Salinometer. BOD was determined as described by the standard method (APHA, 1992). COD and SS were determined using DR/2010 HACH portable data logging spectrophotometer (DWAF, 1992)

\section{Identification and Biochemical} Characterization of the Bacterial Isolates

The bacteria were isolated from the effluents using Serial Dilution according to the method described by APHA (1989). The biochemical tests such as oxidase, catalase, coagulase, indole (from $1 \%$ tryptone broth), citrate (Simmons citrate agar), methyl red/VogesProskauer (MR/VP), nitrate reduction, Starch Hydrolysis, Glucose, Maltose, and Lactose tests were carried out on the bacterial isolates to identify the bacteria through the bacteria biochemical characteristics according to Ajao et al. (2011).

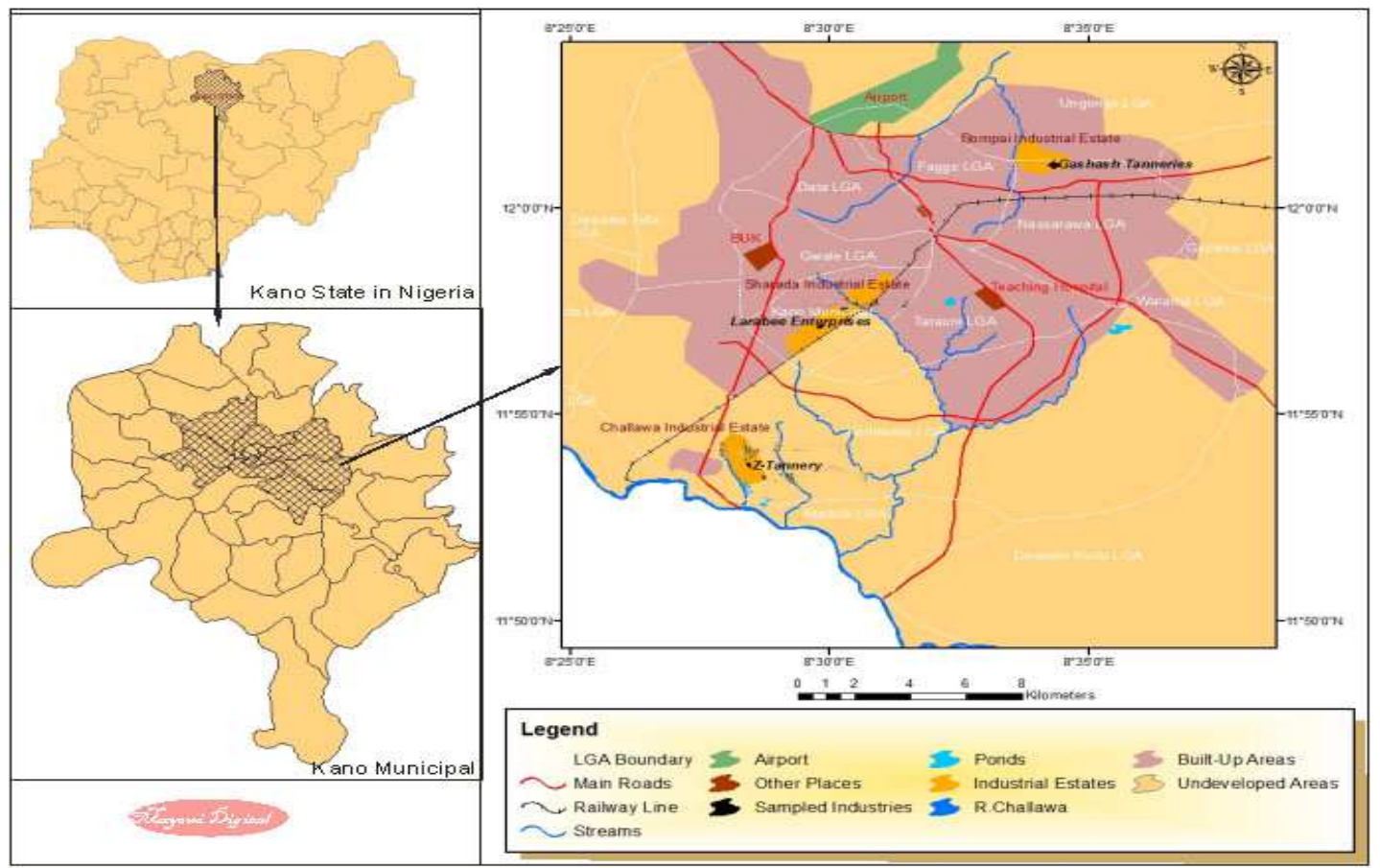

Fig. 1 Map showing the study areas

Source: Mayomi Digital Productions, GIS Laboratory, Department of Geography, UNIMAID (2017)

\section{Determination of Growth Rate of the Bacteria in Effluent Sample}

The bacteria growth rates were determined by transferring $2 \mathrm{~mL}$ of the bacterial isolates from the tannery effluent in broth medium into 100 $\mathrm{mL}$ sterile effluents in conical flasks and kept in an incubator (Giffrin cool) for 10 days. Control was also set up by incubating another $100 \mathrm{~mL}$ each of the sterile effluents without the bacteria. The optical density of the content was determined at the wavelength of $600 \mathrm{~nm}$ on a daily interval and recorded. 
BAJOPAS Volume 13 Number 2, December, 2020 Immobilization of Bacteria

Agar solution and inoculi were prepared separately. Fifty milliliters $(50 \mathrm{~mL})$ of nutrient broth each of the inoculi was prepared in a McCartney bottle and incubated for 24 hours. A solution of agar-agar was prepared by dissolving $10 \mathrm{~g}$ of the powder in distilled water and made up to $500 \mathrm{~mL}$ mark in an Erlenmeyer flask and was sterilized in an autoclave (280A) for 15 minutes and allowed to cool to $40-45^{\circ} \mathrm{C}$ (Ajao et al., 2011). Four milliliters ( $4 \mathrm{~mL})$ of the bacterial isolates in the nutrient broth was mixed with 36 $\mathrm{ml}$ of the prepared agar-agar media in petri-dish plates and then allowed to solidify. This was kept in the refrigerator for bioremediation.

\section{Bioremediation (Treatment) of the Effluents}

The solidified agar block (immobilized bacteria) was cut into cubes using a sterile knife; $0.1 \mathrm{~mL}$ phosphate buffer ( $\mathrm{pH} \mathrm{7.0)}$ was added and kept in the refrigerator for 1 hour for curing. The phosphate buffer was decanted after 1 hour and the cubes were washed with sterile distilled water 3-4 times before it was used (Ajao et al., 2011). Two liters (2 L) of the effluent was supplemented with the minimum basal medium in $\mathrm{g} / \mathrm{L}: \mathrm{NaCl}(0.8), \mathrm{MgSO}_{4} .7 \mathrm{H}_{2} \mathrm{O}(0.001), \mathrm{KH}_{2} \mathrm{PO}_{4}$ (2), $\mathrm{NaNO}_{3}$ (2), $\quad \mathrm{CaCl}_{2} .2 \mathrm{H}_{2} \mathrm{O} \quad(0.5)$ and $\mathrm{NaHPO}_{4} .12 \mathrm{H}_{2} \mathrm{O}(2)$ and sterilized in an autoclave at $121^{\circ} \mathrm{C}$ for 15 minutes (Margesin and Schinner, 2001). Two hundred and fifty milliliters $(250 \mathrm{~mL})$ of the effluents were transferred into different $250 \mathrm{ml}$ conical flasks. The content was covered with a cotton-wool ramped with foil paper to avoid contamination. Five grams $(5 \mathrm{~g})$ of the immobilized bacteria were quickly transferred into each of the effluents in the conical flasks in an inoculating chamber. The same procedures were carried out for the $10 \mathrm{~g}, 15 \mathrm{~g}, 20 \mathrm{~g}$ and 25 $\mathrm{g}$ of the immobilized bacteria in separate $250 \mathrm{~mL}$ effluents in conical flasks and agitated for ten days in a shaker incubator (Gallenkamp-OC4364-L) at a temperature $30^{\circ} \mathrm{C}$ and speed of 60 rpm. The treated effluent samples were taken on the tenth day and analyzed for the parameters $\mathrm{pH}$, SS, TDS, COD, and BOD, (Posttreatment determination) for the different grams of bacteria to evaluate and compare the biodegradation potential. (Baba et al., 2020).

\section{Statistical Analysis}

The data were represented as Mean \pm Standard deviation and analyzed statistically using oneway Analysis of Variance (ANOVA) and Tukey's HSD as Post Hoc Tests with the aid of SPSS 16.0. The correlation coefficient was also used to measure the strength of the relationship between the different masses of the bacteria and the parameters. All $\mathrm{p} \leq 0.05$ were considered as statistically significant.

\section{RESULTS AND DISCUSSION Physico-chemical parameters in the Industrial Effluents before the Biodegradation.}

Results of the Physico-chemical parameters in the industrial effluents before the Biodegradation is shown in table 1 . The mean temperatures $\left({ }^{\circ} \mathrm{C}\right)$ observed in TAN1, TAN2, and TAN3 samples were $28.07 \pm 0.65 ; 27.77 \pm 0.64$ and $26.38 \pm 3.81$ respectively. The order of the mean temperature of the samples from the three industries can be arranged as TAN1 > TAN2>TAN3. The temperature observed at TAN1, TAN2, and TAN3 samples were found below the WHO $\left(35^{\circ} \mathrm{C}\right)$ and NESREA $\left(40^{\circ} \mathrm{C}\right)$ limits. The low values of temperature might be due to the processes used at the time of sampling. High temperature brings down the solubility of gases in water that ultimately expresses as high BOD and COD. Statistical analysis shows that there is no significant difference $(p<0.05)$ between the mean values of temperature among the industries. This might be due to similar tannery activities involved in the tannery industries at the time of sampling. The average values of temperature observed in this present study are less than those observed by Akan et al. (2007), Akan et al. (2009) and Baba et al. (2020).

The mean level of $\mathrm{pH}$ observed in TAN1, TAN2 and TAN3, samples were $7.77 \pm 2.93$; $8.35 \pm 0.28$ and $7.52 \pm 0.76$ respectively. The order of the mean $\mathrm{pH}$ of the samples from the three industries can be arranged as TAN2> TAN1 $>$ TAN3. The $\mathrm{pH}$ of the samples falls within the WHO (7.0-8.5) and NESREA (6-9) standard limits. Statistical analysis shows that there is no significant difference $(p<0.05)$ between the mean values of $\mathrm{pH}$ among the industries. This might be due to similar tannery activities involved in the tannery industries at the time of sampling. Maheshwari et al. (2017) reported that the level of $\mathrm{pH}$ in the effluents from the tannery industry in Vaniyambadi, India was 6.5 which was lower than that observed in the present study. The $\mathrm{pH}$ in the effluents from the tannery industries in Kano and Kaduna were reported to be 7.64 and 6.89, respectively (Akan et al., 2007; Mohammed et al., 2017). The average values of $\mathrm{pH}$ observed in this present study are less than those observed by Mohammed et al. (2017) and Baba et al. (2020). The mean level of SS $(\mathrm{mg} / \mathrm{l})$ observed in TAN1, TAN2, and TAN3 samples were 374 \pm 124 ; $358 \pm 335$ and $780 \pm 739$ respectively. The order of the mean SS in the samples from the three industries can be arranged as TAN3 > TAN1 $>$ TAN2. 
The SS observed in the samples were far above the recommended standard limits of regulating bodies WHO $(30 \mathrm{mg} / \mathrm{l})$ and NESREA $(10 \mathrm{mg} / \mathrm{l})$. Statistical analysis shows that there is no significant difference $(p<0.05)$ between the mean values of SS among the industries. This might be due to similar tannery activities involved in the tannery industries at the time of sampling. The average values of SS observed in this present study are less than that observed $(3700 \pm 122 \mathrm{mg} / \mathrm{l})$ by Akan et al. (2009) for tanneries in Kano. Also, the average values of SS observed in this present study are less than that observed by Mohammed et al. (2017) and Baba et al. (2020) with the exception in TAN3.

The mean level of TDS (mg/l) observed in TAN1, TAN2, and TAN3 samples were $3941 \pm 3703$; $3300 \pm 1714$ and $2653 \pm 1240$ respectively. The order of the mean TDS in the samples from the three industries can be arranged as TAN1>TAN2>TAN3. The TDS observed in the samples were far above the recommended standard limits of WHO $(250 \mathrm{mg} / \mathrm{l})$ and NESREA $(500 \mathrm{mg} / \mathrm{l})$. Statistical analysis shows that there is no significant difference $(p<0.05)$ between the mean values of TDS among the industries. This might be due to similar tannery activities involved in the tannery industries at the time of sampling. TDS in the effluents from the tannery industries in Kano, Nigeria was reported to be $1281 \mathrm{mg} / \mathrm{l}$ (Akan et al., 2007). The average values of SS observed in this present study are less than those observed by Mohammed et al. (2017) and Baba et al. 2020)

The mean level of COD (mg/l) observed in TAN1, TAN2 and TAN3 samples seasons were $2372 \pm 938 ; \quad 1406 \pm 208$ and $3532 \pm 1373$ respectively. The order of the mean COD of the samples from the three industries can be arranged as TAN3>TAN1> TAN2. The COD observed in TAN1, TAN2 and TAN3 samples were far above the recommended standard limits of regulating bodies $\mathrm{WHO}(40 \mathrm{mg} / \mathrm{l})$ and NESREA (40 mg/l). Statistical analysis shows that there is no significant difference $(p<0.05)$ in COD among the industries. This might be due to similar tannery activities involved in the tannery industries as at the time of sampling. The Chemical Oxygen demand (COD) is the amount of oxygen, in $\mathrm{mg} / \mathrm{L}$, required for the degradation of the compound of wastewater to occur. In comparison, the average values of COD observed in this present study were higher than that observed by Mohammed et al. (2017) but lower than that observed by Baba et al. (2020).

The mean levels of BOD $(\mathrm{mg} / \mathrm{l})$ observed in TAN1, TAN2 and TAN3 samples were $13.85 \pm 6.42 ; \quad 19.46 \pm 0.50$ and $17.13 \pm 3.14$ respectively. The order of the mean BOD in the samples from the three industries can be arranged as TAN2>TAN3>TAN1. The BOD observed in TAN1, TAN2 and TAN3 samples were found below the recommended limits of NESREA (200 mg/l) but above WHO (10 mg/l). Statistical analysis shows that there is no significant difference $(p<0.05)$ between the mean values of BOD among the industries. This might be due to similar tannery activities involved in the tannery industries at the time of sampling. The low level of BOD recorded in this study is an indication of the low level of biodegradable organic solids in the effluent. The average values of BOD observed in this present study were lower than those observed by Mohammed et al. (2017) and Baba et al. (2020).

Table 1: Mean Values \pm S.D of Physico-chemical parameters of effluents from the Tannery Industries before Treatment.

\begin{tabular}{llllllll}
\hline Parameter & Tannery 1 & Tannery 2 & Tannery 3 & $\mathrm{a}$ & $\mathrm{b}$ & $\mathrm{c}$ & $\mathrm{d}$ \\
\cline { 2 - 7 } Temperature $\left({ }^{\circ} \mathrm{C}\right)$ & $28.07 \mathrm{a} \pm 0.65$ & $27.77 \mathrm{a} \pm 0.64$ & $26.38 \mathrm{a} \pm 3.81$ & & $29.50 \pm 4.68$ & 35 & 40 \\
pH & $7.77 \mathrm{a} \pm 2.93$ & $8.35 \mathrm{a} \pm 0.28$ & $7.52 \mathrm{a} \pm 0.76$ & 6.89 & $5.35 \pm 1.57$ & $7.0-8.5$ & $6.0-9.0$ \\
$\mathrm{COD}(\mathrm{mg} / \mathrm{l})$ & $2372 \mathrm{a} \pm 938$ & $1406 \mathrm{a} \pm 208$ & $3532 \mathrm{a} \pm 1373$ & 2.2 & $3106 \pm 2753$ & 40 & 40 \\
$\mathrm{BOD}(\mathrm{mg} / \mathrm{l})$ & $13.85 \mathrm{a} \pm 6.42$ & $19.46 \mathrm{a} \pm 0.50$ & $17.13 \mathrm{a} \pm 3.14$ & 1032 & $26.17 \pm 9.49$ & 10 & 200 \\
$\mathrm{SS}(\mathrm{mg} / \mathrm{l})$ & $374 \mathrm{a} \pm 124$ & $358 \mathrm{a} \pm 335$ & $780 \mathrm{a} \pm 739$ & 501 & $562 \pm 482$ & 30 & 10 \\
TDS $(\mathrm{mg} / \mathrm{l})$ & $3941 \mathrm{a} \pm 3703$ & $3300 \mathrm{a} \pm 1714$ & $2653 \mathrm{a} \pm 1240$ & 532.7 & $444 \pm 507$ & 250 & 500 \\
\hline
\end{tabular}

The values given in the table above are means of 6 replicate values, $\mathrm{n}=6$ ( 1 sample was taken monthly for 6 months). Within the rows, means with different alphabets are statistically different $(p<0.05)$. WHO: World Health Organisation. NESREA: National Environmental Standard and Regulatory Enforcement Agency. a = Mohammed et al.(2017), b = Baba et al. (2020), c = WHO (2006), $d=$ NESSRA (2009) 
BAJOPAS Volume 13 Number 2, December, 2020

Identification, Biochemical Characterization and growth rates of the Bacterial Isolates

Results of identification and biochemical characterization of the bacterial isolates were shown in table 2. After 24 hours of incubation, the nutrient agar media plates were checked for bacterial growth. The results showed the presence of different strains in the samples. The TAN1 bacteria isolate was found to be gramnegative cocci while TAN3 was gram-positive cocci. TAN2 bacteria isolate was found to be gram-positive, rod-shaped. TAN1, TAN2, and TAN3 bacteria isolates recorded positive results for spore former.

The results of the biochemical tests indicated that all the bacteria were positive for catalase, oxidase, citrate, maltose, glucose, lactose (negative in TAN1), mannitol (negative in TAN2), starch hydrolysis and coagulase (negative in TAN2) tests. The bacteria showed negative results for nitrate reduction, $M R$ (positive in TAN2), VP (positive in TAN1), Indole (positive in TAN2) tests. Base on the morphological and biochemical test results, TAN1, TAN2, and TAN3 bacteria isolates were identified to be Nesseria spp, Bacillus cereus, and Staphylococcus aureus respectively.

The growth rate of the TAN1, TAN2 and TAN3 Isolates were shown in figure 2. Generally, the optical density increase with the increase in time (day) and decrease as time goes on. The highest optical density was shown by bacillus cereus in TAN2 while the lowest was shown by Staphylococcus aureus in TAN3.

The initial growth phase of TAN1 Isolate bacteria occurred within 2-day of incubation as the growth rate increases up to the 6th-day incubation when the maximum growth was observed. Beyond the 6th day, the growth of the bacteria declined (which might be due to a shortage of nutrients in the effluents) until it reached its death phase (which might be due to the unavailability of nutrients in the effluents).

A similar trend of growth was also observed for TAN2 Isolate as the initial growth phase also occurred within 2-day of incubation but maximum growth rate observed on the 4th day of incubation. The stationary stage occurred between the 4th day and the 8th day. Beyond the 8th day, the growth of the bacteria declined (which might be due to a shortage of nutrients in the effluents) until it reached its death phase (which might be due to the unavailability of nutrients in the effluents).

The initial growth phase of TAN3 bacterial Isolate occurred within the 3-day incubation as the growth rate increases up to the 6th-day incubation when the maximum growth was observed. Beyond the 6th day, the growth of the bacteria declined (which might be due to a shortage of nutrients in the effluents) until it reached its death phase (which might be due to the unavailability of nutrients in the effluents).

Table 2: Morphological and Biochemical characteristics of bacterial isolates

\begin{tabular}{lllll} 
Bacterial Isolates & & TAN1 & TAN2 & TAN3 \\
\hline $\begin{array}{lllll}\text { Morphological } \\
\text { characteristics }\end{array}$ & Shape & Cocci & Rod & Cocci \\
& Spore & & & \\
& former & + & + & + \\
Gram & & & \\
Biochemical characteristics & reaction & - & + & + \\
& Citrate & + & + & + \\
& Catalase & + & + & + \\
& Coagulase & + & - & + \\
Starch & + & + & + \\
& Glucose & + & + & + \\
Oxidase & + & + & + \\
& Indo & - & + & - \\
Lactose & - & + & + \\
Manitol & + & - & + \\
Maltose & + & + & + \\
MR & - & + & - \\
VP & + & - & - \\
& Nitrate & - & - & - \\
Reduction & - Neisseria & Bacillus & Staphylococcus \\
& Bacterial & cereus & aureus \\
& name & spp & cas
\end{tabular}

+ = Positive; - = Negative; MR=Methyl Red; VP= Voges-Proskauer 


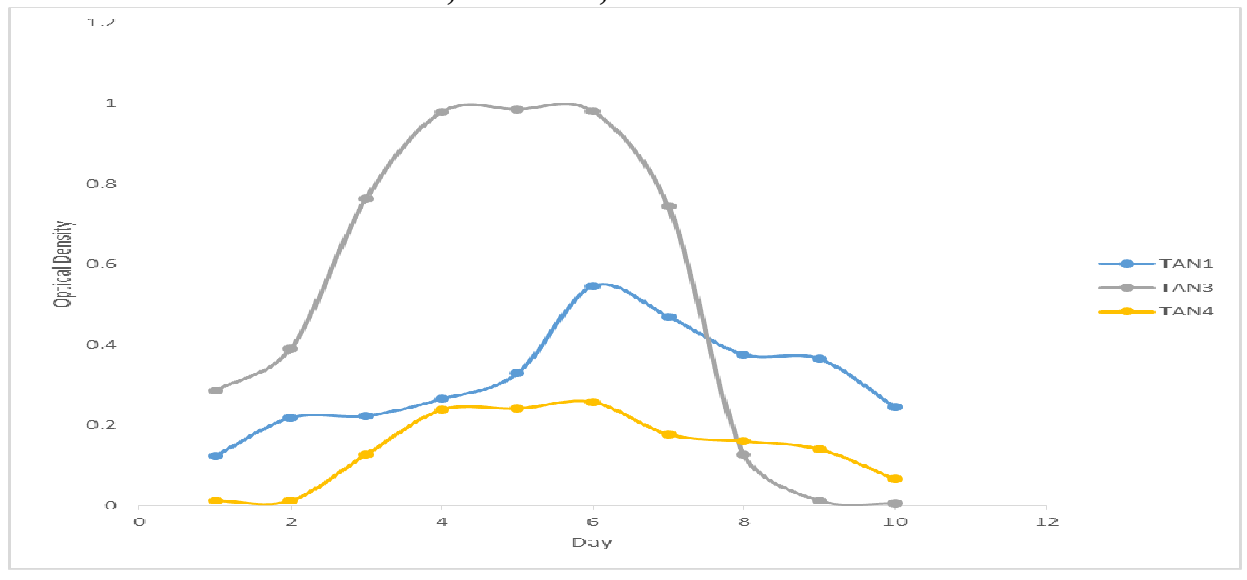

Fig. 2 Growth rates of the isolates in the effluents from the Tannery Industries

\section{Physico-chemical Parameters in the Industrial Effluents after the biodegradation.}

Table 3 shows the mean results of the physicochemical parameter before and after bioremediation using the different masses $(5 \mathrm{~g}$, $10 \mathrm{~g}, 15 \mathrm{~g}, 20 \mathrm{~g}$, and $25 \mathrm{~g}$ ) of the respective immobilized bacteria. Also, Table 4 shows the mean results of correlation coefficient ( $r$ ) between different masses of bacteria and physicochemical parameters.

The mean values $(\mathrm{mg} / \mathrm{l})$ of the SS after the bioremediation varies between $243 \pm 45$ and $898 \pm 672$. The mean concentration $(\mathrm{mg} / \mathrm{l})$ of SS remediated by the different masses $(5 \mathrm{~g}, 10 \mathrm{~g}$, $15 \mathrm{~g}, 20 \mathrm{~g}$, and $25 \mathrm{~g}$ ) of the bacteria varies. The SS in the samples fluctuates up and down after the bioremediation process when compared with the SS of the raw samples before the bioremediation. The increase in the levels of the SS might be due to the aggregation of the TDS which are large enough to result into SS. The increase in the levels of the SS might be also due to the influence of the nutrients which was added into the effluents in order to make the microorganisms more active and viable for fast degradation of organic contaminants in the effluent. The relative potential or efficiency of the different masses of the bacteria in remediating SS in TAN1 samples was in the order $25 \mathrm{~g}>20 \mathrm{~g}>15 \mathrm{~g}>10 \mathrm{~g}>5 \mathrm{~g}$. For TAN2 and TAN3 samples, the order was $25 \mathrm{~g}>20 \mathrm{~g}>15$ $\mathrm{g}>10 \mathrm{~g}>5 \mathrm{~g}$. These might be due to the variations in the surface areas of the different masses of the immobilized bacteria. Statistical analysis shows that there is no significant difference $(p<0.05)$ between the mean values of SS among the masses in the respective industries. Positive and significant correlations exist between the masses of bacteria and Suspended Solid (SS). This showed that there is general increase in the levels of the SS as the masses of the immobilized bacteria increases. TAN3 (90\%) and TAN1 (80\%) showed a very high correlation with the masses of the bacteria while TAN2 (61\%) showed a very low correlation.

The mean values $(\mathrm{mg} / \mathrm{l})$ of the TDS after the bioremediation varies between $46 \pm 11$ and $83 \pm 78$. The mean concentration $(\mathrm{mg} / \mathrm{l})$ of TDS remediated by the different masses $(5 \mathrm{~g}, 10 \mathrm{~g}$, $15 \mathrm{~g}, 20 \mathrm{~g}$, and $25 \mathrm{~g}$ ) of the bacteria varies. There is a reduction in all the TDS of all the samples after the bioremediation process compared with the TDS of the raw samples before the bioremediation. The relative potential or efficiency of the different masses of the bacteria in remediating TDS in TAN1 and TAN3 samples was in the order $5 \mathrm{~g}>10 \mathrm{~g}>15 \mathrm{~g}>20$ $\mathrm{g}>25 \mathrm{~g}$. For TAN2 samples, the order was 20 $g>10 \quad g>25 \quad g>15 \quad g>5 \quad g$. Statistical analysis shows that there is no significant difference $(p<0.05)$ between the mean values of TDS among the masses in the respective industries. These might be due to the variations in the surface areas of the different masses of the immobilized bacteria. Positive and significant correlations exist between the masses of bacteria and TDS with the exception in TAN2 (negative and insignificant correlation). The positive correlations showed that there is general increase in the levels of the TDS as the masses of the immobilized bacteria increases. TAN1 $(96 \%)$ showed a very high correlation with the masses of the bacteria while TAN2 (47\%) showed a very low correlation.

The mean values $(\mathrm{mg} / \mathrm{l})$ of the BOD after the bioremediation varies between $1.56 \pm 0.20 \mathrm{mg} / \mathrm{l}$ and $6.92 \pm 5.49 \mathrm{mg} / \mathrm{l}$. The mean concentration $(\mathrm{mg} / \mathrm{l})$ of BOD remediated by the different masses $(5 \mathrm{~g}, 10 \mathrm{~g}, 15 \mathrm{~g}, 20 \mathrm{~g}$, and $25 \mathrm{~g}$ ) of the bacteria varies. There is a reduction in all the BOD of all the samples after the bioremediation process compared with the $\mathrm{BOD}$ of the raw 
BAJOPAS Volume 13 Number 2, December, 2020 samples before the bioremediation. The relative potential or efficiency of the different masses of the bacteria in remediating BOD in TAN1, TAN2 and TAN3 samples were in the order $25 \mathrm{~g}>20$ $\mathrm{g}>15 \mathrm{~g}>10 \mathrm{~g}>5 \mathrm{~g}, 25 \mathrm{~g}>15 \mathrm{~g}>5 \mathrm{~g}>10 \mathrm{~g}>20 \mathrm{~g}$ and $20 \mathrm{~g}>10 \mathrm{~g}>25 \mathrm{~g}>15 \mathrm{~g}>5 \mathrm{~g}$ respectively. Statistical analysis shows that there is significant difference $(p<0.05)$ between the mean values of BOD among the masses in the respective industries. These might be due to the variations in the surface areas of the different masses of the immobilized bacteria. Negative and significant correlations exist between the masses of bacteria and BOD. This showed that there is general decrease in the levels of the BOD as the masses of the immobilized bacteria increases. TAN1 (94\%) showed a very high correlation with the masses of the bacteria while TAN2 (4\%) showed a very low correlation.

The mean values $(\mathrm{mg} / \mathrm{l})$ of the COD after the bioremediation varies between $250 \pm 154$ and $3134 \pm 1595$. The mean concentration $(\mathrm{mg} / \mathrm{l})$ of COD remediated by the different masses $(5 \mathrm{~g}$, $10 \mathrm{~g}, 15 \mathrm{~g} 20 \mathrm{~g}$, and $25 \mathrm{~g}$ ) of the bacteria varies. There is a reduction in all the COD of all the samples after the bioremediation process compared with the COD of the raw samples before the bioremediation. The relative potential or efficiency of the different masses of the bacteria in remediating COD in TAN1, TAN2 and TAN3 samples were in the order $25 \mathrm{~g}>20 \mathrm{~g}>15$ $\mathrm{g}>5 \mathrm{~g}>10 \mathrm{~g}, 25 \mathrm{~g}>20 \mathrm{~g}>15 \mathrm{~g}>10 \mathrm{~g}>5 \mathrm{~g}$ and 10 g>5 g>25 g>15 g>20 g respectively. Statistical analysis shows that there were significant difference $(p<0.05)$ between the mean values of COD among the masses in the respective industries except for effluents treated with $25 \mathrm{~g}$. These might be due to the variations in the surface areas of the different masses of the immobilized bacteria. Negative and insignificant correlations exist between the masses of bacteria and COD with the exception in TAN3 (positive and significant correlation). The negative correlations showed that there is general decrease in the levels of the COD as the masses of the immobilized bacteria increases. TAN2 (100\%) showed a very high correlation with the masses of the bacteria while TAN3 (36\%) showed a very low correlation.

Generally, there was an overall decrease in the concentration of these physicochemical parameters after the bioremediation using the different masses of the bacterial isolates. These might be due to the variations in the surface areas of the different masses of the immobilized bacteria. This is in line with the work of Jimoh et al. (2018) and Baba et al. (2020).

Table 3: Mean Values $(\mathrm{mg} / \mathrm{l}) \pm$ S.D of Physicochemical parameters in effluents from the Tannery Industries before and after Treatment of the effluents $(250 \mathrm{ml})$ with the different masses $(5 \mathrm{~g}, 10 \mathrm{~g}$, $15 \mathrm{~g}, 20 \mathrm{~g}$, and $25 \mathrm{~g}$ ) of the bacteria.

\begin{tabular}{llllllll}
\hline $\mathrm{P}$ & IND & Before & \multicolumn{5}{c}{ After } \\
\cline { 4 - 7 } & & & $5 \mathrm{~g}$ & $10 \mathrm{~g}$ & $15 \mathrm{~g}$ & $20 \mathrm{~g}$ & $25 \mathrm{~g}$ \\
\hline \multirow{2}{*}{ COD } & TAN1 & $2372 \pm 938$ & $1708 \mathrm{a} \pm 861$ & $2045 \mathrm{a} \pm 1205$ & $845 \mathrm{a} \pm 369$ & $300 \mathrm{a} \pm 167$ & $250 \mathrm{a} \pm 154$ \\
& TAN2 & $1406 \pm 208$ & $1195 \mathrm{a} \pm 208$ & $1125 \mathrm{a} \pm 384$ & $1055 \mathrm{a} \pm 317$ & $956 \mathrm{a} \pm 310$ & $870 \mathrm{ab} \pm 240$ \\
& TAN3 & $3532 \pm 1373$ & $2374 \mathrm{a} \pm 1344$ & $1976 \mathrm{a} \pm 1405$ & $2757 \mathrm{a} \pm 1266$ & $3134 \mathrm{a} \pm 1595$ & $2614 \mathrm{~b} \pm 1105$ \\
BOD & TAN1 & $13.85 \pm 6.42$ & $6.92 \mathrm{a} \pm 5.49$ & $6.42 \mathrm{a} \pm 5.07$ & $5.72 \mathrm{a} \pm 5.35$ & $4.62 \mathrm{a} \pm 4.37$ & $2.82 \mathrm{ab} \pm 1.26$ \\
& TAN2 & $19.46 \pm 0.50$ & $1.75 \mathrm{~b} \pm 0.22$ & $1.73 \mathrm{~b} \pm 0.18$ & $1.58 \mathrm{a} \pm 0.16$ & $1.91 \mathrm{a} \pm 0.22$ & $1.56 \mathrm{~b} \pm 0.20$ \\
& TAN3 & $17.13 \pm 3.14$ & $4.24 \mathrm{ab} \pm 0.77$ & $3.29 \mathrm{ab} \pm 0.37$ & $4.11 \mathrm{a} \pm 0.07$ & $3.23 \mathrm{a} \pm 0.91$ & $3.33 \mathrm{a} \pm 1.28$ \\
SS & TAN1 & $374 \pm 124$ & $243 \mathrm{a} \pm 45$ & $471 \mathrm{a} \pm 226$ & $475 \mathrm{a} \pm 182$ & $492 \mathrm{a} \pm 128$ & $611 \mathrm{a} \pm 217$ \\
& TAN2 & $358 \pm 335$ & $460 \mathrm{a} \pm 400$ & $543 \mathrm{a} \pm 414$ & $544 \mathrm{a} \pm 402$ & $551 \mathrm{a} \pm 414$ & $554 \mathrm{a} \pm 405$ \\
& TAN3 & $780 \pm 739$ & $586 \mathrm{a} \pm 594$ & $758 \mathrm{a} \pm 656$ & $787 \mathrm{a} \pm 676$ & $861 \mathrm{a} \pm 635$ & $898 \mathrm{a} \pm 672$ \\
TDS & TAN1 & $3941 \pm 3703$ & $51 \mathrm{a} \pm 10$ & $53 \mathrm{a} \pm 10$ & $55 \mathrm{a} \pm 15$ & $61 \mathrm{a} \pm 20$ & $63 \mathrm{a} \pm 26$ \\
& TAN2 & $3300 \pm 1714$ & $83 \mathrm{a} \pm 78$ & $47 \mathrm{a} \pm 20$ & $48 \mathrm{a} \pm 22$ & $47 \mathrm{a} \pm 17$ & $48 \mathrm{a} \pm 17$ \\
& TAN3 & $2653 \pm 1240$ & $46 \mathrm{a} \pm 11$ & $55 \mathrm{a} \pm 24$ & $55 \mathrm{a} \pm 25$ & $58 \mathrm{a} \pm 23$ & $61 \mathrm{a} \pm 28$ \\
\hline
\end{tabular}

Replicate $=6$ (months)

Within the rows, for the same parameter, means with different alphabets are statistically different $(p<0.05)$.

$\mathrm{P}=$ parameter, IND = Industries 
BAJOPAS Volume 13 Number 2, December, 2020

Table 4: Correlation coefficient $(r)$ between different masses of the bacteria and the physicochemical parameters.

\begin{tabular}{llll}
\hline Industries & Parameter & Correlation coefficient $(r)$ & $\begin{array}{l}\text { Percent dependence (rxrx100) } \\
(\%)\end{array}$ \\
\hline TAN1 & COD & -0.9 & 82 \\
& BOD & -0.97 & 94 \\
& SS & $0.90^{*}$ & 80 \\
TAN2 & TDS & $0.98^{*}$ & 96 \\
& COD & -1 & 100 \\
& BOD & -0.21 & 4 \\
& SS & $0.78^{*}$ & 61 \\
& TDS & -0.69 & 47 \\
& COD & $0.60^{*}$ & 36 \\
& BOD & -0.6 & 37 \\
& SS & $0.95^{*}$ & 90 \\
& TDS & $0.94^{*}$ & 89 \\
\hline
\end{tabular}

The correlation coefficient $(r)$ with * is statistically significant $(p<0.05)$.

Percentage reduction of the Parameters

Table 5 shows the percentage reduction of Parameters in industrial samples before and after the treatment of the effluents $(250 \mathrm{ml})$ with the different masses $(5 \mathrm{~g}, 10 \mathrm{~g}, 15 \mathrm{~g}, 20 \mathrm{~g}$, and $25 \mathrm{~g}$ ) of the Immobilized Bacteria.

In TAN1 samples, the percentage reduction (\%) of COD ranged (14-89); BOD (50-80); SS (-32$35)$ and TDS (98-99). In TAN2 samples, the percentage decrease $(\%)$ of COD ranged (15$38) ;$ BOD (90-92); SS [-28-(-55)] and TDS (9798). In TAN3 samples, the percentage decrease (\%) of COD ranged (11-44); BOD (76-81); SS (15-25) and TDS (98). The percentage increase in the levels COD, BOD and TDS might be due to the increase in the surface area of the different masses of the immobilized bacteria. However, the percentage decrease in the levels of the SS might be due to the aggregation of the TDS which are large enough to result into SS. The percentage decrease in the levels of the SS might be also due to the influence of the nutrients which was added into the effluents in order to make the microorganisms more active and viable for fast degradation of organic contaminants in the effluent. This is in line with the work of Jimoh et al. (2018) in which the concentration of the SS increase after the bioremediation of effluents.

Sreemoyee and Priti (2013) assessed and reduced several Physico-chemical parameters of dairy wastewater using Niesseria $s p$. and concluded that the species are well known to degrade organic compounds. This is in agreement with the current study in which the immobilized Niesseria $s p$ degrade the organic contaminants as indicated by the BOD, COD and TDS.

Jimoh et al. (2018) observed that TSS of the effluents was increased after treatment with immobilized bacteria and concluded that it might be due to the biostimulation method adopted for the research.

The optimum $\mathrm{pH}$ Biosorption of Chromium by Bacillus spp and Staphylococcus spp. from tannery effluent was investigated by Mythili and Karthikeyan (2011). The maximum adsorption of Chromium $(86.4 \mathrm{mg} / \mathrm{L})$ was showed by Bacillus spp and Staphylococcus spp showed $70.6 \mathrm{mg} / \mathrm{L}$ at an initial concentration of $100 \mathrm{mg} / \mathrm{L}$. In the present study, immobilised Bacillus spp and Staphylococcus spp. from the tannery industrial effluents reduced the levels of the organic pollutants with high potential as indicated by the percentage reduction of BOD, COD and TDS.

Enzymes often can work in multiple environments especially if they are immobilized. This makes the microorganisms' enzymes even more resistant to harsh environments and enables the enzymes to be recovered and recycled after they are no longer needed (Gianfreda and Rao 2004). Ramesh and Singh (1993) reported that the immobilized bacteria having more efficiency to remove the suspended particles than free cells. Using the immobilized cell is preferable due to its capability for using several times with the same efficiency, which makes it more economical. Similar work was done by Sikander et al. (2007) showing the higher reduction with permeabilized cells of Ochrobactrum intermedium strain SDCr-5. 
BAJOPAS Volume 13 Number 2, December, 2020

The results revealed the isolation and identification of isolates with the potential for the reduction of $\mathrm{Cr}$ (VI) to $\mathrm{Cr}$ (III). Results indicated that immobilized $B$. cereus could be efficiently used for the reduction of $\mathrm{Cr}$ (VI).

Table 5: Percentage reduction of the tested Parameters from the tannery industrial samples of the Immobilized Bacteria.

\begin{tabular}{lllllll}
\hline \multirow{2}{*}{ Industries } & & \multicolumn{5}{c}{ Percentage Reduction $(\%)$} \\
\cline { 3 - 7 } & & $5 \mathrm{~g}$ & $10 \mathrm{~g}$ & $15 \mathrm{~g}$ & $20 \mathrm{~g}$ & $25 \mathrm{~g}$ \\
\hline TAN1 & COD & 28 & 14 & 64 & 87 & 89 \\
& BOD & 50 & 54 & 59 & 67 & 80 \\
& SS & 35 & -26 & -27 & -32 & -63 \\
& TDS & 99 & 99 & 99 & 98 & 98 \\
TAN2 & COD & 15 & 20 & 25 & 32 & 38 \\
& BOD & 91 & 91 & 92 & 90 & 92 \\
& SS & -28 & -52 & -52 & -54 & -55 \\
& TDS & 97 & 99 & 99 & 99 & 99 \\
& COD & 33 & 44 & 22 & 11 & 26 \\
& BOD & 75 & 81 & 76 & 81 & 81 \\
& SS & 25 & 3 & -1 & -10 & -15 \\
& TDS & 98 & 98 & 98 & 98 & 98 \\
\hline
\end{tabular}

Percentage Reduction $=(B-A) / B \times 100 \%$

$A=$ Concentration of the parameter after treatment

$\mathrm{B}=$ Concentration of the parameter before treatment

$+=$ percentage decrease

- = percentage increase

In general, immobilization makes the enzyme more resistant to temperature, $\mathrm{pH}$, and substrate concentration swings giving it a longer lifetime and higher productivity per active unit (Gianfreda and Rao, 2004; FuIlbrook, 1996; Russell et al, 2003; Kandelbauer et al., 2004). Immobilized cells have been used and studied extensively for the production of useful chemicals (Ohtake and Silver, 1994), the treatment of wastewaters (Chen et al., 2003; Wang et al., 2010). Although many workers described microbial degradation of tannery effluent, limited literature is available on the bioremediation of tannery effluent using immobilized bacterial cells in the Kano Industrial Estates.

\section{CONCLUSION}

The samples contained variable levels of the physicochemical parameters. The results of the Analysis of variance revealed that, no statistical difference $(p<0.05)$ was observed for the temperature, $\mathrm{pH}, \mathrm{SS}, \mathrm{TDS}, \mathrm{BOD}$ and $\mathrm{COD}$ among the three tannery industries before the treatment. The levels of some of the parameters
(SS, TDS and COD) observed in the samples were found above the recommended limits of WHO and NESREA, which called for the treatment of the effluents before discharge into the environment. Base on the morphological and biochemical test results, TAN1, TAN2, and TAN3 bacterial isolates were identified to be Neisseria spp, Bacillus cereus, and Staphylococcus aureus respectively. The results of Post-treatment analysis showed that there is overall decrease in the levels of the parameters determined when compared with that of the pre-treatment. The overall percentage reduction of the immobilised bacteria in the treatment of the respective effluents was in the order TAN2 (72\%)>TAN1 $(70 \%)>$ TAN3 $(62 \%)$. Hence, the immobilized bacteria are having higher biodegradation potential for the treatment of the tannery effluents.

\section{Acknowledgments}

The authors wish to acknowledge the University of Maiduguri for the financial support. The authors are grateful to the Kano State Ministry of Environment for their support in obtaining the effluent samples. 


\section{REFERENCES}

Ajao, A. T., Adebayo, G. B., and Yakubu, S. E. (2011). Bioremediation of textile industrial effluent using mixed culture of Pseudomonas aeruginosa and Bacillus subtilis immobilized on agar-agar in a bioreactor. J. Microbiol. Biotech. Res, 1(3), 50-56.

Akan, J. C., Moses, E. A., Ogugbuaja, V. O., and Abah, J. (2007). Assessment of tannery industrial effluents from Kano metropolis, Kano State, Nigeria. Journal of Applied Sciences, 7(19), 2788-2793.

Akan, J. C., Ogugbuaja, V. O., Abdulrahman, F. I., and Ayodele, J. T. (2009). Pollutant levels in effluent samples from tanneries and textiles of Kano industrial areas, Nigeria. Global journal of pure and applied sciences, 15(3-4).

APHA (1989). Standard methods for Examination of Will bete and Will betewater.15 $5^{\text {th }}$ edition. Brydpass Springfield Will behington DC. pp. 164-176

APHA (1992). Standard Methods for the Examination of Water and Wastewater. Health, 69, 1116-9.

Baba, A., Garba, S. T., and Bello, H. S. (2020). Bioremediation Potential of Immobilized corynebacterium kutsceri in the Treatment of Tannery Industrial Effluent from Challawa Industrial Estate, Kano State, Nigeria. Journal of the Turkish Chemical Society Section A: Chemistry, $7(2), 335-350$.

Beem, E. I. V. (1994). reduction of solvent VOC emission. J. Oil Col. Chem. Ass, 77, 158.

Bouwer, E. J., and Zehnder, A. J. (1993). Bioremediation of organic compoundsputting microbial metabolism to work. Trends in biotechnology, 11(8), 360367.

Chen, K. C., Wu, J. Y., Liou, D. J., and Hwang, S. C. J. (2003). Decolorization of the textile dyes by newly isolated bacterial strains. Journal of Biotechnology, 101(1), 57-68.

Dan'Azumi, S., and Bichi, M. H. (2010). INDUSTRIAL POLLUTION AND HEAVY METALS PROFILE OF CHALLAWA RIVER IN KANO, NIGERIA. Journal of Applied Sciences in Environmental Sanitation, $5(1)$.

DWAF. (1992). Analytical Methods Manual, TR 151. Department of Water Affairs and Forestry, Pretoria.

El-Bestawy, E. (2013). Biological treatment of leather-tanning industrial wastewater using free living bacteria.
Elsheikh, M. A. S. (2009). Tannery wastewater pre-treatment. Water Science and Technology, 60(2), 433-440.

FuIlbrook, P. D. (1996). "Kinetics." Industrial enzymology: The application of enzymes in Industry. 2nd Ed. T. Godfrey and J Reichelt. eds.. Nature. New York.

Gianfreda, L., and Rao, M. A. (2004). Potential of extra cellular enzymes in remediation of polluted soils: a review. Enzyme and microbial technology, 35(4), 339354.

Hugo Springer. (1994). John Arthur Wilson Memorial Lecture "Treatment of Industrial Wastes of the Leather Industry - is it still a Major Problem". JALCA, 89, 153-185

Jimoh, A. A., Ganiyu, B. A., Baba, D., and Baba, A. (2018) Bioremediation Process of Effluent from Detergent and Food Industries in Jos, Nigeria: Kinetics and Thermodynamics. International Journal of Engineering Science Invention (IJESI), 762-73

Kandelbauer, A., Maute, O., Kessler, R. W., Erlacher, A., and Gübitz, G. M. (2004). Study of dye decolorization in an immobilized laccase enzyme-reactor using online spectroscopy. Biotechnology and bioengineering, 87(4), 552-563.

Kongjao, S., Damronglerd, S., and Hunsom, M. (2008). Simultaneous removal of organic and inorganic Pollutants in tannery wastewater using electrocoagulation technique. Korean Journal of chemical engineering, 25(4), 703.

Maheshwari, U. M., Aruna, S., Gomathi, M., and AbdulJaffar, A. H. (2017). Bioremediation by Free and Immobilized Bacteria Isolated from Tannery Effluent. International Journal of Research in Applied, Natural and Social Sciences. 5(7), 75-90

Margesin, R., and Schinner, F. (2001). Bioremediation (natural attenuation and biostimulation) of diesel-oilcontaminated soil in an alpine glacier skiing area. Applied and environmental microbiology, 677), 3127-3133.

Mohammed, A., Sekar, P., and George, J. (2011). Efficacy of microbes in bioremediation of tannery effluent. Inter. J. Curr. Res, 3(4), 324-326.

Mohammed, S. S. D., Orukotan, A. A., and Abdullahi, H. (2017). Physicochemical and Bacteriological Assessment of Tannery Effluent from Samaru-Zaria, 
BAJOPAS Volume 13 Number 2, December, 2020 Kaduna State, Nigeria. Journal of Applied

Sciences and Environmental Management, 21(4), 734-740.

Munz, G., De Angelis, D., Gori, R., Mori, G., Casarci, M., and Lubello, C. (2009). The role of tannins in conventional and membrane treatment of tannery wastewater. Journal of hazardous materials, 164(2-3), 733-739

Mythili, K., and Karthikeyan, B. (2011). Bioremediation of $\mathrm{Cr}$ (VI) from tannery effluent using Bacillus spp and Staphylococcus spp. International Multidisciplinary Research Journal, 1(6).

NESREA (2009). National Environmental Standards for Effluent Limitations and Regulation. 1233-1236

Noorjahan, C. M. (2014). Physicochemical characteristics, identification of bacteria and biodegradation of industrial effluent. Journal of bioremediation and Biodegradation, 5(3).

Ohtake, H. I., and Silver, A. O. (1994). Bacterial reduction of toxic chromate. Biological degradation and bioremediation of toxic chemicals, 403-415.

Omoleke, I. I. (2004). Management of environmental pollution in Ibadan, an African city: the challenges of health hazard facing government and the people. Journal of Human Ecology, 15(4), 265-275.

Rajor, A., Reddy, A.S., and Singh, B. (2004). Determination of BOD kinetic Parameters and evaluation of alternate methods, M.Sc. Thesis, Department of biotechnology \& environmental Science, Thapar Institute of Engineering and Technology, Patiala

Ramasami, T., Rajamani, S., and Rao, J. R. (1994, March). Pollution control in leather industry: Emerging technological options. In International symposium on surface and colloidal science and its relevance to soil pollution, madras.

Ramesh, J. V. S., and Singh, S. P. (1993). Yearly variation in certain physicochemical parameters of pond at eastern Doon Valley. Uttar Pradesh J. Zoo, 12 (1), 7577.

Ranen, S., and Sharadinadra, C. (2009). Biotechnology applications to environmental remediation in resource exploitation. Current science, 97, 6-25
Russell, A. J., Berberich, J. A., Drevon, G. F., and Koepsel, R. R. (2003). Biomaterials for mediation of

chemical and biological warfare agents. Annual review of biomedical engineering, 5(1), 1-27.

Saravanan, P., and Saravanan, A. (1999). Decolourization of tannery effluent by Flavobacterium sp. EK 1. Indian Journal of Environmental Protection, 19, 19-24.

Sikander, S., and Shahida, H. (2007). Reduction of toxic hexavalent chromium by Ochrobactrum intermedium strain SDCr5 stimulated by heavy metals. Bioresource Technol, 98, 340-344.

Singh, N., Sharma, B. K., and Bohra, P. C. (2000). Impact assessment of industrial effluent of arid soils by using satellite imageries. Journal of the Indian Society of Remote Sensing, 28(2-3), 79.

Sreemoyee, C., and Priti, P. (2013). Assessment of physico-chemical parameters of dairy waste water and isolation and characterization of bacterial strains in terms of cod reduction. Int J Sci, 2(3), 395-400.

Verheijen, L. A. H. M., Wiersema, D., Pol, L. H., and De Wit, J. (1996). Management of wastes from animal product processing. Livestock and environment, Finding a balance. International Agriculture Center, Wageningen, The Netherlands.

Wang, F., Yao, J., Si, Y., Chen, H., Russel, M., Chen, K., and Bramanti, E. (2010). Short-time effect of heavy metals upon microbial community activity. Journal of Hazardous Materials, 173(13), 510-516.

WHO (World Health Organization). (2006). Air quality guidelines: global update 2005: particulate matter, ozone, nitrogen dioxide, and sulfur dioxide. World Health Organization.

World Bank. (1995). Nigeria's strategic options for redressing industrial pollution. World Bank, industry and energy division. 1st edition, West Central Africa Department; Annexes: 1995; pp 60-62.

Zahoor, A., and Abdul, R. (2009). Enumeration of Coliforms. Journal of Environmental Sciences. 21, 814-820 


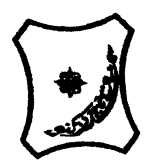

Bayero Journal of Pure and Applied Sciences, 13(2): 1 - 12

Received: November, 2020

Accepted: December, 2020

ISSN $2006-6996$

\title{
BIODEGRADATION POTENTIAL OF IMMOBILIZED BACTERIA IN THE TREATMENT OF TANNERY INDUSTRIAL EFFLUENTS FROM INDUSTRIAL ESTATES IN KANO STATE, NIGERIA
}

\author{
Abdullateef, B., ${ }^{1 *}$ Shuaibu, T. G., ${ }^{1}$ Babagana, K., ${ }^{1}$ Suleman, H. B. ${ }^{2}$ and Dauda, B. ${ }^{3}$ \\ ${ }^{1}$ Department of Pure and Applied Chemistry, Faculty of Science, University of Maiduguri, Borno State, \\ Nigeria \\ ${ }^{2}$ Department of Microbiology, Faculty of Science, University of Maiduguri, Borno State, Nigeria \\ ${ }^{3}$ Department of Chemical Engineering, Faculty of Engineering, University of Maiduguri, Borno State, \\ Nigeria \\ *Corresponding author: babslega@gmail.com; abelega2007@yahoo.com; +2348061309753
}

\section{ABSTRACT}

Industrial Effluents Samples from Gashash Tanneries (TAN1) in Bompai Industrial estate, Larabee Tannery Industry (TAN2) in Sharada Industrial estate and Z Tannery Industries (TAN3) in Challawa Industrial estate, Kano State, Nigeria were collected over a period of six months (August 2017 to January 2018) for assessing the biodegradation potentials of bacteria in the treatment of organic pollutants within the effluents. Bacteria were isolated from the effluents and immobilized on agar-agar. Different masses (5 g, $10 \mathrm{gr}, 15$ $\mathrm{g}, 20 \mathrm{~g}$, and $25 \mathrm{~g}$ ) of the bacteria were used in the treatment of $250 \mathrm{ml}$ of the effluents for ten days in a shaker incubator (Gallenkamp-OC-4364-L) at the temperature $30{ }^{\circ} \mathrm{C}$ and speed of $60 \mathrm{rpm}$. Pre-treatment analysis of the effluents for Temperature, pH, Biochemical Oxygen Demand (BOD), Chemical Oxygen Demand (COD), Suspended Solid (SS) and Total Dissolved Solids (TDS) gives the following results; temperature $\left({ }^{\circ} \mathrm{C}\right.$ )

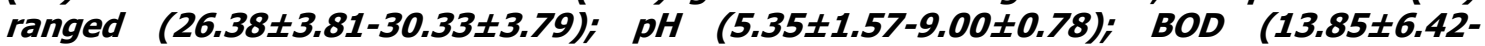
$38.75 \pm 16.20) ;$ COD (1406 $\pm 208-3532 \pm 1373) ;$ SS (208 $\pm 235-780 \pm 739)$ and TDS (266 $\pm 253-5276 \pm 2971)$. No statistical differences ( $p \leq 0.05)$ was observed for all the results among the different industries. The bacterial isolates were identified as Neisseria spp, Bacillus cereus, and Staphylococcus aureus, in TAN1, TAN2, and TAN3, respectively. After treatment of the effluent with the different masses of the isolated bacteria, the mean level of BOD was found to range as (0.55 $\pm 0.36-6.92 \pm 5.49) ; C O D$ (ND-3134 \pm 1595$)$;

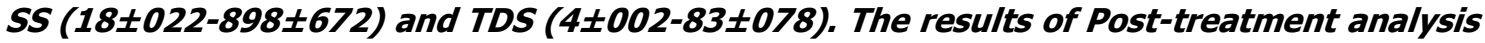
showed that there is overall decrease in the levels of the parameters determined when compared with that of the pre-treatment. The overall percentage reduction of the immobilised bacteria in the treatment of the respective effluents was in the order TAN2 (72\%)>TAN1 (70\%)>TAN3 (62\%). Hence, the immobilized bacteria are having higher biodegradation potential for the treatment of the tannery effluents.

Keywords: Biodegradation, bacteria, effluent, immobilization, tannery.

\section{INTRODUCTION}

Tannery industrial wastewater is a serious consequence of the pollution point of view for streams, freshwater, and land used for agriculture. The lack of awareness in the modern industrial practice has resulted in the discharge of tannery effluents which exhibit very high value of chromium ( $\mathrm{Cr}$ ), Sulfide, and chloride, Total Dissolved Solid (TDS), Total Suspended Solid (TSS), Biochemical Oxygen Demand (BOD) and Chemical Oxygen Demand (COD) in the water stream or land (Mohammed et al., 2001). Tanning is the process, which One ton of skin generally leads to the production of 20 to $80 \mathrm{~m}^{3}$ of turbid and foul-smelling converts the protein of the rawhide or skin into a stable material, which will not putrefy and is suitable for a wide variety of end applications (Elsheikh, 2009). The highly polluting chromium is the most commonly used tanning material producing leather that is more flexible and pliable than vegetable-tanned leather and does not discolor or lose shape in water as drastically as vegetable-tan (Elsheikh, 2009). Tannery effluent is among the most hazardous industrial pollutants due to its huge organic and inorganic load, which is highly toxic to human life and the environment (Kongjao et al., 2008). wastewater including chromium (100-400 mg/l), sulfide $(200-800 \mathrm{mg} / \mathrm{l})$, high levels of fat and 
BAJOPAS Volume 13 Number 2, December, 2020 other solid wastes, and notable pathogen contamination as well as pesticides added for skin conservation during transport (Elsheikh, 2009). There are more than 6000 tanneries in Nigeria with an annual processing capacity of 700,000 tons of hides and skins (Omoleke, 2004; Singh et al., 2008). It was reported that the total amount of waste produced per animal slaughtered is approximately $35 \%$ of its weight (World Bank, 1995). Also, for every $1000 \mathrm{~kg}$ of carcass weight, a slaughtered beef produces 5.5 $\mathrm{kg}$ of manure (excluding rumen contents or stockyard manure) and $100 \mathrm{~kg}$ of paunch manure (undigested food) (Verheijen et al., 1996). Tanneries generate wastewater in the range of 30-35 $\mathrm{L} \mathrm{kg}^{-1}$ skin/hide processed with variable $\mathrm{pH}$, Biological Oxygen Demand (BOD), Chemical Oxygen Demand (COD), high concentrations of suspended solids (SS), and tannins as well as chromium (Zahoor and Abdul, 2009).

Being heterogeneous and composed of a wide variety of compounds, it is very difficult to select a unique direct method for estimating the biodegradability of organic contents and biokinetic parameters for a wastewater sample (Rajor, 2004). For this purpose, some indirect estimation such as determination of biochemical oxygen demand (BOD) and chemical oxygen demand (COD) are applied as common laboratory investigations [9]. During retanning procedures, synthetic tannins (Syntan), oils and resins are added to form softer leather at varying doses (Munz et al., 2009). One of the refractory groups of chemicals in tannery effluents derives mainly from tannins (Ramasami et al., 2004). Syntans are characterized by complex chemical structures, because they are composed of an extended set of chemicals such as phenol-, naphthalene-, formaldehyde- and melamine-based syntans, and acrylic resins (Beem, 1994). Organic pollutants (proteic and lipidic components) are originated from skins (it is calculated that the raw skin has $30 \%$ loss of organic material during the working cycle) or they are introduced during processes (Hugo Springer, 1994).

Many conventional processes such as oxidation, chemical and biological processes were carried out to treat tanneries wastewater (Ebtesam et al, 2013). Biological processes have received more attention because of their costeffectiveness, lower sludge production and environmental friendliness (Noorjahan, 2014). Naturally occurring micro-organisms degrade the hazardous organic wastes including xenobiotic compounds, such as pesticides, polycyclic aromatic hydrocarbons (PAHs) and polychlorinated biphenyls (PCBs) in due course of time (Ranen and Sharadinadra, 2009). Bioremediation is based on the idea that all organisms remove substances from the environment to carry outgrowth and metabolism (Bouwer and Zehnder, 1993). Bacteria, protista and fungi are found to be very good at degrading complex molecules and incorporating the breakdown products into their metabolism (Bouwer and Zehnder, 1993). The resultant metabolic wastes that they produce are generally safe and somehow recycled into other organisms (Ranen and Sharadinadra, 2009). An acclimatized indigenous population of microorganisms capable of degradation of the compounds of interest must exist at the site for a successful bioremediation mode (Ranen and Sharadinadra, 2009). It has been observed that for a successful bioremediation mode, an acclimatized indigenous population of microorganisms capable of degradation of the compounds of interest must exist at the site under investigation (Ranen and Sharadinadra, 2009). Even though there are numerous physical and chemical methods employed in the disposal of wastes the advantage in using bacterium is that they play a key role in the reduction of COD, BOD, total protein, total tannin and total phenol (Saravanan and Saravanan, 1998)

Baba et al. (2020) studied the bioremediation potential of immobilized corynebacterium kutsceri in the Treatment of tannery industrial effluent from Challawa Industrial Estate, Kano State, Nigeria. The aim of the work is to study the reduction in the level of the contaminants through the process of bioremediation using the isolated bacteria. Immobilized bacteria can withstand various temperatures, $\mathrm{pH}$ and substrate concentrations; consequently, increasing the efficiency and the lifespan of the bacteria. Immobilized bacteria are widely applied in the treatment of wastewater and can be separated and recovered after the treatment with the same efficiency (Baba et al., 2020).

\section{MATERIALS AND METHODS \\ Study Area}

This study was carried out in Bompai, Sharada and Challawa industrial estates in Kano, Figure 1. Kano lies on Latitude $11^{\circ} 30^{\prime} \mathrm{N}$ and $8^{\circ} 30^{\prime} \mathrm{E}$ and Longitude $11^{\circ} 5^{\prime} \mathrm{N}$ and $8^{\circ} 5^{\prime} \mathrm{E}$ in Northern Nigeria. It is one of the developed industrial cities in Nigeria. Tannery activities are the dominating industries and this could be one of the reasons for her high population density (Dan'Azumi and Bichi, 2010). Many researchers have studied biodegradation of tannery effluent using microorganisms. However, limited literature is available on the biodegradation of tannery effluent in Kano industrial estates using 
BAJOPAS Volume 13 Number 2, December, 2020 immobilized bacterial cells. This research work focuses on the potential of the use of the indigenous immobilized bacterial isolates in the treatment of tannery effluents in the industrial estates.

\section{Sample Collection}

Effluents were collected from the Tannery Industries from Bompai, Challawa and Sharada Industrial Estates, Kano, Nigeria. The effluents were collected over a period of six months (August 2017 to January 2018). Samples collected in a sterile 4-liter plastic container with a unique identification number were preserved using an ice-box that was transported to the Microbiology Laboratory, Department of Microbiology, Bayero University of Kano for analysis

\section{Sample Preparation and Sample Analysis}

Immediately after the collection of the effluent, $\mathrm{pH}$, TSS, TDS, COD, BOD levels were determined before treatment (Pre-treatment determination) and ten days after treatment (Post-treatment determination) as described in
APHA (1989) standard methods. $\mathrm{pH}$ was determined using Ecotests $\mathrm{pH}$ meter and TDS was determined using AQUALYTIC TDS Salinometer. BOD was determined as described by the standard method (APHA, 1992). COD and SS were determined using DR/2010 HACH portable data logging spectrophotometer (DWAF, 1992)

\section{Identification and Biochemical} Characterization of the Bacterial Isolates

The bacteria were isolated from the effluents using Serial Dilution according to the method described by APHA (1989). The biochemical tests such as oxidase, catalase, coagulase, indole (from $1 \%$ tryptone broth), citrate (Simmons citrate agar), methyl red/VogesProskauer (MR/VP), nitrate reduction, Starch Hydrolysis, Glucose, Maltose, and Lactose tests were carried out on the bacterial isolates to identify the bacteria through the bacteria biochemical characteristics according to Ajao et al. (2011).

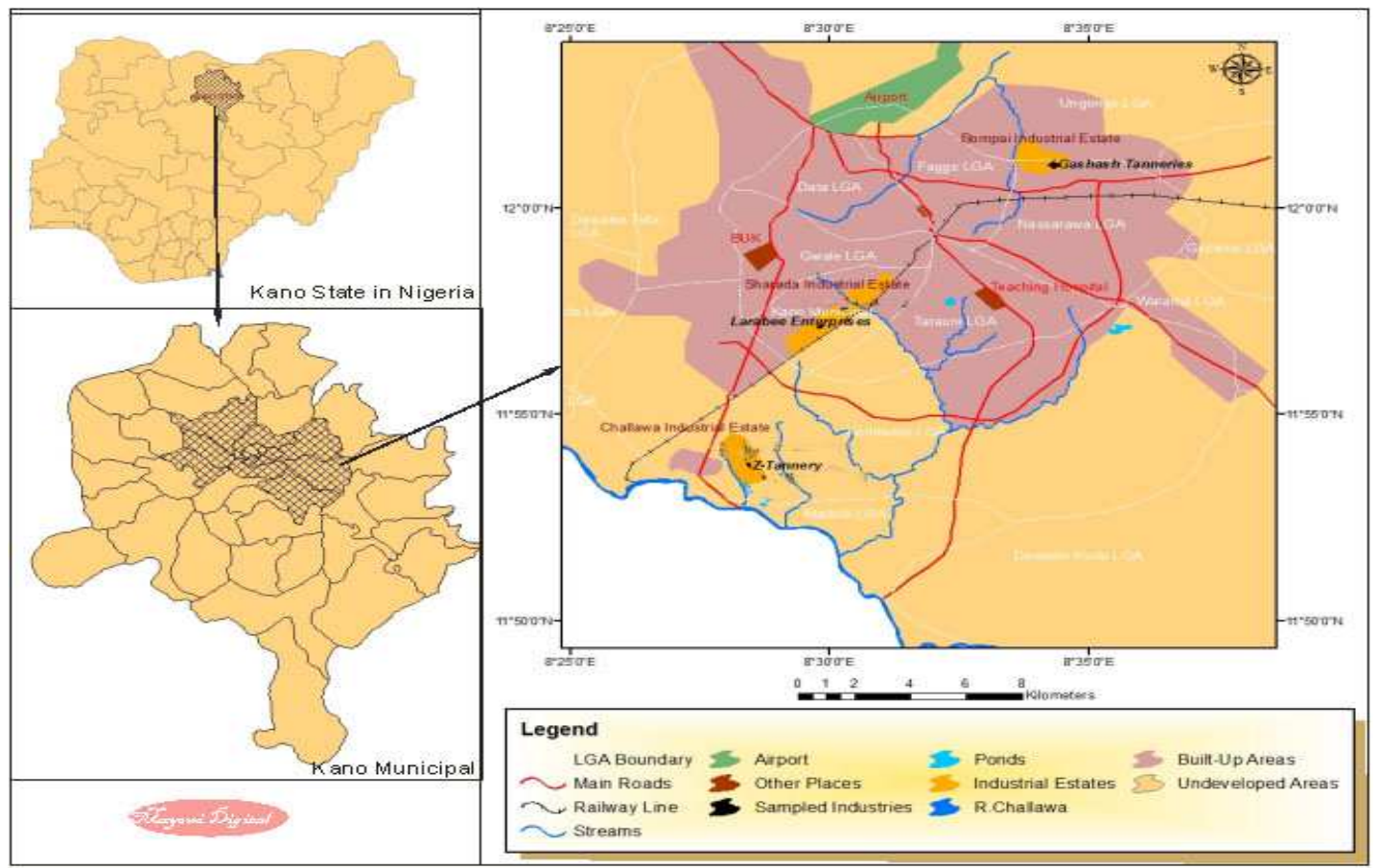

Fig. 1 Map showing the study areas

Source: Mayomi Digital Productions, GIS Laboratory, Department of Geography, UNIMAID (2017)

\section{Determination of Growth Rate of the Bacteria in Effluent Sample}

The bacteria growth rates were determined by transferring $2 \mathrm{~mL}$ of the bacterial isolates from the tannery effluent in broth medium into 100 $\mathrm{mL}$ sterile effluents in conical flasks and kept in an incubator (Giffrin cool) for 10 days. Control was also set up by incubating another $100 \mathrm{~mL}$ each of the sterile effluents without the bacteria. The optical density of the content was determined at the wavelength of $600 \mathrm{~nm}$ on a daily interval and recorded. 
BAJOPAS Volume 13 Number 2, December, 2020 Immobilization of Bacteria

Agar solution and inoculi were prepared separately. Fifty milliliters $(50 \mathrm{~mL})$ of nutrient broth each of the inoculi was prepared in a McCartney bottle and incubated for 24 hours. A solution of agar-agar was prepared by dissolving $10 \mathrm{~g}$ of the powder in distilled water and made up to $500 \mathrm{~mL}$ mark in an Erlenmeyer flask and was sterilized in an autoclave (280A) for 15 minutes and allowed to cool to $40-45^{\circ} \mathrm{C}$ (Ajao et al., 2011). Four milliliters ( $4 \mathrm{~mL})$ of the bacterial isolates in the nutrient broth was mixed with 36 $\mathrm{ml}$ of the prepared agar-agar media in petri-dish plates and then allowed to solidify. This was kept in the refrigerator for bioremediation.

\section{Bioremediation (Treatment) of the Effluents}

The solidified agar block (immobilized bacteria) was cut into cubes using a sterile knife; $0.1 \mathrm{~mL}$ phosphate buffer ( $\mathrm{pH} \mathrm{7.0)}$ was added and kept in the refrigerator for 1 hour for curing. The phosphate buffer was decanted after 1 hour and the cubes were washed with sterile distilled water 3-4 times before it was used (Ajao et al., 2011). Two liters (2 L) of the effluent was supplemented with the minimum basal medium in $\mathrm{g} / \mathrm{L}: \mathrm{NaCl}(0.8), \mathrm{MgSO}_{4} .7 \mathrm{H}_{2} \mathrm{O}(0.001), \mathrm{KH}_{2} \mathrm{PO}_{4}$ (2), $\mathrm{NaNO}_{3}$ (2), $\quad \mathrm{CaCl}_{2} .2 \mathrm{H}_{2} \mathrm{O} \quad(0.5)$ and $\mathrm{NaHPO}_{4} .12 \mathrm{H}_{2} \mathrm{O}(2)$ and sterilized in an autoclave at $121^{\circ} \mathrm{C}$ for 15 minutes (Margesin and Schinner, 2001). Two hundred and fifty milliliters $(250 \mathrm{~mL})$ of the effluents were transferred into different $250 \mathrm{ml}$ conical flasks. The content was covered with a cotton-wool ramped with foil paper to avoid contamination. Five grams $(5 \mathrm{~g})$ of the immobilized bacteria were quickly transferred into each of the effluents in the conical flasks in an inoculating chamber. The same procedures were carried out for the $10 \mathrm{~g}, 15 \mathrm{~g}, 20 \mathrm{~g}$ and 25 $\mathrm{g}$ of the immobilized bacteria in separate $250 \mathrm{~mL}$ effluents in conical flasks and agitated for ten days in a shaker incubator (Gallenkamp-OC4364-L) at a temperature $30^{\circ} \mathrm{C}$ and speed of 60 rpm. The treated effluent samples were taken on the tenth day and analyzed for the parameters $\mathrm{pH}$, SS, TDS, COD, and BOD, (Posttreatment determination) for the different grams of bacteria to evaluate and compare the biodegradation potential. (Baba et al., 2020).

\section{Statistical Analysis}

The data were represented as Mean \pm Standard deviation and analyzed statistically using oneway Analysis of Variance (ANOVA) and Tukey's HSD as Post Hoc Tests with the aid of SPSS 16.0. The correlation coefficient was also used to measure the strength of the relationship between the different masses of the bacteria and the parameters. All $\mathrm{p} \leq 0.05$ were considered as statistically significant.

\section{RESULTS AND DISCUSSION Physico-chemical parameters in the Industrial Effluents before the Biodegradation.}

Results of the Physico-chemical parameters in the industrial effluents before the Biodegradation is shown in table 1 . The mean temperatures $\left({ }^{\circ} \mathrm{C}\right)$ observed in TAN1, TAN2, and TAN3 samples were $28.07 \pm 0.65 ; 27.77 \pm 0.64$ and $26.38 \pm 3.81$ respectively. The order of the mean temperature of the samples from the three industries can be arranged as TAN1 > TAN2>TAN3. The temperature observed at TAN1, TAN2, and TAN3 samples were found below the WHO $\left(35^{\circ} \mathrm{C}\right)$ and NESREA $\left(40^{\circ} \mathrm{C}\right)$ limits. The low values of temperature might be due to the processes used at the time of sampling. High temperature brings down the solubility of gases in water that ultimately expresses as high BOD and COD. Statistical analysis shows that there is no significant difference $(p<0.05)$ between the mean values of temperature among the industries. This might be due to similar tannery activities involved in the tannery industries at the time of sampling. The average values of temperature observed in this present study are less than those observed by Akan et al. (2007), Akan et al. (2009) and Baba et al. (2020).

The mean level of $\mathrm{pH}$ observed in TAN1, TAN2 and TAN3, samples were $7.77 \pm 2.93$; $8.35 \pm 0.28$ and $7.52 \pm 0.76$ respectively. The order of the mean $\mathrm{pH}$ of the samples from the three industries can be arranged as TAN2> TAN1 $>$ TAN3. The $\mathrm{pH}$ of the samples falls within the WHO (7.0-8.5) and NESREA (6-9) standard limits. Statistical analysis shows that there is no significant difference $(p<0.05)$ between the mean values of $\mathrm{pH}$ among the industries. This might be due to similar tannery activities involved in the tannery industries at the time of sampling. Maheshwari et al. (2017) reported that the level of $\mathrm{pH}$ in the effluents from the tannery industry in Vaniyambadi, India was 6.5 which was lower than that observed in the present study. The $\mathrm{pH}$ in the effluents from the tannery industries in Kano and Kaduna were reported to be 7.64 and 6.89, respectively (Akan et al., 2007; Mohammed et al., 2017). The average values of $\mathrm{pH}$ observed in this present study are less than those observed by Mohammed et al. (2017) and Baba et al. (2020). The mean level of SS $(\mathrm{mg} / \mathrm{l})$ observed in TAN1, TAN2, and TAN3 samples were 374 \pm 124 ; $358 \pm 335$ and $780 \pm 739$ respectively. The order of the mean SS in the samples from the three industries can be arranged as TAN3 > TAN1 $>$ TAN2. 
The SS observed in the samples were far above the recommended standard limits of regulating bodies WHO $(30 \mathrm{mg} / \mathrm{l})$ and NESREA $(10 \mathrm{mg} / \mathrm{l})$. Statistical analysis shows that there is no significant difference $(p<0.05)$ between the mean values of SS among the industries. This might be due to similar tannery activities involved in the tannery industries at the time of sampling. The average values of SS observed in this present study are less than that observed $(3700 \pm 122 \mathrm{mg} / \mathrm{l})$ by Akan et al. (2009) for tanneries in Kano. Also, the average values of SS observed in this present study are less than that observed by Mohammed et al. (2017) and Baba et al. (2020) with the exception in TAN3.

The mean level of TDS (mg/l) observed in TAN1, TAN2, and TAN3 samples were $3941 \pm 3703$; $3300 \pm 1714$ and $2653 \pm 1240$ respectively. The order of the mean TDS in the samples from the three industries can be arranged as TAN1>TAN2>TAN3. The TDS observed in the samples were far above the recommended standard limits of WHO $(250 \mathrm{mg} / \mathrm{l})$ and NESREA $(500 \mathrm{mg} / \mathrm{l})$. Statistical analysis shows that there is no significant difference $(p<0.05)$ between the mean values of TDS among the industries. This might be due to similar tannery activities involved in the tannery industries at the time of sampling. TDS in the effluents from the tannery industries in Kano, Nigeria was reported to be $1281 \mathrm{mg} / \mathrm{l}$ (Akan et al., 2007). The average values of SS observed in this present study are less than those observed by Mohammed et al. (2017) and Baba et al. 2020)

The mean level of COD (mg/l) observed in TAN1, TAN2 and TAN3 samples seasons were $2372 \pm 938 ; \quad 1406 \pm 208$ and $3532 \pm 1373$ respectively. The order of the mean COD of the samples from the three industries can be arranged as TAN3>TAN1> TAN2. The COD observed in TAN1, TAN2 and TAN3 samples were far above the recommended standard limits of regulating bodies $\mathrm{WHO}(40 \mathrm{mg} / \mathrm{l})$ and NESREA (40 mg/l). Statistical analysis shows that there is no significant difference $(p<0.05)$ in COD among the industries. This might be due to similar tannery activities involved in the tannery industries as at the time of sampling. The Chemical Oxygen demand (COD) is the amount of oxygen, in $\mathrm{mg} / \mathrm{L}$, required for the degradation of the compound of wastewater to occur. In comparison, the average values of COD observed in this present study were higher than that observed by Mohammed et al. (2017) but lower than that observed by Baba et al. (2020).

The mean levels of BOD $(\mathrm{mg} / \mathrm{l})$ observed in TAN1, TAN2 and TAN3 samples were $13.85 \pm 6.42 ; \quad 19.46 \pm 0.50$ and $17.13 \pm 3.14$ respectively. The order of the mean BOD in the samples from the three industries can be arranged as TAN2>TAN3>TAN1. The BOD observed in TAN1, TAN2 and TAN3 samples were found below the recommended limits of NESREA (200 mg/l) but above WHO (10 mg/l). Statistical analysis shows that there is no significant difference $(p<0.05)$ between the mean values of BOD among the industries. This might be due to similar tannery activities involved in the tannery industries at the time of sampling. The low level of BOD recorded in this study is an indication of the low level of biodegradable organic solids in the effluent. The average values of BOD observed in this present study were lower than those observed by Mohammed et al. (2017) and Baba et al. (2020).

Table 1: Mean Values \pm S.D of Physico-chemical parameters of effluents from the Tannery Industries before Treatment.

\begin{tabular}{llllllll}
\hline Parameter & Tannery 1 & Tannery 2 & Tannery 3 & $\mathrm{a}$ & $\mathrm{b}$ & $\mathrm{c}$ & $\mathrm{d}$ \\
\cline { 2 - 7 } Temperature $\left({ }^{\circ} \mathrm{C}\right)$ & $28.07 \mathrm{a} \pm 0.65$ & $27.77 \mathrm{a} \pm 0.64$ & $26.38 \mathrm{a} \pm 3.81$ & & $29.50 \pm 4.68$ & 35 & 40 \\
pH & $7.77 \mathrm{a} \pm 2.93$ & $8.35 \mathrm{a} \pm 0.28$ & $7.52 \mathrm{a} \pm 0.76$ & 6.89 & $5.35 \pm 1.57$ & $7.0-8.5$ & $6.0-9.0$ \\
$\mathrm{COD}(\mathrm{mg} / \mathrm{l})$ & $2372 \mathrm{a} \pm 938$ & $1406 \mathrm{a} \pm 208$ & $3532 \mathrm{a} \pm 1373$ & 2.2 & $3106 \pm 2753$ & 40 & 40 \\
$\mathrm{BOD}(\mathrm{mg} / \mathrm{l})$ & $13.85 \mathrm{a} \pm 6.42$ & $19.46 \mathrm{a} \pm 0.50$ & $17.13 \mathrm{a} \pm 3.14$ & 1032 & $26.17 \pm 9.49$ & 10 & 200 \\
$\mathrm{SS}(\mathrm{mg} / \mathrm{l})$ & $374 \mathrm{a} \pm 124$ & $358 \mathrm{a} \pm 335$ & $780 \mathrm{a} \pm 739$ & 501 & $562 \pm 482$ & 30 & 10 \\
TDS $(\mathrm{mg} / \mathrm{l})$ & $3941 \mathrm{a} \pm 3703$ & $3300 \mathrm{a} \pm 1714$ & $2653 \mathrm{a} \pm 1240$ & 532.7 & $444 \pm 507$ & 250 & 500 \\
\hline
\end{tabular}

The values given in the table above are means of 6 replicate values, $\mathrm{n}=6$ ( 1 sample was taken monthly for 6 months). Within the rows, means with different alphabets are statistically different $(p<0.05)$. WHO: World Health Organisation. NESREA: National Environmental Standard and Regulatory Enforcement Agency. a = Mohammed et al.(2017), b = Baba et al. (2020), c = WHO (2006), $d=$ NESSRA (2009) 
BAJOPAS Volume 13 Number 2, December, 2020

Identification, Biochemical Characterization and growth rates of the Bacterial Isolates

Results of identification and biochemical characterization of the bacterial isolates were shown in table 2. After 24 hours of incubation, the nutrient agar media plates were checked for bacterial growth. The results showed the presence of different strains in the samples. The TAN1 bacteria isolate was found to be gramnegative cocci while TAN3 was gram-positive cocci. TAN2 bacteria isolate was found to be gram-positive, rod-shaped. TAN1, TAN2, and TAN3 bacteria isolates recorded positive results for spore former.

The results of the biochemical tests indicated that all the bacteria were positive for catalase, oxidase, citrate, maltose, glucose, lactose (negative in TAN1), mannitol (negative in TAN2), starch hydrolysis and coagulase (negative in TAN2) tests. The bacteria showed negative results for nitrate reduction, $M R$ (positive in TAN2), VP (positive in TAN1), Indole (positive in TAN2) tests. Base on the morphological and biochemical test results, TAN1, TAN2, and TAN3 bacteria isolates were identified to be Nesseria spp, Bacillus cereus, and Staphylococcus aureus respectively.

The growth rate of the TAN1, TAN2 and TAN3 Isolates were shown in figure 2. Generally, the optical density increase with the increase in time (day) and decrease as time goes on. The highest optical density was shown by bacillus cereus in TAN2 while the lowest was shown by Staphylococcus aureus in TAN3.

The initial growth phase of TAN1 Isolate bacteria occurred within 2-day of incubation as the growth rate increases up to the 6th-day incubation when the maximum growth was observed. Beyond the 6th day, the growth of the bacteria declined (which might be due to a shortage of nutrients in the effluents) until it reached its death phase (which might be due to the unavailability of nutrients in the effluents).

A similar trend of growth was also observed for TAN2 Isolate as the initial growth phase also occurred within 2-day of incubation but maximum growth rate observed on the 4th day of incubation. The stationary stage occurred between the 4th day and the 8th day. Beyond the 8th day, the growth of the bacteria declined (which might be due to a shortage of nutrients in the effluents) until it reached its death phase (which might be due to the unavailability of nutrients in the effluents).

The initial growth phase of TAN3 bacterial Isolate occurred within the 3-day incubation as the growth rate increases up to the 6th-day incubation when the maximum growth was observed. Beyond the 6th day, the growth of the bacteria declined (which might be due to a shortage of nutrients in the effluents) until it reached its death phase (which might be due to the unavailability of nutrients in the effluents).

Table 2: Morphological and Biochemical characteristics of bacterial isolates

\begin{tabular}{lllll} 
Bacterial Isolates & & TAN1 & TAN2 & TAN3 \\
\hline $\begin{array}{lllll}\text { Morphological } \\
\text { characteristics }\end{array}$ & Shape & Cocci & Rod & Cocci \\
& Spore & & & \\
& former & + & + & + \\
Gram & & & \\
Biochemical characteristics & reaction & - & + & + \\
& Citrate & + & + & + \\
& Catalase & + & + & + \\
& Coagulase & + & - & + \\
Starch & + & + & + \\
& Glucose & + & + & + \\
Oxidase & + & + & + \\
& Indo & - & + & - \\
Lactose & - & + & + \\
Manitol & + & - & + \\
Maltose & + & + & + \\
MR & - & + & - \\
VP & + & - & - \\
& Nitrate & - & - & - \\
Reduction & - Neisseria & Bacillus & Staphylococcus \\
& Bacterial & cereus & aureus \\
& name & spp & cas
\end{tabular}

+ = Positive; - = Negative; MR=Methyl Red; VP= Voges-Proskauer 


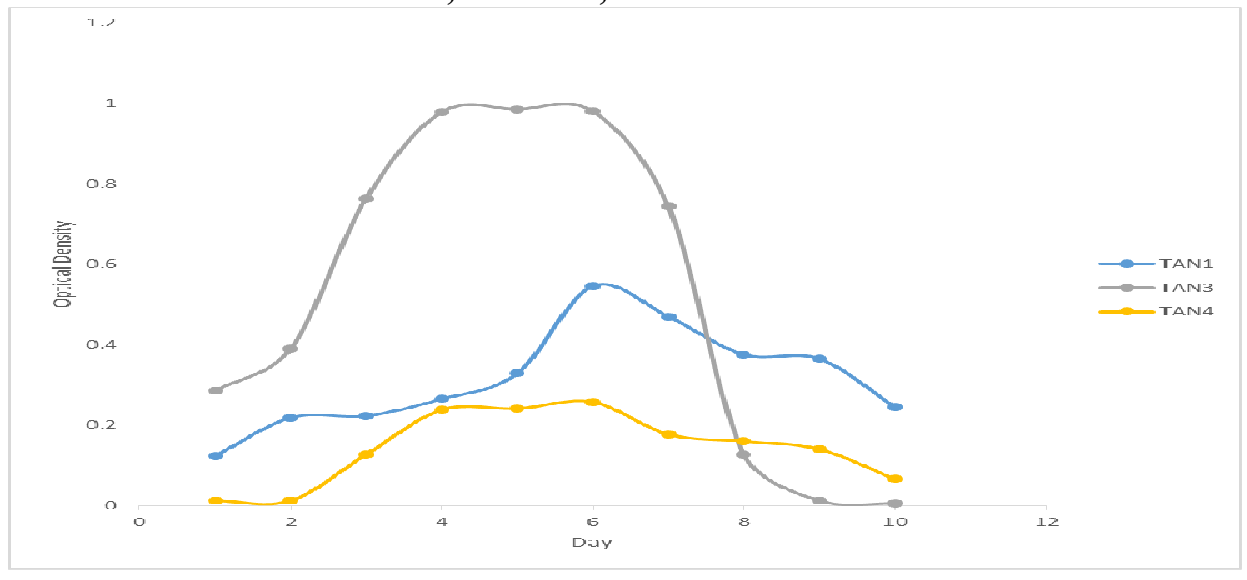

Fig. 2 Growth rates of the isolates in the effluents from the Tannery Industries

\section{Physico-chemical Parameters in the Industrial Effluents after the biodegradation.}

Table 3 shows the mean results of the physicochemical parameter before and after bioremediation using the different masses $(5 \mathrm{~g}$, $10 \mathrm{~g}, 15 \mathrm{~g}, 20 \mathrm{~g}$, and $25 \mathrm{~g}$ ) of the respective immobilized bacteria. Also, Table 4 shows the mean results of correlation coefficient ( $r$ ) between different masses of bacteria and physicochemical parameters.

The mean values $(\mathrm{mg} / \mathrm{l})$ of the SS after the bioremediation varies between $243 \pm 45$ and $898 \pm 672$. The mean concentration $(\mathrm{mg} / \mathrm{l})$ of SS remediated by the different masses $(5 \mathrm{~g}, 10 \mathrm{~g}$, $15 \mathrm{~g}, 20 \mathrm{~g}$, and $25 \mathrm{~g}$ ) of the bacteria varies. The SS in the samples fluctuates up and down after the bioremediation process when compared with the SS of the raw samples before the bioremediation. The increase in the levels of the SS might be due to the aggregation of the TDS which are large enough to result into SS. The increase in the levels of the SS might be also due to the influence of the nutrients which was added into the effluents in order to make the microorganisms more active and viable for fast degradation of organic contaminants in the effluent. The relative potential or efficiency of the different masses of the bacteria in remediating SS in TAN1 samples was in the order $25 \mathrm{~g}>20 \mathrm{~g}>15 \mathrm{~g}>10 \mathrm{~g}>5 \mathrm{~g}$. For TAN2 and TAN3 samples, the order was $25 \mathrm{~g}>20 \mathrm{~g}>15$ $\mathrm{g}>10 \mathrm{~g}>5 \mathrm{~g}$. These might be due to the variations in the surface areas of the different masses of the immobilized bacteria. Statistical analysis shows that there is no significant difference $(p<0.05)$ between the mean values of SS among the masses in the respective industries. Positive and significant correlations exist between the masses of bacteria and Suspended Solid (SS). This showed that there is general increase in the levels of the SS as the masses of the immobilized bacteria increases. TAN3 (90\%) and TAN1 (80\%) showed a very high correlation with the masses of the bacteria while TAN2 (61\%) showed a very low correlation.

The mean values $(\mathrm{mg} / \mathrm{l})$ of the TDS after the bioremediation varies between $46 \pm 11$ and $83 \pm 78$. The mean concentration $(\mathrm{mg} / \mathrm{l})$ of TDS remediated by the different masses $(5 \mathrm{~g}, 10 \mathrm{~g}$, $15 \mathrm{~g}, 20 \mathrm{~g}$, and $25 \mathrm{~g}$ ) of the bacteria varies. There is a reduction in all the TDS of all the samples after the bioremediation process compared with the TDS of the raw samples before the bioremediation. The relative potential or efficiency of the different masses of the bacteria in remediating TDS in TAN1 and TAN3 samples was in the order $5 \mathrm{~g}>10 \mathrm{~g}>15 \mathrm{~g}>20$ $\mathrm{g}>25 \mathrm{~g}$. For TAN2 samples, the order was 20 $g>10 \quad g>25 \quad g>15 \quad g>5 \quad g$. Statistical analysis shows that there is no significant difference $(p<0.05)$ between the mean values of TDS among the masses in the respective industries. These might be due to the variations in the surface areas of the different masses of the immobilized bacteria. Positive and significant correlations exist between the masses of bacteria and TDS with the exception in TAN2 (negative and insignificant correlation). The positive correlations showed that there is general increase in the levels of the TDS as the masses of the immobilized bacteria increases. TAN1 $(96 \%)$ showed a very high correlation with the masses of the bacteria while TAN2 (47\%) showed a very low correlation.

The mean values $(\mathrm{mg} / \mathrm{l})$ of the BOD after the bioremediation varies between $1.56 \pm 0.20 \mathrm{mg} / \mathrm{l}$ and $6.92 \pm 5.49 \mathrm{mg} / \mathrm{l}$. The mean concentration $(\mathrm{mg} / \mathrm{l})$ of BOD remediated by the different masses $(5 \mathrm{~g}, 10 \mathrm{~g}, 15 \mathrm{~g}, 20 \mathrm{~g}$, and $25 \mathrm{~g}$ ) of the bacteria varies. There is a reduction in all the BOD of all the samples after the bioremediation process compared with the $\mathrm{BOD}$ of the raw 
BAJOPAS Volume 13 Number 2, December, 2020 samples before the bioremediation. The relative potential or efficiency of the different masses of the bacteria in remediating BOD in TAN1, TAN2 and TAN3 samples were in the order $25 \mathrm{~g}>20$ $\mathrm{g}>15 \mathrm{~g}>10 \mathrm{~g}>5 \mathrm{~g}, 25 \mathrm{~g}>15 \mathrm{~g}>5 \mathrm{~g}>10 \mathrm{~g}>20 \mathrm{~g}$ and $20 \mathrm{~g}>10 \mathrm{~g}>25 \mathrm{~g}>15 \mathrm{~g}>5 \mathrm{~g}$ respectively. Statistical analysis shows that there is significant difference $(p<0.05)$ between the mean values of BOD among the masses in the respective industries. These might be due to the variations in the surface areas of the different masses of the immobilized bacteria. Negative and significant correlations exist between the masses of bacteria and BOD. This showed that there is general decrease in the levels of the BOD as the masses of the immobilized bacteria increases. TAN1 (94\%) showed a very high correlation with the masses of the bacteria while TAN2 (4\%) showed a very low correlation.

The mean values $(\mathrm{mg} / \mathrm{l})$ of the COD after the bioremediation varies between $250 \pm 154$ and $3134 \pm 1595$. The mean concentration $(\mathrm{mg} / \mathrm{l})$ of COD remediated by the different masses $(5 \mathrm{~g}$, $10 \mathrm{~g}, 15 \mathrm{~g} 20 \mathrm{~g}$, and $25 \mathrm{~g}$ ) of the bacteria varies. There is a reduction in all the COD of all the samples after the bioremediation process compared with the COD of the raw samples before the bioremediation. The relative potential or efficiency of the different masses of the bacteria in remediating COD in TAN1, TAN2 and TAN3 samples were in the order $25 \mathrm{~g}>20 \mathrm{~g}>15$ $\mathrm{g}>5 \mathrm{~g}>10 \mathrm{~g}, 25 \mathrm{~g}>20 \mathrm{~g}>15 \mathrm{~g}>10 \mathrm{~g}>5 \mathrm{~g}$ and 10 g>5 g>25 g>15 g>20 g respectively. Statistical analysis shows that there were significant difference $(p<0.05)$ between the mean values of COD among the masses in the respective industries except for effluents treated with $25 \mathrm{~g}$. These might be due to the variations in the surface areas of the different masses of the immobilized bacteria. Negative and insignificant correlations exist between the masses of bacteria and COD with the exception in TAN3 (positive and significant correlation). The negative correlations showed that there is general decrease in the levels of the COD as the masses of the immobilized bacteria increases. TAN2 (100\%) showed a very high correlation with the masses of the bacteria while TAN3 (36\%) showed a very low correlation.

Generally, there was an overall decrease in the concentration of these physicochemical parameters after the bioremediation using the different masses of the bacterial isolates. These might be due to the variations in the surface areas of the different masses of the immobilized bacteria. This is in line with the work of Jimoh et al. (2018) and Baba et al. (2020).

Table 3: Mean Values $(\mathrm{mg} / \mathrm{l}) \pm$ S.D of Physicochemical parameters in effluents from the Tannery Industries before and after Treatment of the effluents $(250 \mathrm{ml})$ with the different masses $(5 \mathrm{~g}, 10 \mathrm{~g}$, $15 \mathrm{~g}, 20 \mathrm{~g}$, and $25 \mathrm{~g}$ ) of the bacteria.

\begin{tabular}{llllllll}
\hline $\mathrm{P}$ & IND & Before & \multicolumn{5}{c}{ After } \\
\cline { 4 - 7 } & & & $5 \mathrm{~g}$ & $10 \mathrm{~g}$ & $15 \mathrm{~g}$ & $20 \mathrm{~g}$ & $25 \mathrm{~g}$ \\
\hline \multirow{2}{*}{ COD } & TAN1 & $2372 \pm 938$ & $1708 \mathrm{a} \pm 861$ & $2045 \mathrm{a} \pm 1205$ & $845 \mathrm{a} \pm 369$ & $300 \mathrm{a} \pm 167$ & $250 \mathrm{a} \pm 154$ \\
& TAN2 & $1406 \pm 208$ & $1195 \mathrm{a} \pm 208$ & $1125 \mathrm{a} \pm 384$ & $1055 \mathrm{a} \pm 317$ & $956 \mathrm{a} \pm 310$ & $870 \mathrm{ab} \pm 240$ \\
& TAN3 & $3532 \pm 1373$ & $2374 \mathrm{a} \pm 1344$ & $1976 \mathrm{a} \pm 1405$ & $2757 \mathrm{a} \pm 1266$ & $3134 \mathrm{a} \pm 1595$ & $2614 \mathrm{~b} \pm 1105$ \\
BOD & TAN1 & $13.85 \pm 6.42$ & $6.92 \mathrm{a} \pm 5.49$ & $6.42 \mathrm{a} \pm 5.07$ & $5.72 \mathrm{a} \pm 5.35$ & $4.62 \mathrm{a} \pm 4.37$ & $2.82 \mathrm{ab} \pm 1.26$ \\
& TAN2 & $19.46 \pm 0.50$ & $1.75 \mathrm{~b} \pm 0.22$ & $1.73 \mathrm{~b} \pm 0.18$ & $1.58 \mathrm{a} \pm 0.16$ & $1.91 \mathrm{a} \pm 0.22$ & $1.56 \mathrm{~b} \pm 0.20$ \\
& TAN3 & $17.13 \pm 3.14$ & $4.24 \mathrm{ab} \pm 0.77$ & $3.29 \mathrm{ab} \pm 0.37$ & $4.11 \mathrm{a} \pm 0.07$ & $3.23 \mathrm{a} \pm 0.91$ & $3.33 \mathrm{a} \pm 1.28$ \\
SS & TAN1 & $374 \pm 124$ & $243 \mathrm{a} \pm 45$ & $471 \mathrm{a} \pm 226$ & $475 \mathrm{a} \pm 182$ & $492 \mathrm{a} \pm 128$ & $611 \mathrm{a} \pm 217$ \\
& TAN2 & $358 \pm 335$ & $460 \mathrm{a} \pm 400$ & $543 \mathrm{a} \pm 414$ & $544 \mathrm{a} \pm 402$ & $551 \mathrm{a} \pm 414$ & $554 \mathrm{a} \pm 405$ \\
& TAN3 & $780 \pm 739$ & $586 \mathrm{a} \pm 594$ & $758 \mathrm{a} \pm 656$ & $787 \mathrm{a} \pm 676$ & $861 \mathrm{a} \pm 635$ & $898 \mathrm{a} \pm 672$ \\
TDS & TAN1 & $3941 \pm 3703$ & $51 \mathrm{a} \pm 10$ & $53 \mathrm{a} \pm 10$ & $55 \mathrm{a} \pm 15$ & $61 \mathrm{a} \pm 20$ & $63 \mathrm{a} \pm 26$ \\
& TAN2 & $3300 \pm 1714$ & $83 \mathrm{a} \pm 78$ & $47 \mathrm{a} \pm 20$ & $48 \mathrm{a} \pm 22$ & $47 \mathrm{a} \pm 17$ & $48 \mathrm{a} \pm 17$ \\
& TAN3 & $2653 \pm 1240$ & $46 \mathrm{a} \pm 11$ & $55 \mathrm{a} \pm 24$ & $55 \mathrm{a} \pm 25$ & $58 \mathrm{a} \pm 23$ & $61 \mathrm{a} \pm 28$ \\
\hline
\end{tabular}

Replicate $=6$ (months)

Within the rows, for the same parameter, means with different alphabets are statistically different $(p<0.05)$.

$\mathrm{P}=$ parameter, IND = Industries 
BAJOPAS Volume 13 Number 2, December, 2020

Table 4: Correlation coefficient $(r)$ between different masses of the bacteria and the physicochemical parameters.

\begin{tabular}{llll}
\hline Industries & Parameter & Correlation coefficient $(r)$ & $\begin{array}{l}\text { Percent dependence (rxrx100) } \\
(\%)\end{array}$ \\
\hline TAN1 & COD & -0.9 & 82 \\
& BOD & -0.97 & 94 \\
& SS & $0.90^{*}$ & 80 \\
TAN2 & TDS & $0.98^{*}$ & 96 \\
& COD & -1 & 100 \\
& BOD & -0.21 & 4 \\
& SS & $0.78^{*}$ & 61 \\
& TDS & -0.69 & 47 \\
& COD & $0.60^{*}$ & 36 \\
& BOD & -0.6 & 37 \\
& SS & $0.95^{*}$ & 90 \\
& TDS & $0.94^{*}$ & 89 \\
\hline
\end{tabular}

The correlation coefficient $(r)$ with * is statistically significant $(p<0.05)$.

Percentage reduction of the Parameters

Table 5 shows the percentage reduction of Parameters in industrial samples before and after the treatment of the effluents $(250 \mathrm{ml})$ with the different masses $(5 \mathrm{~g}, 10 \mathrm{~g}, 15 \mathrm{~g}, 20 \mathrm{~g}$, and $25 \mathrm{~g}$ ) of the Immobilized Bacteria.

In TAN1 samples, the percentage reduction (\%) of COD ranged (14-89); BOD (50-80); SS (-32$35)$ and TDS (98-99). In TAN2 samples, the percentage decrease $(\%)$ of COD ranged (15$38) ;$ BOD (90-92); SS [-28-(-55)] and TDS (9798). In TAN3 samples, the percentage decrease (\%) of COD ranged (11-44); BOD (76-81); SS (15-25) and TDS (98). The percentage increase in the levels COD, BOD and TDS might be due to the increase in the surface area of the different masses of the immobilized bacteria. However, the percentage decrease in the levels of the SS might be due to the aggregation of the TDS which are large enough to result into SS. The percentage decrease in the levels of the SS might be also due to the influence of the nutrients which was added into the effluents in order to make the microorganisms more active and viable for fast degradation of organic contaminants in the effluent. This is in line with the work of Jimoh et al. (2018) in which the concentration of the SS increase after the bioremediation of effluents.

Sreemoyee and Priti (2013) assessed and reduced several Physico-chemical parameters of dairy wastewater using Niesseria $s p$. and concluded that the species are well known to degrade organic compounds. This is in agreement with the current study in which the immobilized Niesseria $s p$ degrade the organic contaminants as indicated by the BOD, COD and TDS.

Jimoh et al. (2018) observed that TSS of the effluents was increased after treatment with immobilized bacteria and concluded that it might be due to the biostimulation method adopted for the research.

The optimum $\mathrm{pH}$ Biosorption of Chromium by Bacillus spp and Staphylococcus spp. from tannery effluent was investigated by Mythili and Karthikeyan (2011). The maximum adsorption of Chromium $(86.4 \mathrm{mg} / \mathrm{L})$ was showed by Bacillus spp and Staphylococcus spp showed $70.6 \mathrm{mg} / \mathrm{L}$ at an initial concentration of $100 \mathrm{mg} / \mathrm{L}$. In the present study, immobilised Bacillus spp and Staphylococcus spp. from the tannery industrial effluents reduced the levels of the organic pollutants with high potential as indicated by the percentage reduction of BOD, COD and TDS.

Enzymes often can work in multiple environments especially if they are immobilized. This makes the microorganisms' enzymes even more resistant to harsh environments and enables the enzymes to be recovered and recycled after they are no longer needed (Gianfreda and Rao 2004). Ramesh and Singh (1993) reported that the immobilized bacteria having more efficiency to remove the suspended particles than free cells. Using the immobilized cell is preferable due to its capability for using several times with the same efficiency, which makes it more economical. Similar work was done by Sikander et al. (2007) showing the higher reduction with permeabilized cells of Ochrobactrum intermedium strain SDCr-5. 
BAJOPAS Volume 13 Number 2, December, 2020

The results revealed the isolation and identification of isolates with the potential for the reduction of $\mathrm{Cr}$ (VI) to $\mathrm{Cr}$ (III). Results indicated that immobilized $B$. cereus could be efficiently used for the reduction of $\mathrm{Cr}$ (VI).

Table 5: Percentage reduction of the tested Parameters from the tannery industrial samples of the Immobilized Bacteria.

\begin{tabular}{lllllll}
\hline \multirow{2}{*}{ Industries } & & \multicolumn{5}{c}{ Percentage Reduction $(\%)$} \\
\cline { 3 - 7 } & & $5 \mathrm{~g}$ & $10 \mathrm{~g}$ & $15 \mathrm{~g}$ & $20 \mathrm{~g}$ & $25 \mathrm{~g}$ \\
\hline TAN1 & COD & 28 & 14 & 64 & 87 & 89 \\
& BOD & 50 & 54 & 59 & 67 & 80 \\
& SS & 35 & -26 & -27 & -32 & -63 \\
& TDS & 99 & 99 & 99 & 98 & 98 \\
TAN2 & COD & 15 & 20 & 25 & 32 & 38 \\
& BOD & 91 & 91 & 92 & 90 & 92 \\
& SS & -28 & -52 & -52 & -54 & -55 \\
& TDS & 97 & 99 & 99 & 99 & 99 \\
& COD & 33 & 44 & 22 & 11 & 26 \\
& BOD & 75 & 81 & 76 & 81 & 81 \\
& SS & 25 & 3 & -1 & -10 & -15 \\
& TDS & 98 & 98 & 98 & 98 & 98 \\
\hline
\end{tabular}

Percentage Reduction $=(B-A) / B \times 100 \%$

$A=$ Concentration of the parameter after treatment

$\mathrm{B}=$ Concentration of the parameter before treatment

$+=$ percentage decrease

- = percentage increase

In general, immobilization makes the enzyme more resistant to temperature, $\mathrm{pH}$, and substrate concentration swings giving it a longer lifetime and higher productivity per active unit (Gianfreda and Rao, 2004; FuIlbrook, 1996; Russell et al, 2003; Kandelbauer et al., 2004). Immobilized cells have been used and studied extensively for the production of useful chemicals (Ohtake and Silver, 1994), the treatment of wastewaters (Chen et al., 2003; Wang et al., 2010). Although many workers described microbial degradation of tannery effluent, limited literature is available on the bioremediation of tannery effluent using immobilized bacterial cells in the Kano Industrial Estates.

\section{CONCLUSION}

The samples contained variable levels of the physicochemical parameters. The results of the Analysis of variance revealed that, no statistical difference $(p<0.05)$ was observed for the temperature, $\mathrm{pH}, \mathrm{SS}, \mathrm{TDS}, \mathrm{BOD}$ and $\mathrm{COD}$ among the three tannery industries before the treatment. The levels of some of the parameters
(SS, TDS and COD) observed in the samples were found above the recommended limits of WHO and NESREA, which called for the treatment of the effluents before discharge into the environment. Base on the morphological and biochemical test results, TAN1, TAN2, and TAN3 bacterial isolates were identified to be Neisseria spp, Bacillus cereus, and Staphylococcus aureus respectively. The results of Post-treatment analysis showed that there is overall decrease in the levels of the parameters determined when compared with that of the pre-treatment. The overall percentage reduction of the immobilised bacteria in the treatment of the respective effluents was in the order TAN2 (72\%)>TAN1 $(70 \%)>$ TAN3 $(62 \%)$. Hence, the immobilized bacteria are having higher biodegradation potential for the treatment of the tannery effluents.

\section{Acknowledgments}

The authors wish to acknowledge the University of Maiduguri for the financial support. The authors are grateful to the Kano State Ministry of Environment for their support in obtaining the effluent samples. 


\section{REFERENCES}

Ajao, A. T., Adebayo, G. B., and Yakubu, S. E. (2011). Bioremediation of textile industrial effluent using mixed culture of Pseudomonas aeruginosa and Bacillus subtilis immobilized on agar-agar in a bioreactor. J. Microbiol. Biotech. Res, 1(3), 50-56.

Akan, J. C., Moses, E. A., Ogugbuaja, V. O., and Abah, J. (2007). Assessment of tannery industrial effluents from Kano metropolis, Kano State, Nigeria. Journal of Applied Sciences, 7(19), 2788-2793.

Akan, J. C., Ogugbuaja, V. O., Abdulrahman, F. I., and Ayodele, J. T. (2009). Pollutant levels in effluent samples from tanneries and textiles of Kano industrial areas, Nigeria. Global journal of pure and applied sciences, 15(3-4).

APHA (1989). Standard methods for Examination of Will bete and Will betewater.15 $5^{\text {th }}$ edition. Brydpass Springfield Will behington DC. pp. 164-176

APHA (1992). Standard Methods for the Examination of Water and Wastewater. Health, 69, 1116-9.

Baba, A., Garba, S. T., and Bello, H. S. (2020). Bioremediation Potential of Immobilized corynebacterium kutsceri in the Treatment of Tannery Industrial Effluent from Challawa Industrial Estate, Kano State, Nigeria. Journal of the Turkish Chemical Society Section A: Chemistry, $7(2), 335-350$.

Beem, E. I. V. (1994). reduction of solvent VOC emission. J. Oil Col. Chem. Ass, 77, 158.

Bouwer, E. J., and Zehnder, A. J. (1993). Bioremediation of organic compoundsputting microbial metabolism to work. Trends in biotechnology, 11(8), 360367.

Chen, K. C., Wu, J. Y., Liou, D. J., and Hwang, S. C. J. (2003). Decolorization of the textile dyes by newly isolated bacterial strains. Journal of Biotechnology, 101(1), 57-68.

Dan'Azumi, S., and Bichi, M. H. (2010). INDUSTRIAL POLLUTION AND HEAVY METALS PROFILE OF CHALLAWA RIVER IN KANO, NIGERIA. Journal of Applied Sciences in Environmental Sanitation, $5(1)$.

DWAF. (1992). Analytical Methods Manual, TR 151. Department of Water Affairs and Forestry, Pretoria.

El-Bestawy, E. (2013). Biological treatment of leather-tanning industrial wastewater using free living bacteria.
Elsheikh, M. A. S. (2009). Tannery wastewater pre-treatment. Water Science and Technology, 60(2), 433-440.

FuIlbrook, P. D. (1996). "Kinetics." Industrial enzymology: The application of enzymes in Industry. 2nd Ed. T. Godfrey and J Reichelt. eds.. Nature. New York.

Gianfreda, L., and Rao, M. A. (2004). Potential of extra cellular enzymes in remediation of polluted soils: a review. Enzyme and microbial technology, 35(4), 339354.

Hugo Springer. (1994). John Arthur Wilson Memorial Lecture "Treatment of Industrial Wastes of the Leather Industry - is it still a Major Problem". JALCA, 89, 153-185

Jimoh, A. A., Ganiyu, B. A., Baba, D., and Baba, A. (2018) Bioremediation Process of Effluent from Detergent and Food Industries in Jos, Nigeria: Kinetics and Thermodynamics. International Journal of Engineering Science Invention (IJESI), 762-73

Kandelbauer, A., Maute, O., Kessler, R. W., Erlacher, A., and Gübitz, G. M. (2004). Study of dye decolorization in an immobilized laccase enzyme-reactor using online spectroscopy. Biotechnology and bioengineering, 87(4), 552-563.

Kongjao, S., Damronglerd, S., and Hunsom, M. (2008). Simultaneous removal of organic and inorganic Pollutants in tannery wastewater using electrocoagulation technique. Korean Journal of chemical engineering, 25(4), 703.

Maheshwari, U. M., Aruna, S., Gomathi, M., and AbdulJaffar, A. H. (2017). Bioremediation by Free and Immobilized Bacteria Isolated from Tannery Effluent. International Journal of Research in Applied, Natural and Social Sciences. 5(7), 75-90

Margesin, R., and Schinner, F. (2001). Bioremediation (natural attenuation and biostimulation) of diesel-oilcontaminated soil in an alpine glacier skiing area. Applied and environmental microbiology, 677), 3127-3133.

Mohammed, A., Sekar, P., and George, J. (2011). Efficacy of microbes in bioremediation of tannery effluent. Inter. J. Curr. Res, 3(4), 324-326.

Mohammed, S. S. D., Orukotan, A. A., and Abdullahi, H. (2017). Physicochemical and Bacteriological Assessment of Tannery Effluent from Samaru-Zaria, 
BAJOPAS Volume 13 Number 2, December, 2020 Kaduna State, Nigeria. Journal of Applied

Sciences and Environmental Management, 21(4), 734-740.

Munz, G., De Angelis, D., Gori, R., Mori, G., Casarci, M., and Lubello, C. (2009). The role of tannins in conventional and membrane treatment of tannery wastewater. Journal of hazardous materials, 164(2-3), 733-739

Mythili, K., and Karthikeyan, B. (2011). Bioremediation of $\mathrm{Cr}$ (VI) from tannery effluent using Bacillus spp and Staphylococcus spp. International Multidisciplinary Research Journal, 1(6).

NESREA (2009). National Environmental Standards for Effluent Limitations and Regulation. 1233-1236

Noorjahan, C. M. (2014). Physicochemical characteristics, identification of bacteria and biodegradation of industrial effluent. Journal of bioremediation and Biodegradation, 5(3).

Ohtake, H. I., and Silver, A. O. (1994). Bacterial reduction of toxic chromate. Biological degradation and bioremediation of toxic chemicals, 403-415.

Omoleke, I. I. (2004). Management of environmental pollution in Ibadan, an African city: the challenges of health hazard facing government and the people. Journal of Human Ecology, 15(4), 265-275.

Rajor, A., Reddy, A.S., and Singh, B. (2004). Determination of BOD kinetic Parameters and evaluation of alternate methods, M.Sc. Thesis, Department of biotechnology \& environmental Science, Thapar Institute of Engineering and Technology, Patiala

Ramasami, T., Rajamani, S., and Rao, J. R. (1994, March). Pollution control in leather industry: Emerging technological options. In International symposium on surface and colloidal science and its relevance to soil pollution, madras.

Ramesh, J. V. S., and Singh, S. P. (1993). Yearly variation in certain physicochemical parameters of pond at eastern Doon Valley. Uttar Pradesh J. Zoo, 12 (1), 7577.

Ranen, S., and Sharadinadra, C. (2009). Biotechnology applications to environmental remediation in resource exploitation. Current science, 97, 6-25
Russell, A. J., Berberich, J. A., Drevon, G. F., and Koepsel, R. R. (2003). Biomaterials for mediation of

chemical and biological warfare agents. Annual review of biomedical engineering, 5(1), 1-27.

Saravanan, P., and Saravanan, A. (1999). Decolourization of tannery effluent by Flavobacterium sp. EK 1. Indian Journal of Environmental Protection, 19, 19-24.

Sikander, S., and Shahida, H. (2007). Reduction of toxic hexavalent chromium by Ochrobactrum intermedium strain SDCr5 stimulated by heavy metals. Bioresource Technol, 98, 340-344.

Singh, N., Sharma, B. K., and Bohra, P. C. (2000). Impact assessment of industrial effluent of arid soils by using satellite imageries. Journal of the Indian Society of Remote Sensing, 28(2-3), 79.

Sreemoyee, C., and Priti, P. (2013). Assessment of physico-chemical parameters of dairy waste water and isolation and characterization of bacterial strains in terms of cod reduction. Int J Sci, 2(3), 395-400.

Verheijen, L. A. H. M., Wiersema, D., Pol, L. H., and De Wit, J. (1996). Management of wastes from animal product processing. Livestock and environment, Finding a balance. International Agriculture Center, Wageningen, The Netherlands.

Wang, F., Yao, J., Si, Y., Chen, H., Russel, M., Chen, K., and Bramanti, E. (2010). Short-time effect of heavy metals upon microbial community activity. Journal of Hazardous Materials, 173(13), 510-516.

WHO (World Health Organization). (2006). Air quality guidelines: global update 2005: particulate matter, ozone, nitrogen dioxide, and sulfur dioxide. World Health Organization.

World Bank. (1995). Nigeria's strategic options for redressing industrial pollution. World Bank, industry and energy division. 1st edition, West Central Africa Department; Annexes: 1995; pp 60-62.

Zahoor, A., and Abdul, R. (2009). Enumeration of Coliforms. Journal of Environmental Sciences. 21, 814-820 


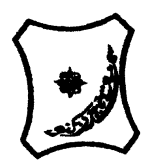

Bayero Journal of Pure and Applied Sciences, 13(2): 1 - 12

Received: November, 2020

Accepted: December, 2020

ISSN $2006-6996$

\title{
BIODEGRADATION POTENTIAL OF IMMOBILIZED BACTERIA IN THE TREATMENT OF TANNERY INDUSTRIAL EFFLUENTS FROM INDUSTRIAL ESTATES IN KANO STATE, NIGERIA
}

\author{
Abdullateef, B., ${ }^{1 *}$ Shuaibu, T. G., ${ }^{1}$ Babagana, K., ${ }^{1}$ Suleman, H. B. ${ }^{2}$ and Dauda, B. ${ }^{3}$ \\ ${ }^{1}$ Department of Pure and Applied Chemistry, Faculty of Science, University of Maiduguri, Borno State, \\ Nigeria \\ ${ }^{2}$ Department of Microbiology, Faculty of Science, University of Maiduguri, Borno State, Nigeria \\ ${ }^{3}$ Department of Chemical Engineering, Faculty of Engineering, University of Maiduguri, Borno State, \\ Nigeria \\ *Corresponding author: babslega@gmail.com; abelega2007@yahoo.com; +2348061309753
}

\section{ABSTRACT}

Industrial Effluents Samples from Gashash Tanneries (TAN1) in Bompai Industrial estate, Larabee Tannery Industry (TAN2) in Sharada Industrial estate and Z Tannery Industries (TAN3) in Challawa Industrial estate, Kano State, Nigeria were collected over a period of six months (August 2017 to January 2018) for assessing the biodegradation potentials of bacteria in the treatment of organic pollutants within the effluents. Bacteria were isolated from the effluents and immobilized on agar-agar. Different masses (5 g, $10 \mathrm{gr}, 15$ $\mathrm{g}, 20 \mathrm{~g}$, and $25 \mathrm{~g}$ ) of the bacteria were used in the treatment of $250 \mathrm{ml}$ of the effluents for ten days in a shaker incubator (Gallenkamp-OC-4364-L) at the temperature $30{ }^{\circ} \mathrm{C}$ and speed of $60 \mathrm{rpm}$. Pre-treatment analysis of the effluents for Temperature, pH, Biochemical Oxygen Demand (BOD), Chemical Oxygen Demand (COD), Suspended Solid (SS) and Total Dissolved Solids (TDS) gives the following results; temperature $\left({ }^{\circ} \mathrm{C}\right.$ )

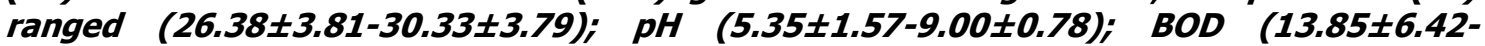
$38.75 \pm 16.20) ;$ COD (1406 $\pm 208-3532 \pm 1373) ;$ SS (208 $\pm 235-780 \pm 739)$ and TDS (266 $\pm 253-5276 \pm 2971)$. No statistical differences ( $p \leq 0.05)$ was observed for all the results among the different industries. The bacterial isolates were identified as Neisseria spp, Bacillus cereus, and Staphylococcus aureus, in TAN1, TAN2, and TAN3, respectively. After treatment of the effluent with the different masses of the isolated bacteria, the mean level of BOD was found to range as (0.55 $\pm 0.36-6.92 \pm 5.49) ; C O D$ (ND-3134 \pm 1595$)$;

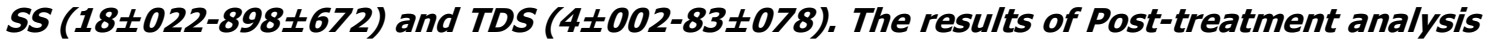
showed that there is overall decrease in the levels of the parameters determined when compared with that of the pre-treatment. The overall percentage reduction of the immobilised bacteria in the treatment of the respective effluents was in the order TAN2 (72\%)>TAN1 (70\%)>TAN3 (62\%). Hence, the immobilized bacteria are having higher biodegradation potential for the treatment of the tannery effluents.

Keywords: Biodegradation, bacteria, effluent, immobilization, tannery.

\section{INTRODUCTION}

Tannery industrial wastewater is a serious consequence of the pollution point of view for streams, freshwater, and land used for agriculture. The lack of awareness in the modern industrial practice has resulted in the discharge of tannery effluents which exhibit very high value of chromium ( $\mathrm{Cr}$ ), Sulfide, and chloride, Total Dissolved Solid (TDS), Total Suspended Solid (TSS), Biochemical Oxygen Demand (BOD) and Chemical Oxygen Demand (COD) in the water stream or land (Mohammed et al., 2001). Tanning is the process, which One ton of skin generally leads to the production of 20 to $80 \mathrm{~m}^{3}$ of turbid and foul-smelling converts the protein of the rawhide or skin into a stable material, which will not putrefy and is suitable for a wide variety of end applications (Elsheikh, 2009). The highly polluting chromium is the most commonly used tanning material producing leather that is more flexible and pliable than vegetable-tanned leather and does not discolor or lose shape in water as drastically as vegetable-tan (Elsheikh, 2009). Tannery effluent is among the most hazardous industrial pollutants due to its huge organic and inorganic load, which is highly toxic to human life and the environment (Kongjao et al., 2008). wastewater including chromium (100-400 mg/l), sulfide $(200-800 \mathrm{mg} / \mathrm{l})$, high levels of fat and 
BAJOPAS Volume 13 Number 2, December, 2020 other solid wastes, and notable pathogen contamination as well as pesticides added for skin conservation during transport (Elsheikh, 2009). There are more than 6000 tanneries in Nigeria with an annual processing capacity of 700,000 tons of hides and skins (Omoleke, 2004; Singh et al., 2008). It was reported that the total amount of waste produced per animal slaughtered is approximately $35 \%$ of its weight (World Bank, 1995). Also, for every $1000 \mathrm{~kg}$ of carcass weight, a slaughtered beef produces 5.5 $\mathrm{kg}$ of manure (excluding rumen contents or stockyard manure) and $100 \mathrm{~kg}$ of paunch manure (undigested food) (Verheijen et al., 1996). Tanneries generate wastewater in the range of 30-35 $\mathrm{L} \mathrm{kg}^{-1}$ skin/hide processed with variable $\mathrm{pH}$, Biological Oxygen Demand (BOD), Chemical Oxygen Demand (COD), high concentrations of suspended solids (SS), and tannins as well as chromium (Zahoor and Abdul, 2009).

Being heterogeneous and composed of a wide variety of compounds, it is very difficult to select a unique direct method for estimating the biodegradability of organic contents and biokinetic parameters for a wastewater sample (Rajor, 2004). For this purpose, some indirect estimation such as determination of biochemical oxygen demand (BOD) and chemical oxygen demand (COD) are applied as common laboratory investigations [9]. During retanning procedures, synthetic tannins (Syntan), oils and resins are added to form softer leather at varying doses (Munz et al., 2009). One of the refractory groups of chemicals in tannery effluents derives mainly from tannins (Ramasami et al., 2004). Syntans are characterized by complex chemical structures, because they are composed of an extended set of chemicals such as phenol-, naphthalene-, formaldehyde- and melamine-based syntans, and acrylic resins (Beem, 1994). Organic pollutants (proteic and lipidic components) are originated from skins (it is calculated that the raw skin has $30 \%$ loss of organic material during the working cycle) or they are introduced during processes (Hugo Springer, 1994).

Many conventional processes such as oxidation, chemical and biological processes were carried out to treat tanneries wastewater (Ebtesam et al, 2013). Biological processes have received more attention because of their costeffectiveness, lower sludge production and environmental friendliness (Noorjahan, 2014). Naturally occurring micro-organisms degrade the hazardous organic wastes including xenobiotic compounds, such as pesticides, polycyclic aromatic hydrocarbons (PAHs) and polychlorinated biphenyls (PCBs) in due course of time (Ranen and Sharadinadra, 2009). Bioremediation is based on the idea that all organisms remove substances from the environment to carry outgrowth and metabolism (Bouwer and Zehnder, 1993). Bacteria, protista and fungi are found to be very good at degrading complex molecules and incorporating the breakdown products into their metabolism (Bouwer and Zehnder, 1993). The resultant metabolic wastes that they produce are generally safe and somehow recycled into other organisms (Ranen and Sharadinadra, 2009). An acclimatized indigenous population of microorganisms capable of degradation of the compounds of interest must exist at the site for a successful bioremediation mode (Ranen and Sharadinadra, 2009). It has been observed that for a successful bioremediation mode, an acclimatized indigenous population of microorganisms capable of degradation of the compounds of interest must exist at the site under investigation (Ranen and Sharadinadra, 2009). Even though there are numerous physical and chemical methods employed in the disposal of wastes the advantage in using bacterium is that they play a key role in the reduction of COD, BOD, total protein, total tannin and total phenol (Saravanan and Saravanan, 1998)

Baba et al. (2020) studied the bioremediation potential of immobilized corynebacterium kutsceri in the Treatment of tannery industrial effluent from Challawa Industrial Estate, Kano State, Nigeria. The aim of the work is to study the reduction in the level of the contaminants through the process of bioremediation using the isolated bacteria. Immobilized bacteria can withstand various temperatures, $\mathrm{pH}$ and substrate concentrations; consequently, increasing the efficiency and the lifespan of the bacteria. Immobilized bacteria are widely applied in the treatment of wastewater and can be separated and recovered after the treatment with the same efficiency (Baba et al., 2020).

\section{MATERIALS AND METHODS \\ Study Area}

This study was carried out in Bompai, Sharada and Challawa industrial estates in Kano, Figure 1. Kano lies on Latitude $11^{\circ} 30^{\prime} \mathrm{N}$ and $8^{\circ} 30^{\prime} \mathrm{E}$ and Longitude $11^{\circ} 5^{\prime} \mathrm{N}$ and $8^{\circ} 5^{\prime} \mathrm{E}$ in Northern Nigeria. It is one of the developed industrial cities in Nigeria. Tannery activities are the dominating industries and this could be one of the reasons for her high population density (Dan'Azumi and Bichi, 2010). Many researchers have studied biodegradation of tannery effluent using microorganisms. However, limited literature is available on the biodegradation of tannery effluent in Kano industrial estates using 
BAJOPAS Volume 13 Number 2, December, 2020 immobilized bacterial cells. This research work focuses on the potential of the use of the indigenous immobilized bacterial isolates in the treatment of tannery effluents in the industrial estates.

\section{Sample Collection}

Effluents were collected from the Tannery Industries from Bompai, Challawa and Sharada Industrial Estates, Kano, Nigeria. The effluents were collected over a period of six months (August 2017 to January 2018). Samples collected in a sterile 4-liter plastic container with a unique identification number were preserved using an ice-box that was transported to the Microbiology Laboratory, Department of Microbiology, Bayero University of Kano for analysis

\section{Sample Preparation and Sample Analysis}

Immediately after the collection of the effluent, $\mathrm{pH}$, TSS, TDS, COD, BOD levels were determined before treatment (Pre-treatment determination) and ten days after treatment (Post-treatment determination) as described in
APHA (1989) standard methods. $\mathrm{pH}$ was determined using Ecotests $\mathrm{pH}$ meter and TDS was determined using AQUALYTIC TDS Salinometer. BOD was determined as described by the standard method (APHA, 1992). COD and SS were determined using DR/2010 HACH portable data logging spectrophotometer (DWAF, 1992)

\section{Identification and Biochemical} Characterization of the Bacterial Isolates

The bacteria were isolated from the effluents using Serial Dilution according to the method described by APHA (1989). The biochemical tests such as oxidase, catalase, coagulase, indole (from $1 \%$ tryptone broth), citrate (Simmons citrate agar), methyl red/VogesProskauer (MR/VP), nitrate reduction, Starch Hydrolysis, Glucose, Maltose, and Lactose tests were carried out on the bacterial isolates to identify the bacteria through the bacteria biochemical characteristics according to Ajao et al. (2011).

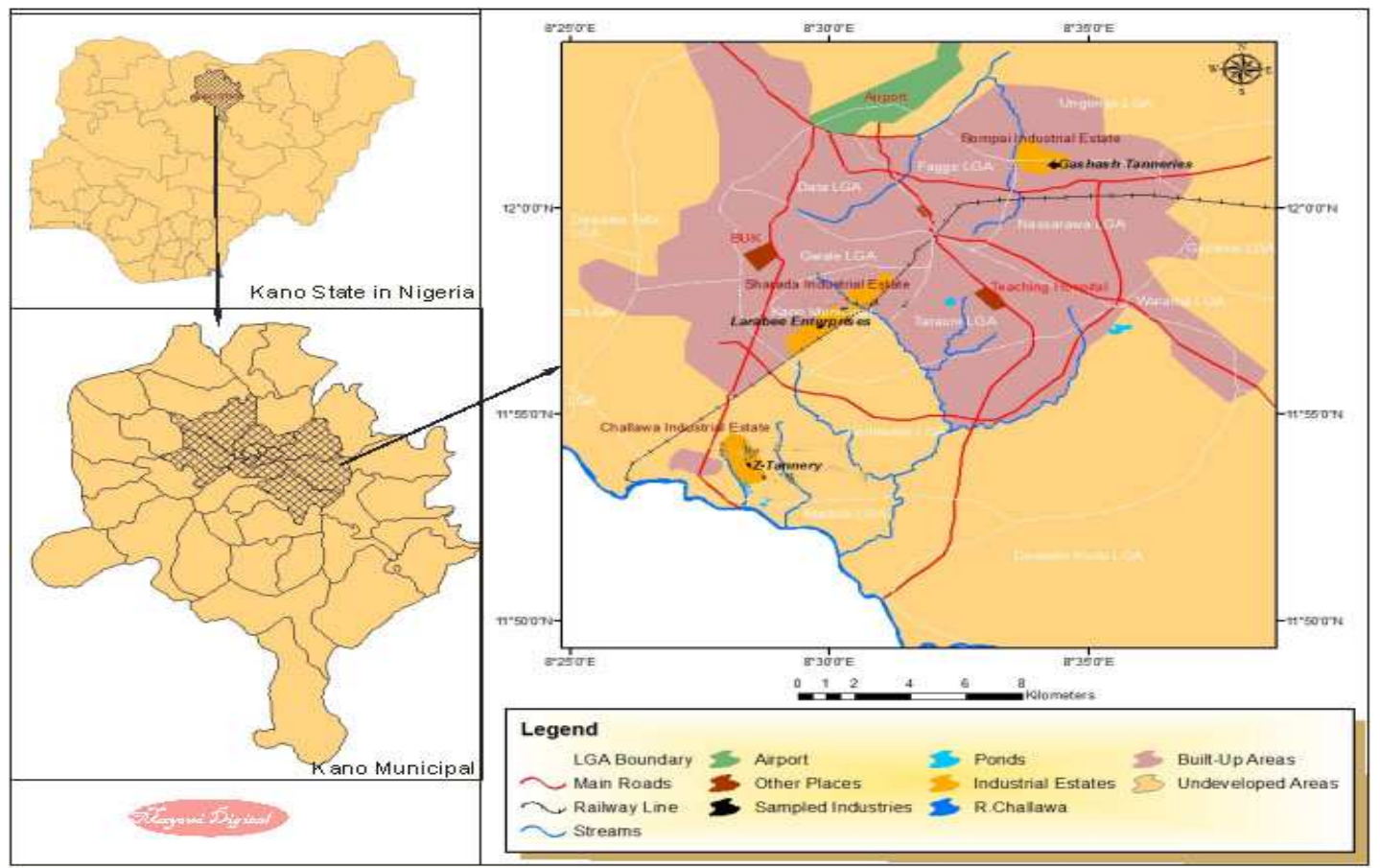

Fig. 1 Map showing the study areas

Source: Mayomi Digital Productions, GIS Laboratory, Department of Geography, UNIMAID (2017)

\section{Determination of Growth Rate of the Bacteria in Effluent Sample}

The bacteria growth rates were determined by transferring $2 \mathrm{~mL}$ of the bacterial isolates from the tannery effluent in broth medium into 100 $\mathrm{mL}$ sterile effluents in conical flasks and kept in an incubator (Giffrin cool) for 10 days. Control was also set up by incubating another $100 \mathrm{~mL}$ each of the sterile effluents without the bacteria. The optical density of the content was determined at the wavelength of $600 \mathrm{~nm}$ on a daily interval and recorded. 
BAJOPAS Volume 13 Number 2, December, 2020 Immobilization of Bacteria

Agar solution and inoculi were prepared separately. Fifty milliliters $(50 \mathrm{~mL})$ of nutrient broth each of the inoculi was prepared in a McCartney bottle and incubated for 24 hours. A solution of agar-agar was prepared by dissolving $10 \mathrm{~g}$ of the powder in distilled water and made up to $500 \mathrm{~mL}$ mark in an Erlenmeyer flask and was sterilized in an autoclave (280A) for 15 minutes and allowed to cool to $40-45^{\circ} \mathrm{C}$ (Ajao et al., 2011). Four milliliters ( $4 \mathrm{~mL})$ of the bacterial isolates in the nutrient broth was mixed with 36 $\mathrm{ml}$ of the prepared agar-agar media in petri-dish plates and then allowed to solidify. This was kept in the refrigerator for bioremediation.

\section{Bioremediation (Treatment) of the Effluents}

The solidified agar block (immobilized bacteria) was cut into cubes using a sterile knife; $0.1 \mathrm{~mL}$ phosphate buffer ( $\mathrm{pH} \mathrm{7.0)}$ was added and kept in the refrigerator for 1 hour for curing. The phosphate buffer was decanted after 1 hour and the cubes were washed with sterile distilled water 3-4 times before it was used (Ajao et al., 2011). Two liters (2 L) of the effluent was supplemented with the minimum basal medium in $\mathrm{g} / \mathrm{L}: \mathrm{NaCl}(0.8), \mathrm{MgSO}_{4} .7 \mathrm{H}_{2} \mathrm{O}(0.001), \mathrm{KH}_{2} \mathrm{PO}_{4}$ (2), $\mathrm{NaNO}_{3}$ (2), $\quad \mathrm{CaCl}_{2} .2 \mathrm{H}_{2} \mathrm{O} \quad(0.5)$ and $\mathrm{NaHPO}_{4} .12 \mathrm{H}_{2} \mathrm{O}(2)$ and sterilized in an autoclave at $121^{\circ} \mathrm{C}$ for 15 minutes (Margesin and Schinner, 2001). Two hundred and fifty milliliters $(250 \mathrm{~mL})$ of the effluents were transferred into different $250 \mathrm{ml}$ conical flasks. The content was covered with a cotton-wool ramped with foil paper to avoid contamination. Five grams $(5 \mathrm{~g})$ of the immobilized bacteria were quickly transferred into each of the effluents in the conical flasks in an inoculating chamber. The same procedures were carried out for the $10 \mathrm{~g}, 15 \mathrm{~g}, 20 \mathrm{~g}$ and 25 $\mathrm{g}$ of the immobilized bacteria in separate $250 \mathrm{~mL}$ effluents in conical flasks and agitated for ten days in a shaker incubator (Gallenkamp-OC4364-L) at a temperature $30^{\circ} \mathrm{C}$ and speed of 60 rpm. The treated effluent samples were taken on the tenth day and analyzed for the parameters $\mathrm{pH}$, SS, TDS, COD, and BOD, (Posttreatment determination) for the different grams of bacteria to evaluate and compare the biodegradation potential. (Baba et al., 2020).

\section{Statistical Analysis}

The data were represented as Mean \pm Standard deviation and analyzed statistically using oneway Analysis of Variance (ANOVA) and Tukey's HSD as Post Hoc Tests with the aid of SPSS 16.0. The correlation coefficient was also used to measure the strength of the relationship between the different masses of the bacteria and the parameters. All $\mathrm{p} \leq 0.05$ were considered as statistically significant.

\section{RESULTS AND DISCUSSION Physico-chemical parameters in the Industrial Effluents before the Biodegradation.}

Results of the Physico-chemical parameters in the industrial effluents before the Biodegradation is shown in table 1 . The mean temperatures $\left({ }^{\circ} \mathrm{C}\right)$ observed in TAN1, TAN2, and TAN3 samples were $28.07 \pm 0.65 ; 27.77 \pm 0.64$ and $26.38 \pm 3.81$ respectively. The order of the mean temperature of the samples from the three industries can be arranged as TAN1 > TAN2>TAN3. The temperature observed at TAN1, TAN2, and TAN3 samples were found below the WHO $\left(35^{\circ} \mathrm{C}\right)$ and NESREA $\left(40^{\circ} \mathrm{C}\right)$ limits. The low values of temperature might be due to the processes used at the time of sampling. High temperature brings down the solubility of gases in water that ultimately expresses as high BOD and COD. Statistical analysis shows that there is no significant difference $(p<0.05)$ between the mean values of temperature among the industries. This might be due to similar tannery activities involved in the tannery industries at the time of sampling. The average values of temperature observed in this present study are less than those observed by Akan et al. (2007), Akan et al. (2009) and Baba et al. (2020).

The mean level of $\mathrm{pH}$ observed in TAN1, TAN2 and TAN3, samples were $7.77 \pm 2.93$; $8.35 \pm 0.28$ and $7.52 \pm 0.76$ respectively. The order of the mean $\mathrm{pH}$ of the samples from the three industries can be arranged as TAN2> TAN1 $>$ TAN3. The $\mathrm{pH}$ of the samples falls within the WHO (7.0-8.5) and NESREA (6-9) standard limits. Statistical analysis shows that there is no significant difference $(p<0.05)$ between the mean values of $\mathrm{pH}$ among the industries. This might be due to similar tannery activities involved in the tannery industries at the time of sampling. Maheshwari et al. (2017) reported that the level of $\mathrm{pH}$ in the effluents from the tannery industry in Vaniyambadi, India was 6.5 which was lower than that observed in the present study. The $\mathrm{pH}$ in the effluents from the tannery industries in Kano and Kaduna were reported to be 7.64 and 6.89, respectively (Akan et al., 2007; Mohammed et al., 2017). The average values of $\mathrm{pH}$ observed in this present study are less than those observed by Mohammed et al. (2017) and Baba et al. (2020). The mean level of SS $(\mathrm{mg} / \mathrm{l})$ observed in TAN1, TAN2, and TAN3 samples were 374 \pm 124 ; $358 \pm 335$ and $780 \pm 739$ respectively. The order of the mean SS in the samples from the three industries can be arranged as TAN3 > TAN1 $>$ TAN2. 
The SS observed in the samples were far above the recommended standard limits of regulating bodies WHO $(30 \mathrm{mg} / \mathrm{l})$ and NESREA $(10 \mathrm{mg} / \mathrm{l})$. Statistical analysis shows that there is no significant difference $(p<0.05)$ between the mean values of SS among the industries. This might be due to similar tannery activities involved in the tannery industries at the time of sampling. The average values of SS observed in this present study are less than that observed $(3700 \pm 122 \mathrm{mg} / \mathrm{l})$ by Akan et al. (2009) for tanneries in Kano. Also, the average values of SS observed in this present study are less than that observed by Mohammed et al. (2017) and Baba et al. (2020) with the exception in TAN3.

The mean level of TDS (mg/l) observed in TAN1, TAN2, and TAN3 samples were $3941 \pm 3703$; $3300 \pm 1714$ and $2653 \pm 1240$ respectively. The order of the mean TDS in the samples from the three industries can be arranged as TAN1>TAN2>TAN3. The TDS observed in the samples were far above the recommended standard limits of WHO $(250 \mathrm{mg} / \mathrm{l})$ and NESREA $(500 \mathrm{mg} / \mathrm{l})$. Statistical analysis shows that there is no significant difference $(p<0.05)$ between the mean values of TDS among the industries. This might be due to similar tannery activities involved in the tannery industries at the time of sampling. TDS in the effluents from the tannery industries in Kano, Nigeria was reported to be $1281 \mathrm{mg} / \mathrm{l}$ (Akan et al., 2007). The average values of SS observed in this present study are less than those observed by Mohammed et al. (2017) and Baba et al. 2020)

The mean level of COD (mg/l) observed in TAN1, TAN2 and TAN3 samples seasons were $2372 \pm 938 ; \quad 1406 \pm 208$ and $3532 \pm 1373$ respectively. The order of the mean COD of the samples from the three industries can be arranged as TAN3>TAN1> TAN2. The COD observed in TAN1, TAN2 and TAN3 samples were far above the recommended standard limits of regulating bodies $\mathrm{WHO}(40 \mathrm{mg} / \mathrm{l})$ and NESREA (40 mg/l). Statistical analysis shows that there is no significant difference $(p<0.05)$ in COD among the industries. This might be due to similar tannery activities involved in the tannery industries as at the time of sampling. The Chemical Oxygen demand (COD) is the amount of oxygen, in $\mathrm{mg} / \mathrm{L}$, required for the degradation of the compound of wastewater to occur. In comparison, the average values of COD observed in this present study were higher than that observed by Mohammed et al. (2017) but lower than that observed by Baba et al. (2020).

The mean levels of BOD $(\mathrm{mg} / \mathrm{l})$ observed in TAN1, TAN2 and TAN3 samples were $13.85 \pm 6.42 ; \quad 19.46 \pm 0.50$ and $17.13 \pm 3.14$ respectively. The order of the mean BOD in the samples from the three industries can be arranged as TAN2>TAN3>TAN1. The BOD observed in TAN1, TAN2 and TAN3 samples were found below the recommended limits of NESREA (200 mg/l) but above WHO (10 mg/l). Statistical analysis shows that there is no significant difference $(p<0.05)$ between the mean values of BOD among the industries. This might be due to similar tannery activities involved in the tannery industries at the time of sampling. The low level of BOD recorded in this study is an indication of the low level of biodegradable organic solids in the effluent. The average values of BOD observed in this present study were lower than those observed by Mohammed et al. (2017) and Baba et al. (2020).

Table 1: Mean Values \pm S.D of Physico-chemical parameters of effluents from the Tannery Industries before Treatment.

\begin{tabular}{llllllll}
\hline Parameter & Tannery 1 & Tannery 2 & Tannery 3 & $\mathrm{a}$ & $\mathrm{b}$ & $\mathrm{c}$ & $\mathrm{d}$ \\
\cline { 2 - 7 } Temperature $\left({ }^{\circ} \mathrm{C}\right)$ & $28.07 \mathrm{a} \pm 0.65$ & $27.77 \mathrm{a} \pm 0.64$ & $26.38 \mathrm{a} \pm 3.81$ & & $29.50 \pm 4.68$ & 35 & 40 \\
pH & $7.77 \mathrm{a} \pm 2.93$ & $8.35 \mathrm{a} \pm 0.28$ & $7.52 \mathrm{a} \pm 0.76$ & 6.89 & $5.35 \pm 1.57$ & $7.0-8.5$ & $6.0-9.0$ \\
$\mathrm{COD}(\mathrm{mg} / \mathrm{l})$ & $2372 \mathrm{a} \pm 938$ & $1406 \mathrm{a} \pm 208$ & $3532 \mathrm{a} \pm 1373$ & 2.2 & $3106 \pm 2753$ & 40 & 40 \\
$\mathrm{BOD}(\mathrm{mg} / \mathrm{l})$ & $13.85 \mathrm{a} \pm 6.42$ & $19.46 \mathrm{a} \pm 0.50$ & $17.13 \mathrm{a} \pm 3.14$ & 1032 & $26.17 \pm 9.49$ & 10 & 200 \\
$\mathrm{SS}(\mathrm{mg} / \mathrm{l})$ & $374 \mathrm{a} \pm 124$ & $358 \mathrm{a} \pm 335$ & $780 \mathrm{a} \pm 739$ & 501 & $562 \pm 482$ & 30 & 10 \\
TDS $(\mathrm{mg} / \mathrm{l})$ & $3941 \mathrm{a} \pm 3703$ & $3300 \mathrm{a} \pm 1714$ & $2653 \mathrm{a} \pm 1240$ & 532.7 & $444 \pm 507$ & 250 & 500 \\
\hline
\end{tabular}

The values given in the table above are means of 6 replicate values, $\mathrm{n}=6$ ( 1 sample was taken monthly for 6 months). Within the rows, means with different alphabets are statistically different $(p<0.05)$. WHO: World Health Organisation. NESREA: National Environmental Standard and Regulatory Enforcement Agency. a = Mohammed et al.(2017), b = Baba et al. (2020), c = WHO (2006), $d=$ NESSRA (2009) 
BAJOPAS Volume 13 Number 2, December, 2020

Identification, Biochemical Characterization and growth rates of the Bacterial Isolates

Results of identification and biochemical characterization of the bacterial isolates were shown in table 2. After 24 hours of incubation, the nutrient agar media plates were checked for bacterial growth. The results showed the presence of different strains in the samples. The TAN1 bacteria isolate was found to be gramnegative cocci while TAN3 was gram-positive cocci. TAN2 bacteria isolate was found to be gram-positive, rod-shaped. TAN1, TAN2, and TAN3 bacteria isolates recorded positive results for spore former.

The results of the biochemical tests indicated that all the bacteria were positive for catalase, oxidase, citrate, maltose, glucose, lactose (negative in TAN1), mannitol (negative in TAN2), starch hydrolysis and coagulase (negative in TAN2) tests. The bacteria showed negative results for nitrate reduction, $M R$ (positive in TAN2), VP (positive in TAN1), Indole (positive in TAN2) tests. Base on the morphological and biochemical test results, TAN1, TAN2, and TAN3 bacteria isolates were identified to be Nesseria spp, Bacillus cereus, and Staphylococcus aureus respectively.

The growth rate of the TAN1, TAN2 and TAN3 Isolates were shown in figure 2. Generally, the optical density increase with the increase in time (day) and decrease as time goes on. The highest optical density was shown by bacillus cereus in TAN2 while the lowest was shown by Staphylococcus aureus in TAN3.

The initial growth phase of TAN1 Isolate bacteria occurred within 2-day of incubation as the growth rate increases up to the 6th-day incubation when the maximum growth was observed. Beyond the 6th day, the growth of the bacteria declined (which might be due to a shortage of nutrients in the effluents) until it reached its death phase (which might be due to the unavailability of nutrients in the effluents).

A similar trend of growth was also observed for TAN2 Isolate as the initial growth phase also occurred within 2-day of incubation but maximum growth rate observed on the 4th day of incubation. The stationary stage occurred between the 4th day and the 8th day. Beyond the 8th day, the growth of the bacteria declined (which might be due to a shortage of nutrients in the effluents) until it reached its death phase (which might be due to the unavailability of nutrients in the effluents).

The initial growth phase of TAN3 bacterial Isolate occurred within the 3-day incubation as the growth rate increases up to the 6th-day incubation when the maximum growth was observed. Beyond the 6th day, the growth of the bacteria declined (which might be due to a shortage of nutrients in the effluents) until it reached its death phase (which might be due to the unavailability of nutrients in the effluents).

Table 2: Morphological and Biochemical characteristics of bacterial isolates

\begin{tabular}{lllll} 
Bacterial Isolates & & TAN1 & TAN2 & TAN3 \\
\hline $\begin{array}{lllll}\text { Morphological } \\
\text { characteristics }\end{array}$ & Shape & Cocci & Rod & Cocci \\
& Spore & & & \\
& former & + & + & + \\
Gram & & & \\
Biochemical characteristics & reaction & - & + & + \\
& Citrate & + & + & + \\
& Catalase & + & + & + \\
& Coagulase & + & - & + \\
Starch & + & + & + \\
& Glucose & + & + & + \\
Oxidase & + & + & + \\
& Indo & - & + & - \\
Lactose & - & + & + \\
Manitol & + & - & + \\
Maltose & + & + & + \\
MR & - & + & - \\
VP & + & - & - \\
& Nitrate & - & - & - \\
Reduction & - Neisseria & Bacillus & Staphylococcus \\
& Bacterial & cereus & aureus \\
& name & spp & cas
\end{tabular}

+ = Positive; - = Negative; MR=Methyl Red; VP= Voges-Proskauer 


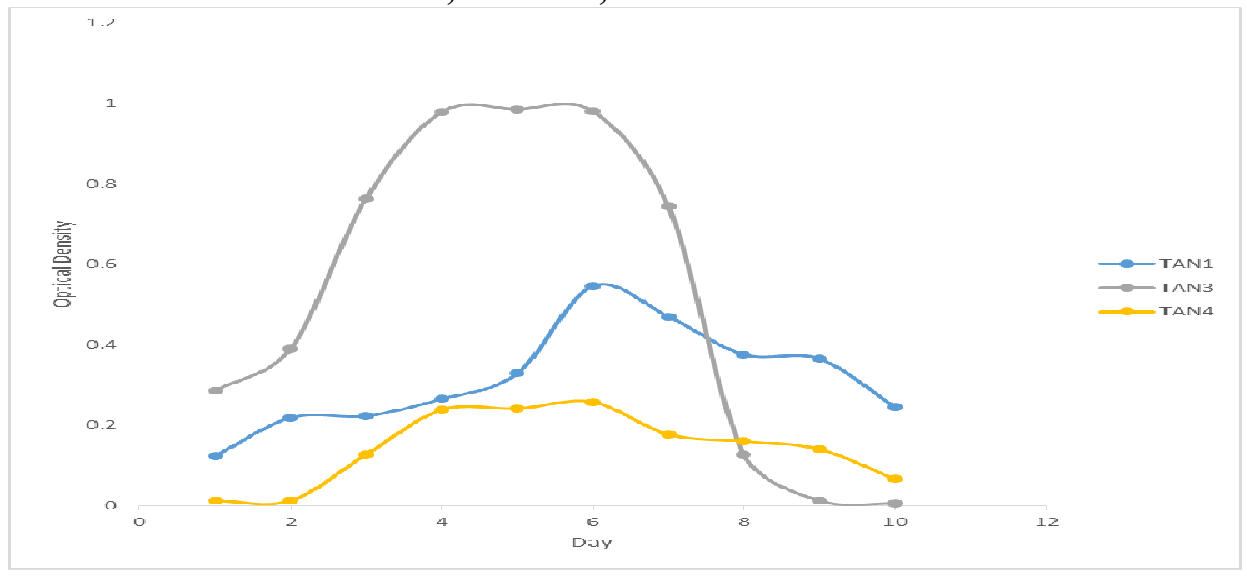

Fig. 2 Growth rates of the isolates in the effluents from the Tannery Industries

\section{Physico-chemical Parameters in the Industrial Effluents after the biodegradation.}

Table 3 shows the mean results of the physicochemical parameter before and after bioremediation using the different masses $(5 \mathrm{~g}$, $10 \mathrm{~g}, 15 \mathrm{~g}, 20 \mathrm{~g}$, and $25 \mathrm{~g}$ ) of the respective immobilized bacteria. Also, Table 4 shows the mean results of correlation coefficient ( $r$ ) between different masses of bacteria and physicochemical parameters.

The mean values $(\mathrm{mg} / \mathrm{l})$ of the SS after the bioremediation varies between $243 \pm 45$ and $898 \pm 672$. The mean concentration $(\mathrm{mg} / \mathrm{l})$ of SS remediated by the different masses $(5 \mathrm{~g}, 10 \mathrm{~g}$, $15 \mathrm{~g}, 20 \mathrm{~g}$, and $25 \mathrm{~g}$ ) of the bacteria varies. The SS in the samples fluctuates up and down after the bioremediation process when compared with the SS of the raw samples before the bioremediation. The increase in the levels of the SS might be due to the aggregation of the TDS which are large enough to result into SS. The increase in the levels of the SS might be also due to the influence of the nutrients which was added into the effluents in order to make the microorganisms more active and viable for fast degradation of organic contaminants in the effluent. The relative potential or efficiency of the different masses of the bacteria in remediating SS in TAN1 samples was in the order $25 \mathrm{~g}>20 \mathrm{~g}>15 \mathrm{~g}>10 \mathrm{~g}>5 \mathrm{~g}$. For TAN2 and TAN3 samples, the order was $25 \mathrm{~g}>20 \mathrm{~g}>15$ $\mathrm{g}>10 \mathrm{~g}>5 \mathrm{~g}$. These might be due to the variations in the surface areas of the different masses of the immobilized bacteria. Statistical analysis shows that there is no significant difference $(p<0.05)$ between the mean values of SS among the masses in the respective industries. Positive and significant correlations exist between the masses of bacteria and Suspended Solid (SS). This showed that there is general increase in the levels of the SS as the masses of the immobilized bacteria increases. TAN3 (90\%) and TAN1 (80\%) showed a very high correlation with the masses of the bacteria while TAN2 (61\%) showed a very low correlation.

The mean values $(\mathrm{mg} / \mathrm{l})$ of the TDS after the bioremediation varies between $46 \pm 11$ and $83 \pm 78$. The mean concentration $(\mathrm{mg} / \mathrm{l})$ of TDS remediated by the different masses $(5 \mathrm{~g}, 10 \mathrm{~g}$, $15 \mathrm{~g}, 20 \mathrm{~g}$, and $25 \mathrm{~g}$ ) of the bacteria varies. There is a reduction in all the TDS of all the samples after the bioremediation process compared with the TDS of the raw samples before the bioremediation. The relative potential or efficiency of the different masses of the bacteria in remediating TDS in TAN1 and TAN3 samples was in the order $5 \mathrm{~g}>10 \mathrm{~g}>15 \mathrm{~g}>20$ $\mathrm{g}>25 \mathrm{~g}$. For TAN2 samples, the order was 20 $g>10 \quad g>25 \quad g>15 \quad g>5 \quad g$. Statistical analysis shows that there is no significant difference $(p<0.05)$ between the mean values of TDS among the masses in the respective industries. These might be due to the variations in the surface areas of the different masses of the immobilized bacteria. Positive and significant correlations exist between the masses of bacteria and TDS with the exception in TAN2 (negative and insignificant correlation). The positive correlations showed that there is general increase in the levels of the TDS as the masses of the immobilized bacteria increases. TAN1 $(96 \%)$ showed a very high correlation with the masses of the bacteria while TAN2 (47\%) showed a very low correlation.

The mean values $(\mathrm{mg} / \mathrm{l})$ of the BOD after the bioremediation varies between $1.56 \pm 0.20 \mathrm{mg} / \mathrm{l}$ and $6.92 \pm 5.49 \mathrm{mg} / \mathrm{l}$. The mean concentration $(\mathrm{mg} / \mathrm{l})$ of BOD remediated by the different masses $(5 \mathrm{~g}, 10 \mathrm{~g}, 15 \mathrm{~g}, 20 \mathrm{~g}$, and $25 \mathrm{~g}$ ) of the bacteria varies. There is a reduction in all the BOD of all the samples after the bioremediation process compared with the $\mathrm{BOD}$ of the raw 
BAJOPAS Volume 13 Number 2, December, 2020 samples before the bioremediation. The relative potential or efficiency of the different masses of the bacteria in remediating BOD in TAN1, TAN2 and TAN3 samples were in the order $25 \mathrm{~g}>20$ $\mathrm{g}>15 \mathrm{~g}>10 \mathrm{~g}>5 \mathrm{~g}, 25 \mathrm{~g}>15 \mathrm{~g}>5 \mathrm{~g}>10 \mathrm{~g}>20 \mathrm{~g}$ and $20 \mathrm{~g}>10 \mathrm{~g}>25 \mathrm{~g}>15 \mathrm{~g}>5 \mathrm{~g}$ respectively. Statistical analysis shows that there is significant difference $(p<0.05)$ between the mean values of BOD among the masses in the respective industries. These might be due to the variations in the surface areas of the different masses of the immobilized bacteria. Negative and significant correlations exist between the masses of bacteria and BOD. This showed that there is general decrease in the levels of the BOD as the masses of the immobilized bacteria increases. TAN1 (94\%) showed a very high correlation with the masses of the bacteria while TAN2 (4\%) showed a very low correlation.

The mean values $(\mathrm{mg} / \mathrm{l})$ of the COD after the bioremediation varies between $250 \pm 154$ and $3134 \pm 1595$. The mean concentration $(\mathrm{mg} / \mathrm{l})$ of COD remediated by the different masses $(5 \mathrm{~g}$, $10 \mathrm{~g}, 15 \mathrm{~g} 20 \mathrm{~g}$, and $25 \mathrm{~g}$ ) of the bacteria varies. There is a reduction in all the COD of all the samples after the bioremediation process compared with the COD of the raw samples before the bioremediation. The relative potential or efficiency of the different masses of the bacteria in remediating COD in TAN1, TAN2 and TAN3 samples were in the order $25 \mathrm{~g}>20 \mathrm{~g}>15$ $\mathrm{g}>5 \mathrm{~g}>10 \mathrm{~g}, 25 \mathrm{~g}>20 \mathrm{~g}>15 \mathrm{~g}>10 \mathrm{~g}>5 \mathrm{~g}$ and 10 g>5 g>25 g>15 g>20 g respectively. Statistical analysis shows that there were significant difference $(p<0.05)$ between the mean values of COD among the masses in the respective industries except for effluents treated with $25 \mathrm{~g}$. These might be due to the variations in the surface areas of the different masses of the immobilized bacteria. Negative and insignificant correlations exist between the masses of bacteria and COD with the exception in TAN3 (positive and significant correlation). The negative correlations showed that there is general decrease in the levels of the COD as the masses of the immobilized bacteria increases. TAN2 (100\%) showed a very high correlation with the masses of the bacteria while TAN3 (36\%) showed a very low correlation.

Generally, there was an overall decrease in the concentration of these physicochemical parameters after the bioremediation using the different masses of the bacterial isolates. These might be due to the variations in the surface areas of the different masses of the immobilized bacteria. This is in line with the work of Jimoh et al. (2018) and Baba et al. (2020).

Table 3: Mean Values $(\mathrm{mg} / \mathrm{l}) \pm$ S.D of Physicochemical parameters in effluents from the Tannery Industries before and after Treatment of the effluents $(250 \mathrm{ml})$ with the different masses $(5 \mathrm{~g}, 10 \mathrm{~g}$, $15 \mathrm{~g}, 20 \mathrm{~g}$, and $25 \mathrm{~g}$ ) of the bacteria.

\begin{tabular}{llllllll}
\hline $\mathrm{P}$ & IND & Before & \multicolumn{5}{c}{ After } \\
\cline { 4 - 7 } & & & $5 \mathrm{~g}$ & $10 \mathrm{~g}$ & $15 \mathrm{~g}$ & $20 \mathrm{~g}$ & $25 \mathrm{~g}$ \\
\hline \multirow{2}{*}{ COD } & TAN1 & $2372 \pm 938$ & $1708 \mathrm{a} \pm 861$ & $2045 \mathrm{a} \pm 1205$ & $845 \mathrm{a} \pm 369$ & $300 \mathrm{a} \pm 167$ & $250 \mathrm{a} \pm 154$ \\
& TAN2 & $1406 \pm 208$ & $1195 \mathrm{a} \pm 208$ & $1125 \mathrm{a} \pm 384$ & $1055 \mathrm{a} \pm 317$ & $956 \mathrm{a} \pm 310$ & $870 \mathrm{ab} \pm 240$ \\
& TAN3 & $3532 \pm 1373$ & $2374 \mathrm{a} \pm 1344$ & $1976 \mathrm{a} \pm 1405$ & $2757 \mathrm{a} \pm 1266$ & $3134 \mathrm{a} \pm 1595$ & $2614 \mathrm{~b} \pm 1105$ \\
BOD & TAN1 & $13.85 \pm 6.42$ & $6.92 \mathrm{a} \pm 5.49$ & $6.42 \mathrm{a} \pm 5.07$ & $5.72 \mathrm{a} \pm 5.35$ & $4.62 \mathrm{a} \pm 4.37$ & $2.82 \mathrm{ab} \pm 1.26$ \\
& TAN2 & $19.46 \pm 0.50$ & $1.75 \mathrm{~b} \pm 0.22$ & $1.73 \mathrm{~b} \pm 0.18$ & $1.58 \mathrm{a} \pm 0.16$ & $1.91 \mathrm{a} \pm 0.22$ & $1.56 \mathrm{~b} \pm 0.20$ \\
& TAN3 & $17.13 \pm 3.14$ & $4.24 \mathrm{ab} \pm 0.77$ & $3.29 \mathrm{ab} \pm 0.37$ & $4.11 \mathrm{a} \pm 0.07$ & $3.23 \mathrm{a} \pm 0.91$ & $3.33 \mathrm{a} \pm 1.28$ \\
SS & TAN1 & $374 \pm 124$ & $243 \mathrm{a} \pm 45$ & $471 \mathrm{a} \pm 226$ & $475 \mathrm{a} \pm 182$ & $492 \mathrm{a} \pm 128$ & $611 \mathrm{a} \pm 217$ \\
& TAN2 & $358 \pm 335$ & $460 \mathrm{a} \pm 400$ & $543 \mathrm{a} \pm 414$ & $544 \mathrm{a} \pm 402$ & $551 \mathrm{a} \pm 414$ & $554 \mathrm{a} \pm 405$ \\
& TAN3 & $780 \pm 739$ & $586 \mathrm{a} \pm 594$ & $758 \mathrm{a} \pm 656$ & $787 \mathrm{a} \pm 676$ & $861 \mathrm{a} \pm 635$ & $898 \mathrm{a} \pm 672$ \\
TDS & TAN1 & $3941 \pm 3703$ & $51 \mathrm{a} \pm 10$ & $53 \mathrm{a} \pm 10$ & $55 \mathrm{a} \pm 15$ & $61 \mathrm{a} \pm 20$ & $63 \mathrm{a} \pm 26$ \\
& TAN2 & $3300 \pm 1714$ & $83 \mathrm{a} \pm 78$ & $47 \mathrm{a} \pm 20$ & $48 \mathrm{a} \pm 22$ & $47 \mathrm{a} \pm 17$ & $48 \mathrm{a} \pm 17$ \\
& TAN3 & $2653 \pm 1240$ & $46 \mathrm{a} \pm 11$ & $55 \mathrm{a} \pm 24$ & $55 \mathrm{a} \pm 25$ & $58 \mathrm{a} \pm 23$ & $61 \mathrm{a} \pm 28$ \\
\hline
\end{tabular}

Replicate $=6$ (months)

Within the rows, for the same parameter, means with different alphabets are statistically different $(p<0.05)$.

$\mathrm{P}=$ parameter, IND = Industries 
BAJOPAS Volume 13 Number 2, December, 2020

Table 4: Correlation coefficient $(r)$ between different masses of the bacteria and the physicochemical parameters.

\begin{tabular}{llll}
\hline Industries & Parameter & Correlation coefficient $(r)$ & $\begin{array}{l}\text { Percent dependence (rxrx100) } \\
(\%)\end{array}$ \\
\hline TAN1 & COD & -0.9 & 82 \\
& BOD & -0.97 & 94 \\
& SS & $0.90^{*}$ & 80 \\
TAN2 & TDS & $0.98^{*}$ & 96 \\
& COD & -1 & 100 \\
& BOD & -0.21 & 4 \\
& SS & $0.78^{*}$ & 61 \\
& TDS & -0.69 & 47 \\
& COD & $0.60^{*}$ & 36 \\
& BOD & -0.6 & 37 \\
& SS & $0.95^{*}$ & 90 \\
& TDS & $0.94^{*}$ & 89 \\
\hline
\end{tabular}

The correlation coefficient $(r)$ with * is statistically significant $(p<0.05)$.

Percentage reduction of the Parameters

Table 5 shows the percentage reduction of Parameters in industrial samples before and after the treatment of the effluents $(250 \mathrm{ml})$ with the different masses $(5 \mathrm{~g}, 10 \mathrm{~g}, 15 \mathrm{~g}, 20 \mathrm{~g}$, and $25 \mathrm{~g}$ ) of the Immobilized Bacteria.

In TAN1 samples, the percentage reduction (\%) of COD ranged (14-89); BOD (50-80); SS (-32$35)$ and TDS (98-99). In TAN2 samples, the percentage decrease $(\%)$ of COD ranged (15$38) ;$ BOD (90-92); SS [-28-(-55)] and TDS (9798). In TAN3 samples, the percentage decrease (\%) of COD ranged (11-44); BOD (76-81); SS (15-25) and TDS (98). The percentage increase in the levels COD, BOD and TDS might be due to the increase in the surface area of the different masses of the immobilized bacteria. However, the percentage decrease in the levels of the SS might be due to the aggregation of the TDS which are large enough to result into SS. The percentage decrease in the levels of the SS might be also due to the influence of the nutrients which was added into the effluents in order to make the microorganisms more active and viable for fast degradation of organic contaminants in the effluent. This is in line with the work of Jimoh et al. (2018) in which the concentration of the SS increase after the bioremediation of effluents.

Sreemoyee and Priti (2013) assessed and reduced several Physico-chemical parameters of dairy wastewater using Niesseria $s p$. and concluded that the species are well known to degrade organic compounds. This is in agreement with the current study in which the immobilized Niesseria $s p$ degrade the organic contaminants as indicated by the BOD, COD and TDS.

Jimoh et al. (2018) observed that TSS of the effluents was increased after treatment with immobilized bacteria and concluded that it might be due to the biostimulation method adopted for the research.

The optimum $\mathrm{pH}$ Biosorption of Chromium by Bacillus spp and Staphylococcus spp. from tannery effluent was investigated by Mythili and Karthikeyan (2011). The maximum adsorption of Chromium $(86.4 \mathrm{mg} / \mathrm{L})$ was showed by Bacillus spp and Staphylococcus spp showed $70.6 \mathrm{mg} / \mathrm{L}$ at an initial concentration of $100 \mathrm{mg} / \mathrm{L}$. In the present study, immobilised Bacillus spp and Staphylococcus spp. from the tannery industrial effluents reduced the levels of the organic pollutants with high potential as indicated by the percentage reduction of BOD, COD and TDS.

Enzymes often can work in multiple environments especially if they are immobilized. This makes the microorganisms' enzymes even more resistant to harsh environments and enables the enzymes to be recovered and recycled after they are no longer needed (Gianfreda and Rao 2004). Ramesh and Singh (1993) reported that the immobilized bacteria having more efficiency to remove the suspended particles than free cells. Using the immobilized cell is preferable due to its capability for using several times with the same efficiency, which makes it more economical. Similar work was done by Sikander et al. (2007) showing the higher reduction with permeabilized cells of Ochrobactrum intermedium strain SDCr-5. 
BAJOPAS Volume 13 Number 2, December, 2020

The results revealed the isolation and identification of isolates with the potential for the reduction of $\mathrm{Cr}$ (VI) to $\mathrm{Cr}$ (III). Results indicated that immobilized $B$. cereus could be efficiently used for the reduction of $\mathrm{Cr}$ (VI).

Table 5: Percentage reduction of the tested Parameters from the tannery industrial samples of the Immobilized Bacteria.

\begin{tabular}{lllllll}
\hline \multirow{2}{*}{ Industries } & & \multicolumn{5}{c}{ Percentage Reduction $(\%)$} \\
\cline { 3 - 7 } & & $5 \mathrm{~g}$ & $10 \mathrm{~g}$ & $15 \mathrm{~g}$ & $20 \mathrm{~g}$ & $25 \mathrm{~g}$ \\
\hline TAN1 & COD & 28 & 14 & 64 & 87 & 89 \\
& BOD & 50 & 54 & 59 & 67 & 80 \\
& SS & 35 & -26 & -27 & -32 & -63 \\
& TDS & 99 & 99 & 99 & 98 & 98 \\
TAN2 & COD & 15 & 20 & 25 & 32 & 38 \\
& BOD & 91 & 91 & 92 & 90 & 92 \\
& SS & -28 & -52 & -52 & -54 & -55 \\
& TDS & 97 & 99 & 99 & 99 & 99 \\
& COD & 33 & 44 & 22 & 11 & 26 \\
& BOD & 75 & 81 & 76 & 81 & 81 \\
& SS & 25 & 3 & -1 & -10 & -15 \\
& TDS & 98 & 98 & 98 & 98 & 98 \\
\hline
\end{tabular}

Percentage Reduction $=(B-A) / B \times 100 \%$

$A=$ Concentration of the parameter after treatment

$\mathrm{B}=$ Concentration of the parameter before treatment

$+=$ percentage decrease

- = percentage increase

In general, immobilization makes the enzyme more resistant to temperature, $\mathrm{pH}$, and substrate concentration swings giving it a longer lifetime and higher productivity per active unit (Gianfreda and Rao, 2004; FuIlbrook, 1996; Russell et al, 2003; Kandelbauer et al., 2004). Immobilized cells have been used and studied extensively for the production of useful chemicals (Ohtake and Silver, 1994), the treatment of wastewaters (Chen et al., 2003; Wang et al., 2010). Although many workers described microbial degradation of tannery effluent, limited literature is available on the bioremediation of tannery effluent using immobilized bacterial cells in the Kano Industrial Estates.

\section{CONCLUSION}

The samples contained variable levels of the physicochemical parameters. The results of the Analysis of variance revealed that, no statistical difference $(p<0.05)$ was observed for the temperature, $\mathrm{pH}, \mathrm{SS}, \mathrm{TDS}, \mathrm{BOD}$ and $\mathrm{COD}$ among the three tannery industries before the treatment. The levels of some of the parameters
(SS, TDS and COD) observed in the samples were found above the recommended limits of WHO and NESREA, which called for the treatment of the effluents before discharge into the environment. Base on the morphological and biochemical test results, TAN1, TAN2, and TAN3 bacterial isolates were identified to be Neisseria spp, Bacillus cereus, and Staphylococcus aureus respectively. The results of Post-treatment analysis showed that there is overall decrease in the levels of the parameters determined when compared with that of the pre-treatment. The overall percentage reduction of the immobilised bacteria in the treatment of the respective effluents was in the order TAN2 (72\%)>TAN1 $(70 \%)>$ TAN3 $(62 \%)$. Hence, the immobilized bacteria are having higher biodegradation potential for the treatment of the tannery effluents.

\section{Acknowledgments}

The authors wish to acknowledge the University of Maiduguri for the financial support. The authors are grateful to the Kano State Ministry of Environment for their support in obtaining the effluent samples. 


\section{REFERENCES}

Ajao, A. T., Adebayo, G. B., and Yakubu, S. E. (2011). Bioremediation of textile industrial effluent using mixed culture of Pseudomonas aeruginosa and Bacillus subtilis immobilized on agar-agar in a bioreactor. J. Microbiol. Biotech. Res, 1(3), 50-56.

Akan, J. C., Moses, E. A., Ogugbuaja, V. O., and Abah, J. (2007). Assessment of tannery industrial effluents from Kano metropolis, Kano State, Nigeria. Journal of Applied Sciences, 7(19), 2788-2793.

Akan, J. C., Ogugbuaja, V. O., Abdulrahman, F. I., and Ayodele, J. T. (2009). Pollutant levels in effluent samples from tanneries and textiles of Kano industrial areas, Nigeria. Global journal of pure and applied sciences, 15(3-4).

APHA (1989). Standard methods for Examination of Will bete and Will betewater.15 $5^{\text {th }}$ edition. Brydpass Springfield Will behington DC. pp. 164-176

APHA (1992). Standard Methods for the Examination of Water and Wastewater. Health, 69, 1116-9.

Baba, A., Garba, S. T., and Bello, H. S. (2020). Bioremediation Potential of Immobilized corynebacterium kutsceri in the Treatment of Tannery Industrial Effluent from Challawa Industrial Estate, Kano State, Nigeria. Journal of the Turkish Chemical Society Section A: Chemistry, $7(2), 335-350$.

Beem, E. I. V. (1994). reduction of solvent VOC emission. J. Oil Col. Chem. Ass, 77, 158.

Bouwer, E. J., and Zehnder, A. J. (1993). Bioremediation of organic compoundsputting microbial metabolism to work. Trends in biotechnology, 11(8), 360367.

Chen, K. C., Wu, J. Y., Liou, D. J., and Hwang, S. C. J. (2003). Decolorization of the textile dyes by newly isolated bacterial strains. Journal of Biotechnology, 101(1), 57-68.

Dan'Azumi, S., and Bichi, M. H. (2010). INDUSTRIAL POLLUTION AND HEAVY METALS PROFILE OF CHALLAWA RIVER IN KANO, NIGERIA. Journal of Applied Sciences in Environmental Sanitation, $5(1)$.

DWAF. (1992). Analytical Methods Manual, TR 151. Department of Water Affairs and Forestry, Pretoria.

El-Bestawy, E. (2013). Biological treatment of leather-tanning industrial wastewater using free living bacteria.
Elsheikh, M. A. S. (2009). Tannery wastewater pre-treatment. Water Science and Technology, 60(2), 433-440.

FuIlbrook, P. D. (1996). "Kinetics." Industrial enzymology: The application of enzymes in Industry. 2nd Ed. T. Godfrey and J Reichelt. eds.. Nature. New York.

Gianfreda, L., and Rao, M. A. (2004). Potential of extra cellular enzymes in remediation of polluted soils: a review. Enzyme and microbial technology, 35(4), 339354.

Hugo Springer. (1994). John Arthur Wilson Memorial Lecture "Treatment of Industrial Wastes of the Leather Industry - is it still a Major Problem". JALCA, 89, 153-185

Jimoh, A. A., Ganiyu, B. A., Baba, D., and Baba, A. (2018) Bioremediation Process of Effluent from Detergent and Food Industries in Jos, Nigeria: Kinetics and Thermodynamics. International Journal of Engineering Science Invention (IJESI), 762-73

Kandelbauer, A., Maute, O., Kessler, R. W., Erlacher, A., and Gübitz, G. M. (2004). Study of dye decolorization in an immobilized laccase enzyme-reactor using online spectroscopy. Biotechnology and bioengineering, 87(4), 552-563.

Kongjao, S., Damronglerd, S., and Hunsom, M. (2008). Simultaneous removal of organic and inorganic Pollutants in tannery wastewater using electrocoagulation technique. Korean Journal of chemical engineering, 25(4), 703.

Maheshwari, U. M., Aruna, S., Gomathi, M., and AbdulJaffar, A. H. (2017). Bioremediation by Free and Immobilized Bacteria Isolated from Tannery Effluent. International Journal of Research in Applied, Natural and Social Sciences. 5(7), 75-90

Margesin, R., and Schinner, F. (2001). Bioremediation (natural attenuation and biostimulation) of diesel-oilcontaminated soil in an alpine glacier skiing area. Applied and environmental microbiology, 677), 3127-3133.

Mohammed, A., Sekar, P., and George, J. (2011). Efficacy of microbes in bioremediation of tannery effluent. Inter. J. Curr. Res, 3(4), 324-326.

Mohammed, S. S. D., Orukotan, A. A., and Abdullahi, H. (2017). Physicochemical and Bacteriological Assessment of Tannery Effluent from Samaru-Zaria, 
BAJOPAS Volume 13 Number 2, December, 2020 Kaduna State, Nigeria. Journal of Applied

Sciences and Environmental Management, 21(4), 734-740.

Munz, G., De Angelis, D., Gori, R., Mori, G., Casarci, M., and Lubello, C. (2009). The role of tannins in conventional and membrane treatment of tannery wastewater. Journal of hazardous materials, 164(2-3), 733-739

Mythili, K., and Karthikeyan, B. (2011). Bioremediation of $\mathrm{Cr}$ (VI) from tannery effluent using Bacillus spp and Staphylococcus spp. International Multidisciplinary Research Journal, 1(6).

NESREA (2009). National Environmental Standards for Effluent Limitations and Regulation. 1233-1236

Noorjahan, C. M. (2014). Physicochemical characteristics, identification of bacteria and biodegradation of industrial effluent. Journal of bioremediation and Biodegradation, 5(3).

Ohtake, H. I., and Silver, A. O. (1994). Bacterial reduction of toxic chromate. Biological degradation and bioremediation of toxic chemicals, 403-415.

Omoleke, I. I. (2004). Management of environmental pollution in Ibadan, an African city: the challenges of health hazard facing government and the people. Journal of Human Ecology, 15(4), 265-275.

Rajor, A., Reddy, A.S., and Singh, B. (2004). Determination of BOD kinetic Parameters and evaluation of alternate methods, M.Sc. Thesis, Department of biotechnology \& environmental Science, Thapar Institute of Engineering and Technology, Patiala

Ramasami, T., Rajamani, S., and Rao, J. R. (1994, March). Pollution control in leather industry: Emerging technological options. In International symposium on surface and colloidal science and its relevance to soil pollution, madras.

Ramesh, J. V. S., and Singh, S. P. (1993). Yearly variation in certain physicochemical parameters of pond at eastern Doon Valley. Uttar Pradesh J. Zoo, 12 (1), 7577.

Ranen, S., and Sharadinadra, C. (2009). Biotechnology applications to environmental remediation in resource exploitation. Current science, 97, 6-25
Russell, A. J., Berberich, J. A., Drevon, G. F., and Koepsel, R. R. (2003). Biomaterials for mediation of

chemical and biological warfare agents. Annual review of biomedical engineering, 5(1), 1-27.

Saravanan, P., and Saravanan, A. (1999). Decolourization of tannery effluent by Flavobacterium sp. EK 1. Indian Journal of Environmental Protection, 19, 19-24.

Sikander, S., and Shahida, H. (2007). Reduction of toxic hexavalent chromium by Ochrobactrum intermedium strain SDCr5 stimulated by heavy metals. Bioresource Technol, 98, 340-344.

Singh, N., Sharma, B. K., and Bohra, P. C. (2000). Impact assessment of industrial effluent of arid soils by using satellite imageries. Journal of the Indian Society of Remote Sensing, 28(2-3), 79.

Sreemoyee, C., and Priti, P. (2013). Assessment of physico-chemical parameters of dairy waste water and isolation and characterization of bacterial strains in terms of cod reduction. Int J Sci, 2(3), 395-400.

Verheijen, L. A. H. M., Wiersema, D., Pol, L. H., and De Wit, J. (1996). Management of wastes from animal product processing. Livestock and environment, Finding a balance. International Agriculture Center, Wageningen, The Netherlands.

Wang, F., Yao, J., Si, Y., Chen, H., Russel, M., Chen, K., and Bramanti, E. (2010). Short-time effect of heavy metals upon microbial community activity. Journal of Hazardous Materials, 173(13), 510-516.

WHO (World Health Organization). (2006). Air quality guidelines: global update 2005: particulate matter, ozone, nitrogen dioxide, and sulfur dioxide. World Health Organization.

World Bank. (1995). Nigeria's strategic options for redressing industrial pollution. World Bank, industry and energy division. 1st edition, West Central Africa Department; Annexes: 1995; pp 60-62.

Zahoor, A., and Abdul, R. (2009). Enumeration of Coliforms. Journal of Environmental Sciences. 21, 814-820 


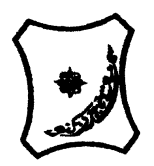

Bayero Journal of Pure and Applied Sciences, 13(2): 1 - 12

Received: November, 2020

Accepted: December, 2020

ISSN $2006-6996$

\title{
BIODEGRADATION POTENTIAL OF IMMOBILIZED BACTERIA IN THE TREATMENT OF TANNERY INDUSTRIAL EFFLUENTS FROM INDUSTRIAL ESTATES IN KANO STATE, NIGERIA
}

\author{
Abdullateef, B., ${ }^{1 *}$ Shuaibu, T. G., ${ }^{1}$ Babagana, K., ${ }^{1}$ Suleman, H. B. ${ }^{2}$ and Dauda, B. ${ }^{3}$ \\ ${ }^{1}$ Department of Pure and Applied Chemistry, Faculty of Science, University of Maiduguri, Borno State, \\ Nigeria \\ ${ }^{2}$ Department of Microbiology, Faculty of Science, University of Maiduguri, Borno State, Nigeria \\ ${ }^{3}$ Department of Chemical Engineering, Faculty of Engineering, University of Maiduguri, Borno State, \\ Nigeria \\ *Corresponding author: babslega@gmail.com; abelega2007@yahoo.com; +2348061309753
}

\section{ABSTRACT}

Industrial Effluents Samples from Gashash Tanneries (TAN1) in Bompai Industrial estate, Larabee Tannery Industry (TAN2) in Sharada Industrial estate and Z Tannery Industries (TAN3) in Challawa Industrial estate, Kano State, Nigeria were collected over a period of six months (August 2017 to January 2018) for assessing the biodegradation potentials of bacteria in the treatment of organic pollutants within the effluents. Bacteria were isolated from the effluents and immobilized on agar-agar. Different masses (5 g, $10 \mathrm{gr}, 15$ $\mathrm{g}, 20 \mathrm{~g}$, and $25 \mathrm{~g}$ ) of the bacteria were used in the treatment of $250 \mathrm{ml}$ of the effluents for ten days in a shaker incubator (Gallenkamp-OC-4364-L) at the temperature $30{ }^{\circ} \mathrm{C}$ and speed of $60 \mathrm{rpm}$. Pre-treatment analysis of the effluents for Temperature, pH, Biochemical Oxygen Demand (BOD), Chemical Oxygen Demand (COD), Suspended Solid (SS) and Total Dissolved Solids (TDS) gives the following results; temperature $\left({ }^{\circ} \mathrm{C}\right.$ )

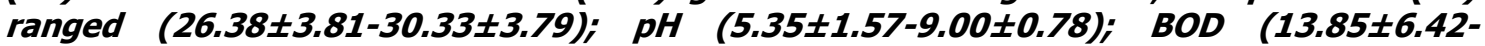
$38.75 \pm 16.20) ;$ COD (1406 $\pm 208-3532 \pm 1373) ;$ SS (208 $\pm 235-780 \pm 739)$ and TDS (266 $\pm 253-5276 \pm 2971)$. No statistical differences ( $p \leq 0.05)$ was observed for all the results among the different industries. The bacterial isolates were identified as Neisseria spp, Bacillus cereus, and Staphylococcus aureus, in TAN1, TAN2, and TAN3, respectively. After treatment of the effluent with the different masses of the isolated bacteria, the mean level of BOD was found to range as (0.55 $\pm 0.36-6.92 \pm 5.49) ; C O D$ (ND-3134 \pm 1595$)$;

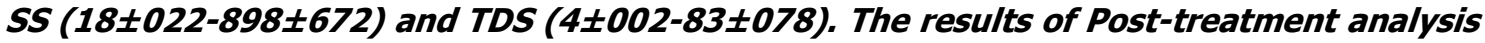
showed that there is overall decrease in the levels of the parameters determined when compared with that of the pre-treatment. The overall percentage reduction of the immobilised bacteria in the treatment of the respective effluents was in the order TAN2 (72\%)>TAN1 (70\%)>TAN3 (62\%). Hence, the immobilized bacteria are having higher biodegradation potential for the treatment of the tannery effluents.

Keywords: Biodegradation, bacteria, effluent, immobilization, tannery.

\section{INTRODUCTION}

Tannery industrial wastewater is a serious consequence of the pollution point of view for streams, freshwater, and land used for agriculture. The lack of awareness in the modern industrial practice has resulted in the discharge of tannery effluents which exhibit very high value of chromium ( $\mathrm{Cr}$ ), Sulfide, and chloride, Total Dissolved Solid (TDS), Total Suspended Solid (TSS), Biochemical Oxygen Demand (BOD) and Chemical Oxygen Demand (COD) in the water stream or land (Mohammed et al., 2001). Tanning is the process, which One ton of skin generally leads to the production of 20 to $80 \mathrm{~m}^{3}$ of turbid and foul-smelling converts the protein of the rawhide or skin into a stable material, which will not putrefy and is suitable for a wide variety of end applications (Elsheikh, 2009). The highly polluting chromium is the most commonly used tanning material producing leather that is more flexible and pliable than vegetable-tanned leather and does not discolor or lose shape in water as drastically as vegetable-tan (Elsheikh, 2009). Tannery effluent is among the most hazardous industrial pollutants due to its huge organic and inorganic load, which is highly toxic to human life and the environment (Kongjao et al., 2008). wastewater including chromium (100-400 mg/l), sulfide $(200-800 \mathrm{mg} / \mathrm{l})$, high levels of fat and 
BAJOPAS Volume 13 Number 2, December, 2020 other solid wastes, and notable pathogen contamination as well as pesticides added for skin conservation during transport (Elsheikh, 2009). There are more than 6000 tanneries in Nigeria with an annual processing capacity of 700,000 tons of hides and skins (Omoleke, 2004; Singh et al., 2008). It was reported that the total amount of waste produced per animal slaughtered is approximately $35 \%$ of its weight (World Bank, 1995). Also, for every $1000 \mathrm{~kg}$ of carcass weight, a slaughtered beef produces 5.5 $\mathrm{kg}$ of manure (excluding rumen contents or stockyard manure) and $100 \mathrm{~kg}$ of paunch manure (undigested food) (Verheijen et al., 1996). Tanneries generate wastewater in the range of 30-35 $\mathrm{L} \mathrm{kg}^{-1}$ skin/hide processed with variable $\mathrm{pH}$, Biological Oxygen Demand (BOD), Chemical Oxygen Demand (COD), high concentrations of suspended solids (SS), and tannins as well as chromium (Zahoor and Abdul, 2009).

Being heterogeneous and composed of a wide variety of compounds, it is very difficult to select a unique direct method for estimating the biodegradability of organic contents and biokinetic parameters for a wastewater sample (Rajor, 2004). For this purpose, some indirect estimation such as determination of biochemical oxygen demand (BOD) and chemical oxygen demand (COD) are applied as common laboratory investigations [9]. During retanning procedures, synthetic tannins (Syntan), oils and resins are added to form softer leather at varying doses (Munz et al., 2009). One of the refractory groups of chemicals in tannery effluents derives mainly from tannins (Ramasami et al., 2004). Syntans are characterized by complex chemical structures, because they are composed of an extended set of chemicals such as phenol-, naphthalene-, formaldehyde- and melamine-based syntans, and acrylic resins (Beem, 1994). Organic pollutants (proteic and lipidic components) are originated from skins (it is calculated that the raw skin has $30 \%$ loss of organic material during the working cycle) or they are introduced during processes (Hugo Springer, 1994).

Many conventional processes such as oxidation, chemical and biological processes were carried out to treat tanneries wastewater (Ebtesam et al, 2013). Biological processes have received more attention because of their costeffectiveness, lower sludge production and environmental friendliness (Noorjahan, 2014). Naturally occurring micro-organisms degrade the hazardous organic wastes including xenobiotic compounds, such as pesticides, polycyclic aromatic hydrocarbons (PAHs) and polychlorinated biphenyls (PCBs) in due course of time (Ranen and Sharadinadra, 2009). Bioremediation is based on the idea that all organisms remove substances from the environment to carry outgrowth and metabolism (Bouwer and Zehnder, 1993). Bacteria, protista and fungi are found to be very good at degrading complex molecules and incorporating the breakdown products into their metabolism (Bouwer and Zehnder, 1993). The resultant metabolic wastes that they produce are generally safe and somehow recycled into other organisms (Ranen and Sharadinadra, 2009). An acclimatized indigenous population of microorganisms capable of degradation of the compounds of interest must exist at the site for a successful bioremediation mode (Ranen and Sharadinadra, 2009). It has been observed that for a successful bioremediation mode, an acclimatized indigenous population of microorganisms capable of degradation of the compounds of interest must exist at the site under investigation (Ranen and Sharadinadra, 2009). Even though there are numerous physical and chemical methods employed in the disposal of wastes the advantage in using bacterium is that they play a key role in the reduction of COD, BOD, total protein, total tannin and total phenol (Saravanan and Saravanan, 1998)

Baba et al. (2020) studied the bioremediation potential of immobilized corynebacterium kutsceri in the Treatment of tannery industrial effluent from Challawa Industrial Estate, Kano State, Nigeria. The aim of the work is to study the reduction in the level of the contaminants through the process of bioremediation using the isolated bacteria. Immobilized bacteria can withstand various temperatures, $\mathrm{pH}$ and substrate concentrations; consequently, increasing the efficiency and the lifespan of the bacteria. Immobilized bacteria are widely applied in the treatment of wastewater and can be separated and recovered after the treatment with the same efficiency (Baba et al., 2020).

\section{MATERIALS AND METHODS \\ Study Area}

This study was carried out in Bompai, Sharada and Challawa industrial estates in Kano, Figure 1. Kano lies on Latitude $11^{\circ} 30^{\prime} \mathrm{N}$ and $8^{\circ} 30^{\prime} \mathrm{E}$ and Longitude $11^{\circ} 5^{\prime} \mathrm{N}$ and $8^{\circ} 5^{\prime} \mathrm{E}$ in Northern Nigeria. It is one of the developed industrial cities in Nigeria. Tannery activities are the dominating industries and this could be one of the reasons for her high population density (Dan'Azumi and Bichi, 2010). Many researchers have studied biodegradation of tannery effluent using microorganisms. However, limited literature is available on the biodegradation of tannery effluent in Kano industrial estates using 
BAJOPAS Volume 13 Number 2, December, 2020 immobilized bacterial cells. This research work focuses on the potential of the use of the indigenous immobilized bacterial isolates in the treatment of tannery effluents in the industrial estates.

\section{Sample Collection}

Effluents were collected from the Tannery Industries from Bompai, Challawa and Sharada Industrial Estates, Kano, Nigeria. The effluents were collected over a period of six months (August 2017 to January 2018). Samples collected in a sterile 4-liter plastic container with a unique identification number were preserved using an ice-box that was transported to the Microbiology Laboratory, Department of Microbiology, Bayero University of Kano for analysis

\section{Sample Preparation and Sample Analysis}

Immediately after the collection of the effluent, $\mathrm{pH}$, TSS, TDS, COD, BOD levels were determined before treatment (Pre-treatment determination) and ten days after treatment (Post-treatment determination) as described in
APHA (1989) standard methods. $\mathrm{pH}$ was determined using Ecotests $\mathrm{pH}$ meter and TDS was determined using AQUALYTIC TDS Salinometer. BOD was determined as described by the standard method (APHA, 1992). COD and SS were determined using DR/2010 HACH portable data logging spectrophotometer (DWAF, 1992)

\section{Identification and Biochemical} Characterization of the Bacterial Isolates

The bacteria were isolated from the effluents using Serial Dilution according to the method described by APHA (1989). The biochemical tests such as oxidase, catalase, coagulase, indole (from $1 \%$ tryptone broth), citrate (Simmons citrate agar), methyl red/VogesProskauer (MR/VP), nitrate reduction, Starch Hydrolysis, Glucose, Maltose, and Lactose tests were carried out on the bacterial isolates to identify the bacteria through the bacteria biochemical characteristics according to Ajao et al. (2011).

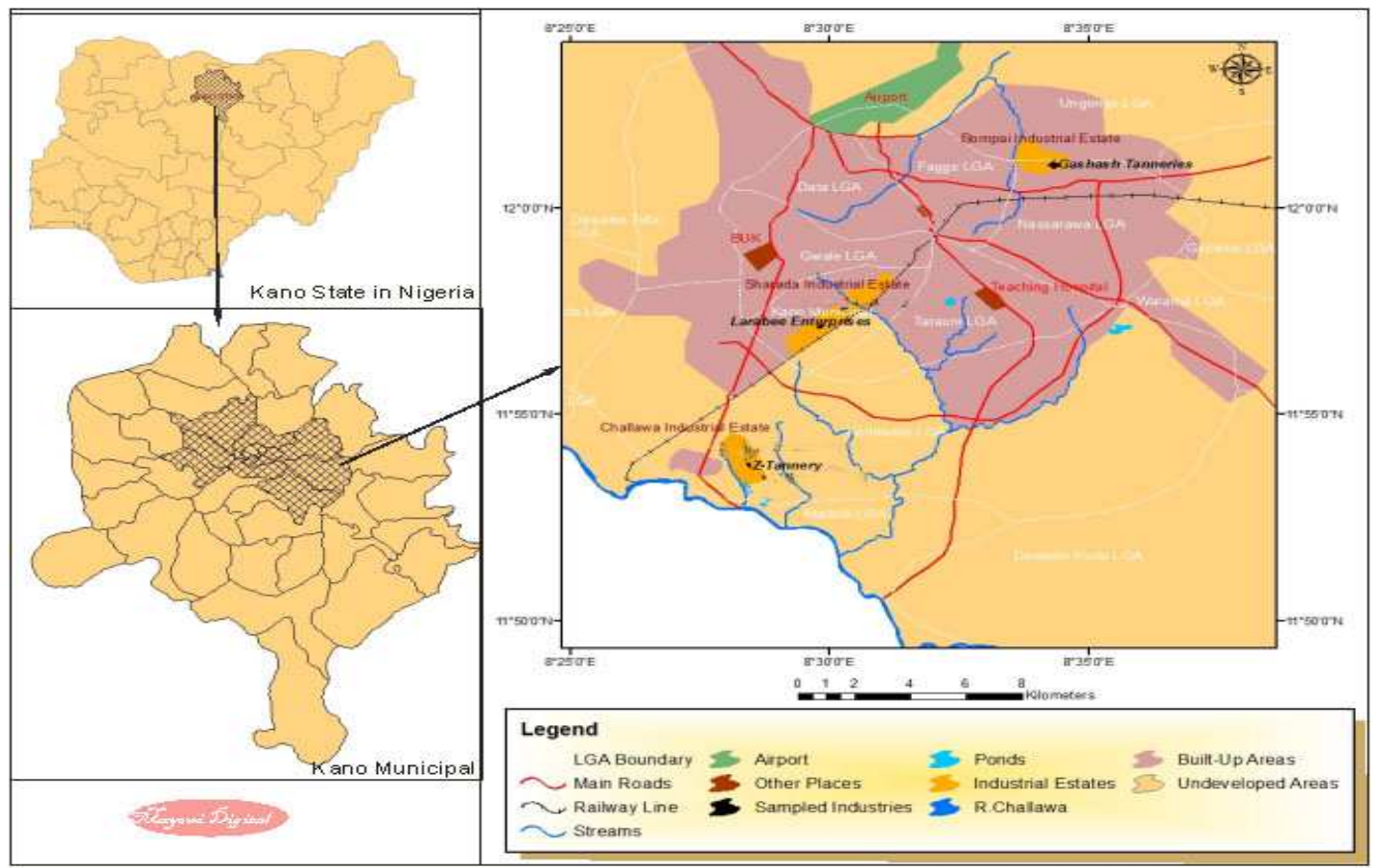

Fig. 1 Map showing the study areas

Source: Mayomi Digital Productions, GIS Laboratory, Department of Geography, UNIMAID (2017)

\section{Determination of Growth Rate of the Bacteria in Effluent Sample}

The bacteria growth rates were determined by transferring $2 \mathrm{~mL}$ of the bacterial isolates from the tannery effluent in broth medium into 100 $\mathrm{mL}$ sterile effluents in conical flasks and kept in an incubator (Giffrin cool) for 10 days. Control was also set up by incubating another $100 \mathrm{~mL}$ each of the sterile effluents without the bacteria. The optical density of the content was determined at the wavelength of $600 \mathrm{~nm}$ on a daily interval and recorded. 
BAJOPAS Volume 13 Number 2, December, 2020 Immobilization of Bacteria

Agar solution and inoculi were prepared separately. Fifty milliliters $(50 \mathrm{~mL})$ of nutrient broth each of the inoculi was prepared in a McCartney bottle and incubated for 24 hours. A solution of agar-agar was prepared by dissolving $10 \mathrm{~g}$ of the powder in distilled water and made up to $500 \mathrm{~mL}$ mark in an Erlenmeyer flask and was sterilized in an autoclave (280A) for 15 minutes and allowed to cool to $40-45^{\circ} \mathrm{C}$ (Ajao et al., 2011). Four milliliters ( $4 \mathrm{~mL})$ of the bacterial isolates in the nutrient broth was mixed with 36 $\mathrm{ml}$ of the prepared agar-agar media in petri-dish plates and then allowed to solidify. This was kept in the refrigerator for bioremediation.

\section{Bioremediation (Treatment) of the Effluents}

The solidified agar block (immobilized bacteria) was cut into cubes using a sterile knife; $0.1 \mathrm{~mL}$ phosphate buffer ( $\mathrm{pH} \mathrm{7.0)}$ was added and kept in the refrigerator for 1 hour for curing. The phosphate buffer was decanted after 1 hour and the cubes were washed with sterile distilled water 3-4 times before it was used (Ajao et al., 2011). Two liters (2 L) of the effluent was supplemented with the minimum basal medium in $\mathrm{g} / \mathrm{L}: \mathrm{NaCl}(0.8), \mathrm{MgSO}_{4} .7 \mathrm{H}_{2} \mathrm{O}(0.001), \mathrm{KH}_{2} \mathrm{PO}_{4}$ (2), $\mathrm{NaNO}_{3}$ (2), $\quad \mathrm{CaCl}_{2} .2 \mathrm{H}_{2} \mathrm{O} \quad(0.5)$ and $\mathrm{NaHPO}_{4} .12 \mathrm{H}_{2} \mathrm{O}(2)$ and sterilized in an autoclave at $121^{\circ} \mathrm{C}$ for 15 minutes (Margesin and Schinner, 2001). Two hundred and fifty milliliters $(250 \mathrm{~mL})$ of the effluents were transferred into different $250 \mathrm{ml}$ conical flasks. The content was covered with a cotton-wool ramped with foil paper to avoid contamination. Five grams $(5 \mathrm{~g})$ of the immobilized bacteria were quickly transferred into each of the effluents in the conical flasks in an inoculating chamber. The same procedures were carried out for the $10 \mathrm{~g}, 15 \mathrm{~g}, 20 \mathrm{~g}$ and 25 $\mathrm{g}$ of the immobilized bacteria in separate $250 \mathrm{~mL}$ effluents in conical flasks and agitated for ten days in a shaker incubator (Gallenkamp-OC4364-L) at a temperature $30^{\circ} \mathrm{C}$ and speed of 60 rpm. The treated effluent samples were taken on the tenth day and analyzed for the parameters $\mathrm{pH}$, SS, TDS, COD, and BOD, (Posttreatment determination) for the different grams of bacteria to evaluate and compare the biodegradation potential. (Baba et al., 2020).

\section{Statistical Analysis}

The data were represented as Mean \pm Standard deviation and analyzed statistically using oneway Analysis of Variance (ANOVA) and Tukey's HSD as Post Hoc Tests with the aid of SPSS 16.0. The correlation coefficient was also used to measure the strength of the relationship between the different masses of the bacteria and the parameters. All $\mathrm{p} \leq 0.05$ were considered as statistically significant.

\section{RESULTS AND DISCUSSION Physico-chemical parameters in the Industrial Effluents before the Biodegradation.}

Results of the Physico-chemical parameters in the industrial effluents before the Biodegradation is shown in table 1 . The mean temperatures $\left({ }^{\circ} \mathrm{C}\right)$ observed in TAN1, TAN2, and TAN3 samples were $28.07 \pm 0.65 ; 27.77 \pm 0.64$ and $26.38 \pm 3.81$ respectively. The order of the mean temperature of the samples from the three industries can be arranged as TAN1 > TAN2>TAN3. The temperature observed at TAN1, TAN2, and TAN3 samples were found below the WHO $\left(35^{\circ} \mathrm{C}\right)$ and NESREA $\left(40^{\circ} \mathrm{C}\right)$ limits. The low values of temperature might be due to the processes used at the time of sampling. High temperature brings down the solubility of gases in water that ultimately expresses as high BOD and COD. Statistical analysis shows that there is no significant difference $(p<0.05)$ between the mean values of temperature among the industries. This might be due to similar tannery activities involved in the tannery industries at the time of sampling. The average values of temperature observed in this present study are less than those observed by Akan et al. (2007), Akan et al. (2009) and Baba et al. (2020).

The mean level of $\mathrm{pH}$ observed in TAN1, TAN2 and TAN3, samples were $7.77 \pm 2.93$; $8.35 \pm 0.28$ and $7.52 \pm 0.76$ respectively. The order of the mean $\mathrm{pH}$ of the samples from the three industries can be arranged as TAN2> TAN1 $>$ TAN3. The $\mathrm{pH}$ of the samples falls within the WHO (7.0-8.5) and NESREA (6-9) standard limits. Statistical analysis shows that there is no significant difference $(p<0.05)$ between the mean values of $\mathrm{pH}$ among the industries. This might be due to similar tannery activities involved in the tannery industries at the time of sampling. Maheshwari et al. (2017) reported that the level of $\mathrm{pH}$ in the effluents from the tannery industry in Vaniyambadi, India was 6.5 which was lower than that observed in the present study. The $\mathrm{pH}$ in the effluents from the tannery industries in Kano and Kaduna were reported to be 7.64 and 6.89, respectively (Akan et al., 2007; Mohammed et al., 2017). The average values of $\mathrm{pH}$ observed in this present study are less than those observed by Mohammed et al. (2017) and Baba et al. (2020). The mean level of SS $(\mathrm{mg} / \mathrm{l})$ observed in TAN1, TAN2, and TAN3 samples were 374 \pm 124 ; $358 \pm 335$ and $780 \pm 739$ respectively. The order of the mean SS in the samples from the three industries can be arranged as TAN3 > TAN1 $>$ TAN2. 
The SS observed in the samples were far above the recommended standard limits of regulating bodies WHO $(30 \mathrm{mg} / \mathrm{l})$ and NESREA $(10 \mathrm{mg} / \mathrm{l})$. Statistical analysis shows that there is no significant difference $(p<0.05)$ between the mean values of SS among the industries. This might be due to similar tannery activities involved in the tannery industries at the time of sampling. The average values of SS observed in this present study are less than that observed $(3700 \pm 122 \mathrm{mg} / \mathrm{l})$ by Akan et al. (2009) for tanneries in Kano. Also, the average values of SS observed in this present study are less than that observed by Mohammed et al. (2017) and Baba et al. (2020) with the exception in TAN3.

The mean level of TDS (mg/l) observed in TAN1, TAN2, and TAN3 samples were $3941 \pm 3703$; $3300 \pm 1714$ and $2653 \pm 1240$ respectively. The order of the mean TDS in the samples from the three industries can be arranged as TAN1>TAN2>TAN3. The TDS observed in the samples were far above the recommended standard limits of WHO $(250 \mathrm{mg} / \mathrm{l})$ and NESREA $(500 \mathrm{mg} / \mathrm{l})$. Statistical analysis shows that there is no significant difference $(p<0.05)$ between the mean values of TDS among the industries. This might be due to similar tannery activities involved in the tannery industries at the time of sampling. TDS in the effluents from the tannery industries in Kano, Nigeria was reported to be $1281 \mathrm{mg} / \mathrm{l}$ (Akan et al., 2007). The average values of SS observed in this present study are less than those observed by Mohammed et al. (2017) and Baba et al. 2020)

The mean level of COD (mg/l) observed in TAN1, TAN2 and TAN3 samples seasons were $2372 \pm 938 ; \quad 1406 \pm 208$ and $3532 \pm 1373$ respectively. The order of the mean COD of the samples from the three industries can be arranged as TAN3>TAN1> TAN2. The COD observed in TAN1, TAN2 and TAN3 samples were far above the recommended standard limits of regulating bodies $\mathrm{WHO}(40 \mathrm{mg} / \mathrm{l})$ and NESREA (40 mg/l). Statistical analysis shows that there is no significant difference $(p<0.05)$ in COD among the industries. This might be due to similar tannery activities involved in the tannery industries as at the time of sampling. The Chemical Oxygen demand (COD) is the amount of oxygen, in $\mathrm{mg} / \mathrm{L}$, required for the degradation of the compound of wastewater to occur. In comparison, the average values of COD observed in this present study were higher than that observed by Mohammed et al. (2017) but lower than that observed by Baba et al. (2020).

The mean levels of BOD $(\mathrm{mg} / \mathrm{l})$ observed in TAN1, TAN2 and TAN3 samples were $13.85 \pm 6.42 ; \quad 19.46 \pm 0.50$ and $17.13 \pm 3.14$ respectively. The order of the mean BOD in the samples from the three industries can be arranged as TAN2>TAN3>TAN1. The BOD observed in TAN1, TAN2 and TAN3 samples were found below the recommended limits of NESREA (200 mg/l) but above WHO (10 mg/l). Statistical analysis shows that there is no significant difference $(p<0.05)$ between the mean values of BOD among the industries. This might be due to similar tannery activities involved in the tannery industries at the time of sampling. The low level of BOD recorded in this study is an indication of the low level of biodegradable organic solids in the effluent. The average values of BOD observed in this present study were lower than those observed by Mohammed et al. (2017) and Baba et al. (2020).

Table 1: Mean Values \pm S.D of Physico-chemical parameters of effluents from the Tannery Industries before Treatment.

\begin{tabular}{llllllll}
\hline Parameter & Tannery 1 & Tannery 2 & Tannery 3 & $\mathrm{a}$ & $\mathrm{b}$ & $\mathrm{c}$ & $\mathrm{d}$ \\
\cline { 2 - 7 } Temperature $\left({ }^{\circ} \mathrm{C}\right)$ & $28.07 \mathrm{a} \pm 0.65$ & $27.77 \mathrm{a} \pm 0.64$ & $26.38 \mathrm{a} \pm 3.81$ & & $29.50 \pm 4.68$ & 35 & 40 \\
pH & $7.77 \mathrm{a} \pm 2.93$ & $8.35 \mathrm{a} \pm 0.28$ & $7.52 \mathrm{a} \pm 0.76$ & 6.89 & $5.35 \pm 1.57$ & $7.0-8.5$ & $6.0-9.0$ \\
$\mathrm{COD}(\mathrm{mg} / \mathrm{l})$ & $2372 \mathrm{a} \pm 938$ & $1406 \mathrm{a} \pm 208$ & $3532 \mathrm{a} \pm 1373$ & 2.2 & $3106 \pm 2753$ & 40 & 40 \\
$\mathrm{BOD}(\mathrm{mg} / \mathrm{l})$ & $13.85 \mathrm{a} \pm 6.42$ & $19.46 \mathrm{a} \pm 0.50$ & $17.13 \mathrm{a} \pm 3.14$ & 1032 & $26.17 \pm 9.49$ & 10 & 200 \\
$\mathrm{SS}(\mathrm{mg} / \mathrm{l})$ & $374 \mathrm{a} \pm 124$ & $358 \mathrm{a} \pm 335$ & $780 \mathrm{a} \pm 739$ & 501 & $562 \pm 482$ & 30 & 10 \\
TDS $(\mathrm{mg} / \mathrm{l})$ & $3941 \mathrm{a} \pm 3703$ & $3300 \mathrm{a} \pm 1714$ & $2653 \mathrm{a} \pm 1240$ & 532.7 & $444 \pm 507$ & 250 & 500 \\
\hline
\end{tabular}

The values given in the table above are means of 6 replicate values, $\mathrm{n}=6$ ( 1 sample was taken monthly for 6 months). Within the rows, means with different alphabets are statistically different $(p<0.05)$. WHO: World Health Organisation. NESREA: National Environmental Standard and Regulatory Enforcement Agency. a = Mohammed et al.(2017), b = Baba et al. (2020), c = WHO (2006), $d=$ NESSRA (2009) 
BAJOPAS Volume 13 Number 2, December, 2020

Identification, Biochemical Characterization and growth rates of the Bacterial Isolates

Results of identification and biochemical characterization of the bacterial isolates were shown in table 2. After 24 hours of incubation, the nutrient agar media plates were checked for bacterial growth. The results showed the presence of different strains in the samples. The TAN1 bacteria isolate was found to be gramnegative cocci while TAN3 was gram-positive cocci. TAN2 bacteria isolate was found to be gram-positive, rod-shaped. TAN1, TAN2, and TAN3 bacteria isolates recorded positive results for spore former.

The results of the biochemical tests indicated that all the bacteria were positive for catalase, oxidase, citrate, maltose, glucose, lactose (negative in TAN1), mannitol (negative in TAN2), starch hydrolysis and coagulase (negative in TAN2) tests. The bacteria showed negative results for nitrate reduction, $M R$ (positive in TAN2), VP (positive in TAN1), Indole (positive in TAN2) tests. Base on the morphological and biochemical test results, TAN1, TAN2, and TAN3 bacteria isolates were identified to be Nesseria spp, Bacillus cereus, and Staphylococcus aureus respectively.

The growth rate of the TAN1, TAN2 and TAN3 Isolates were shown in figure 2. Generally, the optical density increase with the increase in time (day) and decrease as time goes on. The highest optical density was shown by bacillus cereus in TAN2 while the lowest was shown by Staphylococcus aureus in TAN3.

The initial growth phase of TAN1 Isolate bacteria occurred within 2-day of incubation as the growth rate increases up to the 6th-day incubation when the maximum growth was observed. Beyond the 6th day, the growth of the bacteria declined (which might be due to a shortage of nutrients in the effluents) until it reached its death phase (which might be due to the unavailability of nutrients in the effluents).

A similar trend of growth was also observed for TAN2 Isolate as the initial growth phase also occurred within 2-day of incubation but maximum growth rate observed on the 4th day of incubation. The stationary stage occurred between the 4th day and the 8th day. Beyond the 8th day, the growth of the bacteria declined (which might be due to a shortage of nutrients in the effluents) until it reached its death phase (which might be due to the unavailability of nutrients in the effluents).

The initial growth phase of TAN3 bacterial Isolate occurred within the 3-day incubation as the growth rate increases up to the 6th-day incubation when the maximum growth was observed. Beyond the 6th day, the growth of the bacteria declined (which might be due to a shortage of nutrients in the effluents) until it reached its death phase (which might be due to the unavailability of nutrients in the effluents).

Table 2: Morphological and Biochemical characteristics of bacterial isolates

\begin{tabular}{lllll} 
Bacterial Isolates & & TAN1 & TAN2 & TAN3 \\
\hline $\begin{array}{lllll}\text { Morphological } \\
\text { characteristics }\end{array}$ & Shape & Cocci & Rod & Cocci \\
& Spore & & & \\
& former & + & + & + \\
Gram & & & \\
Biochemical characteristics & reaction & - & + & + \\
& Citrate & + & + & + \\
& Catalase & + & + & + \\
& Coagulase & + & - & + \\
Starch & + & + & + \\
& Glucose & + & + & + \\
Oxidase & + & + & + \\
& Indo & - & + & - \\
Lactose & - & + & + \\
Manitol & + & - & + \\
Maltose & + & + & + \\
MR & - & + & - \\
VP & + & - & - \\
& Nitrate & - & - & - \\
Reduction & - Neisseria & Bacillus & Staphylococcus \\
& Bacterial & cereus & aureus \\
& name & spp & cas
\end{tabular}

+ = Positive; - = Negative; MR=Methyl Red; VP= Voges-Proskauer 


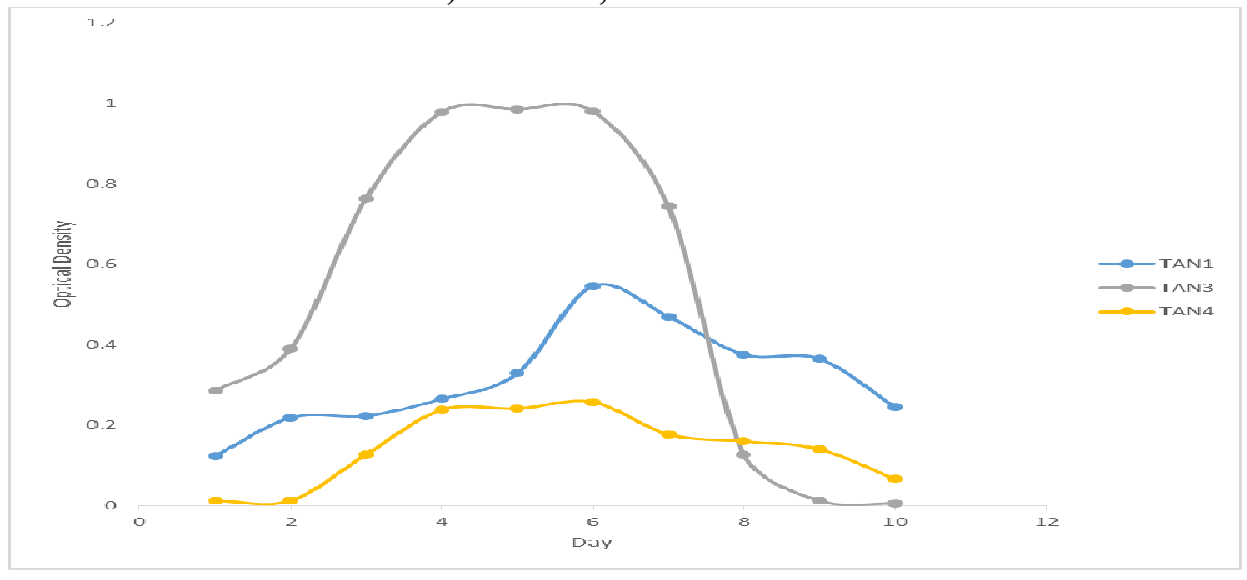

Fig. 2 Growth rates of the isolates in the effluents from the Tannery Industries

\section{Physico-chemical Parameters in the Industrial Effluents after the biodegradation.}

Table 3 shows the mean results of the physicochemical parameter before and after bioremediation using the different masses $(5 \mathrm{~g}$, $10 \mathrm{~g}, 15 \mathrm{~g}, 20 \mathrm{~g}$, and $25 \mathrm{~g}$ ) of the respective immobilized bacteria. Also, Table 4 shows the mean results of correlation coefficient ( $r$ ) between different masses of bacteria and physicochemical parameters.

The mean values $(\mathrm{mg} / \mathrm{l})$ of the SS after the bioremediation varies between $243 \pm 45$ and $898 \pm 672$. The mean concentration $(\mathrm{mg} / \mathrm{l})$ of SS remediated by the different masses $(5 \mathrm{~g}, 10 \mathrm{~g}$, $15 \mathrm{~g}, 20 \mathrm{~g}$, and $25 \mathrm{~g}$ ) of the bacteria varies. The SS in the samples fluctuates up and down after the bioremediation process when compared with the SS of the raw samples before the bioremediation. The increase in the levels of the SS might be due to the aggregation of the TDS which are large enough to result into SS. The increase in the levels of the SS might be also due to the influence of the nutrients which was added into the effluents in order to make the microorganisms more active and viable for fast degradation of organic contaminants in the effluent. The relative potential or efficiency of the different masses of the bacteria in remediating SS in TAN1 samples was in the order $25 \mathrm{~g}>20 \mathrm{~g}>15 \mathrm{~g}>10 \mathrm{~g}>5 \mathrm{~g}$. For TAN2 and TAN3 samples, the order was $25 \mathrm{~g}>20 \mathrm{~g}>15$ $\mathrm{g}>10 \mathrm{~g}>5 \mathrm{~g}$. These might be due to the variations in the surface areas of the different masses of the immobilized bacteria. Statistical analysis shows that there is no significant difference $(p<0.05)$ between the mean values of SS among the masses in the respective industries. Positive and significant correlations exist between the masses of bacteria and Suspended Solid (SS). This showed that there is general increase in the levels of the SS as the masses of the immobilized bacteria increases. TAN3 (90\%) and TAN1 (80\%) showed a very high correlation with the masses of the bacteria while TAN2 (61\%) showed a very low correlation.

The mean values $(\mathrm{mg} / \mathrm{l})$ of the TDS after the bioremediation varies between $46 \pm 11$ and $83 \pm 78$. The mean concentration $(\mathrm{mg} / \mathrm{l})$ of TDS remediated by the different masses $(5 \mathrm{~g}, 10 \mathrm{~g}$, $15 \mathrm{~g}, 20 \mathrm{~g}$, and $25 \mathrm{~g}$ ) of the bacteria varies. There is a reduction in all the TDS of all the samples after the bioremediation process compared with the TDS of the raw samples before the bioremediation. The relative potential or efficiency of the different masses of the bacteria in remediating TDS in TAN1 and TAN3 samples was in the order $5 \mathrm{~g}>10 \mathrm{~g}>15 \mathrm{~g}>20$ $\mathrm{g}>25 \mathrm{~g}$. For TAN2 samples, the order was 20 $g>10 \quad g>25 \quad g>15 \quad g>5 \quad g$. Statistical analysis shows that there is no significant difference $(p<0.05)$ between the mean values of TDS among the masses in the respective industries. These might be due to the variations in the surface areas of the different masses of the immobilized bacteria. Positive and significant correlations exist between the masses of bacteria and TDS with the exception in TAN2 (negative and insignificant correlation). The positive correlations showed that there is general increase in the levels of the TDS as the masses of the immobilized bacteria increases. TAN1 $(96 \%)$ showed a very high correlation with the masses of the bacteria while TAN2 (47\%) showed a very low correlation.

The mean values $(\mathrm{mg} / \mathrm{l})$ of the BOD after the bioremediation varies between $1.56 \pm 0.20 \mathrm{mg} / \mathrm{l}$ and $6.92 \pm 5.49 \mathrm{mg} / \mathrm{l}$. The mean concentration $(\mathrm{mg} / \mathrm{l})$ of BOD remediated by the different masses $(5 \mathrm{~g}, 10 \mathrm{~g}, 15 \mathrm{~g}, 20 \mathrm{~g}$, and $25 \mathrm{~g}$ ) of the bacteria varies. There is a reduction in all the BOD of all the samples after the bioremediation process compared with the $\mathrm{BOD}$ of the raw 
BAJOPAS Volume 13 Number 2, December, 2020 samples before the bioremediation. The relative potential or efficiency of the different masses of the bacteria in remediating BOD in TAN1, TAN2 and TAN3 samples were in the order $25 \mathrm{~g}>20$ $\mathrm{g}>15 \mathrm{~g}>10 \mathrm{~g}>5 \mathrm{~g}, 25 \mathrm{~g}>15 \mathrm{~g}>5 \mathrm{~g}>10 \mathrm{~g}>20 \mathrm{~g}$ and $20 \mathrm{~g}>10 \mathrm{~g}>25 \mathrm{~g}>15 \mathrm{~g}>5 \mathrm{~g}$ respectively. Statistical analysis shows that there is significant difference $(p<0.05)$ between the mean values of BOD among the masses in the respective industries. These might be due to the variations in the surface areas of the different masses of the immobilized bacteria. Negative and significant correlations exist between the masses of bacteria and BOD. This showed that there is general decrease in the levels of the BOD as the masses of the immobilized bacteria increases. TAN1 (94\%) showed a very high correlation with the masses of the bacteria while TAN2 (4\%) showed a very low correlation.

The mean values $(\mathrm{mg} / \mathrm{l})$ of the COD after the bioremediation varies between $250 \pm 154$ and $3134 \pm 1595$. The mean concentration $(\mathrm{mg} / \mathrm{l})$ of COD remediated by the different masses $(5 \mathrm{~g}$, $10 \mathrm{~g}, 15 \mathrm{~g} 20 \mathrm{~g}$, and $25 \mathrm{~g}$ ) of the bacteria varies. There is a reduction in all the COD of all the samples after the bioremediation process compared with the COD of the raw samples before the bioremediation. The relative potential or efficiency of the different masses of the bacteria in remediating COD in TAN1, TAN2 and TAN3 samples were in the order $25 \mathrm{~g}>20 \mathrm{~g}>15$ $\mathrm{g}>5 \mathrm{~g}>10 \mathrm{~g}, 25 \mathrm{~g}>20 \mathrm{~g}>15 \mathrm{~g}>10 \mathrm{~g}>5 \mathrm{~g}$ and 10 g>5 g>25 g>15 g>20 g respectively. Statistical analysis shows that there were significant difference $(p<0.05)$ between the mean values of COD among the masses in the respective industries except for effluents treated with $25 \mathrm{~g}$. These might be due to the variations in the surface areas of the different masses of the immobilized bacteria. Negative and insignificant correlations exist between the masses of bacteria and COD with the exception in TAN3 (positive and significant correlation). The negative correlations showed that there is general decrease in the levels of the COD as the masses of the immobilized bacteria increases. TAN2 (100\%) showed a very high correlation with the masses of the bacteria while TAN3 (36\%) showed a very low correlation.

Generally, there was an overall decrease in the concentration of these physicochemical parameters after the bioremediation using the different masses of the bacterial isolates. These might be due to the variations in the surface areas of the different masses of the immobilized bacteria. This is in line with the work of Jimoh et al. (2018) and Baba et al. (2020).

Table 3: Mean Values $(\mathrm{mg} / \mathrm{l}) \pm$ S.D of Physicochemical parameters in effluents from the Tannery Industries before and after Treatment of the effluents $(250 \mathrm{ml})$ with the different masses $(5 \mathrm{~g}, 10 \mathrm{~g}$, $15 \mathrm{~g}, 20 \mathrm{~g}$, and $25 \mathrm{~g}$ ) of the bacteria.

\begin{tabular}{llllllll}
\hline $\mathrm{P}$ & IND & Before & \multicolumn{5}{c}{ After } \\
\cline { 4 - 7 } & & & $5 \mathrm{~g}$ & $10 \mathrm{~g}$ & $15 \mathrm{~g}$ & $20 \mathrm{~g}$ & $25 \mathrm{~g}$ \\
\hline \multirow{2}{*}{ COD } & TAN1 & $2372 \pm 938$ & $1708 \mathrm{a} \pm 861$ & $2045 \mathrm{a} \pm 1205$ & $845 \mathrm{a} \pm 369$ & $300 \mathrm{a} \pm 167$ & $250 \mathrm{a} \pm 154$ \\
& TAN2 & $1406 \pm 208$ & $1195 \mathrm{a} \pm 208$ & $1125 \mathrm{a} \pm 384$ & $1055 \mathrm{a} \pm 317$ & $956 \mathrm{a} \pm 310$ & $870 \mathrm{ab} \pm 240$ \\
& TAN3 & $3532 \pm 1373$ & $2374 \mathrm{a} \pm 1344$ & $1976 \mathrm{a} \pm 1405$ & $2757 \mathrm{a} \pm 1266$ & $3134 \mathrm{a} \pm 1595$ & $2614 \mathrm{~b} \pm 1105$ \\
BOD & TAN1 & $13.85 \pm 6.42$ & $6.92 \mathrm{a} \pm 5.49$ & $6.42 \mathrm{a} \pm 5.07$ & $5.72 \mathrm{a} \pm 5.35$ & $4.62 \mathrm{a} \pm 4.37$ & $2.82 \mathrm{ab} \pm 1.26$ \\
& TAN2 & $19.46 \pm 0.50$ & $1.75 \mathrm{~b} \pm 0.22$ & $1.73 \mathrm{~b} \pm 0.18$ & $1.58 \mathrm{a} \pm 0.16$ & $1.91 \mathrm{a} \pm 0.22$ & $1.56 \mathrm{~b} \pm 0.20$ \\
& TAN3 & $17.13 \pm 3.14$ & $4.24 \mathrm{ab} \pm 0.77$ & $3.29 \mathrm{ab} \pm 0.37$ & $4.11 \mathrm{a} \pm 0.07$ & $3.23 \mathrm{a} \pm 0.91$ & $3.33 \mathrm{a} \pm 1.28$ \\
SS & TAN1 & $374 \pm 124$ & $243 \mathrm{a} \pm 45$ & $471 \mathrm{a} \pm 226$ & $475 \mathrm{a} \pm 182$ & $492 \mathrm{a} \pm 128$ & $611 \mathrm{a} \pm 217$ \\
& TAN2 & $358 \pm 335$ & $460 \mathrm{a} \pm 400$ & $543 \mathrm{a} \pm 414$ & $544 \mathrm{a} \pm 402$ & $551 \mathrm{a} \pm 414$ & $554 \mathrm{a} \pm 405$ \\
& TAN3 & $780 \pm 739$ & $586 \mathrm{a} \pm 594$ & $758 \mathrm{a} \pm 656$ & $787 \mathrm{a} \pm 676$ & $861 \mathrm{a} \pm 635$ & $898 \mathrm{a} \pm 672$ \\
TDS & TAN1 & $3941 \pm 3703$ & $51 \mathrm{a} \pm 10$ & $53 \mathrm{a} \pm 10$ & $55 \mathrm{a} \pm 15$ & $61 \mathrm{a} \pm 20$ & $63 \mathrm{a} \pm 26$ \\
& TAN2 & $3300 \pm 1714$ & $83 \mathrm{a} \pm 78$ & $47 \mathrm{a} \pm 20$ & $48 \mathrm{a} \pm 22$ & $47 \mathrm{a} \pm 17$ & $48 \mathrm{a} \pm 17$ \\
& TAN3 & $2653 \pm 1240$ & $46 \mathrm{a} \pm 11$ & $55 \mathrm{a} \pm 24$ & $55 \mathrm{a} \pm 25$ & $58 \mathrm{a} \pm 23$ & $61 \mathrm{a} \pm 28$ \\
\hline
\end{tabular}

Replicate $=6$ (months)

Within the rows, for the same parameter, means with different alphabets are statistically different $(p<0.05)$.

$\mathrm{P}=$ parameter, IND = Industries 
BAJOPAS Volume 13 Number 2, December, 2020

Table 4: Correlation coefficient $(r)$ between different masses of the bacteria and the physicochemical parameters.

\begin{tabular}{llll}
\hline Industries & Parameter & Correlation coefficient $(r)$ & $\begin{array}{l}\text { Percent dependence (rxrx100) } \\
(\%)\end{array}$ \\
\hline TAN1 & COD & -0.9 & 82 \\
& BOD & -0.97 & 94 \\
& SS & $0.90^{*}$ & 80 \\
TAN2 & TDS & $0.98^{*}$ & 96 \\
& COD & -1 & 100 \\
& BOD & -0.21 & 4 \\
& SS & $0.78^{*}$ & 61 \\
& TDS & -0.69 & 47 \\
& COD & $0.60^{*}$ & 36 \\
& BOD & -0.6 & 37 \\
& SS & $0.95^{*}$ & 90 \\
& TDS & $0.94^{*}$ & 89 \\
\hline
\end{tabular}

The correlation coefficient $(r)$ with * is statistically significant $(p<0.05)$.

Percentage reduction of the Parameters

Table 5 shows the percentage reduction of Parameters in industrial samples before and after the treatment of the effluents $(250 \mathrm{ml})$ with the different masses $(5 \mathrm{~g}, 10 \mathrm{~g}, 15 \mathrm{~g}, 20 \mathrm{~g}$, and $25 \mathrm{~g}$ ) of the Immobilized Bacteria.

In TAN1 samples, the percentage reduction (\%) of COD ranged (14-89); BOD (50-80); SS (-32$35)$ and TDS (98-99). In TAN2 samples, the percentage decrease $(\%)$ of COD ranged (15$38) ;$ BOD (90-92); SS [-28-(-55)] and TDS (9798). In TAN3 samples, the percentage decrease (\%) of COD ranged (11-44); BOD (76-81); SS (15-25) and TDS (98). The percentage increase in the levels COD, BOD and TDS might be due to the increase in the surface area of the different masses of the immobilized bacteria. However, the percentage decrease in the levels of the SS might be due to the aggregation of the TDS which are large enough to result into SS. The percentage decrease in the levels of the SS might be also due to the influence of the nutrients which was added into the effluents in order to make the microorganisms more active and viable for fast degradation of organic contaminants in the effluent. This is in line with the work of Jimoh et al. (2018) in which the concentration of the SS increase after the bioremediation of effluents.

Sreemoyee and Priti (2013) assessed and reduced several Physico-chemical parameters of dairy wastewater using Niesseria $s p$. and concluded that the species are well known to degrade organic compounds. This is in agreement with the current study in which the immobilized Niesseria $s p$ degrade the organic contaminants as indicated by the BOD, COD and TDS.

Jimoh et al. (2018) observed that TSS of the effluents was increased after treatment with immobilized bacteria and concluded that it might be due to the biostimulation method adopted for the research.

The optimum $\mathrm{pH}$ Biosorption of Chromium by Bacillus spp and Staphylococcus spp. from tannery effluent was investigated by Mythili and Karthikeyan (2011). The maximum adsorption of Chromium $(86.4 \mathrm{mg} / \mathrm{L})$ was showed by Bacillus spp and Staphylococcus spp showed $70.6 \mathrm{mg} / \mathrm{L}$ at an initial concentration of $100 \mathrm{mg} / \mathrm{L}$. In the present study, immobilised Bacillus spp and Staphylococcus spp. from the tannery industrial effluents reduced the levels of the organic pollutants with high potential as indicated by the percentage reduction of BOD, COD and TDS.

Enzymes often can work in multiple environments especially if they are immobilized. This makes the microorganisms' enzymes even more resistant to harsh environments and enables the enzymes to be recovered and recycled after they are no longer needed (Gianfreda and Rao 2004). Ramesh and Singh (1993) reported that the immobilized bacteria having more efficiency to remove the suspended particles than free cells. Using the immobilized cell is preferable due to its capability for using several times with the same efficiency, which makes it more economical. Similar work was done by Sikander et al. (2007) showing the higher reduction with permeabilized cells of Ochrobactrum intermedium strain SDCr-5. 
BAJOPAS Volume 13 Number 2, December, 2020

The results revealed the isolation and identification of isolates with the potential for the reduction of $\mathrm{Cr}$ (VI) to $\mathrm{Cr}$ (III). Results indicated that immobilized $B$. cereus could be efficiently used for the reduction of $\mathrm{Cr}$ (VI).

Table 5: Percentage reduction of the tested Parameters from the tannery industrial samples of the Immobilized Bacteria.

\begin{tabular}{lllllll}
\hline \multirow{2}{*}{ Industries } & & \multicolumn{5}{c}{ Percentage Reduction $(\%)$} \\
\cline { 3 - 7 } & & $5 \mathrm{~g}$ & $10 \mathrm{~g}$ & $15 \mathrm{~g}$ & $20 \mathrm{~g}$ & $25 \mathrm{~g}$ \\
\hline TAN1 & COD & 28 & 14 & 64 & 87 & 89 \\
& BOD & 50 & 54 & 59 & 67 & 80 \\
& SS & 35 & -26 & -27 & -32 & -63 \\
& TDS & 99 & 99 & 99 & 98 & 98 \\
TAN2 & COD & 15 & 20 & 25 & 32 & 38 \\
& BOD & 91 & 91 & 92 & 90 & 92 \\
& SS & -28 & -52 & -52 & -54 & -55 \\
& TDS & 97 & 99 & 99 & 99 & 99 \\
& COD & 33 & 44 & 22 & 11 & 26 \\
& BOD & 75 & 81 & 76 & 81 & 81 \\
& SS & 25 & 3 & -1 & -10 & -15 \\
& TDS & 98 & 98 & 98 & 98 & 98 \\
\hline
\end{tabular}

Percentage Reduction $=(B-A) / B \times 100 \%$

$A=$ Concentration of the parameter after treatment

$\mathrm{B}=$ Concentration of the parameter before treatment

$+=$ percentage decrease

- = percentage increase

In general, immobilization makes the enzyme more resistant to temperature, $\mathrm{pH}$, and substrate concentration swings giving it a longer lifetime and higher productivity per active unit (Gianfreda and Rao, 2004; FuIlbrook, 1996; Russell et al, 2003; Kandelbauer et al., 2004). Immobilized cells have been used and studied extensively for the production of useful chemicals (Ohtake and Silver, 1994), the treatment of wastewaters (Chen et al., 2003; Wang et al., 2010). Although many workers described microbial degradation of tannery effluent, limited literature is available on the bioremediation of tannery effluent using immobilized bacterial cells in the Kano Industrial Estates.

\section{CONCLUSION}

The samples contained variable levels of the physicochemical parameters. The results of the Analysis of variance revealed that, no statistical difference $(p<0.05)$ was observed for the temperature, $\mathrm{pH}, \mathrm{SS}, \mathrm{TDS}, \mathrm{BOD}$ and $\mathrm{COD}$ among the three tannery industries before the treatment. The levels of some of the parameters
(SS, TDS and COD) observed in the samples were found above the recommended limits of WHO and NESREA, which called for the treatment of the effluents before discharge into the environment. Base on the morphological and biochemical test results, TAN1, TAN2, and TAN3 bacterial isolates were identified to be Neisseria spp, Bacillus cereus, and Staphylococcus aureus respectively. The results of Post-treatment analysis showed that there is overall decrease in the levels of the parameters determined when compared with that of the pre-treatment. The overall percentage reduction of the immobilised bacteria in the treatment of the respective effluents was in the order TAN2 (72\%)>TAN1 $(70 \%)>$ TAN3 $(62 \%)$. Hence, the immobilized bacteria are having higher biodegradation potential for the treatment of the tannery effluents.

\section{Acknowledgments}

The authors wish to acknowledge the University of Maiduguri for the financial support. The authors are grateful to the Kano State Ministry of Environment for their support in obtaining the effluent samples. 


\section{REFERENCES}

Ajao, A. T., Adebayo, G. B., and Yakubu, S. E. (2011). Bioremediation of textile industrial effluent using mixed culture of Pseudomonas aeruginosa and Bacillus subtilis immobilized on agar-agar in a bioreactor. J. Microbiol. Biotech. Res, 1(3), 50-56.

Akan, J. C., Moses, E. A., Ogugbuaja, V. O., and Abah, J. (2007). Assessment of tannery industrial effluents from Kano metropolis, Kano State, Nigeria. Journal of Applied Sciences, 7(19), 2788-2793.

Akan, J. C., Ogugbuaja, V. O., Abdulrahman, F. I., and Ayodele, J. T. (2009). Pollutant levels in effluent samples from tanneries and textiles of Kano industrial areas, Nigeria. Global journal of pure and applied sciences, 15(3-4).

APHA (1989). Standard methods for Examination of Will bete and Will betewater.15 $5^{\text {th }}$ edition. Brydpass Springfield Will behington DC. pp. 164-176

APHA (1992). Standard Methods for the Examination of Water and Wastewater. Health, 69, 1116-9.

Baba, A., Garba, S. T., and Bello, H. S. (2020). Bioremediation Potential of Immobilized corynebacterium kutsceri in the Treatment of Tannery Industrial Effluent from Challawa Industrial Estate, Kano State, Nigeria. Journal of the Turkish Chemical Society Section A: Chemistry, $7(2), 335-350$.

Beem, E. I. V. (1994). reduction of solvent VOC emission. J. Oil Col. Chem. Ass, 77, 158.

Bouwer, E. J., and Zehnder, A. J. (1993). Bioremediation of organic compoundsputting microbial metabolism to work. Trends in biotechnology, 11(8), 360367.

Chen, K. C., Wu, J. Y., Liou, D. J., and Hwang, S. C. J. (2003). Decolorization of the textile dyes by newly isolated bacterial strains. Journal of Biotechnology, 101(1), 57-68.

Dan'Azumi, S., and Bichi, M. H. (2010). INDUSTRIAL POLLUTION AND HEAVY METALS PROFILE OF CHALLAWA RIVER IN KANO, NIGERIA. Journal of Applied Sciences in Environmental Sanitation, $5(1)$.

DWAF. (1992). Analytical Methods Manual, TR 151. Department of Water Affairs and Forestry, Pretoria.

El-Bestawy, E. (2013). Biological treatment of leather-tanning industrial wastewater using free living bacteria.
Elsheikh, M. A. S. (2009). Tannery wastewater pre-treatment. Water Science and Technology, 60(2), 433-440.

FuIlbrook, P. D. (1996). "Kinetics." Industrial enzymology: The application of enzymes in Industry. 2nd Ed. T. Godfrey and J Reichelt. eds.. Nature. New York.

Gianfreda, L., and Rao, M. A. (2004). Potential of extra cellular enzymes in remediation of polluted soils: a review. Enzyme and microbial technology, 35(4), 339354.

Hugo Springer. (1994). John Arthur Wilson Memorial Lecture "Treatment of Industrial Wastes of the Leather Industry - is it still a Major Problem". JALCA, 89, 153-185

Jimoh, A. A., Ganiyu, B. A., Baba, D., and Baba, A. (2018) Bioremediation Process of Effluent from Detergent and Food Industries in Jos, Nigeria: Kinetics and Thermodynamics. International Journal of Engineering Science Invention (IJESI), 762-73

Kandelbauer, A., Maute, O., Kessler, R. W., Erlacher, A., and Gübitz, G. M. (2004). Study of dye decolorization in an immobilized laccase enzyme-reactor using online spectroscopy. Biotechnology and bioengineering, 87(4), 552-563.

Kongjao, S., Damronglerd, S., and Hunsom, M. (2008). Simultaneous removal of organic and inorganic Pollutants in tannery wastewater using electrocoagulation technique. Korean Journal of chemical engineering, 25(4), 703.

Maheshwari, U. M., Aruna, S., Gomathi, M., and AbdulJaffar, A. H. (2017). Bioremediation by Free and Immobilized Bacteria Isolated from Tannery Effluent. International Journal of Research in Applied, Natural and Social Sciences. 5(7), 75-90

Margesin, R., and Schinner, F. (2001). Bioremediation (natural attenuation and biostimulation) of diesel-oilcontaminated soil in an alpine glacier skiing area. Applied and environmental microbiology, 677), 3127-3133.

Mohammed, A., Sekar, P., and George, J. (2011). Efficacy of microbes in bioremediation of tannery effluent. Inter. J. Curr. Res, 3(4), 324-326.

Mohammed, S. S. D., Orukotan, A. A., and Abdullahi, H. (2017). Physicochemical and Bacteriological Assessment of Tannery Effluent from Samaru-Zaria, 
BAJOPAS Volume 13 Number 2, December, 2020 Kaduna State, Nigeria. Journal of Applied

Sciences and Environmental Management, 21(4), 734-740.

Munz, G., De Angelis, D., Gori, R., Mori, G., Casarci, M., and Lubello, C. (2009). The role of tannins in conventional and membrane treatment of tannery wastewater. Journal of hazardous materials, 164(2-3), 733-739

Mythili, K., and Karthikeyan, B. (2011). Bioremediation of $\mathrm{Cr}$ (VI) from tannery effluent using Bacillus spp and Staphylococcus spp. International Multidisciplinary Research Journal, 1(6).

NESREA (2009). National Environmental Standards for Effluent Limitations and Regulation. 1233-1236

Noorjahan, C. M. (2014). Physicochemical characteristics, identification of bacteria and biodegradation of industrial effluent. Journal of bioremediation and Biodegradation, 5(3).

Ohtake, H. I., and Silver, A. O. (1994). Bacterial reduction of toxic chromate. Biological degradation and bioremediation of toxic chemicals, 403-415.

Omoleke, I. I. (2004). Management of environmental pollution in Ibadan, an African city: the challenges of health hazard facing government and the people. Journal of Human Ecology, 15(4), 265-275.

Rajor, A., Reddy, A.S., and Singh, B. (2004). Determination of BOD kinetic Parameters and evaluation of alternate methods, M.Sc. Thesis, Department of biotechnology \& environmental Science, Thapar Institute of Engineering and Technology, Patiala

Ramasami, T., Rajamani, S., and Rao, J. R. (1994, March). Pollution control in leather industry: Emerging technological options. In International symposium on surface and colloidal science and its relevance to soil pollution, madras.

Ramesh, J. V. S., and Singh, S. P. (1993). Yearly variation in certain physicochemical parameters of pond at eastern Doon Valley. Uttar Pradesh J. Zoo, 12 (1), 7577.

Ranen, S., and Sharadinadra, C. (2009). Biotechnology applications to environmental remediation in resource exploitation. Current science, 97, 6-25
Russell, A. J., Berberich, J. A., Drevon, G. F., and Koepsel, R. R. (2003). Biomaterials for mediation of

chemical and biological warfare agents. Annual review of biomedical engineering, 5(1), 1-27.

Saravanan, P., and Saravanan, A. (1999). Decolourization of tannery effluent by Flavobacterium sp. EK 1. Indian Journal of Environmental Protection, 19, 19-24.

Sikander, S., and Shahida, H. (2007). Reduction of toxic hexavalent chromium by Ochrobactrum intermedium strain SDCr5 stimulated by heavy metals. Bioresource Technol, 98, 340-344.

Singh, N., Sharma, B. K., and Bohra, P. C. (2000). Impact assessment of industrial effluent of arid soils by using satellite imageries. Journal of the Indian Society of Remote Sensing, 28(2-3), 79.

Sreemoyee, C., and Priti, P. (2013). Assessment of physico-chemical parameters of dairy waste water and isolation and characterization of bacterial strains in terms of cod reduction. Int J Sci, 2(3), 395-400.

Verheijen, L. A. H. M., Wiersema, D., Pol, L. H., and De Wit, J. (1996). Management of wastes from animal product processing. Livestock and environment, Finding a balance. International Agriculture Center, Wageningen, The Netherlands.

Wang, F., Yao, J., Si, Y., Chen, H., Russel, M., Chen, K., and Bramanti, E. (2010). Short-time effect of heavy metals upon microbial community activity. Journal of Hazardous Materials, 173(13), 510-516.

WHO (World Health Organization). (2006). Air quality guidelines: global update 2005: particulate matter, ozone, nitrogen dioxide, and sulfur dioxide. World Health Organization.

World Bank. (1995). Nigeria's strategic options for redressing industrial pollution. World Bank, industry and energy division. 1st edition, West Central Africa Department; Annexes: 1995; pp 60-62.

Zahoor, A., and Abdul, R. (2009). Enumeration of Coliforms. Journal of Environmental Sciences. 21, 814-820 


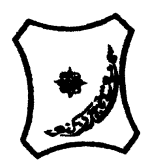

Bayero Journal of Pure and Applied Sciences, 13(2): 1 - 12

Received: November, 2020

Accepted: December, 2020

ISSN $2006-6996$

\title{
BIODEGRADATION POTENTIAL OF IMMOBILIZED BACTERIA IN THE TREATMENT OF TANNERY INDUSTRIAL EFFLUENTS FROM INDUSTRIAL ESTATES IN KANO STATE, NIGERIA
}

\author{
Abdullateef, B., ${ }^{1 *}$ Shuaibu, T. G., ${ }^{1}$ Babagana, K., ${ }^{1}$ Suleman, H. B. ${ }^{2}$ and Dauda, B. ${ }^{3}$ \\ ${ }^{1}$ Department of Pure and Applied Chemistry, Faculty of Science, University of Maiduguri, Borno State, \\ Nigeria \\ ${ }^{2}$ Department of Microbiology, Faculty of Science, University of Maiduguri, Borno State, Nigeria \\ ${ }^{3}$ Department of Chemical Engineering, Faculty of Engineering, University of Maiduguri, Borno State, \\ Nigeria \\ *Corresponding author: babslega@gmail.com; abelega2007@yahoo.com; +2348061309753
}

\section{ABSTRACT}

Industrial Effluents Samples from Gashash Tanneries (TAN1) in Bompai Industrial estate, Larabee Tannery Industry (TAN2) in Sharada Industrial estate and Z Tannery Industries (TAN3) in Challawa Industrial estate, Kano State, Nigeria were collected over a period of six months (August 2017 to January 2018) for assessing the biodegradation potentials of bacteria in the treatment of organic pollutants within the effluents. Bacteria were isolated from the effluents and immobilized on agar-agar. Different masses (5 g, $10 \mathrm{gr}, 15$ $\mathrm{g}, 20 \mathrm{~g}$, and $25 \mathrm{~g}$ ) of the bacteria were used in the treatment of $250 \mathrm{ml}$ of the effluents for ten days in a shaker incubator (Gallenkamp-OC-4364-L) at the temperature $30{ }^{\circ} \mathrm{C}$ and speed of $60 \mathrm{rpm}$. Pre-treatment analysis of the effluents for Temperature, pH, Biochemical Oxygen Demand (BOD), Chemical Oxygen Demand (COD), Suspended Solid (SS) and Total Dissolved Solids (TDS) gives the following results; temperature $\left({ }^{\circ} \mathrm{C}\right.$ )

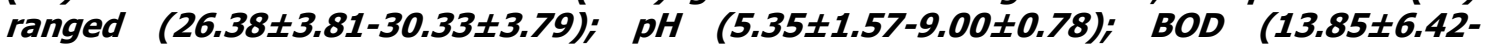
$38.75 \pm 16.20) ;$ COD (1406 $\pm 208-3532 \pm 1373) ;$ SS (208 $\pm 235-780 \pm 739)$ and TDS (266 $\pm 253-5276 \pm 2971)$. No statistical differences ( $p \leq 0.05)$ was observed for all the results among the different industries. The bacterial isolates were identified as Neisseria spp, Bacillus cereus, and Staphylococcus aureus, in TAN1, TAN2, and TAN3, respectively. After treatment of the effluent with the different masses of the isolated bacteria, the mean level of BOD was found to range as (0.55 $\pm 0.36-6.92 \pm 5.49) ; C O D$ (ND-3134 \pm 1595$)$;

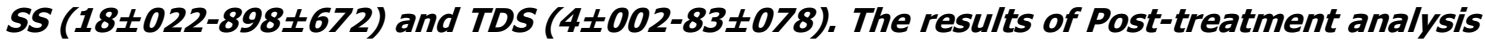
showed that there is overall decrease in the levels of the parameters determined when compared with that of the pre-treatment. The overall percentage reduction of the immobilised bacteria in the treatment of the respective effluents was in the order TAN2 (72\%)>TAN1 (70\%)>TAN3 (62\%). Hence, the immobilized bacteria are having higher biodegradation potential for the treatment of the tannery effluents.

Keywords: Biodegradation, bacteria, effluent, immobilization, tannery.

\section{INTRODUCTION}

Tannery industrial wastewater is a serious consequence of the pollution point of view for streams, freshwater, and land used for agriculture. The lack of awareness in the modern industrial practice has resulted in the discharge of tannery effluents which exhibit very high value of chromium ( $\mathrm{Cr}$ ), Sulfide, and chloride, Total Dissolved Solid (TDS), Total Suspended Solid (TSS), Biochemical Oxygen Demand (BOD) and Chemical Oxygen Demand (COD) in the water stream or land (Mohammed et al., 2001). Tanning is the process, which One ton of skin generally leads to the production of 20 to $80 \mathrm{~m}^{3}$ of turbid and foul-smelling converts the protein of the rawhide or skin into a stable material, which will not putrefy and is suitable for a wide variety of end applications (Elsheikh, 2009). The highly polluting chromium is the most commonly used tanning material producing leather that is more flexible and pliable than vegetable-tanned leather and does not discolor or lose shape in water as drastically as vegetable-tan (Elsheikh, 2009). Tannery effluent is among the most hazardous industrial pollutants due to its huge organic and inorganic load, which is highly toxic to human life and the environment (Kongjao et al., 2008). wastewater including chromium (100-400 mg/l), sulfide $(200-800 \mathrm{mg} / \mathrm{l})$, high levels of fat and 
BAJOPAS Volume 13 Number 2, December, 2020 other solid wastes, and notable pathogen contamination as well as pesticides added for skin conservation during transport (Elsheikh, 2009). There are more than 6000 tanneries in Nigeria with an annual processing capacity of 700,000 tons of hides and skins (Omoleke, 2004; Singh et al., 2008). It was reported that the total amount of waste produced per animal slaughtered is approximately $35 \%$ of its weight (World Bank, 1995). Also, for every $1000 \mathrm{~kg}$ of carcass weight, a slaughtered beef produces 5.5 $\mathrm{kg}$ of manure (excluding rumen contents or stockyard manure) and $100 \mathrm{~kg}$ of paunch manure (undigested food) (Verheijen et al., 1996). Tanneries generate wastewater in the range of 30-35 $\mathrm{L} \mathrm{kg}^{-1}$ skin/hide processed with variable $\mathrm{pH}$, Biological Oxygen Demand (BOD), Chemical Oxygen Demand (COD), high concentrations of suspended solids (SS), and tannins as well as chromium (Zahoor and Abdul, 2009).

Being heterogeneous and composed of a wide variety of compounds, it is very difficult to select a unique direct method for estimating the biodegradability of organic contents and biokinetic parameters for a wastewater sample (Rajor, 2004). For this purpose, some indirect estimation such as determination of biochemical oxygen demand (BOD) and chemical oxygen demand (COD) are applied as common laboratory investigations [9]. During retanning procedures, synthetic tannins (Syntan), oils and resins are added to form softer leather at varying doses (Munz et al., 2009). One of the refractory groups of chemicals in tannery effluents derives mainly from tannins (Ramasami et al., 2004). Syntans are characterized by complex chemical structures, because they are composed of an extended set of chemicals such as phenol-, naphthalene-, formaldehyde- and melamine-based syntans, and acrylic resins (Beem, 1994). Organic pollutants (proteic and lipidic components) are originated from skins (it is calculated that the raw skin has $30 \%$ loss of organic material during the working cycle) or they are introduced during processes (Hugo Springer, 1994).

Many conventional processes such as oxidation, chemical and biological processes were carried out to treat tanneries wastewater (Ebtesam et al, 2013). Biological processes have received more attention because of their costeffectiveness, lower sludge production and environmental friendliness (Noorjahan, 2014). Naturally occurring micro-organisms degrade the hazardous organic wastes including xenobiotic compounds, such as pesticides, polycyclic aromatic hydrocarbons (PAHs) and polychlorinated biphenyls (PCBs) in due course of time (Ranen and Sharadinadra, 2009). Bioremediation is based on the idea that all organisms remove substances from the environment to carry outgrowth and metabolism (Bouwer and Zehnder, 1993). Bacteria, protista and fungi are found to be very good at degrading complex molecules and incorporating the breakdown products into their metabolism (Bouwer and Zehnder, 1993). The resultant metabolic wastes that they produce are generally safe and somehow recycled into other organisms (Ranen and Sharadinadra, 2009). An acclimatized indigenous population of microorganisms capable of degradation of the compounds of interest must exist at the site for a successful bioremediation mode (Ranen and Sharadinadra, 2009). It has been observed that for a successful bioremediation mode, an acclimatized indigenous population of microorganisms capable of degradation of the compounds of interest must exist at the site under investigation (Ranen and Sharadinadra, 2009). Even though there are numerous physical and chemical methods employed in the disposal of wastes the advantage in using bacterium is that they play a key role in the reduction of COD, BOD, total protein, total tannin and total phenol (Saravanan and Saravanan, 1998)

Baba et al. (2020) studied the bioremediation potential of immobilized corynebacterium kutsceri in the Treatment of tannery industrial effluent from Challawa Industrial Estate, Kano State, Nigeria. The aim of the work is to study the reduction in the level of the contaminants through the process of bioremediation using the isolated bacteria. Immobilized bacteria can withstand various temperatures, $\mathrm{pH}$ and substrate concentrations; consequently, increasing the efficiency and the lifespan of the bacteria. Immobilized bacteria are widely applied in the treatment of wastewater and can be separated and recovered after the treatment with the same efficiency (Baba et al., 2020).

\section{MATERIALS AND METHODS \\ Study Area}

This study was carried out in Bompai, Sharada and Challawa industrial estates in Kano, Figure 1. Kano lies on Latitude $11^{\circ} 30^{\prime} \mathrm{N}$ and $8^{\circ} 30^{\prime} \mathrm{E}$ and Longitude $11^{\circ} 5^{\prime} \mathrm{N}$ and $8^{\circ} 5^{\prime} \mathrm{E}$ in Northern Nigeria. It is one of the developed industrial cities in Nigeria. Tannery activities are the dominating industries and this could be one of the reasons for her high population density (Dan'Azumi and Bichi, 2010). Many researchers have studied biodegradation of tannery effluent using microorganisms. However, limited literature is available on the biodegradation of tannery effluent in Kano industrial estates using 
BAJOPAS Volume 13 Number 2, December, 2020 immobilized bacterial cells. This research work focuses on the potential of the use of the indigenous immobilized bacterial isolates in the treatment of tannery effluents in the industrial estates.

\section{Sample Collection}

Effluents were collected from the Tannery Industries from Bompai, Challawa and Sharada Industrial Estates, Kano, Nigeria. The effluents were collected over a period of six months (August 2017 to January 2018). Samples collected in a sterile 4-liter plastic container with a unique identification number were preserved using an ice-box that was transported to the Microbiology Laboratory, Department of Microbiology, Bayero University of Kano for analysis

\section{Sample Preparation and Sample Analysis}

Immediately after the collection of the effluent, $\mathrm{pH}$, TSS, TDS, COD, BOD levels were determined before treatment (Pre-treatment determination) and ten days after treatment (Post-treatment determination) as described in
APHA (1989) standard methods. $\mathrm{pH}$ was determined using Ecotests $\mathrm{pH}$ meter and TDS was determined using AQUALYTIC TDS Salinometer. BOD was determined as described by the standard method (APHA, 1992). COD and SS were determined using DR/2010 HACH portable data logging spectrophotometer (DWAF, 1992)

\section{Identification and Biochemical} Characterization of the Bacterial Isolates

The bacteria were isolated from the effluents using Serial Dilution according to the method described by APHA (1989). The biochemical tests such as oxidase, catalase, coagulase, indole (from $1 \%$ tryptone broth), citrate (Simmons citrate agar), methyl red/VogesProskauer (MR/VP), nitrate reduction, Starch Hydrolysis, Glucose, Maltose, and Lactose tests were carried out on the bacterial isolates to identify the bacteria through the bacteria biochemical characteristics according to Ajao et al. (2011).

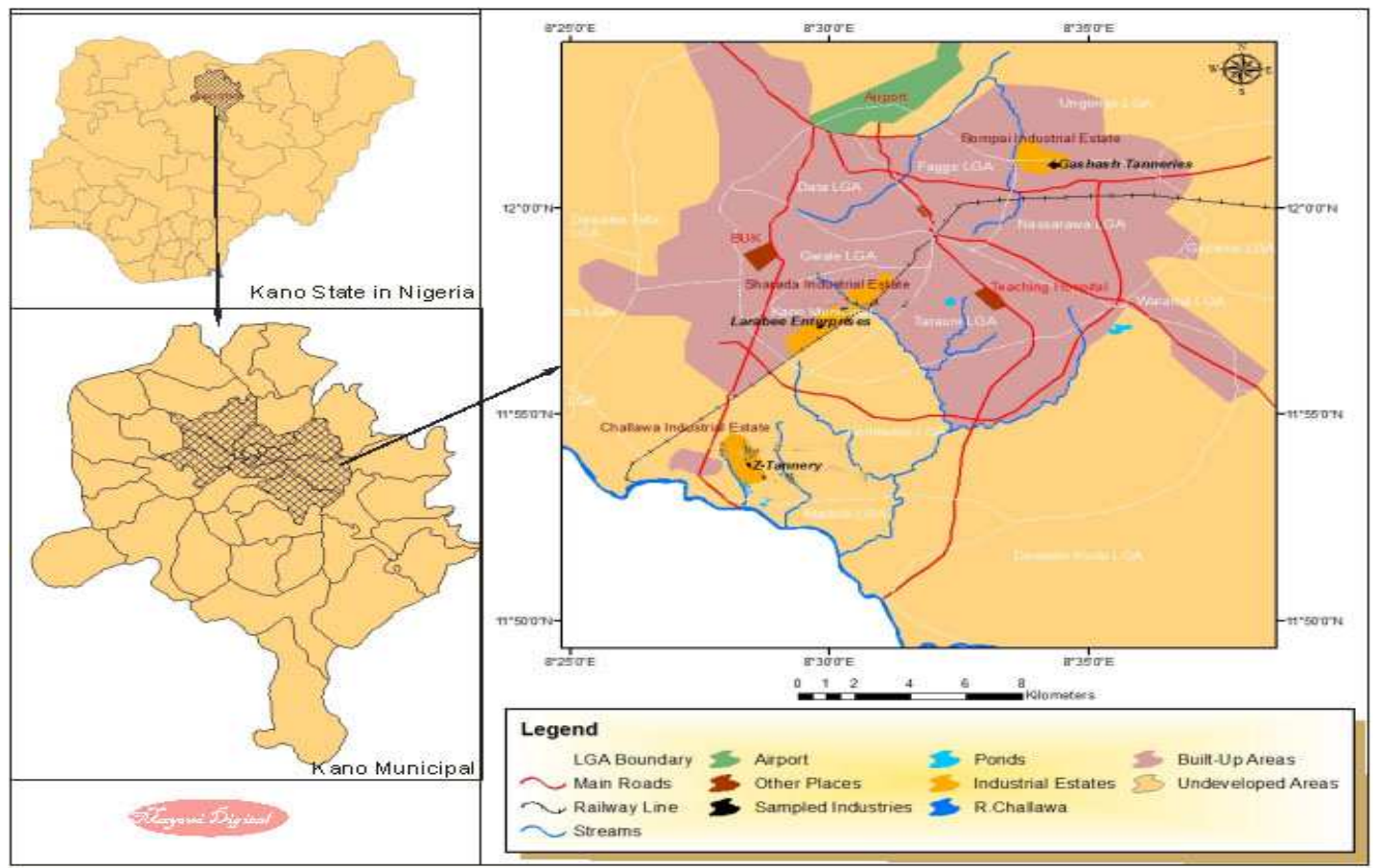

Fig. 1 Map showing the study areas

Source: Mayomi Digital Productions, GIS Laboratory, Department of Geography, UNIMAID (2017)

\section{Determination of Growth Rate of the Bacteria in Effluent Sample}

The bacteria growth rates were determined by transferring $2 \mathrm{~mL}$ of the bacterial isolates from the tannery effluent in broth medium into 100 $\mathrm{mL}$ sterile effluents in conical flasks and kept in an incubator (Giffrin cool) for 10 days. Control was also set up by incubating another $100 \mathrm{~mL}$ each of the sterile effluents without the bacteria. The optical density of the content was determined at the wavelength of $600 \mathrm{~nm}$ on a daily interval and recorded. 
BAJOPAS Volume 13 Number 2, December, 2020 Immobilization of Bacteria

Agar solution and inoculi were prepared separately. Fifty milliliters $(50 \mathrm{~mL})$ of nutrient broth each of the inoculi was prepared in a McCartney bottle and incubated for 24 hours. A solution of agar-agar was prepared by dissolving $10 \mathrm{~g}$ of the powder in distilled water and made up to $500 \mathrm{~mL}$ mark in an Erlenmeyer flask and was sterilized in an autoclave (280A) for 15 minutes and allowed to cool to $40-45^{\circ} \mathrm{C}$ (Ajao et al., 2011). Four milliliters ( $4 \mathrm{~mL})$ of the bacterial isolates in the nutrient broth was mixed with 36 $\mathrm{ml}$ of the prepared agar-agar media in petri-dish plates and then allowed to solidify. This was kept in the refrigerator for bioremediation.

\section{Bioremediation (Treatment) of the Effluents}

The solidified agar block (immobilized bacteria) was cut into cubes using a sterile knife; $0.1 \mathrm{~mL}$ phosphate buffer ( $\mathrm{pH} \mathrm{7.0)}$ was added and kept in the refrigerator for 1 hour for curing. The phosphate buffer was decanted after 1 hour and the cubes were washed with sterile distilled water 3-4 times before it was used (Ajao et al., 2011). Two liters (2 L) of the effluent was supplemented with the minimum basal medium in $\mathrm{g} / \mathrm{L}: \mathrm{NaCl}(0.8), \mathrm{MgSO}_{4} .7 \mathrm{H}_{2} \mathrm{O}(0.001), \mathrm{KH}_{2} \mathrm{PO}_{4}$ (2), $\mathrm{NaNO}_{3}$ (2), $\quad \mathrm{CaCl}_{2} .2 \mathrm{H}_{2} \mathrm{O} \quad(0.5)$ and $\mathrm{NaHPO}_{4} .12 \mathrm{H}_{2} \mathrm{O}(2)$ and sterilized in an autoclave at $121^{\circ} \mathrm{C}$ for 15 minutes (Margesin and Schinner, 2001). Two hundred and fifty milliliters $(250 \mathrm{~mL})$ of the effluents were transferred into different $250 \mathrm{ml}$ conical flasks. The content was covered with a cotton-wool ramped with foil paper to avoid contamination. Five grams $(5 \mathrm{~g})$ of the immobilized bacteria were quickly transferred into each of the effluents in the conical flasks in an inoculating chamber. The same procedures were carried out for the $10 \mathrm{~g}, 15 \mathrm{~g}, 20 \mathrm{~g}$ and 25 $\mathrm{g}$ of the immobilized bacteria in separate $250 \mathrm{~mL}$ effluents in conical flasks and agitated for ten days in a shaker incubator (Gallenkamp-OC4364-L) at a temperature $30^{\circ} \mathrm{C}$ and speed of 60 rpm. The treated effluent samples were taken on the tenth day and analyzed for the parameters $\mathrm{pH}$, SS, TDS, COD, and BOD, (Posttreatment determination) for the different grams of bacteria to evaluate and compare the biodegradation potential. (Baba et al., 2020).

\section{Statistical Analysis}

The data were represented as Mean \pm Standard deviation and analyzed statistically using oneway Analysis of Variance (ANOVA) and Tukey's HSD as Post Hoc Tests with the aid of SPSS 16.0. The correlation coefficient was also used to measure the strength of the relationship between the different masses of the bacteria and the parameters. All $\mathrm{p} \leq 0.05$ were considered as statistically significant.

\section{RESULTS AND DISCUSSION Physico-chemical parameters in the Industrial Effluents before the Biodegradation.}

Results of the Physico-chemical parameters in the industrial effluents before the Biodegradation is shown in table 1 . The mean temperatures $\left({ }^{\circ} \mathrm{C}\right)$ observed in TAN1, TAN2, and TAN3 samples were $28.07 \pm 0.65 ; 27.77 \pm 0.64$ and $26.38 \pm 3.81$ respectively. The order of the mean temperature of the samples from the three industries can be arranged as TAN1 > TAN2>TAN3. The temperature observed at TAN1, TAN2, and TAN3 samples were found below the WHO $\left(35^{\circ} \mathrm{C}\right)$ and NESREA $\left(40^{\circ} \mathrm{C}\right)$ limits. The low values of temperature might be due to the processes used at the time of sampling. High temperature brings down the solubility of gases in water that ultimately expresses as high BOD and COD. Statistical analysis shows that there is no significant difference $(p<0.05)$ between the mean values of temperature among the industries. This might be due to similar tannery activities involved in the tannery industries at the time of sampling. The average values of temperature observed in this present study are less than those observed by Akan et al. (2007), Akan et al. (2009) and Baba et al. (2020).

The mean level of $\mathrm{pH}$ observed in TAN1, TAN2 and TAN3, samples were $7.77 \pm 2.93$; $8.35 \pm 0.28$ and $7.52 \pm 0.76$ respectively. The order of the mean $\mathrm{pH}$ of the samples from the three industries can be arranged as TAN2> TAN1 $>$ TAN3. The $\mathrm{pH}$ of the samples falls within the WHO (7.0-8.5) and NESREA (6-9) standard limits. Statistical analysis shows that there is no significant difference $(p<0.05)$ between the mean values of $\mathrm{pH}$ among the industries. This might be due to similar tannery activities involved in the tannery industries at the time of sampling. Maheshwari et al. (2017) reported that the level of $\mathrm{pH}$ in the effluents from the tannery industry in Vaniyambadi, India was 6.5 which was lower than that observed in the present study. The $\mathrm{pH}$ in the effluents from the tannery industries in Kano and Kaduna were reported to be 7.64 and 6.89, respectively (Akan et al., 2007; Mohammed et al., 2017). The average values of $\mathrm{pH}$ observed in this present study are less than those observed by Mohammed et al. (2017) and Baba et al. (2020). The mean level of SS $(\mathrm{mg} / \mathrm{l})$ observed in TAN1, TAN2, and TAN3 samples were 374 \pm 124 ; $358 \pm 335$ and $780 \pm 739$ respectively. The order of the mean SS in the samples from the three industries can be arranged as TAN3 > TAN1 $>$ TAN2. 
The SS observed in the samples were far above the recommended standard limits of regulating bodies WHO $(30 \mathrm{mg} / \mathrm{l})$ and NESREA $(10 \mathrm{mg} / \mathrm{l})$. Statistical analysis shows that there is no significant difference $(p<0.05)$ between the mean values of SS among the industries. This might be due to similar tannery activities involved in the tannery industries at the time of sampling. The average values of SS observed in this present study are less than that observed $(3700 \pm 122 \mathrm{mg} / \mathrm{l})$ by Akan et al. (2009) for tanneries in Kano. Also, the average values of SS observed in this present study are less than that observed by Mohammed et al. (2017) and Baba et al. (2020) with the exception in TAN3.

The mean level of TDS (mg/l) observed in TAN1, TAN2, and TAN3 samples were $3941 \pm 3703$; $3300 \pm 1714$ and $2653 \pm 1240$ respectively. The order of the mean TDS in the samples from the three industries can be arranged as TAN1>TAN2>TAN3. The TDS observed in the samples were far above the recommended standard limits of WHO $(250 \mathrm{mg} / \mathrm{l})$ and NESREA $(500 \mathrm{mg} / \mathrm{l})$. Statistical analysis shows that there is no significant difference $(p<0.05)$ between the mean values of TDS among the industries. This might be due to similar tannery activities involved in the tannery industries at the time of sampling. TDS in the effluents from the tannery industries in Kano, Nigeria was reported to be $1281 \mathrm{mg} / \mathrm{l}$ (Akan et al., 2007). The average values of SS observed in this present study are less than those observed by Mohammed et al. (2017) and Baba et al. 2020)

The mean level of COD (mg/l) observed in TAN1, TAN2 and TAN3 samples seasons were $2372 \pm 938 ; \quad 1406 \pm 208$ and $3532 \pm 1373$ respectively. The order of the mean COD of the samples from the three industries can be arranged as TAN3>TAN1> TAN2. The COD observed in TAN1, TAN2 and TAN3 samples were far above the recommended standard limits of regulating bodies $\mathrm{WHO}(40 \mathrm{mg} / \mathrm{l})$ and NESREA (40 mg/l). Statistical analysis shows that there is no significant difference $(p<0.05)$ in COD among the industries. This might be due to similar tannery activities involved in the tannery industries as at the time of sampling. The Chemical Oxygen demand (COD) is the amount of oxygen, in $\mathrm{mg} / \mathrm{L}$, required for the degradation of the compound of wastewater to occur. In comparison, the average values of COD observed in this present study were higher than that observed by Mohammed et al. (2017) but lower than that observed by Baba et al. (2020).

The mean levels of BOD $(\mathrm{mg} / \mathrm{l})$ observed in TAN1, TAN2 and TAN3 samples were $13.85 \pm 6.42 ; \quad 19.46 \pm 0.50$ and $17.13 \pm 3.14$ respectively. The order of the mean BOD in the samples from the three industries can be arranged as TAN2>TAN3>TAN1. The BOD observed in TAN1, TAN2 and TAN3 samples were found below the recommended limits of NESREA (200 mg/l) but above WHO (10 mg/l). Statistical analysis shows that there is no significant difference $(p<0.05)$ between the mean values of BOD among the industries. This might be due to similar tannery activities involved in the tannery industries at the time of sampling. The low level of BOD recorded in this study is an indication of the low level of biodegradable organic solids in the effluent. The average values of BOD observed in this present study were lower than those observed by Mohammed et al. (2017) and Baba et al. (2020).

Table 1: Mean Values \pm S.D of Physico-chemical parameters of effluents from the Tannery Industries before Treatment.

\begin{tabular}{llllllll}
\hline Parameter & Tannery 1 & Tannery 2 & Tannery 3 & $\mathrm{a}$ & $\mathrm{b}$ & $\mathrm{c}$ & $\mathrm{d}$ \\
\cline { 2 - 7 } Temperature $\left({ }^{\circ} \mathrm{C}\right)$ & $28.07 \mathrm{a} \pm 0.65$ & $27.77 \mathrm{a} \pm 0.64$ & $26.38 \mathrm{a} \pm 3.81$ & & $29.50 \pm 4.68$ & 35 & 40 \\
pH & $7.77 \mathrm{a} \pm 2.93$ & $8.35 \mathrm{a} \pm 0.28$ & $7.52 \mathrm{a} \pm 0.76$ & 6.89 & $5.35 \pm 1.57$ & $7.0-8.5$ & $6.0-9.0$ \\
$\mathrm{COD}(\mathrm{mg} / \mathrm{l})$ & $2372 \mathrm{a} \pm 938$ & $1406 \mathrm{a} \pm 208$ & $3532 \mathrm{a} \pm 1373$ & 2.2 & $3106 \pm 2753$ & 40 & 40 \\
$\mathrm{BOD}(\mathrm{mg} / \mathrm{l})$ & $13.85 \mathrm{a} \pm 6.42$ & $19.46 \mathrm{a} \pm 0.50$ & $17.13 \mathrm{a} \pm 3.14$ & 1032 & $26.17 \pm 9.49$ & 10 & 200 \\
$\mathrm{SS}(\mathrm{mg} / \mathrm{l})$ & $374 \mathrm{a} \pm 124$ & $358 \mathrm{a} \pm 335$ & $780 \mathrm{a} \pm 739$ & 501 & $562 \pm 482$ & 30 & 10 \\
TDS $(\mathrm{mg} / \mathrm{l})$ & $3941 \mathrm{a} \pm 3703$ & $3300 \mathrm{a} \pm 1714$ & $2653 \mathrm{a} \pm 1240$ & 532.7 & $444 \pm 507$ & 250 & 500 \\
\hline
\end{tabular}

The values given in the table above are means of 6 replicate values, $\mathrm{n}=6$ ( 1 sample was taken monthly for 6 months). Within the rows, means with different alphabets are statistically different $(p<0.05)$. WHO: World Health Organisation. NESREA: National Environmental Standard and Regulatory Enforcement Agency. a = Mohammed et al.(2017), b = Baba et al. (2020), c = WHO (2006), $d=$ NESSRA (2009) 
BAJOPAS Volume 13 Number 2, December, 2020

Identification, Biochemical Characterization and growth rates of the Bacterial Isolates

Results of identification and biochemical characterization of the bacterial isolates were shown in table 2. After 24 hours of incubation, the nutrient agar media plates were checked for bacterial growth. The results showed the presence of different strains in the samples. The TAN1 bacteria isolate was found to be gramnegative cocci while TAN3 was gram-positive cocci. TAN2 bacteria isolate was found to be gram-positive, rod-shaped. TAN1, TAN2, and TAN3 bacteria isolates recorded positive results for spore former.

The results of the biochemical tests indicated that all the bacteria were positive for catalase, oxidase, citrate, maltose, glucose, lactose (negative in TAN1), mannitol (negative in TAN2), starch hydrolysis and coagulase (negative in TAN2) tests. The bacteria showed negative results for nitrate reduction, $M R$ (positive in TAN2), VP (positive in TAN1), Indole (positive in TAN2) tests. Base on the morphological and biochemical test results, TAN1, TAN2, and TAN3 bacteria isolates were identified to be Nesseria spp, Bacillus cereus, and Staphylococcus aureus respectively.

The growth rate of the TAN1, TAN2 and TAN3 Isolates were shown in figure 2. Generally, the optical density increase with the increase in time (day) and decrease as time goes on. The highest optical density was shown by bacillus cereus in TAN2 while the lowest was shown by Staphylococcus aureus in TAN3.

The initial growth phase of TAN1 Isolate bacteria occurred within 2-day of incubation as the growth rate increases up to the 6th-day incubation when the maximum growth was observed. Beyond the 6th day, the growth of the bacteria declined (which might be due to a shortage of nutrients in the effluents) until it reached its death phase (which might be due to the unavailability of nutrients in the effluents).

A similar trend of growth was also observed for TAN2 Isolate as the initial growth phase also occurred within 2-day of incubation but maximum growth rate observed on the 4th day of incubation. The stationary stage occurred between the 4th day and the 8th day. Beyond the 8th day, the growth of the bacteria declined (which might be due to a shortage of nutrients in the effluents) until it reached its death phase (which might be due to the unavailability of nutrients in the effluents).

The initial growth phase of TAN3 bacterial Isolate occurred within the 3-day incubation as the growth rate increases up to the 6th-day incubation when the maximum growth was observed. Beyond the 6th day, the growth of the bacteria declined (which might be due to a shortage of nutrients in the effluents) until it reached its death phase (which might be due to the unavailability of nutrients in the effluents).

Table 2: Morphological and Biochemical characteristics of bacterial isolates

\begin{tabular}{lllll} 
Bacterial Isolates & & TAN1 & TAN2 & TAN3 \\
\hline $\begin{array}{lllll}\text { Morphological } \\
\text { characteristics }\end{array}$ & Shape & Cocci & Rod & Cocci \\
& Spore & & & \\
& former & + & + & + \\
Gram & & & \\
Biochemical characteristics & reaction & - & + & + \\
& Citrate & + & + & + \\
& Catalase & + & + & + \\
& Coagulase & + & - & + \\
Starch & + & + & + \\
& Glucose & + & + & + \\
Oxidase & + & + & + \\
& Indo & - & + & - \\
Lactose & - & + & + \\
Manitol & + & - & + \\
Maltose & + & + & + \\
MR & - & + & - \\
VP & + & - & - \\
& Nitrate & - & - & - \\
Reduction & - Neisseria & Bacillus & Staphylococcus \\
& Bacterial & cereus & aureus \\
& name & spp & cas
\end{tabular}

+ = Positive; - = Negative; MR=Methyl Red; VP= Voges-Proskauer 


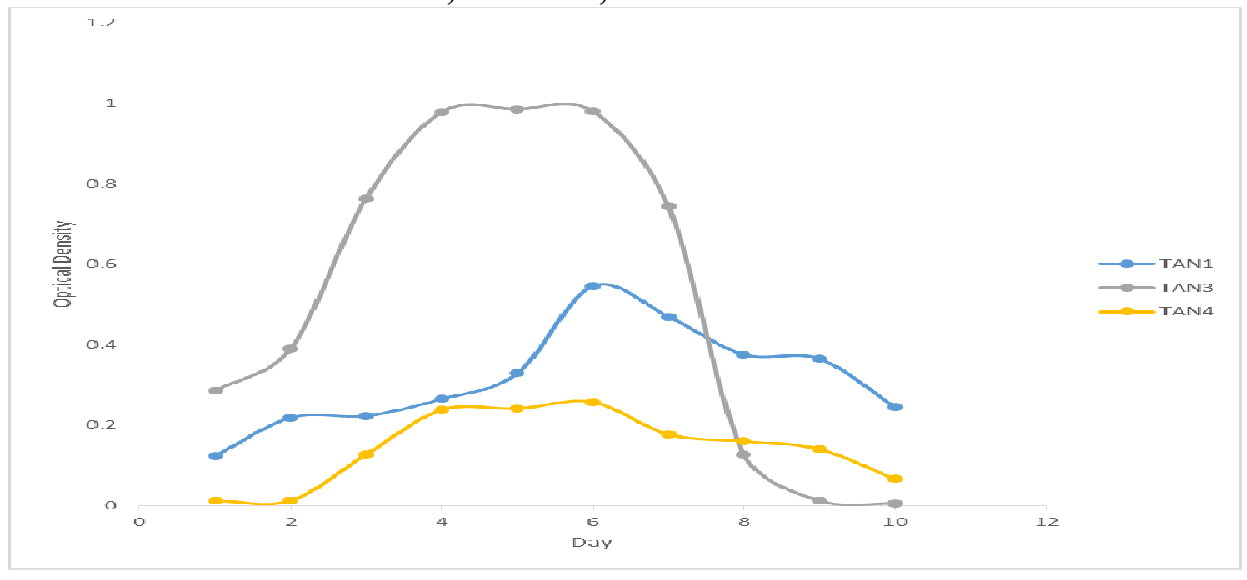

Fig. 2 Growth rates of the isolates in the effluents from the Tannery Industries

\section{Physico-chemical Parameters in the Industrial Effluents after the biodegradation.}

Table 3 shows the mean results of the physicochemical parameter before and after bioremediation using the different masses $(5 \mathrm{~g}$, $10 \mathrm{~g}, 15 \mathrm{~g}, 20 \mathrm{~g}$, and $25 \mathrm{~g}$ ) of the respective immobilized bacteria. Also, Table 4 shows the mean results of correlation coefficient ( $r$ ) between different masses of bacteria and physicochemical parameters.

The mean values $(\mathrm{mg} / \mathrm{l})$ of the SS after the bioremediation varies between $243 \pm 45$ and $898 \pm 672$. The mean concentration $(\mathrm{mg} / \mathrm{l})$ of SS remediated by the different masses $(5 \mathrm{~g}, 10 \mathrm{~g}$, $15 \mathrm{~g}, 20 \mathrm{~g}$, and $25 \mathrm{~g}$ ) of the bacteria varies. The SS in the samples fluctuates up and down after the bioremediation process when compared with the SS of the raw samples before the bioremediation. The increase in the levels of the SS might be due to the aggregation of the TDS which are large enough to result into SS. The increase in the levels of the SS might be also due to the influence of the nutrients which was added into the effluents in order to make the microorganisms more active and viable for fast degradation of organic contaminants in the effluent. The relative potential or efficiency of the different masses of the bacteria in remediating SS in TAN1 samples was in the order $25 \mathrm{~g}>20 \mathrm{~g}>15 \mathrm{~g}>10 \mathrm{~g}>5 \mathrm{~g}$. For TAN2 and TAN3 samples, the order was $25 \mathrm{~g}>20 \mathrm{~g}>15$ $\mathrm{g}>10 \mathrm{~g}>5 \mathrm{~g}$. These might be due to the variations in the surface areas of the different masses of the immobilized bacteria. Statistical analysis shows that there is no significant difference $(p<0.05)$ between the mean values of SS among the masses in the respective industries. Positive and significant correlations exist between the masses of bacteria and Suspended Solid (SS). This showed that there is general increase in the levels of the SS as the masses of the immobilized bacteria increases. TAN3 (90\%) and TAN1 (80\%) showed a very high correlation with the masses of the bacteria while TAN2 (61\%) showed a very low correlation.

The mean values $(\mathrm{mg} / \mathrm{l})$ of the TDS after the bioremediation varies between $46 \pm 11$ and $83 \pm 78$. The mean concentration $(\mathrm{mg} / \mathrm{l})$ of TDS remediated by the different masses $(5 \mathrm{~g}, 10 \mathrm{~g}$, $15 \mathrm{~g}, 20 \mathrm{~g}$, and $25 \mathrm{~g}$ ) of the bacteria varies. There is a reduction in all the TDS of all the samples after the bioremediation process compared with the TDS of the raw samples before the bioremediation. The relative potential or efficiency of the different masses of the bacteria in remediating TDS in TAN1 and TAN3 samples was in the order $5 \mathrm{~g}>10 \mathrm{~g}>15 \mathrm{~g}>20$ $\mathrm{g}>25 \mathrm{~g}$. For TAN2 samples, the order was 20 $g>10 \quad g>25 \quad g>15 \quad g>5 \quad g$. Statistical analysis shows that there is no significant difference $(p<0.05)$ between the mean values of TDS among the masses in the respective industries. These might be due to the variations in the surface areas of the different masses of the immobilized bacteria. Positive and significant correlations exist between the masses of bacteria and TDS with the exception in TAN2 (negative and insignificant correlation). The positive correlations showed that there is general increase in the levels of the TDS as the masses of the immobilized bacteria increases. TAN1 $(96 \%)$ showed a very high correlation with the masses of the bacteria while TAN2 (47\%) showed a very low correlation.

The mean values $(\mathrm{mg} / \mathrm{l})$ of the BOD after the bioremediation varies between $1.56 \pm 0.20 \mathrm{mg} / \mathrm{l}$ and $6.92 \pm 5.49 \mathrm{mg} / \mathrm{l}$. The mean concentration $(\mathrm{mg} / \mathrm{l})$ of BOD remediated by the different masses $(5 \mathrm{~g}, 10 \mathrm{~g}, 15 \mathrm{~g}, 20 \mathrm{~g}$, and $25 \mathrm{~g}$ ) of the bacteria varies. There is a reduction in all the BOD of all the samples after the bioremediation process compared with the $\mathrm{BOD}$ of the raw 
BAJOPAS Volume 13 Number 2, December, 2020 samples before the bioremediation. The relative potential or efficiency of the different masses of the bacteria in remediating BOD in TAN1, TAN2 and TAN3 samples were in the order $25 \mathrm{~g}>20$ $\mathrm{g}>15 \mathrm{~g}>10 \mathrm{~g}>5 \mathrm{~g}, 25 \mathrm{~g}>15 \mathrm{~g}>5 \mathrm{~g}>10 \mathrm{~g}>20 \mathrm{~g}$ and $20 \mathrm{~g}>10 \mathrm{~g}>25 \mathrm{~g}>15 \mathrm{~g}>5 \mathrm{~g}$ respectively. Statistical analysis shows that there is significant difference $(p<0.05)$ between the mean values of BOD among the masses in the respective industries. These might be due to the variations in the surface areas of the different masses of the immobilized bacteria. Negative and significant correlations exist between the masses of bacteria and BOD. This showed that there is general decrease in the levels of the BOD as the masses of the immobilized bacteria increases. TAN1 (94\%) showed a very high correlation with the masses of the bacteria while TAN2 (4\%) showed a very low correlation.

The mean values $(\mathrm{mg} / \mathrm{l})$ of the COD after the bioremediation varies between $250 \pm 154$ and $3134 \pm 1595$. The mean concentration $(\mathrm{mg} / \mathrm{l})$ of COD remediated by the different masses $(5 \mathrm{~g}$, $10 \mathrm{~g}, 15 \mathrm{~g} 20 \mathrm{~g}$, and $25 \mathrm{~g}$ ) of the bacteria varies. There is a reduction in all the COD of all the samples after the bioremediation process compared with the COD of the raw samples before the bioremediation. The relative potential or efficiency of the different masses of the bacteria in remediating COD in TAN1, TAN2 and TAN3 samples were in the order $25 \mathrm{~g}>20 \mathrm{~g}>15$ $\mathrm{g}>5 \mathrm{~g}>10 \mathrm{~g}, 25 \mathrm{~g}>20 \mathrm{~g}>15 \mathrm{~g}>10 \mathrm{~g}>5 \mathrm{~g}$ and 10 g>5 g>25 g>15 g>20 g respectively. Statistical analysis shows that there were significant difference $(p<0.05)$ between the mean values of COD among the masses in the respective industries except for effluents treated with $25 \mathrm{~g}$. These might be due to the variations in the surface areas of the different masses of the immobilized bacteria. Negative and insignificant correlations exist between the masses of bacteria and COD with the exception in TAN3 (positive and significant correlation). The negative correlations showed that there is general decrease in the levels of the COD as the masses of the immobilized bacteria increases. TAN2 (100\%) showed a very high correlation with the masses of the bacteria while TAN3 (36\%) showed a very low correlation.

Generally, there was an overall decrease in the concentration of these physicochemical parameters after the bioremediation using the different masses of the bacterial isolates. These might be due to the variations in the surface areas of the different masses of the immobilized bacteria. This is in line with the work of Jimoh et al. (2018) and Baba et al. (2020).

Table 3: Mean Values $(\mathrm{mg} / \mathrm{l}) \pm$ S.D of Physicochemical parameters in effluents from the Tannery Industries before and after Treatment of the effluents $(250 \mathrm{ml})$ with the different masses $(5 \mathrm{~g}, 10 \mathrm{~g}$, $15 \mathrm{~g}, 20 \mathrm{~g}$, and $25 \mathrm{~g}$ ) of the bacteria.

\begin{tabular}{llllllll}
\hline $\mathrm{P}$ & IND & Before & \multicolumn{5}{c}{ After } \\
\cline { 4 - 7 } & & & $5 \mathrm{~g}$ & $10 \mathrm{~g}$ & $15 \mathrm{~g}$ & $20 \mathrm{~g}$ & $25 \mathrm{~g}$ \\
\hline \multirow{2}{*}{ COD } & TAN1 & $2372 \pm 938$ & $1708 \mathrm{a} \pm 861$ & $2045 \mathrm{a} \pm 1205$ & $845 \mathrm{a} \pm 369$ & $300 \mathrm{a} \pm 167$ & $250 \mathrm{a} \pm 154$ \\
& TAN2 & $1406 \pm 208$ & $1195 \mathrm{a} \pm 208$ & $1125 \mathrm{a} \pm 384$ & $1055 \mathrm{a} \pm 317$ & $956 \mathrm{a} \pm 310$ & $870 \mathrm{ab} \pm 240$ \\
& TAN3 & $3532 \pm 1373$ & $2374 \mathrm{a} \pm 1344$ & $1976 \mathrm{a} \pm 1405$ & $2757 \mathrm{a} \pm 1266$ & $3134 \mathrm{a} \pm 1595$ & $2614 \mathrm{~b} \pm 1105$ \\
BOD & TAN1 & $13.85 \pm 6.42$ & $6.92 \mathrm{a} \pm 5.49$ & $6.42 \mathrm{a} \pm 5.07$ & $5.72 \mathrm{a} \pm 5.35$ & $4.62 \mathrm{a} \pm 4.37$ & $2.82 \mathrm{ab} \pm 1.26$ \\
& TAN2 & $19.46 \pm 0.50$ & $1.75 \mathrm{~b} \pm 0.22$ & $1.73 \mathrm{~b} \pm 0.18$ & $1.58 \mathrm{a} \pm 0.16$ & $1.91 \mathrm{a} \pm 0.22$ & $1.56 \mathrm{~b} \pm 0.20$ \\
& TAN3 & $17.13 \pm 3.14$ & $4.24 \mathrm{ab} \pm 0.77$ & $3.29 \mathrm{ab} \pm 0.37$ & $4.11 \mathrm{a} \pm 0.07$ & $3.23 \mathrm{a} \pm 0.91$ & $3.33 \mathrm{a} \pm 1.28$ \\
SS & TAN1 & $374 \pm 124$ & $243 \mathrm{a} \pm 45$ & $471 \mathrm{a} \pm 226$ & $475 \mathrm{a} \pm 182$ & $492 \mathrm{a} \pm 128$ & $611 \mathrm{a} \pm 217$ \\
& TAN2 & $358 \pm 335$ & $460 \mathrm{a} \pm 400$ & $543 \mathrm{a} \pm 414$ & $544 \mathrm{a} \pm 402$ & $551 \mathrm{a} \pm 414$ & $554 \mathrm{a} \pm 405$ \\
& TAN3 & $780 \pm 739$ & $586 \mathrm{a} \pm 594$ & $758 \mathrm{a} \pm 656$ & $787 \mathrm{a} \pm 676$ & $861 \mathrm{a} \pm 635$ & $898 \mathrm{a} \pm 672$ \\
TDS & TAN1 & $3941 \pm 3703$ & $51 \mathrm{a} \pm 10$ & $53 \mathrm{a} \pm 10$ & $55 \mathrm{a} \pm 15$ & $61 \mathrm{a} \pm 20$ & $63 \mathrm{a} \pm 26$ \\
& TAN2 & $3300 \pm 1714$ & $83 \mathrm{a} \pm 78$ & $47 \mathrm{a} \pm 20$ & $48 \mathrm{a} \pm 22$ & $47 \mathrm{a} \pm 17$ & $48 \mathrm{a} \pm 17$ \\
& TAN3 & $2653 \pm 1240$ & $46 \mathrm{a} \pm 11$ & $55 \mathrm{a} \pm 24$ & $55 \mathrm{a} \pm 25$ & $58 \mathrm{a} \pm 23$ & $61 \mathrm{a} \pm 28$ \\
\hline
\end{tabular}

Replicate $=6$ (months)

Within the rows, for the same parameter, means with different alphabets are statistically different $(p<0.05)$.

$\mathrm{P}=$ parameter, IND = Industries 
BAJOPAS Volume 13 Number 2, December, 2020

Table 4: Correlation coefficient $(r)$ between different masses of the bacteria and the physicochemical parameters.

\begin{tabular}{llll}
\hline Industries & Parameter & Correlation coefficient $(r)$ & $\begin{array}{l}\text { Percent dependence (rxrx100) } \\
(\%)\end{array}$ \\
\hline TAN1 & COD & -0.9 & 82 \\
& BOD & -0.97 & 94 \\
& SS & $0.90^{*}$ & 80 \\
TAN2 & TDS & $0.98^{*}$ & 96 \\
& COD & -1 & 100 \\
& BOD & -0.21 & 4 \\
& SS & $0.78^{*}$ & 61 \\
& TDS & -0.69 & 47 \\
& COD & $0.60^{*}$ & 36 \\
& BOD & -0.6 & 37 \\
& SS & $0.95^{*}$ & 90 \\
& TDS & $0.94^{*}$ & 89 \\
\hline
\end{tabular}

The correlation coefficient $(r)$ with * is statistically significant $(p<0.05)$.

Percentage reduction of the Parameters

Table 5 shows the percentage reduction of Parameters in industrial samples before and after the treatment of the effluents $(250 \mathrm{ml})$ with the different masses $(5 \mathrm{~g}, 10 \mathrm{~g}, 15 \mathrm{~g}, 20 \mathrm{~g}$, and $25 \mathrm{~g}$ ) of the Immobilized Bacteria.

In TAN1 samples, the percentage reduction (\%) of COD ranged (14-89); BOD (50-80); SS (-32$35)$ and TDS (98-99). In TAN2 samples, the percentage decrease $(\%)$ of COD ranged (15$38) ;$ BOD (90-92); SS [-28-(-55)] and TDS (9798). In TAN3 samples, the percentage decrease (\%) of COD ranged (11-44); BOD (76-81); SS (15-25) and TDS (98). The percentage increase in the levels COD, BOD and TDS might be due to the increase in the surface area of the different masses of the immobilized bacteria. However, the percentage decrease in the levels of the SS might be due to the aggregation of the TDS which are large enough to result into SS. The percentage decrease in the levels of the SS might be also due to the influence of the nutrients which was added into the effluents in order to make the microorganisms more active and viable for fast degradation of organic contaminants in the effluent. This is in line with the work of Jimoh et al. (2018) in which the concentration of the SS increase after the bioremediation of effluents.

Sreemoyee and Priti (2013) assessed and reduced several Physico-chemical parameters of dairy wastewater using Niesseria $s p$. and concluded that the species are well known to degrade organic compounds. This is in agreement with the current study in which the immobilized Niesseria $s p$ degrade the organic contaminants as indicated by the BOD, COD and TDS.

Jimoh et al. (2018) observed that TSS of the effluents was increased after treatment with immobilized bacteria and concluded that it might be due to the biostimulation method adopted for the research.

The optimum $\mathrm{pH}$ Biosorption of Chromium by Bacillus spp and Staphylococcus spp. from tannery effluent was investigated by Mythili and Karthikeyan (2011). The maximum adsorption of Chromium $(86.4 \mathrm{mg} / \mathrm{L})$ was showed by Bacillus spp and Staphylococcus spp showed $70.6 \mathrm{mg} / \mathrm{L}$ at an initial concentration of $100 \mathrm{mg} / \mathrm{L}$. In the present study, immobilised Bacillus spp and Staphylococcus spp. from the tannery industrial effluents reduced the levels of the organic pollutants with high potential as indicated by the percentage reduction of BOD, COD and TDS.

Enzymes often can work in multiple environments especially if they are immobilized. This makes the microorganisms' enzymes even more resistant to harsh environments and enables the enzymes to be recovered and recycled after they are no longer needed (Gianfreda and Rao 2004). Ramesh and Singh (1993) reported that the immobilized bacteria having more efficiency to remove the suspended particles than free cells. Using the immobilized cell is preferable due to its capability for using several times with the same efficiency, which makes it more economical. Similar work was done by Sikander et al. (2007) showing the higher reduction with permeabilized cells of Ochrobactrum intermedium strain SDCr-5. 
BAJOPAS Volume 13 Number 2, December, 2020

The results revealed the isolation and identification of isolates with the potential for the reduction of $\mathrm{Cr}$ (VI) to $\mathrm{Cr}$ (III). Results indicated that immobilized $B$. cereus could be efficiently used for the reduction of $\mathrm{Cr}$ (VI).

Table 5: Percentage reduction of the tested Parameters from the tannery industrial samples of the Immobilized Bacteria.

\begin{tabular}{lllllll}
\hline \multirow{2}{*}{ Industries } & & \multicolumn{5}{c}{ Percentage Reduction $(\%)$} \\
\cline { 3 - 7 } & & $5 \mathrm{~g}$ & $10 \mathrm{~g}$ & $15 \mathrm{~g}$ & $20 \mathrm{~g}$ & $25 \mathrm{~g}$ \\
\hline TAN1 & COD & 28 & 14 & 64 & 87 & 89 \\
& BOD & 50 & 54 & 59 & 67 & 80 \\
& SS & 35 & -26 & -27 & -32 & -63 \\
& TDS & 99 & 99 & 99 & 98 & 98 \\
TAN2 & COD & 15 & 20 & 25 & 32 & 38 \\
& BOD & 91 & 91 & 92 & 90 & 92 \\
& SS & -28 & -52 & -52 & -54 & -55 \\
& TDS & 97 & 99 & 99 & 99 & 99 \\
& COD & 33 & 44 & 22 & 11 & 26 \\
& BOD & 75 & 81 & 76 & 81 & 81 \\
& SS & 25 & 3 & -1 & -10 & -15 \\
& TDS & 98 & 98 & 98 & 98 & 98 \\
\hline
\end{tabular}

Percentage Reduction $=(B-A) / B \times 100 \%$

$A=$ Concentration of the parameter after treatment

$\mathrm{B}=$ Concentration of the parameter before treatment

$+=$ percentage decrease

- = percentage increase

In general, immobilization makes the enzyme more resistant to temperature, $\mathrm{pH}$, and substrate concentration swings giving it a longer lifetime and higher productivity per active unit (Gianfreda and Rao, 2004; FuIlbrook, 1996; Russell et al, 2003; Kandelbauer et al., 2004). Immobilized cells have been used and studied extensively for the production of useful chemicals (Ohtake and Silver, 1994), the treatment of wastewaters (Chen et al., 2003; Wang et al., 2010). Although many workers described microbial degradation of tannery effluent, limited literature is available on the bioremediation of tannery effluent using immobilized bacterial cells in the Kano Industrial Estates.

\section{CONCLUSION}

The samples contained variable levels of the physicochemical parameters. The results of the Analysis of variance revealed that, no statistical difference $(p<0.05)$ was observed for the temperature, $\mathrm{pH}, \mathrm{SS}, \mathrm{TDS}, \mathrm{BOD}$ and $\mathrm{COD}$ among the three tannery industries before the treatment. The levels of some of the parameters
(SS, TDS and COD) observed in the samples were found above the recommended limits of WHO and NESREA, which called for the treatment of the effluents before discharge into the environment. Base on the morphological and biochemical test results, TAN1, TAN2, and TAN3 bacterial isolates were identified to be Neisseria spp, Bacillus cereus, and Staphylococcus aureus respectively. The results of Post-treatment analysis showed that there is overall decrease in the levels of the parameters determined when compared with that of the pre-treatment. The overall percentage reduction of the immobilised bacteria in the treatment of the respective effluents was in the order TAN2 (72\%)>TAN1 $(70 \%)>$ TAN3 $(62 \%)$. Hence, the immobilized bacteria are having higher biodegradation potential for the treatment of the tannery effluents.

\section{Acknowledgments}

The authors wish to acknowledge the University of Maiduguri for the financial support. The authors are grateful to the Kano State Ministry of Environment for their support in obtaining the effluent samples. 


\section{REFERENCES}

Ajao, A. T., Adebayo, G. B., and Yakubu, S. E. (2011). Bioremediation of textile industrial effluent using mixed culture of Pseudomonas aeruginosa and Bacillus subtilis immobilized on agar-agar in a bioreactor. J. Microbiol. Biotech. Res, 1(3), 50-56.

Akan, J. C., Moses, E. A., Ogugbuaja, V. O., and Abah, J. (2007). Assessment of tannery industrial effluents from Kano metropolis, Kano State, Nigeria. Journal of Applied Sciences, 7(19), 2788-2793.

Akan, J. C., Ogugbuaja, V. O., Abdulrahman, F. I., and Ayodele, J. T. (2009). Pollutant levels in effluent samples from tanneries and textiles of Kano industrial areas, Nigeria. Global journal of pure and applied sciences, 15(3-4).

APHA (1989). Standard methods for Examination of Will bete and Will betewater.15 $5^{\text {th }}$ edition. Brydpass Springfield Will behington DC. pp. 164-176

APHA (1992). Standard Methods for the Examination of Water and Wastewater. Health, 69, 1116-9.

Baba, A., Garba, S. T., and Bello, H. S. (2020). Bioremediation Potential of Immobilized corynebacterium kutsceri in the Treatment of Tannery Industrial Effluent from Challawa Industrial Estate, Kano State, Nigeria. Journal of the Turkish Chemical Society Section A: Chemistry, $7(2), 335-350$.

Beem, E. I. V. (1994). reduction of solvent VOC emission. J. Oil Col. Chem. Ass, 77, 158.

Bouwer, E. J., and Zehnder, A. J. (1993). Bioremediation of organic compoundsputting microbial metabolism to work. Trends in biotechnology, 11(8), 360367.

Chen, K. C., Wu, J. Y., Liou, D. J., and Hwang, S. C. J. (2003). Decolorization of the textile dyes by newly isolated bacterial strains. Journal of Biotechnology, 101(1), 57-68.

Dan'Azumi, S., and Bichi, M. H. (2010). INDUSTRIAL POLLUTION AND HEAVY METALS PROFILE OF CHALLAWA RIVER IN KANO, NIGERIA. Journal of Applied Sciences in Environmental Sanitation, $5(1)$.

DWAF. (1992). Analytical Methods Manual, TR 151. Department of Water Affairs and Forestry, Pretoria.

El-Bestawy, E. (2013). Biological treatment of leather-tanning industrial wastewater using free living bacteria.
Elsheikh, M. A. S. (2009). Tannery wastewater pre-treatment. Water Science and Technology, 60(2), 433-440.

FuIlbrook, P. D. (1996). "Kinetics." Industrial enzymology: The application of enzymes in Industry. 2nd Ed. T. Godfrey and J Reichelt. eds.. Nature. New York.

Gianfreda, L., and Rao, M. A. (2004). Potential of extra cellular enzymes in remediation of polluted soils: a review. Enzyme and microbial technology, 35(4), 339354.

Hugo Springer. (1994). John Arthur Wilson Memorial Lecture "Treatment of Industrial Wastes of the Leather Industry - is it still a Major Problem". JALCA, 89, 153-185

Jimoh, A. A., Ganiyu, B. A., Baba, D., and Baba, A. (2018) Bioremediation Process of Effluent from Detergent and Food Industries in Jos, Nigeria: Kinetics and Thermodynamics. International Journal of Engineering Science Invention (IJESI), 762-73

Kandelbauer, A., Maute, O., Kessler, R. W., Erlacher, A., and Gübitz, G. M. (2004). Study of dye decolorization in an immobilized laccase enzyme-reactor using online spectroscopy. Biotechnology and bioengineering, 87(4), 552-563.

Kongjao, S., Damronglerd, S., and Hunsom, M. (2008). Simultaneous removal of organic and inorganic Pollutants in tannery wastewater using electrocoagulation technique. Korean Journal of chemical engineering, 25(4), 703.

Maheshwari, U. M., Aruna, S., Gomathi, M., and AbdulJaffar, A. H. (2017). Bioremediation by Free and Immobilized Bacteria Isolated from Tannery Effluent. International Journal of Research in Applied, Natural and Social Sciences. 5(7), 75-90

Margesin, R., and Schinner, F. (2001). Bioremediation (natural attenuation and biostimulation) of diesel-oilcontaminated soil in an alpine glacier skiing area. Applied and environmental microbiology, 677), 3127-3133.

Mohammed, A., Sekar, P., and George, J. (2011). Efficacy of microbes in bioremediation of tannery effluent. Inter. J. Curr. Res, 3(4), 324-326.

Mohammed, S. S. D., Orukotan, A. A., and Abdullahi, H. (2017). Physicochemical and Bacteriological Assessment of Tannery Effluent from Samaru-Zaria, 
BAJOPAS Volume 13 Number 2, December, 2020 Kaduna State, Nigeria. Journal of Applied

Sciences and Environmental Management, 21(4), 734-740.

Munz, G., De Angelis, D., Gori, R., Mori, G., Casarci, M., and Lubello, C. (2009). The role of tannins in conventional and membrane treatment of tannery wastewater. Journal of hazardous materials, 164(2-3), 733-739

Mythili, K., and Karthikeyan, B. (2011). Bioremediation of $\mathrm{Cr}$ (VI) from tannery effluent using Bacillus spp and Staphylococcus spp. International Multidisciplinary Research Journal, 1(6).

NESREA (2009). National Environmental Standards for Effluent Limitations and Regulation. 1233-1236

Noorjahan, C. M. (2014). Physicochemical characteristics, identification of bacteria and biodegradation of industrial effluent. Journal of bioremediation and Biodegradation, 5(3).

Ohtake, H. I., and Silver, A. O. (1994). Bacterial reduction of toxic chromate. Biological degradation and bioremediation of toxic chemicals, 403-415.

Omoleke, I. I. (2004). Management of environmental pollution in Ibadan, an African city: the challenges of health hazard facing government and the people. Journal of Human Ecology, 15(4), 265-275.

Rajor, A., Reddy, A.S., and Singh, B. (2004). Determination of BOD kinetic Parameters and evaluation of alternate methods, M.Sc. Thesis, Department of biotechnology \& environmental Science, Thapar Institute of Engineering and Technology, Patiala

Ramasami, T., Rajamani, S., and Rao, J. R. (1994, March). Pollution control in leather industry: Emerging technological options. In International symposium on surface and colloidal science and its relevance to soil pollution, madras.

Ramesh, J. V. S., and Singh, S. P. (1993). Yearly variation in certain physicochemical parameters of pond at eastern Doon Valley. Uttar Pradesh J. Zoo, 12 (1), 7577.

Ranen, S., and Sharadinadra, C. (2009). Biotechnology applications to environmental remediation in resource exploitation. Current science, 97, 6-25
Russell, A. J., Berberich, J. A., Drevon, G. F., and Koepsel, R. R. (2003). Biomaterials for mediation of

chemical and biological warfare agents. Annual review of biomedical engineering, 5(1), 1-27.

Saravanan, P., and Saravanan, A. (1999). Decolourization of tannery effluent by Flavobacterium sp. EK 1. Indian Journal of Environmental Protection, 19, 19-24.

Sikander, S., and Shahida, H. (2007). Reduction of toxic hexavalent chromium by Ochrobactrum intermedium strain SDCr5 stimulated by heavy metals. Bioresource Technol, 98, 340-344.

Singh, N., Sharma, B. K., and Bohra, P. C. (2000). Impact assessment of industrial effluent of arid soils by using satellite imageries. Journal of the Indian Society of Remote Sensing, 28(2-3), 79.

Sreemoyee, C., and Priti, P. (2013). Assessment of physico-chemical parameters of dairy waste water and isolation and characterization of bacterial strains in terms of cod reduction. Int J Sci, 2(3), 395-400.

Verheijen, L. A. H. M., Wiersema, D., Pol, L. H., and De Wit, J. (1996). Management of wastes from animal product processing. Livestock and environment, Finding a balance. International Agriculture Center, Wageningen, The Netherlands.

Wang, F., Yao, J., Si, Y., Chen, H., Russel, M., Chen, K., and Bramanti, E. (2010). Short-time effect of heavy metals upon microbial community activity. Journal of Hazardous Materials, 173(13), 510-516.

WHO (World Health Organization). (2006). Air quality guidelines: global update 2005: particulate matter, ozone, nitrogen dioxide, and sulfur dioxide. World Health Organization.

World Bank. (1995). Nigeria's strategic options for redressing industrial pollution. World Bank, industry and energy division. 1st edition, West Central Africa Department; Annexes: 1995; pp 60-62.

Zahoor, A., and Abdul, R. (2009). Enumeration of Coliforms. Journal of Environmental Sciences. 21, 814-820 


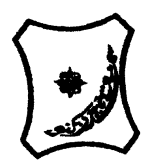

Bayero Journal of Pure and Applied Sciences, 13(2): 1 - 12

Received: November, 2020

Accepted: December, 2020

ISSN $2006-6996$

\title{
BIODEGRADATION POTENTIAL OF IMMOBILIZED BACTERIA IN THE TREATMENT OF TANNERY INDUSTRIAL EFFLUENTS FROM INDUSTRIAL ESTATES IN KANO STATE, NIGERIA
}

\author{
Abdullateef, B., ${ }^{1 *}$ Shuaibu, T. G., ${ }^{1}$ Babagana, K., ${ }^{1}$ Suleman, H. B. ${ }^{2}$ and Dauda, B. ${ }^{3}$ \\ ${ }^{1}$ Department of Pure and Applied Chemistry, Faculty of Science, University of Maiduguri, Borno State, \\ Nigeria \\ ${ }^{2}$ Department of Microbiology, Faculty of Science, University of Maiduguri, Borno State, Nigeria \\ ${ }^{3}$ Department of Chemical Engineering, Faculty of Engineering, University of Maiduguri, Borno State, \\ Nigeria \\ *Corresponding author: babslega@gmail.com; abelega2007@yahoo.com; +2348061309753
}

\section{ABSTRACT}

Industrial Effluents Samples from Gashash Tanneries (TAN1) in Bompai Industrial estate, Larabee Tannery Industry (TAN2) in Sharada Industrial estate and Z Tannery Industries (TAN3) in Challawa Industrial estate, Kano State, Nigeria were collected over a period of six months (August 2017 to January 2018) for assessing the biodegradation potentials of bacteria in the treatment of organic pollutants within the effluents. Bacteria were isolated from the effluents and immobilized on agar-agar. Different masses (5 g, $10 \mathrm{gr}, 15$ $\mathrm{g}, 20 \mathrm{~g}$, and $25 \mathrm{~g}$ ) of the bacteria were used in the treatment of $250 \mathrm{ml}$ of the effluents for ten days in a shaker incubator (Gallenkamp-OC-4364-L) at the temperature $30{ }^{\circ} \mathrm{C}$ and speed of $60 \mathrm{rpm}$. Pre-treatment analysis of the effluents for Temperature, pH, Biochemical Oxygen Demand (BOD), Chemical Oxygen Demand (COD), Suspended Solid (SS) and Total Dissolved Solids (TDS) gives the following results; temperature $\left({ }^{\circ} \mathrm{C}\right.$ )

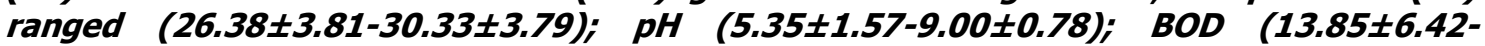
$38.75 \pm 16.20) ;$ COD (1406 $\pm 208-3532 \pm 1373) ;$ SS (208 $\pm 235-780 \pm 739)$ and TDS (266 $\pm 253-5276 \pm 2971)$. No statistical differences ( $p \leq 0.05)$ was observed for all the results among the different industries. The bacterial isolates were identified as Neisseria spp, Bacillus cereus, and Staphylococcus aureus, in TAN1, TAN2, and TAN3, respectively. After treatment of the effluent with the different masses of the isolated bacteria, the mean level of BOD was found to range as (0.55 $\pm 0.36-6.92 \pm 5.49) ; C O D$ (ND-3134 \pm 1595$)$;

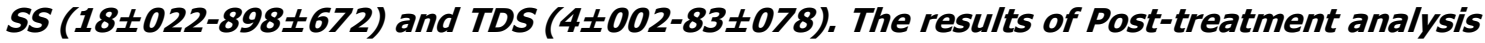
showed that there is overall decrease in the levels of the parameters determined when compared with that of the pre-treatment. The overall percentage reduction of the immobilised bacteria in the treatment of the respective effluents was in the order TAN2 (72\%)>TAN1 (70\%)>TAN3 (62\%). Hence, the immobilized bacteria are having higher biodegradation potential for the treatment of the tannery effluents.

Keywords: Biodegradation, bacteria, effluent, immobilization, tannery.

\section{INTRODUCTION}

Tannery industrial wastewater is a serious consequence of the pollution point of view for streams, freshwater, and land used for agriculture. The lack of awareness in the modern industrial practice has resulted in the discharge of tannery effluents which exhibit very high value of chromium ( $\mathrm{Cr}$ ), Sulfide, and chloride, Total Dissolved Solid (TDS), Total Suspended Solid (TSS), Biochemical Oxygen Demand (BOD) and Chemical Oxygen Demand (COD) in the water stream or land (Mohammed et al., 2001). Tanning is the process, which One ton of skin generally leads to the production of 20 to $80 \mathrm{~m}^{3}$ of turbid and foul-smelling converts the protein of the rawhide or skin into a stable material, which will not putrefy and is suitable for a wide variety of end applications (Elsheikh, 2009). The highly polluting chromium is the most commonly used tanning material producing leather that is more flexible and pliable than vegetable-tanned leather and does not discolor or lose shape in water as drastically as vegetable-tan (Elsheikh, 2009). Tannery effluent is among the most hazardous industrial pollutants due to its huge organic and inorganic load, which is highly toxic to human life and the environment (Kongjao et al., 2008). wastewater including chromium (100-400 mg/l), sulfide $(200-800 \mathrm{mg} / \mathrm{l})$, high levels of fat and 
BAJOPAS Volume 13 Number 2, December, 2020 other solid wastes, and notable pathogen contamination as well as pesticides added for skin conservation during transport (Elsheikh, 2009). There are more than 6000 tanneries in Nigeria with an annual processing capacity of 700,000 tons of hides and skins (Omoleke, 2004; Singh et al., 2008). It was reported that the total amount of waste produced per animal slaughtered is approximately $35 \%$ of its weight (World Bank, 1995). Also, for every $1000 \mathrm{~kg}$ of carcass weight, a slaughtered beef produces 5.5 $\mathrm{kg}$ of manure (excluding rumen contents or stockyard manure) and $100 \mathrm{~kg}$ of paunch manure (undigested food) (Verheijen et al., 1996). Tanneries generate wastewater in the range of 30-35 $\mathrm{L} \mathrm{kg}^{-1}$ skin/hide processed with variable $\mathrm{pH}$, Biological Oxygen Demand (BOD), Chemical Oxygen Demand (COD), high concentrations of suspended solids (SS), and tannins as well as chromium (Zahoor and Abdul, 2009).

Being heterogeneous and composed of a wide variety of compounds, it is very difficult to select a unique direct method for estimating the biodegradability of organic contents and biokinetic parameters for a wastewater sample (Rajor, 2004). For this purpose, some indirect estimation such as determination of biochemical oxygen demand (BOD) and chemical oxygen demand (COD) are applied as common laboratory investigations [9]. During retanning procedures, synthetic tannins (Syntan), oils and resins are added to form softer leather at varying doses (Munz et al., 2009). One of the refractory groups of chemicals in tannery effluents derives mainly from tannins (Ramasami et al., 2004). Syntans are characterized by complex chemical structures, because they are composed of an extended set of chemicals such as phenol-, naphthalene-, formaldehyde- and melamine-based syntans, and acrylic resins (Beem, 1994). Organic pollutants (proteic and lipidic components) are originated from skins (it is calculated that the raw skin has $30 \%$ loss of organic material during the working cycle) or they are introduced during processes (Hugo Springer, 1994).

Many conventional processes such as oxidation, chemical and biological processes were carried out to treat tanneries wastewater (Ebtesam et al, 2013). Biological processes have received more attention because of their costeffectiveness, lower sludge production and environmental friendliness (Noorjahan, 2014). Naturally occurring micro-organisms degrade the hazardous organic wastes including xenobiotic compounds, such as pesticides, polycyclic aromatic hydrocarbons (PAHs) and polychlorinated biphenyls (PCBs) in due course of time (Ranen and Sharadinadra, 2009). Bioremediation is based on the idea that all organisms remove substances from the environment to carry outgrowth and metabolism (Bouwer and Zehnder, 1993). Bacteria, protista and fungi are found to be very good at degrading complex molecules and incorporating the breakdown products into their metabolism (Bouwer and Zehnder, 1993). The resultant metabolic wastes that they produce are generally safe and somehow recycled into other organisms (Ranen and Sharadinadra, 2009). An acclimatized indigenous population of microorganisms capable of degradation of the compounds of interest must exist at the site for a successful bioremediation mode (Ranen and Sharadinadra, 2009). It has been observed that for a successful bioremediation mode, an acclimatized indigenous population of microorganisms capable of degradation of the compounds of interest must exist at the site under investigation (Ranen and Sharadinadra, 2009). Even though there are numerous physical and chemical methods employed in the disposal of wastes the advantage in using bacterium is that they play a key role in the reduction of COD, BOD, total protein, total tannin and total phenol (Saravanan and Saravanan, 1998)

Baba et al. (2020) studied the bioremediation potential of immobilized corynebacterium kutsceri in the Treatment of tannery industrial effluent from Challawa Industrial Estate, Kano State, Nigeria. The aim of the work is to study the reduction in the level of the contaminants through the process of bioremediation using the isolated bacteria. Immobilized bacteria can withstand various temperatures, $\mathrm{pH}$ and substrate concentrations; consequently, increasing the efficiency and the lifespan of the bacteria. Immobilized bacteria are widely applied in the treatment of wastewater and can be separated and recovered after the treatment with the same efficiency (Baba et al., 2020).

\section{MATERIALS AND METHODS \\ Study Area}

This study was carried out in Bompai, Sharada and Challawa industrial estates in Kano, Figure 1. Kano lies on Latitude $11^{\circ} 30^{\prime} \mathrm{N}$ and $8^{\circ} 30^{\prime} \mathrm{E}$ and Longitude $11^{\circ} 5^{\prime} \mathrm{N}$ and $8^{\circ} 5^{\prime} \mathrm{E}$ in Northern Nigeria. It is one of the developed industrial cities in Nigeria. Tannery activities are the dominating industries and this could be one of the reasons for her high population density (Dan'Azumi and Bichi, 2010). Many researchers have studied biodegradation of tannery effluent using microorganisms. However, limited literature is available on the biodegradation of tannery effluent in Kano industrial estates using 
BAJOPAS Volume 13 Number 2, December, 2020 immobilized bacterial cells. This research work focuses on the potential of the use of the indigenous immobilized bacterial isolates in the treatment of tannery effluents in the industrial estates.

\section{Sample Collection}

Effluents were collected from the Tannery Industries from Bompai, Challawa and Sharada Industrial Estates, Kano, Nigeria. The effluents were collected over a period of six months (August 2017 to January 2018). Samples collected in a sterile 4-liter plastic container with a unique identification number were preserved using an ice-box that was transported to the Microbiology Laboratory, Department of Microbiology, Bayero University of Kano for analysis

\section{Sample Preparation and Sample Analysis}

Immediately after the collection of the effluent, $\mathrm{pH}$, TSS, TDS, COD, BOD levels were determined before treatment (Pre-treatment determination) and ten days after treatment (Post-treatment determination) as described in
APHA (1989) standard methods. $\mathrm{pH}$ was determined using Ecotests $\mathrm{pH}$ meter and TDS was determined using AQUALYTIC TDS Salinometer. BOD was determined as described by the standard method (APHA, 1992). COD and SS were determined using DR/2010 HACH portable data logging spectrophotometer (DWAF, 1992)

\section{Identification and Biochemical} Characterization of the Bacterial Isolates

The bacteria were isolated from the effluents using Serial Dilution according to the method described by APHA (1989). The biochemical tests such as oxidase, catalase, coagulase, indole (from $1 \%$ tryptone broth), citrate (Simmons citrate agar), methyl red/VogesProskauer (MR/VP), nitrate reduction, Starch Hydrolysis, Glucose, Maltose, and Lactose tests were carried out on the bacterial isolates to identify the bacteria through the bacteria biochemical characteristics according to Ajao et al. (2011).

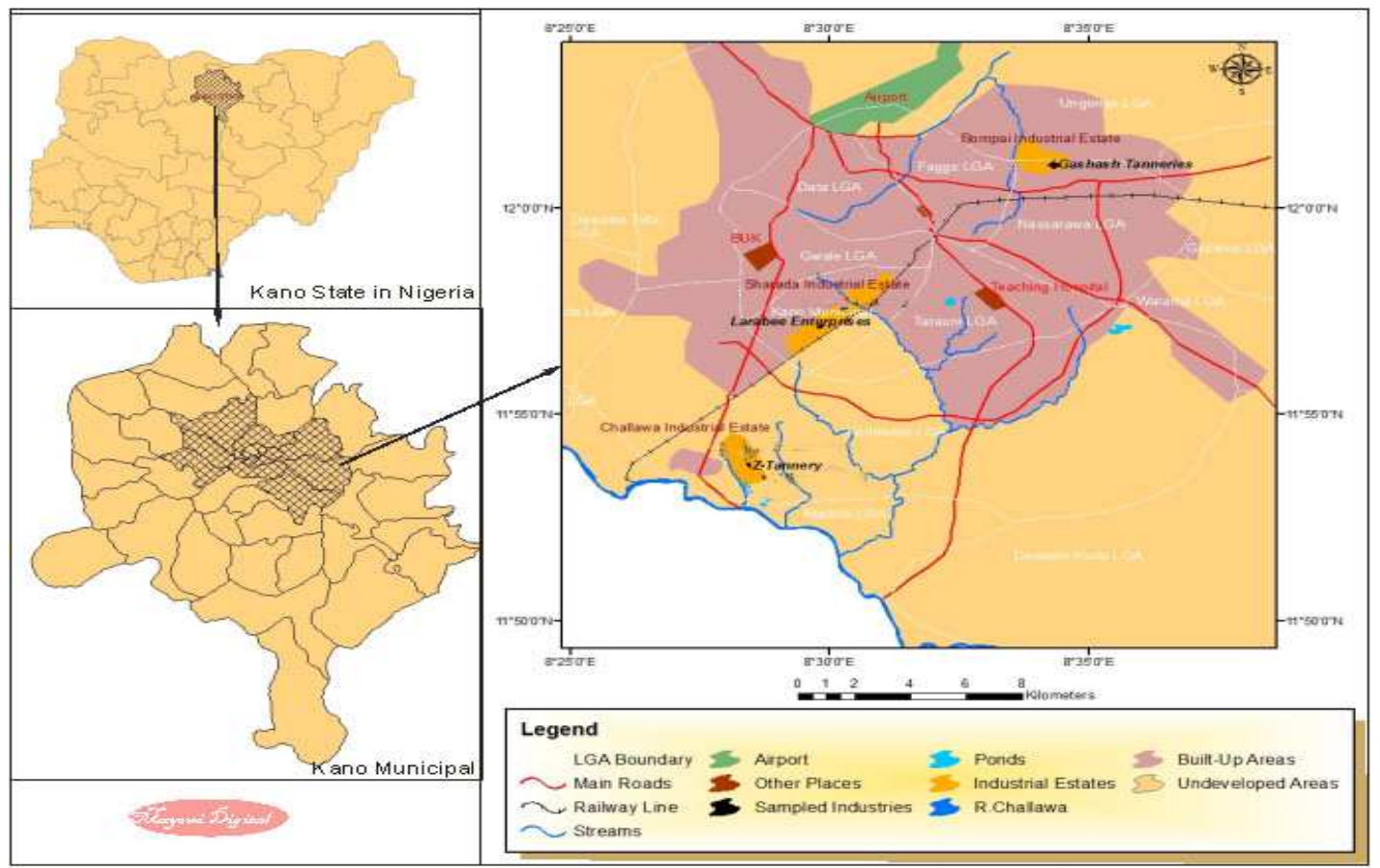

Fig. 1 Map showing the study areas

Source: Mayomi Digital Productions, GIS Laboratory, Department of Geography, UNIMAID (2017)

\section{Determination of Growth Rate of the Bacteria in Effluent Sample}

The bacteria growth rates were determined by transferring $2 \mathrm{~mL}$ of the bacterial isolates from the tannery effluent in broth medium into 100 $\mathrm{mL}$ sterile effluents in conical flasks and kept in an incubator (Giffrin cool) for 10 days. Control was also set up by incubating another $100 \mathrm{~mL}$ each of the sterile effluents without the bacteria. The optical density of the content was determined at the wavelength of $600 \mathrm{~nm}$ on a daily interval and recorded. 
BAJOPAS Volume 13 Number 2, December, 2020 Immobilization of Bacteria

Agar solution and inoculi were prepared separately. Fifty milliliters $(50 \mathrm{~mL})$ of nutrient broth each of the inoculi was prepared in a McCartney bottle and incubated for 24 hours. A solution of agar-agar was prepared by dissolving $10 \mathrm{~g}$ of the powder in distilled water and made up to $500 \mathrm{~mL}$ mark in an Erlenmeyer flask and was sterilized in an autoclave (280A) for 15 minutes and allowed to cool to $40-45^{\circ} \mathrm{C}$ (Ajao et al., 2011). Four milliliters ( $4 \mathrm{~mL})$ of the bacterial isolates in the nutrient broth was mixed with 36 $\mathrm{ml}$ of the prepared agar-agar media in petri-dish plates and then allowed to solidify. This was kept in the refrigerator for bioremediation.

\section{Bioremediation (Treatment) of the Effluents}

The solidified agar block (immobilized bacteria) was cut into cubes using a sterile knife; $0.1 \mathrm{~mL}$ phosphate buffer ( $\mathrm{pH} \mathrm{7.0)}$ was added and kept in the refrigerator for 1 hour for curing. The phosphate buffer was decanted after 1 hour and the cubes were washed with sterile distilled water 3-4 times before it was used (Ajao et al., 2011). Two liters (2 L) of the effluent was supplemented with the minimum basal medium in $\mathrm{g} / \mathrm{L}: \mathrm{NaCl}(0.8), \mathrm{MgSO}_{4} .7 \mathrm{H}_{2} \mathrm{O}(0.001), \mathrm{KH}_{2} \mathrm{PO}_{4}$ (2), $\mathrm{NaNO}_{3}$ (2), $\quad \mathrm{CaCl}_{2} .2 \mathrm{H}_{2} \mathrm{O} \quad(0.5)$ and $\mathrm{NaHPO}_{4} .12 \mathrm{H}_{2} \mathrm{O}(2)$ and sterilized in an autoclave at $121^{\circ} \mathrm{C}$ for 15 minutes (Margesin and Schinner, 2001). Two hundred and fifty milliliters $(250 \mathrm{~mL})$ of the effluents were transferred into different $250 \mathrm{ml}$ conical flasks. The content was covered with a cotton-wool ramped with foil paper to avoid contamination. Five grams $(5 \mathrm{~g})$ of the immobilized bacteria were quickly transferred into each of the effluents in the conical flasks in an inoculating chamber. The same procedures were carried out for the $10 \mathrm{~g}, 15 \mathrm{~g}, 20 \mathrm{~g}$ and 25 $\mathrm{g}$ of the immobilized bacteria in separate $250 \mathrm{~mL}$ effluents in conical flasks and agitated for ten days in a shaker incubator (Gallenkamp-OC4364-L) at a temperature $30^{\circ} \mathrm{C}$ and speed of 60 rpm. The treated effluent samples were taken on the tenth day and analyzed for the parameters $\mathrm{pH}$, SS, TDS, COD, and BOD, (Posttreatment determination) for the different grams of bacteria to evaluate and compare the biodegradation potential. (Baba et al., 2020).

\section{Statistical Analysis}

The data were represented as Mean \pm Standard deviation and analyzed statistically using oneway Analysis of Variance (ANOVA) and Tukey's HSD as Post Hoc Tests with the aid of SPSS 16.0. The correlation coefficient was also used to measure the strength of the relationship between the different masses of the bacteria and the parameters. All $\mathrm{p} \leq 0.05$ were considered as statistically significant.

\section{RESULTS AND DISCUSSION Physico-chemical parameters in the Industrial Effluents before the Biodegradation.}

Results of the Physico-chemical parameters in the industrial effluents before the Biodegradation is shown in table 1 . The mean temperatures $\left({ }^{\circ} \mathrm{C}\right)$ observed in TAN1, TAN2, and TAN3 samples were $28.07 \pm 0.65 ; 27.77 \pm 0.64$ and $26.38 \pm 3.81$ respectively. The order of the mean temperature of the samples from the three industries can be arranged as TAN1 > TAN2>TAN3. The temperature observed at TAN1, TAN2, and TAN3 samples were found below the WHO $\left(35^{\circ} \mathrm{C}\right)$ and NESREA $\left(40^{\circ} \mathrm{C}\right)$ limits. The low values of temperature might be due to the processes used at the time of sampling. High temperature brings down the solubility of gases in water that ultimately expresses as high BOD and COD. Statistical analysis shows that there is no significant difference $(p<0.05)$ between the mean values of temperature among the industries. This might be due to similar tannery activities involved in the tannery industries at the time of sampling. The average values of temperature observed in this present study are less than those observed by Akan et al. (2007), Akan et al. (2009) and Baba et al. (2020).

The mean level of $\mathrm{pH}$ observed in TAN1, TAN2 and TAN3, samples were $7.77 \pm 2.93$; $8.35 \pm 0.28$ and $7.52 \pm 0.76$ respectively. The order of the mean $\mathrm{pH}$ of the samples from the three industries can be arranged as TAN2> TAN1 $>$ TAN3. The $\mathrm{pH}$ of the samples falls within the WHO (7.0-8.5) and NESREA (6-9) standard limits. Statistical analysis shows that there is no significant difference $(p<0.05)$ between the mean values of $\mathrm{pH}$ among the industries. This might be due to similar tannery activities involved in the tannery industries at the time of sampling. Maheshwari et al. (2017) reported that the level of $\mathrm{pH}$ in the effluents from the tannery industry in Vaniyambadi, India was 6.5 which was lower than that observed in the present study. The $\mathrm{pH}$ in the effluents from the tannery industries in Kano and Kaduna were reported to be 7.64 and 6.89, respectively (Akan et al., 2007; Mohammed et al., 2017). The average values of $\mathrm{pH}$ observed in this present study are less than those observed by Mohammed et al. (2017) and Baba et al. (2020). The mean level of SS $(\mathrm{mg} / \mathrm{l})$ observed in TAN1, TAN2, and TAN3 samples were 374 \pm 124 ; $358 \pm 335$ and $780 \pm 739$ respectively. The order of the mean SS in the samples from the three industries can be arranged as TAN3 > TAN1 $>$ TAN2. 
The SS observed in the samples were far above the recommended standard limits of regulating bodies WHO $(30 \mathrm{mg} / \mathrm{l})$ and NESREA $(10 \mathrm{mg} / \mathrm{l})$. Statistical analysis shows that there is no significant difference $(p<0.05)$ between the mean values of SS among the industries. This might be due to similar tannery activities involved in the tannery industries at the time of sampling. The average values of SS observed in this present study are less than that observed $(3700 \pm 122 \mathrm{mg} / \mathrm{l})$ by Akan et al. (2009) for tanneries in Kano. Also, the average values of SS observed in this present study are less than that observed by Mohammed et al. (2017) and Baba et al. (2020) with the exception in TAN3.

The mean level of TDS (mg/l) observed in TAN1, TAN2, and TAN3 samples were $3941 \pm 3703$; $3300 \pm 1714$ and $2653 \pm 1240$ respectively. The order of the mean TDS in the samples from the three industries can be arranged as TAN1>TAN2>TAN3. The TDS observed in the samples were far above the recommended standard limits of WHO $(250 \mathrm{mg} / \mathrm{l})$ and NESREA $(500 \mathrm{mg} / \mathrm{l})$. Statistical analysis shows that there is no significant difference $(p<0.05)$ between the mean values of TDS among the industries. This might be due to similar tannery activities involved in the tannery industries at the time of sampling. TDS in the effluents from the tannery industries in Kano, Nigeria was reported to be $1281 \mathrm{mg} / \mathrm{l}$ (Akan et al., 2007). The average values of SS observed in this present study are less than those observed by Mohammed et al. (2017) and Baba et al. 2020)

The mean level of COD (mg/l) observed in TAN1, TAN2 and TAN3 samples seasons were $2372 \pm 938 ; \quad 1406 \pm 208$ and $3532 \pm 1373$ respectively. The order of the mean COD of the samples from the three industries can be arranged as TAN3>TAN1> TAN2. The COD observed in TAN1, TAN2 and TAN3 samples were far above the recommended standard limits of regulating bodies $\mathrm{WHO}(40 \mathrm{mg} / \mathrm{l})$ and NESREA (40 mg/l). Statistical analysis shows that there is no significant difference $(p<0.05)$ in COD among the industries. This might be due to similar tannery activities involved in the tannery industries as at the time of sampling. The Chemical Oxygen demand (COD) is the amount of oxygen, in $\mathrm{mg} / \mathrm{L}$, required for the degradation of the compound of wastewater to occur. In comparison, the average values of COD observed in this present study were higher than that observed by Mohammed et al. (2017) but lower than that observed by Baba et al. (2020).

The mean levels of BOD $(\mathrm{mg} / \mathrm{l})$ observed in TAN1, TAN2 and TAN3 samples were $13.85 \pm 6.42 ; \quad 19.46 \pm 0.50$ and $17.13 \pm 3.14$ respectively. The order of the mean BOD in the samples from the three industries can be arranged as TAN2>TAN3>TAN1. The BOD observed in TAN1, TAN2 and TAN3 samples were found below the recommended limits of NESREA (200 mg/l) but above WHO (10 mg/l). Statistical analysis shows that there is no significant difference $(p<0.05)$ between the mean values of BOD among the industries. This might be due to similar tannery activities involved in the tannery industries at the time of sampling. The low level of BOD recorded in this study is an indication of the low level of biodegradable organic solids in the effluent. The average values of BOD observed in this present study were lower than those observed by Mohammed et al. (2017) and Baba et al. (2020).

Table 1: Mean Values \pm S.D of Physico-chemical parameters of effluents from the Tannery Industries before Treatment.

\begin{tabular}{llllllll}
\hline Parameter & Tannery 1 & Tannery 2 & Tannery 3 & $\mathrm{a}$ & $\mathrm{b}$ & $\mathrm{c}$ & $\mathrm{d}$ \\
\cline { 2 - 7 } Temperature $\left({ }^{\circ} \mathrm{C}\right)$ & $28.07 \mathrm{a} \pm 0.65$ & $27.77 \mathrm{a} \pm 0.64$ & $26.38 \mathrm{a} \pm 3.81$ & & $29.50 \pm 4.68$ & 35 & 40 \\
pH & $7.77 \mathrm{a} \pm 2.93$ & $8.35 \mathrm{a} \pm 0.28$ & $7.52 \mathrm{a} \pm 0.76$ & 6.89 & $5.35 \pm 1.57$ & $7.0-8.5$ & $6.0-9.0$ \\
$\mathrm{COD}(\mathrm{mg} / \mathrm{l})$ & $2372 \mathrm{a} \pm 938$ & $1406 \mathrm{a} \pm 208$ & $3532 \mathrm{a} \pm 1373$ & 2.2 & $3106 \pm 2753$ & 40 & 40 \\
$\mathrm{BOD}(\mathrm{mg} / \mathrm{l})$ & $13.85 \mathrm{a} \pm 6.42$ & $19.46 \mathrm{a} \pm 0.50$ & $17.13 \mathrm{a} \pm 3.14$ & 1032 & $26.17 \pm 9.49$ & 10 & 200 \\
$\mathrm{SS}(\mathrm{mg} / \mathrm{l})$ & $374 \mathrm{a} \pm 124$ & $358 \mathrm{a} \pm 335$ & $780 \mathrm{a} \pm 739$ & 501 & $562 \pm 482$ & 30 & 10 \\
TDS $(\mathrm{mg} / \mathrm{l})$ & $3941 \mathrm{a} \pm 3703$ & $3300 \mathrm{a} \pm 1714$ & $2653 \mathrm{a} \pm 1240$ & 532.7 & $444 \pm 507$ & 250 & 500 \\
\hline
\end{tabular}

The values given in the table above are means of 6 replicate values, $\mathrm{n}=6$ ( 1 sample was taken monthly for 6 months). Within the rows, means with different alphabets are statistically different $(p<0.05)$. WHO: World Health Organisation. NESREA: National Environmental Standard and Regulatory Enforcement Agency. a = Mohammed et al.(2017), b = Baba et al. (2020), c = WHO (2006), $d=$ NESSRA (2009) 
BAJOPAS Volume 13 Number 2, December, 2020

Identification, Biochemical Characterization and growth rates of the Bacterial Isolates

Results of identification and biochemical characterization of the bacterial isolates were shown in table 2. After 24 hours of incubation, the nutrient agar media plates were checked for bacterial growth. The results showed the presence of different strains in the samples. The TAN1 bacteria isolate was found to be gramnegative cocci while TAN3 was gram-positive cocci. TAN2 bacteria isolate was found to be gram-positive, rod-shaped. TAN1, TAN2, and TAN3 bacteria isolates recorded positive results for spore former.

The results of the biochemical tests indicated that all the bacteria were positive for catalase, oxidase, citrate, maltose, glucose, lactose (negative in TAN1), mannitol (negative in TAN2), starch hydrolysis and coagulase (negative in TAN2) tests. The bacteria showed negative results for nitrate reduction, $M R$ (positive in TAN2), VP (positive in TAN1), Indole (positive in TAN2) tests. Base on the morphological and biochemical test results, TAN1, TAN2, and TAN3 bacteria isolates were identified to be Nesseria spp, Bacillus cereus, and Staphylococcus aureus respectively.

The growth rate of the TAN1, TAN2 and TAN3 Isolates were shown in figure 2. Generally, the optical density increase with the increase in time (day) and decrease as time goes on. The highest optical density was shown by bacillus cereus in TAN2 while the lowest was shown by Staphylococcus aureus in TAN3.

The initial growth phase of TAN1 Isolate bacteria occurred within 2-day of incubation as the growth rate increases up to the 6th-day incubation when the maximum growth was observed. Beyond the 6th day, the growth of the bacteria declined (which might be due to a shortage of nutrients in the effluents) until it reached its death phase (which might be due to the unavailability of nutrients in the effluents).

A similar trend of growth was also observed for TAN2 Isolate as the initial growth phase also occurred within 2-day of incubation but maximum growth rate observed on the 4th day of incubation. The stationary stage occurred between the 4th day and the 8th day. Beyond the 8th day, the growth of the bacteria declined (which might be due to a shortage of nutrients in the effluents) until it reached its death phase (which might be due to the unavailability of nutrients in the effluents).

The initial growth phase of TAN3 bacterial Isolate occurred within the 3-day incubation as the growth rate increases up to the 6th-day incubation when the maximum growth was observed. Beyond the 6th day, the growth of the bacteria declined (which might be due to a shortage of nutrients in the effluents) until it reached its death phase (which might be due to the unavailability of nutrients in the effluents).

Table 2: Morphological and Biochemical characteristics of bacterial isolates

\begin{tabular}{lllll} 
Bacterial Isolates & & TAN1 & TAN2 & TAN3 \\
\hline $\begin{array}{lllll}\text { Morphological } \\
\text { characteristics }\end{array}$ & Shape & Cocci & Rod & Cocci \\
& Spore & & & \\
& former & + & + & + \\
Gram & & & \\
Biochemical characteristics & reaction & - & + & + \\
& Citrate & + & + & + \\
& Catalase & + & + & + \\
& Coagulase & + & - & + \\
Starch & + & + & + \\
& Glucose & + & + & + \\
Oxidase & + & + & + \\
& Indo & - & + & - \\
Lactose & - & + & + \\
Manitol & + & - & + \\
Maltose & + & + & + \\
MR & - & + & - \\
VP & + & - & - \\
& Nitrate & - & - & - \\
Reduction & - Neisseria & Bacillus & Staphylococcus \\
& Bacterial & cereus & aureus \\
& name & spp & cas
\end{tabular}

+ = Positive; - = Negative; MR=Methyl Red; VP= Voges-Proskauer 


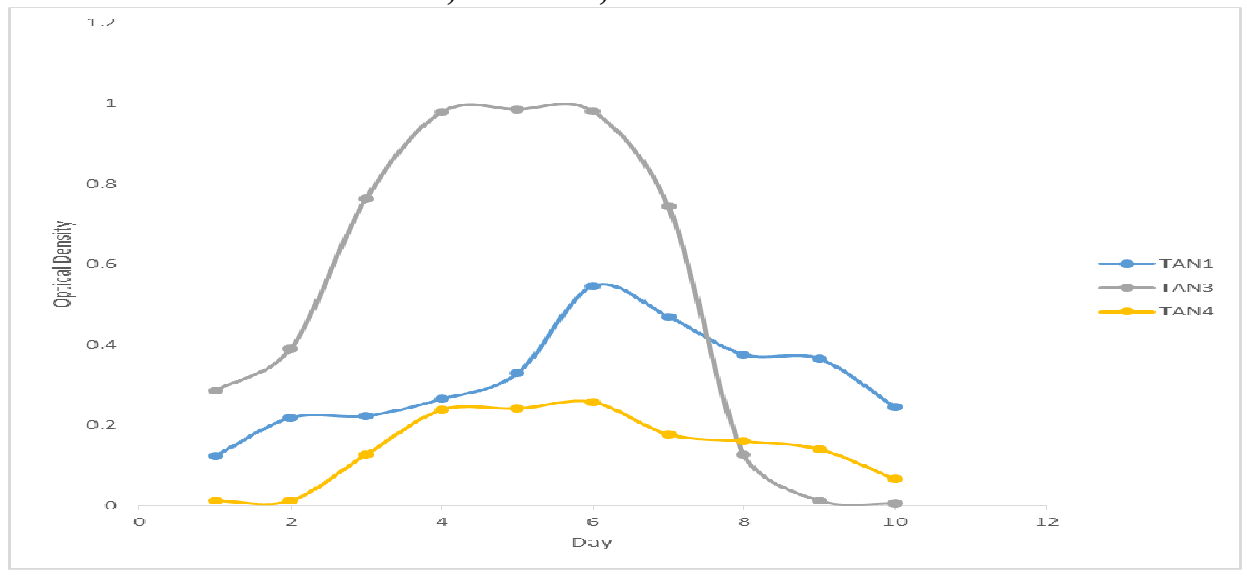

Fig. 2 Growth rates of the isolates in the effluents from the Tannery Industries

\section{Physico-chemical Parameters in the Industrial Effluents after the biodegradation.}

Table 3 shows the mean results of the physicochemical parameter before and after bioremediation using the different masses $(5 \mathrm{~g}$, $10 \mathrm{~g}, 15 \mathrm{~g}, 20 \mathrm{~g}$, and $25 \mathrm{~g}$ ) of the respective immobilized bacteria. Also, Table 4 shows the mean results of correlation coefficient ( $r$ ) between different masses of bacteria and physicochemical parameters.

The mean values $(\mathrm{mg} / \mathrm{l})$ of the SS after the bioremediation varies between $243 \pm 45$ and $898 \pm 672$. The mean concentration $(\mathrm{mg} / \mathrm{l})$ of SS remediated by the different masses $(5 \mathrm{~g}, 10 \mathrm{~g}$, $15 \mathrm{~g}, 20 \mathrm{~g}$, and $25 \mathrm{~g}$ ) of the bacteria varies. The SS in the samples fluctuates up and down after the bioremediation process when compared with the SS of the raw samples before the bioremediation. The increase in the levels of the SS might be due to the aggregation of the TDS which are large enough to result into SS. The increase in the levels of the SS might be also due to the influence of the nutrients which was added into the effluents in order to make the microorganisms more active and viable for fast degradation of organic contaminants in the effluent. The relative potential or efficiency of the different masses of the bacteria in remediating SS in TAN1 samples was in the order $25 \mathrm{~g}>20 \mathrm{~g}>15 \mathrm{~g}>10 \mathrm{~g}>5 \mathrm{~g}$. For TAN2 and TAN3 samples, the order was $25 \mathrm{~g}>20 \mathrm{~g}>15$ $\mathrm{g}>10 \mathrm{~g}>5 \mathrm{~g}$. These might be due to the variations in the surface areas of the different masses of the immobilized bacteria. Statistical analysis shows that there is no significant difference $(p<0.05)$ between the mean values of SS among the masses in the respective industries. Positive and significant correlations exist between the masses of bacteria and Suspended Solid (SS). This showed that there is general increase in the levels of the SS as the masses of the immobilized bacteria increases. TAN3 (90\%) and TAN1 (80\%) showed a very high correlation with the masses of the bacteria while TAN2 (61\%) showed a very low correlation.

The mean values $(\mathrm{mg} / \mathrm{l})$ of the TDS after the bioremediation varies between $46 \pm 11$ and $83 \pm 78$. The mean concentration $(\mathrm{mg} / \mathrm{l})$ of TDS remediated by the different masses $(5 \mathrm{~g}, 10 \mathrm{~g}$, $15 \mathrm{~g}, 20 \mathrm{~g}$, and $25 \mathrm{~g}$ ) of the bacteria varies. There is a reduction in all the TDS of all the samples after the bioremediation process compared with the TDS of the raw samples before the bioremediation. The relative potential or efficiency of the different masses of the bacteria in remediating TDS in TAN1 and TAN3 samples was in the order $5 \mathrm{~g}>10 \mathrm{~g}>15 \mathrm{~g}>20$ $\mathrm{g}>25 \mathrm{~g}$. For TAN2 samples, the order was 20 $g>10 \quad g>25 \quad g>15 \quad g>5 \quad g$. Statistical analysis shows that there is no significant difference $(p<0.05)$ between the mean values of TDS among the masses in the respective industries. These might be due to the variations in the surface areas of the different masses of the immobilized bacteria. Positive and significant correlations exist between the masses of bacteria and TDS with the exception in TAN2 (negative and insignificant correlation). The positive correlations showed that there is general increase in the levels of the TDS as the masses of the immobilized bacteria increases. TAN1 $(96 \%)$ showed a very high correlation with the masses of the bacteria while TAN2 (47\%) showed a very low correlation.

The mean values $(\mathrm{mg} / \mathrm{l})$ of the BOD after the bioremediation varies between $1.56 \pm 0.20 \mathrm{mg} / \mathrm{l}$ and $6.92 \pm 5.49 \mathrm{mg} / \mathrm{l}$. The mean concentration $(\mathrm{mg} / \mathrm{l})$ of BOD remediated by the different masses $(5 \mathrm{~g}, 10 \mathrm{~g}, 15 \mathrm{~g}, 20 \mathrm{~g}$, and $25 \mathrm{~g}$ ) of the bacteria varies. There is a reduction in all the BOD of all the samples after the bioremediation process compared with the $\mathrm{BOD}$ of the raw 
BAJOPAS Volume 13 Number 2, December, 2020 samples before the bioremediation. The relative potential or efficiency of the different masses of the bacteria in remediating BOD in TAN1, TAN2 and TAN3 samples were in the order $25 \mathrm{~g}>20$ $\mathrm{g}>15 \mathrm{~g}>10 \mathrm{~g}>5 \mathrm{~g}, 25 \mathrm{~g}>15 \mathrm{~g}>5 \mathrm{~g}>10 \mathrm{~g}>20 \mathrm{~g}$ and $20 \mathrm{~g}>10 \mathrm{~g}>25 \mathrm{~g}>15 \mathrm{~g}>5 \mathrm{~g}$ respectively. Statistical analysis shows that there is significant difference $(p<0.05)$ between the mean values of BOD among the masses in the respective industries. These might be due to the variations in the surface areas of the different masses of the immobilized bacteria. Negative and significant correlations exist between the masses of bacteria and BOD. This showed that there is general decrease in the levels of the BOD as the masses of the immobilized bacteria increases. TAN1 (94\%) showed a very high correlation with the masses of the bacteria while TAN2 (4\%) showed a very low correlation.

The mean values $(\mathrm{mg} / \mathrm{l})$ of the COD after the bioremediation varies between $250 \pm 154$ and $3134 \pm 1595$. The mean concentration $(\mathrm{mg} / \mathrm{l})$ of COD remediated by the different masses $(5 \mathrm{~g}$, $10 \mathrm{~g}, 15 \mathrm{~g} 20 \mathrm{~g}$, and $25 \mathrm{~g}$ ) of the bacteria varies. There is a reduction in all the COD of all the samples after the bioremediation process compared with the COD of the raw samples before the bioremediation. The relative potential or efficiency of the different masses of the bacteria in remediating COD in TAN1, TAN2 and TAN3 samples were in the order $25 \mathrm{~g}>20 \mathrm{~g}>15$ $\mathrm{g}>5 \mathrm{~g}>10 \mathrm{~g}, 25 \mathrm{~g}>20 \mathrm{~g}>15 \mathrm{~g}>10 \mathrm{~g}>5 \mathrm{~g}$ and 10 g>5 g>25 g>15 g>20 g respectively. Statistical analysis shows that there were significant difference $(p<0.05)$ between the mean values of COD among the masses in the respective industries except for effluents treated with $25 \mathrm{~g}$. These might be due to the variations in the surface areas of the different masses of the immobilized bacteria. Negative and insignificant correlations exist between the masses of bacteria and COD with the exception in TAN3 (positive and significant correlation). The negative correlations showed that there is general decrease in the levels of the COD as the masses of the immobilized bacteria increases. TAN2 (100\%) showed a very high correlation with the masses of the bacteria while TAN3 (36\%) showed a very low correlation.

Generally, there was an overall decrease in the concentration of these physicochemical parameters after the bioremediation using the different masses of the bacterial isolates. These might be due to the variations in the surface areas of the different masses of the immobilized bacteria. This is in line with the work of Jimoh et al. (2018) and Baba et al. (2020).

Table 3: Mean Values $(\mathrm{mg} / \mathrm{l}) \pm$ S.D of Physicochemical parameters in effluents from the Tannery Industries before and after Treatment of the effluents $(250 \mathrm{ml})$ with the different masses $(5 \mathrm{~g}, 10 \mathrm{~g}$, $15 \mathrm{~g}, 20 \mathrm{~g}$, and $25 \mathrm{~g}$ ) of the bacteria.

\begin{tabular}{llllllll}
\hline $\mathrm{P}$ & IND & Before & \multicolumn{5}{c}{ After } \\
\cline { 4 - 7 } & & & $5 \mathrm{~g}$ & $10 \mathrm{~g}$ & $15 \mathrm{~g}$ & $20 \mathrm{~g}$ & $25 \mathrm{~g}$ \\
\hline \multirow{2}{*}{ COD } & TAN1 & $2372 \pm 938$ & $1708 \mathrm{a} \pm 861$ & $2045 \mathrm{a} \pm 1205$ & $845 \mathrm{a} \pm 369$ & $300 \mathrm{a} \pm 167$ & $250 \mathrm{a} \pm 154$ \\
& TAN2 & $1406 \pm 208$ & $1195 \mathrm{a} \pm 208$ & $1125 \mathrm{a} \pm 384$ & $1055 \mathrm{a} \pm 317$ & $956 \mathrm{a} \pm 310$ & $870 \mathrm{ab} \pm 240$ \\
& TAN3 & $3532 \pm 1373$ & $2374 \mathrm{a} \pm 1344$ & $1976 \mathrm{a} \pm 1405$ & $2757 \mathrm{a} \pm 1266$ & $3134 \mathrm{a} \pm 1595$ & $2614 \mathrm{~b} \pm 1105$ \\
BOD & TAN1 & $13.85 \pm 6.42$ & $6.92 \mathrm{a} \pm 5.49$ & $6.42 \mathrm{a} \pm 5.07$ & $5.72 \mathrm{a} \pm 5.35$ & $4.62 \mathrm{a} \pm 4.37$ & $2.82 \mathrm{ab} \pm 1.26$ \\
& TAN2 & $19.46 \pm 0.50$ & $1.75 \mathrm{~b} \pm 0.22$ & $1.73 \mathrm{~b} \pm 0.18$ & $1.58 \mathrm{a} \pm 0.16$ & $1.91 \mathrm{a} \pm 0.22$ & $1.56 \mathrm{~b} \pm 0.20$ \\
& TAN3 & $17.13 \pm 3.14$ & $4.24 \mathrm{ab} \pm 0.77$ & $3.29 \mathrm{ab} \pm 0.37$ & $4.11 \mathrm{a} \pm 0.07$ & $3.23 \mathrm{a} \pm 0.91$ & $3.33 \mathrm{a} \pm 1.28$ \\
SS & TAN1 & $374 \pm 124$ & $243 \mathrm{a} \pm 45$ & $471 \mathrm{a} \pm 226$ & $475 \mathrm{a} \pm 182$ & $492 \mathrm{a} \pm 128$ & $611 \mathrm{a} \pm 217$ \\
& TAN2 & $358 \pm 335$ & $460 \mathrm{a} \pm 400$ & $543 \mathrm{a} \pm 414$ & $544 \mathrm{a} \pm 402$ & $551 \mathrm{a} \pm 414$ & $554 \mathrm{a} \pm 405$ \\
& TAN3 & $780 \pm 739$ & $586 \mathrm{a} \pm 594$ & $758 \mathrm{a} \pm 656$ & $787 \mathrm{a} \pm 676$ & $861 \mathrm{a} \pm 635$ & $898 \mathrm{a} \pm 672$ \\
TDS & TAN1 & $3941 \pm 3703$ & $51 \mathrm{a} \pm 10$ & $53 \mathrm{a} \pm 10$ & $55 \mathrm{a} \pm 15$ & $61 \mathrm{a} \pm 20$ & $63 \mathrm{a} \pm 26$ \\
& TAN2 & $3300 \pm 1714$ & $83 \mathrm{a} \pm 78$ & $47 \mathrm{a} \pm 20$ & $48 \mathrm{a} \pm 22$ & $47 \mathrm{a} \pm 17$ & $48 \mathrm{a} \pm 17$ \\
& TAN3 & $2653 \pm 1240$ & $46 \mathrm{a} \pm 11$ & $55 \mathrm{a} \pm 24$ & $55 \mathrm{a} \pm 25$ & $58 \mathrm{a} \pm 23$ & $61 \mathrm{a} \pm 28$ \\
\hline
\end{tabular}

Replicate $=6$ (months)

Within the rows, for the same parameter, means with different alphabets are statistically different $(p<0.05)$.

$\mathrm{P}=$ parameter, IND = Industries 
BAJOPAS Volume 13 Number 2, December, 2020

Table 4: Correlation coefficient $(r)$ between different masses of the bacteria and the physicochemical parameters.

\begin{tabular}{llll}
\hline Industries & Parameter & Correlation coefficient $(r)$ & $\begin{array}{l}\text { Percent dependence (rxrx100) } \\
(\%)\end{array}$ \\
\hline TAN1 & COD & -0.9 & 82 \\
& BOD & -0.97 & 94 \\
& SS & $0.90^{*}$ & 80 \\
TAN2 & TDS & $0.98^{*}$ & 96 \\
& COD & -1 & 100 \\
& BOD & -0.21 & 4 \\
& SS & $0.78^{*}$ & 61 \\
& TDS & -0.69 & 47 \\
& COD & $0.60^{*}$ & 36 \\
& BOD & -0.6 & 37 \\
& SS & $0.95^{*}$ & 90 \\
& TDS & $0.94^{*}$ & 89 \\
\hline
\end{tabular}

The correlation coefficient $(r)$ with * is statistically significant $(p<0.05)$.

Percentage reduction of the Parameters

Table 5 shows the percentage reduction of Parameters in industrial samples before and after the treatment of the effluents $(250 \mathrm{ml})$ with the different masses $(5 \mathrm{~g}, 10 \mathrm{~g}, 15 \mathrm{~g}, 20 \mathrm{~g}$, and $25 \mathrm{~g}$ ) of the Immobilized Bacteria.

In TAN1 samples, the percentage reduction (\%) of COD ranged (14-89); BOD (50-80); SS (-32$35)$ and TDS (98-99). In TAN2 samples, the percentage decrease $(\%)$ of COD ranged (15$38) ;$ BOD (90-92); SS [-28-(-55)] and TDS (9798). In TAN3 samples, the percentage decrease (\%) of COD ranged (11-44); BOD (76-81); SS (15-25) and TDS (98). The percentage increase in the levels COD, BOD and TDS might be due to the increase in the surface area of the different masses of the immobilized bacteria. However, the percentage decrease in the levels of the SS might be due to the aggregation of the TDS which are large enough to result into SS. The percentage decrease in the levels of the SS might be also due to the influence of the nutrients which was added into the effluents in order to make the microorganisms more active and viable for fast degradation of organic contaminants in the effluent. This is in line with the work of Jimoh et al. (2018) in which the concentration of the SS increase after the bioremediation of effluents.

Sreemoyee and Priti (2013) assessed and reduced several Physico-chemical parameters of dairy wastewater using Niesseria $s p$. and concluded that the species are well known to degrade organic compounds. This is in agreement with the current study in which the immobilized Niesseria $s p$ degrade the organic contaminants as indicated by the BOD, COD and TDS.

Jimoh et al. (2018) observed that TSS of the effluents was increased after treatment with immobilized bacteria and concluded that it might be due to the biostimulation method adopted for the research.

The optimum $\mathrm{pH}$ Biosorption of Chromium by Bacillus spp and Staphylococcus spp. from tannery effluent was investigated by Mythili and Karthikeyan (2011). The maximum adsorption of Chromium $(86.4 \mathrm{mg} / \mathrm{L})$ was showed by Bacillus spp and Staphylococcus spp showed $70.6 \mathrm{mg} / \mathrm{L}$ at an initial concentration of $100 \mathrm{mg} / \mathrm{L}$. In the present study, immobilised Bacillus spp and Staphylococcus spp. from the tannery industrial effluents reduced the levels of the organic pollutants with high potential as indicated by the percentage reduction of BOD, COD and TDS.

Enzymes often can work in multiple environments especially if they are immobilized. This makes the microorganisms' enzymes even more resistant to harsh environments and enables the enzymes to be recovered and recycled after they are no longer needed (Gianfreda and Rao 2004). Ramesh and Singh (1993) reported that the immobilized bacteria having more efficiency to remove the suspended particles than free cells. Using the immobilized cell is preferable due to its capability for using several times with the same efficiency, which makes it more economical. Similar work was done by Sikander et al. (2007) showing the higher reduction with permeabilized cells of Ochrobactrum intermedium strain SDCr-5. 
BAJOPAS Volume 13 Number 2, December, 2020

The results revealed the isolation and identification of isolates with the potential for the reduction of $\mathrm{Cr}$ (VI) to $\mathrm{Cr}$ (III). Results indicated that immobilized $B$. cereus could be efficiently used for the reduction of $\mathrm{Cr}$ (VI).

Table 5: Percentage reduction of the tested Parameters from the tannery industrial samples of the Immobilized Bacteria.

\begin{tabular}{lllllll}
\hline \multirow{2}{*}{ Industries } & & \multicolumn{5}{c}{ Percentage Reduction $(\%)$} \\
\cline { 3 - 7 } & & $5 \mathrm{~g}$ & $10 \mathrm{~g}$ & $15 \mathrm{~g}$ & $20 \mathrm{~g}$ & $25 \mathrm{~g}$ \\
\hline TAN1 & COD & 28 & 14 & 64 & 87 & 89 \\
& BOD & 50 & 54 & 59 & 67 & 80 \\
& SS & 35 & -26 & -27 & -32 & -63 \\
& TDS & 99 & 99 & 99 & 98 & 98 \\
TAN2 & COD & 15 & 20 & 25 & 32 & 38 \\
& BOD & 91 & 91 & 92 & 90 & 92 \\
& SS & -28 & -52 & -52 & -54 & -55 \\
& TDS & 97 & 99 & 99 & 99 & 99 \\
& COD & 33 & 44 & 22 & 11 & 26 \\
& BOD & 75 & 81 & 76 & 81 & 81 \\
& SS & 25 & 3 & -1 & -10 & -15 \\
& TDS & 98 & 98 & 98 & 98 & 98 \\
\hline
\end{tabular}

Percentage Reduction $=(B-A) / B \times 100 \%$

$A=$ Concentration of the parameter after treatment

$\mathrm{B}=$ Concentration of the parameter before treatment

$+=$ percentage decrease

- = percentage increase

In general, immobilization makes the enzyme more resistant to temperature, $\mathrm{pH}$, and substrate concentration swings giving it a longer lifetime and higher productivity per active unit (Gianfreda and Rao, 2004; FuIlbrook, 1996; Russell et al, 2003; Kandelbauer et al., 2004). Immobilized cells have been used and studied extensively for the production of useful chemicals (Ohtake and Silver, 1994), the treatment of wastewaters (Chen et al., 2003; Wang et al., 2010). Although many workers described microbial degradation of tannery effluent, limited literature is available on the bioremediation of tannery effluent using immobilized bacterial cells in the Kano Industrial Estates.

\section{CONCLUSION}

The samples contained variable levels of the physicochemical parameters. The results of the Analysis of variance revealed that, no statistical difference $(p<0.05)$ was observed for the temperature, $\mathrm{pH}, \mathrm{SS}, \mathrm{TDS}, \mathrm{BOD}$ and $\mathrm{COD}$ among the three tannery industries before the treatment. The levels of some of the parameters
(SS, TDS and COD) observed in the samples were found above the recommended limits of WHO and NESREA, which called for the treatment of the effluents before discharge into the environment. Base on the morphological and biochemical test results, TAN1, TAN2, and TAN3 bacterial isolates were identified to be Neisseria spp, Bacillus cereus, and Staphylococcus aureus respectively. The results of Post-treatment analysis showed that there is overall decrease in the levels of the parameters determined when compared with that of the pre-treatment. The overall percentage reduction of the immobilised bacteria in the treatment of the respective effluents was in the order TAN2 (72\%)>TAN1 $(70 \%)>$ TAN3 $(62 \%)$. Hence, the immobilized bacteria are having higher biodegradation potential for the treatment of the tannery effluents.

\section{Acknowledgments}

The authors wish to acknowledge the University of Maiduguri for the financial support. The authors are grateful to the Kano State Ministry of Environment for their support in obtaining the effluent samples. 


\section{REFERENCES}

Ajao, A. T., Adebayo, G. B., and Yakubu, S. E. (2011). Bioremediation of textile industrial effluent using mixed culture of Pseudomonas aeruginosa and Bacillus subtilis immobilized on agar-agar in a bioreactor. J. Microbiol. Biotech. Res, 1(3), 50-56.

Akan, J. C., Moses, E. A., Ogugbuaja, V. O., and Abah, J. (2007). Assessment of tannery industrial effluents from Kano metropolis, Kano State, Nigeria. Journal of Applied Sciences, 7(19), 2788-2793.

Akan, J. C., Ogugbuaja, V. O., Abdulrahman, F. I., and Ayodele, J. T. (2009). Pollutant levels in effluent samples from tanneries and textiles of Kano industrial areas, Nigeria. Global journal of pure and applied sciences, 15(3-4).

APHA (1989). Standard methods for Examination of Will bete and Will betewater.15 $5^{\text {th }}$ edition. Brydpass Springfield Will behington DC. pp. 164-176

APHA (1992). Standard Methods for the Examination of Water and Wastewater. Health, 69, 1116-9.

Baba, A., Garba, S. T., and Bello, H. S. (2020). Bioremediation Potential of Immobilized corynebacterium kutsceri in the Treatment of Tannery Industrial Effluent from Challawa Industrial Estate, Kano State, Nigeria. Journal of the Turkish Chemical Society Section A: Chemistry, $7(2), 335-350$.

Beem, E. I. V. (1994). reduction of solvent VOC emission. J. Oil Col. Chem. Ass, 77, 158.

Bouwer, E. J., and Zehnder, A. J. (1993). Bioremediation of organic compoundsputting microbial metabolism to work. Trends in biotechnology, 11(8), 360367.

Chen, K. C., Wu, J. Y., Liou, D. J., and Hwang, S. C. J. (2003). Decolorization of the textile dyes by newly isolated bacterial strains. Journal of Biotechnology, 101(1), 57-68.

Dan'Azumi, S., and Bichi, M. H. (2010). INDUSTRIAL POLLUTION AND HEAVY METALS PROFILE OF CHALLAWA RIVER IN KANO, NIGERIA. Journal of Applied Sciences in Environmental Sanitation, $5(1)$.

DWAF. (1992). Analytical Methods Manual, TR 151. Department of Water Affairs and Forestry, Pretoria.

El-Bestawy, E. (2013). Biological treatment of leather-tanning industrial wastewater using free living bacteria.
Elsheikh, M. A. S. (2009). Tannery wastewater pre-treatment. Water Science and Technology, 60(2), 433-440.

FuIlbrook, P. D. (1996). "Kinetics." Industrial enzymology: The application of enzymes in Industry. 2nd Ed. T. Godfrey and J Reichelt. eds.. Nature. New York.

Gianfreda, L., and Rao, M. A. (2004). Potential of extra cellular enzymes in remediation of polluted soils: a review. Enzyme and microbial technology, 35(4), 339354.

Hugo Springer. (1994). John Arthur Wilson Memorial Lecture "Treatment of Industrial Wastes of the Leather Industry - is it still a Major Problem". JALCA, 89, 153-185

Jimoh, A. A., Ganiyu, B. A., Baba, D., and Baba, A. (2018) Bioremediation Process of Effluent from Detergent and Food Industries in Jos, Nigeria: Kinetics and Thermodynamics. International Journal of Engineering Science Invention (IJESI), 762-73

Kandelbauer, A., Maute, O., Kessler, R. W., Erlacher, A., and Gübitz, G. M. (2004). Study of dye decolorization in an immobilized laccase enzyme-reactor using online spectroscopy. Biotechnology and bioengineering, 87(4), 552-563.

Kongjao, S., Damronglerd, S., and Hunsom, M. (2008). Simultaneous removal of organic and inorganic Pollutants in tannery wastewater using electrocoagulation technique. Korean Journal of chemical engineering, 25(4), 703.

Maheshwari, U. M., Aruna, S., Gomathi, M., and AbdulJaffar, A. H. (2017). Bioremediation by Free and Immobilized Bacteria Isolated from Tannery Effluent. International Journal of Research in Applied, Natural and Social Sciences. 5(7), 75-90

Margesin, R., and Schinner, F. (2001). Bioremediation (natural attenuation and biostimulation) of diesel-oilcontaminated soil in an alpine glacier skiing area. Applied and environmental microbiology, 677), 3127-3133.

Mohammed, A., Sekar, P., and George, J. (2011). Efficacy of microbes in bioremediation of tannery effluent. Inter. J. Curr. Res, 3(4), 324-326.

Mohammed, S. S. D., Orukotan, A. A., and Abdullahi, H. (2017). Physicochemical and Bacteriological Assessment of Tannery Effluent from Samaru-Zaria, 
BAJOPAS Volume 13 Number 2, December, 2020 Kaduna State, Nigeria. Journal of Applied

Sciences and Environmental Management, 21(4), 734-740.

Munz, G., De Angelis, D., Gori, R., Mori, G., Casarci, M., and Lubello, C. (2009). The role of tannins in conventional and membrane treatment of tannery wastewater. Journal of hazardous materials, 164(2-3), 733-739

Mythili, K., and Karthikeyan, B. (2011). Bioremediation of $\mathrm{Cr}$ (VI) from tannery effluent using Bacillus spp and Staphylococcus spp. International Multidisciplinary Research Journal, 1(6).

NESREA (2009). National Environmental Standards for Effluent Limitations and Regulation. 1233-1236

Noorjahan, C. M. (2014). Physicochemical characteristics, identification of bacteria and biodegradation of industrial effluent. Journal of bioremediation and Biodegradation, 5(3).

Ohtake, H. I., and Silver, A. O. (1994). Bacterial reduction of toxic chromate. Biological degradation and bioremediation of toxic chemicals, 403-415.

Omoleke, I. I. (2004). Management of environmental pollution in Ibadan, an African city: the challenges of health hazard facing government and the people. Journal of Human Ecology, 15(4), 265-275.

Rajor, A., Reddy, A.S., and Singh, B. (2004). Determination of BOD kinetic Parameters and evaluation of alternate methods, M.Sc. Thesis, Department of biotechnology \& environmental Science, Thapar Institute of Engineering and Technology, Patiala

Ramasami, T., Rajamani, S., and Rao, J. R. (1994, March). Pollution control in leather industry: Emerging technological options. In International symposium on surface and colloidal science and its relevance to soil pollution, madras.

Ramesh, J. V. S., and Singh, S. P. (1993). Yearly variation in certain physicochemical parameters of pond at eastern Doon Valley. Uttar Pradesh J. Zoo, 12 (1), 7577.

Ranen, S., and Sharadinadra, C. (2009). Biotechnology applications to environmental remediation in resource exploitation. Current science, 97, 6-25
Russell, A. J., Berberich, J. A., Drevon, G. F., and Koepsel, R. R. (2003). Biomaterials for mediation of

chemical and biological warfare agents. Annual review of biomedical engineering, 5(1), 1-27.

Saravanan, P., and Saravanan, A. (1999). Decolourization of tannery effluent by Flavobacterium sp. EK 1. Indian Journal of Environmental Protection, 19, 19-24.

Sikander, S., and Shahida, H. (2007). Reduction of toxic hexavalent chromium by Ochrobactrum intermedium strain SDCr5 stimulated by heavy metals. Bioresource Technol, 98, 340-344.

Singh, N., Sharma, B. K., and Bohra, P. C. (2000). Impact assessment of industrial effluent of arid soils by using satellite imageries. Journal of the Indian Society of Remote Sensing, 28(2-3), 79.

Sreemoyee, C., and Priti, P. (2013). Assessment of physico-chemical parameters of dairy waste water and isolation and characterization of bacterial strains in terms of cod reduction. Int J Sci, 2(3), 395-400.

Verheijen, L. A. H. M., Wiersema, D., Pol, L. H., and De Wit, J. (1996). Management of wastes from animal product processing. Livestock and environment, Finding a balance. International Agriculture Center, Wageningen, The Netherlands.

Wang, F., Yao, J., Si, Y., Chen, H., Russel, M., Chen, K., and Bramanti, E. (2010). Short-time effect of heavy metals upon microbial community activity. Journal of Hazardous Materials, 173(13), 510-516.

WHO (World Health Organization). (2006). Air quality guidelines: global update 2005: particulate matter, ozone, nitrogen dioxide, and sulfur dioxide. World Health Organization.

World Bank. (1995). Nigeria's strategic options for redressing industrial pollution. World Bank, industry and energy division. 1st edition, West Central Africa Department; Annexes: 1995; pp 60-62.

Zahoor, A., and Abdul, R. (2009). Enumeration of Coliforms. Journal of Environmental Sciences. 21, 814-820 


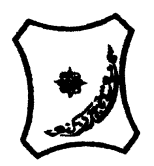

Bayero Journal of Pure and Applied Sciences, 13(2): 1 - 12

Received: November, 2020

Accepted: December, 2020

ISSN $2006-6996$

\title{
BIODEGRADATION POTENTIAL OF IMMOBILIZED BACTERIA IN THE TREATMENT OF TANNERY INDUSTRIAL EFFLUENTS FROM INDUSTRIAL ESTATES IN KANO STATE, NIGERIA
}

\author{
Abdullateef, B., ${ }^{1 *}$ Shuaibu, T. G., ${ }^{1}$ Babagana, K., ${ }^{1}$ Suleman, H. B. ${ }^{2}$ and Dauda, B. ${ }^{3}$ \\ ${ }^{1}$ Department of Pure and Applied Chemistry, Faculty of Science, University of Maiduguri, Borno State, \\ Nigeria \\ ${ }^{2}$ Department of Microbiology, Faculty of Science, University of Maiduguri, Borno State, Nigeria \\ ${ }^{3}$ Department of Chemical Engineering, Faculty of Engineering, University of Maiduguri, Borno State, \\ Nigeria \\ *Corresponding author: babslega@gmail.com; abelega2007@yahoo.com; +2348061309753
}

\section{ABSTRACT}

Industrial Effluents Samples from Gashash Tanneries (TAN1) in Bompai Industrial estate, Larabee Tannery Industry (TAN2) in Sharada Industrial estate and Z Tannery Industries (TAN3) in Challawa Industrial estate, Kano State, Nigeria were collected over a period of six months (August 2017 to January 2018) for assessing the biodegradation potentials of bacteria in the treatment of organic pollutants within the effluents. Bacteria were isolated from the effluents and immobilized on agar-agar. Different masses (5 g, $10 \mathrm{gr}, 15$ $\mathrm{g}, 20 \mathrm{~g}$, and $25 \mathrm{~g}$ ) of the bacteria were used in the treatment of $250 \mathrm{ml}$ of the effluents for ten days in a shaker incubator (Gallenkamp-OC-4364-L) at the temperature $30{ }^{\circ} \mathrm{C}$ and speed of $60 \mathrm{rpm}$. Pre-treatment analysis of the effluents for Temperature, pH, Biochemical Oxygen Demand (BOD), Chemical Oxygen Demand (COD), Suspended Solid (SS) and Total Dissolved Solids (TDS) gives the following results; temperature $\left({ }^{\circ} \mathrm{C}\right.$ )

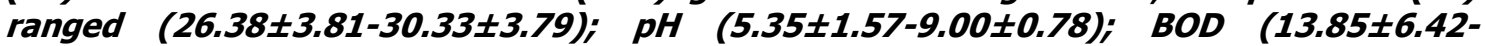
$38.75 \pm 16.20) ;$ COD (1406 $\pm 208-3532 \pm 1373) ;$ SS (208 $\pm 235-780 \pm 739)$ and TDS (266 $\pm 253-5276 \pm 2971)$. No statistical differences ( $p \leq 0.05)$ was observed for all the results among the different industries. The bacterial isolates were identified as Neisseria spp, Bacillus cereus, and Staphylococcus aureus, in TAN1, TAN2, and TAN3, respectively. After treatment of the effluent with the different masses of the isolated bacteria, the mean level of BOD was found to range as (0.55 $\pm 0.36-6.92 \pm 5.49) ; C O D$ (ND-3134 \pm 1595$)$;

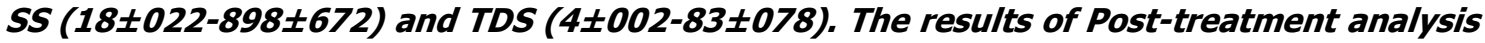
showed that there is overall decrease in the levels of the parameters determined when compared with that of the pre-treatment. The overall percentage reduction of the immobilised bacteria in the treatment of the respective effluents was in the order TAN2 (72\%)>TAN1 (70\%)>TAN3 (62\%). Hence, the immobilized bacteria are having higher biodegradation potential for the treatment of the tannery effluents.

Keywords: Biodegradation, bacteria, effluent, immobilization, tannery.

\section{INTRODUCTION}

Tannery industrial wastewater is a serious consequence of the pollution point of view for streams, freshwater, and land used for agriculture. The lack of awareness in the modern industrial practice has resulted in the discharge of tannery effluents which exhibit very high value of chromium ( $\mathrm{Cr}$ ), Sulfide, and chloride, Total Dissolved Solid (TDS), Total Suspended Solid (TSS), Biochemical Oxygen Demand (BOD) and Chemical Oxygen Demand (COD) in the water stream or land (Mohammed et al., 2001). Tanning is the process, which One ton of skin generally leads to the production of 20 to $80 \mathrm{~m}^{3}$ of turbid and foul-smelling converts the protein of the rawhide or skin into a stable material, which will not putrefy and is suitable for a wide variety of end applications (Elsheikh, 2009). The highly polluting chromium is the most commonly used tanning material producing leather that is more flexible and pliable than vegetable-tanned leather and does not discolor or lose shape in water as drastically as vegetable-tan (Elsheikh, 2009). Tannery effluent is among the most hazardous industrial pollutants due to its huge organic and inorganic load, which is highly toxic to human life and the environment (Kongjao et al., 2008). wastewater including chromium (100-400 mg/l), sulfide $(200-800 \mathrm{mg} / \mathrm{l})$, high levels of fat and 
BAJOPAS Volume 13 Number 2, December, 2020 other solid wastes, and notable pathogen contamination as well as pesticides added for skin conservation during transport (Elsheikh, 2009). There are more than 6000 tanneries in Nigeria with an annual processing capacity of 700,000 tons of hides and skins (Omoleke, 2004; Singh et al., 2008). It was reported that the total amount of waste produced per animal slaughtered is approximately $35 \%$ of its weight (World Bank, 1995). Also, for every $1000 \mathrm{~kg}$ of carcass weight, a slaughtered beef produces 5.5 $\mathrm{kg}$ of manure (excluding rumen contents or stockyard manure) and $100 \mathrm{~kg}$ of paunch manure (undigested food) (Verheijen et al., 1996). Tanneries generate wastewater in the range of 30-35 $\mathrm{L} \mathrm{kg}^{-1}$ skin/hide processed with variable $\mathrm{pH}$, Biological Oxygen Demand (BOD), Chemical Oxygen Demand (COD), high concentrations of suspended solids (SS), and tannins as well as chromium (Zahoor and Abdul, 2009).

Being heterogeneous and composed of a wide variety of compounds, it is very difficult to select a unique direct method for estimating the biodegradability of organic contents and biokinetic parameters for a wastewater sample (Rajor, 2004). For this purpose, some indirect estimation such as determination of biochemical oxygen demand (BOD) and chemical oxygen demand (COD) are applied as common laboratory investigations [9]. During retanning procedures, synthetic tannins (Syntan), oils and resins are added to form softer leather at varying doses (Munz et al., 2009). One of the refractory groups of chemicals in tannery effluents derives mainly from tannins (Ramasami et al., 2004). Syntans are characterized by complex chemical structures, because they are composed of an extended set of chemicals such as phenol-, naphthalene-, formaldehyde- and melamine-based syntans, and acrylic resins (Beem, 1994). Organic pollutants (proteic and lipidic components) are originated from skins (it is calculated that the raw skin has $30 \%$ loss of organic material during the working cycle) or they are introduced during processes (Hugo Springer, 1994).

Many conventional processes such as oxidation, chemical and biological processes were carried out to treat tanneries wastewater (Ebtesam et al, 2013). Biological processes have received more attention because of their costeffectiveness, lower sludge production and environmental friendliness (Noorjahan, 2014). Naturally occurring micro-organisms degrade the hazardous organic wastes including xenobiotic compounds, such as pesticides, polycyclic aromatic hydrocarbons (PAHs) and polychlorinated biphenyls (PCBs) in due course of time (Ranen and Sharadinadra, 2009). Bioremediation is based on the idea that all organisms remove substances from the environment to carry outgrowth and metabolism (Bouwer and Zehnder, 1993). Bacteria, protista and fungi are found to be very good at degrading complex molecules and incorporating the breakdown products into their metabolism (Bouwer and Zehnder, 1993). The resultant metabolic wastes that they produce are generally safe and somehow recycled into other organisms (Ranen and Sharadinadra, 2009). An acclimatized indigenous population of microorganisms capable of degradation of the compounds of interest must exist at the site for a successful bioremediation mode (Ranen and Sharadinadra, 2009). It has been observed that for a successful bioremediation mode, an acclimatized indigenous population of microorganisms capable of degradation of the compounds of interest must exist at the site under investigation (Ranen and Sharadinadra, 2009). Even though there are numerous physical and chemical methods employed in the disposal of wastes the advantage in using bacterium is that they play a key role in the reduction of COD, BOD, total protein, total tannin and total phenol (Saravanan and Saravanan, 1998)

Baba et al. (2020) studied the bioremediation potential of immobilized corynebacterium kutsceri in the Treatment of tannery industrial effluent from Challawa Industrial Estate, Kano State, Nigeria. The aim of the work is to study the reduction in the level of the contaminants through the process of bioremediation using the isolated bacteria. Immobilized bacteria can withstand various temperatures, $\mathrm{pH}$ and substrate concentrations; consequently, increasing the efficiency and the lifespan of the bacteria. Immobilized bacteria are widely applied in the treatment of wastewater and can be separated and recovered after the treatment with the same efficiency (Baba et al., 2020).

\section{MATERIALS AND METHODS \\ Study Area}

This study was carried out in Bompai, Sharada and Challawa industrial estates in Kano, Figure 1. Kano lies on Latitude $11^{\circ} 30^{\prime} \mathrm{N}$ and $8^{\circ} 30^{\prime} \mathrm{E}$ and Longitude $11^{\circ} 5^{\prime} \mathrm{N}$ and $8^{\circ} 5^{\prime} \mathrm{E}$ in Northern Nigeria. It is one of the developed industrial cities in Nigeria. Tannery activities are the dominating industries and this could be one of the reasons for her high population density (Dan'Azumi and Bichi, 2010). Many researchers have studied biodegradation of tannery effluent using microorganisms. However, limited literature is available on the biodegradation of tannery effluent in Kano industrial estates using 
BAJOPAS Volume 13 Number 2, December, 2020 immobilized bacterial cells. This research work focuses on the potential of the use of the indigenous immobilized bacterial isolates in the treatment of tannery effluents in the industrial estates.

\section{Sample Collection}

Effluents were collected from the Tannery Industries from Bompai, Challawa and Sharada Industrial Estates, Kano, Nigeria. The effluents were collected over a period of six months (August 2017 to January 2018). Samples collected in a sterile 4-liter plastic container with a unique identification number were preserved using an ice-box that was transported to the Microbiology Laboratory, Department of Microbiology, Bayero University of Kano for analysis

\section{Sample Preparation and Sample Analysis}

Immediately after the collection of the effluent, $\mathrm{pH}$, TSS, TDS, COD, BOD levels were determined before treatment (Pre-treatment determination) and ten days after treatment (Post-treatment determination) as described in
APHA (1989) standard methods. $\mathrm{pH}$ was determined using Ecotests $\mathrm{pH}$ meter and TDS was determined using AQUALYTIC TDS Salinometer. BOD was determined as described by the standard method (APHA, 1992). COD and SS were determined using DR/2010 HACH portable data logging spectrophotometer (DWAF, 1992)

\section{Identification and Biochemical} Characterization of the Bacterial Isolates

The bacteria were isolated from the effluents using Serial Dilution according to the method described by APHA (1989). The biochemical tests such as oxidase, catalase, coagulase, indole (from $1 \%$ tryptone broth), citrate (Simmons citrate agar), methyl red/VogesProskauer (MR/VP), nitrate reduction, Starch Hydrolysis, Glucose, Maltose, and Lactose tests were carried out on the bacterial isolates to identify the bacteria through the bacteria biochemical characteristics according to Ajao et al. (2011).

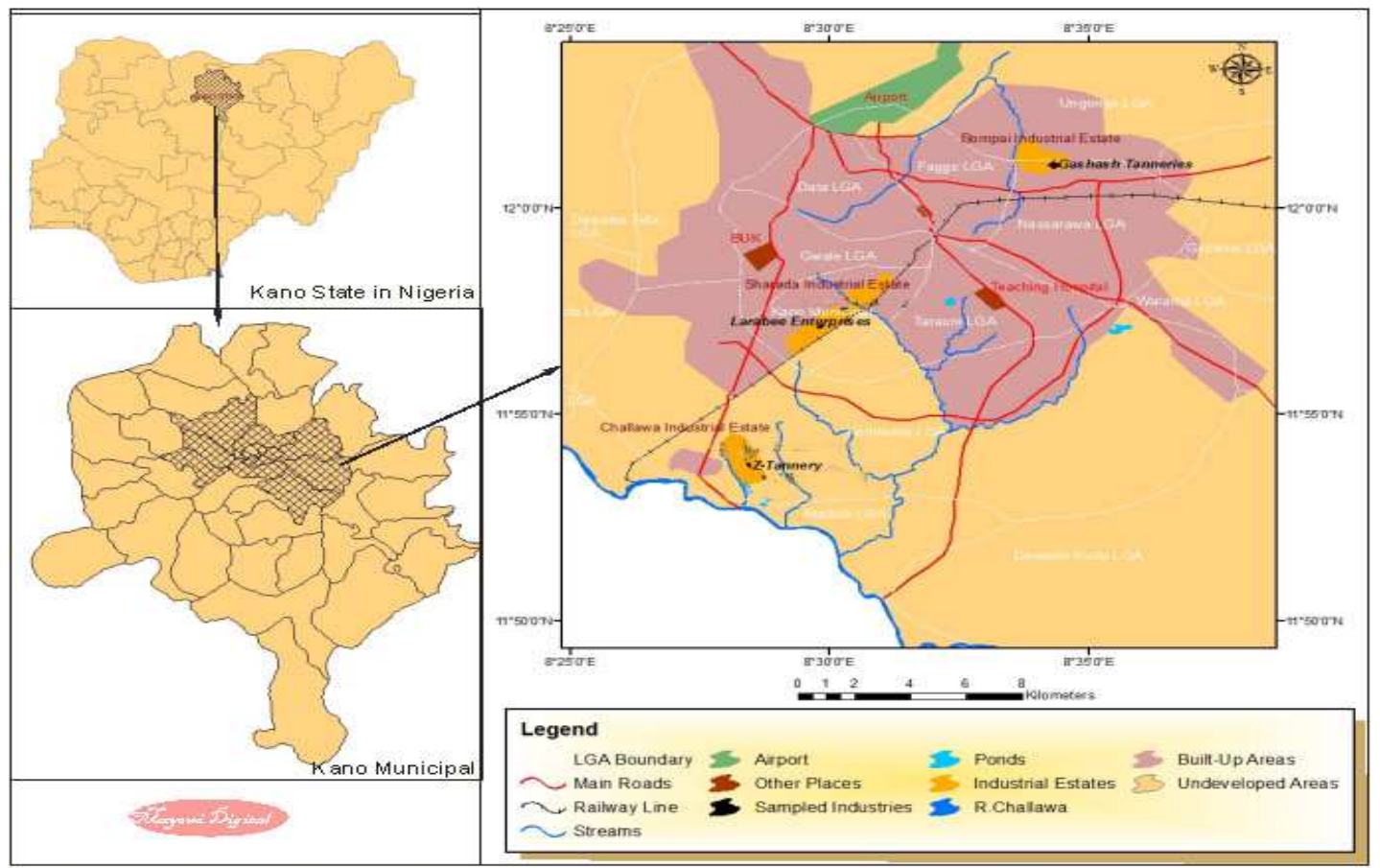

Fig. 1 Map showing the study areas

Source: Mayomi Digital Productions, GIS Laboratory, Department of Geography, UNIMAID (2017)

\section{Determination of Growth Rate of the Bacteria in Effluent Sample}

The bacteria growth rates were determined by transferring $2 \mathrm{~mL}$ of the bacterial isolates from the tannery effluent in broth medium into 100 $\mathrm{mL}$ sterile effluents in conical flasks and kept in an incubator (Giffrin cool) for 10 days. Control was also set up by incubating another $100 \mathrm{~mL}$ each of the sterile effluents without the bacteria. The optical density of the content was determined at the wavelength of $600 \mathrm{~nm}$ on a daily interval and recorded. 
BAJOPAS Volume 13 Number 2, December, 2020 Immobilization of Bacteria

Agar solution and inoculi were prepared separately. Fifty milliliters $(50 \mathrm{~mL})$ of nutrient broth each of the inoculi was prepared in a McCartney bottle and incubated for 24 hours. A solution of agar-agar was prepared by dissolving $10 \mathrm{~g}$ of the powder in distilled water and made up to $500 \mathrm{~mL}$ mark in an Erlenmeyer flask and was sterilized in an autoclave (280A) for 15 minutes and allowed to cool to $40-45^{\circ} \mathrm{C}$ (Ajao et al., 2011). Four milliliters ( $4 \mathrm{~mL})$ of the bacterial isolates in the nutrient broth was mixed with 36 $\mathrm{ml}$ of the prepared agar-agar media in petri-dish plates and then allowed to solidify. This was kept in the refrigerator for bioremediation.

\section{Bioremediation (Treatment) of the Effluents}

The solidified agar block (immobilized bacteria) was cut into cubes using a sterile knife; $0.1 \mathrm{~mL}$ phosphate buffer ( $\mathrm{pH} \mathrm{7.0)}$ was added and kept in the refrigerator for 1 hour for curing. The phosphate buffer was decanted after 1 hour and the cubes were washed with sterile distilled water 3-4 times before it was used (Ajao et al., 2011). Two liters (2 L) of the effluent was supplemented with the minimum basal medium in $\mathrm{g} / \mathrm{L}: \mathrm{NaCl}(0.8), \mathrm{MgSO}_{4} .7 \mathrm{H}_{2} \mathrm{O}(0.001), \mathrm{KH}_{2} \mathrm{PO}_{4}$ (2), $\mathrm{NaNO}_{3}$ (2), $\quad \mathrm{CaCl}_{2} .2 \mathrm{H}_{2} \mathrm{O} \quad(0.5)$ and $\mathrm{NaHPO}_{4} .12 \mathrm{H}_{2} \mathrm{O}(2)$ and sterilized in an autoclave at $121^{\circ} \mathrm{C}$ for 15 minutes (Margesin and Schinner, 2001). Two hundred and fifty milliliters $(250 \mathrm{~mL})$ of the effluents were transferred into different $250 \mathrm{ml}$ conical flasks. The content was covered with a cotton-wool ramped with foil paper to avoid contamination. Five grams $(5 \mathrm{~g})$ of the immobilized bacteria were quickly transferred into each of the effluents in the conical flasks in an inoculating chamber. The same procedures were carried out for the $10 \mathrm{~g}, 15 \mathrm{~g}, 20 \mathrm{~g}$ and 25 $\mathrm{g}$ of the immobilized bacteria in separate $250 \mathrm{~mL}$ effluents in conical flasks and agitated for ten days in a shaker incubator (Gallenkamp-OC4364-L) at a temperature $30^{\circ} \mathrm{C}$ and speed of 60 rpm. The treated effluent samples were taken on the tenth day and analyzed for the parameters $\mathrm{pH}$, SS, TDS, COD, and BOD, (Posttreatment determination) for the different grams of bacteria to evaluate and compare the biodegradation potential. (Baba et al., 2020).

\section{Statistical Analysis}

The data were represented as Mean \pm Standard deviation and analyzed statistically using oneway Analysis of Variance (ANOVA) and Tukey's HSD as Post Hoc Tests with the aid of SPSS 16.0. The correlation coefficient was also used to measure the strength of the relationship between the different masses of the bacteria and the parameters. All $\mathrm{p} \leq 0.05$ were considered as statistically significant.

\section{RESULTS AND DISCUSSION Physico-chemical parameters in the Industrial Effluents before the Biodegradation.}

Results of the Physico-chemical parameters in the industrial effluents before the Biodegradation is shown in table 1 . The mean temperatures $\left({ }^{\circ} \mathrm{C}\right)$ observed in TAN1, TAN2, and TAN3 samples were $28.07 \pm 0.65 ; 27.77 \pm 0.64$ and $26.38 \pm 3.81$ respectively. The order of the mean temperature of the samples from the three industries can be arranged as TAN1 > TAN2>TAN3. The temperature observed at TAN1, TAN2, and TAN3 samples were found below the WHO $\left(35^{\circ} \mathrm{C}\right)$ and NESREA $\left(40^{\circ} \mathrm{C}\right)$ limits. The low values of temperature might be due to the processes used at the time of sampling. High temperature brings down the solubility of gases in water that ultimately expresses as high BOD and COD. Statistical analysis shows that there is no significant difference $(p<0.05)$ between the mean values of temperature among the industries. This might be due to similar tannery activities involved in the tannery industries at the time of sampling. The average values of temperature observed in this present study are less than those observed by Akan et al. (2007), Akan et al. (2009) and Baba et al. (2020).

The mean level of $\mathrm{pH}$ observed in TAN1, TAN2 and TAN3, samples were $7.77 \pm 2.93$; $8.35 \pm 0.28$ and $7.52 \pm 0.76$ respectively. The order of the mean $\mathrm{pH}$ of the samples from the three industries can be arranged as TAN2> TAN1 $>$ TAN3. The $\mathrm{pH}$ of the samples falls within the WHO (7.0-8.5) and NESREA (6-9) standard limits. Statistical analysis shows that there is no significant difference $(p<0.05)$ between the mean values of $\mathrm{pH}$ among the industries. This might be due to similar tannery activities involved in the tannery industries at the time of sampling. Maheshwari et al. (2017) reported that the level of $\mathrm{pH}$ in the effluents from the tannery industry in Vaniyambadi, India was 6.5 which was lower than that observed in the present study. The $\mathrm{pH}$ in the effluents from the tannery industries in Kano and Kaduna were reported to be 7.64 and 6.89, respectively (Akan et al., 2007; Mohammed et al., 2017). The average values of $\mathrm{pH}$ observed in this present study are less than those observed by Mohammed et al. (2017) and Baba et al. (2020). The mean level of SS $(\mathrm{mg} / \mathrm{l})$ observed in TAN1, TAN2, and TAN3 samples were 374 \pm 124 ; $358 \pm 335$ and $780 \pm 739$ respectively. The order of the mean SS in the samples from the three industries can be arranged as TAN3 > TAN1 $>$ TAN2. 
The SS observed in the samples were far above the recommended standard limits of regulating bodies WHO $(30 \mathrm{mg} / \mathrm{l})$ and NESREA $(10 \mathrm{mg} / \mathrm{l})$. Statistical analysis shows that there is no significant difference $(p<0.05)$ between the mean values of SS among the industries. This might be due to similar tannery activities involved in the tannery industries at the time of sampling. The average values of SS observed in this present study are less than that observed $(3700 \pm 122 \mathrm{mg} / \mathrm{l})$ by Akan et al. (2009) for tanneries in Kano. Also, the average values of SS observed in this present study are less than that observed by Mohammed et al. (2017) and Baba et al. (2020) with the exception in TAN3.

The mean level of TDS (mg/l) observed in TAN1, TAN2, and TAN3 samples were $3941 \pm 3703$; $3300 \pm 1714$ and $2653 \pm 1240$ respectively. The order of the mean TDS in the samples from the three industries can be arranged as TAN1>TAN2>TAN3. The TDS observed in the samples were far above the recommended standard limits of WHO $(250 \mathrm{mg} / \mathrm{l})$ and NESREA $(500 \mathrm{mg} / \mathrm{l})$. Statistical analysis shows that there is no significant difference $(p<0.05)$ between the mean values of TDS among the industries. This might be due to similar tannery activities involved in the tannery industries at the time of sampling. TDS in the effluents from the tannery industries in Kano, Nigeria was reported to be $1281 \mathrm{mg} / \mathrm{l}$ (Akan et al., 2007). The average values of SS observed in this present study are less than those observed by Mohammed et al. (2017) and Baba et al. 2020)

The mean level of COD (mg/l) observed in TAN1, TAN2 and TAN3 samples seasons were $2372 \pm 938 ; \quad 1406 \pm 208$ and $3532 \pm 1373$ respectively. The order of the mean COD of the samples from the three industries can be arranged as TAN3>TAN1> TAN2. The COD observed in TAN1, TAN2 and TAN3 samples were far above the recommended standard limits of regulating bodies $\mathrm{WHO}(40 \mathrm{mg} / \mathrm{l})$ and NESREA (40 mg/l). Statistical analysis shows that there is no significant difference $(p<0.05)$ in COD among the industries. This might be due to similar tannery activities involved in the tannery industries as at the time of sampling. The Chemical Oxygen demand (COD) is the amount of oxygen, in $\mathrm{mg} / \mathrm{L}$, required for the degradation of the compound of wastewater to occur. In comparison, the average values of COD observed in this present study were higher than that observed by Mohammed et al. (2017) but lower than that observed by Baba et al. (2020).

The mean levels of BOD $(\mathrm{mg} / \mathrm{l})$ observed in TAN1, TAN2 and TAN3 samples were $13.85 \pm 6.42 ; \quad 19.46 \pm 0.50$ and $17.13 \pm 3.14$ respectively. The order of the mean BOD in the samples from the three industries can be arranged as TAN2>TAN3>TAN1. The BOD observed in TAN1, TAN2 and TAN3 samples were found below the recommended limits of NESREA (200 mg/l) but above WHO (10 mg/l). Statistical analysis shows that there is no significant difference $(p<0.05)$ between the mean values of BOD among the industries. This might be due to similar tannery activities involved in the tannery industries at the time of sampling. The low level of BOD recorded in this study is an indication of the low level of biodegradable organic solids in the effluent. The average values of BOD observed in this present study were lower than those observed by Mohammed et al. (2017) and Baba et al. (2020).

Table 1: Mean Values \pm S.D of Physico-chemical parameters of effluents from the Tannery Industries before Treatment.

\begin{tabular}{llllllll}
\hline Parameter & Tannery 1 & Tannery 2 & Tannery 3 & $\mathrm{a}$ & $\mathrm{b}$ & $\mathrm{c}$ & $\mathrm{d}$ \\
\cline { 2 - 7 } Temperature $\left({ }^{\circ} \mathrm{C}\right)$ & $28.07 \mathrm{a} \pm 0.65$ & $27.77 \mathrm{a} \pm 0.64$ & $26.38 \mathrm{a} \pm 3.81$ & & $29.50 \pm 4.68$ & 35 & 40 \\
pH & $7.77 \mathrm{a} \pm 2.93$ & $8.35 \mathrm{a} \pm 0.28$ & $7.52 \mathrm{a} \pm 0.76$ & 6.89 & $5.35 \pm 1.57$ & $7.0-8.5$ & $6.0-9.0$ \\
$\mathrm{COD}(\mathrm{mg} / \mathrm{l})$ & $2372 \mathrm{a} \pm 938$ & $1406 \mathrm{a} \pm 208$ & $3532 \mathrm{a} \pm 1373$ & 2.2 & $3106 \pm 2753$ & 40 & 40 \\
$\mathrm{BOD}(\mathrm{mg} / \mathrm{l})$ & $13.85 \mathrm{a} \pm 6.42$ & $19.46 \mathrm{a} \pm 0.50$ & $17.13 \mathrm{a} \pm 3.14$ & 1032 & $26.17 \pm 9.49$ & 10 & 200 \\
$\mathrm{SS}(\mathrm{mg} / \mathrm{l})$ & $374 \mathrm{a} \pm 124$ & $358 \mathrm{a} \pm 335$ & $780 \mathrm{a} \pm 739$ & 501 & $562 \pm 482$ & 30 & 10 \\
TDS $(\mathrm{mg} / \mathrm{l})$ & $3941 \mathrm{a} \pm 3703$ & $3300 \mathrm{a} \pm 1714$ & $2653 \mathrm{a} \pm 1240$ & 532.7 & $444 \pm 507$ & 250 & 500 \\
\hline
\end{tabular}

The values given in the table above are means of 6 replicate values, $\mathrm{n}=6$ ( 1 sample was taken monthly for 6 months). Within the rows, means with different alphabets are statistically different $(p<0.05)$. WHO: World Health Organisation. NESREA: National Environmental Standard and Regulatory Enforcement Agency. a = Mohammed et al.(2017), b = Baba et al. (2020), c = WHO (2006), $d=$ NESSRA (2009) 
BAJOPAS Volume 13 Number 2, December, 2020

Identification, Biochemical Characterization and growth rates of the Bacterial Isolates

Results of identification and biochemical characterization of the bacterial isolates were shown in table 2. After 24 hours of incubation, the nutrient agar media plates were checked for bacterial growth. The results showed the presence of different strains in the samples. The TAN1 bacteria isolate was found to be gramnegative cocci while TAN3 was gram-positive cocci. TAN2 bacteria isolate was found to be gram-positive, rod-shaped. TAN1, TAN2, and TAN3 bacteria isolates recorded positive results for spore former.

The results of the biochemical tests indicated that all the bacteria were positive for catalase, oxidase, citrate, maltose, glucose, lactose (negative in TAN1), mannitol (negative in TAN2), starch hydrolysis and coagulase (negative in TAN2) tests. The bacteria showed negative results for nitrate reduction, $M R$ (positive in TAN2), VP (positive in TAN1), Indole (positive in TAN2) tests. Base on the morphological and biochemical test results, TAN1, TAN2, and TAN3 bacteria isolates were identified to be Nesseria spp, Bacillus cereus, and Staphylococcus aureus respectively.

The growth rate of the TAN1, TAN2 and TAN3 Isolates were shown in figure 2. Generally, the optical density increase with the increase in time (day) and decrease as time goes on. The highest optical density was shown by bacillus cereus in TAN2 while the lowest was shown by Staphylococcus aureus in TAN3.

The initial growth phase of TAN1 Isolate bacteria occurred within 2-day of incubation as the growth rate increases up to the 6th-day incubation when the maximum growth was observed. Beyond the 6th day, the growth of the bacteria declined (which might be due to a shortage of nutrients in the effluents) until it reached its death phase (which might be due to the unavailability of nutrients in the effluents).

A similar trend of growth was also observed for TAN2 Isolate as the initial growth phase also occurred within 2-day of incubation but maximum growth rate observed on the 4th day of incubation. The stationary stage occurred between the 4th day and the 8th day. Beyond the 8th day, the growth of the bacteria declined (which might be due to a shortage of nutrients in the effluents) until it reached its death phase (which might be due to the unavailability of nutrients in the effluents).

The initial growth phase of TAN3 bacterial Isolate occurred within the 3-day incubation as the growth rate increases up to the 6th-day incubation when the maximum growth was observed. Beyond the 6th day, the growth of the bacteria declined (which might be due to a shortage of nutrients in the effluents) until it reached its death phase (which might be due to the unavailability of nutrients in the effluents).

Table 2: Morphological and Biochemical characteristics of bacterial isolates

\begin{tabular}{lllll} 
Bacterial Isolates & & TAN1 & TAN2 & TAN3 \\
\hline $\begin{array}{lllll}\text { Morphological } \\
\text { characteristics }\end{array}$ & Shape & Cocci & Rod & Cocci \\
& Spore & & & \\
& former & + & + & + \\
Gram & & & \\
Biochemical characteristics & reaction & - & + & + \\
& Citrate & + & + & + \\
& Catalase & + & + & + \\
& Coagulase & + & - & + \\
Starch & + & + & + \\
& Glucose & + & + & + \\
Oxidase & + & + & + \\
& Indo & - & + & - \\
Lactose & - & + & + \\
Manitol & + & - & + \\
Maltose & + & + & + \\
MR & - & + & - \\
VP & + & - & - \\
& Nitrate & - & - & - \\
Reduction & - Neisseria & Bacillus & Staphylococcus \\
& Bacterial & cereus & aureus \\
& name & spp & cas
\end{tabular}

+ = Positive; - = Negative; MR=Methyl Red; VP= Voges-Proskauer 


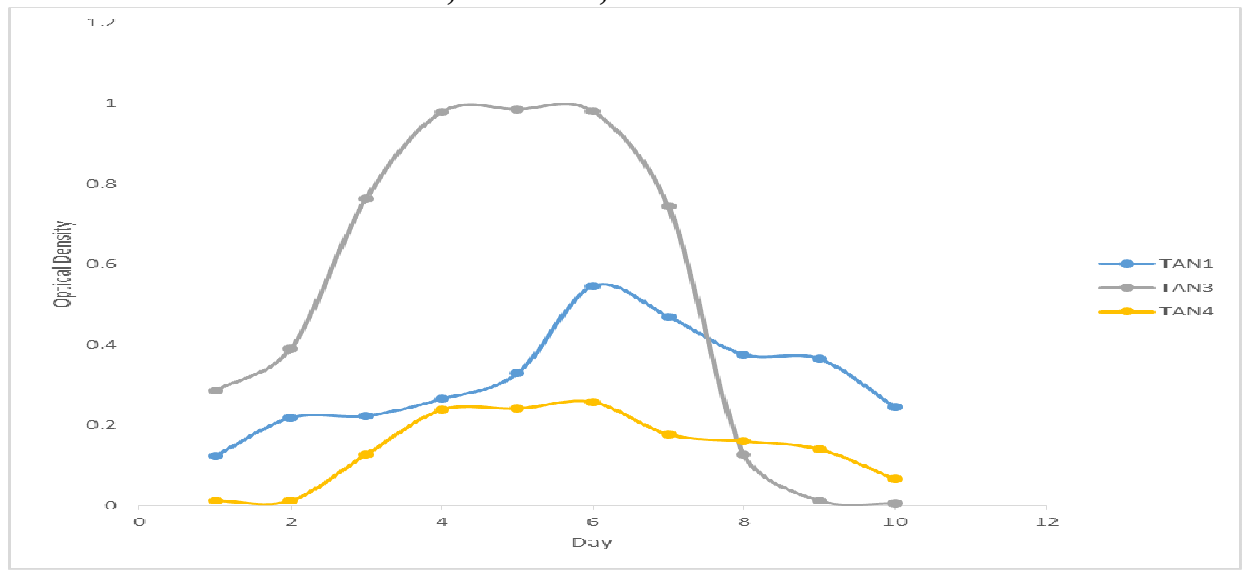

Fig. 2 Growth rates of the isolates in the effluents from the Tannery Industries

\section{Physico-chemical Parameters in the Industrial Effluents after the biodegradation.}

Table 3 shows the mean results of the physicochemical parameter before and after bioremediation using the different masses $(5 \mathrm{~g}$, $10 \mathrm{~g}, 15 \mathrm{~g}, 20 \mathrm{~g}$, and $25 \mathrm{~g}$ ) of the respective immobilized bacteria. Also, Table 4 shows the mean results of correlation coefficient ( $r$ ) between different masses of bacteria and physicochemical parameters.

The mean values $(\mathrm{mg} / \mathrm{l})$ of the SS after the bioremediation varies between $243 \pm 45$ and $898 \pm 672$. The mean concentration $(\mathrm{mg} / \mathrm{l})$ of SS remediated by the different masses $(5 \mathrm{~g}, 10 \mathrm{~g}$, $15 \mathrm{~g}, 20 \mathrm{~g}$, and $25 \mathrm{~g}$ ) of the bacteria varies. The SS in the samples fluctuates up and down after the bioremediation process when compared with the SS of the raw samples before the bioremediation. The increase in the levels of the SS might be due to the aggregation of the TDS which are large enough to result into SS. The increase in the levels of the SS might be also due to the influence of the nutrients which was added into the effluents in order to make the microorganisms more active and viable for fast degradation of organic contaminants in the effluent. The relative potential or efficiency of the different masses of the bacteria in remediating SS in TAN1 samples was in the order $25 \mathrm{~g}>20 \mathrm{~g}>15 \mathrm{~g}>10 \mathrm{~g}>5 \mathrm{~g}$. For TAN2 and TAN3 samples, the order was $25 \mathrm{~g}>20 \mathrm{~g}>15$ $\mathrm{g}>10 \mathrm{~g}>5 \mathrm{~g}$. These might be due to the variations in the surface areas of the different masses of the immobilized bacteria. Statistical analysis shows that there is no significant difference $(p<0.05)$ between the mean values of SS among the masses in the respective industries. Positive and significant correlations exist between the masses of bacteria and Suspended Solid (SS). This showed that there is general increase in the levels of the SS as the masses of the immobilized bacteria increases. TAN3 (90\%) and TAN1 (80\%) showed a very high correlation with the masses of the bacteria while TAN2 (61\%) showed a very low correlation.

The mean values $(\mathrm{mg} / \mathrm{l})$ of the TDS after the bioremediation varies between $46 \pm 11$ and $83 \pm 78$. The mean concentration $(\mathrm{mg} / \mathrm{l})$ of TDS remediated by the different masses $(5 \mathrm{~g}, 10 \mathrm{~g}$, $15 \mathrm{~g}, 20 \mathrm{~g}$, and $25 \mathrm{~g}$ ) of the bacteria varies. There is a reduction in all the TDS of all the samples after the bioremediation process compared with the TDS of the raw samples before the bioremediation. The relative potential or efficiency of the different masses of the bacteria in remediating TDS in TAN1 and TAN3 samples was in the order $5 \mathrm{~g}>10 \mathrm{~g}>15 \mathrm{~g}>20$ $\mathrm{g}>25 \mathrm{~g}$. For TAN2 samples, the order was 20 $g>10 \quad g>25 \quad g>15 \quad g>5 \quad g$. Statistical analysis shows that there is no significant difference $(p<0.05)$ between the mean values of TDS among the masses in the respective industries. These might be due to the variations in the surface areas of the different masses of the immobilized bacteria. Positive and significant correlations exist between the masses of bacteria and TDS with the exception in TAN2 (negative and insignificant correlation). The positive correlations showed that there is general increase in the levels of the TDS as the masses of the immobilized bacteria increases. TAN1 $(96 \%)$ showed a very high correlation with the masses of the bacteria while TAN2 (47\%) showed a very low correlation.

The mean values $(\mathrm{mg} / \mathrm{l})$ of the BOD after the bioremediation varies between $1.56 \pm 0.20 \mathrm{mg} / \mathrm{l}$ and $6.92 \pm 5.49 \mathrm{mg} / \mathrm{l}$. The mean concentration $(\mathrm{mg} / \mathrm{l})$ of BOD remediated by the different masses $(5 \mathrm{~g}, 10 \mathrm{~g}, 15 \mathrm{~g}, 20 \mathrm{~g}$, and $25 \mathrm{~g}$ ) of the bacteria varies. There is a reduction in all the BOD of all the samples after the bioremediation process compared with the $\mathrm{BOD}$ of the raw 
BAJOPAS Volume 13 Number 2, December, 2020 samples before the bioremediation. The relative potential or efficiency of the different masses of the bacteria in remediating BOD in TAN1, TAN2 and TAN3 samples were in the order $25 \mathrm{~g}>20$ $\mathrm{g}>15 \mathrm{~g}>10 \mathrm{~g}>5 \mathrm{~g}, 25 \mathrm{~g}>15 \mathrm{~g}>5 \mathrm{~g}>10 \mathrm{~g}>20 \mathrm{~g}$ and $20 \mathrm{~g}>10 \mathrm{~g}>25 \mathrm{~g}>15 \mathrm{~g}>5 \mathrm{~g}$ respectively. Statistical analysis shows that there is significant difference $(p<0.05)$ between the mean values of BOD among the masses in the respective industries. These might be due to the variations in the surface areas of the different masses of the immobilized bacteria. Negative and significant correlations exist between the masses of bacteria and BOD. This showed that there is general decrease in the levels of the BOD as the masses of the immobilized bacteria increases. TAN1 (94\%) showed a very high correlation with the masses of the bacteria while TAN2 (4\%) showed a very low correlation.

The mean values $(\mathrm{mg} / \mathrm{l})$ of the COD after the bioremediation varies between $250 \pm 154$ and $3134 \pm 1595$. The mean concentration $(\mathrm{mg} / \mathrm{l})$ of COD remediated by the different masses $(5 \mathrm{~g}$, $10 \mathrm{~g}, 15 \mathrm{~g} 20 \mathrm{~g}$, and $25 \mathrm{~g}$ ) of the bacteria varies. There is a reduction in all the COD of all the samples after the bioremediation process compared with the COD of the raw samples before the bioremediation. The relative potential or efficiency of the different masses of the bacteria in remediating COD in TAN1, TAN2 and TAN3 samples were in the order $25 \mathrm{~g}>20 \mathrm{~g}>15$ $\mathrm{g}>5 \mathrm{~g}>10 \mathrm{~g}, 25 \mathrm{~g}>20 \mathrm{~g}>15 \mathrm{~g}>10 \mathrm{~g}>5 \mathrm{~g}$ and 10 g>5 g>25 g>15 g>20 g respectively. Statistical analysis shows that there were significant difference $(p<0.05)$ between the mean values of COD among the masses in the respective industries except for effluents treated with $25 \mathrm{~g}$. These might be due to the variations in the surface areas of the different masses of the immobilized bacteria. Negative and insignificant correlations exist between the masses of bacteria and COD with the exception in TAN3 (positive and significant correlation). The negative correlations showed that there is general decrease in the levels of the COD as the masses of the immobilized bacteria increases. TAN2 (100\%) showed a very high correlation with the masses of the bacteria while TAN3 (36\%) showed a very low correlation.

Generally, there was an overall decrease in the concentration of these physicochemical parameters after the bioremediation using the different masses of the bacterial isolates. These might be due to the variations in the surface areas of the different masses of the immobilized bacteria. This is in line with the work of Jimoh et al. (2018) and Baba et al. (2020).

Table 3: Mean Values $(\mathrm{mg} / \mathrm{l}) \pm$ S.D of Physicochemical parameters in effluents from the Tannery Industries before and after Treatment of the effluents $(250 \mathrm{ml})$ with the different masses $(5 \mathrm{~g}, 10 \mathrm{~g}$, $15 \mathrm{~g}, 20 \mathrm{~g}$, and $25 \mathrm{~g}$ ) of the bacteria.

\begin{tabular}{llllllll}
\hline $\mathrm{P}$ & IND & Before & \multicolumn{5}{c}{ After } \\
\cline { 4 - 7 } & & & $5 \mathrm{~g}$ & $10 \mathrm{~g}$ & $15 \mathrm{~g}$ & $20 \mathrm{~g}$ & $25 \mathrm{~g}$ \\
\hline \multirow{2}{*}{ COD } & TAN1 & $2372 \pm 938$ & $1708 \mathrm{a} \pm 861$ & $2045 \mathrm{a} \pm 1205$ & $845 \mathrm{a} \pm 369$ & $300 \mathrm{a} \pm 167$ & $250 \mathrm{a} \pm 154$ \\
& TAN2 & $1406 \pm 208$ & $1195 \mathrm{a} \pm 208$ & $1125 \mathrm{a} \pm 384$ & $1055 \mathrm{a} \pm 317$ & $956 \mathrm{a} \pm 310$ & $870 \mathrm{ab} \pm 240$ \\
& TAN3 & $3532 \pm 1373$ & $2374 \mathrm{a} \pm 1344$ & $1976 \mathrm{a} \pm 1405$ & $2757 \mathrm{a} \pm 1266$ & $3134 \mathrm{a} \pm 1595$ & $2614 \mathrm{~b} \pm 1105$ \\
BOD & TAN1 & $13.85 \pm 6.42$ & $6.92 \mathrm{a} \pm 5.49$ & $6.42 \mathrm{a} \pm 5.07$ & $5.72 \mathrm{a} \pm 5.35$ & $4.62 \mathrm{a} \pm 4.37$ & $2.82 \mathrm{ab} \pm 1.26$ \\
& TAN2 & $19.46 \pm 0.50$ & $1.75 \mathrm{~b} \pm 0.22$ & $1.73 \mathrm{~b} \pm 0.18$ & $1.58 \mathrm{a} \pm 0.16$ & $1.91 \mathrm{a} \pm 0.22$ & $1.56 \mathrm{~b} \pm 0.20$ \\
& TAN3 & $17.13 \pm 3.14$ & $4.24 \mathrm{ab} \pm 0.77$ & $3.29 \mathrm{ab} \pm 0.37$ & $4.11 \mathrm{a} \pm 0.07$ & $3.23 \mathrm{a} \pm 0.91$ & $3.33 \mathrm{a} \pm 1.28$ \\
SS & TAN1 & $374 \pm 124$ & $243 \mathrm{a} \pm 45$ & $471 \mathrm{a} \pm 226$ & $475 \mathrm{a} \pm 182$ & $492 \mathrm{a} \pm 128$ & $611 \mathrm{a} \pm 217$ \\
& TAN2 & $358 \pm 335$ & $460 \mathrm{a} \pm 400$ & $543 \mathrm{a} \pm 414$ & $544 \mathrm{a} \pm 402$ & $551 \mathrm{a} \pm 414$ & $554 \mathrm{a} \pm 405$ \\
& TAN3 & $780 \pm 739$ & $586 \mathrm{a} \pm 594$ & $758 \mathrm{a} \pm 656$ & $787 \mathrm{a} \pm 676$ & $861 \mathrm{a} \pm 635$ & $898 \mathrm{a} \pm 672$ \\
TDS & TAN1 & $3941 \pm 3703$ & $51 \mathrm{a} \pm 10$ & $53 \mathrm{a} \pm 10$ & $55 \mathrm{a} \pm 15$ & $61 \mathrm{a} \pm 20$ & $63 \mathrm{a} \pm 26$ \\
& TAN2 & $3300 \pm 1714$ & $83 \mathrm{a} \pm 78$ & $47 \mathrm{a} \pm 20$ & $48 \mathrm{a} \pm 22$ & $47 \mathrm{a} \pm 17$ & $48 \mathrm{a} \pm 17$ \\
& TAN3 & $2653 \pm 1240$ & $46 \mathrm{a} \pm 11$ & $55 \mathrm{a} \pm 24$ & $55 \mathrm{a} \pm 25$ & $58 \mathrm{a} \pm 23$ & $61 \mathrm{a} \pm 28$ \\
\hline
\end{tabular}

Replicate $=6$ (months)

Within the rows, for the same parameter, means with different alphabets are statistically different $(p<0.05)$.

$\mathrm{P}=$ parameter, IND = Industries 
BAJOPAS Volume 13 Number 2, December, 2020

Table 4: Correlation coefficient $(r)$ between different masses of the bacteria and the physicochemical parameters.

\begin{tabular}{llll}
\hline Industries & Parameter & Correlation coefficient $(r)$ & $\begin{array}{l}\text { Percent dependence (rxrx100) } \\
(\%)\end{array}$ \\
\hline TAN1 & COD & -0.9 & 82 \\
& BOD & -0.97 & 94 \\
& SS & $0.90^{*}$ & 80 \\
TAN2 & TDS & $0.98^{*}$ & 96 \\
& COD & -1 & 100 \\
& BOD & -0.21 & 4 \\
& SS & $0.78^{*}$ & 61 \\
& TDS & -0.69 & 47 \\
& COD & $0.60^{*}$ & 36 \\
& BOD & -0.6 & 37 \\
& SS & $0.95^{*}$ & 90 \\
& TDS & $0.94^{*}$ & 89 \\
\hline
\end{tabular}

The correlation coefficient $(r)$ with * is statistically significant $(p<0.05)$.

Percentage reduction of the Parameters

Table 5 shows the percentage reduction of Parameters in industrial samples before and after the treatment of the effluents $(250 \mathrm{ml})$ with the different masses $(5 \mathrm{~g}, 10 \mathrm{~g}, 15 \mathrm{~g}, 20 \mathrm{~g}$, and $25 \mathrm{~g}$ ) of the Immobilized Bacteria.

In TAN1 samples, the percentage reduction (\%) of COD ranged (14-89); BOD (50-80); SS (-32$35)$ and TDS (98-99). In TAN2 samples, the percentage decrease $(\%)$ of COD ranged (15$38) ;$ BOD (90-92); SS [-28-(-55)] and TDS (9798). In TAN3 samples, the percentage decrease (\%) of COD ranged (11-44); BOD (76-81); SS (15-25) and TDS (98). The percentage increase in the levels COD, BOD and TDS might be due to the increase in the surface area of the different masses of the immobilized bacteria. However, the percentage decrease in the levels of the SS might be due to the aggregation of the TDS which are large enough to result into SS. The percentage decrease in the levels of the SS might be also due to the influence of the nutrients which was added into the effluents in order to make the microorganisms more active and viable for fast degradation of organic contaminants in the effluent. This is in line with the work of Jimoh et al. (2018) in which the concentration of the SS increase after the bioremediation of effluents.

Sreemoyee and Priti (2013) assessed and reduced several Physico-chemical parameters of dairy wastewater using Niesseria $s p$. and concluded that the species are well known to degrade organic compounds. This is in agreement with the current study in which the immobilized Niesseria $s p$ degrade the organic contaminants as indicated by the BOD, COD and TDS.

Jimoh et al. (2018) observed that TSS of the effluents was increased after treatment with immobilized bacteria and concluded that it might be due to the biostimulation method adopted for the research.

The optimum $\mathrm{pH}$ Biosorption of Chromium by Bacillus spp and Staphylococcus spp. from tannery effluent was investigated by Mythili and Karthikeyan (2011). The maximum adsorption of Chromium $(86.4 \mathrm{mg} / \mathrm{L})$ was showed by Bacillus spp and Staphylococcus spp showed $70.6 \mathrm{mg} / \mathrm{L}$ at an initial concentration of $100 \mathrm{mg} / \mathrm{L}$. In the present study, immobilised Bacillus spp and Staphylococcus spp. from the tannery industrial effluents reduced the levels of the organic pollutants with high potential as indicated by the percentage reduction of BOD, COD and TDS.

Enzymes often can work in multiple environments especially if they are immobilized. This makes the microorganisms' enzymes even more resistant to harsh environments and enables the enzymes to be recovered and recycled after they are no longer needed (Gianfreda and Rao 2004). Ramesh and Singh (1993) reported that the immobilized bacteria having more efficiency to remove the suspended particles than free cells. Using the immobilized cell is preferable due to its capability for using several times with the same efficiency, which makes it more economical. Similar work was done by Sikander et al. (2007) showing the higher reduction with permeabilized cells of Ochrobactrum intermedium strain SDCr-5. 
BAJOPAS Volume 13 Number 2, December, 2020

The results revealed the isolation and identification of isolates with the potential for the reduction of $\mathrm{Cr}$ (VI) to $\mathrm{Cr}$ (III). Results indicated that immobilized $B$. cereus could be efficiently used for the reduction of $\mathrm{Cr}$ (VI).

Table 5: Percentage reduction of the tested Parameters from the tannery industrial samples of the Immobilized Bacteria.

\begin{tabular}{lllllll}
\hline \multirow{2}{*}{ Industries } & & \multicolumn{5}{c}{ Percentage Reduction $(\%)$} \\
\cline { 3 - 7 } & & $5 \mathrm{~g}$ & $10 \mathrm{~g}$ & $15 \mathrm{~g}$ & $20 \mathrm{~g}$ & $25 \mathrm{~g}$ \\
\hline TAN1 & COD & 28 & 14 & 64 & 87 & 89 \\
& BOD & 50 & 54 & 59 & 67 & 80 \\
& SS & 35 & -26 & -27 & -32 & -63 \\
& TDS & 99 & 99 & 99 & 98 & 98 \\
TAN2 & COD & 15 & 20 & 25 & 32 & 38 \\
& BOD & 91 & 91 & 92 & 90 & 92 \\
& SS & -28 & -52 & -52 & -54 & -55 \\
& TDS & 97 & 99 & 99 & 99 & 99 \\
& COD & 33 & 44 & 22 & 11 & 26 \\
& BOD & 75 & 81 & 76 & 81 & 81 \\
& SS & 25 & 3 & -1 & -10 & -15 \\
& TDS & 98 & 98 & 98 & 98 & 98 \\
\hline
\end{tabular}

Percentage Reduction $=(B-A) / B \times 100 \%$

$A=$ Concentration of the parameter after treatment

$\mathrm{B}=$ Concentration of the parameter before treatment

$+=$ percentage decrease

- = percentage increase

In general, immobilization makes the enzyme more resistant to temperature, $\mathrm{pH}$, and substrate concentration swings giving it a longer lifetime and higher productivity per active unit (Gianfreda and Rao, 2004; FuIlbrook, 1996; Russell et al, 2003; Kandelbauer et al., 2004). Immobilized cells have been used and studied extensively for the production of useful chemicals (Ohtake and Silver, 1994), the treatment of wastewaters (Chen et al., 2003; Wang et al., 2010). Although many workers described microbial degradation of tannery effluent, limited literature is available on the bioremediation of tannery effluent using immobilized bacterial cells in the Kano Industrial Estates.

\section{CONCLUSION}

The samples contained variable levels of the physicochemical parameters. The results of the Analysis of variance revealed that, no statistical difference $(p<0.05)$ was observed for the temperature, $\mathrm{pH}, \mathrm{SS}, \mathrm{TDS}, \mathrm{BOD}$ and $\mathrm{COD}$ among the three tannery industries before the treatment. The levels of some of the parameters
(SS, TDS and COD) observed in the samples were found above the recommended limits of WHO and NESREA, which called for the treatment of the effluents before discharge into the environment. Base on the morphological and biochemical test results, TAN1, TAN2, and TAN3 bacterial isolates were identified to be Neisseria spp, Bacillus cereus, and Staphylococcus aureus respectively. The results of Post-treatment analysis showed that there is overall decrease in the levels of the parameters determined when compared with that of the pre-treatment. The overall percentage reduction of the immobilised bacteria in the treatment of the respective effluents was in the order TAN2 (72\%)>TAN1 $(70 \%)>$ TAN3 $(62 \%)$. Hence, the immobilized bacteria are having higher biodegradation potential for the treatment of the tannery effluents.

\section{Acknowledgments}

The authors wish to acknowledge the University of Maiduguri for the financial support. The authors are grateful to the Kano State Ministry of Environment for their support in obtaining the effluent samples. 


\section{REFERENCES}

Ajao, A. T., Adebayo, G. B., and Yakubu, S. E. (2011). Bioremediation of textile industrial effluent using mixed culture of Pseudomonas aeruginosa and Bacillus subtilis immobilized on agar-agar in a bioreactor. J. Microbiol. Biotech. Res, 1(3), 50-56.

Akan, J. C., Moses, E. A., Ogugbuaja, V. O., and Abah, J. (2007). Assessment of tannery industrial effluents from Kano metropolis, Kano State, Nigeria. Journal of Applied Sciences, 7(19), 2788-2793.

Akan, J. C., Ogugbuaja, V. O., Abdulrahman, F. I., and Ayodele, J. T. (2009). Pollutant levels in effluent samples from tanneries and textiles of Kano industrial areas, Nigeria. Global journal of pure and applied sciences, 15(3-4).

APHA (1989). Standard methods for Examination of Will bete and Will betewater.15 $5^{\text {th }}$ edition. Brydpass Springfield Will behington DC. pp. 164-176

APHA (1992). Standard Methods for the Examination of Water and Wastewater. Health, 69, 1116-9.

Baba, A., Garba, S. T., and Bello, H. S. (2020). Bioremediation Potential of Immobilized corynebacterium kutsceri in the Treatment of Tannery Industrial Effluent from Challawa Industrial Estate, Kano State, Nigeria. Journal of the Turkish Chemical Society Section A: Chemistry, $7(2), 335-350$.

Beem, E. I. V. (1994). reduction of solvent VOC emission. J. Oil Col. Chem. Ass, 77, 158.

Bouwer, E. J., and Zehnder, A. J. (1993). Bioremediation of organic compoundsputting microbial metabolism to work. Trends in biotechnology, 11(8), 360367.

Chen, K. C., Wu, J. Y., Liou, D. J., and Hwang, S. C. J. (2003). Decolorization of the textile dyes by newly isolated bacterial strains. Journal of Biotechnology, 101(1), 57-68.

Dan'Azumi, S., and Bichi, M. H. (2010). INDUSTRIAL POLLUTION AND HEAVY METALS PROFILE OF CHALLAWA RIVER IN KANO, NIGERIA. Journal of Applied Sciences in Environmental Sanitation, $5(1)$.

DWAF. (1992). Analytical Methods Manual, TR 151. Department of Water Affairs and Forestry, Pretoria.

El-Bestawy, E. (2013). Biological treatment of leather-tanning industrial wastewater using free living bacteria.
Elsheikh, M. A. S. (2009). Tannery wastewater pre-treatment. Water Science and Technology, 60(2), 433-440.

FuIlbrook, P. D. (1996). "Kinetics." Industrial enzymology: The application of enzymes in Industry. 2nd Ed. T. Godfrey and J Reichelt. eds.. Nature. New York.

Gianfreda, L., and Rao, M. A. (2004). Potential of extra cellular enzymes in remediation of polluted soils: a review. Enzyme and microbial technology, 35(4), 339354.

Hugo Springer. (1994). John Arthur Wilson Memorial Lecture "Treatment of Industrial Wastes of the Leather Industry - is it still a Major Problem". JALCA, 89, 153-185

Jimoh, A. A., Ganiyu, B. A., Baba, D., and Baba, A. (2018) Bioremediation Process of Effluent from Detergent and Food Industries in Jos, Nigeria: Kinetics and Thermodynamics. International Journal of Engineering Science Invention (IJESI), 762-73

Kandelbauer, A., Maute, O., Kessler, R. W., Erlacher, A., and Gübitz, G. M. (2004). Study of dye decolorization in an immobilized laccase enzyme-reactor using online spectroscopy. Biotechnology and bioengineering, 87(4), 552-563.

Kongjao, S., Damronglerd, S., and Hunsom, M. (2008). Simultaneous removal of organic and inorganic Pollutants in tannery wastewater using electrocoagulation technique. Korean Journal of chemical engineering, 25(4), 703.

Maheshwari, U. M., Aruna, S., Gomathi, M., and AbdulJaffar, A. H. (2017). Bioremediation by Free and Immobilized Bacteria Isolated from Tannery Effluent. International Journal of Research in Applied, Natural and Social Sciences. 5(7), 75-90

Margesin, R., and Schinner, F. (2001). Bioremediation (natural attenuation and biostimulation) of diesel-oilcontaminated soil in an alpine glacier skiing area. Applied and environmental microbiology, 677), 3127-3133.

Mohammed, A., Sekar, P., and George, J. (2011). Efficacy of microbes in bioremediation of tannery effluent. Inter. J. Curr. Res, 3(4), 324-326.

Mohammed, S. S. D., Orukotan, A. A., and Abdullahi, H. (2017). Physicochemical and Bacteriological Assessment of Tannery Effluent from Samaru-Zaria, 
BAJOPAS Volume 13 Number 2, December, 2020 Kaduna State, Nigeria. Journal of Applied

Sciences and Environmental Management, 21(4), 734-740.

Munz, G., De Angelis, D., Gori, R., Mori, G., Casarci, M., and Lubello, C. (2009). The role of tannins in conventional and membrane treatment of tannery wastewater. Journal of hazardous materials, 164(2-3), 733-739

Mythili, K., and Karthikeyan, B. (2011). Bioremediation of $\mathrm{Cr}$ (VI) from tannery effluent using Bacillus spp and Staphylococcus spp. International Multidisciplinary Research Journal, 1(6).

NESREA (2009). National Environmental Standards for Effluent Limitations and Regulation. 1233-1236

Noorjahan, C. M. (2014). Physicochemical characteristics, identification of bacteria and biodegradation of industrial effluent. Journal of bioremediation and Biodegradation, 5(3).

Ohtake, H. I., and Silver, A. O. (1994). Bacterial reduction of toxic chromate. Biological degradation and bioremediation of toxic chemicals, 403-415.

Omoleke, I. I. (2004). Management of environmental pollution in Ibadan, an African city: the challenges of health hazard facing government and the people. Journal of Human Ecology, 15(4), 265-275.

Rajor, A., Reddy, A.S., and Singh, B. (2004). Determination of BOD kinetic Parameters and evaluation of alternate methods, M.Sc. Thesis, Department of biotechnology \& environmental Science, Thapar Institute of Engineering and Technology, Patiala

Ramasami, T., Rajamani, S., and Rao, J. R. (1994, March). Pollution control in leather industry: Emerging technological options. In International symposium on surface and colloidal science and its relevance to soil pollution, madras.

Ramesh, J. V. S., and Singh, S. P. (1993). Yearly variation in certain physicochemical parameters of pond at eastern Doon Valley. Uttar Pradesh J. Zoo, 12 (1), 7577.

Ranen, S., and Sharadinadra, C. (2009). Biotechnology applications to environmental remediation in resource exploitation. Current science, 97, 6-25
Russell, A. J., Berberich, J. A., Drevon, G. F., and Koepsel, R. R. (2003). Biomaterials for mediation of

chemical and biological warfare agents. Annual review of biomedical engineering, 5(1), 1-27.

Saravanan, P., and Saravanan, A. (1999). Decolourization of tannery effluent by Flavobacterium sp. EK 1. Indian Journal of Environmental Protection, 19, 19-24.

Sikander, S., and Shahida, H. (2007). Reduction of toxic hexavalent chromium by Ochrobactrum intermedium strain SDCr5 stimulated by heavy metals. Bioresource Technol, 98, 340-344.

Singh, N., Sharma, B. K., and Bohra, P. C. (2000). Impact assessment of industrial effluent of arid soils by using satellite imageries. Journal of the Indian Society of Remote Sensing, 28(2-3), 79.

Sreemoyee, C., and Priti, P. (2013). Assessment of physico-chemical parameters of dairy waste water and isolation and characterization of bacterial strains in terms of cod reduction. Int J Sci, 2(3), 395-400.

Verheijen, L. A. H. M., Wiersema, D., Pol, L. H., and De Wit, J. (1996). Management of wastes from animal product processing. Livestock and environment, Finding a balance. International Agriculture Center, Wageningen, The Netherlands.

Wang, F., Yao, J., Si, Y., Chen, H., Russel, M., Chen, K., and Bramanti, E. (2010). Short-time effect of heavy metals upon microbial community activity. Journal of Hazardous Materials, 173(13), 510-516.

WHO (World Health Organization). (2006). Air quality guidelines: global update 2005: particulate matter, ozone, nitrogen dioxide, and sulfur dioxide. World Health Organization.

World Bank. (1995). Nigeria's strategic options for redressing industrial pollution. World Bank, industry and energy division. 1st edition, West Central Africa Department; Annexes: 1995; pp 60-62.

Zahoor, A., and Abdul, R. (2009). Enumeration of Coliforms. Journal of Environmental Sciences. 21, 814-820 


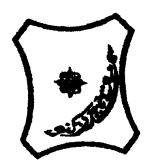

Bayero Journal of Pure and Applied Sciences, 13(2): 1 - 12

Received: November, 2020

Accepted: December, 2020

ISSN $2006-6996$

\title{
BIODEGRADATION POTENTIAL OF IMMOBILIZED BACTERIA IN THE TREATMENT OF TANNERY INDUSTRIAL EFFLUENTS FROM INDUSTRIAL ESTATES IN KANO STATE, NIGERIA
}

\author{
Abdullateef, B., ${ }^{1 *}$ Shuaibu, T. G., ${ }^{1}$ Babagana, K., ${ }^{1}$ Suleman, H. B. ${ }^{2}$ and Dauda, B. ${ }^{3}$ \\ ${ }^{1}$ Department of Pure and Applied Chemistry, Faculty of Science, University of Maiduguri, Borno State, \\ Nigeria \\ ${ }^{2}$ Department of Microbiology, Faculty of Science, University of Maiduguri, Borno State, Nigeria \\ ${ }^{3}$ Department of Chemical Engineering, Faculty of Engineering, University of Maiduguri, Borno State, \\ Nigeria \\ *Corresponding author: babslega@gmail.com; abelega2007@yahoo.com; +2348061309753
}

\section{ABSTRACT}

Industrial Effluents Samples from Gashash Tanneries (TAN1) in Bompai Industrial estate, Larabee Tannery Industry (TAN2) in Sharada Industrial estate and Z Tannery Industries (TAN3) in Challawa Industrial estate, Kano State, Nigeria were collected over a period of six months (August 2017 to January 2018) for assessing the biodegradation potentials of bacteria in the treatment of organic pollutants within the effluents. Bacteria were isolated from the effluents and immobilized on agar-agar. Different masses (5 g, $10 \mathrm{gr}, 15$ $\mathrm{g}, 20 \mathrm{~g}$, and $25 \mathrm{~g}$ ) of the bacteria were used in the treatment of $250 \mathrm{ml}$ of the effluents for ten days in a shaker incubator (Gallenkamp-OC-4364-L) at the temperature $30{ }^{\circ} \mathrm{C}$ and speed of $60 \mathrm{rpm}$. Pre-treatment analysis of the effluents for Temperature, pH, Biochemical Oxygen Demand (BOD), Chemical Oxygen Demand (COD), Suspended Solid (SS) and Total Dissolved Solids (TDS) gives the following results; temperature $\left({ }^{\circ} \mathrm{C}\right.$ )

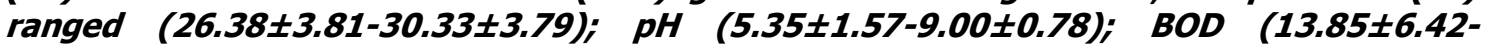
$38.75 \pm 16.20) ;$ COD (1406 $\pm 208-3532 \pm 1373) ;$ SS (208 $\pm 235-780 \pm 739)$ and TDS (266 $\pm 253-5276 \pm 2971)$. No statistical differences ( $p \leq 0.05)$ was observed for all the results among the different industries. The bacterial isolates were identified as Neisseria spp, Bacillus cereus, and Staphylococcus aureus, in TAN1, TAN2, and TAN3, respectively. After treatment of the effluent with the different masses of the isolated bacteria, the mean level of BOD was found to range as (0.55 $\pm 0.36-6.92 \pm 5.49) ; C O D$ (ND-3134 \pm 1595$)$;

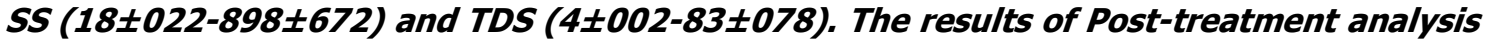
showed that there is overall decrease in the levels of the parameters determined when compared with that of the pre-treatment. The overall percentage reduction of the immobilised bacteria in the treatment of the respective effluents was in the order TAN2 (72\%)>TAN1 (70\%)>TAN3 (62\%). Hence, the immobilized bacteria are having higher biodegradation potential for the treatment of the tannery effluents.

Keywords: Biodegradation, bacteria, effluent, immobilization, tannery.

\section{INTRODUCTION}

Tannery industrial wastewater is a serious consequence of the pollution point of view for streams, freshwater, and land used for agriculture. The lack of awareness in the modern industrial practice has resulted in the discharge of tannery effluents which exhibit very high value of chromium ( $\mathrm{Cr}$ ), Sulfide, and chloride, Total Dissolved Solid (TDS), Total Suspended Solid (TSS), Biochemical Oxygen Demand (BOD) and Chemical Oxygen Demand (COD) in the water stream or land (Mohammed et al., 2001). Tanning is the process, which One ton of skin generally leads to the production of 20 to $80 \mathrm{~m}^{3}$ of turbid and foul-smelling converts the protein of the rawhide or skin into a stable material, which will not putrefy and is suitable for a wide variety of end applications (Elsheikh, 2009). The highly polluting chromium is the most commonly used tanning material producing leather that is more flexible and pliable than vegetable-tanned leather and does not discolor or lose shape in water as drastically as vegetable-tan (Elsheikh, 2009). Tannery effluent is among the most hazardous industrial pollutants due to its huge organic and inorganic load, which is highly toxic to human life and the environment (Kongjao et al., 2008). wastewater including chromium (100-400 mg/l), sulfide $(200-800 \mathrm{mg} / \mathrm{l})$, high levels of fat and 
BAJOPAS Volume 13 Number 2, December, 2020 other solid wastes, and notable pathogen contamination as well as pesticides added for skin conservation during transport (Elsheikh, 2009). There are more than 6000 tanneries in Nigeria with an annual processing capacity of 700,000 tons of hides and skins (Omoleke, 2004; Singh et al., 2008). It was reported that the total amount of waste produced per animal slaughtered is approximately $35 \%$ of its weight (World Bank, 1995). Also, for every $1000 \mathrm{~kg}$ of carcass weight, a slaughtered beef produces 5.5 $\mathrm{kg}$ of manure (excluding rumen contents or stockyard manure) and $100 \mathrm{~kg}$ of paunch manure (undigested food) (Verheijen et al., 1996). Tanneries generate wastewater in the range of 30-35 $\mathrm{L} \mathrm{kg}^{-1}$ skin/hide processed with variable $\mathrm{pH}$, Biological Oxygen Demand (BOD), Chemical Oxygen Demand (COD), high concentrations of suspended solids (SS), and tannins as well as chromium (Zahoor and Abdul, 2009).

Being heterogeneous and composed of a wide variety of compounds, it is very difficult to select a unique direct method for estimating the biodegradability of organic contents and biokinetic parameters for a wastewater sample (Rajor, 2004). For this purpose, some indirect estimation such as determination of biochemical oxygen demand (BOD) and chemical oxygen demand (COD) are applied as common laboratory investigations [9]. During retanning procedures, synthetic tannins (Syntan), oils and resins are added to form softer leather at varying doses (Munz et al., 2009). One of the refractory groups of chemicals in tannery effluents derives mainly from tannins (Ramasami et al., 2004). Syntans are characterized by complex chemical structures, because they are composed of an extended set of chemicals such as phenol-, naphthalene-, formaldehyde- and melamine-based syntans, and acrylic resins (Beem, 1994). Organic pollutants (proteic and lipidic components) are originated from skins (it is calculated that the raw skin has $30 \%$ loss of organic material during the working cycle) or they are introduced during processes (Hugo Springer, 1994).

Many conventional processes such as oxidation, chemical and biological processes were carried out to treat tanneries wastewater (Ebtesam et al, 2013). Biological processes have received more attention because of their costeffectiveness, lower sludge production and environmental friendliness (Noorjahan, 2014). Naturally occurring micro-organisms degrade the hazardous organic wastes including xenobiotic compounds, such as pesticides, polycyclic aromatic hydrocarbons (PAHs) and polychlorinated biphenyls (PCBs) in due course of time (Ranen and Sharadinadra, 2009). Bioremediation is based on the idea that all organisms remove substances from the environment to carry outgrowth and metabolism (Bouwer and Zehnder, 1993). Bacteria, protista and fungi are found to be very good at degrading complex molecules and incorporating the breakdown products into their metabolism (Bouwer and Zehnder, 1993). The resultant metabolic wastes that they produce are generally safe and somehow recycled into other organisms (Ranen and Sharadinadra, 2009). An acclimatized indigenous population of microorganisms capable of degradation of the compounds of interest must exist at the site for a successful bioremediation mode (Ranen and Sharadinadra, 2009). It has been observed that for a successful bioremediation mode, an acclimatized indigenous population of microorganisms capable of degradation of the compounds of interest must exist at the site under investigation (Ranen and Sharadinadra, 2009). Even though there are numerous physical and chemical methods employed in the disposal of wastes the advantage in using bacterium is that they play a key role in the reduction of COD, BOD, total protein, total tannin and total phenol (Saravanan and Saravanan, 1998)

Baba et al. (2020) studied the bioremediation potential of immobilized corynebacterium kutsceri in the Treatment of tannery industrial effluent from Challawa Industrial Estate, Kano State, Nigeria. The aim of the work is to study the reduction in the level of the contaminants through the process of bioremediation using the isolated bacteria. Immobilized bacteria can withstand various temperatures, $\mathrm{pH}$ and substrate concentrations; consequently, increasing the efficiency and the lifespan of the bacteria. Immobilized bacteria are widely applied in the treatment of wastewater and can be separated and recovered after the treatment with the same efficiency (Baba et al., 2020).

\section{MATERIALS AND METHODS \\ Study Area}

This study was carried out in Bompai, Sharada and Challawa industrial estates in Kano, Figure 1. Kano lies on Latitude $11^{\circ} 30^{\prime} \mathrm{N}$ and $8^{\circ} 30^{\prime} \mathrm{E}$ and Longitude $11^{\circ} 5^{\prime} \mathrm{N}$ and $8^{\circ} 5^{\prime} \mathrm{E}$ in Northern Nigeria. It is one of the developed industrial cities in Nigeria. Tannery activities are the dominating industries and this could be one of the reasons for her high population density (Dan'Azumi and Bichi, 2010). Many researchers have studied biodegradation of tannery effluent using microorganisms. However, limited literature is available on the biodegradation of tannery effluent in Kano industrial estates using 
BAJOPAS Volume 13 Number 2, December, 2020 immobilized bacterial cells. This research work focuses on the potential of the use of the indigenous immobilized bacterial isolates in the treatment of tannery effluents in the industrial estates.

\section{Sample Collection}

Effluents were collected from the Tannery Industries from Bompai, Challawa and Sharada Industrial Estates, Kano, Nigeria. The effluents were collected over a period of six months (August 2017 to January 2018). Samples collected in a sterile 4-liter plastic container with a unique identification number were preserved using an ice-box that was transported to the Microbiology Laboratory, Department of Microbiology, Bayero University of Kano for analysis

\section{Sample Preparation and Sample Analysis}

Immediately after the collection of the effluent, $\mathrm{pH}$, TSS, TDS, COD, BOD levels were determined before treatment (Pre-treatment determination) and ten days after treatment (Post-treatment determination) as described in
APHA (1989) standard methods. $\mathrm{pH}$ was determined using Ecotests $\mathrm{pH}$ meter and TDS was determined using AQUALYTIC TDS Salinometer. BOD was determined as described by the standard method (APHA, 1992). COD and SS were determined using DR/2010 HACH portable data logging spectrophotometer (DWAF, 1992)

\section{Identification and Biochemical} Characterization of the Bacterial Isolates

The bacteria were isolated from the effluents using Serial Dilution according to the method described by APHA (1989). The biochemical tests such as oxidase, catalase, coagulase, indole (from $1 \%$ tryptone broth), citrate (Simmons citrate agar), methyl red/VogesProskauer (MR/VP), nitrate reduction, Starch Hydrolysis, Glucose, Maltose, and Lactose tests were carried out on the bacterial isolates to identify the bacteria through the bacteria biochemical characteristics according to Ajao et al. (2011).

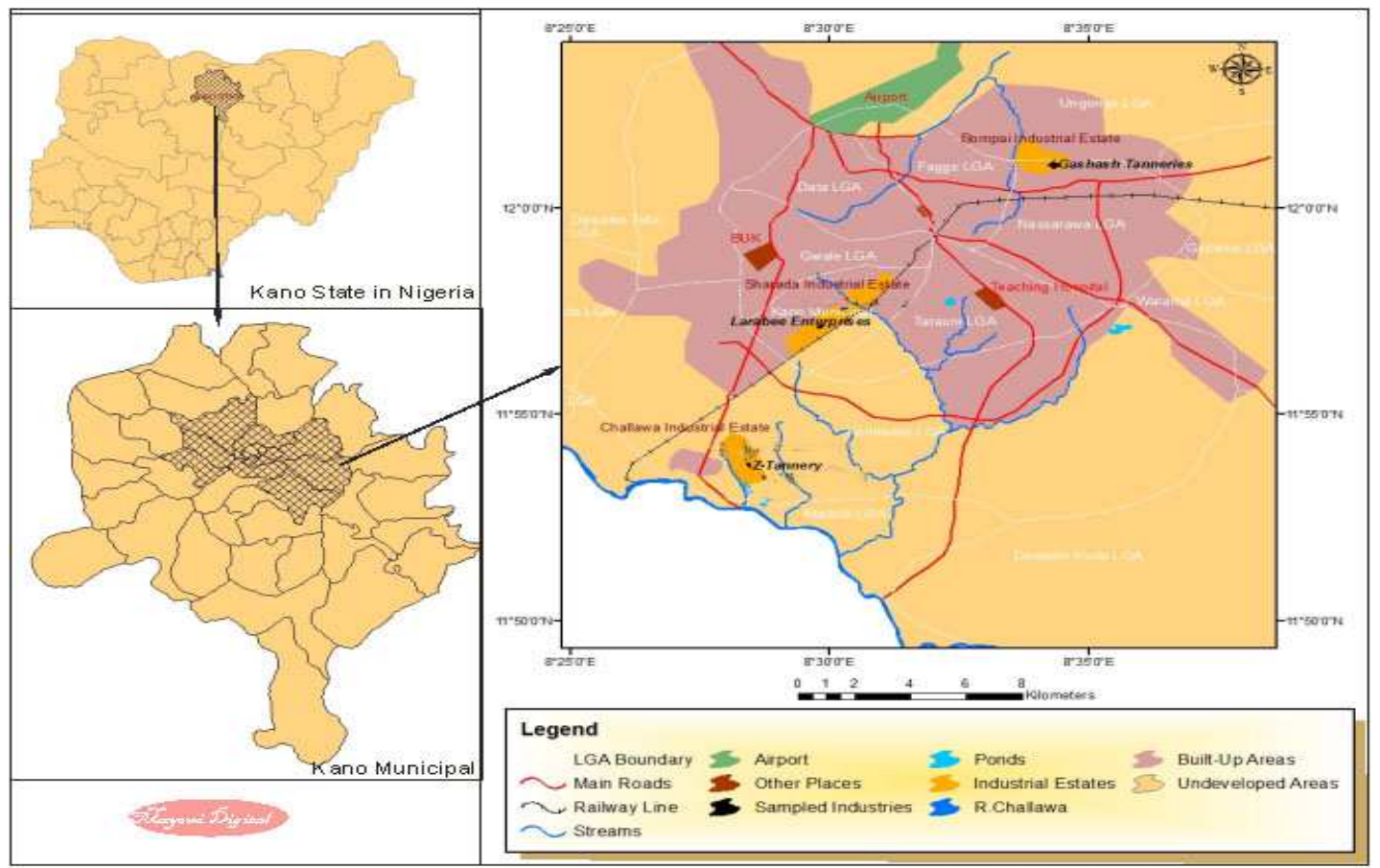

Fig. 1 Map showing the study areas

Source: Mayomi Digital Productions, GIS Laboratory, Department of Geography, UNIMAID (2017)

\section{Determination of Growth Rate of the Bacteria in Effluent Sample}

The bacteria growth rates were determined by transferring $2 \mathrm{~mL}$ of the bacterial isolates from the tannery effluent in broth medium into 100 $\mathrm{mL}$ sterile effluents in conical flasks and kept in an incubator (Giffrin cool) for 10 days. Control was also set up by incubating another $100 \mathrm{~mL}$ each of the sterile effluents without the bacteria. The optical density of the content was determined at the wavelength of $600 \mathrm{~nm}$ on a daily interval and recorded. 
BAJOPAS Volume 13 Number 2, December, 2020 Immobilization of Bacteria

Agar solution and inoculi were prepared separately. Fifty milliliters $(50 \mathrm{~mL})$ of nutrient broth each of the inoculi was prepared in a McCartney bottle and incubated for 24 hours. A solution of agar-agar was prepared by dissolving $10 \mathrm{~g}$ of the powder in distilled water and made up to $500 \mathrm{~mL}$ mark in an Erlenmeyer flask and was sterilized in an autoclave (280A) for 15 minutes and allowed to cool to $40-45^{\circ} \mathrm{C}$ (Ajao et al., 2011). Four milliliters ( $4 \mathrm{~mL})$ of the bacterial isolates in the nutrient broth was mixed with 36 $\mathrm{ml}$ of the prepared agar-agar media in petri-dish plates and then allowed to solidify. This was kept in the refrigerator for bioremediation.

\section{Bioremediation (Treatment) of the Effluents}

The solidified agar block (immobilized bacteria) was cut into cubes using a sterile knife; $0.1 \mathrm{~mL}$ phosphate buffer ( $\mathrm{pH} \mathrm{7.0)}$ was added and kept in the refrigerator for 1 hour for curing. The phosphate buffer was decanted after 1 hour and the cubes were washed with sterile distilled water 3-4 times before it was used (Ajao et al., 2011). Two liters (2 L) of the effluent was supplemented with the minimum basal medium in $\mathrm{g} / \mathrm{L}: \mathrm{NaCl}(0.8), \mathrm{MgSO}_{4} .7 \mathrm{H}_{2} \mathrm{O}(0.001), \mathrm{KH}_{2} \mathrm{PO}_{4}$ (2), $\mathrm{NaNO}_{3}$ (2), $\quad \mathrm{CaCl}_{2} .2 \mathrm{H}_{2} \mathrm{O} \quad(0.5)$ and $\mathrm{NaHPO}_{4} .12 \mathrm{H}_{2} \mathrm{O}(2)$ and sterilized in an autoclave at $121^{\circ} \mathrm{C}$ for 15 minutes (Margesin and Schinner, 2001). Two hundred and fifty milliliters $(250 \mathrm{~mL})$ of the effluents were transferred into different $250 \mathrm{ml}$ conical flasks. The content was covered with a cotton-wool ramped with foil paper to avoid contamination. Five grams $(5 \mathrm{~g})$ of the immobilized bacteria were quickly transferred into each of the effluents in the conical flasks in an inoculating chamber. The same procedures were carried out for the $10 \mathrm{~g}, 15 \mathrm{~g}, 20 \mathrm{~g}$ and 25 $\mathrm{g}$ of the immobilized bacteria in separate $250 \mathrm{~mL}$ effluents in conical flasks and agitated for ten days in a shaker incubator (Gallenkamp-OC4364-L) at a temperature $30^{\circ} \mathrm{C}$ and speed of 60 rpm. The treated effluent samples were taken on the tenth day and analyzed for the parameters $\mathrm{pH}$, SS, TDS, COD, and BOD, (Posttreatment determination) for the different grams of bacteria to evaluate and compare the biodegradation potential. (Baba et al., 2020).

\section{Statistical Analysis}

The data were represented as Mean \pm Standard deviation and analyzed statistically using oneway Analysis of Variance (ANOVA) and Tukey's HSD as Post Hoc Tests with the aid of SPSS 16.0. The correlation coefficient was also used to measure the strength of the relationship between the different masses of the bacteria and the parameters. All $\mathrm{p} \leq 0.05$ were considered as statistically significant.

\section{RESULTS AND DISCUSSION Physico-chemical parameters in the Industrial Effluents before the Biodegradation.}

Results of the Physico-chemical parameters in the industrial effluents before the Biodegradation is shown in table 1 . The mean temperatures $\left({ }^{\circ} \mathrm{C}\right)$ observed in TAN1, TAN2, and TAN3 samples were $28.07 \pm 0.65 ; 27.77 \pm 0.64$ and $26.38 \pm 3.81$ respectively. The order of the mean temperature of the samples from the three industries can be arranged as TAN1 > TAN2>TAN3. The temperature observed at TAN1, TAN2, and TAN3 samples were found below the WHO $\left(35^{\circ} \mathrm{C}\right)$ and NESREA $\left(40^{\circ} \mathrm{C}\right)$ limits. The low values of temperature might be due to the processes used at the time of sampling. High temperature brings down the solubility of gases in water that ultimately expresses as high BOD and COD. Statistical analysis shows that there is no significant difference $(p<0.05)$ between the mean values of temperature among the industries. This might be due to similar tannery activities involved in the tannery industries at the time of sampling. The average values of temperature observed in this present study are less than those observed by Akan et al. (2007), Akan et al. (2009) and Baba et al. (2020).

The mean level of $\mathrm{pH}$ observed in TAN1, TAN2 and TAN3, samples were $7.77 \pm 2.93$; $8.35 \pm 0.28$ and $7.52 \pm 0.76$ respectively. The order of the mean $\mathrm{pH}$ of the samples from the three industries can be arranged as TAN2> TAN1 $>$ TAN3. The $\mathrm{pH}$ of the samples falls within the WHO (7.0-8.5) and NESREA (6-9) standard limits. Statistical analysis shows that there is no significant difference $(p<0.05)$ between the mean values of $\mathrm{pH}$ among the industries. This might be due to similar tannery activities involved in the tannery industries at the time of sampling. Maheshwari et al. (2017) reported that the level of $\mathrm{pH}$ in the effluents from the tannery industry in Vaniyambadi, India was 6.5 which was lower than that observed in the present study. The $\mathrm{pH}$ in the effluents from the tannery industries in Kano and Kaduna were reported to be 7.64 and 6.89, respectively (Akan et al., 2007; Mohammed et al., 2017). The average values of $\mathrm{pH}$ observed in this present study are less than those observed by Mohammed et al. (2017) and Baba et al. (2020). The mean level of SS $(\mathrm{mg} / \mathrm{l})$ observed in TAN1, TAN2, and TAN3 samples were 374 \pm 124 ; $358 \pm 335$ and $780 \pm 739$ respectively. The order of the mean SS in the samples from the three industries can be arranged as TAN3 > TAN1 $>$ TAN2. 
The SS observed in the samples were far above the recommended standard limits of regulating bodies WHO $(30 \mathrm{mg} / \mathrm{l})$ and NESREA $(10 \mathrm{mg} / \mathrm{l})$. Statistical analysis shows that there is no significant difference $(p<0.05)$ between the mean values of SS among the industries. This might be due to similar tannery activities involved in the tannery industries at the time of sampling. The average values of SS observed in this present study are less than that observed $(3700 \pm 122 \mathrm{mg} / \mathrm{l})$ by Akan et al. (2009) for tanneries in Kano. Also, the average values of SS observed in this present study are less than that observed by Mohammed et al. (2017) and Baba et al. (2020) with the exception in TAN3.

The mean level of TDS (mg/l) observed in TAN1, TAN2, and TAN3 samples were $3941 \pm 3703$; $3300 \pm 1714$ and $2653 \pm 1240$ respectively. The order of the mean TDS in the samples from the three industries can be arranged as TAN1>TAN2>TAN3. The TDS observed in the samples were far above the recommended standard limits of WHO $(250 \mathrm{mg} / \mathrm{l})$ and NESREA $(500 \mathrm{mg} / \mathrm{l})$. Statistical analysis shows that there is no significant difference $(p<0.05)$ between the mean values of TDS among the industries. This might be due to similar tannery activities involved in the tannery industries at the time of sampling. TDS in the effluents from the tannery industries in Kano, Nigeria was reported to be $1281 \mathrm{mg} / \mathrm{l}$ (Akan et al., 2007). The average values of SS observed in this present study are less than those observed by Mohammed et al. (2017) and Baba et al. 2020)

The mean level of COD (mg/l) observed in TAN1, TAN2 and TAN3 samples seasons were $2372 \pm 938 ; \quad 1406 \pm 208$ and $3532 \pm 1373$ respectively. The order of the mean COD of the samples from the three industries can be arranged as TAN3>TAN1> TAN2. The COD observed in TAN1, TAN2 and TAN3 samples were far above the recommended standard limits of regulating bodies $\mathrm{WHO}(40 \mathrm{mg} / \mathrm{l})$ and NESREA (40 mg/l). Statistical analysis shows that there is no significant difference $(p<0.05)$ in COD among the industries. This might be due to similar tannery activities involved in the tannery industries as at the time of sampling. The Chemical Oxygen demand (COD) is the amount of oxygen, in $\mathrm{mg} / \mathrm{L}$, required for the degradation of the compound of wastewater to occur. In comparison, the average values of COD observed in this present study were higher than that observed by Mohammed et al. (2017) but lower than that observed by Baba et al. (2020).

The mean levels of BOD $(\mathrm{mg} / \mathrm{l})$ observed in TAN1, TAN2 and TAN3 samples were $13.85 \pm 6.42 ; \quad 19.46 \pm 0.50$ and $17.13 \pm 3.14$ respectively. The order of the mean BOD in the samples from the three industries can be arranged as TAN2>TAN3>TAN1. The BOD observed in TAN1, TAN2 and TAN3 samples were found below the recommended limits of NESREA (200 mg/l) but above WHO (10 mg/l). Statistical analysis shows that there is no significant difference $(p<0.05)$ between the mean values of BOD among the industries. This might be due to similar tannery activities involved in the tannery industries at the time of sampling. The low level of BOD recorded in this study is an indication of the low level of biodegradable organic solids in the effluent. The average values of BOD observed in this present study were lower than those observed by Mohammed et al. (2017) and Baba et al. (2020).

Table 1: Mean Values \pm S.D of Physico-chemical parameters of effluents from the Tannery Industries before Treatment.

\begin{tabular}{llllllll}
\hline Parameter & Tannery 1 & Tannery 2 & Tannery 3 & $\mathrm{a}$ & $\mathrm{b}$ & $\mathrm{c}$ & $\mathrm{d}$ \\
\cline { 2 - 7 } Temperature $\left({ }^{\circ} \mathrm{C}\right)$ & $28.07 \mathrm{a} \pm 0.65$ & $27.77 \mathrm{a} \pm 0.64$ & $26.38 \mathrm{a} \pm 3.81$ & & $29.50 \pm 4.68$ & 35 & 40 \\
pH & $7.77 \mathrm{a} \pm 2.93$ & $8.35 \mathrm{a} \pm 0.28$ & $7.52 \mathrm{a} \pm 0.76$ & 6.89 & $5.35 \pm 1.57$ & $7.0-8.5$ & $6.0-9.0$ \\
$\mathrm{COD}(\mathrm{mg} / \mathrm{l})$ & $2372 \mathrm{a} \pm 938$ & $1406 \mathrm{a} \pm 208$ & $3532 \mathrm{a} \pm 1373$ & 2.2 & $3106 \pm 2753$ & 40 & 40 \\
$\mathrm{BOD}(\mathrm{mg} / \mathrm{l})$ & $13.85 \mathrm{a} \pm 6.42$ & $19.46 \mathrm{a} \pm 0.50$ & $17.13 \mathrm{a} \pm 3.14$ & 1032 & $26.17 \pm 9.49$ & 10 & 200 \\
$\mathrm{SS}(\mathrm{mg} / \mathrm{l})$ & $374 \mathrm{a} \pm 124$ & $358 \mathrm{a} \pm 335$ & $780 \mathrm{a} \pm 739$ & 501 & $562 \pm 482$ & 30 & 10 \\
TDS $(\mathrm{mg} / \mathrm{l})$ & $3941 \mathrm{a} \pm 3703$ & $3300 \mathrm{a} \pm 1714$ & $2653 \mathrm{a} \pm 1240$ & 532.7 & $444 \pm 507$ & 250 & 500 \\
\hline
\end{tabular}

The values given in the table above are means of 6 replicate values, $\mathrm{n}=6$ ( 1 sample was taken monthly for 6 months). Within the rows, means with different alphabets are statistically different $(p<0.05)$. WHO: World Health Organisation. NESREA: National Environmental Standard and Regulatory Enforcement Agency. a = Mohammed et al.(2017), b = Baba et al. (2020), c = WHO (2006), $d=$ NESSRA (2009) 
BAJOPAS Volume 13 Number 2, December, 2020

Identification, Biochemical Characterization and growth rates of the Bacterial Isolates

Results of identification and biochemical characterization of the bacterial isolates were shown in table 2. After 24 hours of incubation, the nutrient agar media plates were checked for bacterial growth. The results showed the presence of different strains in the samples. The TAN1 bacteria isolate was found to be gramnegative cocci while TAN3 was gram-positive cocci. TAN2 bacteria isolate was found to be gram-positive, rod-shaped. TAN1, TAN2, and TAN3 bacteria isolates recorded positive results for spore former.

The results of the biochemical tests indicated that all the bacteria were positive for catalase, oxidase, citrate, maltose, glucose, lactose (negative in TAN1), mannitol (negative in TAN2), starch hydrolysis and coagulase (negative in TAN2) tests. The bacteria showed negative results for nitrate reduction, $M R$ (positive in TAN2), VP (positive in TAN1), Indole (positive in TAN2) tests. Base on the morphological and biochemical test results, TAN1, TAN2, and TAN3 bacteria isolates were identified to be Nesseria spp, Bacillus cereus, and Staphylococcus aureus respectively.

The growth rate of the TAN1, TAN2 and TAN3 Isolates were shown in figure 2. Generally, the optical density increase with the increase in time (day) and decrease as time goes on. The highest optical density was shown by bacillus cereus in TAN2 while the lowest was shown by Staphylococcus aureus in TAN3.

The initial growth phase of TAN1 Isolate bacteria occurred within 2-day of incubation as the growth rate increases up to the 6th-day incubation when the maximum growth was observed. Beyond the 6th day, the growth of the bacteria declined (which might be due to a shortage of nutrients in the effluents) until it reached its death phase (which might be due to the unavailability of nutrients in the effluents).

A similar trend of growth was also observed for TAN2 Isolate as the initial growth phase also occurred within 2-day of incubation but maximum growth rate observed on the 4th day of incubation. The stationary stage occurred between the 4th day and the 8th day. Beyond the 8th day, the growth of the bacteria declined (which might be due to a shortage of nutrients in the effluents) until it reached its death phase (which might be due to the unavailability of nutrients in the effluents).

The initial growth phase of TAN3 bacterial Isolate occurred within the 3-day incubation as the growth rate increases up to the 6th-day incubation when the maximum growth was observed. Beyond the 6th day, the growth of the bacteria declined (which might be due to a shortage of nutrients in the effluents) until it reached its death phase (which might be due to the unavailability of nutrients in the effluents).

Table 2: Morphological and Biochemical characteristics of bacterial isolates

\begin{tabular}{lllll} 
Bacterial Isolates & & TAN1 & TAN2 & TAN3 \\
\hline $\begin{array}{lllll}\text { Morphological } \\
\text { characteristics }\end{array}$ & Shape & Cocci & Rod & Cocci \\
& Spore & & & \\
& former & + & + & + \\
Gram & & & \\
Biochemical characteristics & reaction & - & + & + \\
& Citrate & + & + & + \\
& Catalase & + & + & + \\
& Coagulase & + & - & + \\
Starch & + & + & + \\
& Glucose & + & + & + \\
Oxidase & + & + & + \\
& Indo & - & + & - \\
Lactose & - & + & + \\
Manitol & + & - & + \\
Maltose & + & + & + \\
MR & - & + & - \\
VP & + & - & - \\
& Nitrate & - & - & - \\
Reduction & - Neisseria & Bacillus & Staphylococcus \\
& Bacterial & cereus & aureus \\
& name & spp & cas
\end{tabular}

+ = Positive; - = Negative; MR=Methyl Red; VP= Voges-Proskauer 


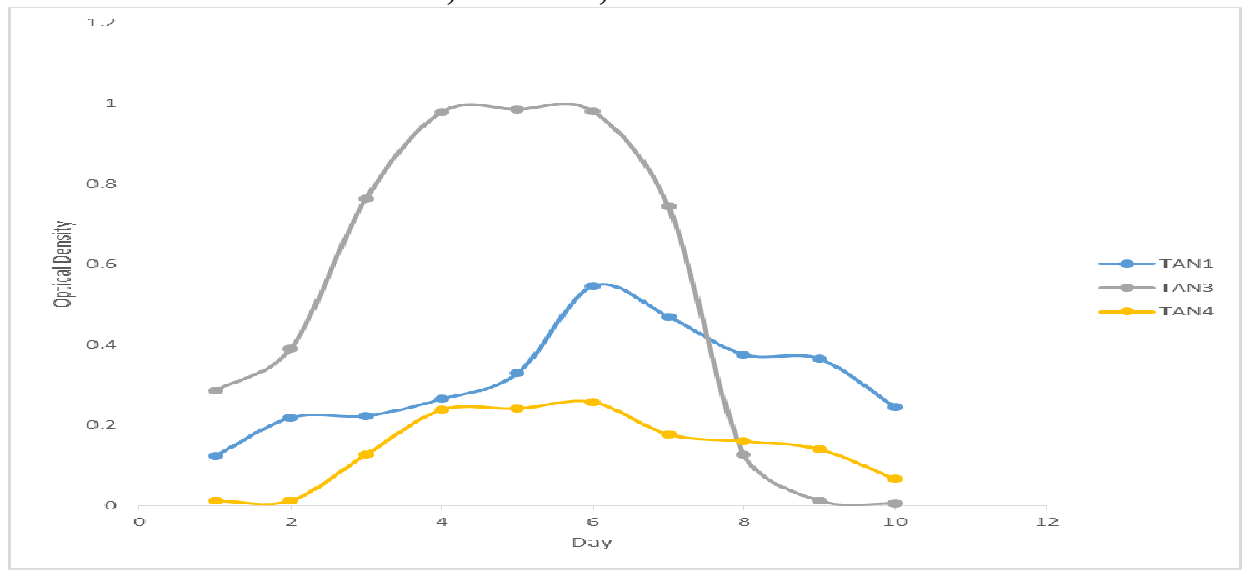

Fig. 2 Growth rates of the isolates in the effluents from the Tannery Industries

\section{Physico-chemical Parameters in the Industrial Effluents after the biodegradation.}

Table 3 shows the mean results of the physicochemical parameter before and after bioremediation using the different masses $(5 \mathrm{~g}$, $10 \mathrm{~g}, 15 \mathrm{~g}, 20 \mathrm{~g}$, and $25 \mathrm{~g}$ ) of the respective immobilized bacteria. Also, Table 4 shows the mean results of correlation coefficient ( $r$ ) between different masses of bacteria and physicochemical parameters.

The mean values $(\mathrm{mg} / \mathrm{l})$ of the SS after the bioremediation varies between $243 \pm 45$ and $898 \pm 672$. The mean concentration $(\mathrm{mg} / \mathrm{l})$ of SS remediated by the different masses $(5 \mathrm{~g}, 10 \mathrm{~g}$, $15 \mathrm{~g}, 20 \mathrm{~g}$, and $25 \mathrm{~g}$ ) of the bacteria varies. The SS in the samples fluctuates up and down after the bioremediation process when compared with the SS of the raw samples before the bioremediation. The increase in the levels of the SS might be due to the aggregation of the TDS which are large enough to result into SS. The increase in the levels of the SS might be also due to the influence of the nutrients which was added into the effluents in order to make the microorganisms more active and viable for fast degradation of organic contaminants in the effluent. The relative potential or efficiency of the different masses of the bacteria in remediating SS in TAN1 samples was in the order $25 \mathrm{~g}>20 \mathrm{~g}>15 \mathrm{~g}>10 \mathrm{~g}>5 \mathrm{~g}$. For TAN2 and TAN3 samples, the order was $25 \mathrm{~g}>20 \mathrm{~g}>15$ $\mathrm{g}>10 \mathrm{~g}>5 \mathrm{~g}$. These might be due to the variations in the surface areas of the different masses of the immobilized bacteria. Statistical analysis shows that there is no significant difference $(p<0.05)$ between the mean values of SS among the masses in the respective industries. Positive and significant correlations exist between the masses of bacteria and Suspended Solid (SS). This showed that there is general increase in the levels of the SS as the masses of the immobilized bacteria increases. TAN3 (90\%) and TAN1 (80\%) showed a very high correlation with the masses of the bacteria while TAN2 (61\%) showed a very low correlation.

The mean values $(\mathrm{mg} / \mathrm{l})$ of the TDS after the bioremediation varies between $46 \pm 11$ and $83 \pm 78$. The mean concentration $(\mathrm{mg} / \mathrm{l})$ of TDS remediated by the different masses $(5 \mathrm{~g}, 10 \mathrm{~g}$, $15 \mathrm{~g}, 20 \mathrm{~g}$, and $25 \mathrm{~g}$ ) of the bacteria varies. There is a reduction in all the TDS of all the samples after the bioremediation process compared with the TDS of the raw samples before the bioremediation. The relative potential or efficiency of the different masses of the bacteria in remediating TDS in TAN1 and TAN3 samples was in the order $5 \mathrm{~g}>10 \mathrm{~g}>15 \mathrm{~g}>20$ $\mathrm{g}>25 \mathrm{~g}$. For TAN2 samples, the order was 20 $g>10 \quad g>25 \quad g>15 \quad g>5 \quad g$. Statistical analysis shows that there is no significant difference $(p<0.05)$ between the mean values of TDS among the masses in the respective industries. These might be due to the variations in the surface areas of the different masses of the immobilized bacteria. Positive and significant correlations exist between the masses of bacteria and TDS with the exception in TAN2 (negative and insignificant correlation). The positive correlations showed that there is general increase in the levels of the TDS as the masses of the immobilized bacteria increases. TAN1 $(96 \%)$ showed a very high correlation with the masses of the bacteria while TAN2 (47\%) showed a very low correlation.

The mean values $(\mathrm{mg} / \mathrm{l})$ of the BOD after the bioremediation varies between $1.56 \pm 0.20 \mathrm{mg} / \mathrm{l}$ and $6.92 \pm 5.49 \mathrm{mg} / \mathrm{l}$. The mean concentration $(\mathrm{mg} / \mathrm{l})$ of BOD remediated by the different masses $(5 \mathrm{~g}, 10 \mathrm{~g}, 15 \mathrm{~g}, 20 \mathrm{~g}$, and $25 \mathrm{~g}$ ) of the bacteria varies. There is a reduction in all the BOD of all the samples after the bioremediation process compared with the $\mathrm{BOD}$ of the raw 
BAJOPAS Volume 13 Number 2, December, 2020 samples before the bioremediation. The relative potential or efficiency of the different masses of the bacteria in remediating BOD in TAN1, TAN2 and TAN3 samples were in the order $25 \mathrm{~g}>20$ $\mathrm{g}>15 \mathrm{~g}>10 \mathrm{~g}>5 \mathrm{~g}, 25 \mathrm{~g}>15 \mathrm{~g}>5 \mathrm{~g}>10 \mathrm{~g}>20 \mathrm{~g}$ and $20 \mathrm{~g}>10 \mathrm{~g}>25 \mathrm{~g}>15 \mathrm{~g}>5 \mathrm{~g}$ respectively. Statistical analysis shows that there is significant difference $(p<0.05)$ between the mean values of BOD among the masses in the respective industries. These might be due to the variations in the surface areas of the different masses of the immobilized bacteria. Negative and significant correlations exist between the masses of bacteria and BOD. This showed that there is general decrease in the levels of the BOD as the masses of the immobilized bacteria increases. TAN1 (94\%) showed a very high correlation with the masses of the bacteria while TAN2 (4\%) showed a very low correlation.

The mean values $(\mathrm{mg} / \mathrm{l})$ of the COD after the bioremediation varies between $250 \pm 154$ and $3134 \pm 1595$. The mean concentration $(\mathrm{mg} / \mathrm{l})$ of COD remediated by the different masses $(5 \mathrm{~g}$, $10 \mathrm{~g}, 15 \mathrm{~g} 20 \mathrm{~g}$, and $25 \mathrm{~g}$ ) of the bacteria varies. There is a reduction in all the COD of all the samples after the bioremediation process compared with the COD of the raw samples before the bioremediation. The relative potential or efficiency of the different masses of the bacteria in remediating COD in TAN1, TAN2 and TAN3 samples were in the order $25 \mathrm{~g}>20 \mathrm{~g}>15$ $\mathrm{g}>5 \mathrm{~g}>10 \mathrm{~g}, 25 \mathrm{~g}>20 \mathrm{~g}>15 \mathrm{~g}>10 \mathrm{~g}>5 \mathrm{~g}$ and 10 g>5 g>25 g>15 g>20 g respectively. Statistical analysis shows that there were significant difference $(p<0.05)$ between the mean values of COD among the masses in the respective industries except for effluents treated with $25 \mathrm{~g}$. These might be due to the variations in the surface areas of the different masses of the immobilized bacteria. Negative and insignificant correlations exist between the masses of bacteria and COD with the exception in TAN3 (positive and significant correlation). The negative correlations showed that there is general decrease in the levels of the COD as the masses of the immobilized bacteria increases. TAN2 (100\%) showed a very high correlation with the masses of the bacteria while TAN3 (36\%) showed a very low correlation.

Generally, there was an overall decrease in the concentration of these physicochemical parameters after the bioremediation using the different masses of the bacterial isolates. These might be due to the variations in the surface areas of the different masses of the immobilized bacteria. This is in line with the work of Jimoh et al. (2018) and Baba et al. (2020).

Table 3: Mean Values $(\mathrm{mg} / \mathrm{l}) \pm$ S.D of Physicochemical parameters in effluents from the Tannery Industries before and after Treatment of the effluents $(250 \mathrm{ml})$ with the different masses $(5 \mathrm{~g}, 10 \mathrm{~g}$, $15 \mathrm{~g}, 20 \mathrm{~g}$, and $25 \mathrm{~g}$ ) of the bacteria.

\begin{tabular}{llllllll}
\hline $\mathrm{P}$ & IND & Before & \multicolumn{5}{c}{ After } \\
\cline { 4 - 7 } & & & $5 \mathrm{~g}$ & $10 \mathrm{~g}$ & $15 \mathrm{~g}$ & $20 \mathrm{~g}$ & $25 \mathrm{~g}$ \\
\hline \multirow{2}{*}{ COD } & TAN1 & $2372 \pm 938$ & $1708 \mathrm{a} \pm 861$ & $2045 \mathrm{a} \pm 1205$ & $845 \mathrm{a} \pm 369$ & $300 \mathrm{a} \pm 167$ & $250 \mathrm{a} \pm 154$ \\
& TAN2 & $1406 \pm 208$ & $1195 \mathrm{a} \pm 208$ & $1125 \mathrm{a} \pm 384$ & $1055 \mathrm{a} \pm 317$ & $956 \mathrm{a} \pm 310$ & $870 \mathrm{ab} \pm 240$ \\
& TAN3 & $3532 \pm 1373$ & $2374 \mathrm{a} \pm 1344$ & $1976 \mathrm{a} \pm 1405$ & $2757 \mathrm{a} \pm 1266$ & $3134 \mathrm{a} \pm 1595$ & $2614 \mathrm{~b} \pm 1105$ \\
BOD & TAN1 & $13.85 \pm 6.42$ & $6.92 \mathrm{a} \pm 5.49$ & $6.42 \mathrm{a} \pm 5.07$ & $5.72 \mathrm{a} \pm 5.35$ & $4.62 \mathrm{a} \pm 4.37$ & $2.82 \mathrm{ab} \pm 1.26$ \\
& TAN2 & $19.46 \pm 0.50$ & $1.75 \mathrm{~b} \pm 0.22$ & $1.73 \mathrm{~b} \pm 0.18$ & $1.58 \mathrm{a} \pm 0.16$ & $1.91 \mathrm{a} \pm 0.22$ & $1.56 \mathrm{~b} \pm 0.20$ \\
& TAN3 & $17.13 \pm 3.14$ & $4.24 \mathrm{ab} \pm 0.77$ & $3.29 \mathrm{ab} \pm 0.37$ & $4.11 \mathrm{a} \pm 0.07$ & $3.23 \mathrm{a} \pm 0.91$ & $3.33 \mathrm{a} \pm 1.28$ \\
SS & TAN1 & $374 \pm 124$ & $243 \mathrm{a} \pm 45$ & $471 \mathrm{a} \pm 226$ & $475 \mathrm{a} \pm 182$ & $492 \mathrm{a} \pm 128$ & $611 \mathrm{a} \pm 217$ \\
& TAN2 & $358 \pm 335$ & $460 \mathrm{a} \pm 400$ & $543 \mathrm{a} \pm 414$ & $544 \mathrm{a} \pm 402$ & $551 \mathrm{a} \pm 414$ & $554 \mathrm{a} \pm 405$ \\
& TAN3 & $780 \pm 739$ & $586 \mathrm{a} \pm 594$ & $758 \mathrm{a} \pm 656$ & $787 \mathrm{a} \pm 676$ & $861 \mathrm{a} \pm 635$ & $898 \mathrm{a} \pm 672$ \\
TDS & TAN1 & $3941 \pm 3703$ & $51 \mathrm{a} \pm 10$ & $53 \mathrm{a} \pm 10$ & $55 \mathrm{a} \pm 15$ & $61 \mathrm{a} \pm 20$ & $63 \mathrm{a} \pm 26$ \\
& TAN2 & $3300 \pm 1714$ & $83 \mathrm{a} \pm 78$ & $47 \mathrm{a} \pm 20$ & $48 \mathrm{a} \pm 22$ & $47 \mathrm{a} \pm 17$ & $48 \mathrm{a} \pm 17$ \\
& TAN3 & $2653 \pm 1240$ & $46 \mathrm{a} \pm 11$ & $55 \mathrm{a} \pm 24$ & $55 \mathrm{a} \pm 25$ & $58 \mathrm{a} \pm 23$ & $61 \mathrm{a} \pm 28$ \\
\hline
\end{tabular}

Replicate $=6$ (months)

Within the rows, for the same parameter, means with different alphabets are statistically different $(p<0.05)$.

$\mathrm{P}=$ parameter, IND = Industries 
BAJOPAS Volume 13 Number 2, December, 2020

Table 4: Correlation coefficient $(r)$ between different masses of the bacteria and the physicochemical parameters.

\begin{tabular}{llll}
\hline Industries & Parameter & Correlation coefficient $(r)$ & $\begin{array}{l}\text { Percent dependence (rxrx100) } \\
(\%)\end{array}$ \\
\hline TAN1 & COD & -0.9 & 82 \\
& BOD & -0.97 & 94 \\
& SS & $0.90^{*}$ & 80 \\
TAN2 & TDS & $0.98^{*}$ & 96 \\
& COD & -1 & 100 \\
& BOD & -0.21 & 4 \\
& SS & $0.78^{*}$ & 61 \\
& TDS & -0.69 & 47 \\
& COD & $0.60^{*}$ & 36 \\
& BOD & -0.6 & 37 \\
& SS & $0.95^{*}$ & 90 \\
& TDS & $0.94^{*}$ & 89 \\
\hline
\end{tabular}

The correlation coefficient $(r)$ with * is statistically significant $(p<0.05)$.

Percentage reduction of the Parameters

Table 5 shows the percentage reduction of Parameters in industrial samples before and after the treatment of the effluents $(250 \mathrm{ml})$ with the different masses $(5 \mathrm{~g}, 10 \mathrm{~g}, 15 \mathrm{~g}, 20 \mathrm{~g}$, and $25 \mathrm{~g}$ ) of the Immobilized Bacteria.

In TAN1 samples, the percentage reduction (\%) of COD ranged (14-89); BOD (50-80); SS (-32$35)$ and TDS (98-99). In TAN2 samples, the percentage decrease $(\%)$ of COD ranged (15$38) ;$ BOD (90-92); SS [-28-(-55)] and TDS (9798). In TAN3 samples, the percentage decrease (\%) of COD ranged (11-44); BOD (76-81); SS (15-25) and TDS (98). The percentage increase in the levels COD, BOD and TDS might be due to the increase in the surface area of the different masses of the immobilized bacteria. However, the percentage decrease in the levels of the SS might be due to the aggregation of the TDS which are large enough to result into SS. The percentage decrease in the levels of the SS might be also due to the influence of the nutrients which was added into the effluents in order to make the microorganisms more active and viable for fast degradation of organic contaminants in the effluent. This is in line with the work of Jimoh et al. (2018) in which the concentration of the SS increase after the bioremediation of effluents.

Sreemoyee and Priti (2013) assessed and reduced several Physico-chemical parameters of dairy wastewater using Niesseria $s p$. and concluded that the species are well known to degrade organic compounds. This is in agreement with the current study in which the immobilized Niesseria $s p$ degrade the organic contaminants as indicated by the BOD, COD and TDS.

Jimoh et al. (2018) observed that TSS of the effluents was increased after treatment with immobilized bacteria and concluded that it might be due to the biostimulation method adopted for the research.

The optimum $\mathrm{pH}$ Biosorption of Chromium by Bacillus spp and Staphylococcus spp. from tannery effluent was investigated by Mythili and Karthikeyan (2011). The maximum adsorption of Chromium $(86.4 \mathrm{mg} / \mathrm{L})$ was showed by Bacillus spp and Staphylococcus spp showed $70.6 \mathrm{mg} / \mathrm{L}$ at an initial concentration of $100 \mathrm{mg} / \mathrm{L}$. In the present study, immobilised Bacillus spp and Staphylococcus spp. from the tannery industrial effluents reduced the levels of the organic pollutants with high potential as indicated by the percentage reduction of BOD, COD and TDS.

Enzymes often can work in multiple environments especially if they are immobilized. This makes the microorganisms' enzymes even more resistant to harsh environments and enables the enzymes to be recovered and recycled after they are no longer needed (Gianfreda and Rao 2004). Ramesh and Singh (1993) reported that the immobilized bacteria having more efficiency to remove the suspended particles than free cells. Using the immobilized cell is preferable due to its capability for using several times with the same efficiency, which makes it more economical. Similar work was done by Sikander et al. (2007) showing the higher reduction with permeabilized cells of Ochrobactrum intermedium strain SDCr-5. 
BAJOPAS Volume 13 Number 2, December, 2020

The results revealed the isolation and identification of isolates with the potential for the reduction of $\mathrm{Cr}$ (VI) to $\mathrm{Cr}$ (III). Results indicated that immobilized $B$. cereus could be efficiently used for the reduction of $\mathrm{Cr}$ (VI).

Table 5: Percentage reduction of the tested Parameters from the tannery industrial samples of the Immobilized Bacteria.

\begin{tabular}{lllllll}
\hline \multirow{2}{*}{ Industries } & & \multicolumn{5}{c}{ Percentage Reduction $(\%)$} \\
\cline { 3 - 7 } & & $5 \mathrm{~g}$ & $10 \mathrm{~g}$ & $15 \mathrm{~g}$ & $20 \mathrm{~g}$ & $25 \mathrm{~g}$ \\
\hline TAN1 & COD & 28 & 14 & 64 & 87 & 89 \\
& BOD & 50 & 54 & 59 & 67 & 80 \\
& SS & 35 & -26 & -27 & -32 & -63 \\
& TDS & 99 & 99 & 99 & 98 & 98 \\
TAN2 & COD & 15 & 20 & 25 & 32 & 38 \\
& BOD & 91 & 91 & 92 & 90 & 92 \\
& SS & -28 & -52 & -52 & -54 & -55 \\
& TDS & 97 & 99 & 99 & 99 & 99 \\
& COD & 33 & 44 & 22 & 11 & 26 \\
& BOD & 75 & 81 & 76 & 81 & 81 \\
& SS & 25 & 3 & -1 & -10 & -15 \\
& TDS & 98 & 98 & 98 & 98 & 98 \\
\hline
\end{tabular}

Percentage Reduction $=(B-A) / B \times 100 \%$

$A=$ Concentration of the parameter after treatment

$\mathrm{B}=$ Concentration of the parameter before treatment

$+=$ percentage decrease

- = percentage increase

In general, immobilization makes the enzyme more resistant to temperature, $\mathrm{pH}$, and substrate concentration swings giving it a longer lifetime and higher productivity per active unit (Gianfreda and Rao, 2004; FuIlbrook, 1996; Russell et al, 2003; Kandelbauer et al., 2004). Immobilized cells have been used and studied extensively for the production of useful chemicals (Ohtake and Silver, 1994), the treatment of wastewaters (Chen et al., 2003; Wang et al., 2010). Although many workers described microbial degradation of tannery effluent, limited literature is available on the bioremediation of tannery effluent using immobilized bacterial cells in the Kano Industrial Estates.

\section{CONCLUSION}

The samples contained variable levels of the physicochemical parameters. The results of the Analysis of variance revealed that, no statistical difference $(p<0.05)$ was observed for the temperature, $\mathrm{pH}, \mathrm{SS}, \mathrm{TDS}, \mathrm{BOD}$ and $\mathrm{COD}$ among the three tannery industries before the treatment. The levels of some of the parameters
(SS, TDS and COD) observed in the samples were found above the recommended limits of WHO and NESREA, which called for the treatment of the effluents before discharge into the environment. Base on the morphological and biochemical test results, TAN1, TAN2, and TAN3 bacterial isolates were identified to be Neisseria spp, Bacillus cereus, and Staphylococcus aureus respectively. The results of Post-treatment analysis showed that there is overall decrease in the levels of the parameters determined when compared with that of the pre-treatment. The overall percentage reduction of the immobilised bacteria in the treatment of the respective effluents was in the order TAN2 (72\%)>TAN1 $(70 \%)>$ TAN3 $(62 \%)$. Hence, the immobilized bacteria are having higher biodegradation potential for the treatment of the tannery effluents.

\section{Acknowledgments}

The authors wish to acknowledge the University of Maiduguri for the financial support. The authors are grateful to the Kano State Ministry of Environment for their support in obtaining the effluent samples. 


\section{REFERENCES}

Ajao, A. T., Adebayo, G. B., and Yakubu, S. E. (2011). Bioremediation of textile industrial effluent using mixed culture of Pseudomonas aeruginosa and Bacillus subtilis immobilized on agar-agar in a bioreactor. J. Microbiol. Biotech. Res, 1(3), 50-56.

Akan, J. C., Moses, E. A., Ogugbuaja, V. O., and Abah, J. (2007). Assessment of tannery industrial effluents from Kano metropolis, Kano State, Nigeria. Journal of Applied Sciences, 7(19), 2788-2793.

Akan, J. C., Ogugbuaja, V. O., Abdulrahman, F. I., and Ayodele, J. T. (2009). Pollutant levels in effluent samples from tanneries and textiles of Kano industrial areas, Nigeria. Global journal of pure and applied sciences, 15(3-4).

APHA (1989). Standard methods for Examination of Will bete and Will betewater.15 $5^{\text {th }}$ edition. Brydpass Springfield Will behington DC. pp. 164-176

APHA (1992). Standard Methods for the Examination of Water and Wastewater. Health, 69, 1116-9.

Baba, A., Garba, S. T., and Bello, H. S. (2020). Bioremediation Potential of Immobilized corynebacterium kutsceri in the Treatment of Tannery Industrial Effluent from Challawa Industrial Estate, Kano State, Nigeria. Journal of the Turkish Chemical Society Section A: Chemistry, $7(2), 335-350$.

Beem, E. I. V. (1994). reduction of solvent VOC emission. J. Oil Col. Chem. Ass, 77, 158.

Bouwer, E. J., and Zehnder, A. J. (1993). Bioremediation of organic compoundsputting microbial metabolism to work. Trends in biotechnology, 11(8), 360367.

Chen, K. C., Wu, J. Y., Liou, D. J., and Hwang, S. C. J. (2003). Decolorization of the textile dyes by newly isolated bacterial strains. Journal of Biotechnology, 101(1), 57-68.

Dan'Azumi, S., and Bichi, M. H. (2010). INDUSTRIAL POLLUTION AND HEAVY METALS PROFILE OF CHALLAWA RIVER IN KANO, NIGERIA. Journal of Applied Sciences in Environmental Sanitation, $5(1)$.

DWAF. (1992). Analytical Methods Manual, TR 151. Department of Water Affairs and Forestry, Pretoria.

El-Bestawy, E. (2013). Biological treatment of leather-tanning industrial wastewater using free living bacteria.
Elsheikh, M. A. S. (2009). Tannery wastewater pre-treatment. Water Science and Technology, 60(2), 433-440.

FuIlbrook, P. D. (1996). "Kinetics." Industrial enzymology: The application of enzymes in Industry. 2nd Ed. T. Godfrey and J Reichelt. eds.. Nature. New York.

Gianfreda, L., and Rao, M. A. (2004). Potential of extra cellular enzymes in remediation of polluted soils: a review. Enzyme and microbial technology, 35(4), 339354.

Hugo Springer. (1994). John Arthur Wilson Memorial Lecture "Treatment of Industrial Wastes of the Leather Industry - is it still a Major Problem". JALCA, 89, 153-185

Jimoh, A. A., Ganiyu, B. A., Baba, D., and Baba, A. (2018) Bioremediation Process of Effluent from Detergent and Food Industries in Jos, Nigeria: Kinetics and Thermodynamics. International Journal of Engineering Science Invention (IJESI), 762-73

Kandelbauer, A., Maute, O., Kessler, R. W., Erlacher, A., and Gübitz, G. M. (2004). Study of dye decolorization in an immobilized laccase enzyme-reactor using online spectroscopy. Biotechnology and bioengineering, 87(4), 552-563.

Kongjao, S., Damronglerd, S., and Hunsom, M. (2008). Simultaneous removal of organic and inorganic Pollutants in tannery wastewater using electrocoagulation technique. Korean Journal of chemical engineering, 25(4), 703.

Maheshwari, U. M., Aruna, S., Gomathi, M., and AbdulJaffar, A. H. (2017). Bioremediation by Free and Immobilized Bacteria Isolated from Tannery Effluent. International Journal of Research in Applied, Natural and Social Sciences. 5(7), 75-90

Margesin, R., and Schinner, F. (2001). Bioremediation (natural attenuation and biostimulation) of diesel-oilcontaminated soil in an alpine glacier skiing area. Applied and environmental microbiology, 677), 3127-3133.

Mohammed, A., Sekar, P., and George, J. (2011). Efficacy of microbes in bioremediation of tannery effluent. Inter. J. Curr. Res, 3(4), 324-326.

Mohammed, S. S. D., Orukotan, A. A., and Abdullahi, H. (2017). Physicochemical and Bacteriological Assessment of Tannery Effluent from Samaru-Zaria, 
BAJOPAS Volume 13 Number 2, December, 2020 Kaduna State, Nigeria. Journal of Applied

Sciences and Environmental Management, 21(4), 734-740.

Munz, G., De Angelis, D., Gori, R., Mori, G., Casarci, M., and Lubello, C. (2009). The role of tannins in conventional and membrane treatment of tannery wastewater. Journal of hazardous materials, 164(2-3), 733-739

Mythili, K., and Karthikeyan, B. (2011). Bioremediation of $\mathrm{Cr}$ (VI) from tannery effluent using Bacillus spp and Staphylococcus spp. International Multidisciplinary Research Journal, 1(6).

NESREA (2009). National Environmental Standards for Effluent Limitations and Regulation. 1233-1236

Noorjahan, C. M. (2014). Physicochemical characteristics, identification of bacteria and biodegradation of industrial effluent. Journal of bioremediation and Biodegradation, 5(3).

Ohtake, H. I., and Silver, A. O. (1994). Bacterial reduction of toxic chromate. Biological degradation and bioremediation of toxic chemicals, 403-415.

Omoleke, I. I. (2004). Management of environmental pollution in Ibadan, an African city: the challenges of health hazard facing government and the people. Journal of Human Ecology, 15(4), 265-275.

Rajor, A., Reddy, A.S., and Singh, B. (2004). Determination of BOD kinetic Parameters and evaluation of alternate methods, M.Sc. Thesis, Department of biotechnology \& environmental Science, Thapar Institute of Engineering and Technology, Patiala

Ramasami, T., Rajamani, S., and Rao, J. R. (1994, March). Pollution control in leather industry: Emerging technological options. In International symposium on surface and colloidal science and its relevance to soil pollution, madras.

Ramesh, J. V. S., and Singh, S. P. (1993). Yearly variation in certain physicochemical parameters of pond at eastern Doon Valley. Uttar Pradesh J. Zoo, 12 (1), 7577.

Ranen, S., and Sharadinadra, C. (2009). Biotechnology applications to environmental remediation in resource exploitation. Current science, 97, 6-25
Russell, A. J., Berberich, J. A., Drevon, G. F., and Koepsel, R. R. (2003). Biomaterials for mediation of

chemical and biological warfare agents. Annual review of biomedical engineering, 5(1), 1-27.

Saravanan, P., and Saravanan, A. (1999). Decolourization of tannery effluent by Flavobacterium sp. EK 1. Indian Journal of Environmental Protection, 19, 19-24.

Sikander, S., and Shahida, H. (2007). Reduction of toxic hexavalent chromium by Ochrobactrum intermedium strain SDCr5 stimulated by heavy metals. Bioresource Technol, 98, 340-344.

Singh, N., Sharma, B. K., and Bohra, P. C. (2000). Impact assessment of industrial effluent of arid soils by using satellite imageries. Journal of the Indian Society of Remote Sensing, 28(2-3), 79.

Sreemoyee, C., and Priti, P. (2013). Assessment of physico-chemical parameters of dairy waste water and isolation and characterization of bacterial strains in terms of cod reduction. Int J Sci, 2(3), 395-400.

Verheijen, L. A. H. M., Wiersema, D., Pol, L. H., and De Wit, J. (1996). Management of wastes from animal product processing. Livestock and environment, Finding a balance. International Agriculture Center, Wageningen, The Netherlands.

Wang, F., Yao, J., Si, Y., Chen, H., Russel, M., Chen, K., and Bramanti, E. (2010). Short-time effect of heavy metals upon microbial community activity. Journal of Hazardous Materials, 173(13), 510-516.

WHO (World Health Organization). (2006). Air quality guidelines: global update 2005: particulate matter, ozone, nitrogen dioxide, and sulfur dioxide. World Health Organization.

World Bank. (1995). Nigeria's strategic options for redressing industrial pollution. World Bank, industry and energy division. 1st edition, West Central Africa Department; Annexes: 1995; pp 60-62.

Zahoor, A., and Abdul, R. (2009). Enumeration of Coliforms. Journal of Environmental Sciences. 21, 814-820 


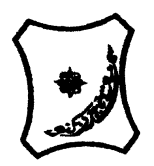

Bayero Journal of Pure and Applied Sciences, 13(2): 1 - 12

Received: November, 2020

Accepted: December, 2020

ISSN $2006-6996$

\title{
BIODEGRADATION POTENTIAL OF IMMOBILIZED BACTERIA IN THE TREATMENT OF TANNERY INDUSTRIAL EFFLUENTS FROM INDUSTRIAL ESTATES IN KANO STATE, NIGERIA
}

\author{
Abdullateef, B., ${ }^{1 *}$ Shuaibu, T. G., ${ }^{1}$ Babagana, K., ${ }^{1}$ Suleman, H. B. ${ }^{2}$ and Dauda, B. ${ }^{3}$ \\ ${ }^{1}$ Department of Pure and Applied Chemistry, Faculty of Science, University of Maiduguri, Borno State, \\ Nigeria \\ ${ }^{2}$ Department of Microbiology, Faculty of Science, University of Maiduguri, Borno State, Nigeria \\ ${ }^{3}$ Department of Chemical Engineering, Faculty of Engineering, University of Maiduguri, Borno State, \\ Nigeria \\ *Corresponding author: babslega@gmail.com; abelega2007@yahoo.com; +2348061309753
}

\section{ABSTRACT}

Industrial Effluents Samples from Gashash Tanneries (TAN1) in Bompai Industrial estate, Larabee Tannery Industry (TAN2) in Sharada Industrial estate and Z Tannery Industries (TAN3) in Challawa Industrial estate, Kano State, Nigeria were collected over a period of six months (August 2017 to January 2018) for assessing the biodegradation potentials of bacteria in the treatment of organic pollutants within the effluents. Bacteria were isolated from the effluents and immobilized on agar-agar. Different masses (5 g, $10 \mathrm{gr}, 15$ $\mathrm{g}, 20 \mathrm{~g}$, and $25 \mathrm{~g}$ ) of the bacteria were used in the treatment of $250 \mathrm{ml}$ of the effluents for ten days in a shaker incubator (Gallenkamp-OC-4364-L) at the temperature $30{ }^{\circ} \mathrm{C}$ and speed of $60 \mathrm{rpm}$. Pre-treatment analysis of the effluents for Temperature, pH, Biochemical Oxygen Demand (BOD), Chemical Oxygen Demand (COD), Suspended Solid (SS) and Total Dissolved Solids (TDS) gives the following results; temperature $\left({ }^{\circ} \mathrm{C}\right.$ )

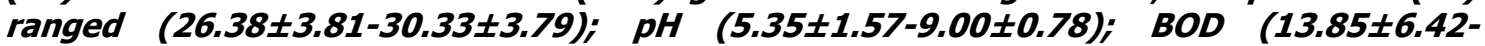
$38.75 \pm 16.20) ;$ COD (1406 $\pm 208-3532 \pm 1373) ;$ SS (208 $\pm 235-780 \pm 739)$ and TDS (266 $\pm 253-5276 \pm 2971)$. No statistical differences ( $p \leq 0.05)$ was observed for all the results among the different industries. The bacterial isolates were identified as Neisseria spp, Bacillus cereus, and Staphylococcus aureus, in TAN1, TAN2, and TAN3, respectively. After treatment of the effluent with the different masses of the isolated bacteria, the mean level of BOD was found to range as (0.55 $\pm 0.36-6.92 \pm 5.49) ; C O D$ (ND-3134 \pm 1595$)$;

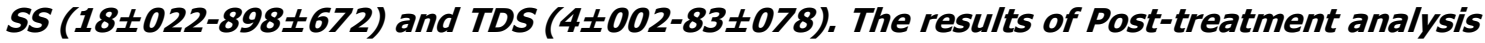
showed that there is overall decrease in the levels of the parameters determined when compared with that of the pre-treatment. The overall percentage reduction of the immobilised bacteria in the treatment of the respective effluents was in the order TAN2 (72\%)>TAN1 (70\%)>TAN3 (62\%). Hence, the immobilized bacteria are having higher biodegradation potential for the treatment of the tannery effluents.

Keywords: Biodegradation, bacteria, effluent, immobilization, tannery.

\section{INTRODUCTION}

Tannery industrial wastewater is a serious consequence of the pollution point of view for streams, freshwater, and land used for agriculture. The lack of awareness in the modern industrial practice has resulted in the discharge of tannery effluents which exhibit very high value of chromium ( $\mathrm{Cr}$ ), Sulfide, and chloride, Total Dissolved Solid (TDS), Total Suspended Solid (TSS), Biochemical Oxygen Demand (BOD) and Chemical Oxygen Demand (COD) in the water stream or land (Mohammed et al., 2001). Tanning is the process, which One ton of skin generally leads to the production of 20 to $80 \mathrm{~m}^{3}$ of turbid and foul-smelling converts the protein of the rawhide or skin into a stable material, which will not putrefy and is suitable for a wide variety of end applications (Elsheikh, 2009). The highly polluting chromium is the most commonly used tanning material producing leather that is more flexible and pliable than vegetable-tanned leather and does not discolor or lose shape in water as drastically as vegetable-tan (Elsheikh, 2009). Tannery effluent is among the most hazardous industrial pollutants due to its huge organic and inorganic load, which is highly toxic to human life and the environment (Kongjao et al., 2008). wastewater including chromium (100-400 mg/l), sulfide $(200-800 \mathrm{mg} / \mathrm{l})$, high levels of fat and 
BAJOPAS Volume 13 Number 2, December, 2020 other solid wastes, and notable pathogen contamination as well as pesticides added for skin conservation during transport (Elsheikh, 2009). There are more than 6000 tanneries in Nigeria with an annual processing capacity of 700,000 tons of hides and skins (Omoleke, 2004; Singh et al., 2008). It was reported that the total amount of waste produced per animal slaughtered is approximately $35 \%$ of its weight (World Bank, 1995). Also, for every $1000 \mathrm{~kg}$ of carcass weight, a slaughtered beef produces 5.5 $\mathrm{kg}$ of manure (excluding rumen contents or stockyard manure) and $100 \mathrm{~kg}$ of paunch manure (undigested food) (Verheijen et al., 1996). Tanneries generate wastewater in the range of 30-35 $\mathrm{L} \mathrm{kg}^{-1}$ skin/hide processed with variable $\mathrm{pH}$, Biological Oxygen Demand (BOD), Chemical Oxygen Demand (COD), high concentrations of suspended solids (SS), and tannins as well as chromium (Zahoor and Abdul, 2009).

Being heterogeneous and composed of a wide variety of compounds, it is very difficult to select a unique direct method for estimating the biodegradability of organic contents and biokinetic parameters for a wastewater sample (Rajor, 2004). For this purpose, some indirect estimation such as determination of biochemical oxygen demand (BOD) and chemical oxygen demand (COD) are applied as common laboratory investigations [9]. During retanning procedures, synthetic tannins (Syntan), oils and resins are added to form softer leather at varying doses (Munz et al., 2009). One of the refractory groups of chemicals in tannery effluents derives mainly from tannins (Ramasami et al., 2004). Syntans are characterized by complex chemical structures, because they are composed of an extended set of chemicals such as phenol-, naphthalene-, formaldehyde- and melamine-based syntans, and acrylic resins (Beem, 1994). Organic pollutants (proteic and lipidic components) are originated from skins (it is calculated that the raw skin has $30 \%$ loss of organic material during the working cycle) or they are introduced during processes (Hugo Springer, 1994).

Many conventional processes such as oxidation, chemical and biological processes were carried out to treat tanneries wastewater (Ebtesam et al, 2013). Biological processes have received more attention because of their costeffectiveness, lower sludge production and environmental friendliness (Noorjahan, 2014). Naturally occurring micro-organisms degrade the hazardous organic wastes including xenobiotic compounds, such as pesticides, polycyclic aromatic hydrocarbons (PAHs) and polychlorinated biphenyls (PCBs) in due course of time (Ranen and Sharadinadra, 2009). Bioremediation is based on the idea that all organisms remove substances from the environment to carry outgrowth and metabolism (Bouwer and Zehnder, 1993). Bacteria, protista and fungi are found to be very good at degrading complex molecules and incorporating the breakdown products into their metabolism (Bouwer and Zehnder, 1993). The resultant metabolic wastes that they produce are generally safe and somehow recycled into other organisms (Ranen and Sharadinadra, 2009). An acclimatized indigenous population of microorganisms capable of degradation of the compounds of interest must exist at the site for a successful bioremediation mode (Ranen and Sharadinadra, 2009). It has been observed that for a successful bioremediation mode, an acclimatized indigenous population of microorganisms capable of degradation of the compounds of interest must exist at the site under investigation (Ranen and Sharadinadra, 2009). Even though there are numerous physical and chemical methods employed in the disposal of wastes the advantage in using bacterium is that they play a key role in the reduction of COD, BOD, total protein, total tannin and total phenol (Saravanan and Saravanan, 1998)

Baba et al. (2020) studied the bioremediation potential of immobilized corynebacterium kutsceri in the Treatment of tannery industrial effluent from Challawa Industrial Estate, Kano State, Nigeria. The aim of the work is to study the reduction in the level of the contaminants through the process of bioremediation using the isolated bacteria. Immobilized bacteria can withstand various temperatures, $\mathrm{pH}$ and substrate concentrations; consequently, increasing the efficiency and the lifespan of the bacteria. Immobilized bacteria are widely applied in the treatment of wastewater and can be separated and recovered after the treatment with the same efficiency (Baba et al., 2020).

\section{MATERIALS AND METHODS \\ Study Area}

This study was carried out in Bompai, Sharada and Challawa industrial estates in Kano, Figure 1. Kano lies on Latitude $11^{\circ} 30^{\prime} \mathrm{N}$ and $8^{\circ} 30^{\prime} \mathrm{E}$ and Longitude $11^{\circ} 5^{\prime} \mathrm{N}$ and $8^{\circ} 5^{\prime} \mathrm{E}$ in Northern Nigeria. It is one of the developed industrial cities in Nigeria. Tannery activities are the dominating industries and this could be one of the reasons for her high population density (Dan'Azumi and Bichi, 2010). Many researchers have studied biodegradation of tannery effluent using microorganisms. However, limited literature is available on the biodegradation of tannery effluent in Kano industrial estates using 
BAJOPAS Volume 13 Number 2, December, 2020 immobilized bacterial cells. This research work focuses on the potential of the use of the indigenous immobilized bacterial isolates in the treatment of tannery effluents in the industrial estates.

\section{Sample Collection}

Effluents were collected from the Tannery Industries from Bompai, Challawa and Sharada Industrial Estates, Kano, Nigeria. The effluents were collected over a period of six months (August 2017 to January 2018). Samples collected in a sterile 4-liter plastic container with a unique identification number were preserved using an ice-box that was transported to the Microbiology Laboratory, Department of Microbiology, Bayero University of Kano for analysis

\section{Sample Preparation and Sample Analysis}

Immediately after the collection of the effluent, $\mathrm{pH}$, TSS, TDS, COD, BOD levels were determined before treatment (Pre-treatment determination) and ten days after treatment (Post-treatment determination) as described in
APHA (1989) standard methods. $\mathrm{pH}$ was determined using Ecotests $\mathrm{pH}$ meter and TDS was determined using AQUALYTIC TDS Salinometer. BOD was determined as described by the standard method (APHA, 1992). COD and SS were determined using DR/2010 HACH portable data logging spectrophotometer (DWAF, 1992)

\section{Identification and Biochemical} Characterization of the Bacterial Isolates

The bacteria were isolated from the effluents using Serial Dilution according to the method described by APHA (1989). The biochemical tests such as oxidase, catalase, coagulase, indole (from $1 \%$ tryptone broth), citrate (Simmons citrate agar), methyl red/VogesProskauer (MR/VP), nitrate reduction, Starch Hydrolysis, Glucose, Maltose, and Lactose tests were carried out on the bacterial isolates to identify the bacteria through the bacteria biochemical characteristics according to Ajao et al. (2011).

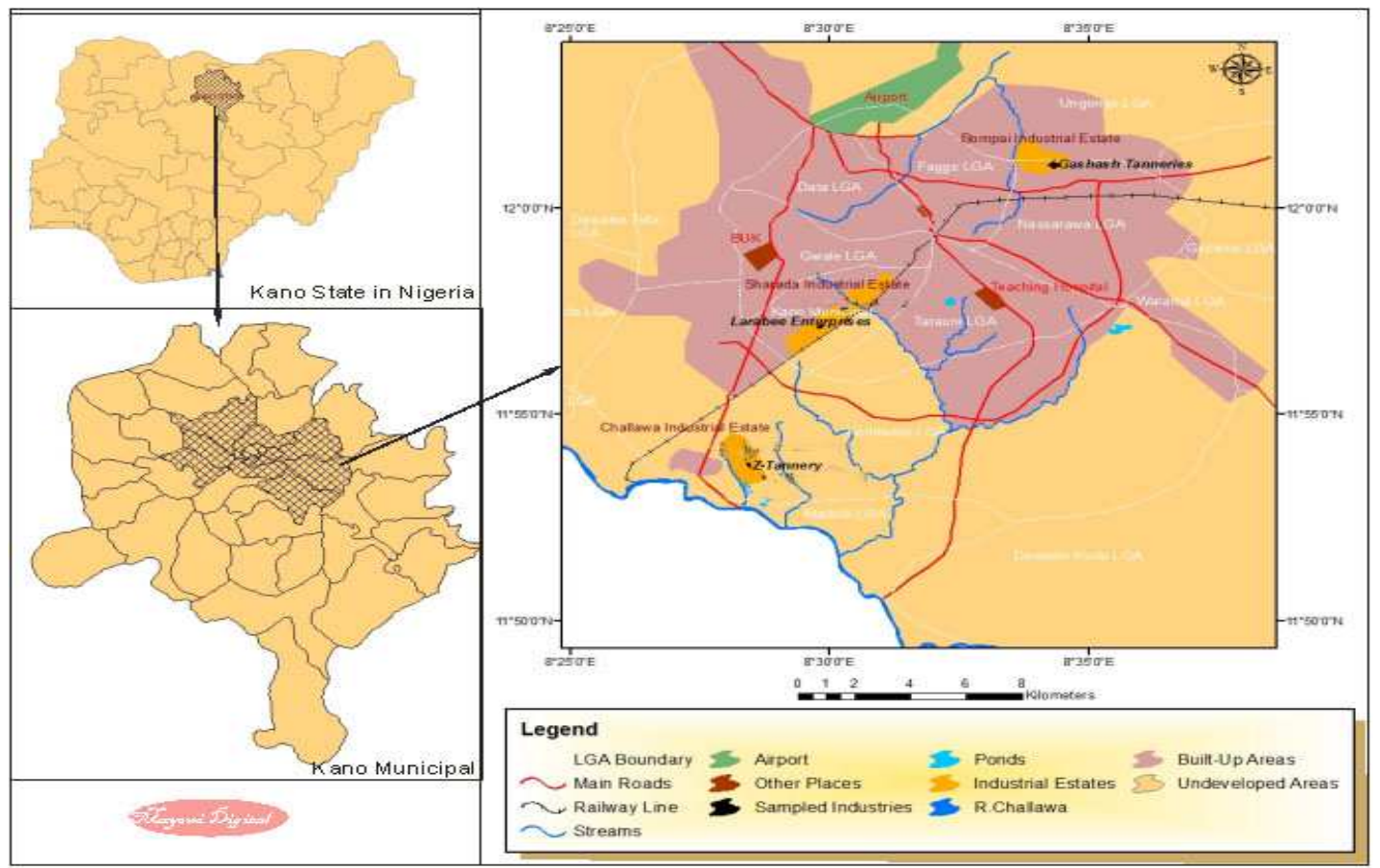

Fig. 1 Map showing the study areas

Source: Mayomi Digital Productions, GIS Laboratory, Department of Geography, UNIMAID (2017)

\section{Determination of Growth Rate of the Bacteria in Effluent Sample}

The bacteria growth rates were determined by transferring $2 \mathrm{~mL}$ of the bacterial isolates from the tannery effluent in broth medium into 100 $\mathrm{mL}$ sterile effluents in conical flasks and kept in an incubator (Giffrin cool) for 10 days. Control was also set up by incubating another $100 \mathrm{~mL}$ each of the sterile effluents without the bacteria. The optical density of the content was determined at the wavelength of $600 \mathrm{~nm}$ on a daily interval and recorded. 
BAJOPAS Volume 13 Number 2, December, 2020 Immobilization of Bacteria

Agar solution and inoculi were prepared separately. Fifty milliliters $(50 \mathrm{~mL})$ of nutrient broth each of the inoculi was prepared in a McCartney bottle and incubated for 24 hours. A solution of agar-agar was prepared by dissolving $10 \mathrm{~g}$ of the powder in distilled water and made up to $500 \mathrm{~mL}$ mark in an Erlenmeyer flask and was sterilized in an autoclave (280A) for 15 minutes and allowed to cool to $40-45^{\circ} \mathrm{C}$ (Ajao et al., 2011). Four milliliters ( $4 \mathrm{~mL})$ of the bacterial isolates in the nutrient broth was mixed with 36 $\mathrm{ml}$ of the prepared agar-agar media in petri-dish plates and then allowed to solidify. This was kept in the refrigerator for bioremediation.

\section{Bioremediation (Treatment) of the Effluents}

The solidified agar block (immobilized bacteria) was cut into cubes using a sterile knife; $0.1 \mathrm{~mL}$ phosphate buffer ( $\mathrm{pH} \mathrm{7.0)}$ was added and kept in the refrigerator for 1 hour for curing. The phosphate buffer was decanted after 1 hour and the cubes were washed with sterile distilled water 3-4 times before it was used (Ajao et al., 2011). Two liters (2 L) of the effluent was supplemented with the minimum basal medium in $\mathrm{g} / \mathrm{L}: \mathrm{NaCl}(0.8), \mathrm{MgSO}_{4} .7 \mathrm{H}_{2} \mathrm{O}(0.001), \mathrm{KH}_{2} \mathrm{PO}_{4}$ (2), $\mathrm{NaNO}_{3}$ (2), $\quad \mathrm{CaCl}_{2} .2 \mathrm{H}_{2} \mathrm{O} \quad(0.5)$ and $\mathrm{NaHPO}_{4} .12 \mathrm{H}_{2} \mathrm{O}(2)$ and sterilized in an autoclave at $121^{\circ} \mathrm{C}$ for 15 minutes (Margesin and Schinner, 2001). Two hundred and fifty milliliters $(250 \mathrm{~mL})$ of the effluents were transferred into different $250 \mathrm{ml}$ conical flasks. The content was covered with a cotton-wool ramped with foil paper to avoid contamination. Five grams $(5 \mathrm{~g})$ of the immobilized bacteria were quickly transferred into each of the effluents in the conical flasks in an inoculating chamber. The same procedures were carried out for the $10 \mathrm{~g}, 15 \mathrm{~g}, 20 \mathrm{~g}$ and 25 $\mathrm{g}$ of the immobilized bacteria in separate $250 \mathrm{~mL}$ effluents in conical flasks and agitated for ten days in a shaker incubator (Gallenkamp-OC4364-L) at a temperature $30^{\circ} \mathrm{C}$ and speed of 60 rpm. The treated effluent samples were taken on the tenth day and analyzed for the parameters $\mathrm{pH}$, SS, TDS, COD, and BOD, (Posttreatment determination) for the different grams of bacteria to evaluate and compare the biodegradation potential. (Baba et al., 2020).

\section{Statistical Analysis}

The data were represented as Mean \pm Standard deviation and analyzed statistically using oneway Analysis of Variance (ANOVA) and Tukey's HSD as Post Hoc Tests with the aid of SPSS 16.0. The correlation coefficient was also used to measure the strength of the relationship between the different masses of the bacteria and the parameters. All $\mathrm{p} \leq 0.05$ were considered as statistically significant.

\section{RESULTS AND DISCUSSION Physico-chemical parameters in the Industrial Effluents before the Biodegradation.}

Results of the Physico-chemical parameters in the industrial effluents before the Biodegradation is shown in table 1 . The mean temperatures $\left({ }^{\circ} \mathrm{C}\right)$ observed in TAN1, TAN2, and TAN3 samples were $28.07 \pm 0.65 ; 27.77 \pm 0.64$ and $26.38 \pm 3.81$ respectively. The order of the mean temperature of the samples from the three industries can be arranged as TAN1 > TAN2>TAN3. The temperature observed at TAN1, TAN2, and TAN3 samples were found below the WHO $\left(35^{\circ} \mathrm{C}\right)$ and NESREA $\left(40^{\circ} \mathrm{C}\right)$ limits. The low values of temperature might be due to the processes used at the time of sampling. High temperature brings down the solubility of gases in water that ultimately expresses as high BOD and COD. Statistical analysis shows that there is no significant difference $(p<0.05)$ between the mean values of temperature among the industries. This might be due to similar tannery activities involved in the tannery industries at the time of sampling. The average values of temperature observed in this present study are less than those observed by Akan et al. (2007), Akan et al. (2009) and Baba et al. (2020).

The mean level of $\mathrm{pH}$ observed in TAN1, TAN2 and TAN3, samples were $7.77 \pm 2.93$; $8.35 \pm 0.28$ and $7.52 \pm 0.76$ respectively. The order of the mean $\mathrm{pH}$ of the samples from the three industries can be arranged as TAN2> TAN1 $>$ TAN3. The $\mathrm{pH}$ of the samples falls within the WHO (7.0-8.5) and NESREA (6-9) standard limits. Statistical analysis shows that there is no significant difference $(p<0.05)$ between the mean values of $\mathrm{pH}$ among the industries. This might be due to similar tannery activities involved in the tannery industries at the time of sampling. Maheshwari et al. (2017) reported that the level of $\mathrm{pH}$ in the effluents from the tannery industry in Vaniyambadi, India was 6.5 which was lower than that observed in the present study. The $\mathrm{pH}$ in the effluents from the tannery industries in Kano and Kaduna were reported to be 7.64 and 6.89, respectively (Akan et al., 2007; Mohammed et al., 2017). The average values of $\mathrm{pH}$ observed in this present study are less than those observed by Mohammed et al. (2017) and Baba et al. (2020). The mean level of SS $(\mathrm{mg} / \mathrm{l})$ observed in TAN1, TAN2, and TAN3 samples were 374 \pm 124 ; $358 \pm 335$ and $780 \pm 739$ respectively. The order of the mean SS in the samples from the three industries can be arranged as TAN3 > TAN1 $>$ TAN2. 
The SS observed in the samples were far above the recommended standard limits of regulating bodies WHO $(30 \mathrm{mg} / \mathrm{l})$ and NESREA $(10 \mathrm{mg} / \mathrm{l})$. Statistical analysis shows that there is no significant difference $(p<0.05)$ between the mean values of SS among the industries. This might be due to similar tannery activities involved in the tannery industries at the time of sampling. The average values of SS observed in this present study are less than that observed $(3700 \pm 122 \mathrm{mg} / \mathrm{l})$ by Akan et al. (2009) for tanneries in Kano. Also, the average values of SS observed in this present study are less than that observed by Mohammed et al. (2017) and Baba et al. (2020) with the exception in TAN3.

The mean level of TDS (mg/l) observed in TAN1, TAN2, and TAN3 samples were $3941 \pm 3703$; $3300 \pm 1714$ and $2653 \pm 1240$ respectively. The order of the mean TDS in the samples from the three industries can be arranged as TAN1>TAN2>TAN3. The TDS observed in the samples were far above the recommended standard limits of WHO $(250 \mathrm{mg} / \mathrm{l})$ and NESREA $(500 \mathrm{mg} / \mathrm{l})$. Statistical analysis shows that there is no significant difference $(p<0.05)$ between the mean values of TDS among the industries. This might be due to similar tannery activities involved in the tannery industries at the time of sampling. TDS in the effluents from the tannery industries in Kano, Nigeria was reported to be $1281 \mathrm{mg} / \mathrm{l}$ (Akan et al., 2007). The average values of SS observed in this present study are less than those observed by Mohammed et al. (2017) and Baba et al. 2020)

The mean level of COD (mg/l) observed in TAN1, TAN2 and TAN3 samples seasons were $2372 \pm 938 ; \quad 1406 \pm 208$ and $3532 \pm 1373$ respectively. The order of the mean COD of the samples from the three industries can be arranged as TAN3>TAN1> TAN2. The COD observed in TAN1, TAN2 and TAN3 samples were far above the recommended standard limits of regulating bodies $\mathrm{WHO}(40 \mathrm{mg} / \mathrm{l})$ and NESREA (40 mg/l). Statistical analysis shows that there is no significant difference $(p<0.05)$ in COD among the industries. This might be due to similar tannery activities involved in the tannery industries as at the time of sampling. The Chemical Oxygen demand (COD) is the amount of oxygen, in $\mathrm{mg} / \mathrm{L}$, required for the degradation of the compound of wastewater to occur. In comparison, the average values of COD observed in this present study were higher than that observed by Mohammed et al. (2017) but lower than that observed by Baba et al. (2020).

The mean levels of BOD $(\mathrm{mg} / \mathrm{l})$ observed in TAN1, TAN2 and TAN3 samples were $13.85 \pm 6.42 ; \quad 19.46 \pm 0.50$ and $17.13 \pm 3.14$ respectively. The order of the mean BOD in the samples from the three industries can be arranged as TAN2>TAN3>TAN1. The BOD observed in TAN1, TAN2 and TAN3 samples were found below the recommended limits of NESREA (200 mg/l) but above WHO (10 mg/l). Statistical analysis shows that there is no significant difference $(p<0.05)$ between the mean values of BOD among the industries. This might be due to similar tannery activities involved in the tannery industries at the time of sampling. The low level of BOD recorded in this study is an indication of the low level of biodegradable organic solids in the effluent. The average values of BOD observed in this present study were lower than those observed by Mohammed et al. (2017) and Baba et al. (2020).

Table 1: Mean Values \pm S.D of Physico-chemical parameters of effluents from the Tannery Industries before Treatment.

\begin{tabular}{llllllll}
\hline Parameter & Tannery 1 & Tannery 2 & Tannery 3 & $\mathrm{a}$ & $\mathrm{b}$ & $\mathrm{c}$ & $\mathrm{d}$ \\
\cline { 2 - 7 } Temperature $\left({ }^{\circ} \mathrm{C}\right)$ & $28.07 \mathrm{a} \pm 0.65$ & $27.77 \mathrm{a} \pm 0.64$ & $26.38 \mathrm{a} \pm 3.81$ & & $29.50 \pm 4.68$ & 35 & 40 \\
pH & $7.77 \mathrm{a} \pm 2.93$ & $8.35 \mathrm{a} \pm 0.28$ & $7.52 \mathrm{a} \pm 0.76$ & 6.89 & $5.35 \pm 1.57$ & $7.0-8.5$ & $6.0-9.0$ \\
$\mathrm{COD}(\mathrm{mg} / \mathrm{l})$ & $2372 \mathrm{a} \pm 938$ & $1406 \mathrm{a} \pm 208$ & $3532 \mathrm{a} \pm 1373$ & 2.2 & $3106 \pm 2753$ & 40 & 40 \\
$\mathrm{BOD}(\mathrm{mg} / \mathrm{l})$ & $13.85 \mathrm{a} \pm 6.42$ & $19.46 \mathrm{a} \pm 0.50$ & $17.13 \mathrm{a} \pm 3.14$ & 1032 & $26.17 \pm 9.49$ & 10 & 200 \\
$\mathrm{SS}(\mathrm{mg} / \mathrm{l})$ & $374 \mathrm{a} \pm 124$ & $358 \mathrm{a} \pm 335$ & $780 \mathrm{a} \pm 739$ & 501 & $562 \pm 482$ & 30 & 10 \\
TDS $(\mathrm{mg} / \mathrm{l})$ & $3941 \mathrm{a} \pm 3703$ & $3300 \mathrm{a} \pm 1714$ & $2653 \mathrm{a} \pm 1240$ & 532.7 & $444 \pm 507$ & 250 & 500 \\
\hline
\end{tabular}

The values given in the table above are means of 6 replicate values, $\mathrm{n}=6$ ( 1 sample was taken monthly for 6 months). Within the rows, means with different alphabets are statistically different $(p<0.05)$. WHO: World Health Organisation. NESREA: National Environmental Standard and Regulatory Enforcement Agency. a = Mohammed et al.(2017), b = Baba et al. (2020), c = WHO (2006), $d=$ NESSRA (2009) 
BAJOPAS Volume 13 Number 2, December, 2020

Identification, Biochemical Characterization and growth rates of the Bacterial Isolates

Results of identification and biochemical characterization of the bacterial isolates were shown in table 2. After 24 hours of incubation, the nutrient agar media plates were checked for bacterial growth. The results showed the presence of different strains in the samples. The TAN1 bacteria isolate was found to be gramnegative cocci while TAN3 was gram-positive cocci. TAN2 bacteria isolate was found to be gram-positive, rod-shaped. TAN1, TAN2, and TAN3 bacteria isolates recorded positive results for spore former.

The results of the biochemical tests indicated that all the bacteria were positive for catalase, oxidase, citrate, maltose, glucose, lactose (negative in TAN1), mannitol (negative in TAN2), starch hydrolysis and coagulase (negative in TAN2) tests. The bacteria showed negative results for nitrate reduction, $M R$ (positive in TAN2), VP (positive in TAN1), Indole (positive in TAN2) tests. Base on the morphological and biochemical test results, TAN1, TAN2, and TAN3 bacteria isolates were identified to be Nesseria spp, Bacillus cereus, and Staphylococcus aureus respectively.

The growth rate of the TAN1, TAN2 and TAN3 Isolates were shown in figure 2. Generally, the optical density increase with the increase in time (day) and decrease as time goes on. The highest optical density was shown by bacillus cereus in TAN2 while the lowest was shown by Staphylococcus aureus in TAN3.

The initial growth phase of TAN1 Isolate bacteria occurred within 2-day of incubation as the growth rate increases up to the 6th-day incubation when the maximum growth was observed. Beyond the 6th day, the growth of the bacteria declined (which might be due to a shortage of nutrients in the effluents) until it reached its death phase (which might be due to the unavailability of nutrients in the effluents).

A similar trend of growth was also observed for TAN2 Isolate as the initial growth phase also occurred within 2-day of incubation but maximum growth rate observed on the 4th day of incubation. The stationary stage occurred between the 4th day and the 8th day. Beyond the 8th day, the growth of the bacteria declined (which might be due to a shortage of nutrients in the effluents) until it reached its death phase (which might be due to the unavailability of nutrients in the effluents).

The initial growth phase of TAN3 bacterial Isolate occurred within the 3-day incubation as the growth rate increases up to the 6th-day incubation when the maximum growth was observed. Beyond the 6th day, the growth of the bacteria declined (which might be due to a shortage of nutrients in the effluents) until it reached its death phase (which might be due to the unavailability of nutrients in the effluents).

Table 2: Morphological and Biochemical characteristics of bacterial isolates

\begin{tabular}{lllll} 
Bacterial Isolates & & TAN1 & TAN2 & TAN3 \\
\hline $\begin{array}{lllll}\text { Morphological } \\
\text { characteristics }\end{array}$ & Shape & Cocci & Rod & Cocci \\
& Spore & & & \\
& former & + & + & + \\
Gram & & & \\
Biochemical characteristics & reaction & - & + & + \\
& Citrate & + & + & + \\
& Catalase & + & + & + \\
& Coagulase & + & - & + \\
Starch & + & + & + \\
& Glucose & + & + & + \\
Oxidase & + & + & + \\
& Indo & - & + & - \\
Lactose & - & + & + \\
Manitol & + & - & + \\
Maltose & + & + & + \\
MR & - & + & - \\
VP & + & - & - \\
& Nitrate & - & - & - \\
Reduction & - Neisseria & Bacillus & Staphylococcus \\
& Bacterial & cereus & aureus \\
& name & spp & cas
\end{tabular}

+ = Positive; - = Negative; MR=Methyl Red; VP= Voges-Proskauer 


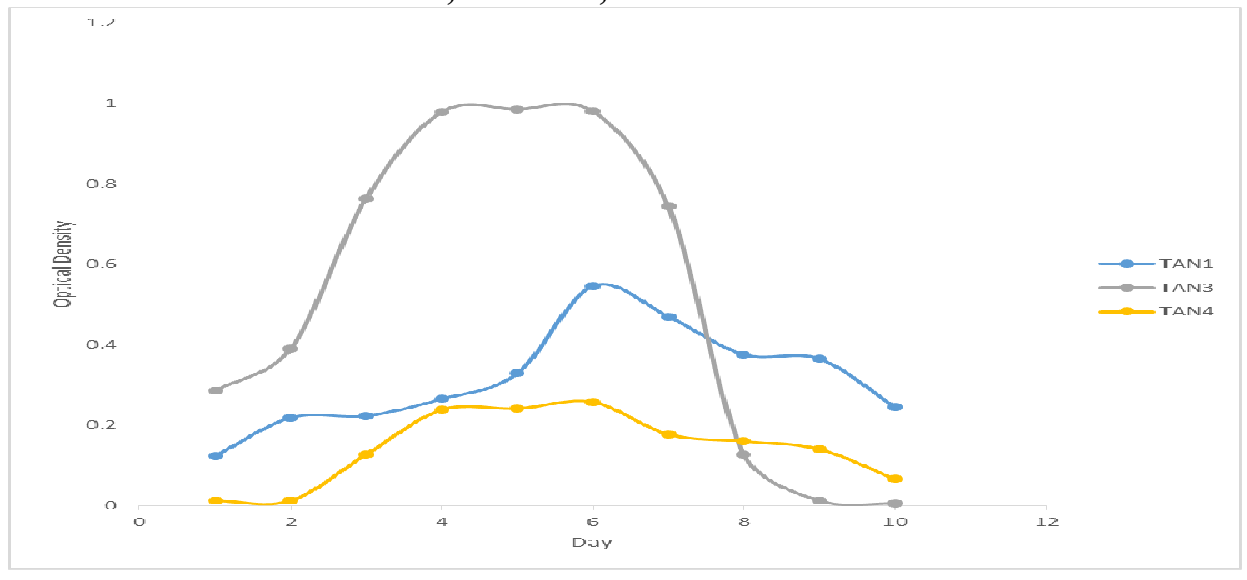

Fig. 2 Growth rates of the isolates in the effluents from the Tannery Industries

\section{Physico-chemical Parameters in the Industrial Effluents after the biodegradation.}

Table 3 shows the mean results of the physicochemical parameter before and after bioremediation using the different masses $(5 \mathrm{~g}$, $10 \mathrm{~g}, 15 \mathrm{~g}, 20 \mathrm{~g}$, and $25 \mathrm{~g}$ ) of the respective immobilized bacteria. Also, Table 4 shows the mean results of correlation coefficient ( $r$ ) between different masses of bacteria and physicochemical parameters.

The mean values $(\mathrm{mg} / \mathrm{l})$ of the SS after the bioremediation varies between $243 \pm 45$ and $898 \pm 672$. The mean concentration $(\mathrm{mg} / \mathrm{l})$ of SS remediated by the different masses $(5 \mathrm{~g}, 10 \mathrm{~g}$, $15 \mathrm{~g}, 20 \mathrm{~g}$, and $25 \mathrm{~g}$ ) of the bacteria varies. The SS in the samples fluctuates up and down after the bioremediation process when compared with the SS of the raw samples before the bioremediation. The increase in the levels of the SS might be due to the aggregation of the TDS which are large enough to result into SS. The increase in the levels of the SS might be also due to the influence of the nutrients which was added into the effluents in order to make the microorganisms more active and viable for fast degradation of organic contaminants in the effluent. The relative potential or efficiency of the different masses of the bacteria in remediating SS in TAN1 samples was in the order $25 \mathrm{~g}>20 \mathrm{~g}>15 \mathrm{~g}>10 \mathrm{~g}>5 \mathrm{~g}$. For TAN2 and TAN3 samples, the order was $25 \mathrm{~g}>20 \mathrm{~g}>15$ $\mathrm{g}>10 \mathrm{~g}>5 \mathrm{~g}$. These might be due to the variations in the surface areas of the different masses of the immobilized bacteria. Statistical analysis shows that there is no significant difference $(p<0.05)$ between the mean values of SS among the masses in the respective industries. Positive and significant correlations exist between the masses of bacteria and Suspended Solid (SS). This showed that there is general increase in the levels of the SS as the masses of the immobilized bacteria increases. TAN3 (90\%) and TAN1 (80\%) showed a very high correlation with the masses of the bacteria while TAN2 (61\%) showed a very low correlation.

The mean values $(\mathrm{mg} / \mathrm{l})$ of the TDS after the bioremediation varies between $46 \pm 11$ and $83 \pm 78$. The mean concentration $(\mathrm{mg} / \mathrm{l})$ of TDS remediated by the different masses $(5 \mathrm{~g}, 10 \mathrm{~g}$, $15 \mathrm{~g}, 20 \mathrm{~g}$, and $25 \mathrm{~g}$ ) of the bacteria varies. There is a reduction in all the TDS of all the samples after the bioremediation process compared with the TDS of the raw samples before the bioremediation. The relative potential or efficiency of the different masses of the bacteria in remediating TDS in TAN1 and TAN3 samples was in the order $5 \mathrm{~g}>10 \mathrm{~g}>15 \mathrm{~g}>20$ $\mathrm{g}>25 \mathrm{~g}$. For TAN2 samples, the order was 20 $g>10 \quad g>25 \quad g>15 \quad g>5 \quad g$. Statistical analysis shows that there is no significant difference $(p<0.05)$ between the mean values of TDS among the masses in the respective industries. These might be due to the variations in the surface areas of the different masses of the immobilized bacteria. Positive and significant correlations exist between the masses of bacteria and TDS with the exception in TAN2 (negative and insignificant correlation). The positive correlations showed that there is general increase in the levels of the TDS as the masses of the immobilized bacteria increases. TAN1 $(96 \%)$ showed a very high correlation with the masses of the bacteria while TAN2 (47\%) showed a very low correlation.

The mean values $(\mathrm{mg} / \mathrm{l})$ of the BOD after the bioremediation varies between $1.56 \pm 0.20 \mathrm{mg} / \mathrm{l}$ and $6.92 \pm 5.49 \mathrm{mg} / \mathrm{l}$. The mean concentration $(\mathrm{mg} / \mathrm{l})$ of BOD remediated by the different masses $(5 \mathrm{~g}, 10 \mathrm{~g}, 15 \mathrm{~g}, 20 \mathrm{~g}$, and $25 \mathrm{~g}$ ) of the bacteria varies. There is a reduction in all the BOD of all the samples after the bioremediation process compared with the $\mathrm{BOD}$ of the raw 
BAJOPAS Volume 13 Number 2, December, 2020 samples before the bioremediation. The relative potential or efficiency of the different masses of the bacteria in remediating BOD in TAN1, TAN2 and TAN3 samples were in the order $25 \mathrm{~g}>20$ $\mathrm{g}>15 \mathrm{~g}>10 \mathrm{~g}>5 \mathrm{~g}, 25 \mathrm{~g}>15 \mathrm{~g}>5 \mathrm{~g}>10 \mathrm{~g}>20 \mathrm{~g}$ and $20 \mathrm{~g}>10 \mathrm{~g}>25 \mathrm{~g}>15 \mathrm{~g}>5 \mathrm{~g}$ respectively. Statistical analysis shows that there is significant difference $(p<0.05)$ between the mean values of BOD among the masses in the respective industries. These might be due to the variations in the surface areas of the different masses of the immobilized bacteria. Negative and significant correlations exist between the masses of bacteria and BOD. This showed that there is general decrease in the levels of the BOD as the masses of the immobilized bacteria increases. TAN1 (94\%) showed a very high correlation with the masses of the bacteria while TAN2 (4\%) showed a very low correlation.

The mean values $(\mathrm{mg} / \mathrm{l})$ of the COD after the bioremediation varies between $250 \pm 154$ and $3134 \pm 1595$. The mean concentration $(\mathrm{mg} / \mathrm{l})$ of COD remediated by the different masses $(5 \mathrm{~g}$, $10 \mathrm{~g}, 15 \mathrm{~g} 20 \mathrm{~g}$, and $25 \mathrm{~g}$ ) of the bacteria varies. There is a reduction in all the COD of all the samples after the bioremediation process compared with the COD of the raw samples before the bioremediation. The relative potential or efficiency of the different masses of the bacteria in remediating COD in TAN1, TAN2 and TAN3 samples were in the order $25 \mathrm{~g}>20 \mathrm{~g}>15$ $\mathrm{g}>5 \mathrm{~g}>10 \mathrm{~g}, 25 \mathrm{~g}>20 \mathrm{~g}>15 \mathrm{~g}>10 \mathrm{~g}>5 \mathrm{~g}$ and 10 g>5 g>25 g>15 g>20 g respectively. Statistical analysis shows that there were significant difference $(p<0.05)$ between the mean values of COD among the masses in the respective industries except for effluents treated with $25 \mathrm{~g}$. These might be due to the variations in the surface areas of the different masses of the immobilized bacteria. Negative and insignificant correlations exist between the masses of bacteria and COD with the exception in TAN3 (positive and significant correlation). The negative correlations showed that there is general decrease in the levels of the COD as the masses of the immobilized bacteria increases. TAN2 (100\%) showed a very high correlation with the masses of the bacteria while TAN3 (36\%) showed a very low correlation.

Generally, there was an overall decrease in the concentration of these physicochemical parameters after the bioremediation using the different masses of the bacterial isolates. These might be due to the variations in the surface areas of the different masses of the immobilized bacteria. This is in line with the work of Jimoh et al. (2018) and Baba et al. (2020).

Table 3: Mean Values $(\mathrm{mg} / \mathrm{l}) \pm$ S.D of Physicochemical parameters in effluents from the Tannery Industries before and after Treatment of the effluents $(250 \mathrm{ml})$ with the different masses $(5 \mathrm{~g}, 10 \mathrm{~g}$, $15 \mathrm{~g}, 20 \mathrm{~g}$, and $25 \mathrm{~g}$ ) of the bacteria.

\begin{tabular}{llllllll}
\hline $\mathrm{P}$ & IND & Before & \multicolumn{5}{c}{ After } \\
\cline { 4 - 7 } & & & $5 \mathrm{~g}$ & $10 \mathrm{~g}$ & $15 \mathrm{~g}$ & $20 \mathrm{~g}$ & $25 \mathrm{~g}$ \\
\hline \multirow{2}{*}{ COD } & TAN1 & $2372 \pm 938$ & $1708 \mathrm{a} \pm 861$ & $2045 \mathrm{a} \pm 1205$ & $845 \mathrm{a} \pm 369$ & $300 \mathrm{a} \pm 167$ & $250 \mathrm{a} \pm 154$ \\
& TAN2 & $1406 \pm 208$ & $1195 \mathrm{a} \pm 208$ & $1125 \mathrm{a} \pm 384$ & $1055 \mathrm{a} \pm 317$ & $956 \mathrm{a} \pm 310$ & $870 \mathrm{ab} \pm 240$ \\
& TAN3 & $3532 \pm 1373$ & $2374 \mathrm{a} \pm 1344$ & $1976 \mathrm{a} \pm 1405$ & $2757 \mathrm{a} \pm 1266$ & $3134 \mathrm{a} \pm 1595$ & $2614 \mathrm{~b} \pm 1105$ \\
BOD & TAN1 & $13.85 \pm 6.42$ & $6.92 \mathrm{a} \pm 5.49$ & $6.42 \mathrm{a} \pm 5.07$ & $5.72 \mathrm{a} \pm 5.35$ & $4.62 \mathrm{a} \pm 4.37$ & $2.82 \mathrm{ab} \pm 1.26$ \\
& TAN2 & $19.46 \pm 0.50$ & $1.75 \mathrm{~b} \pm 0.22$ & $1.73 \mathrm{~b} \pm 0.18$ & $1.58 \mathrm{a} \pm 0.16$ & $1.91 \mathrm{a} \pm 0.22$ & $1.56 \mathrm{~b} \pm 0.20$ \\
& TAN3 & $17.13 \pm 3.14$ & $4.24 \mathrm{ab} \pm 0.77$ & $3.29 \mathrm{ab} \pm 0.37$ & $4.11 \mathrm{a} \pm 0.07$ & $3.23 \mathrm{a} \pm 0.91$ & $3.33 \mathrm{a} \pm 1.28$ \\
SS & TAN1 & $374 \pm 124$ & $243 \mathrm{a} \pm 45$ & $471 \mathrm{a} \pm 226$ & $475 \mathrm{a} \pm 182$ & $492 \mathrm{a} \pm 128$ & $611 \mathrm{a} \pm 217$ \\
& TAN2 & $358 \pm 335$ & $460 \mathrm{a} \pm 400$ & $543 \mathrm{a} \pm 414$ & $544 \mathrm{a} \pm 402$ & $551 \mathrm{a} \pm 414$ & $554 \mathrm{a} \pm 405$ \\
& TAN3 & $780 \pm 739$ & $586 \mathrm{a} \pm 594$ & $758 \mathrm{a} \pm 656$ & $787 \mathrm{a} \pm 676$ & $861 \mathrm{a} \pm 635$ & $898 \mathrm{a} \pm 672$ \\
TDS & TAN1 & $3941 \pm 3703$ & $51 \mathrm{a} \pm 10$ & $53 \mathrm{a} \pm 10$ & $55 \mathrm{a} \pm 15$ & $61 \mathrm{a} \pm 20$ & $63 \mathrm{a} \pm 26$ \\
& TAN2 & $3300 \pm 1714$ & $83 \mathrm{a} \pm 78$ & $47 \mathrm{a} \pm 20$ & $48 \mathrm{a} \pm 22$ & $47 \mathrm{a} \pm 17$ & $48 \mathrm{a} \pm 17$ \\
& TAN3 & $2653 \pm 1240$ & $46 \mathrm{a} \pm 11$ & $55 \mathrm{a} \pm 24$ & $55 \mathrm{a} \pm 25$ & $58 \mathrm{a} \pm 23$ & $61 \mathrm{a} \pm 28$ \\
\hline
\end{tabular}

Replicate $=6$ (months)

Within the rows, for the same parameter, means with different alphabets are statistically different $(p<0.05)$.

$\mathrm{P}=$ parameter, IND = Industries 
BAJOPAS Volume 13 Number 2, December, 2020

Table 4: Correlation coefficient $(r)$ between different masses of the bacteria and the physicochemical parameters.

\begin{tabular}{llll}
\hline Industries & Parameter & Correlation coefficient $(r)$ & $\begin{array}{l}\text { Percent dependence (rxrx100) } \\
(\%)\end{array}$ \\
\hline TAN1 & COD & -0.9 & 82 \\
& BOD & -0.97 & 94 \\
& SS & $0.90^{*}$ & 80 \\
TAN2 & TDS & $0.98^{*}$ & 96 \\
& COD & -1 & 100 \\
& BOD & -0.21 & 4 \\
& SS & $0.78^{*}$ & 61 \\
& TDS & -0.69 & 47 \\
& COD & $0.60^{*}$ & 36 \\
& BOD & -0.6 & 37 \\
& SS & $0.95^{*}$ & 90 \\
& TDS & $0.94^{*}$ & 89 \\
\hline
\end{tabular}

The correlation coefficient $(r)$ with * is statistically significant $(p<0.05)$.

Percentage reduction of the Parameters

Table 5 shows the percentage reduction of Parameters in industrial samples before and after the treatment of the effluents $(250 \mathrm{ml})$ with the different masses $(5 \mathrm{~g}, 10 \mathrm{~g}, 15 \mathrm{~g}, 20 \mathrm{~g}$, and $25 \mathrm{~g}$ ) of the Immobilized Bacteria.

In TAN1 samples, the percentage reduction (\%) of COD ranged (14-89); BOD (50-80); SS (-32$35)$ and TDS (98-99). In TAN2 samples, the percentage decrease $(\%)$ of COD ranged (15$38) ;$ BOD (90-92); SS [-28-(-55)] and TDS (9798). In TAN3 samples, the percentage decrease (\%) of COD ranged (11-44); BOD (76-81); SS (15-25) and TDS (98). The percentage increase in the levels COD, BOD and TDS might be due to the increase in the surface area of the different masses of the immobilized bacteria. However, the percentage decrease in the levels of the SS might be due to the aggregation of the TDS which are large enough to result into SS. The percentage decrease in the levels of the SS might be also due to the influence of the nutrients which was added into the effluents in order to make the microorganisms more active and viable for fast degradation of organic contaminants in the effluent. This is in line with the work of Jimoh et al. (2018) in which the concentration of the SS increase after the bioremediation of effluents.

Sreemoyee and Priti (2013) assessed and reduced several Physico-chemical parameters of dairy wastewater using Niesseria $s p$. and concluded that the species are well known to degrade organic compounds. This is in agreement with the current study in which the immobilized Niesseria $s p$ degrade the organic contaminants as indicated by the BOD, COD and TDS.

Jimoh et al. (2018) observed that TSS of the effluents was increased after treatment with immobilized bacteria and concluded that it might be due to the biostimulation method adopted for the research.

The optimum $\mathrm{pH}$ Biosorption of Chromium by Bacillus spp and Staphylococcus spp. from tannery effluent was investigated by Mythili and Karthikeyan (2011). The maximum adsorption of Chromium $(86.4 \mathrm{mg} / \mathrm{L})$ was showed by Bacillus spp and Staphylococcus spp showed $70.6 \mathrm{mg} / \mathrm{L}$ at an initial concentration of $100 \mathrm{mg} / \mathrm{L}$. In the present study, immobilised Bacillus spp and Staphylococcus spp. from the tannery industrial effluents reduced the levels of the organic pollutants with high potential as indicated by the percentage reduction of BOD, COD and TDS.

Enzymes often can work in multiple environments especially if they are immobilized. This makes the microorganisms' enzymes even more resistant to harsh environments and enables the enzymes to be recovered and recycled after they are no longer needed (Gianfreda and Rao 2004). Ramesh and Singh (1993) reported that the immobilized bacteria having more efficiency to remove the suspended particles than free cells. Using the immobilized cell is preferable due to its capability for using several times with the same efficiency, which makes it more economical. Similar work was done by Sikander et al. (2007) showing the higher reduction with permeabilized cells of Ochrobactrum intermedium strain SDCr-5. 
BAJOPAS Volume 13 Number 2, December, 2020

The results revealed the isolation and identification of isolates with the potential for the reduction of $\mathrm{Cr}$ (VI) to $\mathrm{Cr}$ (III). Results indicated that immobilized $B$. cereus could be efficiently used for the reduction of $\mathrm{Cr}$ (VI).

Table 5: Percentage reduction of the tested Parameters from the tannery industrial samples of the Immobilized Bacteria.

\begin{tabular}{lllllll}
\hline \multirow{2}{*}{ Industries } & & \multicolumn{5}{c}{ Percentage Reduction $(\%)$} \\
\cline { 3 - 7 } & & $5 \mathrm{~g}$ & $10 \mathrm{~g}$ & $15 \mathrm{~g}$ & $20 \mathrm{~g}$ & $25 \mathrm{~g}$ \\
\hline TAN1 & COD & 28 & 14 & 64 & 87 & 89 \\
& BOD & 50 & 54 & 59 & 67 & 80 \\
& SS & 35 & -26 & -27 & -32 & -63 \\
& TDS & 99 & 99 & 99 & 98 & 98 \\
TAN2 & COD & 15 & 20 & 25 & 32 & 38 \\
& BOD & 91 & 91 & 92 & 90 & 92 \\
& SS & -28 & -52 & -52 & -54 & -55 \\
& TDS & 97 & 99 & 99 & 99 & 99 \\
& COD & 33 & 44 & 22 & 11 & 26 \\
& BOD & 75 & 81 & 76 & 81 & 81 \\
& SS & 25 & 3 & -1 & -10 & -15 \\
& TDS & 98 & 98 & 98 & 98 & 98 \\
\hline
\end{tabular}

Percentage Reduction $=(B-A) / B \times 100 \%$

$A=$ Concentration of the parameter after treatment

$\mathrm{B}=$ Concentration of the parameter before treatment

$+=$ percentage decrease

- = percentage increase

In general, immobilization makes the enzyme more resistant to temperature, $\mathrm{pH}$, and substrate concentration swings giving it a longer lifetime and higher productivity per active unit (Gianfreda and Rao, 2004; FuIlbrook, 1996; Russell et al, 2003; Kandelbauer et al., 2004). Immobilized cells have been used and studied extensively for the production of useful chemicals (Ohtake and Silver, 1994), the treatment of wastewaters (Chen et al., 2003; Wang et al., 2010). Although many workers described microbial degradation of tannery effluent, limited literature is available on the bioremediation of tannery effluent using immobilized bacterial cells in the Kano Industrial Estates.

\section{CONCLUSION}

The samples contained variable levels of the physicochemical parameters. The results of the Analysis of variance revealed that, no statistical difference $(p<0.05)$ was observed for the temperature, $\mathrm{pH}, \mathrm{SS}, \mathrm{TDS}, \mathrm{BOD}$ and $\mathrm{COD}$ among the three tannery industries before the treatment. The levels of some of the parameters
(SS, TDS and COD) observed in the samples were found above the recommended limits of WHO and NESREA, which called for the treatment of the effluents before discharge into the environment. Base on the morphological and biochemical test results, TAN1, TAN2, and TAN3 bacterial isolates were identified to be Neisseria spp, Bacillus cereus, and Staphylococcus aureus respectively. The results of Post-treatment analysis showed that there is overall decrease in the levels of the parameters determined when compared with that of the pre-treatment. The overall percentage reduction of the immobilised bacteria in the treatment of the respective effluents was in the order TAN2 (72\%)>TAN1 $(70 \%)>$ TAN3 $(62 \%)$. Hence, the immobilized bacteria are having higher biodegradation potential for the treatment of the tannery effluents.

\section{Acknowledgments}

The authors wish to acknowledge the University of Maiduguri for the financial support. The authors are grateful to the Kano State Ministry of Environment for their support in obtaining the effluent samples. 


\section{REFERENCES}

Ajao, A. T., Adebayo, G. B., and Yakubu, S. E. (2011). Bioremediation of textile industrial effluent using mixed culture of Pseudomonas aeruginosa and Bacillus subtilis immobilized on agar-agar in a bioreactor. J. Microbiol. Biotech. Res, 1(3), 50-56.

Akan, J. C., Moses, E. A., Ogugbuaja, V. O., and Abah, J. (2007). Assessment of tannery industrial effluents from Kano metropolis, Kano State, Nigeria. Journal of Applied Sciences, 7(19), 2788-2793.

Akan, J. C., Ogugbuaja, V. O., Abdulrahman, F. I., and Ayodele, J. T. (2009). Pollutant levels in effluent samples from tanneries and textiles of Kano industrial areas, Nigeria. Global journal of pure and applied sciences, 15(3-4).

APHA (1989). Standard methods for Examination of Will bete and Will betewater.15 $5^{\text {th }}$ edition. Brydpass Springfield Will behington DC. pp. 164-176

APHA (1992). Standard Methods for the Examination of Water and Wastewater. Health, 69, 1116-9.

Baba, A., Garba, S. T., and Bello, H. S. (2020). Bioremediation Potential of Immobilized corynebacterium kutsceri in the Treatment of Tannery Industrial Effluent from Challawa Industrial Estate, Kano State, Nigeria. Journal of the Turkish Chemical Society Section A: Chemistry, $7(2), 335-350$.

Beem, E. I. V. (1994). reduction of solvent VOC emission. J. Oil Col. Chem. Ass, 77, 158.

Bouwer, E. J., and Zehnder, A. J. (1993). Bioremediation of organic compoundsputting microbial metabolism to work. Trends in biotechnology, 11(8), 360367.

Chen, K. C., Wu, J. Y., Liou, D. J., and Hwang, S. C. J. (2003). Decolorization of the textile dyes by newly isolated bacterial strains. Journal of Biotechnology, 101(1), 57-68.

Dan'Azumi, S., and Bichi, M. H. (2010). INDUSTRIAL POLLUTION AND HEAVY METALS PROFILE OF CHALLAWA RIVER IN KANO, NIGERIA. Journal of Applied Sciences in Environmental Sanitation, $5(1)$.

DWAF. (1992). Analytical Methods Manual, TR 151. Department of Water Affairs and Forestry, Pretoria.

El-Bestawy, E. (2013). Biological treatment of leather-tanning industrial wastewater using free living bacteria.
Elsheikh, M. A. S. (2009). Tannery wastewater pre-treatment. Water Science and Technology, 60(2), 433-440.

FuIlbrook, P. D. (1996). "Kinetics." Industrial enzymology: The application of enzymes in Industry. 2nd Ed. T. Godfrey and J Reichelt. eds.. Nature. New York.

Gianfreda, L., and Rao, M. A. (2004). Potential of extra cellular enzymes in remediation of polluted soils: a review. Enzyme and microbial technology, 35(4), 339354.

Hugo Springer. (1994). John Arthur Wilson Memorial Lecture "Treatment of Industrial Wastes of the Leather Industry - is it still a Major Problem". JALCA, 89, 153-185

Jimoh, A. A., Ganiyu, B. A., Baba, D., and Baba, A. (2018) Bioremediation Process of Effluent from Detergent and Food Industries in Jos, Nigeria: Kinetics and Thermodynamics. International Journal of Engineering Science Invention (IJESI), 762-73

Kandelbauer, A., Maute, O., Kessler, R. W., Erlacher, A., and Gübitz, G. M. (2004). Study of dye decolorization in an immobilized laccase enzyme-reactor using online spectroscopy. Biotechnology and bioengineering, 87(4), 552-563.

Kongjao, S., Damronglerd, S., and Hunsom, M. (2008). Simultaneous removal of organic and inorganic Pollutants in tannery wastewater using electrocoagulation technique. Korean Journal of chemical engineering, 25(4), 703.

Maheshwari, U. M., Aruna, S., Gomathi, M., and AbdulJaffar, A. H. (2017). Bioremediation by Free and Immobilized Bacteria Isolated from Tannery Effluent. International Journal of Research in Applied, Natural and Social Sciences. 5(7), 75-90

Margesin, R., and Schinner, F. (2001). Bioremediation (natural attenuation and biostimulation) of diesel-oilcontaminated soil in an alpine glacier skiing area. Applied and environmental microbiology, 677), 3127-3133.

Mohammed, A., Sekar, P., and George, J. (2011). Efficacy of microbes in bioremediation of tannery effluent. Inter. J. Curr. Res, 3(4), 324-326.

Mohammed, S. S. D., Orukotan, A. A., and Abdullahi, H. (2017). Physicochemical and Bacteriological Assessment of Tannery Effluent from Samaru-Zaria, 
BAJOPAS Volume 13 Number 2, December, 2020 Kaduna State, Nigeria. Journal of Applied

Sciences and Environmental Management, 21(4), 734-740.

Munz, G., De Angelis, D., Gori, R., Mori, G., Casarci, M., and Lubello, C. (2009). The role of tannins in conventional and membrane treatment of tannery wastewater. Journal of hazardous materials, 164(2-3), 733-739

Mythili, K., and Karthikeyan, B. (2011). Bioremediation of $\mathrm{Cr}$ (VI) from tannery effluent using Bacillus spp and Staphylococcus spp. International Multidisciplinary Research Journal, 1(6).

NESREA (2009). National Environmental Standards for Effluent Limitations and Regulation. 1233-1236

Noorjahan, C. M. (2014). Physicochemical characteristics, identification of bacteria and biodegradation of industrial effluent. Journal of bioremediation and Biodegradation, 5(3).

Ohtake, H. I., and Silver, A. O. (1994). Bacterial reduction of toxic chromate. Biological degradation and bioremediation of toxic chemicals, 403-415.

Omoleke, I. I. (2004). Management of environmental pollution in Ibadan, an African city: the challenges of health hazard facing government and the people. Journal of Human Ecology, 15(4), 265-275.

Rajor, A., Reddy, A.S., and Singh, B. (2004). Determination of BOD kinetic Parameters and evaluation of alternate methods, M.Sc. Thesis, Department of biotechnology \& environmental Science, Thapar Institute of Engineering and Technology, Patiala

Ramasami, T., Rajamani, S., and Rao, J. R. (1994, March). Pollution control in leather industry: Emerging technological options. In International symposium on surface and colloidal science and its relevance to soil pollution, madras.

Ramesh, J. V. S., and Singh, S. P. (1993). Yearly variation in certain physicochemical parameters of pond at eastern Doon Valley. Uttar Pradesh J. Zoo, 12 (1), 7577.

Ranen, S., and Sharadinadra, C. (2009). Biotechnology applications to environmental remediation in resource exploitation. Current science, 97, 6-25
Russell, A. J., Berberich, J. A., Drevon, G. F., and Koepsel, R. R. (2003). Biomaterials for mediation of

chemical and biological warfare agents. Annual review of biomedical engineering, 5(1), 1-27.

Saravanan, P., and Saravanan, A. (1999). Decolourization of tannery effluent by Flavobacterium sp. EK 1. Indian Journal of Environmental Protection, 19, 19-24.

Sikander, S., and Shahida, H. (2007). Reduction of toxic hexavalent chromium by Ochrobactrum intermedium strain SDCr5 stimulated by heavy metals. Bioresource Technol, 98, 340-344.

Singh, N., Sharma, B. K., and Bohra, P. C. (2000). Impact assessment of industrial effluent of arid soils by using satellite imageries. Journal of the Indian Society of Remote Sensing, 28(2-3), 79.

Sreemoyee, C., and Priti, P. (2013). Assessment of physico-chemical parameters of dairy waste water and isolation and characterization of bacterial strains in terms of cod reduction. Int J Sci, 2(3), 395-400.

Verheijen, L. A. H. M., Wiersema, D., Pol, L. H., and De Wit, J. (1996). Management of wastes from animal product processing. Livestock and environment, Finding a balance. International Agriculture Center, Wageningen, The Netherlands.

Wang, F., Yao, J., Si, Y., Chen, H., Russel, M., Chen, K., and Bramanti, E. (2010). Short-time effect of heavy metals upon microbial community activity. Journal of Hazardous Materials, 173(13), 510-516.

WHO (World Health Organization). (2006). Air quality guidelines: global update 2005: particulate matter, ozone, nitrogen dioxide, and sulfur dioxide. World Health Organization.

World Bank. (1995). Nigeria's strategic options for redressing industrial pollution. World Bank, industry and energy division. 1st edition, West Central Africa Department; Annexes: 1995; pp 60-62.

Zahoor, A., and Abdul, R. (2009). Enumeration of Coliforms. Journal of Environmental Sciences. 21, 814-820 


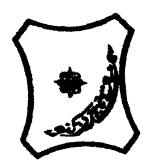

Bayero Journal of Pure and Applied Sciences, 13(2): 1 - 12

Received: November, 2020

Accepted: December, 2020

ISSN $2006-6996$

\title{
BIODEGRADATION POTENTIAL OF IMMOBILIZED BACTERIA IN THE TREATMENT OF TANNERY INDUSTRIAL EFFLUENTS FROM INDUSTRIAL ESTATES IN KANO STATE, NIGERIA
}

\author{
Abdullateef, B., ${ }^{1 *}$ Shuaibu, T. G., ${ }^{1}$ Babagana, K., ${ }^{1}$ Suleman, H. B. ${ }^{2}$ and Dauda, B. ${ }^{3}$ \\ ${ }^{1}$ Department of Pure and Applied Chemistry, Faculty of Science, University of Maiduguri, Borno State, \\ Nigeria \\ ${ }^{2}$ Department of Microbiology, Faculty of Science, University of Maiduguri, Borno State, Nigeria \\ ${ }^{3}$ Department of Chemical Engineering, Faculty of Engineering, University of Maiduguri, Borno State, \\ Nigeria \\ *Corresponding author: babslega@gmail.com; abelega2007@yahoo.com; +2348061309753
}

\section{ABSTRACT}

Industrial Effluents Samples from Gashash Tanneries (TAN1) in Bompai Industrial estate, Larabee Tannery Industry (TAN2) in Sharada Industrial estate and Z Tannery Industries (TAN3) in Challawa Industrial estate, Kano State, Nigeria were collected over a period of six months (August 2017 to January 2018) for assessing the biodegradation potentials of bacteria in the treatment of organic pollutants within the effluents. Bacteria were isolated from the effluents and immobilized on agar-agar. Different masses (5 g, $10 \mathrm{gr}, 15$ $\mathrm{g}, 20 \mathrm{~g}$, and $25 \mathrm{~g}$ ) of the bacteria were used in the treatment of $250 \mathrm{ml}$ of the effluents for ten days in a shaker incubator (Gallenkamp-OC-4364-L) at the temperature $30{ }^{\circ} \mathrm{C}$ and speed of $60 \mathrm{rpm}$. Pre-treatment analysis of the effluents for Temperature, pH, Biochemical Oxygen Demand (BOD), Chemical Oxygen Demand (COD), Suspended Solid (SS) and Total Dissolved Solids (TDS) gives the following results; temperature $\left({ }^{\circ} \mathrm{C}\right.$ )

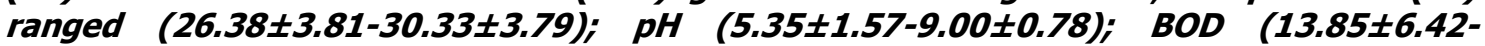
$38.75 \pm 16.20) ;$ COD (1406 $\pm 208-3532 \pm 1373) ;$ SS (208 $\pm 235-780 \pm 739)$ and TDS (266 $\pm 253-5276 \pm 2971)$. No statistical differences ( $p \leq 0.05)$ was observed for all the results among the different industries. The bacterial isolates were identified as Neisseria spp, Bacillus cereus, and Staphylococcus aureus, in TAN1, TAN2, and TAN3, respectively. After treatment of the effluent with the different masses of the isolated bacteria, the mean level of BOD was found to range as (0.55 $\pm 0.36-6.92 \pm 5.49) ; C O D$ (ND-3134 \pm 1595$)$;

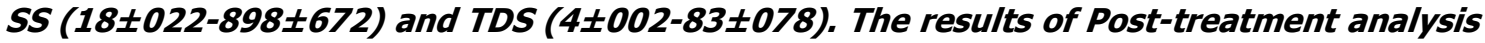
showed that there is overall decrease in the levels of the parameters determined when compared with that of the pre-treatment. The overall percentage reduction of the immobilised bacteria in the treatment of the respective effluents was in the order TAN2 (72\%)>TAN1 (70\%)>TAN3 (62\%). Hence, the immobilized bacteria are having higher biodegradation potential for the treatment of the tannery effluents.

Keywords: Biodegradation, bacteria, effluent, immobilization, tannery.

\section{INTRODUCTION}

Tannery industrial wastewater is a serious consequence of the pollution point of view for streams, freshwater, and land used for agriculture. The lack of awareness in the modern industrial practice has resulted in the discharge of tannery effluents which exhibit very high value of chromium ( $\mathrm{Cr}$ ), Sulfide, and chloride, Total Dissolved Solid (TDS), Total Suspended Solid (TSS), Biochemical Oxygen Demand (BOD) and Chemical Oxygen Demand (COD) in the water stream or land (Mohammed et al., 2001). Tanning is the process, which One ton of skin generally leads to the production of 20 to $80 \mathrm{~m}^{3}$ of turbid and foul-smelling converts the protein of the rawhide or skin into a stable material, which will not putrefy and is suitable for a wide variety of end applications (Elsheikh, 2009). The highly polluting chromium is the most commonly used tanning material producing leather that is more flexible and pliable than vegetable-tanned leather and does not discolor or lose shape in water as drastically as vegetable-tan (Elsheikh, 2009). Tannery effluent is among the most hazardous industrial pollutants due to its huge organic and inorganic load, which is highly toxic to human life and the environment (Kongjao et al., 2008). wastewater including chromium (100-400 mg/l), sulfide $(200-800 \mathrm{mg} / \mathrm{l})$, high levels of fat and 
BAJOPAS Volume 13 Number 2, December, 2020 other solid wastes, and notable pathogen contamination as well as pesticides added for skin conservation during transport (Elsheikh, 2009). There are more than 6000 tanneries in Nigeria with an annual processing capacity of 700,000 tons of hides and skins (Omoleke, 2004; Singh et al., 2008). It was reported that the total amount of waste produced per animal slaughtered is approximately $35 \%$ of its weight (World Bank, 1995). Also, for every $1000 \mathrm{~kg}$ of carcass weight, a slaughtered beef produces 5.5 $\mathrm{kg}$ of manure (excluding rumen contents or stockyard manure) and $100 \mathrm{~kg}$ of paunch manure (undigested food) (Verheijen et al., 1996). Tanneries generate wastewater in the range of 30-35 $\mathrm{L} \mathrm{kg}^{-1}$ skin/hide processed with variable $\mathrm{pH}$, Biological Oxygen Demand (BOD), Chemical Oxygen Demand (COD), high concentrations of suspended solids (SS), and tannins as well as chromium (Zahoor and Abdul, 2009).

Being heterogeneous and composed of a wide variety of compounds, it is very difficult to select a unique direct method for estimating the biodegradability of organic contents and biokinetic parameters for a wastewater sample (Rajor, 2004). For this purpose, some indirect estimation such as determination of biochemical oxygen demand (BOD) and chemical oxygen demand (COD) are applied as common laboratory investigations [9]. During retanning procedures, synthetic tannins (Syntan), oils and resins are added to form softer leather at varying doses (Munz et al., 2009). One of the refractory groups of chemicals in tannery effluents derives mainly from tannins (Ramasami et al., 2004). Syntans are characterized by complex chemical structures, because they are composed of an extended set of chemicals such as phenol-, naphthalene-, formaldehyde- and melamine-based syntans, and acrylic resins (Beem, 1994). Organic pollutants (proteic and lipidic components) are originated from skins (it is calculated that the raw skin has $30 \%$ loss of organic material during the working cycle) or they are introduced during processes (Hugo Springer, 1994).

Many conventional processes such as oxidation, chemical and biological processes were carried out to treat tanneries wastewater (Ebtesam et al, 2013). Biological processes have received more attention because of their costeffectiveness, lower sludge production and environmental friendliness (Noorjahan, 2014). Naturally occurring micro-organisms degrade the hazardous organic wastes including xenobiotic compounds, such as pesticides, polycyclic aromatic hydrocarbons (PAHs) and polychlorinated biphenyls (PCBs) in due course of time (Ranen and Sharadinadra, 2009). Bioremediation is based on the idea that all organisms remove substances from the environment to carry outgrowth and metabolism (Bouwer and Zehnder, 1993). Bacteria, protista and fungi are found to be very good at degrading complex molecules and incorporating the breakdown products into their metabolism (Bouwer and Zehnder, 1993). The resultant metabolic wastes that they produce are generally safe and somehow recycled into other organisms (Ranen and Sharadinadra, 2009). An acclimatized indigenous population of microorganisms capable of degradation of the compounds of interest must exist at the site for a successful bioremediation mode (Ranen and Sharadinadra, 2009). It has been observed that for a successful bioremediation mode, an acclimatized indigenous population of microorganisms capable of degradation of the compounds of interest must exist at the site under investigation (Ranen and Sharadinadra, 2009). Even though there are numerous physical and chemical methods employed in the disposal of wastes the advantage in using bacterium is that they play a key role in the reduction of COD, BOD, total protein, total tannin and total phenol (Saravanan and Saravanan, 1998)

Baba et al. (2020) studied the bioremediation potential of immobilized corynebacterium kutsceri in the Treatment of tannery industrial effluent from Challawa Industrial Estate, Kano State, Nigeria. The aim of the work is to study the reduction in the level of the contaminants through the process of bioremediation using the isolated bacteria. Immobilized bacteria can withstand various temperatures, $\mathrm{pH}$ and substrate concentrations; consequently, increasing the efficiency and the lifespan of the bacteria. Immobilized bacteria are widely applied in the treatment of wastewater and can be separated and recovered after the treatment with the same efficiency (Baba et al., 2020).

\section{MATERIALS AND METHODS \\ Study Area}

This study was carried out in Bompai, Sharada and Challawa industrial estates in Kano, Figure 1. Kano lies on Latitude $11^{\circ} 30^{\prime} \mathrm{N}$ and $8^{\circ} 30^{\prime} \mathrm{E}$ and Longitude $11^{\circ} 5^{\prime} \mathrm{N}$ and $8^{\circ} 5^{\prime} \mathrm{E}$ in Northern Nigeria. It is one of the developed industrial cities in Nigeria. Tannery activities are the dominating industries and this could be one of the reasons for her high population density (Dan'Azumi and Bichi, 2010). Many researchers have studied biodegradation of tannery effluent using microorganisms. However, limited literature is available on the biodegradation of tannery effluent in Kano industrial estates using 
BAJOPAS Volume 13 Number 2, December, 2020 immobilized bacterial cells. This research work focuses on the potential of the use of the indigenous immobilized bacterial isolates in the treatment of tannery effluents in the industrial estates.

\section{Sample Collection}

Effluents were collected from the Tannery Industries from Bompai, Challawa and Sharada Industrial Estates, Kano, Nigeria. The effluents were collected over a period of six months (August 2017 to January 2018). Samples collected in a sterile 4-liter plastic container with a unique identification number were preserved using an ice-box that was transported to the Microbiology Laboratory, Department of Microbiology, Bayero University of Kano for analysis

\section{Sample Preparation and Sample Analysis}

Immediately after the collection of the effluent, $\mathrm{pH}$, TSS, TDS, COD, BOD levels were determined before treatment (Pre-treatment determination) and ten days after treatment (Post-treatment determination) as described in
APHA (1989) standard methods. $\mathrm{pH}$ was determined using Ecotests $\mathrm{pH}$ meter and TDS was determined using AQUALYTIC TDS Salinometer. BOD was determined as described by the standard method (APHA, 1992). COD and SS were determined using DR/2010 HACH portable data logging spectrophotometer (DWAF, 1992)

\section{Identification and Biochemical} Characterization of the Bacterial Isolates

The bacteria were isolated from the effluents using Serial Dilution according to the method described by APHA (1989). The biochemical tests such as oxidase, catalase, coagulase, indole (from $1 \%$ tryptone broth), citrate (Simmons citrate agar), methyl red/VogesProskauer (MR/VP), nitrate reduction, Starch Hydrolysis, Glucose, Maltose, and Lactose tests were carried out on the bacterial isolates to identify the bacteria through the bacteria biochemical characteristics according to Ajao et al. (2011).

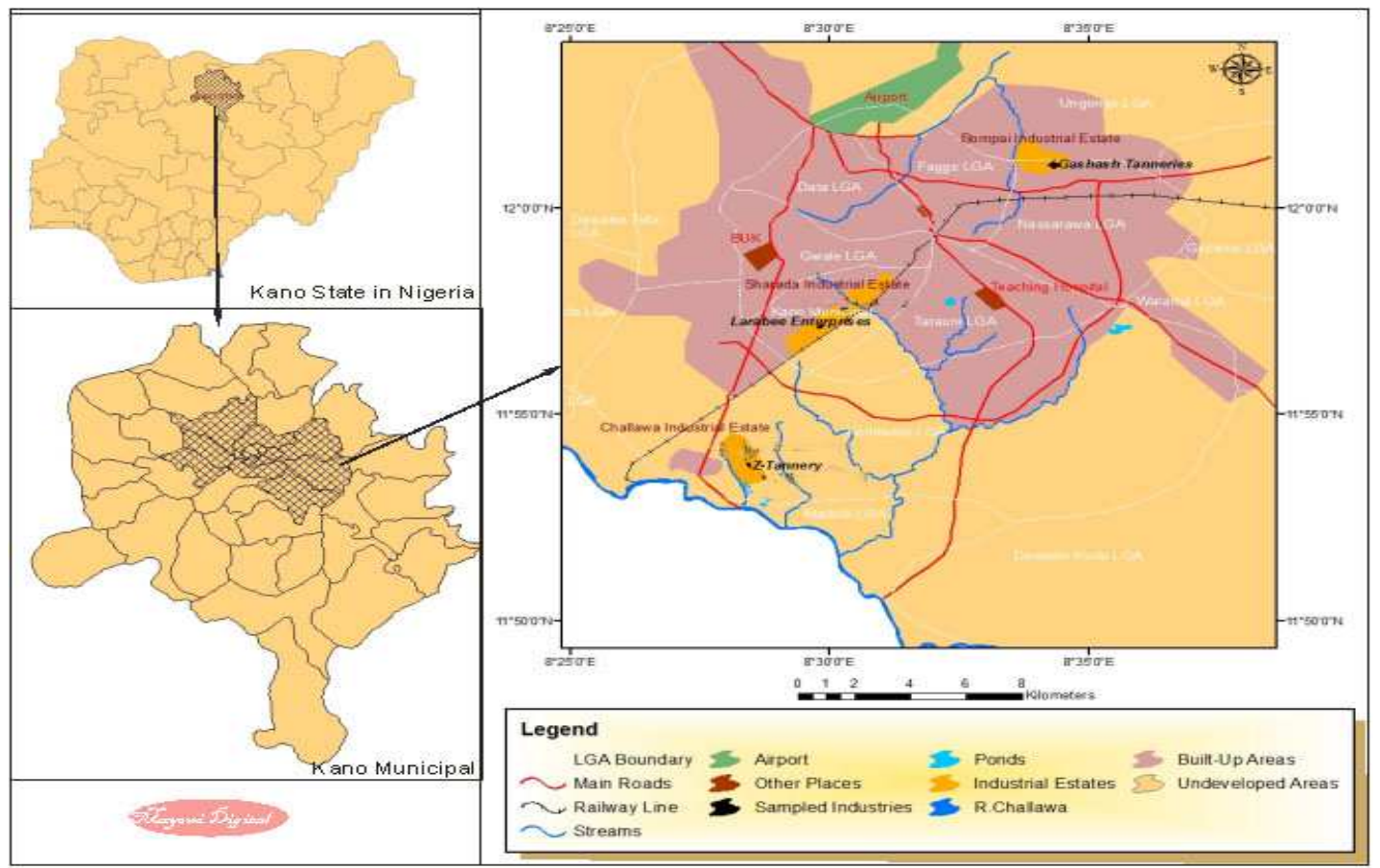

Fig. 1 Map showing the study areas

Source: Mayomi Digital Productions, GIS Laboratory, Department of Geography, UNIMAID (2017)

\section{Determination of Growth Rate of the Bacteria in Effluent Sample}

The bacteria growth rates were determined by transferring $2 \mathrm{~mL}$ of the bacterial isolates from the tannery effluent in broth medium into 100 $\mathrm{mL}$ sterile effluents in conical flasks and kept in an incubator (Giffrin cool) for 10 days. Control was also set up by incubating another $100 \mathrm{~mL}$ each of the sterile effluents without the bacteria. The optical density of the content was determined at the wavelength of $600 \mathrm{~nm}$ on a daily interval and recorded. 
BAJOPAS Volume 13 Number 2, December, 2020 Immobilization of Bacteria

Agar solution and inoculi were prepared separately. Fifty milliliters $(50 \mathrm{~mL})$ of nutrient broth each of the inoculi was prepared in a McCartney bottle and incubated for 24 hours. A solution of agar-agar was prepared by dissolving $10 \mathrm{~g}$ of the powder in distilled water and made up to $500 \mathrm{~mL}$ mark in an Erlenmeyer flask and was sterilized in an autoclave (280A) for 15 minutes and allowed to cool to $40-45^{\circ} \mathrm{C}$ (Ajao et al., 2011). Four milliliters ( $4 \mathrm{~mL})$ of the bacterial isolates in the nutrient broth was mixed with 36 $\mathrm{ml}$ of the prepared agar-agar media in petri-dish plates and then allowed to solidify. This was kept in the refrigerator for bioremediation.

\section{Bioremediation (Treatment) of the Effluents}

The solidified agar block (immobilized bacteria) was cut into cubes using a sterile knife; $0.1 \mathrm{~mL}$ phosphate buffer ( $\mathrm{pH} \mathrm{7.0)}$ was added and kept in the refrigerator for 1 hour for curing. The phosphate buffer was decanted after 1 hour and the cubes were washed with sterile distilled water 3-4 times before it was used (Ajao et al., 2011). Two liters (2 L) of the effluent was supplemented with the minimum basal medium in $\mathrm{g} / \mathrm{L}: \mathrm{NaCl}(0.8), \mathrm{MgSO}_{4} .7 \mathrm{H}_{2} \mathrm{O}(0.001), \mathrm{KH}_{2} \mathrm{PO}_{4}$ (2), $\mathrm{NaNO}_{3}$ (2), $\quad \mathrm{CaCl}_{2} .2 \mathrm{H}_{2} \mathrm{O} \quad(0.5)$ and $\mathrm{NaHPO}_{4} .12 \mathrm{H}_{2} \mathrm{O}(2)$ and sterilized in an autoclave at $121^{\circ} \mathrm{C}$ for 15 minutes (Margesin and Schinner, 2001). Two hundred and fifty milliliters $(250 \mathrm{~mL})$ of the effluents were transferred into different $250 \mathrm{ml}$ conical flasks. The content was covered with a cotton-wool ramped with foil paper to avoid contamination. Five grams $(5 \mathrm{~g})$ of the immobilized bacteria were quickly transferred into each of the effluents in the conical flasks in an inoculating chamber. The same procedures were carried out for the $10 \mathrm{~g}, 15 \mathrm{~g}, 20 \mathrm{~g}$ and 25 $\mathrm{g}$ of the immobilized bacteria in separate $250 \mathrm{~mL}$ effluents in conical flasks and agitated for ten days in a shaker incubator (Gallenkamp-OC4364-L) at a temperature $30^{\circ} \mathrm{C}$ and speed of 60 rpm. The treated effluent samples were taken on the tenth day and analyzed for the parameters $\mathrm{pH}$, SS, TDS, COD, and BOD, (Posttreatment determination) for the different grams of bacteria to evaluate and compare the biodegradation potential. (Baba et al., 2020).

\section{Statistical Analysis}

The data were represented as Mean \pm Standard deviation and analyzed statistically using oneway Analysis of Variance (ANOVA) and Tukey's HSD as Post Hoc Tests with the aid of SPSS 16.0. The correlation coefficient was also used to measure the strength of the relationship between the different masses of the bacteria and the parameters. All $\mathrm{p} \leq 0.05$ were considered as statistically significant.

\section{RESULTS AND DISCUSSION Physico-chemical parameters in the Industrial Effluents before the Biodegradation.}

Results of the Physico-chemical parameters in the industrial effluents before the Biodegradation is shown in table 1 . The mean temperatures $\left({ }^{\circ} \mathrm{C}\right)$ observed in TAN1, TAN2, and TAN3 samples were $28.07 \pm 0.65 ; 27.77 \pm 0.64$ and $26.38 \pm 3.81$ respectively. The order of the mean temperature of the samples from the three industries can be arranged as TAN1 > TAN2>TAN3. The temperature observed at TAN1, TAN2, and TAN3 samples were found below the WHO $\left(35^{\circ} \mathrm{C}\right)$ and NESREA $\left(40^{\circ} \mathrm{C}\right)$ limits. The low values of temperature might be due to the processes used at the time of sampling. High temperature brings down the solubility of gases in water that ultimately expresses as high BOD and COD. Statistical analysis shows that there is no significant difference $(p<0.05)$ between the mean values of temperature among the industries. This might be due to similar tannery activities involved in the tannery industries at the time of sampling. The average values of temperature observed in this present study are less than those observed by Akan et al. (2007), Akan et al. (2009) and Baba et al. (2020).

The mean level of $\mathrm{pH}$ observed in TAN1, TAN2 and TAN3, samples were $7.77 \pm 2.93$; $8.35 \pm 0.28$ and $7.52 \pm 0.76$ respectively. The order of the mean $\mathrm{pH}$ of the samples from the three industries can be arranged as TAN2> TAN1 $>$ TAN3. The $\mathrm{pH}$ of the samples falls within the WHO (7.0-8.5) and NESREA (6-9) standard limits. Statistical analysis shows that there is no significant difference $(p<0.05)$ between the mean values of $\mathrm{pH}$ among the industries. This might be due to similar tannery activities involved in the tannery industries at the time of sampling. Maheshwari et al. (2017) reported that the level of $\mathrm{pH}$ in the effluents from the tannery industry in Vaniyambadi, India was 6.5 which was lower than that observed in the present study. The $\mathrm{pH}$ in the effluents from the tannery industries in Kano and Kaduna were reported to be 7.64 and 6.89, respectively (Akan et al., 2007; Mohammed et al., 2017). The average values of $\mathrm{pH}$ observed in this present study are less than those observed by Mohammed et al. (2017) and Baba et al. (2020). The mean level of SS $(\mathrm{mg} / \mathrm{l})$ observed in TAN1, TAN2, and TAN3 samples were 374 \pm 124 ; $358 \pm 335$ and $780 \pm 739$ respectively. The order of the mean SS in the samples from the three industries can be arranged as TAN3 > TAN1 $>$ TAN2. 
The SS observed in the samples were far above the recommended standard limits of regulating bodies WHO $(30 \mathrm{mg} / \mathrm{l})$ and NESREA $(10 \mathrm{mg} / \mathrm{l})$. Statistical analysis shows that there is no significant difference $(p<0.05)$ between the mean values of SS among the industries. This might be due to similar tannery activities involved in the tannery industries at the time of sampling. The average values of SS observed in this present study are less than that observed $(3700 \pm 122 \mathrm{mg} / \mathrm{l})$ by Akan et al. (2009) for tanneries in Kano. Also, the average values of SS observed in this present study are less than that observed by Mohammed et al. (2017) and Baba et al. (2020) with the exception in TAN3.

The mean level of TDS (mg/l) observed in TAN1, TAN2, and TAN3 samples were $3941 \pm 3703$; $3300 \pm 1714$ and $2653 \pm 1240$ respectively. The order of the mean TDS in the samples from the three industries can be arranged as TAN1>TAN2>TAN3. The TDS observed in the samples were far above the recommended standard limits of WHO $(250 \mathrm{mg} / \mathrm{l})$ and NESREA $(500 \mathrm{mg} / \mathrm{l})$. Statistical analysis shows that there is no significant difference $(p<0.05)$ between the mean values of TDS among the industries. This might be due to similar tannery activities involved in the tannery industries at the time of sampling. TDS in the effluents from the tannery industries in Kano, Nigeria was reported to be $1281 \mathrm{mg} / \mathrm{l}$ (Akan et al., 2007). The average values of SS observed in this present study are less than those observed by Mohammed et al. (2017) and Baba et al. 2020)

The mean level of COD (mg/l) observed in TAN1, TAN2 and TAN3 samples seasons were $2372 \pm 938 ; \quad 1406 \pm 208$ and $3532 \pm 1373$ respectively. The order of the mean COD of the samples from the three industries can be arranged as TAN3>TAN1> TAN2. The COD observed in TAN1, TAN2 and TAN3 samples were far above the recommended standard limits of regulating bodies $\mathrm{WHO}(40 \mathrm{mg} / \mathrm{l})$ and NESREA (40 mg/l). Statistical analysis shows that there is no significant difference $(p<0.05)$ in COD among the industries. This might be due to similar tannery activities involved in the tannery industries as at the time of sampling. The Chemical Oxygen demand (COD) is the amount of oxygen, in $\mathrm{mg} / \mathrm{L}$, required for the degradation of the compound of wastewater to occur. In comparison, the average values of COD observed in this present study were higher than that observed by Mohammed et al. (2017) but lower than that observed by Baba et al. (2020).

The mean levels of BOD $(\mathrm{mg} / \mathrm{l})$ observed in TAN1, TAN2 and TAN3 samples were $13.85 \pm 6.42 ; \quad 19.46 \pm 0.50$ and $17.13 \pm 3.14$ respectively. The order of the mean BOD in the samples from the three industries can be arranged as TAN2>TAN3>TAN1. The BOD observed in TAN1, TAN2 and TAN3 samples were found below the recommended limits of NESREA (200 mg/l) but above WHO (10 mg/l). Statistical analysis shows that there is no significant difference $(p<0.05)$ between the mean values of BOD among the industries. This might be due to similar tannery activities involved in the tannery industries at the time of sampling. The low level of BOD recorded in this study is an indication of the low level of biodegradable organic solids in the effluent. The average values of BOD observed in this present study were lower than those observed by Mohammed et al. (2017) and Baba et al. (2020).

Table 1: Mean Values \pm S.D of Physico-chemical parameters of effluents from the Tannery Industries before Treatment.

\begin{tabular}{llllllll}
\hline Parameter & Tannery 1 & Tannery 2 & Tannery 3 & $\mathrm{a}$ & $\mathrm{b}$ & $\mathrm{c}$ & $\mathrm{d}$ \\
\cline { 2 - 7 } Temperature $\left({ }^{\circ} \mathrm{C}\right)$ & $28.07 \mathrm{a} \pm 0.65$ & $27.77 \mathrm{a} \pm 0.64$ & $26.38 \mathrm{a} \pm 3.81$ & & $29.50 \pm 4.68$ & 35 & 40 \\
pH & $7.77 \mathrm{a} \pm 2.93$ & $8.35 \mathrm{a} \pm 0.28$ & $7.52 \mathrm{a} \pm 0.76$ & 6.89 & $5.35 \pm 1.57$ & $7.0-8.5$ & $6.0-9.0$ \\
$\mathrm{COD}(\mathrm{mg} / \mathrm{l})$ & $2372 \mathrm{a} \pm 938$ & $1406 \mathrm{a} \pm 208$ & $3532 \mathrm{a} \pm 1373$ & 2.2 & $3106 \pm 2753$ & 40 & 40 \\
$\mathrm{BOD}(\mathrm{mg} / \mathrm{l})$ & $13.85 \mathrm{a} \pm 6.42$ & $19.46 \mathrm{a} \pm 0.50$ & $17.13 \mathrm{a} \pm 3.14$ & 1032 & $26.17 \pm 9.49$ & 10 & 200 \\
$\mathrm{SS}(\mathrm{mg} / \mathrm{l})$ & $374 \mathrm{a} \pm 124$ & $358 \mathrm{a} \pm 335$ & $780 \mathrm{a} \pm 739$ & 501 & $562 \pm 482$ & 30 & 10 \\
TDS $(\mathrm{mg} / \mathrm{l})$ & $3941 \mathrm{a} \pm 3703$ & $3300 \mathrm{a} \pm 1714$ & $2653 \mathrm{a} \pm 1240$ & 532.7 & $444 \pm 507$ & 250 & 500 \\
\hline
\end{tabular}

The values given in the table above are means of 6 replicate values, $\mathrm{n}=6$ ( 1 sample was taken monthly for 6 months). Within the rows, means with different alphabets are statistically different $(p<0.05)$. WHO: World Health Organisation. NESREA: National Environmental Standard and Regulatory Enforcement Agency. a = Mohammed et al.(2017), b = Baba et al. (2020), c = WHO (2006), $d=$ NESSRA (2009) 
BAJOPAS Volume 13 Number 2, December, 2020

Identification, Biochemical Characterization and growth rates of the Bacterial Isolates

Results of identification and biochemical characterization of the bacterial isolates were shown in table 2. After 24 hours of incubation, the nutrient agar media plates were checked for bacterial growth. The results showed the presence of different strains in the samples. The TAN1 bacteria isolate was found to be gramnegative cocci while TAN3 was gram-positive cocci. TAN2 bacteria isolate was found to be gram-positive, rod-shaped. TAN1, TAN2, and TAN3 bacteria isolates recorded positive results for spore former.

The results of the biochemical tests indicated that all the bacteria were positive for catalase, oxidase, citrate, maltose, glucose, lactose (negative in TAN1), mannitol (negative in TAN2), starch hydrolysis and coagulase (negative in TAN2) tests. The bacteria showed negative results for nitrate reduction, $M R$ (positive in TAN2), VP (positive in TAN1), Indole (positive in TAN2) tests. Base on the morphological and biochemical test results, TAN1, TAN2, and TAN3 bacteria isolates were identified to be Nesseria spp, Bacillus cereus, and Staphylococcus aureus respectively.

The growth rate of the TAN1, TAN2 and TAN3 Isolates were shown in figure 2. Generally, the optical density increase with the increase in time (day) and decrease as time goes on. The highest optical density was shown by bacillus cereus in TAN2 while the lowest was shown by Staphylococcus aureus in TAN3.

The initial growth phase of TAN1 Isolate bacteria occurred within 2-day of incubation as the growth rate increases up to the 6th-day incubation when the maximum growth was observed. Beyond the 6th day, the growth of the bacteria declined (which might be due to a shortage of nutrients in the effluents) until it reached its death phase (which might be due to the unavailability of nutrients in the effluents).

A similar trend of growth was also observed for TAN2 Isolate as the initial growth phase also occurred within 2-day of incubation but maximum growth rate observed on the 4th day of incubation. The stationary stage occurred between the 4th day and the 8th day. Beyond the 8th day, the growth of the bacteria declined (which might be due to a shortage of nutrients in the effluents) until it reached its death phase (which might be due to the unavailability of nutrients in the effluents).

The initial growth phase of TAN3 bacterial Isolate occurred within the 3-day incubation as the growth rate increases up to the 6th-day incubation when the maximum growth was observed. Beyond the 6th day, the growth of the bacteria declined (which might be due to a shortage of nutrients in the effluents) until it reached its death phase (which might be due to the unavailability of nutrients in the effluents).

Table 2: Morphological and Biochemical characteristics of bacterial isolates

\begin{tabular}{lllll} 
Bacterial Isolates & & TAN1 & TAN2 & TAN3 \\
\hline $\begin{array}{lllll}\text { Morphological } \\
\text { characteristics }\end{array}$ & Shape & Cocci & Rod & Cocci \\
& Spore & & & \\
& former & + & + & + \\
Gram & & & \\
Biochemical characteristics & reaction & - & + & + \\
& Citrate & + & + & + \\
& Catalase & + & + & + \\
& Coagulase & + & - & + \\
Starch & + & + & + \\
& Glucose & + & + & + \\
Oxidase & + & + & + \\
& Indo & - & + & - \\
Lactose & - & + & + \\
Manitol & + & - & + \\
Maltose & + & + & + \\
MR & - & + & - \\
VP & + & - & - \\
& Nitrate & - & - & - \\
Reduction & - Neisseria & Bacillus & Staphylococcus \\
& Bacterial & cereus & aureus \\
& name & spp & cas
\end{tabular}

+ = Positive; - = Negative; MR=Methyl Red; VP= Voges-Proskauer 


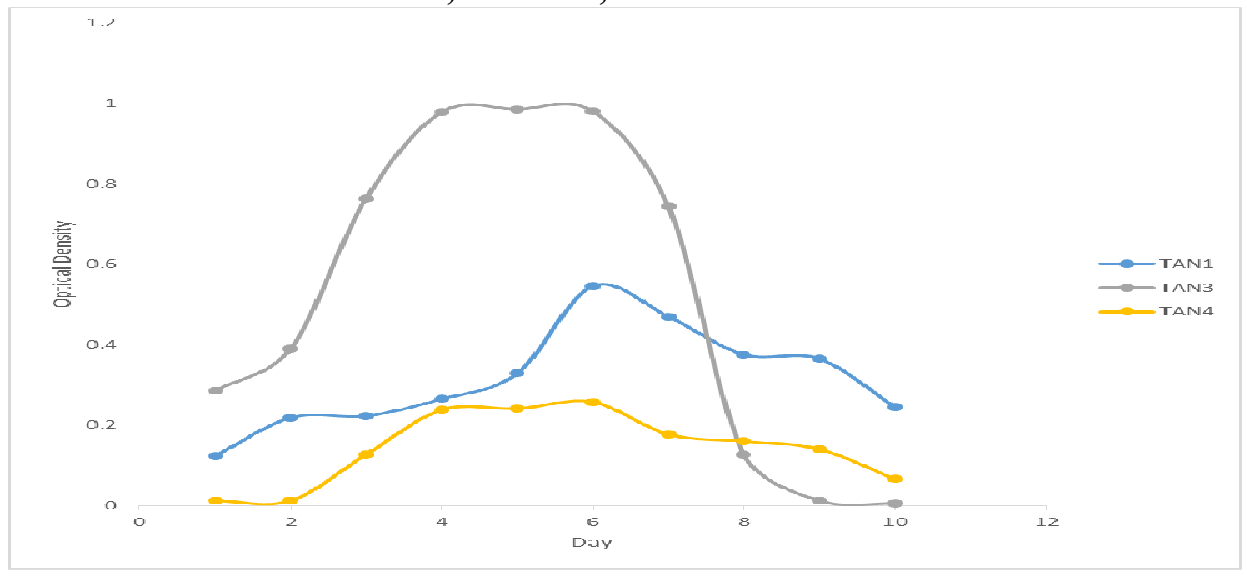

Fig. 2 Growth rates of the isolates in the effluents from the Tannery Industries

\section{Physico-chemical Parameters in the Industrial Effluents after the biodegradation.}

Table 3 shows the mean results of the physicochemical parameter before and after bioremediation using the different masses $(5 \mathrm{~g}$, $10 \mathrm{~g}, 15 \mathrm{~g}, 20 \mathrm{~g}$, and $25 \mathrm{~g}$ ) of the respective immobilized bacteria. Also, Table 4 shows the mean results of correlation coefficient ( $r$ ) between different masses of bacteria and physicochemical parameters.

The mean values $(\mathrm{mg} / \mathrm{l})$ of the SS after the bioremediation varies between $243 \pm 45$ and $898 \pm 672$. The mean concentration $(\mathrm{mg} / \mathrm{l})$ of SS remediated by the different masses $(5 \mathrm{~g}, 10 \mathrm{~g}$, $15 \mathrm{~g}, 20 \mathrm{~g}$, and $25 \mathrm{~g}$ ) of the bacteria varies. The SS in the samples fluctuates up and down after the bioremediation process when compared with the SS of the raw samples before the bioremediation. The increase in the levels of the SS might be due to the aggregation of the TDS which are large enough to result into SS. The increase in the levels of the SS might be also due to the influence of the nutrients which was added into the effluents in order to make the microorganisms more active and viable for fast degradation of organic contaminants in the effluent. The relative potential or efficiency of the different masses of the bacteria in remediating SS in TAN1 samples was in the order $25 \mathrm{~g}>20 \mathrm{~g}>15 \mathrm{~g}>10 \mathrm{~g}>5 \mathrm{~g}$. For TAN2 and TAN3 samples, the order was $25 \mathrm{~g}>20 \mathrm{~g}>15$ $\mathrm{g}>10 \mathrm{~g}>5 \mathrm{~g}$. These might be due to the variations in the surface areas of the different masses of the immobilized bacteria. Statistical analysis shows that there is no significant difference $(p<0.05)$ between the mean values of SS among the masses in the respective industries. Positive and significant correlations exist between the masses of bacteria and Suspended Solid (SS). This showed that there is general increase in the levels of the SS as the masses of the immobilized bacteria increases. TAN3 (90\%) and TAN1 (80\%) showed a very high correlation with the masses of the bacteria while TAN2 (61\%) showed a very low correlation.

The mean values $(\mathrm{mg} / \mathrm{l})$ of the TDS after the bioremediation varies between $46 \pm 11$ and $83 \pm 78$. The mean concentration $(\mathrm{mg} / \mathrm{l})$ of TDS remediated by the different masses $(5 \mathrm{~g}, 10 \mathrm{~g}$, $15 \mathrm{~g}, 20 \mathrm{~g}$, and $25 \mathrm{~g}$ ) of the bacteria varies. There is a reduction in all the TDS of all the samples after the bioremediation process compared with the TDS of the raw samples before the bioremediation. The relative potential or efficiency of the different masses of the bacteria in remediating TDS in TAN1 and TAN3 samples was in the order $5 \mathrm{~g}>10 \mathrm{~g}>15 \mathrm{~g}>20$ $\mathrm{g}>25 \mathrm{~g}$. For TAN2 samples, the order was 20 $g>10 \quad g>25 \quad g>15 \quad g>5 \quad g$. Statistical analysis shows that there is no significant difference $(p<0.05)$ between the mean values of TDS among the masses in the respective industries. These might be due to the variations in the surface areas of the different masses of the immobilized bacteria. Positive and significant correlations exist between the masses of bacteria and TDS with the exception in TAN2 (negative and insignificant correlation). The positive correlations showed that there is general increase in the levels of the TDS as the masses of the immobilized bacteria increases. TAN1 $(96 \%)$ showed a very high correlation with the masses of the bacteria while TAN2 (47\%) showed a very low correlation.

The mean values $(\mathrm{mg} / \mathrm{l})$ of the BOD after the bioremediation varies between $1.56 \pm 0.20 \mathrm{mg} / \mathrm{l}$ and $6.92 \pm 5.49 \mathrm{mg} / \mathrm{l}$. The mean concentration $(\mathrm{mg} / \mathrm{l})$ of BOD remediated by the different masses $(5 \mathrm{~g}, 10 \mathrm{~g}, 15 \mathrm{~g}, 20 \mathrm{~g}$, and $25 \mathrm{~g}$ ) of the bacteria varies. There is a reduction in all the BOD of all the samples after the bioremediation process compared with the $\mathrm{BOD}$ of the raw 
BAJOPAS Volume 13 Number 2, December, 2020 samples before the bioremediation. The relative potential or efficiency of the different masses of the bacteria in remediating BOD in TAN1, TAN2 and TAN3 samples were in the order $25 \mathrm{~g}>20$ $\mathrm{g}>15 \mathrm{~g}>10 \mathrm{~g}>5 \mathrm{~g}, 25 \mathrm{~g}>15 \mathrm{~g}>5 \mathrm{~g}>10 \mathrm{~g}>20 \mathrm{~g}$ and $20 \mathrm{~g}>10 \mathrm{~g}>25 \mathrm{~g}>15 \mathrm{~g}>5 \mathrm{~g}$ respectively. Statistical analysis shows that there is significant difference $(p<0.05)$ between the mean values of BOD among the masses in the respective industries. These might be due to the variations in the surface areas of the different masses of the immobilized bacteria. Negative and significant correlations exist between the masses of bacteria and BOD. This showed that there is general decrease in the levels of the BOD as the masses of the immobilized bacteria increases. TAN1 (94\%) showed a very high correlation with the masses of the bacteria while TAN2 (4\%) showed a very low correlation.

The mean values $(\mathrm{mg} / \mathrm{l})$ of the COD after the bioremediation varies between $250 \pm 154$ and $3134 \pm 1595$. The mean concentration $(\mathrm{mg} / \mathrm{l})$ of COD remediated by the different masses $(5 \mathrm{~g}$, $10 \mathrm{~g}, 15 \mathrm{~g} 20 \mathrm{~g}$, and $25 \mathrm{~g}$ ) of the bacteria varies. There is a reduction in all the COD of all the samples after the bioremediation process compared with the COD of the raw samples before the bioremediation. The relative potential or efficiency of the different masses of the bacteria in remediating COD in TAN1, TAN2 and TAN3 samples were in the order $25 \mathrm{~g}>20 \mathrm{~g}>15$ $\mathrm{g}>5 \mathrm{~g}>10 \mathrm{~g}, 25 \mathrm{~g}>20 \mathrm{~g}>15 \mathrm{~g}>10 \mathrm{~g}>5 \mathrm{~g}$ and 10 g>5 g>25 g>15 g>20 g respectively. Statistical analysis shows that there were significant difference $(p<0.05)$ between the mean values of COD among the masses in the respective industries except for effluents treated with $25 \mathrm{~g}$. These might be due to the variations in the surface areas of the different masses of the immobilized bacteria. Negative and insignificant correlations exist between the masses of bacteria and COD with the exception in TAN3 (positive and significant correlation). The negative correlations showed that there is general decrease in the levels of the COD as the masses of the immobilized bacteria increases. TAN2 (100\%) showed a very high correlation with the masses of the bacteria while TAN3 (36\%) showed a very low correlation.

Generally, there was an overall decrease in the concentration of these physicochemical parameters after the bioremediation using the different masses of the bacterial isolates. These might be due to the variations in the surface areas of the different masses of the immobilized bacteria. This is in line with the work of Jimoh et al. (2018) and Baba et al. (2020).

Table 3: Mean Values $(\mathrm{mg} / \mathrm{l}) \pm$ S.D of Physicochemical parameters in effluents from the Tannery Industries before and after Treatment of the effluents $(250 \mathrm{ml})$ with the different masses $(5 \mathrm{~g}, 10 \mathrm{~g}$, $15 \mathrm{~g}, 20 \mathrm{~g}$, and $25 \mathrm{~g}$ ) of the bacteria.

\begin{tabular}{llllllll}
\hline $\mathrm{P}$ & IND & Before & \multicolumn{5}{c}{ After } \\
\cline { 4 - 7 } & & & $5 \mathrm{~g}$ & $10 \mathrm{~g}$ & $15 \mathrm{~g}$ & $20 \mathrm{~g}$ & $25 \mathrm{~g}$ \\
\hline \multirow{2}{*}{ COD } & TAN1 & $2372 \pm 938$ & $1708 \mathrm{a} \pm 861$ & $2045 \mathrm{a} \pm 1205$ & $845 \mathrm{a} \pm 369$ & $300 \mathrm{a} \pm 167$ & $250 \mathrm{a} \pm 154$ \\
& TAN2 & $1406 \pm 208$ & $1195 \mathrm{a} \pm 208$ & $1125 \mathrm{a} \pm 384$ & $1055 \mathrm{a} \pm 317$ & $956 \mathrm{a} \pm 310$ & $870 \mathrm{ab} \pm 240$ \\
& TAN3 & $3532 \pm 1373$ & $2374 \mathrm{a} \pm 1344$ & $1976 \mathrm{a} \pm 1405$ & $2757 \mathrm{a} \pm 1266$ & $3134 \mathrm{a} \pm 1595$ & $2614 \mathrm{~b} \pm 1105$ \\
BOD & TAN1 & $13.85 \pm 6.42$ & $6.92 \mathrm{a} \pm 5.49$ & $6.42 \mathrm{a} \pm 5.07$ & $5.72 \mathrm{a} \pm 5.35$ & $4.62 \mathrm{a} \pm 4.37$ & $2.82 \mathrm{ab} \pm 1.26$ \\
& TAN2 & $19.46 \pm 0.50$ & $1.75 \mathrm{~b} \pm 0.22$ & $1.73 \mathrm{~b} \pm 0.18$ & $1.58 \mathrm{a} \pm 0.16$ & $1.91 \mathrm{a} \pm 0.22$ & $1.56 \mathrm{~b} \pm 0.20$ \\
& TAN3 & $17.13 \pm 3.14$ & $4.24 \mathrm{ab} \pm 0.77$ & $3.29 \mathrm{ab} \pm 0.37$ & $4.11 \mathrm{a} \pm 0.07$ & $3.23 \mathrm{a} \pm 0.91$ & $3.33 \mathrm{a} \pm 1.28$ \\
SS & TAN1 & $374 \pm 124$ & $243 \mathrm{a} \pm 45$ & $471 \mathrm{a} \pm 226$ & $475 \mathrm{a} \pm 182$ & $492 \mathrm{a} \pm 128$ & $611 \mathrm{a} \pm 217$ \\
& TAN2 & $358 \pm 335$ & $460 \mathrm{a} \pm 400$ & $543 \mathrm{a} \pm 414$ & $544 \mathrm{a} \pm 402$ & $551 \mathrm{a} \pm 414$ & $554 \mathrm{a} \pm 405$ \\
& TAN3 & $780 \pm 739$ & $586 \mathrm{a} \pm 594$ & $758 \mathrm{a} \pm 656$ & $787 \mathrm{a} \pm 676$ & $861 \mathrm{a} \pm 635$ & $898 \mathrm{a} \pm 672$ \\
TDS & TAN1 & $3941 \pm 3703$ & $51 \mathrm{a} \pm 10$ & $53 \mathrm{a} \pm 10$ & $55 \mathrm{a} \pm 15$ & $61 \mathrm{a} \pm 20$ & $63 \mathrm{a} \pm 26$ \\
& TAN2 & $3300 \pm 1714$ & $83 \mathrm{a} \pm 78$ & $47 \mathrm{a} \pm 20$ & $48 \mathrm{a} \pm 22$ & $47 \mathrm{a} \pm 17$ & $48 \mathrm{a} \pm 17$ \\
& TAN3 & $2653 \pm 1240$ & $46 \mathrm{a} \pm 11$ & $55 \mathrm{a} \pm 24$ & $55 \mathrm{a} \pm 25$ & $58 \mathrm{a} \pm 23$ & $61 \mathrm{a} \pm 28$ \\
\hline
\end{tabular}

Replicate $=6$ (months)

Within the rows, for the same parameter, means with different alphabets are statistically different $(p<0.05)$.

$\mathrm{P}=$ parameter, IND = Industries 
BAJOPAS Volume 13 Number 2, December, 2020

Table 4: Correlation coefficient $(r)$ between different masses of the bacteria and the physicochemical parameters.

\begin{tabular}{llll}
\hline Industries & Parameter & Correlation coefficient $(r)$ & $\begin{array}{l}\text { Percent dependence (rxrx100) } \\
(\%)\end{array}$ \\
\hline TAN1 & COD & -0.9 & 82 \\
& BOD & -0.97 & 94 \\
& SS & $0.90^{*}$ & 80 \\
TAN2 & TDS & $0.98^{*}$ & 96 \\
& COD & -1 & 100 \\
& BOD & -0.21 & 4 \\
& SS & $0.78^{*}$ & 61 \\
& TDS & -0.69 & 47 \\
& COD & $0.60^{*}$ & 36 \\
& BOD & -0.6 & 37 \\
& SS & $0.95^{*}$ & 90 \\
& TDS & $0.94^{*}$ & 89 \\
\hline
\end{tabular}

The correlation coefficient $(r)$ with * is statistically significant $(p<0.05)$.

Percentage reduction of the Parameters

Table 5 shows the percentage reduction of Parameters in industrial samples before and after the treatment of the effluents $(250 \mathrm{ml})$ with the different masses $(5 \mathrm{~g}, 10 \mathrm{~g}, 15 \mathrm{~g}, 20 \mathrm{~g}$, and $25 \mathrm{~g}$ ) of the Immobilized Bacteria.

In TAN1 samples, the percentage reduction (\%) of COD ranged (14-89); BOD (50-80); SS (-32$35)$ and TDS (98-99). In TAN2 samples, the percentage decrease $(\%)$ of COD ranged (15$38) ;$ BOD (90-92); SS [-28-(-55)] and TDS (9798). In TAN3 samples, the percentage decrease (\%) of COD ranged (11-44); BOD (76-81); SS (15-25) and TDS (98). The percentage increase in the levels COD, BOD and TDS might be due to the increase in the surface area of the different masses of the immobilized bacteria. However, the percentage decrease in the levels of the SS might be due to the aggregation of the TDS which are large enough to result into SS. The percentage decrease in the levels of the SS might be also due to the influence of the nutrients which was added into the effluents in order to make the microorganisms more active and viable for fast degradation of organic contaminants in the effluent. This is in line with the work of Jimoh et al. (2018) in which the concentration of the SS increase after the bioremediation of effluents.

Sreemoyee and Priti (2013) assessed and reduced several Physico-chemical parameters of dairy wastewater using Niesseria $s p$. and concluded that the species are well known to degrade organic compounds. This is in agreement with the current study in which the immobilized Niesseria $s p$ degrade the organic contaminants as indicated by the BOD, COD and TDS.

Jimoh et al. (2018) observed that TSS of the effluents was increased after treatment with immobilized bacteria and concluded that it might be due to the biostimulation method adopted for the research.

The optimum $\mathrm{pH}$ Biosorption of Chromium by Bacillus spp and Staphylococcus spp. from tannery effluent was investigated by Mythili and Karthikeyan (2011). The maximum adsorption of Chromium $(86.4 \mathrm{mg} / \mathrm{L})$ was showed by Bacillus spp and Staphylococcus spp showed $70.6 \mathrm{mg} / \mathrm{L}$ at an initial concentration of $100 \mathrm{mg} / \mathrm{L}$. In the present study, immobilised Bacillus spp and Staphylococcus spp. from the tannery industrial effluents reduced the levels of the organic pollutants with high potential as indicated by the percentage reduction of BOD, COD and TDS.

Enzymes often can work in multiple environments especially if they are immobilized. This makes the microorganisms' enzymes even more resistant to harsh environments and enables the enzymes to be recovered and recycled after they are no longer needed (Gianfreda and Rao 2004). Ramesh and Singh (1993) reported that the immobilized bacteria having more efficiency to remove the suspended particles than free cells. Using the immobilized cell is preferable due to its capability for using several times with the same efficiency, which makes it more economical. Similar work was done by Sikander et al. (2007) showing the higher reduction with permeabilized cells of Ochrobactrum intermedium strain SDCr-5. 
BAJOPAS Volume 13 Number 2, December, 2020

The results revealed the isolation and identification of isolates with the potential for the reduction of $\mathrm{Cr}$ (VI) to $\mathrm{Cr}$ (III). Results indicated that immobilized $B$. cereus could be efficiently used for the reduction of $\mathrm{Cr}$ (VI).

Table 5: Percentage reduction of the tested Parameters from the tannery industrial samples of the Immobilized Bacteria.

\begin{tabular}{lllllll}
\hline \multirow{2}{*}{ Industries } & & \multicolumn{5}{c}{ Percentage Reduction $(\%)$} \\
\cline { 3 - 7 } & & $5 \mathrm{~g}$ & $10 \mathrm{~g}$ & $15 \mathrm{~g}$ & $20 \mathrm{~g}$ & $25 \mathrm{~g}$ \\
\hline TAN1 & COD & 28 & 14 & 64 & 87 & 89 \\
& BOD & 50 & 54 & 59 & 67 & 80 \\
& SS & 35 & -26 & -27 & -32 & -63 \\
& TDS & 99 & 99 & 99 & 98 & 98 \\
TAN2 & COD & 15 & 20 & 25 & 32 & 38 \\
& BOD & 91 & 91 & 92 & 90 & 92 \\
& SS & -28 & -52 & -52 & -54 & -55 \\
& TDS & 97 & 99 & 99 & 99 & 99 \\
& COD & 33 & 44 & 22 & 11 & 26 \\
& BOD & 75 & 81 & 76 & 81 & 81 \\
& SS & 25 & 3 & -1 & -10 & -15 \\
& TDS & 98 & 98 & 98 & 98 & 98 \\
\hline
\end{tabular}

Percentage Reduction $=(B-A) / B \times 100 \%$

$A=$ Concentration of the parameter after treatment

$\mathrm{B}=$ Concentration of the parameter before treatment

$+=$ percentage decrease

- = percentage increase

In general, immobilization makes the enzyme more resistant to temperature, $\mathrm{pH}$, and substrate concentration swings giving it a longer lifetime and higher productivity per active unit (Gianfreda and Rao, 2004; FuIlbrook, 1996; Russell et al, 2003; Kandelbauer et al., 2004). Immobilized cells have been used and studied extensively for the production of useful chemicals (Ohtake and Silver, 1994), the treatment of wastewaters (Chen et al., 2003; Wang et al., 2010). Although many workers described microbial degradation of tannery effluent, limited literature is available on the bioremediation of tannery effluent using immobilized bacterial cells in the Kano Industrial Estates.

\section{CONCLUSION}

The samples contained variable levels of the physicochemical parameters. The results of the Analysis of variance revealed that, no statistical difference $(p<0.05)$ was observed for the temperature, $\mathrm{pH}, \mathrm{SS}, \mathrm{TDS}, \mathrm{BOD}$ and $\mathrm{COD}$ among the three tannery industries before the treatment. The levels of some of the parameters
(SS, TDS and COD) observed in the samples were found above the recommended limits of WHO and NESREA, which called for the treatment of the effluents before discharge into the environment. Base on the morphological and biochemical test results, TAN1, TAN2, and TAN3 bacterial isolates were identified to be Neisseria spp, Bacillus cereus, and Staphylococcus aureus respectively. The results of Post-treatment analysis showed that there is overall decrease in the levels of the parameters determined when compared with that of the pre-treatment. The overall percentage reduction of the immobilised bacteria in the treatment of the respective effluents was in the order TAN2 (72\%)>TAN1 $(70 \%)>$ TAN3 $(62 \%)$. Hence, the immobilized bacteria are having higher biodegradation potential for the treatment of the tannery effluents.

\section{Acknowledgments}

The authors wish to acknowledge the University of Maiduguri for the financial support. The authors are grateful to the Kano State Ministry of Environment for their support in obtaining the effluent samples. 


\section{REFERENCES}

Ajao, A. T., Adebayo, G. B., and Yakubu, S. E. (2011). Bioremediation of textile industrial effluent using mixed culture of Pseudomonas aeruginosa and Bacillus subtilis immobilized on agar-agar in a bioreactor. J. Microbiol. Biotech. Res, 1(3), 50-56.

Akan, J. C., Moses, E. A., Ogugbuaja, V. O., and Abah, J. (2007). Assessment of tannery industrial effluents from Kano metropolis, Kano State, Nigeria. Journal of Applied Sciences, 7(19), 2788-2793.

Akan, J. C., Ogugbuaja, V. O., Abdulrahman, F. I., and Ayodele, J. T. (2009). Pollutant levels in effluent samples from tanneries and textiles of Kano industrial areas, Nigeria. Global journal of pure and applied sciences, 15(3-4).

APHA (1989). Standard methods for Examination of Will bete and Will betewater.15 $5^{\text {th }}$ edition. Brydpass Springfield Will behington DC. pp. 164-176

APHA (1992). Standard Methods for the Examination of Water and Wastewater. Health, 69, 1116-9.

Baba, A., Garba, S. T., and Bello, H. S. (2020). Bioremediation Potential of Immobilized corynebacterium kutsceri in the Treatment of Tannery Industrial Effluent from Challawa Industrial Estate, Kano State, Nigeria. Journal of the Turkish Chemical Society Section A: Chemistry, $7(2), 335-350$.

Beem, E. I. V. (1994). reduction of solvent VOC emission. J. Oil Col. Chem. Ass, 77, 158.

Bouwer, E. J., and Zehnder, A. J. (1993). Bioremediation of organic compoundsputting microbial metabolism to work. Trends in biotechnology, 11(8), 360367.

Chen, K. C., Wu, J. Y., Liou, D. J., and Hwang, S. C. J. (2003). Decolorization of the textile dyes by newly isolated bacterial strains. Journal of Biotechnology, 101(1), 57-68.

Dan'Azumi, S., and Bichi, M. H. (2010). INDUSTRIAL POLLUTION AND HEAVY METALS PROFILE OF CHALLAWA RIVER IN KANO, NIGERIA. Journal of Applied Sciences in Environmental Sanitation, $5(1)$.

DWAF. (1992). Analytical Methods Manual, TR 151. Department of Water Affairs and Forestry, Pretoria.

El-Bestawy, E. (2013). Biological treatment of leather-tanning industrial wastewater using free living bacteria.
Elsheikh, M. A. S. (2009). Tannery wastewater pre-treatment. Water Science and Technology, 60(2), 433-440.

FuIlbrook, P. D. (1996). "Kinetics." Industrial enzymology: The application of enzymes in Industry. 2nd Ed. T. Godfrey and J Reichelt. eds.. Nature. New York.

Gianfreda, L., and Rao, M. A. (2004). Potential of extra cellular enzymes in remediation of polluted soils: a review. Enzyme and microbial technology, 35(4), 339354.

Hugo Springer. (1994). John Arthur Wilson Memorial Lecture "Treatment of Industrial Wastes of the Leather Industry - is it still a Major Problem". JALCA, 89, 153-185

Jimoh, A. A., Ganiyu, B. A., Baba, D., and Baba, A. (2018) Bioremediation Process of Effluent from Detergent and Food Industries in Jos, Nigeria: Kinetics and Thermodynamics. International Journal of Engineering Science Invention (IJESI), 762-73

Kandelbauer, A., Maute, O., Kessler, R. W., Erlacher, A., and Gübitz, G. M. (2004). Study of dye decolorization in an immobilized laccase enzyme-reactor using online spectroscopy. Biotechnology and bioengineering, 87(4), 552-563.

Kongjao, S., Damronglerd, S., and Hunsom, M. (2008). Simultaneous removal of organic and inorganic Pollutants in tannery wastewater using electrocoagulation technique. Korean Journal of chemical engineering, 25(4), 703.

Maheshwari, U. M., Aruna, S., Gomathi, M., and AbdulJaffar, A. H. (2017). Bioremediation by Free and Immobilized Bacteria Isolated from Tannery Effluent. International Journal of Research in Applied, Natural and Social Sciences. 5(7), 75-90

Margesin, R., and Schinner, F. (2001). Bioremediation (natural attenuation and biostimulation) of diesel-oilcontaminated soil in an alpine glacier skiing area. Applied and environmental microbiology, 677), 3127-3133.

Mohammed, A., Sekar, P., and George, J. (2011). Efficacy of microbes in bioremediation of tannery effluent. Inter. J. Curr. Res, 3(4), 324-326.

Mohammed, S. S. D., Orukotan, A. A., and Abdullahi, H. (2017). Physicochemical and Bacteriological Assessment of Tannery Effluent from Samaru-Zaria, 
BAJOPAS Volume 13 Number 2, December, 2020 Kaduna State, Nigeria. Journal of Applied

Sciences and Environmental Management, 21(4), 734-740.

Munz, G., De Angelis, D., Gori, R., Mori, G., Casarci, M., and Lubello, C. (2009). The role of tannins in conventional and membrane treatment of tannery wastewater. Journal of hazardous materials, 164(2-3), 733-739

Mythili, K., and Karthikeyan, B. (2011). Bioremediation of $\mathrm{Cr}$ (VI) from tannery effluent using Bacillus spp and Staphylococcus spp. International Multidisciplinary Research Journal, 1(6).

NESREA (2009). National Environmental Standards for Effluent Limitations and Regulation. 1233-1236

Noorjahan, C. M. (2014). Physicochemical characteristics, identification of bacteria and biodegradation of industrial effluent. Journal of bioremediation and Biodegradation, 5(3).

Ohtake, H. I., and Silver, A. O. (1994). Bacterial reduction of toxic chromate. Biological degradation and bioremediation of toxic chemicals, 403-415.

Omoleke, I. I. (2004). Management of environmental pollution in Ibadan, an African city: the challenges of health hazard facing government and the people. Journal of Human Ecology, 15(4), 265-275.

Rajor, A., Reddy, A.S., and Singh, B. (2004). Determination of BOD kinetic Parameters and evaluation of alternate methods, M.Sc. Thesis, Department of biotechnology \& environmental Science, Thapar Institute of Engineering and Technology, Patiala

Ramasami, T., Rajamani, S., and Rao, J. R. (1994, March). Pollution control in leather industry: Emerging technological options. In International symposium on surface and colloidal science and its relevance to soil pollution, madras.

Ramesh, J. V. S., and Singh, S. P. (1993). Yearly variation in certain physicochemical parameters of pond at eastern Doon Valley. Uttar Pradesh J. Zoo, 12 (1), 7577.

Ranen, S., and Sharadinadra, C. (2009). Biotechnology applications to environmental remediation in resource exploitation. Current science, 97, 6-25
Russell, A. J., Berberich, J. A., Drevon, G. F., and Koepsel, R. R. (2003). Biomaterials for mediation of

chemical and biological warfare agents. Annual review of biomedical engineering, 5(1), 1-27.

Saravanan, P., and Saravanan, A. (1999). Decolourization of tannery effluent by Flavobacterium sp. EK 1. Indian Journal of Environmental Protection, 19, 19-24.

Sikander, S., and Shahida, H. (2007). Reduction of toxic hexavalent chromium by Ochrobactrum intermedium strain SDCr5 stimulated by heavy metals. Bioresource Technol, 98, 340-344.

Singh, N., Sharma, B. K., and Bohra, P. C. (2000). Impact assessment of industrial effluent of arid soils by using satellite imageries. Journal of the Indian Society of Remote Sensing, 28(2-3), 79.

Sreemoyee, C., and Priti, P. (2013). Assessment of physico-chemical parameters of dairy waste water and isolation and characterization of bacterial strains in terms of cod reduction. Int J Sci, 2(3), 395-400.

Verheijen, L. A. H. M., Wiersema, D., Pol, L. H., and De Wit, J. (1996). Management of wastes from animal product processing. Livestock and environment, Finding a balance. International Agriculture Center, Wageningen, The Netherlands.

Wang, F., Yao, J., Si, Y., Chen, H., Russel, M., Chen, K., and Bramanti, E. (2010). Short-time effect of heavy metals upon microbial community activity. Journal of Hazardous Materials, 173(13), 510-516.

WHO (World Health Organization). (2006). Air quality guidelines: global update 2005: particulate matter, ozone, nitrogen dioxide, and sulfur dioxide. World Health Organization.

World Bank. (1995). Nigeria's strategic options for redressing industrial pollution. World Bank, industry and energy division. 1st edition, West Central Africa Department; Annexes: 1995; pp 60-62.

Zahoor, A., and Abdul, R. (2009). Enumeration of Coliforms. Journal of Environmental Sciences. 21, 814-820 


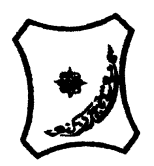

Bayero Journal of Pure and Applied Sciences, 13(2): 1 - 12

Received: November, 2020

Accepted: December, 2020

ISSN $2006-6996$

\title{
BIODEGRADATION POTENTIAL OF IMMOBILIZED BACTERIA IN THE TREATMENT OF TANNERY INDUSTRIAL EFFLUENTS FROM INDUSTRIAL ESTATES IN KANO STATE, NIGERIA
}

\author{
Abdullateef, B., ${ }^{1 *}$ Shuaibu, T. G., ${ }^{1}$ Babagana, K., ${ }^{1}$ Suleman, H. B. ${ }^{2}$ and Dauda, B. ${ }^{3}$ \\ ${ }^{1}$ Department of Pure and Applied Chemistry, Faculty of Science, University of Maiduguri, Borno State, \\ Nigeria \\ ${ }^{2}$ Department of Microbiology, Faculty of Science, University of Maiduguri, Borno State, Nigeria \\ ${ }^{3}$ Department of Chemical Engineering, Faculty of Engineering, University of Maiduguri, Borno State, \\ Nigeria \\ *Corresponding author: babslega@gmail.com; abelega2007@yahoo.com; +2348061309753
}

\section{ABSTRACT}

Industrial Effluents Samples from Gashash Tanneries (TAN1) in Bompai Industrial estate, Larabee Tannery Industry (TAN2) in Sharada Industrial estate and Z Tannery Industries (TAN3) in Challawa Industrial estate, Kano State, Nigeria were collected over a period of six months (August 2017 to January 2018) for assessing the biodegradation potentials of bacteria in the treatment of organic pollutants within the effluents. Bacteria were isolated from the effluents and immobilized on agar-agar. Different masses (5 g, $10 \mathrm{gr}, 15$ $\mathrm{g}, 20 \mathrm{~g}$, and $25 \mathrm{~g}$ ) of the bacteria were used in the treatment of $250 \mathrm{ml}$ of the effluents for ten days in a shaker incubator (Gallenkamp-OC-4364-L) at the temperature $30{ }^{\circ} \mathrm{C}$ and speed of $60 \mathrm{rpm}$. Pre-treatment analysis of the effluents for Temperature, pH, Biochemical Oxygen Demand (BOD), Chemical Oxygen Demand (COD), Suspended Solid (SS) and Total Dissolved Solids (TDS) gives the following results; temperature $\left({ }^{\circ} \mathrm{C}\right.$ )

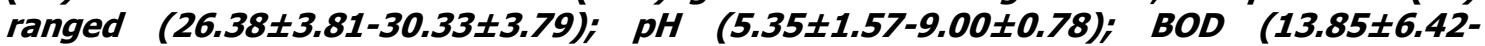
$38.75 \pm 16.20) ;$ COD (1406 $\pm 208-3532 \pm 1373) ;$ SS (208 $\pm 235-780 \pm 739)$ and TDS (266 $\pm 253-5276 \pm 2971)$. No statistical differences ( $p \leq 0.05)$ was observed for all the results among the different industries. The bacterial isolates were identified as Neisseria spp, Bacillus cereus, and Staphylococcus aureus, in TAN1, TAN2, and TAN3, respectively. After treatment of the effluent with the different masses of the isolated bacteria, the mean level of BOD was found to range as (0.55 $\pm 0.36-6.92 \pm 5.49) ; C O D$ (ND-3134 \pm 1595$)$;

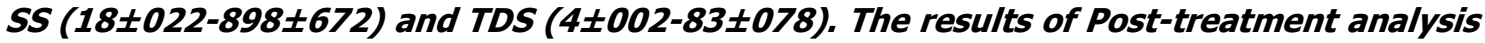
showed that there is overall decrease in the levels of the parameters determined when compared with that of the pre-treatment. The overall percentage reduction of the immobilised bacteria in the treatment of the respective effluents was in the order TAN2 (72\%)>TAN1 (70\%)>TAN3 (62\%). Hence, the immobilized bacteria are having higher biodegradation potential for the treatment of the tannery effluents.

Keywords: Biodegradation, bacteria, effluent, immobilization, tannery.

\section{INTRODUCTION}

Tannery industrial wastewater is a serious consequence of the pollution point of view for streams, freshwater, and land used for agriculture. The lack of awareness in the modern industrial practice has resulted in the discharge of tannery effluents which exhibit very high value of chromium ( $\mathrm{Cr}$ ), Sulfide, and chloride, Total Dissolved Solid (TDS), Total Suspended Solid (TSS), Biochemical Oxygen Demand (BOD) and Chemical Oxygen Demand (COD) in the water stream or land (Mohammed et al., 2001). Tanning is the process, which One ton of skin generally leads to the production of 20 to $80 \mathrm{~m}^{3}$ of turbid and foul-smelling converts the protein of the rawhide or skin into a stable material, which will not putrefy and is suitable for a wide variety of end applications (Elsheikh, 2009). The highly polluting chromium is the most commonly used tanning material producing leather that is more flexible and pliable than vegetable-tanned leather and does not discolor or lose shape in water as drastically as vegetable-tan (Elsheikh, 2009). Tannery effluent is among the most hazardous industrial pollutants due to its huge organic and inorganic load, which is highly toxic to human life and the environment (Kongjao et al., 2008). wastewater including chromium (100-400 mg/l), sulfide $(200-800 \mathrm{mg} / \mathrm{l})$, high levels of fat and 
BAJOPAS Volume 13 Number 2, December, 2020 other solid wastes, and notable pathogen contamination as well as pesticides added for skin conservation during transport (Elsheikh, 2009). There are more than 6000 tanneries in Nigeria with an annual processing capacity of 700,000 tons of hides and skins (Omoleke, 2004; Singh et al., 2008). It was reported that the total amount of waste produced per animal slaughtered is approximately $35 \%$ of its weight (World Bank, 1995). Also, for every $1000 \mathrm{~kg}$ of carcass weight, a slaughtered beef produces 5.5 $\mathrm{kg}$ of manure (excluding rumen contents or stockyard manure) and $100 \mathrm{~kg}$ of paunch manure (undigested food) (Verheijen et al., 1996). Tanneries generate wastewater in the range of 30-35 $\mathrm{L} \mathrm{kg}^{-1}$ skin/hide processed with variable $\mathrm{pH}$, Biological Oxygen Demand (BOD), Chemical Oxygen Demand (COD), high concentrations of suspended solids (SS), and tannins as well as chromium (Zahoor and Abdul, 2009).

Being heterogeneous and composed of a wide variety of compounds, it is very difficult to select a unique direct method for estimating the biodegradability of organic contents and biokinetic parameters for a wastewater sample (Rajor, 2004). For this purpose, some indirect estimation such as determination of biochemical oxygen demand (BOD) and chemical oxygen demand (COD) are applied as common laboratory investigations [9]. During retanning procedures, synthetic tannins (Syntan), oils and resins are added to form softer leather at varying doses (Munz et al., 2009). One of the refractory groups of chemicals in tannery effluents derives mainly from tannins (Ramasami et al., 2004). Syntans are characterized by complex chemical structures, because they are composed of an extended set of chemicals such as phenol-, naphthalene-, formaldehyde- and melamine-based syntans, and acrylic resins (Beem, 1994). Organic pollutants (proteic and lipidic components) are originated from skins (it is calculated that the raw skin has $30 \%$ loss of organic material during the working cycle) or they are introduced during processes (Hugo Springer, 1994).

Many conventional processes such as oxidation, chemical and biological processes were carried out to treat tanneries wastewater (Ebtesam et al, 2013). Biological processes have received more attention because of their costeffectiveness, lower sludge production and environmental friendliness (Noorjahan, 2014). Naturally occurring micro-organisms degrade the hazardous organic wastes including xenobiotic compounds, such as pesticides, polycyclic aromatic hydrocarbons (PAHs) and polychlorinated biphenyls (PCBs) in due course of time (Ranen and Sharadinadra, 2009). Bioremediation is based on the idea that all organisms remove substances from the environment to carry outgrowth and metabolism (Bouwer and Zehnder, 1993). Bacteria, protista and fungi are found to be very good at degrading complex molecules and incorporating the breakdown products into their metabolism (Bouwer and Zehnder, 1993). The resultant metabolic wastes that they produce are generally safe and somehow recycled into other organisms (Ranen and Sharadinadra, 2009). An acclimatized indigenous population of microorganisms capable of degradation of the compounds of interest must exist at the site for a successful bioremediation mode (Ranen and Sharadinadra, 2009). It has been observed that for a successful bioremediation mode, an acclimatized indigenous population of microorganisms capable of degradation of the compounds of interest must exist at the site under investigation (Ranen and Sharadinadra, 2009). Even though there are numerous physical and chemical methods employed in the disposal of wastes the advantage in using bacterium is that they play a key role in the reduction of COD, BOD, total protein, total tannin and total phenol (Saravanan and Saravanan, 1998)

Baba et al. (2020) studied the bioremediation potential of immobilized corynebacterium kutsceri in the Treatment of tannery industrial effluent from Challawa Industrial Estate, Kano State, Nigeria. The aim of the work is to study the reduction in the level of the contaminants through the process of bioremediation using the isolated bacteria. Immobilized bacteria can withstand various temperatures, $\mathrm{pH}$ and substrate concentrations; consequently, increasing the efficiency and the lifespan of the bacteria. Immobilized bacteria are widely applied in the treatment of wastewater and can be separated and recovered after the treatment with the same efficiency (Baba et al., 2020).

\section{MATERIALS AND METHODS \\ Study Area}

This study was carried out in Bompai, Sharada and Challawa industrial estates in Kano, Figure 1. Kano lies on Latitude $11^{\circ} 30^{\prime} \mathrm{N}$ and $8^{\circ} 30^{\prime} \mathrm{E}$ and Longitude $11^{\circ} 5^{\prime} \mathrm{N}$ and $8^{\circ} 5^{\prime} \mathrm{E}$ in Northern Nigeria. It is one of the developed industrial cities in Nigeria. Tannery activities are the dominating industries and this could be one of the reasons for her high population density (Dan'Azumi and Bichi, 2010). Many researchers have studied biodegradation of tannery effluent using microorganisms. However, limited literature is available on the biodegradation of tannery effluent in Kano industrial estates using 
BAJOPAS Volume 13 Number 2, December, 2020 immobilized bacterial cells. This research work focuses on the potential of the use of the indigenous immobilized bacterial isolates in the treatment of tannery effluents in the industrial estates.

\section{Sample Collection}

Effluents were collected from the Tannery Industries from Bompai, Challawa and Sharada Industrial Estates, Kano, Nigeria. The effluents were collected over a period of six months (August 2017 to January 2018). Samples collected in a sterile 4-liter plastic container with a unique identification number were preserved using an ice-box that was transported to the Microbiology Laboratory, Department of Microbiology, Bayero University of Kano for analysis

\section{Sample Preparation and Sample Analysis}

Immediately after the collection of the effluent, $\mathrm{pH}$, TSS, TDS, COD, BOD levels were determined before treatment (Pre-treatment determination) and ten days after treatment (Post-treatment determination) as described in
APHA (1989) standard methods. $\mathrm{pH}$ was determined using Ecotests $\mathrm{pH}$ meter and TDS was determined using AQUALYTIC TDS Salinometer. BOD was determined as described by the standard method (APHA, 1992). COD and SS were determined using DR/2010 HACH portable data logging spectrophotometer (DWAF, 1992)

\section{Identification and Biochemical} Characterization of the Bacterial Isolates

The bacteria were isolated from the effluents using Serial Dilution according to the method described by APHA (1989). The biochemical tests such as oxidase, catalase, coagulase, indole (from $1 \%$ tryptone broth), citrate (Simmons citrate agar), methyl red/VogesProskauer (MR/VP), nitrate reduction, Starch Hydrolysis, Glucose, Maltose, and Lactose tests were carried out on the bacterial isolates to identify the bacteria through the bacteria biochemical characteristics according to Ajao et al. (2011).

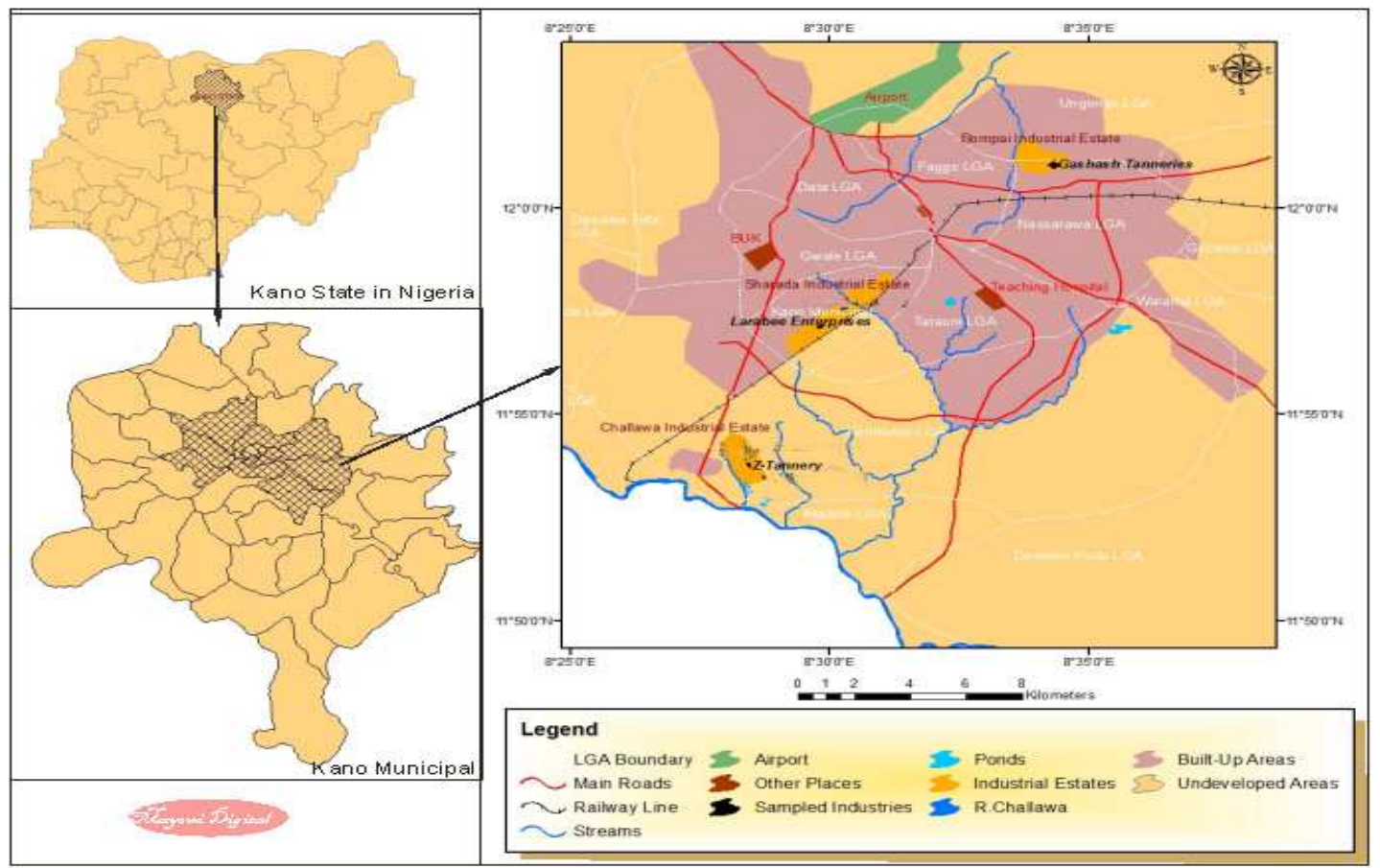

Fig. 1 Map showing the study areas

Source: Mayomi Digital Productions, GIS Laboratory, Department of Geography, UNIMAID (2017)

\section{Determination of Growth Rate of the Bacteria in Effluent Sample}

The bacteria growth rates were determined by transferring $2 \mathrm{~mL}$ of the bacterial isolates from the tannery effluent in broth medium into 100 $\mathrm{mL}$ sterile effluents in conical flasks and kept in an incubator (Giffrin cool) for 10 days. Control was also set up by incubating another $100 \mathrm{~mL}$ each of the sterile effluents without the bacteria. The optical density of the content was determined at the wavelength of $600 \mathrm{~nm}$ on a daily interval and recorded. 
BAJOPAS Volume 13 Number 2, December, 2020 Immobilization of Bacteria

Agar solution and inoculi were prepared separately. Fifty milliliters $(50 \mathrm{~mL})$ of nutrient broth each of the inoculi was prepared in a McCartney bottle and incubated for 24 hours. A solution of agar-agar was prepared by dissolving $10 \mathrm{~g}$ of the powder in distilled water and made up to $500 \mathrm{~mL}$ mark in an Erlenmeyer flask and was sterilized in an autoclave (280A) for 15 minutes and allowed to cool to $40-45^{\circ} \mathrm{C}$ (Ajao et al., 2011). Four milliliters ( $4 \mathrm{~mL})$ of the bacterial isolates in the nutrient broth was mixed with 36 $\mathrm{ml}$ of the prepared agar-agar media in petri-dish plates and then allowed to solidify. This was kept in the refrigerator for bioremediation.

\section{Bioremediation (Treatment) of the Effluents}

The solidified agar block (immobilized bacteria) was cut into cubes using a sterile knife; $0.1 \mathrm{~mL}$ phosphate buffer ( $\mathrm{pH} \mathrm{7.0)}$ was added and kept in the refrigerator for 1 hour for curing. The phosphate buffer was decanted after 1 hour and the cubes were washed with sterile distilled water 3-4 times before it was used (Ajao et al., 2011). Two liters (2 L) of the effluent was supplemented with the minimum basal medium in $\mathrm{g} / \mathrm{L}: \mathrm{NaCl}(0.8), \mathrm{MgSO}_{4} .7 \mathrm{H}_{2} \mathrm{O}(0.001), \mathrm{KH}_{2} \mathrm{PO}_{4}$ (2), $\mathrm{NaNO}_{3}$ (2), $\quad \mathrm{CaCl}_{2} .2 \mathrm{H}_{2} \mathrm{O} \quad(0.5)$ and $\mathrm{NaHPO}_{4} .12 \mathrm{H}_{2} \mathrm{O}(2)$ and sterilized in an autoclave at $121^{\circ} \mathrm{C}$ for 15 minutes (Margesin and Schinner, 2001). Two hundred and fifty milliliters $(250 \mathrm{~mL})$ of the effluents were transferred into different $250 \mathrm{ml}$ conical flasks. The content was covered with a cotton-wool ramped with foil paper to avoid contamination. Five grams $(5 \mathrm{~g})$ of the immobilized bacteria were quickly transferred into each of the effluents in the conical flasks in an inoculating chamber. The same procedures were carried out for the $10 \mathrm{~g}, 15 \mathrm{~g}, 20 \mathrm{~g}$ and 25 $\mathrm{g}$ of the immobilized bacteria in separate $250 \mathrm{~mL}$ effluents in conical flasks and agitated for ten days in a shaker incubator (Gallenkamp-OC4364-L) at a temperature $30^{\circ} \mathrm{C}$ and speed of 60 rpm. The treated effluent samples were taken on the tenth day and analyzed for the parameters $\mathrm{pH}$, SS, TDS, COD, and BOD, (Posttreatment determination) for the different grams of bacteria to evaluate and compare the biodegradation potential. (Baba et al., 2020).

\section{Statistical Analysis}

The data were represented as Mean \pm Standard deviation and analyzed statistically using oneway Analysis of Variance (ANOVA) and Tukey's HSD as Post Hoc Tests with the aid of SPSS 16.0. The correlation coefficient was also used to measure the strength of the relationship between the different masses of the bacteria and the parameters. All $\mathrm{p} \leq 0.05$ were considered as statistically significant.

\section{RESULTS AND DISCUSSION Physico-chemical parameters in the Industrial Effluents before the Biodegradation.}

Results of the Physico-chemical parameters in the industrial effluents before the Biodegradation is shown in table 1 . The mean temperatures $\left({ }^{\circ} \mathrm{C}\right)$ observed in TAN1, TAN2, and TAN3 samples were $28.07 \pm 0.65 ; 27.77 \pm 0.64$ and $26.38 \pm 3.81$ respectively. The order of the mean temperature of the samples from the three industries can be arranged as TAN1 > TAN2>TAN3. The temperature observed at TAN1, TAN2, and TAN3 samples were found below the WHO $\left(35^{\circ} \mathrm{C}\right)$ and NESREA $\left(40^{\circ} \mathrm{C}\right)$ limits. The low values of temperature might be due to the processes used at the time of sampling. High temperature brings down the solubility of gases in water that ultimately expresses as high BOD and COD. Statistical analysis shows that there is no significant difference $(p<0.05)$ between the mean values of temperature among the industries. This might be due to similar tannery activities involved in the tannery industries at the time of sampling. The average values of temperature observed in this present study are less than those observed by Akan et al. (2007), Akan et al. (2009) and Baba et al. (2020).

The mean level of $\mathrm{pH}$ observed in TAN1, TAN2 and TAN3, samples were $7.77 \pm 2.93$; $8.35 \pm 0.28$ and $7.52 \pm 0.76$ respectively. The order of the mean $\mathrm{pH}$ of the samples from the three industries can be arranged as TAN2> TAN1 $>$ TAN3. The $\mathrm{pH}$ of the samples falls within the WHO (7.0-8.5) and NESREA (6-9) standard limits. Statistical analysis shows that there is no significant difference $(p<0.05)$ between the mean values of $\mathrm{pH}$ among the industries. This might be due to similar tannery activities involved in the tannery industries at the time of sampling. Maheshwari et al. (2017) reported that the level of $\mathrm{pH}$ in the effluents from the tannery industry in Vaniyambadi, India was 6.5 which was lower than that observed in the present study. The $\mathrm{pH}$ in the effluents from the tannery industries in Kano and Kaduna were reported to be 7.64 and 6.89, respectively (Akan et al., 2007; Mohammed et al., 2017). The average values of $\mathrm{pH}$ observed in this present study are less than those observed by Mohammed et al. (2017) and Baba et al. (2020). The mean level of SS $(\mathrm{mg} / \mathrm{l})$ observed in TAN1, TAN2, and TAN3 samples were 374 \pm 124 ; $358 \pm 335$ and $780 \pm 739$ respectively. The order of the mean SS in the samples from the three industries can be arranged as TAN3 > TAN1 $>$ TAN2. 
The SS observed in the samples were far above the recommended standard limits of regulating bodies WHO $(30 \mathrm{mg} / \mathrm{l})$ and NESREA $(10 \mathrm{mg} / \mathrm{l})$. Statistical analysis shows that there is no significant difference $(p<0.05)$ between the mean values of SS among the industries. This might be due to similar tannery activities involved in the tannery industries at the time of sampling. The average values of SS observed in this present study are less than that observed $(3700 \pm 122 \mathrm{mg} / \mathrm{l})$ by Akan et al. (2009) for tanneries in Kano. Also, the average values of SS observed in this present study are less than that observed by Mohammed et al. (2017) and Baba et al. (2020) with the exception in TAN3.

The mean level of TDS (mg/l) observed in TAN1, TAN2, and TAN3 samples were $3941 \pm 3703$; $3300 \pm 1714$ and $2653 \pm 1240$ respectively. The order of the mean TDS in the samples from the three industries can be arranged as TAN1>TAN2>TAN3. The TDS observed in the samples were far above the recommended standard limits of WHO $(250 \mathrm{mg} / \mathrm{l})$ and NESREA $(500 \mathrm{mg} / \mathrm{l})$. Statistical analysis shows that there is no significant difference $(p<0.05)$ between the mean values of TDS among the industries. This might be due to similar tannery activities involved in the tannery industries at the time of sampling. TDS in the effluents from the tannery industries in Kano, Nigeria was reported to be $1281 \mathrm{mg} / \mathrm{l}$ (Akan et al., 2007). The average values of SS observed in this present study are less than those observed by Mohammed et al. (2017) and Baba et al. 2020)

The mean level of COD (mg/l) observed in TAN1, TAN2 and TAN3 samples seasons were $2372 \pm 938 ; \quad 1406 \pm 208$ and $3532 \pm 1373$ respectively. The order of the mean COD of the samples from the three industries can be arranged as TAN3>TAN1> TAN2. The COD observed in TAN1, TAN2 and TAN3 samples were far above the recommended standard limits of regulating bodies $\mathrm{WHO}(40 \mathrm{mg} / \mathrm{l})$ and NESREA (40 mg/l). Statistical analysis shows that there is no significant difference $(p<0.05)$ in COD among the industries. This might be due to similar tannery activities involved in the tannery industries as at the time of sampling. The Chemical Oxygen demand (COD) is the amount of oxygen, in $\mathrm{mg} / \mathrm{L}$, required for the degradation of the compound of wastewater to occur. In comparison, the average values of COD observed in this present study were higher than that observed by Mohammed et al. (2017) but lower than that observed by Baba et al. (2020).

The mean levels of BOD $(\mathrm{mg} / \mathrm{l})$ observed in TAN1, TAN2 and TAN3 samples were $13.85 \pm 6.42 ; \quad 19.46 \pm 0.50$ and $17.13 \pm 3.14$ respectively. The order of the mean BOD in the samples from the three industries can be arranged as TAN2>TAN3>TAN1. The BOD observed in TAN1, TAN2 and TAN3 samples were found below the recommended limits of NESREA (200 mg/l) but above WHO (10 mg/l). Statistical analysis shows that there is no significant difference $(p<0.05)$ between the mean values of BOD among the industries. This might be due to similar tannery activities involved in the tannery industries at the time of sampling. The low level of BOD recorded in this study is an indication of the low level of biodegradable organic solids in the effluent. The average values of BOD observed in this present study were lower than those observed by Mohammed et al. (2017) and Baba et al. (2020).

Table 1: Mean Values \pm S.D of Physico-chemical parameters of effluents from the Tannery Industries before Treatment.

\begin{tabular}{llllllll}
\hline Parameter & Tannery 1 & Tannery 2 & Tannery 3 & $\mathrm{a}$ & $\mathrm{b}$ & $\mathrm{c}$ & $\mathrm{d}$ \\
\cline { 2 - 7 } Temperature $\left({ }^{\circ} \mathrm{C}\right)$ & $28.07 \mathrm{a} \pm 0.65$ & $27.77 \mathrm{a} \pm 0.64$ & $26.38 \mathrm{a} \pm 3.81$ & & $29.50 \pm 4.68$ & 35 & 40 \\
pH & $7.77 \mathrm{a} \pm 2.93$ & $8.35 \mathrm{a} \pm 0.28$ & $7.52 \mathrm{a} \pm 0.76$ & 6.89 & $5.35 \pm 1.57$ & $7.0-8.5$ & $6.0-9.0$ \\
$\mathrm{COD}(\mathrm{mg} / \mathrm{l})$ & $2372 \mathrm{a} \pm 938$ & $1406 \mathrm{a} \pm 208$ & $3532 \mathrm{a} \pm 1373$ & 2.2 & $3106 \pm 2753$ & 40 & 40 \\
$\mathrm{BOD}(\mathrm{mg} / \mathrm{l})$ & $13.85 \mathrm{a} \pm 6.42$ & $19.46 \mathrm{a} \pm 0.50$ & $17.13 \mathrm{a} \pm 3.14$ & 1032 & $26.17 \pm 9.49$ & 10 & 200 \\
$\mathrm{SS}(\mathrm{mg} / \mathrm{l})$ & $374 \mathrm{a} \pm 124$ & $358 \mathrm{a} \pm 335$ & $780 \mathrm{a} \pm 739$ & 501 & $562 \pm 482$ & 30 & 10 \\
TDS $(\mathrm{mg} / \mathrm{l})$ & $3941 \mathrm{a} \pm 3703$ & $3300 \mathrm{a} \pm 1714$ & $2653 \mathrm{a} \pm 1240$ & 532.7 & $444 \pm 507$ & 250 & 500 \\
\hline
\end{tabular}

The values given in the table above are means of 6 replicate values, $\mathrm{n}=6$ ( 1 sample was taken monthly for 6 months). Within the rows, means with different alphabets are statistically different $(p<0.05)$. WHO: World Health Organisation. NESREA: National Environmental Standard and Regulatory Enforcement Agency. a = Mohammed et al.(2017), b = Baba et al. (2020), c = WHO (2006), $d=$ NESSRA (2009) 
BAJOPAS Volume 13 Number 2, December, 2020

Identification, Biochemical Characterization and growth rates of the Bacterial Isolates

Results of identification and biochemical characterization of the bacterial isolates were shown in table 2. After 24 hours of incubation, the nutrient agar media plates were checked for bacterial growth. The results showed the presence of different strains in the samples. The TAN1 bacteria isolate was found to be gramnegative cocci while TAN3 was gram-positive cocci. TAN2 bacteria isolate was found to be gram-positive, rod-shaped. TAN1, TAN2, and TAN3 bacteria isolates recorded positive results for spore former.

The results of the biochemical tests indicated that all the bacteria were positive for catalase, oxidase, citrate, maltose, glucose, lactose (negative in TAN1), mannitol (negative in TAN2), starch hydrolysis and coagulase (negative in TAN2) tests. The bacteria showed negative results for nitrate reduction, $M R$ (positive in TAN2), VP (positive in TAN1), Indole (positive in TAN2) tests. Base on the morphological and biochemical test results, TAN1, TAN2, and TAN3 bacteria isolates were identified to be Nesseria spp, Bacillus cereus, and Staphylococcus aureus respectively.

The growth rate of the TAN1, TAN2 and TAN3 Isolates were shown in figure 2. Generally, the optical density increase with the increase in time (day) and decrease as time goes on. The highest optical density was shown by bacillus cereus in TAN2 while the lowest was shown by Staphylococcus aureus in TAN3.

The initial growth phase of TAN1 Isolate bacteria occurred within 2-day of incubation as the growth rate increases up to the 6th-day incubation when the maximum growth was observed. Beyond the 6th day, the growth of the bacteria declined (which might be due to a shortage of nutrients in the effluents) until it reached its death phase (which might be due to the unavailability of nutrients in the effluents).

A similar trend of growth was also observed for TAN2 Isolate as the initial growth phase also occurred within 2-day of incubation but maximum growth rate observed on the 4th day of incubation. The stationary stage occurred between the 4th day and the 8th day. Beyond the 8th day, the growth of the bacteria declined (which might be due to a shortage of nutrients in the effluents) until it reached its death phase (which might be due to the unavailability of nutrients in the effluents).

The initial growth phase of TAN3 bacterial Isolate occurred within the 3-day incubation as the growth rate increases up to the 6th-day incubation when the maximum growth was observed. Beyond the 6th day, the growth of the bacteria declined (which might be due to a shortage of nutrients in the effluents) until it reached its death phase (which might be due to the unavailability of nutrients in the effluents).

Table 2: Morphological and Biochemical characteristics of bacterial isolates

\begin{tabular}{lllll} 
Bacterial Isolates & & TAN1 & TAN2 & TAN3 \\
\hline $\begin{array}{lllll}\text { Morphological } \\
\text { characteristics }\end{array}$ & Shape & Cocci & Rod & Cocci \\
& Spore & & & \\
& former & + & + & + \\
Gram & & & \\
Biochemical characteristics & reaction & - & + & + \\
& Citrate & + & + & + \\
& Catalase & + & + & + \\
& Coagulase & + & - & + \\
Starch & + & + & + \\
& Glucose & + & + & + \\
Oxidase & + & + & + \\
& Indo & - & + & - \\
Lactose & - & + & + \\
Manitol & + & - & + \\
Maltose & + & + & + \\
MR & - & + & - \\
VP & + & - & - \\
& Nitrate & - & - & - \\
Reduction & - Neisseria & Bacillus & Staphylococcus \\
& Bacterial & cereus & aureus \\
& name & spp & cas
\end{tabular}

+ = Positive; - = Negative; MR=Methyl Red; VP= Voges-Proskauer 


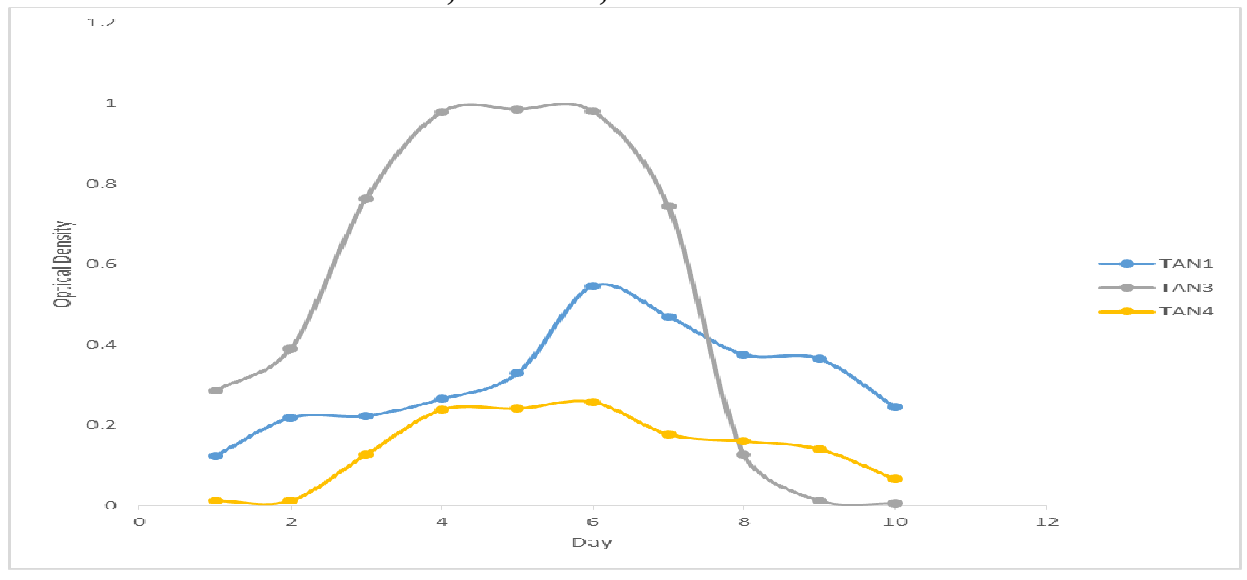

Fig. 2 Growth rates of the isolates in the effluents from the Tannery Industries

\section{Physico-chemical Parameters in the Industrial Effluents after the biodegradation.}

Table 3 shows the mean results of the physicochemical parameter before and after bioremediation using the different masses $(5 \mathrm{~g}$, $10 \mathrm{~g}, 15 \mathrm{~g}, 20 \mathrm{~g}$, and $25 \mathrm{~g}$ ) of the respective immobilized bacteria. Also, Table 4 shows the mean results of correlation coefficient ( $r$ ) between different masses of bacteria and physicochemical parameters.

The mean values $(\mathrm{mg} / \mathrm{l})$ of the SS after the bioremediation varies between $243 \pm 45$ and $898 \pm 672$. The mean concentration $(\mathrm{mg} / \mathrm{l})$ of SS remediated by the different masses $(5 \mathrm{~g}, 10 \mathrm{~g}$, $15 \mathrm{~g}, 20 \mathrm{~g}$, and $25 \mathrm{~g}$ ) of the bacteria varies. The SS in the samples fluctuates up and down after the bioremediation process when compared with the SS of the raw samples before the bioremediation. The increase in the levels of the SS might be due to the aggregation of the TDS which are large enough to result into SS. The increase in the levels of the SS might be also due to the influence of the nutrients which was added into the effluents in order to make the microorganisms more active and viable for fast degradation of organic contaminants in the effluent. The relative potential or efficiency of the different masses of the bacteria in remediating SS in TAN1 samples was in the order $25 \mathrm{~g}>20 \mathrm{~g}>15 \mathrm{~g}>10 \mathrm{~g}>5 \mathrm{~g}$. For TAN2 and TAN3 samples, the order was $25 \mathrm{~g}>20 \mathrm{~g}>15$ $\mathrm{g}>10 \mathrm{~g}>5 \mathrm{~g}$. These might be due to the variations in the surface areas of the different masses of the immobilized bacteria. Statistical analysis shows that there is no significant difference $(p<0.05)$ between the mean values of SS among the masses in the respective industries. Positive and significant correlations exist between the masses of bacteria and Suspended Solid (SS). This showed that there is general increase in the levels of the SS as the masses of the immobilized bacteria increases. TAN3 (90\%) and TAN1 (80\%) showed a very high correlation with the masses of the bacteria while TAN2 (61\%) showed a very low correlation.

The mean values $(\mathrm{mg} / \mathrm{l})$ of the TDS after the bioremediation varies between $46 \pm 11$ and $83 \pm 78$. The mean concentration $(\mathrm{mg} / \mathrm{l})$ of TDS remediated by the different masses $(5 \mathrm{~g}, 10 \mathrm{~g}$, $15 \mathrm{~g}, 20 \mathrm{~g}$, and $25 \mathrm{~g}$ ) of the bacteria varies. There is a reduction in all the TDS of all the samples after the bioremediation process compared with the TDS of the raw samples before the bioremediation. The relative potential or efficiency of the different masses of the bacteria in remediating TDS in TAN1 and TAN3 samples was in the order $5 \mathrm{~g}>10 \mathrm{~g}>15 \mathrm{~g}>20$ $\mathrm{g}>25 \mathrm{~g}$. For TAN2 samples, the order was 20 $g>10 \quad g>25 \quad g>15 \quad g>5 \quad g$. Statistical analysis shows that there is no significant difference $(p<0.05)$ between the mean values of TDS among the masses in the respective industries. These might be due to the variations in the surface areas of the different masses of the immobilized bacteria. Positive and significant correlations exist between the masses of bacteria and TDS with the exception in TAN2 (negative and insignificant correlation). The positive correlations showed that there is general increase in the levels of the TDS as the masses of the immobilized bacteria increases. TAN1 $(96 \%)$ showed a very high correlation with the masses of the bacteria while TAN2 (47\%) showed a very low correlation.

The mean values $(\mathrm{mg} / \mathrm{l})$ of the BOD after the bioremediation varies between $1.56 \pm 0.20 \mathrm{mg} / \mathrm{l}$ and $6.92 \pm 5.49 \mathrm{mg} / \mathrm{l}$. The mean concentration $(\mathrm{mg} / \mathrm{l})$ of BOD remediated by the different masses $(5 \mathrm{~g}, 10 \mathrm{~g}, 15 \mathrm{~g}, 20 \mathrm{~g}$, and $25 \mathrm{~g}$ ) of the bacteria varies. There is a reduction in all the BOD of all the samples after the bioremediation process compared with the $\mathrm{BOD}$ of the raw 
BAJOPAS Volume 13 Number 2, December, 2020 samples before the bioremediation. The relative potential or efficiency of the different masses of the bacteria in remediating BOD in TAN1, TAN2 and TAN3 samples were in the order $25 \mathrm{~g}>20$ $\mathrm{g}>15 \mathrm{~g}>10 \mathrm{~g}>5 \mathrm{~g}, 25 \mathrm{~g}>15 \mathrm{~g}>5 \mathrm{~g}>10 \mathrm{~g}>20 \mathrm{~g}$ and $20 \mathrm{~g}>10 \mathrm{~g}>25 \mathrm{~g}>15 \mathrm{~g}>5 \mathrm{~g}$ respectively. Statistical analysis shows that there is significant difference $(p<0.05)$ between the mean values of BOD among the masses in the respective industries. These might be due to the variations in the surface areas of the different masses of the immobilized bacteria. Negative and significant correlations exist between the masses of bacteria and BOD. This showed that there is general decrease in the levels of the BOD as the masses of the immobilized bacteria increases. TAN1 (94\%) showed a very high correlation with the masses of the bacteria while TAN2 (4\%) showed a very low correlation.

The mean values $(\mathrm{mg} / \mathrm{l})$ of the COD after the bioremediation varies between $250 \pm 154$ and $3134 \pm 1595$. The mean concentration $(\mathrm{mg} / \mathrm{l})$ of COD remediated by the different masses $(5 \mathrm{~g}$, $10 \mathrm{~g}, 15 \mathrm{~g} 20 \mathrm{~g}$, and $25 \mathrm{~g}$ ) of the bacteria varies. There is a reduction in all the COD of all the samples after the bioremediation process compared with the COD of the raw samples before the bioremediation. The relative potential or efficiency of the different masses of the bacteria in remediating COD in TAN1, TAN2 and TAN3 samples were in the order $25 \mathrm{~g}>20 \mathrm{~g}>15$ $\mathrm{g}>5 \mathrm{~g}>10 \mathrm{~g}, 25 \mathrm{~g}>20 \mathrm{~g}>15 \mathrm{~g}>10 \mathrm{~g}>5 \mathrm{~g}$ and 10 g>5 g>25 g>15 g>20 g respectively. Statistical analysis shows that there were significant difference $(p<0.05)$ between the mean values of COD among the masses in the respective industries except for effluents treated with $25 \mathrm{~g}$. These might be due to the variations in the surface areas of the different masses of the immobilized bacteria. Negative and insignificant correlations exist between the masses of bacteria and COD with the exception in TAN3 (positive and significant correlation). The negative correlations showed that there is general decrease in the levels of the COD as the masses of the immobilized bacteria increases. TAN2 (100\%) showed a very high correlation with the masses of the bacteria while TAN3 (36\%) showed a very low correlation.

Generally, there was an overall decrease in the concentration of these physicochemical parameters after the bioremediation using the different masses of the bacterial isolates. These might be due to the variations in the surface areas of the different masses of the immobilized bacteria. This is in line with the work of Jimoh et al. (2018) and Baba et al. (2020).

Table 3: Mean Values $(\mathrm{mg} / \mathrm{l}) \pm$ S.D of Physicochemical parameters in effluents from the Tannery Industries before and after Treatment of the effluents $(250 \mathrm{ml})$ with the different masses $(5 \mathrm{~g}, 10 \mathrm{~g}$, $15 \mathrm{~g}, 20 \mathrm{~g}$, and $25 \mathrm{~g}$ ) of the bacteria.

\begin{tabular}{llllllll}
\hline $\mathrm{P}$ & IND & Before & \multicolumn{5}{c}{ After } \\
\cline { 4 - 7 } & & & $5 \mathrm{~g}$ & $10 \mathrm{~g}$ & $15 \mathrm{~g}$ & $20 \mathrm{~g}$ & $25 \mathrm{~g}$ \\
\hline \multirow{2}{*}{ COD } & TAN1 & $2372 \pm 938$ & $1708 \mathrm{a} \pm 861$ & $2045 \mathrm{a} \pm 1205$ & $845 \mathrm{a} \pm 369$ & $300 \mathrm{a} \pm 167$ & $250 \mathrm{a} \pm 154$ \\
& TAN2 & $1406 \pm 208$ & $1195 \mathrm{a} \pm 208$ & $1125 \mathrm{a} \pm 384$ & $1055 \mathrm{a} \pm 317$ & $956 \mathrm{a} \pm 310$ & $870 \mathrm{ab} \pm 240$ \\
& TAN3 & $3532 \pm 1373$ & $2374 \mathrm{a} \pm 1344$ & $1976 \mathrm{a} \pm 1405$ & $2757 \mathrm{a} \pm 1266$ & $3134 \mathrm{a} \pm 1595$ & $2614 \mathrm{~b} \pm 1105$ \\
BOD & TAN1 & $13.85 \pm 6.42$ & $6.92 \mathrm{a} \pm 5.49$ & $6.42 \mathrm{a} \pm 5.07$ & $5.72 \mathrm{a} \pm 5.35$ & $4.62 \mathrm{a} \pm 4.37$ & $2.82 \mathrm{ab} \pm 1.26$ \\
& TAN2 & $19.46 \pm 0.50$ & $1.75 \mathrm{~b} \pm 0.22$ & $1.73 \mathrm{~b} \pm 0.18$ & $1.58 \mathrm{a} \pm 0.16$ & $1.91 \mathrm{a} \pm 0.22$ & $1.56 \mathrm{~b} \pm 0.20$ \\
& TAN3 & $17.13 \pm 3.14$ & $4.24 \mathrm{ab} \pm 0.77$ & $3.29 \mathrm{ab} \pm 0.37$ & $4.11 \mathrm{a} \pm 0.07$ & $3.23 \mathrm{a} \pm 0.91$ & $3.33 \mathrm{a} \pm 1.28$ \\
SS & TAN1 & $374 \pm 124$ & $243 \mathrm{a} \pm 45$ & $471 \mathrm{a} \pm 226$ & $475 \mathrm{a} \pm 182$ & $492 \mathrm{a} \pm 128$ & $611 \mathrm{a} \pm 217$ \\
& TAN2 & $358 \pm 335$ & $460 \mathrm{a} \pm 400$ & $543 \mathrm{a} \pm 414$ & $544 \mathrm{a} \pm 402$ & $551 \mathrm{a} \pm 414$ & $554 \mathrm{a} \pm 405$ \\
& TAN3 & $780 \pm 739$ & $586 \mathrm{a} \pm 594$ & $758 \mathrm{a} \pm 656$ & $787 \mathrm{a} \pm 676$ & $861 \mathrm{a} \pm 635$ & $898 \mathrm{a} \pm 672$ \\
TDS & TAN1 & $3941 \pm 3703$ & $51 \mathrm{a} \pm 10$ & $53 \mathrm{a} \pm 10$ & $55 \mathrm{a} \pm 15$ & $61 \mathrm{a} \pm 20$ & $63 \mathrm{a} \pm 26$ \\
& TAN2 & $3300 \pm 1714$ & $83 \mathrm{a} \pm 78$ & $47 \mathrm{a} \pm 20$ & $48 \mathrm{a} \pm 22$ & $47 \mathrm{a} \pm 17$ & $48 \mathrm{a} \pm 17$ \\
& TAN3 & $2653 \pm 1240$ & $46 \mathrm{a} \pm 11$ & $55 \mathrm{a} \pm 24$ & $55 \mathrm{a} \pm 25$ & $58 \mathrm{a} \pm 23$ & $61 \mathrm{a} \pm 28$ \\
\hline
\end{tabular}

Replicate $=6$ (months)

Within the rows, for the same parameter, means with different alphabets are statistically different $(p<0.05)$.

$\mathrm{P}=$ parameter, IND = Industries 
BAJOPAS Volume 13 Number 2, December, 2020

Table 4: Correlation coefficient $(r)$ between different masses of the bacteria and the physicochemical parameters.

\begin{tabular}{llll}
\hline Industries & Parameter & Correlation coefficient $(r)$ & $\begin{array}{l}\text { Percent dependence (rxrx100) } \\
(\%)\end{array}$ \\
\hline TAN1 & COD & -0.9 & 82 \\
& BOD & -0.97 & 94 \\
& SS & $0.90^{*}$ & 80 \\
TAN2 & TDS & $0.98^{*}$ & 96 \\
& COD & -1 & 100 \\
& BOD & -0.21 & 4 \\
& SS & $0.78^{*}$ & 61 \\
& TDS & -0.69 & 47 \\
& COD & $0.60^{*}$ & 36 \\
& BOD & -0.6 & 37 \\
& SS & $0.95^{*}$ & 90 \\
& TDS & $0.94^{*}$ & 89 \\
\hline
\end{tabular}

The correlation coefficient $(r)$ with * is statistically significant $(p<0.05)$.

Percentage reduction of the Parameters

Table 5 shows the percentage reduction of Parameters in industrial samples before and after the treatment of the effluents $(250 \mathrm{ml})$ with the different masses $(5 \mathrm{~g}, 10 \mathrm{~g}, 15 \mathrm{~g}, 20 \mathrm{~g}$, and $25 \mathrm{~g}$ ) of the Immobilized Bacteria.

In TAN1 samples, the percentage reduction (\%) of COD ranged (14-89); BOD (50-80); SS (-32$35)$ and TDS (98-99). In TAN2 samples, the percentage decrease $(\%)$ of COD ranged (15$38) ;$ BOD (90-92); SS [-28-(-55)] and TDS (9798). In TAN3 samples, the percentage decrease (\%) of COD ranged (11-44); BOD (76-81); SS (15-25) and TDS (98). The percentage increase in the levels COD, BOD and TDS might be due to the increase in the surface area of the different masses of the immobilized bacteria. However, the percentage decrease in the levels of the SS might be due to the aggregation of the TDS which are large enough to result into SS. The percentage decrease in the levels of the SS might be also due to the influence of the nutrients which was added into the effluents in order to make the microorganisms more active and viable for fast degradation of organic contaminants in the effluent. This is in line with the work of Jimoh et al. (2018) in which the concentration of the SS increase after the bioremediation of effluents.

Sreemoyee and Priti (2013) assessed and reduced several Physico-chemical parameters of dairy wastewater using Niesseria $s p$. and concluded that the species are well known to degrade organic compounds. This is in agreement with the current study in which the immobilized Niesseria $s p$ degrade the organic contaminants as indicated by the BOD, COD and TDS.

Jimoh et al. (2018) observed that TSS of the effluents was increased after treatment with immobilized bacteria and concluded that it might be due to the biostimulation method adopted for the research.

The optimum $\mathrm{pH}$ Biosorption of Chromium by Bacillus spp and Staphylococcus spp. from tannery effluent was investigated by Mythili and Karthikeyan (2011). The maximum adsorption of Chromium $(86.4 \mathrm{mg} / \mathrm{L})$ was showed by Bacillus spp and Staphylococcus spp showed $70.6 \mathrm{mg} / \mathrm{L}$ at an initial concentration of $100 \mathrm{mg} / \mathrm{L}$. In the present study, immobilised Bacillus spp and Staphylococcus spp. from the tannery industrial effluents reduced the levels of the organic pollutants with high potential as indicated by the percentage reduction of BOD, COD and TDS.

Enzymes often can work in multiple environments especially if they are immobilized. This makes the microorganisms' enzymes even more resistant to harsh environments and enables the enzymes to be recovered and recycled after they are no longer needed (Gianfreda and Rao 2004). Ramesh and Singh (1993) reported that the immobilized bacteria having more efficiency to remove the suspended particles than free cells. Using the immobilized cell is preferable due to its capability for using several times with the same efficiency, which makes it more economical. Similar work was done by Sikander et al. (2007) showing the higher reduction with permeabilized cells of Ochrobactrum intermedium strain SDCr-5. 
BAJOPAS Volume 13 Number 2, December, 2020

The results revealed the isolation and identification of isolates with the potential for the reduction of $\mathrm{Cr}$ (VI) to $\mathrm{Cr}$ (III). Results indicated that immobilized $B$. cereus could be efficiently used for the reduction of $\mathrm{Cr}$ (VI).

Table 5: Percentage reduction of the tested Parameters from the tannery industrial samples of the Immobilized Bacteria.

\begin{tabular}{lllllll}
\hline \multirow{2}{*}{ Industries } & & \multicolumn{5}{c}{ Percentage Reduction $(\%)$} \\
\cline { 3 - 7 } & & $5 \mathrm{~g}$ & $10 \mathrm{~g}$ & $15 \mathrm{~g}$ & $20 \mathrm{~g}$ & $25 \mathrm{~g}$ \\
\hline TAN1 & COD & 28 & 14 & 64 & 87 & 89 \\
& BOD & 50 & 54 & 59 & 67 & 80 \\
& SS & 35 & -26 & -27 & -32 & -63 \\
& TDS & 99 & 99 & 99 & 98 & 98 \\
TAN2 & COD & 15 & 20 & 25 & 32 & 38 \\
& BOD & 91 & 91 & 92 & 90 & 92 \\
& SS & -28 & -52 & -52 & -54 & -55 \\
& TDS & 97 & 99 & 99 & 99 & 99 \\
& COD & 33 & 44 & 22 & 11 & 26 \\
& BOD & 75 & 81 & 76 & 81 & 81 \\
& SS & 25 & 3 & -1 & -10 & -15 \\
& TDS & 98 & 98 & 98 & 98 & 98 \\
\hline
\end{tabular}

Percentage Reduction $=(B-A) / B \times 100 \%$

$A=$ Concentration of the parameter after treatment

$\mathrm{B}=$ Concentration of the parameter before treatment

$+=$ percentage decrease

- = percentage increase

In general, immobilization makes the enzyme more resistant to temperature, $\mathrm{pH}$, and substrate concentration swings giving it a longer lifetime and higher productivity per active unit (Gianfreda and Rao, 2004; FuIlbrook, 1996; Russell et al, 2003; Kandelbauer et al., 2004). Immobilized cells have been used and studied extensively for the production of useful chemicals (Ohtake and Silver, 1994), the treatment of wastewaters (Chen et al., 2003; Wang et al., 2010). Although many workers described microbial degradation of tannery effluent, limited literature is available on the bioremediation of tannery effluent using immobilized bacterial cells in the Kano Industrial Estates.

\section{CONCLUSION}

The samples contained variable levels of the physicochemical parameters. The results of the Analysis of variance revealed that, no statistical difference $(p<0.05)$ was observed for the temperature, $\mathrm{pH}, \mathrm{SS}, \mathrm{TDS}, \mathrm{BOD}$ and $\mathrm{COD}$ among the three tannery industries before the treatment. The levels of some of the parameters
(SS, TDS and COD) observed in the samples were found above the recommended limits of WHO and NESREA, which called for the treatment of the effluents before discharge into the environment. Base on the morphological and biochemical test results, TAN1, TAN2, and TAN3 bacterial isolates were identified to be Neisseria spp, Bacillus cereus, and Staphylococcus aureus respectively. The results of Post-treatment analysis showed that there is overall decrease in the levels of the parameters determined when compared with that of the pre-treatment. The overall percentage reduction of the immobilised bacteria in the treatment of the respective effluents was in the order TAN2 (72\%)>TAN1 $(70 \%)>$ TAN3 $(62 \%)$. Hence, the immobilized bacteria are having higher biodegradation potential for the treatment of the tannery effluents.

\section{Acknowledgments}

The authors wish to acknowledge the University of Maiduguri for the financial support. The authors are grateful to the Kano State Ministry of Environment for their support in obtaining the effluent samples. 


\section{REFERENCES}

Ajao, A. T., Adebayo, G. B., and Yakubu, S. E. (2011). Bioremediation of textile industrial effluent using mixed culture of Pseudomonas aeruginosa and Bacillus subtilis immobilized on agar-agar in a bioreactor. J. Microbiol. Biotech. Res, 1(3), 50-56.

Akan, J. C., Moses, E. A., Ogugbuaja, V. O., and Abah, J. (2007). Assessment of tannery industrial effluents from Kano metropolis, Kano State, Nigeria. Journal of Applied Sciences, 7(19), 2788-2793.

Akan, J. C., Ogugbuaja, V. O., Abdulrahman, F. I., and Ayodele, J. T. (2009). Pollutant levels in effluent samples from tanneries and textiles of Kano industrial areas, Nigeria. Global journal of pure and applied sciences, 15(3-4).

APHA (1989). Standard methods for Examination of Will bete and Will betewater.15 $5^{\text {th }}$ edition. Brydpass Springfield Will behington DC. pp. 164-176

APHA (1992). Standard Methods for the Examination of Water and Wastewater. Health, 69, 1116-9.

Baba, A., Garba, S. T., and Bello, H. S. (2020). Bioremediation Potential of Immobilized corynebacterium kutsceri in the Treatment of Tannery Industrial Effluent from Challawa Industrial Estate, Kano State, Nigeria. Journal of the Turkish Chemical Society Section A: Chemistry, $7(2), 335-350$.

Beem, E. I. V. (1994). reduction of solvent VOC emission. J. Oil Col. Chem. Ass, 77, 158.

Bouwer, E. J., and Zehnder, A. J. (1993). Bioremediation of organic compoundsputting microbial metabolism to work. Trends in biotechnology, 11(8), 360367.

Chen, K. C., Wu, J. Y., Liou, D. J., and Hwang, S. C. J. (2003). Decolorization of the textile dyes by newly isolated bacterial strains. Journal of Biotechnology, 101(1), 57-68.

Dan'Azumi, S., and Bichi, M. H. (2010). INDUSTRIAL POLLUTION AND HEAVY METALS PROFILE OF CHALLAWA RIVER IN KANO, NIGERIA. Journal of Applied Sciences in Environmental Sanitation, $5(1)$.

DWAF. (1992). Analytical Methods Manual, TR 151. Department of Water Affairs and Forestry, Pretoria.

El-Bestawy, E. (2013). Biological treatment of leather-tanning industrial wastewater using free living bacteria.
Elsheikh, M. A. S. (2009). Tannery wastewater pre-treatment. Water Science and Technology, 60(2), 433-440.

FuIlbrook, P. D. (1996). "Kinetics." Industrial enzymology: The application of enzymes in Industry. 2nd Ed. T. Godfrey and J Reichelt. eds.. Nature. New York.

Gianfreda, L., and Rao, M. A. (2004). Potential of extra cellular enzymes in remediation of polluted soils: a review. Enzyme and microbial technology, 35(4), 339354.

Hugo Springer. (1994). John Arthur Wilson Memorial Lecture "Treatment of Industrial Wastes of the Leather Industry - is it still a Major Problem". JALCA, 89, 153-185

Jimoh, A. A., Ganiyu, B. A., Baba, D., and Baba, A. (2018) Bioremediation Process of Effluent from Detergent and Food Industries in Jos, Nigeria: Kinetics and Thermodynamics. International Journal of Engineering Science Invention (IJESI), 762-73

Kandelbauer, A., Maute, O., Kessler, R. W., Erlacher, A., and Gübitz, G. M. (2004). Study of dye decolorization in an immobilized laccase enzyme-reactor using online spectroscopy. Biotechnology and bioengineering, 87(4), 552-563.

Kongjao, S., Damronglerd, S., and Hunsom, M. (2008). Simultaneous removal of organic and inorganic Pollutants in tannery wastewater using electrocoagulation technique. Korean Journal of chemical engineering, 25(4), 703.

Maheshwari, U. M., Aruna, S., Gomathi, M., and AbdulJaffar, A. H. (2017). Bioremediation by Free and Immobilized Bacteria Isolated from Tannery Effluent. International Journal of Research in Applied, Natural and Social Sciences. 5(7), 75-90

Margesin, R., and Schinner, F. (2001). Bioremediation (natural attenuation and biostimulation) of diesel-oilcontaminated soil in an alpine glacier skiing area. Applied and environmental microbiology, 677), 3127-3133.

Mohammed, A., Sekar, P., and George, J. (2011). Efficacy of microbes in bioremediation of tannery effluent. Inter. J. Curr. Res, 3(4), 324-326.

Mohammed, S. S. D., Orukotan, A. A., and Abdullahi, H. (2017). Physicochemical and Bacteriological Assessment of Tannery Effluent from Samaru-Zaria, 
BAJOPAS Volume 13 Number 2, December, 2020 Kaduna State, Nigeria. Journal of Applied

Sciences and Environmental Management, 21(4), 734-740.

Munz, G., De Angelis, D., Gori, R., Mori, G., Casarci, M., and Lubello, C. (2009). The role of tannins in conventional and membrane treatment of tannery wastewater. Journal of hazardous materials, 164(2-3), 733-739

Mythili, K., and Karthikeyan, B. (2011). Bioremediation of $\mathrm{Cr}$ (VI) from tannery effluent using Bacillus spp and Staphylococcus spp. International Multidisciplinary Research Journal, 1(6).

NESREA (2009). National Environmental Standards for Effluent Limitations and Regulation. 1233-1236

Noorjahan, C. M. (2014). Physicochemical characteristics, identification of bacteria and biodegradation of industrial effluent. Journal of bioremediation and Biodegradation, 5(3).

Ohtake, H. I., and Silver, A. O. (1994). Bacterial reduction of toxic chromate. Biological degradation and bioremediation of toxic chemicals, 403-415.

Omoleke, I. I. (2004). Management of environmental pollution in Ibadan, an African city: the challenges of health hazard facing government and the people. Journal of Human Ecology, 15(4), 265-275.

Rajor, A., Reddy, A.S., and Singh, B. (2004). Determination of BOD kinetic Parameters and evaluation of alternate methods, M.Sc. Thesis, Department of biotechnology \& environmental Science, Thapar Institute of Engineering and Technology, Patiala

Ramasami, T., Rajamani, S., and Rao, J. R. (1994, March). Pollution control in leather industry: Emerging technological options. In International symposium on surface and colloidal science and its relevance to soil pollution, madras.

Ramesh, J. V. S., and Singh, S. P. (1993). Yearly variation in certain physicochemical parameters of pond at eastern Doon Valley. Uttar Pradesh J. Zoo, 12 (1), 7577.

Ranen, S., and Sharadinadra, C. (2009). Biotechnology applications to environmental remediation in resource exploitation. Current science, 97, 6-25
Russell, A. J., Berberich, J. A., Drevon, G. F., and Koepsel, R. R. (2003). Biomaterials for mediation of

chemical and biological warfare agents. Annual review of biomedical engineering, 5(1), 1-27.

Saravanan, P., and Saravanan, A. (1999). Decolourization of tannery effluent by Flavobacterium sp. EK 1. Indian Journal of Environmental Protection, 19, 19-24.

Sikander, S., and Shahida, H. (2007). Reduction of toxic hexavalent chromium by Ochrobactrum intermedium strain SDCr5 stimulated by heavy metals. Bioresource Technol, 98, 340-344.

Singh, N., Sharma, B. K., and Bohra, P. C. (2000). Impact assessment of industrial effluent of arid soils by using satellite imageries. Journal of the Indian Society of Remote Sensing, 28(2-3), 79.

Sreemoyee, C., and Priti, P. (2013). Assessment of physico-chemical parameters of dairy waste water and isolation and characterization of bacterial strains in terms of cod reduction. Int J Sci, 2(3), 395-400.

Verheijen, L. A. H. M., Wiersema, D., Pol, L. H., and De Wit, J. (1996). Management of wastes from animal product processing. Livestock and environment, Finding a balance. International Agriculture Center, Wageningen, The Netherlands.

Wang, F., Yao, J., Si, Y., Chen, H., Russel, M., Chen, K., and Bramanti, E. (2010). Short-time effect of heavy metals upon microbial community activity. Journal of Hazardous Materials, 173(13), 510-516.

WHO (World Health Organization). (2006). Air quality guidelines: global update 2005: particulate matter, ozone, nitrogen dioxide, and sulfur dioxide. World Health Organization.

World Bank. (1995). Nigeria's strategic options for redressing industrial pollution. World Bank, industry and energy division. 1st edition, West Central Africa Department; Annexes: 1995; pp 60-62.

Zahoor, A., and Abdul, R. (2009). Enumeration of Coliforms. Journal of Environmental Sciences. 21, 814-820 


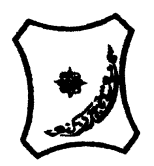

Bayero Journal of Pure and Applied Sciences, 13(2): 1 - 12

Received: November, 2020

Accepted: December, 2020

ISSN $2006-6996$

\title{
BIODEGRADATION POTENTIAL OF IMMOBILIZED BACTERIA IN THE TREATMENT OF TANNERY INDUSTRIAL EFFLUENTS FROM INDUSTRIAL ESTATES IN KANO STATE, NIGERIA
}

\author{
Abdullateef, B., ${ }^{1 *}$ Shuaibu, T. G., ${ }^{1}$ Babagana, K., ${ }^{1}$ Suleman, H. B. ${ }^{2}$ and Dauda, B. ${ }^{3}$ \\ ${ }^{1}$ Department of Pure and Applied Chemistry, Faculty of Science, University of Maiduguri, Borno State, \\ Nigeria \\ ${ }^{2}$ Department of Microbiology, Faculty of Science, University of Maiduguri, Borno State, Nigeria \\ ${ }^{3}$ Department of Chemical Engineering, Faculty of Engineering, University of Maiduguri, Borno State, \\ Nigeria \\ *Corresponding author: babslega@gmail.com; abelega2007@yahoo.com; +2348061309753
}

\section{ABSTRACT}

Industrial Effluents Samples from Gashash Tanneries (TAN1) in Bompai Industrial estate, Larabee Tannery Industry (TAN2) in Sharada Industrial estate and Z Tannery Industries (TAN3) in Challawa Industrial estate, Kano State, Nigeria were collected over a period of six months (August 2017 to January 2018) for assessing the biodegradation potentials of bacteria in the treatment of organic pollutants within the effluents. Bacteria were isolated from the effluents and immobilized on agar-agar. Different masses (5 g, $10 \mathrm{gr}, 15$ $\mathrm{g}, 20 \mathrm{~g}$, and $25 \mathrm{~g}$ ) of the bacteria were used in the treatment of $250 \mathrm{ml}$ of the effluents for ten days in a shaker incubator (Gallenkamp-OC-4364-L) at the temperature $30{ }^{\circ} \mathrm{C}$ and speed of $60 \mathrm{rpm}$. Pre-treatment analysis of the effluents for Temperature, pH, Biochemical Oxygen Demand (BOD), Chemical Oxygen Demand (COD), Suspended Solid (SS) and Total Dissolved Solids (TDS) gives the following results; temperature $\left({ }^{\circ} \mathrm{C}\right.$ )

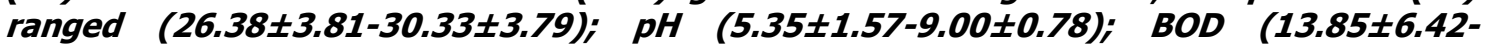
$38.75 \pm 16.20) ;$ COD (1406 $\pm 208-3532 \pm 1373) ;$ SS (208 $\pm 235-780 \pm 739)$ and TDS (266 $\pm 253-5276 \pm 2971)$. No statistical differences ( $p \leq 0.05)$ was observed for all the results among the different industries. The bacterial isolates were identified as Neisseria spp, Bacillus cereus, and Staphylococcus aureus, in TAN1, TAN2, and TAN3, respectively. After treatment of the effluent with the different masses of the isolated bacteria, the mean level of BOD was found to range as (0.55 $\pm 0.36-6.92 \pm 5.49) ; C O D$ (ND-3134 \pm 1595$)$;

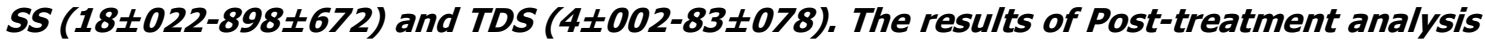
showed that there is overall decrease in the levels of the parameters determined when compared with that of the pre-treatment. The overall percentage reduction of the immobilised bacteria in the treatment of the respective effluents was in the order TAN2 (72\%)>TAN1 (70\%)>TAN3 (62\%). Hence, the immobilized bacteria are having higher biodegradation potential for the treatment of the tannery effluents.

Keywords: Biodegradation, bacteria, effluent, immobilization, tannery.

\section{INTRODUCTION}

Tannery industrial wastewater is a serious consequence of the pollution point of view for streams, freshwater, and land used for agriculture. The lack of awareness in the modern industrial practice has resulted in the discharge of tannery effluents which exhibit very high value of chromium ( $\mathrm{Cr}$ ), Sulfide, and chloride, Total Dissolved Solid (TDS), Total Suspended Solid (TSS), Biochemical Oxygen Demand (BOD) and Chemical Oxygen Demand (COD) in the water stream or land (Mohammed et al., 2001). Tanning is the process, which One ton of skin generally leads to the production of 20 to $80 \mathrm{~m}^{3}$ of turbid and foul-smelling converts the protein of the rawhide or skin into a stable material, which will not putrefy and is suitable for a wide variety of end applications (Elsheikh, 2009). The highly polluting chromium is the most commonly used tanning material producing leather that is more flexible and pliable than vegetable-tanned leather and does not discolor or lose shape in water as drastically as vegetable-tan (Elsheikh, 2009). Tannery effluent is among the most hazardous industrial pollutants due to its huge organic and inorganic load, which is highly toxic to human life and the environment (Kongjao et al., 2008). wastewater including chromium (100-400 mg/l), sulfide $(200-800 \mathrm{mg} / \mathrm{l})$, high levels of fat and 
BAJOPAS Volume 13 Number 2, December, 2020 other solid wastes, and notable pathogen contamination as well as pesticides added for skin conservation during transport (Elsheikh, 2009). There are more than 6000 tanneries in Nigeria with an annual processing capacity of 700,000 tons of hides and skins (Omoleke, 2004; Singh et al., 2008). It was reported that the total amount of waste produced per animal slaughtered is approximately $35 \%$ of its weight (World Bank, 1995). Also, for every $1000 \mathrm{~kg}$ of carcass weight, a slaughtered beef produces 5.5 $\mathrm{kg}$ of manure (excluding rumen contents or stockyard manure) and $100 \mathrm{~kg}$ of paunch manure (undigested food) (Verheijen et al., 1996). Tanneries generate wastewater in the range of 30-35 $\mathrm{L} \mathrm{kg}^{-1}$ skin/hide processed with variable $\mathrm{pH}$, Biological Oxygen Demand (BOD), Chemical Oxygen Demand (COD), high concentrations of suspended solids (SS), and tannins as well as chromium (Zahoor and Abdul, 2009).

Being heterogeneous and composed of a wide variety of compounds, it is very difficult to select a unique direct method for estimating the biodegradability of organic contents and biokinetic parameters for a wastewater sample (Rajor, 2004). For this purpose, some indirect estimation such as determination of biochemical oxygen demand (BOD) and chemical oxygen demand (COD) are applied as common laboratory investigations [9]. During retanning procedures, synthetic tannins (Syntan), oils and resins are added to form softer leather at varying doses (Munz et al., 2009). One of the refractory groups of chemicals in tannery effluents derives mainly from tannins (Ramasami et al., 2004). Syntans are characterized by complex chemical structures, because they are composed of an extended set of chemicals such as phenol-, naphthalene-, formaldehyde- and melamine-based syntans, and acrylic resins (Beem, 1994). Organic pollutants (proteic and lipidic components) are originated from skins (it is calculated that the raw skin has $30 \%$ loss of organic material during the working cycle) or they are introduced during processes (Hugo Springer, 1994).

Many conventional processes such as oxidation, chemical and biological processes were carried out to treat tanneries wastewater (Ebtesam et al, 2013). Biological processes have received more attention because of their costeffectiveness, lower sludge production and environmental friendliness (Noorjahan, 2014). Naturally occurring micro-organisms degrade the hazardous organic wastes including xenobiotic compounds, such as pesticides, polycyclic aromatic hydrocarbons (PAHs) and polychlorinated biphenyls (PCBs) in due course of time (Ranen and Sharadinadra, 2009). Bioremediation is based on the idea that all organisms remove substances from the environment to carry outgrowth and metabolism (Bouwer and Zehnder, 1993). Bacteria, protista and fungi are found to be very good at degrading complex molecules and incorporating the breakdown products into their metabolism (Bouwer and Zehnder, 1993). The resultant metabolic wastes that they produce are generally safe and somehow recycled into other organisms (Ranen and Sharadinadra, 2009). An acclimatized indigenous population of microorganisms capable of degradation of the compounds of interest must exist at the site for a successful bioremediation mode (Ranen and Sharadinadra, 2009). It has been observed that for a successful bioremediation mode, an acclimatized indigenous population of microorganisms capable of degradation of the compounds of interest must exist at the site under investigation (Ranen and Sharadinadra, 2009). Even though there are numerous physical and chemical methods employed in the disposal of wastes the advantage in using bacterium is that they play a key role in the reduction of COD, BOD, total protein, total tannin and total phenol (Saravanan and Saravanan, 1998)

Baba et al. (2020) studied the bioremediation potential of immobilized corynebacterium kutsceri in the Treatment of tannery industrial effluent from Challawa Industrial Estate, Kano State, Nigeria. The aim of the work is to study the reduction in the level of the contaminants through the process of bioremediation using the isolated bacteria. Immobilized bacteria can withstand various temperatures, $\mathrm{pH}$ and substrate concentrations; consequently, increasing the efficiency and the lifespan of the bacteria. Immobilized bacteria are widely applied in the treatment of wastewater and can be separated and recovered after the treatment with the same efficiency (Baba et al., 2020).

\section{MATERIALS AND METHODS \\ Study Area}

This study was carried out in Bompai, Sharada and Challawa industrial estates in Kano, Figure 1. Kano lies on Latitude $11^{\circ} 30^{\prime} \mathrm{N}$ and $8^{\circ} 30^{\prime} \mathrm{E}$ and Longitude $11^{\circ} 5^{\prime} \mathrm{N}$ and $8^{\circ} 5^{\prime} \mathrm{E}$ in Northern Nigeria. It is one of the developed industrial cities in Nigeria. Tannery activities are the dominating industries and this could be one of the reasons for her high population density (Dan'Azumi and Bichi, 2010). Many researchers have studied biodegradation of tannery effluent using microorganisms. However, limited literature is available on the biodegradation of tannery effluent in Kano industrial estates using 
BAJOPAS Volume 13 Number 2, December, 2020 immobilized bacterial cells. This research work focuses on the potential of the use of the indigenous immobilized bacterial isolates in the treatment of tannery effluents in the industrial estates.

\section{Sample Collection}

Effluents were collected from the Tannery Industries from Bompai, Challawa and Sharada Industrial Estates, Kano, Nigeria. The effluents were collected over a period of six months (August 2017 to January 2018). Samples collected in a sterile 4-liter plastic container with a unique identification number were preserved using an ice-box that was transported to the Microbiology Laboratory, Department of Microbiology, Bayero University of Kano for analysis

\section{Sample Preparation and Sample Analysis}

Immediately after the collection of the effluent, $\mathrm{pH}$, TSS, TDS, COD, BOD levels were determined before treatment (Pre-treatment determination) and ten days after treatment (Post-treatment determination) as described in
APHA (1989) standard methods. $\mathrm{pH}$ was determined using Ecotests $\mathrm{pH}$ meter and TDS was determined using AQUALYTIC TDS Salinometer. BOD was determined as described by the standard method (APHA, 1992). COD and SS were determined using DR/2010 HACH portable data logging spectrophotometer (DWAF, 1992)

\section{Identification and Biochemical} Characterization of the Bacterial Isolates

The bacteria were isolated from the effluents using Serial Dilution according to the method described by APHA (1989). The biochemical tests such as oxidase, catalase, coagulase, indole (from $1 \%$ tryptone broth), citrate (Simmons citrate agar), methyl red/VogesProskauer (MR/VP), nitrate reduction, Starch Hydrolysis, Glucose, Maltose, and Lactose tests were carried out on the bacterial isolates to identify the bacteria through the bacteria biochemical characteristics according to Ajao et al. (2011).

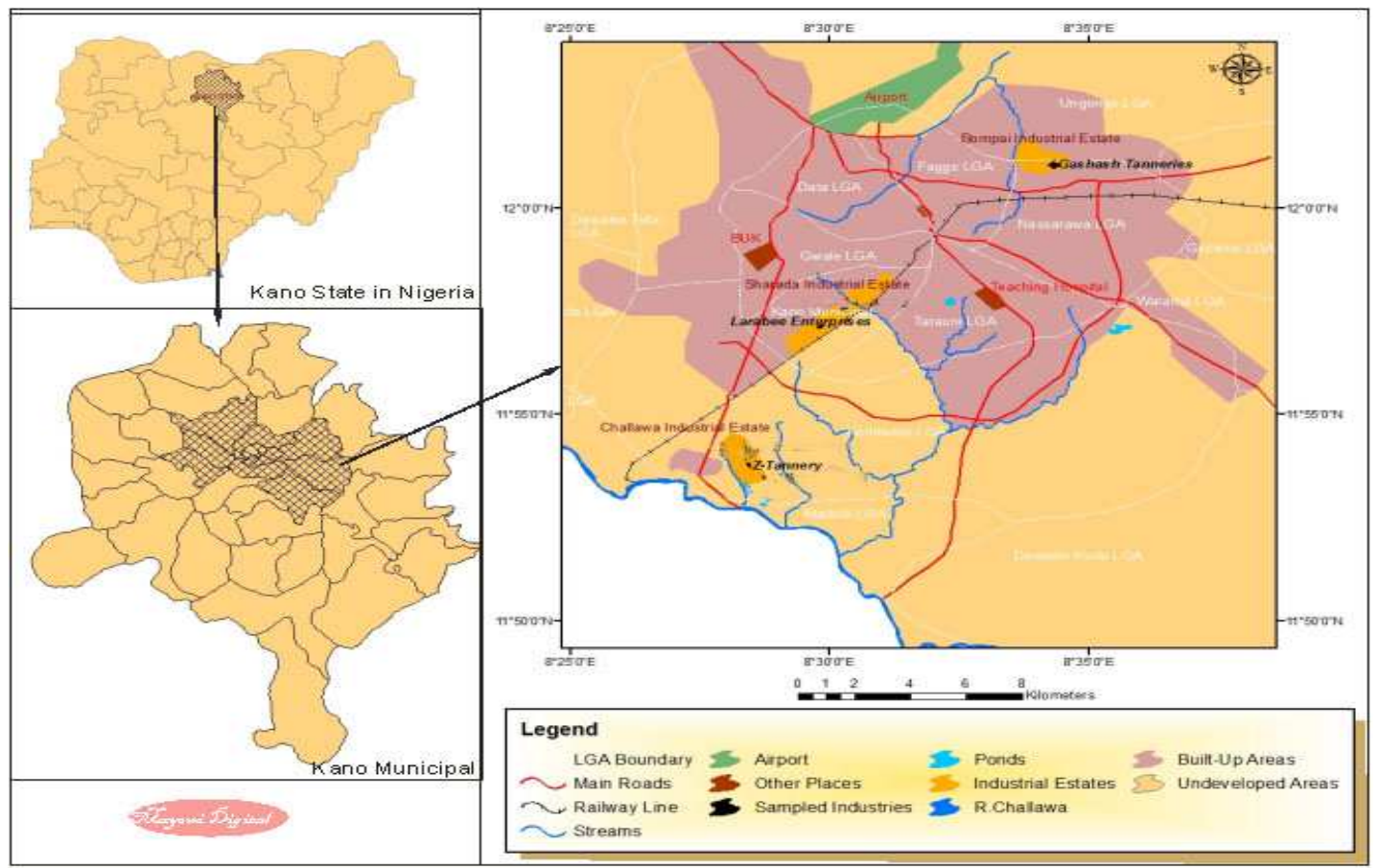

Fig. 1 Map showing the study areas

Source: Mayomi Digital Productions, GIS Laboratory, Department of Geography, UNIMAID (2017)

\section{Determination of Growth Rate of the Bacteria in Effluent Sample}

The bacteria growth rates were determined by transferring $2 \mathrm{~mL}$ of the bacterial isolates from the tannery effluent in broth medium into 100 $\mathrm{mL}$ sterile effluents in conical flasks and kept in an incubator (Giffrin cool) for 10 days. Control was also set up by incubating another $100 \mathrm{~mL}$ each of the sterile effluents without the bacteria. The optical density of the content was determined at the wavelength of $600 \mathrm{~nm}$ on a daily interval and recorded. 
BAJOPAS Volume 13 Number 2, December, 2020 Immobilization of Bacteria

Agar solution and inoculi were prepared separately. Fifty milliliters $(50 \mathrm{~mL})$ of nutrient broth each of the inoculi was prepared in a McCartney bottle and incubated for 24 hours. A solution of agar-agar was prepared by dissolving $10 \mathrm{~g}$ of the powder in distilled water and made up to $500 \mathrm{~mL}$ mark in an Erlenmeyer flask and was sterilized in an autoclave (280A) for 15 minutes and allowed to cool to $40-45^{\circ} \mathrm{C}$ (Ajao et al., 2011). Four milliliters ( $4 \mathrm{~mL})$ of the bacterial isolates in the nutrient broth was mixed with 36 $\mathrm{ml}$ of the prepared agar-agar media in petri-dish plates and then allowed to solidify. This was kept in the refrigerator for bioremediation.

\section{Bioremediation (Treatment) of the Effluents}

The solidified agar block (immobilized bacteria) was cut into cubes using a sterile knife; $0.1 \mathrm{~mL}$ phosphate buffer ( $\mathrm{pH} \mathrm{7.0)}$ was added and kept in the refrigerator for 1 hour for curing. The phosphate buffer was decanted after 1 hour and the cubes were washed with sterile distilled water 3-4 times before it was used (Ajao et al., 2011). Two liters (2 L) of the effluent was supplemented with the minimum basal medium in $\mathrm{g} / \mathrm{L}: \mathrm{NaCl}(0.8), \mathrm{MgSO}_{4} .7 \mathrm{H}_{2} \mathrm{O}(0.001), \mathrm{KH}_{2} \mathrm{PO}_{4}$ (2), $\mathrm{NaNO}_{3}$ (2), $\quad \mathrm{CaCl}_{2} .2 \mathrm{H}_{2} \mathrm{O} \quad(0.5)$ and $\mathrm{NaHPO}_{4} .12 \mathrm{H}_{2} \mathrm{O}(2)$ and sterilized in an autoclave at $121^{\circ} \mathrm{C}$ for 15 minutes (Margesin and Schinner, 2001). Two hundred and fifty milliliters $(250 \mathrm{~mL})$ of the effluents were transferred into different $250 \mathrm{ml}$ conical flasks. The content was covered with a cotton-wool ramped with foil paper to avoid contamination. Five grams $(5 \mathrm{~g})$ of the immobilized bacteria were quickly transferred into each of the effluents in the conical flasks in an inoculating chamber. The same procedures were carried out for the $10 \mathrm{~g}, 15 \mathrm{~g}, 20 \mathrm{~g}$ and 25 $\mathrm{g}$ of the immobilized bacteria in separate $250 \mathrm{~mL}$ effluents in conical flasks and agitated for ten days in a shaker incubator (Gallenkamp-OC4364-L) at a temperature $30^{\circ} \mathrm{C}$ and speed of 60 rpm. The treated effluent samples were taken on the tenth day and analyzed for the parameters $\mathrm{pH}$, SS, TDS, COD, and BOD, (Posttreatment determination) for the different grams of bacteria to evaluate and compare the biodegradation potential. (Baba et al., 2020).

\section{Statistical Analysis}

The data were represented as Mean \pm Standard deviation and analyzed statistically using oneway Analysis of Variance (ANOVA) and Tukey's HSD as Post Hoc Tests with the aid of SPSS 16.0. The correlation coefficient was also used to measure the strength of the relationship between the different masses of the bacteria and the parameters. All $\mathrm{p} \leq 0.05$ were considered as statistically significant.

\section{RESULTS AND DISCUSSION Physico-chemical parameters in the Industrial Effluents before the Biodegradation.}

Results of the Physico-chemical parameters in the industrial effluents before the Biodegradation is shown in table 1 . The mean temperatures $\left({ }^{\circ} \mathrm{C}\right)$ observed in TAN1, TAN2, and TAN3 samples were $28.07 \pm 0.65 ; 27.77 \pm 0.64$ and $26.38 \pm 3.81$ respectively. The order of the mean temperature of the samples from the three industries can be arranged as TAN1 > TAN2>TAN3. The temperature observed at TAN1, TAN2, and TAN3 samples were found below the WHO $\left(35^{\circ} \mathrm{C}\right)$ and NESREA $\left(40^{\circ} \mathrm{C}\right)$ limits. The low values of temperature might be due to the processes used at the time of sampling. High temperature brings down the solubility of gases in water that ultimately expresses as high BOD and COD. Statistical analysis shows that there is no significant difference $(p<0.05)$ between the mean values of temperature among the industries. This might be due to similar tannery activities involved in the tannery industries at the time of sampling. The average values of temperature observed in this present study are less than those observed by Akan et al. (2007), Akan et al. (2009) and Baba et al. (2020).

The mean level of $\mathrm{pH}$ observed in TAN1, TAN2 and TAN3, samples were $7.77 \pm 2.93$; $8.35 \pm 0.28$ and $7.52 \pm 0.76$ respectively. The order of the mean $\mathrm{pH}$ of the samples from the three industries can be arranged as TAN2> TAN1 $>$ TAN3. The $\mathrm{pH}$ of the samples falls within the WHO (7.0-8.5) and NESREA (6-9) standard limits. Statistical analysis shows that there is no significant difference $(p<0.05)$ between the mean values of $\mathrm{pH}$ among the industries. This might be due to similar tannery activities involved in the tannery industries at the time of sampling. Maheshwari et al. (2017) reported that the level of $\mathrm{pH}$ in the effluents from the tannery industry in Vaniyambadi, India was 6.5 which was lower than that observed in the present study. The $\mathrm{pH}$ in the effluents from the tannery industries in Kano and Kaduna were reported to be 7.64 and 6.89, respectively (Akan et al., 2007; Mohammed et al., 2017). The average values of $\mathrm{pH}$ observed in this present study are less than those observed by Mohammed et al. (2017) and Baba et al. (2020). The mean level of SS $(\mathrm{mg} / \mathrm{l})$ observed in TAN1, TAN2, and TAN3 samples were 374 \pm 124 ; $358 \pm 335$ and $780 \pm 739$ respectively. The order of the mean SS in the samples from the three industries can be arranged as TAN3 > TAN1 $>$ TAN2. 
The SS observed in the samples were far above the recommended standard limits of regulating bodies WHO $(30 \mathrm{mg} / \mathrm{l})$ and NESREA $(10 \mathrm{mg} / \mathrm{l})$. Statistical analysis shows that there is no significant difference $(p<0.05)$ between the mean values of SS among the industries. This might be due to similar tannery activities involved in the tannery industries at the time of sampling. The average values of SS observed in this present study are less than that observed $(3700 \pm 122 \mathrm{mg} / \mathrm{l})$ by Akan et al. (2009) for tanneries in Kano. Also, the average values of SS observed in this present study are less than that observed by Mohammed et al. (2017) and Baba et al. (2020) with the exception in TAN3.

The mean level of TDS (mg/l) observed in TAN1, TAN2, and TAN3 samples were $3941 \pm 3703$; $3300 \pm 1714$ and $2653 \pm 1240$ respectively. The order of the mean TDS in the samples from the three industries can be arranged as TAN1>TAN2>TAN3. The TDS observed in the samples were far above the recommended standard limits of WHO $(250 \mathrm{mg} / \mathrm{l})$ and NESREA $(500 \mathrm{mg} / \mathrm{l})$. Statistical analysis shows that there is no significant difference $(p<0.05)$ between the mean values of TDS among the industries. This might be due to similar tannery activities involved in the tannery industries at the time of sampling. TDS in the effluents from the tannery industries in Kano, Nigeria was reported to be $1281 \mathrm{mg} / \mathrm{l}$ (Akan et al., 2007). The average values of SS observed in this present study are less than those observed by Mohammed et al. (2017) and Baba et al. 2020)

The mean level of COD (mg/l) observed in TAN1, TAN2 and TAN3 samples seasons were $2372 \pm 938 ; \quad 1406 \pm 208$ and $3532 \pm 1373$ respectively. The order of the mean COD of the samples from the three industries can be arranged as TAN3>TAN1> TAN2. The COD observed in TAN1, TAN2 and TAN3 samples were far above the recommended standard limits of regulating bodies $\mathrm{WHO}(40 \mathrm{mg} / \mathrm{l})$ and NESREA (40 mg/l). Statistical analysis shows that there is no significant difference $(p<0.05)$ in COD among the industries. This might be due to similar tannery activities involved in the tannery industries as at the time of sampling. The Chemical Oxygen demand (COD) is the amount of oxygen, in $\mathrm{mg} / \mathrm{L}$, required for the degradation of the compound of wastewater to occur. In comparison, the average values of COD observed in this present study were higher than that observed by Mohammed et al. (2017) but lower than that observed by Baba et al. (2020).

The mean levels of BOD $(\mathrm{mg} / \mathrm{l})$ observed in TAN1, TAN2 and TAN3 samples were $13.85 \pm 6.42 ; \quad 19.46 \pm 0.50$ and $17.13 \pm 3.14$ respectively. The order of the mean BOD in the samples from the three industries can be arranged as TAN2>TAN3>TAN1. The BOD observed in TAN1, TAN2 and TAN3 samples were found below the recommended limits of NESREA (200 mg/l) but above WHO (10 mg/l). Statistical analysis shows that there is no significant difference $(p<0.05)$ between the mean values of BOD among the industries. This might be due to similar tannery activities involved in the tannery industries at the time of sampling. The low level of BOD recorded in this study is an indication of the low level of biodegradable organic solids in the effluent. The average values of BOD observed in this present study were lower than those observed by Mohammed et al. (2017) and Baba et al. (2020).

Table 1: Mean Values \pm S.D of Physico-chemical parameters of effluents from the Tannery Industries before Treatment.

\begin{tabular}{llllllll}
\hline Parameter & Tannery 1 & Tannery 2 & Tannery 3 & $\mathrm{a}$ & $\mathrm{b}$ & $\mathrm{c}$ & $\mathrm{d}$ \\
\cline { 2 - 7 } Temperature $\left({ }^{\circ} \mathrm{C}\right)$ & $28.07 \mathrm{a} \pm 0.65$ & $27.77 \mathrm{a} \pm 0.64$ & $26.38 \mathrm{a} \pm 3.81$ & & $29.50 \pm 4.68$ & 35 & 40 \\
pH & $7.77 \mathrm{a} \pm 2.93$ & $8.35 \mathrm{a} \pm 0.28$ & $7.52 \mathrm{a} \pm 0.76$ & 6.89 & $5.35 \pm 1.57$ & $7.0-8.5$ & $6.0-9.0$ \\
$\mathrm{COD}(\mathrm{mg} / \mathrm{l})$ & $2372 \mathrm{a} \pm 938$ & $1406 \mathrm{a} \pm 208$ & $3532 \mathrm{a} \pm 1373$ & 2.2 & $3106 \pm 2753$ & 40 & 40 \\
$\mathrm{BOD}(\mathrm{mg} / \mathrm{l})$ & $13.85 \mathrm{a} \pm 6.42$ & $19.46 \mathrm{a} \pm 0.50$ & $17.13 \mathrm{a} \pm 3.14$ & 1032 & $26.17 \pm 9.49$ & 10 & 200 \\
$\mathrm{SS}(\mathrm{mg} / \mathrm{l})$ & $374 \mathrm{a} \pm 124$ & $358 \mathrm{a} \pm 335$ & $780 \mathrm{a} \pm 739$ & 501 & $562 \pm 482$ & 30 & 10 \\
TDS $(\mathrm{mg} / \mathrm{l})$ & $3941 \mathrm{a} \pm 3703$ & $3300 \mathrm{a} \pm 1714$ & $2653 \mathrm{a} \pm 1240$ & 532.7 & $444 \pm 507$ & 250 & 500 \\
\hline
\end{tabular}

The values given in the table above are means of 6 replicate values, $\mathrm{n}=6$ ( 1 sample was taken monthly for 6 months). Within the rows, means with different alphabets are statistically different $(p<0.05)$. WHO: World Health Organisation. NESREA: National Environmental Standard and Regulatory Enforcement Agency. a = Mohammed et al.(2017), b = Baba et al. (2020), c = WHO (2006), $d=$ NESSRA (2009) 
BAJOPAS Volume 13 Number 2, December, 2020

Identification, Biochemical Characterization and growth rates of the Bacterial Isolates

Results of identification and biochemical characterization of the bacterial isolates were shown in table 2. After 24 hours of incubation, the nutrient agar media plates were checked for bacterial growth. The results showed the presence of different strains in the samples. The TAN1 bacteria isolate was found to be gramnegative cocci while TAN3 was gram-positive cocci. TAN2 bacteria isolate was found to be gram-positive, rod-shaped. TAN1, TAN2, and TAN3 bacteria isolates recorded positive results for spore former.

The results of the biochemical tests indicated that all the bacteria were positive for catalase, oxidase, citrate, maltose, glucose, lactose (negative in TAN1), mannitol (negative in TAN2), starch hydrolysis and coagulase (negative in TAN2) tests. The bacteria showed negative results for nitrate reduction, $M R$ (positive in TAN2), VP (positive in TAN1), Indole (positive in TAN2) tests. Base on the morphological and biochemical test results, TAN1, TAN2, and TAN3 bacteria isolates were identified to be Nesseria spp, Bacillus cereus, and Staphylococcus aureus respectively.

The growth rate of the TAN1, TAN2 and TAN3 Isolates were shown in figure 2. Generally, the optical density increase with the increase in time (day) and decrease as time goes on. The highest optical density was shown by bacillus cereus in TAN2 while the lowest was shown by Staphylococcus aureus in TAN3.

The initial growth phase of TAN1 Isolate bacteria occurred within 2-day of incubation as the growth rate increases up to the 6th-day incubation when the maximum growth was observed. Beyond the 6th day, the growth of the bacteria declined (which might be due to a shortage of nutrients in the effluents) until it reached its death phase (which might be due to the unavailability of nutrients in the effluents).

A similar trend of growth was also observed for TAN2 Isolate as the initial growth phase also occurred within 2-day of incubation but maximum growth rate observed on the 4th day of incubation. The stationary stage occurred between the 4th day and the 8th day. Beyond the 8th day, the growth of the bacteria declined (which might be due to a shortage of nutrients in the effluents) until it reached its death phase (which might be due to the unavailability of nutrients in the effluents).

The initial growth phase of TAN3 bacterial Isolate occurred within the 3-day incubation as the growth rate increases up to the 6th-day incubation when the maximum growth was observed. Beyond the 6th day, the growth of the bacteria declined (which might be due to a shortage of nutrients in the effluents) until it reached its death phase (which might be due to the unavailability of nutrients in the effluents).

Table 2: Morphological and Biochemical characteristics of bacterial isolates

\begin{tabular}{lllll} 
Bacterial Isolates & & TAN1 & TAN2 & TAN3 \\
\hline $\begin{array}{lllll}\text { Morphological } \\
\text { characteristics }\end{array}$ & Shape & Cocci & Rod & Cocci \\
& Spore & & & \\
& former & + & + & + \\
Gram & & & \\
Biochemical characteristics & reaction & - & + & + \\
& Citrate & + & + & + \\
& Catalase & + & + & + \\
& Coagulase & + & - & + \\
Starch & + & + & + \\
& Glucose & + & + & + \\
Oxidase & + & + & + \\
& Indo & - & + & - \\
Lactose & - & + & + \\
Manitol & + & - & + \\
Maltose & + & + & + \\
MR & - & + & - \\
VP & + & - & - \\
& Nitrate & - & - & - \\
Reduction & - Neisseria & Bacillus & Staphylococcus \\
& Bacterial & cereus & aureus \\
& name & spp & cas
\end{tabular}

+ = Positive; - = Negative; MR=Methyl Red; VP= Voges-Proskauer 


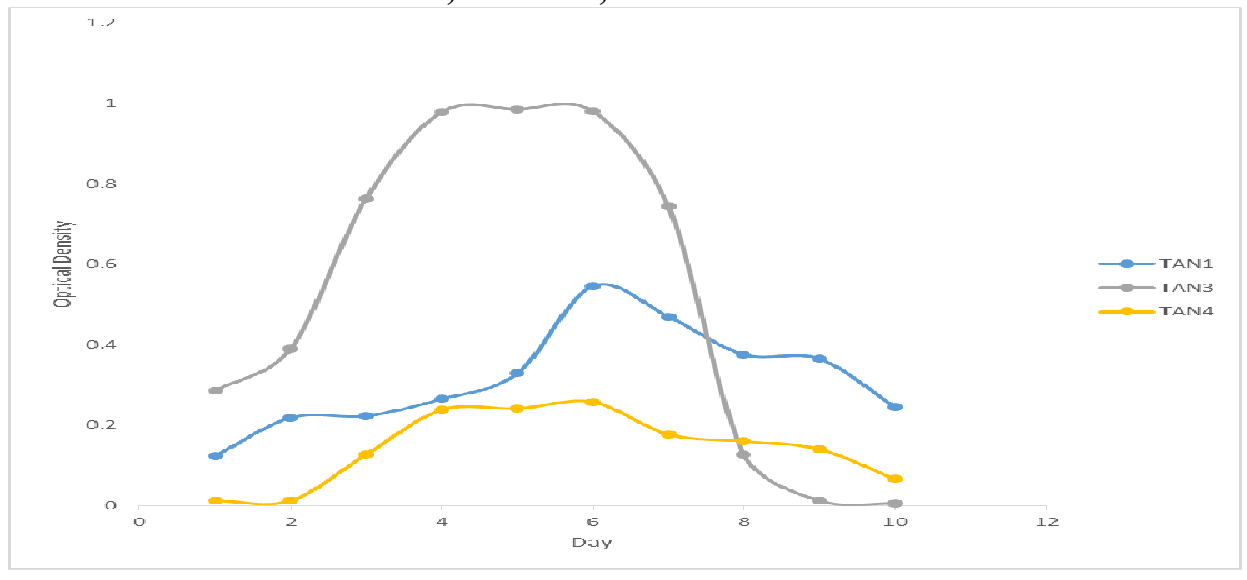

Fig. 2 Growth rates of the isolates in the effluents from the Tannery Industries

\section{Physico-chemical Parameters in the Industrial Effluents after the biodegradation.}

Table 3 shows the mean results of the physicochemical parameter before and after bioremediation using the different masses $(5 \mathrm{~g}$, $10 \mathrm{~g}, 15 \mathrm{~g}, 20 \mathrm{~g}$, and $25 \mathrm{~g}$ ) of the respective immobilized bacteria. Also, Table 4 shows the mean results of correlation coefficient ( $r$ ) between different masses of bacteria and physicochemical parameters.

The mean values $(\mathrm{mg} / \mathrm{l})$ of the SS after the bioremediation varies between $243 \pm 45$ and $898 \pm 672$. The mean concentration $(\mathrm{mg} / \mathrm{l})$ of SS remediated by the different masses $(5 \mathrm{~g}, 10 \mathrm{~g}$, $15 \mathrm{~g}, 20 \mathrm{~g}$, and $25 \mathrm{~g}$ ) of the bacteria varies. The SS in the samples fluctuates up and down after the bioremediation process when compared with the SS of the raw samples before the bioremediation. The increase in the levels of the SS might be due to the aggregation of the TDS which are large enough to result into SS. The increase in the levels of the SS might be also due to the influence of the nutrients which was added into the effluents in order to make the microorganisms more active and viable for fast degradation of organic contaminants in the effluent. The relative potential or efficiency of the different masses of the bacteria in remediating SS in TAN1 samples was in the order $25 \mathrm{~g}>20 \mathrm{~g}>15 \mathrm{~g}>10 \mathrm{~g}>5 \mathrm{~g}$. For TAN2 and TAN3 samples, the order was $25 \mathrm{~g}>20 \mathrm{~g}>15$ $\mathrm{g}>10 \mathrm{~g}>5 \mathrm{~g}$. These might be due to the variations in the surface areas of the different masses of the immobilized bacteria. Statistical analysis shows that there is no significant difference $(p<0.05)$ between the mean values of SS among the masses in the respective industries. Positive and significant correlations exist between the masses of bacteria and Suspended Solid (SS). This showed that there is general increase in the levels of the SS as the masses of the immobilized bacteria increases. TAN3 (90\%) and TAN1 (80\%) showed a very high correlation with the masses of the bacteria while TAN2 (61\%) showed a very low correlation.

The mean values $(\mathrm{mg} / \mathrm{l})$ of the TDS after the bioremediation varies between $46 \pm 11$ and $83 \pm 78$. The mean concentration $(\mathrm{mg} / \mathrm{l})$ of TDS remediated by the different masses $(5 \mathrm{~g}, 10 \mathrm{~g}$, $15 \mathrm{~g}, 20 \mathrm{~g}$, and $25 \mathrm{~g}$ ) of the bacteria varies. There is a reduction in all the TDS of all the samples after the bioremediation process compared with the TDS of the raw samples before the bioremediation. The relative potential or efficiency of the different masses of the bacteria in remediating TDS in TAN1 and TAN3 samples was in the order $5 \mathrm{~g}>10 \mathrm{~g}>15 \mathrm{~g}>20$ $\mathrm{g}>25 \mathrm{~g}$. For TAN2 samples, the order was 20 $g>10 \quad g>25 \quad g>15 \quad g>5 \quad g$. Statistical analysis shows that there is no significant difference $(p<0.05)$ between the mean values of TDS among the masses in the respective industries. These might be due to the variations in the surface areas of the different masses of the immobilized bacteria. Positive and significant correlations exist between the masses of bacteria and TDS with the exception in TAN2 (negative and insignificant correlation). The positive correlations showed that there is general increase in the levels of the TDS as the masses of the immobilized bacteria increases. TAN1 $(96 \%)$ showed a very high correlation with the masses of the bacteria while TAN2 (47\%) showed a very low correlation.

The mean values $(\mathrm{mg} / \mathrm{l})$ of the BOD after the bioremediation varies between $1.56 \pm 0.20 \mathrm{mg} / \mathrm{l}$ and $6.92 \pm 5.49 \mathrm{mg} / \mathrm{l}$. The mean concentration $(\mathrm{mg} / \mathrm{l})$ of BOD remediated by the different masses $(5 \mathrm{~g}, 10 \mathrm{~g}, 15 \mathrm{~g}, 20 \mathrm{~g}$, and $25 \mathrm{~g}$ ) of the bacteria varies. There is a reduction in all the BOD of all the samples after the bioremediation process compared with the $\mathrm{BOD}$ of the raw 
BAJOPAS Volume 13 Number 2, December, 2020 samples before the bioremediation. The relative potential or efficiency of the different masses of the bacteria in remediating BOD in TAN1, TAN2 and TAN3 samples were in the order $25 \mathrm{~g}>20$ $\mathrm{g}>15 \mathrm{~g}>10 \mathrm{~g}>5 \mathrm{~g}, 25 \mathrm{~g}>15 \mathrm{~g}>5 \mathrm{~g}>10 \mathrm{~g}>20 \mathrm{~g}$ and $20 \mathrm{~g}>10 \mathrm{~g}>25 \mathrm{~g}>15 \mathrm{~g}>5 \mathrm{~g}$ respectively. Statistical analysis shows that there is significant difference $(p<0.05)$ between the mean values of BOD among the masses in the respective industries. These might be due to the variations in the surface areas of the different masses of the immobilized bacteria. Negative and significant correlations exist between the masses of bacteria and BOD. This showed that there is general decrease in the levels of the BOD as the masses of the immobilized bacteria increases. TAN1 (94\%) showed a very high correlation with the masses of the bacteria while TAN2 (4\%) showed a very low correlation.

The mean values $(\mathrm{mg} / \mathrm{l})$ of the COD after the bioremediation varies between $250 \pm 154$ and $3134 \pm 1595$. The mean concentration $(\mathrm{mg} / \mathrm{l})$ of COD remediated by the different masses $(5 \mathrm{~g}$, $10 \mathrm{~g}, 15 \mathrm{~g} 20 \mathrm{~g}$, and $25 \mathrm{~g}$ ) of the bacteria varies. There is a reduction in all the COD of all the samples after the bioremediation process compared with the COD of the raw samples before the bioremediation. The relative potential or efficiency of the different masses of the bacteria in remediating COD in TAN1, TAN2 and TAN3 samples were in the order $25 \mathrm{~g}>20 \mathrm{~g}>15$ $\mathrm{g}>5 \mathrm{~g}>10 \mathrm{~g}, 25 \mathrm{~g}>20 \mathrm{~g}>15 \mathrm{~g}>10 \mathrm{~g}>5 \mathrm{~g}$ and 10 g>5 g>25 g>15 g>20 g respectively. Statistical analysis shows that there were significant difference $(p<0.05)$ between the mean values of COD among the masses in the respective industries except for effluents treated with $25 \mathrm{~g}$. These might be due to the variations in the surface areas of the different masses of the immobilized bacteria. Negative and insignificant correlations exist between the masses of bacteria and COD with the exception in TAN3 (positive and significant correlation). The negative correlations showed that there is general decrease in the levels of the COD as the masses of the immobilized bacteria increases. TAN2 (100\%) showed a very high correlation with the masses of the bacteria while TAN3 (36\%) showed a very low correlation.

Generally, there was an overall decrease in the concentration of these physicochemical parameters after the bioremediation using the different masses of the bacterial isolates. These might be due to the variations in the surface areas of the different masses of the immobilized bacteria. This is in line with the work of Jimoh et al. (2018) and Baba et al. (2020).

Table 3: Mean Values $(\mathrm{mg} / \mathrm{l}) \pm$ S.D of Physicochemical parameters in effluents from the Tannery Industries before and after Treatment of the effluents $(250 \mathrm{ml})$ with the different masses $(5 \mathrm{~g}, 10 \mathrm{~g}$, $15 \mathrm{~g}, 20 \mathrm{~g}$, and $25 \mathrm{~g}$ ) of the bacteria.

\begin{tabular}{llllllll}
\hline $\mathrm{P}$ & IND & Before & \multicolumn{5}{c}{ After } \\
\cline { 4 - 7 } & & & $5 \mathrm{~g}$ & $10 \mathrm{~g}$ & $15 \mathrm{~g}$ & $20 \mathrm{~g}$ & $25 \mathrm{~g}$ \\
\hline \multirow{2}{*}{ COD } & TAN1 & $2372 \pm 938$ & $1708 \mathrm{a} \pm 861$ & $2045 \mathrm{a} \pm 1205$ & $845 \mathrm{a} \pm 369$ & $300 \mathrm{a} \pm 167$ & $250 \mathrm{a} \pm 154$ \\
& TAN2 & $1406 \pm 208$ & $1195 \mathrm{a} \pm 208$ & $1125 \mathrm{a} \pm 384$ & $1055 \mathrm{a} \pm 317$ & $956 \mathrm{a} \pm 310$ & $870 \mathrm{ab} \pm 240$ \\
& TAN3 & $3532 \pm 1373$ & $2374 \mathrm{a} \pm 1344$ & $1976 \mathrm{a} \pm 1405$ & $2757 \mathrm{a} \pm 1266$ & $3134 \mathrm{a} \pm 1595$ & $2614 \mathrm{~b} \pm 1105$ \\
BOD & TAN1 & $13.85 \pm 6.42$ & $6.92 \mathrm{a} \pm 5.49$ & $6.42 \mathrm{a} \pm 5.07$ & $5.72 \mathrm{a} \pm 5.35$ & $4.62 \mathrm{a} \pm 4.37$ & $2.82 \mathrm{ab} \pm 1.26$ \\
& TAN2 & $19.46 \pm 0.50$ & $1.75 \mathrm{~b} \pm 0.22$ & $1.73 \mathrm{~b} \pm 0.18$ & $1.58 \mathrm{a} \pm 0.16$ & $1.91 \mathrm{a} \pm 0.22$ & $1.56 \mathrm{~b} \pm 0.20$ \\
& TAN3 & $17.13 \pm 3.14$ & $4.24 \mathrm{ab} \pm 0.77$ & $3.29 \mathrm{ab} \pm 0.37$ & $4.11 \mathrm{a} \pm 0.07$ & $3.23 \mathrm{a} \pm 0.91$ & $3.33 \mathrm{a} \pm 1.28$ \\
SS & TAN1 & $374 \pm 124$ & $243 \mathrm{a} \pm 45$ & $471 \mathrm{a} \pm 226$ & $475 \mathrm{a} \pm 182$ & $492 \mathrm{a} \pm 128$ & $611 \mathrm{a} \pm 217$ \\
& TAN2 & $358 \pm 335$ & $460 \mathrm{a} \pm 400$ & $543 \mathrm{a} \pm 414$ & $544 \mathrm{a} \pm 402$ & $551 \mathrm{a} \pm 414$ & $554 \mathrm{a} \pm 405$ \\
& TAN3 & $780 \pm 739$ & $586 \mathrm{a} \pm 594$ & $758 \mathrm{a} \pm 656$ & $787 \mathrm{a} \pm 676$ & $861 \mathrm{a} \pm 635$ & $898 \mathrm{a} \pm 672$ \\
TDS & TAN1 & $3941 \pm 3703$ & $51 \mathrm{a} \pm 10$ & $53 \mathrm{a} \pm 10$ & $55 \mathrm{a} \pm 15$ & $61 \mathrm{a} \pm 20$ & $63 \mathrm{a} \pm 26$ \\
& TAN2 & $3300 \pm 1714$ & $83 \mathrm{a} \pm 78$ & $47 \mathrm{a} \pm 20$ & $48 \mathrm{a} \pm 22$ & $47 \mathrm{a} \pm 17$ & $48 \mathrm{a} \pm 17$ \\
& TAN3 & $2653 \pm 1240$ & $46 \mathrm{a} \pm 11$ & $55 \mathrm{a} \pm 24$ & $55 \mathrm{a} \pm 25$ & $58 \mathrm{a} \pm 23$ & $61 \mathrm{a} \pm 28$ \\
\hline
\end{tabular}

Replicate $=6$ (months)

Within the rows, for the same parameter, means with different alphabets are statistically different $(p<0.05)$.

$\mathrm{P}=$ parameter, IND = Industries 
BAJOPAS Volume 13 Number 2, December, 2020

Table 4: Correlation coefficient $(r)$ between different masses of the bacteria and the physicochemical parameters.

\begin{tabular}{llll}
\hline Industries & Parameter & Correlation coefficient $(r)$ & $\begin{array}{l}\text { Percent dependence (rxrx100) } \\
(\%)\end{array}$ \\
\hline TAN1 & COD & -0.9 & 82 \\
& BOD & -0.97 & 94 \\
& SS & $0.90^{*}$ & 80 \\
TAN2 & TDS & $0.98^{*}$ & 96 \\
& COD & -1 & 100 \\
& BOD & -0.21 & 4 \\
& SS & $0.78^{*}$ & 61 \\
& TDS & -0.69 & 47 \\
& COD & $0.60^{*}$ & 36 \\
& BOD & -0.6 & 37 \\
& SS & $0.95^{*}$ & 90 \\
& TDS & $0.94^{*}$ & 89 \\
\hline
\end{tabular}

The correlation coefficient $(r)$ with * is statistically significant $(p<0.05)$.

Percentage reduction of the Parameters

Table 5 shows the percentage reduction of Parameters in industrial samples before and after the treatment of the effluents $(250 \mathrm{ml})$ with the different masses $(5 \mathrm{~g}, 10 \mathrm{~g}, 15 \mathrm{~g}, 20 \mathrm{~g}$, and $25 \mathrm{~g}$ ) of the Immobilized Bacteria.

In TAN1 samples, the percentage reduction (\%) of COD ranged (14-89); BOD (50-80); SS (-32$35)$ and TDS (98-99). In TAN2 samples, the percentage decrease $(\%)$ of COD ranged (15$38) ;$ BOD (90-92); SS [-28-(-55)] and TDS (9798). In TAN3 samples, the percentage decrease (\%) of COD ranged (11-44); BOD (76-81); SS (15-25) and TDS (98). The percentage increase in the levels COD, BOD and TDS might be due to the increase in the surface area of the different masses of the immobilized bacteria. However, the percentage decrease in the levels of the SS might be due to the aggregation of the TDS which are large enough to result into SS. The percentage decrease in the levels of the SS might be also due to the influence of the nutrients which was added into the effluents in order to make the microorganisms more active and viable for fast degradation of organic contaminants in the effluent. This is in line with the work of Jimoh et al. (2018) in which the concentration of the SS increase after the bioremediation of effluents.

Sreemoyee and Priti (2013) assessed and reduced several Physico-chemical parameters of dairy wastewater using Niesseria $s p$. and concluded that the species are well known to degrade organic compounds. This is in agreement with the current study in which the immobilized Niesseria $s p$ degrade the organic contaminants as indicated by the BOD, COD and TDS.

Jimoh et al. (2018) observed that TSS of the effluents was increased after treatment with immobilized bacteria and concluded that it might be due to the biostimulation method adopted for the research.

The optimum $\mathrm{pH}$ Biosorption of Chromium by Bacillus spp and Staphylococcus spp. from tannery effluent was investigated by Mythili and Karthikeyan (2011). The maximum adsorption of Chromium $(86.4 \mathrm{mg} / \mathrm{L})$ was showed by Bacillus spp and Staphylococcus spp showed $70.6 \mathrm{mg} / \mathrm{L}$ at an initial concentration of $100 \mathrm{mg} / \mathrm{L}$. In the present study, immobilised Bacillus spp and Staphylococcus spp. from the tannery industrial effluents reduced the levels of the organic pollutants with high potential as indicated by the percentage reduction of BOD, COD and TDS.

Enzymes often can work in multiple environments especially if they are immobilized. This makes the microorganisms' enzymes even more resistant to harsh environments and enables the enzymes to be recovered and recycled after they are no longer needed (Gianfreda and Rao 2004). Ramesh and Singh (1993) reported that the immobilized bacteria having more efficiency to remove the suspended particles than free cells. Using the immobilized cell is preferable due to its capability for using several times with the same efficiency, which makes it more economical. Similar work was done by Sikander et al. (2007) showing the higher reduction with permeabilized cells of Ochrobactrum intermedium strain SDCr-5. 
BAJOPAS Volume 13 Number 2, December, 2020

The results revealed the isolation and identification of isolates with the potential for the reduction of $\mathrm{Cr}$ (VI) to $\mathrm{Cr}$ (III). Results indicated that immobilized $B$. cereus could be efficiently used for the reduction of $\mathrm{Cr}$ (VI).

Table 5: Percentage reduction of the tested Parameters from the tannery industrial samples of the Immobilized Bacteria.

\begin{tabular}{lllllll}
\hline \multirow{2}{*}{ Industries } & & \multicolumn{5}{c}{ Percentage Reduction $(\%)$} \\
\cline { 3 - 7 } & & $5 \mathrm{~g}$ & $10 \mathrm{~g}$ & $15 \mathrm{~g}$ & $20 \mathrm{~g}$ & $25 \mathrm{~g}$ \\
\hline TAN1 & COD & 28 & 14 & 64 & 87 & 89 \\
& BOD & 50 & 54 & 59 & 67 & 80 \\
& SS & 35 & -26 & -27 & -32 & -63 \\
& TDS & 99 & 99 & 99 & 98 & 98 \\
TAN2 & COD & 15 & 20 & 25 & 32 & 38 \\
& BOD & 91 & 91 & 92 & 90 & 92 \\
& SS & -28 & -52 & -52 & -54 & -55 \\
& TDS & 97 & 99 & 99 & 99 & 99 \\
& COD & 33 & 44 & 22 & 11 & 26 \\
& BOD & 75 & 81 & 76 & 81 & 81 \\
& SS & 25 & 3 & -1 & -10 & -15 \\
& TDS & 98 & 98 & 98 & 98 & 98 \\
\hline
\end{tabular}

Percentage Reduction $=(B-A) / B \times 100 \%$

$A=$ Concentration of the parameter after treatment

$\mathrm{B}=$ Concentration of the parameter before treatment

$+=$ percentage decrease

- = percentage increase

In general, immobilization makes the enzyme more resistant to temperature, $\mathrm{pH}$, and substrate concentration swings giving it a longer lifetime and higher productivity per active unit (Gianfreda and Rao, 2004; FuIlbrook, 1996; Russell et al, 2003; Kandelbauer et al., 2004). Immobilized cells have been used and studied extensively for the production of useful chemicals (Ohtake and Silver, 1994), the treatment of wastewaters (Chen et al., 2003; Wang et al., 2010). Although many workers described microbial degradation of tannery effluent, limited literature is available on the bioremediation of tannery effluent using immobilized bacterial cells in the Kano Industrial Estates.

\section{CONCLUSION}

The samples contained variable levels of the physicochemical parameters. The results of the Analysis of variance revealed that, no statistical difference $(p<0.05)$ was observed for the temperature, $\mathrm{pH}, \mathrm{SS}, \mathrm{TDS}, \mathrm{BOD}$ and $\mathrm{COD}$ among the three tannery industries before the treatment. The levels of some of the parameters
(SS, TDS and COD) observed in the samples were found above the recommended limits of WHO and NESREA, which called for the treatment of the effluents before discharge into the environment. Base on the morphological and biochemical test results, TAN1, TAN2, and TAN3 bacterial isolates were identified to be Neisseria spp, Bacillus cereus, and Staphylococcus aureus respectively. The results of Post-treatment analysis showed that there is overall decrease in the levels of the parameters determined when compared with that of the pre-treatment. The overall percentage reduction of the immobilised bacteria in the treatment of the respective effluents was in the order TAN2 (72\%)>TAN1 $(70 \%)>$ TAN3 $(62 \%)$. Hence, the immobilized bacteria are having higher biodegradation potential for the treatment of the tannery effluents.

\section{Acknowledgments}

The authors wish to acknowledge the University of Maiduguri for the financial support. The authors are grateful to the Kano State Ministry of Environment for their support in obtaining the effluent samples. 


\section{REFERENCES}

Ajao, A. T., Adebayo, G. B., and Yakubu, S. E. (2011). Bioremediation of textile industrial effluent using mixed culture of Pseudomonas aeruginosa and Bacillus subtilis immobilized on agar-agar in a bioreactor. J. Microbiol. Biotech. Res, 1(3), 50-56.

Akan, J. C., Moses, E. A., Ogugbuaja, V. O., and Abah, J. (2007). Assessment of tannery industrial effluents from Kano metropolis, Kano State, Nigeria. Journal of Applied Sciences, 7(19), 2788-2793.

Akan, J. C., Ogugbuaja, V. O., Abdulrahman, F. I., and Ayodele, J. T. (2009). Pollutant levels in effluent samples from tanneries and textiles of Kano industrial areas, Nigeria. Global journal of pure and applied sciences, 15(3-4).

APHA (1989). Standard methods for Examination of Will bete and Will betewater.15 $5^{\text {th }}$ edition. Brydpass Springfield Will behington DC. pp. 164-176

APHA (1992). Standard Methods for the Examination of Water and Wastewater. Health, 69, 1116-9.

Baba, A., Garba, S. T., and Bello, H. S. (2020). Bioremediation Potential of Immobilized corynebacterium kutsceri in the Treatment of Tannery Industrial Effluent from Challawa Industrial Estate, Kano State, Nigeria. Journal of the Turkish Chemical Society Section A: Chemistry, $7(2), 335-350$.

Beem, E. I. V. (1994). reduction of solvent VOC emission. J. Oil Col. Chem. Ass, 77, 158.

Bouwer, E. J., and Zehnder, A. J. (1993). Bioremediation of organic compoundsputting microbial metabolism to work. Trends in biotechnology, 11(8), 360367.

Chen, K. C., Wu, J. Y., Liou, D. J., and Hwang, S. C. J. (2003). Decolorization of the textile dyes by newly isolated bacterial strains. Journal of Biotechnology, 101(1), 57-68.

Dan'Azumi, S., and Bichi, M. H. (2010). INDUSTRIAL POLLUTION AND HEAVY METALS PROFILE OF CHALLAWA RIVER IN KANO, NIGERIA. Journal of Applied Sciences in Environmental Sanitation, $5(1)$.

DWAF. (1992). Analytical Methods Manual, TR 151. Department of Water Affairs and Forestry, Pretoria.

El-Bestawy, E. (2013). Biological treatment of leather-tanning industrial wastewater using free living bacteria.
Elsheikh, M. A. S. (2009). Tannery wastewater pre-treatment. Water Science and Technology, 60(2), 433-440.

FuIlbrook, P. D. (1996). "Kinetics." Industrial enzymology: The application of enzymes in Industry. 2nd Ed. T. Godfrey and J Reichelt. eds.. Nature. New York.

Gianfreda, L., and Rao, M. A. (2004). Potential of extra cellular enzymes in remediation of polluted soils: a review. Enzyme and microbial technology, 35(4), 339354.

Hugo Springer. (1994). John Arthur Wilson Memorial Lecture "Treatment of Industrial Wastes of the Leather Industry - is it still a Major Problem". JALCA, 89, 153-185

Jimoh, A. A., Ganiyu, B. A., Baba, D., and Baba, A. (2018) Bioremediation Process of Effluent from Detergent and Food Industries in Jos, Nigeria: Kinetics and Thermodynamics. International Journal of Engineering Science Invention (IJESI), 762-73

Kandelbauer, A., Maute, O., Kessler, R. W., Erlacher, A., and Gübitz, G. M. (2004). Study of dye decolorization in an immobilized laccase enzyme-reactor using online spectroscopy. Biotechnology and bioengineering, 87(4), 552-563.

Kongjao, S., Damronglerd, S., and Hunsom, M. (2008). Simultaneous removal of organic and inorganic Pollutants in tannery wastewater using electrocoagulation technique. Korean Journal of chemical engineering, 25(4), 703.

Maheshwari, U. M., Aruna, S., Gomathi, M., and AbdulJaffar, A. H. (2017). Bioremediation by Free and Immobilized Bacteria Isolated from Tannery Effluent. International Journal of Research in Applied, Natural and Social Sciences. 5(7), 75-90

Margesin, R., and Schinner, F. (2001). Bioremediation (natural attenuation and biostimulation) of diesel-oilcontaminated soil in an alpine glacier skiing area. Applied and environmental microbiology, 677), 3127-3133.

Mohammed, A., Sekar, P., and George, J. (2011). Efficacy of microbes in bioremediation of tannery effluent. Inter. J. Curr. Res, 3(4), 324-326.

Mohammed, S. S. D., Orukotan, A. A., and Abdullahi, H. (2017). Physicochemical and Bacteriological Assessment of Tannery Effluent from Samaru-Zaria, 
BAJOPAS Volume 13 Number 2, December, 2020 Kaduna State, Nigeria. Journal of Applied

Sciences and Environmental Management, 21(4), 734-740.

Munz, G., De Angelis, D., Gori, R., Mori, G., Casarci, M., and Lubello, C. (2009). The role of tannins in conventional and membrane treatment of tannery wastewater. Journal of hazardous materials, 164(2-3), 733-739

Mythili, K., and Karthikeyan, B. (2011). Bioremediation of $\mathrm{Cr}$ (VI) from tannery effluent using Bacillus spp and Staphylococcus spp. International Multidisciplinary Research Journal, 1(6).

NESREA (2009). National Environmental Standards for Effluent Limitations and Regulation. 1233-1236

Noorjahan, C. M. (2014). Physicochemical characteristics, identification of bacteria and biodegradation of industrial effluent. Journal of bioremediation and Biodegradation, 5(3).

Ohtake, H. I., and Silver, A. O. (1994). Bacterial reduction of toxic chromate. Biological degradation and bioremediation of toxic chemicals, 403-415.

Omoleke, I. I. (2004). Management of environmental pollution in Ibadan, an African city: the challenges of health hazard facing government and the people. Journal of Human Ecology, 15(4), 265-275.

Rajor, A., Reddy, A.S., and Singh, B. (2004). Determination of BOD kinetic Parameters and evaluation of alternate methods, M.Sc. Thesis, Department of biotechnology \& environmental Science, Thapar Institute of Engineering and Technology, Patiala

Ramasami, T., Rajamani, S., and Rao, J. R. (1994, March). Pollution control in leather industry: Emerging technological options. In International symposium on surface and colloidal science and its relevance to soil pollution, madras.

Ramesh, J. V. S., and Singh, S. P. (1993). Yearly variation in certain physicochemical parameters of pond at eastern Doon Valley. Uttar Pradesh J. Zoo, 12 (1), 7577.

Ranen, S., and Sharadinadra, C. (2009). Biotechnology applications to environmental remediation in resource exploitation. Current science, 97, 6-25
Russell, A. J., Berberich, J. A., Drevon, G. F., and Koepsel, R. R. (2003). Biomaterials for mediation of

chemical and biological warfare agents. Annual review of biomedical engineering, 5(1), 1-27.

Saravanan, P., and Saravanan, A. (1999). Decolourization of tannery effluent by Flavobacterium sp. EK 1. Indian Journal of Environmental Protection, 19, 19-24.

Sikander, S., and Shahida, H. (2007). Reduction of toxic hexavalent chromium by Ochrobactrum intermedium strain SDCr5 stimulated by heavy metals. Bioresource Technol, 98, 340-344.

Singh, N., Sharma, B. K., and Bohra, P. C. (2000). Impact assessment of industrial effluent of arid soils by using satellite imageries. Journal of the Indian Society of Remote Sensing, 28(2-3), 79.

Sreemoyee, C., and Priti, P. (2013). Assessment of physico-chemical parameters of dairy waste water and isolation and characterization of bacterial strains in terms of cod reduction. Int J Sci, 2(3), 395-400.

Verheijen, L. A. H. M., Wiersema, D., Pol, L. H., and De Wit, J. (1996). Management of wastes from animal product processing. Livestock and environment, Finding a balance. International Agriculture Center, Wageningen, The Netherlands.

Wang, F., Yao, J., Si, Y., Chen, H., Russel, M., Chen, K., and Bramanti, E. (2010). Short-time effect of heavy metals upon microbial community activity. Journal of Hazardous Materials, 173(13), 510-516.

WHO (World Health Organization). (2006). Air quality guidelines: global update 2005: particulate matter, ozone, nitrogen dioxide, and sulfur dioxide. World Health Organization.

World Bank. (1995). Nigeria's strategic options for redressing industrial pollution. World Bank, industry and energy division. 1st edition, West Central Africa Department; Annexes: 1995; pp 60-62.

Zahoor, A., and Abdul, R. (2009). Enumeration of Coliforms. Journal of Environmental Sciences. 21, 814-820 


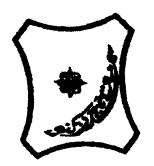

Bayero Journal of Pure and Applied Sciences, 13(2): 1 - 12

Received: November, 2020

Accepted: December, 2020

ISSN $2006-6996$

\title{
BIODEGRADATION POTENTIAL OF IMMOBILIZED BACTERIA IN THE TREATMENT OF TANNERY INDUSTRIAL EFFLUENTS FROM INDUSTRIAL ESTATES IN KANO STATE, NIGERIA
}

\author{
Abdullateef, B., ${ }^{1 *}$ Shuaibu, T. G., ${ }^{1}$ Babagana, K., ${ }^{1}$ Suleman, H. B. ${ }^{2}$ and Dauda, B. ${ }^{3}$ \\ ${ }^{1}$ Department of Pure and Applied Chemistry, Faculty of Science, University of Maiduguri, Borno State, \\ Nigeria \\ ${ }^{2}$ Department of Microbiology, Faculty of Science, University of Maiduguri, Borno State, Nigeria \\ ${ }^{3}$ Department of Chemical Engineering, Faculty of Engineering, University of Maiduguri, Borno State, \\ Nigeria \\ *Corresponding author: babslega@gmail.com; abelega2007@yahoo.com; +2348061309753
}

\section{ABSTRACT}

Industrial Effluents Samples from Gashash Tanneries (TAN1) in Bompai Industrial estate, Larabee Tannery Industry (TAN2) in Sharada Industrial estate and Z Tannery Industries (TAN3) in Challawa Industrial estate, Kano State, Nigeria were collected over a period of six months (August 2017 to January 2018) for assessing the biodegradation potentials of bacteria in the treatment of organic pollutants within the effluents. Bacteria were isolated from the effluents and immobilized on agar-agar. Different masses (5 g, $10 \mathrm{gr}, 15$ $\mathrm{g}, 20 \mathrm{~g}$, and $25 \mathrm{~g}$ ) of the bacteria were used in the treatment of $250 \mathrm{ml}$ of the effluents for ten days in a shaker incubator (Gallenkamp-OC-4364-L) at the temperature $30{ }^{\circ} \mathrm{C}$ and speed of $60 \mathrm{rpm}$. Pre-treatment analysis of the effluents for Temperature, pH, Biochemical Oxygen Demand (BOD), Chemical Oxygen Demand (COD), Suspended Solid (SS) and Total Dissolved Solids (TDS) gives the following results; temperature $\left({ }^{\circ} \mathrm{C}\right.$ )

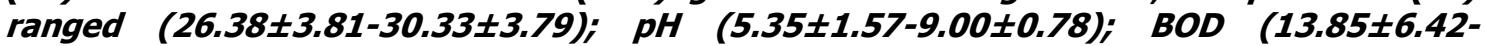
$38.75 \pm 16.20) ;$ COD (1406 $\pm 208-3532 \pm 1373) ;$ SS (208 $\pm 235-780 \pm 739)$ and TDS (266 $\pm 253-5276 \pm 2971)$. No statistical differences ( $p \leq 0.05)$ was observed for all the results among the different industries. The bacterial isolates were identified as Neisseria spp, Bacillus cereus, and Staphylococcus aureus, in TAN1, TAN2, and TAN3, respectively. After treatment of the effluent with the different masses of the isolated bacteria, the mean level of BOD was found to range as (0.55 $\pm 0.36-6.92 \pm 5.49) ; C O D$ (ND-3134 \pm 1595$)$;

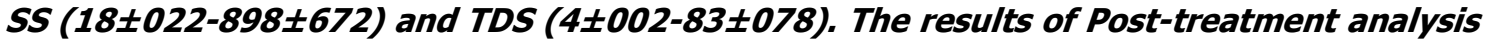
showed that there is overall decrease in the levels of the parameters determined when compared with that of the pre-treatment. The overall percentage reduction of the immobilised bacteria in the treatment of the respective effluents was in the order TAN2 (72\%)>TAN1 (70\%)>TAN3 (62\%). Hence, the immobilized bacteria are having higher biodegradation potential for the treatment of the tannery effluents.

Keywords: Biodegradation, bacteria, effluent, immobilization, tannery.

\section{INTRODUCTION}

Tannery industrial wastewater is a serious consequence of the pollution point of view for streams, freshwater, and land used for agriculture. The lack of awareness in the modern industrial practice has resulted in the discharge of tannery effluents which exhibit very high value of chromium ( $\mathrm{Cr}$ ), Sulfide, and chloride, Total Dissolved Solid (TDS), Total Suspended Solid (TSS), Biochemical Oxygen Demand (BOD) and Chemical Oxygen Demand (COD) in the water stream or land (Mohammed et al., 2001). Tanning is the process, which One ton of skin generally leads to the production of 20 to $80 \mathrm{~m}^{3}$ of turbid and foul-smelling converts the protein of the rawhide or skin into a stable material, which will not putrefy and is suitable for a wide variety of end applications (Elsheikh, 2009). The highly polluting chromium is the most commonly used tanning material producing leather that is more flexible and pliable than vegetable-tanned leather and does not discolor or lose shape in water as drastically as vegetable-tan (Elsheikh, 2009). Tannery effluent is among the most hazardous industrial pollutants due to its huge organic and inorganic load, which is highly toxic to human life and the environment (Kongjao et al., 2008). wastewater including chromium (100-400 mg/l), sulfide $(200-800 \mathrm{mg} / \mathrm{l})$, high levels of fat and 
BAJOPAS Volume 13 Number 2, December, 2020 other solid wastes, and notable pathogen contamination as well as pesticides added for skin conservation during transport (Elsheikh, 2009). There are more than 6000 tanneries in Nigeria with an annual processing capacity of 700,000 tons of hides and skins (Omoleke, 2004; Singh et al., 2008). It was reported that the total amount of waste produced per animal slaughtered is approximately $35 \%$ of its weight (World Bank, 1995). Also, for every $1000 \mathrm{~kg}$ of carcass weight, a slaughtered beef produces 5.5 $\mathrm{kg}$ of manure (excluding rumen contents or stockyard manure) and $100 \mathrm{~kg}$ of paunch manure (undigested food) (Verheijen et al., 1996). Tanneries generate wastewater in the range of 30-35 $\mathrm{L} \mathrm{kg}^{-1}$ skin/hide processed with variable $\mathrm{pH}$, Biological Oxygen Demand (BOD), Chemical Oxygen Demand (COD), high concentrations of suspended solids (SS), and tannins as well as chromium (Zahoor and Abdul, 2009).

Being heterogeneous and composed of a wide variety of compounds, it is very difficult to select a unique direct method for estimating the biodegradability of organic contents and biokinetic parameters for a wastewater sample (Rajor, 2004). For this purpose, some indirect estimation such as determination of biochemical oxygen demand (BOD) and chemical oxygen demand (COD) are applied as common laboratory investigations [9]. During retanning procedures, synthetic tannins (Syntan), oils and resins are added to form softer leather at varying doses (Munz et al., 2009). One of the refractory groups of chemicals in tannery effluents derives mainly from tannins (Ramasami et al., 2004). Syntans are characterized by complex chemical structures, because they are composed of an extended set of chemicals such as phenol-, naphthalene-, formaldehyde- and melamine-based syntans, and acrylic resins (Beem, 1994). Organic pollutants (proteic and lipidic components) are originated from skins (it is calculated that the raw skin has $30 \%$ loss of organic material during the working cycle) or they are introduced during processes (Hugo Springer, 1994).

Many conventional processes such as oxidation, chemical and biological processes were carried out to treat tanneries wastewater (Ebtesam et al, 2013). Biological processes have received more attention because of their costeffectiveness, lower sludge production and environmental friendliness (Noorjahan, 2014). Naturally occurring micro-organisms degrade the hazardous organic wastes including xenobiotic compounds, such as pesticides, polycyclic aromatic hydrocarbons (PAHs) and polychlorinated biphenyls (PCBs) in due course of time (Ranen and Sharadinadra, 2009). Bioremediation is based on the idea that all organisms remove substances from the environment to carry outgrowth and metabolism (Bouwer and Zehnder, 1993). Bacteria, protista and fungi are found to be very good at degrading complex molecules and incorporating the breakdown products into their metabolism (Bouwer and Zehnder, 1993). The resultant metabolic wastes that they produce are generally safe and somehow recycled into other organisms (Ranen and Sharadinadra, 2009). An acclimatized indigenous population of microorganisms capable of degradation of the compounds of interest must exist at the site for a successful bioremediation mode (Ranen and Sharadinadra, 2009). It has been observed that for a successful bioremediation mode, an acclimatized indigenous population of microorganisms capable of degradation of the compounds of interest must exist at the site under investigation (Ranen and Sharadinadra, 2009). Even though there are numerous physical and chemical methods employed in the disposal of wastes the advantage in using bacterium is that they play a key role in the reduction of COD, BOD, total protein, total tannin and total phenol (Saravanan and Saravanan, 1998)

Baba et al. (2020) studied the bioremediation potential of immobilized corynebacterium kutsceri in the Treatment of tannery industrial effluent from Challawa Industrial Estate, Kano State, Nigeria. The aim of the work is to study the reduction in the level of the contaminants through the process of bioremediation using the isolated bacteria. Immobilized bacteria can withstand various temperatures, $\mathrm{pH}$ and substrate concentrations; consequently, increasing the efficiency and the lifespan of the bacteria. Immobilized bacteria are widely applied in the treatment of wastewater and can be separated and recovered after the treatment with the same efficiency (Baba et al., 2020).

\section{MATERIALS AND METHODS \\ Study Area}

This study was carried out in Bompai, Sharada and Challawa industrial estates in Kano, Figure 1. Kano lies on Latitude $11^{\circ} 30^{\prime} \mathrm{N}$ and $8^{\circ} 30^{\prime} \mathrm{E}$ and Longitude $11^{\circ} 5^{\prime} \mathrm{N}$ and $8^{\circ} 5^{\prime} \mathrm{E}$ in Northern Nigeria. It is one of the developed industrial cities in Nigeria. Tannery activities are the dominating industries and this could be one of the reasons for her high population density (Dan'Azumi and Bichi, 2010). Many researchers have studied biodegradation of tannery effluent using microorganisms. However, limited literature is available on the biodegradation of tannery effluent in Kano industrial estates using 
BAJOPAS Volume 13 Number 2, December, 2020 immobilized bacterial cells. This research work focuses on the potential of the use of the indigenous immobilized bacterial isolates in the treatment of tannery effluents in the industrial estates.

\section{Sample Collection}

Effluents were collected from the Tannery Industries from Bompai, Challawa and Sharada Industrial Estates, Kano, Nigeria. The effluents were collected over a period of six months (August 2017 to January 2018). Samples collected in a sterile 4-liter plastic container with a unique identification number were preserved using an ice-box that was transported to the Microbiology Laboratory, Department of Microbiology, Bayero University of Kano for analysis

\section{Sample Preparation and Sample Analysis}

Immediately after the collection of the effluent, $\mathrm{pH}$, TSS, TDS, COD, BOD levels were determined before treatment (Pre-treatment determination) and ten days after treatment (Post-treatment determination) as described in
APHA (1989) standard methods. $\mathrm{pH}$ was determined using Ecotests $\mathrm{pH}$ meter and TDS was determined using AQUALYTIC TDS Salinometer. BOD was determined as described by the standard method (APHA, 1992). COD and SS were determined using DR/2010 HACH portable data logging spectrophotometer (DWAF, 1992)

\section{Identification and Biochemical} Characterization of the Bacterial Isolates

The bacteria were isolated from the effluents using Serial Dilution according to the method described by APHA (1989). The biochemical tests such as oxidase, catalase, coagulase, indole (from $1 \%$ tryptone broth), citrate (Simmons citrate agar), methyl red/VogesProskauer (MR/VP), nitrate reduction, Starch Hydrolysis, Glucose, Maltose, and Lactose tests were carried out on the bacterial isolates to identify the bacteria through the bacteria biochemical characteristics according to Ajao et al. (2011).

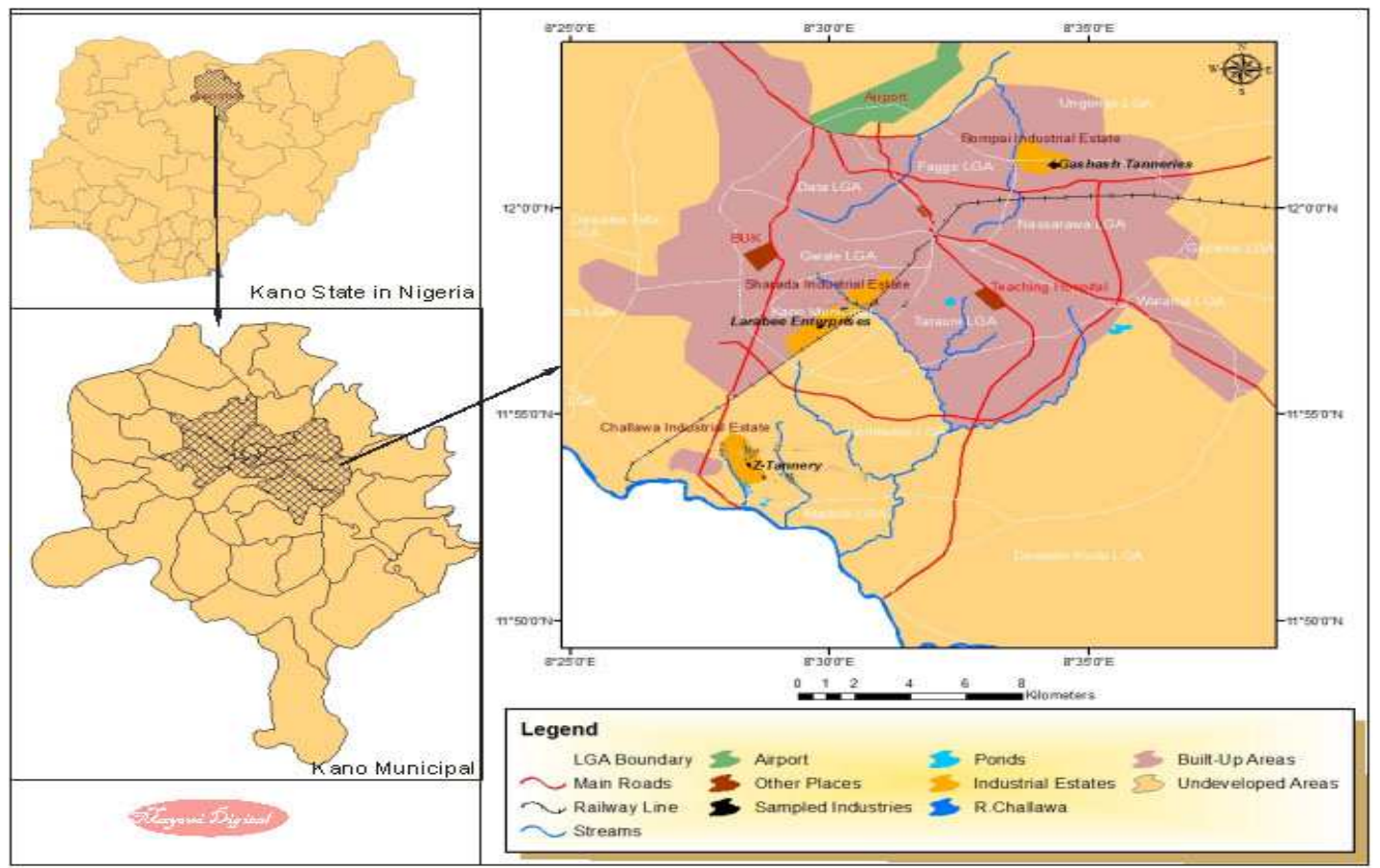

Fig. 1 Map showing the study areas

Source: Mayomi Digital Productions, GIS Laboratory, Department of Geography, UNIMAID (2017)

\section{Determination of Growth Rate of the Bacteria in Effluent Sample}

The bacteria growth rates were determined by transferring $2 \mathrm{~mL}$ of the bacterial isolates from the tannery effluent in broth medium into 100 $\mathrm{mL}$ sterile effluents in conical flasks and kept in an incubator (Giffrin cool) for 10 days. Control was also set up by incubating another $100 \mathrm{~mL}$ each of the sterile effluents without the bacteria. The optical density of the content was determined at the wavelength of $600 \mathrm{~nm}$ on a daily interval and recorded. 
BAJOPAS Volume 13 Number 2, December, 2020 Immobilization of Bacteria

Agar solution and inoculi were prepared separately. Fifty milliliters $(50 \mathrm{~mL})$ of nutrient broth each of the inoculi was prepared in a McCartney bottle and incubated for 24 hours. A solution of agar-agar was prepared by dissolving $10 \mathrm{~g}$ of the powder in distilled water and made up to $500 \mathrm{~mL}$ mark in an Erlenmeyer flask and was sterilized in an autoclave (280A) for 15 minutes and allowed to cool to $40-45^{\circ} \mathrm{C}$ (Ajao et al., 2011). Four milliliters ( $4 \mathrm{~mL})$ of the bacterial isolates in the nutrient broth was mixed with 36 $\mathrm{ml}$ of the prepared agar-agar media in petri-dish plates and then allowed to solidify. This was kept in the refrigerator for bioremediation.

\section{Bioremediation (Treatment) of the Effluents}

The solidified agar block (immobilized bacteria) was cut into cubes using a sterile knife; $0.1 \mathrm{~mL}$ phosphate buffer ( $\mathrm{pH} \mathrm{7.0)}$ was added and kept in the refrigerator for 1 hour for curing. The phosphate buffer was decanted after 1 hour and the cubes were washed with sterile distilled water 3-4 times before it was used (Ajao et al., 2011). Two liters (2 L) of the effluent was supplemented with the minimum basal medium in $\mathrm{g} / \mathrm{L}: \mathrm{NaCl}(0.8), \mathrm{MgSO}_{4} .7 \mathrm{H}_{2} \mathrm{O}(0.001), \mathrm{KH}_{2} \mathrm{PO}_{4}$ (2), $\mathrm{NaNO}_{3}$ (2), $\quad \mathrm{CaCl}_{2} .2 \mathrm{H}_{2} \mathrm{O} \quad(0.5)$ and $\mathrm{NaHPO}_{4} .12 \mathrm{H}_{2} \mathrm{O}(2)$ and sterilized in an autoclave at $121^{\circ} \mathrm{C}$ for 15 minutes (Margesin and Schinner, 2001). Two hundred and fifty milliliters $(250 \mathrm{~mL})$ of the effluents were transferred into different $250 \mathrm{ml}$ conical flasks. The content was covered with a cotton-wool ramped with foil paper to avoid contamination. Five grams $(5 \mathrm{~g})$ of the immobilized bacteria were quickly transferred into each of the effluents in the conical flasks in an inoculating chamber. The same procedures were carried out for the $10 \mathrm{~g}, 15 \mathrm{~g}, 20 \mathrm{~g}$ and 25 $\mathrm{g}$ of the immobilized bacteria in separate $250 \mathrm{~mL}$ effluents in conical flasks and agitated for ten days in a shaker incubator (Gallenkamp-OC4364-L) at a temperature $30^{\circ} \mathrm{C}$ and speed of 60 rpm. The treated effluent samples were taken on the tenth day and analyzed for the parameters $\mathrm{pH}$, SS, TDS, COD, and BOD, (Posttreatment determination) for the different grams of bacteria to evaluate and compare the biodegradation potential. (Baba et al., 2020).

\section{Statistical Analysis}

The data were represented as Mean \pm Standard deviation and analyzed statistically using oneway Analysis of Variance (ANOVA) and Tukey's HSD as Post Hoc Tests with the aid of SPSS 16.0. The correlation coefficient was also used to measure the strength of the relationship between the different masses of the bacteria and the parameters. All $\mathrm{p} \leq 0.05$ were considered as statistically significant.

\section{RESULTS AND DISCUSSION Physico-chemical parameters in the Industrial Effluents before the Biodegradation.}

Results of the Physico-chemical parameters in the industrial effluents before the Biodegradation is shown in table 1 . The mean temperatures $\left({ }^{\circ} \mathrm{C}\right)$ observed in TAN1, TAN2, and TAN3 samples were $28.07 \pm 0.65 ; 27.77 \pm 0.64$ and $26.38 \pm 3.81$ respectively. The order of the mean temperature of the samples from the three industries can be arranged as TAN1 > TAN2>TAN3. The temperature observed at TAN1, TAN2, and TAN3 samples were found below the WHO $\left(35^{\circ} \mathrm{C}\right)$ and NESREA $\left(40^{\circ} \mathrm{C}\right)$ limits. The low values of temperature might be due to the processes used at the time of sampling. High temperature brings down the solubility of gases in water that ultimately expresses as high BOD and COD. Statistical analysis shows that there is no significant difference $(p<0.05)$ between the mean values of temperature among the industries. This might be due to similar tannery activities involved in the tannery industries at the time of sampling. The average values of temperature observed in this present study are less than those observed by Akan et al. (2007), Akan et al. (2009) and Baba et al. (2020).

The mean level of $\mathrm{pH}$ observed in TAN1, TAN2 and TAN3, samples were $7.77 \pm 2.93$; $8.35 \pm 0.28$ and $7.52 \pm 0.76$ respectively. The order of the mean $\mathrm{pH}$ of the samples from the three industries can be arranged as TAN2> TAN1 $>$ TAN3. The $\mathrm{pH}$ of the samples falls within the WHO (7.0-8.5) and NESREA (6-9) standard limits. Statistical analysis shows that there is no significant difference $(p<0.05)$ between the mean values of $\mathrm{pH}$ among the industries. This might be due to similar tannery activities involved in the tannery industries at the time of sampling. Maheshwari et al. (2017) reported that the level of $\mathrm{pH}$ in the effluents from the tannery industry in Vaniyambadi, India was 6.5 which was lower than that observed in the present study. The $\mathrm{pH}$ in the effluents from the tannery industries in Kano and Kaduna were reported to be 7.64 and 6.89, respectively (Akan et al., 2007; Mohammed et al., 2017). The average values of $\mathrm{pH}$ observed in this present study are less than those observed by Mohammed et al. (2017) and Baba et al. (2020). The mean level of SS $(\mathrm{mg} / \mathrm{l})$ observed in TAN1, TAN2, and TAN3 samples were 374 \pm 124 ; $358 \pm 335$ and $780 \pm 739$ respectively. The order of the mean SS in the samples from the three industries can be arranged as TAN3 > TAN1 $>$ TAN2. 
The SS observed in the samples were far above the recommended standard limits of regulating bodies WHO $(30 \mathrm{mg} / \mathrm{l})$ and NESREA $(10 \mathrm{mg} / \mathrm{l})$. Statistical analysis shows that there is no significant difference $(p<0.05)$ between the mean values of SS among the industries. This might be due to similar tannery activities involved in the tannery industries at the time of sampling. The average values of SS observed in this present study are less than that observed $(3700 \pm 122 \mathrm{mg} / \mathrm{l})$ by Akan et al. (2009) for tanneries in Kano. Also, the average values of SS observed in this present study are less than that observed by Mohammed et al. (2017) and Baba et al. (2020) with the exception in TAN3.

The mean level of TDS (mg/l) observed in TAN1, TAN2, and TAN3 samples were $3941 \pm 3703$; $3300 \pm 1714$ and $2653 \pm 1240$ respectively. The order of the mean TDS in the samples from the three industries can be arranged as TAN1>TAN2>TAN3. The TDS observed in the samples were far above the recommended standard limits of WHO $(250 \mathrm{mg} / \mathrm{l})$ and NESREA $(500 \mathrm{mg} / \mathrm{l})$. Statistical analysis shows that there is no significant difference $(p<0.05)$ between the mean values of TDS among the industries. This might be due to similar tannery activities involved in the tannery industries at the time of sampling. TDS in the effluents from the tannery industries in Kano, Nigeria was reported to be $1281 \mathrm{mg} / \mathrm{l}$ (Akan et al., 2007). The average values of SS observed in this present study are less than those observed by Mohammed et al. (2017) and Baba et al. 2020)

The mean level of COD (mg/l) observed in TAN1, TAN2 and TAN3 samples seasons were $2372 \pm 938 ; \quad 1406 \pm 208$ and $3532 \pm 1373$ respectively. The order of the mean COD of the samples from the three industries can be arranged as TAN3>TAN1> TAN2. The COD observed in TAN1, TAN2 and TAN3 samples were far above the recommended standard limits of regulating bodies $\mathrm{WHO}(40 \mathrm{mg} / \mathrm{l})$ and NESREA (40 mg/l). Statistical analysis shows that there is no significant difference $(p<0.05)$ in COD among the industries. This might be due to similar tannery activities involved in the tannery industries as at the time of sampling. The Chemical Oxygen demand (COD) is the amount of oxygen, in $\mathrm{mg} / \mathrm{L}$, required for the degradation of the compound of wastewater to occur. In comparison, the average values of COD observed in this present study were higher than that observed by Mohammed et al. (2017) but lower than that observed by Baba et al. (2020).

The mean levels of BOD $(\mathrm{mg} / \mathrm{l})$ observed in TAN1, TAN2 and TAN3 samples were $13.85 \pm 6.42 ; \quad 19.46 \pm 0.50$ and $17.13 \pm 3.14$ respectively. The order of the mean BOD in the samples from the three industries can be arranged as TAN2>TAN3>TAN1. The BOD observed in TAN1, TAN2 and TAN3 samples were found below the recommended limits of NESREA (200 mg/l) but above WHO (10 mg/l). Statistical analysis shows that there is no significant difference $(p<0.05)$ between the mean values of BOD among the industries. This might be due to similar tannery activities involved in the tannery industries at the time of sampling. The low level of BOD recorded in this study is an indication of the low level of biodegradable organic solids in the effluent. The average values of BOD observed in this present study were lower than those observed by Mohammed et al. (2017) and Baba et al. (2020).

Table 1: Mean Values \pm S.D of Physico-chemical parameters of effluents from the Tannery Industries before Treatment.

\begin{tabular}{llllllll}
\hline Parameter & Tannery 1 & Tannery 2 & Tannery 3 & $\mathrm{a}$ & $\mathrm{b}$ & $\mathrm{c}$ & $\mathrm{d}$ \\
\cline { 2 - 7 } Temperature $\left({ }^{\circ} \mathrm{C}\right)$ & $28.07 \mathrm{a} \pm 0.65$ & $27.77 \mathrm{a} \pm 0.64$ & $26.38 \mathrm{a} \pm 3.81$ & & $29.50 \pm 4.68$ & 35 & 40 \\
pH & $7.77 \mathrm{a} \pm 2.93$ & $8.35 \mathrm{a} \pm 0.28$ & $7.52 \mathrm{a} \pm 0.76$ & 6.89 & $5.35 \pm 1.57$ & $7.0-8.5$ & $6.0-9.0$ \\
$\mathrm{COD}(\mathrm{mg} / \mathrm{l})$ & $2372 \mathrm{a} \pm 938$ & $1406 \mathrm{a} \pm 208$ & $3532 \mathrm{a} \pm 1373$ & 2.2 & $3106 \pm 2753$ & 40 & 40 \\
$\mathrm{BOD}(\mathrm{mg} / \mathrm{l})$ & $13.85 \mathrm{a} \pm 6.42$ & $19.46 \mathrm{a} \pm 0.50$ & $17.13 \mathrm{a} \pm 3.14$ & 1032 & $26.17 \pm 9.49$ & 10 & 200 \\
$\mathrm{SS}(\mathrm{mg} / \mathrm{l})$ & $374 \mathrm{a} \pm 124$ & $358 \mathrm{a} \pm 335$ & $780 \mathrm{a} \pm 739$ & 501 & $562 \pm 482$ & 30 & 10 \\
TDS $(\mathrm{mg} / \mathrm{l})$ & $3941 \mathrm{a} \pm 3703$ & $3300 \mathrm{a} \pm 1714$ & $2653 \mathrm{a} \pm 1240$ & 532.7 & $444 \pm 507$ & 250 & 500 \\
\hline
\end{tabular}

The values given in the table above are means of 6 replicate values, $\mathrm{n}=6$ ( 1 sample was taken monthly for 6 months). Within the rows, means with different alphabets are statistically different $(p<0.05)$. WHO: World Health Organisation. NESREA: National Environmental Standard and Regulatory Enforcement Agency. a = Mohammed et al.(2017), b = Baba et al. (2020), c = WHO (2006), $d=$ NESSRA (2009) 
BAJOPAS Volume 13 Number 2, December, 2020

Identification, Biochemical Characterization and growth rates of the Bacterial Isolates

Results of identification and biochemical characterization of the bacterial isolates were shown in table 2. After 24 hours of incubation, the nutrient agar media plates were checked for bacterial growth. The results showed the presence of different strains in the samples. The TAN1 bacteria isolate was found to be gramnegative cocci while TAN3 was gram-positive cocci. TAN2 bacteria isolate was found to be gram-positive, rod-shaped. TAN1, TAN2, and TAN3 bacteria isolates recorded positive results for spore former.

The results of the biochemical tests indicated that all the bacteria were positive for catalase, oxidase, citrate, maltose, glucose, lactose (negative in TAN1), mannitol (negative in TAN2), starch hydrolysis and coagulase (negative in TAN2) tests. The bacteria showed negative results for nitrate reduction, $M R$ (positive in TAN2), VP (positive in TAN1), Indole (positive in TAN2) tests. Base on the morphological and biochemical test results, TAN1, TAN2, and TAN3 bacteria isolates were identified to be Nesseria spp, Bacillus cereus, and Staphylococcus aureus respectively.

The growth rate of the TAN1, TAN2 and TAN3 Isolates were shown in figure 2. Generally, the optical density increase with the increase in time (day) and decrease as time goes on. The highest optical density was shown by bacillus cereus in TAN2 while the lowest was shown by Staphylococcus aureus in TAN3.

The initial growth phase of TAN1 Isolate bacteria occurred within 2-day of incubation as the growth rate increases up to the 6th-day incubation when the maximum growth was observed. Beyond the 6th day, the growth of the bacteria declined (which might be due to a shortage of nutrients in the effluents) until it reached its death phase (which might be due to the unavailability of nutrients in the effluents).

A similar trend of growth was also observed for TAN2 Isolate as the initial growth phase also occurred within 2-day of incubation but maximum growth rate observed on the 4th day of incubation. The stationary stage occurred between the 4th day and the 8th day. Beyond the 8th day, the growth of the bacteria declined (which might be due to a shortage of nutrients in the effluents) until it reached its death phase (which might be due to the unavailability of nutrients in the effluents).

The initial growth phase of TAN3 bacterial Isolate occurred within the 3-day incubation as the growth rate increases up to the 6th-day incubation when the maximum growth was observed. Beyond the 6th day, the growth of the bacteria declined (which might be due to a shortage of nutrients in the effluents) until it reached its death phase (which might be due to the unavailability of nutrients in the effluents).

Table 2: Morphological and Biochemical characteristics of bacterial isolates

\begin{tabular}{lllll} 
Bacterial Isolates & & TAN1 & TAN2 & TAN3 \\
\hline $\begin{array}{lllll}\text { Morphological } \\
\text { characteristics }\end{array}$ & Shape & Cocci & Rod & Cocci \\
& Spore & & & \\
& former & + & + & + \\
Gram & & & \\
Biochemical characteristics & reaction & - & + & + \\
& Citrate & + & + & + \\
& Catalase & + & + & + \\
& Coagulase & + & - & + \\
Starch & + & + & + \\
& Glucose & + & + & + \\
Oxidase & + & + & + \\
& Indo & - & + & - \\
Lactose & - & + & + \\
Manitol & + & - & + \\
Maltose & + & + & + \\
MR & - & + & - \\
VP & + & - & - \\
& Nitrate & - & - & - \\
Reduction & - Neisseria & Bacillus & Staphylococcus \\
& Bacterial & cereus & aureus \\
& name & spp & cas
\end{tabular}

+ = Positive; - = Negative; MR=Methyl Red; VP= Voges-Proskauer 


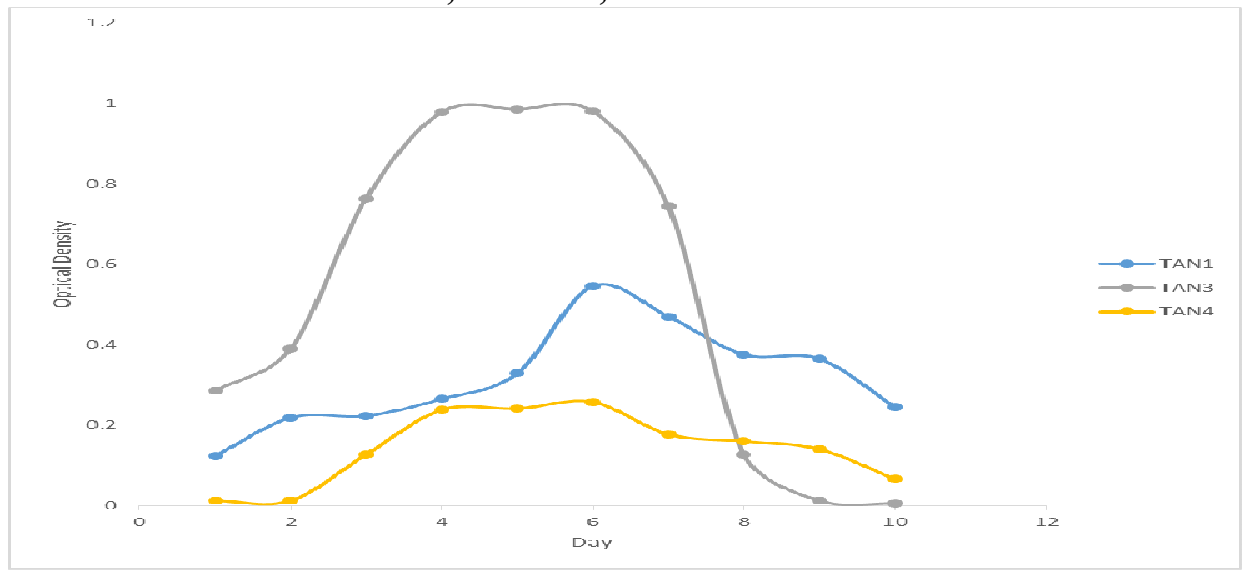

Fig. 2 Growth rates of the isolates in the effluents from the Tannery Industries

\section{Physico-chemical Parameters in the Industrial Effluents after the biodegradation.}

Table 3 shows the mean results of the physicochemical parameter before and after bioremediation using the different masses $(5 \mathrm{~g}$, $10 \mathrm{~g}, 15 \mathrm{~g}, 20 \mathrm{~g}$, and $25 \mathrm{~g}$ ) of the respective immobilized bacteria. Also, Table 4 shows the mean results of correlation coefficient ( $r$ ) between different masses of bacteria and physicochemical parameters.

The mean values $(\mathrm{mg} / \mathrm{l})$ of the SS after the bioremediation varies between $243 \pm 45$ and $898 \pm 672$. The mean concentration $(\mathrm{mg} / \mathrm{l})$ of SS remediated by the different masses $(5 \mathrm{~g}, 10 \mathrm{~g}$, $15 \mathrm{~g}, 20 \mathrm{~g}$, and $25 \mathrm{~g}$ ) of the bacteria varies. The SS in the samples fluctuates up and down after the bioremediation process when compared with the SS of the raw samples before the bioremediation. The increase in the levels of the SS might be due to the aggregation of the TDS which are large enough to result into SS. The increase in the levels of the SS might be also due to the influence of the nutrients which was added into the effluents in order to make the microorganisms more active and viable for fast degradation of organic contaminants in the effluent. The relative potential or efficiency of the different masses of the bacteria in remediating SS in TAN1 samples was in the order $25 \mathrm{~g}>20 \mathrm{~g}>15 \mathrm{~g}>10 \mathrm{~g}>5 \mathrm{~g}$. For TAN2 and TAN3 samples, the order was $25 \mathrm{~g}>20 \mathrm{~g}>15$ $\mathrm{g}>10 \mathrm{~g}>5 \mathrm{~g}$. These might be due to the variations in the surface areas of the different masses of the immobilized bacteria. Statistical analysis shows that there is no significant difference $(p<0.05)$ between the mean values of SS among the masses in the respective industries. Positive and significant correlations exist between the masses of bacteria and Suspended Solid (SS). This showed that there is general increase in the levels of the SS as the masses of the immobilized bacteria increases. TAN3 (90\%) and TAN1 (80\%) showed a very high correlation with the masses of the bacteria while TAN2 (61\%) showed a very low correlation.

The mean values $(\mathrm{mg} / \mathrm{l})$ of the TDS after the bioremediation varies between $46 \pm 11$ and $83 \pm 78$. The mean concentration $(\mathrm{mg} / \mathrm{l})$ of TDS remediated by the different masses $(5 \mathrm{~g}, 10 \mathrm{~g}$, $15 \mathrm{~g}, 20 \mathrm{~g}$, and $25 \mathrm{~g}$ ) of the bacteria varies. There is a reduction in all the TDS of all the samples after the bioremediation process compared with the TDS of the raw samples before the bioremediation. The relative potential or efficiency of the different masses of the bacteria in remediating TDS in TAN1 and TAN3 samples was in the order $5 \mathrm{~g}>10 \mathrm{~g}>15 \mathrm{~g}>20$ $\mathrm{g}>25 \mathrm{~g}$. For TAN2 samples, the order was 20 $g>10 \quad g>25 \quad g>15 \quad g>5 \quad g$. Statistical analysis shows that there is no significant difference $(p<0.05)$ between the mean values of TDS among the masses in the respective industries. These might be due to the variations in the surface areas of the different masses of the immobilized bacteria. Positive and significant correlations exist between the masses of bacteria and TDS with the exception in TAN2 (negative and insignificant correlation). The positive correlations showed that there is general increase in the levels of the TDS as the masses of the immobilized bacteria increases. TAN1 $(96 \%)$ showed a very high correlation with the masses of the bacteria while TAN2 (47\%) showed a very low correlation.

The mean values $(\mathrm{mg} / \mathrm{l})$ of the BOD after the bioremediation varies between $1.56 \pm 0.20 \mathrm{mg} / \mathrm{l}$ and $6.92 \pm 5.49 \mathrm{mg} / \mathrm{l}$. The mean concentration $(\mathrm{mg} / \mathrm{l})$ of BOD remediated by the different masses $(5 \mathrm{~g}, 10 \mathrm{~g}, 15 \mathrm{~g}, 20 \mathrm{~g}$, and $25 \mathrm{~g}$ ) of the bacteria varies. There is a reduction in all the BOD of all the samples after the bioremediation process compared with the $\mathrm{BOD}$ of the raw 
BAJOPAS Volume 13 Number 2, December, 2020 samples before the bioremediation. The relative potential or efficiency of the different masses of the bacteria in remediating BOD in TAN1, TAN2 and TAN3 samples were in the order $25 \mathrm{~g}>20$ $\mathrm{g}>15 \mathrm{~g}>10 \mathrm{~g}>5 \mathrm{~g}, 25 \mathrm{~g}>15 \mathrm{~g}>5 \mathrm{~g}>10 \mathrm{~g}>20 \mathrm{~g}$ and $20 \mathrm{~g}>10 \mathrm{~g}>25 \mathrm{~g}>15 \mathrm{~g}>5 \mathrm{~g}$ respectively. Statistical analysis shows that there is significant difference $(p<0.05)$ between the mean values of BOD among the masses in the respective industries. These might be due to the variations in the surface areas of the different masses of the immobilized bacteria. Negative and significant correlations exist between the masses of bacteria and BOD. This showed that there is general decrease in the levels of the BOD as the masses of the immobilized bacteria increases. TAN1 (94\%) showed a very high correlation with the masses of the bacteria while TAN2 (4\%) showed a very low correlation.

The mean values $(\mathrm{mg} / \mathrm{l})$ of the COD after the bioremediation varies between $250 \pm 154$ and $3134 \pm 1595$. The mean concentration $(\mathrm{mg} / \mathrm{l})$ of COD remediated by the different masses $(5 \mathrm{~g}$, $10 \mathrm{~g}, 15 \mathrm{~g} 20 \mathrm{~g}$, and $25 \mathrm{~g}$ ) of the bacteria varies. There is a reduction in all the COD of all the samples after the bioremediation process compared with the COD of the raw samples before the bioremediation. The relative potential or efficiency of the different masses of the bacteria in remediating COD in TAN1, TAN2 and TAN3 samples were in the order $25 \mathrm{~g}>20 \mathrm{~g}>15$ $\mathrm{g}>5 \mathrm{~g}>10 \mathrm{~g}, 25 \mathrm{~g}>20 \mathrm{~g}>15 \mathrm{~g}>10 \mathrm{~g}>5 \mathrm{~g}$ and 10 g>5 g>25 g>15 g>20 g respectively. Statistical analysis shows that there were significant difference $(p<0.05)$ between the mean values of COD among the masses in the respective industries except for effluents treated with $25 \mathrm{~g}$. These might be due to the variations in the surface areas of the different masses of the immobilized bacteria. Negative and insignificant correlations exist between the masses of bacteria and COD with the exception in TAN3 (positive and significant correlation). The negative correlations showed that there is general decrease in the levels of the COD as the masses of the immobilized bacteria increases. TAN2 (100\%) showed a very high correlation with the masses of the bacteria while TAN3 (36\%) showed a very low correlation.

Generally, there was an overall decrease in the concentration of these physicochemical parameters after the bioremediation using the different masses of the bacterial isolates. These might be due to the variations in the surface areas of the different masses of the immobilized bacteria. This is in line with the work of Jimoh et al. (2018) and Baba et al. (2020).

Table 3: Mean Values $(\mathrm{mg} / \mathrm{l}) \pm$ S.D of Physicochemical parameters in effluents from the Tannery Industries before and after Treatment of the effluents $(250 \mathrm{ml})$ with the different masses $(5 \mathrm{~g}, 10 \mathrm{~g}$, $15 \mathrm{~g}, 20 \mathrm{~g}$, and $25 \mathrm{~g}$ ) of the bacteria.

\begin{tabular}{llllllll}
\hline $\mathrm{P}$ & IND & Before & \multicolumn{5}{c}{ After } \\
\cline { 4 - 7 } & & & $5 \mathrm{~g}$ & $10 \mathrm{~g}$ & $15 \mathrm{~g}$ & $20 \mathrm{~g}$ & $25 \mathrm{~g}$ \\
\hline \multirow{2}{*}{ COD } & TAN1 & $2372 \pm 938$ & $1708 \mathrm{a} \pm 861$ & $2045 \mathrm{a} \pm 1205$ & $845 \mathrm{a} \pm 369$ & $300 \mathrm{a} \pm 167$ & $250 \mathrm{a} \pm 154$ \\
& TAN2 & $1406 \pm 208$ & $1195 \mathrm{a} \pm 208$ & $1125 \mathrm{a} \pm 384$ & $1055 \mathrm{a} \pm 317$ & $956 \mathrm{a} \pm 310$ & $870 \mathrm{ab} \pm 240$ \\
& TAN3 & $3532 \pm 1373$ & $2374 \mathrm{a} \pm 1344$ & $1976 \mathrm{a} \pm 1405$ & $2757 \mathrm{a} \pm 1266$ & $3134 \mathrm{a} \pm 1595$ & $2614 \mathrm{~b} \pm 1105$ \\
BOD & TAN1 & $13.85 \pm 6.42$ & $6.92 \mathrm{a} \pm 5.49$ & $6.42 \mathrm{a} \pm 5.07$ & $5.72 \mathrm{a} \pm 5.35$ & $4.62 \mathrm{a} \pm 4.37$ & $2.82 \mathrm{ab} \pm 1.26$ \\
& TAN2 & $19.46 \pm 0.50$ & $1.75 \mathrm{~b} \pm 0.22$ & $1.73 \mathrm{~b} \pm 0.18$ & $1.58 \mathrm{a} \pm 0.16$ & $1.91 \mathrm{a} \pm 0.22$ & $1.56 \mathrm{~b} \pm 0.20$ \\
& TAN3 & $17.13 \pm 3.14$ & $4.24 \mathrm{ab} \pm 0.77$ & $3.29 \mathrm{ab} \pm 0.37$ & $4.11 \mathrm{a} \pm 0.07$ & $3.23 \mathrm{a} \pm 0.91$ & $3.33 \mathrm{a} \pm 1.28$ \\
SS & TAN1 & $374 \pm 124$ & $243 \mathrm{a} \pm 45$ & $471 \mathrm{a} \pm 226$ & $475 \mathrm{a} \pm 182$ & $492 \mathrm{a} \pm 128$ & $611 \mathrm{a} \pm 217$ \\
& TAN2 & $358 \pm 335$ & $460 \mathrm{a} \pm 400$ & $543 \mathrm{a} \pm 414$ & $544 \mathrm{a} \pm 402$ & $551 \mathrm{a} \pm 414$ & $554 \mathrm{a} \pm 405$ \\
& TAN3 & $780 \pm 739$ & $586 \mathrm{a} \pm 594$ & $758 \mathrm{a} \pm 656$ & $787 \mathrm{a} \pm 676$ & $861 \mathrm{a} \pm 635$ & $898 \mathrm{a} \pm 672$ \\
TDS & TAN1 & $3941 \pm 3703$ & $51 \mathrm{a} \pm 10$ & $53 \mathrm{a} \pm 10$ & $55 \mathrm{a} \pm 15$ & $61 \mathrm{a} \pm 20$ & $63 \mathrm{a} \pm 26$ \\
& TAN2 & $3300 \pm 1714$ & $83 \mathrm{a} \pm 78$ & $47 \mathrm{a} \pm 20$ & $48 \mathrm{a} \pm 22$ & $47 \mathrm{a} \pm 17$ & $48 \mathrm{a} \pm 17$ \\
& TAN3 & $2653 \pm 1240$ & $46 \mathrm{a} \pm 11$ & $55 \mathrm{a} \pm 24$ & $55 \mathrm{a} \pm 25$ & $58 \mathrm{a} \pm 23$ & $61 \mathrm{a} \pm 28$ \\
\hline
\end{tabular}

Replicate $=6$ (months)

Within the rows, for the same parameter, means with different alphabets are statistically different $(p<0.05)$.

$\mathrm{P}=$ parameter, IND = Industries 
BAJOPAS Volume 13 Number 2, December, 2020

Table 4: Correlation coefficient $(r)$ between different masses of the bacteria and the physicochemical parameters.

\begin{tabular}{llll}
\hline Industries & Parameter & Correlation coefficient $(r)$ & $\begin{array}{l}\text { Percent dependence (rxrx100) } \\
(\%)\end{array}$ \\
\hline TAN1 & COD & -0.9 & 82 \\
& BOD & -0.97 & 94 \\
& SS & $0.90^{*}$ & 80 \\
TAN2 & TDS & $0.98^{*}$ & 96 \\
& COD & -1 & 100 \\
& BOD & -0.21 & 4 \\
& SS & $0.78^{*}$ & 61 \\
& TDS & -0.69 & 47 \\
& COD & $0.60^{*}$ & 36 \\
& BOD & -0.6 & 37 \\
& SS & $0.95^{*}$ & 90 \\
& TDS & $0.94^{*}$ & 89 \\
\hline
\end{tabular}

The correlation coefficient $(r)$ with * is statistically significant $(p<0.05)$.

Percentage reduction of the Parameters

Table 5 shows the percentage reduction of Parameters in industrial samples before and after the treatment of the effluents $(250 \mathrm{ml})$ with the different masses $(5 \mathrm{~g}, 10 \mathrm{~g}, 15 \mathrm{~g}, 20 \mathrm{~g}$, and $25 \mathrm{~g}$ ) of the Immobilized Bacteria.

In TAN1 samples, the percentage reduction (\%) of COD ranged (14-89); BOD (50-80); SS (-32$35)$ and TDS (98-99). In TAN2 samples, the percentage decrease $(\%)$ of COD ranged (15$38) ;$ BOD (90-92); SS [-28-(-55)] and TDS (9798). In TAN3 samples, the percentage decrease (\%) of COD ranged (11-44); BOD (76-81); SS (15-25) and TDS (98). The percentage increase in the levels COD, BOD and TDS might be due to the increase in the surface area of the different masses of the immobilized bacteria. However, the percentage decrease in the levels of the SS might be due to the aggregation of the TDS which are large enough to result into SS. The percentage decrease in the levels of the SS might be also due to the influence of the nutrients which was added into the effluents in order to make the microorganisms more active and viable for fast degradation of organic contaminants in the effluent. This is in line with the work of Jimoh et al. (2018) in which the concentration of the SS increase after the bioremediation of effluents.

Sreemoyee and Priti (2013) assessed and reduced several Physico-chemical parameters of dairy wastewater using Niesseria $s p$. and concluded that the species are well known to degrade organic compounds. This is in agreement with the current study in which the immobilized Niesseria $s p$ degrade the organic contaminants as indicated by the BOD, COD and TDS.

Jimoh et al. (2018) observed that TSS of the effluents was increased after treatment with immobilized bacteria and concluded that it might be due to the biostimulation method adopted for the research.

The optimum $\mathrm{pH}$ Biosorption of Chromium by Bacillus spp and Staphylococcus spp. from tannery effluent was investigated by Mythili and Karthikeyan (2011). The maximum adsorption of Chromium $(86.4 \mathrm{mg} / \mathrm{L})$ was showed by Bacillus spp and Staphylococcus spp showed $70.6 \mathrm{mg} / \mathrm{L}$ at an initial concentration of $100 \mathrm{mg} / \mathrm{L}$. In the present study, immobilised Bacillus spp and Staphylococcus spp. from the tannery industrial effluents reduced the levels of the organic pollutants with high potential as indicated by the percentage reduction of BOD, COD and TDS.

Enzymes often can work in multiple environments especially if they are immobilized. This makes the microorganisms' enzymes even more resistant to harsh environments and enables the enzymes to be recovered and recycled after they are no longer needed (Gianfreda and Rao 2004). Ramesh and Singh (1993) reported that the immobilized bacteria having more efficiency to remove the suspended particles than free cells. Using the immobilized cell is preferable due to its capability for using several times with the same efficiency, which makes it more economical. Similar work was done by Sikander et al. (2007) showing the higher reduction with permeabilized cells of Ochrobactrum intermedium strain SDCr-5. 
BAJOPAS Volume 13 Number 2, December, 2020

The results revealed the isolation and identification of isolates with the potential for the reduction of $\mathrm{Cr}$ (VI) to $\mathrm{Cr}$ (III). Results indicated that immobilized $B$. cereus could be efficiently used for the reduction of $\mathrm{Cr}$ (VI).

Table 5: Percentage reduction of the tested Parameters from the tannery industrial samples of the Immobilized Bacteria.

\begin{tabular}{lllllll}
\hline \multirow{2}{*}{ Industries } & & \multicolumn{5}{c}{ Percentage Reduction $(\%)$} \\
\cline { 3 - 7 } & & $5 \mathrm{~g}$ & $10 \mathrm{~g}$ & $15 \mathrm{~g}$ & $20 \mathrm{~g}$ & $25 \mathrm{~g}$ \\
\hline TAN1 & COD & 28 & 14 & 64 & 87 & 89 \\
& BOD & 50 & 54 & 59 & 67 & 80 \\
& SS & 35 & -26 & -27 & -32 & -63 \\
& TDS & 99 & 99 & 99 & 98 & 98 \\
TAN2 & COD & 15 & 20 & 25 & 32 & 38 \\
& BOD & 91 & 91 & 92 & 90 & 92 \\
& SS & -28 & -52 & -52 & -54 & -55 \\
& TDS & 97 & 99 & 99 & 99 & 99 \\
& COD & 33 & 44 & 22 & 11 & 26 \\
& BOD & 75 & 81 & 76 & 81 & 81 \\
& SS & 25 & 3 & -1 & -10 & -15 \\
& TDS & 98 & 98 & 98 & 98 & 98 \\
\hline
\end{tabular}

Percentage Reduction $=(B-A) / B \times 100 \%$

$A=$ Concentration of the parameter after treatment

$\mathrm{B}=$ Concentration of the parameter before treatment

$+=$ percentage decrease

- = percentage increase

In general, immobilization makes the enzyme more resistant to temperature, $\mathrm{pH}$, and substrate concentration swings giving it a longer lifetime and higher productivity per active unit (Gianfreda and Rao, 2004; FuIlbrook, 1996; Russell et al, 2003; Kandelbauer et al., 2004). Immobilized cells have been used and studied extensively for the production of useful chemicals (Ohtake and Silver, 1994), the treatment of wastewaters (Chen et al., 2003; Wang et al., 2010). Although many workers described microbial degradation of tannery effluent, limited literature is available on the bioremediation of tannery effluent using immobilized bacterial cells in the Kano Industrial Estates.

\section{CONCLUSION}

The samples contained variable levels of the physicochemical parameters. The results of the Analysis of variance revealed that, no statistical difference $(p<0.05)$ was observed for the temperature, $\mathrm{pH}, \mathrm{SS}, \mathrm{TDS}, \mathrm{BOD}$ and $\mathrm{COD}$ among the three tannery industries before the treatment. The levels of some of the parameters
(SS, TDS and COD) observed in the samples were found above the recommended limits of WHO and NESREA, which called for the treatment of the effluents before discharge into the environment. Base on the morphological and biochemical test results, TAN1, TAN2, and TAN3 bacterial isolates were identified to be Neisseria spp, Bacillus cereus, and Staphylococcus aureus respectively. The results of Post-treatment analysis showed that there is overall decrease in the levels of the parameters determined when compared with that of the pre-treatment. The overall percentage reduction of the immobilised bacteria in the treatment of the respective effluents was in the order TAN2 (72\%)>TAN1 $(70 \%)>$ TAN3 $(62 \%)$. Hence, the immobilized bacteria are having higher biodegradation potential for the treatment of the tannery effluents.

\section{Acknowledgments}

The authors wish to acknowledge the University of Maiduguri for the financial support. The authors are grateful to the Kano State Ministry of Environment for their support in obtaining the effluent samples. 


\section{REFERENCES}

Ajao, A. T., Adebayo, G. B., and Yakubu, S. E. (2011). Bioremediation of textile industrial effluent using mixed culture of Pseudomonas aeruginosa and Bacillus subtilis immobilized on agar-agar in a bioreactor. J. Microbiol. Biotech. Res, 1(3), 50-56.

Akan, J. C., Moses, E. A., Ogugbuaja, V. O., and Abah, J. (2007). Assessment of tannery industrial effluents from Kano metropolis, Kano State, Nigeria. Journal of Applied Sciences, 7(19), 2788-2793.

Akan, J. C., Ogugbuaja, V. O., Abdulrahman, F. I., and Ayodele, J. T. (2009). Pollutant levels in effluent samples from tanneries and textiles of Kano industrial areas, Nigeria. Global journal of pure and applied sciences, 15(3-4).

APHA (1989). Standard methods for Examination of Will bete and Will betewater.15 $5^{\text {th }}$ edition. Brydpass Springfield Will behington DC. pp. 164-176

APHA (1992). Standard Methods for the Examination of Water and Wastewater. Health, 69, 1116-9.

Baba, A., Garba, S. T., and Bello, H. S. (2020). Bioremediation Potential of Immobilized corynebacterium kutsceri in the Treatment of Tannery Industrial Effluent from Challawa Industrial Estate, Kano State, Nigeria. Journal of the Turkish Chemical Society Section A: Chemistry, $7(2), 335-350$.

Beem, E. I. V. (1994). reduction of solvent VOC emission. J. Oil Col. Chem. Ass, 77, 158.

Bouwer, E. J., and Zehnder, A. J. (1993). Bioremediation of organic compoundsputting microbial metabolism to work. Trends in biotechnology, 11(8), 360367.

Chen, K. C., Wu, J. Y., Liou, D. J., and Hwang, S. C. J. (2003). Decolorization of the textile dyes by newly isolated bacterial strains. Journal of Biotechnology, 101(1), 57-68.

Dan'Azumi, S., and Bichi, M. H. (2010). INDUSTRIAL POLLUTION AND HEAVY METALS PROFILE OF CHALLAWA RIVER IN KANO, NIGERIA. Journal of Applied Sciences in Environmental Sanitation, $5(1)$.

DWAF. (1992). Analytical Methods Manual, TR 151. Department of Water Affairs and Forestry, Pretoria.

El-Bestawy, E. (2013). Biological treatment of leather-tanning industrial wastewater using free living bacteria.
Elsheikh, M. A. S. (2009). Tannery wastewater pre-treatment. Water Science and Technology, 60(2), 433-440.

FuIlbrook, P. D. (1996). "Kinetics." Industrial enzymology: The application of enzymes in Industry. 2nd Ed. T. Godfrey and J Reichelt. eds.. Nature. New York.

Gianfreda, L., and Rao, M. A. (2004). Potential of extra cellular enzymes in remediation of polluted soils: a review. Enzyme and microbial technology, 35(4), 339354.

Hugo Springer. (1994). John Arthur Wilson Memorial Lecture "Treatment of Industrial Wastes of the Leather Industry - is it still a Major Problem". JALCA, 89, 153-185

Jimoh, A. A., Ganiyu, B. A., Baba, D., and Baba, A. (2018) Bioremediation Process of Effluent from Detergent and Food Industries in Jos, Nigeria: Kinetics and Thermodynamics. International Journal of Engineering Science Invention (IJESI), 762-73

Kandelbauer, A., Maute, O., Kessler, R. W., Erlacher, A., and Gübitz, G. M. (2004). Study of dye decolorization in an immobilized laccase enzyme-reactor using online spectroscopy. Biotechnology and bioengineering, 87(4), 552-563.

Kongjao, S., Damronglerd, S., and Hunsom, M. (2008). Simultaneous removal of organic and inorganic Pollutants in tannery wastewater using electrocoagulation technique. Korean Journal of chemical engineering, 25(4), 703.

Maheshwari, U. M., Aruna, S., Gomathi, M., and AbdulJaffar, A. H. (2017). Bioremediation by Free and Immobilized Bacteria Isolated from Tannery Effluent. International Journal of Research in Applied, Natural and Social Sciences. 5(7), 75-90

Margesin, R., and Schinner, F. (2001). Bioremediation (natural attenuation and biostimulation) of diesel-oilcontaminated soil in an alpine glacier skiing area. Applied and environmental microbiology, 677), 3127-3133.

Mohammed, A., Sekar, P., and George, J. (2011). Efficacy of microbes in bioremediation of tannery effluent. Inter. J. Curr. Res, 3(4), 324-326.

Mohammed, S. S. D., Orukotan, A. A., and Abdullahi, H. (2017). Physicochemical and Bacteriological Assessment of Tannery Effluent from Samaru-Zaria, 
BAJOPAS Volume 13 Number 2, December, 2020 Kaduna State, Nigeria. Journal of Applied

Sciences and Environmental Management, 21(4), 734-740.

Munz, G., De Angelis, D., Gori, R., Mori, G., Casarci, M., and Lubello, C. (2009). The role of tannins in conventional and membrane treatment of tannery wastewater. Journal of hazardous materials, 164(2-3), 733-739

Mythili, K., and Karthikeyan, B. (2011). Bioremediation of $\mathrm{Cr}$ (VI) from tannery effluent using Bacillus spp and Staphylococcus spp. International Multidisciplinary Research Journal, 1(6).

NESREA (2009). National Environmental Standards for Effluent Limitations and Regulation. 1233-1236

Noorjahan, C. M. (2014). Physicochemical characteristics, identification of bacteria and biodegradation of industrial effluent. Journal of bioremediation and Biodegradation, 5(3).

Ohtake, H. I., and Silver, A. O. (1994). Bacterial reduction of toxic chromate. Biological degradation and bioremediation of toxic chemicals, 403-415.

Omoleke, I. I. (2004). Management of environmental pollution in Ibadan, an African city: the challenges of health hazard facing government and the people. Journal of Human Ecology, 15(4), 265-275.

Rajor, A., Reddy, A.S., and Singh, B. (2004). Determination of BOD kinetic Parameters and evaluation of alternate methods, M.Sc. Thesis, Department of biotechnology \& environmental Science, Thapar Institute of Engineering and Technology, Patiala

Ramasami, T., Rajamani, S., and Rao, J. R. (1994, March). Pollution control in leather industry: Emerging technological options. In International symposium on surface and colloidal science and its relevance to soil pollution, madras.

Ramesh, J. V. S., and Singh, S. P. (1993). Yearly variation in certain physicochemical parameters of pond at eastern Doon Valley. Uttar Pradesh J. Zoo, 12 (1), 7577.

Ranen, S., and Sharadinadra, C. (2009). Biotechnology applications to environmental remediation in resource exploitation. Current science, 97, 6-25
Russell, A. J., Berberich, J. A., Drevon, G. F., and Koepsel, R. R. (2003). Biomaterials for mediation of

chemical and biological warfare agents. Annual review of biomedical engineering, 5(1), 1-27.

Saravanan, P., and Saravanan, A. (1999). Decolourization of tannery effluent by Flavobacterium sp. EK 1. Indian Journal of Environmental Protection, 19, 19-24.

Sikander, S., and Shahida, H. (2007). Reduction of toxic hexavalent chromium by Ochrobactrum intermedium strain SDCr5 stimulated by heavy metals. Bioresource Technol, 98, 340-344.

Singh, N., Sharma, B. K., and Bohra, P. C. (2000). Impact assessment of industrial effluent of arid soils by using satellite imageries. Journal of the Indian Society of Remote Sensing, 28(2-3), 79.

Sreemoyee, C., and Priti, P. (2013). Assessment of physico-chemical parameters of dairy waste water and isolation and characterization of bacterial strains in terms of cod reduction. Int J Sci, 2(3), 395-400.

Verheijen, L. A. H. M., Wiersema, D., Pol, L. H., and De Wit, J. (1996). Management of wastes from animal product processing. Livestock and environment, Finding a balance. International Agriculture Center, Wageningen, The Netherlands.

Wang, F., Yao, J., Si, Y., Chen, H., Russel, M., Chen, K., and Bramanti, E. (2010). Short-time effect of heavy metals upon microbial community activity. Journal of Hazardous Materials, 173(13), 510-516.

WHO (World Health Organization). (2006). Air quality guidelines: global update 2005: particulate matter, ozone, nitrogen dioxide, and sulfur dioxide. World Health Organization.

World Bank. (1995). Nigeria's strategic options for redressing industrial pollution. World Bank, industry and energy division. 1st edition, West Central Africa Department; Annexes: 1995; pp 60-62.

Zahoor, A., and Abdul, R. (2009). Enumeration of Coliforms. Journal of Environmental Sciences. 21, 814-820 


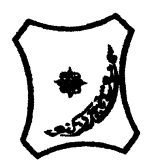

Bayero Journal of Pure and Applied Sciences, 13(2): 1 - 12

Received: November, 2020

Accepted: December, 2020

ISSN $2006-6996$

\title{
BIODEGRADATION POTENTIAL OF IMMOBILIZED BACTERIA IN THE TREATMENT OF TANNERY INDUSTRIAL EFFLUENTS FROM INDUSTRIAL ESTATES IN KANO STATE, NIGERIA
}

\author{
Abdullateef, B., ${ }^{1 *}$ Shuaibu, T. G., ${ }^{1}$ Babagana, K., ${ }^{1}$ Suleman, H. B. ${ }^{2}$ and Dauda, B. ${ }^{3}$ \\ ${ }^{1}$ Department of Pure and Applied Chemistry, Faculty of Science, University of Maiduguri, Borno State, \\ Nigeria \\ ${ }^{2}$ Department of Microbiology, Faculty of Science, University of Maiduguri, Borno State, Nigeria \\ ${ }^{3}$ Department of Chemical Engineering, Faculty of Engineering, University of Maiduguri, Borno State, \\ Nigeria \\ *Corresponding author: babslega@gmail.com; abelega2007@yahoo.com; +2348061309753
}

\section{ABSTRACT}

Industrial Effluents Samples from Gashash Tanneries (TAN1) in Bompai Industrial estate, Larabee Tannery Industry (TAN2) in Sharada Industrial estate and Z Tannery Industries (TAN3) in Challawa Industrial estate, Kano State, Nigeria were collected over a period of six months (August 2017 to January 2018) for assessing the biodegradation potentials of bacteria in the treatment of organic pollutants within the effluents. Bacteria were isolated from the effluents and immobilized on agar-agar. Different masses (5 g, $10 \mathrm{gr}, 15$ $\mathrm{g}, 20 \mathrm{~g}$, and $25 \mathrm{~g}$ ) of the bacteria were used in the treatment of $250 \mathrm{ml}$ of the effluents for ten days in a shaker incubator (Gallenkamp-OC-4364-L) at the temperature $30{ }^{\circ} \mathrm{C}$ and speed of $60 \mathrm{rpm}$. Pre-treatment analysis of the effluents for Temperature, pH, Biochemical Oxygen Demand (BOD), Chemical Oxygen Demand (COD), Suspended Solid (SS) and Total Dissolved Solids (TDS) gives the following results; temperature $\left({ }^{\circ} \mathrm{C}\right.$ )

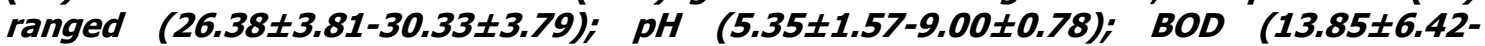
$38.75 \pm 16.20) ;$ COD (1406 $\pm 208-3532 \pm 1373) ;$ SS (208 $\pm 235-780 \pm 739)$ and TDS (266 $\pm 253-5276 \pm 2971)$. No statistical differences ( $p \leq 0.05)$ was observed for all the results among the different industries. The bacterial isolates were identified as Neisseria spp, Bacillus cereus, and Staphylococcus aureus, in TAN1, TAN2, and TAN3, respectively. After treatment of the effluent with the different masses of the isolated bacteria, the mean level of BOD was found to range as (0.55 $\pm 0.36-6.92 \pm 5.49) ; C O D$ (ND-3134 \pm 1595$)$;

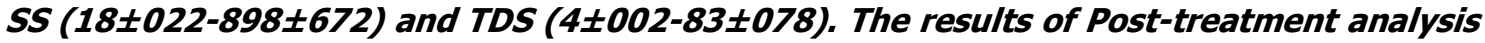
showed that there is overall decrease in the levels of the parameters determined when compared with that of the pre-treatment. The overall percentage reduction of the immobilised bacteria in the treatment of the respective effluents was in the order TAN2 (72\%)>TAN1 (70\%)>TAN3 (62\%). Hence, the immobilized bacteria are having higher biodegradation potential for the treatment of the tannery effluents.

Keywords: Biodegradation, bacteria, effluent, immobilization, tannery.

\section{INTRODUCTION}

Tannery industrial wastewater is a serious consequence of the pollution point of view for streams, freshwater, and land used for agriculture. The lack of awareness in the modern industrial practice has resulted in the discharge of tannery effluents which exhibit very high value of chromium ( $\mathrm{Cr}$ ), Sulfide, and chloride, Total Dissolved Solid (TDS), Total Suspended Solid (TSS), Biochemical Oxygen Demand (BOD) and Chemical Oxygen Demand (COD) in the water stream or land (Mohammed et al., 2001). Tanning is the process, which One ton of skin generally leads to the production of 20 to $80 \mathrm{~m}^{3}$ of turbid and foul-smelling converts the protein of the rawhide or skin into a stable material, which will not putrefy and is suitable for a wide variety of end applications (Elsheikh, 2009). The highly polluting chromium is the most commonly used tanning material producing leather that is more flexible and pliable than vegetable-tanned leather and does not discolor or lose shape in water as drastically as vegetable-tan (Elsheikh, 2009). Tannery effluent is among the most hazardous industrial pollutants due to its huge organic and inorganic load, which is highly toxic to human life and the environment (Kongjao et al., 2008). wastewater including chromium (100-400 mg/l), sulfide $(200-800 \mathrm{mg} / \mathrm{l})$, high levels of fat and 
BAJOPAS Volume 13 Number 2, December, 2020 other solid wastes, and notable pathogen contamination as well as pesticides added for skin conservation during transport (Elsheikh, 2009). There are more than 6000 tanneries in Nigeria with an annual processing capacity of 700,000 tons of hides and skins (Omoleke, 2004; Singh et al., 2008). It was reported that the total amount of waste produced per animal slaughtered is approximately $35 \%$ of its weight (World Bank, 1995). Also, for every $1000 \mathrm{~kg}$ of carcass weight, a slaughtered beef produces 5.5 $\mathrm{kg}$ of manure (excluding rumen contents or stockyard manure) and $100 \mathrm{~kg}$ of paunch manure (undigested food) (Verheijen et al., 1996). Tanneries generate wastewater in the range of 30-35 $\mathrm{L} \mathrm{kg}^{-1}$ skin/hide processed with variable $\mathrm{pH}$, Biological Oxygen Demand (BOD), Chemical Oxygen Demand (COD), high concentrations of suspended solids (SS), and tannins as well as chromium (Zahoor and Abdul, 2009).

Being heterogeneous and composed of a wide variety of compounds, it is very difficult to select a unique direct method for estimating the biodegradability of organic contents and biokinetic parameters for a wastewater sample (Rajor, 2004). For this purpose, some indirect estimation such as determination of biochemical oxygen demand (BOD) and chemical oxygen demand (COD) are applied as common laboratory investigations [9]. During retanning procedures, synthetic tannins (Syntan), oils and resins are added to form softer leather at varying doses (Munz et al., 2009). One of the refractory groups of chemicals in tannery effluents derives mainly from tannins (Ramasami et al., 2004). Syntans are characterized by complex chemical structures, because they are composed of an extended set of chemicals such as phenol-, naphthalene-, formaldehyde- and melamine-based syntans, and acrylic resins (Beem, 1994). Organic pollutants (proteic and lipidic components) are originated from skins (it is calculated that the raw skin has $30 \%$ loss of organic material during the working cycle) or they are introduced during processes (Hugo Springer, 1994).

Many conventional processes such as oxidation, chemical and biological processes were carried out to treat tanneries wastewater (Ebtesam et al, 2013). Biological processes have received more attention because of their costeffectiveness, lower sludge production and environmental friendliness (Noorjahan, 2014). Naturally occurring micro-organisms degrade the hazardous organic wastes including xenobiotic compounds, such as pesticides, polycyclic aromatic hydrocarbons (PAHs) and polychlorinated biphenyls (PCBs) in due course of time (Ranen and Sharadinadra, 2009). Bioremediation is based on the idea that all organisms remove substances from the environment to carry outgrowth and metabolism (Bouwer and Zehnder, 1993). Bacteria, protista and fungi are found to be very good at degrading complex molecules and incorporating the breakdown products into their metabolism (Bouwer and Zehnder, 1993). The resultant metabolic wastes that they produce are generally safe and somehow recycled into other organisms (Ranen and Sharadinadra, 2009). An acclimatized indigenous population of microorganisms capable of degradation of the compounds of interest must exist at the site for a successful bioremediation mode (Ranen and Sharadinadra, 2009). It has been observed that for a successful bioremediation mode, an acclimatized indigenous population of microorganisms capable of degradation of the compounds of interest must exist at the site under investigation (Ranen and Sharadinadra, 2009). Even though there are numerous physical and chemical methods employed in the disposal of wastes the advantage in using bacterium is that they play a key role in the reduction of COD, BOD, total protein, total tannin and total phenol (Saravanan and Saravanan, 1998)

Baba et al. (2020) studied the bioremediation potential of immobilized corynebacterium kutsceri in the Treatment of tannery industrial effluent from Challawa Industrial Estate, Kano State, Nigeria. The aim of the work is to study the reduction in the level of the contaminants through the process of bioremediation using the isolated bacteria. Immobilized bacteria can withstand various temperatures, $\mathrm{pH}$ and substrate concentrations; consequently, increasing the efficiency and the lifespan of the bacteria. Immobilized bacteria are widely applied in the treatment of wastewater and can be separated and recovered after the treatment with the same efficiency (Baba et al., 2020).

\section{MATERIALS AND METHODS \\ Study Area}

This study was carried out in Bompai, Sharada and Challawa industrial estates in Kano, Figure 1. Kano lies on Latitude $11^{\circ} 30^{\prime} \mathrm{N}$ and $8^{\circ} 30^{\prime} \mathrm{E}$ and Longitude $11^{\circ} 5^{\prime} \mathrm{N}$ and $8^{\circ} 5^{\prime} \mathrm{E}$ in Northern Nigeria. It is one of the developed industrial cities in Nigeria. Tannery activities are the dominating industries and this could be one of the reasons for her high population density (Dan'Azumi and Bichi, 2010). Many researchers have studied biodegradation of tannery effluent using microorganisms. However, limited literature is available on the biodegradation of tannery effluent in Kano industrial estates using 
BAJOPAS Volume 13 Number 2, December, 2020 immobilized bacterial cells. This research work focuses on the potential of the use of the indigenous immobilized bacterial isolates in the treatment of tannery effluents in the industrial estates.

\section{Sample Collection}

Effluents were collected from the Tannery Industries from Bompai, Challawa and Sharada Industrial Estates, Kano, Nigeria. The effluents were collected over a period of six months (August 2017 to January 2018). Samples collected in a sterile 4-liter plastic container with a unique identification number were preserved using an ice-box that was transported to the Microbiology Laboratory, Department of Microbiology, Bayero University of Kano for analysis

\section{Sample Preparation and Sample Analysis}

Immediately after the collection of the effluent, $\mathrm{pH}$, TSS, TDS, COD, BOD levels were determined before treatment (Pre-treatment determination) and ten days after treatment (Post-treatment determination) as described in
APHA (1989) standard methods. $\mathrm{pH}$ was determined using Ecotests $\mathrm{pH}$ meter and TDS was determined using AQUALYTIC TDS Salinometer. BOD was determined as described by the standard method (APHA, 1992). COD and SS were determined using DR/2010 HACH portable data logging spectrophotometer (DWAF, 1992)

\section{Identification and Biochemical} Characterization of the Bacterial Isolates

The bacteria were isolated from the effluents using Serial Dilution according to the method described by APHA (1989). The biochemical tests such as oxidase, catalase, coagulase, indole (from $1 \%$ tryptone broth), citrate (Simmons citrate agar), methyl red/VogesProskauer (MR/VP), nitrate reduction, Starch Hydrolysis, Glucose, Maltose, and Lactose tests were carried out on the bacterial isolates to identify the bacteria through the bacteria biochemical characteristics according to Ajao et al. (2011).

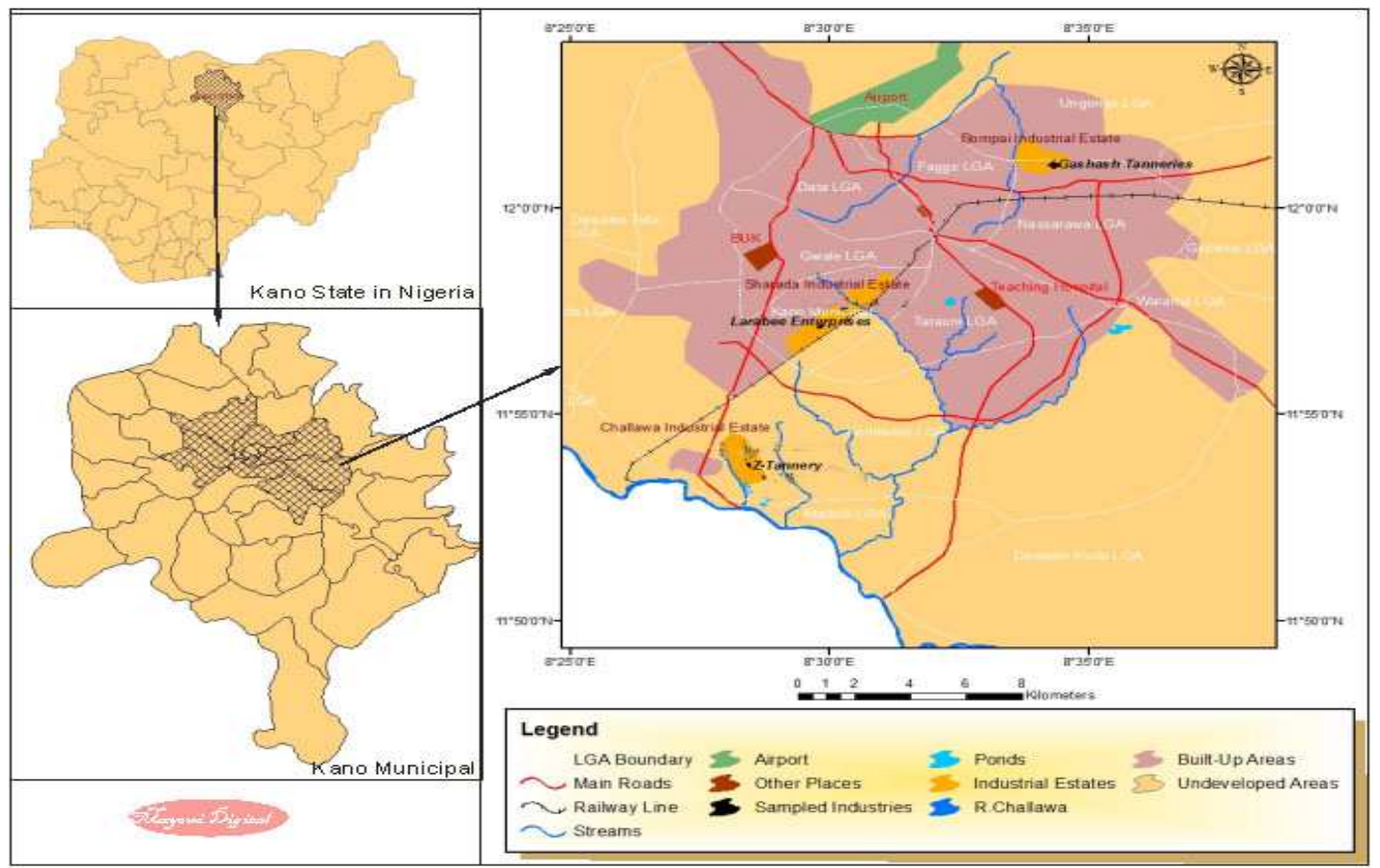

Fig. 1 Map showing the study areas

Source: Mayomi Digital Productions, GIS Laboratory, Department of Geography, UNIMAID (2017)

\section{Determination of Growth Rate of the Bacteria in Effluent Sample}

The bacteria growth rates were determined by transferring $2 \mathrm{~mL}$ of the bacterial isolates from the tannery effluent in broth medium into 100 $\mathrm{mL}$ sterile effluents in conical flasks and kept in an incubator (Giffrin cool) for 10 days. Control was also set up by incubating another $100 \mathrm{~mL}$ each of the sterile effluents without the bacteria. The optical density of the content was determined at the wavelength of $600 \mathrm{~nm}$ on a daily interval and recorded. 
BAJOPAS Volume 13 Number 2, December, 2020 Immobilization of Bacteria

Agar solution and inoculi were prepared separately. Fifty milliliters $(50 \mathrm{~mL})$ of nutrient broth each of the inoculi was prepared in a McCartney bottle and incubated for 24 hours. A solution of agar-agar was prepared by dissolving $10 \mathrm{~g}$ of the powder in distilled water and made up to $500 \mathrm{~mL}$ mark in an Erlenmeyer flask and was sterilized in an autoclave (280A) for 15 minutes and allowed to cool to $40-45^{\circ} \mathrm{C}$ (Ajao et al., 2011). Four milliliters ( $4 \mathrm{~mL})$ of the bacterial isolates in the nutrient broth was mixed with 36 $\mathrm{ml}$ of the prepared agar-agar media in petri-dish plates and then allowed to solidify. This was kept in the refrigerator for bioremediation.

\section{Bioremediation (Treatment) of the Effluents}

The solidified agar block (immobilized bacteria) was cut into cubes using a sterile knife; $0.1 \mathrm{~mL}$ phosphate buffer ( $\mathrm{pH} \mathrm{7.0)}$ was added and kept in the refrigerator for 1 hour for curing. The phosphate buffer was decanted after 1 hour and the cubes were washed with sterile distilled water 3-4 times before it was used (Ajao et al., 2011). Two liters (2 L) of the effluent was supplemented with the minimum basal medium in $\mathrm{g} / \mathrm{L}: \mathrm{NaCl}(0.8), \mathrm{MgSO}_{4} .7 \mathrm{H}_{2} \mathrm{O}(0.001), \mathrm{KH}_{2} \mathrm{PO}_{4}$ (2), $\mathrm{NaNO}_{3}$ (2), $\quad \mathrm{CaCl}_{2} .2 \mathrm{H}_{2} \mathrm{O} \quad(0.5)$ and $\mathrm{NaHPO}_{4} .12 \mathrm{H}_{2} \mathrm{O}(2)$ and sterilized in an autoclave at $121^{\circ} \mathrm{C}$ for 15 minutes (Margesin and Schinner, 2001). Two hundred and fifty milliliters $(250 \mathrm{~mL})$ of the effluents were transferred into different $250 \mathrm{ml}$ conical flasks. The content was covered with a cotton-wool ramped with foil paper to avoid contamination. Five grams $(5 \mathrm{~g})$ of the immobilized bacteria were quickly transferred into each of the effluents in the conical flasks in an inoculating chamber. The same procedures were carried out for the $10 \mathrm{~g}, 15 \mathrm{~g}, 20 \mathrm{~g}$ and 25 $\mathrm{g}$ of the immobilized bacteria in separate $250 \mathrm{~mL}$ effluents in conical flasks and agitated for ten days in a shaker incubator (Gallenkamp-OC4364-L) at a temperature $30^{\circ} \mathrm{C}$ and speed of 60 rpm. The treated effluent samples were taken on the tenth day and analyzed for the parameters $\mathrm{pH}$, SS, TDS, COD, and BOD, (Posttreatment determination) for the different grams of bacteria to evaluate and compare the biodegradation potential. (Baba et al., 2020).

\section{Statistical Analysis}

The data were represented as Mean \pm Standard deviation and analyzed statistically using oneway Analysis of Variance (ANOVA) and Tukey's HSD as Post Hoc Tests with the aid of SPSS 16.0. The correlation coefficient was also used to measure the strength of the relationship between the different masses of the bacteria and the parameters. All $\mathrm{p} \leq 0.05$ were considered as statistically significant.

\section{RESULTS AND DISCUSSION Physico-chemical parameters in the Industrial Effluents before the Biodegradation.}

Results of the Physico-chemical parameters in the industrial effluents before the Biodegradation is shown in table 1 . The mean temperatures $\left({ }^{\circ} \mathrm{C}\right)$ observed in TAN1, TAN2, and TAN3 samples were $28.07 \pm 0.65 ; 27.77 \pm 0.64$ and $26.38 \pm 3.81$ respectively. The order of the mean temperature of the samples from the three industries can be arranged as TAN1 > TAN2>TAN3. The temperature observed at TAN1, TAN2, and TAN3 samples were found below the WHO $\left(35^{\circ} \mathrm{C}\right)$ and NESREA $\left(40^{\circ} \mathrm{C}\right)$ limits. The low values of temperature might be due to the processes used at the time of sampling. High temperature brings down the solubility of gases in water that ultimately expresses as high BOD and COD. Statistical analysis shows that there is no significant difference $(p<0.05)$ between the mean values of temperature among the industries. This might be due to similar tannery activities involved in the tannery industries at the time of sampling. The average values of temperature observed in this present study are less than those observed by Akan et al. (2007), Akan et al. (2009) and Baba et al. (2020).

The mean level of $\mathrm{pH}$ observed in TAN1, TAN2 and TAN3, samples were $7.77 \pm 2.93$; $8.35 \pm 0.28$ and $7.52 \pm 0.76$ respectively. The order of the mean $\mathrm{pH}$ of the samples from the three industries can be arranged as TAN2> TAN1 $>$ TAN3. The $\mathrm{pH}$ of the samples falls within the WHO (7.0-8.5) and NESREA (6-9) standard limits. Statistical analysis shows that there is no significant difference $(p<0.05)$ between the mean values of $\mathrm{pH}$ among the industries. This might be due to similar tannery activities involved in the tannery industries at the time of sampling. Maheshwari et al. (2017) reported that the level of $\mathrm{pH}$ in the effluents from the tannery industry in Vaniyambadi, India was 6.5 which was lower than that observed in the present study. The $\mathrm{pH}$ in the effluents from the tannery industries in Kano and Kaduna were reported to be 7.64 and 6.89, respectively (Akan et al., 2007; Mohammed et al., 2017). The average values of $\mathrm{pH}$ observed in this present study are less than those observed by Mohammed et al. (2017) and Baba et al. (2020). The mean level of SS $(\mathrm{mg} / \mathrm{l})$ observed in TAN1, TAN2, and TAN3 samples were 374 \pm 124 ; $358 \pm 335$ and $780 \pm 739$ respectively. The order of the mean SS in the samples from the three industries can be arranged as TAN3 > TAN1 $>$ TAN2. 
The SS observed in the samples were far above the recommended standard limits of regulating bodies WHO $(30 \mathrm{mg} / \mathrm{l})$ and NESREA $(10 \mathrm{mg} / \mathrm{l})$. Statistical analysis shows that there is no significant difference $(p<0.05)$ between the mean values of SS among the industries. This might be due to similar tannery activities involved in the tannery industries at the time of sampling. The average values of SS observed in this present study are less than that observed $(3700 \pm 122 \mathrm{mg} / \mathrm{l})$ by Akan et al. (2009) for tanneries in Kano. Also, the average values of SS observed in this present study are less than that observed by Mohammed et al. (2017) and Baba et al. (2020) with the exception in TAN3.

The mean level of TDS (mg/l) observed in TAN1, TAN2, and TAN3 samples were $3941 \pm 3703$; $3300 \pm 1714$ and $2653 \pm 1240$ respectively. The order of the mean TDS in the samples from the three industries can be arranged as TAN1>TAN2>TAN3. The TDS observed in the samples were far above the recommended standard limits of WHO $(250 \mathrm{mg} / \mathrm{l})$ and NESREA $(500 \mathrm{mg} / \mathrm{l})$. Statistical analysis shows that there is no significant difference $(p<0.05)$ between the mean values of TDS among the industries. This might be due to similar tannery activities involved in the tannery industries at the time of sampling. TDS in the effluents from the tannery industries in Kano, Nigeria was reported to be $1281 \mathrm{mg} / \mathrm{l}$ (Akan et al., 2007). The average values of SS observed in this present study are less than those observed by Mohammed et al. (2017) and Baba et al. 2020)

The mean level of COD (mg/l) observed in TAN1, TAN2 and TAN3 samples seasons were $2372 \pm 938 ; \quad 1406 \pm 208$ and $3532 \pm 1373$ respectively. The order of the mean COD of the samples from the three industries can be arranged as TAN3>TAN1> TAN2. The COD observed in TAN1, TAN2 and TAN3 samples were far above the recommended standard limits of regulating bodies $\mathrm{WHO}(40 \mathrm{mg} / \mathrm{l})$ and NESREA (40 mg/l). Statistical analysis shows that there is no significant difference $(p<0.05)$ in COD among the industries. This might be due to similar tannery activities involved in the tannery industries as at the time of sampling. The Chemical Oxygen demand (COD) is the amount of oxygen, in $\mathrm{mg} / \mathrm{L}$, required for the degradation of the compound of wastewater to occur. In comparison, the average values of COD observed in this present study were higher than that observed by Mohammed et al. (2017) but lower than that observed by Baba et al. (2020).

The mean levels of BOD $(\mathrm{mg} / \mathrm{l})$ observed in TAN1, TAN2 and TAN3 samples were $13.85 \pm 6.42 ; \quad 19.46 \pm 0.50$ and $17.13 \pm 3.14$ respectively. The order of the mean BOD in the samples from the three industries can be arranged as TAN2>TAN3>TAN1. The BOD observed in TAN1, TAN2 and TAN3 samples were found below the recommended limits of NESREA (200 mg/l) but above WHO (10 mg/l). Statistical analysis shows that there is no significant difference $(p<0.05)$ between the mean values of BOD among the industries. This might be due to similar tannery activities involved in the tannery industries at the time of sampling. The low level of BOD recorded in this study is an indication of the low level of biodegradable organic solids in the effluent. The average values of BOD observed in this present study were lower than those observed by Mohammed et al. (2017) and Baba et al. (2020).

Table 1: Mean Values \pm S.D of Physico-chemical parameters of effluents from the Tannery Industries before Treatment.

\begin{tabular}{llllllll}
\hline Parameter & Tannery 1 & Tannery 2 & Tannery 3 & $\mathrm{a}$ & $\mathrm{b}$ & $\mathrm{c}$ & $\mathrm{d}$ \\
\cline { 2 - 7 } Temperature $\left({ }^{\circ} \mathrm{C}\right)$ & $28.07 \mathrm{a} \pm 0.65$ & $27.77 \mathrm{a} \pm 0.64$ & $26.38 \mathrm{a} \pm 3.81$ & & $29.50 \pm 4.68$ & 35 & 40 \\
pH & $7.77 \mathrm{a} \pm 2.93$ & $8.35 \mathrm{a} \pm 0.28$ & $7.52 \mathrm{a} \pm 0.76$ & 6.89 & $5.35 \pm 1.57$ & $7.0-8.5$ & $6.0-9.0$ \\
$\mathrm{COD}(\mathrm{mg} / \mathrm{l})$ & $2372 \mathrm{a} \pm 938$ & $1406 \mathrm{a} \pm 208$ & $3532 \mathrm{a} \pm 1373$ & 2.2 & $3106 \pm 2753$ & 40 & 40 \\
$\mathrm{BOD}(\mathrm{mg} / \mathrm{l})$ & $13.85 \mathrm{a} \pm 6.42$ & $19.46 \mathrm{a} \pm 0.50$ & $17.13 \mathrm{a} \pm 3.14$ & 1032 & $26.17 \pm 9.49$ & 10 & 200 \\
$\mathrm{SS}(\mathrm{mg} / \mathrm{l})$ & $374 \mathrm{a} \pm 124$ & $358 \mathrm{a} \pm 335$ & $780 \mathrm{a} \pm 739$ & 501 & $562 \pm 482$ & 30 & 10 \\
TDS $(\mathrm{mg} / \mathrm{l})$ & $3941 \mathrm{a} \pm 3703$ & $3300 \mathrm{a} \pm 1714$ & $2653 \mathrm{a} \pm 1240$ & 532.7 & $444 \pm 507$ & 250 & 500 \\
\hline
\end{tabular}

The values given in the table above are means of 6 replicate values, $\mathrm{n}=6$ ( 1 sample was taken monthly for 6 months). Within the rows, means with different alphabets are statistically different $(p<0.05)$. WHO: World Health Organisation. NESREA: National Environmental Standard and Regulatory Enforcement Agency. a = Mohammed et al.(2017), b = Baba et al. (2020), c = WHO (2006), $d=$ NESSRA (2009) 
BAJOPAS Volume 13 Number 2, December, 2020

Identification, Biochemical Characterization and growth rates of the Bacterial Isolates

Results of identification and biochemical characterization of the bacterial isolates were shown in table 2. After 24 hours of incubation, the nutrient agar media plates were checked for bacterial growth. The results showed the presence of different strains in the samples. The TAN1 bacteria isolate was found to be gramnegative cocci while TAN3 was gram-positive cocci. TAN2 bacteria isolate was found to be gram-positive, rod-shaped. TAN1, TAN2, and TAN3 bacteria isolates recorded positive results for spore former.

The results of the biochemical tests indicated that all the bacteria were positive for catalase, oxidase, citrate, maltose, glucose, lactose (negative in TAN1), mannitol (negative in TAN2), starch hydrolysis and coagulase (negative in TAN2) tests. The bacteria showed negative results for nitrate reduction, $M R$ (positive in TAN2), VP (positive in TAN1), Indole (positive in TAN2) tests. Base on the morphological and biochemical test results, TAN1, TAN2, and TAN3 bacteria isolates were identified to be Nesseria spp, Bacillus cereus, and Staphylococcus aureus respectively.

The growth rate of the TAN1, TAN2 and TAN3 Isolates were shown in figure 2. Generally, the optical density increase with the increase in time (day) and decrease as time goes on. The highest optical density was shown by bacillus cereus in TAN2 while the lowest was shown by Staphylococcus aureus in TAN3.

The initial growth phase of TAN1 Isolate bacteria occurred within 2-day of incubation as the growth rate increases up to the 6th-day incubation when the maximum growth was observed. Beyond the 6th day, the growth of the bacteria declined (which might be due to a shortage of nutrients in the effluents) until it reached its death phase (which might be due to the unavailability of nutrients in the effluents).

A similar trend of growth was also observed for TAN2 Isolate as the initial growth phase also occurred within 2-day of incubation but maximum growth rate observed on the 4th day of incubation. The stationary stage occurred between the 4th day and the 8th day. Beyond the 8th day, the growth of the bacteria declined (which might be due to a shortage of nutrients in the effluents) until it reached its death phase (which might be due to the unavailability of nutrients in the effluents).

The initial growth phase of TAN3 bacterial Isolate occurred within the 3-day incubation as the growth rate increases up to the 6th-day incubation when the maximum growth was observed. Beyond the 6th day, the growth of the bacteria declined (which might be due to a shortage of nutrients in the effluents) until it reached its death phase (which might be due to the unavailability of nutrients in the effluents).

Table 2: Morphological and Biochemical characteristics of bacterial isolates

\begin{tabular}{lllll} 
Bacterial Isolates & & TAN1 & TAN2 & TAN3 \\
\hline $\begin{array}{lllll}\text { Morphological } \\
\text { characteristics }\end{array}$ & Shape & Cocci & Rod & Cocci \\
& Spore & & & \\
& former & + & + & + \\
Gram & & & \\
Biochemical characteristics & reaction & - & + & + \\
& Citrate & + & + & + \\
& Catalase & + & + & + \\
& Coagulase & + & - & + \\
Starch & + & + & + \\
& Glucose & + & + & + \\
Oxidase & + & + & + \\
& Indo & - & + & - \\
Lactose & - & + & + \\
Manitol & + & - & + \\
Maltose & + & + & + \\
MR & - & + & - \\
VP & + & - & - \\
& Nitrate & - & - & - \\
Reduction & - Neisseria & Bacillus & Staphylococcus \\
& Bacterial & cereus & aureus \\
& name & spp & cas
\end{tabular}

+ = Positive; - = Negative; MR=Methyl Red; VP= Voges-Proskauer 


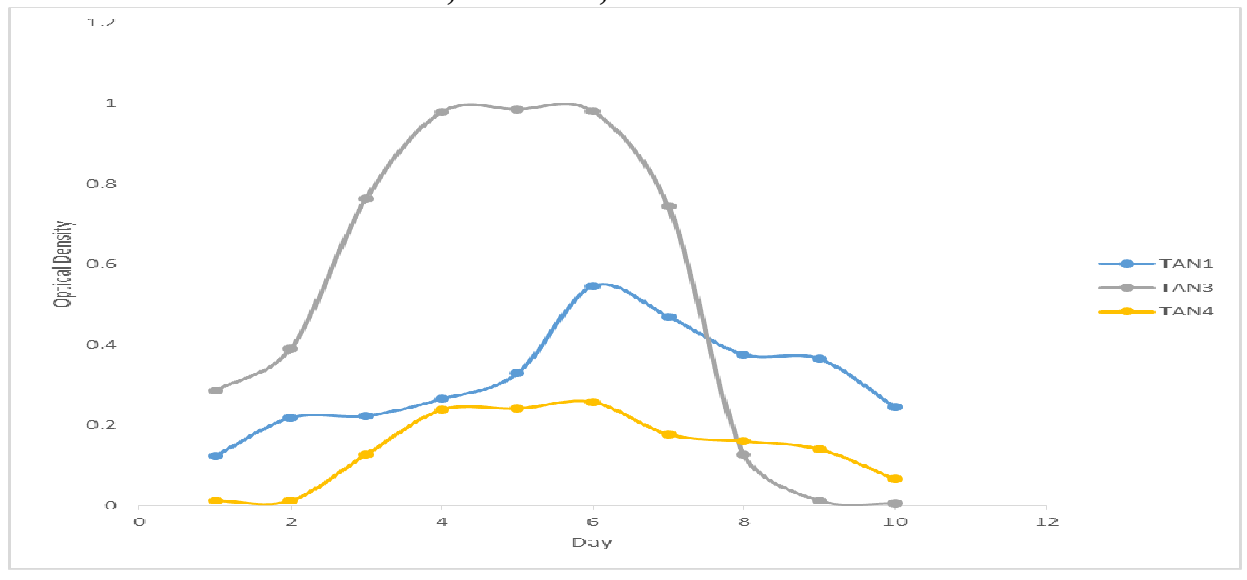

Fig. 2 Growth rates of the isolates in the effluents from the Tannery Industries

\section{Physico-chemical Parameters in the Industrial Effluents after the biodegradation.}

Table 3 shows the mean results of the physicochemical parameter before and after bioremediation using the different masses $(5 \mathrm{~g}$, $10 \mathrm{~g}, 15 \mathrm{~g}, 20 \mathrm{~g}$, and $25 \mathrm{~g}$ ) of the respective immobilized bacteria. Also, Table 4 shows the mean results of correlation coefficient ( $r$ ) between different masses of bacteria and physicochemical parameters.

The mean values $(\mathrm{mg} / \mathrm{l})$ of the SS after the bioremediation varies between $243 \pm 45$ and $898 \pm 672$. The mean concentration $(\mathrm{mg} / \mathrm{l})$ of SS remediated by the different masses $(5 \mathrm{~g}, 10 \mathrm{~g}$, $15 \mathrm{~g}, 20 \mathrm{~g}$, and $25 \mathrm{~g}$ ) of the bacteria varies. The SS in the samples fluctuates up and down after the bioremediation process when compared with the SS of the raw samples before the bioremediation. The increase in the levels of the SS might be due to the aggregation of the TDS which are large enough to result into SS. The increase in the levels of the SS might be also due to the influence of the nutrients which was added into the effluents in order to make the microorganisms more active and viable for fast degradation of organic contaminants in the effluent. The relative potential or efficiency of the different masses of the bacteria in remediating SS in TAN1 samples was in the order $25 \mathrm{~g}>20 \mathrm{~g}>15 \mathrm{~g}>10 \mathrm{~g}>5 \mathrm{~g}$. For TAN2 and TAN3 samples, the order was $25 \mathrm{~g}>20 \mathrm{~g}>15$ $\mathrm{g}>10 \mathrm{~g}>5 \mathrm{~g}$. These might be due to the variations in the surface areas of the different masses of the immobilized bacteria. Statistical analysis shows that there is no significant difference $(p<0.05)$ between the mean values of SS among the masses in the respective industries. Positive and significant correlations exist between the masses of bacteria and Suspended Solid (SS). This showed that there is general increase in the levels of the SS as the masses of the immobilized bacteria increases. TAN3 (90\%) and TAN1 (80\%) showed a very high correlation with the masses of the bacteria while TAN2 (61\%) showed a very low correlation.

The mean values $(\mathrm{mg} / \mathrm{l})$ of the TDS after the bioremediation varies between $46 \pm 11$ and $83 \pm 78$. The mean concentration $(\mathrm{mg} / \mathrm{l})$ of TDS remediated by the different masses $(5 \mathrm{~g}, 10 \mathrm{~g}$, $15 \mathrm{~g}, 20 \mathrm{~g}$, and $25 \mathrm{~g}$ ) of the bacteria varies. There is a reduction in all the TDS of all the samples after the bioremediation process compared with the TDS of the raw samples before the bioremediation. The relative potential or efficiency of the different masses of the bacteria in remediating TDS in TAN1 and TAN3 samples was in the order $5 \mathrm{~g}>10 \mathrm{~g}>15 \mathrm{~g}>20$ $\mathrm{g}>25 \mathrm{~g}$. For TAN2 samples, the order was 20 $g>10 \quad g>25 \quad g>15 \quad g>5 \quad g$. Statistical analysis shows that there is no significant difference $(p<0.05)$ between the mean values of TDS among the masses in the respective industries. These might be due to the variations in the surface areas of the different masses of the immobilized bacteria. Positive and significant correlations exist between the masses of bacteria and TDS with the exception in TAN2 (negative and insignificant correlation). The positive correlations showed that there is general increase in the levels of the TDS as the masses of the immobilized bacteria increases. TAN1 $(96 \%)$ showed a very high correlation with the masses of the bacteria while TAN2 (47\%) showed a very low correlation.

The mean values $(\mathrm{mg} / \mathrm{l})$ of the BOD after the bioremediation varies between $1.56 \pm 0.20 \mathrm{mg} / \mathrm{l}$ and $6.92 \pm 5.49 \mathrm{mg} / \mathrm{l}$. The mean concentration $(\mathrm{mg} / \mathrm{l})$ of BOD remediated by the different masses $(5 \mathrm{~g}, 10 \mathrm{~g}, 15 \mathrm{~g}, 20 \mathrm{~g}$, and $25 \mathrm{~g}$ ) of the bacteria varies. There is a reduction in all the BOD of all the samples after the bioremediation process compared with the $\mathrm{BOD}$ of the raw 
BAJOPAS Volume 13 Number 2, December, 2020 samples before the bioremediation. The relative potential or efficiency of the different masses of the bacteria in remediating BOD in TAN1, TAN2 and TAN3 samples were in the order $25 \mathrm{~g}>20$ $\mathrm{g}>15 \mathrm{~g}>10 \mathrm{~g}>5 \mathrm{~g}, 25 \mathrm{~g}>15 \mathrm{~g}>5 \mathrm{~g}>10 \mathrm{~g}>20 \mathrm{~g}$ and $20 \mathrm{~g}>10 \mathrm{~g}>25 \mathrm{~g}>15 \mathrm{~g}>5 \mathrm{~g}$ respectively. Statistical analysis shows that there is significant difference $(p<0.05)$ between the mean values of BOD among the masses in the respective industries. These might be due to the variations in the surface areas of the different masses of the immobilized bacteria. Negative and significant correlations exist between the masses of bacteria and BOD. This showed that there is general decrease in the levels of the BOD as the masses of the immobilized bacteria increases. TAN1 (94\%) showed a very high correlation with the masses of the bacteria while TAN2 (4\%) showed a very low correlation.

The mean values $(\mathrm{mg} / \mathrm{l})$ of the COD after the bioremediation varies between $250 \pm 154$ and $3134 \pm 1595$. The mean concentration $(\mathrm{mg} / \mathrm{l})$ of COD remediated by the different masses $(5 \mathrm{~g}$, $10 \mathrm{~g}, 15 \mathrm{~g} 20 \mathrm{~g}$, and $25 \mathrm{~g}$ ) of the bacteria varies. There is a reduction in all the COD of all the samples after the bioremediation process compared with the COD of the raw samples before the bioremediation. The relative potential or efficiency of the different masses of the bacteria in remediating COD in TAN1, TAN2 and TAN3 samples were in the order $25 \mathrm{~g}>20 \mathrm{~g}>15$ $\mathrm{g}>5 \mathrm{~g}>10 \mathrm{~g}, 25 \mathrm{~g}>20 \mathrm{~g}>15 \mathrm{~g}>10 \mathrm{~g}>5 \mathrm{~g}$ and 10 g>5 g>25 g>15 g>20 g respectively. Statistical analysis shows that there were significant difference $(p<0.05)$ between the mean values of COD among the masses in the respective industries except for effluents treated with $25 \mathrm{~g}$. These might be due to the variations in the surface areas of the different masses of the immobilized bacteria. Negative and insignificant correlations exist between the masses of bacteria and COD with the exception in TAN3 (positive and significant correlation). The negative correlations showed that there is general decrease in the levels of the COD as the masses of the immobilized bacteria increases. TAN2 (100\%) showed a very high correlation with the masses of the bacteria while TAN3 (36\%) showed a very low correlation.

Generally, there was an overall decrease in the concentration of these physicochemical parameters after the bioremediation using the different masses of the bacterial isolates. These might be due to the variations in the surface areas of the different masses of the immobilized bacteria. This is in line with the work of Jimoh et al. (2018) and Baba et al. (2020).

Table 3: Mean Values $(\mathrm{mg} / \mathrm{l}) \pm$ S.D of Physicochemical parameters in effluents from the Tannery Industries before and after Treatment of the effluents $(250 \mathrm{ml})$ with the different masses $(5 \mathrm{~g}, 10 \mathrm{~g}$, $15 \mathrm{~g}, 20 \mathrm{~g}$, and $25 \mathrm{~g}$ ) of the bacteria.

\begin{tabular}{llllllll}
\hline $\mathrm{P}$ & IND & Before & \multicolumn{5}{c}{ After } \\
\cline { 4 - 7 } & & & $5 \mathrm{~g}$ & $10 \mathrm{~g}$ & $15 \mathrm{~g}$ & $20 \mathrm{~g}$ & $25 \mathrm{~g}$ \\
\hline \multirow{2}{*}{ COD } & TAN1 & $2372 \pm 938$ & $1708 \mathrm{a} \pm 861$ & $2045 \mathrm{a} \pm 1205$ & $845 \mathrm{a} \pm 369$ & $300 \mathrm{a} \pm 167$ & $250 \mathrm{a} \pm 154$ \\
& TAN2 & $1406 \pm 208$ & $1195 \mathrm{a} \pm 208$ & $1125 \mathrm{a} \pm 384$ & $1055 \mathrm{a} \pm 317$ & $956 \mathrm{a} \pm 310$ & $870 \mathrm{ab} \pm 240$ \\
& TAN3 & $3532 \pm 1373$ & $2374 \mathrm{a} \pm 1344$ & $1976 \mathrm{a} \pm 1405$ & $2757 \mathrm{a} \pm 1266$ & $3134 \mathrm{a} \pm 1595$ & $2614 \mathrm{~b} \pm 1105$ \\
BOD & TAN1 & $13.85 \pm 6.42$ & $6.92 \mathrm{a} \pm 5.49$ & $6.42 \mathrm{a} \pm 5.07$ & $5.72 \mathrm{a} \pm 5.35$ & $4.62 \mathrm{a} \pm 4.37$ & $2.82 \mathrm{ab} \pm 1.26$ \\
& TAN2 & $19.46 \pm 0.50$ & $1.75 \mathrm{~b} \pm 0.22$ & $1.73 \mathrm{~b} \pm 0.18$ & $1.58 \mathrm{a} \pm 0.16$ & $1.91 \mathrm{a} \pm 0.22$ & $1.56 \mathrm{~b} \pm 0.20$ \\
& TAN3 & $17.13 \pm 3.14$ & $4.24 \mathrm{ab} \pm 0.77$ & $3.29 \mathrm{ab} \pm 0.37$ & $4.11 \mathrm{a} \pm 0.07$ & $3.23 \mathrm{a} \pm 0.91$ & $3.33 \mathrm{a} \pm 1.28$ \\
SS & TAN1 & $374 \pm 124$ & $243 \mathrm{a} \pm 45$ & $471 \mathrm{a} \pm 226$ & $475 \mathrm{a} \pm 182$ & $492 \mathrm{a} \pm 128$ & $611 \mathrm{a} \pm 217$ \\
& TAN2 & $358 \pm 335$ & $460 \mathrm{a} \pm 400$ & $543 \mathrm{a} \pm 414$ & $544 \mathrm{a} \pm 402$ & $551 \mathrm{a} \pm 414$ & $554 \mathrm{a} \pm 405$ \\
& TAN3 & $780 \pm 739$ & $586 \mathrm{a} \pm 594$ & $758 \mathrm{a} \pm 656$ & $787 \mathrm{a} \pm 676$ & $861 \mathrm{a} \pm 635$ & $898 \mathrm{a} \pm 672$ \\
TDS & TAN1 & $3941 \pm 3703$ & $51 \mathrm{a} \pm 10$ & $53 \mathrm{a} \pm 10$ & $55 \mathrm{a} \pm 15$ & $61 \mathrm{a} \pm 20$ & $63 \mathrm{a} \pm 26$ \\
& TAN2 & $3300 \pm 1714$ & $83 \mathrm{a} \pm 78$ & $47 \mathrm{a} \pm 20$ & $48 \mathrm{a} \pm 22$ & $47 \mathrm{a} \pm 17$ & $48 \mathrm{a} \pm 17$ \\
& TAN3 & $2653 \pm 1240$ & $46 \mathrm{a} \pm 11$ & $55 \mathrm{a} \pm 24$ & $55 \mathrm{a} \pm 25$ & $58 \mathrm{a} \pm 23$ & $61 \mathrm{a} \pm 28$ \\
\hline
\end{tabular}

Replicate $=6$ (months)

Within the rows, for the same parameter, means with different alphabets are statistically different $(p<0.05)$.

$\mathrm{P}=$ parameter, IND = Industries 
BAJOPAS Volume 13 Number 2, December, 2020

Table 4: Correlation coefficient $(r)$ between different masses of the bacteria and the physicochemical parameters.

\begin{tabular}{llll}
\hline Industries & Parameter & Correlation coefficient $(r)$ & $\begin{array}{l}\text { Percent dependence (rxrx100) } \\
(\%)\end{array}$ \\
\hline TAN1 & COD & -0.9 & 82 \\
& BOD & -0.97 & 94 \\
& SS & $0.90^{*}$ & 80 \\
TAN2 & TDS & $0.98^{*}$ & 96 \\
& COD & -1 & 100 \\
& BOD & -0.21 & 4 \\
& SS & $0.78^{*}$ & 61 \\
& TDS & -0.69 & 47 \\
& COD & $0.60^{*}$ & 36 \\
& BOD & -0.6 & 37 \\
& SS & $0.95^{*}$ & 90 \\
& TDS & $0.94^{*}$ & 89 \\
\hline
\end{tabular}

The correlation coefficient $(r)$ with * is statistically significant $(p<0.05)$.

Percentage reduction of the Parameters

Table 5 shows the percentage reduction of Parameters in industrial samples before and after the treatment of the effluents $(250 \mathrm{ml})$ with the different masses $(5 \mathrm{~g}, 10 \mathrm{~g}, 15 \mathrm{~g}, 20 \mathrm{~g}$, and $25 \mathrm{~g}$ ) of the Immobilized Bacteria.

In TAN1 samples, the percentage reduction (\%) of COD ranged (14-89); BOD (50-80); SS (-32$35)$ and TDS (98-99). In TAN2 samples, the percentage decrease $(\%)$ of COD ranged (15$38) ;$ BOD (90-92); SS [-28-(-55)] and TDS (9798). In TAN3 samples, the percentage decrease (\%) of COD ranged (11-44); BOD (76-81); SS (15-25) and TDS (98). The percentage increase in the levels COD, BOD and TDS might be due to the increase in the surface area of the different masses of the immobilized bacteria. However, the percentage decrease in the levels of the SS might be due to the aggregation of the TDS which are large enough to result into SS. The percentage decrease in the levels of the SS might be also due to the influence of the nutrients which was added into the effluents in order to make the microorganisms more active and viable for fast degradation of organic contaminants in the effluent. This is in line with the work of Jimoh et al. (2018) in which the concentration of the SS increase after the bioremediation of effluents.

Sreemoyee and Priti (2013) assessed and reduced several Physico-chemical parameters of dairy wastewater using Niesseria $s p$. and concluded that the species are well known to degrade organic compounds. This is in agreement with the current study in which the immobilized Niesseria $s p$ degrade the organic contaminants as indicated by the BOD, COD and TDS.

Jimoh et al. (2018) observed that TSS of the effluents was increased after treatment with immobilized bacteria and concluded that it might be due to the biostimulation method adopted for the research.

The optimum $\mathrm{pH}$ Biosorption of Chromium by Bacillus spp and Staphylococcus spp. from tannery effluent was investigated by Mythili and Karthikeyan (2011). The maximum adsorption of Chromium $(86.4 \mathrm{mg} / \mathrm{L})$ was showed by Bacillus spp and Staphylococcus spp showed $70.6 \mathrm{mg} / \mathrm{L}$ at an initial concentration of $100 \mathrm{mg} / \mathrm{L}$. In the present study, immobilised Bacillus spp and Staphylococcus spp. from the tannery industrial effluents reduced the levels of the organic pollutants with high potential as indicated by the percentage reduction of BOD, COD and TDS.

Enzymes often can work in multiple environments especially if they are immobilized. This makes the microorganisms' enzymes even more resistant to harsh environments and enables the enzymes to be recovered and recycled after they are no longer needed (Gianfreda and Rao 2004). Ramesh and Singh (1993) reported that the immobilized bacteria having more efficiency to remove the suspended particles than free cells. Using the immobilized cell is preferable due to its capability for using several times with the same efficiency, which makes it more economical. Similar work was done by Sikander et al. (2007) showing the higher reduction with permeabilized cells of Ochrobactrum intermedium strain SDCr-5. 
BAJOPAS Volume 13 Number 2, December, 2020

The results revealed the isolation and identification of isolates with the potential for the reduction of $\mathrm{Cr}$ (VI) to $\mathrm{Cr}$ (III). Results indicated that immobilized $B$. cereus could be efficiently used for the reduction of $\mathrm{Cr}$ (VI).

Table 5: Percentage reduction of the tested Parameters from the tannery industrial samples of the Immobilized Bacteria.

\begin{tabular}{lllllll}
\hline \multirow{2}{*}{ Industries } & & \multicolumn{5}{c}{ Percentage Reduction $(\%)$} \\
\cline { 3 - 7 } & & $5 \mathrm{~g}$ & $10 \mathrm{~g}$ & $15 \mathrm{~g}$ & $20 \mathrm{~g}$ & $25 \mathrm{~g}$ \\
\hline TAN1 & COD & 28 & 14 & 64 & 87 & 89 \\
& BOD & 50 & 54 & 59 & 67 & 80 \\
& SS & 35 & -26 & -27 & -32 & -63 \\
& TDS & 99 & 99 & 99 & 98 & 98 \\
TAN2 & COD & 15 & 20 & 25 & 32 & 38 \\
& BOD & 91 & 91 & 92 & 90 & 92 \\
& SS & -28 & -52 & -52 & -54 & -55 \\
& TDS & 97 & 99 & 99 & 99 & 99 \\
& COD & 33 & 44 & 22 & 11 & 26 \\
& BOD & 75 & 81 & 76 & 81 & 81 \\
& SS & 25 & 3 & -1 & -10 & -15 \\
& TDS & 98 & 98 & 98 & 98 & 98 \\
\hline
\end{tabular}

Percentage Reduction $=(B-A) / B \times 100 \%$

$A=$ Concentration of the parameter after treatment

$\mathrm{B}=$ Concentration of the parameter before treatment

$+=$ percentage decrease

- = percentage increase

In general, immobilization makes the enzyme more resistant to temperature, $\mathrm{pH}$, and substrate concentration swings giving it a longer lifetime and higher productivity per active unit (Gianfreda and Rao, 2004; FuIlbrook, 1996; Russell et al, 2003; Kandelbauer et al., 2004). Immobilized cells have been used and studied extensively for the production of useful chemicals (Ohtake and Silver, 1994), the treatment of wastewaters (Chen et al., 2003; Wang et al., 2010). Although many workers described microbial degradation of tannery effluent, limited literature is available on the bioremediation of tannery effluent using immobilized bacterial cells in the Kano Industrial Estates.

\section{CONCLUSION}

The samples contained variable levels of the physicochemical parameters. The results of the Analysis of variance revealed that, no statistical difference $(p<0.05)$ was observed for the temperature, $\mathrm{pH}, \mathrm{SS}, \mathrm{TDS}, \mathrm{BOD}$ and $\mathrm{COD}$ among the three tannery industries before the treatment. The levels of some of the parameters
(SS, TDS and COD) observed in the samples were found above the recommended limits of WHO and NESREA, which called for the treatment of the effluents before discharge into the environment. Base on the morphological and biochemical test results, TAN1, TAN2, and TAN3 bacterial isolates were identified to be Neisseria spp, Bacillus cereus, and Staphylococcus aureus respectively. The results of Post-treatment analysis showed that there is overall decrease in the levels of the parameters determined when compared with that of the pre-treatment. The overall percentage reduction of the immobilised bacteria in the treatment of the respective effluents was in the order TAN2 (72\%)>TAN1 $(70 \%)>$ TAN3 $(62 \%)$. Hence, the immobilized bacteria are having higher biodegradation potential for the treatment of the tannery effluents.

\section{Acknowledgments}

The authors wish to acknowledge the University of Maiduguri for the financial support. The authors are grateful to the Kano State Ministry of Environment for their support in obtaining the effluent samples. 


\section{REFERENCES}

Ajao, A. T., Adebayo, G. B., and Yakubu, S. E. (2011). Bioremediation of textile industrial effluent using mixed culture of Pseudomonas aeruginosa and Bacillus subtilis immobilized on agar-agar in a bioreactor. J. Microbiol. Biotech. Res, 1(3), 50-56.

Akan, J. C., Moses, E. A., Ogugbuaja, V. O., and Abah, J. (2007). Assessment of tannery industrial effluents from Kano metropolis, Kano State, Nigeria. Journal of Applied Sciences, 7(19), 2788-2793.

Akan, J. C., Ogugbuaja, V. O., Abdulrahman, F. I., and Ayodele, J. T. (2009). Pollutant levels in effluent samples from tanneries and textiles of Kano industrial areas, Nigeria. Global journal of pure and applied sciences, 15(3-4).

APHA (1989). Standard methods for Examination of Will bete and Will betewater.15 $5^{\text {th }}$ edition. Brydpass Springfield Will behington DC. pp. 164-176

APHA (1992). Standard Methods for the Examination of Water and Wastewater. Health, 69, 1116-9.

Baba, A., Garba, S. T., and Bello, H. S. (2020). Bioremediation Potential of Immobilized corynebacterium kutsceri in the Treatment of Tannery Industrial Effluent from Challawa Industrial Estate, Kano State, Nigeria. Journal of the Turkish Chemical Society Section A: Chemistry, $7(2), 335-350$.

Beem, E. I. V. (1994). reduction of solvent VOC emission. J. Oil Col. Chem. Ass, 77, 158.

Bouwer, E. J., and Zehnder, A. J. (1993). Bioremediation of organic compoundsputting microbial metabolism to work. Trends in biotechnology, 11(8), 360367.

Chen, K. C., Wu, J. Y., Liou, D. J., and Hwang, S. C. J. (2003). Decolorization of the textile dyes by newly isolated bacterial strains. Journal of Biotechnology, 101(1), 57-68.

Dan'Azumi, S., and Bichi, M. H. (2010). INDUSTRIAL POLLUTION AND HEAVY METALS PROFILE OF CHALLAWA RIVER IN KANO, NIGERIA. Journal of Applied Sciences in Environmental Sanitation, $5(1)$.

DWAF. (1992). Analytical Methods Manual, TR 151. Department of Water Affairs and Forestry, Pretoria.

El-Bestawy, E. (2013). Biological treatment of leather-tanning industrial wastewater using free living bacteria.
Elsheikh, M. A. S. (2009). Tannery wastewater pre-treatment. Water Science and Technology, 60(2), 433-440.

FuIlbrook, P. D. (1996). "Kinetics." Industrial enzymology: The application of enzymes in Industry. 2nd Ed. T. Godfrey and J Reichelt. eds.. Nature. New York.

Gianfreda, L., and Rao, M. A. (2004). Potential of extra cellular enzymes in remediation of polluted soils: a review. Enzyme and microbial technology, 35(4), 339354.

Hugo Springer. (1994). John Arthur Wilson Memorial Lecture "Treatment of Industrial Wastes of the Leather Industry - is it still a Major Problem". JALCA, 89, 153-185

Jimoh, A. A., Ganiyu, B. A., Baba, D., and Baba, A. (2018) Bioremediation Process of Effluent from Detergent and Food Industries in Jos, Nigeria: Kinetics and Thermodynamics. International Journal of Engineering Science Invention (IJESI), 762-73

Kandelbauer, A., Maute, O., Kessler, R. W., Erlacher, A., and Gübitz, G. M. (2004). Study of dye decolorization in an immobilized laccase enzyme-reactor using online spectroscopy. Biotechnology and bioengineering, 87(4), 552-563.

Kongjao, S., Damronglerd, S., and Hunsom, M. (2008). Simultaneous removal of organic and inorganic Pollutants in tannery wastewater using electrocoagulation technique. Korean Journal of chemical engineering, 25(4), 703.

Maheshwari, U. M., Aruna, S., Gomathi, M., and AbdulJaffar, A. H. (2017). Bioremediation by Free and Immobilized Bacteria Isolated from Tannery Effluent. International Journal of Research in Applied, Natural and Social Sciences. 5(7), 75-90

Margesin, R., and Schinner, F. (2001). Bioremediation (natural attenuation and biostimulation) of diesel-oilcontaminated soil in an alpine glacier skiing area. Applied and environmental microbiology, 677), 3127-3133.

Mohammed, A., Sekar, P., and George, J. (2011). Efficacy of microbes in bioremediation of tannery effluent. Inter. J. Curr. Res, 3(4), 324-326.

Mohammed, S. S. D., Orukotan, A. A., and Abdullahi, H. (2017). Physicochemical and Bacteriological Assessment of Tannery Effluent from Samaru-Zaria, 
BAJOPAS Volume 13 Number 2, December, 2020 Kaduna State, Nigeria. Journal of Applied

Sciences and Environmental Management, 21(4), 734-740.

Munz, G., De Angelis, D., Gori, R., Mori, G., Casarci, M., and Lubello, C. (2009). The role of tannins in conventional and membrane treatment of tannery wastewater. Journal of hazardous materials, 164(2-3), 733-739

Mythili, K., and Karthikeyan, B. (2011). Bioremediation of $\mathrm{Cr}$ (VI) from tannery effluent using Bacillus spp and Staphylococcus spp. International Multidisciplinary Research Journal, 1(6).

NESREA (2009). National Environmental Standards for Effluent Limitations and Regulation. 1233-1236

Noorjahan, C. M. (2014). Physicochemical characteristics, identification of bacteria and biodegradation of industrial effluent. Journal of bioremediation and Biodegradation, 5(3).

Ohtake, H. I., and Silver, A. O. (1994). Bacterial reduction of toxic chromate. Biological degradation and bioremediation of toxic chemicals, 403-415.

Omoleke, I. I. (2004). Management of environmental pollution in Ibadan, an African city: the challenges of health hazard facing government and the people. Journal of Human Ecology, 15(4), 265-275.

Rajor, A., Reddy, A.S., and Singh, B. (2004). Determination of BOD kinetic Parameters and evaluation of alternate methods, M.Sc. Thesis, Department of biotechnology \& environmental Science, Thapar Institute of Engineering and Technology, Patiala

Ramasami, T., Rajamani, S., and Rao, J. R. (1994, March). Pollution control in leather industry: Emerging technological options. In International symposium on surface and colloidal science and its relevance to soil pollution, madras.

Ramesh, J. V. S., and Singh, S. P. (1993). Yearly variation in certain physicochemical parameters of pond at eastern Doon Valley. Uttar Pradesh J. Zoo, 12 (1), 7577.

Ranen, S., and Sharadinadra, C. (2009). Biotechnology applications to environmental remediation in resource exploitation. Current science, 97, 6-25
Russell, A. J., Berberich, J. A., Drevon, G. F., and Koepsel, R. R. (2003). Biomaterials for mediation of

chemical and biological warfare agents. Annual review of biomedical engineering, 5(1), 1-27.

Saravanan, P., and Saravanan, A. (1999). Decolourization of tannery effluent by Flavobacterium sp. EK 1. Indian Journal of Environmental Protection, 19, 19-24.

Sikander, S., and Shahida, H. (2007). Reduction of toxic hexavalent chromium by Ochrobactrum intermedium strain SDCr5 stimulated by heavy metals. Bioresource Technol, 98, 340-344.

Singh, N., Sharma, B. K., and Bohra, P. C. (2000). Impact assessment of industrial effluent of arid soils by using satellite imageries. Journal of the Indian Society of Remote Sensing, 28(2-3), 79.

Sreemoyee, C., and Priti, P. (2013). Assessment of physico-chemical parameters of dairy waste water and isolation and characterization of bacterial strains in terms of cod reduction. Int J Sci, 2(3), 395-400.

Verheijen, L. A. H. M., Wiersema, D., Pol, L. H., and De Wit, J. (1996). Management of wastes from animal product processing. Livestock and environment, Finding a balance. International Agriculture Center, Wageningen, The Netherlands.

Wang, F., Yao, J., Si, Y., Chen, H., Russel, M., Chen, K., and Bramanti, E. (2010). Short-time effect of heavy metals upon microbial community activity. Journal of Hazardous Materials, 173(13), 510-516.

WHO (World Health Organization). (2006). Air quality guidelines: global update 2005: particulate matter, ozone, nitrogen dioxide, and sulfur dioxide. World Health Organization.

World Bank. (1995). Nigeria's strategic options for redressing industrial pollution. World Bank, industry and energy division. 1st edition, West Central Africa Department; Annexes: 1995; pp 60-62.

Zahoor, A., and Abdul, R. (2009). Enumeration of Coliforms. Journal of Environmental Sciences. 21, 814-820 


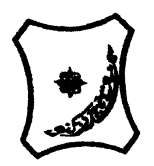

Bayero Journal of Pure and Applied Sciences, 13(2): 1 - 12

Received: November, 2020

Accepted: December, 2020

ISSN $2006-6996$

\title{
BIODEGRADATION POTENTIAL OF IMMOBILIZED BACTERIA IN THE TREATMENT OF TANNERY INDUSTRIAL EFFLUENTS FROM INDUSTRIAL ESTATES IN KANO STATE, NIGERIA
}

\author{
Abdullateef, B., ${ }^{1 *}$ Shuaibu, T. G., ${ }^{1}$ Babagana, K., ${ }^{1}$ Suleman, H. B. ${ }^{2}$ and Dauda, B. ${ }^{3}$ \\ ${ }^{1}$ Department of Pure and Applied Chemistry, Faculty of Science, University of Maiduguri, Borno State, \\ Nigeria \\ ${ }^{2}$ Department of Microbiology, Faculty of Science, University of Maiduguri, Borno State, Nigeria \\ ${ }^{3}$ Department of Chemical Engineering, Faculty of Engineering, University of Maiduguri, Borno State, \\ Nigeria \\ *Corresponding author: babslega@gmail.com; abelega2007@yahoo.com; +2348061309753
}

\section{ABSTRACT}

Industrial Effluents Samples from Gashash Tanneries (TAN1) in Bompai Industrial estate, Larabee Tannery Industry (TAN2) in Sharada Industrial estate and Z Tannery Industries (TAN3) in Challawa Industrial estate, Kano State, Nigeria were collected over a period of six months (August 2017 to January 2018) for assessing the biodegradation potentials of bacteria in the treatment of organic pollutants within the effluents. Bacteria were isolated from the effluents and immobilized on agar-agar. Different masses (5 g, $10 \mathrm{gr}, 15$ $\mathrm{g}, 20 \mathrm{~g}$, and $25 \mathrm{~g}$ ) of the bacteria were used in the treatment of $250 \mathrm{ml}$ of the effluents for ten days in a shaker incubator (Gallenkamp-OC-4364-L) at the temperature $30{ }^{\circ} \mathrm{C}$ and speed of $60 \mathrm{rpm}$. Pre-treatment analysis of the effluents for Temperature, pH, Biochemical Oxygen Demand (BOD), Chemical Oxygen Demand (COD), Suspended Solid (SS) and Total Dissolved Solids (TDS) gives the following results; temperature $\left({ }^{\circ} \mathrm{C}\right.$ )

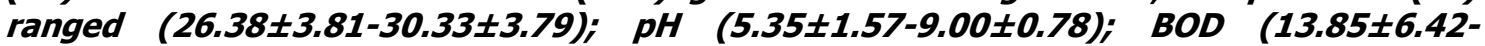
$38.75 \pm 16.20) ;$ COD (1406 $\pm 208-3532 \pm 1373) ;$ SS (208 $\pm 235-780 \pm 739)$ and TDS (266 $\pm 253-5276 \pm 2971)$. No statistical differences ( $p \leq 0.05)$ was observed for all the results among the different industries. The bacterial isolates were identified as Neisseria spp, Bacillus cereus, and Staphylococcus aureus, in TAN1, TAN2, and TAN3, respectively. After treatment of the effluent with the different masses of the isolated bacteria, the mean level of BOD was found to range as (0.55 $\pm 0.36-6.92 \pm 5.49) ; C O D$ (ND-3134 \pm 1595$)$;

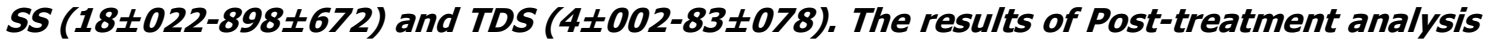
showed that there is overall decrease in the levels of the parameters determined when compared with that of the pre-treatment. The overall percentage reduction of the immobilised bacteria in the treatment of the respective effluents was in the order TAN2 (72\%)>TAN1 (70\%)>TAN3 (62\%). Hence, the immobilized bacteria are having higher biodegradation potential for the treatment of the tannery effluents.

Keywords: Biodegradation, bacteria, effluent, immobilization, tannery.

\section{INTRODUCTION}

Tannery industrial wastewater is a serious consequence of the pollution point of view for streams, freshwater, and land used for agriculture. The lack of awareness in the modern industrial practice has resulted in the discharge of tannery effluents which exhibit very high value of chromium ( $\mathrm{Cr}$ ), Sulfide, and chloride, Total Dissolved Solid (TDS), Total Suspended Solid (TSS), Biochemical Oxygen Demand (BOD) and Chemical Oxygen Demand (COD) in the water stream or land (Mohammed et al., 2001). Tanning is the process, which One ton of skin generally leads to the production of 20 to $80 \mathrm{~m}^{3}$ of turbid and foul-smelling converts the protein of the rawhide or skin into a stable material, which will not putrefy and is suitable for a wide variety of end applications (Elsheikh, 2009). The highly polluting chromium is the most commonly used tanning material producing leather that is more flexible and pliable than vegetable-tanned leather and does not discolor or lose shape in water as drastically as vegetable-tan (Elsheikh, 2009). Tannery effluent is among the most hazardous industrial pollutants due to its huge organic and inorganic load, which is highly toxic to human life and the environment (Kongjao et al., 2008). wastewater including chromium (100-400 mg/l), sulfide $(200-800 \mathrm{mg} / \mathrm{l})$, high levels of fat and 
BAJOPAS Volume 13 Number 2, December, 2020 other solid wastes, and notable pathogen contamination as well as pesticides added for skin conservation during transport (Elsheikh, 2009). There are more than 6000 tanneries in Nigeria with an annual processing capacity of 700,000 tons of hides and skins (Omoleke, 2004; Singh et al., 2008). It was reported that the total amount of waste produced per animal slaughtered is approximately $35 \%$ of its weight (World Bank, 1995). Also, for every $1000 \mathrm{~kg}$ of carcass weight, a slaughtered beef produces 5.5 $\mathrm{kg}$ of manure (excluding rumen contents or stockyard manure) and $100 \mathrm{~kg}$ of paunch manure (undigested food) (Verheijen et al., 1996). Tanneries generate wastewater in the range of 30-35 $\mathrm{L} \mathrm{kg}^{-1}$ skin/hide processed with variable $\mathrm{pH}$, Biological Oxygen Demand (BOD), Chemical Oxygen Demand (COD), high concentrations of suspended solids (SS), and tannins as well as chromium (Zahoor and Abdul, 2009).

Being heterogeneous and composed of a wide variety of compounds, it is very difficult to select a unique direct method for estimating the biodegradability of organic contents and biokinetic parameters for a wastewater sample (Rajor, 2004). For this purpose, some indirect estimation such as determination of biochemical oxygen demand (BOD) and chemical oxygen demand (COD) are applied as common laboratory investigations [9]. During retanning procedures, synthetic tannins (Syntan), oils and resins are added to form softer leather at varying doses (Munz et al., 2009). One of the refractory groups of chemicals in tannery effluents derives mainly from tannins (Ramasami et al., 2004). Syntans are characterized by complex chemical structures, because they are composed of an extended set of chemicals such as phenol-, naphthalene-, formaldehyde- and melamine-based syntans, and acrylic resins (Beem, 1994). Organic pollutants (proteic and lipidic components) are originated from skins (it is calculated that the raw skin has $30 \%$ loss of organic material during the working cycle) or they are introduced during processes (Hugo Springer, 1994).

Many conventional processes such as oxidation, chemical and biological processes were carried out to treat tanneries wastewater (Ebtesam et al, 2013). Biological processes have received more attention because of their costeffectiveness, lower sludge production and environmental friendliness (Noorjahan, 2014). Naturally occurring micro-organisms degrade the hazardous organic wastes including xenobiotic compounds, such as pesticides, polycyclic aromatic hydrocarbons (PAHs) and polychlorinated biphenyls (PCBs) in due course of time (Ranen and Sharadinadra, 2009). Bioremediation is based on the idea that all organisms remove substances from the environment to carry outgrowth and metabolism (Bouwer and Zehnder, 1993). Bacteria, protista and fungi are found to be very good at degrading complex molecules and incorporating the breakdown products into their metabolism (Bouwer and Zehnder, 1993). The resultant metabolic wastes that they produce are generally safe and somehow recycled into other organisms (Ranen and Sharadinadra, 2009). An acclimatized indigenous population of microorganisms capable of degradation of the compounds of interest must exist at the site for a successful bioremediation mode (Ranen and Sharadinadra, 2009). It has been observed that for a successful bioremediation mode, an acclimatized indigenous population of microorganisms capable of degradation of the compounds of interest must exist at the site under investigation (Ranen and Sharadinadra, 2009). Even though there are numerous physical and chemical methods employed in the disposal of wastes the advantage in using bacterium is that they play a key role in the reduction of COD, BOD, total protein, total tannin and total phenol (Saravanan and Saravanan, 1998)

Baba et al. (2020) studied the bioremediation potential of immobilized corynebacterium kutsceri in the Treatment of tannery industrial effluent from Challawa Industrial Estate, Kano State, Nigeria. The aim of the work is to study the reduction in the level of the contaminants through the process of bioremediation using the isolated bacteria. Immobilized bacteria can withstand various temperatures, $\mathrm{pH}$ and substrate concentrations; consequently, increasing the efficiency and the lifespan of the bacteria. Immobilized bacteria are widely applied in the treatment of wastewater and can be separated and recovered after the treatment with the same efficiency (Baba et al., 2020).

\section{MATERIALS AND METHODS \\ Study Area}

This study was carried out in Bompai, Sharada and Challawa industrial estates in Kano, Figure 1. Kano lies on Latitude $11^{\circ} 30^{\prime} \mathrm{N}$ and $8^{\circ} 30^{\prime} \mathrm{E}$ and Longitude $11^{\circ} 5^{\prime} \mathrm{N}$ and $8^{\circ} 5^{\prime} \mathrm{E}$ in Northern Nigeria. It is one of the developed industrial cities in Nigeria. Tannery activities are the dominating industries and this could be one of the reasons for her high population density (Dan'Azumi and Bichi, 2010). Many researchers have studied biodegradation of tannery effluent using microorganisms. However, limited literature is available on the biodegradation of tannery effluent in Kano industrial estates using 
BAJOPAS Volume 13 Number 2, December, 2020 immobilized bacterial cells. This research work focuses on the potential of the use of the indigenous immobilized bacterial isolates in the treatment of tannery effluents in the industrial estates.

\section{Sample Collection}

Effluents were collected from the Tannery Industries from Bompai, Challawa and Sharada Industrial Estates, Kano, Nigeria. The effluents were collected over a period of six months (August 2017 to January 2018). Samples collected in a sterile 4-liter plastic container with a unique identification number were preserved using an ice-box that was transported to the Microbiology Laboratory, Department of Microbiology, Bayero University of Kano for analysis

\section{Sample Preparation and Sample Analysis}

Immediately after the collection of the effluent, $\mathrm{pH}$, TSS, TDS, COD, BOD levels were determined before treatment (Pre-treatment determination) and ten days after treatment (Post-treatment determination) as described in
APHA (1989) standard methods. $\mathrm{pH}$ was determined using Ecotests $\mathrm{pH}$ meter and TDS was determined using AQUALYTIC TDS Salinometer. BOD was determined as described by the standard method (APHA, 1992). COD and SS were determined using DR/2010 HACH portable data logging spectrophotometer (DWAF, 1992)

\section{Identification and Biochemical} Characterization of the Bacterial Isolates

The bacteria were isolated from the effluents using Serial Dilution according to the method described by APHA (1989). The biochemical tests such as oxidase, catalase, coagulase, indole (from $1 \%$ tryptone broth), citrate (Simmons citrate agar), methyl red/VogesProskauer (MR/VP), nitrate reduction, Starch Hydrolysis, Glucose, Maltose, and Lactose tests were carried out on the bacterial isolates to identify the bacteria through the bacteria biochemical characteristics according to Ajao et al. (2011).

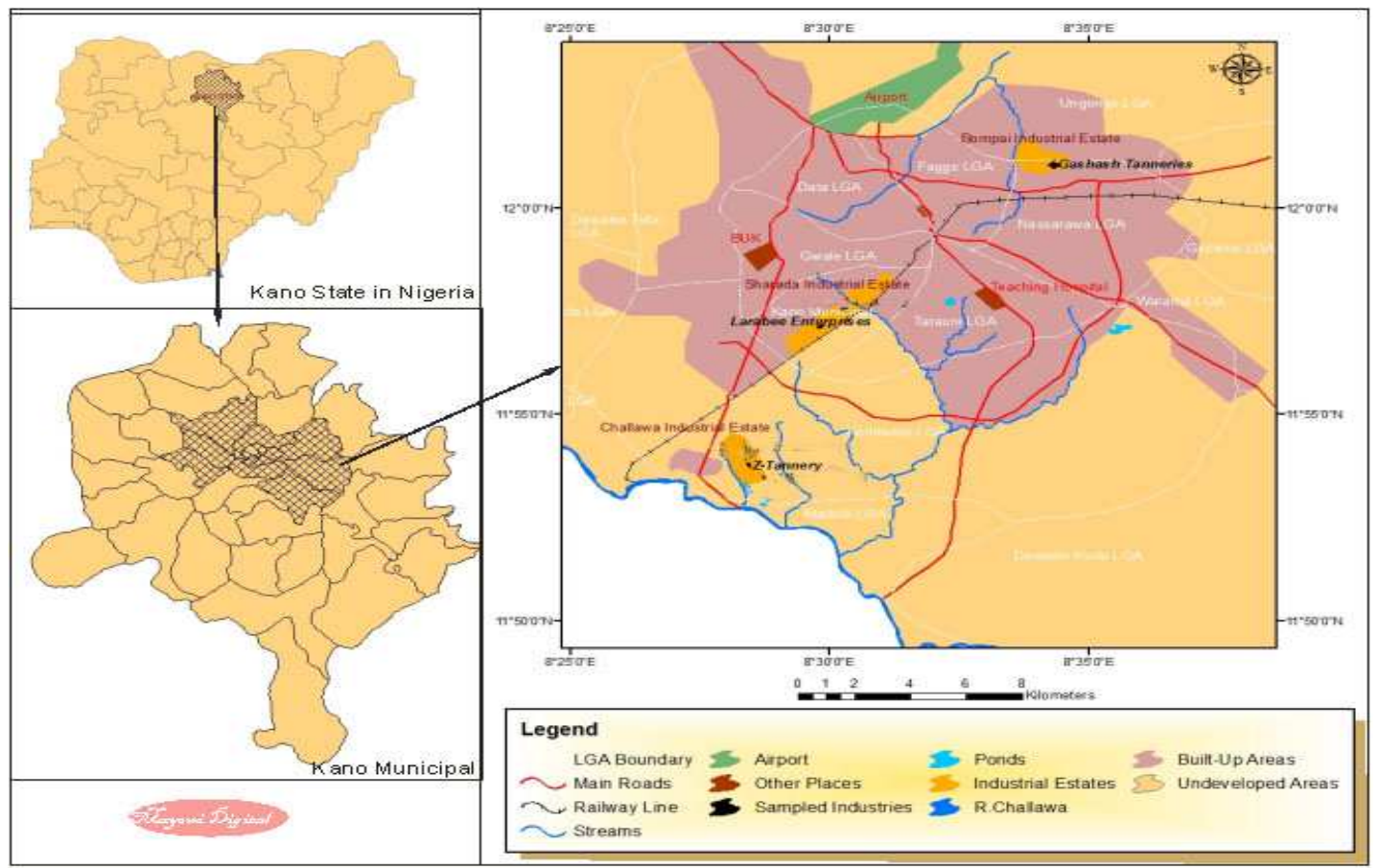

Fig. 1 Map showing the study areas

Source: Mayomi Digital Productions, GIS Laboratory, Department of Geography, UNIMAID (2017)

\section{Determination of Growth Rate of the Bacteria in Effluent Sample}

The bacteria growth rates were determined by transferring $2 \mathrm{~mL}$ of the bacterial isolates from the tannery effluent in broth medium into 100 $\mathrm{mL}$ sterile effluents in conical flasks and kept in an incubator (Giffrin cool) for 10 days. Control was also set up by incubating another $100 \mathrm{~mL}$ each of the sterile effluents without the bacteria. The optical density of the content was determined at the wavelength of $600 \mathrm{~nm}$ on a daily interval and recorded. 
BAJOPAS Volume 13 Number 2, December, 2020 Immobilization of Bacteria

Agar solution and inoculi were prepared separately. Fifty milliliters $(50 \mathrm{~mL})$ of nutrient broth each of the inoculi was prepared in a McCartney bottle and incubated for 24 hours. A solution of agar-agar was prepared by dissolving $10 \mathrm{~g}$ of the powder in distilled water and made up to $500 \mathrm{~mL}$ mark in an Erlenmeyer flask and was sterilized in an autoclave (280A) for 15 minutes and allowed to cool to $40-45^{\circ} \mathrm{C}$ (Ajao et al., 2011). Four milliliters ( $4 \mathrm{~mL})$ of the bacterial isolates in the nutrient broth was mixed with 36 $\mathrm{ml}$ of the prepared agar-agar media in petri-dish plates and then allowed to solidify. This was kept in the refrigerator for bioremediation.

\section{Bioremediation (Treatment) of the Effluents}

The solidified agar block (immobilized bacteria) was cut into cubes using a sterile knife; $0.1 \mathrm{~mL}$ phosphate buffer ( $\mathrm{pH} \mathrm{7.0)}$ was added and kept in the refrigerator for 1 hour for curing. The phosphate buffer was decanted after 1 hour and the cubes were washed with sterile distilled water 3-4 times before it was used (Ajao et al., 2011). Two liters (2 L) of the effluent was supplemented with the minimum basal medium in $\mathrm{g} / \mathrm{L}: \mathrm{NaCl}(0.8), \mathrm{MgSO}_{4} .7 \mathrm{H}_{2} \mathrm{O}(0.001), \mathrm{KH}_{2} \mathrm{PO}_{4}$ (2), $\mathrm{NaNO}_{3}$ (2), $\quad \mathrm{CaCl}_{2} .2 \mathrm{H}_{2} \mathrm{O} \quad(0.5)$ and $\mathrm{NaHPO}_{4} .12 \mathrm{H}_{2} \mathrm{O}(2)$ and sterilized in an autoclave at $121^{\circ} \mathrm{C}$ for 15 minutes (Margesin and Schinner, 2001). Two hundred and fifty milliliters $(250 \mathrm{~mL})$ of the effluents were transferred into different $250 \mathrm{ml}$ conical flasks. The content was covered with a cotton-wool ramped with foil paper to avoid contamination. Five grams $(5 \mathrm{~g})$ of the immobilized bacteria were quickly transferred into each of the effluents in the conical flasks in an inoculating chamber. The same procedures were carried out for the $10 \mathrm{~g}, 15 \mathrm{~g}, 20 \mathrm{~g}$ and 25 $\mathrm{g}$ of the immobilized bacteria in separate $250 \mathrm{~mL}$ effluents in conical flasks and agitated for ten days in a shaker incubator (Gallenkamp-OC4364-L) at a temperature $30^{\circ} \mathrm{C}$ and speed of 60 rpm. The treated effluent samples were taken on the tenth day and analyzed for the parameters $\mathrm{pH}$, SS, TDS, COD, and BOD, (Posttreatment determination) for the different grams of bacteria to evaluate and compare the biodegradation potential. (Baba et al., 2020).

\section{Statistical Analysis}

The data were represented as Mean \pm Standard deviation and analyzed statistically using oneway Analysis of Variance (ANOVA) and Tukey's HSD as Post Hoc Tests with the aid of SPSS 16.0. The correlation coefficient was also used to measure the strength of the relationship between the different masses of the bacteria and the parameters. All $\mathrm{p} \leq 0.05$ were considered as statistically significant.

\section{RESULTS AND DISCUSSION Physico-chemical parameters in the Industrial Effluents before the Biodegradation.}

Results of the Physico-chemical parameters in the industrial effluents before the Biodegradation is shown in table 1 . The mean temperatures $\left({ }^{\circ} \mathrm{C}\right)$ observed in TAN1, TAN2, and TAN3 samples were $28.07 \pm 0.65 ; 27.77 \pm 0.64$ and $26.38 \pm 3.81$ respectively. The order of the mean temperature of the samples from the three industries can be arranged as TAN1 > TAN2>TAN3. The temperature observed at TAN1, TAN2, and TAN3 samples were found below the WHO $\left(35^{\circ} \mathrm{C}\right)$ and NESREA $\left(40^{\circ} \mathrm{C}\right)$ limits. The low values of temperature might be due to the processes used at the time of sampling. High temperature brings down the solubility of gases in water that ultimately expresses as high BOD and COD. Statistical analysis shows that there is no significant difference $(p<0.05)$ between the mean values of temperature among the industries. This might be due to similar tannery activities involved in the tannery industries at the time of sampling. The average values of temperature observed in this present study are less than those observed by Akan et al. (2007), Akan et al. (2009) and Baba et al. (2020).

The mean level of $\mathrm{pH}$ observed in TAN1, TAN2 and TAN3, samples were $7.77 \pm 2.93$; $8.35 \pm 0.28$ and $7.52 \pm 0.76$ respectively. The order of the mean $\mathrm{pH}$ of the samples from the three industries can be arranged as TAN2> TAN1 $>$ TAN3. The $\mathrm{pH}$ of the samples falls within the WHO (7.0-8.5) and NESREA (6-9) standard limits. Statistical analysis shows that there is no significant difference $(p<0.05)$ between the mean values of $\mathrm{pH}$ among the industries. This might be due to similar tannery activities involved in the tannery industries at the time of sampling. Maheshwari et al. (2017) reported that the level of $\mathrm{pH}$ in the effluents from the tannery industry in Vaniyambadi, India was 6.5 which was lower than that observed in the present study. The $\mathrm{pH}$ in the effluents from the tannery industries in Kano and Kaduna were reported to be 7.64 and 6.89, respectively (Akan et al., 2007; Mohammed et al., 2017). The average values of $\mathrm{pH}$ observed in this present study are less than those observed by Mohammed et al. (2017) and Baba et al. (2020). The mean level of SS $(\mathrm{mg} / \mathrm{l})$ observed in TAN1, TAN2, and TAN3 samples were 374 \pm 124 ; $358 \pm 335$ and $780 \pm 739$ respectively. The order of the mean SS in the samples from the three industries can be arranged as TAN3 > TAN1 $>$ TAN2. 
The SS observed in the samples were far above the recommended standard limits of regulating bodies WHO $(30 \mathrm{mg} / \mathrm{l})$ and NESREA $(10 \mathrm{mg} / \mathrm{l})$. Statistical analysis shows that there is no significant difference $(p<0.05)$ between the mean values of SS among the industries. This might be due to similar tannery activities involved in the tannery industries at the time of sampling. The average values of SS observed in this present study are less than that observed $(3700 \pm 122 \mathrm{mg} / \mathrm{l})$ by Akan et al. (2009) for tanneries in Kano. Also, the average values of SS observed in this present study are less than that observed by Mohammed et al. (2017) and Baba et al. (2020) with the exception in TAN3.

The mean level of TDS (mg/l) observed in TAN1, TAN2, and TAN3 samples were $3941 \pm 3703$; $3300 \pm 1714$ and $2653 \pm 1240$ respectively. The order of the mean TDS in the samples from the three industries can be arranged as TAN1>TAN2>TAN3. The TDS observed in the samples were far above the recommended standard limits of WHO $(250 \mathrm{mg} / \mathrm{l})$ and NESREA $(500 \mathrm{mg} / \mathrm{l})$. Statistical analysis shows that there is no significant difference $(p<0.05)$ between the mean values of TDS among the industries. This might be due to similar tannery activities involved in the tannery industries at the time of sampling. TDS in the effluents from the tannery industries in Kano, Nigeria was reported to be $1281 \mathrm{mg} / \mathrm{l}$ (Akan et al., 2007). The average values of SS observed in this present study are less than those observed by Mohammed et al. (2017) and Baba et al. 2020)

The mean level of COD (mg/l) observed in TAN1, TAN2 and TAN3 samples seasons were $2372 \pm 938 ; \quad 1406 \pm 208$ and $3532 \pm 1373$ respectively. The order of the mean COD of the samples from the three industries can be arranged as TAN3>TAN1> TAN2. The COD observed in TAN1, TAN2 and TAN3 samples were far above the recommended standard limits of regulating bodies $\mathrm{WHO}(40 \mathrm{mg} / \mathrm{l})$ and NESREA (40 mg/l). Statistical analysis shows that there is no significant difference $(p<0.05)$ in COD among the industries. This might be due to similar tannery activities involved in the tannery industries as at the time of sampling. The Chemical Oxygen demand (COD) is the amount of oxygen, in $\mathrm{mg} / \mathrm{L}$, required for the degradation of the compound of wastewater to occur. In comparison, the average values of COD observed in this present study were higher than that observed by Mohammed et al. (2017) but lower than that observed by Baba et al. (2020).

The mean levels of BOD $(\mathrm{mg} / \mathrm{l})$ observed in TAN1, TAN2 and TAN3 samples were $13.85 \pm 6.42 ; \quad 19.46 \pm 0.50$ and $17.13 \pm 3.14$ respectively. The order of the mean BOD in the samples from the three industries can be arranged as TAN2>TAN3>TAN1. The BOD observed in TAN1, TAN2 and TAN3 samples were found below the recommended limits of NESREA (200 mg/l) but above WHO (10 mg/l). Statistical analysis shows that there is no significant difference $(p<0.05)$ between the mean values of BOD among the industries. This might be due to similar tannery activities involved in the tannery industries at the time of sampling. The low level of BOD recorded in this study is an indication of the low level of biodegradable organic solids in the effluent. The average values of BOD observed in this present study were lower than those observed by Mohammed et al. (2017) and Baba et al. (2020).

Table 1: Mean Values \pm S.D of Physico-chemical parameters of effluents from the Tannery Industries before Treatment.

\begin{tabular}{llllllll}
\hline Parameter & Tannery 1 & Tannery 2 & Tannery 3 & $\mathrm{a}$ & $\mathrm{b}$ & $\mathrm{c}$ & $\mathrm{d}$ \\
\cline { 2 - 7 } Temperature $\left({ }^{\circ} \mathrm{C}\right)$ & $28.07 \mathrm{a} \pm 0.65$ & $27.77 \mathrm{a} \pm 0.64$ & $26.38 \mathrm{a} \pm 3.81$ & & $29.50 \pm 4.68$ & 35 & 40 \\
pH & $7.77 \mathrm{a} \pm 2.93$ & $8.35 \mathrm{a} \pm 0.28$ & $7.52 \mathrm{a} \pm 0.76$ & 6.89 & $5.35 \pm 1.57$ & $7.0-8.5$ & $6.0-9.0$ \\
$\mathrm{COD}(\mathrm{mg} / \mathrm{l})$ & $2372 \mathrm{a} \pm 938$ & $1406 \mathrm{a} \pm 208$ & $3532 \mathrm{a} \pm 1373$ & 2.2 & $3106 \pm 2753$ & 40 & 40 \\
$\mathrm{BOD}(\mathrm{mg} / \mathrm{l})$ & $13.85 \mathrm{a} \pm 6.42$ & $19.46 \mathrm{a} \pm 0.50$ & $17.13 \mathrm{a} \pm 3.14$ & 1032 & $26.17 \pm 9.49$ & 10 & 200 \\
$\mathrm{SS}(\mathrm{mg} / \mathrm{l})$ & $374 \mathrm{a} \pm 124$ & $358 \mathrm{a} \pm 335$ & $780 \mathrm{a} \pm 739$ & 501 & $562 \pm 482$ & 30 & 10 \\
TDS $(\mathrm{mg} / \mathrm{l})$ & $3941 \mathrm{a} \pm 3703$ & $3300 \mathrm{a} \pm 1714$ & $2653 \mathrm{a} \pm 1240$ & 532.7 & $444 \pm 507$ & 250 & 500 \\
\hline
\end{tabular}

The values given in the table above are means of 6 replicate values, $\mathrm{n}=6$ ( 1 sample was taken monthly for 6 months). Within the rows, means with different alphabets are statistically different $(p<0.05)$. WHO: World Health Organisation. NESREA: National Environmental Standard and Regulatory Enforcement Agency. a = Mohammed et al.(2017), b = Baba et al. (2020), c = WHO (2006), $d=$ NESSRA (2009) 
BAJOPAS Volume 13 Number 2, December, 2020

Identification, Biochemical Characterization and growth rates of the Bacterial Isolates

Results of identification and biochemical characterization of the bacterial isolates were shown in table 2. After 24 hours of incubation, the nutrient agar media plates were checked for bacterial growth. The results showed the presence of different strains in the samples. The TAN1 bacteria isolate was found to be gramnegative cocci while TAN3 was gram-positive cocci. TAN2 bacteria isolate was found to be gram-positive, rod-shaped. TAN1, TAN2, and TAN3 bacteria isolates recorded positive results for spore former.

The results of the biochemical tests indicated that all the bacteria were positive for catalase, oxidase, citrate, maltose, glucose, lactose (negative in TAN1), mannitol (negative in TAN2), starch hydrolysis and coagulase (negative in TAN2) tests. The bacteria showed negative results for nitrate reduction, $M R$ (positive in TAN2), VP (positive in TAN1), Indole (positive in TAN2) tests. Base on the morphological and biochemical test results, TAN1, TAN2, and TAN3 bacteria isolates were identified to be Nesseria spp, Bacillus cereus, and Staphylococcus aureus respectively.

The growth rate of the TAN1, TAN2 and TAN3 Isolates were shown in figure 2. Generally, the optical density increase with the increase in time (day) and decrease as time goes on. The highest optical density was shown by bacillus cereus in TAN2 while the lowest was shown by Staphylococcus aureus in TAN3.

The initial growth phase of TAN1 Isolate bacteria occurred within 2-day of incubation as the growth rate increases up to the 6th-day incubation when the maximum growth was observed. Beyond the 6th day, the growth of the bacteria declined (which might be due to a shortage of nutrients in the effluents) until it reached its death phase (which might be due to the unavailability of nutrients in the effluents).

A similar trend of growth was also observed for TAN2 Isolate as the initial growth phase also occurred within 2-day of incubation but maximum growth rate observed on the 4th day of incubation. The stationary stage occurred between the 4th day and the 8th day. Beyond the 8th day, the growth of the bacteria declined (which might be due to a shortage of nutrients in the effluents) until it reached its death phase (which might be due to the unavailability of nutrients in the effluents).

The initial growth phase of TAN3 bacterial Isolate occurred within the 3-day incubation as the growth rate increases up to the 6th-day incubation when the maximum growth was observed. Beyond the 6th day, the growth of the bacteria declined (which might be due to a shortage of nutrients in the effluents) until it reached its death phase (which might be due to the unavailability of nutrients in the effluents).

Table 2: Morphological and Biochemical characteristics of bacterial isolates

\begin{tabular}{lllll} 
Bacterial Isolates & & TAN1 & TAN2 & TAN3 \\
\hline $\begin{array}{lllll}\text { Morphological } \\
\text { characteristics }\end{array}$ & Shape & Cocci & Rod & Cocci \\
& Spore & & & \\
& former & + & + & + \\
Gram & & & \\
Biochemical characteristics & reaction & - & + & + \\
& Citrate & + & + & + \\
& Catalase & + & + & + \\
& Coagulase & + & - & + \\
Starch & + & + & + \\
& Glucose & + & + & + \\
Oxidase & + & + & + \\
& Indo & - & + & - \\
Lactose & - & + & + \\
Manitol & + & - & + \\
Maltose & + & + & + \\
MR & - & + & - \\
VP & + & - & - \\
& Nitrate & - & - & - \\
Reduction & - Neisseria & Bacillus & Staphylococcus \\
& Bacterial & cereus & aureus \\
& name & spp & cas
\end{tabular}

+ = Positive; - = Negative; MR=Methyl Red; VP= Voges-Proskauer 


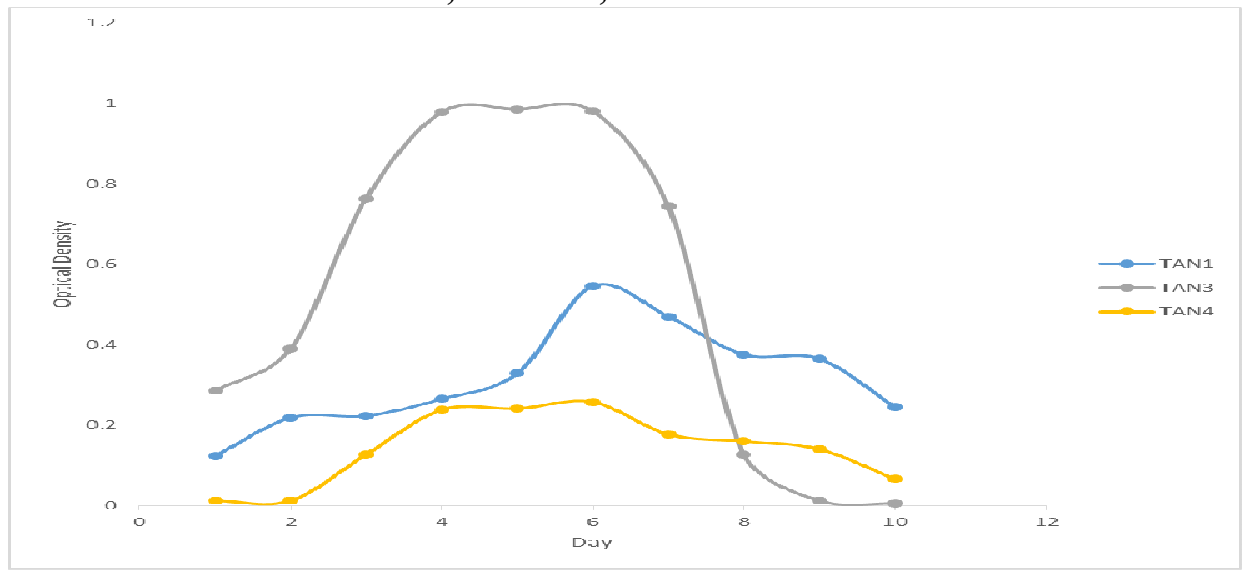

Fig. 2 Growth rates of the isolates in the effluents from the Tannery Industries

\section{Physico-chemical Parameters in the Industrial Effluents after the biodegradation.}

Table 3 shows the mean results of the physicochemical parameter before and after bioremediation using the different masses $(5 \mathrm{~g}$, $10 \mathrm{~g}, 15 \mathrm{~g}, 20 \mathrm{~g}$, and $25 \mathrm{~g}$ ) of the respective immobilized bacteria. Also, Table 4 shows the mean results of correlation coefficient ( $r$ ) between different masses of bacteria and physicochemical parameters.

The mean values $(\mathrm{mg} / \mathrm{l})$ of the SS after the bioremediation varies between $243 \pm 45$ and $898 \pm 672$. The mean concentration $(\mathrm{mg} / \mathrm{l})$ of SS remediated by the different masses $(5 \mathrm{~g}, 10 \mathrm{~g}$, $15 \mathrm{~g}, 20 \mathrm{~g}$, and $25 \mathrm{~g}$ ) of the bacteria varies. The SS in the samples fluctuates up and down after the bioremediation process when compared with the SS of the raw samples before the bioremediation. The increase in the levels of the SS might be due to the aggregation of the TDS which are large enough to result into SS. The increase in the levels of the SS might be also due to the influence of the nutrients which was added into the effluents in order to make the microorganisms more active and viable for fast degradation of organic contaminants in the effluent. The relative potential or efficiency of the different masses of the bacteria in remediating SS in TAN1 samples was in the order $25 \mathrm{~g}>20 \mathrm{~g}>15 \mathrm{~g}>10 \mathrm{~g}>5 \mathrm{~g}$. For TAN2 and TAN3 samples, the order was $25 \mathrm{~g}>20 \mathrm{~g}>15$ $\mathrm{g}>10 \mathrm{~g}>5 \mathrm{~g}$. These might be due to the variations in the surface areas of the different masses of the immobilized bacteria. Statistical analysis shows that there is no significant difference $(p<0.05)$ between the mean values of SS among the masses in the respective industries. Positive and significant correlations exist between the masses of bacteria and Suspended Solid (SS). This showed that there is general increase in the levels of the SS as the masses of the immobilized bacteria increases. TAN3 (90\%) and TAN1 (80\%) showed a very high correlation with the masses of the bacteria while TAN2 (61\%) showed a very low correlation.

The mean values $(\mathrm{mg} / \mathrm{l})$ of the TDS after the bioremediation varies between $46 \pm 11$ and $83 \pm 78$. The mean concentration $(\mathrm{mg} / \mathrm{l})$ of TDS remediated by the different masses $(5 \mathrm{~g}, 10 \mathrm{~g}$, $15 \mathrm{~g}, 20 \mathrm{~g}$, and $25 \mathrm{~g}$ ) of the bacteria varies. There is a reduction in all the TDS of all the samples after the bioremediation process compared with the TDS of the raw samples before the bioremediation. The relative potential or efficiency of the different masses of the bacteria in remediating TDS in TAN1 and TAN3 samples was in the order $5 \mathrm{~g}>10 \mathrm{~g}>15 \mathrm{~g}>20$ $\mathrm{g}>25 \mathrm{~g}$. For TAN2 samples, the order was 20 $g>10 \quad g>25 \quad g>15 \quad g>5 \quad g$. Statistical analysis shows that there is no significant difference $(p<0.05)$ between the mean values of TDS among the masses in the respective industries. These might be due to the variations in the surface areas of the different masses of the immobilized bacteria. Positive and significant correlations exist between the masses of bacteria and TDS with the exception in TAN2 (negative and insignificant correlation). The positive correlations showed that there is general increase in the levels of the TDS as the masses of the immobilized bacteria increases. TAN1 $(96 \%)$ showed a very high correlation with the masses of the bacteria while TAN2 (47\%) showed a very low correlation.

The mean values $(\mathrm{mg} / \mathrm{l})$ of the BOD after the bioremediation varies between $1.56 \pm 0.20 \mathrm{mg} / \mathrm{l}$ and $6.92 \pm 5.49 \mathrm{mg} / \mathrm{l}$. The mean concentration $(\mathrm{mg} / \mathrm{l})$ of BOD remediated by the different masses $(5 \mathrm{~g}, 10 \mathrm{~g}, 15 \mathrm{~g}, 20 \mathrm{~g}$, and $25 \mathrm{~g}$ ) of the bacteria varies. There is a reduction in all the BOD of all the samples after the bioremediation process compared with the $\mathrm{BOD}$ of the raw 
BAJOPAS Volume 13 Number 2, December, 2020 samples before the bioremediation. The relative potential or efficiency of the different masses of the bacteria in remediating BOD in TAN1, TAN2 and TAN3 samples were in the order $25 \mathrm{~g}>20$ $\mathrm{g}>15 \mathrm{~g}>10 \mathrm{~g}>5 \mathrm{~g}, 25 \mathrm{~g}>15 \mathrm{~g}>5 \mathrm{~g}>10 \mathrm{~g}>20 \mathrm{~g}$ and $20 \mathrm{~g}>10 \mathrm{~g}>25 \mathrm{~g}>15 \mathrm{~g}>5 \mathrm{~g}$ respectively. Statistical analysis shows that there is significant difference $(p<0.05)$ between the mean values of BOD among the masses in the respective industries. These might be due to the variations in the surface areas of the different masses of the immobilized bacteria. Negative and significant correlations exist between the masses of bacteria and BOD. This showed that there is general decrease in the levels of the BOD as the masses of the immobilized bacteria increases. TAN1 (94\%) showed a very high correlation with the masses of the bacteria while TAN2 (4\%) showed a very low correlation.

The mean values $(\mathrm{mg} / \mathrm{l})$ of the COD after the bioremediation varies between $250 \pm 154$ and $3134 \pm 1595$. The mean concentration $(\mathrm{mg} / \mathrm{l})$ of COD remediated by the different masses $(5 \mathrm{~g}$, $10 \mathrm{~g}, 15 \mathrm{~g} 20 \mathrm{~g}$, and $25 \mathrm{~g}$ ) of the bacteria varies. There is a reduction in all the COD of all the samples after the bioremediation process compared with the COD of the raw samples before the bioremediation. The relative potential or efficiency of the different masses of the bacteria in remediating COD in TAN1, TAN2 and TAN3 samples were in the order $25 \mathrm{~g}>20 \mathrm{~g}>15$ $\mathrm{g}>5 \mathrm{~g}>10 \mathrm{~g}, 25 \mathrm{~g}>20 \mathrm{~g}>15 \mathrm{~g}>10 \mathrm{~g}>5 \mathrm{~g}$ and 10 g>5 g>25 g>15 g>20 g respectively. Statistical analysis shows that there were significant difference $(p<0.05)$ between the mean values of COD among the masses in the respective industries except for effluents treated with $25 \mathrm{~g}$. These might be due to the variations in the surface areas of the different masses of the immobilized bacteria. Negative and insignificant correlations exist between the masses of bacteria and COD with the exception in TAN3 (positive and significant correlation). The negative correlations showed that there is general decrease in the levels of the COD as the masses of the immobilized bacteria increases. TAN2 (100\%) showed a very high correlation with the masses of the bacteria while TAN3 (36\%) showed a very low correlation.

Generally, there was an overall decrease in the concentration of these physicochemical parameters after the bioremediation using the different masses of the bacterial isolates. These might be due to the variations in the surface areas of the different masses of the immobilized bacteria. This is in line with the work of Jimoh et al. (2018) and Baba et al. (2020).

Table 3: Mean Values $(\mathrm{mg} / \mathrm{l}) \pm$ S.D of Physicochemical parameters in effluents from the Tannery Industries before and after Treatment of the effluents $(250 \mathrm{ml})$ with the different masses $(5 \mathrm{~g}, 10 \mathrm{~g}$, $15 \mathrm{~g}, 20 \mathrm{~g}$, and $25 \mathrm{~g}$ ) of the bacteria.

\begin{tabular}{llllllll}
\hline $\mathrm{P}$ & IND & Before & \multicolumn{5}{c}{ After } \\
\cline { 4 - 7 } & & & $5 \mathrm{~g}$ & $10 \mathrm{~g}$ & $15 \mathrm{~g}$ & $20 \mathrm{~g}$ & $25 \mathrm{~g}$ \\
\hline \multirow{2}{*}{ COD } & TAN1 & $2372 \pm 938$ & $1708 \mathrm{a} \pm 861$ & $2045 \mathrm{a} \pm 1205$ & $845 \mathrm{a} \pm 369$ & $300 \mathrm{a} \pm 167$ & $250 \mathrm{a} \pm 154$ \\
& TAN2 & $1406 \pm 208$ & $1195 \mathrm{a} \pm 208$ & $1125 \mathrm{a} \pm 384$ & $1055 \mathrm{a} \pm 317$ & $956 \mathrm{a} \pm 310$ & $870 \mathrm{ab} \pm 240$ \\
& TAN3 & $3532 \pm 1373$ & $2374 \mathrm{a} \pm 1344$ & $1976 \mathrm{a} \pm 1405$ & $2757 \mathrm{a} \pm 1266$ & $3134 \mathrm{a} \pm 1595$ & $2614 \mathrm{~b} \pm 1105$ \\
BOD & TAN1 & $13.85 \pm 6.42$ & $6.92 \mathrm{a} \pm 5.49$ & $6.42 \mathrm{a} \pm 5.07$ & $5.72 \mathrm{a} \pm 5.35$ & $4.62 \mathrm{a} \pm 4.37$ & $2.82 \mathrm{ab} \pm 1.26$ \\
& TAN2 & $19.46 \pm 0.50$ & $1.75 \mathrm{~b} \pm 0.22$ & $1.73 \mathrm{~b} \pm 0.18$ & $1.58 \mathrm{a} \pm 0.16$ & $1.91 \mathrm{a} \pm 0.22$ & $1.56 \mathrm{~b} \pm 0.20$ \\
& TAN3 & $17.13 \pm 3.14$ & $4.24 \mathrm{ab} \pm 0.77$ & $3.29 \mathrm{ab} \pm 0.37$ & $4.11 \mathrm{a} \pm 0.07$ & $3.23 \mathrm{a} \pm 0.91$ & $3.33 \mathrm{a} \pm 1.28$ \\
SS & TAN1 & $374 \pm 124$ & $243 \mathrm{a} \pm 45$ & $471 \mathrm{a} \pm 226$ & $475 \mathrm{a} \pm 182$ & $492 \mathrm{a} \pm 128$ & $611 \mathrm{a} \pm 217$ \\
& TAN2 & $358 \pm 335$ & $460 \mathrm{a} \pm 400$ & $543 \mathrm{a} \pm 414$ & $544 \mathrm{a} \pm 402$ & $551 \mathrm{a} \pm 414$ & $554 \mathrm{a} \pm 405$ \\
& TAN3 & $780 \pm 739$ & $586 \mathrm{a} \pm 594$ & $758 \mathrm{a} \pm 656$ & $787 \mathrm{a} \pm 676$ & $861 \mathrm{a} \pm 635$ & $898 \mathrm{a} \pm 672$ \\
TDS & TAN1 & $3941 \pm 3703$ & $51 \mathrm{a} \pm 10$ & $53 \mathrm{a} \pm 10$ & $55 \mathrm{a} \pm 15$ & $61 \mathrm{a} \pm 20$ & $63 \mathrm{a} \pm 26$ \\
& TAN2 & $3300 \pm 1714$ & $83 \mathrm{a} \pm 78$ & $47 \mathrm{a} \pm 20$ & $48 \mathrm{a} \pm 22$ & $47 \mathrm{a} \pm 17$ & $48 \mathrm{a} \pm 17$ \\
& TAN3 & $2653 \pm 1240$ & $46 \mathrm{a} \pm 11$ & $55 \mathrm{a} \pm 24$ & $55 \mathrm{a} \pm 25$ & $58 \mathrm{a} \pm 23$ & $61 \mathrm{a} \pm 28$ \\
\hline
\end{tabular}

Replicate $=6$ (months)

Within the rows, for the same parameter, means with different alphabets are statistically different $(p<0.05)$.

$\mathrm{P}=$ parameter, IND = Industries 
BAJOPAS Volume 13 Number 2, December, 2020

Table 4: Correlation coefficient $(r)$ between different masses of the bacteria and the physicochemical parameters.

\begin{tabular}{llll}
\hline Industries & Parameter & Correlation coefficient $(r)$ & $\begin{array}{l}\text { Percent dependence (rxrx100) } \\
(\%)\end{array}$ \\
\hline TAN1 & COD & -0.9 & 82 \\
& BOD & -0.97 & 94 \\
& SS & $0.90^{*}$ & 80 \\
TAN2 & TDS & $0.98^{*}$ & 96 \\
& COD & -1 & 100 \\
& BOD & -0.21 & 4 \\
& SS & $0.78^{*}$ & 61 \\
& TDS & -0.69 & 47 \\
& COD & $0.60^{*}$ & 36 \\
& BOD & -0.6 & 37 \\
& SS & $0.95^{*}$ & 90 \\
& TDS & $0.94^{*}$ & 89 \\
\hline
\end{tabular}

The correlation coefficient $(r)$ with * is statistically significant $(p<0.05)$.

Percentage reduction of the Parameters

Table 5 shows the percentage reduction of Parameters in industrial samples before and after the treatment of the effluents $(250 \mathrm{ml})$ with the different masses $(5 \mathrm{~g}, 10 \mathrm{~g}, 15 \mathrm{~g}, 20 \mathrm{~g}$, and $25 \mathrm{~g}$ ) of the Immobilized Bacteria.

In TAN1 samples, the percentage reduction (\%) of COD ranged (14-89); BOD (50-80); SS (-32$35)$ and TDS (98-99). In TAN2 samples, the percentage decrease $(\%)$ of COD ranged (15$38) ;$ BOD (90-92); SS [-28-(-55)] and TDS (9798). In TAN3 samples, the percentage decrease (\%) of COD ranged (11-44); BOD (76-81); SS (15-25) and TDS (98). The percentage increase in the levels COD, BOD and TDS might be due to the increase in the surface area of the different masses of the immobilized bacteria. However, the percentage decrease in the levels of the SS might be due to the aggregation of the TDS which are large enough to result into SS. The percentage decrease in the levels of the SS might be also due to the influence of the nutrients which was added into the effluents in order to make the microorganisms more active and viable for fast degradation of organic contaminants in the effluent. This is in line with the work of Jimoh et al. (2018) in which the concentration of the SS increase after the bioremediation of effluents.

Sreemoyee and Priti (2013) assessed and reduced several Physico-chemical parameters of dairy wastewater using Niesseria $s p$. and concluded that the species are well known to degrade organic compounds. This is in agreement with the current study in which the immobilized Niesseria $s p$ degrade the organic contaminants as indicated by the BOD, COD and TDS.

Jimoh et al. (2018) observed that TSS of the effluents was increased after treatment with immobilized bacteria and concluded that it might be due to the biostimulation method adopted for the research.

The optimum $\mathrm{pH}$ Biosorption of Chromium by Bacillus spp and Staphylococcus spp. from tannery effluent was investigated by Mythili and Karthikeyan (2011). The maximum adsorption of Chromium $(86.4 \mathrm{mg} / \mathrm{L})$ was showed by Bacillus spp and Staphylococcus spp showed $70.6 \mathrm{mg} / \mathrm{L}$ at an initial concentration of $100 \mathrm{mg} / \mathrm{L}$. In the present study, immobilised Bacillus spp and Staphylococcus spp. from the tannery industrial effluents reduced the levels of the organic pollutants with high potential as indicated by the percentage reduction of BOD, COD and TDS.

Enzymes often can work in multiple environments especially if they are immobilized. This makes the microorganisms' enzymes even more resistant to harsh environments and enables the enzymes to be recovered and recycled after they are no longer needed (Gianfreda and Rao 2004). Ramesh and Singh (1993) reported that the immobilized bacteria having more efficiency to remove the suspended particles than free cells. Using the immobilized cell is preferable due to its capability for using several times with the same efficiency, which makes it more economical. Similar work was done by Sikander et al. (2007) showing the higher reduction with permeabilized cells of Ochrobactrum intermedium strain SDCr-5. 
BAJOPAS Volume 13 Number 2, December, 2020

The results revealed the isolation and identification of isolates with the potential for the reduction of $\mathrm{Cr}$ (VI) to $\mathrm{Cr}$ (III). Results indicated that immobilized $B$. cereus could be efficiently used for the reduction of $\mathrm{Cr}$ (VI).

Table 5: Percentage reduction of the tested Parameters from the tannery industrial samples of the Immobilized Bacteria.

\begin{tabular}{lllllll}
\hline \multirow{2}{*}{ Industries } & & \multicolumn{5}{c}{ Percentage Reduction $(\%)$} \\
\cline { 3 - 7 } & & $5 \mathrm{~g}$ & $10 \mathrm{~g}$ & $15 \mathrm{~g}$ & $20 \mathrm{~g}$ & $25 \mathrm{~g}$ \\
\hline TAN1 & COD & 28 & 14 & 64 & 87 & 89 \\
& BOD & 50 & 54 & 59 & 67 & 80 \\
& SS & 35 & -26 & -27 & -32 & -63 \\
& TDS & 99 & 99 & 99 & 98 & 98 \\
TAN2 & COD & 15 & 20 & 25 & 32 & 38 \\
& BOD & 91 & 91 & 92 & 90 & 92 \\
& SS & -28 & -52 & -52 & -54 & -55 \\
& TDS & 97 & 99 & 99 & 99 & 99 \\
& COD & 33 & 44 & 22 & 11 & 26 \\
& BOD & 75 & 81 & 76 & 81 & 81 \\
& SS & 25 & 3 & -1 & -10 & -15 \\
& TDS & 98 & 98 & 98 & 98 & 98 \\
\hline
\end{tabular}

Percentage Reduction $=(B-A) / B \times 100 \%$

$A=$ Concentration of the parameter after treatment

$\mathrm{B}=$ Concentration of the parameter before treatment

$+=$ percentage decrease

- = percentage increase

In general, immobilization makes the enzyme more resistant to temperature, $\mathrm{pH}$, and substrate concentration swings giving it a longer lifetime and higher productivity per active unit (Gianfreda and Rao, 2004; FuIlbrook, 1996; Russell et al, 2003; Kandelbauer et al., 2004). Immobilized cells have been used and studied extensively for the production of useful chemicals (Ohtake and Silver, 1994), the treatment of wastewaters (Chen et al., 2003; Wang et al., 2010). Although many workers described microbial degradation of tannery effluent, limited literature is available on the bioremediation of tannery effluent using immobilized bacterial cells in the Kano Industrial Estates.

\section{CONCLUSION}

The samples contained variable levels of the physicochemical parameters. The results of the Analysis of variance revealed that, no statistical difference $(p<0.05)$ was observed for the temperature, $\mathrm{pH}, \mathrm{SS}, \mathrm{TDS}, \mathrm{BOD}$ and $\mathrm{COD}$ among the three tannery industries before the treatment. The levels of some of the parameters
(SS, TDS and COD) observed in the samples were found above the recommended limits of WHO and NESREA, which called for the treatment of the effluents before discharge into the environment. Base on the morphological and biochemical test results, TAN1, TAN2, and TAN3 bacterial isolates were identified to be Neisseria spp, Bacillus cereus, and Staphylococcus aureus respectively. The results of Post-treatment analysis showed that there is overall decrease in the levels of the parameters determined when compared with that of the pre-treatment. The overall percentage reduction of the immobilised bacteria in the treatment of the respective effluents was in the order TAN2 (72\%)>TAN1 $(70 \%)>$ TAN3 $(62 \%)$. Hence, the immobilized bacteria are having higher biodegradation potential for the treatment of the tannery effluents.

\section{Acknowledgments}

The authors wish to acknowledge the University of Maiduguri for the financial support. The authors are grateful to the Kano State Ministry of Environment for their support in obtaining the effluent samples. 


\section{REFERENCES}

Ajao, A. T., Adebayo, G. B., and Yakubu, S. E. (2011). Bioremediation of textile industrial effluent using mixed culture of Pseudomonas aeruginosa and Bacillus subtilis immobilized on agar-agar in a bioreactor. J. Microbiol. Biotech. Res, 1(3), 50-56.

Akan, J. C., Moses, E. A., Ogugbuaja, V. O., and Abah, J. (2007). Assessment of tannery industrial effluents from Kano metropolis, Kano State, Nigeria. Journal of Applied Sciences, 7(19), 2788-2793.

Akan, J. C., Ogugbuaja, V. O., Abdulrahman, F. I., and Ayodele, J. T. (2009). Pollutant levels in effluent samples from tanneries and textiles of Kano industrial areas, Nigeria. Global journal of pure and applied sciences, 15(3-4).

APHA (1989). Standard methods for Examination of Will bete and Will betewater.15 $5^{\text {th }}$ edition. Brydpass Springfield Will behington DC. pp. 164-176

APHA (1992). Standard Methods for the Examination of Water and Wastewater. Health, 69, 1116-9.

Baba, A., Garba, S. T., and Bello, H. S. (2020). Bioremediation Potential of Immobilized corynebacterium kutsceri in the Treatment of Tannery Industrial Effluent from Challawa Industrial Estate, Kano State, Nigeria. Journal of the Turkish Chemical Society Section A: Chemistry, $7(2), 335-350$.

Beem, E. I. V. (1994). reduction of solvent VOC emission. J. Oil Col. Chem. Ass, 77, 158.

Bouwer, E. J., and Zehnder, A. J. (1993). Bioremediation of organic compoundsputting microbial metabolism to work. Trends in biotechnology, 11(8), 360367.

Chen, K. C., Wu, J. Y., Liou, D. J., and Hwang, S. C. J. (2003). Decolorization of the textile dyes by newly isolated bacterial strains. Journal of Biotechnology, 101(1), 57-68.

Dan'Azumi, S., and Bichi, M. H. (2010). INDUSTRIAL POLLUTION AND HEAVY METALS PROFILE OF CHALLAWA RIVER IN KANO, NIGERIA. Journal of Applied Sciences in Environmental Sanitation, $5(1)$.

DWAF. (1992). Analytical Methods Manual, TR 151. Department of Water Affairs and Forestry, Pretoria.

El-Bestawy, E. (2013). Biological treatment of leather-tanning industrial wastewater using free living bacteria.
Elsheikh, M. A. S. (2009). Tannery wastewater pre-treatment. Water Science and Technology, 60(2), 433-440.

FuIlbrook, P. D. (1996). "Kinetics." Industrial enzymology: The application of enzymes in Industry. 2nd Ed. T. Godfrey and J Reichelt. eds.. Nature. New York.

Gianfreda, L., and Rao, M. A. (2004). Potential of extra cellular enzymes in remediation of polluted soils: a review. Enzyme and microbial technology, 35(4), 339354.

Hugo Springer. (1994). John Arthur Wilson Memorial Lecture "Treatment of Industrial Wastes of the Leather Industry - is it still a Major Problem". JALCA, 89, 153-185

Jimoh, A. A., Ganiyu, B. A., Baba, D., and Baba, A. (2018) Bioremediation Process of Effluent from Detergent and Food Industries in Jos, Nigeria: Kinetics and Thermodynamics. International Journal of Engineering Science Invention (IJESI), 762-73

Kandelbauer, A., Maute, O., Kessler, R. W., Erlacher, A., and Gübitz, G. M. (2004). Study of dye decolorization in an immobilized laccase enzyme-reactor using online spectroscopy. Biotechnology and bioengineering, 87(4), 552-563.

Kongjao, S., Damronglerd, S., and Hunsom, M. (2008). Simultaneous removal of organic and inorganic Pollutants in tannery wastewater using electrocoagulation technique. Korean Journal of chemical engineering, 25(4), 703.

Maheshwari, U. M., Aruna, S., Gomathi, M., and AbdulJaffar, A. H. (2017). Bioremediation by Free and Immobilized Bacteria Isolated from Tannery Effluent. International Journal of Research in Applied, Natural and Social Sciences. 5(7), 75-90

Margesin, R., and Schinner, F. (2001). Bioremediation (natural attenuation and biostimulation) of diesel-oilcontaminated soil in an alpine glacier skiing area. Applied and environmental microbiology, 677), 3127-3133.

Mohammed, A., Sekar, P., and George, J. (2011). Efficacy of microbes in bioremediation of tannery effluent. Inter. J. Curr. Res, 3(4), 324-326.

Mohammed, S. S. D., Orukotan, A. A., and Abdullahi, H. (2017). Physicochemical and Bacteriological Assessment of Tannery Effluent from Samaru-Zaria, 
BAJOPAS Volume 13 Number 2, December, 2020 Kaduna State, Nigeria. Journal of Applied

Sciences and Environmental Management, 21(4), 734-740.

Munz, G., De Angelis, D., Gori, R., Mori, G., Casarci, M., and Lubello, C. (2009). The role of tannins in conventional and membrane treatment of tannery wastewater. Journal of hazardous materials, 164(2-3), 733-739

Mythili, K., and Karthikeyan, B. (2011). Bioremediation of $\mathrm{Cr}$ (VI) from tannery effluent using Bacillus spp and Staphylococcus spp. International Multidisciplinary Research Journal, 1(6).

NESREA (2009). National Environmental Standards for Effluent Limitations and Regulation. 1233-1236

Noorjahan, C. M. (2014). Physicochemical characteristics, identification of bacteria and biodegradation of industrial effluent. Journal of bioremediation and Biodegradation, 5(3).

Ohtake, H. I., and Silver, A. O. (1994). Bacterial reduction of toxic chromate. Biological degradation and bioremediation of toxic chemicals, 403-415.

Omoleke, I. I. (2004). Management of environmental pollution in Ibadan, an African city: the challenges of health hazard facing government and the people. Journal of Human Ecology, 15(4), 265-275.

Rajor, A., Reddy, A.S., and Singh, B. (2004). Determination of BOD kinetic Parameters and evaluation of alternate methods, M.Sc. Thesis, Department of biotechnology \& environmental Science, Thapar Institute of Engineering and Technology, Patiala

Ramasami, T., Rajamani, S., and Rao, J. R. (1994, March). Pollution control in leather industry: Emerging technological options. In International symposium on surface and colloidal science and its relevance to soil pollution, madras.

Ramesh, J. V. S., and Singh, S. P. (1993). Yearly variation in certain physicochemical parameters of pond at eastern Doon Valley. Uttar Pradesh J. Zoo, 12 (1), 7577.

Ranen, S., and Sharadinadra, C. (2009). Biotechnology applications to environmental remediation in resource exploitation. Current science, 97, 6-25
Russell, A. J., Berberich, J. A., Drevon, G. F., and Koepsel, R. R. (2003). Biomaterials for mediation of

chemical and biological warfare agents. Annual review of biomedical engineering, 5(1), 1-27.

Saravanan, P., and Saravanan, A. (1999). Decolourization of tannery effluent by Flavobacterium sp. EK 1. Indian Journal of Environmental Protection, 19, 19-24.

Sikander, S., and Shahida, H. (2007). Reduction of toxic hexavalent chromium by Ochrobactrum intermedium strain SDCr5 stimulated by heavy metals. Bioresource Technol, 98, 340-344.

Singh, N., Sharma, B. K., and Bohra, P. C. (2000). Impact assessment of industrial effluent of arid soils by using satellite imageries. Journal of the Indian Society of Remote Sensing, 28(2-3), 79.

Sreemoyee, C., and Priti, P. (2013). Assessment of physico-chemical parameters of dairy waste water and isolation and characterization of bacterial strains in terms of cod reduction. Int J Sci, 2(3), 395-400.

Verheijen, L. A. H. M., Wiersema, D., Pol, L. H., and De Wit, J. (1996). Management of wastes from animal product processing. Livestock and environment, Finding a balance. International Agriculture Center, Wageningen, The Netherlands.

Wang, F., Yao, J., Si, Y., Chen, H., Russel, M., Chen, K., and Bramanti, E. (2010). Short-time effect of heavy metals upon microbial community activity. Journal of Hazardous Materials, 173(13), 510-516.

WHO (World Health Organization). (2006). Air quality guidelines: global update 2005: particulate matter, ozone, nitrogen dioxide, and sulfur dioxide. World Health Organization.

World Bank. (1995). Nigeria's strategic options for redressing industrial pollution. World Bank, industry and energy division. 1st edition, West Central Africa Department; Annexes: 1995; pp 60-62.

Zahoor, A., and Abdul, R. (2009). Enumeration of Coliforms. Journal of Environmental Sciences. 21, 814-820 


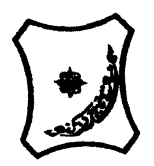

Bayero Journal of Pure and Applied Sciences, 13(2): 1 - 12

Received: November, 2020

Accepted: December, 2020

ISSN $2006-6996$

\title{
BIODEGRADATION POTENTIAL OF IMMOBILIZED BACTERIA IN THE TREATMENT OF TANNERY INDUSTRIAL EFFLUENTS FROM INDUSTRIAL ESTATES IN KANO STATE, NIGERIA
}

\author{
Abdullateef, B., ${ }^{1 *}$ Shuaibu, T. G., ${ }^{1}$ Babagana, K., ${ }^{1}$ Suleman, H. B. ${ }^{2}$ and Dauda, B. ${ }^{3}$ \\ ${ }^{1}$ Department of Pure and Applied Chemistry, Faculty of Science, University of Maiduguri, Borno State, \\ Nigeria \\ ${ }^{2}$ Department of Microbiology, Faculty of Science, University of Maiduguri, Borno State, Nigeria \\ ${ }^{3}$ Department of Chemical Engineering, Faculty of Engineering, University of Maiduguri, Borno State, \\ Nigeria \\ *Corresponding author: babslega@gmail.com; abelega2007@yahoo.com; +2348061309753
}

\section{ABSTRACT}

Industrial Effluents Samples from Gashash Tanneries (TAN1) in Bompai Industrial estate, Larabee Tannery Industry (TAN2) in Sharada Industrial estate and Z Tannery Industries (TAN3) in Challawa Industrial estate, Kano State, Nigeria were collected over a period of six months (August 2017 to January 2018) for assessing the biodegradation potentials of bacteria in the treatment of organic pollutants within the effluents. Bacteria were isolated from the effluents and immobilized on agar-agar. Different masses (5 g, $10 \mathrm{gr}, 15$ $\mathrm{g}, 20 \mathrm{~g}$, and $25 \mathrm{~g}$ ) of the bacteria were used in the treatment of $250 \mathrm{ml}$ of the effluents for ten days in a shaker incubator (Gallenkamp-OC-4364-L) at the temperature $30{ }^{\circ} \mathrm{C}$ and speed of $60 \mathrm{rpm}$. Pre-treatment analysis of the effluents for Temperature, pH, Biochemical Oxygen Demand (BOD), Chemical Oxygen Demand (COD), Suspended Solid (SS) and Total Dissolved Solids (TDS) gives the following results; temperature $\left({ }^{\circ} \mathrm{C}\right.$ )

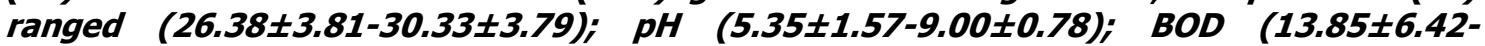
$38.75 \pm 16.20) ;$ COD (1406 $\pm 208-3532 \pm 1373) ;$ SS (208 $\pm 235-780 \pm 739)$ and TDS (266 $\pm 253-5276 \pm 2971)$. No statistical differences ( $p \leq 0.05)$ was observed for all the results among the different industries. The bacterial isolates were identified as Neisseria spp, Bacillus cereus, and Staphylococcus aureus, in TAN1, TAN2, and TAN3, respectively. After treatment of the effluent with the different masses of the isolated bacteria, the mean level of BOD was found to range as (0.55 $\pm 0.36-6.92 \pm 5.49) ; C O D$ (ND-3134 \pm 1595$)$;

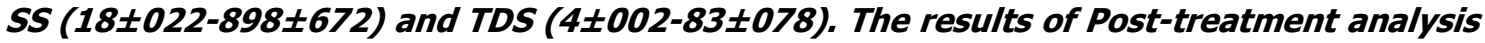
showed that there is overall decrease in the levels of the parameters determined when compared with that of the pre-treatment. The overall percentage reduction of the immobilised bacteria in the treatment of the respective effluents was in the order TAN2 (72\%)>TAN1 (70\%)>TAN3 (62\%). Hence, the immobilized bacteria are having higher biodegradation potential for the treatment of the tannery effluents.

Keywords: Biodegradation, bacteria, effluent, immobilization, tannery.

\section{INTRODUCTION}

Tannery industrial wastewater is a serious consequence of the pollution point of view for streams, freshwater, and land used for agriculture. The lack of awareness in the modern industrial practice has resulted in the discharge of tannery effluents which exhibit very high value of chromium ( $\mathrm{Cr}$ ), Sulfide, and chloride, Total Dissolved Solid (TDS), Total Suspended Solid (TSS), Biochemical Oxygen Demand (BOD) and Chemical Oxygen Demand (COD) in the water stream or land (Mohammed et al., 2001). Tanning is the process, which One ton of skin generally leads to the production of 20 to $80 \mathrm{~m}^{3}$ of turbid and foul-smelling converts the protein of the rawhide or skin into a stable material, which will not putrefy and is suitable for a wide variety of end applications (Elsheikh, 2009). The highly polluting chromium is the most commonly used tanning material producing leather that is more flexible and pliable than vegetable-tanned leather and does not discolor or lose shape in water as drastically as vegetable-tan (Elsheikh, 2009). Tannery effluent is among the most hazardous industrial pollutants due to its huge organic and inorganic load, which is highly toxic to human life and the environment (Kongjao et al., 2008). wastewater including chromium (100-400 mg/l), sulfide $(200-800 \mathrm{mg} / \mathrm{l})$, high levels of fat and 
BAJOPAS Volume 13 Number 2, December, 2020 other solid wastes, and notable pathogen contamination as well as pesticides added for skin conservation during transport (Elsheikh, 2009). There are more than 6000 tanneries in Nigeria with an annual processing capacity of 700,000 tons of hides and skins (Omoleke, 2004; Singh et al., 2008). It was reported that the total amount of waste produced per animal slaughtered is approximately $35 \%$ of its weight (World Bank, 1995). Also, for every $1000 \mathrm{~kg}$ of carcass weight, a slaughtered beef produces 5.5 $\mathrm{kg}$ of manure (excluding rumen contents or stockyard manure) and $100 \mathrm{~kg}$ of paunch manure (undigested food) (Verheijen et al., 1996). Tanneries generate wastewater in the range of 30-35 $\mathrm{L} \mathrm{kg}^{-1}$ skin/hide processed with variable $\mathrm{pH}$, Biological Oxygen Demand (BOD), Chemical Oxygen Demand (COD), high concentrations of suspended solids (SS), and tannins as well as chromium (Zahoor and Abdul, 2009).

Being heterogeneous and composed of a wide variety of compounds, it is very difficult to select a unique direct method for estimating the biodegradability of organic contents and biokinetic parameters for a wastewater sample (Rajor, 2004). For this purpose, some indirect estimation such as determination of biochemical oxygen demand (BOD) and chemical oxygen demand (COD) are applied as common laboratory investigations [9]. During retanning procedures, synthetic tannins (Syntan), oils and resins are added to form softer leather at varying doses (Munz et al., 2009). One of the refractory groups of chemicals in tannery effluents derives mainly from tannins (Ramasami et al., 2004). Syntans are characterized by complex chemical structures, because they are composed of an extended set of chemicals such as phenol-, naphthalene-, formaldehyde- and melamine-based syntans, and acrylic resins (Beem, 1994). Organic pollutants (proteic and lipidic components) are originated from skins (it is calculated that the raw skin has $30 \%$ loss of organic material during the working cycle) or they are introduced during processes (Hugo Springer, 1994).

Many conventional processes such as oxidation, chemical and biological processes were carried out to treat tanneries wastewater (Ebtesam et al, 2013). Biological processes have received more attention because of their costeffectiveness, lower sludge production and environmental friendliness (Noorjahan, 2014). Naturally occurring micro-organisms degrade the hazardous organic wastes including xenobiotic compounds, such as pesticides, polycyclic aromatic hydrocarbons (PAHs) and polychlorinated biphenyls (PCBs) in due course of time (Ranen and Sharadinadra, 2009). Bioremediation is based on the idea that all organisms remove substances from the environment to carry outgrowth and metabolism (Bouwer and Zehnder, 1993). Bacteria, protista and fungi are found to be very good at degrading complex molecules and incorporating the breakdown products into their metabolism (Bouwer and Zehnder, 1993). The resultant metabolic wastes that they produce are generally safe and somehow recycled into other organisms (Ranen and Sharadinadra, 2009). An acclimatized indigenous population of microorganisms capable of degradation of the compounds of interest must exist at the site for a successful bioremediation mode (Ranen and Sharadinadra, 2009). It has been observed that for a successful bioremediation mode, an acclimatized indigenous population of microorganisms capable of degradation of the compounds of interest must exist at the site under investigation (Ranen and Sharadinadra, 2009). Even though there are numerous physical and chemical methods employed in the disposal of wastes the advantage in using bacterium is that they play a key role in the reduction of COD, BOD, total protein, total tannin and total phenol (Saravanan and Saravanan, 1998)

Baba et al. (2020) studied the bioremediation potential of immobilized corynebacterium kutsceri in the Treatment of tannery industrial effluent from Challawa Industrial Estate, Kano State, Nigeria. The aim of the work is to study the reduction in the level of the contaminants through the process of bioremediation using the isolated bacteria. Immobilized bacteria can withstand various temperatures, $\mathrm{pH}$ and substrate concentrations; consequently, increasing the efficiency and the lifespan of the bacteria. Immobilized bacteria are widely applied in the treatment of wastewater and can be separated and recovered after the treatment with the same efficiency (Baba et al., 2020).

\section{MATERIALS AND METHODS \\ Study Area}

This study was carried out in Bompai, Sharada and Challawa industrial estates in Kano, Figure 1. Kano lies on Latitude $11^{\circ} 30^{\prime} \mathrm{N}$ and $8^{\circ} 30^{\prime} \mathrm{E}$ and Longitude $11^{\circ} 5^{\prime} \mathrm{N}$ and $8^{\circ} 5^{\prime} \mathrm{E}$ in Northern Nigeria. It is one of the developed industrial cities in Nigeria. Tannery activities are the dominating industries and this could be one of the reasons for her high population density (Dan'Azumi and Bichi, 2010). Many researchers have studied biodegradation of tannery effluent using microorganisms. However, limited literature is available on the biodegradation of tannery effluent in Kano industrial estates using 
BAJOPAS Volume 13 Number 2, December, 2020 immobilized bacterial cells. This research work focuses on the potential of the use of the indigenous immobilized bacterial isolates in the treatment of tannery effluents in the industrial estates.

\section{Sample Collection}

Effluents were collected from the Tannery Industries from Bompai, Challawa and Sharada Industrial Estates, Kano, Nigeria. The effluents were collected over a period of six months (August 2017 to January 2018). Samples collected in a sterile 4-liter plastic container with a unique identification number were preserved using an ice-box that was transported to the Microbiology Laboratory, Department of Microbiology, Bayero University of Kano for analysis

\section{Sample Preparation and Sample Analysis}

Immediately after the collection of the effluent, $\mathrm{pH}$, TSS, TDS, COD, BOD levels were determined before treatment (Pre-treatment determination) and ten days after treatment (Post-treatment determination) as described in
APHA (1989) standard methods. $\mathrm{pH}$ was determined using Ecotests $\mathrm{pH}$ meter and TDS was determined using AQUALYTIC TDS Salinometer. BOD was determined as described by the standard method (APHA, 1992). COD and SS were determined using DR/2010 HACH portable data logging spectrophotometer (DWAF, 1992)

\section{Identification and Biochemical} Characterization of the Bacterial Isolates

The bacteria were isolated from the effluents using Serial Dilution according to the method described by APHA (1989). The biochemical tests such as oxidase, catalase, coagulase, indole (from $1 \%$ tryptone broth), citrate (Simmons citrate agar), methyl red/VogesProskauer (MR/VP), nitrate reduction, Starch Hydrolysis, Glucose, Maltose, and Lactose tests were carried out on the bacterial isolates to identify the bacteria through the bacteria biochemical characteristics according to Ajao et al. (2011).

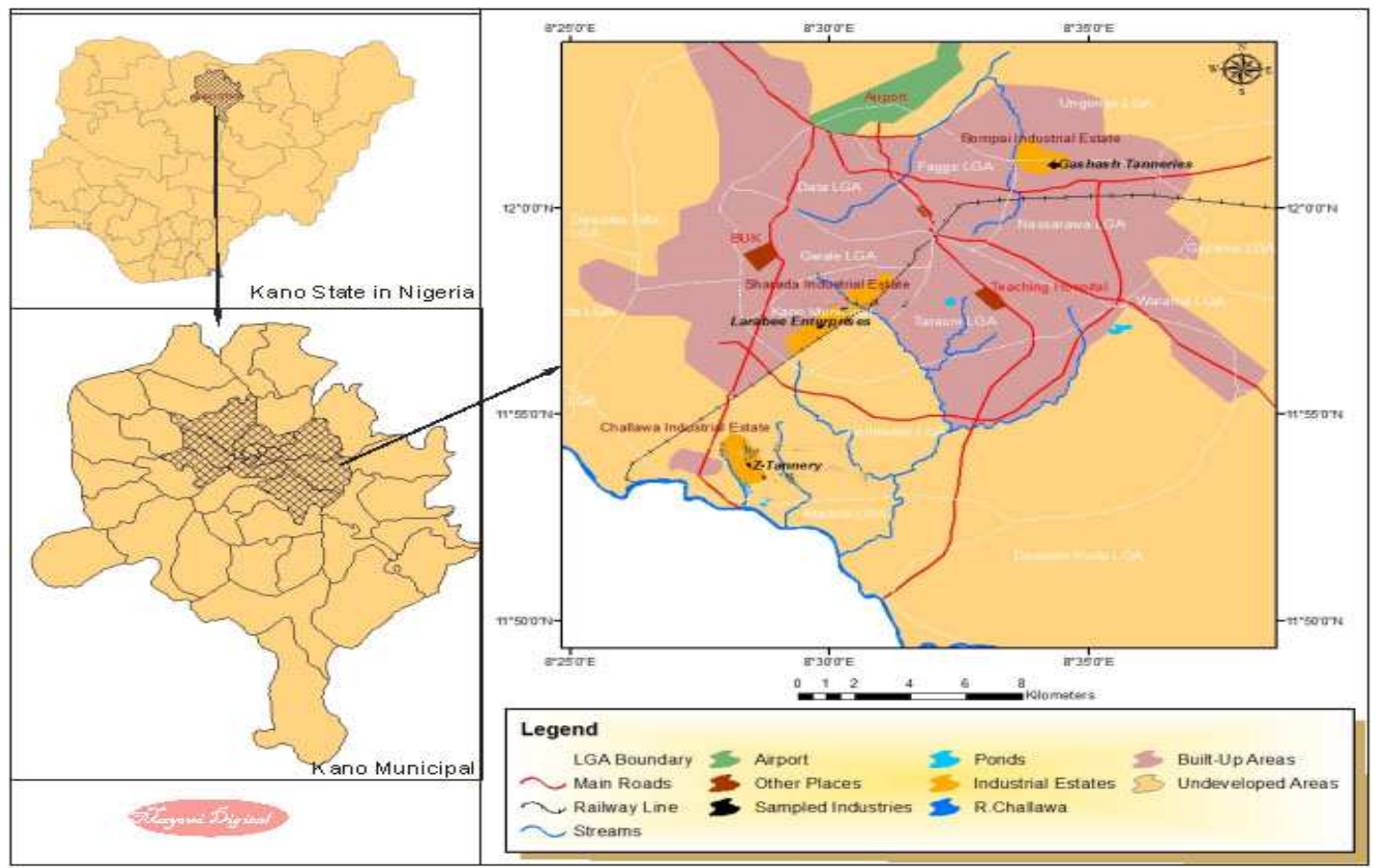

Fig. 1 Map showing the study areas

Source: Mayomi Digital Productions, GIS Laboratory, Department of Geography, UNIMAID (2017)

\section{Determination of Growth Rate of the Bacteria in Effluent Sample}

The bacteria growth rates were determined by transferring $2 \mathrm{~mL}$ of the bacterial isolates from the tannery effluent in broth medium into 100 $\mathrm{mL}$ sterile effluents in conical flasks and kept in an incubator (Giffrin cool) for 10 days. Control was also set up by incubating another $100 \mathrm{~mL}$ each of the sterile effluents without the bacteria. The optical density of the content was determined at the wavelength of $600 \mathrm{~nm}$ on a daily interval and recorded. 
BAJOPAS Volume 13 Number 2, December, 2020 Immobilization of Bacteria

Agar solution and inoculi were prepared separately. Fifty milliliters $(50 \mathrm{~mL})$ of nutrient broth each of the inoculi was prepared in a McCartney bottle and incubated for 24 hours. A solution of agar-agar was prepared by dissolving $10 \mathrm{~g}$ of the powder in distilled water and made up to $500 \mathrm{~mL}$ mark in an Erlenmeyer flask and was sterilized in an autoclave (280A) for 15 minutes and allowed to cool to $40-45^{\circ} \mathrm{C}$ (Ajao et al., 2011). Four milliliters ( $4 \mathrm{~mL})$ of the bacterial isolates in the nutrient broth was mixed with 36 $\mathrm{ml}$ of the prepared agar-agar media in petri-dish plates and then allowed to solidify. This was kept in the refrigerator for bioremediation.

\section{Bioremediation (Treatment) of the Effluents}

The solidified agar block (immobilized bacteria) was cut into cubes using a sterile knife; $0.1 \mathrm{~mL}$ phosphate buffer ( $\mathrm{pH} \mathrm{7.0)}$ was added and kept in the refrigerator for 1 hour for curing. The phosphate buffer was decanted after 1 hour and the cubes were washed with sterile distilled water 3-4 times before it was used (Ajao et al., 2011). Two liters (2 L) of the effluent was supplemented with the minimum basal medium in $\mathrm{g} / \mathrm{L}: \mathrm{NaCl}(0.8), \mathrm{MgSO}_{4} .7 \mathrm{H}_{2} \mathrm{O}(0.001), \mathrm{KH}_{2} \mathrm{PO}_{4}$ (2), $\mathrm{NaNO}_{3}$ (2), $\quad \mathrm{CaCl}_{2} .2 \mathrm{H}_{2} \mathrm{O} \quad(0.5)$ and $\mathrm{NaHPO}_{4} .12 \mathrm{H}_{2} \mathrm{O}(2)$ and sterilized in an autoclave at $121^{\circ} \mathrm{C}$ for 15 minutes (Margesin and Schinner, 2001). Two hundred and fifty milliliters $(250 \mathrm{~mL})$ of the effluents were transferred into different $250 \mathrm{ml}$ conical flasks. The content was covered with a cotton-wool ramped with foil paper to avoid contamination. Five grams $(5 \mathrm{~g})$ of the immobilized bacteria were quickly transferred into each of the effluents in the conical flasks in an inoculating chamber. The same procedures were carried out for the $10 \mathrm{~g}, 15 \mathrm{~g}, 20 \mathrm{~g}$ and 25 $\mathrm{g}$ of the immobilized bacteria in separate $250 \mathrm{~mL}$ effluents in conical flasks and agitated for ten days in a shaker incubator (Gallenkamp-OC4364-L) at a temperature $30^{\circ} \mathrm{C}$ and speed of 60 rpm. The treated effluent samples were taken on the tenth day and analyzed for the parameters $\mathrm{pH}$, SS, TDS, COD, and BOD, (Posttreatment determination) for the different grams of bacteria to evaluate and compare the biodegradation potential. (Baba et al., 2020).

\section{Statistical Analysis}

The data were represented as Mean \pm Standard deviation and analyzed statistically using oneway Analysis of Variance (ANOVA) and Tukey's HSD as Post Hoc Tests with the aid of SPSS 16.0. The correlation coefficient was also used to measure the strength of the relationship between the different masses of the bacteria and the parameters. All $\mathrm{p} \leq 0.05$ were considered as statistically significant.

\section{RESULTS AND DISCUSSION Physico-chemical parameters in the Industrial Effluents before the Biodegradation.}

Results of the Physico-chemical parameters in the industrial effluents before the Biodegradation is shown in table 1 . The mean temperatures $\left({ }^{\circ} \mathrm{C}\right)$ observed in TAN1, TAN2, and TAN3 samples were $28.07 \pm 0.65 ; 27.77 \pm 0.64$ and $26.38 \pm 3.81$ respectively. The order of the mean temperature of the samples from the three industries can be arranged as TAN1 > TAN2>TAN3. The temperature observed at TAN1, TAN2, and TAN3 samples were found below the WHO $\left(35^{\circ} \mathrm{C}\right)$ and NESREA $\left(40^{\circ} \mathrm{C}\right)$ limits. The low values of temperature might be due to the processes used at the time of sampling. High temperature brings down the solubility of gases in water that ultimately expresses as high BOD and COD. Statistical analysis shows that there is no significant difference $(p<0.05)$ between the mean values of temperature among the industries. This might be due to similar tannery activities involved in the tannery industries at the time of sampling. The average values of temperature observed in this present study are less than those observed by Akan et al. (2007), Akan et al. (2009) and Baba et al. (2020).

The mean level of $\mathrm{pH}$ observed in TAN1, TAN2 and TAN3, samples were $7.77 \pm 2.93$; $8.35 \pm 0.28$ and $7.52 \pm 0.76$ respectively. The order of the mean $\mathrm{pH}$ of the samples from the three industries can be arranged as TAN2> TAN1 $>$ TAN3. The $\mathrm{pH}$ of the samples falls within the WHO (7.0-8.5) and NESREA (6-9) standard limits. Statistical analysis shows that there is no significant difference $(p<0.05)$ between the mean values of $\mathrm{pH}$ among the industries. This might be due to similar tannery activities involved in the tannery industries at the time of sampling. Maheshwari et al. (2017) reported that the level of $\mathrm{pH}$ in the effluents from the tannery industry in Vaniyambadi, India was 6.5 which was lower than that observed in the present study. The $\mathrm{pH}$ in the effluents from the tannery industries in Kano and Kaduna were reported to be 7.64 and 6.89, respectively (Akan et al., 2007; Mohammed et al., 2017). The average values of $\mathrm{pH}$ observed in this present study are less than those observed by Mohammed et al. (2017) and Baba et al. (2020). The mean level of SS $(\mathrm{mg} / \mathrm{l})$ observed in TAN1, TAN2, and TAN3 samples were 374 \pm 124 ; $358 \pm 335$ and $780 \pm 739$ respectively. The order of the mean SS in the samples from the three industries can be arranged as TAN3 > TAN1 $>$ TAN2. 
The SS observed in the samples were far above the recommended standard limits of regulating bodies WHO $(30 \mathrm{mg} / \mathrm{l})$ and NESREA $(10 \mathrm{mg} / \mathrm{l})$. Statistical analysis shows that there is no significant difference $(p<0.05)$ between the mean values of SS among the industries. This might be due to similar tannery activities involved in the tannery industries at the time of sampling. The average values of SS observed in this present study are less than that observed $(3700 \pm 122 \mathrm{mg} / \mathrm{l})$ by Akan et al. (2009) for tanneries in Kano. Also, the average values of SS observed in this present study are less than that observed by Mohammed et al. (2017) and Baba et al. (2020) with the exception in TAN3.

The mean level of TDS (mg/l) observed in TAN1, TAN2, and TAN3 samples were $3941 \pm 3703$; $3300 \pm 1714$ and $2653 \pm 1240$ respectively. The order of the mean TDS in the samples from the three industries can be arranged as TAN1>TAN2>TAN3. The TDS observed in the samples were far above the recommended standard limits of WHO $(250 \mathrm{mg} / \mathrm{l})$ and NESREA $(500 \mathrm{mg} / \mathrm{l})$. Statistical analysis shows that there is no significant difference $(p<0.05)$ between the mean values of TDS among the industries. This might be due to similar tannery activities involved in the tannery industries at the time of sampling. TDS in the effluents from the tannery industries in Kano, Nigeria was reported to be $1281 \mathrm{mg} / \mathrm{l}$ (Akan et al., 2007). The average values of SS observed in this present study are less than those observed by Mohammed et al. (2017) and Baba et al. 2020)

The mean level of COD (mg/l) observed in TAN1, TAN2 and TAN3 samples seasons were $2372 \pm 938 ; \quad 1406 \pm 208$ and $3532 \pm 1373$ respectively. The order of the mean COD of the samples from the three industries can be arranged as TAN3>TAN1> TAN2. The COD observed in TAN1, TAN2 and TAN3 samples were far above the recommended standard limits of regulating bodies $\mathrm{WHO}(40 \mathrm{mg} / \mathrm{l})$ and NESREA (40 mg/l). Statistical analysis shows that there is no significant difference $(p<0.05)$ in COD among the industries. This might be due to similar tannery activities involved in the tannery industries as at the time of sampling. The Chemical Oxygen demand (COD) is the amount of oxygen, in $\mathrm{mg} / \mathrm{L}$, required for the degradation of the compound of wastewater to occur. In comparison, the average values of COD observed in this present study were higher than that observed by Mohammed et al. (2017) but lower than that observed by Baba et al. (2020).

The mean levels of BOD $(\mathrm{mg} / \mathrm{l})$ observed in TAN1, TAN2 and TAN3 samples were $13.85 \pm 6.42 ; \quad 19.46 \pm 0.50$ and $17.13 \pm 3.14$ respectively. The order of the mean BOD in the samples from the three industries can be arranged as TAN2>TAN3>TAN1. The BOD observed in TAN1, TAN2 and TAN3 samples were found below the recommended limits of NESREA (200 mg/l) but above WHO (10 mg/l). Statistical analysis shows that there is no significant difference $(p<0.05)$ between the mean values of BOD among the industries. This might be due to similar tannery activities involved in the tannery industries at the time of sampling. The low level of BOD recorded in this study is an indication of the low level of biodegradable organic solids in the effluent. The average values of BOD observed in this present study were lower than those observed by Mohammed et al. (2017) and Baba et al. (2020).

Table 1: Mean Values \pm S.D of Physico-chemical parameters of effluents from the Tannery Industries before Treatment.

\begin{tabular}{llllllll}
\hline Parameter & Tannery 1 & Tannery 2 & Tannery 3 & $\mathrm{a}$ & $\mathrm{b}$ & $\mathrm{c}$ & $\mathrm{d}$ \\
\cline { 2 - 7 } Temperature $\left({ }^{\circ} \mathrm{C}\right)$ & $28.07 \mathrm{a} \pm 0.65$ & $27.77 \mathrm{a} \pm 0.64$ & $26.38 \mathrm{a} \pm 3.81$ & & $29.50 \pm 4.68$ & 35 & 40 \\
pH & $7.77 \mathrm{a} \pm 2.93$ & $8.35 \mathrm{a} \pm 0.28$ & $7.52 \mathrm{a} \pm 0.76$ & 6.89 & $5.35 \pm 1.57$ & $7.0-8.5$ & $6.0-9.0$ \\
$\mathrm{COD}(\mathrm{mg} / \mathrm{l})$ & $2372 \mathrm{a} \pm 938$ & $1406 \mathrm{a} \pm 208$ & $3532 \mathrm{a} \pm 1373$ & 2.2 & $3106 \pm 2753$ & 40 & 40 \\
$\mathrm{BOD}(\mathrm{mg} / \mathrm{l})$ & $13.85 \mathrm{a} \pm 6.42$ & $19.46 \mathrm{a} \pm 0.50$ & $17.13 \mathrm{a} \pm 3.14$ & 1032 & $26.17 \pm 9.49$ & 10 & 200 \\
$\mathrm{SS}(\mathrm{mg} / \mathrm{l})$ & $374 \mathrm{a} \pm 124$ & $358 \mathrm{a} \pm 335$ & $780 \mathrm{a} \pm 739$ & 501 & $562 \pm 482$ & 30 & 10 \\
TDS $(\mathrm{mg} / \mathrm{l})$ & $3941 \mathrm{a} \pm 3703$ & $3300 \mathrm{a} \pm 1714$ & $2653 \mathrm{a} \pm 1240$ & 532.7 & $444 \pm 507$ & 250 & 500 \\
\hline
\end{tabular}

The values given in the table above are means of 6 replicate values, $\mathrm{n}=6$ ( 1 sample was taken monthly for 6 months). Within the rows, means with different alphabets are statistically different $(p<0.05)$. WHO: World Health Organisation. NESREA: National Environmental Standard and Regulatory Enforcement Agency. a = Mohammed et al.(2017), b = Baba et al. (2020), c = WHO (2006), $d=$ NESSRA (2009) 
BAJOPAS Volume 13 Number 2, December, 2020

Identification, Biochemical Characterization and growth rates of the Bacterial Isolates

Results of identification and biochemical characterization of the bacterial isolates were shown in table 2. After 24 hours of incubation, the nutrient agar media plates were checked for bacterial growth. The results showed the presence of different strains in the samples. The TAN1 bacteria isolate was found to be gramnegative cocci while TAN3 was gram-positive cocci. TAN2 bacteria isolate was found to be gram-positive, rod-shaped. TAN1, TAN2, and TAN3 bacteria isolates recorded positive results for spore former.

The results of the biochemical tests indicated that all the bacteria were positive for catalase, oxidase, citrate, maltose, glucose, lactose (negative in TAN1), mannitol (negative in TAN2), starch hydrolysis and coagulase (negative in TAN2) tests. The bacteria showed negative results for nitrate reduction, $M R$ (positive in TAN2), VP (positive in TAN1), Indole (positive in TAN2) tests. Base on the morphological and biochemical test results, TAN1, TAN2, and TAN3 bacteria isolates were identified to be Nesseria spp, Bacillus cereus, and Staphylococcus aureus respectively.

The growth rate of the TAN1, TAN2 and TAN3 Isolates were shown in figure 2. Generally, the optical density increase with the increase in time (day) and decrease as time goes on. The highest optical density was shown by bacillus cereus in TAN2 while the lowest was shown by Staphylococcus aureus in TAN3.

The initial growth phase of TAN1 Isolate bacteria occurred within 2-day of incubation as the growth rate increases up to the 6th-day incubation when the maximum growth was observed. Beyond the 6th day, the growth of the bacteria declined (which might be due to a shortage of nutrients in the effluents) until it reached its death phase (which might be due to the unavailability of nutrients in the effluents).

A similar trend of growth was also observed for TAN2 Isolate as the initial growth phase also occurred within 2-day of incubation but maximum growth rate observed on the 4th day of incubation. The stationary stage occurred between the 4th day and the 8th day. Beyond the 8th day, the growth of the bacteria declined (which might be due to a shortage of nutrients in the effluents) until it reached its death phase (which might be due to the unavailability of nutrients in the effluents).

The initial growth phase of TAN3 bacterial Isolate occurred within the 3-day incubation as the growth rate increases up to the 6th-day incubation when the maximum growth was observed. Beyond the 6th day, the growth of the bacteria declined (which might be due to a shortage of nutrients in the effluents) until it reached its death phase (which might be due to the unavailability of nutrients in the effluents).

Table 2: Morphological and Biochemical characteristics of bacterial isolates

\begin{tabular}{lllll} 
Bacterial Isolates & & TAN1 & TAN2 & TAN3 \\
\hline $\begin{array}{lllll}\text { Morphological } \\
\text { characteristics }\end{array}$ & Shape & Cocci & Rod & Cocci \\
& Spore & & & \\
& former & + & + & + \\
Gram & & & \\
Biochemical characteristics & reaction & - & + & + \\
& Citrate & + & + & + \\
& Catalase & + & + & + \\
& Coagulase & + & - & + \\
Starch & + & + & + \\
& Glucose & + & + & + \\
Oxidase & + & + & + \\
& Indo & - & + & - \\
Lactose & - & + & + \\
Manitol & + & - & + \\
Maltose & + & + & + \\
MR & - & + & - \\
VP & + & - & - \\
& Nitrate & - & - & - \\
Reduction & - Neisseria & Bacillus & Staphylococcus \\
& Bacterial & cereus & aureus \\
& name & spp & cas
\end{tabular}

+ = Positive; - = Negative; MR=Methyl Red; VP= Voges-Proskauer 


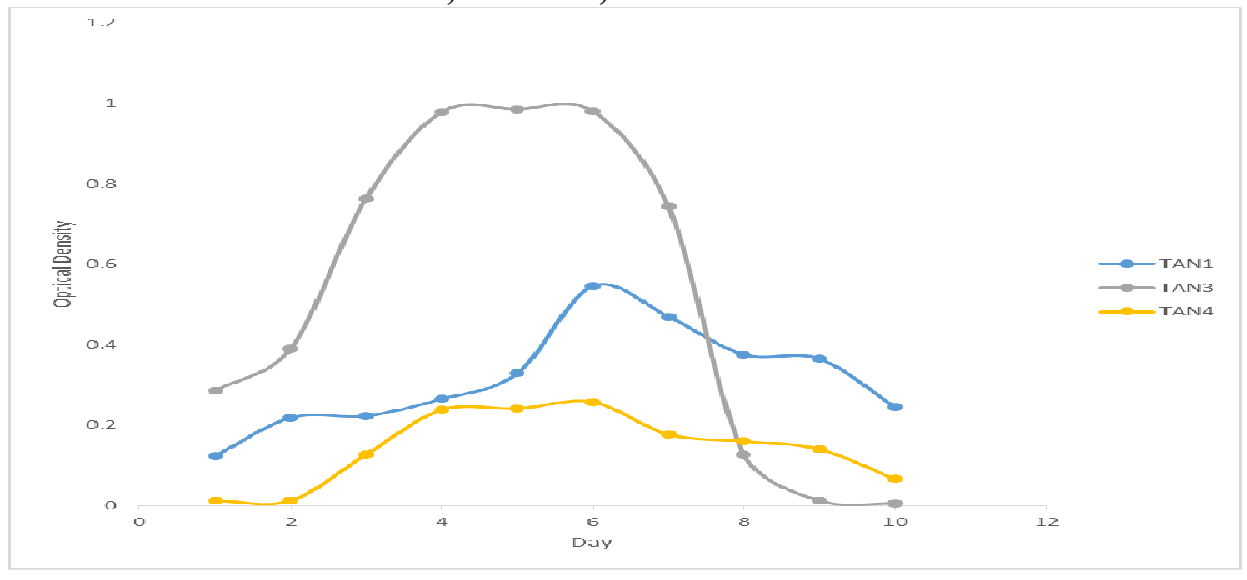

Fig. 2 Growth rates of the isolates in the effluents from the Tannery Industries

\section{Physico-chemical Parameters in the Industrial Effluents after the biodegradation.}

Table 3 shows the mean results of the physicochemical parameter before and after bioremediation using the different masses $(5 \mathrm{~g}$, $10 \mathrm{~g}, 15 \mathrm{~g}, 20 \mathrm{~g}$, and $25 \mathrm{~g}$ ) of the respective immobilized bacteria. Also, Table 4 shows the mean results of correlation coefficient ( $r$ ) between different masses of bacteria and physicochemical parameters.

The mean values $(\mathrm{mg} / \mathrm{l})$ of the SS after the bioremediation varies between $243 \pm 45$ and $898 \pm 672$. The mean concentration $(\mathrm{mg} / \mathrm{l})$ of SS remediated by the different masses $(5 \mathrm{~g}, 10 \mathrm{~g}$, $15 \mathrm{~g}, 20 \mathrm{~g}$, and $25 \mathrm{~g}$ ) of the bacteria varies. The SS in the samples fluctuates up and down after the bioremediation process when compared with the SS of the raw samples before the bioremediation. The increase in the levels of the SS might be due to the aggregation of the TDS which are large enough to result into SS. The increase in the levels of the SS might be also due to the influence of the nutrients which was added into the effluents in order to make the microorganisms more active and viable for fast degradation of organic contaminants in the effluent. The relative potential or efficiency of the different masses of the bacteria in remediating SS in TAN1 samples was in the order $25 \mathrm{~g}>20 \mathrm{~g}>15 \mathrm{~g}>10 \mathrm{~g}>5 \mathrm{~g}$. For TAN2 and TAN3 samples, the order was $25 \mathrm{~g}>20 \mathrm{~g}>15$ $\mathrm{g}>10 \mathrm{~g}>5 \mathrm{~g}$. These might be due to the variations in the surface areas of the different masses of the immobilized bacteria. Statistical analysis shows that there is no significant difference $(p<0.05)$ between the mean values of SS among the masses in the respective industries. Positive and significant correlations exist between the masses of bacteria and Suspended Solid (SS). This showed that there is general increase in the levels of the SS as the masses of the immobilized bacteria increases. TAN3 (90\%) and TAN1 (80\%) showed a very high correlation with the masses of the bacteria while TAN2 (61\%) showed a very low correlation.

The mean values $(\mathrm{mg} / \mathrm{l})$ of the TDS after the bioremediation varies between $46 \pm 11$ and $83 \pm 78$. The mean concentration $(\mathrm{mg} / \mathrm{l})$ of TDS remediated by the different masses $(5 \mathrm{~g}, 10 \mathrm{~g}$, $15 \mathrm{~g}, 20 \mathrm{~g}$, and $25 \mathrm{~g}$ ) of the bacteria varies. There is a reduction in all the TDS of all the samples after the bioremediation process compared with the TDS of the raw samples before the bioremediation. The relative potential or efficiency of the different masses of the bacteria in remediating TDS in TAN1 and TAN3 samples was in the order $5 \mathrm{~g}>10 \mathrm{~g}>15 \mathrm{~g}>20$ $\mathrm{g}>25 \mathrm{~g}$. For TAN2 samples, the order was 20 $g>10 \quad g>25 \quad g>15 \quad g>5 \quad g$. Statistical analysis shows that there is no significant difference $(p<0.05)$ between the mean values of TDS among the masses in the respective industries. These might be due to the variations in the surface areas of the different masses of the immobilized bacteria. Positive and significant correlations exist between the masses of bacteria and TDS with the exception in TAN2 (negative and insignificant correlation). The positive correlations showed that there is general increase in the levels of the TDS as the masses of the immobilized bacteria increases. TAN1 $(96 \%)$ showed a very high correlation with the masses of the bacteria while TAN2 (47\%) showed a very low correlation.

The mean values $(\mathrm{mg} / \mathrm{l})$ of the BOD after the bioremediation varies between $1.56 \pm 0.20 \mathrm{mg} / \mathrm{l}$ and $6.92 \pm 5.49 \mathrm{mg} / \mathrm{l}$. The mean concentration $(\mathrm{mg} / \mathrm{l})$ of BOD remediated by the different masses $(5 \mathrm{~g}, 10 \mathrm{~g}, 15 \mathrm{~g}, 20 \mathrm{~g}$, and $25 \mathrm{~g}$ ) of the bacteria varies. There is a reduction in all the BOD of all the samples after the bioremediation process compared with the $\mathrm{BOD}$ of the raw 
BAJOPAS Volume 13 Number 2, December, 2020 samples before the bioremediation. The relative potential or efficiency of the different masses of the bacteria in remediating BOD in TAN1, TAN2 and TAN3 samples were in the order $25 \mathrm{~g}>20$ $\mathrm{g}>15 \mathrm{~g}>10 \mathrm{~g}>5 \mathrm{~g}, 25 \mathrm{~g}>15 \mathrm{~g}>5 \mathrm{~g}>10 \mathrm{~g}>20 \mathrm{~g}$ and $20 \mathrm{~g}>10 \mathrm{~g}>25 \mathrm{~g}>15 \mathrm{~g}>5 \mathrm{~g}$ respectively. Statistical analysis shows that there is significant difference $(p<0.05)$ between the mean values of BOD among the masses in the respective industries. These might be due to the variations in the surface areas of the different masses of the immobilized bacteria. Negative and significant correlations exist between the masses of bacteria and BOD. This showed that there is general decrease in the levels of the BOD as the masses of the immobilized bacteria increases. TAN1 (94\%) showed a very high correlation with the masses of the bacteria while TAN2 (4\%) showed a very low correlation.

The mean values $(\mathrm{mg} / \mathrm{l})$ of the COD after the bioremediation varies between $250 \pm 154$ and $3134 \pm 1595$. The mean concentration $(\mathrm{mg} / \mathrm{l})$ of COD remediated by the different masses $(5 \mathrm{~g}$, $10 \mathrm{~g}, 15 \mathrm{~g} 20 \mathrm{~g}$, and $25 \mathrm{~g}$ ) of the bacteria varies. There is a reduction in all the COD of all the samples after the bioremediation process compared with the COD of the raw samples before the bioremediation. The relative potential or efficiency of the different masses of the bacteria in remediating COD in TAN1, TAN2 and TAN3 samples were in the order $25 \mathrm{~g}>20 \mathrm{~g}>15$ $\mathrm{g}>5 \mathrm{~g}>10 \mathrm{~g}, 25 \mathrm{~g}>20 \mathrm{~g}>15 \mathrm{~g}>10 \mathrm{~g}>5 \mathrm{~g}$ and 10 g>5 g>25 g>15 g>20 g respectively. Statistical analysis shows that there were significant difference $(p<0.05)$ between the mean values of COD among the masses in the respective industries except for effluents treated with $25 \mathrm{~g}$. These might be due to the variations in the surface areas of the different masses of the immobilized bacteria. Negative and insignificant correlations exist between the masses of bacteria and COD with the exception in TAN3 (positive and significant correlation). The negative correlations showed that there is general decrease in the levels of the COD as the masses of the immobilized bacteria increases. TAN2 (100\%) showed a very high correlation with the masses of the bacteria while TAN3 (36\%) showed a very low correlation.

Generally, there was an overall decrease in the concentration of these physicochemical parameters after the bioremediation using the different masses of the bacterial isolates. These might be due to the variations in the surface areas of the different masses of the immobilized bacteria. This is in line with the work of Jimoh et al. (2018) and Baba et al. (2020).

Table 3: Mean Values $(\mathrm{mg} / \mathrm{l}) \pm$ S.D of Physicochemical parameters in effluents from the Tannery Industries before and after Treatment of the effluents $(250 \mathrm{ml})$ with the different masses $(5 \mathrm{~g}, 10 \mathrm{~g}$, $15 \mathrm{~g}, 20 \mathrm{~g}$, and $25 \mathrm{~g}$ ) of the bacteria.

\begin{tabular}{llllllll}
\hline $\mathrm{P}$ & IND & Before & \multicolumn{5}{c}{ After } \\
\cline { 4 - 7 } & & & $5 \mathrm{~g}$ & $10 \mathrm{~g}$ & $15 \mathrm{~g}$ & $20 \mathrm{~g}$ & $25 \mathrm{~g}$ \\
\hline \multirow{2}{*}{ COD } & TAN1 & $2372 \pm 938$ & $1708 \mathrm{a} \pm 861$ & $2045 \mathrm{a} \pm 1205$ & $845 \mathrm{a} \pm 369$ & $300 \mathrm{a} \pm 167$ & $250 \mathrm{a} \pm 154$ \\
& TAN2 & $1406 \pm 208$ & $1195 \mathrm{a} \pm 208$ & $1125 \mathrm{a} \pm 384$ & $1055 \mathrm{a} \pm 317$ & $956 \mathrm{a} \pm 310$ & $870 \mathrm{ab} \pm 240$ \\
& TAN3 & $3532 \pm 1373$ & $2374 \mathrm{a} \pm 1344$ & $1976 \mathrm{a} \pm 1405$ & $2757 \mathrm{a} \pm 1266$ & $3134 \mathrm{a} \pm 1595$ & $2614 \mathrm{~b} \pm 1105$ \\
BOD & TAN1 & $13.85 \pm 6.42$ & $6.92 \mathrm{a} \pm 5.49$ & $6.42 \mathrm{a} \pm 5.07$ & $5.72 \mathrm{a} \pm 5.35$ & $4.62 \mathrm{a} \pm 4.37$ & $2.82 \mathrm{ab} \pm 1.26$ \\
& TAN2 & $19.46 \pm 0.50$ & $1.75 \mathrm{~b} \pm 0.22$ & $1.73 \mathrm{~b} \pm 0.18$ & $1.58 \mathrm{a} \pm 0.16$ & $1.91 \mathrm{a} \pm 0.22$ & $1.56 \mathrm{~b} \pm 0.20$ \\
& TAN3 & $17.13 \pm 3.14$ & $4.24 \mathrm{ab} \pm 0.77$ & $3.29 \mathrm{ab} \pm 0.37$ & $4.11 \mathrm{a} \pm 0.07$ & $3.23 \mathrm{a} \pm 0.91$ & $3.33 \mathrm{a} \pm 1.28$ \\
SS & TAN1 & $374 \pm 124$ & $243 \mathrm{a} \pm 45$ & $471 \mathrm{a} \pm 226$ & $475 \mathrm{a} \pm 182$ & $492 \mathrm{a} \pm 128$ & $611 \mathrm{a} \pm 217$ \\
& TAN2 & $358 \pm 335$ & $460 \mathrm{a} \pm 400$ & $543 \mathrm{a} \pm 414$ & $544 \mathrm{a} \pm 402$ & $551 \mathrm{a} \pm 414$ & $554 \mathrm{a} \pm 405$ \\
& TAN3 & $780 \pm 739$ & $586 \mathrm{a} \pm 594$ & $758 \mathrm{a} \pm 656$ & $787 \mathrm{a} \pm 676$ & $861 \mathrm{a} \pm 635$ & $898 \mathrm{a} \pm 672$ \\
TDS & TAN1 & $3941 \pm 3703$ & $51 \mathrm{a} \pm 10$ & $53 \mathrm{a} \pm 10$ & $55 \mathrm{a} \pm 15$ & $61 \mathrm{a} \pm 20$ & $63 \mathrm{a} \pm 26$ \\
& TAN2 & $3300 \pm 1714$ & $83 \mathrm{a} \pm 78$ & $47 \mathrm{a} \pm 20$ & $48 \mathrm{a} \pm 22$ & $47 \mathrm{a} \pm 17$ & $48 \mathrm{a} \pm 17$ \\
& TAN3 & $2653 \pm 1240$ & $46 \mathrm{a} \pm 11$ & $55 \mathrm{a} \pm 24$ & $55 \mathrm{a} \pm 25$ & $58 \mathrm{a} \pm 23$ & $61 \mathrm{a} \pm 28$ \\
\hline
\end{tabular}

Replicate $=6$ (months)

Within the rows, for the same parameter, means with different alphabets are statistically different $(p<0.05)$.

$\mathrm{P}=$ parameter, IND = Industries 
BAJOPAS Volume 13 Number 2, December, 2020

Table 4: Correlation coefficient $(r)$ between different masses of the bacteria and the physicochemical parameters.

\begin{tabular}{llll}
\hline Industries & Parameter & Correlation coefficient $(r)$ & $\begin{array}{l}\text { Percent dependence (rxrx100) } \\
(\%)\end{array}$ \\
\hline TAN1 & COD & -0.9 & 82 \\
& BOD & -0.97 & 94 \\
& SS & $0.90^{*}$ & 80 \\
TAN2 & TDS & $0.98^{*}$ & 96 \\
& COD & -1 & 100 \\
& BOD & -0.21 & 4 \\
& SS & $0.78^{*}$ & 61 \\
& TDS & -0.69 & 47 \\
& COD & $0.60^{*}$ & 36 \\
& BOD & -0.6 & 37 \\
& SS & $0.95^{*}$ & 90 \\
& TDS & $0.94^{*}$ & 89 \\
\hline
\end{tabular}

The correlation coefficient $(r)$ with * is statistically significant $(p<0.05)$.

Percentage reduction of the Parameters

Table 5 shows the percentage reduction of Parameters in industrial samples before and after the treatment of the effluents $(250 \mathrm{ml})$ with the different masses $(5 \mathrm{~g}, 10 \mathrm{~g}, 15 \mathrm{~g}, 20 \mathrm{~g}$, and $25 \mathrm{~g}$ ) of the Immobilized Bacteria.

In TAN1 samples, the percentage reduction (\%) of COD ranged (14-89); BOD (50-80); SS (-32$35)$ and TDS (98-99). In TAN2 samples, the percentage decrease $(\%)$ of COD ranged (15$38) ;$ BOD (90-92); SS [-28-(-55)] and TDS (9798). In TAN3 samples, the percentage decrease (\%) of COD ranged (11-44); BOD (76-81); SS (15-25) and TDS (98). The percentage increase in the levels COD, BOD and TDS might be due to the increase in the surface area of the different masses of the immobilized bacteria. However, the percentage decrease in the levels of the SS might be due to the aggregation of the TDS which are large enough to result into SS. The percentage decrease in the levels of the SS might be also due to the influence of the nutrients which was added into the effluents in order to make the microorganisms more active and viable for fast degradation of organic contaminants in the effluent. This is in line with the work of Jimoh et al. (2018) in which the concentration of the SS increase after the bioremediation of effluents.

Sreemoyee and Priti (2013) assessed and reduced several Physico-chemical parameters of dairy wastewater using Niesseria $s p$. and concluded that the species are well known to degrade organic compounds. This is in agreement with the current study in which the immobilized Niesseria $s p$ degrade the organic contaminants as indicated by the BOD, COD and TDS.

Jimoh et al. (2018) observed that TSS of the effluents was increased after treatment with immobilized bacteria and concluded that it might be due to the biostimulation method adopted for the research.

The optimum $\mathrm{pH}$ Biosorption of Chromium by Bacillus spp and Staphylococcus spp. from tannery effluent was investigated by Mythili and Karthikeyan (2011). The maximum adsorption of Chromium $(86.4 \mathrm{mg} / \mathrm{L})$ was showed by Bacillus spp and Staphylococcus spp showed $70.6 \mathrm{mg} / \mathrm{L}$ at an initial concentration of $100 \mathrm{mg} / \mathrm{L}$. In the present study, immobilised Bacillus spp and Staphylococcus spp. from the tannery industrial effluents reduced the levels of the organic pollutants with high potential as indicated by the percentage reduction of BOD, COD and TDS.

Enzymes often can work in multiple environments especially if they are immobilized. This makes the microorganisms' enzymes even more resistant to harsh environments and enables the enzymes to be recovered and recycled after they are no longer needed (Gianfreda and Rao 2004). Ramesh and Singh (1993) reported that the immobilized bacteria having more efficiency to remove the suspended particles than free cells. Using the immobilized cell is preferable due to its capability for using several times with the same efficiency, which makes it more economical. Similar work was done by Sikander et al. (2007) showing the higher reduction with permeabilized cells of Ochrobactrum intermedium strain SDCr-5. 
BAJOPAS Volume 13 Number 2, December, 2020

The results revealed the isolation and identification of isolates with the potential for the reduction of $\mathrm{Cr}$ (VI) to $\mathrm{Cr}$ (III). Results indicated that immobilized $B$. cereus could be efficiently used for the reduction of $\mathrm{Cr}$ (VI).

Table 5: Percentage reduction of the tested Parameters from the tannery industrial samples of the Immobilized Bacteria.

\begin{tabular}{lllllll}
\hline \multirow{2}{*}{ Industries } & & \multicolumn{5}{c}{ Percentage Reduction $(\%)$} \\
\cline { 3 - 7 } & & $5 \mathrm{~g}$ & $10 \mathrm{~g}$ & $15 \mathrm{~g}$ & $20 \mathrm{~g}$ & $25 \mathrm{~g}$ \\
\hline TAN1 & COD & 28 & 14 & 64 & 87 & 89 \\
& BOD & 50 & 54 & 59 & 67 & 80 \\
& SS & 35 & -26 & -27 & -32 & -63 \\
& TDS & 99 & 99 & 99 & 98 & 98 \\
TAN2 & COD & 15 & 20 & 25 & 32 & 38 \\
& BOD & 91 & 91 & 92 & 90 & 92 \\
& SS & -28 & -52 & -52 & -54 & -55 \\
& TDS & 97 & 99 & 99 & 99 & 99 \\
& COD & 33 & 44 & 22 & 11 & 26 \\
& BOD & 75 & 81 & 76 & 81 & 81 \\
& SS & 25 & 3 & -1 & -10 & -15 \\
& TDS & 98 & 98 & 98 & 98 & 98 \\
\hline
\end{tabular}

Percentage Reduction $=(B-A) / B \times 100 \%$

$A=$ Concentration of the parameter after treatment

$\mathrm{B}=$ Concentration of the parameter before treatment

$+=$ percentage decrease

- = percentage increase

In general, immobilization makes the enzyme more resistant to temperature, $\mathrm{pH}$, and substrate concentration swings giving it a longer lifetime and higher productivity per active unit (Gianfreda and Rao, 2004; FuIlbrook, 1996; Russell et al, 2003; Kandelbauer et al., 2004). Immobilized cells have been used and studied extensively for the production of useful chemicals (Ohtake and Silver, 1994), the treatment of wastewaters (Chen et al., 2003; Wang et al., 2010). Although many workers described microbial degradation of tannery effluent, limited literature is available on the bioremediation of tannery effluent using immobilized bacterial cells in the Kano Industrial Estates.

\section{CONCLUSION}

The samples contained variable levels of the physicochemical parameters. The results of the Analysis of variance revealed that, no statistical difference $(p<0.05)$ was observed for the temperature, $\mathrm{pH}, \mathrm{SS}, \mathrm{TDS}, \mathrm{BOD}$ and $\mathrm{COD}$ among the three tannery industries before the treatment. The levels of some of the parameters
(SS, TDS and COD) observed in the samples were found above the recommended limits of WHO and NESREA, which called for the treatment of the effluents before discharge into the environment. Base on the morphological and biochemical test results, TAN1, TAN2, and TAN3 bacterial isolates were identified to be Neisseria spp, Bacillus cereus, and Staphylococcus aureus respectively. The results of Post-treatment analysis showed that there is overall decrease in the levels of the parameters determined when compared with that of the pre-treatment. The overall percentage reduction of the immobilised bacteria in the treatment of the respective effluents was in the order TAN2 (72\%)>TAN1 $(70 \%)>$ TAN3 $(62 \%)$. Hence, the immobilized bacteria are having higher biodegradation potential for the treatment of the tannery effluents.

\section{Acknowledgments}

The authors wish to acknowledge the University of Maiduguri for the financial support. The authors are grateful to the Kano State Ministry of Environment for their support in obtaining the effluent samples. 


\section{REFERENCES}

Ajao, A. T., Adebayo, G. B., and Yakubu, S. E. (2011). Bioremediation of textile industrial effluent using mixed culture of Pseudomonas aeruginosa and Bacillus subtilis immobilized on agar-agar in a bioreactor. J. Microbiol. Biotech. Res, 1(3), 50-56.

Akan, J. C., Moses, E. A., Ogugbuaja, V. O., and Abah, J. (2007). Assessment of tannery industrial effluents from Kano metropolis, Kano State, Nigeria. Journal of Applied Sciences, 7(19), 2788-2793.

Akan, J. C., Ogugbuaja, V. O., Abdulrahman, F. I., and Ayodele, J. T. (2009). Pollutant levels in effluent samples from tanneries and textiles of Kano industrial areas, Nigeria. Global journal of pure and applied sciences, 15(3-4).

APHA (1989). Standard methods for Examination of Will bete and Will betewater.15 $5^{\text {th }}$ edition. Brydpass Springfield Will behington DC. pp. 164-176

APHA (1992). Standard Methods for the Examination of Water and Wastewater. Health, 69, 1116-9.

Baba, A., Garba, S. T., and Bello, H. S. (2020). Bioremediation Potential of Immobilized corynebacterium kutsceri in the Treatment of Tannery Industrial Effluent from Challawa Industrial Estate, Kano State, Nigeria. Journal of the Turkish Chemical Society Section A: Chemistry, $7(2), 335-350$.

Beem, E. I. V. (1994). reduction of solvent VOC emission. J. Oil Col. Chem. Ass, 77, 158.

Bouwer, E. J., and Zehnder, A. J. (1993). Bioremediation of organic compoundsputting microbial metabolism to work. Trends in biotechnology, 11(8), 360367.

Chen, K. C., Wu, J. Y., Liou, D. J., and Hwang, S. C. J. (2003). Decolorization of the textile dyes by newly isolated bacterial strains. Journal of Biotechnology, 101(1), 57-68.

Dan'Azumi, S., and Bichi, M. H. (2010). INDUSTRIAL POLLUTION AND HEAVY METALS PROFILE OF CHALLAWA RIVER IN KANO, NIGERIA. Journal of Applied Sciences in Environmental Sanitation, $5(1)$.

DWAF. (1992). Analytical Methods Manual, TR 151. Department of Water Affairs and Forestry, Pretoria.

El-Bestawy, E. (2013). Biological treatment of leather-tanning industrial wastewater using free living bacteria.
Elsheikh, M. A. S. (2009). Tannery wastewater pre-treatment. Water Science and Technology, 60(2), 433-440.

FuIlbrook, P. D. (1996). "Kinetics." Industrial enzymology: The application of enzymes in Industry. 2nd Ed. T. Godfrey and J Reichelt. eds.. Nature. New York.

Gianfreda, L., and Rao, M. A. (2004). Potential of extra cellular enzymes in remediation of polluted soils: a review. Enzyme and microbial technology, 35(4), 339354.

Hugo Springer. (1994). John Arthur Wilson Memorial Lecture "Treatment of Industrial Wastes of the Leather Industry - is it still a Major Problem". JALCA, 89, 153-185

Jimoh, A. A., Ganiyu, B. A., Baba, D., and Baba, A. (2018) Bioremediation Process of Effluent from Detergent and Food Industries in Jos, Nigeria: Kinetics and Thermodynamics. International Journal of Engineering Science Invention (IJESI), 762-73

Kandelbauer, A., Maute, O., Kessler, R. W., Erlacher, A., and Gübitz, G. M. (2004). Study of dye decolorization in an immobilized laccase enzyme-reactor using online spectroscopy. Biotechnology and bioengineering, 87(4), 552-563.

Kongjao, S., Damronglerd, S., and Hunsom, M. (2008). Simultaneous removal of organic and inorganic Pollutants in tannery wastewater using electrocoagulation technique. Korean Journal of chemical engineering, 25(4), 703.

Maheshwari, U. M., Aruna, S., Gomathi, M., and AbdulJaffar, A. H. (2017). Bioremediation by Free and Immobilized Bacteria Isolated from Tannery Effluent. International Journal of Research in Applied, Natural and Social Sciences. 5(7), 75-90

Margesin, R., and Schinner, F. (2001). Bioremediation (natural attenuation and biostimulation) of diesel-oilcontaminated soil in an alpine glacier skiing area. Applied and environmental microbiology, 677), 3127-3133.

Mohammed, A., Sekar, P., and George, J. (2011). Efficacy of microbes in bioremediation of tannery effluent. Inter. J. Curr. Res, 3(4), 324-326.

Mohammed, S. S. D., Orukotan, A. A., and Abdullahi, H. (2017). Physicochemical and Bacteriological Assessment of Tannery Effluent from Samaru-Zaria, 
BAJOPAS Volume 13 Number 2, December, 2020 Kaduna State, Nigeria. Journal of Applied

Sciences and Environmental Management, 21(4), 734-740.

Munz, G., De Angelis, D., Gori, R., Mori, G., Casarci, M., and Lubello, C. (2009). The role of tannins in conventional and membrane treatment of tannery wastewater. Journal of hazardous materials, 164(2-3), 733-739

Mythili, K., and Karthikeyan, B. (2011). Bioremediation of $\mathrm{Cr}$ (VI) from tannery effluent using Bacillus spp and Staphylococcus spp. International Multidisciplinary Research Journal, 1(6).

NESREA (2009). National Environmental Standards for Effluent Limitations and Regulation. 1233-1236

Noorjahan, C. M. (2014). Physicochemical characteristics, identification of bacteria and biodegradation of industrial effluent. Journal of bioremediation and Biodegradation, 5(3).

Ohtake, H. I., and Silver, A. O. (1994). Bacterial reduction of toxic chromate. Biological degradation and bioremediation of toxic chemicals, 403-415.

Omoleke, I. I. (2004). Management of environmental pollution in Ibadan, an African city: the challenges of health hazard facing government and the people. Journal of Human Ecology, 15(4), 265-275.

Rajor, A., Reddy, A.S., and Singh, B. (2004). Determination of BOD kinetic Parameters and evaluation of alternate methods, M.Sc. Thesis, Department of biotechnology \& environmental Science, Thapar Institute of Engineering and Technology, Patiala

Ramasami, T., Rajamani, S., and Rao, J. R. (1994, March). Pollution control in leather industry: Emerging technological options. In International symposium on surface and colloidal science and its relevance to soil pollution, madras.

Ramesh, J. V. S., and Singh, S. P. (1993). Yearly variation in certain physicochemical parameters of pond at eastern Doon Valley. Uttar Pradesh J. Zoo, 12 (1), 7577.

Ranen, S., and Sharadinadra, C. (2009). Biotechnology applications to environmental remediation in resource exploitation. Current science, 97, 6-25
Russell, A. J., Berberich, J. A., Drevon, G. F., and Koepsel, R. R. (2003). Biomaterials for mediation of

chemical and biological warfare agents. Annual review of biomedical engineering, 5(1), 1-27.

Saravanan, P., and Saravanan, A. (1999). Decolourization of tannery effluent by Flavobacterium sp. EK 1. Indian Journal of Environmental Protection, 19, 19-24.

Sikander, S., and Shahida, H. (2007). Reduction of toxic hexavalent chromium by Ochrobactrum intermedium strain SDCr5 stimulated by heavy metals. Bioresource Technol, 98, 340-344.

Singh, N., Sharma, B. K., and Bohra, P. C. (2000). Impact assessment of industrial effluent of arid soils by using satellite imageries. Journal of the Indian Society of Remote Sensing, 28(2-3), 79.

Sreemoyee, C., and Priti, P. (2013). Assessment of physico-chemical parameters of dairy waste water and isolation and characterization of bacterial strains in terms of cod reduction. Int J Sci, 2(3), 395-400.

Verheijen, L. A. H. M., Wiersema, D., Pol, L. H., and De Wit, J. (1996). Management of wastes from animal product processing. Livestock and environment, Finding a balance. International Agriculture Center, Wageningen, The Netherlands.

Wang, F., Yao, J., Si, Y., Chen, H., Russel, M., Chen, K., and Bramanti, E. (2010). Short-time effect of heavy metals upon microbial community activity. Journal of Hazardous Materials, 173(13), 510-516.

WHO (World Health Organization). (2006). Air quality guidelines: global update 2005: particulate matter, ozone, nitrogen dioxide, and sulfur dioxide. World Health Organization.

World Bank. (1995). Nigeria's strategic options for redressing industrial pollution. World Bank, industry and energy division. 1st edition, West Central Africa Department; Annexes: 1995; pp 60-62.

Zahoor, A., and Abdul, R. (2009). Enumeration of Coliforms. Journal of Environmental Sciences. 21, 814-820 


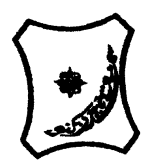

Bayero Journal of Pure and Applied Sciences, 13(2): 1 - 12

Received: November, 2020

Accepted: December, 2020

ISSN $2006-6996$

\title{
BIODEGRADATION POTENTIAL OF IMMOBILIZED BACTERIA IN THE TREATMENT OF TANNERY INDUSTRIAL EFFLUENTS FROM INDUSTRIAL ESTATES IN KANO STATE, NIGERIA
}

\author{
Abdullateef, B., ${ }^{1 *}$ Shuaibu, T. G., ${ }^{1}$ Babagana, K., ${ }^{1}$ Suleman, H. B. ${ }^{2}$ and Dauda, B. ${ }^{3}$ \\ ${ }^{1}$ Department of Pure and Applied Chemistry, Faculty of Science, University of Maiduguri, Borno State, \\ Nigeria \\ ${ }^{2}$ Department of Microbiology, Faculty of Science, University of Maiduguri, Borno State, Nigeria \\ ${ }^{3}$ Department of Chemical Engineering, Faculty of Engineering, University of Maiduguri, Borno State, \\ Nigeria \\ *Corresponding author: babslega@gmail.com; abelega2007@yahoo.com; +2348061309753
}

\section{ABSTRACT}

Industrial Effluents Samples from Gashash Tanneries (TAN1) in Bompai Industrial estate, Larabee Tannery Industry (TAN2) in Sharada Industrial estate and Z Tannery Industries (TAN3) in Challawa Industrial estate, Kano State, Nigeria were collected over a period of six months (August 2017 to January 2018) for assessing the biodegradation potentials of bacteria in the treatment of organic pollutants within the effluents. Bacteria were isolated from the effluents and immobilized on agar-agar. Different masses (5 g, $10 \mathrm{gr}, 15$ $\mathrm{g}, 20 \mathrm{~g}$, and $25 \mathrm{~g}$ ) of the bacteria were used in the treatment of $250 \mathrm{ml}$ of the effluents for ten days in a shaker incubator (Gallenkamp-OC-4364-L) at the temperature $30{ }^{\circ} \mathrm{C}$ and speed of $60 \mathrm{rpm}$. Pre-treatment analysis of the effluents for Temperature, pH, Biochemical Oxygen Demand (BOD), Chemical Oxygen Demand (COD), Suspended Solid (SS) and Total Dissolved Solids (TDS) gives the following results; temperature $\left({ }^{\circ} \mathrm{C}\right.$ )

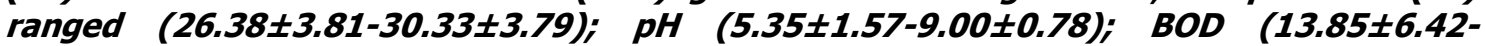
$38.75 \pm 16.20) ;$ COD (1406 $\pm 208-3532 \pm 1373) ;$ SS (208 $\pm 235-780 \pm 739)$ and TDS (266 $\pm 253-5276 \pm 2971)$. No statistical differences ( $p \leq 0.05)$ was observed for all the results among the different industries. The bacterial isolates were identified as Neisseria spp, Bacillus cereus, and Staphylococcus aureus, in TAN1, TAN2, and TAN3, respectively. After treatment of the effluent with the different masses of the isolated bacteria, the mean level of BOD was found to range as (0.55 $\pm 0.36-6.92 \pm 5.49) ; C O D$ (ND-3134 \pm 1595$)$;

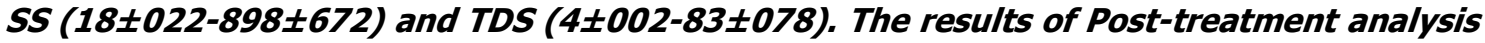
showed that there is overall decrease in the levels of the parameters determined when compared with that of the pre-treatment. The overall percentage reduction of the immobilised bacteria in the treatment of the respective effluents was in the order TAN2 (72\%)>TAN1 (70\%)>TAN3 (62\%). Hence, the immobilized bacteria are having higher biodegradation potential for the treatment of the tannery effluents.

Keywords: Biodegradation, bacteria, effluent, immobilization, tannery.

\section{INTRODUCTION}

Tannery industrial wastewater is a serious consequence of the pollution point of view for streams, freshwater, and land used for agriculture. The lack of awareness in the modern industrial practice has resulted in the discharge of tannery effluents which exhibit very high value of chromium ( $\mathrm{Cr}$ ), Sulfide, and chloride, Total Dissolved Solid (TDS), Total Suspended Solid (TSS), Biochemical Oxygen Demand (BOD) and Chemical Oxygen Demand (COD) in the water stream or land (Mohammed et al., 2001). Tanning is the process, which One ton of skin generally leads to the production of 20 to $80 \mathrm{~m}^{3}$ of turbid and foul-smelling converts the protein of the rawhide or skin into a stable material, which will not putrefy and is suitable for a wide variety of end applications (Elsheikh, 2009). The highly polluting chromium is the most commonly used tanning material producing leather that is more flexible and pliable than vegetable-tanned leather and does not discolor or lose shape in water as drastically as vegetable-tan (Elsheikh, 2009). Tannery effluent is among the most hazardous industrial pollutants due to its huge organic and inorganic load, which is highly toxic to human life and the environment (Kongjao et al., 2008). wastewater including chromium (100-400 mg/l), sulfide $(200-800 \mathrm{mg} / \mathrm{l})$, high levels of fat and 
BAJOPAS Volume 13 Number 2, December, 2020 other solid wastes, and notable pathogen contamination as well as pesticides added for skin conservation during transport (Elsheikh, 2009). There are more than 6000 tanneries in Nigeria with an annual processing capacity of 700,000 tons of hides and skins (Omoleke, 2004; Singh et al., 2008). It was reported that the total amount of waste produced per animal slaughtered is approximately $35 \%$ of its weight (World Bank, 1995). Also, for every $1000 \mathrm{~kg}$ of carcass weight, a slaughtered beef produces 5.5 $\mathrm{kg}$ of manure (excluding rumen contents or stockyard manure) and $100 \mathrm{~kg}$ of paunch manure (undigested food) (Verheijen et al., 1996). Tanneries generate wastewater in the range of 30-35 $\mathrm{L} \mathrm{kg}^{-1}$ skin/hide processed with variable $\mathrm{pH}$, Biological Oxygen Demand (BOD), Chemical Oxygen Demand (COD), high concentrations of suspended solids (SS), and tannins as well as chromium (Zahoor and Abdul, 2009).

Being heterogeneous and composed of a wide variety of compounds, it is very difficult to select a unique direct method for estimating the biodegradability of organic contents and biokinetic parameters for a wastewater sample (Rajor, 2004). For this purpose, some indirect estimation such as determination of biochemical oxygen demand (BOD) and chemical oxygen demand (COD) are applied as common laboratory investigations [9]. During retanning procedures, synthetic tannins (Syntan), oils and resins are added to form softer leather at varying doses (Munz et al., 2009). One of the refractory groups of chemicals in tannery effluents derives mainly from tannins (Ramasami et al., 2004). Syntans are characterized by complex chemical structures, because they are composed of an extended set of chemicals such as phenol-, naphthalene-, formaldehyde- and melamine-based syntans, and acrylic resins (Beem, 1994). Organic pollutants (proteic and lipidic components) are originated from skins (it is calculated that the raw skin has $30 \%$ loss of organic material during the working cycle) or they are introduced during processes (Hugo Springer, 1994).

Many conventional processes such as oxidation, chemical and biological processes were carried out to treat tanneries wastewater (Ebtesam et al, 2013). Biological processes have received more attention because of their costeffectiveness, lower sludge production and environmental friendliness (Noorjahan, 2014). Naturally occurring micro-organisms degrade the hazardous organic wastes including xenobiotic compounds, such as pesticides, polycyclic aromatic hydrocarbons (PAHs) and polychlorinated biphenyls (PCBs) in due course of time (Ranen and Sharadinadra, 2009). Bioremediation is based on the idea that all organisms remove substances from the environment to carry outgrowth and metabolism (Bouwer and Zehnder, 1993). Bacteria, protista and fungi are found to be very good at degrading complex molecules and incorporating the breakdown products into their metabolism (Bouwer and Zehnder, 1993). The resultant metabolic wastes that they produce are generally safe and somehow recycled into other organisms (Ranen and Sharadinadra, 2009). An acclimatized indigenous population of microorganisms capable of degradation of the compounds of interest must exist at the site for a successful bioremediation mode (Ranen and Sharadinadra, 2009). It has been observed that for a successful bioremediation mode, an acclimatized indigenous population of microorganisms capable of degradation of the compounds of interest must exist at the site under investigation (Ranen and Sharadinadra, 2009). Even though there are numerous physical and chemical methods employed in the disposal of wastes the advantage in using bacterium is that they play a key role in the reduction of COD, BOD, total protein, total tannin and total phenol (Saravanan and Saravanan, 1998)

Baba et al. (2020) studied the bioremediation potential of immobilized corynebacterium kutsceri in the Treatment of tannery industrial effluent from Challawa Industrial Estate, Kano State, Nigeria. The aim of the work is to study the reduction in the level of the contaminants through the process of bioremediation using the isolated bacteria. Immobilized bacteria can withstand various temperatures, $\mathrm{pH}$ and substrate concentrations; consequently, increasing the efficiency and the lifespan of the bacteria. Immobilized bacteria are widely applied in the treatment of wastewater and can be separated and recovered after the treatment with the same efficiency (Baba et al., 2020).

\section{MATERIALS AND METHODS \\ Study Area}

This study was carried out in Bompai, Sharada and Challawa industrial estates in Kano, Figure 1. Kano lies on Latitude $11^{\circ} 30^{\prime} \mathrm{N}$ and $8^{\circ} 30^{\prime} \mathrm{E}$ and Longitude $11^{\circ} 5^{\prime} \mathrm{N}$ and $8^{\circ} 5^{\prime} \mathrm{E}$ in Northern Nigeria. It is one of the developed industrial cities in Nigeria. Tannery activities are the dominating industries and this could be one of the reasons for her high population density (Dan'Azumi and Bichi, 2010). Many researchers have studied biodegradation of tannery effluent using microorganisms. However, limited literature is available on the biodegradation of tannery effluent in Kano industrial estates using 
BAJOPAS Volume 13 Number 2, December, 2020 immobilized bacterial cells. This research work focuses on the potential of the use of the indigenous immobilized bacterial isolates in the treatment of tannery effluents in the industrial estates.

\section{Sample Collection}

Effluents were collected from the Tannery Industries from Bompai, Challawa and Sharada Industrial Estates, Kano, Nigeria. The effluents were collected over a period of six months (August 2017 to January 2018). Samples collected in a sterile 4-liter plastic container with a unique identification number were preserved using an ice-box that was transported to the Microbiology Laboratory, Department of Microbiology, Bayero University of Kano for analysis

\section{Sample Preparation and Sample Analysis}

Immediately after the collection of the effluent, $\mathrm{pH}$, TSS, TDS, COD, BOD levels were determined before treatment (Pre-treatment determination) and ten days after treatment (Post-treatment determination) as described in
APHA (1989) standard methods. $\mathrm{pH}$ was determined using Ecotests $\mathrm{pH}$ meter and TDS was determined using AQUALYTIC TDS Salinometer. BOD was determined as described by the standard method (APHA, 1992). COD and SS were determined using DR/2010 HACH portable data logging spectrophotometer (DWAF, 1992)

\section{Identification and Biochemical} Characterization of the Bacterial Isolates

The bacteria were isolated from the effluents using Serial Dilution according to the method described by APHA (1989). The biochemical tests such as oxidase, catalase, coagulase, indole (from $1 \%$ tryptone broth), citrate (Simmons citrate agar), methyl red/VogesProskauer (MR/VP), nitrate reduction, Starch Hydrolysis, Glucose, Maltose, and Lactose tests were carried out on the bacterial isolates to identify the bacteria through the bacteria biochemical characteristics according to Ajao et al. (2011).

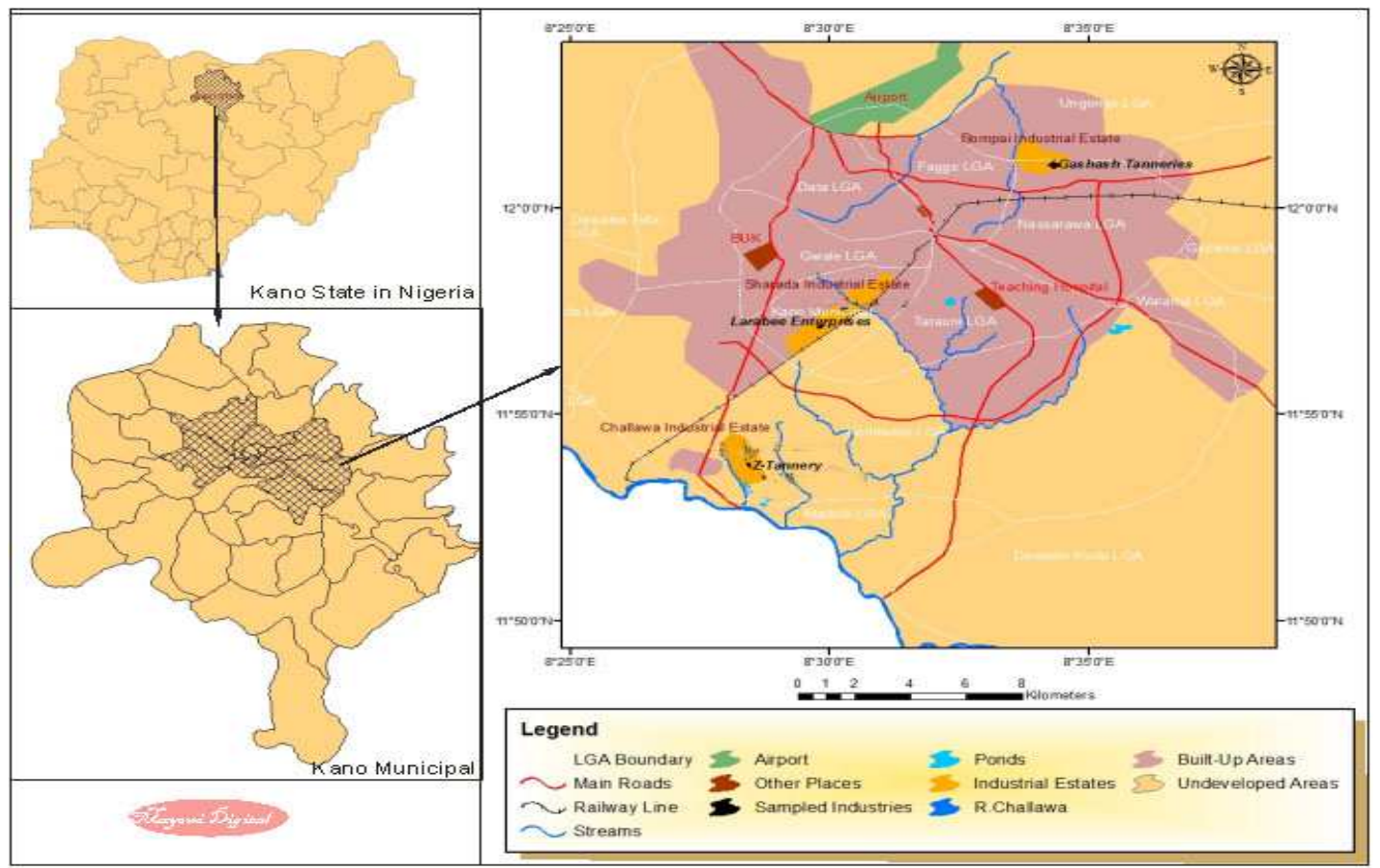

Fig. 1 Map showing the study areas

Source: Mayomi Digital Productions, GIS Laboratory, Department of Geography, UNIMAID (2017)

\section{Determination of Growth Rate of the Bacteria in Effluent Sample}

The bacteria growth rates were determined by transferring $2 \mathrm{~mL}$ of the bacterial isolates from the tannery effluent in broth medium into 100 $\mathrm{mL}$ sterile effluents in conical flasks and kept in an incubator (Giffrin cool) for 10 days. Control was also set up by incubating another $100 \mathrm{~mL}$ each of the sterile effluents without the bacteria. The optical density of the content was determined at the wavelength of $600 \mathrm{~nm}$ on a daily interval and recorded. 
BAJOPAS Volume 13 Number 2, December, 2020 Immobilization of Bacteria

Agar solution and inoculi were prepared separately. Fifty milliliters $(50 \mathrm{~mL})$ of nutrient broth each of the inoculi was prepared in a McCartney bottle and incubated for 24 hours. A solution of agar-agar was prepared by dissolving $10 \mathrm{~g}$ of the powder in distilled water and made up to $500 \mathrm{~mL}$ mark in an Erlenmeyer flask and was sterilized in an autoclave (280A) for 15 minutes and allowed to cool to $40-45^{\circ} \mathrm{C}$ (Ajao et al., 2011). Four milliliters ( $4 \mathrm{~mL})$ of the bacterial isolates in the nutrient broth was mixed with 36 $\mathrm{ml}$ of the prepared agar-agar media in petri-dish plates and then allowed to solidify. This was kept in the refrigerator for bioremediation.

\section{Bioremediation (Treatment) of the Effluents}

The solidified agar block (immobilized bacteria) was cut into cubes using a sterile knife; $0.1 \mathrm{~mL}$ phosphate buffer ( $\mathrm{pH} \mathrm{7.0)}$ was added and kept in the refrigerator for 1 hour for curing. The phosphate buffer was decanted after 1 hour and the cubes were washed with sterile distilled water 3-4 times before it was used (Ajao et al., 2011). Two liters (2 L) of the effluent was supplemented with the minimum basal medium in $\mathrm{g} / \mathrm{L}: \mathrm{NaCl}(0.8), \mathrm{MgSO}_{4} .7 \mathrm{H}_{2} \mathrm{O}(0.001), \mathrm{KH}_{2} \mathrm{PO}_{4}$ (2), $\mathrm{NaNO}_{3}$ (2), $\quad \mathrm{CaCl}_{2} .2 \mathrm{H}_{2} \mathrm{O} \quad(0.5)$ and $\mathrm{NaHPO}_{4} .12 \mathrm{H}_{2} \mathrm{O}(2)$ and sterilized in an autoclave at $121^{\circ} \mathrm{C}$ for 15 minutes (Margesin and Schinner, 2001). Two hundred and fifty milliliters $(250 \mathrm{~mL})$ of the effluents were transferred into different $250 \mathrm{ml}$ conical flasks. The content was covered with a cotton-wool ramped with foil paper to avoid contamination. Five grams $(5 \mathrm{~g})$ of the immobilized bacteria were quickly transferred into each of the effluents in the conical flasks in an inoculating chamber. The same procedures were carried out for the $10 \mathrm{~g}, 15 \mathrm{~g}, 20 \mathrm{~g}$ and 25 $\mathrm{g}$ of the immobilized bacteria in separate $250 \mathrm{~mL}$ effluents in conical flasks and agitated for ten days in a shaker incubator (Gallenkamp-OC4364-L) at a temperature $30^{\circ} \mathrm{C}$ and speed of 60 rpm. The treated effluent samples were taken on the tenth day and analyzed for the parameters $\mathrm{pH}$, SS, TDS, COD, and BOD, (Posttreatment determination) for the different grams of bacteria to evaluate and compare the biodegradation potential. (Baba et al., 2020).

\section{Statistical Analysis}

The data were represented as Mean \pm Standard deviation and analyzed statistically using oneway Analysis of Variance (ANOVA) and Tukey's HSD as Post Hoc Tests with the aid of SPSS 16.0. The correlation coefficient was also used to measure the strength of the relationship between the different masses of the bacteria and the parameters. All $\mathrm{p} \leq 0.05$ were considered as statistically significant.

\section{RESULTS AND DISCUSSION Physico-chemical parameters in the Industrial Effluents before the Biodegradation.}

Results of the Physico-chemical parameters in the industrial effluents before the Biodegradation is shown in table 1 . The mean temperatures $\left({ }^{\circ} \mathrm{C}\right)$ observed in TAN1, TAN2, and TAN3 samples were $28.07 \pm 0.65 ; 27.77 \pm 0.64$ and $26.38 \pm 3.81$ respectively. The order of the mean temperature of the samples from the three industries can be arranged as TAN1 > TAN2>TAN3. The temperature observed at TAN1, TAN2, and TAN3 samples were found below the WHO $\left(35^{\circ} \mathrm{C}\right)$ and NESREA $\left(40^{\circ} \mathrm{C}\right)$ limits. The low values of temperature might be due to the processes used at the time of sampling. High temperature brings down the solubility of gases in water that ultimately expresses as high BOD and COD. Statistical analysis shows that there is no significant difference $(p<0.05)$ between the mean values of temperature among the industries. This might be due to similar tannery activities involved in the tannery industries at the time of sampling. The average values of temperature observed in this present study are less than those observed by Akan et al. (2007), Akan et al. (2009) and Baba et al. (2020).

The mean level of $\mathrm{pH}$ observed in TAN1, TAN2 and TAN3, samples were $7.77 \pm 2.93$; $8.35 \pm 0.28$ and $7.52 \pm 0.76$ respectively. The order of the mean $\mathrm{pH}$ of the samples from the three industries can be arranged as TAN2> TAN1 $>$ TAN3. The $\mathrm{pH}$ of the samples falls within the WHO (7.0-8.5) and NESREA (6-9) standard limits. Statistical analysis shows that there is no significant difference $(p<0.05)$ between the mean values of $\mathrm{pH}$ among the industries. This might be due to similar tannery activities involved in the tannery industries at the time of sampling. Maheshwari et al. (2017) reported that the level of $\mathrm{pH}$ in the effluents from the tannery industry in Vaniyambadi, India was 6.5 which was lower than that observed in the present study. The $\mathrm{pH}$ in the effluents from the tannery industries in Kano and Kaduna were reported to be 7.64 and 6.89, respectively (Akan et al., 2007; Mohammed et al., 2017). The average values of $\mathrm{pH}$ observed in this present study are less than those observed by Mohammed et al. (2017) and Baba et al. (2020). The mean level of SS $(\mathrm{mg} / \mathrm{l})$ observed in TAN1, TAN2, and TAN3 samples were 374 \pm 124 ; $358 \pm 335$ and $780 \pm 739$ respectively. The order of the mean SS in the samples from the three industries can be arranged as TAN3 > TAN1 $>$ TAN2. 
The SS observed in the samples were far above the recommended standard limits of regulating bodies WHO $(30 \mathrm{mg} / \mathrm{l})$ and NESREA $(10 \mathrm{mg} / \mathrm{l})$. Statistical analysis shows that there is no significant difference $(p<0.05)$ between the mean values of SS among the industries. This might be due to similar tannery activities involved in the tannery industries at the time of sampling. The average values of SS observed in this present study are less than that observed $(3700 \pm 122 \mathrm{mg} / \mathrm{l})$ by Akan et al. (2009) for tanneries in Kano. Also, the average values of SS observed in this present study are less than that observed by Mohammed et al. (2017) and Baba et al. (2020) with the exception in TAN3.

The mean level of TDS (mg/l) observed in TAN1, TAN2, and TAN3 samples were $3941 \pm 3703$; $3300 \pm 1714$ and $2653 \pm 1240$ respectively. The order of the mean TDS in the samples from the three industries can be arranged as TAN1>TAN2>TAN3. The TDS observed in the samples were far above the recommended standard limits of WHO $(250 \mathrm{mg} / \mathrm{l})$ and NESREA $(500 \mathrm{mg} / \mathrm{l})$. Statistical analysis shows that there is no significant difference $(p<0.05)$ between the mean values of TDS among the industries. This might be due to similar tannery activities involved in the tannery industries at the time of sampling. TDS in the effluents from the tannery industries in Kano, Nigeria was reported to be $1281 \mathrm{mg} / \mathrm{l}$ (Akan et al., 2007). The average values of SS observed in this present study are less than those observed by Mohammed et al. (2017) and Baba et al. 2020)

The mean level of COD (mg/l) observed in TAN1, TAN2 and TAN3 samples seasons were $2372 \pm 938 ; \quad 1406 \pm 208$ and $3532 \pm 1373$ respectively. The order of the mean COD of the samples from the three industries can be arranged as TAN3>TAN1> TAN2. The COD observed in TAN1, TAN2 and TAN3 samples were far above the recommended standard limits of regulating bodies $\mathrm{WHO}(40 \mathrm{mg} / \mathrm{l})$ and NESREA (40 mg/l). Statistical analysis shows that there is no significant difference $(p<0.05)$ in COD among the industries. This might be due to similar tannery activities involved in the tannery industries as at the time of sampling. The Chemical Oxygen demand (COD) is the amount of oxygen, in $\mathrm{mg} / \mathrm{L}$, required for the degradation of the compound of wastewater to occur. In comparison, the average values of COD observed in this present study were higher than that observed by Mohammed et al. (2017) but lower than that observed by Baba et al. (2020).

The mean levels of BOD $(\mathrm{mg} / \mathrm{l})$ observed in TAN1, TAN2 and TAN3 samples were $13.85 \pm 6.42 ; \quad 19.46 \pm 0.50$ and $17.13 \pm 3.14$ respectively. The order of the mean BOD in the samples from the three industries can be arranged as TAN2>TAN3>TAN1. The BOD observed in TAN1, TAN2 and TAN3 samples were found below the recommended limits of NESREA (200 mg/l) but above WHO (10 mg/l). Statistical analysis shows that there is no significant difference $(p<0.05)$ between the mean values of BOD among the industries. This might be due to similar tannery activities involved in the tannery industries at the time of sampling. The low level of BOD recorded in this study is an indication of the low level of biodegradable organic solids in the effluent. The average values of BOD observed in this present study were lower than those observed by Mohammed et al. (2017) and Baba et al. (2020).

Table 1: Mean Values \pm S.D of Physico-chemical parameters of effluents from the Tannery Industries before Treatment.

\begin{tabular}{llllllll}
\hline Parameter & Tannery 1 & Tannery 2 & Tannery 3 & $\mathrm{a}$ & $\mathrm{b}$ & $\mathrm{c}$ & $\mathrm{d}$ \\
\cline { 2 - 7 } Temperature $\left({ }^{\circ} \mathrm{C}\right)$ & $28.07 \mathrm{a} \pm 0.65$ & $27.77 \mathrm{a} \pm 0.64$ & $26.38 \mathrm{a} \pm 3.81$ & & $29.50 \pm 4.68$ & 35 & 40 \\
pH & $7.77 \mathrm{a} \pm 2.93$ & $8.35 \mathrm{a} \pm 0.28$ & $7.52 \mathrm{a} \pm 0.76$ & 6.89 & $5.35 \pm 1.57$ & $7.0-8.5$ & $6.0-9.0$ \\
$\mathrm{COD}(\mathrm{mg} / \mathrm{l})$ & $2372 \mathrm{a} \pm 938$ & $1406 \mathrm{a} \pm 208$ & $3532 \mathrm{a} \pm 1373$ & 2.2 & $3106 \pm 2753$ & 40 & 40 \\
$\mathrm{BOD}(\mathrm{mg} / \mathrm{l})$ & $13.85 \mathrm{a} \pm 6.42$ & $19.46 \mathrm{a} \pm 0.50$ & $17.13 \mathrm{a} \pm 3.14$ & 1032 & $26.17 \pm 9.49$ & 10 & 200 \\
$\mathrm{SS}(\mathrm{mg} / \mathrm{l})$ & $374 \mathrm{a} \pm 124$ & $358 \mathrm{a} \pm 335$ & $780 \mathrm{a} \pm 739$ & 501 & $562 \pm 482$ & 30 & 10 \\
TDS $(\mathrm{mg} / \mathrm{l})$ & $3941 \mathrm{a} \pm 3703$ & $3300 \mathrm{a} \pm 1714$ & $2653 \mathrm{a} \pm 1240$ & 532.7 & $444 \pm 507$ & 250 & 500 \\
\hline
\end{tabular}

The values given in the table above are means of 6 replicate values, $\mathrm{n}=6$ ( 1 sample was taken monthly for 6 months). Within the rows, means with different alphabets are statistically different $(p<0.05)$. WHO: World Health Organisation. NESREA: National Environmental Standard and Regulatory Enforcement Agency. a = Mohammed et al.(2017), b = Baba et al. (2020), c = WHO (2006), $d=$ NESSRA (2009) 
BAJOPAS Volume 13 Number 2, December, 2020

Identification, Biochemical Characterization and growth rates of the Bacterial Isolates

Results of identification and biochemical characterization of the bacterial isolates were shown in table 2. After 24 hours of incubation, the nutrient agar media plates were checked for bacterial growth. The results showed the presence of different strains in the samples. The TAN1 bacteria isolate was found to be gramnegative cocci while TAN3 was gram-positive cocci. TAN2 bacteria isolate was found to be gram-positive, rod-shaped. TAN1, TAN2, and TAN3 bacteria isolates recorded positive results for spore former.

The results of the biochemical tests indicated that all the bacteria were positive for catalase, oxidase, citrate, maltose, glucose, lactose (negative in TAN1), mannitol (negative in TAN2), starch hydrolysis and coagulase (negative in TAN2) tests. The bacteria showed negative results for nitrate reduction, $M R$ (positive in TAN2), VP (positive in TAN1), Indole (positive in TAN2) tests. Base on the morphological and biochemical test results, TAN1, TAN2, and TAN3 bacteria isolates were identified to be Nesseria spp, Bacillus cereus, and Staphylococcus aureus respectively.

The growth rate of the TAN1, TAN2 and TAN3 Isolates were shown in figure 2. Generally, the optical density increase with the increase in time (day) and decrease as time goes on. The highest optical density was shown by bacillus cereus in TAN2 while the lowest was shown by Staphylococcus aureus in TAN3.

The initial growth phase of TAN1 Isolate bacteria occurred within 2-day of incubation as the growth rate increases up to the 6th-day incubation when the maximum growth was observed. Beyond the 6th day, the growth of the bacteria declined (which might be due to a shortage of nutrients in the effluents) until it reached its death phase (which might be due to the unavailability of nutrients in the effluents).

A similar trend of growth was also observed for TAN2 Isolate as the initial growth phase also occurred within 2-day of incubation but maximum growth rate observed on the 4th day of incubation. The stationary stage occurred between the 4th day and the 8th day. Beyond the 8th day, the growth of the bacteria declined (which might be due to a shortage of nutrients in the effluents) until it reached its death phase (which might be due to the unavailability of nutrients in the effluents).

The initial growth phase of TAN3 bacterial Isolate occurred within the 3-day incubation as the growth rate increases up to the 6th-day incubation when the maximum growth was observed. Beyond the 6th day, the growth of the bacteria declined (which might be due to a shortage of nutrients in the effluents) until it reached its death phase (which might be due to the unavailability of nutrients in the effluents).

Table 2: Morphological and Biochemical characteristics of bacterial isolates

\begin{tabular}{lllll} 
Bacterial Isolates & & TAN1 & TAN2 & TAN3 \\
\hline $\begin{array}{lllll}\text { Morphological } \\
\text { characteristics }\end{array}$ & Shape & Cocci & Rod & Cocci \\
& Spore & & & \\
& former & + & + & + \\
Gram & & & \\
Biochemical characteristics & reaction & - & + & + \\
& Citrate & + & + & + \\
& Catalase & + & + & + \\
& Coagulase & + & - & + \\
Starch & + & + & + \\
& Glucose & + & + & + \\
Oxidase & + & + & + \\
& Indo & - & + & - \\
Lactose & - & + & + \\
Manitol & + & - & + \\
Maltose & + & + & + \\
MR & - & + & - \\
VP & + & - & - \\
& Nitrate & - & - & - \\
Reduction & - Neisseria & Bacillus & Staphylococcus \\
& Bacterial & cereus & aureus \\
& name & spp & cas
\end{tabular}

+ = Positive; - = Negative; MR=Methyl Red; VP= Voges-Proskauer 


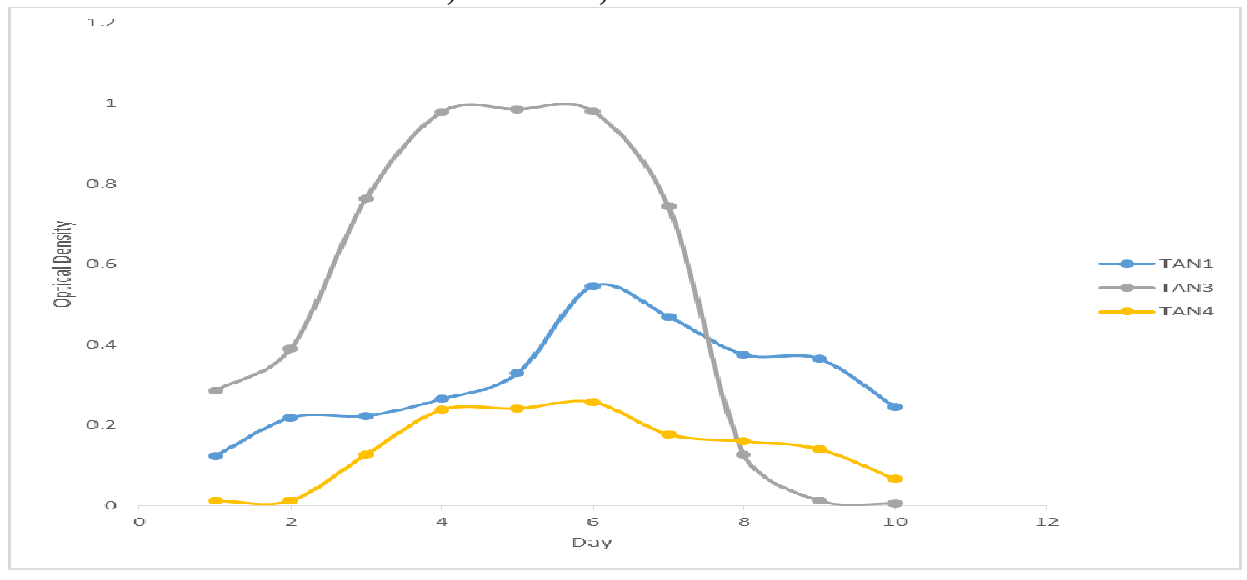

Fig. 2 Growth rates of the isolates in the effluents from the Tannery Industries

\section{Physico-chemical Parameters in the Industrial Effluents after the biodegradation.}

Table 3 shows the mean results of the physicochemical parameter before and after bioremediation using the different masses $(5 \mathrm{~g}$, $10 \mathrm{~g}, 15 \mathrm{~g}, 20 \mathrm{~g}$, and $25 \mathrm{~g}$ ) of the respective immobilized bacteria. Also, Table 4 shows the mean results of correlation coefficient ( $r$ ) between different masses of bacteria and physicochemical parameters.

The mean values $(\mathrm{mg} / \mathrm{l})$ of the SS after the bioremediation varies between $243 \pm 45$ and $898 \pm 672$. The mean concentration $(\mathrm{mg} / \mathrm{l})$ of SS remediated by the different masses $(5 \mathrm{~g}, 10 \mathrm{~g}$, $15 \mathrm{~g}, 20 \mathrm{~g}$, and $25 \mathrm{~g}$ ) of the bacteria varies. The SS in the samples fluctuates up and down after the bioremediation process when compared with the SS of the raw samples before the bioremediation. The increase in the levels of the SS might be due to the aggregation of the TDS which are large enough to result into SS. The increase in the levels of the SS might be also due to the influence of the nutrients which was added into the effluents in order to make the microorganisms more active and viable for fast degradation of organic contaminants in the effluent. The relative potential or efficiency of the different masses of the bacteria in remediating SS in TAN1 samples was in the order $25 \mathrm{~g}>20 \mathrm{~g}>15 \mathrm{~g}>10 \mathrm{~g}>5 \mathrm{~g}$. For TAN2 and TAN3 samples, the order was $25 \mathrm{~g}>20 \mathrm{~g}>15$ $\mathrm{g}>10 \mathrm{~g}>5 \mathrm{~g}$. These might be due to the variations in the surface areas of the different masses of the immobilized bacteria. Statistical analysis shows that there is no significant difference $(p<0.05)$ between the mean values of SS among the masses in the respective industries. Positive and significant correlations exist between the masses of bacteria and Suspended Solid (SS). This showed that there is general increase in the levels of the SS as the masses of the immobilized bacteria increases. TAN3 (90\%) and TAN1 (80\%) showed a very high correlation with the masses of the bacteria while TAN2 (61\%) showed a very low correlation.

The mean values $(\mathrm{mg} / \mathrm{l})$ of the TDS after the bioremediation varies between $46 \pm 11$ and $83 \pm 78$. The mean concentration $(\mathrm{mg} / \mathrm{l})$ of TDS remediated by the different masses $(5 \mathrm{~g}, 10 \mathrm{~g}$, $15 \mathrm{~g}, 20 \mathrm{~g}$, and $25 \mathrm{~g}$ ) of the bacteria varies. There is a reduction in all the TDS of all the samples after the bioremediation process compared with the TDS of the raw samples before the bioremediation. The relative potential or efficiency of the different masses of the bacteria in remediating TDS in TAN1 and TAN3 samples was in the order $5 \mathrm{~g}>10 \mathrm{~g}>15 \mathrm{~g}>20$ $\mathrm{g}>25 \mathrm{~g}$. For TAN2 samples, the order was 20 $g>10 \quad g>25 \quad g>15 \quad g>5 \quad g$. Statistical analysis shows that there is no significant difference $(p<0.05)$ between the mean values of TDS among the masses in the respective industries. These might be due to the variations in the surface areas of the different masses of the immobilized bacteria. Positive and significant correlations exist between the masses of bacteria and TDS with the exception in TAN2 (negative and insignificant correlation). The positive correlations showed that there is general increase in the levels of the TDS as the masses of the immobilized bacteria increases. TAN1 $(96 \%)$ showed a very high correlation with the masses of the bacteria while TAN2 (47\%) showed a very low correlation.

The mean values $(\mathrm{mg} / \mathrm{l})$ of the BOD after the bioremediation varies between $1.56 \pm 0.20 \mathrm{mg} / \mathrm{l}$ and $6.92 \pm 5.49 \mathrm{mg} / \mathrm{l}$. The mean concentration $(\mathrm{mg} / \mathrm{l})$ of BOD remediated by the different masses $(5 \mathrm{~g}, 10 \mathrm{~g}, 15 \mathrm{~g}, 20 \mathrm{~g}$, and $25 \mathrm{~g}$ ) of the bacteria varies. There is a reduction in all the BOD of all the samples after the bioremediation process compared with the $\mathrm{BOD}$ of the raw 
BAJOPAS Volume 13 Number 2, December, 2020 samples before the bioremediation. The relative potential or efficiency of the different masses of the bacteria in remediating BOD in TAN1, TAN2 and TAN3 samples were in the order $25 \mathrm{~g}>20$ $\mathrm{g}>15 \mathrm{~g}>10 \mathrm{~g}>5 \mathrm{~g}, 25 \mathrm{~g}>15 \mathrm{~g}>5 \mathrm{~g}>10 \mathrm{~g}>20 \mathrm{~g}$ and $20 \mathrm{~g}>10 \mathrm{~g}>25 \mathrm{~g}>15 \mathrm{~g}>5 \mathrm{~g}$ respectively. Statistical analysis shows that there is significant difference $(p<0.05)$ between the mean values of BOD among the masses in the respective industries. These might be due to the variations in the surface areas of the different masses of the immobilized bacteria. Negative and significant correlations exist between the masses of bacteria and BOD. This showed that there is general decrease in the levels of the BOD as the masses of the immobilized bacteria increases. TAN1 (94\%) showed a very high correlation with the masses of the bacteria while TAN2 (4\%) showed a very low correlation.

The mean values $(\mathrm{mg} / \mathrm{l})$ of the COD after the bioremediation varies between $250 \pm 154$ and $3134 \pm 1595$. The mean concentration $(\mathrm{mg} / \mathrm{l})$ of COD remediated by the different masses $(5 \mathrm{~g}$, $10 \mathrm{~g}, 15 \mathrm{~g} 20 \mathrm{~g}$, and $25 \mathrm{~g}$ ) of the bacteria varies. There is a reduction in all the COD of all the samples after the bioremediation process compared with the COD of the raw samples before the bioremediation. The relative potential or efficiency of the different masses of the bacteria in remediating COD in TAN1, TAN2 and TAN3 samples were in the order $25 \mathrm{~g}>20 \mathrm{~g}>15$ $\mathrm{g}>5 \mathrm{~g}>10 \mathrm{~g}, 25 \mathrm{~g}>20 \mathrm{~g}>15 \mathrm{~g}>10 \mathrm{~g}>5 \mathrm{~g}$ and 10 g>5 g>25 g>15 g>20 g respectively. Statistical analysis shows that there were significant difference $(p<0.05)$ between the mean values of COD among the masses in the respective industries except for effluents treated with $25 \mathrm{~g}$. These might be due to the variations in the surface areas of the different masses of the immobilized bacteria. Negative and insignificant correlations exist between the masses of bacteria and COD with the exception in TAN3 (positive and significant correlation). The negative correlations showed that there is general decrease in the levels of the COD as the masses of the immobilized bacteria increases. TAN2 (100\%) showed a very high correlation with the masses of the bacteria while TAN3 (36\%) showed a very low correlation.

Generally, there was an overall decrease in the concentration of these physicochemical parameters after the bioremediation using the different masses of the bacterial isolates. These might be due to the variations in the surface areas of the different masses of the immobilized bacteria. This is in line with the work of Jimoh et al. (2018) and Baba et al. (2020).

Table 3: Mean Values $(\mathrm{mg} / \mathrm{l}) \pm$ S.D of Physicochemical parameters in effluents from the Tannery Industries before and after Treatment of the effluents $(250 \mathrm{ml})$ with the different masses $(5 \mathrm{~g}, 10 \mathrm{~g}$, $15 \mathrm{~g}, 20 \mathrm{~g}$, and $25 \mathrm{~g}$ ) of the bacteria.

\begin{tabular}{llllllll}
\hline $\mathrm{P}$ & IND & Before & \multicolumn{5}{c}{ After } \\
\cline { 4 - 7 } & & & $5 \mathrm{~g}$ & $10 \mathrm{~g}$ & $15 \mathrm{~g}$ & $20 \mathrm{~g}$ & $25 \mathrm{~g}$ \\
\hline \multirow{2}{*}{ COD } & TAN1 & $2372 \pm 938$ & $1708 \mathrm{a} \pm 861$ & $2045 \mathrm{a} \pm 1205$ & $845 \mathrm{a} \pm 369$ & $300 \mathrm{a} \pm 167$ & $250 \mathrm{a} \pm 154$ \\
& TAN2 & $1406 \pm 208$ & $1195 \mathrm{a} \pm 208$ & $1125 \mathrm{a} \pm 384$ & $1055 \mathrm{a} \pm 317$ & $956 \mathrm{a} \pm 310$ & $870 \mathrm{ab} \pm 240$ \\
& TAN3 & $3532 \pm 1373$ & $2374 \mathrm{a} \pm 1344$ & $1976 \mathrm{a} \pm 1405$ & $2757 \mathrm{a} \pm 1266$ & $3134 \mathrm{a} \pm 1595$ & $2614 \mathrm{~b} \pm 1105$ \\
BOD & TAN1 & $13.85 \pm 6.42$ & $6.92 \mathrm{a} \pm 5.49$ & $6.42 \mathrm{a} \pm 5.07$ & $5.72 \mathrm{a} \pm 5.35$ & $4.62 \mathrm{a} \pm 4.37$ & $2.82 \mathrm{ab} \pm 1.26$ \\
& TAN2 & $19.46 \pm 0.50$ & $1.75 \mathrm{~b} \pm 0.22$ & $1.73 \mathrm{~b} \pm 0.18$ & $1.58 \mathrm{a} \pm 0.16$ & $1.91 \mathrm{a} \pm 0.22$ & $1.56 \mathrm{~b} \pm 0.20$ \\
& TAN3 & $17.13 \pm 3.14$ & $4.24 \mathrm{ab} \pm 0.77$ & $3.29 \mathrm{ab} \pm 0.37$ & $4.11 \mathrm{a} \pm 0.07$ & $3.23 \mathrm{a} \pm 0.91$ & $3.33 \mathrm{a} \pm 1.28$ \\
SS & TAN1 & $374 \pm 124$ & $243 \mathrm{a} \pm 45$ & $471 \mathrm{a} \pm 226$ & $475 \mathrm{a} \pm 182$ & $492 \mathrm{a} \pm 128$ & $611 \mathrm{a} \pm 217$ \\
& TAN2 & $358 \pm 335$ & $460 \mathrm{a} \pm 400$ & $543 \mathrm{a} \pm 414$ & $544 \mathrm{a} \pm 402$ & $551 \mathrm{a} \pm 414$ & $554 \mathrm{a} \pm 405$ \\
& TAN3 & $780 \pm 739$ & $586 \mathrm{a} \pm 594$ & $758 \mathrm{a} \pm 656$ & $787 \mathrm{a} \pm 676$ & $861 \mathrm{a} \pm 635$ & $898 \mathrm{a} \pm 672$ \\
TDS & TAN1 & $3941 \pm 3703$ & $51 \mathrm{a} \pm 10$ & $53 \mathrm{a} \pm 10$ & $55 \mathrm{a} \pm 15$ & $61 \mathrm{a} \pm 20$ & $63 \mathrm{a} \pm 26$ \\
& TAN2 & $3300 \pm 1714$ & $83 \mathrm{a} \pm 78$ & $47 \mathrm{a} \pm 20$ & $48 \mathrm{a} \pm 22$ & $47 \mathrm{a} \pm 17$ & $48 \mathrm{a} \pm 17$ \\
& TAN3 & $2653 \pm 1240$ & $46 \mathrm{a} \pm 11$ & $55 \mathrm{a} \pm 24$ & $55 \mathrm{a} \pm 25$ & $58 \mathrm{a} \pm 23$ & $61 \mathrm{a} \pm 28$ \\
\hline
\end{tabular}

Replicate $=6$ (months)

Within the rows, for the same parameter, means with different alphabets are statistically different $(p<0.05)$.

$\mathrm{P}=$ parameter, IND = Industries 
BAJOPAS Volume 13 Number 2, December, 2020

Table 4: Correlation coefficient $(r)$ between different masses of the bacteria and the physicochemical parameters.

\begin{tabular}{llll}
\hline Industries & Parameter & Correlation coefficient $(r)$ & $\begin{array}{l}\text { Percent dependence (rxrx100) } \\
(\%)\end{array}$ \\
\hline TAN1 & COD & -0.9 & 82 \\
& BOD & -0.97 & 94 \\
& SS & $0.90^{*}$ & 80 \\
TAN2 & TDS & $0.98^{*}$ & 96 \\
& COD & -1 & 100 \\
& BOD & -0.21 & 4 \\
& SS & $0.78^{*}$ & 61 \\
& TDS & -0.69 & 47 \\
& COD & $0.60^{*}$ & 36 \\
& BOD & -0.6 & 37 \\
& SS & $0.95^{*}$ & 90 \\
& TDS & $0.94^{*}$ & 89 \\
\hline
\end{tabular}

The correlation coefficient $(r)$ with * is statistically significant $(p<0.05)$.

Percentage reduction of the Parameters

Table 5 shows the percentage reduction of Parameters in industrial samples before and after the treatment of the effluents $(250 \mathrm{ml})$ with the different masses $(5 \mathrm{~g}, 10 \mathrm{~g}, 15 \mathrm{~g}, 20 \mathrm{~g}$, and $25 \mathrm{~g}$ ) of the Immobilized Bacteria.

In TAN1 samples, the percentage reduction (\%) of COD ranged (14-89); BOD (50-80); SS (-32$35)$ and TDS (98-99). In TAN2 samples, the percentage decrease $(\%)$ of COD ranged (15$38) ;$ BOD (90-92); SS [-28-(-55)] and TDS (9798). In TAN3 samples, the percentage decrease (\%) of COD ranged (11-44); BOD (76-81); SS (15-25) and TDS (98). The percentage increase in the levels COD, BOD and TDS might be due to the increase in the surface area of the different masses of the immobilized bacteria. However, the percentage decrease in the levels of the SS might be due to the aggregation of the TDS which are large enough to result into SS. The percentage decrease in the levels of the SS might be also due to the influence of the nutrients which was added into the effluents in order to make the microorganisms more active and viable for fast degradation of organic contaminants in the effluent. This is in line with the work of Jimoh et al. (2018) in which the concentration of the SS increase after the bioremediation of effluents.

Sreemoyee and Priti (2013) assessed and reduced several Physico-chemical parameters of dairy wastewater using Niesseria $s p$. and concluded that the species are well known to degrade organic compounds. This is in agreement with the current study in which the immobilized Niesseria $s p$ degrade the organic contaminants as indicated by the BOD, COD and TDS.

Jimoh et al. (2018) observed that TSS of the effluents was increased after treatment with immobilized bacteria and concluded that it might be due to the biostimulation method adopted for the research.

The optimum $\mathrm{pH}$ Biosorption of Chromium by Bacillus spp and Staphylococcus spp. from tannery effluent was investigated by Mythili and Karthikeyan (2011). The maximum adsorption of Chromium $(86.4 \mathrm{mg} / \mathrm{L})$ was showed by Bacillus spp and Staphylococcus spp showed $70.6 \mathrm{mg} / \mathrm{L}$ at an initial concentration of $100 \mathrm{mg} / \mathrm{L}$. In the present study, immobilised Bacillus spp and Staphylococcus spp. from the tannery industrial effluents reduced the levels of the organic pollutants with high potential as indicated by the percentage reduction of BOD, COD and TDS.

Enzymes often can work in multiple environments especially if they are immobilized. This makes the microorganisms' enzymes even more resistant to harsh environments and enables the enzymes to be recovered and recycled after they are no longer needed (Gianfreda and Rao 2004). Ramesh and Singh (1993) reported that the immobilized bacteria having more efficiency to remove the suspended particles than free cells. Using the immobilized cell is preferable due to its capability for using several times with the same efficiency, which makes it more economical. Similar work was done by Sikander et al. (2007) showing the higher reduction with permeabilized cells of Ochrobactrum intermedium strain SDCr-5. 
BAJOPAS Volume 13 Number 2, December, 2020

The results revealed the isolation and identification of isolates with the potential for the reduction of $\mathrm{Cr}$ (VI) to $\mathrm{Cr}$ (III). Results indicated that immobilized $B$. cereus could be efficiently used for the reduction of $\mathrm{Cr}$ (VI).

Table 5: Percentage reduction of the tested Parameters from the tannery industrial samples of the Immobilized Bacteria.

\begin{tabular}{lllllll}
\hline \multirow{2}{*}{ Industries } & & \multicolumn{5}{c}{ Percentage Reduction $(\%)$} \\
\cline { 3 - 7 } & & $5 \mathrm{~g}$ & $10 \mathrm{~g}$ & $15 \mathrm{~g}$ & $20 \mathrm{~g}$ & $25 \mathrm{~g}$ \\
\hline TAN1 & COD & 28 & 14 & 64 & 87 & 89 \\
& BOD & 50 & 54 & 59 & 67 & 80 \\
& SS & 35 & -26 & -27 & -32 & -63 \\
& TDS & 99 & 99 & 99 & 98 & 98 \\
TAN2 & COD & 15 & 20 & 25 & 32 & 38 \\
& BOD & 91 & 91 & 92 & 90 & 92 \\
& SS & -28 & -52 & -52 & -54 & -55 \\
& TDS & 97 & 99 & 99 & 99 & 99 \\
& COD & 33 & 44 & 22 & 11 & 26 \\
& BOD & 75 & 81 & 76 & 81 & 81 \\
& SS & 25 & 3 & -1 & -10 & -15 \\
& TDS & 98 & 98 & 98 & 98 & 98 \\
\hline
\end{tabular}

Percentage Reduction $=(B-A) / B \times 100 \%$

$A=$ Concentration of the parameter after treatment

$\mathrm{B}=$ Concentration of the parameter before treatment

$+=$ percentage decrease

- = percentage increase

In general, immobilization makes the enzyme more resistant to temperature, $\mathrm{pH}$, and substrate concentration swings giving it a longer lifetime and higher productivity per active unit (Gianfreda and Rao, 2004; FuIlbrook, 1996; Russell et al, 2003; Kandelbauer et al., 2004). Immobilized cells have been used and studied extensively for the production of useful chemicals (Ohtake and Silver, 1994), the treatment of wastewaters (Chen et al., 2003; Wang et al., 2010). Although many workers described microbial degradation of tannery effluent, limited literature is available on the bioremediation of tannery effluent using immobilized bacterial cells in the Kano Industrial Estates.

\section{CONCLUSION}

The samples contained variable levels of the physicochemical parameters. The results of the Analysis of variance revealed that, no statistical difference $(p<0.05)$ was observed for the temperature, $\mathrm{pH}, \mathrm{SS}, \mathrm{TDS}, \mathrm{BOD}$ and $\mathrm{COD}$ among the three tannery industries before the treatment. The levels of some of the parameters
(SS, TDS and COD) observed in the samples were found above the recommended limits of WHO and NESREA, which called for the treatment of the effluents before discharge into the environment. Base on the morphological and biochemical test results, TAN1, TAN2, and TAN3 bacterial isolates were identified to be Neisseria spp, Bacillus cereus, and Staphylococcus aureus respectively. The results of Post-treatment analysis showed that there is overall decrease in the levels of the parameters determined when compared with that of the pre-treatment. The overall percentage reduction of the immobilised bacteria in the treatment of the respective effluents was in the order TAN2 (72\%)>TAN1 $(70 \%)>$ TAN3 $(62 \%)$. Hence, the immobilized bacteria are having higher biodegradation potential for the treatment of the tannery effluents.

\section{Acknowledgments}

The authors wish to acknowledge the University of Maiduguri for the financial support. The authors are grateful to the Kano State Ministry of Environment for their support in obtaining the effluent samples. 


\section{REFERENCES}

Ajao, A. T., Adebayo, G. B., and Yakubu, S. E. (2011). Bioremediation of textile industrial effluent using mixed culture of Pseudomonas aeruginosa and Bacillus subtilis immobilized on agar-agar in a bioreactor. J. Microbiol. Biotech. Res, 1(3), 50-56.

Akan, J. C., Moses, E. A., Ogugbuaja, V. O., and Abah, J. (2007). Assessment of tannery industrial effluents from Kano metropolis, Kano State, Nigeria. Journal of Applied Sciences, 7(19), 2788-2793.

Akan, J. C., Ogugbuaja, V. O., Abdulrahman, F. I., and Ayodele, J. T. (2009). Pollutant levels in effluent samples from tanneries and textiles of Kano industrial areas, Nigeria. Global journal of pure and applied sciences, 15(3-4).

APHA (1989). Standard methods for Examination of Will bete and Will betewater.15 $5^{\text {th }}$ edition. Brydpass Springfield Will behington DC. pp. 164-176

APHA (1992). Standard Methods for the Examination of Water and Wastewater. Health, 69, 1116-9.

Baba, A., Garba, S. T., and Bello, H. S. (2020). Bioremediation Potential of Immobilized corynebacterium kutsceri in the Treatment of Tannery Industrial Effluent from Challawa Industrial Estate, Kano State, Nigeria. Journal of the Turkish Chemical Society Section A: Chemistry, $7(2), 335-350$.

Beem, E. I. V. (1994). reduction of solvent VOC emission. J. Oil Col. Chem. Ass, 77, 158.

Bouwer, E. J., and Zehnder, A. J. (1993). Bioremediation of organic compoundsputting microbial metabolism to work. Trends in biotechnology, 11(8), 360367.

Chen, K. C., Wu, J. Y., Liou, D. J., and Hwang, S. C. J. (2003). Decolorization of the textile dyes by newly isolated bacterial strains. Journal of Biotechnology, 101(1), 57-68.

Dan'Azumi, S., and Bichi, M. H. (2010). INDUSTRIAL POLLUTION AND HEAVY METALS PROFILE OF CHALLAWA RIVER IN KANO, NIGERIA. Journal of Applied Sciences in Environmental Sanitation, $5(1)$.

DWAF. (1992). Analytical Methods Manual, TR 151. Department of Water Affairs and Forestry, Pretoria.

El-Bestawy, E. (2013). Biological treatment of leather-tanning industrial wastewater using free living bacteria.
Elsheikh, M. A. S. (2009). Tannery wastewater pre-treatment. Water Science and Technology, 60(2), 433-440.

FuIlbrook, P. D. (1996). "Kinetics." Industrial enzymology: The application of enzymes in Industry. 2nd Ed. T. Godfrey and J Reichelt. eds.. Nature. New York.

Gianfreda, L., and Rao, M. A. (2004). Potential of extra cellular enzymes in remediation of polluted soils: a review. Enzyme and microbial technology, 35(4), 339354.

Hugo Springer. (1994). John Arthur Wilson Memorial Lecture "Treatment of Industrial Wastes of the Leather Industry - is it still a Major Problem". JALCA, 89, 153-185

Jimoh, A. A., Ganiyu, B. A., Baba, D., and Baba, A. (2018) Bioremediation Process of Effluent from Detergent and Food Industries in Jos, Nigeria: Kinetics and Thermodynamics. International Journal of Engineering Science Invention (IJESI), 762-73

Kandelbauer, A., Maute, O., Kessler, R. W., Erlacher, A., and Gübitz, G. M. (2004). Study of dye decolorization in an immobilized laccase enzyme-reactor using online spectroscopy. Biotechnology and bioengineering, 87(4), 552-563.

Kongjao, S., Damronglerd, S., and Hunsom, M. (2008). Simultaneous removal of organic and inorganic Pollutants in tannery wastewater using electrocoagulation technique. Korean Journal of chemical engineering, 25(4), 703.

Maheshwari, U. M., Aruna, S., Gomathi, M., and AbdulJaffar, A. H. (2017). Bioremediation by Free and Immobilized Bacteria Isolated from Tannery Effluent. International Journal of Research in Applied, Natural and Social Sciences. 5(7), 75-90

Margesin, R., and Schinner, F. (2001). Bioremediation (natural attenuation and biostimulation) of diesel-oilcontaminated soil in an alpine glacier skiing area. Applied and environmental microbiology, 677), 3127-3133.

Mohammed, A., Sekar, P., and George, J. (2011). Efficacy of microbes in bioremediation of tannery effluent. Inter. J. Curr. Res, 3(4), 324-326.

Mohammed, S. S. D., Orukotan, A. A., and Abdullahi, H. (2017). Physicochemical and Bacteriological Assessment of Tannery Effluent from Samaru-Zaria, 
BAJOPAS Volume 13 Number 2, December, 2020 Kaduna State, Nigeria. Journal of Applied

Sciences and Environmental Management, 21(4), 734-740.

Munz, G., De Angelis, D., Gori, R., Mori, G., Casarci, M., and Lubello, C. (2009). The role of tannins in conventional and membrane treatment of tannery wastewater. Journal of hazardous materials, 164(2-3), 733-739

Mythili, K., and Karthikeyan, B. (2011). Bioremediation of $\mathrm{Cr}$ (VI) from tannery effluent using Bacillus spp and Staphylococcus spp. International Multidisciplinary Research Journal, 1(6).

NESREA (2009). National Environmental Standards for Effluent Limitations and Regulation. 1233-1236

Noorjahan, C. M. (2014). Physicochemical characteristics, identification of bacteria and biodegradation of industrial effluent. Journal of bioremediation and Biodegradation, 5(3).

Ohtake, H. I., and Silver, A. O. (1994). Bacterial reduction of toxic chromate. Biological degradation and bioremediation of toxic chemicals, 403-415.

Omoleke, I. I. (2004). Management of environmental pollution in Ibadan, an African city: the challenges of health hazard facing government and the people. Journal of Human Ecology, 15(4), 265-275.

Rajor, A., Reddy, A.S., and Singh, B. (2004). Determination of BOD kinetic Parameters and evaluation of alternate methods, M.Sc. Thesis, Department of biotechnology \& environmental Science, Thapar Institute of Engineering and Technology, Patiala

Ramasami, T., Rajamani, S., and Rao, J. R. (1994, March). Pollution control in leather industry: Emerging technological options. In International symposium on surface and colloidal science and its relevance to soil pollution, madras.

Ramesh, J. V. S., and Singh, S. P. (1993). Yearly variation in certain physicochemical parameters of pond at eastern Doon Valley. Uttar Pradesh J. Zoo, 12 (1), 7577.

Ranen, S., and Sharadinadra, C. (2009). Biotechnology applications to environmental remediation in resource exploitation. Current science, 97, 6-25
Russell, A. J., Berberich, J. A., Drevon, G. F., and Koepsel, R. R. (2003). Biomaterials for mediation of

chemical and biological warfare agents. Annual review of biomedical engineering, 5(1), 1-27.

Saravanan, P., and Saravanan, A. (1999). Decolourization of tannery effluent by Flavobacterium sp. EK 1. Indian Journal of Environmental Protection, 19, 19-24.

Sikander, S., and Shahida, H. (2007). Reduction of toxic hexavalent chromium by Ochrobactrum intermedium strain SDCr5 stimulated by heavy metals. Bioresource Technol, 98, 340-344.

Singh, N., Sharma, B. K., and Bohra, P. C. (2000). Impact assessment of industrial effluent of arid soils by using satellite imageries. Journal of the Indian Society of Remote Sensing, 28(2-3), 79.

Sreemoyee, C., and Priti, P. (2013). Assessment of physico-chemical parameters of dairy waste water and isolation and characterization of bacterial strains in terms of cod reduction. Int J Sci, 2(3), 395-400.

Verheijen, L. A. H. M., Wiersema, D., Pol, L. H., and De Wit, J. (1996). Management of wastes from animal product processing. Livestock and environment, Finding a balance. International Agriculture Center, Wageningen, The Netherlands.

Wang, F., Yao, J., Si, Y., Chen, H., Russel, M., Chen, K., and Bramanti, E. (2010). Short-time effect of heavy metals upon microbial community activity. Journal of Hazardous Materials, 173(13), 510-516.

WHO (World Health Organization). (2006). Air quality guidelines: global update 2005: particulate matter, ozone, nitrogen dioxide, and sulfur dioxide. World Health Organization.

World Bank. (1995). Nigeria's strategic options for redressing industrial pollution. World Bank, industry and energy division. 1st edition, West Central Africa Department; Annexes: 1995; pp 60-62.

Zahoor, A., and Abdul, R. (2009). Enumeration of Coliforms. Journal of Environmental Sciences. 21, 814-820 


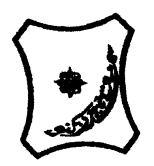

Bayero Journal of Pure and Applied Sciences, 13(2): 1 - 12

Received: November, 2020

Accepted: December, 2020

ISSN $2006-6996$

\title{
BIODEGRADATION POTENTIAL OF IMMOBILIZED BACTERIA IN THE TREATMENT OF TANNERY INDUSTRIAL EFFLUENTS FROM INDUSTRIAL ESTATES IN KANO STATE, NIGERIA
}

\author{
Abdullateef, B., ${ }^{1 *}$ Shuaibu, T. G., ${ }^{1}$ Babagana, K., ${ }^{1}$ Suleman, H. B. ${ }^{2}$ and Dauda, B. ${ }^{3}$ \\ ${ }^{1}$ Department of Pure and Applied Chemistry, Faculty of Science, University of Maiduguri, Borno State, \\ Nigeria \\ ${ }^{2}$ Department of Microbiology, Faculty of Science, University of Maiduguri, Borno State, Nigeria \\ ${ }^{3}$ Department of Chemical Engineering, Faculty of Engineering, University of Maiduguri, Borno State, \\ Nigeria \\ *Corresponding author: babslega@gmail.com; abelega2007@yahoo.com; +2348061309753
}

\section{ABSTRACT}

Industrial Effluents Samples from Gashash Tanneries (TAN1) in Bompai Industrial estate, Larabee Tannery Industry (TAN2) in Sharada Industrial estate and Z Tannery Industries (TAN3) in Challawa Industrial estate, Kano State, Nigeria were collected over a period of six months (August 2017 to January 2018) for assessing the biodegradation potentials of bacteria in the treatment of organic pollutants within the effluents. Bacteria were isolated from the effluents and immobilized on agar-agar. Different masses (5 g, $10 \mathrm{gr}, 15$ $\mathrm{g}, 20 \mathrm{~g}$, and $25 \mathrm{~g}$ ) of the bacteria were used in the treatment of $250 \mathrm{ml}$ of the effluents for ten days in a shaker incubator (Gallenkamp-OC-4364-L) at the temperature $30{ }^{\circ} \mathrm{C}$ and speed of $60 \mathrm{rpm}$. Pre-treatment analysis of the effluents for Temperature, pH, Biochemical Oxygen Demand (BOD), Chemical Oxygen Demand (COD), Suspended Solid (SS) and Total Dissolved Solids (TDS) gives the following results; temperature $\left({ }^{\circ} \mathrm{C}\right.$ )

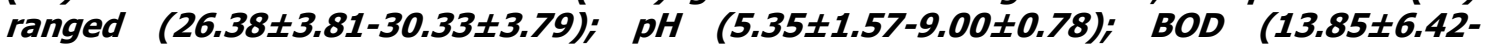
$38.75 \pm 16.20) ;$ COD (1406 $\pm 208-3532 \pm 1373) ;$ SS (208 $\pm 235-780 \pm 739)$ and TDS (266 $\pm 253-5276 \pm 2971)$. No statistical differences ( $p \leq 0.05)$ was observed for all the results among the different industries. The bacterial isolates were identified as Neisseria spp, Bacillus cereus, and Staphylococcus aureus, in TAN1, TAN2, and TAN3, respectively. After treatment of the effluent with the different masses of the isolated bacteria, the mean level of BOD was found to range as (0.55 $\pm 0.36-6.92 \pm 5.49) ; C O D$ (ND-3134 \pm 1595$)$;

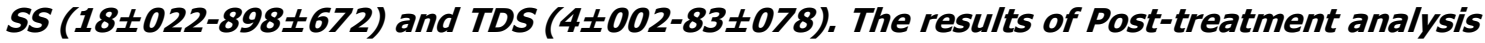
showed that there is overall decrease in the levels of the parameters determined when compared with that of the pre-treatment. The overall percentage reduction of the immobilised bacteria in the treatment of the respective effluents was in the order TAN2 (72\%)>TAN1 (70\%)>TAN3 (62\%). Hence, the immobilized bacteria are having higher biodegradation potential for the treatment of the tannery effluents.

Keywords: Biodegradation, bacteria, effluent, immobilization, tannery.

\section{INTRODUCTION}

Tannery industrial wastewater is a serious consequence of the pollution point of view for streams, freshwater, and land used for agriculture. The lack of awareness in the modern industrial practice has resulted in the discharge of tannery effluents which exhibit very high value of chromium ( $\mathrm{Cr}$ ), Sulfide, and chloride, Total Dissolved Solid (TDS), Total Suspended Solid (TSS), Biochemical Oxygen Demand (BOD) and Chemical Oxygen Demand (COD) in the water stream or land (Mohammed et al., 2001). Tanning is the process, which One ton of skin generally leads to the production of 20 to $80 \mathrm{~m}^{3}$ of turbid and foul-smelling converts the protein of the rawhide or skin into a stable material, which will not putrefy and is suitable for a wide variety of end applications (Elsheikh, 2009). The highly polluting chromium is the most commonly used tanning material producing leather that is more flexible and pliable than vegetable-tanned leather and does not discolor or lose shape in water as drastically as vegetable-tan (Elsheikh, 2009). Tannery effluent is among the most hazardous industrial pollutants due to its huge organic and inorganic load, which is highly toxic to human life and the environment (Kongjao et al., 2008). wastewater including chromium (100-400 mg/l), sulfide $(200-800 \mathrm{mg} / \mathrm{l})$, high levels of fat and 
BAJOPAS Volume 13 Number 2, December, 2020 other solid wastes, and notable pathogen contamination as well as pesticides added for skin conservation during transport (Elsheikh, 2009). There are more than 6000 tanneries in Nigeria with an annual processing capacity of 700,000 tons of hides and skins (Omoleke, 2004; Singh et al., 2008). It was reported that the total amount of waste produced per animal slaughtered is approximately $35 \%$ of its weight (World Bank, 1995). Also, for every $1000 \mathrm{~kg}$ of carcass weight, a slaughtered beef produces 5.5 $\mathrm{kg}$ of manure (excluding rumen contents or stockyard manure) and $100 \mathrm{~kg}$ of paunch manure (undigested food) (Verheijen et al., 1996). Tanneries generate wastewater in the range of 30-35 $\mathrm{L} \mathrm{kg}^{-1}$ skin/hide processed with variable $\mathrm{pH}$, Biological Oxygen Demand (BOD), Chemical Oxygen Demand (COD), high concentrations of suspended solids (SS), and tannins as well as chromium (Zahoor and Abdul, 2009).

Being heterogeneous and composed of a wide variety of compounds, it is very difficult to select a unique direct method for estimating the biodegradability of organic contents and biokinetic parameters for a wastewater sample (Rajor, 2004). For this purpose, some indirect estimation such as determination of biochemical oxygen demand (BOD) and chemical oxygen demand (COD) are applied as common laboratory investigations [9]. During retanning procedures, synthetic tannins (Syntan), oils and resins are added to form softer leather at varying doses (Munz et al., 2009). One of the refractory groups of chemicals in tannery effluents derives mainly from tannins (Ramasami et al., 2004). Syntans are characterized by complex chemical structures, because they are composed of an extended set of chemicals such as phenol-, naphthalene-, formaldehyde- and melamine-based syntans, and acrylic resins (Beem, 1994). Organic pollutants (proteic and lipidic components) are originated from skins (it is calculated that the raw skin has $30 \%$ loss of organic material during the working cycle) or they are introduced during processes (Hugo Springer, 1994).

Many conventional processes such as oxidation, chemical and biological processes were carried out to treat tanneries wastewater (Ebtesam et al, 2013). Biological processes have received more attention because of their costeffectiveness, lower sludge production and environmental friendliness (Noorjahan, 2014). Naturally occurring micro-organisms degrade the hazardous organic wastes including xenobiotic compounds, such as pesticides, polycyclic aromatic hydrocarbons (PAHs) and polychlorinated biphenyls (PCBs) in due course of time (Ranen and Sharadinadra, 2009). Bioremediation is based on the idea that all organisms remove substances from the environment to carry outgrowth and metabolism (Bouwer and Zehnder, 1993). Bacteria, protista and fungi are found to be very good at degrading complex molecules and incorporating the breakdown products into their metabolism (Bouwer and Zehnder, 1993). The resultant metabolic wastes that they produce are generally safe and somehow recycled into other organisms (Ranen and Sharadinadra, 2009). An acclimatized indigenous population of microorganisms capable of degradation of the compounds of interest must exist at the site for a successful bioremediation mode (Ranen and Sharadinadra, 2009). It has been observed that for a successful bioremediation mode, an acclimatized indigenous population of microorganisms capable of degradation of the compounds of interest must exist at the site under investigation (Ranen and Sharadinadra, 2009). Even though there are numerous physical and chemical methods employed in the disposal of wastes the advantage in using bacterium is that they play a key role in the reduction of COD, BOD, total protein, total tannin and total phenol (Saravanan and Saravanan, 1998)

Baba et al. (2020) studied the bioremediation potential of immobilized corynebacterium kutsceri in the Treatment of tannery industrial effluent from Challawa Industrial Estate, Kano State, Nigeria. The aim of the work is to study the reduction in the level of the contaminants through the process of bioremediation using the isolated bacteria. Immobilized bacteria can withstand various temperatures, $\mathrm{pH}$ and substrate concentrations; consequently, increasing the efficiency and the lifespan of the bacteria. Immobilized bacteria are widely applied in the treatment of wastewater and can be separated and recovered after the treatment with the same efficiency (Baba et al., 2020).

\section{MATERIALS AND METHODS \\ Study Area}

This study was carried out in Bompai, Sharada and Challawa industrial estates in Kano, Figure 1. Kano lies on Latitude $11^{\circ} 30^{\prime} \mathrm{N}$ and $8^{\circ} 30^{\prime} \mathrm{E}$ and Longitude $11^{\circ} 5^{\prime} \mathrm{N}$ and $8^{\circ} 5^{\prime} \mathrm{E}$ in Northern Nigeria. It is one of the developed industrial cities in Nigeria. Tannery activities are the dominating industries and this could be one of the reasons for her high population density (Dan'Azumi and Bichi, 2010). Many researchers have studied biodegradation of tannery effluent using microorganisms. However, limited literature is available on the biodegradation of tannery effluent in Kano industrial estates using 
BAJOPAS Volume 13 Number 2, December, 2020 immobilized bacterial cells. This research work focuses on the potential of the use of the indigenous immobilized bacterial isolates in the treatment of tannery effluents in the industrial estates.

\section{Sample Collection}

Effluents were collected from the Tannery Industries from Bompai, Challawa and Sharada Industrial Estates, Kano, Nigeria. The effluents were collected over a period of six months (August 2017 to January 2018). Samples collected in a sterile 4-liter plastic container with a unique identification number were preserved using an ice-box that was transported to the Microbiology Laboratory, Department of Microbiology, Bayero University of Kano for analysis

\section{Sample Preparation and Sample Analysis}

Immediately after the collection of the effluent, $\mathrm{pH}$, TSS, TDS, COD, BOD levels were determined before treatment (Pre-treatment determination) and ten days after treatment (Post-treatment determination) as described in
APHA (1989) standard methods. $\mathrm{pH}$ was determined using Ecotests $\mathrm{pH}$ meter and TDS was determined using AQUALYTIC TDS Salinometer. BOD was determined as described by the standard method (APHA, 1992). COD and SS were determined using DR/2010 HACH portable data logging spectrophotometer (DWAF, 1992)

\section{Identification and Biochemical} Characterization of the Bacterial Isolates

The bacteria were isolated from the effluents using Serial Dilution according to the method described by APHA (1989). The biochemical tests such as oxidase, catalase, coagulase, indole (from $1 \%$ tryptone broth), citrate (Simmons citrate agar), methyl red/VogesProskauer (MR/VP), nitrate reduction, Starch Hydrolysis, Glucose, Maltose, and Lactose tests were carried out on the bacterial isolates to identify the bacteria through the bacteria biochemical characteristics according to Ajao et al. (2011).

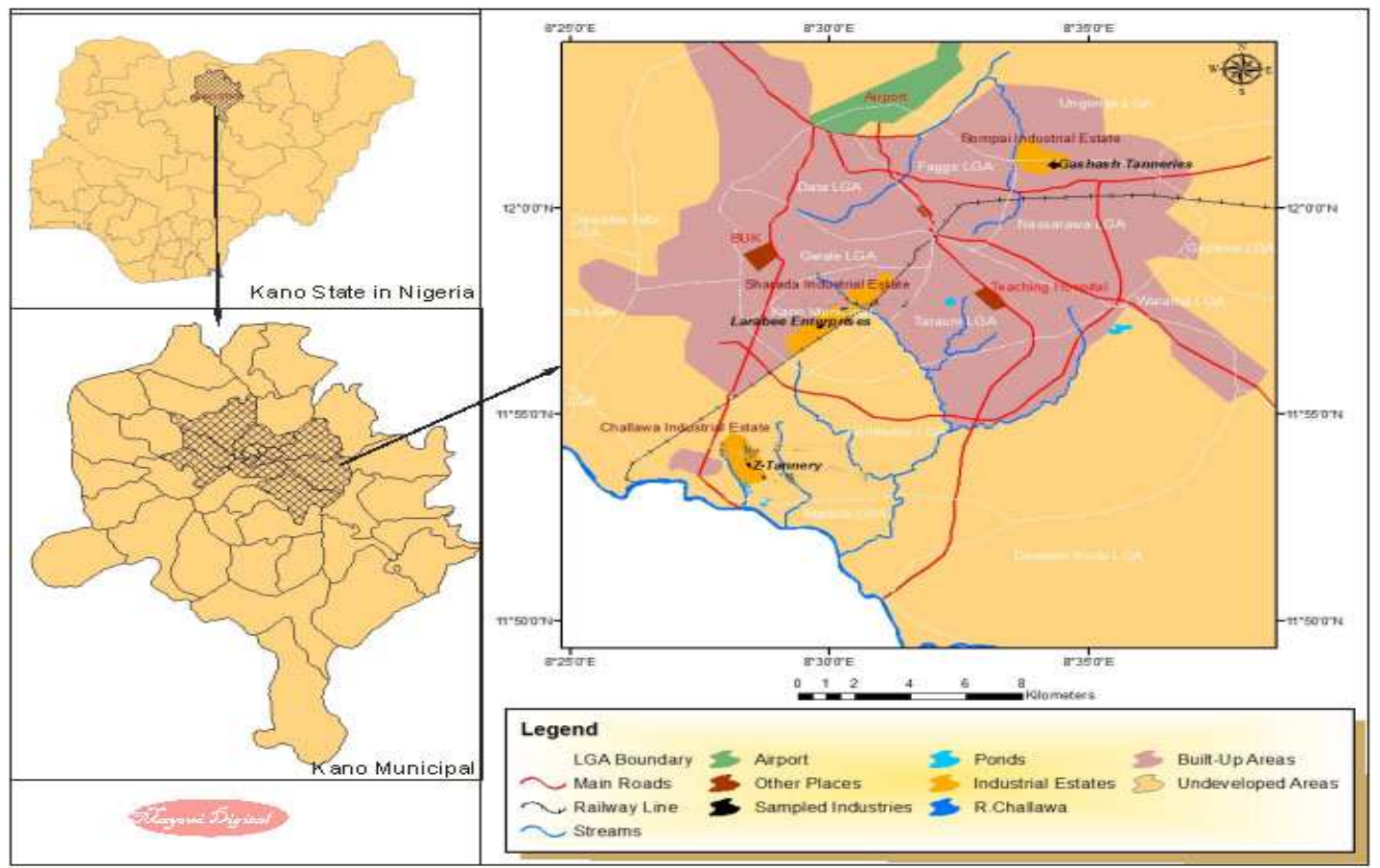

Fig. 1 Map showing the study areas

Source: Mayomi Digital Productions, GIS Laboratory, Department of Geography, UNIMAID (2017)

\section{Determination of Growth Rate of the Bacteria in Effluent Sample}

The bacteria growth rates were determined by transferring $2 \mathrm{~mL}$ of the bacterial isolates from the tannery effluent in broth medium into 100 $\mathrm{mL}$ sterile effluents in conical flasks and kept in an incubator (Giffrin cool) for 10 days. Control was also set up by incubating another $100 \mathrm{~mL}$ each of the sterile effluents without the bacteria. The optical density of the content was determined at the wavelength of $600 \mathrm{~nm}$ on a daily interval and recorded. 
BAJOPAS Volume 13 Number 2, December, 2020 Immobilization of Bacteria

Agar solution and inoculi were prepared separately. Fifty milliliters $(50 \mathrm{~mL})$ of nutrient broth each of the inoculi was prepared in a McCartney bottle and incubated for 24 hours. A solution of agar-agar was prepared by dissolving $10 \mathrm{~g}$ of the powder in distilled water and made up to $500 \mathrm{~mL}$ mark in an Erlenmeyer flask and was sterilized in an autoclave (280A) for 15 minutes and allowed to cool to $40-45^{\circ} \mathrm{C}$ (Ajao et al., 2011). Four milliliters ( $4 \mathrm{~mL})$ of the bacterial isolates in the nutrient broth was mixed with 36 $\mathrm{ml}$ of the prepared agar-agar media in petri-dish plates and then allowed to solidify. This was kept in the refrigerator for bioremediation.

\section{Bioremediation (Treatment) of the Effluents}

The solidified agar block (immobilized bacteria) was cut into cubes using a sterile knife; $0.1 \mathrm{~mL}$ phosphate buffer ( $\mathrm{pH} \mathrm{7.0)}$ was added and kept in the refrigerator for 1 hour for curing. The phosphate buffer was decanted after 1 hour and the cubes were washed with sterile distilled water 3-4 times before it was used (Ajao et al., 2011). Two liters (2 L) of the effluent was supplemented with the minimum basal medium in $\mathrm{g} / \mathrm{L}: \mathrm{NaCl}(0.8), \mathrm{MgSO}_{4} .7 \mathrm{H}_{2} \mathrm{O}(0.001), \mathrm{KH}_{2} \mathrm{PO}_{4}$ (2), $\mathrm{NaNO}_{3}$ (2), $\quad \mathrm{CaCl}_{2} .2 \mathrm{H}_{2} \mathrm{O} \quad(0.5)$ and $\mathrm{NaHPO}_{4} .12 \mathrm{H}_{2} \mathrm{O}(2)$ and sterilized in an autoclave at $121^{\circ} \mathrm{C}$ for 15 minutes (Margesin and Schinner, 2001). Two hundred and fifty milliliters $(250 \mathrm{~mL})$ of the effluents were transferred into different $250 \mathrm{ml}$ conical flasks. The content was covered with a cotton-wool ramped with foil paper to avoid contamination. Five grams $(5 \mathrm{~g})$ of the immobilized bacteria were quickly transferred into each of the effluents in the conical flasks in an inoculating chamber. The same procedures were carried out for the $10 \mathrm{~g}, 15 \mathrm{~g}, 20 \mathrm{~g}$ and 25 $\mathrm{g}$ of the immobilized bacteria in separate $250 \mathrm{~mL}$ effluents in conical flasks and agitated for ten days in a shaker incubator (Gallenkamp-OC4364-L) at a temperature $30^{\circ} \mathrm{C}$ and speed of 60 rpm. The treated effluent samples were taken on the tenth day and analyzed for the parameters $\mathrm{pH}$, SS, TDS, COD, and BOD, (Posttreatment determination) for the different grams of bacteria to evaluate and compare the biodegradation potential. (Baba et al., 2020).

\section{Statistical Analysis}

The data were represented as Mean \pm Standard deviation and analyzed statistically using oneway Analysis of Variance (ANOVA) and Tukey's HSD as Post Hoc Tests with the aid of SPSS 16.0. The correlation coefficient was also used to measure the strength of the relationship between the different masses of the bacteria and the parameters. All $\mathrm{p} \leq 0.05$ were considered as statistically significant.

\section{RESULTS AND DISCUSSION Physico-chemical parameters in the Industrial Effluents before the Biodegradation.}

Results of the Physico-chemical parameters in the industrial effluents before the Biodegradation is shown in table 1 . The mean temperatures $\left({ }^{\circ} \mathrm{C}\right)$ observed in TAN1, TAN2, and TAN3 samples were $28.07 \pm 0.65 ; 27.77 \pm 0.64$ and $26.38 \pm 3.81$ respectively. The order of the mean temperature of the samples from the three industries can be arranged as TAN1 > TAN2>TAN3. The temperature observed at TAN1, TAN2, and TAN3 samples were found below the WHO $\left(35^{\circ} \mathrm{C}\right)$ and NESREA $\left(40^{\circ} \mathrm{C}\right)$ limits. The low values of temperature might be due to the processes used at the time of sampling. High temperature brings down the solubility of gases in water that ultimately expresses as high BOD and COD. Statistical analysis shows that there is no significant difference $(p<0.05)$ between the mean values of temperature among the industries. This might be due to similar tannery activities involved in the tannery industries at the time of sampling. The average values of temperature observed in this present study are less than those observed by Akan et al. (2007), Akan et al. (2009) and Baba et al. (2020).

The mean level of $\mathrm{pH}$ observed in TAN1, TAN2 and TAN3, samples were $7.77 \pm 2.93$; $8.35 \pm 0.28$ and $7.52 \pm 0.76$ respectively. The order of the mean $\mathrm{pH}$ of the samples from the three industries can be arranged as TAN2> TAN1 $>$ TAN3. The $\mathrm{pH}$ of the samples falls within the WHO (7.0-8.5) and NESREA (6-9) standard limits. Statistical analysis shows that there is no significant difference $(p<0.05)$ between the mean values of $\mathrm{pH}$ among the industries. This might be due to similar tannery activities involved in the tannery industries at the time of sampling. Maheshwari et al. (2017) reported that the level of $\mathrm{pH}$ in the effluents from the tannery industry in Vaniyambadi, India was 6.5 which was lower than that observed in the present study. The $\mathrm{pH}$ in the effluents from the tannery industries in Kano and Kaduna were reported to be 7.64 and 6.89, respectively (Akan et al., 2007; Mohammed et al., 2017). The average values of $\mathrm{pH}$ observed in this present study are less than those observed by Mohammed et al. (2017) and Baba et al. (2020). The mean level of SS $(\mathrm{mg} / \mathrm{l})$ observed in TAN1, TAN2, and TAN3 samples were 374 \pm 124 ; $358 \pm 335$ and $780 \pm 739$ respectively. The order of the mean SS in the samples from the three industries can be arranged as TAN3 > TAN1 $>$ TAN2. 
The SS observed in the samples were far above the recommended standard limits of regulating bodies WHO $(30 \mathrm{mg} / \mathrm{l})$ and NESREA $(10 \mathrm{mg} / \mathrm{l})$. Statistical analysis shows that there is no significant difference $(p<0.05)$ between the mean values of SS among the industries. This might be due to similar tannery activities involved in the tannery industries at the time of sampling. The average values of SS observed in this present study are less than that observed $(3700 \pm 122 \mathrm{mg} / \mathrm{l})$ by Akan et al. (2009) for tanneries in Kano. Also, the average values of SS observed in this present study are less than that observed by Mohammed et al. (2017) and Baba et al. (2020) with the exception in TAN3.

The mean level of TDS (mg/l) observed in TAN1, TAN2, and TAN3 samples were $3941 \pm 3703$; $3300 \pm 1714$ and $2653 \pm 1240$ respectively. The order of the mean TDS in the samples from the three industries can be arranged as TAN1>TAN2>TAN3. The TDS observed in the samples were far above the recommended standard limits of WHO $(250 \mathrm{mg} / \mathrm{l})$ and NESREA $(500 \mathrm{mg} / \mathrm{l})$. Statistical analysis shows that there is no significant difference $(p<0.05)$ between the mean values of TDS among the industries. This might be due to similar tannery activities involved in the tannery industries at the time of sampling. TDS in the effluents from the tannery industries in Kano, Nigeria was reported to be $1281 \mathrm{mg} / \mathrm{l}$ (Akan et al., 2007). The average values of SS observed in this present study are less than those observed by Mohammed et al. (2017) and Baba et al. 2020)

The mean level of COD (mg/l) observed in TAN1, TAN2 and TAN3 samples seasons were $2372 \pm 938 ; \quad 1406 \pm 208$ and $3532 \pm 1373$ respectively. The order of the mean COD of the samples from the three industries can be arranged as TAN3>TAN1> TAN2. The COD observed in TAN1, TAN2 and TAN3 samples were far above the recommended standard limits of regulating bodies $\mathrm{WHO}(40 \mathrm{mg} / \mathrm{l})$ and NESREA (40 mg/l). Statistical analysis shows that there is no significant difference $(p<0.05)$ in COD among the industries. This might be due to similar tannery activities involved in the tannery industries as at the time of sampling. The Chemical Oxygen demand (COD) is the amount of oxygen, in $\mathrm{mg} / \mathrm{L}$, required for the degradation of the compound of wastewater to occur. In comparison, the average values of COD observed in this present study were higher than that observed by Mohammed et al. (2017) but lower than that observed by Baba et al. (2020).

The mean levels of BOD $(\mathrm{mg} / \mathrm{l})$ observed in TAN1, TAN2 and TAN3 samples were $13.85 \pm 6.42 ; \quad 19.46 \pm 0.50$ and $17.13 \pm 3.14$ respectively. The order of the mean BOD in the samples from the three industries can be arranged as TAN2>TAN3>TAN1. The BOD observed in TAN1, TAN2 and TAN3 samples were found below the recommended limits of NESREA (200 mg/l) but above WHO (10 mg/l). Statistical analysis shows that there is no significant difference $(p<0.05)$ between the mean values of BOD among the industries. This might be due to similar tannery activities involved in the tannery industries at the time of sampling. The low level of BOD recorded in this study is an indication of the low level of biodegradable organic solids in the effluent. The average values of BOD observed in this present study were lower than those observed by Mohammed et al. (2017) and Baba et al. (2020).

Table 1: Mean Values \pm S.D of Physico-chemical parameters of effluents from the Tannery Industries before Treatment.

\begin{tabular}{llllllll}
\hline Parameter & Tannery 1 & Tannery 2 & Tannery 3 & $\mathrm{a}$ & $\mathrm{b}$ & $\mathrm{c}$ & $\mathrm{d}$ \\
\cline { 2 - 7 } Temperature $\left({ }^{\circ} \mathrm{C}\right)$ & $28.07 \mathrm{a} \pm 0.65$ & $27.77 \mathrm{a} \pm 0.64$ & $26.38 \mathrm{a} \pm 3.81$ & & $29.50 \pm 4.68$ & 35 & 40 \\
pH & $7.77 \mathrm{a} \pm 2.93$ & $8.35 \mathrm{a} \pm 0.28$ & $7.52 \mathrm{a} \pm 0.76$ & 6.89 & $5.35 \pm 1.57$ & $7.0-8.5$ & $6.0-9.0$ \\
$\mathrm{COD}(\mathrm{mg} / \mathrm{l})$ & $2372 \mathrm{a} \pm 938$ & $1406 \mathrm{a} \pm 208$ & $3532 \mathrm{a} \pm 1373$ & 2.2 & $3106 \pm 2753$ & 40 & 40 \\
$\mathrm{BOD}(\mathrm{mg} / \mathrm{l})$ & $13.85 \mathrm{a} \pm 6.42$ & $19.46 \mathrm{a} \pm 0.50$ & $17.13 \mathrm{a} \pm 3.14$ & 1032 & $26.17 \pm 9.49$ & 10 & 200 \\
$\mathrm{SS}(\mathrm{mg} / \mathrm{l})$ & $374 \mathrm{a} \pm 124$ & $358 \mathrm{a} \pm 335$ & $780 \mathrm{a} \pm 739$ & 501 & $562 \pm 482$ & 30 & 10 \\
TDS $(\mathrm{mg} / \mathrm{l})$ & $3941 \mathrm{a} \pm 3703$ & $3300 \mathrm{a} \pm 1714$ & $2653 \mathrm{a} \pm 1240$ & 532.7 & $444 \pm 507$ & 250 & 500 \\
\hline
\end{tabular}

The values given in the table above are means of 6 replicate values, $\mathrm{n}=6$ ( 1 sample was taken monthly for 6 months). Within the rows, means with different alphabets are statistically different $(p<0.05)$. WHO: World Health Organisation. NESREA: National Environmental Standard and Regulatory Enforcement Agency. a = Mohammed et al.(2017), b = Baba et al. (2020), c = WHO (2006), $d=$ NESSRA (2009) 
BAJOPAS Volume 13 Number 2, December, 2020

Identification, Biochemical Characterization and growth rates of the Bacterial Isolates

Results of identification and biochemical characterization of the bacterial isolates were shown in table 2. After 24 hours of incubation, the nutrient agar media plates were checked for bacterial growth. The results showed the presence of different strains in the samples. The TAN1 bacteria isolate was found to be gramnegative cocci while TAN3 was gram-positive cocci. TAN2 bacteria isolate was found to be gram-positive, rod-shaped. TAN1, TAN2, and TAN3 bacteria isolates recorded positive results for spore former.

The results of the biochemical tests indicated that all the bacteria were positive for catalase, oxidase, citrate, maltose, glucose, lactose (negative in TAN1), mannitol (negative in TAN2), starch hydrolysis and coagulase (negative in TAN2) tests. The bacteria showed negative results for nitrate reduction, $M R$ (positive in TAN2), VP (positive in TAN1), Indole (positive in TAN2) tests. Base on the morphological and biochemical test results, TAN1, TAN2, and TAN3 bacteria isolates were identified to be Nesseria spp, Bacillus cereus, and Staphylococcus aureus respectively.

The growth rate of the TAN1, TAN2 and TAN3 Isolates were shown in figure 2. Generally, the optical density increase with the increase in time (day) and decrease as time goes on. The highest optical density was shown by bacillus cereus in TAN2 while the lowest was shown by Staphylococcus aureus in TAN3.

The initial growth phase of TAN1 Isolate bacteria occurred within 2-day of incubation as the growth rate increases up to the 6th-day incubation when the maximum growth was observed. Beyond the 6th day, the growth of the bacteria declined (which might be due to a shortage of nutrients in the effluents) until it reached its death phase (which might be due to the unavailability of nutrients in the effluents).

A similar trend of growth was also observed for TAN2 Isolate as the initial growth phase also occurred within 2-day of incubation but maximum growth rate observed on the 4th day of incubation. The stationary stage occurred between the 4th day and the 8th day. Beyond the 8th day, the growth of the bacteria declined (which might be due to a shortage of nutrients in the effluents) until it reached its death phase (which might be due to the unavailability of nutrients in the effluents).

The initial growth phase of TAN3 bacterial Isolate occurred within the 3-day incubation as the growth rate increases up to the 6th-day incubation when the maximum growth was observed. Beyond the 6th day, the growth of the bacteria declined (which might be due to a shortage of nutrients in the effluents) until it reached its death phase (which might be due to the unavailability of nutrients in the effluents).

Table 2: Morphological and Biochemical characteristics of bacterial isolates

\begin{tabular}{lllll} 
Bacterial Isolates & & TAN1 & TAN2 & TAN3 \\
\hline $\begin{array}{lllll}\text { Morphological } \\
\text { characteristics }\end{array}$ & Shape & Cocci & Rod & Cocci \\
& Spore & & & \\
& former & + & + & + \\
Gram & & & \\
Biochemical characteristics & reaction & - & + & + \\
& Citrate & + & + & + \\
& Catalase & + & + & + \\
& Coagulase & + & - & + \\
Starch & + & + & + \\
& Glucose & + & + & + \\
Oxidase & + & + & + \\
& Indo & - & + & - \\
Lactose & - & + & + \\
Manitol & + & - & + \\
Maltose & + & + & + \\
MR & - & + & - \\
VP & + & - & - \\
& Nitrate & - & - & - \\
Reduction & - Neisseria & Bacillus & Staphylococcus \\
& Bacterial & cereus & aureus \\
& name & spp & cas
\end{tabular}

+ = Positive; - = Negative; MR=Methyl Red; VP= Voges-Proskauer 


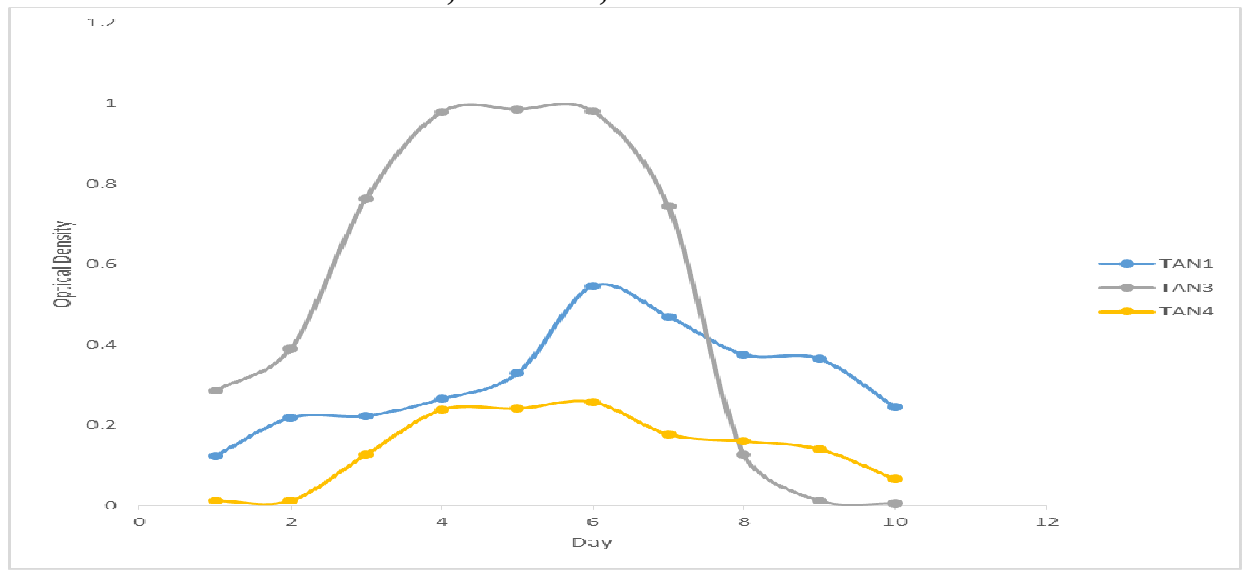

Fig. 2 Growth rates of the isolates in the effluents from the Tannery Industries

\section{Physico-chemical Parameters in the Industrial Effluents after the biodegradation.}

Table 3 shows the mean results of the physicochemical parameter before and after bioremediation using the different masses $(5 \mathrm{~g}$, $10 \mathrm{~g}, 15 \mathrm{~g}, 20 \mathrm{~g}$, and $25 \mathrm{~g}$ ) of the respective immobilized bacteria. Also, Table 4 shows the mean results of correlation coefficient ( $r$ ) between different masses of bacteria and physicochemical parameters.

The mean values $(\mathrm{mg} / \mathrm{l})$ of the SS after the bioremediation varies between $243 \pm 45$ and $898 \pm 672$. The mean concentration $(\mathrm{mg} / \mathrm{l})$ of SS remediated by the different masses $(5 \mathrm{~g}, 10 \mathrm{~g}$, $15 \mathrm{~g}, 20 \mathrm{~g}$, and $25 \mathrm{~g}$ ) of the bacteria varies. The SS in the samples fluctuates up and down after the bioremediation process when compared with the SS of the raw samples before the bioremediation. The increase in the levels of the SS might be due to the aggregation of the TDS which are large enough to result into SS. The increase in the levels of the SS might be also due to the influence of the nutrients which was added into the effluents in order to make the microorganisms more active and viable for fast degradation of organic contaminants in the effluent. The relative potential or efficiency of the different masses of the bacteria in remediating SS in TAN1 samples was in the order $25 \mathrm{~g}>20 \mathrm{~g}>15 \mathrm{~g}>10 \mathrm{~g}>5 \mathrm{~g}$. For TAN2 and TAN3 samples, the order was $25 \mathrm{~g}>20 \mathrm{~g}>15$ $\mathrm{g}>10 \mathrm{~g}>5 \mathrm{~g}$. These might be due to the variations in the surface areas of the different masses of the immobilized bacteria. Statistical analysis shows that there is no significant difference $(p<0.05)$ between the mean values of SS among the masses in the respective industries. Positive and significant correlations exist between the masses of bacteria and Suspended Solid (SS). This showed that there is general increase in the levels of the SS as the masses of the immobilized bacteria increases. TAN3 (90\%) and TAN1 (80\%) showed a very high correlation with the masses of the bacteria while TAN2 (61\%) showed a very low correlation.

The mean values $(\mathrm{mg} / \mathrm{l})$ of the TDS after the bioremediation varies between $46 \pm 11$ and $83 \pm 78$. The mean concentration $(\mathrm{mg} / \mathrm{l})$ of TDS remediated by the different masses $(5 \mathrm{~g}, 10 \mathrm{~g}$, $15 \mathrm{~g}, 20 \mathrm{~g}$, and $25 \mathrm{~g}$ ) of the bacteria varies. There is a reduction in all the TDS of all the samples after the bioremediation process compared with the TDS of the raw samples before the bioremediation. The relative potential or efficiency of the different masses of the bacteria in remediating TDS in TAN1 and TAN3 samples was in the order $5 \mathrm{~g}>10 \mathrm{~g}>15 \mathrm{~g}>20$ $\mathrm{g}>25 \mathrm{~g}$. For TAN2 samples, the order was 20 $g>10 \quad g>25 \quad g>15 \quad g>5 \quad g$. Statistical analysis shows that there is no significant difference $(p<0.05)$ between the mean values of TDS among the masses in the respective industries. These might be due to the variations in the surface areas of the different masses of the immobilized bacteria. Positive and significant correlations exist between the masses of bacteria and TDS with the exception in TAN2 (negative and insignificant correlation). The positive correlations showed that there is general increase in the levels of the TDS as the masses of the immobilized bacteria increases. TAN1 $(96 \%)$ showed a very high correlation with the masses of the bacteria while TAN2 (47\%) showed a very low correlation.

The mean values $(\mathrm{mg} / \mathrm{l})$ of the BOD after the bioremediation varies between $1.56 \pm 0.20 \mathrm{mg} / \mathrm{l}$ and $6.92 \pm 5.49 \mathrm{mg} / \mathrm{l}$. The mean concentration $(\mathrm{mg} / \mathrm{l})$ of BOD remediated by the different masses $(5 \mathrm{~g}, 10 \mathrm{~g}, 15 \mathrm{~g}, 20 \mathrm{~g}$, and $25 \mathrm{~g}$ ) of the bacteria varies. There is a reduction in all the BOD of all the samples after the bioremediation process compared with the $\mathrm{BOD}$ of the raw 
BAJOPAS Volume 13 Number 2, December, 2020 samples before the bioremediation. The relative potential or efficiency of the different masses of the bacteria in remediating BOD in TAN1, TAN2 and TAN3 samples were in the order $25 \mathrm{~g}>20$ $\mathrm{g}>15 \mathrm{~g}>10 \mathrm{~g}>5 \mathrm{~g}, 25 \mathrm{~g}>15 \mathrm{~g}>5 \mathrm{~g}>10 \mathrm{~g}>20 \mathrm{~g}$ and $20 \mathrm{~g}>10 \mathrm{~g}>25 \mathrm{~g}>15 \mathrm{~g}>5 \mathrm{~g}$ respectively. Statistical analysis shows that there is significant difference $(p<0.05)$ between the mean values of BOD among the masses in the respective industries. These might be due to the variations in the surface areas of the different masses of the immobilized bacteria. Negative and significant correlations exist between the masses of bacteria and BOD. This showed that there is general decrease in the levels of the BOD as the masses of the immobilized bacteria increases. TAN1 (94\%) showed a very high correlation with the masses of the bacteria while TAN2 (4\%) showed a very low correlation.

The mean values $(\mathrm{mg} / \mathrm{l})$ of the COD after the bioremediation varies between $250 \pm 154$ and $3134 \pm 1595$. The mean concentration $(\mathrm{mg} / \mathrm{l})$ of COD remediated by the different masses $(5 \mathrm{~g}$, $10 \mathrm{~g}, 15 \mathrm{~g} 20 \mathrm{~g}$, and $25 \mathrm{~g}$ ) of the bacteria varies. There is a reduction in all the COD of all the samples after the bioremediation process compared with the COD of the raw samples before the bioremediation. The relative potential or efficiency of the different masses of the bacteria in remediating COD in TAN1, TAN2 and TAN3 samples were in the order $25 \mathrm{~g}>20 \mathrm{~g}>15$ $\mathrm{g}>5 \mathrm{~g}>10 \mathrm{~g}, 25 \mathrm{~g}>20 \mathrm{~g}>15 \mathrm{~g}>10 \mathrm{~g}>5 \mathrm{~g}$ and 10 g>5 g>25 g>15 g>20 g respectively. Statistical analysis shows that there were significant difference $(p<0.05)$ between the mean values of COD among the masses in the respective industries except for effluents treated with $25 \mathrm{~g}$. These might be due to the variations in the surface areas of the different masses of the immobilized bacteria. Negative and insignificant correlations exist between the masses of bacteria and COD with the exception in TAN3 (positive and significant correlation). The negative correlations showed that there is general decrease in the levels of the COD as the masses of the immobilized bacteria increases. TAN2 (100\%) showed a very high correlation with the masses of the bacteria while TAN3 (36\%) showed a very low correlation.

Generally, there was an overall decrease in the concentration of these physicochemical parameters after the bioremediation using the different masses of the bacterial isolates. These might be due to the variations in the surface areas of the different masses of the immobilized bacteria. This is in line with the work of Jimoh et al. (2018) and Baba et al. (2020).

Table 3: Mean Values $(\mathrm{mg} / \mathrm{l}) \pm$ S.D of Physicochemical parameters in effluents from the Tannery Industries before and after Treatment of the effluents $(250 \mathrm{ml})$ with the different masses $(5 \mathrm{~g}, 10 \mathrm{~g}$, $15 \mathrm{~g}, 20 \mathrm{~g}$, and $25 \mathrm{~g}$ ) of the bacteria.

\begin{tabular}{llllllll}
\hline $\mathrm{P}$ & IND & Before & \multicolumn{5}{c}{ After } \\
\cline { 4 - 7 } & & & $5 \mathrm{~g}$ & $10 \mathrm{~g}$ & $15 \mathrm{~g}$ & $20 \mathrm{~g}$ & $25 \mathrm{~g}$ \\
\hline \multirow{2}{*}{ COD } & TAN1 & $2372 \pm 938$ & $1708 \mathrm{a} \pm 861$ & $2045 \mathrm{a} \pm 1205$ & $845 \mathrm{a} \pm 369$ & $300 \mathrm{a} \pm 167$ & $250 \mathrm{a} \pm 154$ \\
& TAN2 & $1406 \pm 208$ & $1195 \mathrm{a} \pm 208$ & $1125 \mathrm{a} \pm 384$ & $1055 \mathrm{a} \pm 317$ & $956 \mathrm{a} \pm 310$ & $870 \mathrm{ab} \pm 240$ \\
& TAN3 & $3532 \pm 1373$ & $2374 \mathrm{a} \pm 1344$ & $1976 \mathrm{a} \pm 1405$ & $2757 \mathrm{a} \pm 1266$ & $3134 \mathrm{a} \pm 1595$ & $2614 \mathrm{~b} \pm 1105$ \\
BOD & TAN1 & $13.85 \pm 6.42$ & $6.92 \mathrm{a} \pm 5.49$ & $6.42 \mathrm{a} \pm 5.07$ & $5.72 \mathrm{a} \pm 5.35$ & $4.62 \mathrm{a} \pm 4.37$ & $2.82 \mathrm{ab} \pm 1.26$ \\
& TAN2 & $19.46 \pm 0.50$ & $1.75 \mathrm{~b} \pm 0.22$ & $1.73 \mathrm{~b} \pm 0.18$ & $1.58 \mathrm{a} \pm 0.16$ & $1.91 \mathrm{a} \pm 0.22$ & $1.56 \mathrm{~b} \pm 0.20$ \\
& TAN3 & $17.13 \pm 3.14$ & $4.24 \mathrm{ab} \pm 0.77$ & $3.29 \mathrm{ab} \pm 0.37$ & $4.11 \mathrm{a} \pm 0.07$ & $3.23 \mathrm{a} \pm 0.91$ & $3.33 \mathrm{a} \pm 1.28$ \\
SS & TAN1 & $374 \pm 124$ & $243 \mathrm{a} \pm 45$ & $471 \mathrm{a} \pm 226$ & $475 \mathrm{a} \pm 182$ & $492 \mathrm{a} \pm 128$ & $611 \mathrm{a} \pm 217$ \\
& TAN2 & $358 \pm 335$ & $460 \mathrm{a} \pm 400$ & $543 \mathrm{a} \pm 414$ & $544 \mathrm{a} \pm 402$ & $551 \mathrm{a} \pm 414$ & $554 \mathrm{a} \pm 405$ \\
& TAN3 & $780 \pm 739$ & $586 \mathrm{a} \pm 594$ & $758 \mathrm{a} \pm 656$ & $787 \mathrm{a} \pm 676$ & $861 \mathrm{a} \pm 635$ & $898 \mathrm{a} \pm 672$ \\
TDS & TAN1 & $3941 \pm 3703$ & $51 \mathrm{a} \pm 10$ & $53 \mathrm{a} \pm 10$ & $55 \mathrm{a} \pm 15$ & $61 \mathrm{a} \pm 20$ & $63 \mathrm{a} \pm 26$ \\
& TAN2 & $3300 \pm 1714$ & $83 \mathrm{a} \pm 78$ & $47 \mathrm{a} \pm 20$ & $48 \mathrm{a} \pm 22$ & $47 \mathrm{a} \pm 17$ & $48 \mathrm{a} \pm 17$ \\
& TAN3 & $2653 \pm 1240$ & $46 \mathrm{a} \pm 11$ & $55 \mathrm{a} \pm 24$ & $55 \mathrm{a} \pm 25$ & $58 \mathrm{a} \pm 23$ & $61 \mathrm{a} \pm 28$ \\
\hline
\end{tabular}

Replicate $=6$ (months)

Within the rows, for the same parameter, means with different alphabets are statistically different $(p<0.05)$.

$\mathrm{P}=$ parameter, IND = Industries 
BAJOPAS Volume 13 Number 2, December, 2020

Table 4: Correlation coefficient $(r)$ between different masses of the bacteria and the physicochemical parameters.

\begin{tabular}{llll}
\hline Industries & Parameter & Correlation coefficient $(r)$ & $\begin{array}{l}\text { Percent dependence (rxrx100) } \\
(\%)\end{array}$ \\
\hline TAN1 & COD & -0.9 & 82 \\
& BOD & -0.97 & 94 \\
& SS & $0.90^{*}$ & 80 \\
TAN2 & TDS & $0.98^{*}$ & 96 \\
& COD & -1 & 100 \\
& BOD & -0.21 & 4 \\
& SS & $0.78^{*}$ & 61 \\
& TDS & -0.69 & 47 \\
& COD & $0.60^{*}$ & 36 \\
& BOD & -0.6 & 37 \\
& SS & $0.95^{*}$ & 90 \\
& TDS & $0.94^{*}$ & 89 \\
\hline
\end{tabular}

The correlation coefficient $(r)$ with * is statistically significant $(p<0.05)$.

Percentage reduction of the Parameters

Table 5 shows the percentage reduction of Parameters in industrial samples before and after the treatment of the effluents $(250 \mathrm{ml})$ with the different masses $(5 \mathrm{~g}, 10 \mathrm{~g}, 15 \mathrm{~g}, 20 \mathrm{~g}$, and $25 \mathrm{~g}$ ) of the Immobilized Bacteria.

In TAN1 samples, the percentage reduction (\%) of COD ranged (14-89); BOD (50-80); SS (-32$35)$ and TDS (98-99). In TAN2 samples, the percentage decrease $(\%)$ of COD ranged (15$38) ;$ BOD (90-92); SS [-28-(-55)] and TDS (9798). In TAN3 samples, the percentage decrease (\%) of COD ranged (11-44); BOD (76-81); SS (15-25) and TDS (98). The percentage increase in the levels COD, BOD and TDS might be due to the increase in the surface area of the different masses of the immobilized bacteria. However, the percentage decrease in the levels of the SS might be due to the aggregation of the TDS which are large enough to result into SS. The percentage decrease in the levels of the SS might be also due to the influence of the nutrients which was added into the effluents in order to make the microorganisms more active and viable for fast degradation of organic contaminants in the effluent. This is in line with the work of Jimoh et al. (2018) in which the concentration of the SS increase after the bioremediation of effluents.

Sreemoyee and Priti (2013) assessed and reduced several Physico-chemical parameters of dairy wastewater using Niesseria $s p$. and concluded that the species are well known to degrade organic compounds. This is in agreement with the current study in which the immobilized Niesseria $s p$ degrade the organic contaminants as indicated by the BOD, COD and TDS.

Jimoh et al. (2018) observed that TSS of the effluents was increased after treatment with immobilized bacteria and concluded that it might be due to the biostimulation method adopted for the research.

The optimum $\mathrm{pH}$ Biosorption of Chromium by Bacillus spp and Staphylococcus spp. from tannery effluent was investigated by Mythili and Karthikeyan (2011). The maximum adsorption of Chromium $(86.4 \mathrm{mg} / \mathrm{L})$ was showed by Bacillus spp and Staphylococcus spp showed $70.6 \mathrm{mg} / \mathrm{L}$ at an initial concentration of $100 \mathrm{mg} / \mathrm{L}$. In the present study, immobilised Bacillus spp and Staphylococcus spp. from the tannery industrial effluents reduced the levels of the organic pollutants with high potential as indicated by the percentage reduction of BOD, COD and TDS.

Enzymes often can work in multiple environments especially if they are immobilized. This makes the microorganisms' enzymes even more resistant to harsh environments and enables the enzymes to be recovered and recycled after they are no longer needed (Gianfreda and Rao 2004). Ramesh and Singh (1993) reported that the immobilized bacteria having more efficiency to remove the suspended particles than free cells. Using the immobilized cell is preferable due to its capability for using several times with the same efficiency, which makes it more economical. Similar work was done by Sikander et al. (2007) showing the higher reduction with permeabilized cells of Ochrobactrum intermedium strain SDCr-5. 
BAJOPAS Volume 13 Number 2, December, 2020

The results revealed the isolation and identification of isolates with the potential for the reduction of $\mathrm{Cr}$ (VI) to $\mathrm{Cr}$ (III). Results indicated that immobilized $B$. cereus could be efficiently used for the reduction of $\mathrm{Cr}$ (VI).

Table 5: Percentage reduction of the tested Parameters from the tannery industrial samples of the Immobilized Bacteria.

\begin{tabular}{lllllll}
\hline \multirow{2}{*}{ Industries } & & \multicolumn{5}{c}{ Percentage Reduction $(\%)$} \\
\cline { 3 - 7 } & & $5 \mathrm{~g}$ & $10 \mathrm{~g}$ & $15 \mathrm{~g}$ & $20 \mathrm{~g}$ & $25 \mathrm{~g}$ \\
\hline TAN1 & COD & 28 & 14 & 64 & 87 & 89 \\
& BOD & 50 & 54 & 59 & 67 & 80 \\
& SS & 35 & -26 & -27 & -32 & -63 \\
& TDS & 99 & 99 & 99 & 98 & 98 \\
TAN2 & COD & 15 & 20 & 25 & 32 & 38 \\
& BOD & 91 & 91 & 92 & 90 & 92 \\
& SS & -28 & -52 & -52 & -54 & -55 \\
& TDS & 97 & 99 & 99 & 99 & 99 \\
& COD & 33 & 44 & 22 & 11 & 26 \\
& BOD & 75 & 81 & 76 & 81 & 81 \\
& SS & 25 & 3 & -1 & -10 & -15 \\
& TDS & 98 & 98 & 98 & 98 & 98 \\
\hline
\end{tabular}

Percentage Reduction $=(B-A) / B \times 100 \%$

$A=$ Concentration of the parameter after treatment

$\mathrm{B}=$ Concentration of the parameter before treatment

$+=$ percentage decrease

- = percentage increase

In general, immobilization makes the enzyme more resistant to temperature, $\mathrm{pH}$, and substrate concentration swings giving it a longer lifetime and higher productivity per active unit (Gianfreda and Rao, 2004; FuIlbrook, 1996; Russell et al, 2003; Kandelbauer et al., 2004). Immobilized cells have been used and studied extensively for the production of useful chemicals (Ohtake and Silver, 1994), the treatment of wastewaters (Chen et al., 2003; Wang et al., 2010). Although many workers described microbial degradation of tannery effluent, limited literature is available on the bioremediation of tannery effluent using immobilized bacterial cells in the Kano Industrial Estates.

\section{CONCLUSION}

The samples contained variable levels of the physicochemical parameters. The results of the Analysis of variance revealed that, no statistical difference $(p<0.05)$ was observed for the temperature, $\mathrm{pH}, \mathrm{SS}, \mathrm{TDS}, \mathrm{BOD}$ and $\mathrm{COD}$ among the three tannery industries before the treatment. The levels of some of the parameters
(SS, TDS and COD) observed in the samples were found above the recommended limits of WHO and NESREA, which called for the treatment of the effluents before discharge into the environment. Base on the morphological and biochemical test results, TAN1, TAN2, and TAN3 bacterial isolates were identified to be Neisseria spp, Bacillus cereus, and Staphylococcus aureus respectively. The results of Post-treatment analysis showed that there is overall decrease in the levels of the parameters determined when compared with that of the pre-treatment. The overall percentage reduction of the immobilised bacteria in the treatment of the respective effluents was in the order TAN2 (72\%)>TAN1 $(70 \%)>$ TAN3 $(62 \%)$. Hence, the immobilized bacteria are having higher biodegradation potential for the treatment of the tannery effluents.

\section{Acknowledgments}

The authors wish to acknowledge the University of Maiduguri for the financial support. The authors are grateful to the Kano State Ministry of Environment for their support in obtaining the effluent samples. 


\section{REFERENCES}

Ajao, A. T., Adebayo, G. B., and Yakubu, S. E. (2011). Bioremediation of textile industrial effluent using mixed culture of Pseudomonas aeruginosa and Bacillus subtilis immobilized on agar-agar in a bioreactor. J. Microbiol. Biotech. Res, 1(3), 50-56.

Akan, J. C., Moses, E. A., Ogugbuaja, V. O., and Abah, J. (2007). Assessment of tannery industrial effluents from Kano metropolis, Kano State, Nigeria. Journal of Applied Sciences, 7(19), 2788-2793.

Akan, J. C., Ogugbuaja, V. O., Abdulrahman, F. I., and Ayodele, J. T. (2009). Pollutant levels in effluent samples from tanneries and textiles of Kano industrial areas, Nigeria. Global journal of pure and applied sciences, 15(3-4).

APHA (1989). Standard methods for Examination of Will bete and Will betewater.15 $5^{\text {th }}$ edition. Brydpass Springfield Will behington DC. pp. 164-176

APHA (1992). Standard Methods for the Examination of Water and Wastewater. Health, 69, 1116-9.

Baba, A., Garba, S. T., and Bello, H. S. (2020). Bioremediation Potential of Immobilized corynebacterium kutsceri in the Treatment of Tannery Industrial Effluent from Challawa Industrial Estate, Kano State, Nigeria. Journal of the Turkish Chemical Society Section A: Chemistry, $7(2), 335-350$.

Beem, E. I. V. (1994). reduction of solvent VOC emission. J. Oil Col. Chem. Ass, 77, 158.

Bouwer, E. J., and Zehnder, A. J. (1993). Bioremediation of organic compoundsputting microbial metabolism to work. Trends in biotechnology, 11(8), 360367.

Chen, K. C., Wu, J. Y., Liou, D. J., and Hwang, S. C. J. (2003). Decolorization of the textile dyes by newly isolated bacterial strains. Journal of Biotechnology, 101(1), 57-68.

Dan'Azumi, S., and Bichi, M. H. (2010). INDUSTRIAL POLLUTION AND HEAVY METALS PROFILE OF CHALLAWA RIVER IN KANO, NIGERIA. Journal of Applied Sciences in Environmental Sanitation, $5(1)$.

DWAF. (1992). Analytical Methods Manual, TR 151. Department of Water Affairs and Forestry, Pretoria.

El-Bestawy, E. (2013). Biological treatment of leather-tanning industrial wastewater using free living bacteria.
Elsheikh, M. A. S. (2009). Tannery wastewater pre-treatment. Water Science and Technology, 60(2), 433-440.

FuIlbrook, P. D. (1996). "Kinetics." Industrial enzymology: The application of enzymes in Industry. 2nd Ed. T. Godfrey and J Reichelt. eds.. Nature. New York.

Gianfreda, L., and Rao, M. A. (2004). Potential of extra cellular enzymes in remediation of polluted soils: a review. Enzyme and microbial technology, 35(4), 339354.

Hugo Springer. (1994). John Arthur Wilson Memorial Lecture "Treatment of Industrial Wastes of the Leather Industry - is it still a Major Problem". JALCA, 89, 153-185

Jimoh, A. A., Ganiyu, B. A., Baba, D., and Baba, A. (2018) Bioremediation Process of Effluent from Detergent and Food Industries in Jos, Nigeria: Kinetics and Thermodynamics. International Journal of Engineering Science Invention (IJESI), 762-73

Kandelbauer, A., Maute, O., Kessler, R. W., Erlacher, A., and Gübitz, G. M. (2004). Study of dye decolorization in an immobilized laccase enzyme-reactor using online spectroscopy. Biotechnology and bioengineering, 87(4), 552-563.

Kongjao, S., Damronglerd, S., and Hunsom, M. (2008). Simultaneous removal of organic and inorganic Pollutants in tannery wastewater using electrocoagulation technique. Korean Journal of chemical engineering, 25(4), 703.

Maheshwari, U. M., Aruna, S., Gomathi, M., and AbdulJaffar, A. H. (2017). Bioremediation by Free and Immobilized Bacteria Isolated from Tannery Effluent. International Journal of Research in Applied, Natural and Social Sciences. 5(7), 75-90

Margesin, R., and Schinner, F. (2001). Bioremediation (natural attenuation and biostimulation) of diesel-oilcontaminated soil in an alpine glacier skiing area. Applied and environmental microbiology, 677), 3127-3133.

Mohammed, A., Sekar, P., and George, J. (2011). Efficacy of microbes in bioremediation of tannery effluent. Inter. J. Curr. Res, 3(4), 324-326.

Mohammed, S. S. D., Orukotan, A. A., and Abdullahi, H. (2017). Physicochemical and Bacteriological Assessment of Tannery Effluent from Samaru-Zaria, 
BAJOPAS Volume 13 Number 2, December, 2020 Kaduna State, Nigeria. Journal of Applied

Sciences and Environmental Management, 21(4), 734-740.

Munz, G., De Angelis, D., Gori, R., Mori, G., Casarci, M., and Lubello, C. (2009). The role of tannins in conventional and membrane treatment of tannery wastewater. Journal of hazardous materials, 164(2-3), 733-739

Mythili, K., and Karthikeyan, B. (2011). Bioremediation of $\mathrm{Cr}$ (VI) from tannery effluent using Bacillus spp and Staphylococcus spp. International Multidisciplinary Research Journal, 1(6).

NESREA (2009). National Environmental Standards for Effluent Limitations and Regulation. 1233-1236

Noorjahan, C. M. (2014). Physicochemical characteristics, identification of bacteria and biodegradation of industrial effluent. Journal of bioremediation and Biodegradation, 5(3).

Ohtake, H. I., and Silver, A. O. (1994). Bacterial reduction of toxic chromate. Biological degradation and bioremediation of toxic chemicals, 403-415.

Omoleke, I. I. (2004). Management of environmental pollution in Ibadan, an African city: the challenges of health hazard facing government and the people. Journal of Human Ecology, 15(4), 265-275.

Rajor, A., Reddy, A.S., and Singh, B. (2004). Determination of BOD kinetic Parameters and evaluation of alternate methods, M.Sc. Thesis, Department of biotechnology \& environmental Science, Thapar Institute of Engineering and Technology, Patiala

Ramasami, T., Rajamani, S., and Rao, J. R. (1994, March). Pollution control in leather industry: Emerging technological options. In International symposium on surface and colloidal science and its relevance to soil pollution, madras.

Ramesh, J. V. S., and Singh, S. P. (1993). Yearly variation in certain physicochemical parameters of pond at eastern Doon Valley. Uttar Pradesh J. Zoo, 12 (1), 7577.

Ranen, S., and Sharadinadra, C. (2009). Biotechnology applications to environmental remediation in resource exploitation. Current science, 97, 6-25
Russell, A. J., Berberich, J. A., Drevon, G. F., and Koepsel, R. R. (2003). Biomaterials for mediation of

chemical and biological warfare agents. Annual review of biomedical engineering, 5(1), 1-27.

Saravanan, P., and Saravanan, A. (1999). Decolourization of tannery effluent by Flavobacterium sp. EK 1. Indian Journal of Environmental Protection, 19, 19-24.

Sikander, S., and Shahida, H. (2007). Reduction of toxic hexavalent chromium by Ochrobactrum intermedium strain SDCr5 stimulated by heavy metals. Bioresource Technol, 98, 340-344.

Singh, N., Sharma, B. K., and Bohra, P. C. (2000). Impact assessment of industrial effluent of arid soils by using satellite imageries. Journal of the Indian Society of Remote Sensing, 28(2-3), 79.

Sreemoyee, C., and Priti, P. (2013). Assessment of physico-chemical parameters of dairy waste water and isolation and characterization of bacterial strains in terms of cod reduction. Int J Sci, 2(3), 395-400.

Verheijen, L. A. H. M., Wiersema, D., Pol, L. H., and De Wit, J. (1996). Management of wastes from animal product processing. Livestock and environment, Finding a balance. International Agriculture Center, Wageningen, The Netherlands.

Wang, F., Yao, J., Si, Y., Chen, H., Russel, M., Chen, K., and Bramanti, E. (2010). Short-time effect of heavy metals upon microbial community activity. Journal of Hazardous Materials, 173(13), 510-516.

WHO (World Health Organization). (2006). Air quality guidelines: global update 2005: particulate matter, ozone, nitrogen dioxide, and sulfur dioxide. World Health Organization.

World Bank. (1995). Nigeria's strategic options for redressing industrial pollution. World Bank, industry and energy division. 1st edition, West Central Africa Department; Annexes: 1995; pp 60-62.

Zahoor, A., and Abdul, R. (2009). Enumeration of Coliforms. Journal of Environmental Sciences. 21, 814-820 


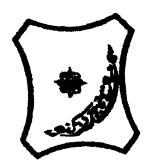

Bayero Journal of Pure and Applied Sciences, 13(2): 1 - 12

Received: November, 2020

Accepted: December, 2020

ISSN $2006-6996$

\title{
BIODEGRADATION POTENTIAL OF IMMOBILIZED BACTERIA IN THE TREATMENT OF TANNERY INDUSTRIAL EFFLUENTS FROM INDUSTRIAL ESTATES IN KANO STATE, NIGERIA
}

\author{
Abdullateef, B., ${ }^{1 *}$ Shuaibu, T. G., ${ }^{1}$ Babagana, K., ${ }^{1}$ Suleman, H. B. ${ }^{2}$ and Dauda, B. ${ }^{3}$ \\ ${ }^{1}$ Department of Pure and Applied Chemistry, Faculty of Science, University of Maiduguri, Borno State, \\ Nigeria \\ ${ }^{2}$ Department of Microbiology, Faculty of Science, University of Maiduguri, Borno State, Nigeria \\ ${ }^{3}$ Department of Chemical Engineering, Faculty of Engineering, University of Maiduguri, Borno State, \\ Nigeria \\ *Corresponding author: babslega@gmail.com; abelega2007@yahoo.com; +2348061309753
}

\section{ABSTRACT}

Industrial Effluents Samples from Gashash Tanneries (TAN1) in Bompai Industrial estate, Larabee Tannery Industry (TAN2) in Sharada Industrial estate and Z Tannery Industries (TAN3) in Challawa Industrial estate, Kano State, Nigeria were collected over a period of six months (August 2017 to January 2018) for assessing the biodegradation potentials of bacteria in the treatment of organic pollutants within the effluents. Bacteria were isolated from the effluents and immobilized on agar-agar. Different masses (5 g, $10 \mathrm{gr}, 15$ $\mathrm{g}, 20 \mathrm{~g}$, and $25 \mathrm{~g}$ ) of the bacteria were used in the treatment of $250 \mathrm{ml}$ of the effluents for ten days in a shaker incubator (Gallenkamp-OC-4364-L) at the temperature $30{ }^{\circ} \mathrm{C}$ and speed of $60 \mathrm{rpm}$. Pre-treatment analysis of the effluents for Temperature, pH, Biochemical Oxygen Demand (BOD), Chemical Oxygen Demand (COD), Suspended Solid (SS) and Total Dissolved Solids (TDS) gives the following results; temperature $\left({ }^{\circ} \mathrm{C}\right.$ )

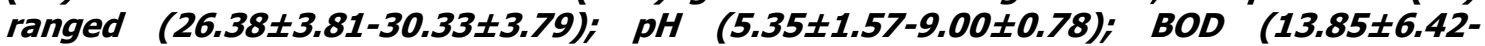
$38.75 \pm 16.20) ;$ COD (1406 $\pm 208-3532 \pm 1373) ;$ SS (208 $\pm 235-780 \pm 739)$ and TDS (266 $\pm 253-5276 \pm 2971)$. No statistical differences ( $p \leq 0.05)$ was observed for all the results among the different industries. The bacterial isolates were identified as Neisseria spp, Bacillus cereus, and Staphylococcus aureus, in TAN1, TAN2, and TAN3, respectively. After treatment of the effluent with the different masses of the isolated bacteria, the mean level of BOD was found to range as (0.55 $\pm 0.36-6.92 \pm 5.49) ; C O D$ (ND-3134 \pm 1595$)$;

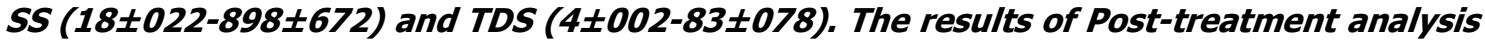
showed that there is overall decrease in the levels of the parameters determined when compared with that of the pre-treatment. The overall percentage reduction of the immobilised bacteria in the treatment of the respective effluents was in the order TAN2 (72\%)>TAN1 (70\%)>TAN3 (62\%). Hence, the immobilized bacteria are having higher biodegradation potential for the treatment of the tannery effluents.

Keywords: Biodegradation, bacteria, effluent, immobilization, tannery.

\section{INTRODUCTION}

Tannery industrial wastewater is a serious consequence of the pollution point of view for streams, freshwater, and land used for agriculture. The lack of awareness in the modern industrial practice has resulted in the discharge of tannery effluents which exhibit very high value of chromium ( $\mathrm{Cr}$ ), Sulfide, and chloride, Total Dissolved Solid (TDS), Total Suspended Solid (TSS), Biochemical Oxygen Demand (BOD) and Chemical Oxygen Demand (COD) in the water stream or land (Mohammed et al., 2001). Tanning is the process, which One ton of skin generally leads to the production of 20 to $80 \mathrm{~m}^{3}$ of turbid and foul-smelling converts the protein of the rawhide or skin into a stable material, which will not putrefy and is suitable for a wide variety of end applications (Elsheikh, 2009). The highly polluting chromium is the most commonly used tanning material producing leather that is more flexible and pliable than vegetable-tanned leather and does not discolor or lose shape in water as drastically as vegetable-tan (Elsheikh, 2009). Tannery effluent is among the most hazardous industrial pollutants due to its huge organic and inorganic load, which is highly toxic to human life and the environment (Kongjao et al., 2008). wastewater including chromium (100-400 mg/l), sulfide $(200-800 \mathrm{mg} / \mathrm{l})$, high levels of fat and 
BAJOPAS Volume 13 Number 2, December, 2020 other solid wastes, and notable pathogen contamination as well as pesticides added for skin conservation during transport (Elsheikh, 2009). There are more than 6000 tanneries in Nigeria with an annual processing capacity of 700,000 tons of hides and skins (Omoleke, 2004; Singh et al., 2008). It was reported that the total amount of waste produced per animal slaughtered is approximately $35 \%$ of its weight (World Bank, 1995). Also, for every $1000 \mathrm{~kg}$ of carcass weight, a slaughtered beef produces 5.5 $\mathrm{kg}$ of manure (excluding rumen contents or stockyard manure) and $100 \mathrm{~kg}$ of paunch manure (undigested food) (Verheijen et al., 1996). Tanneries generate wastewater in the range of 30-35 $\mathrm{L} \mathrm{kg}^{-1}$ skin/hide processed with variable $\mathrm{pH}$, Biological Oxygen Demand (BOD), Chemical Oxygen Demand (COD), high concentrations of suspended solids (SS), and tannins as well as chromium (Zahoor and Abdul, 2009).

Being heterogeneous and composed of a wide variety of compounds, it is very difficult to select a unique direct method for estimating the biodegradability of organic contents and biokinetic parameters for a wastewater sample (Rajor, 2004). For this purpose, some indirect estimation such as determination of biochemical oxygen demand (BOD) and chemical oxygen demand (COD) are applied as common laboratory investigations [9]. During retanning procedures, synthetic tannins (Syntan), oils and resins are added to form softer leather at varying doses (Munz et al., 2009). One of the refractory groups of chemicals in tannery effluents derives mainly from tannins (Ramasami et al., 2004). Syntans are characterized by complex chemical structures, because they are composed of an extended set of chemicals such as phenol-, naphthalene-, formaldehyde- and melamine-based syntans, and acrylic resins (Beem, 1994). Organic pollutants (proteic and lipidic components) are originated from skins (it is calculated that the raw skin has $30 \%$ loss of organic material during the working cycle) or they are introduced during processes (Hugo Springer, 1994).

Many conventional processes such as oxidation, chemical and biological processes were carried out to treat tanneries wastewater (Ebtesam et al, 2013). Biological processes have received more attention because of their costeffectiveness, lower sludge production and environmental friendliness (Noorjahan, 2014). Naturally occurring micro-organisms degrade the hazardous organic wastes including xenobiotic compounds, such as pesticides, polycyclic aromatic hydrocarbons (PAHs) and polychlorinated biphenyls (PCBs) in due course of time (Ranen and Sharadinadra, 2009). Bioremediation is based on the idea that all organisms remove substances from the environment to carry outgrowth and metabolism (Bouwer and Zehnder, 1993). Bacteria, protista and fungi are found to be very good at degrading complex molecules and incorporating the breakdown products into their metabolism (Bouwer and Zehnder, 1993). The resultant metabolic wastes that they produce are generally safe and somehow recycled into other organisms (Ranen and Sharadinadra, 2009). An acclimatized indigenous population of microorganisms capable of degradation of the compounds of interest must exist at the site for a successful bioremediation mode (Ranen and Sharadinadra, 2009). It has been observed that for a successful bioremediation mode, an acclimatized indigenous population of microorganisms capable of degradation of the compounds of interest must exist at the site under investigation (Ranen and Sharadinadra, 2009). Even though there are numerous physical and chemical methods employed in the disposal of wastes the advantage in using bacterium is that they play a key role in the reduction of COD, BOD, total protein, total tannin and total phenol (Saravanan and Saravanan, 1998)

Baba et al. (2020) studied the bioremediation potential of immobilized corynebacterium kutsceri in the Treatment of tannery industrial effluent from Challawa Industrial Estate, Kano State, Nigeria. The aim of the work is to study the reduction in the level of the contaminants through the process of bioremediation using the isolated bacteria. Immobilized bacteria can withstand various temperatures, $\mathrm{pH}$ and substrate concentrations; consequently, increasing the efficiency and the lifespan of the bacteria. Immobilized bacteria are widely applied in the treatment of wastewater and can be separated and recovered after the treatment with the same efficiency (Baba et al., 2020).

\section{MATERIALS AND METHODS \\ Study Area}

This study was carried out in Bompai, Sharada and Challawa industrial estates in Kano, Figure 1. Kano lies on Latitude $11^{\circ} 30^{\prime} \mathrm{N}$ and $8^{\circ} 30^{\prime} \mathrm{E}$ and Longitude $11^{\circ} 5^{\prime} \mathrm{N}$ and $8^{\circ} 5^{\prime} \mathrm{E}$ in Northern Nigeria. It is one of the developed industrial cities in Nigeria. Tannery activities are the dominating industries and this could be one of the reasons for her high population density (Dan'Azumi and Bichi, 2010). Many researchers have studied biodegradation of tannery effluent using microorganisms. However, limited literature is available on the biodegradation of tannery effluent in Kano industrial estates using 
BAJOPAS Volume 13 Number 2, December, 2020 immobilized bacterial cells. This research work focuses on the potential of the use of the indigenous immobilized bacterial isolates in the treatment of tannery effluents in the industrial estates.

\section{Sample Collection}

Effluents were collected from the Tannery Industries from Bompai, Challawa and Sharada Industrial Estates, Kano, Nigeria. The effluents were collected over a period of six months (August 2017 to January 2018). Samples collected in a sterile 4-liter plastic container with a unique identification number were preserved using an ice-box that was transported to the Microbiology Laboratory, Department of Microbiology, Bayero University of Kano for analysis

\section{Sample Preparation and Sample Analysis}

Immediately after the collection of the effluent, $\mathrm{pH}$, TSS, TDS, COD, BOD levels were determined before treatment (Pre-treatment determination) and ten days after treatment (Post-treatment determination) as described in
APHA (1989) standard methods. $\mathrm{pH}$ was determined using Ecotests $\mathrm{pH}$ meter and TDS was determined using AQUALYTIC TDS Salinometer. BOD was determined as described by the standard method (APHA, 1992). COD and SS were determined using DR/2010 HACH portable data logging spectrophotometer (DWAF, 1992)

\section{Identification and Biochemical} Characterization of the Bacterial Isolates

The bacteria were isolated from the effluents using Serial Dilution according to the method described by APHA (1989). The biochemical tests such as oxidase, catalase, coagulase, indole (from $1 \%$ tryptone broth), citrate (Simmons citrate agar), methyl red/VogesProskauer (MR/VP), nitrate reduction, Starch Hydrolysis, Glucose, Maltose, and Lactose tests were carried out on the bacterial isolates to identify the bacteria through the bacteria biochemical characteristics according to Ajao et al. (2011).

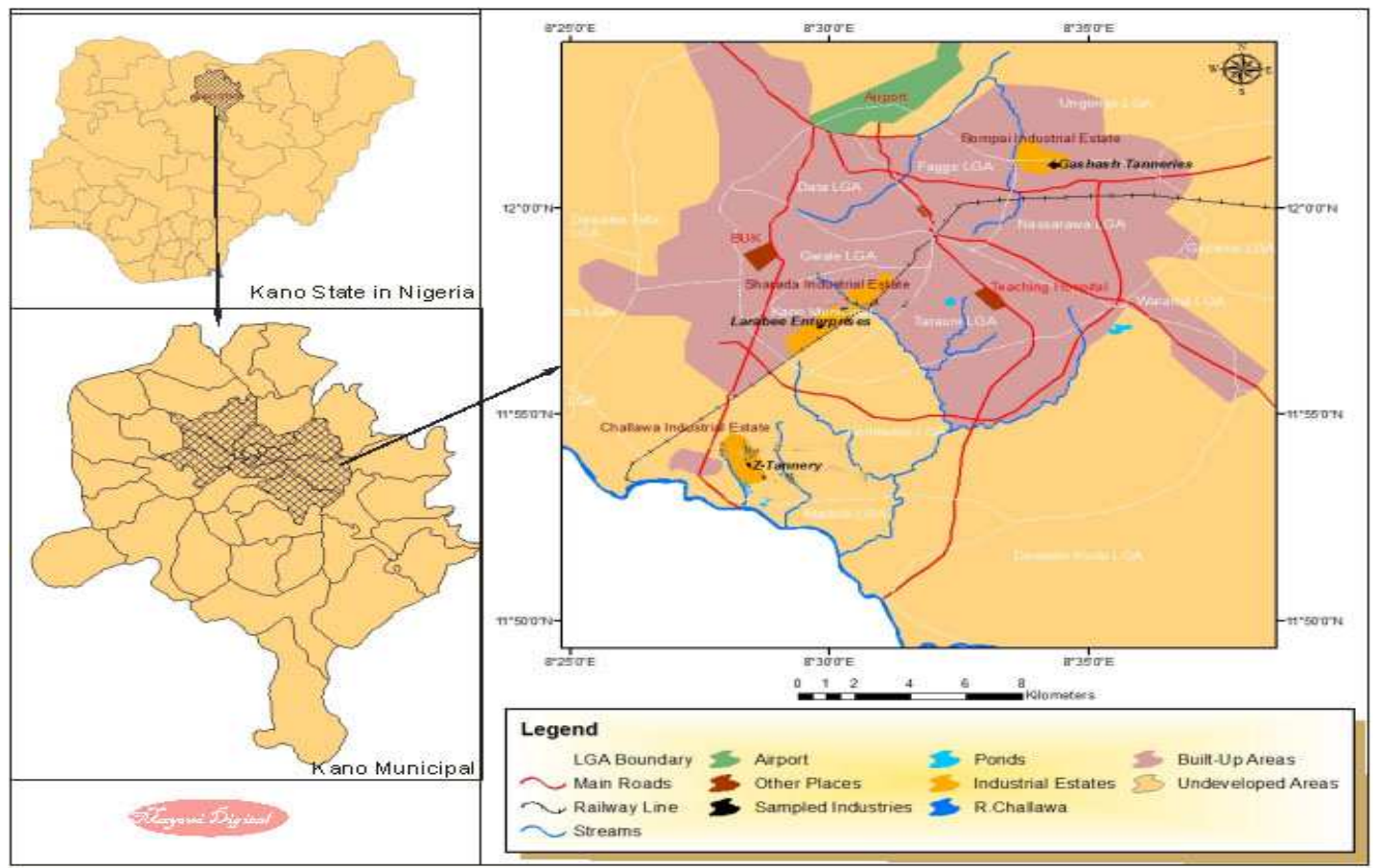

Fig. 1 Map showing the study areas

Source: Mayomi Digital Productions, GIS Laboratory, Department of Geography, UNIMAID (2017)

\section{Determination of Growth Rate of the Bacteria in Effluent Sample}

The bacteria growth rates were determined by transferring $2 \mathrm{~mL}$ of the bacterial isolates from the tannery effluent in broth medium into 100 $\mathrm{mL}$ sterile effluents in conical flasks and kept in an incubator (Giffrin cool) for 10 days. Control was also set up by incubating another $100 \mathrm{~mL}$ each of the sterile effluents without the bacteria. The optical density of the content was determined at the wavelength of $600 \mathrm{~nm}$ on a daily interval and recorded. 
BAJOPAS Volume 13 Number 2, December, 2020 Immobilization of Bacteria

Agar solution and inoculi were prepared separately. Fifty milliliters $(50 \mathrm{~mL})$ of nutrient broth each of the inoculi was prepared in a McCartney bottle and incubated for 24 hours. A solution of agar-agar was prepared by dissolving $10 \mathrm{~g}$ of the powder in distilled water and made up to $500 \mathrm{~mL}$ mark in an Erlenmeyer flask and was sterilized in an autoclave (280A) for 15 minutes and allowed to cool to $40-45^{\circ} \mathrm{C}$ (Ajao et al., 2011). Four milliliters ( $4 \mathrm{~mL})$ of the bacterial isolates in the nutrient broth was mixed with 36 $\mathrm{ml}$ of the prepared agar-agar media in petri-dish plates and then allowed to solidify. This was kept in the refrigerator for bioremediation.

\section{Bioremediation (Treatment) of the Effluents}

The solidified agar block (immobilized bacteria) was cut into cubes using a sterile knife; $0.1 \mathrm{~mL}$ phosphate buffer ( $\mathrm{pH} \mathrm{7.0)}$ was added and kept in the refrigerator for 1 hour for curing. The phosphate buffer was decanted after 1 hour and the cubes were washed with sterile distilled water 3-4 times before it was used (Ajao et al., 2011). Two liters (2 L) of the effluent was supplemented with the minimum basal medium in $\mathrm{g} / \mathrm{L}: \mathrm{NaCl}(0.8), \mathrm{MgSO}_{4} .7 \mathrm{H}_{2} \mathrm{O}(0.001), \mathrm{KH}_{2} \mathrm{PO}_{4}$ (2), $\mathrm{NaNO}_{3}$ (2), $\quad \mathrm{CaCl}_{2} .2 \mathrm{H}_{2} \mathrm{O} \quad(0.5)$ and $\mathrm{NaHPO}_{4} .12 \mathrm{H}_{2} \mathrm{O}(2)$ and sterilized in an autoclave at $121^{\circ} \mathrm{C}$ for 15 minutes (Margesin and Schinner, 2001). Two hundred and fifty milliliters $(250 \mathrm{~mL})$ of the effluents were transferred into different $250 \mathrm{ml}$ conical flasks. The content was covered with a cotton-wool ramped with foil paper to avoid contamination. Five grams $(5 \mathrm{~g})$ of the immobilized bacteria were quickly transferred into each of the effluents in the conical flasks in an inoculating chamber. The same procedures were carried out for the $10 \mathrm{~g}, 15 \mathrm{~g}, 20 \mathrm{~g}$ and 25 $\mathrm{g}$ of the immobilized bacteria in separate $250 \mathrm{~mL}$ effluents in conical flasks and agitated for ten days in a shaker incubator (Gallenkamp-OC4364-L) at a temperature $30^{\circ} \mathrm{C}$ and speed of 60 rpm. The treated effluent samples were taken on the tenth day and analyzed for the parameters $\mathrm{pH}$, SS, TDS, COD, and BOD, (Posttreatment determination) for the different grams of bacteria to evaluate and compare the biodegradation potential. (Baba et al., 2020).

\section{Statistical Analysis}

The data were represented as Mean \pm Standard deviation and analyzed statistically using oneway Analysis of Variance (ANOVA) and Tukey's HSD as Post Hoc Tests with the aid of SPSS 16.0. The correlation coefficient was also used to measure the strength of the relationship between the different masses of the bacteria and the parameters. All $\mathrm{p} \leq 0.05$ were considered as statistically significant.

\section{RESULTS AND DISCUSSION Physico-chemical parameters in the Industrial Effluents before the Biodegradation.}

Results of the Physico-chemical parameters in the industrial effluents before the Biodegradation is shown in table 1 . The mean temperatures $\left({ }^{\circ} \mathrm{C}\right)$ observed in TAN1, TAN2, and TAN3 samples were $28.07 \pm 0.65 ; 27.77 \pm 0.64$ and $26.38 \pm 3.81$ respectively. The order of the mean temperature of the samples from the three industries can be arranged as TAN1 > TAN2>TAN3. The temperature observed at TAN1, TAN2, and TAN3 samples were found below the WHO $\left(35^{\circ} \mathrm{C}\right)$ and NESREA $\left(40^{\circ} \mathrm{C}\right)$ limits. The low values of temperature might be due to the processes used at the time of sampling. High temperature brings down the solubility of gases in water that ultimately expresses as high BOD and COD. Statistical analysis shows that there is no significant difference $(p<0.05)$ between the mean values of temperature among the industries. This might be due to similar tannery activities involved in the tannery industries at the time of sampling. The average values of temperature observed in this present study are less than those observed by Akan et al. (2007), Akan et al. (2009) and Baba et al. (2020).

The mean level of $\mathrm{pH}$ observed in TAN1, TAN2 and TAN3, samples were $7.77 \pm 2.93$; $8.35 \pm 0.28$ and $7.52 \pm 0.76$ respectively. The order of the mean $\mathrm{pH}$ of the samples from the three industries can be arranged as TAN2> TAN1 $>$ TAN3. The $\mathrm{pH}$ of the samples falls within the WHO (7.0-8.5) and NESREA (6-9) standard limits. Statistical analysis shows that there is no significant difference $(p<0.05)$ between the mean values of $\mathrm{pH}$ among the industries. This might be due to similar tannery activities involved in the tannery industries at the time of sampling. Maheshwari et al. (2017) reported that the level of $\mathrm{pH}$ in the effluents from the tannery industry in Vaniyambadi, India was 6.5 which was lower than that observed in the present study. The $\mathrm{pH}$ in the effluents from the tannery industries in Kano and Kaduna were reported to be 7.64 and 6.89, respectively (Akan et al., 2007; Mohammed et al., 2017). The average values of $\mathrm{pH}$ observed in this present study are less than those observed by Mohammed et al. (2017) and Baba et al. (2020). The mean level of SS $(\mathrm{mg} / \mathrm{l})$ observed in TAN1, TAN2, and TAN3 samples were 374 \pm 124 ; $358 \pm 335$ and $780 \pm 739$ respectively. The order of the mean SS in the samples from the three industries can be arranged as TAN3 > TAN1 $>$ TAN2. 
The SS observed in the samples were far above the recommended standard limits of regulating bodies WHO $(30 \mathrm{mg} / \mathrm{l})$ and NESREA $(10 \mathrm{mg} / \mathrm{l})$. Statistical analysis shows that there is no significant difference $(p<0.05)$ between the mean values of SS among the industries. This might be due to similar tannery activities involved in the tannery industries at the time of sampling. The average values of SS observed in this present study are less than that observed $(3700 \pm 122 \mathrm{mg} / \mathrm{l})$ by Akan et al. (2009) for tanneries in Kano. Also, the average values of SS observed in this present study are less than that observed by Mohammed et al. (2017) and Baba et al. (2020) with the exception in TAN3.

The mean level of TDS (mg/l) observed in TAN1, TAN2, and TAN3 samples were $3941 \pm 3703$; $3300 \pm 1714$ and $2653 \pm 1240$ respectively. The order of the mean TDS in the samples from the three industries can be arranged as TAN1>TAN2>TAN3. The TDS observed in the samples were far above the recommended standard limits of WHO $(250 \mathrm{mg} / \mathrm{l})$ and NESREA $(500 \mathrm{mg} / \mathrm{l})$. Statistical analysis shows that there is no significant difference $(p<0.05)$ between the mean values of TDS among the industries. This might be due to similar tannery activities involved in the tannery industries at the time of sampling. TDS in the effluents from the tannery industries in Kano, Nigeria was reported to be $1281 \mathrm{mg} / \mathrm{l}$ (Akan et al., 2007). The average values of SS observed in this present study are less than those observed by Mohammed et al. (2017) and Baba et al. 2020)

The mean level of COD (mg/l) observed in TAN1, TAN2 and TAN3 samples seasons were $2372 \pm 938 ; \quad 1406 \pm 208$ and $3532 \pm 1373$ respectively. The order of the mean COD of the samples from the three industries can be arranged as TAN3>TAN1> TAN2. The COD observed in TAN1, TAN2 and TAN3 samples were far above the recommended standard limits of regulating bodies $\mathrm{WHO}(40 \mathrm{mg} / \mathrm{l})$ and NESREA (40 mg/l). Statistical analysis shows that there is no significant difference $(p<0.05)$ in COD among the industries. This might be due to similar tannery activities involved in the tannery industries as at the time of sampling. The Chemical Oxygen demand (COD) is the amount of oxygen, in $\mathrm{mg} / \mathrm{L}$, required for the degradation of the compound of wastewater to occur. In comparison, the average values of COD observed in this present study were higher than that observed by Mohammed et al. (2017) but lower than that observed by Baba et al. (2020).

The mean levels of BOD $(\mathrm{mg} / \mathrm{l})$ observed in TAN1, TAN2 and TAN3 samples were $13.85 \pm 6.42 ; \quad 19.46 \pm 0.50$ and $17.13 \pm 3.14$ respectively. The order of the mean BOD in the samples from the three industries can be arranged as TAN2>TAN3>TAN1. The BOD observed in TAN1, TAN2 and TAN3 samples were found below the recommended limits of NESREA (200 mg/l) but above WHO (10 mg/l). Statistical analysis shows that there is no significant difference $(p<0.05)$ between the mean values of BOD among the industries. This might be due to similar tannery activities involved in the tannery industries at the time of sampling. The low level of BOD recorded in this study is an indication of the low level of biodegradable organic solids in the effluent. The average values of BOD observed in this present study were lower than those observed by Mohammed et al. (2017) and Baba et al. (2020).

Table 1: Mean Values \pm S.D of Physico-chemical parameters of effluents from the Tannery Industries before Treatment.

\begin{tabular}{llllllll}
\hline Parameter & Tannery 1 & Tannery 2 & Tannery 3 & $\mathrm{a}$ & $\mathrm{b}$ & $\mathrm{c}$ & $\mathrm{d}$ \\
\cline { 2 - 7 } Temperature $\left({ }^{\circ} \mathrm{C}\right)$ & $28.07 \mathrm{a} \pm 0.65$ & $27.77 \mathrm{a} \pm 0.64$ & $26.38 \mathrm{a} \pm 3.81$ & & $29.50 \pm 4.68$ & 35 & 40 \\
pH & $7.77 \mathrm{a} \pm 2.93$ & $8.35 \mathrm{a} \pm 0.28$ & $7.52 \mathrm{a} \pm 0.76$ & 6.89 & $5.35 \pm 1.57$ & $7.0-8.5$ & $6.0-9.0$ \\
$\mathrm{COD}(\mathrm{mg} / \mathrm{l})$ & $2372 \mathrm{a} \pm 938$ & $1406 \mathrm{a} \pm 208$ & $3532 \mathrm{a} \pm 1373$ & 2.2 & $3106 \pm 2753$ & 40 & 40 \\
$\mathrm{BOD}(\mathrm{mg} / \mathrm{l})$ & $13.85 \mathrm{a} \pm 6.42$ & $19.46 \mathrm{a} \pm 0.50$ & $17.13 \mathrm{a} \pm 3.14$ & 1032 & $26.17 \pm 9.49$ & 10 & 200 \\
$\mathrm{SS}(\mathrm{mg} / \mathrm{l})$ & $374 \mathrm{a} \pm 124$ & $358 \mathrm{a} \pm 335$ & $780 \mathrm{a} \pm 739$ & 501 & $562 \pm 482$ & 30 & 10 \\
TDS $(\mathrm{mg} / \mathrm{l})$ & $3941 \mathrm{a} \pm 3703$ & $3300 \mathrm{a} \pm 1714$ & $2653 \mathrm{a} \pm 1240$ & 532.7 & $444 \pm 507$ & 250 & 500 \\
\hline
\end{tabular}

The values given in the table above are means of 6 replicate values, $\mathrm{n}=6$ ( 1 sample was taken monthly for 6 months). Within the rows, means with different alphabets are statistically different $(p<0.05)$. WHO: World Health Organisation. NESREA: National Environmental Standard and Regulatory Enforcement Agency. a = Mohammed et al.(2017), b = Baba et al. (2020), c = WHO (2006), $d=$ NESSRA (2009) 
BAJOPAS Volume 13 Number 2, December, 2020

Identification, Biochemical Characterization and growth rates of the Bacterial Isolates

Results of identification and biochemical characterization of the bacterial isolates were shown in table 2. After 24 hours of incubation, the nutrient agar media plates were checked for bacterial growth. The results showed the presence of different strains in the samples. The TAN1 bacteria isolate was found to be gramnegative cocci while TAN3 was gram-positive cocci. TAN2 bacteria isolate was found to be gram-positive, rod-shaped. TAN1, TAN2, and TAN3 bacteria isolates recorded positive results for spore former.

The results of the biochemical tests indicated that all the bacteria were positive for catalase, oxidase, citrate, maltose, glucose, lactose (negative in TAN1), mannitol (negative in TAN2), starch hydrolysis and coagulase (negative in TAN2) tests. The bacteria showed negative results for nitrate reduction, $M R$ (positive in TAN2), VP (positive in TAN1), Indole (positive in TAN2) tests. Base on the morphological and biochemical test results, TAN1, TAN2, and TAN3 bacteria isolates were identified to be Nesseria spp, Bacillus cereus, and Staphylococcus aureus respectively.

The growth rate of the TAN1, TAN2 and TAN3 Isolates were shown in figure 2. Generally, the optical density increase with the increase in time (day) and decrease as time goes on. The highest optical density was shown by bacillus cereus in TAN2 while the lowest was shown by Staphylococcus aureus in TAN3.

The initial growth phase of TAN1 Isolate bacteria occurred within 2-day of incubation as the growth rate increases up to the 6th-day incubation when the maximum growth was observed. Beyond the 6th day, the growth of the bacteria declined (which might be due to a shortage of nutrients in the effluents) until it reached its death phase (which might be due to the unavailability of nutrients in the effluents).

A similar trend of growth was also observed for TAN2 Isolate as the initial growth phase also occurred within 2-day of incubation but maximum growth rate observed on the 4th day of incubation. The stationary stage occurred between the 4th day and the 8th day. Beyond the 8th day, the growth of the bacteria declined (which might be due to a shortage of nutrients in the effluents) until it reached its death phase (which might be due to the unavailability of nutrients in the effluents).

The initial growth phase of TAN3 bacterial Isolate occurred within the 3-day incubation as the growth rate increases up to the 6th-day incubation when the maximum growth was observed. Beyond the 6th day, the growth of the bacteria declined (which might be due to a shortage of nutrients in the effluents) until it reached its death phase (which might be due to the unavailability of nutrients in the effluents).

Table 2: Morphological and Biochemical characteristics of bacterial isolates

\begin{tabular}{lllll} 
Bacterial Isolates & & TAN1 & TAN2 & TAN3 \\
\hline $\begin{array}{lllll}\text { Morphological } \\
\text { characteristics }\end{array}$ & Shape & Cocci & Rod & Cocci \\
& Spore & & & \\
& former & + & + & + \\
Gram & & & \\
Biochemical characteristics & reaction & - & + & + \\
& Citrate & + & + & + \\
& Catalase & + & + & + \\
& Coagulase & + & - & + \\
Starch & + & + & + \\
& Glucose & + & + & + \\
Oxidase & + & + & + \\
& Indo & - & + & - \\
Lactose & - & + & + \\
Manitol & + & - & + \\
Maltose & + & + & + \\
MR & - & + & - \\
VP & + & - & - \\
& Nitrate & - & - & - \\
Reduction & - Neisseria & Bacillus & Staphylococcus \\
& Bacterial & cereus & aureus \\
& name & spp & cas
\end{tabular}

+ = Positive; - = Negative; MR=Methyl Red; VP= Voges-Proskauer 


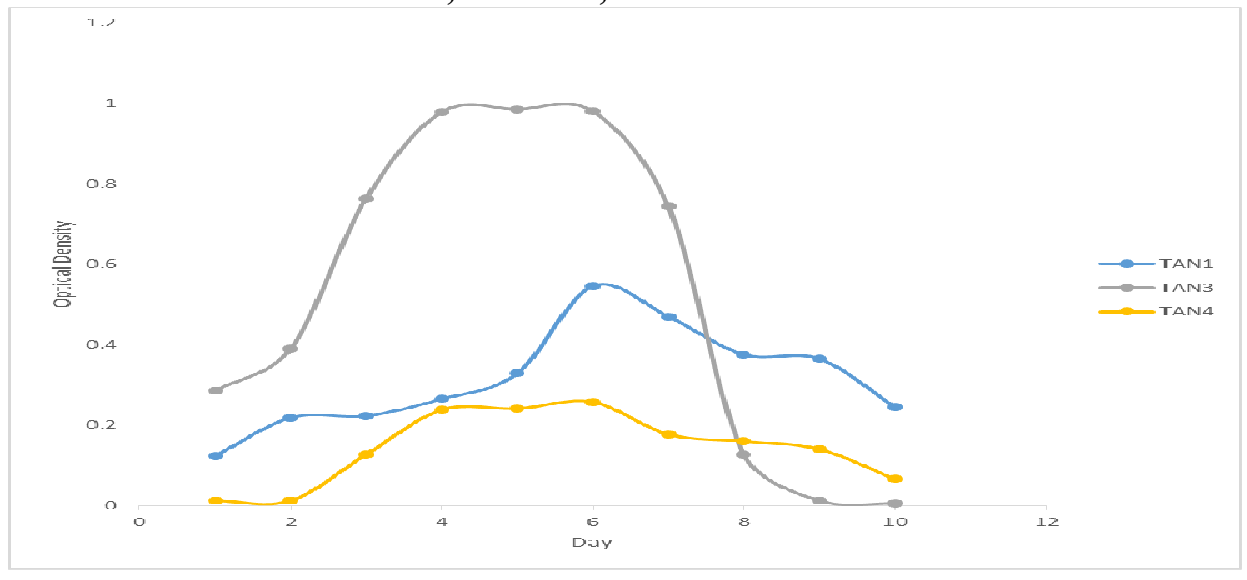

Fig. 2 Growth rates of the isolates in the effluents from the Tannery Industries

\section{Physico-chemical Parameters in the Industrial Effluents after the biodegradation.}

Table 3 shows the mean results of the physicochemical parameter before and after bioremediation using the different masses $(5 \mathrm{~g}$, $10 \mathrm{~g}, 15 \mathrm{~g}, 20 \mathrm{~g}$, and $25 \mathrm{~g}$ ) of the respective immobilized bacteria. Also, Table 4 shows the mean results of correlation coefficient ( $r$ ) between different masses of bacteria and physicochemical parameters.

The mean values $(\mathrm{mg} / \mathrm{l})$ of the SS after the bioremediation varies between $243 \pm 45$ and $898 \pm 672$. The mean concentration $(\mathrm{mg} / \mathrm{l})$ of SS remediated by the different masses $(5 \mathrm{~g}, 10 \mathrm{~g}$, $15 \mathrm{~g}, 20 \mathrm{~g}$, and $25 \mathrm{~g}$ ) of the bacteria varies. The SS in the samples fluctuates up and down after the bioremediation process when compared with the SS of the raw samples before the bioremediation. The increase in the levels of the SS might be due to the aggregation of the TDS which are large enough to result into SS. The increase in the levels of the SS might be also due to the influence of the nutrients which was added into the effluents in order to make the microorganisms more active and viable for fast degradation of organic contaminants in the effluent. The relative potential or efficiency of the different masses of the bacteria in remediating SS in TAN1 samples was in the order $25 \mathrm{~g}>20 \mathrm{~g}>15 \mathrm{~g}>10 \mathrm{~g}>5 \mathrm{~g}$. For TAN2 and TAN3 samples, the order was $25 \mathrm{~g}>20 \mathrm{~g}>15$ $\mathrm{g}>10 \mathrm{~g}>5 \mathrm{~g}$. These might be due to the variations in the surface areas of the different masses of the immobilized bacteria. Statistical analysis shows that there is no significant difference $(p<0.05)$ between the mean values of SS among the masses in the respective industries. Positive and significant correlations exist between the masses of bacteria and Suspended Solid (SS). This showed that there is general increase in the levels of the SS as the masses of the immobilized bacteria increases. TAN3 (90\%) and TAN1 (80\%) showed a very high correlation with the masses of the bacteria while TAN2 (61\%) showed a very low correlation.

The mean values $(\mathrm{mg} / \mathrm{l})$ of the TDS after the bioremediation varies between $46 \pm 11$ and $83 \pm 78$. The mean concentration $(\mathrm{mg} / \mathrm{l})$ of TDS remediated by the different masses $(5 \mathrm{~g}, 10 \mathrm{~g}$, $15 \mathrm{~g}, 20 \mathrm{~g}$, and $25 \mathrm{~g}$ ) of the bacteria varies. There is a reduction in all the TDS of all the samples after the bioremediation process compared with the TDS of the raw samples before the bioremediation. The relative potential or efficiency of the different masses of the bacteria in remediating TDS in TAN1 and TAN3 samples was in the order $5 \mathrm{~g}>10 \mathrm{~g}>15 \mathrm{~g}>20$ $\mathrm{g}>25 \mathrm{~g}$. For TAN2 samples, the order was 20 $g>10 \quad g>25 \quad g>15 \quad g>5 \quad g$. Statistical analysis shows that there is no significant difference $(p<0.05)$ between the mean values of TDS among the masses in the respective industries. These might be due to the variations in the surface areas of the different masses of the immobilized bacteria. Positive and significant correlations exist between the masses of bacteria and TDS with the exception in TAN2 (negative and insignificant correlation). The positive correlations showed that there is general increase in the levels of the TDS as the masses of the immobilized bacteria increases. TAN1 $(96 \%)$ showed a very high correlation with the masses of the bacteria while TAN2 (47\%) showed a very low correlation.

The mean values $(\mathrm{mg} / \mathrm{l})$ of the BOD after the bioremediation varies between $1.56 \pm 0.20 \mathrm{mg} / \mathrm{l}$ and $6.92 \pm 5.49 \mathrm{mg} / \mathrm{l}$. The mean concentration $(\mathrm{mg} / \mathrm{l})$ of BOD remediated by the different masses $(5 \mathrm{~g}, 10 \mathrm{~g}, 15 \mathrm{~g}, 20 \mathrm{~g}$, and $25 \mathrm{~g}$ ) of the bacteria varies. There is a reduction in all the BOD of all the samples after the bioremediation process compared with the $\mathrm{BOD}$ of the raw 
BAJOPAS Volume 13 Number 2, December, 2020 samples before the bioremediation. The relative potential or efficiency of the different masses of the bacteria in remediating BOD in TAN1, TAN2 and TAN3 samples were in the order $25 \mathrm{~g}>20$ $\mathrm{g}>15 \mathrm{~g}>10 \mathrm{~g}>5 \mathrm{~g}, 25 \mathrm{~g}>15 \mathrm{~g}>5 \mathrm{~g}>10 \mathrm{~g}>20 \mathrm{~g}$ and $20 \mathrm{~g}>10 \mathrm{~g}>25 \mathrm{~g}>15 \mathrm{~g}>5 \mathrm{~g}$ respectively. Statistical analysis shows that there is significant difference $(p<0.05)$ between the mean values of BOD among the masses in the respective industries. These might be due to the variations in the surface areas of the different masses of the immobilized bacteria. Negative and significant correlations exist between the masses of bacteria and BOD. This showed that there is general decrease in the levels of the BOD as the masses of the immobilized bacteria increases. TAN1 (94\%) showed a very high correlation with the masses of the bacteria while TAN2 (4\%) showed a very low correlation.

The mean values $(\mathrm{mg} / \mathrm{l})$ of the COD after the bioremediation varies between $250 \pm 154$ and $3134 \pm 1595$. The mean concentration $(\mathrm{mg} / \mathrm{l})$ of COD remediated by the different masses $(5 \mathrm{~g}$, $10 \mathrm{~g}, 15 \mathrm{~g} 20 \mathrm{~g}$, and $25 \mathrm{~g}$ ) of the bacteria varies. There is a reduction in all the COD of all the samples after the bioremediation process compared with the COD of the raw samples before the bioremediation. The relative potential or efficiency of the different masses of the bacteria in remediating COD in TAN1, TAN2 and TAN3 samples were in the order $25 \mathrm{~g}>20 \mathrm{~g}>15$ $\mathrm{g}>5 \mathrm{~g}>10 \mathrm{~g}, 25 \mathrm{~g}>20 \mathrm{~g}>15 \mathrm{~g}>10 \mathrm{~g}>5 \mathrm{~g}$ and 10 g>5 g>25 g>15 g>20 g respectively. Statistical analysis shows that there were significant difference $(p<0.05)$ between the mean values of COD among the masses in the respective industries except for effluents treated with $25 \mathrm{~g}$. These might be due to the variations in the surface areas of the different masses of the immobilized bacteria. Negative and insignificant correlations exist between the masses of bacteria and COD with the exception in TAN3 (positive and significant correlation). The negative correlations showed that there is general decrease in the levels of the COD as the masses of the immobilized bacteria increases. TAN2 (100\%) showed a very high correlation with the masses of the bacteria while TAN3 (36\%) showed a very low correlation.

Generally, there was an overall decrease in the concentration of these physicochemical parameters after the bioremediation using the different masses of the bacterial isolates. These might be due to the variations in the surface areas of the different masses of the immobilized bacteria. This is in line with the work of Jimoh et al. (2018) and Baba et al. (2020).

Table 3: Mean Values $(\mathrm{mg} / \mathrm{l}) \pm$ S.D of Physicochemical parameters in effluents from the Tannery Industries before and after Treatment of the effluents $(250 \mathrm{ml})$ with the different masses $(5 \mathrm{~g}, 10 \mathrm{~g}$, $15 \mathrm{~g}, 20 \mathrm{~g}$, and $25 \mathrm{~g}$ ) of the bacteria.

\begin{tabular}{llllllll}
\hline $\mathrm{P}$ & IND & Before & \multicolumn{5}{c}{ After } \\
\cline { 4 - 7 } & & & $5 \mathrm{~g}$ & $10 \mathrm{~g}$ & $15 \mathrm{~g}$ & $20 \mathrm{~g}$ & $25 \mathrm{~g}$ \\
\hline \multirow{2}{*}{ COD } & TAN1 & $2372 \pm 938$ & $1708 \mathrm{a} \pm 861$ & $2045 \mathrm{a} \pm 1205$ & $845 \mathrm{a} \pm 369$ & $300 \mathrm{a} \pm 167$ & $250 \mathrm{a} \pm 154$ \\
& TAN2 & $1406 \pm 208$ & $1195 \mathrm{a} \pm 208$ & $1125 \mathrm{a} \pm 384$ & $1055 \mathrm{a} \pm 317$ & $956 \mathrm{a} \pm 310$ & $870 \mathrm{ab} \pm 240$ \\
& TAN3 & $3532 \pm 1373$ & $2374 \mathrm{a} \pm 1344$ & $1976 \mathrm{a} \pm 1405$ & $2757 \mathrm{a} \pm 1266$ & $3134 \mathrm{a} \pm 1595$ & $2614 \mathrm{~b} \pm 1105$ \\
BOD & TAN1 & $13.85 \pm 6.42$ & $6.92 \mathrm{a} \pm 5.49$ & $6.42 \mathrm{a} \pm 5.07$ & $5.72 \mathrm{a} \pm 5.35$ & $4.62 \mathrm{a} \pm 4.37$ & $2.82 \mathrm{ab} \pm 1.26$ \\
& TAN2 & $19.46 \pm 0.50$ & $1.75 \mathrm{~b} \pm 0.22$ & $1.73 \mathrm{~b} \pm 0.18$ & $1.58 \mathrm{a} \pm 0.16$ & $1.91 \mathrm{a} \pm 0.22$ & $1.56 \mathrm{~b} \pm 0.20$ \\
& TAN3 & $17.13 \pm 3.14$ & $4.24 \mathrm{ab} \pm 0.77$ & $3.29 \mathrm{ab} \pm 0.37$ & $4.11 \mathrm{a} \pm 0.07$ & $3.23 \mathrm{a} \pm 0.91$ & $3.33 \mathrm{a} \pm 1.28$ \\
SS & TAN1 & $374 \pm 124$ & $243 \mathrm{a} \pm 45$ & $471 \mathrm{a} \pm 226$ & $475 \mathrm{a} \pm 182$ & $492 \mathrm{a} \pm 128$ & $611 \mathrm{a} \pm 217$ \\
& TAN2 & $358 \pm 335$ & $460 \mathrm{a} \pm 400$ & $543 \mathrm{a} \pm 414$ & $544 \mathrm{a} \pm 402$ & $551 \mathrm{a} \pm 414$ & $554 \mathrm{a} \pm 405$ \\
& TAN3 & $780 \pm 739$ & $586 \mathrm{a} \pm 594$ & $758 \mathrm{a} \pm 656$ & $787 \mathrm{a} \pm 676$ & $861 \mathrm{a} \pm 635$ & $898 \mathrm{a} \pm 672$ \\
TDS & TAN1 & $3941 \pm 3703$ & $51 \mathrm{a} \pm 10$ & $53 \mathrm{a} \pm 10$ & $55 \mathrm{a} \pm 15$ & $61 \mathrm{a} \pm 20$ & $63 \mathrm{a} \pm 26$ \\
& TAN2 & $3300 \pm 1714$ & $83 \mathrm{a} \pm 78$ & $47 \mathrm{a} \pm 20$ & $48 \mathrm{a} \pm 22$ & $47 \mathrm{a} \pm 17$ & $48 \mathrm{a} \pm 17$ \\
& TAN3 & $2653 \pm 1240$ & $46 \mathrm{a} \pm 11$ & $55 \mathrm{a} \pm 24$ & $55 \mathrm{a} \pm 25$ & $58 \mathrm{a} \pm 23$ & $61 \mathrm{a} \pm 28$ \\
\hline
\end{tabular}

Replicate $=6$ (months)

Within the rows, for the same parameter, means with different alphabets are statistically different $(p<0.05)$.

$\mathrm{P}=$ parameter, IND = Industries 
BAJOPAS Volume 13 Number 2, December, 2020

Table 4: Correlation coefficient $(r)$ between different masses of the bacteria and the physicochemical parameters.

\begin{tabular}{llll}
\hline Industries & Parameter & Correlation coefficient $(r)$ & $\begin{array}{l}\text { Percent dependence (rxrx100) } \\
(\%)\end{array}$ \\
\hline TAN1 & COD & -0.9 & 82 \\
& BOD & -0.97 & 94 \\
& SS & $0.90^{*}$ & 80 \\
TAN2 & TDS & $0.98^{*}$ & 96 \\
& COD & -1 & 100 \\
& BOD & -0.21 & 4 \\
& SS & $0.78^{*}$ & 61 \\
& TDS & -0.69 & 47 \\
& COD & $0.60^{*}$ & 36 \\
& BOD & -0.6 & 37 \\
& SS & $0.95^{*}$ & 90 \\
& TDS & $0.94^{*}$ & 89 \\
\hline
\end{tabular}

The correlation coefficient $(r)$ with * is statistically significant $(p<0.05)$.

Percentage reduction of the Parameters

Table 5 shows the percentage reduction of Parameters in industrial samples before and after the treatment of the effluents $(250 \mathrm{ml})$ with the different masses $(5 \mathrm{~g}, 10 \mathrm{~g}, 15 \mathrm{~g}, 20 \mathrm{~g}$, and $25 \mathrm{~g}$ ) of the Immobilized Bacteria.

In TAN1 samples, the percentage reduction (\%) of COD ranged (14-89); BOD (50-80); SS (-32$35)$ and TDS (98-99). In TAN2 samples, the percentage decrease $(\%)$ of COD ranged (15$38) ;$ BOD (90-92); SS [-28-(-55)] and TDS (9798). In TAN3 samples, the percentage decrease (\%) of COD ranged (11-44); BOD (76-81); SS (15-25) and TDS (98). The percentage increase in the levels COD, BOD and TDS might be due to the increase in the surface area of the different masses of the immobilized bacteria. However, the percentage decrease in the levels of the SS might be due to the aggregation of the TDS which are large enough to result into SS. The percentage decrease in the levels of the SS might be also due to the influence of the nutrients which was added into the effluents in order to make the microorganisms more active and viable for fast degradation of organic contaminants in the effluent. This is in line with the work of Jimoh et al. (2018) in which the concentration of the SS increase after the bioremediation of effluents.

Sreemoyee and Priti (2013) assessed and reduced several Physico-chemical parameters of dairy wastewater using Niesseria $s p$. and concluded that the species are well known to degrade organic compounds. This is in agreement with the current study in which the immobilized Niesseria $s p$ degrade the organic contaminants as indicated by the BOD, COD and TDS.

Jimoh et al. (2018) observed that TSS of the effluents was increased after treatment with immobilized bacteria and concluded that it might be due to the biostimulation method adopted for the research.

The optimum $\mathrm{pH}$ Biosorption of Chromium by Bacillus spp and Staphylococcus spp. from tannery effluent was investigated by Mythili and Karthikeyan (2011). The maximum adsorption of Chromium $(86.4 \mathrm{mg} / \mathrm{L})$ was showed by Bacillus spp and Staphylococcus spp showed $70.6 \mathrm{mg} / \mathrm{L}$ at an initial concentration of $100 \mathrm{mg} / \mathrm{L}$. In the present study, immobilised Bacillus spp and Staphylococcus spp. from the tannery industrial effluents reduced the levels of the organic pollutants with high potential as indicated by the percentage reduction of BOD, COD and TDS.

Enzymes often can work in multiple environments especially if they are immobilized. This makes the microorganisms' enzymes even more resistant to harsh environments and enables the enzymes to be recovered and recycled after they are no longer needed (Gianfreda and Rao 2004). Ramesh and Singh (1993) reported that the immobilized bacteria having more efficiency to remove the suspended particles than free cells. Using the immobilized cell is preferable due to its capability for using several times with the same efficiency, which makes it more economical. Similar work was done by Sikander et al. (2007) showing the higher reduction with permeabilized cells of Ochrobactrum intermedium strain SDCr-5. 
BAJOPAS Volume 13 Number 2, December, 2020

The results revealed the isolation and identification of isolates with the potential for the reduction of $\mathrm{Cr}$ (VI) to $\mathrm{Cr}$ (III). Results indicated that immobilized $B$. cereus could be efficiently used for the reduction of $\mathrm{Cr}$ (VI).

Table 5: Percentage reduction of the tested Parameters from the tannery industrial samples of the Immobilized Bacteria.

\begin{tabular}{lllllll}
\hline \multirow{2}{*}{ Industries } & & \multicolumn{5}{c}{ Percentage Reduction $(\%)$} \\
\cline { 3 - 7 } & & $5 \mathrm{~g}$ & $10 \mathrm{~g}$ & $15 \mathrm{~g}$ & $20 \mathrm{~g}$ & $25 \mathrm{~g}$ \\
\hline TAN1 & COD & 28 & 14 & 64 & 87 & 89 \\
& BOD & 50 & 54 & 59 & 67 & 80 \\
& SS & 35 & -26 & -27 & -32 & -63 \\
& TDS & 99 & 99 & 99 & 98 & 98 \\
TAN2 & COD & 15 & 20 & 25 & 32 & 38 \\
& BOD & 91 & 91 & 92 & 90 & 92 \\
& SS & -28 & -52 & -52 & -54 & -55 \\
& TDS & 97 & 99 & 99 & 99 & 99 \\
& COD & 33 & 44 & 22 & 11 & 26 \\
& BOD & 75 & 81 & 76 & 81 & 81 \\
& SS & 25 & 3 & -1 & -10 & -15 \\
& TDS & 98 & 98 & 98 & 98 & 98 \\
\hline
\end{tabular}

Percentage Reduction $=(B-A) / B \times 100 \%$

$A=$ Concentration of the parameter after treatment

$\mathrm{B}=$ Concentration of the parameter before treatment

$+=$ percentage decrease

- = percentage increase

In general, immobilization makes the enzyme more resistant to temperature, $\mathrm{pH}$, and substrate concentration swings giving it a longer lifetime and higher productivity per active unit (Gianfreda and Rao, 2004; FuIlbrook, 1996; Russell et al, 2003; Kandelbauer et al., 2004). Immobilized cells have been used and studied extensively for the production of useful chemicals (Ohtake and Silver, 1994), the treatment of wastewaters (Chen et al., 2003; Wang et al., 2010). Although many workers described microbial degradation of tannery effluent, limited literature is available on the bioremediation of tannery effluent using immobilized bacterial cells in the Kano Industrial Estates.

\section{CONCLUSION}

The samples contained variable levels of the physicochemical parameters. The results of the Analysis of variance revealed that, no statistical difference $(p<0.05)$ was observed for the temperature, $\mathrm{pH}, \mathrm{SS}, \mathrm{TDS}, \mathrm{BOD}$ and $\mathrm{COD}$ among the three tannery industries before the treatment. The levels of some of the parameters
(SS, TDS and COD) observed in the samples were found above the recommended limits of WHO and NESREA, which called for the treatment of the effluents before discharge into the environment. Base on the morphological and biochemical test results, TAN1, TAN2, and TAN3 bacterial isolates were identified to be Neisseria spp, Bacillus cereus, and Staphylococcus aureus respectively. The results of Post-treatment analysis showed that there is overall decrease in the levels of the parameters determined when compared with that of the pre-treatment. The overall percentage reduction of the immobilised bacteria in the treatment of the respective effluents was in the order TAN2 (72\%)>TAN1 $(70 \%)>$ TAN3 $(62 \%)$. Hence, the immobilized bacteria are having higher biodegradation potential for the treatment of the tannery effluents.

\section{Acknowledgments}

The authors wish to acknowledge the University of Maiduguri for the financial support. The authors are grateful to the Kano State Ministry of Environment for their support in obtaining the effluent samples. 


\section{REFERENCES}

Ajao, A. T., Adebayo, G. B., and Yakubu, S. E. (2011). Bioremediation of textile industrial effluent using mixed culture of Pseudomonas aeruginosa and Bacillus subtilis immobilized on agar-agar in a bioreactor. J. Microbiol. Biotech. Res, 1(3), 50-56.

Akan, J. C., Moses, E. A., Ogugbuaja, V. O., and Abah, J. (2007). Assessment of tannery industrial effluents from Kano metropolis, Kano State, Nigeria. Journal of Applied Sciences, 7(19), 2788-2793.

Akan, J. C., Ogugbuaja, V. O., Abdulrahman, F. I., and Ayodele, J. T. (2009). Pollutant levels in effluent samples from tanneries and textiles of Kano industrial areas, Nigeria. Global journal of pure and applied sciences, 15(3-4).

APHA (1989). Standard methods for Examination of Will bete and Will betewater.15 $5^{\text {th }}$ edition. Brydpass Springfield Will behington DC. pp. 164-176

APHA (1992). Standard Methods for the Examination of Water and Wastewater. Health, 69, 1116-9.

Baba, A., Garba, S. T., and Bello, H. S. (2020). Bioremediation Potential of Immobilized corynebacterium kutsceri in the Treatment of Tannery Industrial Effluent from Challawa Industrial Estate, Kano State, Nigeria. Journal of the Turkish Chemical Society Section A: Chemistry, $7(2), 335-350$.

Beem, E. I. V. (1994). reduction of solvent VOC emission. J. Oil Col. Chem. Ass, 77, 158.

Bouwer, E. J., and Zehnder, A. J. (1993). Bioremediation of organic compoundsputting microbial metabolism to work. Trends in biotechnology, 11(8), 360367.

Chen, K. C., Wu, J. Y., Liou, D. J., and Hwang, S. C. J. (2003). Decolorization of the textile dyes by newly isolated bacterial strains. Journal of Biotechnology, 101(1), 57-68.

Dan'Azumi, S., and Bichi, M. H. (2010). INDUSTRIAL POLLUTION AND HEAVY METALS PROFILE OF CHALLAWA RIVER IN KANO, NIGERIA. Journal of Applied Sciences in Environmental Sanitation, $5(1)$.

DWAF. (1992). Analytical Methods Manual, TR 151. Department of Water Affairs and Forestry, Pretoria.

El-Bestawy, E. (2013). Biological treatment of leather-tanning industrial wastewater using free living bacteria.
Elsheikh, M. A. S. (2009). Tannery wastewater pre-treatment. Water Science and Technology, 60(2), 433-440.

FuIlbrook, P. D. (1996). "Kinetics." Industrial enzymology: The application of enzymes in Industry. 2nd Ed. T. Godfrey and J Reichelt. eds.. Nature. New York.

Gianfreda, L., and Rao, M. A. (2004). Potential of extra cellular enzymes in remediation of polluted soils: a review. Enzyme and microbial technology, 35(4), 339354.

Hugo Springer. (1994). John Arthur Wilson Memorial Lecture "Treatment of Industrial Wastes of the Leather Industry - is it still a Major Problem". JALCA, 89, 153-185

Jimoh, A. A., Ganiyu, B. A., Baba, D., and Baba, A. (2018) Bioremediation Process of Effluent from Detergent and Food Industries in Jos, Nigeria: Kinetics and Thermodynamics. International Journal of Engineering Science Invention (IJESI), 762-73

Kandelbauer, A., Maute, O., Kessler, R. W., Erlacher, A., and Gübitz, G. M. (2004). Study of dye decolorization in an immobilized laccase enzyme-reactor using online spectroscopy. Biotechnology and bioengineering, 87(4), 552-563.

Kongjao, S., Damronglerd, S., and Hunsom, M. (2008). Simultaneous removal of organic and inorganic Pollutants in tannery wastewater using electrocoagulation technique. Korean Journal of chemical engineering, 25(4), 703.

Maheshwari, U. M., Aruna, S., Gomathi, M., and AbdulJaffar, A. H. (2017). Bioremediation by Free and Immobilized Bacteria Isolated from Tannery Effluent. International Journal of Research in Applied, Natural and Social Sciences. 5(7), 75-90

Margesin, R., and Schinner, F. (2001). Bioremediation (natural attenuation and biostimulation) of diesel-oilcontaminated soil in an alpine glacier skiing area. Applied and environmental microbiology, 677), 3127-3133.

Mohammed, A., Sekar, P., and George, J. (2011). Efficacy of microbes in bioremediation of tannery effluent. Inter. J. Curr. Res, 3(4), 324-326.

Mohammed, S. S. D., Orukotan, A. A., and Abdullahi, H. (2017). Physicochemical and Bacteriological Assessment of Tannery Effluent from Samaru-Zaria, 
BAJOPAS Volume 13 Number 2, December, 2020 Kaduna State, Nigeria. Journal of Applied

Sciences and Environmental Management, 21(4), 734-740.

Munz, G., De Angelis, D., Gori, R., Mori, G., Casarci, M., and Lubello, C. (2009). The role of tannins in conventional and membrane treatment of tannery wastewater. Journal of hazardous materials, 164(2-3), 733-739

Mythili, K., and Karthikeyan, B. (2011). Bioremediation of $\mathrm{Cr}$ (VI) from tannery effluent using Bacillus spp and Staphylococcus spp. International Multidisciplinary Research Journal, 1(6).

NESREA (2009). National Environmental Standards for Effluent Limitations and Regulation. 1233-1236

Noorjahan, C. M. (2014). Physicochemical characteristics, identification of bacteria and biodegradation of industrial effluent. Journal of bioremediation and Biodegradation, 5(3).

Ohtake, H. I., and Silver, A. O. (1994). Bacterial reduction of toxic chromate. Biological degradation and bioremediation of toxic chemicals, 403-415.

Omoleke, I. I. (2004). Management of environmental pollution in Ibadan, an African city: the challenges of health hazard facing government and the people. Journal of Human Ecology, 15(4), 265-275.

Rajor, A., Reddy, A.S., and Singh, B. (2004). Determination of BOD kinetic Parameters and evaluation of alternate methods, M.Sc. Thesis, Department of biotechnology \& environmental Science, Thapar Institute of Engineering and Technology, Patiala

Ramasami, T., Rajamani, S., and Rao, J. R. (1994, March). Pollution control in leather industry: Emerging technological options. In International symposium on surface and colloidal science and its relevance to soil pollution, madras.

Ramesh, J. V. S., and Singh, S. P. (1993). Yearly variation in certain physicochemical parameters of pond at eastern Doon Valley. Uttar Pradesh J. Zoo, 12 (1), 7577.

Ranen, S., and Sharadinadra, C. (2009). Biotechnology applications to environmental remediation in resource exploitation. Current science, 97, 6-25
Russell, A. J., Berberich, J. A., Drevon, G. F., and Koepsel, R. R. (2003). Biomaterials for mediation of

chemical and biological warfare agents. Annual review of biomedical engineering, 5(1), 1-27.

Saravanan, P., and Saravanan, A. (1999). Decolourization of tannery effluent by Flavobacterium sp. EK 1. Indian Journal of Environmental Protection, 19, 19-24.

Sikander, S., and Shahida, H. (2007). Reduction of toxic hexavalent chromium by Ochrobactrum intermedium strain SDCr5 stimulated by heavy metals. Bioresource Technol, 98, 340-344.

Singh, N., Sharma, B. K., and Bohra, P. C. (2000). Impact assessment of industrial effluent of arid soils by using satellite imageries. Journal of the Indian Society of Remote Sensing, 28(2-3), 79.

Sreemoyee, C., and Priti, P. (2013). Assessment of physico-chemical parameters of dairy waste water and isolation and characterization of bacterial strains in terms of cod reduction. Int J Sci, 2(3), 395-400.

Verheijen, L. A. H. M., Wiersema, D., Pol, L. H., and De Wit, J. (1996). Management of wastes from animal product processing. Livestock and environment, Finding a balance. International Agriculture Center, Wageningen, The Netherlands.

Wang, F., Yao, J., Si, Y., Chen, H., Russel, M., Chen, K., and Bramanti, E. (2010). Short-time effect of heavy metals upon microbial community activity. Journal of Hazardous Materials, 173(13), 510-516.

WHO (World Health Organization). (2006). Air quality guidelines: global update 2005: particulate matter, ozone, nitrogen dioxide, and sulfur dioxide. World Health Organization.

World Bank. (1995). Nigeria's strategic options for redressing industrial pollution. World Bank, industry and energy division. 1st edition, West Central Africa Department; Annexes: 1995; pp 60-62.

Zahoor, A., and Abdul, R. (2009). Enumeration of Coliforms. Journal of Environmental Sciences. 21, 814-820 


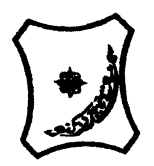

Bayero Journal of Pure and Applied Sciences, 13(2): 1 - 12

Received: November, 2020

Accepted: December, 2020

ISSN $2006-6996$

\title{
BIODEGRADATION POTENTIAL OF IMMOBILIZED BACTERIA IN THE TREATMENT OF TANNERY INDUSTRIAL EFFLUENTS FROM INDUSTRIAL ESTATES IN KANO STATE, NIGERIA
}

\author{
Abdullateef, B., ${ }^{1 *}$ Shuaibu, T. G., ${ }^{1}$ Babagana, K., ${ }^{1}$ Suleman, H. B. ${ }^{2}$ and Dauda, B. ${ }^{3}$ \\ ${ }^{1}$ Department of Pure and Applied Chemistry, Faculty of Science, University of Maiduguri, Borno State, \\ Nigeria \\ ${ }^{2}$ Department of Microbiology, Faculty of Science, University of Maiduguri, Borno State, Nigeria \\ ${ }^{3}$ Department of Chemical Engineering, Faculty of Engineering, University of Maiduguri, Borno State, \\ Nigeria \\ *Corresponding author: babslega@gmail.com; abelega2007@yahoo.com; +2348061309753
}

\section{ABSTRACT}

Industrial Effluents Samples from Gashash Tanneries (TAN1) in Bompai Industrial estate, Larabee Tannery Industry (TAN2) in Sharada Industrial estate and Z Tannery Industries (TAN3) in Challawa Industrial estate, Kano State, Nigeria were collected over a period of six months (August 2017 to January 2018) for assessing the biodegradation potentials of bacteria in the treatment of organic pollutants within the effluents. Bacteria were isolated from the effluents and immobilized on agar-agar. Different masses (5 g, $10 \mathrm{gr}, 15$ $\mathrm{g}, 20 \mathrm{~g}$, and $25 \mathrm{~g}$ ) of the bacteria were used in the treatment of $250 \mathrm{ml}$ of the effluents for ten days in a shaker incubator (Gallenkamp-OC-4364-L) at the temperature $30{ }^{\circ} \mathrm{C}$ and speed of $60 \mathrm{rpm}$. Pre-treatment analysis of the effluents for Temperature, pH, Biochemical Oxygen Demand (BOD), Chemical Oxygen Demand (COD), Suspended Solid (SS) and Total Dissolved Solids (TDS) gives the following results; temperature $\left({ }^{\circ} \mathrm{C}\right.$ )

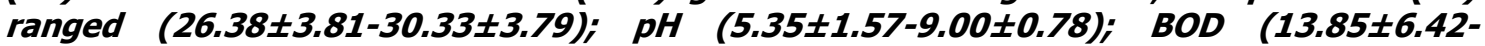
$38.75 \pm 16.20) ;$ COD (1406 $\pm 208-3532 \pm 1373) ;$ SS (208 $\pm 235-780 \pm 739)$ and TDS (266 $\pm 253-5276 \pm 2971)$. No statistical differences ( $p \leq 0.05)$ was observed for all the results among the different industries. The bacterial isolates were identified as Neisseria spp, Bacillus cereus, and Staphylococcus aureus, in TAN1, TAN2, and TAN3, respectively. After treatment of the effluent with the different masses of the isolated bacteria, the mean level of BOD was found to range as (0.55 $\pm 0.36-6.92 \pm 5.49) ; C O D$ (ND-3134 \pm 1595$)$;

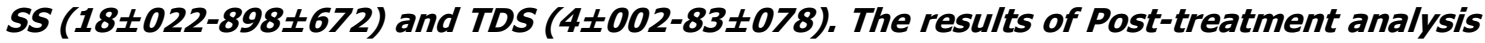
showed that there is overall decrease in the levels of the parameters determined when compared with that of the pre-treatment. The overall percentage reduction of the immobilised bacteria in the treatment of the respective effluents was in the order TAN2 (72\%)>TAN1 (70\%)>TAN3 (62\%). Hence, the immobilized bacteria are having higher biodegradation potential for the treatment of the tannery effluents.

Keywords: Biodegradation, bacteria, effluent, immobilization, tannery.

\section{INTRODUCTION}

Tannery industrial wastewater is a serious consequence of the pollution point of view for streams, freshwater, and land used for agriculture. The lack of awareness in the modern industrial practice has resulted in the discharge of tannery effluents which exhibit very high value of chromium ( $\mathrm{Cr}$ ), Sulfide, and chloride, Total Dissolved Solid (TDS), Total Suspended Solid (TSS), Biochemical Oxygen Demand (BOD) and Chemical Oxygen Demand (COD) in the water stream or land (Mohammed et al., 2001). Tanning is the process, which One ton of skin generally leads to the production of 20 to $80 \mathrm{~m}^{3}$ of turbid and foul-smelling converts the protein of the rawhide or skin into a stable material, which will not putrefy and is suitable for a wide variety of end applications (Elsheikh, 2009). The highly polluting chromium is the most commonly used tanning material producing leather that is more flexible and pliable than vegetable-tanned leather and does not discolor or lose shape in water as drastically as vegetable-tan (Elsheikh, 2009). Tannery effluent is among the most hazardous industrial pollutants due to its huge organic and inorganic load, which is highly toxic to human life and the environment (Kongjao et al., 2008). wastewater including chromium (100-400 mg/l), sulfide $(200-800 \mathrm{mg} / \mathrm{l})$, high levels of fat and 
BAJOPAS Volume 13 Number 2, December, 2020 other solid wastes, and notable pathogen contamination as well as pesticides added for skin conservation during transport (Elsheikh, 2009). There are more than 6000 tanneries in Nigeria with an annual processing capacity of 700,000 tons of hides and skins (Omoleke, 2004; Singh et al., 2008). It was reported that the total amount of waste produced per animal slaughtered is approximately $35 \%$ of its weight (World Bank, 1995). Also, for every $1000 \mathrm{~kg}$ of carcass weight, a slaughtered beef produces 5.5 $\mathrm{kg}$ of manure (excluding rumen contents or stockyard manure) and $100 \mathrm{~kg}$ of paunch manure (undigested food) (Verheijen et al., 1996). Tanneries generate wastewater in the range of 30-35 $\mathrm{L} \mathrm{kg}^{-1}$ skin/hide processed with variable $\mathrm{pH}$, Biological Oxygen Demand (BOD), Chemical Oxygen Demand (COD), high concentrations of suspended solids (SS), and tannins as well as chromium (Zahoor and Abdul, 2009).

Being heterogeneous and composed of a wide variety of compounds, it is very difficult to select a unique direct method for estimating the biodegradability of organic contents and biokinetic parameters for a wastewater sample (Rajor, 2004). For this purpose, some indirect estimation such as determination of biochemical oxygen demand (BOD) and chemical oxygen demand (COD) are applied as common laboratory investigations [9]. During retanning procedures, synthetic tannins (Syntan), oils and resins are added to form softer leather at varying doses (Munz et al., 2009). One of the refractory groups of chemicals in tannery effluents derives mainly from tannins (Ramasami et al., 2004). Syntans are characterized by complex chemical structures, because they are composed of an extended set of chemicals such as phenol-, naphthalene-, formaldehyde- and melamine-based syntans, and acrylic resins (Beem, 1994). Organic pollutants (proteic and lipidic components) are originated from skins (it is calculated that the raw skin has $30 \%$ loss of organic material during the working cycle) or they are introduced during processes (Hugo Springer, 1994).

Many conventional processes such as oxidation, chemical and biological processes were carried out to treat tanneries wastewater (Ebtesam et al, 2013). Biological processes have received more attention because of their costeffectiveness, lower sludge production and environmental friendliness (Noorjahan, 2014). Naturally occurring micro-organisms degrade the hazardous organic wastes including xenobiotic compounds, such as pesticides, polycyclic aromatic hydrocarbons (PAHs) and polychlorinated biphenyls (PCBs) in due course of time (Ranen and Sharadinadra, 2009). Bioremediation is based on the idea that all organisms remove substances from the environment to carry outgrowth and metabolism (Bouwer and Zehnder, 1993). Bacteria, protista and fungi are found to be very good at degrading complex molecules and incorporating the breakdown products into their metabolism (Bouwer and Zehnder, 1993). The resultant metabolic wastes that they produce are generally safe and somehow recycled into other organisms (Ranen and Sharadinadra, 2009). An acclimatized indigenous population of microorganisms capable of degradation of the compounds of interest must exist at the site for a successful bioremediation mode (Ranen and Sharadinadra, 2009). It has been observed that for a successful bioremediation mode, an acclimatized indigenous population of microorganisms capable of degradation of the compounds of interest must exist at the site under investigation (Ranen and Sharadinadra, 2009). Even though there are numerous physical and chemical methods employed in the disposal of wastes the advantage in using bacterium is that they play a key role in the reduction of COD, BOD, total protein, total tannin and total phenol (Saravanan and Saravanan, 1998)

Baba et al. (2020) studied the bioremediation potential of immobilized corynebacterium kutsceri in the Treatment of tannery industrial effluent from Challawa Industrial Estate, Kano State, Nigeria. The aim of the work is to study the reduction in the level of the contaminants through the process of bioremediation using the isolated bacteria. Immobilized bacteria can withstand various temperatures, $\mathrm{pH}$ and substrate concentrations; consequently, increasing the efficiency and the lifespan of the bacteria. Immobilized bacteria are widely applied in the treatment of wastewater and can be separated and recovered after the treatment with the same efficiency (Baba et al., 2020).

\section{MATERIALS AND METHODS \\ Study Area}

This study was carried out in Bompai, Sharada and Challawa industrial estates in Kano, Figure 1. Kano lies on Latitude $11^{\circ} 30^{\prime} \mathrm{N}$ and $8^{\circ} 30^{\prime} \mathrm{E}$ and Longitude $11^{\circ} 5^{\prime} \mathrm{N}$ and $8^{\circ} 5^{\prime} \mathrm{E}$ in Northern Nigeria. It is one of the developed industrial cities in Nigeria. Tannery activities are the dominating industries and this could be one of the reasons for her high population density (Dan'Azumi and Bichi, 2010). Many researchers have studied biodegradation of tannery effluent using microorganisms. However, limited literature is available on the biodegradation of tannery effluent in Kano industrial estates using 
BAJOPAS Volume 13 Number 2, December, 2020 immobilized bacterial cells. This research work focuses on the potential of the use of the indigenous immobilized bacterial isolates in the treatment of tannery effluents in the industrial estates.

\section{Sample Collection}

Effluents were collected from the Tannery Industries from Bompai, Challawa and Sharada Industrial Estates, Kano, Nigeria. The effluents were collected over a period of six months (August 2017 to January 2018). Samples collected in a sterile 4-liter plastic container with a unique identification number were preserved using an ice-box that was transported to the Microbiology Laboratory, Department of Microbiology, Bayero University of Kano for analysis

\section{Sample Preparation and Sample Analysis}

Immediately after the collection of the effluent, $\mathrm{pH}$, TSS, TDS, COD, BOD levels were determined before treatment (Pre-treatment determination) and ten days after treatment (Post-treatment determination) as described in
APHA (1989) standard methods. $\mathrm{pH}$ was determined using Ecotests $\mathrm{pH}$ meter and TDS was determined using AQUALYTIC TDS Salinometer. BOD was determined as described by the standard method (APHA, 1992). COD and SS were determined using DR/2010 HACH portable data logging spectrophotometer (DWAF, 1992)

\section{Identification and Biochemical} Characterization of the Bacterial Isolates

The bacteria were isolated from the effluents using Serial Dilution according to the method described by APHA (1989). The biochemical tests such as oxidase, catalase, coagulase, indole (from $1 \%$ tryptone broth), citrate (Simmons citrate agar), methyl red/VogesProskauer (MR/VP), nitrate reduction, Starch Hydrolysis, Glucose, Maltose, and Lactose tests were carried out on the bacterial isolates to identify the bacteria through the bacteria biochemical characteristics according to Ajao et al. (2011).

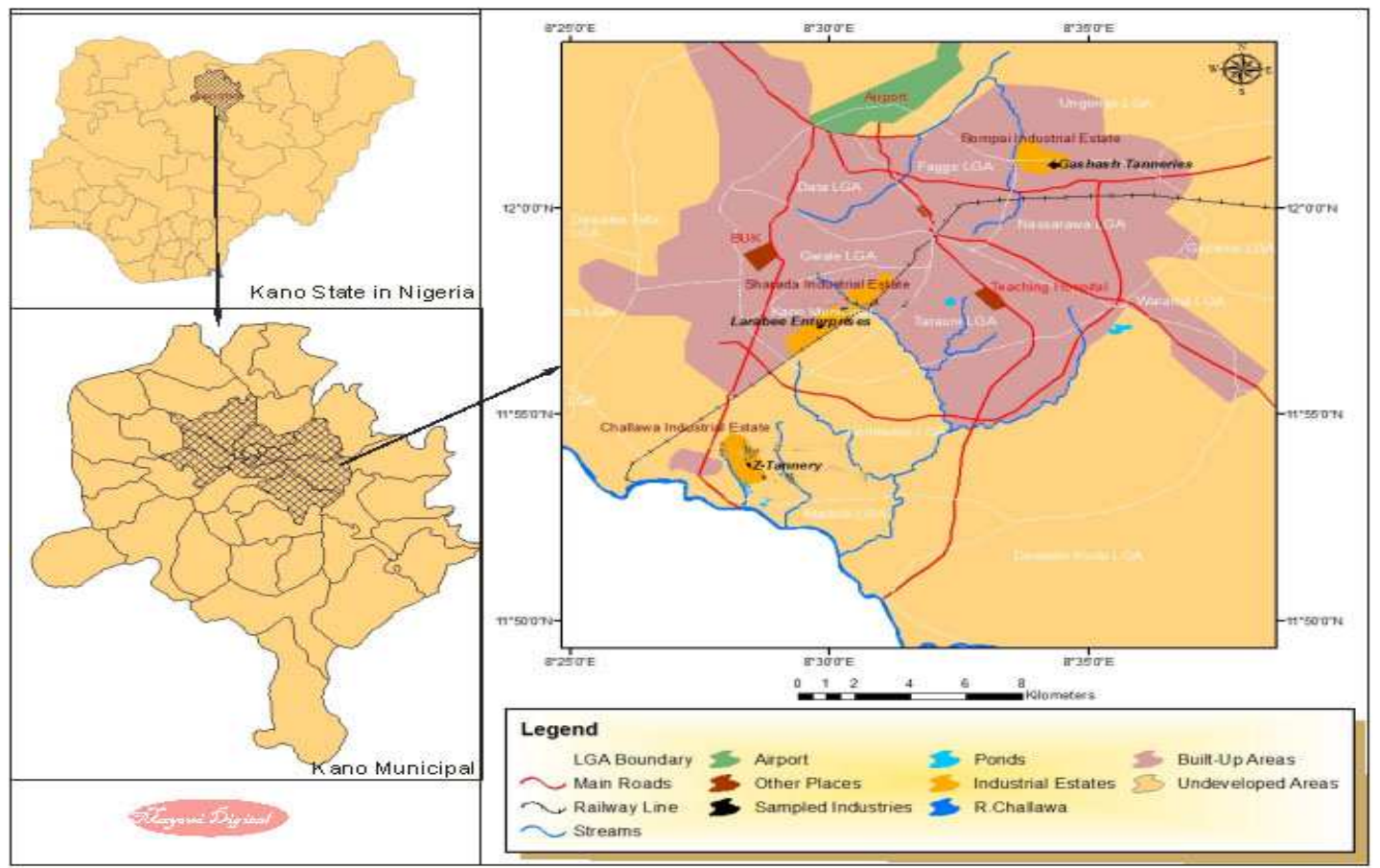

Fig. 1 Map showing the study areas

Source: Mayomi Digital Productions, GIS Laboratory, Department of Geography, UNIMAID (2017)

\section{Determination of Growth Rate of the Bacteria in Effluent Sample}

The bacteria growth rates were determined by transferring $2 \mathrm{~mL}$ of the bacterial isolates from the tannery effluent in broth medium into 100 $\mathrm{mL}$ sterile effluents in conical flasks and kept in an incubator (Giffrin cool) for 10 days. Control was also set up by incubating another $100 \mathrm{~mL}$ each of the sterile effluents without the bacteria. The optical density of the content was determined at the wavelength of $600 \mathrm{~nm}$ on a daily interval and recorded. 
BAJOPAS Volume 13 Number 2, December, 2020 Immobilization of Bacteria

Agar solution and inoculi were prepared separately. Fifty milliliters $(50 \mathrm{~mL})$ of nutrient broth each of the inoculi was prepared in a McCartney bottle and incubated for 24 hours. A solution of agar-agar was prepared by dissolving $10 \mathrm{~g}$ of the powder in distilled water and made up to $500 \mathrm{~mL}$ mark in an Erlenmeyer flask and was sterilized in an autoclave (280A) for 15 minutes and allowed to cool to $40-45^{\circ} \mathrm{C}$ (Ajao et al., 2011). Four milliliters ( $4 \mathrm{~mL})$ of the bacterial isolates in the nutrient broth was mixed with 36 $\mathrm{ml}$ of the prepared agar-agar media in petri-dish plates and then allowed to solidify. This was kept in the refrigerator for bioremediation.

\section{Bioremediation (Treatment) of the Effluents}

The solidified agar block (immobilized bacteria) was cut into cubes using a sterile knife; $0.1 \mathrm{~mL}$ phosphate buffer ( $\mathrm{pH} \mathrm{7.0)}$ was added and kept in the refrigerator for 1 hour for curing. The phosphate buffer was decanted after 1 hour and the cubes were washed with sterile distilled water 3-4 times before it was used (Ajao et al., 2011). Two liters (2 L) of the effluent was supplemented with the minimum basal medium in $\mathrm{g} / \mathrm{L}: \mathrm{NaCl}(0.8), \mathrm{MgSO}_{4} .7 \mathrm{H}_{2} \mathrm{O}(0.001), \mathrm{KH}_{2} \mathrm{PO}_{4}$ (2), $\mathrm{NaNO}_{3}$ (2), $\quad \mathrm{CaCl}_{2} .2 \mathrm{H}_{2} \mathrm{O} \quad(0.5)$ and $\mathrm{NaHPO}_{4} .12 \mathrm{H}_{2} \mathrm{O}(2)$ and sterilized in an autoclave at $121^{\circ} \mathrm{C}$ for 15 minutes (Margesin and Schinner, 2001). Two hundred and fifty milliliters $(250 \mathrm{~mL})$ of the effluents were transferred into different $250 \mathrm{ml}$ conical flasks. The content was covered with a cotton-wool ramped with foil paper to avoid contamination. Five grams $(5 \mathrm{~g})$ of the immobilized bacteria were quickly transferred into each of the effluents in the conical flasks in an inoculating chamber. The same procedures were carried out for the $10 \mathrm{~g}, 15 \mathrm{~g}, 20 \mathrm{~g}$ and 25 $\mathrm{g}$ of the immobilized bacteria in separate $250 \mathrm{~mL}$ effluents in conical flasks and agitated for ten days in a shaker incubator (Gallenkamp-OC4364-L) at a temperature $30^{\circ} \mathrm{C}$ and speed of 60 rpm. The treated effluent samples were taken on the tenth day and analyzed for the parameters $\mathrm{pH}$, SS, TDS, COD, and BOD, (Posttreatment determination) for the different grams of bacteria to evaluate and compare the biodegradation potential. (Baba et al., 2020).

\section{Statistical Analysis}

The data were represented as Mean \pm Standard deviation and analyzed statistically using oneway Analysis of Variance (ANOVA) and Tukey's HSD as Post Hoc Tests with the aid of SPSS 16.0. The correlation coefficient was also used to measure the strength of the relationship between the different masses of the bacteria and the parameters. All $\mathrm{p} \leq 0.05$ were considered as statistically significant.

\section{RESULTS AND DISCUSSION Physico-chemical parameters in the Industrial Effluents before the Biodegradation.}

Results of the Physico-chemical parameters in the industrial effluents before the Biodegradation is shown in table 1 . The mean temperatures $\left({ }^{\circ} \mathrm{C}\right)$ observed in TAN1, TAN2, and TAN3 samples were $28.07 \pm 0.65 ; 27.77 \pm 0.64$ and $26.38 \pm 3.81$ respectively. The order of the mean temperature of the samples from the three industries can be arranged as TAN1 > TAN2>TAN3. The temperature observed at TAN1, TAN2, and TAN3 samples were found below the WHO $\left(35^{\circ} \mathrm{C}\right)$ and NESREA $\left(40^{\circ} \mathrm{C}\right)$ limits. The low values of temperature might be due to the processes used at the time of sampling. High temperature brings down the solubility of gases in water that ultimately expresses as high BOD and COD. Statistical analysis shows that there is no significant difference $(p<0.05)$ between the mean values of temperature among the industries. This might be due to similar tannery activities involved in the tannery industries at the time of sampling. The average values of temperature observed in this present study are less than those observed by Akan et al. (2007), Akan et al. (2009) and Baba et al. (2020).

The mean level of $\mathrm{pH}$ observed in TAN1, TAN2 and TAN3, samples were $7.77 \pm 2.93$; $8.35 \pm 0.28$ and $7.52 \pm 0.76$ respectively. The order of the mean $\mathrm{pH}$ of the samples from the three industries can be arranged as TAN2> TAN1 $>$ TAN3. The $\mathrm{pH}$ of the samples falls within the WHO (7.0-8.5) and NESREA (6-9) standard limits. Statistical analysis shows that there is no significant difference $(p<0.05)$ between the mean values of $\mathrm{pH}$ among the industries. This might be due to similar tannery activities involved in the tannery industries at the time of sampling. Maheshwari et al. (2017) reported that the level of $\mathrm{pH}$ in the effluents from the tannery industry in Vaniyambadi, India was 6.5 which was lower than that observed in the present study. The $\mathrm{pH}$ in the effluents from the tannery industries in Kano and Kaduna were reported to be 7.64 and 6.89, respectively (Akan et al., 2007; Mohammed et al., 2017). The average values of $\mathrm{pH}$ observed in this present study are less than those observed by Mohammed et al. (2017) and Baba et al. (2020). The mean level of SS $(\mathrm{mg} / \mathrm{l})$ observed in TAN1, TAN2, and TAN3 samples were 374 \pm 124 ; $358 \pm 335$ and $780 \pm 739$ respectively. The order of the mean SS in the samples from the three industries can be arranged as TAN3 > TAN1 $>$ TAN2. 
The SS observed in the samples were far above the recommended standard limits of regulating bodies WHO $(30 \mathrm{mg} / \mathrm{l})$ and NESREA $(10 \mathrm{mg} / \mathrm{l})$. Statistical analysis shows that there is no significant difference $(p<0.05)$ between the mean values of SS among the industries. This might be due to similar tannery activities involved in the tannery industries at the time of sampling. The average values of SS observed in this present study are less than that observed $(3700 \pm 122 \mathrm{mg} / \mathrm{l})$ by Akan et al. (2009) for tanneries in Kano. Also, the average values of SS observed in this present study are less than that observed by Mohammed et al. (2017) and Baba et al. (2020) with the exception in TAN3.

The mean level of TDS (mg/l) observed in TAN1, TAN2, and TAN3 samples were $3941 \pm 3703$; $3300 \pm 1714$ and $2653 \pm 1240$ respectively. The order of the mean TDS in the samples from the three industries can be arranged as TAN1>TAN2>TAN3. The TDS observed in the samples were far above the recommended standard limits of WHO $(250 \mathrm{mg} / \mathrm{l})$ and NESREA $(500 \mathrm{mg} / \mathrm{l})$. Statistical analysis shows that there is no significant difference $(p<0.05)$ between the mean values of TDS among the industries. This might be due to similar tannery activities involved in the tannery industries at the time of sampling. TDS in the effluents from the tannery industries in Kano, Nigeria was reported to be $1281 \mathrm{mg} / \mathrm{l}$ (Akan et al., 2007). The average values of SS observed in this present study are less than those observed by Mohammed et al. (2017) and Baba et al. 2020)

The mean level of COD (mg/l) observed in TAN1, TAN2 and TAN3 samples seasons were $2372 \pm 938 ; \quad 1406 \pm 208$ and $3532 \pm 1373$ respectively. The order of the mean COD of the samples from the three industries can be arranged as TAN3>TAN1> TAN2. The COD observed in TAN1, TAN2 and TAN3 samples were far above the recommended standard limits of regulating bodies $\mathrm{WHO}(40 \mathrm{mg} / \mathrm{l})$ and NESREA (40 mg/l). Statistical analysis shows that there is no significant difference $(p<0.05)$ in COD among the industries. This might be due to similar tannery activities involved in the tannery industries as at the time of sampling. The Chemical Oxygen demand (COD) is the amount of oxygen, in $\mathrm{mg} / \mathrm{L}$, required for the degradation of the compound of wastewater to occur. In comparison, the average values of COD observed in this present study were higher than that observed by Mohammed et al. (2017) but lower than that observed by Baba et al. (2020).

The mean levels of BOD $(\mathrm{mg} / \mathrm{l})$ observed in TAN1, TAN2 and TAN3 samples were $13.85 \pm 6.42 ; \quad 19.46 \pm 0.50$ and $17.13 \pm 3.14$ respectively. The order of the mean BOD in the samples from the three industries can be arranged as TAN2>TAN3>TAN1. The BOD observed in TAN1, TAN2 and TAN3 samples were found below the recommended limits of NESREA (200 mg/l) but above WHO (10 mg/l). Statistical analysis shows that there is no significant difference $(p<0.05)$ between the mean values of BOD among the industries. This might be due to similar tannery activities involved in the tannery industries at the time of sampling. The low level of BOD recorded in this study is an indication of the low level of biodegradable organic solids in the effluent. The average values of BOD observed in this present study were lower than those observed by Mohammed et al. (2017) and Baba et al. (2020).

Table 1: Mean Values \pm S.D of Physico-chemical parameters of effluents from the Tannery Industries before Treatment.

\begin{tabular}{llllllll}
\hline Parameter & Tannery 1 & Tannery 2 & Tannery 3 & $\mathrm{a}$ & $\mathrm{b}$ & $\mathrm{c}$ & $\mathrm{d}$ \\
\cline { 2 - 7 } Temperature $\left({ }^{\circ} \mathrm{C}\right)$ & $28.07 \mathrm{a} \pm 0.65$ & $27.77 \mathrm{a} \pm 0.64$ & $26.38 \mathrm{a} \pm 3.81$ & & $29.50 \pm 4.68$ & 35 & 40 \\
pH & $7.77 \mathrm{a} \pm 2.93$ & $8.35 \mathrm{a} \pm 0.28$ & $7.52 \mathrm{a} \pm 0.76$ & 6.89 & $5.35 \pm 1.57$ & $7.0-8.5$ & $6.0-9.0$ \\
$\mathrm{COD}(\mathrm{mg} / \mathrm{l})$ & $2372 \mathrm{a} \pm 938$ & $1406 \mathrm{a} \pm 208$ & $3532 \mathrm{a} \pm 1373$ & 2.2 & $3106 \pm 2753$ & 40 & 40 \\
$\mathrm{BOD}(\mathrm{mg} / \mathrm{l})$ & $13.85 \mathrm{a} \pm 6.42$ & $19.46 \mathrm{a} \pm 0.50$ & $17.13 \mathrm{a} \pm 3.14$ & 1032 & $26.17 \pm 9.49$ & 10 & 200 \\
$\mathrm{SS}(\mathrm{mg} / \mathrm{l})$ & $374 \mathrm{a} \pm 124$ & $358 \mathrm{a} \pm 335$ & $780 \mathrm{a} \pm 739$ & 501 & $562 \pm 482$ & 30 & 10 \\
TDS $(\mathrm{mg} / \mathrm{l})$ & $3941 \mathrm{a} \pm 3703$ & $3300 \mathrm{a} \pm 1714$ & $2653 \mathrm{a} \pm 1240$ & 532.7 & $444 \pm 507$ & 250 & 500 \\
\hline
\end{tabular}

The values given in the table above are means of 6 replicate values, $\mathrm{n}=6$ ( 1 sample was taken monthly for 6 months). Within the rows, means with different alphabets are statistically different $(p<0.05)$. WHO: World Health Organisation. NESREA: National Environmental Standard and Regulatory Enforcement Agency. a = Mohammed et al.(2017), b = Baba et al. (2020), c = WHO (2006), $d=$ NESSRA (2009) 
BAJOPAS Volume 13 Number 2, December, 2020

Identification, Biochemical Characterization and growth rates of the Bacterial Isolates

Results of identification and biochemical characterization of the bacterial isolates were shown in table 2. After 24 hours of incubation, the nutrient agar media plates were checked for bacterial growth. The results showed the presence of different strains in the samples. The TAN1 bacteria isolate was found to be gramnegative cocci while TAN3 was gram-positive cocci. TAN2 bacteria isolate was found to be gram-positive, rod-shaped. TAN1, TAN2, and TAN3 bacteria isolates recorded positive results for spore former.

The results of the biochemical tests indicated that all the bacteria were positive for catalase, oxidase, citrate, maltose, glucose, lactose (negative in TAN1), mannitol (negative in TAN2), starch hydrolysis and coagulase (negative in TAN2) tests. The bacteria showed negative results for nitrate reduction, $M R$ (positive in TAN2), VP (positive in TAN1), Indole (positive in TAN2) tests. Base on the morphological and biochemical test results, TAN1, TAN2, and TAN3 bacteria isolates were identified to be Nesseria spp, Bacillus cereus, and Staphylococcus aureus respectively.

The growth rate of the TAN1, TAN2 and TAN3 Isolates were shown in figure 2. Generally, the optical density increase with the increase in time (day) and decrease as time goes on. The highest optical density was shown by bacillus cereus in TAN2 while the lowest was shown by Staphylococcus aureus in TAN3.

The initial growth phase of TAN1 Isolate bacteria occurred within 2-day of incubation as the growth rate increases up to the 6th-day incubation when the maximum growth was observed. Beyond the 6th day, the growth of the bacteria declined (which might be due to a shortage of nutrients in the effluents) until it reached its death phase (which might be due to the unavailability of nutrients in the effluents).

A similar trend of growth was also observed for TAN2 Isolate as the initial growth phase also occurred within 2-day of incubation but maximum growth rate observed on the 4th day of incubation. The stationary stage occurred between the 4th day and the 8th day. Beyond the 8th day, the growth of the bacteria declined (which might be due to a shortage of nutrients in the effluents) until it reached its death phase (which might be due to the unavailability of nutrients in the effluents).

The initial growth phase of TAN3 bacterial Isolate occurred within the 3-day incubation as the growth rate increases up to the 6th-day incubation when the maximum growth was observed. Beyond the 6th day, the growth of the bacteria declined (which might be due to a shortage of nutrients in the effluents) until it reached its death phase (which might be due to the unavailability of nutrients in the effluents).

Table 2: Morphological and Biochemical characteristics of bacterial isolates

\begin{tabular}{lllll} 
Bacterial Isolates & & TAN1 & TAN2 & TAN3 \\
\hline $\begin{array}{lllll}\text { Morphological } \\
\text { characteristics }\end{array}$ & Shape & Cocci & Rod & Cocci \\
& Spore & & & \\
& former & + & + & + \\
Gram & & & \\
Biochemical characteristics & reaction & - & + & + \\
& Citrate & + & + & + \\
& Catalase & + & + & + \\
& Coagulase & + & - & + \\
Starch & + & + & + \\
& Glucose & + & + & + \\
Oxidase & + & + & + \\
& Indo & - & + & - \\
Lactose & - & + & + \\
Manitol & + & - & + \\
Maltose & + & + & + \\
MR & - & + & - \\
VP & + & - & - \\
& Nitrate & - & - & - \\
Reduction & - Neisseria & Bacillus & Staphylococcus \\
& Bacterial & cereus & aureus \\
& name & spp & cas
\end{tabular}

+ = Positive; - = Negative; MR=Methyl Red; VP= Voges-Proskauer 


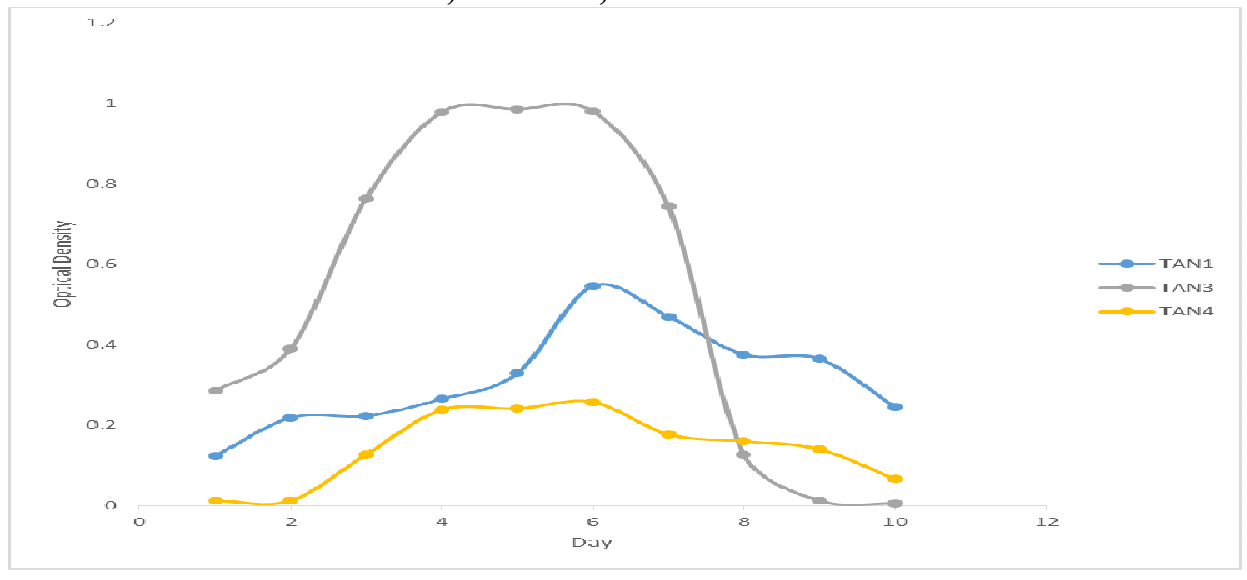

Fig. 2 Growth rates of the isolates in the effluents from the Tannery Industries

\section{Physico-chemical Parameters in the Industrial Effluents after the biodegradation.}

Table 3 shows the mean results of the physicochemical parameter before and after bioremediation using the different masses $(5 \mathrm{~g}$, $10 \mathrm{~g}, 15 \mathrm{~g}, 20 \mathrm{~g}$, and $25 \mathrm{~g}$ ) of the respective immobilized bacteria. Also, Table 4 shows the mean results of correlation coefficient ( $r$ ) between different masses of bacteria and physicochemical parameters.

The mean values $(\mathrm{mg} / \mathrm{l})$ of the SS after the bioremediation varies between $243 \pm 45$ and $898 \pm 672$. The mean concentration $(\mathrm{mg} / \mathrm{l})$ of SS remediated by the different masses $(5 \mathrm{~g}, 10 \mathrm{~g}$, $15 \mathrm{~g}, 20 \mathrm{~g}$, and $25 \mathrm{~g}$ ) of the bacteria varies. The SS in the samples fluctuates up and down after the bioremediation process when compared with the SS of the raw samples before the bioremediation. The increase in the levels of the SS might be due to the aggregation of the TDS which are large enough to result into SS. The increase in the levels of the SS might be also due to the influence of the nutrients which was added into the effluents in order to make the microorganisms more active and viable for fast degradation of organic contaminants in the effluent. The relative potential or efficiency of the different masses of the bacteria in remediating SS in TAN1 samples was in the order $25 \mathrm{~g}>20 \mathrm{~g}>15 \mathrm{~g}>10 \mathrm{~g}>5 \mathrm{~g}$. For TAN2 and TAN3 samples, the order was $25 \mathrm{~g}>20 \mathrm{~g}>15$ $\mathrm{g}>10 \mathrm{~g}>5 \mathrm{~g}$. These might be due to the variations in the surface areas of the different masses of the immobilized bacteria. Statistical analysis shows that there is no significant difference $(p<0.05)$ between the mean values of SS among the masses in the respective industries. Positive and significant correlations exist between the masses of bacteria and Suspended Solid (SS). This showed that there is general increase in the levels of the SS as the masses of the immobilized bacteria increases. TAN3 (90\%) and TAN1 (80\%) showed a very high correlation with the masses of the bacteria while TAN2 (61\%) showed a very low correlation.

The mean values $(\mathrm{mg} / \mathrm{l})$ of the TDS after the bioremediation varies between $46 \pm 11$ and $83 \pm 78$. The mean concentration $(\mathrm{mg} / \mathrm{l})$ of TDS remediated by the different masses $(5 \mathrm{~g}, 10 \mathrm{~g}$, $15 \mathrm{~g}, 20 \mathrm{~g}$, and $25 \mathrm{~g}$ ) of the bacteria varies. There is a reduction in all the TDS of all the samples after the bioremediation process compared with the TDS of the raw samples before the bioremediation. The relative potential or efficiency of the different masses of the bacteria in remediating TDS in TAN1 and TAN3 samples was in the order $5 \mathrm{~g}>10 \mathrm{~g}>15 \mathrm{~g}>20$ $\mathrm{g}>25 \mathrm{~g}$. For TAN2 samples, the order was 20 $g>10 \quad g>25 \quad g>15 \quad g>5 \quad g$. Statistical analysis shows that there is no significant difference $(p<0.05)$ between the mean values of TDS among the masses in the respective industries. These might be due to the variations in the surface areas of the different masses of the immobilized bacteria. Positive and significant correlations exist between the masses of bacteria and TDS with the exception in TAN2 (negative and insignificant correlation). The positive correlations showed that there is general increase in the levels of the TDS as the masses of the immobilized bacteria increases. TAN1 $(96 \%)$ showed a very high correlation with the masses of the bacteria while TAN2 (47\%) showed a very low correlation.

The mean values $(\mathrm{mg} / \mathrm{l})$ of the BOD after the bioremediation varies between $1.56 \pm 0.20 \mathrm{mg} / \mathrm{l}$ and $6.92 \pm 5.49 \mathrm{mg} / \mathrm{l}$. The mean concentration $(\mathrm{mg} / \mathrm{l})$ of BOD remediated by the different masses $(5 \mathrm{~g}, 10 \mathrm{~g}, 15 \mathrm{~g}, 20 \mathrm{~g}$, and $25 \mathrm{~g}$ ) of the bacteria varies. There is a reduction in all the BOD of all the samples after the bioremediation process compared with the $\mathrm{BOD}$ of the raw 
BAJOPAS Volume 13 Number 2, December, 2020 samples before the bioremediation. The relative potential or efficiency of the different masses of the bacteria in remediating BOD in TAN1, TAN2 and TAN3 samples were in the order $25 \mathrm{~g}>20$ $\mathrm{g}>15 \mathrm{~g}>10 \mathrm{~g}>5 \mathrm{~g}, 25 \mathrm{~g}>15 \mathrm{~g}>5 \mathrm{~g}>10 \mathrm{~g}>20 \mathrm{~g}$ and $20 \mathrm{~g}>10 \mathrm{~g}>25 \mathrm{~g}>15 \mathrm{~g}>5 \mathrm{~g}$ respectively. Statistical analysis shows that there is significant difference $(p<0.05)$ between the mean values of BOD among the masses in the respective industries. These might be due to the variations in the surface areas of the different masses of the immobilized bacteria. Negative and significant correlations exist between the masses of bacteria and BOD. This showed that there is general decrease in the levels of the BOD as the masses of the immobilized bacteria increases. TAN1 (94\%) showed a very high correlation with the masses of the bacteria while TAN2 (4\%) showed a very low correlation.

The mean values $(\mathrm{mg} / \mathrm{l})$ of the COD after the bioremediation varies between $250 \pm 154$ and $3134 \pm 1595$. The mean concentration $(\mathrm{mg} / \mathrm{l})$ of COD remediated by the different masses $(5 \mathrm{~g}$, $10 \mathrm{~g}, 15 \mathrm{~g} 20 \mathrm{~g}$, and $25 \mathrm{~g}$ ) of the bacteria varies. There is a reduction in all the COD of all the samples after the bioremediation process compared with the COD of the raw samples before the bioremediation. The relative potential or efficiency of the different masses of the bacteria in remediating COD in TAN1, TAN2 and TAN3 samples were in the order $25 \mathrm{~g}>20 \mathrm{~g}>15$ $\mathrm{g}>5 \mathrm{~g}>10 \mathrm{~g}, 25 \mathrm{~g}>20 \mathrm{~g}>15 \mathrm{~g}>10 \mathrm{~g}>5 \mathrm{~g}$ and 10 g>5 g>25 g>15 g>20 g respectively. Statistical analysis shows that there were significant difference $(p<0.05)$ between the mean values of COD among the masses in the respective industries except for effluents treated with $25 \mathrm{~g}$. These might be due to the variations in the surface areas of the different masses of the immobilized bacteria. Negative and insignificant correlations exist between the masses of bacteria and COD with the exception in TAN3 (positive and significant correlation). The negative correlations showed that there is general decrease in the levels of the COD as the masses of the immobilized bacteria increases. TAN2 (100\%) showed a very high correlation with the masses of the bacteria while TAN3 (36\%) showed a very low correlation.

Generally, there was an overall decrease in the concentration of these physicochemical parameters after the bioremediation using the different masses of the bacterial isolates. These might be due to the variations in the surface areas of the different masses of the immobilized bacteria. This is in line with the work of Jimoh et al. (2018) and Baba et al. (2020).

Table 3: Mean Values $(\mathrm{mg} / \mathrm{l}) \pm$ S.D of Physicochemical parameters in effluents from the Tannery Industries before and after Treatment of the effluents $(250 \mathrm{ml})$ with the different masses $(5 \mathrm{~g}, 10 \mathrm{~g}$, $15 \mathrm{~g}, 20 \mathrm{~g}$, and $25 \mathrm{~g}$ ) of the bacteria.

\begin{tabular}{llllllll}
\hline $\mathrm{P}$ & IND & Before & \multicolumn{5}{c}{ After } \\
\cline { 4 - 7 } & & & $5 \mathrm{~g}$ & $10 \mathrm{~g}$ & $15 \mathrm{~g}$ & $20 \mathrm{~g}$ & $25 \mathrm{~g}$ \\
\hline \multirow{2}{*}{ COD } & TAN1 & $2372 \pm 938$ & $1708 \mathrm{a} \pm 861$ & $2045 \mathrm{a} \pm 1205$ & $845 \mathrm{a} \pm 369$ & $300 \mathrm{a} \pm 167$ & $250 \mathrm{a} \pm 154$ \\
& TAN2 & $1406 \pm 208$ & $1195 \mathrm{a} \pm 208$ & $1125 \mathrm{a} \pm 384$ & $1055 \mathrm{a} \pm 317$ & $956 \mathrm{a} \pm 310$ & $870 \mathrm{ab} \pm 240$ \\
& TAN3 & $3532 \pm 1373$ & $2374 \mathrm{a} \pm 1344$ & $1976 \mathrm{a} \pm 1405$ & $2757 \mathrm{a} \pm 1266$ & $3134 \mathrm{a} \pm 1595$ & $2614 \mathrm{~b} \pm 1105$ \\
BOD & TAN1 & $13.85 \pm 6.42$ & $6.92 \mathrm{a} \pm 5.49$ & $6.42 \mathrm{a} \pm 5.07$ & $5.72 \mathrm{a} \pm 5.35$ & $4.62 \mathrm{a} \pm 4.37$ & $2.82 \mathrm{ab} \pm 1.26$ \\
& TAN2 & $19.46 \pm 0.50$ & $1.75 \mathrm{~b} \pm 0.22$ & $1.73 \mathrm{~b} \pm 0.18$ & $1.58 \mathrm{a} \pm 0.16$ & $1.91 \mathrm{a} \pm 0.22$ & $1.56 \mathrm{~b} \pm 0.20$ \\
& TAN3 & $17.13 \pm 3.14$ & $4.24 \mathrm{ab} \pm 0.77$ & $3.29 \mathrm{ab} \pm 0.37$ & $4.11 \mathrm{a} \pm 0.07$ & $3.23 \mathrm{a} \pm 0.91$ & $3.33 \mathrm{a} \pm 1.28$ \\
SS & TAN1 & $374 \pm 124$ & $243 \mathrm{a} \pm 45$ & $471 \mathrm{a} \pm 226$ & $475 \mathrm{a} \pm 182$ & $492 \mathrm{a} \pm 128$ & $611 \mathrm{a} \pm 217$ \\
& TAN2 & $358 \pm 335$ & $460 \mathrm{a} \pm 400$ & $543 \mathrm{a} \pm 414$ & $544 \mathrm{a} \pm 402$ & $551 \mathrm{a} \pm 414$ & $554 \mathrm{a} \pm 405$ \\
& TAN3 & $780 \pm 739$ & $586 \mathrm{a} \pm 594$ & $758 \mathrm{a} \pm 656$ & $787 \mathrm{a} \pm 676$ & $861 \mathrm{a} \pm 635$ & $898 \mathrm{a} \pm 672$ \\
TDS & TAN1 & $3941 \pm 3703$ & $51 \mathrm{a} \pm 10$ & $53 \mathrm{a} \pm 10$ & $55 \mathrm{a} \pm 15$ & $61 \mathrm{a} \pm 20$ & $63 \mathrm{a} \pm 26$ \\
& TAN2 & $3300 \pm 1714$ & $83 \mathrm{a} \pm 78$ & $47 \mathrm{a} \pm 20$ & $48 \mathrm{a} \pm 22$ & $47 \mathrm{a} \pm 17$ & $48 \mathrm{a} \pm 17$ \\
& TAN3 & $2653 \pm 1240$ & $46 \mathrm{a} \pm 11$ & $55 \mathrm{a} \pm 24$ & $55 \mathrm{a} \pm 25$ & $58 \mathrm{a} \pm 23$ & $61 \mathrm{a} \pm 28$ \\
\hline
\end{tabular}

Replicate $=6$ (months)

Within the rows, for the same parameter, means with different alphabets are statistically different $(p<0.05)$.

$\mathrm{P}=$ parameter, IND = Industries 
BAJOPAS Volume 13 Number 2, December, 2020

Table 4: Correlation coefficient $(r)$ between different masses of the bacteria and the physicochemical parameters.

\begin{tabular}{llll}
\hline Industries & Parameter & Correlation coefficient $(r)$ & $\begin{array}{l}\text { Percent dependence (rxrx100) } \\
(\%)\end{array}$ \\
\hline TAN1 & COD & -0.9 & 82 \\
& BOD & -0.97 & 94 \\
& SS & $0.90^{*}$ & 80 \\
TAN2 & TDS & $0.98^{*}$ & 96 \\
& COD & -1 & 100 \\
& BOD & -0.21 & 4 \\
& SS & $0.78^{*}$ & 61 \\
& TDS & -0.69 & 47 \\
& COD & $0.60^{*}$ & 36 \\
& BOD & -0.6 & 37 \\
& SS & $0.95^{*}$ & 90 \\
& TDS & $0.94^{*}$ & 89 \\
\hline
\end{tabular}

The correlation coefficient $(r)$ with * is statistically significant $(p<0.05)$.

Percentage reduction of the Parameters

Table 5 shows the percentage reduction of Parameters in industrial samples before and after the treatment of the effluents $(250 \mathrm{ml})$ with the different masses $(5 \mathrm{~g}, 10 \mathrm{~g}, 15 \mathrm{~g}, 20 \mathrm{~g}$, and $25 \mathrm{~g}$ ) of the Immobilized Bacteria.

In TAN1 samples, the percentage reduction (\%) of COD ranged (14-89); BOD (50-80); SS (-32$35)$ and TDS (98-99). In TAN2 samples, the percentage decrease $(\%)$ of COD ranged (15$38) ;$ BOD (90-92); SS [-28-(-55)] and TDS (9798). In TAN3 samples, the percentage decrease (\%) of COD ranged (11-44); BOD (76-81); SS (15-25) and TDS (98). The percentage increase in the levels COD, BOD and TDS might be due to the increase in the surface area of the different masses of the immobilized bacteria. However, the percentage decrease in the levels of the SS might be due to the aggregation of the TDS which are large enough to result into SS. The percentage decrease in the levels of the SS might be also due to the influence of the nutrients which was added into the effluents in order to make the microorganisms more active and viable for fast degradation of organic contaminants in the effluent. This is in line with the work of Jimoh et al. (2018) in which the concentration of the SS increase after the bioremediation of effluents.

Sreemoyee and Priti (2013) assessed and reduced several Physico-chemical parameters of dairy wastewater using Niesseria $s p$. and concluded that the species are well known to degrade organic compounds. This is in agreement with the current study in which the immobilized Niesseria $s p$ degrade the organic contaminants as indicated by the BOD, COD and TDS.

Jimoh et al. (2018) observed that TSS of the effluents was increased after treatment with immobilized bacteria and concluded that it might be due to the biostimulation method adopted for the research.

The optimum $\mathrm{pH}$ Biosorption of Chromium by Bacillus spp and Staphylococcus spp. from tannery effluent was investigated by Mythili and Karthikeyan (2011). The maximum adsorption of Chromium $(86.4 \mathrm{mg} / \mathrm{L})$ was showed by Bacillus spp and Staphylococcus spp showed $70.6 \mathrm{mg} / \mathrm{L}$ at an initial concentration of $100 \mathrm{mg} / \mathrm{L}$. In the present study, immobilised Bacillus spp and Staphylococcus spp. from the tannery industrial effluents reduced the levels of the organic pollutants with high potential as indicated by the percentage reduction of BOD, COD and TDS.

Enzymes often can work in multiple environments especially if they are immobilized. This makes the microorganisms' enzymes even more resistant to harsh environments and enables the enzymes to be recovered and recycled after they are no longer needed (Gianfreda and Rao 2004). Ramesh and Singh (1993) reported that the immobilized bacteria having more efficiency to remove the suspended particles than free cells. Using the immobilized cell is preferable due to its capability for using several times with the same efficiency, which makes it more economical. Similar work was done by Sikander et al. (2007) showing the higher reduction with permeabilized cells of Ochrobactrum intermedium strain SDCr-5. 
BAJOPAS Volume 13 Number 2, December, 2020

The results revealed the isolation and identification of isolates with the potential for the reduction of $\mathrm{Cr}$ (VI) to $\mathrm{Cr}$ (III). Results indicated that immobilized $B$. cereus could be efficiently used for the reduction of $\mathrm{Cr}$ (VI).

Table 5: Percentage reduction of the tested Parameters from the tannery industrial samples of the Immobilized Bacteria.

\begin{tabular}{lllllll}
\hline \multirow{2}{*}{ Industries } & & \multicolumn{5}{c}{ Percentage Reduction $(\%)$} \\
\cline { 3 - 7 } & & $5 \mathrm{~g}$ & $10 \mathrm{~g}$ & $15 \mathrm{~g}$ & $20 \mathrm{~g}$ & $25 \mathrm{~g}$ \\
\hline TAN1 & COD & 28 & 14 & 64 & 87 & 89 \\
& BOD & 50 & 54 & 59 & 67 & 80 \\
& SS & 35 & -26 & -27 & -32 & -63 \\
& TDS & 99 & 99 & 99 & 98 & 98 \\
TAN2 & COD & 15 & 20 & 25 & 32 & 38 \\
& BOD & 91 & 91 & 92 & 90 & 92 \\
& SS & -28 & -52 & -52 & -54 & -55 \\
& TDS & 97 & 99 & 99 & 99 & 99 \\
& COD & 33 & 44 & 22 & 11 & 26 \\
& BOD & 75 & 81 & 76 & 81 & 81 \\
& SS & 25 & 3 & -1 & -10 & -15 \\
& TDS & 98 & 98 & 98 & 98 & 98 \\
\hline
\end{tabular}

Percentage Reduction $=(B-A) / B \times 100 \%$

$A=$ Concentration of the parameter after treatment

$\mathrm{B}=$ Concentration of the parameter before treatment

$+=$ percentage decrease

- = percentage increase

In general, immobilization makes the enzyme more resistant to temperature, $\mathrm{pH}$, and substrate concentration swings giving it a longer lifetime and higher productivity per active unit (Gianfreda and Rao, 2004; FuIlbrook, 1996; Russell et al, 2003; Kandelbauer et al., 2004). Immobilized cells have been used and studied extensively for the production of useful chemicals (Ohtake and Silver, 1994), the treatment of wastewaters (Chen et al., 2003; Wang et al., 2010). Although many workers described microbial degradation of tannery effluent, limited literature is available on the bioremediation of tannery effluent using immobilized bacterial cells in the Kano Industrial Estates.

\section{CONCLUSION}

The samples contained variable levels of the physicochemical parameters. The results of the Analysis of variance revealed that, no statistical difference $(p<0.05)$ was observed for the temperature, $\mathrm{pH}, \mathrm{SS}, \mathrm{TDS}, \mathrm{BOD}$ and $\mathrm{COD}$ among the three tannery industries before the treatment. The levels of some of the parameters
(SS, TDS and COD) observed in the samples were found above the recommended limits of WHO and NESREA, which called for the treatment of the effluents before discharge into the environment. Base on the morphological and biochemical test results, TAN1, TAN2, and TAN3 bacterial isolates were identified to be Neisseria spp, Bacillus cereus, and Staphylococcus aureus respectively. The results of Post-treatment analysis showed that there is overall decrease in the levels of the parameters determined when compared with that of the pre-treatment. The overall percentage reduction of the immobilised bacteria in the treatment of the respective effluents was in the order TAN2 (72\%)>TAN1 $(70 \%)>$ TAN3 $(62 \%)$. Hence, the immobilized bacteria are having higher biodegradation potential for the treatment of the tannery effluents.

\section{Acknowledgments}

The authors wish to acknowledge the University of Maiduguri for the financial support. The authors are grateful to the Kano State Ministry of Environment for their support in obtaining the effluent samples. 


\section{REFERENCES}

Ajao, A. T., Adebayo, G. B., and Yakubu, S. E. (2011). Bioremediation of textile industrial effluent using mixed culture of Pseudomonas aeruginosa and Bacillus subtilis immobilized on agar-agar in a bioreactor. J. Microbiol. Biotech. Res, 1(3), 50-56.

Akan, J. C., Moses, E. A., Ogugbuaja, V. O., and Abah, J. (2007). Assessment of tannery industrial effluents from Kano metropolis, Kano State, Nigeria. Journal of Applied Sciences, 7(19), 2788-2793.

Akan, J. C., Ogugbuaja, V. O., Abdulrahman, F. I., and Ayodele, J. T. (2009). Pollutant levels in effluent samples from tanneries and textiles of Kano industrial areas, Nigeria. Global journal of pure and applied sciences, 15(3-4).

APHA (1989). Standard methods for Examination of Will bete and Will betewater.15 $5^{\text {th }}$ edition. Brydpass Springfield Will behington DC. pp. 164-176

APHA (1992). Standard Methods for the Examination of Water and Wastewater. Health, 69, 1116-9.

Baba, A., Garba, S. T., and Bello, H. S. (2020). Bioremediation Potential of Immobilized corynebacterium kutsceri in the Treatment of Tannery Industrial Effluent from Challawa Industrial Estate, Kano State, Nigeria. Journal of the Turkish Chemical Society Section A: Chemistry, $7(2), 335-350$.

Beem, E. I. V. (1994). reduction of solvent VOC emission. J. Oil Col. Chem. Ass, 77, 158.

Bouwer, E. J., and Zehnder, A. J. (1993). Bioremediation of organic compoundsputting microbial metabolism to work. Trends in biotechnology, 11(8), 360367.

Chen, K. C., Wu, J. Y., Liou, D. J., and Hwang, S. C. J. (2003). Decolorization of the textile dyes by newly isolated bacterial strains. Journal of Biotechnology, 101(1), 57-68.

Dan'Azumi, S., and Bichi, M. H. (2010). INDUSTRIAL POLLUTION AND HEAVY METALS PROFILE OF CHALLAWA RIVER IN KANO, NIGERIA. Journal of Applied Sciences in Environmental Sanitation, $5(1)$.

DWAF. (1992). Analytical Methods Manual, TR 151. Department of Water Affairs and Forestry, Pretoria.

El-Bestawy, E. (2013). Biological treatment of leather-tanning industrial wastewater using free living bacteria.
Elsheikh, M. A. S. (2009). Tannery wastewater pre-treatment. Water Science and Technology, 60(2), 433-440.

FuIlbrook, P. D. (1996). "Kinetics." Industrial enzymology: The application of enzymes in Industry. 2nd Ed. T. Godfrey and J Reichelt. eds.. Nature. New York.

Gianfreda, L., and Rao, M. A. (2004). Potential of extra cellular enzymes in remediation of polluted soils: a review. Enzyme and microbial technology, 35(4), 339354.

Hugo Springer. (1994). John Arthur Wilson Memorial Lecture "Treatment of Industrial Wastes of the Leather Industry - is it still a Major Problem". JALCA, 89, 153-185

Jimoh, A. A., Ganiyu, B. A., Baba, D., and Baba, A. (2018) Bioremediation Process of Effluent from Detergent and Food Industries in Jos, Nigeria: Kinetics and Thermodynamics. International Journal of Engineering Science Invention (IJESI), 762-73

Kandelbauer, A., Maute, O., Kessler, R. W., Erlacher, A., and Gübitz, G. M. (2004). Study of dye decolorization in an immobilized laccase enzyme-reactor using online spectroscopy. Biotechnology and bioengineering, 87(4), 552-563.

Kongjao, S., Damronglerd, S., and Hunsom, M. (2008). Simultaneous removal of organic and inorganic Pollutants in tannery wastewater using electrocoagulation technique. Korean Journal of chemical engineering, 25(4), 703.

Maheshwari, U. M., Aruna, S., Gomathi, M., and AbdulJaffar, A. H. (2017). Bioremediation by Free and Immobilized Bacteria Isolated from Tannery Effluent. International Journal of Research in Applied, Natural and Social Sciences. 5(7), 75-90

Margesin, R., and Schinner, F. (2001). Bioremediation (natural attenuation and biostimulation) of diesel-oilcontaminated soil in an alpine glacier skiing area. Applied and environmental microbiology, 677), 3127-3133.

Mohammed, A., Sekar, P., and George, J. (2011). Efficacy of microbes in bioremediation of tannery effluent. Inter. J. Curr. Res, 3(4), 324-326.

Mohammed, S. S. D., Orukotan, A. A., and Abdullahi, H. (2017). Physicochemical and Bacteriological Assessment of Tannery Effluent from Samaru-Zaria, 
BAJOPAS Volume 13 Number 2, December, 2020 Kaduna State, Nigeria. Journal of Applied

Sciences and Environmental Management, 21(4), 734-740.

Munz, G., De Angelis, D., Gori, R., Mori, G., Casarci, M., and Lubello, C. (2009). The role of tannins in conventional and membrane treatment of tannery wastewater. Journal of hazardous materials, 164(2-3), 733-739

Mythili, K., and Karthikeyan, B. (2011). Bioremediation of $\mathrm{Cr}$ (VI) from tannery effluent using Bacillus spp and Staphylococcus spp. International Multidisciplinary Research Journal, 1(6).

NESREA (2009). National Environmental Standards for Effluent Limitations and Regulation. 1233-1236

Noorjahan, C. M. (2014). Physicochemical characteristics, identification of bacteria and biodegradation of industrial effluent. Journal of bioremediation and Biodegradation, 5(3).

Ohtake, H. I., and Silver, A. O. (1994). Bacterial reduction of toxic chromate. Biological degradation and bioremediation of toxic chemicals, 403-415.

Omoleke, I. I. (2004). Management of environmental pollution in Ibadan, an African city: the challenges of health hazard facing government and the people. Journal of Human Ecology, 15(4), 265-275.

Rajor, A., Reddy, A.S., and Singh, B. (2004). Determination of BOD kinetic Parameters and evaluation of alternate methods, M.Sc. Thesis, Department of biotechnology \& environmental Science, Thapar Institute of Engineering and Technology, Patiala

Ramasami, T., Rajamani, S., and Rao, J. R. (1994, March). Pollution control in leather industry: Emerging technological options. In International symposium on surface and colloidal science and its relevance to soil pollution, madras.

Ramesh, J. V. S., and Singh, S. P. (1993). Yearly variation in certain physicochemical parameters of pond at eastern Doon Valley. Uttar Pradesh J. Zoo, 12 (1), 7577.

Ranen, S., and Sharadinadra, C. (2009). Biotechnology applications to environmental remediation in resource exploitation. Current science, 97, 6-25
Russell, A. J., Berberich, J. A., Drevon, G. F., and Koepsel, R. R. (2003). Biomaterials for mediation of

chemical and biological warfare agents. Annual review of biomedical engineering, 5(1), 1-27.

Saravanan, P., and Saravanan, A. (1999). Decolourization of tannery effluent by Flavobacterium sp. EK 1. Indian Journal of Environmental Protection, 19, 19-24.

Sikander, S., and Shahida, H. (2007). Reduction of toxic hexavalent chromium by Ochrobactrum intermedium strain SDCr5 stimulated by heavy metals. Bioresource Technol, 98, 340-344.

Singh, N., Sharma, B. K., and Bohra, P. C. (2000). Impact assessment of industrial effluent of arid soils by using satellite imageries. Journal of the Indian Society of Remote Sensing, 28(2-3), 79.

Sreemoyee, C., and Priti, P. (2013). Assessment of physico-chemical parameters of dairy waste water and isolation and characterization of bacterial strains in terms of cod reduction. Int J Sci, 2(3), 395-400.

Verheijen, L. A. H. M., Wiersema, D., Pol, L. H., and De Wit, J. (1996). Management of wastes from animal product processing. Livestock and environment, Finding a balance. International Agriculture Center, Wageningen, The Netherlands.

Wang, F., Yao, J., Si, Y., Chen, H., Russel, M., Chen, K., and Bramanti, E. (2010). Short-time effect of heavy metals upon microbial community activity. Journal of Hazardous Materials, 173(13), 510-516.

WHO (World Health Organization). (2006). Air quality guidelines: global update 2005: particulate matter, ozone, nitrogen dioxide, and sulfur dioxide. World Health Organization.

World Bank. (1995). Nigeria's strategic options for redressing industrial pollution. World Bank, industry and energy division. 1st edition, West Central Africa Department; Annexes: 1995; pp 60-62.

Zahoor, A., and Abdul, R. (2009). Enumeration of Coliforms. Journal of Environmental Sciences. 21, 814-820 


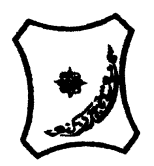

Bayero Journal of Pure and Applied Sciences, 13(2): 1 - 12

Received: November, 2020

Accepted: December, 2020

ISSN $2006-6996$

\title{
BIODEGRADATION POTENTIAL OF IMMOBILIZED BACTERIA IN THE TREATMENT OF TANNERY INDUSTRIAL EFFLUENTS FROM INDUSTRIAL ESTATES IN KANO STATE, NIGERIA
}

\author{
Abdullateef, B., ${ }^{1 *}$ Shuaibu, T. G., ${ }^{1}$ Babagana, K., ${ }^{1}$ Suleman, H. B. ${ }^{2}$ and Dauda, B. ${ }^{3}$ \\ ${ }^{1}$ Department of Pure and Applied Chemistry, Faculty of Science, University of Maiduguri, Borno State, \\ Nigeria \\ ${ }^{2}$ Department of Microbiology, Faculty of Science, University of Maiduguri, Borno State, Nigeria \\ ${ }^{3}$ Department of Chemical Engineering, Faculty of Engineering, University of Maiduguri, Borno State, \\ Nigeria \\ *Corresponding author: babslega@gmail.com; abelega2007@yahoo.com; +2348061309753
}

\section{ABSTRACT}

Industrial Effluents Samples from Gashash Tanneries (TAN1) in Bompai Industrial estate, Larabee Tannery Industry (TAN2) in Sharada Industrial estate and Z Tannery Industries (TAN3) in Challawa Industrial estate, Kano State, Nigeria were collected over a period of six months (August 2017 to January 2018) for assessing the biodegradation potentials of bacteria in the treatment of organic pollutants within the effluents. Bacteria were isolated from the effluents and immobilized on agar-agar. Different masses (5 g, $10 \mathrm{gr}, 15$ $\mathrm{g}, 20 \mathrm{~g}$, and $25 \mathrm{~g}$ ) of the bacteria were used in the treatment of $250 \mathrm{ml}$ of the effluents for ten days in a shaker incubator (Gallenkamp-OC-4364-L) at the temperature $30{ }^{\circ} \mathrm{C}$ and speed of $60 \mathrm{rpm}$. Pre-treatment analysis of the effluents for Temperature, pH, Biochemical Oxygen Demand (BOD), Chemical Oxygen Demand (COD), Suspended Solid (SS) and Total Dissolved Solids (TDS) gives the following results; temperature $\left({ }^{\circ} \mathrm{C}\right.$ )

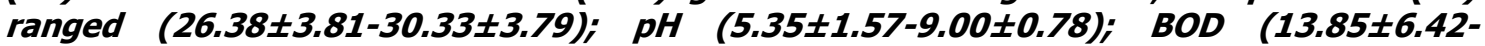
$38.75 \pm 16.20) ;$ COD (1406 $\pm 208-3532 \pm 1373) ;$ SS (208 $\pm 235-780 \pm 739)$ and TDS (266 $\pm 253-5276 \pm 2971)$. No statistical differences ( $p \leq 0.05)$ was observed for all the results among the different industries. The bacterial isolates were identified as Neisseria spp, Bacillus cereus, and Staphylococcus aureus, in TAN1, TAN2, and TAN3, respectively. After treatment of the effluent with the different masses of the isolated bacteria, the mean level of BOD was found to range as (0.55 $\pm 0.36-6.92 \pm 5.49) ; C O D$ (ND-3134 \pm 1595$)$;

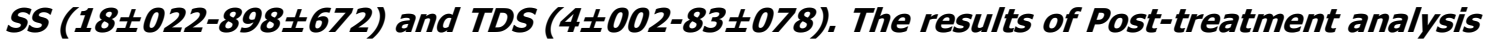
showed that there is overall decrease in the levels of the parameters determined when compared with that of the pre-treatment. The overall percentage reduction of the immobilised bacteria in the treatment of the respective effluents was in the order TAN2 (72\%)>TAN1 (70\%)>TAN3 (62\%). Hence, the immobilized bacteria are having higher biodegradation potential for the treatment of the tannery effluents.

Keywords: Biodegradation, bacteria, effluent, immobilization, tannery.

\section{INTRODUCTION}

Tannery industrial wastewater is a serious consequence of the pollution point of view for streams, freshwater, and land used for agriculture. The lack of awareness in the modern industrial practice has resulted in the discharge of tannery effluents which exhibit very high value of chromium ( $\mathrm{Cr}$ ), Sulfide, and chloride, Total Dissolved Solid (TDS), Total Suspended Solid (TSS), Biochemical Oxygen Demand (BOD) and Chemical Oxygen Demand (COD) in the water stream or land (Mohammed et al., 2001). Tanning is the process, which One ton of skin generally leads to the production of 20 to $80 \mathrm{~m}^{3}$ of turbid and foul-smelling converts the protein of the rawhide or skin into a stable material, which will not putrefy and is suitable for a wide variety of end applications (Elsheikh, 2009). The highly polluting chromium is the most commonly used tanning material producing leather that is more flexible and pliable than vegetable-tanned leather and does not discolor or lose shape in water as drastically as vegetable-tan (Elsheikh, 2009). Tannery effluent is among the most hazardous industrial pollutants due to its huge organic and inorganic load, which is highly toxic to human life and the environment (Kongjao et al., 2008). wastewater including chromium (100-400 mg/l), sulfide $(200-800 \mathrm{mg} / \mathrm{l})$, high levels of fat and 
BAJOPAS Volume 13 Number 2, December, 2020 other solid wastes, and notable pathogen contamination as well as pesticides added for skin conservation during transport (Elsheikh, 2009). There are more than 6000 tanneries in Nigeria with an annual processing capacity of 700,000 tons of hides and skins (Omoleke, 2004; Singh et al., 2008). It was reported that the total amount of waste produced per animal slaughtered is approximately $35 \%$ of its weight (World Bank, 1995). Also, for every $1000 \mathrm{~kg}$ of carcass weight, a slaughtered beef produces 5.5 $\mathrm{kg}$ of manure (excluding rumen contents or stockyard manure) and $100 \mathrm{~kg}$ of paunch manure (undigested food) (Verheijen et al., 1996). Tanneries generate wastewater in the range of 30-35 $\mathrm{L} \mathrm{kg}^{-1}$ skin/hide processed with variable $\mathrm{pH}$, Biological Oxygen Demand (BOD), Chemical Oxygen Demand (COD), high concentrations of suspended solids (SS), and tannins as well as chromium (Zahoor and Abdul, 2009).

Being heterogeneous and composed of a wide variety of compounds, it is very difficult to select a unique direct method for estimating the biodegradability of organic contents and biokinetic parameters for a wastewater sample (Rajor, 2004). For this purpose, some indirect estimation such as determination of biochemical oxygen demand (BOD) and chemical oxygen demand (COD) are applied as common laboratory investigations [9]. During retanning procedures, synthetic tannins (Syntan), oils and resins are added to form softer leather at varying doses (Munz et al., 2009). One of the refractory groups of chemicals in tannery effluents derives mainly from tannins (Ramasami et al., 2004). Syntans are characterized by complex chemical structures, because they are composed of an extended set of chemicals such as phenol-, naphthalene-, formaldehyde- and melamine-based syntans, and acrylic resins (Beem, 1994). Organic pollutants (proteic and lipidic components) are originated from skins (it is calculated that the raw skin has $30 \%$ loss of organic material during the working cycle) or they are introduced during processes (Hugo Springer, 1994).

Many conventional processes such as oxidation, chemical and biological processes were carried out to treat tanneries wastewater (Ebtesam et al, 2013). Biological processes have received more attention because of their costeffectiveness, lower sludge production and environmental friendliness (Noorjahan, 2014). Naturally occurring micro-organisms degrade the hazardous organic wastes including xenobiotic compounds, such as pesticides, polycyclic aromatic hydrocarbons (PAHs) and polychlorinated biphenyls (PCBs) in due course of time (Ranen and Sharadinadra, 2009). Bioremediation is based on the idea that all organisms remove substances from the environment to carry outgrowth and metabolism (Bouwer and Zehnder, 1993). Bacteria, protista and fungi are found to be very good at degrading complex molecules and incorporating the breakdown products into their metabolism (Bouwer and Zehnder, 1993). The resultant metabolic wastes that they produce are generally safe and somehow recycled into other organisms (Ranen and Sharadinadra, 2009). An acclimatized indigenous population of microorganisms capable of degradation of the compounds of interest must exist at the site for a successful bioremediation mode (Ranen and Sharadinadra, 2009). It has been observed that for a successful bioremediation mode, an acclimatized indigenous population of microorganisms capable of degradation of the compounds of interest must exist at the site under investigation (Ranen and Sharadinadra, 2009). Even though there are numerous physical and chemical methods employed in the disposal of wastes the advantage in using bacterium is that they play a key role in the reduction of COD, BOD, total protein, total tannin and total phenol (Saravanan and Saravanan, 1998)

Baba et al. (2020) studied the bioremediation potential of immobilized corynebacterium kutsceri in the Treatment of tannery industrial effluent from Challawa Industrial Estate, Kano State, Nigeria. The aim of the work is to study the reduction in the level of the contaminants through the process of bioremediation using the isolated bacteria. Immobilized bacteria can withstand various temperatures, $\mathrm{pH}$ and substrate concentrations; consequently, increasing the efficiency and the lifespan of the bacteria. Immobilized bacteria are widely applied in the treatment of wastewater and can be separated and recovered after the treatment with the same efficiency (Baba et al., 2020).

\section{MATERIALS AND METHODS \\ Study Area}

This study was carried out in Bompai, Sharada and Challawa industrial estates in Kano, Figure 1. Kano lies on Latitude $11^{\circ} 30^{\prime} \mathrm{N}$ and $8^{\circ} 30^{\prime} \mathrm{E}$ and Longitude $11^{\circ} 5^{\prime} \mathrm{N}$ and $8^{\circ} 5^{\prime} \mathrm{E}$ in Northern Nigeria. It is one of the developed industrial cities in Nigeria. Tannery activities are the dominating industries and this could be one of the reasons for her high population density (Dan'Azumi and Bichi, 2010). Many researchers have studied biodegradation of tannery effluent using microorganisms. However, limited literature is available on the biodegradation of tannery effluent in Kano industrial estates using 
BAJOPAS Volume 13 Number 2, December, 2020 immobilized bacterial cells. This research work focuses on the potential of the use of the indigenous immobilized bacterial isolates in the treatment of tannery effluents in the industrial estates.

\section{Sample Collection}

Effluents were collected from the Tannery Industries from Bompai, Challawa and Sharada Industrial Estates, Kano, Nigeria. The effluents were collected over a period of six months (August 2017 to January 2018). Samples collected in a sterile 4-liter plastic container with a unique identification number were preserved using an ice-box that was transported to the Microbiology Laboratory, Department of Microbiology, Bayero University of Kano for analysis

\section{Sample Preparation and Sample Analysis}

Immediately after the collection of the effluent, $\mathrm{pH}$, TSS, TDS, COD, BOD levels were determined before treatment (Pre-treatment determination) and ten days after treatment (Post-treatment determination) as described in
APHA (1989) standard methods. $\mathrm{pH}$ was determined using Ecotests $\mathrm{pH}$ meter and TDS was determined using AQUALYTIC TDS Salinometer. BOD was determined as described by the standard method (APHA, 1992). COD and SS were determined using DR/2010 HACH portable data logging spectrophotometer (DWAF, 1992)

\section{Identification and Biochemical} Characterization of the Bacterial Isolates

The bacteria were isolated from the effluents using Serial Dilution according to the method described by APHA (1989). The biochemical tests such as oxidase, catalase, coagulase, indole (from $1 \%$ tryptone broth), citrate (Simmons citrate agar), methyl red/VogesProskauer (MR/VP), nitrate reduction, Starch Hydrolysis, Glucose, Maltose, and Lactose tests were carried out on the bacterial isolates to identify the bacteria through the bacteria biochemical characteristics according to Ajao et al. (2011).

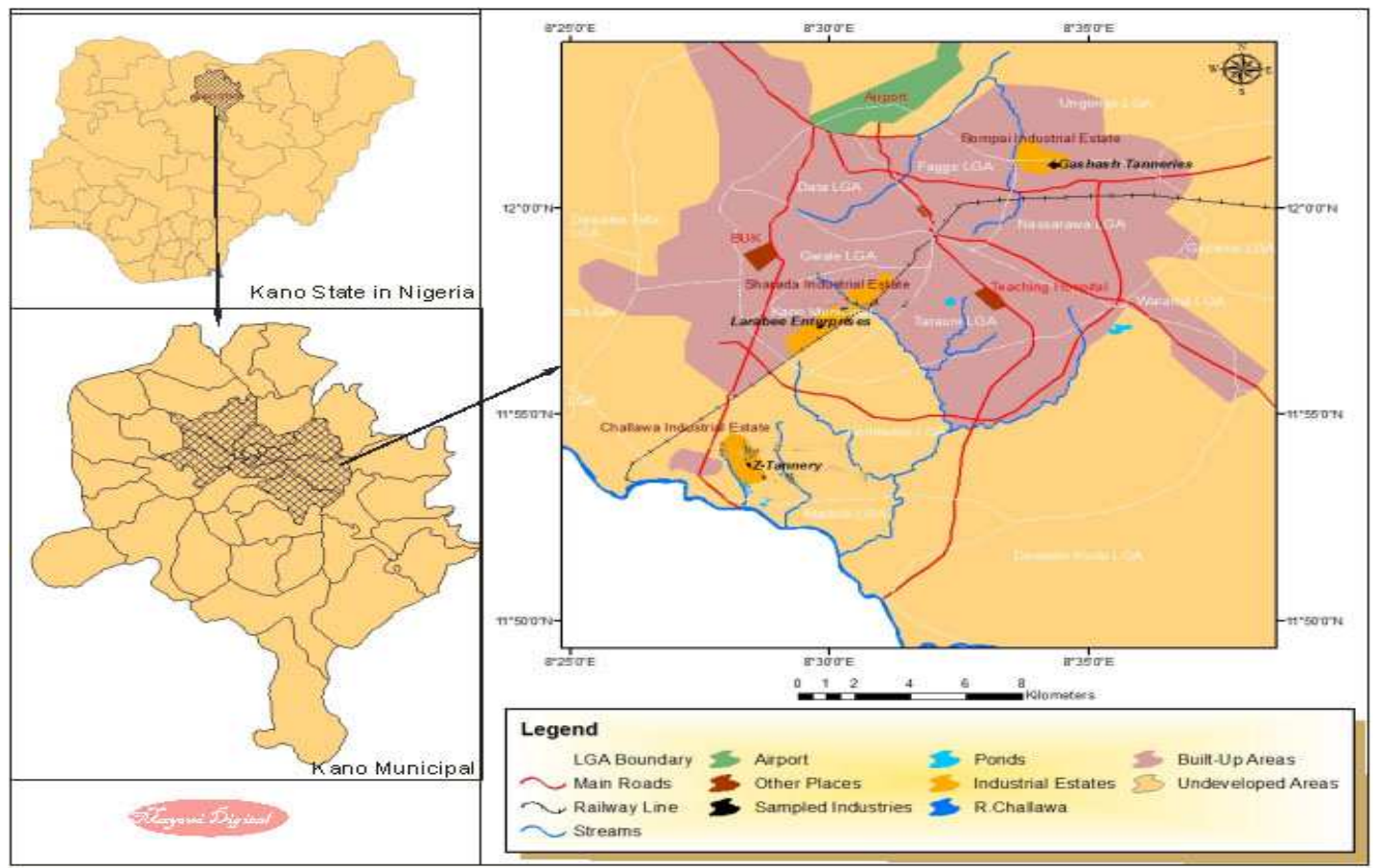

Fig. 1 Map showing the study areas

Source: Mayomi Digital Productions, GIS Laboratory, Department of Geography, UNIMAID (2017)

\section{Determination of Growth Rate of the Bacteria in Effluent Sample}

The bacteria growth rates were determined by transferring $2 \mathrm{~mL}$ of the bacterial isolates from the tannery effluent in broth medium into 100 $\mathrm{mL}$ sterile effluents in conical flasks and kept in an incubator (Giffrin cool) for 10 days. Control was also set up by incubating another $100 \mathrm{~mL}$ each of the sterile effluents without the bacteria. The optical density of the content was determined at the wavelength of $600 \mathrm{~nm}$ on a daily interval and recorded. 
BAJOPAS Volume 13 Number 2, December, 2020 Immobilization of Bacteria

Agar solution and inoculi were prepared separately. Fifty milliliters $(50 \mathrm{~mL})$ of nutrient broth each of the inoculi was prepared in a McCartney bottle and incubated for 24 hours. A solution of agar-agar was prepared by dissolving $10 \mathrm{~g}$ of the powder in distilled water and made up to $500 \mathrm{~mL}$ mark in an Erlenmeyer flask and was sterilized in an autoclave (280A) for 15 minutes and allowed to cool to $40-45^{\circ} \mathrm{C}$ (Ajao et al., 2011). Four milliliters ( $4 \mathrm{~mL})$ of the bacterial isolates in the nutrient broth was mixed with 36 $\mathrm{ml}$ of the prepared agar-agar media in petri-dish plates and then allowed to solidify. This was kept in the refrigerator for bioremediation.

\section{Bioremediation (Treatment) of the Effluents}

The solidified agar block (immobilized bacteria) was cut into cubes using a sterile knife; $0.1 \mathrm{~mL}$ phosphate buffer ( $\mathrm{pH} \mathrm{7.0)}$ was added and kept in the refrigerator for 1 hour for curing. The phosphate buffer was decanted after 1 hour and the cubes were washed with sterile distilled water 3-4 times before it was used (Ajao et al., 2011). Two liters (2 L) of the effluent was supplemented with the minimum basal medium in $\mathrm{g} / \mathrm{L}: \mathrm{NaCl}(0.8), \mathrm{MgSO}_{4} .7 \mathrm{H}_{2} \mathrm{O}(0.001), \mathrm{KH}_{2} \mathrm{PO}_{4}$ (2), $\mathrm{NaNO}_{3}$ (2), $\quad \mathrm{CaCl}_{2} .2 \mathrm{H}_{2} \mathrm{O} \quad(0.5)$ and $\mathrm{NaHPO}_{4} .12 \mathrm{H}_{2} \mathrm{O}(2)$ and sterilized in an autoclave at $121^{\circ} \mathrm{C}$ for 15 minutes (Margesin and Schinner, 2001). Two hundred and fifty milliliters $(250 \mathrm{~mL})$ of the effluents were transferred into different $250 \mathrm{ml}$ conical flasks. The content was covered with a cotton-wool ramped with foil paper to avoid contamination. Five grams $(5 \mathrm{~g})$ of the immobilized bacteria were quickly transferred into each of the effluents in the conical flasks in an inoculating chamber. The same procedures were carried out for the $10 \mathrm{~g}, 15 \mathrm{~g}, 20 \mathrm{~g}$ and 25 $\mathrm{g}$ of the immobilized bacteria in separate $250 \mathrm{~mL}$ effluents in conical flasks and agitated for ten days in a shaker incubator (Gallenkamp-OC4364-L) at a temperature $30^{\circ} \mathrm{C}$ and speed of 60 rpm. The treated effluent samples were taken on the tenth day and analyzed for the parameters $\mathrm{pH}$, SS, TDS, COD, and BOD, (Posttreatment determination) for the different grams of bacteria to evaluate and compare the biodegradation potential. (Baba et al., 2020).

\section{Statistical Analysis}

The data were represented as Mean \pm Standard deviation and analyzed statistically using oneway Analysis of Variance (ANOVA) and Tukey's HSD as Post Hoc Tests with the aid of SPSS 16.0. The correlation coefficient was also used to measure the strength of the relationship between the different masses of the bacteria and the parameters. All $\mathrm{p} \leq 0.05$ were considered as statistically significant.

\section{RESULTS AND DISCUSSION Physico-chemical parameters in the Industrial Effluents before the Biodegradation.}

Results of the Physico-chemical parameters in the industrial effluents before the Biodegradation is shown in table 1 . The mean temperatures $\left({ }^{\circ} \mathrm{C}\right)$ observed in TAN1, TAN2, and TAN3 samples were $28.07 \pm 0.65 ; 27.77 \pm 0.64$ and $26.38 \pm 3.81$ respectively. The order of the mean temperature of the samples from the three industries can be arranged as TAN1 > TAN2>TAN3. The temperature observed at TAN1, TAN2, and TAN3 samples were found below the WHO $\left(35^{\circ} \mathrm{C}\right)$ and NESREA $\left(40^{\circ} \mathrm{C}\right)$ limits. The low values of temperature might be due to the processes used at the time of sampling. High temperature brings down the solubility of gases in water that ultimately expresses as high BOD and COD. Statistical analysis shows that there is no significant difference $(p<0.05)$ between the mean values of temperature among the industries. This might be due to similar tannery activities involved in the tannery industries at the time of sampling. The average values of temperature observed in this present study are less than those observed by Akan et al. (2007), Akan et al. (2009) and Baba et al. (2020).

The mean level of $\mathrm{pH}$ observed in TAN1, TAN2 and TAN3, samples were $7.77 \pm 2.93$; $8.35 \pm 0.28$ and $7.52 \pm 0.76$ respectively. The order of the mean $\mathrm{pH}$ of the samples from the three industries can be arranged as TAN2> TAN1 $>$ TAN3. The $\mathrm{pH}$ of the samples falls within the WHO (7.0-8.5) and NESREA (6-9) standard limits. Statistical analysis shows that there is no significant difference $(p<0.05)$ between the mean values of $\mathrm{pH}$ among the industries. This might be due to similar tannery activities involved in the tannery industries at the time of sampling. Maheshwari et al. (2017) reported that the level of $\mathrm{pH}$ in the effluents from the tannery industry in Vaniyambadi, India was 6.5 which was lower than that observed in the present study. The $\mathrm{pH}$ in the effluents from the tannery industries in Kano and Kaduna were reported to be 7.64 and 6.89, respectively (Akan et al., 2007; Mohammed et al., 2017). The average values of $\mathrm{pH}$ observed in this present study are less than those observed by Mohammed et al. (2017) and Baba et al. (2020). The mean level of SS $(\mathrm{mg} / \mathrm{l})$ observed in TAN1, TAN2, and TAN3 samples were 374 \pm 124 ; $358 \pm 335$ and $780 \pm 739$ respectively. The order of the mean SS in the samples from the three industries can be arranged as TAN3 > TAN1 $>$ TAN2. 
The SS observed in the samples were far above the recommended standard limits of regulating bodies WHO $(30 \mathrm{mg} / \mathrm{l})$ and NESREA $(10 \mathrm{mg} / \mathrm{l})$. Statistical analysis shows that there is no significant difference $(p<0.05)$ between the mean values of SS among the industries. This might be due to similar tannery activities involved in the tannery industries at the time of sampling. The average values of SS observed in this present study are less than that observed $(3700 \pm 122 \mathrm{mg} / \mathrm{l})$ by Akan et al. (2009) for tanneries in Kano. Also, the average values of SS observed in this present study are less than that observed by Mohammed et al. (2017) and Baba et al. (2020) with the exception in TAN3.

The mean level of TDS (mg/l) observed in TAN1, TAN2, and TAN3 samples were $3941 \pm 3703$; $3300 \pm 1714$ and $2653 \pm 1240$ respectively. The order of the mean TDS in the samples from the three industries can be arranged as TAN1>TAN2>TAN3. The TDS observed in the samples were far above the recommended standard limits of WHO $(250 \mathrm{mg} / \mathrm{l})$ and NESREA $(500 \mathrm{mg} / \mathrm{l})$. Statistical analysis shows that there is no significant difference $(p<0.05)$ between the mean values of TDS among the industries. This might be due to similar tannery activities involved in the tannery industries at the time of sampling. TDS in the effluents from the tannery industries in Kano, Nigeria was reported to be $1281 \mathrm{mg} / \mathrm{l}$ (Akan et al., 2007). The average values of SS observed in this present study are less than those observed by Mohammed et al. (2017) and Baba et al. 2020)

The mean level of COD (mg/l) observed in TAN1, TAN2 and TAN3 samples seasons were $2372 \pm 938 ; \quad 1406 \pm 208$ and $3532 \pm 1373$ respectively. The order of the mean COD of the samples from the three industries can be arranged as TAN3>TAN1> TAN2. The COD observed in TAN1, TAN2 and TAN3 samples were far above the recommended standard limits of regulating bodies $\mathrm{WHO}(40 \mathrm{mg} / \mathrm{l})$ and NESREA (40 mg/l). Statistical analysis shows that there is no significant difference $(p<0.05)$ in COD among the industries. This might be due to similar tannery activities involved in the tannery industries as at the time of sampling. The Chemical Oxygen demand (COD) is the amount of oxygen, in $\mathrm{mg} / \mathrm{L}$, required for the degradation of the compound of wastewater to occur. In comparison, the average values of COD observed in this present study were higher than that observed by Mohammed et al. (2017) but lower than that observed by Baba et al. (2020).

The mean levels of BOD $(\mathrm{mg} / \mathrm{l})$ observed in TAN1, TAN2 and TAN3 samples were $13.85 \pm 6.42 ; \quad 19.46 \pm 0.50$ and $17.13 \pm 3.14$ respectively. The order of the mean BOD in the samples from the three industries can be arranged as TAN2>TAN3>TAN1. The BOD observed in TAN1, TAN2 and TAN3 samples were found below the recommended limits of NESREA (200 mg/l) but above WHO (10 mg/l). Statistical analysis shows that there is no significant difference $(p<0.05)$ between the mean values of BOD among the industries. This might be due to similar tannery activities involved in the tannery industries at the time of sampling. The low level of BOD recorded in this study is an indication of the low level of biodegradable organic solids in the effluent. The average values of BOD observed in this present study were lower than those observed by Mohammed et al. (2017) and Baba et al. (2020).

Table 1: Mean Values \pm S.D of Physico-chemical parameters of effluents from the Tannery Industries before Treatment.

\begin{tabular}{llllllll}
\hline Parameter & Tannery 1 & Tannery 2 & Tannery 3 & $\mathrm{a}$ & $\mathrm{b}$ & $\mathrm{c}$ & $\mathrm{d}$ \\
\cline { 2 - 7 } Temperature $\left({ }^{\circ} \mathrm{C}\right)$ & $28.07 \mathrm{a} \pm 0.65$ & $27.77 \mathrm{a} \pm 0.64$ & $26.38 \mathrm{a} \pm 3.81$ & & $29.50 \pm 4.68$ & 35 & 40 \\
pH & $7.77 \mathrm{a} \pm 2.93$ & $8.35 \mathrm{a} \pm 0.28$ & $7.52 \mathrm{a} \pm 0.76$ & 6.89 & $5.35 \pm 1.57$ & $7.0-8.5$ & $6.0-9.0$ \\
$\mathrm{COD}(\mathrm{mg} / \mathrm{l})$ & $2372 \mathrm{a} \pm 938$ & $1406 \mathrm{a} \pm 208$ & $3532 \mathrm{a} \pm 1373$ & 2.2 & $3106 \pm 2753$ & 40 & 40 \\
$\mathrm{BOD}(\mathrm{mg} / \mathrm{l})$ & $13.85 \mathrm{a} \pm 6.42$ & $19.46 \mathrm{a} \pm 0.50$ & $17.13 \mathrm{a} \pm 3.14$ & 1032 & $26.17 \pm 9.49$ & 10 & 200 \\
$\mathrm{SS}(\mathrm{mg} / \mathrm{l})$ & $374 \mathrm{a} \pm 124$ & $358 \mathrm{a} \pm 335$ & $780 \mathrm{a} \pm 739$ & 501 & $562 \pm 482$ & 30 & 10 \\
TDS $(\mathrm{mg} / \mathrm{l})$ & $3941 \mathrm{a} \pm 3703$ & $3300 \mathrm{a} \pm 1714$ & $2653 \mathrm{a} \pm 1240$ & 532.7 & $444 \pm 507$ & 250 & 500 \\
\hline
\end{tabular}

The values given in the table above are means of 6 replicate values, $\mathrm{n}=6$ ( 1 sample was taken monthly for 6 months). Within the rows, means with different alphabets are statistically different $(p<0.05)$. WHO: World Health Organisation. NESREA: National Environmental Standard and Regulatory Enforcement Agency. a = Mohammed et al.(2017), b = Baba et al. (2020), c = WHO (2006), $d=$ NESSRA (2009) 
BAJOPAS Volume 13 Number 2, December, 2020

Identification, Biochemical Characterization and growth rates of the Bacterial Isolates

Results of identification and biochemical characterization of the bacterial isolates were shown in table 2. After 24 hours of incubation, the nutrient agar media plates were checked for bacterial growth. The results showed the presence of different strains in the samples. The TAN1 bacteria isolate was found to be gramnegative cocci while TAN3 was gram-positive cocci. TAN2 bacteria isolate was found to be gram-positive, rod-shaped. TAN1, TAN2, and TAN3 bacteria isolates recorded positive results for spore former.

The results of the biochemical tests indicated that all the bacteria were positive for catalase, oxidase, citrate, maltose, glucose, lactose (negative in TAN1), mannitol (negative in TAN2), starch hydrolysis and coagulase (negative in TAN2) tests. The bacteria showed negative results for nitrate reduction, $M R$ (positive in TAN2), VP (positive in TAN1), Indole (positive in TAN2) tests. Base on the morphological and biochemical test results, TAN1, TAN2, and TAN3 bacteria isolates were identified to be Nesseria spp, Bacillus cereus, and Staphylococcus aureus respectively.

The growth rate of the TAN1, TAN2 and TAN3 Isolates were shown in figure 2. Generally, the optical density increase with the increase in time (day) and decrease as time goes on. The highest optical density was shown by bacillus cereus in TAN2 while the lowest was shown by Staphylococcus aureus in TAN3.

The initial growth phase of TAN1 Isolate bacteria occurred within 2-day of incubation as the growth rate increases up to the 6th-day incubation when the maximum growth was observed. Beyond the 6th day, the growth of the bacteria declined (which might be due to a shortage of nutrients in the effluents) until it reached its death phase (which might be due to the unavailability of nutrients in the effluents).

A similar trend of growth was also observed for TAN2 Isolate as the initial growth phase also occurred within 2-day of incubation but maximum growth rate observed on the 4th day of incubation. The stationary stage occurred between the 4th day and the 8th day. Beyond the 8th day, the growth of the bacteria declined (which might be due to a shortage of nutrients in the effluents) until it reached its death phase (which might be due to the unavailability of nutrients in the effluents).

The initial growth phase of TAN3 bacterial Isolate occurred within the 3-day incubation as the growth rate increases up to the 6th-day incubation when the maximum growth was observed. Beyond the 6th day, the growth of the bacteria declined (which might be due to a shortage of nutrients in the effluents) until it reached its death phase (which might be due to the unavailability of nutrients in the effluents).

Table 2: Morphological and Biochemical characteristics of bacterial isolates

\begin{tabular}{lllll} 
Bacterial Isolates & & TAN1 & TAN2 & TAN3 \\
\hline $\begin{array}{lllll}\text { Morphological } \\
\text { characteristics }\end{array}$ & Shape & Cocci & Rod & Cocci \\
& Spore & & & \\
& former & + & + & + \\
Gram & & & \\
Biochemical characteristics & reaction & - & + & + \\
& Citrate & + & + & + \\
& Catalase & + & + & + \\
& Coagulase & + & - & + \\
Starch & + & + & + \\
& Glucose & + & + & + \\
Oxidase & + & + & + \\
& Indo & - & + & - \\
Lactose & - & + & + \\
Manitol & + & - & + \\
Maltose & + & + & + \\
MR & - & + & - \\
VP & + & - & - \\
& Nitrate & - & - & - \\
Reduction & - Neisseria & Bacillus & Staphylococcus \\
& Bacterial & cereus & aureus \\
& name & spp & cas
\end{tabular}

+ = Positive; - = Negative; MR=Methyl Red; VP= Voges-Proskauer 


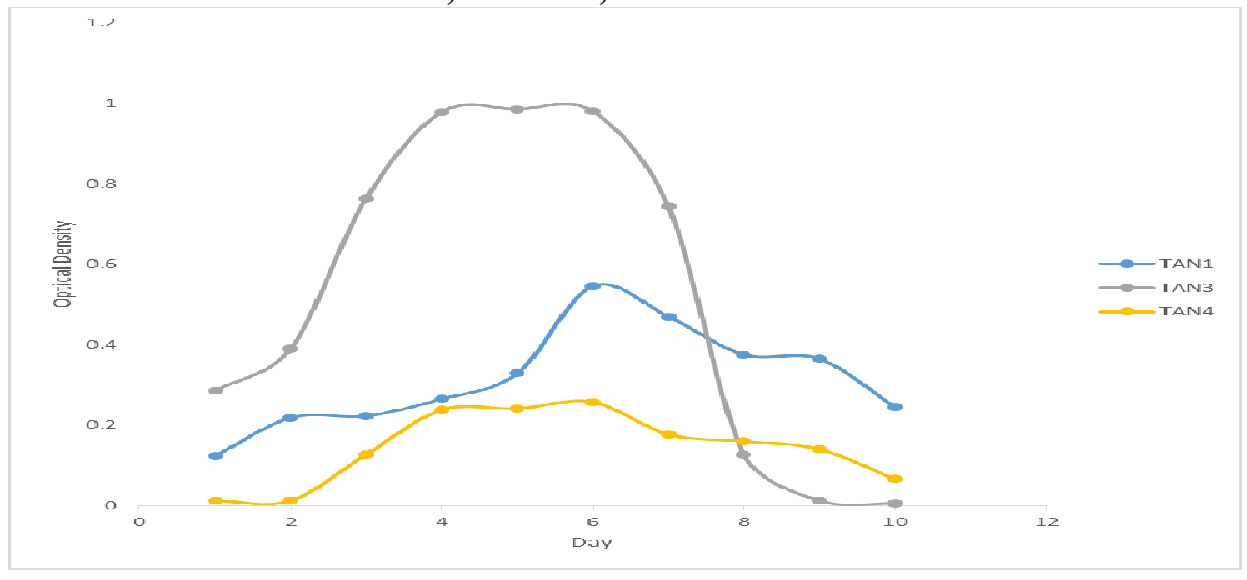

Fig. 2 Growth rates of the isolates in the effluents from the Tannery Industries

\section{Physico-chemical Parameters in the Industrial Effluents after the biodegradation.}

Table 3 shows the mean results of the physicochemical parameter before and after bioremediation using the different masses $(5 \mathrm{~g}$, $10 \mathrm{~g}, 15 \mathrm{~g}, 20 \mathrm{~g}$, and $25 \mathrm{~g}$ ) of the respective immobilized bacteria. Also, Table 4 shows the mean results of correlation coefficient ( $r$ ) between different masses of bacteria and physicochemical parameters.

The mean values $(\mathrm{mg} / \mathrm{l})$ of the SS after the bioremediation varies between $243 \pm 45$ and $898 \pm 672$. The mean concentration $(\mathrm{mg} / \mathrm{l})$ of SS remediated by the different masses $(5 \mathrm{~g}, 10 \mathrm{~g}$, $15 \mathrm{~g}, 20 \mathrm{~g}$, and $25 \mathrm{~g}$ ) of the bacteria varies. The SS in the samples fluctuates up and down after the bioremediation process when compared with the SS of the raw samples before the bioremediation. The increase in the levels of the SS might be due to the aggregation of the TDS which are large enough to result into SS. The increase in the levels of the SS might be also due to the influence of the nutrients which was added into the effluents in order to make the microorganisms more active and viable for fast degradation of organic contaminants in the effluent. The relative potential or efficiency of the different masses of the bacteria in remediating SS in TAN1 samples was in the order $25 \mathrm{~g}>20 \mathrm{~g}>15 \mathrm{~g}>10 \mathrm{~g}>5 \mathrm{~g}$. For TAN2 and TAN3 samples, the order was $25 \mathrm{~g}>20 \mathrm{~g}>15$ $\mathrm{g}>10 \mathrm{~g}>5 \mathrm{~g}$. These might be due to the variations in the surface areas of the different masses of the immobilized bacteria. Statistical analysis shows that there is no significant difference $(p<0.05)$ between the mean values of SS among the masses in the respective industries. Positive and significant correlations exist between the masses of bacteria and Suspended Solid (SS). This showed that there is general increase in the levels of the SS as the masses of the immobilized bacteria increases. TAN3 (90\%) and TAN1 (80\%) showed a very high correlation with the masses of the bacteria while TAN2 (61\%) showed a very low correlation.

The mean values $(\mathrm{mg} / \mathrm{l})$ of the TDS after the bioremediation varies between $46 \pm 11$ and $83 \pm 78$. The mean concentration $(\mathrm{mg} / \mathrm{l})$ of TDS remediated by the different masses $(5 \mathrm{~g}, 10 \mathrm{~g}$, $15 \mathrm{~g}, 20 \mathrm{~g}$, and $25 \mathrm{~g}$ ) of the bacteria varies. There is a reduction in all the TDS of all the samples after the bioremediation process compared with the TDS of the raw samples before the bioremediation. The relative potential or efficiency of the different masses of the bacteria in remediating TDS in TAN1 and TAN3 samples was in the order $5 \mathrm{~g}>10 \mathrm{~g}>15 \mathrm{~g}>20$ $\mathrm{g}>25 \mathrm{~g}$. For TAN2 samples, the order was 20 $g>10 \quad g>25 \quad g>15 \quad g>5 \quad g$. Statistical analysis shows that there is no significant difference $(p<0.05)$ between the mean values of TDS among the masses in the respective industries. These might be due to the variations in the surface areas of the different masses of the immobilized bacteria. Positive and significant correlations exist between the masses of bacteria and TDS with the exception in TAN2 (negative and insignificant correlation). The positive correlations showed that there is general increase in the levels of the TDS as the masses of the immobilized bacteria increases. TAN1 $(96 \%)$ showed a very high correlation with the masses of the bacteria while TAN2 (47\%) showed a very low correlation.

The mean values $(\mathrm{mg} / \mathrm{l})$ of the BOD after the bioremediation varies between $1.56 \pm 0.20 \mathrm{mg} / \mathrm{l}$ and $6.92 \pm 5.49 \mathrm{mg} / \mathrm{l}$. The mean concentration $(\mathrm{mg} / \mathrm{l})$ of BOD remediated by the different masses $(5 \mathrm{~g}, 10 \mathrm{~g}, 15 \mathrm{~g}, 20 \mathrm{~g}$, and $25 \mathrm{~g}$ ) of the bacteria varies. There is a reduction in all the BOD of all the samples after the bioremediation process compared with the $\mathrm{BOD}$ of the raw 
BAJOPAS Volume 13 Number 2, December, 2020 samples before the bioremediation. The relative potential or efficiency of the different masses of the bacteria in remediating BOD in TAN1, TAN2 and TAN3 samples were in the order $25 \mathrm{~g}>20$ $\mathrm{g}>15 \mathrm{~g}>10 \mathrm{~g}>5 \mathrm{~g}, 25 \mathrm{~g}>15 \mathrm{~g}>5 \mathrm{~g}>10 \mathrm{~g}>20 \mathrm{~g}$ and $20 \mathrm{~g}>10 \mathrm{~g}>25 \mathrm{~g}>15 \mathrm{~g}>5 \mathrm{~g}$ respectively. Statistical analysis shows that there is significant difference $(p<0.05)$ between the mean values of BOD among the masses in the respective industries. These might be due to the variations in the surface areas of the different masses of the immobilized bacteria. Negative and significant correlations exist between the masses of bacteria and BOD. This showed that there is general decrease in the levels of the BOD as the masses of the immobilized bacteria increases. TAN1 (94\%) showed a very high correlation with the masses of the bacteria while TAN2 (4\%) showed a very low correlation.

The mean values $(\mathrm{mg} / \mathrm{l})$ of the COD after the bioremediation varies between $250 \pm 154$ and $3134 \pm 1595$. The mean concentration $(\mathrm{mg} / \mathrm{l})$ of COD remediated by the different masses $(5 \mathrm{~g}$, $10 \mathrm{~g}, 15 \mathrm{~g} 20 \mathrm{~g}$, and $25 \mathrm{~g}$ ) of the bacteria varies. There is a reduction in all the COD of all the samples after the bioremediation process compared with the COD of the raw samples before the bioremediation. The relative potential or efficiency of the different masses of the bacteria in remediating COD in TAN1, TAN2 and TAN3 samples were in the order $25 \mathrm{~g}>20 \mathrm{~g}>15$ $\mathrm{g}>5 \mathrm{~g}>10 \mathrm{~g}, 25 \mathrm{~g}>20 \mathrm{~g}>15 \mathrm{~g}>10 \mathrm{~g}>5 \mathrm{~g}$ and 10 g>5 g>25 g>15 g>20 g respectively. Statistical analysis shows that there were significant difference $(p<0.05)$ between the mean values of COD among the masses in the respective industries except for effluents treated with $25 \mathrm{~g}$. These might be due to the variations in the surface areas of the different masses of the immobilized bacteria. Negative and insignificant correlations exist between the masses of bacteria and COD with the exception in TAN3 (positive and significant correlation). The negative correlations showed that there is general decrease in the levels of the COD as the masses of the immobilized bacteria increases. TAN2 (100\%) showed a very high correlation with the masses of the bacteria while TAN3 (36\%) showed a very low correlation.

Generally, there was an overall decrease in the concentration of these physicochemical parameters after the bioremediation using the different masses of the bacterial isolates. These might be due to the variations in the surface areas of the different masses of the immobilized bacteria. This is in line with the work of Jimoh et al. (2018) and Baba et al. (2020).

Table 3: Mean Values $(\mathrm{mg} / \mathrm{l}) \pm$ S.D of Physicochemical parameters in effluents from the Tannery Industries before and after Treatment of the effluents $(250 \mathrm{ml})$ with the different masses $(5 \mathrm{~g}, 10 \mathrm{~g}$, $15 \mathrm{~g}, 20 \mathrm{~g}$, and $25 \mathrm{~g}$ ) of the bacteria.

\begin{tabular}{llllllll}
\hline $\mathrm{P}$ & IND & Before & \multicolumn{5}{c}{ After } \\
\cline { 4 - 7 } & & & $5 \mathrm{~g}$ & $10 \mathrm{~g}$ & $15 \mathrm{~g}$ & $20 \mathrm{~g}$ & $25 \mathrm{~g}$ \\
\hline \multirow{2}{*}{ COD } & TAN1 & $2372 \pm 938$ & $1708 \mathrm{a} \pm 861$ & $2045 \mathrm{a} \pm 1205$ & $845 \mathrm{a} \pm 369$ & $300 \mathrm{a} \pm 167$ & $250 \mathrm{a} \pm 154$ \\
& TAN2 & $1406 \pm 208$ & $1195 \mathrm{a} \pm 208$ & $1125 \mathrm{a} \pm 384$ & $1055 \mathrm{a} \pm 317$ & $956 \mathrm{a} \pm 310$ & $870 \mathrm{ab} \pm 240$ \\
& TAN3 & $3532 \pm 1373$ & $2374 \mathrm{a} \pm 1344$ & $1976 \mathrm{a} \pm 1405$ & $2757 \mathrm{a} \pm 1266$ & $3134 \mathrm{a} \pm 1595$ & $2614 \mathrm{~b} \pm 1105$ \\
BOD & TAN1 & $13.85 \pm 6.42$ & $6.92 \mathrm{a} \pm 5.49$ & $6.42 \mathrm{a} \pm 5.07$ & $5.72 \mathrm{a} \pm 5.35$ & $4.62 \mathrm{a} \pm 4.37$ & $2.82 \mathrm{ab} \pm 1.26$ \\
& TAN2 & $19.46 \pm 0.50$ & $1.75 \mathrm{~b} \pm 0.22$ & $1.73 \mathrm{~b} \pm 0.18$ & $1.58 \mathrm{a} \pm 0.16$ & $1.91 \mathrm{a} \pm 0.22$ & $1.56 \mathrm{~b} \pm 0.20$ \\
& TAN3 & $17.13 \pm 3.14$ & $4.24 \mathrm{ab} \pm 0.77$ & $3.29 \mathrm{ab} \pm 0.37$ & $4.11 \mathrm{a} \pm 0.07$ & $3.23 \mathrm{a} \pm 0.91$ & $3.33 \mathrm{a} \pm 1.28$ \\
SS & TAN1 & $374 \pm 124$ & $243 \mathrm{a} \pm 45$ & $471 \mathrm{a} \pm 226$ & $475 \mathrm{a} \pm 182$ & $492 \mathrm{a} \pm 128$ & $611 \mathrm{a} \pm 217$ \\
& TAN2 & $358 \pm 335$ & $460 \mathrm{a} \pm 400$ & $543 \mathrm{a} \pm 414$ & $544 \mathrm{a} \pm 402$ & $551 \mathrm{a} \pm 414$ & $554 \mathrm{a} \pm 405$ \\
& TAN3 & $780 \pm 739$ & $586 \mathrm{a} \pm 594$ & $758 \mathrm{a} \pm 656$ & $787 \mathrm{a} \pm 676$ & $861 \mathrm{a} \pm 635$ & $898 \mathrm{a} \pm 672$ \\
TDS & TAN1 & $3941 \pm 3703$ & $51 \mathrm{a} \pm 10$ & $53 \mathrm{a} \pm 10$ & $55 \mathrm{a} \pm 15$ & $61 \mathrm{a} \pm 20$ & $63 \mathrm{a} \pm 26$ \\
& TAN2 & $3300 \pm 1714$ & $83 \mathrm{a} \pm 78$ & $47 \mathrm{a} \pm 20$ & $48 \mathrm{a} \pm 22$ & $47 \mathrm{a} \pm 17$ & $48 \mathrm{a} \pm 17$ \\
& TAN3 & $2653 \pm 1240$ & $46 \mathrm{a} \pm 11$ & $55 \mathrm{a} \pm 24$ & $55 \mathrm{a} \pm 25$ & $58 \mathrm{a} \pm 23$ & $61 \mathrm{a} \pm 28$ \\
\hline
\end{tabular}

Replicate $=6$ (months)

Within the rows, for the same parameter, means with different alphabets are statistically different $(p<0.05)$.

$\mathrm{P}=$ parameter, IND = Industries 
BAJOPAS Volume 13 Number 2, December, 2020

Table 4: Correlation coefficient $(r)$ between different masses of the bacteria and the physicochemical parameters.

\begin{tabular}{llll}
\hline Industries & Parameter & Correlation coefficient $(r)$ & $\begin{array}{l}\text { Percent dependence (rxrx100) } \\
(\%)\end{array}$ \\
\hline TAN1 & COD & -0.9 & 82 \\
& BOD & -0.97 & 94 \\
& SS & $0.90^{*}$ & 80 \\
TAN2 & TDS & $0.98^{*}$ & 96 \\
& COD & -1 & 100 \\
& BOD & -0.21 & 4 \\
& SS & $0.78^{*}$ & 61 \\
& TDS & -0.69 & 47 \\
& COD & $0.60^{*}$ & 36 \\
& BOD & -0.6 & 37 \\
& SS & $0.95^{*}$ & 90 \\
& TDS & $0.94^{*}$ & 89 \\
\hline
\end{tabular}

The correlation coefficient $(r)$ with * is statistically significant $(p<0.05)$.

Percentage reduction of the Parameters

Table 5 shows the percentage reduction of Parameters in industrial samples before and after the treatment of the effluents $(250 \mathrm{ml})$ with the different masses $(5 \mathrm{~g}, 10 \mathrm{~g}, 15 \mathrm{~g}, 20 \mathrm{~g}$, and $25 \mathrm{~g}$ ) of the Immobilized Bacteria.

In TAN1 samples, the percentage reduction (\%) of COD ranged (14-89); BOD (50-80); SS (-32$35)$ and TDS (98-99). In TAN2 samples, the percentage decrease $(\%)$ of COD ranged (15$38) ;$ BOD (90-92); SS [-28-(-55)] and TDS (9798). In TAN3 samples, the percentage decrease (\%) of COD ranged (11-44); BOD (76-81); SS (15-25) and TDS (98). The percentage increase in the levels COD, BOD and TDS might be due to the increase in the surface area of the different masses of the immobilized bacteria. However, the percentage decrease in the levels of the SS might be due to the aggregation of the TDS which are large enough to result into SS. The percentage decrease in the levels of the SS might be also due to the influence of the nutrients which was added into the effluents in order to make the microorganisms more active and viable for fast degradation of organic contaminants in the effluent. This is in line with the work of Jimoh et al. (2018) in which the concentration of the SS increase after the bioremediation of effluents.

Sreemoyee and Priti (2013) assessed and reduced several Physico-chemical parameters of dairy wastewater using Niesseria $s p$. and concluded that the species are well known to degrade organic compounds. This is in agreement with the current study in which the immobilized Niesseria $s p$ degrade the organic contaminants as indicated by the BOD, COD and TDS.

Jimoh et al. (2018) observed that TSS of the effluents was increased after treatment with immobilized bacteria and concluded that it might be due to the biostimulation method adopted for the research.

The optimum $\mathrm{pH}$ Biosorption of Chromium by Bacillus spp and Staphylococcus spp. from tannery effluent was investigated by Mythili and Karthikeyan (2011). The maximum adsorption of Chromium $(86.4 \mathrm{mg} / \mathrm{L})$ was showed by Bacillus spp and Staphylococcus spp showed $70.6 \mathrm{mg} / \mathrm{L}$ at an initial concentration of $100 \mathrm{mg} / \mathrm{L}$. In the present study, immobilised Bacillus spp and Staphylococcus spp. from the tannery industrial effluents reduced the levels of the organic pollutants with high potential as indicated by the percentage reduction of BOD, COD and TDS.

Enzymes often can work in multiple environments especially if they are immobilized. This makes the microorganisms' enzymes even more resistant to harsh environments and enables the enzymes to be recovered and recycled after they are no longer needed (Gianfreda and Rao 2004). Ramesh and Singh (1993) reported that the immobilized bacteria having more efficiency to remove the suspended particles than free cells. Using the immobilized cell is preferable due to its capability for using several times with the same efficiency, which makes it more economical. Similar work was done by Sikander et al. (2007) showing the higher reduction with permeabilized cells of Ochrobactrum intermedium strain SDCr-5. 
BAJOPAS Volume 13 Number 2, December, 2020

The results revealed the isolation and identification of isolates with the potential for the reduction of $\mathrm{Cr}$ (VI) to $\mathrm{Cr}$ (III). Results indicated that immobilized $B$. cereus could be efficiently used for the reduction of $\mathrm{Cr}$ (VI).

Table 5: Percentage reduction of the tested Parameters from the tannery industrial samples of the Immobilized Bacteria.

\begin{tabular}{lllllll}
\hline \multirow{2}{*}{ Industries } & & \multicolumn{5}{c}{ Percentage Reduction $(\%)$} \\
\cline { 3 - 7 } & & $5 \mathrm{~g}$ & $10 \mathrm{~g}$ & $15 \mathrm{~g}$ & $20 \mathrm{~g}$ & $25 \mathrm{~g}$ \\
\hline TAN1 & COD & 28 & 14 & 64 & 87 & 89 \\
& BOD & 50 & 54 & 59 & 67 & 80 \\
& SS & 35 & -26 & -27 & -32 & -63 \\
& TDS & 99 & 99 & 99 & 98 & 98 \\
TAN2 & COD & 15 & 20 & 25 & 32 & 38 \\
& BOD & 91 & 91 & 92 & 90 & 92 \\
& SS & -28 & -52 & -52 & -54 & -55 \\
& TDS & 97 & 99 & 99 & 99 & 99 \\
& COD & 33 & 44 & 22 & 11 & 26 \\
& BOD & 75 & 81 & 76 & 81 & 81 \\
& SS & 25 & 3 & -1 & -10 & -15 \\
& TDS & 98 & 98 & 98 & 98 & 98 \\
\hline
\end{tabular}

Percentage Reduction $=(B-A) / B \times 100 \%$

$A=$ Concentration of the parameter after treatment

$\mathrm{B}=$ Concentration of the parameter before treatment

$+=$ percentage decrease

- = percentage increase

In general, immobilization makes the enzyme more resistant to temperature, $\mathrm{pH}$, and substrate concentration swings giving it a longer lifetime and higher productivity per active unit (Gianfreda and Rao, 2004; FuIlbrook, 1996; Russell et al, 2003; Kandelbauer et al., 2004). Immobilized cells have been used and studied extensively for the production of useful chemicals (Ohtake and Silver, 1994), the treatment of wastewaters (Chen et al., 2003; Wang et al., 2010). Although many workers described microbial degradation of tannery effluent, limited literature is available on the bioremediation of tannery effluent using immobilized bacterial cells in the Kano Industrial Estates.

\section{CONCLUSION}

The samples contained variable levels of the physicochemical parameters. The results of the Analysis of variance revealed that, no statistical difference $(p<0.05)$ was observed for the temperature, $\mathrm{pH}, \mathrm{SS}, \mathrm{TDS}, \mathrm{BOD}$ and $\mathrm{COD}$ among the three tannery industries before the treatment. The levels of some of the parameters
(SS, TDS and COD) observed in the samples were found above the recommended limits of WHO and NESREA, which called for the treatment of the effluents before discharge into the environment. Base on the morphological and biochemical test results, TAN1, TAN2, and TAN3 bacterial isolates were identified to be Neisseria spp, Bacillus cereus, and Staphylococcus aureus respectively. The results of Post-treatment analysis showed that there is overall decrease in the levels of the parameters determined when compared with that of the pre-treatment. The overall percentage reduction of the immobilised bacteria in the treatment of the respective effluents was in the order TAN2 (72\%)>TAN1 $(70 \%)>$ TAN3 $(62 \%)$. Hence, the immobilized bacteria are having higher biodegradation potential for the treatment of the tannery effluents.

\section{Acknowledgments}

The authors wish to acknowledge the University of Maiduguri for the financial support. The authors are grateful to the Kano State Ministry of Environment for their support in obtaining the effluent samples. 


\section{REFERENCES}

Ajao, A. T., Adebayo, G. B., and Yakubu, S. E. (2011). Bioremediation of textile industrial effluent using mixed culture of Pseudomonas aeruginosa and Bacillus subtilis immobilized on agar-agar in a bioreactor. J. Microbiol. Biotech. Res, 1(3), 50-56.

Akan, J. C., Moses, E. A., Ogugbuaja, V. O., and Abah, J. (2007). Assessment of tannery industrial effluents from Kano metropolis, Kano State, Nigeria. Journal of Applied Sciences, 7(19), 2788-2793.

Akan, J. C., Ogugbuaja, V. O., Abdulrahman, F. I., and Ayodele, J. T. (2009). Pollutant levels in effluent samples from tanneries and textiles of Kano industrial areas, Nigeria. Global journal of pure and applied sciences, 15(3-4).

APHA (1989). Standard methods for Examination of Will bete and Will betewater.15 $5^{\text {th }}$ edition. Brydpass Springfield Will behington DC. pp. 164-176

APHA (1992). Standard Methods for the Examination of Water and Wastewater. Health, 69, 1116-9.

Baba, A., Garba, S. T., and Bello, H. S. (2020). Bioremediation Potential of Immobilized corynebacterium kutsceri in the Treatment of Tannery Industrial Effluent from Challawa Industrial Estate, Kano State, Nigeria. Journal of the Turkish Chemical Society Section A: Chemistry, $7(2), 335-350$.

Beem, E. I. V. (1994). reduction of solvent VOC emission. J. Oil Col. Chem. Ass, 77, 158.

Bouwer, E. J., and Zehnder, A. J. (1993). Bioremediation of organic compoundsputting microbial metabolism to work. Trends in biotechnology, 11(8), 360367.

Chen, K. C., Wu, J. Y., Liou, D. J., and Hwang, S. C. J. (2003). Decolorization of the textile dyes by newly isolated bacterial strains. Journal of Biotechnology, 101(1), 57-68.

Dan'Azumi, S., and Bichi, M. H. (2010). INDUSTRIAL POLLUTION AND HEAVY METALS PROFILE OF CHALLAWA RIVER IN KANO, NIGERIA. Journal of Applied Sciences in Environmental Sanitation, $5(1)$.

DWAF. (1992). Analytical Methods Manual, TR 151. Department of Water Affairs and Forestry, Pretoria.

El-Bestawy, E. (2013). Biological treatment of leather-tanning industrial wastewater using free living bacteria.
Elsheikh, M. A. S. (2009). Tannery wastewater pre-treatment. Water Science and Technology, 60(2), 433-440.

FuIlbrook, P. D. (1996). "Kinetics." Industrial enzymology: The application of enzymes in Industry. 2nd Ed. T. Godfrey and J Reichelt. eds.. Nature. New York.

Gianfreda, L., and Rao, M. A. (2004). Potential of extra cellular enzymes in remediation of polluted soils: a review. Enzyme and microbial technology, 35(4), 339354.

Hugo Springer. (1994). John Arthur Wilson Memorial Lecture "Treatment of Industrial Wastes of the Leather Industry - is it still a Major Problem". JALCA, 89, 153-185

Jimoh, A. A., Ganiyu, B. A., Baba, D., and Baba, A. (2018) Bioremediation Process of Effluent from Detergent and Food Industries in Jos, Nigeria: Kinetics and Thermodynamics. International Journal of Engineering Science Invention (IJESI), 762-73

Kandelbauer, A., Maute, O., Kessler, R. W., Erlacher, A., and Gübitz, G. M. (2004). Study of dye decolorization in an immobilized laccase enzyme-reactor using online spectroscopy. Biotechnology and bioengineering, 87(4), 552-563.

Kongjao, S., Damronglerd, S., and Hunsom, M. (2008). Simultaneous removal of organic and inorganic Pollutants in tannery wastewater using electrocoagulation technique. Korean Journal of chemical engineering, 25(4), 703.

Maheshwari, U. M., Aruna, S., Gomathi, M., and AbdulJaffar, A. H. (2017). Bioremediation by Free and Immobilized Bacteria Isolated from Tannery Effluent. International Journal of Research in Applied, Natural and Social Sciences. 5(7), 75-90

Margesin, R., and Schinner, F. (2001). Bioremediation (natural attenuation and biostimulation) of diesel-oilcontaminated soil in an alpine glacier skiing area. Applied and environmental microbiology, 677), 3127-3133.

Mohammed, A., Sekar, P., and George, J. (2011). Efficacy of microbes in bioremediation of tannery effluent. Inter. J. Curr. Res, 3(4), 324-326.

Mohammed, S. S. D., Orukotan, A. A., and Abdullahi, H. (2017). Physicochemical and Bacteriological Assessment of Tannery Effluent from Samaru-Zaria, 
BAJOPAS Volume 13 Number 2, December, 2020 Kaduna State, Nigeria. Journal of Applied

Sciences and Environmental Management, 21(4), 734-740.

Munz, G., De Angelis, D., Gori, R., Mori, G., Casarci, M., and Lubello, C. (2009). The role of tannins in conventional and membrane treatment of tannery wastewater. Journal of hazardous materials, 164(2-3), 733-739

Mythili, K., and Karthikeyan, B. (2011). Bioremediation of $\mathrm{Cr}$ (VI) from tannery effluent using Bacillus spp and Staphylococcus spp. International Multidisciplinary Research Journal, 1(6).

NESREA (2009). National Environmental Standards for Effluent Limitations and Regulation. 1233-1236

Noorjahan, C. M. (2014). Physicochemical characteristics, identification of bacteria and biodegradation of industrial effluent. Journal of bioremediation and Biodegradation, 5(3).

Ohtake, H. I., and Silver, A. O. (1994). Bacterial reduction of toxic chromate. Biological degradation and bioremediation of toxic chemicals, 403-415.

Omoleke, I. I. (2004). Management of environmental pollution in Ibadan, an African city: the challenges of health hazard facing government and the people. Journal of Human Ecology, 15(4), 265-275.

Rajor, A., Reddy, A.S., and Singh, B. (2004). Determination of BOD kinetic Parameters and evaluation of alternate methods, M.Sc. Thesis, Department of biotechnology \& environmental Science, Thapar Institute of Engineering and Technology, Patiala

Ramasami, T., Rajamani, S., and Rao, J. R. (1994, March). Pollution control in leather industry: Emerging technological options. In International symposium on surface and colloidal science and its relevance to soil pollution, madras.

Ramesh, J. V. S., and Singh, S. P. (1993). Yearly variation in certain physicochemical parameters of pond at eastern Doon Valley. Uttar Pradesh J. Zoo, 12 (1), 7577.

Ranen, S., and Sharadinadra, C. (2009). Biotechnology applications to environmental remediation in resource exploitation. Current science, 97, 6-25
Russell, A. J., Berberich, J. A., Drevon, G. F., and Koepsel, R. R. (2003). Biomaterials for mediation of

chemical and biological warfare agents. Annual review of biomedical engineering, 5(1), 1-27.

Saravanan, P., and Saravanan, A. (1999). Decolourization of tannery effluent by Flavobacterium sp. EK 1. Indian Journal of Environmental Protection, 19, 19-24.

Sikander, S., and Shahida, H. (2007). Reduction of toxic hexavalent chromium by Ochrobactrum intermedium strain SDCr5 stimulated by heavy metals. Bioresource Technol, 98, 340-344.

Singh, N., Sharma, B. K., and Bohra, P. C. (2000). Impact assessment of industrial effluent of arid soils by using satellite imageries. Journal of the Indian Society of Remote Sensing, 28(2-3), 79.

Sreemoyee, C., and Priti, P. (2013). Assessment of physico-chemical parameters of dairy waste water and isolation and characterization of bacterial strains in terms of cod reduction. Int J Sci, 2(3), 395-400.

Verheijen, L. A. H. M., Wiersema, D., Pol, L. H., and De Wit, J. (1996). Management of wastes from animal product processing. Livestock and environment, Finding a balance. International Agriculture Center, Wageningen, The Netherlands.

Wang, F., Yao, J., Si, Y., Chen, H., Russel, M., Chen, K., and Bramanti, E. (2010). Short-time effect of heavy metals upon microbial community activity. Journal of Hazardous Materials, 173(13), 510-516.

WHO (World Health Organization). (2006). Air quality guidelines: global update 2005: particulate matter, ozone, nitrogen dioxide, and sulfur dioxide. World Health Organization.

World Bank. (1995). Nigeria's strategic options for redressing industrial pollution. World Bank, industry and energy division. 1st edition, West Central Africa Department; Annexes: 1995; pp 60-62.

Zahoor, A., and Abdul, R. (2009). Enumeration of Coliforms. Journal of Environmental Sciences. 21, 814-820 


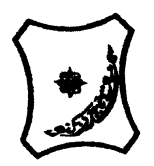

Bayero Journal of Pure and Applied Sciences, 13(2): 1 - 12

Received: November, 2020

Accepted: December, 2020

ISSN $2006-6996$

\title{
BIODEGRADATION POTENTIAL OF IMMOBILIZED BACTERIA IN THE TREATMENT OF TANNERY INDUSTRIAL EFFLUENTS FROM INDUSTRIAL ESTATES IN KANO STATE, NIGERIA
}

\author{
Abdullateef, B., ${ }^{1 *}$ Shuaibu, T. G., ${ }^{1}$ Babagana, K., ${ }^{1}$ Suleman, H. B. ${ }^{2}$ and Dauda, B. ${ }^{3}$ \\ ${ }^{1}$ Department of Pure and Applied Chemistry, Faculty of Science, University of Maiduguri, Borno State, \\ Nigeria \\ ${ }^{2}$ Department of Microbiology, Faculty of Science, University of Maiduguri, Borno State, Nigeria \\ ${ }^{3}$ Department of Chemical Engineering, Faculty of Engineering, University of Maiduguri, Borno State, \\ Nigeria \\ *Corresponding author: babslega@gmail.com; abelega2007@yahoo.com; +2348061309753
}

\section{ABSTRACT}

Industrial Effluents Samples from Gashash Tanneries (TAN1) in Bompai Industrial estate, Larabee Tannery Industry (TAN2) in Sharada Industrial estate and Z Tannery Industries (TAN3) in Challawa Industrial estate, Kano State, Nigeria were collected over a period of six months (August 2017 to January 2018) for assessing the biodegradation potentials of bacteria in the treatment of organic pollutants within the effluents. Bacteria were isolated from the effluents and immobilized on agar-agar. Different masses (5 g, $10 \mathrm{gr}, 15$ $\mathrm{g}, 20 \mathrm{~g}$, and $25 \mathrm{~g}$ ) of the bacteria were used in the treatment of $250 \mathrm{ml}$ of the effluents for ten days in a shaker incubator (Gallenkamp-OC-4364-L) at the temperature $30{ }^{\circ} \mathrm{C}$ and speed of $60 \mathrm{rpm}$. Pre-treatment analysis of the effluents for Temperature, pH, Biochemical Oxygen Demand (BOD), Chemical Oxygen Demand (COD), Suspended Solid (SS) and Total Dissolved Solids (TDS) gives the following results; temperature $\left({ }^{\circ} \mathrm{C}\right.$ )

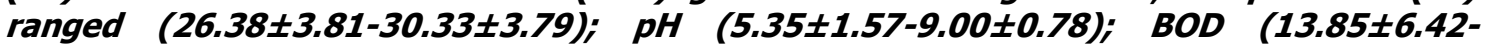
$38.75 \pm 16.20) ;$ COD (1406 $\pm 208-3532 \pm 1373) ;$ SS (208 $\pm 235-780 \pm 739)$ and TDS (266 $\pm 253-5276 \pm 2971)$. No statistical differences ( $p \leq 0.05)$ was observed for all the results among the different industries. The bacterial isolates were identified as Neisseria spp, Bacillus cereus, and Staphylococcus aureus, in TAN1, TAN2, and TAN3, respectively. After treatment of the effluent with the different masses of the isolated bacteria, the mean level of BOD was found to range as (0.55 $\pm 0.36-6.92 \pm 5.49) ; C O D$ (ND-3134 \pm 1595$)$;

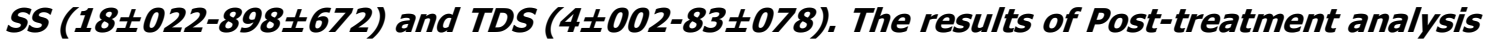
showed that there is overall decrease in the levels of the parameters determined when compared with that of the pre-treatment. The overall percentage reduction of the immobilised bacteria in the treatment of the respective effluents was in the order TAN2 (72\%)>TAN1 (70\%)>TAN3 (62\%). Hence, the immobilized bacteria are having higher biodegradation potential for the treatment of the tannery effluents.

Keywords: Biodegradation, bacteria, effluent, immobilization, tannery.

\section{INTRODUCTION}

Tannery industrial wastewater is a serious consequence of the pollution point of view for streams, freshwater, and land used for agriculture. The lack of awareness in the modern industrial practice has resulted in the discharge of tannery effluents which exhibit very high value of chromium ( $\mathrm{Cr}$ ), Sulfide, and chloride, Total Dissolved Solid (TDS), Total Suspended Solid (TSS), Biochemical Oxygen Demand (BOD) and Chemical Oxygen Demand (COD) in the water stream or land (Mohammed et al., 2001). Tanning is the process, which One ton of skin generally leads to the production of 20 to $80 \mathrm{~m}^{3}$ of turbid and foul-smelling converts the protein of the rawhide or skin into a stable material, which will not putrefy and is suitable for a wide variety of end applications (Elsheikh, 2009). The highly polluting chromium is the most commonly used tanning material producing leather that is more flexible and pliable than vegetable-tanned leather and does not discolor or lose shape in water as drastically as vegetable-tan (Elsheikh, 2009). Tannery effluent is among the most hazardous industrial pollutants due to its huge organic and inorganic load, which is highly toxic to human life and the environment (Kongjao et al., 2008). wastewater including chromium (100-400 mg/l), sulfide $(200-800 \mathrm{mg} / \mathrm{l})$, high levels of fat and 
BAJOPAS Volume 13 Number 2, December, 2020 other solid wastes, and notable pathogen contamination as well as pesticides added for skin conservation during transport (Elsheikh, 2009). There are more than 6000 tanneries in Nigeria with an annual processing capacity of 700,000 tons of hides and skins (Omoleke, 2004; Singh et al., 2008). It was reported that the total amount of waste produced per animal slaughtered is approximately $35 \%$ of its weight (World Bank, 1995). Also, for every $1000 \mathrm{~kg}$ of carcass weight, a slaughtered beef produces 5.5 $\mathrm{kg}$ of manure (excluding rumen contents or stockyard manure) and $100 \mathrm{~kg}$ of paunch manure (undigested food) (Verheijen et al., 1996). Tanneries generate wastewater in the range of 30-35 $\mathrm{L} \mathrm{kg}^{-1}$ skin/hide processed with variable $\mathrm{pH}$, Biological Oxygen Demand (BOD), Chemical Oxygen Demand (COD), high concentrations of suspended solids (SS), and tannins as well as chromium (Zahoor and Abdul, 2009).

Being heterogeneous and composed of a wide variety of compounds, it is very difficult to select a unique direct method for estimating the biodegradability of organic contents and biokinetic parameters for a wastewater sample (Rajor, 2004). For this purpose, some indirect estimation such as determination of biochemical oxygen demand (BOD) and chemical oxygen demand (COD) are applied as common laboratory investigations [9]. During retanning procedures, synthetic tannins (Syntan), oils and resins are added to form softer leather at varying doses (Munz et al., 2009). One of the refractory groups of chemicals in tannery effluents derives mainly from tannins (Ramasami et al., 2004). Syntans are characterized by complex chemical structures, because they are composed of an extended set of chemicals such as phenol-, naphthalene-, formaldehyde- and melamine-based syntans, and acrylic resins (Beem, 1994). Organic pollutants (proteic and lipidic components) are originated from skins (it is calculated that the raw skin has $30 \%$ loss of organic material during the working cycle) or they are introduced during processes (Hugo Springer, 1994).

Many conventional processes such as oxidation, chemical and biological processes were carried out to treat tanneries wastewater (Ebtesam et al, 2013). Biological processes have received more attention because of their costeffectiveness, lower sludge production and environmental friendliness (Noorjahan, 2014). Naturally occurring micro-organisms degrade the hazardous organic wastes including xenobiotic compounds, such as pesticides, polycyclic aromatic hydrocarbons (PAHs) and polychlorinated biphenyls (PCBs) in due course of time (Ranen and Sharadinadra, 2009). Bioremediation is based on the idea that all organisms remove substances from the environment to carry outgrowth and metabolism (Bouwer and Zehnder, 1993). Bacteria, protista and fungi are found to be very good at degrading complex molecules and incorporating the breakdown products into their metabolism (Bouwer and Zehnder, 1993). The resultant metabolic wastes that they produce are generally safe and somehow recycled into other organisms (Ranen and Sharadinadra, 2009). An acclimatized indigenous population of microorganisms capable of degradation of the compounds of interest must exist at the site for a successful bioremediation mode (Ranen and Sharadinadra, 2009). It has been observed that for a successful bioremediation mode, an acclimatized indigenous population of microorganisms capable of degradation of the compounds of interest must exist at the site under investigation (Ranen and Sharadinadra, 2009). Even though there are numerous physical and chemical methods employed in the disposal of wastes the advantage in using bacterium is that they play a key role in the reduction of COD, BOD, total protein, total tannin and total phenol (Saravanan and Saravanan, 1998)

Baba et al. (2020) studied the bioremediation potential of immobilized corynebacterium kutsceri in the Treatment of tannery industrial effluent from Challawa Industrial Estate, Kano State, Nigeria. The aim of the work is to study the reduction in the level of the contaminants through the process of bioremediation using the isolated bacteria. Immobilized bacteria can withstand various temperatures, $\mathrm{pH}$ and substrate concentrations; consequently, increasing the efficiency and the lifespan of the bacteria. Immobilized bacteria are widely applied in the treatment of wastewater and can be separated and recovered after the treatment with the same efficiency (Baba et al., 2020).

\section{MATERIALS AND METHODS \\ Study Area}

This study was carried out in Bompai, Sharada and Challawa industrial estates in Kano, Figure 1. Kano lies on Latitude $11^{\circ} 30^{\prime} \mathrm{N}$ and $8^{\circ} 30^{\prime} \mathrm{E}$ and Longitude $11^{\circ} 5^{\prime} \mathrm{N}$ and $8^{\circ} 5^{\prime} \mathrm{E}$ in Northern Nigeria. It is one of the developed industrial cities in Nigeria. Tannery activities are the dominating industries and this could be one of the reasons for her high population density (Dan'Azumi and Bichi, 2010). Many researchers have studied biodegradation of tannery effluent using microorganisms. However, limited literature is available on the biodegradation of tannery effluent in Kano industrial estates using 
BAJOPAS Volume 13 Number 2, December, 2020 immobilized bacterial cells. This research work focuses on the potential of the use of the indigenous immobilized bacterial isolates in the treatment of tannery effluents in the industrial estates.

\section{Sample Collection}

Effluents were collected from the Tannery Industries from Bompai, Challawa and Sharada Industrial Estates, Kano, Nigeria. The effluents were collected over a period of six months (August 2017 to January 2018). Samples collected in a sterile 4-liter plastic container with a unique identification number were preserved using an ice-box that was transported to the Microbiology Laboratory, Department of Microbiology, Bayero University of Kano for analysis

\section{Sample Preparation and Sample Analysis}

Immediately after the collection of the effluent, $\mathrm{pH}$, TSS, TDS, COD, BOD levels were determined before treatment (Pre-treatment determination) and ten days after treatment (Post-treatment determination) as described in
APHA (1989) standard methods. $\mathrm{pH}$ was determined using Ecotests $\mathrm{pH}$ meter and TDS was determined using AQUALYTIC TDS Salinometer. BOD was determined as described by the standard method (APHA, 1992). COD and SS were determined using DR/2010 HACH portable data logging spectrophotometer (DWAF, 1992)

\section{Identification and Biochemical} Characterization of the Bacterial Isolates

The bacteria were isolated from the effluents using Serial Dilution according to the method described by APHA (1989). The biochemical tests such as oxidase, catalase, coagulase, indole (from $1 \%$ tryptone broth), citrate (Simmons citrate agar), methyl red/VogesProskauer (MR/VP), nitrate reduction, Starch Hydrolysis, Glucose, Maltose, and Lactose tests were carried out on the bacterial isolates to identify the bacteria through the bacteria biochemical characteristics according to Ajao et al. (2011).

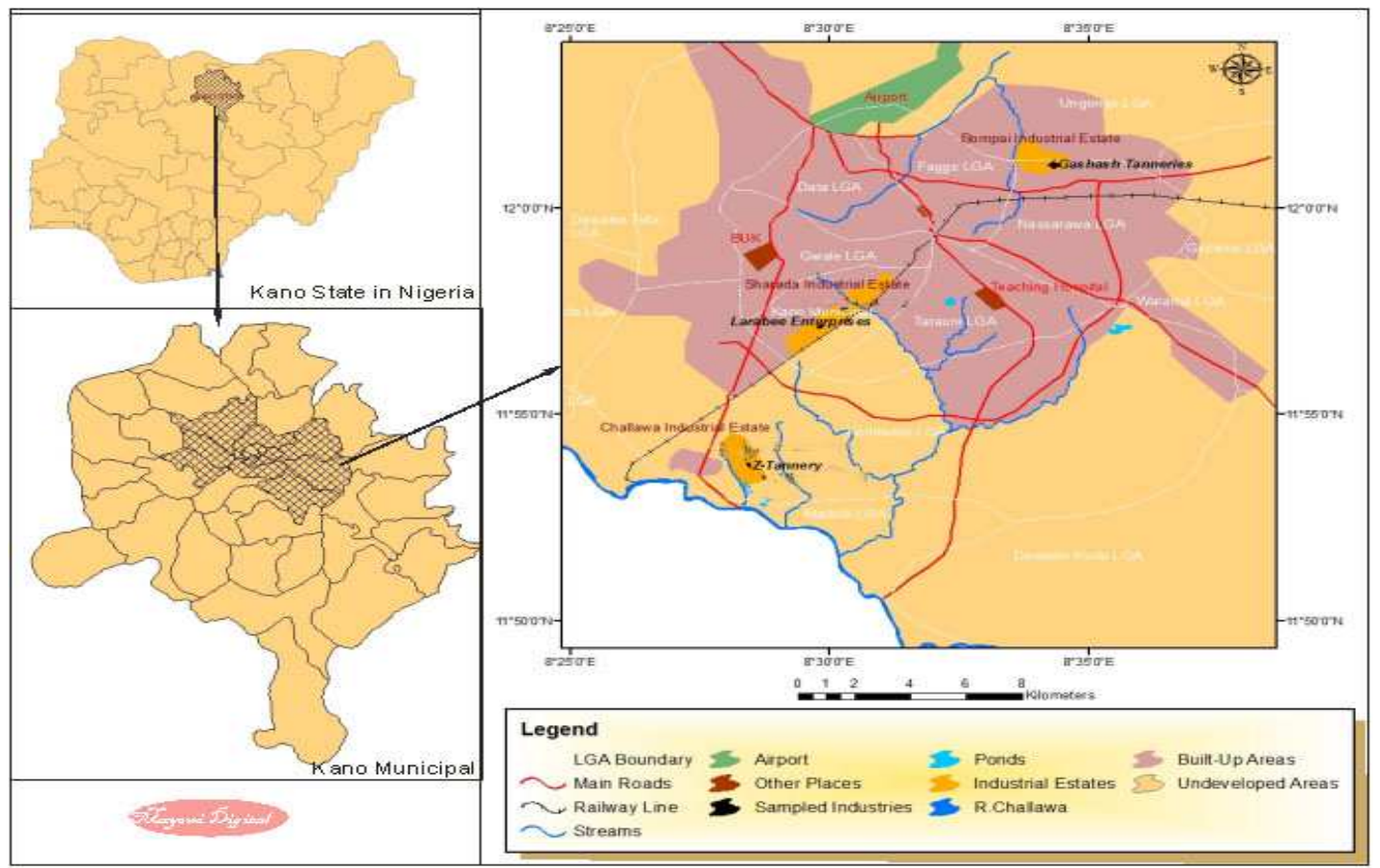

Fig. 1 Map showing the study areas

Source: Mayomi Digital Productions, GIS Laboratory, Department of Geography, UNIMAID (2017)

\section{Determination of Growth Rate of the Bacteria in Effluent Sample}

The bacteria growth rates were determined by transferring $2 \mathrm{~mL}$ of the bacterial isolates from the tannery effluent in broth medium into 100 $\mathrm{mL}$ sterile effluents in conical flasks and kept in an incubator (Giffrin cool) for 10 days. Control was also set up by incubating another $100 \mathrm{~mL}$ each of the sterile effluents without the bacteria. The optical density of the content was determined at the wavelength of $600 \mathrm{~nm}$ on a daily interval and recorded. 
BAJOPAS Volume 13 Number 2, December, 2020 Immobilization of Bacteria

Agar solution and inoculi were prepared separately. Fifty milliliters $(50 \mathrm{~mL})$ of nutrient broth each of the inoculi was prepared in a McCartney bottle and incubated for 24 hours. A solution of agar-agar was prepared by dissolving $10 \mathrm{~g}$ of the powder in distilled water and made up to $500 \mathrm{~mL}$ mark in an Erlenmeyer flask and was sterilized in an autoclave (280A) for 15 minutes and allowed to cool to $40-45^{\circ} \mathrm{C}$ (Ajao et al., 2011). Four milliliters ( $4 \mathrm{~mL})$ of the bacterial isolates in the nutrient broth was mixed with 36 $\mathrm{ml}$ of the prepared agar-agar media in petri-dish plates and then allowed to solidify. This was kept in the refrigerator for bioremediation.

\section{Bioremediation (Treatment) of the Effluents}

The solidified agar block (immobilized bacteria) was cut into cubes using a sterile knife; $0.1 \mathrm{~mL}$ phosphate buffer ( $\mathrm{pH} \mathrm{7.0)}$ was added and kept in the refrigerator for 1 hour for curing. The phosphate buffer was decanted after 1 hour and the cubes were washed with sterile distilled water 3-4 times before it was used (Ajao et al., 2011). Two liters (2 L) of the effluent was supplemented with the minimum basal medium in $\mathrm{g} / \mathrm{L}: \mathrm{NaCl}(0.8), \mathrm{MgSO}_{4} .7 \mathrm{H}_{2} \mathrm{O}(0.001), \mathrm{KH}_{2} \mathrm{PO}_{4}$ (2), $\mathrm{NaNO}_{3}$ (2), $\quad \mathrm{CaCl}_{2} .2 \mathrm{H}_{2} \mathrm{O} \quad(0.5)$ and $\mathrm{NaHPO}_{4} .12 \mathrm{H}_{2} \mathrm{O}(2)$ and sterilized in an autoclave at $121^{\circ} \mathrm{C}$ for 15 minutes (Margesin and Schinner, 2001). Two hundred and fifty milliliters $(250 \mathrm{~mL})$ of the effluents were transferred into different $250 \mathrm{ml}$ conical flasks. The content was covered with a cotton-wool ramped with foil paper to avoid contamination. Five grams $(5 \mathrm{~g})$ of the immobilized bacteria were quickly transferred into each of the effluents in the conical flasks in an inoculating chamber. The same procedures were carried out for the $10 \mathrm{~g}, 15 \mathrm{~g}, 20 \mathrm{~g}$ and 25 $\mathrm{g}$ of the immobilized bacteria in separate $250 \mathrm{~mL}$ effluents in conical flasks and agitated for ten days in a shaker incubator (Gallenkamp-OC4364-L) at a temperature $30^{\circ} \mathrm{C}$ and speed of 60 rpm. The treated effluent samples were taken on the tenth day and analyzed for the parameters $\mathrm{pH}$, SS, TDS, COD, and BOD, (Posttreatment determination) for the different grams of bacteria to evaluate and compare the biodegradation potential. (Baba et al., 2020).

\section{Statistical Analysis}

The data were represented as Mean \pm Standard deviation and analyzed statistically using oneway Analysis of Variance (ANOVA) and Tukey's HSD as Post Hoc Tests with the aid of SPSS 16.0. The correlation coefficient was also used to measure the strength of the relationship between the different masses of the bacteria and the parameters. All $\mathrm{p} \leq 0.05$ were considered as statistically significant.

\section{RESULTS AND DISCUSSION Physico-chemical parameters in the Industrial Effluents before the Biodegradation.}

Results of the Physico-chemical parameters in the industrial effluents before the Biodegradation is shown in table 1 . The mean temperatures $\left({ }^{\circ} \mathrm{C}\right)$ observed in TAN1, TAN2, and TAN3 samples were $28.07 \pm 0.65 ; 27.77 \pm 0.64$ and $26.38 \pm 3.81$ respectively. The order of the mean temperature of the samples from the three industries can be arranged as TAN1 > TAN2>TAN3. The temperature observed at TAN1, TAN2, and TAN3 samples were found below the WHO $\left(35^{\circ} \mathrm{C}\right)$ and NESREA $\left(40^{\circ} \mathrm{C}\right)$ limits. The low values of temperature might be due to the processes used at the time of sampling. High temperature brings down the solubility of gases in water that ultimately expresses as high BOD and COD. Statistical analysis shows that there is no significant difference $(p<0.05)$ between the mean values of temperature among the industries. This might be due to similar tannery activities involved in the tannery industries at the time of sampling. The average values of temperature observed in this present study are less than those observed by Akan et al. (2007), Akan et al. (2009) and Baba et al. (2020).

The mean level of $\mathrm{pH}$ observed in TAN1, TAN2 and TAN3, samples were $7.77 \pm 2.93$; $8.35 \pm 0.28$ and $7.52 \pm 0.76$ respectively. The order of the mean $\mathrm{pH}$ of the samples from the three industries can be arranged as TAN2> TAN1 $>$ TAN3. The $\mathrm{pH}$ of the samples falls within the WHO (7.0-8.5) and NESREA (6-9) standard limits. Statistical analysis shows that there is no significant difference $(p<0.05)$ between the mean values of $\mathrm{pH}$ among the industries. This might be due to similar tannery activities involved in the tannery industries at the time of sampling. Maheshwari et al. (2017) reported that the level of $\mathrm{pH}$ in the effluents from the tannery industry in Vaniyambadi, India was 6.5 which was lower than that observed in the present study. The $\mathrm{pH}$ in the effluents from the tannery industries in Kano and Kaduna were reported to be 7.64 and 6.89, respectively (Akan et al., 2007; Mohammed et al., 2017). The average values of $\mathrm{pH}$ observed in this present study are less than those observed by Mohammed et al. (2017) and Baba et al. (2020). The mean level of SS $(\mathrm{mg} / \mathrm{l})$ observed in TAN1, TAN2, and TAN3 samples were 374 \pm 124 ; $358 \pm 335$ and $780 \pm 739$ respectively. The order of the mean SS in the samples from the three industries can be arranged as TAN3 > TAN1 $>$ TAN2. 
The SS observed in the samples were far above the recommended standard limits of regulating bodies WHO $(30 \mathrm{mg} / \mathrm{l})$ and NESREA $(10 \mathrm{mg} / \mathrm{l})$. Statistical analysis shows that there is no significant difference $(p<0.05)$ between the mean values of SS among the industries. This might be due to similar tannery activities involved in the tannery industries at the time of sampling. The average values of SS observed in this present study are less than that observed $(3700 \pm 122 \mathrm{mg} / \mathrm{l})$ by Akan et al. (2009) for tanneries in Kano. Also, the average values of SS observed in this present study are less than that observed by Mohammed et al. (2017) and Baba et al. (2020) with the exception in TAN3.

The mean level of TDS (mg/l) observed in TAN1, TAN2, and TAN3 samples were $3941 \pm 3703$; $3300 \pm 1714$ and $2653 \pm 1240$ respectively. The order of the mean TDS in the samples from the three industries can be arranged as TAN1>TAN2>TAN3. The TDS observed in the samples were far above the recommended standard limits of WHO $(250 \mathrm{mg} / \mathrm{l})$ and NESREA $(500 \mathrm{mg} / \mathrm{l})$. Statistical analysis shows that there is no significant difference $(p<0.05)$ between the mean values of TDS among the industries. This might be due to similar tannery activities involved in the tannery industries at the time of sampling. TDS in the effluents from the tannery industries in Kano, Nigeria was reported to be $1281 \mathrm{mg} / \mathrm{l}$ (Akan et al., 2007). The average values of SS observed in this present study are less than those observed by Mohammed et al. (2017) and Baba et al. 2020)

The mean level of COD (mg/l) observed in TAN1, TAN2 and TAN3 samples seasons were $2372 \pm 938 ; \quad 1406 \pm 208$ and $3532 \pm 1373$ respectively. The order of the mean COD of the samples from the three industries can be arranged as TAN3>TAN1> TAN2. The COD observed in TAN1, TAN2 and TAN3 samples were far above the recommended standard limits of regulating bodies $\mathrm{WHO}(40 \mathrm{mg} / \mathrm{l})$ and NESREA (40 mg/l). Statistical analysis shows that there is no significant difference $(p<0.05)$ in COD among the industries. This might be due to similar tannery activities involved in the tannery industries as at the time of sampling. The Chemical Oxygen demand (COD) is the amount of oxygen, in $\mathrm{mg} / \mathrm{L}$, required for the degradation of the compound of wastewater to occur. In comparison, the average values of COD observed in this present study were higher than that observed by Mohammed et al. (2017) but lower than that observed by Baba et al. (2020).

The mean levels of BOD $(\mathrm{mg} / \mathrm{l})$ observed in TAN1, TAN2 and TAN3 samples were $13.85 \pm 6.42 ; \quad 19.46 \pm 0.50$ and $17.13 \pm 3.14$ respectively. The order of the mean BOD in the samples from the three industries can be arranged as TAN2>TAN3>TAN1. The BOD observed in TAN1, TAN2 and TAN3 samples were found below the recommended limits of NESREA (200 mg/l) but above WHO (10 mg/l). Statistical analysis shows that there is no significant difference $(p<0.05)$ between the mean values of BOD among the industries. This might be due to similar tannery activities involved in the tannery industries at the time of sampling. The low level of BOD recorded in this study is an indication of the low level of biodegradable organic solids in the effluent. The average values of BOD observed in this present study were lower than those observed by Mohammed et al. (2017) and Baba et al. (2020).

Table 1: Mean Values \pm S.D of Physico-chemical parameters of effluents from the Tannery Industries before Treatment.

\begin{tabular}{llllllll}
\hline Parameter & Tannery 1 & Tannery 2 & Tannery 3 & $\mathrm{a}$ & $\mathrm{b}$ & $\mathrm{c}$ & $\mathrm{d}$ \\
\cline { 2 - 7 } Temperature $\left({ }^{\circ} \mathrm{C}\right)$ & $28.07 \mathrm{a} \pm 0.65$ & $27.77 \mathrm{a} \pm 0.64$ & $26.38 \mathrm{a} \pm 3.81$ & & $29.50 \pm 4.68$ & 35 & 40 \\
pH & $7.77 \mathrm{a} \pm 2.93$ & $8.35 \mathrm{a} \pm 0.28$ & $7.52 \mathrm{a} \pm 0.76$ & 6.89 & $5.35 \pm 1.57$ & $7.0-8.5$ & $6.0-9.0$ \\
$\mathrm{COD}(\mathrm{mg} / \mathrm{l})$ & $2372 \mathrm{a} \pm 938$ & $1406 \mathrm{a} \pm 208$ & $3532 \mathrm{a} \pm 1373$ & 2.2 & $3106 \pm 2753$ & 40 & 40 \\
$\mathrm{BOD}(\mathrm{mg} / \mathrm{l})$ & $13.85 \mathrm{a} \pm 6.42$ & $19.46 \mathrm{a} \pm 0.50$ & $17.13 \mathrm{a} \pm 3.14$ & 1032 & $26.17 \pm 9.49$ & 10 & 200 \\
$\mathrm{SS}(\mathrm{mg} / \mathrm{l})$ & $374 \mathrm{a} \pm 124$ & $358 \mathrm{a} \pm 335$ & $780 \mathrm{a} \pm 739$ & 501 & $562 \pm 482$ & 30 & 10 \\
TDS $(\mathrm{mg} / \mathrm{l})$ & $3941 \mathrm{a} \pm 3703$ & $3300 \mathrm{a} \pm 1714$ & $2653 \mathrm{a} \pm 1240$ & 532.7 & $444 \pm 507$ & 250 & 500 \\
\hline
\end{tabular}

The values given in the table above are means of 6 replicate values, $\mathrm{n}=6$ ( 1 sample was taken monthly for 6 months). Within the rows, means with different alphabets are statistically different $(p<0.05)$. WHO: World Health Organisation. NESREA: National Environmental Standard and Regulatory Enforcement Agency. a = Mohammed et al.(2017), b = Baba et al. (2020), c = WHO (2006), $d=$ NESSRA (2009) 
BAJOPAS Volume 13 Number 2, December, 2020

Identification, Biochemical Characterization and growth rates of the Bacterial Isolates

Results of identification and biochemical characterization of the bacterial isolates were shown in table 2. After 24 hours of incubation, the nutrient agar media plates were checked for bacterial growth. The results showed the presence of different strains in the samples. The TAN1 bacteria isolate was found to be gramnegative cocci while TAN3 was gram-positive cocci. TAN2 bacteria isolate was found to be gram-positive, rod-shaped. TAN1, TAN2, and TAN3 bacteria isolates recorded positive results for spore former.

The results of the biochemical tests indicated that all the bacteria were positive for catalase, oxidase, citrate, maltose, glucose, lactose (negative in TAN1), mannitol (negative in TAN2), starch hydrolysis and coagulase (negative in TAN2) tests. The bacteria showed negative results for nitrate reduction, $M R$ (positive in TAN2), VP (positive in TAN1), Indole (positive in TAN2) tests. Base on the morphological and biochemical test results, TAN1, TAN2, and TAN3 bacteria isolates were identified to be Nesseria spp, Bacillus cereus, and Staphylococcus aureus respectively.

The growth rate of the TAN1, TAN2 and TAN3 Isolates were shown in figure 2. Generally, the optical density increase with the increase in time (day) and decrease as time goes on. The highest optical density was shown by bacillus cereus in TAN2 while the lowest was shown by Staphylococcus aureus in TAN3.

The initial growth phase of TAN1 Isolate bacteria occurred within 2-day of incubation as the growth rate increases up to the 6th-day incubation when the maximum growth was observed. Beyond the 6th day, the growth of the bacteria declined (which might be due to a shortage of nutrients in the effluents) until it reached its death phase (which might be due to the unavailability of nutrients in the effluents).

A similar trend of growth was also observed for TAN2 Isolate as the initial growth phase also occurred within 2-day of incubation but maximum growth rate observed on the 4th day of incubation. The stationary stage occurred between the 4th day and the 8th day. Beyond the 8th day, the growth of the bacteria declined (which might be due to a shortage of nutrients in the effluents) until it reached its death phase (which might be due to the unavailability of nutrients in the effluents).

The initial growth phase of TAN3 bacterial Isolate occurred within the 3-day incubation as the growth rate increases up to the 6th-day incubation when the maximum growth was observed. Beyond the 6th day, the growth of the bacteria declined (which might be due to a shortage of nutrients in the effluents) until it reached its death phase (which might be due to the unavailability of nutrients in the effluents).

Table 2: Morphological and Biochemical characteristics of bacterial isolates

\begin{tabular}{lllll} 
Bacterial Isolates & & TAN1 & TAN2 & TAN3 \\
\hline $\begin{array}{lllll}\text { Morphological } \\
\text { characteristics }\end{array}$ & Shape & Cocci & Rod & Cocci \\
& Spore & & & \\
& former & + & + & + \\
Gram & & & \\
Biochemical characteristics & reaction & - & + & + \\
& Citrate & + & + & + \\
& Catalase & + & + & + \\
& Coagulase & + & - & + \\
Starch & + & + & + \\
& Glucose & + & + & + \\
Oxidase & + & + & + \\
& Indo & - & + & - \\
Lactose & - & + & + \\
Manitol & + & - & + \\
Maltose & + & + & + \\
MR & - & + & - \\
VP & + & - & - \\
& Nitrate & - & - & - \\
Reduction & - Neisseria & Bacillus & Staphylococcus \\
& Bacterial & cereus & aureus \\
& name & spp & cas
\end{tabular}

+ = Positive; - = Negative; MR=Methyl Red; VP= Voges-Proskauer 


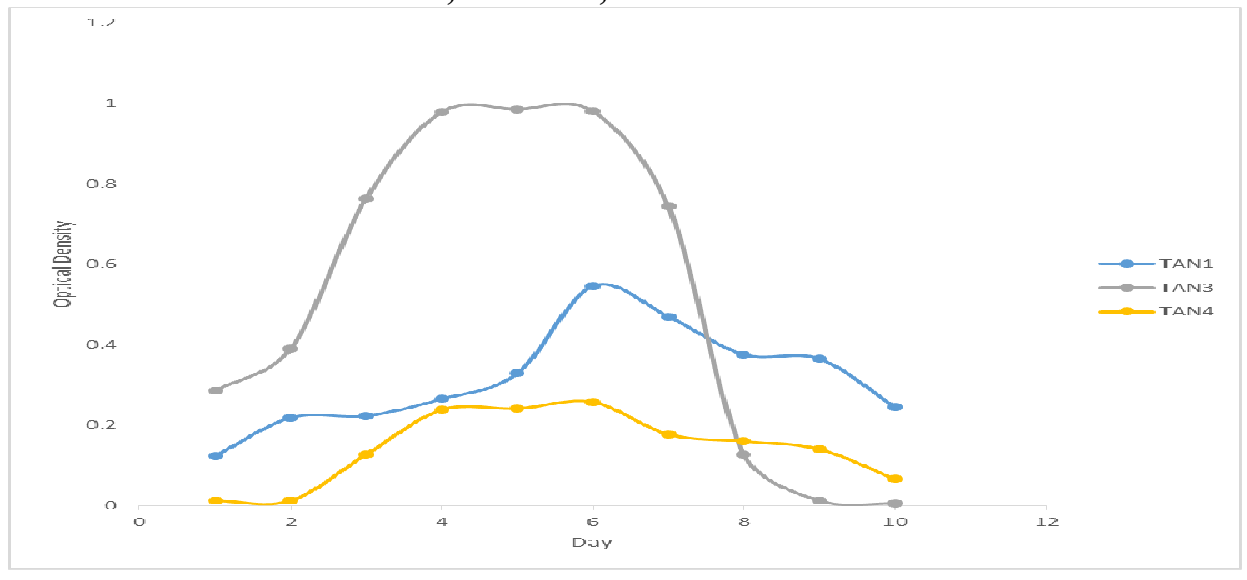

Fig. 2 Growth rates of the isolates in the effluents from the Tannery Industries

\section{Physico-chemical Parameters in the Industrial Effluents after the biodegradation.}

Table 3 shows the mean results of the physicochemical parameter before and after bioremediation using the different masses $(5 \mathrm{~g}$, $10 \mathrm{~g}, 15 \mathrm{~g}, 20 \mathrm{~g}$, and $25 \mathrm{~g}$ ) of the respective immobilized bacteria. Also, Table 4 shows the mean results of correlation coefficient ( $r$ ) between different masses of bacteria and physicochemical parameters.

The mean values $(\mathrm{mg} / \mathrm{l})$ of the SS after the bioremediation varies between $243 \pm 45$ and $898 \pm 672$. The mean concentration $(\mathrm{mg} / \mathrm{l})$ of SS remediated by the different masses $(5 \mathrm{~g}, 10 \mathrm{~g}$, $15 \mathrm{~g}, 20 \mathrm{~g}$, and $25 \mathrm{~g}$ ) of the bacteria varies. The SS in the samples fluctuates up and down after the bioremediation process when compared with the SS of the raw samples before the bioremediation. The increase in the levels of the SS might be due to the aggregation of the TDS which are large enough to result into SS. The increase in the levels of the SS might be also due to the influence of the nutrients which was added into the effluents in order to make the microorganisms more active and viable for fast degradation of organic contaminants in the effluent. The relative potential or efficiency of the different masses of the bacteria in remediating SS in TAN1 samples was in the order $25 \mathrm{~g}>20 \mathrm{~g}>15 \mathrm{~g}>10 \mathrm{~g}>5 \mathrm{~g}$. For TAN2 and TAN3 samples, the order was $25 \mathrm{~g}>20 \mathrm{~g}>15$ $\mathrm{g}>10 \mathrm{~g}>5 \mathrm{~g}$. These might be due to the variations in the surface areas of the different masses of the immobilized bacteria. Statistical analysis shows that there is no significant difference $(p<0.05)$ between the mean values of SS among the masses in the respective industries. Positive and significant correlations exist between the masses of bacteria and Suspended Solid (SS). This showed that there is general increase in the levels of the SS as the masses of the immobilized bacteria increases. TAN3 (90\%) and TAN1 (80\%) showed a very high correlation with the masses of the bacteria while TAN2 (61\%) showed a very low correlation.

The mean values $(\mathrm{mg} / \mathrm{l})$ of the TDS after the bioremediation varies between $46 \pm 11$ and $83 \pm 78$. The mean concentration $(\mathrm{mg} / \mathrm{l})$ of TDS remediated by the different masses $(5 \mathrm{~g}, 10 \mathrm{~g}$, $15 \mathrm{~g}, 20 \mathrm{~g}$, and $25 \mathrm{~g}$ ) of the bacteria varies. There is a reduction in all the TDS of all the samples after the bioremediation process compared with the TDS of the raw samples before the bioremediation. The relative potential or efficiency of the different masses of the bacteria in remediating TDS in TAN1 and TAN3 samples was in the order $5 \mathrm{~g}>10 \mathrm{~g}>15 \mathrm{~g}>20$ $\mathrm{g}>25 \mathrm{~g}$. For TAN2 samples, the order was 20 $g>10 \quad g>25 \quad g>15 \quad g>5 \quad g$. Statistical analysis shows that there is no significant difference $(p<0.05)$ between the mean values of TDS among the masses in the respective industries. These might be due to the variations in the surface areas of the different masses of the immobilized bacteria. Positive and significant correlations exist between the masses of bacteria and TDS with the exception in TAN2 (negative and insignificant correlation). The positive correlations showed that there is general increase in the levels of the TDS as the masses of the immobilized bacteria increases. TAN1 $(96 \%)$ showed a very high correlation with the masses of the bacteria while TAN2 (47\%) showed a very low correlation.

The mean values $(\mathrm{mg} / \mathrm{l})$ of the BOD after the bioremediation varies between $1.56 \pm 0.20 \mathrm{mg} / \mathrm{l}$ and $6.92 \pm 5.49 \mathrm{mg} / \mathrm{l}$. The mean concentration $(\mathrm{mg} / \mathrm{l})$ of BOD remediated by the different masses $(5 \mathrm{~g}, 10 \mathrm{~g}, 15 \mathrm{~g}, 20 \mathrm{~g}$, and $25 \mathrm{~g}$ ) of the bacteria varies. There is a reduction in all the BOD of all the samples after the bioremediation process compared with the $\mathrm{BOD}$ of the raw 
BAJOPAS Volume 13 Number 2, December, 2020 samples before the bioremediation. The relative potential or efficiency of the different masses of the bacteria in remediating BOD in TAN1, TAN2 and TAN3 samples were in the order $25 \mathrm{~g}>20$ $\mathrm{g}>15 \mathrm{~g}>10 \mathrm{~g}>5 \mathrm{~g}, 25 \mathrm{~g}>15 \mathrm{~g}>5 \mathrm{~g}>10 \mathrm{~g}>20 \mathrm{~g}$ and $20 \mathrm{~g}>10 \mathrm{~g}>25 \mathrm{~g}>15 \mathrm{~g}>5 \mathrm{~g}$ respectively. Statistical analysis shows that there is significant difference $(p<0.05)$ between the mean values of BOD among the masses in the respective industries. These might be due to the variations in the surface areas of the different masses of the immobilized bacteria. Negative and significant correlations exist between the masses of bacteria and BOD. This showed that there is general decrease in the levels of the BOD as the masses of the immobilized bacteria increases. TAN1 (94\%) showed a very high correlation with the masses of the bacteria while TAN2 (4\%) showed a very low correlation.

The mean values $(\mathrm{mg} / \mathrm{l})$ of the COD after the bioremediation varies between $250 \pm 154$ and $3134 \pm 1595$. The mean concentration $(\mathrm{mg} / \mathrm{l})$ of COD remediated by the different masses $(5 \mathrm{~g}$, $10 \mathrm{~g}, 15 \mathrm{~g} 20 \mathrm{~g}$, and $25 \mathrm{~g}$ ) of the bacteria varies. There is a reduction in all the COD of all the samples after the bioremediation process compared with the COD of the raw samples before the bioremediation. The relative potential or efficiency of the different masses of the bacteria in remediating COD in TAN1, TAN2 and TAN3 samples were in the order $25 \mathrm{~g}>20 \mathrm{~g}>15$ $\mathrm{g}>5 \mathrm{~g}>10 \mathrm{~g}, 25 \mathrm{~g}>20 \mathrm{~g}>15 \mathrm{~g}>10 \mathrm{~g}>5 \mathrm{~g}$ and 10 g>5 g>25 g>15 g>20 g respectively. Statistical analysis shows that there were significant difference $(p<0.05)$ between the mean values of COD among the masses in the respective industries except for effluents treated with $25 \mathrm{~g}$. These might be due to the variations in the surface areas of the different masses of the immobilized bacteria. Negative and insignificant correlations exist between the masses of bacteria and COD with the exception in TAN3 (positive and significant correlation). The negative correlations showed that there is general decrease in the levels of the COD as the masses of the immobilized bacteria increases. TAN2 (100\%) showed a very high correlation with the masses of the bacteria while TAN3 (36\%) showed a very low correlation.

Generally, there was an overall decrease in the concentration of these physicochemical parameters after the bioremediation using the different masses of the bacterial isolates. These might be due to the variations in the surface areas of the different masses of the immobilized bacteria. This is in line with the work of Jimoh et al. (2018) and Baba et al. (2020).

Table 3: Mean Values $(\mathrm{mg} / \mathrm{l}) \pm$ S.D of Physicochemical parameters in effluents from the Tannery Industries before and after Treatment of the effluents $(250 \mathrm{ml})$ with the different masses $(5 \mathrm{~g}, 10 \mathrm{~g}$, $15 \mathrm{~g}, 20 \mathrm{~g}$, and $25 \mathrm{~g}$ ) of the bacteria.

\begin{tabular}{llllllll}
\hline $\mathrm{P}$ & IND & Before & \multicolumn{5}{c}{ After } \\
\cline { 4 - 7 } & & & $5 \mathrm{~g}$ & $10 \mathrm{~g}$ & $15 \mathrm{~g}$ & $20 \mathrm{~g}$ & $25 \mathrm{~g}$ \\
\hline \multirow{2}{*}{ COD } & TAN1 & $2372 \pm 938$ & $1708 \mathrm{a} \pm 861$ & $2045 \mathrm{a} \pm 1205$ & $845 \mathrm{a} \pm 369$ & $300 \mathrm{a} \pm 167$ & $250 \mathrm{a} \pm 154$ \\
& TAN2 & $1406 \pm 208$ & $1195 \mathrm{a} \pm 208$ & $1125 \mathrm{a} \pm 384$ & $1055 \mathrm{a} \pm 317$ & $956 \mathrm{a} \pm 310$ & $870 \mathrm{ab} \pm 240$ \\
& TAN3 & $3532 \pm 1373$ & $2374 \mathrm{a} \pm 1344$ & $1976 \mathrm{a} \pm 1405$ & $2757 \mathrm{a} \pm 1266$ & $3134 \mathrm{a} \pm 1595$ & $2614 \mathrm{~b} \pm 1105$ \\
BOD & TAN1 & $13.85 \pm 6.42$ & $6.92 \mathrm{a} \pm 5.49$ & $6.42 \mathrm{a} \pm 5.07$ & $5.72 \mathrm{a} \pm 5.35$ & $4.62 \mathrm{a} \pm 4.37$ & $2.82 \mathrm{ab} \pm 1.26$ \\
& TAN2 & $19.46 \pm 0.50$ & $1.75 \mathrm{~b} \pm 0.22$ & $1.73 \mathrm{~b} \pm 0.18$ & $1.58 \mathrm{a} \pm 0.16$ & $1.91 \mathrm{a} \pm 0.22$ & $1.56 \mathrm{~b} \pm 0.20$ \\
& TAN3 & $17.13 \pm 3.14$ & $4.24 \mathrm{ab} \pm 0.77$ & $3.29 \mathrm{ab} \pm 0.37$ & $4.11 \mathrm{a} \pm 0.07$ & $3.23 \mathrm{a} \pm 0.91$ & $3.33 \mathrm{a} \pm 1.28$ \\
SS & TAN1 & $374 \pm 124$ & $243 \mathrm{a} \pm 45$ & $471 \mathrm{a} \pm 226$ & $475 \mathrm{a} \pm 182$ & $492 \mathrm{a} \pm 128$ & $611 \mathrm{a} \pm 217$ \\
& TAN2 & $358 \pm 335$ & $460 \mathrm{a} \pm 400$ & $543 \mathrm{a} \pm 414$ & $544 \mathrm{a} \pm 402$ & $551 \mathrm{a} \pm 414$ & $554 \mathrm{a} \pm 405$ \\
& TAN3 & $780 \pm 739$ & $586 \mathrm{a} \pm 594$ & $758 \mathrm{a} \pm 656$ & $787 \mathrm{a} \pm 676$ & $861 \mathrm{a} \pm 635$ & $898 \mathrm{a} \pm 672$ \\
TDS & TAN1 & $3941 \pm 3703$ & $51 \mathrm{a} \pm 10$ & $53 \mathrm{a} \pm 10$ & $55 \mathrm{a} \pm 15$ & $61 \mathrm{a} \pm 20$ & $63 \mathrm{a} \pm 26$ \\
& TAN2 & $3300 \pm 1714$ & $83 \mathrm{a} \pm 78$ & $47 \mathrm{a} \pm 20$ & $48 \mathrm{a} \pm 22$ & $47 \mathrm{a} \pm 17$ & $48 \mathrm{a} \pm 17$ \\
& TAN3 & $2653 \pm 1240$ & $46 \mathrm{a} \pm 11$ & $55 \mathrm{a} \pm 24$ & $55 \mathrm{a} \pm 25$ & $58 \mathrm{a} \pm 23$ & $61 \mathrm{a} \pm 28$ \\
\hline
\end{tabular}

Replicate $=6$ (months)

Within the rows, for the same parameter, means with different alphabets are statistically different $(p<0.05)$.

$\mathrm{P}=$ parameter, IND = Industries 
BAJOPAS Volume 13 Number 2, December, 2020

Table 4: Correlation coefficient $(r)$ between different masses of the bacteria and the physicochemical parameters.

\begin{tabular}{llll}
\hline Industries & Parameter & Correlation coefficient $(r)$ & $\begin{array}{l}\text { Percent dependence (rxrx100) } \\
(\%)\end{array}$ \\
\hline TAN1 & COD & -0.9 & 82 \\
& BOD & -0.97 & 94 \\
& SS & $0.90^{*}$ & 80 \\
TAN2 & TDS & $0.98^{*}$ & 96 \\
& COD & -1 & 100 \\
& BOD & -0.21 & 4 \\
& SS & $0.78^{*}$ & 61 \\
& TDS & -0.69 & 47 \\
& COD & $0.60^{*}$ & 36 \\
& BOD & -0.6 & 37 \\
& SS & $0.95^{*}$ & 90 \\
& TDS & $0.94^{*}$ & 89 \\
\hline
\end{tabular}

The correlation coefficient $(r)$ with * is statistically significant $(p<0.05)$.

Percentage reduction of the Parameters

Table 5 shows the percentage reduction of Parameters in industrial samples before and after the treatment of the effluents $(250 \mathrm{ml})$ with the different masses $(5 \mathrm{~g}, 10 \mathrm{~g}, 15 \mathrm{~g}, 20 \mathrm{~g}$, and $25 \mathrm{~g}$ ) of the Immobilized Bacteria.

In TAN1 samples, the percentage reduction (\%) of COD ranged (14-89); BOD (50-80); SS (-32$35)$ and TDS (98-99). In TAN2 samples, the percentage decrease $(\%)$ of COD ranged (15$38) ;$ BOD (90-92); SS [-28-(-55)] and TDS (9798). In TAN3 samples, the percentage decrease (\%) of COD ranged (11-44); BOD (76-81); SS (15-25) and TDS (98). The percentage increase in the levels COD, BOD and TDS might be due to the increase in the surface area of the different masses of the immobilized bacteria. However, the percentage decrease in the levels of the SS might be due to the aggregation of the TDS which are large enough to result into SS. The percentage decrease in the levels of the SS might be also due to the influence of the nutrients which was added into the effluents in order to make the microorganisms more active and viable for fast degradation of organic contaminants in the effluent. This is in line with the work of Jimoh et al. (2018) in which the concentration of the SS increase after the bioremediation of effluents.

Sreemoyee and Priti (2013) assessed and reduced several Physico-chemical parameters of dairy wastewater using Niesseria $s p$. and concluded that the species are well known to degrade organic compounds. This is in agreement with the current study in which the immobilized Niesseria $s p$ degrade the organic contaminants as indicated by the BOD, COD and TDS.

Jimoh et al. (2018) observed that TSS of the effluents was increased after treatment with immobilized bacteria and concluded that it might be due to the biostimulation method adopted for the research.

The optimum $\mathrm{pH}$ Biosorption of Chromium by Bacillus spp and Staphylococcus spp. from tannery effluent was investigated by Mythili and Karthikeyan (2011). The maximum adsorption of Chromium $(86.4 \mathrm{mg} / \mathrm{L})$ was showed by Bacillus spp and Staphylococcus spp showed $70.6 \mathrm{mg} / \mathrm{L}$ at an initial concentration of $100 \mathrm{mg} / \mathrm{L}$. In the present study, immobilised Bacillus spp and Staphylococcus spp. from the tannery industrial effluents reduced the levels of the organic pollutants with high potential as indicated by the percentage reduction of BOD, COD and TDS.

Enzymes often can work in multiple environments especially if they are immobilized. This makes the microorganisms' enzymes even more resistant to harsh environments and enables the enzymes to be recovered and recycled after they are no longer needed (Gianfreda and Rao 2004). Ramesh and Singh (1993) reported that the immobilized bacteria having more efficiency to remove the suspended particles than free cells. Using the immobilized cell is preferable due to its capability for using several times with the same efficiency, which makes it more economical. Similar work was done by Sikander et al. (2007) showing the higher reduction with permeabilized cells of Ochrobactrum intermedium strain SDCr-5. 
BAJOPAS Volume 13 Number 2, December, 2020

The results revealed the isolation and identification of isolates with the potential for the reduction of $\mathrm{Cr}$ (VI) to $\mathrm{Cr}$ (III). Results indicated that immobilized $B$. cereus could be efficiently used for the reduction of $\mathrm{Cr}$ (VI).

Table 5: Percentage reduction of the tested Parameters from the tannery industrial samples of the Immobilized Bacteria.

\begin{tabular}{lllllll}
\hline \multirow{2}{*}{ Industries } & & \multicolumn{5}{c}{ Percentage Reduction $(\%)$} \\
\cline { 3 - 7 } & & $5 \mathrm{~g}$ & $10 \mathrm{~g}$ & $15 \mathrm{~g}$ & $20 \mathrm{~g}$ & $25 \mathrm{~g}$ \\
\hline TAN1 & COD & 28 & 14 & 64 & 87 & 89 \\
& BOD & 50 & 54 & 59 & 67 & 80 \\
& SS & 35 & -26 & -27 & -32 & -63 \\
& TDS & 99 & 99 & 99 & 98 & 98 \\
TAN2 & COD & 15 & 20 & 25 & 32 & 38 \\
& BOD & 91 & 91 & 92 & 90 & 92 \\
& SS & -28 & -52 & -52 & -54 & -55 \\
& TDS & 97 & 99 & 99 & 99 & 99 \\
& COD & 33 & 44 & 22 & 11 & 26 \\
& BOD & 75 & 81 & 76 & 81 & 81 \\
& SS & 25 & 3 & -1 & -10 & -15 \\
& TDS & 98 & 98 & 98 & 98 & 98 \\
\hline
\end{tabular}

Percentage Reduction $=(B-A) / B \times 100 \%$

$A=$ Concentration of the parameter after treatment

$\mathrm{B}=$ Concentration of the parameter before treatment

$+=$ percentage decrease

- = percentage increase

In general, immobilization makes the enzyme more resistant to temperature, $\mathrm{pH}$, and substrate concentration swings giving it a longer lifetime and higher productivity per active unit (Gianfreda and Rao, 2004; FuIlbrook, 1996; Russell et al, 2003; Kandelbauer et al., 2004). Immobilized cells have been used and studied extensively for the production of useful chemicals (Ohtake and Silver, 1994), the treatment of wastewaters (Chen et al., 2003; Wang et al., 2010). Although many workers described microbial degradation of tannery effluent, limited literature is available on the bioremediation of tannery effluent using immobilized bacterial cells in the Kano Industrial Estates.

\section{CONCLUSION}

The samples contained variable levels of the physicochemical parameters. The results of the Analysis of variance revealed that, no statistical difference $(p<0.05)$ was observed for the temperature, $\mathrm{pH}, \mathrm{SS}, \mathrm{TDS}, \mathrm{BOD}$ and $\mathrm{COD}$ among the three tannery industries before the treatment. The levels of some of the parameters
(SS, TDS and COD) observed in the samples were found above the recommended limits of WHO and NESREA, which called for the treatment of the effluents before discharge into the environment. Base on the morphological and biochemical test results, TAN1, TAN2, and TAN3 bacterial isolates were identified to be Neisseria spp, Bacillus cereus, and Staphylococcus aureus respectively. The results of Post-treatment analysis showed that there is overall decrease in the levels of the parameters determined when compared with that of the pre-treatment. The overall percentage reduction of the immobilised bacteria in the treatment of the respective effluents was in the order TAN2 (72\%)>TAN1 $(70 \%)>$ TAN3 $(62 \%)$. Hence, the immobilized bacteria are having higher biodegradation potential for the treatment of the tannery effluents.

\section{Acknowledgments}

The authors wish to acknowledge the University of Maiduguri for the financial support. The authors are grateful to the Kano State Ministry of Environment for their support in obtaining the effluent samples. 


\section{REFERENCES}

Ajao, A. T., Adebayo, G. B., and Yakubu, S. E. (2011). Bioremediation of textile industrial effluent using mixed culture of Pseudomonas aeruginosa and Bacillus subtilis immobilized on agar-agar in a bioreactor. J. Microbiol. Biotech. Res, 1(3), 50-56.

Akan, J. C., Moses, E. A., Ogugbuaja, V. O., and Abah, J. (2007). Assessment of tannery industrial effluents from Kano metropolis, Kano State, Nigeria. Journal of Applied Sciences, 7(19), 2788-2793.

Akan, J. C., Ogugbuaja, V. O., Abdulrahman, F. I., and Ayodele, J. T. (2009). Pollutant levels in effluent samples from tanneries and textiles of Kano industrial areas, Nigeria. Global journal of pure and applied sciences, 15(3-4).

APHA (1989). Standard methods for Examination of Will bete and Will betewater.15 $5^{\text {th }}$ edition. Brydpass Springfield Will behington DC. pp. 164-176

APHA (1992). Standard Methods for the Examination of Water and Wastewater. Health, 69, 1116-9.

Baba, A., Garba, S. T., and Bello, H. S. (2020). Bioremediation Potential of Immobilized corynebacterium kutsceri in the Treatment of Tannery Industrial Effluent from Challawa Industrial Estate, Kano State, Nigeria. Journal of the Turkish Chemical Society Section A: Chemistry, $7(2), 335-350$.

Beem, E. I. V. (1994). reduction of solvent VOC emission. J. Oil Col. Chem. Ass, 77, 158.

Bouwer, E. J., and Zehnder, A. J. (1993). Bioremediation of organic compoundsputting microbial metabolism to work. Trends in biotechnology, 11(8), 360367.

Chen, K. C., Wu, J. Y., Liou, D. J., and Hwang, S. C. J. (2003). Decolorization of the textile dyes by newly isolated bacterial strains. Journal of Biotechnology, 101(1), 57-68.

Dan'Azumi, S., and Bichi, M. H. (2010). INDUSTRIAL POLLUTION AND HEAVY METALS PROFILE OF CHALLAWA RIVER IN KANO, NIGERIA. Journal of Applied Sciences in Environmental Sanitation, $5(1)$.

DWAF. (1992). Analytical Methods Manual, TR 151. Department of Water Affairs and Forestry, Pretoria.

El-Bestawy, E. (2013). Biological treatment of leather-tanning industrial wastewater using free living bacteria.
Elsheikh, M. A. S. (2009). Tannery wastewater pre-treatment. Water Science and Technology, 60(2), 433-440.

FuIlbrook, P. D. (1996). "Kinetics." Industrial enzymology: The application of enzymes in Industry. 2nd Ed. T. Godfrey and J Reichelt. eds.. Nature. New York.

Gianfreda, L., and Rao, M. A. (2004). Potential of extra cellular enzymes in remediation of polluted soils: a review. Enzyme and microbial technology, 35(4), 339354.

Hugo Springer. (1994). John Arthur Wilson Memorial Lecture "Treatment of Industrial Wastes of the Leather Industry - is it still a Major Problem". JALCA, 89, 153-185

Jimoh, A. A., Ganiyu, B. A., Baba, D., and Baba, A. (2018) Bioremediation Process of Effluent from Detergent and Food Industries in Jos, Nigeria: Kinetics and Thermodynamics. International Journal of Engineering Science Invention (IJESI), 762-73

Kandelbauer, A., Maute, O., Kessler, R. W., Erlacher, A., and Gübitz, G. M. (2004). Study of dye decolorization in an immobilized laccase enzyme-reactor using online spectroscopy. Biotechnology and bioengineering, 87(4), 552-563.

Kongjao, S., Damronglerd, S., and Hunsom, M. (2008). Simultaneous removal of organic and inorganic Pollutants in tannery wastewater using electrocoagulation technique. Korean Journal of chemical engineering, 25(4), 703.

Maheshwari, U. M., Aruna, S., Gomathi, M., and AbdulJaffar, A. H. (2017). Bioremediation by Free and Immobilized Bacteria Isolated from Tannery Effluent. International Journal of Research in Applied, Natural and Social Sciences. 5(7), 75-90

Margesin, R., and Schinner, F. (2001). Bioremediation (natural attenuation and biostimulation) of diesel-oilcontaminated soil in an alpine glacier skiing area. Applied and environmental microbiology, 677), 3127-3133.

Mohammed, A., Sekar, P., and George, J. (2011). Efficacy of microbes in bioremediation of tannery effluent. Inter. J. Curr. Res, 3(4), 324-326.

Mohammed, S. S. D., Orukotan, A. A., and Abdullahi, H. (2017). Physicochemical and Bacteriological Assessment of Tannery Effluent from Samaru-Zaria, 
BAJOPAS Volume 13 Number 2, December, 2020 Kaduna State, Nigeria. Journal of Applied

Sciences and Environmental Management, 21(4), 734-740.

Munz, G., De Angelis, D., Gori, R., Mori, G., Casarci, M., and Lubello, C. (2009). The role of tannins in conventional and membrane treatment of tannery wastewater. Journal of hazardous materials, 164(2-3), 733-739

Mythili, K., and Karthikeyan, B. (2011). Bioremediation of $\mathrm{Cr}$ (VI) from tannery effluent using Bacillus spp and Staphylococcus spp. International Multidisciplinary Research Journal, 1(6).

NESREA (2009). National Environmental Standards for Effluent Limitations and Regulation. 1233-1236

Noorjahan, C. M. (2014). Physicochemical characteristics, identification of bacteria and biodegradation of industrial effluent. Journal of bioremediation and Biodegradation, 5(3).

Ohtake, H. I., and Silver, A. O. (1994). Bacterial reduction of toxic chromate. Biological degradation and bioremediation of toxic chemicals, 403-415.

Omoleke, I. I. (2004). Management of environmental pollution in Ibadan, an African city: the challenges of health hazard facing government and the people. Journal of Human Ecology, 15(4), 265-275.

Rajor, A., Reddy, A.S., and Singh, B. (2004). Determination of BOD kinetic Parameters and evaluation of alternate methods, M.Sc. Thesis, Department of biotechnology \& environmental Science, Thapar Institute of Engineering and Technology, Patiala

Ramasami, T., Rajamani, S., and Rao, J. R. (1994, March). Pollution control in leather industry: Emerging technological options. In International symposium on surface and colloidal science and its relevance to soil pollution, madras.

Ramesh, J. V. S., and Singh, S. P. (1993). Yearly variation in certain physicochemical parameters of pond at eastern Doon Valley. Uttar Pradesh J. Zoo, 12 (1), 7577.

Ranen, S., and Sharadinadra, C. (2009). Biotechnology applications to environmental remediation in resource exploitation. Current science, 97, 6-25
Russell, A. J., Berberich, J. A., Drevon, G. F., and Koepsel, R. R. (2003). Biomaterials for mediation of

chemical and biological warfare agents. Annual review of biomedical engineering, 5(1), 1-27.

Saravanan, P., and Saravanan, A. (1999). Decolourization of tannery effluent by Flavobacterium sp. EK 1. Indian Journal of Environmental Protection, 19, 19-24.

Sikander, S., and Shahida, H. (2007). Reduction of toxic hexavalent chromium by Ochrobactrum intermedium strain SDCr5 stimulated by heavy metals. Bioresource Technol, 98, 340-344.

Singh, N., Sharma, B. K., and Bohra, P. C. (2000). Impact assessment of industrial effluent of arid soils by using satellite imageries. Journal of the Indian Society of Remote Sensing, 28(2-3), 79.

Sreemoyee, C., and Priti, P. (2013). Assessment of physico-chemical parameters of dairy waste water and isolation and characterization of bacterial strains in terms of cod reduction. Int J Sci, 2(3), 395-400.

Verheijen, L. A. H. M., Wiersema, D., Pol, L. H., and De Wit, J. (1996). Management of wastes from animal product processing. Livestock and environment, Finding a balance. International Agriculture Center, Wageningen, The Netherlands.

Wang, F., Yao, J., Si, Y., Chen, H., Russel, M., Chen, K., and Bramanti, E. (2010). Short-time effect of heavy metals upon microbial community activity. Journal of Hazardous Materials, 173(13), 510-516.

WHO (World Health Organization). (2006). Air quality guidelines: global update 2005: particulate matter, ozone, nitrogen dioxide, and sulfur dioxide. World Health Organization.

World Bank. (1995). Nigeria's strategic options for redressing industrial pollution. World Bank, industry and energy division. 1st edition, West Central Africa Department; Annexes: 1995; pp 60-62.

Zahoor, A., and Abdul, R. (2009). Enumeration of Coliforms. Journal of Environmental Sciences. 21, 814-820 


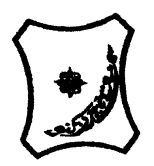

Bayero Journal of Pure and Applied Sciences, 13(2): 1 - 12

Received: November, 2020

Accepted: December, 2020

ISSN $2006-6996$

\title{
BIODEGRADATION POTENTIAL OF IMMOBILIZED BACTERIA IN THE TREATMENT OF TANNERY INDUSTRIAL EFFLUENTS FROM INDUSTRIAL ESTATES IN KANO STATE, NIGERIA
}

\author{
Abdullateef, B., ${ }^{1 *}$ Shuaibu, T. G., ${ }^{1}$ Babagana, K., ${ }^{1}$ Suleman, H. B. ${ }^{2}$ and Dauda, B. ${ }^{3}$ \\ ${ }^{1}$ Department of Pure and Applied Chemistry, Faculty of Science, University of Maiduguri, Borno State, \\ Nigeria \\ ${ }^{2}$ Department of Microbiology, Faculty of Science, University of Maiduguri, Borno State, Nigeria \\ ${ }^{3}$ Department of Chemical Engineering, Faculty of Engineering, University of Maiduguri, Borno State, \\ Nigeria \\ *Corresponding author: babslega@gmail.com; abelega2007@yahoo.com; +2348061309753
}

\section{ABSTRACT}

Industrial Effluents Samples from Gashash Tanneries (TAN1) in Bompai Industrial estate, Larabee Tannery Industry (TAN2) in Sharada Industrial estate and Z Tannery Industries (TAN3) in Challawa Industrial estate, Kano State, Nigeria were collected over a period of six months (August 2017 to January 2018) for assessing the biodegradation potentials of bacteria in the treatment of organic pollutants within the effluents. Bacteria were isolated from the effluents and immobilized on agar-agar. Different masses (5 g, $10 \mathrm{gr}, 15$ $\mathrm{g}, 20 \mathrm{~g}$, and $25 \mathrm{~g}$ ) of the bacteria were used in the treatment of $250 \mathrm{ml}$ of the effluents for ten days in a shaker incubator (Gallenkamp-OC-4364-L) at the temperature $30{ }^{\circ} \mathrm{C}$ and speed of $60 \mathrm{rpm}$. Pre-treatment analysis of the effluents for Temperature, pH, Biochemical Oxygen Demand (BOD), Chemical Oxygen Demand (COD), Suspended Solid (SS) and Total Dissolved Solids (TDS) gives the following results; temperature $\left({ }^{\circ} \mathrm{C}\right.$ )

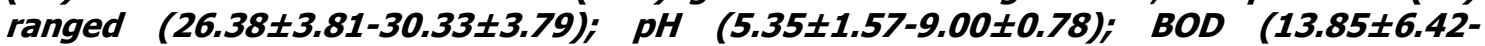
$38.75 \pm 16.20) ;$ COD (1406 $\pm 208-3532 \pm 1373) ;$ SS (208 $\pm 235-780 \pm 739)$ and TDS (266 $\pm 253-5276 \pm 2971)$. No statistical differences ( $p \leq 0.05)$ was observed for all the results among the different industries. The bacterial isolates were identified as Neisseria spp, Bacillus cereus, and Staphylococcus aureus, in TAN1, TAN2, and TAN3, respectively. After treatment of the effluent with the different masses of the isolated bacteria, the mean level of BOD was found to range as (0.55 $\pm 0.36-6.92 \pm 5.49) ; C O D$ (ND-3134 \pm 1595$)$;

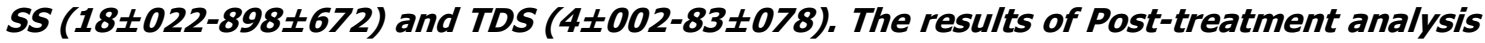
showed that there is overall decrease in the levels of the parameters determined when compared with that of the pre-treatment. The overall percentage reduction of the immobilised bacteria in the treatment of the respective effluents was in the order TAN2 (72\%)>TAN1 (70\%)>TAN3 (62\%). Hence, the immobilized bacteria are having higher biodegradation potential for the treatment of the tannery effluents.

Keywords: Biodegradation, bacteria, effluent, immobilization, tannery.

\section{INTRODUCTION}

Tannery industrial wastewater is a serious consequence of the pollution point of view for streams, freshwater, and land used for agriculture. The lack of awareness in the modern industrial practice has resulted in the discharge of tannery effluents which exhibit very high value of chromium ( $\mathrm{Cr}$ ), Sulfide, and chloride, Total Dissolved Solid (TDS), Total Suspended Solid (TSS), Biochemical Oxygen Demand (BOD) and Chemical Oxygen Demand (COD) in the water stream or land (Mohammed et al., 2001). Tanning is the process, which One ton of skin generally leads to the production of 20 to $80 \mathrm{~m}^{3}$ of turbid and foul-smelling converts the protein of the rawhide or skin into a stable material, which will not putrefy and is suitable for a wide variety of end applications (Elsheikh, 2009). The highly polluting chromium is the most commonly used tanning material producing leather that is more flexible and pliable than vegetable-tanned leather and does not discolor or lose shape in water as drastically as vegetable-tan (Elsheikh, 2009). Tannery effluent is among the most hazardous industrial pollutants due to its huge organic and inorganic load, which is highly toxic to human life and the environment (Kongjao et al., 2008). wastewater including chromium (100-400 mg/l), sulfide $(200-800 \mathrm{mg} / \mathrm{l})$, high levels of fat and 
BAJOPAS Volume 13 Number 2, December, 2020 other solid wastes, and notable pathogen contamination as well as pesticides added for skin conservation during transport (Elsheikh, 2009). There are more than 6000 tanneries in Nigeria with an annual processing capacity of 700,000 tons of hides and skins (Omoleke, 2004; Singh et al., 2008). It was reported that the total amount of waste produced per animal slaughtered is approximately $35 \%$ of its weight (World Bank, 1995). Also, for every $1000 \mathrm{~kg}$ of carcass weight, a slaughtered beef produces 5.5 $\mathrm{kg}$ of manure (excluding rumen contents or stockyard manure) and $100 \mathrm{~kg}$ of paunch manure (undigested food) (Verheijen et al., 1996). Tanneries generate wastewater in the range of 30-35 $\mathrm{L} \mathrm{kg}^{-1}$ skin/hide processed with variable $\mathrm{pH}$, Biological Oxygen Demand (BOD), Chemical Oxygen Demand (COD), high concentrations of suspended solids (SS), and tannins as well as chromium (Zahoor and Abdul, 2009).

Being heterogeneous and composed of a wide variety of compounds, it is very difficult to select a unique direct method for estimating the biodegradability of organic contents and biokinetic parameters for a wastewater sample (Rajor, 2004). For this purpose, some indirect estimation such as determination of biochemical oxygen demand (BOD) and chemical oxygen demand (COD) are applied as common laboratory investigations [9]. During retanning procedures, synthetic tannins (Syntan), oils and resins are added to form softer leather at varying doses (Munz et al., 2009). One of the refractory groups of chemicals in tannery effluents derives mainly from tannins (Ramasami et al., 2004). Syntans are characterized by complex chemical structures, because they are composed of an extended set of chemicals such as phenol-, naphthalene-, formaldehyde- and melamine-based syntans, and acrylic resins (Beem, 1994). Organic pollutants (proteic and lipidic components) are originated from skins (it is calculated that the raw skin has $30 \%$ loss of organic material during the working cycle) or they are introduced during processes (Hugo Springer, 1994).

Many conventional processes such as oxidation, chemical and biological processes were carried out to treat tanneries wastewater (Ebtesam et al, 2013). Biological processes have received more attention because of their costeffectiveness, lower sludge production and environmental friendliness (Noorjahan, 2014). Naturally occurring micro-organisms degrade the hazardous organic wastes including xenobiotic compounds, such as pesticides, polycyclic aromatic hydrocarbons (PAHs) and polychlorinated biphenyls (PCBs) in due course of time (Ranen and Sharadinadra, 2009). Bioremediation is based on the idea that all organisms remove substances from the environment to carry outgrowth and metabolism (Bouwer and Zehnder, 1993). Bacteria, protista and fungi are found to be very good at degrading complex molecules and incorporating the breakdown products into their metabolism (Bouwer and Zehnder, 1993). The resultant metabolic wastes that they produce are generally safe and somehow recycled into other organisms (Ranen and Sharadinadra, 2009). An acclimatized indigenous population of microorganisms capable of degradation of the compounds of interest must exist at the site for a successful bioremediation mode (Ranen and Sharadinadra, 2009). It has been observed that for a successful bioremediation mode, an acclimatized indigenous population of microorganisms capable of degradation of the compounds of interest must exist at the site under investigation (Ranen and Sharadinadra, 2009). Even though there are numerous physical and chemical methods employed in the disposal of wastes the advantage in using bacterium is that they play a key role in the reduction of COD, BOD, total protein, total tannin and total phenol (Saravanan and Saravanan, 1998)

Baba et al. (2020) studied the bioremediation potential of immobilized corynebacterium kutsceri in the Treatment of tannery industrial effluent from Challawa Industrial Estate, Kano State, Nigeria. The aim of the work is to study the reduction in the level of the contaminants through the process of bioremediation using the isolated bacteria. Immobilized bacteria can withstand various temperatures, $\mathrm{pH}$ and substrate concentrations; consequently, increasing the efficiency and the lifespan of the bacteria. Immobilized bacteria are widely applied in the treatment of wastewater and can be separated and recovered after the treatment with the same efficiency (Baba et al., 2020).

\section{MATERIALS AND METHODS \\ Study Area}

This study was carried out in Bompai, Sharada and Challawa industrial estates in Kano, Figure 1. Kano lies on Latitude $11^{\circ} 30^{\prime} \mathrm{N}$ and $8^{\circ} 30^{\prime} \mathrm{E}$ and Longitude $11^{\circ} 5^{\prime} \mathrm{N}$ and $8^{\circ} 5^{\prime} \mathrm{E}$ in Northern Nigeria. It is one of the developed industrial cities in Nigeria. Tannery activities are the dominating industries and this could be one of the reasons for her high population density (Dan'Azumi and Bichi, 2010). Many researchers have studied biodegradation of tannery effluent using microorganisms. However, limited literature is available on the biodegradation of tannery effluent in Kano industrial estates using 
BAJOPAS Volume 13 Number 2, December, 2020 immobilized bacterial cells. This research work focuses on the potential of the use of the indigenous immobilized bacterial isolates in the treatment of tannery effluents in the industrial estates.

\section{Sample Collection}

Effluents were collected from the Tannery Industries from Bompai, Challawa and Sharada Industrial Estates, Kano, Nigeria. The effluents were collected over a period of six months (August 2017 to January 2018). Samples collected in a sterile 4-liter plastic container with a unique identification number were preserved using an ice-box that was transported to the Microbiology Laboratory, Department of Microbiology, Bayero University of Kano for analysis

\section{Sample Preparation and Sample Analysis}

Immediately after the collection of the effluent, $\mathrm{pH}$, TSS, TDS, COD, BOD levels were determined before treatment (Pre-treatment determination) and ten days after treatment (Post-treatment determination) as described in
APHA (1989) standard methods. $\mathrm{pH}$ was determined using Ecotests $\mathrm{pH}$ meter and TDS was determined using AQUALYTIC TDS Salinometer. BOD was determined as described by the standard method (APHA, 1992). COD and SS were determined using DR/2010 HACH portable data logging spectrophotometer (DWAF, 1992)

\section{Identification and Biochemical} Characterization of the Bacterial Isolates

The bacteria were isolated from the effluents using Serial Dilution according to the method described by APHA (1989). The biochemical tests such as oxidase, catalase, coagulase, indole (from $1 \%$ tryptone broth), citrate (Simmons citrate agar), methyl red/VogesProskauer (MR/VP), nitrate reduction, Starch Hydrolysis, Glucose, Maltose, and Lactose tests were carried out on the bacterial isolates to identify the bacteria through the bacteria biochemical characteristics according to Ajao et al. (2011).

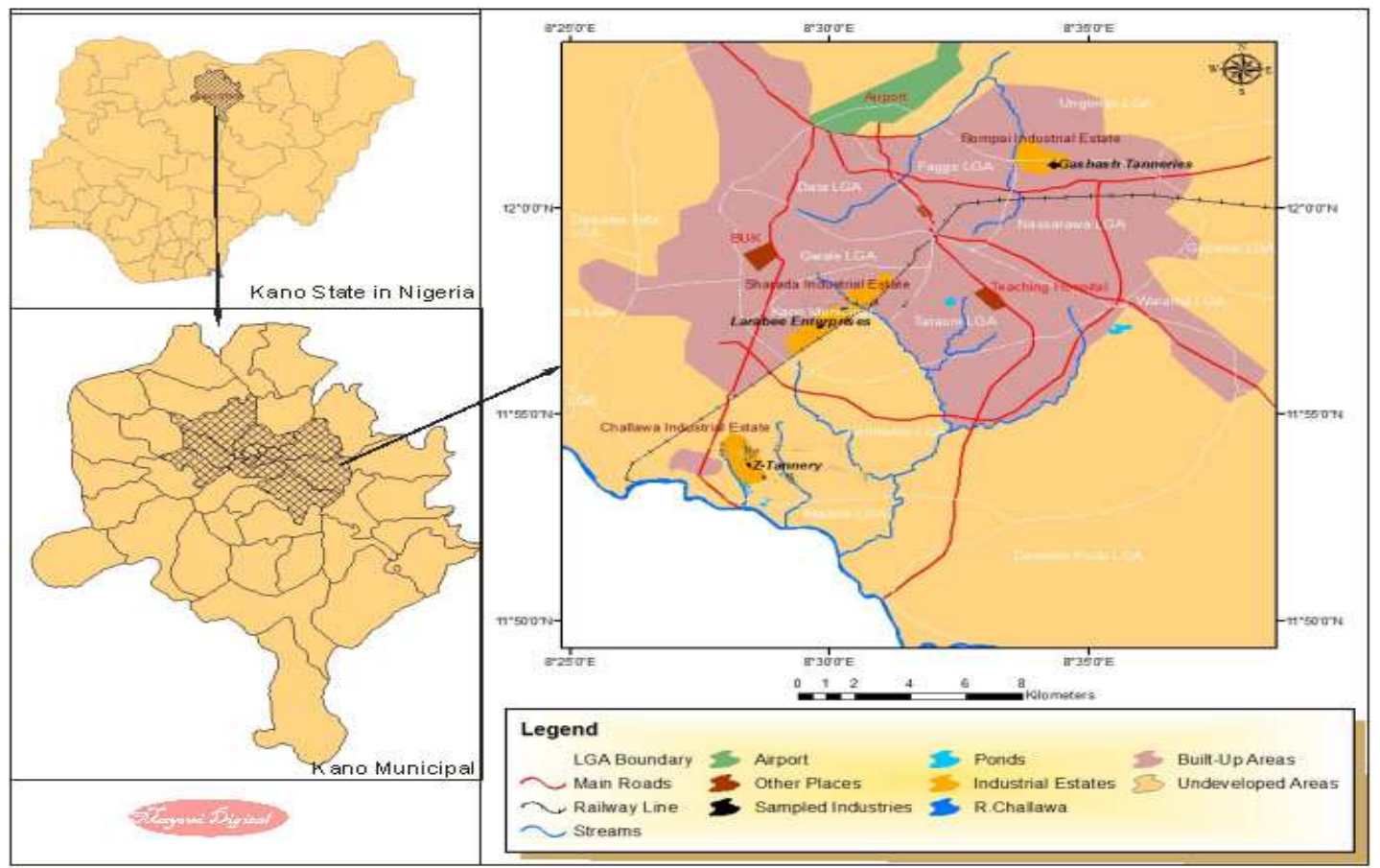

Fig. 1 Map showing the study areas

Source: Mayomi Digital Productions, GIS Laboratory, Department of Geography, UNIMAID (2017)

\section{Determination of Growth Rate of the Bacteria in Effluent Sample}

The bacteria growth rates were determined by transferring $2 \mathrm{~mL}$ of the bacterial isolates from the tannery effluent in broth medium into 100 $\mathrm{mL}$ sterile effluents in conical flasks and kept in an incubator (Giffrin cool) for 10 days. Control was also set up by incubating another $100 \mathrm{~mL}$ each of the sterile effluents without the bacteria. The optical density of the content was determined at the wavelength of $600 \mathrm{~nm}$ on a daily interval and recorded. 
BAJOPAS Volume 13 Number 2, December, 2020 Immobilization of Bacteria

Agar solution and inoculi were prepared separately. Fifty milliliters $(50 \mathrm{~mL})$ of nutrient broth each of the inoculi was prepared in a McCartney bottle and incubated for 24 hours. A solution of agar-agar was prepared by dissolving $10 \mathrm{~g}$ of the powder in distilled water and made up to $500 \mathrm{~mL}$ mark in an Erlenmeyer flask and was sterilized in an autoclave (280A) for 15 minutes and allowed to cool to $40-45^{\circ} \mathrm{C}$ (Ajao et al., 2011). Four milliliters ( $4 \mathrm{~mL})$ of the bacterial isolates in the nutrient broth was mixed with 36 $\mathrm{ml}$ of the prepared agar-agar media in petri-dish plates and then allowed to solidify. This was kept in the refrigerator for bioremediation.

\section{Bioremediation (Treatment) of the Effluents}

The solidified agar block (immobilized bacteria) was cut into cubes using a sterile knife; $0.1 \mathrm{~mL}$ phosphate buffer ( $\mathrm{pH} \mathrm{7.0)}$ was added and kept in the refrigerator for 1 hour for curing. The phosphate buffer was decanted after 1 hour and the cubes were washed with sterile distilled water 3-4 times before it was used (Ajao et al., 2011). Two liters (2 L) of the effluent was supplemented with the minimum basal medium in $\mathrm{g} / \mathrm{L}: \mathrm{NaCl}(0.8), \mathrm{MgSO}_{4} .7 \mathrm{H}_{2} \mathrm{O}(0.001), \mathrm{KH}_{2} \mathrm{PO}_{4}$ (2), $\mathrm{NaNO}_{3}$ (2), $\quad \mathrm{CaCl}_{2} .2 \mathrm{H}_{2} \mathrm{O} \quad(0.5)$ and $\mathrm{NaHPO}_{4} .12 \mathrm{H}_{2} \mathrm{O}(2)$ and sterilized in an autoclave at $121^{\circ} \mathrm{C}$ for 15 minutes (Margesin and Schinner, 2001). Two hundred and fifty milliliters $(250 \mathrm{~mL})$ of the effluents were transferred into different $250 \mathrm{ml}$ conical flasks. The content was covered with a cotton-wool ramped with foil paper to avoid contamination. Five grams $(5 \mathrm{~g})$ of the immobilized bacteria were quickly transferred into each of the effluents in the conical flasks in an inoculating chamber. The same procedures were carried out for the $10 \mathrm{~g}, 15 \mathrm{~g}, 20 \mathrm{~g}$ and 25 $\mathrm{g}$ of the immobilized bacteria in separate $250 \mathrm{~mL}$ effluents in conical flasks and agitated for ten days in a shaker incubator (Gallenkamp-OC4364-L) at a temperature $30^{\circ} \mathrm{C}$ and speed of 60 rpm. The treated effluent samples were taken on the tenth day and analyzed for the parameters $\mathrm{pH}$, SS, TDS, COD, and BOD, (Posttreatment determination) for the different grams of bacteria to evaluate and compare the biodegradation potential. (Baba et al., 2020).

\section{Statistical Analysis}

The data were represented as Mean \pm Standard deviation and analyzed statistically using oneway Analysis of Variance (ANOVA) and Tukey's HSD as Post Hoc Tests with the aid of SPSS 16.0. The correlation coefficient was also used to measure the strength of the relationship between the different masses of the bacteria and the parameters. All $\mathrm{p} \leq 0.05$ were considered as statistically significant.

\section{RESULTS AND DISCUSSION Physico-chemical parameters in the Industrial Effluents before the Biodegradation.}

Results of the Physico-chemical parameters in the industrial effluents before the Biodegradation is shown in table 1 . The mean temperatures $\left({ }^{\circ} \mathrm{C}\right)$ observed in TAN1, TAN2, and TAN3 samples were $28.07 \pm 0.65 ; 27.77 \pm 0.64$ and $26.38 \pm 3.81$ respectively. The order of the mean temperature of the samples from the three industries can be arranged as TAN1 > TAN2>TAN3. The temperature observed at TAN1, TAN2, and TAN3 samples were found below the WHO $\left(35^{\circ} \mathrm{C}\right)$ and NESREA $\left(40^{\circ} \mathrm{C}\right)$ limits. The low values of temperature might be due to the processes used at the time of sampling. High temperature brings down the solubility of gases in water that ultimately expresses as high BOD and COD. Statistical analysis shows that there is no significant difference $(p<0.05)$ between the mean values of temperature among the industries. This might be due to similar tannery activities involved in the tannery industries at the time of sampling. The average values of temperature observed in this present study are less than those observed by Akan et al. (2007), Akan et al. (2009) and Baba et al. (2020).

The mean level of $\mathrm{pH}$ observed in TAN1, TAN2 and TAN3, samples were $7.77 \pm 2.93$; $8.35 \pm 0.28$ and $7.52 \pm 0.76$ respectively. The order of the mean $\mathrm{pH}$ of the samples from the three industries can be arranged as TAN2> TAN1 $>$ TAN3. The $\mathrm{pH}$ of the samples falls within the WHO (7.0-8.5) and NESREA (6-9) standard limits. Statistical analysis shows that there is no significant difference $(p<0.05)$ between the mean values of $\mathrm{pH}$ among the industries. This might be due to similar tannery activities involved in the tannery industries at the time of sampling. Maheshwari et al. (2017) reported that the level of $\mathrm{pH}$ in the effluents from the tannery industry in Vaniyambadi, India was 6.5 which was lower than that observed in the present study. The $\mathrm{pH}$ in the effluents from the tannery industries in Kano and Kaduna were reported to be 7.64 and 6.89, respectively (Akan et al., 2007; Mohammed et al., 2017). The average values of $\mathrm{pH}$ observed in this present study are less than those observed by Mohammed et al. (2017) and Baba et al. (2020). The mean level of SS $(\mathrm{mg} / \mathrm{l})$ observed in TAN1, TAN2, and TAN3 samples were 374 \pm 124 ; $358 \pm 335$ and $780 \pm 739$ respectively. The order of the mean SS in the samples from the three industries can be arranged as TAN3 > TAN1 $>$ TAN2. 
The SS observed in the samples were far above the recommended standard limits of regulating bodies WHO $(30 \mathrm{mg} / \mathrm{l})$ and NESREA $(10 \mathrm{mg} / \mathrm{l})$. Statistical analysis shows that there is no significant difference $(p<0.05)$ between the mean values of SS among the industries. This might be due to similar tannery activities involved in the tannery industries at the time of sampling. The average values of SS observed in this present study are less than that observed $(3700 \pm 122 \mathrm{mg} / \mathrm{l})$ by Akan et al. (2009) for tanneries in Kano. Also, the average values of SS observed in this present study are less than that observed by Mohammed et al. (2017) and Baba et al. (2020) with the exception in TAN3.

The mean level of TDS (mg/l) observed in TAN1, TAN2, and TAN3 samples were $3941 \pm 3703$; $3300 \pm 1714$ and $2653 \pm 1240$ respectively. The order of the mean TDS in the samples from the three industries can be arranged as TAN1>TAN2>TAN3. The TDS observed in the samples were far above the recommended standard limits of WHO $(250 \mathrm{mg} / \mathrm{l})$ and NESREA $(500 \mathrm{mg} / \mathrm{l})$. Statistical analysis shows that there is no significant difference $(p<0.05)$ between the mean values of TDS among the industries. This might be due to similar tannery activities involved in the tannery industries at the time of sampling. TDS in the effluents from the tannery industries in Kano, Nigeria was reported to be $1281 \mathrm{mg} / \mathrm{l}$ (Akan et al., 2007). The average values of SS observed in this present study are less than those observed by Mohammed et al. (2017) and Baba et al. 2020)

The mean level of COD (mg/l) observed in TAN1, TAN2 and TAN3 samples seasons were $2372 \pm 938 ; \quad 1406 \pm 208$ and $3532 \pm 1373$ respectively. The order of the mean COD of the samples from the three industries can be arranged as TAN3>TAN1> TAN2. The COD observed in TAN1, TAN2 and TAN3 samples were far above the recommended standard limits of regulating bodies $\mathrm{WHO}(40 \mathrm{mg} / \mathrm{l})$ and NESREA (40 mg/l). Statistical analysis shows that there is no significant difference $(p<0.05)$ in COD among the industries. This might be due to similar tannery activities involved in the tannery industries as at the time of sampling. The Chemical Oxygen demand (COD) is the amount of oxygen, in $\mathrm{mg} / \mathrm{L}$, required for the degradation of the compound of wastewater to occur. In comparison, the average values of COD observed in this present study were higher than that observed by Mohammed et al. (2017) but lower than that observed by Baba et al. (2020).

The mean levels of BOD $(\mathrm{mg} / \mathrm{l})$ observed in TAN1, TAN2 and TAN3 samples were $13.85 \pm 6.42 ; \quad 19.46 \pm 0.50$ and $17.13 \pm 3.14$ respectively. The order of the mean BOD in the samples from the three industries can be arranged as TAN2>TAN3>TAN1. The BOD observed in TAN1, TAN2 and TAN3 samples were found below the recommended limits of NESREA (200 mg/l) but above WHO (10 mg/l). Statistical analysis shows that there is no significant difference $(p<0.05)$ between the mean values of BOD among the industries. This might be due to similar tannery activities involved in the tannery industries at the time of sampling. The low level of BOD recorded in this study is an indication of the low level of biodegradable organic solids in the effluent. The average values of BOD observed in this present study were lower than those observed by Mohammed et al. (2017) and Baba et al. (2020).

Table 1: Mean Values \pm S.D of Physico-chemical parameters of effluents from the Tannery Industries before Treatment.

\begin{tabular}{llllllll}
\hline Parameter & Tannery 1 & Tannery 2 & Tannery 3 & $\mathrm{a}$ & $\mathrm{b}$ & $\mathrm{c}$ & $\mathrm{d}$ \\
\cline { 2 - 7 } Temperature $\left({ }^{\circ} \mathrm{C}\right)$ & $28.07 \mathrm{a} \pm 0.65$ & $27.77 \mathrm{a} \pm 0.64$ & $26.38 \mathrm{a} \pm 3.81$ & & $29.50 \pm 4.68$ & 35 & 40 \\
pH & $7.77 \mathrm{a} \pm 2.93$ & $8.35 \mathrm{a} \pm 0.28$ & $7.52 \mathrm{a} \pm 0.76$ & 6.89 & $5.35 \pm 1.57$ & $7.0-8.5$ & $6.0-9.0$ \\
$\mathrm{COD}(\mathrm{mg} / \mathrm{l})$ & $2372 \mathrm{a} \pm 938$ & $1406 \mathrm{a} \pm 208$ & $3532 \mathrm{a} \pm 1373$ & 2.2 & $3106 \pm 2753$ & 40 & 40 \\
$\mathrm{BOD}(\mathrm{mg} / \mathrm{l})$ & $13.85 \mathrm{a} \pm 6.42$ & $19.46 \mathrm{a} \pm 0.50$ & $17.13 \mathrm{a} \pm 3.14$ & 1032 & $26.17 \pm 9.49$ & 10 & 200 \\
$\mathrm{SS}(\mathrm{mg} / \mathrm{l})$ & $374 \mathrm{a} \pm 124$ & $358 \mathrm{a} \pm 335$ & $780 \mathrm{a} \pm 739$ & 501 & $562 \pm 482$ & 30 & 10 \\
TDS $(\mathrm{mg} / \mathrm{l})$ & $3941 \mathrm{a} \pm 3703$ & $3300 \mathrm{a} \pm 1714$ & $2653 \mathrm{a} \pm 1240$ & 532.7 & $444 \pm 507$ & 250 & 500 \\
\hline
\end{tabular}

The values given in the table above are means of 6 replicate values, $\mathrm{n}=6$ ( 1 sample was taken monthly for 6 months). Within the rows, means with different alphabets are statistically different $(p<0.05)$. WHO: World Health Organisation. NESREA: National Environmental Standard and Regulatory Enforcement Agency. a = Mohammed et al.(2017), b = Baba et al. (2020), c = WHO (2006), $d=$ NESSRA (2009) 
BAJOPAS Volume 13 Number 2, December, 2020

Identification, Biochemical Characterization and growth rates of the Bacterial Isolates

Results of identification and biochemical characterization of the bacterial isolates were shown in table 2. After 24 hours of incubation, the nutrient agar media plates were checked for bacterial growth. The results showed the presence of different strains in the samples. The TAN1 bacteria isolate was found to be gramnegative cocci while TAN3 was gram-positive cocci. TAN2 bacteria isolate was found to be gram-positive, rod-shaped. TAN1, TAN2, and TAN3 bacteria isolates recorded positive results for spore former.

The results of the biochemical tests indicated that all the bacteria were positive for catalase, oxidase, citrate, maltose, glucose, lactose (negative in TAN1), mannitol (negative in TAN2), starch hydrolysis and coagulase (negative in TAN2) tests. The bacteria showed negative results for nitrate reduction, $M R$ (positive in TAN2), VP (positive in TAN1), Indole (positive in TAN2) tests. Base on the morphological and biochemical test results, TAN1, TAN2, and TAN3 bacteria isolates were identified to be Nesseria spp, Bacillus cereus, and Staphylococcus aureus respectively.

The growth rate of the TAN1, TAN2 and TAN3 Isolates were shown in figure 2. Generally, the optical density increase with the increase in time (day) and decrease as time goes on. The highest optical density was shown by bacillus cereus in TAN2 while the lowest was shown by Staphylococcus aureus in TAN3.

The initial growth phase of TAN1 Isolate bacteria occurred within 2-day of incubation as the growth rate increases up to the 6th-day incubation when the maximum growth was observed. Beyond the 6th day, the growth of the bacteria declined (which might be due to a shortage of nutrients in the effluents) until it reached its death phase (which might be due to the unavailability of nutrients in the effluents).

A similar trend of growth was also observed for TAN2 Isolate as the initial growth phase also occurred within 2-day of incubation but maximum growth rate observed on the 4th day of incubation. The stationary stage occurred between the 4th day and the 8th day. Beyond the 8th day, the growth of the bacteria declined (which might be due to a shortage of nutrients in the effluents) until it reached its death phase (which might be due to the unavailability of nutrients in the effluents).

The initial growth phase of TAN3 bacterial Isolate occurred within the 3-day incubation as the growth rate increases up to the 6th-day incubation when the maximum growth was observed. Beyond the 6th day, the growth of the bacteria declined (which might be due to a shortage of nutrients in the effluents) until it reached its death phase (which might be due to the unavailability of nutrients in the effluents).

Table 2: Morphological and Biochemical characteristics of bacterial isolates

\begin{tabular}{lllll} 
Bacterial Isolates & & TAN1 & TAN2 & TAN3 \\
\hline $\begin{array}{lllll}\text { Morphological } \\
\text { characteristics }\end{array}$ & Shape & Cocci & Rod & Cocci \\
& Spore & & & \\
& former & + & + & + \\
Gram & & & \\
Biochemical characteristics & reaction & - & + & + \\
& Citrate & + & + & + \\
& Catalase & + & + & + \\
& Coagulase & + & - & + \\
Starch & + & + & + \\
& Glucose & + & + & + \\
Oxidase & + & + & + \\
& Indo & - & + & - \\
Lactose & - & + & + \\
Manitol & + & - & + \\
Maltose & + & + & + \\
MR & - & + & - \\
VP & + & - & - \\
& Nitrate & - & - & - \\
Reduction & - Neisseria & Bacillus & Staphylococcus \\
& Bacterial & cereus & aureus \\
& name & spp & cas
\end{tabular}

+ = Positive; - = Negative; MR=Methyl Red; VP= Voges-Proskauer 


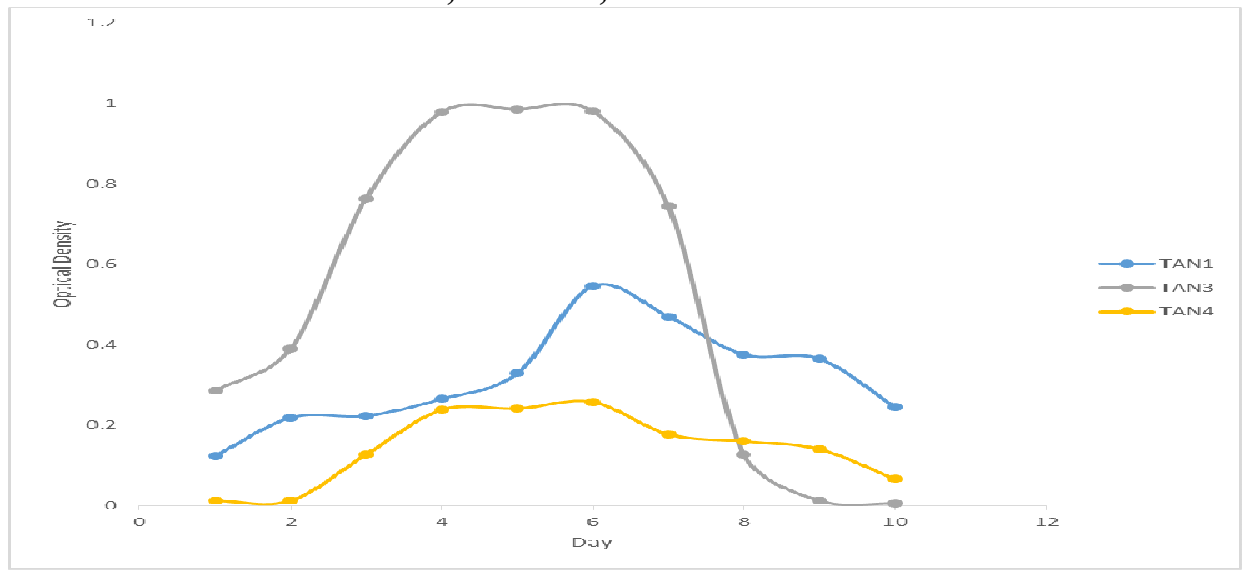

Fig. 2 Growth rates of the isolates in the effluents from the Tannery Industries

\section{Physico-chemical Parameters in the Industrial Effluents after the biodegradation.}

Table 3 shows the mean results of the physicochemical parameter before and after bioremediation using the different masses $(5 \mathrm{~g}$, $10 \mathrm{~g}, 15 \mathrm{~g}, 20 \mathrm{~g}$, and $25 \mathrm{~g}$ ) of the respective immobilized bacteria. Also, Table 4 shows the mean results of correlation coefficient ( $r$ ) between different masses of bacteria and physicochemical parameters.

The mean values $(\mathrm{mg} / \mathrm{l})$ of the SS after the bioremediation varies between $243 \pm 45$ and $898 \pm 672$. The mean concentration $(\mathrm{mg} / \mathrm{l})$ of SS remediated by the different masses $(5 \mathrm{~g}, 10 \mathrm{~g}$, $15 \mathrm{~g}, 20 \mathrm{~g}$, and $25 \mathrm{~g}$ ) of the bacteria varies. The SS in the samples fluctuates up and down after the bioremediation process when compared with the SS of the raw samples before the bioremediation. The increase in the levels of the SS might be due to the aggregation of the TDS which are large enough to result into SS. The increase in the levels of the SS might be also due to the influence of the nutrients which was added into the effluents in order to make the microorganisms more active and viable for fast degradation of organic contaminants in the effluent. The relative potential or efficiency of the different masses of the bacteria in remediating SS in TAN1 samples was in the order $25 \mathrm{~g}>20 \mathrm{~g}>15 \mathrm{~g}>10 \mathrm{~g}>5 \mathrm{~g}$. For TAN2 and TAN3 samples, the order was $25 \mathrm{~g}>20 \mathrm{~g}>15$ $\mathrm{g}>10 \mathrm{~g}>5 \mathrm{~g}$. These might be due to the variations in the surface areas of the different masses of the immobilized bacteria. Statistical analysis shows that there is no significant difference $(p<0.05)$ between the mean values of SS among the masses in the respective industries. Positive and significant correlations exist between the masses of bacteria and Suspended Solid (SS). This showed that there is general increase in the levels of the SS as the masses of the immobilized bacteria increases. TAN3 (90\%) and TAN1 (80\%) showed a very high correlation with the masses of the bacteria while TAN2 (61\%) showed a very low correlation.

The mean values $(\mathrm{mg} / \mathrm{l})$ of the TDS after the bioremediation varies between $46 \pm 11$ and $83 \pm 78$. The mean concentration $(\mathrm{mg} / \mathrm{l})$ of TDS remediated by the different masses $(5 \mathrm{~g}, 10 \mathrm{~g}$, $15 \mathrm{~g}, 20 \mathrm{~g}$, and $25 \mathrm{~g}$ ) of the bacteria varies. There is a reduction in all the TDS of all the samples after the bioremediation process compared with the TDS of the raw samples before the bioremediation. The relative potential or efficiency of the different masses of the bacteria in remediating TDS in TAN1 and TAN3 samples was in the order $5 \mathrm{~g}>10 \mathrm{~g}>15 \mathrm{~g}>20$ $\mathrm{g}>25 \mathrm{~g}$. For TAN2 samples, the order was 20 $g>10 \quad g>25 \quad g>15 \quad g>5 \quad g$. Statistical analysis shows that there is no significant difference $(p<0.05)$ between the mean values of TDS among the masses in the respective industries. These might be due to the variations in the surface areas of the different masses of the immobilized bacteria. Positive and significant correlations exist between the masses of bacteria and TDS with the exception in TAN2 (negative and insignificant correlation). The positive correlations showed that there is general increase in the levels of the TDS as the masses of the immobilized bacteria increases. TAN1 $(96 \%)$ showed a very high correlation with the masses of the bacteria while TAN2 (47\%) showed a very low correlation.

The mean values $(\mathrm{mg} / \mathrm{l})$ of the BOD after the bioremediation varies between $1.56 \pm 0.20 \mathrm{mg} / \mathrm{l}$ and $6.92 \pm 5.49 \mathrm{mg} / \mathrm{l}$. The mean concentration $(\mathrm{mg} / \mathrm{l})$ of BOD remediated by the different masses $(5 \mathrm{~g}, 10 \mathrm{~g}, 15 \mathrm{~g}, 20 \mathrm{~g}$, and $25 \mathrm{~g}$ ) of the bacteria varies. There is a reduction in all the BOD of all the samples after the bioremediation process compared with the $\mathrm{BOD}$ of the raw 
BAJOPAS Volume 13 Number 2, December, 2020 samples before the bioremediation. The relative potential or efficiency of the different masses of the bacteria in remediating BOD in TAN1, TAN2 and TAN3 samples were in the order $25 \mathrm{~g}>20$ $\mathrm{g}>15 \mathrm{~g}>10 \mathrm{~g}>5 \mathrm{~g}, 25 \mathrm{~g}>15 \mathrm{~g}>5 \mathrm{~g}>10 \mathrm{~g}>20 \mathrm{~g}$ and $20 \mathrm{~g}>10 \mathrm{~g}>25 \mathrm{~g}>15 \mathrm{~g}>5 \mathrm{~g}$ respectively. Statistical analysis shows that there is significant difference $(p<0.05)$ between the mean values of BOD among the masses in the respective industries. These might be due to the variations in the surface areas of the different masses of the immobilized bacteria. Negative and significant correlations exist between the masses of bacteria and BOD. This showed that there is general decrease in the levels of the BOD as the masses of the immobilized bacteria increases. TAN1 (94\%) showed a very high correlation with the masses of the bacteria while TAN2 (4\%) showed a very low correlation.

The mean values $(\mathrm{mg} / \mathrm{l})$ of the COD after the bioremediation varies between $250 \pm 154$ and $3134 \pm 1595$. The mean concentration $(\mathrm{mg} / \mathrm{l})$ of COD remediated by the different masses $(5 \mathrm{~g}$, $10 \mathrm{~g}, 15 \mathrm{~g} 20 \mathrm{~g}$, and $25 \mathrm{~g}$ ) of the bacteria varies. There is a reduction in all the COD of all the samples after the bioremediation process compared with the COD of the raw samples before the bioremediation. The relative potential or efficiency of the different masses of the bacteria in remediating COD in TAN1, TAN2 and TAN3 samples were in the order $25 \mathrm{~g}>20 \mathrm{~g}>15$ $\mathrm{g}>5 \mathrm{~g}>10 \mathrm{~g}, 25 \mathrm{~g}>20 \mathrm{~g}>15 \mathrm{~g}>10 \mathrm{~g}>5 \mathrm{~g}$ and 10 g>5 g>25 g>15 g>20 g respectively. Statistical analysis shows that there were significant difference $(p<0.05)$ between the mean values of COD among the masses in the respective industries except for effluents treated with $25 \mathrm{~g}$. These might be due to the variations in the surface areas of the different masses of the immobilized bacteria. Negative and insignificant correlations exist between the masses of bacteria and COD with the exception in TAN3 (positive and significant correlation). The negative correlations showed that there is general decrease in the levels of the COD as the masses of the immobilized bacteria increases. TAN2 (100\%) showed a very high correlation with the masses of the bacteria while TAN3 (36\%) showed a very low correlation.

Generally, there was an overall decrease in the concentration of these physicochemical parameters after the bioremediation using the different masses of the bacterial isolates. These might be due to the variations in the surface areas of the different masses of the immobilized bacteria. This is in line with the work of Jimoh et al. (2018) and Baba et al. (2020).

Table 3: Mean Values $(\mathrm{mg} / \mathrm{l}) \pm$ S.D of Physicochemical parameters in effluents from the Tannery Industries before and after Treatment of the effluents $(250 \mathrm{ml})$ with the different masses $(5 \mathrm{~g}, 10 \mathrm{~g}$, $15 \mathrm{~g}, 20 \mathrm{~g}$, and $25 \mathrm{~g}$ ) of the bacteria.

\begin{tabular}{llllllll}
\hline $\mathrm{P}$ & IND & Before & \multicolumn{5}{c}{ After } \\
\cline { 4 - 7 } & & & $5 \mathrm{~g}$ & $10 \mathrm{~g}$ & $15 \mathrm{~g}$ & $20 \mathrm{~g}$ & $25 \mathrm{~g}$ \\
\hline \multirow{2}{*}{ COD } & TAN1 & $2372 \pm 938$ & $1708 \mathrm{a} \pm 861$ & $2045 \mathrm{a} \pm 1205$ & $845 \mathrm{a} \pm 369$ & $300 \mathrm{a} \pm 167$ & $250 \mathrm{a} \pm 154$ \\
& TAN2 & $1406 \pm 208$ & $1195 \mathrm{a} \pm 208$ & $1125 \mathrm{a} \pm 384$ & $1055 \mathrm{a} \pm 317$ & $956 \mathrm{a} \pm 310$ & $870 \mathrm{ab} \pm 240$ \\
& TAN3 & $3532 \pm 1373$ & $2374 \mathrm{a} \pm 1344$ & $1976 \mathrm{a} \pm 1405$ & $2757 \mathrm{a} \pm 1266$ & $3134 \mathrm{a} \pm 1595$ & $2614 \mathrm{~b} \pm 1105$ \\
BOD & TAN1 & $13.85 \pm 6.42$ & $6.92 \mathrm{a} \pm 5.49$ & $6.42 \mathrm{a} \pm 5.07$ & $5.72 \mathrm{a} \pm 5.35$ & $4.62 \mathrm{a} \pm 4.37$ & $2.82 \mathrm{ab} \pm 1.26$ \\
& TAN2 & $19.46 \pm 0.50$ & $1.75 \mathrm{~b} \pm 0.22$ & $1.73 \mathrm{~b} \pm 0.18$ & $1.58 \mathrm{a} \pm 0.16$ & $1.91 \mathrm{a} \pm 0.22$ & $1.56 \mathrm{~b} \pm 0.20$ \\
& TAN3 & $17.13 \pm 3.14$ & $4.24 \mathrm{ab} \pm 0.77$ & $3.29 \mathrm{ab} \pm 0.37$ & $4.11 \mathrm{a} \pm 0.07$ & $3.23 \mathrm{a} \pm 0.91$ & $3.33 \mathrm{a} \pm 1.28$ \\
SS & TAN1 & $374 \pm 124$ & $243 \mathrm{a} \pm 45$ & $471 \mathrm{a} \pm 226$ & $475 \mathrm{a} \pm 182$ & $492 \mathrm{a} \pm 128$ & $611 \mathrm{a} \pm 217$ \\
& TAN2 & $358 \pm 335$ & $460 \mathrm{a} \pm 400$ & $543 \mathrm{a} \pm 414$ & $544 \mathrm{a} \pm 402$ & $551 \mathrm{a} \pm 414$ & $554 \mathrm{a} \pm 405$ \\
& TAN3 & $780 \pm 739$ & $586 \mathrm{a} \pm 594$ & $758 \mathrm{a} \pm 656$ & $787 \mathrm{a} \pm 676$ & $861 \mathrm{a} \pm 635$ & $898 \mathrm{a} \pm 672$ \\
TDS & TAN1 & $3941 \pm 3703$ & $51 \mathrm{a} \pm 10$ & $53 \mathrm{a} \pm 10$ & $55 \mathrm{a} \pm 15$ & $61 \mathrm{a} \pm 20$ & $63 \mathrm{a} \pm 26$ \\
& TAN2 & $3300 \pm 1714$ & $83 \mathrm{a} \pm 78$ & $47 \mathrm{a} \pm 20$ & $48 \mathrm{a} \pm 22$ & $47 \mathrm{a} \pm 17$ & $48 \mathrm{a} \pm 17$ \\
& TAN3 & $2653 \pm 1240$ & $46 \mathrm{a} \pm 11$ & $55 \mathrm{a} \pm 24$ & $55 \mathrm{a} \pm 25$ & $58 \mathrm{a} \pm 23$ & $61 \mathrm{a} \pm 28$ \\
\hline
\end{tabular}

Replicate $=6$ (months)

Within the rows, for the same parameter, means with different alphabets are statistically different $(p<0.05)$.

$\mathrm{P}=$ parameter, IND = Industries 
BAJOPAS Volume 13 Number 2, December, 2020

Table 4: Correlation coefficient $(r)$ between different masses of the bacteria and the physicochemical parameters.

\begin{tabular}{llll}
\hline Industries & Parameter & Correlation coefficient $(r)$ & $\begin{array}{l}\text { Percent dependence (rxrx100) } \\
(\%)\end{array}$ \\
\hline TAN1 & COD & -0.9 & 82 \\
& BOD & -0.97 & 94 \\
& SS & $0.90^{*}$ & 80 \\
TAN2 & TDS & $0.98^{*}$ & 96 \\
& COD & -1 & 100 \\
& BOD & -0.21 & 4 \\
& SS & $0.78^{*}$ & 61 \\
& TDS & -0.69 & 47 \\
& COD & $0.60^{*}$ & 36 \\
& BOD & -0.6 & 37 \\
& SS & $0.95^{*}$ & 90 \\
& TDS & $0.94^{*}$ & 89 \\
\hline
\end{tabular}

The correlation coefficient $(r)$ with * is statistically significant $(p<0.05)$.

Percentage reduction of the Parameters

Table 5 shows the percentage reduction of Parameters in industrial samples before and after the treatment of the effluents $(250 \mathrm{ml})$ with the different masses $(5 \mathrm{~g}, 10 \mathrm{~g}, 15 \mathrm{~g}, 20 \mathrm{~g}$, and $25 \mathrm{~g}$ ) of the Immobilized Bacteria.

In TAN1 samples, the percentage reduction (\%) of COD ranged (14-89); BOD (50-80); SS (-32$35)$ and TDS (98-99). In TAN2 samples, the percentage decrease $(\%)$ of COD ranged (15$38) ;$ BOD (90-92); SS [-28-(-55)] and TDS (9798). In TAN3 samples, the percentage decrease (\%) of COD ranged (11-44); BOD (76-81); SS (15-25) and TDS (98). The percentage increase in the levels COD, BOD and TDS might be due to the increase in the surface area of the different masses of the immobilized bacteria. However, the percentage decrease in the levels of the SS might be due to the aggregation of the TDS which are large enough to result into SS. The percentage decrease in the levels of the SS might be also due to the influence of the nutrients which was added into the effluents in order to make the microorganisms more active and viable for fast degradation of organic contaminants in the effluent. This is in line with the work of Jimoh et al. (2018) in which the concentration of the SS increase after the bioremediation of effluents.

Sreemoyee and Priti (2013) assessed and reduced several Physico-chemical parameters of dairy wastewater using Niesseria $s p$. and concluded that the species are well known to degrade organic compounds. This is in agreement with the current study in which the immobilized Niesseria $s p$ degrade the organic contaminants as indicated by the BOD, COD and TDS.

Jimoh et al. (2018) observed that TSS of the effluents was increased after treatment with immobilized bacteria and concluded that it might be due to the biostimulation method adopted for the research.

The optimum $\mathrm{pH}$ Biosorption of Chromium by Bacillus spp and Staphylococcus spp. from tannery effluent was investigated by Mythili and Karthikeyan (2011). The maximum adsorption of Chromium $(86.4 \mathrm{mg} / \mathrm{L})$ was showed by Bacillus spp and Staphylococcus spp showed $70.6 \mathrm{mg} / \mathrm{L}$ at an initial concentration of $100 \mathrm{mg} / \mathrm{L}$. In the present study, immobilised Bacillus spp and Staphylococcus spp. from the tannery industrial effluents reduced the levels of the organic pollutants with high potential as indicated by the percentage reduction of BOD, COD and TDS.

Enzymes often can work in multiple environments especially if they are immobilized. This makes the microorganisms' enzymes even more resistant to harsh environments and enables the enzymes to be recovered and recycled after they are no longer needed (Gianfreda and Rao 2004). Ramesh and Singh (1993) reported that the immobilized bacteria having more efficiency to remove the suspended particles than free cells. Using the immobilized cell is preferable due to its capability for using several times with the same efficiency, which makes it more economical. Similar work was done by Sikander et al. (2007) showing the higher reduction with permeabilized cells of Ochrobactrum intermedium strain SDCr-5. 
BAJOPAS Volume 13 Number 2, December, 2020

The results revealed the isolation and identification of isolates with the potential for the reduction of $\mathrm{Cr}$ (VI) to $\mathrm{Cr}$ (III). Results indicated that immobilized $B$. cereus could be efficiently used for the reduction of $\mathrm{Cr}$ (VI).

Table 5: Percentage reduction of the tested Parameters from the tannery industrial samples of the Immobilized Bacteria.

\begin{tabular}{lllllll}
\hline \multirow{2}{*}{ Industries } & & \multicolumn{5}{c}{ Percentage Reduction $(\%)$} \\
\cline { 3 - 7 } & & $5 \mathrm{~g}$ & $10 \mathrm{~g}$ & $15 \mathrm{~g}$ & $20 \mathrm{~g}$ & $25 \mathrm{~g}$ \\
\hline TAN1 & COD & 28 & 14 & 64 & 87 & 89 \\
& BOD & 50 & 54 & 59 & 67 & 80 \\
& SS & 35 & -26 & -27 & -32 & -63 \\
& TDS & 99 & 99 & 99 & 98 & 98 \\
TAN2 & COD & 15 & 20 & 25 & 32 & 38 \\
& BOD & 91 & 91 & 92 & 90 & 92 \\
& SS & -28 & -52 & -52 & -54 & -55 \\
& TDS & 97 & 99 & 99 & 99 & 99 \\
& COD & 33 & 44 & 22 & 11 & 26 \\
& BOD & 75 & 81 & 76 & 81 & 81 \\
& SS & 25 & 3 & -1 & -10 & -15 \\
& TDS & 98 & 98 & 98 & 98 & 98 \\
\hline
\end{tabular}

Percentage Reduction $=(B-A) / B \times 100 \%$

$A=$ Concentration of the parameter after treatment

$\mathrm{B}=$ Concentration of the parameter before treatment

$+=$ percentage decrease

- = percentage increase

In general, immobilization makes the enzyme more resistant to temperature, $\mathrm{pH}$, and substrate concentration swings giving it a longer lifetime and higher productivity per active unit (Gianfreda and Rao, 2004; FuIlbrook, 1996; Russell et al, 2003; Kandelbauer et al., 2004). Immobilized cells have been used and studied extensively for the production of useful chemicals (Ohtake and Silver, 1994), the treatment of wastewaters (Chen et al., 2003; Wang et al., 2010). Although many workers described microbial degradation of tannery effluent, limited literature is available on the bioremediation of tannery effluent using immobilized bacterial cells in the Kano Industrial Estates.

\section{CONCLUSION}

The samples contained variable levels of the physicochemical parameters. The results of the Analysis of variance revealed that, no statistical difference $(p<0.05)$ was observed for the temperature, $\mathrm{pH}, \mathrm{SS}, \mathrm{TDS}, \mathrm{BOD}$ and $\mathrm{COD}$ among the three tannery industries before the treatment. The levels of some of the parameters
(SS, TDS and COD) observed in the samples were found above the recommended limits of WHO and NESREA, which called for the treatment of the effluents before discharge into the environment. Base on the morphological and biochemical test results, TAN1, TAN2, and TAN3 bacterial isolates were identified to be Neisseria spp, Bacillus cereus, and Staphylococcus aureus respectively. The results of Post-treatment analysis showed that there is overall decrease in the levels of the parameters determined when compared with that of the pre-treatment. The overall percentage reduction of the immobilised bacteria in the treatment of the respective effluents was in the order TAN2 (72\%)>TAN1 $(70 \%)>$ TAN3 $(62 \%)$. Hence, the immobilized bacteria are having higher biodegradation potential for the treatment of the tannery effluents.

\section{Acknowledgments}

The authors wish to acknowledge the University of Maiduguri for the financial support. The authors are grateful to the Kano State Ministry of Environment for their support in obtaining the effluent samples. 


\section{REFERENCES}

Ajao, A. T., Adebayo, G. B., and Yakubu, S. E. (2011). Bioremediation of textile industrial effluent using mixed culture of Pseudomonas aeruginosa and Bacillus subtilis immobilized on agar-agar in a bioreactor. J. Microbiol. Biotech. Res, 1(3), 50-56.

Akan, J. C., Moses, E. A., Ogugbuaja, V. O., and Abah, J. (2007). Assessment of tannery industrial effluents from Kano metropolis, Kano State, Nigeria. Journal of Applied Sciences, 7(19), 2788-2793.

Akan, J. C., Ogugbuaja, V. O., Abdulrahman, F. I., and Ayodele, J. T. (2009). Pollutant levels in effluent samples from tanneries and textiles of Kano industrial areas, Nigeria. Global journal of pure and applied sciences, 15(3-4).

APHA (1989). Standard methods for Examination of Will bete and Will betewater.15 $5^{\text {th }}$ edition. Brydpass Springfield Will behington DC. pp. 164-176

APHA (1992). Standard Methods for the Examination of Water and Wastewater. Health, 69, 1116-9.

Baba, A., Garba, S. T., and Bello, H. S. (2020). Bioremediation Potential of Immobilized corynebacterium kutsceri in the Treatment of Tannery Industrial Effluent from Challawa Industrial Estate, Kano State, Nigeria. Journal of the Turkish Chemical Society Section A: Chemistry, $7(2), 335-350$.

Beem, E. I. V. (1994). reduction of solvent VOC emission. J. Oil Col. Chem. Ass, 77, 158.

Bouwer, E. J., and Zehnder, A. J. (1993). Bioremediation of organic compoundsputting microbial metabolism to work. Trends in biotechnology, 11(8), 360367.

Chen, K. C., Wu, J. Y., Liou, D. J., and Hwang, S. C. J. (2003). Decolorization of the textile dyes by newly isolated bacterial strains. Journal of Biotechnology, 101(1), 57-68.

Dan'Azumi, S., and Bichi, M. H. (2010). INDUSTRIAL POLLUTION AND HEAVY METALS PROFILE OF CHALLAWA RIVER IN KANO, NIGERIA. Journal of Applied Sciences in Environmental Sanitation, $5(1)$.

DWAF. (1992). Analytical Methods Manual, TR 151. Department of Water Affairs and Forestry, Pretoria.

El-Bestawy, E. (2013). Biological treatment of leather-tanning industrial wastewater using free living bacteria.
Elsheikh, M. A. S. (2009). Tannery wastewater pre-treatment. Water Science and Technology, 60(2), 433-440.

FuIlbrook, P. D. (1996). "Kinetics." Industrial enzymology: The application of enzymes in Industry. 2nd Ed. T. Godfrey and J Reichelt. eds.. Nature. New York.

Gianfreda, L., and Rao, M. A. (2004). Potential of extra cellular enzymes in remediation of polluted soils: a review. Enzyme and microbial technology, 35(4), 339354.

Hugo Springer. (1994). John Arthur Wilson Memorial Lecture "Treatment of Industrial Wastes of the Leather Industry - is it still a Major Problem". JALCA, 89, 153-185

Jimoh, A. A., Ganiyu, B. A., Baba, D., and Baba, A. (2018) Bioremediation Process of Effluent from Detergent and Food Industries in Jos, Nigeria: Kinetics and Thermodynamics. International Journal of Engineering Science Invention (IJESI), 762-73

Kandelbauer, A., Maute, O., Kessler, R. W., Erlacher, A., and Gübitz, G. M. (2004). Study of dye decolorization in an immobilized laccase enzyme-reactor using online spectroscopy. Biotechnology and bioengineering, 87(4), 552-563.

Kongjao, S., Damronglerd, S., and Hunsom, M. (2008). Simultaneous removal of organic and inorganic Pollutants in tannery wastewater using electrocoagulation technique. Korean Journal of chemical engineering, 25(4), 703.

Maheshwari, U. M., Aruna, S., Gomathi, M., and AbdulJaffar, A. H. (2017). Bioremediation by Free and Immobilized Bacteria Isolated from Tannery Effluent. International Journal of Research in Applied, Natural and Social Sciences. 5(7), 75-90

Margesin, R., and Schinner, F. (2001). Bioremediation (natural attenuation and biostimulation) of diesel-oilcontaminated soil in an alpine glacier skiing area. Applied and environmental microbiology, 677), 3127-3133.

Mohammed, A., Sekar, P., and George, J. (2011). Efficacy of microbes in bioremediation of tannery effluent. Inter. J. Curr. Res, 3(4), 324-326.

Mohammed, S. S. D., Orukotan, A. A., and Abdullahi, H. (2017). Physicochemical and Bacteriological Assessment of Tannery Effluent from Samaru-Zaria, 
BAJOPAS Volume 13 Number 2, December, 2020 Kaduna State, Nigeria. Journal of Applied

Sciences and Environmental Management, 21(4), 734-740.

Munz, G., De Angelis, D., Gori, R., Mori, G., Casarci, M., and Lubello, C. (2009). The role of tannins in conventional and membrane treatment of tannery wastewater. Journal of hazardous materials, 164(2-3), 733-739

Mythili, K., and Karthikeyan, B. (2011). Bioremediation of $\mathrm{Cr}$ (VI) from tannery effluent using Bacillus spp and Staphylococcus spp. International Multidisciplinary Research Journal, 1(6).

NESREA (2009). National Environmental Standards for Effluent Limitations and Regulation. 1233-1236

Noorjahan, C. M. (2014). Physicochemical characteristics, identification of bacteria and biodegradation of industrial effluent. Journal of bioremediation and Biodegradation, 5(3).

Ohtake, H. I., and Silver, A. O. (1994). Bacterial reduction of toxic chromate. Biological degradation and bioremediation of toxic chemicals, 403-415.

Omoleke, I. I. (2004). Management of environmental pollution in Ibadan, an African city: the challenges of health hazard facing government and the people. Journal of Human Ecology, 15(4), 265-275.

Rajor, A., Reddy, A.S., and Singh, B. (2004). Determination of BOD kinetic Parameters and evaluation of alternate methods, M.Sc. Thesis, Department of biotechnology \& environmental Science, Thapar Institute of Engineering and Technology, Patiala

Ramasami, T., Rajamani, S., and Rao, J. R. (1994, March). Pollution control in leather industry: Emerging technological options. In International symposium on surface and colloidal science and its relevance to soil pollution, madras.

Ramesh, J. V. S., and Singh, S. P. (1993). Yearly variation in certain physicochemical parameters of pond at eastern Doon Valley. Uttar Pradesh J. Zoo, 12 (1), 7577.

Ranen, S., and Sharadinadra, C. (2009). Biotechnology applications to environmental remediation in resource exploitation. Current science, 97, 6-25
Russell, A. J., Berberich, J. A., Drevon, G. F., and Koepsel, R. R. (2003). Biomaterials for mediation of

chemical and biological warfare agents. Annual review of biomedical engineering, 5(1), 1-27.

Saravanan, P., and Saravanan, A. (1999). Decolourization of tannery effluent by Flavobacterium sp. EK 1. Indian Journal of Environmental Protection, 19, 19-24.

Sikander, S., and Shahida, H. (2007). Reduction of toxic hexavalent chromium by Ochrobactrum intermedium strain SDCr5 stimulated by heavy metals. Bioresource Technol, 98, 340-344.

Singh, N., Sharma, B. K., and Bohra, P. C. (2000). Impact assessment of industrial effluent of arid soils by using satellite imageries. Journal of the Indian Society of Remote Sensing, 28(2-3), 79.

Sreemoyee, C., and Priti, P. (2013). Assessment of physico-chemical parameters of dairy waste water and isolation and characterization of bacterial strains in terms of cod reduction. Int J Sci, 2(3), 395-400.

Verheijen, L. A. H. M., Wiersema, D., Pol, L. H., and De Wit, J. (1996). Management of wastes from animal product processing. Livestock and environment, Finding a balance. International Agriculture Center, Wageningen, The Netherlands.

Wang, F., Yao, J., Si, Y., Chen, H., Russel, M., Chen, K., and Bramanti, E. (2010). Short-time effect of heavy metals upon microbial community activity. Journal of Hazardous Materials, 173(13), 510-516.

WHO (World Health Organization). (2006). Air quality guidelines: global update 2005: particulate matter, ozone, nitrogen dioxide, and sulfur dioxide. World Health Organization.

World Bank. (1995). Nigeria's strategic options for redressing industrial pollution. World Bank, industry and energy division. 1st edition, West Central Africa Department; Annexes: 1995; pp 60-62.

Zahoor, A., and Abdul, R. (2009). Enumeration of Coliforms. Journal of Environmental Sciences. 21, 814-820 


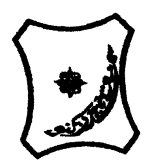

Bayero Journal of Pure and Applied Sciences, 13(2): 1 - 12

Received: November, 2020

Accepted: December, 2020

ISSN $2006-6996$

\title{
BIODEGRADATION POTENTIAL OF IMMOBILIZED BACTERIA IN THE TREATMENT OF TANNERY INDUSTRIAL EFFLUENTS FROM INDUSTRIAL ESTATES IN KANO STATE, NIGERIA
}

\author{
Abdullateef, B., ${ }^{1 *}$ Shuaibu, T. G., ${ }^{1}$ Babagana, K., ${ }^{1}$ Suleman, H. B. ${ }^{2}$ and Dauda, B. ${ }^{3}$ \\ ${ }^{1}$ Department of Pure and Applied Chemistry, Faculty of Science, University of Maiduguri, Borno State, \\ Nigeria \\ ${ }^{2}$ Department of Microbiology, Faculty of Science, University of Maiduguri, Borno State, Nigeria \\ ${ }^{3}$ Department of Chemical Engineering, Faculty of Engineering, University of Maiduguri, Borno State, \\ Nigeria \\ *Corresponding author: babslega@gmail.com; abelega2007@yahoo.com; +2348061309753
}

\section{ABSTRACT}

Industrial Effluents Samples from Gashash Tanneries (TAN1) in Bompai Industrial estate, Larabee Tannery Industry (TAN2) in Sharada Industrial estate and Z Tannery Industries (TAN3) in Challawa Industrial estate, Kano State, Nigeria were collected over a period of six months (August 2017 to January 2018) for assessing the biodegradation potentials of bacteria in the treatment of organic pollutants within the effluents. Bacteria were isolated from the effluents and immobilized on agar-agar. Different masses (5 g, $10 \mathrm{gr}, 15$ $\mathrm{g}, 20 \mathrm{~g}$, and $25 \mathrm{~g}$ ) of the bacteria were used in the treatment of $250 \mathrm{ml}$ of the effluents for ten days in a shaker incubator (Gallenkamp-OC-4364-L) at the temperature $30{ }^{\circ} \mathrm{C}$ and speed of $60 \mathrm{rpm}$. Pre-treatment analysis of the effluents for Temperature, pH, Biochemical Oxygen Demand (BOD), Chemical Oxygen Demand (COD), Suspended Solid (SS) and Total Dissolved Solids (TDS) gives the following results; temperature $\left({ }^{\circ} \mathrm{C}\right.$ )

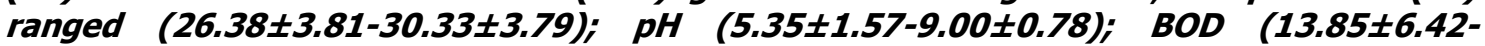
$38.75 \pm 16.20) ;$ COD (1406 $\pm 208-3532 \pm 1373) ;$ SS (208 $\pm 235-780 \pm 739)$ and TDS (266 $\pm 253-5276 \pm 2971)$. No statistical differences ( $p \leq 0.05)$ was observed for all the results among the different industries. The bacterial isolates were identified as Neisseria spp, Bacillus cereus, and Staphylococcus aureus, in TAN1, TAN2, and TAN3, respectively. After treatment of the effluent with the different masses of the isolated bacteria, the mean level of BOD was found to range as (0.55 $\pm 0.36-6.92 \pm 5.49) ; C O D$ (ND-3134 \pm 1595$)$;

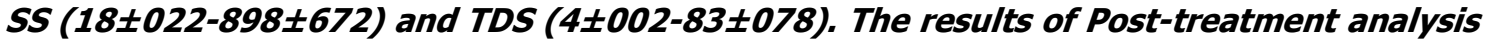
showed that there is overall decrease in the levels of the parameters determined when compared with that of the pre-treatment. The overall percentage reduction of the immobilised bacteria in the treatment of the respective effluents was in the order TAN2 (72\%)>TAN1 (70\%)>TAN3 (62\%). Hence, the immobilized bacteria are having higher biodegradation potential for the treatment of the tannery effluents.

Keywords: Biodegradation, bacteria, effluent, immobilization, tannery.

\section{INTRODUCTION}

Tannery industrial wastewater is a serious consequence of the pollution point of view for streams, freshwater, and land used for agriculture. The lack of awareness in the modern industrial practice has resulted in the discharge of tannery effluents which exhibit very high value of chromium ( $\mathrm{Cr}$ ), Sulfide, and chloride, Total Dissolved Solid (TDS), Total Suspended Solid (TSS), Biochemical Oxygen Demand (BOD) and Chemical Oxygen Demand (COD) in the water stream or land (Mohammed et al., 2001). Tanning is the process, which One ton of skin generally leads to the production of 20 to $80 \mathrm{~m}^{3}$ of turbid and foul-smelling converts the protein of the rawhide or skin into a stable material, which will not putrefy and is suitable for a wide variety of end applications (Elsheikh, 2009). The highly polluting chromium is the most commonly used tanning material producing leather that is more flexible and pliable than vegetable-tanned leather and does not discolor or lose shape in water as drastically as vegetable-tan (Elsheikh, 2009). Tannery effluent is among the most hazardous industrial pollutants due to its huge organic and inorganic load, which is highly toxic to human life and the environment (Kongjao et al., 2008). wastewater including chromium (100-400 mg/l), sulfide $(200-800 \mathrm{mg} / \mathrm{l})$, high levels of fat and 
BAJOPAS Volume 13 Number 2, December, 2020 other solid wastes, and notable pathogen contamination as well as pesticides added for skin conservation during transport (Elsheikh, 2009). There are more than 6000 tanneries in Nigeria with an annual processing capacity of 700,000 tons of hides and skins (Omoleke, 2004; Singh et al., 2008). It was reported that the total amount of waste produced per animal slaughtered is approximately $35 \%$ of its weight (World Bank, 1995). Also, for every $1000 \mathrm{~kg}$ of carcass weight, a slaughtered beef produces 5.5 $\mathrm{kg}$ of manure (excluding rumen contents or stockyard manure) and $100 \mathrm{~kg}$ of paunch manure (undigested food) (Verheijen et al., 1996). Tanneries generate wastewater in the range of 30-35 $\mathrm{L} \mathrm{kg}^{-1}$ skin/hide processed with variable $\mathrm{pH}$, Biological Oxygen Demand (BOD), Chemical Oxygen Demand (COD), high concentrations of suspended solids (SS), and tannins as well as chromium (Zahoor and Abdul, 2009).

Being heterogeneous and composed of a wide variety of compounds, it is very difficult to select a unique direct method for estimating the biodegradability of organic contents and biokinetic parameters for a wastewater sample (Rajor, 2004). For this purpose, some indirect estimation such as determination of biochemical oxygen demand (BOD) and chemical oxygen demand (COD) are applied as common laboratory investigations [9]. During retanning procedures, synthetic tannins (Syntan), oils and resins are added to form softer leather at varying doses (Munz et al., 2009). One of the refractory groups of chemicals in tannery effluents derives mainly from tannins (Ramasami et al., 2004). Syntans are characterized by complex chemical structures, because they are composed of an extended set of chemicals such as phenol-, naphthalene-, formaldehyde- and melamine-based syntans, and acrylic resins (Beem, 1994). Organic pollutants (proteic and lipidic components) are originated from skins (it is calculated that the raw skin has $30 \%$ loss of organic material during the working cycle) or they are introduced during processes (Hugo Springer, 1994).

Many conventional processes such as oxidation, chemical and biological processes were carried out to treat tanneries wastewater (Ebtesam et al, 2013). Biological processes have received more attention because of their costeffectiveness, lower sludge production and environmental friendliness (Noorjahan, 2014). Naturally occurring micro-organisms degrade the hazardous organic wastes including xenobiotic compounds, such as pesticides, polycyclic aromatic hydrocarbons (PAHs) and polychlorinated biphenyls (PCBs) in due course of time (Ranen and Sharadinadra, 2009). Bioremediation is based on the idea that all organisms remove substances from the environment to carry outgrowth and metabolism (Bouwer and Zehnder, 1993). Bacteria, protista and fungi are found to be very good at degrading complex molecules and incorporating the breakdown products into their metabolism (Bouwer and Zehnder, 1993). The resultant metabolic wastes that they produce are generally safe and somehow recycled into other organisms (Ranen and Sharadinadra, 2009). An acclimatized indigenous population of microorganisms capable of degradation of the compounds of interest must exist at the site for a successful bioremediation mode (Ranen and Sharadinadra, 2009). It has been observed that for a successful bioremediation mode, an acclimatized indigenous population of microorganisms capable of degradation of the compounds of interest must exist at the site under investigation (Ranen and Sharadinadra, 2009). Even though there are numerous physical and chemical methods employed in the disposal of wastes the advantage in using bacterium is that they play a key role in the reduction of COD, BOD, total protein, total tannin and total phenol (Saravanan and Saravanan, 1998)

Baba et al. (2020) studied the bioremediation potential of immobilized corynebacterium kutsceri in the Treatment of tannery industrial effluent from Challawa Industrial Estate, Kano State, Nigeria. The aim of the work is to study the reduction in the level of the contaminants through the process of bioremediation using the isolated bacteria. Immobilized bacteria can withstand various temperatures, $\mathrm{pH}$ and substrate concentrations; consequently, increasing the efficiency and the lifespan of the bacteria. Immobilized bacteria are widely applied in the treatment of wastewater and can be separated and recovered after the treatment with the same efficiency (Baba et al., 2020).

\section{MATERIALS AND METHODS \\ Study Area}

This study was carried out in Bompai, Sharada and Challawa industrial estates in Kano, Figure 1. Kano lies on Latitude $11^{\circ} 30^{\prime} \mathrm{N}$ and $8^{\circ} 30^{\prime} \mathrm{E}$ and Longitude $11^{\circ} 5^{\prime} \mathrm{N}$ and $8^{\circ} 5^{\prime} \mathrm{E}$ in Northern Nigeria. It is one of the developed industrial cities in Nigeria. Tannery activities are the dominating industries and this could be one of the reasons for her high population density (Dan'Azumi and Bichi, 2010). Many researchers have studied biodegradation of tannery effluent using microorganisms. However, limited literature is available on the biodegradation of tannery effluent in Kano industrial estates using 
BAJOPAS Volume 13 Number 2, December, 2020 immobilized bacterial cells. This research work focuses on the potential of the use of the indigenous immobilized bacterial isolates in the treatment of tannery effluents in the industrial estates.

\section{Sample Collection}

Effluents were collected from the Tannery Industries from Bompai, Challawa and Sharada Industrial Estates, Kano, Nigeria. The effluents were collected over a period of six months (August 2017 to January 2018). Samples collected in a sterile 4-liter plastic container with a unique identification number were preserved using an ice-box that was transported to the Microbiology Laboratory, Department of Microbiology, Bayero University of Kano for analysis

\section{Sample Preparation and Sample Analysis}

Immediately after the collection of the effluent, $\mathrm{pH}$, TSS, TDS, COD, BOD levels were determined before treatment (Pre-treatment determination) and ten days after treatment (Post-treatment determination) as described in
APHA (1989) standard methods. $\mathrm{pH}$ was determined using Ecotests $\mathrm{pH}$ meter and TDS was determined using AQUALYTIC TDS Salinometer. BOD was determined as described by the standard method (APHA, 1992). COD and SS were determined using DR/2010 HACH portable data logging spectrophotometer (DWAF, 1992)

\section{Identification and Biochemical} Characterization of the Bacterial Isolates

The bacteria were isolated from the effluents using Serial Dilution according to the method described by APHA (1989). The biochemical tests such as oxidase, catalase, coagulase, indole (from $1 \%$ tryptone broth), citrate (Simmons citrate agar), methyl red/VogesProskauer (MR/VP), nitrate reduction, Starch Hydrolysis, Glucose, Maltose, and Lactose tests were carried out on the bacterial isolates to identify the bacteria through the bacteria biochemical characteristics according to Ajao et al. (2011).

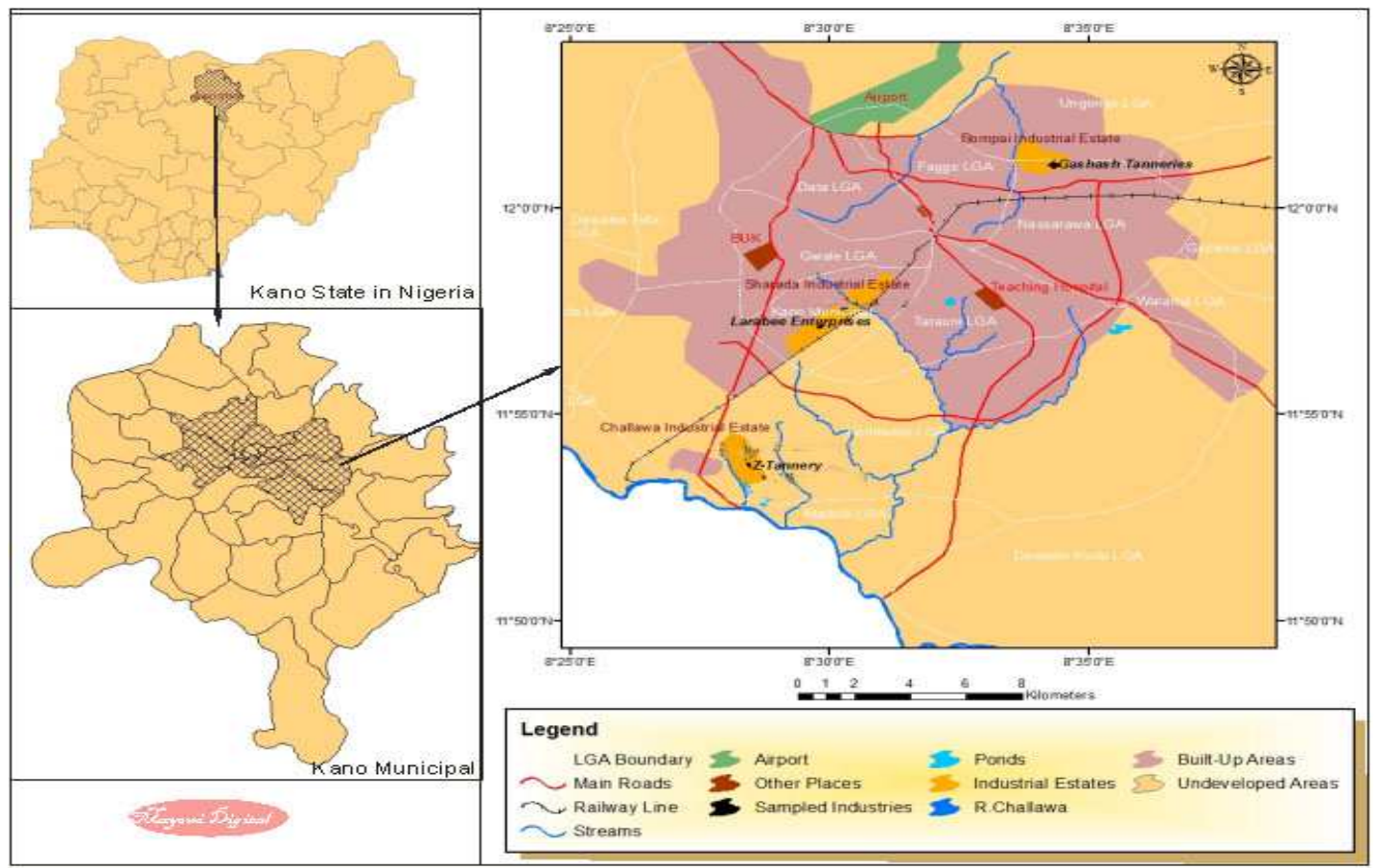

Fig. 1 Map showing the study areas

Source: Mayomi Digital Productions, GIS Laboratory, Department of Geography, UNIMAID (2017)

\section{Determination of Growth Rate of the Bacteria in Effluent Sample}

The bacteria growth rates were determined by transferring $2 \mathrm{~mL}$ of the bacterial isolates from the tannery effluent in broth medium into 100 $\mathrm{mL}$ sterile effluents in conical flasks and kept in an incubator (Giffrin cool) for 10 days. Control was also set up by incubating another $100 \mathrm{~mL}$ each of the sterile effluents without the bacteria. The optical density of the content was determined at the wavelength of $600 \mathrm{~nm}$ on a daily interval and recorded. 
BAJOPAS Volume 13 Number 2, December, 2020 Immobilization of Bacteria

Agar solution and inoculi were prepared separately. Fifty milliliters $(50 \mathrm{~mL})$ of nutrient broth each of the inoculi was prepared in a McCartney bottle and incubated for 24 hours. A solution of agar-agar was prepared by dissolving $10 \mathrm{~g}$ of the powder in distilled water and made up to $500 \mathrm{~mL}$ mark in an Erlenmeyer flask and was sterilized in an autoclave (280A) for 15 minutes and allowed to cool to $40-45^{\circ} \mathrm{C}$ (Ajao et al., 2011). Four milliliters ( $4 \mathrm{~mL})$ of the bacterial isolates in the nutrient broth was mixed with 36 $\mathrm{ml}$ of the prepared agar-agar media in petri-dish plates and then allowed to solidify. This was kept in the refrigerator for bioremediation.

\section{Bioremediation (Treatment) of the Effluents}

The solidified agar block (immobilized bacteria) was cut into cubes using a sterile knife; $0.1 \mathrm{~mL}$ phosphate buffer ( $\mathrm{pH} \mathrm{7.0)}$ was added and kept in the refrigerator for 1 hour for curing. The phosphate buffer was decanted after 1 hour and the cubes were washed with sterile distilled water 3-4 times before it was used (Ajao et al., 2011). Two liters (2 L) of the effluent was supplemented with the minimum basal medium in $\mathrm{g} / \mathrm{L}: \mathrm{NaCl}(0.8), \mathrm{MgSO}_{4} .7 \mathrm{H}_{2} \mathrm{O}(0.001), \mathrm{KH}_{2} \mathrm{PO}_{4}$ (2), $\mathrm{NaNO}_{3}$ (2), $\quad \mathrm{CaCl}_{2} .2 \mathrm{H}_{2} \mathrm{O} \quad(0.5)$ and $\mathrm{NaHPO}_{4} .12 \mathrm{H}_{2} \mathrm{O}(2)$ and sterilized in an autoclave at $121^{\circ} \mathrm{C}$ for 15 minutes (Margesin and Schinner, 2001). Two hundred and fifty milliliters $(250 \mathrm{~mL})$ of the effluents were transferred into different $250 \mathrm{ml}$ conical flasks. The content was covered with a cotton-wool ramped with foil paper to avoid contamination. Five grams $(5 \mathrm{~g})$ of the immobilized bacteria were quickly transferred into each of the effluents in the conical flasks in an inoculating chamber. The same procedures were carried out for the $10 \mathrm{~g}, 15 \mathrm{~g}, 20 \mathrm{~g}$ and 25 $\mathrm{g}$ of the immobilized bacteria in separate $250 \mathrm{~mL}$ effluents in conical flasks and agitated for ten days in a shaker incubator (Gallenkamp-OC4364-L) at a temperature $30^{\circ} \mathrm{C}$ and speed of 60 rpm. The treated effluent samples were taken on the tenth day and analyzed for the parameters $\mathrm{pH}$, SS, TDS, COD, and BOD, (Posttreatment determination) for the different grams of bacteria to evaluate and compare the biodegradation potential. (Baba et al., 2020).

\section{Statistical Analysis}

The data were represented as Mean \pm Standard deviation and analyzed statistically using oneway Analysis of Variance (ANOVA) and Tukey's HSD as Post Hoc Tests with the aid of SPSS 16.0. The correlation coefficient was also used to measure the strength of the relationship between the different masses of the bacteria and the parameters. All $\mathrm{p} \leq 0.05$ were considered as statistically significant.

\section{RESULTS AND DISCUSSION Physico-chemical parameters in the Industrial Effluents before the Biodegradation.}

Results of the Physico-chemical parameters in the industrial effluents before the Biodegradation is shown in table 1 . The mean temperatures $\left({ }^{\circ} \mathrm{C}\right)$ observed in TAN1, TAN2, and TAN3 samples were $28.07 \pm 0.65 ; 27.77 \pm 0.64$ and $26.38 \pm 3.81$ respectively. The order of the mean temperature of the samples from the three industries can be arranged as TAN1 > TAN2>TAN3. The temperature observed at TAN1, TAN2, and TAN3 samples were found below the WHO $\left(35^{\circ} \mathrm{C}\right)$ and NESREA $\left(40^{\circ} \mathrm{C}\right)$ limits. The low values of temperature might be due to the processes used at the time of sampling. High temperature brings down the solubility of gases in water that ultimately expresses as high BOD and COD. Statistical analysis shows that there is no significant difference $(p<0.05)$ between the mean values of temperature among the industries. This might be due to similar tannery activities involved in the tannery industries at the time of sampling. The average values of temperature observed in this present study are less than those observed by Akan et al. (2007), Akan et al. (2009) and Baba et al. (2020).

The mean level of $\mathrm{pH}$ observed in TAN1, TAN2 and TAN3, samples were $7.77 \pm 2.93$; $8.35 \pm 0.28$ and $7.52 \pm 0.76$ respectively. The order of the mean $\mathrm{pH}$ of the samples from the three industries can be arranged as TAN2> TAN1 $>$ TAN3. The $\mathrm{pH}$ of the samples falls within the WHO (7.0-8.5) and NESREA (6-9) standard limits. Statistical analysis shows that there is no significant difference $(p<0.05)$ between the mean values of $\mathrm{pH}$ among the industries. This might be due to similar tannery activities involved in the tannery industries at the time of sampling. Maheshwari et al. (2017) reported that the level of $\mathrm{pH}$ in the effluents from the tannery industry in Vaniyambadi, India was 6.5 which was lower than that observed in the present study. The $\mathrm{pH}$ in the effluents from the tannery industries in Kano and Kaduna were reported to be 7.64 and 6.89, respectively (Akan et al., 2007; Mohammed et al., 2017). The average values of $\mathrm{pH}$ observed in this present study are less than those observed by Mohammed et al. (2017) and Baba et al. (2020). The mean level of SS $(\mathrm{mg} / \mathrm{l})$ observed in TAN1, TAN2, and TAN3 samples were 374 \pm 124 ; $358 \pm 335$ and $780 \pm 739$ respectively. The order of the mean SS in the samples from the three industries can be arranged as TAN3 > TAN1 $>$ TAN2. 
The SS observed in the samples were far above the recommended standard limits of regulating bodies WHO $(30 \mathrm{mg} / \mathrm{l})$ and NESREA $(10 \mathrm{mg} / \mathrm{l})$. Statistical analysis shows that there is no significant difference $(p<0.05)$ between the mean values of SS among the industries. This might be due to similar tannery activities involved in the tannery industries at the time of sampling. The average values of SS observed in this present study are less than that observed $(3700 \pm 122 \mathrm{mg} / \mathrm{l})$ by Akan et al. (2009) for tanneries in Kano. Also, the average values of SS observed in this present study are less than that observed by Mohammed et al. (2017) and Baba et al. (2020) with the exception in TAN3.

The mean level of TDS (mg/l) observed in TAN1, TAN2, and TAN3 samples were $3941 \pm 3703$; $3300 \pm 1714$ and $2653 \pm 1240$ respectively. The order of the mean TDS in the samples from the three industries can be arranged as TAN1>TAN2>TAN3. The TDS observed in the samples were far above the recommended standard limits of WHO $(250 \mathrm{mg} / \mathrm{l})$ and NESREA $(500 \mathrm{mg} / \mathrm{l})$. Statistical analysis shows that there is no significant difference $(p<0.05)$ between the mean values of TDS among the industries. This might be due to similar tannery activities involved in the tannery industries at the time of sampling. TDS in the effluents from the tannery industries in Kano, Nigeria was reported to be $1281 \mathrm{mg} / \mathrm{l}$ (Akan et al., 2007). The average values of SS observed in this present study are less than those observed by Mohammed et al. (2017) and Baba et al. 2020)

The mean level of COD (mg/l) observed in TAN1, TAN2 and TAN3 samples seasons were $2372 \pm 938 ; \quad 1406 \pm 208$ and $3532 \pm 1373$ respectively. The order of the mean COD of the samples from the three industries can be arranged as TAN3>TAN1> TAN2. The COD observed in TAN1, TAN2 and TAN3 samples were far above the recommended standard limits of regulating bodies $\mathrm{WHO}(40 \mathrm{mg} / \mathrm{l})$ and NESREA (40 mg/l). Statistical analysis shows that there is no significant difference $(p<0.05)$ in COD among the industries. This might be due to similar tannery activities involved in the tannery industries as at the time of sampling. The Chemical Oxygen demand (COD) is the amount of oxygen, in $\mathrm{mg} / \mathrm{L}$, required for the degradation of the compound of wastewater to occur. In comparison, the average values of COD observed in this present study were higher than that observed by Mohammed et al. (2017) but lower than that observed by Baba et al. (2020).

The mean levels of BOD $(\mathrm{mg} / \mathrm{l})$ observed in TAN1, TAN2 and TAN3 samples were $13.85 \pm 6.42 ; \quad 19.46 \pm 0.50$ and $17.13 \pm 3.14$ respectively. The order of the mean BOD in the samples from the three industries can be arranged as TAN2>TAN3>TAN1. The BOD observed in TAN1, TAN2 and TAN3 samples were found below the recommended limits of NESREA (200 mg/l) but above WHO (10 mg/l). Statistical analysis shows that there is no significant difference $(p<0.05)$ between the mean values of BOD among the industries. This might be due to similar tannery activities involved in the tannery industries at the time of sampling. The low level of BOD recorded in this study is an indication of the low level of biodegradable organic solids in the effluent. The average values of BOD observed in this present study were lower than those observed by Mohammed et al. (2017) and Baba et al. (2020).

Table 1: Mean Values \pm S.D of Physico-chemical parameters of effluents from the Tannery Industries before Treatment.

\begin{tabular}{llllllll}
\hline Parameter & Tannery 1 & Tannery 2 & Tannery 3 & $\mathrm{a}$ & $\mathrm{b}$ & $\mathrm{c}$ & $\mathrm{d}$ \\
\cline { 2 - 7 } Temperature $\left({ }^{\circ} \mathrm{C}\right)$ & $28.07 \mathrm{a} \pm 0.65$ & $27.77 \mathrm{a} \pm 0.64$ & $26.38 \mathrm{a} \pm 3.81$ & & $29.50 \pm 4.68$ & 35 & 40 \\
pH & $7.77 \mathrm{a} \pm 2.93$ & $8.35 \mathrm{a} \pm 0.28$ & $7.52 \mathrm{a} \pm 0.76$ & 6.89 & $5.35 \pm 1.57$ & $7.0-8.5$ & $6.0-9.0$ \\
$\mathrm{COD}(\mathrm{mg} / \mathrm{l})$ & $2372 \mathrm{a} \pm 938$ & $1406 \mathrm{a} \pm 208$ & $3532 \mathrm{a} \pm 1373$ & 2.2 & $3106 \pm 2753$ & 40 & 40 \\
$\mathrm{BOD}(\mathrm{mg} / \mathrm{l})$ & $13.85 \mathrm{a} \pm 6.42$ & $19.46 \mathrm{a} \pm 0.50$ & $17.13 \mathrm{a} \pm 3.14$ & 1032 & $26.17 \pm 9.49$ & 10 & 200 \\
$\mathrm{SS}(\mathrm{mg} / \mathrm{l})$ & $374 \mathrm{a} \pm 124$ & $358 \mathrm{a} \pm 335$ & $780 \mathrm{a} \pm 739$ & 501 & $562 \pm 482$ & 30 & 10 \\
TDS $(\mathrm{mg} / \mathrm{l})$ & $3941 \mathrm{a} \pm 3703$ & $3300 \mathrm{a} \pm 1714$ & $2653 \mathrm{a} \pm 1240$ & 532.7 & $444 \pm 507$ & 250 & 500 \\
\hline
\end{tabular}

The values given in the table above are means of 6 replicate values, $\mathrm{n}=6$ ( 1 sample was taken monthly for 6 months). Within the rows, means with different alphabets are statistically different $(p<0.05)$. WHO: World Health Organisation. NESREA: National Environmental Standard and Regulatory Enforcement Agency. a = Mohammed et al.(2017), b = Baba et al. (2020), c = WHO (2006), $d=$ NESSRA (2009) 
BAJOPAS Volume 13 Number 2, December, 2020

Identification, Biochemical Characterization and growth rates of the Bacterial Isolates

Results of identification and biochemical characterization of the bacterial isolates were shown in table 2. After 24 hours of incubation, the nutrient agar media plates were checked for bacterial growth. The results showed the presence of different strains in the samples. The TAN1 bacteria isolate was found to be gramnegative cocci while TAN3 was gram-positive cocci. TAN2 bacteria isolate was found to be gram-positive, rod-shaped. TAN1, TAN2, and TAN3 bacteria isolates recorded positive results for spore former.

The results of the biochemical tests indicated that all the bacteria were positive for catalase, oxidase, citrate, maltose, glucose, lactose (negative in TAN1), mannitol (negative in TAN2), starch hydrolysis and coagulase (negative in TAN2) tests. The bacteria showed negative results for nitrate reduction, $M R$ (positive in TAN2), VP (positive in TAN1), Indole (positive in TAN2) tests. Base on the morphological and biochemical test results, TAN1, TAN2, and TAN3 bacteria isolates were identified to be Nesseria spp, Bacillus cereus, and Staphylococcus aureus respectively.

The growth rate of the TAN1, TAN2 and TAN3 Isolates were shown in figure 2. Generally, the optical density increase with the increase in time (day) and decrease as time goes on. The highest optical density was shown by bacillus cereus in TAN2 while the lowest was shown by Staphylococcus aureus in TAN3.

The initial growth phase of TAN1 Isolate bacteria occurred within 2-day of incubation as the growth rate increases up to the 6th-day incubation when the maximum growth was observed. Beyond the 6th day, the growth of the bacteria declined (which might be due to a shortage of nutrients in the effluents) until it reached its death phase (which might be due to the unavailability of nutrients in the effluents).

A similar trend of growth was also observed for TAN2 Isolate as the initial growth phase also occurred within 2-day of incubation but maximum growth rate observed on the 4th day of incubation. The stationary stage occurred between the 4th day and the 8th day. Beyond the 8th day, the growth of the bacteria declined (which might be due to a shortage of nutrients in the effluents) until it reached its death phase (which might be due to the unavailability of nutrients in the effluents).

The initial growth phase of TAN3 bacterial Isolate occurred within the 3-day incubation as the growth rate increases up to the 6th-day incubation when the maximum growth was observed. Beyond the 6th day, the growth of the bacteria declined (which might be due to a shortage of nutrients in the effluents) until it reached its death phase (which might be due to the unavailability of nutrients in the effluents).

Table 2: Morphological and Biochemical characteristics of bacterial isolates

\begin{tabular}{lllll} 
Bacterial Isolates & & TAN1 & TAN2 & TAN3 \\
\hline $\begin{array}{lllll}\text { Morphological } \\
\text { characteristics }\end{array}$ & Shape & Cocci & Rod & Cocci \\
& Spore & & & \\
& former & + & + & + \\
Gram & & & \\
Biochemical characteristics & reaction & - & + & + \\
& Citrate & + & + & + \\
& Catalase & + & + & + \\
& Coagulase & + & - & + \\
Starch & + & + & + \\
& Glucose & + & + & + \\
Oxidase & + & + & + \\
& Indo & - & + & - \\
Lactose & - & + & + \\
Manitol & + & - & + \\
Maltose & + & + & + \\
MR & - & + & - \\
VP & + & - & - \\
& Nitrate & - & - & - \\
Reduction & - Neisseria & Bacillus & Staphylococcus \\
& Bacterial & cereus & aureus \\
& name & spp & cas
\end{tabular}

+ = Positive; - = Negative; MR=Methyl Red; VP= Voges-Proskauer 


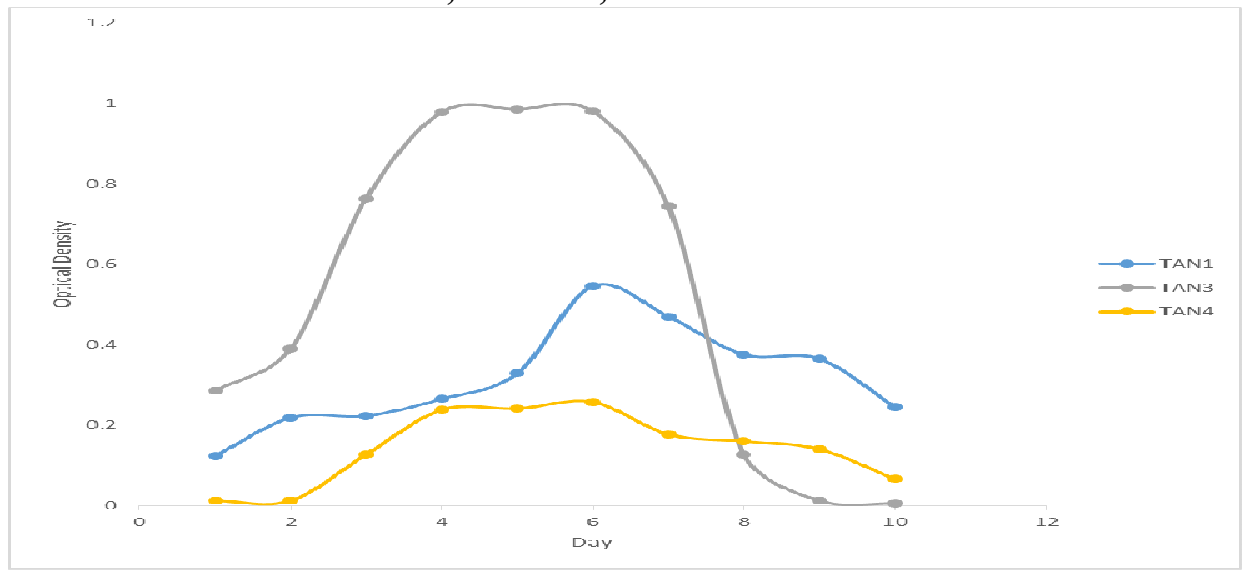

Fig. 2 Growth rates of the isolates in the effluents from the Tannery Industries

\section{Physico-chemical Parameters in the Industrial Effluents after the biodegradation.}

Table 3 shows the mean results of the physicochemical parameter before and after bioremediation using the different masses $(5 \mathrm{~g}$, $10 \mathrm{~g}, 15 \mathrm{~g}, 20 \mathrm{~g}$, and $25 \mathrm{~g}$ ) of the respective immobilized bacteria. Also, Table 4 shows the mean results of correlation coefficient ( $r$ ) between different masses of bacteria and physicochemical parameters.

The mean values $(\mathrm{mg} / \mathrm{l})$ of the SS after the bioremediation varies between $243 \pm 45$ and $898 \pm 672$. The mean concentration $(\mathrm{mg} / \mathrm{l})$ of SS remediated by the different masses $(5 \mathrm{~g}, 10 \mathrm{~g}$, $15 \mathrm{~g}, 20 \mathrm{~g}$, and $25 \mathrm{~g}$ ) of the bacteria varies. The SS in the samples fluctuates up and down after the bioremediation process when compared with the SS of the raw samples before the bioremediation. The increase in the levels of the SS might be due to the aggregation of the TDS which are large enough to result into SS. The increase in the levels of the SS might be also due to the influence of the nutrients which was added into the effluents in order to make the microorganisms more active and viable for fast degradation of organic contaminants in the effluent. The relative potential or efficiency of the different masses of the bacteria in remediating SS in TAN1 samples was in the order $25 \mathrm{~g}>20 \mathrm{~g}>15 \mathrm{~g}>10 \mathrm{~g}>5 \mathrm{~g}$. For TAN2 and TAN3 samples, the order was $25 \mathrm{~g}>20 \mathrm{~g}>15$ $\mathrm{g}>10 \mathrm{~g}>5 \mathrm{~g}$. These might be due to the variations in the surface areas of the different masses of the immobilized bacteria. Statistical analysis shows that there is no significant difference $(p<0.05)$ between the mean values of SS among the masses in the respective industries. Positive and significant correlations exist between the masses of bacteria and Suspended Solid (SS). This showed that there is general increase in the levels of the SS as the masses of the immobilized bacteria increases. TAN3 (90\%) and TAN1 (80\%) showed a very high correlation with the masses of the bacteria while TAN2 (61\%) showed a very low correlation.

The mean values $(\mathrm{mg} / \mathrm{l})$ of the TDS after the bioremediation varies between $46 \pm 11$ and $83 \pm 78$. The mean concentration $(\mathrm{mg} / \mathrm{l})$ of TDS remediated by the different masses $(5 \mathrm{~g}, 10 \mathrm{~g}$, $15 \mathrm{~g}, 20 \mathrm{~g}$, and $25 \mathrm{~g}$ ) of the bacteria varies. There is a reduction in all the TDS of all the samples after the bioremediation process compared with the TDS of the raw samples before the bioremediation. The relative potential or efficiency of the different masses of the bacteria in remediating TDS in TAN1 and TAN3 samples was in the order $5 \mathrm{~g}>10 \mathrm{~g}>15 \mathrm{~g}>20$ $\mathrm{g}>25 \mathrm{~g}$. For TAN2 samples, the order was 20 $g>10 \quad g>25 \quad g>15 \quad g>5 \quad g$. Statistical analysis shows that there is no significant difference $(p<0.05)$ between the mean values of TDS among the masses in the respective industries. These might be due to the variations in the surface areas of the different masses of the immobilized bacteria. Positive and significant correlations exist between the masses of bacteria and TDS with the exception in TAN2 (negative and insignificant correlation). The positive correlations showed that there is general increase in the levels of the TDS as the masses of the immobilized bacteria increases. TAN1 $(96 \%)$ showed a very high correlation with the masses of the bacteria while TAN2 (47\%) showed a very low correlation.

The mean values $(\mathrm{mg} / \mathrm{l})$ of the BOD after the bioremediation varies between $1.56 \pm 0.20 \mathrm{mg} / \mathrm{l}$ and $6.92 \pm 5.49 \mathrm{mg} / \mathrm{l}$. The mean concentration $(\mathrm{mg} / \mathrm{l})$ of BOD remediated by the different masses $(5 \mathrm{~g}, 10 \mathrm{~g}, 15 \mathrm{~g}, 20 \mathrm{~g}$, and $25 \mathrm{~g}$ ) of the bacteria varies. There is a reduction in all the BOD of all the samples after the bioremediation process compared with the $\mathrm{BOD}$ of the raw 
BAJOPAS Volume 13 Number 2, December, 2020 samples before the bioremediation. The relative potential or efficiency of the different masses of the bacteria in remediating BOD in TAN1, TAN2 and TAN3 samples were in the order $25 \mathrm{~g}>20$ $\mathrm{g}>15 \mathrm{~g}>10 \mathrm{~g}>5 \mathrm{~g}, 25 \mathrm{~g}>15 \mathrm{~g}>5 \mathrm{~g}>10 \mathrm{~g}>20 \mathrm{~g}$ and $20 \mathrm{~g}>10 \mathrm{~g}>25 \mathrm{~g}>15 \mathrm{~g}>5 \mathrm{~g}$ respectively. Statistical analysis shows that there is significant difference $(p<0.05)$ between the mean values of BOD among the masses in the respective industries. These might be due to the variations in the surface areas of the different masses of the immobilized bacteria. Negative and significant correlations exist between the masses of bacteria and BOD. This showed that there is general decrease in the levels of the BOD as the masses of the immobilized bacteria increases. TAN1 (94\%) showed a very high correlation with the masses of the bacteria while TAN2 (4\%) showed a very low correlation.

The mean values $(\mathrm{mg} / \mathrm{l})$ of the COD after the bioremediation varies between $250 \pm 154$ and $3134 \pm 1595$. The mean concentration $(\mathrm{mg} / \mathrm{l})$ of COD remediated by the different masses $(5 \mathrm{~g}$, $10 \mathrm{~g}, 15 \mathrm{~g} 20 \mathrm{~g}$, and $25 \mathrm{~g}$ ) of the bacteria varies. There is a reduction in all the COD of all the samples after the bioremediation process compared with the COD of the raw samples before the bioremediation. The relative potential or efficiency of the different masses of the bacteria in remediating COD in TAN1, TAN2 and TAN3 samples were in the order $25 \mathrm{~g}>20 \mathrm{~g}>15$ $\mathrm{g}>5 \mathrm{~g}>10 \mathrm{~g}, 25 \mathrm{~g}>20 \mathrm{~g}>15 \mathrm{~g}>10 \mathrm{~g}>5 \mathrm{~g}$ and 10 g>5 g>25 g>15 g>20 g respectively. Statistical analysis shows that there were significant difference $(p<0.05)$ between the mean values of COD among the masses in the respective industries except for effluents treated with $25 \mathrm{~g}$. These might be due to the variations in the surface areas of the different masses of the immobilized bacteria. Negative and insignificant correlations exist between the masses of bacteria and COD with the exception in TAN3 (positive and significant correlation). The negative correlations showed that there is general decrease in the levels of the COD as the masses of the immobilized bacteria increases. TAN2 (100\%) showed a very high correlation with the masses of the bacteria while TAN3 (36\%) showed a very low correlation.

Generally, there was an overall decrease in the concentration of these physicochemical parameters after the bioremediation using the different masses of the bacterial isolates. These might be due to the variations in the surface areas of the different masses of the immobilized bacteria. This is in line with the work of Jimoh et al. (2018) and Baba et al. (2020).

Table 3: Mean Values $(\mathrm{mg} / \mathrm{l}) \pm$ S.D of Physicochemical parameters in effluents from the Tannery Industries before and after Treatment of the effluents $(250 \mathrm{ml})$ with the different masses $(5 \mathrm{~g}, 10 \mathrm{~g}$, $15 \mathrm{~g}, 20 \mathrm{~g}$, and $25 \mathrm{~g}$ ) of the bacteria.

\begin{tabular}{llllllll}
\hline $\mathrm{P}$ & IND & Before & \multicolumn{5}{c}{ After } \\
\cline { 4 - 7 } & & & $5 \mathrm{~g}$ & $10 \mathrm{~g}$ & $15 \mathrm{~g}$ & $20 \mathrm{~g}$ & $25 \mathrm{~g}$ \\
\hline \multirow{2}{*}{ COD } & TAN1 & $2372 \pm 938$ & $1708 \mathrm{a} \pm 861$ & $2045 \mathrm{a} \pm 1205$ & $845 \mathrm{a} \pm 369$ & $300 \mathrm{a} \pm 167$ & $250 \mathrm{a} \pm 154$ \\
& TAN2 & $1406 \pm 208$ & $1195 \mathrm{a} \pm 208$ & $1125 \mathrm{a} \pm 384$ & $1055 \mathrm{a} \pm 317$ & $956 \mathrm{a} \pm 310$ & $870 \mathrm{ab} \pm 240$ \\
& TAN3 & $3532 \pm 1373$ & $2374 \mathrm{a} \pm 1344$ & $1976 \mathrm{a} \pm 1405$ & $2757 \mathrm{a} \pm 1266$ & $3134 \mathrm{a} \pm 1595$ & $2614 \mathrm{~b} \pm 1105$ \\
BOD & TAN1 & $13.85 \pm 6.42$ & $6.92 \mathrm{a} \pm 5.49$ & $6.42 \mathrm{a} \pm 5.07$ & $5.72 \mathrm{a} \pm 5.35$ & $4.62 \mathrm{a} \pm 4.37$ & $2.82 \mathrm{ab} \pm 1.26$ \\
& TAN2 & $19.46 \pm 0.50$ & $1.75 \mathrm{~b} \pm 0.22$ & $1.73 \mathrm{~b} \pm 0.18$ & $1.58 \mathrm{a} \pm 0.16$ & $1.91 \mathrm{a} \pm 0.22$ & $1.56 \mathrm{~b} \pm 0.20$ \\
& TAN3 & $17.13 \pm 3.14$ & $4.24 \mathrm{ab} \pm 0.77$ & $3.29 \mathrm{ab} \pm 0.37$ & $4.11 \mathrm{a} \pm 0.07$ & $3.23 \mathrm{a} \pm 0.91$ & $3.33 \mathrm{a} \pm 1.28$ \\
SS & TAN1 & $374 \pm 124$ & $243 \mathrm{a} \pm 45$ & $471 \mathrm{a} \pm 226$ & $475 \mathrm{a} \pm 182$ & $492 \mathrm{a} \pm 128$ & $611 \mathrm{a} \pm 217$ \\
& TAN2 & $358 \pm 335$ & $460 \mathrm{a} \pm 400$ & $543 \mathrm{a} \pm 414$ & $544 \mathrm{a} \pm 402$ & $551 \mathrm{a} \pm 414$ & $554 \mathrm{a} \pm 405$ \\
& TAN3 & $780 \pm 739$ & $586 \mathrm{a} \pm 594$ & $758 \mathrm{a} \pm 656$ & $787 \mathrm{a} \pm 676$ & $861 \mathrm{a} \pm 635$ & $898 \mathrm{a} \pm 672$ \\
TDS & TAN1 & $3941 \pm 3703$ & $51 \mathrm{a} \pm 10$ & $53 \mathrm{a} \pm 10$ & $55 \mathrm{a} \pm 15$ & $61 \mathrm{a} \pm 20$ & $63 \mathrm{a} \pm 26$ \\
& TAN2 & $3300 \pm 1714$ & $83 \mathrm{a} \pm 78$ & $47 \mathrm{a} \pm 20$ & $48 \mathrm{a} \pm 22$ & $47 \mathrm{a} \pm 17$ & $48 \mathrm{a} \pm 17$ \\
& TAN3 & $2653 \pm 1240$ & $46 \mathrm{a} \pm 11$ & $55 \mathrm{a} \pm 24$ & $55 \mathrm{a} \pm 25$ & $58 \mathrm{a} \pm 23$ & $61 \mathrm{a} \pm 28$ \\
\hline
\end{tabular}

Replicate $=6$ (months)

Within the rows, for the same parameter, means with different alphabets are statistically different $(p<0.05)$.

$\mathrm{P}=$ parameter, IND = Industries 
BAJOPAS Volume 13 Number 2, December, 2020

Table 4: Correlation coefficient $(r)$ between different masses of the bacteria and the physicochemical parameters.

\begin{tabular}{llll}
\hline Industries & Parameter & Correlation coefficient $(r)$ & $\begin{array}{l}\text { Percent dependence (rxrx100) } \\
(\%)\end{array}$ \\
\hline TAN1 & COD & -0.9 & 82 \\
& BOD & -0.97 & 94 \\
& SS & $0.90^{*}$ & 80 \\
TAN2 & TDS & $0.98^{*}$ & 96 \\
& COD & -1 & 100 \\
& BOD & -0.21 & 4 \\
& SS & $0.78^{*}$ & 61 \\
& TDS & -0.69 & 47 \\
& COD & $0.60^{*}$ & 36 \\
& BOD & -0.6 & 37 \\
& SS & $0.95^{*}$ & 90 \\
& TDS & $0.94^{*}$ & 89 \\
\hline
\end{tabular}

The correlation coefficient $(r)$ with * is statistically significant $(p<0.05)$.

Percentage reduction of the Parameters

Table 5 shows the percentage reduction of Parameters in industrial samples before and after the treatment of the effluents $(250 \mathrm{ml})$ with the different masses $(5 \mathrm{~g}, 10 \mathrm{~g}, 15 \mathrm{~g}, 20 \mathrm{~g}$, and $25 \mathrm{~g}$ ) of the Immobilized Bacteria.

In TAN1 samples, the percentage reduction (\%) of COD ranged (14-89); BOD (50-80); SS (-32$35)$ and TDS (98-99). In TAN2 samples, the percentage decrease $(\%)$ of COD ranged (15$38) ;$ BOD (90-92); SS [-28-(-55)] and TDS (9798). In TAN3 samples, the percentage decrease (\%) of COD ranged (11-44); BOD (76-81); SS (15-25) and TDS (98). The percentage increase in the levels COD, BOD and TDS might be due to the increase in the surface area of the different masses of the immobilized bacteria. However, the percentage decrease in the levels of the SS might be due to the aggregation of the TDS which are large enough to result into SS. The percentage decrease in the levels of the SS might be also due to the influence of the nutrients which was added into the effluents in order to make the microorganisms more active and viable for fast degradation of organic contaminants in the effluent. This is in line with the work of Jimoh et al. (2018) in which the concentration of the SS increase after the bioremediation of effluents.

Sreemoyee and Priti (2013) assessed and reduced several Physico-chemical parameters of dairy wastewater using Niesseria $s p$. and concluded that the species are well known to degrade organic compounds. This is in agreement with the current study in which the immobilized Niesseria $s p$ degrade the organic contaminants as indicated by the BOD, COD and TDS.

Jimoh et al. (2018) observed that TSS of the effluents was increased after treatment with immobilized bacteria and concluded that it might be due to the biostimulation method adopted for the research.

The optimum $\mathrm{pH}$ Biosorption of Chromium by Bacillus spp and Staphylococcus spp. from tannery effluent was investigated by Mythili and Karthikeyan (2011). The maximum adsorption of Chromium $(86.4 \mathrm{mg} / \mathrm{L})$ was showed by Bacillus spp and Staphylococcus spp showed $70.6 \mathrm{mg} / \mathrm{L}$ at an initial concentration of $100 \mathrm{mg} / \mathrm{L}$. In the present study, immobilised Bacillus spp and Staphylococcus spp. from the tannery industrial effluents reduced the levels of the organic pollutants with high potential as indicated by the percentage reduction of BOD, COD and TDS.

Enzymes often can work in multiple environments especially if they are immobilized. This makes the microorganisms' enzymes even more resistant to harsh environments and enables the enzymes to be recovered and recycled after they are no longer needed (Gianfreda and Rao 2004). Ramesh and Singh (1993) reported that the immobilized bacteria having more efficiency to remove the suspended particles than free cells. Using the immobilized cell is preferable due to its capability for using several times with the same efficiency, which makes it more economical. Similar work was done by Sikander et al. (2007) showing the higher reduction with permeabilized cells of Ochrobactrum intermedium strain SDCr-5. 
BAJOPAS Volume 13 Number 2, December, 2020

The results revealed the isolation and identification of isolates with the potential for the reduction of $\mathrm{Cr}$ (VI) to $\mathrm{Cr}$ (III). Results indicated that immobilized $B$. cereus could be efficiently used for the reduction of $\mathrm{Cr}$ (VI).

Table 5: Percentage reduction of the tested Parameters from the tannery industrial samples of the Immobilized Bacteria.

\begin{tabular}{lllllll}
\hline \multirow{2}{*}{ Industries } & & \multicolumn{5}{c}{ Percentage Reduction $(\%)$} \\
\cline { 3 - 7 } & & $5 \mathrm{~g}$ & $10 \mathrm{~g}$ & $15 \mathrm{~g}$ & $20 \mathrm{~g}$ & $25 \mathrm{~g}$ \\
\hline TAN1 & COD & 28 & 14 & 64 & 87 & 89 \\
& BOD & 50 & 54 & 59 & 67 & 80 \\
& SS & 35 & -26 & -27 & -32 & -63 \\
& TDS & 99 & 99 & 99 & 98 & 98 \\
TAN2 & COD & 15 & 20 & 25 & 32 & 38 \\
& BOD & 91 & 91 & 92 & 90 & 92 \\
& SS & -28 & -52 & -52 & -54 & -55 \\
& TDS & 97 & 99 & 99 & 99 & 99 \\
& COD & 33 & 44 & 22 & 11 & 26 \\
& BOD & 75 & 81 & 76 & 81 & 81 \\
& SS & 25 & 3 & -1 & -10 & -15 \\
& TDS & 98 & 98 & 98 & 98 & 98 \\
\hline
\end{tabular}

Percentage Reduction $=(B-A) / B \times 100 \%$

$A=$ Concentration of the parameter after treatment

$\mathrm{B}=$ Concentration of the parameter before treatment

$+=$ percentage decrease

- = percentage increase

In general, immobilization makes the enzyme more resistant to temperature, $\mathrm{pH}$, and substrate concentration swings giving it a longer lifetime and higher productivity per active unit (Gianfreda and Rao, 2004; FuIlbrook, 1996; Russell et al, 2003; Kandelbauer et al., 2004). Immobilized cells have been used and studied extensively for the production of useful chemicals (Ohtake and Silver, 1994), the treatment of wastewaters (Chen et al., 2003; Wang et al., 2010). Although many workers described microbial degradation of tannery effluent, limited literature is available on the bioremediation of tannery effluent using immobilized bacterial cells in the Kano Industrial Estates.

\section{CONCLUSION}

The samples contained variable levels of the physicochemical parameters. The results of the Analysis of variance revealed that, no statistical difference $(p<0.05)$ was observed for the temperature, $\mathrm{pH}, \mathrm{SS}, \mathrm{TDS}, \mathrm{BOD}$ and $\mathrm{COD}$ among the three tannery industries before the treatment. The levels of some of the parameters
(SS, TDS and COD) observed in the samples were found above the recommended limits of WHO and NESREA, which called for the treatment of the effluents before discharge into the environment. Base on the morphological and biochemical test results, TAN1, TAN2, and TAN3 bacterial isolates were identified to be Neisseria spp, Bacillus cereus, and Staphylococcus aureus respectively. The results of Post-treatment analysis showed that there is overall decrease in the levels of the parameters determined when compared with that of the pre-treatment. The overall percentage reduction of the immobilised bacteria in the treatment of the respective effluents was in the order TAN2 (72\%)>TAN1 $(70 \%)>$ TAN3 $(62 \%)$. Hence, the immobilized bacteria are having higher biodegradation potential for the treatment of the tannery effluents.

\section{Acknowledgments}

The authors wish to acknowledge the University of Maiduguri for the financial support. The authors are grateful to the Kano State Ministry of Environment for their support in obtaining the effluent samples. 


\section{REFERENCES}

Ajao, A. T., Adebayo, G. B., and Yakubu, S. E. (2011). Bioremediation of textile industrial effluent using mixed culture of Pseudomonas aeruginosa and Bacillus subtilis immobilized on agar-agar in a bioreactor. J. Microbiol. Biotech. Res, 1(3), 50-56.

Akan, J. C., Moses, E. A., Ogugbuaja, V. O., and Abah, J. (2007). Assessment of tannery industrial effluents from Kano metropolis, Kano State, Nigeria. Journal of Applied Sciences, 7(19), 2788-2793.

Akan, J. C., Ogugbuaja, V. O., Abdulrahman, F. I., and Ayodele, J. T. (2009). Pollutant levels in effluent samples from tanneries and textiles of Kano industrial areas, Nigeria. Global journal of pure and applied sciences, 15(3-4).

APHA (1989). Standard methods for Examination of Will bete and Will betewater.15 $5^{\text {th }}$ edition. Brydpass Springfield Will behington DC. pp. 164-176

APHA (1992). Standard Methods for the Examination of Water and Wastewater. Health, 69, 1116-9.

Baba, A., Garba, S. T., and Bello, H. S. (2020). Bioremediation Potential of Immobilized corynebacterium kutsceri in the Treatment of Tannery Industrial Effluent from Challawa Industrial Estate, Kano State, Nigeria. Journal of the Turkish Chemical Society Section A: Chemistry, $7(2), 335-350$.

Beem, E. I. V. (1994). reduction of solvent VOC emission. J. Oil Col. Chem. Ass, 77, 158.

Bouwer, E. J., and Zehnder, A. J. (1993). Bioremediation of organic compoundsputting microbial metabolism to work. Trends in biotechnology, 11(8), 360367.

Chen, K. C., Wu, J. Y., Liou, D. J., and Hwang, S. C. J. (2003). Decolorization of the textile dyes by newly isolated bacterial strains. Journal of Biotechnology, 101(1), 57-68.

Dan'Azumi, S., and Bichi, M. H. (2010). INDUSTRIAL POLLUTION AND HEAVY METALS PROFILE OF CHALLAWA RIVER IN KANO, NIGERIA. Journal of Applied Sciences in Environmental Sanitation, $5(1)$.

DWAF. (1992). Analytical Methods Manual, TR 151. Department of Water Affairs and Forestry, Pretoria.

El-Bestawy, E. (2013). Biological treatment of leather-tanning industrial wastewater using free living bacteria.
Elsheikh, M. A. S. (2009). Tannery wastewater pre-treatment. Water Science and Technology, 60(2), 433-440.

FuIlbrook, P. D. (1996). "Kinetics." Industrial enzymology: The application of enzymes in Industry. 2nd Ed. T. Godfrey and J Reichelt. eds.. Nature. New York.

Gianfreda, L., and Rao, M. A. (2004). Potential of extra cellular enzymes in remediation of polluted soils: a review. Enzyme and microbial technology, 35(4), 339354.

Hugo Springer. (1994). John Arthur Wilson Memorial Lecture "Treatment of Industrial Wastes of the Leather Industry - is it still a Major Problem". JALCA, 89, 153-185

Jimoh, A. A., Ganiyu, B. A., Baba, D., and Baba, A. (2018) Bioremediation Process of Effluent from Detergent and Food Industries in Jos, Nigeria: Kinetics and Thermodynamics. International Journal of Engineering Science Invention (IJESI), 762-73

Kandelbauer, A., Maute, O., Kessler, R. W., Erlacher, A., and Gübitz, G. M. (2004). Study of dye decolorization in an immobilized laccase enzyme-reactor using online spectroscopy. Biotechnology and bioengineering, 87(4), 552-563.

Kongjao, S., Damronglerd, S., and Hunsom, M. (2008). Simultaneous removal of organic and inorganic Pollutants in tannery wastewater using electrocoagulation technique. Korean Journal of chemical engineering, 25(4), 703.

Maheshwari, U. M., Aruna, S., Gomathi, M., and AbdulJaffar, A. H. (2017). Bioremediation by Free and Immobilized Bacteria Isolated from Tannery Effluent. International Journal of Research in Applied, Natural and Social Sciences. 5(7), 75-90

Margesin, R., and Schinner, F. (2001). Bioremediation (natural attenuation and biostimulation) of diesel-oilcontaminated soil in an alpine glacier skiing area. Applied and environmental microbiology, 677), 3127-3133.

Mohammed, A., Sekar, P., and George, J. (2011). Efficacy of microbes in bioremediation of tannery effluent. Inter. J. Curr. Res, 3(4), 324-326.

Mohammed, S. S. D., Orukotan, A. A., and Abdullahi, H. (2017). Physicochemical and Bacteriological Assessment of Tannery Effluent from Samaru-Zaria, 
BAJOPAS Volume 13 Number 2, December, 2020 Kaduna State, Nigeria. Journal of Applied

Sciences and Environmental Management, 21(4), 734-740.

Munz, G., De Angelis, D., Gori, R., Mori, G., Casarci, M., and Lubello, C. (2009). The role of tannins in conventional and membrane treatment of tannery wastewater. Journal of hazardous materials, 164(2-3), 733-739

Mythili, K., and Karthikeyan, B. (2011). Bioremediation of $\mathrm{Cr}$ (VI) from tannery effluent using Bacillus spp and Staphylococcus spp. International Multidisciplinary Research Journal, 1(6).

NESREA (2009). National Environmental Standards for Effluent Limitations and Regulation. 1233-1236

Noorjahan, C. M. (2014). Physicochemical characteristics, identification of bacteria and biodegradation of industrial effluent. Journal of bioremediation and Biodegradation, 5(3).

Ohtake, H. I., and Silver, A. O. (1994). Bacterial reduction of toxic chromate. Biological degradation and bioremediation of toxic chemicals, 403-415.

Omoleke, I. I. (2004). Management of environmental pollution in Ibadan, an African city: the challenges of health hazard facing government and the people. Journal of Human Ecology, 15(4), 265-275.

Rajor, A., Reddy, A.S., and Singh, B. (2004). Determination of BOD kinetic Parameters and evaluation of alternate methods, M.Sc. Thesis, Department of biotechnology \& environmental Science, Thapar Institute of Engineering and Technology, Patiala

Ramasami, T., Rajamani, S., and Rao, J. R. (1994, March). Pollution control in leather industry: Emerging technological options. In International symposium on surface and colloidal science and its relevance to soil pollution, madras.

Ramesh, J. V. S., and Singh, S. P. (1993). Yearly variation in certain physicochemical parameters of pond at eastern Doon Valley. Uttar Pradesh J. Zoo, 12 (1), 7577.

Ranen, S., and Sharadinadra, C. (2009). Biotechnology applications to environmental remediation in resource exploitation. Current science, 97, 6-25
Russell, A. J., Berberich, J. A., Drevon, G. F., and Koepsel, R. R. (2003). Biomaterials for mediation of

chemical and biological warfare agents. Annual review of biomedical engineering, 5(1), 1-27.

Saravanan, P., and Saravanan, A. (1999). Decolourization of tannery effluent by Flavobacterium sp. EK 1. Indian Journal of Environmental Protection, 19, 19-24.

Sikander, S., and Shahida, H. (2007). Reduction of toxic hexavalent chromium by Ochrobactrum intermedium strain SDCr5 stimulated by heavy metals. Bioresource Technol, 98, 340-344.

Singh, N., Sharma, B. K., and Bohra, P. C. (2000). Impact assessment of industrial effluent of arid soils by using satellite imageries. Journal of the Indian Society of Remote Sensing, 28(2-3), 79.

Sreemoyee, C., and Priti, P. (2013). Assessment of physico-chemical parameters of dairy waste water and isolation and characterization of bacterial strains in terms of cod reduction. Int J Sci, 2(3), 395-400.

Verheijen, L. A. H. M., Wiersema, D., Pol, L. H., and De Wit, J. (1996). Management of wastes from animal product processing. Livestock and environment, Finding a balance. International Agriculture Center, Wageningen, The Netherlands.

Wang, F., Yao, J., Si, Y., Chen, H., Russel, M., Chen, K., and Bramanti, E. (2010). Short-time effect of heavy metals upon microbial community activity. Journal of Hazardous Materials, 173(13), 510-516.

WHO (World Health Organization). (2006). Air quality guidelines: global update 2005: particulate matter, ozone, nitrogen dioxide, and sulfur dioxide. World Health Organization.

World Bank. (1995). Nigeria's strategic options for redressing industrial pollution. World Bank, industry and energy division. 1st edition, West Central Africa Department; Annexes: 1995; pp 60-62.

Zahoor, A., and Abdul, R. (2009). Enumeration of Coliforms. Journal of Environmental Sciences. 21, 814-820 


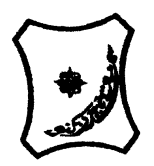

Bayero Journal of Pure and Applied Sciences, 13(2): 1 - 12

Received: November, 2020

Accepted: December, 2020

ISSN $2006-6996$

\title{
BIODEGRADATION POTENTIAL OF IMMOBILIZED BACTERIA IN THE TREATMENT OF TANNERY INDUSTRIAL EFFLUENTS FROM INDUSTRIAL ESTATES IN KANO STATE, NIGERIA
}

\author{
Abdullateef, B., ${ }^{1 *}$ Shuaibu, T. G., ${ }^{1}$ Babagana, K., ${ }^{1}$ Suleman, H. B. ${ }^{2}$ and Dauda, B. ${ }^{3}$ \\ ${ }^{1}$ Department of Pure and Applied Chemistry, Faculty of Science, University of Maiduguri, Borno State, \\ Nigeria \\ ${ }^{2}$ Department of Microbiology, Faculty of Science, University of Maiduguri, Borno State, Nigeria \\ ${ }^{3}$ Department of Chemical Engineering, Faculty of Engineering, University of Maiduguri, Borno State, \\ Nigeria \\ *Corresponding author: babslega@gmail.com; abelega2007@yahoo.com; +2348061309753
}

\section{ABSTRACT}

Industrial Effluents Samples from Gashash Tanneries (TAN1) in Bompai Industrial estate, Larabee Tannery Industry (TAN2) in Sharada Industrial estate and Z Tannery Industries (TAN3) in Challawa Industrial estate, Kano State, Nigeria were collected over a period of six months (August 2017 to January 2018) for assessing the biodegradation potentials of bacteria in the treatment of organic pollutants within the effluents. Bacteria were isolated from the effluents and immobilized on agar-agar. Different masses (5 g, $10 \mathrm{gr}, 15$ $\mathrm{g}, 20 \mathrm{~g}$, and $25 \mathrm{~g}$ ) of the bacteria were used in the treatment of $250 \mathrm{ml}$ of the effluents for ten days in a shaker incubator (Gallenkamp-OC-4364-L) at the temperature $30{ }^{\circ} \mathrm{C}$ and speed of $60 \mathrm{rpm}$. Pre-treatment analysis of the effluents for Temperature, pH, Biochemical Oxygen Demand (BOD), Chemical Oxygen Demand (COD), Suspended Solid (SS) and Total Dissolved Solids (TDS) gives the following results; temperature $\left({ }^{\circ} \mathrm{C}\right.$ )

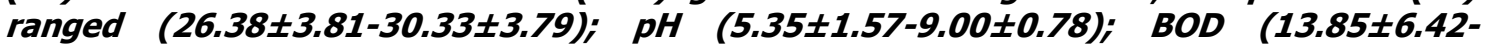
$38.75 \pm 16.20) ;$ COD (1406 $\pm 208-3532 \pm 1373) ;$ SS (208 $\pm 235-780 \pm 739)$ and TDS (266 $\pm 253-5276 \pm 2971)$. No statistical differences ( $p \leq 0.05)$ was observed for all the results among the different industries. The bacterial isolates were identified as Neisseria spp, Bacillus cereus, and Staphylococcus aureus, in TAN1, TAN2, and TAN3, respectively. After treatment of the effluent with the different masses of the isolated bacteria, the mean level of BOD was found to range as (0.55 $\pm 0.36-6.92 \pm 5.49) ; C O D$ (ND-3134 \pm 1595$)$;

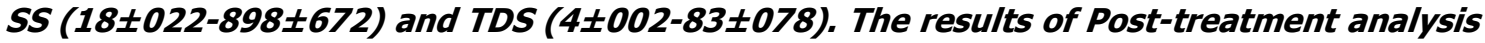
showed that there is overall decrease in the levels of the parameters determined when compared with that of the pre-treatment. The overall percentage reduction of the immobilised bacteria in the treatment of the respective effluents was in the order TAN2 (72\%)>TAN1 (70\%)>TAN3 (62\%). Hence, the immobilized bacteria are having higher biodegradation potential for the treatment of the tannery effluents.

Keywords: Biodegradation, bacteria, effluent, immobilization, tannery.

\section{INTRODUCTION}

Tannery industrial wastewater is a serious consequence of the pollution point of view for streams, freshwater, and land used for agriculture. The lack of awareness in the modern industrial practice has resulted in the discharge of tannery effluents which exhibit very high value of chromium ( $\mathrm{Cr}$ ), Sulfide, and chloride, Total Dissolved Solid (TDS), Total Suspended Solid (TSS), Biochemical Oxygen Demand (BOD) and Chemical Oxygen Demand (COD) in the water stream or land (Mohammed et al., 2001). Tanning is the process, which One ton of skin generally leads to the production of 20 to $80 \mathrm{~m}^{3}$ of turbid and foul-smelling converts the protein of the rawhide or skin into a stable material, which will not putrefy and is suitable for a wide variety of end applications (Elsheikh, 2009). The highly polluting chromium is the most commonly used tanning material producing leather that is more flexible and pliable than vegetable-tanned leather and does not discolor or lose shape in water as drastically as vegetable-tan (Elsheikh, 2009). Tannery effluent is among the most hazardous industrial pollutants due to its huge organic and inorganic load, which is highly toxic to human life and the environment (Kongjao et al., 2008). wastewater including chromium (100-400 mg/l), sulfide $(200-800 \mathrm{mg} / \mathrm{l})$, high levels of fat and 
BAJOPAS Volume 13 Number 2, December, 2020 other solid wastes, and notable pathogen contamination as well as pesticides added for skin conservation during transport (Elsheikh, 2009). There are more than 6000 tanneries in Nigeria with an annual processing capacity of 700,000 tons of hides and skins (Omoleke, 2004; Singh et al., 2008). It was reported that the total amount of waste produced per animal slaughtered is approximately $35 \%$ of its weight (World Bank, 1995). Also, for every $1000 \mathrm{~kg}$ of carcass weight, a slaughtered beef produces 5.5 $\mathrm{kg}$ of manure (excluding rumen contents or stockyard manure) and $100 \mathrm{~kg}$ of paunch manure (undigested food) (Verheijen et al., 1996). Tanneries generate wastewater in the range of 30-35 $\mathrm{L} \mathrm{kg}^{-1}$ skin/hide processed with variable $\mathrm{pH}$, Biological Oxygen Demand (BOD), Chemical Oxygen Demand (COD), high concentrations of suspended solids (SS), and tannins as well as chromium (Zahoor and Abdul, 2009).

Being heterogeneous and composed of a wide variety of compounds, it is very difficult to select a unique direct method for estimating the biodegradability of organic contents and biokinetic parameters for a wastewater sample (Rajor, 2004). For this purpose, some indirect estimation such as determination of biochemical oxygen demand (BOD) and chemical oxygen demand (COD) are applied as common laboratory investigations [9]. During retanning procedures, synthetic tannins (Syntan), oils and resins are added to form softer leather at varying doses (Munz et al., 2009). One of the refractory groups of chemicals in tannery effluents derives mainly from tannins (Ramasami et al., 2004). Syntans are characterized by complex chemical structures, because they are composed of an extended set of chemicals such as phenol-, naphthalene-, formaldehyde- and melamine-based syntans, and acrylic resins (Beem, 1994). Organic pollutants (proteic and lipidic components) are originated from skins (it is calculated that the raw skin has $30 \%$ loss of organic material during the working cycle) or they are introduced during processes (Hugo Springer, 1994).

Many conventional processes such as oxidation, chemical and biological processes were carried out to treat tanneries wastewater (Ebtesam et al, 2013). Biological processes have received more attention because of their costeffectiveness, lower sludge production and environmental friendliness (Noorjahan, 2014). Naturally occurring micro-organisms degrade the hazardous organic wastes including xenobiotic compounds, such as pesticides, polycyclic aromatic hydrocarbons (PAHs) and polychlorinated biphenyls (PCBs) in due course of time (Ranen and Sharadinadra, 2009). Bioremediation is based on the idea that all organisms remove substances from the environment to carry outgrowth and metabolism (Bouwer and Zehnder, 1993). Bacteria, protista and fungi are found to be very good at degrading complex molecules and incorporating the breakdown products into their metabolism (Bouwer and Zehnder, 1993). The resultant metabolic wastes that they produce are generally safe and somehow recycled into other organisms (Ranen and Sharadinadra, 2009). An acclimatized indigenous population of microorganisms capable of degradation of the compounds of interest must exist at the site for a successful bioremediation mode (Ranen and Sharadinadra, 2009). It has been observed that for a successful bioremediation mode, an acclimatized indigenous population of microorganisms capable of degradation of the compounds of interest must exist at the site under investigation (Ranen and Sharadinadra, 2009). Even though there are numerous physical and chemical methods employed in the disposal of wastes the advantage in using bacterium is that they play a key role in the reduction of COD, BOD, total protein, total tannin and total phenol (Saravanan and Saravanan, 1998)

Baba et al. (2020) studied the bioremediation potential of immobilized corynebacterium kutsceri in the Treatment of tannery industrial effluent from Challawa Industrial Estate, Kano State, Nigeria. The aim of the work is to study the reduction in the level of the contaminants through the process of bioremediation using the isolated bacteria. Immobilized bacteria can withstand various temperatures, $\mathrm{pH}$ and substrate concentrations; consequently, increasing the efficiency and the lifespan of the bacteria. Immobilized bacteria are widely applied in the treatment of wastewater and can be separated and recovered after the treatment with the same efficiency (Baba et al., 2020).

\section{MATERIALS AND METHODS \\ Study Area}

This study was carried out in Bompai, Sharada and Challawa industrial estates in Kano, Figure 1. Kano lies on Latitude $11^{\circ} 30^{\prime} \mathrm{N}$ and $8^{\circ} 30^{\prime} \mathrm{E}$ and Longitude $11^{\circ} 5^{\prime} \mathrm{N}$ and $8^{\circ} 5^{\prime} \mathrm{E}$ in Northern Nigeria. It is one of the developed industrial cities in Nigeria. Tannery activities are the dominating industries and this could be one of the reasons for her high population density (Dan'Azumi and Bichi, 2010). Many researchers have studied biodegradation of tannery effluent using microorganisms. However, limited literature is available on the biodegradation of tannery effluent in Kano industrial estates using 
BAJOPAS Volume 13 Number 2, December, 2020 immobilized bacterial cells. This research work focuses on the potential of the use of the indigenous immobilized bacterial isolates in the treatment of tannery effluents in the industrial estates.

\section{Sample Collection}

Effluents were collected from the Tannery Industries from Bompai, Challawa and Sharada Industrial Estates, Kano, Nigeria. The effluents were collected over a period of six months (August 2017 to January 2018). Samples collected in a sterile 4-liter plastic container with a unique identification number were preserved using an ice-box that was transported to the Microbiology Laboratory, Department of Microbiology, Bayero University of Kano for analysis

\section{Sample Preparation and Sample Analysis}

Immediately after the collection of the effluent, $\mathrm{pH}$, TSS, TDS, COD, BOD levels were determined before treatment (Pre-treatment determination) and ten days after treatment (Post-treatment determination) as described in
APHA (1989) standard methods. $\mathrm{pH}$ was determined using Ecotests $\mathrm{pH}$ meter and TDS was determined using AQUALYTIC TDS Salinometer. BOD was determined as described by the standard method (APHA, 1992). COD and SS were determined using DR/2010 HACH portable data logging spectrophotometer (DWAF, 1992)

\section{Identification and Biochemical} Characterization of the Bacterial Isolates

The bacteria were isolated from the effluents using Serial Dilution according to the method described by APHA (1989). The biochemical tests such as oxidase, catalase, coagulase, indole (from $1 \%$ tryptone broth), citrate (Simmons citrate agar), methyl red/VogesProskauer (MR/VP), nitrate reduction, Starch Hydrolysis, Glucose, Maltose, and Lactose tests were carried out on the bacterial isolates to identify the bacteria through the bacteria biochemical characteristics according to Ajao et al. (2011).

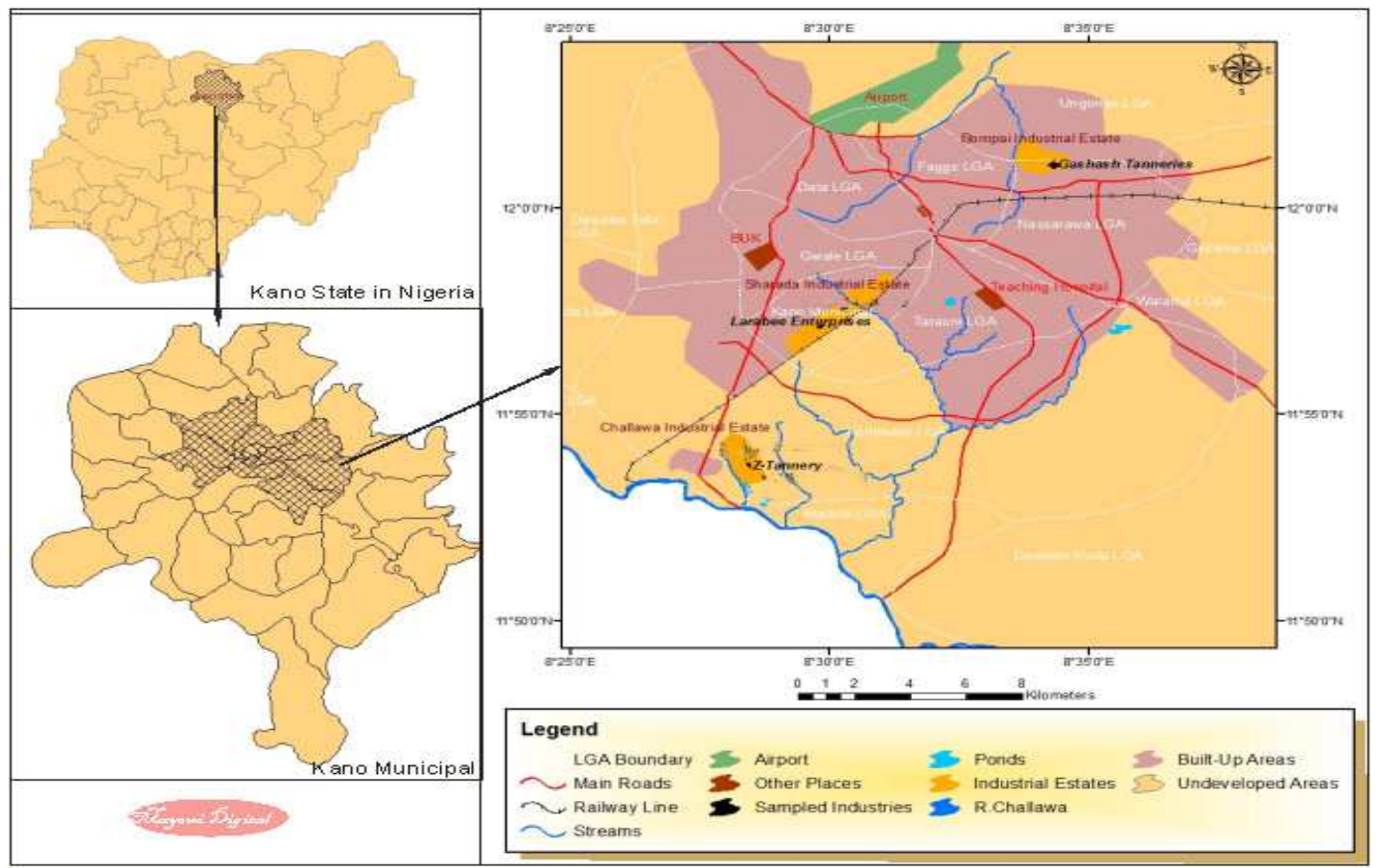

Fig. 1 Map showing the study areas

Source: Mayomi Digital Productions, GIS Laboratory, Department of Geography, UNIMAID (2017)

\section{Determination of Growth Rate of the Bacteria in Effluent Sample}

The bacteria growth rates were determined by transferring $2 \mathrm{~mL}$ of the bacterial isolates from the tannery effluent in broth medium into 100 $\mathrm{mL}$ sterile effluents in conical flasks and kept in an incubator (Giffrin cool) for 10 days. Control was also set up by incubating another $100 \mathrm{~mL}$ each of the sterile effluents without the bacteria. The optical density of the content was determined at the wavelength of $600 \mathrm{~nm}$ on a daily interval and recorded. 
BAJOPAS Volume 13 Number 2, December, 2020 Immobilization of Bacteria

Agar solution and inoculi were prepared separately. Fifty milliliters $(50 \mathrm{~mL})$ of nutrient broth each of the inoculi was prepared in a McCartney bottle and incubated for 24 hours. A solution of agar-agar was prepared by dissolving $10 \mathrm{~g}$ of the powder in distilled water and made up to $500 \mathrm{~mL}$ mark in an Erlenmeyer flask and was sterilized in an autoclave (280A) for 15 minutes and allowed to cool to $40-45^{\circ} \mathrm{C}$ (Ajao et al., 2011). Four milliliters ( $4 \mathrm{~mL})$ of the bacterial isolates in the nutrient broth was mixed with 36 $\mathrm{ml}$ of the prepared agar-agar media in petri-dish plates and then allowed to solidify. This was kept in the refrigerator for bioremediation.

\section{Bioremediation (Treatment) of the Effluents}

The solidified agar block (immobilized bacteria) was cut into cubes using a sterile knife; $0.1 \mathrm{~mL}$ phosphate buffer ( $\mathrm{pH} \mathrm{7.0)}$ was added and kept in the refrigerator for 1 hour for curing. The phosphate buffer was decanted after 1 hour and the cubes were washed with sterile distilled water 3-4 times before it was used (Ajao et al., 2011). Two liters (2 L) of the effluent was supplemented with the minimum basal medium in $\mathrm{g} / \mathrm{L}: \mathrm{NaCl}(0.8), \mathrm{MgSO}_{4} .7 \mathrm{H}_{2} \mathrm{O}(0.001), \mathrm{KH}_{2} \mathrm{PO}_{4}$ (2), $\mathrm{NaNO}_{3}$ (2), $\quad \mathrm{CaCl}_{2} .2 \mathrm{H}_{2} \mathrm{O} \quad(0.5)$ and $\mathrm{NaHPO}_{4} .12 \mathrm{H}_{2} \mathrm{O}(2)$ and sterilized in an autoclave at $121^{\circ} \mathrm{C}$ for 15 minutes (Margesin and Schinner, 2001). Two hundred and fifty milliliters $(250 \mathrm{~mL})$ of the effluents were transferred into different $250 \mathrm{ml}$ conical flasks. The content was covered with a cotton-wool ramped with foil paper to avoid contamination. Five grams $(5 \mathrm{~g})$ of the immobilized bacteria were quickly transferred into each of the effluents in the conical flasks in an inoculating chamber. The same procedures were carried out for the $10 \mathrm{~g}, 15 \mathrm{~g}, 20 \mathrm{~g}$ and 25 $\mathrm{g}$ of the immobilized bacteria in separate $250 \mathrm{~mL}$ effluents in conical flasks and agitated for ten days in a shaker incubator (Gallenkamp-OC4364-L) at a temperature $30^{\circ} \mathrm{C}$ and speed of 60 rpm. The treated effluent samples were taken on the tenth day and analyzed for the parameters $\mathrm{pH}$, SS, TDS, COD, and BOD, (Posttreatment determination) for the different grams of bacteria to evaluate and compare the biodegradation potential. (Baba et al., 2020).

\section{Statistical Analysis}

The data were represented as Mean \pm Standard deviation and analyzed statistically using oneway Analysis of Variance (ANOVA) and Tukey's HSD as Post Hoc Tests with the aid of SPSS 16.0. The correlation coefficient was also used to measure the strength of the relationship between the different masses of the bacteria and the parameters. All $\mathrm{p} \leq 0.05$ were considered as statistically significant.

\section{RESULTS AND DISCUSSION Physico-chemical parameters in the Industrial Effluents before the Biodegradation.}

Results of the Physico-chemical parameters in the industrial effluents before the Biodegradation is shown in table 1 . The mean temperatures $\left({ }^{\circ} \mathrm{C}\right)$ observed in TAN1, TAN2, and TAN3 samples were $28.07 \pm 0.65 ; 27.77 \pm 0.64$ and $26.38 \pm 3.81$ respectively. The order of the mean temperature of the samples from the three industries can be arranged as TAN1 > TAN2>TAN3. The temperature observed at TAN1, TAN2, and TAN3 samples were found below the WHO $\left(35^{\circ} \mathrm{C}\right)$ and NESREA $\left(40^{\circ} \mathrm{C}\right)$ limits. The low values of temperature might be due to the processes used at the time of sampling. High temperature brings down the solubility of gases in water that ultimately expresses as high BOD and COD. Statistical analysis shows that there is no significant difference $(p<0.05)$ between the mean values of temperature among the industries. This might be due to similar tannery activities involved in the tannery industries at the time of sampling. The average values of temperature observed in this present study are less than those observed by Akan et al. (2007), Akan et al. (2009) and Baba et al. (2020).

The mean level of $\mathrm{pH}$ observed in TAN1, TAN2 and TAN3, samples were $7.77 \pm 2.93$; $8.35 \pm 0.28$ and $7.52 \pm 0.76$ respectively. The order of the mean $\mathrm{pH}$ of the samples from the three industries can be arranged as TAN2> TAN1 $>$ TAN3. The $\mathrm{pH}$ of the samples falls within the WHO (7.0-8.5) and NESREA (6-9) standard limits. Statistical analysis shows that there is no significant difference $(p<0.05)$ between the mean values of $\mathrm{pH}$ among the industries. This might be due to similar tannery activities involved in the tannery industries at the time of sampling. Maheshwari et al. (2017) reported that the level of $\mathrm{pH}$ in the effluents from the tannery industry in Vaniyambadi, India was 6.5 which was lower than that observed in the present study. The $\mathrm{pH}$ in the effluents from the tannery industries in Kano and Kaduna were reported to be 7.64 and 6.89, respectively (Akan et al., 2007; Mohammed et al., 2017). The average values of $\mathrm{pH}$ observed in this present study are less than those observed by Mohammed et al. (2017) and Baba et al. (2020). The mean level of SS $(\mathrm{mg} / \mathrm{l})$ observed in TAN1, TAN2, and TAN3 samples were 374 \pm 124 ; $358 \pm 335$ and $780 \pm 739$ respectively. The order of the mean SS in the samples from the three industries can be arranged as TAN3 > TAN1 $>$ TAN2. 
The SS observed in the samples were far above the recommended standard limits of regulating bodies WHO $(30 \mathrm{mg} / \mathrm{l})$ and NESREA $(10 \mathrm{mg} / \mathrm{l})$. Statistical analysis shows that there is no significant difference $(p<0.05)$ between the mean values of SS among the industries. This might be due to similar tannery activities involved in the tannery industries at the time of sampling. The average values of SS observed in this present study are less than that observed $(3700 \pm 122 \mathrm{mg} / \mathrm{l})$ by Akan et al. (2009) for tanneries in Kano. Also, the average values of SS observed in this present study are less than that observed by Mohammed et al. (2017) and Baba et al. (2020) with the exception in TAN3.

The mean level of TDS (mg/l) observed in TAN1, TAN2, and TAN3 samples were $3941 \pm 3703$; $3300 \pm 1714$ and $2653 \pm 1240$ respectively. The order of the mean TDS in the samples from the three industries can be arranged as TAN1>TAN2>TAN3. The TDS observed in the samples were far above the recommended standard limits of WHO $(250 \mathrm{mg} / \mathrm{l})$ and NESREA $(500 \mathrm{mg} / \mathrm{l})$. Statistical analysis shows that there is no significant difference $(p<0.05)$ between the mean values of TDS among the industries. This might be due to similar tannery activities involved in the tannery industries at the time of sampling. TDS in the effluents from the tannery industries in Kano, Nigeria was reported to be $1281 \mathrm{mg} / \mathrm{l}$ (Akan et al., 2007). The average values of SS observed in this present study are less than those observed by Mohammed et al. (2017) and Baba et al. 2020)

The mean level of COD (mg/l) observed in TAN1, TAN2 and TAN3 samples seasons were $2372 \pm 938 ; \quad 1406 \pm 208$ and $3532 \pm 1373$ respectively. The order of the mean COD of the samples from the three industries can be arranged as TAN3>TAN1> TAN2. The COD observed in TAN1, TAN2 and TAN3 samples were far above the recommended standard limits of regulating bodies $\mathrm{WHO}(40 \mathrm{mg} / \mathrm{l})$ and NESREA (40 mg/l). Statistical analysis shows that there is no significant difference $(p<0.05)$ in COD among the industries. This might be due to similar tannery activities involved in the tannery industries as at the time of sampling. The Chemical Oxygen demand (COD) is the amount of oxygen, in $\mathrm{mg} / \mathrm{L}$, required for the degradation of the compound of wastewater to occur. In comparison, the average values of COD observed in this present study were higher than that observed by Mohammed et al. (2017) but lower than that observed by Baba et al. (2020).

The mean levels of BOD $(\mathrm{mg} / \mathrm{l})$ observed in TAN1, TAN2 and TAN3 samples were $13.85 \pm 6.42 ; \quad 19.46 \pm 0.50$ and $17.13 \pm 3.14$ respectively. The order of the mean BOD in the samples from the three industries can be arranged as TAN2>TAN3>TAN1. The BOD observed in TAN1, TAN2 and TAN3 samples were found below the recommended limits of NESREA (200 mg/l) but above WHO (10 mg/l). Statistical analysis shows that there is no significant difference $(p<0.05)$ between the mean values of BOD among the industries. This might be due to similar tannery activities involved in the tannery industries at the time of sampling. The low level of BOD recorded in this study is an indication of the low level of biodegradable organic solids in the effluent. The average values of BOD observed in this present study were lower than those observed by Mohammed et al. (2017) and Baba et al. (2020).

Table 1: Mean Values \pm S.D of Physico-chemical parameters of effluents from the Tannery Industries before Treatment.

\begin{tabular}{llllllll}
\hline Parameter & Tannery 1 & Tannery 2 & Tannery 3 & $\mathrm{a}$ & $\mathrm{b}$ & $\mathrm{c}$ & $\mathrm{d}$ \\
\cline { 2 - 7 } Temperature $\left({ }^{\circ} \mathrm{C}\right)$ & $28.07 \mathrm{a} \pm 0.65$ & $27.77 \mathrm{a} \pm 0.64$ & $26.38 \mathrm{a} \pm 3.81$ & & $29.50 \pm 4.68$ & 35 & 40 \\
pH & $7.77 \mathrm{a} \pm 2.93$ & $8.35 \mathrm{a} \pm 0.28$ & $7.52 \mathrm{a} \pm 0.76$ & 6.89 & $5.35 \pm 1.57$ & $7.0-8.5$ & $6.0-9.0$ \\
$\mathrm{COD}(\mathrm{mg} / \mathrm{l})$ & $2372 \mathrm{a} \pm 938$ & $1406 \mathrm{a} \pm 208$ & $3532 \mathrm{a} \pm 1373$ & 2.2 & $3106 \pm 2753$ & 40 & 40 \\
$\mathrm{BOD}(\mathrm{mg} / \mathrm{l})$ & $13.85 \mathrm{a} \pm 6.42$ & $19.46 \mathrm{a} \pm 0.50$ & $17.13 \mathrm{a} \pm 3.14$ & 1032 & $26.17 \pm 9.49$ & 10 & 200 \\
$\mathrm{SS}(\mathrm{mg} / \mathrm{l})$ & $374 \mathrm{a} \pm 124$ & $358 \mathrm{a} \pm 335$ & $780 \mathrm{a} \pm 739$ & 501 & $562 \pm 482$ & 30 & 10 \\
TDS $(\mathrm{mg} / \mathrm{l})$ & $3941 \mathrm{a} \pm 3703$ & $3300 \mathrm{a} \pm 1714$ & $2653 \mathrm{a} \pm 1240$ & 532.7 & $444 \pm 507$ & 250 & 500 \\
\hline
\end{tabular}

The values given in the table above are means of 6 replicate values, $\mathrm{n}=6$ ( 1 sample was taken monthly for 6 months). Within the rows, means with different alphabets are statistically different $(p<0.05)$. WHO: World Health Organisation. NESREA: National Environmental Standard and Regulatory Enforcement Agency. a = Mohammed et al.(2017), b = Baba et al. (2020), c = WHO (2006), $d=$ NESSRA (2009) 
BAJOPAS Volume 13 Number 2, December, 2020

Identification, Biochemical Characterization and growth rates of the Bacterial Isolates

Results of identification and biochemical characterization of the bacterial isolates were shown in table 2. After 24 hours of incubation, the nutrient agar media plates were checked for bacterial growth. The results showed the presence of different strains in the samples. The TAN1 bacteria isolate was found to be gramnegative cocci while TAN3 was gram-positive cocci. TAN2 bacteria isolate was found to be gram-positive, rod-shaped. TAN1, TAN2, and TAN3 bacteria isolates recorded positive results for spore former.

The results of the biochemical tests indicated that all the bacteria were positive for catalase, oxidase, citrate, maltose, glucose, lactose (negative in TAN1), mannitol (negative in TAN2), starch hydrolysis and coagulase (negative in TAN2) tests. The bacteria showed negative results for nitrate reduction, $M R$ (positive in TAN2), VP (positive in TAN1), Indole (positive in TAN2) tests. Base on the morphological and biochemical test results, TAN1, TAN2, and TAN3 bacteria isolates were identified to be Nesseria spp, Bacillus cereus, and Staphylococcus aureus respectively.

The growth rate of the TAN1, TAN2 and TAN3 Isolates were shown in figure 2. Generally, the optical density increase with the increase in time (day) and decrease as time goes on. The highest optical density was shown by bacillus cereus in TAN2 while the lowest was shown by Staphylococcus aureus in TAN3.

The initial growth phase of TAN1 Isolate bacteria occurred within 2-day of incubation as the growth rate increases up to the 6th-day incubation when the maximum growth was observed. Beyond the 6th day, the growth of the bacteria declined (which might be due to a shortage of nutrients in the effluents) until it reached its death phase (which might be due to the unavailability of nutrients in the effluents).

A similar trend of growth was also observed for TAN2 Isolate as the initial growth phase also occurred within 2-day of incubation but maximum growth rate observed on the 4th day of incubation. The stationary stage occurred between the 4th day and the 8th day. Beyond the 8th day, the growth of the bacteria declined (which might be due to a shortage of nutrients in the effluents) until it reached its death phase (which might be due to the unavailability of nutrients in the effluents).

The initial growth phase of TAN3 bacterial Isolate occurred within the 3-day incubation as the growth rate increases up to the 6th-day incubation when the maximum growth was observed. Beyond the 6th day, the growth of the bacteria declined (which might be due to a shortage of nutrients in the effluents) until it reached its death phase (which might be due to the unavailability of nutrients in the effluents).

Table 2: Morphological and Biochemical characteristics of bacterial isolates

\begin{tabular}{lllll} 
Bacterial Isolates & & TAN1 & TAN2 & TAN3 \\
\hline $\begin{array}{lllll}\text { Morphological } \\
\text { characteristics }\end{array}$ & Shape & Cocci & Rod & Cocci \\
& Spore & & & \\
& former & + & + & + \\
Gram & & & \\
Biochemical characteristics & reaction & - & + & + \\
& Citrate & + & + & + \\
& Catalase & + & + & + \\
& Coagulase & + & - & + \\
Starch & + & + & + \\
& Glucose & + & + & + \\
Oxidase & + & + & + \\
& Indo & - & + & - \\
Lactose & - & + & + \\
Manitol & + & - & + \\
Maltose & + & + & + \\
MR & - & + & - \\
VP & + & - & - \\
& Nitrate & - & - & - \\
Reduction & - Neisseria & Bacillus & Staphylococcus \\
& Bacterial & cereus & aureus \\
& name & spp & cas
\end{tabular}

+ = Positive; - = Negative; MR=Methyl Red; VP= Voges-Proskauer 


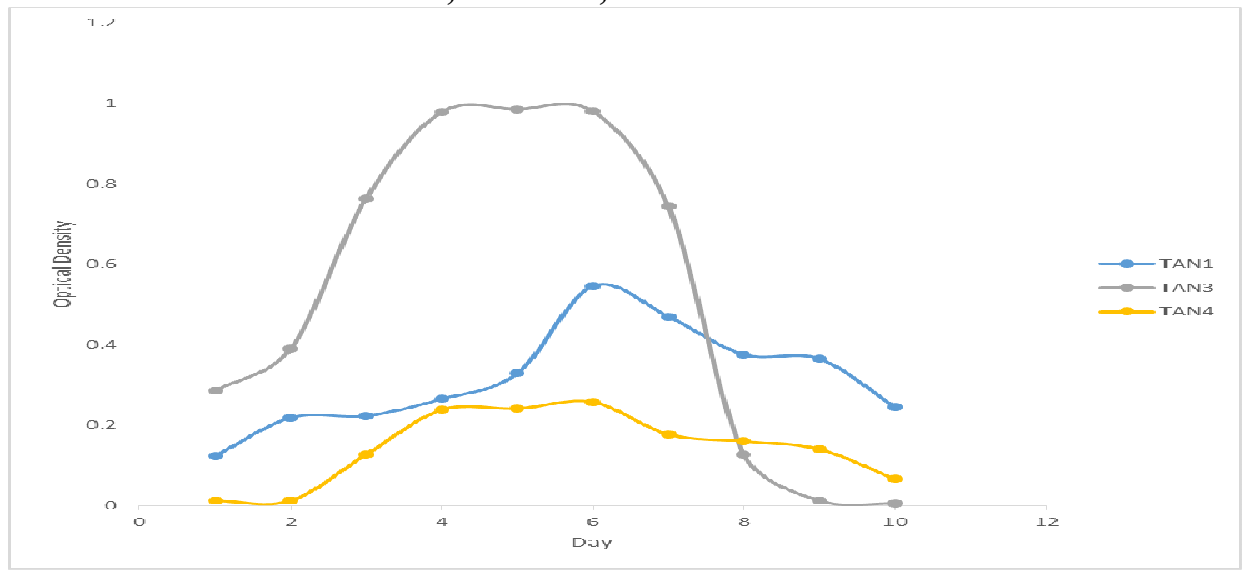

Fig. 2 Growth rates of the isolates in the effluents from the Tannery Industries

\section{Physico-chemical Parameters in the Industrial Effluents after the biodegradation.}

Table 3 shows the mean results of the physicochemical parameter before and after bioremediation using the different masses $(5 \mathrm{~g}$, $10 \mathrm{~g}, 15 \mathrm{~g}, 20 \mathrm{~g}$, and $25 \mathrm{~g}$ ) of the respective immobilized bacteria. Also, Table 4 shows the mean results of correlation coefficient ( $r$ ) between different masses of bacteria and physicochemical parameters.

The mean values $(\mathrm{mg} / \mathrm{l})$ of the SS after the bioremediation varies between $243 \pm 45$ and $898 \pm 672$. The mean concentration $(\mathrm{mg} / \mathrm{l})$ of SS remediated by the different masses $(5 \mathrm{~g}, 10 \mathrm{~g}$, $15 \mathrm{~g}, 20 \mathrm{~g}$, and $25 \mathrm{~g}$ ) of the bacteria varies. The SS in the samples fluctuates up and down after the bioremediation process when compared with the SS of the raw samples before the bioremediation. The increase in the levels of the SS might be due to the aggregation of the TDS which are large enough to result into SS. The increase in the levels of the SS might be also due to the influence of the nutrients which was added into the effluents in order to make the microorganisms more active and viable for fast degradation of organic contaminants in the effluent. The relative potential or efficiency of the different masses of the bacteria in remediating SS in TAN1 samples was in the order $25 \mathrm{~g}>20 \mathrm{~g}>15 \mathrm{~g}>10 \mathrm{~g}>5 \mathrm{~g}$. For TAN2 and TAN3 samples, the order was $25 \mathrm{~g}>20 \mathrm{~g}>15$ $\mathrm{g}>10 \mathrm{~g}>5 \mathrm{~g}$. These might be due to the variations in the surface areas of the different masses of the immobilized bacteria. Statistical analysis shows that there is no significant difference $(p<0.05)$ between the mean values of SS among the masses in the respective industries. Positive and significant correlations exist between the masses of bacteria and Suspended Solid (SS). This showed that there is general increase in the levels of the SS as the masses of the immobilized bacteria increases. TAN3 (90\%) and TAN1 (80\%) showed a very high correlation with the masses of the bacteria while TAN2 (61\%) showed a very low correlation.

The mean values $(\mathrm{mg} / \mathrm{l})$ of the TDS after the bioremediation varies between $46 \pm 11$ and $83 \pm 78$. The mean concentration $(\mathrm{mg} / \mathrm{l})$ of TDS remediated by the different masses $(5 \mathrm{~g}, 10 \mathrm{~g}$, $15 \mathrm{~g}, 20 \mathrm{~g}$, and $25 \mathrm{~g}$ ) of the bacteria varies. There is a reduction in all the TDS of all the samples after the bioremediation process compared with the TDS of the raw samples before the bioremediation. The relative potential or efficiency of the different masses of the bacteria in remediating TDS in TAN1 and TAN3 samples was in the order $5 \mathrm{~g}>10 \mathrm{~g}>15 \mathrm{~g}>20$ $\mathrm{g}>25 \mathrm{~g}$. For TAN2 samples, the order was 20 $g>10 \quad g>25 \quad g>15 \quad g>5 \quad g$. Statistical analysis shows that there is no significant difference $(p<0.05)$ between the mean values of TDS among the masses in the respective industries. These might be due to the variations in the surface areas of the different masses of the immobilized bacteria. Positive and significant correlations exist between the masses of bacteria and TDS with the exception in TAN2 (negative and insignificant correlation). The positive correlations showed that there is general increase in the levels of the TDS as the masses of the immobilized bacteria increases. TAN1 $(96 \%)$ showed a very high correlation with the masses of the bacteria while TAN2 (47\%) showed a very low correlation.

The mean values $(\mathrm{mg} / \mathrm{l})$ of the BOD after the bioremediation varies between $1.56 \pm 0.20 \mathrm{mg} / \mathrm{l}$ and $6.92 \pm 5.49 \mathrm{mg} / \mathrm{l}$. The mean concentration $(\mathrm{mg} / \mathrm{l})$ of BOD remediated by the different masses $(5 \mathrm{~g}, 10 \mathrm{~g}, 15 \mathrm{~g}, 20 \mathrm{~g}$, and $25 \mathrm{~g}$ ) of the bacteria varies. There is a reduction in all the BOD of all the samples after the bioremediation process compared with the $\mathrm{BOD}$ of the raw 
BAJOPAS Volume 13 Number 2, December, 2020 samples before the bioremediation. The relative potential or efficiency of the different masses of the bacteria in remediating BOD in TAN1, TAN2 and TAN3 samples were in the order $25 \mathrm{~g}>20$ $\mathrm{g}>15 \mathrm{~g}>10 \mathrm{~g}>5 \mathrm{~g}, 25 \mathrm{~g}>15 \mathrm{~g}>5 \mathrm{~g}>10 \mathrm{~g}>20 \mathrm{~g}$ and $20 \mathrm{~g}>10 \mathrm{~g}>25 \mathrm{~g}>15 \mathrm{~g}>5 \mathrm{~g}$ respectively. Statistical analysis shows that there is significant difference $(p<0.05)$ between the mean values of BOD among the masses in the respective industries. These might be due to the variations in the surface areas of the different masses of the immobilized bacteria. Negative and significant correlations exist between the masses of bacteria and BOD. This showed that there is general decrease in the levels of the BOD as the masses of the immobilized bacteria increases. TAN1 (94\%) showed a very high correlation with the masses of the bacteria while TAN2 (4\%) showed a very low correlation.

The mean values $(\mathrm{mg} / \mathrm{l})$ of the COD after the bioremediation varies between $250 \pm 154$ and $3134 \pm 1595$. The mean concentration $(\mathrm{mg} / \mathrm{l})$ of COD remediated by the different masses $(5 \mathrm{~g}$, $10 \mathrm{~g}, 15 \mathrm{~g} 20 \mathrm{~g}$, and $25 \mathrm{~g}$ ) of the bacteria varies. There is a reduction in all the COD of all the samples after the bioremediation process compared with the COD of the raw samples before the bioremediation. The relative potential or efficiency of the different masses of the bacteria in remediating COD in TAN1, TAN2 and TAN3 samples were in the order $25 \mathrm{~g}>20 \mathrm{~g}>15$ $\mathrm{g}>5 \mathrm{~g}>10 \mathrm{~g}, 25 \mathrm{~g}>20 \mathrm{~g}>15 \mathrm{~g}>10 \mathrm{~g}>5 \mathrm{~g}$ and 10 g>5 g>25 g>15 g>20 g respectively. Statistical analysis shows that there were significant difference $(p<0.05)$ between the mean values of COD among the masses in the respective industries except for effluents treated with $25 \mathrm{~g}$. These might be due to the variations in the surface areas of the different masses of the immobilized bacteria. Negative and insignificant correlations exist between the masses of bacteria and COD with the exception in TAN3 (positive and significant correlation). The negative correlations showed that there is general decrease in the levels of the COD as the masses of the immobilized bacteria increases. TAN2 (100\%) showed a very high correlation with the masses of the bacteria while TAN3 (36\%) showed a very low correlation.

Generally, there was an overall decrease in the concentration of these physicochemical parameters after the bioremediation using the different masses of the bacterial isolates. These might be due to the variations in the surface areas of the different masses of the immobilized bacteria. This is in line with the work of Jimoh et al. (2018) and Baba et al. (2020).

Table 3: Mean Values $(\mathrm{mg} / \mathrm{l}) \pm$ S.D of Physicochemical parameters in effluents from the Tannery Industries before and after Treatment of the effluents $(250 \mathrm{ml})$ with the different masses $(5 \mathrm{~g}, 10 \mathrm{~g}$, $15 \mathrm{~g}, 20 \mathrm{~g}$, and $25 \mathrm{~g}$ ) of the bacteria.

\begin{tabular}{llllllll}
\hline $\mathrm{P}$ & IND & Before & \multicolumn{5}{c}{ After } \\
\cline { 4 - 7 } & & & $5 \mathrm{~g}$ & $10 \mathrm{~g}$ & $15 \mathrm{~g}$ & $20 \mathrm{~g}$ & $25 \mathrm{~g}$ \\
\hline \multirow{2}{*}{ COD } & TAN1 & $2372 \pm 938$ & $1708 \mathrm{a} \pm 861$ & $2045 \mathrm{a} \pm 1205$ & $845 \mathrm{a} \pm 369$ & $300 \mathrm{a} \pm 167$ & $250 \mathrm{a} \pm 154$ \\
& TAN2 & $1406 \pm 208$ & $1195 \mathrm{a} \pm 208$ & $1125 \mathrm{a} \pm 384$ & $1055 \mathrm{a} \pm 317$ & $956 \mathrm{a} \pm 310$ & $870 \mathrm{ab} \pm 240$ \\
& TAN3 & $3532 \pm 1373$ & $2374 \mathrm{a} \pm 1344$ & $1976 \mathrm{a} \pm 1405$ & $2757 \mathrm{a} \pm 1266$ & $3134 \mathrm{a} \pm 1595$ & $2614 \mathrm{~b} \pm 1105$ \\
BOD & TAN1 & $13.85 \pm 6.42$ & $6.92 \mathrm{a} \pm 5.49$ & $6.42 \mathrm{a} \pm 5.07$ & $5.72 \mathrm{a} \pm 5.35$ & $4.62 \mathrm{a} \pm 4.37$ & $2.82 \mathrm{ab} \pm 1.26$ \\
& TAN2 & $19.46 \pm 0.50$ & $1.75 \mathrm{~b} \pm 0.22$ & $1.73 \mathrm{~b} \pm 0.18$ & $1.58 \mathrm{a} \pm 0.16$ & $1.91 \mathrm{a} \pm 0.22$ & $1.56 \mathrm{~b} \pm 0.20$ \\
& TAN3 & $17.13 \pm 3.14$ & $4.24 \mathrm{ab} \pm 0.77$ & $3.29 \mathrm{ab} \pm 0.37$ & $4.11 \mathrm{a} \pm 0.07$ & $3.23 \mathrm{a} \pm 0.91$ & $3.33 \mathrm{a} \pm 1.28$ \\
SS & TAN1 & $374 \pm 124$ & $243 \mathrm{a} \pm 45$ & $471 \mathrm{a} \pm 226$ & $475 \mathrm{a} \pm 182$ & $492 \mathrm{a} \pm 128$ & $611 \mathrm{a} \pm 217$ \\
& TAN2 & $358 \pm 335$ & $460 \mathrm{a} \pm 400$ & $543 \mathrm{a} \pm 414$ & $544 \mathrm{a} \pm 402$ & $551 \mathrm{a} \pm 414$ & $554 \mathrm{a} \pm 405$ \\
& TAN3 & $780 \pm 739$ & $586 \mathrm{a} \pm 594$ & $758 \mathrm{a} \pm 656$ & $787 \mathrm{a} \pm 676$ & $861 \mathrm{a} \pm 635$ & $898 \mathrm{a} \pm 672$ \\
TDS & TAN1 & $3941 \pm 3703$ & $51 \mathrm{a} \pm 10$ & $53 \mathrm{a} \pm 10$ & $55 \mathrm{a} \pm 15$ & $61 \mathrm{a} \pm 20$ & $63 \mathrm{a} \pm 26$ \\
& TAN2 & $3300 \pm 1714$ & $83 \mathrm{a} \pm 78$ & $47 \mathrm{a} \pm 20$ & $48 \mathrm{a} \pm 22$ & $47 \mathrm{a} \pm 17$ & $48 \mathrm{a} \pm 17$ \\
& TAN3 & $2653 \pm 1240$ & $46 \mathrm{a} \pm 11$ & $55 \mathrm{a} \pm 24$ & $55 \mathrm{a} \pm 25$ & $58 \mathrm{a} \pm 23$ & $61 \mathrm{a} \pm 28$ \\
\hline
\end{tabular}

Replicate $=6$ (months)

Within the rows, for the same parameter, means with different alphabets are statistically different $(p<0.05)$.

$\mathrm{P}=$ parameter, IND = Industries 
BAJOPAS Volume 13 Number 2, December, 2020

Table 4: Correlation coefficient $(r)$ between different masses of the bacteria and the physicochemical parameters.

\begin{tabular}{llll}
\hline Industries & Parameter & Correlation coefficient $(r)$ & $\begin{array}{l}\text { Percent dependence (rxrx100) } \\
(\%)\end{array}$ \\
\hline TAN1 & COD & -0.9 & 82 \\
& BOD & -0.97 & 94 \\
& SS & $0.90^{*}$ & 80 \\
TAN2 & TDS & $0.98^{*}$ & 96 \\
& COD & -1 & 100 \\
& BOD & -0.21 & 4 \\
& SS & $0.78^{*}$ & 61 \\
& TDS & -0.69 & 47 \\
& COD & $0.60^{*}$ & 36 \\
& BOD & -0.6 & 37 \\
& SS & $0.95^{*}$ & 90 \\
& TDS & $0.94^{*}$ & 89 \\
\hline
\end{tabular}

The correlation coefficient $(r)$ with * is statistically significant $(p<0.05)$.

Percentage reduction of the Parameters

Table 5 shows the percentage reduction of Parameters in industrial samples before and after the treatment of the effluents $(250 \mathrm{ml})$ with the different masses $(5 \mathrm{~g}, 10 \mathrm{~g}, 15 \mathrm{~g}, 20 \mathrm{~g}$, and $25 \mathrm{~g}$ ) of the Immobilized Bacteria.

In TAN1 samples, the percentage reduction (\%) of COD ranged (14-89); BOD (50-80); SS (-32$35)$ and TDS (98-99). In TAN2 samples, the percentage decrease $(\%)$ of COD ranged (15$38) ;$ BOD (90-92); SS [-28-(-55)] and TDS (9798). In TAN3 samples, the percentage decrease (\%) of COD ranged (11-44); BOD (76-81); SS (15-25) and TDS (98). The percentage increase in the levels COD, BOD and TDS might be due to the increase in the surface area of the different masses of the immobilized bacteria. However, the percentage decrease in the levels of the SS might be due to the aggregation of the TDS which are large enough to result into SS. The percentage decrease in the levels of the SS might be also due to the influence of the nutrients which was added into the effluents in order to make the microorganisms more active and viable for fast degradation of organic contaminants in the effluent. This is in line with the work of Jimoh et al. (2018) in which the concentration of the SS increase after the bioremediation of effluents.

Sreemoyee and Priti (2013) assessed and reduced several Physico-chemical parameters of dairy wastewater using Niesseria $s p$. and concluded that the species are well known to degrade organic compounds. This is in agreement with the current study in which the immobilized Niesseria $s p$ degrade the organic contaminants as indicated by the BOD, COD and TDS.

Jimoh et al. (2018) observed that TSS of the effluents was increased after treatment with immobilized bacteria and concluded that it might be due to the biostimulation method adopted for the research.

The optimum $\mathrm{pH}$ Biosorption of Chromium by Bacillus spp and Staphylococcus spp. from tannery effluent was investigated by Mythili and Karthikeyan (2011). The maximum adsorption of Chromium $(86.4 \mathrm{mg} / \mathrm{L})$ was showed by Bacillus spp and Staphylococcus spp showed $70.6 \mathrm{mg} / \mathrm{L}$ at an initial concentration of $100 \mathrm{mg} / \mathrm{L}$. In the present study, immobilised Bacillus spp and Staphylococcus spp. from the tannery industrial effluents reduced the levels of the organic pollutants with high potential as indicated by the percentage reduction of BOD, COD and TDS.

Enzymes often can work in multiple environments especially if they are immobilized. This makes the microorganisms' enzymes even more resistant to harsh environments and enables the enzymes to be recovered and recycled after they are no longer needed (Gianfreda and Rao 2004). Ramesh and Singh (1993) reported that the immobilized bacteria having more efficiency to remove the suspended particles than free cells. Using the immobilized cell is preferable due to its capability for using several times with the same efficiency, which makes it more economical. Similar work was done by Sikander et al. (2007) showing the higher reduction with permeabilized cells of Ochrobactrum intermedium strain SDCr-5. 
BAJOPAS Volume 13 Number 2, December, 2020

The results revealed the isolation and identification of isolates with the potential for the reduction of $\mathrm{Cr}$ (VI) to $\mathrm{Cr}$ (III). Results indicated that immobilized $B$. cereus could be efficiently used for the reduction of $\mathrm{Cr}$ (VI).

Table 5: Percentage reduction of the tested Parameters from the tannery industrial samples of the Immobilized Bacteria.

\begin{tabular}{lllllll}
\hline \multirow{2}{*}{ Industries } & & \multicolumn{5}{c}{ Percentage Reduction $(\%)$} \\
\cline { 3 - 7 } & & $5 \mathrm{~g}$ & $10 \mathrm{~g}$ & $15 \mathrm{~g}$ & $20 \mathrm{~g}$ & $25 \mathrm{~g}$ \\
\hline TAN1 & COD & 28 & 14 & 64 & 87 & 89 \\
& BOD & 50 & 54 & 59 & 67 & 80 \\
& SS & 35 & -26 & -27 & -32 & -63 \\
& TDS & 99 & 99 & 99 & 98 & 98 \\
TAN2 & COD & 15 & 20 & 25 & 32 & 38 \\
& BOD & 91 & 91 & 92 & 90 & 92 \\
& SS & -28 & -52 & -52 & -54 & -55 \\
& TDS & 97 & 99 & 99 & 99 & 99 \\
& COD & 33 & 44 & 22 & 11 & 26 \\
& BOD & 75 & 81 & 76 & 81 & 81 \\
& SS & 25 & 3 & -1 & -10 & -15 \\
& TDS & 98 & 98 & 98 & 98 & 98 \\
\hline
\end{tabular}

Percentage Reduction $=(B-A) / B \times 100 \%$

$A=$ Concentration of the parameter after treatment

$\mathrm{B}=$ Concentration of the parameter before treatment

$+=$ percentage decrease

- = percentage increase

In general, immobilization makes the enzyme more resistant to temperature, $\mathrm{pH}$, and substrate concentration swings giving it a longer lifetime and higher productivity per active unit (Gianfreda and Rao, 2004; FuIlbrook, 1996; Russell et al, 2003; Kandelbauer et al., 2004). Immobilized cells have been used and studied extensively for the production of useful chemicals (Ohtake and Silver, 1994), the treatment of wastewaters (Chen et al., 2003; Wang et al., 2010). Although many workers described microbial degradation of tannery effluent, limited literature is available on the bioremediation of tannery effluent using immobilized bacterial cells in the Kano Industrial Estates.

\section{CONCLUSION}

The samples contained variable levels of the physicochemical parameters. The results of the Analysis of variance revealed that, no statistical difference $(p<0.05)$ was observed for the temperature, $\mathrm{pH}, \mathrm{SS}, \mathrm{TDS}, \mathrm{BOD}$ and $\mathrm{COD}$ among the three tannery industries before the treatment. The levels of some of the parameters
(SS, TDS and COD) observed in the samples were found above the recommended limits of WHO and NESREA, which called for the treatment of the effluents before discharge into the environment. Base on the morphological and biochemical test results, TAN1, TAN2, and TAN3 bacterial isolates were identified to be Neisseria spp, Bacillus cereus, and Staphylococcus aureus respectively. The results of Post-treatment analysis showed that there is overall decrease in the levels of the parameters determined when compared with that of the pre-treatment. The overall percentage reduction of the immobilised bacteria in the treatment of the respective effluents was in the order TAN2 (72\%)>TAN1 $(70 \%)>$ TAN3 $(62 \%)$. Hence, the immobilized bacteria are having higher biodegradation potential for the treatment of the tannery effluents.

\section{Acknowledgments}

The authors wish to acknowledge the University of Maiduguri for the financial support. The authors are grateful to the Kano State Ministry of Environment for their support in obtaining the effluent samples. 


\section{REFERENCES}

Ajao, A. T., Adebayo, G. B., and Yakubu, S. E. (2011). Bioremediation of textile industrial effluent using mixed culture of Pseudomonas aeruginosa and Bacillus subtilis immobilized on agar-agar in a bioreactor. J. Microbiol. Biotech. Res, 1(3), 50-56.

Akan, J. C., Moses, E. A., Ogugbuaja, V. O., and Abah, J. (2007). Assessment of tannery industrial effluents from Kano metropolis, Kano State, Nigeria. Journal of Applied Sciences, 7(19), 2788-2793.

Akan, J. C., Ogugbuaja, V. O., Abdulrahman, F. I., and Ayodele, J. T. (2009). Pollutant levels in effluent samples from tanneries and textiles of Kano industrial areas, Nigeria. Global journal of pure and applied sciences, 15(3-4).

APHA (1989). Standard methods for Examination of Will bete and Will betewater.15 $5^{\text {th }}$ edition. Brydpass Springfield Will behington DC. pp. 164-176

APHA (1992). Standard Methods for the Examination of Water and Wastewater. Health, 69, 1116-9.

Baba, A., Garba, S. T., and Bello, H. S. (2020). Bioremediation Potential of Immobilized corynebacterium kutsceri in the Treatment of Tannery Industrial Effluent from Challawa Industrial Estate, Kano State, Nigeria. Journal of the Turkish Chemical Society Section A: Chemistry, $7(2), 335-350$.

Beem, E. I. V. (1994). reduction of solvent VOC emission. J. Oil Col. Chem. Ass, 77, 158.

Bouwer, E. J., and Zehnder, A. J. (1993). Bioremediation of organic compoundsputting microbial metabolism to work. Trends in biotechnology, 11(8), 360367.

Chen, K. C., Wu, J. Y., Liou, D. J., and Hwang, S. C. J. (2003). Decolorization of the textile dyes by newly isolated bacterial strains. Journal of Biotechnology, 101(1), 57-68.

Dan'Azumi, S., and Bichi, M. H. (2010). INDUSTRIAL POLLUTION AND HEAVY METALS PROFILE OF CHALLAWA RIVER IN KANO, NIGERIA. Journal of Applied Sciences in Environmental Sanitation, $5(1)$.

DWAF. (1992). Analytical Methods Manual, TR 151. Department of Water Affairs and Forestry, Pretoria.

El-Bestawy, E. (2013). Biological treatment of leather-tanning industrial wastewater using free living bacteria.
Elsheikh, M. A. S. (2009). Tannery wastewater pre-treatment. Water Science and Technology, 60(2), 433-440.

FuIlbrook, P. D. (1996). "Kinetics." Industrial enzymology: The application of enzymes in Industry. 2nd Ed. T. Godfrey and J Reichelt. eds.. Nature. New York.

Gianfreda, L., and Rao, M. A. (2004). Potential of extra cellular enzymes in remediation of polluted soils: a review. Enzyme and microbial technology, 35(4), 339354.

Hugo Springer. (1994). John Arthur Wilson Memorial Lecture "Treatment of Industrial Wastes of the Leather Industry - is it still a Major Problem". JALCA, 89, 153-185

Jimoh, A. A., Ganiyu, B. A., Baba, D., and Baba, A. (2018) Bioremediation Process of Effluent from Detergent and Food Industries in Jos, Nigeria: Kinetics and Thermodynamics. International Journal of Engineering Science Invention (IJESI), 762-73

Kandelbauer, A., Maute, O., Kessler, R. W., Erlacher, A., and Gübitz, G. M. (2004). Study of dye decolorization in an immobilized laccase enzyme-reactor using online spectroscopy. Biotechnology and bioengineering, 87(4), 552-563.

Kongjao, S., Damronglerd, S., and Hunsom, M. (2008). Simultaneous removal of organic and inorganic Pollutants in tannery wastewater using electrocoagulation technique. Korean Journal of chemical engineering, 25(4), 703.

Maheshwari, U. M., Aruna, S., Gomathi, M., and AbdulJaffar, A. H. (2017). Bioremediation by Free and Immobilized Bacteria Isolated from Tannery Effluent. International Journal of Research in Applied, Natural and Social Sciences. 5(7), 75-90

Margesin, R., and Schinner, F. (2001). Bioremediation (natural attenuation and biostimulation) of diesel-oilcontaminated soil in an alpine glacier skiing area. Applied and environmental microbiology, 677), 3127-3133.

Mohammed, A., Sekar, P., and George, J. (2011). Efficacy of microbes in bioremediation of tannery effluent. Inter. J. Curr. Res, 3(4), 324-326.

Mohammed, S. S. D., Orukotan, A. A., and Abdullahi, H. (2017). Physicochemical and Bacteriological Assessment of Tannery Effluent from Samaru-Zaria, 
BAJOPAS Volume 13 Number 2, December, 2020 Kaduna State, Nigeria. Journal of Applied

Sciences and Environmental Management, 21(4), 734-740.

Munz, G., De Angelis, D., Gori, R., Mori, G., Casarci, M., and Lubello, C. (2009). The role of tannins in conventional and membrane treatment of tannery wastewater. Journal of hazardous materials, 164(2-3), 733-739

Mythili, K., and Karthikeyan, B. (2011). Bioremediation of $\mathrm{Cr}$ (VI) from tannery effluent using Bacillus spp and Staphylococcus spp. International Multidisciplinary Research Journal, 1(6).

NESREA (2009). National Environmental Standards for Effluent Limitations and Regulation. 1233-1236

Noorjahan, C. M. (2014). Physicochemical characteristics, identification of bacteria and biodegradation of industrial effluent. Journal of bioremediation and Biodegradation, 5(3).

Ohtake, H. I., and Silver, A. O. (1994). Bacterial reduction of toxic chromate. Biological degradation and bioremediation of toxic chemicals, 403-415.

Omoleke, I. I. (2004). Management of environmental pollution in Ibadan, an African city: the challenges of health hazard facing government and the people. Journal of Human Ecology, 15(4), 265-275.

Rajor, A., Reddy, A.S., and Singh, B. (2004). Determination of BOD kinetic Parameters and evaluation of alternate methods, M.Sc. Thesis, Department of biotechnology \& environmental Science, Thapar Institute of Engineering and Technology, Patiala

Ramasami, T., Rajamani, S., and Rao, J. R. (1994, March). Pollution control in leather industry: Emerging technological options. In International symposium on surface and colloidal science and its relevance to soil pollution, madras.

Ramesh, J. V. S., and Singh, S. P. (1993). Yearly variation in certain physicochemical parameters of pond at eastern Doon Valley. Uttar Pradesh J. Zoo, 12 (1), 7577.

Ranen, S., and Sharadinadra, C. (2009). Biotechnology applications to environmental remediation in resource exploitation. Current science, 97, 6-25
Russell, A. J., Berberich, J. A., Drevon, G. F., and Koepsel, R. R. (2003). Biomaterials for mediation of

chemical and biological warfare agents. Annual review of biomedical engineering, 5(1), 1-27.

Saravanan, P., and Saravanan, A. (1999). Decolourization of tannery effluent by Flavobacterium sp. EK 1. Indian Journal of Environmental Protection, 19, 19-24.

Sikander, S., and Shahida, H. (2007). Reduction of toxic hexavalent chromium by Ochrobactrum intermedium strain SDCr5 stimulated by heavy metals. Bioresource Technol, 98, 340-344.

Singh, N., Sharma, B. K., and Bohra, P. C. (2000). Impact assessment of industrial effluent of arid soils by using satellite imageries. Journal of the Indian Society of Remote Sensing, 28(2-3), 79.

Sreemoyee, C., and Priti, P. (2013). Assessment of physico-chemical parameters of dairy waste water and isolation and characterization of bacterial strains in terms of cod reduction. Int J Sci, 2(3), 395-400.

Verheijen, L. A. H. M., Wiersema, D., Pol, L. H., and De Wit, J. (1996). Management of wastes from animal product processing. Livestock and environment, Finding a balance. International Agriculture Center, Wageningen, The Netherlands.

Wang, F., Yao, J., Si, Y., Chen, H., Russel, M., Chen, K., and Bramanti, E. (2010). Short-time effect of heavy metals upon microbial community activity. Journal of Hazardous Materials, 173(13), 510-516.

WHO (World Health Organization). (2006). Air quality guidelines: global update 2005: particulate matter, ozone, nitrogen dioxide, and sulfur dioxide. World Health Organization.

World Bank. (1995). Nigeria's strategic options for redressing industrial pollution. World Bank, industry and energy division. 1st edition, West Central Africa Department; Annexes: 1995; pp 60-62.

Zahoor, A., and Abdul, R. (2009). Enumeration of Coliforms. Journal of Environmental Sciences. 21, 814-820 


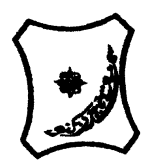

Bayero Journal of Pure and Applied Sciences, 13(2): 1 - 12

Received: November, 2020

Accepted: December, 2020

ISSN $2006-6996$

\title{
BIODEGRADATION POTENTIAL OF IMMOBILIZED BACTERIA IN THE TREATMENT OF TANNERY INDUSTRIAL EFFLUENTS FROM INDUSTRIAL ESTATES IN KANO STATE, NIGERIA
}

\author{
Abdullateef, B., ${ }^{1 *}$ Shuaibu, T. G., ${ }^{1}$ Babagana, K., ${ }^{1}$ Suleman, H. B. ${ }^{2}$ and Dauda, B. ${ }^{3}$ \\ ${ }^{1}$ Department of Pure and Applied Chemistry, Faculty of Science, University of Maiduguri, Borno State, \\ Nigeria \\ ${ }^{2}$ Department of Microbiology, Faculty of Science, University of Maiduguri, Borno State, Nigeria \\ ${ }^{3}$ Department of Chemical Engineering, Faculty of Engineering, University of Maiduguri, Borno State, \\ Nigeria \\ *Corresponding author: babslega@gmail.com; abelega2007@yahoo.com; +2348061309753
}

\section{ABSTRACT}

Industrial Effluents Samples from Gashash Tanneries (TAN1) in Bompai Industrial estate, Larabee Tannery Industry (TAN2) in Sharada Industrial estate and Z Tannery Industries (TAN3) in Challawa Industrial estate, Kano State, Nigeria were collected over a period of six months (August 2017 to January 2018) for assessing the biodegradation potentials of bacteria in the treatment of organic pollutants within the effluents. Bacteria were isolated from the effluents and immobilized on agar-agar. Different masses (5 g, $10 \mathrm{gr}, 15$ $\mathrm{g}, 20 \mathrm{~g}$, and $25 \mathrm{~g}$ ) of the bacteria were used in the treatment of $250 \mathrm{ml}$ of the effluents for ten days in a shaker incubator (Gallenkamp-OC-4364-L) at the temperature $30{ }^{\circ} \mathrm{C}$ and speed of $60 \mathrm{rpm}$. Pre-treatment analysis of the effluents for Temperature, pH, Biochemical Oxygen Demand (BOD), Chemical Oxygen Demand (COD), Suspended Solid (SS) and Total Dissolved Solids (TDS) gives the following results; temperature $\left({ }^{\circ} \mathrm{C}\right.$ )

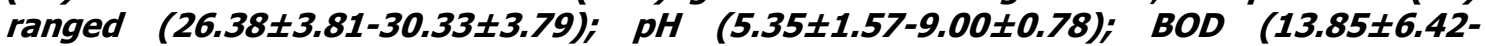
$38.75 \pm 16.20) ;$ COD (1406 $\pm 208-3532 \pm 1373) ;$ SS (208 $\pm 235-780 \pm 739)$ and TDS (266 $\pm 253-5276 \pm 2971)$. No statistical differences ( $p \leq 0.05)$ was observed for all the results among the different industries. The bacterial isolates were identified as Neisseria spp, Bacillus cereus, and Staphylococcus aureus, in TAN1, TAN2, and TAN3, respectively. After treatment of the effluent with the different masses of the isolated bacteria, the mean level of BOD was found to range as (0.55 $\pm 0.36-6.92 \pm 5.49) ; C O D$ (ND-3134 \pm 1595$)$;

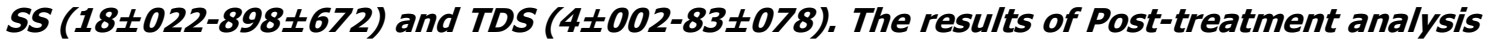
showed that there is overall decrease in the levels of the parameters determined when compared with that of the pre-treatment. The overall percentage reduction of the immobilised bacteria in the treatment of the respective effluents was in the order TAN2 (72\%)>TAN1 (70\%)>TAN3 (62\%). Hence, the immobilized bacteria are having higher biodegradation potential for the treatment of the tannery effluents.

Keywords: Biodegradation, bacteria, effluent, immobilization, tannery.

\section{INTRODUCTION}

Tannery industrial wastewater is a serious consequence of the pollution point of view for streams, freshwater, and land used for agriculture. The lack of awareness in the modern industrial practice has resulted in the discharge of tannery effluents which exhibit very high value of chromium ( $\mathrm{Cr}$ ), Sulfide, and chloride, Total Dissolved Solid (TDS), Total Suspended Solid (TSS), Biochemical Oxygen Demand (BOD) and Chemical Oxygen Demand (COD) in the water stream or land (Mohammed et al., 2001). Tanning is the process, which One ton of skin generally leads to the production of 20 to $80 \mathrm{~m}^{3}$ of turbid and foul-smelling converts the protein of the rawhide or skin into a stable material, which will not putrefy and is suitable for a wide variety of end applications (Elsheikh, 2009). The highly polluting chromium is the most commonly used tanning material producing leather that is more flexible and pliable than vegetable-tanned leather and does not discolor or lose shape in water as drastically as vegetable-tan (Elsheikh, 2009). Tannery effluent is among the most hazardous industrial pollutants due to its huge organic and inorganic load, which is highly toxic to human life and the environment (Kongjao et al., 2008). wastewater including chromium (100-400 mg/l), sulfide $(200-800 \mathrm{mg} / \mathrm{l})$, high levels of fat and 
BAJOPAS Volume 13 Number 2, December, 2020 other solid wastes, and notable pathogen contamination as well as pesticides added for skin conservation during transport (Elsheikh, 2009). There are more than 6000 tanneries in Nigeria with an annual processing capacity of 700,000 tons of hides and skins (Omoleke, 2004; Singh et al., 2008). It was reported that the total amount of waste produced per animal slaughtered is approximately $35 \%$ of its weight (World Bank, 1995). Also, for every $1000 \mathrm{~kg}$ of carcass weight, a slaughtered beef produces 5.5 $\mathrm{kg}$ of manure (excluding rumen contents or stockyard manure) and $100 \mathrm{~kg}$ of paunch manure (undigested food) (Verheijen et al., 1996). Tanneries generate wastewater in the range of 30-35 $\mathrm{L} \mathrm{kg}^{-1}$ skin/hide processed with variable $\mathrm{pH}$, Biological Oxygen Demand (BOD), Chemical Oxygen Demand (COD), high concentrations of suspended solids (SS), and tannins as well as chromium (Zahoor and Abdul, 2009).

Being heterogeneous and composed of a wide variety of compounds, it is very difficult to select a unique direct method for estimating the biodegradability of organic contents and biokinetic parameters for a wastewater sample (Rajor, 2004). For this purpose, some indirect estimation such as determination of biochemical oxygen demand (BOD) and chemical oxygen demand (COD) are applied as common laboratory investigations [9]. During retanning procedures, synthetic tannins (Syntan), oils and resins are added to form softer leather at varying doses (Munz et al., 2009). One of the refractory groups of chemicals in tannery effluents derives mainly from tannins (Ramasami et al., 2004). Syntans are characterized by complex chemical structures, because they are composed of an extended set of chemicals such as phenol-, naphthalene-, formaldehyde- and melamine-based syntans, and acrylic resins (Beem, 1994). Organic pollutants (proteic and lipidic components) are originated from skins (it is calculated that the raw skin has $30 \%$ loss of organic material during the working cycle) or they are introduced during processes (Hugo Springer, 1994).

Many conventional processes such as oxidation, chemical and biological processes were carried out to treat tanneries wastewater (Ebtesam et al, 2013). Biological processes have received more attention because of their costeffectiveness, lower sludge production and environmental friendliness (Noorjahan, 2014). Naturally occurring micro-organisms degrade the hazardous organic wastes including xenobiotic compounds, such as pesticides, polycyclic aromatic hydrocarbons (PAHs) and polychlorinated biphenyls (PCBs) in due course of time (Ranen and Sharadinadra, 2009). Bioremediation is based on the idea that all organisms remove substances from the environment to carry outgrowth and metabolism (Bouwer and Zehnder, 1993). Bacteria, protista and fungi are found to be very good at degrading complex molecules and incorporating the breakdown products into their metabolism (Bouwer and Zehnder, 1993). The resultant metabolic wastes that they produce are generally safe and somehow recycled into other organisms (Ranen and Sharadinadra, 2009). An acclimatized indigenous population of microorganisms capable of degradation of the compounds of interest must exist at the site for a successful bioremediation mode (Ranen and Sharadinadra, 2009). It has been observed that for a successful bioremediation mode, an acclimatized indigenous population of microorganisms capable of degradation of the compounds of interest must exist at the site under investigation (Ranen and Sharadinadra, 2009). Even though there are numerous physical and chemical methods employed in the disposal of wastes the advantage in using bacterium is that they play a key role in the reduction of COD, BOD, total protein, total tannin and total phenol (Saravanan and Saravanan, 1998)

Baba et al. (2020) studied the bioremediation potential of immobilized corynebacterium kutsceri in the Treatment of tannery industrial effluent from Challawa Industrial Estate, Kano State, Nigeria. The aim of the work is to study the reduction in the level of the contaminants through the process of bioremediation using the isolated bacteria. Immobilized bacteria can withstand various temperatures, $\mathrm{pH}$ and substrate concentrations; consequently, increasing the efficiency and the lifespan of the bacteria. Immobilized bacteria are widely applied in the treatment of wastewater and can be separated and recovered after the treatment with the same efficiency (Baba et al., 2020).

\section{MATERIALS AND METHODS \\ Study Area}

This study was carried out in Bompai, Sharada and Challawa industrial estates in Kano, Figure 1. Kano lies on Latitude $11^{\circ} 30^{\prime} \mathrm{N}$ and $8^{\circ} 30^{\prime} \mathrm{E}$ and Longitude $11^{\circ} 5^{\prime} \mathrm{N}$ and $8^{\circ} 5^{\prime} \mathrm{E}$ in Northern Nigeria. It is one of the developed industrial cities in Nigeria. Tannery activities are the dominating industries and this could be one of the reasons for her high population density (Dan'Azumi and Bichi, 2010). Many researchers have studied biodegradation of tannery effluent using microorganisms. However, limited literature is available on the biodegradation of tannery effluent in Kano industrial estates using 
BAJOPAS Volume 13 Number 2, December, 2020 immobilized bacterial cells. This research work focuses on the potential of the use of the indigenous immobilized bacterial isolates in the treatment of tannery effluents in the industrial estates.

\section{Sample Collection}

Effluents were collected from the Tannery Industries from Bompai, Challawa and Sharada Industrial Estates, Kano, Nigeria. The effluents were collected over a period of six months (August 2017 to January 2018). Samples collected in a sterile 4-liter plastic container with a unique identification number were preserved using an ice-box that was transported to the Microbiology Laboratory, Department of Microbiology, Bayero University of Kano for analysis

\section{Sample Preparation and Sample Analysis}

Immediately after the collection of the effluent, $\mathrm{pH}$, TSS, TDS, COD, BOD levels were determined before treatment (Pre-treatment determination) and ten days after treatment (Post-treatment determination) as described in
APHA (1989) standard methods. $\mathrm{pH}$ was determined using Ecotests $\mathrm{pH}$ meter and TDS was determined using AQUALYTIC TDS Salinometer. BOD was determined as described by the standard method (APHA, 1992). COD and SS were determined using DR/2010 HACH portable data logging spectrophotometer (DWAF, 1992)

\section{Identification and Biochemical} Characterization of the Bacterial Isolates

The bacteria were isolated from the effluents using Serial Dilution according to the method described by APHA (1989). The biochemical tests such as oxidase, catalase, coagulase, indole (from $1 \%$ tryptone broth), citrate (Simmons citrate agar), methyl red/VogesProskauer (MR/VP), nitrate reduction, Starch Hydrolysis, Glucose, Maltose, and Lactose tests were carried out on the bacterial isolates to identify the bacteria through the bacteria biochemical characteristics according to Ajao et al. (2011).

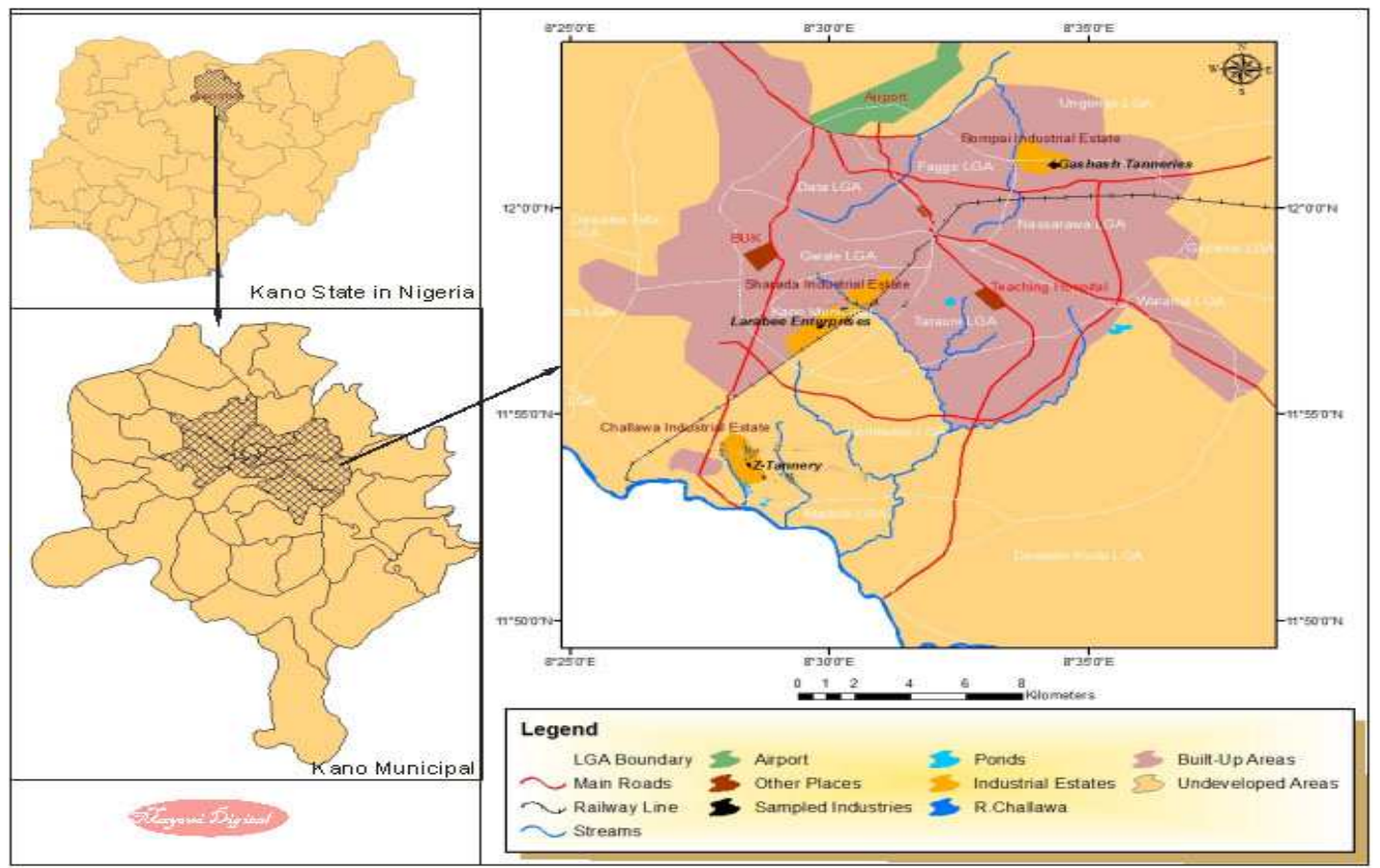

Fig. 1 Map showing the study areas

Source: Mayomi Digital Productions, GIS Laboratory, Department of Geography, UNIMAID (2017)

\section{Determination of Growth Rate of the Bacteria in Effluent Sample}

The bacteria growth rates were determined by transferring $2 \mathrm{~mL}$ of the bacterial isolates from the tannery effluent in broth medium into 100 $\mathrm{mL}$ sterile effluents in conical flasks and kept in an incubator (Giffrin cool) for 10 days. Control was also set up by incubating another $100 \mathrm{~mL}$ each of the sterile effluents without the bacteria. The optical density of the content was determined at the wavelength of $600 \mathrm{~nm}$ on a daily interval and recorded. 
BAJOPAS Volume 13 Number 2, December, 2020 Immobilization of Bacteria

Agar solution and inoculi were prepared separately. Fifty milliliters $(50 \mathrm{~mL})$ of nutrient broth each of the inoculi was prepared in a McCartney bottle and incubated for 24 hours. A solution of agar-agar was prepared by dissolving $10 \mathrm{~g}$ of the powder in distilled water and made up to $500 \mathrm{~mL}$ mark in an Erlenmeyer flask and was sterilized in an autoclave (280A) for 15 minutes and allowed to cool to $40-45^{\circ} \mathrm{C}$ (Ajao et al., 2011). Four milliliters ( $4 \mathrm{~mL})$ of the bacterial isolates in the nutrient broth was mixed with 36 $\mathrm{ml}$ of the prepared agar-agar media in petri-dish plates and then allowed to solidify. This was kept in the refrigerator for bioremediation.

\section{Bioremediation (Treatment) of the Effluents}

The solidified agar block (immobilized bacteria) was cut into cubes using a sterile knife; $0.1 \mathrm{~mL}$ phosphate buffer ( $\mathrm{pH} \mathrm{7.0)}$ was added and kept in the refrigerator for 1 hour for curing. The phosphate buffer was decanted after 1 hour and the cubes were washed with sterile distilled water 3-4 times before it was used (Ajao et al., 2011). Two liters (2 L) of the effluent was supplemented with the minimum basal medium in $\mathrm{g} / \mathrm{L}: \mathrm{NaCl}(0.8), \mathrm{MgSO}_{4} .7 \mathrm{H}_{2} \mathrm{O}(0.001), \mathrm{KH}_{2} \mathrm{PO}_{4}$ (2), $\mathrm{NaNO}_{3}$ (2), $\quad \mathrm{CaCl}_{2} .2 \mathrm{H}_{2} \mathrm{O} \quad(0.5)$ and $\mathrm{NaHPO}_{4} .12 \mathrm{H}_{2} \mathrm{O}(2)$ and sterilized in an autoclave at $121^{\circ} \mathrm{C}$ for 15 minutes (Margesin and Schinner, 2001). Two hundred and fifty milliliters $(250 \mathrm{~mL})$ of the effluents were transferred into different $250 \mathrm{ml}$ conical flasks. The content was covered with a cotton-wool ramped with foil paper to avoid contamination. Five grams $(5 \mathrm{~g})$ of the immobilized bacteria were quickly transferred into each of the effluents in the conical flasks in an inoculating chamber. The same procedures were carried out for the $10 \mathrm{~g}, 15 \mathrm{~g}, 20 \mathrm{~g}$ and 25 $\mathrm{g}$ of the immobilized bacteria in separate $250 \mathrm{~mL}$ effluents in conical flasks and agitated for ten days in a shaker incubator (Gallenkamp-OC4364-L) at a temperature $30^{\circ} \mathrm{C}$ and speed of 60 rpm. The treated effluent samples were taken on the tenth day and analyzed for the parameters $\mathrm{pH}$, SS, TDS, COD, and BOD, (Posttreatment determination) for the different grams of bacteria to evaluate and compare the biodegradation potential. (Baba et al., 2020).

\section{Statistical Analysis}

The data were represented as Mean \pm Standard deviation and analyzed statistically using oneway Analysis of Variance (ANOVA) and Tukey's HSD as Post Hoc Tests with the aid of SPSS 16.0. The correlation coefficient was also used to measure the strength of the relationship between the different masses of the bacteria and the parameters. All $\mathrm{p} \leq 0.05$ were considered as statistically significant.

\section{RESULTS AND DISCUSSION Physico-chemical parameters in the Industrial Effluents before the Biodegradation.}

Results of the Physico-chemical parameters in the industrial effluents before the Biodegradation is shown in table 1 . The mean temperatures $\left({ }^{\circ} \mathrm{C}\right)$ observed in TAN1, TAN2, and TAN3 samples were $28.07 \pm 0.65 ; 27.77 \pm 0.64$ and $26.38 \pm 3.81$ respectively. The order of the mean temperature of the samples from the three industries can be arranged as TAN1 > TAN2>TAN3. The temperature observed at TAN1, TAN2, and TAN3 samples were found below the WHO $\left(35^{\circ} \mathrm{C}\right)$ and NESREA $\left(40^{\circ} \mathrm{C}\right)$ limits. The low values of temperature might be due to the processes used at the time of sampling. High temperature brings down the solubility of gases in water that ultimately expresses as high BOD and COD. Statistical analysis shows that there is no significant difference $(p<0.05)$ between the mean values of temperature among the industries. This might be due to similar tannery activities involved in the tannery industries at the time of sampling. The average values of temperature observed in this present study are less than those observed by Akan et al. (2007), Akan et al. (2009) and Baba et al. (2020).

The mean level of $\mathrm{pH}$ observed in TAN1, TAN2 and TAN3, samples were $7.77 \pm 2.93$; $8.35 \pm 0.28$ and $7.52 \pm 0.76$ respectively. The order of the mean $\mathrm{pH}$ of the samples from the three industries can be arranged as TAN2> TAN1 $>$ TAN3. The $\mathrm{pH}$ of the samples falls within the WHO (7.0-8.5) and NESREA (6-9) standard limits. Statistical analysis shows that there is no significant difference $(p<0.05)$ between the mean values of $\mathrm{pH}$ among the industries. This might be due to similar tannery activities involved in the tannery industries at the time of sampling. Maheshwari et al. (2017) reported that the level of $\mathrm{pH}$ in the effluents from the tannery industry in Vaniyambadi, India was 6.5 which was lower than that observed in the present study. The $\mathrm{pH}$ in the effluents from the tannery industries in Kano and Kaduna were reported to be 7.64 and 6.89, respectively (Akan et al., 2007; Mohammed et al., 2017). The average values of $\mathrm{pH}$ observed in this present study are less than those observed by Mohammed et al. (2017) and Baba et al. (2020). The mean level of SS $(\mathrm{mg} / \mathrm{l})$ observed in TAN1, TAN2, and TAN3 samples were 374 \pm 124 ; $358 \pm 335$ and $780 \pm 739$ respectively. The order of the mean SS in the samples from the three industries can be arranged as TAN3 > TAN1 $>$ TAN2. 
The SS observed in the samples were far above the recommended standard limits of regulating bodies WHO $(30 \mathrm{mg} / \mathrm{l})$ and NESREA $(10 \mathrm{mg} / \mathrm{l})$. Statistical analysis shows that there is no significant difference $(p<0.05)$ between the mean values of SS among the industries. This might be due to similar tannery activities involved in the tannery industries at the time of sampling. The average values of SS observed in this present study are less than that observed $(3700 \pm 122 \mathrm{mg} / \mathrm{l})$ by Akan et al. (2009) for tanneries in Kano. Also, the average values of SS observed in this present study are less than that observed by Mohammed et al. (2017) and Baba et al. (2020) with the exception in TAN3.

The mean level of TDS (mg/l) observed in TAN1, TAN2, and TAN3 samples were $3941 \pm 3703$; $3300 \pm 1714$ and $2653 \pm 1240$ respectively. The order of the mean TDS in the samples from the three industries can be arranged as TAN1>TAN2>TAN3. The TDS observed in the samples were far above the recommended standard limits of WHO $(250 \mathrm{mg} / \mathrm{l})$ and NESREA $(500 \mathrm{mg} / \mathrm{l})$. Statistical analysis shows that there is no significant difference $(p<0.05)$ between the mean values of TDS among the industries. This might be due to similar tannery activities involved in the tannery industries at the time of sampling. TDS in the effluents from the tannery industries in Kano, Nigeria was reported to be $1281 \mathrm{mg} / \mathrm{l}$ (Akan et al., 2007). The average values of SS observed in this present study are less than those observed by Mohammed et al. (2017) and Baba et al. 2020)

The mean level of COD (mg/l) observed in TAN1, TAN2 and TAN3 samples seasons were $2372 \pm 938 ; \quad 1406 \pm 208$ and $3532 \pm 1373$ respectively. The order of the mean COD of the samples from the three industries can be arranged as TAN3>TAN1> TAN2. The COD observed in TAN1, TAN2 and TAN3 samples were far above the recommended standard limits of regulating bodies $\mathrm{WHO}(40 \mathrm{mg} / \mathrm{l})$ and NESREA (40 mg/l). Statistical analysis shows that there is no significant difference $(p<0.05)$ in COD among the industries. This might be due to similar tannery activities involved in the tannery industries as at the time of sampling. The Chemical Oxygen demand (COD) is the amount of oxygen, in $\mathrm{mg} / \mathrm{L}$, required for the degradation of the compound of wastewater to occur. In comparison, the average values of COD observed in this present study were higher than that observed by Mohammed et al. (2017) but lower than that observed by Baba et al. (2020).

The mean levels of BOD $(\mathrm{mg} / \mathrm{l})$ observed in TAN1, TAN2 and TAN3 samples were $13.85 \pm 6.42 ; \quad 19.46 \pm 0.50$ and $17.13 \pm 3.14$ respectively. The order of the mean BOD in the samples from the three industries can be arranged as TAN2>TAN3>TAN1. The BOD observed in TAN1, TAN2 and TAN3 samples were found below the recommended limits of NESREA (200 mg/l) but above WHO (10 mg/l). Statistical analysis shows that there is no significant difference $(p<0.05)$ between the mean values of BOD among the industries. This might be due to similar tannery activities involved in the tannery industries at the time of sampling. The low level of BOD recorded in this study is an indication of the low level of biodegradable organic solids in the effluent. The average values of BOD observed in this present study were lower than those observed by Mohammed et al. (2017) and Baba et al. (2020).

Table 1: Mean Values \pm S.D of Physico-chemical parameters of effluents from the Tannery Industries before Treatment.

\begin{tabular}{llllllll}
\hline Parameter & Tannery 1 & Tannery 2 & Tannery 3 & $\mathrm{a}$ & $\mathrm{b}$ & $\mathrm{c}$ & $\mathrm{d}$ \\
\cline { 2 - 7 } Temperature $\left({ }^{\circ} \mathrm{C}\right)$ & $28.07 \mathrm{a} \pm 0.65$ & $27.77 \mathrm{a} \pm 0.64$ & $26.38 \mathrm{a} \pm 3.81$ & & $29.50 \pm 4.68$ & 35 & 40 \\
pH & $7.77 \mathrm{a} \pm 2.93$ & $8.35 \mathrm{a} \pm 0.28$ & $7.52 \mathrm{a} \pm 0.76$ & 6.89 & $5.35 \pm 1.57$ & $7.0-8.5$ & $6.0-9.0$ \\
$\mathrm{COD}(\mathrm{mg} / \mathrm{l})$ & $2372 \mathrm{a} \pm 938$ & $1406 \mathrm{a} \pm 208$ & $3532 \mathrm{a} \pm 1373$ & 2.2 & $3106 \pm 2753$ & 40 & 40 \\
$\mathrm{BOD}(\mathrm{mg} / \mathrm{l})$ & $13.85 \mathrm{a} \pm 6.42$ & $19.46 \mathrm{a} \pm 0.50$ & $17.13 \mathrm{a} \pm 3.14$ & 1032 & $26.17 \pm 9.49$ & 10 & 200 \\
$\mathrm{SS}(\mathrm{mg} / \mathrm{l})$ & $374 \mathrm{a} \pm 124$ & $358 \mathrm{a} \pm 335$ & $780 \mathrm{a} \pm 739$ & 501 & $562 \pm 482$ & 30 & 10 \\
TDS $(\mathrm{mg} / \mathrm{l})$ & $3941 \mathrm{a} \pm 3703$ & $3300 \mathrm{a} \pm 1714$ & $2653 \mathrm{a} \pm 1240$ & 532.7 & $444 \pm 507$ & 250 & 500 \\
\hline
\end{tabular}

The values given in the table above are means of 6 replicate values, $\mathrm{n}=6$ ( 1 sample was taken monthly for 6 months). Within the rows, means with different alphabets are statistically different $(p<0.05)$. WHO: World Health Organisation. NESREA: National Environmental Standard and Regulatory Enforcement Agency. a = Mohammed et al.(2017), b = Baba et al. (2020), c = WHO (2006), $d=$ NESSRA (2009) 
BAJOPAS Volume 13 Number 2, December, 2020

Identification, Biochemical Characterization and growth rates of the Bacterial Isolates

Results of identification and biochemical characterization of the bacterial isolates were shown in table 2. After 24 hours of incubation, the nutrient agar media plates were checked for bacterial growth. The results showed the presence of different strains in the samples. The TAN1 bacteria isolate was found to be gramnegative cocci while TAN3 was gram-positive cocci. TAN2 bacteria isolate was found to be gram-positive, rod-shaped. TAN1, TAN2, and TAN3 bacteria isolates recorded positive results for spore former.

The results of the biochemical tests indicated that all the bacteria were positive for catalase, oxidase, citrate, maltose, glucose, lactose (negative in TAN1), mannitol (negative in TAN2), starch hydrolysis and coagulase (negative in TAN2) tests. The bacteria showed negative results for nitrate reduction, $M R$ (positive in TAN2), VP (positive in TAN1), Indole (positive in TAN2) tests. Base on the morphological and biochemical test results, TAN1, TAN2, and TAN3 bacteria isolates were identified to be Nesseria spp, Bacillus cereus, and Staphylococcus aureus respectively.

The growth rate of the TAN1, TAN2 and TAN3 Isolates were shown in figure 2. Generally, the optical density increase with the increase in time (day) and decrease as time goes on. The highest optical density was shown by bacillus cereus in TAN2 while the lowest was shown by Staphylococcus aureus in TAN3.

The initial growth phase of TAN1 Isolate bacteria occurred within 2-day of incubation as the growth rate increases up to the 6th-day incubation when the maximum growth was observed. Beyond the 6th day, the growth of the bacteria declined (which might be due to a shortage of nutrients in the effluents) until it reached its death phase (which might be due to the unavailability of nutrients in the effluents).

A similar trend of growth was also observed for TAN2 Isolate as the initial growth phase also occurred within 2-day of incubation but maximum growth rate observed on the 4th day of incubation. The stationary stage occurred between the 4th day and the 8th day. Beyond the 8th day, the growth of the bacteria declined (which might be due to a shortage of nutrients in the effluents) until it reached its death phase (which might be due to the unavailability of nutrients in the effluents).

The initial growth phase of TAN3 bacterial Isolate occurred within the 3-day incubation as the growth rate increases up to the 6th-day incubation when the maximum growth was observed. Beyond the 6th day, the growth of the bacteria declined (which might be due to a shortage of nutrients in the effluents) until it reached its death phase (which might be due to the unavailability of nutrients in the effluents).

Table 2: Morphological and Biochemical characteristics of bacterial isolates

\begin{tabular}{lllll} 
Bacterial Isolates & & TAN1 & TAN2 & TAN3 \\
\hline $\begin{array}{lllll}\text { Morphological } \\
\text { characteristics }\end{array}$ & Shape & Cocci & Rod & Cocci \\
& Spore & & & \\
& former & + & + & + \\
Gram & & & \\
Biochemical characteristics & reaction & - & + & + \\
& Citrate & + & + & + \\
& Catalase & + & + & + \\
& Coagulase & + & - & + \\
Starch & + & + & + \\
& Glucose & + & + & + \\
Oxidase & + & + & + \\
& Indo & - & + & - \\
Lactose & - & + & + \\
Manitol & + & - & + \\
Maltose & + & + & + \\
MR & - & + & - \\
VP & + & - & - \\
& Nitrate & - & - & - \\
Reduction & - Neisseria & Bacillus & Staphylococcus \\
& Bacterial & cereus & aureus \\
& name & spp & cas
\end{tabular}

+ = Positive; - = Negative; MR=Methyl Red; VP= Voges-Proskauer 


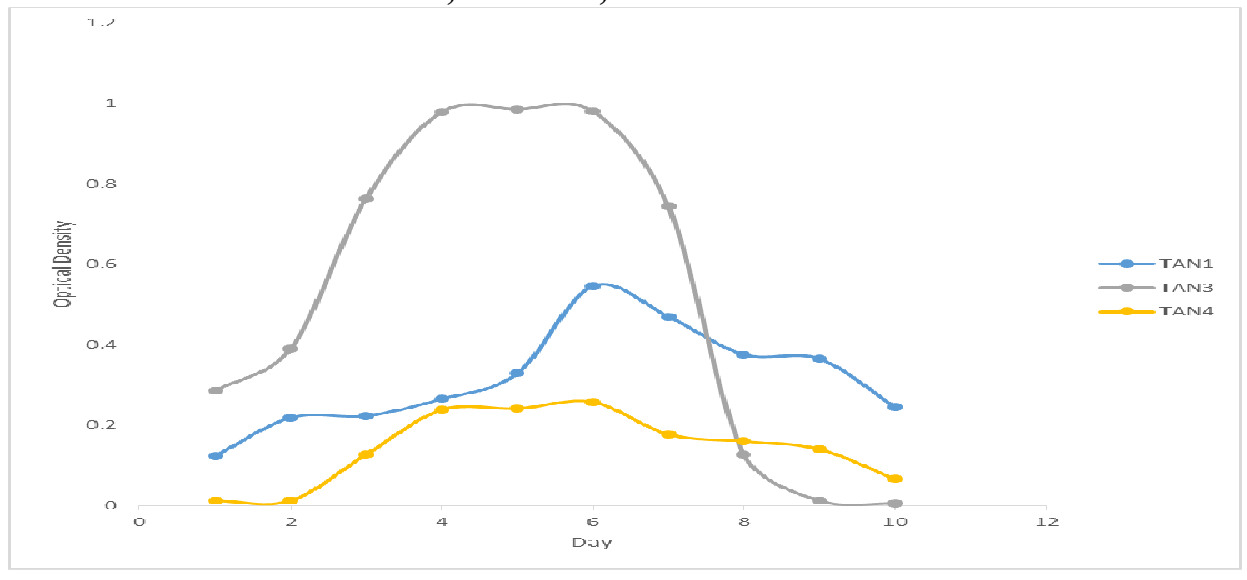

Fig. 2 Growth rates of the isolates in the effluents from the Tannery Industries

\section{Physico-chemical Parameters in the Industrial Effluents after the biodegradation.}

Table 3 shows the mean results of the physicochemical parameter before and after bioremediation using the different masses $(5 \mathrm{~g}$, $10 \mathrm{~g}, 15 \mathrm{~g}, 20 \mathrm{~g}$, and $25 \mathrm{~g}$ ) of the respective immobilized bacteria. Also, Table 4 shows the mean results of correlation coefficient ( $r$ ) between different masses of bacteria and physicochemical parameters.

The mean values $(\mathrm{mg} / \mathrm{l})$ of the SS after the bioremediation varies between $243 \pm 45$ and $898 \pm 672$. The mean concentration $(\mathrm{mg} / \mathrm{l})$ of SS remediated by the different masses $(5 \mathrm{~g}, 10 \mathrm{~g}$, $15 \mathrm{~g}, 20 \mathrm{~g}$, and $25 \mathrm{~g}$ ) of the bacteria varies. The SS in the samples fluctuates up and down after the bioremediation process when compared with the SS of the raw samples before the bioremediation. The increase in the levels of the SS might be due to the aggregation of the TDS which are large enough to result into SS. The increase in the levels of the SS might be also due to the influence of the nutrients which was added into the effluents in order to make the microorganisms more active and viable for fast degradation of organic contaminants in the effluent. The relative potential or efficiency of the different masses of the bacteria in remediating SS in TAN1 samples was in the order $25 \mathrm{~g}>20 \mathrm{~g}>15 \mathrm{~g}>10 \mathrm{~g}>5 \mathrm{~g}$. For TAN2 and TAN3 samples, the order was $25 \mathrm{~g}>20 \mathrm{~g}>15$ $\mathrm{g}>10 \mathrm{~g}>5 \mathrm{~g}$. These might be due to the variations in the surface areas of the different masses of the immobilized bacteria. Statistical analysis shows that there is no significant difference $(p<0.05)$ between the mean values of SS among the masses in the respective industries. Positive and significant correlations exist between the masses of bacteria and Suspended Solid (SS). This showed that there is general increase in the levels of the SS as the masses of the immobilized bacteria increases. TAN3 (90\%) and TAN1 (80\%) showed a very high correlation with the masses of the bacteria while TAN2 (61\%) showed a very low correlation.

The mean values $(\mathrm{mg} / \mathrm{l})$ of the TDS after the bioremediation varies between $46 \pm 11$ and $83 \pm 78$. The mean concentration $(\mathrm{mg} / \mathrm{l})$ of TDS remediated by the different masses $(5 \mathrm{~g}, 10 \mathrm{~g}$, $15 \mathrm{~g}, 20 \mathrm{~g}$, and $25 \mathrm{~g}$ ) of the bacteria varies. There is a reduction in all the TDS of all the samples after the bioremediation process compared with the TDS of the raw samples before the bioremediation. The relative potential or efficiency of the different masses of the bacteria in remediating TDS in TAN1 and TAN3 samples was in the order $5 \mathrm{~g}>10 \mathrm{~g}>15 \mathrm{~g}>20$ $\mathrm{g}>25 \mathrm{~g}$. For TAN2 samples, the order was 20 $g>10 \quad g>25 \quad g>15 \quad g>5 \quad g$. Statistical analysis shows that there is no significant difference $(p<0.05)$ between the mean values of TDS among the masses in the respective industries. These might be due to the variations in the surface areas of the different masses of the immobilized bacteria. Positive and significant correlations exist between the masses of bacteria and TDS with the exception in TAN2 (negative and insignificant correlation). The positive correlations showed that there is general increase in the levels of the TDS as the masses of the immobilized bacteria increases. TAN1 $(96 \%)$ showed a very high correlation with the masses of the bacteria while TAN2 (47\%) showed a very low correlation.

The mean values $(\mathrm{mg} / \mathrm{l})$ of the BOD after the bioremediation varies between $1.56 \pm 0.20 \mathrm{mg} / \mathrm{l}$ and $6.92 \pm 5.49 \mathrm{mg} / \mathrm{l}$. The mean concentration $(\mathrm{mg} / \mathrm{l})$ of BOD remediated by the different masses $(5 \mathrm{~g}, 10 \mathrm{~g}, 15 \mathrm{~g}, 20 \mathrm{~g}$, and $25 \mathrm{~g}$ ) of the bacteria varies. There is a reduction in all the BOD of all the samples after the bioremediation process compared with the $\mathrm{BOD}$ of the raw 
BAJOPAS Volume 13 Number 2, December, 2020 samples before the bioremediation. The relative potential or efficiency of the different masses of the bacteria in remediating BOD in TAN1, TAN2 and TAN3 samples were in the order $25 \mathrm{~g}>20$ $\mathrm{g}>15 \mathrm{~g}>10 \mathrm{~g}>5 \mathrm{~g}, 25 \mathrm{~g}>15 \mathrm{~g}>5 \mathrm{~g}>10 \mathrm{~g}>20 \mathrm{~g}$ and $20 \mathrm{~g}>10 \mathrm{~g}>25 \mathrm{~g}>15 \mathrm{~g}>5 \mathrm{~g}$ respectively. Statistical analysis shows that there is significant difference $(p<0.05)$ between the mean values of BOD among the masses in the respective industries. These might be due to the variations in the surface areas of the different masses of the immobilized bacteria. Negative and significant correlations exist between the masses of bacteria and BOD. This showed that there is general decrease in the levels of the BOD as the masses of the immobilized bacteria increases. TAN1 (94\%) showed a very high correlation with the masses of the bacteria while TAN2 (4\%) showed a very low correlation.

The mean values $(\mathrm{mg} / \mathrm{l})$ of the COD after the bioremediation varies between $250 \pm 154$ and $3134 \pm 1595$. The mean concentration $(\mathrm{mg} / \mathrm{l})$ of COD remediated by the different masses $(5 \mathrm{~g}$, $10 \mathrm{~g}, 15 \mathrm{~g} 20 \mathrm{~g}$, and $25 \mathrm{~g}$ ) of the bacteria varies. There is a reduction in all the COD of all the samples after the bioremediation process compared with the COD of the raw samples before the bioremediation. The relative potential or efficiency of the different masses of the bacteria in remediating COD in TAN1, TAN2 and TAN3 samples were in the order $25 \mathrm{~g}>20 \mathrm{~g}>15$ $\mathrm{g}>5 \mathrm{~g}>10 \mathrm{~g}, 25 \mathrm{~g}>20 \mathrm{~g}>15 \mathrm{~g}>10 \mathrm{~g}>5 \mathrm{~g}$ and 10 g>5 g>25 g>15 g>20 g respectively. Statistical analysis shows that there were significant difference $(p<0.05)$ between the mean values of COD among the masses in the respective industries except for effluents treated with $25 \mathrm{~g}$. These might be due to the variations in the surface areas of the different masses of the immobilized bacteria. Negative and insignificant correlations exist between the masses of bacteria and COD with the exception in TAN3 (positive and significant correlation). The negative correlations showed that there is general decrease in the levels of the COD as the masses of the immobilized bacteria increases. TAN2 (100\%) showed a very high correlation with the masses of the bacteria while TAN3 (36\%) showed a very low correlation.

Generally, there was an overall decrease in the concentration of these physicochemical parameters after the bioremediation using the different masses of the bacterial isolates. These might be due to the variations in the surface areas of the different masses of the immobilized bacteria. This is in line with the work of Jimoh et al. (2018) and Baba et al. (2020).

Table 3: Mean Values $(\mathrm{mg} / \mathrm{l}) \pm$ S.D of Physicochemical parameters in effluents from the Tannery Industries before and after Treatment of the effluents $(250 \mathrm{ml})$ with the different masses $(5 \mathrm{~g}, 10 \mathrm{~g}$, $15 \mathrm{~g}, 20 \mathrm{~g}$, and $25 \mathrm{~g}$ ) of the bacteria.

\begin{tabular}{llllllll}
\hline $\mathrm{P}$ & IND & Before & \multicolumn{5}{c}{ After } \\
\cline { 4 - 7 } & & & $5 \mathrm{~g}$ & $10 \mathrm{~g}$ & $15 \mathrm{~g}$ & $20 \mathrm{~g}$ & $25 \mathrm{~g}$ \\
\hline \multirow{2}{*}{ COD } & TAN1 & $2372 \pm 938$ & $1708 \mathrm{a} \pm 861$ & $2045 \mathrm{a} \pm 1205$ & $845 \mathrm{a} \pm 369$ & $300 \mathrm{a} \pm 167$ & $250 \mathrm{a} \pm 154$ \\
& TAN2 & $1406 \pm 208$ & $1195 \mathrm{a} \pm 208$ & $1125 \mathrm{a} \pm 384$ & $1055 \mathrm{a} \pm 317$ & $956 \mathrm{a} \pm 310$ & $870 \mathrm{ab} \pm 240$ \\
& TAN3 & $3532 \pm 1373$ & $2374 \mathrm{a} \pm 1344$ & $1976 \mathrm{a} \pm 1405$ & $2757 \mathrm{a} \pm 1266$ & $3134 \mathrm{a} \pm 1595$ & $2614 \mathrm{~b} \pm 1105$ \\
BOD & TAN1 & $13.85 \pm 6.42$ & $6.92 \mathrm{a} \pm 5.49$ & $6.42 \mathrm{a} \pm 5.07$ & $5.72 \mathrm{a} \pm 5.35$ & $4.62 \mathrm{a} \pm 4.37$ & $2.82 \mathrm{ab} \pm 1.26$ \\
& TAN2 & $19.46 \pm 0.50$ & $1.75 \mathrm{~b} \pm 0.22$ & $1.73 \mathrm{~b} \pm 0.18$ & $1.58 \mathrm{a} \pm 0.16$ & $1.91 \mathrm{a} \pm 0.22$ & $1.56 \mathrm{~b} \pm 0.20$ \\
& TAN3 & $17.13 \pm 3.14$ & $4.24 \mathrm{ab} \pm 0.77$ & $3.29 \mathrm{ab} \pm 0.37$ & $4.11 \mathrm{a} \pm 0.07$ & $3.23 \mathrm{a} \pm 0.91$ & $3.33 \mathrm{a} \pm 1.28$ \\
SS & TAN1 & $374 \pm 124$ & $243 \mathrm{a} \pm 45$ & $471 \mathrm{a} \pm 226$ & $475 \mathrm{a} \pm 182$ & $492 \mathrm{a} \pm 128$ & $611 \mathrm{a} \pm 217$ \\
& TAN2 & $358 \pm 335$ & $460 \mathrm{a} \pm 400$ & $543 \mathrm{a} \pm 414$ & $544 \mathrm{a} \pm 402$ & $551 \mathrm{a} \pm 414$ & $554 \mathrm{a} \pm 405$ \\
& TAN3 & $780 \pm 739$ & $586 \mathrm{a} \pm 594$ & $758 \mathrm{a} \pm 656$ & $787 \mathrm{a} \pm 676$ & $861 \mathrm{a} \pm 635$ & $898 \mathrm{a} \pm 672$ \\
TDS & TAN1 & $3941 \pm 3703$ & $51 \mathrm{a} \pm 10$ & $53 \mathrm{a} \pm 10$ & $55 \mathrm{a} \pm 15$ & $61 \mathrm{a} \pm 20$ & $63 \mathrm{a} \pm 26$ \\
& TAN2 & $3300 \pm 1714$ & $83 \mathrm{a} \pm 78$ & $47 \mathrm{a} \pm 20$ & $48 \mathrm{a} \pm 22$ & $47 \mathrm{a} \pm 17$ & $48 \mathrm{a} \pm 17$ \\
& TAN3 & $2653 \pm 1240$ & $46 \mathrm{a} \pm 11$ & $55 \mathrm{a} \pm 24$ & $55 \mathrm{a} \pm 25$ & $58 \mathrm{a} \pm 23$ & $61 \mathrm{a} \pm 28$ \\
\hline
\end{tabular}

Replicate $=6$ (months)

Within the rows, for the same parameter, means with different alphabets are statistically different $(p<0.05)$.

$\mathrm{P}=$ parameter, IND = Industries 
BAJOPAS Volume 13 Number 2, December, 2020

Table 4: Correlation coefficient $(r)$ between different masses of the bacteria and the physicochemical parameters.

\begin{tabular}{llll}
\hline Industries & Parameter & Correlation coefficient $(r)$ & $\begin{array}{l}\text { Percent dependence (rxrx100) } \\
(\%)\end{array}$ \\
\hline TAN1 & COD & -0.9 & 82 \\
& BOD & -0.97 & 94 \\
& SS & $0.90^{*}$ & 80 \\
TAN2 & TDS & $0.98^{*}$ & 96 \\
& COD & -1 & 100 \\
& BOD & -0.21 & 4 \\
& SS & $0.78^{*}$ & 61 \\
& TDS & -0.69 & 47 \\
& COD & $0.60^{*}$ & 36 \\
& BOD & -0.6 & 37 \\
& SS & $0.95^{*}$ & 90 \\
& TDS & $0.94^{*}$ & 89 \\
\hline
\end{tabular}

The correlation coefficient $(r)$ with * is statistically significant $(p<0.05)$.

Percentage reduction of the Parameters

Table 5 shows the percentage reduction of Parameters in industrial samples before and after the treatment of the effluents $(250 \mathrm{ml})$ with the different masses $(5 \mathrm{~g}, 10 \mathrm{~g}, 15 \mathrm{~g}, 20 \mathrm{~g}$, and $25 \mathrm{~g}$ ) of the Immobilized Bacteria.

In TAN1 samples, the percentage reduction (\%) of COD ranged (14-89); BOD (50-80); SS (-32$35)$ and TDS (98-99). In TAN2 samples, the percentage decrease $(\%)$ of COD ranged (15$38) ;$ BOD (90-92); SS [-28-(-55)] and TDS (9798). In TAN3 samples, the percentage decrease (\%) of COD ranged (11-44); BOD (76-81); SS (15-25) and TDS (98). The percentage increase in the levels COD, BOD and TDS might be due to the increase in the surface area of the different masses of the immobilized bacteria. However, the percentage decrease in the levels of the SS might be due to the aggregation of the TDS which are large enough to result into SS. The percentage decrease in the levels of the SS might be also due to the influence of the nutrients which was added into the effluents in order to make the microorganisms more active and viable for fast degradation of organic contaminants in the effluent. This is in line with the work of Jimoh et al. (2018) in which the concentration of the SS increase after the bioremediation of effluents.

Sreemoyee and Priti (2013) assessed and reduced several Physico-chemical parameters of dairy wastewater using Niesseria $s p$. and concluded that the species are well known to degrade organic compounds. This is in agreement with the current study in which the immobilized Niesseria $s p$ degrade the organic contaminants as indicated by the BOD, COD and TDS.

Jimoh et al. (2018) observed that TSS of the effluents was increased after treatment with immobilized bacteria and concluded that it might be due to the biostimulation method adopted for the research.

The optimum $\mathrm{pH}$ Biosorption of Chromium by Bacillus spp and Staphylococcus spp. from tannery effluent was investigated by Mythili and Karthikeyan (2011). The maximum adsorption of Chromium $(86.4 \mathrm{mg} / \mathrm{L})$ was showed by Bacillus spp and Staphylococcus spp showed $70.6 \mathrm{mg} / \mathrm{L}$ at an initial concentration of $100 \mathrm{mg} / \mathrm{L}$. In the present study, immobilised Bacillus spp and Staphylococcus spp. from the tannery industrial effluents reduced the levels of the organic pollutants with high potential as indicated by the percentage reduction of BOD, COD and TDS.

Enzymes often can work in multiple environments especially if they are immobilized. This makes the microorganisms' enzymes even more resistant to harsh environments and enables the enzymes to be recovered and recycled after they are no longer needed (Gianfreda and Rao 2004). Ramesh and Singh (1993) reported that the immobilized bacteria having more efficiency to remove the suspended particles than free cells. Using the immobilized cell is preferable due to its capability for using several times with the same efficiency, which makes it more economical. Similar work was done by Sikander et al. (2007) showing the higher reduction with permeabilized cells of Ochrobactrum intermedium strain SDCr-5. 
BAJOPAS Volume 13 Number 2, December, 2020

The results revealed the isolation and identification of isolates with the potential for the reduction of $\mathrm{Cr}$ (VI) to $\mathrm{Cr}$ (III). Results indicated that immobilized $B$. cereus could be efficiently used for the reduction of $\mathrm{Cr}$ (VI).

Table 5: Percentage reduction of the tested Parameters from the tannery industrial samples of the Immobilized Bacteria.

\begin{tabular}{lllllll}
\hline \multirow{2}{*}{ Industries } & & \multicolumn{5}{c}{ Percentage Reduction $(\%)$} \\
\cline { 3 - 7 } & & $5 \mathrm{~g}$ & $10 \mathrm{~g}$ & $15 \mathrm{~g}$ & $20 \mathrm{~g}$ & $25 \mathrm{~g}$ \\
\hline TAN1 & COD & 28 & 14 & 64 & 87 & 89 \\
& BOD & 50 & 54 & 59 & 67 & 80 \\
& SS & 35 & -26 & -27 & -32 & -63 \\
& TDS & 99 & 99 & 99 & 98 & 98 \\
TAN2 & COD & 15 & 20 & 25 & 32 & 38 \\
& BOD & 91 & 91 & 92 & 90 & 92 \\
& SS & -28 & -52 & -52 & -54 & -55 \\
& TDS & 97 & 99 & 99 & 99 & 99 \\
& COD & 33 & 44 & 22 & 11 & 26 \\
& BOD & 75 & 81 & 76 & 81 & 81 \\
& SS & 25 & 3 & -1 & -10 & -15 \\
& TDS & 98 & 98 & 98 & 98 & 98 \\
\hline
\end{tabular}

Percentage Reduction $=(B-A) / B \times 100 \%$

$A=$ Concentration of the parameter after treatment

$\mathrm{B}=$ Concentration of the parameter before treatment

$+=$ percentage decrease

- = percentage increase

In general, immobilization makes the enzyme more resistant to temperature, $\mathrm{pH}$, and substrate concentration swings giving it a longer lifetime and higher productivity per active unit (Gianfreda and Rao, 2004; FuIlbrook, 1996; Russell et al, 2003; Kandelbauer et al., 2004). Immobilized cells have been used and studied extensively for the production of useful chemicals (Ohtake and Silver, 1994), the treatment of wastewaters (Chen et al., 2003; Wang et al., 2010). Although many workers described microbial degradation of tannery effluent, limited literature is available on the bioremediation of tannery effluent using immobilized bacterial cells in the Kano Industrial Estates.

\section{CONCLUSION}

The samples contained variable levels of the physicochemical parameters. The results of the Analysis of variance revealed that, no statistical difference $(p<0.05)$ was observed for the temperature, $\mathrm{pH}, \mathrm{SS}, \mathrm{TDS}, \mathrm{BOD}$ and $\mathrm{COD}$ among the three tannery industries before the treatment. The levels of some of the parameters
(SS, TDS and COD) observed in the samples were found above the recommended limits of WHO and NESREA, which called for the treatment of the effluents before discharge into the environment. Base on the morphological and biochemical test results, TAN1, TAN2, and TAN3 bacterial isolates were identified to be Neisseria spp, Bacillus cereus, and Staphylococcus aureus respectively. The results of Post-treatment analysis showed that there is overall decrease in the levels of the parameters determined when compared with that of the pre-treatment. The overall percentage reduction of the immobilised bacteria in the treatment of the respective effluents was in the order TAN2 (72\%)>TAN1 $(70 \%)>$ TAN3 $(62 \%)$. Hence, the immobilized bacteria are having higher biodegradation potential for the treatment of the tannery effluents.

\section{Acknowledgments}

The authors wish to acknowledge the University of Maiduguri for the financial support. The authors are grateful to the Kano State Ministry of Environment for their support in obtaining the effluent samples. 


\section{REFERENCES}

Ajao, A. T., Adebayo, G. B., and Yakubu, S. E. (2011). Bioremediation of textile industrial effluent using mixed culture of Pseudomonas aeruginosa and Bacillus subtilis immobilized on agar-agar in a bioreactor. J. Microbiol. Biotech. Res, 1(3), 50-56.

Akan, J. C., Moses, E. A., Ogugbuaja, V. O., and Abah, J. (2007). Assessment of tannery industrial effluents from Kano metropolis, Kano State, Nigeria. Journal of Applied Sciences, 7(19), 2788-2793.

Akan, J. C., Ogugbuaja, V. O., Abdulrahman, F. I., and Ayodele, J. T. (2009). Pollutant levels in effluent samples from tanneries and textiles of Kano industrial areas, Nigeria. Global journal of pure and applied sciences, 15(3-4).

APHA (1989). Standard methods for Examination of Will bete and Will betewater.15 $5^{\text {th }}$ edition. Brydpass Springfield Will behington DC. pp. 164-176

APHA (1992). Standard Methods for the Examination of Water and Wastewater. Health, 69, 1116-9.

Baba, A., Garba, S. T., and Bello, H. S. (2020). Bioremediation Potential of Immobilized corynebacterium kutsceri in the Treatment of Tannery Industrial Effluent from Challawa Industrial Estate, Kano State, Nigeria. Journal of the Turkish Chemical Society Section A: Chemistry, $7(2), 335-350$.

Beem, E. I. V. (1994). reduction of solvent VOC emission. J. Oil Col. Chem. Ass, 77, 158.

Bouwer, E. J., and Zehnder, A. J. (1993). Bioremediation of organic compoundsputting microbial metabolism to work. Trends in biotechnology, 11(8), 360367.

Chen, K. C., Wu, J. Y., Liou, D. J., and Hwang, S. C. J. (2003). Decolorization of the textile dyes by newly isolated bacterial strains. Journal of Biotechnology, 101(1), 57-68.

Dan'Azumi, S., and Bichi, M. H. (2010). INDUSTRIAL POLLUTION AND HEAVY METALS PROFILE OF CHALLAWA RIVER IN KANO, NIGERIA. Journal of Applied Sciences in Environmental Sanitation, $5(1)$.

DWAF. (1992). Analytical Methods Manual, TR 151. Department of Water Affairs and Forestry, Pretoria.

El-Bestawy, E. (2013). Biological treatment of leather-tanning industrial wastewater using free living bacteria.
Elsheikh, M. A. S. (2009). Tannery wastewater pre-treatment. Water Science and Technology, 60(2), 433-440.

FuIlbrook, P. D. (1996). "Kinetics." Industrial enzymology: The application of enzymes in Industry. 2nd Ed. T. Godfrey and J Reichelt. eds.. Nature. New York.

Gianfreda, L., and Rao, M. A. (2004). Potential of extra cellular enzymes in remediation of polluted soils: a review. Enzyme and microbial technology, 35(4), 339354.

Hugo Springer. (1994). John Arthur Wilson Memorial Lecture "Treatment of Industrial Wastes of the Leather Industry - is it still a Major Problem". JALCA, 89, 153-185

Jimoh, A. A., Ganiyu, B. A., Baba, D., and Baba, A. (2018) Bioremediation Process of Effluent from Detergent and Food Industries in Jos, Nigeria: Kinetics and Thermodynamics. International Journal of Engineering Science Invention (IJESI), 762-73

Kandelbauer, A., Maute, O., Kessler, R. W., Erlacher, A., and Gübitz, G. M. (2004). Study of dye decolorization in an immobilized laccase enzyme-reactor using online spectroscopy. Biotechnology and bioengineering, 87(4), 552-563.

Kongjao, S., Damronglerd, S., and Hunsom, M. (2008). Simultaneous removal of organic and inorganic Pollutants in tannery wastewater using electrocoagulation technique. Korean Journal of chemical engineering, 25(4), 703.

Maheshwari, U. M., Aruna, S., Gomathi, M., and AbdulJaffar, A. H. (2017). Bioremediation by Free and Immobilized Bacteria Isolated from Tannery Effluent. International Journal of Research in Applied, Natural and Social Sciences. 5(7), 75-90

Margesin, R., and Schinner, F. (2001). Bioremediation (natural attenuation and biostimulation) of diesel-oilcontaminated soil in an alpine glacier skiing area. Applied and environmental microbiology, 677), 3127-3133.

Mohammed, A., Sekar, P., and George, J. (2011). Efficacy of microbes in bioremediation of tannery effluent. Inter. J. Curr. Res, 3(4), 324-326.

Mohammed, S. S. D., Orukotan, A. A., and Abdullahi, H. (2017). Physicochemical and Bacteriological Assessment of Tannery Effluent from Samaru-Zaria, 
BAJOPAS Volume 13 Number 2, December, 2020 Kaduna State, Nigeria. Journal of Applied

Sciences and Environmental Management, 21(4), 734-740.

Munz, G., De Angelis, D., Gori, R., Mori, G., Casarci, M., and Lubello, C. (2009). The role of tannins in conventional and membrane treatment of tannery wastewater. Journal of hazardous materials, 164(2-3), 733-739

Mythili, K., and Karthikeyan, B. (2011). Bioremediation of $\mathrm{Cr}$ (VI) from tannery effluent using Bacillus spp and Staphylococcus spp. International Multidisciplinary Research Journal, 1(6).

NESREA (2009). National Environmental Standards for Effluent Limitations and Regulation. 1233-1236

Noorjahan, C. M. (2014). Physicochemical characteristics, identification of bacteria and biodegradation of industrial effluent. Journal of bioremediation and Biodegradation, 5(3).

Ohtake, H. I., and Silver, A. O. (1994). Bacterial reduction of toxic chromate. Biological degradation and bioremediation of toxic chemicals, 403-415.

Omoleke, I. I. (2004). Management of environmental pollution in Ibadan, an African city: the challenges of health hazard facing government and the people. Journal of Human Ecology, 15(4), 265-275.

Rajor, A., Reddy, A.S., and Singh, B. (2004). Determination of BOD kinetic Parameters and evaluation of alternate methods, M.Sc. Thesis, Department of biotechnology \& environmental Science, Thapar Institute of Engineering and Technology, Patiala

Ramasami, T., Rajamani, S., and Rao, J. R. (1994, March). Pollution control in leather industry: Emerging technological options. In International symposium on surface and colloidal science and its relevance to soil pollution, madras.

Ramesh, J. V. S., and Singh, S. P. (1993). Yearly variation in certain physicochemical parameters of pond at eastern Doon Valley. Uttar Pradesh J. Zoo, 12 (1), 7577.

Ranen, S., and Sharadinadra, C. (2009). Biotechnology applications to environmental remediation in resource exploitation. Current science, 97, 6-25
Russell, A. J., Berberich, J. A., Drevon, G. F., and Koepsel, R. R. (2003). Biomaterials for mediation of

chemical and biological warfare agents. Annual review of biomedical engineering, 5(1), 1-27.

Saravanan, P., and Saravanan, A. (1999). Decolourization of tannery effluent by Flavobacterium sp. EK 1. Indian Journal of Environmental Protection, 19, 19-24.

Sikander, S., and Shahida, H. (2007). Reduction of toxic hexavalent chromium by Ochrobactrum intermedium strain SDCr5 stimulated by heavy metals. Bioresource Technol, 98, 340-344.

Singh, N., Sharma, B. K., and Bohra, P. C. (2000). Impact assessment of industrial effluent of arid soils by using satellite imageries. Journal of the Indian Society of Remote Sensing, 28(2-3), 79.

Sreemoyee, C., and Priti, P. (2013). Assessment of physico-chemical parameters of dairy waste water and isolation and characterization of bacterial strains in terms of cod reduction. Int J Sci, 2(3), 395-400.

Verheijen, L. A. H. M., Wiersema, D., Pol, L. H., and De Wit, J. (1996). Management of wastes from animal product processing. Livestock and environment, Finding a balance. International Agriculture Center, Wageningen, The Netherlands.

Wang, F., Yao, J., Si, Y., Chen, H., Russel, M., Chen, K., and Bramanti, E. (2010). Short-time effect of heavy metals upon microbial community activity. Journal of Hazardous Materials, 173(13), 510-516.

WHO (World Health Organization). (2006). Air quality guidelines: global update 2005: particulate matter, ozone, nitrogen dioxide, and sulfur dioxide. World Health Organization.

World Bank. (1995). Nigeria's strategic options for redressing industrial pollution. World Bank, industry and energy division. 1st edition, West Central Africa Department; Annexes: 1995; pp 60-62.

Zahoor, A., and Abdul, R. (2009). Enumeration of Coliforms. Journal of Environmental Sciences. 21, 814-820 


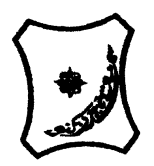

Bayero Journal of Pure and Applied Sciences, 13(2): 1 - 12

Received: November, 2020

Accepted: December, 2020

ISSN $2006-6996$

\title{
BIODEGRADATION POTENTIAL OF IMMOBILIZED BACTERIA IN THE TREATMENT OF TANNERY INDUSTRIAL EFFLUENTS FROM INDUSTRIAL ESTATES IN KANO STATE, NIGERIA
}

\author{
Abdullateef, B., ${ }^{1 *}$ Shuaibu, T. G., ${ }^{1}$ Babagana, K., ${ }^{1}$ Suleman, H. B. ${ }^{2}$ and Dauda, B. ${ }^{3}$ \\ ${ }^{1}$ Department of Pure and Applied Chemistry, Faculty of Science, University of Maiduguri, Borno State, \\ Nigeria \\ ${ }^{2}$ Department of Microbiology, Faculty of Science, University of Maiduguri, Borno State, Nigeria \\ ${ }^{3}$ Department of Chemical Engineering, Faculty of Engineering, University of Maiduguri, Borno State, \\ Nigeria \\ *Corresponding author: babslega@gmail.com; abelega2007@yahoo.com; +2348061309753
}

\section{ABSTRACT}

Industrial Effluents Samples from Gashash Tanneries (TAN1) in Bompai Industrial estate, Larabee Tannery Industry (TAN2) in Sharada Industrial estate and Z Tannery Industries (TAN3) in Challawa Industrial estate, Kano State, Nigeria were collected over a period of six months (August 2017 to January 2018) for assessing the biodegradation potentials of bacteria in the treatment of organic pollutants within the effluents. Bacteria were isolated from the effluents and immobilized on agar-agar. Different masses (5 g, $10 \mathrm{gr}, 15$ $\mathrm{g}, 20 \mathrm{~g}$, and $25 \mathrm{~g}$ ) of the bacteria were used in the treatment of $250 \mathrm{ml}$ of the effluents for ten days in a shaker incubator (Gallenkamp-OC-4364-L) at the temperature $30{ }^{\circ} \mathrm{C}$ and speed of $60 \mathrm{rpm}$. Pre-treatment analysis of the effluents for Temperature, pH, Biochemical Oxygen Demand (BOD), Chemical Oxygen Demand (COD), Suspended Solid (SS) and Total Dissolved Solids (TDS) gives the following results; temperature $\left({ }^{\circ} \mathrm{C}\right.$ )

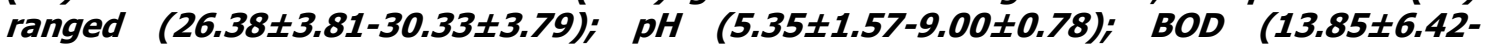
$38.75 \pm 16.20) ;$ COD (1406 $\pm 208-3532 \pm 1373) ;$ SS (208 $\pm 235-780 \pm 739)$ and TDS (266 $\pm 253-5276 \pm 2971)$. No statistical differences ( $p \leq 0.05)$ was observed for all the results among the different industries. The bacterial isolates were identified as Neisseria spp, Bacillus cereus, and Staphylococcus aureus, in TAN1, TAN2, and TAN3, respectively. After treatment of the effluent with the different masses of the isolated bacteria, the mean level of BOD was found to range as (0.55 $\pm 0.36-6.92 \pm 5.49) ; C O D$ (ND-3134 \pm 1595$)$;

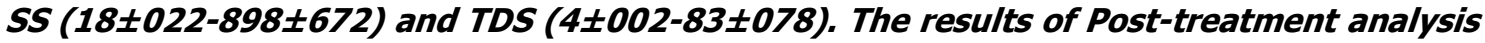
showed that there is overall decrease in the levels of the parameters determined when compared with that of the pre-treatment. The overall percentage reduction of the immobilised bacteria in the treatment of the respective effluents was in the order TAN2 (72\%)>TAN1 (70\%)>TAN3 (62\%). Hence, the immobilized bacteria are having higher biodegradation potential for the treatment of the tannery effluents.

Keywords: Biodegradation, bacteria, effluent, immobilization, tannery.

\section{INTRODUCTION}

Tannery industrial wastewater is a serious consequence of the pollution point of view for streams, freshwater, and land used for agriculture. The lack of awareness in the modern industrial practice has resulted in the discharge of tannery effluents which exhibit very high value of chromium ( $\mathrm{Cr}$ ), Sulfide, and chloride, Total Dissolved Solid (TDS), Total Suspended Solid (TSS), Biochemical Oxygen Demand (BOD) and Chemical Oxygen Demand (COD) in the water stream or land (Mohammed et al., 2001). Tanning is the process, which One ton of skin generally leads to the production of 20 to $80 \mathrm{~m}^{3}$ of turbid and foul-smelling converts the protein of the rawhide or skin into a stable material, which will not putrefy and is suitable for a wide variety of end applications (Elsheikh, 2009). The highly polluting chromium is the most commonly used tanning material producing leather that is more flexible and pliable than vegetable-tanned leather and does not discolor or lose shape in water as drastically as vegetable-tan (Elsheikh, 2009). Tannery effluent is among the most hazardous industrial pollutants due to its huge organic and inorganic load, which is highly toxic to human life and the environment (Kongjao et al., 2008). wastewater including chromium (100-400 mg/l), sulfide $(200-800 \mathrm{mg} / \mathrm{l})$, high levels of fat and 
BAJOPAS Volume 13 Number 2, December, 2020 other solid wastes, and notable pathogen contamination as well as pesticides added for skin conservation during transport (Elsheikh, 2009). There are more than 6000 tanneries in Nigeria with an annual processing capacity of 700,000 tons of hides and skins (Omoleke, 2004; Singh et al., 2008). It was reported that the total amount of waste produced per animal slaughtered is approximately $35 \%$ of its weight (World Bank, 1995). Also, for every $1000 \mathrm{~kg}$ of carcass weight, a slaughtered beef produces 5.5 $\mathrm{kg}$ of manure (excluding rumen contents or stockyard manure) and $100 \mathrm{~kg}$ of paunch manure (undigested food) (Verheijen et al., 1996). Tanneries generate wastewater in the range of 30-35 $\mathrm{L} \mathrm{kg}^{-1}$ skin/hide processed with variable $\mathrm{pH}$, Biological Oxygen Demand (BOD), Chemical Oxygen Demand (COD), high concentrations of suspended solids (SS), and tannins as well as chromium (Zahoor and Abdul, 2009).

Being heterogeneous and composed of a wide variety of compounds, it is very difficult to select a unique direct method for estimating the biodegradability of organic contents and biokinetic parameters for a wastewater sample (Rajor, 2004). For this purpose, some indirect estimation such as determination of biochemical oxygen demand (BOD) and chemical oxygen demand (COD) are applied as common laboratory investigations [9]. During retanning procedures, synthetic tannins (Syntan), oils and resins are added to form softer leather at varying doses (Munz et al., 2009). One of the refractory groups of chemicals in tannery effluents derives mainly from tannins (Ramasami et al., 2004). Syntans are characterized by complex chemical structures, because they are composed of an extended set of chemicals such as phenol-, naphthalene-, formaldehyde- and melamine-based syntans, and acrylic resins (Beem, 1994). Organic pollutants (proteic and lipidic components) are originated from skins (it is calculated that the raw skin has $30 \%$ loss of organic material during the working cycle) or they are introduced during processes (Hugo Springer, 1994).

Many conventional processes such as oxidation, chemical and biological processes were carried out to treat tanneries wastewater (Ebtesam et al, 2013). Biological processes have received more attention because of their costeffectiveness, lower sludge production and environmental friendliness (Noorjahan, 2014). Naturally occurring micro-organisms degrade the hazardous organic wastes including xenobiotic compounds, such as pesticides, polycyclic aromatic hydrocarbons (PAHs) and polychlorinated biphenyls (PCBs) in due course of time (Ranen and Sharadinadra, 2009). Bioremediation is based on the idea that all organisms remove substances from the environment to carry outgrowth and metabolism (Bouwer and Zehnder, 1993). Bacteria, protista and fungi are found to be very good at degrading complex molecules and incorporating the breakdown products into their metabolism (Bouwer and Zehnder, 1993). The resultant metabolic wastes that they produce are generally safe and somehow recycled into other organisms (Ranen and Sharadinadra, 2009). An acclimatized indigenous population of microorganisms capable of degradation of the compounds of interest must exist at the site for a successful bioremediation mode (Ranen and Sharadinadra, 2009). It has been observed that for a successful bioremediation mode, an acclimatized indigenous population of microorganisms capable of degradation of the compounds of interest must exist at the site under investigation (Ranen and Sharadinadra, 2009). Even though there are numerous physical and chemical methods employed in the disposal of wastes the advantage in using bacterium is that they play a key role in the reduction of COD, BOD, total protein, total tannin and total phenol (Saravanan and Saravanan, 1998)

Baba et al. (2020) studied the bioremediation potential of immobilized corynebacterium kutsceri in the Treatment of tannery industrial effluent from Challawa Industrial Estate, Kano State, Nigeria. The aim of the work is to study the reduction in the level of the contaminants through the process of bioremediation using the isolated bacteria. Immobilized bacteria can withstand various temperatures, $\mathrm{pH}$ and substrate concentrations; consequently, increasing the efficiency and the lifespan of the bacteria. Immobilized bacteria are widely applied in the treatment of wastewater and can be separated and recovered after the treatment with the same efficiency (Baba et al., 2020).

\section{MATERIALS AND METHODS \\ Study Area}

This study was carried out in Bompai, Sharada and Challawa industrial estates in Kano, Figure 1. Kano lies on Latitude $11^{\circ} 30^{\prime} \mathrm{N}$ and $8^{\circ} 30^{\prime} \mathrm{E}$ and Longitude $11^{\circ} 5^{\prime} \mathrm{N}$ and $8^{\circ} 5^{\prime} \mathrm{E}$ in Northern Nigeria. It is one of the developed industrial cities in Nigeria. Tannery activities are the dominating industries and this could be one of the reasons for her high population density (Dan'Azumi and Bichi, 2010). Many researchers have studied biodegradation of tannery effluent using microorganisms. However, limited literature is available on the biodegradation of tannery effluent in Kano industrial estates using 
BAJOPAS Volume 13 Number 2, December, 2020 immobilized bacterial cells. This research work focuses on the potential of the use of the indigenous immobilized bacterial isolates in the treatment of tannery effluents in the industrial estates.

\section{Sample Collection}

Effluents were collected from the Tannery Industries from Bompai, Challawa and Sharada Industrial Estates, Kano, Nigeria. The effluents were collected over a period of six months (August 2017 to January 2018). Samples collected in a sterile 4-liter plastic container with a unique identification number were preserved using an ice-box that was transported to the Microbiology Laboratory, Department of Microbiology, Bayero University of Kano for analysis

\section{Sample Preparation and Sample Analysis}

Immediately after the collection of the effluent, $\mathrm{pH}$, TSS, TDS, COD, BOD levels were determined before treatment (Pre-treatment determination) and ten days after treatment (Post-treatment determination) as described in
APHA (1989) standard methods. $\mathrm{pH}$ was determined using Ecotests $\mathrm{pH}$ meter and TDS was determined using AQUALYTIC TDS Salinometer. BOD was determined as described by the standard method (APHA, 1992). COD and SS were determined using DR/2010 HACH portable data logging spectrophotometer (DWAF, 1992)

\section{Identification and Biochemical} Characterization of the Bacterial Isolates

The bacteria were isolated from the effluents using Serial Dilution according to the method described by APHA (1989). The biochemical tests such as oxidase, catalase, coagulase, indole (from $1 \%$ tryptone broth), citrate (Simmons citrate agar), methyl red/VogesProskauer (MR/VP), nitrate reduction, Starch Hydrolysis, Glucose, Maltose, and Lactose tests were carried out on the bacterial isolates to identify the bacteria through the bacteria biochemical characteristics according to Ajao et al. (2011).

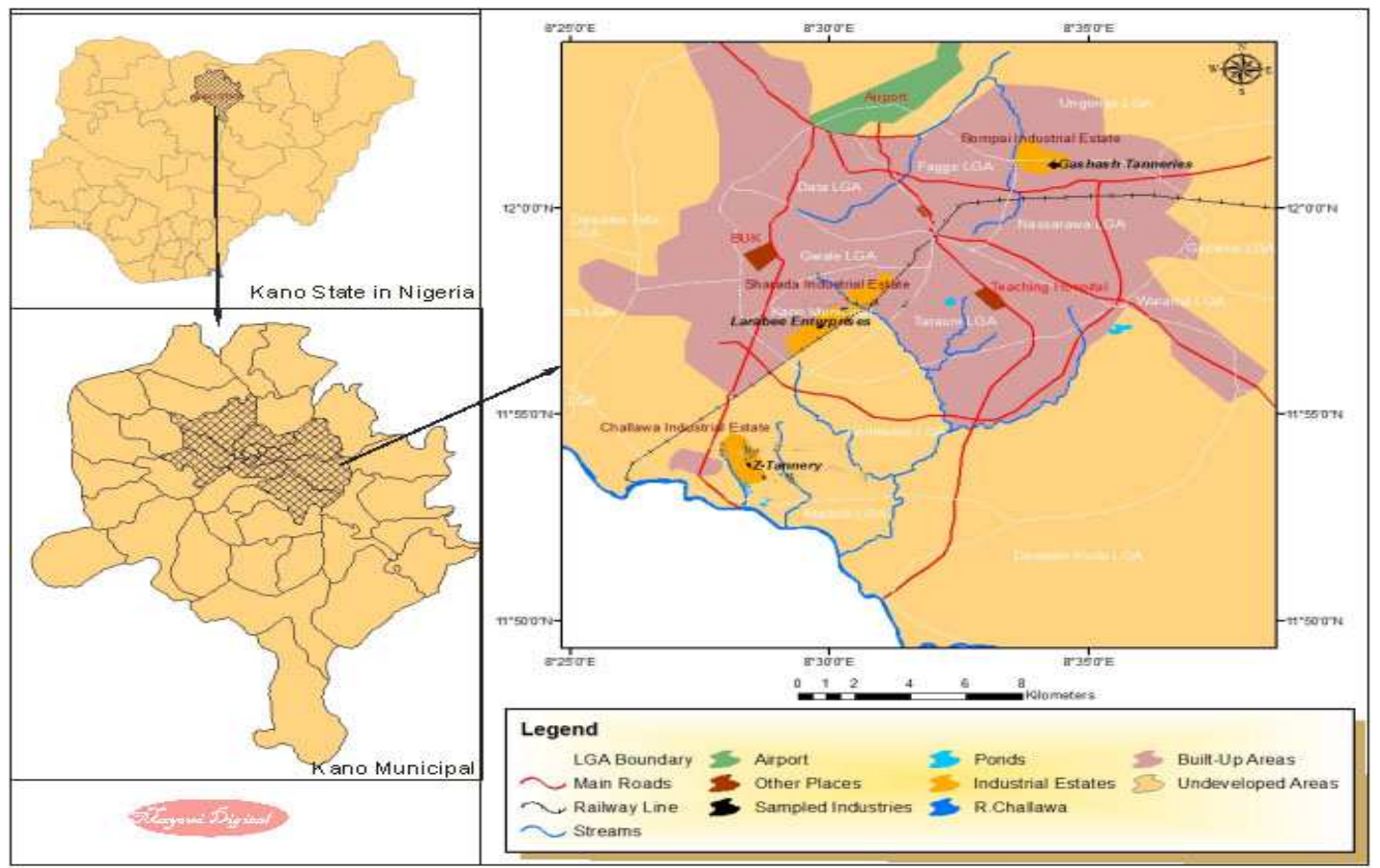

Fig. 1 Map showing the study areas

Source: Mayomi Digital Productions, GIS Laboratory, Department of Geography, UNIMAID (2017)

\section{Determination of Growth Rate of the Bacteria in Effluent Sample}

The bacteria growth rates were determined by transferring $2 \mathrm{~mL}$ of the bacterial isolates from the tannery effluent in broth medium into 100 $\mathrm{mL}$ sterile effluents in conical flasks and kept in an incubator (Giffrin cool) for 10 days. Control was also set up by incubating another $100 \mathrm{~mL}$ each of the sterile effluents without the bacteria. The optical density of the content was determined at the wavelength of $600 \mathrm{~nm}$ on a daily interval and recorded. 
BAJOPAS Volume 13 Number 2, December, 2020 Immobilization of Bacteria

Agar solution and inoculi were prepared separately. Fifty milliliters $(50 \mathrm{~mL})$ of nutrient broth each of the inoculi was prepared in a McCartney bottle and incubated for 24 hours. A solution of agar-agar was prepared by dissolving $10 \mathrm{~g}$ of the powder in distilled water and made up to $500 \mathrm{~mL}$ mark in an Erlenmeyer flask and was sterilized in an autoclave (280A) for 15 minutes and allowed to cool to $40-45^{\circ} \mathrm{C}$ (Ajao et al., 2011). Four milliliters ( $4 \mathrm{~mL})$ of the bacterial isolates in the nutrient broth was mixed with 36 $\mathrm{ml}$ of the prepared agar-agar media in petri-dish plates and then allowed to solidify. This was kept in the refrigerator for bioremediation.

\section{Bioremediation (Treatment) of the Effluents}

The solidified agar block (immobilized bacteria) was cut into cubes using a sterile knife; $0.1 \mathrm{~mL}$ phosphate buffer ( $\mathrm{pH} \mathrm{7.0)}$ was added and kept in the refrigerator for 1 hour for curing. The phosphate buffer was decanted after 1 hour and the cubes were washed with sterile distilled water 3-4 times before it was used (Ajao et al., 2011). Two liters (2 L) of the effluent was supplemented with the minimum basal medium in $\mathrm{g} / \mathrm{L}: \mathrm{NaCl}(0.8), \mathrm{MgSO}_{4} .7 \mathrm{H}_{2} \mathrm{O}(0.001), \mathrm{KH}_{2} \mathrm{PO}_{4}$ (2), $\mathrm{NaNO}_{3}$ (2), $\quad \mathrm{CaCl}_{2} .2 \mathrm{H}_{2} \mathrm{O} \quad(0.5)$ and $\mathrm{NaHPO}_{4} .12 \mathrm{H}_{2} \mathrm{O}(2)$ and sterilized in an autoclave at $121^{\circ} \mathrm{C}$ for 15 minutes (Margesin and Schinner, 2001). Two hundred and fifty milliliters $(250 \mathrm{~mL})$ of the effluents were transferred into different $250 \mathrm{ml}$ conical flasks. The content was covered with a cotton-wool ramped with foil paper to avoid contamination. Five grams $(5 \mathrm{~g})$ of the immobilized bacteria were quickly transferred into each of the effluents in the conical flasks in an inoculating chamber. The same procedures were carried out for the $10 \mathrm{~g}, 15 \mathrm{~g}, 20 \mathrm{~g}$ and 25 $\mathrm{g}$ of the immobilized bacteria in separate $250 \mathrm{~mL}$ effluents in conical flasks and agitated for ten days in a shaker incubator (Gallenkamp-OC4364-L) at a temperature $30^{\circ} \mathrm{C}$ and speed of 60 rpm. The treated effluent samples were taken on the tenth day and analyzed for the parameters $\mathrm{pH}$, SS, TDS, COD, and BOD, (Posttreatment determination) for the different grams of bacteria to evaluate and compare the biodegradation potential. (Baba et al., 2020).

\section{Statistical Analysis}

The data were represented as Mean \pm Standard deviation and analyzed statistically using oneway Analysis of Variance (ANOVA) and Tukey's HSD as Post Hoc Tests with the aid of SPSS 16.0. The correlation coefficient was also used to measure the strength of the relationship between the different masses of the bacteria and the parameters. All $\mathrm{p} \leq 0.05$ were considered as statistically significant.

\section{RESULTS AND DISCUSSION Physico-chemical parameters in the Industrial Effluents before the Biodegradation.}

Results of the Physico-chemical parameters in the industrial effluents before the Biodegradation is shown in table 1 . The mean temperatures $\left({ }^{\circ} \mathrm{C}\right)$ observed in TAN1, TAN2, and TAN3 samples were $28.07 \pm 0.65 ; 27.77 \pm 0.64$ and $26.38 \pm 3.81$ respectively. The order of the mean temperature of the samples from the three industries can be arranged as TAN1 > TAN2>TAN3. The temperature observed at TAN1, TAN2, and TAN3 samples were found below the WHO $\left(35^{\circ} \mathrm{C}\right)$ and NESREA $\left(40^{\circ} \mathrm{C}\right)$ limits. The low values of temperature might be due to the processes used at the time of sampling. High temperature brings down the solubility of gases in water that ultimately expresses as high BOD and COD. Statistical analysis shows that there is no significant difference $(p<0.05)$ between the mean values of temperature among the industries. This might be due to similar tannery activities involved in the tannery industries at the time of sampling. The average values of temperature observed in this present study are less than those observed by Akan et al. (2007), Akan et al. (2009) and Baba et al. (2020).

The mean level of $\mathrm{pH}$ observed in TAN1, TAN2 and TAN3, samples were $7.77 \pm 2.93$; $8.35 \pm 0.28$ and $7.52 \pm 0.76$ respectively. The order of the mean $\mathrm{pH}$ of the samples from the three industries can be arranged as TAN2> TAN1 $>$ TAN3. The $\mathrm{pH}$ of the samples falls within the WHO (7.0-8.5) and NESREA (6-9) standard limits. Statistical analysis shows that there is no significant difference $(p<0.05)$ between the mean values of $\mathrm{pH}$ among the industries. This might be due to similar tannery activities involved in the tannery industries at the time of sampling. Maheshwari et al. (2017) reported that the level of $\mathrm{pH}$ in the effluents from the tannery industry in Vaniyambadi, India was 6.5 which was lower than that observed in the present study. The $\mathrm{pH}$ in the effluents from the tannery industries in Kano and Kaduna were reported to be 7.64 and 6.89, respectively (Akan et al., 2007; Mohammed et al., 2017). The average values of $\mathrm{pH}$ observed in this present study are less than those observed by Mohammed et al. (2017) and Baba et al. (2020). The mean level of SS $(\mathrm{mg} / \mathrm{l})$ observed in TAN1, TAN2, and TAN3 samples were 374 \pm 124 ; $358 \pm 335$ and $780 \pm 739$ respectively. The order of the mean SS in the samples from the three industries can be arranged as TAN3 > TAN1 $>$ TAN2. 
The SS observed in the samples were far above the recommended standard limits of regulating bodies WHO $(30 \mathrm{mg} / \mathrm{l})$ and NESREA $(10 \mathrm{mg} / \mathrm{l})$. Statistical analysis shows that there is no significant difference $(p<0.05)$ between the mean values of SS among the industries. This might be due to similar tannery activities involved in the tannery industries at the time of sampling. The average values of SS observed in this present study are less than that observed $(3700 \pm 122 \mathrm{mg} / \mathrm{l})$ by Akan et al. (2009) for tanneries in Kano. Also, the average values of SS observed in this present study are less than that observed by Mohammed et al. (2017) and Baba et al. (2020) with the exception in TAN3.

The mean level of TDS (mg/l) observed in TAN1, TAN2, and TAN3 samples were $3941 \pm 3703$; $3300 \pm 1714$ and $2653 \pm 1240$ respectively. The order of the mean TDS in the samples from the three industries can be arranged as TAN1>TAN2>TAN3. The TDS observed in the samples were far above the recommended standard limits of WHO $(250 \mathrm{mg} / \mathrm{l})$ and NESREA $(500 \mathrm{mg} / \mathrm{l})$. Statistical analysis shows that there is no significant difference $(p<0.05)$ between the mean values of TDS among the industries. This might be due to similar tannery activities involved in the tannery industries at the time of sampling. TDS in the effluents from the tannery industries in Kano, Nigeria was reported to be $1281 \mathrm{mg} / \mathrm{l}$ (Akan et al., 2007). The average values of SS observed in this present study are less than those observed by Mohammed et al. (2017) and Baba et al. 2020)

The mean level of COD (mg/l) observed in TAN1, TAN2 and TAN3 samples seasons were $2372 \pm 938 ; \quad 1406 \pm 208$ and $3532 \pm 1373$ respectively. The order of the mean COD of the samples from the three industries can be arranged as TAN3>TAN1> TAN2. The COD observed in TAN1, TAN2 and TAN3 samples were far above the recommended standard limits of regulating bodies $\mathrm{WHO}(40 \mathrm{mg} / \mathrm{l})$ and NESREA (40 mg/l). Statistical analysis shows that there is no significant difference $(p<0.05)$ in COD among the industries. This might be due to similar tannery activities involved in the tannery industries as at the time of sampling. The Chemical Oxygen demand (COD) is the amount of oxygen, in $\mathrm{mg} / \mathrm{L}$, required for the degradation of the compound of wastewater to occur. In comparison, the average values of COD observed in this present study were higher than that observed by Mohammed et al. (2017) but lower than that observed by Baba et al. (2020).

The mean levels of BOD $(\mathrm{mg} / \mathrm{l})$ observed in TAN1, TAN2 and TAN3 samples were $13.85 \pm 6.42 ; \quad 19.46 \pm 0.50$ and $17.13 \pm 3.14$ respectively. The order of the mean BOD in the samples from the three industries can be arranged as TAN2>TAN3>TAN1. The BOD observed in TAN1, TAN2 and TAN3 samples were found below the recommended limits of NESREA (200 mg/l) but above WHO (10 mg/l). Statistical analysis shows that there is no significant difference $(p<0.05)$ between the mean values of BOD among the industries. This might be due to similar tannery activities involved in the tannery industries at the time of sampling. The low level of BOD recorded in this study is an indication of the low level of biodegradable organic solids in the effluent. The average values of BOD observed in this present study were lower than those observed by Mohammed et al. (2017) and Baba et al. (2020).

Table 1: Mean Values \pm S.D of Physico-chemical parameters of effluents from the Tannery Industries before Treatment.

\begin{tabular}{llllllll}
\hline Parameter & Tannery 1 & Tannery 2 & Tannery 3 & $\mathrm{a}$ & $\mathrm{b}$ & $\mathrm{c}$ & $\mathrm{d}$ \\
\cline { 2 - 7 } Temperature $\left({ }^{\circ} \mathrm{C}\right)$ & $28.07 \mathrm{a} \pm 0.65$ & $27.77 \mathrm{a} \pm 0.64$ & $26.38 \mathrm{a} \pm 3.81$ & & $29.50 \pm 4.68$ & 35 & 40 \\
pH & $7.77 \mathrm{a} \pm 2.93$ & $8.35 \mathrm{a} \pm 0.28$ & $7.52 \mathrm{a} \pm 0.76$ & 6.89 & $5.35 \pm 1.57$ & $7.0-8.5$ & $6.0-9.0$ \\
$\mathrm{COD}(\mathrm{mg} / \mathrm{l})$ & $2372 \mathrm{a} \pm 938$ & $1406 \mathrm{a} \pm 208$ & $3532 \mathrm{a} \pm 1373$ & 2.2 & $3106 \pm 2753$ & 40 & 40 \\
$\mathrm{BOD}(\mathrm{mg} / \mathrm{l})$ & $13.85 \mathrm{a} \pm 6.42$ & $19.46 \mathrm{a} \pm 0.50$ & $17.13 \mathrm{a} \pm 3.14$ & 1032 & $26.17 \pm 9.49$ & 10 & 200 \\
$\mathrm{SS}(\mathrm{mg} / \mathrm{l})$ & $374 \mathrm{a} \pm 124$ & $358 \mathrm{a} \pm 335$ & $780 \mathrm{a} \pm 739$ & 501 & $562 \pm 482$ & 30 & 10 \\
TDS $(\mathrm{mg} / \mathrm{l})$ & $3941 \mathrm{a} \pm 3703$ & $3300 \mathrm{a} \pm 1714$ & $2653 \mathrm{a} \pm 1240$ & 532.7 & $444 \pm 507$ & 250 & 500 \\
\hline
\end{tabular}

The values given in the table above are means of 6 replicate values, $\mathrm{n}=6$ ( 1 sample was taken monthly for 6 months). Within the rows, means with different alphabets are statistically different $(p<0.05)$. WHO: World Health Organisation. NESREA: National Environmental Standard and Regulatory Enforcement Agency. a = Mohammed et al.(2017), b = Baba et al. (2020), c = WHO (2006), $d=$ NESSRA (2009) 
BAJOPAS Volume 13 Number 2, December, 2020

Identification, Biochemical Characterization and growth rates of the Bacterial Isolates

Results of identification and biochemical characterization of the bacterial isolates were shown in table 2. After 24 hours of incubation, the nutrient agar media plates were checked for bacterial growth. The results showed the presence of different strains in the samples. The TAN1 bacteria isolate was found to be gramnegative cocci while TAN3 was gram-positive cocci. TAN2 bacteria isolate was found to be gram-positive, rod-shaped. TAN1, TAN2, and TAN3 bacteria isolates recorded positive results for spore former.

The results of the biochemical tests indicated that all the bacteria were positive for catalase, oxidase, citrate, maltose, glucose, lactose (negative in TAN1), mannitol (negative in TAN2), starch hydrolysis and coagulase (negative in TAN2) tests. The bacteria showed negative results for nitrate reduction, $M R$ (positive in TAN2), VP (positive in TAN1), Indole (positive in TAN2) tests. Base on the morphological and biochemical test results, TAN1, TAN2, and TAN3 bacteria isolates were identified to be Nesseria spp, Bacillus cereus, and Staphylococcus aureus respectively.

The growth rate of the TAN1, TAN2 and TAN3 Isolates were shown in figure 2. Generally, the optical density increase with the increase in time (day) and decrease as time goes on. The highest optical density was shown by bacillus cereus in TAN2 while the lowest was shown by Staphylococcus aureus in TAN3.

The initial growth phase of TAN1 Isolate bacteria occurred within 2-day of incubation as the growth rate increases up to the 6th-day incubation when the maximum growth was observed. Beyond the 6th day, the growth of the bacteria declined (which might be due to a shortage of nutrients in the effluents) until it reached its death phase (which might be due to the unavailability of nutrients in the effluents).

A similar trend of growth was also observed for TAN2 Isolate as the initial growth phase also occurred within 2-day of incubation but maximum growth rate observed on the 4th day of incubation. The stationary stage occurred between the 4th day and the 8th day. Beyond the 8th day, the growth of the bacteria declined (which might be due to a shortage of nutrients in the effluents) until it reached its death phase (which might be due to the unavailability of nutrients in the effluents).

The initial growth phase of TAN3 bacterial Isolate occurred within the 3-day incubation as the growth rate increases up to the 6th-day incubation when the maximum growth was observed. Beyond the 6th day, the growth of the bacteria declined (which might be due to a shortage of nutrients in the effluents) until it reached its death phase (which might be due to the unavailability of nutrients in the effluents).

Table 2: Morphological and Biochemical characteristics of bacterial isolates

\begin{tabular}{lllll} 
Bacterial Isolates & & TAN1 & TAN2 & TAN3 \\
\hline $\begin{array}{lllll}\text { Morphological } \\
\text { characteristics }\end{array}$ & Shape & Cocci & Rod & Cocci \\
& Spore & & & \\
& former & + & + & + \\
Gram & & & \\
Biochemical characteristics & reaction & - & + & + \\
& Citrate & + & + & + \\
& Catalase & + & + & + \\
& Coagulase & + & - & + \\
Starch & + & + & + \\
& Glucose & + & + & + \\
Oxidase & + & + & + \\
& Indo & - & + & - \\
Lactose & - & + & + \\
Manitol & + & - & + \\
Maltose & + & + & + \\
MR & - & + & - \\
VP & + & - & - \\
& Nitrate & - & - & - \\
Reduction & - Neisseria & Bacillus & Staphylococcus \\
& Bacterial & cereus & aureus \\
& name & spp & cas
\end{tabular}

+ = Positive; - = Negative; MR=Methyl Red; VP= Voges-Proskauer 


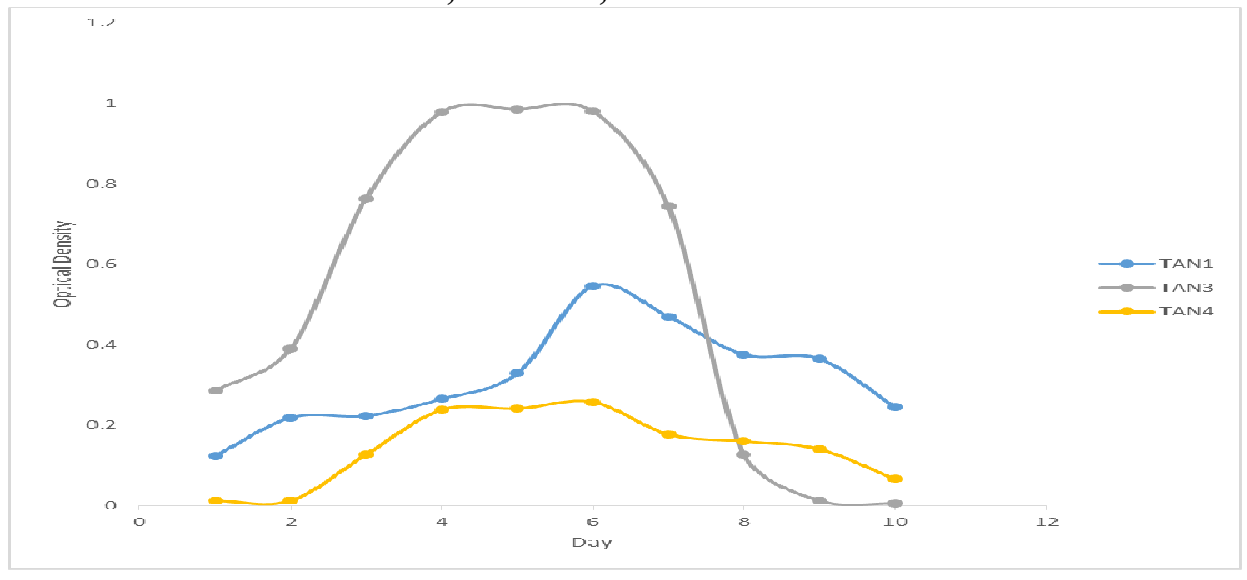

Fig. 2 Growth rates of the isolates in the effluents from the Tannery Industries

\section{Physico-chemical Parameters in the Industrial Effluents after the biodegradation.}

Table 3 shows the mean results of the physicochemical parameter before and after bioremediation using the different masses $(5 \mathrm{~g}$, $10 \mathrm{~g}, 15 \mathrm{~g}, 20 \mathrm{~g}$, and $25 \mathrm{~g}$ ) of the respective immobilized bacteria. Also, Table 4 shows the mean results of correlation coefficient ( $r$ ) between different masses of bacteria and physicochemical parameters.

The mean values $(\mathrm{mg} / \mathrm{l})$ of the SS after the bioremediation varies between $243 \pm 45$ and $898 \pm 672$. The mean concentration $(\mathrm{mg} / \mathrm{l})$ of SS remediated by the different masses $(5 \mathrm{~g}, 10 \mathrm{~g}$, $15 \mathrm{~g}, 20 \mathrm{~g}$, and $25 \mathrm{~g}$ ) of the bacteria varies. The SS in the samples fluctuates up and down after the bioremediation process when compared with the SS of the raw samples before the bioremediation. The increase in the levels of the SS might be due to the aggregation of the TDS which are large enough to result into SS. The increase in the levels of the SS might be also due to the influence of the nutrients which was added into the effluents in order to make the microorganisms more active and viable for fast degradation of organic contaminants in the effluent. The relative potential or efficiency of the different masses of the bacteria in remediating SS in TAN1 samples was in the order $25 \mathrm{~g}>20 \mathrm{~g}>15 \mathrm{~g}>10 \mathrm{~g}>5 \mathrm{~g}$. For TAN2 and TAN3 samples, the order was $25 \mathrm{~g}>20 \mathrm{~g}>15$ $\mathrm{g}>10 \mathrm{~g}>5 \mathrm{~g}$. These might be due to the variations in the surface areas of the different masses of the immobilized bacteria. Statistical analysis shows that there is no significant difference $(p<0.05)$ between the mean values of SS among the masses in the respective industries. Positive and significant correlations exist between the masses of bacteria and Suspended Solid (SS). This showed that there is general increase in the levels of the SS as the masses of the immobilized bacteria increases. TAN3 (90\%) and TAN1 (80\%) showed a very high correlation with the masses of the bacteria while TAN2 (61\%) showed a very low correlation.

The mean values $(\mathrm{mg} / \mathrm{l})$ of the TDS after the bioremediation varies between $46 \pm 11$ and $83 \pm 78$. The mean concentration $(\mathrm{mg} / \mathrm{l})$ of TDS remediated by the different masses $(5 \mathrm{~g}, 10 \mathrm{~g}$, $15 \mathrm{~g}, 20 \mathrm{~g}$, and $25 \mathrm{~g}$ ) of the bacteria varies. There is a reduction in all the TDS of all the samples after the bioremediation process compared with the TDS of the raw samples before the bioremediation. The relative potential or efficiency of the different masses of the bacteria in remediating TDS in TAN1 and TAN3 samples was in the order $5 \mathrm{~g}>10 \mathrm{~g}>15 \mathrm{~g}>20$ $\mathrm{g}>25 \mathrm{~g}$. For TAN2 samples, the order was 20 $g>10 \quad g>25 \quad g>15 \quad g>5 \quad g$. Statistical analysis shows that there is no significant difference $(p<0.05)$ between the mean values of TDS among the masses in the respective industries. These might be due to the variations in the surface areas of the different masses of the immobilized bacteria. Positive and significant correlations exist between the masses of bacteria and TDS with the exception in TAN2 (negative and insignificant correlation). The positive correlations showed that there is general increase in the levels of the TDS as the masses of the immobilized bacteria increases. TAN1 $(96 \%)$ showed a very high correlation with the masses of the bacteria while TAN2 (47\%) showed a very low correlation.

The mean values $(\mathrm{mg} / \mathrm{l})$ of the BOD after the bioremediation varies between $1.56 \pm 0.20 \mathrm{mg} / \mathrm{l}$ and $6.92 \pm 5.49 \mathrm{mg} / \mathrm{l}$. The mean concentration $(\mathrm{mg} / \mathrm{l})$ of BOD remediated by the different masses $(5 \mathrm{~g}, 10 \mathrm{~g}, 15 \mathrm{~g}, 20 \mathrm{~g}$, and $25 \mathrm{~g}$ ) of the bacteria varies. There is a reduction in all the BOD of all the samples after the bioremediation process compared with the $\mathrm{BOD}$ of the raw 
BAJOPAS Volume 13 Number 2, December, 2020 samples before the bioremediation. The relative potential or efficiency of the different masses of the bacteria in remediating BOD in TAN1, TAN2 and TAN3 samples were in the order $25 \mathrm{~g}>20$ $\mathrm{g}>15 \mathrm{~g}>10 \mathrm{~g}>5 \mathrm{~g}, 25 \mathrm{~g}>15 \mathrm{~g}>5 \mathrm{~g}>10 \mathrm{~g}>20 \mathrm{~g}$ and $20 \mathrm{~g}>10 \mathrm{~g}>25 \mathrm{~g}>15 \mathrm{~g}>5 \mathrm{~g}$ respectively. Statistical analysis shows that there is significant difference $(p<0.05)$ between the mean values of BOD among the masses in the respective industries. These might be due to the variations in the surface areas of the different masses of the immobilized bacteria. Negative and significant correlations exist between the masses of bacteria and BOD. This showed that there is general decrease in the levels of the BOD as the masses of the immobilized bacteria increases. TAN1 (94\%) showed a very high correlation with the masses of the bacteria while TAN2 (4\%) showed a very low correlation.

The mean values $(\mathrm{mg} / \mathrm{l})$ of the COD after the bioremediation varies between $250 \pm 154$ and $3134 \pm 1595$. The mean concentration $(\mathrm{mg} / \mathrm{l})$ of COD remediated by the different masses $(5 \mathrm{~g}$, $10 \mathrm{~g}, 15 \mathrm{~g} 20 \mathrm{~g}$, and $25 \mathrm{~g}$ ) of the bacteria varies. There is a reduction in all the COD of all the samples after the bioremediation process compared with the COD of the raw samples before the bioremediation. The relative potential or efficiency of the different masses of the bacteria in remediating COD in TAN1, TAN2 and TAN3 samples were in the order $25 \mathrm{~g}>20 \mathrm{~g}>15$ $\mathrm{g}>5 \mathrm{~g}>10 \mathrm{~g}, 25 \mathrm{~g}>20 \mathrm{~g}>15 \mathrm{~g}>10 \mathrm{~g}>5 \mathrm{~g}$ and 10 g>5 g>25 g>15 g>20 g respectively. Statistical analysis shows that there were significant difference $(p<0.05)$ between the mean values of COD among the masses in the respective industries except for effluents treated with $25 \mathrm{~g}$. These might be due to the variations in the surface areas of the different masses of the immobilized bacteria. Negative and insignificant correlations exist between the masses of bacteria and COD with the exception in TAN3 (positive and significant correlation). The negative correlations showed that there is general decrease in the levels of the COD as the masses of the immobilized bacteria increases. TAN2 (100\%) showed a very high correlation with the masses of the bacteria while TAN3 (36\%) showed a very low correlation.

Generally, there was an overall decrease in the concentration of these physicochemical parameters after the bioremediation using the different masses of the bacterial isolates. These might be due to the variations in the surface areas of the different masses of the immobilized bacteria. This is in line with the work of Jimoh et al. (2018) and Baba et al. (2020).

Table 3: Mean Values $(\mathrm{mg} / \mathrm{l}) \pm$ S.D of Physicochemical parameters in effluents from the Tannery Industries before and after Treatment of the effluents $(250 \mathrm{ml})$ with the different masses $(5 \mathrm{~g}, 10 \mathrm{~g}$, $15 \mathrm{~g}, 20 \mathrm{~g}$, and $25 \mathrm{~g}$ ) of the bacteria.

\begin{tabular}{llllllll}
\hline $\mathrm{P}$ & IND & Before & \multicolumn{5}{c}{ After } \\
\cline { 4 - 7 } & & & $5 \mathrm{~g}$ & $10 \mathrm{~g}$ & $15 \mathrm{~g}$ & $20 \mathrm{~g}$ & $25 \mathrm{~g}$ \\
\hline \multirow{2}{*}{ COD } & TAN1 & $2372 \pm 938$ & $1708 \mathrm{a} \pm 861$ & $2045 \mathrm{a} \pm 1205$ & $845 \mathrm{a} \pm 369$ & $300 \mathrm{a} \pm 167$ & $250 \mathrm{a} \pm 154$ \\
& TAN2 & $1406 \pm 208$ & $1195 \mathrm{a} \pm 208$ & $1125 \mathrm{a} \pm 384$ & $1055 \mathrm{a} \pm 317$ & $956 \mathrm{a} \pm 310$ & $870 \mathrm{ab} \pm 240$ \\
& TAN3 & $3532 \pm 1373$ & $2374 \mathrm{a} \pm 1344$ & $1976 \mathrm{a} \pm 1405$ & $2757 \mathrm{a} \pm 1266$ & $3134 \mathrm{a} \pm 1595$ & $2614 \mathrm{~b} \pm 1105$ \\
BOD & TAN1 & $13.85 \pm 6.42$ & $6.92 \mathrm{a} \pm 5.49$ & $6.42 \mathrm{a} \pm 5.07$ & $5.72 \mathrm{a} \pm 5.35$ & $4.62 \mathrm{a} \pm 4.37$ & $2.82 \mathrm{ab} \pm 1.26$ \\
& TAN2 & $19.46 \pm 0.50$ & $1.75 \mathrm{~b} \pm 0.22$ & $1.73 \mathrm{~b} \pm 0.18$ & $1.58 \mathrm{a} \pm 0.16$ & $1.91 \mathrm{a} \pm 0.22$ & $1.56 \mathrm{~b} \pm 0.20$ \\
& TAN3 & $17.13 \pm 3.14$ & $4.24 \mathrm{ab} \pm 0.77$ & $3.29 \mathrm{ab} \pm 0.37$ & $4.11 \mathrm{a} \pm 0.07$ & $3.23 \mathrm{a} \pm 0.91$ & $3.33 \mathrm{a} \pm 1.28$ \\
SS & TAN1 & $374 \pm 124$ & $243 \mathrm{a} \pm 45$ & $471 \mathrm{a} \pm 226$ & $475 \mathrm{a} \pm 182$ & $492 \mathrm{a} \pm 128$ & $611 \mathrm{a} \pm 217$ \\
& TAN2 & $358 \pm 335$ & $460 \mathrm{a} \pm 400$ & $543 \mathrm{a} \pm 414$ & $544 \mathrm{a} \pm 402$ & $551 \mathrm{a} \pm 414$ & $554 \mathrm{a} \pm 405$ \\
& TAN3 & $780 \pm 739$ & $586 \mathrm{a} \pm 594$ & $758 \mathrm{a} \pm 656$ & $787 \mathrm{a} \pm 676$ & $861 \mathrm{a} \pm 635$ & $898 \mathrm{a} \pm 672$ \\
TDS & TAN1 & $3941 \pm 3703$ & $51 \mathrm{a} \pm 10$ & $53 \mathrm{a} \pm 10$ & $55 \mathrm{a} \pm 15$ & $61 \mathrm{a} \pm 20$ & $63 \mathrm{a} \pm 26$ \\
& TAN2 & $3300 \pm 1714$ & $83 \mathrm{a} \pm 78$ & $47 \mathrm{a} \pm 20$ & $48 \mathrm{a} \pm 22$ & $47 \mathrm{a} \pm 17$ & $48 \mathrm{a} \pm 17$ \\
& TAN3 & $2653 \pm 1240$ & $46 \mathrm{a} \pm 11$ & $55 \mathrm{a} \pm 24$ & $55 \mathrm{a} \pm 25$ & $58 \mathrm{a} \pm 23$ & $61 \mathrm{a} \pm 28$ \\
\hline
\end{tabular}

Replicate $=6$ (months)

Within the rows, for the same parameter, means with different alphabets are statistically different $(p<0.05)$.

$\mathrm{P}=$ parameter, IND = Industries 
BAJOPAS Volume 13 Number 2, December, 2020

Table 4: Correlation coefficient $(r)$ between different masses of the bacteria and the physicochemical parameters.

\begin{tabular}{llll}
\hline Industries & Parameter & Correlation coefficient $(r)$ & $\begin{array}{l}\text { Percent dependence (rxrx100) } \\
(\%)\end{array}$ \\
\hline TAN1 & COD & -0.9 & 82 \\
& BOD & -0.97 & 94 \\
& SS & $0.90^{*}$ & 80 \\
TAN2 & TDS & $0.98^{*}$ & 96 \\
& COD & -1 & 100 \\
& BOD & -0.21 & 4 \\
& SS & $0.78^{*}$ & 61 \\
& TDS & -0.69 & 47 \\
& COD & $0.60^{*}$ & 36 \\
& BOD & -0.6 & 37 \\
& SS & $0.95^{*}$ & 90 \\
& TDS & $0.94^{*}$ & 89 \\
\hline
\end{tabular}

The correlation coefficient $(r)$ with * is statistically significant $(p<0.05)$.

Percentage reduction of the Parameters

Table 5 shows the percentage reduction of Parameters in industrial samples before and after the treatment of the effluents $(250 \mathrm{ml})$ with the different masses $(5 \mathrm{~g}, 10 \mathrm{~g}, 15 \mathrm{~g}, 20 \mathrm{~g}$, and $25 \mathrm{~g}$ ) of the Immobilized Bacteria.

In TAN1 samples, the percentage reduction (\%) of COD ranged (14-89); BOD (50-80); SS (-32$35)$ and TDS (98-99). In TAN2 samples, the percentage decrease $(\%)$ of COD ranged (15$38) ;$ BOD (90-92); SS [-28-(-55)] and TDS (9798). In TAN3 samples, the percentage decrease (\%) of COD ranged (11-44); BOD (76-81); SS (15-25) and TDS (98). The percentage increase in the levels COD, BOD and TDS might be due to the increase in the surface area of the different masses of the immobilized bacteria. However, the percentage decrease in the levels of the SS might be due to the aggregation of the TDS which are large enough to result into SS. The percentage decrease in the levels of the SS might be also due to the influence of the nutrients which was added into the effluents in order to make the microorganisms more active and viable for fast degradation of organic contaminants in the effluent. This is in line with the work of Jimoh et al. (2018) in which the concentration of the SS increase after the bioremediation of effluents.

Sreemoyee and Priti (2013) assessed and reduced several Physico-chemical parameters of dairy wastewater using Niesseria $s p$. and concluded that the species are well known to degrade organic compounds. This is in agreement with the current study in which the immobilized Niesseria $s p$ degrade the organic contaminants as indicated by the BOD, COD and TDS.

Jimoh et al. (2018) observed that TSS of the effluents was increased after treatment with immobilized bacteria and concluded that it might be due to the biostimulation method adopted for the research.

The optimum $\mathrm{pH}$ Biosorption of Chromium by Bacillus spp and Staphylococcus spp. from tannery effluent was investigated by Mythili and Karthikeyan (2011). The maximum adsorption of Chromium $(86.4 \mathrm{mg} / \mathrm{L})$ was showed by Bacillus spp and Staphylococcus spp showed $70.6 \mathrm{mg} / \mathrm{L}$ at an initial concentration of $100 \mathrm{mg} / \mathrm{L}$. In the present study, immobilised Bacillus spp and Staphylococcus spp. from the tannery industrial effluents reduced the levels of the organic pollutants with high potential as indicated by the percentage reduction of BOD, COD and TDS.

Enzymes often can work in multiple environments especially if they are immobilized. This makes the microorganisms' enzymes even more resistant to harsh environments and enables the enzymes to be recovered and recycled after they are no longer needed (Gianfreda and Rao 2004). Ramesh and Singh (1993) reported that the immobilized bacteria having more efficiency to remove the suspended particles than free cells. Using the immobilized cell is preferable due to its capability for using several times with the same efficiency, which makes it more economical. Similar work was done by Sikander et al. (2007) showing the higher reduction with permeabilized cells of Ochrobactrum intermedium strain SDCr-5. 
BAJOPAS Volume 13 Number 2, December, 2020

The results revealed the isolation and identification of isolates with the potential for the reduction of $\mathrm{Cr}$ (VI) to $\mathrm{Cr}$ (III). Results indicated that immobilized $B$. cereus could be efficiently used for the reduction of $\mathrm{Cr}$ (VI).

Table 5: Percentage reduction of the tested Parameters from the tannery industrial samples of the Immobilized Bacteria.

\begin{tabular}{lllllll}
\hline \multirow{2}{*}{ Industries } & & \multicolumn{5}{c}{ Percentage Reduction $(\%)$} \\
\cline { 3 - 7 } & & $5 \mathrm{~g}$ & $10 \mathrm{~g}$ & $15 \mathrm{~g}$ & $20 \mathrm{~g}$ & $25 \mathrm{~g}$ \\
\hline TAN1 & COD & 28 & 14 & 64 & 87 & 89 \\
& BOD & 50 & 54 & 59 & 67 & 80 \\
& SS & 35 & -26 & -27 & -32 & -63 \\
& TDS & 99 & 99 & 99 & 98 & 98 \\
TAN2 & COD & 15 & 20 & 25 & 32 & 38 \\
& BOD & 91 & 91 & 92 & 90 & 92 \\
& SS & -28 & -52 & -52 & -54 & -55 \\
& TDS & 97 & 99 & 99 & 99 & 99 \\
& COD & 33 & 44 & 22 & 11 & 26 \\
& BOD & 75 & 81 & 76 & 81 & 81 \\
& SS & 25 & 3 & -1 & -10 & -15 \\
& TDS & 98 & 98 & 98 & 98 & 98 \\
\hline
\end{tabular}

Percentage Reduction $=(B-A) / B \times 100 \%$

$A=$ Concentration of the parameter after treatment

$\mathrm{B}=$ Concentration of the parameter before treatment

$+=$ percentage decrease

- = percentage increase

In general, immobilization makes the enzyme more resistant to temperature, $\mathrm{pH}$, and substrate concentration swings giving it a longer lifetime and higher productivity per active unit (Gianfreda and Rao, 2004; FuIlbrook, 1996; Russell et al, 2003; Kandelbauer et al., 2004). Immobilized cells have been used and studied extensively for the production of useful chemicals (Ohtake and Silver, 1994), the treatment of wastewaters (Chen et al., 2003; Wang et al., 2010). Although many workers described microbial degradation of tannery effluent, limited literature is available on the bioremediation of tannery effluent using immobilized bacterial cells in the Kano Industrial Estates.

\section{CONCLUSION}

The samples contained variable levels of the physicochemical parameters. The results of the Analysis of variance revealed that, no statistical difference $(p<0.05)$ was observed for the temperature, $\mathrm{pH}, \mathrm{SS}, \mathrm{TDS}, \mathrm{BOD}$ and $\mathrm{COD}$ among the three tannery industries before the treatment. The levels of some of the parameters
(SS, TDS and COD) observed in the samples were found above the recommended limits of WHO and NESREA, which called for the treatment of the effluents before discharge into the environment. Base on the morphological and biochemical test results, TAN1, TAN2, and TAN3 bacterial isolates were identified to be Neisseria spp, Bacillus cereus, and Staphylococcus aureus respectively. The results of Post-treatment analysis showed that there is overall decrease in the levels of the parameters determined when compared with that of the pre-treatment. The overall percentage reduction of the immobilised bacteria in the treatment of the respective effluents was in the order TAN2 (72\%)>TAN1 $(70 \%)>$ TAN3 $(62 \%)$. Hence, the immobilized bacteria are having higher biodegradation potential for the treatment of the tannery effluents.

\section{Acknowledgments}

The authors wish to acknowledge the University of Maiduguri for the financial support. The authors are grateful to the Kano State Ministry of Environment for their support in obtaining the effluent samples. 


\section{REFERENCES}

Ajao, A. T., Adebayo, G. B., and Yakubu, S. E. (2011). Bioremediation of textile industrial effluent using mixed culture of Pseudomonas aeruginosa and Bacillus subtilis immobilized on agar-agar in a bioreactor. J. Microbiol. Biotech. Res, 1(3), 50-56.

Akan, J. C., Moses, E. A., Ogugbuaja, V. O., and Abah, J. (2007). Assessment of tannery industrial effluents from Kano metropolis, Kano State, Nigeria. Journal of Applied Sciences, 7(19), 2788-2793.

Akan, J. C., Ogugbuaja, V. O., Abdulrahman, F. I., and Ayodele, J. T. (2009). Pollutant levels in effluent samples from tanneries and textiles of Kano industrial areas, Nigeria. Global journal of pure and applied sciences, 15(3-4).

APHA (1989). Standard methods for Examination of Will bete and Will betewater.15 $5^{\text {th }}$ edition. Brydpass Springfield Will behington DC. pp. 164-176

APHA (1992). Standard Methods for the Examination of Water and Wastewater. Health, 69, 1116-9.

Baba, A., Garba, S. T., and Bello, H. S. (2020). Bioremediation Potential of Immobilized corynebacterium kutsceri in the Treatment of Tannery Industrial Effluent from Challawa Industrial Estate, Kano State, Nigeria. Journal of the Turkish Chemical Society Section A: Chemistry, $7(2), 335-350$.

Beem, E. I. V. (1994). reduction of solvent VOC emission. J. Oil Col. Chem. Ass, 77, 158.

Bouwer, E. J., and Zehnder, A. J. (1993). Bioremediation of organic compoundsputting microbial metabolism to work. Trends in biotechnology, 11(8), 360367.

Chen, K. C., Wu, J. Y., Liou, D. J., and Hwang, S. C. J. (2003). Decolorization of the textile dyes by newly isolated bacterial strains. Journal of Biotechnology, 101(1), 57-68.

Dan'Azumi, S., and Bichi, M. H. (2010). INDUSTRIAL POLLUTION AND HEAVY METALS PROFILE OF CHALLAWA RIVER IN KANO, NIGERIA. Journal of Applied Sciences in Environmental Sanitation, $5(1)$.

DWAF. (1992). Analytical Methods Manual, TR 151. Department of Water Affairs and Forestry, Pretoria.

El-Bestawy, E. (2013). Biological treatment of leather-tanning industrial wastewater using free living bacteria.
Elsheikh, M. A. S. (2009). Tannery wastewater pre-treatment. Water Science and Technology, 60(2), 433-440.

FuIlbrook, P. D. (1996). "Kinetics." Industrial enzymology: The application of enzymes in Industry. 2nd Ed. T. Godfrey and J Reichelt. eds.. Nature. New York.

Gianfreda, L., and Rao, M. A. (2004). Potential of extra cellular enzymes in remediation of polluted soils: a review. Enzyme and microbial technology, 35(4), 339354.

Hugo Springer. (1994). John Arthur Wilson Memorial Lecture "Treatment of Industrial Wastes of the Leather Industry - is it still a Major Problem". JALCA, 89, 153-185

Jimoh, A. A., Ganiyu, B. A., Baba, D., and Baba, A. (2018) Bioremediation Process of Effluent from Detergent and Food Industries in Jos, Nigeria: Kinetics and Thermodynamics. International Journal of Engineering Science Invention (IJESI), 762-73

Kandelbauer, A., Maute, O., Kessler, R. W., Erlacher, A., and Gübitz, G. M. (2004). Study of dye decolorization in an immobilized laccase enzyme-reactor using online spectroscopy. Biotechnology and bioengineering, 87(4), 552-563.

Kongjao, S., Damronglerd, S., and Hunsom, M. (2008). Simultaneous removal of organic and inorganic Pollutants in tannery wastewater using electrocoagulation technique. Korean Journal of chemical engineering, 25(4), 703.

Maheshwari, U. M., Aruna, S., Gomathi, M., and AbdulJaffar, A. H. (2017). Bioremediation by Free and Immobilized Bacteria Isolated from Tannery Effluent. International Journal of Research in Applied, Natural and Social Sciences. 5(7), 75-90

Margesin, R., and Schinner, F. (2001). Bioremediation (natural attenuation and biostimulation) of diesel-oilcontaminated soil in an alpine glacier skiing area. Applied and environmental microbiology, 677), 3127-3133.

Mohammed, A., Sekar, P., and George, J. (2011). Efficacy of microbes in bioremediation of tannery effluent. Inter. J. Curr. Res, 3(4), 324-326.

Mohammed, S. S. D., Orukotan, A. A., and Abdullahi, H. (2017). Physicochemical and Bacteriological Assessment of Tannery Effluent from Samaru-Zaria, 
BAJOPAS Volume 13 Number 2, December, 2020 Kaduna State, Nigeria. Journal of Applied

Sciences and Environmental Management, 21(4), 734-740.

Munz, G., De Angelis, D., Gori, R., Mori, G., Casarci, M., and Lubello, C. (2009). The role of tannins in conventional and membrane treatment of tannery wastewater. Journal of hazardous materials, 164(2-3), 733-739

Mythili, K., and Karthikeyan, B. (2011). Bioremediation of $\mathrm{Cr}$ (VI) from tannery effluent using Bacillus spp and Staphylococcus spp. International Multidisciplinary Research Journal, 1(6).

NESREA (2009). National Environmental Standards for Effluent Limitations and Regulation. 1233-1236

Noorjahan, C. M. (2014). Physicochemical characteristics, identification of bacteria and biodegradation of industrial effluent. Journal of bioremediation and Biodegradation, 5(3).

Ohtake, H. I., and Silver, A. O. (1994). Bacterial reduction of toxic chromate. Biological degradation and bioremediation of toxic chemicals, 403-415.

Omoleke, I. I. (2004). Management of environmental pollution in Ibadan, an African city: the challenges of health hazard facing government and the people. Journal of Human Ecology, 15(4), 265-275.

Rajor, A., Reddy, A.S., and Singh, B. (2004). Determination of BOD kinetic Parameters and evaluation of alternate methods, M.Sc. Thesis, Department of biotechnology \& environmental Science, Thapar Institute of Engineering and Technology, Patiala

Ramasami, T., Rajamani, S., and Rao, J. R. (1994, March). Pollution control in leather industry: Emerging technological options. In International symposium on surface and colloidal science and its relevance to soil pollution, madras.

Ramesh, J. V. S., and Singh, S. P. (1993). Yearly variation in certain physicochemical parameters of pond at eastern Doon Valley. Uttar Pradesh J. Zoo, 12 (1), 7577.

Ranen, S., and Sharadinadra, C. (2009). Biotechnology applications to environmental remediation in resource exploitation. Current science, 97, 6-25
Russell, A. J., Berberich, J. A., Drevon, G. F., and Koepsel, R. R. (2003). Biomaterials for mediation of

chemical and biological warfare agents. Annual review of biomedical engineering, 5(1), 1-27.

Saravanan, P., and Saravanan, A. (1999). Decolourization of tannery effluent by Flavobacterium sp. EK 1. Indian Journal of Environmental Protection, 19, 19-24.

Sikander, S., and Shahida, H. (2007). Reduction of toxic hexavalent chromium by Ochrobactrum intermedium strain SDCr5 stimulated by heavy metals. Bioresource Technol, 98, 340-344.

Singh, N., Sharma, B. K., and Bohra, P. C. (2000). Impact assessment of industrial effluent of arid soils by using satellite imageries. Journal of the Indian Society of Remote Sensing, 28(2-3), 79.

Sreemoyee, C., and Priti, P. (2013). Assessment of physico-chemical parameters of dairy waste water and isolation and characterization of bacterial strains in terms of cod reduction. Int J Sci, 2(3), 395-400.

Verheijen, L. A. H. M., Wiersema, D., Pol, L. H., and De Wit, J. (1996). Management of wastes from animal product processing. Livestock and environment, Finding a balance. International Agriculture Center, Wageningen, The Netherlands.

Wang, F., Yao, J., Si, Y., Chen, H., Russel, M., Chen, K., and Bramanti, E. (2010). Short-time effect of heavy metals upon microbial community activity. Journal of Hazardous Materials, 173(13), 510-516.

WHO (World Health Organization). (2006). Air quality guidelines: global update 2005: particulate matter, ozone, nitrogen dioxide, and sulfur dioxide. World Health Organization.

World Bank. (1995). Nigeria's strategic options for redressing industrial pollution. World Bank, industry and energy division. 1st edition, West Central Africa Department; Annexes: 1995; pp 60-62.

Zahoor, A., and Abdul, R. (2009). Enumeration of Coliforms. Journal of Environmental Sciences. 21, 814-820 


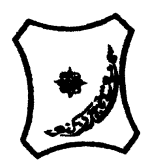

Bayero Journal of Pure and Applied Sciences, 13(2): 1 - 12

Received: November, 2020

Accepted: December, 2020

ISSN $2006-6996$

\title{
BIODEGRADATION POTENTIAL OF IMMOBILIZED BACTERIA IN THE TREATMENT OF TANNERY INDUSTRIAL EFFLUENTS FROM INDUSTRIAL ESTATES IN KANO STATE, NIGERIA
}

\author{
Abdullateef, B., ${ }^{1 *}$ Shuaibu, T. G., ${ }^{1}$ Babagana, K., ${ }^{1}$ Suleman, H. B. ${ }^{2}$ and Dauda, B. ${ }^{3}$ \\ ${ }^{1}$ Department of Pure and Applied Chemistry, Faculty of Science, University of Maiduguri, Borno State, \\ Nigeria \\ ${ }^{2}$ Department of Microbiology, Faculty of Science, University of Maiduguri, Borno State, Nigeria \\ ${ }^{3}$ Department of Chemical Engineering, Faculty of Engineering, University of Maiduguri, Borno State, \\ Nigeria \\ *Corresponding author: babslega@gmail.com; abelega2007@yahoo.com; +2348061309753
}

\section{ABSTRACT}

Industrial Effluents Samples from Gashash Tanneries (TAN1) in Bompai Industrial estate, Larabee Tannery Industry (TAN2) in Sharada Industrial estate and Z Tannery Industries (TAN3) in Challawa Industrial estate, Kano State, Nigeria were collected over a period of six months (August 2017 to January 2018) for assessing the biodegradation potentials of bacteria in the treatment of organic pollutants within the effluents. Bacteria were isolated from the effluents and immobilized on agar-agar. Different masses (5 g, $10 \mathrm{gr}, 15$ $\mathrm{g}, 20 \mathrm{~g}$, and $25 \mathrm{~g}$ ) of the bacteria were used in the treatment of $250 \mathrm{ml}$ of the effluents for ten days in a shaker incubator (Gallenkamp-OC-4364-L) at the temperature $30{ }^{\circ} \mathrm{C}$ and speed of $60 \mathrm{rpm}$. Pre-treatment analysis of the effluents for Temperature, pH, Biochemical Oxygen Demand (BOD), Chemical Oxygen Demand (COD), Suspended Solid (SS) and Total Dissolved Solids (TDS) gives the following results; temperature $\left({ }^{\circ} \mathrm{C}\right.$ )

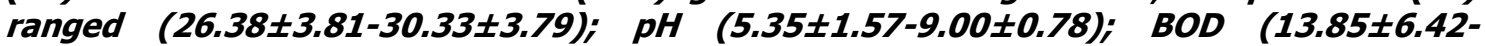
$38.75 \pm 16.20) ;$ COD (1406 $\pm 208-3532 \pm 1373) ;$ SS (208 $\pm 235-780 \pm 739)$ and TDS (266 $\pm 253-5276 \pm 2971)$. No statistical differences ( $p \leq 0.05)$ was observed for all the results among the different industries. The bacterial isolates were identified as Neisseria spp, Bacillus cereus, and Staphylococcus aureus, in TAN1, TAN2, and TAN3, respectively. After treatment of the effluent with the different masses of the isolated bacteria, the mean level of BOD was found to range as (0.55 $\pm 0.36-6.92 \pm 5.49) ; C O D$ (ND-3134 \pm 1595$)$;

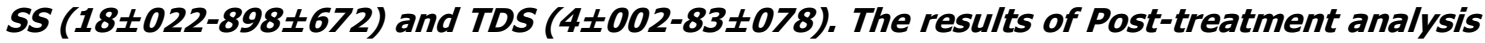
showed that there is overall decrease in the levels of the parameters determined when compared with that of the pre-treatment. The overall percentage reduction of the immobilised bacteria in the treatment of the respective effluents was in the order TAN2 (72\%)>TAN1 (70\%)>TAN3 (62\%). Hence, the immobilized bacteria are having higher biodegradation potential for the treatment of the tannery effluents.

Keywords: Biodegradation, bacteria, effluent, immobilization, tannery.

\section{INTRODUCTION}

Tannery industrial wastewater is a serious consequence of the pollution point of view for streams, freshwater, and land used for agriculture. The lack of awareness in the modern industrial practice has resulted in the discharge of tannery effluents which exhibit very high value of chromium ( $\mathrm{Cr}$ ), Sulfide, and chloride, Total Dissolved Solid (TDS), Total Suspended Solid (TSS), Biochemical Oxygen Demand (BOD) and Chemical Oxygen Demand (COD) in the water stream or land (Mohammed et al., 2001). Tanning is the process, which One ton of skin generally leads to the production of 20 to $80 \mathrm{~m}^{3}$ of turbid and foul-smelling converts the protein of the rawhide or skin into a stable material, which will not putrefy and is suitable for a wide variety of end applications (Elsheikh, 2009). The highly polluting chromium is the most commonly used tanning material producing leather that is more flexible and pliable than vegetable-tanned leather and does not discolor or lose shape in water as drastically as vegetable-tan (Elsheikh, 2009). Tannery effluent is among the most hazardous industrial pollutants due to its huge organic and inorganic load, which is highly toxic to human life and the environment (Kongjao et al., 2008). wastewater including chromium (100-400 mg/l), sulfide $(200-800 \mathrm{mg} / \mathrm{l})$, high levels of fat and 
BAJOPAS Volume 13 Number 2, December, 2020 other solid wastes, and notable pathogen contamination as well as pesticides added for skin conservation during transport (Elsheikh, 2009). There are more than 6000 tanneries in Nigeria with an annual processing capacity of 700,000 tons of hides and skins (Omoleke, 2004; Singh et al., 2008). It was reported that the total amount of waste produced per animal slaughtered is approximately $35 \%$ of its weight (World Bank, 1995). Also, for every $1000 \mathrm{~kg}$ of carcass weight, a slaughtered beef produces 5.5 $\mathrm{kg}$ of manure (excluding rumen contents or stockyard manure) and $100 \mathrm{~kg}$ of paunch manure (undigested food) (Verheijen et al., 1996). Tanneries generate wastewater in the range of 30-35 $\mathrm{L} \mathrm{kg}^{-1}$ skin/hide processed with variable $\mathrm{pH}$, Biological Oxygen Demand (BOD), Chemical Oxygen Demand (COD), high concentrations of suspended solids (SS), and tannins as well as chromium (Zahoor and Abdul, 2009).

Being heterogeneous and composed of a wide variety of compounds, it is very difficult to select a unique direct method for estimating the biodegradability of organic contents and biokinetic parameters for a wastewater sample (Rajor, 2004). For this purpose, some indirect estimation such as determination of biochemical oxygen demand (BOD) and chemical oxygen demand (COD) are applied as common laboratory investigations [9]. During retanning procedures, synthetic tannins (Syntan), oils and resins are added to form softer leather at varying doses (Munz et al., 2009). One of the refractory groups of chemicals in tannery effluents derives mainly from tannins (Ramasami et al., 2004). Syntans are characterized by complex chemical structures, because they are composed of an extended set of chemicals such as phenol-, naphthalene-, formaldehyde- and melamine-based syntans, and acrylic resins (Beem, 1994). Organic pollutants (proteic and lipidic components) are originated from skins (it is calculated that the raw skin has $30 \%$ loss of organic material during the working cycle) or they are introduced during processes (Hugo Springer, 1994).

Many conventional processes such as oxidation, chemical and biological processes were carried out to treat tanneries wastewater (Ebtesam et al, 2013). Biological processes have received more attention because of their costeffectiveness, lower sludge production and environmental friendliness (Noorjahan, 2014). Naturally occurring micro-organisms degrade the hazardous organic wastes including xenobiotic compounds, such as pesticides, polycyclic aromatic hydrocarbons (PAHs) and polychlorinated biphenyls (PCBs) in due course of time (Ranen and Sharadinadra, 2009). Bioremediation is based on the idea that all organisms remove substances from the environment to carry outgrowth and metabolism (Bouwer and Zehnder, 1993). Bacteria, protista and fungi are found to be very good at degrading complex molecules and incorporating the breakdown products into their metabolism (Bouwer and Zehnder, 1993). The resultant metabolic wastes that they produce are generally safe and somehow recycled into other organisms (Ranen and Sharadinadra, 2009). An acclimatized indigenous population of microorganisms capable of degradation of the compounds of interest must exist at the site for a successful bioremediation mode (Ranen and Sharadinadra, 2009). It has been observed that for a successful bioremediation mode, an acclimatized indigenous population of microorganisms capable of degradation of the compounds of interest must exist at the site under investigation (Ranen and Sharadinadra, 2009). Even though there are numerous physical and chemical methods employed in the disposal of wastes the advantage in using bacterium is that they play a key role in the reduction of COD, BOD, total protein, total tannin and total phenol (Saravanan and Saravanan, 1998)

Baba et al. (2020) studied the bioremediation potential of immobilized corynebacterium kutsceri in the Treatment of tannery industrial effluent from Challawa Industrial Estate, Kano State, Nigeria. The aim of the work is to study the reduction in the level of the contaminants through the process of bioremediation using the isolated bacteria. Immobilized bacteria can withstand various temperatures, $\mathrm{pH}$ and substrate concentrations; consequently, increasing the efficiency and the lifespan of the bacteria. Immobilized bacteria are widely applied in the treatment of wastewater and can be separated and recovered after the treatment with the same efficiency (Baba et al., 2020).

\section{MATERIALS AND METHODS \\ Study Area}

This study was carried out in Bompai, Sharada and Challawa industrial estates in Kano, Figure 1. Kano lies on Latitude $11^{\circ} 30^{\prime} \mathrm{N}$ and $8^{\circ} 30^{\prime} \mathrm{E}$ and Longitude $11^{\circ} 5^{\prime} \mathrm{N}$ and $8^{\circ} 5^{\prime} \mathrm{E}$ in Northern Nigeria. It is one of the developed industrial cities in Nigeria. Tannery activities are the dominating industries and this could be one of the reasons for her high population density (Dan'Azumi and Bichi, 2010). Many researchers have studied biodegradation of tannery effluent using microorganisms. However, limited literature is available on the biodegradation of tannery effluent in Kano industrial estates using 
BAJOPAS Volume 13 Number 2, December, 2020 immobilized bacterial cells. This research work focuses on the potential of the use of the indigenous immobilized bacterial isolates in the treatment of tannery effluents in the industrial estates.

\section{Sample Collection}

Effluents were collected from the Tannery Industries from Bompai, Challawa and Sharada Industrial Estates, Kano, Nigeria. The effluents were collected over a period of six months (August 2017 to January 2018). Samples collected in a sterile 4-liter plastic container with a unique identification number were preserved using an ice-box that was transported to the Microbiology Laboratory, Department of Microbiology, Bayero University of Kano for analysis

\section{Sample Preparation and Sample Analysis}

Immediately after the collection of the effluent, $\mathrm{pH}$, TSS, TDS, COD, BOD levels were determined before treatment (Pre-treatment determination) and ten days after treatment (Post-treatment determination) as described in
APHA (1989) standard methods. $\mathrm{pH}$ was determined using Ecotests $\mathrm{pH}$ meter and TDS was determined using AQUALYTIC TDS Salinometer. BOD was determined as described by the standard method (APHA, 1992). COD and SS were determined using DR/2010 HACH portable data logging spectrophotometer (DWAF, 1992)

\section{Identification and Biochemical} Characterization of the Bacterial Isolates

The bacteria were isolated from the effluents using Serial Dilution according to the method described by APHA (1989). The biochemical tests such as oxidase, catalase, coagulase, indole (from $1 \%$ tryptone broth), citrate (Simmons citrate agar), methyl red/VogesProskauer (MR/VP), nitrate reduction, Starch Hydrolysis, Glucose, Maltose, and Lactose tests were carried out on the bacterial isolates to identify the bacteria through the bacteria biochemical characteristics according to Ajao et al. (2011).

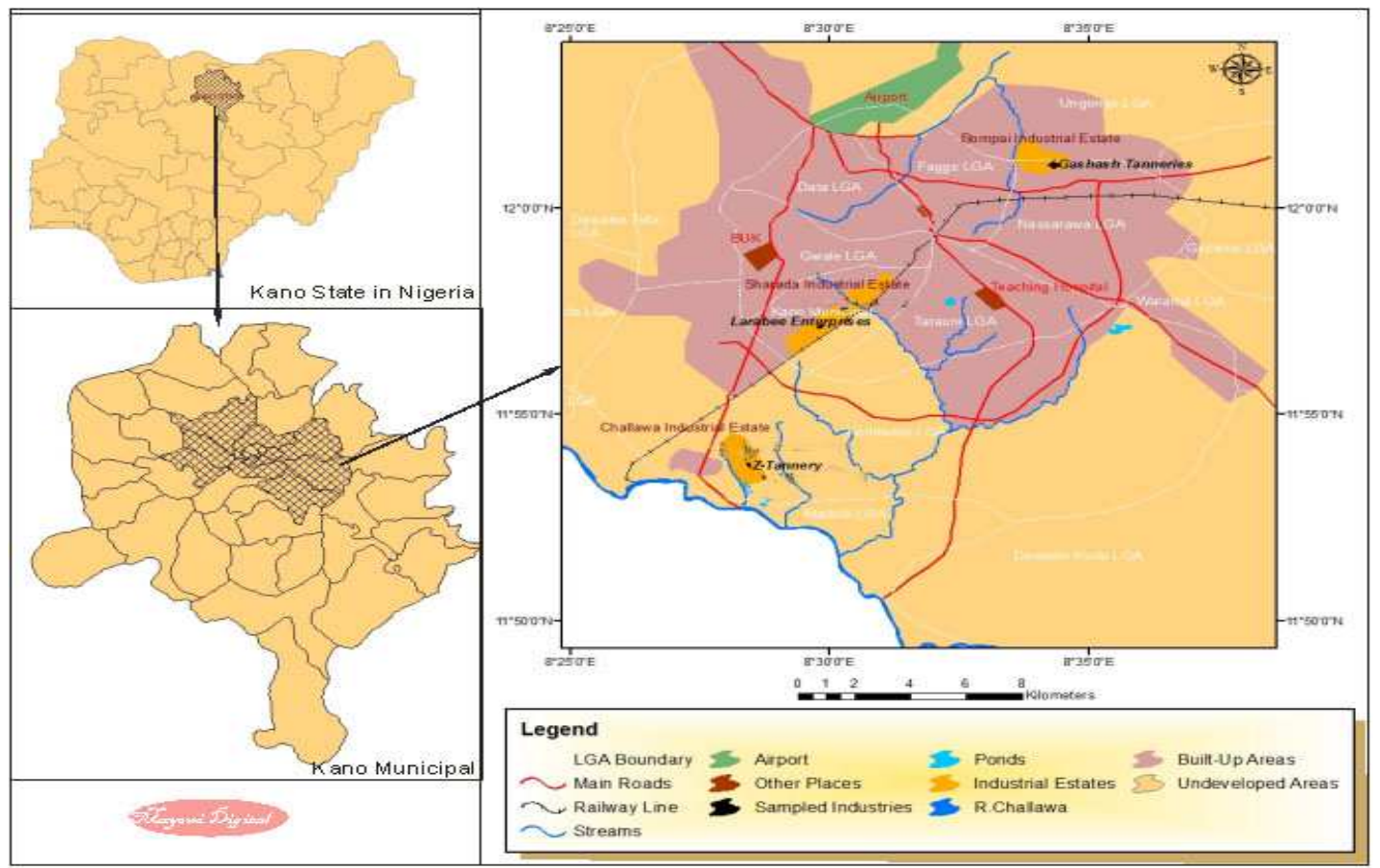

Fig. 1 Map showing the study areas

Source: Mayomi Digital Productions, GIS Laboratory, Department of Geography, UNIMAID (2017)

\section{Determination of Growth Rate of the Bacteria in Effluent Sample}

The bacteria growth rates were determined by transferring $2 \mathrm{~mL}$ of the bacterial isolates from the tannery effluent in broth medium into 100 $\mathrm{mL}$ sterile effluents in conical flasks and kept in an incubator (Giffrin cool) for 10 days. Control was also set up by incubating another $100 \mathrm{~mL}$ each of the sterile effluents without the bacteria. The optical density of the content was determined at the wavelength of $600 \mathrm{~nm}$ on a daily interval and recorded. 
BAJOPAS Volume 13 Number 2, December, 2020 Immobilization of Bacteria

Agar solution and inoculi were prepared separately. Fifty milliliters $(50 \mathrm{~mL})$ of nutrient broth each of the inoculi was prepared in a McCartney bottle and incubated for 24 hours. A solution of agar-agar was prepared by dissolving $10 \mathrm{~g}$ of the powder in distilled water and made up to $500 \mathrm{~mL}$ mark in an Erlenmeyer flask and was sterilized in an autoclave (280A) for 15 minutes and allowed to cool to $40-45^{\circ} \mathrm{C}$ (Ajao et al., 2011). Four milliliters ( $4 \mathrm{~mL})$ of the bacterial isolates in the nutrient broth was mixed with 36 $\mathrm{ml}$ of the prepared agar-agar media in petri-dish plates and then allowed to solidify. This was kept in the refrigerator for bioremediation.

\section{Bioremediation (Treatment) of the Effluents}

The solidified agar block (immobilized bacteria) was cut into cubes using a sterile knife; $0.1 \mathrm{~mL}$ phosphate buffer ( $\mathrm{pH} \mathrm{7.0)}$ was added and kept in the refrigerator for 1 hour for curing. The phosphate buffer was decanted after 1 hour and the cubes were washed with sterile distilled water 3-4 times before it was used (Ajao et al., 2011). Two liters (2 L) of the effluent was supplemented with the minimum basal medium in $\mathrm{g} / \mathrm{L}: \mathrm{NaCl}(0.8), \mathrm{MgSO}_{4} .7 \mathrm{H}_{2} \mathrm{O}(0.001), \mathrm{KH}_{2} \mathrm{PO}_{4}$ (2), $\mathrm{NaNO}_{3}$ (2), $\quad \mathrm{CaCl}_{2} .2 \mathrm{H}_{2} \mathrm{O} \quad(0.5)$ and $\mathrm{NaHPO}_{4} .12 \mathrm{H}_{2} \mathrm{O}(2)$ and sterilized in an autoclave at $121^{\circ} \mathrm{C}$ for 15 minutes (Margesin and Schinner, 2001). Two hundred and fifty milliliters $(250 \mathrm{~mL})$ of the effluents were transferred into different $250 \mathrm{ml}$ conical flasks. The content was covered with a cotton-wool ramped with foil paper to avoid contamination. Five grams $(5 \mathrm{~g})$ of the immobilized bacteria were quickly transferred into each of the effluents in the conical flasks in an inoculating chamber. The same procedures were carried out for the $10 \mathrm{~g}, 15 \mathrm{~g}, 20 \mathrm{~g}$ and 25 $\mathrm{g}$ of the immobilized bacteria in separate $250 \mathrm{~mL}$ effluents in conical flasks and agitated for ten days in a shaker incubator (Gallenkamp-OC4364-L) at a temperature $30^{\circ} \mathrm{C}$ and speed of 60 rpm. The treated effluent samples were taken on the tenth day and analyzed for the parameters $\mathrm{pH}$, SS, TDS, COD, and BOD, (Posttreatment determination) for the different grams of bacteria to evaluate and compare the biodegradation potential. (Baba et al., 2020).

\section{Statistical Analysis}

The data were represented as Mean \pm Standard deviation and analyzed statistically using oneway Analysis of Variance (ANOVA) and Tukey's HSD as Post Hoc Tests with the aid of SPSS 16.0. The correlation coefficient was also used to measure the strength of the relationship between the different masses of the bacteria and the parameters. All $\mathrm{p} \leq 0.05$ were considered as statistically significant.

\section{RESULTS AND DISCUSSION Physico-chemical parameters in the Industrial Effluents before the Biodegradation.}

Results of the Physico-chemical parameters in the industrial effluents before the Biodegradation is shown in table 1 . The mean temperatures $\left({ }^{\circ} \mathrm{C}\right)$ observed in TAN1, TAN2, and TAN3 samples were $28.07 \pm 0.65 ; 27.77 \pm 0.64$ and $26.38 \pm 3.81$ respectively. The order of the mean temperature of the samples from the three industries can be arranged as TAN1 > TAN2>TAN3. The temperature observed at TAN1, TAN2, and TAN3 samples were found below the WHO $\left(35^{\circ} \mathrm{C}\right)$ and NESREA $\left(40^{\circ} \mathrm{C}\right)$ limits. The low values of temperature might be due to the processes used at the time of sampling. High temperature brings down the solubility of gases in water that ultimately expresses as high BOD and COD. Statistical analysis shows that there is no significant difference $(p<0.05)$ between the mean values of temperature among the industries. This might be due to similar tannery activities involved in the tannery industries at the time of sampling. The average values of temperature observed in this present study are less than those observed by Akan et al. (2007), Akan et al. (2009) and Baba et al. (2020).

The mean level of $\mathrm{pH}$ observed in TAN1, TAN2 and TAN3, samples were $7.77 \pm 2.93$; $8.35 \pm 0.28$ and $7.52 \pm 0.76$ respectively. The order of the mean $\mathrm{pH}$ of the samples from the three industries can be arranged as TAN2> TAN1 $>$ TAN3. The $\mathrm{pH}$ of the samples falls within the WHO (7.0-8.5) and NESREA (6-9) standard limits. Statistical analysis shows that there is no significant difference $(p<0.05)$ between the mean values of $\mathrm{pH}$ among the industries. This might be due to similar tannery activities involved in the tannery industries at the time of sampling. Maheshwari et al. (2017) reported that the level of $\mathrm{pH}$ in the effluents from the tannery industry in Vaniyambadi, India was 6.5 which was lower than that observed in the present study. The $\mathrm{pH}$ in the effluents from the tannery industries in Kano and Kaduna were reported to be 7.64 and 6.89, respectively (Akan et al., 2007; Mohammed et al., 2017). The average values of $\mathrm{pH}$ observed in this present study are less than those observed by Mohammed et al. (2017) and Baba et al. (2020). The mean level of SS $(\mathrm{mg} / \mathrm{l})$ observed in TAN1, TAN2, and TAN3 samples were 374 \pm 124 ; $358 \pm 335$ and $780 \pm 739$ respectively. The order of the mean SS in the samples from the three industries can be arranged as TAN3 > TAN1 $>$ TAN2. 
The SS observed in the samples were far above the recommended standard limits of regulating bodies WHO $(30 \mathrm{mg} / \mathrm{l})$ and NESREA $(10 \mathrm{mg} / \mathrm{l})$. Statistical analysis shows that there is no significant difference $(p<0.05)$ between the mean values of SS among the industries. This might be due to similar tannery activities involved in the tannery industries at the time of sampling. The average values of SS observed in this present study are less than that observed $(3700 \pm 122 \mathrm{mg} / \mathrm{l})$ by Akan et al. (2009) for tanneries in Kano. Also, the average values of SS observed in this present study are less than that observed by Mohammed et al. (2017) and Baba et al. (2020) with the exception in TAN3.

The mean level of TDS (mg/l) observed in TAN1, TAN2, and TAN3 samples were $3941 \pm 3703$; $3300 \pm 1714$ and $2653 \pm 1240$ respectively. The order of the mean TDS in the samples from the three industries can be arranged as TAN1>TAN2>TAN3. The TDS observed in the samples were far above the recommended standard limits of WHO $(250 \mathrm{mg} / \mathrm{l})$ and NESREA $(500 \mathrm{mg} / \mathrm{l})$. Statistical analysis shows that there is no significant difference $(p<0.05)$ between the mean values of TDS among the industries. This might be due to similar tannery activities involved in the tannery industries at the time of sampling. TDS in the effluents from the tannery industries in Kano, Nigeria was reported to be $1281 \mathrm{mg} / \mathrm{l}$ (Akan et al., 2007). The average values of SS observed in this present study are less than those observed by Mohammed et al. (2017) and Baba et al. 2020)

The mean level of COD (mg/l) observed in TAN1, TAN2 and TAN3 samples seasons were $2372 \pm 938 ; \quad 1406 \pm 208$ and $3532 \pm 1373$ respectively. The order of the mean COD of the samples from the three industries can be arranged as TAN3>TAN1> TAN2. The COD observed in TAN1, TAN2 and TAN3 samples were far above the recommended standard limits of regulating bodies $\mathrm{WHO}(40 \mathrm{mg} / \mathrm{l})$ and NESREA (40 mg/l). Statistical analysis shows that there is no significant difference $(p<0.05)$ in COD among the industries. This might be due to similar tannery activities involved in the tannery industries as at the time of sampling. The Chemical Oxygen demand (COD) is the amount of oxygen, in $\mathrm{mg} / \mathrm{L}$, required for the degradation of the compound of wastewater to occur. In comparison, the average values of COD observed in this present study were higher than that observed by Mohammed et al. (2017) but lower than that observed by Baba et al. (2020).

The mean levels of BOD $(\mathrm{mg} / \mathrm{l})$ observed in TAN1, TAN2 and TAN3 samples were $13.85 \pm 6.42 ; \quad 19.46 \pm 0.50$ and $17.13 \pm 3.14$ respectively. The order of the mean BOD in the samples from the three industries can be arranged as TAN2>TAN3>TAN1. The BOD observed in TAN1, TAN2 and TAN3 samples were found below the recommended limits of NESREA (200 mg/l) but above WHO (10 mg/l). Statistical analysis shows that there is no significant difference $(p<0.05)$ between the mean values of BOD among the industries. This might be due to similar tannery activities involved in the tannery industries at the time of sampling. The low level of BOD recorded in this study is an indication of the low level of biodegradable organic solids in the effluent. The average values of BOD observed in this present study were lower than those observed by Mohammed et al. (2017) and Baba et al. (2020).

Table 1: Mean Values \pm S.D of Physico-chemical parameters of effluents from the Tannery Industries before Treatment.

\begin{tabular}{llllllll}
\hline Parameter & Tannery 1 & Tannery 2 & Tannery 3 & $\mathrm{a}$ & $\mathrm{b}$ & $\mathrm{c}$ & $\mathrm{d}$ \\
\cline { 2 - 7 } Temperature $\left({ }^{\circ} \mathrm{C}\right)$ & $28.07 \mathrm{a} \pm 0.65$ & $27.77 \mathrm{a} \pm 0.64$ & $26.38 \mathrm{a} \pm 3.81$ & & $29.50 \pm 4.68$ & 35 & 40 \\
pH & $7.77 \mathrm{a} \pm 2.93$ & $8.35 \mathrm{a} \pm 0.28$ & $7.52 \mathrm{a} \pm 0.76$ & 6.89 & $5.35 \pm 1.57$ & $7.0-8.5$ & $6.0-9.0$ \\
$\mathrm{COD}(\mathrm{mg} / \mathrm{l})$ & $2372 \mathrm{a} \pm 938$ & $1406 \mathrm{a} \pm 208$ & $3532 \mathrm{a} \pm 1373$ & 2.2 & $3106 \pm 2753$ & 40 & 40 \\
$\mathrm{BOD}(\mathrm{mg} / \mathrm{l})$ & $13.85 \mathrm{a} \pm 6.42$ & $19.46 \mathrm{a} \pm 0.50$ & $17.13 \mathrm{a} \pm 3.14$ & 1032 & $26.17 \pm 9.49$ & 10 & 200 \\
$\mathrm{SS}(\mathrm{mg} / \mathrm{l})$ & $374 \mathrm{a} \pm 124$ & $358 \mathrm{a} \pm 335$ & $780 \mathrm{a} \pm 739$ & 501 & $562 \pm 482$ & 30 & 10 \\
TDS $(\mathrm{mg} / \mathrm{l})$ & $3941 \mathrm{a} \pm 3703$ & $3300 \mathrm{a} \pm 1714$ & $2653 \mathrm{a} \pm 1240$ & 532.7 & $444 \pm 507$ & 250 & 500 \\
\hline
\end{tabular}

The values given in the table above are means of 6 replicate values, $\mathrm{n}=6$ ( 1 sample was taken monthly for 6 months). Within the rows, means with different alphabets are statistically different $(p<0.05)$. WHO: World Health Organisation. NESREA: National Environmental Standard and Regulatory Enforcement Agency. a = Mohammed et al.(2017), b = Baba et al. (2020), c = WHO (2006), $d=$ NESSRA (2009) 
BAJOPAS Volume 13 Number 2, December, 2020

Identification, Biochemical Characterization and growth rates of the Bacterial Isolates

Results of identification and biochemical characterization of the bacterial isolates were shown in table 2. After 24 hours of incubation, the nutrient agar media plates were checked for bacterial growth. The results showed the presence of different strains in the samples. The TAN1 bacteria isolate was found to be gramnegative cocci while TAN3 was gram-positive cocci. TAN2 bacteria isolate was found to be gram-positive, rod-shaped. TAN1, TAN2, and TAN3 bacteria isolates recorded positive results for spore former.

The results of the biochemical tests indicated that all the bacteria were positive for catalase, oxidase, citrate, maltose, glucose, lactose (negative in TAN1), mannitol (negative in TAN2), starch hydrolysis and coagulase (negative in TAN2) tests. The bacteria showed negative results for nitrate reduction, $M R$ (positive in TAN2), VP (positive in TAN1), Indole (positive in TAN2) tests. Base on the morphological and biochemical test results, TAN1, TAN2, and TAN3 bacteria isolates were identified to be Nesseria spp, Bacillus cereus, and Staphylococcus aureus respectively.

The growth rate of the TAN1, TAN2 and TAN3 Isolates were shown in figure 2. Generally, the optical density increase with the increase in time (day) and decrease as time goes on. The highest optical density was shown by bacillus cereus in TAN2 while the lowest was shown by Staphylococcus aureus in TAN3.

The initial growth phase of TAN1 Isolate bacteria occurred within 2-day of incubation as the growth rate increases up to the 6th-day incubation when the maximum growth was observed. Beyond the 6th day, the growth of the bacteria declined (which might be due to a shortage of nutrients in the effluents) until it reached its death phase (which might be due to the unavailability of nutrients in the effluents).

A similar trend of growth was also observed for TAN2 Isolate as the initial growth phase also occurred within 2-day of incubation but maximum growth rate observed on the 4th day of incubation. The stationary stage occurred between the 4th day and the 8th day. Beyond the 8th day, the growth of the bacteria declined (which might be due to a shortage of nutrients in the effluents) until it reached its death phase (which might be due to the unavailability of nutrients in the effluents).

The initial growth phase of TAN3 bacterial Isolate occurred within the 3-day incubation as the growth rate increases up to the 6th-day incubation when the maximum growth was observed. Beyond the 6th day, the growth of the bacteria declined (which might be due to a shortage of nutrients in the effluents) until it reached its death phase (which might be due to the unavailability of nutrients in the effluents).

Table 2: Morphological and Biochemical characteristics of bacterial isolates

\begin{tabular}{lllll} 
Bacterial Isolates & & TAN1 & TAN2 & TAN3 \\
\hline $\begin{array}{lllll}\text { Morphological } \\
\text { characteristics }\end{array}$ & Shape & Cocci & Rod & Cocci \\
& Spore & & & \\
& former & + & + & + \\
Gram & & & \\
Biochemical characteristics & reaction & - & + & + \\
& Citrate & + & + & + \\
& Catalase & + & + & + \\
& Coagulase & + & - & + \\
Starch & + & + & + \\
& Glucose & + & + & + \\
Oxidase & + & + & + \\
& Indo & - & + & - \\
Lactose & - & + & + \\
Manitol & + & - & + \\
Maltose & + & + & + \\
MR & - & + & - \\
VP & + & - & - \\
& Nitrate & - & - & - \\
Reduction & - Neisseria & Bacillus & Staphylococcus \\
& Bacterial & cereus & aureus \\
& name & spp & cas
\end{tabular}

+ = Positive; - = Negative; MR=Methyl Red; VP= Voges-Proskauer 


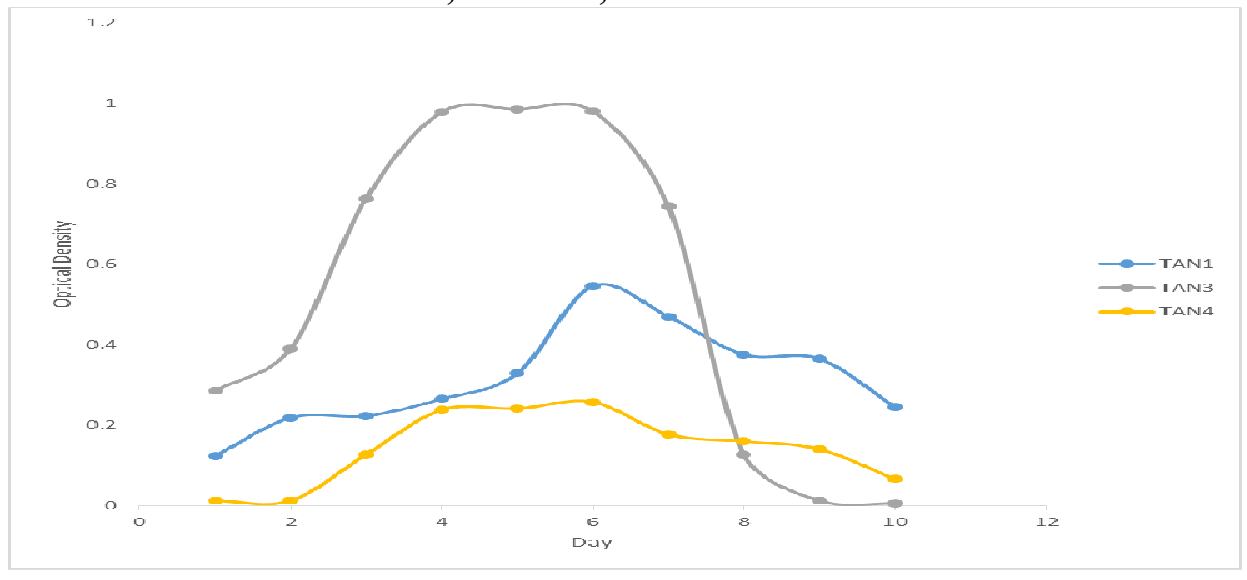

Fig. 2 Growth rates of the isolates in the effluents from the Tannery Industries

\section{Physico-chemical Parameters in the Industrial Effluents after the biodegradation.}

Table 3 shows the mean results of the physicochemical parameter before and after bioremediation using the different masses $(5 \mathrm{~g}$, $10 \mathrm{~g}, 15 \mathrm{~g}, 20 \mathrm{~g}$, and $25 \mathrm{~g}$ ) of the respective immobilized bacteria. Also, Table 4 shows the mean results of correlation coefficient ( $r$ ) between different masses of bacteria and physicochemical parameters.

The mean values $(\mathrm{mg} / \mathrm{l})$ of the SS after the bioremediation varies between $243 \pm 45$ and $898 \pm 672$. The mean concentration $(\mathrm{mg} / \mathrm{l})$ of SS remediated by the different masses $(5 \mathrm{~g}, 10 \mathrm{~g}$, $15 \mathrm{~g}, 20 \mathrm{~g}$, and $25 \mathrm{~g}$ ) of the bacteria varies. The SS in the samples fluctuates up and down after the bioremediation process when compared with the SS of the raw samples before the bioremediation. The increase in the levels of the SS might be due to the aggregation of the TDS which are large enough to result into SS. The increase in the levels of the SS might be also due to the influence of the nutrients which was added into the effluents in order to make the microorganisms more active and viable for fast degradation of organic contaminants in the effluent. The relative potential or efficiency of the different masses of the bacteria in remediating SS in TAN1 samples was in the order $25 \mathrm{~g}>20 \mathrm{~g}>15 \mathrm{~g}>10 \mathrm{~g}>5 \mathrm{~g}$. For TAN2 and TAN3 samples, the order was $25 \mathrm{~g}>20 \mathrm{~g}>15$ $\mathrm{g}>10 \mathrm{~g}>5 \mathrm{~g}$. These might be due to the variations in the surface areas of the different masses of the immobilized bacteria. Statistical analysis shows that there is no significant difference $(p<0.05)$ between the mean values of SS among the masses in the respective industries. Positive and significant correlations exist between the masses of bacteria and Suspended Solid (SS). This showed that there is general increase in the levels of the SS as the masses of the immobilized bacteria increases. TAN3 (90\%) and TAN1 (80\%) showed a very high correlation with the masses of the bacteria while TAN2 (61\%) showed a very low correlation.

The mean values $(\mathrm{mg} / \mathrm{l})$ of the TDS after the bioremediation varies between $46 \pm 11$ and $83 \pm 78$. The mean concentration $(\mathrm{mg} / \mathrm{l})$ of TDS remediated by the different masses $(5 \mathrm{~g}, 10 \mathrm{~g}$, $15 \mathrm{~g}, 20 \mathrm{~g}$, and $25 \mathrm{~g}$ ) of the bacteria varies. There is a reduction in all the TDS of all the samples after the bioremediation process compared with the TDS of the raw samples before the bioremediation. The relative potential or efficiency of the different masses of the bacteria in remediating TDS in TAN1 and TAN3 samples was in the order $5 \mathrm{~g}>10 \mathrm{~g}>15 \mathrm{~g}>20$ $\mathrm{g}>25 \mathrm{~g}$. For TAN2 samples, the order was 20 $g>10 \quad g>25 \quad g>15 \quad g>5 \quad g$. Statistical analysis shows that there is no significant difference $(p<0.05)$ between the mean values of TDS among the masses in the respective industries. These might be due to the variations in the surface areas of the different masses of the immobilized bacteria. Positive and significant correlations exist between the masses of bacteria and TDS with the exception in TAN2 (negative and insignificant correlation). The positive correlations showed that there is general increase in the levels of the TDS as the masses of the immobilized bacteria increases. TAN1 $(96 \%)$ showed a very high correlation with the masses of the bacteria while TAN2 (47\%) showed a very low correlation.

The mean values $(\mathrm{mg} / \mathrm{l})$ of the BOD after the bioremediation varies between $1.56 \pm 0.20 \mathrm{mg} / \mathrm{l}$ and $6.92 \pm 5.49 \mathrm{mg} / \mathrm{l}$. The mean concentration $(\mathrm{mg} / \mathrm{l})$ of BOD remediated by the different masses $(5 \mathrm{~g}, 10 \mathrm{~g}, 15 \mathrm{~g}, 20 \mathrm{~g}$, and $25 \mathrm{~g}$ ) of the bacteria varies. There is a reduction in all the BOD of all the samples after the bioremediation process compared with the $\mathrm{BOD}$ of the raw 
BAJOPAS Volume 13 Number 2, December, 2020 samples before the bioremediation. The relative potential or efficiency of the different masses of the bacteria in remediating BOD in TAN1, TAN2 and TAN3 samples were in the order $25 \mathrm{~g}>20$ $\mathrm{g}>15 \mathrm{~g}>10 \mathrm{~g}>5 \mathrm{~g}, 25 \mathrm{~g}>15 \mathrm{~g}>5 \mathrm{~g}>10 \mathrm{~g}>20 \mathrm{~g}$ and $20 \mathrm{~g}>10 \mathrm{~g}>25 \mathrm{~g}>15 \mathrm{~g}>5 \mathrm{~g}$ respectively. Statistical analysis shows that there is significant difference $(p<0.05)$ between the mean values of BOD among the masses in the respective industries. These might be due to the variations in the surface areas of the different masses of the immobilized bacteria. Negative and significant correlations exist between the masses of bacteria and BOD. This showed that there is general decrease in the levels of the BOD as the masses of the immobilized bacteria increases. TAN1 (94\%) showed a very high correlation with the masses of the bacteria while TAN2 (4\%) showed a very low correlation.

The mean values $(\mathrm{mg} / \mathrm{l})$ of the COD after the bioremediation varies between $250 \pm 154$ and $3134 \pm 1595$. The mean concentration $(\mathrm{mg} / \mathrm{l})$ of COD remediated by the different masses $(5 \mathrm{~g}$, $10 \mathrm{~g}, 15 \mathrm{~g} 20 \mathrm{~g}$, and $25 \mathrm{~g}$ ) of the bacteria varies. There is a reduction in all the COD of all the samples after the bioremediation process compared with the COD of the raw samples before the bioremediation. The relative potential or efficiency of the different masses of the bacteria in remediating COD in TAN1, TAN2 and TAN3 samples were in the order $25 \mathrm{~g}>20 \mathrm{~g}>15$ $\mathrm{g}>5 \mathrm{~g}>10 \mathrm{~g}, 25 \mathrm{~g}>20 \mathrm{~g}>15 \mathrm{~g}>10 \mathrm{~g}>5 \mathrm{~g}$ and 10 g>5 g>25 g>15 g>20 g respectively. Statistical analysis shows that there were significant difference $(p<0.05)$ between the mean values of COD among the masses in the respective industries except for effluents treated with $25 \mathrm{~g}$. These might be due to the variations in the surface areas of the different masses of the immobilized bacteria. Negative and insignificant correlations exist between the masses of bacteria and COD with the exception in TAN3 (positive and significant correlation). The negative correlations showed that there is general decrease in the levels of the COD as the masses of the immobilized bacteria increases. TAN2 (100\%) showed a very high correlation with the masses of the bacteria while TAN3 (36\%) showed a very low correlation.

Generally, there was an overall decrease in the concentration of these physicochemical parameters after the bioremediation using the different masses of the bacterial isolates. These might be due to the variations in the surface areas of the different masses of the immobilized bacteria. This is in line with the work of Jimoh et al. (2018) and Baba et al. (2020).

Table 3: Mean Values $(\mathrm{mg} / \mathrm{l}) \pm$ S.D of Physicochemical parameters in effluents from the Tannery Industries before and after Treatment of the effluents $(250 \mathrm{ml})$ with the different masses $(5 \mathrm{~g}, 10 \mathrm{~g}$, $15 \mathrm{~g}, 20 \mathrm{~g}$, and $25 \mathrm{~g}$ ) of the bacteria.

\begin{tabular}{llllllll}
\hline $\mathrm{P}$ & IND & Before & \multicolumn{5}{c}{ After } \\
\cline { 4 - 7 } & & & $5 \mathrm{~g}$ & $10 \mathrm{~g}$ & $15 \mathrm{~g}$ & $20 \mathrm{~g}$ & $25 \mathrm{~g}$ \\
\hline \multirow{2}{*}{ COD } & TAN1 & $2372 \pm 938$ & $1708 \mathrm{a} \pm 861$ & $2045 \mathrm{a} \pm 1205$ & $845 \mathrm{a} \pm 369$ & $300 \mathrm{a} \pm 167$ & $250 \mathrm{a} \pm 154$ \\
& TAN2 & $1406 \pm 208$ & $1195 \mathrm{a} \pm 208$ & $1125 \mathrm{a} \pm 384$ & $1055 \mathrm{a} \pm 317$ & $956 \mathrm{a} \pm 310$ & $870 \mathrm{ab} \pm 240$ \\
& TAN3 & $3532 \pm 1373$ & $2374 \mathrm{a} \pm 1344$ & $1976 \mathrm{a} \pm 1405$ & $2757 \mathrm{a} \pm 1266$ & $3134 \mathrm{a} \pm 1595$ & $2614 \mathrm{~b} \pm 1105$ \\
BOD & TAN1 & $13.85 \pm 6.42$ & $6.92 \mathrm{a} \pm 5.49$ & $6.42 \mathrm{a} \pm 5.07$ & $5.72 \mathrm{a} \pm 5.35$ & $4.62 \mathrm{a} \pm 4.37$ & $2.82 \mathrm{ab} \pm 1.26$ \\
& TAN2 & $19.46 \pm 0.50$ & $1.75 \mathrm{~b} \pm 0.22$ & $1.73 \mathrm{~b} \pm 0.18$ & $1.58 \mathrm{a} \pm 0.16$ & $1.91 \mathrm{a} \pm 0.22$ & $1.56 \mathrm{~b} \pm 0.20$ \\
& TAN3 & $17.13 \pm 3.14$ & $4.24 \mathrm{ab} \pm 0.77$ & $3.29 \mathrm{ab} \pm 0.37$ & $4.11 \mathrm{a} \pm 0.07$ & $3.23 \mathrm{a} \pm 0.91$ & $3.33 \mathrm{a} \pm 1.28$ \\
SS & TAN1 & $374 \pm 124$ & $243 \mathrm{a} \pm 45$ & $471 \mathrm{a} \pm 226$ & $475 \mathrm{a} \pm 182$ & $492 \mathrm{a} \pm 128$ & $611 \mathrm{a} \pm 217$ \\
& TAN2 & $358 \pm 335$ & $460 \mathrm{a} \pm 400$ & $543 \mathrm{a} \pm 414$ & $544 \mathrm{a} \pm 402$ & $551 \mathrm{a} \pm 414$ & $554 \mathrm{a} \pm 405$ \\
& TAN3 & $780 \pm 739$ & $586 \mathrm{a} \pm 594$ & $758 \mathrm{a} \pm 656$ & $787 \mathrm{a} \pm 676$ & $861 \mathrm{a} \pm 635$ & $898 \mathrm{a} \pm 672$ \\
TDS & TAN1 & $3941 \pm 3703$ & $51 \mathrm{a} \pm 10$ & $53 \mathrm{a} \pm 10$ & $55 \mathrm{a} \pm 15$ & $61 \mathrm{a} \pm 20$ & $63 \mathrm{a} \pm 26$ \\
& TAN2 & $3300 \pm 1714$ & $83 \mathrm{a} \pm 78$ & $47 \mathrm{a} \pm 20$ & $48 \mathrm{a} \pm 22$ & $47 \mathrm{a} \pm 17$ & $48 \mathrm{a} \pm 17$ \\
& TAN3 & $2653 \pm 1240$ & $46 \mathrm{a} \pm 11$ & $55 \mathrm{a} \pm 24$ & $55 \mathrm{a} \pm 25$ & $58 \mathrm{a} \pm 23$ & $61 \mathrm{a} \pm 28$ \\
\hline
\end{tabular}

Replicate $=6$ (months)

Within the rows, for the same parameter, means with different alphabets are statistically different $(p<0.05)$.

$\mathrm{P}=$ parameter, IND = Industries 
BAJOPAS Volume 13 Number 2, December, 2020

Table 4: Correlation coefficient $(r)$ between different masses of the bacteria and the physicochemical parameters.

\begin{tabular}{llll}
\hline Industries & Parameter & Correlation coefficient $(r)$ & $\begin{array}{l}\text { Percent dependence (rxrx100) } \\
(\%)\end{array}$ \\
\hline TAN1 & COD & -0.9 & 82 \\
& BOD & -0.97 & 94 \\
& SS & $0.90^{*}$ & 80 \\
TAN2 & TDS & $0.98^{*}$ & 96 \\
& COD & -1 & 100 \\
& BOD & -0.21 & 4 \\
& SS & $0.78^{*}$ & 61 \\
& TDS & -0.69 & 47 \\
& COD & $0.60^{*}$ & 36 \\
& BOD & -0.6 & 37 \\
& SS & $0.95^{*}$ & 90 \\
& TDS & $0.94^{*}$ & 89 \\
\hline
\end{tabular}

The correlation coefficient $(r)$ with * is statistically significant $(p<0.05)$.

Percentage reduction of the Parameters

Table 5 shows the percentage reduction of Parameters in industrial samples before and after the treatment of the effluents $(250 \mathrm{ml})$ with the different masses $(5 \mathrm{~g}, 10 \mathrm{~g}, 15 \mathrm{~g}, 20 \mathrm{~g}$, and $25 \mathrm{~g}$ ) of the Immobilized Bacteria.

In TAN1 samples, the percentage reduction (\%) of COD ranged (14-89); BOD (50-80); SS (-32$35)$ and TDS (98-99). In TAN2 samples, the percentage decrease $(\%)$ of COD ranged (15$38) ;$ BOD (90-92); SS [-28-(-55)] and TDS (9798). In TAN3 samples, the percentage decrease (\%) of COD ranged (11-44); BOD (76-81); SS (15-25) and TDS (98). The percentage increase in the levels COD, BOD and TDS might be due to the increase in the surface area of the different masses of the immobilized bacteria. However, the percentage decrease in the levels of the SS might be due to the aggregation of the TDS which are large enough to result into SS. The percentage decrease in the levels of the SS might be also due to the influence of the nutrients which was added into the effluents in order to make the microorganisms more active and viable for fast degradation of organic contaminants in the effluent. This is in line with the work of Jimoh et al. (2018) in which the concentration of the SS increase after the bioremediation of effluents.

Sreemoyee and Priti (2013) assessed and reduced several Physico-chemical parameters of dairy wastewater using Niesseria $s p$. and concluded that the species are well known to degrade organic compounds. This is in agreement with the current study in which the immobilized Niesseria $s p$ degrade the organic contaminants as indicated by the BOD, COD and TDS.

Jimoh et al. (2018) observed that TSS of the effluents was increased after treatment with immobilized bacteria and concluded that it might be due to the biostimulation method adopted for the research.

The optimum $\mathrm{pH}$ Biosorption of Chromium by Bacillus spp and Staphylococcus spp. from tannery effluent was investigated by Mythili and Karthikeyan (2011). The maximum adsorption of Chromium $(86.4 \mathrm{mg} / \mathrm{L})$ was showed by Bacillus spp and Staphylococcus spp showed $70.6 \mathrm{mg} / \mathrm{L}$ at an initial concentration of $100 \mathrm{mg} / \mathrm{L}$. In the present study, immobilised Bacillus spp and Staphylococcus spp. from the tannery industrial effluents reduced the levels of the organic pollutants with high potential as indicated by the percentage reduction of BOD, COD and TDS.

Enzymes often can work in multiple environments especially if they are immobilized. This makes the microorganisms' enzymes even more resistant to harsh environments and enables the enzymes to be recovered and recycled after they are no longer needed (Gianfreda and Rao 2004). Ramesh and Singh (1993) reported that the immobilized bacteria having more efficiency to remove the suspended particles than free cells. Using the immobilized cell is preferable due to its capability for using several times with the same efficiency, which makes it more economical. Similar work was done by Sikander et al. (2007) showing the higher reduction with permeabilized cells of Ochrobactrum intermedium strain SDCr-5. 
BAJOPAS Volume 13 Number 2, December, 2020

The results revealed the isolation and identification of isolates with the potential for the reduction of $\mathrm{Cr}$ (VI) to $\mathrm{Cr}$ (III). Results indicated that immobilized $B$. cereus could be efficiently used for the reduction of $\mathrm{Cr}$ (VI).

Table 5: Percentage reduction of the tested Parameters from the tannery industrial samples of the Immobilized Bacteria.

\begin{tabular}{lllllll}
\hline \multirow{2}{*}{ Industries } & & \multicolumn{5}{c}{ Percentage Reduction $(\%)$} \\
\cline { 3 - 7 } & & $5 \mathrm{~g}$ & $10 \mathrm{~g}$ & $15 \mathrm{~g}$ & $20 \mathrm{~g}$ & $25 \mathrm{~g}$ \\
\hline TAN1 & COD & 28 & 14 & 64 & 87 & 89 \\
& BOD & 50 & 54 & 59 & 67 & 80 \\
& SS & 35 & -26 & -27 & -32 & -63 \\
& TDS & 99 & 99 & 99 & 98 & 98 \\
TAN2 & COD & 15 & 20 & 25 & 32 & 38 \\
& BOD & 91 & 91 & 92 & 90 & 92 \\
& SS & -28 & -52 & -52 & -54 & -55 \\
& TDS & 97 & 99 & 99 & 99 & 99 \\
& COD & 33 & 44 & 22 & 11 & 26 \\
& BOD & 75 & 81 & 76 & 81 & 81 \\
& SS & 25 & 3 & -1 & -10 & -15 \\
& TDS & 98 & 98 & 98 & 98 & 98 \\
\hline
\end{tabular}

Percentage Reduction $=(B-A) / B \times 100 \%$

$A=$ Concentration of the parameter after treatment

$\mathrm{B}=$ Concentration of the parameter before treatment

$+=$ percentage decrease

- = percentage increase

In general, immobilization makes the enzyme more resistant to temperature, $\mathrm{pH}$, and substrate concentration swings giving it a longer lifetime and higher productivity per active unit (Gianfreda and Rao, 2004; FuIlbrook, 1996; Russell et al, 2003; Kandelbauer et al., 2004). Immobilized cells have been used and studied extensively for the production of useful chemicals (Ohtake and Silver, 1994), the treatment of wastewaters (Chen et al., 2003; Wang et al., 2010). Although many workers described microbial degradation of tannery effluent, limited literature is available on the bioremediation of tannery effluent using immobilized bacterial cells in the Kano Industrial Estates.

\section{CONCLUSION}

The samples contained variable levels of the physicochemical parameters. The results of the Analysis of variance revealed that, no statistical difference $(p<0.05)$ was observed for the temperature, $\mathrm{pH}, \mathrm{SS}, \mathrm{TDS}, \mathrm{BOD}$ and $\mathrm{COD}$ among the three tannery industries before the treatment. The levels of some of the parameters
(SS, TDS and COD) observed in the samples were found above the recommended limits of WHO and NESREA, which called for the treatment of the effluents before discharge into the environment. Base on the morphological and biochemical test results, TAN1, TAN2, and TAN3 bacterial isolates were identified to be Neisseria spp, Bacillus cereus, and Staphylococcus aureus respectively. The results of Post-treatment analysis showed that there is overall decrease in the levels of the parameters determined when compared with that of the pre-treatment. The overall percentage reduction of the immobilised bacteria in the treatment of the respective effluents was in the order TAN2 (72\%)>TAN1 $(70 \%)>$ TAN3 $(62 \%)$. Hence, the immobilized bacteria are having higher biodegradation potential for the treatment of the tannery effluents.

\section{Acknowledgments}

The authors wish to acknowledge the University of Maiduguri for the financial support. The authors are grateful to the Kano State Ministry of Environment for their support in obtaining the effluent samples. 


\section{REFERENCES}

Ajao, A. T., Adebayo, G. B., and Yakubu, S. E. (2011). Bioremediation of textile industrial effluent using mixed culture of Pseudomonas aeruginosa and Bacillus subtilis immobilized on agar-agar in a bioreactor. J. Microbiol. Biotech. Res, 1(3), 50-56.

Akan, J. C., Moses, E. A., Ogugbuaja, V. O., and Abah, J. (2007). Assessment of tannery industrial effluents from Kano metropolis, Kano State, Nigeria. Journal of Applied Sciences, 7(19), 2788-2793.

Akan, J. C., Ogugbuaja, V. O., Abdulrahman, F. I., and Ayodele, J. T. (2009). Pollutant levels in effluent samples from tanneries and textiles of Kano industrial areas, Nigeria. Global journal of pure and applied sciences, 15(3-4).

APHA (1989). Standard methods for Examination of Will bete and Will betewater.15 $5^{\text {th }}$ edition. Brydpass Springfield Will behington DC. pp. 164-176

APHA (1992). Standard Methods for the Examination of Water and Wastewater. Health, 69, 1116-9.

Baba, A., Garba, S. T., and Bello, H. S. (2020). Bioremediation Potential of Immobilized corynebacterium kutsceri in the Treatment of Tannery Industrial Effluent from Challawa Industrial Estate, Kano State, Nigeria. Journal of the Turkish Chemical Society Section A: Chemistry, $7(2), 335-350$.

Beem, E. I. V. (1994). reduction of solvent VOC emission. J. Oil Col. Chem. Ass, 77, 158.

Bouwer, E. J., and Zehnder, A. J. (1993). Bioremediation of organic compoundsputting microbial metabolism to work. Trends in biotechnology, 11(8), 360367.

Chen, K. C., Wu, J. Y., Liou, D. J., and Hwang, S. C. J. (2003). Decolorization of the textile dyes by newly isolated bacterial strains. Journal of Biotechnology, 101(1), 57-68.

Dan'Azumi, S., and Bichi, M. H. (2010). INDUSTRIAL POLLUTION AND HEAVY METALS PROFILE OF CHALLAWA RIVER IN KANO, NIGERIA. Journal of Applied Sciences in Environmental Sanitation, $5(1)$.

DWAF. (1992). Analytical Methods Manual, TR 151. Department of Water Affairs and Forestry, Pretoria.

El-Bestawy, E. (2013). Biological treatment of leather-tanning industrial wastewater using free living bacteria.
Elsheikh, M. A. S. (2009). Tannery wastewater pre-treatment. Water Science and Technology, 60(2), 433-440.

FuIlbrook, P. D. (1996). "Kinetics." Industrial enzymology: The application of enzymes in Industry. 2nd Ed. T. Godfrey and J Reichelt. eds.. Nature. New York.

Gianfreda, L., and Rao, M. A. (2004). Potential of extra cellular enzymes in remediation of polluted soils: a review. Enzyme and microbial technology, 35(4), 339354.

Hugo Springer. (1994). John Arthur Wilson Memorial Lecture "Treatment of Industrial Wastes of the Leather Industry - is it still a Major Problem". JALCA, 89, 153-185

Jimoh, A. A., Ganiyu, B. A., Baba, D., and Baba, A. (2018) Bioremediation Process of Effluent from Detergent and Food Industries in Jos, Nigeria: Kinetics and Thermodynamics. International Journal of Engineering Science Invention (IJESI), 762-73

Kandelbauer, A., Maute, O., Kessler, R. W., Erlacher, A., and Gübitz, G. M. (2004). Study of dye decolorization in an immobilized laccase enzyme-reactor using online spectroscopy. Biotechnology and bioengineering, 87(4), 552-563.

Kongjao, S., Damronglerd, S., and Hunsom, M. (2008). Simultaneous removal of organic and inorganic Pollutants in tannery wastewater using electrocoagulation technique. Korean Journal of chemical engineering, 25(4), 703.

Maheshwari, U. M., Aruna, S., Gomathi, M., and AbdulJaffar, A. H. (2017). Bioremediation by Free and Immobilized Bacteria Isolated from Tannery Effluent. International Journal of Research in Applied, Natural and Social Sciences. 5(7), 75-90

Margesin, R., and Schinner, F. (2001). Bioremediation (natural attenuation and biostimulation) of diesel-oilcontaminated soil in an alpine glacier skiing area. Applied and environmental microbiology, 677), 3127-3133.

Mohammed, A., Sekar, P., and George, J. (2011). Efficacy of microbes in bioremediation of tannery effluent. Inter. J. Curr. Res, 3(4), 324-326.

Mohammed, S. S. D., Orukotan, A. A., and Abdullahi, H. (2017). Physicochemical and Bacteriological Assessment of Tannery Effluent from Samaru-Zaria, 
BAJOPAS Volume 13 Number 2, December, 2020 Kaduna State, Nigeria. Journal of Applied

Sciences and Environmental Management, 21(4), 734-740.

Munz, G., De Angelis, D., Gori, R., Mori, G., Casarci, M., and Lubello, C. (2009). The role of tannins in conventional and membrane treatment of tannery wastewater. Journal of hazardous materials, 164(2-3), 733-739

Mythili, K., and Karthikeyan, B. (2011). Bioremediation of $\mathrm{Cr}$ (VI) from tannery effluent using Bacillus spp and Staphylococcus spp. International Multidisciplinary Research Journal, 1(6).

NESREA (2009). National Environmental Standards for Effluent Limitations and Regulation. 1233-1236

Noorjahan, C. M. (2014). Physicochemical characteristics, identification of bacteria and biodegradation of industrial effluent. Journal of bioremediation and Biodegradation, 5(3).

Ohtake, H. I., and Silver, A. O. (1994). Bacterial reduction of toxic chromate. Biological degradation and bioremediation of toxic chemicals, 403-415.

Omoleke, I. I. (2004). Management of environmental pollution in Ibadan, an African city: the challenges of health hazard facing government and the people. Journal of Human Ecology, 15(4), 265-275.

Rajor, A., Reddy, A.S., and Singh, B. (2004). Determination of BOD kinetic Parameters and evaluation of alternate methods, M.Sc. Thesis, Department of biotechnology \& environmental Science, Thapar Institute of Engineering and Technology, Patiala

Ramasami, T., Rajamani, S., and Rao, J. R. (1994, March). Pollution control in leather industry: Emerging technological options. In International symposium on surface and colloidal science and its relevance to soil pollution, madras.

Ramesh, J. V. S., and Singh, S. P. (1993). Yearly variation in certain physicochemical parameters of pond at eastern Doon Valley. Uttar Pradesh J. Zoo, 12 (1), 7577.

Ranen, S., and Sharadinadra, C. (2009). Biotechnology applications to environmental remediation in resource exploitation. Current science, 97, 6-25
Russell, A. J., Berberich, J. A., Drevon, G. F., and Koepsel, R. R. (2003). Biomaterials for mediation of

chemical and biological warfare agents. Annual review of biomedical engineering, 5(1), 1-27.

Saravanan, P., and Saravanan, A. (1999). Decolourization of tannery effluent by Flavobacterium sp. EK 1. Indian Journal of Environmental Protection, 19, 19-24.

Sikander, S., and Shahida, H. (2007). Reduction of toxic hexavalent chromium by Ochrobactrum intermedium strain SDCr5 stimulated by heavy metals. Bioresource Technol, 98, 340-344.

Singh, N., Sharma, B. K., and Bohra, P. C. (2000). Impact assessment of industrial effluent of arid soils by using satellite imageries. Journal of the Indian Society of Remote Sensing, 28(2-3), 79.

Sreemoyee, C., and Priti, P. (2013). Assessment of physico-chemical parameters of dairy waste water and isolation and characterization of bacterial strains in terms of cod reduction. Int J Sci, 2(3), 395-400.

Verheijen, L. A. H. M., Wiersema, D., Pol, L. H., and De Wit, J. (1996). Management of wastes from animal product processing. Livestock and environment, Finding a balance. International Agriculture Center, Wageningen, The Netherlands.

Wang, F., Yao, J., Si, Y., Chen, H., Russel, M., Chen, K., and Bramanti, E. (2010). Short-time effect of heavy metals upon microbial community activity. Journal of Hazardous Materials, 173(13), 510-516.

WHO (World Health Organization). (2006). Air quality guidelines: global update 2005: particulate matter, ozone, nitrogen dioxide, and sulfur dioxide. World Health Organization.

World Bank. (1995). Nigeria's strategic options for redressing industrial pollution. World Bank, industry and energy division. 1st edition, West Central Africa Department; Annexes: 1995; pp 60-62.

Zahoor, A., and Abdul, R. (2009). Enumeration of Coliforms. Journal of Environmental Sciences. 21, 814-820 


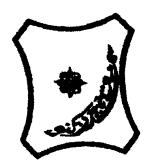

Bayero Journal of Pure and Applied Sciences, 13(2): 1 - 12

Received: November, 2020

Accepted: December, 2020

ISSN $2006-6996$

\title{
BIODEGRADATION POTENTIAL OF IMMOBILIZED BACTERIA IN THE TREATMENT OF TANNERY INDUSTRIAL EFFLUENTS FROM INDUSTRIAL ESTATES IN KANO STATE, NIGERIA
}

\author{
Abdullateef, B., ${ }^{1 *}$ Shuaibu, T. G., ${ }^{1}$ Babagana, K., ${ }^{1}$ Suleman, H. B. ${ }^{2}$ and Dauda, B. ${ }^{3}$ \\ ${ }^{1}$ Department of Pure and Applied Chemistry, Faculty of Science, University of Maiduguri, Borno State, \\ Nigeria \\ ${ }^{2}$ Department of Microbiology, Faculty of Science, University of Maiduguri, Borno State, Nigeria \\ ${ }^{3}$ Department of Chemical Engineering, Faculty of Engineering, University of Maiduguri, Borno State, \\ Nigeria \\ *Corresponding author: babslega@gmail.com; abelega2007@yahoo.com; +2348061309753
}

\section{ABSTRACT}

Industrial Effluents Samples from Gashash Tanneries (TAN1) in Bompai Industrial estate, Larabee Tannery Industry (TAN2) in Sharada Industrial estate and Z Tannery Industries (TAN3) in Challawa Industrial estate, Kano State, Nigeria were collected over a period of six months (August 2017 to January 2018) for assessing the biodegradation potentials of bacteria in the treatment of organic pollutants within the effluents. Bacteria were isolated from the effluents and immobilized on agar-agar. Different masses (5 g, $10 \mathrm{gr}, 15$ $\mathrm{g}, 20 \mathrm{~g}$, and $25 \mathrm{~g}$ ) of the bacteria were used in the treatment of $250 \mathrm{ml}$ of the effluents for ten days in a shaker incubator (Gallenkamp-OC-4364-L) at the temperature $30{ }^{\circ} \mathrm{C}$ and speed of $60 \mathrm{rpm}$. Pre-treatment analysis of the effluents for Temperature, pH, Biochemical Oxygen Demand (BOD), Chemical Oxygen Demand (COD), Suspended Solid (SS) and Total Dissolved Solids (TDS) gives the following results; temperature $\left({ }^{\circ} \mathrm{C}\right.$ )

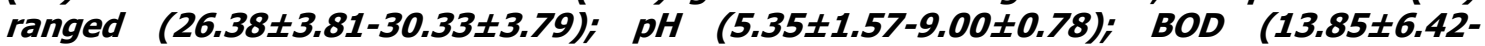
$38.75 \pm 16.20) ;$ COD (1406 $\pm 208-3532 \pm 1373) ;$ SS (208 $\pm 235-780 \pm 739)$ and TDS (266 $\pm 253-5276 \pm 2971)$. No statistical differences ( $p \leq 0.05)$ was observed for all the results among the different industries. The bacterial isolates were identified as Neisseria spp, Bacillus cereus, and Staphylococcus aureus, in TAN1, TAN2, and TAN3, respectively. After treatment of the effluent with the different masses of the isolated bacteria, the mean level of BOD was found to range as (0.55 $\pm 0.36-6.92 \pm 5.49) ; C O D$ (ND-3134 \pm 1595$)$;

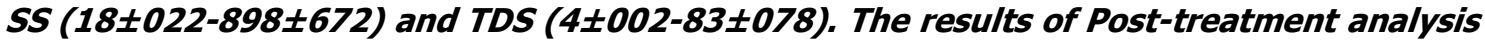
showed that there is overall decrease in the levels of the parameters determined when compared with that of the pre-treatment. The overall percentage reduction of the immobilised bacteria in the treatment of the respective effluents was in the order TAN2 (72\%)>TAN1 (70\%)>TAN3 (62\%). Hence, the immobilized bacteria are having higher biodegradation potential for the treatment of the tannery effluents.

Keywords: Biodegradation, bacteria, effluent, immobilization, tannery.

\section{INTRODUCTION}

Tannery industrial wastewater is a serious consequence of the pollution point of view for streams, freshwater, and land used for agriculture. The lack of awareness in the modern industrial practice has resulted in the discharge of tannery effluents which exhibit very high value of chromium ( $\mathrm{Cr}$ ), Sulfide, and chloride, Total Dissolved Solid (TDS), Total Suspended Solid (TSS), Biochemical Oxygen Demand (BOD) and Chemical Oxygen Demand (COD) in the water stream or land (Mohammed et al., 2001). Tanning is the process, which One ton of skin generally leads to the production of 20 to $80 \mathrm{~m}^{3}$ of turbid and foul-smelling converts the protein of the rawhide or skin into a stable material, which will not putrefy and is suitable for a wide variety of end applications (Elsheikh, 2009). The highly polluting chromium is the most commonly used tanning material producing leather that is more flexible and pliable than vegetable-tanned leather and does not discolor or lose shape in water as drastically as vegetable-tan (Elsheikh, 2009). Tannery effluent is among the most hazardous industrial pollutants due to its huge organic and inorganic load, which is highly toxic to human life and the environment (Kongjao et al., 2008). wastewater including chromium (100-400 mg/l), sulfide $(200-800 \mathrm{mg} / \mathrm{l})$, high levels of fat and 
BAJOPAS Volume 13 Number 2, December, 2020 other solid wastes, and notable pathogen contamination as well as pesticides added for skin conservation during transport (Elsheikh, 2009). There are more than 6000 tanneries in Nigeria with an annual processing capacity of 700,000 tons of hides and skins (Omoleke, 2004; Singh et al., 2008). It was reported that the total amount of waste produced per animal slaughtered is approximately $35 \%$ of its weight (World Bank, 1995). Also, for every $1000 \mathrm{~kg}$ of carcass weight, a slaughtered beef produces 5.5 $\mathrm{kg}$ of manure (excluding rumen contents or stockyard manure) and $100 \mathrm{~kg}$ of paunch manure (undigested food) (Verheijen et al., 1996). Tanneries generate wastewater in the range of 30-35 $\mathrm{L} \mathrm{kg}^{-1}$ skin/hide processed with variable $\mathrm{pH}$, Biological Oxygen Demand (BOD), Chemical Oxygen Demand (COD), high concentrations of suspended solids (SS), and tannins as well as chromium (Zahoor and Abdul, 2009).

Being heterogeneous and composed of a wide variety of compounds, it is very difficult to select a unique direct method for estimating the biodegradability of organic contents and biokinetic parameters for a wastewater sample (Rajor, 2004). For this purpose, some indirect estimation such as determination of biochemical oxygen demand (BOD) and chemical oxygen demand (COD) are applied as common laboratory investigations [9]. During retanning procedures, synthetic tannins (Syntan), oils and resins are added to form softer leather at varying doses (Munz et al., 2009). One of the refractory groups of chemicals in tannery effluents derives mainly from tannins (Ramasami et al., 2004). Syntans are characterized by complex chemical structures, because they are composed of an extended set of chemicals such as phenol-, naphthalene-, formaldehyde- and melamine-based syntans, and acrylic resins (Beem, 1994). Organic pollutants (proteic and lipidic components) are originated from skins (it is calculated that the raw skin has $30 \%$ loss of organic material during the working cycle) or they are introduced during processes (Hugo Springer, 1994).

Many conventional processes such as oxidation, chemical and biological processes were carried out to treat tanneries wastewater (Ebtesam et al, 2013). Biological processes have received more attention because of their costeffectiveness, lower sludge production and environmental friendliness (Noorjahan, 2014). Naturally occurring micro-organisms degrade the hazardous organic wastes including xenobiotic compounds, such as pesticides, polycyclic aromatic hydrocarbons (PAHs) and polychlorinated biphenyls (PCBs) in due course of time (Ranen and Sharadinadra, 2009). Bioremediation is based on the idea that all organisms remove substances from the environment to carry outgrowth and metabolism (Bouwer and Zehnder, 1993). Bacteria, protista and fungi are found to be very good at degrading complex molecules and incorporating the breakdown products into their metabolism (Bouwer and Zehnder, 1993). The resultant metabolic wastes that they produce are generally safe and somehow recycled into other organisms (Ranen and Sharadinadra, 2009). An acclimatized indigenous population of microorganisms capable of degradation of the compounds of interest must exist at the site for a successful bioremediation mode (Ranen and Sharadinadra, 2009). It has been observed that for a successful bioremediation mode, an acclimatized indigenous population of microorganisms capable of degradation of the compounds of interest must exist at the site under investigation (Ranen and Sharadinadra, 2009). Even though there are numerous physical and chemical methods employed in the disposal of wastes the advantage in using bacterium is that they play a key role in the reduction of COD, BOD, total protein, total tannin and total phenol (Saravanan and Saravanan, 1998)

Baba et al. (2020) studied the bioremediation potential of immobilized corynebacterium kutsceri in the Treatment of tannery industrial effluent from Challawa Industrial Estate, Kano State, Nigeria. The aim of the work is to study the reduction in the level of the contaminants through the process of bioremediation using the isolated bacteria. Immobilized bacteria can withstand various temperatures, $\mathrm{pH}$ and substrate concentrations; consequently, increasing the efficiency and the lifespan of the bacteria. Immobilized bacteria are widely applied in the treatment of wastewater and can be separated and recovered after the treatment with the same efficiency (Baba et al., 2020).

\section{MATERIALS AND METHODS \\ Study Area}

This study was carried out in Bompai, Sharada and Challawa industrial estates in Kano, Figure 1. Kano lies on Latitude $11^{\circ} 30^{\prime} \mathrm{N}$ and $8^{\circ} 30^{\prime} \mathrm{E}$ and Longitude $11^{\circ} 5^{\prime} \mathrm{N}$ and $8^{\circ} 5^{\prime} \mathrm{E}$ in Northern Nigeria. It is one of the developed industrial cities in Nigeria. Tannery activities are the dominating industries and this could be one of the reasons for her high population density (Dan'Azumi and Bichi, 2010). Many researchers have studied biodegradation of tannery effluent using microorganisms. However, limited literature is available on the biodegradation of tannery effluent in Kano industrial estates using 
BAJOPAS Volume 13 Number 2, December, 2020 immobilized bacterial cells. This research work focuses on the potential of the use of the indigenous immobilized bacterial isolates in the treatment of tannery effluents in the industrial estates.

\section{Sample Collection}

Effluents were collected from the Tannery Industries from Bompai, Challawa and Sharada Industrial Estates, Kano, Nigeria. The effluents were collected over a period of six months (August 2017 to January 2018). Samples collected in a sterile 4-liter plastic container with a unique identification number were preserved using an ice-box that was transported to the Microbiology Laboratory, Department of Microbiology, Bayero University of Kano for analysis

\section{Sample Preparation and Sample Analysis}

Immediately after the collection of the effluent, $\mathrm{pH}$, TSS, TDS, COD, BOD levels were determined before treatment (Pre-treatment determination) and ten days after treatment (Post-treatment determination) as described in
APHA (1989) standard methods. $\mathrm{pH}$ was determined using Ecotests $\mathrm{pH}$ meter and TDS was determined using AQUALYTIC TDS Salinometer. BOD was determined as described by the standard method (APHA, 1992). COD and SS were determined using DR/2010 HACH portable data logging spectrophotometer (DWAF, 1992)

\section{Identification and Biochemical} Characterization of the Bacterial Isolates

The bacteria were isolated from the effluents using Serial Dilution according to the method described by APHA (1989). The biochemical tests such as oxidase, catalase, coagulase, indole (from $1 \%$ tryptone broth), citrate (Simmons citrate agar), methyl red/VogesProskauer (MR/VP), nitrate reduction, Starch Hydrolysis, Glucose, Maltose, and Lactose tests were carried out on the bacterial isolates to identify the bacteria through the bacteria biochemical characteristics according to Ajao et al. (2011).

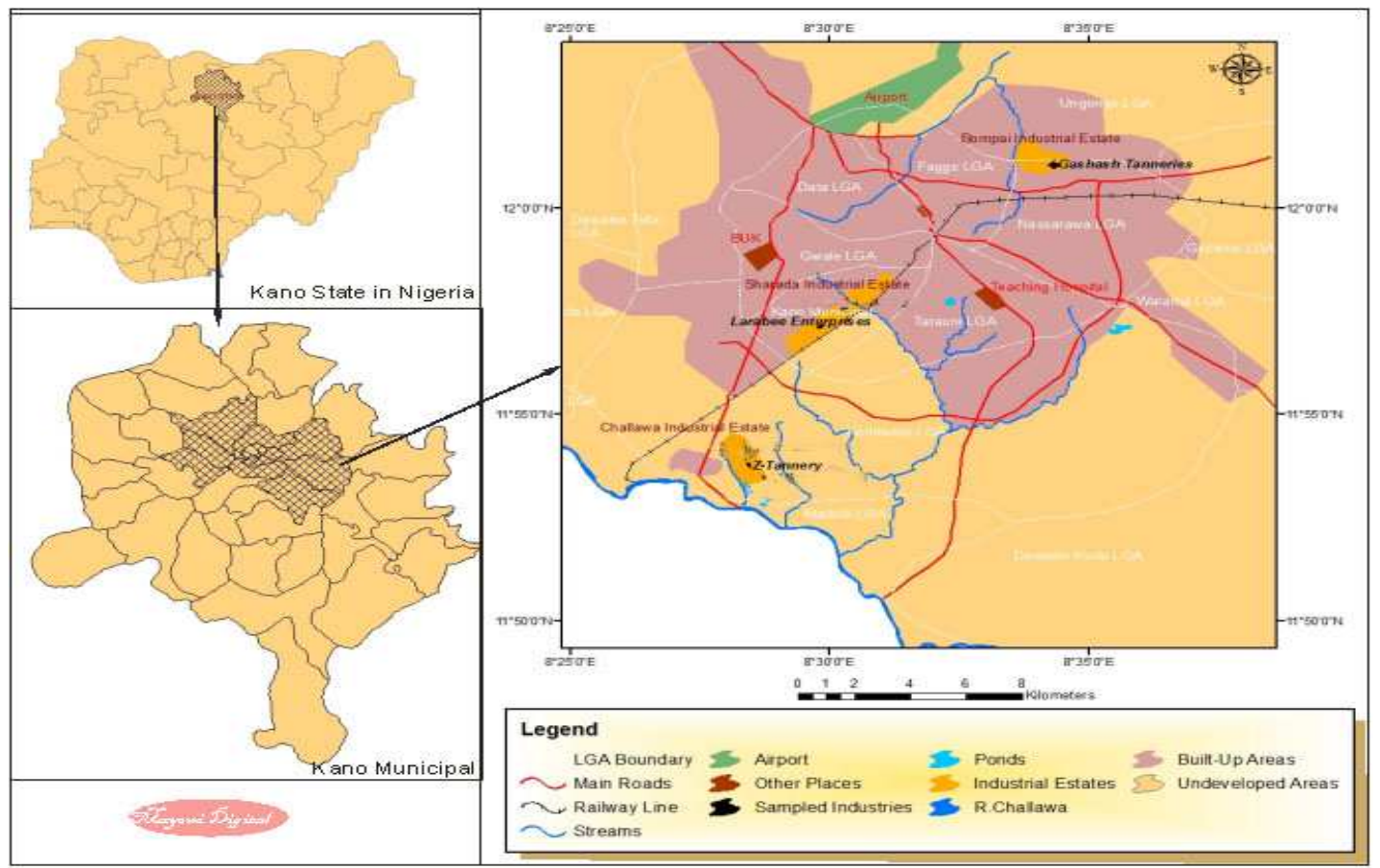

Fig. 1 Map showing the study areas

Source: Mayomi Digital Productions, GIS Laboratory, Department of Geography, UNIMAID (2017)

\section{Determination of Growth Rate of the Bacteria in Effluent Sample}

The bacteria growth rates were determined by transferring $2 \mathrm{~mL}$ of the bacterial isolates from the tannery effluent in broth medium into 100 $\mathrm{mL}$ sterile effluents in conical flasks and kept in an incubator (Giffrin cool) for 10 days. Control was also set up by incubating another $100 \mathrm{~mL}$ each of the sterile effluents without the bacteria. The optical density of the content was determined at the wavelength of $600 \mathrm{~nm}$ on a daily interval and recorded. 
BAJOPAS Volume 13 Number 2, December, 2020 Immobilization of Bacteria

Agar solution and inoculi were prepared separately. Fifty milliliters $(50 \mathrm{~mL})$ of nutrient broth each of the inoculi was prepared in a McCartney bottle and incubated for 24 hours. A solution of agar-agar was prepared by dissolving $10 \mathrm{~g}$ of the powder in distilled water and made up to $500 \mathrm{~mL}$ mark in an Erlenmeyer flask and was sterilized in an autoclave (280A) for 15 minutes and allowed to cool to $40-45^{\circ} \mathrm{C}$ (Ajao et al., 2011). Four milliliters ( $4 \mathrm{~mL})$ of the bacterial isolates in the nutrient broth was mixed with 36 $\mathrm{ml}$ of the prepared agar-agar media in petri-dish plates and then allowed to solidify. This was kept in the refrigerator for bioremediation.

\section{Bioremediation (Treatment) of the Effluents}

The solidified agar block (immobilized bacteria) was cut into cubes using a sterile knife; $0.1 \mathrm{~mL}$ phosphate buffer ( $\mathrm{pH} \mathrm{7.0)}$ was added and kept in the refrigerator for 1 hour for curing. The phosphate buffer was decanted after 1 hour and the cubes were washed with sterile distilled water 3-4 times before it was used (Ajao et al., 2011). Two liters (2 L) of the effluent was supplemented with the minimum basal medium in $\mathrm{g} / \mathrm{L}: \mathrm{NaCl}(0.8), \mathrm{MgSO}_{4} .7 \mathrm{H}_{2} \mathrm{O}(0.001), \mathrm{KH}_{2} \mathrm{PO}_{4}$ (2), $\mathrm{NaNO}_{3}$ (2), $\quad \mathrm{CaCl}_{2} .2 \mathrm{H}_{2} \mathrm{O} \quad(0.5)$ and $\mathrm{NaHPO}_{4} .12 \mathrm{H}_{2} \mathrm{O}(2)$ and sterilized in an autoclave at $121^{\circ} \mathrm{C}$ for 15 minutes (Margesin and Schinner, 2001). Two hundred and fifty milliliters $(250 \mathrm{~mL})$ of the effluents were transferred into different $250 \mathrm{ml}$ conical flasks. The content was covered with a cotton-wool ramped with foil paper to avoid contamination. Five grams $(5 \mathrm{~g})$ of the immobilized bacteria were quickly transferred into each of the effluents in the conical flasks in an inoculating chamber. The same procedures were carried out for the $10 \mathrm{~g}, 15 \mathrm{~g}, 20 \mathrm{~g}$ and 25 $\mathrm{g}$ of the immobilized bacteria in separate $250 \mathrm{~mL}$ effluents in conical flasks and agitated for ten days in a shaker incubator (Gallenkamp-OC4364-L) at a temperature $30^{\circ} \mathrm{C}$ and speed of 60 rpm. The treated effluent samples were taken on the tenth day and analyzed for the parameters $\mathrm{pH}$, SS, TDS, COD, and BOD, (Posttreatment determination) for the different grams of bacteria to evaluate and compare the biodegradation potential. (Baba et al., 2020).

\section{Statistical Analysis}

The data were represented as Mean \pm Standard deviation and analyzed statistically using oneway Analysis of Variance (ANOVA) and Tukey's HSD as Post Hoc Tests with the aid of SPSS 16.0. The correlation coefficient was also used to measure the strength of the relationship between the different masses of the bacteria and the parameters. All $\mathrm{p} \leq 0.05$ were considered as statistically significant.

\section{RESULTS AND DISCUSSION Physico-chemical parameters in the Industrial Effluents before the Biodegradation.}

Results of the Physico-chemical parameters in the industrial effluents before the Biodegradation is shown in table 1 . The mean temperatures $\left({ }^{\circ} \mathrm{C}\right)$ observed in TAN1, TAN2, and TAN3 samples were $28.07 \pm 0.65 ; 27.77 \pm 0.64$ and $26.38 \pm 3.81$ respectively. The order of the mean temperature of the samples from the three industries can be arranged as TAN1 > TAN2>TAN3. The temperature observed at TAN1, TAN2, and TAN3 samples were found below the WHO $\left(35^{\circ} \mathrm{C}\right)$ and NESREA $\left(40^{\circ} \mathrm{C}\right)$ limits. The low values of temperature might be due to the processes used at the time of sampling. High temperature brings down the solubility of gases in water that ultimately expresses as high BOD and COD. Statistical analysis shows that there is no significant difference $(p<0.05)$ between the mean values of temperature among the industries. This might be due to similar tannery activities involved in the tannery industries at the time of sampling. The average values of temperature observed in this present study are less than those observed by Akan et al. (2007), Akan et al. (2009) and Baba et al. (2020).

The mean level of $\mathrm{pH}$ observed in TAN1, TAN2 and TAN3, samples were $7.77 \pm 2.93$; $8.35 \pm 0.28$ and $7.52 \pm 0.76$ respectively. The order of the mean $\mathrm{pH}$ of the samples from the three industries can be arranged as TAN2> TAN1 $>$ TAN3. The $\mathrm{pH}$ of the samples falls within the WHO (7.0-8.5) and NESREA (6-9) standard limits. Statistical analysis shows that there is no significant difference $(p<0.05)$ between the mean values of $\mathrm{pH}$ among the industries. This might be due to similar tannery activities involved in the tannery industries at the time of sampling. Maheshwari et al. (2017) reported that the level of $\mathrm{pH}$ in the effluents from the tannery industry in Vaniyambadi, India was 6.5 which was lower than that observed in the present study. The $\mathrm{pH}$ in the effluents from the tannery industries in Kano and Kaduna were reported to be 7.64 and 6.89, respectively (Akan et al., 2007; Mohammed et al., 2017). The average values of $\mathrm{pH}$ observed in this present study are less than those observed by Mohammed et al. (2017) and Baba et al. (2020). The mean level of SS $(\mathrm{mg} / \mathrm{l})$ observed in TAN1, TAN2, and TAN3 samples were 374 \pm 124 ; $358 \pm 335$ and $780 \pm 739$ respectively. The order of the mean SS in the samples from the three industries can be arranged as TAN3 > TAN1 $>$ TAN2. 
The SS observed in the samples were far above the recommended standard limits of regulating bodies WHO $(30 \mathrm{mg} / \mathrm{l})$ and NESREA $(10 \mathrm{mg} / \mathrm{l})$. Statistical analysis shows that there is no significant difference $(p<0.05)$ between the mean values of SS among the industries. This might be due to similar tannery activities involved in the tannery industries at the time of sampling. The average values of SS observed in this present study are less than that observed $(3700 \pm 122 \mathrm{mg} / \mathrm{l})$ by Akan et al. (2009) for tanneries in Kano. Also, the average values of SS observed in this present study are less than that observed by Mohammed et al. (2017) and Baba et al. (2020) with the exception in TAN3.

The mean level of TDS (mg/l) observed in TAN1, TAN2, and TAN3 samples were $3941 \pm 3703$; $3300 \pm 1714$ and $2653 \pm 1240$ respectively. The order of the mean TDS in the samples from the three industries can be arranged as TAN1>TAN2>TAN3. The TDS observed in the samples were far above the recommended standard limits of WHO $(250 \mathrm{mg} / \mathrm{l})$ and NESREA $(500 \mathrm{mg} / \mathrm{l})$. Statistical analysis shows that there is no significant difference $(p<0.05)$ between the mean values of TDS among the industries. This might be due to similar tannery activities involved in the tannery industries at the time of sampling. TDS in the effluents from the tannery industries in Kano, Nigeria was reported to be $1281 \mathrm{mg} / \mathrm{l}$ (Akan et al., 2007). The average values of SS observed in this present study are less than those observed by Mohammed et al. (2017) and Baba et al. 2020)

The mean level of COD (mg/l) observed in TAN1, TAN2 and TAN3 samples seasons were $2372 \pm 938 ; \quad 1406 \pm 208$ and $3532 \pm 1373$ respectively. The order of the mean COD of the samples from the three industries can be arranged as TAN3>TAN1> TAN2. The COD observed in TAN1, TAN2 and TAN3 samples were far above the recommended standard limits of regulating bodies $\mathrm{WHO}(40 \mathrm{mg} / \mathrm{l})$ and NESREA (40 mg/l). Statistical analysis shows that there is no significant difference $(p<0.05)$ in COD among the industries. This might be due to similar tannery activities involved in the tannery industries as at the time of sampling. The Chemical Oxygen demand (COD) is the amount of oxygen, in $\mathrm{mg} / \mathrm{L}$, required for the degradation of the compound of wastewater to occur. In comparison, the average values of COD observed in this present study were higher than that observed by Mohammed et al. (2017) but lower than that observed by Baba et al. (2020).

The mean levels of BOD $(\mathrm{mg} / \mathrm{l})$ observed in TAN1, TAN2 and TAN3 samples were $13.85 \pm 6.42 ; \quad 19.46 \pm 0.50$ and $17.13 \pm 3.14$ respectively. The order of the mean BOD in the samples from the three industries can be arranged as TAN2>TAN3>TAN1. The BOD observed in TAN1, TAN2 and TAN3 samples were found below the recommended limits of NESREA (200 mg/l) but above WHO (10 mg/l). Statistical analysis shows that there is no significant difference $(p<0.05)$ between the mean values of BOD among the industries. This might be due to similar tannery activities involved in the tannery industries at the time of sampling. The low level of BOD recorded in this study is an indication of the low level of biodegradable organic solids in the effluent. The average values of BOD observed in this present study were lower than those observed by Mohammed et al. (2017) and Baba et al. (2020).

Table 1: Mean Values \pm S.D of Physico-chemical parameters of effluents from the Tannery Industries before Treatment.

\begin{tabular}{llllllll}
\hline Parameter & Tannery 1 & Tannery 2 & Tannery 3 & $\mathrm{a}$ & $\mathrm{b}$ & $\mathrm{c}$ & $\mathrm{d}$ \\
\cline { 2 - 7 } Temperature $\left({ }^{\circ} \mathrm{C}\right)$ & $28.07 \mathrm{a} \pm 0.65$ & $27.77 \mathrm{a} \pm 0.64$ & $26.38 \mathrm{a} \pm 3.81$ & & $29.50 \pm 4.68$ & 35 & 40 \\
pH & $7.77 \mathrm{a} \pm 2.93$ & $8.35 \mathrm{a} \pm 0.28$ & $7.52 \mathrm{a} \pm 0.76$ & 6.89 & $5.35 \pm 1.57$ & $7.0-8.5$ & $6.0-9.0$ \\
$\mathrm{COD}(\mathrm{mg} / \mathrm{l})$ & $2372 \mathrm{a} \pm 938$ & $1406 \mathrm{a} \pm 208$ & $3532 \mathrm{a} \pm 1373$ & 2.2 & $3106 \pm 2753$ & 40 & 40 \\
$\mathrm{BOD}(\mathrm{mg} / \mathrm{l})$ & $13.85 \mathrm{a} \pm 6.42$ & $19.46 \mathrm{a} \pm 0.50$ & $17.13 \mathrm{a} \pm 3.14$ & 1032 & $26.17 \pm 9.49$ & 10 & 200 \\
$\mathrm{SS}(\mathrm{mg} / \mathrm{l})$ & $374 \mathrm{a} \pm 124$ & $358 \mathrm{a} \pm 335$ & $780 \mathrm{a} \pm 739$ & 501 & $562 \pm 482$ & 30 & 10 \\
TDS $(\mathrm{mg} / \mathrm{l})$ & $3941 \mathrm{a} \pm 3703$ & $3300 \mathrm{a} \pm 1714$ & $2653 \mathrm{a} \pm 1240$ & 532.7 & $444 \pm 507$ & 250 & 500 \\
\hline
\end{tabular}

The values given in the table above are means of 6 replicate values, $\mathrm{n}=6$ ( 1 sample was taken monthly for 6 months). Within the rows, means with different alphabets are statistically different $(p<0.05)$. WHO: World Health Organisation. NESREA: National Environmental Standard and Regulatory Enforcement Agency. a = Mohammed et al.(2017), b = Baba et al. (2020), c = WHO (2006), $d=$ NESSRA (2009) 
BAJOPAS Volume 13 Number 2, December, 2020

Identification, Biochemical Characterization and growth rates of the Bacterial Isolates

Results of identification and biochemical characterization of the bacterial isolates were shown in table 2. After 24 hours of incubation, the nutrient agar media plates were checked for bacterial growth. The results showed the presence of different strains in the samples. The TAN1 bacteria isolate was found to be gramnegative cocci while TAN3 was gram-positive cocci. TAN2 bacteria isolate was found to be gram-positive, rod-shaped. TAN1, TAN2, and TAN3 bacteria isolates recorded positive results for spore former.

The results of the biochemical tests indicated that all the bacteria were positive for catalase, oxidase, citrate, maltose, glucose, lactose (negative in TAN1), mannitol (negative in TAN2), starch hydrolysis and coagulase (negative in TAN2) tests. The bacteria showed negative results for nitrate reduction, $M R$ (positive in TAN2), VP (positive in TAN1), Indole (positive in TAN2) tests. Base on the morphological and biochemical test results, TAN1, TAN2, and TAN3 bacteria isolates were identified to be Nesseria spp, Bacillus cereus, and Staphylococcus aureus respectively.

The growth rate of the TAN1, TAN2 and TAN3 Isolates were shown in figure 2. Generally, the optical density increase with the increase in time (day) and decrease as time goes on. The highest optical density was shown by bacillus cereus in TAN2 while the lowest was shown by Staphylococcus aureus in TAN3.

The initial growth phase of TAN1 Isolate bacteria occurred within 2-day of incubation as the growth rate increases up to the 6th-day incubation when the maximum growth was observed. Beyond the 6th day, the growth of the bacteria declined (which might be due to a shortage of nutrients in the effluents) until it reached its death phase (which might be due to the unavailability of nutrients in the effluents).

A similar trend of growth was also observed for TAN2 Isolate as the initial growth phase also occurred within 2-day of incubation but maximum growth rate observed on the 4th day of incubation. The stationary stage occurred between the 4th day and the 8th day. Beyond the 8th day, the growth of the bacteria declined (which might be due to a shortage of nutrients in the effluents) until it reached its death phase (which might be due to the unavailability of nutrients in the effluents).

The initial growth phase of TAN3 bacterial Isolate occurred within the 3-day incubation as the growth rate increases up to the 6th-day incubation when the maximum growth was observed. Beyond the 6th day, the growth of the bacteria declined (which might be due to a shortage of nutrients in the effluents) until it reached its death phase (which might be due to the unavailability of nutrients in the effluents).

Table 2: Morphological and Biochemical characteristics of bacterial isolates

\begin{tabular}{lllll} 
Bacterial Isolates & & TAN1 & TAN2 & TAN3 \\
\hline $\begin{array}{lllll}\text { Morphological } \\
\text { characteristics }\end{array}$ & Shape & Cocci & Rod & Cocci \\
& Spore & & & \\
& former & + & + & + \\
Gram & & & \\
Biochemical characteristics & reaction & - & + & + \\
& Citrate & + & + & + \\
& Catalase & + & + & + \\
& Coagulase & + & - & + \\
Starch & + & + & + \\
& Glucose & + & + & + \\
Oxidase & + & + & + \\
& Indo & - & + & - \\
Lactose & - & + & + \\
Manitol & + & - & + \\
Maltose & + & + & + \\
MR & - & + & - \\
VP & + & - & - \\
& Nitrate & - & - & - \\
Reduction & - Neisseria & Bacillus & Staphylococcus \\
& Bacterial & cereus & aureus \\
& name & spp & cas
\end{tabular}

+ = Positive; - = Negative; MR=Methyl Red; VP= Voges-Proskauer 


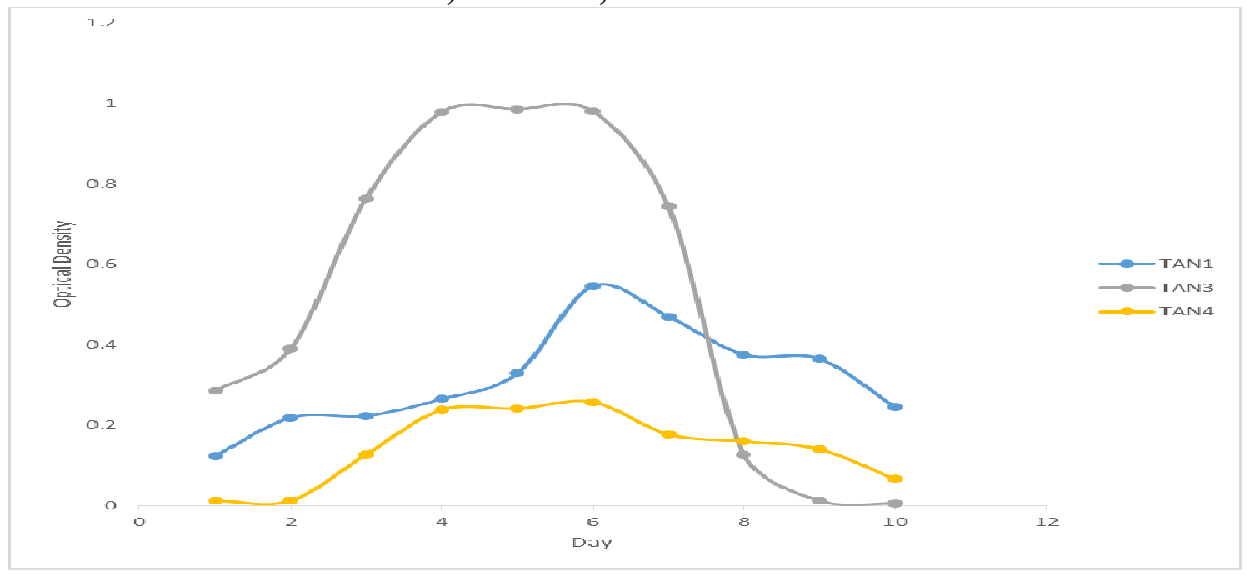

Fig. 2 Growth rates of the isolates in the effluents from the Tannery Industries

\section{Physico-chemical Parameters in the Industrial Effluents after the biodegradation.}

Table 3 shows the mean results of the physicochemical parameter before and after bioremediation using the different masses $(5 \mathrm{~g}$, $10 \mathrm{~g}, 15 \mathrm{~g}, 20 \mathrm{~g}$, and $25 \mathrm{~g}$ ) of the respective immobilized bacteria. Also, Table 4 shows the mean results of correlation coefficient ( $r$ ) between different masses of bacteria and physicochemical parameters.

The mean values $(\mathrm{mg} / \mathrm{l})$ of the SS after the bioremediation varies between $243 \pm 45$ and $898 \pm 672$. The mean concentration $(\mathrm{mg} / \mathrm{l})$ of SS remediated by the different masses $(5 \mathrm{~g}, 10 \mathrm{~g}$, $15 \mathrm{~g}, 20 \mathrm{~g}$, and $25 \mathrm{~g}$ ) of the bacteria varies. The SS in the samples fluctuates up and down after the bioremediation process when compared with the SS of the raw samples before the bioremediation. The increase in the levels of the SS might be due to the aggregation of the TDS which are large enough to result into SS. The increase in the levels of the SS might be also due to the influence of the nutrients which was added into the effluents in order to make the microorganisms more active and viable for fast degradation of organic contaminants in the effluent. The relative potential or efficiency of the different masses of the bacteria in remediating SS in TAN1 samples was in the order $25 \mathrm{~g}>20 \mathrm{~g}>15 \mathrm{~g}>10 \mathrm{~g}>5 \mathrm{~g}$. For TAN2 and TAN3 samples, the order was $25 \mathrm{~g}>20 \mathrm{~g}>15$ $\mathrm{g}>10 \mathrm{~g}>5 \mathrm{~g}$. These might be due to the variations in the surface areas of the different masses of the immobilized bacteria. Statistical analysis shows that there is no significant difference $(p<0.05)$ between the mean values of SS among the masses in the respective industries. Positive and significant correlations exist between the masses of bacteria and Suspended Solid (SS). This showed that there is general increase in the levels of the SS as the masses of the immobilized bacteria increases. TAN3 (90\%) and TAN1 (80\%) showed a very high correlation with the masses of the bacteria while TAN2 (61\%) showed a very low correlation.

The mean values $(\mathrm{mg} / \mathrm{l})$ of the TDS after the bioremediation varies between $46 \pm 11$ and $83 \pm 78$. The mean concentration $(\mathrm{mg} / \mathrm{l})$ of TDS remediated by the different masses $(5 \mathrm{~g}, 10 \mathrm{~g}$, $15 \mathrm{~g}, 20 \mathrm{~g}$, and $25 \mathrm{~g}$ ) of the bacteria varies. There is a reduction in all the TDS of all the samples after the bioremediation process compared with the TDS of the raw samples before the bioremediation. The relative potential or efficiency of the different masses of the bacteria in remediating TDS in TAN1 and TAN3 samples was in the order $5 \mathrm{~g}>10 \mathrm{~g}>15 \mathrm{~g}>20$ $\mathrm{g}>25 \mathrm{~g}$. For TAN2 samples, the order was 20 $g>10 \quad g>25 \quad g>15 \quad g>5 \quad g$. Statistical analysis shows that there is no significant difference $(p<0.05)$ between the mean values of TDS among the masses in the respective industries. These might be due to the variations in the surface areas of the different masses of the immobilized bacteria. Positive and significant correlations exist between the masses of bacteria and TDS with the exception in TAN2 (negative and insignificant correlation). The positive correlations showed that there is general increase in the levels of the TDS as the masses of the immobilized bacteria increases. TAN1 $(96 \%)$ showed a very high correlation with the masses of the bacteria while TAN2 (47\%) showed a very low correlation.

The mean values $(\mathrm{mg} / \mathrm{l})$ of the BOD after the bioremediation varies between $1.56 \pm 0.20 \mathrm{mg} / \mathrm{l}$ and $6.92 \pm 5.49 \mathrm{mg} / \mathrm{l}$. The mean concentration $(\mathrm{mg} / \mathrm{l})$ of BOD remediated by the different masses $(5 \mathrm{~g}, 10 \mathrm{~g}, 15 \mathrm{~g}, 20 \mathrm{~g}$, and $25 \mathrm{~g}$ ) of the bacteria varies. There is a reduction in all the BOD of all the samples after the bioremediation process compared with the $\mathrm{BOD}$ of the raw 
BAJOPAS Volume 13 Number 2, December, 2020 samples before the bioremediation. The relative potential or efficiency of the different masses of the bacteria in remediating BOD in TAN1, TAN2 and TAN3 samples were in the order $25 \mathrm{~g}>20$ $\mathrm{g}>15 \mathrm{~g}>10 \mathrm{~g}>5 \mathrm{~g}, 25 \mathrm{~g}>15 \mathrm{~g}>5 \mathrm{~g}>10 \mathrm{~g}>20 \mathrm{~g}$ and $20 \mathrm{~g}>10 \mathrm{~g}>25 \mathrm{~g}>15 \mathrm{~g}>5 \mathrm{~g}$ respectively. Statistical analysis shows that there is significant difference $(p<0.05)$ between the mean values of BOD among the masses in the respective industries. These might be due to the variations in the surface areas of the different masses of the immobilized bacteria. Negative and significant correlations exist between the masses of bacteria and BOD. This showed that there is general decrease in the levels of the BOD as the masses of the immobilized bacteria increases. TAN1 (94\%) showed a very high correlation with the masses of the bacteria while TAN2 (4\%) showed a very low correlation.

The mean values $(\mathrm{mg} / \mathrm{l})$ of the COD after the bioremediation varies between $250 \pm 154$ and $3134 \pm 1595$. The mean concentration $(\mathrm{mg} / \mathrm{l})$ of COD remediated by the different masses $(5 \mathrm{~g}$, $10 \mathrm{~g}, 15 \mathrm{~g} 20 \mathrm{~g}$, and $25 \mathrm{~g}$ ) of the bacteria varies. There is a reduction in all the COD of all the samples after the bioremediation process compared with the COD of the raw samples before the bioremediation. The relative potential or efficiency of the different masses of the bacteria in remediating COD in TAN1, TAN2 and TAN3 samples were in the order $25 \mathrm{~g}>20 \mathrm{~g}>15$ $\mathrm{g}>5 \mathrm{~g}>10 \mathrm{~g}, 25 \mathrm{~g}>20 \mathrm{~g}>15 \mathrm{~g}>10 \mathrm{~g}>5 \mathrm{~g}$ and 10 g>5 g>25 g>15 g>20 g respectively. Statistical analysis shows that there were significant difference $(p<0.05)$ between the mean values of COD among the masses in the respective industries except for effluents treated with $25 \mathrm{~g}$. These might be due to the variations in the surface areas of the different masses of the immobilized bacteria. Negative and insignificant correlations exist between the masses of bacteria and COD with the exception in TAN3 (positive and significant correlation). The negative correlations showed that there is general decrease in the levels of the COD as the masses of the immobilized bacteria increases. TAN2 (100\%) showed a very high correlation with the masses of the bacteria while TAN3 (36\%) showed a very low correlation.

Generally, there was an overall decrease in the concentration of these physicochemical parameters after the bioremediation using the different masses of the bacterial isolates. These might be due to the variations in the surface areas of the different masses of the immobilized bacteria. This is in line with the work of Jimoh et al. (2018) and Baba et al. (2020).

Table 3: Mean Values $(\mathrm{mg} / \mathrm{l}) \pm$ S.D of Physicochemical parameters in effluents from the Tannery Industries before and after Treatment of the effluents $(250 \mathrm{ml})$ with the different masses $(5 \mathrm{~g}, 10 \mathrm{~g}$, $15 \mathrm{~g}, 20 \mathrm{~g}$, and $25 \mathrm{~g}$ ) of the bacteria.

\begin{tabular}{llllllll}
\hline $\mathrm{P}$ & IND & Before & \multicolumn{5}{c}{ After } \\
\cline { 4 - 7 } & & & $5 \mathrm{~g}$ & $10 \mathrm{~g}$ & $15 \mathrm{~g}$ & $20 \mathrm{~g}$ & $25 \mathrm{~g}$ \\
\hline \multirow{2}{*}{ COD } & TAN1 & $2372 \pm 938$ & $1708 \mathrm{a} \pm 861$ & $2045 \mathrm{a} \pm 1205$ & $845 \mathrm{a} \pm 369$ & $300 \mathrm{a} \pm 167$ & $250 \mathrm{a} \pm 154$ \\
& TAN2 & $1406 \pm 208$ & $1195 \mathrm{a} \pm 208$ & $1125 \mathrm{a} \pm 384$ & $1055 \mathrm{a} \pm 317$ & $956 \mathrm{a} \pm 310$ & $870 \mathrm{ab} \pm 240$ \\
& TAN3 & $3532 \pm 1373$ & $2374 \mathrm{a} \pm 1344$ & $1976 \mathrm{a} \pm 1405$ & $2757 \mathrm{a} \pm 1266$ & $3134 \mathrm{a} \pm 1595$ & $2614 \mathrm{~b} \pm 1105$ \\
BOD & TAN1 & $13.85 \pm 6.42$ & $6.92 \mathrm{a} \pm 5.49$ & $6.42 \mathrm{a} \pm 5.07$ & $5.72 \mathrm{a} \pm 5.35$ & $4.62 \mathrm{a} \pm 4.37$ & $2.82 \mathrm{ab} \pm 1.26$ \\
& TAN2 & $19.46 \pm 0.50$ & $1.75 \mathrm{~b} \pm 0.22$ & $1.73 \mathrm{~b} \pm 0.18$ & $1.58 \mathrm{a} \pm 0.16$ & $1.91 \mathrm{a} \pm 0.22$ & $1.56 \mathrm{~b} \pm 0.20$ \\
& TAN3 & $17.13 \pm 3.14$ & $4.24 \mathrm{ab} \pm 0.77$ & $3.29 \mathrm{ab} \pm 0.37$ & $4.11 \mathrm{a} \pm 0.07$ & $3.23 \mathrm{a} \pm 0.91$ & $3.33 \mathrm{a} \pm 1.28$ \\
SS & TAN1 & $374 \pm 124$ & $243 \mathrm{a} \pm 45$ & $471 \mathrm{a} \pm 226$ & $475 \mathrm{a} \pm 182$ & $492 \mathrm{a} \pm 128$ & $611 \mathrm{a} \pm 217$ \\
& TAN2 & $358 \pm 335$ & $460 \mathrm{a} \pm 400$ & $543 \mathrm{a} \pm 414$ & $544 \mathrm{a} \pm 402$ & $551 \mathrm{a} \pm 414$ & $554 \mathrm{a} \pm 405$ \\
& TAN3 & $780 \pm 739$ & $586 \mathrm{a} \pm 594$ & $758 \mathrm{a} \pm 656$ & $787 \mathrm{a} \pm 676$ & $861 \mathrm{a} \pm 635$ & $898 \mathrm{a} \pm 672$ \\
TDS & TAN1 & $3941 \pm 3703$ & $51 \mathrm{a} \pm 10$ & $53 \mathrm{a} \pm 10$ & $55 \mathrm{a} \pm 15$ & $61 \mathrm{a} \pm 20$ & $63 \mathrm{a} \pm 26$ \\
& TAN2 & $3300 \pm 1714$ & $83 \mathrm{a} \pm 78$ & $47 \mathrm{a} \pm 20$ & $48 \mathrm{a} \pm 22$ & $47 \mathrm{a} \pm 17$ & $48 \mathrm{a} \pm 17$ \\
& TAN3 & $2653 \pm 1240$ & $46 \mathrm{a} \pm 11$ & $55 \mathrm{a} \pm 24$ & $55 \mathrm{a} \pm 25$ & $58 \mathrm{a} \pm 23$ & $61 \mathrm{a} \pm 28$ \\
\hline
\end{tabular}

Replicate $=6$ (months)

Within the rows, for the same parameter, means with different alphabets are statistically different $(p<0.05)$.

$\mathrm{P}=$ parameter, IND = Industries 
BAJOPAS Volume 13 Number 2, December, 2020

Table 4: Correlation coefficient $(r)$ between different masses of the bacteria and the physicochemical parameters.

\begin{tabular}{llll}
\hline Industries & Parameter & Correlation coefficient $(r)$ & $\begin{array}{l}\text { Percent dependence (rxrx100) } \\
(\%)\end{array}$ \\
\hline TAN1 & COD & -0.9 & 82 \\
& BOD & -0.97 & 94 \\
& SS & $0.90^{*}$ & 80 \\
TAN2 & TDS & $0.98^{*}$ & 96 \\
& COD & -1 & 100 \\
& BOD & -0.21 & 4 \\
& SS & $0.78^{*}$ & 61 \\
& TDS & -0.69 & 47 \\
& COD & $0.60^{*}$ & 36 \\
& BOD & -0.6 & 37 \\
& SS & $0.95^{*}$ & 90 \\
& TDS & $0.94^{*}$ & 89 \\
\hline
\end{tabular}

The correlation coefficient $(r)$ with * is statistically significant $(p<0.05)$.

Percentage reduction of the Parameters

Table 5 shows the percentage reduction of Parameters in industrial samples before and after the treatment of the effluents $(250 \mathrm{ml})$ with the different masses $(5 \mathrm{~g}, 10 \mathrm{~g}, 15 \mathrm{~g}, 20 \mathrm{~g}$, and $25 \mathrm{~g}$ ) of the Immobilized Bacteria.

In TAN1 samples, the percentage reduction (\%) of COD ranged (14-89); BOD (50-80); SS (-32$35)$ and TDS (98-99). In TAN2 samples, the percentage decrease $(\%)$ of COD ranged (15$38) ;$ BOD (90-92); SS [-28-(-55)] and TDS (9798). In TAN3 samples, the percentage decrease (\%) of COD ranged (11-44); BOD (76-81); SS (15-25) and TDS (98). The percentage increase in the levels COD, BOD and TDS might be due to the increase in the surface area of the different masses of the immobilized bacteria. However, the percentage decrease in the levels of the SS might be due to the aggregation of the TDS which are large enough to result into SS. The percentage decrease in the levels of the SS might be also due to the influence of the nutrients which was added into the effluents in order to make the microorganisms more active and viable for fast degradation of organic contaminants in the effluent. This is in line with the work of Jimoh et al. (2018) in which the concentration of the SS increase after the bioremediation of effluents.

Sreemoyee and Priti (2013) assessed and reduced several Physico-chemical parameters of dairy wastewater using Niesseria $s p$. and concluded that the species are well known to degrade organic compounds. This is in agreement with the current study in which the immobilized Niesseria $s p$ degrade the organic contaminants as indicated by the BOD, COD and TDS.

Jimoh et al. (2018) observed that TSS of the effluents was increased after treatment with immobilized bacteria and concluded that it might be due to the biostimulation method adopted for the research.

The optimum $\mathrm{pH}$ Biosorption of Chromium by Bacillus spp and Staphylococcus spp. from tannery effluent was investigated by Mythili and Karthikeyan (2011). The maximum adsorption of Chromium $(86.4 \mathrm{mg} / \mathrm{L})$ was showed by Bacillus spp and Staphylococcus spp showed $70.6 \mathrm{mg} / \mathrm{L}$ at an initial concentration of $100 \mathrm{mg} / \mathrm{L}$. In the present study, immobilised Bacillus spp and Staphylococcus spp. from the tannery industrial effluents reduced the levels of the organic pollutants with high potential as indicated by the percentage reduction of BOD, COD and TDS.

Enzymes often can work in multiple environments especially if they are immobilized. This makes the microorganisms' enzymes even more resistant to harsh environments and enables the enzymes to be recovered and recycled after they are no longer needed (Gianfreda and Rao 2004). Ramesh and Singh (1993) reported that the immobilized bacteria having more efficiency to remove the suspended particles than free cells. Using the immobilized cell is preferable due to its capability for using several times with the same efficiency, which makes it more economical. Similar work was done by Sikander et al. (2007) showing the higher reduction with permeabilized cells of Ochrobactrum intermedium strain SDCr-5. 
BAJOPAS Volume 13 Number 2, December, 2020

The results revealed the isolation and identification of isolates with the potential for the reduction of $\mathrm{Cr}$ (VI) to $\mathrm{Cr}$ (III). Results indicated that immobilized $B$. cereus could be efficiently used for the reduction of $\mathrm{Cr}$ (VI).

Table 5: Percentage reduction of the tested Parameters from the tannery industrial samples of the Immobilized Bacteria.

\begin{tabular}{lllllll}
\hline \multirow{2}{*}{ Industries } & & \multicolumn{5}{c}{ Percentage Reduction $(\%)$} \\
\cline { 3 - 7 } & & $5 \mathrm{~g}$ & $10 \mathrm{~g}$ & $15 \mathrm{~g}$ & $20 \mathrm{~g}$ & $25 \mathrm{~g}$ \\
\hline TAN1 & COD & 28 & 14 & 64 & 87 & 89 \\
& BOD & 50 & 54 & 59 & 67 & 80 \\
& SS & 35 & -26 & -27 & -32 & -63 \\
& TDS & 99 & 99 & 99 & 98 & 98 \\
TAN2 & COD & 15 & 20 & 25 & 32 & 38 \\
& BOD & 91 & 91 & 92 & 90 & 92 \\
& SS & -28 & -52 & -52 & -54 & -55 \\
& TDS & 97 & 99 & 99 & 99 & 99 \\
& COD & 33 & 44 & 22 & 11 & 26 \\
& BOD & 75 & 81 & 76 & 81 & 81 \\
& SS & 25 & 3 & -1 & -10 & -15 \\
& TDS & 98 & 98 & 98 & 98 & 98 \\
\hline
\end{tabular}

Percentage Reduction $=(B-A) / B \times 100 \%$

$A=$ Concentration of the parameter after treatment

$\mathrm{B}=$ Concentration of the parameter before treatment

$+=$ percentage decrease

- = percentage increase

In general, immobilization makes the enzyme more resistant to temperature, $\mathrm{pH}$, and substrate concentration swings giving it a longer lifetime and higher productivity per active unit (Gianfreda and Rao, 2004; FuIlbrook, 1996; Russell et al, 2003; Kandelbauer et al., 2004). Immobilized cells have been used and studied extensively for the production of useful chemicals (Ohtake and Silver, 1994), the treatment of wastewaters (Chen et al., 2003; Wang et al., 2010). Although many workers described microbial degradation of tannery effluent, limited literature is available on the bioremediation of tannery effluent using immobilized bacterial cells in the Kano Industrial Estates.

\section{CONCLUSION}

The samples contained variable levels of the physicochemical parameters. The results of the Analysis of variance revealed that, no statistical difference $(p<0.05)$ was observed for the temperature, $\mathrm{pH}, \mathrm{SS}, \mathrm{TDS}, \mathrm{BOD}$ and $\mathrm{COD}$ among the three tannery industries before the treatment. The levels of some of the parameters
(SS, TDS and COD) observed in the samples were found above the recommended limits of WHO and NESREA, which called for the treatment of the effluents before discharge into the environment. Base on the morphological and biochemical test results, TAN1, TAN2, and TAN3 bacterial isolates were identified to be Neisseria spp, Bacillus cereus, and Staphylococcus aureus respectively. The results of Post-treatment analysis showed that there is overall decrease in the levels of the parameters determined when compared with that of the pre-treatment. The overall percentage reduction of the immobilised bacteria in the treatment of the respective effluents was in the order TAN2 (72\%)>TAN1 $(70 \%)>$ TAN3 $(62 \%)$. Hence, the immobilized bacteria are having higher biodegradation potential for the treatment of the tannery effluents.

\section{Acknowledgments}

The authors wish to acknowledge the University of Maiduguri for the financial support. The authors are grateful to the Kano State Ministry of Environment for their support in obtaining the effluent samples. 


\section{REFERENCES}

Ajao, A. T., Adebayo, G. B., and Yakubu, S. E. (2011). Bioremediation of textile industrial effluent using mixed culture of Pseudomonas aeruginosa and Bacillus subtilis immobilized on agar-agar in a bioreactor. J. Microbiol. Biotech. Res, 1(3), 50-56.

Akan, J. C., Moses, E. A., Ogugbuaja, V. O., and Abah, J. (2007). Assessment of tannery industrial effluents from Kano metropolis, Kano State, Nigeria. Journal of Applied Sciences, 7(19), 2788-2793.

Akan, J. C., Ogugbuaja, V. O., Abdulrahman, F. I., and Ayodele, J. T. (2009). Pollutant levels in effluent samples from tanneries and textiles of Kano industrial areas, Nigeria. Global journal of pure and applied sciences, 15(3-4).

APHA (1989). Standard methods for Examination of Will bete and Will betewater.15 $5^{\text {th }}$ edition. Brydpass Springfield Will behington DC. pp. 164-176

APHA (1992). Standard Methods for the Examination of Water and Wastewater. Health, 69, 1116-9.

Baba, A., Garba, S. T., and Bello, H. S. (2020). Bioremediation Potential of Immobilized corynebacterium kutsceri in the Treatment of Tannery Industrial Effluent from Challawa Industrial Estate, Kano State, Nigeria. Journal of the Turkish Chemical Society Section A: Chemistry, $7(2), 335-350$.

Beem, E. I. V. (1994). reduction of solvent VOC emission. J. Oil Col. Chem. Ass, 77, 158.

Bouwer, E. J., and Zehnder, A. J. (1993). Bioremediation of organic compoundsputting microbial metabolism to work. Trends in biotechnology, 11(8), 360367.

Chen, K. C., Wu, J. Y., Liou, D. J., and Hwang, S. C. J. (2003). Decolorization of the textile dyes by newly isolated bacterial strains. Journal of Biotechnology, 101(1), 57-68.

Dan'Azumi, S., and Bichi, M. H. (2010). INDUSTRIAL POLLUTION AND HEAVY METALS PROFILE OF CHALLAWA RIVER IN KANO, NIGERIA. Journal of Applied Sciences in Environmental Sanitation, $5(1)$.

DWAF. (1992). Analytical Methods Manual, TR 151. Department of Water Affairs and Forestry, Pretoria.

El-Bestawy, E. (2013). Biological treatment of leather-tanning industrial wastewater using free living bacteria.
Elsheikh, M. A. S. (2009). Tannery wastewater pre-treatment. Water Science and Technology, 60(2), 433-440.

FuIlbrook, P. D. (1996). "Kinetics." Industrial enzymology: The application of enzymes in Industry. 2nd Ed. T. Godfrey and J Reichelt. eds.. Nature. New York.

Gianfreda, L., and Rao, M. A. (2004). Potential of extra cellular enzymes in remediation of polluted soils: a review. Enzyme and microbial technology, 35(4), 339354.

Hugo Springer. (1994). John Arthur Wilson Memorial Lecture "Treatment of Industrial Wastes of the Leather Industry - is it still a Major Problem". JALCA, 89, 153-185

Jimoh, A. A., Ganiyu, B. A., Baba, D., and Baba, A. (2018) Bioremediation Process of Effluent from Detergent and Food Industries in Jos, Nigeria: Kinetics and Thermodynamics. International Journal of Engineering Science Invention (IJESI), 762-73

Kandelbauer, A., Maute, O., Kessler, R. W., Erlacher, A., and Gübitz, G. M. (2004). Study of dye decolorization in an immobilized laccase enzyme-reactor using online spectroscopy. Biotechnology and bioengineering, 87(4), 552-563.

Kongjao, S., Damronglerd, S., and Hunsom, M. (2008). Simultaneous removal of organic and inorganic Pollutants in tannery wastewater using electrocoagulation technique. Korean Journal of chemical engineering, 25(4), 703.

Maheshwari, U. M., Aruna, S., Gomathi, M., and AbdulJaffar, A. H. (2017). Bioremediation by Free and Immobilized Bacteria Isolated from Tannery Effluent. International Journal of Research in Applied, Natural and Social Sciences. 5(7), 75-90

Margesin, R., and Schinner, F. (2001). Bioremediation (natural attenuation and biostimulation) of diesel-oilcontaminated soil in an alpine glacier skiing area. Applied and environmental microbiology, 677), 3127-3133.

Mohammed, A., Sekar, P., and George, J. (2011). Efficacy of microbes in bioremediation of tannery effluent. Inter. J. Curr. Res, 3(4), 324-326.

Mohammed, S. S. D., Orukotan, A. A., and Abdullahi, H. (2017). Physicochemical and Bacteriological Assessment of Tannery Effluent from Samaru-Zaria, 
BAJOPAS Volume 13 Number 2, December, 2020 Kaduna State, Nigeria. Journal of Applied

Sciences and Environmental Management, 21(4), 734-740.

Munz, G., De Angelis, D., Gori, R., Mori, G., Casarci, M., and Lubello, C. (2009). The role of tannins in conventional and membrane treatment of tannery wastewater. Journal of hazardous materials, 164(2-3), 733-739

Mythili, K., and Karthikeyan, B. (2011). Bioremediation of $\mathrm{Cr}$ (VI) from tannery effluent using Bacillus spp and Staphylococcus spp. International Multidisciplinary Research Journal, 1(6).

NESREA (2009). National Environmental Standards for Effluent Limitations and Regulation. 1233-1236

Noorjahan, C. M. (2014). Physicochemical characteristics, identification of bacteria and biodegradation of industrial effluent. Journal of bioremediation and Biodegradation, 5(3).

Ohtake, H. I., and Silver, A. O. (1994). Bacterial reduction of toxic chromate. Biological degradation and bioremediation of toxic chemicals, 403-415.

Omoleke, I. I. (2004). Management of environmental pollution in Ibadan, an African city: the challenges of health hazard facing government and the people. Journal of Human Ecology, 15(4), 265-275.

Rajor, A., Reddy, A.S., and Singh, B. (2004). Determination of BOD kinetic Parameters and evaluation of alternate methods, M.Sc. Thesis, Department of biotechnology \& environmental Science, Thapar Institute of Engineering and Technology, Patiala

Ramasami, T., Rajamani, S., and Rao, J. R. (1994, March). Pollution control in leather industry: Emerging technological options. In International symposium on surface and colloidal science and its relevance to soil pollution, madras.

Ramesh, J. V. S., and Singh, S. P. (1993). Yearly variation in certain physicochemical parameters of pond at eastern Doon Valley. Uttar Pradesh J. Zoo, 12 (1), 7577.

Ranen, S., and Sharadinadra, C. (2009). Biotechnology applications to environmental remediation in resource exploitation. Current science, 97, 6-25
Russell, A. J., Berberich, J. A., Drevon, G. F., and Koepsel, R. R. (2003). Biomaterials for mediation of

chemical and biological warfare agents. Annual review of biomedical engineering, 5(1), 1-27.

Saravanan, P., and Saravanan, A. (1999). Decolourization of tannery effluent by Flavobacterium sp. EK 1. Indian Journal of Environmental Protection, 19, 19-24.

Sikander, S., and Shahida, H. (2007). Reduction of toxic hexavalent chromium by Ochrobactrum intermedium strain SDCr5 stimulated by heavy metals. Bioresource Technol, 98, 340-344.

Singh, N., Sharma, B. K., and Bohra, P. C. (2000). Impact assessment of industrial effluent of arid soils by using satellite imageries. Journal of the Indian Society of Remote Sensing, 28(2-3), 79.

Sreemoyee, C., and Priti, P. (2013). Assessment of physico-chemical parameters of dairy waste water and isolation and characterization of bacterial strains in terms of cod reduction. Int J Sci, 2(3), 395-400.

Verheijen, L. A. H. M., Wiersema, D., Pol, L. H., and De Wit, J. (1996). Management of wastes from animal product processing. Livestock and environment, Finding a balance. International Agriculture Center, Wageningen, The Netherlands.

Wang, F., Yao, J., Si, Y., Chen, H., Russel, M., Chen, K., and Bramanti, E. (2010). Short-time effect of heavy metals upon microbial community activity. Journal of Hazardous Materials, 173(13), 510-516.

WHO (World Health Organization). (2006). Air quality guidelines: global update 2005: particulate matter, ozone, nitrogen dioxide, and sulfur dioxide. World Health Organization.

World Bank. (1995). Nigeria's strategic options for redressing industrial pollution. World Bank, industry and energy division. 1st edition, West Central Africa Department; Annexes: 1995; pp 60-62.

Zahoor, A., and Abdul, R. (2009). Enumeration of Coliforms. Journal of Environmental Sciences. 21, 814-820 


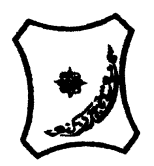

Bayero Journal of Pure and Applied Sciences, 13(2): 1 - 12

Received: November, 2020

Accepted: December, 2020

ISSN $2006-6996$

\title{
BIODEGRADATION POTENTIAL OF IMMOBILIZED BACTERIA IN THE TREATMENT OF TANNERY INDUSTRIAL EFFLUENTS FROM INDUSTRIAL ESTATES IN KANO STATE, NIGERIA
}

\author{
Abdullateef, B., ${ }^{1 *}$ Shuaibu, T. G., ${ }^{1}$ Babagana, K., ${ }^{1}$ Suleman, H. B. ${ }^{2}$ and Dauda, B. ${ }^{3}$ \\ ${ }^{1}$ Department of Pure and Applied Chemistry, Faculty of Science, University of Maiduguri, Borno State, \\ Nigeria \\ ${ }^{2}$ Department of Microbiology, Faculty of Science, University of Maiduguri, Borno State, Nigeria \\ ${ }^{3}$ Department of Chemical Engineering, Faculty of Engineering, University of Maiduguri, Borno State, \\ Nigeria \\ *Corresponding author: babslega@gmail.com; abelega2007@yahoo.com; +2348061309753
}

\section{ABSTRACT}

Industrial Effluents Samples from Gashash Tanneries (TAN1) in Bompai Industrial estate, Larabee Tannery Industry (TAN2) in Sharada Industrial estate and Z Tannery Industries (TAN3) in Challawa Industrial estate, Kano State, Nigeria were collected over a period of six months (August 2017 to January 2018) for assessing the biodegradation potentials of bacteria in the treatment of organic pollutants within the effluents. Bacteria were isolated from the effluents and immobilized on agar-agar. Different masses (5 g, $10 \mathrm{gr}, 15$ $\mathrm{g}, 20 \mathrm{~g}$, and $25 \mathrm{~g}$ ) of the bacteria were used in the treatment of $250 \mathrm{ml}$ of the effluents for ten days in a shaker incubator (Gallenkamp-OC-4364-L) at the temperature $30{ }^{\circ} \mathrm{C}$ and speed of $60 \mathrm{rpm}$. Pre-treatment analysis of the effluents for Temperature, pH, Biochemical Oxygen Demand (BOD), Chemical Oxygen Demand (COD), Suspended Solid (SS) and Total Dissolved Solids (TDS) gives the following results; temperature $\left({ }^{\circ} \mathrm{C}\right.$ )

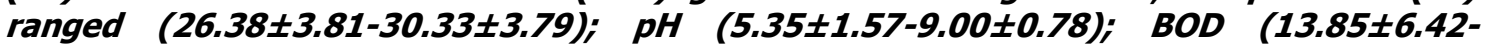
$38.75 \pm 16.20) ;$ COD (1406 $\pm 208-3532 \pm 1373) ;$ SS (208 $\pm 235-780 \pm 739)$ and TDS (266 $\pm 253-5276 \pm 2971)$. No statistical differences ( $p \leq 0.05)$ was observed for all the results among the different industries. The bacterial isolates were identified as Neisseria spp, Bacillus cereus, and Staphylococcus aureus, in TAN1, TAN2, and TAN3, respectively. After treatment of the effluent with the different masses of the isolated bacteria, the mean level of BOD was found to range as (0.55 $\pm 0.36-6.92 \pm 5.49) ; C O D$ (ND-3134 \pm 1595$)$;

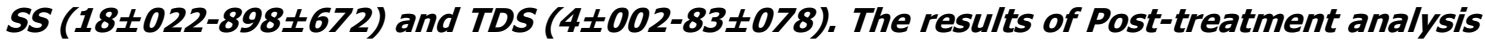
showed that there is overall decrease in the levels of the parameters determined when compared with that of the pre-treatment. The overall percentage reduction of the immobilised bacteria in the treatment of the respective effluents was in the order TAN2 (72\%)>TAN1 (70\%)>TAN3 (62\%). Hence, the immobilized bacteria are having higher biodegradation potential for the treatment of the tannery effluents.

Keywords: Biodegradation, bacteria, effluent, immobilization, tannery.

\section{INTRODUCTION}

Tannery industrial wastewater is a serious consequence of the pollution point of view for streams, freshwater, and land used for agriculture. The lack of awareness in the modern industrial practice has resulted in the discharge of tannery effluents which exhibit very high value of chromium ( $\mathrm{Cr}$ ), Sulfide, and chloride, Total Dissolved Solid (TDS), Total Suspended Solid (TSS), Biochemical Oxygen Demand (BOD) and Chemical Oxygen Demand (COD) in the water stream or land (Mohammed et al., 2001). Tanning is the process, which One ton of skin generally leads to the production of 20 to $80 \mathrm{~m}^{3}$ of turbid and foul-smelling converts the protein of the rawhide or skin into a stable material, which will not putrefy and is suitable for a wide variety of end applications (Elsheikh, 2009). The highly polluting chromium is the most commonly used tanning material producing leather that is more flexible and pliable than vegetable-tanned leather and does not discolor or lose shape in water as drastically as vegetable-tan (Elsheikh, 2009). Tannery effluent is among the most hazardous industrial pollutants due to its huge organic and inorganic load, which is highly toxic to human life and the environment (Kongjao et al., 2008). wastewater including chromium (100-400 mg/l), sulfide $(200-800 \mathrm{mg} / \mathrm{l})$, high levels of fat and 
BAJOPAS Volume 13 Number 2, December, 2020 other solid wastes, and notable pathogen contamination as well as pesticides added for skin conservation during transport (Elsheikh, 2009). There are more than 6000 tanneries in Nigeria with an annual processing capacity of 700,000 tons of hides and skins (Omoleke, 2004; Singh et al., 2008). It was reported that the total amount of waste produced per animal slaughtered is approximately $35 \%$ of its weight (World Bank, 1995). Also, for every $1000 \mathrm{~kg}$ of carcass weight, a slaughtered beef produces 5.5 $\mathrm{kg}$ of manure (excluding rumen contents or stockyard manure) and $100 \mathrm{~kg}$ of paunch manure (undigested food) (Verheijen et al., 1996). Tanneries generate wastewater in the range of 30-35 $\mathrm{L} \mathrm{kg}^{-1}$ skin/hide processed with variable $\mathrm{pH}$, Biological Oxygen Demand (BOD), Chemical Oxygen Demand (COD), high concentrations of suspended solids (SS), and tannins as well as chromium (Zahoor and Abdul, 2009).

Being heterogeneous and composed of a wide variety of compounds, it is very difficult to select a unique direct method for estimating the biodegradability of organic contents and biokinetic parameters for a wastewater sample (Rajor, 2004). For this purpose, some indirect estimation such as determination of biochemical oxygen demand (BOD) and chemical oxygen demand (COD) are applied as common laboratory investigations [9]. During retanning procedures, synthetic tannins (Syntan), oils and resins are added to form softer leather at varying doses (Munz et al., 2009). One of the refractory groups of chemicals in tannery effluents derives mainly from tannins (Ramasami et al., 2004). Syntans are characterized by complex chemical structures, because they are composed of an extended set of chemicals such as phenol-, naphthalene-, formaldehyde- and melamine-based syntans, and acrylic resins (Beem, 1994). Organic pollutants (proteic and lipidic components) are originated from skins (it is calculated that the raw skin has $30 \%$ loss of organic material during the working cycle) or they are introduced during processes (Hugo Springer, 1994).

Many conventional processes such as oxidation, chemical and biological processes were carried out to treat tanneries wastewater (Ebtesam et al, 2013). Biological processes have received more attention because of their costeffectiveness, lower sludge production and environmental friendliness (Noorjahan, 2014). Naturally occurring micro-organisms degrade the hazardous organic wastes including xenobiotic compounds, such as pesticides, polycyclic aromatic hydrocarbons (PAHs) and polychlorinated biphenyls (PCBs) in due course of time (Ranen and Sharadinadra, 2009). Bioremediation is based on the idea that all organisms remove substances from the environment to carry outgrowth and metabolism (Bouwer and Zehnder, 1993). Bacteria, protista and fungi are found to be very good at degrading complex molecules and incorporating the breakdown products into their metabolism (Bouwer and Zehnder, 1993). The resultant metabolic wastes that they produce are generally safe and somehow recycled into other organisms (Ranen and Sharadinadra, 2009). An acclimatized indigenous population of microorganisms capable of degradation of the compounds of interest must exist at the site for a successful bioremediation mode (Ranen and Sharadinadra, 2009). It has been observed that for a successful bioremediation mode, an acclimatized indigenous population of microorganisms capable of degradation of the compounds of interest must exist at the site under investigation (Ranen and Sharadinadra, 2009). Even though there are numerous physical and chemical methods employed in the disposal of wastes the advantage in using bacterium is that they play a key role in the reduction of COD, BOD, total protein, total tannin and total phenol (Saravanan and Saravanan, 1998)

Baba et al. (2020) studied the bioremediation potential of immobilized corynebacterium kutsceri in the Treatment of tannery industrial effluent from Challawa Industrial Estate, Kano State, Nigeria. The aim of the work is to study the reduction in the level of the contaminants through the process of bioremediation using the isolated bacteria. Immobilized bacteria can withstand various temperatures, $\mathrm{pH}$ and substrate concentrations; consequently, increasing the efficiency and the lifespan of the bacteria. Immobilized bacteria are widely applied in the treatment of wastewater and can be separated and recovered after the treatment with the same efficiency (Baba et al., 2020).

\section{MATERIALS AND METHODS \\ Study Area}

This study was carried out in Bompai, Sharada and Challawa industrial estates in Kano, Figure 1. Kano lies on Latitude $11^{\circ} 30^{\prime} \mathrm{N}$ and $8^{\circ} 30^{\prime} \mathrm{E}$ and Longitude $11^{\circ} 5^{\prime} \mathrm{N}$ and $8^{\circ} 5^{\prime} \mathrm{E}$ in Northern Nigeria. It is one of the developed industrial cities in Nigeria. Tannery activities are the dominating industries and this could be one of the reasons for her high population density (Dan'Azumi and Bichi, 2010). Many researchers have studied biodegradation of tannery effluent using microorganisms. However, limited literature is available on the biodegradation of tannery effluent in Kano industrial estates using 
BAJOPAS Volume 13 Number 2, December, 2020 immobilized bacterial cells. This research work focuses on the potential of the use of the indigenous immobilized bacterial isolates in the treatment of tannery effluents in the industrial estates.

\section{Sample Collection}

Effluents were collected from the Tannery Industries from Bompai, Challawa and Sharada Industrial Estates, Kano, Nigeria. The effluents were collected over a period of six months (August 2017 to January 2018). Samples collected in a sterile 4-liter plastic container with a unique identification number were preserved using an ice-box that was transported to the Microbiology Laboratory, Department of Microbiology, Bayero University of Kano for analysis

\section{Sample Preparation and Sample Analysis}

Immediately after the collection of the effluent, $\mathrm{pH}$, TSS, TDS, COD, BOD levels were determined before treatment (Pre-treatment determination) and ten days after treatment (Post-treatment determination) as described in
APHA (1989) standard methods. $\mathrm{pH}$ was determined using Ecotests $\mathrm{pH}$ meter and TDS was determined using AQUALYTIC TDS Salinometer. BOD was determined as described by the standard method (APHA, 1992). COD and SS were determined using DR/2010 HACH portable data logging spectrophotometer (DWAF, 1992)

\section{Identification and Biochemical} Characterization of the Bacterial Isolates

The bacteria were isolated from the effluents using Serial Dilution according to the method described by APHA (1989). The biochemical tests such as oxidase, catalase, coagulase, indole (from $1 \%$ tryptone broth), citrate (Simmons citrate agar), methyl red/VogesProskauer (MR/VP), nitrate reduction, Starch Hydrolysis, Glucose, Maltose, and Lactose tests were carried out on the bacterial isolates to identify the bacteria through the bacteria biochemical characteristics according to Ajao et al. (2011).

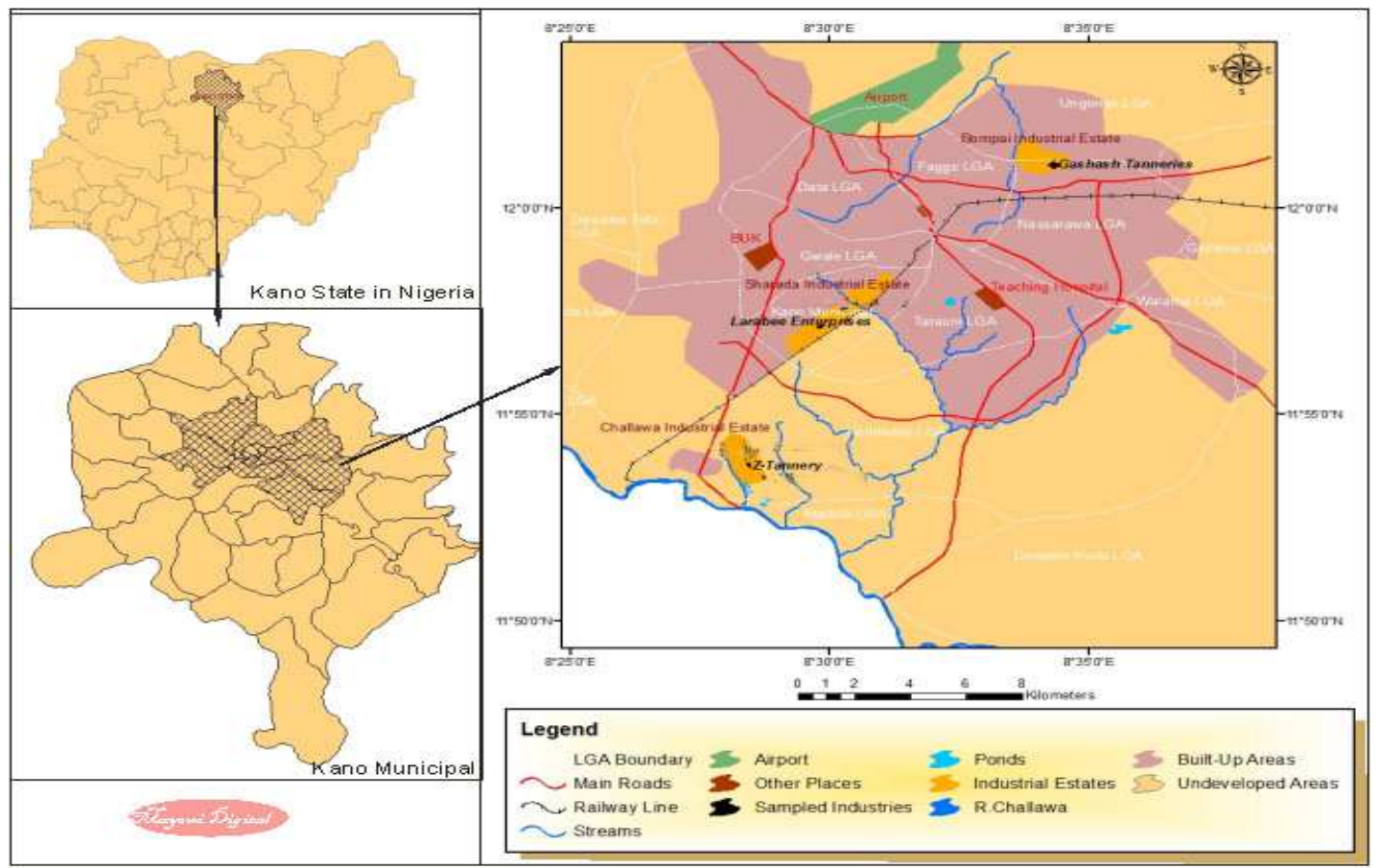

Fig. 1 Map showing the study areas

Source: Mayomi Digital Productions, GIS Laboratory, Department of Geography, UNIMAID (2017)

\section{Determination of Growth Rate of the Bacteria in Effluent Sample}

The bacteria growth rates were determined by transferring $2 \mathrm{~mL}$ of the bacterial isolates from the tannery effluent in broth medium into 100 $\mathrm{mL}$ sterile effluents in conical flasks and kept in an incubator (Giffrin cool) for 10 days. Control was also set up by incubating another $100 \mathrm{~mL}$ each of the sterile effluents without the bacteria. The optical density of the content was determined at the wavelength of $600 \mathrm{~nm}$ on a daily interval and recorded. 
BAJOPAS Volume 13 Number 2, December, 2020 Immobilization of Bacteria

Agar solution and inoculi were prepared separately. Fifty milliliters $(50 \mathrm{~mL})$ of nutrient broth each of the inoculi was prepared in a McCartney bottle and incubated for 24 hours. A solution of agar-agar was prepared by dissolving $10 \mathrm{~g}$ of the powder in distilled water and made up to $500 \mathrm{~mL}$ mark in an Erlenmeyer flask and was sterilized in an autoclave (280A) for 15 minutes and allowed to cool to $40-45^{\circ} \mathrm{C}$ (Ajao et al., 2011). Four milliliters ( $4 \mathrm{~mL})$ of the bacterial isolates in the nutrient broth was mixed with 36 $\mathrm{ml}$ of the prepared agar-agar media in petri-dish plates and then allowed to solidify. This was kept in the refrigerator for bioremediation.

\section{Bioremediation (Treatment) of the Effluents}

The solidified agar block (immobilized bacteria) was cut into cubes using a sterile knife; $0.1 \mathrm{~mL}$ phosphate buffer ( $\mathrm{pH} \mathrm{7.0)}$ was added and kept in the refrigerator for 1 hour for curing. The phosphate buffer was decanted after 1 hour and the cubes were washed with sterile distilled water 3-4 times before it was used (Ajao et al., 2011). Two liters (2 L) of the effluent was supplemented with the minimum basal medium in $\mathrm{g} / \mathrm{L}: \mathrm{NaCl}(0.8), \mathrm{MgSO}_{4} .7 \mathrm{H}_{2} \mathrm{O}(0.001), \mathrm{KH}_{2} \mathrm{PO}_{4}$ (2), $\mathrm{NaNO}_{3}$ (2), $\quad \mathrm{CaCl}_{2} .2 \mathrm{H}_{2} \mathrm{O} \quad(0.5)$ and $\mathrm{NaHPO}_{4} .12 \mathrm{H}_{2} \mathrm{O}(2)$ and sterilized in an autoclave at $121^{\circ} \mathrm{C}$ for 15 minutes (Margesin and Schinner, 2001). Two hundred and fifty milliliters $(250 \mathrm{~mL})$ of the effluents were transferred into different $250 \mathrm{ml}$ conical flasks. The content was covered with a cotton-wool ramped with foil paper to avoid contamination. Five grams $(5 \mathrm{~g})$ of the immobilized bacteria were quickly transferred into each of the effluents in the conical flasks in an inoculating chamber. The same procedures were carried out for the $10 \mathrm{~g}, 15 \mathrm{~g}, 20 \mathrm{~g}$ and 25 $\mathrm{g}$ of the immobilized bacteria in separate $250 \mathrm{~mL}$ effluents in conical flasks and agitated for ten days in a shaker incubator (Gallenkamp-OC4364-L) at a temperature $30^{\circ} \mathrm{C}$ and speed of 60 rpm. The treated effluent samples were taken on the tenth day and analyzed for the parameters $\mathrm{pH}$, SS, TDS, COD, and BOD, (Posttreatment determination) for the different grams of bacteria to evaluate and compare the biodegradation potential. (Baba et al., 2020).

\section{Statistical Analysis}

The data were represented as Mean \pm Standard deviation and analyzed statistically using oneway Analysis of Variance (ANOVA) and Tukey's HSD as Post Hoc Tests with the aid of SPSS 16.0. The correlation coefficient was also used to measure the strength of the relationship between the different masses of the bacteria and the parameters. All $\mathrm{p} \leq 0.05$ were considered as statistically significant.

\section{RESULTS AND DISCUSSION Physico-chemical parameters in the Industrial Effluents before the Biodegradation.}

Results of the Physico-chemical parameters in the industrial effluents before the Biodegradation is shown in table 1 . The mean temperatures $\left({ }^{\circ} \mathrm{C}\right)$ observed in TAN1, TAN2, and TAN3 samples were $28.07 \pm 0.65 ; 27.77 \pm 0.64$ and $26.38 \pm 3.81$ respectively. The order of the mean temperature of the samples from the three industries can be arranged as TAN1 > TAN2>TAN3. The temperature observed at TAN1, TAN2, and TAN3 samples were found below the WHO $\left(35^{\circ} \mathrm{C}\right)$ and NESREA $\left(40^{\circ} \mathrm{C}\right)$ limits. The low values of temperature might be due to the processes used at the time of sampling. High temperature brings down the solubility of gases in water that ultimately expresses as high BOD and COD. Statistical analysis shows that there is no significant difference $(p<0.05)$ between the mean values of temperature among the industries. This might be due to similar tannery activities involved in the tannery industries at the time of sampling. The average values of temperature observed in this present study are less than those observed by Akan et al. (2007), Akan et al. (2009) and Baba et al. (2020).

The mean level of $\mathrm{pH}$ observed in TAN1, TAN2 and TAN3, samples were $7.77 \pm 2.93$; $8.35 \pm 0.28$ and $7.52 \pm 0.76$ respectively. The order of the mean $\mathrm{pH}$ of the samples from the three industries can be arranged as TAN2> TAN1 $>$ TAN3. The $\mathrm{pH}$ of the samples falls within the WHO (7.0-8.5) and NESREA (6-9) standard limits. Statistical analysis shows that there is no significant difference $(p<0.05)$ between the mean values of $\mathrm{pH}$ among the industries. This might be due to similar tannery activities involved in the tannery industries at the time of sampling. Maheshwari et al. (2017) reported that the level of $\mathrm{pH}$ in the effluents from the tannery industry in Vaniyambadi, India was 6.5 which was lower than that observed in the present study. The $\mathrm{pH}$ in the effluents from the tannery industries in Kano and Kaduna were reported to be 7.64 and 6.89, respectively (Akan et al., 2007; Mohammed et al., 2017). The average values of $\mathrm{pH}$ observed in this present study are less than those observed by Mohammed et al. (2017) and Baba et al. (2020). The mean level of SS $(\mathrm{mg} / \mathrm{l})$ observed in TAN1, TAN2, and TAN3 samples were 374 \pm 124 ; $358 \pm 335$ and $780 \pm 739$ respectively. The order of the mean SS in the samples from the three industries can be arranged as TAN3 > TAN1 $>$ TAN2. 
The SS observed in the samples were far above the recommended standard limits of regulating bodies WHO $(30 \mathrm{mg} / \mathrm{l})$ and NESREA $(10 \mathrm{mg} / \mathrm{l})$. Statistical analysis shows that there is no significant difference $(p<0.05)$ between the mean values of SS among the industries. This might be due to similar tannery activities involved in the tannery industries at the time of sampling. The average values of SS observed in this present study are less than that observed $(3700 \pm 122 \mathrm{mg} / \mathrm{l})$ by Akan et al. (2009) for tanneries in Kano. Also, the average values of SS observed in this present study are less than that observed by Mohammed et al. (2017) and Baba et al. (2020) with the exception in TAN3.

The mean level of TDS (mg/l) observed in TAN1, TAN2, and TAN3 samples were $3941 \pm 3703$; $3300 \pm 1714$ and $2653 \pm 1240$ respectively. The order of the mean TDS in the samples from the three industries can be arranged as TAN1>TAN2>TAN3. The TDS observed in the samples were far above the recommended standard limits of WHO $(250 \mathrm{mg} / \mathrm{l})$ and NESREA $(500 \mathrm{mg} / \mathrm{l})$. Statistical analysis shows that there is no significant difference $(p<0.05)$ between the mean values of TDS among the industries. This might be due to similar tannery activities involved in the tannery industries at the time of sampling. TDS in the effluents from the tannery industries in Kano, Nigeria was reported to be $1281 \mathrm{mg} / \mathrm{l}$ (Akan et al., 2007). The average values of SS observed in this present study are less than those observed by Mohammed et al. (2017) and Baba et al. 2020)

The mean level of COD (mg/l) observed in TAN1, TAN2 and TAN3 samples seasons were $2372 \pm 938 ; \quad 1406 \pm 208$ and $3532 \pm 1373$ respectively. The order of the mean COD of the samples from the three industries can be arranged as TAN3>TAN1> TAN2. The COD observed in TAN1, TAN2 and TAN3 samples were far above the recommended standard limits of regulating bodies $\mathrm{WHO}(40 \mathrm{mg} / \mathrm{l})$ and NESREA (40 mg/l). Statistical analysis shows that there is no significant difference $(p<0.05)$ in COD among the industries. This might be due to similar tannery activities involved in the tannery industries as at the time of sampling. The Chemical Oxygen demand (COD) is the amount of oxygen, in $\mathrm{mg} / \mathrm{L}$, required for the degradation of the compound of wastewater to occur. In comparison, the average values of COD observed in this present study were higher than that observed by Mohammed et al. (2017) but lower than that observed by Baba et al. (2020).

The mean levels of BOD $(\mathrm{mg} / \mathrm{l})$ observed in TAN1, TAN2 and TAN3 samples were $13.85 \pm 6.42 ; \quad 19.46 \pm 0.50$ and $17.13 \pm 3.14$ respectively. The order of the mean BOD in the samples from the three industries can be arranged as TAN2>TAN3>TAN1. The BOD observed in TAN1, TAN2 and TAN3 samples were found below the recommended limits of NESREA (200 mg/l) but above WHO (10 mg/l). Statistical analysis shows that there is no significant difference $(p<0.05)$ between the mean values of BOD among the industries. This might be due to similar tannery activities involved in the tannery industries at the time of sampling. The low level of BOD recorded in this study is an indication of the low level of biodegradable organic solids in the effluent. The average values of BOD observed in this present study were lower than those observed by Mohammed et al. (2017) and Baba et al. (2020).

Table 1: Mean Values \pm S.D of Physico-chemical parameters of effluents from the Tannery Industries before Treatment.

\begin{tabular}{llllllll}
\hline Parameter & Tannery 1 & Tannery 2 & Tannery 3 & $\mathrm{a}$ & $\mathrm{b}$ & $\mathrm{c}$ & $\mathrm{d}$ \\
\cline { 2 - 7 } Temperature $\left({ }^{\circ} \mathrm{C}\right)$ & $28.07 \mathrm{a} \pm 0.65$ & $27.77 \mathrm{a} \pm 0.64$ & $26.38 \mathrm{a} \pm 3.81$ & & $29.50 \pm 4.68$ & 35 & 40 \\
pH & $7.77 \mathrm{a} \pm 2.93$ & $8.35 \mathrm{a} \pm 0.28$ & $7.52 \mathrm{a} \pm 0.76$ & 6.89 & $5.35 \pm 1.57$ & $7.0-8.5$ & $6.0-9.0$ \\
$\mathrm{COD}(\mathrm{mg} / \mathrm{l})$ & $2372 \mathrm{a} \pm 938$ & $1406 \mathrm{a} \pm 208$ & $3532 \mathrm{a} \pm 1373$ & 2.2 & $3106 \pm 2753$ & 40 & 40 \\
$\mathrm{BOD}(\mathrm{mg} / \mathrm{l})$ & $13.85 \mathrm{a} \pm 6.42$ & $19.46 \mathrm{a} \pm 0.50$ & $17.13 \mathrm{a} \pm 3.14$ & 1032 & $26.17 \pm 9.49$ & 10 & 200 \\
$\mathrm{SS}(\mathrm{mg} / \mathrm{l})$ & $374 \mathrm{a} \pm 124$ & $358 \mathrm{a} \pm 335$ & $780 \mathrm{a} \pm 739$ & 501 & $562 \pm 482$ & 30 & 10 \\
TDS $(\mathrm{mg} / \mathrm{l})$ & $3941 \mathrm{a} \pm 3703$ & $3300 \mathrm{a} \pm 1714$ & $2653 \mathrm{a} \pm 1240$ & 532.7 & $444 \pm 507$ & 250 & 500 \\
\hline
\end{tabular}

The values given in the table above are means of 6 replicate values, $\mathrm{n}=6$ ( 1 sample was taken monthly for 6 months). Within the rows, means with different alphabets are statistically different $(p<0.05)$. WHO: World Health Organisation. NESREA: National Environmental Standard and Regulatory Enforcement Agency. a = Mohammed et al.(2017), b = Baba et al. (2020), c = WHO (2006), $d=$ NESSRA (2009) 
BAJOPAS Volume 13 Number 2, December, 2020

Identification, Biochemical Characterization and growth rates of the Bacterial Isolates

Results of identification and biochemical characterization of the bacterial isolates were shown in table 2. After 24 hours of incubation, the nutrient agar media plates were checked for bacterial growth. The results showed the presence of different strains in the samples. The TAN1 bacteria isolate was found to be gramnegative cocci while TAN3 was gram-positive cocci. TAN2 bacteria isolate was found to be gram-positive, rod-shaped. TAN1, TAN2, and TAN3 bacteria isolates recorded positive results for spore former.

The results of the biochemical tests indicated that all the bacteria were positive for catalase, oxidase, citrate, maltose, glucose, lactose (negative in TAN1), mannitol (negative in TAN2), starch hydrolysis and coagulase (negative in TAN2) tests. The bacteria showed negative results for nitrate reduction, $M R$ (positive in TAN2), VP (positive in TAN1), Indole (positive in TAN2) tests. Base on the morphological and biochemical test results, TAN1, TAN2, and TAN3 bacteria isolates were identified to be Nesseria spp, Bacillus cereus, and Staphylococcus aureus respectively.

The growth rate of the TAN1, TAN2 and TAN3 Isolates were shown in figure 2. Generally, the optical density increase with the increase in time (day) and decrease as time goes on. The highest optical density was shown by bacillus cereus in TAN2 while the lowest was shown by Staphylococcus aureus in TAN3.

The initial growth phase of TAN1 Isolate bacteria occurred within 2-day of incubation as the growth rate increases up to the 6th-day incubation when the maximum growth was observed. Beyond the 6th day, the growth of the bacteria declined (which might be due to a shortage of nutrients in the effluents) until it reached its death phase (which might be due to the unavailability of nutrients in the effluents).

A similar trend of growth was also observed for TAN2 Isolate as the initial growth phase also occurred within 2-day of incubation but maximum growth rate observed on the 4th day of incubation. The stationary stage occurred between the 4th day and the 8th day. Beyond the 8th day, the growth of the bacteria declined (which might be due to a shortage of nutrients in the effluents) until it reached its death phase (which might be due to the unavailability of nutrients in the effluents).

The initial growth phase of TAN3 bacterial Isolate occurred within the 3-day incubation as the growth rate increases up to the 6th-day incubation when the maximum growth was observed. Beyond the 6th day, the growth of the bacteria declined (which might be due to a shortage of nutrients in the effluents) until it reached its death phase (which might be due to the unavailability of nutrients in the effluents).

Table 2: Morphological and Biochemical characteristics of bacterial isolates

\begin{tabular}{lllll} 
Bacterial Isolates & & TAN1 & TAN2 & TAN3 \\
\hline $\begin{array}{lllll}\text { Morphological } \\
\text { characteristics }\end{array}$ & Shape & Cocci & Rod & Cocci \\
& Spore & & & \\
& former & + & + & + \\
Gram & & & \\
Biochemical characteristics & reaction & - & + & + \\
& Citrate & + & + & + \\
& Catalase & + & + & + \\
& Coagulase & + & - & + \\
Starch & + & + & + \\
& Glucose & + & + & + \\
Oxidase & + & + & + \\
& Indo & - & + & - \\
Lactose & - & + & + \\
Manitol & + & - & + \\
Maltose & + & + & + \\
MR & - & + & - \\
VP & + & - & - \\
& Nitrate & - & - & - \\
Reduction & - Neisseria & Bacillus & Staphylococcus \\
& Bacterial & cereus & aureus \\
& name & spp & cas
\end{tabular}

+ = Positive; - = Negative; MR=Methyl Red; VP= Voges-Proskauer 


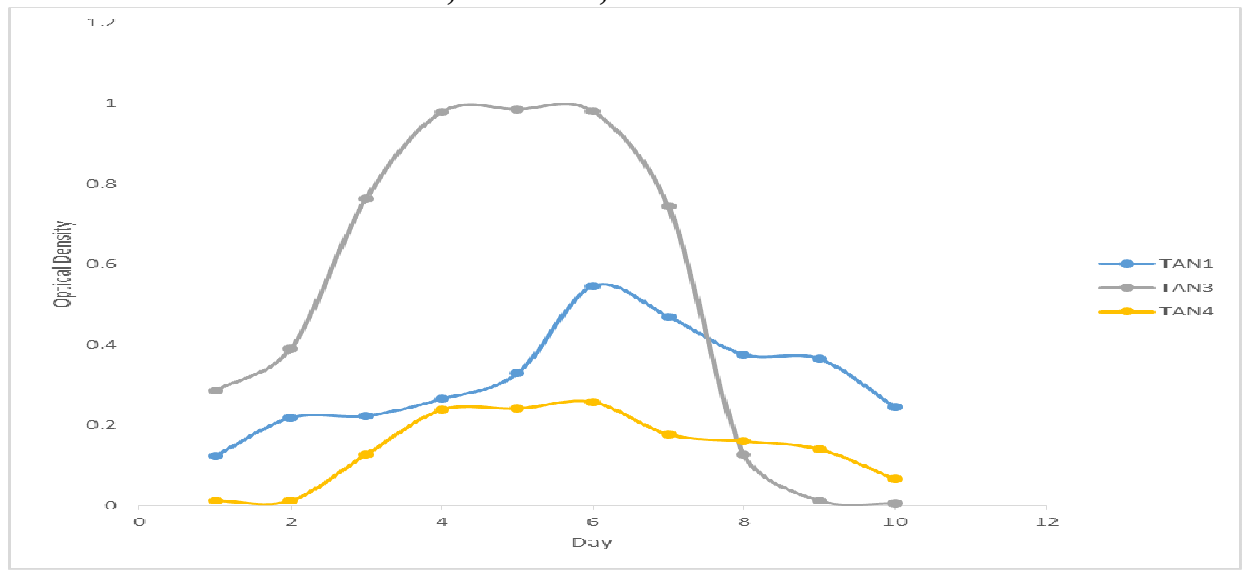

Fig. 2 Growth rates of the isolates in the effluents from the Tannery Industries

\section{Physico-chemical Parameters in the Industrial Effluents after the biodegradation.}

Table 3 shows the mean results of the physicochemical parameter before and after bioremediation using the different masses $(5 \mathrm{~g}$, $10 \mathrm{~g}, 15 \mathrm{~g}, 20 \mathrm{~g}$, and $25 \mathrm{~g}$ ) of the respective immobilized bacteria. Also, Table 4 shows the mean results of correlation coefficient ( $r$ ) between different masses of bacteria and physicochemical parameters.

The mean values $(\mathrm{mg} / \mathrm{l})$ of the SS after the bioremediation varies between $243 \pm 45$ and $898 \pm 672$. The mean concentration $(\mathrm{mg} / \mathrm{l})$ of SS remediated by the different masses $(5 \mathrm{~g}, 10 \mathrm{~g}$, $15 \mathrm{~g}, 20 \mathrm{~g}$, and $25 \mathrm{~g}$ ) of the bacteria varies. The SS in the samples fluctuates up and down after the bioremediation process when compared with the SS of the raw samples before the bioremediation. The increase in the levels of the SS might be due to the aggregation of the TDS which are large enough to result into SS. The increase in the levels of the SS might be also due to the influence of the nutrients which was added into the effluents in order to make the microorganisms more active and viable for fast degradation of organic contaminants in the effluent. The relative potential or efficiency of the different masses of the bacteria in remediating SS in TAN1 samples was in the order $25 \mathrm{~g}>20 \mathrm{~g}>15 \mathrm{~g}>10 \mathrm{~g}>5 \mathrm{~g}$. For TAN2 and TAN3 samples, the order was $25 \mathrm{~g}>20 \mathrm{~g}>15$ $\mathrm{g}>10 \mathrm{~g}>5 \mathrm{~g}$. These might be due to the variations in the surface areas of the different masses of the immobilized bacteria. Statistical analysis shows that there is no significant difference $(p<0.05)$ between the mean values of SS among the masses in the respective industries. Positive and significant correlations exist between the masses of bacteria and Suspended Solid (SS). This showed that there is general increase in the levels of the SS as the masses of the immobilized bacteria increases. TAN3 (90\%) and TAN1 (80\%) showed a very high correlation with the masses of the bacteria while TAN2 (61\%) showed a very low correlation.

The mean values $(\mathrm{mg} / \mathrm{l})$ of the TDS after the bioremediation varies between $46 \pm 11$ and $83 \pm 78$. The mean concentration $(\mathrm{mg} / \mathrm{l})$ of TDS remediated by the different masses $(5 \mathrm{~g}, 10 \mathrm{~g}$, $15 \mathrm{~g}, 20 \mathrm{~g}$, and $25 \mathrm{~g}$ ) of the bacteria varies. There is a reduction in all the TDS of all the samples after the bioremediation process compared with the TDS of the raw samples before the bioremediation. The relative potential or efficiency of the different masses of the bacteria in remediating TDS in TAN1 and TAN3 samples was in the order $5 \mathrm{~g}>10 \mathrm{~g}>15 \mathrm{~g}>20$ $\mathrm{g}>25 \mathrm{~g}$. For TAN2 samples, the order was 20 $g>10 \quad g>25 \quad g>15 \quad g>5 \quad g$. Statistical analysis shows that there is no significant difference $(p<0.05)$ between the mean values of TDS among the masses in the respective industries. These might be due to the variations in the surface areas of the different masses of the immobilized bacteria. Positive and significant correlations exist between the masses of bacteria and TDS with the exception in TAN2 (negative and insignificant correlation). The positive correlations showed that there is general increase in the levels of the TDS as the masses of the immobilized bacteria increases. TAN1 $(96 \%)$ showed a very high correlation with the masses of the bacteria while TAN2 (47\%) showed a very low correlation.

The mean values $(\mathrm{mg} / \mathrm{l})$ of the BOD after the bioremediation varies between $1.56 \pm 0.20 \mathrm{mg} / \mathrm{l}$ and $6.92 \pm 5.49 \mathrm{mg} / \mathrm{l}$. The mean concentration $(\mathrm{mg} / \mathrm{l})$ of BOD remediated by the different masses $(5 \mathrm{~g}, 10 \mathrm{~g}, 15 \mathrm{~g}, 20 \mathrm{~g}$, and $25 \mathrm{~g}$ ) of the bacteria varies. There is a reduction in all the BOD of all the samples after the bioremediation process compared with the $\mathrm{BOD}$ of the raw 
BAJOPAS Volume 13 Number 2, December, 2020 samples before the bioremediation. The relative potential or efficiency of the different masses of the bacteria in remediating BOD in TAN1, TAN2 and TAN3 samples were in the order $25 \mathrm{~g}>20$ $\mathrm{g}>15 \mathrm{~g}>10 \mathrm{~g}>5 \mathrm{~g}, 25 \mathrm{~g}>15 \mathrm{~g}>5 \mathrm{~g}>10 \mathrm{~g}>20 \mathrm{~g}$ and $20 \mathrm{~g}>10 \mathrm{~g}>25 \mathrm{~g}>15 \mathrm{~g}>5 \mathrm{~g}$ respectively. Statistical analysis shows that there is significant difference $(p<0.05)$ between the mean values of BOD among the masses in the respective industries. These might be due to the variations in the surface areas of the different masses of the immobilized bacteria. Negative and significant correlations exist between the masses of bacteria and BOD. This showed that there is general decrease in the levels of the BOD as the masses of the immobilized bacteria increases. TAN1 (94\%) showed a very high correlation with the masses of the bacteria while TAN2 (4\%) showed a very low correlation.

The mean values $(\mathrm{mg} / \mathrm{l})$ of the COD after the bioremediation varies between $250 \pm 154$ and $3134 \pm 1595$. The mean concentration $(\mathrm{mg} / \mathrm{l})$ of COD remediated by the different masses $(5 \mathrm{~g}$, $10 \mathrm{~g}, 15 \mathrm{~g} 20 \mathrm{~g}$, and $25 \mathrm{~g}$ ) of the bacteria varies. There is a reduction in all the COD of all the samples after the bioremediation process compared with the COD of the raw samples before the bioremediation. The relative potential or efficiency of the different masses of the bacteria in remediating COD in TAN1, TAN2 and TAN3 samples were in the order $25 \mathrm{~g}>20 \mathrm{~g}>15$ $\mathrm{g}>5 \mathrm{~g}>10 \mathrm{~g}, 25 \mathrm{~g}>20 \mathrm{~g}>15 \mathrm{~g}>10 \mathrm{~g}>5 \mathrm{~g}$ and 10 g>5 g>25 g>15 g>20 g respectively. Statistical analysis shows that there were significant difference $(p<0.05)$ between the mean values of COD among the masses in the respective industries except for effluents treated with $25 \mathrm{~g}$. These might be due to the variations in the surface areas of the different masses of the immobilized bacteria. Negative and insignificant correlations exist between the masses of bacteria and COD with the exception in TAN3 (positive and significant correlation). The negative correlations showed that there is general decrease in the levels of the COD as the masses of the immobilized bacteria increases. TAN2 (100\%) showed a very high correlation with the masses of the bacteria while TAN3 (36\%) showed a very low correlation.

Generally, there was an overall decrease in the concentration of these physicochemical parameters after the bioremediation using the different masses of the bacterial isolates. These might be due to the variations in the surface areas of the different masses of the immobilized bacteria. This is in line with the work of Jimoh et al. (2018) and Baba et al. (2020).

Table 3: Mean Values $(\mathrm{mg} / \mathrm{l}) \pm$ S.D of Physicochemical parameters in effluents from the Tannery Industries before and after Treatment of the effluents $(250 \mathrm{ml})$ with the different masses $(5 \mathrm{~g}, 10 \mathrm{~g}$, $15 \mathrm{~g}, 20 \mathrm{~g}$, and $25 \mathrm{~g}$ ) of the bacteria.

\begin{tabular}{llllllll}
\hline $\mathrm{P}$ & IND & Before & \multicolumn{5}{c}{ After } \\
\cline { 4 - 7 } & & & $5 \mathrm{~g}$ & $10 \mathrm{~g}$ & $15 \mathrm{~g}$ & $20 \mathrm{~g}$ & $25 \mathrm{~g}$ \\
\hline \multirow{2}{*}{ COD } & TAN1 & $2372 \pm 938$ & $1708 \mathrm{a} \pm 861$ & $2045 \mathrm{a} \pm 1205$ & $845 \mathrm{a} \pm 369$ & $300 \mathrm{a} \pm 167$ & $250 \mathrm{a} \pm 154$ \\
& TAN2 & $1406 \pm 208$ & $1195 \mathrm{a} \pm 208$ & $1125 \mathrm{a} \pm 384$ & $1055 \mathrm{a} \pm 317$ & $956 \mathrm{a} \pm 310$ & $870 \mathrm{ab} \pm 240$ \\
& TAN3 & $3532 \pm 1373$ & $2374 \mathrm{a} \pm 1344$ & $1976 \mathrm{a} \pm 1405$ & $2757 \mathrm{a} \pm 1266$ & $3134 \mathrm{a} \pm 1595$ & $2614 \mathrm{~b} \pm 1105$ \\
BOD & TAN1 & $13.85 \pm 6.42$ & $6.92 \mathrm{a} \pm 5.49$ & $6.42 \mathrm{a} \pm 5.07$ & $5.72 \mathrm{a} \pm 5.35$ & $4.62 \mathrm{a} \pm 4.37$ & $2.82 \mathrm{ab} \pm 1.26$ \\
& TAN2 & $19.46 \pm 0.50$ & $1.75 \mathrm{~b} \pm 0.22$ & $1.73 \mathrm{~b} \pm 0.18$ & $1.58 \mathrm{a} \pm 0.16$ & $1.91 \mathrm{a} \pm 0.22$ & $1.56 \mathrm{~b} \pm 0.20$ \\
& TAN3 & $17.13 \pm 3.14$ & $4.24 \mathrm{ab} \pm 0.77$ & $3.29 \mathrm{ab} \pm 0.37$ & $4.11 \mathrm{a} \pm 0.07$ & $3.23 \mathrm{a} \pm 0.91$ & $3.33 \mathrm{a} \pm 1.28$ \\
SS & TAN1 & $374 \pm 124$ & $243 \mathrm{a} \pm 45$ & $471 \mathrm{a} \pm 226$ & $475 \mathrm{a} \pm 182$ & $492 \mathrm{a} \pm 128$ & $611 \mathrm{a} \pm 217$ \\
& TAN2 & $358 \pm 335$ & $460 \mathrm{a} \pm 400$ & $543 \mathrm{a} \pm 414$ & $544 \mathrm{a} \pm 402$ & $551 \mathrm{a} \pm 414$ & $554 \mathrm{a} \pm 405$ \\
& TAN3 & $780 \pm 739$ & $586 \mathrm{a} \pm 594$ & $758 \mathrm{a} \pm 656$ & $787 \mathrm{a} \pm 676$ & $861 \mathrm{a} \pm 635$ & $898 \mathrm{a} \pm 672$ \\
TDS & TAN1 & $3941 \pm 3703$ & $51 \mathrm{a} \pm 10$ & $53 \mathrm{a} \pm 10$ & $55 \mathrm{a} \pm 15$ & $61 \mathrm{a} \pm 20$ & $63 \mathrm{a} \pm 26$ \\
& TAN2 & $3300 \pm 1714$ & $83 \mathrm{a} \pm 78$ & $47 \mathrm{a} \pm 20$ & $48 \mathrm{a} \pm 22$ & $47 \mathrm{a} \pm 17$ & $48 \mathrm{a} \pm 17$ \\
& TAN3 & $2653 \pm 1240$ & $46 \mathrm{a} \pm 11$ & $55 \mathrm{a} \pm 24$ & $55 \mathrm{a} \pm 25$ & $58 \mathrm{a} \pm 23$ & $61 \mathrm{a} \pm 28$ \\
\hline
\end{tabular}

Replicate $=6$ (months)

Within the rows, for the same parameter, means with different alphabets are statistically different $(p<0.05)$.

$\mathrm{P}=$ parameter, IND = Industries 
BAJOPAS Volume 13 Number 2, December, 2020

Table 4: Correlation coefficient $(r)$ between different masses of the bacteria and the physicochemical parameters.

\begin{tabular}{llll}
\hline Industries & Parameter & Correlation coefficient $(r)$ & $\begin{array}{l}\text { Percent dependence (rxrx100) } \\
(\%)\end{array}$ \\
\hline TAN1 & COD & -0.9 & 82 \\
& BOD & -0.97 & 94 \\
& SS & $0.90^{*}$ & 80 \\
TAN2 & TDS & $0.98^{*}$ & 96 \\
& COD & -1 & 100 \\
& BOD & -0.21 & 4 \\
& SS & $0.78^{*}$ & 61 \\
& TDS & -0.69 & 47 \\
& COD & $0.60^{*}$ & 36 \\
& BOD & -0.6 & 37 \\
& SS & $0.95^{*}$ & 90 \\
& TDS & $0.94^{*}$ & 89 \\
\hline
\end{tabular}

The correlation coefficient $(r)$ with * is statistically significant $(p<0.05)$.

Percentage reduction of the Parameters

Table 5 shows the percentage reduction of Parameters in industrial samples before and after the treatment of the effluents $(250 \mathrm{ml})$ with the different masses $(5 \mathrm{~g}, 10 \mathrm{~g}, 15 \mathrm{~g}, 20 \mathrm{~g}$, and $25 \mathrm{~g}$ ) of the Immobilized Bacteria.

In TAN1 samples, the percentage reduction (\%) of COD ranged (14-89); BOD (50-80); SS (-32$35)$ and TDS (98-99). In TAN2 samples, the percentage decrease $(\%)$ of COD ranged (15$38) ;$ BOD (90-92); SS [-28-(-55)] and TDS (9798). In TAN3 samples, the percentage decrease (\%) of COD ranged (11-44); BOD (76-81); SS (15-25) and TDS (98). The percentage increase in the levels COD, BOD and TDS might be due to the increase in the surface area of the different masses of the immobilized bacteria. However, the percentage decrease in the levels of the SS might be due to the aggregation of the TDS which are large enough to result into SS. The percentage decrease in the levels of the SS might be also due to the influence of the nutrients which was added into the effluents in order to make the microorganisms more active and viable for fast degradation of organic contaminants in the effluent. This is in line with the work of Jimoh et al. (2018) in which the concentration of the SS increase after the bioremediation of effluents.

Sreemoyee and Priti (2013) assessed and reduced several Physico-chemical parameters of dairy wastewater using Niesseria $s p$. and concluded that the species are well known to degrade organic compounds. This is in agreement with the current study in which the immobilized Niesseria $s p$ degrade the organic contaminants as indicated by the BOD, COD and TDS.

Jimoh et al. (2018) observed that TSS of the effluents was increased after treatment with immobilized bacteria and concluded that it might be due to the biostimulation method adopted for the research.

The optimum $\mathrm{pH}$ Biosorption of Chromium by Bacillus spp and Staphylococcus spp. from tannery effluent was investigated by Mythili and Karthikeyan (2011). The maximum adsorption of Chromium $(86.4 \mathrm{mg} / \mathrm{L})$ was showed by Bacillus spp and Staphylococcus spp showed $70.6 \mathrm{mg} / \mathrm{L}$ at an initial concentration of $100 \mathrm{mg} / \mathrm{L}$. In the present study, immobilised Bacillus spp and Staphylococcus spp. from the tannery industrial effluents reduced the levels of the organic pollutants with high potential as indicated by the percentage reduction of BOD, COD and TDS.

Enzymes often can work in multiple environments especially if they are immobilized. This makes the microorganisms' enzymes even more resistant to harsh environments and enables the enzymes to be recovered and recycled after they are no longer needed (Gianfreda and Rao 2004). Ramesh and Singh (1993) reported that the immobilized bacteria having more efficiency to remove the suspended particles than free cells. Using the immobilized cell is preferable due to its capability for using several times with the same efficiency, which makes it more economical. Similar work was done by Sikander et al. (2007) showing the higher reduction with permeabilized cells of Ochrobactrum intermedium strain SDCr-5. 
BAJOPAS Volume 13 Number 2, December, 2020

The results revealed the isolation and identification of isolates with the potential for the reduction of $\mathrm{Cr}$ (VI) to $\mathrm{Cr}$ (III). Results indicated that immobilized $B$. cereus could be efficiently used for the reduction of $\mathrm{Cr}$ (VI).

Table 5: Percentage reduction of the tested Parameters from the tannery industrial samples of the Immobilized Bacteria.

\begin{tabular}{lllllll}
\hline \multirow{2}{*}{ Industries } & & \multicolumn{5}{c}{ Percentage Reduction $(\%)$} \\
\cline { 3 - 7 } & & $5 \mathrm{~g}$ & $10 \mathrm{~g}$ & $15 \mathrm{~g}$ & $20 \mathrm{~g}$ & $25 \mathrm{~g}$ \\
\hline TAN1 & COD & 28 & 14 & 64 & 87 & 89 \\
& BOD & 50 & 54 & 59 & 67 & 80 \\
& SS & 35 & -26 & -27 & -32 & -63 \\
& TDS & 99 & 99 & 99 & 98 & 98 \\
TAN2 & COD & 15 & 20 & 25 & 32 & 38 \\
& BOD & 91 & 91 & 92 & 90 & 92 \\
& SS & -28 & -52 & -52 & -54 & -55 \\
& TDS & 97 & 99 & 99 & 99 & 99 \\
& COD & 33 & 44 & 22 & 11 & 26 \\
& BOD & 75 & 81 & 76 & 81 & 81 \\
& SS & 25 & 3 & -1 & -10 & -15 \\
& TDS & 98 & 98 & 98 & 98 & 98 \\
\hline
\end{tabular}

Percentage Reduction $=(B-A) / B \times 100 \%$

$A=$ Concentration of the parameter after treatment

$\mathrm{B}=$ Concentration of the parameter before treatment

$+=$ percentage decrease

- = percentage increase

In general, immobilization makes the enzyme more resistant to temperature, $\mathrm{pH}$, and substrate concentration swings giving it a longer lifetime and higher productivity per active unit (Gianfreda and Rao, 2004; FuIlbrook, 1996; Russell et al, 2003; Kandelbauer et al., 2004). Immobilized cells have been used and studied extensively for the production of useful chemicals (Ohtake and Silver, 1994), the treatment of wastewaters (Chen et al., 2003; Wang et al., 2010). Although many workers described microbial degradation of tannery effluent, limited literature is available on the bioremediation of tannery effluent using immobilized bacterial cells in the Kano Industrial Estates.

\section{CONCLUSION}

The samples contained variable levels of the physicochemical parameters. The results of the Analysis of variance revealed that, no statistical difference $(p<0.05)$ was observed for the temperature, $\mathrm{pH}, \mathrm{SS}, \mathrm{TDS}, \mathrm{BOD}$ and $\mathrm{COD}$ among the three tannery industries before the treatment. The levels of some of the parameters
(SS, TDS and COD) observed in the samples were found above the recommended limits of WHO and NESREA, which called for the treatment of the effluents before discharge into the environment. Base on the morphological and biochemical test results, TAN1, TAN2, and TAN3 bacterial isolates were identified to be Neisseria spp, Bacillus cereus, and Staphylococcus aureus respectively. The results of Post-treatment analysis showed that there is overall decrease in the levels of the parameters determined when compared with that of the pre-treatment. The overall percentage reduction of the immobilised bacteria in the treatment of the respective effluents was in the order TAN2 (72\%)>TAN1 $(70 \%)>$ TAN3 $(62 \%)$. Hence, the immobilized bacteria are having higher biodegradation potential for the treatment of the tannery effluents.

\section{Acknowledgments}

The authors wish to acknowledge the University of Maiduguri for the financial support. The authors are grateful to the Kano State Ministry of Environment for their support in obtaining the effluent samples. 


\section{REFERENCES}

Ajao, A. T., Adebayo, G. B., and Yakubu, S. E. (2011). Bioremediation of textile industrial effluent using mixed culture of Pseudomonas aeruginosa and Bacillus subtilis immobilized on agar-agar in a bioreactor. J. Microbiol. Biotech. Res, 1(3), 50-56.

Akan, J. C., Moses, E. A., Ogugbuaja, V. O., and Abah, J. (2007). Assessment of tannery industrial effluents from Kano metropolis, Kano State, Nigeria. Journal of Applied Sciences, 7(19), 2788-2793.

Akan, J. C., Ogugbuaja, V. O., Abdulrahman, F. I., and Ayodele, J. T. (2009). Pollutant levels in effluent samples from tanneries and textiles of Kano industrial areas, Nigeria. Global journal of pure and applied sciences, 15(3-4).

APHA (1989). Standard methods for Examination of Will bete and Will betewater.15 $5^{\text {th }}$ edition. Brydpass Springfield Will behington DC. pp. 164-176

APHA (1992). Standard Methods for the Examination of Water and Wastewater. Health, 69, 1116-9.

Baba, A., Garba, S. T., and Bello, H. S. (2020). Bioremediation Potential of Immobilized corynebacterium kutsceri in the Treatment of Tannery Industrial Effluent from Challawa Industrial Estate, Kano State, Nigeria. Journal of the Turkish Chemical Society Section A: Chemistry, $7(2), 335-350$.

Beem, E. I. V. (1994). reduction of solvent VOC emission. J. Oil Col. Chem. Ass, 77, 158.

Bouwer, E. J., and Zehnder, A. J. (1993). Bioremediation of organic compoundsputting microbial metabolism to work. Trends in biotechnology, 11(8), 360367.

Chen, K. C., Wu, J. Y., Liou, D. J., and Hwang, S. C. J. (2003). Decolorization of the textile dyes by newly isolated bacterial strains. Journal of Biotechnology, 101(1), 57-68.

Dan'Azumi, S., and Bichi, M. H. (2010). INDUSTRIAL POLLUTION AND HEAVY METALS PROFILE OF CHALLAWA RIVER IN KANO, NIGERIA. Journal of Applied Sciences in Environmental Sanitation, $5(1)$.

DWAF. (1992). Analytical Methods Manual, TR 151. Department of Water Affairs and Forestry, Pretoria.

El-Bestawy, E. (2013). Biological treatment of leather-tanning industrial wastewater using free living bacteria.
Elsheikh, M. A. S. (2009). Tannery wastewater pre-treatment. Water Science and Technology, 60(2), 433-440.

FuIlbrook, P. D. (1996). "Kinetics." Industrial enzymology: The application of enzymes in Industry. 2nd Ed. T. Godfrey and J Reichelt. eds.. Nature. New York.

Gianfreda, L., and Rao, M. A. (2004). Potential of extra cellular enzymes in remediation of polluted soils: a review. Enzyme and microbial technology, 35(4), 339354.

Hugo Springer. (1994). John Arthur Wilson Memorial Lecture "Treatment of Industrial Wastes of the Leather Industry - is it still a Major Problem". JALCA, 89, 153-185

Jimoh, A. A., Ganiyu, B. A., Baba, D., and Baba, A. (2018) Bioremediation Process of Effluent from Detergent and Food Industries in Jos, Nigeria: Kinetics and Thermodynamics. International Journal of Engineering Science Invention (IJESI), 762-73

Kandelbauer, A., Maute, O., Kessler, R. W., Erlacher, A., and Gübitz, G. M. (2004). Study of dye decolorization in an immobilized laccase enzyme-reactor using online spectroscopy. Biotechnology and bioengineering, 87(4), 552-563.

Kongjao, S., Damronglerd, S., and Hunsom, M. (2008). Simultaneous removal of organic and inorganic Pollutants in tannery wastewater using electrocoagulation technique. Korean Journal of chemical engineering, 25(4), 703.

Maheshwari, U. M., Aruna, S., Gomathi, M., and AbdulJaffar, A. H. (2017). Bioremediation by Free and Immobilized Bacteria Isolated from Tannery Effluent. International Journal of Research in Applied, Natural and Social Sciences. 5(7), 75-90

Margesin, R., and Schinner, F. (2001). Bioremediation (natural attenuation and biostimulation) of diesel-oilcontaminated soil in an alpine glacier skiing area. Applied and environmental microbiology, 677), 3127-3133.

Mohammed, A., Sekar, P., and George, J. (2011). Efficacy of microbes in bioremediation of tannery effluent. Inter. J. Curr. Res, 3(4), 324-326.

Mohammed, S. S. D., Orukotan, A. A., and Abdullahi, H. (2017). Physicochemical and Bacteriological Assessment of Tannery Effluent from Samaru-Zaria, 
BAJOPAS Volume 13 Number 2, December, 2020 Kaduna State, Nigeria. Journal of Applied

Sciences and Environmental Management, 21(4), 734-740.

Munz, G., De Angelis, D., Gori, R., Mori, G., Casarci, M., and Lubello, C. (2009). The role of tannins in conventional and membrane treatment of tannery wastewater. Journal of hazardous materials, 164(2-3), 733-739

Mythili, K., and Karthikeyan, B. (2011). Bioremediation of $\mathrm{Cr}$ (VI) from tannery effluent using Bacillus spp and Staphylococcus spp. International Multidisciplinary Research Journal, 1(6).

NESREA (2009). National Environmental Standards for Effluent Limitations and Regulation. 1233-1236

Noorjahan, C. M. (2014). Physicochemical characteristics, identification of bacteria and biodegradation of industrial effluent. Journal of bioremediation and Biodegradation, 5(3).

Ohtake, H. I., and Silver, A. O. (1994). Bacterial reduction of toxic chromate. Biological degradation and bioremediation of toxic chemicals, 403-415.

Omoleke, I. I. (2004). Management of environmental pollution in Ibadan, an African city: the challenges of health hazard facing government and the people. Journal of Human Ecology, 15(4), 265-275.

Rajor, A., Reddy, A.S., and Singh, B. (2004). Determination of BOD kinetic Parameters and evaluation of alternate methods, M.Sc. Thesis, Department of biotechnology \& environmental Science, Thapar Institute of Engineering and Technology, Patiala

Ramasami, T., Rajamani, S., and Rao, J. R. (1994, March). Pollution control in leather industry: Emerging technological options. In International symposium on surface and colloidal science and its relevance to soil pollution, madras.

Ramesh, J. V. S., and Singh, S. P. (1993). Yearly variation in certain physicochemical parameters of pond at eastern Doon Valley. Uttar Pradesh J. Zoo, 12 (1), 7577.

Ranen, S., and Sharadinadra, C. (2009). Biotechnology applications to environmental remediation in resource exploitation. Current science, 97, 6-25
Russell, A. J., Berberich, J. A., Drevon, G. F., and Koepsel, R. R. (2003). Biomaterials for mediation of

chemical and biological warfare agents. Annual review of biomedical engineering, 5(1), 1-27.

Saravanan, P., and Saravanan, A. (1999). Decolourization of tannery effluent by Flavobacterium sp. EK 1. Indian Journal of Environmental Protection, 19, 19-24.

Sikander, S., and Shahida, H. (2007). Reduction of toxic hexavalent chromium by Ochrobactrum intermedium strain SDCr5 stimulated by heavy metals. Bioresource Technol, 98, 340-344.

Singh, N., Sharma, B. K., and Bohra, P. C. (2000). Impact assessment of industrial effluent of arid soils by using satellite imageries. Journal of the Indian Society of Remote Sensing, 28(2-3), 79.

Sreemoyee, C., and Priti, P. (2013). Assessment of physico-chemical parameters of dairy waste water and isolation and characterization of bacterial strains in terms of cod reduction. Int J Sci, 2(3), 395-400.

Verheijen, L. A. H. M., Wiersema, D., Pol, L. H., and De Wit, J. (1996). Management of wastes from animal product processing. Livestock and environment, Finding a balance. International Agriculture Center, Wageningen, The Netherlands.

Wang, F., Yao, J., Si, Y., Chen, H., Russel, M., Chen, K., and Bramanti, E. (2010). Short-time effect of heavy metals upon microbial community activity. Journal of Hazardous Materials, 173(13), 510-516.

WHO (World Health Organization). (2006). Air quality guidelines: global update 2005: particulate matter, ozone, nitrogen dioxide, and sulfur dioxide. World Health Organization.

World Bank. (1995). Nigeria's strategic options for redressing industrial pollution. World Bank, industry and energy division. 1st edition, West Central Africa Department; Annexes: 1995; pp 60-62.

Zahoor, A., and Abdul, R. (2009). Enumeration of Coliforms. Journal of Environmental Sciences. 21, 814-820 


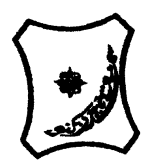

Bayero Journal of Pure and Applied Sciences, 13(2): 1 - 12

Received: November, 2020

Accepted: December, 2020

ISSN $2006-6996$

\title{
BIODEGRADATION POTENTIAL OF IMMOBILIZED BACTERIA IN THE TREATMENT OF TANNERY INDUSTRIAL EFFLUENTS FROM INDUSTRIAL ESTATES IN KANO STATE, NIGERIA
}

\author{
Abdullateef, B., ${ }^{1 *}$ Shuaibu, T. G., ${ }^{1}$ Babagana, K., ${ }^{1}$ Suleman, H. B. ${ }^{2}$ and Dauda, B. ${ }^{3}$ \\ ${ }^{1}$ Department of Pure and Applied Chemistry, Faculty of Science, University of Maiduguri, Borno State, \\ Nigeria \\ ${ }^{2}$ Department of Microbiology, Faculty of Science, University of Maiduguri, Borno State, Nigeria \\ ${ }^{3}$ Department of Chemical Engineering, Faculty of Engineering, University of Maiduguri, Borno State, \\ Nigeria \\ *Corresponding author: babslega@gmail.com; abelega2007@yahoo.com; +2348061309753
}

\section{ABSTRACT}

Industrial Effluents Samples from Gashash Tanneries (TAN1) in Bompai Industrial estate, Larabee Tannery Industry (TAN2) in Sharada Industrial estate and Z Tannery Industries (TAN3) in Challawa Industrial estate, Kano State, Nigeria were collected over a period of six months (August 2017 to January 2018) for assessing the biodegradation potentials of bacteria in the treatment of organic pollutants within the effluents. Bacteria were isolated from the effluents and immobilized on agar-agar. Different masses (5 g, $10 \mathrm{gr}, 15$ $\mathrm{g}, 20 \mathrm{~g}$, and $25 \mathrm{~g}$ ) of the bacteria were used in the treatment of $250 \mathrm{ml}$ of the effluents for ten days in a shaker incubator (Gallenkamp-OC-4364-L) at the temperature $30{ }^{\circ} \mathrm{C}$ and speed of $60 \mathrm{rpm}$. Pre-treatment analysis of the effluents for Temperature, pH, Biochemical Oxygen Demand (BOD), Chemical Oxygen Demand (COD), Suspended Solid (SS) and Total Dissolved Solids (TDS) gives the following results; temperature $\left({ }^{\circ} \mathrm{C}\right.$ )

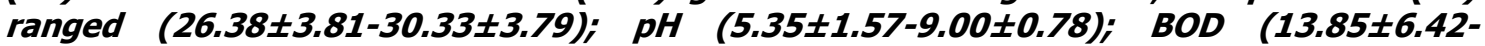
$38.75 \pm 16.20) ;$ COD (1406 $\pm 208-3532 \pm 1373) ;$ SS (208 $\pm 235-780 \pm 739)$ and TDS (266 $\pm 253-5276 \pm 2971)$. No statistical differences ( $p \leq 0.05)$ was observed for all the results among the different industries. The bacterial isolates were identified as Neisseria spp, Bacillus cereus, and Staphylococcus aureus, in TAN1, TAN2, and TAN3, respectively. After treatment of the effluent with the different masses of the isolated bacteria, the mean level of BOD was found to range as (0.55 $\pm 0.36-6.92 \pm 5.49) ; C O D$ (ND-3134 \pm 1595$)$;

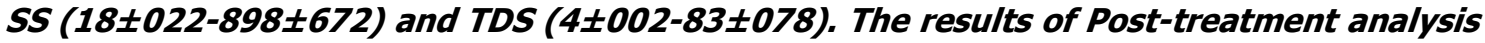
showed that there is overall decrease in the levels of the parameters determined when compared with that of the pre-treatment. The overall percentage reduction of the immobilised bacteria in the treatment of the respective effluents was in the order TAN2 (72\%)>TAN1 (70\%)>TAN3 (62\%). Hence, the immobilized bacteria are having higher biodegradation potential for the treatment of the tannery effluents.

Keywords: Biodegradation, bacteria, effluent, immobilization, tannery.

\section{INTRODUCTION}

Tannery industrial wastewater is a serious consequence of the pollution point of view for streams, freshwater, and land used for agriculture. The lack of awareness in the modern industrial practice has resulted in the discharge of tannery effluents which exhibit very high value of chromium ( $\mathrm{Cr}$ ), Sulfide, and chloride, Total Dissolved Solid (TDS), Total Suspended Solid (TSS), Biochemical Oxygen Demand (BOD) and Chemical Oxygen Demand (COD) in the water stream or land (Mohammed et al., 2001). Tanning is the process, which One ton of skin generally leads to the production of 20 to $80 \mathrm{~m}^{3}$ of turbid and foul-smelling converts the protein of the rawhide or skin into a stable material, which will not putrefy and is suitable for a wide variety of end applications (Elsheikh, 2009). The highly polluting chromium is the most commonly used tanning material producing leather that is more flexible and pliable than vegetable-tanned leather and does not discolor or lose shape in water as drastically as vegetable-tan (Elsheikh, 2009). Tannery effluent is among the most hazardous industrial pollutants due to its huge organic and inorganic load, which is highly toxic to human life and the environment (Kongjao et al., 2008). wastewater including chromium (100-400 mg/l), sulfide $(200-800 \mathrm{mg} / \mathrm{l})$, high levels of fat and 
BAJOPAS Volume 13 Number 2, December, 2020 other solid wastes, and notable pathogen contamination as well as pesticides added for skin conservation during transport (Elsheikh, 2009). There are more than 6000 tanneries in Nigeria with an annual processing capacity of 700,000 tons of hides and skins (Omoleke, 2004; Singh et al., 2008). It was reported that the total amount of waste produced per animal slaughtered is approximately $35 \%$ of its weight (World Bank, 1995). Also, for every $1000 \mathrm{~kg}$ of carcass weight, a slaughtered beef produces 5.5 $\mathrm{kg}$ of manure (excluding rumen contents or stockyard manure) and $100 \mathrm{~kg}$ of paunch manure (undigested food) (Verheijen et al., 1996). Tanneries generate wastewater in the range of 30-35 $\mathrm{L} \mathrm{kg}^{-1}$ skin/hide processed with variable $\mathrm{pH}$, Biological Oxygen Demand (BOD), Chemical Oxygen Demand (COD), high concentrations of suspended solids (SS), and tannins as well as chromium (Zahoor and Abdul, 2009).

Being heterogeneous and composed of a wide variety of compounds, it is very difficult to select a unique direct method for estimating the biodegradability of organic contents and biokinetic parameters for a wastewater sample (Rajor, 2004). For this purpose, some indirect estimation such as determination of biochemical oxygen demand (BOD) and chemical oxygen demand (COD) are applied as common laboratory investigations [9]. During retanning procedures, synthetic tannins (Syntan), oils and resins are added to form softer leather at varying doses (Munz et al., 2009). One of the refractory groups of chemicals in tannery effluents derives mainly from tannins (Ramasami et al., 2004). Syntans are characterized by complex chemical structures, because they are composed of an extended set of chemicals such as phenol-, naphthalene-, formaldehyde- and melamine-based syntans, and acrylic resins (Beem, 1994). Organic pollutants (proteic and lipidic components) are originated from skins (it is calculated that the raw skin has $30 \%$ loss of organic material during the working cycle) or they are introduced during processes (Hugo Springer, 1994).

Many conventional processes such as oxidation, chemical and biological processes were carried out to treat tanneries wastewater (Ebtesam et al, 2013). Biological processes have received more attention because of their costeffectiveness, lower sludge production and environmental friendliness (Noorjahan, 2014). Naturally occurring micro-organisms degrade the hazardous organic wastes including xenobiotic compounds, such as pesticides, polycyclic aromatic hydrocarbons (PAHs) and polychlorinated biphenyls (PCBs) in due course of time (Ranen and Sharadinadra, 2009). Bioremediation is based on the idea that all organisms remove substances from the environment to carry outgrowth and metabolism (Bouwer and Zehnder, 1993). Bacteria, protista and fungi are found to be very good at degrading complex molecules and incorporating the breakdown products into their metabolism (Bouwer and Zehnder, 1993). The resultant metabolic wastes that they produce are generally safe and somehow recycled into other organisms (Ranen and Sharadinadra, 2009). An acclimatized indigenous population of microorganisms capable of degradation of the compounds of interest must exist at the site for a successful bioremediation mode (Ranen and Sharadinadra, 2009). It has been observed that for a successful bioremediation mode, an acclimatized indigenous population of microorganisms capable of degradation of the compounds of interest must exist at the site under investigation (Ranen and Sharadinadra, 2009). Even though there are numerous physical and chemical methods employed in the disposal of wastes the advantage in using bacterium is that they play a key role in the reduction of COD, BOD, total protein, total tannin and total phenol (Saravanan and Saravanan, 1998)

Baba et al. (2020) studied the bioremediation potential of immobilized corynebacterium kutsceri in the Treatment of tannery industrial effluent from Challawa Industrial Estate, Kano State, Nigeria. The aim of the work is to study the reduction in the level of the contaminants through the process of bioremediation using the isolated bacteria. Immobilized bacteria can withstand various temperatures, $\mathrm{pH}$ and substrate concentrations; consequently, increasing the efficiency and the lifespan of the bacteria. Immobilized bacteria are widely applied in the treatment of wastewater and can be separated and recovered after the treatment with the same efficiency (Baba et al., 2020).

\section{MATERIALS AND METHODS \\ Study Area}

This study was carried out in Bompai, Sharada and Challawa industrial estates in Kano, Figure 1. Kano lies on Latitude $11^{\circ} 30^{\prime} \mathrm{N}$ and $8^{\circ} 30^{\prime} \mathrm{E}$ and Longitude $11^{\circ} 5^{\prime} \mathrm{N}$ and $8^{\circ} 5^{\prime} \mathrm{E}$ in Northern Nigeria. It is one of the developed industrial cities in Nigeria. Tannery activities are the dominating industries and this could be one of the reasons for her high population density (Dan'Azumi and Bichi, 2010). Many researchers have studied biodegradation of tannery effluent using microorganisms. However, limited literature is available on the biodegradation of tannery effluent in Kano industrial estates using 
BAJOPAS Volume 13 Number 2, December, 2020 immobilized bacterial cells. This research work focuses on the potential of the use of the indigenous immobilized bacterial isolates in the treatment of tannery effluents in the industrial estates.

\section{Sample Collection}

Effluents were collected from the Tannery Industries from Bompai, Challawa and Sharada Industrial Estates, Kano, Nigeria. The effluents were collected over a period of six months (August 2017 to January 2018). Samples collected in a sterile 4-liter plastic container with a unique identification number were preserved using an ice-box that was transported to the Microbiology Laboratory, Department of Microbiology, Bayero University of Kano for analysis

\section{Sample Preparation and Sample Analysis}

Immediately after the collection of the effluent, $\mathrm{pH}$, TSS, TDS, COD, BOD levels were determined before treatment (Pre-treatment determination) and ten days after treatment (Post-treatment determination) as described in
APHA (1989) standard methods. $\mathrm{pH}$ was determined using Ecotests $\mathrm{pH}$ meter and TDS was determined using AQUALYTIC TDS Salinometer. BOD was determined as described by the standard method (APHA, 1992). COD and SS were determined using DR/2010 HACH portable data logging spectrophotometer (DWAF, 1992)

\section{Identification and Biochemical} Characterization of the Bacterial Isolates

The bacteria were isolated from the effluents using Serial Dilution according to the method described by APHA (1989). The biochemical tests such as oxidase, catalase, coagulase, indole (from $1 \%$ tryptone broth), citrate (Simmons citrate agar), methyl red/VogesProskauer (MR/VP), nitrate reduction, Starch Hydrolysis, Glucose, Maltose, and Lactose tests were carried out on the bacterial isolates to identify the bacteria through the bacteria biochemical characteristics according to Ajao et al. (2011).

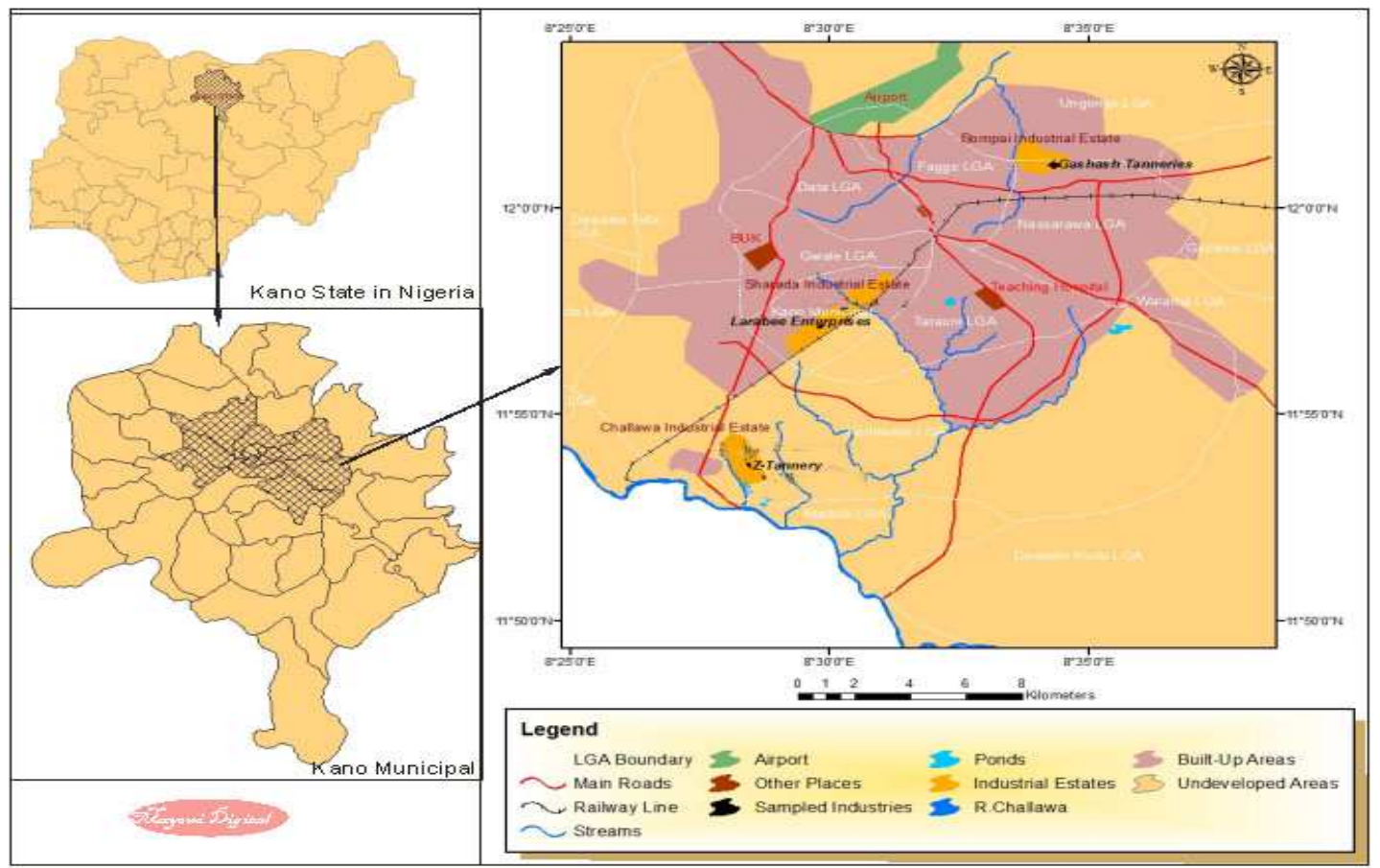

Fig. 1 Map showing the study areas

Source: Mayomi Digital Productions, GIS Laboratory, Department of Geography, UNIMAID (2017)

\section{Determination of Growth Rate of the Bacteria in Effluent Sample}

The bacteria growth rates were determined by transferring $2 \mathrm{~mL}$ of the bacterial isolates from the tannery effluent in broth medium into 100 $\mathrm{mL}$ sterile effluents in conical flasks and kept in an incubator (Giffrin cool) for 10 days. Control was also set up by incubating another $100 \mathrm{~mL}$ each of the sterile effluents without the bacteria. The optical density of the content was determined at the wavelength of $600 \mathrm{~nm}$ on a daily interval and recorded. 
BAJOPAS Volume 13 Number 2, December, 2020 Immobilization of Bacteria

Agar solution and inoculi were prepared separately. Fifty milliliters $(50 \mathrm{~mL})$ of nutrient broth each of the inoculi was prepared in a McCartney bottle and incubated for 24 hours. A solution of agar-agar was prepared by dissolving $10 \mathrm{~g}$ of the powder in distilled water and made up to $500 \mathrm{~mL}$ mark in an Erlenmeyer flask and was sterilized in an autoclave (280A) for 15 minutes and allowed to cool to $40-45^{\circ} \mathrm{C}$ (Ajao et al., 2011). Four milliliters ( $4 \mathrm{~mL})$ of the bacterial isolates in the nutrient broth was mixed with 36 $\mathrm{ml}$ of the prepared agar-agar media in petri-dish plates and then allowed to solidify. This was kept in the refrigerator for bioremediation.

\section{Bioremediation (Treatment) of the Effluents}

The solidified agar block (immobilized bacteria) was cut into cubes using a sterile knife; $0.1 \mathrm{~mL}$ phosphate buffer ( $\mathrm{pH} \mathrm{7.0)}$ was added and kept in the refrigerator for 1 hour for curing. The phosphate buffer was decanted after 1 hour and the cubes were washed with sterile distilled water 3-4 times before it was used (Ajao et al., 2011). Two liters (2 L) of the effluent was supplemented with the minimum basal medium in $\mathrm{g} / \mathrm{L}: \mathrm{NaCl}(0.8), \mathrm{MgSO}_{4} .7 \mathrm{H}_{2} \mathrm{O}(0.001), \mathrm{KH}_{2} \mathrm{PO}_{4}$ (2), $\mathrm{NaNO}_{3}$ (2), $\quad \mathrm{CaCl}_{2} .2 \mathrm{H}_{2} \mathrm{O} \quad(0.5)$ and $\mathrm{NaHPO}_{4} .12 \mathrm{H}_{2} \mathrm{O}(2)$ and sterilized in an autoclave at $121^{\circ} \mathrm{C}$ for 15 minutes (Margesin and Schinner, 2001). Two hundred and fifty milliliters $(250 \mathrm{~mL})$ of the effluents were transferred into different $250 \mathrm{ml}$ conical flasks. The content was covered with a cotton-wool ramped with foil paper to avoid contamination. Five grams $(5 \mathrm{~g})$ of the immobilized bacteria were quickly transferred into each of the effluents in the conical flasks in an inoculating chamber. The same procedures were carried out for the $10 \mathrm{~g}, 15 \mathrm{~g}, 20 \mathrm{~g}$ and 25 $\mathrm{g}$ of the immobilized bacteria in separate $250 \mathrm{~mL}$ effluents in conical flasks and agitated for ten days in a shaker incubator (Gallenkamp-OC4364-L) at a temperature $30^{\circ} \mathrm{C}$ and speed of 60 rpm. The treated effluent samples were taken on the tenth day and analyzed for the parameters $\mathrm{pH}$, SS, TDS, COD, and BOD, (Posttreatment determination) for the different grams of bacteria to evaluate and compare the biodegradation potential. (Baba et al., 2020).

\section{Statistical Analysis}

The data were represented as Mean \pm Standard deviation and analyzed statistically using oneway Analysis of Variance (ANOVA) and Tukey's HSD as Post Hoc Tests with the aid of SPSS 16.0. The correlation coefficient was also used to measure the strength of the relationship between the different masses of the bacteria and the parameters. All $\mathrm{p} \leq 0.05$ were considered as statistically significant.

\section{RESULTS AND DISCUSSION Physico-chemical parameters in the Industrial Effluents before the Biodegradation.}

Results of the Physico-chemical parameters in the industrial effluents before the Biodegradation is shown in table 1 . The mean temperatures $\left({ }^{\circ} \mathrm{C}\right)$ observed in TAN1, TAN2, and TAN3 samples were $28.07 \pm 0.65 ; 27.77 \pm 0.64$ and $26.38 \pm 3.81$ respectively. The order of the mean temperature of the samples from the three industries can be arranged as TAN1 > TAN2>TAN3. The temperature observed at TAN1, TAN2, and TAN3 samples were found below the WHO $\left(35^{\circ} \mathrm{C}\right)$ and NESREA $\left(40^{\circ} \mathrm{C}\right)$ limits. The low values of temperature might be due to the processes used at the time of sampling. High temperature brings down the solubility of gases in water that ultimately expresses as high BOD and COD. Statistical analysis shows that there is no significant difference $(p<0.05)$ between the mean values of temperature among the industries. This might be due to similar tannery activities involved in the tannery industries at the time of sampling. The average values of temperature observed in this present study are less than those observed by Akan et al. (2007), Akan et al. (2009) and Baba et al. (2020).

The mean level of $\mathrm{pH}$ observed in TAN1, TAN2 and TAN3, samples were $7.77 \pm 2.93$; $8.35 \pm 0.28$ and $7.52 \pm 0.76$ respectively. The order of the mean $\mathrm{pH}$ of the samples from the three industries can be arranged as TAN2> TAN1 $>$ TAN3. The $\mathrm{pH}$ of the samples falls within the WHO (7.0-8.5) and NESREA (6-9) standard limits. Statistical analysis shows that there is no significant difference $(p<0.05)$ between the mean values of $\mathrm{pH}$ among the industries. This might be due to similar tannery activities involved in the tannery industries at the time of sampling. Maheshwari et al. (2017) reported that the level of $\mathrm{pH}$ in the effluents from the tannery industry in Vaniyambadi, India was 6.5 which was lower than that observed in the present study. The $\mathrm{pH}$ in the effluents from the tannery industries in Kano and Kaduna were reported to be 7.64 and 6.89, respectively (Akan et al., 2007; Mohammed et al., 2017). The average values of $\mathrm{pH}$ observed in this present study are less than those observed by Mohammed et al. (2017) and Baba et al. (2020). The mean level of SS $(\mathrm{mg} / \mathrm{l})$ observed in TAN1, TAN2, and TAN3 samples were 374 \pm 124 ; $358 \pm 335$ and $780 \pm 739$ respectively. The order of the mean SS in the samples from the three industries can be arranged as TAN3 > TAN1 $>$ TAN2. 
The SS observed in the samples were far above the recommended standard limits of regulating bodies WHO $(30 \mathrm{mg} / \mathrm{l})$ and NESREA $(10 \mathrm{mg} / \mathrm{l})$. Statistical analysis shows that there is no significant difference $(p<0.05)$ between the mean values of SS among the industries. This might be due to similar tannery activities involved in the tannery industries at the time of sampling. The average values of SS observed in this present study are less than that observed $(3700 \pm 122 \mathrm{mg} / \mathrm{l})$ by Akan et al. (2009) for tanneries in Kano. Also, the average values of SS observed in this present study are less than that observed by Mohammed et al. (2017) and Baba et al. (2020) with the exception in TAN3.

The mean level of TDS (mg/l) observed in TAN1, TAN2, and TAN3 samples were $3941 \pm 3703$; $3300 \pm 1714$ and $2653 \pm 1240$ respectively. The order of the mean TDS in the samples from the three industries can be arranged as TAN1>TAN2>TAN3. The TDS observed in the samples were far above the recommended standard limits of WHO $(250 \mathrm{mg} / \mathrm{l})$ and NESREA $(500 \mathrm{mg} / \mathrm{l})$. Statistical analysis shows that there is no significant difference $(p<0.05)$ between the mean values of TDS among the industries. This might be due to similar tannery activities involved in the tannery industries at the time of sampling. TDS in the effluents from the tannery industries in Kano, Nigeria was reported to be $1281 \mathrm{mg} / \mathrm{l}$ (Akan et al., 2007). The average values of SS observed in this present study are less than those observed by Mohammed et al. (2017) and Baba et al. 2020)

The mean level of COD (mg/l) observed in TAN1, TAN2 and TAN3 samples seasons were $2372 \pm 938 ; \quad 1406 \pm 208$ and $3532 \pm 1373$ respectively. The order of the mean COD of the samples from the three industries can be arranged as TAN3>TAN1> TAN2. The COD observed in TAN1, TAN2 and TAN3 samples were far above the recommended standard limits of regulating bodies $\mathrm{WHO}(40 \mathrm{mg} / \mathrm{l})$ and NESREA (40 mg/l). Statistical analysis shows that there is no significant difference $(p<0.05)$ in COD among the industries. This might be due to similar tannery activities involved in the tannery industries as at the time of sampling. The Chemical Oxygen demand (COD) is the amount of oxygen, in $\mathrm{mg} / \mathrm{L}$, required for the degradation of the compound of wastewater to occur. In comparison, the average values of COD observed in this present study were higher than that observed by Mohammed et al. (2017) but lower than that observed by Baba et al. (2020).

The mean levels of BOD $(\mathrm{mg} / \mathrm{l})$ observed in TAN1, TAN2 and TAN3 samples were $13.85 \pm 6.42 ; \quad 19.46 \pm 0.50$ and $17.13 \pm 3.14$ respectively. The order of the mean BOD in the samples from the three industries can be arranged as TAN2>TAN3>TAN1. The BOD observed in TAN1, TAN2 and TAN3 samples were found below the recommended limits of NESREA (200 mg/l) but above WHO (10 mg/l). Statistical analysis shows that there is no significant difference $(p<0.05)$ between the mean values of BOD among the industries. This might be due to similar tannery activities involved in the tannery industries at the time of sampling. The low level of BOD recorded in this study is an indication of the low level of biodegradable organic solids in the effluent. The average values of BOD observed in this present study were lower than those observed by Mohammed et al. (2017) and Baba et al. (2020).

Table 1: Mean Values \pm S.D of Physico-chemical parameters of effluents from the Tannery Industries before Treatment.

\begin{tabular}{llllllll}
\hline Parameter & Tannery 1 & Tannery 2 & Tannery 3 & $\mathrm{a}$ & $\mathrm{b}$ & $\mathrm{c}$ & $\mathrm{d}$ \\
\cline { 2 - 7 } Temperature $\left({ }^{\circ} \mathrm{C}\right)$ & $28.07 \mathrm{a} \pm 0.65$ & $27.77 \mathrm{a} \pm 0.64$ & $26.38 \mathrm{a} \pm 3.81$ & & $29.50 \pm 4.68$ & 35 & 40 \\
pH & $7.77 \mathrm{a} \pm 2.93$ & $8.35 \mathrm{a} \pm 0.28$ & $7.52 \mathrm{a} \pm 0.76$ & 6.89 & $5.35 \pm 1.57$ & $7.0-8.5$ & $6.0-9.0$ \\
$\mathrm{COD}(\mathrm{mg} / \mathrm{l})$ & $2372 \mathrm{a} \pm 938$ & $1406 \mathrm{a} \pm 208$ & $3532 \mathrm{a} \pm 1373$ & 2.2 & $3106 \pm 2753$ & 40 & 40 \\
$\mathrm{BOD}(\mathrm{mg} / \mathrm{l})$ & $13.85 \mathrm{a} \pm 6.42$ & $19.46 \mathrm{a} \pm 0.50$ & $17.13 \mathrm{a} \pm 3.14$ & 1032 & $26.17 \pm 9.49$ & 10 & 200 \\
$\mathrm{SS}(\mathrm{mg} / \mathrm{l})$ & $374 \mathrm{a} \pm 124$ & $358 \mathrm{a} \pm 335$ & $780 \mathrm{a} \pm 739$ & 501 & $562 \pm 482$ & 30 & 10 \\
TDS $(\mathrm{mg} / \mathrm{l})$ & $3941 \mathrm{a} \pm 3703$ & $3300 \mathrm{a} \pm 1714$ & $2653 \mathrm{a} \pm 1240$ & 532.7 & $444 \pm 507$ & 250 & 500 \\
\hline
\end{tabular}

The values given in the table above are means of 6 replicate values, $\mathrm{n}=6$ ( 1 sample was taken monthly for 6 months). Within the rows, means with different alphabets are statistically different $(p<0.05)$. WHO: World Health Organisation. NESREA: National Environmental Standard and Regulatory Enforcement Agency. a = Mohammed et al.(2017), b = Baba et al. (2020), c = WHO (2006), $d=$ NESSRA (2009) 
BAJOPAS Volume 13 Number 2, December, 2020

Identification, Biochemical Characterization and growth rates of the Bacterial Isolates

Results of identification and biochemical characterization of the bacterial isolates were shown in table 2. After 24 hours of incubation, the nutrient agar media plates were checked for bacterial growth. The results showed the presence of different strains in the samples. The TAN1 bacteria isolate was found to be gramnegative cocci while TAN3 was gram-positive cocci. TAN2 bacteria isolate was found to be gram-positive, rod-shaped. TAN1, TAN2, and TAN3 bacteria isolates recorded positive results for spore former.

The results of the biochemical tests indicated that all the bacteria were positive for catalase, oxidase, citrate, maltose, glucose, lactose (negative in TAN1), mannitol (negative in TAN2), starch hydrolysis and coagulase (negative in TAN2) tests. The bacteria showed negative results for nitrate reduction, $M R$ (positive in TAN2), VP (positive in TAN1), Indole (positive in TAN2) tests. Base on the morphological and biochemical test results, TAN1, TAN2, and TAN3 bacteria isolates were identified to be Nesseria spp, Bacillus cereus, and Staphylococcus aureus respectively.

The growth rate of the TAN1, TAN2 and TAN3 Isolates were shown in figure 2. Generally, the optical density increase with the increase in time (day) and decrease as time goes on. The highest optical density was shown by bacillus cereus in TAN2 while the lowest was shown by Staphylococcus aureus in TAN3.

The initial growth phase of TAN1 Isolate bacteria occurred within 2-day of incubation as the growth rate increases up to the 6th-day incubation when the maximum growth was observed. Beyond the 6th day, the growth of the bacteria declined (which might be due to a shortage of nutrients in the effluents) until it reached its death phase (which might be due to the unavailability of nutrients in the effluents).

A similar trend of growth was also observed for TAN2 Isolate as the initial growth phase also occurred within 2-day of incubation but maximum growth rate observed on the 4th day of incubation. The stationary stage occurred between the 4th day and the 8th day. Beyond the 8th day, the growth of the bacteria declined (which might be due to a shortage of nutrients in the effluents) until it reached its death phase (which might be due to the unavailability of nutrients in the effluents).

The initial growth phase of TAN3 bacterial Isolate occurred within the 3-day incubation as the growth rate increases up to the 6th-day incubation when the maximum growth was observed. Beyond the 6th day, the growth of the bacteria declined (which might be due to a shortage of nutrients in the effluents) until it reached its death phase (which might be due to the unavailability of nutrients in the effluents).

Table 2: Morphological and Biochemical characteristics of bacterial isolates

\begin{tabular}{lllll} 
Bacterial Isolates & & TAN1 & TAN2 & TAN3 \\
\hline $\begin{array}{lllll}\text { Morphological } \\
\text { characteristics }\end{array}$ & Shape & Cocci & Rod & Cocci \\
& Spore & & & \\
& former & + & + & + \\
Gram & & & \\
Biochemical characteristics & reaction & - & + & + \\
& Citrate & + & + & + \\
& Catalase & + & + & + \\
& Coagulase & + & - & + \\
Starch & + & + & + \\
& Glucose & + & + & + \\
Oxidase & + & + & + \\
& Indo & - & + & - \\
Lactose & - & + & + \\
Manitol & + & - & + \\
Maltose & + & + & + \\
MR & - & + & - \\
VP & + & - & - \\
& Nitrate & - & - & - \\
Reduction & - Neisseria & Bacillus & Staphylococcus \\
& Bacterial & cereus & aureus \\
& name & spp & cas
\end{tabular}

+ = Positive; - = Negative; MR=Methyl Red; VP= Voges-Proskauer 


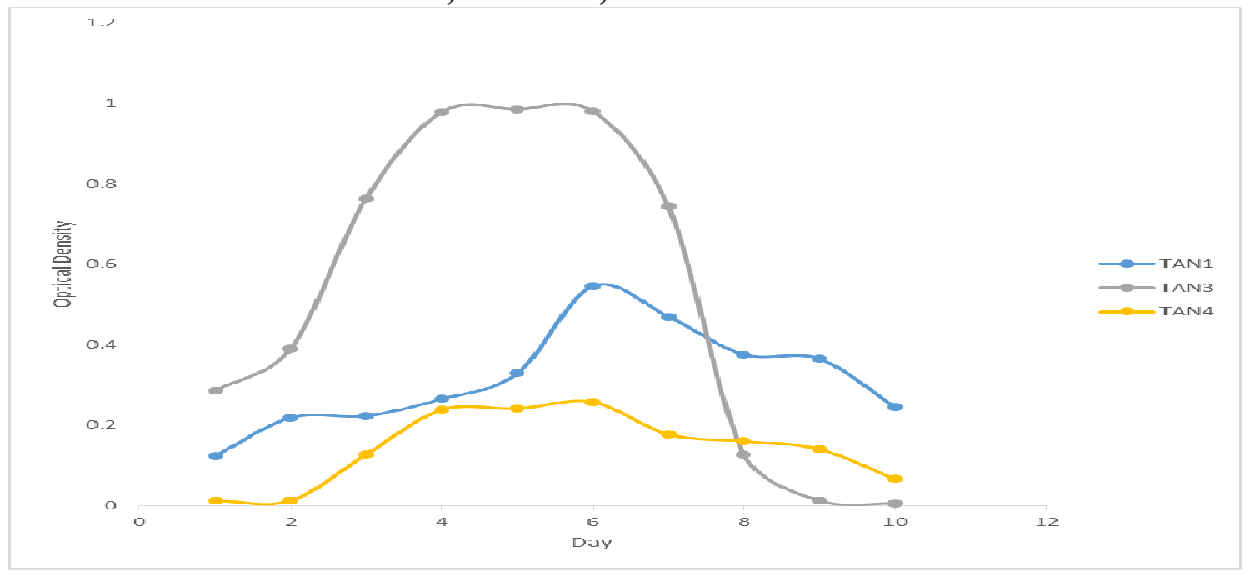

Fig. 2 Growth rates of the isolates in the effluents from the Tannery Industries

\section{Physico-chemical Parameters in the Industrial Effluents after the biodegradation.}

Table 3 shows the mean results of the physicochemical parameter before and after bioremediation using the different masses $(5 \mathrm{~g}$, $10 \mathrm{~g}, 15 \mathrm{~g}, 20 \mathrm{~g}$, and $25 \mathrm{~g}$ ) of the respective immobilized bacteria. Also, Table 4 shows the mean results of correlation coefficient ( $r$ ) between different masses of bacteria and physicochemical parameters.

The mean values $(\mathrm{mg} / \mathrm{l})$ of the SS after the bioremediation varies between $243 \pm 45$ and $898 \pm 672$. The mean concentration $(\mathrm{mg} / \mathrm{l})$ of SS remediated by the different masses $(5 \mathrm{~g}, 10 \mathrm{~g}$, $15 \mathrm{~g}, 20 \mathrm{~g}$, and $25 \mathrm{~g}$ ) of the bacteria varies. The SS in the samples fluctuates up and down after the bioremediation process when compared with the SS of the raw samples before the bioremediation. The increase in the levels of the SS might be due to the aggregation of the TDS which are large enough to result into SS. The increase in the levels of the SS might be also due to the influence of the nutrients which was added into the effluents in order to make the microorganisms more active and viable for fast degradation of organic contaminants in the effluent. The relative potential or efficiency of the different masses of the bacteria in remediating SS in TAN1 samples was in the order $25 \mathrm{~g}>20 \mathrm{~g}>15 \mathrm{~g}>10 \mathrm{~g}>5 \mathrm{~g}$. For TAN2 and TAN3 samples, the order was $25 \mathrm{~g}>20 \mathrm{~g}>15$ $\mathrm{g}>10 \mathrm{~g}>5 \mathrm{~g}$. These might be due to the variations in the surface areas of the different masses of the immobilized bacteria. Statistical analysis shows that there is no significant difference $(p<0.05)$ between the mean values of SS among the masses in the respective industries. Positive and significant correlations exist between the masses of bacteria and Suspended Solid (SS). This showed that there is general increase in the levels of the SS as the masses of the immobilized bacteria increases. TAN3 (90\%) and TAN1 (80\%) showed a very high correlation with the masses of the bacteria while TAN2 (61\%) showed a very low correlation.

The mean values $(\mathrm{mg} / \mathrm{l})$ of the TDS after the bioremediation varies between $46 \pm 11$ and $83 \pm 78$. The mean concentration $(\mathrm{mg} / \mathrm{l})$ of TDS remediated by the different masses $(5 \mathrm{~g}, 10 \mathrm{~g}$, $15 \mathrm{~g}, 20 \mathrm{~g}$, and $25 \mathrm{~g}$ ) of the bacteria varies. There is a reduction in all the TDS of all the samples after the bioremediation process compared with the TDS of the raw samples before the bioremediation. The relative potential or efficiency of the different masses of the bacteria in remediating TDS in TAN1 and TAN3 samples was in the order $5 \mathrm{~g}>10 \mathrm{~g}>15 \mathrm{~g}>20$ $\mathrm{g}>25 \mathrm{~g}$. For TAN2 samples, the order was 20 $g>10 \quad g>25 \quad g>15 \quad g>5 \quad g$. Statistical analysis shows that there is no significant difference $(p<0.05)$ between the mean values of TDS among the masses in the respective industries. These might be due to the variations in the surface areas of the different masses of the immobilized bacteria. Positive and significant correlations exist between the masses of bacteria and TDS with the exception in TAN2 (negative and insignificant correlation). The positive correlations showed that there is general increase in the levels of the TDS as the masses of the immobilized bacteria increases. TAN1 $(96 \%)$ showed a very high correlation with the masses of the bacteria while TAN2 (47\%) showed a very low correlation.

The mean values $(\mathrm{mg} / \mathrm{l})$ of the BOD after the bioremediation varies between $1.56 \pm 0.20 \mathrm{mg} / \mathrm{l}$ and $6.92 \pm 5.49 \mathrm{mg} / \mathrm{l}$. The mean concentration $(\mathrm{mg} / \mathrm{l})$ of BOD remediated by the different masses $(5 \mathrm{~g}, 10 \mathrm{~g}, 15 \mathrm{~g}, 20 \mathrm{~g}$, and $25 \mathrm{~g}$ ) of the bacteria varies. There is a reduction in all the BOD of all the samples after the bioremediation process compared with the $\mathrm{BOD}$ of the raw 
BAJOPAS Volume 13 Number 2, December, 2020 samples before the bioremediation. The relative potential or efficiency of the different masses of the bacteria in remediating BOD in TAN1, TAN2 and TAN3 samples were in the order $25 \mathrm{~g}>20$ $\mathrm{g}>15 \mathrm{~g}>10 \mathrm{~g}>5 \mathrm{~g}, 25 \mathrm{~g}>15 \mathrm{~g}>5 \mathrm{~g}>10 \mathrm{~g}>20 \mathrm{~g}$ and $20 \mathrm{~g}>10 \mathrm{~g}>25 \mathrm{~g}>15 \mathrm{~g}>5 \mathrm{~g}$ respectively. Statistical analysis shows that there is significant difference $(p<0.05)$ between the mean values of BOD among the masses in the respective industries. These might be due to the variations in the surface areas of the different masses of the immobilized bacteria. Negative and significant correlations exist between the masses of bacteria and BOD. This showed that there is general decrease in the levels of the BOD as the masses of the immobilized bacteria increases. TAN1 (94\%) showed a very high correlation with the masses of the bacteria while TAN2 (4\%) showed a very low correlation.

The mean values $(\mathrm{mg} / \mathrm{l})$ of the COD after the bioremediation varies between $250 \pm 154$ and $3134 \pm 1595$. The mean concentration $(\mathrm{mg} / \mathrm{l})$ of COD remediated by the different masses $(5 \mathrm{~g}$, $10 \mathrm{~g}, 15 \mathrm{~g} 20 \mathrm{~g}$, and $25 \mathrm{~g}$ ) of the bacteria varies. There is a reduction in all the COD of all the samples after the bioremediation process compared with the COD of the raw samples before the bioremediation. The relative potential or efficiency of the different masses of the bacteria in remediating COD in TAN1, TAN2 and TAN3 samples were in the order $25 \mathrm{~g}>20 \mathrm{~g}>15$ $\mathrm{g}>5 \mathrm{~g}>10 \mathrm{~g}, 25 \mathrm{~g}>20 \mathrm{~g}>15 \mathrm{~g}>10 \mathrm{~g}>5 \mathrm{~g}$ and 10 g>5 g>25 g>15 g>20 g respectively. Statistical analysis shows that there were significant difference $(p<0.05)$ between the mean values of COD among the masses in the respective industries except for effluents treated with $25 \mathrm{~g}$. These might be due to the variations in the surface areas of the different masses of the immobilized bacteria. Negative and insignificant correlations exist between the masses of bacteria and COD with the exception in TAN3 (positive and significant correlation). The negative correlations showed that there is general decrease in the levels of the COD as the masses of the immobilized bacteria increases. TAN2 (100\%) showed a very high correlation with the masses of the bacteria while TAN3 (36\%) showed a very low correlation.

Generally, there was an overall decrease in the concentration of these physicochemical parameters after the bioremediation using the different masses of the bacterial isolates. These might be due to the variations in the surface areas of the different masses of the immobilized bacteria. This is in line with the work of Jimoh et al. (2018) and Baba et al. (2020).

Table 3: Mean Values $(\mathrm{mg} / \mathrm{l}) \pm$ S.D of Physicochemical parameters in effluents from the Tannery Industries before and after Treatment of the effluents $(250 \mathrm{ml})$ with the different masses $(5 \mathrm{~g}, 10 \mathrm{~g}$, $15 \mathrm{~g}, 20 \mathrm{~g}$, and $25 \mathrm{~g}$ ) of the bacteria.

\begin{tabular}{llllllll}
\hline $\mathrm{P}$ & IND & Before & \multicolumn{5}{c}{ After } \\
\cline { 4 - 7 } & & & $5 \mathrm{~g}$ & $10 \mathrm{~g}$ & $15 \mathrm{~g}$ & $20 \mathrm{~g}$ & $25 \mathrm{~g}$ \\
\hline \multirow{2}{*}{ COD } & TAN1 & $2372 \pm 938$ & $1708 \mathrm{a} \pm 861$ & $2045 \mathrm{a} \pm 1205$ & $845 \mathrm{a} \pm 369$ & $300 \mathrm{a} \pm 167$ & $250 \mathrm{a} \pm 154$ \\
& TAN2 & $1406 \pm 208$ & $1195 \mathrm{a} \pm 208$ & $1125 \mathrm{a} \pm 384$ & $1055 \mathrm{a} \pm 317$ & $956 \mathrm{a} \pm 310$ & $870 \mathrm{ab} \pm 240$ \\
& TAN3 & $3532 \pm 1373$ & $2374 \mathrm{a} \pm 1344$ & $1976 \mathrm{a} \pm 1405$ & $2757 \mathrm{a} \pm 1266$ & $3134 \mathrm{a} \pm 1595$ & $2614 \mathrm{~b} \pm 1105$ \\
BOD & TAN1 & $13.85 \pm 6.42$ & $6.92 \mathrm{a} \pm 5.49$ & $6.42 \mathrm{a} \pm 5.07$ & $5.72 \mathrm{a} \pm 5.35$ & $4.62 \mathrm{a} \pm 4.37$ & $2.82 \mathrm{ab} \pm 1.26$ \\
& TAN2 & $19.46 \pm 0.50$ & $1.75 \mathrm{~b} \pm 0.22$ & $1.73 \mathrm{~b} \pm 0.18$ & $1.58 \mathrm{a} \pm 0.16$ & $1.91 \mathrm{a} \pm 0.22$ & $1.56 \mathrm{~b} \pm 0.20$ \\
& TAN3 & $17.13 \pm 3.14$ & $4.24 \mathrm{ab} \pm 0.77$ & $3.29 \mathrm{ab} \pm 0.37$ & $4.11 \mathrm{a} \pm 0.07$ & $3.23 \mathrm{a} \pm 0.91$ & $3.33 \mathrm{a} \pm 1.28$ \\
SS & TAN1 & $374 \pm 124$ & $243 \mathrm{a} \pm 45$ & $471 \mathrm{a} \pm 226$ & $475 \mathrm{a} \pm 182$ & $492 \mathrm{a} \pm 128$ & $611 \mathrm{a} \pm 217$ \\
& TAN2 & $358 \pm 335$ & $460 \mathrm{a} \pm 400$ & $543 \mathrm{a} \pm 414$ & $544 \mathrm{a} \pm 402$ & $551 \mathrm{a} \pm 414$ & $554 \mathrm{a} \pm 405$ \\
& TAN3 & $780 \pm 739$ & $586 \mathrm{a} \pm 594$ & $758 \mathrm{a} \pm 656$ & $787 \mathrm{a} \pm 676$ & $861 \mathrm{a} \pm 635$ & $898 \mathrm{a} \pm 672$ \\
TDS & TAN1 & $3941 \pm 3703$ & $51 \mathrm{a} \pm 10$ & $53 \mathrm{a} \pm 10$ & $55 \mathrm{a} \pm 15$ & $61 \mathrm{a} \pm 20$ & $63 \mathrm{a} \pm 26$ \\
& TAN2 & $3300 \pm 1714$ & $83 \mathrm{a} \pm 78$ & $47 \mathrm{a} \pm 20$ & $48 \mathrm{a} \pm 22$ & $47 \mathrm{a} \pm 17$ & $48 \mathrm{a} \pm 17$ \\
& TAN3 & $2653 \pm 1240$ & $46 \mathrm{a} \pm 11$ & $55 \mathrm{a} \pm 24$ & $55 \mathrm{a} \pm 25$ & $58 \mathrm{a} \pm 23$ & $61 \mathrm{a} \pm 28$ \\
\hline
\end{tabular}

Replicate $=6$ (months)

Within the rows, for the same parameter, means with different alphabets are statistically different $(p<0.05)$.

$\mathrm{P}=$ parameter, IND = Industries 
BAJOPAS Volume 13 Number 2, December, 2020

Table 4: Correlation coefficient $(r)$ between different masses of the bacteria and the physicochemical parameters.

\begin{tabular}{llll}
\hline Industries & Parameter & Correlation coefficient $(r)$ & $\begin{array}{l}\text { Percent dependence (rxrx100) } \\
(\%)\end{array}$ \\
\hline TAN1 & COD & -0.9 & 82 \\
& BOD & -0.97 & 94 \\
& SS & $0.90^{*}$ & 80 \\
TAN2 & TDS & $0.98^{*}$ & 96 \\
& COD & -1 & 100 \\
& BOD & -0.21 & 4 \\
& SS & $0.78^{*}$ & 61 \\
& TDS & -0.69 & 47 \\
& COD & $0.60^{*}$ & 36 \\
& BOD & -0.6 & 37 \\
& SS & $0.95^{*}$ & 90 \\
& TDS & $0.94^{*}$ & 89 \\
\hline
\end{tabular}

The correlation coefficient $(r)$ with * is statistically significant $(p<0.05)$.

Percentage reduction of the Parameters

Table 5 shows the percentage reduction of Parameters in industrial samples before and after the treatment of the effluents $(250 \mathrm{ml})$ with the different masses $(5 \mathrm{~g}, 10 \mathrm{~g}, 15 \mathrm{~g}, 20 \mathrm{~g}$, and $25 \mathrm{~g}$ ) of the Immobilized Bacteria.

In TAN1 samples, the percentage reduction (\%) of COD ranged (14-89); BOD (50-80); SS (-32$35)$ and TDS (98-99). In TAN2 samples, the percentage decrease $(\%)$ of COD ranged (15$38) ;$ BOD (90-92); SS [-28-(-55)] and TDS (9798). In TAN3 samples, the percentage decrease (\%) of COD ranged (11-44); BOD (76-81); SS (15-25) and TDS (98). The percentage increase in the levels COD, BOD and TDS might be due to the increase in the surface area of the different masses of the immobilized bacteria. However, the percentage decrease in the levels of the SS might be due to the aggregation of the TDS which are large enough to result into SS. The percentage decrease in the levels of the SS might be also due to the influence of the nutrients which was added into the effluents in order to make the microorganisms more active and viable for fast degradation of organic contaminants in the effluent. This is in line with the work of Jimoh et al. (2018) in which the concentration of the SS increase after the bioremediation of effluents.

Sreemoyee and Priti (2013) assessed and reduced several Physico-chemical parameters of dairy wastewater using Niesseria $s p$. and concluded that the species are well known to degrade organic compounds. This is in agreement with the current study in which the immobilized Niesseria $s p$ degrade the organic contaminants as indicated by the BOD, COD and TDS.

Jimoh et al. (2018) observed that TSS of the effluents was increased after treatment with immobilized bacteria and concluded that it might be due to the biostimulation method adopted for the research.

The optimum $\mathrm{pH}$ Biosorption of Chromium by Bacillus spp and Staphylococcus spp. from tannery effluent was investigated by Mythili and Karthikeyan (2011). The maximum adsorption of Chromium $(86.4 \mathrm{mg} / \mathrm{L})$ was showed by Bacillus spp and Staphylococcus spp showed $70.6 \mathrm{mg} / \mathrm{L}$ at an initial concentration of $100 \mathrm{mg} / \mathrm{L}$. In the present study, immobilised Bacillus spp and Staphylococcus spp. from the tannery industrial effluents reduced the levels of the organic pollutants with high potential as indicated by the percentage reduction of BOD, COD and TDS.

Enzymes often can work in multiple environments especially if they are immobilized. This makes the microorganisms' enzymes even more resistant to harsh environments and enables the enzymes to be recovered and recycled after they are no longer needed (Gianfreda and Rao 2004). Ramesh and Singh (1993) reported that the immobilized bacteria having more efficiency to remove the suspended particles than free cells. Using the immobilized cell is preferable due to its capability for using several times with the same efficiency, which makes it more economical. Similar work was done by Sikander et al. (2007) showing the higher reduction with permeabilized cells of Ochrobactrum intermedium strain SDCr-5. 
BAJOPAS Volume 13 Number 2, December, 2020

The results revealed the isolation and identification of isolates with the potential for the reduction of $\mathrm{Cr}$ (VI) to $\mathrm{Cr}$ (III). Results indicated that immobilized $B$. cereus could be efficiently used for the reduction of $\mathrm{Cr}$ (VI).

Table 5: Percentage reduction of the tested Parameters from the tannery industrial samples of the Immobilized Bacteria.

\begin{tabular}{lllllll}
\hline \multirow{2}{*}{ Industries } & & \multicolumn{5}{c}{ Percentage Reduction $(\%)$} \\
\cline { 3 - 7 } & & $5 \mathrm{~g}$ & $10 \mathrm{~g}$ & $15 \mathrm{~g}$ & $20 \mathrm{~g}$ & $25 \mathrm{~g}$ \\
\hline TAN1 & COD & 28 & 14 & 64 & 87 & 89 \\
& BOD & 50 & 54 & 59 & 67 & 80 \\
& SS & 35 & -26 & -27 & -32 & -63 \\
& TDS & 99 & 99 & 99 & 98 & 98 \\
TAN2 & COD & 15 & 20 & 25 & 32 & 38 \\
& BOD & 91 & 91 & 92 & 90 & 92 \\
& SS & -28 & -52 & -52 & -54 & -55 \\
& TDS & 97 & 99 & 99 & 99 & 99 \\
& COD & 33 & 44 & 22 & 11 & 26 \\
& BOD & 75 & 81 & 76 & 81 & 81 \\
& SS & 25 & 3 & -1 & -10 & -15 \\
& TDS & 98 & 98 & 98 & 98 & 98 \\
\hline
\end{tabular}

Percentage Reduction $=(B-A) / B \times 100 \%$

$A=$ Concentration of the parameter after treatment

$\mathrm{B}=$ Concentration of the parameter before treatment

$+=$ percentage decrease

- = percentage increase

In general, immobilization makes the enzyme more resistant to temperature, $\mathrm{pH}$, and substrate concentration swings giving it a longer lifetime and higher productivity per active unit (Gianfreda and Rao, 2004; FuIlbrook, 1996; Russell et al, 2003; Kandelbauer et al., 2004). Immobilized cells have been used and studied extensively for the production of useful chemicals (Ohtake and Silver, 1994), the treatment of wastewaters (Chen et al., 2003; Wang et al., 2010). Although many workers described microbial degradation of tannery effluent, limited literature is available on the bioremediation of tannery effluent using immobilized bacterial cells in the Kano Industrial Estates.

\section{CONCLUSION}

The samples contained variable levels of the physicochemical parameters. The results of the Analysis of variance revealed that, no statistical difference $(p<0.05)$ was observed for the temperature, $\mathrm{pH}, \mathrm{SS}, \mathrm{TDS}, \mathrm{BOD}$ and $\mathrm{COD}$ among the three tannery industries before the treatment. The levels of some of the parameters
(SS, TDS and COD) observed in the samples were found above the recommended limits of WHO and NESREA, which called for the treatment of the effluents before discharge into the environment. Base on the morphological and biochemical test results, TAN1, TAN2, and TAN3 bacterial isolates were identified to be Neisseria spp, Bacillus cereus, and Staphylococcus aureus respectively. The results of Post-treatment analysis showed that there is overall decrease in the levels of the parameters determined when compared with that of the pre-treatment. The overall percentage reduction of the immobilised bacteria in the treatment of the respective effluents was in the order TAN2 (72\%)>TAN1 $(70 \%)>$ TAN3 $(62 \%)$. Hence, the immobilized bacteria are having higher biodegradation potential for the treatment of the tannery effluents.

\section{Acknowledgments}

The authors wish to acknowledge the University of Maiduguri for the financial support. The authors are grateful to the Kano State Ministry of Environment for their support in obtaining the effluent samples. 


\section{REFERENCES}

Ajao, A. T., Adebayo, G. B., and Yakubu, S. E. (2011). Bioremediation of textile industrial effluent using mixed culture of Pseudomonas aeruginosa and Bacillus subtilis immobilized on agar-agar in a bioreactor. J. Microbiol. Biotech. Res, 1(3), 50-56.

Akan, J. C., Moses, E. A., Ogugbuaja, V. O., and Abah, J. (2007). Assessment of tannery industrial effluents from Kano metropolis, Kano State, Nigeria. Journal of Applied Sciences, 7(19), 2788-2793.

Akan, J. C., Ogugbuaja, V. O., Abdulrahman, F. I., and Ayodele, J. T. (2009). Pollutant levels in effluent samples from tanneries and textiles of Kano industrial areas, Nigeria. Global journal of pure and applied sciences, 15(3-4).

APHA (1989). Standard methods for Examination of Will bete and Will betewater.15 $5^{\text {th }}$ edition. Brydpass Springfield Will behington DC. pp. 164-176

APHA (1992). Standard Methods for the Examination of Water and Wastewater. Health, 69, 1116-9.

Baba, A., Garba, S. T., and Bello, H. S. (2020). Bioremediation Potential of Immobilized corynebacterium kutsceri in the Treatment of Tannery Industrial Effluent from Challawa Industrial Estate, Kano State, Nigeria. Journal of the Turkish Chemical Society Section A: Chemistry, $7(2), 335-350$.

Beem, E. I. V. (1994). reduction of solvent VOC emission. J. Oil Col. Chem. Ass, 77, 158.

Bouwer, E. J., and Zehnder, A. J. (1993). Bioremediation of organic compoundsputting microbial metabolism to work. Trends in biotechnology, 11(8), 360367.

Chen, K. C., Wu, J. Y., Liou, D. J., and Hwang, S. C. J. (2003). Decolorization of the textile dyes by newly isolated bacterial strains. Journal of Biotechnology, 101(1), 57-68.

Dan'Azumi, S., and Bichi, M. H. (2010). INDUSTRIAL POLLUTION AND HEAVY METALS PROFILE OF CHALLAWA RIVER IN KANO, NIGERIA. Journal of Applied Sciences in Environmental Sanitation, $5(1)$.

DWAF. (1992). Analytical Methods Manual, TR 151. Department of Water Affairs and Forestry, Pretoria.

El-Bestawy, E. (2013). Biological treatment of leather-tanning industrial wastewater using free living bacteria.
Elsheikh, M. A. S. (2009). Tannery wastewater pre-treatment. Water Science and Technology, 60(2), 433-440.

FuIlbrook, P. D. (1996). "Kinetics." Industrial enzymology: The application of enzymes in Industry. 2nd Ed. T. Godfrey and J Reichelt. eds.. Nature. New York.

Gianfreda, L., and Rao, M. A. (2004). Potential of extra cellular enzymes in remediation of polluted soils: a review. Enzyme and microbial technology, 35(4), 339354.

Hugo Springer. (1994). John Arthur Wilson Memorial Lecture "Treatment of Industrial Wastes of the Leather Industry - is it still a Major Problem". JALCA, 89, 153-185

Jimoh, A. A., Ganiyu, B. A., Baba, D., and Baba, A. (2018) Bioremediation Process of Effluent from Detergent and Food Industries in Jos, Nigeria: Kinetics and Thermodynamics. International Journal of Engineering Science Invention (IJESI), 762-73

Kandelbauer, A., Maute, O., Kessler, R. W., Erlacher, A., and Gübitz, G. M. (2004). Study of dye decolorization in an immobilized laccase enzyme-reactor using online spectroscopy. Biotechnology and bioengineering, 87(4), 552-563.

Kongjao, S., Damronglerd, S., and Hunsom, M. (2008). Simultaneous removal of organic and inorganic Pollutants in tannery wastewater using electrocoagulation technique. Korean Journal of chemical engineering, 25(4), 703.

Maheshwari, U. M., Aruna, S., Gomathi, M., and AbdulJaffar, A. H. (2017). Bioremediation by Free and Immobilized Bacteria Isolated from Tannery Effluent. International Journal of Research in Applied, Natural and Social Sciences. 5(7), 75-90

Margesin, R., and Schinner, F. (2001). Bioremediation (natural attenuation and biostimulation) of diesel-oilcontaminated soil in an alpine glacier skiing area. Applied and environmental microbiology, 677), 3127-3133.

Mohammed, A., Sekar, P., and George, J. (2011). Efficacy of microbes in bioremediation of tannery effluent. Inter. J. Curr. Res, 3(4), 324-326.

Mohammed, S. S. D., Orukotan, A. A., and Abdullahi, H. (2017). Physicochemical and Bacteriological Assessment of Tannery Effluent from Samaru-Zaria, 
BAJOPAS Volume 13 Number 2, December, 2020 Kaduna State, Nigeria. Journal of Applied

Sciences and Environmental Management, 21(4), 734-740.

Munz, G., De Angelis, D., Gori, R., Mori, G., Casarci, M., and Lubello, C. (2009). The role of tannins in conventional and membrane treatment of tannery wastewater. Journal of hazardous materials, 164(2-3), 733-739

Mythili, K., and Karthikeyan, B. (2011). Bioremediation of $\mathrm{Cr}$ (VI) from tannery effluent using Bacillus spp and Staphylococcus spp. International Multidisciplinary Research Journal, 1(6).

NESREA (2009). National Environmental Standards for Effluent Limitations and Regulation. 1233-1236

Noorjahan, C. M. (2014). Physicochemical characteristics, identification of bacteria and biodegradation of industrial effluent. Journal of bioremediation and Biodegradation, 5(3).

Ohtake, H. I., and Silver, A. O. (1994). Bacterial reduction of toxic chromate. Biological degradation and bioremediation of toxic chemicals, 403-415.

Omoleke, I. I. (2004). Management of environmental pollution in Ibadan, an African city: the challenges of health hazard facing government and the people. Journal of Human Ecology, 15(4), 265-275.

Rajor, A., Reddy, A.S., and Singh, B. (2004). Determination of BOD kinetic Parameters and evaluation of alternate methods, M.Sc. Thesis, Department of biotechnology \& environmental Science, Thapar Institute of Engineering and Technology, Patiala

Ramasami, T., Rajamani, S., and Rao, J. R. (1994, March). Pollution control in leather industry: Emerging technological options. In International symposium on surface and colloidal science and its relevance to soil pollution, madras.

Ramesh, J. V. S., and Singh, S. P. (1993). Yearly variation in certain physicochemical parameters of pond at eastern Doon Valley. Uttar Pradesh J. Zoo, 12 (1), 7577.

Ranen, S., and Sharadinadra, C. (2009). Biotechnology applications to environmental remediation in resource exploitation. Current science, 97, 6-25
Russell, A. J., Berberich, J. A., Drevon, G. F., and Koepsel, R. R. (2003). Biomaterials for mediation of

chemical and biological warfare agents. Annual review of biomedical engineering, 5(1), 1-27.

Saravanan, P., and Saravanan, A. (1999). Decolourization of tannery effluent by Flavobacterium sp. EK 1. Indian Journal of Environmental Protection, 19, 19-24.

Sikander, S., and Shahida, H. (2007). Reduction of toxic hexavalent chromium by Ochrobactrum intermedium strain SDCr5 stimulated by heavy metals. Bioresource Technol, 98, 340-344.

Singh, N., Sharma, B. K., and Bohra, P. C. (2000). Impact assessment of industrial effluent of arid soils by using satellite imageries. Journal of the Indian Society of Remote Sensing, 28(2-3), 79.

Sreemoyee, C., and Priti, P. (2013). Assessment of physico-chemical parameters of dairy waste water and isolation and characterization of bacterial strains in terms of cod reduction. Int J Sci, 2(3), 395-400.

Verheijen, L. A. H. M., Wiersema, D., Pol, L. H., and De Wit, J. (1996). Management of wastes from animal product processing. Livestock and environment, Finding a balance. International Agriculture Center, Wageningen, The Netherlands.

Wang, F., Yao, J., Si, Y., Chen, H., Russel, M., Chen, K., and Bramanti, E. (2010). Short-time effect of heavy metals upon microbial community activity. Journal of Hazardous Materials, 173(13), 510-516.

WHO (World Health Organization). (2006). Air quality guidelines: global update 2005: particulate matter, ozone, nitrogen dioxide, and sulfur dioxide. World Health Organization.

World Bank. (1995). Nigeria's strategic options for redressing industrial pollution. World Bank, industry and energy division. 1st edition, West Central Africa Department; Annexes: 1995; pp 60-62.

Zahoor, A., and Abdul, R. (2009). Enumeration of Coliforms. Journal of Environmental Sciences. 21, 814-820 


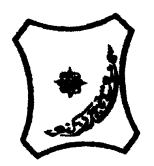

Bayero Journal of Pure and Applied Sciences, 13(2): 1 - 12

Received: November, 2020

Accepted: December, 2020

ISSN $2006-6996$

\title{
BIODEGRADATION POTENTIAL OF IMMOBILIZED BACTERIA IN THE TREATMENT OF TANNERY INDUSTRIAL EFFLUENTS FROM INDUSTRIAL ESTATES IN KANO STATE, NIGERIA
}

\author{
Abdullateef, B., ${ }^{1 *}$ Shuaibu, T. G., ${ }^{1}$ Babagana, K., ${ }^{1}$ Suleman, H. B. ${ }^{2}$ and Dauda, B. ${ }^{3}$ \\ ${ }^{1}$ Department of Pure and Applied Chemistry, Faculty of Science, University of Maiduguri, Borno State, \\ Nigeria \\ ${ }^{2}$ Department of Microbiology, Faculty of Science, University of Maiduguri, Borno State, Nigeria \\ ${ }^{3}$ Department of Chemical Engineering, Faculty of Engineering, University of Maiduguri, Borno State, \\ Nigeria \\ *Corresponding author: babslega@gmail.com; abelega2007@yahoo.com; +2348061309753
}

\section{ABSTRACT}

Industrial Effluents Samples from Gashash Tanneries (TAN1) in Bompai Industrial estate, Larabee Tannery Industry (TAN2) in Sharada Industrial estate and Z Tannery Industries (TAN3) in Challawa Industrial estate, Kano State, Nigeria were collected over a period of six months (August 2017 to January 2018) for assessing the biodegradation potentials of bacteria in the treatment of organic pollutants within the effluents. Bacteria were isolated from the effluents and immobilized on agar-agar. Different masses (5 g, $10 \mathrm{gr}, 15$ $\mathrm{g}, 20 \mathrm{~g}$, and $25 \mathrm{~g}$ ) of the bacteria were used in the treatment of $250 \mathrm{ml}$ of the effluents for ten days in a shaker incubator (Gallenkamp-OC-4364-L) at the temperature $30{ }^{\circ} \mathrm{C}$ and speed of $60 \mathrm{rpm}$. Pre-treatment analysis of the effluents for Temperature, pH, Biochemical Oxygen Demand (BOD), Chemical Oxygen Demand (COD), Suspended Solid (SS) and Total Dissolved Solids (TDS) gives the following results; temperature $\left({ }^{\circ} \mathrm{C}\right.$ )

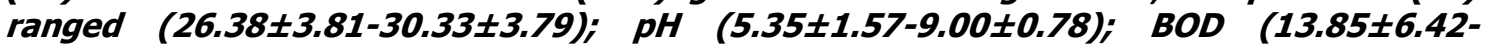
$38.75 \pm 16.20) ;$ COD (1406 $\pm 208-3532 \pm 1373) ;$ SS (208 $\pm 235-780 \pm 739)$ and TDS (266 $\pm 253-5276 \pm 2971)$. No statistical differences ( $p \leq 0.05)$ was observed for all the results among the different industries. The bacterial isolates were identified as Neisseria spp, Bacillus cereus, and Staphylococcus aureus, in TAN1, TAN2, and TAN3, respectively. After treatment of the effluent with the different masses of the isolated bacteria, the mean level of BOD was found to range as (0.55 $\pm 0.36-6.92 \pm 5.49) ; C O D$ (ND-3134 \pm 1595$)$;

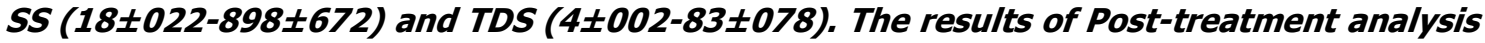
showed that there is overall decrease in the levels of the parameters determined when compared with that of the pre-treatment. The overall percentage reduction of the immobilised bacteria in the treatment of the respective effluents was in the order TAN2 (72\%)>TAN1 (70\%)>TAN3 (62\%). Hence, the immobilized bacteria are having higher biodegradation potential for the treatment of the tannery effluents.

Keywords: Biodegradation, bacteria, effluent, immobilization, tannery.

\section{INTRODUCTION}

Tannery industrial wastewater is a serious consequence of the pollution point of view for streams, freshwater, and land used for agriculture. The lack of awareness in the modern industrial practice has resulted in the discharge of tannery effluents which exhibit very high value of chromium ( $\mathrm{Cr}$ ), Sulfide, and chloride, Total Dissolved Solid (TDS), Total Suspended Solid (TSS), Biochemical Oxygen Demand (BOD) and Chemical Oxygen Demand (COD) in the water stream or land (Mohammed et al., 2001). Tanning is the process, which One ton of skin generally leads to the production of 20 to $80 \mathrm{~m}^{3}$ of turbid and foul-smelling converts the protein of the rawhide or skin into a stable material, which will not putrefy and is suitable for a wide variety of end applications (Elsheikh, 2009). The highly polluting chromium is the most commonly used tanning material producing leather that is more flexible and pliable than vegetable-tanned leather and does not discolor or lose shape in water as drastically as vegetable-tan (Elsheikh, 2009). Tannery effluent is among the most hazardous industrial pollutants due to its huge organic and inorganic load, which is highly toxic to human life and the environment (Kongjao et al., 2008). wastewater including chromium (100-400 mg/l), sulfide $(200-800 \mathrm{mg} / \mathrm{l})$, high levels of fat and 
BAJOPAS Volume 13 Number 2, December, 2020 other solid wastes, and notable pathogen contamination as well as pesticides added for skin conservation during transport (Elsheikh, 2009). There are more than 6000 tanneries in Nigeria with an annual processing capacity of 700,000 tons of hides and skins (Omoleke, 2004; Singh et al., 2008). It was reported that the total amount of waste produced per animal slaughtered is approximately $35 \%$ of its weight (World Bank, 1995). Also, for every $1000 \mathrm{~kg}$ of carcass weight, a slaughtered beef produces 5.5 $\mathrm{kg}$ of manure (excluding rumen contents or stockyard manure) and $100 \mathrm{~kg}$ of paunch manure (undigested food) (Verheijen et al., 1996). Tanneries generate wastewater in the range of 30-35 $\mathrm{L} \mathrm{kg}^{-1}$ skin/hide processed with variable $\mathrm{pH}$, Biological Oxygen Demand (BOD), Chemical Oxygen Demand (COD), high concentrations of suspended solids (SS), and tannins as well as chromium (Zahoor and Abdul, 2009).

Being heterogeneous and composed of a wide variety of compounds, it is very difficult to select a unique direct method for estimating the biodegradability of organic contents and biokinetic parameters for a wastewater sample (Rajor, 2004). For this purpose, some indirect estimation such as determination of biochemical oxygen demand (BOD) and chemical oxygen demand (COD) are applied as common laboratory investigations [9]. During retanning procedures, synthetic tannins (Syntan), oils and resins are added to form softer leather at varying doses (Munz et al., 2009). One of the refractory groups of chemicals in tannery effluents derives mainly from tannins (Ramasami et al., 2004). Syntans are characterized by complex chemical structures, because they are composed of an extended set of chemicals such as phenol-, naphthalene-, formaldehyde- and melamine-based syntans, and acrylic resins (Beem, 1994). Organic pollutants (proteic and lipidic components) are originated from skins (it is calculated that the raw skin has $30 \%$ loss of organic material during the working cycle) or they are introduced during processes (Hugo Springer, 1994).

Many conventional processes such as oxidation, chemical and biological processes were carried out to treat tanneries wastewater (Ebtesam et al, 2013). Biological processes have received more attention because of their costeffectiveness, lower sludge production and environmental friendliness (Noorjahan, 2014). Naturally occurring micro-organisms degrade the hazardous organic wastes including xenobiotic compounds, such as pesticides, polycyclic aromatic hydrocarbons (PAHs) and polychlorinated biphenyls (PCBs) in due course of time (Ranen and Sharadinadra, 2009). Bioremediation is based on the idea that all organisms remove substances from the environment to carry outgrowth and metabolism (Bouwer and Zehnder, 1993). Bacteria, protista and fungi are found to be very good at degrading complex molecules and incorporating the breakdown products into their metabolism (Bouwer and Zehnder, 1993). The resultant metabolic wastes that they produce are generally safe and somehow recycled into other organisms (Ranen and Sharadinadra, 2009). An acclimatized indigenous population of microorganisms capable of degradation of the compounds of interest must exist at the site for a successful bioremediation mode (Ranen and Sharadinadra, 2009). It has been observed that for a successful bioremediation mode, an acclimatized indigenous population of microorganisms capable of degradation of the compounds of interest must exist at the site under investigation (Ranen and Sharadinadra, 2009). Even though there are numerous physical and chemical methods employed in the disposal of wastes the advantage in using bacterium is that they play a key role in the reduction of COD, BOD, total protein, total tannin and total phenol (Saravanan and Saravanan, 1998)

Baba et al. (2020) studied the bioremediation potential of immobilized corynebacterium kutsceri in the Treatment of tannery industrial effluent from Challawa Industrial Estate, Kano State, Nigeria. The aim of the work is to study the reduction in the level of the contaminants through the process of bioremediation using the isolated bacteria. Immobilized bacteria can withstand various temperatures, $\mathrm{pH}$ and substrate concentrations; consequently, increasing the efficiency and the lifespan of the bacteria. Immobilized bacteria are widely applied in the treatment of wastewater and can be separated and recovered after the treatment with the same efficiency (Baba et al., 2020).

\section{MATERIALS AND METHODS \\ Study Area}

This study was carried out in Bompai, Sharada and Challawa industrial estates in Kano, Figure 1. Kano lies on Latitude $11^{\circ} 30^{\prime} \mathrm{N}$ and $8^{\circ} 30^{\prime} \mathrm{E}$ and Longitude $11^{\circ} 5^{\prime} \mathrm{N}$ and $8^{\circ} 5^{\prime} \mathrm{E}$ in Northern Nigeria. It is one of the developed industrial cities in Nigeria. Tannery activities are the dominating industries and this could be one of the reasons for her high population density (Dan'Azumi and Bichi, 2010). Many researchers have studied biodegradation of tannery effluent using microorganisms. However, limited literature is available on the biodegradation of tannery effluent in Kano industrial estates using 
BAJOPAS Volume 13 Number 2, December, 2020 immobilized bacterial cells. This research work focuses on the potential of the use of the indigenous immobilized bacterial isolates in the treatment of tannery effluents in the industrial estates.

\section{Sample Collection}

Effluents were collected from the Tannery Industries from Bompai, Challawa and Sharada Industrial Estates, Kano, Nigeria. The effluents were collected over a period of six months (August 2017 to January 2018). Samples collected in a sterile 4-liter plastic container with a unique identification number were preserved using an ice-box that was transported to the Microbiology Laboratory, Department of Microbiology, Bayero University of Kano for analysis

\section{Sample Preparation and Sample Analysis}

Immediately after the collection of the effluent, $\mathrm{pH}$, TSS, TDS, COD, BOD levels were determined before treatment (Pre-treatment determination) and ten days after treatment (Post-treatment determination) as described in
APHA (1989) standard methods. $\mathrm{pH}$ was determined using Ecotests $\mathrm{pH}$ meter and TDS was determined using AQUALYTIC TDS Salinometer. BOD was determined as described by the standard method (APHA, 1992). COD and SS were determined using DR/2010 HACH portable data logging spectrophotometer (DWAF, 1992)

\section{Identification and Biochemical} Characterization of the Bacterial Isolates

The bacteria were isolated from the effluents using Serial Dilution according to the method described by APHA (1989). The biochemical tests such as oxidase, catalase, coagulase, indole (from $1 \%$ tryptone broth), citrate (Simmons citrate agar), methyl red/VogesProskauer (MR/VP), nitrate reduction, Starch Hydrolysis, Glucose, Maltose, and Lactose tests were carried out on the bacterial isolates to identify the bacteria through the bacteria biochemical characteristics according to Ajao et al. (2011).

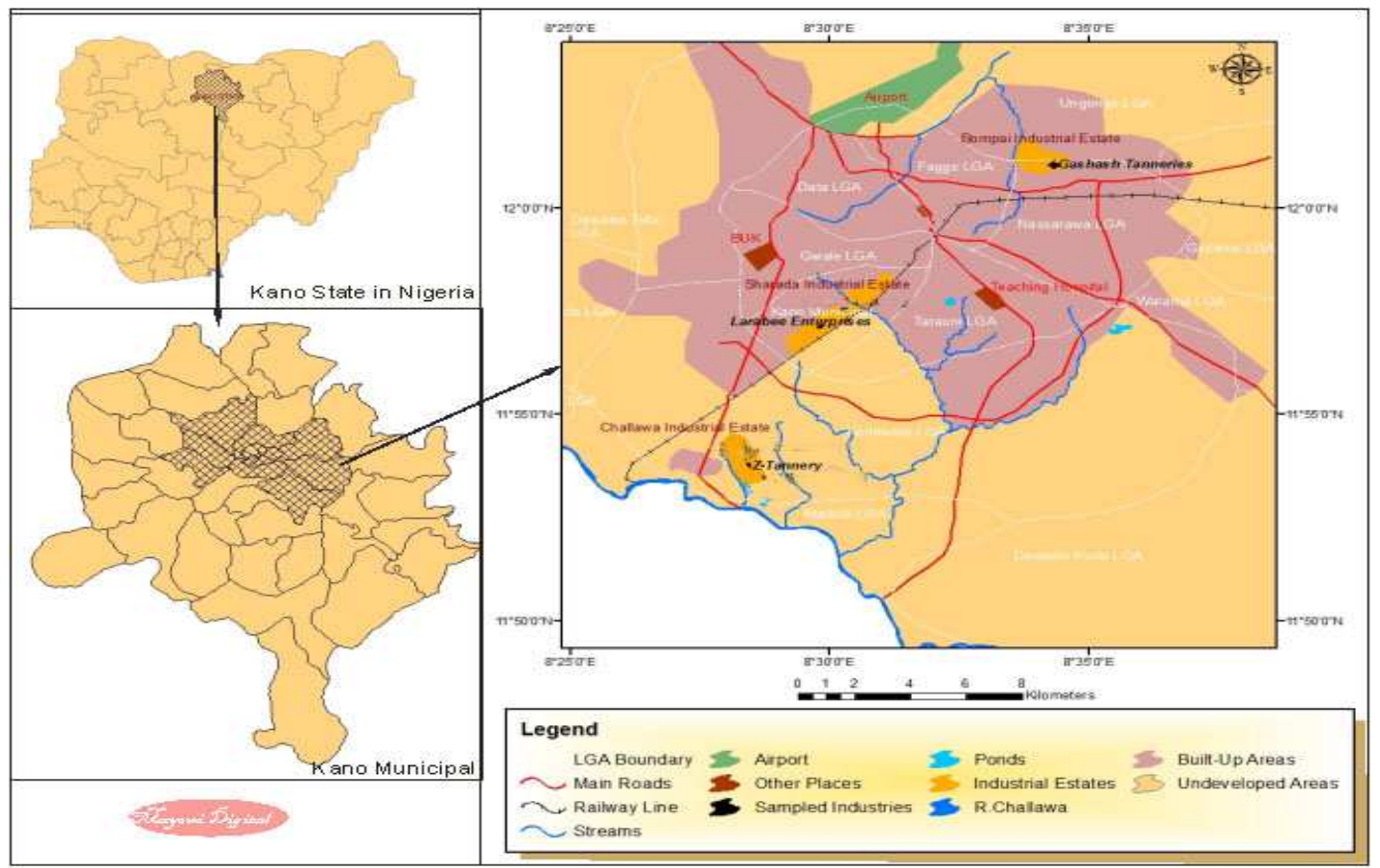

Fig. 1 Map showing the study areas

Source: Mayomi Digital Productions, GIS Laboratory, Department of Geography, UNIMAID (2017)

\section{Determination of Growth Rate of the Bacteria in Effluent Sample}

The bacteria growth rates were determined by transferring $2 \mathrm{~mL}$ of the bacterial isolates from the tannery effluent in broth medium into 100 $\mathrm{mL}$ sterile effluents in conical flasks and kept in an incubator (Giffrin cool) for 10 days. Control was also set up by incubating another $100 \mathrm{~mL}$ each of the sterile effluents without the bacteria. The optical density of the content was determined at the wavelength of $600 \mathrm{~nm}$ on a daily interval and recorded. 
BAJOPAS Volume 13 Number 2, December, 2020 Immobilization of Bacteria

Agar solution and inoculi were prepared separately. Fifty milliliters $(50 \mathrm{~mL})$ of nutrient broth each of the inoculi was prepared in a McCartney bottle and incubated for 24 hours. A solution of agar-agar was prepared by dissolving $10 \mathrm{~g}$ of the powder in distilled water and made up to $500 \mathrm{~mL}$ mark in an Erlenmeyer flask and was sterilized in an autoclave (280A) for 15 minutes and allowed to cool to $40-45^{\circ} \mathrm{C}$ (Ajao et al., 2011). Four milliliters ( $4 \mathrm{~mL})$ of the bacterial isolates in the nutrient broth was mixed with 36 $\mathrm{ml}$ of the prepared agar-agar media in petri-dish plates and then allowed to solidify. This was kept in the refrigerator for bioremediation.

\section{Bioremediation (Treatment) of the Effluents}

The solidified agar block (immobilized bacteria) was cut into cubes using a sterile knife; $0.1 \mathrm{~mL}$ phosphate buffer ( $\mathrm{pH} \mathrm{7.0)}$ was added and kept in the refrigerator for 1 hour for curing. The phosphate buffer was decanted after 1 hour and the cubes were washed with sterile distilled water 3-4 times before it was used (Ajao et al., 2011). Two liters (2 L) of the effluent was supplemented with the minimum basal medium in $\mathrm{g} / \mathrm{L}: \mathrm{NaCl}(0.8), \mathrm{MgSO}_{4} .7 \mathrm{H}_{2} \mathrm{O}(0.001), \mathrm{KH}_{2} \mathrm{PO}_{4}$ (2), $\mathrm{NaNO}_{3}$ (2), $\quad \mathrm{CaCl}_{2} .2 \mathrm{H}_{2} \mathrm{O} \quad(0.5)$ and $\mathrm{NaHPO}_{4} .12 \mathrm{H}_{2} \mathrm{O}(2)$ and sterilized in an autoclave at $121^{\circ} \mathrm{C}$ for 15 minutes (Margesin and Schinner, 2001). Two hundred and fifty milliliters $(250 \mathrm{~mL})$ of the effluents were transferred into different $250 \mathrm{ml}$ conical flasks. The content was covered with a cotton-wool ramped with foil paper to avoid contamination. Five grams $(5 \mathrm{~g})$ of the immobilized bacteria were quickly transferred into each of the effluents in the conical flasks in an inoculating chamber. The same procedures were carried out for the $10 \mathrm{~g}, 15 \mathrm{~g}, 20 \mathrm{~g}$ and 25 $\mathrm{g}$ of the immobilized bacteria in separate $250 \mathrm{~mL}$ effluents in conical flasks and agitated for ten days in a shaker incubator (Gallenkamp-OC4364-L) at a temperature $30^{\circ} \mathrm{C}$ and speed of 60 rpm. The treated effluent samples were taken on the tenth day and analyzed for the parameters $\mathrm{pH}$, SS, TDS, COD, and BOD, (Posttreatment determination) for the different grams of bacteria to evaluate and compare the biodegradation potential. (Baba et al., 2020).

\section{Statistical Analysis}

The data were represented as Mean \pm Standard deviation and analyzed statistically using oneway Analysis of Variance (ANOVA) and Tukey's HSD as Post Hoc Tests with the aid of SPSS 16.0. The correlation coefficient was also used to measure the strength of the relationship between the different masses of the bacteria and the parameters. All $\mathrm{p} \leq 0.05$ were considered as statistically significant.

\section{RESULTS AND DISCUSSION Physico-chemical parameters in the Industrial Effluents before the Biodegradation.}

Results of the Physico-chemical parameters in the industrial effluents before the Biodegradation is shown in table 1 . The mean temperatures $\left({ }^{\circ} \mathrm{C}\right)$ observed in TAN1, TAN2, and TAN3 samples were $28.07 \pm 0.65 ; 27.77 \pm 0.64$ and $26.38 \pm 3.81$ respectively. The order of the mean temperature of the samples from the three industries can be arranged as TAN1 > TAN2>TAN3. The temperature observed at TAN1, TAN2, and TAN3 samples were found below the WHO $\left(35^{\circ} \mathrm{C}\right)$ and NESREA $\left(40^{\circ} \mathrm{C}\right)$ limits. The low values of temperature might be due to the processes used at the time of sampling. High temperature brings down the solubility of gases in water that ultimately expresses as high BOD and COD. Statistical analysis shows that there is no significant difference $(p<0.05)$ between the mean values of temperature among the industries. This might be due to similar tannery activities involved in the tannery industries at the time of sampling. The average values of temperature observed in this present study are less than those observed by Akan et al. (2007), Akan et al. (2009) and Baba et al. (2020).

The mean level of $\mathrm{pH}$ observed in TAN1, TAN2 and TAN3, samples were $7.77 \pm 2.93$; $8.35 \pm 0.28$ and $7.52 \pm 0.76$ respectively. The order of the mean $\mathrm{pH}$ of the samples from the three industries can be arranged as TAN2> TAN1 $>$ TAN3. The $\mathrm{pH}$ of the samples falls within the WHO (7.0-8.5) and NESREA (6-9) standard limits. Statistical analysis shows that there is no significant difference $(p<0.05)$ between the mean values of $\mathrm{pH}$ among the industries. This might be due to similar tannery activities involved in the tannery industries at the time of sampling. Maheshwari et al. (2017) reported that the level of $\mathrm{pH}$ in the effluents from the tannery industry in Vaniyambadi, India was 6.5 which was lower than that observed in the present study. The $\mathrm{pH}$ in the effluents from the tannery industries in Kano and Kaduna were reported to be 7.64 and 6.89, respectively (Akan et al., 2007; Mohammed et al., 2017). The average values of $\mathrm{pH}$ observed in this present study are less than those observed by Mohammed et al. (2017) and Baba et al. (2020). The mean level of SS $(\mathrm{mg} / \mathrm{l})$ observed in TAN1, TAN2, and TAN3 samples were 374 \pm 124 ; $358 \pm 335$ and $780 \pm 739$ respectively. The order of the mean SS in the samples from the three industries can be arranged as TAN3 > TAN1 $>$ TAN2. 
The SS observed in the samples were far above the recommended standard limits of regulating bodies WHO $(30 \mathrm{mg} / \mathrm{l})$ and NESREA $(10 \mathrm{mg} / \mathrm{l})$. Statistical analysis shows that there is no significant difference $(p<0.05)$ between the mean values of SS among the industries. This might be due to similar tannery activities involved in the tannery industries at the time of sampling. The average values of SS observed in this present study are less than that observed $(3700 \pm 122 \mathrm{mg} / \mathrm{l})$ by Akan et al. (2009) for tanneries in Kano. Also, the average values of SS observed in this present study are less than that observed by Mohammed et al. (2017) and Baba et al. (2020) with the exception in TAN3.

The mean level of TDS (mg/l) observed in TAN1, TAN2, and TAN3 samples were $3941 \pm 3703$; $3300 \pm 1714$ and $2653 \pm 1240$ respectively. The order of the mean TDS in the samples from the three industries can be arranged as TAN1>TAN2>TAN3. The TDS observed in the samples were far above the recommended standard limits of WHO $(250 \mathrm{mg} / \mathrm{l})$ and NESREA $(500 \mathrm{mg} / \mathrm{l})$. Statistical analysis shows that there is no significant difference $(p<0.05)$ between the mean values of TDS among the industries. This might be due to similar tannery activities involved in the tannery industries at the time of sampling. TDS in the effluents from the tannery industries in Kano, Nigeria was reported to be $1281 \mathrm{mg} / \mathrm{l}$ (Akan et al., 2007). The average values of SS observed in this present study are less than those observed by Mohammed et al. (2017) and Baba et al. 2020)

The mean level of COD (mg/l) observed in TAN1, TAN2 and TAN3 samples seasons were $2372 \pm 938 ; \quad 1406 \pm 208$ and $3532 \pm 1373$ respectively. The order of the mean COD of the samples from the three industries can be arranged as TAN3>TAN1> TAN2. The COD observed in TAN1, TAN2 and TAN3 samples were far above the recommended standard limits of regulating bodies $\mathrm{WHO}(40 \mathrm{mg} / \mathrm{l})$ and NESREA (40 mg/l). Statistical analysis shows that there is no significant difference $(p<0.05)$ in COD among the industries. This might be due to similar tannery activities involved in the tannery industries as at the time of sampling. The Chemical Oxygen demand (COD) is the amount of oxygen, in $\mathrm{mg} / \mathrm{L}$, required for the degradation of the compound of wastewater to occur. In comparison, the average values of COD observed in this present study were higher than that observed by Mohammed et al. (2017) but lower than that observed by Baba et al. (2020).

The mean levels of BOD $(\mathrm{mg} / \mathrm{l})$ observed in TAN1, TAN2 and TAN3 samples were $13.85 \pm 6.42 ; \quad 19.46 \pm 0.50$ and $17.13 \pm 3.14$ respectively. The order of the mean BOD in the samples from the three industries can be arranged as TAN2>TAN3>TAN1. The BOD observed in TAN1, TAN2 and TAN3 samples were found below the recommended limits of NESREA (200 mg/l) but above WHO (10 mg/l). Statistical analysis shows that there is no significant difference $(p<0.05)$ between the mean values of BOD among the industries. This might be due to similar tannery activities involved in the tannery industries at the time of sampling. The low level of BOD recorded in this study is an indication of the low level of biodegradable organic solids in the effluent. The average values of BOD observed in this present study were lower than those observed by Mohammed et al. (2017) and Baba et al. (2020).

Table 1: Mean Values \pm S.D of Physico-chemical parameters of effluents from the Tannery Industries before Treatment.

\begin{tabular}{llllllll}
\hline Parameter & Tannery 1 & Tannery 2 & Tannery 3 & $\mathrm{a}$ & $\mathrm{b}$ & $\mathrm{c}$ & $\mathrm{d}$ \\
\cline { 2 - 7 } Temperature $\left({ }^{\circ} \mathrm{C}\right)$ & $28.07 \mathrm{a} \pm 0.65$ & $27.77 \mathrm{a} \pm 0.64$ & $26.38 \mathrm{a} \pm 3.81$ & & $29.50 \pm 4.68$ & 35 & 40 \\
pH & $7.77 \mathrm{a} \pm 2.93$ & $8.35 \mathrm{a} \pm 0.28$ & $7.52 \mathrm{a} \pm 0.76$ & 6.89 & $5.35 \pm 1.57$ & $7.0-8.5$ & $6.0-9.0$ \\
$\mathrm{COD}(\mathrm{mg} / \mathrm{l})$ & $2372 \mathrm{a} \pm 938$ & $1406 \mathrm{a} \pm 208$ & $3532 \mathrm{a} \pm 1373$ & 2.2 & $3106 \pm 2753$ & 40 & 40 \\
$\mathrm{BOD}(\mathrm{mg} / \mathrm{l})$ & $13.85 \mathrm{a} \pm 6.42$ & $19.46 \mathrm{a} \pm 0.50$ & $17.13 \mathrm{a} \pm 3.14$ & 1032 & $26.17 \pm 9.49$ & 10 & 200 \\
$\mathrm{SS}(\mathrm{mg} / \mathrm{l})$ & $374 \mathrm{a} \pm 124$ & $358 \mathrm{a} \pm 335$ & $780 \mathrm{a} \pm 739$ & 501 & $562 \pm 482$ & 30 & 10 \\
TDS $(\mathrm{mg} / \mathrm{l})$ & $3941 \mathrm{a} \pm 3703$ & $3300 \mathrm{a} \pm 1714$ & $2653 \mathrm{a} \pm 1240$ & 532.7 & $444 \pm 507$ & 250 & 500 \\
\hline
\end{tabular}

The values given in the table above are means of 6 replicate values, $\mathrm{n}=6$ ( 1 sample was taken monthly for 6 months). Within the rows, means with different alphabets are statistically different $(p<0.05)$. WHO: World Health Organisation. NESREA: National Environmental Standard and Regulatory Enforcement Agency. a = Mohammed et al.(2017), b = Baba et al. (2020), c = WHO (2006), $d=$ NESSRA (2009) 
BAJOPAS Volume 13 Number 2, December, 2020

Identification, Biochemical Characterization and growth rates of the Bacterial Isolates

Results of identification and biochemical characterization of the bacterial isolates were shown in table 2. After 24 hours of incubation, the nutrient agar media plates were checked for bacterial growth. The results showed the presence of different strains in the samples. The TAN1 bacteria isolate was found to be gramnegative cocci while TAN3 was gram-positive cocci. TAN2 bacteria isolate was found to be gram-positive, rod-shaped. TAN1, TAN2, and TAN3 bacteria isolates recorded positive results for spore former.

The results of the biochemical tests indicated that all the bacteria were positive for catalase, oxidase, citrate, maltose, glucose, lactose (negative in TAN1), mannitol (negative in TAN2), starch hydrolysis and coagulase (negative in TAN2) tests. The bacteria showed negative results for nitrate reduction, $M R$ (positive in TAN2), VP (positive in TAN1), Indole (positive in TAN2) tests. Base on the morphological and biochemical test results, TAN1, TAN2, and TAN3 bacteria isolates were identified to be Nesseria spp, Bacillus cereus, and Staphylococcus aureus respectively.

The growth rate of the TAN1, TAN2 and TAN3 Isolates were shown in figure 2. Generally, the optical density increase with the increase in time (day) and decrease as time goes on. The highest optical density was shown by bacillus cereus in TAN2 while the lowest was shown by Staphylococcus aureus in TAN3.

The initial growth phase of TAN1 Isolate bacteria occurred within 2-day of incubation as the growth rate increases up to the 6th-day incubation when the maximum growth was observed. Beyond the 6th day, the growth of the bacteria declined (which might be due to a shortage of nutrients in the effluents) until it reached its death phase (which might be due to the unavailability of nutrients in the effluents).

A similar trend of growth was also observed for TAN2 Isolate as the initial growth phase also occurred within 2-day of incubation but maximum growth rate observed on the 4th day of incubation. The stationary stage occurred between the 4th day and the 8th day. Beyond the 8th day, the growth of the bacteria declined (which might be due to a shortage of nutrients in the effluents) until it reached its death phase (which might be due to the unavailability of nutrients in the effluents).

The initial growth phase of TAN3 bacterial Isolate occurred within the 3-day incubation as the growth rate increases up to the 6th-day incubation when the maximum growth was observed. Beyond the 6th day, the growth of the bacteria declined (which might be due to a shortage of nutrients in the effluents) until it reached its death phase (which might be due to the unavailability of nutrients in the effluents).

Table 2: Morphological and Biochemical characteristics of bacterial isolates

\begin{tabular}{lllll} 
Bacterial Isolates & & TAN1 & TAN2 & TAN3 \\
\hline $\begin{array}{lllll}\text { Morphological } \\
\text { characteristics }\end{array}$ & Shape & Cocci & Rod & Cocci \\
& Spore & & & \\
& former & + & + & + \\
Gram & & & \\
Biochemical characteristics & reaction & - & + & + \\
& Citrate & + & + & + \\
& Catalase & + & + & + \\
& Coagulase & + & - & + \\
Starch & + & + & + \\
& Glucose & + & + & + \\
Oxidase & + & + & + \\
& Indo & - & + & - \\
Lactose & - & + & + \\
Manitol & + & - & + \\
Maltose & + & + & + \\
MR & - & + & - \\
VP & + & - & - \\
& Nitrate & - & - & - \\
Reduction & - Neisseria & Bacillus & Staphylococcus \\
& Bacterial & cereus & aureus \\
& name & spp & cas
\end{tabular}

+ = Positive; - = Negative; MR=Methyl Red; VP= Voges-Proskauer 


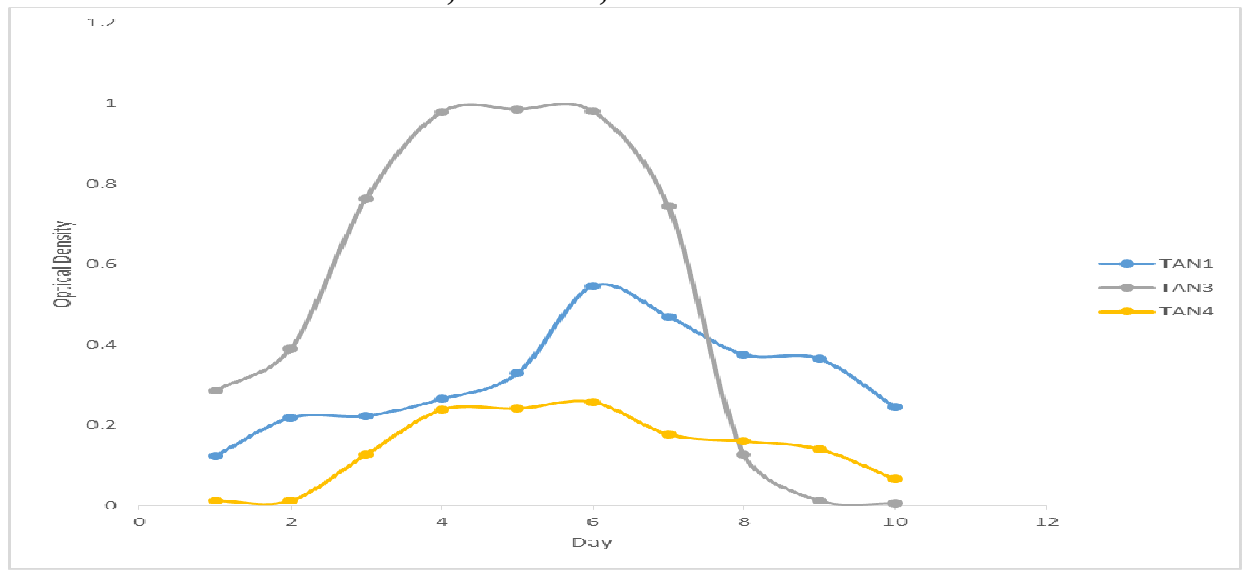

Fig. 2 Growth rates of the isolates in the effluents from the Tannery Industries

\section{Physico-chemical Parameters in the Industrial Effluents after the biodegradation.}

Table 3 shows the mean results of the physicochemical parameter before and after bioremediation using the different masses $(5 \mathrm{~g}$, $10 \mathrm{~g}, 15 \mathrm{~g}, 20 \mathrm{~g}$, and $25 \mathrm{~g}$ ) of the respective immobilized bacteria. Also, Table 4 shows the mean results of correlation coefficient ( $r$ ) between different masses of bacteria and physicochemical parameters.

The mean values $(\mathrm{mg} / \mathrm{l})$ of the SS after the bioremediation varies between $243 \pm 45$ and $898 \pm 672$. The mean concentration $(\mathrm{mg} / \mathrm{l})$ of SS remediated by the different masses $(5 \mathrm{~g}, 10 \mathrm{~g}$, $15 \mathrm{~g}, 20 \mathrm{~g}$, and $25 \mathrm{~g}$ ) of the bacteria varies. The SS in the samples fluctuates up and down after the bioremediation process when compared with the SS of the raw samples before the bioremediation. The increase in the levels of the SS might be due to the aggregation of the TDS which are large enough to result into SS. The increase in the levels of the SS might be also due to the influence of the nutrients which was added into the effluents in order to make the microorganisms more active and viable for fast degradation of organic contaminants in the effluent. The relative potential or efficiency of the different masses of the bacteria in remediating SS in TAN1 samples was in the order $25 \mathrm{~g}>20 \mathrm{~g}>15 \mathrm{~g}>10 \mathrm{~g}>5 \mathrm{~g}$. For TAN2 and TAN3 samples, the order was $25 \mathrm{~g}>20 \mathrm{~g}>15$ $\mathrm{g}>10 \mathrm{~g}>5 \mathrm{~g}$. These might be due to the variations in the surface areas of the different masses of the immobilized bacteria. Statistical analysis shows that there is no significant difference $(p<0.05)$ between the mean values of SS among the masses in the respective industries. Positive and significant correlations exist between the masses of bacteria and Suspended Solid (SS). This showed that there is general increase in the levels of the SS as the masses of the immobilized bacteria increases. TAN3 (90\%) and TAN1 (80\%) showed a very high correlation with the masses of the bacteria while TAN2 (61\%) showed a very low correlation.

The mean values $(\mathrm{mg} / \mathrm{l})$ of the TDS after the bioremediation varies between $46 \pm 11$ and $83 \pm 78$. The mean concentration $(\mathrm{mg} / \mathrm{l})$ of TDS remediated by the different masses $(5 \mathrm{~g}, 10 \mathrm{~g}$, $15 \mathrm{~g}, 20 \mathrm{~g}$, and $25 \mathrm{~g}$ ) of the bacteria varies. There is a reduction in all the TDS of all the samples after the bioremediation process compared with the TDS of the raw samples before the bioremediation. The relative potential or efficiency of the different masses of the bacteria in remediating TDS in TAN1 and TAN3 samples was in the order $5 \mathrm{~g}>10 \mathrm{~g}>15 \mathrm{~g}>20$ $\mathrm{g}>25 \mathrm{~g}$. For TAN2 samples, the order was 20 $g>10 \quad g>25 \quad g>15 \quad g>5 \quad g$. Statistical analysis shows that there is no significant difference $(p<0.05)$ between the mean values of TDS among the masses in the respective industries. These might be due to the variations in the surface areas of the different masses of the immobilized bacteria. Positive and significant correlations exist between the masses of bacteria and TDS with the exception in TAN2 (negative and insignificant correlation). The positive correlations showed that there is general increase in the levels of the TDS as the masses of the immobilized bacteria increases. TAN1 $(96 \%)$ showed a very high correlation with the masses of the bacteria while TAN2 (47\%) showed a very low correlation.

The mean values $(\mathrm{mg} / \mathrm{l})$ of the BOD after the bioremediation varies between $1.56 \pm 0.20 \mathrm{mg} / \mathrm{l}$ and $6.92 \pm 5.49 \mathrm{mg} / \mathrm{l}$. The mean concentration $(\mathrm{mg} / \mathrm{l})$ of BOD remediated by the different masses $(5 \mathrm{~g}, 10 \mathrm{~g}, 15 \mathrm{~g}, 20 \mathrm{~g}$, and $25 \mathrm{~g}$ ) of the bacteria varies. There is a reduction in all the BOD of all the samples after the bioremediation process compared with the $\mathrm{BOD}$ of the raw 
BAJOPAS Volume 13 Number 2, December, 2020 samples before the bioremediation. The relative potential or efficiency of the different masses of the bacteria in remediating BOD in TAN1, TAN2 and TAN3 samples were in the order $25 \mathrm{~g}>20$ $\mathrm{g}>15 \mathrm{~g}>10 \mathrm{~g}>5 \mathrm{~g}, 25 \mathrm{~g}>15 \mathrm{~g}>5 \mathrm{~g}>10 \mathrm{~g}>20 \mathrm{~g}$ and $20 \mathrm{~g}>10 \mathrm{~g}>25 \mathrm{~g}>15 \mathrm{~g}>5 \mathrm{~g}$ respectively. Statistical analysis shows that there is significant difference $(p<0.05)$ between the mean values of BOD among the masses in the respective industries. These might be due to the variations in the surface areas of the different masses of the immobilized bacteria. Negative and significant correlations exist between the masses of bacteria and BOD. This showed that there is general decrease in the levels of the BOD as the masses of the immobilized bacteria increases. TAN1 (94\%) showed a very high correlation with the masses of the bacteria while TAN2 (4\%) showed a very low correlation.

The mean values $(\mathrm{mg} / \mathrm{l})$ of the COD after the bioremediation varies between $250 \pm 154$ and $3134 \pm 1595$. The mean concentration $(\mathrm{mg} / \mathrm{l})$ of COD remediated by the different masses $(5 \mathrm{~g}$, $10 \mathrm{~g}, 15 \mathrm{~g} 20 \mathrm{~g}$, and $25 \mathrm{~g}$ ) of the bacteria varies. There is a reduction in all the COD of all the samples after the bioremediation process compared with the COD of the raw samples before the bioremediation. The relative potential or efficiency of the different masses of the bacteria in remediating COD in TAN1, TAN2 and TAN3 samples were in the order $25 \mathrm{~g}>20 \mathrm{~g}>15$ $\mathrm{g}>5 \mathrm{~g}>10 \mathrm{~g}, 25 \mathrm{~g}>20 \mathrm{~g}>15 \mathrm{~g}>10 \mathrm{~g}>5 \mathrm{~g}$ and 10 g>5 g>25 g>15 g>20 g respectively. Statistical analysis shows that there were significant difference $(p<0.05)$ between the mean values of COD among the masses in the respective industries except for effluents treated with $25 \mathrm{~g}$. These might be due to the variations in the surface areas of the different masses of the immobilized bacteria. Negative and insignificant correlations exist between the masses of bacteria and COD with the exception in TAN3 (positive and significant correlation). The negative correlations showed that there is general decrease in the levels of the COD as the masses of the immobilized bacteria increases. TAN2 (100\%) showed a very high correlation with the masses of the bacteria while TAN3 (36\%) showed a very low correlation.

Generally, there was an overall decrease in the concentration of these physicochemical parameters after the bioremediation using the different masses of the bacterial isolates. These might be due to the variations in the surface areas of the different masses of the immobilized bacteria. This is in line with the work of Jimoh et al. (2018) and Baba et al. (2020).

Table 3: Mean Values $(\mathrm{mg} / \mathrm{l}) \pm$ S.D of Physicochemical parameters in effluents from the Tannery Industries before and after Treatment of the effluents $(250 \mathrm{ml})$ with the different masses $(5 \mathrm{~g}, 10 \mathrm{~g}$, $15 \mathrm{~g}, 20 \mathrm{~g}$, and $25 \mathrm{~g}$ ) of the bacteria.

\begin{tabular}{llllllll}
\hline $\mathrm{P}$ & IND & Before & \multicolumn{5}{c}{ After } \\
\cline { 4 - 7 } & & & $5 \mathrm{~g}$ & $10 \mathrm{~g}$ & $15 \mathrm{~g}$ & $20 \mathrm{~g}$ & $25 \mathrm{~g}$ \\
\hline \multirow{2}{*}{ COD } & TAN1 & $2372 \pm 938$ & $1708 \mathrm{a} \pm 861$ & $2045 \mathrm{a} \pm 1205$ & $845 \mathrm{a} \pm 369$ & $300 \mathrm{a} \pm 167$ & $250 \mathrm{a} \pm 154$ \\
& TAN2 & $1406 \pm 208$ & $1195 \mathrm{a} \pm 208$ & $1125 \mathrm{a} \pm 384$ & $1055 \mathrm{a} \pm 317$ & $956 \mathrm{a} \pm 310$ & $870 \mathrm{ab} \pm 240$ \\
& TAN3 & $3532 \pm 1373$ & $2374 \mathrm{a} \pm 1344$ & $1976 \mathrm{a} \pm 1405$ & $2757 \mathrm{a} \pm 1266$ & $3134 \mathrm{a} \pm 1595$ & $2614 \mathrm{~b} \pm 1105$ \\
BOD & TAN1 & $13.85 \pm 6.42$ & $6.92 \mathrm{a} \pm 5.49$ & $6.42 \mathrm{a} \pm 5.07$ & $5.72 \mathrm{a} \pm 5.35$ & $4.62 \mathrm{a} \pm 4.37$ & $2.82 \mathrm{ab} \pm 1.26$ \\
& TAN2 & $19.46 \pm 0.50$ & $1.75 \mathrm{~b} \pm 0.22$ & $1.73 \mathrm{~b} \pm 0.18$ & $1.58 \mathrm{a} \pm 0.16$ & $1.91 \mathrm{a} \pm 0.22$ & $1.56 \mathrm{~b} \pm 0.20$ \\
& TAN3 & $17.13 \pm 3.14$ & $4.24 \mathrm{ab} \pm 0.77$ & $3.29 \mathrm{ab} \pm 0.37$ & $4.11 \mathrm{a} \pm 0.07$ & $3.23 \mathrm{a} \pm 0.91$ & $3.33 \mathrm{a} \pm 1.28$ \\
SS & TAN1 & $374 \pm 124$ & $243 \mathrm{a} \pm 45$ & $471 \mathrm{a} \pm 226$ & $475 \mathrm{a} \pm 182$ & $492 \mathrm{a} \pm 128$ & $611 \mathrm{a} \pm 217$ \\
& TAN2 & $358 \pm 335$ & $460 \mathrm{a} \pm 400$ & $543 \mathrm{a} \pm 414$ & $544 \mathrm{a} \pm 402$ & $551 \mathrm{a} \pm 414$ & $554 \mathrm{a} \pm 405$ \\
& TAN3 & $780 \pm 739$ & $586 \mathrm{a} \pm 594$ & $758 \mathrm{a} \pm 656$ & $787 \mathrm{a} \pm 676$ & $861 \mathrm{a} \pm 635$ & $898 \mathrm{a} \pm 672$ \\
TDS & TAN1 & $3941 \pm 3703$ & $51 \mathrm{a} \pm 10$ & $53 \mathrm{a} \pm 10$ & $55 \mathrm{a} \pm 15$ & $61 \mathrm{a} \pm 20$ & $63 \mathrm{a} \pm 26$ \\
& TAN2 & $3300 \pm 1714$ & $83 \mathrm{a} \pm 78$ & $47 \mathrm{a} \pm 20$ & $48 \mathrm{a} \pm 22$ & $47 \mathrm{a} \pm 17$ & $48 \mathrm{a} \pm 17$ \\
& TAN3 & $2653 \pm 1240$ & $46 \mathrm{a} \pm 11$ & $55 \mathrm{a} \pm 24$ & $55 \mathrm{a} \pm 25$ & $58 \mathrm{a} \pm 23$ & $61 \mathrm{a} \pm 28$ \\
\hline
\end{tabular}

Replicate $=6$ (months)

Within the rows, for the same parameter, means with different alphabets are statistically different $(p<0.05)$.

$\mathrm{P}=$ parameter, IND = Industries 
BAJOPAS Volume 13 Number 2, December, 2020

Table 4: Correlation coefficient $(r)$ between different masses of the bacteria and the physicochemical parameters.

\begin{tabular}{llll}
\hline Industries & Parameter & Correlation coefficient $(r)$ & $\begin{array}{l}\text { Percent dependence (rxrx100) } \\
(\%)\end{array}$ \\
\hline TAN1 & COD & -0.9 & 82 \\
& BOD & -0.97 & 94 \\
& SS & $0.90^{*}$ & 80 \\
TAN2 & TDS & $0.98^{*}$ & 96 \\
& COD & -1 & 100 \\
& BOD & -0.21 & 4 \\
& SS & $0.78^{*}$ & 61 \\
& TDS & -0.69 & 47 \\
& COD & $0.60^{*}$ & 36 \\
& BOD & -0.6 & 37 \\
& SS & $0.95^{*}$ & 90 \\
& TDS & $0.94^{*}$ & 89 \\
\hline
\end{tabular}

The correlation coefficient $(r)$ with * is statistically significant $(p<0.05)$.

Percentage reduction of the Parameters

Table 5 shows the percentage reduction of Parameters in industrial samples before and after the treatment of the effluents $(250 \mathrm{ml})$ with the different masses $(5 \mathrm{~g}, 10 \mathrm{~g}, 15 \mathrm{~g}, 20 \mathrm{~g}$, and $25 \mathrm{~g}$ ) of the Immobilized Bacteria.

In TAN1 samples, the percentage reduction (\%) of COD ranged (14-89); BOD (50-80); SS (-32$35)$ and TDS (98-99). In TAN2 samples, the percentage decrease $(\%)$ of COD ranged (15$38) ;$ BOD (90-92); SS [-28-(-55)] and TDS (9798). In TAN3 samples, the percentage decrease (\%) of COD ranged (11-44); BOD (76-81); SS (15-25) and TDS (98). The percentage increase in the levels COD, BOD and TDS might be due to the increase in the surface area of the different masses of the immobilized bacteria. However, the percentage decrease in the levels of the SS might be due to the aggregation of the TDS which are large enough to result into SS. The percentage decrease in the levels of the SS might be also due to the influence of the nutrients which was added into the effluents in order to make the microorganisms more active and viable for fast degradation of organic contaminants in the effluent. This is in line with the work of Jimoh et al. (2018) in which the concentration of the SS increase after the bioremediation of effluents.

Sreemoyee and Priti (2013) assessed and reduced several Physico-chemical parameters of dairy wastewater using Niesseria $s p$. and concluded that the species are well known to degrade organic compounds. This is in agreement with the current study in which the immobilized Niesseria $s p$ degrade the organic contaminants as indicated by the BOD, COD and TDS.

Jimoh et al. (2018) observed that TSS of the effluents was increased after treatment with immobilized bacteria and concluded that it might be due to the biostimulation method adopted for the research.

The optimum $\mathrm{pH}$ Biosorption of Chromium by Bacillus spp and Staphylococcus spp. from tannery effluent was investigated by Mythili and Karthikeyan (2011). The maximum adsorption of Chromium $(86.4 \mathrm{mg} / \mathrm{L})$ was showed by Bacillus spp and Staphylococcus spp showed $70.6 \mathrm{mg} / \mathrm{L}$ at an initial concentration of $100 \mathrm{mg} / \mathrm{L}$. In the present study, immobilised Bacillus spp and Staphylococcus spp. from the tannery industrial effluents reduced the levels of the organic pollutants with high potential as indicated by the percentage reduction of BOD, COD and TDS.

Enzymes often can work in multiple environments especially if they are immobilized. This makes the microorganisms' enzymes even more resistant to harsh environments and enables the enzymes to be recovered and recycled after they are no longer needed (Gianfreda and Rao 2004). Ramesh and Singh (1993) reported that the immobilized bacteria having more efficiency to remove the suspended particles than free cells. Using the immobilized cell is preferable due to its capability for using several times with the same efficiency, which makes it more economical. Similar work was done by Sikander et al. (2007) showing the higher reduction with permeabilized cells of Ochrobactrum intermedium strain SDCr-5. 
BAJOPAS Volume 13 Number 2, December, 2020

The results revealed the isolation and identification of isolates with the potential for the reduction of $\mathrm{Cr}$ (VI) to $\mathrm{Cr}$ (III). Results indicated that immobilized $B$. cereus could be efficiently used for the reduction of $\mathrm{Cr}$ (VI).

Table 5: Percentage reduction of the tested Parameters from the tannery industrial samples of the Immobilized Bacteria.

\begin{tabular}{lllllll}
\hline \multirow{2}{*}{ Industries } & & \multicolumn{5}{c}{ Percentage Reduction $(\%)$} \\
\cline { 3 - 7 } & & $5 \mathrm{~g}$ & $10 \mathrm{~g}$ & $15 \mathrm{~g}$ & $20 \mathrm{~g}$ & $25 \mathrm{~g}$ \\
\hline TAN1 & COD & 28 & 14 & 64 & 87 & 89 \\
& BOD & 50 & 54 & 59 & 67 & 80 \\
& SS & 35 & -26 & -27 & -32 & -63 \\
& TDS & 99 & 99 & 99 & 98 & 98 \\
TAN2 & COD & 15 & 20 & 25 & 32 & 38 \\
& BOD & 91 & 91 & 92 & 90 & 92 \\
& SS & -28 & -52 & -52 & -54 & -55 \\
& TDS & 97 & 99 & 99 & 99 & 99 \\
& COD & 33 & 44 & 22 & 11 & 26 \\
& BOD & 75 & 81 & 76 & 81 & 81 \\
& SS & 25 & 3 & -1 & -10 & -15 \\
& TDS & 98 & 98 & 98 & 98 & 98 \\
\hline
\end{tabular}

Percentage Reduction $=(B-A) / B \times 100 \%$

$A=$ Concentration of the parameter after treatment

$\mathrm{B}=$ Concentration of the parameter before treatment

$+=$ percentage decrease

- = percentage increase

In general, immobilization makes the enzyme more resistant to temperature, $\mathrm{pH}$, and substrate concentration swings giving it a longer lifetime and higher productivity per active unit (Gianfreda and Rao, 2004; FuIlbrook, 1996; Russell et al, 2003; Kandelbauer et al., 2004). Immobilized cells have been used and studied extensively for the production of useful chemicals (Ohtake and Silver, 1994), the treatment of wastewaters (Chen et al., 2003; Wang et al., 2010). Although many workers described microbial degradation of tannery effluent, limited literature is available on the bioremediation of tannery effluent using immobilized bacterial cells in the Kano Industrial Estates.

\section{CONCLUSION}

The samples contained variable levels of the physicochemical parameters. The results of the Analysis of variance revealed that, no statistical difference $(p<0.05)$ was observed for the temperature, $\mathrm{pH}, \mathrm{SS}, \mathrm{TDS}, \mathrm{BOD}$ and $\mathrm{COD}$ among the three tannery industries before the treatment. The levels of some of the parameters
(SS, TDS and COD) observed in the samples were found above the recommended limits of WHO and NESREA, which called for the treatment of the effluents before discharge into the environment. Base on the morphological and biochemical test results, TAN1, TAN2, and TAN3 bacterial isolates were identified to be Neisseria spp, Bacillus cereus, and Staphylococcus aureus respectively. The results of Post-treatment analysis showed that there is overall decrease in the levels of the parameters determined when compared with that of the pre-treatment. The overall percentage reduction of the immobilised bacteria in the treatment of the respective effluents was in the order TAN2 (72\%)>TAN1 $(70 \%)>$ TAN3 $(62 \%)$. Hence, the immobilized bacteria are having higher biodegradation potential for the treatment of the tannery effluents.

\section{Acknowledgments}

The authors wish to acknowledge the University of Maiduguri for the financial support. The authors are grateful to the Kano State Ministry of Environment for their support in obtaining the effluent samples. 


\section{REFERENCES}

Ajao, A. T., Adebayo, G. B., and Yakubu, S. E. (2011). Bioremediation of textile industrial effluent using mixed culture of Pseudomonas aeruginosa and Bacillus subtilis immobilized on agar-agar in a bioreactor. J. Microbiol. Biotech. Res, 1(3), 50-56.

Akan, J. C., Moses, E. A., Ogugbuaja, V. O., and Abah, J. (2007). Assessment of tannery industrial effluents from Kano metropolis, Kano State, Nigeria. Journal of Applied Sciences, 7(19), 2788-2793.

Akan, J. C., Ogugbuaja, V. O., Abdulrahman, F. I., and Ayodele, J. T. (2009). Pollutant levels in effluent samples from tanneries and textiles of Kano industrial areas, Nigeria. Global journal of pure and applied sciences, 15(3-4).

APHA (1989). Standard methods for Examination of Will bete and Will betewater.15 $5^{\text {th }}$ edition. Brydpass Springfield Will behington DC. pp. 164-176

APHA (1992). Standard Methods for the Examination of Water and Wastewater. Health, 69, 1116-9.

Baba, A., Garba, S. T., and Bello, H. S. (2020). Bioremediation Potential of Immobilized corynebacterium kutsceri in the Treatment of Tannery Industrial Effluent from Challawa Industrial Estate, Kano State, Nigeria. Journal of the Turkish Chemical Society Section A: Chemistry, $7(2), 335-350$.

Beem, E. I. V. (1994). reduction of solvent VOC emission. J. Oil Col. Chem. Ass, 77, 158.

Bouwer, E. J., and Zehnder, A. J. (1993). Bioremediation of organic compoundsputting microbial metabolism to work. Trends in biotechnology, 11(8), 360367.

Chen, K. C., Wu, J. Y., Liou, D. J., and Hwang, S. C. J. (2003). Decolorization of the textile dyes by newly isolated bacterial strains. Journal of Biotechnology, 101(1), 57-68.

Dan'Azumi, S., and Bichi, M. H. (2010). INDUSTRIAL POLLUTION AND HEAVY METALS PROFILE OF CHALLAWA RIVER IN KANO, NIGERIA. Journal of Applied Sciences in Environmental Sanitation, $5(1)$.

DWAF. (1992). Analytical Methods Manual, TR 151. Department of Water Affairs and Forestry, Pretoria.

El-Bestawy, E. (2013). Biological treatment of leather-tanning industrial wastewater using free living bacteria.
Elsheikh, M. A. S. (2009). Tannery wastewater pre-treatment. Water Science and Technology, 60(2), 433-440.

FuIlbrook, P. D. (1996). "Kinetics." Industrial enzymology: The application of enzymes in Industry. 2nd Ed. T. Godfrey and J Reichelt. eds.. Nature. New York.

Gianfreda, L., and Rao, M. A. (2004). Potential of extra cellular enzymes in remediation of polluted soils: a review. Enzyme and microbial technology, 35(4), 339354.

Hugo Springer. (1994). John Arthur Wilson Memorial Lecture "Treatment of Industrial Wastes of the Leather Industry - is it still a Major Problem". JALCA, 89, 153-185

Jimoh, A. A., Ganiyu, B. A., Baba, D., and Baba, A. (2018) Bioremediation Process of Effluent from Detergent and Food Industries in Jos, Nigeria: Kinetics and Thermodynamics. International Journal of Engineering Science Invention (IJESI), 762-73

Kandelbauer, A., Maute, O., Kessler, R. W., Erlacher, A., and Gübitz, G. M. (2004). Study of dye decolorization in an immobilized laccase enzyme-reactor using online spectroscopy. Biotechnology and bioengineering, 87(4), 552-563.

Kongjao, S., Damronglerd, S., and Hunsom, M. (2008). Simultaneous removal of organic and inorganic Pollutants in tannery wastewater using electrocoagulation technique. Korean Journal of chemical engineering, 25(4), 703.

Maheshwari, U. M., Aruna, S., Gomathi, M., and AbdulJaffar, A. H. (2017). Bioremediation by Free and Immobilized Bacteria Isolated from Tannery Effluent. International Journal of Research in Applied, Natural and Social Sciences. 5(7), 75-90

Margesin, R., and Schinner, F. (2001). Bioremediation (natural attenuation and biostimulation) of diesel-oilcontaminated soil in an alpine glacier skiing area. Applied and environmental microbiology, 677), 3127-3133.

Mohammed, A., Sekar, P., and George, J. (2011). Efficacy of microbes in bioremediation of tannery effluent. Inter. J. Curr. Res, 3(4), 324-326.

Mohammed, S. S. D., Orukotan, A. A., and Abdullahi, H. (2017). Physicochemical and Bacteriological Assessment of Tannery Effluent from Samaru-Zaria, 
BAJOPAS Volume 13 Number 2, December, 2020 Kaduna State, Nigeria. Journal of Applied

Sciences and Environmental Management, 21(4), 734-740.

Munz, G., De Angelis, D., Gori, R., Mori, G., Casarci, M., and Lubello, C. (2009). The role of tannins in conventional and membrane treatment of tannery wastewater. Journal of hazardous materials, 164(2-3), 733-739

Mythili, K., and Karthikeyan, B. (2011). Bioremediation of $\mathrm{Cr}$ (VI) from tannery effluent using Bacillus spp and Staphylococcus spp. International Multidisciplinary Research Journal, 1(6).

NESREA (2009). National Environmental Standards for Effluent Limitations and Regulation. 1233-1236

Noorjahan, C. M. (2014). Physicochemical characteristics, identification of bacteria and biodegradation of industrial effluent. Journal of bioremediation and Biodegradation, 5(3).

Ohtake, H. I., and Silver, A. O. (1994). Bacterial reduction of toxic chromate. Biological degradation and bioremediation of toxic chemicals, 403-415.

Omoleke, I. I. (2004). Management of environmental pollution in Ibadan, an African city: the challenges of health hazard facing government and the people. Journal of Human Ecology, 15(4), 265-275.

Rajor, A., Reddy, A.S., and Singh, B. (2004). Determination of BOD kinetic Parameters and evaluation of alternate methods, M.Sc. Thesis, Department of biotechnology \& environmental Science, Thapar Institute of Engineering and Technology, Patiala

Ramasami, T., Rajamani, S., and Rao, J. R. (1994, March). Pollution control in leather industry: Emerging technological options. In International symposium on surface and colloidal science and its relevance to soil pollution, madras.

Ramesh, J. V. S., and Singh, S. P. (1993). Yearly variation in certain physicochemical parameters of pond at eastern Doon Valley. Uttar Pradesh J. Zoo, 12 (1), 7577.

Ranen, S., and Sharadinadra, C. (2009). Biotechnology applications to environmental remediation in resource exploitation. Current science, 97, 6-25
Russell, A. J., Berberich, J. A., Drevon, G. F., and Koepsel, R. R. (2003). Biomaterials for mediation of

chemical and biological warfare agents. Annual review of biomedical engineering, 5(1), 1-27.

Saravanan, P., and Saravanan, A. (1999). Decolourization of tannery effluent by Flavobacterium sp. EK 1. Indian Journal of Environmental Protection, 19, 19-24.

Sikander, S., and Shahida, H. (2007). Reduction of toxic hexavalent chromium by Ochrobactrum intermedium strain SDCr5 stimulated by heavy metals. Bioresource Technol, 98, 340-344.

Singh, N., Sharma, B. K., and Bohra, P. C. (2000). Impact assessment of industrial effluent of arid soils by using satellite imageries. Journal of the Indian Society of Remote Sensing, 28(2-3), 79.

Sreemoyee, C., and Priti, P. (2013). Assessment of physico-chemical parameters of dairy waste water and isolation and characterization of bacterial strains in terms of cod reduction. Int J Sci, 2(3), 395-400.

Verheijen, L. A. H. M., Wiersema, D., Pol, L. H., and De Wit, J. (1996). Management of wastes from animal product processing. Livestock and environment, Finding a balance. International Agriculture Center, Wageningen, The Netherlands.

Wang, F., Yao, J., Si, Y., Chen, H., Russel, M., Chen, K., and Bramanti, E. (2010). Short-time effect of heavy metals upon microbial community activity. Journal of Hazardous Materials, 173(13), 510-516.

WHO (World Health Organization). (2006). Air quality guidelines: global update 2005: particulate matter, ozone, nitrogen dioxide, and sulfur dioxide. World Health Organization.

World Bank. (1995). Nigeria's strategic options for redressing industrial pollution. World Bank, industry and energy division. 1st edition, West Central Africa Department; Annexes: 1995; pp 60-62.

Zahoor, A., and Abdul, R. (2009). Enumeration of Coliforms. Journal of Environmental Sciences. 21, 814-820 


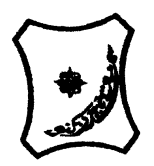

Bayero Journal of Pure and Applied Sciences, 13(2): 1 - 12

Received: November, 2020

Accepted: December, 2020

ISSN $2006-6996$

\title{
BIODEGRADATION POTENTIAL OF IMMOBILIZED BACTERIA IN THE TREATMENT OF TANNERY INDUSTRIAL EFFLUENTS FROM INDUSTRIAL ESTATES IN KANO STATE, NIGERIA
}

\author{
Abdullateef, B., ${ }^{1 *}$ Shuaibu, T. G., ${ }^{1}$ Babagana, K., ${ }^{1}$ Suleman, H. B. ${ }^{2}$ and Dauda, B. ${ }^{3}$ \\ ${ }^{1}$ Department of Pure and Applied Chemistry, Faculty of Science, University of Maiduguri, Borno State, \\ Nigeria \\ ${ }^{2}$ Department of Microbiology, Faculty of Science, University of Maiduguri, Borno State, Nigeria \\ ${ }^{3}$ Department of Chemical Engineering, Faculty of Engineering, University of Maiduguri, Borno State, \\ Nigeria \\ *Corresponding author: babslega@gmail.com; abelega2007@yahoo.com; +2348061309753
}

\section{ABSTRACT}

Industrial Effluents Samples from Gashash Tanneries (TAN1) in Bompai Industrial estate, Larabee Tannery Industry (TAN2) in Sharada Industrial estate and Z Tannery Industries (TAN3) in Challawa Industrial estate, Kano State, Nigeria were collected over a period of six months (August 2017 to January 2018) for assessing the biodegradation potentials of bacteria in the treatment of organic pollutants within the effluents. Bacteria were isolated from the effluents and immobilized on agar-agar. Different masses (5 g, $10 \mathrm{gr}, 15$ $\mathrm{g}, 20 \mathrm{~g}$, and $25 \mathrm{~g}$ ) of the bacteria were used in the treatment of $250 \mathrm{ml}$ of the effluents for ten days in a shaker incubator (Gallenkamp-OC-4364-L) at the temperature $30{ }^{\circ} \mathrm{C}$ and speed of $60 \mathrm{rpm}$. Pre-treatment analysis of the effluents for Temperature, pH, Biochemical Oxygen Demand (BOD), Chemical Oxygen Demand (COD), Suspended Solid (SS) and Total Dissolved Solids (TDS) gives the following results; temperature $\left({ }^{\circ} \mathrm{C}\right.$ )

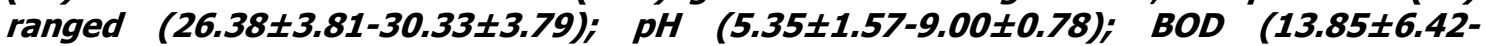
$38.75 \pm 16.20) ;$ COD (1406 $\pm 208-3532 \pm 1373) ;$ SS (208 $\pm 235-780 \pm 739)$ and TDS (266 $\pm 253-5276 \pm 2971)$. No statistical differences ( $p \leq 0.05)$ was observed for all the results among the different industries. The bacterial isolates were identified as Neisseria spp, Bacillus cereus, and Staphylococcus aureus, in TAN1, TAN2, and TAN3, respectively. After treatment of the effluent with the different masses of the isolated bacteria, the mean level of BOD was found to range as (0.55 $\pm 0.36-6.92 \pm 5.49) ; C O D$ (ND-3134 \pm 1595$)$;

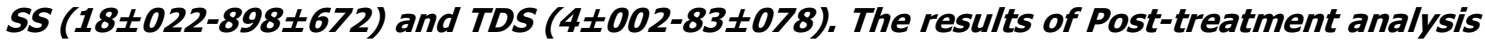
showed that there is overall decrease in the levels of the parameters determined when compared with that of the pre-treatment. The overall percentage reduction of the immobilised bacteria in the treatment of the respective effluents was in the order TAN2 (72\%)>TAN1 (70\%)>TAN3 (62\%). Hence, the immobilized bacteria are having higher biodegradation potential for the treatment of the tannery effluents.

Keywords: Biodegradation, bacteria, effluent, immobilization, tannery.

\section{INTRODUCTION}

Tannery industrial wastewater is a serious consequence of the pollution point of view for streams, freshwater, and land used for agriculture. The lack of awareness in the modern industrial practice has resulted in the discharge of tannery effluents which exhibit very high value of chromium ( $\mathrm{Cr}$ ), Sulfide, and chloride, Total Dissolved Solid (TDS), Total Suspended Solid (TSS), Biochemical Oxygen Demand (BOD) and Chemical Oxygen Demand (COD) in the water stream or land (Mohammed et al., 2001). Tanning is the process, which One ton of skin generally leads to the production of 20 to $80 \mathrm{~m}^{3}$ of turbid and foul-smelling converts the protein of the rawhide or skin into a stable material, which will not putrefy and is suitable for a wide variety of end applications (Elsheikh, 2009). The highly polluting chromium is the most commonly used tanning material producing leather that is more flexible and pliable than vegetable-tanned leather and does not discolor or lose shape in water as drastically as vegetable-tan (Elsheikh, 2009). Tannery effluent is among the most hazardous industrial pollutants due to its huge organic and inorganic load, which is highly toxic to human life and the environment (Kongjao et al., 2008). wastewater including chromium (100-400 mg/l), sulfide $(200-800 \mathrm{mg} / \mathrm{l})$, high levels of fat and 
BAJOPAS Volume 13 Number 2, December, 2020 other solid wastes, and notable pathogen contamination as well as pesticides added for skin conservation during transport (Elsheikh, 2009). There are more than 6000 tanneries in Nigeria with an annual processing capacity of 700,000 tons of hides and skins (Omoleke, 2004; Singh et al., 2008). It was reported that the total amount of waste produced per animal slaughtered is approximately $35 \%$ of its weight (World Bank, 1995). Also, for every $1000 \mathrm{~kg}$ of carcass weight, a slaughtered beef produces 5.5 $\mathrm{kg}$ of manure (excluding rumen contents or stockyard manure) and $100 \mathrm{~kg}$ of paunch manure (undigested food) (Verheijen et al., 1996). Tanneries generate wastewater in the range of 30-35 $\mathrm{L} \mathrm{kg}^{-1}$ skin/hide processed with variable $\mathrm{pH}$, Biological Oxygen Demand (BOD), Chemical Oxygen Demand (COD), high concentrations of suspended solids (SS), and tannins as well as chromium (Zahoor and Abdul, 2009).

Being heterogeneous and composed of a wide variety of compounds, it is very difficult to select a unique direct method for estimating the biodegradability of organic contents and biokinetic parameters for a wastewater sample (Rajor, 2004). For this purpose, some indirect estimation such as determination of biochemical oxygen demand (BOD) and chemical oxygen demand (COD) are applied as common laboratory investigations [9]. During retanning procedures, synthetic tannins (Syntan), oils and resins are added to form softer leather at varying doses (Munz et al., 2009). One of the refractory groups of chemicals in tannery effluents derives mainly from tannins (Ramasami et al., 2004). Syntans are characterized by complex chemical structures, because they are composed of an extended set of chemicals such as phenol-, naphthalene-, formaldehyde- and melamine-based syntans, and acrylic resins (Beem, 1994). Organic pollutants (proteic and lipidic components) are originated from skins (it is calculated that the raw skin has $30 \%$ loss of organic material during the working cycle) or they are introduced during processes (Hugo Springer, 1994).

Many conventional processes such as oxidation, chemical and biological processes were carried out to treat tanneries wastewater (Ebtesam et al, 2013). Biological processes have received more attention because of their costeffectiveness, lower sludge production and environmental friendliness (Noorjahan, 2014). Naturally occurring micro-organisms degrade the hazardous organic wastes including xenobiotic compounds, such as pesticides, polycyclic aromatic hydrocarbons (PAHs) and polychlorinated biphenyls (PCBs) in due course of time (Ranen and Sharadinadra, 2009). Bioremediation is based on the idea that all organisms remove substances from the environment to carry outgrowth and metabolism (Bouwer and Zehnder, 1993). Bacteria, protista and fungi are found to be very good at degrading complex molecules and incorporating the breakdown products into their metabolism (Bouwer and Zehnder, 1993). The resultant metabolic wastes that they produce are generally safe and somehow recycled into other organisms (Ranen and Sharadinadra, 2009). An acclimatized indigenous population of microorganisms capable of degradation of the compounds of interest must exist at the site for a successful bioremediation mode (Ranen and Sharadinadra, 2009). It has been observed that for a successful bioremediation mode, an acclimatized indigenous population of microorganisms capable of degradation of the compounds of interest must exist at the site under investigation (Ranen and Sharadinadra, 2009). Even though there are numerous physical and chemical methods employed in the disposal of wastes the advantage in using bacterium is that they play a key role in the reduction of COD, BOD, total protein, total tannin and total phenol (Saravanan and Saravanan, 1998)

Baba et al. (2020) studied the bioremediation potential of immobilized corynebacterium kutsceri in the Treatment of tannery industrial effluent from Challawa Industrial Estate, Kano State, Nigeria. The aim of the work is to study the reduction in the level of the contaminants through the process of bioremediation using the isolated bacteria. Immobilized bacteria can withstand various temperatures, $\mathrm{pH}$ and substrate concentrations; consequently, increasing the efficiency and the lifespan of the bacteria. Immobilized bacteria are widely applied in the treatment of wastewater and can be separated and recovered after the treatment with the same efficiency (Baba et al., 2020).

\section{MATERIALS AND METHODS \\ Study Area}

This study was carried out in Bompai, Sharada and Challawa industrial estates in Kano, Figure 1. Kano lies on Latitude $11^{\circ} 30^{\prime} \mathrm{N}$ and $8^{\circ} 30^{\prime} \mathrm{E}$ and Longitude $11^{\circ} 5^{\prime} \mathrm{N}$ and $8^{\circ} 5^{\prime} \mathrm{E}$ in Northern Nigeria. It is one of the developed industrial cities in Nigeria. Tannery activities are the dominating industries and this could be one of the reasons for her high population density (Dan'Azumi and Bichi, 2010). Many researchers have studied biodegradation of tannery effluent using microorganisms. However, limited literature is available on the biodegradation of tannery effluent in Kano industrial estates using 
BAJOPAS Volume 13 Number 2, December, 2020 immobilized bacterial cells. This research work focuses on the potential of the use of the indigenous immobilized bacterial isolates in the treatment of tannery effluents in the industrial estates.

\section{Sample Collection}

Effluents were collected from the Tannery Industries from Bompai, Challawa and Sharada Industrial Estates, Kano, Nigeria. The effluents were collected over a period of six months (August 2017 to January 2018). Samples collected in a sterile 4-liter plastic container with a unique identification number were preserved using an ice-box that was transported to the Microbiology Laboratory, Department of Microbiology, Bayero University of Kano for analysis

\section{Sample Preparation and Sample Analysis}

Immediately after the collection of the effluent, $\mathrm{pH}$, TSS, TDS, COD, BOD levels were determined before treatment (Pre-treatment determination) and ten days after treatment (Post-treatment determination) as described in
APHA (1989) standard methods. $\mathrm{pH}$ was determined using Ecotests $\mathrm{pH}$ meter and TDS was determined using AQUALYTIC TDS Salinometer. BOD was determined as described by the standard method (APHA, 1992). COD and SS were determined using DR/2010 HACH portable data logging spectrophotometer (DWAF, 1992)

\section{Identification and Biochemical} Characterization of the Bacterial Isolates

The bacteria were isolated from the effluents using Serial Dilution according to the method described by APHA (1989). The biochemical tests such as oxidase, catalase, coagulase, indole (from $1 \%$ tryptone broth), citrate (Simmons citrate agar), methyl red/VogesProskauer (MR/VP), nitrate reduction, Starch Hydrolysis, Glucose, Maltose, and Lactose tests were carried out on the bacterial isolates to identify the bacteria through the bacteria biochemical characteristics according to Ajao et al. (2011).

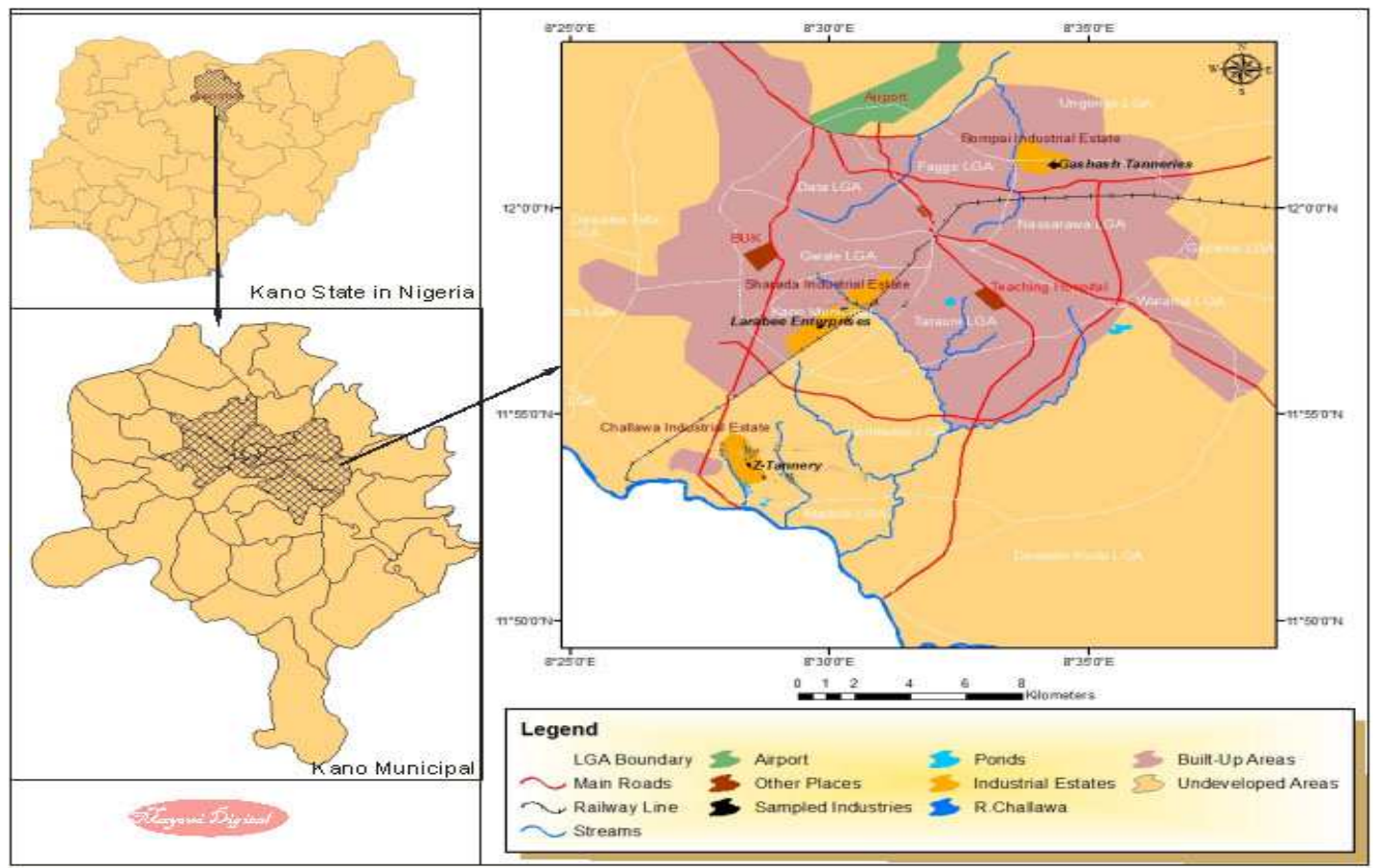

Fig. 1 Map showing the study areas

Source: Mayomi Digital Productions, GIS Laboratory, Department of Geography, UNIMAID (2017)

\section{Determination of Growth Rate of the Bacteria in Effluent Sample}

The bacteria growth rates were determined by transferring $2 \mathrm{~mL}$ of the bacterial isolates from the tannery effluent in broth medium into 100 $\mathrm{mL}$ sterile effluents in conical flasks and kept in an incubator (Giffrin cool) for 10 days. Control was also set up by incubating another $100 \mathrm{~mL}$ each of the sterile effluents without the bacteria. The optical density of the content was determined at the wavelength of $600 \mathrm{~nm}$ on a daily interval and recorded. 
BAJOPAS Volume 13 Number 2, December, 2020 Immobilization of Bacteria

Agar solution and inoculi were prepared separately. Fifty milliliters $(50 \mathrm{~mL})$ of nutrient broth each of the inoculi was prepared in a McCartney bottle and incubated for 24 hours. A solution of agar-agar was prepared by dissolving $10 \mathrm{~g}$ of the powder in distilled water and made up to $500 \mathrm{~mL}$ mark in an Erlenmeyer flask and was sterilized in an autoclave (280A) for 15 minutes and allowed to cool to $40-45^{\circ} \mathrm{C}$ (Ajao et al., 2011). Four milliliters ( $4 \mathrm{~mL})$ of the bacterial isolates in the nutrient broth was mixed with 36 $\mathrm{ml}$ of the prepared agar-agar media in petri-dish plates and then allowed to solidify. This was kept in the refrigerator for bioremediation.

\section{Bioremediation (Treatment) of the Effluents}

The solidified agar block (immobilized bacteria) was cut into cubes using a sterile knife; $0.1 \mathrm{~mL}$ phosphate buffer ( $\mathrm{pH} \mathrm{7.0)}$ was added and kept in the refrigerator for 1 hour for curing. The phosphate buffer was decanted after 1 hour and the cubes were washed with sterile distilled water 3-4 times before it was used (Ajao et al., 2011). Two liters (2 L) of the effluent was supplemented with the minimum basal medium in $\mathrm{g} / \mathrm{L}: \mathrm{NaCl}(0.8), \mathrm{MgSO}_{4} .7 \mathrm{H}_{2} \mathrm{O}(0.001), \mathrm{KH}_{2} \mathrm{PO}_{4}$ (2), $\mathrm{NaNO}_{3}$ (2), $\quad \mathrm{CaCl}_{2} .2 \mathrm{H}_{2} \mathrm{O} \quad(0.5)$ and $\mathrm{NaHPO}_{4} .12 \mathrm{H}_{2} \mathrm{O}(2)$ and sterilized in an autoclave at $121^{\circ} \mathrm{C}$ for 15 minutes (Margesin and Schinner, 2001). Two hundred and fifty milliliters $(250 \mathrm{~mL})$ of the effluents were transferred into different $250 \mathrm{ml}$ conical flasks. The content was covered with a cotton-wool ramped with foil paper to avoid contamination. Five grams $(5 \mathrm{~g})$ of the immobilized bacteria were quickly transferred into each of the effluents in the conical flasks in an inoculating chamber. The same procedures were carried out for the $10 \mathrm{~g}, 15 \mathrm{~g}, 20 \mathrm{~g}$ and 25 $\mathrm{g}$ of the immobilized bacteria in separate $250 \mathrm{~mL}$ effluents in conical flasks and agitated for ten days in a shaker incubator (Gallenkamp-OC4364-L) at a temperature $30^{\circ} \mathrm{C}$ and speed of 60 rpm. The treated effluent samples were taken on the tenth day and analyzed for the parameters $\mathrm{pH}$, SS, TDS, COD, and BOD, (Posttreatment determination) for the different grams of bacteria to evaluate and compare the biodegradation potential. (Baba et al., 2020).

\section{Statistical Analysis}

The data were represented as Mean \pm Standard deviation and analyzed statistically using oneway Analysis of Variance (ANOVA) and Tukey's HSD as Post Hoc Tests with the aid of SPSS 16.0. The correlation coefficient was also used to measure the strength of the relationship between the different masses of the bacteria and the parameters. All $\mathrm{p} \leq 0.05$ were considered as statistically significant.

\section{RESULTS AND DISCUSSION Physico-chemical parameters in the Industrial Effluents before the Biodegradation.}

Results of the Physico-chemical parameters in the industrial effluents before the Biodegradation is shown in table 1 . The mean temperatures $\left({ }^{\circ} \mathrm{C}\right)$ observed in TAN1, TAN2, and TAN3 samples were $28.07 \pm 0.65 ; 27.77 \pm 0.64$ and $26.38 \pm 3.81$ respectively. The order of the mean temperature of the samples from the three industries can be arranged as TAN1 > TAN2>TAN3. The temperature observed at TAN1, TAN2, and TAN3 samples were found below the WHO $\left(35^{\circ} \mathrm{C}\right)$ and NESREA $\left(40^{\circ} \mathrm{C}\right)$ limits. The low values of temperature might be due to the processes used at the time of sampling. High temperature brings down the solubility of gases in water that ultimately expresses as high BOD and COD. Statistical analysis shows that there is no significant difference $(p<0.05)$ between the mean values of temperature among the industries. This might be due to similar tannery activities involved in the tannery industries at the time of sampling. The average values of temperature observed in this present study are less than those observed by Akan et al. (2007), Akan et al. (2009) and Baba et al. (2020).

The mean level of $\mathrm{pH}$ observed in TAN1, TAN2 and TAN3, samples were $7.77 \pm 2.93$; $8.35 \pm 0.28$ and $7.52 \pm 0.76$ respectively. The order of the mean $\mathrm{pH}$ of the samples from the three industries can be arranged as TAN2> TAN1 $>$ TAN3. The $\mathrm{pH}$ of the samples falls within the WHO (7.0-8.5) and NESREA (6-9) standard limits. Statistical analysis shows that there is no significant difference $(p<0.05)$ between the mean values of $\mathrm{pH}$ among the industries. This might be due to similar tannery activities involved in the tannery industries at the time of sampling. Maheshwari et al. (2017) reported that the level of $\mathrm{pH}$ in the effluents from the tannery industry in Vaniyambadi, India was 6.5 which was lower than that observed in the present study. The $\mathrm{pH}$ in the effluents from the tannery industries in Kano and Kaduna were reported to be 7.64 and 6.89, respectively (Akan et al., 2007; Mohammed et al., 2017). The average values of $\mathrm{pH}$ observed in this present study are less than those observed by Mohammed et al. (2017) and Baba et al. (2020). The mean level of SS $(\mathrm{mg} / \mathrm{l})$ observed in TAN1, TAN2, and TAN3 samples were 374 \pm 124 ; $358 \pm 335$ and $780 \pm 739$ respectively. The order of the mean SS in the samples from the three industries can be arranged as TAN3 > TAN1 $>$ TAN2. 
The SS observed in the samples were far above the recommended standard limits of regulating bodies WHO $(30 \mathrm{mg} / \mathrm{l})$ and NESREA $(10 \mathrm{mg} / \mathrm{l})$. Statistical analysis shows that there is no significant difference $(p<0.05)$ between the mean values of SS among the industries. This might be due to similar tannery activities involved in the tannery industries at the time of sampling. The average values of SS observed in this present study are less than that observed $(3700 \pm 122 \mathrm{mg} / \mathrm{l})$ by Akan et al. (2009) for tanneries in Kano. Also, the average values of SS observed in this present study are less than that observed by Mohammed et al. (2017) and Baba et al. (2020) with the exception in TAN3.

The mean level of TDS (mg/l) observed in TAN1, TAN2, and TAN3 samples were $3941 \pm 3703$; $3300 \pm 1714$ and $2653 \pm 1240$ respectively. The order of the mean TDS in the samples from the three industries can be arranged as TAN1>TAN2>TAN3. The TDS observed in the samples were far above the recommended standard limits of WHO $(250 \mathrm{mg} / \mathrm{l})$ and NESREA $(500 \mathrm{mg} / \mathrm{l})$. Statistical analysis shows that there is no significant difference $(p<0.05)$ between the mean values of TDS among the industries. This might be due to similar tannery activities involved in the tannery industries at the time of sampling. TDS in the effluents from the tannery industries in Kano, Nigeria was reported to be $1281 \mathrm{mg} / \mathrm{l}$ (Akan et al., 2007). The average values of SS observed in this present study are less than those observed by Mohammed et al. (2017) and Baba et al. 2020)

The mean level of COD (mg/l) observed in TAN1, TAN2 and TAN3 samples seasons were $2372 \pm 938 ; \quad 1406 \pm 208$ and $3532 \pm 1373$ respectively. The order of the mean COD of the samples from the three industries can be arranged as TAN3>TAN1> TAN2. The COD observed in TAN1, TAN2 and TAN3 samples were far above the recommended standard limits of regulating bodies $\mathrm{WHO}(40 \mathrm{mg} / \mathrm{l})$ and NESREA (40 mg/l). Statistical analysis shows that there is no significant difference $(p<0.05)$ in COD among the industries. This might be due to similar tannery activities involved in the tannery industries as at the time of sampling. The Chemical Oxygen demand (COD) is the amount of oxygen, in $\mathrm{mg} / \mathrm{L}$, required for the degradation of the compound of wastewater to occur. In comparison, the average values of COD observed in this present study were higher than that observed by Mohammed et al. (2017) but lower than that observed by Baba et al. (2020).

The mean levels of BOD $(\mathrm{mg} / \mathrm{l})$ observed in TAN1, TAN2 and TAN3 samples were $13.85 \pm 6.42 ; \quad 19.46 \pm 0.50$ and $17.13 \pm 3.14$ respectively. The order of the mean BOD in the samples from the three industries can be arranged as TAN2>TAN3>TAN1. The BOD observed in TAN1, TAN2 and TAN3 samples were found below the recommended limits of NESREA (200 mg/l) but above WHO (10 mg/l). Statistical analysis shows that there is no significant difference $(p<0.05)$ between the mean values of BOD among the industries. This might be due to similar tannery activities involved in the tannery industries at the time of sampling. The low level of BOD recorded in this study is an indication of the low level of biodegradable organic solids in the effluent. The average values of BOD observed in this present study were lower than those observed by Mohammed et al. (2017) and Baba et al. (2020).

Table 1: Mean Values \pm S.D of Physico-chemical parameters of effluents from the Tannery Industries before Treatment.

\begin{tabular}{llllllll}
\hline Parameter & Tannery 1 & Tannery 2 & Tannery 3 & $\mathrm{a}$ & $\mathrm{b}$ & $\mathrm{c}$ & $\mathrm{d}$ \\
\cline { 2 - 7 } Temperature $\left({ }^{\circ} \mathrm{C}\right)$ & $28.07 \mathrm{a} \pm 0.65$ & $27.77 \mathrm{a} \pm 0.64$ & $26.38 \mathrm{a} \pm 3.81$ & & $29.50 \pm 4.68$ & 35 & 40 \\
pH & $7.77 \mathrm{a} \pm 2.93$ & $8.35 \mathrm{a} \pm 0.28$ & $7.52 \mathrm{a} \pm 0.76$ & 6.89 & $5.35 \pm 1.57$ & $7.0-8.5$ & $6.0-9.0$ \\
$\mathrm{COD}(\mathrm{mg} / \mathrm{l})$ & $2372 \mathrm{a} \pm 938$ & $1406 \mathrm{a} \pm 208$ & $3532 \mathrm{a} \pm 1373$ & 2.2 & $3106 \pm 2753$ & 40 & 40 \\
$\mathrm{BOD}(\mathrm{mg} / \mathrm{l})$ & $13.85 \mathrm{a} \pm 6.42$ & $19.46 \mathrm{a} \pm 0.50$ & $17.13 \mathrm{a} \pm 3.14$ & 1032 & $26.17 \pm 9.49$ & 10 & 200 \\
$\mathrm{SS}(\mathrm{mg} / \mathrm{l})$ & $374 \mathrm{a} \pm 124$ & $358 \mathrm{a} \pm 335$ & $780 \mathrm{a} \pm 739$ & 501 & $562 \pm 482$ & 30 & 10 \\
TDS $(\mathrm{mg} / \mathrm{l})$ & $3941 \mathrm{a} \pm 3703$ & $3300 \mathrm{a} \pm 1714$ & $2653 \mathrm{a} \pm 1240$ & 532.7 & $444 \pm 507$ & 250 & 500 \\
\hline
\end{tabular}

The values given in the table above are means of 6 replicate values, $\mathrm{n}=6$ ( 1 sample was taken monthly for 6 months). Within the rows, means with different alphabets are statistically different $(p<0.05)$. WHO: World Health Organisation. NESREA: National Environmental Standard and Regulatory Enforcement Agency. a = Mohammed et al.(2017), b = Baba et al. (2020), c = WHO (2006), $d=$ NESSRA (2009) 
BAJOPAS Volume 13 Number 2, December, 2020

Identification, Biochemical Characterization and growth rates of the Bacterial Isolates

Results of identification and biochemical characterization of the bacterial isolates were shown in table 2. After 24 hours of incubation, the nutrient agar media plates were checked for bacterial growth. The results showed the presence of different strains in the samples. The TAN1 bacteria isolate was found to be gramnegative cocci while TAN3 was gram-positive cocci. TAN2 bacteria isolate was found to be gram-positive, rod-shaped. TAN1, TAN2, and TAN3 bacteria isolates recorded positive results for spore former.

The results of the biochemical tests indicated that all the bacteria were positive for catalase, oxidase, citrate, maltose, glucose, lactose (negative in TAN1), mannitol (negative in TAN2), starch hydrolysis and coagulase (negative in TAN2) tests. The bacteria showed negative results for nitrate reduction, $M R$ (positive in TAN2), VP (positive in TAN1), Indole (positive in TAN2) tests. Base on the morphological and biochemical test results, TAN1, TAN2, and TAN3 bacteria isolates were identified to be Nesseria spp, Bacillus cereus, and Staphylococcus aureus respectively.

The growth rate of the TAN1, TAN2 and TAN3 Isolates were shown in figure 2. Generally, the optical density increase with the increase in time (day) and decrease as time goes on. The highest optical density was shown by bacillus cereus in TAN2 while the lowest was shown by Staphylococcus aureus in TAN3.

The initial growth phase of TAN1 Isolate bacteria occurred within 2-day of incubation as the growth rate increases up to the 6th-day incubation when the maximum growth was observed. Beyond the 6th day, the growth of the bacteria declined (which might be due to a shortage of nutrients in the effluents) until it reached its death phase (which might be due to the unavailability of nutrients in the effluents).

A similar trend of growth was also observed for TAN2 Isolate as the initial growth phase also occurred within 2-day of incubation but maximum growth rate observed on the 4th day of incubation. The stationary stage occurred between the 4th day and the 8th day. Beyond the 8th day, the growth of the bacteria declined (which might be due to a shortage of nutrients in the effluents) until it reached its death phase (which might be due to the unavailability of nutrients in the effluents).

The initial growth phase of TAN3 bacterial Isolate occurred within the 3-day incubation as the growth rate increases up to the 6th-day incubation when the maximum growth was observed. Beyond the 6th day, the growth of the bacteria declined (which might be due to a shortage of nutrients in the effluents) until it reached its death phase (which might be due to the unavailability of nutrients in the effluents).

Table 2: Morphological and Biochemical characteristics of bacterial isolates

\begin{tabular}{lllll} 
Bacterial Isolates & & TAN1 & TAN2 & TAN3 \\
\hline $\begin{array}{lllll}\text { Morphological } \\
\text { characteristics }\end{array}$ & Shape & Cocci & Rod & Cocci \\
& Spore & & & \\
& former & + & + & + \\
Gram & & & \\
Biochemical characteristics & reaction & - & + & + \\
& Citrate & + & + & + \\
& Catalase & + & + & + \\
& Coagulase & + & - & + \\
Starch & + & + & + \\
& Glucose & + & + & + \\
Oxidase & + & + & + \\
& Indo & - & + & - \\
Lactose & - & + & + \\
Manitol & + & - & + \\
Maltose & + & + & + \\
MR & - & + & - \\
VP & + & - & - \\
& Nitrate & - & - & - \\
Reduction & - Neisseria & Bacillus & Staphylococcus \\
& Bacterial & cereus & aureus \\
& name & spp & cas
\end{tabular}

+ = Positive; - = Negative; MR=Methyl Red; VP= Voges-Proskauer 


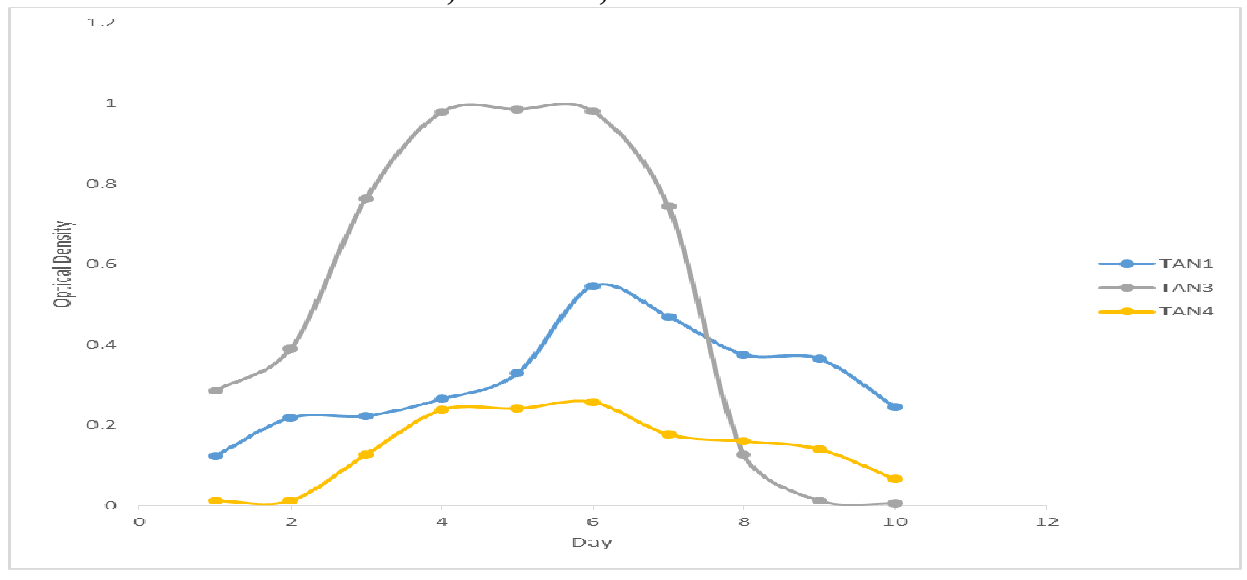

Fig. 2 Growth rates of the isolates in the effluents from the Tannery Industries

\section{Physico-chemical Parameters in the Industrial Effluents after the biodegradation.}

Table 3 shows the mean results of the physicochemical parameter before and after bioremediation using the different masses $(5 \mathrm{~g}$, $10 \mathrm{~g}, 15 \mathrm{~g}, 20 \mathrm{~g}$, and $25 \mathrm{~g}$ ) of the respective immobilized bacteria. Also, Table 4 shows the mean results of correlation coefficient ( $r$ ) between different masses of bacteria and physicochemical parameters.

The mean values $(\mathrm{mg} / \mathrm{l})$ of the SS after the bioremediation varies between $243 \pm 45$ and $898 \pm 672$. The mean concentration $(\mathrm{mg} / \mathrm{l})$ of SS remediated by the different masses $(5 \mathrm{~g}, 10 \mathrm{~g}$, $15 \mathrm{~g}, 20 \mathrm{~g}$, and $25 \mathrm{~g}$ ) of the bacteria varies. The SS in the samples fluctuates up and down after the bioremediation process when compared with the SS of the raw samples before the bioremediation. The increase in the levels of the SS might be due to the aggregation of the TDS which are large enough to result into SS. The increase in the levels of the SS might be also due to the influence of the nutrients which was added into the effluents in order to make the microorganisms more active and viable for fast degradation of organic contaminants in the effluent. The relative potential or efficiency of the different masses of the bacteria in remediating SS in TAN1 samples was in the order $25 \mathrm{~g}>20 \mathrm{~g}>15 \mathrm{~g}>10 \mathrm{~g}>5 \mathrm{~g}$. For TAN2 and TAN3 samples, the order was $25 \mathrm{~g}>20 \mathrm{~g}>15$ $\mathrm{g}>10 \mathrm{~g}>5 \mathrm{~g}$. These might be due to the variations in the surface areas of the different masses of the immobilized bacteria. Statistical analysis shows that there is no significant difference $(p<0.05)$ between the mean values of SS among the masses in the respective industries. Positive and significant correlations exist between the masses of bacteria and Suspended Solid (SS). This showed that there is general increase in the levels of the SS as the masses of the immobilized bacteria increases. TAN3 (90\%) and TAN1 (80\%) showed a very high correlation with the masses of the bacteria while TAN2 (61\%) showed a very low correlation.

The mean values $(\mathrm{mg} / \mathrm{l})$ of the TDS after the bioremediation varies between $46 \pm 11$ and $83 \pm 78$. The mean concentration $(\mathrm{mg} / \mathrm{l})$ of TDS remediated by the different masses $(5 \mathrm{~g}, 10 \mathrm{~g}$, $15 \mathrm{~g}, 20 \mathrm{~g}$, and $25 \mathrm{~g}$ ) of the bacteria varies. There is a reduction in all the TDS of all the samples after the bioremediation process compared with the TDS of the raw samples before the bioremediation. The relative potential or efficiency of the different masses of the bacteria in remediating TDS in TAN1 and TAN3 samples was in the order $5 \mathrm{~g}>10 \mathrm{~g}>15 \mathrm{~g}>20$ $\mathrm{g}>25 \mathrm{~g}$. For TAN2 samples, the order was 20 $g>10 \quad g>25 \quad g>15 \quad g>5 \quad g$. Statistical analysis shows that there is no significant difference $(p<0.05)$ between the mean values of TDS among the masses in the respective industries. These might be due to the variations in the surface areas of the different masses of the immobilized bacteria. Positive and significant correlations exist between the masses of bacteria and TDS with the exception in TAN2 (negative and insignificant correlation). The positive correlations showed that there is general increase in the levels of the TDS as the masses of the immobilized bacteria increases. TAN1 $(96 \%)$ showed a very high correlation with the masses of the bacteria while TAN2 (47\%) showed a very low correlation.

The mean values $(\mathrm{mg} / \mathrm{l})$ of the BOD after the bioremediation varies between $1.56 \pm 0.20 \mathrm{mg} / \mathrm{l}$ and $6.92 \pm 5.49 \mathrm{mg} / \mathrm{l}$. The mean concentration $(\mathrm{mg} / \mathrm{l})$ of BOD remediated by the different masses $(5 \mathrm{~g}, 10 \mathrm{~g}, 15 \mathrm{~g}, 20 \mathrm{~g}$, and $25 \mathrm{~g}$ ) of the bacteria varies. There is a reduction in all the BOD of all the samples after the bioremediation process compared with the $\mathrm{BOD}$ of the raw 
BAJOPAS Volume 13 Number 2, December, 2020 samples before the bioremediation. The relative potential or efficiency of the different masses of the bacteria in remediating BOD in TAN1, TAN2 and TAN3 samples were in the order $25 \mathrm{~g}>20$ $\mathrm{g}>15 \mathrm{~g}>10 \mathrm{~g}>5 \mathrm{~g}, 25 \mathrm{~g}>15 \mathrm{~g}>5 \mathrm{~g}>10 \mathrm{~g}>20 \mathrm{~g}$ and $20 \mathrm{~g}>10 \mathrm{~g}>25 \mathrm{~g}>15 \mathrm{~g}>5 \mathrm{~g}$ respectively. Statistical analysis shows that there is significant difference $(p<0.05)$ between the mean values of BOD among the masses in the respective industries. These might be due to the variations in the surface areas of the different masses of the immobilized bacteria. Negative and significant correlations exist between the masses of bacteria and BOD. This showed that there is general decrease in the levels of the BOD as the masses of the immobilized bacteria increases. TAN1 (94\%) showed a very high correlation with the masses of the bacteria while TAN2 (4\%) showed a very low correlation.

The mean values $(\mathrm{mg} / \mathrm{l})$ of the COD after the bioremediation varies between $250 \pm 154$ and $3134 \pm 1595$. The mean concentration $(\mathrm{mg} / \mathrm{l})$ of COD remediated by the different masses $(5 \mathrm{~g}$, $10 \mathrm{~g}, 15 \mathrm{~g} 20 \mathrm{~g}$, and $25 \mathrm{~g}$ ) of the bacteria varies. There is a reduction in all the COD of all the samples after the bioremediation process compared with the COD of the raw samples before the bioremediation. The relative potential or efficiency of the different masses of the bacteria in remediating COD in TAN1, TAN2 and TAN3 samples were in the order $25 \mathrm{~g}>20 \mathrm{~g}>15$ $\mathrm{g}>5 \mathrm{~g}>10 \mathrm{~g}, 25 \mathrm{~g}>20 \mathrm{~g}>15 \mathrm{~g}>10 \mathrm{~g}>5 \mathrm{~g}$ and 10 g>5 g>25 g>15 g>20 g respectively. Statistical analysis shows that there were significant difference $(p<0.05)$ between the mean values of COD among the masses in the respective industries except for effluents treated with $25 \mathrm{~g}$. These might be due to the variations in the surface areas of the different masses of the immobilized bacteria. Negative and insignificant correlations exist between the masses of bacteria and COD with the exception in TAN3 (positive and significant correlation). The negative correlations showed that there is general decrease in the levels of the COD as the masses of the immobilized bacteria increases. TAN2 (100\%) showed a very high correlation with the masses of the bacteria while TAN3 (36\%) showed a very low correlation.

Generally, there was an overall decrease in the concentration of these physicochemical parameters after the bioremediation using the different masses of the bacterial isolates. These might be due to the variations in the surface areas of the different masses of the immobilized bacteria. This is in line with the work of Jimoh et al. (2018) and Baba et al. (2020).

Table 3: Mean Values $(\mathrm{mg} / \mathrm{l}) \pm$ S.D of Physicochemical parameters in effluents from the Tannery Industries before and after Treatment of the effluents $(250 \mathrm{ml})$ with the different masses $(5 \mathrm{~g}, 10 \mathrm{~g}$, $15 \mathrm{~g}, 20 \mathrm{~g}$, and $25 \mathrm{~g}$ ) of the bacteria.

\begin{tabular}{llllllll}
\hline $\mathrm{P}$ & IND & Before & \multicolumn{5}{c}{ After } \\
\cline { 4 - 7 } & & & $5 \mathrm{~g}$ & $10 \mathrm{~g}$ & $15 \mathrm{~g}$ & $20 \mathrm{~g}$ & $25 \mathrm{~g}$ \\
\hline \multirow{2}{*}{ COD } & TAN1 & $2372 \pm 938$ & $1708 \mathrm{a} \pm 861$ & $2045 \mathrm{a} \pm 1205$ & $845 \mathrm{a} \pm 369$ & $300 \mathrm{a} \pm 167$ & $250 \mathrm{a} \pm 154$ \\
& TAN2 & $1406 \pm 208$ & $1195 \mathrm{a} \pm 208$ & $1125 \mathrm{a} \pm 384$ & $1055 \mathrm{a} \pm 317$ & $956 \mathrm{a} \pm 310$ & $870 \mathrm{ab} \pm 240$ \\
& TAN3 & $3532 \pm 1373$ & $2374 \mathrm{a} \pm 1344$ & $1976 \mathrm{a} \pm 1405$ & $2757 \mathrm{a} \pm 1266$ & $3134 \mathrm{a} \pm 1595$ & $2614 \mathrm{~b} \pm 1105$ \\
BOD & TAN1 & $13.85 \pm 6.42$ & $6.92 \mathrm{a} \pm 5.49$ & $6.42 \mathrm{a} \pm 5.07$ & $5.72 \mathrm{a} \pm 5.35$ & $4.62 \mathrm{a} \pm 4.37$ & $2.82 \mathrm{ab} \pm 1.26$ \\
& TAN2 & $19.46 \pm 0.50$ & $1.75 \mathrm{~b} \pm 0.22$ & $1.73 \mathrm{~b} \pm 0.18$ & $1.58 \mathrm{a} \pm 0.16$ & $1.91 \mathrm{a} \pm 0.22$ & $1.56 \mathrm{~b} \pm 0.20$ \\
& TAN3 & $17.13 \pm 3.14$ & $4.24 \mathrm{ab} \pm 0.77$ & $3.29 \mathrm{ab} \pm 0.37$ & $4.11 \mathrm{a} \pm 0.07$ & $3.23 \mathrm{a} \pm 0.91$ & $3.33 \mathrm{a} \pm 1.28$ \\
SS & TAN1 & $374 \pm 124$ & $243 \mathrm{a} \pm 45$ & $471 \mathrm{a} \pm 226$ & $475 \mathrm{a} \pm 182$ & $492 \mathrm{a} \pm 128$ & $611 \mathrm{a} \pm 217$ \\
& TAN2 & $358 \pm 335$ & $460 \mathrm{a} \pm 400$ & $543 \mathrm{a} \pm 414$ & $544 \mathrm{a} \pm 402$ & $551 \mathrm{a} \pm 414$ & $554 \mathrm{a} \pm 405$ \\
& TAN3 & $780 \pm 739$ & $586 \mathrm{a} \pm 594$ & $758 \mathrm{a} \pm 656$ & $787 \mathrm{a} \pm 676$ & $861 \mathrm{a} \pm 635$ & $898 \mathrm{a} \pm 672$ \\
TDS & TAN1 & $3941 \pm 3703$ & $51 \mathrm{a} \pm 10$ & $53 \mathrm{a} \pm 10$ & $55 \mathrm{a} \pm 15$ & $61 \mathrm{a} \pm 20$ & $63 \mathrm{a} \pm 26$ \\
& TAN2 & $3300 \pm 1714$ & $83 \mathrm{a} \pm 78$ & $47 \mathrm{a} \pm 20$ & $48 \mathrm{a} \pm 22$ & $47 \mathrm{a} \pm 17$ & $48 \mathrm{a} \pm 17$ \\
& TAN3 & $2653 \pm 1240$ & $46 \mathrm{a} \pm 11$ & $55 \mathrm{a} \pm 24$ & $55 \mathrm{a} \pm 25$ & $58 \mathrm{a} \pm 23$ & $61 \mathrm{a} \pm 28$ \\
\hline
\end{tabular}

Replicate $=6$ (months)

Within the rows, for the same parameter, means with different alphabets are statistically different $(p<0.05)$.

$\mathrm{P}=$ parameter, IND = Industries 
BAJOPAS Volume 13 Number 2, December, 2020

Table 4: Correlation coefficient $(r)$ between different masses of the bacteria and the physicochemical parameters.

\begin{tabular}{llll}
\hline Industries & Parameter & Correlation coefficient $(r)$ & $\begin{array}{l}\text { Percent dependence (rxrx100) } \\
(\%)\end{array}$ \\
\hline TAN1 & COD & -0.9 & 82 \\
& BOD & -0.97 & 94 \\
& SS & $0.90^{*}$ & 80 \\
TAN2 & TDS & $0.98^{*}$ & 96 \\
& COD & -1 & 100 \\
& BOD & -0.21 & 4 \\
& SS & $0.78^{*}$ & 61 \\
& TDS & -0.69 & 47 \\
& COD & $0.60^{*}$ & 36 \\
& BOD & -0.6 & 37 \\
& SS & $0.95^{*}$ & 90 \\
& TDS & $0.94^{*}$ & 89 \\
\hline
\end{tabular}

The correlation coefficient $(r)$ with * is statistically significant $(p<0.05)$.

Percentage reduction of the Parameters

Table 5 shows the percentage reduction of Parameters in industrial samples before and after the treatment of the effluents $(250 \mathrm{ml})$ with the different masses $(5 \mathrm{~g}, 10 \mathrm{~g}, 15 \mathrm{~g}, 20 \mathrm{~g}$, and $25 \mathrm{~g}$ ) of the Immobilized Bacteria.

In TAN1 samples, the percentage reduction (\%) of COD ranged (14-89); BOD (50-80); SS (-32$35)$ and TDS (98-99). In TAN2 samples, the percentage decrease $(\%)$ of COD ranged (15$38) ;$ BOD (90-92); SS [-28-(-55)] and TDS (9798). In TAN3 samples, the percentage decrease (\%) of COD ranged (11-44); BOD (76-81); SS (15-25) and TDS (98). The percentage increase in the levels COD, BOD and TDS might be due to the increase in the surface area of the different masses of the immobilized bacteria. However, the percentage decrease in the levels of the SS might be due to the aggregation of the TDS which are large enough to result into SS. The percentage decrease in the levels of the SS might be also due to the influence of the nutrients which was added into the effluents in order to make the microorganisms more active and viable for fast degradation of organic contaminants in the effluent. This is in line with the work of Jimoh et al. (2018) in which the concentration of the SS increase after the bioremediation of effluents.

Sreemoyee and Priti (2013) assessed and reduced several Physico-chemical parameters of dairy wastewater using Niesseria $s p$. and concluded that the species are well known to degrade organic compounds. This is in agreement with the current study in which the immobilized Niesseria $s p$ degrade the organic contaminants as indicated by the BOD, COD and TDS.

Jimoh et al. (2018) observed that TSS of the effluents was increased after treatment with immobilized bacteria and concluded that it might be due to the biostimulation method adopted for the research.

The optimum $\mathrm{pH}$ Biosorption of Chromium by Bacillus spp and Staphylococcus spp. from tannery effluent was investigated by Mythili and Karthikeyan (2011). The maximum adsorption of Chromium $(86.4 \mathrm{mg} / \mathrm{L})$ was showed by Bacillus spp and Staphylococcus spp showed $70.6 \mathrm{mg} / \mathrm{L}$ at an initial concentration of $100 \mathrm{mg} / \mathrm{L}$. In the present study, immobilised Bacillus spp and Staphylococcus spp. from the tannery industrial effluents reduced the levels of the organic pollutants with high potential as indicated by the percentage reduction of BOD, COD and TDS.

Enzymes often can work in multiple environments especially if they are immobilized. This makes the microorganisms' enzymes even more resistant to harsh environments and enables the enzymes to be recovered and recycled after they are no longer needed (Gianfreda and Rao 2004). Ramesh and Singh (1993) reported that the immobilized bacteria having more efficiency to remove the suspended particles than free cells. Using the immobilized cell is preferable due to its capability for using several times with the same efficiency, which makes it more economical. Similar work was done by Sikander et al. (2007) showing the higher reduction with permeabilized cells of Ochrobactrum intermedium strain SDCr-5. 
BAJOPAS Volume 13 Number 2, December, 2020

The results revealed the isolation and identification of isolates with the potential for the reduction of $\mathrm{Cr}$ (VI) to $\mathrm{Cr}$ (III). Results indicated that immobilized $B$. cereus could be efficiently used for the reduction of $\mathrm{Cr}$ (VI).

Table 5: Percentage reduction of the tested Parameters from the tannery industrial samples of the Immobilized Bacteria.

\begin{tabular}{lllllll}
\hline \multirow{2}{*}{ Industries } & & \multicolumn{5}{c}{ Percentage Reduction $(\%)$} \\
\cline { 3 - 7 } & & $5 \mathrm{~g}$ & $10 \mathrm{~g}$ & $15 \mathrm{~g}$ & $20 \mathrm{~g}$ & $25 \mathrm{~g}$ \\
\hline TAN1 & COD & 28 & 14 & 64 & 87 & 89 \\
& BOD & 50 & 54 & 59 & 67 & 80 \\
& SS & 35 & -26 & -27 & -32 & -63 \\
& TDS & 99 & 99 & 99 & 98 & 98 \\
TAN2 & COD & 15 & 20 & 25 & 32 & 38 \\
& BOD & 91 & 91 & 92 & 90 & 92 \\
& SS & -28 & -52 & -52 & -54 & -55 \\
& TDS & 97 & 99 & 99 & 99 & 99 \\
& COD & 33 & 44 & 22 & 11 & 26 \\
& BOD & 75 & 81 & 76 & 81 & 81 \\
& SS & 25 & 3 & -1 & -10 & -15 \\
& TDS & 98 & 98 & 98 & 98 & 98 \\
\hline
\end{tabular}

Percentage Reduction $=(B-A) / B \times 100 \%$

$A=$ Concentration of the parameter after treatment

$\mathrm{B}=$ Concentration of the parameter before treatment

$+=$ percentage decrease

- = percentage increase

In general, immobilization makes the enzyme more resistant to temperature, $\mathrm{pH}$, and substrate concentration swings giving it a longer lifetime and higher productivity per active unit (Gianfreda and Rao, 2004; FuIlbrook, 1996; Russell et al, 2003; Kandelbauer et al., 2004). Immobilized cells have been used and studied extensively for the production of useful chemicals (Ohtake and Silver, 1994), the treatment of wastewaters (Chen et al., 2003; Wang et al., 2010). Although many workers described microbial degradation of tannery effluent, limited literature is available on the bioremediation of tannery effluent using immobilized bacterial cells in the Kano Industrial Estates.

\section{CONCLUSION}

The samples contained variable levels of the physicochemical parameters. The results of the Analysis of variance revealed that, no statistical difference $(p<0.05)$ was observed for the temperature, $\mathrm{pH}, \mathrm{SS}, \mathrm{TDS}, \mathrm{BOD}$ and $\mathrm{COD}$ among the three tannery industries before the treatment. The levels of some of the parameters
(SS, TDS and COD) observed in the samples were found above the recommended limits of WHO and NESREA, which called for the treatment of the effluents before discharge into the environment. Base on the morphological and biochemical test results, TAN1, TAN2, and TAN3 bacterial isolates were identified to be Neisseria spp, Bacillus cereus, and Staphylococcus aureus respectively. The results of Post-treatment analysis showed that there is overall decrease in the levels of the parameters determined when compared with that of the pre-treatment. The overall percentage reduction of the immobilised bacteria in the treatment of the respective effluents was in the order TAN2 (72\%)>TAN1 $(70 \%)>$ TAN3 $(62 \%)$. Hence, the immobilized bacteria are having higher biodegradation potential for the treatment of the tannery effluents.

\section{Acknowledgments}

The authors wish to acknowledge the University of Maiduguri for the financial support. The authors are grateful to the Kano State Ministry of Environment for their support in obtaining the effluent samples. 


\section{REFERENCES}

Ajao, A. T., Adebayo, G. B., and Yakubu, S. E. (2011). Bioremediation of textile industrial effluent using mixed culture of Pseudomonas aeruginosa and Bacillus subtilis immobilized on agar-agar in a bioreactor. J. Microbiol. Biotech. Res, 1(3), 50-56.

Akan, J. C., Moses, E. A., Ogugbuaja, V. O., and Abah, J. (2007). Assessment of tannery industrial effluents from Kano metropolis, Kano State, Nigeria. Journal of Applied Sciences, 7(19), 2788-2793.

Akan, J. C., Ogugbuaja, V. O., Abdulrahman, F. I., and Ayodele, J. T. (2009). Pollutant levels in effluent samples from tanneries and textiles of Kano industrial areas, Nigeria. Global journal of pure and applied sciences, 15(3-4).

APHA (1989). Standard methods for Examination of Will bete and Will betewater.15 $5^{\text {th }}$ edition. Brydpass Springfield Will behington DC. pp. 164-176

APHA (1992). Standard Methods for the Examination of Water and Wastewater. Health, 69, 1116-9.

Baba, A., Garba, S. T., and Bello, H. S. (2020). Bioremediation Potential of Immobilized corynebacterium kutsceri in the Treatment of Tannery Industrial Effluent from Challawa Industrial Estate, Kano State, Nigeria. Journal of the Turkish Chemical Society Section A: Chemistry, $7(2), 335-350$.

Beem, E. I. V. (1994). reduction of solvent VOC emission. J. Oil Col. Chem. Ass, 77, 158.

Bouwer, E. J., and Zehnder, A. J. (1993). Bioremediation of organic compoundsputting microbial metabolism to work. Trends in biotechnology, 11(8), 360367.

Chen, K. C., Wu, J. Y., Liou, D. J., and Hwang, S. C. J. (2003). Decolorization of the textile dyes by newly isolated bacterial strains. Journal of Biotechnology, 101(1), 57-68.

Dan'Azumi, S., and Bichi, M. H. (2010). INDUSTRIAL POLLUTION AND HEAVY METALS PROFILE OF CHALLAWA RIVER IN KANO, NIGERIA. Journal of Applied Sciences in Environmental Sanitation, $5(1)$.

DWAF. (1992). Analytical Methods Manual, TR 151. Department of Water Affairs and Forestry, Pretoria.

El-Bestawy, E. (2013). Biological treatment of leather-tanning industrial wastewater using free living bacteria.
Elsheikh, M. A. S. (2009). Tannery wastewater pre-treatment. Water Science and Technology, 60(2), 433-440.

FuIlbrook, P. D. (1996). "Kinetics." Industrial enzymology: The application of enzymes in Industry. 2nd Ed. T. Godfrey and J Reichelt. eds.. Nature. New York.

Gianfreda, L., and Rao, M. A. (2004). Potential of extra cellular enzymes in remediation of polluted soils: a review. Enzyme and microbial technology, 35(4), 339354.

Hugo Springer. (1994). John Arthur Wilson Memorial Lecture "Treatment of Industrial Wastes of the Leather Industry - is it still a Major Problem". JALCA, 89, 153-185

Jimoh, A. A., Ganiyu, B. A., Baba, D., and Baba, A. (2018) Bioremediation Process of Effluent from Detergent and Food Industries in Jos, Nigeria: Kinetics and Thermodynamics. International Journal of Engineering Science Invention (IJESI), 762-73

Kandelbauer, A., Maute, O., Kessler, R. W., Erlacher, A., and Gübitz, G. M. (2004). Study of dye decolorization in an immobilized laccase enzyme-reactor using online spectroscopy. Biotechnology and bioengineering, 87(4), 552-563.

Kongjao, S., Damronglerd, S., and Hunsom, M. (2008). Simultaneous removal of organic and inorganic Pollutants in tannery wastewater using electrocoagulation technique. Korean Journal of chemical engineering, 25(4), 703.

Maheshwari, U. M., Aruna, S., Gomathi, M., and AbdulJaffar, A. H. (2017). Bioremediation by Free and Immobilized Bacteria Isolated from Tannery Effluent. International Journal of Research in Applied, Natural and Social Sciences. 5(7), 75-90

Margesin, R., and Schinner, F. (2001). Bioremediation (natural attenuation and biostimulation) of diesel-oilcontaminated soil in an alpine glacier skiing area. Applied and environmental microbiology, 677), 3127-3133.

Mohammed, A., Sekar, P., and George, J. (2011). Efficacy of microbes in bioremediation of tannery effluent. Inter. J. Curr. Res, 3(4), 324-326.

Mohammed, S. S. D., Orukotan, A. A., and Abdullahi, H. (2017). Physicochemical and Bacteriological Assessment of Tannery Effluent from Samaru-Zaria, 
BAJOPAS Volume 13 Number 2, December, 2020 Kaduna State, Nigeria. Journal of Applied

Sciences and Environmental Management, 21(4), 734-740.

Munz, G., De Angelis, D., Gori, R., Mori, G., Casarci, M., and Lubello, C. (2009). The role of tannins in conventional and membrane treatment of tannery wastewater. Journal of hazardous materials, 164(2-3), 733-739

Mythili, K., and Karthikeyan, B. (2011). Bioremediation of $\mathrm{Cr}$ (VI) from tannery effluent using Bacillus spp and Staphylococcus spp. International Multidisciplinary Research Journal, 1(6).

NESREA (2009). National Environmental Standards for Effluent Limitations and Regulation. 1233-1236

Noorjahan, C. M. (2014). Physicochemical characteristics, identification of bacteria and biodegradation of industrial effluent. Journal of bioremediation and Biodegradation, 5(3).

Ohtake, H. I., and Silver, A. O. (1994). Bacterial reduction of toxic chromate. Biological degradation and bioremediation of toxic chemicals, 403-415.

Omoleke, I. I. (2004). Management of environmental pollution in Ibadan, an African city: the challenges of health hazard facing government and the people. Journal of Human Ecology, 15(4), 265-275.

Rajor, A., Reddy, A.S., and Singh, B. (2004). Determination of BOD kinetic Parameters and evaluation of alternate methods, M.Sc. Thesis, Department of biotechnology \& environmental Science, Thapar Institute of Engineering and Technology, Patiala

Ramasami, T., Rajamani, S., and Rao, J. R. (1994, March). Pollution control in leather industry: Emerging technological options. In International symposium on surface and colloidal science and its relevance to soil pollution, madras.

Ramesh, J. V. S., and Singh, S. P. (1993). Yearly variation in certain physicochemical parameters of pond at eastern Doon Valley. Uttar Pradesh J. Zoo, 12 (1), 7577.

Ranen, S., and Sharadinadra, C. (2009). Biotechnology applications to environmental remediation in resource exploitation. Current science, 97, 6-25
Russell, A. J., Berberich, J. A., Drevon, G. F., and Koepsel, R. R. (2003). Biomaterials for mediation of

chemical and biological warfare agents. Annual review of biomedical engineering, 5(1), 1-27.

Saravanan, P., and Saravanan, A. (1999). Decolourization of tannery effluent by Flavobacterium sp. EK 1. Indian Journal of Environmental Protection, 19, 19-24.

Sikander, S., and Shahida, H. (2007). Reduction of toxic hexavalent chromium by Ochrobactrum intermedium strain SDCr5 stimulated by heavy metals. Bioresource Technol, 98, 340-344.

Singh, N., Sharma, B. K., and Bohra, P. C. (2000). Impact assessment of industrial effluent of arid soils by using satellite imageries. Journal of the Indian Society of Remote Sensing, 28(2-3), 79.

Sreemoyee, C., and Priti, P. (2013). Assessment of physico-chemical parameters of dairy waste water and isolation and characterization of bacterial strains in terms of cod reduction. Int J Sci, 2(3), 395-400.

Verheijen, L. A. H. M., Wiersema, D., Pol, L. H., and De Wit, J. (1996). Management of wastes from animal product processing. Livestock and environment, Finding a balance. International Agriculture Center, Wageningen, The Netherlands.

Wang, F., Yao, J., Si, Y., Chen, H., Russel, M., Chen, K., and Bramanti, E. (2010). Short-time effect of heavy metals upon microbial community activity. Journal of Hazardous Materials, 173(13), 510-516.

WHO (World Health Organization). (2006). Air quality guidelines: global update 2005: particulate matter, ozone, nitrogen dioxide, and sulfur dioxide. World Health Organization.

World Bank. (1995). Nigeria's strategic options for redressing industrial pollution. World Bank, industry and energy division. 1st edition, West Central Africa Department; Annexes: 1995; pp 60-62.

Zahoor, A., and Abdul, R. (2009). Enumeration of Coliforms. Journal of Environmental Sciences. 21, 814-820 


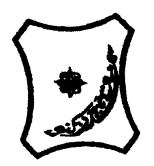

Bayero Journal of Pure and Applied Sciences, 13(2): 1 - 12

Received: November, 2020

Accepted: December, 2020

ISSN $2006-6996$

\title{
BIODEGRADATION POTENTIAL OF IMMOBILIZED BACTERIA IN THE TREATMENT OF TANNERY INDUSTRIAL EFFLUENTS FROM INDUSTRIAL ESTATES IN KANO STATE, NIGERIA
}

\author{
Abdullateef, B., ${ }^{1 *}$ Shuaibu, T. G., ${ }^{1}$ Babagana, K., ${ }^{1}$ Suleman, H. B. ${ }^{2}$ and Dauda, B. ${ }^{3}$ \\ ${ }^{1}$ Department of Pure and Applied Chemistry, Faculty of Science, University of Maiduguri, Borno State, \\ Nigeria \\ ${ }^{2}$ Department of Microbiology, Faculty of Science, University of Maiduguri, Borno State, Nigeria \\ ${ }^{3}$ Department of Chemical Engineering, Faculty of Engineering, University of Maiduguri, Borno State, \\ Nigeria \\ *Corresponding author: babslega@gmail.com; abelega2007@yahoo.com; +2348061309753
}

\section{ABSTRACT}

Industrial Effluents Samples from Gashash Tanneries (TAN1) in Bompai Industrial estate, Larabee Tannery Industry (TAN2) in Sharada Industrial estate and Z Tannery Industries (TAN3) in Challawa Industrial estate, Kano State, Nigeria were collected over a period of six months (August 2017 to January 2018) for assessing the biodegradation potentials of bacteria in the treatment of organic pollutants within the effluents. Bacteria were isolated from the effluents and immobilized on agar-agar. Different masses (5 g, $10 \mathrm{gr}, 15$ $\mathrm{g}, 20 \mathrm{~g}$, and $25 \mathrm{~g}$ ) of the bacteria were used in the treatment of $250 \mathrm{ml}$ of the effluents for ten days in a shaker incubator (Gallenkamp-OC-4364-L) at the temperature $30{ }^{\circ} \mathrm{C}$ and speed of $60 \mathrm{rpm}$. Pre-treatment analysis of the effluents for Temperature, pH, Biochemical Oxygen Demand (BOD), Chemical Oxygen Demand (COD), Suspended Solid (SS) and Total Dissolved Solids (TDS) gives the following results; temperature $\left({ }^{\circ} \mathrm{C}\right.$ )

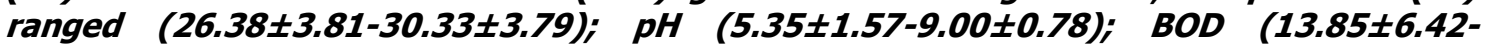
$38.75 \pm 16.20) ;$ COD (1406 $\pm 208-3532 \pm 1373) ;$ SS (208 $\pm 235-780 \pm 739)$ and TDS (266 $\pm 253-5276 \pm 2971)$. No statistical differences ( $p \leq 0.05)$ was observed for all the results among the different industries. The bacterial isolates were identified as Neisseria spp, Bacillus cereus, and Staphylococcus aureus, in TAN1, TAN2, and TAN3, respectively. After treatment of the effluent with the different masses of the isolated bacteria, the mean level of BOD was found to range as (0.55 $\pm 0.36-6.92 \pm 5.49) ; C O D$ (ND-3134 \pm 1595$)$;

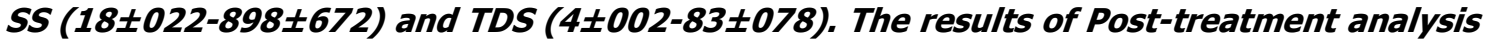
showed that there is overall decrease in the levels of the parameters determined when compared with that of the pre-treatment. The overall percentage reduction of the immobilised bacteria in the treatment of the respective effluents was in the order TAN2 (72\%)>TAN1 (70\%)>TAN3 (62\%). Hence, the immobilized bacteria are having higher biodegradation potential for the treatment of the tannery effluents.

Keywords: Biodegradation, bacteria, effluent, immobilization, tannery.

\section{INTRODUCTION}

Tannery industrial wastewater is a serious consequence of the pollution point of view for streams, freshwater, and land used for agriculture. The lack of awareness in the modern industrial practice has resulted in the discharge of tannery effluents which exhibit very high value of chromium ( $\mathrm{Cr}$ ), Sulfide, and chloride, Total Dissolved Solid (TDS), Total Suspended Solid (TSS), Biochemical Oxygen Demand (BOD) and Chemical Oxygen Demand (COD) in the water stream or land (Mohammed et al., 2001). Tanning is the process, which One ton of skin generally leads to the production of 20 to $80 \mathrm{~m}^{3}$ of turbid and foul-smelling converts the protein of the rawhide or skin into a stable material, which will not putrefy and is suitable for a wide variety of end applications (Elsheikh, 2009). The highly polluting chromium is the most commonly used tanning material producing leather that is more flexible and pliable than vegetable-tanned leather and does not discolor or lose shape in water as drastically as vegetable-tan (Elsheikh, 2009). Tannery effluent is among the most hazardous industrial pollutants due to its huge organic and inorganic load, which is highly toxic to human life and the environment (Kongjao et al., 2008). wastewater including chromium (100-400 mg/l), sulfide $(200-800 \mathrm{mg} / \mathrm{l})$, high levels of fat and 
BAJOPAS Volume 13 Number 2, December, 2020 other solid wastes, and notable pathogen contamination as well as pesticides added for skin conservation during transport (Elsheikh, 2009). There are more than 6000 tanneries in Nigeria with an annual processing capacity of 700,000 tons of hides and skins (Omoleke, 2004; Singh et al., 2008). It was reported that the total amount of waste produced per animal slaughtered is approximately $35 \%$ of its weight (World Bank, 1995). Also, for every $1000 \mathrm{~kg}$ of carcass weight, a slaughtered beef produces 5.5 $\mathrm{kg}$ of manure (excluding rumen contents or stockyard manure) and $100 \mathrm{~kg}$ of paunch manure (undigested food) (Verheijen et al., 1996). Tanneries generate wastewater in the range of 30-35 $\mathrm{L} \mathrm{kg}^{-1}$ skin/hide processed with variable $\mathrm{pH}$, Biological Oxygen Demand (BOD), Chemical Oxygen Demand (COD), high concentrations of suspended solids (SS), and tannins as well as chromium (Zahoor and Abdul, 2009).

Being heterogeneous and composed of a wide variety of compounds, it is very difficult to select a unique direct method for estimating the biodegradability of organic contents and biokinetic parameters for a wastewater sample (Rajor, 2004). For this purpose, some indirect estimation such as determination of biochemical oxygen demand (BOD) and chemical oxygen demand (COD) are applied as common laboratory investigations [9]. During retanning procedures, synthetic tannins (Syntan), oils and resins are added to form softer leather at varying doses (Munz et al., 2009). One of the refractory groups of chemicals in tannery effluents derives mainly from tannins (Ramasami et al., 2004). Syntans are characterized by complex chemical structures, because they are composed of an extended set of chemicals such as phenol-, naphthalene-, formaldehyde- and melamine-based syntans, and acrylic resins (Beem, 1994). Organic pollutants (proteic and lipidic components) are originated from skins (it is calculated that the raw skin has $30 \%$ loss of organic material during the working cycle) or they are introduced during processes (Hugo Springer, 1994).

Many conventional processes such as oxidation, chemical and biological processes were carried out to treat tanneries wastewater (Ebtesam et al, 2013). Biological processes have received more attention because of their costeffectiveness, lower sludge production and environmental friendliness (Noorjahan, 2014). Naturally occurring micro-organisms degrade the hazardous organic wastes including xenobiotic compounds, such as pesticides, polycyclic aromatic hydrocarbons (PAHs) and polychlorinated biphenyls (PCBs) in due course of time (Ranen and Sharadinadra, 2009). Bioremediation is based on the idea that all organisms remove substances from the environment to carry outgrowth and metabolism (Bouwer and Zehnder, 1993). Bacteria, protista and fungi are found to be very good at degrading complex molecules and incorporating the breakdown products into their metabolism (Bouwer and Zehnder, 1993). The resultant metabolic wastes that they produce are generally safe and somehow recycled into other organisms (Ranen and Sharadinadra, 2009). An acclimatized indigenous population of microorganisms capable of degradation of the compounds of interest must exist at the site for a successful bioremediation mode (Ranen and Sharadinadra, 2009). It has been observed that for a successful bioremediation mode, an acclimatized indigenous population of microorganisms capable of degradation of the compounds of interest must exist at the site under investigation (Ranen and Sharadinadra, 2009). Even though there are numerous physical and chemical methods employed in the disposal of wastes the advantage in using bacterium is that they play a key role in the reduction of COD, BOD, total protein, total tannin and total phenol (Saravanan and Saravanan, 1998)

Baba et al. (2020) studied the bioremediation potential of immobilized corynebacterium kutsceri in the Treatment of tannery industrial effluent from Challawa Industrial Estate, Kano State, Nigeria. The aim of the work is to study the reduction in the level of the contaminants through the process of bioremediation using the isolated bacteria. Immobilized bacteria can withstand various temperatures, $\mathrm{pH}$ and substrate concentrations; consequently, increasing the efficiency and the lifespan of the bacteria. Immobilized bacteria are widely applied in the treatment of wastewater and can be separated and recovered after the treatment with the same efficiency (Baba et al., 2020).

\section{MATERIALS AND METHODS \\ Study Area}

This study was carried out in Bompai, Sharada and Challawa industrial estates in Kano, Figure 1. Kano lies on Latitude $11^{\circ} 30^{\prime} \mathrm{N}$ and $8^{\circ} 30^{\prime} \mathrm{E}$ and Longitude $11^{\circ} 5^{\prime} \mathrm{N}$ and $8^{\circ} 5^{\prime} \mathrm{E}$ in Northern Nigeria. It is one of the developed industrial cities in Nigeria. Tannery activities are the dominating industries and this could be one of the reasons for her high population density (Dan'Azumi and Bichi, 2010). Many researchers have studied biodegradation of tannery effluent using microorganisms. However, limited literature is available on the biodegradation of tannery effluent in Kano industrial estates using 
BAJOPAS Volume 13 Number 2, December, 2020 immobilized bacterial cells. This research work focuses on the potential of the use of the indigenous immobilized bacterial isolates in the treatment of tannery effluents in the industrial estates.

\section{Sample Collection}

Effluents were collected from the Tannery Industries from Bompai, Challawa and Sharada Industrial Estates, Kano, Nigeria. The effluents were collected over a period of six months (August 2017 to January 2018). Samples collected in a sterile 4-liter plastic container with a unique identification number were preserved using an ice-box that was transported to the Microbiology Laboratory, Department of Microbiology, Bayero University of Kano for analysis

\section{Sample Preparation and Sample Analysis}

Immediately after the collection of the effluent, $\mathrm{pH}$, TSS, TDS, COD, BOD levels were determined before treatment (Pre-treatment determination) and ten days after treatment (Post-treatment determination) as described in
APHA (1989) standard methods. $\mathrm{pH}$ was determined using Ecotests $\mathrm{pH}$ meter and TDS was determined using AQUALYTIC TDS Salinometer. BOD was determined as described by the standard method (APHA, 1992). COD and SS were determined using DR/2010 HACH portable data logging spectrophotometer (DWAF, 1992)

\section{Identification and Biochemical} Characterization of the Bacterial Isolates

The bacteria were isolated from the effluents using Serial Dilution according to the method described by APHA (1989). The biochemical tests such as oxidase, catalase, coagulase, indole (from $1 \%$ tryptone broth), citrate (Simmons citrate agar), methyl red/VogesProskauer (MR/VP), nitrate reduction, Starch Hydrolysis, Glucose, Maltose, and Lactose tests were carried out on the bacterial isolates to identify the bacteria through the bacteria biochemical characteristics according to Ajao et al. (2011).

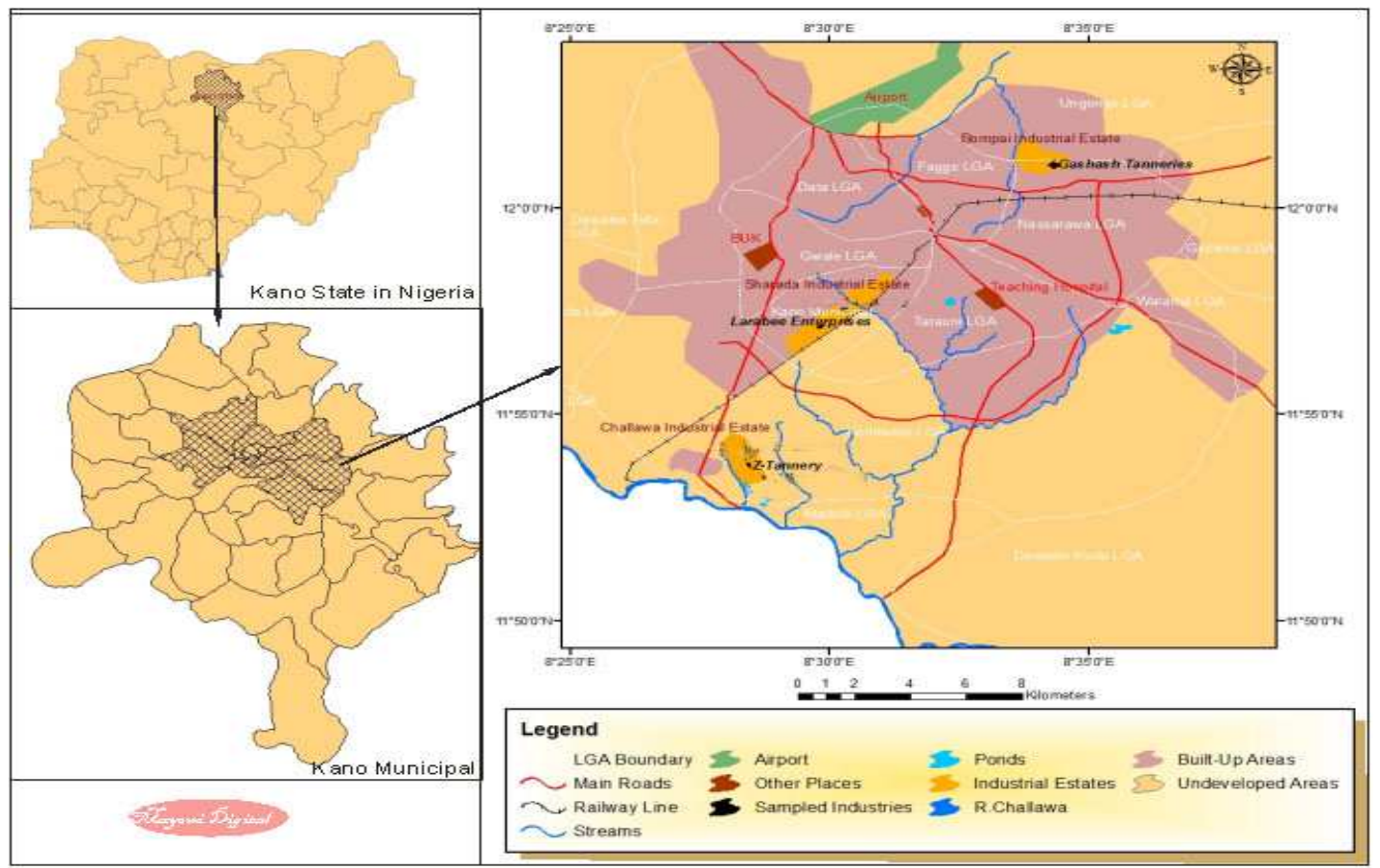

Fig. 1 Map showing the study areas

Source: Mayomi Digital Productions, GIS Laboratory, Department of Geography, UNIMAID (2017)

\section{Determination of Growth Rate of the Bacteria in Effluent Sample}

The bacteria growth rates were determined by transferring $2 \mathrm{~mL}$ of the bacterial isolates from the tannery effluent in broth medium into 100 $\mathrm{mL}$ sterile effluents in conical flasks and kept in an incubator (Giffrin cool) for 10 days. Control was also set up by incubating another $100 \mathrm{~mL}$ each of the sterile effluents without the bacteria. The optical density of the content was determined at the wavelength of $600 \mathrm{~nm}$ on a daily interval and recorded. 
BAJOPAS Volume 13 Number 2, December, 2020 Immobilization of Bacteria

Agar solution and inoculi were prepared separately. Fifty milliliters $(50 \mathrm{~mL})$ of nutrient broth each of the inoculi was prepared in a McCartney bottle and incubated for 24 hours. A solution of agar-agar was prepared by dissolving $10 \mathrm{~g}$ of the powder in distilled water and made up to $500 \mathrm{~mL}$ mark in an Erlenmeyer flask and was sterilized in an autoclave (280A) for 15 minutes and allowed to cool to $40-45^{\circ} \mathrm{C}$ (Ajao et al., 2011). Four milliliters ( $4 \mathrm{~mL})$ of the bacterial isolates in the nutrient broth was mixed with 36 $\mathrm{ml}$ of the prepared agar-agar media in petri-dish plates and then allowed to solidify. This was kept in the refrigerator for bioremediation.

\section{Bioremediation (Treatment) of the Effluents}

The solidified agar block (immobilized bacteria) was cut into cubes using a sterile knife; $0.1 \mathrm{~mL}$ phosphate buffer ( $\mathrm{pH} \mathrm{7.0)}$ was added and kept in the refrigerator for 1 hour for curing. The phosphate buffer was decanted after 1 hour and the cubes were washed with sterile distilled water 3-4 times before it was used (Ajao et al., 2011). Two liters (2 L) of the effluent was supplemented with the minimum basal medium in $\mathrm{g} / \mathrm{L}: \mathrm{NaCl}(0.8), \mathrm{MgSO}_{4} .7 \mathrm{H}_{2} \mathrm{O}(0.001), \mathrm{KH}_{2} \mathrm{PO}_{4}$ (2), $\mathrm{NaNO}_{3}$ (2), $\quad \mathrm{CaCl}_{2} .2 \mathrm{H}_{2} \mathrm{O} \quad(0.5)$ and $\mathrm{NaHPO}_{4} .12 \mathrm{H}_{2} \mathrm{O}(2)$ and sterilized in an autoclave at $121^{\circ} \mathrm{C}$ for 15 minutes (Margesin and Schinner, 2001). Two hundred and fifty milliliters $(250 \mathrm{~mL})$ of the effluents were transferred into different $250 \mathrm{ml}$ conical flasks. The content was covered with a cotton-wool ramped with foil paper to avoid contamination. Five grams $(5 \mathrm{~g})$ of the immobilized bacteria were quickly transferred into each of the effluents in the conical flasks in an inoculating chamber. The same procedures were carried out for the $10 \mathrm{~g}, 15 \mathrm{~g}, 20 \mathrm{~g}$ and 25 $\mathrm{g}$ of the immobilized bacteria in separate $250 \mathrm{~mL}$ effluents in conical flasks and agitated for ten days in a shaker incubator (Gallenkamp-OC4364-L) at a temperature $30^{\circ} \mathrm{C}$ and speed of 60 rpm. The treated effluent samples were taken on the tenth day and analyzed for the parameters $\mathrm{pH}$, SS, TDS, COD, and BOD, (Posttreatment determination) for the different grams of bacteria to evaluate and compare the biodegradation potential. (Baba et al., 2020).

\section{Statistical Analysis}

The data were represented as Mean \pm Standard deviation and analyzed statistically using oneway Analysis of Variance (ANOVA) and Tukey's HSD as Post Hoc Tests with the aid of SPSS 16.0. The correlation coefficient was also used to measure the strength of the relationship between the different masses of the bacteria and the parameters. All $\mathrm{p} \leq 0.05$ were considered as statistically significant.

\section{RESULTS AND DISCUSSION Physico-chemical parameters in the Industrial Effluents before the Biodegradation.}

Results of the Physico-chemical parameters in the industrial effluents before the Biodegradation is shown in table 1 . The mean temperatures $\left({ }^{\circ} \mathrm{C}\right)$ observed in TAN1, TAN2, and TAN3 samples were $28.07 \pm 0.65 ; 27.77 \pm 0.64$ and $26.38 \pm 3.81$ respectively. The order of the mean temperature of the samples from the three industries can be arranged as TAN1 > TAN2>TAN3. The temperature observed at TAN1, TAN2, and TAN3 samples were found below the WHO $\left(35^{\circ} \mathrm{C}\right)$ and NESREA $\left(40^{\circ} \mathrm{C}\right)$ limits. The low values of temperature might be due to the processes used at the time of sampling. High temperature brings down the solubility of gases in water that ultimately expresses as high BOD and COD. Statistical analysis shows that there is no significant difference $(p<0.05)$ between the mean values of temperature among the industries. This might be due to similar tannery activities involved in the tannery industries at the time of sampling. The average values of temperature observed in this present study are less than those observed by Akan et al. (2007), Akan et al. (2009) and Baba et al. (2020).

The mean level of $\mathrm{pH}$ observed in TAN1, TAN2 and TAN3, samples were $7.77 \pm 2.93$; $8.35 \pm 0.28$ and $7.52 \pm 0.76$ respectively. The order of the mean $\mathrm{pH}$ of the samples from the three industries can be arranged as TAN2> TAN1 $>$ TAN3. The $\mathrm{pH}$ of the samples falls within the WHO (7.0-8.5) and NESREA (6-9) standard limits. Statistical analysis shows that there is no significant difference $(p<0.05)$ between the mean values of $\mathrm{pH}$ among the industries. This might be due to similar tannery activities involved in the tannery industries at the time of sampling. Maheshwari et al. (2017) reported that the level of $\mathrm{pH}$ in the effluents from the tannery industry in Vaniyambadi, India was 6.5 which was lower than that observed in the present study. The $\mathrm{pH}$ in the effluents from the tannery industries in Kano and Kaduna were reported to be 7.64 and 6.89, respectively (Akan et al., 2007; Mohammed et al., 2017). The average values of $\mathrm{pH}$ observed in this present study are less than those observed by Mohammed et al. (2017) and Baba et al. (2020). The mean level of SS $(\mathrm{mg} / \mathrm{l})$ observed in TAN1, TAN2, and TAN3 samples were 374 \pm 124 ; $358 \pm 335$ and $780 \pm 739$ respectively. The order of the mean SS in the samples from the three industries can be arranged as TAN3 > TAN1 $>$ TAN2. 
The SS observed in the samples were far above the recommended standard limits of regulating bodies WHO $(30 \mathrm{mg} / \mathrm{l})$ and NESREA $(10 \mathrm{mg} / \mathrm{l})$. Statistical analysis shows that there is no significant difference $(p<0.05)$ between the mean values of SS among the industries. This might be due to similar tannery activities involved in the tannery industries at the time of sampling. The average values of SS observed in this present study are less than that observed $(3700 \pm 122 \mathrm{mg} / \mathrm{l})$ by Akan et al. (2009) for tanneries in Kano. Also, the average values of SS observed in this present study are less than that observed by Mohammed et al. (2017) and Baba et al. (2020) with the exception in TAN3.

The mean level of TDS (mg/l) observed in TAN1, TAN2, and TAN3 samples were $3941 \pm 3703$; $3300 \pm 1714$ and $2653 \pm 1240$ respectively. The order of the mean TDS in the samples from the three industries can be arranged as TAN1>TAN2>TAN3. The TDS observed in the samples were far above the recommended standard limits of WHO $(250 \mathrm{mg} / \mathrm{l})$ and NESREA $(500 \mathrm{mg} / \mathrm{l})$. Statistical analysis shows that there is no significant difference $(p<0.05)$ between the mean values of TDS among the industries. This might be due to similar tannery activities involved in the tannery industries at the time of sampling. TDS in the effluents from the tannery industries in Kano, Nigeria was reported to be $1281 \mathrm{mg} / \mathrm{l}$ (Akan et al., 2007). The average values of SS observed in this present study are less than those observed by Mohammed et al. (2017) and Baba et al. 2020)

The mean level of COD (mg/l) observed in TAN1, TAN2 and TAN3 samples seasons were $2372 \pm 938 ; \quad 1406 \pm 208$ and $3532 \pm 1373$ respectively. The order of the mean COD of the samples from the three industries can be arranged as TAN3>TAN1> TAN2. The COD observed in TAN1, TAN2 and TAN3 samples were far above the recommended standard limits of regulating bodies $\mathrm{WHO}(40 \mathrm{mg} / \mathrm{l})$ and NESREA (40 mg/l). Statistical analysis shows that there is no significant difference $(p<0.05)$ in COD among the industries. This might be due to similar tannery activities involved in the tannery industries as at the time of sampling. The Chemical Oxygen demand (COD) is the amount of oxygen, in $\mathrm{mg} / \mathrm{L}$, required for the degradation of the compound of wastewater to occur. In comparison, the average values of COD observed in this present study were higher than that observed by Mohammed et al. (2017) but lower than that observed by Baba et al. (2020).

The mean levels of BOD $(\mathrm{mg} / \mathrm{l})$ observed in TAN1, TAN2 and TAN3 samples were $13.85 \pm 6.42 ; \quad 19.46 \pm 0.50$ and $17.13 \pm 3.14$ respectively. The order of the mean BOD in the samples from the three industries can be arranged as TAN2>TAN3>TAN1. The BOD observed in TAN1, TAN2 and TAN3 samples were found below the recommended limits of NESREA (200 mg/l) but above WHO (10 mg/l). Statistical analysis shows that there is no significant difference $(p<0.05)$ between the mean values of BOD among the industries. This might be due to similar tannery activities involved in the tannery industries at the time of sampling. The low level of BOD recorded in this study is an indication of the low level of biodegradable organic solids in the effluent. The average values of BOD observed in this present study were lower than those observed by Mohammed et al. (2017) and Baba et al. (2020).

Table 1: Mean Values \pm S.D of Physico-chemical parameters of effluents from the Tannery Industries before Treatment.

\begin{tabular}{llllllll}
\hline Parameter & Tannery 1 & Tannery 2 & Tannery 3 & $\mathrm{a}$ & $\mathrm{b}$ & $\mathrm{c}$ & $\mathrm{d}$ \\
\cline { 2 - 7 } Temperature $\left({ }^{\circ} \mathrm{C}\right)$ & $28.07 \mathrm{a} \pm 0.65$ & $27.77 \mathrm{a} \pm 0.64$ & $26.38 \mathrm{a} \pm 3.81$ & & $29.50 \pm 4.68$ & 35 & 40 \\
pH & $7.77 \mathrm{a} \pm 2.93$ & $8.35 \mathrm{a} \pm 0.28$ & $7.52 \mathrm{a} \pm 0.76$ & 6.89 & $5.35 \pm 1.57$ & $7.0-8.5$ & $6.0-9.0$ \\
$\mathrm{COD}(\mathrm{mg} / \mathrm{l})$ & $2372 \mathrm{a} \pm 938$ & $1406 \mathrm{a} \pm 208$ & $3532 \mathrm{a} \pm 1373$ & 2.2 & $3106 \pm 2753$ & 40 & 40 \\
$\mathrm{BOD}(\mathrm{mg} / \mathrm{l})$ & $13.85 \mathrm{a} \pm 6.42$ & $19.46 \mathrm{a} \pm 0.50$ & $17.13 \mathrm{a} \pm 3.14$ & 1032 & $26.17 \pm 9.49$ & 10 & 200 \\
$\mathrm{SS}(\mathrm{mg} / \mathrm{l})$ & $374 \mathrm{a} \pm 124$ & $358 \mathrm{a} \pm 335$ & $780 \mathrm{a} \pm 739$ & 501 & $562 \pm 482$ & 30 & 10 \\
TDS $(\mathrm{mg} / \mathrm{l})$ & $3941 \mathrm{a} \pm 3703$ & $3300 \mathrm{a} \pm 1714$ & $2653 \mathrm{a} \pm 1240$ & 532.7 & $444 \pm 507$ & 250 & 500 \\
\hline
\end{tabular}

The values given in the table above are means of 6 replicate values, $\mathrm{n}=6$ ( 1 sample was taken monthly for 6 months). Within the rows, means with different alphabets are statistically different $(p<0.05)$. WHO: World Health Organisation. NESREA: National Environmental Standard and Regulatory Enforcement Agency. a = Mohammed et al.(2017), b = Baba et al. (2020), c = WHO (2006), $d=$ NESSRA (2009) 
BAJOPAS Volume 13 Number 2, December, 2020

Identification, Biochemical Characterization and growth rates of the Bacterial Isolates

Results of identification and biochemical characterization of the bacterial isolates were shown in table 2. After 24 hours of incubation, the nutrient agar media plates were checked for bacterial growth. The results showed the presence of different strains in the samples. The TAN1 bacteria isolate was found to be gramnegative cocci while TAN3 was gram-positive cocci. TAN2 bacteria isolate was found to be gram-positive, rod-shaped. TAN1, TAN2, and TAN3 bacteria isolates recorded positive results for spore former.

The results of the biochemical tests indicated that all the bacteria were positive for catalase, oxidase, citrate, maltose, glucose, lactose (negative in TAN1), mannitol (negative in TAN2), starch hydrolysis and coagulase (negative in TAN2) tests. The bacteria showed negative results for nitrate reduction, $M R$ (positive in TAN2), VP (positive in TAN1), Indole (positive in TAN2) tests. Base on the morphological and biochemical test results, TAN1, TAN2, and TAN3 bacteria isolates were identified to be Nesseria spp, Bacillus cereus, and Staphylococcus aureus respectively.

The growth rate of the TAN1, TAN2 and TAN3 Isolates were shown in figure 2. Generally, the optical density increase with the increase in time (day) and decrease as time goes on. The highest optical density was shown by bacillus cereus in TAN2 while the lowest was shown by Staphylococcus aureus in TAN3.

The initial growth phase of TAN1 Isolate bacteria occurred within 2-day of incubation as the growth rate increases up to the 6th-day incubation when the maximum growth was observed. Beyond the 6th day, the growth of the bacteria declined (which might be due to a shortage of nutrients in the effluents) until it reached its death phase (which might be due to the unavailability of nutrients in the effluents).

A similar trend of growth was also observed for TAN2 Isolate as the initial growth phase also occurred within 2-day of incubation but maximum growth rate observed on the 4th day of incubation. The stationary stage occurred between the 4th day and the 8th day. Beyond the 8th day, the growth of the bacteria declined (which might be due to a shortage of nutrients in the effluents) until it reached its death phase (which might be due to the unavailability of nutrients in the effluents).

The initial growth phase of TAN3 bacterial Isolate occurred within the 3-day incubation as the growth rate increases up to the 6th-day incubation when the maximum growth was observed. Beyond the 6th day, the growth of the bacteria declined (which might be due to a shortage of nutrients in the effluents) until it reached its death phase (which might be due to the unavailability of nutrients in the effluents).

Table 2: Morphological and Biochemical characteristics of bacterial isolates

\begin{tabular}{lllll} 
Bacterial Isolates & & TAN1 & TAN2 & TAN3 \\
\hline $\begin{array}{lllll}\text { Morphological } \\
\text { characteristics }\end{array}$ & Shape & Cocci & Rod & Cocci \\
& Spore & & & \\
& former & + & + & + \\
Gram & & & \\
Biochemical characteristics & reaction & - & + & + \\
& Citrate & + & + & + \\
& Catalase & + & + & + \\
& Coagulase & + & - & + \\
Starch & + & + & + \\
& Glucose & + & + & + \\
Oxidase & + & + & + \\
& Indo & - & + & - \\
Lactose & - & + & + \\
Manitol & + & - & + \\
Maltose & + & + & + \\
MR & - & + & - \\
VP & + & - & - \\
& Nitrate & - & - & - \\
Reduction & - Neisseria & Bacillus & Staphylococcus \\
& Bacterial & cereus & aureus \\
& name & spp & cas
\end{tabular}

+ = Positive; - = Negative; MR=Methyl Red; VP= Voges-Proskauer 


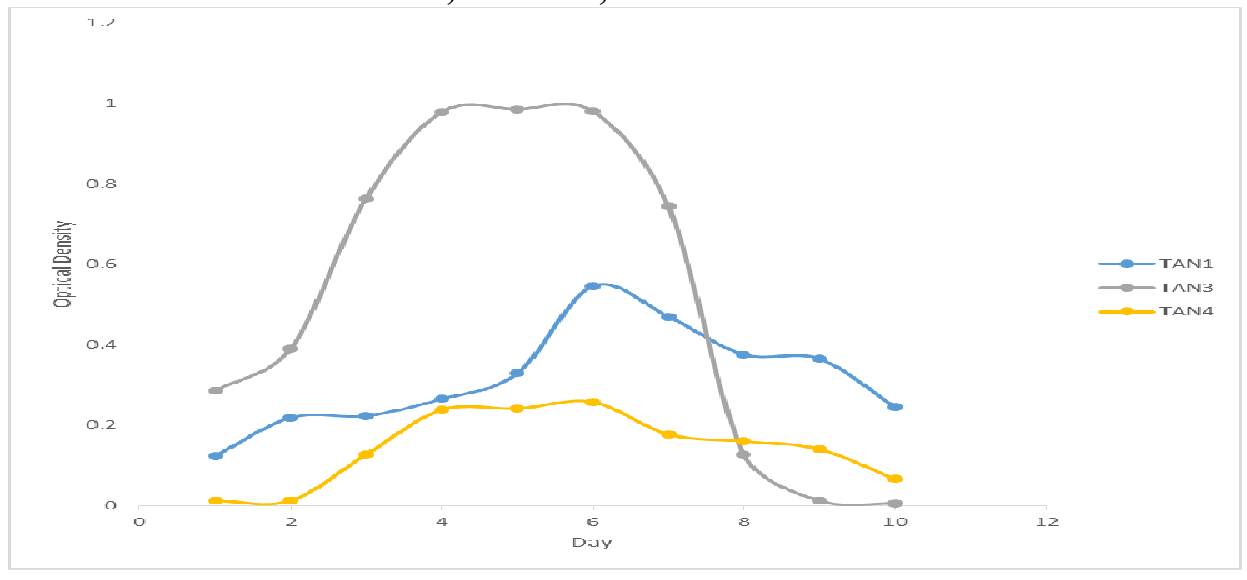

Fig. 2 Growth rates of the isolates in the effluents from the Tannery Industries

\section{Physico-chemical Parameters in the Industrial Effluents after the biodegradation.}

Table 3 shows the mean results of the physicochemical parameter before and after bioremediation using the different masses $(5 \mathrm{~g}$, $10 \mathrm{~g}, 15 \mathrm{~g}, 20 \mathrm{~g}$, and $25 \mathrm{~g}$ ) of the respective immobilized bacteria. Also, Table 4 shows the mean results of correlation coefficient ( $r$ ) between different masses of bacteria and physicochemical parameters.

The mean values $(\mathrm{mg} / \mathrm{l})$ of the SS after the bioremediation varies between $243 \pm 45$ and $898 \pm 672$. The mean concentration $(\mathrm{mg} / \mathrm{l})$ of SS remediated by the different masses $(5 \mathrm{~g}, 10 \mathrm{~g}$, $15 \mathrm{~g}, 20 \mathrm{~g}$, and $25 \mathrm{~g}$ ) of the bacteria varies. The SS in the samples fluctuates up and down after the bioremediation process when compared with the SS of the raw samples before the bioremediation. The increase in the levels of the SS might be due to the aggregation of the TDS which are large enough to result into SS. The increase in the levels of the SS might be also due to the influence of the nutrients which was added into the effluents in order to make the microorganisms more active and viable for fast degradation of organic contaminants in the effluent. The relative potential or efficiency of the different masses of the bacteria in remediating SS in TAN1 samples was in the order $25 \mathrm{~g}>20 \mathrm{~g}>15 \mathrm{~g}>10 \mathrm{~g}>5 \mathrm{~g}$. For TAN2 and TAN3 samples, the order was $25 \mathrm{~g}>20 \mathrm{~g}>15$ $\mathrm{g}>10 \mathrm{~g}>5 \mathrm{~g}$. These might be due to the variations in the surface areas of the different masses of the immobilized bacteria. Statistical analysis shows that there is no significant difference $(p<0.05)$ between the mean values of SS among the masses in the respective industries. Positive and significant correlations exist between the masses of bacteria and Suspended Solid (SS). This showed that there is general increase in the levels of the SS as the masses of the immobilized bacteria increases. TAN3 (90\%) and TAN1 (80\%) showed a very high correlation with the masses of the bacteria while TAN2 (61\%) showed a very low correlation.

The mean values $(\mathrm{mg} / \mathrm{l})$ of the TDS after the bioremediation varies between $46 \pm 11$ and $83 \pm 78$. The mean concentration $(\mathrm{mg} / \mathrm{l})$ of TDS remediated by the different masses $(5 \mathrm{~g}, 10 \mathrm{~g}$, $15 \mathrm{~g}, 20 \mathrm{~g}$, and $25 \mathrm{~g}$ ) of the bacteria varies. There is a reduction in all the TDS of all the samples after the bioremediation process compared with the TDS of the raw samples before the bioremediation. The relative potential or efficiency of the different masses of the bacteria in remediating TDS in TAN1 and TAN3 samples was in the order $5 \mathrm{~g}>10 \mathrm{~g}>15 \mathrm{~g}>20$ $\mathrm{g}>25 \mathrm{~g}$. For TAN2 samples, the order was 20 $g>10 \quad g>25 \quad g>15 \quad g>5 \quad g$. Statistical analysis shows that there is no significant difference $(p<0.05)$ between the mean values of TDS among the masses in the respective industries. These might be due to the variations in the surface areas of the different masses of the immobilized bacteria. Positive and significant correlations exist between the masses of bacteria and TDS with the exception in TAN2 (negative and insignificant correlation). The positive correlations showed that there is general increase in the levels of the TDS as the masses of the immobilized bacteria increases. TAN1 $(96 \%)$ showed a very high correlation with the masses of the bacteria while TAN2 (47\%) showed a very low correlation.

The mean values $(\mathrm{mg} / \mathrm{l})$ of the BOD after the bioremediation varies between $1.56 \pm 0.20 \mathrm{mg} / \mathrm{l}$ and $6.92 \pm 5.49 \mathrm{mg} / \mathrm{l}$. The mean concentration $(\mathrm{mg} / \mathrm{l})$ of BOD remediated by the different masses $(5 \mathrm{~g}, 10 \mathrm{~g}, 15 \mathrm{~g}, 20 \mathrm{~g}$, and $25 \mathrm{~g}$ ) of the bacteria varies. There is a reduction in all the BOD of all the samples after the bioremediation process compared with the $\mathrm{BOD}$ of the raw 
BAJOPAS Volume 13 Number 2, December, 2020 samples before the bioremediation. The relative potential or efficiency of the different masses of the bacteria in remediating BOD in TAN1, TAN2 and TAN3 samples were in the order $25 \mathrm{~g}>20$ $\mathrm{g}>15 \mathrm{~g}>10 \mathrm{~g}>5 \mathrm{~g}, 25 \mathrm{~g}>15 \mathrm{~g}>5 \mathrm{~g}>10 \mathrm{~g}>20 \mathrm{~g}$ and $20 \mathrm{~g}>10 \mathrm{~g}>25 \mathrm{~g}>15 \mathrm{~g}>5 \mathrm{~g}$ respectively. Statistical analysis shows that there is significant difference $(p<0.05)$ between the mean values of BOD among the masses in the respective industries. These might be due to the variations in the surface areas of the different masses of the immobilized bacteria. Negative and significant correlations exist between the masses of bacteria and BOD. This showed that there is general decrease in the levels of the BOD as the masses of the immobilized bacteria increases. TAN1 (94\%) showed a very high correlation with the masses of the bacteria while TAN2 (4\%) showed a very low correlation.

The mean values $(\mathrm{mg} / \mathrm{l})$ of the COD after the bioremediation varies between $250 \pm 154$ and $3134 \pm 1595$. The mean concentration $(\mathrm{mg} / \mathrm{l})$ of COD remediated by the different masses $(5 \mathrm{~g}$, $10 \mathrm{~g}, 15 \mathrm{~g} 20 \mathrm{~g}$, and $25 \mathrm{~g}$ ) of the bacteria varies. There is a reduction in all the COD of all the samples after the bioremediation process compared with the COD of the raw samples before the bioremediation. The relative potential or efficiency of the different masses of the bacteria in remediating COD in TAN1, TAN2 and TAN3 samples were in the order $25 \mathrm{~g}>20 \mathrm{~g}>15$ $\mathrm{g}>5 \mathrm{~g}>10 \mathrm{~g}, 25 \mathrm{~g}>20 \mathrm{~g}>15 \mathrm{~g}>10 \mathrm{~g}>5 \mathrm{~g}$ and 10 g>5 g>25 g>15 g>20 g respectively. Statistical analysis shows that there were significant difference $(p<0.05)$ between the mean values of COD among the masses in the respective industries except for effluents treated with $25 \mathrm{~g}$. These might be due to the variations in the surface areas of the different masses of the immobilized bacteria. Negative and insignificant correlations exist between the masses of bacteria and COD with the exception in TAN3 (positive and significant correlation). The negative correlations showed that there is general decrease in the levels of the COD as the masses of the immobilized bacteria increases. TAN2 (100\%) showed a very high correlation with the masses of the bacteria while TAN3 (36\%) showed a very low correlation.

Generally, there was an overall decrease in the concentration of these physicochemical parameters after the bioremediation using the different masses of the bacterial isolates. These might be due to the variations in the surface areas of the different masses of the immobilized bacteria. This is in line with the work of Jimoh et al. (2018) and Baba et al. (2020).

Table 3: Mean Values $(\mathrm{mg} / \mathrm{l}) \pm$ S.D of Physicochemical parameters in effluents from the Tannery Industries before and after Treatment of the effluents $(250 \mathrm{ml})$ with the different masses $(5 \mathrm{~g}, 10 \mathrm{~g}$, $15 \mathrm{~g}, 20 \mathrm{~g}$, and $25 \mathrm{~g}$ ) of the bacteria.

\begin{tabular}{llllllll}
\hline $\mathrm{P}$ & IND & Before & \multicolumn{5}{c}{ After } \\
\cline { 4 - 7 } & & & $5 \mathrm{~g}$ & $10 \mathrm{~g}$ & $15 \mathrm{~g}$ & $20 \mathrm{~g}$ & $25 \mathrm{~g}$ \\
\hline \multirow{2}{*}{ COD } & TAN1 & $2372 \pm 938$ & $1708 \mathrm{a} \pm 861$ & $2045 \mathrm{a} \pm 1205$ & $845 \mathrm{a} \pm 369$ & $300 \mathrm{a} \pm 167$ & $250 \mathrm{a} \pm 154$ \\
& TAN2 & $1406 \pm 208$ & $1195 \mathrm{a} \pm 208$ & $1125 \mathrm{a} \pm 384$ & $1055 \mathrm{a} \pm 317$ & $956 \mathrm{a} \pm 310$ & $870 \mathrm{ab} \pm 240$ \\
& TAN3 & $3532 \pm 1373$ & $2374 \mathrm{a} \pm 1344$ & $1976 \mathrm{a} \pm 1405$ & $2757 \mathrm{a} \pm 1266$ & $3134 \mathrm{a} \pm 1595$ & $2614 \mathrm{~b} \pm 1105$ \\
BOD & TAN1 & $13.85 \pm 6.42$ & $6.92 \mathrm{a} \pm 5.49$ & $6.42 \mathrm{a} \pm 5.07$ & $5.72 \mathrm{a} \pm 5.35$ & $4.62 \mathrm{a} \pm 4.37$ & $2.82 \mathrm{ab} \pm 1.26$ \\
& TAN2 & $19.46 \pm 0.50$ & $1.75 \mathrm{~b} \pm 0.22$ & $1.73 \mathrm{~b} \pm 0.18$ & $1.58 \mathrm{a} \pm 0.16$ & $1.91 \mathrm{a} \pm 0.22$ & $1.56 \mathrm{~b} \pm 0.20$ \\
& TAN3 & $17.13 \pm 3.14$ & $4.24 \mathrm{ab} \pm 0.77$ & $3.29 \mathrm{ab} \pm 0.37$ & $4.11 \mathrm{a} \pm 0.07$ & $3.23 \mathrm{a} \pm 0.91$ & $3.33 \mathrm{a} \pm 1.28$ \\
SS & TAN1 & $374 \pm 124$ & $243 \mathrm{a} \pm 45$ & $471 \mathrm{a} \pm 226$ & $475 \mathrm{a} \pm 182$ & $492 \mathrm{a} \pm 128$ & $611 \mathrm{a} \pm 217$ \\
& TAN2 & $358 \pm 335$ & $460 \mathrm{a} \pm 400$ & $543 \mathrm{a} \pm 414$ & $544 \mathrm{a} \pm 402$ & $551 \mathrm{a} \pm 414$ & $554 \mathrm{a} \pm 405$ \\
& TAN3 & $780 \pm 739$ & $586 \mathrm{a} \pm 594$ & $758 \mathrm{a} \pm 656$ & $787 \mathrm{a} \pm 676$ & $861 \mathrm{a} \pm 635$ & $898 \mathrm{a} \pm 672$ \\
TDS & TAN1 & $3941 \pm 3703$ & $51 \mathrm{a} \pm 10$ & $53 \mathrm{a} \pm 10$ & $55 \mathrm{a} \pm 15$ & $61 \mathrm{a} \pm 20$ & $63 \mathrm{a} \pm 26$ \\
& TAN2 & $3300 \pm 1714$ & $83 \mathrm{a} \pm 78$ & $47 \mathrm{a} \pm 20$ & $48 \mathrm{a} \pm 22$ & $47 \mathrm{a} \pm 17$ & $48 \mathrm{a} \pm 17$ \\
& TAN3 & $2653 \pm 1240$ & $46 \mathrm{a} \pm 11$ & $55 \mathrm{a} \pm 24$ & $55 \mathrm{a} \pm 25$ & $58 \mathrm{a} \pm 23$ & $61 \mathrm{a} \pm 28$ \\
\hline
\end{tabular}

Replicate $=6$ (months)

Within the rows, for the same parameter, means with different alphabets are statistically different $(p<0.05)$.

$\mathrm{P}=$ parameter, IND = Industries 
BAJOPAS Volume 13 Number 2, December, 2020

Table 4: Correlation coefficient $(r)$ between different masses of the bacteria and the physicochemical parameters.

\begin{tabular}{llll}
\hline Industries & Parameter & Correlation coefficient $(r)$ & $\begin{array}{l}\text { Percent dependence (rxrx100) } \\
(\%)\end{array}$ \\
\hline TAN1 & COD & -0.9 & 82 \\
& BOD & -0.97 & 94 \\
& SS & $0.90^{*}$ & 80 \\
TAN2 & TDS & $0.98^{*}$ & 96 \\
& COD & -1 & 100 \\
& BOD & -0.21 & 4 \\
& SS & $0.78^{*}$ & 61 \\
& TDS & -0.69 & 47 \\
& COD & $0.60^{*}$ & 36 \\
& BOD & -0.6 & 37 \\
& SS & $0.95^{*}$ & 90 \\
& TDS & $0.94^{*}$ & 89 \\
\hline
\end{tabular}

The correlation coefficient $(r)$ with * is statistically significant $(p<0.05)$.

Percentage reduction of the Parameters

Table 5 shows the percentage reduction of Parameters in industrial samples before and after the treatment of the effluents $(250 \mathrm{ml})$ with the different masses $(5 \mathrm{~g}, 10 \mathrm{~g}, 15 \mathrm{~g}, 20 \mathrm{~g}$, and $25 \mathrm{~g}$ ) of the Immobilized Bacteria.

In TAN1 samples, the percentage reduction (\%) of COD ranged (14-89); BOD (50-80); SS (-32$35)$ and TDS (98-99). In TAN2 samples, the percentage decrease $(\%)$ of COD ranged (15$38) ;$ BOD (90-92); SS [-28-(-55)] and TDS (9798). In TAN3 samples, the percentage decrease (\%) of COD ranged (11-44); BOD (76-81); SS (15-25) and TDS (98). The percentage increase in the levels COD, BOD and TDS might be due to the increase in the surface area of the different masses of the immobilized bacteria. However, the percentage decrease in the levels of the SS might be due to the aggregation of the TDS which are large enough to result into SS. The percentage decrease in the levels of the SS might be also due to the influence of the nutrients which was added into the effluents in order to make the microorganisms more active and viable for fast degradation of organic contaminants in the effluent. This is in line with the work of Jimoh et al. (2018) in which the concentration of the SS increase after the bioremediation of effluents.

Sreemoyee and Priti (2013) assessed and reduced several Physico-chemical parameters of dairy wastewater using Niesseria $s p$. and concluded that the species are well known to degrade organic compounds. This is in agreement with the current study in which the immobilized Niesseria $s p$ degrade the organic contaminants as indicated by the BOD, COD and TDS.

Jimoh et al. (2018) observed that TSS of the effluents was increased after treatment with immobilized bacteria and concluded that it might be due to the biostimulation method adopted for the research.

The optimum $\mathrm{pH}$ Biosorption of Chromium by Bacillus spp and Staphylococcus spp. from tannery effluent was investigated by Mythili and Karthikeyan (2011). The maximum adsorption of Chromium $(86.4 \mathrm{mg} / \mathrm{L})$ was showed by Bacillus spp and Staphylococcus spp showed $70.6 \mathrm{mg} / \mathrm{L}$ at an initial concentration of $100 \mathrm{mg} / \mathrm{L}$. In the present study, immobilised Bacillus spp and Staphylococcus spp. from the tannery industrial effluents reduced the levels of the organic pollutants with high potential as indicated by the percentage reduction of BOD, COD and TDS.

Enzymes often can work in multiple environments especially if they are immobilized. This makes the microorganisms' enzymes even more resistant to harsh environments and enables the enzymes to be recovered and recycled after they are no longer needed (Gianfreda and Rao 2004). Ramesh and Singh (1993) reported that the immobilized bacteria having more efficiency to remove the suspended particles than free cells. Using the immobilized cell is preferable due to its capability for using several times with the same efficiency, which makes it more economical. Similar work was done by Sikander et al. (2007) showing the higher reduction with permeabilized cells of Ochrobactrum intermedium strain SDCr-5. 
BAJOPAS Volume 13 Number 2, December, 2020

The results revealed the isolation and identification of isolates with the potential for the reduction of $\mathrm{Cr}$ (VI) to $\mathrm{Cr}$ (III). Results indicated that immobilized $B$. cereus could be efficiently used for the reduction of $\mathrm{Cr}$ (VI).

Table 5: Percentage reduction of the tested Parameters from the tannery industrial samples of the Immobilized Bacteria.

\begin{tabular}{lllllll}
\hline \multirow{2}{*}{ Industries } & & \multicolumn{5}{c}{ Percentage Reduction $(\%)$} \\
\cline { 3 - 7 } & & $5 \mathrm{~g}$ & $10 \mathrm{~g}$ & $15 \mathrm{~g}$ & $20 \mathrm{~g}$ & $25 \mathrm{~g}$ \\
\hline TAN1 & COD & 28 & 14 & 64 & 87 & 89 \\
& BOD & 50 & 54 & 59 & 67 & 80 \\
& SS & 35 & -26 & -27 & -32 & -63 \\
& TDS & 99 & 99 & 99 & 98 & 98 \\
TAN2 & COD & 15 & 20 & 25 & 32 & 38 \\
& BOD & 91 & 91 & 92 & 90 & 92 \\
& SS & -28 & -52 & -52 & -54 & -55 \\
& TDS & 97 & 99 & 99 & 99 & 99 \\
& COD & 33 & 44 & 22 & 11 & 26 \\
& BOD & 75 & 81 & 76 & 81 & 81 \\
& SS & 25 & 3 & -1 & -10 & -15 \\
& TDS & 98 & 98 & 98 & 98 & 98 \\
\hline
\end{tabular}

Percentage Reduction $=(B-A) / B \times 100 \%$

$A=$ Concentration of the parameter after treatment

$\mathrm{B}=$ Concentration of the parameter before treatment

$+=$ percentage decrease

- = percentage increase

In general, immobilization makes the enzyme more resistant to temperature, $\mathrm{pH}$, and substrate concentration swings giving it a longer lifetime and higher productivity per active unit (Gianfreda and Rao, 2004; FuIlbrook, 1996; Russell et al, 2003; Kandelbauer et al., 2004). Immobilized cells have been used and studied extensively for the production of useful chemicals (Ohtake and Silver, 1994), the treatment of wastewaters (Chen et al., 2003; Wang et al., 2010). Although many workers described microbial degradation of tannery effluent, limited literature is available on the bioremediation of tannery effluent using immobilized bacterial cells in the Kano Industrial Estates.

\section{CONCLUSION}

The samples contained variable levels of the physicochemical parameters. The results of the Analysis of variance revealed that, no statistical difference $(p<0.05)$ was observed for the temperature, $\mathrm{pH}, \mathrm{SS}, \mathrm{TDS}, \mathrm{BOD}$ and $\mathrm{COD}$ among the three tannery industries before the treatment. The levels of some of the parameters
(SS, TDS and COD) observed in the samples were found above the recommended limits of WHO and NESREA, which called for the treatment of the effluents before discharge into the environment. Base on the morphological and biochemical test results, TAN1, TAN2, and TAN3 bacterial isolates were identified to be Neisseria spp, Bacillus cereus, and Staphylococcus aureus respectively. The results of Post-treatment analysis showed that there is overall decrease in the levels of the parameters determined when compared with that of the pre-treatment. The overall percentage reduction of the immobilised bacteria in the treatment of the respective effluents was in the order TAN2 (72\%)>TAN1 $(70 \%)>$ TAN3 $(62 \%)$. Hence, the immobilized bacteria are having higher biodegradation potential for the treatment of the tannery effluents.

\section{Acknowledgments}

The authors wish to acknowledge the University of Maiduguri for the financial support. The authors are grateful to the Kano State Ministry of Environment for their support in obtaining the effluent samples. 


\section{REFERENCES}

Ajao, A. T., Adebayo, G. B., and Yakubu, S. E. (2011). Bioremediation of textile industrial effluent using mixed culture of Pseudomonas aeruginosa and Bacillus subtilis immobilized on agar-agar in a bioreactor. J. Microbiol. Biotech. Res, 1(3), 50-56.

Akan, J. C., Moses, E. A., Ogugbuaja, V. O., and Abah, J. (2007). Assessment of tannery industrial effluents from Kano metropolis, Kano State, Nigeria. Journal of Applied Sciences, 7(19), 2788-2793.

Akan, J. C., Ogugbuaja, V. O., Abdulrahman, F. I., and Ayodele, J. T. (2009). Pollutant levels in effluent samples from tanneries and textiles of Kano industrial areas, Nigeria. Global journal of pure and applied sciences, 15(3-4).

APHA (1989). Standard methods for Examination of Will bete and Will betewater.15 $5^{\text {th }}$ edition. Brydpass Springfield Will behington DC. pp. 164-176

APHA (1992). Standard Methods for the Examination of Water and Wastewater. Health, 69, 1116-9.

Baba, A., Garba, S. T., and Bello, H. S. (2020). Bioremediation Potential of Immobilized corynebacterium kutsceri in the Treatment of Tannery Industrial Effluent from Challawa Industrial Estate, Kano State, Nigeria. Journal of the Turkish Chemical Society Section A: Chemistry, $7(2), 335-350$.

Beem, E. I. V. (1994). reduction of solvent VOC emission. J. Oil Col. Chem. Ass, 77, 158.

Bouwer, E. J., and Zehnder, A. J. (1993). Bioremediation of organic compoundsputting microbial metabolism to work. Trends in biotechnology, 11(8), 360367.

Chen, K. C., Wu, J. Y., Liou, D. J., and Hwang, S. C. J. (2003). Decolorization of the textile dyes by newly isolated bacterial strains. Journal of Biotechnology, 101(1), 57-68.

Dan'Azumi, S., and Bichi, M. H. (2010). INDUSTRIAL POLLUTION AND HEAVY METALS PROFILE OF CHALLAWA RIVER IN KANO, NIGERIA. Journal of Applied Sciences in Environmental Sanitation, $5(1)$.

DWAF. (1992). Analytical Methods Manual, TR 151. Department of Water Affairs and Forestry, Pretoria.

El-Bestawy, E. (2013). Biological treatment of leather-tanning industrial wastewater using free living bacteria.
Elsheikh, M. A. S. (2009). Tannery wastewater pre-treatment. Water Science and Technology, 60(2), 433-440.

FuIlbrook, P. D. (1996). "Kinetics." Industrial enzymology: The application of enzymes in Industry. 2nd Ed. T. Godfrey and J Reichelt. eds.. Nature. New York.

Gianfreda, L., and Rao, M. A. (2004). Potential of extra cellular enzymes in remediation of polluted soils: a review. Enzyme and microbial technology, 35(4), 339354.

Hugo Springer. (1994). John Arthur Wilson Memorial Lecture "Treatment of Industrial Wastes of the Leather Industry - is it still a Major Problem". JALCA, 89, 153-185

Jimoh, A. A., Ganiyu, B. A., Baba, D., and Baba, A. (2018) Bioremediation Process of Effluent from Detergent and Food Industries in Jos, Nigeria: Kinetics and Thermodynamics. International Journal of Engineering Science Invention (IJESI), 762-73

Kandelbauer, A., Maute, O., Kessler, R. W., Erlacher, A., and Gübitz, G. M. (2004). Study of dye decolorization in an immobilized laccase enzyme-reactor using online spectroscopy. Biotechnology and bioengineering, 87(4), 552-563.

Kongjao, S., Damronglerd, S., and Hunsom, M. (2008). Simultaneous removal of organic and inorganic Pollutants in tannery wastewater using electrocoagulation technique. Korean Journal of chemical engineering, 25(4), 703.

Maheshwari, U. M., Aruna, S., Gomathi, M., and AbdulJaffar, A. H. (2017). Bioremediation by Free and Immobilized Bacteria Isolated from Tannery Effluent. International Journal of Research in Applied, Natural and Social Sciences. 5(7), 75-90

Margesin, R., and Schinner, F. (2001). Bioremediation (natural attenuation and biostimulation) of diesel-oilcontaminated soil in an alpine glacier skiing area. Applied and environmental microbiology, 677), 3127-3133.

Mohammed, A., Sekar, P., and George, J. (2011). Efficacy of microbes in bioremediation of tannery effluent. Inter. J. Curr. Res, 3(4), 324-326.

Mohammed, S. S. D., Orukotan, A. A., and Abdullahi, H. (2017). Physicochemical and Bacteriological Assessment of Tannery Effluent from Samaru-Zaria, 
BAJOPAS Volume 13 Number 2, December, 2020 Kaduna State, Nigeria. Journal of Applied

Sciences and Environmental Management, 21(4), 734-740.

Munz, G., De Angelis, D., Gori, R., Mori, G., Casarci, M., and Lubello, C. (2009). The role of tannins in conventional and membrane treatment of tannery wastewater. Journal of hazardous materials, 164(2-3), 733-739

Mythili, K., and Karthikeyan, B. (2011). Bioremediation of $\mathrm{Cr}$ (VI) from tannery effluent using Bacillus spp and Staphylococcus spp. International Multidisciplinary Research Journal, 1(6).

NESREA (2009). National Environmental Standards for Effluent Limitations and Regulation. 1233-1236

Noorjahan, C. M. (2014). Physicochemical characteristics, identification of bacteria and biodegradation of industrial effluent. Journal of bioremediation and Biodegradation, 5(3).

Ohtake, H. I., and Silver, A. O. (1994). Bacterial reduction of toxic chromate. Biological degradation and bioremediation of toxic chemicals, 403-415.

Omoleke, I. I. (2004). Management of environmental pollution in Ibadan, an African city: the challenges of health hazard facing government and the people. Journal of Human Ecology, 15(4), 265-275.

Rajor, A., Reddy, A.S., and Singh, B. (2004). Determination of BOD kinetic Parameters and evaluation of alternate methods, M.Sc. Thesis, Department of biotechnology \& environmental Science, Thapar Institute of Engineering and Technology, Patiala

Ramasami, T., Rajamani, S., and Rao, J. R. (1994, March). Pollution control in leather industry: Emerging technological options. In International symposium on surface and colloidal science and its relevance to soil pollution, madras.

Ramesh, J. V. S., and Singh, S. P. (1993). Yearly variation in certain physicochemical parameters of pond at eastern Doon Valley. Uttar Pradesh J. Zoo, 12 (1), 7577.

Ranen, S., and Sharadinadra, C. (2009). Biotechnology applications to environmental remediation in resource exploitation. Current science, 97, 6-25
Russell, A. J., Berberich, J. A., Drevon, G. F., and Koepsel, R. R. (2003). Biomaterials for mediation of

chemical and biological warfare agents. Annual review of biomedical engineering, 5(1), 1-27.

Saravanan, P., and Saravanan, A. (1999). Decolourization of tannery effluent by Flavobacterium sp. EK 1. Indian Journal of Environmental Protection, 19, 19-24.

Sikander, S., and Shahida, H. (2007). Reduction of toxic hexavalent chromium by Ochrobactrum intermedium strain SDCr5 stimulated by heavy metals. Bioresource Technol, 98, 340-344.

Singh, N., Sharma, B. K., and Bohra, P. C. (2000). Impact assessment of industrial effluent of arid soils by using satellite imageries. Journal of the Indian Society of Remote Sensing, 28(2-3), 79.

Sreemoyee, C., and Priti, P. (2013). Assessment of physico-chemical parameters of dairy waste water and isolation and characterization of bacterial strains in terms of cod reduction. Int J Sci, 2(3), 395-400.

Verheijen, L. A. H. M., Wiersema, D., Pol, L. H., and De Wit, J. (1996). Management of wastes from animal product processing. Livestock and environment, Finding a balance. International Agriculture Center, Wageningen, The Netherlands.

Wang, F., Yao, J., Si, Y., Chen, H., Russel, M., Chen, K., and Bramanti, E. (2010). Short-time effect of heavy metals upon microbial community activity. Journal of Hazardous Materials, 173(13), 510-516.

WHO (World Health Organization). (2006). Air quality guidelines: global update 2005: particulate matter, ozone, nitrogen dioxide, and sulfur dioxide. World Health Organization.

World Bank. (1995). Nigeria's strategic options for redressing industrial pollution. World Bank, industry and energy division. 1st edition, West Central Africa Department; Annexes: 1995; pp 60-62.

Zahoor, A., and Abdul, R. (2009). Enumeration of Coliforms. Journal of Environmental Sciences. 21, 814-820 


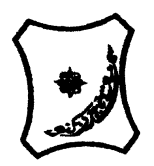

Bayero Journal of Pure and Applied Sciences, 13(2): 1 - 12

Received: November, 2020

Accepted: December, 2020

ISSN $2006-6996$

\title{
BIODEGRADATION POTENTIAL OF IMMOBILIZED BACTERIA IN THE TREATMENT OF TANNERY INDUSTRIAL EFFLUENTS FROM INDUSTRIAL ESTATES IN KANO STATE, NIGERIA
}

\author{
Abdullateef, B., ${ }^{1 *}$ Shuaibu, T. G., ${ }^{1}$ Babagana, K., ${ }^{1}$ Suleman, H. B. ${ }^{2}$ and Dauda, B. ${ }^{3}$ \\ ${ }^{1}$ Department of Pure and Applied Chemistry, Faculty of Science, University of Maiduguri, Borno State, \\ Nigeria \\ ${ }^{2}$ Department of Microbiology, Faculty of Science, University of Maiduguri, Borno State, Nigeria \\ ${ }^{3}$ Department of Chemical Engineering, Faculty of Engineering, University of Maiduguri, Borno State, \\ Nigeria \\ *Corresponding author: babslega@gmail.com; abelega2007@yahoo.com; +2348061309753
}

\section{ABSTRACT}

Industrial Effluents Samples from Gashash Tanneries (TAN1) in Bompai Industrial estate, Larabee Tannery Industry (TAN2) in Sharada Industrial estate and Z Tannery Industries (TAN3) in Challawa Industrial estate, Kano State, Nigeria were collected over a period of six months (August 2017 to January 2018) for assessing the biodegradation potentials of bacteria in the treatment of organic pollutants within the effluents. Bacteria were isolated from the effluents and immobilized on agar-agar. Different masses (5 g, $10 \mathrm{gr}, 15$ $\mathrm{g}, 20 \mathrm{~g}$, and $25 \mathrm{~g}$ ) of the bacteria were used in the treatment of $250 \mathrm{ml}$ of the effluents for ten days in a shaker incubator (Gallenkamp-OC-4364-L) at the temperature $30{ }^{\circ} \mathrm{C}$ and speed of $60 \mathrm{rpm}$. Pre-treatment analysis of the effluents for Temperature, pH, Biochemical Oxygen Demand (BOD), Chemical Oxygen Demand (COD), Suspended Solid (SS) and Total Dissolved Solids (TDS) gives the following results; temperature $\left({ }^{\circ} \mathrm{C}\right.$ )

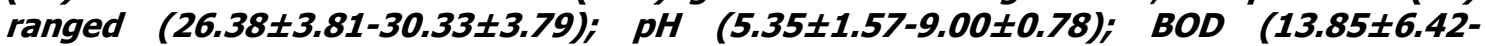
$38.75 \pm 16.20) ;$ COD (1406 $\pm 208-3532 \pm 1373) ;$ SS (208 $\pm 235-780 \pm 739)$ and TDS (266 $\pm 253-5276 \pm 2971)$. No statistical differences ( $p \leq 0.05)$ was observed for all the results among the different industries. The bacterial isolates were identified as Neisseria spp, Bacillus cereus, and Staphylococcus aureus, in TAN1, TAN2, and TAN3, respectively. After treatment of the effluent with the different masses of the isolated bacteria, the mean level of BOD was found to range as (0.55 $\pm 0.36-6.92 \pm 5.49) ; C O D$ (ND-3134 \pm 1595$)$;

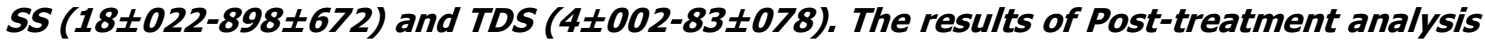
showed that there is overall decrease in the levels of the parameters determined when compared with that of the pre-treatment. The overall percentage reduction of the immobilised bacteria in the treatment of the respective effluents was in the order TAN2 (72\%)>TAN1 (70\%)>TAN3 (62\%). Hence, the immobilized bacteria are having higher biodegradation potential for the treatment of the tannery effluents.

Keywords: Biodegradation, bacteria, effluent, immobilization, tannery.

\section{INTRODUCTION}

Tannery industrial wastewater is a serious consequence of the pollution point of view for streams, freshwater, and land used for agriculture. The lack of awareness in the modern industrial practice has resulted in the discharge of tannery effluents which exhibit very high value of chromium ( $\mathrm{Cr}$ ), Sulfide, and chloride, Total Dissolved Solid (TDS), Total Suspended Solid (TSS), Biochemical Oxygen Demand (BOD) and Chemical Oxygen Demand (COD) in the water stream or land (Mohammed et al., 2001). Tanning is the process, which One ton of skin generally leads to the production of 20 to $80 \mathrm{~m}^{3}$ of turbid and foul-smelling converts the protein of the rawhide or skin into a stable material, which will not putrefy and is suitable for a wide variety of end applications (Elsheikh, 2009). The highly polluting chromium is the most commonly used tanning material producing leather that is more flexible and pliable than vegetable-tanned leather and does not discolor or lose shape in water as drastically as vegetable-tan (Elsheikh, 2009). Tannery effluent is among the most hazardous industrial pollutants due to its huge organic and inorganic load, which is highly toxic to human life and the environment (Kongjao et al., 2008). wastewater including chromium (100-400 mg/l), sulfide $(200-800 \mathrm{mg} / \mathrm{l})$, high levels of fat and 
BAJOPAS Volume 13 Number 2, December, 2020 other solid wastes, and notable pathogen contamination as well as pesticides added for skin conservation during transport (Elsheikh, 2009). There are more than 6000 tanneries in Nigeria with an annual processing capacity of 700,000 tons of hides and skins (Omoleke, 2004; Singh et al., 2008). It was reported that the total amount of waste produced per animal slaughtered is approximately $35 \%$ of its weight (World Bank, 1995). Also, for every $1000 \mathrm{~kg}$ of carcass weight, a slaughtered beef produces 5.5 $\mathrm{kg}$ of manure (excluding rumen contents or stockyard manure) and $100 \mathrm{~kg}$ of paunch manure (undigested food) (Verheijen et al., 1996). Tanneries generate wastewater in the range of 30-35 $\mathrm{L} \mathrm{kg}^{-1}$ skin/hide processed with variable $\mathrm{pH}$, Biological Oxygen Demand (BOD), Chemical Oxygen Demand (COD), high concentrations of suspended solids (SS), and tannins as well as chromium (Zahoor and Abdul, 2009).

Being heterogeneous and composed of a wide variety of compounds, it is very difficult to select a unique direct method for estimating the biodegradability of organic contents and biokinetic parameters for a wastewater sample (Rajor, 2004). For this purpose, some indirect estimation such as determination of biochemical oxygen demand (BOD) and chemical oxygen demand (COD) are applied as common laboratory investigations [9]. During retanning procedures, synthetic tannins (Syntan), oils and resins are added to form softer leather at varying doses (Munz et al., 2009). One of the refractory groups of chemicals in tannery effluents derives mainly from tannins (Ramasami et al., 2004). Syntans are characterized by complex chemical structures, because they are composed of an extended set of chemicals such as phenol-, naphthalene-, formaldehyde- and melamine-based syntans, and acrylic resins (Beem, 1994). Organic pollutants (proteic and lipidic components) are originated from skins (it is calculated that the raw skin has $30 \%$ loss of organic material during the working cycle) or they are introduced during processes (Hugo Springer, 1994).

Many conventional processes such as oxidation, chemical and biological processes were carried out to treat tanneries wastewater (Ebtesam et al, 2013). Biological processes have received more attention because of their costeffectiveness, lower sludge production and environmental friendliness (Noorjahan, 2014). Naturally occurring micro-organisms degrade the hazardous organic wastes including xenobiotic compounds, such as pesticides, polycyclic aromatic hydrocarbons (PAHs) and polychlorinated biphenyls (PCBs) in due course of time (Ranen and Sharadinadra, 2009). Bioremediation is based on the idea that all organisms remove substances from the environment to carry outgrowth and metabolism (Bouwer and Zehnder, 1993). Bacteria, protista and fungi are found to be very good at degrading complex molecules and incorporating the breakdown products into their metabolism (Bouwer and Zehnder, 1993). The resultant metabolic wastes that they produce are generally safe and somehow recycled into other organisms (Ranen and Sharadinadra, 2009). An acclimatized indigenous population of microorganisms capable of degradation of the compounds of interest must exist at the site for a successful bioremediation mode (Ranen and Sharadinadra, 2009). It has been observed that for a successful bioremediation mode, an acclimatized indigenous population of microorganisms capable of degradation of the compounds of interest must exist at the site under investigation (Ranen and Sharadinadra, 2009). Even though there are numerous physical and chemical methods employed in the disposal of wastes the advantage in using bacterium is that they play a key role in the reduction of COD, BOD, total protein, total tannin and total phenol (Saravanan and Saravanan, 1998)

Baba et al. (2020) studied the bioremediation potential of immobilized corynebacterium kutsceri in the Treatment of tannery industrial effluent from Challawa Industrial Estate, Kano State, Nigeria. The aim of the work is to study the reduction in the level of the contaminants through the process of bioremediation using the isolated bacteria. Immobilized bacteria can withstand various temperatures, $\mathrm{pH}$ and substrate concentrations; consequently, increasing the efficiency and the lifespan of the bacteria. Immobilized bacteria are widely applied in the treatment of wastewater and can be separated and recovered after the treatment with the same efficiency (Baba et al., 2020).

\section{MATERIALS AND METHODS \\ Study Area}

This study was carried out in Bompai, Sharada and Challawa industrial estates in Kano, Figure 1. Kano lies on Latitude $11^{\circ} 30^{\prime} \mathrm{N}$ and $8^{\circ} 30^{\prime} \mathrm{E}$ and Longitude $11^{\circ} 5^{\prime} \mathrm{N}$ and $8^{\circ} 5^{\prime} \mathrm{E}$ in Northern Nigeria. It is one of the developed industrial cities in Nigeria. Tannery activities are the dominating industries and this could be one of the reasons for her high population density (Dan'Azumi and Bichi, 2010). Many researchers have studied biodegradation of tannery effluent using microorganisms. However, limited literature is available on the biodegradation of tannery effluent in Kano industrial estates using 
BAJOPAS Volume 13 Number 2, December, 2020 immobilized bacterial cells. This research work focuses on the potential of the use of the indigenous immobilized bacterial isolates in the treatment of tannery effluents in the industrial estates.

\section{Sample Collection}

Effluents were collected from the Tannery Industries from Bompai, Challawa and Sharada Industrial Estates, Kano, Nigeria. The effluents were collected over a period of six months (August 2017 to January 2018). Samples collected in a sterile 4-liter plastic container with a unique identification number were preserved using an ice-box that was transported to the Microbiology Laboratory, Department of Microbiology, Bayero University of Kano for analysis

\section{Sample Preparation and Sample Analysis}

Immediately after the collection of the effluent, $\mathrm{pH}$, TSS, TDS, COD, BOD levels were determined before treatment (Pre-treatment determination) and ten days after treatment (Post-treatment determination) as described in
APHA (1989) standard methods. $\mathrm{pH}$ was determined using Ecotests $\mathrm{pH}$ meter and TDS was determined using AQUALYTIC TDS Salinometer. BOD was determined as described by the standard method (APHA, 1992). COD and SS were determined using DR/2010 HACH portable data logging spectrophotometer (DWAF, 1992)

\section{Identification and Biochemical} Characterization of the Bacterial Isolates

The bacteria were isolated from the effluents using Serial Dilution according to the method described by APHA (1989). The biochemical tests such as oxidase, catalase, coagulase, indole (from $1 \%$ tryptone broth), citrate (Simmons citrate agar), methyl red/VogesProskauer (MR/VP), nitrate reduction, Starch Hydrolysis, Glucose, Maltose, and Lactose tests were carried out on the bacterial isolates to identify the bacteria through the bacteria biochemical characteristics according to Ajao et al. (2011).

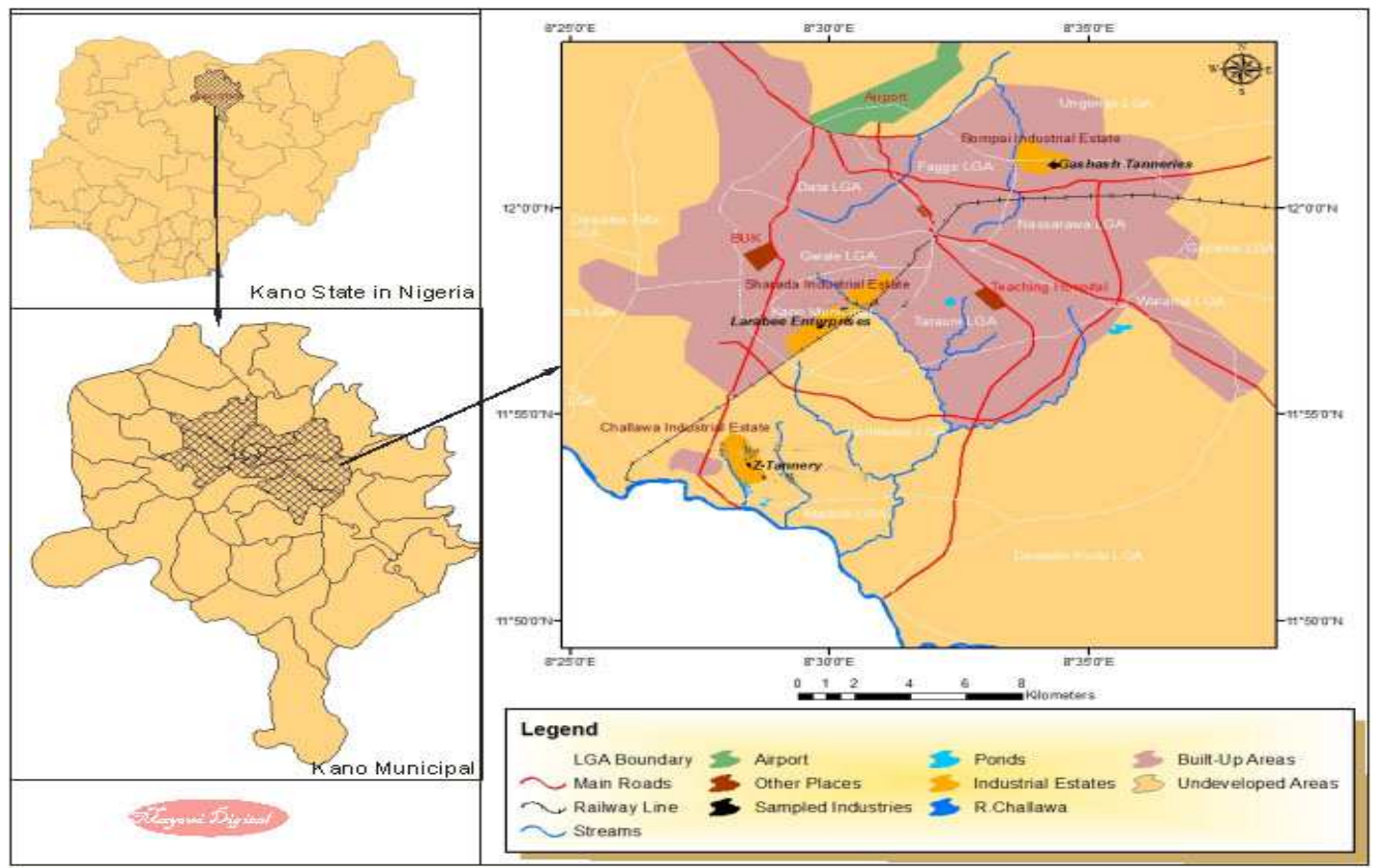

Fig. 1 Map showing the study areas

Source: Mayomi Digital Productions, GIS Laboratory, Department of Geography, UNIMAID (2017)

\section{Determination of Growth Rate of the Bacteria in Effluent Sample}

The bacteria growth rates were determined by transferring $2 \mathrm{~mL}$ of the bacterial isolates from the tannery effluent in broth medium into 100 $\mathrm{mL}$ sterile effluents in conical flasks and kept in an incubator (Giffrin cool) for 10 days. Control was also set up by incubating another $100 \mathrm{~mL}$ each of the sterile effluents without the bacteria. The optical density of the content was determined at the wavelength of $600 \mathrm{~nm}$ on a daily interval and recorded. 
BAJOPAS Volume 13 Number 2, December, 2020 Immobilization of Bacteria

Agar solution and inoculi were prepared separately. Fifty milliliters $(50 \mathrm{~mL})$ of nutrient broth each of the inoculi was prepared in a McCartney bottle and incubated for 24 hours. A solution of agar-agar was prepared by dissolving $10 \mathrm{~g}$ of the powder in distilled water and made up to $500 \mathrm{~mL}$ mark in an Erlenmeyer flask and was sterilized in an autoclave (280A) for 15 minutes and allowed to cool to $40-45^{\circ} \mathrm{C}$ (Ajao et al., 2011). Four milliliters ( $4 \mathrm{~mL})$ of the bacterial isolates in the nutrient broth was mixed with 36 $\mathrm{ml}$ of the prepared agar-agar media in petri-dish plates and then allowed to solidify. This was kept in the refrigerator for bioremediation.

\section{Bioremediation (Treatment) of the Effluents}

The solidified agar block (immobilized bacteria) was cut into cubes using a sterile knife; $0.1 \mathrm{~mL}$ phosphate buffer ( $\mathrm{pH} \mathrm{7.0)}$ was added and kept in the refrigerator for 1 hour for curing. The phosphate buffer was decanted after 1 hour and the cubes were washed with sterile distilled water 3-4 times before it was used (Ajao et al., 2011). Two liters (2 L) of the effluent was supplemented with the minimum basal medium in $\mathrm{g} / \mathrm{L}: \mathrm{NaCl}(0.8), \mathrm{MgSO}_{4} .7 \mathrm{H}_{2} \mathrm{O}(0.001), \mathrm{KH}_{2} \mathrm{PO}_{4}$ (2), $\mathrm{NaNO}_{3}$ (2), $\quad \mathrm{CaCl}_{2} .2 \mathrm{H}_{2} \mathrm{O} \quad(0.5)$ and $\mathrm{NaHPO}_{4} .12 \mathrm{H}_{2} \mathrm{O}(2)$ and sterilized in an autoclave at $121^{\circ} \mathrm{C}$ for 15 minutes (Margesin and Schinner, 2001). Two hundred and fifty milliliters $(250 \mathrm{~mL})$ of the effluents were transferred into different $250 \mathrm{ml}$ conical flasks. The content was covered with a cotton-wool ramped with foil paper to avoid contamination. Five grams $(5 \mathrm{~g})$ of the immobilized bacteria were quickly transferred into each of the effluents in the conical flasks in an inoculating chamber. The same procedures were carried out for the $10 \mathrm{~g}, 15 \mathrm{~g}, 20 \mathrm{~g}$ and 25 $\mathrm{g}$ of the immobilized bacteria in separate $250 \mathrm{~mL}$ effluents in conical flasks and agitated for ten days in a shaker incubator (Gallenkamp-OC4364-L) at a temperature $30^{\circ} \mathrm{C}$ and speed of 60 rpm. The treated effluent samples were taken on the tenth day and analyzed for the parameters $\mathrm{pH}$, SS, TDS, COD, and BOD, (Posttreatment determination) for the different grams of bacteria to evaluate and compare the biodegradation potential. (Baba et al., 2020).

\section{Statistical Analysis}

The data were represented as Mean \pm Standard deviation and analyzed statistically using oneway Analysis of Variance (ANOVA) and Tukey's HSD as Post Hoc Tests with the aid of SPSS 16.0. The correlation coefficient was also used to measure the strength of the relationship between the different masses of the bacteria and the parameters. All $\mathrm{p} \leq 0.05$ were considered as statistically significant.

\section{RESULTS AND DISCUSSION Physico-chemical parameters in the Industrial Effluents before the Biodegradation.}

Results of the Physico-chemical parameters in the industrial effluents before the Biodegradation is shown in table 1 . The mean temperatures $\left({ }^{\circ} \mathrm{C}\right)$ observed in TAN1, TAN2, and TAN3 samples were $28.07 \pm 0.65 ; 27.77 \pm 0.64$ and $26.38 \pm 3.81$ respectively. The order of the mean temperature of the samples from the three industries can be arranged as TAN1 > TAN2>TAN3. The temperature observed at TAN1, TAN2, and TAN3 samples were found below the WHO $\left(35^{\circ} \mathrm{C}\right)$ and NESREA $\left(40^{\circ} \mathrm{C}\right)$ limits. The low values of temperature might be due to the processes used at the time of sampling. High temperature brings down the solubility of gases in water that ultimately expresses as high BOD and COD. Statistical analysis shows that there is no significant difference $(p<0.05)$ between the mean values of temperature among the industries. This might be due to similar tannery activities involved in the tannery industries at the time of sampling. The average values of temperature observed in this present study are less than those observed by Akan et al. (2007), Akan et al. (2009) and Baba et al. (2020).

The mean level of $\mathrm{pH}$ observed in TAN1, TAN2 and TAN3, samples were $7.77 \pm 2.93$; $8.35 \pm 0.28$ and $7.52 \pm 0.76$ respectively. The order of the mean $\mathrm{pH}$ of the samples from the three industries can be arranged as TAN2> TAN1 $>$ TAN3. The $\mathrm{pH}$ of the samples falls within the WHO (7.0-8.5) and NESREA (6-9) standard limits. Statistical analysis shows that there is no significant difference $(p<0.05)$ between the mean values of $\mathrm{pH}$ among the industries. This might be due to similar tannery activities involved in the tannery industries at the time of sampling. Maheshwari et al. (2017) reported that the level of $\mathrm{pH}$ in the effluents from the tannery industry in Vaniyambadi, India was 6.5 which was lower than that observed in the present study. The $\mathrm{pH}$ in the effluents from the tannery industries in Kano and Kaduna were reported to be 7.64 and 6.89, respectively (Akan et al., 2007; Mohammed et al., 2017). The average values of $\mathrm{pH}$ observed in this present study are less than those observed by Mohammed et al. (2017) and Baba et al. (2020). The mean level of SS $(\mathrm{mg} / \mathrm{l})$ observed in TAN1, TAN2, and TAN3 samples were 374 \pm 124 ; $358 \pm 335$ and $780 \pm 739$ respectively. The order of the mean SS in the samples from the three industries can be arranged as TAN3 > TAN1 $>$ TAN2. 
The SS observed in the samples were far above the recommended standard limits of regulating bodies WHO $(30 \mathrm{mg} / \mathrm{l})$ and NESREA $(10 \mathrm{mg} / \mathrm{l})$. Statistical analysis shows that there is no significant difference $(p<0.05)$ between the mean values of SS among the industries. This might be due to similar tannery activities involved in the tannery industries at the time of sampling. The average values of SS observed in this present study are less than that observed $(3700 \pm 122 \mathrm{mg} / \mathrm{l})$ by Akan et al. (2009) for tanneries in Kano. Also, the average values of SS observed in this present study are less than that observed by Mohammed et al. (2017) and Baba et al. (2020) with the exception in TAN3.

The mean level of TDS (mg/l) observed in TAN1, TAN2, and TAN3 samples were $3941 \pm 3703$; $3300 \pm 1714$ and $2653 \pm 1240$ respectively. The order of the mean TDS in the samples from the three industries can be arranged as TAN1>TAN2>TAN3. The TDS observed in the samples were far above the recommended standard limits of WHO $(250 \mathrm{mg} / \mathrm{l})$ and NESREA $(500 \mathrm{mg} / \mathrm{l})$. Statistical analysis shows that there is no significant difference $(p<0.05)$ between the mean values of TDS among the industries. This might be due to similar tannery activities involved in the tannery industries at the time of sampling. TDS in the effluents from the tannery industries in Kano, Nigeria was reported to be $1281 \mathrm{mg} / \mathrm{l}$ (Akan et al., 2007). The average values of SS observed in this present study are less than those observed by Mohammed et al. (2017) and Baba et al. 2020)

The mean level of COD (mg/l) observed in TAN1, TAN2 and TAN3 samples seasons were $2372 \pm 938 ; \quad 1406 \pm 208$ and $3532 \pm 1373$ respectively. The order of the mean COD of the samples from the three industries can be arranged as TAN3>TAN1> TAN2. The COD observed in TAN1, TAN2 and TAN3 samples were far above the recommended standard limits of regulating bodies $\mathrm{WHO}(40 \mathrm{mg} / \mathrm{l})$ and NESREA (40 mg/l). Statistical analysis shows that there is no significant difference $(p<0.05)$ in COD among the industries. This might be due to similar tannery activities involved in the tannery industries as at the time of sampling. The Chemical Oxygen demand (COD) is the amount of oxygen, in $\mathrm{mg} / \mathrm{L}$, required for the degradation of the compound of wastewater to occur. In comparison, the average values of COD observed in this present study were higher than that observed by Mohammed et al. (2017) but lower than that observed by Baba et al. (2020).

The mean levels of BOD $(\mathrm{mg} / \mathrm{l})$ observed in TAN1, TAN2 and TAN3 samples were $13.85 \pm 6.42 ; \quad 19.46 \pm 0.50$ and $17.13 \pm 3.14$ respectively. The order of the mean BOD in the samples from the three industries can be arranged as TAN2>TAN3>TAN1. The BOD observed in TAN1, TAN2 and TAN3 samples were found below the recommended limits of NESREA (200 mg/l) but above WHO (10 mg/l). Statistical analysis shows that there is no significant difference $(p<0.05)$ between the mean values of BOD among the industries. This might be due to similar tannery activities involved in the tannery industries at the time of sampling. The low level of BOD recorded in this study is an indication of the low level of biodegradable organic solids in the effluent. The average values of BOD observed in this present study were lower than those observed by Mohammed et al. (2017) and Baba et al. (2020).

Table 1: Mean Values \pm S.D of Physico-chemical parameters of effluents from the Tannery Industries before Treatment.

\begin{tabular}{llllllll}
\hline Parameter & Tannery 1 & Tannery 2 & Tannery 3 & $\mathrm{a}$ & $\mathrm{b}$ & $\mathrm{c}$ & $\mathrm{d}$ \\
\cline { 2 - 7 } Temperature $\left({ }^{\circ} \mathrm{C}\right)$ & $28.07 \mathrm{a} \pm 0.65$ & $27.77 \mathrm{a} \pm 0.64$ & $26.38 \mathrm{a} \pm 3.81$ & & $29.50 \pm 4.68$ & 35 & 40 \\
pH & $7.77 \mathrm{a} \pm 2.93$ & $8.35 \mathrm{a} \pm 0.28$ & $7.52 \mathrm{a} \pm 0.76$ & 6.89 & $5.35 \pm 1.57$ & $7.0-8.5$ & $6.0-9.0$ \\
$\mathrm{COD}(\mathrm{mg} / \mathrm{l})$ & $2372 \mathrm{a} \pm 938$ & $1406 \mathrm{a} \pm 208$ & $3532 \mathrm{a} \pm 1373$ & 2.2 & $3106 \pm 2753$ & 40 & 40 \\
$\mathrm{BOD}(\mathrm{mg} / \mathrm{l})$ & $13.85 \mathrm{a} \pm 6.42$ & $19.46 \mathrm{a} \pm 0.50$ & $17.13 \mathrm{a} \pm 3.14$ & 1032 & $26.17 \pm 9.49$ & 10 & 200 \\
$\mathrm{SS}(\mathrm{mg} / \mathrm{l})$ & $374 \mathrm{a} \pm 124$ & $358 \mathrm{a} \pm 335$ & $780 \mathrm{a} \pm 739$ & 501 & $562 \pm 482$ & 30 & 10 \\
TDS $(\mathrm{mg} / \mathrm{l})$ & $3941 \mathrm{a} \pm 3703$ & $3300 \mathrm{a} \pm 1714$ & $2653 \mathrm{a} \pm 1240$ & 532.7 & $444 \pm 507$ & 250 & 500 \\
\hline
\end{tabular}

The values given in the table above are means of 6 replicate values, $\mathrm{n}=6$ ( 1 sample was taken monthly for 6 months). Within the rows, means with different alphabets are statistically different $(p<0.05)$. WHO: World Health Organisation. NESREA: National Environmental Standard and Regulatory Enforcement Agency. a = Mohammed et al.(2017), b = Baba et al. (2020), c = WHO (2006), $d=$ NESSRA (2009) 
BAJOPAS Volume 13 Number 2, December, 2020

Identification, Biochemical Characterization and growth rates of the Bacterial Isolates

Results of identification and biochemical characterization of the bacterial isolates were shown in table 2. After 24 hours of incubation, the nutrient agar media plates were checked for bacterial growth. The results showed the presence of different strains in the samples. The TAN1 bacteria isolate was found to be gramnegative cocci while TAN3 was gram-positive cocci. TAN2 bacteria isolate was found to be gram-positive, rod-shaped. TAN1, TAN2, and TAN3 bacteria isolates recorded positive results for spore former.

The results of the biochemical tests indicated that all the bacteria were positive for catalase, oxidase, citrate, maltose, glucose, lactose (negative in TAN1), mannitol (negative in TAN2), starch hydrolysis and coagulase (negative in TAN2) tests. The bacteria showed negative results for nitrate reduction, $M R$ (positive in TAN2), VP (positive in TAN1), Indole (positive in TAN2) tests. Base on the morphological and biochemical test results, TAN1, TAN2, and TAN3 bacteria isolates were identified to be Nesseria spp, Bacillus cereus, and Staphylococcus aureus respectively.

The growth rate of the TAN1, TAN2 and TAN3 Isolates were shown in figure 2. Generally, the optical density increase with the increase in time (day) and decrease as time goes on. The highest optical density was shown by bacillus cereus in TAN2 while the lowest was shown by Staphylococcus aureus in TAN3.

The initial growth phase of TAN1 Isolate bacteria occurred within 2-day of incubation as the growth rate increases up to the 6th-day incubation when the maximum growth was observed. Beyond the 6th day, the growth of the bacteria declined (which might be due to a shortage of nutrients in the effluents) until it reached its death phase (which might be due to the unavailability of nutrients in the effluents).

A similar trend of growth was also observed for TAN2 Isolate as the initial growth phase also occurred within 2-day of incubation but maximum growth rate observed on the 4th day of incubation. The stationary stage occurred between the 4th day and the 8th day. Beyond the 8th day, the growth of the bacteria declined (which might be due to a shortage of nutrients in the effluents) until it reached its death phase (which might be due to the unavailability of nutrients in the effluents).

The initial growth phase of TAN3 bacterial Isolate occurred within the 3-day incubation as the growth rate increases up to the 6th-day incubation when the maximum growth was observed. Beyond the 6th day, the growth of the bacteria declined (which might be due to a shortage of nutrients in the effluents) until it reached its death phase (which might be due to the unavailability of nutrients in the effluents).

Table 2: Morphological and Biochemical characteristics of bacterial isolates

\begin{tabular}{lllll} 
Bacterial Isolates & & TAN1 & TAN2 & TAN3 \\
\hline $\begin{array}{lllll}\text { Morphological } \\
\text { characteristics }\end{array}$ & Shape & Cocci & Rod & Cocci \\
& Spore & & & \\
& former & + & + & + \\
Gram & & & \\
Biochemical characteristics & reaction & - & + & + \\
& Citrate & + & + & + \\
& Catalase & + & + & + \\
& Coagulase & + & - & + \\
Starch & + & + & + \\
& Glucose & + & + & + \\
Oxidase & + & + & + \\
& Indo & - & + & - \\
Lactose & - & + & + \\
Manitol & + & - & + \\
Maltose & + & + & + \\
MR & - & + & - \\
VP & + & - & - \\
& Nitrate & - & - & - \\
Reduction & - Neisseria & Bacillus & Staphylococcus \\
& Bacterial & cereus & aureus \\
& name & spp & cas
\end{tabular}

+ = Positive; - = Negative; MR=Methyl Red; VP= Voges-Proskauer 


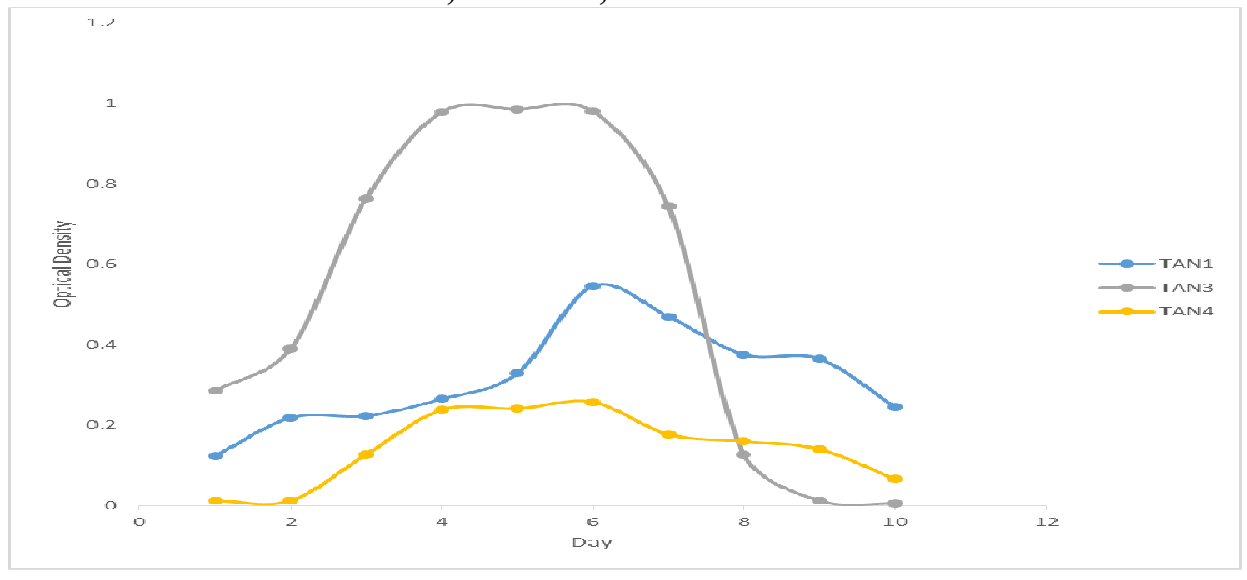

Fig. 2 Growth rates of the isolates in the effluents from the Tannery Industries

\section{Physico-chemical Parameters in the Industrial Effluents after the biodegradation.}

Table 3 shows the mean results of the physicochemical parameter before and after bioremediation using the different masses $(5 \mathrm{~g}$, $10 \mathrm{~g}, 15 \mathrm{~g}, 20 \mathrm{~g}$, and $25 \mathrm{~g}$ ) of the respective immobilized bacteria. Also, Table 4 shows the mean results of correlation coefficient ( $r$ ) between different masses of bacteria and physicochemical parameters.

The mean values $(\mathrm{mg} / \mathrm{l})$ of the SS after the bioremediation varies between $243 \pm 45$ and $898 \pm 672$. The mean concentration $(\mathrm{mg} / \mathrm{l})$ of SS remediated by the different masses $(5 \mathrm{~g}, 10 \mathrm{~g}$, $15 \mathrm{~g}, 20 \mathrm{~g}$, and $25 \mathrm{~g}$ ) of the bacteria varies. The SS in the samples fluctuates up and down after the bioremediation process when compared with the SS of the raw samples before the bioremediation. The increase in the levels of the SS might be due to the aggregation of the TDS which are large enough to result into SS. The increase in the levels of the SS might be also due to the influence of the nutrients which was added into the effluents in order to make the microorganisms more active and viable for fast degradation of organic contaminants in the effluent. The relative potential or efficiency of the different masses of the bacteria in remediating SS in TAN1 samples was in the order $25 \mathrm{~g}>20 \mathrm{~g}>15 \mathrm{~g}>10 \mathrm{~g}>5 \mathrm{~g}$. For TAN2 and TAN3 samples, the order was $25 \mathrm{~g}>20 \mathrm{~g}>15$ $\mathrm{g}>10 \mathrm{~g}>5 \mathrm{~g}$. These might be due to the variations in the surface areas of the different masses of the immobilized bacteria. Statistical analysis shows that there is no significant difference $(p<0.05)$ between the mean values of SS among the masses in the respective industries. Positive and significant correlations exist between the masses of bacteria and Suspended Solid (SS). This showed that there is general increase in the levels of the SS as the masses of the immobilized bacteria increases. TAN3 (90\%) and TAN1 (80\%) showed a very high correlation with the masses of the bacteria while TAN2 (61\%) showed a very low correlation.

The mean values $(\mathrm{mg} / \mathrm{l})$ of the TDS after the bioremediation varies between $46 \pm 11$ and $83 \pm 78$. The mean concentration $(\mathrm{mg} / \mathrm{l})$ of TDS remediated by the different masses $(5 \mathrm{~g}, 10 \mathrm{~g}$, $15 \mathrm{~g}, 20 \mathrm{~g}$, and $25 \mathrm{~g}$ ) of the bacteria varies. There is a reduction in all the TDS of all the samples after the bioremediation process compared with the TDS of the raw samples before the bioremediation. The relative potential or efficiency of the different masses of the bacteria in remediating TDS in TAN1 and TAN3 samples was in the order $5 \mathrm{~g}>10 \mathrm{~g}>15 \mathrm{~g}>20$ $\mathrm{g}>25 \mathrm{~g}$. For TAN2 samples, the order was 20 $g>10 \quad g>25 \quad g>15 \quad g>5 \quad g$. Statistical analysis shows that there is no significant difference $(p<0.05)$ between the mean values of TDS among the masses in the respective industries. These might be due to the variations in the surface areas of the different masses of the immobilized bacteria. Positive and significant correlations exist between the masses of bacteria and TDS with the exception in TAN2 (negative and insignificant correlation). The positive correlations showed that there is general increase in the levels of the TDS as the masses of the immobilized bacteria increases. TAN1 $(96 \%)$ showed a very high correlation with the masses of the bacteria while TAN2 (47\%) showed a very low correlation.

The mean values $(\mathrm{mg} / \mathrm{l})$ of the BOD after the bioremediation varies between $1.56 \pm 0.20 \mathrm{mg} / \mathrm{l}$ and $6.92 \pm 5.49 \mathrm{mg} / \mathrm{l}$. The mean concentration $(\mathrm{mg} / \mathrm{l})$ of BOD remediated by the different masses $(5 \mathrm{~g}, 10 \mathrm{~g}, 15 \mathrm{~g}, 20 \mathrm{~g}$, and $25 \mathrm{~g}$ ) of the bacteria varies. There is a reduction in all the BOD of all the samples after the bioremediation process compared with the $\mathrm{BOD}$ of the raw 
BAJOPAS Volume 13 Number 2, December, 2020 samples before the bioremediation. The relative potential or efficiency of the different masses of the bacteria in remediating BOD in TAN1, TAN2 and TAN3 samples were in the order $25 \mathrm{~g}>20$ $\mathrm{g}>15 \mathrm{~g}>10 \mathrm{~g}>5 \mathrm{~g}, 25 \mathrm{~g}>15 \mathrm{~g}>5 \mathrm{~g}>10 \mathrm{~g}>20 \mathrm{~g}$ and $20 \mathrm{~g}>10 \mathrm{~g}>25 \mathrm{~g}>15 \mathrm{~g}>5 \mathrm{~g}$ respectively. Statistical analysis shows that there is significant difference $(p<0.05)$ between the mean values of BOD among the masses in the respective industries. These might be due to the variations in the surface areas of the different masses of the immobilized bacteria. Negative and significant correlations exist between the masses of bacteria and BOD. This showed that there is general decrease in the levels of the BOD as the masses of the immobilized bacteria increases. TAN1 (94\%) showed a very high correlation with the masses of the bacteria while TAN2 (4\%) showed a very low correlation.

The mean values $(\mathrm{mg} / \mathrm{l})$ of the COD after the bioremediation varies between $250 \pm 154$ and $3134 \pm 1595$. The mean concentration $(\mathrm{mg} / \mathrm{l})$ of COD remediated by the different masses $(5 \mathrm{~g}$, $10 \mathrm{~g}, 15 \mathrm{~g} 20 \mathrm{~g}$, and $25 \mathrm{~g}$ ) of the bacteria varies. There is a reduction in all the COD of all the samples after the bioremediation process compared with the COD of the raw samples before the bioremediation. The relative potential or efficiency of the different masses of the bacteria in remediating COD in TAN1, TAN2 and TAN3 samples were in the order $25 \mathrm{~g}>20 \mathrm{~g}>15$ $\mathrm{g}>5 \mathrm{~g}>10 \mathrm{~g}, 25 \mathrm{~g}>20 \mathrm{~g}>15 \mathrm{~g}>10 \mathrm{~g}>5 \mathrm{~g}$ and 10 g>5 g>25 g>15 g>20 g respectively. Statistical analysis shows that there were significant difference $(p<0.05)$ between the mean values of COD among the masses in the respective industries except for effluents treated with $25 \mathrm{~g}$. These might be due to the variations in the surface areas of the different masses of the immobilized bacteria. Negative and insignificant correlations exist between the masses of bacteria and COD with the exception in TAN3 (positive and significant correlation). The negative correlations showed that there is general decrease in the levels of the COD as the masses of the immobilized bacteria increases. TAN2 (100\%) showed a very high correlation with the masses of the bacteria while TAN3 (36\%) showed a very low correlation.

Generally, there was an overall decrease in the concentration of these physicochemical parameters after the bioremediation using the different masses of the bacterial isolates. These might be due to the variations in the surface areas of the different masses of the immobilized bacteria. This is in line with the work of Jimoh et al. (2018) and Baba et al. (2020).

Table 3: Mean Values $(\mathrm{mg} / \mathrm{l}) \pm$ S.D of Physicochemical parameters in effluents from the Tannery Industries before and after Treatment of the effluents $(250 \mathrm{ml})$ with the different masses $(5 \mathrm{~g}, 10 \mathrm{~g}$, $15 \mathrm{~g}, 20 \mathrm{~g}$, and $25 \mathrm{~g}$ ) of the bacteria.

\begin{tabular}{llllllll}
\hline $\mathrm{P}$ & IND & Before & \multicolumn{5}{c}{ After } \\
\cline { 4 - 7 } & & & $5 \mathrm{~g}$ & $10 \mathrm{~g}$ & $15 \mathrm{~g}$ & $20 \mathrm{~g}$ & $25 \mathrm{~g}$ \\
\hline \multirow{2}{*}{ COD } & TAN1 & $2372 \pm 938$ & $1708 \mathrm{a} \pm 861$ & $2045 \mathrm{a} \pm 1205$ & $845 \mathrm{a} \pm 369$ & $300 \mathrm{a} \pm 167$ & $250 \mathrm{a} \pm 154$ \\
& TAN2 & $1406 \pm 208$ & $1195 \mathrm{a} \pm 208$ & $1125 \mathrm{a} \pm 384$ & $1055 \mathrm{a} \pm 317$ & $956 \mathrm{a} \pm 310$ & $870 \mathrm{ab} \pm 240$ \\
& TAN3 & $3532 \pm 1373$ & $2374 \mathrm{a} \pm 1344$ & $1976 \mathrm{a} \pm 1405$ & $2757 \mathrm{a} \pm 1266$ & $3134 \mathrm{a} \pm 1595$ & $2614 \mathrm{~b} \pm 1105$ \\
BOD & TAN1 & $13.85 \pm 6.42$ & $6.92 \mathrm{a} \pm 5.49$ & $6.42 \mathrm{a} \pm 5.07$ & $5.72 \mathrm{a} \pm 5.35$ & $4.62 \mathrm{a} \pm 4.37$ & $2.82 \mathrm{ab} \pm 1.26$ \\
& TAN2 & $19.46 \pm 0.50$ & $1.75 \mathrm{~b} \pm 0.22$ & $1.73 \mathrm{~b} \pm 0.18$ & $1.58 \mathrm{a} \pm 0.16$ & $1.91 \mathrm{a} \pm 0.22$ & $1.56 \mathrm{~b} \pm 0.20$ \\
& TAN3 & $17.13 \pm 3.14$ & $4.24 \mathrm{ab} \pm 0.77$ & $3.29 \mathrm{ab} \pm 0.37$ & $4.11 \mathrm{a} \pm 0.07$ & $3.23 \mathrm{a} \pm 0.91$ & $3.33 \mathrm{a} \pm 1.28$ \\
SS & TAN1 & $374 \pm 124$ & $243 \mathrm{a} \pm 45$ & $471 \mathrm{a} \pm 226$ & $475 \mathrm{a} \pm 182$ & $492 \mathrm{a} \pm 128$ & $611 \mathrm{a} \pm 217$ \\
& TAN2 & $358 \pm 335$ & $460 \mathrm{a} \pm 400$ & $543 \mathrm{a} \pm 414$ & $544 \mathrm{a} \pm 402$ & $551 \mathrm{a} \pm 414$ & $554 \mathrm{a} \pm 405$ \\
& TAN3 & $780 \pm 739$ & $586 \mathrm{a} \pm 594$ & $758 \mathrm{a} \pm 656$ & $787 \mathrm{a} \pm 676$ & $861 \mathrm{a} \pm 635$ & $898 \mathrm{a} \pm 672$ \\
TDS & TAN1 & $3941 \pm 3703$ & $51 \mathrm{a} \pm 10$ & $53 \mathrm{a} \pm 10$ & $55 \mathrm{a} \pm 15$ & $61 \mathrm{a} \pm 20$ & $63 \mathrm{a} \pm 26$ \\
& TAN2 & $3300 \pm 1714$ & $83 \mathrm{a} \pm 78$ & $47 \mathrm{a} \pm 20$ & $48 \mathrm{a} \pm 22$ & $47 \mathrm{a} \pm 17$ & $48 \mathrm{a} \pm 17$ \\
& TAN3 & $2653 \pm 1240$ & $46 \mathrm{a} \pm 11$ & $55 \mathrm{a} \pm 24$ & $55 \mathrm{a} \pm 25$ & $58 \mathrm{a} \pm 23$ & $61 \mathrm{a} \pm 28$ \\
\hline
\end{tabular}

Replicate $=6$ (months)

Within the rows, for the same parameter, means with different alphabets are statistically different $(p<0.05)$.

$\mathrm{P}=$ parameter, IND = Industries 
BAJOPAS Volume 13 Number 2, December, 2020

Table 4: Correlation coefficient $(r)$ between different masses of the bacteria and the physicochemical parameters.

\begin{tabular}{llll}
\hline Industries & Parameter & Correlation coefficient $(r)$ & $\begin{array}{l}\text { Percent dependence (rxrx100) } \\
(\%)\end{array}$ \\
\hline TAN1 & COD & -0.9 & 82 \\
& BOD & -0.97 & 94 \\
& SS & $0.90^{*}$ & 80 \\
TAN2 & TDS & $0.98^{*}$ & 96 \\
& COD & -1 & 100 \\
& BOD & -0.21 & 4 \\
& SS & $0.78^{*}$ & 61 \\
& TDS & -0.69 & 47 \\
& COD & $0.60^{*}$ & 36 \\
& BOD & -0.6 & 37 \\
& SS & $0.95^{*}$ & 90 \\
& TDS & $0.94^{*}$ & 89 \\
\hline
\end{tabular}

The correlation coefficient $(r)$ with * is statistically significant $(p<0.05)$.

Percentage reduction of the Parameters

Table 5 shows the percentage reduction of Parameters in industrial samples before and after the treatment of the effluents $(250 \mathrm{ml})$ with the different masses $(5 \mathrm{~g}, 10 \mathrm{~g}, 15 \mathrm{~g}, 20 \mathrm{~g}$, and $25 \mathrm{~g}$ ) of the Immobilized Bacteria.

In TAN1 samples, the percentage reduction (\%) of COD ranged (14-89); BOD (50-80); SS (-32$35)$ and TDS (98-99). In TAN2 samples, the percentage decrease $(\%)$ of COD ranged (15$38) ;$ BOD (90-92); SS [-28-(-55)] and TDS (9798). In TAN3 samples, the percentage decrease (\%) of COD ranged (11-44); BOD (76-81); SS (15-25) and TDS (98). The percentage increase in the levels COD, BOD and TDS might be due to the increase in the surface area of the different masses of the immobilized bacteria. However, the percentage decrease in the levels of the SS might be due to the aggregation of the TDS which are large enough to result into SS. The percentage decrease in the levels of the SS might be also due to the influence of the nutrients which was added into the effluents in order to make the microorganisms more active and viable for fast degradation of organic contaminants in the effluent. This is in line with the work of Jimoh et al. (2018) in which the concentration of the SS increase after the bioremediation of effluents.

Sreemoyee and Priti (2013) assessed and reduced several Physico-chemical parameters of dairy wastewater using Niesseria $s p$. and concluded that the species are well known to degrade organic compounds. This is in agreement with the current study in which the immobilized Niesseria $s p$ degrade the organic contaminants as indicated by the BOD, COD and TDS.

Jimoh et al. (2018) observed that TSS of the effluents was increased after treatment with immobilized bacteria and concluded that it might be due to the biostimulation method adopted for the research.

The optimum $\mathrm{pH}$ Biosorption of Chromium by Bacillus spp and Staphylococcus spp. from tannery effluent was investigated by Mythili and Karthikeyan (2011). The maximum adsorption of Chromium $(86.4 \mathrm{mg} / \mathrm{L})$ was showed by Bacillus spp and Staphylococcus spp showed $70.6 \mathrm{mg} / \mathrm{L}$ at an initial concentration of $100 \mathrm{mg} / \mathrm{L}$. In the present study, immobilised Bacillus spp and Staphylococcus spp. from the tannery industrial effluents reduced the levels of the organic pollutants with high potential as indicated by the percentage reduction of BOD, COD and TDS.

Enzymes often can work in multiple environments especially if they are immobilized. This makes the microorganisms' enzymes even more resistant to harsh environments and enables the enzymes to be recovered and recycled after they are no longer needed (Gianfreda and Rao 2004). Ramesh and Singh (1993) reported that the immobilized bacteria having more efficiency to remove the suspended particles than free cells. Using the immobilized cell is preferable due to its capability for using several times with the same efficiency, which makes it more economical. Similar work was done by Sikander et al. (2007) showing the higher reduction with permeabilized cells of Ochrobactrum intermedium strain SDCr-5. 
BAJOPAS Volume 13 Number 2, December, 2020

The results revealed the isolation and identification of isolates with the potential for the reduction of $\mathrm{Cr}$ (VI) to $\mathrm{Cr}$ (III). Results indicated that immobilized $B$. cereus could be efficiently used for the reduction of $\mathrm{Cr}$ (VI).

Table 5: Percentage reduction of the tested Parameters from the tannery industrial samples of the Immobilized Bacteria.

\begin{tabular}{lllllll}
\hline \multirow{2}{*}{ Industries } & & \multicolumn{5}{c}{ Percentage Reduction $(\%)$} \\
\cline { 3 - 7 } & & $5 \mathrm{~g}$ & $10 \mathrm{~g}$ & $15 \mathrm{~g}$ & $20 \mathrm{~g}$ & $25 \mathrm{~g}$ \\
\hline TAN1 & COD & 28 & 14 & 64 & 87 & 89 \\
& BOD & 50 & 54 & 59 & 67 & 80 \\
& SS & 35 & -26 & -27 & -32 & -63 \\
& TDS & 99 & 99 & 99 & 98 & 98 \\
TAN2 & COD & 15 & 20 & 25 & 32 & 38 \\
& BOD & 91 & 91 & 92 & 90 & 92 \\
& SS & -28 & -52 & -52 & -54 & -55 \\
& TDS & 97 & 99 & 99 & 99 & 99 \\
& COD & 33 & 44 & 22 & 11 & 26 \\
& BOD & 75 & 81 & 76 & 81 & 81 \\
& SS & 25 & 3 & -1 & -10 & -15 \\
& TDS & 98 & 98 & 98 & 98 & 98 \\
\hline
\end{tabular}

Percentage Reduction $=(B-A) / B \times 100 \%$

$A=$ Concentration of the parameter after treatment

$\mathrm{B}=$ Concentration of the parameter before treatment

$+=$ percentage decrease

- = percentage increase

In general, immobilization makes the enzyme more resistant to temperature, $\mathrm{pH}$, and substrate concentration swings giving it a longer lifetime and higher productivity per active unit (Gianfreda and Rao, 2004; FuIlbrook, 1996; Russell et al, 2003; Kandelbauer et al., 2004). Immobilized cells have been used and studied extensively for the production of useful chemicals (Ohtake and Silver, 1994), the treatment of wastewaters (Chen et al., 2003; Wang et al., 2010). Although many workers described microbial degradation of tannery effluent, limited literature is available on the bioremediation of tannery effluent using immobilized bacterial cells in the Kano Industrial Estates.

\section{CONCLUSION}

The samples contained variable levels of the physicochemical parameters. The results of the Analysis of variance revealed that, no statistical difference $(p<0.05)$ was observed for the temperature, $\mathrm{pH}, \mathrm{SS}, \mathrm{TDS}, \mathrm{BOD}$ and $\mathrm{COD}$ among the three tannery industries before the treatment. The levels of some of the parameters
(SS, TDS and COD) observed in the samples were found above the recommended limits of WHO and NESREA, which called for the treatment of the effluents before discharge into the environment. Base on the morphological and biochemical test results, TAN1, TAN2, and TAN3 bacterial isolates were identified to be Neisseria spp, Bacillus cereus, and Staphylococcus aureus respectively. The results of Post-treatment analysis showed that there is overall decrease in the levels of the parameters determined when compared with that of the pre-treatment. The overall percentage reduction of the immobilised bacteria in the treatment of the respective effluents was in the order TAN2 (72\%)>TAN1 $(70 \%)>$ TAN3 $(62 \%)$. Hence, the immobilized bacteria are having higher biodegradation potential for the treatment of the tannery effluents.

\section{Acknowledgments}

The authors wish to acknowledge the University of Maiduguri for the financial support. The authors are grateful to the Kano State Ministry of Environment for their support in obtaining the effluent samples. 


\section{REFERENCES}

Ajao, A. T., Adebayo, G. B., and Yakubu, S. E. (2011). Bioremediation of textile industrial effluent using mixed culture of Pseudomonas aeruginosa and Bacillus subtilis immobilized on agar-agar in a bioreactor. J. Microbiol. Biotech. Res, 1(3), 50-56.

Akan, J. C., Moses, E. A., Ogugbuaja, V. O., and Abah, J. (2007). Assessment of tannery industrial effluents from Kano metropolis, Kano State, Nigeria. Journal of Applied Sciences, 7(19), 2788-2793.

Akan, J. C., Ogugbuaja, V. O., Abdulrahman, F. I., and Ayodele, J. T. (2009). Pollutant levels in effluent samples from tanneries and textiles of Kano industrial areas, Nigeria. Global journal of pure and applied sciences, 15(3-4).

APHA (1989). Standard methods for Examination of Will bete and Will betewater.15 $5^{\text {th }}$ edition. Brydpass Springfield Will behington DC. pp. 164-176

APHA (1992). Standard Methods for the Examination of Water and Wastewater. Health, 69, 1116-9.

Baba, A., Garba, S. T., and Bello, H. S. (2020). Bioremediation Potential of Immobilized corynebacterium kutsceri in the Treatment of Tannery Industrial Effluent from Challawa Industrial Estate, Kano State, Nigeria. Journal of the Turkish Chemical Society Section A: Chemistry, $7(2), 335-350$.

Beem, E. I. V. (1994). reduction of solvent VOC emission. J. Oil Col. Chem. Ass, 77, 158.

Bouwer, E. J., and Zehnder, A. J. (1993). Bioremediation of organic compoundsputting microbial metabolism to work. Trends in biotechnology, 11(8), 360367.

Chen, K. C., Wu, J. Y., Liou, D. J., and Hwang, S. C. J. (2003). Decolorization of the textile dyes by newly isolated bacterial strains. Journal of Biotechnology, 101(1), 57-68.

Dan'Azumi, S., and Bichi, M. H. (2010). INDUSTRIAL POLLUTION AND HEAVY METALS PROFILE OF CHALLAWA RIVER IN KANO, NIGERIA. Journal of Applied Sciences in Environmental Sanitation, $5(1)$.

DWAF. (1992). Analytical Methods Manual, TR 151. Department of Water Affairs and Forestry, Pretoria.

El-Bestawy, E. (2013). Biological treatment of leather-tanning industrial wastewater using free living bacteria.
Elsheikh, M. A. S. (2009). Tannery wastewater pre-treatment. Water Science and Technology, 60(2), 433-440.

FuIlbrook, P. D. (1996). "Kinetics." Industrial enzymology: The application of enzymes in Industry. 2nd Ed. T. Godfrey and J Reichelt. eds.. Nature. New York.

Gianfreda, L., and Rao, M. A. (2004). Potential of extra cellular enzymes in remediation of polluted soils: a review. Enzyme and microbial technology, 35(4), 339354.

Hugo Springer. (1994). John Arthur Wilson Memorial Lecture "Treatment of Industrial Wastes of the Leather Industry - is it still a Major Problem". JALCA, 89, 153-185

Jimoh, A. A., Ganiyu, B. A., Baba, D., and Baba, A. (2018) Bioremediation Process of Effluent from Detergent and Food Industries in Jos, Nigeria: Kinetics and Thermodynamics. International Journal of Engineering Science Invention (IJESI), 762-73

Kandelbauer, A., Maute, O., Kessler, R. W., Erlacher, A., and Gübitz, G. M. (2004). Study of dye decolorization in an immobilized laccase enzyme-reactor using online spectroscopy. Biotechnology and bioengineering, 87(4), 552-563.

Kongjao, S., Damronglerd, S., and Hunsom, M. (2008). Simultaneous removal of organic and inorganic Pollutants in tannery wastewater using electrocoagulation technique. Korean Journal of chemical engineering, 25(4), 703.

Maheshwari, U. M., Aruna, S., Gomathi, M., and AbdulJaffar, A. H. (2017). Bioremediation by Free and Immobilized Bacteria Isolated from Tannery Effluent. International Journal of Research in Applied, Natural and Social Sciences. 5(7), 75-90

Margesin, R., and Schinner, F. (2001). Bioremediation (natural attenuation and biostimulation) of diesel-oilcontaminated soil in an alpine glacier skiing area. Applied and environmental microbiology, 677), 3127-3133.

Mohammed, A., Sekar, P., and George, J. (2011). Efficacy of microbes in bioremediation of tannery effluent. Inter. J. Curr. Res, 3(4), 324-326.

Mohammed, S. S. D., Orukotan, A. A., and Abdullahi, H. (2017). Physicochemical and Bacteriological Assessment of Tannery Effluent from Samaru-Zaria, 
BAJOPAS Volume 13 Number 2, December, 2020 Kaduna State, Nigeria. Journal of Applied

Sciences and Environmental Management, 21(4), 734-740.

Munz, G., De Angelis, D., Gori, R., Mori, G., Casarci, M., and Lubello, C. (2009). The role of tannins in conventional and membrane treatment of tannery wastewater. Journal of hazardous materials, 164(2-3), 733-739

Mythili, K., and Karthikeyan, B. (2011). Bioremediation of $\mathrm{Cr}$ (VI) from tannery effluent using Bacillus spp and Staphylococcus spp. International Multidisciplinary Research Journal, 1(6).

NESREA (2009). National Environmental Standards for Effluent Limitations and Regulation. 1233-1236

Noorjahan, C. M. (2014). Physicochemical characteristics, identification of bacteria and biodegradation of industrial effluent. Journal of bioremediation and Biodegradation, 5(3).

Ohtake, H. I., and Silver, A. O. (1994). Bacterial reduction of toxic chromate. Biological degradation and bioremediation of toxic chemicals, 403-415.

Omoleke, I. I. (2004). Management of environmental pollution in Ibadan, an African city: the challenges of health hazard facing government and the people. Journal of Human Ecology, 15(4), 265-275.

Rajor, A., Reddy, A.S., and Singh, B. (2004). Determination of BOD kinetic Parameters and evaluation of alternate methods, M.Sc. Thesis, Department of biotechnology \& environmental Science, Thapar Institute of Engineering and Technology, Patiala

Ramasami, T., Rajamani, S., and Rao, J. R. (1994, March). Pollution control in leather industry: Emerging technological options. In International symposium on surface and colloidal science and its relevance to soil pollution, madras.

Ramesh, J. V. S., and Singh, S. P. (1993). Yearly variation in certain physicochemical parameters of pond at eastern Doon Valley. Uttar Pradesh J. Zoo, 12 (1), 7577.

Ranen, S., and Sharadinadra, C. (2009). Biotechnology applications to environmental remediation in resource exploitation. Current science, 97, 6-25
Russell, A. J., Berberich, J. A., Drevon, G. F., and Koepsel, R. R. (2003). Biomaterials for mediation of

chemical and biological warfare agents. Annual review of biomedical engineering, 5(1), 1-27.

Saravanan, P., and Saravanan, A. (1999). Decolourization of tannery effluent by Flavobacterium sp. EK 1. Indian Journal of Environmental Protection, 19, 19-24.

Sikander, S., and Shahida, H. (2007). Reduction of toxic hexavalent chromium by Ochrobactrum intermedium strain SDCr5 stimulated by heavy metals. Bioresource Technol, 98, 340-344.

Singh, N., Sharma, B. K., and Bohra, P. C. (2000). Impact assessment of industrial effluent of arid soils by using satellite imageries. Journal of the Indian Society of Remote Sensing, 28(2-3), 79.

Sreemoyee, C., and Priti, P. (2013). Assessment of physico-chemical parameters of dairy waste water and isolation and characterization of bacterial strains in terms of cod reduction. Int J Sci, 2(3), 395-400.

Verheijen, L. A. H. M., Wiersema, D., Pol, L. H., and De Wit, J. (1996). Management of wastes from animal product processing. Livestock and environment, Finding a balance. International Agriculture Center, Wageningen, The Netherlands.

Wang, F., Yao, J., Si, Y., Chen, H., Russel, M., Chen, K., and Bramanti, E. (2010). Short-time effect of heavy metals upon microbial community activity. Journal of Hazardous Materials, 173(13), 510-516.

WHO (World Health Organization). (2006). Air quality guidelines: global update 2005: particulate matter, ozone, nitrogen dioxide, and sulfur dioxide. World Health Organization.

World Bank. (1995). Nigeria's strategic options for redressing industrial pollution. World Bank, industry and energy division. 1st edition, West Central Africa Department; Annexes: 1995; pp 60-62.

Zahoor, A., and Abdul, R. (2009). Enumeration of Coliforms. Journal of Environmental Sciences. 21, 814-820 


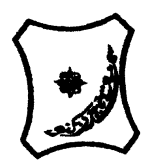

Bayero Journal of Pure and Applied Sciences, 13(2): 1 - 12

Received: November, 2020

Accepted: December, 2020

ISSN $2006-6996$

\title{
BIODEGRADATION POTENTIAL OF IMMOBILIZED BACTERIA IN THE TREATMENT OF TANNERY INDUSTRIAL EFFLUENTS FROM INDUSTRIAL ESTATES IN KANO STATE, NIGERIA
}

\author{
Abdullateef, B., ${ }^{1 *}$ Shuaibu, T. G., ${ }^{1}$ Babagana, K., ${ }^{1}$ Suleman, H. B. ${ }^{2}$ and Dauda, B. ${ }^{3}$ \\ ${ }^{1}$ Department of Pure and Applied Chemistry, Faculty of Science, University of Maiduguri, Borno State, \\ Nigeria \\ ${ }^{2}$ Department of Microbiology, Faculty of Science, University of Maiduguri, Borno State, Nigeria \\ ${ }^{3}$ Department of Chemical Engineering, Faculty of Engineering, University of Maiduguri, Borno State, \\ Nigeria \\ *Corresponding author: babslega@gmail.com; abelega2007@yahoo.com; +2348061309753
}

\section{ABSTRACT}

Industrial Effluents Samples from Gashash Tanneries (TAN1) in Bompai Industrial estate, Larabee Tannery Industry (TAN2) in Sharada Industrial estate and Z Tannery Industries (TAN3) in Challawa Industrial estate, Kano State, Nigeria were collected over a period of six months (August 2017 to January 2018) for assessing the biodegradation potentials of bacteria in the treatment of organic pollutants within the effluents. Bacteria were isolated from the effluents and immobilized on agar-agar. Different masses (5 g, $10 \mathrm{gr}, 15$ $\mathrm{g}, 20 \mathrm{~g}$, and $25 \mathrm{~g}$ ) of the bacteria were used in the treatment of $250 \mathrm{ml}$ of the effluents for ten days in a shaker incubator (Gallenkamp-OC-4364-L) at the temperature $30{ }^{\circ} \mathrm{C}$ and speed of $60 \mathrm{rpm}$. Pre-treatment analysis of the effluents for Temperature, pH, Biochemical Oxygen Demand (BOD), Chemical Oxygen Demand (COD), Suspended Solid (SS) and Total Dissolved Solids (TDS) gives the following results; temperature $\left({ }^{\circ} \mathrm{C}\right.$ )

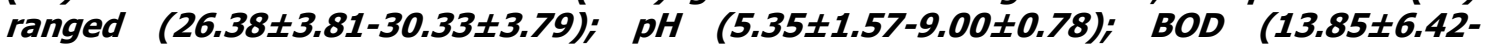
$38.75 \pm 16.20) ;$ COD (1406 $\pm 208-3532 \pm 1373) ;$ SS (208 $\pm 235-780 \pm 739)$ and TDS (266 $\pm 253-5276 \pm 2971)$. No statistical differences ( $p \leq 0.05)$ was observed for all the results among the different industries. The bacterial isolates were identified as Neisseria spp, Bacillus cereus, and Staphylococcus aureus, in TAN1, TAN2, and TAN3, respectively. After treatment of the effluent with the different masses of the isolated bacteria, the mean level of BOD was found to range as (0.55 $\pm 0.36-6.92 \pm 5.49) ; C O D$ (ND-3134 \pm 1595$)$;

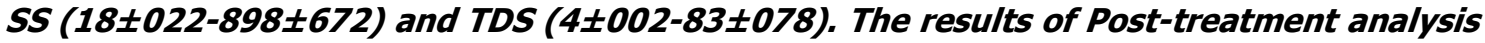
showed that there is overall decrease in the levels of the parameters determined when compared with that of the pre-treatment. The overall percentage reduction of the immobilised bacteria in the treatment of the respective effluents was in the order TAN2 (72\%)>TAN1 (70\%)>TAN3 (62\%). Hence, the immobilized bacteria are having higher biodegradation potential for the treatment of the tannery effluents.

Keywords: Biodegradation, bacteria, effluent, immobilization, tannery.

\section{INTRODUCTION}

Tannery industrial wastewater is a serious consequence of the pollution point of view for streams, freshwater, and land used for agriculture. The lack of awareness in the modern industrial practice has resulted in the discharge of tannery effluents which exhibit very high value of chromium ( $\mathrm{Cr}$ ), Sulfide, and chloride, Total Dissolved Solid (TDS), Total Suspended Solid (TSS), Biochemical Oxygen Demand (BOD) and Chemical Oxygen Demand (COD) in the water stream or land (Mohammed et al., 2001). Tanning is the process, which One ton of skin generally leads to the production of 20 to $80 \mathrm{~m}^{3}$ of turbid and foul-smelling converts the protein of the rawhide or skin into a stable material, which will not putrefy and is suitable for a wide variety of end applications (Elsheikh, 2009). The highly polluting chromium is the most commonly used tanning material producing leather that is more flexible and pliable than vegetable-tanned leather and does not discolor or lose shape in water as drastically as vegetable-tan (Elsheikh, 2009). Tannery effluent is among the most hazardous industrial pollutants due to its huge organic and inorganic load, which is highly toxic to human life and the environment (Kongjao et al., 2008). wastewater including chromium (100-400 mg/l), sulfide $(200-800 \mathrm{mg} / \mathrm{l})$, high levels of fat and 
BAJOPAS Volume 13 Number 2, December, 2020 other solid wastes, and notable pathogen contamination as well as pesticides added for skin conservation during transport (Elsheikh, 2009). There are more than 6000 tanneries in Nigeria with an annual processing capacity of 700,000 tons of hides and skins (Omoleke, 2004; Singh et al., 2008). It was reported that the total amount of waste produced per animal slaughtered is approximately $35 \%$ of its weight (World Bank, 1995). Also, for every $1000 \mathrm{~kg}$ of carcass weight, a slaughtered beef produces 5.5 $\mathrm{kg}$ of manure (excluding rumen contents or stockyard manure) and $100 \mathrm{~kg}$ of paunch manure (undigested food) (Verheijen et al., 1996). Tanneries generate wastewater in the range of 30-35 $\mathrm{L} \mathrm{kg}^{-1}$ skin/hide processed with variable $\mathrm{pH}$, Biological Oxygen Demand (BOD), Chemical Oxygen Demand (COD), high concentrations of suspended solids (SS), and tannins as well as chromium (Zahoor and Abdul, 2009).

Being heterogeneous and composed of a wide variety of compounds, it is very difficult to select a unique direct method for estimating the biodegradability of organic contents and biokinetic parameters for a wastewater sample (Rajor, 2004). For this purpose, some indirect estimation such as determination of biochemical oxygen demand (BOD) and chemical oxygen demand (COD) are applied as common laboratory investigations [9]. During retanning procedures, synthetic tannins (Syntan), oils and resins are added to form softer leather at varying doses (Munz et al., 2009). One of the refractory groups of chemicals in tannery effluents derives mainly from tannins (Ramasami et al., 2004). Syntans are characterized by complex chemical structures, because they are composed of an extended set of chemicals such as phenol-, naphthalene-, formaldehyde- and melamine-based syntans, and acrylic resins (Beem, 1994). Organic pollutants (proteic and lipidic components) are originated from skins (it is calculated that the raw skin has $30 \%$ loss of organic material during the working cycle) or they are introduced during processes (Hugo Springer, 1994).

Many conventional processes such as oxidation, chemical and biological processes were carried out to treat tanneries wastewater (Ebtesam et al, 2013). Biological processes have received more attention because of their costeffectiveness, lower sludge production and environmental friendliness (Noorjahan, 2014). Naturally occurring micro-organisms degrade the hazardous organic wastes including xenobiotic compounds, such as pesticides, polycyclic aromatic hydrocarbons (PAHs) and polychlorinated biphenyls (PCBs) in due course of time (Ranen and Sharadinadra, 2009). Bioremediation is based on the idea that all organisms remove substances from the environment to carry outgrowth and metabolism (Bouwer and Zehnder, 1993). Bacteria, protista and fungi are found to be very good at degrading complex molecules and incorporating the breakdown products into their metabolism (Bouwer and Zehnder, 1993). The resultant metabolic wastes that they produce are generally safe and somehow recycled into other organisms (Ranen and Sharadinadra, 2009). An acclimatized indigenous population of microorganisms capable of degradation of the compounds of interest must exist at the site for a successful bioremediation mode (Ranen and Sharadinadra, 2009). It has been observed that for a successful bioremediation mode, an acclimatized indigenous population of microorganisms capable of degradation of the compounds of interest must exist at the site under investigation (Ranen and Sharadinadra, 2009). Even though there are numerous physical and chemical methods employed in the disposal of wastes the advantage in using bacterium is that they play a key role in the reduction of COD, BOD, total protein, total tannin and total phenol (Saravanan and Saravanan, 1998)

Baba et al. (2020) studied the bioremediation potential of immobilized corynebacterium kutsceri in the Treatment of tannery industrial effluent from Challawa Industrial Estate, Kano State, Nigeria. The aim of the work is to study the reduction in the level of the contaminants through the process of bioremediation using the isolated bacteria. Immobilized bacteria can withstand various temperatures, $\mathrm{pH}$ and substrate concentrations; consequently, increasing the efficiency and the lifespan of the bacteria. Immobilized bacteria are widely applied in the treatment of wastewater and can be separated and recovered after the treatment with the same efficiency (Baba et al., 2020).

\section{MATERIALS AND METHODS \\ Study Area}

This study was carried out in Bompai, Sharada and Challawa industrial estates in Kano, Figure 1. Kano lies on Latitude $11^{\circ} 30^{\prime} \mathrm{N}$ and $8^{\circ} 30^{\prime} \mathrm{E}$ and Longitude $11^{\circ} 5^{\prime} \mathrm{N}$ and $8^{\circ} 5^{\prime} \mathrm{E}$ in Northern Nigeria. It is one of the developed industrial cities in Nigeria. Tannery activities are the dominating industries and this could be one of the reasons for her high population density (Dan'Azumi and Bichi, 2010). Many researchers have studied biodegradation of tannery effluent using microorganisms. However, limited literature is available on the biodegradation of tannery effluent in Kano industrial estates using 
BAJOPAS Volume 13 Number 2, December, 2020 immobilized bacterial cells. This research work focuses on the potential of the use of the indigenous immobilized bacterial isolates in the treatment of tannery effluents in the industrial estates.

\section{Sample Collection}

Effluents were collected from the Tannery Industries from Bompai, Challawa and Sharada Industrial Estates, Kano, Nigeria. The effluents were collected over a period of six months (August 2017 to January 2018). Samples collected in a sterile 4-liter plastic container with a unique identification number were preserved using an ice-box that was transported to the Microbiology Laboratory, Department of Microbiology, Bayero University of Kano for analysis

\section{Sample Preparation and Sample Analysis}

Immediately after the collection of the effluent, $\mathrm{pH}$, TSS, TDS, COD, BOD levels were determined before treatment (Pre-treatment determination) and ten days after treatment (Post-treatment determination) as described in
APHA (1989) standard methods. $\mathrm{pH}$ was determined using Ecotests $\mathrm{pH}$ meter and TDS was determined using AQUALYTIC TDS Salinometer. BOD was determined as described by the standard method (APHA, 1992). COD and SS were determined using DR/2010 HACH portable data logging spectrophotometer (DWAF, 1992)

\section{Identification and Biochemical} Characterization of the Bacterial Isolates

The bacteria were isolated from the effluents using Serial Dilution according to the method described by APHA (1989). The biochemical tests such as oxidase, catalase, coagulase, indole (from $1 \%$ tryptone broth), citrate (Simmons citrate agar), methyl red/VogesProskauer (MR/VP), nitrate reduction, Starch Hydrolysis, Glucose, Maltose, and Lactose tests were carried out on the bacterial isolates to identify the bacteria through the bacteria biochemical characteristics according to Ajao et al. (2011).

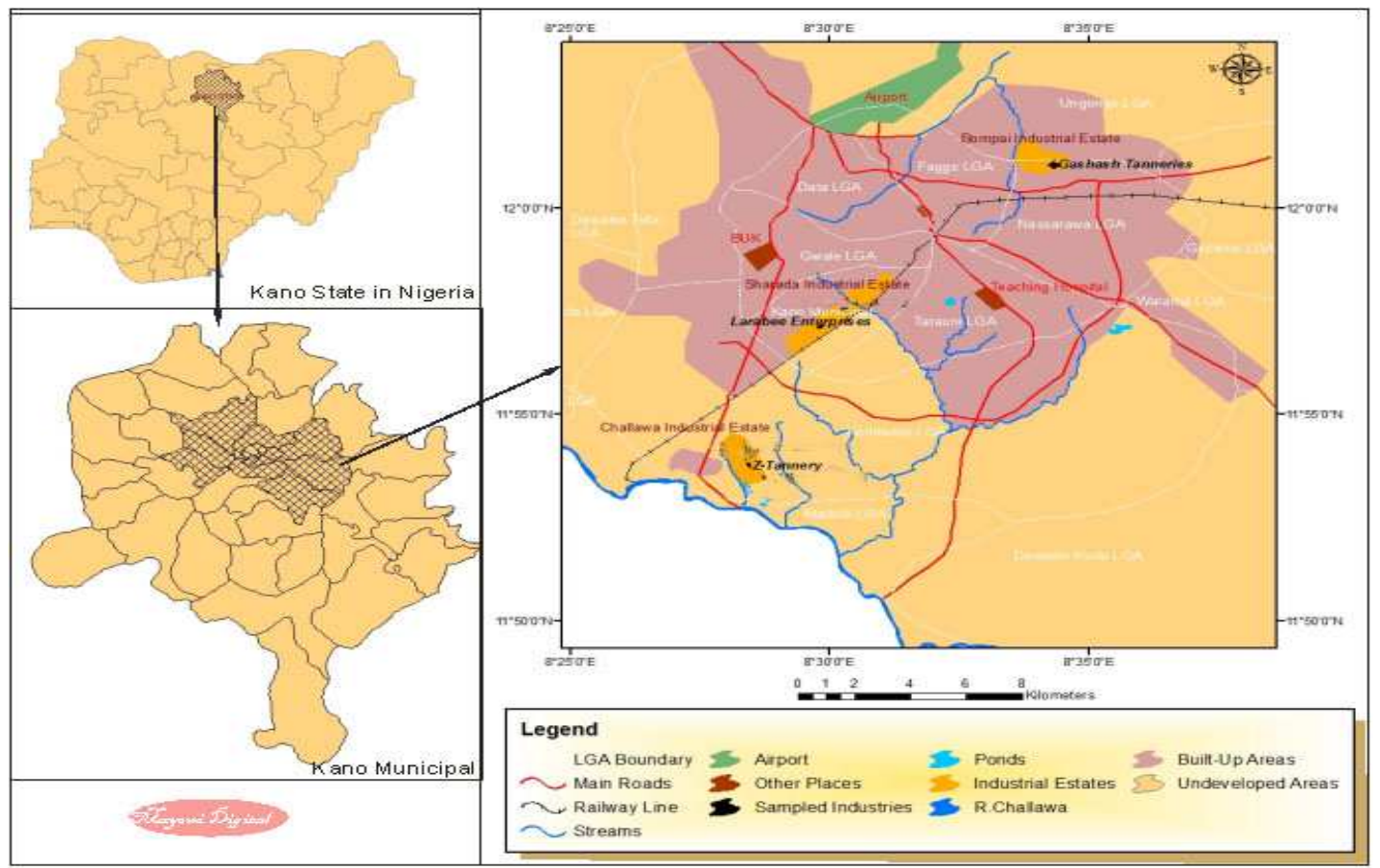

Fig. 1 Map showing the study areas

Source: Mayomi Digital Productions, GIS Laboratory, Department of Geography, UNIMAID (2017)

\section{Determination of Growth Rate of the Bacteria in Effluent Sample}

The bacteria growth rates were determined by transferring $2 \mathrm{~mL}$ of the bacterial isolates from the tannery effluent in broth medium into 100 $\mathrm{mL}$ sterile effluents in conical flasks and kept in an incubator (Giffrin cool) for 10 days. Control was also set up by incubating another $100 \mathrm{~mL}$ each of the sterile effluents without the bacteria. The optical density of the content was determined at the wavelength of $600 \mathrm{~nm}$ on a daily interval and recorded. 
BAJOPAS Volume 13 Number 2, December, 2020 Immobilization of Bacteria

Agar solution and inoculi were prepared separately. Fifty milliliters $(50 \mathrm{~mL})$ of nutrient broth each of the inoculi was prepared in a McCartney bottle and incubated for 24 hours. A solution of agar-agar was prepared by dissolving $10 \mathrm{~g}$ of the powder in distilled water and made up to $500 \mathrm{~mL}$ mark in an Erlenmeyer flask and was sterilized in an autoclave (280A) for 15 minutes and allowed to cool to $40-45^{\circ} \mathrm{C}$ (Ajao et al., 2011). Four milliliters ( $4 \mathrm{~mL})$ of the bacterial isolates in the nutrient broth was mixed with 36 $\mathrm{ml}$ of the prepared agar-agar media in petri-dish plates and then allowed to solidify. This was kept in the refrigerator for bioremediation.

\section{Bioremediation (Treatment) of the Effluents}

The solidified agar block (immobilized bacteria) was cut into cubes using a sterile knife; $0.1 \mathrm{~mL}$ phosphate buffer ( $\mathrm{pH} \mathrm{7.0)}$ was added and kept in the refrigerator for 1 hour for curing. The phosphate buffer was decanted after 1 hour and the cubes were washed with sterile distilled water 3-4 times before it was used (Ajao et al., 2011). Two liters (2 L) of the effluent was supplemented with the minimum basal medium in $\mathrm{g} / \mathrm{L}: \mathrm{NaCl}(0.8), \mathrm{MgSO}_{4} .7 \mathrm{H}_{2} \mathrm{O}(0.001), \mathrm{KH}_{2} \mathrm{PO}_{4}$ (2), $\mathrm{NaNO}_{3}$ (2), $\quad \mathrm{CaCl}_{2} .2 \mathrm{H}_{2} \mathrm{O} \quad(0.5)$ and $\mathrm{NaHPO}_{4} .12 \mathrm{H}_{2} \mathrm{O}(2)$ and sterilized in an autoclave at $121^{\circ} \mathrm{C}$ for 15 minutes (Margesin and Schinner, 2001). Two hundred and fifty milliliters $(250 \mathrm{~mL})$ of the effluents were transferred into different $250 \mathrm{ml}$ conical flasks. The content was covered with a cotton-wool ramped with foil paper to avoid contamination. Five grams $(5 \mathrm{~g})$ of the immobilized bacteria were quickly transferred into each of the effluents in the conical flasks in an inoculating chamber. The same procedures were carried out for the $10 \mathrm{~g}, 15 \mathrm{~g}, 20 \mathrm{~g}$ and 25 $\mathrm{g}$ of the immobilized bacteria in separate $250 \mathrm{~mL}$ effluents in conical flasks and agitated for ten days in a shaker incubator (Gallenkamp-OC4364-L) at a temperature $30^{\circ} \mathrm{C}$ and speed of 60 rpm. The treated effluent samples were taken on the tenth day and analyzed for the parameters $\mathrm{pH}$, SS, TDS, COD, and BOD, (Posttreatment determination) for the different grams of bacteria to evaluate and compare the biodegradation potential. (Baba et al., 2020).

\section{Statistical Analysis}

The data were represented as Mean \pm Standard deviation and analyzed statistically using oneway Analysis of Variance (ANOVA) and Tukey's HSD as Post Hoc Tests with the aid of SPSS 16.0. The correlation coefficient was also used to measure the strength of the relationship between the different masses of the bacteria and the parameters. All $\mathrm{p} \leq 0.05$ were considered as statistically significant.

\section{RESULTS AND DISCUSSION Physico-chemical parameters in the Industrial Effluents before the Biodegradation.}

Results of the Physico-chemical parameters in the industrial effluents before the Biodegradation is shown in table 1 . The mean temperatures $\left({ }^{\circ} \mathrm{C}\right)$ observed in TAN1, TAN2, and TAN3 samples were $28.07 \pm 0.65 ; 27.77 \pm 0.64$ and $26.38 \pm 3.81$ respectively. The order of the mean temperature of the samples from the three industries can be arranged as TAN1 > TAN2>TAN3. The temperature observed at TAN1, TAN2, and TAN3 samples were found below the WHO $\left(35^{\circ} \mathrm{C}\right)$ and NESREA $\left(40^{\circ} \mathrm{C}\right)$ limits. The low values of temperature might be due to the processes used at the time of sampling. High temperature brings down the solubility of gases in water that ultimately expresses as high BOD and COD. Statistical analysis shows that there is no significant difference $(p<0.05)$ between the mean values of temperature among the industries. This might be due to similar tannery activities involved in the tannery industries at the time of sampling. The average values of temperature observed in this present study are less than those observed by Akan et al. (2007), Akan et al. (2009) and Baba et al. (2020).

The mean level of $\mathrm{pH}$ observed in TAN1, TAN2 and TAN3, samples were $7.77 \pm 2.93$; $8.35 \pm 0.28$ and $7.52 \pm 0.76$ respectively. The order of the mean $\mathrm{pH}$ of the samples from the three industries can be arranged as TAN2> TAN1 $>$ TAN3. The $\mathrm{pH}$ of the samples falls within the WHO (7.0-8.5) and NESREA (6-9) standard limits. Statistical analysis shows that there is no significant difference $(p<0.05)$ between the mean values of $\mathrm{pH}$ among the industries. This might be due to similar tannery activities involved in the tannery industries at the time of sampling. Maheshwari et al. (2017) reported that the level of $\mathrm{pH}$ in the effluents from the tannery industry in Vaniyambadi, India was 6.5 which was lower than that observed in the present study. The $\mathrm{pH}$ in the effluents from the tannery industries in Kano and Kaduna were reported to be 7.64 and 6.89, respectively (Akan et al., 2007; Mohammed et al., 2017). The average values of $\mathrm{pH}$ observed in this present study are less than those observed by Mohammed et al. (2017) and Baba et al. (2020). The mean level of SS $(\mathrm{mg} / \mathrm{l})$ observed in TAN1, TAN2, and TAN3 samples were 374 \pm 124 ; $358 \pm 335$ and $780 \pm 739$ respectively. The order of the mean SS in the samples from the three industries can be arranged as TAN3 > TAN1 $>$ TAN2. 
The SS observed in the samples were far above the recommended standard limits of regulating bodies WHO $(30 \mathrm{mg} / \mathrm{l})$ and NESREA $(10 \mathrm{mg} / \mathrm{l})$. Statistical analysis shows that there is no significant difference $(p<0.05)$ between the mean values of SS among the industries. This might be due to similar tannery activities involved in the tannery industries at the time of sampling. The average values of SS observed in this present study are less than that observed $(3700 \pm 122 \mathrm{mg} / \mathrm{l})$ by Akan et al. (2009) for tanneries in Kano. Also, the average values of SS observed in this present study are less than that observed by Mohammed et al. (2017) and Baba et al. (2020) with the exception in TAN3.

The mean level of TDS (mg/l) observed in TAN1, TAN2, and TAN3 samples were $3941 \pm 3703$; $3300 \pm 1714$ and $2653 \pm 1240$ respectively. The order of the mean TDS in the samples from the three industries can be arranged as TAN1>TAN2>TAN3. The TDS observed in the samples were far above the recommended standard limits of WHO $(250 \mathrm{mg} / \mathrm{l})$ and NESREA $(500 \mathrm{mg} / \mathrm{l})$. Statistical analysis shows that there is no significant difference $(p<0.05)$ between the mean values of TDS among the industries. This might be due to similar tannery activities involved in the tannery industries at the time of sampling. TDS in the effluents from the tannery industries in Kano, Nigeria was reported to be $1281 \mathrm{mg} / \mathrm{l}$ (Akan et al., 2007). The average values of SS observed in this present study are less than those observed by Mohammed et al. (2017) and Baba et al. 2020)

The mean level of COD (mg/l) observed in TAN1, TAN2 and TAN3 samples seasons were $2372 \pm 938 ; \quad 1406 \pm 208$ and $3532 \pm 1373$ respectively. The order of the mean COD of the samples from the three industries can be arranged as TAN3>TAN1> TAN2. The COD observed in TAN1, TAN2 and TAN3 samples were far above the recommended standard limits of regulating bodies $\mathrm{WHO}(40 \mathrm{mg} / \mathrm{l})$ and NESREA (40 mg/l). Statistical analysis shows that there is no significant difference $(p<0.05)$ in COD among the industries. This might be due to similar tannery activities involved in the tannery industries as at the time of sampling. The Chemical Oxygen demand (COD) is the amount of oxygen, in $\mathrm{mg} / \mathrm{L}$, required for the degradation of the compound of wastewater to occur. In comparison, the average values of COD observed in this present study were higher than that observed by Mohammed et al. (2017) but lower than that observed by Baba et al. (2020).

The mean levels of BOD $(\mathrm{mg} / \mathrm{l})$ observed in TAN1, TAN2 and TAN3 samples were $13.85 \pm 6.42 ; \quad 19.46 \pm 0.50$ and $17.13 \pm 3.14$ respectively. The order of the mean BOD in the samples from the three industries can be arranged as TAN2>TAN3>TAN1. The BOD observed in TAN1, TAN2 and TAN3 samples were found below the recommended limits of NESREA (200 mg/l) but above WHO (10 mg/l). Statistical analysis shows that there is no significant difference $(p<0.05)$ between the mean values of BOD among the industries. This might be due to similar tannery activities involved in the tannery industries at the time of sampling. The low level of BOD recorded in this study is an indication of the low level of biodegradable organic solids in the effluent. The average values of BOD observed in this present study were lower than those observed by Mohammed et al. (2017) and Baba et al. (2020).

Table 1: Mean Values \pm S.D of Physico-chemical parameters of effluents from the Tannery Industries before Treatment.

\begin{tabular}{llllllll}
\hline Parameter & Tannery 1 & Tannery 2 & Tannery 3 & $\mathrm{a}$ & $\mathrm{b}$ & $\mathrm{c}$ & $\mathrm{d}$ \\
\cline { 2 - 7 } Temperature $\left({ }^{\circ} \mathrm{C}\right)$ & $28.07 \mathrm{a} \pm 0.65$ & $27.77 \mathrm{a} \pm 0.64$ & $26.38 \mathrm{a} \pm 3.81$ & & $29.50 \pm 4.68$ & 35 & 40 \\
pH & $7.77 \mathrm{a} \pm 2.93$ & $8.35 \mathrm{a} \pm 0.28$ & $7.52 \mathrm{a} \pm 0.76$ & 6.89 & $5.35 \pm 1.57$ & $7.0-8.5$ & $6.0-9.0$ \\
$\mathrm{COD}(\mathrm{mg} / \mathrm{l})$ & $2372 \mathrm{a} \pm 938$ & $1406 \mathrm{a} \pm 208$ & $3532 \mathrm{a} \pm 1373$ & 2.2 & $3106 \pm 2753$ & 40 & 40 \\
$\mathrm{BOD}(\mathrm{mg} / \mathrm{l})$ & $13.85 \mathrm{a} \pm 6.42$ & $19.46 \mathrm{a} \pm 0.50$ & $17.13 \mathrm{a} \pm 3.14$ & 1032 & $26.17 \pm 9.49$ & 10 & 200 \\
$\mathrm{SS}(\mathrm{mg} / \mathrm{l})$ & $374 \mathrm{a} \pm 124$ & $358 \mathrm{a} \pm 335$ & $780 \mathrm{a} \pm 739$ & 501 & $562 \pm 482$ & 30 & 10 \\
TDS $(\mathrm{mg} / \mathrm{l})$ & $3941 \mathrm{a} \pm 3703$ & $3300 \mathrm{a} \pm 1714$ & $2653 \mathrm{a} \pm 1240$ & 532.7 & $444 \pm 507$ & 250 & 500 \\
\hline
\end{tabular}

The values given in the table above are means of 6 replicate values, $\mathrm{n}=6$ ( 1 sample was taken monthly for 6 months). Within the rows, means with different alphabets are statistically different $(p<0.05)$. WHO: World Health Organisation. NESREA: National Environmental Standard and Regulatory Enforcement Agency. a = Mohammed et al.(2017), b = Baba et al. (2020), c = WHO (2006), $d=$ NESSRA (2009) 
BAJOPAS Volume 13 Number 2, December, 2020

Identification, Biochemical Characterization and growth rates of the Bacterial Isolates

Results of identification and biochemical characterization of the bacterial isolates were shown in table 2. After 24 hours of incubation, the nutrient agar media plates were checked for bacterial growth. The results showed the presence of different strains in the samples. The TAN1 bacteria isolate was found to be gramnegative cocci while TAN3 was gram-positive cocci. TAN2 bacteria isolate was found to be gram-positive, rod-shaped. TAN1, TAN2, and TAN3 bacteria isolates recorded positive results for spore former.

The results of the biochemical tests indicated that all the bacteria were positive for catalase, oxidase, citrate, maltose, glucose, lactose (negative in TAN1), mannitol (negative in TAN2), starch hydrolysis and coagulase (negative in TAN2) tests. The bacteria showed negative results for nitrate reduction, $M R$ (positive in TAN2), VP (positive in TAN1), Indole (positive in TAN2) tests. Base on the morphological and biochemical test results, TAN1, TAN2, and TAN3 bacteria isolates were identified to be Nesseria spp, Bacillus cereus, and Staphylococcus aureus respectively.

The growth rate of the TAN1, TAN2 and TAN3 Isolates were shown in figure 2. Generally, the optical density increase with the increase in time (day) and decrease as time goes on. The highest optical density was shown by bacillus cereus in TAN2 while the lowest was shown by Staphylococcus aureus in TAN3.

The initial growth phase of TAN1 Isolate bacteria occurred within 2-day of incubation as the growth rate increases up to the 6th-day incubation when the maximum growth was observed. Beyond the 6th day, the growth of the bacteria declined (which might be due to a shortage of nutrients in the effluents) until it reached its death phase (which might be due to the unavailability of nutrients in the effluents).

A similar trend of growth was also observed for TAN2 Isolate as the initial growth phase also occurred within 2-day of incubation but maximum growth rate observed on the 4th day of incubation. The stationary stage occurred between the 4th day and the 8th day. Beyond the 8th day, the growth of the bacteria declined (which might be due to a shortage of nutrients in the effluents) until it reached its death phase (which might be due to the unavailability of nutrients in the effluents).

The initial growth phase of TAN3 bacterial Isolate occurred within the 3-day incubation as the growth rate increases up to the 6th-day incubation when the maximum growth was observed. Beyond the 6th day, the growth of the bacteria declined (which might be due to a shortage of nutrients in the effluents) until it reached its death phase (which might be due to the unavailability of nutrients in the effluents).

Table 2: Morphological and Biochemical characteristics of bacterial isolates

\begin{tabular}{lllll} 
Bacterial Isolates & & TAN1 & TAN2 & TAN3 \\
\hline $\begin{array}{lllll}\text { Morphological } \\
\text { characteristics }\end{array}$ & Shape & Cocci & Rod & Cocci \\
& Spore & & & \\
& former & + & + & + \\
Gram & & & \\
Biochemical characteristics & reaction & - & + & + \\
& Citrate & + & + & + \\
& Catalase & + & + & + \\
& Coagulase & + & - & + \\
Starch & + & + & + \\
& Glucose & + & + & + \\
Oxidase & + & + & + \\
& Indo & - & + & - \\
Lactose & - & + & + \\
Manitol & + & - & + \\
Maltose & + & + & + \\
MR & - & + & - \\
VP & + & - & - \\
& Nitrate & - & - & - \\
Reduction & - Neisseria & Bacillus & Staphylococcus \\
& Bacterial & cereus & aureus \\
& name & spp & cas
\end{tabular}

+ = Positive; - = Negative; MR=Methyl Red; VP= Voges-Proskauer 


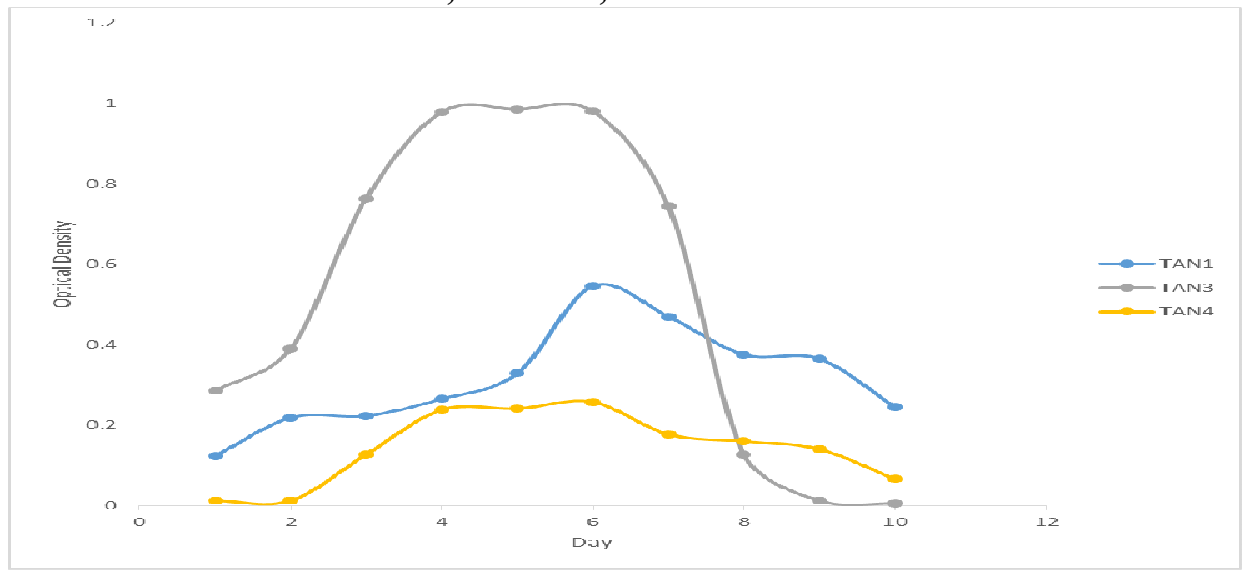

Fig. 2 Growth rates of the isolates in the effluents from the Tannery Industries

\section{Physico-chemical Parameters in the Industrial Effluents after the biodegradation.}

Table 3 shows the mean results of the physicochemical parameter before and after bioremediation using the different masses $(5 \mathrm{~g}$, $10 \mathrm{~g}, 15 \mathrm{~g}, 20 \mathrm{~g}$, and $25 \mathrm{~g}$ ) of the respective immobilized bacteria. Also, Table 4 shows the mean results of correlation coefficient ( $r$ ) between different masses of bacteria and physicochemical parameters.

The mean values $(\mathrm{mg} / \mathrm{l})$ of the SS after the bioremediation varies between $243 \pm 45$ and $898 \pm 672$. The mean concentration $(\mathrm{mg} / \mathrm{l})$ of SS remediated by the different masses $(5 \mathrm{~g}, 10 \mathrm{~g}$, $15 \mathrm{~g}, 20 \mathrm{~g}$, and $25 \mathrm{~g}$ ) of the bacteria varies. The SS in the samples fluctuates up and down after the bioremediation process when compared with the SS of the raw samples before the bioremediation. The increase in the levels of the SS might be due to the aggregation of the TDS which are large enough to result into SS. The increase in the levels of the SS might be also due to the influence of the nutrients which was added into the effluents in order to make the microorganisms more active and viable for fast degradation of organic contaminants in the effluent. The relative potential or efficiency of the different masses of the bacteria in remediating SS in TAN1 samples was in the order $25 \mathrm{~g}>20 \mathrm{~g}>15 \mathrm{~g}>10 \mathrm{~g}>5 \mathrm{~g}$. For TAN2 and TAN3 samples, the order was $25 \mathrm{~g}>20 \mathrm{~g}>15$ $\mathrm{g}>10 \mathrm{~g}>5 \mathrm{~g}$. These might be due to the variations in the surface areas of the different masses of the immobilized bacteria. Statistical analysis shows that there is no significant difference $(p<0.05)$ between the mean values of SS among the masses in the respective industries. Positive and significant correlations exist between the masses of bacteria and Suspended Solid (SS). This showed that there is general increase in the levels of the SS as the masses of the immobilized bacteria increases. TAN3 (90\%) and TAN1 (80\%) showed a very high correlation with the masses of the bacteria while TAN2 (61\%) showed a very low correlation.

The mean values $(\mathrm{mg} / \mathrm{l})$ of the TDS after the bioremediation varies between $46 \pm 11$ and $83 \pm 78$. The mean concentration $(\mathrm{mg} / \mathrm{l})$ of TDS remediated by the different masses $(5 \mathrm{~g}, 10 \mathrm{~g}$, $15 \mathrm{~g}, 20 \mathrm{~g}$, and $25 \mathrm{~g}$ ) of the bacteria varies. There is a reduction in all the TDS of all the samples after the bioremediation process compared with the TDS of the raw samples before the bioremediation. The relative potential or efficiency of the different masses of the bacteria in remediating TDS in TAN1 and TAN3 samples was in the order $5 \mathrm{~g}>10 \mathrm{~g}>15 \mathrm{~g}>20$ $\mathrm{g}>25 \mathrm{~g}$. For TAN2 samples, the order was 20 $g>10 \quad g>25 \quad g>15 \quad g>5 \quad g$. Statistical analysis shows that there is no significant difference $(p<0.05)$ between the mean values of TDS among the masses in the respective industries. These might be due to the variations in the surface areas of the different masses of the immobilized bacteria. Positive and significant correlations exist between the masses of bacteria and TDS with the exception in TAN2 (negative and insignificant correlation). The positive correlations showed that there is general increase in the levels of the TDS as the masses of the immobilized bacteria increases. TAN1 $(96 \%)$ showed a very high correlation with the masses of the bacteria while TAN2 (47\%) showed a very low correlation.

The mean values $(\mathrm{mg} / \mathrm{l})$ of the BOD after the bioremediation varies between $1.56 \pm 0.20 \mathrm{mg} / \mathrm{l}$ and $6.92 \pm 5.49 \mathrm{mg} / \mathrm{l}$. The mean concentration $(\mathrm{mg} / \mathrm{l})$ of BOD remediated by the different masses $(5 \mathrm{~g}, 10 \mathrm{~g}, 15 \mathrm{~g}, 20 \mathrm{~g}$, and $25 \mathrm{~g}$ ) of the bacteria varies. There is a reduction in all the BOD of all the samples after the bioremediation process compared with the $\mathrm{BOD}$ of the raw 
BAJOPAS Volume 13 Number 2, December, 2020 samples before the bioremediation. The relative potential or efficiency of the different masses of the bacteria in remediating BOD in TAN1, TAN2 and TAN3 samples were in the order $25 \mathrm{~g}>20$ $\mathrm{g}>15 \mathrm{~g}>10 \mathrm{~g}>5 \mathrm{~g}, 25 \mathrm{~g}>15 \mathrm{~g}>5 \mathrm{~g}>10 \mathrm{~g}>20 \mathrm{~g}$ and $20 \mathrm{~g}>10 \mathrm{~g}>25 \mathrm{~g}>15 \mathrm{~g}>5 \mathrm{~g}$ respectively. Statistical analysis shows that there is significant difference $(p<0.05)$ between the mean values of BOD among the masses in the respective industries. These might be due to the variations in the surface areas of the different masses of the immobilized bacteria. Negative and significant correlations exist between the masses of bacteria and BOD. This showed that there is general decrease in the levels of the BOD as the masses of the immobilized bacteria increases. TAN1 (94\%) showed a very high correlation with the masses of the bacteria while TAN2 (4\%) showed a very low correlation.

The mean values $(\mathrm{mg} / \mathrm{l})$ of the COD after the bioremediation varies between $250 \pm 154$ and $3134 \pm 1595$. The mean concentration $(\mathrm{mg} / \mathrm{l})$ of COD remediated by the different masses $(5 \mathrm{~g}$, $10 \mathrm{~g}, 15 \mathrm{~g} 20 \mathrm{~g}$, and $25 \mathrm{~g}$ ) of the bacteria varies. There is a reduction in all the COD of all the samples after the bioremediation process compared with the COD of the raw samples before the bioremediation. The relative potential or efficiency of the different masses of the bacteria in remediating COD in TAN1, TAN2 and TAN3 samples were in the order $25 \mathrm{~g}>20 \mathrm{~g}>15$ $\mathrm{g}>5 \mathrm{~g}>10 \mathrm{~g}, 25 \mathrm{~g}>20 \mathrm{~g}>15 \mathrm{~g}>10 \mathrm{~g}>5 \mathrm{~g}$ and 10 g>5 g>25 g>15 g>20 g respectively. Statistical analysis shows that there were significant difference $(p<0.05)$ between the mean values of COD among the masses in the respective industries except for effluents treated with $25 \mathrm{~g}$. These might be due to the variations in the surface areas of the different masses of the immobilized bacteria. Negative and insignificant correlations exist between the masses of bacteria and COD with the exception in TAN3 (positive and significant correlation). The negative correlations showed that there is general decrease in the levels of the COD as the masses of the immobilized bacteria increases. TAN2 (100\%) showed a very high correlation with the masses of the bacteria while TAN3 (36\%) showed a very low correlation.

Generally, there was an overall decrease in the concentration of these physicochemical parameters after the bioremediation using the different masses of the bacterial isolates. These might be due to the variations in the surface areas of the different masses of the immobilized bacteria. This is in line with the work of Jimoh et al. (2018) and Baba et al. (2020).

Table 3: Mean Values $(\mathrm{mg} / \mathrm{l}) \pm$ S.D of Physicochemical parameters in effluents from the Tannery Industries before and after Treatment of the effluents $(250 \mathrm{ml})$ with the different masses $(5 \mathrm{~g}, 10 \mathrm{~g}$, $15 \mathrm{~g}, 20 \mathrm{~g}$, and $25 \mathrm{~g}$ ) of the bacteria.

\begin{tabular}{llllllll}
\hline $\mathrm{P}$ & IND & Before & \multicolumn{5}{c}{ After } \\
\cline { 4 - 7 } & & & $5 \mathrm{~g}$ & $10 \mathrm{~g}$ & $15 \mathrm{~g}$ & $20 \mathrm{~g}$ & $25 \mathrm{~g}$ \\
\hline \multirow{2}{*}{ COD } & TAN1 & $2372 \pm 938$ & $1708 \mathrm{a} \pm 861$ & $2045 \mathrm{a} \pm 1205$ & $845 \mathrm{a} \pm 369$ & $300 \mathrm{a} \pm 167$ & $250 \mathrm{a} \pm 154$ \\
& TAN2 & $1406 \pm 208$ & $1195 \mathrm{a} \pm 208$ & $1125 \mathrm{a} \pm 384$ & $1055 \mathrm{a} \pm 317$ & $956 \mathrm{a} \pm 310$ & $870 \mathrm{ab} \pm 240$ \\
& TAN3 & $3532 \pm 1373$ & $2374 \mathrm{a} \pm 1344$ & $1976 \mathrm{a} \pm 1405$ & $2757 \mathrm{a} \pm 1266$ & $3134 \mathrm{a} \pm 1595$ & $2614 \mathrm{~b} \pm 1105$ \\
BOD & TAN1 & $13.85 \pm 6.42$ & $6.92 \mathrm{a} \pm 5.49$ & $6.42 \mathrm{a} \pm 5.07$ & $5.72 \mathrm{a} \pm 5.35$ & $4.62 \mathrm{a} \pm 4.37$ & $2.82 \mathrm{ab} \pm 1.26$ \\
& TAN2 & $19.46 \pm 0.50$ & $1.75 \mathrm{~b} \pm 0.22$ & $1.73 \mathrm{~b} \pm 0.18$ & $1.58 \mathrm{a} \pm 0.16$ & $1.91 \mathrm{a} \pm 0.22$ & $1.56 \mathrm{~b} \pm 0.20$ \\
& TAN3 & $17.13 \pm 3.14$ & $4.24 \mathrm{ab} \pm 0.77$ & $3.29 \mathrm{ab} \pm 0.37$ & $4.11 \mathrm{a} \pm 0.07$ & $3.23 \mathrm{a} \pm 0.91$ & $3.33 \mathrm{a} \pm 1.28$ \\
SS & TAN1 & $374 \pm 124$ & $243 \mathrm{a} \pm 45$ & $471 \mathrm{a} \pm 226$ & $475 \mathrm{a} \pm 182$ & $492 \mathrm{a} \pm 128$ & $611 \mathrm{a} \pm 217$ \\
& TAN2 & $358 \pm 335$ & $460 \mathrm{a} \pm 400$ & $543 \mathrm{a} \pm 414$ & $544 \mathrm{a} \pm 402$ & $551 \mathrm{a} \pm 414$ & $554 \mathrm{a} \pm 405$ \\
& TAN3 & $780 \pm 739$ & $586 \mathrm{a} \pm 594$ & $758 \mathrm{a} \pm 656$ & $787 \mathrm{a} \pm 676$ & $861 \mathrm{a} \pm 635$ & $898 \mathrm{a} \pm 672$ \\
TDS & TAN1 & $3941 \pm 3703$ & $51 \mathrm{a} \pm 10$ & $53 \mathrm{a} \pm 10$ & $55 \mathrm{a} \pm 15$ & $61 \mathrm{a} \pm 20$ & $63 \mathrm{a} \pm 26$ \\
& TAN2 & $3300 \pm 1714$ & $83 \mathrm{a} \pm 78$ & $47 \mathrm{a} \pm 20$ & $48 \mathrm{a} \pm 22$ & $47 \mathrm{a} \pm 17$ & $48 \mathrm{a} \pm 17$ \\
& TAN3 & $2653 \pm 1240$ & $46 \mathrm{a} \pm 11$ & $55 \mathrm{a} \pm 24$ & $55 \mathrm{a} \pm 25$ & $58 \mathrm{a} \pm 23$ & $61 \mathrm{a} \pm 28$ \\
\hline
\end{tabular}

Replicate $=6$ (months)

Within the rows, for the same parameter, means with different alphabets are statistically different $(p<0.05)$.

$\mathrm{P}=$ parameter, IND = Industries 
BAJOPAS Volume 13 Number 2, December, 2020

Table 4: Correlation coefficient $(r)$ between different masses of the bacteria and the physicochemical parameters.

\begin{tabular}{llll}
\hline Industries & Parameter & Correlation coefficient $(r)$ & $\begin{array}{l}\text { Percent dependence (rxrx100) } \\
(\%)\end{array}$ \\
\hline TAN1 & COD & -0.9 & 82 \\
& BOD & -0.97 & 94 \\
& SS & $0.90^{*}$ & 80 \\
TAN2 & TDS & $0.98^{*}$ & 96 \\
& COD & -1 & 100 \\
& BOD & -0.21 & 4 \\
& SS & $0.78^{*}$ & 61 \\
& TDS & -0.69 & 47 \\
& COD & $0.60^{*}$ & 36 \\
& BOD & -0.6 & 37 \\
& SS & $0.95^{*}$ & 90 \\
& TDS & $0.94^{*}$ & 89 \\
\hline
\end{tabular}

The correlation coefficient $(r)$ with * is statistically significant $(p<0.05)$.

Percentage reduction of the Parameters

Table 5 shows the percentage reduction of Parameters in industrial samples before and after the treatment of the effluents $(250 \mathrm{ml})$ with the different masses $(5 \mathrm{~g}, 10 \mathrm{~g}, 15 \mathrm{~g}, 20 \mathrm{~g}$, and $25 \mathrm{~g}$ ) of the Immobilized Bacteria.

In TAN1 samples, the percentage reduction (\%) of COD ranged (14-89); BOD (50-80); SS (-32$35)$ and TDS (98-99). In TAN2 samples, the percentage decrease $(\%)$ of COD ranged (15$38) ;$ BOD (90-92); SS [-28-(-55)] and TDS (9798). In TAN3 samples, the percentage decrease (\%) of COD ranged (11-44); BOD (76-81); SS (15-25) and TDS (98). The percentage increase in the levels COD, BOD and TDS might be due to the increase in the surface area of the different masses of the immobilized bacteria. However, the percentage decrease in the levels of the SS might be due to the aggregation of the TDS which are large enough to result into SS. The percentage decrease in the levels of the SS might be also due to the influence of the nutrients which was added into the effluents in order to make the microorganisms more active and viable for fast degradation of organic contaminants in the effluent. This is in line with the work of Jimoh et al. (2018) in which the concentration of the SS increase after the bioremediation of effluents.

Sreemoyee and Priti (2013) assessed and reduced several Physico-chemical parameters of dairy wastewater using Niesseria $s p$. and concluded that the species are well known to degrade organic compounds. This is in agreement with the current study in which the immobilized Niesseria $s p$ degrade the organic contaminants as indicated by the BOD, COD and TDS.

Jimoh et al. (2018) observed that TSS of the effluents was increased after treatment with immobilized bacteria and concluded that it might be due to the biostimulation method adopted for the research.

The optimum $\mathrm{pH}$ Biosorption of Chromium by Bacillus spp and Staphylococcus spp. from tannery effluent was investigated by Mythili and Karthikeyan (2011). The maximum adsorption of Chromium $(86.4 \mathrm{mg} / \mathrm{L})$ was showed by Bacillus spp and Staphylococcus spp showed $70.6 \mathrm{mg} / \mathrm{L}$ at an initial concentration of $100 \mathrm{mg} / \mathrm{L}$. In the present study, immobilised Bacillus spp and Staphylococcus spp. from the tannery industrial effluents reduced the levels of the organic pollutants with high potential as indicated by the percentage reduction of BOD, COD and TDS.

Enzymes often can work in multiple environments especially if they are immobilized. This makes the microorganisms' enzymes even more resistant to harsh environments and enables the enzymes to be recovered and recycled after they are no longer needed (Gianfreda and Rao 2004). Ramesh and Singh (1993) reported that the immobilized bacteria having more efficiency to remove the suspended particles than free cells. Using the immobilized cell is preferable due to its capability for using several times with the same efficiency, which makes it more economical. Similar work was done by Sikander et al. (2007) showing the higher reduction with permeabilized cells of Ochrobactrum intermedium strain SDCr-5. 
BAJOPAS Volume 13 Number 2, December, 2020

The results revealed the isolation and identification of isolates with the potential for the reduction of $\mathrm{Cr}$ (VI) to $\mathrm{Cr}$ (III). Results indicated that immobilized $B$. cereus could be efficiently used for the reduction of $\mathrm{Cr}$ (VI).

Table 5: Percentage reduction of the tested Parameters from the tannery industrial samples of the Immobilized Bacteria.

\begin{tabular}{lllllll}
\hline \multirow{2}{*}{ Industries } & & \multicolumn{5}{c}{ Percentage Reduction $(\%)$} \\
\cline { 3 - 7 } & & $5 \mathrm{~g}$ & $10 \mathrm{~g}$ & $15 \mathrm{~g}$ & $20 \mathrm{~g}$ & $25 \mathrm{~g}$ \\
\hline TAN1 & COD & 28 & 14 & 64 & 87 & 89 \\
& BOD & 50 & 54 & 59 & 67 & 80 \\
& SS & 35 & -26 & -27 & -32 & -63 \\
& TDS & 99 & 99 & 99 & 98 & 98 \\
TAN2 & COD & 15 & 20 & 25 & 32 & 38 \\
& BOD & 91 & 91 & 92 & 90 & 92 \\
& SS & -28 & -52 & -52 & -54 & -55 \\
& TDS & 97 & 99 & 99 & 99 & 99 \\
& COD & 33 & 44 & 22 & 11 & 26 \\
& BOD & 75 & 81 & 76 & 81 & 81 \\
& SS & 25 & 3 & -1 & -10 & -15 \\
& TDS & 98 & 98 & 98 & 98 & 98 \\
\hline
\end{tabular}

Percentage Reduction $=(B-A) / B \times 100 \%$

$A=$ Concentration of the parameter after treatment

$\mathrm{B}=$ Concentration of the parameter before treatment

$+=$ percentage decrease

- = percentage increase

In general, immobilization makes the enzyme more resistant to temperature, $\mathrm{pH}$, and substrate concentration swings giving it a longer lifetime and higher productivity per active unit (Gianfreda and Rao, 2004; FuIlbrook, 1996; Russell et al, 2003; Kandelbauer et al., 2004). Immobilized cells have been used and studied extensively for the production of useful chemicals (Ohtake and Silver, 1994), the treatment of wastewaters (Chen et al., 2003; Wang et al., 2010). Although many workers described microbial degradation of tannery effluent, limited literature is available on the bioremediation of tannery effluent using immobilized bacterial cells in the Kano Industrial Estates.

\section{CONCLUSION}

The samples contained variable levels of the physicochemical parameters. The results of the Analysis of variance revealed that, no statistical difference $(p<0.05)$ was observed for the temperature, $\mathrm{pH}, \mathrm{SS}, \mathrm{TDS}, \mathrm{BOD}$ and $\mathrm{COD}$ among the three tannery industries before the treatment. The levels of some of the parameters
(SS, TDS and COD) observed in the samples were found above the recommended limits of WHO and NESREA, which called for the treatment of the effluents before discharge into the environment. Base on the morphological and biochemical test results, TAN1, TAN2, and TAN3 bacterial isolates were identified to be Neisseria spp, Bacillus cereus, and Staphylococcus aureus respectively. The results of Post-treatment analysis showed that there is overall decrease in the levels of the parameters determined when compared with that of the pre-treatment. The overall percentage reduction of the immobilised bacteria in the treatment of the respective effluents was in the order TAN2 (72\%)>TAN1 $(70 \%)>$ TAN3 $(62 \%)$. Hence, the immobilized bacteria are having higher biodegradation potential for the treatment of the tannery effluents.

\section{Acknowledgments}

The authors wish to acknowledge the University of Maiduguri for the financial support. The authors are grateful to the Kano State Ministry of Environment for their support in obtaining the effluent samples. 


\section{REFERENCES}

Ajao, A. T., Adebayo, G. B., and Yakubu, S. E. (2011). Bioremediation of textile industrial effluent using mixed culture of Pseudomonas aeruginosa and Bacillus subtilis immobilized on agar-agar in a bioreactor. J. Microbiol. Biotech. Res, 1(3), 50-56.

Akan, J. C., Moses, E. A., Ogugbuaja, V. O., and Abah, J. (2007). Assessment of tannery industrial effluents from Kano metropolis, Kano State, Nigeria. Journal of Applied Sciences, 7(19), 2788-2793.

Akan, J. C., Ogugbuaja, V. O., Abdulrahman, F. I., and Ayodele, J. T. (2009). Pollutant levels in effluent samples from tanneries and textiles of Kano industrial areas, Nigeria. Global journal of pure and applied sciences, 15(3-4).

APHA (1989). Standard methods for Examination of Will bete and Will betewater.15 $5^{\text {th }}$ edition. Brydpass Springfield Will behington DC. pp. 164-176

APHA (1992). Standard Methods for the Examination of Water and Wastewater. Health, 69, 1116-9.

Baba, A., Garba, S. T., and Bello, H. S. (2020). Bioremediation Potential of Immobilized corynebacterium kutsceri in the Treatment of Tannery Industrial Effluent from Challawa Industrial Estate, Kano State, Nigeria. Journal of the Turkish Chemical Society Section A: Chemistry, $7(2), 335-350$.

Beem, E. I. V. (1994). reduction of solvent VOC emission. J. Oil Col. Chem. Ass, 77, 158.

Bouwer, E. J., and Zehnder, A. J. (1993). Bioremediation of organic compoundsputting microbial metabolism to work. Trends in biotechnology, 11(8), 360367.

Chen, K. C., Wu, J. Y., Liou, D. J., and Hwang, S. C. J. (2003). Decolorization of the textile dyes by newly isolated bacterial strains. Journal of Biotechnology, 101(1), 57-68.

Dan'Azumi, S., and Bichi, M. H. (2010). INDUSTRIAL POLLUTION AND HEAVY METALS PROFILE OF CHALLAWA RIVER IN KANO, NIGERIA. Journal of Applied Sciences in Environmental Sanitation, $5(1)$.

DWAF. (1992). Analytical Methods Manual, TR 151. Department of Water Affairs and Forestry, Pretoria.

El-Bestawy, E. (2013). Biological treatment of leather-tanning industrial wastewater using free living bacteria.
Elsheikh, M. A. S. (2009). Tannery wastewater pre-treatment. Water Science and Technology, 60(2), 433-440.

FuIlbrook, P. D. (1996). "Kinetics." Industrial enzymology: The application of enzymes in Industry. 2nd Ed. T. Godfrey and J Reichelt. eds.. Nature. New York.

Gianfreda, L., and Rao, M. A. (2004). Potential of extra cellular enzymes in remediation of polluted soils: a review. Enzyme and microbial technology, 35(4), 339354.

Hugo Springer. (1994). John Arthur Wilson Memorial Lecture "Treatment of Industrial Wastes of the Leather Industry - is it still a Major Problem". JALCA, 89, 153-185

Jimoh, A. A., Ganiyu, B. A., Baba, D., and Baba, A. (2018) Bioremediation Process of Effluent from Detergent and Food Industries in Jos, Nigeria: Kinetics and Thermodynamics. International Journal of Engineering Science Invention (IJESI), 762-73

Kandelbauer, A., Maute, O., Kessler, R. W., Erlacher, A., and Gübitz, G. M. (2004). Study of dye decolorization in an immobilized laccase enzyme-reactor using online spectroscopy. Biotechnology and bioengineering, 87(4), 552-563.

Kongjao, S., Damronglerd, S., and Hunsom, M. (2008). Simultaneous removal of organic and inorganic Pollutants in tannery wastewater using electrocoagulation technique. Korean Journal of chemical engineering, 25(4), 703.

Maheshwari, U. M., Aruna, S., Gomathi, M., and AbdulJaffar, A. H. (2017). Bioremediation by Free and Immobilized Bacteria Isolated from Tannery Effluent. International Journal of Research in Applied, Natural and Social Sciences. 5(7), 75-90

Margesin, R., and Schinner, F. (2001). Bioremediation (natural attenuation and biostimulation) of diesel-oilcontaminated soil in an alpine glacier skiing area. Applied and environmental microbiology, 677), 3127-3133.

Mohammed, A., Sekar, P., and George, J. (2011). Efficacy of microbes in bioremediation of tannery effluent. Inter. J. Curr. Res, 3(4), 324-326.

Mohammed, S. S. D., Orukotan, A. A., and Abdullahi, H. (2017). Physicochemical and Bacteriological Assessment of Tannery Effluent from Samaru-Zaria, 
BAJOPAS Volume 13 Number 2, December, 2020 Kaduna State, Nigeria. Journal of Applied

Sciences and Environmental Management, 21(4), 734-740.

Munz, G., De Angelis, D., Gori, R., Mori, G., Casarci, M., and Lubello, C. (2009). The role of tannins in conventional and membrane treatment of tannery wastewater. Journal of hazardous materials, 164(2-3), 733-739

Mythili, K., and Karthikeyan, B. (2011). Bioremediation of $\mathrm{Cr}$ (VI) from tannery effluent using Bacillus spp and Staphylococcus spp. International Multidisciplinary Research Journal, 1(6).

NESREA (2009). National Environmental Standards for Effluent Limitations and Regulation. 1233-1236

Noorjahan, C. M. (2014). Physicochemical characteristics, identification of bacteria and biodegradation of industrial effluent. Journal of bioremediation and Biodegradation, 5(3).

Ohtake, H. I., and Silver, A. O. (1994). Bacterial reduction of toxic chromate. Biological degradation and bioremediation of toxic chemicals, 403-415.

Omoleke, I. I. (2004). Management of environmental pollution in Ibadan, an African city: the challenges of health hazard facing government and the people. Journal of Human Ecology, 15(4), 265-275.

Rajor, A., Reddy, A.S., and Singh, B. (2004). Determination of BOD kinetic Parameters and evaluation of alternate methods, M.Sc. Thesis, Department of biotechnology \& environmental Science, Thapar Institute of Engineering and Technology, Patiala

Ramasami, T., Rajamani, S., and Rao, J. R. (1994, March). Pollution control in leather industry: Emerging technological options. In International symposium on surface and colloidal science and its relevance to soil pollution, madras.

Ramesh, J. V. S., and Singh, S. P. (1993). Yearly variation in certain physicochemical parameters of pond at eastern Doon Valley. Uttar Pradesh J. Zoo, 12 (1), 7577.

Ranen, S., and Sharadinadra, C. (2009). Biotechnology applications to environmental remediation in resource exploitation. Current science, 97, 6-25
Russell, A. J., Berberich, J. A., Drevon, G. F., and Koepsel, R. R. (2003). Biomaterials for mediation of

chemical and biological warfare agents. Annual review of biomedical engineering, 5(1), 1-27.

Saravanan, P., and Saravanan, A. (1999). Decolourization of tannery effluent by Flavobacterium sp. EK 1. Indian Journal of Environmental Protection, 19, 19-24.

Sikander, S., and Shahida, H. (2007). Reduction of toxic hexavalent chromium by Ochrobactrum intermedium strain SDCr5 stimulated by heavy metals. Bioresource Technol, 98, 340-344.

Singh, N., Sharma, B. K., and Bohra, P. C. (2000). Impact assessment of industrial effluent of arid soils by using satellite imageries. Journal of the Indian Society of Remote Sensing, 28(2-3), 79.

Sreemoyee, C., and Priti, P. (2013). Assessment of physico-chemical parameters of dairy waste water and isolation and characterization of bacterial strains in terms of cod reduction. Int J Sci, 2(3), 395-400.

Verheijen, L. A. H. M., Wiersema, D., Pol, L. H., and De Wit, J. (1996). Management of wastes from animal product processing. Livestock and environment, Finding a balance. International Agriculture Center, Wageningen, The Netherlands.

Wang, F., Yao, J., Si, Y., Chen, H., Russel, M., Chen, K., and Bramanti, E. (2010). Short-time effect of heavy metals upon microbial community activity. Journal of Hazardous Materials, 173(13), 510-516.

WHO (World Health Organization). (2006). Air quality guidelines: global update 2005: particulate matter, ozone, nitrogen dioxide, and sulfur dioxide. World Health Organization.

World Bank. (1995). Nigeria's strategic options for redressing industrial pollution. World Bank, industry and energy division. 1st edition, West Central Africa Department; Annexes: 1995; pp 60-62.

Zahoor, A., and Abdul, R. (2009). Enumeration of Coliforms. Journal of Environmental Sciences. 21, 814-820 